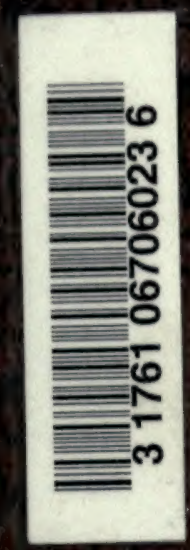




Digitized by the Internet Archive in 2007 with funding from Microsoft Corporation 


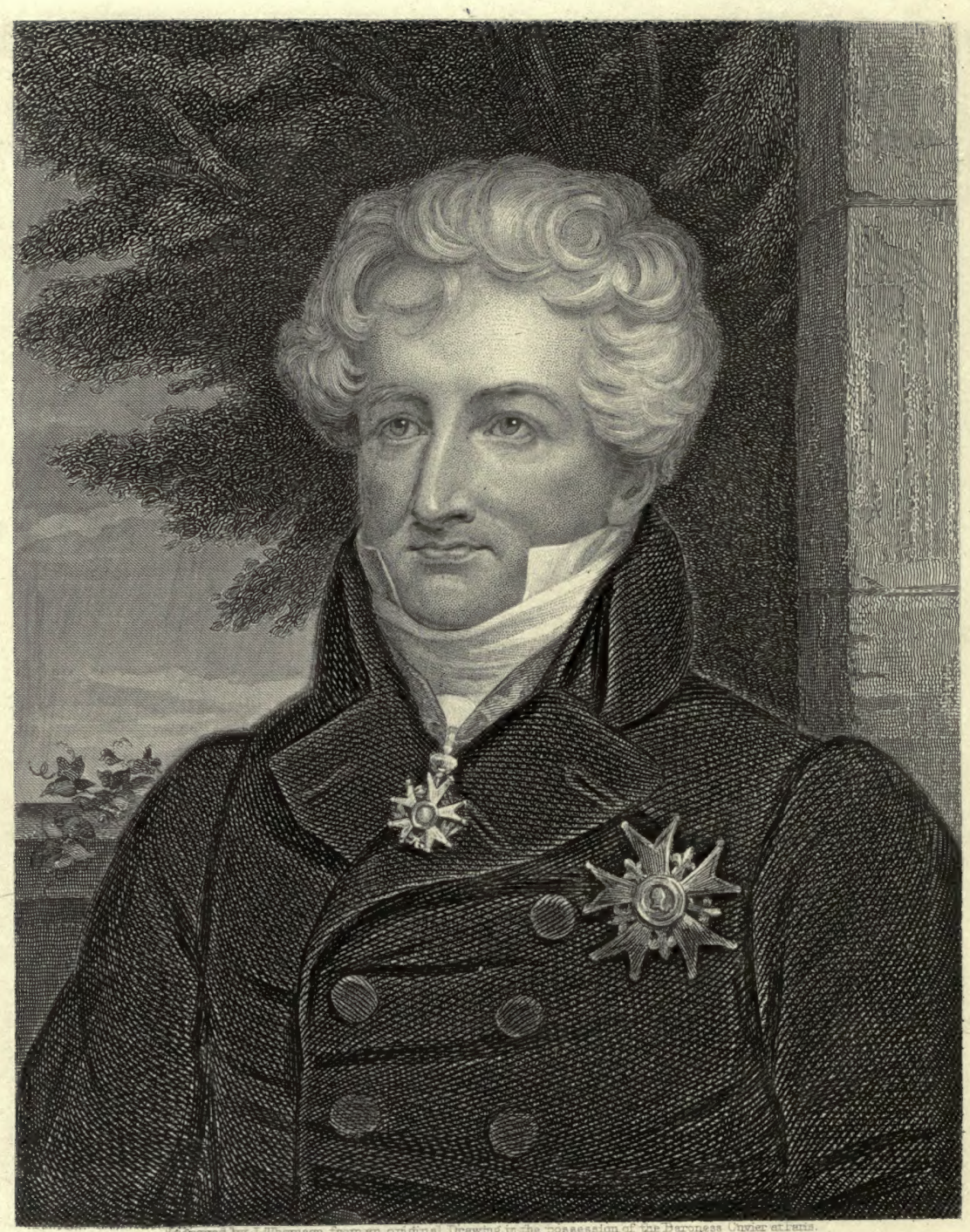

C U V V E 


\section{CH A MBER S'S}

\section{ENCYCLOPADIA}

A DICTIONARY

OF

\section{UNIVERSAL KNOWLEDGE}

NEW EDITION

V 0 L. III

CATARRH TO DION
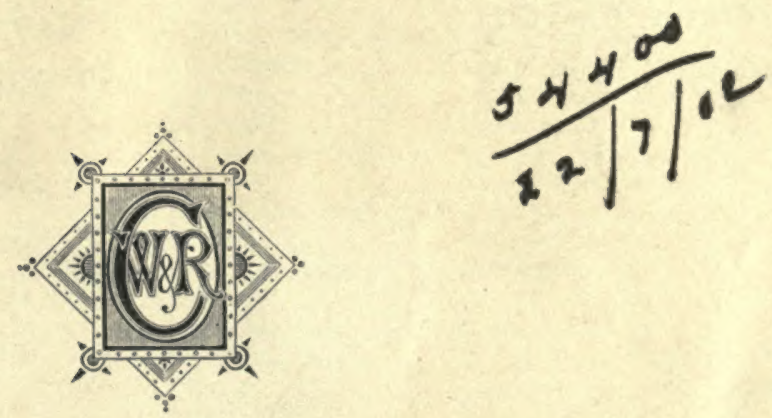

WILLIAM \& ROBERT CHAMBERS, LIMITED LONDON AND EDINBURGH

J. B. LIPPINCOTT COMPANY, PHILADELPHIA 1902 
The following Articles in this Volume, originally Copyrighted in 1889, as now revised are Copyrighted by J. B. Lippincott Company, in 1897 and 1900, in the United States of America:

Charleston.

Chavtaugua.

Cheese and Cheesemaking, American.

Chicago.

Cincinnati.

Clay, Henry.

Ciemens, S. L. (Mark Twain).

Cleveland (Ohio).

Cleveland, Grover.

Colorado (river).
Colorado (State).

Columbers (Ohio).

Colcures, Christopher.

Congress of the United States. Connecticut.

Cooper, James Fenimore.

Dairy Factories.

DAKOTA.

Delaware (State).

Detroit. 


\section{Among the more important articles in this Volume are the following:}

Caterpinars, Crel,

Cras, \& other articles Profeasor J. ARtrus Thompsos.

CATTLR. ..................... J. Macdosald of the Farming World.

Catroe Plague, \&e.... Principal Wizhuse.

Catullus................... Walter WhYte.

CausahtixY.................. Professor W. R. Sorley.

Cavalry................... Lieut. COol. Dualop, R.A.

Certs......................... Professor RHYs.

Cervantes; Crb....... Johs Orassy.

CEXLON..................... J. L. SHAND.

Chancerry; Common

LaW ; Copyright.... Thomas Raleigh, D.C.L.

Channel Islands...... H. G. Krege, C.I.E.

Channel Tunnel....... Sir Rdward W. Watkns.

ChaP-BOOKS................. H. В. WheATLEY.

Chapman; DekKer.... A. H. Bullew.

Charles I. and II...... F. Hindes Groomr.

Charles V.............. P. HuMe Brows, LL.D.

Chatham, Earl OF..... R. B. Haldane, Q.C., M.P.

Chatterton............... F. Hindes Grooms

Chavorr. .................... Professor J. W. Hales.

Chrmistry................. Lenard Dobin, Ph.D.

Cherubini................. Colin Stalker.

Chrss,...................... R. F. Green, Ed. Brit. Chess Magazine

Chicago..................... Georee Forrester.

CHILl........................ J. SAMson (South American Journal),

China ; Confuctus...... Professor Ligge.

Chloroform............... W. Inglis Clark, D.Se.

Cholera .................... Dr R. W. Felkin.

Chopin ..................... Charles L. Graves.

Christianity ............ Edyond de Pressenssé, D.D.

Christaras................. Rev, T. F. Thisklton Dyer.

Chronology.............. R. E. AKDerson.

Church, Crypt, \&c..... D. Macoibbon.

ChURCh History....... Rev. A. P. Davidson,

Cibber ; Colman........ Robert W. Lowe.

Cicero....................... Rev. W. J. BrodribB.

Circulation.............. David Hepburs, M.D.

Civil Service. ....... W. A. Casson, F.S.S.

Clan ............ The Duke of ARoxLL.

Chimate..................... Dr Alex. Buohas.

Cuouds..................... R. T. OMosd (Ben Nevis).

Clovgh, A. H............. Tromas Davidson.

Clubs,........................ Henary R. Tedder.

Condhing.................. W. C. BLew, of the Field.

Coal, Coral Islands,

and Geology generally. Professor JaMes Geiriz.

Coaling Stations.,.... Lord Brassey.

CODE ......................... Professor Goudy, D.C.L

Colchestrer................ Rev, E. L. CutTs.

Colenso ................... G. BarnetT SMTth.

Coleridgr................. Professor W. Kiviaht

Colombia................... W. Dundas WaLker.

ColonY ...................... James 8. Cotron.

Colorado................... Charles W. Greese, M.D.

COLOUR..................... AlFred DANIELL, D.Se.

CoLour-BLINDNESS...... Dr R. A. Lundie.

Columba ; Culdees ... Dr Joseph Robertson, revised.

Coldmbia, British..... J. G. Colmer, C.M.G.

Compressibility.......... A. C. Mitchel.

Congo ...................... Sir Francis de Wintos.

Congress U.S....... D. Y. Kmoore.

Congreve ................. Theodore Wattg-Duntow.

ConJuring................. A. J. Lewis, M.A. ('Prof. Hoffmann')

Connectiout. Oharles W. Greane, M.D.
Consolovsness ........... Professor Axdaw Betr.

Constable, Corkegro,

Cruikshank, de...... J. M. Gray.

Constantinople, Copts Btanlegy Laxe-Pooln

Consumption.............. Dr R. W, Pumis.

Convocation, \&c....... Rev. Dr R, F. Litrumale

Cook, Captan........... Johr \&. Kettis, F.R G.8.

COOKerY ; COFYeE...... W. Matriev Whluaka.

Co-operation ; Demo.

CRAOY.................... THOMAs KrRKUP.

CORNEILLE.................. WALTER WhYTE

CoRnWALL.................. F. N. Wonth.

Cortes ..................... Thоми Davidsos,

Cotron....................... Thosas ElLLiBoN.

CounTY...................... W. A. CAsson, F.S.S.

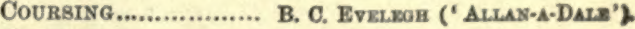

Coventry.................. W. F. Dawsos.

COWLEX..................... P. HuMg Brows, LL.D.

COWPER, WHLIAM...... Mrs OLIPHANT.

Crangrer ................... F. Hindes Groóme.

Creation .............. Profesgor Henky Drummord.

Cremation................. W. Eassin, C.E.

CrICKET .................... C. J. Butcher, of the Field.

Criminal Law........... Gerorge P. M'Nethi.

Crofters................... Lord Napier and EtTrick.

Cromweli, OLIVER..... Professor Goldwis SMith.

Cross ...................... Rev. 8. Baring-Gould.

Croup....................... Dr George Gilray.

Crystallography...... c. J. Woodward.

CunEIfoRM................ EMandel Devtsch, revised by E. A. Wallis Budge

Curling.................... Robert Chambers, revised

Currency................... Professor Nicholsos.

CuTTLE-FISH ................ WM. E. HoYLE.

CYOADS, and the other

Botanical articles ..... Professor PAtrick Geddes

CYCLING..................... E. R. SHIPTOs, Secy. C.T.C.

CYPRUS .................... Ulick RALPH BURKE.

DAIRY ....................... Professor ROBERT WALLACK,

DAIRY FACTORIES....... HENRY StrWART.

DaMascus.................. Rev, W. Wrught, D.D.

DANTE..................... Rev. EdwARd MoORE, D.D.

DARWIN .................... Grant AlLEN.

Darwinian Theory... Professor Patrick Geddes

DAUDET ............... Professor SAINT8BUB.

DEAF AND DUMB......... J. D. BUXTON, LL.D.

DEBT ........................ WILliam C. SMтth.

DEER Forests............. J. WATSON LyaLL.

DEFoE........................ Rev. A. P. DAvidsox

DEFORMITIES,.............. Professor A. HARE.

Detagoa BAY............ E. P. Mathers, F.R.G.S.

DELHI...................... A. MACDONALD, Caleutta Englishman

DEMONOLOGY.............. Thomas Davidson.

DEMOSTHENES, F............ JeVONg

DenMark (Literature) Rev. A. P. Davinson.

DeNTISTRY................ Dr JoHN Smтth.

DE QUINCEY................ J, R. Findi.AY.

Derby ; Derbyshirk. Rev. J. Charles Cox, LL.D., P.S.A.

DESOARTES.................. Professor ANDREW SETH

Devon; Dartyoor... F. N. Worth.

Dew ; Diffusion ........ W. Pedpre, D.Se.

DIAMOND

DIALEOT..................... ALEXANDER J. ELL.18, F.R.\&

DIOKRNB..................... Sir WALTER BERANT.

Diet ; Digestion....... Professor Haycrayt.

The Publishers beg is tender their thanks for suggestions or corrections on the following articles: To Lord Kingsburgr, on 'Catholic and A postolic Church;' to Bishop Westcott and Rev. Charles Bigg, D.D., on 'Clement ;' to Sir Frederick Pollock, on 'Clifford;' to His Excellency General A. B. Cuervo, on 'Colombia;' to Sir EDWARd Walter, on 'Commissionaires;' to JACOB HolyoAKE, Esq., on 'Co-operation;' to the Head-Masters of the Charterhouse and Christ's Hospital; to EDMund Gosss, Esq., on 'Denmark (Literature);' and to the Editor of the Field, on 'Derby Day.' 



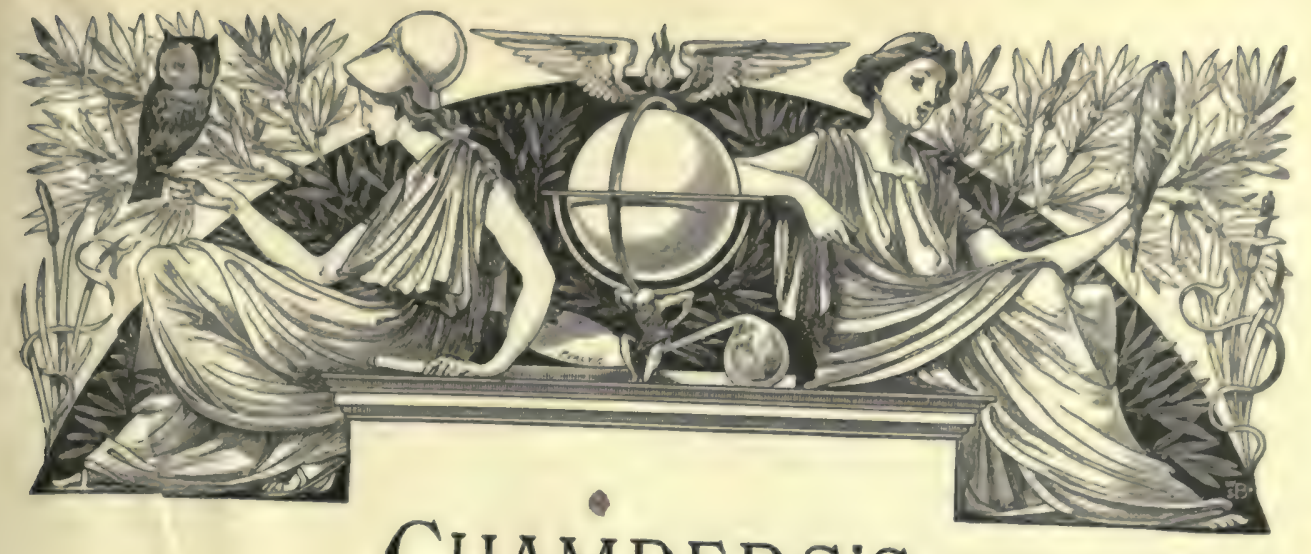

CHAMBER S'S

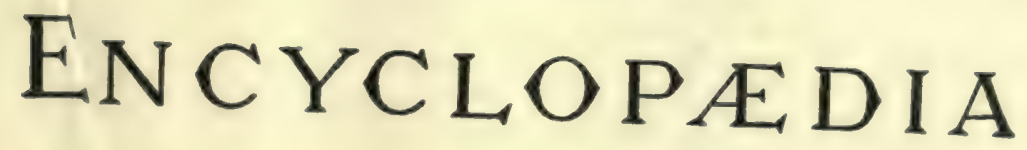

1 DICTIONARY OF UNIVERSAL KNOWLEDGE

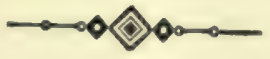

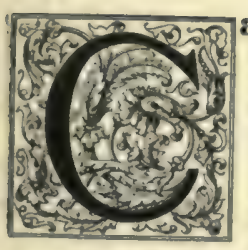

atarI (Gr. katarreo, 'I flow down a disease of great frequencyn temperate latitudes, especia in changeable moist From in the winter season. From i well-known connection witsudden falls of temperature, $\mathrm{nd}$ other epidemic or ENZA), as also from the chill eauses (see INFLU. commencement of the disease, $n$ experienced at the a cold-a term, however pe, is popularly called definite in its meaninger, pes.ps somewhat less is usually restricted to the tarrh, which word the chest, and attended with a cold affecting by coughing. A 'cold in the strict scientific language, Coryz is termed, in ever, keep both forms in view in $t$ we shall, howCatarrh, or cold, commonly begicesent article. of chilliness, which may or may with a feeling able to external causes. Sometimf, be attributthere being only a sense of languo his is alsent, tion; not unfrequently there is no ${ }^{2}$ indisposiunusual kind, until a stuffing is no 'sation of an nostrils, or severe headache, is exp nced in the cough, or oppression of the breathi eness with commonly attacks the nostrils first, It most the air-passagres lealing to the ches fterwards mucous membranes of the eyes and mou But the affected, as well as those of the nose, lungs; and the disease may begin in, oat, and situations, and either spread to them of these one or more unaffected. When it lave attacks the chest, without running it itually ordinary course as indicated above, there ${ }^{h}$ its some special cruse of delicacy in the often some constitutional tendency towards Consl, or (q.v.). The affected mucous membrane is tion abnormally red and swollen, and its ser irst diminished. But it soon begins to pour discharge, at first watery, but afterwards a and of a yellowish colour, or purulent. The stages of the disease are attended by consider 105 irritation of the surfaces affected, and probably no one of the little miseries of life is more prostrating and discouraging for the time than a bad cold in the head. The tendency of catarrh to attack the chest, and thus to pass into Bronchitis (q.v.) or Pneumonia (q.v.), or to lay the foundation of danger.
dasease, constitutes almost its only

The treatment of a cold is commonly a simple matter, so far as the particular attack is concerned. But so many colds disappear in a little time without any special treatment that few persons, unless in delicate health, are willing to subject themselves to the confinement which is necessary to give any form of treatment a chance of success. In the earliest stage a warm hip $n$ foot bath, and a large opiate (Dover's powder especially) at bed. time, if followed by confinement to the house, and, in severe cases, to bed or to the sofa for a day or two, light farinaceous diet, and, if the stomach and bowels are at all loaded, a dose or two of some gentle laxative, will generally cut short the disease. In some persons it yields readily and quickly to spirit of camphor, five drops on a lump of sugar every half-hour; but in others no effect is produced. Free bathing of the nose with hot water may relieve the irritability and dis. charge. In most cases frequent sipping of warm sonthing drinks-gruel, barley-water, black-currant tea, \&c. - is grateful to the patient; sometimes ice gives more relief. Some persons cure their colds by entire abstinence from food, and as much as possible from drink; others by spirit of mindererus popular moric ; some even profess to carry out the popular maxim, 'stuff a cold, and starve a fever, whisky main that a good dinner and a tumbler of whisky or brandy toldy are the best specities. That colds get well under all these methods need not be denied; but multiplied experience has shown that 'stuffing a cold' at its commencement is by no means to be commended. In the later stages, however, a more liberal diet than at first and in some cases even a moderate allowance of 
stimulants, affords considerable relief from the feeling of depression that remains for a time on the subsidence of a catarrh. The tendency to this disease, when habitual, and when not dependent on any form of constitutional disorder requiring special means for its cure, is best met by the daily use of the cold bath, with frequent exercise in the open air, and proper ventilation of the sleepingapartment; also by friction of the skin, and by clothing which, without being oppressive, is comfortably warm. Exposure to draughts or sudden chills when the surface is perspiring is to be avoided; but a close confined air habitually breathed in a workshop or bedroom is a fruitful predisposing cause of the disease.

Catarrh or catarrhal inflammation is also used in modern pathology of an inflammation with the characters above described in any mucous membrane whatever; we have, for example, catarrh of the stomach, intestines, bladder, \&c.

Catarrhini, Old-World monkeys, with a narrow partition between the nostrils, with a dental formula $\frac{21}{2} \frac{23}{2}$, and including two distinct sets of forms, $(a)$ the lower 'dog-like' apes (Cynomorpha), and (b) the higher 'man-like' forms (Anthropomorpha). See APE, ANTHRopoId APES, MONKEY.

Catawba, a name of wines, both still and sparkling, produced in various parts of the United States from the Catawba grape, the fruit of a variety of the Vitis Labrusca, a North American and Asiatic species, from which have been derived most of the cultivated North American varieties of the vine. It is often said that it was 'first found growing on the banks of the Catawba River' (in North and South Carolina); but it is on record that it was named by Major Adlum, who found it growing wild near Washington, D.C., about 1825. Catawba wines are of various grades, the best being of very decided value. The vine is extremely prolific, the fruit being large, of a deep coppery red, and very sweet. The Catawba grape does best on southern slopes, and on limestone soils. Its slight musky aroma pervades the wines made from it, and causes some connoisseurs to reject all but the very choicest of the vintage from the catalogue of first-class wines.

Cat-bird (Turdus or Galeoscoptes carolinensis), an American thrush, of the same group as the mocking-bird, which it resembles in its vocal powers. Its name refers to its mew-like cry when disturbed. It feeds on many kinds of fruit and berries, also on worms and insects; builds a large nest of dry twigs, weeds, \&c., without any attempt at concealment, in a bush or tree, often in the immediate vicinity of human habitations, and shows extraordinary boldness in the defence of its young. It is a bird of passage, making its way northward in spring through Georgia and Carolina as far as Massachusetts. In winter it migrates southwards, and strayed specimens have been seen as great rarities on the continental coast of the North Sea.

Catch, a species of musical composition peculiar to England, written generally in three or four parts, and in the canon form. It was origin. ally synonymous with the Round (q.v.), but the name has been appropriated to a species of it to which an absurd or humorous effect is given by the successive entries of the parts, interrupting or distorting the sense of the words into a new and unexpected meaning. They abounded in the Restoration period, when, as may be surmised, they often had a more than questionable coarseness. Hayes, Webbe, and Callcott, towards the end of last century, were fertile composers in this form. The 'Catch Club' was founded in 1761 .
Catchfly, the name of the genus Silene, of which many species produce a sticky secretion on the caly $x$, the joints of the stem, \&c., which prevents the access of ants and other creeping insects to the honey, so preserving it for the bees or other flying insects by which alone cross fertilisation is effected. Other Caryophyllacen, notably Lychnis Viscaria, possess the same means of defence. The Nottingham Catchfly is Silene nutans. The unrelated Dionca muscipula is also sometines called

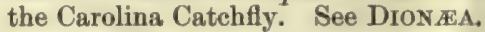

Catchpoll, a sheriff's officer or bailjif, who had power to arrest. From catch and poll, the head;' not as is suggested by the spelling cochpole from pare; though in various places a lon pole was in use for eatehing or holding criminals by the neck, having at the end of it an iron collar with a $\mathrm{V}$-shaped opening, occasionally arm d with spikes. on the inside.

Cateau, Le, or Cateau-Caybresis, a town. in the French department of Nod, on the Selle, 14 miles ESE. of Cambrai. Po. (1891) 10,529. Here in 1559 the treaty of Cat uu-Cambresis was. concluded between Henry II. of France and Philip. II. of Spain.

Catechism, any compendidis system of teaching drawn up in the form of diestion and answer. It is derived, throngh low Fatin, from a Greek word katecheō, which means to resound, or sound into one's ears; to instruc by word of mouth. Persons undergoing instrucjon in the principles of Christianity were hence calld Catechumens (q.v.).

Catechisms have long for hed one of the principal means employed for popflar instruction in the truths and duties of the Christian religion. The composition of the firs catechisms was, in all probability, suggested the ordinary oral instruction of eatechumes, and was intended for the help both of teach 5 and pupils. It appears. to have been in the $8 \mathrm{tl}$ and $9 \mathrm{th}$ centuries that the first regular catechisis were compiled, of which that by Kero, a mon of St Gall, that of Notker Labeo of St Gall, an that ascribed to Otfried of Weissenburg in Alspe, are among the most noted. At later periods th use of catechisms prevailed chiefly among the pponents of the hierarchy, as among the Walden $\mathrm{s}$, the Albigenses, the Wyclifites, and, above all fmong the Bohemian Brethren. The term catechio appears to have been first employed in its prefnt sense among the latter. At. an early period the history of the Reformation. the Reformens /gan to avail themselves of this method of popu instruction, and their catechisms became import instruments in that great religious movement After Luther published in 1520. his primer of religion, entitled $A$ Short Form of the Ten Ommandments, the Creed, and the Lord's Prays several catechisms were prepared by leading potestant theologians, that of Brenz (1527-28) bhig the most notable. In 1525 Justus Jonas and Phn Agricola had been intrusted with the preparion of a catechism, and Luther's visita. tion of th Saxon churches in 1528 led to his preparing hi Larger and Smaller Catechisms (1529), which fofd a place among the standards of the Luthera churches. The Larger he meant to be for teacers, the Smaller for the people. The latter 1 , been constantly reprinted, and is very extensily used at the present day. A number of catech ms were published also by the theologians of the Reformed churches. The most noteworthy are $t$ Geneva and Heidelberg catechisms, and thos of CEcolampadius (Basel, 1526), Leo Judæ (Zu h, 1534), and Bullinger (Zurich, 1555). The Gen ra catechisms, Larger and Smaller, were the rork of Calvin. The latter was published in french in 1536 (Lat. ed. 1538); the former 
appeared in French in 1541 or 1542 (Lat. ed. 1545), was speedily translated into varions languages, and became an acknowledged standard of the Reformed churches, not only in Switzerland but in the Low Cisuntries, in France, and in Hungary. The First Burk of Discipline of the Scottish Church (1560) directs that the children be taught this catechism - which catechism is the most perfect that ever yet was used in the kirk'-every 'Sonday' afternoon in the presence of the people. The Church of Geneva has set aside the anthority of Calvin's catechisms. The Heidelberg or Palatinate Catechism is of greater importance, however, than any other as a siendand of the Swiss Reformed churches. It was compiled by the Heidelberg theologians, Caspar Olevianus and Zacharias Ursinus, at the request of the Elector Frederic III. of the Palatinate; it was published in 1563, was approved by several synods, and recognised as a symbolical book by the Synod of Dort in 1619, and has been translated into all the languages of Europe. It is the standard of the Dutch and German Reformed churches of America. A tercentenary edition of this catechism was published in German, Latin, and English at New York in 1863. - King James said at the Hampton Court Conference that in Scotland 'every one who was the son of a good man' thought himself competent to write a catechism. The catechisms of the Scottish Reformation must have been numerous. The most popular, until it was superseded by the Westminster Catechism, was John Craig's Smaller Catechism (Edin, 1581 ; edited by T. G Law, 1883). - The doctrines of the Socinians are embodied in the greater and smaller Racovian Catechisms (Polish ed. Racow, 1605; Latin ed. 1609). Besides a catechism of 1660 , in the form of a conversation between father and son, said to have been written by George Fox, the Quakers have that of Robert Barclay (1673), in which the answers are in the languare of the Bible, the distinctive peculiarities of the sect being involved in the questions.

In the Church of Rome there were several crtechisms published in Germany and elsewhere before the Tridentine settlement of doctrine. A Scottish eatechism, known as Archbishop Hamil ton's, was issued by anthority of a provincial council in 1552, and was ordered to be read in church by the parish priests. But in 1563 the Council of Trent in its twenty-fourth session determined to compose and prescribe for the whole church an authorised form of eatechism, which the bishops were to have translated into the vulgar tongue, and expounded to the people by the eurates. The work was, however, not carried through by the council itself, and Pius IV. intrusted its completion to a commission of four theologians. Eminent scholars were also appointed to perfect its latinity, and when finished in 1564 it was once again submitted to a new commission under Cardinal Sirletus. It finally appeared in 1566 under the title Catechismus Romanus ex decreto Concilii Tridentini Pii V. Pont. Mrx. jussu editus. In form it is not catechetical, and it is addressed, not to the people, bnt to the curates as a guide to them in their instructions. It possesses very high authority, but is ill adapted for popular ase. For lay teaching it has fallen into desuetude, and has been superseded by various catechisms of more private origin. The most popular of these were prepared by the Jesuit Peter Canisius. His larger work, entitled Summa Doctrinos et Institutionis Christiana, was published in 1554, and the shorter (1556) reached more than 400 editions, and was used in the schools of all countries. In the present day, as a general rule, each diocese posgesses a catechism of its own approved by the bishop. In England the short 'Penny Catechism' is used by authority of all the bishops in concert.
The catechism called the Orthodox Confescion of the C'atholic and Apostolic Eastern Churrh, was prepared about 1640 by Peter Mogilas, metropolitan of Kief, and received nymbolical authority from a synod at Jerusulem in 1672 . It is often ealled the Larger Russian Catechism, to distinguish it from the Smaller Catechism jrepared by order of Peter the Great in 1723. These were practically superseded by the catechisms of Platon, metropolitan of Moscow (first published in 1762 ), and of Philaret, also metropolitan of Moscow, which has since 1839 been in general use in the schools and churches of Russia, - Besides these catechisms, which have a historic interest, or are of importance from their symbolical character, there have appeared at all periods, since the Reformation, many others, both Protestant and Roman Catholic, some doctrinal, some controversial, some devoted to particular subjects, as the sacramente, or to partieular purposes, as the preparation of candidates for admission to the Lord's Supper, some adapted to the mental capacity of very young children, \&c. The opinion, however, has become prevalent, that doctrinal abstracts are not the best form in which religion can be presented to the young, and the use of catechisms has accord. ingly been in some measure relinquished in favour of other methods of instruction.

The catechism of the Church of England with which we are most familiar is the smaller one published in the Book of Common Prayer. It is in two parts : the first contains and explains the Baptismal Covenant, the Creed, the Ten Commandments, and the Lord's Prayer; the second explains the two sacraments, Baptism and the Lord's Supper. It is not known with absolute certainty who was the author of the first part; probably Cranmer and Ridley had the principal hand in framing the questions and answers. It was originally put forth in the reign of Edward VI., and condemned as heretical in the reign of Mary, and underwent several modifications from 1549 to 1661. It must not be confounded with Cranmer's Catechism (1548), which was a larger work, differently arranged, and probably translated chiefly from the Latin catechism of Justus Jonas. This first part of the church eatechism was formerly spoken of as the Shorter Catechism. There was a larger church catechism compiled also in the reign of Edward VI. by Poynet, Bishop of Winchester, and published, together with the 42 Articles, in 1553, and it corresponds in some degree with the smaller work above described. It was afterwards revised and enlarged by Dean Nowell, and published in 1570 ; and, though never officially promulgated by the church, it has some authority from having been approved by the lower house of Convocation. At the Hampton Court Conference (1604), the Shorter Catechism was considered too short, and Nowell's larger one 'too long for novices to learn by heart; accordingly, at James I.'s suggestion, an addition was made to the former of that explanation of the two sacraments which now forms the second part of the church catechism. This is attributed to Dean Overall. The whole is a work much esteemed by all sections of the church as remarkable for its simplicity, truth, and catholicity. It, however, states sacramental doctrine in a way that is not very acceptable to the extreme Low Church party. Hence, the Prayer-book put forth by the Church of Ireland, while leaving the catechism otherwise untouched, ingeniously interpolates an additional question and answer (based on Article XXVIII.), which, in the opinion of many, tends to modify the ideas suggested by the catechism concerning Holy Communion. Modifications occur, too, in the Catechism of the American Episcopal Church. The rubrics in the Common Prayer-book enjoin 
the teaching of the catechism in the church on Sundays and holidays after the second lesson at Evening Prayer; and the 59th canon contains a like injunction, imposing penalties on the clergy who neglect this. The custom of catechising in the church had fallen into almost universal disuse, but in many parishes it has been revived with excellent results.

The Larger and Shorter Catechisms, which, with the Westminster Confession of Faith, constitute the standards or symbolical books of the Presbyterian churches throughout the British empire and the United States of America, were compiled by the Assembly of Divines at Westminster (q.v.): the Shorter Catechism 'to be a directory for catechising such as are of weaker capacity; the Larger, 'for eatechising such as have made some proficiency in the knowledge of the Christian religion.' The Larger Catechism was presented to the English House of Commons on 22d October 1647 ; the Shorter on the 25th November 1647 and both, with proofs added, on or before the 14th April 1648; and in July 1648 both received the sanction of the General Assembly of the Church of Scotland - the General Assembly, in the act approving of the Larger Catechism, declaring it to be 'a rich treasure for increasing knowledge among the people of God,' and that 'they bless the Lord that so excellent a catechism has been prepared.' The Shorter Catechism has, however, been far more generally used for the purpose of instruction than the Larger, which has been generally felt to be too minute in its statements, and too burdensome to the memory to be employed as a catechism. Even the Shorter Catechism is regarded by many, who substantially adhere to its doctrine, as carrying the statement of dogmatic theology beyond what is proper for elementary instruction, whilst it has been long felt to be unsuitable for the very young and the very ignorant, and its use is now almost always preceded by that of catechisms more adapted to their capacity. Its influence, however, has been very great in forming the religious opinions, and in exercising and training the intellectual faculties, wherever Presbyterianism has prevailed; for it has been, and still is, in almost universal use among Presbyterians speaking the English language, and to a considerable extent among Independents or Congregationalists both in Britain and America. In Holland also, a translation of it has been much used. It is very generally regarded, by those whose doctrinal views are in accordance with it, as an admirable compend of Christian doctrine and duty. 'The older I grow,' said Carlyle-'and I now stand upon the brink of eternity-the more comes back to me the first sentence in the catechism which I learned when a child, and the fuller and deeper its meaning becomes: "What is the chief end of man?-To glorify God, and to enjoy Him for ever," - Catechisms without number had been issued by Puritan divines in England between 1600 and 1645. A large proportion of the members of the Westminster Assembly had previously published catechisms of their own. The authorship of the Assembly's Catechisms has been the subject of much debate, or at least the authorship of the first drafts of them; it being admitted that they were prepared with great care by committees of the Assembly. Probably their authorship is to be ascribed entirely to these committees; and, like the Westminster Confession of Faith, they are thus the result of the joint labours of many.

See Ehrenfeuchter, Geschichte des Katechismus (1857); Niemeyer, Collectio Confesaionum (1840); Schaff's History of the Creeds of Christendom ( 3 vols. New York, 1876; Lond. 1877) ; and Prof. Mitchell's Catechisms of the Second Reformation (1887).
Ca'techu, a substance employed in tanning and dyeing and medicinally as an astringent. The catechu of commerce is obtained chiefly from two East Indian trees (Acacia Catechu and A. Suma). The former is common in most parts of India, and also in tropical East Africa, and the latter grows in Southern India, Bengal, and Gujerat. Catechu is known in India by the name kat or kut. Cutch is another form of one or other of these names, and is a common commercial name. The trees are eut down when they are about a foot in diameter, and according to some accounts only the heartwood is used, but other reports say that the whole of the woody part of the trunk is utilised. The catechu is obtained by cutting it into small chips, and boiling it in water, straining the liquid from time to time, and adding fresh supplies of chips, till the extract is of sufficient consistence to be poured into clay moulds; or when of the thickness of tar, it is allowed to harden for two days, so that it will not run, and is formed into balls about the size of oranges, which are placed on husks of rice or on leaves, and appear in commerce enveloped in them. Catechu is of a dark-brown colour, hard and brittle, and when broken has a shining surface. It possesses an astringent taste, but no odour. It is a very permanent colour, and is employed in the dyeing of blacks, browns, fawns, drabs, \&c. Ordinary commercial eatechu or eutch is composed of satechu-tannic acid, which is soluble in cold water, and catechin or catechuic acid, which is nearly insoluble in cold but soluble in boiling water. The latter can be separated in the state of minute, acicular, colourless crystals. It is often adulterated with earthy substances, but its ready solubility in water and alcohol should at once show the presence of such by leaving them behind in an insoluble state. Areca or Palm Catechu, sometimes called Ceylon Catechu, differs wholly from the above. It is got from the ripe nuts of the Betel palm, which yield, by boiling, a black, very astringent extract, resembling true catechu, but of inferior quality. This substance is rarely exported from India (see ARECA, BETEL). - Gambir (q.v.) may be regarded as a kind of catechu. Terro Japonica, or Japan Earth, is an old name for catechu, not quite disused, given in mistake as to its nature and origin. About 6000 tons of catechu or cutch are annually imported into Great Britain from India.

Catechu'mens (Gr. katēchoumenoi, persons undergoing a course of instruction; see CATECHISM), the appellation given, in the early Christian church, to those converted Jews and heathens who had not yet received baptism, but were undergoing a course of training and instruction preparatory to it. They had a place assigned them in the congregation, but were not permitted to be present at the dispensation of the Lord's Supper, which from the end of the $2 d$ century was regarded as a sacred mystery. The name Catechumens first occurs as the designation of a separate body in the time of Tertullian, and their distribution into different classes or grades according to their proficiency, is first referred to by Origen. The most famous catechetical school of the early church was that of Alexandria, which had Pantrenus, Clement, Origen, Dionysius and others among its teachers. The only extant specimens of the ancient catechetical teaching (which was not necessarily by question and answer) are twenty-three lectures by Cyril of Jerusalem (348), and Augustine's De catechizandis Rudibus. - The term Catechumens was afterwards employed to designate young members of the Christian church who were receiving instruction to prepare them for confirmation or for the Lord's Supper, and it is still often used in this sense. See Disciplina ARCANI. 
Ca'tegories, in philosophy, the lighest classes mider which objects of knowledge can be systematically arranged, understood as an attempt at a comprehensive classification of all that exists. The nume has come down to us from Aristotle, in whose system the entegories are ten in number: Substumre, quantity, quality, relation, place, time, situation, pussession, action, and suffering. From the puint of view of logic, these may be reduced to two : substance and attribute; of metaphysics, to being und accident. The Cartesians had the three cate. gories - substance, attribute, and mode; Leibnitzsubstance, quantity, quality, action or passion, and rulation; and Locke-substance, mode, and relation. J. S. Mill classifies all existences or describuble things as follows: (1) Feelings, or states of (unscionsness, the most comprehensive experience that the human mind can attain to, since even the external world is only known as conceived by our minds; (2) the minds which experience those feelings; (3) the boties, or external objects, which are supposed to excite all that class of feelings that we denominate sensations; $(4)$ the successions and coexistences, the likenesses and unlikenesses, between feelings or states of consciousness. Although those relations are considered by ns to subsist between the bodies, or things, external to our minds, we are driven in the last resort to consider them as really subsisting between the states of each one's own individual mind.

The categories of Kant are conceived under a totally different point of view. The Root-notions of the understanding (Stummbegriffe des Verstandes), they are the specific forms of the $\alpha$ priori or formal element in rational cognition-forms inherent in the understanding, under which the mind embraces the ebjects of actual experience. The Kantian philosophy supposes that human knowledge is partly made up of the sensations of outward thingscolour, sound, touch-and partly of mental elements or functions exi sting prior to all experience of the sctual world. (This is the point of difference between the school of Locke, who rejected all innate idess, conceptions, or forms, and the school of Kant. No such question was raised under the Aristotelian categories.) Kant's categories are as follows: (1) Quantity, including unity, multitude, totality ; (2) Quality, including reality, negation, limitation; (3) Relation, including substance and accident, cause and effect; action and reaction; (4) Modality, which includes possibility, existence, necessity. These indicate the elements of our knowledge a priori; and though they are the necessary conditions nnder which alone experiences can be realised to the mind, are merely subjective forms of its own activity, distinet from and inapplicable to the world of novmena - the thing in itself - that lies outaide and beyond. Fichte based the whole system of the eategories of reality on the affirmation of itself by the Ego- the primitive function of self-conscions. ness. Hegel carried this further, and showed that this primitive function supplied the principle needed to harmonise and unify the objective and subjective elements in thought. Thought and being are ultimately identical, and the categories are thus merely definite aspects or determinations (Bestimmungen) of the universal of thought, which is identical with reality or actual existence.

Ca'tenary. The catenary is the curve formed by a flexible homogeneous cord hanging freely between two points of support, and acted on by no other force than gravity, the name being suggested by Lat. cutcur, 'a chain.' The catenary possesses several remarkable properties, one of which is, that its centre of Gravity $(q . v$.$) is lower than that of any$ curve of equal perimeter, and with the same fixed points for its extremities. It is of importance for the theory of suspension bridges. See BRIDGR.
Cateni'vora, a genus of fossil tabulate corals peculiar to Palrozoic strata, confined in Britain to the Silurian measures. See Coral.

Cateran (Gaelic, ceatharnach, 'a soldier'), originally an Irish or Iligliand soldier, a kern; usually, however, a Highland reiver or freebooter. See Clan, Blackmail, Rob Roy.

Caterpillar, the larval stage of butterflies and moths (Lepidoptera), and the representative in this special order of the grub, maggot, or larva pliase in the life-history of many insects.

General Structure.-The caterpillar, so familiar in its external appearance, has nsually 12 body. rings, not including the head, is provided with strong biting jaws, strikingly contrasted with the mouth organs of the adult, has three pains of fivejointed clawed legs on the region corresponding to the thorax, and usually five rudimentary stumps or pro-legs on the abdomen. These unjointed append. ages are borme on the sixth to the ninth, and on the twelfth segments of the body; some of them may be absent; in the majority of cases they are adapted for clambering. The body may be naked or covered with hairs, bristles, and spines, which, in caterpillars
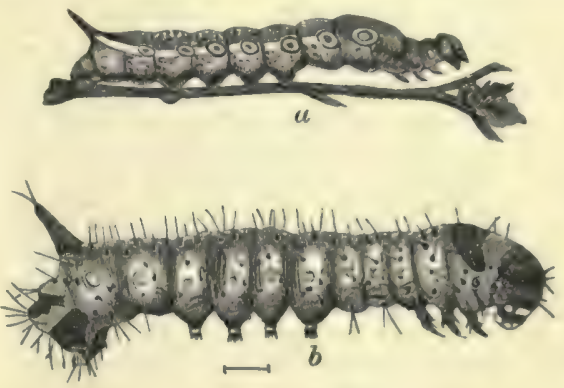

Fig. 1.

$a$, Chocrocampa tersa, showing eye-like spots; $b$, young caterpillar of Deilephila Euphorbide (after Weismann). Cr. fig. 5.

living an exposed life, are usually brightly coloured. The large head is divided by a median line, and bears six eye-spots on each side, a pair of short threejointed feelers, strong upper jaws or mandibles, besides jointed palps on the two successive pairs of mouth appendages. Two well-developed spinning organs open on the second pair of maxillw forming the lower lip or labium. On each side, on the first ring, and on the fourth to the eleventh, there are nine pairs of stigmata or openings into the respiratory air-tubes. Hatschek has observed the appearance of three pairs of stigmata on the jaw-segments of the head. The colours are familiarly bright in many instances, and may have their seat in the cuticle or in the skin below, or very frequently in deeper regions of the body. A metallic sheen is sometimes superadded. The surface is often beautifully marked longitudinally, or transversely, or with ring-spots and eye-spots. Odoriferous and other glands frequently occur on the skin, and are in some cases (Dieranura, Orgyia) eversible. The internal anatomy of the caterpillar, though essentially resembling that of the adult, differs in some striking features. Thus while the larva has 11 to 12 separate nerve ganglia in the ventral chain, the adult insect has usually only two separate ganglia in the thorax, and five in the abdomen. The digestive system is comparatively short and simple; the circulatory and respiratory systems much like those of the adult; a few aquatic caterpillars have gill-like appendages.

History. - The caterpillar develops like any other larva from the segmented egg and differentiating embryo; its life is usually more or less active and voracious; it undergoes several moult- 
ings or ecdyses; begins to develop some of the adult structures, and falls into a quiescent pupa, chrysalis, or aurelia stage. The pupa is usually (except in butterflies) insheathed in a silken cocoon, may be fixed or free, suspended by one thread or more to leaf or branch, or hidden away underground. Among butterflies, the uninsheathed pupa may be fastened head downwards by a single silken rope fastened to the tail end (pupos suspensa), or head upwards with an extra suspensor round the body (suscinctce). The intimate structural changes associated with the remarkable alteration in habit of life have not yet been fully followed. One of the most important features is the appearance on the caterpillar of what are known as 'imaginal dises," which appear to arise from the skin, and give origin to the limbs and wings of the adult insect. In the quiescent pupa stage very important changes go on, amounting to more or less of a remaking of the entire body; but it is not possible within the present limits to describe the changes undergone by the digestive, nervous, and other systems, or the very marked transformation of the mouth appendages. The cocoon in which the pupa becomes the perfect insect may be altogether absent, or very slight, or strikingly compact and protective. Some firm cocoons open very neatly from the inside by valvular lips, and in other cases the moth is known to soften the walls of its prison by means of some secretion. The gilded colour of some pupæ (chrysalids indeed), so minerallike in appearance, not improbably arose, it has been suggested, in hot dry countries, and had a protective value among dry rocks. It has been shown experimentally to arise as a direct consequence of bright surroundings. The cocoon occasionally consists solely, or almost solely, of the hairs of the larva; in some cases leaves, wood, earth, \&c. are used in construction; in most moths it is spun. The work of spinning the usual cocoon is carried on almost ceaselessly, sometimes for four or five days, and Trouvelot calculates that the larva of Polyphemus in distributing its silk must have moved its head to and fro about 254,000 times.

A very primitive insect type is represented by a widely distributed genus Peripatus (q.v.), which remains permanently at a sort of caterpillar level, and serves to connect jointed-footed animals or arthropods with worm-like forms. The caterpillar may be interpreted as in part a recapitulation of this historical stage in the evolution of insects.

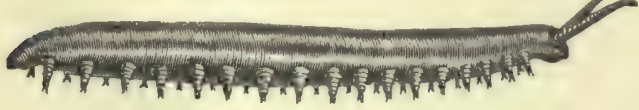

Fig. 2. -Peripatus :

Survival of ancestral insects (from Moseley).

The caterpillar thus represents the prolongation of an ancestral and embryonic stage, while many of its characters have arisen as secondary adaptations to its peculiar mode of life. Between each moult there is a period of quiescence, and this becomes greatly prolonged in that all-important moult in which the mouth organs of the larva are modified into those of the adult. Free life at a period so momentous would evidently be disadvantageous even if it were possible. The pupa, furthermore, may come to have a secondary importance other than that of simply being an exhausted quiescence at the final moulting; it may come to be of vital moment as a protective phase, by means of which the insect survives the cold of winter or the drought of the dry season. In one case (Cossus) the preparatory stages may be prolonged for three years. From another point of view the life-history may become more intelligible-viz. from the side of its physiology. In the embryonic development the young form is built up at the expense of its endow. ment of food-capital. The first chapter is one of passivity and living on past gains. When these are exhausted, and the embryonic processes completed, the larva emerges, hungry, voracious, active. In its ravages and moultings it exhibits alternate minor rhythms of activity and passivity. Finally having laid up a store of food-capital in the recesses of its 'fatty body,' it falls asleep into the more emphasised quiescence of the pupa stage. During this phase of fasting and passivity, and of life sustained by past gains, momentous changes, associated with gradual loss of weight, take place, and the final debut is made by the appearance of the active, frugal, sexually-mature, comparatively short-lived adult. It is not yet possible to rationalise the details of the life-history, but in the alternations of activity and passivity common to all living organisms, and here more marked than in any other case, the solution must be sought.

Protection and Colour.-Caterpillars are evidently enough tempting juicy morsels to birds and other insect-eating animals; their slow movements render them liable to ready capture, and, as Wallace has pointed out, their soft-walled tense structure is 'extremely dangerous, for a slight wound entails great loss of blood, while a moderate injury must prove fatal.' It is therefore not surprising to find that caterpillars, in common with the larvæ of other insects, have found out, or have become the subjects of, various devices for evading their enemies. The more conspicuous forms almost always possess some unpleasant attribute in taste or smell, either in the tissues generally or in special glands. Weismann notes how a curious lashing about of the tail may preserve one form, and how the juices of another attract a protective bodyguard of ants. Others are so uncanny in the disposition of their hair-tufts and colour, or in the 'terrifying atti. tudes' which they assume, that their cautious though hungry foes leave them alone. But distaste and repulsion may on stress of hunger be overcome, and only a relatively small number of larvæ trust to this mode of defence. Thus others are in their colour and

markings so like the plants on which they feed, or the ground on which they crawl, that they avoid detection, and this protective resemblance is often not merely general and superficial, but detailed and exact. Thus some when fixed as pupre to the stems of plants, are almost indistinguishable from knobs or stunted twigs. In the twig-like attitude the supporting thread is sometimes dispensed with. Others are like little splinters of wood, or the curled margins of withered leaves. The hairs and fleshy tubercles may prevent the casting of a sharp shadow. Nor is the 'mimicry" confined to resembling the parts of plants, but a palatable insect may probably save itself by approximating in colour to one that is distasteful. $\mathrm{Mr}$ Bates observed a large caterpillar deceptively like a small venomous snake. Protective resemblance may be further abetted by unpalatable taste or unpleasant smell. Some forms hide during the 
rlay; others feign deuth when caught. In more than one species (Dieranura) the larva spurts out formic acid.

Darwin had been impresed with the colours of caterpillars, which, occurring as they do on larvis, could not be referred to the action of sexual solection. Though, as an exception, a male caterpillar may be much brighter than the female, the two sexes are all but invariably the same, and no sexuality or sexual choice is yet devel. oped. Wallace attacked the problem, and maintained that the conspicuous forms were distasteful to birds and reptiles, and that the conspicuous colours were advantageous reminders of unpalatableness. To this Poul ton has added the necessary caution, that animals forced by hunger will eat the distasteful beauties, and come to like them.

For a most interesting series of studies on the colour and markings of caterpillars, the reader should consult Professor Weismann's Studies in

Fig. 4.-Hawthorn twig with at tached twig-like Rumia Crado gata (after Poul. ton). the Theory of Descent, and the valuable editorial
notes of the translator. Professor Meldola. The whole burden of Weismann's work is to show that in the marking and colouring (of the Sphingidx in particular) no action of an impelling vital force can be recognised, but that 'the origination and perfection of these characters depend entirely on the known factors of natural selection and correla. tion,' though of counse natural selection can only operate on the variations possible to the physical constitution and conditions of the organism. In tracing the presumed historical evolution of the Sphingidre, which is more or less fully recapitulated in the individual development, he starts (1) from concealed or subterranean, white or yellow, forms, with a horn on the tail and with bristles, but without markings; (2) in adaptation to life on linear plants like grasses, longitudinal markings are evolved and confirmed by natural selection;
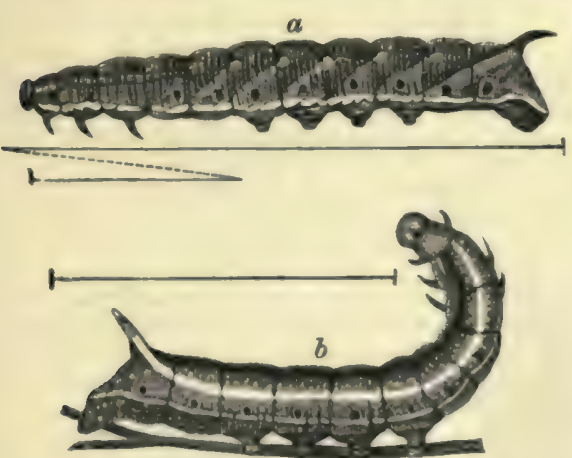

Fig. 5.

a, Caterpillar of Sphins Convolvuli ; b, larva of Maonoglosen. Stellatarum, thowing lines and spots (after Weismann).

(3) these are succeeded by oblique stripes, spread. ing from one segment to another, evolved by natural selection and correlation, and followed by the disappearance of the longritudinal lines which spoil the effect; (4) on the second last segment ring-spots then appear, and tend to spread to other rings; these are deceptively like the berries of the food-plant at one time, or have a terrifying eye- like sppearance afterwards, and are often sigmals of distastefulness.

Poulton made a long series of experiment of a most interesting nature on the subtle relatjons between Lepidopterous larves and their surroundings. The colours and markinge have a double source: (1) pigments derived from the food-plants; (2) pigments proper to the larve. A larva may be coloured from either or both of these sources; all greens seem due to the chlorophyll, and most yellows to the xanthophyll of plants; other colours to the proper pigments of the larva. The derived pigments are more frequently the basis of general resemblances to surroundings, the true pigments of special and detailed likeness, Poulton arranges the causes of colour in larve, in the presumed historic order of their employment, thus: (1) Ready-made colour in the internal tissues and organs, in the digestive tract, fat, and dorsal blood-vessel; (2) derived pigments which have passed through the walls of the digestive tract into the blood or the tissue under the cuticle; $(3)$ true pigment in the cuticle and in the layer immediately below (the hypuler. $m i s)$. But the point of most general intereat is the relation between the colour of the larve and that of their food-plants. Within the same species the colours may vary to suit the colour of the feeding. ground. Ábundant instances of this are recorded in Meldola's notes to Weismann's Studies. MeLachlan noted for instance that the larvo of Eupithecia absynthiata were yellowish on the yellow ragweed (Senecio jucoboea), reddish on the purplish centaury (Centaurea nigra), and white on the mayweed (Matricaria). Poulton has the credit of analysing this interesting relation. He has shown that the influence of the food-plant must act throughout a long period of larval life, that the effects probably sccumulate during successive generations, and that the result cannot be referred to the direct influence of the material eaten. The interpretation is rendered particularly difficult 'by the gradual working of the process, often incomplete in a single life, by the excessively complex and diverse result, and by the special character of the stimulus, for it is only part of the environment which produces any effect.' In the crse of the larva of Smerinthus ocellatus, Poulton has shown that the colour relation is adjustable within the limits of a single life, and that the predominant colour of the plant is the inciting stimn. lus. The colour adaptation is not in this case at anyrate due to the gradual working of natural selection, but to relatively immediate power enabling the larva to suit itself to its conditions. But the influence, though in one sense direct, is a very subtle one. Poulton's investigations show (1) that larvæ have certain hereditarily trans. mitted tendencies towards certain colours; (2) that the colour of the leaf, and not the substance eaten, is the agent which influences the larval colours; (3) that the influence is an intricate nervous one, 'making itself felt by affecting the absorption and production of pigments rather than their modification when formed;' and (4) that individual variations are comparatively unimport. ant, though it is quite possible that variation began somewhat uselessly in the pigments in the blood, \&c., and were afterwards 'rendered efficacious by co-ordination with the environment.' Some of Mr Poulton's mast beautiful recent ex. periments (1887) are those which show how the golden surroundings of a gilt-lined box favour the production of golden pupæ. The above naturalist, to whose observations this article is 80 much in. debted, has done more than any one else to penetrate into the physiological conditions of caterpillar colour, but much still remains to be 
done in elucidating the rôle of colour in the constitution of these and other animals.

General Life.-As already noted, most caterpillars lead an active life, some roving only at night, others also in the daytime. Young larvæ have been observed to seek the light. Their movements are guided by an appreciation of the force of gravitation; they usually crawl upwards; and they always know their food-plant when they come to it. Their frequent falls from, for them, considerable heights, are broken, it has been suggested, by the springy hairs with which they are so often covered. Many of them seem to have an insatiable hunger, and eat straight on. Their ravages among vegetables and other plants are only too well known. Some forms are carnivorous, and Mr Poulton has suggested that this might arise from cannibalism induced by searcity of food, as his observations vividly indicate. While older larvæ will apparently rather starve than take to a new food-plant, it has been conclusively shown that the newly hatched larva is not so fastidious, but 'is free to form special relations with occasional or rare foodplants.' Trouvelot's experiments on the larvæ of Polyphemus showed that a caterpillar, fifty-six days old, had consumed not less than one hundred and twenty oak leaves, weighing in all threefourths of a pound, and had drunk not less than half an ounce of water. The food would weigh 86,000 times the original weight of the larva. "Of this, about one-fourth of a pound becomes excrementitious matter; 207 grains are assimilated, and over five ounces evaporated.' A few larva (Nymphula, \&c.) are aquatic, many bore in wood, leaves, and soft vegetable substances, others are largely subterranean.

The caterpillars of some of the silkworm suborder (Bombycina) live together within a common pouch-like cradle, and others move in file-like processions (see ARMY-WORM). Migrating caterpillars (Noctua) have been described, which move in search of food in vast armies, marching straight on over everything, until a fit pasturage is found. In one case (quoted by Kirby and Spence from the Charleston Courier, May 1842) the passage of such a host is said to have made the ground black for days; in another instance reported from America, they stopped a heavy train going at the rate of 10 or 12 miles an hour.

Comparatively few caterpillars reach maturity (happily for the sake of the plants in the next season); many are destroyed by the weather, many by hungry birds, reptiles, and other animals, and many by insect pests of the families Ichneumonidæ (see Art. ICHNEUMON) and Tachinariæ. The ichneumon flies pierce the caterpillars, and make them the receptacles of their eggs and the edible cradles of their larvæ.

As typical injurious caterpillars may be noticed, (1) on vegetables, those of the cabbage-moths ( $\mathrm{e} . \mathrm{g}$. Mamestra brassica, and several species of Pieris or Pontia), the turnip-moths (Noctua segetum, Cerostoma xylostella), the silver Y-moth (Plusia gamma), the carrot-moths (Depressaria), the hopmoths (Dasychira, Hepialus, Pyralis), the peamoth (Grapholitha pisana), the death's - head (Sphinxatropos); (2) on trees, those of the goatmoth (Cossus ligniperda), the wood leopard-moth (Zeuzera asculi), the buff-tip moth (Pygara bucephala), the lackey-moth (Bombyx (clisiocampa) neustria), \&c. See Miss Ormerod's Injurious Insects.

The devastations of caterpillars are to some extent compensated for by the fertilising work of the adults, and by the silk of the silkworms. But apart from their destructiveness and utility, they are full of interest and of scientific puzzles. old Swammierdam saw in their metamorphosis 'the resurrection painted before our eyes,' w\} ile moralists and poets have often delighted in pointing out the analogies suggested by the crawling immature eaterpillar, with faint promise of its future, by the seeming death and coffin-like cocoon of the chrysalids, by the new birth, glory, and heavenward flight of the perfected forms.

LiteratURF, - Balfour, Embryology, vol i.; Kirby and Spence, Introduction to Entomology; Lubbock, Metamorphoses of Insects ('Nature' series); Packard, Guide to the Study of Insects : Poulton, Transactions of Entomological Society (1885-6-7), British Association Report (1887), Proceedings of Zoological Society (1887); Wallace, Proceedings of Entomological Society (1867); Weismann (translated by Meldola), Studies in the Theory of Descent (1880-82); Wilson, Larva of British Lepidoptera and their Food Plants (London, 1880).

Catesby, MARK, naturalist, born about 1679 , probably in London, travelled in North America in 1710-19 and 1722-26, and published Natural His. tory of Carolina, Florida, and the Bahama Islands ( 2 vols. 1731-43), Hortus Britanno-Americanus, and a work on the fishes, reptiles, and insects of the Isle of Providence. German translations of the first and last appeared at Nuremberg. He died in London, 23d December 1749.

Catesby, Roвert, born in 1573, was a. Northamptonshire Catholic of good fortune and lineage, being sixth in descent from Richard III.'s Catesby, who was hanged three days after Bosworth. 'Robert, however, had suffered much,as a recusant both by fines and imprisonment, when in 1604 he engaged in the Gunpowder Plot (q.v.). He was shot dead in the defence of Holbeache House, 8th November 1605.

Cat-fish, in Britain, is usually a name for the Wolf-fish (q.v.).-In America the name is commonly applied to a very different fish, one of the genus Pimelodus and family Siluridæ. Sixteen species occur in the lakes and rivers of North America. The skin is naked, and the head has. eight fleshy barbules. The Common Cat-fish ( $P$. atrarius), or Horned Pout, is one of the commonest. river fishes of the United States, especially in the east and north. It is from 7 to 9 inches in length, and is a very important food fish, though its flesh, like that of all the cat-fishes, is insipid. Like all its congeners it prefers muddy bottoms, and is. sluggish in its movements. The Great Lake Catfish ( $P$. nigricans) is from 2 to 4 feet long, weighs. from 6 to 30 pounds, and is found in lakes Erie: and Ontario.

Catgut is employed in the fabrication of the strings of violins, harps, guitars, and other musical. instruments; as also in the cords used by clockmakers, in the bows of archers, and in whipcord. It is generally prepared from the intestines of the sheep, rarely from those of the horse, ass, or mule, and not those of the cat. The first stage in the operation is the thorough cleansing of the intestines from adherent feculent and fatty matters; after which they are steeped in water for several days, so as to loosen the external membrane, which can then be removed by seraping with a blunt knife. The material which is thus scraped off is employed for the cords of battledoors and rackets, and also as thread in sewing the ends of intestines together. The scraped intestines are then steeped in water, and scraped again, when the large intestines are cut off and placed in tubs with salt, to preserve them for the sausage-maker; and the smaller intestines are steeped in water, thereafter treated with a dilute solution of alkali $(4 \mathrm{oz}$. potash. $4 \mathrm{oz}$, carbonate of potash, and 3 to 4 gallons of water, with occasionally a little alum), and are lastly drawn through a perforated brass thimble, and assorted into their respective sizes. In orderto destroy any adherent matter which would lead. 
to putrafaction, and the consequent development of offensive odoun, it is customary to subject the eatgut to the fumes of burning sulphur-i.e. sulphurous acid, which acts as an Antiseptic (q.v.), and arrests decomposition. The best strings come from Italy, and are used for musical instruments. These are known as Roman strings, but they are made in several Italian towns, the most valuable coming from Naples. About 10 per cent. of the violin strings manufactured are false-i.e. they proshce two sounds. Gut strings for musical instruments become nseless after being kept a few years. Cord for elockmakers is made from the smallest of the intestines, and occasionally from larger ones, which have been split longitudinally into several lengths, The catgut obtained from the intestines of horses, asses, and mules is principally made in France, and is employed in the same way as leather belts for driving lathes and other small machines.

Catha, a genus of Celastracere, often reckoned under Celastrus. C. edulis, Arabian Tea, the Khat of the Arabs, is a shrub highly valued by them on account of its leaves, which are chewed or infused like coffee or tea, to which its properties seem esentially similar. It is cultivated along with coffee.

Cathari (Gr., 'pure'), or CATHARISTs, a name assumed by a widely diffused Gnostic sect of the middle ages, which took its rise most probably among the Slavs in Southern Macedonia, and spread over the whole of Southern and Western Europe. In Thrace it found a kindred sect in the Paulicians (q.v.), who had been transported thither about 970, and they were there known as Bogomili (q.v.). In the second half of the 12th century they were in great strength in Bulgaria, Albania, and Slavonia, and divided into two branches, distinguished as the Albanensians (the more extreme section), and the Concorezensians (named from Goriza in Albania). It is remarkable that the name Bulgari, by which they were known to the returning French erusaders, is the origin of the low French word Bougre, just as the German word for 'heretic' (Ketzer) is derived from Gazzari, the Lombard form of Cathari. In Italy the heresy first appeared at Turin about 1035, and existed down to the 14th century. Its adherents were called Patarini, from Pataria, a street in Milan frequented by rag-gatherers, where they held their secret meetings in 1058. The Cathari reached their greatest numbers in Southern France, where they were commonly called Albigenses (q.v.) or Poblicants, the latter term being a corruption of Paulicians, with whom they were confounded. After the great Albigensian wars, they were gradually rooted out by the Inquisition, and after the first half of the 14th century they disappear from history. The Cathari based their teaching on the New Testament and an apocryphal 'Vision of Isaiah' and 'Gospel of John.' The only extant Catharist writing is a short ritual in the Romance language of the 13th-century troubalours (printed at Jena in 1852 by Professor Cunitz from the MS. at Lyons). All the Cathari held more or less Manichrean views, and practised a rigid asceticism. Deliverance from evil was only to be attained by renunciation of the (material) world, including marriage, property, and the use of animal food. They distinguished between the grent mass of their Credentes or 'Believers,' and the Perfecti, who hai received the Baptism of the Spirit by the laying on of hands, called Consolamentum, because in it the Comforter was imparted. These 'pure' ones, esti. mated at only 4000 in all Europe about the year 1240, formed the Catharist Church-the 'only true and pure chureh on earth.' Their worship was extremely simple, and their church government was by bishops (each with two armintints, the filius Major and the Filius Minor) and deacons.

See C. Sohmidt, La Secte des Cachares (1849); Lombard, Pauliciens et Bons-hommes (1879); Lea, Hitory of the Inquivition (1888); and Dölliuger, Seltenyeachichte (1889).

Catharine, the name of several Chrietian saints: (1) St Catharine proper, a virgin of royal descent in Alexandria, who publicly con. fessed the gospel at a sacrificial feast appointed by the Emperor Maximinus, and was therefore put to death, after they had vainly attempted to torture her on toothed wheels, 307 A.D. Hence the name of "Catharine wheel." No less than

fifty heathen philosophers sent by the em. peror to convert her in prison were themselves converted by her winning eloquence; whence she is the patroness of philosophers and learned schools. Having steadily rejected all offers of earthly mar. riage, she was taken in vision to heaven, when the Virgin presented her to her son, and Christ plighted his troth to her with a ring. This subject has been a favourite one with many artists (as signifying the union of the redeemed soul with Christ); the Christ being usually represented as an infant. It has been suggested that the attributes of the unhistorical St Catharine seem to have been derived from those of the actual Hypatis (q.v.), a heathen who suffered death at the hands of Christian fanatics. St Catharine's festival falls on 25th Novenber.-(2) St Catharine of Sienna, one of the most famous saints of Italy, was the daughter of a dyer in Sienna, and was born there in 1347 . While yet a child she practised extraordinary mortifications, and devoted herself to perpetual virginity. She became a Dominican, and therefore afterwards a patron saint of the Dominicans. Her enthusiasm converted the most hardened ainners, and she was able to prevail upon Pope Gregory XI. for the sake of the church to return from Avignon to Rome. She was favoured, it was said, with extraordinary tokens of favour by Christ, whose Stigmatr (see STIGMATISATION) were imprinted upon her body. She wrote devotional pieces, letters, and poems, an edition of which is Tomasseo's (Florence, 1860). Her festival falls on 30th A pril. See Drune's History of St Catharine of Sienna (3d ed. 2 vols. 1899 ). - St Catharine of Bologna (141363; festival 9th March) and St Catharine of Sweden (died 1381, festival 22d March) are of less note.

Catharine de' Medici, the wife of one king of France, and the mother of three, was the daughter of Lorenzo de' Medici, Duke of Urbino, and was born at Florence in 1519. In her fourteenth year she was brought to France, and married to Henry, the second son of Francis I. The marriage was a part of the political schemes of her uncle, Pope Clement VII., but as he died soon after, she found herself friendless and neglected at the French court. In these circumstances she conducted herself with a submission which seemed even to indicate a want of proper spirit, but which gained her the favour of the old king, and in some measure also of her husband. The accession of the latter to the throne of France, however, made very little difference in her situation. It was not till the accession of her eldest son, Francis II., in 1559, that she found some scope for her ambition. The Guises at this time possessed a power which seemed dangernus to that of the throne, and Catharine entered into a secret alliance with the Huguenots to oppose them. On the death of Francis II. in 1560, and accession of her second son, Charles IX., the govern. ment fell entirely into her hands. Caring little for religion in itself, although she was very prone to 
superstition, she disliked the Protestants, chiefly because their principles were opposed to the absolute despotism which she desired to maintain. Yet she sought to rally the Protestant leaders around the throne in order to serve as a counterpoise to the Guises. This attempt having failed, and the civil war which ensued having ended in the peace of Amboise, highly favourable to the Protestants, she became alarmed at the increase of their power, and entered into a secret treaty with Spain for the extirpation of hereties; and subsequently into a plot with the Guises, which resulted in the fearful massacre of St Bartholomew's Day. This event brought the whole power of the state into the hands of the queen-mother, who boasted of the deed to Roman Catholic governments, and excused it to Protestant ones, for she now managed all the correspondence of the court. About this time she succeeded, by gold and intrigues, in getting her third son, afterwards Henry III., eleeted to the Polish throne. But her arbitrary and tyrannical administration roused the opposition of a Roman Catholic party, at the head of which was her own fourth son, the Duke of Alencon. It was very generally believed that she was privy to the machinations that led to his death. When, after the death of Charles IX., Henry III. returned from Poland to be king of France, his mother still ruled the court, and had the principal share in all the intrigues, treacheries, and political transactions of that wretched time. Having betrayed all who trusted them, she and her son found themselves at last forsaken and abhorred by all. The League and the Guises had no more confidence in them than had the Protestants and Henry of Navarre. Vexation on this account preyed on the proud heart of the queen-mother in her last days; and amidst the confusion and strife of parties, she died at Blois on 5th January 1589, unheeded and unlamented. Catharine de' Medici may fairly be regarded as a representative woman of an age when the first principles of human conduct were hopelessly confounded by religious strife and the intrigues and corruptions of courts. Virtue had given place to luxury, extravagance, cunning sensuality, and cruelty. She was only a prominent example of qualities which the prevailing conditions of the time tended to develop. See Reumont's Jugend Caterinas de' Medici (Berlin, 1854), T. A. Trollope's Girlhood of Catharine de' Medici (1856), Capefigue's Catherine de Médicis (Paris, 1856), and La Ferrière's Lettres de Catherine de Médicis (4 vols. Paris, 1880-92).

Catharine I., wife of Peter the Great, and Empress of Russia. She was a peasant's daughter, and her original name was Martha Skavrouska. The date of her birth is about 1680 . Being left an orphan, she was brought up chiefly by a Lutheran pastor, Gluick, in Marienburg, Livonia. In 1702 she married a Swedish dragoon, but Marienburg being taken by the Russians in the same year, she was made prisoner, and became the mistress of Prince Menschikoff. She then attracted the notice of Peter the Great. In 1703 she went over to the Greek Church, and took the name of Catharina Alexievna. After being for some years the emperor's mistress, she was privately married to him in 1707 ; and the marriage was publicly avowed in 1711. When Peter the Great and his army seemed entirely in the power of the Turkish army on the Pruth in 1711, Catharine, according to the common account, managed by skilful bribery to procure the deliverance of the Russians. Catharine was now received into greater favour than ever, and was solemnly crowned in 1712. The story, however, does not rest on sufficient evidence. At anyrate Catharine continued to enjoy her high position till the death of Peter in 1725. The new party con- cerned in promoting the reforms of Peter the Great supported Catharine's claim to be his successor, and she was acknowledged Empress and sole Ruler of All the Russias. Under Menschikoff's direction, the affairs of govermment went on well enough for a time; but the empress ere long began to yield to the influence of a number of favourites, addicted herself to drunkenness, and lived such a life as could not fail to hurry her to the grave. She died 17th May 1727. See PETER THE GREAT.

Catharine II.. Empress of Russia, was born at Stettin in 1729. Her father, the Prince of AnhaltZerbst, was a Prussian field-marshal, and governor of Stettin. She received the name of Sophia Augusta; but the Empress Elizabeth of Russia having selected her for the wife of 'her nephew and intended successor, Peter, she passed from the Lutheran to the Greek Church, and took (like the Empress Catharine I.) the name of Catharina Alexievna. In 1745 her marriage took place. She soon quarrelled with her husband, and both of them lived a life of unrestrained vice. Among his attendants was a Count Soltikoff, with whom her intimacy soon became scandalous; and Soltikoff was sent on an embassy abroad. But the young Polish count, Stanislaus Poniatowski, almost immediately supplied his place. After the death of the Empress Elizabeth in 1761, Peter III. ascended the Russian throne; but the conjugal differences became continually wider. Catharine was banished to a separate abode; and the emperor seemed to entertain the design of divorcing her, declaring her only son, Paul, illegitimate, and marrying his mistress, Elizabeth Woronzoff. The popular dislike to Peter, however, rapidly increased; and at length, he being dethroned by a conspiracy, Catharine was made empress. A few days afterwards Peter was murdered (July 1762). What participation his wife had in his murder has never been well ascertained.

Catharine now exerted herself to please the people, and among other things, made a great show of regard for the outward forms of the Greek Chureh, although her principles were, in reality, those prevalent among the French philosophers of the 18th century. The government of the country was carried on with great energy ; and her reign was remarkable for the rapid increase of the dominions and power of Russia. Not long after her accession to the throne her influence secured the election of her former favourite, Stanislaus Poniatowski, to the throne of Poland. In her own empire, however, discontentment was seriously manifested, the hopes of the disaffected being centred in the young prince Ivan, who was forth with murdered in the castle of Schluisselburg. From that time the internal politics of Russia consisted chiefly of court intrigues for the humiliation of one favourite and the exaltation of another. The revolt of the Cossack Pugatcheff in 1773, though for a time it looked serious, only served to fortify her throne. The finst partition of Poland in 1772, and the Turkish war which terminated in the peace of Kainardji in 1774 , vastly increased the empire. In 1787 she made a progress in her southern provinces through flourishing towns, villages, and festive scenes; but the whole was a sham, having been got up for the occasion by Potemkin to impress Catharine with the prosperity of her empire. The Turkish war which terminated in the peace of Jassy in 1792 had similar results, and also the war witl Sweden, which terminated in 1790 . The second and third partitions of Poland, and the incorporation of Courland with Russia, completed the triumphs of Catharine's reign. She also began a war with Persia, and cherished a scheme for the overthrow of the British power in India; but a stroke of apoplexy cut her off, 17 th November 1796. 
She was a woman of great ability, but ahe had in a large measure the vices of the time and station in which she lived. Her gallantries were both libersl and systematic. She always had a paramour who dwelt in her palace, and might be regarded as filling an acknowledged office of state, with large revenues and fixed privileges. Of these Potemkin (q.v.) is best remembered. Yet distinguished authors flattered her; and she invited to her court some of the literati and philosophers of France. She professed the desire to model her rule on the enlightened theories of these men, and she did effect some real improvements; but the French revolution made her reactionary. See Russia; Catharine's own Memoirs (Eng. trans. 1859): Carlyle's Friedrich; and works by Waliszewski (trans. 1893 and 1894).

Catharine Archipelago. See Aleutian ISLANDS.

Catharine Howard. See How ARD.

Catharime of Aragon, Queen of England, the first wife of Henry VIII., and fourth daughter of Ferdinand and Isabella, king and queen of Castile and Aragon, was born December 1485. She oceupies a prominent place in English history, not for what she herself was, but for what she was the occasion of - the Reformation. Married on 14th November 1501, when searcely sixteen, to Arthur (1486-1502), Prince of Wales, son of Henry VII., she was left a widow on $2 \mathrm{~d}$ April, and on 25th June was betrothed to her brother-in-law Henry, as yet a boy of only eleven years old. The pope's ilispeneation enabling such near relatives to marry was obtained in 1504, and the marriage took place in June 1509, seven weeks after Henry's accession to the crown as Henry VIII. Between 1510 and 1518 she bore him five children, one only of whom, the Princess Mary, survived; but, though Henry was very far from being a model husband, and though he had conceived a passion for Anne Boleyn (q.v.) as early as 1522, he appears to have treated Queen Catharine with all due respect, until 1527. He now expressed doubts as to the legality of his marriage, and set about obtaining a divorce, which, all other means failing, was at length pronounced by Cranmer in May 1533 (see HeNry VIII.). Queen Catharine, who had offered a dignified passive resistance to all the proceedings, did not quit the kingdom, but took up her residence first at Ampthill, in Bedfordshire, and afterwards at Kim. bolton Castle, Huntingdonshire, where she led an austere religious life until, on 7th January 1536, she died, by poison said rumour, bnt most likely of cancer of the heart. Queen Catharine's personal character was unimpeachable, and her disposition gentle. See Froude's monograph (1891).

Catharine of Braganza. See Charles II. Catharine Parr. See Parr (Catharine).

Catharties (Gr. kathairō, 'I purify'), a name originally for all medicines supposed to purify the system from the matter of disease (materies morbi), which was generally presumed by the ancients to exist in all cases of fever and acute disease, and to require to be separated or thrown off by the different excretions of the body. Ultimately the term eathartics became limited in its signification to remedies acting on the bowels, which are popularly called Purgatives (q.v.) - a mere translation of the Greek word. See also Constipation,

Cathay is the name by which the Chinese empire was commonly known in Europe during medieval times - in connection with Marco Polo's travels, for example ; and Kitai is still the Russian name for China. Cathay, originally Khitai, is derived from the Khitan, the earliest of the northern races known to have conquered China (possibly akin to the Tunguses), who disappeared about the beginning of the 12th century. See CHINA; and Yule, Cathoy and the Road Thither (Hakluyt Society, 1866).

Catheart, William Schaw, finst Earl Cathcart, \& British general and diplomatist, non of the ninth Baron Cetheart of Cathcart, Renfrewshire, was born September 17, 1755. Educated at Eton and Glasgow, and admitted an advocate in 1776, when he succeeded his father, he next year entered the army, took a prominent part in the American war, and fought with distinetion in Flanders and North Germany. In 1803 he was made commander. in-chief in Ireland. In 1805 he was engaged on a diplomatic mission to Russia; in 1807 commanded the land-forces co-operating with the fleet in the attack on Copenhagen, and, for his services, was made a British peer, with the title of viscount, and received a vote of thanks from both Houses of Parliament. Sent in 1813 as ambassador to St Petersburg, he accompanied the Czar Alexander in the campaigns of 1813 and 1814 , and was present at the congresses of Chatillon and Vienna. In 1814 he was raised to the rank of earl ; and he died June 16, 1843. - His eldest son and successor, CHARLES MURRAY, long known as Lord Greenock, was born in 1783, served in Spain and at Waterloo, afterwards acted in Canada, and was made a general. He died 16th July 1859. - A younger son, SIR GEoRge CATHCART, was born in 1794 . Educated at Eton and Edinburgh, he entered the army in 1810 , served with the Russians in the campaigns of 1812 and 1813, and as aide-de-camp to the Duke of Wellington, was present at Quatre Bras and Waterloo. After helping to suppress the Canadian rebellion of 1835, and after holding the post of deputy lientenant of the Tower for five years, in 1852 he was made governor at the Cape, with command of the forces, and brought to a successful end the harassing Kaffir war. He returned to England in 1854 in time to be sent out to the Crimes as general of division. His bravery here was conspicuous, especially in the battle of Inkermann (November 5), where the odds were so terribly against the British, and where he fell, shot through the heart. He was buried on the spot where he fell, which in his honour was named Cathcart's Hill. Catheart was the author of a very valuable work entitled Commentaries on the War in Russia and Germany in 1812-13 (Lond. 1850). See vol. v. of Kinglake's Invasion of the Crimea.

Cathe'dral, from a Greek word cathedra, signifying \& seat. 'Thus, 'to speak $e x$ cathedra,' is to speak as from a seat of suthority. The cathedral city is the seat of the bishop of the diocese, and his throne is placed in the cathedral church, which is the parish church of the whole diocese. The diocese was, in fart, anciently called parochia, until the application of this name to the smaller portions into which it was divided. Cathedrals vary in rank with the dignity of the see to which they belong, and may be episcopal, arehiepiscopal, metropolitan, or patriarchal. Anciently only a cathedral was styled matrix ecclesia, but now this title is applied to all churches, even parochial only, which have other churches or chapels dependent on them. When two cathedrals are found in the same town (as is sometimes the case), they are called 'con-cathedrals.' In the Roman Church the establishment, suppression, or union of cathedrals is reserved to the pope alone. A cathedral town has generally been understood to be entitled to the honours of a eity, even although the town be not a borough incorporate ; but in the case of Manchester the claim was disallowed by a court of law. The distinction between cathedral and collegiate churches consists principally in the see of the bishop being at the former. The governing body 
of a cathedral is called the dean and chapter-i.e. the dean and canons who meet for corporate purposes in the chapter-house of the cathedral. The property of the cathedral vests in this body. In England they elect the bishop of the diocese on the issue of a congé d'elire from the crown, but as the person to be elected is always named, and they may be compelled by a mandamus to elect that person and no other, the election is merely a form.

The bishop is 'visitor' of the dean and chapter, and the metropolitan is visitor of all cathedrals within his province; while the crown holds that office during the vacancy of the archbishopric. In England, all cathedrals are distinguished as being either of the old or the new foundation. The cathedrals of the old foundation are those which have from the first been served by secular canons; those of the new foundation were originally monastic churches, and served by monks. These were dissolved at the Reformation, being then refounded on the footing of the secular churches. By the Act of 1840, all members of cathedrals, except the dean, are styled canons. Their seat in the cathedral is called their stall. They are no longer called prebendaries in most cathedrals, but this title is retained in the cathedrals of York, London, Wells, Chichester, Exeter, Hereford, Lichfield, St Davids, and St Asaph. In two cathedrals, Lincoln and Salisbury, both titles are used simultaneously, and the holders are styled 'canons and prebendaries.' In all these cases, however, the prebendaries rank below the canons residentiary, and save for their slender prebends, are on almost the same footing as the 'honorary canons' of recent institution, who have no share in the eathedral revenues or government. At St Davids the first 'cursal prebend' vests in the crown, and the sovereign is senior prebendary of that cathedral. The French kings enjoyed similar privileges in six chapters, and the German emperor was ex officio canon of St Peter's at Rome. Canons must reside three months in each year. The Act of 1840 allows to the canons of Durham, Manchester, St Paul's, and Westminster, an income of $£ 1000$ per annum; to those of every other cathedral in England, £500. The bishop was always considered of common right to have the patronage of canonries, but formerly there were exceptions. Now, the appointment to all canonries is vested either in the bishop or in the crown. Where the bishop is patron, he 'collates,' and the dean and chapter 'induct,' by placing the new canon in a stall in the church. The crown appoints by letters-patent, and the canon is installed without collation. Honorary canons have no emoluments, but rank after the canons residentiary. Minor canons, of whom there are from two to six in each cathedral, perform the daily choral services; see SERVICK (MUsicat). For the general plan of cathedral buildings, see CHurch. The English and Welsh eathedrals, some forty in number, are noticed under their respective cities.

See Dean Goulburn's Cathedral System (1871); F. H. Allen, The Great Cathedrals of the World (Boston, 1888); W. J. Ioftie, The Cathedrals of England and Wales (1892); Mrs Rensselaer, English Cathedrals (1892).

Cathelineau, JACQUES, leader of the Vendeans in their resistance to the Republic, was born at Pinen-Mauge, Anjou, in 1759. A poor linen-merchant at the outbreak of the Revolution, in the spring of 1793 he put himself at the head of a handful of stubborn recruits, and soon became famous for the courage and success of his exploits, the greatest of which was the storming of Cholet. Spite of his own modesty, the supreme command was forced upon him after the victory of Saumur. He immediately determined to make an attack upon Nantes, and managed to penetrate into the town, but was mortally wounded by a musket-ball, and his troops immediately dispersed. He was carried to St Florent, where he died twelve days later, July 11, 1793. Cathelineau was a man of great simplicity and honesty of character, and his piety was such that he was called the Saint of Anjou.

\section{Catherine. See Catharine.}

Ca'theter (Gr. kathièmi, 'I thrust into') was a name applied indifferently to all instruments for passing along mucous canals. In modern times, however, it has generally been reserved for tubular rods through which fluids or air may pass, and is now restricted to those used for emptying the urinary bladder, and those used for injecting air or fluids into the Eustachian tube (Eustachian Catheter). The catheter for the former purpose is a very old surgical instrument. The ancients made theirs of copper, which accumulated verdigris. In the 9th century silver was substituted by the Arabian surgeons as a cleanlier metal, and is still used by all who are not obliged, for economical reasons, to have their catheters made of German silver or pewter. The urinary catheter for the male varies in length from 10 to 11 inches; the female catheter need not be more than 4 or 5 inches. The form is a matter of less importance, but most surgeons prefer an instrument straight to within the last few inches of its length; the latter should be curved into the segment of a small circle. Others, however, use a double curve, and indeed nearly every surgeon has a peculiar fancy in this respect. Flexible catheters are made of gum elastic (see Bougres), which may be used either alone or supported on a wire. Many other materials have been proposed, but vulcanised india-rubber is the only one generally in use. The Eustachian catheter is generally made of metal or vulcanite, 6 or 7 inches in length, with the last inch or less slightly curved. It is introduced into the Eustachian tube along the floor of the nose, and air or fluid, as may be necessary, forced along it by an india-rubber bag which can be attached to it. See DISEASES OF THE EAR, Vol. IV. p. 158.

\section{Ca'thode. See ANODE.}

Catholic and Apostolic Chureh is the only name recognised by those often termed 'Irvingites' - a name which they repudiate as implying that they are sectarians and followers of a man. In the winter of 1829-30 the Rev. Edward Irving (q.v.), then a minister of the Scotch Church, Regent Square, London, delivered a series of lectures on spiritual gifts, in which he maintained that those which we are in the habit of ealling 'extraordinary' or 'miraculous' were not meant to be confined to the primitive church, but to be continued through the whole period of the present dispensation. About the same time, as if to confirm the views of the great preacher, there occurred at Port-Glasgow, in the west of Scotland, and elsewhere, certain strange phenomena. It was alleged that miraculous acts of healing had happened, and that the gift of tongues had returned. After what seemed to be a sufficient investigation on the part of some of the nembers of Mr Irving's church, it was concluded that the manifestations were genuine. Similar manifestations shortly after occurred in his own church, which were also pronounced to be genuine. They were held to be of two kinds : 1st, speaking in tongues, and $2 \mathrm{~d}$, prophesying. As the former bore no resemblance to any language with which men were conversant, it was believed to be strictly an 'unknown tongue," the Holy Ghost 'using the tongue of man as a sign in a manner which neither his own intellect could dictate, nor that of any other man comprehend.' The latter, 'prophesying,' consisted chiefly of 'exhortations to holiness, light upon Scripture, open- 
ings of prophecy, and explanations of symbols.' In 18:31 Irving was deposed from his oflice for heresy by the Church of Scotland, but meanwhile the truths of which he was 80 eminent an exponent had been assuming a more definite shape. He died in 1834. It was not till July 1835 that the Catholic and Apostolic Church took definite ecelesiastical shape. Witb this organisation Irving had no concern, nor had he anticipated it.

The organisation comprises a fourfold ministry (Ezek. i. and Eph. iv.)-18t, 'Apostle;' 2d, 'Prophet;' 3d, 'Evangelist ;' and 4th, 'Pastor.' The apostles are investel with spiritual prerogatives; they alone can minister the Holy (rhost by the laving on of hands, directly or by delegation; through them the mysteries of God are unfolded to the church; and they decide on matters of order and discipline. Nothing that occurs in any church in the way of 'prophetic utterance' can be authoritatively explained save by them; and the various ' angels of the churches' are bound to bring all such utterances under their cognisance. The function of the 'prophet' has been already indicated. The work of an 'evangelist' consists in declaring the truths of the gospel, and bringing home to the church generally the principles taught by apostles. The office of the "pastor' is that of ministering to the help and comfort of the various members of the flock. The 'angel' of the Catholic Apostolic congregation corresponds in a limited sense to the bishop of other Christian denominations; but he has only the rank of angelpastor in the universal church. The ministers of each full congregation comprise an angel, with a four-fold ministry (consisting of elders, prophets, evangelists, and pastors), and a ministry of deacons to give diaconal instruction and to take charge of temporal matters. The ministry is supported by tithes, the people giving a tenth of their income for the support of the priesthood. The ordinary affairs of the church are managed by the angel in a council of deacons, or if needful, of priests and deacons. The whole organisation is based on the types of the Mosaic tabernacle, in which the con. stitution of the Christian church is held to have been shadowed forth.

The congregation of this communion do not arrogate to themselves the title of the Catholic Apostolic Church. There is but one church built on the foundation of the apostles and prophets; the members of it throughout the world are not bap. tised into any section-Greek, Roman, Protestant, established, or non-established-but into the Eternal Trinity. A community of them holding the views above indicated regard themselves as a congregation of the Catholic and Apostolic Chureh assembling at a given place.

The Catholic and Apostolic Church does not differ from other Christian bodies in regard to the common doctrines of the Christian religion; it only accepts, in what it considers to be a fuller and more real sense, the phenomena of Christian life. It believes that the wonder, mystery, and miracle of the apostolic times were not sccidental, but are essential to the divinely instituted church of God, and expressive of its supernatural life, whereby a people are preparing for the second advent of Christ, the hope of which is held in instant expectation. It is held that the end of this dispensation has two phases-the gathering of a first-fruits, and the subsequent great harvest, of which it is the earnest. The doctrine of Symbolism is firmly maintained, of which the most marked feature regards the mystical presence of the Lord under the elements of bread and wine, duly consecrated by the words of the institution and the presence of the Holy Ghost. Both transubstantiation and consubstantiation are repudiated. There are services daily at 6 o'clock A.M, and 5 P.M. ; prayers at 9 A.M. and 3 P.M.; the litany every Wednesday and Friday; and the encharist is celebrated every Lond'. Day, or, where there are clergy enough, daily. The liturgy, dating from 1842, in mainly based on those of the Greek, Roman and Anglican liturgies, with additional prayers. Lights and incense are used; and the vestments (sur. plice, alb, cope, chasuble, and stole) are similar to those of the Roman communion. The Catholic and Apostolic Church has established itself not only in the United Kingdom and its colonies, but on the Continent and in the United States.

See the Liturgy of the Divine Uffires, and The Purpose of God in Creation and Redemption (6th ed. 1888). Miller's History and Doctrines of Irvingism (1878) is not authoritative, but contains much matter of interest.

Catholic Church. The term catholic liter. ally signifies 'universal.' The phrase Catholic Church is therefore equivalent to "universal church," and cannot properly be applied to any particular sect or body, such as the Roman, Greek, Anglican, Reformed, Lutheran, or Presbyterian, all of which form merely portions more or less pure of the ' church universal.' It occurs for the first time in the pseudo-Ignatian Epistle to the Smyrnseans. It was first employed from about 160 A.D. to mark the difference between the orthodox 'universal' Christian church and the various sects of the Gnostic heretics; though, afterwards, it served also to distinguish the all-embracing Christian church from the religious exclusiveness of the pre-Christian ages, in which the church was restricted to a single nation. The formal principle of the Catholic Church is thus expressed in the famous canon of Vincentius of Lerinum (434 A.D.), 'Quod ubique, quod semper, quod ab omnibus creditum est'i.e. the marks of the Catholic Church are universality, antiquity, and unity. The name has been retained by the Church of Rome, which claims to be the visible successor of the primitive one; and although Protestant divines have been careful to deny its applicability to a church which they consider essentially changed by the corrupt accre. tions of centuries, yet the term Catholic is still used by the populace of almost every Protestant country as synonymous with Roman Catholic, so that from their minds all conception of the literal meaning of the word has vanished. For an account of the Church of Rome, see article Roman Catholic Church.

Catholic Creditor, in the law of Scotland, is one whose debt is secured over several or the whole subjects belonging to the debtor-e.g. over two or more heritable estates. Questions of difficulty arise where one of these subjects is also burdened with other securities, but the other is burdened only with the catholic security. In such circumstances the catholic creditor is bound 80 to exercise his right as not unnecessarily to injure the securities of the other creditors. Thus, if he draw his whole debt from that subject on which there are other burdens postponed to his security, he must assign to the postponed creditors his security over the unburdened subject.

Catholic Emancipation. After the Reformation, both in England and in Scotland, Roman Catholics were subjected to many penal regulations and restrictions. As late as 1780 the law of England-which was actually enforced in 1764-65-made it felony in a foreign Catholic priest, and high treason in one who was a native of the kingdom, to teach the doctrines or perform divine service according to the rites of his church. Catholics were debarred from acquiring land by purchase. Persons educated abroad in the Catholio 
faith were declared incapable of succeeding to real property, and their estates were forfeited to the next Protestant heir. A son or other nearest relation being a Protestant, was empowered to take possession of the estate of his Catholic father or other kinsman during his life. A Catholic was disqualified from undertaking the guardianship even of Catholic children. Catholics were excluded from the legal profession, and it was presumed that a Protestant lawyer who married a Catholic had adopted the faith of his wife. It was a capital offence for a Catholic priest to celebrate a narriage between a Protestant and Catholic. Such was the state of the law, not only in England but in Ireland, where the large majority of the population adhered to the old faith. In Scotland, also, Catholies were prohibited from purchasing or taking by succession landed property. The inexpedieney and irrationality of imposing fetters of this description on persons not suspected of disloyalty, and from whom danger was no longer apprehended, began about 1778 to occupy the attention of liberal-minded statesmen ; and in 1780 Sir George Savile introduced a bill for the repeal of some of the most severe disqualifications in the case of such Catholics as would submit to a proposed test. This test included an oath of allegiance to the sovereign, and abjuration of the Pretender, a declaration of disbelief in the several doctrines, that it is lawful to put individuals to death on pretence of their being heretics; that no faith is to be kept with heretics.; that princes excommunicated may be deposed or put to death; and that the pope is entitled to any temporal jurisdiction within the realm. The bill, from the operation of which Scotland was exempted, eventually prased into law. An attempt which had been made at the same time to obtain a like measure of relief for the Catholics of Scotland, was defeated by an outburst of religious fanaticism. The populace of Edinburgh, stirred up by a body called 'The Committee for the Protestant Interest,' attacked and set fire to the Catholic chapel and the houses of the clergy and of such persons as were suspected to be favourable to Catholic relief. The frenzy. spread to England, where a "Protestant Association' had been formed to oppose the resolutions of the legislature. See GORDON (LORD GEORGE). In 1791 a bill was passed affording further relief to such Catholics as would sign a protest against the temporal power of the pope, and his authority to release from eivil obligations; and in the following year, by the statute $33 \mathrm{Geo}$. III. chap. 44 , the most highly penal of the restrictions bearing on the Scottish Catholics were removed without opposition, a form of oath and declaration being prescribed, on taking which they could freely purchase or inherit landed property.

Endeavours were made at the same time by the Irish parliament to get rid of the more important disqualifications, and place Ireland on an equality in point of religious freedom with England. In 1780 Grattan carried his resolution that the king and parliament of Ireland could alone make laws that would bind the Irish, and separation from England was urged as the alternative with repeal of the disqualifying statutes. The agitation culminated in the Irish rebellion of 1798 ; the union of 1800 followed, which was partly carried by means of virtual pledges given by Pitt-pledges which Pitt was unable to redeem owing to the king's scruples about his coronation oath, and Pitt resigned. Meantime, in England, Catholies continued subject to many minor disabilities which the above-mentioned acts failed to remove. They were excluded from sitting in parliament, and from enjoying numerous offices, franchises, and civil rights, by the requirement of signing the declaration against transubstantiation, the invoca- tion of saints, and the sacrifice of the mass. In the early part of this century many measures were proposed for the removal of these disqualifications, and in 1813 and succeeding years one bill after another for this end was thrown out. Fox, Grenville, Canning, Castlereagh, and Burdett were among those who made efforts in the direction of emancipation. Meanwhile, the agitation on the subject among the Catholies themselves greatly increased, and in 1824 it assumed an organised shape by the formation of the 'Roman Catholic Association' in Ireland, with its systematic collections for the 'Catholic rent.' The Duke of Wellington, who for a long time felt great repugnance to admit the Catholic claims, was at last brought to the conviction that the security of the empire would be imperilled by further resisting them, and in 1829 a measure was introduced by the duke's ministry for Catholic emancipation. An act having been first passed for the suppression of the Roman Catholic Association-which had already voted its own dissolution-the celebrated Roman Catholic Relief Bill was introduced by Peel in the House of Commons on the 5th of March, and after passing both Houses, received the royal assent on the 13th April. By this act (10 Geo. IV. chap. 7) an oath is substituted for the oaths of allegiance, supremacy, and abjuration, on taking which Catholics may sit and vote in either House of Parliament, and be admitted to most other offices from which they were before excluded. They, however, continue to be excluded from the offices of Guardian and Justice or Regent of the United Kingdom, Lord Chancellor, Lord Keeper, or Lord Commissioner of the Great Seal of Great Britain or Ireland, and Lord High Commissioner to the General Assembly of the Church of Scotland. As members of corporations they could not vote in the disposal of church property or patronage. But the public use of their insignia of office, and of episcopal titles and names, was denied them; the extension of monachism was prohibited; and it was enacted that the number of Jesuits should not be increased, and that they should henceforth be subject to registration. By the Acts 7 and 8 , and 9 and 10 Vict., most of the acts still in force against Catholics were removed; 30 and 31 Vict. removed a still remaining disability, the office of Chancellor of Ireland being thrown open; though a Catholic priest may not sit in the House of Commons. For the prohibition (ultimately repealed) against the assumption of ecclesiastical titles in respect of places in the United Kingdom, see Ecclesiastical Trtles Assumption Act. See also O'Connell, AbJuration, AllegiANCE; and the History of Catholic Emancipation, by W. J. Amherst, S.J. (2 vols. 1886).

Catholic Epistles, the name given, according to Clemens Alexandrinus and Origen, to certain epistles addressed not to particular churches or individuals, but either to the ehurch universal or to a large and indefinite circle of readers. Originally the Catholic Epistles comprised only the first epistle of John and the first of Peter, but at least as early as the $3 \mathrm{~d}$ century, and especially after the time of Eusebius, they included also the Epistles of James, of Jude, the 2d of Peter, and the 2d and $3 d$ of John. These seven thus constituted the Catholic Epistles, althongh the genuineness and authenticity of the last-mentioned five were not universally acknowledged; but the designation commended itself as supplying a convenient distinction of these letters from the fourteen bearing the name of $\mathrm{Paul}$; and this very incorporation with epistles whose canonicity was not questioned, naturally had the effect of confirming their authority. so that in a short time the entire seven came to be considered a portion of the canon. 
Catholles, Old. See Old Catholics.

Catholikos is the title of the head of the Armenian Church. See ARMENiA.

Oatili'na, Lucius Sragius, the Roman conspirator, was horn about the year 108 B.C. of an asuient patrician but impoverislıed family. His routh was stained with profligacy and crime. He attached himself to the party of Sulla, and revelled in the bloodshed and confusion that dis. graued its triumph. His body was eapable of enduring any labour or fatigue, and his mind was masterful, resolute, and remorseless. Despite his infamies he was elected pretor in the year 68 B.C., and next year governor of Africa, but was disqualified as a candidate for the consulship in 66 by charyes of maladministration in his province. Disappointed thus in his ambition, and burdened with debts, he saw no hope for hinself but in the chances of a political revolution, and therefore entered into a conspiracy, including many other young Roman nobles, in morals and circumstances like limself. The plot, however, was revealed to Cicero by Fulvia, mistress of one of the conspirators. Operations were to commence with the assassination of Cicero in the Campus Martius, but the latter was kept aware of every step of the conspiracy, and contrived to frustrate the whole design. In the night of November 6 (63 B.C.), Catiline assembled his confederates, and explained to them a new plan for assassinating Cicero; for bringing up the Tusean army (which he had seduced from its allegiance), under Manlius, from the encampment at Fresulæ; for setting fire to Rome, and putting to death the hostile senators and citizens. In the course of a few hours, every. thing was made known to Cicero. Accordingly, when the chosen assassins came to the house of the consul, on pretence of a visit, they were immediately repulsed. Two days later, Catiline with his usual reckless andacity, appeared in the senate, when Cicero-who had received intelligence that the insurrection had already broken out in Etruria -commenced the celebrated invective beginning: Quousque tandem abutére, Catilina, patientia nostra? ('How long now, Catiline, will you abuse our patience?') The conspirator was confounded, not by the keenness of Cicero's attack, but by the minute knowledge he displayed of the plot. His attempt at a reply was miserable, and was drowned in cries of execration. With curses on his lips, he rushed out of the senate, and escaped from Rome during the night. Catiline and Manlius were now denounced as traitors, and an army under the consul Antonius was sent against them. The conspirators who remained in Rome, of whom the chief were Lentulus and Cethegus, were at once arrested. After a great debate in the senate (December 5), in which Cresar and Cato took a leading part on opposite sides, the conspirators were condemned to death. The sentence was executed that night in prison, The insurrections in several parts of Italy were meanwhile suppressed; many who had resorted to Catiline's camp in Etruria deserted when they heard what had taken place in Rome, and his intention to proceed into Gaul was frustrated. In the beginning of January he returned by Pistoria (now Pistoja) into Etruria, where he encountered the forces under Antonius, and after a desperate battle in which he fought with more than the courage of despair, he was defeated and slain. Catiline's appearance was in perfect keeping with his character. His face was reckless and defiant in expression, and haggard with a sense of erime; his eyes were wild and bloodshot; his gait restless and unsteady from nightly debauchery and the constant fever of inastiable and disappointed ambition. The Bellum
Catilinarium of Sallust is a masterpiece, For the view that Catilina was a misrepresented democrat, see Beesly's Catiline, Clodius, and Tiberius (1878).

Cat Island, See Baramas.

Catkin (amentum). Although the vegetative growth of all inflorescences tends to be more or less shortened and compreseed in consequence of their reproductive purpose, we have this peculiarly mani. fested in the catkin, which is a crowded spike or tuft of small unisexual flowers with reduced scalelike bracts. Examples are found in the willow, hazel, ook, birch, alder, \&c. (q.v.). In some, as in the hazel and oak, the male flowers only are

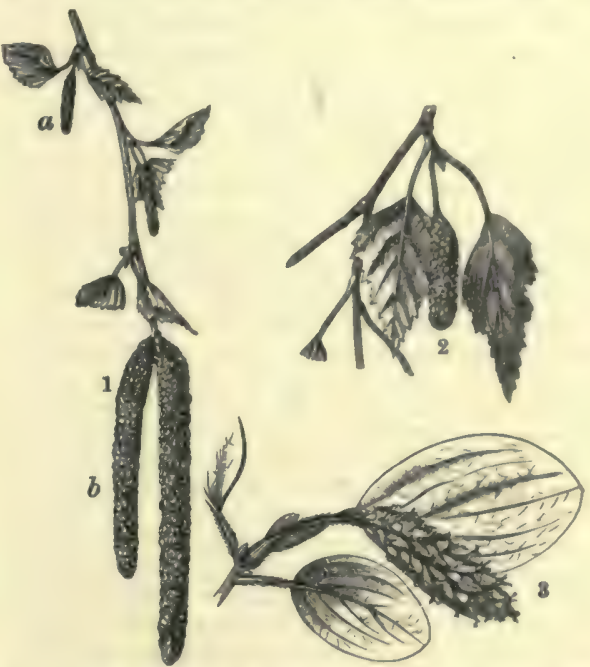

1, Shoot of Birch in spring, bearing large terminal Male (b) and Female (a) Catkins. 2 Shoot of Birch in autumn with ripe Female Catkin. 3, Female Catkin of Willow.

in catkins, the female catkin of the flower being reduced to a few brown scales, while the female flowers of the oak are solitary, each on its own branchlet. Male catkins fall off after shedding their pollen, and even during life are frequently weak and pendulous, like the stamens of grasses, but these consequences of extremely reduced vegetative life become no doubt also of advantage at first in developing, and later in scattering, the pollen.

Catlin, Georar, one of the finst authorities on the habits of the North American Indians, was born in Pennsylvania in 1796. He was bred to the law, but soon turned to drawing and painting, which he had taught himself. In 1832 he went to the Far West to study the native Indians, and spent the next eight years among them, everywhere painting portraits of individuals (not less than 470 full length) and pictures illustrative of life and manners, which are now in the National Museum at Washington. Catlin next travelled (1852-57) in South and Central America, and lived in Europe until 1871. At London in 1841 he published his learned and amply illustrated Manners, Customs, and Condition of the Nurth American Indians, and in 1844 The North American Portfolio. He died at Jersey City, December 23, 1872. Other books are Notes of Eight Years in Europe (1848); The Breath of Life, or Mal-Respiration (1861), on the benefit of keeping one's mouth always closed.

Catmint, or Catnep (Nep'eta Cataria), a labiate herb, very common in North America, of which the peculiar fragrance is very attractive to cats, much in the same way as valerian. 
Cato, Dionysius, is the name prefixed to a little volume of moral precepts in verse, which was a great favourite during the middle ages, but the author of which is unknown. Its usual title is Dionysii Catonis Disticha de Moribus ad Filium. It begins with a preface addressed by the supposed author to his son, after which come fifty-six injunetions of rather a simple character, such as parentem ama. Next follow 164 moral precepts, each expressed in two dactylic hexameters, the whole monotheistic in tone without being distinctly Christian. The book was early translated into most of the western languages. An English version by Benedict Burgh was printed by Caxton before 1479 . A good edition is Hauthal's (Berlin, 1869).

Cato, Marcus Porcius, frequently surnamed Censorius or Censor, also Sapiens ("the wise'), and afterwards PRISCUS or MAJOR-to distinguish him from his great-grandson, Cato of Utica-was born at Tusculum in 234 B.C. He was brought up on his father's farm in the Sabine country, and here he learned to love the simple and severe manners of his Roman forefathers. He made his first campaign in his seventeenth year, distinguished himself at the capture of Tarentum (209), at the defeat of Hasdrubal on the Metaurus (207), and in the later years of the second Punic war. At the same time he had been making himself a reputation as an orator and statesman. He became quastor in 204 , and served under the pro-consul Scipio Africanus in Sicily and Africa, denouncing his commander's luxury and extravagance on his return to Rome. He was redile in 199, and pretor the following year, when he obtained Sardinia as his province. So high was his reputation for capacity and virtue, that in 195 , although his family had hitherto been unknown, he was raised to the consulship. Spain fell to him as his province, and here he showed such vigour and military genius in crushing a formidable insurrection, that in the following year he was honoured by a triumph. In 191 he served in the campaign against Antiochus, and to him the great victory won at Thermopylre was mainly due. $\mathrm{He}$ now turned himself strenuously to civil affairs, and strove with all his might to stem the tide of Greek refinement and luxury, and advocate a return to a simpler and stricter social life after the ancient Roman pattern. In 187 he opposed the granting of a triumph to $M$. Fulvius Nobilior after his return from Atolia victorious, on the ground that he was too indulgent to his soldiers, that he cherished literary tastes, and even kept poets in his camp. These rude prejudices of Cato were not acceptable to the senate, and his opposition was fruitless. In 184 Cato was elected censor, and discharged so rigorously the duties of his office that the epithet Censorius, formerly applied to all persons in the same station, became his permanent surname. He repaired the watercourses, paved the reservoirs, cleansed the drains, raised the rents paid by the publicans for the farming of the taxes, and diminished the contract prices paid by the state to the undertakers of public works. More questionable reforms were those in regard to the price of slaves, dress, furniture, equipage, and the like. Good and bad innovations he opposed with equal animosity and intolerance, and his despotism in enforcing his own idea of decency may be illustrated from the fact that he degraded Manilius, a man of pryetorian rank, for having kissed his wife in his daughter's presence in open day.

In th year 175 Cato was sent to Carthage to arbitrate between the Carthaginians and King Masinissa, and was so impressed by the dangerous power of Carthage that ever afterwards he ended every speech in the senate-house-whatever the inmediate subject might be-with the well-known words: 'Ceterum censeo Carthaginem esse delendam'
('For the rest, I vote that Carthage must be destroyed '). Cato died in the year 149, at the age of 85. He had been twice married, and in his eightieth year his second wife bore him a son, the grandfather of Cato of Utica. Cato treated his slaves with old-fashioned harshness and eruelty, and in his old age became greedy of gain, although it cannot be said that his avarice impaired his honesty. He wrote several works, of which only the De Re Rustica (ed. by Keil, 1882-94), a kind of collection of the rules of good husbandry, has come down to us. There exist but a few fragments of his Origines, a summary of the Roman annals. These are reprinted by Jordan (Leip. 1860 ). Of his speeches, which were read with approval by Cicero, none remain. We possess his life as written by Cornelius Nepos, Plutarch, and Aurelius Victor.

Cato, Marcus Porcius, named Cato the YOUNGER, or CATO UTICENSIS (from the place of his death), was born 95 B.C. Having lost, during childhood, both parents, he was educated in the house of his uncle, M. Livius Drusus, and, even in his boyhood, gave proofs of his decision and strength of character. In the year 72 B.C. he served with distinction in the campaign against Spartacus, but without finding satisfaction in military life, though he proved himself a good soldier. From Macedonia, where he was military tribune in 67 , he went to Pergamus in search of the Stoic philosopher, Athenodorus. He brought him back to his camp, and induced him to proceed with him to Rome, where he spent the time partly in philosophical studies, and partly in forensic discussions. Desirous of honestly qualifying himself for the quæstorship, he commenced to study all the financial questions connected with it. Immediately after his election he introduced, in spite of violent opposition from those interested, a rigorous reform into the treasury offices. He quittea the quæstorship at the appointed time amid general applause. In 63 B.C. he was elected tribune, and also delivered his famous speech on the conspiracy of Catiline, in which he denounced Cresar as an accomplice of that political desperado, and determined the sentence of the senate. Strongly dreading the influence of unbridled greatness, and not discerning that an imperial genius-like that of Cresar-was the only thing that could remedy the evils of that overgrown monster, the Roman Republic, he commenced a career of what now appears to us blind pragmatical opposition to the three most powerful men in Rome-Crassus, Pom pey, and Cresar. Cato was a noble but strait-laced theorist, who lacked the intuition into circumstances which belongs to men like Cresar and Cromwell. His first opposition to Pompey was successful; but his opposition to Cæsar's consulate for the year 59 not only failed, but even served to hasten the formation of the first triumvirate between Cæesar, Pompey, and Crassus. He was afterwards forced to side with Pompey, who had withdrawn from his connection with Cresar, and become reconciled to the aristocracy. After the battle of Pharsalia (48), Cato intended to join Pompey, but hearing the news of his death, escaped into Africa, where he was elected commander by the partisans of Pompey, but resigned the post in favour of Metellus Scipio, and undertook the defence of Utica. Here, when he had tidings of Cresar's decisive victory over Scipio at Thapsus (46), Cato, finding that his troops were wholly intimidated, advised the Roman senators and knights to escape from Utica, and make terms with the victor, but prohibited all intercessions on his own behalf. He resolved to die rather than surrender, and, after spending the night in reading. Plato's Phoedo, committed suicide by stabbing himself in the breast. 
His example was more fruitful in results than the achievements of his life, for he became the typical example of the stoie that kindled to imitation the imaginations of the noblest Romans for two centuries under the empire.

\section{Cat-o'-nine-tails. See Flogara.}

Catoptrics is that division of geometrical optics which treats of the phenomena of light incident upon the surfaces of bodies, and reflected therefrom. See OpTICs.

Cato Street Conspiracy, a plot formed in London in 1820 by a handful of crazy ruffians for the murder of Lord Castlereagh and the other ministers of the crown, so called from the place of meeting in Cato Street, Edgeware Road. As usual the plot was revesled beforehand to the police by one of the gang, and accordingly the conspirators were seized, after a short scuffle, in a stable in Cato Street. Arthur Thistlewood, the ringleader, and four of his dupes, were hanged, while five more were transported for life.

Catrail (also known as the Picts' Work or Picts' Work Ditch) is the name applied to the remains of a large earthwork, about 50 miles in length, which, beginning at Torwoodlee Hill, near the junction of the Gala Water with the Tweed, runs with a semi- circular sweep southward through the counties of Selkirk and Roxburgh to a point under Peel Fell, in the Cheviots. The earthwork consisted of a - deep ditch, with a rampart on each side, and varied in breadth from 20 to 26 feet. The cultivation of land and other causes have resulted in the destruction of the ramparts in many places. The Catrail was first described by Gordon in his Itinerarium Septentrionale (1726), and since then has been the :subject of much speculation among antiquaries. For a full description of the Catrail, see paper in Transactions of the Berwickshire Naturalists Club for 1880, by James Smail, F.S.A. An account of the various theories which have been promulgated regarding the Catrail will be found in Blackwood's Magazine for 1888.

Cats, JACOB, a Dutch statesman and poet, was born at Brouwershaven, in Zeeland, in 1577, and after studying law at Leyden and Orleans, finally : settled at Middelburg. He rose to high offices in the state, and was twice sent as ambassador to England, first in 1627, and again in 1652, while Cromwell was at the head of affairs. From this time till his death, September 1660, he lived in retirement at his villa near the Hague. Here he wrote his autobiography, which, however, was not published until 1709. As a poet, 'Father Cats' enjoyed the highest popularity. His poems are characterised by simplicity, rich fancy, clearness, homely vigour, and purity of style, and by their excellent moral tendency; while throughout are richly scattered those shrewd maxims and worldly. wise axioms which have heen so dear to his practical countrymen. The most highly prized of his productions were the Houvelyk, and the Trowwing (a series of romantic stories relating to remarkable marriages), and the Spiegel van den Ouden on Nieuven Tyd. His works were first collected in a folio volume in 1658. A late edition is that by Wolterink (Dordrecht, 1878-82).

Cat's-eye, a beautiful variety of chalcedonic quartz receiving its name from the resemblance which the reflection of light from it, especially when cut en cabochon, or in a convex form, is supposed to exhibit to the light that seems to emanate from the interior of the eye of a cat. It has a sort of pearly appearance, and is chatoyant, or characterised by a fine play of light, which is wupposed to result from the parallel arrangement of tine fibres of some foreign substance, such as ami- anthus, or of minute hollow tubules similarly arranged. It is of various colours, and is obtained chiofly from India and Ceylon, but oceurs also in the Harz. A chatoyant variety of felspar has been sometimes confounded with cat's-eye.

Catskill, a village of New York, on the Hud. son, 34 miles by rail below AJbany. P. (1890) 4920.

Catskill Mountains, a group of mountains in the state of New York, U.S., west of the Hudson River, and south of the Mohswk. They belong to the Appalachian system, and are con. tinuous northward with the Helderbergs, nouthward with the Shawangunks, south-westward with the Delaware Mountains, and westward with a high plateau which occupies much of the region of the southern half of Western New York, and a part of the northern counties of Pennsylvania. The Catskills proper cover about $5000 \mathrm{gq}$. m., ehiefly in Greene County, N.Y. Some peaks reach nearly 4000 feet in height. The mountains generally have steep and often precipitons ascents, and their summits are broad and rocky. The deep valleys or ' cloves' of this region, with almost perpendicular walls, form a remarkable scenic feature. What is known as 'the Catskill red sandstone' is regarded by most geologists as the very latest formed of the Devonian strata of North America. The mountains are well wooded, and afford many summerresorts for the people of the larger cities. See Searing's Land of Rip Van Winkle (1885).

\section{Cat's-tail. See Bulrush.}

\section{Cat's-tail Grass. See Timothy Grass.}

Cat'taro, a strongly fortified port in the Austrian crown-land of Dalmatia, lies at the head of the Gulf of Cattaro, $\mathbf{4 0}$ miles SE. of Ragusa, under the steep Montenegrin hills, Cattaro has a cathedral, a naval school, and a population of 5453, chiefly engaged in the Montenegrin trade. At one time the capital of a small republic, the town in 1420 joined the republic of Venice, and after varied fortunes was handed over to Austria in 1814 by the treaty of Vienna.-The Gulf of Cattaro, an inlet of the Adriatic, consists of three basins or lakes, connected by straits of about half a mile in breadth. Its length is 19 miles, and its depth from 15 to 20 fathoms.

Cattegat, or KATTEGAT, the bay or arm of the sea between the east coast of Jutland and the west coast of Sweden, to the north of the Danish islands. It is connected with the Baltic Sea by the Great and Little Belt (q.v.), and by the Sound; and the Skager Rack (q.v.) connects it with the North Sea. The length of the Cattegat is about 150 miles, and its greatest breadth 85 miles. Its greatest depth is 36 fathoms, but it has numerous sand-banks; and navigation is rendered more dangerous by its strong currents and violent storms. The Danish shores are low, with stretches of sand or reefs, but the Swedish shore is very steep and rocky.

Cattermole, Georas, water-colour painter and book-illustrator, was born at Dickleborough, Norfolk, 8th August 1800. He began life as a topographical draftsmen. At the age of sixteen he was engaged upon Britton's English Cathedrals, and in 1830 he visited Scotland to obtain materials for his fine series of illustrations to the Waverley Novels. He was soon known as a brilliant designer, and was largely employed by the publishers, contributing to the annuals, his best work of this class being the illustrations to his brother, the Rev. C. Cattermole's Historical Annual, dealing with the period of the Civil War. In 1822 he was elected an associate exhibitor, and in 1833 a member, of the Water-colour Society, to whose exhibitions he contributed 'Sir Walter Raleigh witnessing the Execution of the Earl of Essex' (1839), 'Old English 
Hospitality' (1839), 'The Castle Chapel' (1840), 'The Assassination of the Regent Murray' (1843), 'Cellini defending the Castle of St Angelo' (1845), and others of his best water-colours, examples of which may be studied in the South Kensington Museum. He retired from the society in 1850 , and turned his attention to oil-painting, exhibiting ' $\mathrm{A}$ Terrible Secret,' a work in this medium, in the Royal Academy of 1863. He died at Clapham Common, 24th July 1868. As an artist he was distinguished by great versatility, and by considerable power of grouping and composition. He was learned in costume, and his works show much dramatic feeling. He gained a first-class gold medal at the Paris Exposition of 1855 , and was a member of the Royal Academy at Amsterdam, and of the Belgian Society of Water-colour Painters.

Catti, or CHATTI, a German people, erroneously included by Cæsar under the name Suevi (q.v.) who inhabited a country pretty nearly corresponding to the present Hesse. They took part in the general rising of the Germans under Arminius; and during the reign of Marcus Aurelius, in the end of the $2 d$ century, they made incursions into Roman Germany and Rhætia. In the $3 \mathrm{~d}$ century their name began to give place to that of the Franks (q.v.).

Cattle. In the United Kingdom there are twelve native breeds of cattle. England claims exactly one-half of these-namely, the Shorthorn, Hereford, Devon, Norfolk and Suffolk Red Polled, Sussex, and Longhorn breeds. There are two or three varieties of eattle in Wales, but for practical purposes they may be reckoned as one breed. Four distinct breeds have arisen in Scotland, these being the Polled Aberdeen-Angus, Galloway, Ayrshire, and West Highland breeds. The remaining one is the native breed of Ireland, the hardy little Kerry, regarded as one of the purest and truest existing representatives of the ancient Bos longifrons. In addition to these twelve native races, other two very useful breeds, the Jersey and Guernsey, have become domiciled in the British Isles, and there are also a few of the famous Dutch milking cows seattered over the country. These various races, with an almost endless variety of crosses between two or more of them, make up the entire cattle stock of the United Kingdom, which, according to the official agricul. tural returns, numbered 10,753,314 head in 1895 .

The Shorthorn is by far the most numerous and most widely diffused. It has not inaptly been titled the 'Cosmopolitan Shorthorn.' It has found a home in almost every county in the United Kingdom. The county of Durham is generally regarded as the 'cradle' of shorthorns; indeed, they have often been spoken of both at home and abroad as the 'Durham breed.' But the valuable race of native cattle from which the improved shorthorn

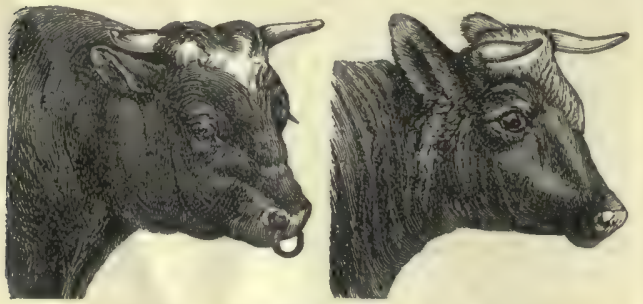

Fig. 1. - Shorthorn Bull and Cow.

was raised abounded freely in adjoining counties as far back as reliable history enables us to trace their career. Early in the 19th century they were also known as 'Teeswater' cattle, the first famous shorthorns having come from the valley of the Tees.
The brothers Charles and Robert Colling were the first to begin the systematic improvement of the breed. In those days the 'rank and file' of shorthorn cattle were large, high-standing cattle, good milkers, but rough in form and slow in fattening. The Collings would seem to have at once directed themselves to the improvement of the native cattle where they were most defective, and they were successful in establishing a stock of cattle of a decidedly more profitable character-wider in the rib, more symmetrical in the frame, shorter in the leg, slightly smaller in size, heavier in flesh, and more speedy in maturing and fattening. It has been said, but not established beyond contention, that in effecting this improvement the Collings made use of an infusion of blood from some of the other smaller breeds. It is more likely that they relied upon 'selection' in breeding-the mating of animals of the shorthorn breed which most nearly approached to their ideal character, and fixing the type by pursuing what is designated as 'in-and-in' breeding - i.e. mating animals which are closely related to each other, a system that is known to assist greatly in stamping or fixing peculiar features and characteristies upon races of stock. The success of the Collings was speedy and complete, for the fame of their cattle spread so rapidly that even earlier than 1810 , the year of the "first great public sale of shorthorns," they had sold cows and bulls at $£ 100$ eacli, and had hired bulls for use to other breeders at premiums of from $£ 50$ to $£ 100$ a year. At Charles. Colling's historical sale at Ketton in 1810, 29 cows. and heifers realised an average of $£ 140,4 s .7 d$.; and 18 bulls $£ 169,8$ s. each. Eight years later, at Robert Colling's sale at Barmpton, in a time of great depression, an average of $£ 128,9 \mathrm{~s}$. $10 \mathrm{~d}$. was obtained for 61 animals. The sensational event of the memorable sale at Ketton was the purchase of the celebrated bull 'Comet' at the fabulous price of 1000 guineas.

The importance and interest attaching to the operations of these two great pioneer breeders will at. once be understood when it is mentioned that there is not at the present day a well-bred living shorthorn in whose pedigree Colling blood does not figure. prominently. Colling's successors were, on the one hand, Thomas Bates; on the other, the Booth family, whose representatives then were Thomas and John Booth. At the Ketton sale. (1810) Thomas Bates purchased the two-yearold heifer 'Young Duchess' for 183 guineas. Thomas Booth bought the bull-calf 'Albion' for 60 guineas; and at the Barmpton sale (1818) his brother, John Booth, secured the yearling bull 'Pilot' for 270 guineas. With these purchases the shorthorn breed drifted into two great channels, which by degrees absorbed the main eurrent of the race, so that for many years the terms 'Booth' and 'Bates' shorthorns have been as applicable in relation to the bovine world as Whig and Tory to the political. These two strains of Bates and Booth, as has been seen, had one common origin in Colling's blood, but in course of time they developed distinctive shapes and characteristics which in the purer representatives are still well maintained. Mr Robert Bruce, than whom there is no higher authority, thus deseribes the characteristics of 'Booth' and 'Bates,' speaking in the first place of 'Bates' cattle: 'They are higher standing, better milking, and perhaps gayer looking cattle than the Booths. They have as a rule more upright shoulders, flatter foreribs, opener sides, with long hindquarters less fully packed with flesh than the rival strain. As a rule their heads are clean cut and pretty wide, while the bulls have long arched muscular necks and keen tempers. The prevailing colours in this strain of blood are, generally 

apeaking, deeper than in the other, being reds and rich rosns. The Booth cattle are wider, deeper, and perhaps leas pretty. Their shoulders are more laid hack, their foreribs and flanks deeper and better filled. They are more a beef than a milk breed, with well-packed quarters and thick loins. The sires remind one more of a fat Smithfield ox, and they move without that courage and dash so peculiar to the "Duke's" and other highly valued Btrains of the Bates tribes." But while these are the two great divisions of the breed, there are a great many excellent shorthorns of mixed breeding which do not show any decided leaning either to the one or the other. The prevailing eolour of shorthorns is roan of varying shades, but many are red, and some white. There is a dislike to red and white in distinct spots as a colour, and quite an unreasonable objection to white.

In precocity, production of meat, and general ntility, the shorthorn is unsurpassed. Other varieties may excel it in special points for peculiar purposes or in certain limited districts, but for a combination of all the more useful properties of domestic cattle and adaptability to varying conditions of soil and climate, there is no equal to the shorthorn. The facility with which the shorthorn adapts itself to changes of soil, climate, and treatment is quite remarkable, and this combined with the valuable property which it also possesses in an unequalled degree -suitability for erossing with and improving other and inferior classes of cattle-has spread the improved shorthorn far and wide, not only in its own native land, but in countries beyond the seas. In North and South America, the continent of Europe, Australia, New Zealand, and other parts, the shorthorn has been extensively introduced. In all these countries, as at home, it has been one of the most active and effective agents in improving the native races of eattle and in inereasing the production of high-elass beef. Many breeders of short. horn cattle have cultivated the fattening to the detriment of the milking properties. Still, while it is quite common to meet with a very light milker amongst shorthorn cows, there is a large section of the breed which possesses dairying properties of the highest order. Good shorthorn cows give from 700 to 1000 gallons of milk in twelve months. At the London Christmas Fat Stock Show in December 1887 the class of shorthorn steers under two years old (averaging 672 days) gave an average liveweight of $1396 \mathrm{lb}$; steens over two and under three years of age (averaging 988 days), $1870 \mathrm{lb}$. and steers over three years old (averaging 1321 days), 2116 lb. each.

Hereford cattle display strongly fixed and peenliarly distinctive characteristics both in outward features and general attributes. The improved breed traces directly from the stock of cattle which were found by the earliest writers on agricultural topics existing in the county of Hereford and adjoining districts - the same aboriginal variety from which have descended the Devon and Sussex breeds. The improvement of the Hereford would seem to have been begun by the Tomkins family far back in the 18th century, and was taken up in a systematic manner by Benjamin Tomkins about 1766, and carried on by him with much energy and success until his death in 1815 . His herd was continued by his daughters till 1819 (one year later than the Barmpton sale of shorthorns), when it was dispersed by public auction. Twenty-eight breeding animals realised an average of $£ 149$ per head; four adult bulls having brought as much as $£ 267,15 \mathrm{~s}$. each ; and two bull-calves $£ 181$, 28. 6d. each. From that time the fortunes of the breed fell into other hands, and never for a moment have the Hereford stock-owners wavered in their loyalty to their fine old breed of cattle. There is little doubt that infusions of foreign blood con. tributed to some extent to the building up of the modern Hereford. In the 17th century cattle had been imported into Hereford from 1 landers by Lord Scudamore, and in later times there had been introductions of stoek from various parts of England and Wales. The dominant ingredient, however, is the aboriginal race of the county, and selection in breeding and careful management have been the principal agencies by which the breed has been brought to the high standard it has now attained. The modern typical Hereford is red in colour, with white face and white marks in the top
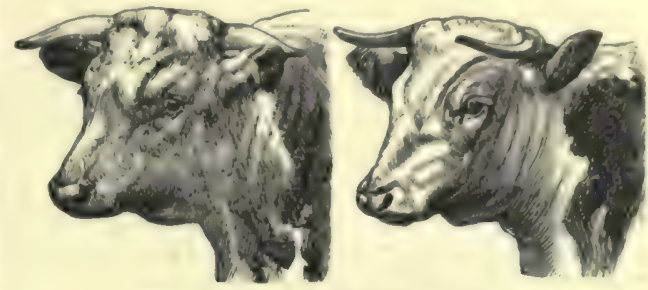

Fig. 2.-Hereford Bull and Cow.

line of the neck, back over the crops, as well as in the chest and bottom line all the way backwards. The 'white face' is indeed the 'tribsl badge' of the Hereford, and with their wide and graceful horns they are singularly handsome in outward appearance. Formerly there were gray-faced or spotted Herefords; and even yet there is in existence a strain of Herefords known as 'smoky-faced Montgomeries.' The Herefords are similar in size to the shorthorn; usually broad along the back and heavily fleshed, but occasionally light in the thighs and deficient in internal fat. Their highest property lies in their value as grazing cattle; and this has led to the extensive employment of Hereford bulls in breeding cattle for the rolling prairie-ranches of the western states of America. They are hardy cattle, with a rank coat of hair and thick mellow hide, and they are excellent 'foragers'-all points of special importance in ranche cattle. It is pre-eminently a beef-producing breed; matures early and yields meat of the finest quality. As a rule the cows are deficient as milkers, for this property has never been cultivated as it ought to have been. The average live-weight of two-year-old Hereford steers (averaging 634 days) at the London Christmas Fat Stock Show in December 1887 was $1390 \mathrm{lb}$; ; of steers over and under three years (averaging 938 days), $1742 \mathrm{lb}$; and of steers over three years (averaging 1310 days), $2041 \mathrm{lb}$. There are a few excellent herds of Herefords in Ireland, and they have been exported in large numbers to foreign countries, notably North and South America, Australia, and New Zealand.

Devon cattle are deep red in colour, and have frequently a white spot on the belly just in front of the udder, with wide round loins, smaller in size than the two breeds just mentioned. It is noted for the almost perfect formation of the shoulder, which is laid into the body with remarkable neatness. The breed has stul its headquarters in Devon and Somerset, where it has held undisputed sway for hundreds of years. It won the admiration of Arthur Young, who gives interesting information regarding the breed in his report dated 1776. Here also there was one 'master mind ' at work on the improvement of the breed. Mr Quartly of Molland is described by Young as the most celebrated of breeders in North Devon; and the greatest of our early writers on agriculture gives a most minute account of the scheme of 
breeding which was pursued by Mr Quartly and his brother, "the clergyman who interests himself much in live-stock.' The ideal animal which the Quartlys kept before them and bred up to exactly corresponds to the typical Devon of to-day; and there is no doubt that their sound and systematic method of breeding imprinted an indelible stamp upon the race through which the blood of their stock has freely permeated. In former times, when cattle were beasts of burden, the Devons were greatly esteemed for their agility and hardiness. Now that the yoke has fallen upon other shoulders, the 'Rubies of the West,' as the plump little Devons have been called by their admirers, are holding a high position as beef-producers. The quality of their meat is excelled by none; and while they are small in size, they give a good return for the food they consume. Garrard, writing in 1800, attributed the excellence of Devon cattle mainly to the mildness of the climate and high dry ground, calcareous soil, and sweet pasture whore they were bred; but he considered it might be ilso to some extent due to an admixture of finer blood from the still warmer continent of Europe. There may have been some slight foundation for this latter suggestion; but it is undeniable that the main forces and features now existing in Devon cattle are distinctively native to the south-west of England. This idea is strengthened by the recollection of the estimate of Devon eattle formed by Bakewell, who declared that they could not be improved by any cross. From the first and greatest of all our early improvers of farm live-stock this testimony is weighty. The dairy properties of the breed are not of a high order. The yield of milk is comparatively small, but its quality is exceptionally rich. Some rare specimens of the breed have reached $19 \mathrm{cwt}$. live-weight at four years old, but the average is much below that. At the London Christmas Fat Stock Show in December 1887 the class of two-year-old Devon steers (averaging 681 days) gave an average live-weight of $1235 \mathrm{lb}$.; steers over two and under three years old (averaging 996 days), $1489 \mathrm{lb}$; and steers over three years (averaging 1320 days), 1734 lb. each.

The Red Polled cattle of Norfolk and Suffolk are supposed to bear a close affinity to the polled breeds of Scotland through the circumstance that formerly Scotch eattle were freely transported tc be fattened on the Norfolk pastures. Be this as it may, the red polled breed has been sufficiently long associated with Norfolk and Suffolk to enable these counties to claim them as natives. Marshall in his Political Economy of Norfolk, published in 1782, tells us that the native cattle of Norfolk were 'a small, hardy thriving race, fattening as freely at three years old as cattle in general do at four or five. They are small boned, short legged, round barrelled, well loined; the favourite colour a blood-red with a white or mottled face.' Arthur Young, writing in 1794, says the Suffolk breed of cattle 'is universally polled, that is, without horns ; the size small; few rise when fattened to above 50 stone ( $14 \mathrm{lb}$.) ; the milk veins remarkably large; cows upon good land give a great quantity of rich milk.' These are the progenitors of the modern red polls, and all the good features of the old breed have been retained and developed. The cattle are now relatively larger, still blood-red in colour, but with no white face, good meat-producers, and, taken as a whole, perhaps the best of all the native English breeds from a dairying point of view. Individual shorthorn cows will be found to exceed them in yield of milk, but red-polled cows are distinguished for high average milking properties. The breed has found much favour in the United States of America and elsewhere abroad. Its uniformity of colour, absence of horns, and usefulness both as beef and milk producers have won for it many hearty admirers in America.

Sussex cattle are also uniformly red in colour, with strong spreading horns, larger in size than the Devons, heavy meat-producers, but deficient in dairying properties. Marshall is probably right in stating (1796-98) that the Sussex, Devon, Hereford, North Wales, and Gloucestershire cattle had all sprung from the same aboriginal stock; and that in fact they were 'varieties arising from soils and management of the native breeds of this island.' Formerly Sussex cows were highly esteemed for their milking properties, but in the rage for beefproduction these have unfortunately been destroyed. Sussex cattle mature early, grow to great weights, and in late years they have been improving in quality. They have also found supporters in foreign countries, chiefly in the United States of America. Young Sussex steers (averaging 659 days) at the London Christmas Fat Stock Show in 1887 reached an average live-weight of $1436 \mathrm{lb}$, and three-year-old steers (averaging 1349 days), $2030 \mathrm{lb}$. each.

Longhorn cattle are now in few hands; so few indeed that the breed may be said to be approaching extinction. They are big, rough, ungainly cattle, with long drooping horns which are often so shaped as to make it difficult for the animals to graze short pasture. The cows give a fair quantity of very rich milk, and the bullocks grow and fatten to great weights. But for general utility they are being ousted by smaller, finer, and more rapidly maturing varieties. Peculiar interest attaches to this breed from the fact that it was upon it that the past great improver of farm live-stock, Robert Bakewell (q.v.) of Dishley, tried his earliest experiments. The improvement of live-stock upon seientifie principles dates from 1755, when Bakewell began his great work with longhorns. These cattle were at one time widely diffused through England, and also obtained a footing in Ireland, but were many years ago supplanted by shorthorns, Herefords, Devons, or other varieties.

Welsh cattle present considerable variety of type and character, yet there is all through a noticeable family likeness, arising of course in their common origin in the aboriginal cattle of the principality. They are black in colour, with long horns, hardy in constitution, good milkers, slow in maturing, but able to subsist and thrive upon scanty fare. In late years they have been considerably improved, especially in their fattening properties. They vary greatly in size, but many of them attain great weights at from three to four years old. The average live-weight of Welsh steers at the London Christmas Fat Stock Show in 1887 was $2111 \mathrm{lb}$. each, their average having been 1286 days.

Amongst the four Seotch breeds of cattle the Polled Aberdeen-Angus is well entitled to precedence. Descended directly from the ancient polled cattle of Angus (Forfarshire) and Buchan (in Aberdeenshire) - two varieties of the same type, known in the former as 'Doddies,' and in the latter as 'Humlies'-this valuable beef-producing breed has made great strides in public favour since 1878 , when, with five plump black polls the late Mr William M'Combie (1805-80) of Tillyfour carried off the champion prize for the best group of 'meatmaking' cattle at the Paris Exhibition, where no fewer than sixty different varieties of cattle were represented, including the best of the English breeds. That remarkable triumph has been followed by grest achievements at home, the breed having in 1881,1885 , and 1887 won the $£ 100$ Champion Plate at the London Christmas Fat Stock Show. The improvement of the breed was begun before the advent of the 19th century, and all 
through its breeders have been eareful to preserve and cultivate its exceptionally high properties in the production of meat of the choicest quality. In this fies the chief excellence of the breed, and in these times the characteristic is one of great value. This property in the northern polls, combined with the sound system of feeding pursued in Scotland, has secured 'prime Scotch' beef the highest favour and longest price in the London market. At one time
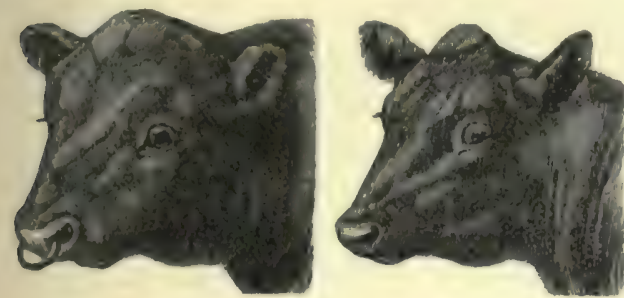

Fig. 3.-Polled Aberdeen-Angus Bull and Cow.

the cows of this breed gave a bountiful yield of rich milk, but owing to the breeders' attention having so long been mainly directed to the cultivation of the fattening properties, they are now only moderate milkers. In recent years the breed has improved considerably in early maturity, and at the London Fat Stock Show in December 1887 it surpassed all other breeds in this importunt property. At that show the class of polled Aberdeen-Angus steers under two years (averaging 667 days in age) gave sn average live-weight of $1475 \mathrm{lb}$, ; and steers over two and under three years (averaging 984 days), $1874 \mathrm{lb}$. Black is the prevailing colour, but oceasionally a red ealf is dropped.

The Galloway breed, which takes its name from the south-west of Scotland, where it has existed it is believed for centuries, has an undeniable claim

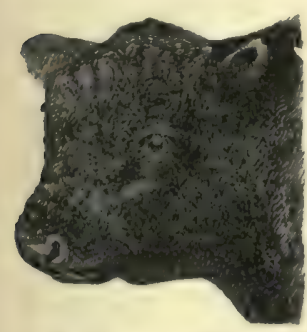

Fig. 4.-Galloway Bull. to an ancient lineage. Its origin is lost in the mists of bygone ages, but enough of its history is known to insure for this breed a high position amongst the native races of British cattle. Black and hornless like the polled Aberdeen-Angus breed, Galloway cattle differ substan. tially from the former, not only in ontward features, but also in their inherent properties. They are similar in size, more shaggy and muscular in appearance, having a thicker hide and ranker coat of hair, but they do not mature so quickly, and are not so well suited for rapid house-feeding as the northern polls. But the Galloways are excellent grazing cattle, and for this property they have been highly esteemed for many genera. tions, both in England and Seotland. In recent years they have been exported in large numbers to America, where they have been found admirably adapted for ranching purposes. They are exceed. ingly robust and hardy, and have surpassed several of the other finer varieties on the ranches of the weatern states of America, where the cattle have to accomplish a great deal of walking in finding food and water.

From a dairy-farmer's point of view, the Ayrshire is the most valuable of all the British breeds of cattle. Its origin is uncertain, but it is considered more than probable that its progenitors were of Dutch extraction. Be this as it may, it was well established as a famous dairy breed in the south-west of Scotland before the close of the 18th century. The prevailing colours are brown and white, but some are almost entirely white, others are almost a whole brown. They are wide, low-set cattle, with fine horns eurving upwards, They are second-rate cattle as beef-producers, but as profitable general dairy cattle they are unmus. passed. A fairly good Ayrshire cow will give 600 gallons of milk in a year, a very large quantity for her moderate size.

There is no more handsome animal of the bovine species than a genuine representative of the West Highland breed. Almost as large in size as the shorthorn, and quite as well proportioned in the frame, the West Highlander gains in appearance by his rank shaggy coat of hair, long, spreading, gracefully turned horns, and hardy, muscular, and defiant gait. With the Wild White cattle of Chillingham and the tiny little Kerry of Ireland, the West Highland is regarded as the finest existing representative of the ancient cattle of Britain. The breed presents con. siderable variety in size and colour. Dun or yellow of various shades is the prevailing

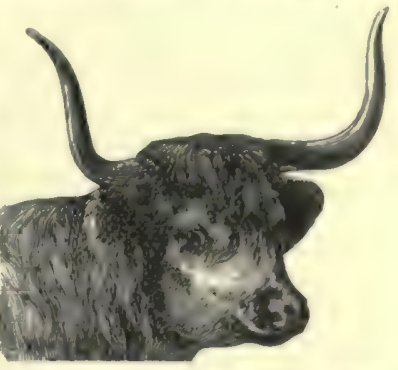

Fig. 5.-West Highland Cow. colour, but many are black or brindled. They mature slowly, but their beef is much esteemed for its quality and flavour. They are unequalled for hardiness, and can be kept with advantage where no other breed would subsist. The cattle of Orkney and Shetland differ considerably from the varieties on the mainland, but they are as a rule of an inferior character and small in size.

The Kerry is the smallest of all the recognised varieties of British cattle. The breed has its headquarters in the bleak hills and upland pastures of the county from which it takes its name, and having been much neglected by Irish farmers, it forms only a very small proportion of the cattle stock of Ireland, which now mainly consists of crosses between the improved shorthorn and 'old Irish cows,' which were of mixed-bred nondescript character. Kerry eattle are very hardy, and the attributes of the Kerry cow have thus been truthfully described by Youatt: 'Truly the poor man's cow, living everywhere, hardy, yielding for her size abundance of milk of good quality, and fattening rapidly when required.' Black is the prevailing colour, and their horns are upturned and often peculiarly ' cocked.' There is a sub-variety called the 'Dexter Kerry,' shorter in the leg, thicker in body, and heavier in the flesh than the Kerry proper.

The extension of dairy-farming in the United Kingdom, and the somewhat meagre milking properties of the greater proportion of British cattle, have led to the importation of large numbers of Channel Island cattle. These-often indiscrimin. ately called Alderney cattle-comprise the Jersey and Guernsey breeds, supposed to be from one common origin, but known to have been bred in purity in the respective islands of these names for upwards of a hundred years. They are both easen. tially dairy breeds, giving an abundant yield of rich highly-coloured milk. The Jersey is the smaller of the two, and is docile, delicate, and of graceful deer-like form. In the production of beef it is of little value. The Guernsey is not only larger, but also hardier and more generally useful. When in 
full milk, whole herds of Jersey cows give an average of $9 \frac{1}{2} \mathrm{lb}$. of butter each cow per week, an exceptional cow occasionally giving as much as $16 \mathrm{lb}$. of

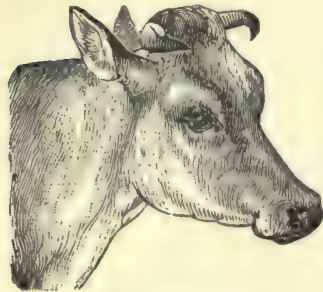

Fig. 6.-Jersey Cow. butter in one week. Good Jersey cows yield from 500 to 700 gallons of milk, and from 300 to $350 \mathrm{lb}$. of butter in twelve months. Guernsey cows have exceeded 800 gallons of milk in a year, and the noted cow 'Select,' when six years old, gave 22t lb. of butter in seven days, this quantity being obtained from 19 quarts of milk per day. In America still higher records have been obtained.

It has been stated that the improvement of cattle-breeding on scientific principles was begun by Bakewell in 1755. Almost continuously since then the good work has been prosecuted with energy and success, and for many years the British Isles have been regarded as the origin and headquarters of almost all the most valuable varieties of farm live-stock. For generations foreign countries have freely resorted to these islands for improved live-stock, and this export trade goes on as briskly and as extensively as ever. The United States of America have in particular drawn very largely upon British herds, and a great stimulus to this trade with the United States has been given by the extension of the ranching system. Vast areas of grazing land in the western states and territories have been acquired by syndicates for the breeding and rearing of cattle; and with the view of improving the stock of native cattle, large numbers of wellbred bulls of the leading British varieties, either imported from the United Kingdom or descended from imported stock, have been sent to the West for use on ranches.

The cattle of the United States and Canada present almost endless variety of form and character. This is what might be expected when it is remembered that they are descended from importations of eattle from Spain, Holland, Sweden, Denmark, France, and England, Scotland, and Ireland. About the year 1525, some six years after the discovery of Mexico by the Spaniard Cortes, cattle were introduced into that country from Spain, and in the abundant pasturage of the Mexican territory they increased rapidly, spreading with the enterprising Spanish settlers into Texas, California, and other parts of the Far West. Exactly a hundred years later the Dutch settlers in New York bronght cattle thither from Holland, and a few years earlier small importations of cattle had been made from the West India Islands into Virginia. The earliest of these arrivals in Virginia are assigned to 1610 and 1611 , but that colony was broken up in 1622 by the Indians, who massacred 347 men, women, and children, and, it is presumed, also destroyed their cattle. In 1624-four years after the landing of the English Plymouth colony there-cattle were introduced into Massachusetts from England, and many other importations followed during the next few years. The Swedes brought cattle into Delaware in 1627, and in 1631 and two following years Danish emigrants introduced cattle from their native country into New Hampshire. English emigrants settled in Maryland in 1633, in North and South Carolina in 1660 and 1670, and in Pennsylvania in 1682, and took with them, or had sent after them, large numbers of English cattle. The French colonists brought cattle into
Quebec as early as 1608 ; and towards the close of the 17th century fresh importations of European cactle poured into the great American continent. It so happens, however, that while importations of cattle were made from all the countries named, and perhaps from others also, the existing cattle stock of America-leaving out the Mexican, now more commonly called Texan, cattle, which are still a race by themselves-are largely of British origin. In the earlier importations, again excluding Mexico, British cattle preponderated ; and just as the English language has submerged all others in the gradual development of the American continent, so has British blood become the dominating element in the main bulk of the cattle stock of the country. There is no authentic information as to the character of the cattle first introduced into America, but all the leading breeds of the British Isles, as well as the chief milking breeds of the European continent, are now strongly represented in North America. There, as at home, the English shorthorn predominates, and there are also strong representations of the Hereford, Polled AberdeenAngus, Galloway, Devon, Norfolk and Suffolk Red Polls, Jersey and Dutch breeds. The cattle of America are being speedily improved, chiefly by the use of well-bred bulls, either imported from the British Isles or bred from imported cattle. Still, the majority of them are of an inferior character-quite unworthy of the rich country which they oecupy. The Texan cattle still retain the rough coarse character which distinguished their Spanish ancestors. Improvement amongst the Texan cattle is proceeding very slowly.

The cattle of Australia, which are small, slowgrowing, and of inferior quality as beef-producers, have also been greatly improved by the introduction of British stock, chiefly of the Shorthorn, Hereford, and Polled Áberdeen-Angus breeds.

In the management of cattle there is perhaps even greater variation than in the character of the cattle themselves. A full description of the various methods of management would itself occupy a moderate volume. It must suffice here to mention two or three leading features in cattle economy. In the British Isles the $o x$ is no longer a beast of burden, save in a very few localities. The yoke has fallen upon the horse, except where both have been relieved by the steam-engine. The two main purposes for which cattle are now reared are the production of milk and butchermeat. Certain breeds, as already indicated, are peculiarly adapted for milk-production, such as the Jersey and Guernsey and Ayrshire cattle; others, notably the shorthorn and red-polled breeds, are distinguished for the combination of both milking and fattening properties of the highest order; while others again, such as the Polled Aberdeen-Angus, the Hereford and Devon, \&c., display remarkable aptitude to fatten, and yield meat of the choicest quality. The farmer of course selects the breed best adapted to the locality in which he lives, and to the purposes he has in view. As a rule cattle of all kinds, whether dairying or fattening, spend the summer on the pasture fields; and it is only in exceptional cases, either where there is a deficiency of grass, or where it is desired to force the growth, fattening, or milking of the animals, that any food beyond what they can pick up for themselves is given to cattle on the fields. Oil-cake, cottoncake, and bruised grain-partly imported, mostly home grown-are the principal auxiliary foods on pasture. Where a careful system of management prevails, the cattle are put into comfortable houses overnight as soon as the chill autumnal evenings set in ; and throughout the winter they are kept almost entirely in the houses, store-cattle getting out now and again about mid-day when the weather 
is favourable. As winter food, turnips and straw or hay preponderate, but in the improved practice of recent years smaller quantities of roots and more of the concentrated foods, such as cake and grain, are being given to cattle. Silage is fast becoming an important article of food for cattle. Now cattle are fattened of at from eighteen to thirty months old, instead of from three to five years, as prior to 1850. The essence of the feeder's art is to produce the maximum quantity of first-class meat in the shortest possible time and at the lowest possible coet; and in the struggle after this the maturing and fattening properties of cattle have been greatly accelerated. The young or 'baby-beef,' as it has been called, is more tender and perhaps more palatable than the substantial 'rounds' of the slow: growing five-year-old beeves of 'fifty years ago ;' but it is questionable if it is either so wholesome or so strength-giving. Be that as it may, the popular taste is entirely in favour of the 'baby-beef; and what the public desire the feeder must endeavour to supply.

Since 1880 there has been considerable growth in dairy-farming throughout the British Isles. When it is mentioned, however, that in 1895 butter to the value of $£ 16,802,400$, and cheese to the value of

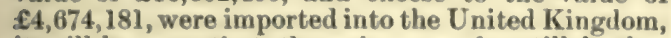
it will be seen that there is room for still further extension. The system of management on dairyfarms varies according to the locality and objects of the farmer. Where the milk can be conveniently disposed of or despatehed to towns, attention is given mainly to milk-selling, which is the least troublesome, and perhaps also the most profitable system of dairying. In other cases butter is the staple produce of the dairy; in other parts again, cheesemaking is the prevailing feature. The consumption of milk as human food has vastly increased in recent years. The rate of consumption keeps on growing, and ingenious facilities are devised for bringing fresh milk from distant dairies-dairies from 50 to 60 miles distant-into towns every morning. As would be expected, the calves bred on dairy-farms get little of their mothers' milk. 'They are reared principally on 'milk substitutes,' either prepared at home or by firms who make the production of cattle foods their sole or chief business. Linseed in various forms is very extensively used in calfrearing.

Cattle are very variously used, and are the only or the chief beasts of draught in many countries, as Cape Colony and large part of America. In India also horned eattle are the only beasts used for ploughing, and are chiefly valued as draught animals. A famous breed was formed for military purposes; and in the Central Provinces there is a high-class breed of trotting bullocks. The best ghee of India is obtained from the milk not of cows but of buffaloes. In China, no use whatever is made of cow's milk, though human milk is sometimes given to old people as a restorative. Nearer home, in Italy even, milk and butter are but little used, and cows are in request mainly for rearing calves. The large Italian breed can do little more than feed their young; and milch cows, if wanted, are brought from Switzerland. In Italy and some other countries, cattle are all stall-fed, vine, elm, and oak lesves forming an important part of their food.

Wild Cattle.-In various parts of the world, species occur of cattle nore or less wild, which are certainly different from any of the domesticated European breeds. Such are the Banteng (Bos banteng), the Gaur Ox (B. gaurus), the Gayal (B. gavaus). But besides these extra-European wild cattle, there are abundent remains of three virtually extinet European species, from which the domesticated breeds are believed to have gradually originated. These are B. primigenius, B. longifroms, B. frontosus. The finst recame virtuslly extinct within historic times, is known as the $U_{r}$ in the Nibelungenlied, was domesticated in Switzerland in the Neolithic period, was common in Britain and on the Continent in the time of Casar, seems to have persisted in Poland till the 17 th century, and still gurvives in a memi-wild stage, 'though much degenerated in aize,' in Chil. lingham Park in the north of Northumberland. In 1692 the flock numbered but 28 ; in 1875,62 in all. At Cadzow near Hamilton is another herd, differing somewhat from those of Chillingham, but presumed to be also representatives of a detachment of the wild eattle that roamed the Caledonian Forest. Other herds are still found at Chartley (Stafford. shire), Somerford (Cheshire), and Kilmory (Argyllshire); whilst that at Gisburn (Yorkshire) became extinct in 1859, and that of Lyme (Cheshire) dwindled from 34 head in 1850 to 4 in 1875 . Though the interesting survivals preserved at Chillingham 'are less altered from the true primigenius type than any other known breed,' there is some reason to suppose from their white colour and some other features that they are descended from a partially domesticated ancestry. As to other descendants of $B$. primigenius, which have diverged further from the primitive type, it is generally supposed that the Podolian cattle of South Russia, Hungary, \&c., the larger breeds in Friesland, Holland, and other parts of the Continent, and the Pembroke breed in England, are to be referred back to the same source.

B. longifrons or brachyceros was a smaller animal with short body. It was domesticated in Switzerland in the Neolithic period; it was early introduced into Britain (vast quantities of its bones having been found in remains of a lake-dwelling at Croyland); and it has its probable descendants in some of the mountain breeds of Switzerland, the Tyrol, and Bavaria (e.g. the Appenzell cattle), and, according to Owen, in some of the Welsh and Highland cattle.

$B$. frontosus is found along with the latter species, to which it is closely allied. It occurs in the peat-mosses of Scandinavia, and also in Ireland. It is regarded as the probable ancestor of the Norwegian mountain cattle, of the Bern cattle, and, according to Owen and others, of some of the Scoteh Highland varieties. In regard to many of these pedigrees, dogmatic statement is quite impossible, and much difference of opinion obtains. The most divergent opinion is that of Wilckens, who maintains that some of the European domestic breeds are descended from the European bison.

Darwin's Animals and Plants under Domestication, vol. i., may be conveniently consulted for facts and references. See the articles BOVID.E, BREED, BULL-FIGHT, GAuk, Musk Ox, RaNchive, Yak, ZkBU, \&c. The diseases of cattle are disoussed under their own headsCattle-plague, Plando-pneumonia, Anthrax, MurRAIN, Bot, BLAOK QUARTER, \&a. the law thereof under Contagrous Disrasrs ; and G. Fleming's Animal Plagues (1871-82). See also DATrY, BuTrer, Cheese, and MrLK. On cattle generally, see Youstt's Complete Grazier (13th ed, rewritten by Dr Wm. Fream, 1893); Pringle's Live Stock of the Farm; Wallace's Farm Live Stock of Areat Britain; Stephens's Book of the Farm (new ed. by Macdonald); and Allen's A merican Cattle (New York). For Wild Cattle, see Wilokens, Rinderrassen Mittel-Europas (Vienna, 1876); J. A. Smith, Ancient Cattle of Scotland (1873); and Harting, Extinct British Animals (1880).

\section{Cattle, in English Law. See Chatrel.}

Cattle-plague (Ger. Rinderpest; Lat. Typhus Bovis Contagiosus). This is a specific malignant and contagious fever indigenous to the Asiatic steppes of Russia, Indis, Persin, China, Burma, Ceylon, \&c. ; never occurring in Britain but as a result of direct or indirect communication with imported 
cattle, or with hides and offal which have been exposed to the contagion; and is hitherto unknown in America, Australia, and New Zealand. It is essentially a disease of the bovine family. (ox, aurochs, and zebu), but may be communicated to the sheep, goat, deer, camel, giraffe, antelope, gazelle, and even the peccary.

Records of fatal plagues in cattle have been handed down from very early dates, but the descriptions are so meagre that it is possible only to surmise their nature. It is probable that one of the plagues of Egypt was a form of anthrax, but in the reign of Nero $(69$ A.D. $)$ Columella describes a disease which resembles cattle-plague. He says: "The fever is present when tears are trickling down the face, when the head is carried low and heavily, and the eyes are closed; when the saliva flows from the mouth, when the respiration is shorter than in health, and seemingly embarrassed or sometimes accompanied by groaning.' About 400 A.D. Vegetius Renatus describes, under the term Malleus, a disease which might have been cattle-plague. In 809-10 A.D., during the wars of Charlemagne, occurred a great outbreak of cattleplague, which spread over nearly the whole of Europe, and particularly Britain. In 1348-49 a plague broke out amongst the cattle in England, just after the black death had destroyed thousands of human beings; it seems to have been similar to cattle-plague. Even in those days the stampingout system was understood, as the diseased cattle were slaughtered, and infected herds, and the herdsmen sttending them, were kept from coming into contact with sound animals.

In 1480 another outbreak occurred which committed great devastation. It cannot be stated positively that these outbreaks were eattle-plague, as the symptoms have not been clearly handed down, but there is evidence to prove that outbreaks occurring in 1715 , in 1745 , and which continued until 1757, were those of the veritable plague. That of 1745 was brought from Holland either by two white calves, or by a parcel of distempered hides brought from Zealand. The disease broke out near London, continued for twelve years, and was only suppressed by most vigorous measures. It again made its appearance in 1865 , and was introduced by 331 cattle shipped at Revel, and landed at Hull. Amongst these were 13 Russian cattle, the remainder of 46 which had been brought from St Petersburg and its neighbourhood. The cargo arrived on 29th May, and a lot of 146 were disposed of at Hull on the 30 th. The remaining 175 were sent to London. Amongst them were 330 sheep which were sold at Hull to the butchers and killed, and all the 175 cattle except 20 were sold for killing, but the remaining 20 were sent to Gosport. From this source the disease spread rapidly, and by the end of July it appeared in Aberdeenshire, brought by 4 calves sent to Huntly from the south. By the beginning of November the plague was present in 30 counties in England, 17 in Scotland, and 1 in Wales; and on December 30 the disease had appeared on 7443 farms or in cattle-sheds in England, 2065 in Scotland, and 245 in Wales; total -9753 centres of infection. The total number of cattle on farms, in sheds, or other places where the disease had been officially reported to exist, was-England, 110,647; Scotland, 44,527; Wales, 4536; total, 159,710 . And the number of healthy animals in contact and slaughtered were-England, 10,636 ; Scotland, 6578; Wales, 152 ; total, 17,366. The number attacked were-England, 48,964; Scotland, 22,298; Wales, 2287 ; total, 73,549. Out of this number 7045 recovered, 41,491 died, 13,931 were killed, and 11,082 remained diseased at this date. The plague continued to spread and to commit great havoc, until an Order in Council was issued making it compulsory to slaughter and bury all diseased cattle, as well as those which had been in contact with them. The beneficial effect of this order was soon made apparent, as the disease gradually diminished and eventually died ont.

Had the restrictions upon cattle traffic been removed, there would have been another visitation in 1872, for in July of that year, animals affected with the disease were sent to Deptford, Hull, and Leith, but owing to its swift recognition, were not allowed to land in Scotland. From Hull, however, it spread to Bridlington, Pocklington, and two other parishes in the East Riding of Yorkshire, but through the activity of the authorities was prevented from spreading further.

Sheep do not readily take the disease when kept in fields with affected cattle, but if kept together in close sheds, they take the disease in a short time.

Symptoms. - The virus absorbed into the blood gives rise to elevation of temperature (fever), which precedes all other symptoms, and occurs in from 36 to 48 hours after an animal has been inoculated. It will be thus seen that the period of latency-ineubation-is very short. Two days after this elevation of temperature, the mucous membrane of the mouth, as well as that of the vagina in the cow, assumes a salmon colour, and is covered with an eruption. Even at this time the pulse is but little affected, but on the fourth day from the first rise of temperature there are marked signs of illness; the constitution is thoroughly invaded, and now ensue the drooping head, hanging ears, distressed look, with rigors and twitching of the muscles, failing pulse, oppressed breathing, diarrhoea, fetid breath, discharge from the eyes, nose, and mouth, and constant moan so characteristic of this dreadful malady; death usually occurs on the seventh day from the first perceptible elevation of temperature, but the third or fourth after the illness is apparent to ordinary observers.

Cause and Cure.-As long ago as 1872 the disease was believed, and has since been proved, to be caused by microbes (see GERM). The awful epidemic which, entering Africa from the north-east about 1889, desolated a great part of South Africa, gave appalling opportunities forstudying the malady and attempting cures. The disease reached the Zambesi in 1895; in Matabeleland between March 1896 and January 1897 it left of all the vast herds of horned cattle probably not 500 alive, buffaloes and antelopes being also exterminated. Bechuanaland, the Transvaal, Orange Free State, and Cape Colony (1897) were successively desolated. In 1897 Koch of Berlin was at work, and his inoculative methods (with cultivated microbes, serum, \&c.) were believed to lend belp if not immunity : and Edington obtained success by inoculating living animals with the blood of those dead of the disease after treating it with citric acid, as also by inoculating with glycerine and bile, \&c.

Cattolica, a town of Sicily, with sulphurworks, 14 miles NW. of Girgenti. Pop. 6591.

Catullus, Gaius Valerius, the greatest lyric poet of ancient Italy, and one of the greatest poets of all ages, was born at Verona either in 87 or, more probably, in 84 B.C. Few of the incidents in his life are known to us, and the dates assigned to these are in most cases only conjectural. He appears to have belonged to the equestrian order, and his years were spent mainly at Rome, where he settled about 62 B.C., and at his villas, to which he was fond of retiring, at Tibur and Sirmio. He began to write verses when a boy of sixteen or seventeen. 'When my primrose youth was in its: 
plesustnt spring,' he says, 'I played enough at rhyming,' In Rome he mingled with the best miciety, becoming intimate with the two Ciceros, che Metelli, Hortensius, and probably with Lu. cretius. And in Rome he met the lady whom, under the name of Lesbia, he has sung in verses which stand at the head of the lyric poetry of pussion. It is almost certain that the Lesbia of Catullus was none other than Clodia, the sister of Cicero's enemy, Publius Clodius Pulcher. One of the most beautiful and accomplished women of her time, she inspired Catullus with a passionate love of which the changing phases are mirrored in a wonderful cycle of poems. There is first a time of rapturous joy; then come doubts, quarrels, and reconciliations, and in the end betrayal and despair. The final rupture seems to have happened in $57 \mathrm{~B}, \mathrm{C}$. and in that year Catullus accompanied the propretor Gaius Memmius to his province of Bithynia. He returned to Rome disappointed in his hopes of enriching himself, and entered impetuously into the contest which was then being waged between the senatorian and the democratic parties. Like Cicero and most of the men of letters of his day, he espoused the cause of the senate. A fiery, unscrupulous partisan, he assailed his enemies with equal seurrility and wit, and directed one of his cosrsest lampoons at the head of Julius Cresar. His closing years were darkened by the loss of a favourite brother, on whose tomb in the Troad, which he visited when returning from Bithynia, he wrote one of the most exquisite of all poems that breathe regret for the dead. He was himself cut off in early life, for, though the exact date of his death can only be conjectured, in all probability he did not survive the year 54 B.C.

The extant works of Catullus comprise 116 pieces, many of which are extremely brief, while the longest of them contains only some 400 lines. There is considerable variety, however, in this somewhat slender body of poetry. There are graceful, playful verses of society, and there are verses, struck out in the heat of party warfare, in which satiric wit sparkles through fescennine raillery. There are elaborate descriptive and mythological pieces, such as the Coma Berenices and the stately and richly-coloured Peleus and Thetis, which appear to have been translated or adapted from the Greek. There is the Attis, a strange poem, unlike any other work of a Latin writer in its wild imaginative power and in the magnificent sound and sweep of its galliambic verse. And there is the erowning series of love-poems, in which the incarnation of burning passion in exquisite language, the mastery of verbal music, are carried to what is seemingly the highest attainable point of perfection. In these 'Lesbia poems there is no sign of the laborious art which produced the mosaic-work of the Horatian odes. They seem to have flowed forth-thought, feeling, phrase, and cadence combined in a perfect whole -at a single creative impulse. Their anthor's mastery of the Latin tongue was unerring and unbounded. In his works it seems endowed with the elastic and radiant strength of the Greek. He revealed all it had of energy, sonority, and sweetness, of monumental dignity and laughing grace. He mouided it into lines which neither Lucretins nor Virgil has surpassed for majesty of rhythm; he wove it into lyrics which for lightness of movement and crressing sweetness of cadence are unmatched in all the fields of Latin verse. For breadth of vision, fertility of thought, insight into human character, we must turn to other writers than Catullus. For fire and music and unlaboured felicity, of phrase he has no superior among the lyric poets of all time.
The text of the works of Catullus, after having been lost for more than three hundred yeans, wea discovered in the 14th century at Verona. The original manuscript was again lost, and until lately only one copy of it, which was preserved at St Germains, and is now in Paris, was believed to be in existence. A manuscript in the Bodleian Library, however, has been discovered by Dr Bahrens to be a sister copy of the St Germains manuscript. The best editions are by Mr Robinson Ellis (1867; new ed. 1878; Commentary, new ed. 1889), Bährens (Leip. 1876; new ed. 1885); Postgate (1889); and S. G. Owen (1893). Anong English verse translations are those of Martin (1861), Cranstoun (1867), Ellis (1871), Hart Davies (1879), and Grant Allen (the Attis, 1892). See also Munro's Criticisms and Elucidations (1878); Sellar's Roman Poets of the Republic (new ed. 1881 ) ; and Lafaye, Catulle et ses Modeles (1894).

\section{Catydid. See Katydid.}

Caub, a town in the Prussian province of HesseNassan, on the right bank of the Rhine, 30 miles WNW. of Wiesbaden by rail. Here Blicher crossed the Rhine with his army, January 1, 1814; and here, too, till 1866, toll was levied by the Duke of Nassan-the only ruler who kept up this feudal privilege-from vessels navigating the Rhine. Caub has underground slate-quarries; and opposite, on an island in the river, where Louis le Débonnaire died in 840 , is a eastle called the Pfals, built in 1326, which is said to have been resorted to for safety by the Countesses Prlatine during childbed. In 1876 and 1879 Caub was the scene of two serious landslips. Pop. 2179.

Cauca, a river of Colombia, in Sonth America, which, after a northerly course of 600 miles, falls into the Magdalena. Its valley is one of the richest and most populous districts of the continent, and it gives name to the largest of the Colombian states, traversed by the Andean coast-range, and extending along the Pacific from Panama to Ecuador. Area, 260,000 sq. m. ; population estimated at 460,000 . It is rich in minerals, and possesses the most productive platinum mine in America. Capital, Popayán.

Caucasus and the Caucasians. The great mountain-range of the Caucasus forms the backbone of a well-marked geographical region, nearly corresponding with the Russian governor-generalship or lieutenancy of Caucasia. The natural and administrative northern limit is the great Manitch depression, extending from the Sea of Azov to the Caspian, and including the basins of the Kuban and Terek rivers. The southern natural limit is along the basins of the Rion and Kur rivers. The Russian province comprises all the Russian territory to the Turkish and Persian frontiers, including also part of the Armenian highlands and the mountain masses adjoining them, now known by the infelicitous name of Little Caucasus, south of the Rion and Kur rivers. Little or Anti-Caucasus is connected with Caucasus proper by the narrow Mesk ridge crossing the Rion-Kur Valley between the headwaters of those streams. The Sea of Azov and the Caspian seem at one time to have been connected by the Manitch depression; south of which extend vast steppes of llat treeless landfertile, but with little or no water. South of the steppe to the northern spurs of the mountains is luxuriant park land covered with magnificent grasses, and also quite level. Beyond this rise the mountains in successive terraces. On the south side, towards the Rion and Kur, the mountain face is much steeper and more sudden.

The Cancasus occupies the isthmus between the Black Sea and the Caspian, its general direction being from west-north-west to east-south-east. 
From the peninsula of Taman on the Black Sea, to the peninsula of Apsheron on the Caspian, it has a length of about 750 miles. The breadth, including the secondary ranges and spurs, is about 150 miles, but that of the higher Caucasus does not exceed 70 miles. This range is sometimes treated as part of the boundary line between Europe and Asia, but the region is really Asiatic in character (see AsIA). The higher and central part of the range is formed of parallel chains, not separated by deep and wide valleys, but remarkably connected by elevated plateaus, which are traversed by narrow fissures of extreme depth. The highest peaks are in the most central ridge or chain, at least six of them well over 16,000 feet, much exceeding the highest Alps. Mount Elburz attains an elevation of 18,540 feet above the sea; Kazbek reaches a height of more than 16,500 feet; and between these come Koshtantau and Dikh-tau. Here the line of perpetual snow is between 10,000 and 11,000 feet high; but the whole amount of perpetual snow is not great, nor are the glaciers very large or numerous. For more than 100 miles' length of the main ridge there are no passes lower than 10,000 feet. The central chain, in its highest part at least, is granitic or even pure granite. On either side of the granitic axis are metamorphic rocks, such as mica-schists and talc-schists ; and beyond these, clay-slates and schists. The secondary parallel chains on both sides of the central ridge are of limestone. The spurs and outlying mountains. or hills are of less extent and importance than those of almost any other mountain-range of similar magnitude, subsiding as they do until they are only about 200 feet high along the shores of the Black Sea. Some parts are entirely destitute of wood, but other parts are very densely wooded, and the secondary ranges near the Black Sea exhibit most magnificent forests of oak, beech, ash, maple, and walnut; grain is cultivated in some parts to a height of 8000 feet, while in the lower valleys rice, tobacco, cotton, indigo, \&c. are produced. As might be expected from the geographical situation of the Caucasus, the climate, though it is generally healthy, is very different on the northern and southern sides, the vine growing wild in great abundance on the south, which is not the case on the north. The south declivity of the mountains towards Georgia presents much exceedingly beautiful and romantic scenery.

There are no active voleanoes in Mount Caucasus, but every evidence of volcanic action. Elburz and Kazbek are both of volcanic origin. There are hot springs and mud voleanoes at each end of the range, and there are also famous petroleum wells in the peninsula of Apsheron (see BAKU). Mineral springs also occur in many places, notably at Vladikavkaz. The bison, or aurochs, is found in the mountains; bears, wolves, and jackals are among the carnivorous animals. Lead, iron, sulphur, coal, and copper are found.

The waters of the Cancasus flow into four principal rivers-the Kuban and the Rion or Faz (the Phasis of the ancients), which flow into the Black Sea; and the Terek and the Kur, which flow into the Caspian. Kuban and Terek are north, Rion and Kur or Kura south of the mountains. The Russians have with great labour carried a military road through a valley somewhat wider than most of the Caucasian valleys. This is the tremendous fissure or ravine of the Dariel gorge about halfway from the Black Sea to the Caspian. The road passes over a height of about 8000 feet, and is protected by many forts. The only other road is by the Pass of Derbend, near the Caspian Sea. There is a railway from Baku by Tiflis to Poti and Batoum; Vladikavkaz is the terminus of the railway from the north.

CaUCasian was the name adopted by Blumen. bach (q.v.) for one of his main ethnological divisions of mankind; and as the Georgian skull he had was. the finest in his collection, the Caucasian was taken as the finest type of the Indo-European stock. Subsequent ethnologists have, mainly on philological grounds, broken up the Caucasian variety of Blumenbach into two well-marked philological groups, the Aryan (q.v.) and the Semitic peoples (q.v.). The name Caucasian was clearly a misnomer when it suggested affinity in blood or in language between the very various races of the Caucasus, classified below, and Aryans or Semites; and Prichard and others proposed actually to connect most of the Caucasus peoples with the Mongolian races of Asia. Later anthropologists, finding the word convenient, use Caucasian or Caucasic for the Fair type of man as opposed to the Mongolic or Yellow type. But they distinctly repudiate any suggestion of community of race or of language between the peoples so named; and desire to indicate a physical fact and an anthropological type. See ETHNologY; also Philology.

The Caucasus has been called the Mountain of Languages from the multiplicity of tongues spoken in this narrow area-tongues many of them totaily distinct from one another, and, with one exception, apparently unconnected with the languages of any other part of the globe, or race of men; though both Aryan and Turkoman affinities have been alleged for Georgian, and Sayce has suggested that the ancient Hittites (q.v.), whose empire in Asia Minor rivalled that of the Assyrians, were of the same stock. There are certain well-marked groups amongst them, within which manifest affinity prevails. (1) The Southern division or Kartveli stock comprises the Georgians or Grusians, mainly in the upper and middle basin of the Kur; the Imeritians, west of the watershed between the Kur and Rion; the Mingrelians, farther west reaching to the Black Sea; the Gurians, south of the Rion; the Laz, on the Turkish frontiers; and the Svans or Suanetians, between the Mingrelians and the higher Caucasus. (2) The Western division contains the Tcherkess or Circassian race, formerly on the left bank of the Kuban, north of Caucasus; the Abkhasians in the narrow strip of land between the Caucasus and the Black Sea on the south; and the Kabards, north and east of Elburz. (3) The Eastern division contains the Chechenz or Tchetchens on the northern slopes of the Eastern Caucasus down to the Terek; and the Lesghians farther east and south. It is doubtiful whether the numerous small tribes called Lesghians have any affinity with the Tchetchens, or how far they are related to one another; only one, the Avars, have a written language, and they use Arabic characters. (4) The Ossetes or Ossetians in the centre of Caucasus, on both slopes about Kazbek, are unquestionably a race of the Aryan stock, and the language has affinity with the Persian branch; they call themselves Irun (probably meaning Aryan). The Kartveli group may contain 850,000 persons; the Western group, 130,000 ; the Eastern, 520,000; the Ossetian, 120,000. All the Caucasian languages are extremely harsh. Some of them are partially inflectional; all save the Ossetian are substantially agglutinative.

In various portions of this territory there are of course other intrusive elements of population of foreign race: Russian Slavs; Tartars; numerous Armenians; Kurds; Greeks; Tats and other Iranians or Tajiks; and a German colony from Wuirtemberg, east of Tiflis. Not merely do the inhabitants of the Caucasus differ widely in race, but they represent great variety of stages of culture, from the indolent, music-loving Georgians to the 
wild and semi-barbarous Suanetians. Christianity is the faith of some races, as the Georgians and Osaetes; Mohammedanism of a fanatical type that of others, as the Lesghians; while primitive pagan superstitions seem largely to underlie both religious professions, One Kartvelian tribe, the Khevsurs, has in some measure combined Cluristianity with Moslem usages.

The resistance which the Caucasian peoples for more than half a century offered to the arms of Russis attracted to them the attention of the world. But with the capture in 1859 of Shamyl, the prophet chief of the Lesghians, who for more than twenty years withstood the armies sent agrainst him, the power of the Caucasians was shattered; by 1870 it was completely broken. The bulk of the Circassians migrated to Turkish territories in Asia or Europe; most of the Abkhasians have done the like. The ancient divisions of the country, Georgia, Imeritia, Svanetia, Mingrelia, \&c., were based on tribal distinctions. These have disappeared from the Russian administrative system. According to the latter, the main range of Caucasus divides the province into Ciscaucasia. north of the mountains, and Transcaucasia to the south of them; the former comprising the govern. ments of Stavropol, Kuban, Terek; the latter, those of Daghestan (really north of Caucasus), Sakatal, Tiflis, Kutais, Sukhum, Black Sea, Elisabetpol, Baku, and Erivan. Add Batoum and Kars (Russian Armenia), and the Transcaspian territory, and then Caucasia in the widest sense has an area of $308,000 \mathrm{sq}$. m., and a pop. of $6,290,000$. The chief town in Ciscaucasia is Vladikavkaz; in Transcaucasia, Tiflis; the two connected by the great military road through the Caucasus. The old capital of Georgia was Mtzkhet, a good specimen of a Georgian word. For Caucasus and Caucasia, see the map of Russia in Vol. VIII., and the articles Circassians, Georgia, Transcaucasia, and, for the wars with Russin, SHAMYL; also Freshfield, The Exploration of the Caucasus (1897); Cuning hame, Eastern Caucasus (1872); Bryce, Transcaucasia (1878); Phillipps. Wolley, Savage Svanetia (1883); Mourier, Contes et Légendes du Caucase (1888); Abereromby, A Trip through the Eastern Caucasus (1890).

Cauchy, AUgustin Lours, mathematician, born in Paris, 21st August 1789, published in 1815 a Mémoire sur la Théorie des Ondes, which contributed greatly to establish the undulatory theory of light. Between 1820 and 1830 he wrote several important treatises; and at Prague, where he resided as tutor to the Comte de Chambord, he published his Memoire sur la Dispersion de la Lumiere (1837). From 1848 to 1852 he was professor of Astronomy at Paris, but refused the oath of allegiance to Napoleon III., and lived in retirement till his death, 23d May 1857. A reissue of his works, in 26 vols., was commenced by the Academy in 1882. See his Life by Valson (2 vols. Paris, 1868).

Caucus, a private meeting of politicians to agree upon candidates to be proposed for an ensuing election, or to fix the business to be laid before a general meeting of their party. The term originated in America, where the caucus has taken fast root, the 'ticket,' or list of candidates for federal, state, and municipal offices, being always decided upon by the party leaders; but of late years the system has been introduced into England, and adopted by the Radicals, especially in Birmingham, though the word is there used rather for the regularly constituted party organisation. In Notes and Queries for 1885 there is a long discussion as to the origin of the word, which Sydney Smith used in 1818, and John Adams in 1763. Professor Skeat is inclined to refer it to an Indian source, Captain
John Smith (1609) having Carocaworasoughes for the Indian councillors of Virginis, and Caucorouse for an Indian captain.

Cauda-galli Crit, the bsement subdivision of the Devonian system of North America. The name (lit. 'cock's tail') is derived from the fouthery forms of a common fossil, supposed to be a reaweed.

Caudebee, two places in the French department of Seine-Inférieure. Caudebec lds Elbeuf, 12 miles S. by W. of Rouen, has a pop. (1886) of 11,038, and manufactures eloth. Caudebec-en. Caux, a pretty antique village of 2200 inhabitants, is on the Seine, 31 miles WNW. of Rouen.

Caudine Forks (Furcula Caudina), two high, narrow, and wooded mountain-gorges near the town of Caudium, in ancient Samnium, on the borders of Campania; noted for the defeat of the Romans in the second Samnite war (321 B.C.). See RomE.

Caul, a portion of the amnion or thin membrane enveloping the foetus, sometimes encompassing the head of a child when born, mentioned here on ac. count of the extraordinary superstitions connected with it from very early ages almost down to the present day. It was the popular belief that chil. dren so born would turn out very fortunate, and that the caul brought fortune even to those who purchased it. This auperstition was so common in the primitive church, that St Chrysostom inveighed against it in several of his homilies. In later times midwives sold the caul to advocates at high prices, as an especial means of making them eloquent, and to seamen, as an infallible preservative against drowning (cf. Dickens's David Copperfield). It was also supposed that the health of the person born with it could be told by the caul, which, if firm and crisp, betokened health, but if relaxed and flaccid, sickness or death (Notes and Queries, 1884-86). During the 17th century canls were often advertised in the newspapers for sale-from $£ 10$ to $£ 30$ being the prices asked; and so recently as 8th May 1848, there was an advertisement in the Times of a caul to be sold, which 'was afloat with its late owner thirty years in all the perils of a seaman's life, and the owner died at last at the place of his birth.' The price asked was six guineas.

Caulaincourt, Armand DE, Duke of Vicenza, a statesman of the French empire, born at Caulaincourt (Aisne), in 1772, early distinguished himself as an officer, was made a general of division in 1805, and shortly after created Duke of Vicenza. Faithful to the last to Napoleon, he was made Minister for Foreign Affairs in 1813, and during the Hundred Days resumed the office, receiving a peerage of France, of which he was deprived after the restoration. He died in Paris, February 19 , 1827. See his Souvenirs (1837-40).

Caulifiower, a variety of the common kale or cabbage. It was cultivated by the Greeks and Romans, but was little attended to in England till the end of the 17th century; yet prior to the French Revolution caulitlower formed an article of export from England to Holland, whilst English cauliflower seed is still preferred on the Continent. The deformed inflorescence or heads of the cauli. flower only are used. Its eultivation for the supply of Covent Garden and other markets occupies the attention of the market-gardeners of London, Cornwall, Devonshire, and the Channel Islands to a very large extent during winter and spring. It is much more tender than Broccoli $(q . v$.$) , and the$ plants that are reared in August for the purpose of supplying the first crop of the following summer require to be protected under hand-glasses or frames during winter. They require to be freely exposed 
to air in mild or comparatively mild weather, but severe frost must be prevented from entering the glasses or frames. From the middle of August to the 24th of that month, make two or three sowings at intervals of three or four days. The plants reared from these sowings are planted out, a certain portion of the strongest under hand-glasses to furnish the earliest crop; and an abundant reserve of the smaller plants are planted a few inches apart in frames, to be planted out finally in the spring in the open ground. To succeed these a sowing may be made in a hotbed in January or February; and again in March and May, plants should be reared for successional crops, these later sowings being made in the open ground. The ground must be rich and the cultivation high to produce cauliflower of first-rate quality ; there is some risk, however, in having the ground too rich for the winter crop in the case of severe weather occurring; if the plants are extra luxuriant, they will the more readily succumb to frost.

Caulking, in wood shipbuilding, is the operation of driving oakum or untwisted rope into the seams of the outside planks, or of the deck planking, to render them watertight. The quantity thus driven in depends on the thickness of the planking; it varies from 1 to 13 double threads of oakum, with 1 or 2 single threads of spun yarn. The caulker first raims or reems the seam-that is, drives a caulking-iron into it, to widen the seam as much as possible, and close any rents or fissures in the wood; he then drives in a little spun yarn or white oskum with a wood mallet and a caulking ehisel, and afterwards a much larger quantity of black or coarse.0akum. The fibres are driven in until they form a densely hard mass, which not only keeps out water, but strengthens the planking. The seam is finally coated or payed with hot pitch or resin.

In iron or steel shipbuilding and boilermaking the term covers the operation of driving the edge of one thickness of plating firmly against the other thickness upon which it is superimposed, or to which it is adjacent, thus rendering the joints watertight. The tool employed is a specially formed chisel, struck by a metal hand-hammer but endeavours have been made to supplant this by steam-driven machines, so far with but indifferent success.

Caulop'teris, a generic name for the stems of certain extinct tree-ferns, which range from the Devonian to the Permian system. They are hollow, and covered with markings similar to the leaf-scars on recent tree-ferns.

Caura, a considerable river of Venezuela, rises among the sierras of the southern frontier, and flows NNW. to the Orinoco. On both sides stretches the territory of Caura $(22,485$ \&q. m.), with immense forests of tonka beans.

Caus, Caulx, or Cauls, Salomon de, engineer, born at Dieppe in 1576, was a Protestant, and lived much in England and Germany. He was in the service of the Prince of Wales in 1612, and of the Elector Palatine, at Heidelberg, in 1614-20; but by 1623 he returned to France, and became engineer and architect to the king. He died in Paris, 6th June 1626. At Frankfort in 1615 appeared his Rairons des Forces Mouvantes, \&c., a work in which is described an apparatus for forcing up water by a steam fountain, differing only in one detail from that of Della Porta (see STrAM. ENGINE). There is no reason to suppose that the apparatus ever was constructed; but on the strength of the description, Arago has claimed for De Caus the invention of the steam-engine. See the article DE CAUs in vol. xiv. of the Diot. of National Biography (1888).
Causality, or the theory of the relation between cause and effect, is one of the most intricate and important questions of philosophical doctrine. All scientific investigation is occupied with the search for the causes of given events, or for the effects of given causes, and with the generalisation of these into laws of nature. But the nature and ground of the relation between cause and effect are obscure and disputed.

The difficulty of the question is largely increased by the uncertain signification of the word cause. Thus the investigation into the cause of things, with which early Greek speculation was occupied, was really an inquiry for the ultimate constituent or element from which the variety of actual existence had proceeded; and from this inquiry the quest for a principle of change or development. was only gradually distinguished. The first important step in the direction of clear diseussion was made in Aristotle's doctrine of the 'four causes:' the material cause, out of which a thing is framed; the formal cause, or the essence or idea of the thing; the efficient or active cause, by means of which it took its present form; and the final cause or purpose it subserves. These, it is to be observed, are not so much causes in the modern sense of the term, as principles which enter into the existence of everything. In modern science the meaning of the term is much more restricted, corresponding in some degree to what Aristotle called the efficient cause. Thus both Bacon and Descartes wished to banish the notion of final cause from the scientific interpretation of nature; and although, in Bacon's own method, science was treated as an inquiry into. the form or true nature of things (corresponding thus to Aristotle's formal cause), this notion has had little influence. What Descartes sought, and what science still seeks, is the connection rather than the essence of things; and its ideal is a mechanical interpretation of nature in terms of matter and motion. In modern science cause may therefore be said to mean the explanation of change. To some extent it corresponds with Aristotle's efficient cause. But the notion of efficient cause has itself undergone a profound modification, which seems to have been carried out alongside of the formulating of the principle of the conservation of energy. The tendency in science has been to replace the notion of power or efficiency by that of order or constant sequence. The genesis and justification of the notion of efficiency are matters of dispute: whether it is an a prion intuition, or derived from the conscionsness of the voluntary direction of attention, or from the sensations of innervation and muscular resistance. Both Berkeley and Hume directed a vigorous polemic against the doctrine of power expressed by Locke, as going beyond the observed facts of the motion of bodies, and Hume refused to see in mind any more than in matter anything else than a succession of impressions and ideas. Into the rights of this controversy it is impossible to enter here. But clearness of scientific statement has certainly been gained by the extrusion of the notion of power, and substitution for it of that of regular sequence. It is in following out. this view of the physical as distinct from the efficient cause that the term comes to be defined as the aggregate of the conditions or antecedents. necessary to the production of the effect: meaning by necessary conditions those conditions without which the effect either would not have existed at. all, or would have been different from what it is. In popular language, however, and even in most. scientific inquiries, the term cause is restricted to the one or two conditions by the intervention of which amongst other more permanent conditions 
the effect is produced. Thus it is noticeable that while the former or more complete definition corresponds with that expressly given in J. S. Mill's Logic, his inductive methods are entirely devoted to explaining modes of discovering causes in the narrower or popular signification.

It is in this meaning of the term that science investigates causes. In doing so, it goes on the presupposition that every event or change has a cause. This has been called the Law of Universal Causation, and may be expressed by saying that the explanation of every event is to be found in antecedent conditions. Scientific investigation also presupposes the Law of the Uniformity of Nature, that the same conditions or cause will be followed (at all times and places) by the same effects. The grounds and mutual relation of these two assumptions form the chief subject of controversy in the philosophical theory of causality. It is to Hume that the credit is due of having drawn attention to the difficulties involved in the principle of causation, in such a way as to determine the whole course of subsequent philosophy. All reasoning about matters of fact, he shows-all physical science, therefore-depends on the relation between cause and effect. Yet, between the cause and the effect there is no discoverable connection. 'There appears not, through all nature, any one instance of connection which is conceivable by us. All events seem entirely loose and separate. One event follows another; but we never can observe any tie between them. They seem conjoined, but never connected.' Hume's own solution of the difficulty is found in the law of mental association. 'The mind,' he says, 'is earried by habit upon the appearance of one event to expect its usual attendant, and to believe that it will exist. This connection, therefore, which we feel in the mind, or customary transition of the imagination from one object to its usual attendant, is the sentiment or impression from which we form the idea of power or necessary connection. Nothing further is in the case. ... When we say, therefore, that one object is connected with another, we mean only that they have acquired a connection in our thoughts, and give rise to this inference by which they became proofs of one another's existence: a conclusion which is somewhat extraordinary, but which seems founded on sufficient evidence.' The conclusion to which Hume is driven is thus that, while all reasoning about matters of fact is founded on the principle of causality, this principle has itself no other basis than the mental tendency to pass from one impression to the idea of another impression previously experienced in conjunction with the former. Hume's solution is thus not sceptical (except as regards the application of causality or any other principle beyond experience), but it is subjective : the connection of things is resolved into a customary succession of ideas. Of the numerous theories of causation put forward since the question was thus opened, the two most important are J. S. Mill's rehabilitation of Hume's doctrine to suit the requirements of scientific investigation, and the opposed doctrine of Kant and his philosophical successors.

It is characteristic of Mill's doctrine that the principle of eausality is made a consequence of the Law of the Uniformity of Nature: 'the familiar trath that invariability of succession is found by observation to obtain between every fact in nature and some other fact which has preceded it." This principle, which is assumed in every scientific induction, is itself held to be the generalisation of a wide and uncontradicted experience.

A different position is given to the causal principle in Kant's philosophy. The Scottish philoso- phers and others, a well as Kant, had attempted replies to Hume, contending that causality is an intuitive judgment antecedent to experience. But such a reply remains an arbitrary assertion until it is shown how the causal judgment is connecterl with experience. In Kant's Critique of Pure Reason this connection is thoroughly investigated; the refutation of Hume is only part or consequence of a complete inquiry into the relation of reason to experience. It was, however, largely Hume's doctrine of causality that led to Kant's new point of view, and to the doctrine that experience is the product of the understanding, the realisation of its a priori forms. It is not the requence of events in time, Kant holds, that gives rise to the principle of causality; but the pure notion of causality finds its realisation in this time-sequence, in which each event is determined by its antecedent. Kant's doctrine, as thus stated, is in full harmony with the principles and methods of modern science; asserting the principle that every change-i.e. each successive state - of the universe is the result of its preceding state, and at the same time leaving to empirical investigation the connection in experience of any one definite thing with any other.

The most important discussions of causality are those of Hume, Treatise of Human Nature, book i. part iii., and Essay Of the Idea of Necessury Connection; Kant, Critique of Pure Reuson; and J. S. Mill, System of Logic, book iii. chaps. iii.-v. There is also elaborate treatment of the subject in the works of Reid, Stewart, and Hamilton. Dr Thomas Brown's Inquiry into the Relation of Cause and Effect contains much acute analytical thinking.

Cause Célebre, a convenient French term for a specially interesting and important legal trial, criminal or civil, such as the Douglas Cause (1769-71), the Ired Scott case in the United States as to the possession of a negro (1856), the Tichborne case (1871-74). There is a great French collection of Causes Célébres et interessantes (22 vols. 1737-45), by Gayot de Pitaval, with modern con-

\section{tinuations. See TrIAL.}

Causerie, a name applied to a somewhat short and informal essay on any subject in a newspaper or magazine. More familiar in manner and slighter in structure than the formal essay as usually understood, it is an excellent medium for a writer whose personality interests the reader as much as the value of his thoughts. The name owes its literary currency mainly to the famous Causeries du Lundi of Sainte-Beuve; hardly less valuable examples were many of Matthew Arnold's occasional essays.

Causses, Les. See France (p. 770 ), and Baring-Gould's Deserts of Southern France (1894).

Caustic (Gr., 'burning'), a term for substances that exert a corroding action on the skin and flesh. Lunar caustic (so called because silver was called luna, 'the moon,' in the alchemists' mystical jargon) is nitrate of silver, and common caustic is potash. When used as a caustic in medicine, the substance is fused and cast into moulds, which yield the caustic in small sticks the thickness of an ordinary lead pencil, or rather less.Caustic is also used in chemistry in an adjective sense-thus caustic lime, or pure lime, $\mathrm{CaO}$, as distinguished from mild lime, or the carbonate of lime, $\mathrm{CaCO}_{3}$, eaustic magnesia, $\mathrm{MgO}$, and mild magnesia, $\mathrm{MgCO}_{3}$, caustic potash, caustic soda (for these, see Potash, Soda, \&c.). See Cautery.

Caustics. When the incident rays are parallel to the principal axis of a reflecting concave mirror, they converge, after reflection, to a single point, called the principal focus. In the case of parabolic mirrors this is rigorously true. For, as is easily seen from the fundamental property of the para- 
bola, any ray falling on the mirror parallel to the axis is reflected so as to pass exactly through the focus. For other mirrors it is approximately true only when the breadth of the mirror is very small in comparison with its radius of curvature. When the breadth of the mirror is large in comparison with its radius of curvature there is no definite image, even of a luminous point. In such cases the image is spread over what is called a Caustic, or sometimes a Catacaustic.

An example of the caustic is given in the annexed figure for the simplest case-namely, that of rays falling directly on a concave spherical mirror, $\mathrm{BAB}^{\prime}$, from a point so distant as to be practically parallel.

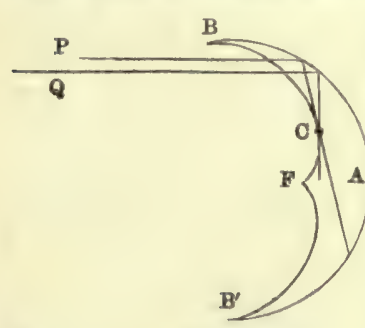

Two very near rays, $\mathbf{P}$ and $\mathbf{Q}$, will after reflection intersect at C. By finding in this way all the points of intersection of the reflected rays, we get a continuous curve, BCFB', which is the section of the caustic surface by a plane passing through its axis.

The curve BCFB' varies of course with the form of the reflecting surface. In the case under considera. tion it is known as an epicycloid.

The reader may see a catacaustic on the surface of tea in a tea-cup half full by holding the circular rim to the sun's light. The space within the caustic curve is all brighter than that without, as it clearly should be, as all the light reflected affects that space, while no point without the curve is affected by more than the light reflected from half of the surface. The rainbow, it may be mentioned, forms one of the most interesting of the whole family of caustics.

When a caustic is produced by refraction, it is sometimes called a Diacaustic. No such simple example can be given of the diacaustic curve as that above given of the catacaustic. It is only in the simplest cases that the curve takes a recognisable form. In the case of refraction at a plane surface, it can be shown that the diacaustic curve is the evolute either of the hyperbola or ellipse, according as the refractive index of the medium is greater or less than unity.

Cauterets, a fashionable French wateringplace in the department of Hautes-Pyrénées, lies 3250 feet above sea-level, in the valley of the Laverdan, 5 miles $\mathbf{S}$. of Pierrefitte, the nearest railway station, and 42 SSE of Pau. The stationary population of the place is only 1260 , but it is annually swelled in summer by 15,000 to 20,000 visitors, for whose accommodation numerous sumptuous hotels and bathing-establishments have been built. It is a good centre and guidestation for ascents among the Pyrenees. The sulphurous springs, twenty-five in number, and varying in temperature from $60^{\circ}$ to $131^{\circ} \mathrm{F}$, , are the most abundant in the Pyrenees (330,000 gallons per day), and have been known from Roman times; though their modern reputation dates from the 16th century, when Margaret, sister of Francis I., held her literary court and wrote much of her Heptameron at Cauterets.

Cautery (Gr. kaio, 'I burn'), in Medicine, is used of any substance which burns the tissues. (The term 'potential cautery,' as applied to caustic substances, is becoming obsolete.) The actual cautery is an instrument with a head or blade of steel, iron, or platinum, which is heated in a fire or spirit-lamp. In the thermo-cautery (or Paquelin's cautery, from its inventor), the head or blade is made of hollow platinum, so arranged that a flame of benzole can be kept burning in its interior. The galvano-cautery consists essentially of a platinum wire which can be heated to any required degree by passing a strong galvanic current through it. The cautery is used for three main purposes in surgery : to produce counter-irritation over an inflamed part (see BLISTERS) (actual eautery); to check bleeding (actual or thermo-cautery), by slowly destroying the tissues at the bleeding point or surface ; to perform operations, where the tissues to be divided are either very vascular (thermo. cautery), or very difficult of access (galvanocautery). See Caustic.

Caution, in the Law of Scotland, like Guaranty (q.v.) in England, is an obligation undertaken by a second party, whereby he binds himself, failing the primary obligant, to fulfil his obligation, whether it be of a pecuniary nature or otherwise. Cautionary obligations are thus essentially of an accessory nature, and cannot subsist apart from the principal obligation. The law of this subject is now largely founded on the Mercantile Law Amendment Acts, 1856, which assimilate the laws of England and Scotland, and according to which the creditor may proceed at once against the cautioner, just as if he were a joint obligant, without suing the primary debtor, unless the cautioner has expressly stipulated that this shall be done. The creditor, however, is in every case bound to use proper precaution in retaining and making available securities. He is not, however, bound to make the same full disclosure of material frets as in insurance, and therefore a cautioner should make careful inquiry for himself. Cautionary obligations are generally gratuitous, being, for the most part, undertaken from motives of friendship; but it is by no means uncommon for them to be entered into in consideration of a premium paid by the person guaranteer, or by those interested in his fortunes. Where a premium is paid, the transaction becomes a mere insurance of solvency, honesty, or efficiency ; and associations of great public utility (see GUARANTEE) have been formed, both in England and Scotland, for the purpose of undertaking to guarantee the fidelity of persons employed either in public or private offices of trust. The tendency of judicial decisions, both in England and Seotland, for many years past, has been to require greater strictness than formerly in the constitution of cautionary obligations; and under the statutes already mentioned all such engagements must be in writing, subscribed by the person undertaking or making them, or by some person duly authorised by him, otherwise they shall have no effect. If a cautionary obligation is dependent on a condition, it will, of course, be ineffectual unless the condition be complied with. The cautioner may, in general, plead every defence which was competent to the principal debtor, and the extinction of the primary obligation extinguishes the secondary one. The cautioner is discharged by any essential charge. being made on the obligation of the debtor, or in respect of the person relied on, without his assent. The statute expressly provides that changes of partnership either of creditor or debtor will extinguish the guarantee. If the creditor gives time - e.g. takes bills from the debtor of an unusual currency-that will also operate discharge. The discharge of one cautioner, moreover, unless consented to by the rest, is a discharge to all. The cautioner is entitled, on full payment, though not on payment by a dividend, to an assignation of the debt and diligence, by which means he comes, in all respects, into the creditor's place; and moreover, if the solvency or other conditions of the principal debtor should seem precarious, he may 
adopt legal measures for his relief. Co-cautioners, or pensens hound together, whether their oljligations be embodied in one or geveral deeds, are entitled to mutual relief. But where a co-cautioner obtains relief from the others, he must communicate to them the benefit of any deduction or ease which may have been allowed him in paying the debt.

Letters of eredit and recommendation raise much the same relation of parties as a formal cautionary obligation, but since 1856 a mere verbal introduc tion cannot have that effect. For the forms and effects of ordinary mercantile guarantees, and for the forms of guarantee insurance of fidelity, see Guarantwe. For the Scottish cautionary obligation in cash-eredit bond, see BANKING, Vol. I. 713.

Judicial Caution, in the Law of Scotland, is of two kinds - for appearance, and for payment. If a creditor makes oath before a magistrate, that he believes his debtor to be meditating flight (in meditatione fugoe), he may obtain a warrant for his apprehension; and should he succeed in proving the alleged intention to flee, he may compel him to find caution to abide the judgment of a court (judicio sisti). The cautioner, or surety, undertakes that the defender shall appear to answer any action that may be brought within six months. The old Bond of Presentation, by which in order to gain time the surety undertook to produce the debtor or pay the debt at a future date, is now superseded by the abolition of imprisonment for debt. There is also a form of judicial caution called judicatum solvi, given in cases of general loosing of arrestment of ships, in which the surety becomes liable for the whole debt. The commonest form of judicial caution, however, is the security usually given in the Bill-chamber (q.v.), when a bill or bond is brought under suspension; the security is for the principal sum and expenses, if the suspension should be refused. Interdict is also frequently granted upon caution for the damages that may result from the interdict, should it turn out to have been wrongly obtained.

Cauvery. See Kavert.

Cava del Tirreni, a town of Italy, in a lovely valley, 51 miles NW. of Salerno by rail, with a cathedral, and manufactures of silk, woollens, cotton, and linen. Pop. 6339. About a mile distant is the Benedictine monastery of the Trinity, celebrated for its archives.

Cavagnari, SIR LouIs, born in France in 1841, was educated at Christ's Hospital, London, and in 1857 was naturalised as a British subject. He had seen twenty-one years' military and political service in India, when on 3d September 1879 he was murdered at Kabul. See AFGHANISTAN.

Cavaignae, Lours Eugrene, born in Paris, 15th October 1802, was a son of General Jean Baptiste Cavaignac (1762-1829), a member of the National Convention. Educated for the military profession, he first served in the Morea, and afterwards in Africa, whither he was sent in 1832 into a kind of honourable exile, in consequence of a too free ex. pression of opinion in favour of republican institutions. Here he won great distinction by his energy, coolness, and intrepidity, was made chef de bataillon in 1837 , and rose to the rank of brigade-general in 1844. In 1848 he was appointed governor-general of Algeria, but in view of the impending revolu. tionary dangers, was called to Paris and assumed the office of Minister of War. He was appointed military dictator in order to suppress the formidable insurrection of June, which he quelled only after a most obstinate contest continued from the 23d to the 26th June. It is estimated that a greater number of Frenchmen fell in the struggle than in the bloodiest battles of the first Empire. Cavaignac's elemency to the vanquished was equal to his generalship. His task being done, bo resigned his power into the hands of the Nutional Assembly, which appointed him President of the Conncil. As a candidate for the presideney of the republic, when Louis Napoleon was elected, he received nearly a million and a half of votes out of 7,327,345. On the coup d'etat of December 1851, Cavaignac was arrested, but released after a short detention; and though he consistently refused to give in his adheaion to the Empire, he was permitted to reside in France without molestation. He died, 28th Oetober 1857, at his country house near Tours. Cavaignac was an able soldier, a zealous republican, and in every way an honourable man. See his Life by Deschamps (2 vols. Paris, 1870).

Cavaillon (ancient Cabellio), a town of the French department of Vaucluse, 18 miles SE. of Avignon by rail, with a cathedral, and some Roman remains. Pop. 5164.

Cavalcanti, Guido, Italian poet, born in 1230 , was banished, for mercantile transactions with a Guelph, by the Ghibellines, a daughter of one of whose chiefs he had married, and returned in broken health to Florence only to die there, about 1300. His works sonnets, ballads, and canzoniare remarkable alike from their language and depth of thought, although his epicurean philosophy gained him, among his contemporaries, the reputation of an atheist. See Ercole, Guido Cavalcanti e le sue Rime (Milan, 1885). - Another of the name, BARTOLOMMEO (1503-62), a noble and eloquent Florentine, led a revolt against the Medici, and was afterwards employed by Pope Paul III.

Cavalcaselle, Giovanni Battista, Italian art writer, born $22 \mathrm{~d}$ January 1820 , at Legnago, early visited the art centres of Italy, and in 1846 proceeded to Germany, where he met J. A. Crowe (q.v.), with whom he returned to Italy. Banished for his share in the revolution of 1848 , he accompanied Crowe to London, and there their first joint work, Early Flemish Painters (1857 ; 3d ed. 1879), was published. Cavalcaselle returned to Italy in 1858, and afterwards published with Crowe the History of Painting in Italy (1864-71), Titian (1876), and Raphael (1883), besides independent works of less importance. He was head of the art department of the ministry of Public Instruction at Rome. Died in 1897.

Cavalier (Fr., from Lat. caballus, 'a nag'), from 'horseman' acquired the meaning of 'knight' or 'gallant,' in which sense it is used by Shakespeare (Henry V., III. 24), like cavalero, in Henry IV., Part II., V. iii. 62. In 164I 'Cavaliens' was applied as a nickname to Charles's partisans in opposition to the Roundheads, or friends of the Parliament; and from a term of reproach it cames to be adopted as a title of honour, until, after 1679 , it was superseded by "Tory." For the "Cavalier Parliament' (1661-79), see CharLes II.

Cavalier, JEAN, a journeyman baker, from Ribaute, near Anduze, who, born in 1681, in 1702 became a famous leader of the Camisards ( $\left.\mathrm{v}_{\mathrm{v}} \mathrm{.}\right)$, withal a prophet and preacher. He surrendered to Villars in 1704, and entered the service of Savoy; but in 1711 we find him settled with a British pension in England, and he died at Chelsea, governor of Jersey, 17th May 1740. See a long article in vol. ix. of the Diet. of National Biography (1887).

Cavaliere Servente. See Cicisbeo.

Cavalry is a general name for horse-soldiers or troopers trained to act in a body. In the British army there are 31 regiments of European, and 30 of native Indian cavalry. The former comprise 2 regiments of Life Guards (red), 1 of Horse Guards 
(blue), and 7 of Dragoon Guards, classified as heavy cavalry ; 3 regiments of Dragoons, and 5 of Lancers, classified as medium; and 13 Hussar regiments or light cavalry-all carrying carbines and swords. The war strength of each is 1 lieutenant-colonel, 1 major, 8 captains, 9 lieutenants, 7 sub-lieutenants, 1 adjutant, 1 paymaster, 1 quartermaster, 1 medical officer, 1 veterinary surgeon, 75 non-commissioned officers, 8 farriers, 8 shoeing-smiths, 8 trumpeters, 4 saddlers, 2 wheelers, 15 bandsmen, 480 troopers, and 22 drivers, 559 riding and 44 draught horses, and 11 wagons.

The native Indian cavalry are all light, and some have the front ranks armed with lances, the rear with sabres. Bengal has 19 regiments, each of 8 troops, consisting of 10 European officers ( 1 in command and 1 surgeon), 17 native officers, and 536 native non-commissioned officers and troopers. Madras has 4 regiments of only 6 troops each, the same number of European, but 12 native officers and 396 of other ranks. Bombay has 7 regiments with the same organisation and numbers as Bengal, but only 518 native non-commissioned officers and troopers. Besides these regiments there is a troop of native cavalry at Aden, and one as a body-guard for each lieutenant-governor, and the governorgeneral of India.

The auxiliary cavalry in Great Britain comprises 39 regiments of Yeomanry, 2 of Volunteer Light Horse, and 1 of Volunteer Mounted Rifles, of various strengths. 'There is a cavalry depôt at Canterbury, and a sehool of instruction for auxiliary cavalry at Aldershot.

After the American civil war, the United States' cavalry was reduced to 10 regiments of 936 privates each. The commissioned officers of a regiment consist of 1 colonel, 1 lieutenantcolonel, 3 majors, 12 captains, 14 first lieutenants, and 12 second lieutenants.

History.-For the place of cavalry in the ancient armies, see ARMY. In the middle ages horsemen - knights, esquires, and their attendants-formed the most importent part of the great armies; but after the disappearance of the Roman cohort with its 132 highly trained horsemen, the organisation of cavalry, as we now understand the word, was neglected until 1445, when Charles VII. of France grouped his men-at-arms into companies 100 strong. The method of fighting, from 1645 until Frederick the Great introduced the charge or shock tactics, was to advance to close quarters, fire pistols from the saddle, and then commence cutting with the sword. The value of dismounted cavalry able to act as infantry was then recognised, and dragoons armed with muskets were much in vogue until the beginning of the 19th century. They then lost favour, and they were taught that the sword was their proper weapon, and the saddle their proper place. Mounted infantry, however, using their horses merely as a means of rapidly covering the ground, have been found so useful in the British army that in 1887 a school for this arm was formed at Aldershot. The great importance of this branch was experienced in the Transvaal war (1899-1900), where all the Boer army were practically mounted infantry, and their mobility gave to them enormous advantage in proportion to their numbers. The future development of all armies is bound to be very largely in this direction. The usefulness of the lance as a weapon for regular cavalry in pursuit and other tacties has led the British war authorities to arm part of nearly all their eavalry regiments with it in addition to their other arms.

Formation. - A cavalry regiment in the field is divided into 4 squadrons, each of 2 troops. The men of each squadron when in line are 6 inches from knee to knee, and formed in two ranks, a horse's length apart. The officers are at a similar distance in front, and the 'serrefiles,' or supernumerary noncommissioned officers, in rear. There is an interval of 12 yards between squadrons. The pace is, walk 4 miles an hour, trot 8, gallop 12. The maximum distance covered by cavalry is 68 miles by day ( 6 A.M. to 10 P.M.) and 18 by night -86 for the 24 hours; but after such a march there must be a rest all next day. For a continuous march 35 miles a day, at 5 miles an hour, is a good rate.

Duties on Service. - In large armies, from one. eighth to one quarter of the whole force should be cavalry. Their duties are to cover the movements of their own army, and to find out those of the enemy-besides taking part in the actual battles by guarding the flanks, seizing all opportunities of charging, completing success by an active pursuit, or covering defeat. The screening and reconnoitring duties are performed by the cavalry divisions, each of two or more brigades, one or two days' march in front of the main body. The light Brigades (q.v.) are perhaps best for the actual scouting, but must be supported by heavy cavalry in order to meet that of the enemy, which would otherwise have the advantage of greater weight in the charge. Each brigade of two or more regiments is accompanied by a battery of Horse Artillery.

The battle of Mars la Tour in the Franco-German war of 1870, supplies the best examples of a cavalry fight on a large scale, and of a charge (that of Barby and Bredows' brigades) directed against infantry. The action of the German cavalry throughout the same campaign illustrates the screening and reconnoitring duties of the arm. The capture of Cairo by the rapid advance of the British cavalry after the battle of Tel-el-Kebir (1882), shows its value after a successful engagement.

Tactics. - Unless acting dismounted, cavalry must either attack or retire; it cannot otherwise defend itself. Against cavalry it must therefore manouvre with its first line, so as to attack to the best advantage-i.e. against the adversary's flank. Its second line following, en échelon, in order to have a clear front, protects the flanks of the first from counter attack, and supports its movement, completing its victory, or covering its retreat. Horse artillery on the protected flank fire upon the enemy up to the last moment before the charge. A third portion, formed into a reserve, follows, and behind it the other two can rally after the charge, which, even when successful, creates great confusion. Cavalry attacks artillery in two bodies-one in line formation charges the escort, and the other in extended order, the men a horse's length apart, converges upon the guns. Infantry can defend itself from a cavalry charge, unless surprised by a flank attack, which would generally be delivered by comparatively small bodies in successive lines, but such an opportunity rarely occurs on a modern battlefield.

Cav'an, an inland county in the south of Ulster. It lies in the narrowest part of Ireland, 18 miles from the Atlantic, and 20 from the Irish Sea. Area, $746 \mathrm{sq} . \mathrm{m}$., of which less than a third is under crops. Bogs and hills, with many small lakes, are found in the north-west, where Cuilcagh attains a maximum altitude of 2188 feet. The chief rivers are the Erne, the Woodford, and the Annalee. The eastern half of Cavan rests on clay-slate and graywacke; the mountain district in the west is carboniferous formation. of minerals, Cavan affords coal, iron, lead, and copper, with many mineral springs. The climate is cold and damp; and the soil is poor, wet, and clayey, except along the streams. The chief crops are oats and potatoes, the cultivation of flax having greatly decreased since 1850 . The farms are small. Agriculture forms the staple industry, but linen is manufactured to a considerable extent. The chief towns are Cavan, Cootehill, and Belturbet. Cavan returns two members to parliament. Pop. (1851) 
174,064 ; (1881) 129,476 ; (1891) 111,679 , of whom 90,329 were Catholics, and 16,325 Episcopalians. Cavar, the county town, stands on a branch of the Aunalee, 85 miles NW. of Dublin by rail. It has a court-house and a grammar-school; and the beautiful demesne of Lord Farnham lies between Cavan and I.ough Onghter, which is about 5 miles west. Pop. about 3000 .

Cavatína, a short form of operatic air, of a smouth and melodious character, differing from the ordinary aris in consisting only of one part, and freyuently appearing as part of a grand scena. Examples of cavatina are found in many well. known operas, as Sonnambula and Les Huguenots. The term is also often used for a complete air or song, such as the 'Salve dimora' in Faust.

Cave, or CAvern (Lat. cavus, 'hollow'). The natural hollows which occur in and underneath rocks have originated in various ways - some being due to the chemical and mechanical action of water, others to dislocations and dismuptions produced by movements of the crust, or by superficial rock-falls and landslips, while yot others are tunnels which now and again oceur in or under thick sheets of lava. Caves formed by marine erosion are frequently met with along the coast-line of Britain and other countries, Fingal's Cave at Staffa (q.v.) being a splendid example. They are not confined to any particular kind of rock-although, other things being equal, they are of course more easily formed in readily yielding rocks than in more durable kinds. It is rather the character of their natural division. planes or beds and joints than their composition and texture that determines whether the rocks at the base of a sea-cliff shall be hollowed out or not by the action of the waves. If the rocks are thinbedded and abundantly and regularly jointed, it is obvious that as soon as any portion is undermined by the sea, the overlying masses will immediately yield along their division-planes and topple down. If, on the other hand, the rocks are meagrely and irregularly jointed, and occur in massive beds, then they will not so readily collapse when undermined, and caves will tend to be formed. Caves which have had this origin are not uncommonly met with along the line of old sea-margins in many regions which have been elevated in recent geological times. Most frequently, however, the entrances to such caves are concealed by the rock-rubbish which has been detached from time to time by the action of the weather from the cliff's above. Caves of erosion are also formed by river-action at the base of erags and cliffs in many valleys. And now and again such hollows may be detected at various levels in river-cliffs, as if they had been formed during the gradual excavation of the ravines in which they occur.

In Britain and other countries long oceupied by man most of such river-cliff caves or rock-shelters have been artificially deepened and widened, and this to such an extent that it is often hard to say how much of the work can be attributed to nature. By far the most important caves, however, are those which owe their origin to the action of underground water. But before these are described, mention may be made of the hollows which occur now and again in and under lavaflows. Where lava has flowed over and solidified above a mass of snow and ice, the subsequent melting of the latter will leave a hollow behind. Near the Casa Inglese, on the south-east side of the highest cone of Etna, a mass of ice of unknown extent and thickness, covered by lava, was seen by Lyell in 1828 and again in 1858. But this, it must be remembered, is at a height of 10,000 feet above the sea. In lava itself, however, caves of considerable extent occur. Many of these are simply great blisten or hollows formed by the expansive power of the highly heated vapours contained in the lava at the time of its eruption. Others again may have been caused by the sudden conversion into steam of the water of lakes or streams suddenly overwhelmed by a lavaflow-the steam thus generated might either violently rupture the lava by its explosive force, or uroluce great tunnels and irregular cavities under the liquid lava, already inclosed in its solid crust, by pressing it upwards. The extensive Fossa della Palomba of Etna is supposed by some to have had such an origin. But probably the greater number of the larger caves under lava have been formed by the escape of the lava itself from its own solidified envelope. When lava pours out from a voleanic orifice it very rapidly coagulates above and below, so that the liquid rock becomes im. prisoned in a hardened erust of its own material. The great pressure of the inclosed lava, however, upon the erust at the terminal point of the flow suffices again and again to rupture it, and the lava then flows out freely until it is again imprisoned in the same manner. In the case of very liquid lavas this escape is often completed in a perfect manner - and a long underground tunnel is left behind, from the roof of which depend long stalactites of black glassy lava. Extensive caves formed in this way - some of them measuring over 100 feet in width-occur in the Azores, the Canary Islands, Iceland, and other volcanic regions.

Another class of caves embraces such hollows as have originated during earthquakes or other movements in the crust of the earth. At such times rocks are rent asunder, and when they fall rudely together irregular cavities are left between the disjointed masses, and similar results often take place when great landslips oceur. But the most extensive caves and underground galleries have been excavated by the chemical and mechanical action of underground water. Sometimes these hollows continue more or less persistently in one direction, but most usually they wind tortuously about, and often open into similar intricate galleries, which, in like manner, communicate with lateral extensions of the same character. There can be no doubt that caves of this kind are the channels of underground streams and rivers, and that they have been excavated, in the first place, by the chemical action of acidulated water making its way downwards from the surface along the natural division-planes of the rocks, until eventually space has been licked out for the passage of a subterranean stream. The cavities would then tend to be enlarged by the filing action of the sand and gravel which the underground stream and its numerous feeders might sweep along. Many such underground watereourses are well known at the present day, and the direction of some of them can be traced by the swallow-holes, chasms, and 'sinks,' which indicate places where the roofs of the cavities have given way, or have been pierced by the action of acidulated water. In certain regions almost all the drainage is thus conducted underground-rivers after llowing for \& considerable distance at the surface suddenly dis. appear, and follow a hidden course, for it may be many miles, before they emerge again to the light of day. Sometimes, indeed, they never come to the surface again, but enter the sea by subterranean channels. Should anything oceur (such as earthquakes, \&c.) to interrupt such a system of underground drainage, and the streams and rivers be compelled into new channels, the old subterranean courses will then become galleries more or less dry, which may be accessible by one or even by several openings.

As it cannot be doubted that all such great 
underground galleries owe their inception entirely to the ehemical action of water seeking its way downwards from the surface, and following the lines of natural division-planes in the rocks, it is obvious that caves will be of most common oceurrence in regions where the rocks yield most readily to such chemical action. Among the more soluble rocks are rock-salt and gypsum, but these are only locally developed in such quantities as to give rise on their removal to underground cavities of any extent. Calcareous rocks, more especially limestone, have not only an almost world-wide distribution, but they also occur in greater mass than either gypsum or rock-salt, and hence, although not so readily acted upon by water as the latter two, it is in limestones that nearly all the most renowned caves and subterranean galleries appear.

Many caverns have a calcareous incrustation lining their interior. Sometimes this deposit is pure white ; it is, however, more generally coloured by the impurities which the water, percolating downwards from the surface, has taken up from the superincumbent rocks. To the incrustations which are suspended from the roof like icicles, the name stalactites is given, while those rising from the floor are called stalagmites. The origin of these is as follows: Water which has percolated down from the surface always contains a certain proportion of carbonic acid-it is acidulated water-the acid being derived from the atmosphere and the decaying organic matter of the soil, \&e. Water thus charged with carbonic acid has the power of dissolving limestone-i.e. it takes up a certain proportion of carbonate of lime and converts it into the soluble bicarbonate. Arrived at the roof of a cave it oozes out and is there subject to evaporation, the excess of carbonic acid is parted with, and a thin pellicle of carbonate of lime is deposited as an incrustation. When the drops fall to the floor they are subject there in the same way to evaporation, and are thus compelled to give up the remainder of the calcareous matter held in solution. By this constant dropping and falling, icicle-like pendants grow downwards from the roof, while sheets, bosses, and domes gradually accumulate upon the floor-until, not infrequently, these stalagmites come at last to unite with the gradually lengthening stalactites, and so to form, as it were, pillars which look as if they had been placed to support the roof. See the articles on ADELsberg, AGTELEK, Kent'S CAVerN, Mammoth CaVE, \&C.

BONE-CAVES. - Caves are of interest to geologists not only because they testify to the potency of the chemical and mechanical action of underground water, but on account of the remarkable evidence they have yielded as to the contemporaneity of man with many extinct and no longer indigenous mammals. This evidence is furnished by the accumulations which so frequently cover the floors of caverns to a greater or less depth. The accumulations in question consist partly of clay, sand, gravel, and shingle, and partly of red earth and sheets of stalagmite. Some of these are doubtless the alluvial detritus carried forward by underground streams. This detritus often consists largely of angular, subangular, and water-worn fragments of limestone, which have doubtless been derived from the roof and walls of the nnderground galleries, but not infrequently the presence of other kinds of rock-fragments shows that no inconsiderable amount of material has been introduced from the outside by the streams as they plunged into their subterranean courses. Much debris also may have been swept in by heavy rain or flooded torrents washing down through the sinks and swallow-holes that so frequently pierce the roofs of subterranean watercourses. These sinks often become pitfalls to unfortunate cattle in our own day, and in former times many animals may have been entrapped in the same way-for broken and rubbed bones often occur, sometimes very abundantly, in the old torrential accumulations of deserted subterranean watercourses. When the galleries ceased to be traversed by streams, stalagmitic accretions would then begin. to accumulate over the shingle and debris beds. In course of time many of these subterranean. hollows, becoming more or less accessible from the outside, were occupied by carnivorous animals, who carried thither their prey, and thus by and by accumulations of bones were formed, which the drip of water from above gradually inclosed in calcareous matter, and eventually covered up under a sheet of stalagmite. Now and again the caves were occupied for shorter or longer periods by man-his presence being still evidenced by his implements and weapons, by charred and split bones, \&c., and occasionally by portions of his own skeleton-and these relics, in like manner, subsequently became sealed up in a more or less thick accumulation of stalagmite. Some of these bone-caves contain the record of many physical changes. Thus, we have evidence to show that after having been the haunt of wild beasts. or the abode of man for some indefinite but often prolonged period, the cave again gave passage to a flow of water, and deposits of loam, clay, or gravel, \&e. were laid down upon the stalagmitic pavement and bone-breccia. Or, as in some cases, the stalagmite, together with bones covered by and inclosed within it, was broken up and partially or wholly removed. Then, at a subsequent date the stream once more deserted its channel, while carnivores or man again returned, and newer heaps of bones and stalagmite accumulated. Commingled with these stalagmites of the bone-caves there is almost always more or less of a reddish earth or clay, which is the insoluble residue of the limestone from the dissolution of which the stalactites and stalagmites are formed. Some of the more remarkable bone-caves which have yielded testimony as to the contemporaneity of man with extinct mammalia, are Kent's Cavern (q.v) and Brixham Cave in England, the caves in the valley of the Lesse in Belgium, the caves of Perigord and the Pyrenees in France, and the Kesserloch near Thäingen in Switzerland. Bone-caves containing the remains of post-tertiary mammals are rave in North America; those of Brazil have many bones of large rodents and edentates. For caves at Wick, in Scotland, still occupied by tinkers, see Sir Arthur Mitchell, The Past in the Present (1880). For accounts of special caves, see the British Association Reports (for Kent's Cav. ern) and the Philosophical Transactions (1822-73). For general descriptions, see Buckland's Reliquice Diluviane, Dupont's L'Homme pendant les Ages. de la Pierre, Lartet's and Christy's Reliquiae Aquitanice, Lubbock's Prehistoric Times, Dawkins' Cave-hunting, J. Geikie's Prehistoric Europe. For further information as to the European cavedwellers of prehistoric times, see MAN, FLINT Implements, Pleistocene SYstem.

Artificial Caves.-The primitive inhabitants of most eivilised countries and many primitive tribes at the present day have been troglodytes or cave-dwellers. In many countries where natural caves are either of rare occurrence or do not occur at all, certain rock-exposures have been artificially excavated, and occupied either permanently as dwelling-places or occasionally as retreats in times of danger, while others have been used as cells, hermitages, or burial-places. Such caves are not uncommon in the cliffs of Scottish river ravines, as at Hawthornden near Edinburgh, and in the valley of the Jed, Roxburghshire. Caves of this kind sccur usually in rocks that are readily dug. into, such as soft sandstone. Now and again, 
they have been excavated in conglomerate, as in the case of Hobbie Noble's Cave, Roxburghshire. In volcanic regions it is the softer tuffs or ashes that are usually holed, as in the caves of the Canary Islands. There the Guanches have also exeavated eaves under the lavas, by simply raking wit the more or less loose scorise and einders which so commonly oceur in that position. Vast areas in Central China are covered with a colierent loam, of the same character as the Loess (q.v.) of the valleys of the Rhine and Danube, in which dug. int dwelling-places are of common occurrence. And a similar deposit, exposed along the bluffs of rivers in the far west of North America, has been utilised by some of the early inhabitants in the same way. In Arizona, parts of Colorado, Nevada, Utah, and south-east California, the rocky precipitous walls of deep eañons are in places riddled with human habitations, so as to look like honeycombs. The strata forming the walls of the caions have been eroded in different degrees, and horizontal caves larger and smaller have been formed. The cliff dwellings are often adobe or stone structures built on the ledges overhung by projecting rock masses; smaller eaves have served as dwellings, and been partially completed by adobe walls. Some of these honses are at a height of 700 feet above the level of the valley, and are with diffieulty accessible. They seem to have been made as places of refuge and defence by the same ancient races as left the pueblos or stone ruins in the valleys, like those occupied by the Pueblos and Moqui Indians now. Some assume them to have heen the ancestors of the present Pueblos; others that they were akin to the Aztees. See Hayden in Stanford's North America; Nadaillac's Prehistoric America (Fng. trans. 1885); and the U.S. Survey Reports since 1874.

Hermitages, belonging to all ages, some of very simple, others of a more elaborate construction, bave in like manner been exeavated in rocks of very different kinds; so that we are presented with every variety of artificial rock-excavation, from simple hollows seraped out of some soft yielding material to the richly ornamented grottoes and temples of Ellora, near Daulatabad, which are cut out in red granite. And so again in the matter of rock-tombs we meet with artificial grottoes of all kinds-from mere holes picked out without much trouble in loess, tuff, sandstone, or other yielding substance, to the great rock-cut sepulchres of Egypt, and the no less famous catacombs of Rome. Many caves have been doubtless partly natural, partly artificial-the cells of the monks of the Thehuid in Erypt, St Serf's cave at Dysart, St Ninian's at Whithorn. For the cave-dwellers known to the ancients, see Troglodytes, PETra. For the Indian cave-temples, gee ElEPHANTA, ELLora.

CAVE-ANimals. - Various caverns, both of the Old and New World, are tenanted by animals which are usually more or less blind. From one point of view the eyes have degenerated from disuse and from the absence of the necessary light stimulus; from another point of view they have degenerated because no longer of use, and no longer maintained by that natural selection which through the struggle for existence is supposed by many to be necessary not only for the establishment, but for the main tenance of organs. The fauna of the Mammoth Cave of Kentucky has been most-studied, and is catalogued with figures in Putnam and Packard's description of that famous cavern. Leydig has made a special study of the highly developed tactile organs borne by some fishes frequenting German caves. Among the cave-animals may be noticed the amphibian Proteus (q.v.) with eyes in an em. bryonic state; various Blind Fish (q.v.), such as Amblyopsis (q.v.), Typhlichthys, \&e.; hundreds of blind insects, of which in some cases (Machorites) only the females are blind; blind spiden and myriaworls; many Crustaceatus (Niphargus putecenus, Titanethes albus, Crangonyx, Asellus sieboldii, \&ce.): a few univalves and other forms.

It is noteworthy that the blindness may exist in various degrees, some being totally blind and other possessing rudimentary eyes. It is also to be remembered that not all cave-animals are blind, but forms with well-developed organs of vision also occur. Fish, insects, spiders, myriapods, and crustaceans with well-developed eyes have been recorded from various caves, and the explanation of this persistence of organs in such environment is still to find. See DEGENERATION, ENVIRONMENT, and Semper's Natural Conditions of Existence as they affect Animal Life (International Science Series, 1881).

Cave Bear, Hyana, Lion, \&e.-(1) U'rsus spelaeus, a fossil bear, like those now living, found very abundantly in the Pleistocene caves of Europe. (2) Hyøena spelaea, once abundant in Britain and other parts of Europe, and very elosely allied to the $H$. crocute now found in Africa. (3) Felis speloea, a fossil lion, very like the modern form, abundant in caves of England and Europe generally. The prefix cave obviously refers to the fact that in caves the fossil remains of recent animals are well preserved and abundantly found.

Cave, EDwarD, the founder of the Gentleman's Magazine, wes born at Newton, Warwickshire, in 1691 ; received some sehooling at Rugby; and after many vicissitudes, became apprentice to a printer. Obtaining money enough to set up a small printing. office, in 1731 he started the Gentleman's Mayazine, the earliest literary journal of the kind. Samuel Johnson became its parliamentary reporter in 1740 ; and with his hand in Johnson's, Cave died on 10th January 1754.

Cave, William, divine, born at Pickwell, Leicestershire, in 1637, from Oakham school passed to St John's College, Cambridge (1653), and was appointed to the vicarage of Islington (1662), to the rectory of Allhallows the Great, London (1679), and to the vicarage of Isleworth, Middlesex (1690). He died at Windsor, 4th July 1713. Among his twelve works on church history are Lives of the Apostles, Lives of the Fathers, and Primitive Christianity, which once were standard authorities.

Caveat is a formal warning, entered in the books of a court or a public office, that no step shall be taken in a particular matter without notice to the person lodging the caveat, so that he may appear and object. Thus, eaveats are frequently entered at the Patent Office to prevent the unopposed granting of letters-patent; or at the Probate Court to prevent the unopposed making up a title to the property of deceased persons; or at the Admiralty Court to prevent the-unopposed arrestment of a ship. The term is also used in ecelesiastical practice in England; although a cavente.g. against an institution to a particular beneficehas not now the high effect attributed to it by the Canon Law. In Scotland the term is confined to such notices as are placed in the Bill Chamber (the summary department of the Supreme Civil Court) or in the Sheriff Courts to prevent any interdict being granted without notice to the person interested. Such caveats require to be renewed every month.

Cavedone, Gracomo, an Italian artist of the Caracci school, born in 1577 at Sassuola, assisted Guido Reni at Rome, and finally settled in Bologna, where many of his religious pictures are preserved. He died in poverty in 1660 .

Cavendish, the surname of the ducal House of Devonshire, a family directly descended from the 
chief-justice Sir John Cavendish, who in 1381 was beheaded at Bury St Edmunds by Jack Straw's followers; and from Sir William Cavendish of Cavendish, Suffolk (circa 1505-57), a brother of Wolsey's biographer. His third wife, the celebrated 'Bess of Hardwick,' afterwards Countess of Shrewsbury, brought Chatsworth (q.v.) into the family; and William, their second son, was in 1618 made Earl of Devonshire. His great-grandson, William (1640-1707), was, under the last two Stuarts, a steadfast member of the Whig opposition, Russell's friend to the death, and an active promoter of the Habeas Corpus Act. He succeeded as fourth earl in 1684, and, for his services at the Revolution, was in 1694 raised to be Duke of Devonshire and Marquis of Hartington. His great-grandson, William (1720-64) succeeded as fourth duke in 1755 , and was prime-minister from November 1756 to the following May. William, fifth duke (1748-1811), was a bit of a poet; but is less remembered than his beautiful duchess, whom Gainsborough and Reynolds painted. William, sixth duke (1790-1858), was chiefly distinguished by his sumptuous embassy to St Petersburg (1826). William, seventh duke (born 1808), had for twenty-four years been Earl Burlington when he succeeded his cousin in the ducal title. He died 21st December 1891, and was succeeded by his eldest son, SPENCER COMPTON CAVENDISH, ninth Duke of Devonshire, born 23d July 1833, and educated at Trinity College, and for thirty-three years known as Marquis of Hartington. He entered parliament in 1857, being first returned for North Lancashire, then in 1869 for the Radnor boroughs, in 1880 for North-east Lancashire, and in 1885 for the Rossendale division of that county. The representative of a great Whig house, he was chosen as early as 1859 to move the vote of want of confidence that overthrew the Derby government, and between 1863 and 1874 held office as a Lord of the Admiralty, Under-secretary for War, War Secretary, Postmaster-general, and, from 1871, Chiefsecretary for Ireland. Neither a born statesman nor great orator, he had yet shown an 'infinite capacity for taking pains,' when, in February 1875, on Mr Gladstone's temporary abdication, he was chosen leader of the Liberal opposition. He led it admirably, and in the spring of 1880 , on the downfall of the Beaconsfield administration, was invited by the Queen to form a ministry. He rejected the offer, and served under Mr Gladstone, first as Secretary of State for India, and then as War Seeretary from 1883 to 1885 . But he wholly dissented from Mr Gladstone's scheme of Irish Home Rule; and from 1886, as head of the Liberal Unionists, he firmly supported Lord Salisbury, both when in power and in opposition.

His younger brother, Lord FREDERICK CAVENDISH, was born 30th November 1836, and was also educated at Trinity், taking his B.A. in 1858. He sat in parliament as Liberal member for the northern division of the West Riding of Yorkshire from 1865 till the spring of 1882 , when he succeeded Mr Forster as Chief-secretary for Ireland. Between seven and eight o'clock, on the evening of 6th May, having only that morning reached Dublin, he and Mr Burke, an unpopular subordinate, were stabbed to death in the Phoenix Park. Eight months later, twenty 'Irish Invincibles' were tried for the murder, and, Carey and two others having turned Queen's evidence, five of the rest were hanged, three sentenced to penal servitude for life, and the remaining aine to various terms of imprisonment. Carey himself disappeared; but in July news came from the Cape that he had been shot dead by an Irishman named O'Donnell on board an emigrant ship. O'Donnell was brought back to London, and hanged.
Cavendish, GEORGE, the biographer of Wolsey, was born about 1500, and became Wolsey's gentleman-usher at least as early as 1527. He remained in close attendance upon his great master till the end (November 28, 1530), after which he retired to his house at Glemsford, in Suffolk, where he lived quietly with his wife, a niece of Sir Thomas More, till the close of his own life in 1561 or 1562 . His affection for the great cardinal was most devotedhe had attached himself to his household, in Wolsey's own words, 'abandoning his own country, wife, and children, his own house and family, his rest and quietness, only to serve me.' He never laid aside his loyalty to his memory, but in the quiet meditation of after-years brooded over his fall, and from it learned for himself 'the blessedness of being little.' Thirty years after he wrote his Life of Cardinal Wolsey, one of the most in. teresting short biographies in the English language. Its pensive wisdom and simple sincerity reflect a pleasing picture of the gentle and refined nature of its author, and enable us to see intimately with our own eyes, but with singular clearness, the outlines of one of the grandest figures in our history. The book, written by a devout Catholic, full of regrets for the past, could not well be printed in Elizabeth's reign, but circulated pretty freely in manuscript copies, as many as twelve of which are still extant. It is almost certain that Shakespeare had read it before writing or collaborating in Henry VIII., as all the redeeming features in the picture of the great cardinal, and the lesson of his fall as a solemn homily upon human ambition, are directly due to the tender and loyal touch of Cavendish. The book was first printed imperfect, for party purposes, in 1641. The best edition is that of $\mathrm{S}$. W. Singer (2 vols. 1815), the text of which was reprinted with a good introduction in Professor Henry Morley's 'Universal Library' (1886).

Cavendish, Henry, natural philosopher, eldest son of Lord Charles Cavendish, and a grandson of the second Duke of Devonshire, was born at Nice, October 10, 1731. From a sehool at Hackney he passed in 1749 to Peterhouse, Cambridge, but quitted it three years later without a degree; thereafter he devoted the whole of his long life to scientific investigations, a large fortune bequeathed him by an uncle enabling him to follow uninterruptedly his favourite pursuits. A silent, solitary man, he hated so to meet strangers, that he had his library - a magnificent onein London, four miles from his residence on Clapham Common, so that he might not encounter persons coming to consult it; whilst his female domestics had orders to keep ont of his sight, on pain of dismissal. His dinner he ordered daily by a. note placed on the hall-table. He died, unmarried, at Clapham, 10th March 1810, leaving more than a million sterling to his relatives. As a philosopher, Cavendish is entitled to the highest rank. To him it may almost be said we owe the foundation of pneumatic chemistry, for prior to his time it had hardly an existence. In 1760 he discovered the extreme levity of inflammable air, now known as hydrogen gas - a discovery which led to balloon experiments and projects for aẻrial navigation; and later, he ascertained that water resulted from the union of two gases-a discovery which has erroneously been claimed for Watt (q.v.; see also WATER). The famous Cavendish Experiment was an ingenious device for estimating the density of the Earth (q.v.). The accuracy and completeness of Cavendish's processes are remarkable. So high an authority as Sir Humphry Davy declared that they "were all of a finished nature, and though many of them were performed in the very infancy of chemical science, yet their accuracy and their beauty have remained unimpaired.' Cavendish also wrote 
on Ratronomical instruments; and his Electrical Reseurihes (1771-81) were edited by Prof essor Clerk Maxwell (1879). See his Life by ('. Wilson, forming vol. i. of the Cavendish Society's Works (1846).

Cavendish. Тномав, cireumnavigator, was born about 1555 at 'Trimley St Martin, near Ipswich, and, after squandering his patrimony at court, shared in Crenville's experlition to Virginia (1585). On 2lst July of the following year he sailed from Plymouth with 122 men and three ships of 10,60 , and 140 tons, and, by Sierra Leone and Brazil, reached the Strait of Magellan, whose passage took seven weeks. During the nine months that he cruised in the Pacific, he burned three Spunish towns and thirteen ships; then, with a rich booty, but only the largest of his three vessels, he returned by way of the Indian Archiwhlagu and the Cape of (rood Hope to England, 10th September 1588. Elizabeth knighted him, and he took to his old mode of life, till in August 1591 he sailed on a second expedition, intended to rival the first. It ended in utter disaster, and in 1592 Cavendish died broken-hearted off Ascension.

Cavendish. WiLina, Duke of Newcastle, son of Sir Charles Cavendish, and nephew of the first Earl of Devonshire, was born in 1592, and edueated at St John's College, Cambridge. His learning and winning address made him a favourite at the court of James I., who in 1610 ereated him Knight of the Bath, and in 1620 Viscount Mansfield. Charles I., who was splendidly entertained by him at Welbeck and Bolsover, in 1628 ereated him Earl of Newcastle, and in 1638 appointed him governor to his son, afterwards Charles II. His support of the king during the contest with the parliament was munificent. He contributed $£ 10,000$ to the treasury, and raised a troop of 200 knights and gentlemen, who served at their own cost. As general of all the forces north of the Trent, he had power to issue declarations, confer knighthood, coin money, and raise men; and the last part of his commission he executed with great zeal. After the battle of Marston Moor (1644), Cavendish retired to the Continent, where he resided, at times in great poverty, till the Restoration. In 1665 he was created Duke of Newcastle; and he died 25th December 1676. He was author of two works on horsemanship, and of several plays, not of a character to increase any man's reputation for intelligence. See his Life by his second wife (1667; new ed. by C. H. Firth, 1886).-She, MARGARET LuCAs (1624-74), the daughter of an Essex house, where 'all the brothers were valiant, and all the sisters virtuous,' had married him in 1645 , and was herself the author of a dozen folio volumes of poems, plays, letters, \&c.

Caviare, the salted roes (immature ovaries) of the common sturgeon (Acipenser sturio) and other fishes of the same genus (see STURGEON). It is chiefly prepared in Russia, where, as in various other countries, it is a favourite delicacy, and is largely made in the United States; though the phrase 'Caviare to the general," shows that the taste is an acquired one. The species of sturgeon from the roe of which it is chiefly prepared inhabit the Caspian and Black seas and their tributary rivers. Among them are the Bie. laga, or Great Sturgeon (A. huso), the Osseter (A. güldenstädtii), the Seherg or Sevruga (A. stellatus), and the Sterlet ( $A$. ruthenus), the last-named problucing a prorticularly delicious eaviare. Astraklan is a principle seat for its preparation. The eggs are separated from the connecting tissue, salted, and packed in small barrels; or, the roes are salted in long troughs, and the eggs are passed through a sieve into kegrs. The Caspian fishery has produced over $400,000 \mathrm{lb}$. in a single year.
Cavité, a seaport of I,uzon, Philippine Islands, on a peninsula in Manila Bay, 8 miles $\$$ W. by 8 . of Manila. It is fortified, has an arsenal, and was formerly the chief naval station of the Spanish pos. sessions in the east. Pop. 1947.

Cavour, Count Camillo Benso Di, the restorer of Italian unity and nationality, was born at Turin, August 10, 1810. He was descended from one of the ancient noble families of Piedmont, and being the younger son was destined for a military career. At the military school he distinguished himself by his mathematical talent, and at an early age was appointed to a post in the engineers. But as his liberal opinions proved unfavourable to his stay in the army, he left it in 1831. His good sense, however, taught him that the deliverance of Italy could not be accomplished by secret conspirscy and spasmodic revolutionary outbreaks. There was nothing for him therefore but to retire into private life.' Here he devoted himself to agriculture, introducing great improvements in the cultivation of the family estates; and his efforts generally to raise the economic condition of Piedmont were thorough and enlightened. But he had a further end in view; he saw that economic improvement must be the basis for a better social and political order. And he widened his knowledge of economic and political questions by foreign travel, especially in France and England. Constitutionalism as established and practised in England was on the whole the form of government he most admired. During a residence in England he made himself intimately acquainted with the political organisation of the country, and also with its industrial institutions; knowledge of which he made good use on his return to his own country.

In this way for sixteen years Cavour energetically laboured as a private gentleman. No opportunity presented itself for any effective influence in politics, and he wisely abstained. It was very different when the spirit of freedom and innovation once more awoke towards the revolutionary period of 1848. In conjunction with Count Cesare Balbo, he in 1847 established a newspaper, Il Risor. gimento, in which he advocated a representative system, somewhat after the pattern of the English constitution, as opposed alike to absolutism on the one hand, and mob rule on the other. On his suggestion, the king was petitioned for a constitution, which was granted in February 1848. In the Chamber of Deputies, during the stormy period which succeeded Charles Albert's declaration of war against Austria in March, Cavour strenuously opposed the ultra-democrats, and counselled an alliance with England as the surest guarantee for the success of the Italian arms. In the Marquis d'Azeglio's ministry, formed soon after the fatal battle of Novara, Cavour was successively Minister of Agriculture and Commerce, Minister of Marine, and Minister of Finance. In 1852 he was appointed to succeed $D^{\prime}$ Azeglio as premier. From this time until his resignation in 1859 , in consequence of the conclusion of the peace of Villafranca, Cavour was the originator as well as the director of the Sardinian policy. Taking upon himself at different times, in addition to the premiership, the duties of the Ministers of Finance, Commerce, and Agriculture, and latterly of Home and Foreign Affairs, he greatly improved the fnancial condition of the country, introduced measures of free trade, consolidated constitu. tionalism, werkened elerical influence, and made Sardinia a power of some account in Europe.

Hitherto the work of Cavour had been to reform Piedmont, and place its affairs on a sound basis. The Crimean war afforded him an opportunity to begin the task of restoring the unity and national 
independence of Italy. It was through his advice and influence that Sardinia took part in the war, and as a result of this he managed to bring the Italian question before the Congress of Paris in 1856. In 1858 Cavour had with the Emperor Napoleon a secret meeting, at which the programme for driving Austria out of Italy was drawn up, and during the early part of 1859 there followed a diplomatic contest with Austria, which Cavour conducted with masterly tact and astuteness. The peace of Villafranca, coming after the successful war of 1859, and leaving Austria in possession of Venetia, was a bitter disappointment to Cavour. He resigned his office; yet he had no reason for despair, as the power of Austria in the Italian peninsula was now really broken. On returning to office in 1860 he resumed his great undertaking, but by new methods. Popular feeling in central Italy declared itself in favour of union with the north, and thus Parma, Modena, and Tuscany came under the sway of Victor Emmanuel. It was the part of Cavour to guide opinion towards this end, gaining time for it while he negotiated with the great powers; but he had to purchase the acquiescence of France by the surrender of Nice and Savoy. He secretly encouraged the expedition of Garibaldi, which in 1860 achieved the deliverance of Sicily and southern Italy. When a Sardinian army marched southwards and on the plains of Campania met the volunteers of Garibaldi, the unity of Italy was already an accomplished fact. In 1861 an Italian parliament was summoned, and Victor Emmanuel was declared king of Italy. For the completion of Italian unity only Rome and Venetia were wanting; with a little patience they too could be won.

Thus had Cavour achieved the task of his life. But it had not been accomplished without a fearful strain on his health. He had to manage the Sardinian parliament, to meet the artifices, protests, and reproaches of many of the great powers, to prevent revolutionary parties from upsetting the practical mission on which he was engaged, and to direct a great popular and national movement towards a reasonable and attainable goal by methods involving the minimum of delay and violence. For the real power of Sardinia was comparatively limited, and a false step might have been serious. The constant strain was too much for him, and he died June 6,1861 , only a few months after the unity of Italy had been proclaimed. The last words he was heard to utter were those so familiar as expressing an important feature of his policy : "Brothers, brothers, the free church in the free state.' Cavour is admitted to be the beau ideal of a practical and constructive statesman, who, aiming at just and reasonable ends, seeks to achieve them by effectual and legitimate methods. He made a reformed Piedmont the basis for attaining the unity and regeneration of Italy. The ambition of Napoleon, the military gallantry of the king, the enthusiasm of Garibaldi, were all made to cooperate towards his plan for atisfying the national aspirations of Italy under a lasting constitutional rule. Through his early death much of the work necessary for a sound and healthy national life was left unfinished, yet the subsequent history of Italy proves that Cavour had built on a solid foundation. He deserves a place among the greatest statesmen of modern times.

The title is taken from the small Piedmontese town of Cavour, 28 miles SW. of Turin. See De la Rive, Le Comte de Cavour, Récits et Souvenirs (Paris, 1863; Eng. trans. of same date); Bianchi, La Politique de Cavour (Turin, 1885); his Lettere, edited by Chiala ( 6 vols. 1883-87); also the biographies of him by Massari (Turin, 1873) and Mazade (Paris, 1877 ; Eng. trans. of same date).
Cavy (Cavia), a genus of Rodents, best known by the domesticated species (Cavia cobaya), the common Guinea-pig (q.v.).

Cawdor, a village in Nairnshire, $5 \frac{1}{2}$ miles SW. of Nairn. Cawdor Castle, near by, the seat of the Earl of Cawdor, was founded in 1454, but is one of the three places which tradition has assigned as the scene of King Duncan's murder by Macbeth in 1040. A series of papers from the charter-room at Cawdor was edited by Cosmo Innes under the title of The Book of the Thanes of Cawdor (1859). See CAMPBELL.

Cawk, a popular name for a massive variety of the mineral called Heavy Spar or Sulphate of Baryta. See BARYTA.

Cawnpore' (Kanhpur), a city of the Northwestern Provinces, on the right bank of the Ganges, 42 miles SW. of Lucknow, $266 \mathrm{SE}$. of Delhi, and $628 \mathrm{NW}$. of Calcutta. The river in front, varying, according to the season, from 500 yards in width to more than a mile, presents a large and motley assemblage of steam-vessels and native craft; the principal landing-place is the beautiful Sarsiya ghat. Cawnpore, at least as a place of note, is of recent origin, being indebted for its growth, besides its commercial facilities, partly to military and political considerations. In 1777, being then an appendage of Oudh, it was assigned by the nawab as the station of a subsidiary force; and in 1801 it became, in name as well as in fact, British property. Its cantonments, having accommodation for 7000 troops, contain a population of abont 38,000 . Pop. of the city (1891) 188,712, giving a total of about 227,000 , of whom 125,000 were Hindus, and 5000 Christians. At the outbreak of the mutiny in May 1857, Cawnpore contained about 1000 Europeans, 560 of whom were women and children. The hasty, ill-chosen entrenchments into which they had thrown themselves, were speedily invested by overwhelming numbers of the mutineers, led on by the infamous Nana Sahib. For three weeks the few defenders held gallantly out; but at last they surrendered on promise of a safe-conduct to Allahabad. The sepoys accompanied them to the banks of the Ganges, and scarcely were they embarked on the boats, when a murderous fire was opened upon them, and only four men eseaped. The women and children, 125 in number, were reserved for a crueller fate, and were carried back to Cawnpore. Hearing that Havelock was within two days' march of the place, Nana Sahib advanced to meet him. He was driven back, and, smarting under defeat, returned to Cawnpore, and gave orders for the instant massacre of his helpless prisoners, who, dead and dying, were cast into a well. Havelock and his small army arrived on 16 th July, only to find to their unutterable horror that they came too late to rescue the women and children. A memorial church, a Romanesque redbrick building, now marks the site of General Wheeler's entrenchment; whilst the scene of the massacre is occupied by the memorial gardens. Over the well itself a mound has been raised, its summit erowned by an octagonal Gothic inclosure, with Marochetti's white marble angel in the centre. But Sir George Trevelyan's Cawnpore (1865) is the best memorial of the tragedy. - The district of Cawnpore has an area of 2370 sq. m., and a population of about $1,300,000$. It is an alluvial plain of great fertility. The vine is cultivated, and indigo Grows wild. Besides its two mighty rivers, the the Ganges Canal traverses the country for 60 miles, and there is ample communication by rail.

Caxias, (1) a town of Brazil, in the state of Maranhão, on the navigable Itapicuru, 190 miles from its mouth, with an active trade in cotton. 
Pop. 10,000. - (2) An Italian agricultural colony in the Brazilian state of Rio Grande do Sul, founded in 1875. Pop. 13,680.

Caxton, Wrulam, the first English printer, was lurn in the Weald of Kent about 1422. He was apprenticed in 1438 to Robert Large, a wealthy London mercer, who was Lord Mayor in 1439-40. On his master's death in 141, he went to Bruges; ho prospered in business, and became in 1462 guvernor of a chartered association of English merchants in the Low Countries. In 1471 he abandoned commerce and attached himself to the lumsehold of Margaret, Duchess of Burgundy, the nister of Edward IV; and apparently towards the end of 1476 he set up his wooden printing-press at the sign of the Red Pale in the Almonry at II estminster. The art of printing he had acyuired during his sojourn in Bruges, doubtless from Colard Mansion, a well-known printer of that city ; and in 1474 he put through the press at Bruges the first book printed in the English tongue, the Recuyell of the Historyes of Troye, a translation of Raoul Lefevre's work. The Game and Playe of the Chesse was another of Caxton's earliest publications; but the Dictes and Sayings of the Philosophers, published in 1477, is the first book which can with certainty be maintained to have been printed in England. All the eight founts of type from which Caxton printed may be called Black Letter. Of the ninety-nine known distinct productions of his press, no less than thirty-eight survive in unique copies or in fragments only. His books have no title-pages, although many have prologues and colophons. Some have no points at all; others the full-stop and colon alone. The semicolon never occurs; the comma is usually marked by short (1) or by long (1) lines. The pages are not numbered and have no catchwords. (For Caxton's imprint, see article Book.) Caxton enjoyed the patronage and friendship of some of the chief men of his time. He was diligent in the exercise of his eraft or in translation till within a few hours of his death, which seems to have happened about the close of the year 1491. Gibbon denounces Caxton's choice of books, and complains that "the world is not indebted to England for one first edition of a elassic anthor; but it should be remembered that Caxton had to make his printing business pay, and that he could therefore supply only books for which there was a demand. Nor can it be said that a printer had no regard for pure literature who produced editions of Chaucer, Lydgate, Gower, Sir Thomas Malory's King Arthur, and translations of Cicero's De Senectute and De Amicitia. Caxton's industry was marvellous. He was an accomplished linguist, and the translations which he executed himself fill more than 4500 printed pages, while the total produce of his press, exclusive of the books printed at Bruges, reaches to above 18,000 , nearly all of folio size. At the Osterley Park sale in 1885, no less than ten Caxtons were sold; one of them, the Chesse, bringing $£ 1950$. In 1877 the printer and his work were fittingly commemorated by a typo. graphical exhibition in London. See The Old Printer aud the New Press, by Charles Knight (1854); Life and Typography of William Caxton (1861-63), by W. Blades; and the Biography and Typography of Caxton (1877; 2d. ed, 1882), by the same author.

Cayenne, a fortified seaport, eapital of French Guiana, on an island at the mouth of a river of the same name. A new town is connected with the older portion by the Place d'Armes, bordered with orange-trees. The harbour is the best on the coast, but insecure and shallow. Cayenne, though it is the entrepot of all the trade of the colony, is chiefly known as a great French penal settlement (since 1852). The climate is extremely unwholesome for
Furopreans, large numbers of the convicts having been carried of by various malignant fevers. The French took possession of the island in 1604, and again, after it had been held by the English and Dutch, in 1677. The name of the capital is some. times used for the whole of French Guiana (q.v.). Pop. about 10,000.

\section{Cayenne Cherry. See Eugrara.}

Cayenne Pepper consists of the powder of the dried pods, and more especially of the dried seeds of species of Capsicum (q.v.).

Cayes, or AUX CAYes, a seaport of Hayti, on the south-west coast, 95 miles WSW. of Port-suPrince. Pop. 8000.

Cayley, Arthur, mathematician, was born at Richmond, Surrey, in 1821. He was educated at King's College, London, and Trinity College, Cam bridge, and graduated as senior wrangler and first Smith's prizeman in 1842. He was called to the bar at Lincoln's Inn in 1849, and established a practice as a conveyancer. In 1863 he was elected first Sadlerian Professor of pure Mathematics at Cambridge, and in 1875 to a fellowship of Trinity College. He received honorary degrees from $0 x$. ford, Dublin, and Leyden. He was president of the Royal Astronomical Society (1872-73), and of the British Association at its Southport meeting in 1883 , where his address on the nltimate possibilities of mathematics attracted much attention. In 1882 he lectured at the Johns Hopkins University, Baltimore, and received the Copley medal of the Royal Society. His ehief book is an Elementary Treatise on Elliptic Functions (1876); a ten-volume edition of his Mathematical Papers was begun in 1889. He died 26th January 1895.

Caylus, Anne Claude Philippe dE TubiiRES, COMTE DE, archroologist, was born in Paris in 1692. After serving in the Spanish War of Suc cession, he travelled in Greece and the East, return. ing to Paris in 1717 to devote himself to the study of antiquities, and the promotion of the fine arts. If his industry sometimes outran his intelligence, it is still true that he did vast service to archæe ology. He died at Paris in 1765. His chief work is his Recueil d'Antiquités égyptiennes, étrusques, greeques, romaines, et gouloises (7 vols. 1752-67). His copperplate engravings have had a longer life than his stories of Eastern life.

Cay'man, a local name loosely applied to various species of alligator-e.g. to Alligator mississipprensis, the single species of the United States, or more frequently to other species found in tropical or subtropical America. The name has also been used, to all appearance unnecessarily, as the scientific title of a genus, and as such has been most frequently applied to A. palpebrosus and $A$. trigonatus. It seems more reasonable to regard all the alligators as within the limits of a single genus. See ALLIGATOR.

Caymans, three fertile coral islands of the Caribbean Sea, 165 miles NW. of Jamaica, of which they form a dependency. Discovered by Columbus, they were by him called Tortugas, from the abundance of turtle, still the staple production of the group. Area, $225 \mathrm{sq}$. m. ; pop. 2400, 2000 inhabiting the largest island, Grand Cayman.

Cazalla de la Sierra, a town of the Spanish province of Seville, 38 miles ENE. of Seville city, on the southern slope of the Sierra Morena, with important mines, and a trade in olives and wine. Pop. 8322.

Cazem Dé, the title of an African prince, whose territory, also called Cazembe, extends between the Moero and Bangweolo lakes, west of $30^{\circ} \mathrm{E}$. long. The people are industrious and skilful husbandmen and smiths, and carry on a brisk trade 
in ivory, copper, \&c. It is now mainly included in British Central Africa or the British sphere. Dr Livingstone died here in 1873.

Cazorla, a town of Andalusia, Spain, 40 miles ENE. of Jaën. Pop. 6651.

Ceano'thus. See RED Root.

Ceara, a state of Brazil, on the north coast. Area, $40,240 \mathrm{sq}$. m. It raises cattle, cotton, coffee, and sugar : iron and gold are found. Pop, about 950,000 . The capital, Ceark, is on an open roadstead. It exports sugar, rubber, hides, \&c., brought from Baturite ( 90 miles inland) by a railroad of which Ceará is the terminus. Pop. about 30,000 .

Cebadilla. See SABadilla.

Ce'bes, a Theban, disciple and friend of Socrates, and reputed author of the Pinax, or 'votive tablet,' a philosophical dialogue, representing allegorically the temptations of this life, and teaching that True Learning can alone make for righteousness. In spite of its pure Attic, and its truly Socratic tendeney, modern eriticism now assigns the work to the $2 d$ century A.D. Extremely popular in the middle ages, a sort of 'Pilgrim's Progress' indeed, it was translated into all the European languages, and into Arabic (possibly about the 9th century), in which latter version alone is found the close of the dialogue. See Jerram's Cebetis Tabula (Oxf. Clar. Press, 1878).

Cebui, or ZEBU, a long and narrow island of the Philippines, NW. of Mindanao. Area, with neighbouring isles, about $2000 \mathrm{sq} . \mathrm{m}$. The valleys are fertile, yielding rice, sugar, cotton, tobacco, cacao, and millet. Pop. 504,076. Capital, Cebu, on the east coast, the oldest city (and capital, 1565-71) of the Philippines. It has a good trade. Pop. 35,243.

Ce'bus (Gr., 'Bn ape' or 'monkey'), a genus of South American monkeys, characterised by a round head and short muzzle, a facial angle of about $60^{\circ}$, long thumbs, and a long prehensile tail entirely covered with hair. The body is covered with short, thick hair. Their voice is soft and pitiful. The species are numerous, all of very lively disposition and gregarious arboreal habits, living in trees. They feed chiefly on fruits, but also on insects, worms, and molluses. Various species are often seen in zoological gardens and menageries. They are included under the popular designation Sapajou in its wider sense, and some of them are the monkeys to which this name is sometimes more strictly appropriated. The names Sajou and Sai or Cail are also given to some of them, and some are ealled Capuchin (q.v.) Monkeys. One of the most common species in Guiana is the Weeper Monkey, or Weeper Sapajou (C. apella). Some of the species are adomed with beards. The term Cebidæ is often used as a family designation for all the broad-nosed New-World Monkeys (Platyrrhini) with prehensile tails, in contrast to the Pithecidæ, in which the tail is not so adapted. In this family are included the Howling Monkeys (Mycetes), the Spider Monkeys (Ateles), and other genera. See MoNkEY.

Cecidomy'ia (Gr. kekidion, 'a gall-nut,' and mvia, 'a fly "or 'gnat'), a genus of dipterous (twowinged) insects in the Tipularia (gnat and mosquito) division. They have beautiful, delicate, downy wings, which have three nervures, and are horizontal when at rest; antennæ as long as the body, with bead-like joints, and whorls of hairs at the joints; long legs, and the first joint of the tarsi very short. The species are numerous ; nearly thirty in Britain, and sixty in Europe. All are of small size, but some of them are very important on account of the ravages which their minute maggots effect in grain-crops. C. cerealis, sometimes called the Barley Midge, a brownish-red fly with silvery wings, of which the maggot is vermilion coloured, is often very destructive to crops of barley and spelt in Germany. The little maggots live in families between the stalk and the sheath of the leaf, abstracting the juice of the plant.-The Wheat-fly (q.v.) and the Hessian Fly (q.v.) belong to this genus. Some of the species of Cecidomyia deposit their eggs on the young buds of trees, which the larvæ transform into galls.

While forms like the Hessian fly are of great economic importance, another Cecidomyia is, on account of its extraordinary mode of reproduction, of great scientific interest. According to Wagner, the female lays her eggs under tree-bark or the like; these develop in winter into larvæ. The larvæ, still immature, become reproductive and parthenogenetic. The ovaries rupture, the eggs fall into the body-cavity, where the stimulus of fertilisation is somehow replaced, for the ova develop into larvæ. These eat their parent larva, and after finishing the viscera, leave the empty skin. The nemesis of reproduction overtakes them also, for within them again, though likewise only larvæ, a fresh batch of larva develops in similar fashion. After several generations of this immature and fatal reproduction, the final set of larvæ metamorphose in summer into sexual winged insects. See REPRODUCTION.

Cecil. See Burghley and Salisbury.

Cecilia, ST, the patroness of music, especially church music, is said to have suffered martyrdom in 230 A.D. Her heathen parents belonged to a noble Roman family, and betrothed their daughter, already a secret convert to Christianity, to a heathen youth named Valerian, who also was soon converted, and ere long suffered martyrdom together with his brother Tiberius. Cecilia, when commanded to sacrifice to idols, firmly refused, and was condemned to death. She was first thrown into a boiling bath, from which she emerged unhurt; next the executioner struck three blows upon her neck with a sword, then fled in horror. Three days later his victim died of her wounds, and received the martyr's crown. She was buried by Pope Urban in the catacombs of Callistus. As early as the 5th century, there is mention of a church dedicated to St Cecilia at Rome; and in 821 , by order of the Pope Paschal, her bones were deposited there. St Cecilia is regarded as the inventor of the organ, and in the Roman Catholic Church her festival-day, November 22, is celebrated with splendid music. Some of our greatest poets, as Chancer, Dryden, and Pope, have laid poetic tributes on the shrine of St Cecilia-the greatest is Dryden's splendid ode. The most famous paintings of St Cecilia are those of Raphael at Bologna, Carlo Dolce in the Dresden Gallery, Domenichino in the Louvre, and Rubens in the Berlin Museum.-Another St Cecilia was born in Africa, and suffered martyrdom by starvation under Diocletian. Her festival falls on the 11 th of February.

Cecrópia, a genus of Artocarpacer. $C$. peltata, the Trumpet-tree of the West Indies and South America, has a hollow stem and branches, exhibiting merely membraneous partitions at the nodes. The branches, these partitions being removed, are made into water-pipes and windinstruments. The wood is very light, and is used to make floats for nets, and by the Indians in kindling fires by friction against a harder piece of wood. The bast yields a cordage fibre, and the outer bark is astringent, the fruit resembles a raspberry, the buds furnish a potherb, while the juice hardens into caoutchouc. The leaves and fruit are. largely consumed by sloths. The hollow stem is. largely inhabited by ants. 
Cecrops, a Pelasgic hero, the first king of Attica, sometimes represented as half $\operatorname{man}$ and half dragon. He divided Attica into twelve communities, founded Athens, the eitadel of which, st first called Cecropia, commemorated his name, instituted marriage and the worship of the gods, and introduced agriculture, navigation, and commerce. Late writers explained Cecrops as the leader of a colony from Sais in Egypt.

Cedar, or Cedar of Lebanon, a tree much celebrated from the most ancient times for its beauty, its magnificence, and its longevity, as well as for the excellence and durability of its timber. It is often mentioned in Seripture ; it supplied the woodwork of Solomon's temple; and in the poetry of the Old Testament it is a frequent emblem of prosperity, strength, and stability. It belongs to the natural order Coniferse, and is the Pinus Cedrus of the older botanists; but is now ranked in the genns Cedrus under the name of C. Libani, in reference to its best-known habitat, Mount Lebanon. It is found, however, on other mountains of Syria and Asia Minor, and also in Cyprus.

Of the celebrated Cedars of Lehanon only a few now remain. Situated at the head of the Kedisha Valley at 6314 feet elevation, they consist of a grove of trees, 377 in number in 1875 , five only being of

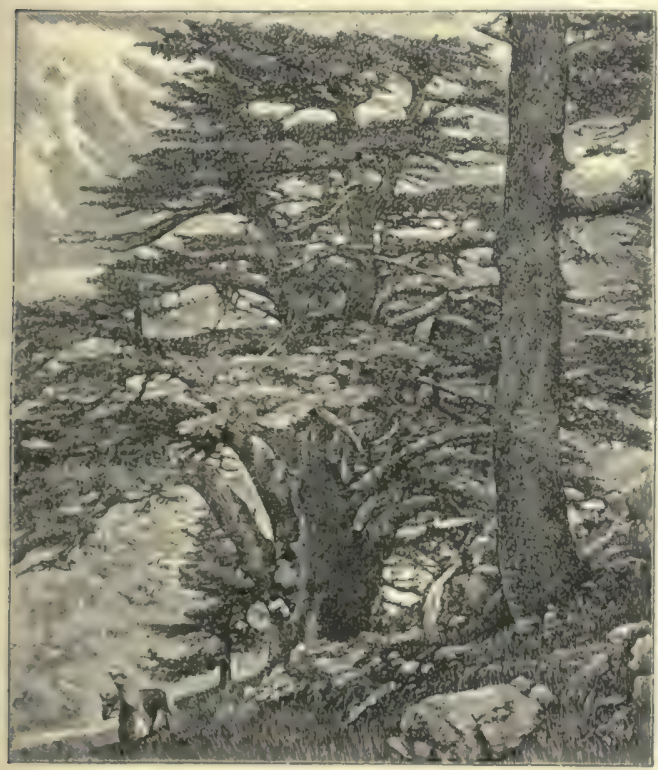

Cedars of Lebanon.

gigantic size, measuring 30 feet round. In age they may vary from 50 or 80 to 800 or 1000 years: but as they have long ceased to add regularly yearly concentric rings of wood to their trunks, there are no reliable data by which to estimate the age of the few patriarchal cedars that yet remain on the Lebanon. Arabs of all creeds have a traditional veneration for these trees; and Maronites, Greeks, and Armenians annually celebrate mass on a homely altar of stone at their feet.

The general aspect of the cedar is distinct and majestic in fully developed trees. The trunk is massive, but attains only a moderate height- 50 to 80 feet-much branched; the branches assume the proportions of timber, are horizontal, and spreading usually so as to exceed the total height. They are arranged in apparent whorls, or stages, and the branchlets springing from them in a flat fan-like fashion in great profusion and density impart a tabu. liform appearance in graduated stages from base to summit of the tree. The leaves are about an inch long, arranged in clusters, pensistent for about two years, at first bright green, but changing with age to a deeper tint, with a glaucous hue, which in some individual trees increases to an almost silvery

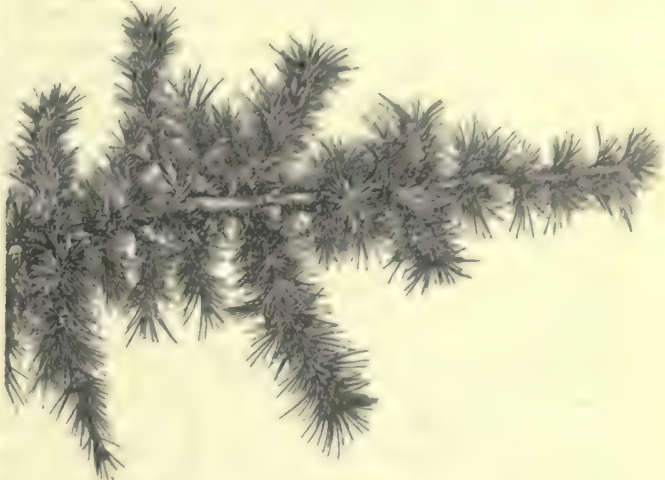

Branch of Cedar of Lebanon.

whiteness that gives to them a strikingly venerable aspect. The cones are erect on the upper sides of the branches, from 3 to 5 inches long and 2 to 21 inches broad, blunt at both ends. They require two years to reach maturity, and do not, as in the case of other allied conifers, drop from the branches, but when ripe the scales only along with the seeds drop to the ground, and leave the axis of the cone attached to the branch.

The timber of the Lebanon cedar enjoyed a high reputation for durability in ancient times, which, however, is hardly supported by modern experience. The wood of trees that have been grown in Britain and other parts of Europe has proved light, soft, brittle, liable to warp, and far from durable, probably owing to the immaturity of these comparatively young, though well-developed, samples, and also perhaps to climatic influence. The superior quality of the timber of the Lebanon trees is attested by Sir Joseph Hooker, who visited the famous cedar grove in 1860.

The secretions of the cedar of Lebanon have long been celebrated for remarkable properties. The whitish resin (Cedria) which it exudes, it is said the Egyptians used in embalming their dead. Ancient writings were kept in cabinets or boxes of cedar-wood, but it would appear to be rather dangerous to commit modern printed documents to such repositories. Mr Smee, in My Garden, says : 'The wood of the cedar contains a volatile essential oil, which has the curious property of unsettling printers' ink and making it run. Some years ago a Bank of England note was offered to the cashier with its printing disturbed. Inquiry was set on foot, and it was traced to several individuals, who satisfactorily explained its custody and possession. It was then brought to me, when I suggested that the detectives should inquire whether it had been kept in a cedar box; it was then discovered that the last possessor had kept it in a new cedar box which she had recently bought, and thus the mystery was solved.' In very ancient times, cedar. oil, a kind of turpentine, was prepared from the wood, and was spread on books in order to their better preservation. The branches of the cedar, like those of the larch in warm countries, exude a sweet substance, which is known by the name of Cedar Manna.

The botanist Belon brought a Lebanon cedar with him to France in 1549 : when it was intro- 
duced into Britain is not exactly known. The distinction of introducing it is ascribed with most evidence of accuracy to Evelyn, who in his Sylva (published 1664) mentions having 'received cones and seeds from the mountains of Libanus,' while describing the beauties of the tree and speaking of its probable adaptability to the English climate. Aiton in Hortus Kewensis makes 1683 the, date of planting the celebrated Chelsea cedars, which are assumed by some to have been the first trees planted in England. There are many fine specimens of the Lebanon cedar in different parts of Britain, notably at Sion House, Goodwood, and Enfield in England, and at Hopetoun, Dalkeith, and Beaufort in Scotland.

The Deodar, or Himalayan Cedar (Cedrus Deodara), a tree held in great veneration by the Hindus, and of which the name is properly Devadara ('divine tree'), is common in the Himalaya mountains at elevations of 7000 to 12,000 feet, forming magnificent forests, and attaining a great size, a height sometimes of 150 feet, with a trunk 30 feet or more in circumference, an ample head, and spreading branches. It and the cedar of Algiers (C. Atlantica or Africana), found in the mountainous regions of the north of Africa, are but sub-species or varieties of the Cedrus Libani. The wood of the deodar is resinous, fragrant, compact, and very durable. It is susceptible of a high polish, and in its polished state has been compared to brown agate. Owing to the abundance of resin, laths of it burn like candles. Its turpentine is very fluid, and although coarse, is much used in India for medical purposes; and tar and pitch are obtained from the trunk. The deodar has now become very common as an ornamental tree in Britain, although few specimens have yet attained a very considerable size. - The name cedar is often given to other coniferons trees besides the true cedars. Thus, the Siberian Stone Pine, or Cembra Pine, is called the Siberian Cedar (see PINE), and a species of fir ( $A$ bies religiosa) is the Red Cedar of California (see FIR). A species of Cypress (q.v.) is known as White Cedar, and another as the Cedar of Goa. Several of the trees which bear the name cedar are species of Juniper (q.v.), among which are the Virginian Cedar, or Red Cedar of North Ameriea, and the Bermuda Cedar-which yield the cedar-wood used for pencils - the Spanish Cedar of the south of Europe, \&c. The name cedar is even given to trees which have no resemblance to the true cedars except in the resinous quality of the wood; thus the Cedar-wood of Guiana is produced by Icica altissima, a tree of the natural order Amyridaceæ (q.v.); the cedar of the West Indies (see next article) belongs to the natural order Cedrelacer; and the name Bastard Cedar is given in India to a tree of the natural order Byttneriacere (q.v.).

Cedar, BARBADoEs, is strictly speaking Juniperus barbadensis; but a more important tree is that called Bastard Barbadoes Cedar (Cedrela odorata), a tree of the order Cedrelacer (q.v.). Its wood has an agreeable fragrance, and being soft and light, it is used for canoes and for shingles. Havannah cigar-boxes are very generally made of it, and in France it is used in making black-lead pencils.

Cedar-bergen, a mountain-range in Cape Colony, stretches north and south on the east side of Olifant River Valley, in Clanwilliam division, and has plantations of Cape cedar (Widdringtonia juniperoides), which are now, however, being fast destroyed. This is the only locality where this species is found. Sneeuwkop (6335 feet) is the highest point of the range.

Cedar Bird. See WAXwing.
Cedar Creek is a river of Virginia, U.S., which gives name to a battle fought 19th October 1862, when the Federals under Sheridan defeated the Confederates under Early.

Cedar Rapids, a town of Linn county, Iowa, on the Red Cedar River, 79 miles SW. of Dubuque. It is an important railway centre, and has several large flour-mills, carriage and machine works, and breweries. Pop. (1860) 1830 ; (1890) 18,020.

Cedilla (Sp., Fr. cédille, It. zediglia; from zeta, the Greek name for $z$, because it has taken the place of $z$ in such words as leczon, mod. lecon, a mark placed under the letter $c(\ell)$, especially in French, where it is desired to give $c$ the sound of $s$ before the vowels $a, 0, u$.

\section{Cedrate. See CITron.}

Cedrelacea, a sub-order of Meliacer (q.vo), all tropical or subtropical trees or shrubs, with pinnate leaves, mostly valuable for their timber - e.g. mahogany, satin-wood, toon, Barbadoes cedar, the yellow-wood of New South Wales, \&c. The barks of some species are febrifugal. See MAHOGANY, Cedar (Barbadoes), \&c.

Cefalì, a town of Sicily, on the north coast, 40 miles ESE. of Palermo. It is situated at the foot of a lofty promontory (1235 feet), with old Greek and Saracenic remains. It has a cathedral, a port, and 12,714 inhabitants, chiefly engaged in marble-quarrying and fishing.

Ceglie, a town in Southern Italy, 21 miles NE. of Taranto. It has a trade in grain, oil, and fruit. Pop. 13,865.

Ceiling (Fr. ciel ; Lat. colum, 'heaven '). This term seems to have been suggested by the use of arched coverings for churches, and even for rooms, which prevailed in the middle ages, and were frequently painted blue and decorated with stars. Arched ceilings among the Romans were known by the name of camerce, and were formed by semicircular beams of wood, at small distances from each other, over which was placed a coating of lath and plaster. But the ceilings most commonly' in nse amongst the Romans were flat, the beams, as in modern times, having been at first visible, and afterwards covered with planks and plaster. Sometimes hollow spaces were left between the beams, which were frequently covered with gold and ivory, or paintings or 'pateræe'-large flowers - such, for instance, as are used in the panels of the vault of the Pantheon. The oldest flat ceiling in existence is believed to be that of Peter. borough Cathedral. Like that at St Albans Abbey, it is made of wood. Ceilings of churches in the middle ages were generally painted and gilded in the most brilliant manner ; and many existing ceilings still exhibit the traces of early decoration of this kind. In French churches the ceilings are generally vaulted, but in England they are more usually of wood. The older ceilings generally follow the line of the timbers of the roof, which, in the Early English and Decorated, are often arranged so as to give the shape of a barrel vault. In ceilings of this deseription there seldom are many ribs, often only a single one along the top. In the Perpendicular style, the ceiling often consists of a series of flat surfaces or cants, formed on the timbers of the roof. Though sometimes altogether destitute of ornament, they are more frequently enriched with ribs, dividing them into square panels, with bosses (see Boss) or flowers at the intersections. Wooden ceilings are sometimes formed in imitation of stone-groining, with ribs and bosses, examples of which will be found at York, Winchester, and Lincoln. In the Elizabethan age ceilings were generally of plaster, but they were ornamented with ribs having boses or 
small pendants at the intersections. It is not unusual for the ceiling immediately over the altar, or the roodloft, to be richly ornamented, whilat the rest is plain. See Roor.

Celakovsky, (1) Franz Ladisuus, Bohemian poet, born in Strakonitz, 7th March 1799, died at Prague, profesaor of Slavonic Philology, 5th August 185.2. His principal works are Echoes of Russian and Bohemian Folk-songs (183i-40), and a cycle of liwe-songs and didactic and politieal poems (1840). He also translated the works of Herder, Goethe, and Seott.-(2) LAdislaus, botanist, born in Prague, 29th November 1834, was appointed pro fessor of Botany there in 1880. Besides severa momographs on particular genera, he has published a reneral book on the Bohemian flora (3 parts, 1867-75) and an elucidation of the Darwinian theory.

Cel'andine is the popular name (and corruption) of Chelidonium majus, a perennial papavera

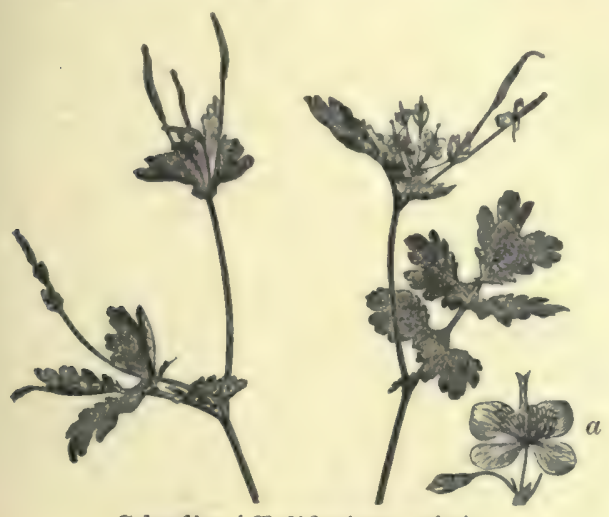

Colandine (Chelidonium majus) : $a$, a flower.

ceous herb, which, although not uncommon in Britain, is doubtfully indigenous. Its pretty foliage

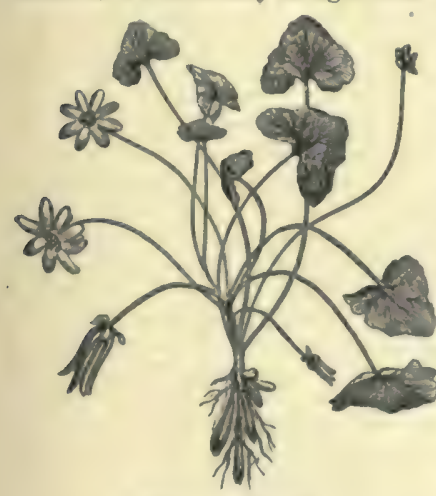
and umbels of small yellow flowers, which bloom from May to August, might alone attract attention, but its ancient repute among herbalists is due to its yellow milky juice, which is very acrid and poisonous. Externally it was applied to warts and ulcers, and internally administered, it

(Ranunculus Ficaria). was supposed to be a specific for jaundice, apparently on no better warrant, however, than that drawn from its colour by the "doctrine of signatures," Its old English name Swallow-wort, which appears to be almost a translation of the botanical one, seems founded on a supposed association between the beginning and ending of its flowering time and the arrival and deperture of the swallows.-It is, however, the LEsser CELANDINE which is more familiar to general readers, at least since Wordsworth devoted no fewer than three poems to its honour. This is Ranunculus Ficaria, also known as the common fig-wort or pile-wort, a quite unre- lated ranunculaceous plant, which grows in abund. ant patches in fields and coppices, and brightens them in early gpring with its plentiful golden flowers. Its tuberous roots and swollen separable buds give it additional botanical interest, while it is also noteworthy that these results of peculiarly vegetative habit are associated with a frequent imperfect maturity of the pollen. See REPRO-

\section{DUCTION.}

Celano, Lago d. See Fucivo (Lake of).

Celastraceae. See SPINDLE-TREe.

Celaya, a town in the Mexican state of Guanajuato, on the Rio Laja, about 150 miles by rail NW. of the city of Mexico, has several fine plazas, handsome churches, and manufactures of cotton and woollen cloths and saddlery. Pop. (1877), with district, 28,336. The burning of its bull-ring, on Easter Sunday 1888, caused considerable loss of life.

Cele'bes (in England nsually pronounced Ce'lebes), the third largest and the central island of the Eastern Archipelago, from $1^{\circ} 45^{\prime} \mathrm{N}$. to $5^{\circ} 37^{\prime}$ S. lat., and from $118^{\circ} 49^{\prime}$ to $125^{\circ} 5^{\prime} \mathrm{E}$. long.; about 800 miles long by 200 broad; total area estimated at $76,260 \mathrm{sq} . \mathrm{m}$. It is practically a Dutch possession, though there are numerous small native states. In configuration, it consists of a central nucleus whence radiate four long mountainous limbs, respectively E., NE., SE., and $\mathrm{S}_{\text {., inclosing }}$ the three gulfs of Gorontalo, running in nearly 200 miles, Tolo 150 miles, and Boni about 200 miles. The gulfs, as also the north and west coasts, are studded with islands, rocks and shoals, and larger outlying islands. Of the central nucleus and the two inner limbs little is known. The east end of the eastern peninsula (north end of island), Minahassa district, is subject to earthquakes, and contains 11 volcanoes, some of them active, such as Mount Sapoetan (5938 feet), and, farther east, Mount Klabat ( 6559 feet), which has now, however, long been quiescent, besides numerous hot springs and sulphur lakes. The mountains of the south peninsula, essentially a limestone formation, seldom rise above 2000 feet. In the extreme south, however, are Maros ( 4225 feet) and Bonthain ( 9994 feet). The uplands of the south peninsula are well wooded, but its vegetation is much less luxuriant than that of the east peninsula. Between the hills and coast of the south peninsula are extensive grassy plains, affording pasture for large herds of cattle, and for the horses for which the district is famous.

Celebes is rich in lakes, among them, Passo, in the central nucleus, 35 miles by 25 miles, and Tondano, nearly 2000 feet above the sea. There are numerous streams, but Celebes, no part of which is more than 50 miles from the sea, offers no sjace for the formation of large rivers. The Sadang, rising near lake Passo, flows due south for nearly 120 miles.

Thanks to the elevation of the land and its sea. exposure, Celebes enjoys a comparatively cool and healthy climate. The vegetation includes rice, maize, coffee, sugar, tobacco, indigo, arecs, betel, pepper, elove and nutmeg growing wild; the tree yielding macassar oil, oak, teak, cedar, ebony, sandalwood, bamboos; also the upas. Minahassa, the most highly cultivated district, 60 by 20 miles, has coffee plantations, producing coffee of a remarkably fine flavour, entirely in the hands of the government, and where alone the 'culture system' has been applied in its integrity since 1822. Many animals, birds, and insects are wholly peculiar to Celebes - $\mathrm{n}$ tailless baboon, two kinds of cuscus, the babiroussa, and Sapi-utan, three kinds of starlings, two magpies, \&c. Gold is obtained from surface washings, principally in Minahassa and Gorontalo districts; iron in the distriets bordering the Guls 
of Tolo. Salt is also abundant. Tin and copper are likewise worked.

The population of the island of Celebes is given at $1,000,000$, who may all be regarded as belong. ing to various Malay stocks, except 7000 Chinese and 2500 Europeans. The Bugis (see BoNI) and Mangkassars of the south peninsula, tall, shapely, and comparatively fair, are the dominant native race, much disposed to trading and seafaring. The 'Alfuros,' a collective name for the other native tribes, are at a very low grade of culture. Celebes was first visited in $\mathbf{1 5 2 5}$ by a Portuguese expedition from the Moluccas. In 1607 the Dutch began to trade with Celebes, and now claim the whole island, which they have divided into the residencies of Macassar and Menado, a third division round the north and west of the Gulf of Tolo being included in the residence of the Ternate. The total value of the exports in 1884 was $£ 600,000$, of which coffee formed nearly a half; and the imports in the same year, f465,714. The women of Celebes weave the sarang, or national garment, which, together with variegated mats, is largely exported. A 'high-road' skirts the coast of the south peninsula from Mandale, 30 miles N. of Macassar, to Balang-Nifra, on the Gulf of Boni; elsewhere are only ordinary roads and footpaths. The chief town is Macassar, with a sea-frontage of nearly 21 miles. Menado, the capital of Minahassa district, and seat of a Dutch resident, is described as the prettiest settlement in the whole of the Dutch East Indies, and has a pop. of 2500 . See Lahure, L'ile de Célébes (Paris, 1879).

Celery (Apium), a widely distributed genus of Umbelliferr. The common celery ( $A$. graveolens) is found wild in Britain and most parts of Europe, in ditches, brooks, \&c., especially near the sea and in saline soils, and is acrid and uneatable. In cultivation, however, abundant nutrition has greatly mollified its properties, and two principal forms have arisen-one in which an abundant development of parenchyma has taken place in the leafstalks; the other in which it affeets the root-while these again possess their sub-varieties. The former sort is the common celery of British gardens, where the familiar long blanched succulent stalks are produced by transplanting the seedlings into richly manured trenches, which are filled up as the plants grow, and finally raised into ridges over which little more than the tops of the leaves appear; and a supply is thus insured throughout the whole winter. The other form is the turnip-rooted celery, or celeriac, and is now largely cultivated on the Continent. Both forms are eaten uncooked alone, or in salads, or in soups, or as a boiled or - stewed vegetable, and are pleasant and wholesome, although when used too freely or frequently they. are diuretic and aphrodisiac. Some authorities identify celery, instead of the closely related Parsley (q.v.), as the Apium with which victors in the lsthmian and other games were crowned, and of which the Greeks were also wont to twine their sepulchral garlands.

Céleste, Madame, dancer, was born in Paris 6th August 1814 (by her own account), more probably three or four years earlier. A pupil at the Conservatoire, she early showed remarkable talent. Slse made her début in 1827 at New York, and during her residence in America married one Elliott, who died early. At Liverpool in 1830 she played Fenella in Masaniello; in 1831-33 she became extremely popular in London. Her second visit to America (1834-37) is said to have brought her

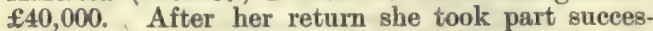
sively in the management of the Theatre Royal, Liverpool, and the Adelphi and Lyceum in London. Her imperfect English long confined her to non- speaking parts. She retired from the stage in 1874, and died at Paris, 12th February 1882.

Celestine, a mineral bearing the relation to Strontium (q.v.) that heavy spar bears to barium. It is essentially sulphate of strontia, $\mathrm{SrOSO}_{3}$, with occasional admixture of sulphate of baryta, earbonate of lime, oxide of iron, \&c., in small proportions. It much resembles heavy spar, but is not quite equal to it in specific gravity; is usually blue, often of a very beautiful indigo-blue; sometimes colourless, more rarely reddish or yellowish. Its crystallisation is rhombic, like that of heavy spar. Most beautiful specimens of crystallised celestine are found in Sicily. Celestine derives its name from its colour. It is the source from which nitrate of strontia, employed in the manufacture of fireworks, is derived.

Celestine was the name of five popes, the first of whom filled St Peter's chair in 422-432 (see POPE). The most notable was the Neapolitan Peter di Morrone, who after a long life of ascetic severities was much against his will elected pope as Celestine V. in 1294, when he was nearly eighty years of age. He resigned his office after five months - 'the great refusal,' for making which he is placed by Dante at the entrance of hell. He was imprisoned by his successor, Boniface VIII., and died in 1296. He was founder of the Celestines, and was canonised in 1313.

Celestines, an order of hermits of St Damianus, founded by Peter di Morrone about 1254, and confirmed as a monkish order by Urban IV. in 1264 and by Gregory $X$. in 1274. They called them. selves Celestines when their founder ascended the papal chair. They follow the rule of St Benedict, wear a white garment with black hood and scapulary, and live a purely contemplative life. In the 13 th and 14th centuries the order spread rapidly through France, Italy, and Germany, but subsequently decayed, and is now almost extinct. The French Celestines were secularised by order of Pope Pius VI. in 1776-78; so also were the Neapolitan Celestines.

Celibacy (from caelebs, 'unmarried '), a state opposed to the first and strongest natural law (Gen. i. 28), has from a variety of causes come to be regarded in certain religious systems as a condition of the most sublime self-sacrifice. The perpetual celibacy of the priests of Isis, and the chastity of the vestal virgins, are familiar instances. But nowhere was this sentiment so strongly and widely manifested as among the millions devoted to the religion of Buddha. The theories of oriental philosophers and the natural tendency of mystics did not fail to influence the early Christian churches, and led before long to the doctrine that virginity is a state in itself more excellent and more holy than the married life, and to the discipline which, in the Roman Church at least, imposed celibacy upon all priests and sacred ministers. The Old Testament is remarkably free from any tendency to exalt celibacy above matrimony. But although texts may be quoted on either side, the germs of the doctrine in question may be discovered in the New Testament. St Paul affirms it to be 'good for a man not to touch a woman,' and wishes that all men were celibate like himself ( 1 Cor. vii. 1, 7). Christ himself speaks mysterious words in commendation of those who "have made themselves eunuchs for the kingdom of heaven's sake ;' and the Lamb is followed on Mount Zion by 144,000 virgins, 'first-fruits unto God and unto the Lamb' (Rev. xiv. 1-5).

The apostolic writings, however, while they suggest the excellence of virginity in general, supply no ground for the law of clerical celibacy. In the first epistle to Timothy, the deacon as well as 
the bishop is told he must be the husband of one wife, and rule his household and his chililren well; and 'forbidding to marry' is reckoned smong the 'doctriues of devils.' But a remote sanotion for the later discipline has been gought for in the regulations of the Jewish priesthood. The Mosaic law forbade priests to marry divorced women or harlots, and enjoined continence apon all when preparing to offer sacrifice. Jerome argues that the Christian priest should offer sacrifice daily, and should therefore be perpetually continent; and Pope Siricius ( 385 A.D.) insists that marriage was permitted to the priest of the old law only because the sacerdotal order was then limited to the tribe of Levi, but now that the tribal restriction is removed, the license is abrogated also.

The ecclesiastical legislation on celibacy was developed gradually and unequally in the several parts of the church. In the $2 d$ century it became a pious custom to make vows of chastity, and it was thought becoming in the higher elergy to renounce matrimony; and although there are examples of bishops and priests in the first three centuries living with their wives and begetting children, it has been confidently asserted that no instance can be quoted of a marriage contracted at this period after ordination. The obligations of the marriage contract were, however, considered sacred; and the Apostolic Canons impose the penalty of deposition on bishop, priest, or descon, who should separate from his wife 'nnder the pretence of piety.' At the end of the $3 \mathrm{~d}$ and beginning of the 4 th century, marriage after ordination was prohibited by formal legislation. A further and important step was taken in the year 305 by the Spanish council of Elvira, which decreed that sacred ministers who were already married, should live in continence. At the Councll of Nicra an attempt was made to impose this new rule upon the whole church, but it was frustrated by the opposition of a venerable monk, Paphnutius, himself a celibate; and the law to this day has never been accepted in the Eastern Church. In the West, however, a series of synodal enactments and papal decrees established or renewed the more rigorous rule. But in no matter of ecclesiastical discipline must the distinction between theory and practice be more carefully observed. The elergy every where resisted the law, and resisted with considerable
success. St Patrick, who tells us that his father and grandfather were in holy orders, when laying down rules in one of his Irish synods for the conduet of his elergy, directs that "their wives should keep their heads covered.' In the province of Milan, indeed, the marriage of priests continued to be perfectly legal. Discipline and usage varied in different countries, but it may be safely said that for many centuries the celibacy of the uncloistered clergy was little more than a pious fiction, until Hildebrand, afterwards Gregory VII., by his great
influence and vigorous measures, secured a more strict observance of the rule.

From the 12th century (first and second Lateran Councils) a great change took place in ecclesiastical law. The marriage of priests was now declared to be not only sinful but invalid. It became henceforward difficult for any priest to justify his marriage on the plen that the prohibition of such marriage was abrogated by custom, or not binding under supposed exceptional circumstances. The clerical consorts became no longer wives but concubines; and, further, the priest who went through the marriage ceremony was held to commit a far greater crime than if he had contented himself with simple fornication. Yet in spite of all this the law was to a large extent set at defiance. In many parts of Europe it was a common thing for benefices to pass from father to son. Influential bishops obtained letters of legitimation for their children, and provided for them out of the property of the ehurch. Avaricious princes and prelates made traffic of the concubinage of the lower elergy by levying a species of blackmail, under the name of fines, on the tacit understanding that the focuria, or occupant of the priest's hearth, should not be disturbed. At the time of the Council of Trent, the Emperor Charles, in the expectation that aome relaxation would be made in the laws on the sub. ject, permitted in 1548 , by the arrangement known as the Interim, married priests to retain their wives until the council should come to a decision. The Emperor Ferdinand a little later (1562) urged upon the same council the abrogation of celibacy. But the Catholic reaction was too strong, and the council in November 1563 pronounced, 'If any one shall say that clerks constituted in holy orders, or reculars who have solemnly professed chastity, are able to contract matrimony, or that, being contracted, such matrimony is valid ... let him be anathema.

It should be observed, however, that in the United Greek Church Rome tolerates a married clergyi.e. a man already married may be ordained priest, and continue to live with his wife, though continence is imposed upon him at certain times. It is the custom for the young candidate for orders to leave the seminary for a while to get a wife, and then return for ordination. If he should become a widower, he cannot of course marry again, and no married priest can be made a bishop. The bishops are therefore, as a rule, taken from the monasteries.

Since the Council of Trent, the observance of celibacy has been comparatively well maintained. This is especially true of those countries where the Catholic community is mixed with or surrounded by Protestant neighbours, and watched by a vigilant press. A way from the high-roads of civilisation, in Mexico, Brazil, and other parts, concubinage has again become the rule, less openly perhaps, but quite as obstinately as in the middle ages.

The moral loss or gain to the chureh from her dis. cipline in this matter is a question of controversy which from time to time has been raised within her own communion. But the attention paid by biologists to the hereditary transmission of human faculties and dispositions has recently exhibited the effects of celibacy in a new light. Mr Galton has remarked that the Roman Church has acted as if she "aimed at selecting the rudest portion of the community to be alone the parent of future generations.' The policy which attracts men and women of gentle natures fitted for deeds of charity, meditation, or study to the unfruitful life of the cloister and the priesthood, appears from this point of view to be 'singularly unwise and suicidal,' tending, as it must, though by imperceptible degrees, to the deterioration of the race. To the enforcing of this discipline in Spain, for example (coupled with the cutting off of independent thinkers by the Inquisition ), Mr Galton attributes much of the decadence of the country during the last three centuries. In France, where the most promising lads of the village are successively picked out by the parish priest for the bishop's seminary, the process of elimination must in the long run tell upon the general character of the population. In small Catholic communities, again, where the priestly vocation is held in high esteem by the educated classes, and where mixed marriages are discountenanced, a similar result cannot fail to occur. The controvensial literature on the matter is abundant. The most complete treatment of the subject, from the historical point of view, will be found in Sacerdotal Celibacy in the Christian Church, by Henry C. Lea (Philadelphia, 1867). See also MonaCHISM. 
Cell, a unit-mass of living matter, whether rounded off by itself, as in the simplest plants or animals and in the youngest stage of all organisms, or associated with other cells to form a higher unity. The great majority of the Protozoa and Protophyta are single cells, and all other organisms begin where the former leave off. From the double unity resulting from the fusion of two sex-cells the higher plants and animals develop by repeated division, and they may be therefore always resolved into more or less close combinations of variously
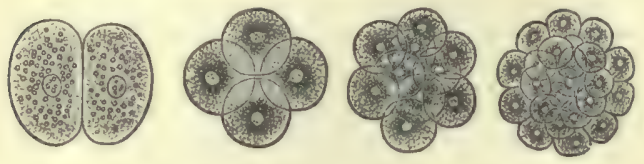

Fig. 1.-Dividing Egg-cell (after Gegenbaur).

modified unit-masses. In most cases these individualities of the simplest order are minute, and their separateness is not to be discerned with the unaided eye, but there are many instances among the simplest plants and animals, as well as in the component elements of higher forms, where the unit-masses are relatively giant-cells and quite visible without the use of the microscope. The giant Amoeba Pelomyser, the common sun-animalcule Actinosphorium, the Alga Botrydium, and some of the cells (e.g. bast) of plants may be noted as illustrations of cells with considerable dimensions. In the great majority of cases the body of the cell includes a well-defined centre or nuclens; and the definition may therefore be extended in the statement that a cell is a nucleated unit-mass of living matter or protoplasm.

I. History. - In the article BroLogr it has been pointed out that a more and more penetrating scrutiny alike of structure and of function led naturalists from organs to tissues, and from tissue to cell. Some of the steps in this gradually deepening analysis deserve fuller record.

Discovery of Cells. - In the latter half of the 17th century the simple microscope afforded to Malpighi and Leeuwenhoek, to Hooke and Grew, what was literally a vision of a new world. In applying their rough and simple instruments to the study of the structure of plants and animals they became pioneers in the investigation of the infinitely little. Leeuwenhoek (Phil. Trans. 1674) seems to have been the first to observe, what are now so familiar, single-celled organisms. In the 18th century Swammerdam and others continued with much enthusiasm to describe the minute intricacies which their 'new eyes' revealed; Fontana (1784) observed the kernel of the cell-the nucleus-and some of the elements of the tissues; but the foundation of seientific histology was not laid until the appearance in 1801 of the Anatomie Generale of Bichat. In this epoch-making work organs were resolved into their component tissues, and their functions were interpreted as the sum-total of the properties of their constituent elements. Such a conclusion was the utmost that could be reached with the appliances then at command.

Early in this century, however, an improvement in the appliances of observation furnished a fulerum for a new advance. Fraunhofer discovered the principle of achromatic Lenses (q.v. ; also ACHROMATISM); these were combined into the compound Microscope (q.v.), and a new era began. 'Fibres" and 'globules,' 'laminæe,' 'nuclei,' and even 'cells' were described. In 1831 Robert Brown emphasised the normal presence of the nucleus discovered by Fontana, and made the first important advances in the study of the vegetable cell. Isolated discoveries, such as that of the nucleolus by Valentin (1836), occurred in rapid succession during those years. Dujardin in 1835 described the sarcode or living matter of the Protozoan Foraminifera and of some other cells, and thus emphasised, as Rösel von Rosenhof had done many years before (1755) in regard to the 'Proteus animalcule' or Amoeba, the most important element to be considered in forming a true conception of the cell. The importance of his description, of which he was apparently himself unconscious, had for some time the same fate as that of his predecessor of almost a century before. Observations had in fact to accumulate before any generalisation became possible. The first definite steps towards a co-ordination of results was probably that of Johannes Müller, who in 1835 pointed ont the resemblance between the cells of the vertebrate notochord and the elements. observed in plants. The cellular nature of the epidermis and the presence of nuclei therein was next ascertained, and similar discoveries were made in regard to several other tissues. $\mathrm{Up}$ to 1838 there was in fact a period of research in which cells were observed rather than understood.

Establishment of the Cell-theory.-As early as 1826 Turpin had maintained that plants were formed by an agglomeration of cells. Professor M'Kendrick well points out, what one would of course expect, that for some years before 1838 botanists were beginning generally to recognise the cellular composition and origin of plants. The conclusion known as the 'cell-theory' was doubtless vaguely present in many minds. Its definite statement was still awanting. In 1838, however, Schleiden proved that a nucleated cell is the only original component of a plant embryo, and that the development of all tissues might be referred to such cells. In the following year Schwann published at Berlin his famous Microscopic Investigations on the Accordance in the Structure and Growth of Plants and Animals (Trans. Sydenham Society, 1847). In this classic work it was shown that all organisms, plants and animals alike, are made up of cells, and spring from cells. In composition and in origin there is unity. The generalisation familiarly known as the cell-theory was thus clearly established, and though now a commonplace and postulate of histology, it may fairly be described in Agassiz'* words as 'the greatest discovery in the natural sciences in modern times." Following up the generalisations of Schwann and Schleiden, come a host of researches by which the essential advance contained in the 'cell-theory' was more and more fully confirmed. Cells were not only observed, their import was recognised.

New Conception of the Cell. - When the cell-theory was established, the general conception of the cell was far from being either accurate or complete. It was usually described as a vesicle closed by a solid membrane, containing a liquid in which float a nucleus and granular bodies. It was also the general opinion that such cells originated within a structureless ground substance. In two ways these notions were speedily corrected. On the one hand as regards the origin of cells, Prevost and Dumas (1824), Martin Barry (1838-9), Reichert (1840), Henle (1841), Kölliker (1846), Remak (1852), showed that in the case of the egg-cell, and in the growth of tissues, each new cell arose by division from a predecessor. This important conclusion was most firmly established by Goodsir in 1845 , and Virchow in 1858, who proved that in all cases, normal and pathological alike, cells arose from preexisting cells, a fapt expressed in the axiom omnis cellula e cellula. In the second place it gradually became apparent that too much importance had been attached to the cell-wall and too little to the contained substance. Referring details to the 
article Protoplasm, we may note some of the important steps. Dujardin (1835) described the 'sarcode' of Protozoa and other cells; Purkinje (Is:3:) emphasised the analogy between the 'protoplasm' of the animal embryo and the 'cambium' of plant-cells; Von Moht (1846) emphasiaed in the cleareat way the importance of the protoplasm in the vegetable cell; Ecker (1849) compared the contractile substance of muscles with that of the amoeba; Donders also referred the contractility from the cell-wall to the contained material: Cohn suspected that the 'sareode' of animal and the 'protoplasm' of plant-cells must he 'in the highest degree analogous substance;' and so throughout another decade did botanists and zoologists unite in laying stress rather on the living matter than on the wall of the cell, and in hinting at the existence of one living substance as the physical basis alike of plants and animals. This view found at length definite expression in 1861, when Max Schultze defined the modern conception of the cell as a unit-mass of nucleated protoplasm. Since then the protoplasmic movement has dominated research, and we think not so much of the cell-containing protoplasm as of the protoplasm which constitutes and gives form to the cell.

II. Structure of the Cell.-While it is impossible to isolate the static from the dynamic aspects of the cell, it will be convenient to discuss the two separately, and to consider the cell at rest and dead, apart from the cell active and alive. In other words, the form, structure, or morphology may be studied for literary clearness apart from the functions, life, and physiology.

(a) General Form.-The typical and primitive form of the cell is spherical. This is illustrated by many of the simplest plants and animals which live freely, and by young cells such as ova. But the typical form is in many, indeed in most cases, lost; and the forms assumed are as diverse as the internal and external conditions of life. The cell may be irregular and protean, as in Amoebr, white blood-corpuseles, and many young eggs; or squeezed into rectangular shape, as in much of the substance of a leaf; or flattened into thinness, as in the outer lining of the lips; or oval and pointed, as in swiftly moving Infusorians and Bacteria; or much branched, as in multipolar ganglion cells of animals or the latex-containing cells of some plants. The typical spherical and self-contained form is that which would naturally be assumed by a complex coherent substance situated in a medium different from itself. The other forms are responses to internal and external conditions. Under the heading Cell-cycle below it will be shown how the relative activity and passivity of the cell naturally expresses itself in such extremes as a long-drawnout Infusorian and a rounded-off Gregarine, or in a highly nourished ovum and a mobile spermatozoon. Further, cells, like entire animals, often show a tendency to become two-ended, to have poles very different from one another. Just as an animal may have a highly nourished head and a scantily nourished tail, so a cell may become distinctly bipolar in form. In other cases the cell is altogether plastic, expressing every impulse of internal change and every impact of external influence in some modification of form. Or the state of nutrition of the living matter may cause alteration in the adhesion of the substance all over, or in particular places, and thus condition an outflowing, regular or irregular, in given directions. Furthermore, external pressure and limitation of growth may square off the cell into a parallelogram, or restrict it to grow like a bast fibre in length alone and not in breadth. In fact the conditions are most manifold, and the resultant forms likewise. (b) General Substance of the Cell. - The cell is much more than a mass of highly complex chemical substance : it has an organised structure. (1) The protoplasm or living matter in the atrictent mense is generally supposed to be an intimate mixture of complex and highly unstable chemical compounds. Inspection under a microscope of such cells as amobre, white blood-corpuscles, ova, simple algre, or such as are readily seen in thin slices of growing plant-shoots, in root-hairs, and transparent parts, will at once furnish an impresion of the general aspect of the substance of the cell. Not all that one sees can of course deserve the name of protoplasm, for apart from definite inclosures like starch. grains and fat-globules, much of the remaining slightly clouded sulsatance is harlly to be strictly called protoplasm, but rather represents stejs in the ceaseless making and unmaking which form the fundamental rhythm of life. Keeping the definite inclosures and products for the moment aside, we may briefly notice in general outline what has been with most conclusiveness observed as to the structure of the general cell-substance or 'cytoplasm' as it is now frequently termed. All otservers agree that the strueture is far removed from the homogeneous, though there is much difference of opinion as to the nature of the hetero. geneity. In a large number of cases at least the substance of the cell has been resolved into two distinct portions-the one an intricate network, knotted and interlaced in a manner baffling deseription; the other a clear substance, filling ap the interstices or meshes of the living net. Leydig, Frommann, and Heitzmann have been peculiarly successful in unravelling this knotted structure in animal cells, and much the same has been recorded by Strasburger and Schmitz as observable in some plants. The reticulate structure is eertainly more doubtful in regard to vegetable cells, and even in some animal cells what some have described as a network others have deemed only a minutely bubbled emulsion.

But besides the real substance of the cell there are to be seen products of various kinds formed from the living matter. The cell may be packed with starch, or laden with fat, or expanded with mucus; it may contain colouring matter in various forms, as in the familiar chlorophyll bodies of many plant-cells; its structure may include, as in some Protozoa, definitely formed fibrils or yet firmer formations of chitin and the like; and again there are concretions of retained waste and reserve products, sometimes in the form of crystals. Not to be overlooked either is the fine 'dust-cloud" of minute granules which are seen suspended in the clearer matrix, and which apparently represent aygresations of diverse chemical substances formed in the building up and breaking down of the protoplasm. As the outside of any mass is bound to be in differ. ent conditions from the inside, it is natural to find the appearance of distinet physical and chemical zones in the cell-substance. Thus in many Protozos. the outer portion, needlessly termed 'ectoplasm, is often denser and more refractive than the more fluid and internal stratum of the 'endoplasm." Or this may go further, and we may have a sweated. off limiting cuticle, or a definitely organised wall of cellulose in vegetable cells. The cuticle may be further substantiated with secretions of horny, flinty, limy, and other material. Even within the cell a stratified structure may be frequently observed, and Berthold and others have recently emphasised the existence of such concentric layers, each characterised by its own special set of deposits.

Worthy of notice, too, are the varions kinds of bubbles or vacuoles which oecur in the cell-aubstance. These may be simply indefinite spaces, 
containing some liquid not protoplasm, and including salts and other substances in solution. In many Protozoa they are 'food-vacuoles,' formed by the
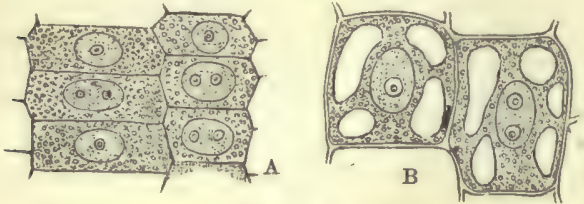

Fig. 2.

A, Embryonic cells from growing point of a root; B, older cells becoming vacuolated. (After Sachs.)

bubbles of water engulfed along with the foodparticles, round which the protoplasm, shrinking from contact, often forms a definite contour. In other cases they are more permanent, and represent minute reservoirs of secreted substance, cisterns of by-products in the vital manufacture of the cell. Finally they may be seats of special activity, where, perhaps, under the stimulus of irritant waste-products, the protoplasm exhibits spasmodic contractions and expansions, and forms the so-called 'contractile vacuoles,' which in alternate dilatation and bursting often seem to serve to remove fluid from the living matter to the exterior.

(c) Nucleus. - In the great majority of cells a central body of definite composition and structure is present which appears to be essential to the life and reproduction of the unit-mass. In many cases the nucleus is well concealed, but as more skilful staining has revealed its presence in many cells which used to be described as non-nucleated, it is rash to conclude too certainly as to its absence in any particular case. Thus some of the Monera, which were formerly defined as the simplest of simple animal organisms without even a nucleus, have been shown to possess them, and the line of division separating Protozoa into Monera and Endoplastica has therefore been removed. Furthermore, the researches of Gruber have shown that in some of the higher Protozoa (ciliated Infusorians) where the nucleus seems entirely absent, dexterous staining prove its diffused presence in the form of numerous granules which take on the characteristic nuclear dye. Yet in some cases, such as the young spores of some Protozoa, the greatest care has not yet been successful in proving the presence of the nucleus. In contrast with these cases, many cells exist in which the nucleus is represented not by one, but by many bodies - the so-called polynuclear state. A further reserve requires to be made, that it is to a large extent an hypothesis that all such definite central inclosures should be slumped together under the one title of nucleus. It is rather probable that in this, as in other organic structures, we have to do with various degrees of development and definiteness.

In the form also of the nucleus numerous modifications occur. In the majority of cases, indeed, it is more or less spherical, but it may be elongated, curved, horseshoe-shaped, necklace-like, and even branched. In the young stages of some ova it is like the entire cell, somewhat plastic, and is pulled in and out in amoeboid movements. In special conditions, furthermore, the nucleus may exhibit peculiar deformations. It is in fact a peculiarly sensitive and all-important part of the cell, suffering with it in degeneration, changing with it in growth and division.

In position the nucleus is typically central, where as the presiding genius of the cell it shares and perhaps controls the general protoplasmic life. But it frequently suffers displacement both of a passive and active nature. In accordance with the growth of the cell it may occupy a position distinctly nearer one of the poles. Accumulations of fat or mucus may push it passively to the side. Or it may actively change, in response to hidden forces of attraction between it and the surrounding protoplasm, in the case of some ova exhibiting a peculiar rotation, or else distinctly shifting its ground from the centre towards the periphery.

Structure. - In many eases, as Leydig especially has shown, the nueleus seems to lie in a nest of its own, in a clear space within the surrounding cellsubstance. Nor is it in many cases at least definitely insulated from the surrounding protoplasm, but is moored to the latter by strands which have intimate relations with both. As of the entire cell, 80 of the nucleus it must be said that in the great majority of cases it is very far from being homogeneous. According to Hertwig, Schleicher, Schnitz, Brass, and others, homogeneous nuelei may indeed occur, but if they do they are rare, and it must always be remembered that the nucleus has its history, and may be less complex at one time than it is at another. To Flemming (1882) above all is due the credit of having elucidated the complexity of the nucleus, and the labyrinthine strueture to which he showed the clue, and to which Frommann (1867) had many years previously directed special attention, has been studied and restudied by seores of expert histologists during the last six years (1888). While their results disagree abundantly on minor points, two conclusions stand out clearly - (1) that the nucleus has a strueture like that of the general cell, consisting of firmer framework and of more fluid intermediate substance, and (2) that apart from detailed difference there is throughout the world of cells a marvellous unity of structure and process, in the nucleus in repose and in the nucleus in action.

In the nucleus the following parts have to be distinguished: (1) The readily stained firmer threadwork, (2) an intermediate clear substance filling up the interstices, (3) definite and usually globular formations known as nucleoli, (4) various granules, and (5) a limiting membrane or nuclear wall. These may be briefly touched upon in order.

(1) The Nuclear Framework (reticulum, trabecular framework, \&c.).-A mere statement of the different descriptions given of this important part of the nucleus would earry us far beyond the limits of this article. The most marked difference of opinion is this, that some describe the framework as distinctly of the nature of a network, while others are as emphatic in calling it a much-coiled band. A third party unite both views, and regarding the nucleus as variable, describe a reticulum at one time and a coiled filament at another. Thus, according to Flemming, Pfitzner, Retzius, Leydig, Van Beneden, \&c., the nuclear framework is typically a reticulum ; according to Strasburger, Balbiani, and Korschelt, a twisted ribbon is the only or most frequent form; according to Brass and Rabl, both types may equally occur. A further complication has been emphasised by Zacharias, Pfitzner, Carnoy, and others-this, namely, that besides the readily stained threadwork noted above (the so-called chromatin), whether this be in the form of a reticulum (Pfitzner) or of a coiled ribbon (Carnoy), there exists another-not readily stained -framework of achromatin. This had indeed been recognised though ñot insisted on by the first series of investigators. To sum up, it is now generally allowed that the framework or threadwork of the nucleus may exist as a network or as a coil, and that it is in a sense double, consisting of readily stainable chromatin on the one hand, and unstainable achromatin on the other. It need hardly be added that as there is considerable diversity of 
mpiniun as to whether given nuclei have a netted or coilunl frumework, there is yet grenter variety in the minuter deseription and figuring. According to Flemming the network is quite disorderly, but Ruuber, Leydig, and others have described distinct
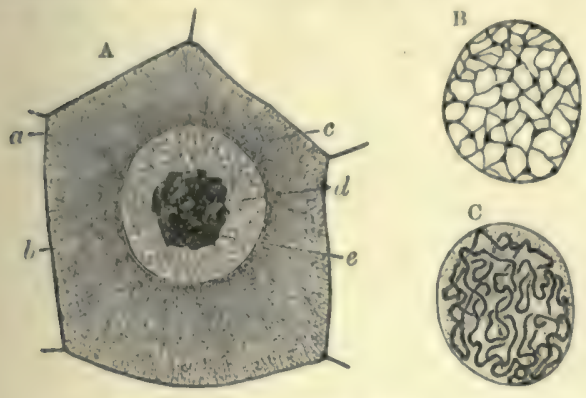

Fig. 3.-(After Carnoy):

A Cell and typical nucleus: $a$, slight membrane; $b$, radiating protoplasmis network; a wall of nucleus; $d$, plasms of protoplasmis network;

B, Nucleus st rest, showing network.

C, Nucleus before division, showing coiled filament.

radial structure; according to some the nuclear coil is endless, while others describe it as divided into portions; and when we descend to such subtleties of observation as the intimate structure of the threadwork or the relations between chromatin and achromatin, the diversity is 80 great that it seems desirable here to leave such minutire untouched.

(2) The Intermediate Nuclear Substance.-Besides the nuclear elements of definite form, what-ever that form may precisely be, all investigators describe an intermediate sulustance of variable consistence, usually semi-liquid, amorphous and .structureless, but with fine granules. It is a clear unstainable 'plasma' filling up the chinks, but nothing definite is known as to its composition. (3) The nucleolus which lies within the nucleus varies greatly in size and position, and more than one -are very generally present. Flemming has defined them as "portions of the nuclear substance, distinct in structure from network and plasma, definitely limited and smoothed, always rounded in outline, nsually suspended in the network, but often independent of it.' But when the minute structure and the relation of nucleoli to nuclear framework are inquired into, or the question of physiological rôle raised, very great diversity of opinion is found to obtain. (4) Bodies different in appearance from nucleoli may occur inside the nucleus, but of these little is known. (5) The wall which bounds the nucleus seems to be a true integral part of the latter, but disappears at the beginning of division.

(d) The Cell-wall.-In the older conception of the cell, which was practically that of a closed bag, the wall of the cell figured very prominently. But Nigeli showed (1845) that some vegetalile cells were destitute of walls, Leydig (1857) defined the cell in respect to its substance, Schultze and others deseribed naked Protozon, and the progress of the 'protoplasmic movement' led to the abandonment of the position that the wall was a necessary or important part of the cell. In many cells, indeed, a limiting layer is very clearly present, and a sheath or cyst is especially charac teristic of passive cells. Plant-cells are almost always distinguished by the possession of a limiting wall, of definite chemical composition, consisting of what is known as cellulose. An analogous wall occasionally occurs round animal cells. In the latter, however, the membrane is usually a comparatively slight thing, and may arise (1) from an aggregation of the threads and lenots of the framework; (2) as a cuticle or capsule formed from the matrix or ground substance; (8) from a combinstion of both these elements. Leydig has shown that in a very wide series of animal cells the membrane, such as it is, is penetrated by small but definite pores. It is very important further to remember that both in plants and animals the cells are in a great number of eases connected with one another by intercellular bridges of protoplasm, and are in nowise to be thought of as closed bags. The cell-wall of plants, which, be it again noted, is a definite chemicel substance, grows in extent and thickness by an intricate organic process, in the course of which new infinitesimal elements form apparently as intercalations between the old. The growth is in very many cases far from uni. form; pits, ridges, and manifold kinds of sculptur. ing thus appear, and give rise to numerous detailed variations. The formation of new boundaries when a cell divides is a question of much difficulty ; but in plant, and apparently in some animal cells, the formation of a 'cellular plate' is one of the last events in the dividing process.

III. Physiology of the Cell.-When the entire organism is simply a cell, as in most of the Protozos and Protophyta, all the vital processes which in higher forms have their seat in special sets of cells, known as tissues and organs, are of course discharged by the unit-mass. Thus a unicellular organism like the Amoba takes in energy as food in nutrition, works it up into living matter in digestion and assimilation, and expends it again in contraction and locomotion. As in any higher organism the oxygen required for the chemical breaking up of the protoplasmic molecules, the air for the vital flame, is taken in by the absorption known as respiration, and the waste carbonic acid gas is in an essentially similar way got rid of. Further, more solid 'ashes' of the vital combustion are formed in the Amoba and in other actively living cells, and may pass out in excretion along with the refuse of unusable foodmaterial. The absence of a circulating fluid, of digestive glands, nerves, sense-organs, lungs, kidneys, and the like, does not in any way restrict the vital functions of a unicellular organism. All goes on as usual, only with greater chemical complexity, since all the different processes have but a unit-mass of protoplasm in which they occur. The physiology of independent cells, instead of being very simple, must be very complex, just because structure or differentiation is all but absent. It is, however, possible to ex press the manifold processes in a comparatively simple way by remembering what Claude Bernard was one of the first clearly to emphasise, that vital processes must be really only twofoldbuilding up and breaking down of living matter. On the one hand the protoplasm or real living matter is being by a series of chemical processes built up or constructed; on the other hand, in activity it is breaking down or being destroyed. The income of food or energy is, at the expense of the cellular organism, gradually raised into more and more complex and unstable compounds, until the genuine most complex and more un. stable living matter itself is reached. On the opposite side, with liberation of energy in the form of work, this living matter breaks down into simpler and simpler compounds, until only the work, the waste products, and heat remain as the equivalent of the income of energy or food on the other side of the life-equation. On the one hand there are constructive processes, on the other, destructive; chemical synthesis and chemical dissolution is another expression of the contrast; while the two sets of processes are in more modern 
language respectively termed anabolism and katabolism (see ProtopLASM).

But only a few cells, comparatively speaking, live a free and independent life. The majority are component elements in higher unities. In these the original many-sidedness of function is more or less lost, or at anyrate in abeyance, and that exactly in proportion to their degree of subordination. Even in individual cells there is a tendency, obviously within narrow limits, towards differentiation-that is, to the restriction and specialisation of certain parts for certain functions. But when the cells form elements of a larger whole, the division of labour finds full effect. From position and other conditions the cells cease to be uniform or metaphorically many-sided. Certain sets predominate in contractility, others in irritability, others in secretion, others again in storage, and so on. In such cases one function predominates over the others, which are subordinate or only dormant possibilities. Thus arise muscle-cells, nerve-cells, glandular cells, fat-cells, and the like. Compared with Amobre, those cells must have a simpler physiology; they may have gained in complexity of structure, but have lost in manifoldness of function. The aggregation of similar cells, usually with one predominant habit or function, results in the formation of tissues (see BIOLOGY, Embryology, Function, Physiology, ReProDUCTION, and cognate articles in this work).

One general physiological fact may, however, be referred to which will greatly assist in understanding the life both of independent cells and of those which form the elements of tissues. A survey of the unit-organisms, both among plants and animals, reveals the existence of three well. marked phases. Some cells are emphatically active, equipped with motile lashes (eilia or flagella), and obviously liberal in their expenditure of energy. Others are just the reverse of this, emphatically passive, wrapped np in themselves and without motile processes, obviously economical in their expenditure, conservative of their income. A third set form a mean between these two extremes, are neither encysted like the latter nor lashed like the former, but furnished with the relatively slow-moving processes characteristic of Amobre, and living in a via media between activity and passivity. These three types may be termed respectively ciliated, encysted, and amoboid, or active, passive, and moderate. That these types generally correspond to the three great divisions of the Protozoa shows that they represent the three main possibilities of cellular life. Now in the very simplest forms all the three phases occur in one life-history; no step has, as it were, been taken in any one of the three directions; the primitive cells are in a state of physiological indifference. What has happened in the

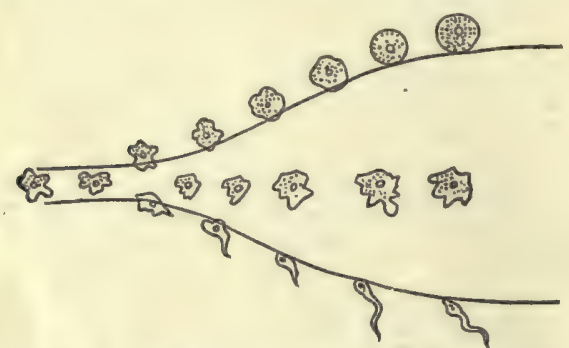

Fig. 4-Phases of Cell-life. (After Geddes.)

Development of passive or resting, intermediate (amoeboid), and active (motile) states.

higher classes of Protozoa - Infusorians, Gregarinids, Rhizopods-is that one phase has been accentuated to the more or less marked subordination of the others. Not that the emphatic adoption of one line of cell-life excludes the others; they may in fact occur as temporary stages, or as. pathological deviations.

But while simple observation is sufficient to. establish the existence of a cycle of phases in the life of primitive cellular organisms, such as. Protomyxa, and the existence of three main lines of specialisation among the Protozoa, the importance of this conception of a 'cell-cycle" becomes increased and justified when the facts are considered physiologically. If we start from a simple cell, such as an Amoeba, it is evident enough, from what has been already said as to the twofold nature of all vital processes, that the prineipal physiological possibilities are the three phases. above indicated. On the one hand, with preponderance of income over expenditure, of constructive over destructive changes, of anabolism. over katabolism, the cell must tend to become larger in size, more weighted with stored material, more sluggish or passive in habit, and more rounded in form. But if the reverse take place, the cell will tend to become less bulky, more active or locomotor in habit, and more elongated.

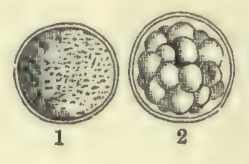

Fig. 5.-Protomyxa :

1, encysted : 2, dividing: 3, spores escaping as ciliated bodies, passing into 4, amoboid state; 5, 'plasmodium' forming from passing into 4, amoeboid
lusion of amueboid cells.

in form. The sweated-off cyst of the former, the motile processes of the latter, are expres. sions of exactly opposite constitutions and conditions. A third physiological possibility remains, that namely of continuing in a position of averageequilibrium between income and expenditure, between anabolism and katabolism, in a middle way between the fitful fever of extreme ciliated activity and the sluggish sleep of encysted passivity.

Now if we take these two facts-the existence: of a primitive cycle through which cells tend to.

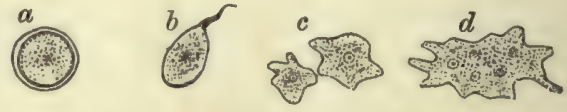

Fig. 6. -The Cycle of Cell-life :

$a$, encysted ; $b$, ciliated ; $c$, amœboid ; $d$, plasmodial.

pass, and the existence of three main physiological possibilities which lie behind the cycle-we are in a better position to understand both the changes. exhibited in normal and pathological conditions by individual cells, and the various forms of cells as they occur in the tissues of the higher organisms. Thus lashed cells such as those of the windpipe of mammals, the skin of many lower worms, the inside of $a$ Hydra, the male elements of most. animals and many lower plants, emphasise one phase in the cycle, and it is not surprising to. find that in certain conditions they may sink down into the amoeboid type. Or again, the amoboid character of young ova, preceding the more passive and encysted condition of the mature cells, is in view of the 'cell-cycle' a most natural procedure. In many cases artificial stimulus of various kinds has been shown to make cells pass from one phase to another of the primitive life-cycle theoretically possible to all. In the same way the preponderance of cellulose in cells. 
encysted is a natural character of the passive plinis, and the insherthed cells of many animal tiswues may be similarly expressed as an exhibition of the same passive plase. But it is enough here to point out the possibility of elassifying and interpreting the various cells composing the tissues of higher orgunisus in terms of an original life. eycle, or deeper still in terms of those twofold protoplasmic possibilities which lie behind all forms anil planses whether of cells, tissues, or organisms themselves. This conception of a cell-cycle is due to (iedles (see Bibliogruphy at end of article).

Cell-division. - When the vital processes are so related that income and upbuilding exceed expenditure and dissolution, the cell must obviously aceumulate capital and increase in size. In some eares the cell may expand into relatively gigantic proportions, as in the alga Botrydium and in many egrgs. Growth, however, brings a nemesis with it, this namely, that the mass to be kept alive increases more rapidly than the surface through which the vital processes are accomplished. In splierieal cells the former increases as the cube, the latter as the square of the radius. The bigger the cell gets, the more difficult do its conditions of life become. The supplies of food and oxygen,
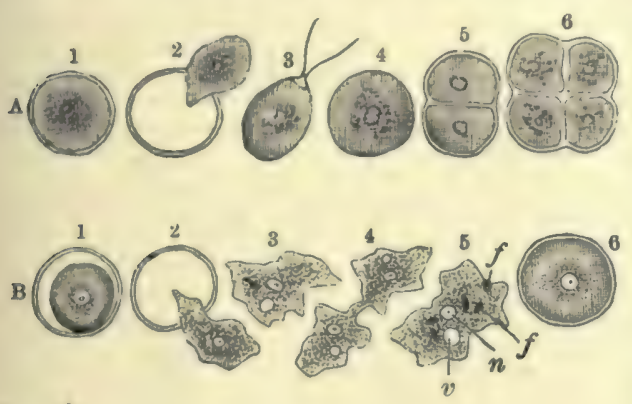

Fig. 7.

4. Life-history of unicellular plant (Protococeus): 1, encysted ; quitting its cell ; 3 , ciliated ; 4 , quiescent ; 5 and 6 , dividing. B, Lifp-history of Amoba: 1 , encysted; 2 , escaping; 3 , free; 4 , dividing ; 5 , free half with vacuole $v$, nucleus $n$, and foodparticles $f ; 6$, encysting anew, 4 and 5 may also represent the union of two Amcebe (conjugation).

the means of accomplishing purification and the like, cannot keep pace with the growth of the living mass if the surface increase only at a much less rapid rate. A limit of growth is thus reached. The cell must stop growing, or go on growing at an increasing risk, or in some way restore the balance between mass and surface. This last course is the one most frequently exhilited-the cell divides. However this may be effected, the result is in all cases the same - namely, the reduction of mass, and corresponding increase of surface. Like other organisms, the cell-organism reproduces at its limit of growth. This rationale of cell-division, due especially to Herbert Spencer, is obviously clearest in reference to free-living cells like Protozos, Protophyta, blood-corpuscles, reproductive cells, and the like, but the general principle holds good throughout.

It is evident, however, that such considerations as the above go to justify rather than to explain cell-division. They show why the cell ought to divide, not how it does. The real mechanism of the process is still a riddle. In its very simplest expressions, indeed, the riddle may be partly read. In a simple and primitive Protozoon like Schizo. genes, the protoplasm seems literally to break. Irregular fissures appear, as well they might if a condition of unstable vital equilibrium has been reached, and portions of the substance are cleft apart from the main mass. From such a crave to the separation of multiple buds, which are little more than overflowings of too large a cell, or to the commoner oceurrence of simple budding, is no great step. The dificulty lwegius, however, when we consider the ordinary coll. division, which appears in most cases as a desliberate and orderly process, including a well-defined series of nuclear changes. As to the mechanicss of this process only a few suggestions of moment have been marle. Thus Platner points ont that the explanation must be in terms either (1) of chemical processeg influencing the cellular sub. stance, or (2) of protoplasmic movement due to the above or to external influences, or (3) of unknown inolecular and attractive forces. He himself finds the condition of nuclear division to be in part a streaming movement of the protoplasm, such as is familiar in many Protozoa, and would regard the division of the protoplasm as a purely mechanical process. In his studies on protoplasmic mechanics, Berthold has also attacked this in. tricate problem, but more in relation to the nature of the dividing partitions than with reference to the forces at work. Professor Van Beneden, who did so much in working ont the details of celldivision in the ovum, expressed himself as follows in regard to the deeper problem in a paper published in 1887: "All the internal movements which are associated with the cellular division have their immediate cause in the contractility of the fibres of the reticular protoplasm which form two antagonistic groups." All that one can at present conclude is that the process represents, as above noticed, a physiological necessity, and that it takes place in connection with very intricate physical and chemical changes within the cell.

Modes of Cell-division. - After abstracting the rare occurrence of almost mechanical ruptures and of overflow buds, various modes of orderly division remain to be noticed. (a) The cell may give off a bud, usually smaller than itself. With this a portion of the nucleus is usually associated, as in many Protozoa; or the processes may occur apart from demonstrable nucleus, as in the common yeast-plant. (b) Division into two is by far the most frequent mode of multiplication, and occurs all but universally. In a small minority of cases the division is accomplished without any intrieate nuclear change, the cell being in an apparently simple way divided into two, with half of the nucleus in each daughter-cell. Such divisions are said to be 'direct.' In most cases the nucleus, apparently taking the initiative, undergoes a striking series of orderly changes before the division is perfect. This is the commonly observed comlition, and such divisions are termed 'indirect.' (c) But in many cases the division occurs in a very different way, being not single but multiple. From one cell more than two daughter-cells arise simultaneously, and that not by external cleavage, but by internal multiplication. Such a mole of multiplication is termed endogenous division or 'free' cell. formation, and is well secn in many Fungi and Algre. It may be compared with the ordinary process by defining it as division taking place in limited space and time, since the daughter-cells arise within the mother-cell, and simultaneously, not successively. It is, in many cases at least, preceded by the rapid division of the nuclei, to form centres round each of which protoplasmic material then becomes agcrearated. In a few cases, Amold has described a peculiar breaking up of the nucleus which he called fragmentation.

Karyokinesis. - One of the most beantiful results of recent histology is the demonstration of the general unity of process which obtains in the 
division of all kinds of cells. Whether the subject of investigation be the pollen-cells of a plant, the skin of a tadpole, the developing ovum, or the growth of a tumour, the same process of ordinary indirect division may be observed to take place along essentially similar lines. This, though but

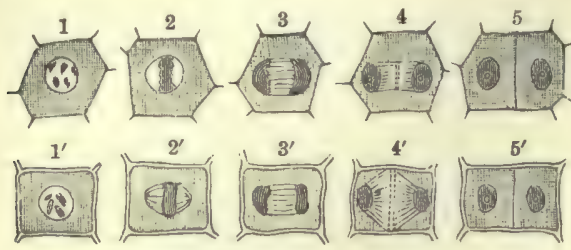

Fig. 8. - Stages of Transverse Division :

$1,2,3,4,5$, in the epidermis of a tadpole; $1^{\prime}, 2,3^{\prime}, 4^{\prime}, 5^{\prime}$, in the epidermis of lily. (After Macfarlane.)

a natural consequence of common descent and similar conditions, is not without its marvel when the complexity of the process (see below) receives due consideration. Even in detail there is in structural as well as in physiological changes a deep-seated unity of process. But while the essential similarity of all cases of simple 'indirect' division must be allowed, it is only fair to recog. nise that in minor details very manifold variations occur. Even in those Protozon where the nuelear changes of division have been followed, considerable diversity of detail obtains ; nor, within a single genus do the ova of two different species of thread. worm (Ascaris) divide in exactly the same fashion. But neglecting at present the detailed divergences, whether these occur normally and constantly, or as they often do atypically and arbitrarily, it is necessary now to notice the general steps usually observed in cell-division.

We have already described the nucleus as consisting of a readily stainable (chromatin) network or ribbon, and of another substance (so-called achromatin) which does not stain so deeply. As a preliminary to division, the nucleus loses its definite boundary, and the chromatin threads no longer exhibit the regular disposition they have when at rest. The threads form an irregular wreath, and as the loops break, their arrangement is comparable to a star in which the open ends of the loops are directed outwards, and the closed ends lie in the centre. By subsequent movement this position is reversed, the loops gather into two groups, which lie with their open ends towards one another in the middle. Mean while, the achromatin elements also exhibit regular arrangement, forming fine streaks stretching from the centre towards the poles, and exhibiting an appearance which is ofter compared to a striated spindle. At the two poles of the cell the granules of the general protoplasm

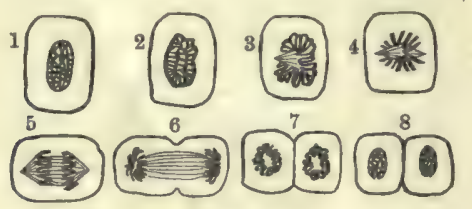

Fig. 9.-Typical Division of Nucleus. (From Haddon, after Flemming.)

are also aggregated into $a$ couple of star-like figures. The chromatin loops now diverge farther and farther from the centre, till they reach a position at the respective poles. A double chromatin atar may then be observed, one at each pole, not to be in any. way confused with unsubstantial polar stars previously mentioned. Soon after this stage is reached, the real cell-division occurs. The pro. toplasm constricts across the middle of the cell, and the division is accomplished. In plant-cells, and apparently in some animal cells also, the division of the protoplasm is accompanied by the formation of a cellular plate, which bounds the open surfaces of the two daughter-cells. With or without cellular plate, the result is the formation of two daughter-cells, each with half of the original nucleus. But this is not all, the half nucleus formed after the above fashion has to be reconstructed into the original resting form. A series of retrogressive stages occur, in the course of which the nucleus passes from star to wreath, and from wreath into the typical network or twisted coil. In some cases the steps of reconstruction seem to correspond very closely to the various steps of the antecedent upbreaking.

Death.-It seems tolerably certain, as Weismann and others have suggested, that the unicellular Protozoa are in the great majority of cases practically immortal. These simple organisms have no 'body' to keep up, in their functions they appear to be continually self-recuperative, and except from entirely abnormal conditions such cells probably never die. The pool in which they live may dry up for ever, or other animals may swallow and digest them, but such casualties are very different from natural death. They may indeed lose their individuality by doubling in division, or the whole cell may break up into spores, but where there is nothing to be buried we can hardly speak of death. It seems in fact justitiable to say that death began with the formation of a many-celled body. Even there, a certain amount of immortality may be claimed for the reproductive cells, which, becoming separate from the parent organism, proceed to divide into a body which will of course eventually die, but also into reproductive cells, which, as some of them at least will form again fresh organisms and reproductive cells, may be said to be links in a continuous and immortal cellular chain. But leaving aside the really immortal Protozoa, and the logically immortal successful reproductive elements, it must be allowed that cells, like organisms, die. And that not only with the body as a whole, but by themselves. Certain superficial cells are constantly being brushed off and replaced by others; the red blood-corpuscles break up in the fluid; others become hardened in death into the 'mummified' cells of supporting and epidermic structures; others surrender themselves into mucus or in the ejection of lassoes as in the Coelenterates; others practically die away into fat and reserve products, or may in manifold ways degenerate. Many surfaces, especially in secreting regions of the body, exhibit continual death of cells, and regeneration by the division of the survivors.

IV. Modern Aspect of the Study of the Cell.With the improvement of appliances and the perfecting of staining methods, the study of the cell has within late years become at once more accurate and more complex. On the one hand, the labours of the early histologists are being amplified and corroborated with ceaseless industry. The forms of cells in different animals and tissues, the minutiæ of their structure, the processes observed in their multiplication, are being each year more and more perfectly investigated. On the other hand, the emphasis which has been laid on the protoplasm is finding expression in numerous attempts to explain the forms and phases of cell-life in terms of the underlying protoplasmic changes, and such investigations as those which seek to disclose the mechanics of cell-division and ovum-segmentation, the conditions of cellular equilibrium and change, 
or the chemistry of the various parts, mark the limit and high-water mark of cellular biology.

Practical Study. - To gain a preliminary acquaintance with the cell, the student should examine with a good microscope-(1) Free cells as seen in unicel. Iulur plants, such as yeast, green mould, simple alga, or in pollen grains, \&c.; in unicellular animals like Amaba, Paramacium, Vorticella; in the elements of the blood; in the ova of animals, as found in spawn of frog, Sc. (2) Simple vegrable tissues as seen in root-hairs, transparent leaves, epiclermis of plants, and common fresh-water algat like Spirogyra; simple animal tissues readily obtained from frog, earthworm, Hydra, and the like. For research in details of structures, staining and section-eutting must be resorted to.

Literature. - (1) For history, see BroLoer, Botary, Embryology, Physiologt, Protoplasm; M'Kendrick, On the Modern Cell-theory (1888); Drysdale, Proto. phasmic Theory of Life (1874)

(2) For structure of cell and process of division, consult tirst modern text-books of histology, such as those of Brass, Fol, Frey, Klein (English), Leydig, Ranvier, and Stöhr. For recent researches, see Journal of Royal Micrascopical Society. $\Lambda$ s one research is rapidly superseding another, detailed references noed not be given. Forgeneral bibliography, see Professor M'Kendrick's paper (above); for nucleus, Van Bambeke, Etat actuel de nos Connaisances auv la Structure du Noyer (Gand, 1885). for cell-division, Waldeyer, 'Uber Karyokinese,' Archiv. f. Anat. u. Physiol. (1887) ; for the vegetable cell in particular, Zimmermann, 'Die Morphologie und Physiologie der Pflanzenzelle,' Schenok's Handbuch d. Botanik (1887). See also Professor Carnoy's cell journal, La Cellule. The Memoirs, which will always be classic in the history of cell-lore, both in themselves and on account of the stimulus which they supplied, will be found in the following and those to which they chiefly refer: Van Beneden, Recherches sur la Maturation de PEEuf, dec. (1883); Flemming, Zell-substanz, Kern und Zell-theilung (1882); and later papers in Archiv. f. mikr. Anatomie; Frommann, Unters. Uber Struktur, Lebenserscheinungen und Reaktionen thieriacher und planzlicher Zellen (1884); O. and R. Hertwig, Beitröje zur Morphologie der Zellen (1875-88); Leydig, Zelle und Gevebe (1885), and previous works; Strasburger, Zellbilduny und Zell-theilung (Jena, 3d. ed, 1880).

(3) For general physiology, consult first Foster's Physiology, chap. i., then general works on physiology of plants and animals-0.g. Sachs' Text-book of Botany and Lectures on the Physiology of Plants, also Vines' similar work (1887), Hermann's Handbuch der Physiologie, \&c. Further, Herbert Spencer's Principles of Biology; P. Ceddes, 'Restatement of the Cell-theory, Proc, Roy. Soc. Edin. (1883) ; M. Foster's article 'Physiology,' Encyclopedia Britannica; Berthold, Studien uber Protoplasma mechanik (Leip. 18×6); Schwarz, Die Morphologische und chemische Zusammensetzung des Protoplasmas (Breslau, 1887); and the article Protoplasm.

\section{Celle. See ZELL.}

Cellini, Benvenuto, a celebrated Italian goldsmith, sculptor, and engraver, and the author of one of the most interesting autobiographies ever written, was born in 1500 in Florence, a city which he was foreed to quit in early life through having taken part in 'an affray.' He then travelled to Rome, where his skill as an artist in metal-work gained him the favour of the highest nobles and prelates. So anxious were his patrons to secure his services that they allowed him the utmost license of conduct. By his own account he was as expert with sword and dagger as with his goldsmith's tools, and he had apparently no scruple in murdering or maiming any who endeavoured to thwart him. He states that at the siege of Rome in 1527 it was he who killed the Constable Bourbon, and that he afterwards shot down the Prince of Orange before the castle of St Angelo. He stood for a time high in favour with Pope Clement VII. but was eventually flung into prison for the murder of a rival goldsmith. In 1534 he was pardoned and set free by Paul IIL, who wished him to engrave dies in the mint; moon afterwards, having spoken contemptuously of the pope's artistic tastes, he was cast into an oubliette of the castle of St Angelo. He escaped through his knowledge of the castle's vaults, but was immediately recaptured, and was only saved from the pope's vengeance by the intercession of Cardinal d'Este. For some years he lived alternately in Rome and Florence, Mantua and Naples. In 1537 he went to the court of Francis I. of France, by whom he was honourably received, and for whom he executed a golden spice-box, the design of which, he tells us, was so exquisite that the king ' uttered a loud outery of astonishment on seeing it,' and 'could not satiate his eyes with gazing on it.' In Paris he became involved in a lawsuit. Having lost his case, he had recourse, as usual, to his dagger. 'I attacked,' he says, 'the plaintiff who had sued me, and one evening I wounded him in the legs and arms so severely (taking care, however, not to kill him) that I deprived him of the use of both his legs.' This act went unpunished. Having given offence, however, to the reigning favourite at the French court, Cellini returned to Florence, where he worked under the patronage of Cosmo de Medici, and where he executed his most successful piece of sculpture, the famous bronze 'Perseus with the head of Medusa' of the Loggia de' Lanzi. He began to write his antobiography in 1558 , and died at Florence in $\mathbf{1 5 7 1}$

Cellini was a man of versatile fancy, passionately devoted to his art, and his technical skill was supreme. But his designs were often feeble and tasteleas, and he seems to have had no sound knowledge of human anatomy. He has, on the whole, been somewhat overrated as an artist, and has been credited with the production of many beautiful cups and vases (such as the "Cellini vase' in the British Museum) which were really the work of German silversmiths in the 16th century. But he has not been, and could not easily be, overrated as an anthor. His autobiography is a work of extraordinary interest. 'From the pages of this book, says Mr Symonds, 'the Genius of the Renaissance, incarnate in a single personality, leans forth and speaks to us.' Though he had not the faculty of self-criticism, Cellini was a shrewd judge of others, and had a remarkable talent for portraying character. His book gives a faithful and a wonderfully vivid picture of Italian society in the 16th century. The animation of the narrative and the racy vigour of the style could hardly be surpassed. The keen insight and unblushing frankness of the writer make his work as fascinating to the student of human character as it is invaluable to the historian of the Renaissance. Cellini reveals all the evil and all the strength of his nature, his vindictiveness, braggartism, and self-worship, no less than his fiery energy and powerful intelleet, his splendid self-reliance and passionate love of art. $\mathrm{He}$ is the most andid of antobiographers, and he is as ignorant of shame as he is candid. There is an admirable translation of this work by J. A. Symonds (1887; 4th ed. 1896). Goethe trunslated it into German. See the monograph by E. Plon (1852).

Cellular Plants. It was formerly attempited by De Candolle and others to nnite all the lowest plants destitute of vascular tissue under the general title Cellulares, as opposed to the Vasculares, in. cluding all the higher plants. Although this classification is long disused, the term 'cellular plants' is often familiarly employed to distinguish the Fungi, Algre, Lichens, Characere, Liverworts, and Mosses (q.v.) from the higher or vascular cryptogams-Ferns, Horsetails, Lycopodiacere and Selaginellere, and Isoetere. See the articles in this work on most of these groups; for cellular tiseue, 
see also the articles Botany, Cell, Tissues, Leaf, BARK, \&c.

Celluloid, or Parkesine. This substance was first made by $\mathrm{Mr}$ A. Parkes of Birmingham in 1855 or 1856. It chiefly consists of a dried solution of gun-cotton (pyroxylin), or of what is nearly the same thing, and oil. A variety of it can be made with pyroxylin and camphor. It resembles ivory, horn, tortoiseshell, and hardened india-rubber, as regards certain properties.

The pyroxylin is prepared by treating Cellulose (q.v.) from such vegetable materials as cotton or flax waste, rags, paper-makers' half-stuff, or paper itself, with a mixture of one part of strong nitric acid and four parts of strong sulphuric acid. It is convenient to call the product so obtained pyroxylin, although the two things are not quite identical. The distillate obtained by distilling wood naphtha with chloride of lime is used as a solvent for the pyroxylin, but other solvents, such as nitrobenzol or aniline, and some camphor are added with advantage. When the excess of solvent is removed from the pyroxylin, it is mixed with a considerable quantity of castor-oil or cotton-seed oil, and made into a dough or paste between heated rollers. For a hard componnd the quantity of oil should be less than the pyroxylin, for a soft one it should be greater. Chloride of sulphur is sometimes added to the oil. When articles made of celluloid are in a partially manufactured state, they are soaked in bisulphide of carbon or chloride of lime to remove any trace of solvent, which would render them apt to shrink if allowed to remain. Celluloid is of a somewhat combustible nature unless the substances used to colour it are such as will neutralise this, or unless some non-combustible chemical, tungstate of soda for example, is added to it.

Properties and Uses.-Celluloid has many valuable properties. It is buff or pale brown in colour, but it can be made as white as ivory, which it much resembles, or manufactured in a transparent state. It can be moulded or pressed into any form, and turned, planed, or carved. Neither the atmosphere nor water affects it. It is elastic and can be united by its own cement. In a plastic condition celluloid can be spread on textile fabries, or it may be made as hard as ivory, for which it is largely used as a substitute. Billiard-balls, piano-keys, and combs are made of it, the latter two articles extensively. It can be coloured to represent amber, tortoiseshell, or malachite. In initation of red coral it has been a good deal used for jewelry. Like vulcanite, which it excels in durability but exceeds in price, it has very numerous applications. We need only mention umbrella-handles, brush-backs, knifehandles, buttons, napkin-rings, card-cases, thimbles, and dolls. It is useful for optical instruments, for cases for artificial teeth, and for some surgical instruments. One special application of it is for shirt fronts and collars. It is used for very pretty imitations of ivory, amber, tortoiseshell, coral, malachite, \&c. Some important developments in the manufacture and application are due to J. W. Hyatt, of Newark, New Jersey.

Cellulose is the substance secreted by the living protoplasm of a vegetable cell to form its investing membrane or cell-wall, passing through the various ligneous, corky, and colloid changes, new arrangement and union in cell-walls, \&c. (see Cell, Leaf, Tissues, Vegetable Physiology, WOOD). It is obtained pure by treating any unaltered cellular tissue with alkalies and acids to remove mineral matter and protoplasm, and snccessive washings with water, alcohol, and ether to remove soluble substances. Cotton-pith or vegetable-ivory, although much contrasted in histological properties, are alike remarkably pure cellulose; in bast the proportion of associated mineral matter becomes much more considerable. Cellulose has the chemical composition $\mathrm{C}_{6} \mathrm{H}_{10} \mathrm{O}_{5}$, and spec. grav. 1.52. Among its familiar natural modifications gum is an isomer, and starch-dextrin and grape-sugar are all of similar ultimate composition, while its woody and corky modifications (lignin and suberin) possess an increasing proportion of carbon. Iodine alone stains cellulose yellow or brown, but blue when strong sulphuric acid has been previously added. Strong hot sulphuric acid chars it, while brief im mersion in the cold converts it into a tough and dense modification, well known in parchment paper, and prolonged treatment dissolves it altogether. Dextrin may thus be prepared and next transmuted, by boiling the watery solution, into grape-sugar (see Dextrine, Glucose). By immergion in a mixture of strong nitric and sulphuric acid we obtain Gun-cotton (q.v.), while dilute nitric acid or potash oxidises it into oxalic acid. Ammoniacal oxide of copper dissolves it without change, as is shown by its reprecipitation on dilution. By heating in closed vessels under pressure a dense coal. ike mass is formed, while in ordinary dry distillation, gas, tar, and acetic acid are given off, processes which throw light on the formation of coal in nature and on the chemistry of gas-making. In natural decomposition cellulose turns yellow and brown with gradual formation of humus. See SoILs.

Although so constant and characteristic a product of vegetable life, the conditions and mode of its formation are still very obscure. From that cellcycle or rhythm of change between the passive and cellulose-walled state and an active and wall-less one, which is so characteristic of the lowest forms of life, and of which we find surviving traces (e.g. the rejuvenescence of the pollen-grain) in the reproductive processes of even the highest plants (see CELL), it would appear that there is some relation between this increased passivity and the formation of cellulose. And in this way arises the speculation that cellulose may be viewed essentially as a (mechanically coherent and thus useful) excretion, an incompletely utilised waste product corresponding to the carbonic acid and water given off by the completer respiratory oxidation and larger evolution of energy of the active phase. Once formed by the plant, it may be again absorbed, as is well seen in the union of a row of cells into a continuous vessel, or in the consumption of endosperm of a seed during germination. Many seeds, such as vegetable-ivory or date, have a great proportion of their reserve material in this form; and this must be digested into glucose by the growing embryo, and again worked up into new protoplasm, which deposits cellulose as before. Like the plant itself, the similar digestive ferments of the animal might thus be naturally expected to digest cellu. lose ; and this is actually, to some extent, the case with the delicate young cell-walls of many green vegetables, as can be experimentally verified, even in man; while in herbivorous animals this power is much developed, and the nutritive utilisation of their fodder is thus increased to an important extent.

The cysts of amcebr and other protozo appear to be at least largely composed of cellulose, and the external tunic of ascidians (see TUNICATA) is of identical, or at least isomeric, composition. Cellulose has been described as a pathological product, even in brain-tissue; and Chitin (q.v.), a very char. acteristic and in many respects comparable animal product, has been sometimes viewed as cellulose in association with a proteid substance.

Celsius, ANDERs, the constructor of the centigrade thermometer, was born at Upsala in Sweden, 27 th November 1701. He was the grandson of 
Magnus Cialsius ( 1621 -79), a professor of Astronomy and decipherer of the Helsing runes, and the nephew of Olof Colsius (1670-1756), professor of Theology at Upsala, author of the Hierobotanicon, and en ourly friend and patron of the great Linnseus. Anders became in 1730 profeseor of Astronomy at Upsals, Two years later he set out on a scientific tour, visiting the observatories of Nuremberg, Rome, and Paris After his return he published his De Ohwervetionibus pro figure telluris determinumela in Collia habitis (Upsala, 1738). In 1740 he had the satisfaction of seeing a splendid olservatory erected at Upsala, and here he laboured till his death, 25th April 1744. The Tranmactions of the Swedish Araleny contrin many papers hy Celsius on astronomy and physics. It is, however, as the first eonstructor (1742) of the thermometer now chiefly used by scientific men, that he is best known. In it the space between the freezing-point and the boiling-point of water is divided into one hundred spraces, hence Celsius's thermometer is often called the centigrade or centesimal scale. See THER-

\section{MOMETER.}

Celsus, a Platonic philosopher, but tinged with Epicureanism, who lived in the $2 d$ century after (Trist, was a friend of Lucian, and wrote, about 176-180, during the persecution of Marcus Aurelius, under the title Logos Alethès ('true word'), the first notable polemic against Christianity. The book itself has perished; but considerable fragments have been preserved as quotations given by Origen in his answer, Contra Celsum, in eight books. In the fragments - which are very interesting, as showing the views of a heathen philosopher in regard to Christianity-Celsus, with great acuteness and wit, but without depth or earnestness of thought, prefers against the new religion charges of unphilosophicalness and blind credulity; and especially endeavours to convict Christians of self-contradiction in their spiritual doctrine contrasted with their anthropomorphic representations of Deity ; in their religious arrogance contrasted with their confession of sinfulness; and in their views of the necessity of redemption. He also reproaches Christians with their party divisions and ever-varying opinion, and ridicules them as worms in a corner who think they occupy the centre of the world. Celsus holds that the Supreme God can have no contact with the material world, the creation of which is the work of inferior deities or demons. He regards evil as an essential property of the material world; he says: "There neither has been in former times, nor is there now, nor ever shall be, an increase or diminution of evil. The nature of the universe is ever identical, and the production of evil is not a variable quantity. .... It is evident that those who sin by nature and by habit cannot be changed in any respect either by punishment or by pardon." He charges Christians with having "remodelled "The Gospel" from th "first writing" three times, four times, and many times.' However, as Origen remarked, almost everything of an historical kind to which Celsus refers is to be found in our Gospels, especially the Synoptics. See Keim, Celsus' Wuhres Wort (1873); Aubé, La Polemique Païenne in Les Persécutions de l'êglise (1878); Pélagaud, Étude sur Celse (1878); Froude's Short Studies, vol. iv.; and the article on ORIGEN.

Celsus, Aulus Connelues, a Latin physician and writer, who probably flourished about $50 \mathrm{~A}$. D., and wrote not only on medicine, but also on rhetoric, history, philosophy, the art of war, and agriculture. His style is succinet and clear, but full of Groecisms. The only great work of his which survives is the De Medirint. The portions relating to surgery are exceedingly valuable, as giving an account of the opinions and observations of the Alexandrian school of medicine. Indeed, to Celsus, next to Hippoerates and (ialen, we usinly owe our knowledge of the medicine of antiquity. Celsus's works were translated into English in 1756. Next to the first edition (1478) the most important are thone of Targa (1769) and Daremberg (1859). See Dr J. Patrick, A pology of Origen in Reply to Celsus (1892).

Celt (Lat. celtis (?), 'a chisel'), a name by which the axe-heads of the early inhabitants of Europe are known among British and French archroologists. The Scandinavian archeologiats use the word 'axe' and not 'celt.' Its use is now considered pedantic, and it is fast becoming obsolete. The word is generally believed to have originated from a misreading of Job, xix. 24 , in the Vulgate, where Celte, understood to mean 'with a chisel,' was read in place of Certe, 'verily' (corresponding to the 'for ever' of the English Bible). Celte or Celtis is not elsewhere found in Latin. See Notes and Queries (1878), vol. ix. p. 463; vol. x. p. 73.

Celts are either of stone or of bronze. Stone celts vary in length from about 1 inch to 22 inches; but the most common size is from 6 to 8 inches in length, and from 2 to 31 inches in breadth. They are made of almost every kind of stone, and show considerable diversity of shape, almost all, however, having more or less resemblance to the mussel-shell. The ruder celts are generally of slate, shale, schist, or grit; the finer, of flint, porphyry, greenstone, syenite, or agate. Many of the finer celts are beautifully shaped and highly polished. Some very remarkable examples of this class are in the National Museum of Antiquities, Edinburgh, and one found near St Andrews, in Scotland, is described by Sir David Brewster in the Philosophical Journal for 1823. The stone celt was fastened into a handle of horn, bone, or wood.

Bronze celts vary in length from about 1 inch to 8 or 10 inches, the most common length being about 6 inches. They show much greater diversity of shape than the stone celt. As many as four classes have been distinguished by archreologists: (1) The flat wedge-shaped celt, most nearly resembling the common form of the stone celt. (2) The flanged celt, with the side edges more or less overlapping, and a stop-ridge or elevation between the blade and the part which received the handle. (3) The flanged-edges celt, with side greatly overlapping, with or without the stop-ridge, but with a loop or ear upon one side. (4) The socketed celt, or the celt with a hollow to receive the handle, and generally with a loop or ear upon one side. They are sometimes ornamented with raised lines or circles formed in the mould in which they were cast.

Both stone and bronze celts were probably used for many purposes, serving for chisels, adzes, and axes, as well as for weapons of war, like the stone hatchets of the South Sea Islanders. See FLINT Implements, Stone AGE, and Bronze AGE.

Celtibe'ri, a brave and powerful people of ancient Spain, supposed to have sprung from a blending of the aboriginal Iberians with Celtic invaders from Gaul. They inhabited a large inland district of the peninsula, corresponding to the south-west half of Aragon, nearly the whole of Cuence and Soria, and a great part of Burgos, but the name Celtiberia had often a wider signification, including the country as far south as the sources of the Gualaluguivir. The Celtiberi were divided into four tribes, the chief the Arevacas and Lusones, and were unquestionably one of the bravest and noblest peoples in the peninsula. Their cavalry and infantry were equally excellent. For many years they withstood the efforts of the Romans to subdue them, and it was not till after 
the death of Sertorius ( 72 B.C.) that they began to adopt the Roman language, dress, and manners. The chief cities were Legobriga, the capital; Bilbilis, the birthplace of Martial ; and Numantia, destroyed by Scipio Africanus after a desperate ten years' resistance, 133 B.c.

Celtic Ornament, a peculiar development of the system of iron-age decoration prevalent in the British Isles. Its history is divided into two periods by the introduction of Christianity, which engrafted on the older style a number of new elements of decoration brought into the country with the manuscripts of the gospels and psalters, and supplied new forms for the display of these elements, such as churches and crosses, shrines, bells, and crosiers. In its pre-Christian stages, ranging approximately from two or three centuries before the Christian era to about the end of the 6th century A.D., it appears principally in connection with the metal mountings of harness and horsetrappings, and on shields, sword-sheaths, mirrors, armlets, and other articles of personal use and ornament. The material is usually bronze, but occasionally silver or gold. The principal characteristics of the pre-Christian style are its preference for elliptical curves and divergent spirals; its use of chased or engraved lines or dots as a diaper in the spaces of the general design in contrast with other spaces left plain; its use of repoussé work, sometimes in very high relief, at other times in low relief on thin plates riveted on in their places in the general design; the production of peculiar patterns often in excessively high relief in the casting; and the employ. ment of champ-leve enamels of red, yellow, blue, and green, and settings of coloured vitreous pastes. One of the finest exsmples of such settings occurs in the decoration of an oval shield of bronze, from the bed of the Thames, ornamented with Celtic patterns in relief, enriched by twenty-seven settings of red enamel, kept in their places by small cruciform ornaments of bronze riveted in the centre of each. There are to be seen in the National Museums of London, Edinburgh, and Dublin enamelled shields, sword-sheaths, and ornaments of horse-trappings in bronze, of great beauty and excellence both of design and workmanship, and other articles in bronze, silver, or gold, ornamented in repoussé work or in relief, with or without enamel as an enrichment, found in many parts of England, Scotland, and Ireland, in pagan grave-mounds, in crannogs or lake-dwellings, in earth-houses, in the beds of lakes and rivers, or in casual deposits under the soil for concealment. In a work entitled Horce Ferales, Mr Franks of the British Museum has figured in colours many of the best of these remarkable products of the earliest known process of champ-levé enamelling, and adduced evidence to show that it and this peculiar style of Celtic omament which accompanies it were of indigenous origin, and at this early period peculiar to the British Isles. The remarkable development of Celtic ornament which succeeded the introduction of Christianity was characterised by the association of interlaced work and fretwork with the elliptical curves and divergent spirals which up to that time had been the principal elements of Celtic design. To these were oceasionally added a step-like pattern, and diapers of the $Z$ and I shaped patterns sometimes seen in Chinese decoration. The interlaced work was elaborated with excessive care into patterns, presenting an infinite variety of combinations pleasing to the eye, and capable of being harmoniously treated in colours. It was sometimes a simple ribbon-like band, which might be plain, or divided in the middle, or divided into three by lines close to the margin; or the inter- lacing band might be replaced by an elongated animal form with its feet, its tail, and its top-knot drawn out to interlace with each other, and with the corresponding parts of other lacertine forms, the whole forming a diaper of quaintly expressed and complicated construction. The fretwork was also elaborated with much ingenuity into most complicated patterns, a special feature of the style being its partiality for diagonal frets and patterns. produced by combinations of oblique lines, in direet contrast to the fretwork of Greek and Roman art, which was essentially rectangular. The elliptical curves and divergent spirals of the older style, which had received their only expression in the solid forms proper to metal-work, were found to be equally capable of adaptation to the purposes of the illuminator, and by a similar process of combination and elaboration they also produced patterns and diapers of inexhaustible variety and beauty. A special feature of Celtic decoration was its tendency to divide the surface to be decorated into a series of panels, each of which was treated as a separate whole. The finest examples of Celtic ornament are unquestionably to be found in the grandly illuminated pages of manuscript copies of the Gospels, from the 7 th to the 9 th century. Of these the most famous for the elaborate nature of their ornament and the beauty of their colouring are the Book of Kells in Trinity College, Dublin, and the Lindisfarne Gospels in the British Museum. Of enamelled metal-work in this period there may he mentioned the Ardagh Chalice, perhaps the most elaborate and beautiful of all the products of Celtic art, the Lismore Crosier, and the Monymusk Shrine. Examples of filigree-work, and chasing or engraving in gold and silver of the highest excellence are found in the Tara Brooch, the Ardagh Brooches, the Rogart Brooches, and the Hunterston Brooch, the Shrine of St Patrick's Bell, the Shrine of St Manchan, and the Cross of Cong. The approximate dates of the metal-work of the highest excellence range from the 10 th to the 12 th century. For sculpture in stone it is only necessary to refer generally to the incised slabs and sculptured crosses of Scotland and Ireland, ranging from the 9th to the 12th centuries, the special characteristics of their decoration being the same as those of the manuscripts and metal-work already mentioned. For illustrations, see Brooch, Cross, Sculp. TURED STONEs. See further Kemble's Hora Fercules, edited by Latham and Franks (1863); Anderson's Scotland in Early Christian and Pagan Times (1881-83); Westwood's Paloeographia Sacra Pictoria (1845), and Fac-similes of the Miniatures and Ornaments of Anglo-Saxon and Irish Manuscripts (1868); $0^{\prime}$ Neill's Fine Arts of Ancient Ireland (1863), and Sculptured Crosses of Ancient Ireland (1857); Stuart's Sculptured Stones of Seotland (Spalding Club, 1856 and 1867); and Miss Stokes's Early Christian Art in Ireland (1887), and Six Months in the Apennines (1892), in which last work Celtic Christian art is largely derived from the Byzantine art of Italy.

Celts. The Celtic nations of antiquity had no. comprehensive name. Those of the Continent were called Galli by the Romans, and less usually Celtce. The Greek equivalents for these terms were Galatai or Galatæ, and Keltoi or Celti. But neither Greeks nor Romans regarded the British Isles as belonging to the Celtic world. They were situated outside it, and lay over against it in the sea; still it was known to men like Julius Cæesar that certain portions of Britain were inhabited by Celts in the sense of Galli or Belgre.

Celtic ethnology involves many difficult questions, and we shall speak of them in this article mostly according to the more palpable distinctions of speech ; 
sad in order to proceed as much as possible from the known to the unknown, we lnegin by clussifving their idioms. Thene, whether dead or still spoken, melong to the Aryan or Indo-Europenn family of languages, and those of them spoken in modern times divide themselves into two groups-viz. Goidelic and Brythonic. (1) The Goidelic group embraces the dialects termed Gaelic, that is to say, Irish Gaolic, or Irish as it is now more frequently and brietly ealled; Manx Gaelic, or the Grelic dialect not yet extinet in the Isle of Man; and Seoteh (inelic, or the (inelic spoken in the Highlands and Islands of Seotland. In ordinary Seoteh and English marlance this is what is understood by the word faelic when it is used without any qualification. In order to resist one of the delusions to which charlatans are always lemling the unwary, it is right to say that the words Guel and Gaelic have nothing to do with Galli. Guel is the simplitied English spelling of a word which is now written in seotch and Irish Gaelic Gaidheal, with an evanescent $d h$; but the most ancient form known of it was Goidel, whence the adjective Goidelic, which has been resorted to by Celtic scholars as applicable equally to all three Gaelic subdivisions of the Celtic group here in question. The Celtic languages of this group are sometimes also called Erse, which is a term derived from the Scoteh form of the adjective Irish; this was Ersch or Yrisch, the longer and shorter forms of which appear, used without any distinction, by Kennedy in his answer to the poet Dunbar, when the latter had called Kennedy an 'Ersch brybour baird' and an 'Erseh katherane,' in reference to his alleged extraction from the Irish Scots of Galloway and Carrick. Kennedy's reply contains the following line (see Murray's Dicilect of the Southern Counties of Scotland, 1873, pp. 43 44) :

\section{Thou luvis nane Erische, elf, I undirstand,}

and he goes on to add

Thy fore fader maid Ersche and Ersohmen thin.

(2) The Brythonic group embraces the following languages: Welsh, Breton, and Cornish, which has been extinet now for about a century. Two of these belong to Great Britain, and one, the Breton or Armoric, to Little Britain on the other side of the English Channel. These three might be collectively termed British or Britannic, but that both these adjectives have connotations which wonld be misleading, as they tend to confusion; so here, also, a neutral form, Brythonic, is used, which is derived from Brython, one of the Welsh words for the Welsh and the so-called Ancient Britons, whence their language is sometimes called Brythoneg in Welsh. This last was in Cornish Brethomec, and in Breton Brézonek, meaning re. spectively the Celtic of Cornwall and of Brittany. Brython or Britto was the national name of all peoples of this branch, just as Goilel or Gael may be treated as the national name of the other branch.

All this applies only to the neo-Celtic nations, or those among whom Celtic languages are or have been in use in modern times, and a question of much greater difficulty presents itself when one attempts to classify likewise the continental Celts of ancient history. The reason for this is chiefly the fact that the linguistic data become more precarious as one goes back. Thus, for example, the language of the ruling people of ancient Gaul has been left as only in a very few inscriptions, so that our knowledge of it from that source has to be complemented by the study of Gaulish proper names, of which a considerable number is extant in Latin inscriptions and in the writings of Roman and Greek authors. Now, when we apply the test of some of the most palpable differences that are known to exist between the Goidelic and the Brythonic idioms to the remains of the Gaulish language, we find at onces that it is to be ranked with the Brythonic dialects, and not with the Goidelic ones, and our Brythonic group becomes what may be more exactly deseribed as a Gallo. Brythonic one. This further sugrests the question whether there was no continental Celtic idiom which partook of the characteristics of the Goidelic branch. The probability in that there was; for one finds Sulpicius Severus, an ecclesiastical writer of the 4th century, distinguishing between Celtic and Gallic or Gaulish, as if both were spoken in his time. (See Dialogue i. 26, in Migne's Patr. Lat. vol. $\mathrm{xx}$. col. 201 : 'Tu vero, inquit Postumianus, vel Celtice, aut, si mavis, Gallice loquere, dum. modo jam Martinum loquaris.') And the use of the two names Celtre and Galli would seem. to point to the same inference-viz. the existence in Ganl of two Celtic peoples, the one, probably, superimposed on the other, as on a vanquished population, or driving it towards the south and west. Thus, if the Celtic language which Sulpicius Severus distinguished from Gaulish should be ranked with the Goidelic dialects, we should have alongside of a Gallo-Brythonic group another which might be called Celto-Brythonic were it not inconvenient to use the words Celt and Celtic in two senses. For while the modern usage applies them indifferently to the whole family, Sulpicius indicates a narrower sense; and 180 , in fact, had Cresar done centuries before, when he wrote that one of the three peoples of Gaul was called Celtre in their own tongue. He states that these Celtre proper, so to say, were separated by the Garonne from the Aquitani, and by the Seine and the Marne from the Belgr. In other words, their country extended from the Garonne to the Seine and Marne, and other Roman writers give it the name of Celtica ; and Dionysins of Halicarnassus had heard of a river Celtus, from which Celtica was supposed to derive its name. From this narrower Celtica, in the sense which Roman writers gave it, one might form the adjective Celtican, to apply to its people, in order to avoid the confusion which must arise from calling them Celts, whilst using that word also of the whole family.

In order to show the philological ressons for this classification, it would be necessary to go into a variety of details; but let one of these suffice for the present. The Gallo-Brythonic dialects nsed $p$ where the others would have qu. Take, for example, the early inseriptional Irish for the genitive of the word for 'son'; it was maqvi, corresponding to a nominative which appears as mace or mac in the oldest manuscript Irish; and mac is still the word for 'boy' or 'son' in all the Goidelic dialects. Now the early Brythonic form of this genitive would have been mapi, while in the oldest manu. script Welsh we have map, and in later Welsh mab, 'boy' or 'son.' From this word was formed another, mabon, a 'boy' or 'youth ;' and this in its old form appears in Latin inscriptions as maponus in Roman inscriptions found in Britain in honour of the Celtic god Apollo Maponus, so called in reference to his youthfulness. Now from Gaul we have such names as Eporedorix, Parisii, Petrocorii, and many others, with the consonant $p$; but every now and then we have also names with qu, such as Sequana and Aquitani, together with several instances from Spain, where a people of the same Celtic branch as those of Celtica had also probably established themselves.

So far, then, as one can get philological data to reason upon, it would seem that the west of Europe had in early times been subjected to two Celtie 
invasions; the one is represented by the Celts whose position, geographically speaking, is the farthest from the home of the Aryans. These would be the Celticans of Gaul and Spain, as compared with the Gallic tribes to the east of them towards the Rhine and the Alps; the same relative position is also taken up by the Goidelic Celts of the British Islands, occupying, as we find them doing, the Isle of Man, Ireland, and, the Scotch Highlands and Islands. The other, here represented by the Brythons, must have come later and driven out the Goidels, or subdued them, in the rest of this island. This may be supposed, also, to have been the case on the Continent, so that we have to regard the later comers, the Galli, as invaders and conquerors forming another Celtic population. In the eastern portions of Gaul they may have formed the bulk of the population, but in the rest of that country they probably only constituted a ruling class of comparatively small importance in point of numbers. Such a state of things would adequately explain the great dearth of linguistic remains belonging to the older and subjugated people. Roman authors and other strangers would naturally speak most of the ruling classes, and information about the others must reach strangers through the medium of the Gallic rulers and their language, at anyrate, so far as concerns the time before Latin became the official tongue of all Gaul. A somewhat similar conclusion has been arrived at by studying the burials and megalithic monuments of France and the neighbouring lands to the east of it. In Central and Western France menhirs, dolmens, and cromlechs prevail, while the eastern side of France shows the prevalence of mounds and barrows, which are here and there found penetrating into the other domain, giving us a sort of rude sketch, as it were, of an invasion advancing irregularly towards the west. See M. Bertrand's Archéologie Celtique et Gauloise; also K. von Becker's Versuch einer Lösung der Celtenfrage (1883), pp. 114-119.

For reasons already indicated, the question of Celtic ethnology is a very difficult one, but it is considerably more difficult than would appear from what has here been mentioned; for besides two Celtic sets of invaders, there are also to be taken into account the non-Aryan races that previously occupied the countries to which the Celts came. These pre-Celtic populations probably survived in considerable numbers, and one of the effects of a second Celtic invasion may be supposed to have been to force the earlier Celtic settlers to amalgamate with the ancient inhabitants, and to make common cause with them against the later Aryan hordes. So it may be expected that the language of the Goidelic Celts will prove to have absorbed a larger non-Aryan element than that of the Brythons. Similarly, one might take for granted that the physical type of the people speaking the Goidelic dialects should prove less purely Aryan; but this feature is obscured by the fact of the counter-invasions which Wales and other western portions of Britain have undergone in historical times at the hands of Ireland. Lastly, it is right to add that in so far as the people, whose language is or has been Celtic, are Arvans, one might expect the type to be that of tall men, with more or less light hair and blue eyes; on the other hand, the smaller men, with dark hair and black eyes, which it was the fashion till lately to regard as the genuine and typical Celts, are probably not to be regarded as Celts at all, but as Ivernians or representatives of the pre-Celtic and non-Aryan race, whose hunting-ground the soil of the British Islands may be said to have been long before the first Aryan set foot in them.

The Celtic languages and literatures will be found under Brittany, Cornwall, Gaelic, Ireland, WALEs. See also Aryan Race and Languages: Ethnology, Philology, Druidism.

Besides the works already mentioned, the following should be consulted: Müllenhoff's Deutsche Altertumskunde (Berlin, 1887); Windisch's article 'Keltische Sprachen' in the Allgemeine Encyklopodie der Wissen. schaften und Kïnste, together with the reviews on the same in the Revre Celtique, vol. vi. pp. 395-400; Hübner's Inscriptiones Britannice Christiance (Berlin, 1876) ; Brambach's Corpus Inscrip. Rhenanarum ; and the volumes of the Corpus Inscrip. Latinarum, published by the Berlin Academy, especially those for Britain (vii.), Spain (ii.), Gallia Narbonensis (xii.), Gallia Cisalpina (v.), and Illyricum (iii.).

Cements. These may be roughly divided into three classes: (1) The stone cements, including Roman and Portland cements, and ordinary mortar, which are used in thickish layers for uniting stone and brick work, and for protective coverings to buildings; (2) substances which form binding joints of much less but still appreciable thickness, such as white lead, red lead, and putty; and (3) cements which require to be used in extremely thin coatings, such as glue, isinglass, and dissolved caoutchouc.

Ordinary Mortar is a mixture of slaked lime (calcium hydroxide) and sand, made into a paste with water. Generally one part of lime to three or four parts of sand are used, but the proportions vary according to the purity of the lime employed. Very pure or fat lime, such as that made by burning white chalk or white marble does not make so good a mortar as lime obtained from less pure limestones, which are by far the most abundant. The more thoroughly the ingredients are inter. mixed, the more complete will be the subsequent hardening of the mortar. As commonly laid in the joints of brick or stone work, mortar sets sutficiently fast to allow building operations to proceed from day to day with occasional longer intervals, but it takes years-perhaps in many cases centuries to reach its maximum hardness. The setting and subsequent slow hardening of mortar are usually considered to be due, in the first instance, simply to the loss of water, and afterwards to the absorption by the lime of carbonic acid from the atmosphere, the carbonate of lime thus formed binding together the sand and stone. It is doubtful, however, if this is an altogether satisfactory explanation. The mortar used in many medieval buildings is largely mixed with small pebbles. In a number of cases this has proved to be of a more durable nature than the stone used along with it.

Puzzolana or Pozzuolana, a loosely coherent volcanic sand found at Pozzuoli, near Naples, has been long celebrated for its property of forming a hydraulic cement when mixed with ordinary lime. It is composed of silica, with a little magnesia and potash or soda, alumina, lime, and oxide of iron.

Roman Cement.-Certain natural mixtures of lime and clay are called cement-stones. The clays of some of the newer geological formations in the south of England, for example, contain courses of septarian nodules (see SEPTARIA), which have been in great request for making the best kinds of Roman cement. They are concretions of impure calcareous matter, many of them having this analysis : Carbonate of lime, 66 ; silica, 18 ; alumina, 7 ; and protoxide of iron, 6 ; or consist of these substances in nearly that proportion. Cement-stones are carefully calcined in kilns, and afterwards ground and sifted. Good Roman cement should set in about 15 minutes, and this quick-setting property makes it valuable for work which requires to be executed between tides and for other purposes where the cement used must harden quickly. It is at best of but medium strength. Some natural 
coments are slow-setting, and these do not contain mure than 22 yer cent. of clay. They set under water when half their weight consists of elay. The proportion of sand used with Roman cement should not much exceed that of the cement. When em. ployed for external coatings of buildings it is apt to effloresce and become unsightly.

Portland Cement. - This is considered by far the most important of the stone cements. It is an artificial product, named from its resemblance to Portland Stone, but is much more largely used than Roman cement. In the manufacture of Portland cement on the banks of the Thames and the Medway by the wet process, three parts of white chalk are mixed with one part of clay or mud from the lower reaches of these rivers. The two substances, along with water, are placed in a 'wash mill 'in which strong revolving knives or eutters reduce the whole to a creamy 'slurry' or slip. The slurry then passes by gravitation to backs or reservoirs. There it is allowed to settle for some weeks, when the superfluous water is removed by decantation. The mixture is next dried on heated iron plates or on the floor of a heated chamber, and then burned in kilns. Finally it is ground to a fine powder. Modifications of the wet process by which the large reservoirs are dispensed with have been introduced in recent years. In other parts of the country Portland cement is manu. factured by the dry process from the hard limestones of other formations than the chalk, along with clay or shale. These limestones are crushed small, mixed in the proper proportion with clay or shale, then roughly burned, and ground to powder. This powder slightly moistened is passed through a pug-mill, and then made into bricks, which are afterwards burned in kilns and reduced to powder.

Since Portland cement is hardly ever employed in the pure or neat state, its strength is perhaps best tested when it is mixed with an equal weight of sand. The best cement so mixed and moulded in the state of a stiff mortar, into any convenient shape, when tested after the lapse of seven days, during six of which it is customary to keep it immersed in water, exceeds in tensile strength 200 lb. per square inch, and in crushing strength, tested by 1 thinch cubes, $1000 \mathrm{lb}$. for the same area. Its strength in the unmixed state is much greater. Much of the Portland cement made is, however, little more than half as strong as the best kind. Roman cement of good quality mixed to the same extent with sand as the above, and tested under the same conditions, has on an average a tensile strength of $30 \mathrm{lb}$, and a erushing strength of $200 \mathrm{lb}$. in each case per square inch. Portland cement is slow in setting compared with most varieties of Roman cement. Both Portland and Roman cement form hydraulic mortars - that is, they set under water. No mortar will do this which contains less than 10 per cent. of silica.

Till close on 1840 Portland cement was hardly known, but the use of it has extended rapidly, especially in recent years. Its most important application is in the construction of docks and harbours, many of which are partly or wholly built of it, mixed with sand and broken stones, in the form of a concrete. In this state, or simply mixed with sand, it is also much employed for other purposes where strength and durability are required. Owing to the nature of some of the extensive engineering works in which Portland cement is largely used, it is plainly of great consequence that its properties should be thoroughly understood. Numerous failures with it have taken place. The chemical investigation into the case of the Aberdeen docks in 1887 distinctly showed the deleterious action of sea-water upon this sub- stance. But it is also known that objects made of unmixed Portland cement from the works of nome of the best makers will sometimes keep good for nearly twenty years, and then crumble to pieces even when not exposed out of doors at all. Of course explanations of these failures are forthcoming. They are generally attributed to careless. ness in the manufacture of the cement, or in the selection of the materials for it. But if they oceur, as they have done, with cements that have stork very well the ordinary mechanical tests, how can any cement of this kind be entirely depended upon for durability? Twenty, thirty, or even fifty years is far too short a time to test the lasting property of a building material of this nature. The use of Portland cement in pavements and for architectural ornaments is not attended with much risk, and for such purposes it is very suitable. The capital employed in the manufacture in Great Britain is probably near two millions sterling. For American cements, see Rosendale.

Scott's Selenic Cement consists of burnt limestone mixed with about 5 per cent. of sulphate of lime in the form of plaster of Paris, and ground to powder. The presence of the sulphate arrests the slaking action of the lime, causes the cement to set more quickly, and adnits of more sand being used with it than ordinary lime does. This cement has been a good deal used for plastering, and to some extent also for mortar.

Plaster of Paris (see ALABaster and Gypsum). -This material is used for cementing marble and alabaster in much the same way as mortar is in brick-work. It is also employed for uniting the separately moulded pieces of any large object cast in the same material. Sometimes it is selected for fixing metal mounts to glass.

Keene's Cement is made by saturating plaster of Paris in small lumps with alum and recalcining it. It then forms a hard plaster for the, projecting portions of halls and rooms, such as pilasters, columns, and skirtings. It is capable of taking a high polish.

Parian or Keating's Cement somewhat resembles Keene's. In its manufacture borax as well as alum is added to the plaster of Paris.

Martin's Cement is another kind, with plaster of Paris for its basis, but instead of borax, carbonate of potash is added, and sometimes hydrochloric acid as well. With the exception of Scott's, these plaster of Paris cements are only used in plastering or other internal work-not for mortars.

Mastic Cement, consisting of a mixture of burnt clay or limestone in a powdered state, with boiled oil and litharge, was more in use formerly than now; but though expensive, it is an excellent material for preventing the admission of rain-water at certain joints about buildings, such as where wood and stone work come together at windows. It was also used for covering external mouldings.

Rust or Iron Cement. - Joints in iron-work, such as those for hot-water pipes, are filled up with a cement of iron borings or turnings, mixed with at least 2 per cent. of sal-ammoniac. Sometimes sulphur in powder is added. The iron oxidises and forms a firm joint.

Sulphur Cement.-For jointing earthenware pipes, and occesionally for fixing bars of iron into stone, a cement is made of sulphur, resin, and brick-dust. It is a cheap but not a strong cement where metal is concerned.

Water-glass Cements. - For furnaces one kind consists of burnt and unburnt fireclay made plastic with silicate of soda or water-glass. Another cement, capable of standing a high heat, is formed of asbestos powder made into a paste with silicate of soda. The same silicate mixed with ground glass makes an acid-proof cement. 
White and Red Lead Cements.-Either white lead or red lead by itself, or a mixture of both, is much in request as a cement for the joints of slate or glass cisterns, such as aquariums. These are also employed for the joints of gas-pipes, for cementing metal mounts to glass tubes, and other chemical and electrical purposes. White and red lead cements are made up with boiled linseed-oil, and sometimes gold size is added. Mixed white and red lead make a very hard and firm cement. A cement of these two substances and ground plumbago in equal parts, mixed with oil, is said to stand a great heat in steam-joints.

Shell-lac Cements.-An excellent cement is made by digesting $4 \mathrm{oz}$. of the finest shell-lac in $3 \mathrm{oz}$. of methylated spirit in a warm place. It should be made into a consistency like thick syrup. This makes a firm cement for mending pieces of glass, china, ornamental stones, and ivory. It is not soluble in water. A cheaper, but still very serviceable cement can be formed by dissolving shell-lac in wood naphtha. For some purposes shell-lac itself is used as cement by simply melting it.

Marine Glue is a mixture of shell-lac in a solution of india-rubber. It is made into thin sheets, and melted when required for use in shipbuilding, \&c.

Gelatin and Isinglass Cements. - Fish-glue, gelatin, or Isinglass $\left(q \cdot v_{0}\right)$, made up with dilute acetic acid and other bodies into a jelly or thick liquid, produces a cement slightly varying in its nature, for mending china, glass, ivory, bone, and other substances. Foulke's cement and liquid fish-glue are cements of this class. These can be obtained in a convenient form for use in hardware or druggists' shops. They are more or less soluble in water, so that articles mended with them must be quickly washed. Cement of mixed glue and glycerine, sometimes with tannin added, is oceasionally used for leather and cloth.

Armenian or Diamond Cement.-The following is the reputed formula for preparing the cement used by the Armenian jewellers for attaching diamonds, \&c., without any metallic setting : 'Dissolve five or six bits of gum-mastic, each the size of a large pea, in as much rectified spirit of wine as will suffice to render it liquid; and in another vessel dissolve as much isinglass, previously a little softened in water-though none of the water must be used-in French brandy, or good rum, as will make a 2-ounce phial of very strong glue, adding two very small bits of galbanum or ammoniacum, which must be rubbed or ground till they are dissolved. Then mix the whole with a sufficient heat. Keep the glue in a phial closely stopped, and when it is to be used, set the phial in boiling water."

Elastic Cements,-One part of eaoutchouc dis. solved in 3 parts of ehloroform; also, 5 parts of caoutchouc in 3 parts of chloroform, with 1 part of powdered gum-mastic added. Benzole is sometimes used instead of chloroform as the solvent. Another elastic cement can be made by a mixture of guttapercha and caoutchoue dissolved in bisulphide of carbon. The solvents of these cements must not be exposed to any but a gentle heat.

Resin Cements.-There are a great number of cements partly formed of ordinary resin. One kind consists of resin 4, beeswax 1 , and whiting 1 part. The proportions of these ingredients in the same order for another are 15, 1 , and 4. Another is made from resin 4, and plaster of Paris 1 part. These cements are used to fix pieces of stone, glass, \&c. to handles when grinding them. Resin, pitch, beeswax, and plaster of Paris or brick-dust are made up in various proportions into cements.

Cutlers' Cement, used for fixing knives and forks in handles, is made of equal weights of resin and brick-dust melted together; or, for a superior quality, 4 parts of resin, 1 of beeswax, and 1 of brick-dust.

Copal varnish, mastic varnish, Canada balsam, and gold size are each nseful occasionally for cementing substances like two pieces of glass together.

Cement-stone, a somewhat argillaceous and ferruginous limestone, generally compact, which is occasionally employed for making hydraulic mortar or cement. The Cement-stone Series is the name of a group of strata occurring in the Carboniferous System of Scotland. See CARboniferous System.

Cemetery (from the Greek koimeterion, literally 'a sleeping-place ") may mean any graveyard, or other place of deposit for the dead; but it has lately acquired a special meaning, applicable to those extensive ornamental burial-grounds which have recently come into use as the practice of burying within and around ehurches was gradually abandoned (see BURIAL). The fine burial-grounds. of the Turks, extending over large tracts adorned by cedars and other trees, may have suggested the plan to western Europeans. Those round Constantinople are famous, and are dense forests of cypresses. A Moslem grave is never reopened, and a cypress is usually planted after every interment. of western cities, Paris took the lead in this respect, and in Britain there are now no considerable towns near which there is not at least one cemetery, and the legislation mentioned under the head of BURIAL has rendered their establishment, to a certain extent, a legal necessity. There was at first a natural feeling of regret at the prospect of deserting places of deposit for the dead so hallowed by ancient use and recent associations as the church and the churchyard. On the other hand, the new places of interment began to become attractive in virtue of their trees and flowers, natural seenery, and works of monumental art. The new cemeteries are in many instances cheerful open places, and in them the place of rest for the dead has rather tended to improve than to undermine the health of the living. One of the first and most celebrated of modern European cemeteries is that of Père la Chaise (q.v.), near Paris, the arrangements of which have been generally followed in the cemeteries of London and other English cities. It was laid out in 1804, and is now within the enceinte of the city. The Campo Santo of Pisa (1228-83), the pantheor of the Pisans, has been the model of many Italian cemeteries. It is an oblong court, surrounded by lofty arcades of marble, and adorned with famous frescoes and works of art. In the centre is a mass of earth brought from the Holy Land. The Genoese Campo Santo contains an enormous wealth of sculpture. One Neapolitan cemetery (the Campo Santo Vecchio) differs widely from most others. It contains 366 deep pits, one of which is opened each day, and in it all the interments of the day take place. At night a funeral service is performed, and the pit is filled with earth and lime, not to be reopened till the year after. The Sicilian catacombs are also a kind of cemetery. Kensal Green Cemetery dates from 1832; other well-known London cemeteries are those of Highgate and Woking (1855), near Guildford, 7000 acres in area, with a crematory. The Dean Cemetery at Edinburgh, and the Necropolis of Glasgow, are notable; that of Glasnevin, outside of Dublin, is the most celebrated in Ireland. English cemeteries are usually divided into two portions-one consecrated for the burials of members of the Established Church, over whose remains the funeral service is read, and one unconsecrated, for the 
burials of dismenters. In the United States great pains are bestowed on the adornment of cemeteries. The most famons are Mount Auburn, near Boston, firesuwood in Brooklyn, and Laurel Hill, near l'hiladelphia. See BURLi.

Cenci, Bentrick, 'the beautiful parricide,' wass the daughter of Francesco Cenci, a Roman nobleman of colossal wealth. According to Muratori (Annales, lib. x.), Francesco was twice married, Beatrice leeing the youngest of twelve children by lles tirst wife. After his second marriage, he treated the children of his first wife in a revolting manner, and was even accused of hiring bandits to murder two of his sons on their return from Spain. The beanty of Beatrice inspired him with the horrible and incestuous desire to possess her person; with mingled lust and hate he persecuted her from day to day, until circumstances enabled him to consummate his brutality. The unfortunate girl besought the help of her relatives, and of Pope Clement VII. (Aldobrandini), but did not receive it; whereupon, in company with her step-mother and her brother, Giacomo, she planned the murder of her unnatural parent, into whose brain two hired assassins drove a large nail (9th September 1598). The crime was discovered, and both she and Giacomo were put to the torture; Giacomo confessed, but Beatrice persisted in the declaration that she was innocent. All, however, were condemned and beheaded (10th September 1599). Such is Muratori's narrative. Others allege that Beatrice was the innocent victim of an infernal plot. The results, however, of Bertolotti's investigations (Francesco Cenci e la sua Famiglia, 1877), Inased on original documents and contemporary notices, go far to deprive the story of the Cenci tragredy of the romantic elements on which Shelley's powerful tragedy mainly turns. Francesco, it would appear, was profligate, but no monster : Beatrice at the time she murdered her father was not sixteen, but twenty-one years of age, was far from beautiful, and was probably the mother of an illegitimate son. And Bertolotti further shows that the sweet and mournful countenance which forms one of the treasures of the Barberini Palace in Rome cannot possibly be a portrait of Beatrice by Guido, who never painted in Rome till some nine years after Beatrice's death. See an article in the Edinburgh Review for January 1879.

Cenis. See Mont Cenis.

\section{Cenobites. See Monachism.}

Cenomanian, the name given by French geo. logists to the Lower Chalk and Upper Greensand of English geologists.

Cenotaph (Gr. kenotafion; kenos, 'empty,' and tafos, 'a tomb'), a monument which does not contain the remains of the deceased. They were originally erected for those whose bones could not be found, as for those who had perished at sea. Latterly the name was applied to tombs built by a man during his lifetime for himself and the members of his family. The memorials in Westminster Abbey to Franklin and Gordon are cenotaphs.

Censer (Fr. encensoir, from Lat. incendo, 'I burn '), a vase, or other sacred vessel, used for burning Incense $(q . v$,$) . Censers were used in the$ Hebrew service of the temple. The ordinary censer, called also a thurible (Lat. thuribulum, from thus, 'frankincense'), used in Catholic services, is a metallic vessel for holding burning charcoal, of bress or latten, silver, silver-plated, or even of gold. It is shaped like a vase or eup, has a movable cover, usually perforated, and is suspended by chains (generally four in number) so as to be swung to and fro for the readier dispersion of the smoke of the incense, which is thrown upon the live charcoal.

Censors, the name of two Roman officers of state of high dignity, whose duties related to the officisl registration of the citizens (census), the superintendence of public morals (regimen morum), and arrangements for the collection of the public revenue and the execution of public works. They were elected in the comitia centuriata, presided over by a consul. The term of office at finst lasted tive years, but was shortly afterwards limited to eighteen months. The censorship was regarded as the highest dignity in the state, except the dictator. ship. It was a sacred and irresponsible magis. tracy, whose powens were vast and undefined, and whose decisions were received with solemn rever. ence. The census or registration was taken in the Campus Martius, in a building called Villa Publica. It was a complete catalogue of the citizens of Rome, stating in detail the age of each, the amount of his property, and the number of his children. Next the censors drew up a list of the equites, entitled to have a horse at the public expense, and made up the roll of senators, supplying the vacancies. The regimen morum was the most dreaded and absolute of their powers. It grew naturally out of the exercise of the previous duty, which compelled them to exclude unworthy persons from the lists of eitizens. Gradually the superintendence of the censor extended from the public to the private life of citizens. They could inflict disgrace (ignominia) on any one whose conduct did not square with their notions of rectitude or duty. For instance, if a man neglected the cultivation of his fields, or carried on a disreputable trade, or refused to marry, or treated his family either too kindly or too harshly, or was extravagant, or guilty of bribery, cowardice, \&c., he might be degraded, according to his rank, or otherwise punished. The administration of the finances of the state included the regulation of the tributum or property-tax; of the vectigalia, such as the tithes paid for the public lands, salt-works, mines, customs, \&c., which were usually leased out to speculators for five years; the preparation of the state budget, \&c. The office of censor continued to be filled by patricians till 351 B.C., when Censor Marcius Rutilus, a plebeian, was elected. Twelve years later it was enacted that one of the censors (there were always two) must be a plebeian. In 131 B.c. both censors for the first time were plebeians.

\section{Censorship of Press. See Press.}

Census means the counting of the people. The word is a Latin one, and was applied to the functions which the Roman Censors (q.v.) performed of periodically enumerating the people, but no records of these enumerations remain, and indeed we have but a few scattered notices of them. In Greece a census was established by Solon at Atheng for the double purpose of facilitating taxation and classifying the citizens. Religious prejudice pre. vented any censuses being taken during the middle ages, and it was not till the 18 th century that the necessity for obtaining correct information as to the population of European countries overcame this feeling. The first country to undertake a census on a scientific brsis was Sweden in 1749; in France an enumeration was made in 1700 , but the first reliable was not taken till 1801. In America the first census was taken in 1790, and in England in 1801. Censuses are now taken in Austria, Belgium, Italy, Norway and Sweden, Russia, Switzerland, the United States of America, India, and most of the British colonies, every ten years; in France and Germany every five years; in Spain at irreg. 
ular intervals, the next after that of 1860 having been in 1877. The International Statistical Congress, which consists of eminent statisticians from all countries, has done much to improve the taking of censuses, and now several countries, such as Austria, Belgium, Italy, Prussia, Russia, and Switzerland, have statistical bureaus for the purpose, amongst other things, of controlling the taking of the periodical census. In a few countries information as to the religion of the population, and in some cases additional particulars, are obtained, such as the census of 'useful domestic animals' in Norway.

In the United Kingdom the practice is for parliament to pass special acts directing the taking of each census. These acts provide that the registrars of births and deaths shall be the officers through whom the census is to be taken by enumerators, of whom at the census of 1881 there were upwards of 30,000 employed in England alone. All the registrars' districts are so subdivided that no enumerator has more houses than he can conveniently visit in one day. The enumerators have to deliver schedules at all houses, requiring particulars concerning every person who is alive at midnight preceding the census day, and on the census day to collect them. Account has also to be taken of all persons not dwelling in houses wherever found, and of persons travelling, and persons in ships, barges, \&c. The enumerators are authorised to require the information necessary for the census, and persons refusing to answer or wilfully giving false answers to the questions are rendered liable to penalties. The particulars to be required in each census are specified in the act directing it to be taken. The Census Act, 1880, required that the census of the following year should show 'the name, sex, age, rank, profession or occupation, condition as to marriage, relation to head of family, and birthplace of every living person who abode in every house on the night of Sunday the 3d of April 1881, and also whether any were blind or deaf and dumb, or imbecile or lunatic.' When the schedules have been collected they are transmitted to the census office, where the work of tabulation, which takes about two years, is carried out. The census when finished is presented to parliament in the form of several bulky volumes. Hardly any two countries agree as to the subjects on which information is demanded; thus some census schedules contain inquiries as to whether there are in the household infirm persons, blind, deaf and dumb, idiots, insane persons, persons who have been convicted of erime; how many languages are spoken by the persons entered; how many are at school; how many exercise the franchise; how many rooms and windows there are in the house, and so on. In 185. an attempt was made to obtain religious statistics of the United Kingdom ; since that year the census shows the religious statistics of Ireland only.

The census of the United States aims at giving a specially full conspectus of the condition of the people, and is illustrated by a large number of maps hearing on almost every branch of the census inquiries. Thus there are maps showing the prevalence of certain diseases; others the area occupied by various erops. The United States census of 1880 extended to 22 volumes, embracing statistics of population, agriculture manufactures, mining, taxation, public indebtedness, with special reports on cotton-growing, petroleum, coal, coke, building. stones, iron and steel products, \&ce. The census of 1890 is comparatively limited in the scope of its inquiries.

Cent and Centime (Lat. centum, 'a hundred '), names of coins. The Dutch cent is a copper coin, the 100th part of the guilder (1s. 8d.); the United States cent is a bronze coin, the 100th part of the dollar, or nearly one halfpenny English, and the Canadian cent has the same value. The centime, the 100th part of the French franc, and of the value of $\frac{1}{10}$ th of an English penny, has been adopted in Belgium, and, under other names, in Greece, Italy, and Switzerland; and the Spanish real ( $2 \frac{1}{2} \mathrm{~d}$.) also is divided into 100 centimes. The cental in the United States, legalised in 1878, is 100 lb. avoirdupois (ef. CeNTNER). See DecrMal System.

Centaurea, a palæaretic genus of Compositæ, containing about two hundred species, all herbaceous annual and perennial, of which five or six are natives of Britain. The species most familiar, on account of its beauty, is the blue $C$. cyanus (see CORN-FLowER), which is sometimes sown as an annual; while its larger perennial ally, $C$. montana, with white or purple ray florets, is a familiar denizen of old-fashioned gardens; $C$. americana is a showy lilac-purple annual (3 or 4 feet); while the oriental Sweet Sultan (C. moschata) and Yellow Sultan (C. amberboa) are also not uncommon; the latter two being often sold under the name of Amberbon. Among perennials, the large, downy $C$. babylonica, with yellow flowers, is often cultivated; also $C$. ragusina and $C$. candidissima, of which the silver-white pinnate leaves furnish an admired contrast to bright-coloured bedding-plants. Several species ( $C$. calcitrapa, \&c.) bear the narne of Star-thistle, from their spiny involucre. Some are common wayside weeds, often troublesome in pastures, notably C. nigra, the Common or Black Knapweed, also called Horse Knot in Scotland; and the closely allied C. Scabiosa. The flowers or roots of several species were formerly used in dyeing, and the astringent roots employed by herbalists.

Cen'taurs ('bull-killers'), a wild race of men who inhabited, in early times, the forests and mountains of Thessaly, and whose chief occupation was bull-hunting. Homer, the first who mentions them, describes them merely as savage, gigantic, and covered with hair. They do not appear as monsters, half-man and half-horse, until the age of Pindar. The most ancient account of the Hippocentaurs, sometimes considered as distinct, but more often confounded with the Centaurs, is that they were the offspring of Magnesian mares and Centaurus, himself the offspring of Ixion and a cloud. The Centaurs are celebrated in Greek mythology on account of their struggles with the Lapithæ (q.v.), and with Hercules. The most famous was Chiron, the teacher of Achilles and other heroes. In works of art the Centaurs were represented as men from the head to the loins, with the rest of the body that of a horse. It is worth mentioning that the Mexicans, who had no native horses, when they first saw the Spaniards on horseback, believed that the horse and man together made but one animal.

Cen'taury (Erythraa), a pretty little annual, genus of Gentianacere, with pink or rose coloured flowers. They possess the tonic and other medicinal virtues of gentian, and the Common Centaury ( $E$. Centaurium) has especially been esteemed in medicine since the days of Dioscorides and Galen; and although no longer in the pharmacopoeia, its flower-tops are still sometimes gathered and dried by country-people in England and the Continent; while the allied Sabbatia angularis enjoys similar repute in the United States and Canada. The Yellow Centaury is Chlora perfoliata; but plants belonging to the wholly distinct composite genus Centaurea (q.v.) are also sometimes called Centaury.

Centenarian. See Longevity. 
Centenary, consisting of a hundred (Lat. centum), a period of a hundred years, is now usually employed to signify a commemoration of an event, 8. the birth (sometimes the death) of a great man. The centenary of Burns's hirth was celebrated in 15.59: the bi-centenary of Pope in 1888 ; the tercentensry of Shakespeare in 1804. The centenary of American Independence was celebrated by a Centemuial Fxhibition in 1876; the octo-centenary of the Bologna University in 1888.

Centering, the framework upon which an arch or vault of stone, brick, or iron is supported during its construction. The simplest form of centering is that used by masons and bricklayers for the arches of common windows and doors. This is merely a deal-board of the required shape, upon the curved edge of which the bricks or stones of the arch are supported until they are keyed in. In building bridges or other structures where arehes of great span are to be constructed, the centering is usually made of framed timbers, or timbers and iron combined. The arrangement of the timbers should be such that the strain upon ench shall be mainly a thrust in the direction of its length, for if the strain were transverse, a comparatively slight force would snap it, and if a longitudinal pull, the whole structure would be no stronger than the joints holding the pieces of timber together. In arches of great span, a longi. tudinal pulling strain is almost inevitable in some parts, as a beam of great length would bend to some extent under \& thrusting strain. In such cases great skill and care are demanded in the designing and construction of the joints. As an arch is built from the piers towards the keystone, the weight upon the haunches during construction tends to push the crown upwards, and therefore the problem of designing a framed centering involves the resistance of this tendency, as well as the supporting of the weight of the materials. Occasionally, when a very great span is required, and the navigation will permit, piers are built on the bed of the river, or piles are driven into it, to support the centering directly, simplifying it, and at the same time facilitating a more rigid disposition than in centering supported only from the sides. See article BRIDGE for descriptions and illustrations of three types of centering: (1) that for the bridge over the Dee at Chester, Vol. II., page 437, supported directly from the bed of the river; also the centering for the Ballochmyle Bridge; (2) inclined struts in pairs supported from the sides, as Rennie's centering for Waterloo Bridge, page 438 ; (3) trussed wooden girders supported from the sides, as Rennie's centering for London Bridge, page 438 .

Cupolas, like those of the Pantheon and St Peter's at Rome, St Paul's in London, or the flat domes of the Turkish mosques, require very effective centerings.

Centigrade. See Celsius and Thermometer.

Centipede, a general name for the members of one of the orders of the class Myriopoda. Popularly they are sometimes called Galley-worms, technically Chilopoda. Like the Millipedes, which form the most important neighbour order, the Centipedes are segmented animals bearing jointed appendages, having a well-defined head furnished with feelers and jaws, and breathing by means of air-tubes or trachese.

Stmucture.-The Centipede is like a primitive insect in its general structure.-(a) Externals.The body is divided into well-marked rings, but the region behind the distinct head is practically uniform, and not divisible into thorax and abdomen. Just behind the head a few rings appear to be fused. The number of rings varies from twelve to more than twelve times as many. In counting the rings the ventral surface should be looked to, for the dorsal shields often overlap. The rings are flattened from alove downwarls, and each besurs a pair of appendages. Dorsally and ventrally the skin is hard and horny. (ilands oecur in various positions. (b) Appendages.-The head, which is covered by a flat shield alove, beary (1) a pair of antennæ, usually of considerable length, and con. sisting of from twelve to over one hundred joints ; (2) a pair of small, strong, toothed, and lrimtly mandibles; (3) a pair of under-jaws, usually with palps. The next appendages are limb-like, and are followed by a modified pair of legs, the basal pieces of which generally meet in the middle line, while the strong joints terminate in a sharp claw, at which a poison-gland opens. These apyendages are obviously of use for seizing and killing the prey. The legs of the other segments are usually seven-jointed, sometimes bear spurs and glands, and are generally clawed. The last pair differ in size and form from the rest, and are turned backwards. (c) Internal Anatomy. - The large brain is connected as usual with a ventral chain of ganglia. Compound eyes occur in one family, simple eyes in many, while the feelers, certain bristles, and portions of the skin are also sensory. In some cases there is a special well-defined sense-organ of undecided function in front of the head, or on one of the jaws. The alimentary canal is straight, and has associated with it salivary and digestive glands, and excretory (Malpighian) tubules. The heart is represented by a chambered dorsal vessel. Trache⿰ or air-tubes open on the sides of the body, sometimes on erch ring, often on alternate segments, ramify throughont the tissues, and are connected together on each side by a longitudinal stem. The reproduetive organs are usually tubular, and open on the last ring of the body. A distinct penis is sometimes present.

Life and Habit. - Centipedes are darkness-loving animals, nocturnal in their food-hunting, lurking under stones or among rotten wood and the like during the day. Their powers of vision are very poorly developed, and most of the sensory work is tactile. Only in one family (Scutigeridr) are there compound eyes, in most forms only simple eyes, in many none at all. The recent researches of Platean and others have shown that these creatures can distinguish light from darkness, but do not need eyes to do this; species with eyes do not apparently get on much better than those without them; those with eyes seem to perceive bright objects reflecting much white light, and in some cases conspicuous movements, but probably in no case the forms of objects. Moving actively about at nights, feeling their way by means of their antennze, which function as a blind man's staff, they light upon insects, worms, and other small animals, which they seize and kill with their poison-bearing appendages. They are all voracious carnivorous forms, not vegetarian like the Millipedes. Some forms can run with some rapidity, and wriggle about in curious serpent-like fashion.

Development.-In some cases the males are said to deposit their reproductive elements in packets (spermatophores) fixed by a web to the ground. In most cases copulation probably occurs. Scolopendra is viviparous, the others lay eggs. The eggs develop into larvo, which are either miniature adults (Scolopendridme and Geophilidre), or differ from the full-grown forms in having only seven pairs of legs (Seutigeridæe and Lithobiida).

Classification and Forms of Interest. - The order of Centipedes is one of the three or four divisions of Myriopoda (q.v.), and, like the class, generally represents a somewhat low grade of development among animals breathing by air-tubes. The most 
evolved centipede is a very uniform and oldfashioned animal when compared with any normal insect or spider. In the order itself we distinguish four families-(1) Scutigeridæ, (2) Lithobiidæ, (3) Scolopendridæ, (4) Geophilidæ. The first of these includes curious forms with compound eyes, very long feelers, eight shields along the back, and fifteen pairs of very long legs. The feelers and the last pair of legs are longer than the, body; there are external generative appendages. In Seutigera, and apparently in some other centipedes, there are peculiar 'lung-like' dorsal aggregations of air-tubes opening on the back, and perhaps the beginning of the "pulmonary chambers' of some arachnids. Scutigera is represented by about a score of species, widely distributed in warm countries, and common in houses. In Lithobiidre, as in the two other families, simple eyes alone are present; there are fifteen pairs of legs, antennæe measuring a third or more of the body length, and fifteen dorsal shields. The genus Lithobius includes over one hundred species- $L$. forficatus (of a reddish-brown colour, and about an inch long) is very common throughout Europe and America; our most familiar British species, L. mutabilis, also very common, has the habit of feigning death. The bite occasions considerable irritation, like that due to nettle-stings.

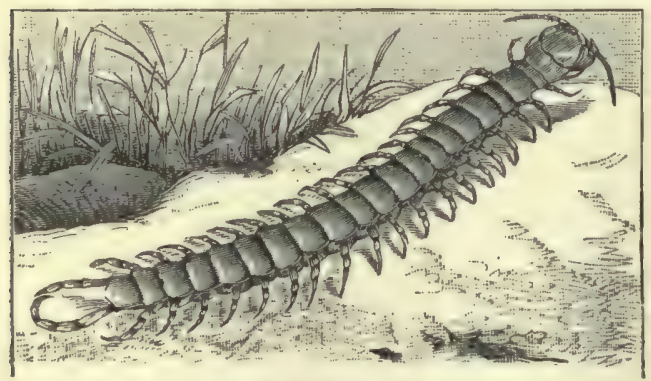

Giant Centipede (Scolopendra gigas ).

The Scolopendridæ have over a score of legs, short many-jointed antennæ, not more than one-fifth of the total length of the body; and simple eyes, not over four pairs in number, or altogether absent. About one hundred species are known, distributed over sixteen genera. They are especially at home in warm countries, where they often attain large size, the Scolopendra gigas, for instance, being sometimes a foot long. The poisonous bite of some of the larger forms is really dangerous to man. Scolopendra is the most important genus. Lastly, the Geophilidæ are very long, worm-like centipedes, of somewhat sluggish habit, with 31 to 173 pairs of legs, short feelers, and no eyes. Some 22 species and 9 genera have been recorded, especially abundant in warm climates. Geophilus electricus and another species, G. longicornis, both found in Britain, shine in the dark. This is probably due to a viscid fluid exsreted all over the ventral surface. Himantarium, found round the Mediterranean, is the largest form of Geophilidæ. Well-developed apinning glands are seen in this family, and their secretion cements together ova and spermatozoa.

Distribution. - The centipedes are world-wide, but abound especially in warm regions. Somewhat unsatisfactory fossil remains have been obtained from the American Carboniferous strata; inetter preserved possible centipedes have been got irom the Solenhofen strata, but it cannot yet be said with certainty that centipedes are known before Tertiary times.
Practical Import.-The centipedes have some direct practical importance as voracious devourers of injurious insects, larvæ, snails, and the like, while some of the large tropical forms are known in a somewhat different connection as animals able to give a painful and poisonous bite. In his Personal Narrative, Humboldt says he saw Indian children draw large centipedes out of the ground. and eat them.

Literature. -Newport, Monograph of the class Myriapoda, order Chilopoda (Trans. Linnzan Society, vol. xix. 1845); Haase, Schlesiens Chilopoden (1880-81); Latzel, Die Myriapoden Oesterreichs (1880-84).

Centlivre, Susannah, an English dramatic authoress, was the daughter of a Lincolnshire gentleman named Freeman, of Holbeach, and born (say some anthorities) in Ireland about 1667. Her early history is obscure; but such were her wit and beauty that on her arrival in London, though a destitute orphan, and only sixteen years of age, she won the heart of a nephew of Sir Stephen Fox, who died shortly after their marriage. Her second husband, an officer named Carroll, lost his life in a duel. Left in extreme poverty, his widow endeavoured to support herself by writing for the stage, and after producing a tragedy called The Perjured Husband (performed first in 1700), made her appearance on the stage at Bath. She afterwards married (1706) Joseph Centlivre, headcook to Queen Anne, with whom she lived happily until the time of her death, December 1, 1723 . Her plays-The Busybody (with 'Marplot' for leading character, 1709), and A Bold Stroke for a Wife (1717) -are lively in their plots, and have kept their place on the stage. Nineteen in all, they were collected in 3 vols. 1761, with a bingraphy, and reprinted 1872 .

Centner is, with metallurgists, a weight of $100 \mathrm{lb}$, and it often has this value in commerce. The German centner is however 50 kilogrammes or $110 \frac{1}{4} \mathrm{~b}$. avoirdupois; the metric or doppel centner is 100 kilogrammes. The cental of the United States is $100 \mathrm{lb}$.

Cento, a town of Central Italy, 16 miles $\mathbf{N}$. by W. of Bologna, on a fertile plain near the Reno, the birthplace of Guercino (q.v.). Pop. 4975.

Cento, a name applied to literary trivialities in the form of poems manufactured by putting together distinct verses or passages of one author, or of several authors, so as to make a new meaning. After the decay of genuine poetry among the Greeks, this worthless verse-manufacture came into vogue, as is proved by the Homero-centones (ed. by Teucher, Leip. 1793), a patchwork of lines taken from Homer and forming a consecutive history of the fate and redemption of man. It was much more common, however, among the Romans in the later times of the Empire, when Virgil was frequently abused in this fashion, as in the Cento Nuptialis of Ausonius, and especially in the Cento Vergilianus, constructed in the 4th century by Probs Falconia, wife of the Proconsul Adelfius, and giving, in Virgil's misplaced words, an epitome of sacred history. The cento was a favourite recreation in the middle ages. In the 12 th century a monk at Tegernsee, named Metellus, contrived to make a cento of spiritual hymns out of Horace and Virgil. See Delepierre, Tableau de la Littérature du Centon (1875).

Central America, a name applied to that part of the American continent which lies between the isthmuses of Tehuantepec, Mexico, and Panama, Colombia. Specifically the new Greater Republic of Central America, formed by treaty at Amapala in 1895 and formally recognised by President Cleveland December 23, 1896, embraces the republics of Salvador, Nicaragua, and Honduras, with provisions 
wer the admisaion of Costa Rica and fiuatemala. See under separate articles; also AMERICA.

Contral City, the name of several villages and hamlets in the United States, and of the eapital of Gilpin county, Colorado, 40 miles W. of Denver by rail, with quartz-mills and rich gold uines, and (1890) 2480 inhabitants; also of a mining town of Lawrence county, Soutl Dakota, in the Black Hills, 280 milés \$W. of Bismarck, with formerly aome twenty quartz-mills for gold. Pop. (1880) 1008 ; (1890) 519.

Central India is the official term for a group of feudatory states in India, which fall into nine political agencies, but are all under the supervision of the governor-general's agent. The region in which these states lie is to the north of the British 'Central Provinces' of India, and touches the North-west Provinces, Rajputana, Khandesh in the Bombay Province, and Chntia-Nagpur in Bengal. The total area is about $75,000 \mathrm{8g}$. m.; pop. in 1891, 10,314,787. The nine subordinate agrencies comprised in the Central India Agency sre the Indore, Bhil or Bhopawar, Deputy Bhil, Western Malwa, Bhopal, Gwalior, Guna, Bundelkhand, and Baghelkhand agencies. The intrusion of two British districts, those of Jhansi and Lalitpur, belonging to the North-west Provinces, separates these nine agencies into two divisionsnative Bundelkhand and Baghelkhand on the east, and Central India proper or Malwa on the west; but the whole country lies between the Nerbudda, the Ganges, and the Chambal rivers, and is mostly fertile and well tilled. The Malwa western division is mainly a tableland 2000 feet sbove the sea; but its rich black soil produces fine whest and much opium. The elimate of Malwa is on the whole mild and equable; but the northern part of Central India is torrid, and unhealthy during the rainy season. The mineral wealth of Central India is great: iron, coal, copper, and lime are plentiful, and diamonds are found in some parts of Bundelkhand. The inhabitants are very diverse in origin, comprising Mahrattas (the ruling race), Rajputs, Bundelas, Baghelas, Jats, Kols, and hill-tribes such as the Gonds $(414,000)$ and Bhils $(217,000)$. The population is mainly Hindu in religion, only 510,718 being Mohammedans. The agent to the governorgeneral of India, whose headquarters are at Indore, has very high and very various duties and powers. He is the adviser of all the native chiefs, and their guardian during minority; exercises the functions of a court of appeal; has at his command large bodies of troops; as "opium. agrent' supervises the opium-tax throughout the agency; and he is of course the medium of communication between the imperial government and the native authorities. The prineipal states and ageneies have separate articles. See INDORE, Baghelkhand, \&c. The Central Provinces (q.v.) are a British commissionership.

Centralisation, a term which has come into general use for expressing a tendency to administer by the sovereign or the central government matters which would otherwise be under local management. The centralising tendency has been a feature in most of the great gtates recorded in history, though not in all of them. The oriental empires admitted of a large degree of local independence among the subject peoples. The Roman empire was one of the most remarkable instances of centralisation the world has ever seen. That empire grew out of the subjugation of all the states round the Mediterranean by the city of Rome, and the control of it passed by the in evitable tendency of events into the hands of a single chief, whose power rested on the army, and who centred in himself all the great functions of government. In the later days of the empire the tendeney increased, until the system broke down with the power that wielded it. Amid the ehaos that followed the downfall of Kome various gystems arose for the restoration of order, political or religious, or both. Of these the greatest is still the Papacy; the greatest in bygone history was the empire of Charlemagne. In those times of struggle, the natural method was centralisation baserl on military supremacy.

Modern attempts to found a great monarehy in Europe on the model of the Roman empire have failed. There have grown up instead a group of powerful states, in the history of which the central. sing tendency is strongly marked. Centralisation was necessary, for in the great struggles which have incessantly been going on, success or even selfpreservation could be secured only through a strong organisation repressing internal division, and through large and efficient armies. As an adequate revenue was required for these objects, there was further involved a strong control by the central power of the economic and industrial functions of the state. Thus it will be seen that centralisation is more or less inevitable in the struggle for existence on the European continent. The most notable examples of the opposite tendency at present are apparent in the colonial empire of Great Britain, and in the United States, where we find extensive groups of self-governing communities with only a limited messure of control by the central government. Such control is most limited of all in the British colonies.

On the other hand, in the French commune and in the Russian mir we see, under governments otherwise strongly centralised, a form of local activity which had been long extinct in Britain. The municipal reform of 1835 has done much to revive local action in the town life of England. The aim of the reform of local government begun in 1888 is to revive, extend, and systematise local responsibility and freedom of action, particularly in rural districts. It is now recognised that efficiency in the central government can be best secured by transferring local interests to local management by decentralisation. A wise decentralisation may be subservient to an effective centralisation, a principle which holds good also on the European continent. No absolute rules can, however, be laid down for marking off the re. spective provinces of the central and local powers. Each country must solve the problem in its own way, as its interests and circumstances require.

Central Provinces, a chief-commissioner ship of India, lying between $17^{\circ} 50^{\prime}$ and $24^{\circ} 27^{\prime} \mathrm{N}$. lat., and between $76^{\circ}$ and $85^{\circ} 15^{\prime} \mathrm{E}$. long., and em. bracing 18 British districts and 15 native states. Area, 115,936 sq. m.; pop. (1891) 12,932,330. The surface is very broken, straggling ranges of hills eropping up even in the level portions. In the north extend the Vindhyan and Satpura (2000 feet) tablelands, with the Nerbudda between; south of these stretches the great Nagpur plain, with the Chatisgarh plain to the east, and a wild forestregion beyond, reaching almost to the Godavari. Besides the two mentioned, the chief rivers of the province are the Wardha and Wainganga; all four are rapid streams, with their erystal waters leaping from point to point, and rushing headlong through the narrow mountain-gorges of their upper course. The climate is hot and dry, except during the south-west monsoon, from June to September, when 41 of the menn annual 45 inches of rain fall. Wheat is grown chiefly in the Nerbudda valley, rice in the Nagpur plain; these are the principal crops, but oil-seeds, cotton, and tobacco are also raised. The only manufactures of note are 
weaving and the smelting and working of iron ores. Iron is abundant, especially in the south, and there are also large coalfields, but the coal is of a very inferior quality. There is considerable trade, but its progress is retarded by the want of means of communication; this drawback, however, is being removed, roads are being made, and the railway system steadily pushed forward. Of the population, three-fourths are Hindus, and one-seventh belong to the so-called aboriginal or non-Aryan tribes, who have found a refuge in the Satpura plateau, and still adhere to their primitive faiths (see GoNDs). From these hill-tribes the Hindus throughout the province have contracted beliefs and habits which they have grafted upon the usual worship of their sect; adoration of the dead, worship of the goddess of smallpox, and belief in witcheraft are universal. The population is almost entirely rural, only 6 per cent. residing in the 52 towns of above 5000 inhabitants, of which three -Nagpur, Jubbulpore, and Kampti-have over 50,000 inhabitants. Central India (q.v.) is a term of quite distinet meaning.

Centre and Central Forces.-Centre of

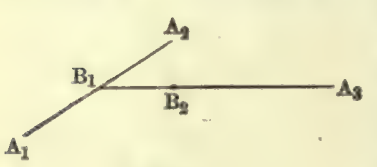

INERTIA (MASS) If $m_{1}$ and $m_{2}$ be the masses of two particles placed at the points $A_{1}$ and $A_{2}$, and if the right line $A_{1} A_{2}$ be divided in $B_{1}$, so that

$m_{1} \mathbf{A}_{1} \mathbf{B}_{1}=m_{2} \mathbf{A}_{2} \mathbf{B}_{1}$,

the point $B_{1}$ is called the centre of inertia, or centre of mass, of the two particles. If $m_{3}$ be a third mass at $A_{3}$, and if $B_{1} A_{3}$ be divided in $B_{2}$, so that

$$
\left(m_{1}+m_{2}\right) \mathrm{B}_{1} \mathbf{B}_{2}=m_{3} \mathbf{A}_{3} \mathbf{B}_{2},
$$

$B_{2}$ is called the centre of inertia of the three particles. In general, if there be any number of particles, a continuation of the above process will enable us to find their centre of inertia. Every body may be supposed to be made up of a multitude of particles connected by cohesion. From this it is obvious that the centre of inertia is a definite point for every piece of matter.

In general, the determination of the centre of inertia requires the use of the integral calculus. In the case of some bodies, such as those which have a simple geometrical form and are of uniform density, elementary mathematical methods will generally be sufficient. Any straight line or plane that divides a homogeneous body symmetrically must contain its centre of inertia. For the particles of the body may be arranged in pairs of equal mass and at equal dis. tances from the straight line, or plane; and, sixice the centre of inertia of each pair lies in the line or plane, the centre of inertia of the whole must also lie in the same line or plane. For example, the centre of inertia of a uniform thin straight rod is its middle point; that of a uniform thin rod bent in the form of a parallelogram, the point of intersection of its diagonals; that of a lamina, uniform in thickness and density and in form a circle, ellipse, or parallelogram, its centre of figure; that of a uniform spherical shell, its centre; that of a homogeneous sphere, its centre; that of a parallelopiped, the intersection of its diagonals; that of $\mathbf{a}$ circular cylinder with parallel ends, the middle point of its axis.

An important case is that of a uniformly thin triangular plate. Let $\mathrm{ABC}$ be the plate. Bisect $A B$ in $P$ and join CP. Let the triangle be divided by right lines parallel to $A B$ into an indefinitely great number of indefinitely narrow strips. The centre of inertia of each strip is its middle point.
But all the middle points lie on CP. The centre of inertia of the whole plate must therefore lie on CP. Again, if $\mathrm{BC}$ be bisected in $Q$, and $A Q$ be joined, the centre of inertia of the whole plate must lie in AQ. The centre of inertia must therefore be 0 , the point of intersection of $\mathrm{CP}$ and $\mathrm{AQ}$. It is easily proved by elementary geo-

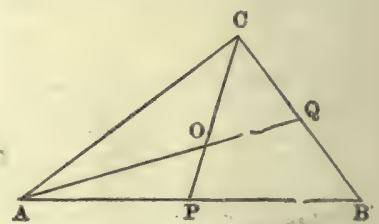

Fig. 2. metry that $O P=$ one-third of CP. Hence, the centre of inertia of a triangular plate is obtained by joining a vertex to the middle point of the opposite side and taking the point two-thirds of this line measured from the vertex. By a similar method the centre of inertia of other plane figures. may be obtained.

CENTRE OF GRAVITY.-If a body be sufficiently small, relatively to the earth, the weights of its particles may be considered as constituting a system of parallel forces acting on the body. Now, the magnitude of the weight of a particle is proportional to its mass. Hence, the line of action of the resultant of the parallel forces will approximately pass. through the centre of inertia. For this reason such bodies are said to have a centre of gravity. Strictly speaking, there is no such point of necessity for every body, since the directions of the forces acting on the body are not accurately parallel. Hence, it is only approximately that we can say of a body that it has a centre of gravity. On the other hand, every piece of matter has, as is shown above, a centre of inertia. For all heavy bodies of moderate dimensions it is, however, sufficiently accurate to assume that the centre of inertia and gravity coincide. For example, the centre of gravity of a uniform homogeneous cylinder with parallel ends is the middle point of its axis, that of a uniformly thin circular lamina its centre, and so on.

The centre of gravity of a body of moderatedimensions may be approximately determined by suspending it by a single cord in two different positions, and finding the single point in the body which, in both positions, is intersected by the axis of the cord.

The term centre of gravity is also used in a stricter sense than the one just explained. Thus, if a body attracts and is attracted by all other gravitating matter as if its whole mass. were concentrated in one point, it is said to have a true centre of gravity at that point, and the body itself is called a centrobaric body. A spherical shell of uniform gravitating matter attracts an extermal particle as if its whole mass were condensed at its centre. Such a body has a true centre of gravity. When such a point exists, it necessarily coincides with the centre of inertia.

Centre of Oscillation.-A heavy particle suspended from a point by a light inextensible. string constitutes what is called a simple or mathematical pendulum. For such a pendulum it is easily proved that the time of an oscillation from side to side of the vertical is proportional to the square root of its length for any small are of vibration. A simple pendulum is, however, a thing of theory, as in all physical problems we have to deal with a rigid mass, and not a particle, oscillating about a horizontal axis. In a pendulum of this kind the time of oscillation will not vary as the square root of the length of the string, for it is obvious that those particles of the body which are nearest the point of suspension will have a tendency to vibrate more rapidly than those more 
remote. The former are therefore retarded by the latter, while the latter are accelerated by the former. There is thus one particle which will be wevelerated and retarded to an equal amount, and which will therefore move as if it were $a$ simple jendulum unconnected with the rest of the body. The point in the brily oceupied by this particle is called the centre of oscillation.

Is all the particles of the borly are rigidly con. rected, they all vibrate in the same time. Hence it follows that the time of vibration of the rigid body will be the same as that of a simple pendulum, inlled the equivalent or isochronous simple yendu. lum, whose length is equal to the distance between the centres of suspension and oscillation.

The determination of the centre of oscillation of a body requires the aid of the calculus. It may be stated, however, that it is always farther from the axis of suspension than the centre of inertia, and is always in the line joining the centres of suspension

A and oscillation. Let $A$ be the centre of suscentre of oscillation, and let AB be equal to $h$, and $k$ be the radius of gyration of the body about an axis through $\mathbf{B}$ parallel to the fixed B axis, then it is easily shown that

c

$$
\mathrm{AC}=\frac{\left(h^{2}+k^{2}\right)}{h} .
$$

Fig. 3. From this there follows the important proposition that the centres of oscillation and suspension are convertible, a proposition which was taken advantage of by Kater for the practical determination of the force of gravity at any station.

Centre of Prrcussion.-If a body receive a blow which makes it begin to rotate about a fixed axis without causing any pressure on the axis, the point in which the direction of the blow intersects the plane in which the fixed axis and the centre of inertia lie is called the centre of percussion. That such a point must exist is easily shown by suspending a straight rod by a long string attached to one end, and striking it with a hammer in different points. If the rod is struck near the top the foot will move in one direction, and if the blow be applied near the foot the top will move in the opposite direction. It is thus evident that there must be some point which does not move at all at the instant of the blow. If a line through this point be regarded as an axis of rotation, the point at which the body was struck is the centre of pereussion, since no pressure is roduced on the axis. It is easily proved by means of higher mathematics that the centre of pereussion with respect to any axis is the same point as the centre of oscillation.

From what has been said it is obvious that in order that no jar may be felt on the hand a cricket ball must be hit in the centre of percussion of the bat with respect to an axis through the hand.

There are, it may be mentioned, many positions which the axis may have in which there will be no centre of percussion. For example, there is no centre of percussion when the axis is a principal axis through the centre of inertia.

Centre of Prassurk. - When a plane surface is immersed in a fluid at rest, and held in any position, the pressures at different points of the surface are perpendicular to the surface. These pressures may therefore be looked upon as constituting a system of parallel forces whose resultant is the whole pressure. The point at which this resultant acts is called the centre of pressure, and may be defined as the point at which the direction of the single force which is equivalent to the fluid pressures on the plane surface meets the surface. The resultant action of fluids on a curved surface is not always reducible to a single force. The defini- tion given above is, therefore, limited to plane surfaces. In the case of a heavy fluid it is clear that the centre of pressure of a horizontal area corresponds with the centre of gravity. When, however, the plane is inclined at any angle to the surface of the fluid, the pressure is not the same at all points, being greater as the depth increases; since in the same liquid the pressure varies with the depth. In general, the centre of pressure will be below the centre of gravity. The determination of the centre of pressure requires the use of the integral calculus, but special cases may be treated by ordinary algebra. In the case of a parallelogram, one edge of which is in the surface of the flnid, the centre of pressure is at a distance of one-third up the middle line from the base. In the case of a triangle, having one side in the surface of the fluid, the centre of pressure is at the middle point of the median corresponding to the vertex immersed; while in the case of a triangle, with its apex in the surface, and the base horizontal, the centre of pressure is on the median corresponding to the vertex and at a distance of three-fourths of the median from the vertex.

CENTRE of Buoyancy.-The pressures which act on every point of a surface immersed in a fluid can be resolved into horizontal and vertical com. ponents. The former balance one another. The resultant pressure must therefore be vertical ; and, as the pressure increases with the depth, it is clear that the upward pressures must be greater than the downward. Hence the resultant pressure on an immersed body must be a force acting vertically upwards. Now it is easily shown that the magnitude of this pressure is equal to the weight of the fluid displaced. The point in the displaced fluid at which the resultant vertical pressure may be supposed to act is called the centre of buoyancy, or centre of displacement. Hence, we see that when a body floats in a fluid, it is kept at rest by two forces, the weight of the body acting downwards through its centre of gravity, and the weight of the fluid acting vertically upwards through its centre of gravity, or centre of buoyancy. The relative positions of the centre of gravity and the centre of buoyancy have an important bearing on the safety of ships at sea. If the centre of buoyancy be above the centre of gravity, the equilibrium is stable; in other words, if the ship is displaced, it will tend to return to its original position. If, on the other hand, the centre of buovancy be below the centre of gravity, the equilibrium will generally be unstable, although a body may float in stable equilibrium even if the centre of buoyancy be below the centre of gravity, as is explained in the article HYDROSTATICS.

Central Forces. - Central forees are forces whose action is to cause a moving body to tend towards a fixed point called the centre of force. By Newton's first law of motion we know that 'every body continues in its state of rest or of uniform motion in a straight line, except in so far as it is compelled by forces to change that state. From this we learn that, if the speed of a body ehanges, or if the line of motion be not straight, whether the speed be unaltered or not, some force must be acting. In the latter case the forces acting are called central forces. The doctrine of central forces considers the paths which bodies will describe round centres of force, and the varying velocity with which they will pass along these paths. It investigates the law of the foree in orfer that a given curve may be described, and many other problems which can only be solved by mathematical methods. Gravity affords the simplest illustration of a central force. If a stone be slung from a string, gravity deflects it from the rectilinear path which it would otherwise pursue, and makes it move in a 
curve called a parabola. Again, the moon is held in her orbit round the earth by the action of gravity, which is constantly preventing her from going off in the line of the tangent to her path at any instant.

In connection with this subject we have to make some remarks on what is called centrifugal force. We have seen that force must always be applied to make a body move in a curved path. Such a force is called a centrifugal force, the old erroneous notion being that bodies have a tendency to fly outwards from the centre about which they are revolving. The use of the term will, however, cause no inconvenience, provided we interpret it merely as indicating that, to keep a body moving in a curve instead of in its natural straight line, $\approx$ force directed towards the centre of curvature is always required.

Many familiar illustrations of the action of the so-called centrifugal force will occur to the reader. A ball fastened to the end of a string, and whirled round, will, if the motion is sufficiently rapid, st last break the string, and fly off in a tangential path. This is due to the fact that the cohesion of the particles of the string are no longer able to supply the force necessary to keep the ball moving in its circular path. For a similar reason a flywheel or a grindstone bursts when it is made to rotate too rapidly. It is found that at a curve on a railway it is the outer of the two rails which is most worn. This is due to the fact that the outer rail has to supply the force necessary to keep the trains moving in curved paths. A glass of water may be whirled so rapidly that, even when the mouth is downwards, the excess of the centrifugal force over the weight of the water is sufficient to prevent the water from falling out. The centrifugal force increases with the velocity. As a matter of fact, it can be shown that when a body moves in a circle of radius $r$, with velocity $v$, its centrifugal force is $\frac{m v^{2}}{r}$. By means of this formula it can be proved that about $\frac{1}{2} \frac{1}{6}$ th of its weight is required merely to keep a body on the earth's surface at the equator. By this amount the weight of a body is diminished. Now 289 is equal to $17^{2}$. Hence it follows that if the earth were to rotate seventeen times as fast as it does now, the attraction of gravitation would only just be able at the equator to keep bodies from fiying off its surface. If the rotating body be plastic, it will swell out in all directions perpendicular to the axis of rotation, and assume the form of an oblate spheroid. For the same reason the earth itself has assumed the form of an oblate spheroid, a result which is seen on a greater scale in the case of Jupiter and Saturn on account of their larger size and more rapid rotation.

Centre-board. See Yacht, Vol. X. p. 770.

Centrífugal and Centrípetal are terms used in Botany to designate two different kinds of leaf development or inflorescence, the former term being applied when the development proceeds from the apex towards the base of the axis or leaf, and the latter when it is from the base upwards towards the apex. See Leaf, INFLORESCENCE.

Centrifugal Force. See Centre.

Centripetal Force. See Centre.

Centum'viri ('a hundred men'), a college of justice in ancient Rome, which had jurisdiction in civil cases. It has been supposed that the body was originally made up of three delegates from each of the thirty-five tribes. There were 180 members in the time of Augustus, and under the emperors it increased in importance, as it became the only scene left for the display of judicial eloquence and of legal knowledge.
Centurion (Lat. centurio, from centum, 'a hundred'), a Roman officer commanding a century or company of foot-soldiers. There were sixty centurions in a Legion (q.v.).

Ceorl, a word which occurs frequently in the laws before the Norman Conquest under somewhat varying senses, but substantially meaning an ordinary freeman not of noble birth. His position gradually sank in social status until it hardly differed from that of the serf, save that the ceorl had the right of choosing his own master in accordance with the law of Athelstan, which required every landless man to find himself a lord. He still remained 'law-worthy, and paid his wer-gild of two hundred shillings; but part of his freedom had disappeared, and ultimately his condition developed into the complete villenage characteristic of feudalism. On the other hand, ceorls who possessed land often contrived to force their way into a higher social class, that of the thegns, a kind of nobility of service who may be roughly put as equivalent to the knights of the period after the Conquest. A ceorl with 5 hides (600 acres) of land was "thegnworthy.' The name ceorl does not occur in Domesday - the very degradation of the meaning of the word churl in modern usage is but a part of the historical degradation of the social class which it denoted.

Ceos (sometimes called by the Italianised name of Zea or Tzia), one of the Cyclades, in the Egean Sea, 14 miles off the Attic coast. It is 13 miles long, 8 broad, and $39 \mathrm{sq} . \mathrm{m}$. in area. The central and culminating point is Mount Elias, 1863 feet high. It is fairly fertile, raising fruit, wine, honey, and valonia. The population is 4311 , of whom 4295 belong to the capital, Zea or Ceos. In ancient times Ceos was noted as the birthplace of the poets Simonides and Bacchylides, and the physician Erasistratus; and the Cean laws were famous for their excellence.

Cephalaspis, a genus of fossil Ganoid fishes, of which six species have been described, two belonging to the Upper Silurian, and four to the Devonian measures. The head was protected by a large ganoid plate, sculptured externally with circular radiating markings. The shield was produced into a horn at each posterior corner, and bore a median and posterior dorsal spine. Agassiz gave the name cephalaspis ('buckler-headed') from this extraordinary covering, which has very much the appearance of, and was formerly supposed to be, the cephalic shield of an Asaphus or Trilobite. The body was covered with rhomboidal enamelled scales, and furnished with dorsal and pectoral fins : it terminated in a large unsymmetrical tail. In a graphic description of this fossil in his old Red Sandstone, Miller thus sketches the general appearance of the animal: 'Has the reader ever seen a saddler's cutting-knife-a tool with a crescentshaped blade, and the handle fixed transversely in the centre of its concave side? In general outline, the cephalaspis resembles this tool; the crescentshaped blade representing the head, the transverse handle the body.' The endo-skeleton was mainly cartilaginous, retaining the notochord through life. The flexible body, assisted by the large tail and the fins, would give the cephalaspis the power of moving rapidly through the water. Being a predaceous fish, it must have been a formidable enemy to its associates in the Palæozoic seas, for, besides its power of rapid motion, the sharp margin of its shield probably did the work of a vigorously hurled javelin, as in the sword-fish. Pteraspis, Asterolepis ( 20 to 30 feet in length), Scaphaspis, Auchenaspis, and a number of other genera, are united in the same family as Cephalaspis. See Ray Lankester, A Monograph of the Fishes of the Old Red Sand- 
stune in Britain, part i. 'Cephalaspida' (Lond. I vis 70 ); R. H. Traquair, The Ganoids of the liritish Carboniforous System (Palaeont. Society, Lomil. 1877).

Cephalodiseus, one of the most curious and interesting orgnnisms dredged by the Challenger expealition. It was found in the Strait of Magellan, wis firmt supposed to be a compound Ascidian, was Imonugraphed (1887) by Professor M'Intosh as one of the Polyzor (section Aspristophora), but is regariled by Mr Harmer as closely allied to that mar. vellous vertelurate-like worm, Balanoglossus (q.v.). The organisus form a sprealing seaweed-like hrownish colony, measuring in some cases 9 inches by 6 , and including a great number of little indiviluals, protected by a membranous, flexible investment or house. Each individual resembles Balanoglossus (and also in part backboned animals) in many important points, such as $(\epsilon)$ the presence of gill-slits; (b) the existence of a notochord as a dorsal ontgrowth from the gut, growing forwards into the anterior rearion or proboscis; and $(c)$ the possession of a dorsal central nervous system, most richly developed in the middle region (or collar), but extending on to the proboscis. As another apparent connecting link letween invertebrates and vertebrates, Cephalodiscus is of the greatest zoological interest. See zoology of the voyage of

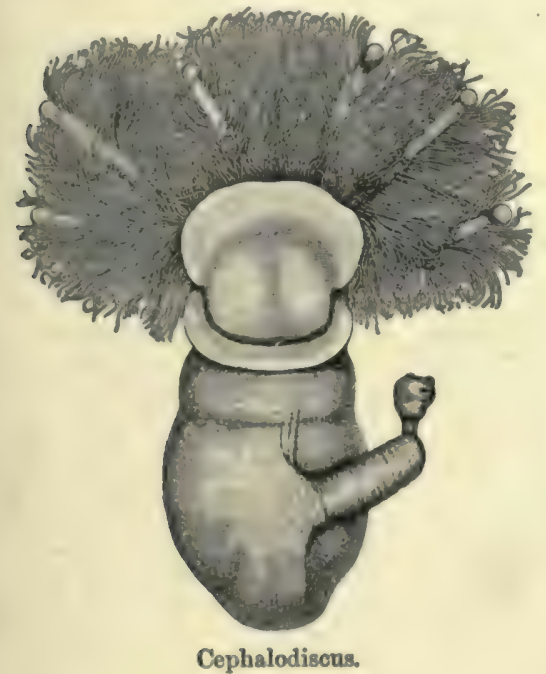

H.M.S. Challenger, Part lxii. ; Report on Cephalo disces, by Professor W. C. M'Intosh and Mr S. F. Harmer.

Cephalonia (anc. Cephallenia; Homeric Samēe), the largest of the seven Ionian Islands (q.v.), lies opposite the entrance of the Gulf of Lepanto or Corinth. It is irregular in shape, with a maximum length of 30 miles, and an aren of $302 \mathrm{sq}$. m. ; pop. 80,178 . The surface is mountrinous, in one point attaining 5310 feet ; the soil for the most part thin, and water scarce. The inhabitants, however, have planted vineyards wherever the grape will grow, and currants and olive-oil are also produced for export. The capital is Argostoli (q.v.).

Cephalo'poda (Gr., 'head-footed'), the highest class of molluses, and in some respects the highest invertebrates. They are usually large animals, exclnsively marine, with well-developed headregrion, but (as the quaint name suggrests) with the 'foot' or ventral surface grown round the mouth, and.split up into 'arms,' which (with one excepfion) bear suckers. Another part of the foot is modified to form a funnel through which water is squirted. Two or four gills are present in the usual

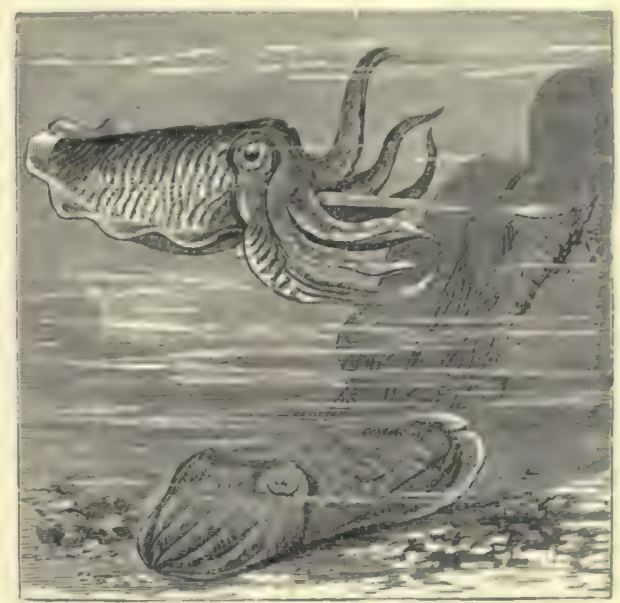

Cuttle-fish (Sepia officinalis), swiunming and at rest.

mantle-cavity. While the ancient forms lived in shells, the Pearly Nautilus alone remains in this state, the shell being in all other cases internal and degenerate. The eyes are peculiarly large, and their ferocions aspect has earned for many common forms the title of 'devil-fish.' The mouth in the midst of the 'arms' is equipped with parrot-like teeth, and with a rasping ribbon on the tongue. The central nervous system, with its closely associated ganglia, is surrounded by a protective cartilaginous sheath, analogous, though in no way homologous, with a vertebrate brain-box. The sexes are separate. The structure and life of these animals is disenssed under the more familiar title CUTTLEFISH ; only the general characters, classification, and distribution are here noticed.

Classification.-The Cephalopoda include two distinct orders, one represented by the Pearly Nautilus, the other by all the other living forms, which are again divided into Octopoda and Decapods, according to the number of the "arms."

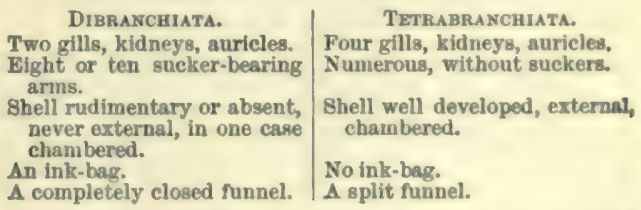

Distribution.-Most species occur in warm and temperate seas, but those found in the colder waters seem much more prolitic. The Tetrabranchiata are the older forms, and begin in the Silurian, whereas the Dibranchiats first appear in Triassic times. The Ammonites (q.v.) are the most familiar representatives of the former, the Belemnites (q.v.) of the latter.

See eepecially CuTrumfish, NaUtudo, Belementes, AMMonites; also Calamary, OCTOPUs, SEPIA; Owen, Memoir of the Pearly Nautilus (1832); Forussac and D'Orbigny, Bistoire naturelle des CEphalopodes (2 vols. Paris, 1835-48); Hoyle, Challenger Repost on Cephalopoda.

Cephaloptera, a name formerly used for a genus of rays, See RAY.

Cephissus, one of the two rivers which water the Athenian plain. It rises on the western slope of Mount Pentelicus and the southern side of Mount Parnes, and flows past Athens on the west into the Saronic Gulf near Phalerum. 
Cepola. See Bandfish.

Ceram' (SERANG), the largest island of the southern Moluceas, lies NE. of Amboyna, to which Dutch residency it belongs, and is divided into Great and Little Ceram by the Isthmus of Taruno. Area, 6605 sq. m. ; pop. 195,000. The island is one of the least explored in the archipelago, and comparatively little is known of the interior, which is, moreover, but scantily populated, the great mass of the people, mostly native Alfuros and immigrant Malays, inhabiting the coast villages. Much of the island is very fertile. A mountain-chain runs through the country, reaching in Nusa Keli some 11,000 feet. The ehief exports are sago, iron, timber, earthenware, birds of Paradise, dried fish, edible nests, \&c.

Ceram'ics (Gr. keramos, 'potter's clay'), a term used to designate the department of plastic art which comprises all objects made of clay, such as vases, cups, bassi-rilievi, cornices, and the like. See PotTery.

Cerastes, or HoRNED VIPER, a genus of serpents of the family Viperidæ, distinguished by a broad depressed heart-shaped head, the scales of which are similar to those of the back, and particularly remarkable for the development of one of the scales of each eyelid into a spine or horn, often of considerable length. The tail is very distinct

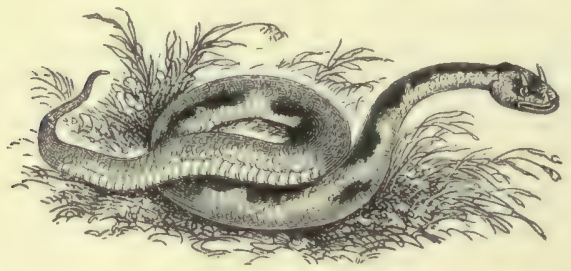

Horned Viper (Cerastes vulgaris).

from the body. This genus is exclusively African, and very venomous. There is probably only one species, Cerastes agyptiacus or cornutus, the Horned Viper of the north of Africa, ealled Cerastes by the ancients, the name being derived from the Greek kerces, ' a horn.' It was correctly described by the traveller Bruce, but his description was for some time regarded with incredulity.

Cerate (Lat. cera, "wax'), a compound of wax with other oily and medicinal substances in such proportions as to have the consistence of an ointment (see OINTMENTs). Simple cerate is made by melting together 6 parts of olive-oil, 3 of white wax, and 1 of spermaceti.

Ceratites, a genus of Ammonites (q.v.) peculiar to, and characteristic of, the Trias.

Cerat'odus, the Queensland mud-fish, one of the remarkable sub-class of double breathers or Dipnoi. The name was originally used for the fossil possessors of certain tooth-plates found in the

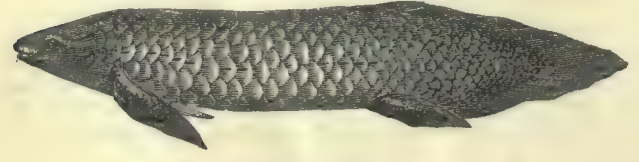

Ceratodus.

Triassic and Jurassic strata, and to this genus the Queensland survivor, which has similar dental arrangements, was referred when discovered in 1870. Barra munda is the local name. The fish may occasionally attain a length of six feet, has a later- ally compressed body with large scales, and possesses very unfish-like limbs with a central jointed axis and latera.l pieces. It lives in muddy water often containing much decaying vegetable matter. In this medium it does not find the gill-respiration sufficient, and comes to the surface to take gulps of air into the swimming-bladder, which functions as a lung. It eats leaves and other parts of plants. At nights Ceratodus sometimes leaves the water, and moves along the river-bank. The expulsion of air from its air-bladder or lung is supposed to account for a grunting noise then often heard. In the dry season it buries itself in the mud.

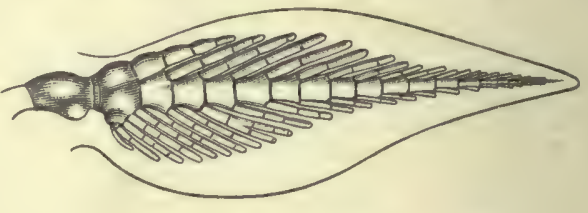

Limb of Ceratodus.

The flesh is much esteemed, and compared with salmon. This interesting animal is discussed, in its more technical relations, along with its neighbour genera-Lepidosiren and Protopterus-under the title Mud-FisHes.

Ceratonia. See Carob.

Cer'berus, in Greek Mythology, the manyheaded dog-according to Hesiod, the offspring of Typhaon and Echidna-who guarded the portal of the infernal regions. Later writers deseribe him as only three-headed, with the tail and mane composed of serpents, though the poets sometimes encumber him with a hundred heads. Orpheus charmed him by the magic of his lyre, and Hercules overcame him by strength and dragged him to the upper world.

Cerca'ria, the technical name applied to an embryonic form of many flukes. In all the twosuckered flat parasitic worms (the Distomer division of Trematodes) the development is indirect or circuitous. The eggs develop into embryos, which, instead of growing into adults, produce asexually one or more sets of intermediate forms. The final form, produced more or less directly from the embryo, is called a cercaria, and grows up into the adult fluke. It differs from the adult in having only rudiments of reproductive organs, in possessing eye-spots, and in being (except in one genus) equipped with a very movable tail. It is (1) born within some host, such as a water-snail ; (2) leaves this and swims freely in the water; (3) becomes sluggish, and enters a second host, or fixes itself on some foreign body. In this state it loses its tail and encapsules itself, and does not experience any further change till (4) it or its host is eaten by a vertebrate, within which the cercaria becomes an adult and sexual fluke. From the latter the em. bryos which eventually enter the first-mentioned host arise. Sometimes the life-history is simpler, but in all cases the cercaria is the form produced (generally indirectly) by the original embryo, and developing into the adult. See FLUKE.

Cercis. See Judas' Tree.

Cercopithe'cus (Gr., 'tail-ape '), a genus of monkeys. See MoNkEY.

Cere (in natural history). See BrLL.

Cerea'lia, or Cereal Grasses, so named from Ceres $(q . v$.$) , are the plants which produce$ grain or corn; in strictness, all the species of grasses (Gramineæ) cultivated for the sake of their seed as an article of food. They are also called Corn-plants or Bread-plants; but in this wide 
pupular sense the term cerenl censes to have any botanienl linits, and includes plants of wholly distinct orders, notably Buckwheat (nntural order, Polygonacese), and Quinon (Chenopodiacese), \&c.; even the Lotus of the Nile, the Victoria regia, and other species of water-lilies might thus be added to the list.

The cereals proper do not belong to any particular tribe of the great onder of grasses, but the employ. ment of particular species as bread-plants seems to have been determined chiefly by the superior size of the seed, or by the facility of procuring it in sufficient quantity, and of freeing it from its unedible envelopes. The most extensively cultivated grains are Wheat (Triticum), Barley (Hordeum), Rye (Secale), Oats (Avena), Rice (Oryza), Maize or Indian Corn (Zes), different kinds of Millet (Setaria, Panicum, Paspalum, Pennisetum, and Penicillaria), and Durra or Guinea Corn (Sorghum or Andropogon). These have all been cultivated from time immemorial, and there is great uncertainty as to the number of species to which the many existing varieties belong; their original forms and native countries often cannot confidently be deter. mined. Barley, oats, and rye are the grains of the coldest regions, the cultivation of the former two extending even within the arctic circle. Wheat is next to these, and in the warmer regions of the temperate zone its cultivation is associated with that of maize and rice, which are extensively cultivated within the tropics. The millets belong to warm climates, and durra is tropical or sub-tropical. Rice is the food of a greater number of the human race than any other kind of grain. See CORN, Barley, Maize, Millet, Rice, Wheat, and - other separate articles.

Cerebration, Unconscious. There can be no doubt that molecular changes in the cerebrum accompany all our conscious mental processes. The doctrine of unconscious cerebration as stated by Carpenter, Laycock, and others, holds that similar changes may go on in the cerebrum without any consciousness on our part, until the fully elaborated mental result is presented. It is an every-day experience that after one has been in vain trying to recall some name or incident, it will suddenly flash into the mind when one is thinking of some entirely different subject. According to Carpenter the cere. brum put in action by our consciousness has gone on working automatically but unconsciously, until the processes accompanying the mental operation of remembering the name or incident have been completed. This is the physiological statement corresponding to the psychological doctrine that the mind may undergo modifications without being conscious of the process until the new combination is presented to consciousness. See Consciousness, Brain, Psychology, Personality.

Cerebro-spinal Fluid is a clear, almost colourless, slightly alkaline fluid, closely resembling lymph in its composition, but containing less albumen. It is contained partly within the ventricular system of the brain, and in part in the loose connective tissue (subarachnoid meshwork), which lies between the Arachnoid and Pia Mater (q.v.), being continued from this latter situation along the fymphatic sheaths, which closely invest all the blood-vessels in the substance of the brain and spinal cord. The spaces which contain it communicate with the lymphaties of the head and of the nerves, and with the venous sinuses in the dura mater. Its main function, besides that of removing waste products, is to equalise the pressure within the skull. As the blood pressure increases that of the cerebro-spinal fluid diminishes, and vice versa. As the brain atrophies it is replaced by a proportionate increase in the fluid. In some dis- eases, such as acute and chronic Hydrocephalus $(q . v$.$) , it is greatly increased, and then it becomes$ a cause of atrophy of the brain. Its value as a water-cushion in diminishing the violence of shock from external injury has been already referred to at BRAIN. Cerebro-spinal means pertaining to the brain and spinal cord together, to the cerebrospinal system. For Cerebro-spinal Meningitis, see Meningitis.

\section{Cerebrum. See Brain.}

Ceremonies, Master of THE, an officer at court, instituted by James I. for the reception of ambassadors and dignitaries. The same name came to be used for the supreme authority on etiquette at public assemblies at Bath and elsewhere; Beau Nash (q.v.) being the most memorable.

Cereopsis (Gr., "wax-face "), a genus of birds of the family Anatidre, to which the New Holland goose ( $C$. nove hollandie) belongs. This bird has been known since the southern shores of Australia were first visited by navigators. There, and on the adjacent islands, they were found in great abundance; and so little were they acquainted with the danger to be apprehended from man, that the earlier navigators easily supplied themselves with fresh provisions by knocking them down with sticks. The flight is slow and heary, and the bird is naturally becoming less abundant. The cere (see BILL) is remarkably large, whence the name.

Ceres, the Roman name of the great Greek goddess Dēmētēr, the protectress of agriculture and the fruits of the earth. Her worship was borrowed by the Romans from Sicily. Her first temple in Rome was vowed by the dictator A. Postumins Albinus ( 496 B.C.), to avert a famine with which the eity was threatened. A great festival, with games, the Cerealia, was instituted in her honour, and her worship acquired great importance in the city. The decrees of the senate were deposited in her temple for the inspection of the tribunes of the people. See DEMETER.

Ceres, one of the Planetoids (q.v.), and the first of them that was discovered. It was first seen by Piazzi at Palermo, January 1, 1801, and is sometimes visible to the naked eye, looking like a star between the seventh and eighth magnitudes.

Cereus, a large genus of Cactacere (q.v.), containing many of the most imposing forms of the order, both as respects vegetation and flowering. C. giganteus reaches a height of 60 feet, often unbranched, its tall pillars giving an extraordinary character to the landscape of New Mexico, while the allied $C$. peruvianus ( 36 feet) takes its place in Peru. Others have thin snake-like branches ( $C$. flagelliformis), while the short obconical $C$. senilis is covered with long silky hairs. Many have splendid flowers, and of these $C$. speciosissimus with scarlet or purplish flowers is often cultivated, while C. grandiflorus is the well-known night-flowering cactus. The fruits are often much esteemed. For illustration, see CACTUS.

Cerignola, a town of Italy, 22 miles SE. of Foggia by rail, with manufactures of linen, and a trade in almonds and cotton. The Spaniards' decisive victory over the French here in 1503 established Spain's supremacy in Naples. Pop. 22,659.

Ceri'go, the southernmost of the seven Ionian Islands (q.v.), now officially known again by its old Greek name of Cythera, is separated from the coest of Morea by a narrow strait. Area, $107 \mathrm{sq} . \mathrm{m}$. ; pop. (1879) 13,259. It is mostly barren and mountainous in some parts; but corn, wine, and olives and fruits are raised. Capsali is the capital. In ancient times the island was sacred to Venus, as the land that received the goddess when she arose from the sea. 
Cerinthus, a heretic who lived at the close of the apostolic age, but of whom we have nothing better than uncertain and confused accounts. He is said to have been a native of Alexandria. He passed from Egypt into Asia Minor, and lived in Ephesus contemporaneously (according to the belief of the church) with the aged apostle John. It is related by Irenreus, on the authority of Polycarp, that John held the heretic in such detestation that, on a certain occasion, when he encountered Cerinthus in the baths of Ephesus, he immediately left the baths, saying to those about him: 'Let us fly, lest the bath fall on us, since Cerinthus is within, the enemy of the truth.' It is also said by Irenaus that the Gospel by St John was written in direct opposition to the tenets of Cerinthus. He held that the world was not made by the highest God, but by some angel or power far removed from and ignorant of the Supreme Being. $\mathrm{He}$ is also said to have held coarse and sensual millenarian views, to have believed the Jewish ceremonial law to be in part binding upon Christians, and to have taught that the Divine Spirit was first united with the man Jesus in his baptism by John. Cerinthus being, so far as is known, the oldest teacher of Judaico-Gnostic principles, and, according to Neander, "the intermediate link between the Judaising and Gnostic sects,' there would naturally be a greater incongruity and want of harmony in his system than in the later developments of Gnosticism (q.v.).

Cerithium, a genus of Prosobranchiate Gas. teropods, and type of a large family, Cerithiadæ. The shell is rough, naked, spiral, elongated, with many coils, and with an oval oblique aperture which has a short canal in front. The species of this family are numerous (140), most of them marine, but many inhabiting estuaries and brackish rather than salt water; some are found in lakes and rivers. A few belong to temperate climates, but most of them are tropical, and in mangrove swamps they particularly abound. The fossil species are very numerous, and almost all limited to the Tertiary formations, C. vulgatum, over six inches in height, is often seen in Italian markets.

Cerium (sym. Ce, eq. 92) is a rare metal found in cerite and a few other minerals. It is $a$, white metal, has not been obtained in any quantity; is not therefore employed in any manu. facture, and forms two basic oxides and a numerous class of salts. The nitrate and oxalate of cerium have been employed in the vomiting of pregnancy, their action being somewhat similar to that of the subnitrate of bismuth. Cerium biscuits are biscuits containing a small proportion of the oxalate, and they form a very convenient medium for the administration of the salt. Cerite or Ochröite is the silicate of cerium, and is found as a mineral in gneiss, near Riddarhytta, in Westmanland in Sweden.

Cerox'ylon. See Wax Palm.

Cerre'to, a cathedral city of South Italy, on a slope of the Apennines, 14 miles NNW. of Benevento. Pop. 5129.

Cerro de Pasco, the capital of the Peruvian department of Junin, stands at an elevation of 14,276 feet, 138 miles NE. of Lima. Near it are some of the richest silver-mines on the continent. The climate is cheerless and inclement. Pop. 7000, mostly Indians and half-breeds.

Cerro Gordo, a plateau in Mexico, the most easterly on the route from Vera Cruz to the capital. Here, on 18th April 1847, the Americans totally defeated the Mexicans.

Cerro Largo, a department in the NE. of Uruguay, well watered, with large savannahs and forests. Area, 5735 sq. m. ' pop. (1894) 36,000, Largo or Melo ;

Certaldo, a town of Central Italy, 19 miles SW of Florence ( 37 by rail). It is noteworthy as the residence of Boccaccio, who was born and died here. His house is still standing, much as it was in the poet's time. Pop. 2500.

Certhiidse, a family of birds, generally placed in the great order Insessores or Passeres. They are best known by their most typical representative the Creeper (q.v.). They are widely distributed birds, absent however from the Ethiopian and neo-tropical regions, and the family includes twelve genera and about fifty species. They are expert climbers, and feed on insects.

Certificate, in the law of England and of the United States, is a written statement by a person having a public or official status concerning some matter within his knowledge and anthority. There are a great many classes of such certificates-e.g. certificate of charge upon land; certificate of the chief-clerk in Chancery proceedings, which is practically a report of what the clerk has done; certificate of discharge of a debtor in liquidation; certificate of incorporation under the Companies Acts; certificate of mortgage on ships under the Merchant Shipping Acts; certificate of naturalisation. In the United States, the word is commonly applied to any formal statement made by a public servant in the exeeution of his duty, as by a collector of taxes, a postmaster, \&c. See CHARACTER.

Certification, in the law of Seotland, signifies the judicial assurance given to a party of the course to be followed by the judge in case he disobeys the will of a summons, or other writ or order of the conrt. Reiterated contumacy on the part of the defender was at one time punished with confiscation of his property (1449, chap. 29), butnow certification merely means that if he fails to. appear in the usual manner, the judge will decern, or pronounce judgment against him.

Certiora'ri is the writ by which, since the abolition of imprisonment for debt and the consequent disuse of the better known writ habeas corpus, causes are removed from inferior courts of record into the High Court of Justice. This is a matter of considerable importance to the commercial public. Such removal is either before or after judgment in the inferior court. Before judgment certiorari is competent as tort, in all cases except where the sum sued for is less than $£ 5$. Either party can remove the cause, but, where the sum is less than $£ 20$, the defendant must give his sureties for the debt and costs. The removal nust be within six weeks after appearance of defendant. In the superior court the plaintiff must make a fresh statement of claim. The certiorari is obeyed by sending up the original record. Under the Judicature Acts there is a further power of removal when any defence or counter-elaim is set up which is beyond the jurisdiction of the inferior court. In the county courts, where the action on contract is above $£ 20$, or on tort above $£ 5$, the defendant has a general right to certiorari on security for costs. Where the discretion of the superior court is. appealed to, such considerations as the difficulty of legal points, the improbability of obtaining an impartial jury, are important. After judgment, certiorari is often applied for by the successful plaintiff for purposes of execution, where the person or effects of the defendant cannot be found in the jurisdiction of the inferior court. Certiorari may also be obtained as of right by the crown to remove an indictment in a criminal cause to the Queen's Bench Division or the Central Criminal Court. This writ used also to be of right to private 
prosecuturs, but since the institution of the Court of Criminal Appeal it is necessary to show cause, ins in a civil case from the county courts, and to give security.

In the United Stutes, certiorari in generally provided for by statute, but where no such provision is mate, or no other mole of review of the proceedings of itl inferior court has been provided by statute, any superior court exereising common law jurisdiclion has an inherent right to issue this writ. It is used in both eivil and eriminal cases to bring the whole record of the inferior tribunal before a -llperior court, to determine whether the former his proceeded within its jurisdiction, and also to enible substantial justice to be done whenever an inferior tribunal has failed to proceed according to the requirements of the law. It is used as an original process to remove a cause, and change venue, only where the superior court is satisfied that an impartial trial will not otherwise be had.

Certo'sa di Pavi'a, a celebrated Carthusian momustery, 5 miles $\mathbf{N}$. of Pavia, was foumled in 1396 by Giovanni Galeazzo Visconti, first Duke of Milan, in atonement for the murder of his uncle. The church is a splendid structure in the form of a Latin eross, the ground-plan being 252 feet long by 177 feet broad. The richly sculptured facade, lesigned by Borgognone, was commenced in 1473 . The building is made up of various styles, but the Pointed prevails in the interior, which is decorated with frescoes, paintings, \&c., and contains a gorgeous high-altar, the mausoleum of the founder, and several monuments. After the battle of Pavia (1525), Francis I. was for three days a prisoner at the Certosa, which, since the dissolution of the monasteries, has been constituted a national monument. The name certosa is a form of Carthusian $\left(q_{*} v_{0}\right)$, and is used of other monasteries of the order, as that to the south of Florence.

Ceru'men is ear-wax, the yellow waxy matter which is secreted by certain glands lying in the passage that leads from the external opening of the ear to the membrane of the tympanum. It lubricates the passage and entangles particles of dust and small insects, preventing them from getting farther in. See EAR.

Cervantes Saavedra, MIGUEL DE, the author of Don Quixote, was born at Alcalá de Henares in 1547. His birthday is unknown, but he was baptised on the 9th of October. He was a descendant of a family that traced its origin back to the loth century through a line of Castilian nobles, of whom one was the renowned warrior Nuno Alfonso, whose grandson took the surname of Cervantes from the old castle of San Servando, or Cervantes, near Toledo. It was borne with honour by many church dignitaries, soldiers, and maristrates of the 14th and 15 th centuries, but at the birth of the man who gave it immortality it had cersed to be one of the prominent names of Spain. The name of Sarvedra came into the poet's branch of the family by marriage in the 15th century. Of Cervantes personally we know little or nothing beyond what he himself tells us, but of the events of his life there is a tolerably complete reeord. The story of his having studied at Salamance is improbable; all we know of his education is that Juan Lopez de Hoyos, a professor of belles-lettres at Madrid, calls him his 'dearly heloved pupil.' The first known productions of his pen appeared in 1569 in a collection of pieces on the death of the queen, edited by the professor. Early in the same year he passed over into Italy in the service of Cardinal Giulio Aequaviva, but shortly afterwards enlisted as a soldier under the command, it would appear, of Mare Antony Colonna. At the battle of Lepanto he was in the thick of the fight, and received three severe gunshot wounds, by one of which his left hand and arm were permanently disabled. After having seen sone further service against the Turks in Tunis, he was returning to Spain in 1575 with letten of recommendation to the king from Don John of Austria and the Viceroy of Sicily, when the galley he sailed in was captured by Algerine corsains, and with his brother Rodrigo and several others he was carried into Algiens. He remained in captivity five years, during which he made four daring attempts to escape, and lived in almost daily expectation of death or torture. It was not for himself alone that he sought freedom. No nobler story of unselfish heroism has ever been told than that in the depositions of his fellow captives at Algiens, where they testify to his selfdevotion, his dauntless spirit, and his generosity, and with touching earnestness strive to give expression to their own gratitude, love, and admira. tion. In 1580 he was ransomed by the charity of the Redemptionist Fathers and by the devo. tion of his family which reduced itself to poverty to provide the sum required; and rejoining his old regiment in Portugal, he served in the expe. dition to the Azores under the Marquis of Santa Cruz. The atory of a liaison with a Portuguese lady is an invention of the biographers to account for a certain Isabel de Saavedra mentioned in an official document of 1605 as his natural daughter. There is no other evidence of her existence, and if this is to be relied upon she was born after his marriage, and nearly two years after his return from Portugal. At the close of the war he retired from military life and turned his attention to literature. His first work was the Galatea, a pastoral romance of the same class as the Diana of Montemayor and the Filida of his friend Montalvo. It was printed at Alcalá in 1585-not, as is commonly said, Madrid, 1584. While it was passing through the press he married, and for two or three years strove to gain a liveli. hood by writing for the stage. He produced between twenty and thirty plays, of which two only, the Numancia and the Trato de Argel, have survived; but from his own account it is plain that, though not ill received, they failed to attract, and that he was driven to seek some other employment. In 1587 he migrated to Seville, where he obtained the post of deputy-purveyor to the fleet. In 1594 he was appointed a collector of revenues for the kingdom of Granada ; but in 1597, failing to make up the sum due to the treasury, he was sent to prison at Seville. He was released, however, on giving security for the balance, but not reinstated; nor ean the government be charged with undue harshness, for though no stain attaches to his integrity, it is clear that as a business-like official he was not faultless. He remained some time longer at Seville, but nothing is known of his movements from 1599 to 1603. Local tradition maintains that he wrote Don Quixote in prison at Argamasilla in La Mancha; but it has nothing to support it save the fact that Argamasilla is Don Quixote's village. In 1603 he was living at Valladolid ; in September 1604 leave was granted to print the first part of Don Quixote, and early in January 1605 the book came out at Madrid. It is commonly asserted that its reception was cold ; but the truth is that it leaped into popularity at once. Within a month two pirated editions were in the press at Lisbon; by the antumn five editions had been published; and Don Quixote and Sancho Panza paraded the streets as familiar characters in the pageants at Valladolid that spring. By a minority, however, it was not welcomed. Lope de Vega wrote sneeringly of it and its author months before it was printed-for it had a pre- 
vious circulation in manuscript-and he and his brother-dramatists showed how bitterly they resented the criticism in chapter 48. Cervantes was slow in taking advantage of his popularity. Instead of giving his readers the sequel they asked for, he busied himself with writing for the stage and composing short tales, or 'exemplary novels' as he called them. The Viage del Parnaso, a poem of over 3000 lines in terza rima, reviewing the poetry and poets of the day, was another of his productions at this time. In 1613 he published his twelve Novelas, and promised his readers the second part of Don Quixote 'shortly.' But in $\mathbf{1 6 1 4}$ a writer, under the pseudonym of Alonso Fernandez de Avellaneda, brought out a spurious second part, with an insulting preface, full of coarse personal abuse of Cervantes. It was the work of a dull plagiarist, an imitator insensible to the merits of his model; but it served as the spur Cervantes needed to urge him to the completion of the genuine second part, which was sent to the press early in 1615 , and published at the end of the year. It was not too soon; his health was already failing, and he died at Madrid on the 23d of April 1616. His last labours were given to things more important in his eyes than Don Quixote. While it was in the press he revised and published his rejected comedies and interludes, and but a short time before his death he finished his romance of Persiles and Sigismunda. There are few pieces of his writing more charac. teristic of the man than the last two that ever came from his pen-written, indeed, upon his very deathbed-the address to the reader and the dedication to the Conde de Lemos, whose generosity had relieved him from the pressure of poverty; and, like every glimpse of himself that his pages give us, they make us wish that we knew more of one so full of wisdom, patience, and charity, so bright and so brave.

It is in right of Don Quixote that the name of Cervantes has a place here; but his minor works entitle him to an honourable one in the history of Spanish literature. His novels are the best of their kind-a kind Spain excelled in ; and though the Galatea is doubtless inferior to the Diana, its greatest fault is that, like the Diana, it belongs to a radically insipid species of romance. The title of poet is commonly denied him; but if a good deal of his poetry is weak, there is much that only a poet could have written, and not even Garcilaso had a finer sense of melody or a truer touch in verse. It would be unjust to judge of his dramatic powers by the comedies printed in 1615. They were nothing more than a desperate attempt to gain a footing on the stage by a concession to the popular taste. To found a great national drama worthy of his country was the ambition of his life, and the first step was to obtain a hearing. The tragedy of Numancia, with all its defects the most powerful and original drama in the language, is a better measure of Cervantes as a dramatist. And if it is impossible to accept his own estimate of the Persiles and Sigismunda, no reader will deny its invention and grace of atyle. His minor works all show signs of the author's care; Don Quixote, on the other hand, is the most carelessly written of all great books. Cervantes, it is plain, did not look upon it in that light. He was very proud of its popularity ; but all he ever claims for it is that it will amuse, and that it did the state some service in laughing chivalry romances oxit of fashion: He wrote it by fits and starts; he neglected it for his other works; he sent it to the printers without revision, and made merry over their blunders and his own oversights. But it may be that we owe more to this carelessness than we think. One of the marvels of this marvellous book is its perennial youth. After well-nigh three centuries it is as fresh and full of life as when it came from $L a$ Cuesta's press. In his other works Cervantes studied recognised models and consulted the tastes of the day ; in Don Quixote he followed the lead of his own genius alone, and wrote only as instinct prompted him. Written in a desultory fashion, it had time to grow and ripen under his hand; Don Quixote and Sancho, outlines at first, became by degrees flesh and blood realities to his mind, and beings that he loved; and the book-the second part especially-served him as a kind of commonplacebook to which he turned to when he was in the mood, making it the depository of his thoughts and record of the experience and observation of a stirring life. We need not commit the disloyalty of doubting his word when he says that all he sought was to cure his countrymen of their passion for chivalry romances. He had motive enough in the magnitude of the evil, and his was only one of scores of voices lifted up against it; nor is there anything extraordinary in a champion of true chivalry, as he was, resenting a mockery that made it contemptible. But the genius of Cervantes was essentially discursive, and many other offenders and offences were comprehended in the indictment that he brought against the romances of chivalry and their readers.

The only complete edition of Cervantes' works is that of Rivadenevra (in 12 vols. large $8 \mathrm{vo}$, Madrid, 1863-64). Editions of the selected works are those of Ibarra ( 16 vols. small 8vo, Madrid, 1803-5), Bossange (10 vols. 12mo, Paris, 1826), and vol. i. of the Biblioteca de Autores Españoles (Madrid, 1846). Of Don Quixote in the original about 150 editions are known, and more than double that number in other languages. The first worthy of the book was Tonson's (Lond. 1738, 4 vols.); other notable ones are the Academy edition ( 4 vols. Madrid, 1780); Bowle's (6 vols. Salisbury and Lond. 1781 ); Pellicer's ( 5 vols. Madrid, 179798) ; Clemencin's ( 6 vols. Madrid, 1833-39); Hartzenbusch's, in vols. iii.-vi. of the complete works, and also in 4 vols. 1863, a beautiful pocket edition printed at Argamasilla, in the house called Cervantes' prison; in these last the editor has often restored the text of the first edition, but often also recklessly tampered with it. F. Lopez Fabra's ( 2 vols. Barcelona, 1871-74) is an admirable reproduction by photography of the first edition. The claim of Señor Ortego's edition (Palencia, 1884) to give corrections made by Cervantes himself cannot be seriously maintained. The reprint of the editio princeps of the first part of Don Quixote by Mr Ormsby and Mr FitzmauriceKelly (Lond. 1898) is a splendid folio. There are translations in fourteen languages. The oldest is the English by Shelton, made in 1608 and printed 1612 (second part, 1620 ), a vigorous but rude and inaccurate version. Other English translations are those of Phillips (1689), Motteux (1702), Jervas (commonly called Jarvis, 1742), Smollett (1755), A. J. Duffield (3 vols. 8vo, 1881 ), John Ormsby (4 vols. 8 vo, 1885 ), and H. E. Watts (5 vols. 4 to, 1888 et seq.). In French there are nine versions, besides abridgments : the oldest is Oudin's (printed in 1616), the best Viardot's (1836). In German there are no less than thirteen, from the earliest in 1621 to the latest and best by Ludwig Braunfels in 1883-84. There are as many as ten Russian versions, but most of these are from the French, or abridgments. Franciosini's Italian version appeared as early as 1622, and has been followed by two others; and there are versions in Dutch, Danish, Polish, Portuguese, Swedish, Hungarian, Bohemian, Servian, and Greek. The best Life of Cervantes is by Navarrete; but there is also a good one by $D$. 
Geronimo Moran, in his Don Quixote (Madrid, 1863), and English Lives by Watts (1895, from his edition), and by J. F. Kelly (1892).

Cervet'ri, a village 19 miles WNW. of Rome, on the site of the great Etrurian eity, Care (see Etruria). Conquered and degraded by the Romans in 353 B.C., it experienced but a brief renewal of prosperity under the empire as a watering-place (the warm Bagni del Susso, still used), and finally fell into decay in the 13th century. Many Etruscan remains have been found near by.

Cer'vidae and Cervus. See DeEr.

Cervin, Mont. See Matterhorn.

Cesalpino. See Casalpinus.

Cesarewitch. See Czar.

Ce'sari, Giuseppe (sometimes called Arpino), sn Italian painter, born at Arpino about 1568, was greatly honoured by no less than five popes, and died at Rome, 3d July 1640. His works-in fresco and oil-display lively imagination, and great tact in execution.

Cesarotti, MeLchionk, an excellent Italian poet, was born 15th May 1730, at Padua, where he filled the ('reek and Hebrew chairs. He gained a reputation by his translation of Macpherson's Ossian (1763). The versification of this work, like that of his free translation of the Iliad, under the title of La Morte di Ettore, was admired by Alfieri, and Cesarotti unquestionably threw fresh life into Italian literature. His Ragionamento sulla Filosofia delle Lingue ( 8 vols. 1785 ) and Ragionamento sulla Filosofia del Gusto are his best works. He died 3d November 1808.

Cese'na, a town of Central Italy, 12 miles SE. of Forli by rail, with a cathedral and a trade in silk, wine, hemp, and sulphur. Cesena gave birth to two popes-Pius VI. ani VII. Pop. 12,500. Here Murat defeated the Austrians, 30th March 1815.

Ces'nola, Count Luigi Palma di, archrologist, was born near Turin, June 29, 1832. He served with the Sardinian contingent in the Crimean war, went to New York in 1860, and served as a volunteer in the civil war. Appointed American consul at Cyprus in 1865, he commenced a series of excava tions which he continued for about ten years with the most remarkable success. His splendid collection of statues and figures, lamps, vases, inscriptions, and other antiquities, was opened in New York in 1872 as the 'Cesnola Collection of Cyprian Antiquities.' Doubts expressed in 1879 as to the authenticity of part of the collection were proved to be groundless. His chief work is Cyprus, its ancient Cities, Tombs, and Temples (1877).

Ces'pedes, PABLo DE, Spanish painter, born at Cordova in 1536, studied at Rome under Michael Angelo and Raphael, and in 1577 hecame a prebendary at Cordova, where he established a school of art, and was also active as an architect, painter, and writer. He died 26th July 1608.

Cess (short for assess). See Land LAws.

Cessio Bonorum (Lat. 'cession or surrender of goods'), a process which the law of Scotland borrowed from that of Rome, and which also appears in most of the continental systems. On making a surrender of estate to his ereditors, the debtor was granted a judicial protection from imprisonment in respect of all debts then due by him. As, however, imprisonment for debt was abolished by the Debtors Act, 1880, except in the case of rates and taxes due, cessio as a process for the protection or liberation from imprisonment of insolvent debtors is now practically obsolete. The Act of 1880, however, introduced a new process of cessio, resembling sequestration, and really a cheap and summary method of distributing a amall estate among the ereditons. The petition must be pre. sented in the sheriff-court either by $\mathrm{a}$ ereditor or by the notour bankrupt himself. Notice is given in the Gazette, there is a meeting of creditors, the debtor is publicly examined, the sheriff grants a decree appointing a trustee and ordering the debtor to convey all his extate (except working tools, alimentary funds, and future acquisitions) to the trustee, who then ranks the various elaims on the estate, subject to an appeal to the sheriff. A most important change was introduced by the Bank. ruptcy and Cessio Act, 1881, which provides for the first time that the debtor under a cessio may obtain a statutory discharge, but only if he pays

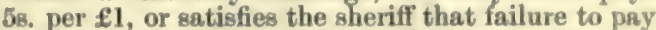
such a dividend is not due to his fault. The process of cessio must be distinguished in some of its effects from the English and American assignment for the benefit of creditors under insolvent statutes. See Bankruptcy, Sequestration; Goudy on Bankruptcy (1886).

Cesspool. See Sewagk.

Cestoid Worms (Cestoda), an order of flat worms (Plathelminthes), of internal parasitic habit, and generally known as Tapeworms (q.v.). The adult consists of an asexual 'head,' attached by hooks or suckers or both to the host, and budding off a long chain of flat sexual, hermaphro. dite 'join's," which become mature at a certain distance from the 'head,' have a measure of in. dividuality and independence, and are eventually expelled. There is no alimentary canal nor vascular system; the nervous system is usually complex, but of a low order; there is a well-developed excretory system of branching tubes. The reproductive organs of the 'joints' are usually very complex. The liberated 'joints' or 'proglottides" break up, and set free embryos, which find their way into other hosts, and undergoing considerable change become bladder-worms, develop a head, or in some cases heads, and only become sexual when their host is in turn eaten by the original species in which the tapeworm flourished. There is thus an alternation of generations between the asexual bladder-worm and the sexual tapeworm. The order includes about 25 genera and 500 species, mostly parasitic in vertebrates. The genus Tænia (tapeworm) includes more than half the known species. The Cestodes are linked to the flukes or Trenatodes by forms like Amphilina, Caryophyllieus, and Areh. igetes, which have no 'joints,' and a single reproductive system; and there is a well-marked series from these up to the most specialised Trenia. Echineibothrium, Phyllobothrium, Anthobothrium, Acanthobothrium, Tetrarhynchus, Ligula, Bothriocephalus $\left(q \cdot v_{0}\right)$, are the important genera besides Tænir. See TAPEWORMS; also BLADDER-WORM, Parasitic Animals, and Leuckart's Parasites of Man.

Cestracion, a genus of sharks, regarded as constituting a distinet family, Cestraciontida, al. though not more than four species are known as now existing. It is characterised by having two donsal fins and one anal, the first dorsal situated over the space between the pectorals and ventrals; a spine forming the front of each dorsal; a short wide tail, with its upper lobe strongly notched beneath; the mouth at the fore end of the snont: spiracles distinetly visible, rather behind the eyes; and small gill-openings. The front of the mouth is armed with obtuse angular teeth, whilst the margins, and inner surface of the jaws are covered with pavement-like teeth, presenting a general continuity of surface, as in skates, and dispresed in rounded oblique serolls - the former evidently adapted to the seizing of food, the latter to the 
crushing and bruising of it. They are of obvious use with a diet of hard-shelled crustaceans and

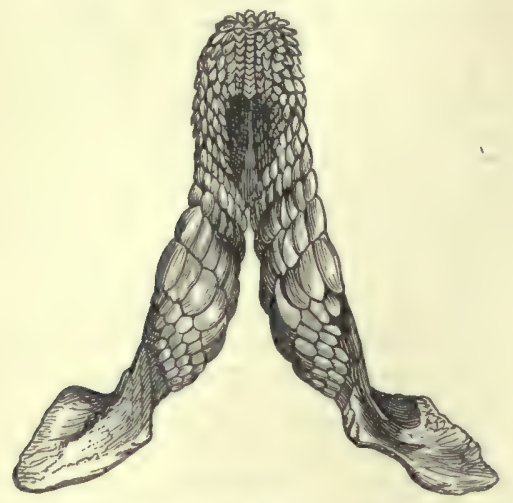

Upper Jaw of Port-Jackson Shark (Cestracion philippi).

molluses. The front teeth are sharp in the young forms. The egg-case has two curious spiral ridges

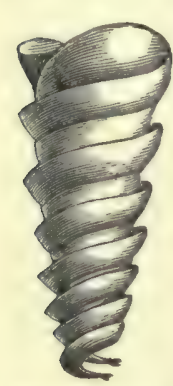

Outside view of Egg-case of Cestracion philippi. surrounding it. The Port-Jackson Shark, or "Nurse' (C. philippi) of the Australian seas, and the Cat Shark of Japan and China ( $C$. zebra), seem to differ chiefly in the patterns of colour. None exceed five feet in length. The Cestraciontidse are particularly interesting to geologists, for the oldest fossil sharks belong in great part to this family. "The remains are found even in the Palrozoic strata; they become more numerous in the Carboniferous series; they are very numerous in the Lias and Chalk formations; but there they cease almost entirely, the strata of the Tertiary series containing scarcely any of them.' In modern times the species are reduced, as we have seen, to four at most, and other types of shark have become more prevalent. The fossil forms were abundant, also much larger, and the cestracions thus furnish a particularly good illustration of a decadent family.

Cestui que Trust, a person for whom another is $\mathbf{s}$ trustee. The term is Norman-French, and means in English law, and also in the United States, exactly what Beneficiary (q.v.) means in Scots law.

Cestus (Gr. kestos, 'embroidered'), a girdle worn by Greek and Roman women, but at what part of the body is somewhat uncertain. It was worn apparently between the cingulum, which was a sash or girdle over the tunic just under the bosom, and the zone, worn mostly by young unmarried women lower down the body, just above the hips. According to Winckelmann, the cestus was itself worn round the loins; according to Heyne and Visconti, immediately under the bosom. The cestus of Aphrodite was covered with such alluring representations of the joys of love that she who wore it was irresistible. It was borrowed by Hera when she desired to win the love of Zeus. -Cestus, or more correctly, CAsSTUS, the boxing gauntlets worn by the ancient prize-fighters, which consisted of leather thongs bound round the hands and wrists. They sometimes reached as high up as the elbows, and were armed with lead or metal bosses to increase the force of the blow.

Cetacea, an order of mammals, of aquatic habit and fish-like form. The head is large, the neck indistinct ; there is generally a median dorsal fin, and the tail has lateral flukes; the fore-limbs are reduced to paddles, the hind-limbs are at most represented by slight internal traces; the skin is smooth, and, with the occasional exception of a few bristles near the mouth, hairless; there is a thick layer of fat or blubber under the skin which serves instead of hair as a heat-retainer. The eve is small, there is no external ear, the nostrils are situated vertically. The bones are spongy and oily, the neck vertebræ are compressed and often fused, there is no union to form a sacrum. The skull is peculiarly modified, the brain-case being high, and the front part prolonged into more or less of a snout. There are no collar-bones; the bones of the arm are flattened and stiff; the joints of the second and third fingers are always above the normal number; the whole arm forms a flipper; the hip-girdle and hind-leg are degenerate. In one group teeth are absent except in the foetus, and are replaced by 'whalebone' growths from the palate; in no case is there more than one set of teeth. The stomach has several chambers; the intestine is simple. The liver is less divided than usual, and there is no gall-bladder. The bloodvessels form wonderful networks (retia mirabilia). The top of the windpipe is prolonged forwards so as to form, when embraced by the soft palate, a continuous air-passage from nostrils to lungs. The brain is large. The placenta is 'non-deciduate and diffuse.' The teats are two in number, and lie beside the female genital aperture; the milk is squeezed into the mouth of the sucking young.

The Cetacea are widely distributed in all seas and in some large rivers. They swim powerfully, and the tail works up and down, not sideways. They rise to the surface to breathe, and do not spout sea-water from their blowholes. The expiration is periodic and violent, and the foreibly expelled air being laden with water, vapour may condense in a pillar of fine spray, or the ascending column may carry up some surface sea-water along with it, but it must be recognised that the process is simply that of ordinary expiration in peculiar conditions. They are mostly inoffensive, generally social in habit, vary from 4 to 60 feet in length, and feed on jelly-fish, erustaceans, pteropods, cuttlefish, fishes, and in one genus (Orea) on seals and on other whales.

Two very distinct series have to be distinguished $-(a)$ the Toothed Whales or Odontoceti, and $(b)$ the Baleen Whales or Mystacoceti. The forner include Sperm Whales (Physeter), the Bottlenose (Hyperoodon), the genus Platanista and its allies, and the great family of Dolphins (q.v.). The latter sub-order includes the Right Whale (Balæna), the 'Humpbacks' (Megaptera), and the Rorquals (Balæenoptera).

In the Eocene, Cetacea are represented by primitive, less specialised forms, known as Zeuglodons, but the remains are, as one would expect, somewhat fragmentary, and the conclusions to be drawn from them very uncertain. In Miocene and Pliocene strata still more fragmentary cetacean remains have been found, and are grouped together in the genus Squalodon.

There is much doubt and dispute in regard to the origin and affinities of Cetacea. They are related by some to Carnivores, but the researches of Professor Flower have made it more probable that they have much closer affinities with Ungulates. He regards it as not unlikely that the whole group had a fresh-water origin. Fuller details must be sought under the article Whale. See Flower's article 'Mammalia,' Ency. Brit.

Ceteosaurus (kètos, 'whale;' sauros, 'lizard'), a large dinosaurian reptile belonging to the Jurassic System (q.v.). According to Professor 
Phillips, it may have reached a length of 50 feet, anl when 'standing at ease' was probably not less thim 10 feet in height and of $a$ bulk in proportion. It appears to have frequented the marshes and river-sides of the period, and to have been a vege. table-feeder. The word is also spelt Cetiosaurus.

Cetewayo. See Zulus.

Cetinje (also spelt Cettigne), capital of Monte nogro, lies in a rocky valley 2093 feet above sealevel, and 17 miles E. of Cattaro, with which it is connected by a carriage road. It is the residence of the prince, and of an archimandrite, and consists of an unpretentious palace, a few private houses, an ahbey, gawl, arrenal, theatre (which serves also for thes state library and national museum), hospital, theological seminary, gymnasium, and a girl's high. school, maintained at the charge of the Empress of Russia. Behind the palace is an elm, under which the prince delivers judgments. Pop. 2200.

Cetotolites, a name given by $O$ wen to fossil cetacean ear-bones, which occur in great abund. ance in the Red Crag of Suffolk (see Pliocene). They are rubbed and water-worn, and have evilently been washed out of some earlier strata, which remain yet unrecognised. The extent of these earlier strate must have been very great, seeing that the erag beds now extend over a large distriet in Essex and Suffolk, and attain a thickness in some places of not less than 40 feet. Professor Henslow in 1843 drew the attention of agricultural chemists to this deposit as a source of materials for manure, and since then superphosphate manures have been manufactured from it to the value of many thousand pounds annually; a striking example of the valuable practical results which frequently flow from a purely scientific dis. covery.

Cette, an important seaport town of France, in the department of Hérault, is built on a neck of land between the lagoon of Thau and the Mediter. ranean, 23 miles SW. of Montpellier. The space inclosed by the piers and breakwater forming the harbour can accommodate about 400 vessels; and the harbour is defended by forts. A broad deep eanal, lined with excellent quays, connects the port with the Lake of Thau, and so with the Canal du Midi and the Rhone, thus giving to Cette an extensive inland traffic; it has likewise an active foreign commerce. The principal trade is in wine, brandy, salt, dried fruits, fish, dyestuffis, perfumery, and verdigris. Cette has shipbuilding yards, salt-works, glass-works, factories for the manufacture of syrups and grape-sugar, \&c. It is a resort for sea-bathing, and has extensive fisheries. Colbert founded it in 1666 . Pop. (1872) 25,181 ; (1891) 36,179 .

Ce'uta, a fortified port belonging to Spain, on the coast of Moroceo, opposite Gibraltar. The town occupies the site of the Roman colony of $A d$ Septem Fratres, so called from the seven hills rising here in a group, of which the most prominent are Montes Almina and Hacho; on the latter, the ancient Abyla (one of the Pillars of Hercules), is a strong fort, and on the former, among beautiful gardens, lies the New Town. Ceuta contains a cathedral, a hospital, and convents, but is chiefly of importance as a military and convict station. The harbour is small, and exposed to the north, but has a lighthouse and some small trade. The mixed population number about 12,500. The place was a flourishing mart under the Arabs, who corrupted its Roman name to Sebtah; there the first paper manufactory in the Western world is said to have been established by an Arab who had brought the industry from China. In 1415 it was captured by the Portuguese, and annexed to Portugal; it fell to Spain in 1580 . It has resisted several sieges by the Moom (1694-1720 and 1732), and is still the most important of the four African Presidios (q,v。).

Cevadilla. See Sabadilla.

Cévennes (ancient Cebenna), the chief moun. tain-range in the south of France. With its eontinuations and offsets, it forms the watershed between the river-systems of the Rhone and the Loire and Garonne. Its general direction is from north-east to south-west, commencing at the southern extremity of the Lyonnais Mountains, and extending under different local names as far as the Canal du Midi, which divides it from the northern slopes of the Pyrenees. The Cevennes extend for over 150 miles, through or into nine departments, the central mass fying in Lozere and Ardeche, where Mont Lozère attains 5584 feet, and Mont Mézene (the culminating point of the chain) $\mathbf{5 7 5 4}$ feet. The average height is from 3000 to 4000 feet. The mountains consist chiefly of primary rocks, covered with tertiary formations, which in many places are interrupted by volcanic rocks. For the religions wars of which the Cevennes have been the arena, see Albigrnses, Camisards, WALDENSES; and for a vivid description of the scenery and the peasantry, Mr R. L. Stevenson's Travels with a Donkey in the Cevennes (1879).

\section{Ceylanite. See SPINEL}

Ceylon (the Taprobane of the Greeks and Romans, and the Serendib of the Arabian Nights), an island and British erown colony in the Indian Ocean, to the south-east of India, from which it is

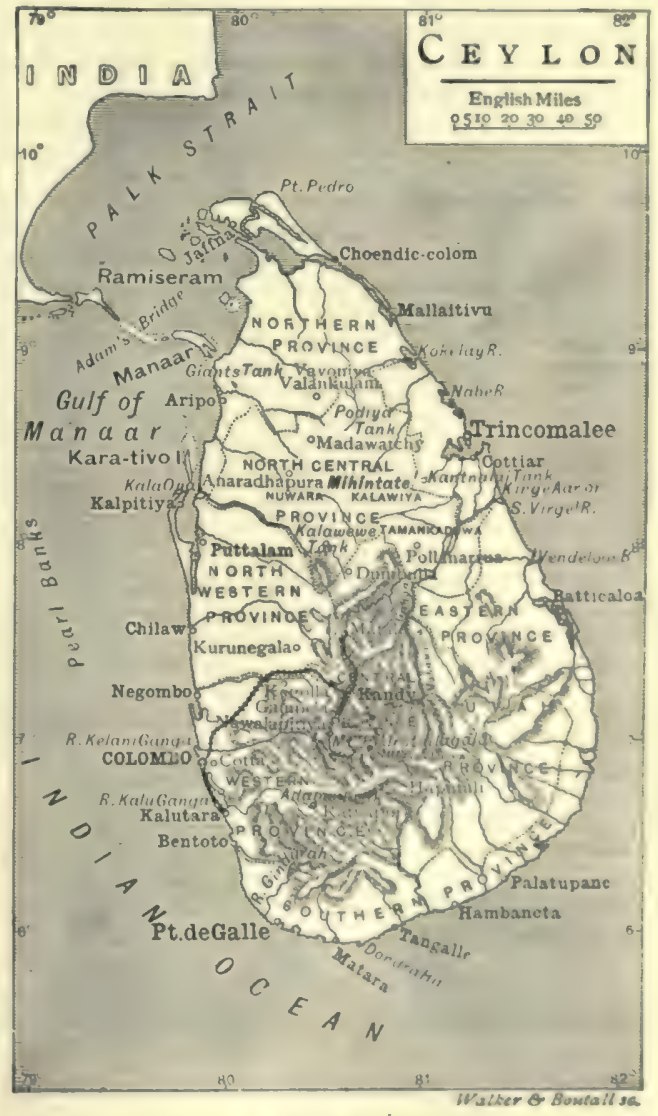

separnted by the Gulf of Mannar and Palk Strait 32 to 120 miles broad. It lies between $5^{\circ} 55^{\prime}$ and $9^{\circ} 51^{\prime} \mathrm{N}$. lat., and $79^{\circ} 42^{\prime}$ and $81^{\circ} 55^{\prime} \mathrm{E}$. long. 
Extreme length from north to south, from Point Palmyra to Dondera Head, 266 miles; greatest width, from Colombo to Sangemankande, 140 miles. Area, 24,702 sq. m., of which more than one-fifth is under eultivation.

Physical Features.-In natural scenery Ceylon can vie with any part of the worid; and as it rises from the ocean, clothed with the rich luxuriance of a tropical vegetation, it seems to the voyager like some enchanted island of Eastern story. Its hills, 'draped with forests of perennial green,' tower grandly from height to height, till they are lost in clouds and mist. Near at hand, a sea of sapphire blue dashes against the battlemented rocks that occur at isolated points, and the yellow strands are shaded by groves of noble palms. In shape Ceylon resembles a pear, but its inhabitants more poetically compare it to one of their elongated pearls. Undulating plains cover about four parts of the island, and the fifth is occupied by the mountain-zone of the central south, which has an elevation of from 6000 to 8000 feet above the sea-level. Pedrotallagalla, the highest mountain in the range, attains the height of 8260 feet ; the celebrated mountain of Adam's Peak, 7420 feet; and the tableland of Nuwara-Eliya, 6210 feet.

Geology. - The mountain-system is mainly composed of metamorphic rocks, chiefly gneiss, frequently broken up by intrusive granite. With the exception of some local beds of dolomitic limestone, the gneiss is everywhere the surface rock, and the soil is composed of its disintegrated materials. The northern part of the island is rising; and the immense masses of corals continually increasing, retain the debris brought from the Indian continent by the currents of the sea, and thus form a flat, ever-increasing madrepore plain.

Metuls and Precious Stones. - Iron can be obtained in great quantities, and anthracite and rich veins of plumbago exist on the southern range of hills. Gold has recently been found. The gems of Ceylon have been celebrated from time immemorial. Sapphires, rubies, the oriental topaz, garnets, amethysts, cinnamon stone, and cat's-eye are the principal gems and precious stones of the island. The declared value of the precious stones exported is about $£ 10,000$ annually; but as large numbers are purchased by passengers calling at Colombo and by native merchants for sale in Southern India, the actual value is doubtless very far in excess of the sum named. The pearl-fisheries of Ceylon were known at a very remote date in the commercial history of the world. Under the Portuguese and Dutch governments, and now under the British government, the pearl-fisheries form a monopoly, and are under the inspection of an officer, who reports when a sufficient number of pearl-yielding oysters have reached maturity, and when the prospect of a successful fishing is thus probable. The fishings are intermittent and occur at irreg. ular dates. In 1863 the value of pearls obtained was $£ 56,000$; in 1874 , it was $£ 10,000$; in 1877 , $£ 19,000$; in $1879-80$, $£ 29,500$; in $1881, £ 59,800$; in 1887, $£ 39,000$; and in the intermediate periods practically nothing. In 1890 the value was $£ 17,000$, in 1891 about $£ 52,000$, but in 1892-95 nothing.

Rivers. - The most important river in Ceylon is the Mahavila-ganga. It has its source in the vicinity of Adam's Peak, and after draining more than $4000 \mathrm{sq}$. m., it separates into several branches, and enters the ocean near Trincomalee. The south side of the island is watered by ten rivers of considerable size.

Harbours. - Galle, at the southern extremity of Ceylon, and Trincomalee on the eastern coast, are the only natural harbours capable of containing ships of large draught. The construction of a breakwater at Colombo, the capital of the island, which provides safe anchorage for ships of any size in all weather, has concentrated the commerce of the island there, and has also attracted from Galle the mail and passenger steamers from Europe, India, Australia, and China, which used to coal and tranship at Galle. At Trincomalee are the navai stores and dockyard, and the harbour is the finest in eastern waters.

In climate, Ceylon has a great advantage over the mainland of India, and as an island enjoys a more equable temperature. The average for the year in Colombo (q.v.) is $80^{\circ}$ in ordinary seasons. April is the hottest month; and in May the southwest monsoon commences amid a deluge of rain, and continues the prevailing wind till October, when the north-east monsoon sets in : 80 inches is the average annual fall of rain, though in an exceptional year 120 inches have been registered. The beautiful tableland of Nuwara-Eliya was first visited by Europeans in 1826, and is now used as a sanatorium. Here the thermometer in the shade never rises above $70^{\circ}$, while the average is $62^{\circ}$; the nights are cool and refreshing. The north of the island, including the peninsula of Jaffina, the plains of Nuwara-Kalawa, and the Wanny, may be reckoned as a third climatic division. Here the annual fall of rain does not exceed 30 inches, and irrigation is largely employed in agriculture.

Flora. -The general botanical features of Ceylon are in many respects similar to those of Southern India. A very large number of the species of plants is, however, peculiar to the island. About 800 species (nearly 30 per cent. of the whole number found in Ceylon) are endemic - that is, found nowhere else in the world. The tree-vegetation of the forests is almost wholly composed of such endemic species, and not a few of endemic genera. The affinities and near alliances of these are with the plants of the Malay Islands and Peninsula. Hence, to speak more correctly, the flora of Ceylon partakes of an Indian as well as a Malayan character, but is identical with neither. As may be expected from the climatic peculiarities of the country the flora is greatly diversified. In the south-west mountainous parts of the island, with the exception of some grassy tracts called patanas and the plantations of tea, coffee, and cinchona, the slopes and summits are forest-clad. The trees are evergreen, with thick coriaceous leaves, growing closely together and forming dark jungles. The undergrowth is largely made up of gregarious plants known as Nilu, species of the genus Strobilanthes, which only flower at regular intervals of five, six, or seven years. Tree-ferns, often 25 feet in height, searlet-flowering rhododendrons, numerous tufted bamboos, melastomads, and orehids are found in mountain forests. In the low country the vegetation is marked by the prevalence of palms, the cocoa-nut being pre-eminent. The beautiful areca-palm, the feathery jaggery or kitul, and the lordly talipat are the glories of Ceylon lowland vegetation. In the recesses of low-country forests the trees are high and closely packed. Amongst the timber-trees the most valuable are the calamander, satin-wood, and ebony. Two very interesting and peculiarly slender tree-ferns grow in the hot steamy forests of Ceylon, as also the most admired of Ceylon orchids, Dendrobium Maccarthioe. There has been extensive cutting down of forest in the mountains of Ceylon to establish plantations, and the lowlands have suffered no less severely by the indolent and improvident practice of native cultivation. As a consequence numerous foreign weeds, such as the lantana, white weed, and Spanish needle, have established themselves to the exclusion of native vegetation in the hills; while in the lowlands coarse grasses and worthless scrub have 
covered the country. The orchids of Ceylon number about 150 species. With the excep. tion of about a dozen Dendrobiums, Erias, and Saccolabiums, and the lovely Wana-rajah, there atr few of a striking character. The ferns number about 270 species. Among the latter is an anomalons variety which bear spores on the upper instead of on the under side of the frond. (Ine of the handsomest native trees of Ceylon is this Muruta (Lagerstromia Flos-reginas). To this might be added the Saraca indica, and the lovely $\mathrm{Na}$ (Mesua ferrea), or ironwood. In the forests climbing plants and epiphytes of prodigious size and striking appearance cover the trees with a mass of parasitical foliage of extraordinary growth. In the north of Ceylon the dry forest-region is remarkable for its valuable timber-trees, such as the Palu, Halmilla or Trincomalee wood, and ebony. The characteristic palm of the north and of the peninsula of Jaffna is the Palmyra (Borassus fabelliformis).

Fauna,-In Ceylon, quadrumanous animals are represented by the Loris gracilis and five species of monkeys. Sixteen species of bats exist in Ceylon, including the flying-fox. Of the larger carnivora, the bear and leopard; and of the smaller, the palm-cat and the glossy genette (the civet of Europeans) may be mentioned. The tiger is not met with in Ceylon. Deer, buffaloes, and the humped ox of India are plentiful; the chev. rotains (q.v.) are also said to be abundant. The elephant, which is for the most part tuskless, is emphatically lord of the forests of Ceylon. The wild boar is also found. Whales are captured off the coast. Three hundred and twenty species of birds are found. The song of the robin and long-tailed thrush, and the flute-like voice of the oriole, are heard over the whole mountain-zone and far down into the neighbouring plains. Eagles, the beautiful peregrine falcon, owls, swallows, kingfishers, sun-birds, bulbuls, erows, parroquets, pigeons, pes-fowl, jungle-fowl, and many others of the feathered tribe, might be mentioned did space permit. Myriads of aquatic birds and waders, amongst which the flamingo is conspicuons, cover the lakes and lagoons. The crocodile is the largest reptile in the island; tortoises and lizsords are also found. There are a few species of venomous snakes, and of these the ticpolonga and the cobra da capello are the most deadly.

Inhabitants.-The Singhalese (Sinhalese, also spelt Cingalese), the most numerous of the natives of Ceylon, are supposed to be the descendants of those colonists from the valley of the Ganges who first settled in the island 543 B. C., and speak an Aryan language elosely allied to the Pali (q.v.). The dress of the men, who have delicate features and slender limbs, looks singularly effeminate, and consists of a comboy or waist-cloth, very much resembling a petticoat; their long hair, turned back from the forehead, is confined with combs, and earrings are worn by way of ornament. Poly. andry still lingers in the interior of Ceylon; but this and many other eustoms repugnant to Christianity are dissppearing under the influence of education, of which the Singhalese readily avail themselves. The Kandyans, or Highlanders, are a more sturly race, and maintained their independ. ence for three centuries after the conquest of the low country by European settlers. The Malabars, or Tamils, have sprung from those early invaders of Ceylon who from time to time swept across from Southern Hindustan, and contended with the Singhalese kings for the sovereignty of the island. They have formed the chief population of Jaffina for full 2000 years, and constitutionally excel the Singhalese and Kandyans. The Moor. men, who are the most energetic and intelligent of the native communities, are met with in every province as enterprising traden, and are generally believed to be of Arab descent. The "burghens" of Ceylon are people of European descent, who have become naturalised. Those of Portuguese extraction hold the lowest place, and are mostly tradesmen and artisans; but the Dutch burghens frequently fill responsible posts, and are employed in the government offices, There is besides a remarkable tribe of outcasts-the Veddals-hardly removed from the wild animals of the foreat, and believed to be descended from the Yakkhos, the aboriginal inhabitants of the country. They occupy a district in the eastern part of the island, and have there preserved their ancient customs and manner of living unaltered for more than 2000 years.

Religion. - The Singhalese are devoted to Bud. dhism (q.v.), which is the prevailing religion of the island. Its sacred books are identical with those of Burma and Siam, and both record the doctrines of Gautama in the Pali language; the deviations are in matters of practice. The Malabar kings adulterated Buddhism to a considerable extent with Brahnanism, introducing the worship of Hindu deities into the Buddhist temples, and this continues more or less to be the case. More than once have the Buddhists of Ceylon sought to restore the purity of their faith-at one time sending deputies to Siam, at another to Burma, with this object in view. The Burman or Amarapura sect have long been the reformers of Singhalese Buddhism, and maintain no very friendly relations with the party who, supported by the priests of Siam, sanction the worship of Hindu deities and the employment of the priesthood in secular occupations, uphold caste, and restrict the sacred books. Caste was acknowledged by the Singhalese prior to the introduction of Buddhism, which in principle is opposed to it; but so firmly was it rooted that it still endures, though more as a social than a sacred institution. Gautama Buddha is said to have visited Ceylon three different times to preach his doctrine, and his Sri-pada, or sacred footstep, on the summit of Adam's Peak (q.v.), still commands the homage of the faithful. Bud dhism was not, however, permanently introduced into Ceylon till 307 B.C. The influence of the priests gradually increased, and, by the piety of the Singhalese kings, monasteries were richly endowed, and at the present day no less than one. third of the cultivated land of the island is computed to belong to the priesthood, and is exempt from taxation. The priests of Ceylon are divided into two orders; any member is at liberty to lay aside his ascetic character, and return to a secular life. The most celebrated Buddhistic relic in Ceylon is the Dalada, or sacred tooth of Gautama, at Kandy, which is guarded with jealous care, and preserved in an elegant shrine; but it is well known that the original relic was destroyed by the Portuguese, and the present snbstitute is a piece of discoloured ivory, bearing no resemblance to a human tooth. Brahmanism or Hinduism (see INDIA) is the faith of the Tamils or Malabars, but the Moormen are Mohammedans. After the expulsion of the Dutch Christians, Proteatant missions to the natives of Ceylon were commenced by the Baptists in 1813. The Wesleyan Methodists followed in 1814, the Americans in 1816, the Church of England in 1818, and Christian instruction has made some progress amongst the native populations. Schools, collegiate institutions, and female seminaries, under the direction of the missionaries, are in successful operation; and there is a government system of education.

Ancient Buildings.-In all Buddhist countries the sacred buildings present, with certain modifica 
tions, the same general character (see articles BuddhisM, BurMa, \&c.); and in Ceylon we find the three classes represented by the dagoba, or relic-shrine, the temple proper, and the vihara or monastery. The labour bestowed on these edifices in the early ages of the Singhalese monarchy is truly astonishing. In the north of the island, ruined cities buried for ages in the depths of the forest have been discovered, revealing monuments that in dimensions may almost compare with the pyramids of Egypt. The most remarkable of these vestiges of an early civilisation is Pollanarrua, the ancient capital of Ceylon; and here is the celebrated Gal-wihara, a rock-hewn temple.

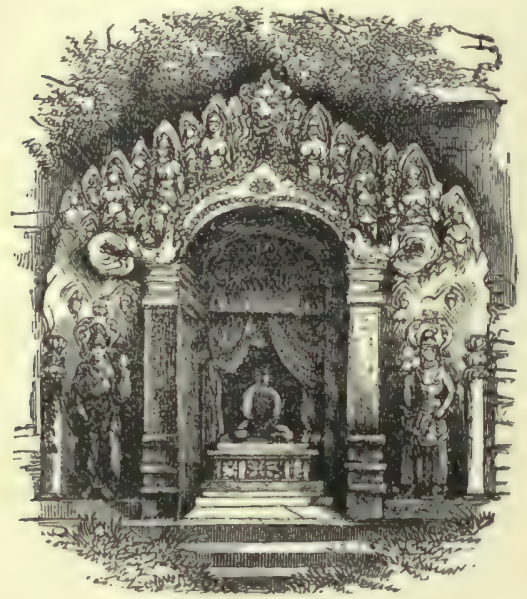

Entrance to the Temple of Dambula.

The cave-temple of Dambula was built 100 B.c., and is the most celebrated in the island. The bell-shaped tapering dagobas of Ceylon, as relicshrines, answer to the pagodas of Burma-which they very much resemble - and the topes of Afghanistan. The ruins of the Jaytawanarama dagoba still reach the height of 249 feet; its diameter is 360 feet; and from base to pinnacle

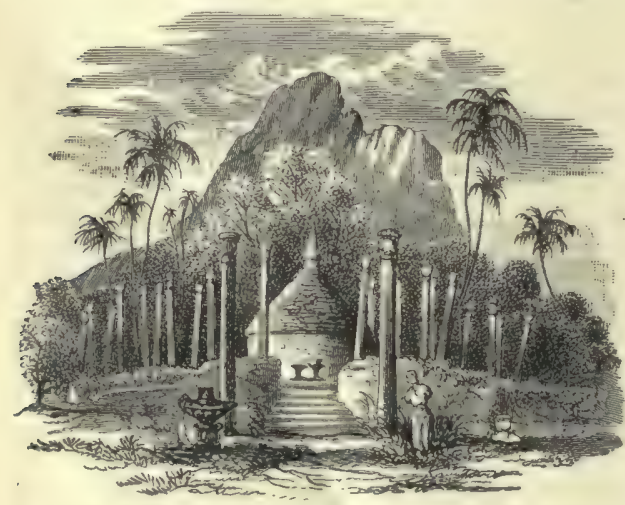

The Ambustella Dagoba, Mihintala.

it is covered with trees of the largest size. The Ambustella of Mihintala is another remarkable dagoba. A very famous object in connection with Buddhism in Ceylon is the sacred Bo-tree (q.v.) of Anuradhapura. Amongst the antiquities of Ceylon must be mentioned those wonderful monuments of the former greatness of the Singhalese people-the ruined tanks, with which scarcely anything of a similar kind, whether ancient or modern, can be compared. Thirty colossal reservoirs, and about 700 smaller tanks, still exist, though for the most part in ruins. The restoration of these magnificent works of irrigation has been for some time carried on by the government. In February 1888 the largest and most important tank in Ceylon, that of Kalawewa, was, after four years of labour, completely restored. It was built 460 A.D. to supply Anuradhapura with water, but has been ruinous for centuries. Now again it contains an area of seven square miles of water 20 feet deep, and supplies smaller tanks more than 50 miles distant.

The history of Ceylon may be conveniently divided into ancient and modern, and the latter into the Portuguese, Dutch, and British periods. The most famous of the Singhalese books is the Mahavansa, a metrical chronicle in the Pali language, extending from the earliest period to 432 A.D., and continued to 1756 . The story begins with the invasion of Wijayo (543 B.C.), son of a petty Indian sovereign in the country watered by the Ganges. He subdued the Yakkhos, the aboriginal inhabitants; founded a dynasty that held undivided sovereignty in Ceylon for nearly eight centuries; and bestowed on his kingdom his patrimonial name of Sihala (whence Singhalese, Ceylon). In the reign of King Devenipiatissa (307 B.C.), Buddhism was established as the national religion, and his reign was further remarkable by the planting of the sacred Bo-tree, 288 B.C.; and now commenced the erection of those stupendous buildings already noticed. The next important epoch in Singhalese history is the usurpation of the Malabars ( 237 B.C.), foreign mercenaries from the Coromandel coast, to whom the native sovereigns had intrusted the defence of the island. In 1071 A.D. a native dynasty was re-established in the person of Wijayo Bahu, which, for 100 years, delivered the eountry from the dominion of the Malabars. Prakrama Bahu commenced a reign in 1153 , the most renowned in the records of Ceylon. He devoted himself to religion and agriculture, and besides many notable religious edifices, he caused no less than 1470 tanks to be constructed, subsequently known as the 'seas of Prakrama.' Thirty years after the death of this monarch, the Malabars landed with a large army, and speedily conquered the whole island. In 1235 a native dynasty recovered a part of the kingdom. During the reign of Dharma Prakrama IX. the Portuguese first visited Ceylon (1505); but it was in 1517 that they first formed a permanent settlement at Colombo for trading purposes. Their encroachments soon met with fierce resistance from the patriotic Kandyans. 'Amity, commerce, and religion,' was the Portuguese motto; but their rule in Ceylon is a sad story of rapacity, bigotry, and cruelty. They were at last driven from the island by the Dutch in 1658, after a contest of twenty years, when the fanatical zeal of Roman Catholic sovereigns for the propagation of the faith was replaced by the eamest toil of the Dutch traders to intrench their trading monopolies. But the purely military tenure of the Dutch was destined to give place to the colonisation of the British. It was during the great European war succeeding the French Revolution that the English gained possession of the island. On the Ist August 1795 an expedition under Colonel James Stuart landed at Trincomalee, which was speedily captured, and finally the garrison of Colombo surrendered on the 16th February 1796. By this capitulation, all the Dutch settlements and strongholds in Ceylon were ceded to the English; though the island was not formally annexed to the British crown till the Peace of Amiens, 
27th March 1802. The native sovereigns, however, cuntinued in the possession of their mountrin territory ; but at length the Kandyan king, Wikrama litjii singhe, after perpetrating the most frightful atrorities on his own people, seized and murdered mrtitin native merehants, British subjects, trading (1) Kandy. War followed, January 1815; Kandy was taken, and the tyrant sent a captive to the furtress of Vellore. On the 2d March 1815, a Ireaty was concluded with the native chiefs, by Which the laing was formally deposed, and his territories annexed to the British crown.

After the settlement of the Kandyan provinces, aliention was drawn to the hill country of Ceylon is a probable field for the profitable investment of Iiritish capital and energy, and among other agriinltural enterprises the cultivation of coffee was mtered upon. The condition of soil and climate proved favmuble, and the abolition of slavery in the West Indies, and the consequent labour diffculties, caused a rush towards Ceylon, and the area under coffee enltivation rapidly extended. The enterprise, though subject to all the vicissitules incidental to tropical agriculture, steadily rrew, and coffee soon became the staple export from the island; and the revenue directly and indireetly derived from it enabled successive governors to bridge rivers, to make roads and railways, and to restore many of the ancient irrigation works which, in the period antecedent to British rule, had fallen into disrepair. In 1869, however, a fingus (Hemileia vastatrix) attacked the leaves of the coffee-trees, and the energy of the tree which had hitherto produced fruit was now required for the constant teproduction of leaf. Everything which practice or science could suggest was tried to mitigate or overcome the pest, but in spite of all efforts it steadily increased in virulence, and the coffee-planters were obliged to turn their attention to other products of the soil.

Cinchona, cacao, cardamoms, and many other products were introduced with varying success, but it soon became plain that Ceylon was capable of becoming a great tea-producing country, and tea has become the chief factor in restoring the finaneial equilibrium. Cinnamon and cocoa-nut cultivation are chiefly in the hands of natives; tea, cinchona, cacao, and cardamom cultivation in the hands of Europeans; and the export table shows how, through the energy of the planters, new products have to a great extent replaced coffee.

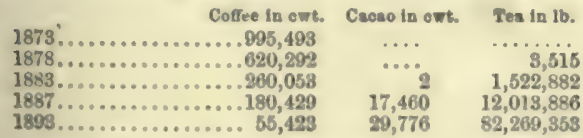

In 1898 the export of coffee had decreased to 12,871 cwt., while that of tea had increased to $122,395,517 \mathrm{lb}$. The other prineipal exports were einchona, 977,760 lb., and cinnamon, 4,281,165 lb. In the same year the value of the exports to the

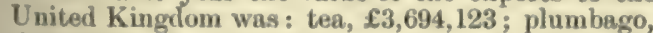
$£ 198,833$; oil, $£ 180,402$; nuts for oil, $£ 164,469$; cocos, £138,521 ; and cinnamon, £62,951. Minor exports are ebony, cardamoms, areca-nuts, and lyes. The principal imports are cotton goods, salt fish, rice, coal and coke, spirits, and wines.

Ceylon is the largest and most important of what are known as the crown colonies of the British Empire. The government is administered by a governor aided by executive and legislative counrils (the former consisting of five members, the latter of fifteen, partially elective), and municipal conneils. Local boards and village tribunals give a measure of self-urovernment to the people. The populution of Ceylon, 2,763,984 at the census of 1881, had risen in 1891 to $3,005,239$, of whom 110
2,000,000 were Singhalese, 750,000 Tamil immi.

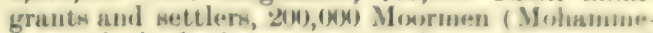
lans of Arab descent), 5500 Europeans, 20,000 Eurasian descendants of Portuguese and Dutch, 2500 Veddahs, 22,000 of mixed race.

The revenue in 1889 was $15,299,877$ rupees, and exceeded the expenditure by 400,000 rupees; in 1898 the revenue lial increases to 25,138 , 65 is rupees, while the expenditure was $22,843,852$ rupees, show. ing a larger surplus. The total imports, including specie, were valued at $97,893,058$ rupees, and the total exports, including specie, at $85,372,622$ rupees. There are 298 miles of ruilways open, and 1727 miles of telegraph wire in operation.

See works on Ceylon by Sir James Bmereon Tennent (2 vols. 1859), Captain Suckling (2 vols. 1876), John Ferguson (1887 and 1893), Miss Gordon Cumming (1891), Alan Walters (1892), H. W. Cave (1894 and 1897), and Emil Schmidt (Leip. 1897).

Cezimbra, a cosst town of Portugal, about 18 miles $\mathrm{S}$. of Lisbon. Pop. 6815.

Chabas, Francois, a great French Egyptolo gist, was born Jánuary 2, 1817, at Briancon Though at first engaged in commerce, he found time to become a learned linguist, but it was not till 1851 that he gave himself up to the study of hieroglyphics. The first results of his studies appeared in 1856, followed by a series of invaluable books and papers, elucidative chiefly of two important periods of ancient Egyptian history - the conquest of the country by the Hyksos, and the time of their expulsion. Among the more important of his many books are-Les Pasteurs en Egypte (1868), Histoire de la XIX. Dynastie et spécialement des Temps de l'Exode (1873), and Études sur l'Antiquite historique d'apres les Sources égytiennes (2d ed. 1873). From 1873 to 1877 he edited L'Egyptologie. He died at Versailles, May 17, 1882.

Chabasite. See Zrolite.

Chablis, a town in the French department of Yonne, 12 miles $\mathbf{E}$. of Auxerre. It gives name to an esteemed white Burgundy (q.v.) wine. Pop. 2363.

Chaco, El Gran. See Gran Chaco.

Chaconne (Fr.), an obsolete dance, probably Spanish (chacona, from Basque chocuna, "pretty'). The movement is slow, and the music, a series of variations on a ground bass, mostly eight bars in length, appears in sonatas as well as in ballets.

Chad, Lake. See Tsad.

Chad, ST (Ceadda), was born in Northumbria, became a pupil of St Aidan, spent part of his youth in Ireland, and in 666 became Bishop of York. Doubt having been east on the validity of his consecration, he withdrew in 669 , bnt was immediately made Bishop of Mercia, fixing the see at Lichfield (q.v.). He died in 672, after a life eminent for humility and sunetity. See Life by Warner (1871).

Chadwick, EDwin, C.B., a social reformer, born in the vicinity of Manchester, 24th January 1801 , studied law, and was called to the bar in 1830 . He attracted the notice of Jeremy Bentham by an article on Life Assurnnces. He early devoted his attention to questions of social, sanitary, and political science, and was by Lord Grey's government appointed an assistant-commissioner to inquire into the operation of the poor-laws: His report, published in 1833, commanded great attention, and faid the foundation of the later systems of government inspection. On the organisation of the new Poor-law Board, Chadwick was appointed secretary. In connection with this Boand, and the General Board of Health, Chadwick for twenty years was energetic in improving the administration of poorlaw funds and the sanitary condition of the country. His report on interments in towns (1843) laid the 
foundation of later legislation on the subject. He served on commissions as to the employment of children in factories, on preventable diseases, and on education. On a change being made in the Board of Health in 1854, Chadwick retired with a pension. He afterwards took great interest in promoting competitive examinations for government offices, and indeed in almost all questions of social economy. He was an active member of the Social Science Association. Some of his papers appear in the Transactions of the Statistical Society and of the British Association. Died July 5, 1890. See Chadwick's Work and Works on Health and Social Reform, by Richardson (2 vols. 1885).

Chreronea, a town in ancient Boetia, near the river Cephissus, memorable for the disastrous defeat of the Athenians here by Philip of Macedon, 338 B. C. This defeat struck a death-blow to the liberties of Greece, and broke the heart of Isocrates; it was the 'dishonest victory' that ' killed with report that old man eloquent.' A colossal marble lion, together with the bones of 260 Greeks, was dug up here in 1880. Here also Sulla defeated the generals of Mithridates in 86 B.C. The famous Plutarch was a native of Chæronea.

Chatoderma, a remarkable primitive gasteropod, which in some respects serves as a connecting link between the worm and snail type. See Chiton.

Chretodon, a typical genus of a family of bony fishes, known as Squamipennes. The body is much compressed sideways, and consequently high; the scales are more or less smooth, and cover portions of the dorsal and anal fins in such a fashion that the boundary between fins and body is indistinct.

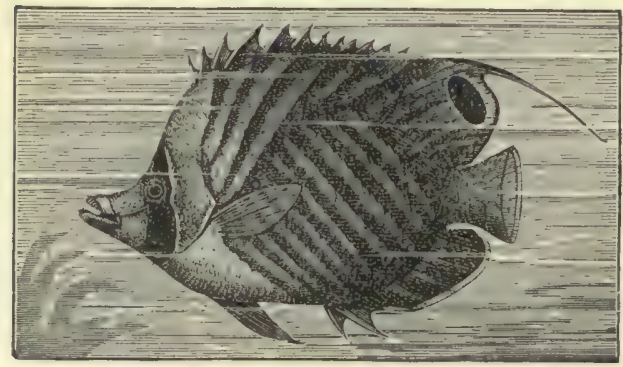

Chætodon setifer.

The mouth is generally small in front of the snout, and the slender teeth are arranged in bands. The lower rays of the pectoral fins are branched, and the hind fins are situated far forward on the thorax. The Squamipennes, or as some would call them, the Chrtodontidæ, are tropical fishes, abounding near coral reefs, and well snited in the beauty of their colouring to such brilliant surroundings. They feed on small animals, are never very large, and but little used for food. Chrtodon itself is a large genus, with some 70 beautiful species from the tropical Atlantic and Indo-Pacific. It has one dorsal fin, and a moderately long snout. In Chelmo the snout is longer, and is used to draw animals from their crevices. It often gets false eredit for catching insects by spouting water. Heniochus is another pretty genus with horns on its head. Holacanthus, one species of which is ealled the "Emperor of Japan" by the Dutch, is yet more brilliantly adorned, and Pomacanthus is peculiarly variable in its colouring. The Atlantic species of Ephippus (E. faber) is peculiar in the pathologicallike enlargement of some of the bones at the back of the head. The Archer-fish (q.v.) is an allied genus. See Günther, Study of Fishes (1880).
Chatopods (Gr., 'bristle-footed'), a class of worms including familiar types like the Earthworm, the Fisherman's Lobworm, and the Seamouse. They are often included under the title of Annelids or ringed worms. The body consists of numerous more or less similar joints; and the locomotor organs are furnished with or represented by bristles. The class is split into two main orders of Oligochæta and Polychæeta, of which the latter is much the larger. The Oligochrta. have very rudimentary locomotor structures, which are in fact reduced to bristles; they are fresh-water or subterranean in habit; the familiar earthworm (Lumbricus) and certain river and pond worms (e.g. Tubifex and Nais) are common representatives. The Polychreta are, with three or four exceptions, marine; the bristles, which are numerous, are fixed in special locomotor outgrowths; and many other characters, such as tho possession of antennæ, gills, \&c., distinguish them from the earthworm order, and are in obvious association with their very different habits. Many of them, described as errant, lead a free life, and are carnivorous in their diet. The common Nereis, or Alitta, and the Sea-mouse (Aphrodite) are good examples. A large number, however, are sedentary in habit, vegetarian in diet, and often inhabit tubes. The lobworm (Arenicola), the common Serpula, and Terebella are characteristic types. To the two main orders of Chrtopods above mentioned, the parasitic Myzostomata causing 'galls' on featherstars (Crinoids), and the primitive aberrant Saccocirrus must be added. Polygordius is another common marine worm which, along with a few others, is usually regarded as a survival of the ancestral Chrtopods or Annelids. See EARTHWorm, LobWorM, SEA-Mouse, Worms, \&c.

Chafer, a common name for beetles or coleop. terous insects, especially for those which, either in the perfect or larval state, are destructive of plants, particularly of the wood, bark, or roots of trees. The word is seldom used alone, but generally as part of a name, with some prefix; thus, we have Cock-chafer, Rose-chafer, Bark-chafer, \&c. Käfer is the German word for "beetle.'

Chaffinch (Fringilla coelebs), one of the commonest British birds, a species of Finch (q.v.), and probably that to which the name Finch, now 80 extended in its signification, originally belonged. Fink, the German form of the name, and pink and twink, still used in England as popular names, have some resemblance in sound to the common call-note of the chaffinch. The whole length of the bird is about six inches. The tail is very slightly forked. The beak is almost equal in breadth and height. The male, in summer, has the top of the head and nape of the neck bluish-gray; the back, chestnut; the wings almost black, with two conspicuous white bars; the tail nearly black. The lower surface is reddish. The colours of the female are much duller than those of the male. The chaffinch is a very widely distributed species, being found in almost all parts of Europe, in some parts of Asia, in the north of Africa, and as far west as the Azores. In the colder northern countries it is migratory; in more southern. regions it is stationary. Linnæus gave it the specific name coelebs, from observing that the flocks seen during winter in Sweden consisted chiefly of males, the females having, as he supposed, sought a milder climate. A partial separation of the sexes is observed also in the great winter-flocks in Britain, but it is only partial; and Yarrell thinks that the young males of the previous season, which resemble the females in plumage, are associated with them, and have been mistaken for them. The flocks seen in Britain in 
winter are believed to be augmented by migration from Seandinavia. The eggs are usually four or five in number, of pale purplish buff colour, spar. ingly streaked and spotted with reddish brown. 'The chaffinch feeds in great part on insects, and does much service in summer by destroying aphides and caterpillars; but ents also seeds, and is some. times persecuted, becanse in spring it pulls up and culs young turnips and radishes when in the geed. leaf. It is particularly fond of the seeds of beeches und conifers. Great numbers of chaffinches are killed for the table in Italy. In Germany this liril was formerly in the highest esteem as a song. bird. Its notes are very clear and loud, but some imlividuals greatly excel the ordinary multitude of their species.-The common Scoteh name of the chatfinch is Shilfa.

Chagny, an important railway junction and commercial centre in the French department of Saone-et-Loire, on the Canal du Centre, 32 miles S. of Dijon. As the key of the roads to the Loire district, it has been strongly fortified. Pop. 4291.

Chagos Islands. See Diego Garcia.

Chagres, a town of the republic of Colombia un the $N$. coast of the Isthmus of Panama, situated at the mouth of the Chagres River. A poor place at best, with a harbour for vessels drawing fron 10 to 12 feet of water, it was almost forsaken on the stoppage of the Panama Canal. Pop. 1000. The river Chagres rises about 10 miles NE. of Panama, makes an immense bend round to the NE. and enters the Caribbean Sea. Though towards its mouth it varies in depth from 16 to $3 v$ feet, it is, by resson of its rapidity and its falls, of little use for navigation. The line of the Panama Canal (see PANAMA ) lay partly by the valley of the Chagres.

Chaillu. Paul du. See Du Charliz.

Chain, in Surveying (called Gunter's Chain, from its inventor, Edmund Gunter, q.v.), is a mea sure of 22 yards long, composed of 100 iron links, each of which is thus 7.92 inches long. As an acre contains 4840 square yards, 10 square chains ( $22 \times 22 \times 10=4840$ square yards $)$ or 100,000 square links make an acre.

Chain Cable. See Cable.

Chain-mail, or CHAIN-ARMoUR, much used in Europe in the 12th and 13th centuries, and stil

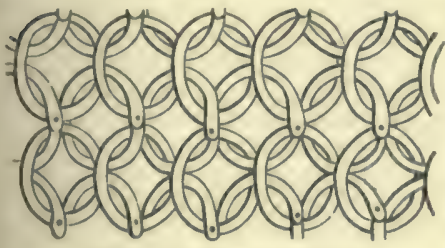
used in Indis and the interior of the Asiatie conti nent, consist of hammered iron links, connected together by riveted links so that each link embraces four Piece of Chain-armour

nthers, and worked into the form of a garment. venient to the wearer than that which was formed of steel or brass plates, but was less fitted to bear the thrust of a lance. See ARMour.

Chain-plates, on shiphoard (wood vessels), are iron plates bolted below the channels to serve its attachments for the dead-eyes, through which the standing rigging or shrouds and back-stays are ruve and secured. In most of the modern iron-steel vessels rigging-serews take the place of the older dicul-eyes, the chain-plates to which they are attached consisting simply of flat palms, having an eye projection, riveted to the inside of the sheer or top strake of shell plating.

Chains. Chain-making being a distinct trade of itself, thoroughly reliable chains can only be made by men trained to the work, although some of the very wmall sizes of common chains are made by women, boys, and girls. Chains are of two generally distinet kinds-mort-link or unstudded (frequently called close-link) chain, and stud-link or stayed chain. The former usually embraces the smaller sizes of chain up to 11 inches, and the latter comprises ships' cables and other heavy chains. Short-link chain is made in the following manner: The end of the bar from which the link is to be made is heated, then ent to gange, and while still hot is bent into U-form; the free ends are then heated to a white heat and flattened or scarphed by a hammer, and in this state they are brought together and welded so as to form the other end of the link. The flattening or scarphing of the two ends and the elosing of them lxeing all done in one heat, the scarphed ends are again heated to welding-point, and the link is placed in a suitable recess under a hollow-faced tool, worked mechanically, which strikes the roughened weld and ultimately finishes it off as smooth as the other end of the link. The result is the finished link, and when the finst has been completed, another piece of iron is bent in the same way and threaded or rove through it, and another link formed and finished in the same manner as the finst. In this way each successive link is added until the required length of chain is made.

The foregoing illustrates the way in which chains generally are made, but as a rule, links of chains of 1 -inch diameter and over are welded at the side instead of at the end, and a stud or stay-pin is welded across from side to side of the link. The larger sizes of chains and chaincables are made by men, and the expert workman when employed making first-class chains of all deseriptions gets an extra price for his skill and labour. Common (not to say inferior) chains, however, are too often welcomed by bargain-loving users if they can at all be made to pass the statutory tests. Chains which stand certain of the standard tests may be found totally unequal to meet certain others, and superior and inferior parts are often purposely mingled in one chain by dis. honest makers to cheapen production and defent the system of testing. The iron used for very superior chains is selected not only for its tensile strength and welding properties, but for its ductility, as high tensile strength is not infrequently possessed by a hard brittle iron, liable to snap upon the application of a sudden jerk, and therefore totally unsuited for chains. The system of testing cables followed by Lloyd's Register Society well exem. plifies what should be adopted in the case of all chains. Every 15-fathom length is subject to a fair standard strain, sufficient to detect bad workmanship, by pulling asunder or opening any defective welds, yet not so severe as to injure the nature of the material by crystallising it-a result invariably produced by overstraining. This standard test, however, not being the extreme limit of strain which the chain ought to bear in actual use at sea, a few links are required to be cut out at random from any part of each 15-fathom length, and submitted to a so-called breaking strain of 50 per cent. in excess of the standard test. If these trial pieces are found to withstand this extra strain satisfactorily, they are then assumed to represent a fair average of the strength of that particular length to which they belong. This operation being gone through with satisfactory results in each length of cable, the whole is then passed, and certified aceordingly. Any unsatisfactory lengths are con. demned, marked, and sent back to the manufac. turer.

In his treatise on Chain Cables and Chains, Mr T. W. Trail, aurveyor-in-chief to the Board of 
Trade, says: 'Since the Act of 1871, which came into operation in the early part of 1873 , until the latter part of 1883 , a period of about eleven years, nearly 165,000 tons of chain have been certified to, in accordance with the act of parliament, as having duly withstood the statutory tests, representing about 3,199,000 fathoms of chain, and for which it is computed that from about two and a quarter million to about two and a half million pounds sterling have been paid.'

Chain-shot, an obsolete artillery projectile, consisting of two balls connected by a short chain, formerly used to destroy the rigging of ships, \&c. As case-shot and shrapnel shell answer the same purpose, its use has been discontinued.

Chalaza. The first layer of albumen deposited upon the yolk of an egg as it descends the bird's oviduct, is peculiarly viscous, and thus becomes twisted into two strands which keep the yolk in the middle of the more fluid albumen. These cords are also called chalaze.

Chalce'don, a city of ancient Bithynia, at the entrance of the Euxine, opposite to Byzantium. It was founded 684 B.C. by a colony from Megara, and soon became a place of considerable trade and importance. Taken by the Persians, it finally merged into the Roman empire, under which it was made a free city. Chosroes, the Persian, captured it in 616 A.D., after which it declined, until it was finally demolished by the Turks, who used its ruins to build mosques and other edifices at Constantinople. Chalcedon was the birthplace of the philosopher Xenocrates.

The council of Chalcedon was the fourth oecumenical council, and was assembled (451 A.D.) by the emperor Marcian for the purpose of drawing up a form of doctrine in regard to the nature of Christ which should equally avoid the errors of the Nestorians (q.v.) and Monophysites (q.v.). Six hundred bishops, almost all of the Eastern Church, were present. The doctrine declared to be orthodox was, that in Christ there were two natures, which could not be intermixed (this clause was directed against the Monophysites), and which also were not in entire separation (this was directed against the Nestorians), but which were so conjoined, that their union destroyed neither the peculiarity of each nature, nor the oneness of Christ's person.

Chalced'ony (often misspelled Calcedony), a beautiful mineral of the quartz family, consisting of quartz with some admixture of opal. It derives its name from Chalcedon in Bithynia, near which it is found in considerable abundance, and has been known by the same name from aneient times. It never occurs in crystals, but usually in mammillary, botryoidal, or stalactitic forms, lining or entirely filling the eavities of rocks, and more particularly old igneous rocks, such as the basalt-rocks of Scotland, the Faröe Isles, Iceland, \&c. It constitutes the whole or the principal part of many agates. It is generally translucent, sometimes semi-transparent, has a somewhat waxy lustre, and is in colour generally white or bluish white, sometimes reddish white, sometimes milk white, less frequently gray, blue, green, yellow, brown, or even black. Its fracture is even, or very slightly conchoidal. Chalcedony is much used in jewelry, for brooches, necklaces, and ornaments of all sorts, the largest pieces being sometimes made into little boxes, cups, \&c. It was much used by the ancients, and many beautiful engraved specimens appear in antiquarian collections. Chalcedonies with disseminated spots of brown and red were once very highly prized, and were called Stigmites or St Stephen's stones. Petrified plants are sometimes found in chalcedony, in which they appear to have been incased whilst it was in course of formation. Specimens of chal- cedony are sometimes found inclosing a little water in the interior, which gives them a very beautiful appearance; but the water easily escapes, and to prevent this, rings or other ornaments made of such stones are kept in distilled water when not worn. The ancients set a very high value on these en. hydrites (Gr. en, 'in,' and hydor, 'water'). See JASPER.

Chalced'onyx (or, erroneously, Calcedonyx), a name given to agates formed of cacholong, or a white opaque chalcedony, alternating with a grayish translucent chalcedony.

Chalchihuitl, the Indian name of a greencoloured stone, taken from a quarry near Santa Fé, and by some regarded as a species of turquoise, by others identified with Jade (q.v.). It was valued above gold by the ancient Mexicans, who fashioned it into beads and ornaments.

Chalcididae, a small family of short-tongued lizards, restricted to America Chalcides ( $C$. flavescens) occurs in tropical America Heterodactylus is an allied Brazilian genus. The same title is applied to a family of insects. See CHALCIs.

Chalcis, the capital of the Greek island of Euboea, on the Euripus, a strait separating the island from Bootia, and here only 120 feet wide. Chalcis is a place of very great antiquity, and it soon became a great trade centre, sending out colonies to Macedonia, where the peninsula of Chalcidice commemorated its name, as well as to Campania (Cumoe), South Italy, and Sicily. Successively Athenian, Macedonian, and Roman, it was a place of great military importance, nearly nine miles in circunference, and had many fine temples, theatres, and other public buildings. Aristotle died here. In the middle ages it was prosperous under the Venetians, who held it for nearly three centuries, until its conquest by the Turks in 1470. Pop. (1879) 6877 ; (1889) 9919.

Chalcis, a typical genus of a large family of Hymenopterous insects, not unlike small wasps. The family (Chalcididæ or Pteromalini) has this great importance that the larvæ of its members are parasitic in the eggs, larvæ, or pupæ of other insects, and as some of the latter are very destructive to plants, their parasites are animals to be thankful for. Thus forms so different as the cabbage butterfly and the destructive Hessian fly have their attend. ant Pteromalini. Many of the so-called gall-wasps (Cynipida) which cause many of the commonest galls-for instance on the oak, or the curious bunches on rose and briar bushes-are preyed upon by Chalcididæ. Some of the hosts of these Chalcidre are themselves parasitic, and thus we have parasites within parasites, or double parasitism, there being in this case no honour among thieves. Altogether over 2000 species of Chalcididre are known.

Chaldaea. See BABylonia ; for Chaldee, see ARAMAA.

Chalder, an old Scotch dry measure, containing 16 bolls. See BoLL and FIARS.

Chaldron (Lat. caldarium, 'a vessel for warm water'), an old dry measure used in selling coal,

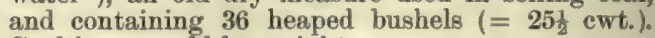
Coal is now sold by weight.

Chalet is the French-Swiss name for the wooden hut of the Swiss herdsmen on the mountains; but is also extended to Swiss dwelling-houses generally, and to picturesque and ornate villas built in imitation of them.

Chaleurs, BAY OF, an inlet of the Gulf of St Lawrence, between Gaspé, a district of Quebec, and New Brunswick, having a depth of 90 miles from east to west, and a width varying from 12 to 20. It is deep and well sheltered, and much frequented for its mackerel fisheries. 
Chalfont St Giles, a village of Buckingham shire, 16 miles SE. of Aylesbury. Milton's cottage ( 1665 ) was purchased by the nation in 1887 .

Chalereve, a village 13 miles SE. of Oxford, the scene of a skirmish in the Civil War between Prince Rupert's cavalry and a parliamentary foree unlor Hampden, in which that patriot received his leath-wound, June 18, 1643.

Chalice (Lat. calix, 'a cup'). The name has lung been spplied only to the cups used for the udministration of the wine in the holy communion. Anciently made of glass, precious stone, horn, and

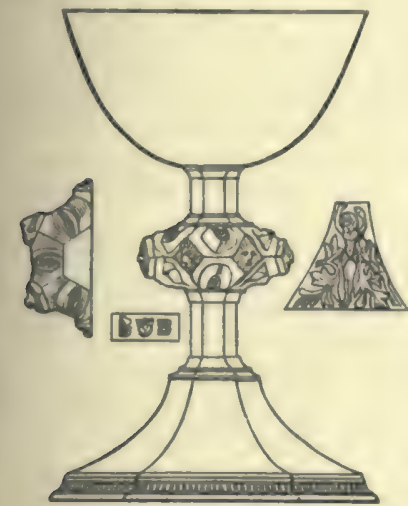

Chalice (1459) at Nettlecombe, County Somerset.

(From Cripps's Old English Plats.) other substances, chalices have for many centuries been formed of silver, or sometimes gold, ocea sionally enriched with jewels. Their fashion has followed the art of the times. thehemispherical bowl and plain circular foot of Romanesque or Norman days giving way to a conical bowl and hexagonal foot in the Perpendicular period, and these in turn to more modern shapes, seldom of such beanty and excellence as those of Gothic design. Before the Reformation a erucifix or other sacred device always occupied one side of the foot. The chalice was usually accompanierl by a paten, which might serve as a cover to the lnowl, as well as for earrying the wafer or bread. In medieval times a chalice of tin or pewter, if not of silver, was placed in the coffin of ecclesiasties at burial. The chalice is the emblem of St John the Evangelist. Old chalices are much sought after by collectors. The glass 'Luck of Edenhall,' preserved in the family of Musgrave, near Penrith, is apparently an old chalice. The use of the mixed chalice, the mingling of water with the wine used in the Lord's Supper, and in the Roman rite, has leen matter of controversy in the Church of England. The chalice veil or corporale was a covering for the chalice.

Chalk, a soft earthy variety of limestone or carbonate of lime, forming great strata, and claim. ing the attention of the geologist even more than of the mineralogist (see CRETACEOUS SYSTEM). It is generally of a yellowish-white colour, but sometimes snow-white. It is easily broken, and has an varthy fracture, is rough and very meagre to the touch, and adheres slightly to the tongue. It urrerally contains a little silica, alumina, or mag. nesia, sometimes all of these. Although often very snft and earthy, it is sometimes so compact that it 'an be used as a building-stone; and it is used for this purpose either in a rough state, or sawn into hlocks of proper shape and size. It is burned into quicklime, and nearly all the houses in London are (*)mented with mortar so procured. The siliceous particles being separated by pounding and diffusing in water, it becomes whiting, of which the domestic uses are familiar to every one. Carpenters and others use it for making marks, which are easily efficed : the blackboard and piece of chalk are now common equally in the lecture-rooms of universities and in the humblest village-schools. Chalk, per. fectly purified, is mixed with vegetable colouring matters, such as turmeric, litmus, saffron, and saygreen, to form pastel colours or coloured chalks; but vegetable colours which contain an acid are changed by it (see Crayos). The Vienna white of artists is simply purified chalk. In a perfectly purified state it is administered as a medicine to correct acidity in the stomach. Chalk is also extensively used as a manure. See LIME, MANURE.

Black ChalK is a mineral quite different from common chalk, and apparently receives its name from resembling it in meagreness to the touch, in soiling the fingers, and in being used for drawing, writing, \&e. It is also ealled Drawing-slate. It is of a slaty structure, of a bluish or grayish-black colour, easily ent and broken, and makes a perfectly black mark on paper. It is used for drawing and as a black colour in painting. It becomess reil by exposure to heat. It is essentially a kind of Clay (q.v.), and derives its colour from carbon, which it contains. It is found associated with schists, \&c. in Spain, France, Italy, \&c., also in the eoal formation in Scotland. - BRIANÇON CHALK and French CHALK are popular names for Soapstone (q.v.).-RED ChALK is ochry red clay-iron ore, consisting of clay and much peroxide of iron. It is of a brownish-red colour, and a somewhat slaty structure, the cross fracture earthy. The coanser varieties are used chiefly by carpenters for making marks on wood; the finer, by painters. It occurs in thin beds in clay-slate and graywacke-slate in some parts of Germany.

Chalking the Door, a mode of warning tenants to remove from burghal tenements, long known and still in use in Scotland. It is thus described by Hunter in his work on Landlord and Tenant: 'A burgh-officer, in presence of witneases, chalks the most patent door forty days before Whitsunday, having made out an execution of 'chalking,' in which his name must be inserted, and which must be subscribed by himself and two witnesses. This ceremony now proceerls simply on the verbal order of the proprietor. The execution of chalking is a warrant under which decree of removal will be pronounced by the burgh court, in virtue of which the tenant may be ejected on the expiration of a charge of six days. See EJECTMENT.

Challenger Expedition, a cireumnavigating scientific exploration of the open sea sent out by the British government in 1872-76-earlier expeditions being those of the Lightning (1868) and Porcupine (1870). In 1872 the Challenger, a corvette of 2306 tons, was completely fitted out and furnished with every scientific appliance for examining the sea from surface to bottom-natural history work-room, chemical laboratory, aquarium, \&e. The ship was given in charge to a naval surveying staff under Captain Nares; aml to a scientific staff, with Professor (afterwands Sir) Wyville Thomson at their head, for the purpose of sounding the depths, mapping the basins, and determining the physical and biological conditions of the Atlantic, the Southern and the Pacific Oceans. With this new commission, the Challenger weighed anchor at Sheerness on the 7 th December 1872, and on the evening of the 24th May 1876 she dropped anchor at Spithead, having in these three and a half years eruised over 68,900 nautienl miles, and made investigations at $\mathbf{3 6 2}$ stations, at each of which were determined the depth of channel; the bottom, surface, and intermediate temperatures, currents, and fauna; and the atmospheric anc meteorological conditions. The route was by Madeira, the Canaries, the Weat Indies, Nova Seotia, Bermudas, Azores, Cape Verd, Fernando Noronha, Bahia, Tristan d'Acunha, Cape of 
Good Hope, Kerguelen, Melbourne, the Chinese Sea, Hong Kong, Japan, Valparaiso, Magellan's Strait, Monte Video, Vigo, and Portsmouth. Between the Admiralty Isles and Japan the Challenger made her deepest sounding, on the 23d March 1875, 4575 fathoms. See the copious Reports on the Scientific Results of the Voyage of H.M.S. Challenger, edited by Sir Wyville Thomson and Sir John Murray, which mark an era in deep-sea exploration. They extend in all to fifty volumes (1880-95), the bulk of the large quartos devoted to Zoology, the others representing Botany (3 vols.), Deep-sed Deposits (1 vol.), Physics and Chemistry ( 3 vols.), and a Narrative (2 vols.). To these invaluable reports many articles in the present work are indehted for materials and illustrations. See also the works of Sir C. Wyville Thomson, H. M. Moseley, Spry, Lord George Campbell, Wild; and the articles in this work on ATLANTIC OCEAN, Pacific Odean, Sounding, and especially Sea.

Challis, JAMES, astronomer, born at Braintree in Essex, 12th December 1803, graduated senior wrangler and first Smith's prizeman at Cambridge in 1825 , was ordained in 1830 , and in 1836 became professor of Astronomy at Cambridge, where he died 3d December 1882 . He was also till 1861 director of the Cambridge Observatory, and published a number of works, including 12 vols. of astronomical observations (1832-64). In August 1846, whilst carefully preparing to test Adams' results, he twice unconsciously noted the position of the planet Neptune before its discovery at Berlin on 23d September. See AdaMs (J. C.).

Challoner, RICHARD, a learned Roman Catholic prelate, born at Lewes in Sussex, September 29, 1691. Becoming a Roman Catholic, he was sent in 1704 to the English College at Douay, where he became a professor, and remained until 1730. In that year he was sent to labour in London, and here he served as a missionary priest until 1741 , when he was raised to the episcopal dignity as Bishop of Debra and coadjutor of Bishop Petre, whom he succeeded as Vicar Apostolic of the London district in 1758. During the 'No Popery' riots of 1780 he was secreted near Highgate, and he died in London, January 12, 1781. Of Challoner's numerous controversial treatises, the best known is his Catholic Christian Instructed, an answer to Conyers Middleton's Letters from Rome. His Garden of the Soul is still the most popular prayerbook with English Catholics, and his revision of the Douay version of the Bible (5 vols. 1750$)$ is substantially the Bible used by them. Of his histori cal works the most valuable are his memoirs of missionary priests and other Catholics of both sexes who suffered death or imprisonment in Eng. land on account of their religion, from the year 15.77 till the end of the reign of Charles II. ( 2 vols. 1741 ), and his Britannia Sancta (2 vols. 1745), a collection of the lives of British and Irish saints.

Chalmers, Alexander, an industrions biographer and miscellanous writer, was boun at Aberdeen in 1759. After a course of study at his native university, he abandoned a projected medical career, and repaired to London, where he soon became an active writer for the press and the busiest of booksellers' hacks. He died in London, 10th December 1834. His editions of Burns, Beattie, Fielding, Gibbon, Bolingbroke, Shakespeare, Johnson, and Boswell's Johnson are now of no importance; but that of The British Essayists, in 45 vols., is still esteemed as accurate and handy. His prefaces to 'Walker's 'Classics ( 45 vols.), and his enlarged edition of Johnson's Collection of the Poets ( 21 vols.), contain much honest work. But his reputation depends mainly on the General Biographical Dictionary (32 vols. 1812-14).
Chalmers, GEorGe, Scottish antiquary, was born in 1742 at Fochabers in Elginshire, and was educated there and at King's College, Aberdeen. Having afterwards studied law at Edinburgh, in 1763 he went to North America, where he practised as a lawyer at Baltimore till the breaking out of the war of independence. Then returning to Britain, he settled in London (1775), and was appointed clerk to the Board of Trade in 1786. The duties of this office he continued to discharge with diligence and ability till his death on 31st May 1825. Of his thirty-three works the ehief is Caledoria; an Account, Historical and Typographical, of North Britain (vols. i.-iii. 1807-24). In 1888-89 it was reprinted at Paisley in 7 vols., comprising the matter prepared for the unpublished 4th vol, and furnished with a much-needed index. Among his other publications are $A$ Collection of Treaties between Great Britain and other Powers ( 2 vols. 1790 ); Lives of Defoe, Paine, Ruddiman, and Mary, Queen of Scots; and editions of Allan Rarnsay and Lyndsay.

Chalmers, Grorge Paul, R.S.A., was born at Montrose in 1833 (not 1836). He served as errandboy to a surgeon, and apprentice to a ship-chandler; but he was resolved to become an artist, and in 1853 he came to Edinburgh, and studied under Scott Lauder. His ' Favourite Air,' attracted attention in 1854, and in 1867 he was elected an A.R.S.A., in 1871 an R.S.A. His untimely death at Edinburgh (28th February 1878) was due to injuries received some days before either from violence or by misadventure. His works are distinguished by admirable breadth, effective concentration of lighting, freedom of handling, and rich and powerful colouring. He executed some important portraits. His landscapes, mainly of his later years, include 'End of the Harvest' (1873) and 'Running Water' (1875). He is represented in the National Gallery of Scotland by 'The Legend,' a large unfinished subject-picture, which, like 'Prayer' (1871), has been etched by Rajon. See his Memoir (1879).

Chalmers, Tномаs, D.D., LL.D., was born at Anstruther, in Fife, 17th March 1780, educated at the university of St Andrews (from 1791), and at the age of nineteen licensed to preach the gospel. In 1803 he was ordained minister of the parish of Kilmany, in Fifeshire, about 9 miles from St Andrews. At this period his attention was almost entirely absorbed by mathematics and natural philosophy. He carried on mathematical and chemistry classes in St Andrews during the winter of 1803-1804, and by his enthusiasm and lucidity of exposition obtained for himself a high reputation as a teacher. In 1808 he published an Inquiry into the Extent and Stability of National Resources. Shortly after this, domestic calamities and severe illness rendered him keenly susceptible of religious impressions. Having to prepare an article on Christianity for Brewster's Edinburgh Encyclopoedia, he commenced a thorough study of the evidences, and rose from his investigations convinced that Christianity was the truth, and the Bible the veritable 'word of God.' Then the great genius of the man broke forth like sunshine. He grew earnest, devout, and faithful to his pastoral duties. In July 1815 he was translated to the Tron Church and parish, Glasgow, where his magnificent oratory took the city by storm. His Astronomical Discourses (1817) and Commercial Discourses (1820) had a widely extended popularity. In 1817 he visited London, where his preaching excited as great a sensation as at home. But Chalmers' energies could not be exhausted by mere oratory. Discovering that his parish was in a state of great ignorance and immorality, he began to devise a scheme for overtaking and checking 
the ularming evil. It seemed to him that the orily means by which this could be accomplished was hy 'revivifying, remolelling, and extending the old parochial economy of Bcotland,' which hat proved so fruitful of good in the rural parishes. In crilus to wrestle more closely with the ignorance anil vice of Glasgow, Chalmers in 1819 became minister of Sit John's parish, of whose 2000 finilies, mostly workpeople, more than 800 had II) connection with any Christian church. Chalmers liroke up his parish into 25 districts, each of which he placed under separate management, unil established two day schools, and between 41) and 50 local Sabbath schools, for the instruc. tion of the children of the "poorer and neglected clisises,' more than 1000 of whom attended. In many other ways he sought to elevate and purify the lives of his parishioners. While in Glas. (row, Chalmers had matured his opinions relative to the best methol of providing for the poor. He disliked the English system of a 'compulsory assessment,' and preferred the old Scotch method (s) voluntary contributions at the church-door, administered by elders. The management of the poor in the parish of St John's was intrusted to his care by the anthorities as an experiment, and in four years he reduced the pauper expenditure from $£ 1400$ to $£ 280$ per annum. Edward Irving was for two years his assistant. But such hereulean toils began to undermine his constitution, and in 1823 he accepted the offer of the Moral Philosophy chair in St Andrews, where he wrote his treatise on the Use and Abuse of Literary and Ecclesiastical Endowments (1827). In the following year he was transferred to the chair of Theology in Edinburgh, and in 1832 he published a work on political economy. In 1833 appeared his Bridgewater treatise, On the Adaptation of External Nature to the Moral and Intellectual Constitution of Man. It was received with great favour, and obtained for the author many literary honours; in 18.4 he was elected by the Royal Society of Edinburgh lirst a fellow and then a vice-president, and by the French Institute a corresponding nember, while in 1835 the university of Oxford conferred on him the degree of D.C.L. In 1834 he was appointed convener of the Church-extension Committee; and after seven years of enthusiastic labour, he announced that upwards of $£ 300,000$ had been collected from the nation, and 220 new churches built. Meanwhile, however, troubles were springing up in the bosom of the church itseif. The Evangelical party had become predominant in the General Assembly; the struggles in regard to patronage between them and the 'Moderate' or 'Erastian' party became keener and more frequent, until the decision of the civil courts in the famous Auchterarder and Strathbogie cases brought matters to a crisis ; and on the 18th of May 1843 Chalmers, followed by 470 clergymen, left the church of his fathers, rather than sacrifice those principles which he believed essential to the purity, honour, and independence of the church (see FREE CHURCH). The rapid formation and organisation of the Free Church were greatly owing to his indefatigable exertions. Chalmers was elected principal of the Free Church College, and spent the close of his life in the zealous performance of his duties there, and in completing his Institutes of Theology. He died suddenly at Morningside, Edinburgh, May 30, 1847.

The works of Chalmers extend to 34 vols. ( 9 of which include his posthumous works). They contain valuable and, in some cases, original contributions to the sciences of natural theology, Cliristian apologetics, and social economy; while on minor topics, such as the church-establishment question, they exhibit both novelty and ingenuity of argument. As a religious orator Chalmen wa unique and unrivalled. There have been few men in whom such gifts of intellect, feeling, and imagin. ation were so harnonipusly combined with the shrewdest common-sense and the highest admini. strative ability. Never did Scotland produce a greater or more lovable soul, one more gentle, guileless, and genial-hearted, or yet more fervin from the strength of a resolute will, before whose impetus difficulties were dashed aside as by torrent. There have been loftier and more purely original minds in Seotland than Chalmers's, but there has never been a truer one, nor a heart whose Christian faith and piety were more intense, sincere, and humane.

See his Memoirs, by his son-in-law, Dr W. Hanns (4 vols. 1849-52), and his Correspondence (1853); also $A$ Biographical Notice by Dean Ramsay (1850), an Essay by Dr John Brown in his Hore Subsecivo, and small bouks on him by D. Fraser (1881) and Mrs Oliphant (1893).

Chalons-sur-Marne, the capital of the French department of Marne, on the right bank of the river Marne, 107 miles E. of Paris liy rail. An old place, with timber houses and many spired churches, it has an interesting cathedral, dating chiefly from the 13th century, \& handsome hotel. de-ville (1772), and a fine public park, though the Germans cut down its inmemorial elms for fuel. It still does a considerable trade in Champagne wine; but its manufacture of the worsted cloth known as 'shalloon' (Chaucer's chalons) is a thing of the past, and the population has dwindled from 60,000 in the 13th century to 19,639 in 1891 . Near Chalons, which takes its name from the Catalaun of Latin writers, the Romans and Goths in 451 A.D. defeated Attila (q.v.) and his host of Huns. In 1856 Napoleon III. formed the celebrated camp of Chalons, $16 \frac{1}{2}$ miles to the north-east of the town. Hence, during the Franco-Prussian war, on the night of August 21, 1870, MacMahon withdrew his troops, and next day the town was occupied by the Germans.

Châlon-sur-Saône (ancient Cabillonum), a town in the French department of Saone-et-Loire, 841 miles by rail $\mathrm{N}$. of Lyons. Lying on the right bank of the Saône, at the point where that river is joined by the Canal du Centre, uniting it with the Loire, Chalon has an extensive traffic with the central districts of France, as well as with the Mediterranean and Atlantic. Fine quays and houses line the river; and the chief building is the church of St Vincent, 14th to 15th century. The industries are copper and iron founding, machinery and shipbuilding, and the manufacture of glass, paper, and chemicals. Pop. (1872) 20,055 ( 1886 ) 22,208 ; ( 1891 ) 22,974 .

Chalybaeus, Heinrich Moritz, philosopher, born at Pfaffroda in Saxony, 3d July 1796, spent some years in teaching, and was appointed in 1839 professor of Philosophy in the univensity of Kiel. He was dismissed, however, in 1852, owing to his Germanic sympathies, and died at Dresden, 22d September 1862. His chief work is his System der speculativen Ethil $(1850)$; and his review of the historical development of speculative philosophy has been translated into English by Tulk (1854) and Edersheim (1860).

Chalyberate Waters are those which contain a consideralle portion of iron in solution. See Mineral Waters.

Chalybite, an iron ore. See IroN.

Cham, the pseudonym assumed by the caricaturist. Amédée de Noé (Cham being the French for Ham, the son of Noah), son of the Comte de Noé by an English mother, and born at Paris in 1819. He studied art under Delaroche, 
and soon acquired a great reputation as a skilful and witty delineator of the humorous side of Parisian life. In 1843 began his famous connection with the Charivari, in which paper and in the Journal des Pelerinages he continued to delight his fellow-citizens until close upon his death on 6th September 1879. He was profoundly sceptical, but not unkindly, and obtained, as Edmond About pointed out, the success of an homme d'esprit. His masterpieces were chiefly social rather than political, and among his skits may be mentioned Proudhomana, Bagneurs et Buveurs d'Eau, Souvenirs de Garrison, and L'Exposition de Londres. Several good collections of his comic illustrations have been made-for instance, Doure Années Comiques (1880), with an introduction by L. Halévy, and Les Folies Parisiennes (1883), with an introduction by Gérôme. In Sala's Paris herself again (1882) are a good many specimens of Cham's art.

Chama, a genus of bivalve molluses, the only surviving type of a family which was once extremely numerous and abundant, especially in the Jurassic and Chalk times. The genus is represented by about half a hundred living forms, restricted to warmer waters, and especially common about coral reefs. The general appearance is somewhat clamlike, the valves are unequal, of considerable thickness, and covered with leaf or scale-like outgrowths. They are very passive animals, usually fixed, with the mantle margins fused together, with very small foot and respiratory apertures, with well-developed hinge and an external ligament, and often of a bright colour. Some forty fossil species are known from Cretaceous and Tertiary strata, and the genus is of interest as the sole survivor of a once much larger family. The common English name for shells of this genus is Clam (q.v.).

Chamaleon (Gr. chamaileōn, 'ground lion'), a large genus of lizards, forming a very distinct family. Among the most distinctive features may be noted the soft tuberculated skin, with its power of changing colour; the coiled tail, adapted for curling round the branches of trees; the division of the toes of fore and hind feet into two bundles; the absence of an external ear-drum or tympanic membrane; the long worm-like insect-catching tongue, capable of extremely rapid protrusion. Even more remarkably distinctive, however, are certain peculiarities in the skeleton, and especially in the skull, which separate the chamæleons from all other lizards.

Description. - The body is flattened, and bears a toothed crest of skin along the back. The head is

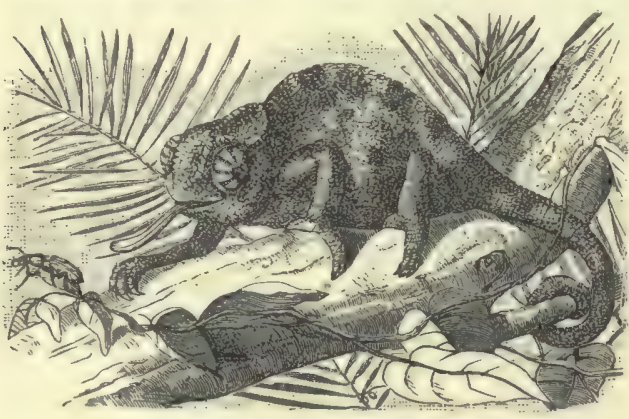

Chamæleon.

triangular, surmounted by a ridge. The animal stands unusually high upon its legs. The fore-feet are divided into three united internal digits and two external; the reverse (and the digits, corresponding to our great and second toes, form one bundle, and the other three-external-another united group) occurs in the hind-feet. The digits are tipped by long sharp claws. The long compressed tail is curled ventralwards. The mouth aperture is small, but the tongue extremely long. It is the most active part of the animal, is cupshaped at the end, covered with a viscid secretion, and very efficient in insect-catching. The large lateral eyes, with circular lids leaving only a small aperture, are very active, and can be rapidly turned in all directions, a possibility which to some extent compensates for the stiffness of the head. The skin is soft, loose, and shagreen-like, the scales being very small. The glandular pores common on the thighs and neax the anus of lizards are absent.

Among the internal peculiarities may be noted the largeness of the lungs, which admit of being greatly distended, so as to puff out the body into marked plumpness. They appear to be connected with surrounding air-spaces. The habit the chamæleon has of thus blowing itself out, taken along with its power of fasting, gave origin to the ancient supposition that it fed on air. The skeletal peculiarities are numerous. The chamæleons differ from all lizards except the Amphisboena (q.v.), in having no 'columella' or epiptery. goid skull-bone, and no interorbital septum, and from all other forms in the fact that the pterygoid and quadrate bones are not united. The latter is firmly fused to the skull, and the parietals are also peculiar in their firm attachments. The teeth are confined to a ridge along the summit of the jaws. The vertebra are hollow in front; the breastbone is small, and only a few anterior ribs reach it; as in the geckos, many of the posterior ribs are united ventrally by hoops across the abdomen; there are no clavicles; the scapula and coracoid of the shoulder-girdle and the ilia of the hip-girdle are peculiarly long and narrow.

Life and Habit.-Except as regards tongue and eyes, the chamæeleons are very sluggish. They are strictly arboreal lizards, moving very slowly, in perfect silence, and waiting rather than hunting for their insect prey. At a distance of several inches, about half as long as the body in some cases, they can most unerringly catch the unconscious insect. Probably the most familiar fact about chamreleons is their power of changing colour. Under the thin outer skin there are two layers of pigment-containing cells, the outer bright yellow, the inner brown to black. Under nerve control the disposition and expansion of the pigment-containing cells vary, and this produces change of colour. The change depends much more on internal emotions, expressing themselves in nervous stimulus and inhibition, than on external physical influences. The change appears to be rather emotional than protective. Most chamæleons are oviparous, and lay 30 to 40 thin-shelled eggs, which are deposited in an excavated hollow and covered over with earth and leaves. Moseley has described a South African species which brings forth its young alive.

Species and Distribution.-The genus Chamæleo is a large one, and some naturalists split it up. Chamæleons are especially at home in the Ethiopian region, but may oceur beyond its limits. The commonest of the numerous species is $C$. vulgaris, which is abundant in Africa, and is also found in South Europe (Andalusia). The predominant colour varies in different species. Many males are adorned with horns on the head. One form, distinguished as a distinct genus (Rhampholeon), has a tail too short for clasping purposes, but this loss is made up for by accessory structures on the feet. The chamæleon was well described by Aristotle, but in later days became the subject of numerous ridiculons fables. It was also in repute 
for supponed medicinal virtues. See LizarD; Huxley'a Anatomy of the Vertebrates; St George Mivart in Nature, vol. xxiv.; Krukenberg's Ver. gleichend-Physiol. Studien, i. 3 (1880), for colour chumge.

Chamárops, a genus of palms, remarkable for its wide range into northern elimates through. ont the world, and of which one species, C. humitis, is the only palm truly indigenous to Europe. This mecies, the common Fan-palm, is widely distributed llirough Southern Europe, extending as far north as Nice. This palm is so tolerant of a cold vimate, that a specimen has lived in the open air in the Botanic Garden of Edinburgh for more than lifty years, with the protection of matting in very severe winters. It forms dense furze-like thickets from the suckers which arise from its ereeping roots, but when these are not allowed to grow, its stem may reach a height of 20 feet or more. In Algeria it is troublesome to agriculturists, but its growth is increasingly becoming of profit on account of the excellent fibre yielded by its stem. This the Arabs mix with camel's hair and make into hut-covers, ie. ; cordage and sailcloth, paper and pasteboard, are also prepared from it, and it also finds many nees under the title of vegetable or African horsehair. The leaves are also used in paper-making, and furnish a convenient thatching material. This species is sometimes called palmetto in Europe. The true Palmetto (q.v.) is C. (Sabal) palmetto of Florida and Carolina (see also Brazilian Grass). In China and Japan $C$. excelsa and $C$. Fortuni are specially prominent; both ean be grown in the open air in the south of England.

Chamalari, a peak (23,944 feet) of the Himalayas, between Tibet and Bhutan, 140 miles $E$. of Mount Everest.

Chamba, one of the Punjab Hill States, immediately SE. of Cashmere, with an estimated area of $3180 \mathrm{sq}$. m. Pop. (1891) 124,032, nearly all Hindus. It is shut in on nearly all sides by lofty hills, and traversed by two ranges of snowy peaks and glaciers, with fertile valleys to the south and west. The banks of the Ravi and Chenab, two of the five great Punjab rivers, are elothed with mighty forests, leased to the British government, which takes $£ 10,000$ to $£ 20,000$ worth of timber from them every year. Agriculture and grazing are the leading industries; iron, copper, and slate are plentiful; and the mountains teem with game. The principality came into the hands of the British in 1846, who in 1847 assigmed it to the present line of rajahs; an annual tribute is paid, reduced, since the establishment of a British sanatorium and two cantonments among the hills, to $£ 500$.

Chambal, a principal tributary of the Jumna River, rises in the Vindhya Range, 2019 feet above sea-level, flows in a north-easterly direction, and after a course of 650 miles falls into the Jumna 40 miles below the town of Etawah. In heavy rains its volume is greater than that of the Jumna.

Chamber, of a firearm, is the name given to that part of the bore which contains the powder, when its diameter is not the same as the Calibre (q.v.) of the gun. Formerly, chambers were always snaller in diameter than the bore, to prevent any uir-spree behind the projectile, but now that much heivier charges are fired, they are made larger. They tend to weaken the gun, but enable a shorter eartridge to be used, and so prevent the dangerous wave action which would be set up in a long one. See CANNon and (under Rifles) RIFLed ARMS.

Chamberlain, an officer appointed by a king or nobleman, or by a corporation, to perform domestic 'and ceremonial duties. The LORD CHAMBERLAIN has been one of the principal officers of state from at least the 13th century, and in 1406 parliament declared that he should alwaym be a member of the council ex officio. Thungh lae has long ceased to have any share in the responsibilities of government, the Chamberlain is still an ofticer of very high standing in the royal household. He has control over all the officers and servants 'above stairs,' except those of the bedchamber, over the establishment attached to the Chapel Royal, the physicians, surgeons, and apothecaries of the houselold. The cluminerlain has further the oversight of the royal musicians, comedians, trumpeters, messengers, \&c. When the office of Keeper of the Great Wardrobe was abolished in 1782 , the duties of providing the state robes of the royal family, the household, and officers of state, devolved on the Lord Chamberlain. All theatres in towns in which a royal palace is situated require to be licensed by the Lord Chamberlain, and no new play can be performed anywhere without his license. His duties as licenser of theatres for the exhibition of plays (see PLAYS) are defined by acts passed in 1751 and 1843. All persons desiring to be presented at levees or drawing-rooms require to send their cards to the Lord Chamberlain, and it is his duty to see that the persons thus applying are entitled by station and character to be presented to the sovereign. The Chamberlain also issues invitations to royal balls, parties, and receptions. In accordance with ancient custom the Lord Chamberlain is still a member of the Privy-council. His salary is $£ 2000$ a year, but his teunre of office depends on that of the political party to which he belongs.

The Vice-chamberlain is the deputy and assistant of the Lord Chamberlain, and in his alssence exercises the full authority which belongs to his principal. His office existed in the time of Richard II. He is also dependent on the administration, and is usually a member of the Privy-council. His salary is $£ 924$ per annum.

Chamberlain, THE Lord GREAT, is a heredi. tary officer of great antiquity, and formerly of great importance. He has the government of the palace at Westminster, and upon solemn occasions the keys of Westminster Hall and of the Court of Requests are delivered to him. At these times the Gentleman Usher of the Black Rod, the Yeoman Usher, and the door-keepers are under his orders. At coronations, state trials, banquets, and the like, the fitting-up of the Hall devolves on him. When the King goes to parliament, the Lord Great Chamberlain delivers the sword of state to any member of the administration whom he chooses, to be borne before His Majesty, he himself walking on his right hand. During the sitting of parliament he has charge of the House of Lords. and issues tickets of admission on the opening or prorogation of parliament. Some fees and perquisites belong to him. This office was con. ferred by Henry I. in 1101 on Alleeric de Vere. Mary, daughter of John de Vere, sixteenth Earl of Oxford, married Peregrine Bertie, the 'brave Lord Willoughby' (1555-1601); and on the death of their last male descendant in 1779 , the honour, after much litigation, was adjudged to belong conjointly to his sisters and co-heiresses-e.g. the Lady Villoughby de Eresby and the Marchioness of Cholmondeley, by whose descendants or their deputies its duties have since been discharged alternately.

Chamberlain, The Right Hox. Joseph, M.P. is the eldest son of the late Mr Joseph Chamberlain, and was born in London in July 1836. He was educated at University College School, and entered his father's serew factory at Birmingham (the name of the firm being Nettlefold), from whicl: 
however, he retired in 1874. Mr Chamberlain had by this time acquired considerable celebrity as a Radical politician. In 1868 he was appointed a member of the Birmingham Town-council; was Mayor of Birmingham from 1873 to 1876, and chairman of the Birmingham School-board from 1874 to 1876. After unsuccessfully contesting Sheffield against $\mathrm{Mr}$ Roebuck in 1874, he was returned for Birmingham without opposition in June 1876. He soon made his mark in parliament, and on the return of the Liberals to power in 1880 he was appointed President of the Board of Trade, with a seat in the cabinet. To Mr Chamberlain's exertions was due the passing of the Bankruptey Bill, but his efforts to amend the Merchant Shipping Acts were unsuccessful. Meanwhile his influence was increasing rapidly outside the House; he came to be regarded as the leader of the extreme Radical party, and enunciated schemes for the regeneration of the masses which were based on the doctrines of the 'restitution' of land and the 'ransom' of property. During the last hours of Mr Gladstone's government he was understood to be opposed to the renewal of the Irish Crimes Act; and during the general election of 1886 he was most severe in his strictures on the moderate Liberals, and produced an ' unauthorised' programme (in opposition to that of Mr Gladstone), which included the readjustment of taxation, free schools, and the creation of allotments by compulsory purchase. He was returned free of expense by the western division of Birming. ham. On February 1, 1886, he became President of the Local Government Board, but resigned on March 26 because of his strong objections to $\mathrm{Mr}$ Gladstone's Home Rule measures for Ireland; and after the 'Round Table" conference had failed to reunite the Liberal party he assumed an atsitude of uncompromising hostility to his old leader's new policy, and was bitterly assailed by Home Rulers as a renegade. He became leader of the LiberalUnionists when the Duke of Devonshire went to the Upper House. Lord Salisbury sent him to Washington as commissioner on the Canadian fishery dispute; and in 1895 he was made Colonial minister in the Unionist Cabinet. As such he had, besides sharing in responsibilities of his collengues (see SALISBURY), to face the troubles in Sonth Africa (see JAmeson, L. S.), and to cherish eloser fellow-feeling with the Colonies, as by welcoming the colonial ministers and colonial troops to London at the Queen's 'Diamond Jubilee' (1897), and by concessions to Canadian commercial autonomy. In 1896 he was elected Lord Rector of Glasgow University. Collections of his speeches (one with an introduction by Mr Lucy) have been published; and see the Life of him by S. H. Jeyes ("Public Men'series, 1896).

Chamber Music, as distinguished from concert or church music or opera, usually means instrumental music for a single instrument or for a small combination, up to the septett or octett.

Chamber of Commerce, a body of merchants, traders, bankers, and others, associated for the purpose of promoting local and general interests of trade and commerce by (1) representing and urging on the legislature the views of their members in mercantile affairs; (2) aiding in the preparation of legislative measures having reference to trade, such, for example, as the Bankrupt and Limited Liability Acts; (3) collecting statistics bearing upon the staple trade of the district; (4) acting in some places as a sort of court of arbitration in mercantile questions; (5) attaining by combination advantages in trade which might be beyond the reach of individual enterprise.

The nldest chamber of commerce is that of
Marseilles, which dates from the end of the 14th or commencement of the 15th century. It shared in the manicipal jurisdiction and in the administration of justice in mercantile questions. It was several times suppressed and re-established, and it was not till 1650 that it received its ultimate organisation. The chamber of Dunkirk was established in 1700. The same year a council. general of commerce was instituted at Paris, which, in addition to six councillors of state, consisted of twelve merchants or traders, delegated by the principal commercial towns of the country, an arrangement which led within the next few years to the formation of chambers of commerce everywhere in France. We thus find that the chamber at Lyons was instituted in 1702, those of Rouen and Toulouse in 1703, of Montpellier in 1704, of Bordeaux in 1705 , \&e. These chambers were all suppressed by a decree of the National Assembly in 1791, but they were re-established by a consular edict in 1802. Their organisation was modified in 1832 , in 1851, and in 1852. The members of these bodies are now elected by the chief merchants of each town chosen for that purpose by the prefect. The number of this elective body cannot be less than 9 nor more than 21 . They hold office for six years, one-third of their number being renewed every two years. The functions now assigned to these chambers in France are-to give to the government advice and information on industrial and commercial subjects; to suggest the means of increas. ing the industry and commerce of their respective districts, or of improving commercial legislation and taxation; to suggest the execution of works requisite for the public service, or which may tend to the increase of trade or commerce, such as the construction of harbours, the deepening of rivers, the formation of railways, and the like. On these and similar subjects the advice of the chambers, when not volunteered, is demanded by the government. In most of the other countries of continental Europe there are similar institutions.

The oldest chamber of commerce in Great Britain is believed to be that of Glasgow, which was instituted 1st January 1783, and obtained a royal charter, registered at Edinburgh on the 31st of the same month. That of Edinburgh was instituted in 1785, and incorporated by royal charter in 1786. The Edinburgh Chamber of Commerce was the first public body which petitioned for the abolition of the Com Laws, and the adoption of free-trade principles; and it stood almost alone in the United Kingdom in advocating the Suez Canal project. It also originated the movement which resulted in placing the telegraph service in eonnection with the Post-office. Between five and six hundred of the bankers, merchants, and ship-owners of Edinburgh and Leith constitute the chamber. The London Chamber of Commerce (1882) may now be regarded as the most important in the United Kingdom. The main branches of commercial enterprise are dealt with by separate departments of the chamber, while by public lectures and the frequent publication of detailed reports it maintains communication with chambers of commerce throughout the country, and serves when necessary to unite and concentrate their action in the promotion of reforms in our mercantile system and in the development of the commercial resources of the empire. The Manchester chamber, so famous for its exertions in the cause of free trade, was not established till 1820, and for many years it continued to be the only institution of the kind in England. Its members number over 900 . In Hull there has been a chamber of commerce since 1837 , but those of Liverpool, Leeds, and Bradford, notwithstanding the great trading and manufacturing 
inturests of these towns, were not eatablighed till $1 \times 50$; in which year also a similar institution wus established in South Australia. The Liverrool Chamber of Commerce numbers 550. The unaul income of the Manchester chamber is upwarde of $£ 1400$, contributed entirely by the subsuriptions, ranging from $\mathrm{el}$, ls. for individual nembers, to $\mathcal{E l 0}, 10 \mathrm{~s}$. for large firms. There are nuw similar chambers in all the great mercantile (1)wns of Great Britain and Ireland, and in 1860 there was established an 'Association of Chambers of Commerce of the United Kingdom,' which meets in aunual conference for the promotion of commerce. 'The Chamber of Commerce of New York, organised in 1768, was incorporated by a royal charter in 1770 , stiterwards superseded by charter granted by the stiate government. Its aims are similar to those in liritain, and it comprises some 800 members, who have establiahed a court of arbitration for differen'os amongst members. Like bodies have been formed in other large American cities. In Canada the Dominion Board of Trade consists of the Chambers of Commerce, or Boards of Trade, as they are indifferently called, of the most important cities of the Dominion.

Chambers are private rooms attached to most of the English courts, in which the judges, or more frequently the masters and chief clerks, transact a larye amount of judicial business. In fact nearly all lusiness which is begun by what is technically called a Srmmons in England goes to chamberse.g. all such incidental matters as the recovery of documents, examination of witnesses about to go abroad, investigation of accounts, settling of deeds between parties. A decree of the court which directs further procedure is carried out by a summons to proceed in chambers. Counsel attend in chambers only in important matters. In Scotland a good deal of this business takes the form of a remit to an accountant or other man of business, a judicial reference, \& commission to examine witnesses, but all initiated by a motion in court.

Chamber-counsel, a barrister or advocate who gives opinions in his own chambers, but does not, or rarely does, plead in court.

Chambers, Ephraim, an amiable but frugal and free-thinking encyclopsedist, was born about 1680 at Kendal, and began life as an apprentice to a globe-naker in London, where he con. ceived the idea of a cyclopredia that should surpass Harris's Lexicon Technicum (1704). It appeared in 2 folio vols. in 1728, and reached a 6th edition in 1750 , Chambers having died meanwhile on 15th May 1740. A French translation gave rise to the more famous Encyclopedie of Diderot and D'Alem. hert; itself expanded into Rees's Encyclopadia. Dr Johnson told Boswell that he had partly formed his atyle upon Chambers's Proposal for his Dictionary. See ENCYCLOPADIA.

Chambers, Sir WILliaM, architect, was born of a Scoteh family at Stockholm in 1726 , but was hrought up in England. At first a sailor, he soon turned to the study of architecture in Italy and at Paris. He rose rapidly, and as early as 1757 was employed by Augusta, Princess-dowager of Wales, to construet the well-known semi-Roman and oriental buildings in Kew Gardens. The king of Sweden made him a knight of the Polar Star. Simerset House (1776) was his design, which Fergusson pronounces 'the greatest architectural work of the reign of George III.' His Treatise of Civil Architecture (1759) was successful, but his absurdly pretentious and ignorant Dissertation on Oriental Gardening (1772) justly covered him with ridicule. Chambers enjoyed the friendship of Johnson, Reynolds, and Garrick, and died in London, March 8, 1796.
Chambers, WILLIAM, publisher, was bom $16 t$ April 1800 at Peebles, his father being a cotton manufacturer there. The boy got a fair elementary education; but owing to the father's misfortunes, his schooling terminated with his thirteenth year. Hence his education for life-work was mainly due to the habit, very early acquired and long main. tained, of miscellaneous and extensive reading. The honsehold migrated to Edinburgh in 1813, and next year William was apprenticed to a bookseller. His five years up, he started business in a humble way for himself (May 1819), to bookselling after. wards adding printing. Between 1825 and 1830 he wrote the Book of Scotland, and in conjunetion with his brother Robert, a Gazetteer of Scotland. His experience gained as a bookseller and printer was next utilised in his attempt 'to take advan. tage of the universal ayjetite for instruction which at present exists,' and to 'supply that appe tite with food of the best kind,' which resulted in the founding of Chambers's Edinburgh Journal on 4th February 1832. This was about six weeks in advance of the Penny Magazine, and it may be considered the pioneer of that class of cheap and popular periodicals of a wholesome kind now so generally diffused. At the end of the fourteenth number he united with his brother Robert in found. ing the business of William \& Robert Chambers, in which they were associated in writing, editing, printing, and publishing. W. \& R. Chambers issued a series of works designed for popular instruction, including besides the Journal, Infor. mation for the People, 2 vols.; the 'Educational Course'series ; Cyclopadia of English Literature, 2 vols.; Miscellany of Useful and Entertaining Tracts, 20 vols.; Papers for the People, 12 vols. and the present Encyclopecdia, 10 vols. (1859-1868; new edition, 1888-92). In 1849 William acquired the estate of Glenormiston, Peeblesshire, and in 1859 founded and endowed an institution in his native town for purposes of social improvement. Twice elected Lord Provost of Edinburgh, William occupied that office for four years (1865-69), during which he promoted several important public acts, including one for the improvement of the older part of the city, which has resulted in a great diminution of the death-rate. (The death-rate of the city in $1865-75$ was 26.26 per 1000 ; in $1875-85$, only 19.94 .) He also carried out at his own cost a thorough restoration of St Giles Cathedral. He died 20th May 1883, having shortly before received the offer of a baronetcy. He was made LL.D. of Edinburgh in 1872. A statue has been erected to his memory in Edinburgh. Besides many contributions to the Journal, he was author and editor of various volumes, and wrote The Youths' Companion and Counsellor, Histury of Peeblesshire (1864), Ailie Gilroy, Stories of Remarkable Persons, Stories of Old Families, and Historical Sketch of St Giles' Cathedral (1879).

Robert Chambers, born in Peebles, 10th July 1802 , took to Latin and books at an early age, and began business as a bookseller in Edinburgh in 1818. His leisure hours were devoted to literary composition, the impulse to which, his brother eays, came upon hin like an inspiration at nineteen years of age. In 1824 he published the Traditions of Edinburgh, the writing of which procured him the friendship of Sir Walter Scott, who furnished some memoranda for the work. Between 182: and 1834 he wrote in all twenty-five volumes, many of them of great literary interest and permanent historical value. He had already won reputation as an author when he joined his brother after the success of the Journal in 1832 ; and this success was materially promoted by his essays, and by his versatility and elegance as a writer, his diligence in collecting and working up stray 
material, and his perception of what was suited to the popular taste in history, poetry, science and arts. In 1844 he published anonymously the remarkable work, Vestiges of Creation, which prepared the way for Darwin's great work, The Origin of Species. The authorship, positively aseribed to him in the Athenoum of $2 \mathrm{~d}$ December 1854, was first acknowledged in $\mathrm{Mr}$ Ireland's introduction to the 12th ed. (1884). He received the degree of LL.D. from St Andrews in 1863. The labour in preparing the Book of Days (2 vols. 1863) broke his health, and he died at St Andrews, 17th March 1871. Other works by Robert are Popular Rhymes of Scotland, a valuable contribution to folklore (1847), History of the Rebellions in Scotland, Life of James I., Scottish Ballads and Songs (3 vols. 1829), Dictionary of Eminent Scotsmen, Ancient Sea Margins (1838), The Life and Works of Robert Burns (4 vols. 1851), Domestic Annals of Scotland (3 vols. 1859-61), and Songs of Scotland prior to Burns (1862). His Select Writings ( 7 vols.) were published in 1847.- His son ROBERT CHAMBERs, born in 1832 , became head of the firm in 1883 , and conducted the Journal till his death, March 23, 1888. - See W. Chambers's Memoir of William and Robert Chambers (1872; 13th ed., with supplementary chapter, 1884).

Chambersburg, capital of Franklin county, Pennsylvania, in a pleasant valley 52 miles WSW. of Harrisburg by rail, has several manufactories, breweries, foundries, and machine-shops. A large part of the borough was burned by the Confederates in 1864. Pop. (1880) 6877 ; (1890) 8006.

Chambertin, a famous red Burgundy, obtained from a vineyard ( 62 acres) of that name in the French department of Côte-d'Or, 7 miles S. of Dijon by rail.

Chambery, capital of the former duchy and present French department of Savoy, beautifully situated between two ridges of hills, amid gardens and country seats, 370 miles SE. of Paris by rail. The scenery around, with the river Laisse flowing through the valley, is exceedingly fine. The town itself, however, is dull and uninteresting, with narrow and gloomy streets winding between high well-built houses. Notable edifices are the small cathedral, the palace of justice, and the old castle of the Dukes of Savoy, restored early in the 19th century. Chambéry has manufactures of elocks, silk-gauze, soap, hats, paper, and a trade in silk, wine, coal, \&c. Pop. (1891) 20,922. From 1525 to 1713 Chamberry was under the dominion of France, and again from the Revolution to 1815 , when it was restored to the House of Savoy ; but in 1860 , by the cession of Savoy, it came again under the rule of France.

Chambeze, the farthest head-stream of the Congo, rises in the highlands south of Tanganyika, about $9^{\circ} 40^{\prime} \mathrm{S}$. lat., and $33^{\circ} 15^{\prime} \mathrm{E}$. long. Its tributaries are large, and form a considerable stream, which flows south-west to Lake Bangweolo (q.v.).

Chambord, a celebrated chateau in the French department of Loir-et-Cher, stands 12 miles $\mathbf{E}$. of Blois, in the midst of a walled, sandy park of 13,000 acres. Commenced by Francis $I$. in 1526 , it is a huge Renaissance pile, with numberless turrets, chimneys, gables, and cupolas, and with four round towers, each 63 feet in diameter. There are no fewer than 440 rooms. Chambord, the 'Versailles of Touraine,' was a residence of the French kings down to Louis XV., who conferred it on Marshal Saxe; and here in 1670 Molière gave the first representation of his Bourgeois Gentilhomme. Anong its various occupants were Diane de Poitiers, Stanislaus of Poland, and Marshal Berthier, upon whom it was bestowed by Napoleon in 1809 . It was bought from his widow in 1821 for $1,542,000$ francs, and presented to the future Comte de Chambord, who spent large sums on its restoration. He left it to his wife, and, after her, to her nephews, by a will which was more than once disputed, but recognised by the state as valid. See La Question de Chambord, by J. B. C. Amauld (1887).

Chambord, Henri Charles Dieudonné, Compe DE, was born in Paris, 29th September 1820 , seven months after the assassination of his father, the Duc de Berri (q.v.). On the day of his baptism with water brought by Chateaubriand from the Jordan, the 'Child of Miracle' was presented by the Legitimists with the chateau of Chambord; hence in 1844 he dropped the title of Duc de Bordeaux for that by which he was most usually known. When Charles $\mathbf{X}$. abdicated at the July revolution of 1830 , he did so in favour of his little grandson; but the people insisted on the 'citizen king,' and the elder Bourbons were driven into exile. 'They fixed their court successively at Holyrood, Prague, and Görz, where the old king died in 1836, and the young count was trained in clerical and absolutist ideas by his aunt, the Duchesse d'Angoulême, and his tutor, the Duc de Damas. A good, dull, timid soul, whom D'Orsay likened to ' $a$ palace with no room furnished but the chapel,' 'Henry V.' had three times a chance of regaining the crown of his ancestors-in 1848 , 1870 , and 1873 , on which last occasion, three months after Thiers's overthrow, he paid an incognito visit to Versailles. Each time he fooled away his opportunities, always vanishing just when his presence was indispensable, and ever protesting that he would 'never abandon the white flag of Joan of Arc.' A fall from his horse (1841) had lamed him for life; his marriage (1846) with the Princess of Modena (1817-86) brought him no suecessor; and in keeping up a stately mimic court, in stag-hunting from a phaeton, in issuing manifestoes, in visiting innumerable churches, and in much travelling, he passed forty years of blameless inertia. His death, after long suffering, at his castle of Frohsdorf, in Lower Austria, 24th August 1883, was a relief at once to himself and to his adherents. The Comte de Paris (1838-1894) inherited his claims. See Bourbon; and the Comte de Falloux' Mémoires d' un Royaliste (2 vols. Paris, 1888).

Chambre Ardente ('the fiery chamber'), a name given at different times in France to an extraordinary court of justice, probably on account of the severity of the punishments which it awarded, the most common being that of death by fire. In the year 1535, Francis I. established an Inquisitorial Tribunal and a Chambre Ardente. Both were intended for the extirpation of heresy. The former searched out cases of heresy, and instructed the processes; while the latter both pronounced and executed the final judgment. Under Henri II., the activity of the Chambre Ardente received a new impulse. In 1679 Louis XIV. employed \& Chambre Ardente to investigate the numerous reports of poisoning cases which the trial of the Marchioness Brinvilliers (q.v.) caused to be circulated. Many persons of the first rank were examined on suspicion, but no one was executed except the pretended sorcerer, Voisin (1680).

Chambre Introuvable (Fr., "the chamber the like of which is not to be found again ') was the name given to that Chamber of Deputies in France which met after the second return of Louis XVIII. (July 1815), and which, by its fanatical royalty, began to throw the country and society anew into commotion. The name was given to it by the king in his gratitude (though some think even he spoke ironically); but it soon came to be used sarcastically for any ultra-royalist assembly. 
chameleon. See CнамжLео.

Chamfer. In Architecture, an angle which is slightly pared off is said to be chamfered; a large - humfer, es in a wall at the window opening, is cullew a splay. The chamfer is sometimes made slirhtiy concave, in which case it is called a hollow chamfer. ('hamfers, in Gothic architecture, have irmuently oruamenta! terminations of various hinds. The term chamfer is applied to wood. work as well as stone.

C'hamfort, NicoLAs, a famous writer of maxims and aneclotes, was born in Auvergne in 1741. He wis of illegitimate birth, and was educated at one ui the Paris colleges, where he obtained a scholarship. Having distinguished himself in the prize competitions of the Academy, he gained an entrance into the highest literary circles in Paris, and for -1) ve years lived literally 'by his wit, if not by his wits.' At one time Madame Helvétius gave him free lodgings at Sèvres, and he was afterwards mule independent by a pension bestowed on him lis a now forgotten man of letters named Chabanon. it the Revolution he espoused the popular side, and was hailed in the clubs as 'La Rochefoucauld. ' 'hamfort.' After a time, however, certain incisive witticisms - such as, 'Be my brother or I will kill yon, - drew down on him the anger of the Jacobin leaters. Threatened with arrest, he tried to commit suicide, wounded himself horribly, and died after several days' suffering, 13th A pril 1794. His writings include tales, dramas, and éloges on Molière and la Fontaine - all of little or no worth $-\mathrm{a}$ brilliant collection of maxims, and an even more admirable collection of anecdotes. Many of his sayings are stnong the sharpest and bitterest ever pennedthe utterances of a reluctant but sincere cynic, whose insight into human weakness was unusually keen. He has never been excelled as a writer of anecdotes; his work under this head contains a series of portraits in miniature, drawn with the hand of a master, of the Parisian society of his duy. Auguis edited his works (5 vols. 1824-25).

Chamier, Frederic, an English novelist, born in 1796 , entered the navy in 1809 , and retiring in 1833, was promoted to be eaptain in 1856 . He had settled near Waltham Abbey, and turned his rttention to literary pursuits. Marryat's success in depicting sea-life led Chamier to try the same field, in which he was not without success, though in invention and humour he falls short of his model. His best romances, now almost forgotten, are Life of a Sailor (1832), Ben Brace (1836). The Arethusa (1837), Jack Adams (1838), and Tom Bowline (1841). He also wrote a continuation of James's Naval History (1837), and a somewhat prejudiced Reriew of the French Revolution of 1848 (1849). He died list November 1870.

Chamisse, ADELBErT vor, one of the most celelorated of German lyric poets, was born in 1781, at the chateau of Boncourt, in Champagne. The French Revolution driving his parents to settle in I'russia in 1790 , he became in 1796 a page of the ifueen, and two years later entered the Prussian service. But when the campaign of 1806 broke out he returned to France, for though no admirer of Nipoleon, he would not fight against his native land. At this time he was thrown into the circle of Madame de Staèl at Coppet, and there began that study of natural science which he afterwards pursued at Berlin. In 1815-18 he accompanied a liusian exploring expedition round the world as naturalist (see CORAL); and on his return was appointed custodian of the Botanical Garden of Berlin. In 1835 he was elected to the Academy of Science; and, after a hapjy domestic life, he died at Berlin, 21st August 1838, universally loved and ionoured. He wrote several works on natural history, but his fame rests partly on bis poetical proluetions, still mure on his quant und humemos fiction called Peter sichlemihl (1813), the mtory of the man who lost his sliadow, which bas been translated into almost all the langunges of Europe. The char. acter of his poetry is wild and gloomy, and be in fond of rugged and horrible subjects. In his politi. eal songs lie succeeds well in humour and iroms; nor is he deficient in deep and genuine feeling. Indeed, several of his balluds mol romaness ar. masterpieces in their way. His collected works have been edited by Hitzig (6th ed. 1874). See lives by Fulda (1881) and Lentzner (Lond. 1893).

Chamois (Antilope or Rupicapra, Ger. Gemse) a goat-like species or genus of Antelope ( $1 . v$. ). It inhabits the Alps and other high mountains of Central and Southern Europe, such as the Pyrenees,

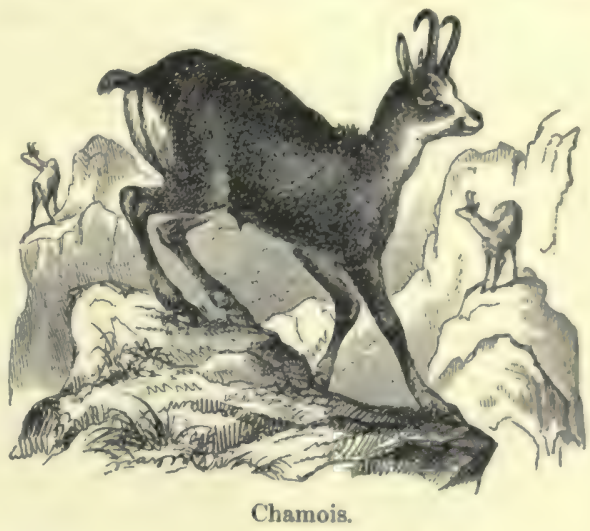

the Carpathians, and the mountains of Greece ; it is also found on some of the Mediterranean islands, and on the Caucasus, Taurus, and other mountains of the west of Asia. In Europe it is now most numerous on the Bavarian and Styrian Alps. The chamois is about the size of a large goat, but the neck is longer in proportion, and the body shorter; the horns on both sexes are seldom more than six or seven inches long, black, rising nearly straight up from the forehead, and so bent back at the tip as to form a hook. A peculiar gland opens at the base of each horn. The summer colour is reddish brown, with a darker dorsal band, and a yellowish ventral surface; the winter colour is a darker brown, but white below. A dark brown band runs from the eye along each cheek. The rest of the head is pale yellow. The short tail is black.

The usual summer-resort of the chamois is in the higher regions of the mountains, not far from the snow-line, and it is often to be seen lying on the snow. In winter it descends to the higher forests. The aromatic and bitter plants of the mountainpastures are its favourite food. Young twigs of rhododendron, willow, juniper, \&c. are greedily devoured. It is-like the ruminants generally very fond of salt, and often licks stones for the saltpetre which forms on them. The chamois is greurarious : flocks of one hundred used sometimes to be seen; but in the Swiss Alps, where the numbers have been much reduced by hunting, the flocks generally consist only of a fow $(4$ to 20$)$ individuals. Old males often live solitarily. The female bears one or rarely two young at a birth, in the month of March or April. The general cry of the chamois is a goat-like bleat.

It is an animal of extraordinary agility, and flocks may often be observed sporting in a remarkable manner among the rocky heights. It can leup over ravines 16 to 18 feet broad; a wall 14 feet high presents no hindrance to it; and it passes readily 
up or down precipices which almost no other quadruped could attempt. The hunting of the chamois is attended with great hardship and much danger. The hunter sometimes goes ont on the adventurous chase alone; but more frequently several go out together, dividing into parties, of which one drives and the other shoots. The scent, sight, and hearing of the chamois are extremely keen. When a flock is feeding, one is always on the watch, and by a sort of whistle, announces apprehended danger. The flesh is highly esteemed. The skin is made into leather, and from it the original shammoy or shammy leather (wash-leather), so much prized for softness and warmth, was obtained, although the name has now become common also to leather prepared from the skins of other animals (see LEATHER and BUFF LEATHER). The horns are often used to adorn alpenstocks. Hairy balls or Concretions (q.v.) found in the stomach used to have a medicinal reputation. When taken young the chamois is easily tamed, and its general disposition is gentle and peaceable. See Keller, Die Gemse (Klagenfurt, 1885 ).

\section{Chamomile. See Camomile.}

Chamouni, or Chamonrx (Lat. Campus munitus, from the shelter of the mountains), a celebrated valley and village among the French Alps, in the department of Upper Savoy, lying 53 miles ESE. of Geneva, at an elevation of about 3400 feet above the level of the sea. The valley, bounded on the $\mathbf{E}$. by the Col de Balme, is about 13 miles long and 2 broad, and is traversed by the Arve. On the north side lies Mont Brévent and the chain of the Aiguilles Rouges, and on the south, the giant group of Mont Blane, from which enormous glaciers glide down, even in summer, almost to the bottom of the valley. The chief of these are the Glacier des Bossons, des Bois, de l'Argentiere, and du Tour ; the Glacier des Bois expands in its upper course into a great mountain-lake of ice called the Mer de Glace. The village of Chamouni owes its origin and its alternative name, Le Prieuré, to the Benedictine convent founded here before 1099. Until 1741, however, the valley was little sought; the region was known, from the savageness of its inhabitants, by the name of Les Montagnes Maudites, or 'accursed mountains.' In that year it was visited by two Englishmen, Pococke and Wyndham, who described it in the Transactions of the Royal Society, but it was only in 1787 that the attention of travellers was effectually called to it by the Genevese naturalist, De Saussure, and others. Since then the number of visitors has gradually increased; now over 15,000 tourists are accommodated annually in the large hotels that have sprung up in the village, where an English chapel was opened in 1860. Grazing and such farming as the elevation allows are carried on, but most of the people are in some fashion dependent on the strangers for their income. Here the best guides are to be found for the neighbouring Alps, and from this point Mont Blane is usually ascended. At the article ALPs there is a view of Chamouni, whose beauties have been celelorated by Byron, Coleridge, Shelley, Wordsworth, Lamartine, and Ruskin. Pop. of village, 600. See E. Whymper's admirable Guide to Chamonix and Mont Blanc (1896).

Champac, or Chu MPAKA (Michelia Champaca), an Indian tree (order Magnoliaceæ) possessing great beauty both of foliage and flowers, and venerated both by Brahmanists and Buddhists. Images of Buddha are made of its wood. Its yellow flowers and their sweet oppressive perfume are much celebrated in the poetry of the Hindus. The timber of this and other species is useful and fragrant, and the bark and root are employed in native medicine.
Champagne, a district and ancient province of France, surrounded by Luxemburg, Lorraine, Burgundy, Ile de France, and Orléanais; now forming the departments of Marne, Haute-Marne, Aube, and Ardennes, and parts of Yonne, Aisne, Seine-et-Marne, and Meuse. It was popularly divided into Upper and Lower Champagne and Brie Champenoise, and was fertile in its western, barren in its eastern part. Its chief towns were Troyes, Bar-sur-Aube, Leon, and Rheims. The province was about 180 miles long by 150 broad, its surface presenting extensive plains with ranges of hills, especially in the north and east.

In ancient times Champagne was known as a part of Gallia Lugdunensis, was subjugated by Cæesar, and afterwards was annexed to the kingdom established by the Franks. After the 11th century it had its own dukes, who were vassals of the French kings. By the marriage of Philip IV. with Joanna, heiress to the kingdom of Navarre, Champagne, and Brie, Champagne in 1284 eame to the French crown, and was incorporated in 1328.

Champagne Wine is the produce of vineyards in the above-mentioned province of Champagne. There are white and red champagnes; the white is either sparkling or still. Sparkling or effervescent (mousseux) champagne is the result of a peculiar treatment during fermentation. In December the wine is racked off, and fined with isinglass, and in March it is bottled and tightly corked. To elear the wine of sediment, the bottles are placed in a sloping position with the necks downward, so that the sediment may be deposited in the necks of the bottles. When this sediment has been poured off, some portion of a liqueur (a solution of sugar-candy in cognae with flavouring essences ) is added to the wine, and every bottle is filled up with bright clarified wine, and securely re-corked. The fermentation being incomplete when the wine is bottled, the carbonic acid gas generated in a confined space exerts pressure on itself, and it thus remains as a liquid in the wine. When this pressure is removed it expands into gas, and thus communicates the sparkling property to champagne. The effervescence of the wine thus prepared bursts many bottles, in some cases 10 per cent.; and in seasons of early and sudden heat, as many as 20 and 25 per cent. have been burst. Still or non-effervescent champagne is first racked off in the March after the vintage. Creaming or slightly effervescent champagne (demimousseux) has more alcohol, but less carbonic acid gas than sparkling champagne.

The best varieties of this wine are produced at Rheims and Epernay, and generally on a chalky soil. Among white champagnes of the first class, the best are those of Sillery, which are of a fine amber hue, dry, spirituous, and possessing a superior bouquet; those of Ay and Mareuil are less spirituous, but are sparkling, with a pleasant bouquet, Other white wines of first class are those of Hautvilliers, Dizy, and Pierry.

The cellars in which the vintages are stored are cut out of the calcareous rock. The fact that the sale of champagne is very extensive and lucrative, has naturally given rise to adulterations. Spurious champagne is readily manufactured by simply charging other light wines with carbonic acid gas. The popular notions about gooseberry champagne have but small foundation, if any. Gooseberryjuice is far more costly than grape-juice, wherever the grape flourishes, and in this country there are no such great gooseberry plantations as would be required for a flourishing champagne industry, which would demand a few hundred tons of fruit per annum. Recently, the German purveyors have succeeded in preparing light wines-such as Rhenish, Main, Neckar, Meissner, and Naumburg 
- very like genuine champagne. And much cham. magne is made on French methods in California. Alingether it is estimated that the French district jroduces about $25,000,000$ bottles, of which nearly $21,(1)(), 000$ are exported ( the export heing five times as great as in 1844). See Vizetelly's monograph on the subject (1882).

Champaign, a eity of Illinois, 128 miles S.WW of Chicago by rail. It has furniture and wagon factories, a female seminary, and the Illi. min Industrial University (1868). Pop. (1890) is:30.

Champaran, a British Indian district in the NiV. corner of Behar, with an area of $3531 \mathrm{sq} . \mathbf{m}$.

Champarty, or CHA MPERTY (a Norman-French worl derived from campi pars = the right of the feulal lord to take part of the produce of land cultivated by his tenants), means in English law a inargain whereby the one party is to assiat the other in recovering property, and is to share in the proreds. All such bargains are illegal, and therefore uull and void. More particularly an agreement to atvance funds, or supply evidence, or professional hasistance, for remuneration contingent on success, Inil proportional to, or to be paid out of property recovered, is illegal; 80 is a purchase by a solicitor from his elient of the subject matter of a pending suit; so is every such purchase, if the real object is only to enable the purchaser to maintain the suit. A man may, however, lawfully sell evidence, and may lawfully purchase an interest in property, though adverse claims exist which make litigation necessary for realising that interest. "The sale of a mere right to sue is bad, the right to complain of "i fraud is not a marketable commodity.' Champarty, as one form of Maintenance (q.v.), was made criminal by various old English statutes, but these are never enforced, and the Criminal Law Commission recommended their repeal. In Scotland there is no law against maintenance and champarty. There is a common-law doctrine against what were in the Roman law called pacta de quota litis-i.e. purchases of litigations by professional men conneeted with the suit, who thus had exceptiona advantages in making such a contract. But this would not probably be held to strike against an agreement by a non-professional person to advance funds for litigation on terms depending on the result, provided the terms were not extortionate or unconscionable. A Scottish act of 1594 prohibits the purchases of pleas by advocates or agents. In both countries a solicitor can lawfully agree to charge nothing except in event of success; and by recent statute, agreements for the division of profits between town and country agents are male legal. Although there are traces of the law of champarty in the United States, the American law resembles that of Scotland more than that of England. Contracts by solicitors for contingent fees, to the extent even of one-half the property in dispute, have been sustained. In general, however, the American law construes professional contracts as merely giving gecurity for the true worth of the services rendered.

Champfleury, the assumed name of JULES FLEURY-HussoN, French author, born at Lnon, 10th September 1821, achieved some distinction as a realistic writer of plays and romances. Works of greater value, however, are those on the history of caricature, of literature, and of art from 1825 to 1840, and his Bibliographie Cramique (1882). He died director of the potteries at Sevres, $7 \mathrm{th}$ December 1889.

Champion (Low Lat. campio, from Low Lat. campus, 'a combat,' whence also A.S. camp, 'a fight'). In the judicial combats of the middle ages, it was allowed to women, children, and aged persons, except in cases of high treason or of parricide, to eppear in the lists by a repre. sentative. Such a hired combatant was called a champion. Those who followed this profes. sion were generally of the lowent class, and were held disreputable (see BATTLE, WAGER of). At a later period, in the age of chivalry, the word champion came to have a more dignified acceptation, and signified a knight who entered the lists on behalf of an injured lady, of a child, or of any one incapable of self-defence (see CHIVALRY). In Eng. land, the crown had its champion, the ('hampion of England, who, mounted on horseback and armed to the teeth, challenged, at every coronation at Westminster, all who should deny the king to be the lawful sovereign. This office is said by Dugdale to have been conferred by William the Conqueror on Robert de Marmion, with the Lincolnshire manor of Serivelsby; and by reason of his tenure of that manor, the championship was claimed under Henry IV. by Thomas Dymoke. Henry Lionel Dymoke, who died in 1875 , was the nineteenth nember of this family who held the office. But the ceremonies of the championship were last exercised at the coronation of George IV. See Notes and Queries (1887) and Lodge's Serivelsby (1893).

Champlain', a beautiful lake separating the states of New York and Vermont, and penetrating, at its north end, about 6 miles into the Dominion of Canada. Lying 91 feet above sea-level, it is 110 miles long, by from 1 to 15 broad, empties itself into the St Lawrence by the Richelieu River, and has communication by canal with the Hudson. The lake, now an important trade channel, was the scene of several incidents of the French and Indian revolutionary wars; and here a British flotilla was defeated by the Americans, 11th September 1814. It was discovered by Champlain in 1609 .

Champlain, SAMUEL DE, French governor of Canada, and founder of Quebec, was born at Brouage in Saintonge in 1567, and in 1603 made his first voyage to Canada. In $1604-7$ he was engaged in exploring the coasts, anc on his third voyage in 1608 he founded Quebec. In 1612 he was appointed lieutenant of Canada (under an honorary governor); and the following years were occupied with attacks on the Iroquois, explorations of the interior, and journeys to France, until 1629, when he had to surrender to an English fleet, and was carried captive to England. Liberated in 1632, he returned to Canada in 1633, and died there in 1635. He published several works, reprinted at Quebec, in 4 vols. 1870.

Champlain Period, the name given by Professor Dana to the period succeeding the glacial, and therefore to some extent equivalent to the postglacial period of English geologists. See PLEIsToCENE OR GLACIAL SYSTEM.

Champollion, JEAx Fraxcors, the founder of modern Egvptology, distinguished from his elder brother as "Champollion the younger," was born December 23, 1791, at Figeac, in the French department of Lot. He was educated at Grenoble, and devoted himself from his boyhood to the study of oriental languages, especially Coptic. In 1807 he went to Paris to pursue these studies, and in 1816 he became professor of History at the Lyceum of Grenoble. He had already pub. lished (1811-14) the first two volumes of a large work entitled L'Egypte sous les Pharaons (3 vols.), in which he reproluced, by means of Coptic docu. ments, the national geography of Egypt, when he was expelled from his chair for his Bonapartist sympathics. Comparison of the monuments with the IISS. led him to the conviction that the three gystems of Egyptian writing, the hieratic, demotic, 
and hieroglyphic, were essentially one; and that the hieroglyphs were not signs for ideas, but for sounds. The first results of his labours were published in De l'beriture hieratique des anciens Egyptiens (1821) and his famous Lettre $a \quad M$. Dacier (1822); and in his Précis du Systeme hieroglyphique (1824; $2 \mathrm{~d}$ ed. 1828) he established the conclusion that the hieroglyphs were partly phonetic or alphabetic characters. The final solution by which he arrived at the whole alphabet of twenty-five letters (see HIEROGLYPHICs) was pronounced by Niebuhr to be the greatest discovery of the century. Champollion was sent by the king on a seientific mission to Italy in 1824-26, and in 1826 was appointed conservator of the Egyptian collections; and about the same time he published his Panthéon Egyptien (1823), with drawings of Egyptian deities from the papyrus-rolls and notes regarding their Egyptian designations, and his Lettres relatives au Musée royal Egyptien de Turin (2 vols. 1824-26). In 1828-30 he accompanied a scientific expedition sent to Egypt by the king of France. On his return to Paris he was made a nember of the Academie des Inseriptions (1830), and a new chair of Egyptology was founded for him in the Collegge de France. He died March 4, 1832. The MSS. which he left unpublished, extending to more than 2000 pages, were bought by the Royal Library at Paris for 50,000 franes. His posthumous works are Lettres écrites d'Égypte et de Nubie (1833; new ed. 1867); Grammaire Lgyptienne, his principal work (3 vols. 1836-41); Monuments de l'Égypte et de la Nubie (5 vols. 1835-45); Dictionnaire Egyptien en ériture hieroglyphique (1842-44); and Monuments de l'Egypte et de la Nubie (1844), the last work being afterwards eontinued and completed under the superintendence of Rougé.

Champollion-Figeac, JEAN JACQUES, an archæologist, was born 5th Oetober 1778 at Figeac, in the department of Lot. After holding at Grenoble the offices of librarian and professor of Greek, he was appointed in 1828 conservator of MSS, in the Royal Library in Paris; but after the February revolition was deposed from office by Carnot. In 1848 he was appointed librarian of the palace of Fontainebleau. Besides the Antiquites de Grenoble (1807) and Recherches sur les patois de France (1809), his chief works include the Annales des Lagides ( 2 vols. 1819 ; supplement, 1821 ), Les Tournois du Roi René (1827-28), and numerous publications of French historical documents. After the death of his younger and more celebrated brother, Champollion-Figeac prepared, with the help of his MSS., L'Egypte ancienne et moderne (1840) and L'écriture démotique égyptienne (1843). Along with his son Aimé he wrote the text to Silvestre's Palocographie universelle (4 vols. 1839 41). He died 9th May 1867.-Armé (1812-94) wrote on the Dukes of Orleans, Francis I., and Les Deux Champollions (1888).

Chance (through the French from Low Lat. cadentia), in its original and strict meaning, may be defined as that which determines the course of events, in the absence of law, ordinary causation, or providence. Strictly speaking, it is an idea which few would now be disposed to admit as corresponding to anything which really exists; the religious mind excluding it as inconsistent with the belief in the divine government, and the philosophical mind rejecting it as inconsistent with a recognition of universal laws of causation. As a word, however, it has always been, and always will be popularly accepted; and its use is correct so far as we overlook, or choose for the moment to throw out of view, the more universal connection of events, and regard them as their emergence, on a superficial view, appears to be determined. It is clear that chance, being only legitimate as an expression in popular parlance, is a term which is much too indefinite to admit of any kind of measurement. What is sometimes ealled the Doctrine of Chances is more properly the Theory of Probabilities, and will be dealt with under the liead of Probabilities. For games of chance, see Gambling.

Chancel (Lat. cancellus, 'a screen'). The chancel, choir, or eastern part of a church was often separated from the nave by a screen of lattice-work, so as to prevent general access thereto, though not to interrupt either sight or sound. As it was in this part of the church that the service was always performed previous to the Reformation, the clergy were held to have a special right to it, in return for which its repairs in general still fall on the impropriator, rector, or vicar, and not on the parish. The chief pew in the chancel belongs to the rector or impropriator, but the disposal of the seats in the church, with this exception, belongs to the ordinary, or, practically, to the churchwardens, to whom the authority of the ordinary is delegated. No monument, moreover, can be set up without the ordinary's consent. And where the freehold of the chancel vests in a lay impropriator, nevertheless the right of possession in it for public worship vests in the minister or churchwardens, so that they cannot be excluded from it, nor be charged with tresspass for making a door into it from the churchyard. The term chancel is usually confined to parish churches which have no aisles around the choir, or chapels behind it or around it; and in this case the chancel and the choir have the same signification. In small churches which have no constructional chancel, the space within the altar rails is sometimes called by this name, but is more strictly styled the 'sanctuary.' But in larger churches there are sometimes chancels at the ends of the side aisles, and this whether the choir has the character of a choir in the larger sense, or of a chancel. See CHURCH.

Chancellor (Lat. cancellarius). It is said that the chief notary or scribe of the Roman emperor was called chancellor, either because he was intrusted with the power of obliterating, cancelling, or crossing out (cancellare, 'to make lattice-work') such expressions in the edicts of the prince as seemed to him to be at variance with the laws, or otherwise erroneous; or (more probably) because he sat intra cancellos, within the lattice-work or railings (cancelli) which were erected to protect the emperor from the crowding of the people when he sat in judgment. Neither the title nor the office of chancellor is at all peculiar to England. The chancellor of France (Chancelier de France) from a very early time was an officer of state of great power and dignity, under whom several other officers, bearing also the title of chancellor, were employed in the administration of justice and in the defence of the public order. The office was abolished at the Revolution; and though it was restored by the Bourbons, many of the functions of the old chancellor were transferred to the minister of justice, and have ever since been held by him.

In most of the other countries of Europe there are officers of state who bear this or analogous titles, though their powers and duties are very various. In medieval Germany the archbishop and elector of Mainz was Arch-chancellor of the Holy Roman empire, and appointed a Vice-chancellor. The chief functionary in the Austrian empire has often been termed chancellor; and on the reconstitution of the German empire, Prince Bismarck was made 'Chancellor of the Empire' (Reichskanzler). 
The Russian minister of Foreign Affrim is somelimes called Vice-chancellor. Besides these statecliancellors, there were officers in many other supucities to whom the title was given. Every lis-hop has his chancellor in the Church of Rome, and there are still chancellors of cathedrals, dicucoses, universities, \&c.

C'lnamellor, LORD. It is usually said that the existence of the office in England, as in the other states of Europe, is to be aseribed to the inlluence which the constitution of the Roman empire had on the constitutions of the modern nations. This influence was exercised in no small measure through the medium of the church, the jrofession of the law being generally exereised by crelesiastics; and it is for this reason, probably, that the bishop and the king are furnished with uffirers bearing the same title, and exercising anilogous functions. Soon after the Nornan Conquest the English chancellor became a judicial ofticer of high rank (see CHANCERY), and a (')nfidential adviser of the sovereign in state atfains, Being charged with the supervision of chatrters and other instruments, he obtained the custody of the great seal. The office of chancellor, or Keeper (q.v.), which in 1576 was declared to be exactly the same, is created without writ or patent, by the mere delivery of the great seal. The chancellor, if $\mathrm{a}$ baron, takes precedence of every temporal lord not a member of the royal family, and of all bishops except the Arehbishop of Canterbury. To slay the chancellor is treason. The chancellor is a privy-councillor hy his office, and prolocutor, or speaker of the House of Lords, by preseription. Though the form in which his tenure of office is terminated is by the resumption of the great seal by the sovereign, the chancellor is now always a cabinet minister, and resigns office with the party to which he is attached. He has the appointment of all justices of the peace throughout the kingdom, but this privilege he exercises generally on the recommendation of the lord-lieutenants. But the most important, and, ss it now seems, somewhat anomalous branch of his patronage, arises out of his having been originally an ecclesiastic. Though the last bishop who held the office was John Williams, Archbishop of York, who was Lord Keeper from 1621 to 1625 , the chancellor still continues to be patron of a large number of crown livings (though in 1863 about 300 were sold to augment the incomes of those sold and those retained), and visitor of all hospitals and colleges of the king's foundation. $A \mathrm{~s}$ representing the paternal character of the sovereign, again, the chancellor is the general protector of all infants, idiots, and lunatics, and has the supervision of all charitable uses in the kinıdom. His jurisdiction 'in lunacy' is committed to him by special delegation from the sovereign. As regards his judicial patronage, the arrangement is, that the chancellor appoints in general all the judges of the superior courts, except the chief-justice, who is nominated by the prime-minister of the day. He also appoints the juilges of the county courts, and various subordinate officers. All these functions the chancellor performs in addition to his extensive duties as a judge in the House of Lords, the Privy-council, the Court of Appeal, and the Chancery Division of the High Court of Justice. Objection has often been taken to the combination of judicial and political offices in the same person, but the proposal to appoint a minister of justice has not yet found favour. The salary of the chancellor is $£ 10,000$ a year, and he has an annuity of $£ 5000$ on retiring from office.

Among the notable Lord Chancellors of England have been Cardinal Wolsey (1515), Sir Thomas
More (1529), Bishop Gardiner (1553) Sir Franein Bacon (1617), Hyde, Earl of Clarendon (1660), Ashley, Earl of Shaftesbury (1672), Lord Jeffrey: (1685), Hardwicke (1737), Thurlow (1778), Kldon (1801, 1807), Enkine (1806), Lyndhunst (1827, 1834, 1841), Brougham (1830), Cranworth (18i2, 1865), Chelmsford (1858, 1866), Campbell (1850), Westbury (1861), Caims (1868, 18j4), Hutherlevy (1868), Selborne (1872, 1880), Halsbury (1885., 1886), Herschell (1886, 1892). See Lord Camphell's Lives of the Chancellors (1845-47).

The office of Chancellor of Scotland, which was analogous to that of England, was abolished at the Union, a keeper of the Great Seal (q.v.) being appointed. The English chancellor is described as Lord High Chancellor of Great Britain and Ire. land; but in Scotland he has searcely any jurisdiction, and in Ireland there is a separate chancellor, whose powers and duties are similar to those of the English chancellor.

ChANCELlor OF A CATHEdRal is an officer who formerly had charge of the chapter library, custody of the common seal, superintendence of the choir practices, and headship of the cathedral schools; sometimes being also visitor of all chureh schools in the diocese. Hence he was often styled Srholusticus or Capischolius (=Caput Schola). These functions are now generally in abeyance.

Chancellor of A Diocese is, as legal adviser to the bishop, an ecclesiastical judge, uniting the functions of vicar-general and official principal, appointed to sssist the bishop in questions of ecelesiastical law, and hold his courts for him. By an act of Henry VIII. it is provided that he may be a layman, whether married or single, provided he be doctor of the civil law, lawfully ereate and made in some university. By the canons of 1603 he must be a bachelor of law, at the least, or a master of arts. There are certain cases, however, in which the bishop must sit in person.

For other Chancellors, see UNIVERsities, ExCHEQUER, LANCASTER (DUCHY OF).

Chancellor, RichARD, a daring English seaman, who seems to have been brought up in the household of the father of Sir Philip Sidney, and was chosen in 1553 as captain of the Boncurenture and 'pilot-general' of Sir Hugh Willoughby's expedition in search of a North-east Passage to India. The ships were parted in a storm off the Lofoden Islands, and Chancellor, after waiting seven days at Vardohus, the rendezvous that had been agreed upon, proceeded alone into the White Sea, and travelled thence overland to the court at Moscow, where he was very hospitably treated, and was able to conclude a treaty giving freedom of trade to English ships. His interesting account of Russia was published in Hakluyt's Navigations. Next spring Chancellor rejoined his ship and returned to England, where his hopeful reports led to the establishment soon after of the Muscory Company. In the summer of 1555 he made a second voyage in the Bona. venture to the White Sea, and was at Moscow once more in the succeeding winter. In July 1556 he set sail on his voyage homewards, but on $10 \mathrm{th}$ November was lost in the wreck of his ship in Aberdour Bay off the Aberdeenshire const.

Chancellorsville, a post-station of Spottsylvania county, Virginia, near the sonth bank of the Rappahannock, 11 miles W. of Fredericksburg. In a desperate battle here, May 2 and 3,1863 , General Lee defeated the Federal forces under Hooker. The Confederates, however, suffered a severe loes in 'Stonewall Jackson,' who was accidentally wounded by his own men. See JACKSON (T.J.)

Chance-medley and Chand-medley aro law expressions, which practically both mean the 
same thing, that a particular homicide was justi fiable because it was done in the hot blood eaused by an unprovoked assault. The phrase has no reference to homicide by accident. See MANSLAUGHTER, SANCTUARY.

Chancery, the office of a chancellor or ambassador; a place in which writs, \&c. are prepared and formally recorded. In England the Chancery was in early times the office in which writs and forms of process were prepared; some of these forms being kept in the Hanaper or hamper, and some in the Petty Bag. When the chancellor became a judicial officer of the first rank, the CoURT OF CHANCERY exercised a very wide jurisdiction. The court could not maintain its hold on criminal cases, or on civil cases in which the common-law courts could do adequate justice; but the equitable jurisdiction of the court was established, after a keen struggle with the common lawyers. The assistance of the chancellor, as 'keeper of the king's conscience,' was invoked in cases where the common law might work injustice. A trustee, for example, was in law the owner of the trust property, but the Court of Chancery, which acted in personam, would compel him to render an account of his trust to the beneficial owner. This power to enforce equitable claims gave the court an administrative jurisdiction which was used for the protection of infants, married women, mortgagors, \&c. The prejudice of the common lawyers against the court was due to the fact that its extensive powers were exercised at the discretion of the chancellor, and not according to settled rules. So late as the time of Charles II., Shaftesbury was thought to be a good chancellor, though he was not a lawyer. A succession of eminent chancellors, from Lord Nottingham to Lord Eldon, developed the rules of equity into a logical system. They did so, it must be admitted, at the expense of unfortunate suitors; and the Court of Chancery became a byword for delay and expense. Some of the evils satirised, and somewhat exaggerated, by Dickens in Bleak House (1853) have been removed by modern legislation.

The judges of the Court of Chancery were the Lord Chancellor, the Master of the Rolls (originally a subordinate officer, but afterwards an independent judge), a Vice-chancellor added in 1813, and two more Vice-chancellors added in 1841, when the equity business of the Court of Exchequer was transferred. Two Lords Justices of Appeal were added in 1851. On the passing of the Judicature Acts the inconvenient and indefensible distinction between courts of equity and law was abolished, and the judges of the Court of Chancery became members of the Court of Appeal, or of the Chancery Division of the High Court of Justice.

Among the officers of the Court of Chancery were the Masters in Chancery, whose office is now abolished, their duties being for the most part assigned to the chief-clerks in the Chancery Division. The office of Accountant-general is also abolished, and Her Majesty's Paymaster-general is charged with the duty of accounting for funds 'in Chancery '-i.e. for cash and stocks standing in the account of any cause or matter before the court. In 1886 there were 39,944 accounts open; the balance of stocks was $£ 71,946,527$; balance of cash, £3,931,054. In 1893 the total funds were $£ 65,481,866$. The dormant and unclaimed Chancery funds are only about $£ 1,000,000$, mostly in very small sums. Under an Act of 1872, unclaimed balances are transferred to the National Debt Commissioners, but the Consolidated Fund is liable in respect of any claim on these balances.

In varions British colonies Courts of Chancery have been established, and the distinction between courts of law and equity has been preserved. But in the colonies and the United States, as in Eng. land, the 'fusion of law and equity' has been: effected by legislation. The anomalies of the old system have been removed; but many of the distinctive doctrines and rules of the Court of Chancery remain. In several of the original thirteen states there are distinct Courts of Chancery, but in most of the United States equity powers have been conferred on the higher law-courts, and the principles of equity are administered therein. By the United States constitution and several Acts of Congress, equity powers commensurate with those of the Court of Chancery in England were conferred on the Federal Courts.

The ChANCERY OFFICE, in Scotland, is an office in the General Register House at Edinburgh, managed by a director, in which all royal charters of novodamus, patents of dignities, gifts of offices, remissions, legitimations, presentations, commissions, and other writs appointed to pass the Great and Quarter Seals, are recorded. Prior to 1874 a great number of royal charters by progress passed through this office; and this is still done with regard to precepts from Chancery in favour of heirs in crown holdings. It is the duty of the director to keep a record of the decrees of service pronounced in favour of heirs by the Sheriff of Chancery, who holds a special court in Edinburgh for considering such petitions, and to send printed indexes of his record to the sheriff-clerks in the various counties. The record kept by the director also includes the decrees of service pronounced in the different sheriff-courts, and of these the director is bound to furnish extracts. See SEAL.

Chancre. See Syphrtis.

Chanda, chief town of a district of India, on the south-west frontier of the Central Provinces, 90 miles S. of Nagpur. Its stone battlemented walls are 5 miles round, and 15 to 20 feet high. Pop. 16,137.

Chandausi, a town of the North-west Provinces of India, 27 miles S. of Moradabad. Pop. 28,111 .

Chanderi, a town of Central India, 105 miles S. of Gwalior. It is now an insignificant place, but its fort and many ruined buildings attest its strength and splendour in former times, when it is said to have contained 14,000 stone houses (not to speak of mosques), and 360 caravanserais.

Chandernagore (properly Chandan-nagar, ' city of sandalwood'), a French eity, with a scanty territory of about $3 \frac{1}{2} \mathrm{sq} . \mathrm{m}$., on the right bank of the Hugli, 22 miles above Calcutta by rail. Established in 1673 , the place for a while rivalled Calcutta; now, through the gradual silting up of the river, it has lost most of its commercial advantages, and has little external trade. It is the seat of a French sub-governor, with a few soldiers, and has in all a population of 25,395 , including some 500 Europeans and Eurasians. The town was bombarded and captured by the English in 1757 , restored in 1763 , twice retaken, and finally restored to the French in 1816.

Chandler, Richard, a learned classical archæologist, was born at Elson, Hants, in 1738, and educated at Winchester and at Queen's and Magdalen colleges, Oxford. His first important work was Marmora Oxoniensia (1763), an elaborate description of the Oxford marbles. He afterwards travelled through Greece and Asia Minor, with Revett, architect, and Pars, a painter, at the expense of the Dilettanti Society, to examine and describe the antiquities. The materials collected were given to the world in the following publications: Ionian Antiquities (1769), Inscriptiones Antiqua (1774), Travels in Asia Minor (1775), and Travels in Greece 
(1776). Chandler was made D.D. in 1773, and nfterwards held preferments in Hants and at Tile. lurst, near Rending, in Berks, where he died 9th Fuloruary 1810 .

Chandler, SAMUEL, an English Nonconformist divine, born at Hungerford in 1693, became ninister of a Presbyterian church at Peckham, and preached t the Old Jewry from 1726 until his death in 1,iti. He was an industrious writer, and published especially a large number of works relating (1) the deist controversy and to catholicism.

Chander, a town in the province of Bombay, (1) miles NE. of Nasik. Its fort, commanding an importunt pass on the route between Khandesh ant Bombay, orowns a hill 3994 feet high. It iurrendered to the British in 1804, and was finally cerled by Holkar in 1818. Pop. 4892.

Chandos, a great English family, descended frum a follower of William the Conqueror, the last representative in the direct male line being Sir Jolun Chandos (died 1428), whose sister married one Giles Brydges. Their descendant, Sir John Brydges, was lieutenant of the Tower under Queen Miry, and was created Baron Chandos in 1554. Janes Brydges (1673-1744), eighth Lord Chandos, sat in parliament for Hereford from 1698 to 1714 , and was created Duke of Chandos in 1719. The lucrative post of paymaster of the forces abroad (170712 ) supplied means for building a palace at Canons, near Edyware, which cost $£ 200,000$, but was torn down at the duke's death. Here Handel lived two years, and produced 'Esther.' In 1796 the title passed by marriage to the Grenvilles, till 1889 the Dukes of Buckingham and Chandos. See Memoir of first Duke by J. R. Robinson ( 1893).

Chandpur, a town of British India, in the North-west Provinces, 19 miles $\mathrm{S}$. of Bijnaur.

\section{Pop. 11,182.}

Chandragupta. See SANDROCoTTUS.

Changarnier, Nicolas ANne Théodule, a French general, born at Autun in 1798, was educated at Saint-Cyr, and went in 1830 to Algeria, where for eighteen years he saw all the active service there was to be seen. On the proclamation of the Republic in 1848 he acted as provisional governor-general of Algeria, but returned to Paris to take command of the garrisons of Paris and of the National Guard. He did much to check the outbreaks of the anarchist party during 1849. In the Legislative Assembly he held a sort of neutral position between the Orleanists and the Legitimists, whilst opposing the Bonapartist party. At the coup d'état in December 1851, after being imprisoned in Ham, he went into exile till the Franco. Prussian war, when he offered his services to Napoleon III. He was in Metz with Bazaine, and, on its capitulation, retired to Brussels. He returned to France in 1871, entered the Assembly, and assisted M. Thiers in reorganising the army. He lied at Versailles, February 14, 1877.

Chang-Chow, a city of China, in the province of Fo-kien, 28 miles W. by S. of Amoy. Pop. estimated at $1,000,000$.

Chang-Chow, a city of China, in the province of Kiang-su, about 50 miles $\mathrm{E}$. by $\mathrm{S}$. of Nanking. l'op. 360,000 .

Changeling. It was at one time a common belief that infants were sometimes taken from their rradles by fairies, who left instead their own weakly and starveling elves. The children so left were called changelings, and were marked by their peevishness, and their backwardness in learning to walk and speak. As it was supposed that the fairies and no power to change chiflren who had been thristened, infants were carefully watched until much time as that ceremony had been performed.
This superstition is allucled to by Shakespeare, Spenser, and other poets, and is an essential part of the doctrine of fairy-lore elmost everywhere. See Sikes's British Goblins (1879).

Chang-Sha, a city of China, capital of the province of Hu-nan, on the Heng-kiang, a tribu. tary of the Yang-tae. Pop. 300,000.

Chank-shell ( $T$ sjanki ), the popular name of the shell of several species of Turbinella, a genum of (Prosobranchiate) Gasteropod molluscs, natives

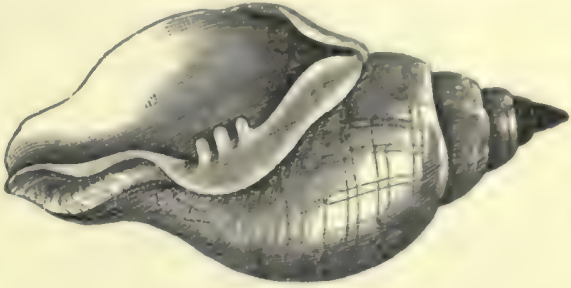

Chank-shell.

of the East Indian seas. These shells (especially T. rapa and T. pyrum) are obtained chiefly on the coasts of the south of India and Ceylon, and form a considerable article of trade to Calcutta. They are much used as ornaments by Hindu women. A chank-shell opening to the right is rare, and is highly prized in Calcutta, so that a price of $\mathbf{f 5 0}$, or even $£ 100$, is sometimes paid for one.

Channel, The Engush ( La Manche, 'Sleeve,' of the French, and the Mare Britannicum of the Romans), is the narrow sea which, since the glacial period, separates England and France. On the east, it joins the North Sea at the Strait of Dover, where it is narrowest, being only 21 miles wide from. Dover to Cape Gris-Nez. From this strait it runs west-south-west for 280 miles, and joins the Atlantic Ocean at the Chops, with a breadth of 100 miles between the Scilly Isles and Ushant Isle. With an average breadth of 70 miles, it is 90 miles wide from Brighton to Havre; 60 miles from Portland Bill to Cape La Hague; 140 miles-its greatest breadth - from Sidmouth to St Malo; and 100 to 110 miles west of the latter line. It occupies 23,900 square geographical miles, and contains the Channel Isles, Ushant Isle, Isle of Wight, and many islets and rocks, especially off the coast of Brittany. It is shallowest at the Strait of Dover, where a chalk ridge at the depth of twelve to thirty fathoms joins England and France. West of this, the average depth of the central portion is thirty fathoms, with hollows from forty to sixty-two fathoms deep. The English coast-line of the Channel is 390 miles long, and the French eonst-line is 570 miles long. Westerly winds prevail, and the current, though imperceptible, is always from west to east. The English Channel abounds in fish, of which the chief are pilchard, mackerel, and oysters. See CHANNEL TUNNEL.

Channel Islands, THE, a group of amall islands off the NW coast of France, which formed part of the old duchy of Normandy, and has remained subject to the British crown. The nearest points are about twelve miles from the French cosst. The principal islands are four in number - Jersey, Alderney, Sark, and Guerneey $\left(\mathbf{q}, \mathbf{v}_{\circ}\right)$; amongst the others being the Casquets, Burhou, Brecphou, Jethou, Herm, the Minquiers, and the Chausseys. The total area is $75 \mathrm{sq} . \mathrm{m}$; ; and the total population has increased slightly, from 90,739 in 1851 to 92,272 in 1891 . Originally a portion of the Continent, they were thinly neoplert by the race - probably neolithic-who raised the eromlechs and other monuments of unhewn stone which are com. 
mon to Brittany and the islands. This population, which came to be represented by what may be termed the Celtiberian nationality, was gradually isolated by the action of the tides and maritime currents. The Christian religion was introduced into the islands by missionaries from Ireland and from Brittany; and the Gallo-Roman hierarchy was centred at Dol. There is some evidence

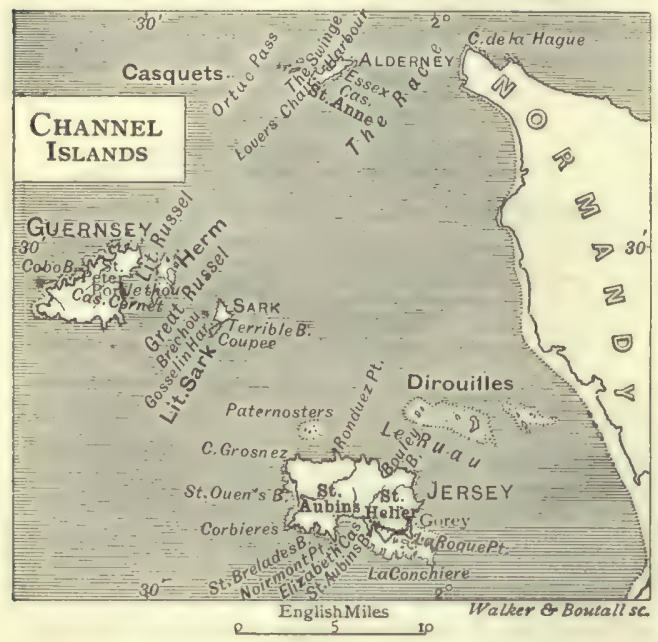

of a partial occupation of the islands by Saxon and Danish sea-rovers. Guernsey is named in the Edda, and arms of Viking character have been dug up there. The islands were probably used as depôts in the conquest of Neustria by the Northmen. Some time elapsed after that event, during which they continued subject to Brittany, but in the early part of the loth century A.D. the Cotentin was added to the duchy of Normandy, and the islands followed in the annexation. The institutions then introduced were those already established on the mainland of Normandy - derived from the Frankish legal system as it existed when the duchy was first separated from the Frank empire by the treaty of St-Clair-sur-Epte (Stubbs's Const. Hist. i. \& 92). The feudal system, however, was only partially introduced. The parishes did not become manors -as happened in England after the Conquest-nor did the Norman seigneurs make a general practice of residing in the islands. They drew rents as absentee landlords from the allodial proprietors who, willingly or otherwise, accepted their protection. But these did not yield military service; and the island militia, when formed, adopted and preserved, till comparatively recent times, a parochial organisation. The 12th century is the beginning of the authentic history of these singular little communities, and of the ecclesiastic organisation already transferred from the see of Dol to that of Coutances. When Philip Augustus declared the duchy of Normandy forfeit on the ground of the alleged contumacy, as a vassal, of John Lackland, he also pronounced the confiscation of the fiefs of those seigneurs who might adhere to John; some of these then settled in Jersey, where they formed the chief notables and members of such local government as might be in existence. John confirmed and strengthened the privileges of this body, and appointed coroners sworn to watch over the judicial interests of the crown. By degrees the seigneurs ceased to attend the sittings of the states, where the rural population was represented by the constables or mayors of the parishes or communes : these, together with the rectors, became associated with the coroners, or ' jurats,' as they came to be called ; and the whole assembly was presided over by a bailiff, or lieutenantgovernor appointed by the crown. There was also a lord-lieutenant, comes, or governor, but he.was often an absentee. In the process of time this latter post became chiefly titular; the office of lieutenant-governor was separated from that of bailiff, though the two were oceasionally held by the same person, and a regular system of judicial and executive administration came into action. From the time of John to that of Henry VI., many attempts were made by France to conquer the islands. Guernsey was held by the French for some years during the 14th century, though finally reconquered by the English with help from Jersey. In 1461 Jersey itself was conquered, and was held by a French governor for about six years, being finally liberated early in the reign of Edward IV. by Sir R. Harleston. Henry VII. carried his repression of the aristocracy into the islands, where he curtailed the feudal jurisdictions and did some. thing for the popularisation of the militia. The Reformation took early and deep root in the Channel Islands, aided by a considerable immigration of exiled Huguenots from the mainland; but the Anglican ritual was not introduced without difficulty. For most of the time the islands continued subject to the spiritual sway of the Bishop of Coutances; but in 1568 Elizabeth attached them to the diocese of Winchester. Other effects of Elizabeth's reign are the foundation of the college (grammar-school) of St Peter Port, in Guernsey, the grant of Sark to the Carterets of Jersey, and the improvement of the Castle of St Helier, in Jersey, which, like the Guernsey 'College,' still bears the name of the virgin queen.

During the reign of Charles I. Guernsey sided for the most part with the English parliament, Jersey with the crown. In the former island, however, Castle Cornet, which commands the harbour, held out for Charles, and was not reduced until after Jersey had been conquered. This took place in 1651. Under the Commonwealth the Channel Islands continued to enjoy their old privileges, being specially excluded from the 'Instrument of Government,' and from the operation of the excise, because not governed by our laws, but by municipal institutions of their own (Burton's Diary).

In the reign of Charles II. the Channel Islands were once more threatened by France, and the militia was improved and formed into regiments. The total population of the Channel Islands was then about 25,000 ; and the chief towns began to increase in importance. The reign of William III. witnessed the famous victory of the British navy at Cape La Hogue, largely due to information conveyed to the admiral by a gentleman of Guernsey. The privilege of neutrality was taken from the inhabitants - to whom it had ceased to be useful-and they entered upon a course of priva. teering, which made them, in the words of Burke, ' one of the naval powers of the world.'

In 1781, after the French had espoused the cause of the revolted British colonies in America, a semiofficial landing took place in Jersey, headed by an adventurer named Macquart, styling himself Baron de Rullecourt. His defeat by Major Pierson, who fell in the engagement, has been rendered famous by Copley's picture in the National Gallery. Since then the chief event has been in Jersey the introduction of elected deputies into the legislature (1856). In the reign of William IV. the militia of the Channel Islands was declared 'Royal.' Queen Victoria visited them in 1849 .

The present constitution of the islands is a development of the ancient institutions, slowly modified to meet changes in surrounding circum- 

munces. The people, especially in Guerusey and
Jursey, odhere to their old speech, a dialect of the unient Langue d'oil, which was once a literary lunguage. Its best-known monument is the Roman d. Rou of Wace, a native of Jersey, who wrote in the 12th contury. In our own days it has been revived by the late Georges Métivier, who has In+1 called the 'Guernsey Burns,' The late Sir livinert Marett was also the author of many poems written in the Jersey form of the language. The innis of the local law is the Contumier de Normandir, which is prima facie evidence of the common hw. Besides this, the local states enact statutes of two kinds - their bylaws (ealled 'ordonnances'), having force for three vears without roval assent, aul irganic statutes, which must be sanctioned by the erown. The French language, in its modern shitue, is the official language of the states and of the law-courts; and a French service is held in the purish churches.

The administration, generally speaking, is of the usual two sorts, the executive and the judicial. The principal officer is the general commanding the troops in each bailiwick, of which Jersey is ono, and Guernsey, with its dependeneies Sark and Allerney, the other. He is called lieutenantguvernor, and is appointed in that capacity for five years. The chief civil officer is the bailiff, who presides in the executive and legislative asremblies, represented when absent by a lieu. temant-bailiff. In judicial matters the bailiff is also the chief, the superior courts being formed by a yuorum of the jurats. In matters of legislation the states are constituted in Jersey of the twelve jurats, twelve rectors, twelve constables, and fourteen deputies; but in Guernsey almost all power has been retained by the royal court. The other crown officers are the attorney-general, the solicitor-general, and the viscount or prévot, who have s right of sitting in the states, but not of voting.

The Channel Islands, as already mentioned, are attrached to the diocese of Winchester, but each bailiwick has its own dean. The livings are in the gift of the crown, but are of small value. The administration is, to a great extent, gratuitous ; such offices as are not so being paid chiefly ont of the local revenues of the crown. These islands have compulsory military service within their own limits - abont one-tenth of the population being in the ranks or the reserve of the militia. Their immunities have been fully and frequently recognised, and much loyalty to England is consequently felt. The industry, thrift, and prosperity of the inhabitants have been testified to by recent observers. Their holdings are small, bnt the agricultural population consists chiefly of yeomen-proprietors who labour with their own hands. The towns are busy and proulous, and the houses, both there and on the farms, are large, substantial, and well kept. The taxation is trifling, the customs duties being very liyht. Living is very cheap. Communication with the ports of the south of England is regular and frequent.

Geology.-Most of the islands are composed of primary or granitic rocks. Alderney is a mass of syenite, with hornblende, porphyry, and oceasional sindstone. The structure of Guernsey is hard venite to the north, and gneiss to the south. The renlogy of Jersey is more varied, presenting a mixture of metamorphic rocks, conglomerstes, and sandstones, with syenites and quartzites. Shale and blown sand are also prevalent. Sark is composed of very hard syenite, with veins of greenstone and felspar. Granite is quarried from all the islands, especially from Guernsey, Herm, and Mont Mado in Jersey, both for home use and for exportation.

The scenery is exquisitely varied and beautiful; probably in no other area of mimilar mize could be found such a combination of envage rocks end pleasing landscapes.

The climute is agreenble and suitable to invalids. The prevailing winds are from north to north. west. The mean annual rainfall is 35 inches in Guernsey ; but the climate is not over moist, the soil being porous, and evaporation rapid. The mean annual temperature of Jersey is $50.8^{\circ}$; of Guernsey, $50.5^{\circ}$, or about $2^{\circ}$ warmer than Greenwich. The range of temperature is very moderate; but the climate of Guernsey is rather more equable than that of Jensey. August is the hottest month; February the coldest. Frost and snow are rare. The autumns are very beautiful and a second summer, called the Petit Ete de Saint Martin, generally sets in about the 10 th of Oetober, and lasts till the middle of December. Flowering plants and shrubs are about a fortnight earlier in the spring than in England. The sunshine averages nearly six hours a day throughout the year.

The produce of the islands is principally agrical. tural ; but horticulture and floriculture are auccess. fully followed-the latter especially in Guernsey. The soil is generally light, deep, and fertile. The system of cultivation is very primitive. The principal manure is seaweed, which is gathered in vast quantities from the shores at certain seasons under strict regulations. Its annual value to Guernsey alone is estimated at $£ 30,000$. A great quantity is burned for the manufacture of kelp and iodine.

The land is held in small parcels ranging from five to twenty English acres. The principal crops are potatoes, hay, wheat, turnips, mangel-wurzel, parsnips, and earrots. The Channel Islands are famous for excellent breeds of horned cattle, usually known as 'Alderneys," though each island has its own speciality (see CATTLE). The other main articles of exportation are granite, fruit, and early potatoes.

There are no good recent books on the Channel Islands. Physical phenomena will be found treated of by Professor Ansted in The Channel Islands (4th ed. 1896). Useful historical information will be found in Lo Quesne's Constitutional History of Jersey (1856), and Tupper's History of Guernsey (1876). See the separate articles on ALDERNEY, JRRgEY, GUERNSEY, and SARK.

Channel Tunnel. The proposed tunnel under the narrow channel dividing England and France, which countries in very early geological times were united, would be 23 miles long, includ. ing land-approaches. It would be made entirely through and within the area of the 'old gray chalk," or cruic de Rouen, as designated by French geologists. This bed of chalk extends from shore to shore. It consists of a mixture of 65 per cent. of chalk and 35 per cent. of clay, aud is therefore impervious to water; though the experimental works have shown cracks here and there which exude for a time a fresh or brackish water, apuarently imprisoned for ages in these small fissures. While the experimental works have been suspended most of these, fissures have run themselves dry. The French Tunnel Company, who possess a concession for making a tunnel to the middle of the Channel, and the English Tunnel Company, associated under 'limited liability, ' have made many thousand soundings and experiments, and consider it proved that the 'gray chalk' is not only in the same position and of the same thickness and consistency on each side of the Channel, but that no erosion or fault interfering with continuity exists as between the two coasts.

The experimental works, alreudy executed by a headway of 7 feet diameter on the English side, have been extended by the using of a 'boring machine, from the foot of Shakespeare's Cliff, near Dover, 
for a distance of 2200 yards under the sea. The similar work on the French side seaward, from Sangatte, near Calais, is of about the same length. Thus, about a tenth of the whole distance has been successfully experimented; and the opinion

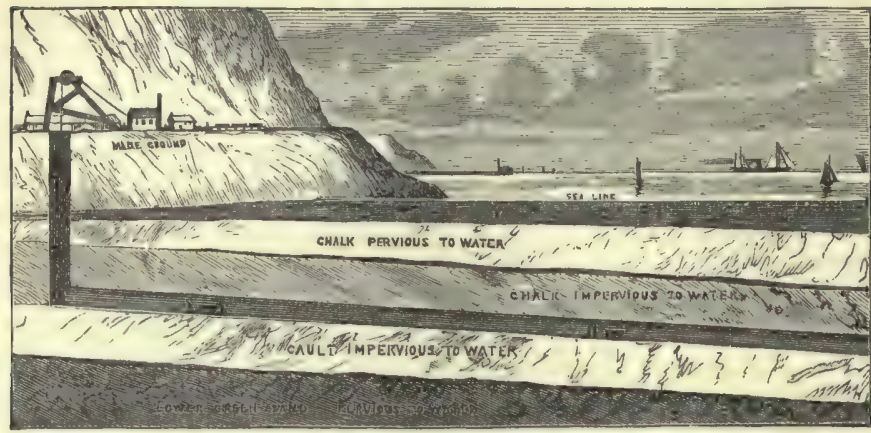

Section of the Bed of the English Channel, showing the proposed tunnel.

of the engineers engaged is that the work presents exceptionally favourable features for cheap and rapid accomplishment. The original estimate, before experiment showed the way through this favourable stratum of 'gray chalk,' was about $£ 10,000,000$; now that estimate is only $£ 4,000,000$. The proposal is to have two single-line tunnelswhich can be multiplied to any extent side by side as traffic might demand-one tunnel ventilating the other, and to work the lines by engines which have been successfully designed and worked experimentally, charged with highly compressed air. In the construction hardly any pumping and no 'timbering' would be required. The machine which bores takes up any modicum of water with the debris it excavates; and every turn of it gives out a portion of the air, which, at a pressure of about $25 \mathrm{lb}$. to the inch, is its motive force (see the article BORING).

The instruction to the engineers by Sir Edward Watkin, the chairman of the English Tunnel Company, to "find the "gray chalk" at its outerop, and never leave it,' would seem to have reduced a work which at one time appeared all but impracticable to the utmost simplicity and ease of eompletion. The scheme for a railway tunnel was discussed in 1867 and succeeding years. In 1876 a convention for carrying it out was concluded between the British and French. governments, and in the same year boring was begun on the French side; but the excavations on the English side were stopped by order of the British government, mainly for military reasons.

Amongst the supporters of such a submarine means of intercourse between England and France have been the late Prince Consort, Mr Cobden, the late and present Lords Derby, the late Lords Beaconsfield and Clarendon, and Mr Gladstone.

The engineers whose names have been associated with various schemes for a Channel Tunnel have been those of Thomè de Gamond and Raoul-duval in France ; and William Low, Frederick Bramwell, Francis Brady, John Hawkshaw, and Brunlees in England.

The experiments near Dover have led to the belief that there is a coal-bed under the Channel. The English Channel Tunnel Company had in 1888 already bored to a depth of 950 . feet, and proposed going down to 12,000 feet with the view of finding this mineral.

Channing, William Ellery, a great American preacher and writer, was born 7 th April 1780, at Newport, Rhode Island. He graduated at
Harvard in 1798, and in 1803 was ordained minister of a Congregational church in Boston, where his sermons soon became famous for their 'fervour, solemnity, and beauty.' Though never a Trinitarian, at first he had Calvinistic leanings, but gradually drifted towards what is now known as Unitarianism, although the name itself was repugnant to him, and he would gladly have seen liberal theology growing naturally outwards from within the ehurch herself. His famous sermon, preached at the ordination of the Rev. Jared Sparks in 1819, was a fearless and plain definition of the Unitarian position. It involved him in con. troversy, a thing which he naturally loathed. To the end of his life he preserved a devoutly Christian heart, shrinking with the delicate instinct of a pious nature from everything cold, one-sided, and dogmatic, whether Unitarian or Trinitarian. As late as 1841 he wrote, 'I am little of a Unitarian, have little sympathy with the system of Priestley and Belsham, and stand aloof from all but those who strive and pray for clearer light.' He had sympathy for social and political as well as purely religious progress, advocated temperance and edu. cation, and denounced war and slavery with more than his accustomed eloquence. In 1821 he received the title of D.D. from Harvard University, and next year he visited Europe, and made the aequaintance of several great English authors, such as Wordsworth and Colerislge, both of whom were strongly impressed in his favour. Coleridge said of him, "He has the love of wisdom and the wisdom of love.' Among his most popular works were his Essay on National Literature, Remarks on the Character and Writings of John Milton, the Character and Writings of Fenelon, his essay on Negro Slavery, and that on Self-culture. Besides these, he wrote a variety of other essays and treatises, all characterised by vigour, eloquence, pure taste, and a lofty tone of moral earnestness. He died October 2, 1842, at Bennington, Vermont. His works were collected before his death in 5 vols. (Boston, 1841), to which a sixth volume was afterwards added. The American Unitarian Association (Boston) has reprinted the whole in a single cheap volume. An interesting memoir of him has been published by his nephew, William Henry Channing (3 vols. Boston, 1848; new ed. 1880). There is also a short Life by Frothingham (1887).

Chansons de Gestes, long narrative poems, dealing with warfare and adventure, which were popular in France during the middle ages. Gestes, from the Latin gesta, signified, first, the deeds of a hero, and secondly, the account of these deeds; the family to which the hero belonged being spoken of as gens de geste. One of these poems, and that the greatest of all, was composed in the 11th century-namely, the Chanson de Roland, which is treated of in the article RoLAND. Most of the others were produced in the 12th and 13th centuries, only a few poems to which the name is strictly applicable having been written after the year 1300 A.D. They were mainly the work of trouveres, and were carried by wandering minstrels, jongleurs and jongleresses, from castle to castle, and from town to town. They are distinguished from the later Arthurian romances and from the Romans d'Aventures both by their matter and their form. Their subjects are invariably taken from French history, or from what passed as such, and they are written in verses of ten or 
twelve syllables, arranged in laisses, or stanzas of irregular length, throughout each of which the sume rhyme or assonance is repeated. In his introIuetion to the Song of Roland, M. Génin points oat that it is the decnsyllabic verse of the Chananss and not the Alexandrine (a form introduced in the 13th century) which is the true epic verse in French literature. A large number of these prems celebrate the exploits of the peers of Charle. inagne, and form what is termed the Carlovingian "vcle, which includes the Song of Roland. But while the anthor of that poem depiets Charlemagne us on the whole a worthy and venerated sovereign, the aim of the later writers is to exalt the vassal molles at the expense of the emperor, who is in. variably presented in an odious or ridiculous light. 'The great emperor, 'says M. Géruzez, 'pays for the misdeeds of his feeble successors; the monarchy of which he remains the representative has been clegraded; consequently he is degraded along with it, to the profit of the feudal hero who is opposed to him.' The prineipal poems of the Carlovingian cycle (setting aside the Song of Roland) are Ogier 1. Danois, Renaut de Montauban, Raoul de Cambrai, Huon de Bordenux, Les Saisnes, Doon de Mryence, Gérard de Viane, and Hugues Capet. Ogier is a typical chanson containing more than 13,000 lines, written by Raimbert of Paris in the first half of the 12 th century. It tells how the vassal noble Ogier, after vainly seeking reparation for the death of his son, who has been slain by a son of Charlemagne, is pursued by the emperor into Italy and captured after a heroic resistance; how, saved from death by the intervention of Archbishop Turpin, he lives in concealment until the Saracens invade France, and the emperor is forced to implore his aid; how he yields at last to repented entreaties, frees the land from the heathen, marries a princess, and lives happily to the end of his days, The style of the poem is clear and vigorous, the characters stand out vividly, the narrative interest is considerable, and the hero rivets the sympathy of the reader. The Voyage du Charlemagne a Constantinople, which belongs to the same cycle, offers a strong contrast to Ogier. It is a mock-heroic piece, full of broad and extravagant pleasantries, and is rather a long fabliau than a true Chanson de Gestes. Among the other chansons which have come to light, the most remarkable are Garin le Loherain (ascribed to Jean de Flagy), which takes us back to the times of Charles Martel and Pepin, and describes the feud between the Counts of Metz and the Counts of Boulogne; Amis et Amiles, and its sequel Jourdains de Blaivies; Berte aus grans Pies, one of the bras; Aliscans, which relates the wars of William of Orange with the Saracens; and Antioche, which gives a singularly animated account of the siege of Antioch by the crusaders, one of whom is sup. posed to have written the original version of the poem. The last forms one of the series known as te Chevalier au Cygne, which is concluded with Bendouin de Sebourc.

The Chansons de Gestes are not, strictly speaking, epics, though they are frequently deseribed is such. They are rather the material out of which a genuine epic, such as the Iliad or the Nibelungenlied, might have been wrought had a great poet appeared to extract the gold from the Aross and mould - a work of art out of this rich mass of national legend. There has been a natural tendency to overestimate their worth on the part of those by whom they have been exhumed and edited. Their literary merit, however, is incontestable, and their historical interest is very great. They faithfully reflect the beliefs and customs of the ages in which they were written; they abound in spirited battle-pieces, and contain not a few panksyros marked by deep and simple pathos. Their plots are somewhat monotonously alike. The strength of their writer does not lie in invention, but in fresh and vivid and sometimes (as in the picture of the sack of the abbey in Raoul de Cambrai) terribly realistic descriptiona. Their verse is by no means unmelodious, and their style is rich in picturesque and poetical epithets.

After lying in negleet for centuries, the Chansons de Gestes have for the last fifty years been assiduously studied and brought into notice by a band of French and German scholars. Some fifty of them are now in print, a numler of these laving been edited by the late M. Paulin Paris, a scholar who did more than any one else to promote the study of this department of literature.

See Léon Gautiers Les Epoptes Françaises (2d ed. 1878); the Histoire Poetique de Charlemagne, by G. Paris (1866); C. d'Héricanlt's Essai sur l'Origine de $T E$ popée Francaise (Frankfort, 1860); Génin's introduction to the Chanoon de Roland (1850); the series, Les Anciens Poëtes de la France, which MM. Guessard and Michelant began to issue in 1858; and Fauriel's Epopée Chevaleresque au Moyen Age.

Chant, in Music, is the name applied to the short tunes used in the English Church since the Reformation for the psalms and, less properly, the canticles. The adaptation of the form to the strueture of the psalms is obvious. Its distinguishing point is that each section is composed of a reciting note of indefinite length, according to the number of words sung to it, followed by a few notes in regular time, called the Mediation or Termination. The tunes were originally derived, as the name indicates, from the Canto Fermo, or Plain Song of the Koman Church, also called Gregorian Tones. These Gregorian tones were preceded by a still earlier form, the Ambrosian Chant, which was the first attempt to systematise the traditional music of the Christian ehureh, carried out by Ambrose, Bishop of Milan, in the 4th century. Of this, next to nothing is now known, the statements of musical historians being founded on slender authority, and curiously at variance. If any fragments still remain in the services of the Roman Clureh, they cannot he distinguished from the later Gregorian music (see Plain-song, Intoning). There has been a revival in the present day of the old Gregorian chants, which are all 'single,' that is, composed of only two sections, and adapted to a single verse, and have the additional feature of an intro. ductory 'intonation' of two notes before the first reciting note; but many consider these of mainly antiquarian interest. The double chant, adapted to a couple of verses, and hence more suitable for antiphonal singing, dates from the time of the Restoration; and in later days there have been added quadruple chants. The repertory has been enriched by almost every English eomposer of the last three centuries, famous or obscure. The objectionable 'florid' style has now happily gone out. On the subject of 'pointing' the psalms-i.e. indicating the division of the verses to accord with the chant, there is great diversity of usage, and no authoritative system. The best treatment of the subject, theoretic and practical, will be found in Helmore's Psalter Noted and Plain Song, the Cathedral Psalter, and Ouseley and Monk's and Oakeley's Psalters. Chanting is gaining ground in the Presbyterian and other churches.

Chantenay, a western suburb of Nantes (q. v.).

Chantibun, or Chantabon, an important commercial port of Siam, near the mouth of the Chantibun River, in the Gulf of Siam, occupied by the French as security for the fulfilment of the treaty of 1893. Pop. 30,000 . 
Chantilly, a town in the French department of Oise, 26 miles NNE. of Paris. One of the most heautiful places in the vicinity of the capital, and the headquarters of French horse-racing, it attracts immense numbers of visitors. Apart from its natural beauty, it is interesting as the place where the Great Condé spent the last twenty years of his life in the society of Molière, Boileau, Racine, La Fontaine, and Bossuet, and where his cook killed himself, on the occasion of a royal visit, because the fish failed to arrive. His magnificent chateau was pulled down at the Revolution of 1793 , but was rebuilt by the Duc d'Aumale, who bought back the estate in 1872 , and who in 1886 presented it to the French Institute, with its priceless art collections, its celebrated stables for 250 horses, and its 16th-century 'Petit Chatean,' one of the finest specimens of Renaissance architecture in France. The grounds, park, and forest, 6050 acres in area, are of great beauty-truly a princely gift, its value nearly $£ 2,000,000$. The manufacture of silk pillow-lace, or blonde, so famous in the 18th century, is all but extinet. Pop. (1891) 4022.

Chantrey, Sir Francis LegatT, an eminent English sculptor, was born at Jordanthorpe, in Derbyshire, on 7th April 1'781 (not 1782, as has been generally said). His father, who was a carpenter, and rented a small farm, died when Chantrey was only twelve years of age, leaving the mother in narrow circumstances. The boy was in 1797 apprenticed for seven years to a carver and gilder in Sheffield called Ramsay. It was in these humble circumstances that Chantrey acquired the rudiments of art. He began to model in clay and to draw portraits and landscapes in pencil. His efforts were encouraged by J. R. Smith, the mezzotint engraver : he acquired some local celebrity as a portrait painter, and in 1802 was enabled to cancel his indentures with Ramsay. Soon afterwards he came to London, and studied for a short time in the schools of the Royal Academy, employing himself also in woodcarving. In 1805 he received his first commission for a marble bust, that of the Rev. J. Wilkinson, for the parish church, Sheffield. This was followed by commissions for colossal busts of admirals for Greenwich Hospital; and having in 1807 married a cousin with some property, his early struggles were over. In 1808 he was suecessful in the competition for the statue of George III. for Guildhall, and during the rest of his life he was largely employed on works of portraiture. The features of the most celebrated men of his time were transcribed by his chisel, and it was in this class of severely realistic work that he most uniformly excelled; though probably his most widely known statue-group is that of the 'Sleeping Children' in Lichfield Cathedral, a subject-its design has been attributed, in error, to Flaxman-in which the real and the ideal seem to meet and blend. His busts include those of James Watt, Wordsworth, and the two very celebrated heads of Sir W. Scott, which he executed in 1820 and 1828. Among his statues are Sir Joseph Banks (1827), Sir John Malcolm (1837), Francis Horner, William Pitt, George IV., and the Duke of Wellington; while his head of Satan and his 'Plenty' designs for Sheaf House, Sheffield, and his 'Penelope" at Woburn, are examples of his rare treatment of ideal and imaginative subjects. In 1816 Chantrey was elected an Associate, in 1818 a Member of the Royal Academy; and in 1835 he was knighted by William IV. Allan Cunningham, the poet, was his secretary and superintendent of works from 1814 till the date of Chantrey's death, 25th November 1841. The sculptor acquired by the practice of his art a fortune of about $£ 150,000$; and bequeathed to the Royal Academy, with liferent to his widow, who died in 1875 , \& sum yielding about $£ 3000$ annually, of which the president was to receive $£ 300$ and the secretary $£ 50$, and the rest was to be devoted to the purchase of works of art executed in Great Britain. Many national acquisitions have already been made by means of this 'Chantrey Fund.' See John Holland's Memorials of Chantrey (1851).

Chantry (Fr. chanterie, from chanter, 'to sing'), a term applied alike to endowments or benefices to provide for the chanting of masses, and to the chapels in which such masses are celebrated. These endowments were commonly made in the form of testamentary bequests, the object being to insure the erection of a chapel near or over the spot where the testator was buried, and to remunerate the priests for saying masses in it for the repose of his soul, or of the souls of others named in his will. Many such chantry chapels are still to be seen in English parish churches; but they were more common in abbeys and monastic establishments, in which it was deemed a privilege to be buried, and where some such offering to the brotherhood was in a measure the price of sepulture. These chapels, which have generally the tomb of the founder in the middle of them, are separated from the aisles or nave of the church by open sereen-work. Sometimes, again, they are separate erections, projecting from the church externally ; but in cathedrals and the larger ehurches they are generally con. structed within the church, often between the piers. Many chantries are lavishly enriched with seulpture and tracery of all descriptions, and some of them are adorned with gilding and painting.

Chanzy, Antoine Eugine Alfred, French general, born at Nouart (Ardennes), 18th March 1823, entered the artillery as a private, received a commission in the Zouaves in 1841, and served almost uninterruptedly in Africa till 1870. After the revolution of the 4 th September the Government of National Defence appointed him a general of division ; in December he was placed at the head of the second Army of the Loire, and resisted the invaders inch by inch with a stubborn valour that won the respect of the Germans and the confidence of his countrymen, and which found a fitting close in the great six days' conflict about Le Mans. He was elected to the National Assembly, and narrowly eseaped being shot by the Communists in 1871. In 1873-79 he was governor-general of Algeria. Chosen a life senator in 1875 , he was put forward for the presidency in 1879. He was ambassador at St Petersburg in 1879-81, and afterwards commanded the 6th army corps at Chalons, where he died suddenly, 4th January 1883 . See Chuquet, Le Général Chanzy (1884).

Chaos signified, in the ancient cosmogonies, that vacant infinite space out of which sprang all things that exist. Some poets make it the single original source of all ; others mention along with it Gra, Tartaros, and Eros. By some also only the rough outlines of heaven and earth were supposed to have proceeded from Chaos, while the organisation and perfecting of all things was the work of Eros. Still later cosmogonists, such as Ovid, represent it as that confused, shapeless mass out of which the universe was formed into a kosmos, or harmonious order. Hesiod makes Chaos the mother of Erebus and Nox. In Gen. i. 1-2, after God created heaven and earth, the earth was yet 'waste and void ( $t \bar{o} h \bar{u} v a-b \bar{o} h \bar{u})$, and darkness was upon the face of the deep' (těhom, the Chaldee tiamat). See ADAM AND EvE.

Chapala, a lake of Mexico, on the high plateau of Jalisco, surrounded by steep, bare mountains. It has an estimated area of 1300 sq. m., contains many islands, and is traversed by the Rio Grande de Santiago. 
Chap-books are little stitched tracts written for the people, and sold by chapmen, or travelling nerllars, whose representative Autolycus is so iividly brought before our eyes by Shakesueare in II inter's Tale. The literary wares of the chapman wore mostly ballads or other broadsides, but he also ilealt in these stitehed booklets. Popular litera. ture has naturally become scarce on account of the icissitudes to which it is subject, and few of the whinr chap-books exist at the present day. Samuel l'ipys coflected some of considerable interest which tho bound in small quarto volumes and lettered Vulgaria. Besides these he left four volumes of chap-books of a smaller size which be lettered Jenny Merriments, Penny Witticisms, Penny Com. jliments and Penny Godlinesses. The small quarto liap-books are the descendants of the black-letter tracts of Wynkyn de Worde, Copland, and other famous printers, and were probably bought from booksellers as well as from chapmen. With the Jilh century came in a much inferior class of literature, which was printed in a smaller size, and forms the bulk of what is known to us now in collections of chap-books. These tracts were printed largely in Aldermary Churchyard, and after. words in Bow Churchyard, as well as at Northamptun, York, Newcastle-on-Tyne, Stokesley, Warrington, Liverpool, Banbury, Aylesbury, Durham, Birmingham, Wolverhampton, Coventry, Whitehaven, Carlisle, Worcester, Penrith, Cirencester, de., in England; at Eilinburgh, Glasgow, Falkirk, Paisley, Dumfries, Kilmarnock. Stirling, \&c., in Scotland; and at Dublin. As ballads are frequently reduced versions of romances, so chap-books usually contain vulgarised versions of popular stories. The subjects of the chap-books are very various; first and foremost are the popular tales, such as Valentine and Orson, Fortunatus, Reynard the Fox, Jack and the Giants, Patient Grissel, Tom Thumb, and Tom Hickathrift; then come the lives of heroes, historical abridgments, travels, religious treatises, and abstracts of popular books like Robinson Crusoe and Don Quncote. Besides these there are the more modern inventions of hack writers. Dougal Graham (1724-1779), bellman to the city of Glasgow, was a popular writer who is supposed to have done much to give a special character to Scottish chap-book literature. Motherwell has styled him the vulgar Juvenal of his age. His works were reprinted at Glasgow in 2 vols, in 1883 .

The chap-books of the 17th century are valuable as illustrations of manners; but little is to be learned from those of the 18 th century, which are altogether of an inferior charncter. An instance of this may be taken from the story of Dick Whittington. The earliest version of this tale which has come down to us is a small quarto tract entitled 'The Famous and Remarkable History of Sir Richard Whittington, three times Lord Mayor of London, who lived in the time of King Henry the Fifth in the year 1419 , with all the remarkable passages, and things of note, which happened in his time: with his Life and Death.' It is without a date, but was probably published about 1670 . In this the historical character of the subject is fairly kept up, although the dates are somewhat mixed, and to this the widespread folk-tale of the cat is added. In the later chap-book versions the historicul incidents are ruthlessly ent down, and the fictitims ones amplified. The three chief points of the story are (1) the poor parentage of the hero, (2) his change of mind at Highgate Hill by reason of hearing Bow Bells, and (3) his good fortune arising from the sale of his cat. Now these are all equally untrue as referring to the historical Whittington, sind the second is apparently an invention of the 18th century. In the 17th-century story we learn that Whittington set out before daybreak on All. Hallows' Day, and before he got as far a Bunhill he heard Bow Bells ring out. Hollowar replaced Bunhill in the later versions, and hence arose the myth connected with Whittington Store on High. gate Hill.

Hannah More's Repository Tracts, and after. wards the publications of the Useful Knowledge Society, Chambers's Miscelluny of Tructs, and the growth of cheap magazines, greatly reduced the popularity of chap-books; but Catnach, a Iondon printer, kept up the supply in the enrly portion of the 19th century, and even now chap-books are still produced in England and elsewhere.

The influence of chap.books can never have been very great in Britain from the inferiority of their literny character. This has not been the case in other countries, and Mr Wentworth Webster has discovered the curious fact that the Pastorales or Basque dramas owe their origin to the chap-books hawked about the country (see article BAsQUEs). A valuable and standard work on the chap-books of France was published in 1854, entitled Histoire des Livres Populaires, ou de la Litterature du Colportage, by M. Ch. Nisard; but little has been done in England for this class of literature. Mr J. 0. Halliwell-Phillipps printed in 1849 Notices of Fugitive Tracts and Chap Books and Descriptive Notices of Popular Engtish Histories; Mr John Ashton published in 1882 a useful work on Chapbooks of the Eighteenth Century; and five of the most interesting of the old chap-books have been reprinted (1885) by the Villon Society, with introductions by $\mathrm{Mr}$ Gomme and $\mathrm{Mr}$ H. B. Wheatley. For German chap-books, the reader should consult Karl Simrock, Die deutschen Volksbücher ( 55 parts, Berlin and Frankfort, 1839-67), and Gotthard Oswald Marbach, Altdeutsche Volksbücher (44 vols. Leip. 1838-47).

Chapel (through Fr. from a late Latin copella, which, according to Brachet, already in the 7 th century had the sense of a chapel, but earlier meant the sanctuary in which was preserved the cappa or cope of St Martin, and was next expanded to mean any sanctuary containing relics). The term now signifies a building erected for the purposes of public worship, but not possessing the full privileges and characteristics of a church. In this sense all places of worship erected by dissenters are now called chapels in England, and the term is also applied to supplementary places of worship, even though in connection with the established churchsuch as parochial chapels, chapels of ease, free chapels, and the like. In former times it was applied either to a domestic oratory, or to a place of worship erected by a private individual or a body corporate. In the latter sense we speak of chapels in colleges. But its earliest significa. tion was that of a separate erection, either within or attached to a large church or cathedral, separately dedicated, and devoted to special services (see CHANTRY). Chapels had no burying-ground attached to them, and the sacrament of baptism was not usually administered in them.-The name is also given to a printer's workshop, hence to a union of the workmen in a printing-office-said to be so applied because Caxton set up his press in a chapel at Westminster.

Chapelain, JKaN, a somewhat curious figure in the gallery of French authors, was born in 1595 , and died in 1674. He was a learned, industrious writer, who passed for a time as a poet, and was accepted as the dominant aathority in the world of French letters between the literary dictatorships of Malherbe and of Boileau. He produced one of the abortive epics which it was the fashion to write during the regency of Mazarin. This work, the 
Pucelle, dealt with the story of Joan of Arc, in twenty-four books. Its appearance covered its author with ridicule. Chapelain was gibbeted in the satires of Boileau, and the critic's severity was in this 3 ease amply justified by the dullness and grotesque absurdities of the work which he attacked. Chapelain also wrote a number of odes, one of which, composed in honour of Cardinal Richelieu, is not without merit. An edition of part of the Pucelle ( 1 vol. folio) was published in 1656. The last twelve books still remain in manuscript in the Bibliothèque Impériale.

Chapel Royal, in England, consists of a dean, sub-dean, forty-eight chaplains, ten priests in ordinary, and a numerous lay choir, styled gentlemen of the chapel, with a clerk of the closet, and deputy-clerks of the closet, and an organist. The chaplain's duty is preaching, a certain number being appointed beforehand to take duty each month of the year; the liturgical offices are performed by the dean, sub-dean, and priests in ordinary. The establishment is bound to attend the sovereign wherever the court happens to be; but in fact the services of the chapel are confined to London-formerly to the chapel at Whitehall, destroyed by fire after the Restoration, more recently to the small oratory in St James's Palace. The earliest records concerning the Chapel Royal date from the reign of Edward IV.

The Chapel Royal of Scotland was an ancient foundation originally located in Stirling. Castle, founded by Alexander I., and liberally endowed by his successors. In the reign of Queen Mary the Chapel Royal was transferred to Holyrood House. After the Reformation 'the minister of the king's household 'conducted service in it, and the chapel was used as their parish church by the people of the Canongate. It was endowed with the teinds of various churches, and the revenues of the abbey of Dundrennan. During the period of Episeopal church government the Chapel Royal of Holyrood was presided over by a dean, generally one of the bishops, and served by a number of chaplains (see HolYROOD). After the Revolution the revenues of the Chapel Royal were bestowed on various ministers and chaplains. In accordance with the report of the University Commission issued in 1863 the whole revenues have latterly been taken to augment the income of several professors of divinity, among whom they are divided. The present Dean of the Order of the Thistle is appointed by his commission from the crown the Dean of the Chapel Royal of Scotland. The other members of the chapel are the chaplains in ordinary, six in number, who are appointed during the pleasure of the crown. Neither the dean nor the chaplains receive any of the revenues of the Chapel Royal, which have been all disposed of in the manner stated, and their duties are purely honorary.

Chaperon, a hood or cap worn by knights of the Garter. Such a hood was at one time in general nse, but was latterly appropriated to doctors and licentiates in colleges. A person who acts as a guide and protector to a lady at public places is called a chaperon, probably from this particular piece of dress having been used on such occasions. The name was also applied to devices which were placed on the heads of horses at pompous funerals.

Chaplain, originally an ecclesiastic who accompanied an army, and carried the relies of the patron saint (see CHAPEL). It now signifies a clergyman employed to officiate at court, in the household of a nobleman or bishop, in prisons, with troops, and on board ship. Such officials appear first in the palaces of the Byzantine emperors. For the royal chaplains in Britain, see CHAPEL RoYAL. For prison and workhouse chaplains, see PRIsON, POOR.
An ARMy Chaplats, in Britain, is a clergyman not having charge of a parish, especially commissioned to do duty with troops. The office, which has existed for many years, was at one time regarded as a saleable perquisite; but the system was reorganised and improved in 1796. The Chaplains' Department, a branch of the Military Department of the War Office, consists of a Chaplain-general, ranking as major-general; 16 Chaplains to the Forces of the first class, ranking as colonels; 10 of the second class, ranking as lieutenant-colonels; 18 of the third class, ranking as majors; and 35 of the fourth class, ranking as captains. Of these, 13 are Roman Catholic and 6 Presbyterian. Their pay, which in the fourth class is 10s. a day, rises to 22s. 6d. in the highest rank, the chaplain-general receiving $£ 1000$ a year. Chaplains are sent on active service with the troops, and in peace are allotted to the various military stations. Their duties are to conduct divine service in camp or barracks, officiate at burials, baptisms, and churchings, visit the hospital and barrack-rooms, give religious instruction in the schools, and generally treat the soldiers and their families as though they were their parishioners. Where the number of troops is small, the parish clergyman is appointed acting chaplain, performs these duties, and receives head-money. Soldiers who do not belong to the Church of England are marched to the nearest place of worship belonging to their denomination, and head-money is granted to the minister in charge. In the United States army, regimental chaplains and post-chaplains may be of any of the regular denominations. They mostly have the rank of captain.

Navy Chaplain. Every large ship in commission has a chaplain. The Navy Estimates provide for above 100 commissioned chaplains, at stipends varying from $£ 219$ to $£ 401$ per annum. The Chaplain of the Fleet has an ineome (with allowances) of $£ 759$ a year. The chaplains perform divine service at stated times on shipboard, visit the sick sailors, and assist in maintaining moral discipline among the erew. The estimates also include a sum of about $£ 3500$ as 'allowances to ministers of religion,' besides the salaries of chaplains. In the United States navy, chaplains on the active list are of various relative ranks, from that of lieutenant to that of captain.

Chapman, a trader, but popularly applied in a more limited sense to a dealer in small articles, who travels as a pedlar or attends markets. Our familiar chap ' a fellow,' is a mere shortening of the name, which is derived from A.S. ceap, 'trade,' seen in Cheapside, Eastcheap, and in cognate form in Copenhagen. See CHAP-BOOK.

Chapman, GEORGE, dramatist and translator of Homer, was born near Hitchin, Hertfordshire, about 1559. He is supposed to have studied at Oxford University, and to have afterwards proceeded to Cambridge. From a passage in his earliest poem, The Shadow of Night (1594), it has been somewhat hastily inferred that he served as a volunteer under Sir Francis Vere in the Netherlands. To Lawrence Keymis's Relation of the Second Voyage to Guiane (1596) he prefixed a spirited poem, De Guiana, Carmen Epicum. His earliest extant play, The Blind Beggar of Alexandria, which has little merit, but was very popular, was produced in February 1595-96, and printed in 1598. The excellent comedy, All Fools, printed in 1605 , was probably produced in 1599; and about this time he wrote other plays, which have perished. In 1598 he completed Marlowe's unfinished poem, Hero and Leander. The first of his Homeric translations was Seven Books of the Iliads of Homer (1598). It
is a translation of books $\mathrm{i}$. ii. vii.-xi., and is 
written in rhymed verses of fourteen syllables. The dedicatory epistle to the Earl of Essex admirably illustrates the writer's dignified temper. Later in 1.598 he published Achilles' Shield, translated from the eighteenth book of the Iliad. In this translation he used rhymed verses of ten syllables, the netre that he afterwards employed in his render. ing of the Odysey. It was not until 1610 or there. uluruts that he published Homer, Prince of Poets: translated according to the Greeke in twelve Bookes of his Iliceds, with a fine dedicatory epistle in verse in Prince Henry. The complete translation of The Iliads of Homer, Prince of Poets, in rhymed verses of fourteen syllables, appeared in 1611. In the I'refice to the Render he states that the last twelve hooks had been translated in less than fifteen weeks Having finished the Iliod, he set to work in the Odyssey, and in 1616 appeared The Whole Worles of Homer, Prince of Poets, in his Iliads and 1)dysseys, which was followed (about 1624) by The (rrmone of all Homer's Workes, Batrachomyomachia, in' the Battaile of Frogs and Mice: His Hymns and Epigrams. In spite of all harshnesses, obscurities, and conceits, Chapman's translation of Homer is a molile achievement. He was not a profound scholar, and has often missed the sense where a schoolbov could set him riglit. But the work is instinct with life, full of heat and energy. By his contemporaries -Jonson, Drayton, Daniel, and the rest-it was spplauded, and in later days it has never lacked admirers. Pope acknowledged its merits; Coleridge declared that it was such a poem as Homer might have written if he had lived in England in the time of Elizabeth; Lamb admired it enthusiastically ; and Keats wrote a famous sonnet in its praise. While he was busy with his Homeric labours, Chapman was also writing for the stage. He joined Jonson and Marston in the composition of Eastward Ho (1605), and in 1606 published a (nriceful comedy, The Gentleman Usher. In 1607 uppeared Bussy d'Ambois: a Tragedie; and The levenge of Bussy $d^{\prime} A m b o i s$ followed in 1613. These tragedies contain much inarticulate bombast intermingled with exalted poetry. Heavy and undramatic though they were, they held the stage for many years by reason of their impassioned earnestness. Two other tragedies, The Conspiracie and Tragedie of Charles, Duke of Byron (1608), are also undramatic, but abound in tine poetry. Lamb was of opinion that of all the Elizabethan dramatists Chapman came nearest to Shakespeare 'in the descriptive and didactic, in passages which are less purely dramatic.' Chapman's other plays are The May Day (1611), The Widow's Tears (1612), and Casar and Pompey (1631). Two posthumous tragedies, published in 1654, Alphonsus and Revenge for Honour, bear his name, but their authorship is uncertain. The Ball, a comedy, and The Tragedie of Chabot were published in 1639 as the joint work of Chapman and Shirley. Among Chapman's non-dramatic works are Enthymice rirptus (1609), Petrarch's Seven Penitentiall Pralmes (1612), The Divine Poem of Musarus (1616), and The Georgicks of Hesiod (1618). Chapman died in the parish of St (iiles's in the Vields, 12th May 1634. Wood describes him 'as a person of reverend aspect, religious and temperate, qualities rarely meeting in a poet.' A complete edition of Chapman's works in 3 vols., with an essay by A. C. Swinburne, appeared in 1873-75.

Chapone, Hester, authoress, daughter of Thomas Mulso, was born at Twywell, Northamptonshire, 27th Octolser 1727. She wrote a short romance in her tenth year, and after her mother's leath her attention was divided between household duties and the study of French, Italian, Latin, music, and drawing. She wrote for the Rumbler (No. 10), Adventurer, and Gentleman's
Magazine, and soon became known to a liternry circle, including Pichardson; but she is now chiefly remembered by ber Letters on the Improvement of the Mind (1772), which went through many editions. She married an attorney in 1760 , but next year was left a widow; she henself died at Hadley, 25th December 1801. See her Works with Life (4 vols. 1807 ).

Chapped IIands, a form of inflammation of the skin of the back of the hands characterised by abnormal dryness and roughness, with the forma. tion of cracks or fissures. It is caused by exposure to cold, and can generally be prevented or cured by earefully drying the hands after they are washed, and applying glycerine, vaseline, or other simple ointment. The hands should also be protected in cold weather by warm gloves.

Chappell, WILLIAM, F.S.A., the author of the most learned work on ancient English music, was born November 20, 1809. Most of his life he lived in London, where he was for some yean a member of a great music publishing house. His first work of importance was $A$ Collection of National English Airs, consisting of Ancient Song, Ballad, and Dance Tunes (2 vols. [1838-40]). This work, which contained 245 airs, ultimately grew into the greater and entirely rewritten work, containing over 400 airs, re-harmonised on a consistent plan by Macfarren, Popular Music of the Olden Time; a Collection of Ancient Songs, Ballads and Dance Tunes, illustrative of the National Music of England (2 vols. 1855-59; new ed. by Wooldridge, 1893). The first volume, containing 200 airs, is a complete collection of English airs, so far as known, down to the reign of Charles I. ; the second is rather a selection, containing, however, all the more interesting or important airs of later date. Mr Chappell took a principal part in the foundation in 1840 of the Musical Autiquarian Society and the Percy Society, and edited some of Dowland's songs for the former and several rare collections for the latter. He published a few papers in the Archoeologia, contributed invaluable notes to Hales and Furnivall's reprint of the Perry Folio MS. (1867-68), and annotated the first three volumes (1869-79) of the Ballad Society edition of The Roxburghe Ballads (continued by his friend $\mathrm{Mr}$ Elosworth). Mr Chappell published in 1874 the first volume of a History of Music. He died in London, 20th August 1888.

Chapra, a town in Bengal, on the Gogra, 1 mile above its confluence with the Ganges. It is capital of the district of Saran." Pop. (1891) 57,352.

Chaptal, Jean Antoine, Comte de Chante. LOUP, French statesman and chemist, was born at Nogaret, Lozère, 4th June 1756, and studied at Montpellier, where in 1781 the states of Languedoc founded for him a chair of Chemistry. A con. siderable fortune left him by his uncle he devoted to the establishment of works for the manufacture of mineral acids, alum, soda, \&c. He was made a member of the Institute in 1798, and in $1800 \mathrm{Min}$. ister of the Interior. He resigned in 1804, but in 1811 was made a count by the emperor. During the Hundred Days he was a minister of state and director of commerce and manufactures; after the Restoration he withdrew into private life, but was admitted to the chamber of peers by Louis XVIII. in 1819. He died in Paris, 30th July 1832.

Chapter. See Brbls, Vol. II. p. 126.

Chapter-house (Fr. salle capitulaiv), the building in which the monks and canons of monastic establishments, and the dean and prebendaries of cathedral and collegiate churches, meet for the management of the affairs of their order or suciety (see Cathedral). Chapter-houses frequently ex. hibit the most elaborate architectural adormuent. 
as, for example, those of York, Southwell, and Wells. The original stained-glass windows remain at York, and are of exquisite beauty. On the walls of that of Westminster the original painting has been discovered. Chapter-houses are of various forms: those at York and Westminster are octagonal; those at Oxford, Exeter, Canterbury,

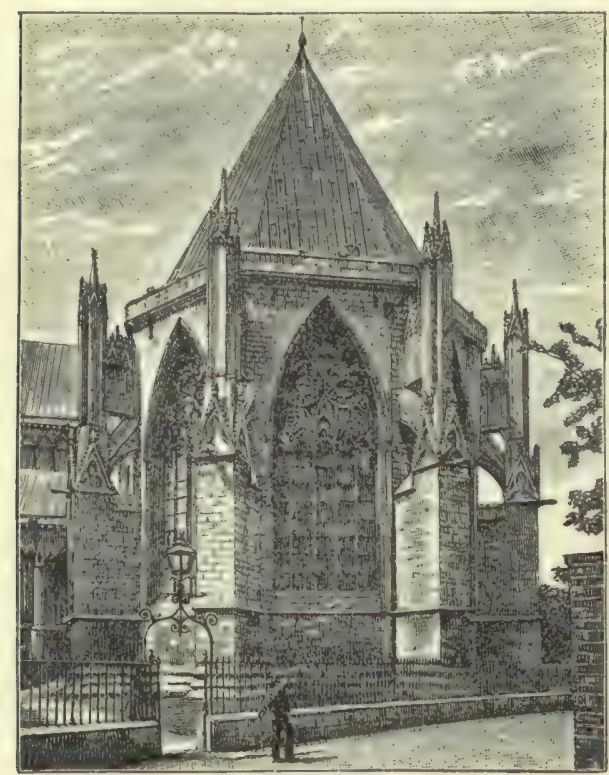

Chapter-house, York.

Gloucester, \&c. are parallelograms ; Lichfield is an oblong octagon; Lincoln, a decagon; and Worcester a circle. In France the chapter-house is generally square. They are always contiguous to the church, and are not generally placed to the west of the transepts. They sometimes open into the church, or are entered by a passage, but are more frequently in connection with the cloisters. In some instances there are arches or windows between the chapter-house and the cloisters to enable those standing in the latter to hear what goes on in the chapter-house. A stone seat on a raised step generally runs round the apartment. Chapter-houses were often used as places of sepulture, and have sometimes crypts under them, as at Wells and Westminster.

Chapul'tepec, a rock 2 miles SW. of the city of Mexico, rising to a height of 150 feet, and crowned by a castle, which was erected by the Spanish viceroy in 1785 on the site of the palace of Montezuma.

Char, a fish. See Charr.

Chara. The Characen or Stoneworts are a small group of common aquatic plants found growing in large tufts, or even covering large expanses on the bottoms of fresh-water ponds and shallow lakes, brackish or even salt-water lagoons, \&c., and of which the systematic position has undergone the most extraordinary and instructive vicissitudes. The early botanists, with K. Bauhin, had no hesitation in describing them as horsetails (Equisetum). In 1719 Vaillant proposed for them a separate genus (Chara), while Linnæus, although at first disposed to regard them as Algæe, as their habitat suggests, decided that the small red male reproductive body must be a stamen, and the larger green female one a pistil, and accordingly placed them as flowering plants among the Monoecia Monandria. His pupils at most ventured to remove these to the Monandria Monogynia, while De Jussieu regarded them as a genus of Naiadaces (q.v.), an order of monocotyledonous aquatics with much reduced flowers. In similar opinions he was followed by De Candolle and other eminent systematists : and it was not until 1851 that a careful re-examination of their structure and mode of reproduction by Thuret finally disproved the phanerogamous view, and established their eryptogamic nature. Since that time the group has attracted great attention, and is now on grounds of peculiar instructiveness, both morpho. logical and physiological, one of the classical forms usually presented to the beginner, not only in eryptogamic botany, but general biology.

Commencing with the vegetative system, we find this apparently consisting of a stem with regular whorls of leaves arising at detinite points (nodes) of the stem. The internodes, or distances between these, are at first considerable; but as we approach the apex these are shorter and shorter, and at length we lose sight of them in the crowded terminal bud. The resemblance to a young shoot of Equisetum is so far satisfactory, and the mineral incrustation (in some species so abundant as to lead to the substitution of the plant for scouring metal) appears to confirm this. The incrustation, however, is calcareous, not siliceous. Even nnder microscopic examination we may at first sympathise with the old observers, and seem to see in the stem a multicellular structure, even a cortex; nay, to see under our very eyes the actual circulation of the sap. More eareful scrutiny, however, enables us to repeat the work of later and more accurate observers. We see that this movement is not the circulation of the sap in a stem, but a streaming of the protoplasm within what is simply a single enormous cell stretching from one node to the next (see CELL). The apparent cortex is a single layer of cells covering this internodal cell; and the whole vegetative structure is unravelled when we roughly dissect out the terminal bud, harden, stain and imbed this in paraffin, and thus cut a fine longitudinal section (fig. 2). An apical cell is seen which continually segments off a lower one ; this divides (still

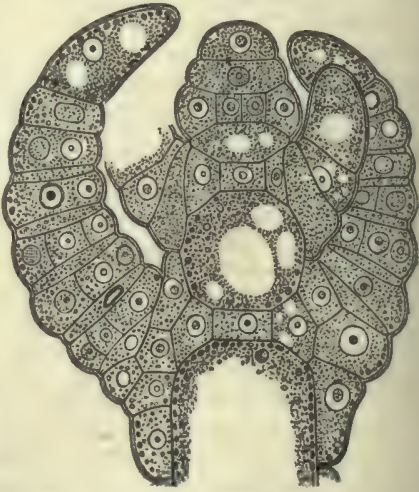

Fig. 2-Longitudinal Section of the apical bud of Chara. transversely to the axis) into two new ones; and the lower of these henceforth steadily lengthens as the internodal cell, while the upper undergoes repeated division, until a plate of nodal cells is formed. In the simpler family (Nitella) the internode thus consists of a single naked cell : in the higher (Chara), this is inclosed by the so-called cortex, a layer of smaller cells proceeding from those of the upper and lower nodes; 
and itself showing a minor nodal and internodal urrangement. In all cases, from the nodal cells there divide off, parallel to the outer surface of the stem, a new set of apical cells, which proceed, like Ihe purent one, to form the 'leaves,' reproducing, that is to say, the stem structure, until they lose the power of division, and end in a single enlarged vegetative cell. A branch may arise from a new formed apical cell out off in the axil of the oldest leaf of any whorl, while the so-called roots, which tix the plant in the mud, are simply unicellular hairs, lemgthenings produced from the superficial cells of huried norles.

The apparently very complex and characteristic reproluctive organs arise also at the nodes of the stem or leaves, in positions and numbers varying with the species. Commencing with the female (fig. $3 a$ ), which arises in the position of a branch,

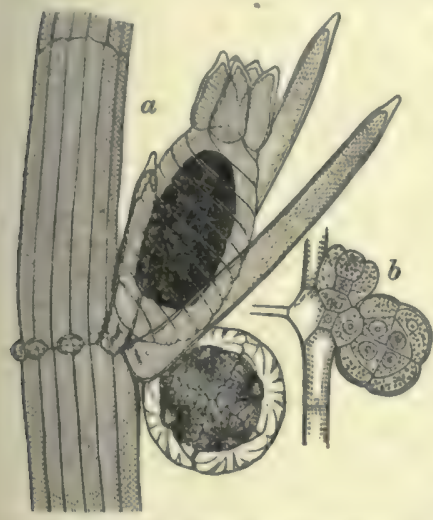

Fig. 3.-Node, bearing reproductive organs:

a. Mrature; $b$, developing. The upper in each case is the female. we find this to be obviously a shortened and modified one. Its apical cell forms only an internode and node, then ceases division, and becomes enlarged and filled with a store of starch and other reserve material to form an eggcell; while the cover or archegonium inclosing this is readily seen to be a mere modification of the familiar cortex. In the male apparatus, or anther-

idinm, the branch structure is further modified : its apical cell similarly remains all but sessile, forming only a short node and internode; but segmentation now begins, thus recalling the behaviour of a nodal cell-with which, in having below it an internodal, and not as in the case of the egg-cell, a nodal cell (fig. $3 b$ ), it so far corresponds. Eight quadrantlike cells are formed, but these now segment of new cells in the interior of the spherical mass, and in the growth and development of these the nodal and internodal alternation of ordinary vegetative growth ean still be traced. Soon, however, a num. ber of long segmented filaments are developed, and the protoplasm of these undergoes rejuvenescence, and becomes modified into a ciliated spermatozoid. When the reproductive organs are ripe, this archegonium is easily broken, and its flaments spread free in the water; the spermatozoids escape in a myriad, and some reach the egg-cell of the archegonium by means of a small opening, which is left by the all but incomplete upgrowth of the cortical cells which form the wall of the archegonium. After a period of rest, the fertilised ovum germin. ates, producing, however, not directly a new Charn plant, but a simple filament of cells ealled a proembryo, of which one cell segments into a node, and the oldest cell of this becomes the growing point of the new plant.

The affinities and systematic position of the group thus still afford ground for diseussion, although now within narrower limits than formerly; some systematists regarding them as a somewhat aberrant group of Algr, while others insist on their resemblance to the archegoniate cryptogams (see VEGE. TABLE KINGDOM). The fruits of what seem to have been gigantic Characere (Spiranginm) occur from the Carboniferous to the Wealden, and ordi nary Characese are abundant in the Tertiary strata. See Howes' Biological Atlas, and Bachs' Botany.

Characin'idae. See SAlmovidA.

Characteristic. See Logarithms.

Character to Servant. The master is under no legal obligation, either in England or in Scotland, to give a character to his servant, however long, faithfully, or efficiently he may have served him; but, if given, the character must be strictly true, or, at all events, in accordance with the master's belief, otherwise he may be exposed to an action of damages, either by the servant wlun he has calumniated, or by a subsequent employer whom he has deceived. If true, however, the fact of its being prejudicial will expose the master to no risk. In order to justify the giving of a bad character, however, it mnst, in general, be asked for by the servant, as the master is not entitled needlessly to publish the servant's defects. Where asked, it will lie with the servant to prove its false. hood, not with the master to prove its truth. The case of the servant being known by the master to have committed a felony while in his service, is, however, an exception to this rule, as, in a case so extreme, the master is at liberty to wam others against taking him into their employment. Even though strictly true, the character, if prejudicial, must not be more so than the circumstances render necessary. Acts of petty dishonesty, such as are too common among servants, will not warrant the master in branding him as a thief. The safe course, in such a case, is to state the offence, and not to describe it by a general epithet, which may convey an erroneous impression of its magnitude.

It is probable that, partly from thoughtleas good. nature, and partly from a selfish desire to get rid of a bad servant in the most comfortable manner, false characters are given in favour of servants very much more frequently than to their prejudice. It is desirable that masters and mistresses should have in view that they may render themselves liable in reparation of any damage which ean be shown to be the direct result of thus inflicting on a stranger a wrong which is unquestionably within the reach of the law.

By an Act of 1816, personating a master, and thus giving a false character to a servant, or asserting in writing that a servant has been hired, contrary to truth; and any person offering himself as a servant, pretending to have served where he has not served, or producing a false certilicate, or altering a certifi. cate, or pretending not to have been in any former service, \&c., are offences at common law, punishable on conviction before two justices with a fine of $\mathbf{f} 20$.

Charade, or 'syllable-puzzle' as the Germans call it, is an amusement which consists in dividing $a$ word of one or more syllables into its component syllables, or into its component letters, predicating something of each; and then, having reunited the whole, and predicated something of that also, the reader or listener is asked to guess the word. As a specimen of the charade depending upon syllables we adduce the following:

My fret is ploughed for various reasons, and grain is fro quently buried in it to little purpose. My acond is neither riches nor honours, yet the former would generally be given for It, and the latter are often tasteless withont it. My whole applies equally to spring, summer, sutumn, and winter: and both fish and flesh, praise and censure, mirth and melanchisly. are the better for being in it. Ans. Soa-con.

As a specimen of the second class of charades, we take the following happy example from the French :

Quatre membres font tout mon bien.

Mon dernier vaut mon tout, et mon tout ae vant ricn.

The word is sero. It is composed of four letters, of 
which the last-viz. o, is equal to zero, the whole; wero itself being equal to nothing.

But besides charades of this nature there is another kind rather popular at evening-partiesthe acted charade, the character of which is entirely dramatic. Half a dozen or so of the company retire to a private apartment, and there agree to select a certain word as the subject of the charade; let us suppose Memento. The next thing done is to take the first syllable, Me, and arrange a little scene and dialogue, each member taking a certain part. This being accomplished, the amateur actors return to the drawing-room, and commence their performance, the rest of the company constituting the spectators. Care is taken to mention conspicuously, and yet not obtrusively, in the course of the dialogue, the word Me, which is the subject of the scene. On its conclusion, they again retire, and devise a new series of incidents for the word Men, and repeat the same process for the final syllable To. This being also represented, they retire for a fourth time to contrive the final scene, into which the whole word, Memento, must be dexterously introduced at an odd moment when the spectators are thought to be off the scent. The company are then asked to guess the word. In order to the effective performance of a charade of this sort, the actors must possess a good share of inventiveness, self-possession, and ready talk, as the greater portion of the dialogue has to be extemporised.

Charadriidae, a large family of birds, placed among the so-called Grallatores, including about 120 species, distributed throughout the world, and especially frequenting the shores of lakes and rivers. They run and fly with equal success, are often seen in migratory flocks, use simple excavations for nests, and feed, often at night, on worms, insects, molluscs, and amphibians. Plovers (q.v., Charadrius), Oyster-catchers (Hæmatopus), Turnstones (Strepsilas), Crocodile-birds (Pluvianus), and Sandpipers (Agialitis) are good examples of the fanily.

Charbon. See Anthrax.

Charbon Roux. See Charcoal (Wood).

Charcoal is a term most frequently applied to charred wood, or coal produced by charring wood. Formerly, charcoal was the name for charred seacoal or mineral coal; and the word is popularly used for the carbonaceous residue of vegetable, animal, or mineral substances when they have undergone smothered combustion.

ANIMAL Charcoal, BONE-BLACK, or IVORYBLACK, is prepared from bones by heating them in close retorts till they undergo the process of destructive distillation, when combustible gases and water, together with the vapours of various salts of ammonia, and oil, are given off, and boneblack is left in the retort. It is generally reduced to coarse grains from about the size of small peas down to large pin-heads, and is extensively used in the arts for decolourising liquids, such as the syrup of sugar, and solutions of argol (impure cream of tartar) and of the alkaloids, as also in filters (see FILTER) for separating chemical impurities from water. The general mode of using the bone-black is to allow the coloured liquid to percolate through a layer of the charcoal, when all colour is arrested, and the syrup or water runs clear and colourless from under the stratum of charcoal. This power of absorbing colouring matters is also observable in vegetable (peat or wood) charcosl, but not to such an extent as in bone-black. The application of heat to the liquids before filtration greatly facilitates the decolourisation, and where the volume of liquid to be operated upon is not great, the most expeditious method is to boil the liquid and bone- black together, and then strain through filteringpaper or cloth. The composition of bone-black in 100 parts is 10 of pure charcoal, associated with 90 of earthy salts-i.e. in the proportion of one of pure charcoal in 10 of the commercial bone-black. The power of absorbing colours appears to be due to the porosity of the substance, and is not resident. simply in the pure charcoal ; indeed, the earthy matters (principally phosphate of lime and carbonate of lime) can be dissolved out of the bone-black by dilute hydrochloric acid, and the pure chareoal thus obtained only possesses about one-third the decolourising power of the total amount of boneblack it was obtained from. Thus, if 100 parts of ordinary bone-black have the power of arresting the colour from ten volumes of a given coloured liquid, then the 10 parts of pure charcosl which can be obtained from the 100 parts of bone-black will be found to decolourise only three volumes of the same coloured liquid; so that it is apparent the earthy matters in the bone-black influence and increase the absorption of the colouring matter, and thus render a given weight of the charcoal of greater commercial value. When syrup of sugar and other liquids have been run through boneblack for some time, the pores of the latter appear to get elogged with the colour, and the clarifying influence ceases, and then the bone-black requires to undergo the process of revivification, which consists in reheating it carefully in ovens, or iron pipes inclosed in a furnace, when the absorbed colour is charred, and the bone-black can be of service once again as an arrester of colour. After several reburnings, the bone-black becomes of very inferior absorptive quality, and is then disposed of for the manufacture of bone-ash and dissolved bones (see BONE MANures). Bone-black has likewise a great power of absorbing odours, especially those of a disagreeable nature, and can thus be employed to deodorise apartments, elothing, outhouses, \&c., or wherever animal matter may be passing into a state of active putrefaction.

WOOD CHARCOAL is the most important, though not the purest kind of Carbon (q.v.). Wood consists of carbon, hydrogen, and oxygen, the last two being in the proportion to form water. When heated in the open air, it burns completely away, with the exception of a small white ash; but if the supply of air be limited, only the more volatile matters burn away, and most of the carbon remains. This is the principle of the process of charcoalburning in countries where wood is abundant. Billets of wood are built up vertically in two or three rows into a large conical heap, which is covered over with turf or moistened charcoalash, and holes left at the bottom for the air to get in. An open space is also left in the middle of the heap to serve as a flue. The heap is set on fire by putting burning wood into the top of the central opening. The combustion proceeds gradually from the top to the bottom, and from the centre to the outside of the heap; and as the central portions burn away, fresh wood is continually thrown in at the top, so as to keep the heap quite full. The smoke is thick and white when the process is going on properly ; if it becomes thin, and especially if a blue flame appears, the wood is burning away too fast, and the combustion must be checked by closing the holes at the bottom, or by heaping fresh ashes on the top and sides. As soon as the combustion is completed, the heap is completely covered with turf or ashes, and left to cool for two or three days. It is then taken to pieces, and the portions still hot are cooled by throwing water or sand upon them. It is found that 100 parts of wood yield on the average from 61 to 65 parts by measure, or 24 parts by weight, of charcoal. The charcoal thus prepared 
is the hest suited for fuel. In England a large yuantity of charcoal. is obtained in the dry dis. tillation of wood in cast-iron cylinders, for the pre. paration of erude acetic acid. The chascoal thus prepared is preferable for making gunpowder, but is inferior for other purposes. A peculiar kind of charrenal of a reddish-brown colour, and hence termed charbon rose or red charcoal, is frequently prepared for the manufacture of the gunpowder uxw for sporting purpuses, by suljecting wool in iron cylinders to the action of superheated steam umler a pressure of two atmospheres. Powiler mide with this charcoal absorbs moisture more rapidly than ordinary gunpowder.

The general properties of woxl-charcoal are, that it is black and brittle, and retains the form of the wood from which it is derived; it is insoluble in water, infusible and non-volatile in the most intense heat; its power of condensing gases is noticed under Carbon (q.v.); and from its power of lestroying bad smells it has been regarded as (u) sessing considerable antiseptic properties. It is frequently stated that charcoal is a bad conductor of hest, but a good conductor of electricity. These properties depend upon the nature of the charcoal, the lighter wood, such as willow, yielding a porous charcosl, with little power of conducting heat or electricity; while boxwood yields a very compact charcoal, which is a good conductor of heat and electricity, and is admirably adapted for the exhibition of the electric light. Charcoal never consists entirely of pure carbon, the degree of purity vary. ing directly with the temperature at which it is formed; thus, charcoal charred at $480^{\circ}\left(249^{\circ} \mathrm{C}\right.$.) contains 65 per cent. of carbon, while that charred at $750^{\circ}\left(399^{\circ}\right.$ C. $)$ contains 80 , and that charred at $2730^{\circ}\left(1499^{\circ}\right.$ C. $)$ contains 96 ; but the loss of charcoal occasioned by these high temperatures is very great, the percentage yield of charcoal correspond. ing to these temperatures being 50,20 , and 15 .

The uses of wood-charcoal are numerous and extensive. It is very largely employed as a fuel, taking the same place in many countries that coal nocupies here. From its being proof against all ordinary chemical agencies, superficial charring is often employed to protect wood from decay, as in the case of fence-posts, of telegraph poles, or of piles which are driven into mud or into the beds of rivers to serve as foundations. With the same design it is not unusual to char the interior of tubs and casks destined to hold liquids. In a finely. divided state it is commonly regarded, as has been already stated, as an antiseptic; and there is no doubt that the offensive effluvia from animal matter in an alvanced stage of putrefaction disappear when the putrefying substance is covered with a layer of charcoal; but in reality the decay goes on, without the emission of any odour, till at length the whole of the carbon is disaipated as carbonic acid gas, and the hydrogen as water, while the nitrogen remains as nitric acid. It has been shown that the action consists in a rapid jrocess of oxidation, dependent upon the power which finely-divided charcoal possesses of condensing oxygen. In a finely-divided state, charcoal not inly condenses gases to a marvellous extent, but has the power of absorbing colouring matters, bitter frinciples, \&c. ; and hence it is of extensive use in the laboratory. From the rapidity of its absorbing action, the nse of a respirator filled with charcoa? has been suggested to protect the mouth and nostrils in an infected atmosphere; trays of powdered wood-charcosl in dissecting-rooms, in the wards of hospitals, and in situations where putrescent animal matter is present, exert a most beneficial influence in sweetening the atmosphere, by absorbing and decomposing the offensive gases. Chareoal is accordingly valuable in filters, not only for decolourising purposes, but likewise for ausisting in purifying water for domestic use. It is almo successfully used to prevent the escape of noxious vapours at the ventilating openings of sewers, as it allows the free parange of air, but condenses the offensive effluvia in its pores, where they are destroyed by a process of oxidation. Besidos its employment in the manufacture of gunpowder it has nany applications in the arts. In mediciue it is uaed to destroy fetor, applied in the form of powder or poultice to gangrenous sores, ulcers, \&c. it is also largely employed in tootlo-powdens. In indigestion arcompanied ly flatulunes it may be given in doses of two or three teaspoonfuls suspended in water, or as chareosl-biscnits (sce Biscuits). For the charcoal blacks, see BLACK.

Charcot, Jean Mantix (1825-93), pathologist, was born at Morvan (in Nievre), studied at Paris, where he became a professor, doctor at the Salpetrière hospital, and a member of the Institute. He contributed much to our knowledge of chronic and nervous diseases, their diagnosis and pathology, and made hypnotism a scientific study. He pub. lished numerons works on these subjects.

Chard, a municipal borough of Somersetshire, 15 miles SSE. of Taunton by rail, with manufactures of lace. Pop. 2575.

Chardin, SIR JoHN (1643-1713), traveller, was born in Paris, travelled as a trader in jewels in India, Persia (where he resided four years), Armenia, Turkey, and published his Voyages (4 vols.) in 1686-1711. To eseape the persecution of Protestants, he settled in England in 1681, became courtjeweller, was knighted, and for some years lived in Holland as agent of the East India Company.

Charente, \& department of France, formed chiefly out of the old province of Angoumois. Area, 2285 sq. m. Pop. (1866) 378,218; (1891) 360,259 . It is generally level, with granite offshoots of the Limousin range in the north, and chalk-hills in the south, abounding in marine deposits ; and it is watered by the river Charente and its tributaries, with the rivers Vienne and Dronne. The hills are in many places clad with chestnut forests. The climate is generally mild and healthy, and a sixth of the surface is devoted to vines, which flourish in the dry, hot limestone soil. The wines grown are spirituous and fiery in flavour, and are chiefly distilled into brandy, which forms the most important of the exports. Truffles grow abundantly in several parts. The principal manufactures besides branty are paper, leatlier, felt, and pottery. Charente is divided into the five arrondissements of Angoulême, Cognac, Ruffec, Barbezieux, and Confolens. Angoulême is the chief town.

Charente-Inférieure, a maritime depart. ment of France, formed principally from the former provinces of Saintonge, Aunis, and a small portion of Poitou. The Bay of Biscay washes its western boundary. Area, 2625 sq. m. Pop. (1866) 479,529; (1891) 456,202 . It is watered on its boundaries by the Sevre-Niortrise and the Gironde, and in the centre by the navigable Charente and the conststream Sendre. The surface is level ; the soil, near the coast protected from the sea by dikes, is mostly chalky and sandy, but very fertile. The commerce is mainly in brandy and sea-salt; the evaporation from the salt-marshes from which the latter is taken renders some parts of the const very un. healthy. The oyster and pilchard fisheries are important. The chief harbours are those of Rochefort and Tonnay-Charente. La Rochelle is the chief town.

Charenton-le-Pont, a town in the French department of Seine, on the right bank of the 
Marne, 4 miles SE. of Paris. The bridge over the river, which is important from a military point of view, is defended by two forts forming a part of the fortifications of Paris. At the other side of the river is the National Lunatic Asylum. Pop. (1872) 7141 ; (1886) 13,535; (1891) 14,458.

Charge is the exposition of the law made by the judge to the jury, in which he comments on the evidence and instructs the jury as to the applieation of the law to the facts. Charge is also the exhortation of a bishop or archdeacon to the clergy.

Chargé d'Afiaires is a fourth-class diplomatic agent, accredited, not to the sovereign, but to the department for foreign affairs; he also holds his credentials only from the minister. See AMBASSADOR.

Chariot, in ancient times a kind of carriage upon two wheels used both in peace and in war. The Roman form, the currus, was entered from behind, was closed in front and uncovered. It was drawn by two, three, or four horses, and earried either one or two persons, both standing. The word biga is often applied to a two-horse chariot for battle or for racing; triga was a name for a chariot drawn by three horses yoked abreast, of which two drew from the pole; while the quadriga was drawn by four horses abreast, the two centre ones (jugales) only yoked, the two outside ones (funales) being attached by ropes. The last was a form common in the racing chariot of the circus, and in processions. The currus triumphatis, in which the Roman generals rode during their triumphal entrance into the city, was a chariot of particular form, being quite round and without any side open, while its panels were richly decorated with carvings in ivory. The Roman writers speak of the use among the Britons and some other foreign nations of war-chariots carrying iron blades or scythes fixed to the end of the pole and axle-tree. The war-chariot of the Homeric heroes (harma) was somewhat lighter than the Roman currus, being partly formed of open rail-work instead of panelling. The oldest war-chariots of which we read are those of Pharaoh (Exodus, xiv. 7). All the eastern nations used them, and many Assyrian tablets represent heroes, such as Sennacherib or Esarhaddon, riding in triumph at the head of their armies in chariots much heavier but otherwise not unlike the Roman forms of chariots with which we are familiar. Two fine four-wheeled chariots with rich ornamentation in bronze-work were dug up by Dr Petersen in a peat-bog in Jutland in 1881 and 1883 , and dated by him a hundred years before Christ. See Assyria.

Charities constitute a marked feature of English life. There are also many excellent institutions in Germany and France. The Deaconess House at Kaiserwerth, founded by Pastor Fliedner, Father Zeller's School at Bengoen, near Basel, the Asylum for Poor Neglected Children at Dusselthal, the Blind School at Illzack, the Evangelical Asylum for Discharged Male Prisoners at Lintorf, the establishments of $\mathrm{Mr} J$. Bost at Laforcethese with many others recur to the mind, and forcibly testify to the amount of philanthropic work being done on the Continent; while in the United States the splendid medical and kindred benevolent institutions of New York and other great towns bear witness to the sympathy and beneficence of that large-hearted nation. But in no country are so many charities of such wide and far-reaching influence to be found as in Great Britain. Taking as an example London alone, there are no less than 1025 institutions of various kinds. This does not include the different bequests under the control of the opulent city companies, which if counted separately would amount to as many as 300 more, or the smaller semi-religious missions of which each parish, as a rule, possesses two or three. Of the 1025 charities, 813 have been established in the nineteenth century, and 58 since the year 1879. The oldest institution is St Bartholomew's Hospital, Smithfield, founded in 1123. Next to this comes St Katharine's Hospital, instituted 1145 , though the present building was erected in 1827. The educational charities are mostly of ancient origin, and the majority were founded in the 16th century-during the reigns of Edward VI. and Elizabeth; but some of less importance, in the gift of the city companies, for the making of small school grants and so on, are even still older. In the 16th century such well-known institutions as St Paul's School (1509), Christ's Hospital (1553), St Peter's College, Westminster (1560), Merchant Taylors' School (1561), and Sir Roger Cholmley's School, Highgate (1565), were founded. There are upwards of $\mathbf{8 0}$ different almshouse buildings connected with the metropolis, affording shelter to more than 2000 inmates. Many are of great age-some indeed, as land rose in value, have been abolished, and the money thus gained devoted to pensions; the oldest are the Salters' Company's Almshouses at Watford, founded in 1454. The hospitals and dispensaries number 135 . The longest established are the general institutions; those devoted to special forms of disease are of more recent origin, a remark that applies with additional force to the provident dispensaries. A curious feature is to be noticed in the principal lying-in charities. These were all founded between the years 1749 and 1765. For the missionary societies, see Missions. The institutions for the blind number 29 ; in the majority of cases, the benefit conferred takes the form of a small annuity or pension. A few of the orphan asylums date their existence from the middle of the last century, but the greater proportion have been founded since 1850. It is to this form of charity that the present generation seems especially prone. Whereas in 1850 there were only 17 institutions of this kind, there are now 58. A great increase has also taken place in the number of convalescent homes, reformatory institutions, night refuges, and societies for the relief of the destitute. Following the example so admirably set at Kaiserwerth, various nursing and philanthropic sisterhoods have been established, and within the last five years no fewer than three prominent charities have been formed to provide poor city children with the means of getting away for a limited period to the country or seaside. Finally, it may be mentioned that the receipts of the metropolitan charities for the year 1887 amounted to upwards of $£ 4,500,000$.

See Low's Handbook to the London Charities (annual), and Fry's; De Liefde, The Charities of Europe (1865); Cammann and Camp, The Charities of New York (1868); Kenny, Legislation with regard to Property given for Charitable Uses (1880).

Charity Commissioners were first appointed in 1853 , under an act for the better administration of charitable trusts. For many years previous to this the subject of the endowed charities had been gradually growing in interest. The old Court of Chancery, with its slow, cumbrous, and ruinously expensive procedure, was felt to be out of date, a new order of things was required, and in especial some investigation into the condition of the charitable funds was needed. By an act dating so far back as 1601 ( 43 Eliz. chap. 4), the Lord Chancellor was empowered under certain conditions to appoint commissioners of inquiry, but these commissions had fallen into disuse, and action was now taken in the person of the Attorney-general $-a$ method that was at once calculated to give rise to many abuses, and prove infinitely vexatious. The first endeavour 
14) (urocure the necesaary inquiry was in 1786 , when m. Mr Mr (iilleert's Aet (26 (ieo. III. chap. 58) information had been obtained on oath from the purvehial cleryy, churchwardens, and overseers; but the received no direet authority from the Charity Trustees to make such inquiry, and their know. ledge was therefore found to be unreliable and inadequate. According to the returns then made to parliament, the endowed charities amounted to $x^{2} 258,710,19 \mathrm{~s}$. 3d. a year - a sum, as was afterwirils shown, greatly below their actual value. In $1812 \mathrm{Mr}$ Lockhart, who was strenuously opposed Iny the eity companies, succeeded in passing an Let (52 Geo. III. chap. 102 ) which required that particulars of the income, capital, object, and trustees of every existing charity, together with the names of the persons holding the deed of endowment, should be registered with the clerk of the peace for the county within six months of the passing of the wet; and a similar provision was made for all future charities. A copy of each registration was also to be enrolled in Chancery. Four years later commenced the memorable investigations with which the name of Lord Brougham is so closely eonnected. In 1816 he moved for the appointment of a Committee of the House of Commons on the subject, and as a result of its deliberations the Committee recommended that an inquiry intes the condition of the endowed charities should be undertaken. The first commission for this jurpose was appointed by the crown, under an Act of 1818, and further commissions of inquiry were issued and prosecuted under that and subsequent acts until 1837. In the words of Lord John Russell, these successive inquiries 'destroyed many flagrant abuses, detected the perversion of a large amount of charitable funds, and led the way ti) those further inquiries and those remedial measures of which we have seen the commencement and the progress, but of which the consummation is yet to come.' As showing the magnitude and extent of these investigations, it may be mentioned that the printed reports occupy no fewer than 38 folio volumes, consisting of some 25,000 lages, describe 28,880 charities with an aggregate income of $£ 1,209,395$, and were compiled at a cost of upwards of half a million of money. The result of the wide attention thus drawn to the subject was that in 1853, after much parliamentary and private agitation, the great Charitable Trusts Act, for the public supervision of public endowments, was passed. The powers placed in the hands of the commissioners and inspectors appointed under the sct, however, were at first exceedingly limited. Beyond a veto on suits by any one but the Attorneygeneral, the commissioners had only rights of in. quiry, of advice, and of rendering assistance in a few cases where the trustees themselves might desire such aid. The act enabled the Lord Chan. cellor to appoint two persons to be, jointly with the secretary for the time being, "the official trustees of charitable funds;' and those officers were constituted in 1854. In 1855 another act empowered the board to apportion parish charities under $£ 30$ a year; but in regard to the remodelling of these institutions, or in any way making new schemes for their extended usefulness, its operations were still subordinate, not only to Chancery, but to the county courts. A further act, passed in 1860 , for the tirst time gave the commissioners judicial power over charities of $\mathbf{t 5 0}$ a year, and like power, with the consent of the trustees, over larger charities; but being judicial, the anthority of the com. missioners can only be called into operation at the suit of persons interested in each case. The powers formerly exereised by the Court of Chancery still exist in the High Court of Justice, but are very rarely called into execution. Should trustees prove obstinate, or in other ways refuse to apply for new gehemes in relation to their institutions, developing combative tendencies with which the commissioners have a difficulty in dealing, then the aid of the High Court of Justice in invoked. Otherwise the whole administration of charitable endowments, under such conditions as above mentioned, lies in the hands of the Charity Commissioners. Under the jurisdiction thus given various improved schemes have been established, and trustees numbering upwards of 400 annually appointed. By the Act $\mathbf{3 7}$ and 38 Viet. chap. 87, the powers previously exereised by the Endowed. Schols Commissioners were transferred to the Charity Commissioners for a period of five years, and the two bodies have since been amalgamated. The commissioners have also an important power under the Municipal Corporations Act, 1883, of framing schemes for the application of the property of the corporations dissolved under that act. Since the year 1854 the amount of stock transferred to the official trustees of charitable funds has amounted

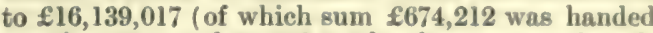

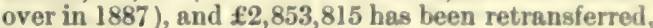
leaving the total sum held by the trustees at the end of $1886, £ 13,285,202$, divided into 14,729 separate accounts.

The Charity Organisation Society, founded in 1869 , took its rise in a sense of the evil of tem. porary relief, which manifestly tends to lower the self-dependence of the recipient and to encourage pauperism. Previous to the advent of the society, many attempts had been made to cope successfully with the dangers that attend the bestowal of thoughtless charity. Amongst others, Edward Dennison and Octavia Hill had been especially noticeable for their efforts to raise the condition, both morally and physically, of the struggling poor, and for some time district visiting committees and several societies for the relief of distress through the agency of unpaid almoners had been at work. Attention, too, had been powerfully directed to the method of poor-law administration carried on at Elberfeld and other continental towns. It was felt that some scheme for uniting the charities of London in friendly business sympathy, so as to utilise their efforts more effectively and prevent imposition, was needed. This impression gaining ground may be said to have originated the Charity Organisation Society. The object of the society, as stated in its report, is the improvement of the condition of the poor (1) by bringing about co-operation between the charities and the poor-law, and amongst the charities; (2) by securing due investigation and fitting action in all cases; and (3) by repressing mendicity. At least one representative committee is formed in each of the poor-law divisions of the metropolis, and the society itself may be said to consist of a federation of those committees, at present numbering forty. Each committee appoints one or more charity agents to act under its instructions, and an important part of their duties is to collect particulars as to the actions of the charities of the district and the relief given by them; to receive applications from persons referred to the office, and to investigate their claims; and to keep up communication with the relieving-officers of the guardians. That there is great need for organisa. tion in the matter of charitable relief is amply evidenced by the fact that the society computes that in London alone from four to seven millions sterling are annually dissipated in indiscriminato almsgiving, thus not only encouraging systematic mendicants and impostors, but recklessly wastin money which, if directed into the right channel, would go far to relieve the poverty and distress that exist.

The number of affiliated or corresponding institu. 
tions throughout the three kingdoms is upwards of eighty. A society based on similar lines to the English Charity Organisation Society was founded at Buffalo, U.S., in 1877; and Philadelphia, Brooklyn, Boston, Newport, Detroit, Baltimore, Washington, New York, and many other American towns have since followed the example.

Charity, Sisters of. Sye Sisterhoods.

Chariva'ri is a French term used to designate a wild tumult and uproar, produced by the beating of pans, kettles, and dishes, mingled with whistling, bawling, groans, and hisses, expressive of displeasure at the person against whom it is directed. Its etymology is obscure; the Germans translate it by Katzenmusik, to which in English Cat's-concert corresponds. In France, during the middle ages, a charivari was generally raised against persons contracting second nuptials, in which case the widow was specially assailed. On these occasions the participators in it, who were masked, accompanied their hubbub by the singing of satirical and indecent verses, and would not cease till the wedding couple had purchased their peace by ransom. Charivari answers to the English concert upon 'marrow-bones and cleavers," popularly termed ' rough music,' with which it was customary to attack a married couple who lived in notorious discord. It was also got up against an unequal match, such as where there was great disparity in age between the bride and bridegroom. The charivari or 'shiveree' is not uncommon in the frontier districts of the United States.

Sometimes these customs were of such a licentious and violent character as to require military interference. As early as the 14th century the church was forced to threaten punishment, and even excommunication, against those who participated in them. In more recent times, the charivari, from its sug. gesting derision, ridicule, and satire, has come to be employed as the name of several satirical journals, the most famous among which is the CHARIVARI, which was established in Paris, December 2, 1832. Punch (q.v.) is the English Charivari.

Charjui, a Russian town of Central Asia, on the Amu-Daria or Oxus, where the Transcaspian railway between Merv and Bokhara crosses the river by a great bridge opened in 1888.

Charkoff'. See Kharkoff.

Char'latan, a mountebank, quack-doctor, or empiric, and hence any one who makes loud pretensions to knowledge or skill that he does not possess. The word was introduced in the 16th century from the Italian ciarlatano, from ciarlare, 'to babble.

Charlemagne, i.e. Charles the Great, king of the Franks (768-814), and Roman emperor (800-14), was born on 2d April 742, perhaps at Aix-la-Chapelle, and was the eldest son of Pepin the Short, the first Carlovingian (q.v.) king of the Franks, and grandson of Charles Martel. On Pepin's death in 768, Charles and his brother Carloman jointly succeeded to the throne; and by Carloman's death, and the exclusion of both his sons from the throne, the former became sole king in 771. In 772 it was resolved in the Diet at Worms to make war against the Saxons, for the security of the frontiers, which they continually threatened, and for the extension of the Christian religion. Charlemagne advanced as far as the Weser in 772, securing his conquests by castles and garrisons. Pope Adrian I. now called him to his aid against Desiderius, king of the Lombards. Charlemagne had married the daughter of Desiderius, and had sent her back to her father because she bore him no children, and married Hildegarde, daughter of the Swabian duke, Godfrey. Desiderius had sought revenge by urging the pope to crown the sons of Carloman, and on the pope's refusal bad laid waste the papal territory. Charlemagne crossed the Alps from Geneva, with two armies, by the Great St Bernard and Mont Cenis, in 773, and overthrew the kingdom of the Lombards in 774. The Lombard dukes acknowledged him as their king, and he secured the pope's favour by confirming the gift which Pepin had made to the papal see of the exarchate of Ravenna. In 775 he was again employed in the most northerly part of his dominions, reducing the Saxons to subjection; in 776 he suppressed an insurrection in Italy ; in 777 he so completed his victory over the Saxons that their nobles generally acknowledged him as their sovereign in an assembly at Paderborn. Being now invited to interpose in the wars of the Arabs and Moors in Spain, he hastened to that country in 778, and added to his dominions the region between the Pyrenees and the Ebro. From Spain he was summoned in haste by a new insurrection of part of the Srxons, who had advanced almost to Cologne, but whom he drove back to the Elbe. In 781 he went to Italy, where the pope crowned his second son, Pepin, king of Italy, and his third son, Louis, a child three years old, king of Aquitaine. The Saxons, once more rising in arms, defeated and destroyed a Frankish army in 782, which Charlemagne, after a new victory, fearfully avenged by causing no fewer than 4500 prisoners to be executed as rebels in a single day. A more general rising of the Saxons followed, but in 783 . 785 the Frankish monarch succeeded in reducing them completely to subjection, and in persuading their principal chiefs to submit to baptism and to become his faithful vassals. In 788 Bavaria was absorbed in the empire of Charlemagne, an event which brought the Franks into contact with the Avars. They, too, were now subdued, and the Frankish dominions extended to the Raab. The eastern ' mark,' the nueleus of the Austrian empire, was established to defend the frontier in that. direction (798).

In 800 Charlemagne undertook an Italian cam. paign which was attended with the most momentous consequences. Its immediate purpose was to support Pope Leo III. against the rebellious Romans. When Charlemagne, on Christmas Day 800 , was worshipping in St Peter's Church, the pope unexpectedly, as it appeared, set a crown upon his head, and, amidst the acclamations of the people, saluted him as Carolus Augustus, emperor of the Romans. Although this added nothing directly to his power, yet it greatly confirmed and increased the respect entertained for him, such was still the lustre of a title with which were associated recollections of all the greatness of the Roman empire. A scheme for the union of the newly revived Western Empire with the Empire of the East by Charlemagne's marriage with Irene (q.v.), the Byzantine empress, failed by reason of Irene's overthrow. The remaining years of his reign were spent in further consolidating his vast empire, which extended from the Ebro to the Elbe. Bishoprics were founded in the Saxon country, many of the Slavs beyond the Elbe were brought into dependence on the empire, and the Eider was recognised as the boundary between the Frankish dominions and Denmark. The empire was divided into districts ruled by counts; counts specially called markgrafen, or counts of the marches, defended the frontiers against attack; and the unity of rule was maintained by officers, the missi dominici, who were sent out in all directions as the organs of the imperial will. This organisation was promoted also by a great annual military muster and by an annual assemblage of the high officials of the empire. Charlemagne: 
senlously endeavoured to promote education, asriculture, srts, manufactures, and commerce. He imojected great national works, one of which was a cumal to conneot the Rhine and the Danube; but le deemed nothing beneath his attention which (v)ncerned the interests of his empire or of his sub-

He required his subjects to plant certain kimis of fruit-trees, the cultivation of which was iluis extended northward in Europe. His own himuins were an example of superior eultivation. He had a school in his palace for the sons of his servants. He built sumptuous palaces, particularly at his favourite residences, Aix-la-Chapelle and lngolheim-for he had no fixed capital -and many cliurches. Learned men were encouraged to come in his court. He himself possessed an amount of learning unusual in his age; he could speak Latin and read Greek. He attempted to draw up a grummar of his own language. Charlemagne was of more than ordinary stature, and of a noble and commanding presence. $\mathrm{He}_{\mathrm{e}}$ was fond of manly exerrises, particularly of hunting. His fame spread to all parts of the world : in 798 Haroun Al-Raschid sont ambassadors to salute him. He enjoyed good health till shortly before his death, 28th January 814. He was buried at Aix-la-Chapelle (q.v.), in a church which he had built there. The greatness of his dynasty terminated with his own life. The rule of Charlemagne was a noble attempt to con. solislate order and Christian culture among the nutions of the West. It was a mighty task which could have been continued and consummated only by a succession of sovereigns of like energy and sagacity with himself. As his successors were weaklings, his empire fell to pieces; yet in many ways he has had a permanent influence on European history. He established much of what were destined to be the beginnings of a new order. Besides his Capitularies (q.v.), there are extant letters and Latin poems ascribed to him. His life was written in Latin by his secretary, Eginhard $(q . \vee$.$) , the best editions being by Jaffe' (1876) and$ Holder (1882). See works by Cutts (1882), Mombert (1889), Hodgkin (1897), and Wells (1898); also Chansuns de Gestes and Romances.

Charleroi, a town in the Belgian province of Hainault, on the Sambre, 35 miles S. by $\mathbf{E}$. of Brussels by rail. It carries on considerable manufartures in hardware, glass, woollen-yarn, \&c. The district is rich in enal, and the number of smelting. furnaces and nail-factories in the neighbourhood is very great; whilst the huge ironworks of Couillet lie within a mile of the town. The fortifications, bermn by the Spaniards in 1666 , fell next year into the hands of the French, and were completed by Vauban. After six exchanges of ownership between the French and Spaniards, the Peace of Aix.laChapelle (1748) left Charleroi in the possession of Austria. In 1794, after a protracted and desperate resistance, it capitulated to the French, when the fortifications were dismantled. The importance of the place from a strategic point of view became apparent during the campaign of 1815, when, thrie days before Waterloo, Charleroi was occupied hy Napoleon, and the fortifications were restored; lint in 1866 they were finally demolished. Pop. 1866) 12,150 ; ( I 886 ) 20,511; (1891 ) 21,376 .

Charles, surnamed Martel ('the Hammer'), was the natural son of Pepin of Heristal, mayor of he palace under the last Merovingian kings, and was born about 688. After his father's death in 714 , he was chosen as their duke by the Austrasian Franks, and at the close of a struggle with the Neustrian Franks became in 720 undisputed mayor of the palace and real ruler of the Franks, the itular kings being mere puppets in his hands. He had much hard fighting with the Saxons and other stubborn Teutonic races, as the Alemenni and Bavarians, but his great service to Christendom and to civilisation was that he rolled back the surging tirle of Moslem eonquest. 'The Saracrens had already taken Bordeaux, overrun the duchy of Aquitania, and advanced to the Loire, when Charles met them between Tours and Poitier. (732), and after a desperate battle, in which their leader, Abd-ur-Rahman, fell, completely defeated them. This was one of the most important victories in the world's history, and saved western civilimation from hopeless retrogression and ruin. "But for it,' says Gilibon, 'perhajs the intes jretation of the Koran would now be taught in the schools of Oxford, and her pulpits might demon. strate to a circumeised people the sanctity and truth of the revelation of Mahomet." Charles finished his work by defeating the Saracens again in 737 , when they had advanced in the Burgundian territories as far as Lyons, and by driving them out of Languedoc. He died on 22d October 741 at Quiercy on the Oise, in the midst of his victories, his projectr, and his greatness, leaving the government of the kingdom to be divided between his two sons-Carloman and Pepin the Short.

Charles I., born at Dunfermline on 19th November 1600 , was a sickly child, unable to speak till his fifth year, and so weak in the ankles that till his seventh he had to erawl upon his hands and knees. Except for a stammer, he outgrew both defects, and became a skilled tilter and marksman, as well as an accomplished scholar and a diligent student of theology. He was created Duke of Albany at his baptism, Duke of York in 1605, and Prince of Wales in 1616, four years after the death of his dear brother, Prince Henry, had left him heir to the-crown of three kingdoms. The Spanish match had been mooted as early as 1614; but it was not till 17th February 1623 that, with Buck. ingham, his inseparable friend, Charles started on the romantic incognito journey to Madrid, its objects to win the liand of the Infanta, and to procure the restitution of the Palatinate to his brotherin-law, Frederick. Both he and his father swore to all possible and many inpossible concessions to the Catholics, but nothing short of his own conversion would have satisfied the Spanish and papal courts; and on 5th October he landed again in England, eager for rupture with Spain. The nation's joy was speedily dashed by his betrothal to the French princess, Henrietta Maria (1609-69); for the marriage articles pledged him, in violation of solemn engagements to parliament, to permit her aul all her domestics the free exercise of the Catholic religion, and to give her the upbringing of their children till the age of thirteen.

On 27th March 1625 Charles succeded his father, James I.; on 13th June he welcomed his little bright-eyed queen at Dover, having married her by proxy six weeks earlier. Barely a twelvemonth was over when he packed off her troublesome retinue to France $-a$ bishop and 29 priests, with 410 more male and female attendants. Thenceforth their domestic life was a happy one; and during the twelve years following the murder of Buckingham (1592-1628), in whose hands he had been a mere tool, Charles gradually came to yield himself up to her unwise influence, not wholly in. deed, but more than to that of Straffurd even, or Laud. Little, meddlesome Laud, made archbishop in 1633 , proceeded to war against the dominant Puritanism, to preach passive olvelience, and up. hold the divine right of kings; whilst great Strafford, from championing the Petition of Right (1628), passed over to the kiny's service, and entered on that policy of 'Thorough' whose aim was to make his master absolute. Three parliaments were sum. moned and dissolved in the first four years of the 
reign; then for eleven years Charles ruled without one, in its stead with subservient judges and the courts of Star Chamber and High Commission. In 1627 he had blundered into an inglorious French war; but with France he concluded peace in 1629, with Spain in 1630. Peace, economy, and arbitrary taxation were to solve the great problem of his policy-how to get money, yet not account for it. Not that Charles cared for money in itself, or had far-reaching projects of tyranny (he failed to enter into Strafford's scheme). But he had inherited a boundless egoism, and, content with his own petty self, had little sympathy with the dead heroism of the Tudor age, none at all with the nascent ardour uf democracy. The extension of the ship-tax to the inland counties was met by Hampden's passive resistance (1637); Laud's attempt to.Anglicise the Scottish Church, by the active resistance of the whole northern nation (1639). Once more Charles had to eall a parliament: two met in 1640 -the Short Parliament, which lasted but three weeks, and the Long, which outlasted Charles.

It met to pronounce Strafford's doom ; and, his plot with the army detected, Charles basely sacrificed his loyal servitor, his own kingly word, to fears for the queen's safety: no act weighed heavier on him afterwards. The same signature that sent Strafford to the block gave assent to a second bill by which the existing parliament might not be dissolved without its own consent. That pledge, as extorted by force, Charles purposed to disregard; and during his visit to Edinburgh, in the autumn of 1641 , he trusted by lavish concessions to bring over the Seots to his side. Instead, he got entangled in dark suspicions of plotting the murder of the Covenanting lords, of connivance even in the Ulster massacre. Still, his return to London was welcomed with some enthusiasm, and a party was forming in the Commons itself of men who revolted from the sweeping changes that menaced both church and state. Pym's 'Grand Remonstrance' justified their fears, and Charles seemed to justify the 'Grand Remonstrance' by his attempt to arrest the five members (4th January 1642); but that illstricken blow was dictated by the knowledge of an impending impeachment of the queen herself. On $22 d$ August he raised the royal standard at Nottingham; and the four years' Civil War commenced, in which, as at Naseby, he showed no lack of physical courage, and which resulted at Naseby in the utter annihilation of his cause (14th June 1645).

No need here to track him through plot and counterplot, with Catholics, Presbyterians, and Sectaries, with the Scots and the Irish, with the parliament and the army; enough, that, quitting his last refuge, Oxford, he surrendered himself on 5th May 1646 to the Scots at Newark, and by them in the following January was handed over to the parliament. His four months' captivity at Holmby House, near Northampton; his seizure, on 3d June, by Cornet Joyce; the three months at Hampton Court; the flight on 11th November; the fresh captivity at Carisbrooke Castle, in the Isle of Wight - these lead up to the 'trial' at Westminster of the "tyrant, traitor, and murderer, Charles Stuart.' He had drawn the sword, and by the sword he perished, for it was the army, not parliament, that stood at the back of his judges. Charles faced them bravely, and with dignity. Thrice he refused to plead, denying the competence of such a court; and his refusal being treated as a confession, on the third day fifty-five out of seventy-one judges - sixty-four more never were present-affixed their names and seals to his death-warrant; four days later, sentence was pronounced.

No need here to tell the well-known story of his meekness towards his persecutors, of the pathetic parting from two of his younger children, of his preparation for a holy death; or how, on the morning of the 30th January 1649 , he passed to that death on the scaffold in front of Whitehall, with a courage worthy of a very martyr. On the snowy 7th of February they bore the 'white king' to his grave at Windsor in Henry VIII.'s vault; in 1813 the Prince Regent had his leaden coffin opened. Six children survived him-Charles and James, his successors; Mary, Princess of Orange (1631-60); Elizabeth (1635-50); Henry, Duke of Gloucester (1639-60); and Henrietta, Duchess of Orleans (1644-70), the last born ten weeks after Charles's final parting from his queen. At the Restoration Charles II. appointed, on his sole authority, a 'form of prayer, with fasting, for the day of the martyrdom of the Blessed King Charles I.,' to be annexed to the Common Prayer-book; with the other 'state-services,' it kept its place there till 1859.

A far stronger man than Charles might searcely have extricated himself from the difficulties that beset him; true, those difficulties were largely of his own ereating. But was he right in abandoning Strafford? should he also have sacrificed wife, faith, and crown? If yes, then was he wholly in the wrong; if no, he was partly - for once at least-in the right. Vices, other than duplicity, he had none, as we use the word. He was vague, vacil. lating, obstinate; unable to lead or be led; superstitious, heedful of omens; unsympathetic and reserved where he did not love; intolerant of opposition to his will. But he was a good husband, a good father, a good churchman-no man so good was ever so bad a king; no man so fallible believed so honestly in his infallibility. For Charles was honest to his own convictions. His very duplicity was due sometimes to schooling in 'kingeraft, but oftener to inability to see two sides of it question. Now he saw one, and now the other, but never both sides at once; and, just as he saw, so he spoke. He was not a liar because he loved a lie. Milton's charges against him of 'all manner of lewdness' rank with Milton's charge that he poisoned his father; and Bishop Heber's rash statement that Jeremy Taylor's second wife was 'generally believed to be a natural daughter of Charles, when Prince of Wales,' is backed by no tittle of evidence. Indeed, as a pattern of culture and purity, one prince alone is worthy to be named beside him-the late Prince Consort; and had Charles's lot fallen, like his, on peaceful days of settled monarchy, admiration, not pity, might now be our feeling towards him. But Charles was predestined to sorrow. 'A tragic face!' said the sculptor Bernini, as he looked on the triple portrait by Vandyke; already, the shadow of a violent death overclouded those fine, weak features.

See the articles Fikon Basilike, Hrankietta Maria, England, SCOTland, IREland, LaUd, Strafford, Eliot, Hampden, Prynne, PyM, Cromwell, BradSHAW, \&c. ; the Histories of Clarendon, Hallam, Green, Guizot, and Ranke; I. D'Israeli's Commentaries on the Life and Reign of Charles $I$. (5 vols. 1828-30); Letters o Charles I. to Henrietta Maria (Camden Soc. 1856); Chancellor's Charles I., 1600-25 (1886); Calendar of State Papers 1625-45 (20 vols. 1858-90); three long articles on the trial in the Athenceum for Jan. and Feb. 1881; the sumptuous Life by Sir J. Skelton (1898); and, specially S. R. Gardiner's Puritan Revolution (1876), History of England, 1603-40, (10 vols. 1863-82; new ed. 1883-84), and History of the Great Civil War, 1648-49 (3 vols. 1886-91).

Charles II., born at St James's on 29th May 1630, was present at Edgehill (1642), and in 1646, after a twelvemonth in the western counties, escaped to France by way of Scilly and Jersey. He got little good from two years spent in Paris; then he passed on to Holland, where he met with a better reception, and whence in 1648, with nineteen 
Enylish royalist war-ghips, he made an expedition th the Thumes. His father behealed-Charles did his ntmost to save him, even sending a carte blanche th the English parliament-and his hopes disap. puinted from Ireland and Montrose, in 1650 he arcepted the terms of the Scottish commissioners, and landed on 23d June at the mouth of the Spey. That was a dreary time of prayers, fastings, and sermuns (six sermons a day) for the gay young prince, Less a king than state-prisoner, he must ign and re-sign the two Covenants, must put away his old friends, must acknowledge the sins of his hrmse, his father's blood-guiltiness and mother's ilulatry. But the defeat at Dunbar and his 'start' for the Highlands gained Charles somewhat more liluerty; and, having on lat January 1651 been erowned at Scone, in the following August he suddenly marched, with 10,000 men, into England. fow joined the Scots, and, catching them up at Worcester, Cromwell utterly routed them on $3 d$ Sieptember. For six weeks Charles wandered a fugitive, a thousand pounds set on his head, through the western and southern counties, now hiling in the oak at Boscobel, now riding disguised as a serving-man, anon lurking at Stonehenge, More than forty persons were privy to his secret, yet on 15th October he embarked at Shoreham for Normandy. Then followed nearly three years of exile in France, nearly two at Cologne, then three in the Low Countries, needy every where, everywhere proflicrate; but at last, on 26th May 1660, Charles landed at Dover, recalled to the throne by the fall of the Protectorate, and the nation's dread of military despotism. "It must be my own fault,' he jested, 'that I did not come sooner back, for I find no one but tells me he has always longed for my home-coming.'

Of the four parliaments that succeeded the Convention, the first or 'Cavalier' parliament lasted through nearly two-thirds of the entire reign, from May 1661 to January 1679; from March 1681 Charles ruled without one. The first seven years (1660-67) were the period of Clarendon's ascendency, of constitutional loyalty to ehurch and state, ats anti-Catholic as it was anti-Puritan. Next came the Catholic-Presbyterian Cabal, broken up by the Test Act of 1673; and then the fierce struggle between the Court and Country factions, in which Shaftesbury played the chief part, and from which, in the end, Charles issued victorious.

As early as 1661 he accepted a secret subsidy from France, and no aet of his reign was more unpopular than the sale next year of Dunkirk. In 1665 a naval Dutch war, due to commercial jealousy, was forced on by Clarendon's enemies, who saw in it a chance of ousting him. In spite of two English victories, with an indecisive engagement between (Lowestoft, Downs, and North Foreland), in June 1667 De Ruyter sailed up the Thames, and burned several war-ships lying at Chatham-that night Charles was very merry in his harem. The peace of Breda (21at July), which in August was followed ly Clarendon's downfall, left both nations exliansted, and France the sole gainer. Temple's 'Triple Alliance (23d January 1668), between England, Holland, and Sweden, was on Charles's part a mere bid for popularity, a means too of raising his price with Louis XIV.; and by the secret Treaty of Dover (20th May 1670) he entered on an offensive alliance with France, became its pensioner, and undertook to effect the conversion of England. A sea-fight with the Dutch in Southwold Bay (1672) was bloody but indecisive; and the strong anti French feeling forced Charles to conclude a peace (1674), and to consent to the marriage of his niece Mary with his nephew William of Orange (1677). Still, by two other secret treaties (1676-78), and by also intriguing with the opposition, Louis secured his end, to cut England off from continental politics.

At home, the abortive Savoy Conference was followed by the ejection of nearly 2000 Noncon. formist ministers (24th August 1602 ); the Grent Plague (May to December i665) earried off nearly seventy thousand Londonens; and the Great Fire (2d to 6th Septemlner 1666) consumed 13,200 houses, St Paul's, and 86 ehurches. Sir John Coventry, for plain speaking, got his nose slit by Charles's bullies (1670); the 'stop of the Ex. chequer' (16:2) plunged the ehief city hankerm in bankruptey; and Charles's two Declarations of Indulgence (1662-72) were met by the Conventicle and Test Acts, the Dissenters themselves declining to share toleration with the Catholics, for whom such toleration was designed. Clarendon's foes had cause to dread Clarendon's son-in-law, the king's brother, James, Duke of York; and his open profession of Catholicism (1672) gave a pretext for Shaftesbury's Exclusion Bill, and colour to Oates's trumped-up 'Popish Plot' (A ugust 1678 to December 1680), which Shaftesbury fostered, and which cost the lives of fifteen Catholic victims. Himself, if anything, at heart a Catholic, Charles sacrificed them basely to his fears; still, honour, brotherly affection, or French gold, would not let him acknowledge Monmouth for his heir. But the tide had already turned. Men's shame at that shame. ful panic, and disgust at the thought of a bastard on the throne, caused a Tory reaction; and the Tory reaction drove the Whigs on to open resistance-the Rye-house Plot (1683). Shaftesbury died beyond seas, Lord Essex by his own hand in the Tower, and Russell and Sidney by the headsman's axe.

What English king so absolute as Charles, that Sunday evening, when Evelyn saw him 'toying with his concubines in the glorious gallery ${ }^{\text {s }}$ of Whitehall? But on the morrow be was struck with apoplexy, and for three days lay in a stupor. When he came to himself on the Thursday, he would not receive the communion from Bishop Ken; bnt, thanks to the Duchess of Portsmouth, a priest who had aided him in his escape from Worcester was brought to his bed-side, and by him he was reconciled to the Catholic Church. Then he blessed his children; blessed, too, the Protestant bishops ; and at last passed away on Friday the 6th of February 1685. On the night of the 14th he was buried in Westminster Abbey.

So ended the worst reign in English history, whose sole great measure was the Haheas Corpus Act (1679), and whose tortuous politics are generally referable to one or other of the following motives: Charles's fear of again being sent on his travels, the nation's fear of a second great civil war, its hatred of Popery and hatred of the French, the littleness of men's aims and greatness of their greed, and 'backstairs' influence, omnipresent, omnipotent. Such as the reign was, such was Charles himself. With a taste for the arts and for science, he was able, shrewd, affable, easy-going, active of habit, physically brave. His talents serve but to enhance his vices of utter selfishness and abject sensual. ism. And yet with his subjects he was always popular; the nicknames 'Old Rowley' and 'The Merry Monarch' attest even now the liking that they bore him.

On 22d May 1662 Charles had married poor plain Catharine of Braganza (1638-1705). The marriage was childless, and her influence on English politics was slight as compared with that of his numberless mistresses. Of these, before the Restoration, two only call for notice-'brown, besutiful, bold, but insipid' Luey Walter (163058), the mother of James, Duke of Monmouth and Buccleuch (1649-85); and Catherine Peg, the 
mother of Charles Fitzcharles, Earl of Plymouth (1657-80). Then came the splendid termagant, Barbara Villiers or Palmer (1640-1709), whom Charles made Countess of Castlemaine in 1661, Duchess of Cleveland in 1670, and who was mother of the three Fitzroy Dukes of Southampton and Cleveland (1662-1730), Grafton (1663-90), and Northumberland (1665-1716). By 'pretty, witty' Nell Gwynn (1650-87) Charles was' father of Eharles Beauclerk, Duke of St Albans (1670-1726); almost his last words were 'Let not poor Nelly, starve." There were, besides, "la belle Stewart" (Duchess of Richmond), the Duchess of Mazarin, and many more, with, last but not least, the hated 'Madam Carwell,' i.e. Louise de Keroualle (16491734), the subtle, 'baby-faced' Breton. She was made Duchess of Portsmouth in 1672, French Duchesse d'Aubigny in 1684; and she was the mother of Charles Lennox, Duke of Richmond (1672-1723).

See the articles England, Scotland, Monk, LauderDALE, LFens (Danby), Halifax, \&c.; the Histories of Clarendon, Burnet, Hallam, Macaulay, Ranke, and Green; the Diaries of Pepys and Evelyn; Grammont's Memoirs; Masson's Life of Milton; the Calendars of State Papers, 1649-67 (21 vols. 1860-87); Harris's Life of Charles II. (2 vols. 1766) ; Jesse's Court of England under the Stuarts (4 vols. 1840); Hoskyn's Charles II. in the Channel Islands (2 vols. 1854); P. Cunningham's Story of Nell Gwynn (1852; new ed. 1893); Molloy's Royalty Restored (1885); Forneron's Louise de Keroualle (trans. 1887) Allan Fea, The Fight of the King (1897).

Charles VII., the third son and successor of Charles VI. of France, was born 22d February 1403. On his father's death (1422) his army held possession of the southern provinces; Paris and the north being in the hands of the English, who proclaimed Henry VI, of England king of France, and appointed the Duke of Bedford regent. For some time the events of war were unfavourable to Charles, who was compelled to evacuate in succession Champagne and Maine. In 1426 the Count Dunois gained the first victory over the English at Montargis; but in the year following the latter laid siege to Orleans, a place of great importance to the French, as securing a connection with the north. At this time also, Joan of Are, the famous Maid of Orleans, by her wonderful courage and confidence of a heavenly mission, roused the fervour both of nobles and people. The siege of Orleans was raised in May 1429; the English retired disheartened, and gradually lost all they had gained in France, while their cause finally became hopeless after the treaty concluded at Arras (1435), between the French king and the Duke of Burgundy. Bayonne, the last stronghold in the south, fell in 1451 , and with the death of Talbot under the walls of Castillon in 1453, the whole south finally passed to France, and the Hundred Years' War came to an end. Nothing now remained to the English across the channel but Calais, with Havre and Guines Castle. In 1436 Charles entered Paris. He next devoted himself to the reorganisation of the government, in which everything had fallen into confusion, and under his rule France recovered in some measure from the effects of the terrible calamities which it had endured. His last years were embittered by the conduct of his son, the Dauphin, afterwards Louis XI. He died at Melun on 22 d July 1461. See the great work by De Beaucourt ( 6 vols. 1881-92).

Charles IX., king of France (1560-74), the second son of Henry II. and of Catharine de' Medici, was born at St Germain-en-Laye in 1550, and succeeded his brother, Francis II., in 1560 . He was a proficient in manly exercises, possessed much physical energy, and considerable literary accomplishments. But weak and wavering, with all his cruelty and cunning, he was completely subject to the will of his mother, whose counsels drove him to authorise an act so diabolical that all Europe stil. shudders at the recollection. The atrocious massacre of St Bartholomew's Day, 24th August 1572, was the culmination of a series of disgraceful treacheries towards the Huguenots. Its consequences politically were the very reverse of favourable to the Catholic cause, while scarce two years later (May 30, 1574) the wretched king died miserably, with all the horrons of hell before his eyes. See BARTHOLOMEW (MASSACRE OF ST).

Charles X., king of France (1824-30), third son of the Dauphin Louis, and grandson of Louis XV., was born at Versailles, 9th October 1757. He received the title of Comte d'Artois, and in 1773 married Maria Theresa of Savoy. The taking of the Bastille on July 14, 1789, prevented the success of a coup d'état planned by Artois and the court party. The first emigration headed by Artois and Condé then followed, and a more disastrous policy was never conceived. The attempts of the émigrés to restore the old state of things in France by means of foreign intervention did more than any single event to insure the fall of the monarchy. After taking 8 small part in the war of 1792 , Charles went to St Petersburg ; thence in May 1793 to England. In spite of the failure of the expedition to Quiberon Bay in June 1795, another was attempted under Artois' leadership in October, but he had not courage to land and place himself at the head of the insurgents, whom he basely left to the vengeance of Hoche and the republicans. After this he lived in obscurity, partly at Holyrood and partly at Hartwell, until the allies entered Paris in 1814, when he appeared in France as lieutenantgeneral of the kingdom, and issued a proclamation announcing the end of despotism, of conseriptions, and of oppressive taxes. After the second restoration, in alliance with the priests, he headed the party of the Ultras in their struggle with the Constitutionalists. The accession of Villele to office and the unconstitutional character of the latter part of Louis XVIII.'s reign attested the success of Artois' reactionary policy. The death of Louis, on 16th September 1824, brought him to the throne as Charles X. He took the oath of adherence to the Charte, and was at first popular with all parties: but he soon displayed his intention of restoring as much as possible the absolutism of the old French monarchy. Popular discontent rapidly increased. The victory of the opposition at the elections of 1827 was followed by the resignation of Villele. A ministry of compromise, headed by Martignac, a moderate politician, succeeded in January 1828 , but in August 1829 Charles called to the head of affairs the Prince Polignac, an extreme royalist. A royal speech, of a threatening character, on $2 \mathrm{ll}$ March 1830, was followed by an address of remonstrance, signed by 221 deputies, upon which the king dissolved the chambers. The deputies who signed the address were all re-elected, but the cour taking fresh courage from the success of the expedi tion to Algiers, the celebrated five ordinances of 25th July were signed by the king, putting an end to the freedom of the press, already largely curtailed, appointing a new mode of election, and dis solving the recently elected chamber. Paris took up arms, the guards were repulsed, the revolu. tion was accomplished in three days, and the king found himself compelled to retire to Rambouillet. As a last resource, he abdicated the throne on $2 d$ Angust 1830 in favour of his grandson, the little Comte de Chambord. But it was too late; the revolution was completed, and Louis-Philippe, Duke of Orleans, was chosen king of the French. Charles then travelled through France to Cherbourg, and embarked for England in an American ship. $\mathrm{He}$ 
resiled for some time at Holyrood ayain, and afterwhrds at Prague, taking no part in the political intrignes aml attempts of the Duchess de Berri. He died of cholern at Görz on 6th November $18: 36$.

Charles V., emperor of Germany, by the extent of his clominions and by virtue of his own genius the greatest European potentate of the lith century, was born at (ihent in 1500. From his father Philip, the son of the Emperor Maximiliun and Mary of Burgundy, he inherited the dominion of the Low Countries, the county of Burrumly, and a strong clium to the imperial grown; from his mother, Joanna, the daughter of Ferdinand and Isabella, he also inherited the kingsloms of Spain and Naples, and the Spanish aequisitions in America. Charles's education was intrusted to Adrian of Utrecht, afterwards pope unler the title of Adrian VI., and William de Croy, an experienced politician, who early initiated his pupil into the arts of government, and gained an ascendency over him which determined Charles's policy during the early years of his rule. To
Adrian Charles owed little, and to the end his scholastic acquirements were but meagre. His grandfather, Ferdinand, died in 1516, and the next year Charles left the Netherlands for Spain, where he was acknowledged joint ruler with his mother Joanna, who was incurably insane. On the death of his grandfather, Maximilian, in 1519 , he was elected to the imperial crown from a number of competitors, little, however, to the satisfaction of his Spanish subjects, who saw in this honour a blow at their own interests and importance. The following year Charles was crowned emperor at Aix-la-Chapelle, and a few months later (1521) presided at the famous Diet of Worms. The main question he had here to settle, the question of the respective claims of the Catholics and the followers of Luther, was to the end of his reign the great problem which Charles had to settle in Germany. At this his first diet, he displayed the poliey which, whenever it was in his power, he ever afterwards pursued-the restoration of Germany to the papal see. The finding of this diet was an edict against Luther and his opinions, and by this edict Charles, at the outset of his reign, leagued himself with Rome against the uational sentiment of Germany.

The history of Western Europe during the next quarter of the century is in large degree the history of the rivalry of Charles and Francis I. of France. According to their respective interests, Henry VIII. of England and the successive popes now favoured the one, and now the other; and the result of the conflicting interests of all these potentates was almost continuous war during the whole of that period. The Trenty of Madrid (1526), the Ladies' Peace of Cambrai (1529), and the Peace of Crespy (1544) may be regarded as marking the successive steps in the struggle. The points in dispute between Charles and Francis were these: Charles laid claim ti) the duchy of Burgundy as having been unjustly appropriated by Louis XI., and also to the duchy of Milan as a fief of the empire. Francis, on his part, maintained his right to these territories, demanded homage of Charles for Flanders and Artois, and made it a ground of offence that Spain had dispossessed Jean d'Albret of his king. llom of Navarre. It was in Italy that the war between the two monarchs was carried on most vigorously; and during the first period the result was altogether in Charles's favour. Mainly at the instance of Wolsey, Henry VIII. actively aided the emperor, who was still further strengthened by Francis' quarrel with his greatest subject, the Constable Bourbon, who formed a league with Charles and Henry VIII. for the complete subjuga- tion of France. In 1524 the troops of Charles drove the French out of Italy, invaded Provence, and unsuccessfully besieged Marseilles. Next year Francis, in the endeavour to recover the duchy of Milan, was defeated and taken prisoner at Pavia, and afterwards conveyed to Madrid. In 1526 he was released after signing a treaty in which he yielded to Charles on all the points at dispute between them. In this year Charles married Isabella, sister of John III. of Portugal, to whom he was much devoted. Meanwhile, there was a growing alarm at the successes of Charles, and the Holy League was formed against him by Pope Clement VII., Henry VIII., Francis, and the Venetians. In 1527 a motley army of Spaniards, Italians, and Germans, led by Bourbon, who fell in the assault, sacked Rome, and imprisoned the pope, to the horror of all Christendom. Charles was denounced as the author of the sacrilege, and cartels of defiance were sent to him by Henry and Francis. He disclaimed all part in the affaír; yet it was altogether in his interest that it should have happened, as the pope was then the nost active of his enemies. The failure of Francis to seize the kingdom of Naples led to the Peace of Cambrai (1529), by which Charles was left master of Italy, and was relieved from his homage for Flanders and Artois:

During all these years Charles had been resident in Spain, where, on his arrival from Germany, he had found things in an extremely un. settled state owing to certain encroachments lately made on the privileges of the great cities. A general insurrection had taken place during his absence, which only after a protracted struggle had been quelled by the help of the nobles. Charles, by his tact and policy, succeeded in com. pletely putting down the sedition; and, while largely increasing the power of the crown, contrived to render himself highly popular throughont the country. All through his reign, however, ho had great difficulty in extorting from the Spanish Cortes the funds necessary to carry on his foreign schemes. In 1529 Charles proceeded to Italy, and at Bologna was erowned by the pope king of Lombardy and emperor of the Romans. As he was on his way to Germany, where the religious difficulty was still the burning question, he urged the pope, though unavailingly, to call a general council which should settle once for all the points at issue. At the Diet of Augsburg (1530) Charles confirmed the Edict of Worms, and the Protestants (now first so called), in self-defence, formed the League of Schmalkald. The threat of an invasion by the Turkish sultan, however, forced Charles to make important concessions, and with the support of the appeased Protestants he was enalued to take the field against the Turks. No battle ensued, but the sultan was forced to retire; and Charles was again at liberty to return to Spain by way of Italy, where once more he earnestly urged on the pope the necessity of a general council. In 1535 Charles achieved in person the most brilliant of all his exploits - the destruction of the power of the great corsair Barbarosas, and the capture of Tunis. Meanwhile, Francis was still in active hostility against him; and in 1536 Charles himself once more proceeded to Italy and invaded Provence with a large army. By making the country a desert, Francis forced his enemy to retire without effecting any actual conquest. As another expedition into Picardy had also miscarried at the anme time, this was the most disastrous year that Charles had yet experienced. War, however, still pro. ceeded; and Francis, in desperation, and to the disgust of Christian Europe, called in the aid of the Turk. In 1538, both parties being now ex. hausted, the pope (Paul III.), Francis, and Charles 
met at Nice, and agreed to a ten years' truce on the condition that they should retain the possessions then in their hands.

The year 1539 was for Spain one of the most important during Charles's rule. To meet his extraordinary expenditure, Charles held in that year a meeting of Cortes with the view of gaining its consent to the imposition of new taxes. As at this meeting the nobles were especially refractory, they were thenceforward excluded from the Cortes; and from this time dates the decline of their power in the state. In the same year, by the romantic courtesy of Francis, Charles travelled through France to the Low Countries, where the insurrection of Ghent, on account of a certain illegal tax, called for his presence. After having quelled this insurrection with the utmost severity, and stripped the town of all its ancient privileges, Charles proceeded to Germany, where another diet held to settle the religious differences was as unsuccessful as its predecessors. During this journey also Charles engaged in the most disastrous of all his enterprises. In the autumn of 1541, against the advice of his most experienced seamen, he conducted from Italy a fleet against Algiers, whose piracies had been the terror of the south of Europe. A succession of storms completely destroyed the fleet, and Charles himself with difficulty reached the coast of Spain. A new quarrel having arisen between Charles and Francis regarding the duchy of Milan, the ten years' truce fell through, and war again went on for the next three years. The most notable event of the war was the wintering of the Turkish fleet at Toulon, by arrangement with the French king, at which Henry VIII. was so indignant that he concerted with Charles an invasion of France, when the emperor actually came within two days' march of Paris. By this double invasion Francis was again forced to make an unfavourable peace-that of Crespy (1544), by which he once more renounced all claims to Italian territory, and agreed in conjunction with Charles to make war on the Turks.

Having thus triumphed over Francis, whose death in 1547 left his hands freer than they had ever been since the beginning of his reign, Charles now sought to carry out the policy he had always had at heart with regard to Germany. In this policy he had two objects-the suppression of Protestantism and the sucession of his son Philip to the imperial crown. The news that Charles had made a league with the pope for the extinction of heresy drove the Protestants to arms, but two campaigns saw their power broken, and two of their most important leaders, the Landgrave of Hesse and the Elector of Saxony, taken prisoners. The Augsburg Interim (1548) followed as a temporary arrangement till a general religious council should settle all difficulties. This arrangement did not satisfy the Catholies, but it was especially objectionable to the Protestants, upon whom it was forced with great violence. Charles's severe enforcement of the Interim, his eruel treatment of the Landgrave of Hesse and the Elector of Saxony, and his evident design to make himself absolute master of Germany, led to the overthrow of all his plans. Maurice of Saxony, a young man of extraordinary talents and great ambition, who, although a Protestant, had hitherto seemed to support Charles in all his schemes, saw that the emperor's power rested in reality on a most insecure foundation. By a subtle line of policy Maurice contrived to gather round him a large army, while Charles, still trusting in his fidelity, had dismissed the troops by whose aid he had lately had Germany at his feet. The emperor all but fell into the hands of Maurice, who was now n a position to command the most favourable con- ditions for the Protestants. Accordingly, by the Treaty of Passau (1552), and, after the death of Maurice, by the Peace of Augsburg (1555), Protestantism received legal recognition, and Charles saw his life's schemes finally baffled. In his other object he was equally unsuccessful. He had tried in vain to persuade his brother Ferdinand to waive his claims to the empire in favour of Philip, and the princes of Germany, Catholic as well as Protestant, refused to entertain Charles's suggestion. Thus disappointed in his dearest hopes, and broken in health by repeated attacks of the gout, to which he had been subject since his 29th year, Charles resigned his kingdoms to his son (1555-56), whom he had married the previous year to Mary of England, and the empire to the electors (1556). Retiring to the monastery of Yuste in Estremadura, he spent the rest of his life in complete seclusion: but he never ceased, almost till his death on 21 st September 1558, to take the keenest interest in affairs of state, and his advice, still given in emergencies, was received by his son with the greatest respect.

Charles V. and Luther, the two most prominent figures of the 16th century, are also the best representatives of its great conflicting principles. The religious revolution, and the spirit of nationality which that revolution evoked wherever it was realised, are the ideas associated with the name of Luther. The aim of Charles was a great empire in Western Europe, of which the pope should be the spiritual, the House of Austria the temporal, head. In opposing this aim, and thus preserving the balance of power as well as the individuality of the Western nations, Francis, according to Ranke, was justified in calling in the Turks. Charles had a mind and heart equal to great undertakings; yet he not only failed to achieve his purpose during his life, but bequeathed to his son a policy attended by the most disastrous results. It was in carrying out this policy that Philip lost the Netherlands to Spain, and that he arrested Spain itself in its national development. The position also in which Charles left the religious question by the Peace of Augsburg inevitably led to the Thirty Years' War, with all its frightful consequences to Germany. Charles's personal qualities were such as to win him the affection of his immediate dependents, and to render him popular with all classes of his subjects among all the peoples under his sway. He was sincerely devoted to the church, and religious motives greatly influenced him in all his counsels. His private morals bear a favourable comparison with those of contem. porary princes. In person he was slight and graceful, and his manners were marked by singular refinement and dignity; but throughout all his life he was haunted by the dread of his mother's mental affliction. Don John (g.v.) of Austria was an illegitimate son of Charles V.

See Robertson's Life of Charles $\boldsymbol{V}$., and Prescott's continuation; Ranke's History of the Reformation in Germany; Sir W. Stirling-Maxwell's Cloister Life of Charles $V_{\text {. ; }}$ and Mignet's Charles-Quint.

Charles $\mathbf{X}$., or Charles-Gustavus, king of Sweden (1654-60), the son of John Casimir, Count Palatine, and Catherine, sister of GustavusAdolphns, was born at Nyköping, 8th November 1622. After his studies at U psala, he took part in the Thirty Years' War under Torstensohn. On the abdication of his eccentric cousin, Queen Christina, whom he had wooed in vain, Charles succeeded as next heir to the throne of a kingdom which the folly and extravagance of the queen had reduced to an almost bankrupt condition. Charles was the second of the three great warrior-monarchs of Sweden, but unlike his uncle, who could plead religious grounds, and his grandson, who was at 
firet forced to fight for gelf-preservation, Charles seemed to make war principally for war's sake. Ho was now free to gratify his passion for war. Finst he attrcked Poland in July 1655, because the Pulish king had not resigned his claim to the siwedish throne, and in a few weeks overran the whole country. Next he forced the Great Elector of Brandenburg to acknowledge his lordship over the duchy of Prussia, then crushed the forces of the ' 'ulish king anew in a terrible three-days' battle at Warsaw (July 28-30, 1656). He next assailed the I the Great and Little Belt on the ice, and speedily mitils himself master of all the continental possess. sions of Denmark. Marehing from isle to isle over the frozen sea, he extorted the Treaty of Roeskild (ith March 1658), which gave to Sweden Halland, Srania, Blekinge, Bornholm, and the other Danish pussessions beyond the Sound, and emancipated swerlen from the Sound Dues. His offers to the Dutch and English to share in the partition of Denmark being declined, he invaded Zealand alone in 1659, and attacked Copenhagen, but was beaten off by the Danes, aided by the Prussians and Dutch. Soon after he died suddenly at Gothen. burg, February 23, 1660. He was succeeded by his sun, Charles XI. (1660-97), then only four years old. See SWEDEN.

Charles XII., king of Sweden (1697-1718), wias the son of Charles XI., and was born at Stockholm, 27th June 1682. On the death of his father in 1697 he ascended the throne, and notwithstanding his youth the States declared him of age to assume the reins of government. The neighbouring powers thought this a favourable time to humble Sweden, then the great power of the north; and Frederick IV. of Denmark, Augustus 1I. of Poland, and the Czar Peter the Great concluded a league for this object. The Danes bearan by invading the territory of the Duke of Holstein Gottorp, husband of the eldest sister of Charles. The young king at once flung an army into Zealand, and in concert with Sir George Rooke's Anglo-Dutch squadron so threatened Copenhagen both by land and sea that the king was fain to sue for peace. Charles now hastened to meet the Russians, who lay under the walls of Narva, 50,000 strong, stormed their camp with but 8000 Swedes, and routed them with great slaughter, 30th November 1700. He next dethroned Augustus II., and procured the election of Stanislaus Leszezynski as king of Poland. Augustus supposed himself safe at least in Saxony, his hereditary dominion, but was followed thither, and humbling terms of peace were dictated at Altranstädt in 1706. Patkul, born a Livonian, but now the Czar's ambassador at Dresden, Charles caused to be broken on the wheel for treason, after a form of trial. In the autumn of 1707 he had collected an army of 43,000 inen in Saxony, and in the January of the following year suddenly burst into Russia, and almost captured the Czar at Grodno. He next drove the Russians before him, and had already forced the Beresina and won a battle at Smolensk, which opened up to him the road to Moscow, when he sudidenly turned southwards to the Ukraine, trust. ing to the promises of the Cossack hetman Mazeppr. But Mazeppa failed to bring forward his 30,000 C'ossacks, and the king's reinforcements from Sweden were cut off by the watchful Cyar, so that the Swedes had no alternative but to endure the hard winter of $1708-9$ in the midst of an impoverished and hostile country. In spring Charles, with a force reduced to 23,000 men, laid siege to Pultowa, but the Crar hastened to oppose him, and defeated him after a desperate strugryle, on the 8th July. Charles fled with a handful of attendants acroses the Turkish frontier to Bender.

Augustus now revoked the trenty of Altranstadt. and the Czar and the king of Denmark in concert assailed the Swedish territories. But the regeney in Stockholm sdopted measures of effective rewist. ance, and Charles prevailed upon the Porte to commence a war ayainst Russia, in which Peter seemed at first likely to suffer a severe defeat. But Russian agents succesded in inspiring the Turks with suspicions concerning the ultimate designs of their impracticable guest, and accord. ingly Charles was seized, resisting desperately sworl in hand, and conveyed to Demotica. At last he contrived to escape, and made his way through Hungary and Germany in sixteen days, till he reached Stralsund on the 21 st of November 1714. A month later the town was forced to eapitulate to an allied army of Danes, Saxons, Prussians, and Russians, on which the king erossed to Lund. His passion for war led him to attack Norway early in 1716; and soon after, under the advice of the Baron von Görtz, he formed a scheme which commended itself to his love of fighting and his vast ambition. He was to make terms with the Czar by surrendering the Baltic provinces of Sweden, then conquer Norway, next land in Scotland and replace the House of Stuart on the English throne, with the help of the Jacobite party within and that of Cardinal Alberoni without. No sooner had he purchased his peace with the Czar than he burst into Norway. Early in 1718 he commenced the siege of Fredrikshall, and while hastening on the works in the dead of winter with all his character. istic impetuosity of impatience, was killed by a musket-shot from the fortress, Some writers have maintained that his death was due to treachery, and $a$ somewhat unscientific examination of his skull in 1746 seemed to give some colour to the belief; but a new examination by command of Charles XV. in 1859 proved conclusively that the fatal shot must have been fired from a height downwards, and that therefore the king's death was due to his own reckless exposure of his person to the fire of the enemy.

The character of Charles was full of strange contradictions, He was brave to the pitch of reckless folly, determined to the point of foolish obstinaey. Pleasure had no attractions for him: he shared the coarsest food and severest labour of the common soldier with an easy cheerfulness that won him the passionate devotion of his men. All external marks of rank he despised his dress was simple, and Swedish in form and colour -a loose blue coat, with turned-down collar, and large plain brass buttons; buff-coloured waistcost; a black kerchief, doubly folded round his neck; coarse felt hat, and high broad-toed riding boots with massive steel spurs. His hardy frame defied alike fatigue and the extremes of heat and cold. He was able and sagacious in counsel, and had a mind capable of the vastest designs. But his ambition was fatal to his country, and after his death, Sweden, exhausted by his wars, ceased to be nambered among the great powers The strange vicissitudes of his career are reviewed in thirty of the finest lines of Johnson's noble poem, The Vunity of Human Wishes the eoneluding passage is as well known as anything in English literature :

$$
\begin{aligned}
& \text { His fall was destin'd to a barren strand, } \\
& \text { A petty fortress, and a dubious hand. } \\
& \text { He left the name at which the world grew pale, } \\
& \text { To point a moral, or adorn a tale. }
\end{aligned}
$$

Voltaire's well-written Histoire de Charles $X I I$. will continue to be the chief life, spite of its errors. An eloquent sketch of his career, read by King Oscar II., then Duke of Ostergötland, at the 
inauguration of a statue to Charles XII. on the 150th anniversary of his death, was translated by Ayreorge, 1879; and see the Lives by Nishet Bain ('Heroes' series, 1896) and Osear Browning (1899).

Charles XIV., king of Sweden and Norway (1818-44), originally JEAN BAPTISTE JULES BERNADOTTE, was born at $\mathrm{Pau}$, in the south of France, January 26, 1764, and was the son of a lawyer. He entered the French army in 1780 as a common soldier; became an ardent partisan of the Revolution, and fought his way up to the command of a division in 1794, and a marshal's baton in 1804 . He distinguished himself greatly in the German campaigns in 1796, and the year after under the eye of his great chief himself in Italy. In 1799 he was minister of war, and for his conduct at Austerlitz was named in 1805 Prince of Pontecorvo. In the campaigns of 1806 he commanded the first army corps. After Jena he pursued the Prussians to Halle, cut off the reserve under the Prince of Wirtemberg, next pursued the redoubtable Blicher to Libeck, and compelled him to surrender (November 7), He recelved the command of the French troops in North Germany and Denmark, and led the Saxon troops at Wagram in the war against Austria. But he had never been liked or trusted by Napoleon, whose jealousy and dislike now became so apparent that Bernadotte left the army in disgust, and returned to Paris. He was afterwards sent by the ministerial council to oppose the British, who had landed at Walcheren, but meantime the breach between the emperor and him grew wider. In 1810 he was elected crown prince and heir to the throne of Sweden. Almost the only condition imposed on him was that of joining the Protestant Church. He changed his name to Charles John; and the health of the Swedish king, Charles XIII., failing in the following year, the reins of government came almost entirely into his hands. He refused to comply with the demands of Napoleon, which were opposed to the interests of Sweden, particularly as to trade with Britain, and was soon involved in war with him. He took part in the great and final struggle of the allies with Napoleon at Leipzig, but showed much reluctance to join in the invasion of France, and was tardy in his progress southward. There seems good reason to believe that the French throne was within his own ambition, and that his disinelination to act against his native country was due as much to policy as to patriotism. He became king of Sweden on the death of Charles XIII. in 1818, and won for himself the character of a wise and good king. Education, agriculture, manufactures, commerce, and great public works, as well as the military strength of the kingdom, were promoted by his care. He died March 8, 1844, and was succeeded by his son Oscar. See French Life by Sehefer ( 1899).

Charles d'Orléans, son of Louis d'Orléans, a duke who was murdered by the Burgundians, and of Valentina of Milan, was born in May 1391. He was the grandson of Charles V. of France, and the father of Louis XII. He was taken prisoner at Agincourt, and kept in captivity in England from 1415 to 1440 , when he was ransomed. He wrote a number of lyries while in prison and after his return to France. At Blois, where he held his court, he gathered together the chief French writers of his time, and took part with them in poetical tournarents, in one of which François Villon competed successfully. He died in 1465 . He has been termed the father of French lyric poetry, but he has no claim to the title. His light and graceful lyrics are the last flowering of the courtly poetry of the middle ages; they show no trace of the modern spirit which appears so strongly in the works of his con- temporary Villon (q.v.). His favourite themes are love and the spring-time; his favourite form is the rondel, with two rhymes, of which he is considered the chief master, as Villon is of the ballade, ant Voiture of the rondeau. An edition of his works (ed. J. M. Guichard) appeared in 1842, and another (ed. Héricault) in 1874 .

Charles the Bold, Duke of Burgundy (146777), son of Philip the Good of Burgundy and of Isabella of Portugal, was born at Dijon on 10t/ November 1433, and bore, during his father's life, the title of Count of Charolais. From his youth he was a declared enemy of Louis XI. of France, the nominal feudal superior of Burgundy, and he early formed an alliance with the Duke of Brit-
tany and some of the great nobles of France for the maintenance of feudal rights against the crown. Their united forces ravaged Picardy and Isle-de-France, threatened Paris, defeated the king at Montlhéry, and extorted from him favourable terms. In 1467 Charles succeeded his father as Duke of Burgundy. Richer and more powerful than any prince of his time, he conceived the design of restoring the old kingdom of Burgundy, and for this purpose of conquering Lorraine, Provence, Dauphiné, and Switzerland. Whilst he was making preparations for war, Louis invited him to a conference, and while his rival hesitated, by his agents stirred up the citizens of Liège to revolt. Charles next consented to the conference, and the news coming of what had taken place at Liège, he seized the king, and had not he been withheld by his councillor Comines, would have put him to death. He compelled Louis, however, to accompany him to Liege, and sanction by his presence the cruelties which he inflicted on the citizens. War raged between them afterwards with little intermission till 1475. In September of that year Charles turned anew to his favourite scheme of conquest, and soon made himself master of Lorraine. Next year he invaded Switzerland, stormed Granson, and hanged and drowned the garrison; but was soon after terribly defeated by the Swiss near that place, and lost his baggage and much treasure. Three months later he appeared again in Switzerland with a new army, and laid siege to Morat, where he sustained another and more terrible defeat (June 22, 1476). The news that the young Duke René of Lorraine was attempting to recover his territories roused him from despair. He laid siege to Nancy; but his army was small, and his Italian mercenaries went over to the enemy. Charles fought in vain with all his wonted reckless. ness and courage, and perished in the battle, Janu. ary 5, 1477. His daughter and heiress, Mary, married the Emperor Maximilian I. Charles' great size and strength, his immense ambition, and reckless audacity, combined to make him the most striking figure of his time. With his life ended the long successful resistance of the great French vassals to the central power of the monarchy. See Comines, Memoires; De Barante's Histoire des Ducs de Bourgogne; and special books by Kirk (3 vols. Lond. 1863) and Hoch (Basel, 1876).

\section{Charles Edward. See Stewart.}

Charles (Karl Ludwrg JohanN), Archduke of Austria and Duke of Teschen, third son of the Emperor Leopold II., was born at Florence, 5th September 1771. Already, spite of his youth, a distinguished soldier, he was intrusted in 1796 with the chief command of the Austrian army on the Rhine. He fought with great success against Moreau at Rastadt, defeated Jourdan in several battles, drove the French over the Rhine, and concluded his victories by taking Kehl in the winter. In 1799 he was again at the head of the army on the Rhine, was several times victorious over 
Jourian, and even successfully opposed Massena. Next year bad health conıpelled him to retire from sotive service; but he accepted the governorgeneralship of Bohemia, where he soon formed a nin army. After the battle of Hohenlinden he was ayain called to the chief command, and sueceoded in staying the rapid progrees of Moreau until the armistice which preceded the peace of Lunéville. In 1805 he commanded the army approsed to Massena in Italy, and fought the hard lattle of Caldiero; but upon bad tidings from (iermany, male a masterly retreat from the left lank of the Adige to Croatia. In 1809 he won the great battle of Aspern, which first showed to Kurope that Napoleon was not invincible; but Napiseon soon retrieved his fortunes at Wayram, and the archduke had to give way before the enemy, till he reached Znaim, where an armistice wis concluded. In the campaigns of $1813-14$ he lind no part; and he died 30th April 1847. See his Ausgevöhlte Schriften (6 vols. 1893-94).

Charles Albert, king of Sardinia (1831-49), born 29th October 1798, was the son of the Prince Charles Emmanuel of Savoy-Carignan, and in 1800 succeeded to his father's title and estates in France and Piedmont. In 1817 he married Maria Theresa, daughter of the Archduke Ferdinand of Tuscany. When the revolutionary movement took place in Piedmont in 1821 , he was made regent, upon the sbdication of Victor Emmanuel, until Charles Felix, the brother of the late king, should arrive to assume the sovereignty. In 1829 he was appointed viceroy of Sardinia, and on the death of Charles Felix in 1831 he ascended the throne. His prudent moderation brought upon him the inpatient denunciations of Mazzini, but earned him the applause of all moderate and far-sighted men throughout the peninsula, who began to see that the salvation of Italy could be worked out through the house of Savoy alone. The king's zeal for the cause of a united Italy was no mere selfish eagerness for the aggrandisement of his house, but a feeling as enlightened and patriotic as the sagracious calculation of Cavour, the fiery and reckless valour of Garibaldi, or the prophetic ardour of Mazzini. In the March of 1848 he declared war against Austria; but gradually lost ground in the struggle, until, after the fatal battle of Novara, 24th March 1849, to save his kingdom he had to resign the crown in favour of his son, Victor Emmanuel. He next retired to Portugal, where he died, broken-hearted and misunderstood, at Oporto on 28th July of the same year. See Life by Cibrario (Turin, 1861).

Charles Martel. See Charles, p. 115.

Charles's Wain. See Ursa MAJor.

Charleston, the metropolis of South Carolina, a port of entry and the capital of a county of its own name, is situated on a tongue / Copyrigh 185, 1697, and of land between the rivers Ash-
ley and Cooper, which unite immediately below the town and form a beautiful and spacious harbour, communicating with the ocean at Sullivan's Island, a popular sea-bathing resort, 7 miles below. It is 115 miles $\mathrm{NE}$. of Sitvannah, 580 miles SW. of Baltimore, and 540 miles SSW. of Washington. The ground on which the city is built is elevated 8 or 9 feet above the level of the harbour at high tide, which rises about 6 feet, flowing by the city with a strong current, thus contributing to its salubrity. It has a water front of 9 miles. A shifting sandbar extends across the mouth of the harbour, affording, however, two entrances, of which the deepest, near Sullivan's Island, has 16 feet of water at low tide. Jetties, which are expected to give a depth of 25 feet of water on the bar, have aince 1878 been under con- struction by the national government. The har. bour is defended by Castle Pinckney and Fort Sumter, each on an island, the former 2 and the latter 6 miles below the city, and aloo by Fort Moultrie, on Sullivan's Island. Forts Ripley and Johnson, now abandoned, lave only an historic interest. At the entrance of the harbour is a lighthouse, with a flashing light, 125 feet high.

Charleston is regularly built, and extends about 3 miles in length and nearly if miles in hreadth. It has a copious water-supply from a large artesian well ( 1970 feet in depth). The streets, many of which are broad and bordered with shade-trees, yass, for the most part, parallel to one another, from the Cooper to the Ashley River, and are intersected by others nearly at right angles. Many of the houses are of brick, some of them of superior elegance; others are of wood, neatly painted, and embowered during the summer season amid a profusion of foliage. Among the public buillings are the custom-house, the city hall, the court-house, the citadel, the academy of music, the theatre, the orphan asylum, and the police barracks. The custom-house is a handsome edifice, built of granite and white marble. At the southern extremity of the city is a small park called the Battery or White Point Garden, with a fine promenade on the sea-wall. The nost important educational and literary institutions are the Charleston College (non-sectarian), which was founded in 1785 and reorganised in 1837 ; the Medical College of South Carolina (1833); the State Military Academy, also ealled the Citadel the high school; the female seminary; a normal school for girls; and the Charleston Library (1748). The Charleston College has an excellent museum of natural history. There are good public, private, and parochial schools for white and coloured children. Charleston is the seat of an Episcopal and a Roman Catholic bishop, and contains forty churches. St Michael's Church (Episcopal) is a brick structure, with a steeple 180 feet high, and a chime of bells imported from England in 1764 . Among the benevolent institutions are the city hospital, the Confederate Home for Widows, the almshouse, the asylum for the aged and infirm, and the orphan asylum, which is liberally endowed, and can accommodate three hundred children. There are also Catholic orphan asylums and a convent.

Charleston is the chief commercial city of South Carolina, and has an advantageous position for trade. Steamships ply regularly between this port and New York, Philadelphia, Baltimore, and Florida; and three railroads meet here, with a large wharf frontage, elevators, and every facility for through shipments and the quick despatch of freight. The coastwise trale far exceeds the foreign in extent and importance. The chief articles of export are cotton, rice, naval stores (rosin, oil of turpentine, tar, \&c.), cotton goods, timber, market-garden protuce, whosphate rock, and erude and manufactured fertilisers; the value of the principal exports reaches $\$ 30,000,000$ in a year (the most important heing plorsplates). The imports are chiefly salt, iron, ale, brimstone, kainite and fruits from the West Indies. There is a large wholesale distributing trade in dry goods, clothing, drugs, \&c. ; and the city has large machine-8hops, cotton-presses, grist-mifls, cotton-mills, rice-mills, ship-yards, a dry-dock for large ships, and extensive manufactures of phosphate of lime, which abounds in the vicinity. Whereas only 6 tons of phosphate were mined in 1867 , the amount now annually raised is about 300,000 tons.

The city was founded in 1680 ; a few years later a company of French Humuenots, exiled for their religion, settled at this place. On the 
28th June 1776 a British squadron attacked the garrison on Sullivan's Island, consisting of 400 men under Colonel Moultrie, who defended the place with success. Charleston was afterwards besieged by Sir Henry Clinton from April 1, 1780, to May 12, when it was surrendered by General Lincoln. On the 12th of April 1861, the Confederates initiated the civil war by the bombardment of Fort Sumter, which they took the next day. In 1861 about half the city was destroyed by fire, and a considerable part was not rebuilt until after 1865. In April 1863 a Federal fleet of nine ironclad vessels, commanded by Admiral Dupont, attacked the fortifications of Charleston without success. After a long siege the place was evacuated by the Confederates, February 17, 1865. On 31st August 1886 the city was visited by a severe earthquake; nearly 7000 buildings were either destroyed or seriously injured, and several lives were lost. The earthquake was followed by a very general reconstruction of the business part of the city. Pop. (1800) 18,$711 ;(1820) 24,780 ;(1840) 29,261 ;(1860)$ 40,522 ; (1870) 48,956 ; (1880) 49,984; ( 1890 ) 54,955 (more than half coloured) ; (1900) 55,807. Charleston was the state eapital till 1790.

Charleston, a city, the capital of West Virginia and of Kanawha county, is situated on the Great Kanawha River, at the mouth of the Elk, 369 miles WNW. of Richmond by rail. Large quantities of bituminous coal and salt are procured near by. Charleston was marle state-capital in 1885 , having been so previously from 1870 to 1875 . Pop. (1880) 4192 ; (1890) 6734.

Charlestown (Massachusetts). See Boston and BUNKER HILL.

Charlet, Nicolas Toussaint, a French painter and engraver, born at Paris in 1792, held a clerkship under the Empire, but lost it at the Restoration (1815), and in consequence betook himself to art. After studying awhile under Gros, he gradually formed for himself a style in which he had no rival. The Beranger of caricature, he was especially successful in his sketches of children and military incident. His drawings numbered about 2000. Charlet died October 29, 1845. See his life by Lacombe (1856) and the study by Dayot (1892).

Charleville, a town in the French department of Ardennes, on the Meuse, opposite Mézières, with which it communicates by a suspension bridge. It has manufactures of hardware, leather, and beer; and the Meuse affords facilities for trade in coal, iron, slate, wine, and nails. Pop. (1872) 12,059 ; (1886) 16,856 ; (1891) 16,440 .

Charlevoix, Pierre François Xavier de, a French Jesuit traveller, was born in St Quentin in 1682, twice visited Canada, and voyaged down the Mississippi to New Orleans. He published his journal, histories of San Domingo, Japan, and Paraguay, and a Histoire de la Nouvelle France (1744; Eng. trans. New York, 6 vols. 1865-72). He died at La Fleche in $\mathbf{1 7 6 1 .}$

Charlock. See Mustard.

Charlotte, capital of Mecklenburg county, North Carolina, 265 miles ENE. of Atlanta, is the terminus of several railways, has manufactures of carriages, cotton goods, tobaceo, \&c., and is the seat of Presbyterian university (1867). Pop. (1880) 7094 ; (1890) 11,555.

Charlotte, Princess, born at Carlton House, London, 7th January 1796, was the only child of the future George IV. and Caroline of Brunswick, who parted immediately after her birth. A bright, lively, warm-tempered girl, she was brought up in strict seclusion, under various governesses and sub-governesses, seeing her father rarely, and her mother only for two hours a week. Her six months' engagement to Prince William of Orange she herself broke off in June 1814, greatly to George's fury; had the match come off it might have been as momentous in its consequences as that of the Princess Mary to another Prince William of Orange. On 2d May 1816 she married Prince Leopold of Saxe-Coburg ; but the mariage, a happy one, was cut short on 5th November 1817 by her death, after giving birth to a still-borm boy. See the Memoir by Lady Rose Weigall (1874), and the monograph by Mrs Herbert Jones (1885).

Charlotte Amalie, the capital of the West Indian island of St Thomas (q.v.).

Charlottenburg, a town of Prussia, on the Spree, 3 miles $W$. of Berlin, with which it is connected by a road leading through the Thiergarten. It contains a royal palace, which was founded in 1696 for Sophie Charlotte, the second wife of Frederick 1., and which has a fine park, with a large orange-grove, a theatre, and a mausoleum here are the remains of Frederick William III. and his queen, with their statues by Rauch, and here their son, the Emperor William I., was interred in 1888. In the town are a royal institute of glass. painting, an artillery and engineering school; the manufactures include iron-wares, machinery, porcelain, glass, paper, leather, chemicals, and beer. Pop. (1885) 42,371; (1890, as extended) 76,859 .

Charlottetown, the capital of Prince Edward Island, on the south coast, stands on the Hillsborough estuary, which forms a secure and commodious harbour for the largest vessels. The town has two colleges, an iron-foundry, a woollenfactory, and shipbuilding yards. Pop. (1881) 11,485 ; (1891) 11,374.

Charm (through Fr. from Lat. carmen, 'a song'), properly a form of words, generally in verse, supposed to possess some occult power of a hurtful, a healing, or a protective kind; hence applied to anything which exercises an irresistible power to please and attract. Charms exert their influence either by being recited, or by being written and worn on the person; and, in this latter case, they may be classed with Amulets (q.v.). The nature of this superstition is considered under INCANTATION; see also MAGIC.

Charnel-house, a chamber situated in a churchyard or other burying-place, in which the bones of the dead which were thrown up by the grave-diggers were reverently deposited. It was often a chapel with a vault beneath.

Charnock, JoB, went to India about 1655 , and as head of the factory at Húgli, transferred the headquarters to Calcutta (thus founding the city) in 1686-90. He died in 1693.

\section{Charnwood Forest. See Leicestershire.}

Charolais is a district in the French department of Saône-et-Loire, noted for its fine cattle.

Charon, in classical mythology, the son of Erebus and Nox, is first mentioned by the later writers of Greece. His duty was to ferry the shades of the buried dead across the rivers of the under-world. For this service he exacted an obolus from each, and consequently this coin was placed in the mouth of the dead. If this rite was neglected, Charon refused to convey the unhappy shade across, and it was doomed to wander restlessly along the shores of Acheron. He is generally represented as a gloomy old man, with a rough beard and wretched clothes. In the Etruscan monuments he holds a hammer. In the folklore of modern Greece Charon still survives as a kind of shadowy representative of death and a mysterious under-world. (The Greek is chărōn; the English pronunciation, kärŏn.) 
('harpie is Lint (q.v.) for medical purposes.

('harqui. See JERKed BEEF.

Charr, or Char, a name applied to a number of fresh-Water fishes in the salmon and trout genus salmo. They are found almost exchsively in mountuinons lakes - e.g. in Switzerland, Scandinavia, and in the English Lake district. The presence of charr has also been recorded in Scotland (especially in Loch Earn), Ireland, and Wales; but their British headquarters are in Windermere and the adjacent ('umberland and Westmoreland lakes. The charr differs from the true salmon only in a few small points, such as the restriction of the vomer teeth to the head of that bone; and the distinetions lx-tween the numerous recorded species of charr seem rather local variations than of specific im. portance. The title $S$, salvelinus is one of the commonest; S. alpinus is also applied to both Swiss snil English charrs; $S$. umbla is sometimes restricted as the title of the ombre chevalier of the lakes of Constance, Neufchatel, and Geneva; and nuiny other names indicate slight differences in size, form, colour, \&c. The common English and Swiss charr is distinguished by the bright red and orange colour of the abdomen during the breeding seasson, but at all seasons the variable colouns are bright and pleasing. They thrive only in clear water, frequent the deeper parts of the lake, and feed on insects and small crustaceans. At the end of antumn and beginning of winter they leave the lake to find in the inflowing streams the stony bottom necessary for the deposition of the ova. The charr is as palatable as it is beautiful, and is much valued as a dainty, both when fresh and potted. It is to be regretted that the habit of eatching them by wholesale netting at the mouths of streams at the beginning of the spawning season has led to a great reduction of their numbers in the English lakes. The American charr ( $S$. fontinalis) is bred by the Fish Commission, and has been introduced into Britain.

Charron, Pierre, a French moralist and theo. logian, born at Paris in 1541. He studied for the Jaw, but after being called to the Paris bar, entered the ehurch, and became a conspicuous member of the politiques, or party of moderate Catholics. He assailed the League in his Discours Chretiens (1589), vindicated Catholicism against Protestantism in his treatise Les Trois Verités (1594), and in his chief work, the treatise De la Sagesse (1601), took a scepti. eal attitude towards all forms of religion. He died in 1603. He was a friend and disciple of Montaigne, to whom he was, as a writer, immeasurably inferior, and from whose essays he borrowed freely. An edition of his principal work was published at Paris in 1789.

Chart, a marine or hydrographical map, exhibiting $\mathrm{a}$ portion of a sea or other water, with the islands, cossts of contiguous land, soundings, eurrents, \&c. (see MAP). Chart-making has been traced back to about the beginning of the 13th century ; now most civilised countries have their system of charts. In the English service, when coasts have been surveyed by the Admiralty, charts are engraved, and are sold at various prices, from $3 \mathrm{~s}$. down to 6d. each. This price is below their cost, the object being to encournge their general ase as much as possible. The navigating charts, showing the dangers of coasts with sufficient clearness ta enable mariners to avoid them, are generally on the scale of half an inch to a mile; those of larger size show all the intricacies of the coast. The merchant-service is supplied with charts by agents, who receive a stock from the Admiralty, and keep them on sale. The preparation of charts is part of the duty of the Hydrographical Depart. ment at the Admiralty. In the financial year as represented in the national estinates, aum of about $\mathbf{£ 1 4 , 0 0 0}$ is provided for the branch that takes charge of the engraving of the charta, irrespective of the surveying, which always costs a much laryer sum. The Admiralty gells sunually some 140,000 charts, besides supplying the navy gratis. Several ships of the navy, besides colonial gunboats and hired steamers, are usually engaged in examining and charting seas and cosate. "See the articles Geography, Sea, Sounding, Challenger Ex. PEDITION, \&c.

The United States const survey, a vast under. taking, was begun in 1807 , carried on intermit. tently till 1845, and since then more systematically, save during the civil war, under Professor Bache and his successor, Professor Pierce. In the Ameri. can service, the coasts of the United States are surveyed and the charts produced by the const and geodetic survey attached to the Treasury Depart. ment, and the unsurveyed foreign coasts are aur. veyed by the Bureau of Navigation, the charts being produced by the Hydrographic Office, Navy Department. The coast and geodetic charts are sold at from 10 cents to $\$ 1$ each, being the cost of printing and paper. Naval vessels are supplied free. The charts are obtainable at cosst and geodetic survey agencies at all seaports of the United States. They exhibit accurate and minute topography as far inland as will supply landmarks for the navigator, or serve for purposes of defence the shore line at high-water and sanding to mean low-water; soundings, contours, and material of bottom at different depths; bars, channels, sailing ranges and directions; true meridian and compass variation, rocks, reefs, buoys, beacons, lights ; tide establishment, detailed explanation of lighthouses and signal stations. They are carefully corrected for every substantial change in any of those features. They range in scale from asto $(30.401$ inches to the nautical mile) to g इण the nautical mile), and comprise sailing charts, general charts, coast charts, and harbour charts.

The term chart is also given to a graphical representation, by curves or otherwise, of the fluctuations of any varying magnitude-temperature, barometric pressure, population, prices, \&c. See Graphic Methods, Temperature, Storms, dc.

Charta, Magna. See Magna Charta.

Charte, a charter or system of constitutional law, embodied in a single document. The first such charter in France is known as the Grande Charte, or the Charter of King John (in 1355). But the constitution to which the term Charte is most frequently applied is that in which Louis XVIII. solemnly acknowledged the richts of the nation on his restoration in 1814 . This Charte has ever since been considered the fundamental law of constitutional monarchy when that form of govern. ment has existed in France. A modification of it was sworn to, 29th August 1830, by Louis-Philippe, in which the sovereignty of the people is explicitly recognised. This Charte in its turn became a nullity by the revolution of February 1848 .

Charter (Lat. charta: Gir. churte, 'paper,' or 'anything written upon, from charasso, 'I serateh' or ' write'). In its most general signification, charter is nearly synonymons with deed and instrument (see DEED), and is applied to almoet any formal writing, in evidence of a grant, contract, or other transaction between man and man. In private law, its most important use is in the alienation of real estates, the writing given to the new proprietor by the old, in proof of the transference title, heing usually called a charter. In public law, the name is given to those formal deeds by which sovereigns guarantee the rights and privileges of their subjects, or by which a sovereign state guarantees those of a 
colony or other dependency (see Charte, Magna ChARTA). There is another sense of the term in which it is in a measure intermediate between the two we have mentioned-viz. where we speak of the charter of a bank or other company or association. In this sense it signifies an instrument by which powers and privileges are conferred by the state on a select body of persons for a special object (see BANKING, CORPORATION, and (under Company) JoINT-STOck CoMPANY, \&c.).

This is the general use of the term in the United States. It is a grant of authority from the state or the United States, creating a corporation, defining its powers, privileges, rights, and franchises. A charter of a private corporation, on the faith of which property has been given, is a contract within the meaning of the United States Constitution, Article I., sect. 10, which declares that no state shall make a law impairing the obligation of contracts. And while the state legislatures have no power to set aside or essentially modify charters that come within thus prohibition, without the consent of the corporators, it is confined to transactions involving property and rights which may be asserted in a court of justice. This prohibition does not debar the state from exercising the right of eminent domain, nor prevent the exercise of its general police power. Charters of municipal and public corporations are not beyond legislative control; and the power to change and adapt them to the purposes for which they were created is implied in every enactment creating them. But most of the charters in the United States have in them a clause reserving to the state the power to alter, amend, or repeal them at pleasure. In some states the courts have power to grant charters to social, charitable, and religious organisations, while the state officers are authorised by law to grant charters for manufacturing, mining, railroad, and other corporations for purposes of trade.

Royal Charters, generally written in Latin, are of two kinds: I. Grants of lands, houses, honours, or liberties to persons who did not previously possess them; II. Charters confirming grants previously made, and therefore called 'Charters of Confirmation.' Confirmation charters are of three kinds: (1) Charters confirming previous grants, without reeiting them; (2) Charters of simple confirmation, without addition of anything new; (3) Charters reciting previous charters and confirming them, with addition of something new. These last two classes of charters are called charters of 'Inspeximus,' or 'Vidimus,' from the word used by the granter in saying that he has seen the charter which he confirms. Royal charters generally contain seven clauses: (1) The 'Premises'-i.e. the name and style of the granter, the persons to whom the charter is addressed, the name and style of the grantee, the reason why the grant is made, and the description of the thing granted; $(2)$ the 'Tenendum and Habendnm '-i.e. the way in which the thing granted is to be held and had; (3) the 'Reddendo,' the return of rent or service which is to be made to the granter by the grantee; (4) the 'Quare Volumus,' or order that the grantee should have the thing granted, under certain penalties ; (5) the 'Sealing' or 'Signature' clause, setting forth the seal, signature, or subscription by which the charter is authenticated; $(6)$ the 'His Testibus,' or testing-clause, enumerating the persons present as witnesses to the granting of the charter; (7) the 'Date,' setting forth the time when, and the place where, the charter was granted.

Charter in the law of Scotland is the written evidence of a grant of heritable property under the conditions imposed by the feudal law-viz. that the grantee, or person obtaining, shall pay at stated periods a sum of money, or perform certain services to the granter, or person conferring the property. The granter of a charter, in virtue of the power which he thus retains over the property and its proprietor, is called the superior; and the grantee, in consequence of the services which he undertakes to render, the vassal; whilst the stipu. lated sum to be paid, or service to be rendered, is called the duty.

Charters are either blench or feu, from the nature of the service stipulated-a me or de me, from the kind of holding or relation between the granter and grantee; and original or by progress, from being first or renewed grants of the subjects in question.

Blench and Feu Charters. - The duty which the superior required of his vassal in former times was almost always military service, and the vassal was then technically said 'to hold ward '- to hold on condition of warding or defending his superior. But subsequent to the rebellion of 1745 , in which the dangerous tendencies of the feudal relation were experienced, this holding was abolished ( 20 Geo. III. chap. 50), and the only duties which it has since been lawful to insert in charters are blench and feu duties. The former is a merely nominal payment-a penny Scots, a red rose, or the like, $s$ petatur tantum (should it be asked); the latter is a consideration of some real value. Original blench charters having lost all object, and having no other effect but that of subjecting superiors to considerable expense in keeping up their titles, have become rare in modern practice. The forms of charters varying according to the circumstances in which they are granted, and the relations established between the granter and grantee, are of a highly technical nature.

The Charter of Resignation proceeds upon the formal surrender of the lands or other rights into the hands of the superior for the purpose of obtaining a new grant in favour of the resigner, with some change of the destination, or in favour of a purchaser or other disponee. This is termed a resignation in favorem. But when the property is surrendered in order to remain with the superior, the resignation is then said to be ad remanentiam. In former times resignations were transacted with solemn formality by delivery of a staff or baton, as the symbol of surrender, into the hands of the superior, who, if the purpose was in favorem, returned the symbolic staff to the person to be invested with the lands, or to his attorney, the whole transaction being recorded in the form of a notarial instrument.

Crown charters of resignation or confirmation proceed upon the warrant of the Barons of $\mathrm{Ex}$ chequer, as the royal commissioners in Scotland since the union of the crowns, for receiving resignations and granting new infeftments to crown vassals. The charter is preceded by the signature or order under the royal superscription, with consent of the barons, setting forth the terms in which the charter is to be expressed. After several other proceedings, the charter is finally completed by sealing. Previous to 1707 the Great Seal of Scotland was appended to crown charters, but by the treaty of union another seal was substituted. The royal charters of Seotland are recorded in the Register of the Great Seal, which is extant from about 1300 A.D., and continued to the present time. There are, however, numerous charters by the early Scottish kings not recorded in the Register, but extant in private collections and in the chartularies of religious houses. Ancient charters are usually remarkable for the excellence of their writing and the brevity and conciseness of - their style. See Innes' Lectures on Legal Antiquities; Chassat's Traité des Statuts, dc. 
(Parie, 1845) ; Bell's Law Dictionary; Menzies on Conveyaneing.

Charterhouse (a corruption of Chartreuse, ('urtbusian') is the name of a famons hospital and chusl which oocupied a joint-building in Charterhouse Square, London, till 1872, when the school wat transferred to Codulming in Surrey. The harterhouse was instituted in 1611 by Thomas iutton, of Castle Camps, Cambridgeshire. The it had been oceupied by a Carthusian monastery founded in 1371), but on the dissolution of the nunasteries by Henry VIII. it was made a place f leposit for his nets and pavilions. After underwing many alterations, and passing into the possesion of various distinguished persons, it was finally inchased from Lord Suffolk for $£ 13,000$ by Chomas Sutton, who endowed it with the revenues f upwards of twenty manors, lordships, and other states in various parts of England. This 'masteriece of Protestant English charity,' as old Fuller alls it, serves three uses-it is an asylum for poor rethren, an educational and a religions instituion ; hence Bacon terms it a 'triple good.' The poor rethren are eighty in number. None are admitted inder fifty years of age, and only those who have eon householders are eligible. Each brother has separate apartment, a share of attendance from lonestics, an ample though plain diet, and an llowance of about $x^{2} 36$ a year for clothes and other aatters, and four weeks holiday every autumn. the brethren must be bachelors and members of he Church of England. Among the poor brethren bygone years were Dryden's antagonist, Elkanah ettle; John Bagford, antiquary ; Isaac de Groot, descendant of Grotius ; Alexander Macbean, who ssisted Johnson in his Dictionary; John Grey, lectrician ; and -one could not omit him-'Colonel jewrome.

There are thirty junior scholarships, worth 175 a year, open to all boys between twelve ind fourteen years of age by public competi. tion on conditions settled in accordance with the irection of the Public Schools Act (1868), the ld system of direct nomination by the goverors having been wholly abolished. There are lso thirty senior scholarships, of $£ 95$ value, for oys of between fourteen and fifteen who have een at least a twelvemonth in the school; and ve annual exhibitions of $£ 80$ for four years for oys leaving school. In addition to the scholars large number of boys are sent to the Charterouse because of its reputation. These either oarl with the masters or attend simply during le day. The number of extra boarders is now bont 460. The institution is under the direction t the Queen, fifteen governors, and the master imself, whose salary from the foundation is $\mathfrak{£} 800$ er annum. The hospital has now a separate zoverning body. Among the eminent persons Incated in this establishment have been Israc I sarrow, Sir William (Judge) Blackstone, Addison, iteele, John Wesley, Bishop Thirlwall, George srote, Thackeray, John Leech, and Sir Charles Eastlake. The new gchool at Godalming, designed y Hardwick, forms a large quadrangle, with a gatehouse tower 130 feet high, and a chapel rich u stained glass. The old school premises were whld to the Merchant Taylors' School, which is ifw installed here in handsome new school build. rigs erected in 1870-72. The quaint Charterhouse I)spital and chapel still remain on the old site. The chapel contains Sutton's tomb. See works by (r Haig Brown (1879), and Eardly-Wilmot and treatfield (1894),

Charter-party (chavta partita-as being origvally written in duplicate on one parchiment, shich was then divided by a straight line, so that the parts should tally) is the common written form in which the contract of affreightment is expressed-viz. the hiring of the whole or part of a ship for the conveyance of goods. The case of carriage of passengen at sea in under different regulations. The carriage of goods is often left to rest on bills of lading, or even mere oral arrange. ment, but a charter-party with a sixpenny stam is the proper and anfe arrangement. It is execuced by the owner or his aceredited agent; abroad, the master has authority to sign. It identifies the ship by name, by tonnage measurement, and by flace. The obligations of parties are generally expressed with fullness. The ehief of these are that the ship is seaworthy, and is furnished with necessary tackle, and with a fit master and crew. Unsen. worthiness may be caused by the manner of stow. age. The master's knowledge of the particular ports and perils on the voyage is included in his fitness. The ship is also bound to have the proper papers and clearances. The ship must be ready to receive eargo at the time specified; and in general, delay on the part of the ship would entitle the charterer to cancel the contract. The voyage must be performed according to the rules of good sea. manship, necessity being required to justify any deviation from the route. The matter of compul. sory pilotage depends upon the Merchant Shipping Acts. Due care is to be shown in loading and unloading, and the goods must be safely delivered at the port of discharge. On the other hand the freighter must have a lawful cargo ready at the time agreed upon; in this case also delay would generally entitle the shipowner to cancel the contract, or at least to clain damages for detention. The freight is sometimes a lump sum for the voyage : sometimes so much per ton or per week.

The execution of a charter-party does not supersede the granting of a Bill of Lading $\left(q, v_{0}\right)$ or receipts for the cargo, which are not only useful in fixing the condition and quantity of the goods, but are the documents of title by which the ownership of cargo may be transferred during voyage. In the case of general ships, which are advertised for a certain voyage, the shfpowner becomes a common carrier, bound to carry goods tendered subject to the conditions of the advertisement, but in this case no charter-party is executed. In coasting voyages mere receipts, not formal bills of lading, are often used. In settling freight at the port of discharge, the weight or measurement of cargo there is prima facie the criterion, but it may be shown that the weight, \&c. has altered during voyage. Where an advance against or prepay. ment of freight is made, the law of Scotland is that this may be recovered, even though the voyage fail ; in England, on the other hand, both shiprer and consignee are liable for freight, and the master has a lien on cargo for freight. But it is common under a cesser clause for the charterer to stipulate that his personal liability for freight and demurrage shall cease when the loading is completed, so that in most cases the master looks to his lien for security. When the goods arrive damaged, the consignee is bound to take them, and settle the freight subject to a claim for damuges; he cannot abandon the goods for the freight. If the freighter take the goods at an intermediste port, the ship being unable to proceed further, a proportion of freight is due ; and this is also the case where some of the goods are lost, if enough was not lost to justify abandonment. Except on a time charter, the duration of a voyage, which may depend on closing of navigation by ice, \&c., is entirely at the risk of the shipowner. Dead freight is paid for unoccupied space in the ship where a full carro has been promised. Apart from stipulation, the shipowner is liable for the goods shipped in their 
original condition, except where that condition is altered by perils of the sea, hostile force, and inevitable accident. It is now common, however, by indemnity clauses in charter-parties to protect the owner from liability for every damage that can be covered by insurance. By statute, owners are not liable for fire, or for the fault of a compulsory pilot; and in no case are they liable beyond a sum representing $£ 15$ per ton of the ship's measurement. It is always an important question whether the arrangements made about the ship place the charterer in the position of an owner, or whether the owner retains such a possession and control of the ship as to be able to exercise a lien for freight, and on the other hand to incur liability for repairs and supplies, and for damages caused by negligence of the master or crew.

In the United States, the law relating to charterparties is the same as that which has just been explained. When the charterer has complete control over the voyage, he is generally considered the owner for the voyage. But if the charter-party lets only the use of the vessel, the owner retaining possession and control over its navigation, the charterer is regarded as merely a contractor for a particular service, and the rights and duties of the owner are unchanged. The usual printed parts of a charter-party are construed like covenants in a deed, but charter-parties are often informal instruments, and are therefore construed as liberally as other mercantile contracts, preserving the intention of the parties. The courts incline to construe a charter-party as a contract for affreightment, charging the shipowners as carriers.

Charters Towers, a mining township of North-east Queensland, situated on the northern spurs of the Towers Mountain, 820 miles NW. of Brisbane. It dates from the gold discovery here of 1871-72, and was incorporated in 1877. It has railway connection with Townsville on the coast. Up till 1891, when the pop. was 4597 (of the field, $14,129)$, the gold-field had yielded over $2,300,000 \mathrm{oz}$.

Chartier, Alarn, who was born at Bayeux in 1386, and died before 1441 - perhaps in 1435 -lived at the court of Charles VI. and Charles VII. as secretary. According to a famous (but quite unhistorical) story, the Dauphine Margaret, daughter of James I. of Scotland, and herself a poetess, once kissed him as he lay asleep, in token of her admiration of his verses. His chief poetical piece is the Livre des Quatre Dames, which was written shortly after Agincourt, and in which four lacies alternately bewail the deaths of their lovers who fell in the battle. The sentiment of the poem is sincere, and the expression is often graceful and dignified. Chartier showed considerable skill in handling the ballade and other lyrical forms, but he is more interesting as a prose-writer than as a poet. In his own day he was known as the 'father of eloquence.' His chief prose works are Le Curial, an exposure of the vices of the court; L'Esperance, an attack on the corruption of the clergy; and the Quadriloge Invectif, a noble appeal to Frenchmen to unite for the deliverance of their land from the foreigner. Chartier was a sincere patriot, and his writing often rises into grave and moving eloquence. He bravely espoused the cause of the oppressed labouring class, and he did much to re-animate his countrymen in their struggle with England. 'It is the eternal glory of Alain Chartier,' says $\mathbf{M}$. Géruzez, 'to have announced the mission of Jeanne d'Arc.' His writings summoned his countrymen to the task which they performed under the Maid of Orleans. He has not received the attention which he deserves. There is no better edition of his works than Duchesne's (1617). See mono- graphs by Delaunay (1876) and Joret-Desclosières (1877).

Chartism, a movement in Great Britain for the extension of political power to the working. classes, rising out of widespread national distress and popular disappointment with the results of the Reform Bill of 1832. Before that period the middle classes had sought popular aid towards obtaining their own enfranchisement. The assistance was given, the people expecting to receive belp in their turn. After the passing of the Reform Bilf, agitation ceased for a time, and the members returned to parliament were indifferent, or opposed, to any further change in the political arrangements of the country. The middle classes were satisfied with their own success, and generally looked with small favour on projects for the further extension of political influence among the masses. Lord John Russell especially deprecated further change as a breach of faith with those who had carried the Reform Bill of 1832. This political discontent on the part of the workmen was greatly increased by the misery due to failing harvests and to a season of commercial depression which set in about 1837 . Food became dear, wages fell, factories were closed, and work was scarce. The people associated their sufferings with their want of direct influence upon the government, and agitation for an extended franchise began.

In 1838 the representatives of the working-men drew up a programme embodying their views on political reform, and called the 'People's Charter.' Its six 'points' were: (1) Manhood suffrage; (2) equal electoral districts; (3) vote by ballot; (4) annual parliaments ; (5) abolition of property qualification for members of the House of Commons; and (6) payment of members of parliament for their services. The programme thus drawn up was received with enthusiasm. Immense meet. ings, attended by enormous crowds of people, were held all over the country. The most prominent leader of the Chartist agitation was Feargus O'Connor, an Irishman, whose paper the Northern Star had a circulation of 50,000 . Others were Attwood, Lovett, Stephens, Vincent, Ernest Jones, and Thomas Cooper. The mass of the working-men in the industrial centres supported the movement; and while many of them exclusively advocated an appeal to moral force, a great number insisted on violent methods. A body calling itself the National Convention, elected by the Chartists throughout the kingdom, met in London and afterwards in Birmingham in 1839. It proposed to the people various means of coercing the legislature into submission, recommending, among other things, a run on the savings-banks for gold, abstinence from excisable articles, exclusive dealing, and in the last resort, universal cessation from labour. During its sittings a collision took place with the military in Birmingham. Public meetings were forbidden, and alarming excesses were committed by the irritated mob. In June 1839 a petition in favour of the Charter was presented to the House of Commons signed by $1,280,000$ persons. The House refused to name a day for its consideration, by a majority of 237 to 148 , and the National Convention retaliated by advising the people to cease from work throughout the country. Fortunately, this advice was not followed; but the disturbances increased, and in November an outbreak at New. port, in Monmouthshire, took place, which resulted in the death of ten persons and the wounding of great numbers. For taking part in this wild insurrection, three of its leaders were sentenced to death, but their punishment was afterwards commuted to transportation. In 1842 great riots took place in the northern and midland districts, not
directly originated by the Chartists, but encouraged 
and aided by them after the disturbances began. It is a strong proof of the revolutionary spirit which animated the Chartists, that they opposed the aritation for the Repeal of the Corn Laws as a mensure likely to make food cheap, to keep wages down, and thereby to benefit only the midale

In 1848 the Chartist movement came to a head through the agitation congequent on the revulution in France. Great uneasiness prevailed, exprecially at many of the industrial centres, and rising were feared. But the greatest demonstration of the movement took place in London, where a grizantic meeting on Kennington Common was anmuncesl for the 10th of April. It was to be atteruled by half $\mathrm{a}$ million of men, who were to carry to parliament a petition for reform signed by six million names. Such rumours excited great slarm. The procession was forbidden. Military measures were taken by the Duke of Wellington to prevent violence, and about 200,000 special constables were enrolled (amongst whom was Louis Napoleon, afterwards emperor). After all this preparation the demonstration proved a failure. Only 50,000 gathered on Kennington Common, and their leaders shrank from a conflict with the authorities. On examining the monster petition it was found that the signatures were fictitious to an unheard-of extent, yet the genuine ones amounted to nearly two millions.

Since 1848 Chartism has gradually died ont. Its political principles were not new. The Duke of Richmond in 1780 introduced a bill into the House of Lords to give universal suffrage and annual parliaments, and earlier than this John Cartwright (q.v.) had advocated earnestly not only these but also vote by ballot. In 1780 Charles James Fox declared himself in favour of the identical gix points which were afterwards included in the Charter. And in 1792 Grey, Erskine, Mackintosh, and many others, formed a 'Society of Friends of the People,' which aimed at obtaining a very large extension of the franchise.

But while the political side of Chartism was the most prominent, it should be recognised that the essence of it was economic and social. As one of its leaders said, it was a 'knife and fork question.' The movement was primarily due to economic suffering, and many of the remedies proposed were strongly socialistic in tendency. The reviving and increasing prosperity of the country after the collapse of Chartism in 1848 effectually prevented a return of the some spirit of discontent. This mrosperity was due not only to the Repeal of the Corn Laws, but to the great industrial and colonial expansion of Britain which took a fresh start about the same time. Through the Reform Bills of 1867 and 1885, and the Ballot Act of 1872, the most important demands of the Charter have been sulsitantially conceded. Industrial prosperity and political reform, with the development of trades. unions and of the co-operative system, have worked a decided change in the position of the workingclasses as contrasted with their wretched lot in the period about 1840. See the articles on CoOPER and O'CoNNor; Cooper's Life, written by Himself; Carlyle's Chartism; Kingsley's Alton Locke; Walpole's History of England; and R. G. Gammage's History of the Chartist Movement (1894).

Chartres, the capital of the French department of Eure-et-Loir, 55 miles SWV. of Paris, is built partly at the base and partly on the declivity of a hill overlooking the river Eure, which is here divided into two channels, one flowing within, and the other without the former ramparts, which are converted into agreeable promenades. It consists ff an upper and lower town, connected by very steep streets ; and the highest point is erowned by the glorious eathedral of Notre Dame-in Street's opinion, the finest in France. Built chiefly between 1194 and 1260 , it has two mpires, of which the south-western is 342 feet high, and the north. western, 371 ; the latter, built in 1507-14, being, on the whole, the most beatiful spire on the Con tinent.' Other features are the three rome-windows, the splendid portals, and the 13th-century stained. glass that fills no fewer than 130 windows. The church of St Pierre (12th century), the Porte Guillaume (14th century), and the obelisk to the memory of General Marcean, are also noteworthy. The weekly corn-market is one of the largest in France, and is remarkable as being under a corporation of women. It has manufactures of woollen, hosiery, and leather. Chartres usually gave the title of Duke to the eldest son of the Orleans branch of the Bourbons (see BoURBON). Pop. (1872) 19,322; (1886) 21,523 ; ( 1891 ) 23, 108. The A utricum of the Carnutes (hence the present name), Chartres in 1594 was the scene of the coronation of Henry IV.

Chartrense, LA Grande, the original Carthusian monastery, founded by St Bruno in 1084, is situated in the French department of Isère, 14 miles NNE. of Grenoble, in a wild and romantic valley, at an altitude of 4268 feet above the sea. The convent is a huge ungainly structure, dating mostly from the 17th century, earlier buildings having been several times destroyed by fire. The monks, who long manufactured a famous green, yellow, or white liqueur from various herbs, had at one time considerable property, but they were despoiled at the Revolution, being exiled from 1793 till 1816 ; and in November 1880 they declined to accept indulgence from the decrees for the expulsion of the religious orders. A remnant of monks still left received Queen Victoria and the Princess Beatrice on the occasion of their visit in 1887. Ruskin in part iv, of his Proterita (1888) describes his disappointment in both the monastery and its occuparits. Certos $\alpha$ and Charter. house are Italian and English forms of the French name. See Carthusians.

Chartulary means a collection of charters. So soon as any body, ecclesiastical or secular, came to be possessed of a considerable number of charters, obvious considerations of convenience and safety would suggest the advantage of having them classi. fied and copied into a book or roll. Such book or roll has generally received the name of a Chartulary. Mabillon traces chartularies in France as far back as the 10th century, and some antiquaries think that chartularies were compiled even still earlier. But it was not until the 12 th and 13 th centuries that chartularies became common. They were kept not only by all kinds of religious and civil corporations, but also by private families. Many of them have been printed, and their contents generally are of the greatest value in historical, archreological, and genealogical inquiries. The name is in Scotland applied to the record of feu-charters kept by the superior's law-agent.

Charybdis. See Scylla and Charybds.

Chase, Salmon Portland, American states. man, born at Cornish, New Hanupshire, 13th Janu. ary 1808 , in 1830 settled as a lawyer in Cincinnati, where he acted as counsel for the defence of numerous fugitive slaves. An uncompromising opponent of slavery, his political course was for niany years guided by the attitude of the two great parties toward this question. In 1841, foreseeing as little assistance from the Whigs as from the Democrats, he was largely instrumental in founding the Liberty party, which in 1844 brought alwut Clay's defeat, Chase was returued to the United States genate in 1849 by the Ohio Democrats, but separated from the party in 1852 , when it 
committed itself to slavery. He was twice elected governor of Ohio by the Republicans (1855-59), and in 1861-64 was secretary of the treasury. His management of the country's finances during these trying years has met with nothing but praise: taking office at a time when public credit was low, and the revenue barely adequate for the needs of the government in time of peace, he secured loans on reasonable terms, issued treasury notes (' greenbacks') bearing no interest, and obtained the establishment of national banks. In 1864 he was appointed by Lincoln chief-justice of the United States, in which capacity he presided at the trial of President Johnson (1868). Unsuccessful efforts were made to secure for Chase the Republican presidential nomination in 1860 and 1864 , and the Democratic nomination in 1868. He died at New York, 7th May 1873. See his Life by J. W. Schuckers (1874).

Chasi'dim (Heb., 'pious'), the name by which the Jewish party afterwards known as the Pharisees was first distinguished. The Chasidim first took definite form as a party in the course of the struggle between Judaism and Hellenism during and immediately before the Maceabean period. When in 167 B.C. the great majority of the Jewish people rose against their heathen masters, the Chasidim joined in the conflict, though separated from the other adherents of Judas Maceabeus as a closer community of those who were distinguished by especial 'piety' -i.e. especial strictness in the observance of the law. They took part in the struggle only so long as the freedom of religion was the question really involved; at a later time, when this was no longer the case, they seem to have withdrawn from it, for under Judas's brothers Jonathan and Simon (160-135 B.C.) they are not mentioned. Under Simon's successor, John Hyrcanus (135-105 B.C.), they appear for the first time in history under the name of Pharisees, and here we already find them in opposition to the family of the Maccabees or Hasmoneans, with whom they had originally pursued a common interest. See Pharisens. - The modern Chasidim are not, like those in the times of the Maccabees, marked by any peculiar spiritualistic tendency in religion, but rather by a strict observance of certain traditional forms and a blind subservience to their teachers. Their doctrine was promulgated in the middle of the 18th century by Israel of Podolia, called BaalShem ('Lord of the Name,' so called beeause he professed to perform miracles by using the great cabalistic name of the Supreme Being). Though condemned by the orthodox rabbis, this new teacher had great success in Galicia, and when he died (1760) left 40,000 converts. They are now broken into several petty sects; their religion is utterly formal, and its ceremonies are coarse and noisy.

Chasing. Metal casting and other raised metalwork, whether stamped or repousse-i.e. hammered or punched up-may be defective in sharpness, or detail, or finish. When such defect is remedied by hand-cutting, as with a chisel or graver, such finishing is called chasing, but this term is not properly applied to the raising of the figures themselves. The backs of watches are sometimes elaborately chased in floral or other designs. When similar work is applied to flat surfaces, such as salvers for example, it is called elther chasing or engraving. It was called colatura by the Romans ; in modern Italian, ceselatura ; in French, ciselure ; in German, ciselirung-i.e. 'chiselling' in each case.

Chasles, MicheL, was born near Chartres on 15th November 1793. He entered the Ecole Poly- technique in 1812, and on leaving was classed among the engineers; but with rare generosity he renounced his place as an officer in order to assure a career to one of his unsuccessful comrades. In December 1829 he addressed to the Brussels Academy a memoir on two general principles of geometry, duality and homography: The introduction to this memoir expanded into the wellknown Apercu historique sur l'Origine et le Develop. pement des Méthodes en Gémétrie, the first edition of which was published in 1837. In 1841 he was appointed to the chair of Machines and Geodesy at the Ecole Polytechnique, and in 1846 to that of Higher Geometry, which had just been instituted at the Sorbonne. In 1852 appeared his Traité de Géométrie supérieure; in 1860, Les Trois Livres de Porismes d'Euclide rétablis pour la Premiere Fois; in 1865, the Traité des Sections Coniques; in 1870, the Rapport sur les Progres de ta Géometrie. These, his principal works, are geometrical and historical. His contributions to the Comptes rendus of the Academy of Seiences and to other scientific publications are extremely numerous, and though in the main geometrical, are not exclusively so. In particular he treated in several memoirs the question of attraction, and gave the first synthetic demonstration of a celebrated theorem of Maclaurin on the attraction of ellipsoids. Two of his memoirs on the properties of cones of the second degree, and on the spherical conies, were translated into English, and published, with additions, by Charles Graves in 1841. The best account of Chasles's writings is that given by himself in the Rapport above mentioned. During his long life he was the recipient of many scientific distinctions, and he will always be cited as one of the great geometers of the 19 th century. He died at Paris on 18th December 1880. An unfortunate episode in his life was that of the autographs. In 1867 he reported to the Academy that he had come into possession of autographs of Pascal's which proved that Pascal had anticipated Newton's greatest discoveries. Ultimately, however, he had to admit that these and about 27,000 other autographs (including letters from Julius Cæesar, Dante, and Shakespeare) were forgeries. The forger, Irène Lucas, was convicted and punished.

Chasles, Philaríte, a voluminous French writer, was born at Mainvilliers, near Chartres, 8th October 1798. Early imbued with Rousseau's ideas by his father, an old Jacobin, he was apprenticed at fifteen to an ardent Jacobin bookseller, along with whom he was sent to jail after the Restoration. Released by Chateaubriand's influence, he went to England, where he found employment in a bookseller's shop, and during his seven years' residence laid the foundation of his large knowledge of English literature. After his return to France he contributed reviews of English books to the Revue encyclopedique. In 1824 his Discours sur Jacques Auguste de Thou, and in 1828 his Tableau de la Langue et Littérature Française, 1500-1610, were crowned by the Academy. In 1837 Chasles became librarian of the Bibliotheque Mazarin, and in 1841 professor of Northern Languages at the Collège de France, which chair he filled until his death, at Venice, July 18, 1873. Besides showing indefatigable activity as a journalist, he published books on Charles I., Cromwell, the middle ages, the 16th century in France, and studies on Spain, on Germany, on the 18th century in Eng. land, 19th-century manners, Shakespeare, Mary Stuart, and Aretino. His Mémoires fill two volumes (1876-78).

Chassé, David HeNdrik, Baron, a famous Dutch soldier, was born at Thiel, in Guelders, March 18, 1765, began his military career when but ten 
years of age, became a lieutenant in 1781, and captain in 1787. After the failure of the revolutionary movement he took French service; was appointed lieutenant-colonel in 1793; and two years later found himself marching towards the Netherlands under the command of Pichegru. He afterwands fought with the French in Ciermany and Spain, gaining great distinction, and from Napoleon himself, from his fondness for bsyonet charges, the name of "Général Baionette," He was imale a haron by Louis Bonaparte in 1809. As lieutenant-general of the Dutch forces in 1815 Chusse did good service at Waterloo against his old comredes, the French. As governor of Antwerp he became famons by his heroie three-weeks' defence of the citadel with 5000 men against 60,000 Belgians and French (1832). He died May 2, 1849.

Chassepot, Antoine Alphossk, French inventor, born 4th March 1833, was an employee in the Paris arsenal of St Thomns, where he became an official in 1858, and in 1863 brought before the government the model of his ritle, adopted three yeurs afterwards (see BREECH-LOADING, RIFLES). In 1895 he was keeping a hotel in Nice.

Chasseurs (Fr., 'hunters') is a name used since 1741 for certain corps d'elite of the French army. The Chasseurs-d-cheval and the Chasseurs d A frique are light cavalry. The latter were raised in 1831 for service in Africa, mounted on Arab horses, and wearing a distinct uniform. There were in 1888 twenty regiments of Chasseurs-à-cheval, and four of Chasseurs d'Afrique. Uniform, sky-blue tunic with red trousers. The Chasseurs-d-pied are light infantry corresponding to the Rifle Corps of the British and the Jägers ('hunters') of the German and Austrian armies. One regiment, the Chasseurs de Vincennes, formed in 1838, has always been especially famous for rapidity and precision of movement, as well as accuracy of fire. There are now thirty battalions of Chasseurs-à-pied in the French army. Uniform, dark-blue tunic and irongray trousers instead of red.

Chastelard, PIerre DE Boscosel DE, a hapless French poet, born in Dauphine about 1540 , became a page in the household of the Constable Montmorency, afterwards in that of the Marshal Damville, and accompanied the latter to Scotland in his escort of Queen Mary (1561). Here he fell madly in love with the queen, and Mary was indiscreet enough to amuse herself with his passion, receiving without displeasure the amorous verses which the poet laid before her. Misinterpreting the goodwill of the queen, Chaste lard ventured to conceal himself under her bed, was discovered and forgiven, but on a repetition of his offence at Bumtisland early in 1563, where the queen was resting on her journey to St Andrews, was seized and executed on the following morning. $\mathrm{He}$ is the subject of a tragedy, the first of the trilogy devoted by $\mathrm{Mr}$ Swinburne to the history of Mary.

\section{Chaste Tree. See VITEX.}

Chasuble (Lat. casula, casubula, and cassibula; also panula, planeta; Gr. phelonion or phainolès), the uppermost garment worn by priests in the Eastern and the Roman Catholic Church when robed for the celebration of the mass; having been at first a secular garment of ceremony common to both sexes. When adopted as an ecclesias. tical robe, it was for some centuries nsed by all grades of the clergy, even as low as that of the acolytes, and its earliest restriction to priests apyears in Canon xxviii. of the Fourth Council of Toledo, in 633 A.D. It was called also 'the Vestment,' though this term more properly denotes col. lectively all the robes worn at mass, of which the chasuble is the principal item. Originally it cov- ered the priest from head to foot, like a little house, whence some writers think it had its name of cosula (Isid. Hispal., Orig. xix. 24). The earliest direct evidence for it as a sacerdotal robe is in the mosaics of San Vitale at Kavenna (547 A.D.), where Arch. bishop Maximian is depicted wearing it. Rich materials, cloth of gold or silver, silk, and velvet, elaborately embroidered, were used for it. In the middle ages it was of an elliptical shape, like a vesica piscis, with a hole in the middle for the head; it had no sleeves. When put on it showed two peaks, one hanging down before ; another, on which a cross was embroidered, hanging down behind, though in Italy the cross was and is usually in front. The Greek chasuble is ampler and rounder than the Latin form, having more 'the nature of a mantle, and the episcopal chasuble is provided with a pattern of crosses. Archbishops do not wear the chas-

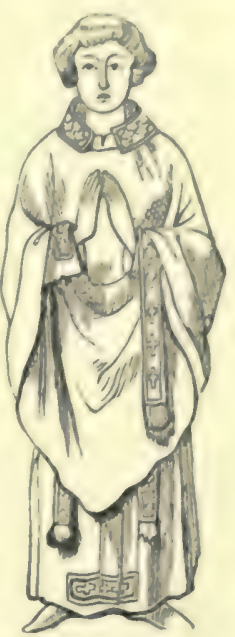

Chasuble. uble, but another vestment named Salikos, which is worn by bishops also in Russia. The modern Latin form is commonly a parallelogram with rounded angles, or else resembles a violin. In the Reformed Church of England the chasuble was enjoined as the celebrant's robe at Holy Com. munion by the Prayer-book of 1549 , prohibited by that of 1552, but again legalised in 1559. It remained, however, in practical abeyance (its place in cathedrals and on solemn occasions being sup. plied by the cope) till recent times, when its use has been partially revived, first in 1851 at $\mathrm{St}$ Thomas the Martyr in Oxford. In France the press or wardrobe in which chasubles were kept was called the chasublier.

Chat (Saxicola), a genus of small birds in the Thrush family (Turdidæ). The bill at the base is broader than its height, and the upper portion is not hooked. The genus includes some thirtysix species, especially at home in northern temperate regions, frequenting dry stony places, and nesting in holes. They are lively birds, flitting about rapidly and untiringly in pursuit of insects, on which they chiefly feed. The Wheatear ( $S$. onanthe) is a good example, fonnd in Europe, North Africa, and North America, and along with other chats frequent in Britain. Yellow-breasted Chat is a popular name for a bird common in the United States, and technically known as Icteria virens.

Chata (Pterocles alchata), a desert fowl of the nature of a grouse, occurring in waste places in Southern Europe, North Africa, Arabia, and Syria. It is very good to eat, and large numbers are shot.

Chatean, Châtel, or CASTEL, from the Lat. castellum, 'a fort,' enters as a component part into many names of places in France. See CAsTlE. A 'chatean en Espagne' is a castle in the air.

Chateaubriand, François René, Vicomte DE, a distinguished French writer and politician, was born at St Malo, in Brittany, on September 4, 1768. He belonged to . n noble Breton family, and was the youngest of ten children. His early years were spent partly by the sea at St Malo and partly in the seclusion of the woodland chatean of Com. bourg. He was educated at Dol and Rennes, and served for a short time as an ensign in the 
regiment of Navarre. In 1791 he sailed to North America, and spent eight months there in the travels which are recounted in his Voyage en Amérique. On hearing of the arrest of Louis XVI. he returned to France and joined the army of the émigrés. During the Prussians' retreat he was left behind for dead near Namur, but contrived to make his way to that town, and thence, with no little difficulty, to England. For some years he maintained himself in London by teaching and writing translations; in 1797 he published an Essai sur les Revolutions, and in 1800 he was enabled to return to France. Atala, a love-story of savage life, the scene of which is laid in the American forests and prairies, appeared in 1801, and established Chateaubriand's literary reputation. The Génie du Christianisme (1802), a vindication of the Church of Rome, raised him to the foremost position among the French men of letters of the day. He was neither a sound thinker nor a skilful controversialist, and the merit of his famous treatise lies almost entirely in its brilliant passages of description. These, however, are often curiously out of place in a work of the kind. Sainte-Beuve, who spoke of the Genie as a coup de theatre et d'autel, declared that many of them would have been more warrantably included in a Genie du Paganisme. But the book appeared when there was a widespread reaction against scepticism, and its eloquent pleadings were favourable to the conciliatory policy which Napoleon had adopted in regard to the pope. Its success in consequence was enormous. Its author was in 1803 appointed secretary to the embassy at Rome, where he wrote his Lettres sur l'Italie, and in 1804 was sent as ambassador to the little republic of Valais. But on the murder of the Duc d'Enghien, Chateaubriand refused to hold office under Napoleon. He set out to the East in 1806, visited Greece, Palestine, and Egypt, and returned to France in 1807. Two years later he issued Les Martyrs, a prose epic, of which the action passes in the days of Diocletian. There is much that is false, much that is extravagant in this singular book, and the borrowed epical machinery works clumsily throughout. But there is genuine passion in the episode of Velleda; and in calling up a vision of the beauty of the ancient world the writer exhibits an almost unsurpassable mastery of ornate prose. In 1814 Chateaubriand published a pamphlet, De Bonaparte et des Bourbons, which Louis XVIII. declared to be worth an army to the Legitimist cause. From 1814 to 1824 he gave a thorough-going support to the Restoration monarchy. He was made a peer and a minister of state, and from 1822 to 1824 held the post of ambassador extraordinary at the British court. It was his ambition to become the guiding power in French politics; he believed that it lay in him to reconcile Legitimism and liberty. He was disappointed, however, in his hope of becoming prime-minister, and from 1824 .to 1830 he figured as a Liberal politician. On the downfall of Charles $X$. he refused to swear allegiance to Louis-Philippe, and went back to the Royalist party. His changes of front were not due to mere selfish ambition. A Breton noble, he was by his birth and associations a Royalist; his writings prove that he was deeply imbued with the anti-social sentimentalism of Rousseau (he claimed Byron as his pupil); he had almost no logical faculty, and he was by tenperament imperious and rebellious. 'In natural disposition, he wrote in 1831, 'I am still a Republican.' His politics were thus a tissue of inconsistencies, but to regard him as a mere time-server is to misunderstand his character. During the reign. of Louis-Philippe he withdrew from public affairs, and occupied himself in preparing his Mémoires d'outre Tombe for posthumous publication. Parts of this eloquent autobiography appeared, however, before his death, which occurred on July 4, 1848 . Besides those mentioned above, his writings include the Itinéraire de Paris à Jerusalem; Les Natchez, a prose epic dealing with savage life in North America; and two works of fiction, René and Le Dernier des Abencérages.

Chateaubriand is a writer whom it is difficult to criticise justly. He was not a thinker, and he produced no book which has the unity and sustained excellence of an enduring work of art. He dealt in false sentiment and extravagant imagery; he was blind to the virtues of simplicity and restraint. Sainte-Beuve said he transferred the capital of prose from Rome to Byzantium and introduced the style of the lower empire. But when he is at his best his brilliant and glowing diction acts on the reader like an enchantment. His writings revealed new capabilities in the French language. There is no French author of earlier date whose prose can compare with Chateaubriand's in the power of conveying the beauty and mystery of nature. His style, with its magieal play of colour, its cunning felicity of descriptive phrase, was a new thing in French literature. It fascinated readers accustomed to the cold and polished prose of the classical school, and marked the beginning of a new literary epoch. Chateaubriand has been justly called the father of the romantic school, and the beauty and grandeur of his finest descriptive passages have been surpassed by none of his followers. See Sainte-Beuve's Chateaubriand et son Groupe Litteraire ( 2 vols. 1877).

Chateaubriant, a town in the French department of Lower Loire, on the Chère, 40 miles NNE. of Nantes by rail, with several old churches and a castle, iron-founding and bell-casting, and productive iron-mines close by. Pop. 5450 .

Chateaudun, a pretty town in the French department of Eure-et-Loir, on the Loir, a tributary of the Loire, 83 miles SW. of Paris by rail. It was almost destroyed by fire in 1723, and on 18th Oetober 1870 was captured by the Germans after an obstinate resistance. Dunois is buried in the chapel of the stately castle. Pop. 6709.

Château Gaillard. See Andelys.

Chateau-Gontier, a town in the French department of Mayenne, on the Mayenne, 180 miles WSW. of Paris by rail. It has linen and woollen manufactures. Pop. 7334.

Chateau Margaux. See Margaux.

Chateauroux, the capital of the French department of Indre, on the left bank of the river Indre, 88 miles $\mathrm{S}$. of Orleans by rail. It has manufactures of woollens, iron, leather, and tobacco. General Bertrand was born and died here, and a statue was erected to him in 1854. Pop. (1872) 16,858 ; ( 1886 ) 21,995 ; (1891) 20,503 .

Chatean-Thierry, a town in the French department of Aisne, 59 miles E. by N. of Paris by rail, with manufactures of mathematical and musical instruments, dye-works, and quarries. It has the ruins of an old castle $(720)$, and is the birthplace of Lafontaine; here, too, Napoleon defeated the Prussians and Russians, 12th February 1814. Pop. 6405

Chatelaine, the wife of the chatelain or Cas. tellan (q.v.), the commander of a feudal castle. A chaine chatelaine or simply chatelaine, a chain such as a lady chatelaine might wear (ef. the English housewife), is a chain depending from the waist, to which are attached keys, scissors, \&c.

Chatelard. See Chastelard.

Chatelet-Lomont, GabrielLe Émilis, MarQUISE DU, a very learned Frenchwoman, notorious 
for her intimacy with Voltaire, was born at Paris, 17th December 1706. At an early period she dis. played a great aptitule for the reyuisition of knowledge. She studied Latin and Italian with her father the Baron de Breteuil, and subsequently betook herself with zeal to mathematics and the physical sciences. Distinguished alike for her beauty and talent, she soon found a host of suitors for her hand. Her choice fell on the Marquis du Chatelet-Lomont, but her narriage did not hinder her from forming, in 1733, a tendresse for Voltaire, who came to reside with her at Cirey, a chateau on the borden of Champagne and Lorraine, belonging to her husband. Here they studied, loved, guar. relled, and loved ayain, for several years. In 1747, however, she became 'not insensible to the brilliant qualities ' of a certain M. Saint-Lambert, a captain of the Lorraine Guards; and the result was, that the philosopher had to make room for the soldier, and content himself for the future with being the 'devoted and indulgent friend' of his former mistress, She died at Lunéville, 10th September 1749, a fow days after having given birth to a child. Her first writing was Institutions de Physique (1740), a treatise on the philosophy of Leibnit\%. She also translated the Principia of Newton into French, accompanying it with algebraic elucidations. It did not, however, appear till 1756. See Voltaire, and the Life of the Marquise by Capefigue (1868).

Chatellerault, a town in the French department of Vienne, on the river Vienne, 40 miles S. of Tours by rail. A handsome stone bridge, with a gateway built by Sully at one end, connects it with a suburb on the other side of the river. It is a smoky, dingy place, one of the chief seats of the cutlery manufacture in France, and since 1820 has had a government small-arms factory. Its riverport makes it the entrepot for the produce of an extensive district. The title of Duke of Chatellerault was conferred by Henry II. in 1548 on James Hamilton, Earl of Arran and Regent of Scotland; and it now is claimed by both the Duke of Abercorn and the Duke of Hamiltonby the latter under an imperial decree (1864) of Napoleon III. Pop. (1872) 13,360 ; (1891) 18,112.

Chatham (Ang.-Sax. Ceteham), a parliamentary, and, since 1891, municipal borough, river-port, fortified town, and naval arsenal, in the county of Kent, situated on the right bank of the Medway, at the upper part of its estuary, 30 miles ESE. of London. It forms almost one continuous town with Rochester (q.v.) on the west, but itself has few objects of interest, being much of it ill built and irregular, although great improvements have been effected in recent years. The High Street is $1 \frac{1}{4}$ mile long, parallel to the river. Chatham owes its importance to its naval and military establishments, situated at Brompton, a suburb on high ground overlooking the Medway. There is also a large convict establishment. The Chatham fortified lines are the frequent scenes of sham-fights and reviews. Pop. (1851) 28,424; (1871) 45,792; (1891) 59,389 , of whom 31,711 were in the municipal borough. The borough sends one member to parliament. Traces of Roman villas have been found, with Roman bricks, tiles, coins, and weapons. The dockyard was founded by Elizabeth before the threatened invasion of the Spanish Armaln. In 1662 it was removed to its present site. In 1667 the Duteh, under De Ruyter, sriled up the Medway, and, in spite of the fire from the castle, destroyed much shipping and stores.

In a military point of view, the lines of detached forts connected with Chatham constitute a fortification of great strength; and the whole is regarded is a flank defence for London in the event of an invoder seeking to march on the capital from the south coast. In 1888 an additional chain of forts was being built by convict labour over a wider area. The place is also defended by some strong forts on the Medway. In and near Chatham are Fort Pitt, a military hospital and strong fort: Melville Hospital, for marines and sailons; barracks for in. fantry, marines, artillery, and engineers; a park of artillery ; and magazines, storehouses, and depota on a large scale.

Chatham is one of the principal royal ship. building establishments in the kingdom, and a visit to it never fails to impreas the stranger with a sense of the naval power of England. The dockyard is nearly two miles in length, containing several building-slips, and wet-docks sufficiently capacions for the largest ships; and the whole is traversed in every direction by tramways for locomotives, with a gauge of 18 inches. Three great wet-docks on reclaimed marsh land were completed in 1883 after the labour of 17 years, and at a total cost of about $£ 3,000,000$ (including cost of site ; as also convict labour valued at $£ 400,000$ ). The reclaimed land extended to 400 acres; and the aggregate water area of the three new wet-docks is 67 acres. A duplieate of Brunel's block-making machinery is kept at Chatham to supplement that at Portsmouth. In the navy estimates provision is made for about 5000 artisans and labourers. A statue of Lieutenant Waghorn, the pioneer of the 'overland route' to India, was erected near the railway station in 1888; but Chatham's most cherished memories are of Dickens and Gordon: of the latter there is a statue, mounted on a camel, by Onslow Ford (1890). Lord Rosebery opened a new town-hall, English Renaissance in style, 23d January 1900.

Chatham, (1) a town of Ontario, on the Thames, 67 miles SW. of London by rail, with a number of mills and foundries, soap and candle works, and an active trade in grain, pork, and wood. Pop. 9052. - (2) A port of entry in the north of New Brunswick, on the Miramichi, 6 miles NE. of Newcastle, with a good harbour, ship-yards, foundries, Catholic cathedral, and a college. Pop. 5000.

Chatham. William PITt, Eari of, sometimes styled PITT THE ELDER, one of the greatest English orators and statesmen of the 18th century, was the younger son of a country gentleman, Robert Pitt of Boconnoc, in Cornwall, and was born November 15, 1708. After an edueation at Eton and Oxford, he travelled on the Continent, and on his return obtained a cornetey in the Blues. In 1735 he entered parliament for Old Sarum-that synonym for electoral corruption $-a$ borough then belonging to his family. He espoused the side of Frederick, Prince of Wales, then at deadly feud with the king, and offered as the leader of $\mathrm{a}$ number of young discontented Whigs known as the 'Patriots' a determined opposition to Walpole, who was at the head of affairs. He was deprived of his commiseion in consequence-an insult and injury which only increased the vehemence of his denunciations of the court and the government. His influence, both in and out of the House of Commons, increased rapidly; and Walpole being driven from power in 1742, the king, notwithstanding his hatred of Pitt, found it necessary, four years later, to allow of his admission to a subordinate place in the Broad Bottom administration; subsequently he was appointed to the lucrative oflice of paymaster-general. The Duchess of Marllorough, pleased with his patriotism and powers of oratory, left him $£ 10,000$; and later, Sir William Pynsent, struck with similar admiration, left him his whole property, amounting to some $£ 3000$ a year, and including what became the family place of the Pitts in Somersetshire. In 
1755, when Henry Fox (afterwards Lord Holland) was made secretary of state, finding himself opposed to the foreign policy of the new minister, Pitt resigned office as paymaster. In the following year, when the king, unwillingly acceding to popular demands, had to dismiss Fox, Pitt became nominally secretary of state, but was virtually premier. He immediately began to put into execution his own plan of carrying on the war with France, and inaugurating a brilliantly successful foreign policy. He raised the militia and strengthened the naval power; but the king's old enmity and German predilections led him to oppose Pitt's policy, who thereupon resigned office in April 1757, tout was recalled in June, in obedience to the loud demands of the people.

Now firmly established in power, Pitt's war policy was characterised by unusual vigour and sagacity. Success returned to the British arms. French armies were beaten everywhere by Britain and her allies-in India, in Africa, in Canada, on the Rhine-and British fleets drove the few French ships they did not capture or destroy from almost every sea. But the prime mover of all these brilliant victories found himself compelled to resign (1761), when, on the accession of George III., and owing to the influence of Lord Bute, an attempt was made to introduce a vacillating policy into the government ; his immediate cause of resignation being the refusal of the majority of the cabinet to declare war with Spain, which Pitt, foreseeing as imminent, wished to commence before the Spaniards were thoroughly prepared. As some recompense for his important services Pitt received a pension of $£ 3000$ a year; and his wife, sister of George Grenville, was created Baroness Chatham. Until 1766 Pitt remained out of office, not offering a factious opposition to government, but employing all his eloquence to defeat some of its most obnoxious measures. In that year he received the royal commands to form a ministry. He undertook the task, choosing for himself-to the astonishment of the public, and the sacrifice, to $a$ considerable extent, of his popularity - the almost sinecure office of Privy Seal, with a seat in the House of Lords as Viscount Pitt and Earl of Chatham. Ill-health prevented Chatham from taking any active part in this ministry, of which he was nominally the head, and which was weak and embarrassed throughout, and he resigned in 1768, to hold office no more. He did not, however, cease to take an interest in public affairs. He spoke strongly against the arbitrary and harsh policy of government towards the American colonies, and warmly urged an amicable settlement of the differences. But when, America having entered into treaty with France, it was proposed by the Duke of Richmond to re. move the ministers, and make peace on any terms, ill though he was, Chatham came down to the House of Lords. In a powerful address he protested against the implied prostration of Britain before the throne of the Bourbons, and declared that war, with whatever issue, would be preferable to the proposed terms of peace. This address secured a majority against the motion, and the war was continued. But it was the orator's last effort; for, exhausted by speaking, on rising again to reply to a query addressed to him by the Duke of Richmond, his physical powers suddenly failed, he fell back into the arms of his friends, and was carried by his second son, William, less than five years later himself prime-minister, from the House. He died May 11, 1778. He was honoured with a public funeral in Westminster Abbey, where a statue was also erected to his memory at the public expense; and in addition, government voted $£ 20,000$ to pay his debts, and conferred a pension of $£ 4000$ a year on his descendants. Chatham's personal appearance was dignified and imposing, and combined with a voice of the most magnificent compass, added greatly to the attractions of his oratory, which was of the most powerful kind. It is said that even his whispers were, when he pleased, distinctly heard outside the House in the lobby. His upright and irreproachable character demanded the admiration of his enemies; but his affectedness and haughtiness not unfrequently disgusted his friends, and pride rather than principle seems to have actuated his course at some important conjunctures of his life. He had, however, an intense love of country; the grand object of his ambition being to make his native land safe against all contingencies, and powerful among nations. See his Life by $\mathbf{F}$. Thackeray ( 2 vols. 1827 ), and his Correspondence (4 vols. 1838-40).

Chatham Islands, a small group in the Pacific, lying 360 miles E. of New Zealand, to which they politically belong. They are the antipodes of Toulouse in France. There are three islands-of which the largest, Chatham Island, is 25 miles long - and some rocky islets. Total area, 375 sq. m. ; population (1891) 459 , of whom 148 are Maoris, and 40 Morioris or aborigines. The Chatham Islands were discovered in 1791 by Lientenant Broughton, of the brig Chatham. A large brackish lake occupies the interior of Chatham Island, which is of volcanic origin and hilly. Stockrearing and seal-fishing are the chief industries, the islanders having no fewer than 65,000 sheep and about 500 cattle, with which they supply passing whalers. Timber of any size is unknown, so that the native canoe is merely wicker-work bound together by cordage of indigenous flax. The Morioris numbered 1200 in 1831, when 800 Maoris were landed from New Zealand, by whom the former were reduced to 90 in nine years' time.

Chati, a small leopard-like cat, smaller than an ocelot, found in South America.

Chatillon, a town in the French department of Cote d'Or, on the Seine, 49 miles NNW. of Dijon. A congress of allied sovereigns was held here in 1814, from February 5 to March 19, and opened fruitless negotiations with Napoleon respecting conditions of peace. Pop. 5120.

Chat Moss, a bog in Lancashire, the largest in England, 7 miles W. of Manchester, and 10 sq. $\mathrm{m}$. in extent. It is celebrated as having in 17931800 been the scene of the first great and successful efforts for the reclaiming of bogs, largely through the instrumentality of Roscoe the historian, and in 1829 of one of George Stephenson's great engineering triumphs in the construction of the Liverpool and Manchester Railway. It is very slightly elevated above the sea, and from 20 to 30 feet in depth. Stephenson laid branches of trees and hedge-cuttings, and in the softest places rude hurdles interwoven with heather, on the natural surface of the ground, containing intertwined roots of heather and long grass; a thin layer of gravel was then spread above all, and on it the sleepers, chairs, and rails were laid in the usual manner. Drains were at the same time cut on both sides of the line, and in the central part of the moss a conduit was formed beneath the line of railway of old tar-barrels placed end to end. Notwithstanding difficulties which every one but himself deemed insuperable, Stephenson constructed the portion of the line through Chat Moss at a smaller expense than any other part of the railway.

Chatrian. See Erckmann-Chatrian.

Chatsworth, the magnificent seat of the Duke of Devonshire, one of the most splendid private mansions in England, is situated in Derbyshire, on the Derwent, 25 miles N. by W. of Derby. The 
domain was purchased by Sir William Cavendish, who in 1553 began the old mansion, which, after his death in 1557, was completed by his widow, 'Bess of Hardwick,' afterwards Countess of Shrews. bury. Here Mary, Queen of Scots, was five times imprisoned during 1573-81. The present edifice includes the old Palladian pile built in 1087-1706 by the first Duke of Devonshire, and the north wing added in 1820. The facade is 720 feet long, or with the terraces, 1200 foet. The building is nearly a square, with an inner quadrangle. Chatsworth is famed for its library, and for its pictures and sculptures by Holbein, Titian, Teniers, Murillo, Rey molds, Lanilseer, Canova, Thorwaldsen, Chantrey, \&e. The gardens and park, 10 miles in eircuit, offer an exquisite variety of hill and dale. They were laid out by Loudon and Paxton, and are celebrated for their trees, shrubs, rockwork, deer, and waterwork8-only surpassed by those at Versailles. The conservatory, unrivalled in Europe, covers nearly an scre, measures 300 by 145 feet, is 65 feet high, and has 70,000 square feet of glass, with a carriage road through it. Hobbes, the philosopher, lived much at Chatsworth. See CAvENDISH.

Chattahoo'chee, a headstream of the Appalachicola (q.v.).

Chattanooga, capital of Hamilton county, Tennessee, a shipping centre on the Tennessee River, 151 miles SE. of Nashville, with good rail way connections. The town has cotton and other manufactories, ironworks, tanneries, and sawmills. There was much fighting near here during the civil war. Pop. (1870) 6093; (1880) 12,892; (1890) 29,100 .

Chattel (Old Fr. chatel, from Low Lat, capitale, meaning the capital or principal sum in a loan; hence goods in general, especially cattle, as distinguished from land), in the law of England, is a term used to designate any kind of property which, with reference either to the nature of the subject or the character of the interest possessed in it, is not freehold. Ownership in personal or movable property is generally absolute. Any estate or interest in lands and tenements not amounting to freehold is a chattel. But as, between property thus 'savouring of realty' and mere personal movables-money, plate, cattle, and the likethere was a manifest distinction, chattels were, consequently, distinguished into chattels-real and chattels-personal. These classes of property differ considerably as to the method of holding and trans. ferring them and their devolution on death. For treatnent of real and personal property, see REAL.

Chatterer, a signiticant popular name, often applied to the birds of a small family (Ampelidie) of finch-like Perching birds (Insessores). The short broad beak with only a hint of a hook, the soft plumage, and tolerably long wings are characteristics of the family. Only about nine species, of small size, are known, and confined to the warmer parts of the nearetic and palearetic regions. The Bohemian Waxwing (Ampelis garrulus), living in the north of Europe, Asia, and America, but coming south in winter, sometimes in vast numbers, and the Cedar Bird of America are the best-known examples. See WAXWING.

Chatterton, Tномаs, was born at Bristol, 20th November 1752. His father, a sub-chanter in the cathedral, and master of a charity school, was a roystering fellow, yet a lover of books and coins, a dabbler in magic; he had died in the August before the poet was born. The mother, a poor schoolmistress and needlewoman, brought up her boy and his sister benesth the shadow of St Mary Redcliffe, that glorious church where their forefathers had been sextons since the days of Elizabeth. He seemed a dull, dreamy child till his seventh year; then he 'fell in love' with an old illuminated music folio, and, quickly learning to read from a black-letter Bible, began to devour every book that fell in his way. He was a acholar of Colston's bluecont hospital from 1760 till 1767 , and then he was bound apprentice to Lambert, an attorney. In December 1762 he wrote his finst prem, On the Last Epiphany; in the summer of 1764, the first of his joeudo-antigues, Elinour and Juga, which imposed on the junior nsher of his school, and which he professed to have got from Canynge's Coffer in the muniment room of $\mathrm{St}$ Mary's, Next, early in 1767, for one Burgum, a pewterer, he concocted a pedigree of the De Berg. ham family (this brought him five shillings); and in 1768 he hoaxed the whole city with a descrip. tion, 'from an old manuscript,' of the opening of Bristol Bridge in 1248.

His life at Lambert's was a sordid one; he slept with the footboy, and took his meals in the kitchen. Yet, his duties over-and he discharged them well - he had ample leisure for lis darling studies, poetry, history, heraldry, music, antiquities. An attempt to draw Dodsley had failed, when, in March 1769, he sent Horace Walpole a 'trankcript' of The Ryse of Peyncteynge, written by T. Ronolie, 1469, for Mastre Canymge. Walpole, quite taken in, wrote at once to his unknown correspondent, expressing a thousand thanks for the manuseript, deploring his igmorance of the 'Saxon language, and half offering to 'usher the Rowley poens to the world. Back came a fresh bateh of manuseript, and with it a sketch of Chatterton's own history. The poems, however, being shown to Mason and Gray, were pronounced by them to be forgeries; and Walpole's next letter was a letter of advice, to stick to his calling, that so, "when he should have made a fortune, he might unbend himself with the studies consonant to his inclinations.' A curt request for the return of the MSS. lay six weeks unanswered during Walpole's absence in Paris. A second, still curter; and, 'snapping up poems and letters,' Walpole 'returned both to him, and thought no more of him or them '-until, two years after, Goldsmith told him of Chatterton's death.

Was it jest or grim earnest, a boyish freak or a suicide's farewell, that 'Last Will and Testament of Thomas Chatterton ... executed in the pres. ence of Omniscience this 14th of April 1770? Anyhow, falling into his master's hands, it procured the hasty cancelling of his indentures; and ten dave later the boy quitted Bristol for Loudon. There he arrived with his poems, and perhaps five guineas in his pocket, and lodgred first at one Walmsley's, a plasterer, in Shoreditch ; next, from the middle of June, at Brooke Street, Holborn. Abstemious, sleepless, he fell to work as with a hundred hands, pouring forth satires, squibs, stories, political essays, burlettas, epistles in Junius' style (for 'Wilkes and liberty'), and the matchless Balade of Charitie. For a while his prospects seemed golden. The publishers spoke him fair; he obtained an interview with the Lord Mayor Beckford; in the first two months he earned eleven guineas (at the rate of from a farthing to twopence a line); and he sent home glowing letters, with a box of presents for his mother and sister. Then Beckford died; the 'patriotic' publishers took fright; the dead season set in; he had overstocked the market with unpaid wares; a last desperate application failed for the post of surgeon to a Bristol slaver. He was penniless, starving, yet too proud to accept the meal his landlaly offered him, when, on 24th August 1770, he locked himself into his garret, tore up his papers, and was found the next morning dead-poisoned with arsenic. They buried him in the paupers' pit of the Shoe Lane Workhouse, a site usurped fifty-six years later by Farringdon Market. 
For eighty years the Rowley controversy was waged with no less bitterness than ignorance, the Rowleyans including Jacob Bryant (1781), Dean Milles (1782), and Dr S. R. Maitland (1857); the anti-Rowleyans, Tyrwhitt (1777-82) and Warton (1778-82). The subject was once and for ever laid to rest by Professor Skeat in his edition of Chatterton's Poetical Works (2 vols. 1875). Vol. i. contains Chatterton's acknowledged poems, 78 in number; vol. ii. the 43 Rowley poems, with an essay thereon by the editor. Almost unconsciously the learned professor establishes Chatterton's wondrous originality. Theft from an unknown poet?there is not 'the slightest indication that Chatterton had ever seen a MS. of early date.' Indebtedness to Chaucer?-he had 'read very little of this excellent author. . . . If he had really taken pains to read and study Chaucer, or Lydgate, or any old author earlier than the age of Spenser, the Rowley Poems would have been very different. They would then have borne some resemblance to the language of the 15th century, whereas they are rather less like the literature of that period than of any other. . . . The metres are mostly wrong, the rimes are sometimes faulty; the words [taken mostly from Kersey's Dictionary, and 93 per cent. of them misused] are wrongly coined, or have the wrong number of syllables; and the phrases often involve anachronisms, or, occasionally, plagiarisms.' These last from such recent poets as Dryden and Gray - from the former of whom he boldly stole the line, 'And tears began to flow;' from the latter adapted the conception, 'closed his eyes in endless (everlasting) night.

An owl mangling a poor dead nightingale,' said Coleridge of Dean Milles; the words apply to many more critics of Chatterton. There are those among them whose patronising praise and commonplace censure enable us to feel how Chatterton was worsted in life's battle, why he blew up the ship sooner than strike his colours. Others there areColeridge, Wordsworth, Shelley, Rossetti-whose precious tributes attest the boy-poet's divinity. No man can tell what Chatterton might have done what he did do is patent to every one. Had Shakespeare died, or Milton, in his eighteenth year, or even Keats, the world had never heard of their existence. But he, a lad, with chances infinitely less than theirs, had written his name by then so high in Fame's temple, that purblind pilgrims must accept his achievement on hearsay. If he had lived to be famous, the fraud of the ' poet-priest Rowley' would not, belike, have been more hardly blamed than that of 'Jedediah Cleishbotham.' As it is, the conseientious critics have found it less difficult to dilate on Chatterton's pride and scepticism, his vices and deceit, nay, on the meteorology of 1770 , than to master the difficult Rowleyan dialect, and to gauge the genius of this nursling of medievalism, this harbinger of the Renascence of Wonder, to use Mr T. Watts-Dunton's definition of the neo-Romantic movement. For him it was reserved to point out Chatterton's metrical inventiveness, and his 'undeniable influence, both as to spirit and as to form, upon the revival in the 19th century of the romantic temper-that temper, without which English poetry can scarcely perhaps hold a place at all when challenged in a court of universal criticism.

As a youthful poet showing that power of artistic self-effacement which is generally found to be incompatible with the eager energies of poetic youth -as a producer, that is to say, of work purely artistic and in its highest reaches unadulterated by lyric egotism - the author of the Rowley Poems (if we leave out of consideration the acknowledged poems), however inferior to Keats in point of sheer beauty, stands alongside him in our literature, and stands with him alone.'
See Mr Watts-Dunton's essay in vol. iii. of Ward's. English Poets (1880); Sir Herbert Croft's Love and Madness (1780); and Lives of Chatterton by Dix (1837), Sir D. Wilson (1869), and Prof. Masson (1874; new ed. 1900).

Chaucer, Geoffrey. The date 1328 for Chaucer's birth is now justly rejected as having no authority and being quite incompatible with some ascertained facts of his later life. There can be little doubt he was born in or about 1340. He was the son of John Chaucer by his second wife Agnes, of unknown surname, a niece of one Hamo de Copton. (His first wife, Joan de Esthalle, was certainly living as late as 1331.) This John Chaucer was son of Robert Chaucer, of Ipswich and London, so that the poet's family can be traced to the eastern counties. John Chancer was a vintner and a tavernkeeper, and may perhaps be identified with the John Chaucer who was deputy to the king's butler in the port of Southampton in 1348, and 'seems. afterwards to have held the same situation in the port of London.' John's house was in Thames Street by Walbrook, at or near the foot of Dowgate Hill; and there we may well suppose the future poet was born.

Of his boyhood we know nothing. There were good schools in London then as now-e.g. Paul's Cathedral School and Anthony's, and Chaucer probably was sent to one of them. At a later period the variety and the minuteness of his knowledge are remarkable, and we know that he was an assid. nous student. Likely enough his studious habits were more or less formed and the basis of his knowledge laid in his early days. It is possible he may have gone to Oxford or to Cambridge, but there is no evidence of value on this point. In his works. he shows some acquaintance with both universities; but this may have been picked up incidentally. What is certain is that in 1357 and 1358 he was a page in the service of Elizabeth, Countess of Ulster, wife of Lionel, Duke of Clarence. From that ser. vice he would seem to have been presently trans. ferred to the king's household. In 1359 he first 'bore arms.' He served in the campaign in France in that year-a campaign famous for the bitter sufferings which the English army had to endure. Chaucer was taken prisoner at Retiers in Brittany, but was presently ransomed, the king contributing $£ 16$ towards the required amount.

And now we lose sight of Chaucer for some eight years. His father died in 1366, and his mother soon after married one Bartholomew Attechapel; but of Geoffrey no mention has yet been found till 1367, when the king grants him a pension for life, 'or until we shall think it right to make some other order to suit his condition.' He is described as 'dilectus valettus noster' ('our beloved yeoman '), and in an Issue Roll as 'unus valettorum cameræ regis' ( 'one of the yeomen of the king's chamber'). It seems fairly certain that by this time Chaucer was married. In 1366 one Philippa Chaucer appears amongst the ladies of the queen's bedchamber, and there is no good reason for doubting that this was the poet's wife. Her maiden name was in all probability Roet. It is commonly supposed that she was the daughter of Sir Payne Roet of Hainault and king-at-arms of Guienne, and so the sister of Katherine who married Sir Hugh Swinford, and afterwards became the mistress and eventually the wife of John of Gaunt. After the queen's death in 1369 she passed into the household in which her sister was such an important figure, and very likely remained there till her death in 1387. She gave birth, it would seem about 1362 : or 1363 , to Thomas, a noticeable personage in the House of Commons in the following century ; probably to Elizabeth (circa 1365), for whose novitiateat the Abbey of Barking John of Gaunt paid some: $£ 50$ in 1381 , and to Lewis, born in the same year in 
which his sister was admitted at Barking, for whom his father wrote some ten years later a treatise on the Astrolabe. But the whole matter of Chaucer's married life is involved in much obecurity. It is in evidence that when he was certainly married he spencis of himself several times as one unblessed with love's favour; nor can these expressions be explained away as being dramatic and not autobiographical. The picture he draws of himself in the House of Fame, a poem undoubtedly written after his marriage, is assuredly that of a forlorn hachelor. On the whole, we believe him to have married about 1360, and that for some reason or other not at present discovered, if ever to be, his married life was disturbed and unhappy.

In the year 1369 Chaucer comes certainly before us as a poet, with his Death of Blanche the Duchess. This is not probably his first writing; but it is highly important, because the date of it is exactly fixerl by the subject. It laments the death of the Laly Blanche, the first wife of John of Gaunt, which took place in September 1369. It is in many ways a crude composition, and a sufficient proof that Chaucer's art was, like that of many of the greatest masters, not precocious but of slow growth. But even so it illustrates his great gift of style, and gives satisfactory promise of his future excellence.

The following years of Chaucer's life exhibit him to $\mathrm{us}$ both as a much-employed man of business and as a rapidly developing man of letters. In 1370 he went abroad on the king's service; in 1372-73 on a royal mission to Italy - to Genoa, Pisa, Florence; in 1376, abroad, it is not known where; in 1377, to Flanders and to France; in 1378, to Italy again. Thus he seems to have been highly valued as a commissioner and a diplomatist. Meanwhile in 1374 he was appointed Comptroller of the Customs and Subsidy of Wools, Skins, and Tanned Hides in the port of London; in 1382, Comptroller of the Petty Customs; and in 1385 he was allowed to nominate a permanent deputy - a most important concession, as by the terms of his appointment he was, like his predecessors, to write the rolls of his office with his own hand and to be continually present. Nor were other marks of royal and of ducal favour wanting. In 1374, on St George's day, the king granted him a pitcher of wine daily, to be received in the port of London from the hands of the king's butler. In the same year John of Gaunt conferred on him a pension of $\mathfrak{£ 1 0}$ for life for the good gervice rendered by him and his wife Philippa to the duke, to his consort (the duke's second wife, Constance, danghter of Peter the Cruel, married in 1371), and to his mother the queen. In 1375 he received from the crown the enstody of the lands and person of Edmond Staplegate of Kent, which brought him in $£ 104$ (well over $\$ 1000$ of our money), and the custody of some property at Soles, also in Kent. In 1386 he was elected a knight of the shire for Kent. These were Chaucer's most prosperous years in an income-making sense.

To turn to his literary work during these years, the following writings certainly belong to the period between 1369 and 1387 -i.e. between the composition of The Book of the Duchess, and that of the Prologue to The Canterbury Tales - and were probably produced in the order in which they are here named: The Assembly of Fouls, The House of Fame, Troilus and Cressida, and The Legend of Good Women: and besides these in unascertained order the Tale of Griselda (afterwards assigned to one of the Canterbury pilgrims-the Clerk), the Tale of Constance (afterwards assigned to the Man of Law), the Legrend of the Martyred Christian Boy (afterwards assigned to the Prioress), the Legend of Saint Cecilia (afterwards assigned to the Second Nun), and the Story of Palamon and Areite in its first shape (afterwards rewritten and assigned to the
Knight). None of these pieces represents the poet's genius in all its fullnems or its naturity; they ex. hibit its gradual expansion and growth. As we see Chaucer in these he is not yet completely master of himself, or wholly satisfied with the instruments at his command-e.g. with the metrical forms then eurrent around him. By far the most important influence acting upon him during this middle period of his literary life was the influence of Italy; and in this respect his going to Genoa in 1372 , as already mentioned, had an importance other than commercial or political. That was a journey that male an epoch in his artistic develojment. It introduced him to pretry in its nol,lest meslieval shape, and in one of the noblest shapes it has ever assumed in any age. Chancer seems to have felt deeply the greatness of Dante. He appreciated worthily the works of Petrarch and Boccaccio; but to the credit of his judgment, it was Dante that most profoundly impressed him. The Assembly of Fowls and The House of Fame largely reflect this impression, the latter so elosely that Lydgate, as Professor Skeat points out, speaks of it as 'Daunt in English.' Much of his subject-matter he derived from his great Italian contemporaries, especially from Boccaccio. Thus the Reeve's Tale, the Franklin's, and the Shipman's are all to be found in the Decameron; Troilus and Cressida is to a considerable extent a translation of Boccaccio's Filostrato; and the story of Palamon and Arcite is based upon that poet's Teseide. The tale of Griselda is taken from a Latin letter of Petrarch's, to whom Chaucer acknowledges his obligation in the Clerk's Prologue. Oddly enough, he never mentions Boccaccio. In one passage in Troilus and Cressida he would seem to denote him by the name of Lollius; but certainly in another, when he speaks of 'mine author called Lollius,' he denotes Petrarch, for he proceeds to give a version of one of Petrarch's sonnets. Dante he mentions by name several times. With both Petrarch and Boccaccio it is probable that he was personally acquainted. Boccaccio was living at or near Florence when Chaucer was there in 1372 , and Petrarch near Padua, only some 120 miles away. Certainly what is said in the Clerk's Prologue points to an actual meeting with Petrarch.

However this may be, the influence of the Italian poets on Chaucer is beyond question. Nor is it to be measured by what he borrowed in the way of plot or incident or expression. It was far profounder than such debts might suggest. It recreated him as an artist, giving him a new and loftier conception of artistic form and beanty. This regeneration is soon visible in the improvement of his style-in its growing dignity and shapeliness. It is strikingly indicated by his metrical progress. The old four-accented complet seems to him 'light and lewd;' he needs something weightier and statelier. He does not satisfy this need by importing the favourite Italian metres. The sonnet form does not appear in any extant work of his, though conceivably he may have attempted it. The terza rima he does seem to have essayed, as Professor Skeat has been the first to notice; but he did not take to it, or it to him. What he did was to imitate not the letter but the spirit of the Italian masters. And in the heroic heptaatich, and presently in the heroic couplet, he found metrical forms that satisfied the highest ideal. The crowning work of the midllle period of his life is certainly Troilus and Cressidaa work in which the abundant wealth of his genius is lavishly displayed. Probably about the year 1384, when his official duties were so considerably lightened, Chaucer, now a complete master of the poetic craft, began to seek for some great subject. The first selection he made proved unsatisfactury ; 
it was the Legend of Good Women. The Prologue to this famous fragment is an admirable piece of writing; but the theme was soon felt to be wearisomely monotonous, and was abandoned. His second choice was happier, as it provided full scope for his various powers - for his humour and his dramatic faculty, as well as for his pathos and more purely poetical gift. This was the Canterbury Pilgrimage.

But before that final choice was made, having been suggested probably by an actual journey to St Thomas's shrine, some strange reverses of fortune had befallen Chaucer. About the close of the year 1386 he was deprived of both his places in the civil service; and from this time to very nearly the end of his life, with slight intermissions, things went ill with him. The cause of his dismissal is obscure; possibly he was involved in the intrigues that disturbed and disordered the court in the reign of King Richard II. ; possibly also there was some genuine dissatisfaction with the way in which his official work had been or was being performed. In 1389 he received a new appointment-he was appointed Clerk of the King's Works at the palace of Westminster, Tower of London, castle of Berk hamstead, the king's manors of Kennington Eltham, Clarendon, Sheen, Byfleet, Langley, and Feckenham, and elsewhere, in this case, too, being allowed to nominate a deputy; but his previous fate seems to have pursued him. Two years afterwards we find him superseded by one John Gedney. It was during this term of office that he went through the odd experience of being robbed twice in one day. What glimpses we have of him in the succeeding years show him in perpetual impecuni osity and distress. It seems fairly clear that thrift was not one of his virtues. No sort of provision seems to have been made against a "rainy day ; and now came many rainy days. For some two years he had to subsist as best he might on John of Gaunt's pension of $\mathfrak{E l 0}$, his salary as one of the foresters of North Petherton Park, Somersetshire, and whatever wages, if any, were paid him as a king's esquire. In 1394 King Richard granted him a. pension of $£ 20$ for life; but the advances of payment he applies for in the following year, and again and again later on, and other signs, such as the issue on his behalf of letters of protection from arrest for debt, sufficiently indicate his unprosperous condition. An improvement came with the accession to the throne of the son of his old friend and patron John of Gaunt. In October 1399, King Henry IV. granted him a pension of 40 marks $(£ 26,13 \mathrm{~s}, 4 \mathrm{~d}$.). This would raise his income to at least $£ 500$ a year of our money. And we may believe his few remaining months were spent in comfort. The following Christmas he took a lease for 53 years, at an annual rent of $£ 2,13 \mathrm{~s} .4 \mathrm{~d}$., of a house situated in the garden of the Lady Chapel, Westminster, the site now of what is commonly known as Henry VII.'s Chapel. But the end was near. Our last trace of him is the payment of a pension instalment in June 1400 , made not to him personally, but to one Henry Somers in his behalf. Before the close of the cen tury, of which he was in England the supreme literary glory, he was laid in that part of the abbey which through his burial there came afterwards to be called the Poet's Corner. His tombstone says he died October 25, 1400; and though the present tomb dates only from the 16 th century, it probably perpetuates some older inscription.

In spite of all his reverses and troubles, it was during this last period of his life that Chaucer's genius shone brightest.

$$
\begin{aligned}
& \text { A merry heart goes all the day ; } \\
& \text { Your sad tires in a mile-a. }
\end{aligned}
$$

Having formed a design that permitted the full expression of his abundant and many-sided genius; he vigorously pursued it amidst the darkness that overclouded him. The design was indeed too huge for completion; and no doubt for all his vigour and buoyaney his troubles interfered with his progress. Moreover he was approaching or had reached what amidst the unhealthy ways and conditions of medieval life was accounted old age. Hence his work remains but a fragment; but it is a fragment of large and splendid dimensions, consisting of parts that are admirably finished wholes, each one of which illustrates some special feature of the poet's versatile mind and art, and justifies and insures his fame. His greatest achievement is the Pro. logue to the Canterbury Tales, which for its variety, humour, grace, reality, and comprehensiveness is, as a piece of descriptive writing, unique in English literature-unique in all literature indeed. It portrays for us the society of the later middle ages in unfading colours, and historically as well as artistically is of inestimable excellence and value. Chaucer is in order of time the first great poet of the English race, if the term English may be used as distinguished from Anglo-Saxon; and in order of merit he is amongst the first of all our poets. It might indeed be disputed whether he does not deserve the place next to Shakespeare. In the middle ages in England he stands supreme.

See Skeat's edition of Chaucer's works (Oxford, 6 vols. 1894-95, vol. vii. the doubtful works), and his one-volume edition (1895); Pollard's Canterbury Tales (1894); his 'Globe' Edition of Chaucer's Works (1899); Lounsbury's Studies on Chaucer (1892); Tyrwhitt's Introductory Discourse to the Canterbury Tales (1775-78); Nicolas' Life of Chaucer in the Aldine Edition; the magnificent Kelmscott Edition (ed. Ellis, folio, 1896); Ten Brink's ChaucerStudien (1870); Child On Chaucer's Language (in Ellis's Early English Pronunciation). As to Chaucer's language - the East Midland variety of Middle Englishmuch will be found in the Clarendon Press volumes of $\mathrm{Dr}$ Morris and of Professor Skeat; editions of the Prologue and three of the tales, issued by W. \& R. Chambers; Sweet's Middle English Primers; and in Ten Brink's Chaucer's Sprache und Verskunst (1884). Invaluable to the Chaucer student is Dr Furnivall's Six-text Print of the Canterbury Tales, and the other issues of the Chaucer Society. A Concordance has been prepared by members of the same society. It must be noted that many works have been ascribed to Chaucer, and are still printed in popular editions, that are certainly not hise.g. The Court of Love, Chaucer's Dream, The Complaint of the Black Knight, The Cuckoo and Nightingale, The Flover and the Leaf, and in all probability the extant Romaunt of the Rose.

For criticism of the poetry, see Ward's Chaucer in the 'English Men of Letters' series; Morley's English Writers ( vol. iv. in new ed.); Warton's History of English Poetry; and a fine essay by J. R. Lowell in My Study Windows.

Chaudes-Aigues, a town in the French department of Cantal, 90 miles S. of Clermont, with four mineral springs, which vary in temperature from $135^{\circ}$ to $177^{\circ} \mathrm{F}$. They have the property of discharging grease from sheep's wool, and vast numbers of fleeces are sent hither annually to be washed. The waters are also useful in rheumatism and cutaneous diseases. Pop. 1182.

Chaudfontaine, a Belgian village charmingly situated in the valley of the Vesdre, 5 miles SSE. of Liège by rail, with mineral springs ( $92^{\circ}$ F.). Pop. 15 2.

Chaudière, a river and lake of Canada. The river joins the St Lawrence from the south 7 miles above Quebec, and, $2 \frac{1}{2}$ miles from its mouth, forms the celebrated falls of Chaudiere. The lakemerely one of the many expansions of the Ottawa -has on its right the city of that name, the capital of the Dominion.

Chaumette, Pierre Gaspard, one of the French Revolutionists, was born a shoemaker's son 
at Nevers in 1763. He was some years a seaman, but the opening of the Revolution found him a clerk at Paris. He attached himself to Camille Des. moulins, and son gained such popularity by his extravagant sansculottism that he was appointed procurator of the esmmune of Paris. In his zeal he rejected his own Christian name, Pierre, as having been sullied by saintly associations, and styled himself "Anaxagoras," The institution of the tribunal of the Revolution, the decree for a revolu. tionary army, and the law against suspected aristuxits, were largely due to his eflorts. One of his proposals was that all Parisians should wear sabots, another that the Tuileries and Luxembourg gardens should be planted with potatoes. His anties in connection with the "worship of resson" excited the disgust of Robespierre, who devised measures for bringing the whole company of actors under Hebert to the scaffold. He was executed April 13, 1794.

Chaumont, a town in the French department of Haute-Marne, on an elevation (1023 feet above sea-level) between the rivers Marne and Suize, 140 miles SE. of Paris. There are manufactures of gloves, eutlery, de. In 1814 the allied powers liere bound themiselves by treaty against Napoleon. Pop. (1872) 8474 ; (1886) 12,333 ; (1891) 11,110.

Chauny, a town in the French department of Aisne, 77 miles NNE, of Paris by rail, partly on the navigable river Oise. It is an old, rather uninteresting place, with manufactures of glass, beetroot sugar, gloves, \&c. Pop. (1891) 9242.

Chausses, in the armour of the middle ages, from the 12th to the 16th century, were defencepieces for the legs. Some were made of padded and quilted cloth, with metal studs ; some of chainmail; and some of riveted plates. It was not unusual to fasten them by lacing either below the knee or behind the leg. "The word is used also in the general sense of hose, and when armour is meant in the Norman romances the phrase is chances de fer.

Chautauqua, famous as the seat of the Chautanqua Assembly, a summer-resort on Chautauqua Lake, in a county of the same | Copsrigbe 1869, 1897, and name near the south-west ex- 1900 in the U., B. by J. B. bremity of New York. The As. Sippincott Company.

sembly was founded in 1874 by John H. Vincent, D.D., and Lewis Miller (1829-99), to provide systematic instruction for Sunday-school teachers, together with popular lecture courses in literature, seience, and art. In 1878 the Chautauqua Literary and Scientific Circle was organised. The distinctive mission of this ' circle' is stated to be 'to direct the reading habits of grown people, both those who have reeeived the best that the educational institutions can give, and desire to pursue an "after school" course, und those who for any reason failed to receive a college education in early life, but who now desire to secure to themselves the college student's general outlook upon the world and life, and to develop the habit of close connected persistent thinking.' The system comprehends a four years' course of home reading and study, to be pursued under the advisory supervision of the officens of the institution, on the completion of which diplomas are awarded. Post-graduate and special courses are also provided for those who desire to prosecnte particular branches of study beyond the limits laid down in the regular course. On the tenth annivensary of the Circle's organisa. tion, it was gtated that about 200,000 persons, scattered through all parts of the world, belonged to the association; most of them are members of local circles formed in accordance with the general plan of the scheme for the more efficient prosecution of the studies. Particulars concerning the
Chautauqua Literary and Scientific Circle, with directions for forming local eircles in connection therewith, may be obtained from the secretary of the institution at Plainfield, New Jermey. 'The Chautauqua College of Liberal Arts' is another department of the work. A faculty of able pro. fessors gives instruction by correspondence; rigir examinations are conducted by the University of the State of New York, and regular collegiate de. grees are conferred. The Choutauquan, a magazine of large circulation, the organ and exponent of "The Chautaugus Idea,' is publisherl at Meadville, $\mathrm{Pa}$.

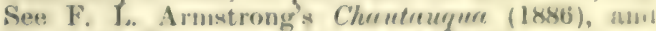
Vincent's Chuuturqua Movement (1886).

Lake Chautauqua is a beautiful sheet of water about 20 miles long, with an average breadth of 2 miles, lying about 700 feet above Lake Erie, from which it is distant 10 miles. The Chautauqua Assembly Grounds, situated upon the northern shore of the lake, comprise about 165 acres, containing over 500 attractive summer cottages, a fine hotel, a museum of archæology, an amphitheatre with a seating capacity of over 5000, several halls for meetings, and numerous other appliances for combining recreation with instruction. Large numbers of students and visitors congregate here in the summer season. 'Chautauguas,' more or less on the plan of the original, with buildings, lectures, de., have been established in various parts of the United States.

Chauvinisme, a term that has come to mean an extravagant and absurd patriotism and pride in one's own country, with a corresponding enmity towards and contempt for foreign nations. It is the French equivalent for the Jingoism of the London music-halls after Lord Beaconsfield's return from the Congress of Berlin in 1878. The origin of the word is due to Chauvin, the name of a figure in the comedy La Cocarde tricolore (1831), by the brothers Théodore and Hippolyte Cognard, the action in which includes the conquest of Algeria. Chauvin is a young recruit who spesks much, displays great courage, and sings several couplets with the refrain: 'J'suis Français, j'suis Chauvin, j'tape sur le Bédouin.' The authors of the comedy, however, borrowed the name from that of Nicolas Chauvin, an old soldier of Napoleon, well known in his time in Paris for his devoted enthusiasm for the emperor. Calvin is a Latinised form of the same family name.

Chaux de Fonds, a town of Switzerland, in the canton of Neuchatel, 18 miles by rail NW. of the city of that name. It is situated in a bleak valley, at an elevation of 3254 feet above the sea, and is seattered over a large area, almost every cottage being surrounded by a garden. It has for two centuries been one of the chief seats of the manufacture of watches in the canton. The mechanists work chiefly at home, each devoting himself to a particular portion of machinery. Pop. ( 1834 ) 6500 ; (1880) 22,456 ; (1893) 27,511 .

Chay Root. Choya, or SAYAN (Oldenlandin umbellata), a perennial herb of the order Cinchonacere, cultivated on the Coromandel coast and in Java for the sake of its long, orange-eoloures roots, the bark of which affords a beautiful red dye. It is the Indian madder.

Chazars were a people of the Finnic stock known in the 7th century on the shores of the Caspian; in the 9th century their kinglom oecu. pied the sonth-enst of Russia from the Caspian and the Volga to the Dnieper. Their capital was long at Astrakhan, called by them Balandshar. They were singularly tolerant of all religions, Jewish, Christian, and Moslem; and a large part of the nation formally adopted the Jewish faith from Jews who fled from the permecutions of the 
Emperor Leo. Cyril converted many to Christianity in the 9th century. The power of the Chazars was ultimately broken in the 12 th century by the Byzantine emperors and the Russians.

Chazy Epoch, the name given by American geologists to that division of Silurian time during which the Chazy limestone of New York, Canada, \&c. was formed.

Cheadle, a market-town in the moorland district of Staffordshire, 14 miles NNE. of Stafford. Lying in a pleasant vale, engirt by wooded hills, it has a parish church, rebuilt in 1837-38, and a Roman Catholic Church, erected in 1846 from designs by Pugin, at a cost of $£ 60,000$. Pop. of parish about 5000 .

Cheating. In the technical language of the English law, cheating means the offence of fraudulently obtaining the property of another by any deceitful or illegal practice short of felony, but in such a way that the public interest may possibly be affected. In order to constitute cheating, the fraud must be of such a kind that it could not be guarded against by common prudence. Cheating, in this sense, is an offence at common law, and indictable, which is not the case with imposition in a private transaction. The law of Seotland has no such distinction. The following are instances of cheating : Selling by a false weight or measure (which is also a statutory offence under the Weights and Measures Act, 1878); selling unwholesome bread as if it were wholesome. Cheating seems, therefore, to be distinguished from obtaining property or credit on false pretences by the absence of any definite false statement. Cheating is also technically used in connection with frauds at play with cards or dice, but is popularly applied to almost every form of fraud. In Scots law, cheating is generally prosecuted under the name of falsehood, fraud, and wilful imposition, and has by one authority been called practical cheating, as distinguished from those cases in which $\mathrm{a}$ spoken or written false pretence occurs. See FrAUd, FALSE Pretences.

\section{Checkerberry. See Wintergrenn.}

Checquy, or CHeckY, in Heraldry, a term applied to a field or charge divided into small

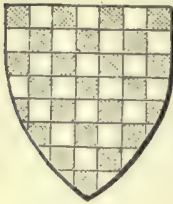

Checquy.

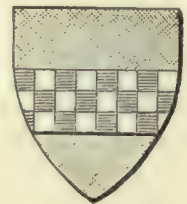

Fess Checquy. squares by transverse perpendicu lar and horizontal lines. Cheequy or and azure is the coat of Vermandois in France, and of Warren, Earl of Surrey, in England. The well known coat of the Scottish family of Stewart, or, a fess checquy azure and argent, is allusive to the checkers of the Steward's board, by which money computations were in old times made.

Cheddar, a village in Somersetshire, on the south side of the Mendip Hills, $21 \frac{1}{2}$ miles SSW. of Bristol by rail. It lies at the entrance of a deep rocky gorge, nearly 1 mile long, whose stupendous limestone cliffs contain caverns-one 300 feet long - filled with fantastic stalactites and stalagmites. For the famous Cheddar cheese, originally made here, see Chense. Pop. of parish, 1941.

Chedu'ba (or Man-aung), a well-wooded island of Arakan, in the Bay of Bengal, with an area of $240 \mathrm{sq} . \mathrm{m}_{\text {. }}$, and a pop. (1881) of 23,867 . The soil is fertile, rice and tobacco being the chief crops; and petroleum is found in several localities.

Cheese is a highly nutritious food substance made from milk by elaborate processes which can only be explained in the light of a knowledge of science, chiefly chemistry. Cheeses may be roughly divided into two great classes-hard and soft. The various English, Scotch, and American cheeses belong to the first class, and are made so that they will generally keep for months, and often continue to improve in quality. Soft cheeses are those which prevail in some parts of the Continent. Many of them require to be consumed immediately after they are manufactured. Their rapid decomposition is associated with a strong and to most people an objectionable smell. Cheese is made from the solids of milk-viz. the casein or clief albuminoid constituent, along with the greater part of the cream or butter-fat, and much of the mineral ash. In fresh milk, which is slightly alkaline, these substances maintain a sort of indescribable union with the watery portion and the milk-sugar-the whole, as is well known, being liquid. The presence of an acid, or of Rennet (q.v.), counteracts the natural affinity of the substances for each other, and the bulk of the solids separate out, forming a soft jelly in the early stages, leaving the bulk of the water containing the sugar as a greenish liquid called Whey (q.v.). The chemical processes involved are as yet only very imperfectly understood.

Milk in decomposing, as it rapidly does in hot and sultry weather, becomes sour in virtue of a natural process of fermentation. Rennet induces another form of fermentation which does not end when the product ceases to be milk, but is carried on in the cheese during the period of its ripening or mellowing. In the early stages of the process of hard cheese-making, the incipient acidity which induces that condition in milk termed 'ripeness,' aids and hastens the action of the rennet. As the work proceeds, and the acidity intensifies, it hardens and contracts the curd, giving it a leathery character, thereby aiding in the expulsion of the whey. One of the most important matters in cheese-making is to wateh the development of acidity both in the milk and its first product, the curd. If this is allowed to go too far, the quality of the cheese is seriously injured, and its keeping power is reduced. It cracks through becoming too dry and brittle. The delicate flavouring oils seem to be expelled, and the smell becomes high and the taste 'acrid' or 'biting.' The formation of the acid is one of the great helps in cheesemaking so long as it is kept in due control. If the acid develops rapidly, as in hot weather, in a temperature which suits the germs producing it, the whole process of manufacture has to be pushed on quickly, whereas in cold weather acidity comes slowly, and the operator must wait until it has come sufficiently. There are several methods adopted in inducing acidity. Acid used to be largely added, as sour whey or buttermilk, but greater uniformity is got by delaying until natural acidity develops. This it does most quickly when the temperature of the material is kept up near to blood-heat. Chilly draughts paralyse the active organisms producing acidity.

Heat is communicated to milk or to its products in the early stages of eheese-making by two methods-either by warming a portion of the milk or whey (though not allowing it to rise much above $100^{\circ} \mathrm{F}$. - say a limit of $150^{\circ} \mathrm{F}$. - as to boil it would do injury by changing its constitution), and putting it into the main bulk, or by having an outer shell of wood to the tin or iron cheese-tub, with a space between into which steam or hot water can be injected. This arrangement possesses the additional advantage of being clean and of saving labour, although the cost of the apparatus is greater. When the temperature of the evening's milk requires to be reduced to insure its keeping overnight, as in hot weather, cold water can be 
omployed in the aame manner a hot water or stem.

It would be misleading to fix definite tempera tures or assume definite rules of any kind in speak. ing of the broad principles and practices of British cheese-making, becnuse there are so many systems which differ materially in important particulars.

A thermometer should be used at all times and in all systems. The old method of testing by the hand hardly now exists, and certainly not among guod eheesemakers. The ordinary temperatures at which milk is set or steeped vary with the system adopted and the temperature of the atmospherefrom $80^{\circ}$ to $90^{\circ}$, more or less, is the nearest indication that it is afe to make. High temperatures are used in making deep cheeses, such as Cheddars; low temperatures in making shallow cheeses, as the old-fashioned Dunlops. The Gloucester is a well known variety set at a temperature nearer to $80^{\circ}$ than $90^{\circ} \mathrm{F}$. By setting at too hicrh a temperature the curd gets hard and tough, though it needs a considerable amount of consistency if it is to retain a symmetrical form in a deep cheese. If worked too cold, the curd is soft and the whey difficult to get out of it, the processes of rennet fermentation and acid fermentation do not go on sufficiently, and their work is imperfect. In all cases the greatest regularity in method should be maintained from day to day.

After heating, the colouring matter (now almost invariably Annatto, q.v.) is put in. This is not considered an adulteration, as it is innocuous. It in no way improves the quality of the cheese, the effect being only upon the colour. All cheeses are not coloured, though the practice is widespread. Rennet is put in about the same time, and after thorough stirring for the purpose of mixing these added ingredients, as well as for keeping down the cream, it is left for 40 or 60 minutes.

Breaking the curd to let out the whey is the next process. Networks of thin wire, or series of thin knives, are passed through it in various directions with great caution, to prevent the curd substance being carried off with the whey, which would give it a white rather than its natural green hue. As the curd hardens it is more quickly worked and finally broken into small particles, so as to allow the whey to escape. The expulsion of the latter is helped on by the contraction of the curd, due to the gradual increase of acidity. Acidity develops naturally if time is allowed, but it is judicions to hasten it by the addition of warm whey during the process of working. Another method of bringing about the necessary amount of acidity is to expose the curd to the air for a time before it is salted. Salt, besides giving a flavour, stops the action of the acidity in cheese after it has done its work of expelling the whey. If allowed to go on, the acidity would destroy the cheese by curtailing the ripening action of rennet. Excess of salt retards the latter process.

After the eurd has been broken thoroughly, on being allowed to settle so as to drain off the whey, it adheres together into an india-rubber-like mass this is ent and broken up into small pieces by its passage through a 'curd-mill.' 'The finest quality of dairy salt should be used; the erystals being large is an indication of its purity, especially from magnesia salts, which give a bitter taste and otherwise injure all dairy products. The quantity employed is, more or less, abont $1 \mathrm{lb}$. of salt to $56 \mathrm{lb}$. of curd dry enongh to be made up and put into the cheese-press. Its amount should vary with the degree of meidity and the amount of moisture present. In some cases salt is applied wholly or in part dry, or as a brine, to the outside of the cheese after it has been so far pressed. In very rare cases salt is put into the milk before coagulation.
The cund is finally packed into a "chesset " or prens vat, which has as a temporary lining a cloth of open texture called a ' cheese-cloth.' The vat, which is a strong wooden or tinned-iron vessel with perforations in the sides and bottom to allow of the escape of any little surplus moisture, is placed in a press, and the cheese subjected gradu. ally to a pressure of about one ton. The curd soon assumes the form in which it is to remain as a cheese. For a few days the eloths are taken off regularly and changed; the cheese being turned over each time to make it keep its shape. Ripening is the next process of importance. Deep cheesess are bandaged, and some are covered with cotton cloths (caps) made to fit tightly. They are then placed in the curing or ripening room, which should be dry, well ventilated, and maintained at an even temperature of about $70^{\circ} \mathrm{F}$. There the green indigestible and insipid curd changes naturally into the sweet, mellow, nutty, and full-flavoured product eheese, which, if taken in moderation, and especially towards the end of a meal, is an aid to digestion. The ripening process, which is also associated with drying and shrinkage of about 10 per cent. in weight, varies in length from a few weeks to a few months. Acid cheeses are soon ready for market, and spoil if kept for a long time. Sweet eheeses are slow in matur. ing, and continue to improve even if kept for years. The tendency in cheese-making both in Great Britain and in America has recently been to early maturity, the strong inducement being that of early returns.

The Cheddar system of cheese-making, which first originated in Somersetshire, is, if we embrace Great Britain, Canada, and the United States of America, the most widely practised system of all. The old methods have been much altered in recent times to suit the tendency in the market for early maturity. The following is an account of the system as now practised, with improvements sug. gested by American and Canadian experience.

The cream is removed from the evening's milk after standing overnight, and is only returned to the full bulk immediately before putting in the rennet; the object is to prevent the eream being made oily by heating to a high temperature. The rennet is added at a temperature ranging from $82^{\circ}$ to $88^{\circ} \mathrm{F}$., but the milk is heated a few degrees above the point fixed upon for steeping, and left to ripen. The temperature falls to the required point meanwhile. The higher range of temperature is adopted when the milk is sweet and recently drawn from the cow. Low temperatures suit old milk or warm weather. If the cheese is to be marketed within twenty days, enough rennet should be added to induce the initial stages of coagulation within eight to twelve minutes. After this it should be left for twelve to eighteen minutes, then breaking begins with the perpendicular and horizontal cutting knives. It is stirred for about fifteen minutes with a hand-rake, and the temperature afterwards raised to $96^{\circ}-98^{\circ} \mathrm{F}$. or even by some up to $102^{\circ} \mathrm{F}$. The whole is allowed to settle and remain nearly an hour to 'cook ' the curd. As soon as the latter is elastic enough for the particles to retain their independent shapes on being grasped and squeezed by hand, the bulk of the whey is run off. What remains and the curd, still in amall pieces, are removed bodily from the steep-tub or vat, and placed in a flat cooler with an inner movable, sparred, false bottom, to secure drainage. The vessel is lined with a cheesecloth. On this the curd is exposed to the air and well worked by hand, so as to preas ont the whey and keep the particles from adhering to one another at too early a stage. After being well worked and exposed it is left to run together, being covered up 
to preserve heat. It is subsequently cut, piled, and left covered with a cloth for perhaps half an hour. The curd then smells and tastes slightly acid. It is either milled or put through Harris's stamp lever breaker, which cuts it into pieces like fingers. It is subsequently weighed, and should amount to fully $1 \mathrm{lb}$. to the gallon of milk, and is again exposed to the air to get quit of taints, and to toughen before salting, which should be done when a velvety feeling is noticeable. The salt is added dry at three separate times, and well mixed. The curd is then left to cool down to about $70^{\circ} \mathrm{F}$. before being put into the vat. Pressure for abont two and a half days is followed by ripening or seasoning. The whole operation of making up the curd may be over in five hours, or may take six or seven hours, according to circumstances. A good Cheddar cheese contains when ripe about 28 per cent. of casein, and nearly 34 per cent. both of butter and of moisture.

Cheshire Cheeses are manufactured in Cheshire, Staffordshire, and Shropshire. In their deep shape and also in many details of their working they resemble Cheddars. Setting is done in a square covered vat, and after making up they are often put into an oven to cook for a night before going to press. In the latter they remain for nearly a week. Derbyshire Cheeses are steeped and worked in a manner which closely corresponds to the Cheshire system. The salt, however, is applied externally. Gloucester Cheeses are made by a sweet process very much the same as the Derbyshire process. Double and Single Gloucesters are identical, with the exception of the thickness and the consequent rate at which they ripen. After a time they are scraped clean and painted with Spanish brown. Leicester Cheeses are small and flat, and made by a sweet process. They are at first lightly salted, but salt continues to be added externally. They take a long time to mature.

Stilton Cheeses are made mostly in Leicester. They used to be double cream cheeses, but are now successfully made of the milk as it comes from the cow. The curd is not subjected to pressure like that used in making the previously mentioned forms. While on the shelves ripening it is supported by a bandage, and during that time the characteristic blue mould should form throughout its substance.

Gruyere Cheese, made in the canton of Fribourg, Switzerland, is a whole-milk cheese, as are also the Dutch cheeses of Gouda and Edam. The fancy cheeses of the Continent, as Camembert, Brie, Roquefort, Limburg, Gorgonzola, \&c., command a high retail price in Britain because of their perishable nature and because their consumption is restricted to a limited and wealthy class. Imitations have been made, but of a spurious and imperfect kind, owing to the impossibility of securing the secrets of their manufacture. The broad facts are known, but not the details. For example, it is quite understood that some soft cheeses are made by mixing old and new eurd together. The quality. of the natural pastures also affects some, notably the Parmesan cheeses from northern Italy. See the works on dairying named at BUTTER; and Harris's Cheese and Butter Maker's Handbook (1885).

American CheEse AND ChEese-MAKING.-Since the introduction of the factory system the art of cheese-making in America has

undergone a radical change. \begin{tabular}{|l} 
Oopyright 1889,1897 , and \\
1000 in the $\mathrm{U.S}$. by $\mathrm{J}$. B,
\end{tabular} Formerly American cheese was Lippincott Company.

pungent in flavour and decomposed rapidly, and consequently it was not popular in foreign markets. With the perfecting of the system, however, the product has been brought to a high condition of excellence, and American cheese now competes favourably, in even the English market, with the home- made Cheddar, Cheshire, and other popular kinds. The system practised in American factories is an improved Cheddar process, and prominent English experts have at times referred to the American system as being worthy of imitation in English dairies. Under the prevailing system the manufacture of cheese in America (the United States and Canada) increased more than 100 per cent. in 20 years, as the following figures show :

\begin{tabular}{|c|c|c|}
\hline E- & United States. & \\
\hline 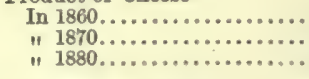 & $\begin{array}{l}103,663,927 \mathrm{lb} . \\
162,947,382 " \text { " } \\
199,022,984 \text { " }\end{array}$ & $\begin{array}{l}\text { none. } \\
6,000,000 \mathrm{lb} \\
15,000,000 \text { ib }\end{array}$ \\
\hline 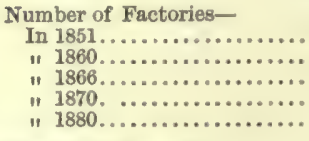 & $\begin{array}{r}1 \\
37 \\
501 \\
946 \\
2532\end{array}$ & $\begin{array}{l}\text { none. } \\
\text { " } 35 \\
75 \\
705\end{array}$ \\
\hline 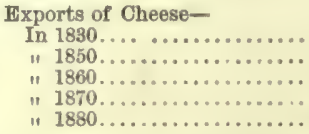 & $\begin{array}{r}10,000 \mathrm{lb} . \\
15,000,000 " \text { " } \\
23,159,391 " \\
49,755,842 ~ " \\
129,584,981 "\end{array}$ & $\begin{array}{c}\text { none. } \\
\text { " } \\
11 \\
12,000,000 \\
40,000,000\end{array}$ \\
\hline
\end{tabular}

From 1880 onwards the manufacture and export of cheese from the United States decreased : thus in 1893 the export was $\$ 7,624,648$, and in 1897 it was only $\$ 4,636,063$. The Canadian product and export, on the other hand, inereased from $\$ 13,407$,470 in 1893 to $\$ 14,676,239$ in 1897 . In 1893 , Britain imported in all $232,675,744 \mathrm{lb}$, worth $£ 5,160,918$. The decrease in exports from the United States was due to the too prevalent adulteration of cheese with oleo-margarine and lard oils, through which the quality fell off, and an unfavourable reputation was acquired, while Canadian cheese has been kept pure. After 1880, Canadian cheese of the best autumn makes sold in England for more than the average English Cheddar.

The American system of cheese-making has been reduced by improved mechanism and association in the form of the factory method to the most economical point. This method of manufacture was a growth by necessity rather than a discovery. A large dairy was divided by the death of the owner, who left three sons. The sons united and manufactured their milk at the old dairy, and in time neighbours joined, and the first factory was established in 1851 under the management of the oldest of the three brothers. In course of time the business increased and became reduced to a most economical basis, while by the employment of skilful operatives the quality of the product was gradually raised. The factories were gradually enlarged until the milk of 1200 cows could be worked up in the largest, and an average factory received the milk of about 400 cows. One Canadian factory makes $216,000 \mathrm{lb}$. of cheese yearly from the milk of 1300 cows.

The curing occupies about three months, the temperature of the curing-room being kept at $65^{\circ} \mathrm{F}$. Gang presses are used, in which a large number of cheeses laid on their sides are pressed at once by turning one screw. A common test by which the ripeness of the curd for pressure is determined is by touching it with a hot iron, and when long strings are drawn from the curd by the iron, the curd is ripe.

Milk is brought to the factory twice daily, and is weighed and run into the vat from the delivery window. The milk is either bought by the factory, or is worked up at a stated charge, or the factory is managed on the co-operative plan in which the net proceeds are divided periodically. Under this factory system the quality of the cheese is uniform and as high as is secured in any well-managed private dairy. About one-fifth of the cheese pro- 
duced in America is made in private dairies in which the same nystem prevails.

There are several other kinds of cheese made in both factories and private dairies, as Edam ( the round Dutch cheese ), a small cylindrical cheese similar to the English Wiltshire, weighing 10 to $14 \mathrm{lb}$; a flat cheese called English dairy cheese, similur to the double Gloucester cheese and coloured as highly ; a fow Stilton cheese; creum cheeses for immediate use; and very good imitations of the European Limburger, Schweizer, Neufchatel, Brié, Gouda, Camembert; and some other fancy makes to supply the French, German, and other immigrant population.

The cows nsed in the cheese dairies in the United States and Canada are mostly "grade" shorthorns, or native cows improved by crosses of shorthorn, Devon, Ayrshire, and Dutch breeds. Jersey and Guernsey cows, and the best of the higher bred animals, are used for the highest class of cheese of the fancy kinds. The profitable ex. ploitation of the dairy in America has raised the value of lands suitable for grazing cows to an sverage value of nearly $\$ 100$ ( $£ 20$ ) per acre for the fee simple, which is twice as much as that of grain farms. The cheese-dairy business prevails mostly in the states of New York, Pennsylvania, Ohio, Iowa, and Wisconsin, and in the province of Ontario, Canada. The cows are chiefly fed upon pasturagre aicled in the latter part of the summer by soiling crops, of which maize is almost universally chiefly depended upon. The cheese-making season begins in April and continues until November. See X. A. Willard's Practical Dairy Hus. bandry (1875), L. B. Amold's American Dairying (1877), and Henry Stewart's American Dairyman's Manwal.

CheEse-Press. - The most common form is the lever press. A powerful steel coil or spring is sometimes substituted for the lever. In large factories the gang press is employed to press a large number of cheeses at one time by means of a cowerful horizontal screw. The old method was by placing a heavy stone (hence the name stoning cheese) on the lid of the chesset, or by hanging it by a ring fixed to its upper side from the end of a wooden beam which acted as a lever and passed over the lid of the cheese-press vat.

Cheese-hopper, the larva of Piophila casei, a small dipterous (two-winged) fly, of the large family Muscidæ, to which the house-fly, blow-fly, \&c. belong. The perfect insect is about a line and a half in length, mostly of a shining black colour; antennz, forehead, and some parts of the legs reddish. It is a pest of dairies and store-closets, lay. ing its eggs in eracks or crevices of cheese, the destined food of its numerous, active, and voracious larvæ. To preserve cheeses from this pest, it is of advantage to brush or rub them frequently, and to

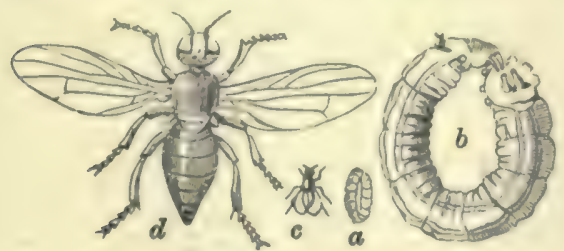

Cheese-hopper :

$a$, Iarva, natural size; $b$, larva, magnifled, preparing to spring: $c$, perfect insect, natural size : $d$, magnifled.

remove all cracked or injured cheeses from large stores, besides keeping them dry and in a well-aired place. The same rules are applicable in regard to the other insect larvie by which cheeses sre some- times infested. Of these the most notable are the larvs of the Breon Beetle (see DERMEstes), and of another species of dipterous fly, Musca corvina.

Cheese-mite (Tyroglyphus siro), familiar on old dry cheese. It is a true Mite, and belongs to the division without special breathing organis. The body is rounded behind, conical in front, with a well-marked groove between the second and third pairs of legs, and with relatively long smooth hairs. The male diflers slightly from the female, for instance in the possession of two posterior suctorial pits. The larvæ have only three pairs of legs, and pass through an immature eightlegred 'nymph' stage before beconing like the adults. The cheese-mite is not confined to cheese, but attacks dried fruits and the like. See Acarina (with cut), ARACHNIDA, CHEESE-HOPPER: also Michael, Journ. Roy. Microscop. Soc. 1884, 1885.

Cheetah, or Huntivg Leopard (Felis jubata or Cymailurus jubatus), an animal of the feline family, distinguished by its longer and narrower

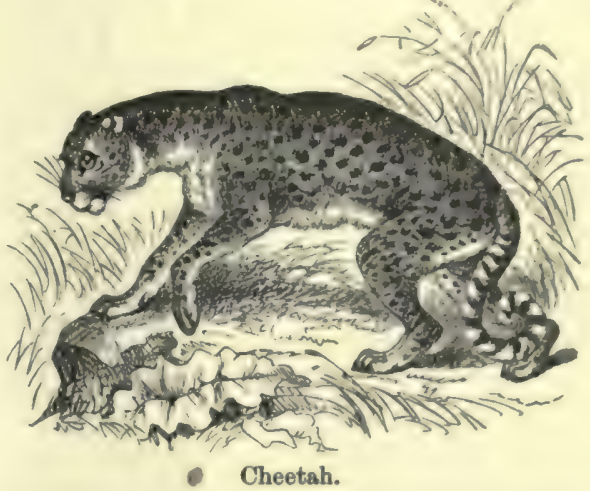

feet and less completely retractile claws, which are also more blunt and less curved. It also differs from other Felida in certain dental characterse.g. of the upper sectorial tooth. With these pecu. liarities are associated a greater length of limb than is usual in feline animals, and the habit of taking its prey by running rather than by leaping. The cheetah is in size about equal to a leopard, but the hody and limbs are longer. The colour is yel. lowish brown, with black and brown spots. It is very widely distributed, being found in Senegal, South Africa, Persia, India, Sumatra, \&e. Its geographic range extends from the Cape of Good Hope as far north as the Caspian Sea and the steppes of the Kirghiz Tartars. The African form is sometimes distinguished as $C$. guttatus, but the differences are trivial. The animal has been long domes. ticated and employed in the chase, both in Persia, where it is called Youze, and in India. Deer and antelopes are the game principally hunted, and packs of cheetah are kept for this purpose by Indian princes. The head of the cheetah is kept covered with a leather hood till within 200 yards of the game. When the hoor is taken off, the cheetah stealthily creeps towards the herd, taking advan. tage of every buch and inequality for concealment, till, on their showing alarm, he is amongst them at a few bounds, and striking down his vietim with a blow of his paw, instantly tears open its throat, and begins to suck the blood. It is then somewhat difficult to withdraw him from his prey, which is generally done by offering him meat. If unsuceessful, the cheetah does not attempt to follow the herd by running-nor does this animal seem to possess the power of maintaining speed through a length. ened chase, but slowly, and as if ashamed, creeps back to the hunters. In a domesticated state it is 
extremely fond of attention, and seems to repay kindness with affection.

Cheever, Georae Barrell, American clergyman, born in Maine in 1807, was educated at Bowdoin College and Andover Theological Seminary, and from 1832 to 1870 was pastor of Congregational and Presbyterian churches in Salem (Massachusetts) and New York. He delivered numerous lectures on religious, literary, and şocial questions, and published a number of works, the most popular of which is his Lectures on the Pilgrim's Progress (1844), which, with his Wanderings of a Pilgrim in the Shadow of Mont Blane (1845-46), has had a wide circulation in England as well as in America. In his prime Dr Cheever was an active and uncompromising opponent of intemperance and slavery. Died October 1, 1890.

Che-foo (properly the name of the European colony of the Chinese town of Yen-Tai), a treaty port on the north side of the peninsula of Shan-tung, at the entrance to the Gulf of Pechili, in which it is the only port that remains open throughout the winter. The foreign quarter, with about 120 Europeans and Americans, is in some sense a colony of Shanghai, and, having the wholesomest climate of all the treaty ports, it is much resorted to by convalescents. The Chinese town, built on the sandy shore, with exceedingly dirty streets, has a fort, a signal-station, and about 32,000 inhabitants. As a market for foreign manufactured goods, particularly English cotton yarn and American sheetings, Chefoo is of great and increasing importance. The annual value of the direct foreign imports is about $£ 300,000$, and, of the exports direct to foreign lands, $£ 150,000$. The principal articles of import besides those mentioned are sugar, paper, iron, edible seaweed, matches, and opium. The chief exports are silk, straw-braid, bean-cake, and vermicelli. About 2000 ships, of $1,600,000$ tons, of which three-fourths of the tonnage represents British bottoms, annually enter and clear. The Che-foo Convention, which settled several disputed points between Chins and Great Britain, and extended certain commercial advantages to the latter country, besides throwing open four new treaty ports, was signed 13th September 1876.

Cheiranthus. See Wallfuower.

Cheiro'lepis, a genus of fossil ganoid fishes, characteristic of the Devonian strata. The generic name, meaning 'scaly-hand,' was given in allusion to the large pectoral scaly fins.

Cheiromys. See AYr-AYE.

Cheironectes, an aberrant genus of Opossums (q.v.), with webbed hind-feet and of unique aquatic habit. There is but one species, $C$. variegatus, palmatus, or Yapock (q.v.).

Cheiroptera ('wing-handed '), the technical name for the order of bats. See BAT.

Cheirothe'rium (Gr., 'hand-beast'), the name originally given to the Labyrinthodonts (q.v.), from the peculiar hand-like impressions left by them in the Triassic rocks.

Cheke, Sir John, one of the revivers of Greek learning in England, was born in 1514 at Cambridge, and in 1529 obtained a fellowship of $\mathrm{St}$ John's College, where he embraced the Reformed doctrines. He laboured earnestly to advance the study of the Greek language and literature; and when a regius professorship of Greek was founded at Cambridge in 1540, Cheke was appointed its first occupant. A new mode of pronouncing Greek which he introduced was assailed by Bishop Gardiner, the chancellor of the university; but notwithstanding, Cheke's system prevailed. It resembled that still in vogue in England, as opposed to the continental system. In 1544 Cheke became tutor to the Prince, afterwards Edward VI., whose elevation to the throne secured him rank, wealth, and honour-a seat in parliament (1547), the provostship of King's College (1548), and knighthood (1552). He was stripped of everything at Mary's accession, and went abroad, but in 1556 was treacherously seized in Belgium, and brought to the Tower. Fear of the stake induced him to abjure Protestantism, and fresh lands were given to him in the place of those he had forfeited, but his recantation preyed on his mind, and he died in the course of the following year, 13th September 1557. Of more than thirty Latin and English books by him, one is a translation of St Matthew's Gospel (edited by Goodwin, 1843), exemplifying a plan for reforming the language by eradicating all words save those of English origin. See his Life by Strype (best ed. Oxford, 1821).

Che-keang, an eastern and maritime province of China (q.v.). Capital, Hang-chow.

Cheli'cerae, biting appendages in spiders (q.v.), scorpions, and other Arachnida.

Chelifer. See Book-scorpion.

Chelmsford (perhaps the Roman Casaromagus; Anglo-Saxon Celmeresforde), the county town of Essex, and, since 1888, a municipal borough, at the confluence of the Chelmer and the Cann, 29 miles NE. of London. It has a corn exchange (1857), a shire hall (1792), a grammar-school, founded by Edward VI. in 1551, and a parish church, which, all but the tower and spire, was rebuilt between 1803 and 1878 . There is a considerable trade in agricultural produce. On a small island in the Chelmer there has long been a ludicrous mock-election during the county elections. Pop. (1851) 6033; (1881) 9885; (1891) 11,008.

Chelmsford, Frederic Thesiger, BaroN, born in 1794, was a midshipman in the navy, but exchanged the sea for law, and was called to the bar in 1818. He was knighted and made solicitorgeneral in 1844, attorney-general in 1845 and 1852 , and lord chancellor in 1858 and 1866. He died October 5, 1878. - His son, Frederic Augustus THESIGER, second BARON, was born in 1827 , entered the Rifle Brigade in 1844, became major in the Grenadier Guards in 1855, and served through the Crimea, the Indian Mutiny, and the Abyssinian campaign of 1868. He was adjutant-general in Bengal (1869-74), and commanded the forees in the Kaffir war of 1878 and in the unfortunate $\mathrm{Zulu}$ war of 1879, having resigned the governorship of Cape Colony. Appointed lieutenant-general in 1882, he was lieutenant of the Tower of London in 1884-89, and retired in 1893.

Chelonia, an order of reptiles including the various forms of tortoise and turtle. Their most distinctive character is the more or less complete inclosure of the body by a dorsal and a ventral shield, of which the former is in part due to a modification of the vertebral spines and of the ribs. Within these shields the head, limbs, and tail can be more or less retracted. The absence of teeth is also very characteristic. The Chelonia include marine, fresh-water, and terrestrial forms : the known living species number about 260 , the majority occurring in warm countries; they are represented by numerous fossil forms from the Upper Jurassic onwards. The large family Testudinidæ, with oval, horny-plated dorsal shield, includes both terrestrial and marsh forms, such as Testudo-e.g. the Greek tortoise, Terrapin, Emys, Chelys; a second small family, Trionychidæ, with oval, softer shield, inclutes river forms, such as the well-known snapping-turtle (Trionyx ferox) a third family, Chelonida, with heart-shaped shield, includes five species of marine turtles-e.g. 
Chelone viridis. The onder is chiefly discussed under the title TORTOISES AND 'TURTLES.

Chelsea, a suburb of London, on the north bank of the Thames, here crosed by bridges to Battersea $\left(\mathrm{q}, \mathrm{v}_{\text {. }}\right.$. In the loth century the village of Chelsea was the residence of Sir Thonas More, Queen ('atharine P'arr, the Princess Elizalueth, and Anne of Cleves. Afterwards Walpole, Swift, Steele, and Sir Hans Sloane, and, in later years, Leigh Hunt, Carlyle, Rossetti, and George Eliot lived here. In the 18th century Ranelagh was much resorted to, and Cremorne (closed 1877) was at one time a popular attraction. Besides its Hospital, Chelsea has a Royal Militery Asylum for soldiers' children, large barracks for the Foot Guards, a Ixtanic garden, water-works (1722) to supply Lomlon, a river-pier, and an embankment (1873) extending to Battersea Bridge on the west. The famous isth-century porcelain is noticed under Potrery. The borough has returned one member to parliament since 1885, when its limits were greatly reduced. Pop. of parish (1891) 96,272.

Chelsea Hospital is an asylum for old and disabled soldiers of the British army. The gradual -decay of the feudal system rendered it necessary to make some new provision for sick and maimed isoldiers, consequently various statutes were passed during the reigns of Elizabeth, James I., and Charles I., throwing their maintenance on their respective parishes, under directions from the county justices. This system was abrogated during the Commonwealth as a matter of poliey, and the expense met out of moneys arising from sequestrations of the estates of the vanquished royalists. After the Restoration a new act was passed (1662) again throwing their maintenance on the parishes, but this was so burdensome that it was never reenacted. Sir Stephen Fox, the first paymastergeneral of the forces, who had long been an exile in France, and was no doubt well acquainted with the erection in 1671 of the Hôpital des Invalides at Paris, first suggested the building of Chelsea Hospital. The foundation stone was laid by Charles II. in 1682, and the building, designed by Wren, was opened in 1692.

The funds for its lands and buildings, and for many years the maintenance of its inmates, were -derived chiefly by deductions from the pay of the troops themselves-viz. 18. in the $\mathrm{fl}$, as well as one day's pay in each year. Since 1783 it has, however, been almost entirely supported by annual parliamentary grants. All Pensions (q.v.) granted to soldiers are awarded by the Commis sioners of Chelsea Hospital, who are appointed by the crown. Originally it was contemplated that all pensioners would become inmates of Chelsea Hospital, but this was soon found impossible, and thus those who eould not gain admittance were granted allowances termed outpensions. The out-pensioners number about 84,000 men, including negroes in the West Indies and West Africa, Maltese, Singhalese, and Lascars, and cost annually some $£ 1,800,000$. The in-pensioners numbered about 550. They are selected from such out-pensioners as desire to hecome inmates, according to merit, age, and sufferings from wounds or other disabilities, and are provided with board, lodging, elothing (including the well-known red coat and cocked hat), nursing, and medical attendance, together with a small weekly allowance in money according to rank. The in-pension vote annually amounts (including, however, charges relating to the grant of ont-pensions, but ex cluding cost of repairs to buildings, \&e.) to about $£ 27,000$, against which there is to set off the amount of the ont-pensions, which mnst by statute be surrendered on admission. Those within can at any time become out-pensioners again. Chelsea
Hospital is locally known as 'Chelsen College'the Hospital having heen erected nearly on the wite of James I.'s short-lived 'College for Religious Controversy' (1610). Bee the official Early Hutory of the Royal IIsospitul at Chelsen (1872); Martin's Old Chelsea (1888); and Alfred Beaver's Memorials of Old Chelsea (1893).

Chelsea in Massachusetts, U.S., is a northeastern suburb of Boston, from which it is separated by the estuary of Mystic River (see Boston). Pop. (1870) 18,547; (1880) 21,782 ; (1890) 27,909.

Cheltenham, a fashionable watering-place of Gloucestershire, on the Chelt, a little affluent of the Severn, 44 miles NNE. of Bristol, 47 SSW. of Birmingham, and 121 WNW. of London (by road only 95). It lies in a picturesque and fertile valley, on the east and south-east half encireled by the Coteswolds. A saline spring was discovered here in 1716, and from a mere village the place gradually increased till 1788, when the benefit derived by George III. from its waters suddenly made it a resort of fashion. The four spas-Royal Old Well, Montpellier, Pittville, and Cambray - are all saline but the last, which is chalybeate; they are deemed eflicacious for liver complaints and dyspepsia. With its squares, crescents, and terraces, its gardens and promenades, its clubs and pump-roons, its August 'cricket week,' its healthy elimate, the cheapness of living, and the happy absence of manufactures, the town offers many attractions both to visitors and residents, the former largely foxhunters in winter, the latter retired Anglo-Indians. It is, besides, a great edueational centre, the seat of the Proprietary College, for 700 boys, founded in 1840 , and occupying a splendid Tudor pile of 1843 ; a grammar-school (1586; reconstituted 1883); a large ladies' college (1854); a Church of England training college for sehoolmasters (1847); and private schools beyond number. Noticeable buildings are the 14th-century parish church; the Roman Catholic Church (18577), with a spire 205 feet high; the Corn Exchange (1863); and the handsome Free Library. Cheltenham has memories of Handel, Tennyson, Frederick Robertson, Sydney Dobell, and Dean Close, under whom (1824-56) it became a strong. hold of Evangelicalism. It was incorporated as a municipal borough in 1876, and has returned one member to parliament since 1832, the parliamentary boundary having been extended in 1885. Pop. (1804) 3076; (1841) 31,411 ; (1881) 43,972; (1891) 42,914.

Chelyuskin, CAPE (formerly North-east Cecpe, and sometimes called Cape Severo), the most northerly point of Asia, on a peninsula of the same name, which forms the western arm of the eastern half of the Taimyr peninsula. It is named after a Russian officer who led an expedition thus far in 1742, and here succumbed, with his wife, to the fatigues of the journey; it was not revisited till 1878, when Nordenskjöld, in the $V e g a$, spent the 19 and 20th of August here. He found it a low promontory, divided into two parts by a small bay ; the lat. of the western is $77^{\circ} 36^{\prime} 37^{\prime \prime} \mathrm{N}$., that of the eastern $77^{\circ} 41^{\prime} \mathrm{N}$.

Chemieal Aftuity is the name given to the tendency to combine with one another which if exhibited by many substances; or to the force by which the substances constituting a compound are held together. The tendency of any given element to unite with a number of other elements varies greatly. Chlorine, for instance, unites with great readiness with most metals and with many nonmetallic elements, much heat being produced dur. ing the union; but it has little or no affinity for, or tendency to combine with, oxygen, 80 that compounds of chlorine with oxygen can only be obtained by roundabout methods, and are very 
liable to sudden and explosive decomposition into chlorine and oxygen. Where the affinity of elements for each other is great, the compounds produced by their union are decomposed with difficulty, and where the atfinity is feeble, decomposition is easily effected. See also CHEMISTRY.

Chemistry. Although chemistry has only taken its place as an exact science based upon accurate experimental investigation within a comparatively recent period, yet its origin dates back to the earliest times of philosophical study. It will be convenient to give in the first place a short sketch of the history of chemistry, and then to state some of the principles of the science, illustrating these from the simplest facts. When possible, such illustrations will be chosen as are likely to be not altogether unfamiliar to non-scientific readers.

Historical Sketch.-The word chemistry has come to us from the Greek through the Arabic, as shown in our article AlCHEMY. With regard to the chemistry of the ancients, we know that the ancient Egyptians, Phøicians, Greeks, and Romans were acquainted with a very considerable number of useful substances, and that their processes for preparing some of these did not differ in any essential particular from those now in use. It does not appear, however, that they have left any chemical records behind them, or that they knew anything of the science of chemistry. Several metals were known to, arid employed by, these ancient peoples, who were acquainted with processes for reducing them from their ores. Amongst these metals were gold, silver, mercury, copper, tin, lead, and iron; whilst they also knew and worked with brass, although they were not aware that it was an alloy of copper and zinc. Various alloys were employed for bronzes for statues, and these usually contained copper, lead, and tin. The processes for manufacturing soap, starch, glass, leather, various mineral and vegetable pigments, stoneware, and other useful substances, were all known and carried on in very early times; and wine and beer appear likewise to have been prepared and used as beverages long before the process of distillation, which was unknown to the ancients, had been introduced. Vinegar, sulphur, and carbonate of soda were also known.

We find the application in medicine of many chemical products at a comparatively early period, and the Arabians appear to have been the first who tried to prepare new medicines by chemical methods. Geber, who lived in the 8 th century A.D., is the most noted of the Arabian chemists, and he has left some writings which show us what was the state of chemistry at that early date. Geber knew, for instance, how to make and distil vinegar and nitric acid, and even sulphurie acid was made and used as a solvent by him. He knew, amongst other substances, white arsenic, borax, common salt, alum, sal-ammoniac (ammonium chloride), copperas (ferrous sulphate), nitre (potassium nitrate), and corrosive sublimate (mercuric chloride), and was acquainted with a number of their properties. He used almost all the kinds of apparatus that were commonly in use down till the 18th century, and understood the processes of distillation, filtration, sublimation, and crystallisation. In one of his works he describes the construction of furnaces for ehemical purposes.

From the 8 th till the 17th century but little real progress was made in chemistry as a science. The new knowledge that was gained during this period was mainly due to the assiduity of the alchemists, who, in their vain search for the philosopher's stone, necessarily made useful discoveries from time to time. Many of the alchemists so called were mere tricksters who deceived their dupes by more or less clumsy experiments, which appeared to demonstrate the production of gold from baser metal. Others, however, were really earnest and untiring in their labours, and held the fullest belief in the prospects of the ultimate success of some fortunate worker. The new substances obtained by the alchemists were frequently used in medicine, and it is to these infatuated workers, therefore, that we owe our first knowledge of many potent medicines. The writings of many of the alchemists are preserved, but numbers of them are entirely worthless from $a$ scientific point of view, as the descriptions of processes are mixed up with so much of mystery and extravagance that they present a wholly unintelligible jargon. For more detail, however, regarding this remarkable period in the history of chemistry, see the article ALCHEMY.

As Geber has been called the patriarch of chem. istry, so Robert Boyle (1627-91) has been called the father of modern chemistry, since it was. Boyle who first tried to free chemistry from the trammels of alchemy and to place it upon a true scientific basis. Boyle in his Sceptical Chemist tried to discredit the salt, sulphur, and mercury of the alchemists (as well as the Aristotelian earth, air, fire, and water) as elements or ultimate constituents of substances, and he gave a scientitic definition of an element. Boyle was an experimental investigator of considerable skill, and to him we owe the introduction of the air-pump and the thermometer into this country. His experiments upon the physical properties of gases led to the formulation of the law concerning the relation of the volume of a gas to the pressure, which is commonly known as Boyle's Law.

Theory in modern chemistry begins with Becher (1635-82) and Stahl (1660-1734). The latter adopted, with some modifications, a theory propounded by the former concerning elements and compounds, and formulated the phlogiston theory of combustion. The views of Becher and Stahl regarding elements were not so enlightened as. those of Boyle, and must be considered as retrograde. Stahl's phlogiston theory (1697) was at once adopted almost universally by chemists, and for fifty years it was held to give the full explanation of the phenomena of combustion. According to. this theory phlogiston was a constituent of all combustible substances. When a substance burned, the phlogiston made its escape, and the product of combustion was regarded as the other substance with which the phlogiston had been previously united. When a metal such as lead was heated in the air, it lost its phlogiston, and the oxide formed was looked upon as the other constituent of lead besides phlogiston. The process of reduction of lead from its oxide by means of charcoal was the transfer of phlogiston from the charcoal to the lead. It did not present itself to the adherents of thetheory as an absurdity that a metal, in losing its. phlogiston on oxidation, gained weight, although some of them at least were aware of the fact. The idea of gain of matter being a necessary accompaniment of gain of weight is so familiar to us that we can scarcely realise that it was not always so regarded. To this may fairly be attributed the persistence with which the phlogiston theory held its ground for so long a period.

The Duteh chemist Boerhare (1668-1738), who. did not accept Stahl's theory, published in 1732 his. system of chemistry, which was a compilation of practically all that was known up till that date, collected with great labour from a large variety of alchemical and other writings.

The interval between the introduction of the phlogiston theory and its overthrow by Lavoisier in 1772-85 was one of great advance in chemical 
knowledge, and a number of very eminent chemists preceded and were contemporaries of Lavoisier.

In Germany, Marggraf (1709-82) studied the properties of the almost unknown alumina and mannesia, and made considerable advances in the qualitative analysis of substances in solution.

Amongst British chemists of note may be men. tioned Ifales (1677-1761), who was amongst the first to experiment on gases; Black (1728-99), who in 1756 published his research on Magnesia Alba, showing the nature of fixed air or earlonic acid grs, and of the difference between caustic and mill (or earlonated) alkalies; Priestley (1733-1804), who, in addition to his discovery of oxygen in 1774 , investigated nitric oxide, nitrous oxide, sulphurous acid, carbonic oxide, hydrochloric acid, and ammonia gases, being specially attracted to the study of gaseous substances and their properties; and Cavendish (1731-1810), who investigated the nature and properties of hydrogen, analysed atmospheric air, and discovered the compound nature and composition of water and of nitric acid.

Lavoisier (1743-94) was one of the ablest chemists of his time, and his labours include a vast variety of subjects. His attack upon, and eventual demoli. tion of the phlogiston theory, and his experiments in connection with his new theory of combustion, occispied him for a considerable number of years. He taught that combustion was the union of the combustible substance with atmospheric oxygen; he was the finst to introduce system into chemistry and chemical research; he determined the con. stituents of a large number of substances, including sulphuric, phosphoric, and carbonic acids, numerous metallic oxides, and many animal and vegetable substances; and he, along with Berthollet, Fourcroy, and Morveau (1737-1816), introduced a new and consistent system of chemical nomenclature. Two contemporary Swedish chemists, Bergman (1735-84) and Scheele (1742-86), must be men. tioned before leaving the phlogiston age. Bergman investigated, amongst other things, carbonic acid gas, studied the phenomena of affinity, and made advances in the processes and reagents used in qualitative analysis. Scheele was one of the most laborious ehemists of his time. He discovered citric, malic, tartaric, oxalic, lactic, hydrocyanic, arsenic and other acids, and chlorine, besides investigating the nature of a large number of other bodies and independently discovering oxygen.

It was towards the end of the 18th century that the value of quantitative analysis of substances began to be generally recognised. The question as to whether the quantitative composition of a given substance was always the same gave rise to a discussion which lasted for several years, and was at length decided in favour of constant composition.

The researches of Richter (1762-1807) on the quantities of various acids neutralised by a given quantity of a base, and of various bases neutralised by a given quantity of an acid, led him to the general conclusion that the quantities of two acids, $a$ and $a^{\prime}$, which form neutral salts, $a b$, and $a^{\prime} b^{\prime}$, with the quantities of two bases, $b$ and $b^{\prime}$, are just the quantities required to form two other neutral salts, $a b^{\prime}$ and $a^{\prime} b$. This fundamental discovery was erroneously attributed to Wenzel by Berzelius in 1819, and the error has been carefully perpetuated in a considerable number of text-books since that time (Kopp, Entwickelung der Chemie in der neueren Zeit, p. 251).

Berthollet (1748-1822), who was one of the most active opponents of the theory of the constant composition of ehemical substances, contributed valuable researches into the laws of chemical affinity, and applied chlorine to processes of bleaching. The processes of chemical analysis were improved, and farge numbers of analyses, especially of minerals, were curried out by Klaproth (1743 1817), Vauquelin (1763-1829), Fourcroy (1755-1809), and others; and many quantitative obeervations of all kinds were made about the end of the 18th century, all preparing the way for Dalton's statement of the Atomic Theory (q.v.) in 1803-4.

The progress of chemistry during the present century has been immense, and it is not possible to do much more than mention the names of some of the most prominent workers. A stimulus was given to research by the publication of Dalton's atomic theory ; and the lalwours of (iay-Lussac (1778-18:0)), who experimented with gases, of Dulong (17851838 ), and Petit (1791-1820), who pointed out the relation between specific heats and atomic weights of elements, and of others, supported and amplified Dalton's views.

Wollaston (1767-1829) discovered palladium in 1803 , and rhodium in 1804. The finst alkaloid (morphine) was obtained pure by Sertuirner in 1816, and this led to the discovery of a number of others in a short time.

The decomposition by electricity of the bases potash and soda by Davy (1778-1829) in 1807, and the separation from these of the metals potassium and sodium, threw an entirely new light on the nature of these sulstances. The metals were more fully investigated by Gay-Lussac and Thénard (1777-1857). Davy is noted also as the inventor of the miners' safety-lamp, and for experiments on the respiration of nitrous oxide and other gases.

Anongst the foremost chemists of the earlier part of the 19th century was the Swede Berzelius (17791848), whose careful and exact analyses of mineral substances contributed a good deal to the confirmation of the law of constant proportions and to the fixing of the atomic weights (see AтоміC THEоRY) of the elements. Berzelius was very conservative with regard to new theories, which he declined to accept without putting them to the strictest experimental tests. He formulated the electro-chemical theory of the constitution of salts, introduced great improvements into the methods of quantitative analysis, increased the value of the blowpipe as an aid in mineral analysis, discovered many new substances, and further examined and elucidated points concerning many already known, both inorganic and organic.

The artificial production of ures in 1828 by Wöhler (1800-82) marks the beginning of a new era in the branch of organic chemistry, and enormous strides have been made in this department since that time by Dumas (1800-84), Liebig (180373), Laurent ( $1807-53)$, Gerhardt (1816-56), W urtz (1817-84), Kolbe (1818-84), Baeyer, Cannizzaro, Frankland, Hofmann, Kekulé, Williamson, and many others. Advances in general inorganic chemistry and analysis have been made by Leopold Gmelin (1788-1853), H. Rose (1795-1864), SainteClaire Deville (1818-81), and Bunsen; whilst in connection with advances in chemical physics may be mentioned Faraday (1791-1867), Mitscherlich (1794-1863), Graham (1805-69), Regnault (1810-78), Andrews (1813-85), and Berthelot. These lists do not include all of even the most prominent names that might be mentioned in connection with each department.

The most striking feature of modern chemistry is the extraordinary development of organic chemistry, the account of one branch of it-the chemistry of the coal-tar products - constituting of itself quite a literature which receives additions every day.

Amongst the most recent triumphs of chemical research may be mentioned the artificial production of indigo and grape-sugar, and the isolation, in sufficient quantities to study its properties, of the hitherto all but unknown element fluorine.

Of the greatest possible interest from a theoretical 
point of view is the fact that since 1870 three new elements have been discovered-gallium, scandium, and germanium-the existence of all of which had been predicted, and the properties of which had to a certain extent been deseribed beforehand by Mendeleëff. (See periodic law in article ATOMIC THEORY.)

Of late much attention has been given to measurements of the quantity of heat produced in various chemical changes, notably by Berthelot and Thomsen.

Elementary Principles of Chemistry.-The science of chemistry deals with a certain class of changes which matter undergoes when subjected to particular conditions. Similar treatment may produce very different effects upon different substances, as, for instance, the effect of strong heat upon a piece of quartz, a piece of limestone, and a piece of sugar. The quartz does not suffer any permanent change, that is, it has the same properties after it is cold again as it had before the action of heat. The limestone, although not necessarily much altered in appearance, has its properties entirely changed, and what remains is a new kind of matter-quicklime. The sugar melts, darkens, and chars, and becomes quite manifestly changed into more than one new kind of matter, for gaseous products, having the smell characteristic of 'burnt sugar,' go off, whilst a black coaly mass remains.

The first of the above changes is merely a physical change, from cold to hot; the other two are chemical changes, which result in the production of new kinds of matter having properties entirely different from those of the kinds of matter from which they were obtained. The existence of chemistry depends upon the existence of different kinds of matter, and it is with such different kinds of matter and the change from one kind to another that chemistry has to do.

When the properties of matter are studied, it is found that for chemical purposes all kinds of matter may be divided into two great classes, which are called respectively elements and compounds. The name element is applied to any kind of matter that has not been proved to be composed of more than one simpler kind of matter. This conception of an elementary substance we owe to Boyle, and it will be noted that some of those substances which are now looked upon as elements (see article ATOMIC THEORY for a list of the 68 known elements) may hereafter be proved to be compounds, or kinds of matter composed of more than one simpler kind, just as some substances which were at one time rightly classed as elements (according to Boyle's definition) are now known to be compounds of two or more elements.

The compound nature of a specimen of matter may be proved in one or other (or both) of two ways. One of these methods is called Synthesis (q.v.), and consists in building up the compound from the component simpler kinds; the other is called Analysis (q.v.), and consists in separating more than one simpler kind from the componnd kind.

The distinction between chemical compounds and mere mechanical mixtures is a fundamental one, and must be fully understood. The substance gunpowder, for instance, is an intimate mixture of finely powdered sulphur, charcoal, and saltpetre (potassium nitrate), certain precautions being observed during the mixing in order to avoid explosion. These substances are not combined together chemically in gunpowder, but are only mixed, a fact as to which we can easily satisfy ourselves in various ways. We may examine the gunpowder under the microseope and identify the separate particles of the ingredients; or, by the use of appropriate solvents, we may dissolve out first the saltpetre and then the sulphur, and thus recover all three ingredients separately. The explosion of gunpowder when heated to a sufficiently high temperature is due to the occurrence of a series of changes of the kind we call chemical, for these changes result in the production of new kinds of matter, gaseous and solid, which possess properties in no way resembling those of sulphur, charcoal, or saltpetre, and from which these substances cannot now be dissolved out.

A mixture possesses to a greater or less extent the properties of its respective ingredients; a compound, on the other hand, has not as a rule any properties resembling those of its constituents. A piece of magnesium wire heated in the air to a sufficiently high temperature takes fire and burns. This is a chemical change in which the metal magnesium combines with the oxygen of the air to form a white, brittle, solid compound called magnesia or magnesium oxide. This magnesia does not in the least resemble either magnesium or oxygen in its properties, and the most powerful microseope fails to reveal particles of either of these substances to our vision.

The Atomic Theory (q.v.) is based upon the assumption that matter of every kind is made up of extremely minute indivisible particles called atoms. The atoms which exist in a substance may be all of the same kind, as in elements, or of different kinds, as in compounds. Chemists believe that the element hydrogen consists of molecules or aggregates of atoms-each molecule consisting of two atoms ; further, that the compound substance water consists of molecules, each composed of two atoms of hydrogen and an atom of oxygen united to each other by that force which is called Chemical Affinity (q.v.); and that similarly every other compound substance is composed of molecules, each molecule consisting of two or more different kinds of atoms united by chemical affinity. The weight of a new compound formed by the union of two or more substances is in every case equal to the sum of the weights of its constituents. In chemical actions it is only the kind of matter which is changed, whilst, as in every physical change, the quantity of matter concerned remains constant and unalterable.

It has already been seen that one of the characteristics of the chemical combination of two sub. stances is that the properties of both disappear and are not observable in the compound. Another and a most important characteristic is the evolution of heat, which is a very frequent although not an invariable accompaniment of chemical action. The best examples of this may be seen in the ordinary phenomena of Combustion (q.v.). All combustion, whether it be of magnesium wire, coal, phosphorus, paraffin oil, or a candle, is nothing more than a chemical action accompanied by the evolution of heat and light, oxygen gas of the atmosphere being almost invariably one of the substances taking part in such action.

The conditions under which substances act chemically upon each other are very various for different substances. In the first place, certain substances cannot be got to act upon each other at all. Such substances may have little affinity for each other, as chlorine and oxygen, or no affinity, as fluorine and oxygen. Other substances, again, only act upon each other with difficulty. The main conditions upon which action of one substance upon another depends are the state of physical aggregation and the temperature. Certain chemical actions take place at ordinary temperatures, as, for instance, the combination of chlorine with metallic antimony or copper, or the spontaneous ignition of one of the compounds of phosphorus and hydrogen when brought into contact with oxygen. Other actions 
only take place when the temperature of the substances which are to take part in them has been sufficiently raised. Thus magnesium requires to be strongly heated in air before it takes fire; once the action is started, however, the heat given out by the combustion of one part of the magnesium is sufficient to raise another part to the temperature necessary for combustion to go on, and so the change is propagated. Coal-gas only burns in air when it is raised to a bright-red heat. A jet of cual-gas escaping into the air may be easily ignited by applying a brightly red-lnot poker, but when the poker cools to dull redness it will no longer ignite the jet. A bar of metallic iron does not undergo any chemical change on exposure to dry air at ordinary temperature, but if iron in the state of very fine powder (a form in which it can easily be obtained by appropriate methors) be thrown into the air, combination at once takes place with the evolution of heat and light. When a piece of iron (say a moderately fine iron wire) is heated to redness in air, combination with the oxygen of the air takes place with the formation of a seale composed of a black oxide of iron, but the quantity of heat given out during the combination is not sufficient to propagate the combustion from particle to particle of the iron after removal of the source of heat. If, however, iron wire be raised to a red heat in an atmosphere of oxygen, it takes fire and burns with great brilliancy. The difference noticed here is due to the presence in the one case, and the absence in the other, of the diluting nitrogen which forms nearly four-fifths of the air by volume.

There are certain chemical actions which in taking place are accompanied, not with evolution, but with absorption of heat. In such cases heat has to be supplied throughout the action, and not merely to start it. This is frequently noticed in the combination of substances which have feeble affinity for each other, and the compounds produced are less stable, or more readily break up into their constitnents, than those which are produced with the evolution of heat. In general terms it may be stated that the quantity of heat given out in the formation of a compound is a measure of the stability of the compound. When a given weight of magnesium unites with oxygen to form magnesia, a quite definite and measurable quantity of heat is given out. In order to separate the magnesium from the oxygen again, exactly the same quantity of heat must be supplied. In the case of those sub. stances in the formation of which heat is absorbed, we find, as we should expect, that heat is given out during their decomposition, and that its quantity is exactly that which was absorbed during their formation.

Chemical Notation.-For the purpose of shortly expressing the composition of chemical substances, and for representing chemical changes, chemists employ a system of notation which is in extremely common use. In the table of Atomic Weights ( see A TOMIC THEORY) it will be noticed that after the name of each element is placed its symbol, which usually consists of the first, or of the first and another letter of the Latin name of the element. Each symbol distinctly indicates the element which it is intended to represent, but it must always be borne in mind that the symbol for an element is not merely a contracted form of its name, but that it stands for a definite quantity of that element, this quantity being the atomic weight expressed in terms of the unit of weight employed. The unit of weight almost universally employed by chemists and seientific men in general is the gramme (see Misrs), and that unit will be adopted for illustrations throughout this article. With the gramme as unit, H stands for 1 gramme of hydrogen, Cl for 35.4 grammes of chlorine, $O$ for 16 grainmes of oxygen, $\mathrm{Mg}$ for 24 grammes of magneaium, and so on. In order to represent the composition of a componnd, the symbols of the various elements which oceur in the compound are written side by side, and this collection of symbols is called a formula. Thus, MgO represents $40(=24+16)$ grammes of magnesium oxide, and $\mathrm{HCl}$ is 36.4 $i=1+35 \cdot 4)$ grammes of hydrogen chloride. When a compound contains more than one atom of the same element the symbol for that element is not repeated, but the number of atoms is indicated by a subseribed numeral. Thus the formula for water is written $\mathrm{H}_{2} \mathrm{O}$, which indicates that the molecule of water contains two atoms of hydrogen and one of oxygen; and the formula for sulphuric acid is written $\mathrm{H}_{2} \mathrm{SO}_{4}$, which indicates that the molecule of sulphuric acid contains two atoms of hydrogen, one of sulphur, and four of oxygen (besides the quantitative signification of these formula already mentioned). A number subseribed to a portion of a formula inclosed in brackets multiplies the portion so inclosed. Thus the formula $\mathrm{Ba}\left(\mathrm{NO}_{3}\right)_{2}$ represents one atom of barium united to twice the quantity of the group $\mathrm{NO}_{3}$, which is represented as united to one atom of potassium in the formula KNO. A number prefixed to a formula multiplies the whole of the formula that follows. Thus $2 \mathrm{H}_{2} \mathrm{O}$ represents twice the quantity of water repreaented by $\mathrm{H}_{2} \mathrm{O}$.

Chemical symbols and formulxe are used to represent shortly chemical changes. A simple illustration of the method of using them may be given to represent the case of the burning of magnesium. The symbols for the magnesium and the oxygen entering into combination (connected by the sign $+)$ are written on one side of what is called a chemical equation, whilst the product is written on the other side, thus :

$$
2 \mathrm{Mg}+\mathrm{O}_{2}=2 \mathrm{MgO} \text {. }
$$

The formula for free (or nncombined) oxygen is written $O_{2}$, because a molecule of oxygen is believed to consist of two atoms (see ATOMIC THEORY). In order to represent the element magnesium, the simplest possible formula ( $\mathrm{Mg}$ ) is employed because there is no evidence for writing a more complicated one. $2 \mathrm{Mg}$ simply represents twice as much magnesium as $\mathrm{Mg}$ does.

The above equation when fully interpreted gives a great deal of information about the change which it is intended to represent. It shows that magnesium and oxygen unite with each other (under conditions which are not expressed) to form an oxide of magnesium, and that these elements are united in the compound in the proportions by weight of 24 of magnesium to 16 of oxygen; and, further, it enables us, by applying a simple and easily remembered rule, to calculate the volume of oxygen taking part in the action as well as its weight. This rule for ascertaining the volume may be conveniently stated here. From certain theoretical considerations, as well as for convenience in calculations concerning the volumes of gases, chemists write the formulae of gaseous substances in such a way that the quantity of a gas represented by its formula, in terms of any unit of weight, shall occupy, under similar conditions of temperature and pressure, the same volume as two units weight of hydrogen. Thus, the unit being the gramme, $\mathbf{H}_{\mathbf{2}}$ represents $\mathbf{2}$ grammes of hydrogen, and 2 grammes of hydrogen at standand temperature $\left(0^{\circ} \mathrm{C}\right.$. $)$ and pressure $(760$ millimetres of mercury) oceupy a volume of $22 \cdot 33$ litres. See (under Metre) Metric System. Similarly, the quantities in granmes of oxygen, carbonic anhydride, and nitrous oxide, represented by their respective formula, $\mathrm{O}_{2}(16 \times 2=32$ grammes $), \mathrm{CO}_{2}$ $(12+32=44$ grammes $)$, and $\mathrm{N}_{2} \mathrm{O}(28+16=44$ 
grammes), each occupy, when measured at $0^{\circ} \mathrm{C}$. and $760 \mathrm{~mm}$. pressure, $22 \cdot 33$ litres. This rule holds for other gases, and also, with a certain qualification, for the vapours of volatile liquids. In the case of the latter, of course, conditions of temperature and pressure must be chosen such that the substance is in the state of vapour; and the quantity in grammes which, as a vapour, occupies the same volume as $\mathbf{2}$ grammes of hydrogen under the same conditions, is the quantity which the formula is chosen to represent. Thus, the formula $\mathrm{H}_{2} \mathrm{O}$ informs us that $18(=2+16)$ grammes of water occupy, in the form of steam, the same - volume as 2 grammes of hydrogen when both are measured at the same temperature and pressure. It must, of course, be understood that the formula for a substance is chosen so as to represent the observed facts. The formula of a volatile liquid is deduced from the determination of the vapour density of the liquid; this determination is made by ascertaining the weight of that quantity of the liquid which, when converted into the state of vapour, occupies the same volume as a given weight of hydrogen, both being measured at the same temperature and pressure.

Returning to the equation already given, it will be seen that from it we learn that $48(=2 \times 24)$ grammes of magnesium unite to form magnesium oxide with a quantity of oxygen ( 32 grammes) which at $0^{\circ} \mathrm{C}$. and $760 \mathrm{~mm}$. occupies $22 \cdot 33$ litres. What volume this quantity of oxygen would occupy under other conditions of temperature and pressure can be calculated from formulæ deduced from the laws of Charles (relation of the volume of a gas to the temperature) and Boyle (relation of the volume of a gas to the pressure). See further in article GAS AND GASES.

As there are certain conditions under which chemical combination takes place, so there are definite laws which regulate combination. The first of these has been called the law of constant proportions, and it states that any chemical compound always contains the same constituents and in the same proportions. Thus magnesium oxide, $\mathrm{MgO}$, always consists of magnesium and oxygen in the proportions by weight of 24 to 16 -one atom of magnesium weighing 24, being combined with one atom of oxygen weighing 16. No compound of magnesium and oxygen containing these elements in any other proportion has ever been obtained. If in preparing magnesium oxide quantities of magnesium and oxygen were employed differing from this proportion, then some either of the magnesium or of the oxygen would remain over after the action, accord. ing as the former or the latter had been employed in excess of the right quantity.

Intimately connected with the foregoing law is the law of multiple proportions. Whilst certain elements combine with each other in only one proportion by weight, others combine in two, and sometimes more than two different proportions. The law of multiple proportions states that when elements combine in two or more proportions these various proportions can be expressed by simple multiples ${ }^{\circ}$ of the atomic weights of the elements concerned. Thus carbon and oxygen unite with each other to form two different compounds: 12 parts by weight of carbon unite with 16 parts by weight of oxygen to form carbonic oxide, $\mathrm{CO} ; 12$ parts by weight of earbon unite with 32 parts by weight of oxygen to form carbonic anhydride, $\mathrm{CO}_{2}$. Here the relation is of the simplest kind, for the one compound contains exactly twice as much oxygen for the same quantity of carbon as the other. Again, iron and oxygen unite with each other to form three different compounds : 56 parts by weight of iron unite with 16 parts by weight of oxygen to form ferrous oxide, FeO; 112 parts by weight of iron unite with 48 parts by weight of oxygen to form ferric oxide, $\mathrm{Fe}_{2} \mathrm{O}_{3} ; 168$ parts by weight of iron unite with 64 parts by weight of oxygen to form ferroso-ferric oxide, $\mathrm{Fe}_{3} \mathrm{O}_{4}$. This case is not quite so simple as that of the oxides of carbon, for here it is necessary to employ multiples of the atomic weights of both elements concerned in order to see the simplicity of the quantitative relations existing amongst these oxides of iron. The law of multiple proportions is, however, fully illustrated by both series of oxides.

It may be useful to call attention here to the simple explanation furnished by the Atomic Theory (q.v.) for the occurrence of compounds illustrating this law of multiple proportions. There is no compound intermediate in composition between carbonic oxide and earbonic anhydride. The atomic theory explains this very simply. Under one set of conditions we can obtain a compound of one atom of carbon with one atom of oxygen, whilst under other conditions we obtain a compound of one atom of carbon with two atoms of oxygen, or exactly twice as much. This is why we find such marked intervals in composition between two or more compounds of the same elements. The molecule of one compound cannot differ from that of the other by less than an atom, and the addition of an atom to a molecule necessarily forms a new molecule differing in weight from the old one by the weight of the added atom.

The last law of combination has been called the law of volumes. It states that when gases combine to form new compounds, the volumes taking part in the action bear a very simple relation to each other and to the volume of the product if gaseous when all the volumes are measured at the same temperature and pressure. Thus, one volume of hydrogen combines with one volume of chlorine to form two volumes of hydrochloric acid gas; two volumes of hydrogen combine with one volume of oxygen to form two volumes of water vapour; two volumes of carbonic oxide combine with one volume of oxygen to form two volumes of earbonic anhydride, and so forth. The very simple relations of the volumes concerned in these examples are sufficiently manifest, and much greater complexity is not frequently met with.

Chemists divide the elements into two great classes, the typical members of which are very different in their physical and chemical characters. These are metals and non-metals, and as representative of each class may be mentioned copper and sulphur. The more prominent physical characteristics of metals are the metallic lustre, malleability, ductility, and the property of conducting heat and electricity, all of which are possessed to a more or less marked degree; whilst non-metallic elements as a rule possess these properties to a very limited extent, if at all. Differences in chemical behaviour are also very striking in typical representatives of each group. It must be borne in mind, however, that all the members of each group are not typical, but that there is a gradual transition from one group to the other, and certain of the transition elements possess some of the properties of both groups, as in the cases, for instance, of arsenic and antimony.

With the exception of bromine and fluorine, all the elements enter into combination directly or indirectly with oxygen to form oxides. The oxides produced from metallic elements are quite different in chemical character from those produced from non-metallic elements. We shall look first at the oxides of the metals. Every metal forms one or more oxides, and at least one oxide of every metal is a basic oxide-i.e. an oxide which has the properties of a Base (q.v.). A distinction is made 
between what are called anhydrous bases and hyllrated bases or hydroxides. The oxide of lead, $\mathrm{H}, \mathrm{O}$, is an anhydrous base (or basic oxide), whilst the compound obtained by the action of water upon calcium oxide, $\mathrm{CaO}$ (a basic oxide, and the only compound of calcium and oxygen known), is called a hydrated base (or hydroxide). The formation of the letter is represented by the equation

$$
\mathrm{CaO}+\mathrm{H}_{2} \mathrm{O}=\mathrm{Ca}(\mathrm{HO})_{2} \text {. }
$$

The oxides produced from non-metallic elements are very frequently acid oxides-i.e. oxides which unite with water to form the class of bodies called Acids (q.v.). The oxides themselves are often called acid anhydrides, whilst the compounds produced by the sction of water upon them are called acids, or hydrogen salts. When phosphorns burns in sir, phosphoric anhydride, $\mathrm{P}_{2} \mathrm{O}_{5}$, is obtained. This is a white solid substance which unites with water with the evolution of much heat to form a solution of metaphosphoric acid, or hydrogen metaphosphate :

$$
\mathrm{P}_{2} \mathrm{O}_{5}+\mathrm{H}_{2} \mathrm{O}=2 \mathrm{HPO}_{5} \text {. }
$$

There are a few acids known which do not contain oxygen, and are not obtuinable by the com. bination of an oxide with water. Examples are hydrochloric acid, $\mathrm{HCl}$, hydrobromic acid, $\mathrm{HBr}$, and hydrocyanic acid, HCN. These are also called hydrogen chloride, bromide, and cyanide respectively.

The two classes of substances, beses and acids, are nearly related to the very large class of salts. A salt is a compound which can be obtained, amongst other ways, by the action of an acid upon a base, water being almost invariably eliminated at the same time; and just as we saw that the properties of two elements are totally different from those of the compound formed by their combination, :so we find that in the formation of a salt the properties of both acid and base to a great extent or altogether become neutralised and disappear.

If to a solution in water of potassium hydroxide, KHO (which is a powerful base), we add a sufficient quantity of nitric acid, $\mathrm{HNO}_{3}$, that is until the liquid on thoroughly mixing does not possess either the acid or the alkaline reaction, we obtain a solution in water of potassium nitrate (saltpetre), and nothing else-the water eliminated in the action simply mixing with that which is already present:

$$
\mathrm{KHO}+\mathrm{HNO}_{3}=\mathrm{KNO}_{3}+\mathrm{H}_{2} \mathrm{O} \text {. }
$$

Acids have already been mentioned as hydrogen salts. The above equation shows how hydrogen nitrate is exactly comparable with potassium nitrate-an atom of potassium taking the place of an atom of hydrogen-and a characteristic of all hydrogen salts, or acids, is that they contain hydrogen, which is capable of removal and of having its place thus taken by an equivalent quantity of another metal. In the example above mentioned every 1 part by weight of hydrogen has its place taken by 39 parts by weight of potassium. These quantities of hydrogen and of potassium are equiv. alent, both being capable of uniting with the group $\mathrm{NO}_{3}$. This group is an example of what is called a compound radical-i.e. a group of elements which is capable of going as a whole through a series of changes. Acids which contain in their molecule one atom of hydrogen replaceable by another metal are called monobasic acids. Nitric acid is thus a monobasic acid, whilst sul. phuric acid, $\mathrm{H}_{2} \mathrm{SO}_{4}$, is dibasic, orthophosphoric acid, $\mathrm{H}_{3} \mathrm{PO}_{4}$, is tribasic, and so on.

Bases, likewise, are sometimes spoken of as monacid, diacid, triacid, and so on, according as one molecule of the base requires one, two, three, \&c. molecules of a monobasic acid (as nitric acid) to form what is called a normal salt, that is, a salt in which all the replaceable hydrogen has heren replaced by snother metal. Thus jostumainm hydroxide, KHO, is a monscid base: calcium hydroxide, or slaked lime, $\mathrm{Ca}(\mathrm{HO})$ is diacid; bismuth hydroxide, $\mathrm{Bi}(\mathrm{HO})$, is triseid, and so on. Equations may make this clearer (see the equation above for a monacid base)

$$
\begin{aligned}
& \mathrm{Ca}(\mathrm{HO})_{2}+2 \mathrm{HNO}_{3}=\mathrm{Ca}\left(\mathrm{NO}_{3}\right)_{2}+2 \mathrm{H}_{3} \mathrm{O}: \\
& \mathrm{Bi}(\mathrm{HO})_{3}+3 \mathrm{HNO}_{3}=\mathrm{Bi}\left(\mathrm{NO}_{3}\right)_{3}+3 \mathrm{H}_{2} \mathrm{O} .
\end{aligned}
$$

Salts are formed in many cases by the replacement of only a purt of the replaceable hydrogen of a hydrogen salt by another metal. Such are called acid salts, and KHSO, is an example. This salt, $\mathrm{KHSO}_{4}$, may be looked upon as intermediate between the acid, $\mathrm{H}_{2} \mathrm{SO}_{4}$, and the normal salt, $\mathrm{K}_{2} \mathrm{SO}_{4}$.

Many salts are known which may be looked upon as bases which have their basic character only partially neutralised by an acid. Such salts are called basic salts, and as examples may be mentioned $\mathrm{BiONO}_{3}$ and $\mathrm{Pb}(\mathrm{OH}) \mathrm{NO}_{8}$. The former is intermediate between the normal nitrate, $\mathrm{Bi}\left(\mathrm{NO}_{3}\right)_{2}$, and the oxide, $\mathrm{Bi}_{2} \mathrm{O}_{3}$, the latter between the normal nitrate, $\mathrm{Pb}\left(\mathrm{NO}_{3}\right)_{2}$, and the hydrate, $\mathrm{Pb}(\mathrm{OH})_{2}$ Such basic salts are often produced by the action of water upon the normal salts, as, for instance, in the case of the basic bismuth nitrate :

$$
\mathrm{Bi}\left(\mathrm{NO}_{3}\right)_{3}+\mathrm{H}_{2} \mathrm{O}=2 \mathrm{HNO}_{3}+\mathrm{BiONO} \text {. }
$$

Salts are looked upon as being composed of metal and salt radical, the latter name being given to all of the salt that is not metal. Thus $\mathrm{SO}_{4}$ is the salt radical of the sulphates, $\mathrm{NO}_{3}$ the salt radical of the nitrates, \&c. This way of looking at salts arises from the phenomena observed when salts are decomposed by Electrolysis (q.v.), metal and salt radical being the primary products of decomposition.

Chemical Nomenclature.-Chemists endeavour to make the nomenclature of compound substances as systematic as possible, and a certain amount of system has even been introduced into the nomenclature of the elements themselves. The oxides of the metals are named after the metal which they contain, as magnesium oxide, $\mathrm{MgO}$; aluminium oxide, $\mathrm{Al}_{2} \mathrm{O}_{3}$; and the series of aalts derivable from these oxides are similarly named after the metal. Thus $\mathrm{MgCl}_{2}$ is magnesium chloride, and $\mathrm{Al}_{2}\left(\mathrm{SO}_{4}\right)_{3}$ is aluminium sulphate. When a metal forms more than one basic oxide, adjectival terminations are employed to distinguish these; thus the two basic oxides of iron are named ferrous and ferric oxides ( $\mathrm{FeO}$ and $\mathrm{Fe}_{2} \mathrm{O}_{3}$ ) respectively, and correspondingly there are ferrous and ferric salts. FeSO is ferrons sulphate; $\mathrm{Fe}_{2} \mathrm{Cl}_{6}$ is ferric chloride. Acid saits and in general salts which contain more than one metal are named after the metals which they contain, the compound radical $\mathrm{NH}_{4}$ (ammonium; see AMMONLA) being regarded as a metal for purposes of nomen. clature. Thus, KHSO is potassium hydrogen sulphate, whilst $\mathrm{HNaNH}{ }_{4} \mathrm{PO}_{4}$ is hydrogen sodium ammonium orthophosphate.

The nomenclature of non-basic metallic oxides has been rendered systematic by the use of names deseriptive of the number of atoms of metal and of oxygen contained in the oxide, as, for instance, trimanganic tetroxide for $\mathrm{Mn}_{3} \mathrm{O}_{4}$. A considerable number of non-basic oxides, as $\mathrm{BaO}_{2}, \mathrm{PbO}_{2}, \mathrm{MnO}_{2}$, dic., are somewhat less systematically called peroxides.

The acid anhydrides, which, as has already been stated, are oxygen compounds or oxides of the non. metallic elements, are named after the elements of which they are oxides. As there are frequently two or more such acid anhydrides derived from one 
element, different terminations and, where necessary, other devices of nomenclature are employed to distinguish amongst these. Thus there are two acid anhydrides derived from sulphur-sulphurous anhydride, $\mathrm{SO}_{2}$, and sulphuric anhydride, $\mathrm{SO}_{8}$. The latter unites with water to form sulphurie acid, $\mathrm{H}_{2} \mathrm{SO}_{4}$, and it is believed by some chemists that the solution in water of sulphurous anhydride (a gaseous substance) contains at least some of the corresponding sulphurous acid, $\mathrm{H}_{2} \mathrm{SO}_{3}$. From sulphuric acid there is derived the series of "salts called sulphates, from sulphurous acid the series called sulphites. It sometimes happens that an acid and series of salts are known of which the corresponding anhydride is unknown, just as the existence of certain acids is doubtful although the corresponding anhydride is known. In other cases series of salts are known, although both the corresponding anhydride and acid are unknown. Certain of these peculiarities, as well as some further forms of nomenclature, are illustrated by the table given below of the compounds corresponding to known or unknown oxides of chlorine :

\begin{tabular}{|c|c|c|c|}
\hline $\begin{array}{l}\text { Oxide. } \\
\mathrm{Cl} 0\end{array}$ & $\begin{array}{l}\text { Acid. } \\
\text { HCIO }\end{array}$ & $\begin{array}{l}\text { Salt. } \\
\text { KCIO }\end{array}$ & $\begin{array}{l}\text { Name of salt. } \\
\text { P }\end{array}$ \\
\hline & $\mathrm{HClO}$ & $\mathrm{KClO}_{2}$ & Chlorite. \\
\hline
\end{tabular}

$\left[\mathrm{ClO}_{2}\right.$, not an acid anhydride].

$\begin{array}{llll}\mathrm{HClO}_{3} & \mathrm{KClO}_{3} & \text { " } & \begin{array}{l}\text { Chlorate. } \\ \mathrm{HClO}_{4}\end{array} \mathrm{KClO}_{4} \\ \text { Perchlorate }\end{array}$

It has recently been proved that the substance described in most text-books as chlorous anhydride, $\mathrm{Cl}_{2} \mathrm{O}_{3}$, is really a mixture, and that as yet $\mathrm{Cl}_{2} \mathrm{O}_{3}$ has not been prepared. The hypothetical chloric and perchloric anhydrides would have the composition $\mathrm{Cl}_{2} \mathrm{O}_{5}$ and $\mathrm{Cl}_{2} \mathrm{O}_{7}$ respectively.

A very large number of salts and other chemical compounds are commonly known by popular names, the latter being frequently of extremely ancient origin. The popular name as a rule conveys no information as to the composition of the substance. For instance, copperas (ferrous sulphate, FeSO; is not recognised by its name as an iron compound, nor calomel (mercurous chloride, $\mathrm{HgCl}$ ) as a mercury compound, nor litharge (lead oxide, $\mathrm{PbO}$ ) as a lead compound. It is the aim to convey, by the systematic name of a substance, the greatest possible amount of information as to its composition. It is not possible to attain to a perfect system of nomenclature, as new discoveries render changes necessary from time to time.

Graphic Formula.-In addition to representing the composition of a substance by means of formulæ, chemists endeavour to express certain ideas as to the constitution, or arrangement of the atoms in the molecule of substances by means of graphic formulæ. It must not be supposed (as has sometimes erroneously been done) that graphic formulæ are intended to represent the shape of molecules or the arrangement in space of the atoms constituting such molecules, but simply as a short method of expressing on paper certain facts. No one supposes that a printed word in any modern language is an attempt to draw the object spoken of, or that it is more than a method of representing on paper a given series of sounds, and yet criticism based upon assumption scarcely less absurd, has been directed against graphic formulæ. In a graphic formula we have the symbols for the different elements grouped in a particular way, so as (1) to indicate the valency (see the article Aтомг THeORY) of each element, and (2) to express ideas based upon observed facts as to the most likely arrangement of the atoms in a molecule, when various arrangements are conceivable.

The following may be given as simple illustrations of (1):
H-Cl, hydrochloric acid; H-S-H, sulphuretted hydrogen; $\mathbf{M g}=0$, magnesium oxide; $\mathbf{N}<\frac{\mathbf{H}}{\mathbf{H}}$, ammonia ; $\mathrm{H}-\mathrm{C}_{\mathrm{H}}^{\mathrm{C}}-\mathrm{H}$, marsh-gas ; $\mathrm{H}-\mathrm{Cl}_{\mathrm{Cl}}^{\mathrm{C}}-\mathrm{Cl}$, chloroform ; $\mathrm{O}=\mathrm{C}<{ }_{\mathrm{Cl}}^{\mathrm{Cl}}$, phosgene; $\mathrm{O}=\mathrm{C}=\mathrm{O}$, carbonic anhydride; $\mathbf{S}=\mathbf{C}=\mathrm{S}$, carbon bisulphide, \&c. The letters representing monovalent atoms are written with one stroke proceeding from them, those representing divalent, trivalent, and tetravalent atoms being written with two, three, and four such strokes respectively.

Illustrations of (2) are :<smiles>[H][Y13]([H])([H])N=NC=O</smiles>

These two substances illustrate two other points of importance. One of these is the occurrence of the nitrogen atom sometimes trivalent, as in ammonia, $\mathrm{NH}_{8}$, sometimes pentavalent, as in the ammonium salts-e.g. ammonium chloride, $\mathrm{NH}_{4} \mathrm{Cl}$. In am monium cyanate one atom of nitrogen is represented as trivalent and the other as pentavalent. The two substances, moreover, illustrate Isomerism (q.v.), or the existence of two or more compounds containing exactly the same elements and in the same proportions, and yet differing from one another in chemical and physical propeities.

Chemical Changes.-There are several kinds of chemical changes which are of very frequent oceurrence, and may conveniently be classified. The simple union of one element with another has already been mentioned, and closely related to this kind of change is the union of a compound with an element or with another compound. Along with these changes may be classed those in which a compound breaks up into two or more elements or simpler compounds, or into one or more of each. All these variations are illustrated by the following equations :

$$
\left.\begin{array}{l}
\mathrm{C}+\mathrm{O}_{2}=\mathrm{CO}_{2} \\
\mathrm{CO}+\mathrm{Cl}_{3}=\mathrm{COCl}_{2} \\
\mathrm{CaO}+\mathrm{CO}_{2}=\mathrm{CaCO}_{3}
\end{array}\right\} \text { direct union. }
$$

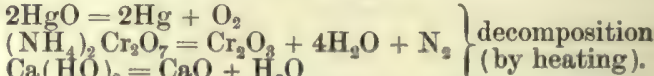
$\mathrm{Ca}(\mathrm{HO})_{2}=\mathrm{CaO}+\mathrm{H}_{2} \mathrm{O} \quad \mathrm{O}(\mathrm{by}$ heating $)$

One of the most important kinds of chemical change is that called double decomposition. This occurs perhaps most frequently when solutions of salts are mixed with each other, and it is characterised by a mutral exchange of metal and salt radical. If an aqueous solution of sodium chloride be mixed with one of potassium bromide, although no visible change takes place, we have reason to believe that double decomposition goes on to a certain extent, with formation of some sodium bromide and some potassium chloride, whilst some of each of the original salts also remains, a state of equilibrium being eventually established amongst the four salts. If, however, one of the new products formed by double decomposition be insoluble or practically insoluble in water, as soon as any of it is formed it will appear as a precipitate, and be thus removed from solution, so that no condition of equilibrium can be established until formation of a precipitate no longer occurs-i.e. until the double decomposition is complete. Thus, if solutions of sodium chloride and silver nitrate be mixed in the proper proportions, the extremely insoluble silver 
chloride will be precipitated, and only sodium nitrate will remain in solution. The action may be represented by an equation:

$\mathrm{NaCl}+\mathrm{AgNO}_{3}=\mathrm{NaNO}_{3}+\mathrm{AgCl}$ (precipitate).

The action of sulphuretted hydrogen on many metallic solutions illustrates double decompositions in which the action is complete, as,

$$
\mathrm{HgCl}_{2}+\mathrm{H}_{2} \mathrm{~S}=\mathrm{HgS}+2 \mathrm{HCl} \text {, }
$$

where the mercuric sulphide formed is insoluble in water, and is consequently obtained as a precipitate.

In connection with the subject of double decomposition the bearing of the law of Richter (already mentioned in the historical sketch) may be illus. trated. Looking at the quantitative signification of the following equations,

$$
\begin{aligned}
& \mathrm{KCl}+\mathrm{AgNO}=\mathrm{AgCl}+\mathrm{KNO}_{3}, \\
& \mathrm{NaCl}+\mathrm{AgNO}_{3}=\mathrm{AgCl}+\mathrm{NaNO}_{3},
\end{aligned}
$$

we ses that the quantity of ehlorine which was united with 39 parts by weight of potassium or 23 of sodium to form a salt is exactly the quantity required to form a salt with 108 parts by weight of silver, whilst, similarly, the quantity of the group $\mathrm{NO}_{3}$ which was united to these 108 parts by weight of silver is exactly the quantity required to form a salt with 39 parts by weight of potassium or 23 of sodium. The same holds good generally for double decompositions.

Another very important kind of chemical change is the displacement of one element in a compound by another. Chlorine, for instance, displaces the iodine in potassium iodide and takes its place :

$$
2 \mathrm{KI}+\mathrm{Cl}_{2}=2 \mathrm{KCl}+\mathrm{I}_{2} \text {. }
$$

The greater affinity of potassium for chlorine than for jodine is the explanation given of this displace. ment. Displacement of one metal by another is a familiar phenomenon, although the chemistry of what is taking place may not be familiar to all who have seen it. When a piece of bright iron or steel, as a key or the blade of a knife, is dipped into an acidulated solution of cupric sulphate (blue vitriol), a reddish deposit of metallic copper is formed almost immediately upon the surface of the metal. This copper is derived from the cupric sulphate solution; but what is not manifest from observation alone, is that at the same time an equivalent quantity of iron is dissolved away and goes into solution as ferrous sulphate. The action is,

$$
\mathrm{CuSO}_{4}+\mathrm{Fe}=\mathrm{FeSO}_{4}+\mathrm{Cu} \text {. }
$$

The whole of the copper would eventually be separated from the solution in the metallic state if enough iron were present, and for every 63 parts of copper precipitated 56 parts of iron would go into solution.

Inorganic and Organic Chemistry.-The whole subject of chemistry has been divided into two great divisions, named respectively inorganic and organic. Made originally to separate from each other the chemistry of purely mineral substances, and that of substances of animal or vegetable origin, which were at the time sup. posed to be capable of formation only as products of vital processes, this subdivision is retained still mainly as a matter of convenience. The division of organic chemistry is sometimes spoken of now as the chemistry of the compounds of carbon; but this is not a very strict definition, as many carbon compounds occur in nature as purely mineral substances, and having really no connection with organic ehemistry, such as numerous mineral carbonates. As has been already stated, it is mainly for convenience that the consideration of the majority of the compounds of carbon is taken as a separate branch, not because of any difference in the chemical principles involved, but really on account of the very great number of these com. pounds, and of the great complexity of many of them.

It is in the domain of organic ehemistry that the atudy of the constitution of substances has been most diligently promecuted, and with the greatest amount of apparent success. The graphic formula which chemists assign to acetic acid (to take a simple example) is,

$\mathrm{H}-\mathrm{C}-\mathrm{C}-\mathrm{O}-\mathrm{H}$. This formula is adopted in order to express a number of ideas concerning the supposed mode of arrangement of the atoms in acetic acid, deduced from the study of its formation, its decompositions, and the action upon it of varions substances. The known facts find suitable expression in the formula, and there is no observation yet made as to the chemical relations of acetic acid which is at variance with the constitution indicated by it. It would not be possible here to quote evidence in favour of a particular constitution for any substance, but it may be stated generally that chemists endeavour to fix the constitution of the simplest compounds on the firmest possible basis, and, in passing from the simple to the more complex, to make secure every step.

The tetravalent character of the carbon atom, and the great facility with which carbon atoms enter into combination with other carbon atoms and with the atoms of other elements, give their impress to the whole of organic chemistry. The gruphic formula of organic substances aniply illustrate the former, whilst the syntheses of a long array of simple and complex organic compounds as amply illustrate the latter.

A certain amount of knowledge of chemistry is eminently useful in almost every walk of life. An intelligent knowledge of the chemistry involved in the processes of the kitchen, the dairy, the dye. house, the farm, or the manufactory, places the possessor engaged in any of these processec on a different level from the rule-of-thumb worker, who is as ignorant of the reason for adopting a particular method as he is of the properties of the materials he employs. Technical chemistry deals especially with the application of the principles and processes of chemistry to the arts and manufactures, and it is to those who are engaged in manufactures of almost every kind that a knowledge of chemistry is a particular advantage. It is not a question of expediency alone, but one of alwolute necessity that a technical education, including chemistry as one of its principal subjects, should form not the least important part of the equipment for his work of any artisan who is to excel in his employment in intelligence and skill.

In connection with this article should be read the articles ATOMIC THEORY, which is to a certain ex. tent supplementary to this, ANiMAL CHEMISTRY, and Vegetable Physiology. See also separate articles on the several elements, those on the various acids, those on the great chemists, and the following as amongst the most important of the many chemical articles throughout this work:

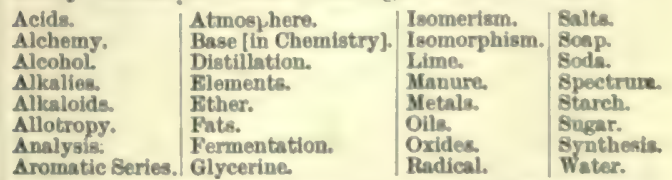

For further information readers may consult : Profeseor Crum Brown's Chemietry (Chambers's Science Manuals); Roscoe and Sohorlemmer, Treatise on Chemiatry (1878- 
89): Watts, Inonganic Chemistry, and Organic Chemistry; Wilson, Inorganic Chemistry (new ed. 1885); Watts, Diotionary of Chemistry (new ed. 4 vols., 1890-94); Thomson, History of Chemistry (1830-31); French works by Hoefer, Chevreul, Berthelot; Ladenburg, Handwörterbuch der Chemie; Kopp, Geschichte der Chemie, Von Meyer, A History of Cnemistry (trans. by McGowan, 1892 ) ; Mendeléf, The Principles of Chemistry (1892) Perkin and Kipping, Organic Chemistry (1894); Thorpe, Dictionary of Applied Chemistry (3 vols. 1890-93).

Chemists and Druggists. Up to the passing of the Pharmacy Act of 1868, any one was free to describe himself as chemist and druggist and to prosecute that calling to the best of his ability, untouched by any special legislation. The class, like the Apothecary (q.v.), was in its beginnings closely allied to, if indeed at all distinguishable from, that of merchants and grocers, and never formed a distinct guild, and, until the Pharmaceutical Society was founded, was without permanent organisation. And owing to the absence in Seotland of the apothecaries, as a class distinguishable from druggists, the history of the latter class in that country does not, at least up to the passing of the Pharmacy Act of 1882, correspond accurately with that of their English brethren. The policy these latter pursued for a long period of their history may be described as purely defensive, and any organisation they formed was in response to some attack from one of the other orders. As early as 1802 such a defensive association was formed, and from 1812 to 1815 engaged in very active opposition to the bill promoted by the 'Associated Apothecaries.' One of the objects of that bill was to bring the chemists and druggists under the control and surveillance of a body consisting chiefly of apothecaries, on which the chemist and druggist was not represented at all. The upshot was that the promoters of the bill introduced a clause into the Act of 1815 , which it was understood at the time would completely exempt the chemist and druggist from the operation of the bill. In spite, however, of this understanding, which seems to have been respected for twentysix years, the bill was in 1841 made use of to punish a chemist and druggist for prescribing medicine, although that was a function which, rightly or wrongly, he had exercised previous to 1815. In 1841 a bill again threatened to subject the chemist and druggist to the control of the apothecaries, but was at length defeated. It now became evident, not only that a permanent society to protect the interests of the craft was necessary, but that the only wise policy was to educate and organise themselves in such a way as would deprive the physicians and apothecaries of any.excuse for further interference. This led to the formation of the Pharmaceutical Society of Great Britain, which was founded in 1841. and incorporated by Royal Charter in 1843. As declared in the charter, the main objects of the society were those of "advancing chemistry and pharmacy and promoting a uniform system of education of those who should practise the same; and also for the protection of those who carry on the business of chemists and druggists ;' and to enable it to carry these out successfully the society appointed professors and examiners, and afterwards proceeded to promote a bill in parliament for the recognition and protection of the titles they proposed to confer on those who passed the examinations. This was naturally a work of time, and in the meanwhile an important act in relation to the sale of poisons - viz. the Sale of Arsenic Act (1851) was passed, and drew the attention of government to the absence of a definite class of persons qualified by training and education to have the custody and sale of poisonous substances intrusted to them; so that this to some extent led up to the passing of the first Pharmacy Act of 1852. The main result of this act was to create a class of 'Pharmaceutical Chemists,' alone empowered to use and exhibit that or any equivalent title, and consisting, 1st, of those already members of the society ; and $2 \mathrm{dly}$, of such persons as should pass the examinations, as conducted by its two Boards in England and Scotland. The bill, as passed, involved no compulsion on any persons to go through these examinations, nor did it confer any privilege or monopoly on the pharmaceutical chemist except the exclusive right to that title. The dispensing of medicines and sale of poisons was still left open to any one who ehose to engage in it. Nor was it till the Act of 1868 that the term chemist and druggist came to signify a specially qualified person or one possessing exclusive rights. By that act all persons not in business on their own account prior to lst August 1868, had (except some who for a time were allowed to pass a 'modified examination') to pass two Preliminary and the Minor Examinations, and after that were entitled to have their names placed on the "Register of Chemists and Druggists for the United Kingdom;' and no person who was not on that register could legally use the title, or (with certain exceptions in favour of physicians, apothecaries, veterinary surgeons, \&c.) sell or dispense certain poisons specified in schedules to the act. Any person wishing to use the style 'Pharmaceutical Chemist,' had to pass a further examination called the 'Major,' and thus arose the two grades in what we may now call, in view of its edueational qualification, the profession of pharmacy. See Pharmacy Acts.

Chemmitz, a town of Saxony, is situated at the base of the Erzgebirge, and at the confluence of the river Chemnitz with three other streams, 51 miles SSE. of Leipzig by rail, and 43 WSW. of Dresden. It is the principal manufacturing town of the kingdom-the 'Saxon Manchester' its townsfolk call it-its industry consisting in weaving cottons, woollens, and silks, and in printing calicoes, chiefly for German consumption. It supplies the world with cheap hosiery, and makes mixed fabrics of wool, cotton, and jute for the markets of Europe and America. It has several extensive machinefactories, producing locomotives and other steamengines, with machinery for flax and wool spinning, weaving, and mining industry. Created a free imperial city as early as 1125, Chemnitz suffered much during the Thirty Years' War, Pop. (1801) 10,835: ( 1861 ) 45,532; ( 1885 ) 110,817 ; (1890) 138,954.

Chemmitz, Martin, the most eminent Lutherantheologian in the second half of the 16th century, was born at Treuenbrietzen, in Brandenburg, 9th November 1522. He had a hard struggle with poverty in his early years, and had repeatedly to interrupt his university studies at Frankfort-onthe-Oder and Wittenberg in order to obtain by school-teaching the means of pursuing them; but at length his proficiency in astrology led to his being appointed librarian of the dueal library at Königsberg in 1550, and from that time he devoted himself entirely to theology. In consequence of his opposition to the teaching of Osiander he was obliged to leave Königsberg and proceed to Wittenberg (1553), where he delivered lectures on the Loci communes of Melanchthon, which were published after his death as Loci theologici (1591). He was appointed a preacher at Brunswick in 1554, and 'superintendent' in 1567, and died there 8th April 1586. The chief works of Chemnitz were his Examen Concilii Tridentini (4 vols. 1565-73; new ed. Berlin, 1862), which was the first thoroughgoing eriticism of Tridentine doctrine from a Protestant point of view; and his share in preparing and securing the acceptance of the 'Formula of 
Coneord '- the next in importance to that of Jacob Andreli. His Corpus Doctrina Pruthenicum, written in conjunction with Mörlin (1567), became a standard work of orthodox Lutheranism. In his De duabus Naturis in Christo (1571) Chemnitz developed the doctrine of the 'ubiquity' of Christ in a form mediating between Luther and Melanchthon. In every other point of his theology he was a stealfast follower of Luther. His Life has been written by Pressel (1862), Lentz (1866), and Hachfeld (1867).

Chemnitxia, a large genus of gasteropod molluses, named in honour of a German conchologist of the 18th century. They have a slender, elongated, many-whorled shell, the whorls striated, a simple semi-oval aperture, and a horny operculum. There are many recent species seattered all over the world. No less than 180 fossil species have been deseribed from the Lower Silurian upwards, but it is proosable that different animals with similar shells are included under this one title.

Chemosh, the national god of Moab, called in 1 and 2 Kings "the abomination of the Mosb. ites.' The derivation of the name is uncertain, the most probable being that of Gesenius, from kämash (=käbhash), 'to trample under foot,' with which the Syrian kemish, 'nightmare,' is connected. Chemosh was essentially one with the Moloch or Milcom ('king') of the Ammonites, and both were simply forms of the Canaanite Baal (q.v.). On the -Moabite Stone King Mesha attributes the Israelite successes over Moab to the wrath of Chemosh, and Moab's deliverance to his assistance. His worship was marked by cruel rites and laseivi. ous orgies. Mesha's first-born son was doubtless sacrificed as a burnt-offering to him (2 Kings, iii. 27 ). Solomon in his later years consecrated 'higl places' (Bāmōth) to Chemosh in Jerusalem.

Chemulpo, a town on the west coast of Corea, 25 miles by road WSW. of the capital, Söul. It is one of the three treaty ports opened in 1883 to foreign commerce, the volume of which has since steadily advanced, in spite of the drawbacks resulting from the great difference between high and low water here ( 33 feet), and the want of wharves. The imports attain a vulue of $\$ 3,500,000$ in some years; the exports, $\$ 1,500,000$. Pop. 30,000 ; the bulk of the $\mathbf{3 0 0 0}$ foreigners are Japanese. Small steamers owned by Japanese run to Söul in summer, and a railway is projected; and Cliemulpo is connected by telegraph both with China and Japan.

Chemung Period, name given by American geologrists to one of the principal divisions of Devonian time.

Chenab', one of the five rivers which give name to the Punjab, rises in the Kashmir rance of the Himalayas, winds through the gorges of Jammu, and enters British territory in Sialkot district. It absorbs the Tavi, forms the boundary between Sialkot and Gujerat districts, and enters Jhang desert, where it runs through a broad enltivated valley. Here its depth varies from 10 feet in the dry season to 16 feet in the rains; but its course often shifts. It unites with the Jhelum at Timmu, afterwards receives the Ravi, and, as the Trimab, joins the Sutlej, 50 miles above Mithankot. Its length is 755 miles.

Chenery, Тномаs, joumalist and orientalist, was born in Barbadoes in 1826, and educated at Eton and Cambridge. He was called to the bar, but was soon after sent out as Times correspondent to Constantinople, where he remained during the Crimean war. Afterwards he was constantly employed on the Times staff until 1877, when he became its editor, a post which he laboriously filled till within ten days of his death. But this was only one side of his life. As a singularly thorough Hebrew and Arabic scholar he had few equals among his con. temporaries, and his translation of the Arabic classic, the Asemblies of Al Hartri (1867), lod to his appointment to a chair of Arabic at Oxford in 1868. He was one of the company of Old Testa. ment revisers, and besides other works, published an edition of the Machberoth Ithiel (1872), a Hebrew version of the 'Assemblies,' He died 11 th February 1884.

\section{Chengalpat. See Chingalpat.}

Chénier, Marie - André, a distinguished French poet, was born at Constantinople in 1762. He was the third son of Louis Chenier, French consul-general in that city. His mother was a Greek lady of remarkable beauty and accomplish. ments. While quite a child be was sent to France; and in his thirteenth year be was placed at the Collège de Navarre, Paris. Partly from predilection, and partly through the influence of his mother, Greek literature was from the beginning his special subject of study. At the age of twenty he entered the army, and served for six months in Strasburg as sub-lieutenant; but disgusted with the frivolity of the military life of that day, he returned to Paris, and gave himself up to a strenuous course of study. To this period belong two of his most famous idyls, Le Mendiant and L'Aveugle. His health giving way, he travelled in Switzerland, Italy, and the Archipelago. In 1786 he returned to Paris, and began several of his most ambitious poems, most of which, however, remained frag. ments. The most noteworthy are Suzanne, L'Inven. tion, and Hermes, the last being in plan and spirit an imitation of the great poem of Lucretius ; for Chenier shared the beliefs of the 18th-century philosophers of France. In 1787 he went to Eng. land as secretary to the French ambassador, but seems to have found his residence there as uncongenial as Heine did. Returning to Paris in 1790, he found himself in the ferment of the Revolution. Up to a certain point he gave the movement his ardent support; but alarmed by its excesses he mortally offended Robespierre by certain denunciatory pamphlets. He was thrown into the prison of Saint-Lazare, and after six months was executed on the 25th July 1794, just three days before the close of the Reign of Terror.

Chénier holds in France a somewhat similar position to Keats in England. They suggest each other also by their early deaths, and by a certain affinity of genius. Other pieces of Chenier that deserve special mention are La Jeune Captive, Le Jeune Malade, and Versailles. Sainte-Beuvo thus sums up the claims of Chénier: "Chenier was one of the great masters of French poetry during the 18th century, and our greatest classic in verse since Boileau and Racine. "The best edition of his poems is Joubert's (1883). See Sainte-Beuve, Critiques et Portraits : Beeq de Fouquières, Lettres critiques sur Chenier (1881); Haraszti, La Poesie d'Andre Chenier (1891).-His younger brother, MARIE-JOSEPH DE CHENIER (1764-1811), was an ardent republican, sat in the Leyislative Assembly, and wrote satires and heavy declamatory plays.

Chenille (Fr., 'enterpillar'), a thick, velvety. looking cord of silk or wool (and so renembling woolly caterpillar), used in ornamental sewing and manufactured trimmings.

Chenonceaux, a famous French chnteau, standing partly on an island in the Cher, partly on a bridge spanning the river, near a station 20 miles E. by S. of Tours by rail. It was commenced in 1524 by the Chancellor Thomas Bohier, continued by Diana of Poitiers, and completed by Catharine de' Medici, who richly embellished the building, and surrounded it with a beautiful park. 
It passed into the hands of the Condés, and afterwards of Madame Dupin, widow of a fermier général, who here was visited by Montesquieu, Bolingbroke, Voltaire, Rousseau, Buffon, and others. The castle is in excellent preservation; it possesses a fine chapel, a theatre, and memorials of its former occupants in furniture, personal relics, ciphers, and a collection of portraits.

Chenopodiacea, an order of apetalous dicotyledons usually regarded as reduced types of Caryophyllaceæ, and closely related to Amaranthaceæ, with which some include them as Oleracer. They are herbaceous or half-shrubby plants, with simple, alternate, exstipulate leaves, and inconspicuous flowers, hermaphrodite or unisexual, usually windfertilised. There are about 500 species, mostly wood-like, and growing in waste places. They are widely diffused over the world, particularly northern Europe and Asia. Beet and spinach are among the best known and most useful plants of the order, but many others are occasionally used as pot-herbs, as some species of Chenopodium, Orache (q.v.), \&e. The fruit of Strawberry Blite (Blitum capitatum and $B$. virgatum), a common weed in the south of Europe and the colder parts of North America, has a sweetish, insipid taste, and some resemblance to a strawberry, from the coherence of the fleshy perianths of a whole head of flowers. The seed of Quinoa (q.v.) is used for food as a kind of grain. Some are aromatic (see CHENOPODIUM). Some inhabit salt-marshes, and abound in soda. See SALTWORT.

Chenopodium, a genus of Chenopodiacer, of which some of the common species are well known by the name of Goosefoot, as weeds growing in gardens, on heaps of rubbish, and in waste places. The species are mostly annuals, with entire or toothed leaves, often with a sort of mealy hoariness, and are widely distributed, or becoming naturalised in all climates. The leaves of many species are used as a substitute for spinach, particularly those of the Good Harry, Wild Spinach, Allgood, or English Mercury (C. bonus-Henricus), a common wayside perennial, which is still sometimes cultivated; the young shoots are also used as asparagus. C. intermedium, C. album, \&c., annuals, common in waste places, are also excellent subistitutes for spinach. C. Vulvaria (Stinking Goosefoot), an annual with an odour compared to that of stale salt fish, growing in waste places, especially near the sea, was formerly in popular repute as an antispasmodic and emmenagogue. C. purpurascens (Atriplex) is a handsome annual introduced from China $C$. Botrys, a native of the south of Europe, with pinnatifid leaves resembling those of the oak, and hence called Jerusalem Oak, is in use as an expectorant and anthelmintic. It is agreeably fragrant. C. ambrosioides has a strong aromatic odour, is used in Mexico instead of tea, and is occasionally cultivated in France, an infusion of it being deemed useful in nervous disorders. The closely allied $C$. anthelminticum, the Wormseed of the United States, has a strong and somewhat aromatic odour, and a high reputation as a vermifuge, due to the presence of an essential oil. More important than any of the species, as affording a principal article of food in the countries of which it is a native, is Quinoa (q.v.).

Cheops (a Grecised form of $K h u f u$ ) was a king of Memphis in Egypt, belonging to the fourth dynasty, famous as the builder of the largest of the existing pyramids. The date usually assigned to him is about 3000 B.C. His successor was his brother Chephren (Khafra), who built the next largest pyramid. See EGYPT, PYRAMID.

Chepstow, a river-port of Monmouthshire, a sub-port to Gloucester, on the right bank of the
Wye, 21 miles from its influx to the Severn estuary, and 17 ENE. of Newport. It lies between bold cliffs, on a slope rising from the river, in the midst of exquisite scenery. Its noble ruined castle, later chiefly than the 12 th century, stood two sieges during the great Rebellion, and has been held successively by FitzOsbornes, Clares, Bigods, Herberts, and Somersets. The railway crosses the Wye by Brunel's tubular suspension bridge (1852), 600 feet long, and 50 above high-water, the principal span being 300 feet long. Here occurs the highest tide in the British Islands; though the accounts of it have been frequently exaggerated. In January 1846 it rose 47 feet above low-water mark, but this level, though often approached, is not known to have been exceeded. Pop. (1851) 4295 ; (1891) 3378. See Fitchett Marsh, Annals of Chepstou Castle (1883).

Cheque is a money order on a banker, payable on demand. It is really a Bill of Exchange (q.v.), and is subject to the provisions of the Act of 1882, which contains special clauses relating to cheques. If it is not presented within a reasonable time, the drawer is discharged should the banker fail, but the holder can claim against the banker's estate. The banker bears the risk of the forgery of the drawer's signature, but is not responsible for a forged indorsement. A cheque is held as payment of a debt until dishonoured on presentation; it is not payable after the drawer's death or bankruptey.

A crossed cheque is an ordinary cheque with two transverse lines drawn across it, which have the effect of making it payable only through a banker. When a particular banker's name is written between the lines, the cheque is said to be specially crossed, and is only payable to the banker whose name it bears. Wanting a particular name, or with the words ' $\&$ Co.,' it is said to be generally crossed, and is payable through any banker. An ordinary cheque may be crossed either generally or specially by the holder. The crossing is a material part of the cheque, and may not be obliterated or altered, except as provided by the Bills of Exchange Act, 1882.

In the United States a cheque is not a bill of exchange, though it has many of its properties. It is not a legal tender, nor is it a payment of debt till honoured at the bank. It has no days of grace, and is due only after presentation. The bank is responsible for paying a forged cheque, and is liable for wrongfully dishonouring it.

Cher, a French river, flowing 200 miles northward and north-westward till it falls into the Loire below Tours. It is navigable from Vierzon. -CHER, to which the river gives its name, is the central department of Franee. The surface consists of plain and well-wooded hills (1600 feet), and produces corn, fruits, wine, hemp, flax, \&c. The climate is mild and pleasant, except in the swampy district in the north, which has, however, been largely drained in late years. Agriculture, sheep and cattle rearing, and bee-keeping, give employment to many. The rivers abound in fish, and wolves are still sometimes seen. Education is backward, nearly two-thirds of the people being unable to read or write. Area, 2770 sq. m. ; pop. (1872) 335,392; (1886) 355,349; (1891) 359,276. Bourges is the chief town.

Cheraseo, a walled town in the province of Cuneo, North Italy, 37 miles SSE. of Turin by rail. Pop. 3341. In the middle ages Cherasco was one of the chief fortresses of North Italy, but its works were destroyed by the French in 1801 . A peace was concluded here between Louis XIII. of France and the Duke of Savoy in 1631, and another between the Sardinian commissioners and Napoleon in 1796. 
Cherbourg, a fortified seaport town and arsenal of France, in the department of Manche, at the head of a deep bay on the northern extremity of the peninsula of Cotentin, 70 miles $\mathrm{S}$. of the Isle of Wight, and 230 WNW. of Paris. Begun by Vauban in 1687, the harbour-works and fortifications were pushed on by the great Napoleon, and were supposed to have been completed in 1858 by Napoleon. III. at a total outlay of 200 million francs ; but less than thirty years after, the French government resolved to spend 49 millions more on the construction of fresh works between 1883 and 1894. The stupendous digue or break. water, inclosing a space of nearly 2000 acres, is deseribed in the article BREAKWATER. In connection with its fortifications, this breakwater assumes an importance that attaches to no other work of the kind in existence. At the apex of the angle formed by the meeting of the two branches of the sligue, there is a centre fort or battery, measuring 509 feet on the inner line of the parapet, which forms a flat semi-ellipse. The circular forts at the extremities of the breakwater are remarkably well placed for purposes of defence. Behind the centre battery there is an elliptical tower, measuring 225 feet on the major, and 123 feet on the minor axis. The entrances to the harbour are round the ends of the dique; and the passages are further defended by the fortifications of the Ile Pélée, and by the batteries of La Roche Chavaignac and Fort Querqueville. A series of coast redoubts, and the large fortifications of Les Flamands, du Homet, Digosville, and Nacqueville, are situated behind this outer zone of defence. 'The arsenal,' says Dr Russell, 'is inclosed by a continuous line of bastion and curtain of a very elevated profile, defended by outworks, wet and dry ditches, and by profuse batteries of the heaviest guns, either in easement or en barbette. Wherever you look, you fancy that on the spot you occupy are speci ally pointed dozens of the dull black eyes from their rigid lids of stone.' The town itself is commanded by $L a$ Roule on the heights behind. The commercial harbour of Cherbourg consists of an outer harbour, 786 feet in length by 654 feet wide, and of an inner basin, 1338 feet long by 416 feet wide. The great inner naval floating-harbour was inaugurated by the Emperor Napoleon in 1858, in presence of Queen Victoria. Entirely eut out of the solid rock, it is 20 acres in area, and is surrounded by building-slips and capacious graving-docks. It is ealeulated that the roads of Cherbourg cannot, on account of the smal depth of the greater portion, shelter more than 25 or 30 sail of the line, and about as many frigates, at one time. The commercial port displays little activity, the principal exports being eggs, butter, and eattle. The town itself is insignificant, the streets being narrow and dirty; the only buildings of note are Trinity Church, founded by the English about 1450, the hotel-de-ville, and the theatre. There are some manufactures of hosiery, chemicals, lace, and leather, sugar and salt refineries, sawing and flour mills; but the industrial eneruies of the great bulk of the population are absorbed in the arsenal and dockyards. Cherbourg is a very ancient place ; originally Casaris Burgum, in the 11th century it was known under the name of Carusbur. In 1758 Cherbourg was taken by the English, who destroyed the naval and military works, and levied a contribution on the town. Pop. (1872) 34,785 ; (1886) 37,013 ; or 51,774 with the three suburbs of Tourlaville, Octeville, and Equeurdreville. Pop. in 1891, 38,554.

Cherbuliez, the name of an infuential family at Geneva, which has produced many eminent scholars and men of letters. Its founder was Abraham Cherbuliez, a prosperous bookseller, who left three sons-(1) A NDrE (1795-1874), profeanor first of Latin, next of Ancient Literature at the Geneva Academy, author of De Libro Job (1829), and an Esai sur La Satire Latine (1829), - (2) A NTOINy ELIsée (1797-1869), an eminent publicist ; profensor of Law and Political Economy at Geneva; after. wards at Paris the redouhtable antagonist, in the pagres of the journals, of Prondhon and the social. ists; died professor at Zurich; author of De la Démocratie en Suisge (1843), Etudes sur les Causes de la Misere (1853), and Precis de la Science Economique (1862).-(3) JOEL (1806-70), who sueceeded to his father's business, and becsme well known as editor of the Revue Critique (1833 et seq.). and an occasional contributor to the Revue des Deux Mondes. His book, Le Lendemain du dernier Jour dun Condamne (1829), was a clever burlesque and more upon Victor Hugo's well-known tour-de-force on the question of capital punishment, while his Geneve, ses Institutions, ses Mcurs, dee. (1867), was a solid contribution to the history of the city. Of the sisters, two made some reputation: the eldest, Madame Tourte-CHERBULIEZ (1793-1863), wrote tales and novels, among them Annette Gervais, and Le Journal d'Amelie; and the young. est, ADRIENNE, born in 1804, translated into French the tales of Zschokke and $\mathbf{H}$. von Kleist. See Rambert's Ecrivains nationaux Suisses (vol. i. Geneva, 1874).

Victor Cherbuliez, son of André, was born at Geneva in 1829, and studied there, at Paris, Bonn, and Berlin, first mathematics, then philology and philosophy; after which he lived in Geneva as a teacher, until his eall to Paris in 1864 to join the Revre des Deux Mondes. Since 1882 an Academician, he died lst July 1899, near Melun. Cherbuliez began his literary career with books which were compounds between fiction and criticism. In the first of these, A propos d'un Cheval, Causeries Atheniennes $(1860$; 2d ed. under the title, Un Cheval de Phidias, 1864), beanty in art, and especially in the sculptures of Phidias, is discussed in a series of conversations by the attendants of a French marquise who is visiting Athens; Le Prince Vitale (1864) treats in a similar way the subject of Tasso's madness; Le Grand Euvre (1867) contains, with many incongruous enough discussions of social and political questions, an account of the unfortunate attempt of an English baronet to grow a wife for himself. From these the anthor turned to work which really proved his powers. In 1863 he published Le Comte Kostia, a strong and striking novel, which at once found its author an audience. It was followed by a series of novels which, always elever and original, if sometimes mannered and over-inventive, have lifted Cherbuliez into the front rank of contemporary Freuch writers of fietion. His style is brilliant and epi. grammatic, his dialogue natural and lively; while he is readable from beginning to end, and his situations are not only full of interest for the moment, but are remembered long. Many of his earlier stories take the form of a narrative by the chief character, but those difficulties in developing a plot in such a method which have been too great for many novelists, M. Cherbuliez has surmounted with consummate art. His best novels, besides those named already, are: Le Roman d une honnete Femme (1866), L'A venture de Ladislas Bolshi (1869), La Revanche de Joseph Noirel (1872), Meta Holdenis (1873), Miss Rowel (1875), Le Fiance de Mlle. de Saint-Maur (1876), Samuel Brohl et C (1877), L'Ides de Jean Teterol (1878), La Ferme du Choquard (1883), and $L a$ Vocation du Comte Ghislain (1888). He published, besides several volumes of political studies on Germany and Spain, as well as Hommes et Choses du Tempes present (1883), a series of papers which appeared in the 
Revue des Deux Mondes-as did also L'Art et la Nature (1892) - under the name of 'G. Valbert.' See Saintsbury, Essays on French Novelists (1891).

Cheribon, a seaport of Java, on the north coast, 125 miles ESE. of Batavia. It has a considerable trade in coffee, indigo, and teak-wood, and is the residence of a Dutch governor. Pop. 11,000.

Cherimoya, or Chirimoya (Anona cherimolia), the most esteemed fruit of Brazil and Peru, now common, and even naturalised in some parts of the East Indies, and other tropical countries of the old World. It is a fruit of most delicious flavour, is sometimes described as the finest of all fruits, and sometimes as inferior only to the mangosteen. Both flowers and fruit emit a pleasant fragrance, but when the tree is covered with blossom the odour is almost overpowering. The fruit varies from the size of an orange to $16 \mathrm{lb}$. or upwards in weight. See CUSTARD-APPLE.

Cherkask. See Tcherkask.

Chernigov. See Tchernigoff.

Cherokees, one of the most civilised of the American Indian tribes, of the Appalachian stock, and formerly the owners of a wide tract of country on either side of the sonthern Appalachian Mountains. In 1838 the great majority of the tribe were deported from Georgia to west of the Missis. sippi, and now they occupy the north-east angle of Indian Territory (q.จ. ; and for the Cherokee Outlet, bought by government and thrown open to settle: ment in 1893, see OKLaномa). The Cherokees have a syllabic alphabet of eighty-five characters, invented in 1826 by George Guess or Sequoyah, a half-breed. They number about 17,000.

Cheroots. See Tовасco.

Cherry (Cerasus), a sub-genus of Prunus (see PLUM), of which the species and their cultivated varieties (see Cultivated Plants) yield the familiar stone-fruit of the same name. The most olvious distinction between the cherries and the plums or Prunus proper is that in the former the leaves are conduplicate, in the latter convolute in bud.

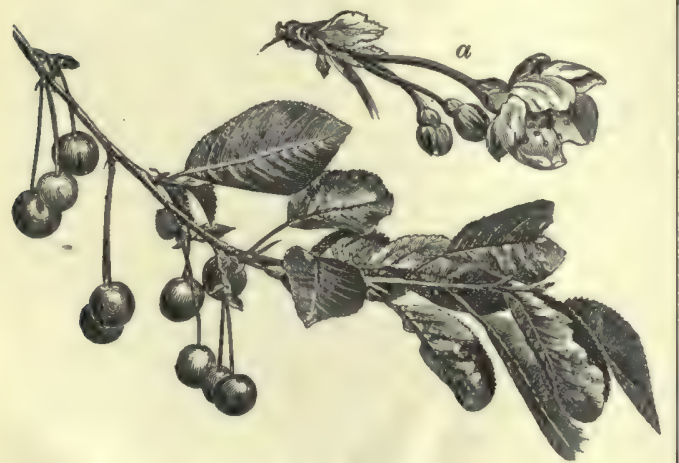

Common Cherry:

$$
a \text {, blossom. }
$$

Two species are chiefly regarded as the parents of the garden cherries usually cultivated, $P$. Avium and $P$. Cerasus, the former attaining a height of 40 or 50 feet, and having its leaves and peduncles drooping, with small austere fruit; the latter having erect smooth shining leaves and a more juicy fruit, but being a much smaller tree. Both have white flowers in clusters or nearly sessile umbels, and both are generally regarded as natives of middle and southern Europe, if not also of Britain, where they are both at anyrate also naturalised. According to the usual reading of Pliny, $\boldsymbol{P}$. Cerasus was, however, introduced by
Lucullus from Cerasus in Pontus to grace his triumph after his victory over Mithridates; Belon, however, plausibly identified this as his own cherry-laurel (see LAUREL). In the wild state, both are often called gean ( $\mathrm{Fr}$. guigne); more accurately, however, this is $P$. Avium. The latter is frequently planted, not only because it is exceedingly ornamental when in flower, but also on account of its value as a timber-tree, being of rapid growth, with firm strong closegrained wood, suitable for the purposes of cabinetmakers, turners, and musical instrument makers. Double varieties of both species are also grown in our shrubberies. The cultivated varieties of the cherry are very numerous, and differ considerably in size, colour, and flavour; opinions hence differ seriously as to their parentage. The fruit is largely eaten fresh, and as an ingredient in preserves, \&c. the woodentters and charcoal-burners in some parts of France make it a principal ingredient in soups. Besides its use for the dessert and for preserves, the cherry is extensively used for making liqueurs (see KIRSCHWASSER and MARASCHINo). Cherry Brandy is a liqueur made by steeping Morello cherries in brandy; whereas kirschwasser is a spirit distilled from cherries. In some parts of Germany the roads are fringed by avenues of cherry-trees; and the cherry ripens in Norway and East Bothnia as far north as $63^{\circ}$ lat. The other species of cherry are numerous. Some species are low or even prostrate shrubs, as $P$. chamacerasus, the Ground Cherry of the south of Europe and of Siberia; and $P$. pumila, the Sand Cherry of North America. The name cherry is also shared by the closely allied Birdcherry (q.v.) and Choke Cherry (q.v.), including the American Wild Cherry, famous for its medicinal bark; the Mahaleb ( $P$. Mahaleb) of the south of Europe, famous for the fragrance of its flowers, and grown in pots to make symmetrical pipestems; the Capollim ( $C$. or $P$. capollim) of Mexico and Peru, famed for the fragrance of its fruit ; and the Laurel-cherry (q.v.). The name cherry is also vaguely and popularly applied in different countries to plants of any kind which happen to recall the true cherry, especially by the size, colour, or taste of their fruit; among these, see Barbadoes Cherry, Winter Cherry, \&c. Thus the 'Native Cherry' of Australia is the fleshy fruit-stalk of Exocarpus cupressiformis (Santalacea), while the Hottentot Cherry is Ilex (Cassine) Maurocenia. The 'Beech Cherry' or 'Brush Cherry' of Australia is Trochocarpa laurina (Epacridacece), and so on.

Cherry-laurel. See LAurel.

Cherso, an island of Illyria, belonging to Austria, in the Gulf of Quarnero, 13 miles SSW. of Fiume. A bridge unites it with the adjoining isle of Lussin. Area, 127 sq. m. ; pop. (1880) 9550. On its rugged hills sheep are fed; there are large forests, and on the const, wine, olives, and fruits are produced. Cherso, the chief town, on the west side, has a spacious harbour. Pop. 4670 .

Cherson. See Kherson.

Chersone'sus, the ancient name of several peninsulas and promontories in Europe, the most important of which are the Crimea (q.v.), C. Taurica; Gallipoli (q.v.), C. Thracica; and Jutland (q.v.), C. Cimbrica. When we speak of the Chersonese, the Malay Peninsula is usually meant.

Chert, or HoRnstone, a variety of quartz, always massive, not unlike flint, but more brittle, breaking with a splintery fracture. It is common in limestones of Palrozoic age, but occurs also in Mesozoic strata (Jurassic, Cretaceous), sometimes forms rocks, and often contains petrifactions. It passes into common quartz and chalcedony, also 
into flint and flinty slate. It colours are gray, white, red, yellow, green, or brown. The name Chert is sometimes linited to the finer varieties, and the coarser are called Hornstone, - The name Chert is very commonly given to the siliceous concretions which oceur as nodules and layers in lime. stone rocks, much in the same way as flints in the chalk. When these materials exist to such an extent as to render the limestone useless for eco. nomical purposes, it is said to be 'cherty.'

Chertsey, a town in Surrey, near the right bank of the Thames, here crossed by a seven-arch bridge (1785), 21 miles WSW. of London. It is irregularly built, chietly consisting of two long cross-streets, and is surrounded by villas. The chief trade is in malt and flour. Many vegetables are raised for the London market. Chertsey arose in a monastery founded in 666 , and refounded in 964 by Edgar for Benedictine monks. Charles James Fox lived on St Anne's Hill, an abrupt elevation about a mile from the town; and the poet Cowley spent the elosing years of his life in Chertsey, in a house that is marked with an inseription. Pop. of parish (1861) 6589; (1891) 11,298.

Cherub (Heb, k'rübh), in the plural Cherubim or Cherubs, is the Hebrew name of a winged creature with a human countenance, which in the Scriptures is almost always represented in connection with Jehovah, and especially as drawing his chariot-throne. In Seripture the elerubim appear to be quite distinct from the angels, who are Jehovah's messengers, while the cherubim are found where God himself is personally present, and are the living bearers of God manifesting himself in his glory on the earth. It is possible to trace a development both of their form and their significance. While they are always conceived as living creatures, their perfectly free power of movement seems to suggest a connection with the thunder-clouds which reveal to the world the majesty of God. In the 18th Psalm it is said Jehovah 'rode upon a cherub, and did fly; yea, he flew swiftly upon the wings of the wind;' and elsewhere the clouds are called the chariot of Jehovah. To the Hebrew idea of the cherub (in this aspect of it) is allied the Indian conception of the bird Garuda, the swift bearer of Vishnu, and the swift-winged four-footed bird which in Eschylus carries Oceanus through the ether, as well as the (later) Greek and Roman representations of the griffins besring Apollo or Artemis. According to Sayce, the word is probably connected with the Assyrian kimubu, the name denoting the winged bull which guarded the honse from the entrance of evil spirits, and at the same time with kurubu, the 'circling' bird -i.e., according to Franz Delitzsch, the vulture. Phøenicia took the idea from Babylonia, and the two cherubs made for Solomon (1 Kings vi. 23-28) were wrought by Phonician artificers. Cherubim are mentioned in the Old Testament as guards of Paradise; a cherub with a flaming sword hindered the return of the expelled human pair. In the Holy of Holies cherubim wrought in embossed metal were represented above the mercy-seat, or covering of the Ark of the Covenant, so that they appeared to rise out of it. Figures of cherubiu were also wrought into the hangings of the Holy of Holies. The cherubim that appen in the visions of Ezekiel and the Revelation of John depart much from the early representations. In Ezekiel they have the boly of a man, whose head, besides a human countenance, has also that of a lion, an $o x$, and an eagle; they are provided with four wings, two of which serve to fly, while the other two cover the body; four human hands and arms are under the wings, and the whole body, before and behind, and on the hands and wings, as well as the wheels of their chariot, is spangled with innumerable eyes. In the Revelation, four cherubim, covered with eyes, and having six wings, surround the throne of Jehovah; the first has the face of a lion, the recond of an $0 x$, the third of a man, and the fourth of an eagle. As the Gospel is a unity, but fourfold, the four elements of the cherub came to be divided among the four evangelists, the human countenance being the rymbol of Matthew, the lion of Mark, the ox of Luke, and tlue eagle of John. Most Jewish writers and Christian Fathers conceived the cherubim as angels; and Dionysius the Areopagite, in his Celesticl Hierarchy, makes them a separate clase in the first hierarchy. Most theologians also considered them as angels, until Michaelis showed them to be a poetical ereation. Herder, in his Spirit of Hebrew Poetry, compared them to the griffins that watch treasures and other fabulous figures. In Christian art they are generally represented as sexless figures, with wings from the shoulders, the legs also being either covered by wings, or having wings substituted for them. Very often they have also an aureole round the head.

Cherubini, Maria Luigi Carlo Zenobio SALVATORE, an eminent composer, was born at Florence on the 8th or the 14th September 1760 , the tenth of a family of twelve children. He began to study music at the age of six, under his father, and at nine was sent to the academy of Bartolommeo Felici. Church works to the number of seventeen proceeded from his juvenile pen at this period, and were mostly actually performed in Florentine churches. In 1778 he went to Bologna and studied under the famous Sarti for four years, removing with him in 1779 to Milan; here he was grounded in the old Italian contrapuntal style, and also frequently assisted his master in writing minor parts of operas. In 1780 his own first opera, Quinto Fabio, was produced at Alessandrin, and for the next fourteen years a succession of dramatic works followed. In 1784 he was invited to London, and held the post of composer to the king for one year. In 1785 he visited Paris, and after another short visit to Turin, returned in 1788 to Paris, which remained thenceforth his home. Up to this period his operas had been in the light Neapolitan style of Paisiello or Cimarosa; they are now forgotten. But after his arrival in Paris a change lecomes gradually apparent, contemporaneously with and in the same direction as the development of the style of Mozart in Figaro and Don Giovanni. Cherubini, however, had no opportunity of hearing these works at this time, and advanced quite independently on the same path. This change is already distinguishable in his first Parisian opera, Demophon, given in 1788 , but is more distinctly developed in Lodoiska, which was received in 1791 with astonishment and admiration. Subsequent works were Elise (1794), Medée (1797), Les deus Journées (or 'The Water-carrier,' 1800), his operatic masterpiece, and Anacreon (1803). His lofty unbending manner, however, had excited a prejudice against him in the mind of Napoleon. He visited Vienna in 1805 , and made the acquaintance of Haydn, Beethoven, and Hummel. Two of his operas were produced there; but the war between Austria and Napoleon cut short his stay, and he returned to France dispirited. In 1808, on a casual visit to Relgium, he entered on a third periol of musical activity with the composition of the first of his great church works, the Mass in F. In December 1814 Louis XVIII. made him a knight of the Legion of Honour. Next year he paid a short visit to England which left a bad effect on his health. Shortly after, he succeeded 
to the post of maitre-de-chapelle to King Louis. The list of his works from this period comprises a Mass in C (1816), and Requiems in C and D ( 1817 and 1836), all of the bighest rank, besides numerous other church pieces, and six string quartets. In 1822 he became director of the Conservatoire of Paris, which his energetic administrative talent soon raised to the greatness it still preserves. His work on counterpoint and fugue appeared in 1835, and remains a standard book. His severe rule over the institution continued till 1842, when, after only a month's retirement, he died on 15th March. The universal feeling in musical Europe at the time was that its foremost figure was gone. Though the greater part of his career was run in Paris, and the most famous French operatic composers of the early part of the century, Boieldieu, Auber, Halévy, \&c., came under his instructions, he has not permanently influenced the French school; his music lives and preserves a strong hold rather in Germany, with the musicians of which he has more affinity. His style has been aptly called that of effect, the means employed being unusual harmonic and orchestral combinations, the agreement of the music with the dramatic situation, and a remark able architectural structure in point of form. $\mathrm{H}_{\mathrm{e}}$ is always careful, however, to keep within orthodox limits. As already indicated, his operas have numerous parallels with those of Mozart; but along with the lustre and polish of skilfully cut gems, they possess also somewhat of their coldness. The emotional element is often strong, but is always dominated by the intellectual. His artistic ideal was a lofty one, and he never stooped from it. His music commanded high admiration from Beethoven, who even took him as a model of style in composition for the voice. His masses and overtures are well known, and frequently performed in this country, and at least Medee and the Deux Journés have kept a place on the stage. The stern manner of the 'grim Florentine' finds illus. tration in his stereotyped reply to all requests in connection with his office, 'It cannot be done,' from which, however, he frequently departed ; and he inspired almost enthusiastic attachment in many of his pupils. The antagonism between him and Berlioz, on the other hand, is strongly brought out in the memoirs of the latter; and he was prejudiced against Beethoven. See the Life of Cherubini by Bellasis (1874); the Life by Pougin, which appeared first in Le Ménéstrel (1882-83), and vindicates him from the repellent asperity with which he has been reproached; and Crowest's Cherubini ('Great Musicians,' 1890).

Cherusci, a German tribe first mentioned by Cresar, whose exact locality is somewhat uncertain, save that they touched the Weser and lay north of the Harz Forest. They are chiefly memorable in connection with their great leader Arminius (q.v.).

Chervil (Anthriscus Cerefolium), an umbelliferous plant, which has been long cultivated, especially on the Continent, as a pot-herb, and used in soups and for a garnish, \&c. in the same manner as parsley. The leaves have a peculiar, somewhat sweetish, pleasantly aromatic smell and taste, by which the plant may be known from its congener Anthriscus vulgaris or Scandix Anthriscus, a poisonous weed, whose leaves have a disagreeable smell, and which is also distinguished by its hispid fruit. A. sylvestris has large roots, for the sake of which it is cultivated. The allied Venus' Comb or Shepherd's Needle (Scandix pecten-Veneris), often found in cornfields, as also $S$. australis of southern Europe, have a similar taste and smell, and are used in the same way on the Continent. Sweet Chervil or Sweet Cicely (Myrrhis odorata; Scandix odorata of the older botanists ), a native of the south of Europe and of some parts of Asia, common in the neighbourhood of houses in Britain, although probably not a true native, is frequently cultivated in Germany under the name of Spanish or Anise Chervil. In Scotland the plant is popularly called Myrh. Its smell is considered attractive to bees; and the insides of empty hives are sometimes rubbed with its leaves. to induce swarms to enter. -The species of Chærophyllum, cosrse weeds, are also called chervil.

Cherwell, a stream falling into the Isis or Thames near Oxford (q.v.).

Chesapeake Bay, in Maryland and Virginia, and dividing the former state into two parts, is the largest inlet on the Atlantic coast of the United States, being 200 miles long, and from 4 to 40 broad. Its entrance, 12 miles wide, has on the north Cape Charles, and on the south Cape Henry, both promontories being in Virginia. The bay has numerous arms, which receive many navigable rivers, such as the Susquehanna on the north, the Potomac, Rappahannock, and York on the west, and the James on the south-west. Unlike the shallow sounds towards the south, this network of gulfs and estuaries, with its noble feeders, affords depth of water for ships of any burden, virtually carrying the ocean up to the wharves of Baltimore and the arsenals of Washington.-For the Chesapeake and Shannon sea-fight, see BROKE.

Cheselden, William, a great surgeon and anatomist, was born in 1688, at Somerby, near Melton-Mowbray, and having in 1711 established himself in London as a lecturer on anatomy, was next year elected a Fellow of the Royal Society. He was afterwards appointed surgeon to St Thomas's, St George's, and Westminster hospitals, where he acquired great reputation, especially by his 'lateral operation for the stone' in 1727 (see LITHотомY). In 1728 he operated on a young man born blind, and the successful result of the operation did much to develop the theory of Vision (q.v.). He died at Bath, 10th April 1752. His four works included Anatomy of the Human Body (1713), long a text. book on the subject in England; and Osteolographia, or Anatomy of the Bones (1733). See an article in the Asclepiad (1886).

Chesham, a market-town of Buckinghamshire, 18 miles NW. of London. Pop. of parish (1891) 8018.

Cheshire, a maritime county in the west of England, on the Welsh border, bounded $\mathbf{N}$. by the river Mersey, separating it from Lancashire, and partly also by the Irish Sea. Its greatest length from north to south is $\mathbf{4 8}$ miles; greatest breadth from east to west, 32 ; total area of land and water, $1102 \mathrm{sq}$. m., of which 76 per cent. is under cultivation. The coast-line is confined to the hammer-headed peninsula, called Wirral, about 8 miles broad, between the estuaries of the Mersey and Dee. The surface forms an extensive nearly level plain between the Derbyshire and Welsh mountains, well wooded, and studded with small lakes or meres. This plain, comprising fourfifths of the surface, rests on new red sandstone, and is crossed, near the middle, by a tract of high ground running south-west from a promontory over. looking the Mersey, near the mouth of the Weaver, to Beeston Castle rock, $36 \&$ feet high. On the east border of the county is a line of new red sandstone hills. In the east are large tracts of peat, and much of the county is wet and rushy. Coal-measures appear on the Flintshire border, and also on the borders of Staffordshire and Derbyshire. The chief rivers are the Dee, Mersey, and Weaver, which are navigable. The Dee skirts the county on the west for 55 miles, and the Mersey on the north for 40 miles. The Weaver rises in the east part of the 
county, and runs 40 miles west-nortl-west to the Mersey. In addition to its river navigation, the county has an alimost unrivalled system of canals, and contains the greater part of the Manchester Ship Canal. It is well intersected by railways. The chief mineral products se rockealt and coal. The rock-salt, discovered in 1670 , and mined by gunpowder, is found near the Weaver and its loranchess, esprecially near Northwich (q.v.), and at Middlewich, Winsford, and Sandbach. Much salt is also made from brine-springs 20 to 40 yards ceep. Coal is worked near Chester and on the eastern borders of the county. Lead and copper mining is now almost extinet. In almost every part of the county freestone, limestone, millstone, and marl are found. The climate is moist. The soil is mostly a clayey or sandy loam, with marl and peat, and very fertile. The soil and climate are well fitted for pasturing, and dairy-farming is largely carried on, the county being noted for its cheese (see CHEEsE). About 90,000 cows are kept in Cheshire, capable of producing about 15,000 tons of cheese. In the cattle-plague of 1865-66 npwards of 70,000 cattle perished, 36,000 of these being slaughtered as a preventive measure. Pop. (1801) 194,305 ; (1841) 395,660 ; (1891) 730,052. There are extensive manufactures in the principal towns, especially Birkenhead, Congleton, Chester (the county town), Crewe, Macclesfield, Stalybridge, and Stockport. The county is formed into -eight parliamentary divisions, each returning one member, and includes the parliamentary boroughs of Birkenhead and Chester, with portions of the boroughs of Ashton-under-Lyne, Stalybridge, Stockport, and Warrington. It contains 503 civil parishes, and is mostly in the diocese of Chester. Cheshire has some Roman roads, tumuli, barrows, remains of religious houses, and many old eastles and halls. Egbert, in 828, added Cheshire to the Anglo-Saxon kingdom of Mercia. William the Conqueror erected Cheshire into a county palatine, under Hugh Lupus, with an independent parliament and eight barons. Henry VIII. subordinated it to the English crown; but Cheshire did not send representatives to the English parliament till 1549. See Ormerod's History of Cheshire ( 3 vols. 1819; new ed. 1875), and Earwaker's East Cheshive (1877).

Cheshunt, a large village of Hertfordshire, 14 miles $\mathrm{N}$, of London. It is famous for its rosegardens, and is the seat of a college, founded in 1768 by the Countess of Huntingdon (q.v.) at Trevecca in Brecknockshire, and removed hither in 1792. The buildings were much enlarged in 1868 . Pop. of parish (1881) 7735 ; (1891) 9620.

Chesil Bank or BEACH, a bank of gravel and shingle extending 16 miles from Bridport harbour and Burton Bradstock to Portland. It varies in height from 20 to 43 feet, and in width from 170 to 200 yards. For some part of its course it hugs the shore, but the Fleet comes between it and the land for nearly 10 miles from Abbotsbury, famous for its swannery. Towards its west end the bank is composed of sand, grit, and fine gravel, but the materials get gradually larger and larger as it is followed eastward. Good authorities believe this bank was formed by the sea as a shingle beach in the ordinary way, that it formerly touched the land throughout its entire course, and that it has since been separated from the shore, and converted into a bar, by the denudation of the land behind it. (See map at BrEAKWATER.)

Chesney, Francis Rawdon, the explorer of the Euphrates, was born in 1789 at Annalong in County Down. He was gazetted to the Royal Artil. lery in 1805. In 1829 he inspected the route for a Suez canal, which he proved to be practicable.
His first exploration of the route to India, by way of Syra and the Euphrates, wa made in 1831, and he made three other voyages with the same object. The idea wa taken up by govern. ment, who male a grant of $\$ 20,000$ after his first expeclition, but owing to the opposition of Russia it was never brought to a practical isaue. He commanded the artillery at Hong-kong from 1843 to 1847. In 1850 he published his Expedition for the Survey of the Rivers Euphrates and Tigris, and in 1868 a Narrative of the Euphrates Expedition. He died at Mourne, 30th January 1872. General Chesney's Life by his wife and daughter, edited by Stanley Lane-Poole, was published in 1885. - His nephew, Colonel Charles Cornwallis Chesney (1826-76), was the author of the wellknown Waterloo Lectures (1861), which were delivered by him as professor at Sandhurst. A younger brother of the latter, General Sir George Toukyns Chesney, K.C.B. (1830-95), was appointed member of the Council of the Viceroy of Indin in 1886 , and became M.P. for Oxford in 1892. He was the author of the clever jeu d'esprit, The Battle of Dorking (1871), and of a remarkable novel, The Private Secretary (1881).

\section{Chesnut. See Chestrut.}

Chess (Fr. echecs; Ital. scacchi; Ger. schach; Dutch schaak; Low Lat. ludus sccccorum. Originally from Persian shah, 'a king,' thus literally 'the game of kings'), a game of skill for two players or parties, played with figures or 'pieces,' which are inoved on a chequered board. The game has acquired a great and unique importance throughout the world; mainly, no doubt, in consequence of its extreme difficulty. It is the snbject of a most ex. tensive literature, and its study has become rather that of a science than a recreation. The laws governing its play are identical in all countries.

History. - The origin of chess is the subject of an almost hopeless controversy. It has been claimed, by writers and by legends, for China, India, Persia, and recently with some show of reason, by a Spanish archrologist, for Egypt. As a matter of fact, traces of the game extend beyond history, and are found among races so widely different that any scientific investigation of the matter may now be considered impossible. The game was probably introluced into Western Europe by the Arabs, or about the time of the Arab invasion (8th century); at all events it was known among the cultured classes before the Crusades (1095). As then played, it differed somewhat from modern chess and from the game as played in the East. One of the earliest references to it in literature is in a work, written about 1300 , by Jacobus de Cessolis, a preaching friar, and entitled Liber de moribus hominum et officiis nobilium super ludo Screcorum. This work seems to have found its way into several European countries, MS. copies of it existing in various languares. An English translation from the French was printed by William Caxton in 1474-75 under the title of The Game and Playe of the Chesse, and was the first book printed with metal types in England. Modern chess-i.e the game as now played, dates from about the middle of the 15 th century. A MS. discovered in the university library of Göttingen and dated 1490 is the earliest treatise extant, although frequent mention of chess is male by earlier pwets and writers. The game found its first home in Spain, where Vicent (1495) and Lucens (1497) pub. lished two volumes, now of little value, of games. They were succeeded in 1510 by Damiano, a Portuguese, whose work, though restricted to a few openings, evinces considerable genius. It was plagiarised most unserupulously by several later writers. Damiano was followed by Ruy Lopez, a cleric of Safra in Estremadura, who is perhaps 
the most valuable of the earlier masters. His work, first published at Alcala in 1561, may be said to have laid the foundation of the modern theory of play, and the opening which bears his name is that which modern analysis has shown to be one of the soundest yet invented. Lopez's treatise was republished in Venice in 1584, and from this date the game seems to have left Spain to find a home in Italy. Here should be mentioned Paolo Boi, a native of Syracuse, who, finding no worthy opponent in his own country, made a lengthened tour through the then most civilised part of Europe. $\mathrm{He}$ encountered and defeated every master of the game, including the hitherto invincible Ruy Lopez. His genius, added to a prepossessing appearance and a courteous demeanour, gained for him general admiration; he was patronised by Catharine de' Medici and by Sebastian, king of Portugal, both of whom conferred high favours upon him. The early Italian school, which extended from about 1550 to 1620 , is identified with the names of Polerio (1590) and his followers, Salvio, Greco, and others. It may claim to be the most versatile and prolific yet founded, some of the most brilliant openings having come down to us from it. At its close, about the time of the Thirty Years' War, the study of chess was somewhat neglected, and there are no writers of note until the middle of the 18th century. At this time, however, two powerful, and to some extent rival, schools sprang up-the later Italian, led by Ercole del Rio and his commentators, Lolli and Ponziani, and the Northern school of Philidor. The former still confined itself to the study of openings and end-games; the latter turned its attention more to the middle game, advocating what is now known as ' play for position.' Both schools, though opposed in theory, were of the greatest practical benefit to students; their work was in a great measure combined by Allgaier, of Eltern, in his well-known treatise published at Vienna in $\mathbf{1 7 9 5 .}$

Begun in 1745 by Stamma, a Syrian, and led so powerfully by Philidor, the English school had, during this period, been steadily gaining strength and importance. Writers like Sarratt, Cochrane, Lewis, and Walker were doing their best to popularise the game, and they succeeded in giving it a footing in Britain which it has never since lost. Throughout northern Europe its study beeame general; in France, though there were few analytical writers-Alexandre being the only one of importance-such players as Deschappelles, Boncourt, and De la Bourdonnais earned for the Parisian school a very high reputation; the last-named player was by far the strongest of his day. In Germany, then as now, chief attention was given to theory; there were no very brilliant players, but the analytical work of Bilguer and Von der Lasa still remains the standard. England, however, continued to maintain its supremacy. Some of the greatest European players crossed the Channel and settled in London, and Howard Staunton, who defeater. the French champion, St Amant, came to be regarded as the leading player in the world. Up to this time America had produced no player of more than local eminence; but at the congress held at New York in 1858, the first prize in the chief tourney was won by a youth of twenty-one, Paul Morphy (1837-84), of New Orleans. This player, who from the age of ten had shown a remarkable aptitude for the game, is admitted to be the greatest chess genius that has yet appeared. After his victory in New York he came over to Europe, meeting and defeating in turn the strongest players of London and Paris. It must always be a souree of regiet that the world so soon lost his wonderful power. After his visit to Europe he abandoned the game in order to follow his profession, that of advocate. He only partially recovered from an attack of insanity, and died at the age of fortyseven. From this time the history of chess ceases to be that of a few celebrated players, and must be gathered from the magazines and weekly newspaper columns devoted to it in nearly every civilised country. Public interest in it has of late years increased with great rapidity, keeping pace, it would seem, with the progress of intellectual development. In England, where at one time or other nearly every great modern player has resided, the game has attained a dignity and importance altogether beyond that of a mere pastime, and its recognition by the state as a means of mental training has been seriously demanded. Every town and many villages have at least one clubLondon having upwards of twenty; and such centres as Dublin, Glasgow, Liverpool, and Manchester, five or six. There are also numerous county and district associations, holding periodical meetings in different towns in their provinces, and offering prizes for competition among their members. The British Chess Association, the most important federation of this kind, may fairly claim to represent national chess. Having its administrative centre in London, it is governed by a committee of the most eminent players throughout the kingdom, and its masters' tournaments attract the strongest playens from the Continent and America. In Germany, where almost equal enthusiasm for chess prevails, every town has its club; there are many state and class associations; national tournaments are held at least once every year, and international tournaments in turn with other countries. One significant association is that of the university and college chess clubs, which, supported by many of the professors and more advanced students, are already beginning to compete with the lay clubs in their respective cities. In France there are yet few provincial clubs, though their number is now increasing. Paris is the centre of a very strong circle of players, and in the Café de la Régence possesses the most celebrated chess resort in Europe. The French govern. ment has shown its regard for the game by providing prizes in more than one national tournament. Among other European countries where chess is studied, must be mentioned Austria and Italy. Of the former it is sufficient to say that the metro. politan club ean produce ten players (the ordinary match team) who could probably defeat the same number from any club in the world. In Italy the game is played in every town, and the Italian Chess Association holds an annual tournament. In the New World, the United States of America is, as may be supposed, in advance of all other countries. Besides numerons city clubs. (New York alone having nine), there are six state associations, and a recently organised federation of the university clubs, In Canada the game has gained entrance into the public schools; there are clubs in nearly every town, and a national association. In Australasia there are state associations in Victoria, New South Wales, and New Zealand. A national tournament has been. held with great success, and it is probable will now take place annually in one or other of the. chief cities.

Description.-THE BOARD.-Chess is played on a square board divided by intersecting lines into 64 squares. To facilitate calculation, every alternate square is black, or of a dark colour. The board should be placed so that each player has a white square at his right-hand corner.

The MEN.-There are 32 men : 16 white, or of light colour, and 16 black, or of dark colour. Each player has 8 pieces (one king, one queen, two rooks or castles, two bishops, and two knights) 
and 8 puums. The following diagram repreaents the board and men properly arranged for play:

\section{BLACK.}

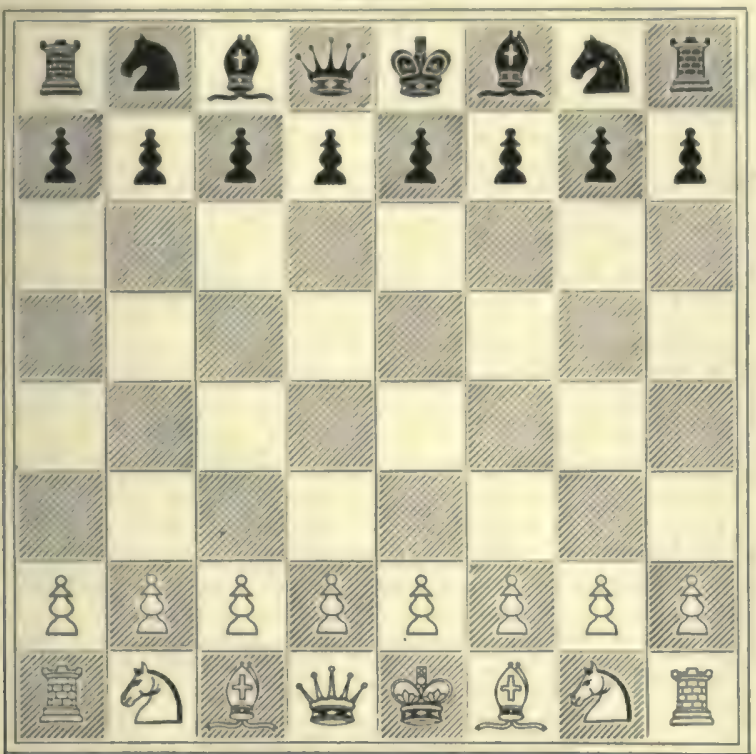

W HITE.

Fig. 1.

(N.B.-The king and queen occupy the two middle squares, the queen being on the square of her own colour.)

The King, = K, moves only one square at a time, but in any direction.

The Queen, $=\mathbf{Q}$, may move any number of squares in any direction in a straight line.

The Rook or Castle, $=\mathbf{R}$, may move any number of squares, but only in a direction parallel to the sides of the board-not diagonally.

(1) The Bishop, $=\mathbf{B}$, may move any number of squares in a straight line diagonally. (It will be seen that each bishop remains

The Knight, = Kt (or sometimes in American literature, S, from the German Springer), moves to the next square but one of different colour from that on which it rests. Its move forms the diagonal of a parallelogram of three squares by two. (The knight is the only piece having power to move over an intervening piece.)

8 The $\mathbf{P a w n},=\mathbf{P}$, moves one square forward only, but captures diagonally. For its first move, but not afterwards, a pawn may move two squares, but if in doing so it pass an opposing pawn, the latter may take it as if it had moved one square only. A pawn which succeeds in crossing the board must be exchanged for a queen or any other piece of the same colour, except a king.

All pieces, except the knight, can move only across unoccupied squares, and all pieces (not the pawns) eapture in the direction of their moves.

The object of the game is to take the opponent's king, and when the king is attacked, warning must be given by the call of 'check.' If the king cannot avoid the 'check'-that is, if he cannot escape capture by his opponent's next move, he is 'check. mate, and the game is over. The game therefore always stops one move short of the actual capture of the ling.
Lnus. - Although the main rules governing cluws play are identical throughout the world, there are several ininor questions a waiting a goneral settlement. A complete code of laws (which would necessarily be complex), published with approval and anthority of the various nationsl associations, has become almost a necesiaty." Where no pub. lished code has been fixed upon, the follow. ing may be enforced without injustice:

$(N . B$. - In cases where no distinction is implied, the word "piece' in to be understood to include piece and pawn.)

Lots to be drawn for finst move, and afterwards thronghout a match or sitting each player has the first move alternately, whatever has been the result of the previous game. The player having finst move has a right to choice of men. If bosrd or pieces have been wrongly placed at the beginning of a game, the mistake may be rectified before four moves have been made, but not after. A piece touched must be moved, if it can be legally, or unless, before touching it, the player say jadoube, or words to that effect. (If the piece cannot be legally moved, the king must be moved, but may not castle.) If more than one piece be touched, the adversary may select which is to be moved. An enemy's piece touched must be taken if it can be legally ; if not, the king must be moved, but may not castle. Moving the king is a penalty enforcesble by the opponent, who must, however, enforce it before he makes his next move. A false or illegal move, and all moves made subsequently, must be revoked, and legal moves made in their stead. No penalty can be enforced if the opponent has made a move or touched a piece in reply. If a player move out of his turn, he must retract the move, but may be called upon by the opponent to play the piece touched on his next move. If a player touch more than one square with a piece, he may not, for that move, play it to any of the squares so touched. If he touch all the squares to which it can be played, he must play it to any one of them his opponent chooses. In castling, the king must be moved first, or both pieces together. A pawn advanced to the eighth square must be exchanged for a piece (not a king) of the same colour, and the move is not complete until a piece is demanded. It is not necessary to call 'check,' but the player neglecting to do so, cannot enforce a penalty if his opponent does not notice the 'check.' A player may at any time call upon his adversary to mate him within fifty moves, and if at the expiration of such fifty moves, no capture has been made, no pawn moved nor mate given, a draw may be claimed. Bystanders may not interfere unless appealed to by a player, unless board or men have been wrongly placed, or unless a false or illegal move has been made. In the last case, however, they have no right to interfere until a move has been made in reply.

Notation.-The necessity for some method of recording moves and games of chess has been re. cognised from a very early period. It is to be regretted that no universal notation has been alopted; as it is, the systems which are in vogue are all more or less dependent upon the language of the nation nsing them. The modern systems of notation are separable into two classes, which differ essentially: The first, that adopted by English and Latin speaking countries (France, Italy, \&c.), has reference to the pieces. It is somewhat cumbrous, but is more descriptive and intelligible. The second, adopted by Germany and northern Europe, has reference mainly to the 
board. It is more concise and exact than the first class.

The following diagram will explain the English or Latin system of notation:

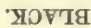

\begin{tabular}{|c|c|c|c|c|c|c|c|}
\hline $\begin{array}{l}\text { - } в \text { y } \\
\text { Q R } 8\end{array}$ & $\begin{array}{l}\text { Бв 7.8 } \\
\text { Q Kt } 8\end{array}$ & $\mid \begin{array}{l}b 8 \mathrm{go} \\
\mathrm{Q} B 8\end{array}$ & $\begin{array}{c}\cdot 680 \\
88\end{array}$ & $\begin{array}{l}\cdot 68 \text { Y } \\
\text { K } 8\end{array}$ & $\mid \begin{array}{l}\cdot \text { bs gr } \\
\text { K B } 8\end{array}$ & $\left|\begin{array}{l}\text { 6в ту प } \\
\text { K Kt 8}\end{array}\right|$ & $\mid \begin{array}{l}\text { bs yृत्र } \\
\text { K R } 8\end{array}$ \\
\hline 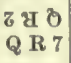 & $\begin{array}{lll}8 & 7 \mathrm{Y} & \mathbf{8} \\
\mathrm{Q} & \mathrm{Kt} & 7\end{array}$ & 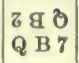 & $\begin{array}{l}88 \\
87\end{array}$ & $\begin{array}{l}\mathbf{8 Y} \\
\mathrm{K} 7\end{array}$ & $\begin{array}{lll}\begin{array}{l}6 \\
\text { K }\end{array} & \mathbf{Y} \\
\mathrm{B} & \mathbf{7}\end{array}$ & $\mid \begin{array}{lll}7 & 7 \mathrm{Y} & \mathrm{Y} \\
\mathrm{K} & \mathrm{Kt} & \mathbf{7}\end{array}$ & 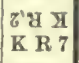 \\
\hline $\begin{array}{l}8 \text { भ } 8 \\
Q R 6\end{array}$ & $\begin{array}{l}87 \mathrm{Y} \mathrm{O} \\
\mathrm{Q} \mathrm{Kt} 6\end{array}$ & $\mid \begin{array}{lll}8 & 8 & 0 \\
Q & B & 6\end{array}$ & $\begin{array}{l}80 \\
Q 6\end{array}$ & $\begin{array}{l}8 \mathrm{H} \\
\mathrm{K} 6\end{array}$ & $\begin{array}{lll}8 & \text { \& } & \text { X } \\
\text { K } & \text { B } & 6\end{array}$ & $\left|\begin{array}{ccc}8 & 7 \mathbf{X} & \mathbf{X} \\
\text { K } & \text { Kt } & 6\end{array}\right|$ & $\mid \begin{array}{lll}8 & \text { y } & \text {. } \\
\text { K } & \text { R } & 6\end{array}$ \\
\hline $\begin{array}{l}\text { 5 ช } 8 \\
\text { Q R } 5\end{array}$ & $\begin{array}{l}7 \mathrm{Y} O \\
\mathrm{Q} \mathrm{Kt} 5\end{array}$ & $\begin{array}{l}7 \mathrm{~g} \\
\mathrm{Q} B\end{array}$ & $\begin{array}{l}70 \\
Q 5\end{array}$ & $\begin{array}{l}\text { Y } \\
\text { K } 5\end{array}$ & $\mid \begin{array}{lll}\mathbf{B} & \mathbf{y} \\
\mathrm{K} & \mathrm{B} & \mathbf{5}\end{array}$ & $\mid \begin{array}{cc}7 \mathbf{Y} & \mathbf{Y} \\
\mathbf{K} & \mathbf{K} \\
\end{array}$ & $\begin{array}{lll}\mathbf{F} & \boldsymbol{u} & \mathbf{Z} \\
\mathrm{K} & \mathrm{R} & \mathbf{5}\end{array}$ \\
\hline $\begin{array}{lll}9 & 4 & 8 \\
Q & R & 4\end{array}$ & $\begin{array}{l}97 \mathrm{Y} \\
Q \\
Q\end{array}$ & 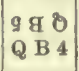 & $\begin{array}{l}98 \\
Q 4\end{array}$ & $\begin{array}{l}9 \text { प } \\
\text { K } 4\end{array}$ & $\mid \begin{array}{lll}9 & \mathbf{g} & \mathbf{X} \\
\mathbf{K} & \mathbf{B} & \mathbf{4}\end{array}$ & $\left|\begin{array}{ccc}9 & 7 \mathbf{X} & \mathbf{X} \\
\mathbf{K} & \mathbf{K} & \mathbf{4}\end{array}\right|$ & $\mid \begin{array}{lll}9 & \text { d } & \text { प्र } \\
\text { K } & \text { R } & 4\end{array}$ \\
\hline $\begin{array}{lll}9 & \mathrm{H} & 0 \\
\mathrm{Q} & \mathrm{R} & 3\end{array}$ & 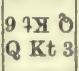 & $\begin{array}{lll}9 & 9 & 8 \\
Q & B & 3\end{array}$ & $\begin{array}{l}90 \\
Q 3\end{array}$ & $\begin{array}{l}9 \text { Y } \\
\text { K } 3\end{array}$ & $\left|\begin{array}{lll}9 & \text { g } & \text { X } \\
\text { K } & \text { B } & 3\end{array}\right|$ & $\mid \begin{array}{lll}9 & 7 \mathrm{Y} & \mathbf{Y} \\
\mathrm{K} & \mathrm{K} & \mathbf{t}\end{array}$ & $\begin{array}{lll}9 & \text { भ } & \text { ㅍ } \\
\mathrm{K} & \mathrm{R} & \mathbf{3}\end{array}$ \\
\hline $\begin{array}{lll} & \text { ห } & 0 \\
Q & R & 2\end{array}$ & $\mid \begin{array}{lll}2 & 7 \mathbf{Y} & \mathbf{O} \\
\mathrm{Q} & \mathrm{K} t & 2\end{array}$ & $\begin{array}{lll}4 & 9 & 3 \\
Q & B & 2\end{array}$ & $\begin{array}{l}40 \\
Q 2\end{array}$ & $\begin{array}{l}L Y Y \\
K 2\end{array}$ & $\begin{array}{l}L \text { g } X \\
\text { K B } 2\end{array}$ & $\begin{array}{l}L \text { ' Y X } \\
\text { K Kt } 2\end{array}$ & $\begin{array}{l}2 \text { \& } \quad \text { X } \\
\text { K R } 2\end{array}$ \\
\hline $\begin{array}{l}8 \text { y } \\
\text { QR } \\
\text { sq. }\end{array}$ & {$\left[\begin{array}{lll}8 & 7 \mathrm{~K} & 0 \\
\mathrm{QKt} & \mathrm{Kq}\end{array}\right.$} & $\left|\begin{array}{lll}8 & 9 & 0 \\
Q & B & \text { sq. }\end{array}\right|$ & $\begin{array}{c}80 \\
Q \mathrm{sq} .\end{array}$ & $\begin{array}{c}8 \mathrm{Y} \\
\mathrm{K} \\
\mathrm{sq}\end{array}$ & $\begin{array}{l}8 \mathrm{~g} \text {. } \\
\mathrm{KB} \mathrm{sq}\end{array}$ & $\mid \begin{array}{l}8 \text { 7Х } \\
\text { KKt sq }\end{array}$ & $\begin{array}{l}8 \boldsymbol{H} \text { X } \\
\mathrm{KR} \text { sq. }\end{array}$ \\
\hline
\end{tabular}

WHITE.

The squares on the first rank are named after the pieces which occupy them at the beginning of the game; thus (beginning at the left hand) the first square is ealled the queen's rook's square $=\mathrm{Q} R \mathrm{Rq}$., since it is occupied by the queen's rook. The second square is called queen's knight's square = Q Kt sq.; the third, queen's bishop's square = Q B sq; the fourth, queen's square $=\mathrm{Q}$ sq., and so on. The squares on the first rank are called home squares. The files are numbered according to their distance from the home square, and take the latter's title. Thus the squares in front of the king's square are called king's second or $\mathrm{K} 2$, king's third $=K 3$, and so on to $K$ 8. Each player numbers the squares from his own side of the board, so that each square has two names (White $K$ B square is Black $K$ B 8 , Black $Q R 4=$ White Q R 5, \&c.). A reference to the diagram will make this clear.

In recording a game, the moves of White and Black pieces are each arranged in column, the name of the piece is then given, and the square is indicated to which it moves-e.g. :

White.

1. P to K 4.

2. Kt to K B 3 .

3. B to B 4 .

4. B takes P (ch.).
Black.

1. $\mathrm{P}$ to $\mathrm{K} 4$.

2. Kt to $\mathrm{Q} B 3$.

3. $\mathrm{B}$ to $\mathrm{B} 4$.

4. $\mathrm{K}$ takes $\mathrm{B}$.

Here the figures give the number of the move, and $1 \mathrm{P}$ to $\mathrm{K} 4$ signifies that White for his first move plays a pawn to the king's fourth square. It is not necessary to say which pawn, since only one-i.e. the king's pawn-can be moved to the king's fourth square. Black then has to play, and makes a similar move, counting from his side of the board. For his second move, White plays his knight to king's bishop's third square, and again it is not necessary to say which knight, since only the king's knight can move to K B 3. Black's second move is his queen's knight to queen's bishop's third square. White's third move is king's bishop to queen's bishop's fourth square. The student

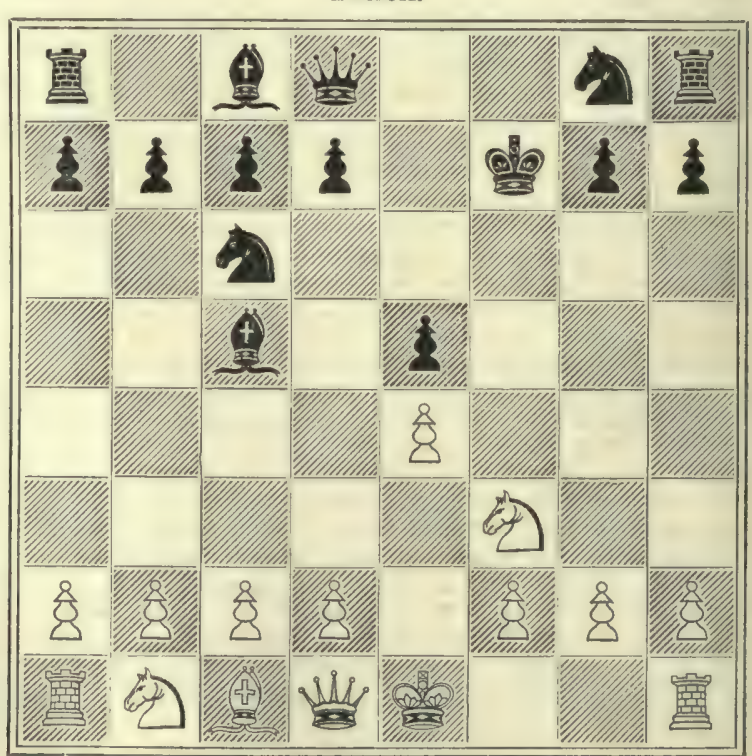

WHITE.

Fig. 3.-Position after Black's Fourth Move.

The German notation (known sometimes as Philidor's, from having been used in that master's treatises on chess) consists in denoting the ranks 
of squares by a figure, and the files by a letter, in accordance with lig. 4 :

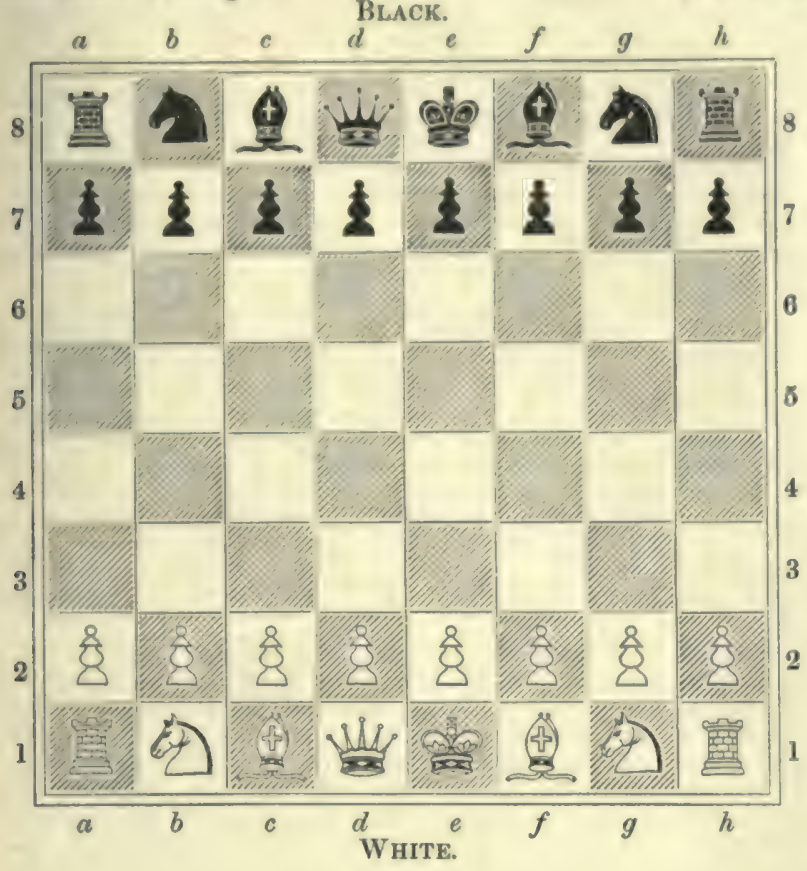

Fig. 4.

Cartling, a double move allowerl once on the part of each player in a gane. The rook in moved to the sunare next the king, and the king is then moved to the other wide. Figs. 5 and 6 show the operation of castling :

The conditions under which castling is allowed are: $(a)$ That neither king nor rook have been moved; $(b)$ that no piece intervenes; $(c)$ that the king is not in check; (d) that the king does not cross a square commanded by an opposing piece or pawn.

Check, the warning which must be given when the opponent's king is attacked.

Checkmate, a position in which the king cannot avoid capture on his opponent's next move. Checkmate is from the Persian shah mat, 'the king is dead.'

Discovered check, an attack which is opened on the king by the removal of an intervening piece or pawn.

In the diagram ( fig. 7 ) the king is not in check ; but if the rook be moved, the diagonal with the bishop is opened, and the rook is said to 'discover check.'

En passant. - A pawn which, having moved two squares for its first move, and thus passed an opposing pawn, may be taken, on the next move only, by the latter, en passant.

En prise. - A piece is said to be en prise when it is in a position to be captured by an opposing piece or pawn, and is not properly defended.

Thus, referring to the English system, the White Exchange, the capture of a piece in return for the king's square is denoted by $e$, the Black queen's loss of one of equal value. To "win the exchange" square by $d 8$. In the German system all the squares are counted from White's side only. To denote a move, the first letter of the piece is given, then the square on which it stands, and lastly, the square to which it moves. The moves of pawns are not preceded by any initial letter. A capture is denoted by a colon placed after the move, check is represented by $t$, or a check and capture by $\ddagger$ Castling on the king's side is denoted by $\mathrm{O}-\mathrm{O}$, and on the queen's side by $\mathrm{O}-\mathrm{O}-\mathrm{O}$. Taking the same moves as before, the game would be recorded therefore as follows:

$$
\text { White. }
$$

1. $e 2-e 4$

2. Kt $g 1=f 3$.

3. B $f 1-c 4$.

4. B $c 4-f 7 \neq$
Black.

1. $e 7-e 5$.

2. Kt $b 8-c 6$.

3. B $f 8-e$.

4. K $\& 8-f 7$ :

This system may be and is in some cases still further abbreviated by the omission $(\alpha)$ of the initial letters of the pieces, or $(b)$ of the square from which the piece moves ; and the moves may also be written in line or fractionally as in the Latin system.

Technical Terms. - The following list is not exhaustive, only the terms in general use being given :

Blindfold Chess, or Chess sans voir, the game played mentally, without sight of board or men. This almost inexplicable feat is not altogether one of memory, as is generally supposed; it is rather the result of a special faculty not necessarily corresponding with that for ordinary chess. Some great masters, notably Mr J. H. Blackburne, of London, can conduct as many as twelve games blind. fold simultaneously; and most players of first and second rate strength ean play at least one in this way.

Fig. 5. - Castling with King's Rools. $a$, before.castling.

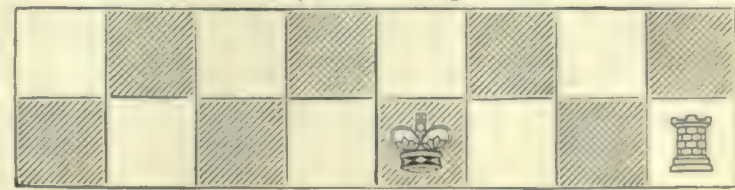

b, after castling.

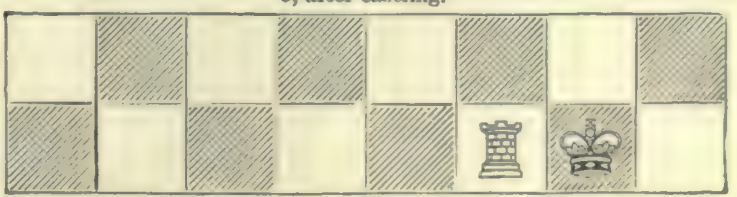

Fig. 6. -Castling with Queen's Rook. $a$, before castling

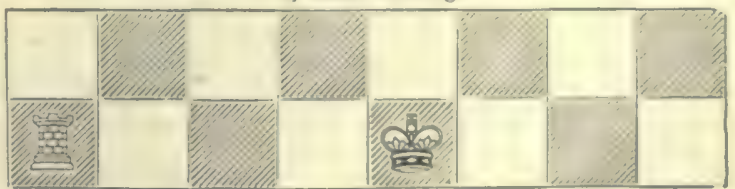

b, after castling.

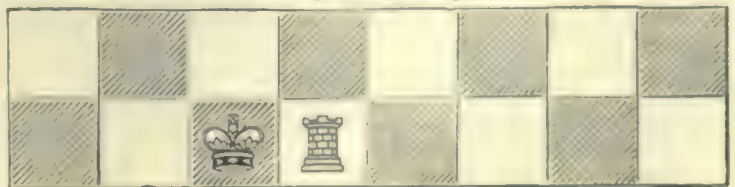

is to capture a rook in return for the loss of a bishop or knight. To 'lose the exchange' is to capture a bishop or knight in return for the loss of a rook. 
Gambit, a game in which one player, at the beginning, voluntarily sacrifices part of his force (often a pawn) for the sake of an ultimate advantage.

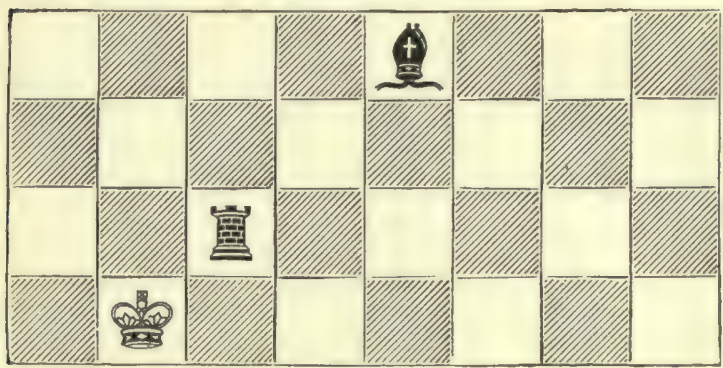

Fig. 7.-Discovered Check.

Jadoube, an expression necessary before a piece or pawn may be touched for the purpose of adjustment, \&c. The rule otherwise is that a piece or pawn touched must be moved.

Opening. - The various methods of beginning the game have been the subjects of much study, and are 80 complex as to elude anything like exhaustive analysis. Openings are classed as: (a) Gambits (see above), (b) Games, in which the line of play does not involve any sacrifice, and (c) Defences, which have reference to the line of play adopted by the second player. Openings in which both players move the king's - pawn to king's fourth square for their first moves are arbitrarily classed as 'Regular,' all others as 'Irregular.' All openings of repute have distinctive titles, often being named after their inventors or from some country where they are popular. Steinitz Gambit, Scotch Game, French Defence, are examples. The study of openings is most difficult and practically endless, and should not be begun until the student has some practical acquaintance with the game.

Problem, an imaginary position in which the winning line of play is artfully concealed, and has to be discovered in accordance with given conditions.
Black (4 pieces).

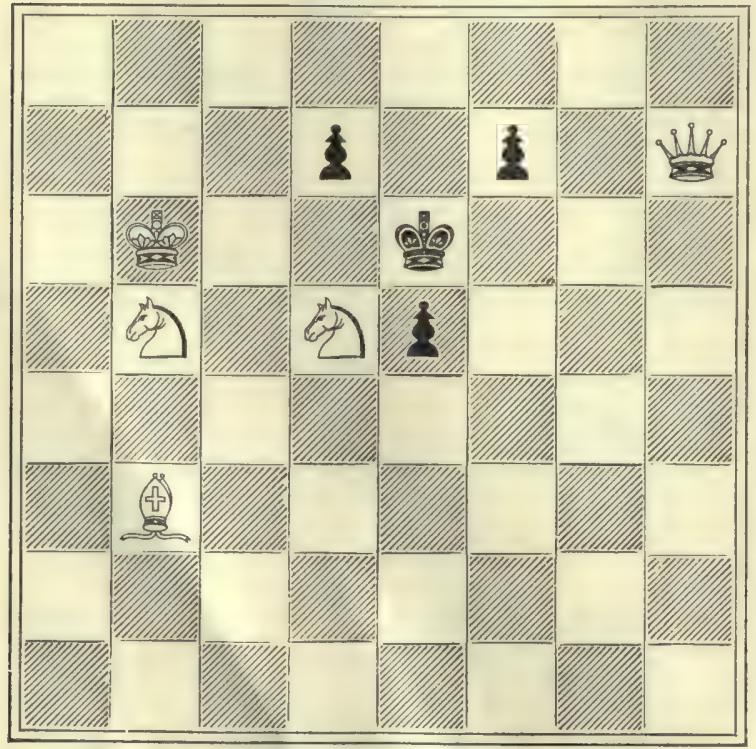

WhIтк ( 5 pieces). White to play and mate in two moves.

Fig. 8.-Problem by W. Skinkman (Key move, B to R4). another piece. (Of course \& queen is selected in most cases, as the most valuable piece.)

Stalemate, a position in which the king, though not attacked, cannot move without being subject to capture, and in which no other move by any other piece or pawn is possible. The game in this case is drawn.

Time Limit, a condition of modern play under which each player is compelled to make a certain number of moves (generally twenty) in each hour. The time is recorded by an ingenious arrangement of clocks, one being set going when the other is stopped.

See The History of Chess, by Forbes (1860); Geschichte des Schachspiels, by Van der Linde (Berlin, 1880); Falkener, Games, Ancient and Oriental (1892); The Chess Player's Handbook, by H. Staunton (1847-49); Chess Openings (1889) and Chess Endings (1892) by Freeborough and Ranken; works by Gossip (1894), Green, Mortimer, \&c. ; Handbuch des Schachspiels, by Bilguer and Von der Lasa (Leip. 1843 ; 6th ed. 1880); Fithrer durch die Sehachtheorie, by O. Cordel (Berlin, 1888): Cook's Synopsis; Book of the London Tournament, 1883; The Chess Problem, by Planck and others. See also the Chess magazines.

Chest, or Thorax, in Anatomy, is the part of the body which lies beneath the neck and above the Abdomen (q.v.), constituting the uppermost of the two divisions of the trunk, or that which contains the heart and lungs. The chest is somewhat conical in form. Its sides are rounded, but in front and behind they are flattened. The apex, or upper end, is truncated, sloping downwards and forwards; of small size, it permits of the passage of the gullet, windpipe, certain large veins and nerves from the neck into the chest, and of certain large arteries out of the chest. The broad or lower end of the cone slopes downwards and backwards, and is shut in by the diaphragm-a large muscular partition which projects upwards from the lower ribs, being convex towards the chest, and concave towards the abdomen. In Respiration (q.v.) the diaphragm descends by its own muscular contraction, while at the same time the ribs are drawn upwards and outwards by the intercostal museles.

The structures forming the walls of the chest are: (1) The backbone or spinal column; (2) twelve pairs of ribs; (3) the sternum or breastbone; (4) the Diaphragm (q.v.); and (5) the intercostal muscles. See Skeleton, Spinal Column, \&c.

The contents of the chest are the heart, the great arteries and veins, the lungs, the trachea or windpipe, the bronchi or branches of the trachea, leading to the lungs, the œsophagus or gullet, and the thoracic duct, or general terminus of the lymphatic system of vessels, by which the chyle and lymph are discharged into the blood. For the organs of the chest, see the cut at ABDoMEN.

The very great importance of these parts to life, and their great liability to deranged action, renders the chest the seat of a large proportion of the diseases which afflict humanity, and especially of those which end in death; for of the three organs which Bichat called the 'tripod of life' - viz. the brain, heart, and lungs - the chest contains two. The diseases of the chest, depend in some cases on alterations in its form, as by Rickets (q.v.) and other diseases affecting the bones in early childhood or in youth, as by too tight lacing in girls. Queening a pawn, the promotion of a pawn | What are commonly called chest diseases are which has crossed the board, to the power of mainly those of the lungs and air-tubes, of which 
the principal are consumption, pneumonia, pleurisy, and bronchitim. These are treated in special urticles : and for the diseases of the heart and other organs of the chest, see Heart, Aonta, CEsophagus, sc. The examination of the chest in disease is largely conducted by Auscultation (q.v.) and Percussion (q.v.). For measurement round the chest, see MaN. See also Diagnosis.

Chest, Military, is a technical name for the money and negotiable securities carried with an army, and intended to defray the current expenses. In the British army it is in the charge of officers of the Army Pay Department.-Chest at ChathaM was the name of a fund for maimed and superannuated seamen, administered at Chatham from 1590 till 1803, and subsequently at Greenwich, till superseded by the regular naval pension system.

Chester, an ancient episcopal eity, municipal and parliamentary borough, and river-port, the capital of Cheshire, on the right bank of the Dee, 22 miles from the mouth of its estuary, 16 miles SE. of Liverpool, and 179 miles NNW. of London. Chester is one of the most picturesque towns in England. It stands on a rocky sandstone height, and is still surrounded by the entire circuit of its ancient walls, nearly 2 miles round, 7 or 8 feet thick, and forming a promenade with parapets, where two persons ean walk abreast. The ancient gateways have been all rebuilt. The castle, with the exception of 'Cresar's Tower, 'has been removed, its site being occupied by barracks and county buildings. The Dee is crossed by two bridges, the old picturesque bridge of seven arches, and the new or Grosvenor Bridge, with a noble single arch of stone 200 feet in length (see BRIDGE, Vol.II. p.437). The two main streets cross each other at right angles, and were cut out of the rock by the Romans 4 to 10 feet below the level of the houses. These streets exhibit the curious arrangement called the 'rows:' the front parts of their second stories, as far back as 16 feet, form a continuous paved promenade or covered gallery, open in front, where there are pillars and steps up from the street below, with private houses above, inferior shops and warehouses below, and the chief shops of the town within. There are a considerable number of the picturesque old timber houses of the 16 th century, and many of the more modern buildings are in the aame style of architecture. Chester Cathedral is an irregular massive structure of crumbling sandstone, 375 by 200 feet, with a massive tower of 127 feet. It was formerly the church of the abbey of St Werburgh, which for 650 years was one of the richest in England. It became a cathedral church after the dissolution of the monasteries. It is of various dates from Norman to Late Perpendicular, its most strik. ing feature being the fine Perpendicular window of the west front. The building has undergone extensive restoration under the direction of the 'late Sir Gilbert Scott. A part of St John's Church, a ruined Norman edifice, has lately been restored. It was a cathedral church for some years during the 11th century, when the See of Lichfield was temporarily transferred to Chester. The present bishoprio of Chester dates from the reign of Henry VIII. Other public buildings are the town-hall, the Grosvenor Hotel, the general pant-office, the free library, and the music-hall. Suburbe of villas have recently prisen outaide the walls ; and a public park was opened in 1867. On the common called the Roodee there is a racecourse. The huge rail. way station, with a frontage of 1010 feet, is the centre of several iniportant railways. Chester has manufactures of lead, oil, and chemicals, iron. foundries, and an iron-shipbuilding yard. The making of boots and shoes is an important industry. The navigation of the Dee has lately been greatly improved. The chief exports are cheese, copper, cast-iron, and coal. Pop. (1851) 27.756 ; (1871) 35,257 ; (1881) 36,788 ; (1891) 37,105 . The city is a county in itself. It has returned members to parliament since the reign of Henry VIII., but by the Distribution of Seats Act, 1885, it lost one of its two members.

Chester was Deva or Devana Castra, an im. portant Roman station, and has yielded many Roman remains - as masonry, coins, inscriptions, fibuløe, altars, a hypoceust, and a statue of Pallas. The British name was Caerleon: Chester, alone or in composition, represents the Anglo-Saxon Ceuster, from the Roman Castra. After the departure of the Romans it was held by Britons, Saxons, and Danes; and in 605 was laid utterly waste by Ethelfrith of Northumbria. It remained an inclosure of waste walls-occupied at times, as in 894 , by a body of marauding Danes, till in 908 it was rebuilt by Ethelred of Mercia; and prosperity came after 942. Chester was the last place in England that held out against William the Conqueror; not till 
castle in 1867 proved abortive. Among the bishops of Chester have been Pearson, Porteus, and Stubbs. Trinity Church contains the graves of Matthew Henry, the commentator, and the poet Parnell.

See CHEshire; and books by Rupert Morris (1895) and G. I. Fenwick (1897).

Chester, a city of Delaware county, Pennsyl. vania, on the Delaware, 15 miles SW. of Philadel. phia by rail, with a military academy, shipbuilding yards, and many manufactures. Originally called Upland, it was founded by the Swedes in 1643 , and is the oldest town in the state. Pop. (1860) 4631 ; (1890) 20,226.--SouTH CHESTER, a manufacturing suburb, had a pop. of 7076 in 1890.

Chester, Joseph LEMUEL, genealogist, born in Norwich, Connecticut, 30th April 1821, was a newspaper editor in Philadelphia, and in 1858 came to England, where he edited the Registers of West minster (1876) and other registers; part of his copy of the Oxford matriculation register has been printed (1887), and his extracts from the Bishop of London's register were published under the title London Marriage Licenses (1887). Chester was an LL.D. of Columbia College, and D.C.L. of Oxford, but always retained the title of Colonel, a reminiscence of the honorary post of aide-de-camp to a Pennsylvania governor which he had once held. He died in London, 26th May 1882. See Dean's Memoir (1884).

Chesterfield, a municipal borough in Derbyshire, on the Rother rivulet, 121 miles SSE. of Sheffield by rail. All-Saints' Chureh (circa 1350) has a curious crooked spire, 228 feet high, and 6 feet off the perpendicular; in Trinity Church (1838) is buried George Stephenson. Other buildings are the town-hall (1857), the Stephenson memorial hall, and the grammar-school (1574; rebuilt 1846). There are manufactures of silk, lace, earthenware, and machinery ; and the neighbourhood is rich in coal, iron, and other minerals. Brindley's Chesterfield Canal ( 1776 ) extends 46 miles to the Trent. Pop. (1851) 7101 ; (1881) 12,221 ; (1891) 13,242. See books by Yeatman (1885) and Á. J. Foster (1896).

Chesterfield, Philip Dormer Stanhope, EARL OF, was the eldest son of the third Earl of Chiesterfield, and was born in London, September 22 1694. He studied at Cambridge, made the grand tour, and sat in the House of Commons as member for St Germains in Cornwall from 1716 to 1726, when he became Earl of Chesterfield. In 1730 he was made Lord Steward of the Household. Until then Chesterfield, who was a Whig, had supported Walpole; but being ousted from his office because he had objected to an excise bill introduced by that minister, he went over to the opposition, and proved himself one of Walpole's bitterest antagonists. He joined the ministry formed by the Pelhams in 1744, and was in 1746 one of the principal secretaries of state. In 1748 he was compelled by ill-health and deafness to retire from public life. He was at one time on terms of intimacy with Swift, Pope, and Bolingbroke. Later in life, by obtruding on Samuel Johnson the patron. age which he had withheld till the publication of the Dictionary, he drew from the lexicographer the indignant letter which will keep his name in remembrance while English literature is read. Besides writing the well-known Letters to his Son, Chesterfield contributed several papers on subjects of the hour to The Craftsman and The World. $\mathrm{He}$ died on March 24, 1773. The object of the Letters was to form his natural son, Philip, into an accomplished man of the world. They contain a good deal of shrewd and solid observation, but their teaching is not of an elevating nature. To shine in the world, to conform to the minute code of etiquette which then ruled society, are the ends on which the writer sets most store. The expression is occasionally coarse, but the worst feature of the book is the manner in which Chesterfield handles the topic of gallantry.

His letters were edited by Lord Mahon (1845-53), Lord Carnarvon (1890), and J. Bradshaw (1892). See his Wit and Wisdom by W. E. Browning and the Memoirs of him by W. Ernst (1893), the Essay by Sainte-Beuve (trans. 1870), and Churton Collins's E'ssays and Studies (1895).

Chesterfield Inlet, a narrow gulf penetrating to the westward from the NW. of Hudson Bay, its extreme dimensions being 250 and 25 miles.

Chester-le-Street, a market-town in the county of Durham, near the left bank of the Wear, 6 miles N. of Durham city. The seat of the Bishop of Bernicia from 883 to 995 , it has an old collegiate church (restored 1862), with a spire 156 feet high; whilst in the neighbourhood are Lambton, Lumley, and Ravensworth Castles, the seats of the Earls of Durham, Scarborough, and Ravensworth. Coal-mines and ironworks are numerous. Pop. of township (1851) 2580 ; (1891) 8623 .

Chestnut, or Chesnut (Castanea), which must be clearly distinguished from the Horse Chestnut described below, a genus of Cupuliferre, closely allied to the Beech (Fagus), and distinguished from it by long male catkins, longitudinally set with groups of flowers, a 5-8-celled ovary, and compressed rounded nuts. The name is derived from the town of Castanum, in Thessaly. The Common,

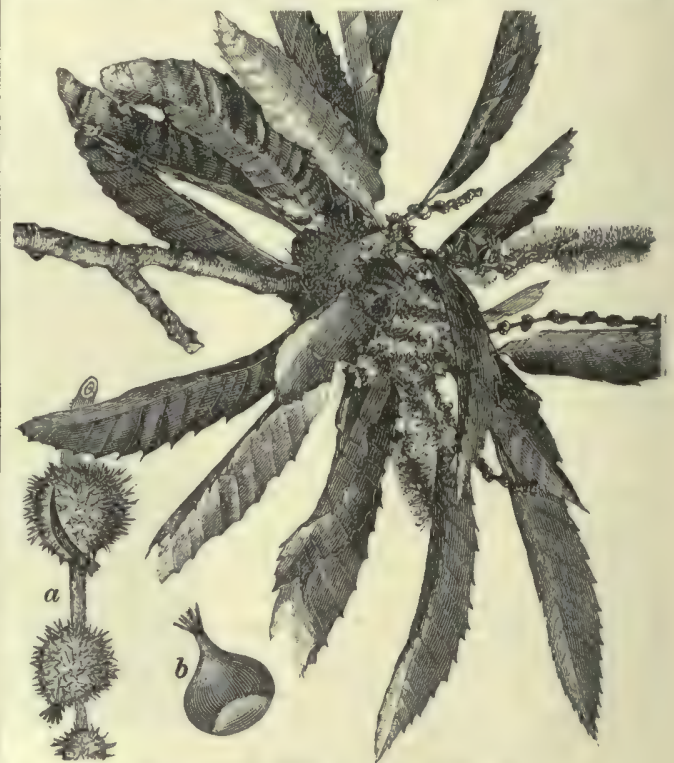

Branchlet, with Catkins, of Common Chestnut (Castanea vulgaris):

$a$, fruit; $b$, seed.

Spanish, or Sweet Chestnut ( $C$, vulgaris), is said to have been first brought from Asia Minor, but has long extended over the sonth of Europe, where it has become completely naturalised, and forms extensive woods. It is an ornamental and stately, or, in exposed situations, a very spreading tree, of great size and longevity: the famous chestnut of Tortworth in England was known as a boundary. mark in the reign of King John; while a yet more celebrated tree on Mount Etna is said to have measured 204 feet in circumference. The timber is durable and hard, and is used in house-building, for making furniture, and for many other purposes. The timber described as chestnut in ancient buildings is usually, however, really oak. The bark is 
used for tanning, but is worth only abont half the price of osk-bark. Young chestnut-trees are much esteemed for hop and espalier poles. The chestnut is therefore frequently grown in England as coppicewink ; but it suceeeds well as a timber-tree even in Beotland, although it does not generally ripen its fruit. In Devonshire, however, and in some other parts of England, it is planted as a fruit-tree. It succeeds throughout an the middle latitudes of Germany, but dislikes a damp foggy atmosphere. It prefers a dry light soil, and succeeds only where there is a dry subsoil. The nuts are generally three in each husk. They form an important part of the food of the poor in the south of Europe, being used either roasted or boiled, and are ground into flour, and made into a kind of bread. They contain 15 per cent. of sugar, and by pressure yield a fer. mentable sugary juice. When cultivated as a fruit-tree it is generally grafted, by which means the better varieties are secured. A variety with golden-edged foliage, and another with thin threallike divided leaves, are sometimes cultivated for their foliage. Other species also bear eatable fruits : those of the American Chestnut ( $C$. americona), a tree much resembling the common chestnut, and of the Dwarf Chestnut, or Chinquapin (C. pumila) a low tree, or more generally a shrub of 7-8 feet high, are used in America. - A number of species are natives of the East. The inhabitants of the mountains of Java eat the fruit of the Silvery Chestnut ( $C$. argentea), and the Tungurrut (C. Tungurrut), boiled or roasted, like the common chestnut. Both of these are large trees, the Tungurrut reaching a height of 150 feet. Closely akin to the true chestnuts is the Californian Chinquapin (Castanopsis Chrysophylla).

The HorSE-CHESTNUT ( Asculus Hippocastanum) is a wholly distinct Sapindaceous tree, supposed to have been introduced from Asia about the middle or latter half of the 16th century; and of which the exceptionally magnificent foliage and blossom, rapid growth, stately size, and general effect have made it a favourite among arboriculturists, though the timber is soft and of little value. It forms singularly effective avenues: those of Bushy Park at Hampton Court Palace near London are well known and largely visited, particularly when in

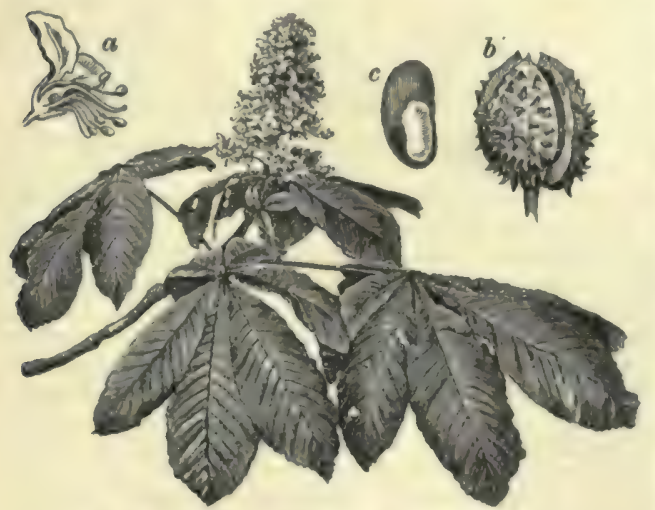

Branch, with Bloseom, of Horse-chestnut (Asculus Hippocastanum):

$a$, vertical section of single flower; $b$, fruit; $a$ a single seed, its coat partly removed.

flower. The palmate leaves and terminal racemes or panicles need no description, while the characteristic 3-lobed, thick, prickly capsule, with its one or two (rarely three fully developed) beautifully marked and coloured seeds, is among the most familiar recollections of childish treasure-trove in early autumn. Other species and varieties have also been introduced, of which $E$. indica in prob. ably the handsomest. $E$. rubicunda, the so-called scarlet-flowered horse-chestnut, al though sometimen deacribed as a native of North Amerien, is perhapm only a variety of the preceding. The American species of . Esculus and its prostically indistinguish. able ally, a sub-genus Pavia, are popularly termed Buck-eye. None is so beautiful, or at least possesses such a combination of beauties, as the common horse-chestnut; but $P$. californica, although only reaching a height of 12 to 15 feet, has a singular wealth of fragrant bloseom. $P$. rubra, with its many varieties, is the Red Buck-eye.

In Queensland the seeds of Castanospermum, a leguminons tree, are sometimes eaten like chestnuts, and 80 called; similarly is it at the Cape with the seeds of Brabejum stellatum, a Proteaceous plant. The so-called water-chestnut of Europe is the curious horned nut of Trapa natans (order Halora(riacer), and is an article of food in southern Europe, China, and Cashmere. See TrapA.

Chetham. Humphrey (1580-1653), a Manchester merchant and cloth manufacturer, founder of a bluecoat hospital and of a public library at Manchester (q,v.). See BooK-CLUB.

Chettle, Henry, a dramatist and pamphleteer of the 16th century, was editor of Greene's Groat's worth of Wit (1592), wrote thirteen plays of considerable merit, and was part author of thirty-five others, including Robin Hood in two parts, Patient Grisel, The Blind Beggar of Bethnal Green, and Jane Shore. In Meres's Palladis Tamia (1598) he is mentioned as one of 'the best for comerly amongst us,' Of his other works, his Kind-Hart's Dreame (1593?) and Englande's Mourning Garment (1603) are of interest, the former as containing an apology undoubtedly intended for Shakespeare as one of those whom Greene had attacked; the latter, a stanza supposed to be addressed to Shakespeare as 'silver-tonged Melicert.' Chettle died about 1607.

Chevalier, an honorary title given, especially in the 18th century, to younger sons of French noble families. Brought up in comparative luxury, and left at the death of their fathers almost entirely unprovided for, these men generally lived at the expense of others, as a sort of aristoeratic parasites, even when they did not prefer recourse to such less honourable means of livelihood as gave occasion to the synonym for swindler, chevalier d'industrie. In the plays of the 18th century the chevalier is a constant figure.-Both the Old and Young Pretender were called the Chevalier by their partisans.

Chevalier, Michel, an eminent French economist, was born at Limoges, January 13,1806 , and was trained as an engineer. At first an ardent St Simonian and busy contributor to the Globe, he attached himself to the party of Enfantin, and took an active part in the compilation of the famous propagandist Livre Nouveau. After six months' imprisonment in 1832 , he had the prudence to retract all that he had written in the (ilube contrary to Christianity and against marriage. Soon after he was sent by Thiers to inquire into the systems of water and railway communication in the United States. In 1837 he published his chief work, Des Interéts Materiels en Frunce. He was made a councillor of state in 1838, and was appointed in 1840 to the chair of Political Economy in the Collège de France. In 1845 he was returned by Aveyron to the Chamber of Deputies. After the revolution of 1848 he male onslaughts that were never met upon the socialism of Louis Blane in Questions de 'Travailleurs, as well as in the Revue des Deux Mondes and the Jormal des Debats. A number of these vigorous and masterly articles were collected under the titles, Lettres sus 
l'Organisation du Travail (1848) and Questions politiques et sociales (1852). A free-trader in economics, Chevalier in 1860 aided Cobden in carrying into effect the commercial treaty between France and England. For this he was created a senator and Grand Officer of the Legion of Honour. He took an active interest in the great exhibitions at London (1862) and Paris (1867). He died at Montpellier, 28th November 1879.

Chevaux-de-Frise (Fr., 'Friesland horses,' so called as having been first used in Fries. land during the wars of the 17th century) is a military obstacle of the form shown in the

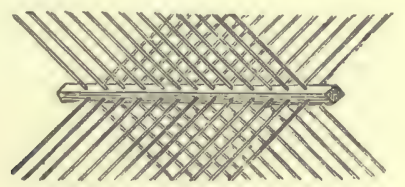

Chevaux-de-Frise.

figure. It is difficult to make unless skilled labour and the necessary materials, such as iron railings, gas-pipes or hop-poles, are at hand, but is kept in a fortress as an article of store. The pattern used by the British army consists of a cylindrical iron tube, 6 feet long and about 5 inches in diameter, pierced with 12 holes to receive as many spears of the same length, which are packed in the tube when not required. Several lengths connected by chains may be used as barriers or as obstacles in the ditch of a fort, or in any place where required. It is, however, generally easy to roll them out of the way, though at the siege of Badajoz, during the Peninsular war, one formed of sword-blades fixed into beams of wood, and placed in the breach, was found to be a very serious obstacle by the British storming party.

Chevet. See APSE.

Cheviot Ilills, a mountain-range occupying contiguous parts of the counties of Northumberland and Roxburgh, on the English and Scotch borders, and running 35 miles from near the junction of the Till and Tweed, in the NE., to the sources of the Liddel, in the SW. The principal points are Cheviot Hill (2676 feet) and Peel Fell (1964). West of Carter Fell, these hills chiefly consist of Silurian rocks overlaid by Old Red Sandstone, and Lower Carboniferous strata, with which various igneous rocks are associated. The east portion of the range, including higher and more or less conical and abrupt hills, is built up almost exclusively of ancient lava-flows and tuffs (porphyrite and porphyrite-tuff), which are traversed by a mass of augite-granite, and by veins of felsite, dikes of basalt, \&c. In the Cheviot Hills are the sources of the Liddel, Tyne, Coquet, and some of the branches of the Tweed. Grouse abound, and the golden eagle is occasionally seen. These hills afford pasture for the Cheviots, a superior breed of sheep. They have been the scene of many a bloody contest between the English and Scotch, and the name is commemorated in that of the famous old ballad of Chevy Chase, for the history in which see OTTERBURN. See five articles by Professor James Geikie in Good Words (1876).

Chevreul, Micher, Eugiene, a great French chemist, born at Angers, August 31, 1786. At seventeen he went to Paris, where he pursued the study of chemistry at the College of France, under the famous Vauquelin, with such zeal and success that at twenty he was allowed to take charge of the laboratory. He next lectured at the Collège Charlemagne, and was appointed special professor of Chemistry in charge of the dyeing department at the Gobelins. In 1826 he took his seat in the Academy of Sciences, and in 1830 became director of the Museum of Natural History. One of his earliest discoveries was that of margarine, oleine, and stearine in oils and fats. His studies in fatty bodies and his theory of saponification opened up vast industries. Between the years 1828 and 1864 Chevreul studied colours, publishing important memoirs from time to time. This patriarch of the scientific world, 'le doyen des étudiants de France,' as he loved to be called, kept up his studies to an age seen by but few. In 1886 the hundredth anniversary of his birth was celebrated with great enthu. siasm. A medal was struck, and a grand fete given at the Museum in his honour, while he was presented with his bust by his colleagues at the Academy of Sciences. Chevreul was F.R.S. and a Commander of the Legion of Honour. Besides papers and memoirs innumerable in the learned journals, he published works on dyeing (1831), on the optical effects of silk stuffs, on colours and their application to the industrial arts (1864), and histories of chemical seience (1866) and of theories of matter (1878). His De la Baguette divinatoire, du Pendule explorateur et des Tables tournantes (1854), is the best book on the subjects which it treats. Died April 9, 1889.

Chevron, in Architecture, a moulding in the form of a succession of chevrons, otherwise called a zigzag moulding. In general, it is characteristic

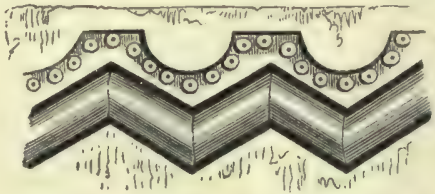

Chevron or Zigzag, Andover, Hants.

of Norman arehitecture, but is also found with the pointed arch, during the transition period from Norman to Early English.

CHEVRON, in Heraldry, an ordinary formed of two bands, joined together at the top, and descending to the extremities of the shield in the form of

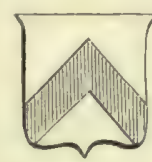

Chevron.

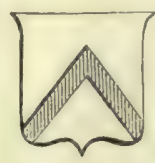

Chevronel. Per Chevron. a pair of compasses. Chevronel, a diminutive-half the size - of the chevron.

Chevror is also the name of a V-shaped band of worsted braid or gold lace, worn on the sleeve by non-commissioned officers of the British army as a badge of rank. Four chevrons indicate a sergeant-major or staff-sergeant, three a sergeant, two a corporal, and one a bombardier in the artillery, a second corporal in the engineers, and a lancecorporal in other branches. Good-conduct badges are precisely similar, but the point is upwards instead of downwards. They are worn by non-commissioned officers below the rank of sergeant, and by private soldiers as well. A similar use is made of chevrons in the army of the United States and other countries.

Chevrotains, or MousE-DEER (Tragulida), a family of small ungulates, intermediate between true deer and hogs. The family includes two genera, Tragulus and Hyomoschus, often confused with musk-deer, with which they have no special connection. As to characters it may be noted that they have no upper front teeth, but well-developed 
pointed canines, especially in the males; there are four complete toes on each foot; there are no horns nor musk-glands; the stomach has no distinct manyplies, and thus only three chambers; the placenta is diffuse. Tragulus is represented by a number of small species from southern and south. eastern Asia, Malay Archipelago, \&c.; $T$. javannicus is much eaten. Hyomoschus is represented by a single species ( $\boldsymbol{H}$. aquaticus) from the west coast of Africa. It is rather larger and stouter than Tragulus, and has aquatio habits. The family dates from the Miocene period. See Ungulata.

\section{Chevy Chase. See OtTerburn.}

Chewing-gum, a preparation the use of which has become $\mathrm{a}$ widespread habit in the United States. It is made from a gum called Chicle, produced by a Mcxican tree allied to the india-rubber tree, and first imported in 1867 with a view to its employment in inlia-rubber manufacture. The gum is sweetened, and may be flavoured with peppermint, liquorice, tolu, or other flavouring substances. Spruce-gum is also much used in its manufacture.

Cheyenne, capital of the state of Wyoming, is situated on the eastern slope of the Laramie Mountains, at the height of 6000 feet above the sea. It is an important station of the Union Pacific Railroad at its junction with the Denver Pacific and Colorado Ceutral railroads, and is 106 miles N. of Denver, and 516 miles $W$. of Omaha, Coal and iron are found in its neighbourhood. Cheyenne, settled in 1867, had in 1870 a population of 1450 ; in 1880,3456 ; in $1890,11,690$.

Cheyenne Indians, a warlike branch of the Algonquin stock, originally on the Red River of the North, later on the Cheyenne River in Wyoming, and as far south as the Arkansas. From 1861 to 1867 the government had frequent wars and other troubles with then. To the number of 2137 they are now (1891) settled in Oklahoma.

Cheyne, Groras, physician, was born in 1671 at Methlick, in Aberdeenshire, and, after studying at Edinburgh under Pitcairn, started a London practice in 1702, in which year he was eleeted a Fellow of the Royal Society. Full living made him enormously fat (thirty-two stone weight), as well as asthmatic, but from a strict adherence to a milk and vegetable diet he derived so much benefit that he recommended it in all the later of his dozen medical treatises, which included $A$ New Theory of Fevers (1701); Philosophical Principles of Natural Religion (1705); Essay of Health and Long Life (1725), and The English Malady, a Treatise on Nervous Disorders (1733). Cheyne died at Bath, 13th April 1743.

Cheyne, Thomas KrLly, one of the foremost old Testament scholars in England, was born in London, September 18, 1841. Edueated at Merchant Taylors' School and Worcester College, Oxford, he carried off among other honours the Chancellor's medal for the English essay, and became Fellow of Balliol College in 1869. He was rector of Tendring in Essex from 1881 to 1885, when he was appointed Oriel professor of the Interpretation of Holy Seripture at Oxford, and Canon of Rochester. He was a member of the Old Testament Revision Company, and has contributed many articles on biblical questions to the magazines and reviews. A critic of ripe scholarship and re. markable clearness in exposition, free from the tendency to rash destructiveness that mars the work of so many of the best contemporary eritics in Germany, he has done much to advance biblical science in England without weakening the real buttresses of the faith. His chief books are The Prophecies of Isaiah (1880; 3d ed. 1885); Exposi- tion of Jeremiah and Lamentations (1883): Book of Pralms (1888); Introduction to Isaiuh (1895); Isaiah (revised text and translation, 1897 ).

Chhatisgarh is the south-east division of the Central Provinces of India, with an area, including feudatory states, of $25,013 \mathrm{sq} . \mathbf{m}$. ; pop. $3,115,997$. It is mainly a vast, fertile, grain-producing plateau. Dongargaion is the capital.

Chiabrera, Gabrello, an Italian poet, born at Savona, 8th June 1552. He was educated at Rome under the care of his uncle, after whone deatl he entered the service of Cardiunl Cornaro, but was obliged to leave it for revenging himself upon a Roman nobleman who had wronged him. He married at fifty, and after an easy and well-gpent life, died at eighty-five, 14 th Octolser 1637 . Chiabrera's poetical faculty blossomed late. An en. thusiastic student of Greek, he conceived a great admiration of Pindar, and strove not unsuccessfully to imitate him. He was not less happy in catching the naif and pleasant spirit of Anacreon; his canzonette being distinguished for their ease and elegance, while his Lettere Famigliari was the first attempt to introduce the poetical epistle into Italian literature. Chiabrera also wrote several epics, bucolics, and dramatic poems. Collections of his lyrics, under the title Rime, were published at Rome in 1718 (3 vols.), at Venice in 1737 (5 vols.), and at Milan in 1807 (3 vols.). Prefixed is a naif but interesting fragment of antobiography.

Chia'na (ancient Clanis), a river of Central Italy, originally a tributary of the Tiber, watering the perfectly level Val di Chiana, which its overflow (see CHIUsI) rendered once the most pestilential district of Italy. The bed was deepened in 1789 1816 , and in 1823 extensive hydraulic works were undertaken for further improving the river-course, and for leading a northern branch, through canals, to the river Ano, a few miles below Arezzo, the southern stream reaching the Tiber, throngh the Paglia at Orvieto. The double stream is 60 miles long, and to 1 mile broad; and the district has since become one of the most fruitful in all Italy.

Chianti, an Italian mountain-range, in the province of Siena, clothed with olive and mulberry trees and vines; the mountain gives name to an excellent red wine grown here.

Chiapas, LAs, a state of Mexico, on the Pacific, adjoining Guatemals. Largely a part of the table land of Central America, it enjoys a delicious climate; and where the navigable Rio Chiapas cuts through the middle of the plateau, the valleys are aniong the most fertile portions of the republic, although the country is still almost everywhere clothed with primeval forest. Area, 27,250 square miles; pop. 270,000, chiefly aborigines. Capital, San Cristobal. Near Palenque, one of its towns, are most extensive and magnificent ruins.

Chiaramon'te, a town of Sicily, 30 miles W. of Syracuse, with trade in wine. Pop. 9364.

Chia'ri, a town of Lombardy, 13 miles W. of Brescia by rail, with manufactures of silk. At one time strongly fortified, it is memorable for the victory here of the Austrians, under Prince Eugene, over the French and Spaniands, under Villeroi, 2d September 1701. Pop. 5999.

Chiar-oseu'ro (Ital.), an artistic term, composed of two Italian words, the one of which signifies light, the other darkness or sladow. Bnt chiar-oscuro signifies neither light nor shadow; neither is it alequately described by saving that it is the art of disposing of both the lights and shadows in a picture, so long as either is regarded apart from the other. It is rather the art of representing light in shadow and shadmo in light, so that the parts represented in shadow shall still 
have the clearness and warmth of those in light, and those in light the depth and softness of those in shadow. It is not the making of the one die softly and gradually away into the other, but the preservation of both in combination, as we constantly see it in nature, when the light is not the mere glare of the sun striking on a particular object, nor the shadow the entire absence of the influence of light. That the skilful treatment of chiar-oscuro is a matter of extreme difficulty is plain enough from the very small number of artists who ever attain to it. Still, it is a branch of art without the mastery of which no painting can be successful in any department. It is as indispensable in portrait-painting as in the highest departments of ideal arts; and though a just and even a lofty conception of the subject may be distinctly indicated by attention to form alone, it is impossible that its realisation can ever be satisfactorily accomplished by any one who has not mastered this most subtle mode of handling colours. The only mode by which a knowledge of chiaroscuro can be attained, so as to apply it to practice, is by studying it as exhibited in the works of such painters as Titian, Rubens, Rembrandt, and Correggio.

Chiastolite, a variety of the mineral Andalusite (q.v.).

Chia'vari, a port of Italy, 24 miles ESE. of Genoa by rail, with a number of fine churches and palaces, fisheries, and some trade. Pop. 8582.

Chiavenna, a town of Lombardy, beautifully situated to the north of Lake Como, on the way to the Splügen Pass. Pop. 2848.

Chica, a dyestuff giving an orange-red colour to cotton. It is obtained by boiling the leaves of a species of Bignonia ( $B$. chica), a climber of the banks of the Cassiquiare and the Orinoco. The Indians use it for painting their bodies. See BIGNONIACEA.-CHICA, or CHICHA, is also the name of a kind of beer niade from Maize (q.v.).

Chicacole, a town of the district of Ganjam, in the Madras province, on the Languliya River, 567 miles NE. of Madras by the Grand Trunk Road. For many years it was a military station, and has a reputation for muslins. Pop. (1891) 15,587.

Chicago (pron. She-kah'-go), the second largest city on the American continent, and the most remarkable example of rapid and

substantial municipal growth in $\begin{aligned} & \text { Copyright } 1888,1897, \text { and } \\ & 1900 \text { in the U.S. by J. B. }\end{aligned}$ the nineteenth century, is the Lippinoot Cumpany. commercial, financial, and political metropolis of the United States west of the Alleghany Mountains. It is situated at the mouth of the Chicago River, on the west shore of Lake Michigan, in $41^{\circ}$ $52^{\prime} \mathrm{N}$. lat., and $87^{\circ} 35^{\prime} \mathrm{W}$. long., and covers an area of 187 square miles. The Chicago River intersects the city first into the north and south sides, and then by its two main forks, parallel with the lake, forms a western division, these divisions being connected by three tunnels and fifty swinging bridges, of which three are used by elevated railways.

The early French explorers Joliet and Marquette visited the spot in 1673 , where they found the portage used by the Indians to pass from the Mississippi River to the lakes and the St Lawrence. A church and fort were built on the present site of the city by the French, but their possession of the place was never continuous, that practically beginning with the building of 'Fort Dearborn' in 1804 by the Americans, who succeeded to the title wrested from the French by the British. For nearly thirty years after that Chicago was little more than a trading post, suffering from the various vicissitudes common to the frontier, its growth being best shown by the United States censuses, viz. :
$1850,29,963 ; 1860,112,172 ; 1870,298,977 ; 1880$, 503,$185 ; 1890,1,099,850$. In 1892 the schonl census gave the eity a population of $1,438,010$, which was increased to $1,616,635$ by the census of 1896 ; the best estimate for 1897 was $1,752,000$, and for January 1, 1899, 1,850,000; but the United States census of 1900 lowered this to $1,698,575$.

From the date of its incorporation Chicago literally began to rise out of its antediluvian mud, just as subsequently it rose above the ashes of the most devastating fire of all history. The eity ordinances required streets to be graded some 8 to 12 feet above the natural level. Houses of all sizes were jacked up to the new grade of the streets, and these gradually became among the finest business and pleasure thoroughfares in America. With some half a dozen diagonal exceptions, these street: are laid out at right angles with mathematical regularity. The minimum width is 60 feet, but those on the quarter section (half-mile lines) are 70 , while State street is 100 , and some of the boulevards are 120 feet. Including the boulevards, which are under the control of Park commissions, the streets of Chicago measure over 2100 miles, and they are daily being extended into the prairies to the south, west, and north, which are now covered by the richest market gardens in the world near a great city. Almost before these streets are staked out, drained, and curbed they are occupied by street ear lines, of which there are ten, having a total length of over 500 miles and stretching from the centre of the city in all directions. Some of these carry passengers from the outskirts to the business centre, a distance of fifteen miles, for the single fare of five cents. Originally operated by horses, these are now almost exclusively worked by the cable or electric trolley systems.

Chicago boasts a park system withont a parallel in the world. It enbraces Lincoln Park along the lake on the north side, Jackson Park on the lake south, Washington Park two miles west of the latter, with which it is connected by the Midway Plaisance of World's Fair fame, and Douglas, Garfield, and Humlıoldt Parks. These parks are linked together by parked boulevards twenty-six mileslong, and are each accessible by boulevards from the business centre of the city. The total road mileage in the park system approaches 100 miles. Besides the parks mentioned, Chicago is now engaged in re. claiming 163 acres of land from the lake immediately in front of the business centre. When this work is completed, the total park area of the city will be 2169 miles. Jackson Park, to the south-east of the eity, was the scene of the national Columbian Exposition or World's Fair, which opened May 1, 1893, in celebration of the fourth centenary of the discovery of America by Columbus. The leading architects of America had been given carte-blanche to design and construct giant buildings upon a common scale so that they would complement each other by contrasts and blend in a whole of wondrous consistency and beauty. The result was the White City. The area occupied for the exposition was 633 acres. Some idea of the size of the buildings may be gained from that of the Manufactures and Liberal Arts building. This was 1687 feet long by 787 wide, and covered $30 \frac{1}{2}$ acres of ground. The exposition remained open until Octoher 30, 1893, and was visited by $23,529,400$ persons. Its cost was over $\$ 18,000,000$, the citizens of Chicago bearing the enormous loss represented in the difference between the expense and the receipts, amounting to over $\$ 10,000,000$.

Chicago has the finest water supply and system of any large city in the world. It is drawn from the depths of Lake Michigan through four tunnels extending from two to four miles from the shore. As the lake is fed by subterranean springs through 
limestone at a depth reaching 1000 feet, the purity as well as the inexhaustible nature of this supply is evident. The danger of its contamination from the sewage of a city rapidly approaching two millions, led in 1889 to the adoption of a plan to ent a monster canal from the Chicago River to Joliet on the Desplaines River, a distance of 30 miles, for the primary purpose of disposing of the eity's sewage, after its dilution by 600,000 cubic feet of lake water per minute, and the ultimate utilization as a ship canal to connect Chicago with New Orleans and the Gulf of Mexico via the Mississippi. This canal was commenced in 1891, and was expected to be completed in five years, at a cost of $\$ 22,000,000$; but by July 1, 1897, the cost had amounted to $\$ 24,000,000$, and it was not until January 17, 1900, that the canal was opened. Through ten miles of its course it is 200 . feet wide and 35 feet deep, cut through the solid rock; the minimum depth is 22 feet. It is altogether one of the great engineering works of the century.

The health of the city is as phenomenal as the growth of Chicago itself. For the year ending March 31,1897 , ealculated on a school census notoriously below the actual population, the death-rate of the city was $14 \cdot 22$ per 1000 . The wenther bureau gives Chicago the lead with more miles of wind per annum than any other observation station in America. Hence its sobriquet of 'The Windy City.'

A railway map of the Uniter States shows that Chicago is the rail centre of the continent. Over 114,000 miles of railroad, or more than one-half of the mileage of the United States, Canada, and Mexico, converge here. The amount of tonnage forwarded via the Chicago lines during 1890 was $4,595,440$ tons. Chicago is a port of entry; this inland city is the greatest shipping port on the conti. nent. In 1896, 8663 vessels arrived at Chicago and 8773 eleared. A remarkable change has recently come over the size of the vessels entering Chicago. In 1890 there were 10,507 entered with a total tonnage of $5,138,253$; the 8663 which entered last year had a tonnage of $6,481,152$.

The Union Stock-yards, situated in the southwestern part of the city, compose the largest livestock market in the world. They cover over 400 acres of land and have accommodations for 25,000 head of cattle, 150,000 hogs, 20,000 sheep, and stabling for 1000 horses. The receipts of live-stock handled here in 1896 comprised $2,600,476$ cattle, 138,337 calves, 7,659,472 hogs, 3,590,655 sheep, and 105,978 horses, aggregating 14,094,918 head, valued at $\$ 187,745,655$, received in 277,437 cars. The shipments of dressed beef made from Chicago to every quarter of the globe amounted for the year 1896 to the enormous total of $980,930,688$ pounds.

The city is also the largest grain market in the world. Of the grand total of $612,714,283$ bushels of flour and grain received at the eight principal grain centres of the United States in 1896, no less than $253,802,134$, or not far from one-half, were received at Chicago.

One of the first things to attract the attention of the visitor to the city is the number and magnificence of its tall buildings called 'sky-scrapers.' All the weight of these immense structures is car. ried on a riveted steel framework instead of walls of masonry. In fact, the steel frame carries the outer shell. Their foundations are laid on cross-sections of steel beams embedded in cement built right on the top of the sulsstratum of blue clay which underlies the whole city. This settles gradually and regularly from 6 to 8 inches as the building goes up, and then stops, affording a foundation seemingly as firm as if laid on the eternal rock. These buifdings (twenty stories tall) have stood as stiff in an 84-mile gale as solid masonry.

Chicago has many public buildings noteworthy for their architectural beauty, among which the Art Instituteand the Public Library on Michigan Bonle. varil and the Newberry Library focing Washington Square on the north side are especially worthy of study. The city-hall and county court-house are twin buildings occupying an entire block. They are built of Silurian limestone and Maine granite, and are more noticeable for their massiveness and cost $(86,000,000)$ than beauty. The Auditorium is one of the finest and best-appointed public halls in the country. Chicago is anply supplied with then tres and music halls, and has such large hotel ac. commodations that it is known as the great conven. tion city of the continent.

The vicinity of cheap coal-fields and its splendid transportation facilities have made Chicago a great manufacturing centre. In 1890 it had 3250 manufacturing establishments, employing $\$ 190,000,000$ capital, giving employment to 177,000 persons, who received $\$ 96,200,000$ in wages, with an annual product valued at $\$ 538,000,000$. The volume of the wholesale trade of Chicago for the same year was $\$ 486,600,000$. Chicagohas 45 bank8, with a total capital of $\$ 33,000,000$ and deposits (December 17, 1896) amounting to $\$ 184,000,000$. The bank clearings for 1896 were $\$ 4,413,054,108$. In 1892 , before the panic of the ensuingyear, they amounted to $\$ 5,135,771,186$.

The assessed valuation of the real and personal property in Chicago for the year 1896 was \$244, 357,286 , upon which the rate of taxation was 5.03 per $\$ 100$. This gives no adequate idea of its true value, being about one-tenth of what it should be, the assessment being kept down because the rate of the tax permissible is excessive.

Chicago spends more than $\$ 6,000,000$ a year on its system of public schools. Of this amount $\$ 3,843,504$ was paid for salaries for teachers alone in 1896 . The enrolment of pupils for that year was 213,825 . The private parochial and denominational schools of the city afford education to about 50,000 pupils. In 1892 the University of Chicago, founded by John D. Rockefeller, was opened. It has a grand quad. rangle of granite building situate on the Midway Plaisance, with accommodations for over 2000 pupils. Its endowment and building funds now amount to over $\$ 12,000,000$, of which sum $\mathrm{Mr}$ Rockefeller has contributed $\$ 7,426,000$. The Yerkes observatory at Lake Geneva, 74 miles from the eity, which boasts the most powerful telescope in the world, is a department of the University of Chicago.

In libraries Chicago easily takes first rank among American cities. Its public library, founded after the fire and supported by taxation, contains 160,287 volumes. A new building has just been completed for it at a cost of $\$ 2,200,000$. The Newberry Library has a building that cost $\$ 500,000$ and an endowment of over $\$ 2,000,000$. The John Crerar Library has 25,000 volumes and an endowment of over $\$ 2,000,000$, and there are many other smaller libraries, notably those of the Chicago Historical Society and the Lewis Institute, with a foundation of over $\$ 1,000,000$. The Field Columbian Musenm, which is an outcome of the Columbian Exposition, has an endowment of $\$ 2,000,000$ and a collection of remarkable scope contributed by numerous exhibitors at the World's Fair.

The great fire of Sunday, October 7, 1871, laid the busineas heart of the city in ashes. Some 17,450 buildings were burned, 98,500 persons - one-third of the population - were rendered homeless, and about 200 lives were lost. The total money loss was estimated at $\$ 190,000,000$, with the result that scores of fire insurance companies were ruined. Not a scar of that terrible conflagration is visible to-day. In the place of the chenp wooden structures and wretched pavements of the sixties, a city of mag. nificent fire-proof bu'ldings and grand thoroughfares has arisen, with the best water supply and fire do 
partment in the world, both the children of that 'Great Fire,' See Andreas' History of Chicago (Chicago, 1885).

Chicha. See Stereulia.

Chichen', one of over fifty ruined towns in the Mexican province of Yucatan, a few miles WSW. of Valladolid, with the remains of an ancient Indian city, comprising a vast temple with basreliefs, a pyramid, houses containing seulptured chambers, \&c.

Chichester, a municipal borough and episcopal city in Sussex, 17 miles ENE. of Portsmouth, and $28 \mathrm{~W}$. of Brighton. It stands on a plain between an arm of the sea and the South Downs, which rise gently on the north. It is well built, and has wide streets. The two main streets cross at right angles, and meet in an elaborate eightsided market-cross ( circa 1500). Within the suburbs the city is surrounded by an ancient wall, $1 \frac{1}{2}$ mile in circuit, with some semicircular bastions, and now a promenade under the shade of elms. The cathedral, erected in the 12th and 13th centuries, on the site of a wooden one founded 1108, and burned 1114 , measures 410 by 131 feet, with a spire 277 feet high (rebuilt 1865-66, after its fall in 1861 ), and a detached bell-tower or campanile, 120 feet, the only structure of the kind retained by an English cathedral. The aisles are double - a mode of construction elsewhere seen only in Manchester Cathedral and in some parish churches. The choir, lady chapel, and cloisters offer in teresting features. The bishop's palace is supposed to have been erected on the site of a Roman villa. Chichester has twelve parish churches, a market-house, corn exchange, guildhall ( formed out of the chapel of the Franciscan monastery), council-house, a theological college (1872), and several other educational establishments. The chief trade is in agricultural produce and live-stock. Wool-stapling, malting, brewing, and tanning are also carried on. Pop. (1851) 8662; (1891) 7842. From the time of Edward I. till 1867 Chichester returned two members, and till 1885 one. The port of Chichester, 2 miles to the south-west of the city, is situated on a deep inlet of the English Channel, of about 8 square miles, and is connected with Chichester by a canal. Chichester was the Roman Regnum, and has afforded Roman remains-as a mosaic pavement, coins, urns, and an inscription of the dedication of a temple to Neptune and Minerva. Chichester was taken and partly destroyed in 491 by the South Saxons. It was soon after rebuilt by Cissa, their king, and called Cissanceaster, or Cissa's Camp. It was for some time the capital of the kingdom of Sussex. The South Saxon see was removed by Stigand from Selsey to Chichester towards the close of the 11th century. Among its bishops have been Reginald Pecock, Lancelot Andrews, John Lake, and Simon Patrick. In December 1642 the royalists of Chichester surrendered to the parliamentarians after an eight days' siege, recaptured the city in the December of 1643, but had again to surrender to Waller a month later after a siege of seventeen days. Among the prisoners of war was the famous Chillingworth, who was allowed to die here, and lies buried in the cathedral. See works by Willis (1861), Stephens (1876), and Swainson (1880).

Chickadee (Parus montanus or atricapillus), a North American titmouse, of sober black and gray plumage, and lively active habit. It is fond of pine-trees, feeds on insect larvæe, has a hardy constitution, and remains through the winter. Its cheerful song is echoed in one of Emerson's poems. See Titmouse.

Chickahom'iny, a river of Virginia, which flows within 5 miles of Richmond, and enters the
James, after a south-easterly course of 90 miles. Four battles were fought near its banks in June 1862.

Chickamauga, a tributary of the Tennessee River, rising in Georgia, and flowing north-west into Tennessee, in which state the Confederate General Bragg defeated Rosecrans in a battle fought on the banks of the stream, September 19 and $20,1863$.

Chickaree is a name given to the red, pine, or Hudson Bay squirrel. See SquirRel.

Chickasaw, a tribe of Indians, allied to the Cherokees (q.v.), formerly occupying the northern parts of Alabama and Mississippi, but now settled in Indian Territory. They number about 6000 .

Chicken-pox, a contagious febrile disease, chiefly of children, and bearing' some resemblance to a very mild form of Smallpox (q.v.). Chickenpox is distinguished by an eruption of vesicles or blebs, which rarely become pustular or yellow, and leave only a very slight incrustation, which falls off in a few days, leaving little or none of the marking or pitting which is such a prominent feature in smallpox. From its vesicular character it has been called the crystal pock. It has been argued that chicken-pox is, in fact, only smallpox modified by previous vaccination; but this opinion, though maintained on good authority, is not accepted by most medical men. It is a disease of little or no danger, the fever being often hardly perceptible, and never lasting long.

Chick Pea (Cicer), a genus of the vetch tribe of Leguminosæ. The common chick pea ( $C$. arietinum) is an annual, $1 \frac{1}{2}$ to 2 feet high, of a stiff upright habit, covered with glandular hairs, with inflated pods containing a few angular and wrinkled peas. It is largely cultivated in southern Europe and in many parts of the East, and hence occurs frequently also as a weed in cornfields. It is also grown in Spanish America. Large quantities of the peas are exported from British India under the name of gram, now well known in commerce; but the name is extended to other East Indian kinds of pulse. The peas are used as food, either boiled or roasted, and are the most common parched pulse of the East. They are a notable article of Spanish and French cookery ; while their importance in Roman times is evidenced by the phrase, fricti ciceris emptor ('buyer of roasted chick peas'), as a conversational equivalent for a poor fellow. Its cultivation extends as far as southern Germany; but in the climate of Britain it is found too tender to be profitable. The herbage affords fodder, and the seeds are one of the oceasional substitutes for coffee. In summer weather drops exude from this plant, which, on drying, leave crystals of almost pure oxalic acid. The too free and prolonged use of chick peas as food is believed to be liable to become the cause of dangerous and obstinate forms of disease.

Chickweed (Stellaria media), one of the most common weeds of gardens and cultivated fields, is a species of Stitchwort $(q . v$,$) . It is a native$ of most parts of Europe and of Asia, appearing during the colder months even on the plains of India; an annual, with a weak procumbent stem and ovate leaves, very variable; some of the smaller varieties in dry sunny situations sometimes puzzling young botanists from having no petals or only five or three instead of ten stamens; but always characterised by having the stem curiously marked with a line of hairs, which at each pair of leaves changes from one side to another, and in four changes completes the circuit of the stem. The leaves of chickweed afford a fine instance of the sleep of plants, closing up on the young shoots 
at night. Chickweed is a good sulsstitute for spinach or greens, al though generally little regarded except as a troublesome weed, or gathered only by the poor to make poultices, for which it is very useful, or for feeling cage-hirds, which are very fond of its leaves and seeds. A number of species of a nearly allied genus, Cerastium, also bear the name of Chickweed, or Mouse-ear Chick. weed, and the name is occasionally given to other plants, either botanically allied, or of somewhat similar appearance.

Chiclana, a pretty town of Andalusia, Spain, 12 miles $\mathrm{SE}$. of Cadiz, with a notable bull-ring and vineyards. Its mineral baths are much frequented. Pop. 11,627.

Chiclayo, a town of Peru, 12 miles SE. of Lambayeque, is the centre of a valuable sugar district. Pop. 11,325.

Chic'opee, a post-village of Hampden county, Massachusetts, on the east bank of the Connecticut River, 4 miles N. of Springfield, with manufactures of cottons, bronze cannon, cutlery, and locks. Pop. 5no0; of the township, including the large manufacturing village of Chicopee Falls, (1885) 11,528; (1890) 14,050.

Chicory, or Succory (Cichorium), a genus of Compositæ (sub-order Ligulifloræ), with few species, all herbaceous perennials, with spreading branches and milky juice, natives of Europe and West Asia.

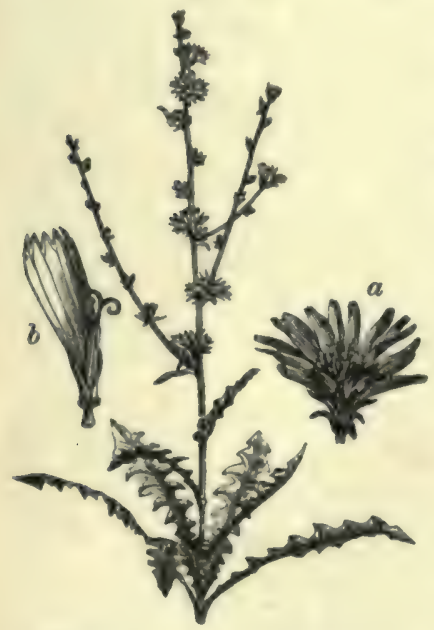

Chicory (Cichorium Intybus):

$a$, single flower: $b$, a neparate floret. The Common Chicory or Succory (C. Intybus) is wild in England and most parts of Europe, growing in way. sides, borders of fields, \&c. It has a long carrot-like root, externally of a dirty or brown is h. yellow colour, and white with. in. The stem rises 1 to 3 feet, the leaves resembling those of the dan. delion; the flower-heads are sessile, axillary, large (1 to $1 \frac{1}{1}$ ch), and beautiful, generally blue, more rarely pink or white. Chicory is pretty extensively cultivated, both in England and on the continent of Europe, as also in California, for its roots, while its herbage is good food for cattle. The blanched leaves are sometimes used as a salad, and are readily procured in winter by placing the roots in a box with a little earth in a cellar. To this genus belongs also the Endive (q.v.).

Chicory has been used as a substitute for coffee, or to mix with coffee, for at least a century. The roots are pulled up, washed, cut into small pieces, and dried on a kiln, which leaves a shrivelled mass not more than one-fourth the weight of the original root. It is then roasted in heated iron cylinclers, which are kept revolving as in coffee-roasting, during which it loses 25 to 30 per cent. of its weight, and evolves at the same time a disagreesble odour, resembling burned gingerbread. An improvement to the chicory during roasting is the addition of $2 \mathrm{lb}$. of lard or butter for every cwt. of chicory, which communicates to it much of the lustre and general sppearance of coffee. It is then hand. picked, to remove chips of wood, stones, \&c, and is reduced to powder, and sold separately as chicory pouvler, or is aulded to ordinary ground.coffee, and is sold as a mixture. Chicory contains a good deal of sugar, but otherwise does not nerve to supply the animal economy with any useful ingredient. It gives off a deep brown colour to water when an infusion is made, and hence its main use in coffee. Some people dislike the taste of chicory, and when largely used, it has a tendency to produce diarrhoes; but many people prefer to use coffee mixed with chicory owing partly to the taste it communicates, but mainly to the appearance of strength which it gives to the coffee. See AdULteration.

Chief, in Heraldry, an ordinary consisting of the upper part of the field eut off by a horizontal line. It is generally made to occupy one-third of the area of the shield. The expression 'in chief' means not on a chief, but that the charge is borne in the upper part of the shield.

Chief-justice. See Justice

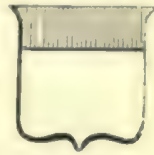

In Chief.

\section{(LORD CHIEF).}

Chiem-See, a lake of Upper Bavaria, the largest in the couritry, lies about 40 miles SE. of Munich, at an elevation of 1650 feet above the sea, with a length of 12 miles, a breadth of 7 , and a greatest depth of 512 feet. It has three islands ; its surplus water is discharged by the $\mathrm{Alz}$ into the Inn. The lake is famous for its fish; and a small steamer plies on it, although the primitive dugout canoes are still its characteristic craft.

Chie'ri, a town of Northern Italy, 12 miles SE. of Turin by rail, with some fine churches, and silk. cotton, and linen manufactures. Pop. 9494.

Chie'ti, an archiepiscopal city of Italy, beantifully situated on a hill near the Pescara, 69 miles E. of Aquila by rail, and only 8 from the Adriatic. It has a fine Gothic cathedral, a lyceum, and a theatre, and manufactures cloth and silk. Pop. (1891) 23,528. Chieti was built on the site of the ancient Teate of the Romans, many of the remains of which are still visible. In $1524 \mathrm{St}$ Gaetano founded here the order of the Theatines.

Chiff-chaff (Sylvia hippolais), a small species of warbler, of very wide distribution. It is common in the south of Europe, and arrives in Britain in early spring as a summer visitor, but does not reach Scotland. Its general colour is brown; the under parts lighter. It is a very sprightly little bird; but its song consists merely of a frequent repetition of two notes resembling the syllables chiff-chaff. It is also called the Lesser Pettychaps. Phylloscopus tristis is sometimes called the Siberian Chiffchaff. See WHITETHROAT.

Chigi, a princely Italian family, whose founder was A gostino Chigh (died 1512), of Siena, who in Rome became banker to the popes, and was noted for his pomp and encouragement of art. See Cugnoni's Agostino Chigi il Magnifico (Rome, 1881). - A descendant, FABIo CHIGI, occupied the papal throne as Alexander VII. (1655-67).-FLAVIo CHIGI, born in 1810, was till 1848 in the papal guard, and then became Bishop of Mira in partibus, nuncio at Munich, and till 1873 at Paris, and died a cardinal, 15th February 1885. The head of the family is Prince of Campagnano and Duke of Ariccia, and is also hereditary marshal of the Conclave.

Chignecto Bay, an inlet at the head of the Bay of Fundy, in British North America It separates Nova Scotia from New Brunswick, is 30 miles long and 8 broad, and has an isthmus of only 
14 miles in width between it and Northumberland Strait, in the Gulf of St Lawrence.

Chigmon (Fr., originally the 'nape of the neck'), a general term for the long back hair of women when gathered up and folded into a roll on the back of the head and neck. Padded and powdered, it was a common mode of the 18th century; in 1866 it reappeared, and with the generous assistance of false hair attained such ungraceful proportions as by 1875 brought about its dismissal.

Chigoe, or JigGer (Sarcopsylla penetrans), a genus of flea, somewhat smaller than the familiar Pulex, and without its jumping legs. It is an American pest, found for about 30 degrees on each side of the equator, but especially abundant in the West Indies and in the north of South America. It is found also in the West African coast region.

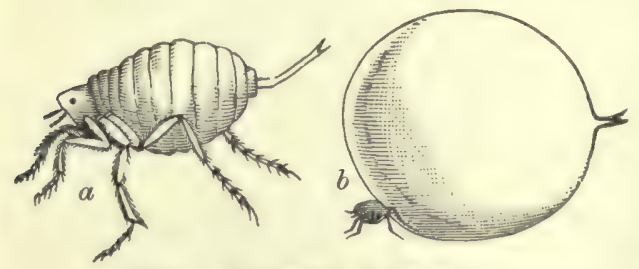

Chigoe (Sarcopsylla penetrans): $a$, male; $b$, gravid female.

One of its many names-the 'sand-flea'-indicates its favourite haunt among sand. It seems always to keep near the abodes of men. The males and immature females live like other fleas on chance bites, and relish of course the blood of animals as well as of man. It is the impregnated female which is the chief trouble. Like many other animals it seeks a safe and quiet breeding-place. This is found under the skin of animals, on the feet or under the toe-nails of man. There the minute creature swells up enormously, attaining under the pressure of the growing eggs the size of a pea. Respiratory communication with the outer world is kept up by an air-hole at the posterior end. In less than a week the eggs are ready to be liberated, for the larvo are not parasitic. The mother-animal has meanwhile undergone a marked degeneration, the internal organs being much squeezed and atrophied by the growth of the ova. The entrance of the female chigoe is marked by a tingling and itching sensation, but if the development be allowed quietly to proceed no evil results seem to follow. Pressure and premature attempts to isolate the intruder may, however, lead to ulceration. Its evil effects seem to have been exaggerated. When the development of eggs has been completed, the entire animal with its progeny may be gently removed, and in this operation the West Indian negresses are experts. Washing with tobaccojuice is also resorted to, and the leaves are sometimes pressed on the feet as a preventive.

Chigwell, a village of Essex, on the border of Hainault Forest, 13 miles NE. of London. Its 'Maypole Inn' is familiar to readers of Barnaby Rudge; and it has a grammar-school, founded by Samuel Harsnet, Archbishop of York, in 1629, and improved and enlarged since 1871 at a cost of $£ 10,000$. Penn was a pupil. Pop. of parish (1861) 2676 ; (1891) 6324 .

Chihuahua, the largest state of Mexico, bounded on the N. and NE. by New Mexico and Texas, has an area of $87,802 \mathrm{sq} ! \mathrm{m}$., and a population of 298,073 . In the east is the Bolson de Mapimi, a vast desert of sand and alkali plains; in the south and west the surface is mountainous, and there are numerous rivers. The state is better adapted for stock-raising than for agriculture; the fertile districts are mainly confined to the valleys and river-courses. Cotton is grown in the south. The silver-mines were for centuries among the richest in Mexico, and though many are now abandoned, mining is still the chief industry. The state is traversed by the Mexican Central Railway. -The capital, Chihuáhua, 225 miles S. of El Paso by rail, rises like an oasis in the desert, among roses and orange-groves. It is well built, with broad, clean streets, an imposing cathedral (171789 ), a mint, and an aqueduct 3 miles long, and is the centre of considerable trade with Texas. Founded in 1691 , it had in the 18th century 80,000 inhabitants. Pop. (1880) 12,116.

Chikislar, a small port in Russian Turkestan, on the eastern shore of the Caspian, north of the mouth of the Atrek.

Chilblains are localised inflammations of the skin which occur in cold weather, and affect the parts farthest from the centre of the circulationviz. the hands and feet, more rarely the ears or nose. They are at first bright red, but as they disappear assume a purplish tinge. Sometimes they break and give rise to ulcers, which are slow to heal. They occur most frequently in young people, affect women more often than men, and are generally associated with weak health and a sluggish circulation. They are often extremely irritable and painful, especially when the affected part has been chilled, and is quickly warmed again. In their treatment, regard must be had to the general health; good feeding, exercise, and tonics should be preseribed. It is very important that tight shoes, gloves, garters, and bracelets should be avoided; and that the affected parts should be warmly covered when exposed to the open air. Locally, when the skin is whole, some stimulating agent answers best; tincture of iodine, spirit of camphor, or mustard applied moist and rubbed till it dries. If the skin be very tender, collodion painted over it is useful. Broken chilblains should be dressed with resin ointment or Peruvian balsam on lint.

Child. See Birth, Fatus, Foundling, HerEDITY, INFANT, MAN ; for legal standing, see AGE, Parent and Child, Guardian, Heir, Infant, Kin (NeXt of); see also AbDuction, Children (Prevention of Cruelty to), Factory Acts, ILLEGITIMACY, INSURANCE, INFANTICIDE.

Child. Francis James, the most learned of ballad editors, was born in Boston, Massachusetts, February 1, 1825. He graduated at Harvard in 1846, and was an instructor there for some time in the department of mathematics, and afterwards in that of rhetoric. After a year or two spent in Europe, he was in 1851 appointed to the chair of Rhetoric at Harvard, which he exchanged in 1876 for that of Anglo-Saxon and Early English Literature. His first work was Four Old Plays (1848); but more important were his annotated edition of Spenser (5 vols. Boston, 1855), and of the English and Scottish Ballads (8 vols. Boston, 185759 ), in a great American series of 'British Poets.' The latter was at once recognised as the best collection of English ballad poetry - a place which it will lose only on the completion of the great comparative collection by the same editor (already 9 parts, Boston, 1882-94). This may be accepted as the final work on its subject, as it contains all the versions and variants collected from all sources, while the introductions to each ballad are masterpieces of luminousness and learning. An édition de luxe in form, and singularly free from typographical and other errors, this work will continue to be indispensable to all serious students of 
popular poetry. Professor Child alao contriluted : anne valuable notea to Hales and Furnivall's reprint of Bisluep P'erey's folio unamuseript (IXtii (ix). Ilis 'Observations on the Languave of Chancer and Gower,' in the Memoirs of the American Acn. demy, and reprinted in Ellis's Éurly Einglish Pronanciation (1869) show a marvellous graxp of Middle English grammar. He died 11 th September 1898.

Child. SIR Josiar, writer on commerce, was born in 1630, the second gon of a merchant of London. He himself made a fortune of $£ 200,000$ as a navy victualler at Portsmouth and a director of the East India Company. In 1678 he was made a baronet, and he died 22d June 1699. His prin. cipal work is Brief Observations concerning Trade and the Interest of Money (1668); \& 3d edition (1690), much enlarged, is entitled $A$ New Dis. course of Trade, and has as an appendix, 'A small Treatise ayainst Usury.' In this work he explains his plans for the relief and employment of the poor, including the substitution of listricts or unions for parishes, and the compulsory transportation of paupers to the colonies.-His brother, SIR JoHN CHILD, was governor of Bombay, where he died, 4th February 1690.

Child (born Francis), Lydia Maria, American author, born in Medford, Massachusetts, in 1802 . jublished her first novel in 1821, and in 1828 married David Lee Child (1794-1874), a joumalist, with whom she edited the Anti-slavery Standard in New York in 1843-44. She was a conspicuous champion of the slaves, for whom she published an Appeal in 1833 ; the principal of her numerous other works are novels, the best of them relating to early New England history, and an ambitious but inaccurate work on the history of religion (1855). She died 20th Oetober 1880.

Childermas, or HoLY InNocents' DAY (28th December), is observed by the Church of Rome with masses in commemoration of the children killed by Herod. It was long considered unlucky to marry or to begin any work on this day, and from Fenn's Letters we learn that the coronation of King Edward IV. was put off till the Monday, because the preceding Sunday was Childermas Day. Innocents' Day is also a red-letter festival of the Church of England.

Children, Prevention of Cruelty to. Experience has proved that defenceless children, even within the range of our boasted civilisation, are not infrequently grossly maltreaterl by parents, their natural protectons, and that therefore special legislation is necessary to secure their proper treatment. To ameliorate the condition of chil dren has therefore entered largely into the scope of modern legislation. The Factory Acts (q.v.), the Erucation Acts, the Reformatory and Indus. trial Schools Acts, the Criminal Law Amendment Act, and the Dangerous Performances Act are all evidence of this fact. The operations of the recently formed Societies for the Prevention of Cruelty to Children show in the strongest light the necessity for their action, though it is but a very few years since this special agency was introduced among us. The first societies of the kind were established in the United States, That in New York was the earliest, as it is the largest and most influential. Liverpool in 1883, and London in 1884, followed this example, and now, by means of other local societies, or of local aid committees affiliated to the London society, the work they have undertaken is rapidly spreading; convictions for cruelty are secured and children are :sheltered and fed. The Rev. Benjamin Wauglı deserves mention as the main promoter of the society (now incorporated by royal ehnrter) and its work. The Prevention of Cruelty to Children Act of 1894 hos given great help to the cause. It imposes penalties on those who intlict needless suf fering on ehildren; punishes neglect, exposure, and assault-especially where insuratse mon: $y$ in a bait; specially deals with offences by drunken parents, and with parents who make their children under eleven beg or vend in the street between nine at night and six in the morning. It also provilles for government inspeetion of plices where acrobats and pantomime children are trained, and abolishes the necessity of the oath in many cases. Sentences of from three months' imprisonment to three years' penal servitude may be inflicted. And the Act further modifies the conditions of guardianship, and brings in the authority of the Home Ottice in connection with the emigration of ill-treated children. Yet further legislation is required. A wife cannot give evidence against her lusband of his drunken midnight cruelty to their child which she alone has witnessed, though a mother's evidence is legally admissible if she is not married to her chill's father. State protection sliould be as freely accorded to the lives and limbs of children as, through the Court of Chancery, it is to their property. This benevolent work for children is indeed essentially a special work, and the police have not the sufficiency of time, resource, and special training which its full discharge requires. Municipal corporations should be empowered to regulate as in America what is called 'street peddling, as of evening newspapers and the like. The hours, varying with the season of the year, in which it may be carried on at all, and the agres of the boys and girls who may be engaged in it, should be fixed and enforced. Once give the necessary powers, aud many present evils will cease. - For the Criminal Law Amendment Act, see ABDUCTION ; see also INFANTICIDE.

Childs, George William, horn in Baltimore, Maryland, 12th May 1829, became clerk in a bookstore in Philadelphia, by 1850 was head of a publish. ing firm, and in 1864 purchased the Public Ledger. He died 2d February 1894. He devoted much of his wealth to beneficence, and he erected a memorial window in Westminster Abbey to Cowper and George Herbert, a monument to Leigh Hunt at Kensal Green, and a fountain to Shakespeare at Stratford-on-Avon. See his Recollections (1890).

Chili (written CHILE by its own eitizens), one of the republics of South America. It is situated on the west coast, and may be deseribed as a long strip of territory lying between the summit of the Andes and the Prcific Ocean, extending from about the 18th parallel of south latitude to the southern extremity of Tierra del Fuego. Boundaries: N. by Peru, E. by Bolivia and Argentine Republic, W. and $\mathrm{S}$. by the Pacific Ocean. By recent treaties the territory of Chili has been considerably extended. After the war with Bolivia and Peru (1879-81), Chili acquired the const between $23^{\circ}$ and $25^{\circ} \mathrm{S}$. claimed by Bolivia, and annexed the Peru. vian province of Tarapaca. She also occupies the Peruvian provinces of Arica and Tacna, subject to the payment of a war-indemnity by Pern. In the south the disputed claims of Chili and Argentina to Patagonia have been settled by Chili taking all territory and islands south of the 52d parallel and west of $68^{\circ} 30^{\prime} \mathrm{W}$. This includes the larger portion of Tierra del Fuego. The Strait of Magellan is by treaty considered neutral. The length of Chili is about 2500 English miles. Its breadth varies from 40 to 200 miles. The Andes extend in two parallel lines throughout nearly the entire length of the country. Between these two ranges of the 'Condillera' there is a central valley or tableland which attains its greatest breadth between $33^{\circ}$ and 
$40^{\circ} \mathrm{S}$. The streams in the north are of little importance, being mostly shallow brooks, which, after a short course, are licked up by the thirsty land; in the south they are larger and more numerons, although most are navigable for only a few miles. The principal are the Maipu, which waters the valley of Santiago; the Maule; the Biobio (q.v.), the largest river in the country; the Cauten, or Rio Imperial; the Bueno; and the Callecalle, or Rio de Valdivia (100 miles), the most important of all, because of the sheltered harbour at its mouth. In the south are also many deep lakes, such as Llanquihne ( 30 miles long by 22 broad) and Ranco (32 miles by 18). Mineral waters, chiefly saline and sulphureous, are abundant; the principal spa is at Chillan (q.v.). The most important islands are those constituting the province of Chiloé (q.v.); Juan Fernandez (q.v.) also belongs to Chili. Owing to its great extension from north to south, Chili comprises regions of very different nature and climate. The north provinces, Tarapacá, Atacama, and part of Coquimbo are arid, rainless districts, where the principal industry is mining and extraction of saltpetre. The middle and southern provinces-viz. Aconeagua, Valparaiso, Santiago, Colchagua, Curicó, Talca, Linares, Máule, Nuble, Concepcion, Arauco, Biobio, and Valdivia, are agricultural and viticultural, and have also valuable coalfields. The Patagonian region is densely wooded and sparsely inhabited by a few Indians. The climate of Chili is temperate. In the north it is moderately hot and rainless, but banks of clouds always hang overhead, and heavy dew falls at night. In the south it is dry for about "eight months of the year, and rainy the other four. The temperature is remarkably even and pleasant, and always cool at nights. The south wind blows fiercely during many days of summer dry and cold; the north wind brings heat, tempest, and rain ; other winds are unknown. In Southern Chili generally the land is poor and of hardly any value for agriculture, which, indeed, is carried on in a very primitive fashion; but the soil of the valleys, where large herds of cattle graze, is very fertile. Vines, also, grow well on the hillsides, and the wines of the country are superseding in Chili the French red wines. The Andes are almost everywhere visible, covered with perpetual snow. The highest peak is Aconcagua, 22,867 feet. The average height of the great range is 8000 feet. There are many volcanic peaks, mostly extinet. Amongst these may be mentioned Tupungato, Descabezada, Chillan, Osorno, Villa Rica, \&c. Chili is subject to frequent shocks of earthquake, and occasionally to destructive terremotos. The most notable of these recorded was in 1822, when the coast near Valparaiso was thrown up permanently between 3 and 4 feet this elevation extended over $100,000 \mathrm{sq}$. m. In 1835 Concepeion and Talcahuano were destroyed by a fearful earthquake which produced disaster all over the southern provinces. In 1868 Iquique was destroyed by a shock which was felt more in the northern distriets, and again in $\mathbf{1 8 7 5}$.

The population of Chili according to the census of 1885 was $2,524,476$, an increase of 352,813 since the preceding census of 1875 , making allowance for the new territories. In 1894 the population was estimated at 2,920,000. The number of foreign residents increased from 26,635 to 40,000 during that period. The natives of Chili are a mixture of Spanish with the Araucanian Indians, In the upper classes the race has been kept more purely Spanish than in any other South American country. The working-classes are laborious and docile, but it cannot be said that there is as yet any effectual protection for property. Wages are still very low. On estates labourers receive about 1s. 6d. per day, but are allowed a patch of land to cultivate for themselves. Since the acquisition of the territory of the Araucanian Indians in 1881 the government has been anxious to attract European emigrants, but British adventure in that direction has been deprecated. There is practically no demand for English mechanics, and the manufactures, properly so called, are confined to coppersmelting, sugar-refining, tanning, brewing, manufactures of soap and candles, biscuits, boots and shoes, woollens, flax, and nitrates. A special effort is being made to introduce new manufacturing industries which will be protected by tariff.

The established religion of Chili is Roman Catholic, but public opinion is now very liberal, and other religions are tolerated. Education receives much attention, and is gratuitous and at the cost of the state. There are 1200 pnblic elementary schools, with 110,000 pupils, besides 500 private schools; but in spite of the elaborate educational apparatus, less than 650,000 persons can both read and write. There is a first-class university at Santiago, normal and agricultural colleges, and a lyceum in every provincial capital. The language spoken in Chili is Spanish, but with many local words of Indian origin.

The value of imports in 1890-94 varied from $\$ 63,000,000$ to $\$ 78,000,000$; and of exports from $\$ 69,000,000$ to $\$ 72,000,000$; a third of the imports and two-thirds of the exports were British, the German and French trade being next in importance. Mineral products represented five-sixths of the total exports. The chief articles of export were nitrate and iodine, copper, silver, gold, manganese, hides, wool, wheat, and barley. The principal imports were cotton, woollen, and jute goods, iron, hardware, coal, machinery, timber, rice, sugar, earthenware, cement, paper, beer, glassware, kerosene, tallow, matches, tea and coffee.

The railway system of Chili is well developed. A government broad-gauge line runs from Valparaiso to Santiago, crossing the coast-range of the Andes, and thence southwards through the central valley to Concepcion, and through Araucania towards Valdivia, making a total length of about 1500 miles. A branch from the Valparaiso and Santiago line also runs to Santa Rosa at the foot of the Andes, from which a line is now in progress, to unite with the Argentine railway system, vid the Uspallata Pass, which it will eross at the elevation. of 9843 feet above sea-level by means of a tunnel 61 miles in length. When this is finished there will be a through communication from the Prcific to the Atlantic Oceans, and by many it is argued that this will be the shortest route from England to the Australian colonies. The length of the railway from Valparaiso to Buenos Ayres will be 880 miles. In the northern provinces there are several mineral railways belonging to English companies. One of these, the Antofagasta line, has been prolonged into Oruro in Bolivia.

The financial position of Chili is satisfactory, and its credit stands higher than that of any other South American state; it has borrowed money in the London market at the rate of $4 \frac{1}{2}$ per cent. per annum, as well as at 5 and 51 . The public debt in 1894 comprised an external debt of $£ 71,780,000$ (usually stated in English pounds sterling), and an internal debt of $\$ 66,000,000$ (paper pesos: the paper peso being worth little more than 18.). The revenue of 1895 was stated at $\$ 70,502,000$ (paper), and the expenditure at $\$ 57,090,000$, showing $a$. large surplus, as is not unusual. The revenue is. mainly derived from eustoms-now producing about $\$ 40,000,000$ (paper) annually. The progress of the country may be tested from this branch of the revenue, which in 1856 amounted to $\$ 4,147,298$, in 
1866 to $89,058,416$, and in 1876 to $87,422,791$, in 1886 reached $\$ 23,416,346$. The current money of Chili previous to the late war was gold and silver and a restricted bank-note issue which stood at par. The necessities of the government caused an insue of inconvertible paper notes which subsequently fell to a serious depreciation. The par value of a dollar is equal to 5 francs or a little over 48d., but its value in exchange during the war with Peru was as low as I6d. Its value in 1895 was about 38d. Owing to this circnmstance it is difficult to form an exact eatimate in sterling of the exports and imports. Elaborate statistics are regularly published by the government. The values are arrived at by official valuation, which is not always in proportion to the real value. Government accounts are also still kept as though the dollar was equivalent to $48 \mathrm{~d}$. The foregoing statistics must therefore be modified in view of these con. ditions.

The constitution of Chili is republican and based upon that of the United States. Every eitizen is entitled to a vote who can read and write and prove that he earns $\$ 150$ or upwards a year, and is twenty-one years of age if married, or twenty-five if single. The president is appointed by a body of electors chosen by the people. His term of office is five years, and his salary $\$ 18,000$ per annum. The cabinet consists of six ministers-viz. of Finance, the Interior, Foreign Affairs, War, Commerce and Public Works, and of Justice, Public Worship, and Instruction. The Council of State consists of five members nominated by the president, and six appointed by congress. The legislature is composed of two chambers - viz. the Deputies, about 100 in num. ber, being in proportion of one to 20,000 inhabitants; and the Senate, numbering one to every five deputies. Deputies must have an income of at least $\$ 500$, and senators of $\$ 2000$. The elections are conducted with considerable fairness, but as the majority of the representatives chosen have come from the ranks of a few leading families, Chili has been well described as 'an aristocratic republic.' This state of affairs, however, has brought excellent results, as the Chilian government has long had a deservedly high reputation for ability and integrity.

History. - The name Chili is snpposed to be derived from an ancient Peruvian word signify. ing 'snow.' The northern portion, as far as the river Máule, formed part of the dominions of the Incas of Peru. The southern was held by the valiant Arancanians, the only aboriginal race which was not subdued by the Spaniards, and which until a few years ago maintained their independence against the Chilians, The first European to land in Chili was the Portuguese discoverer Magellan, after his famous voyage through the strait which now bears his name. He landed at Chiloe in 1520. After the conquest of Peru by Pizarro, an expedition was made to Chili from that country overland under the leadership of Diego de Almagro in 1535. This expedition penetrated as far as the Rio Clano, but returned un. successful. Another was sent under command of Pedro Valdivia in 1540, which succeeded in annexing the territory as far as the river Maipu. Santiago, the capital, was founded by Valdivia in 1542. During the colonial period the governors of Chili were appointed by the viceroys of Peru. In 1810 a revolt against the Spanish power broke out, in which Don Bernardo O'Higrins, son of one of the last viceroys of Peru, but a native of Chili, played a conspicuous part, and finally became the first dictator of the new republic. The conflict between the Spanish troops and the republican army continued until 1826, when peace was definitely settled, and Chili left to govern itself. The first constitutional president was General Blaneo Enealadr. The gov. ernment was unsettled until 1847. A revolution broke out in 1851, but since then there bas been no serious attempt to overturn the government by force of arms. In 1864 Chili gave Pern very valu. able support in her war with Sjain. Valjaraiso was bombarded by the Spaniards in 1866 . In 1879 Chili declared war against Bolivis, and immediately thereafter against Peru, with which Bolivia was allied. For a time the Peruvian fleet kept the Chilians in check, but in August 1879 the Peru. vian ironelad Huascar was eaptured by the Chilian men-of-war Cochrane and Blanco Encalada, both armour-plated. After this event the success of the Chilians was uninterrupted-Peruvian towns were bombarded, war-ships captured, and Lima taken by storm 21st June 1881. The Chilians occupied Lima and Callao until 1883, when a treaty of peace was signed. President Balmaceda's unconstitutional government led to civil war in 1891 , when the congressionalists were victorious. The decisive battle was fought near Valparaiso on 28th August, and Balmaceda committed suicide.

See books on Chili by Dr W. H. Russel (1890), M. H. Hervey (1891), Hancock (1894), W. Anderson Smith (1900), Rumbold (Paris, 1877), Robiano (Paris, 1882), Ochsenius (Leip. 1884), Boyd (1881), Sir Clements R. Markhain (1883); Lord Cochrane, in the Fortnightly Review (1884); the Historia General by Arana (1863), and that by Rosales (1878). - For Chili Pine, Chili Nettle, nee ARAUCaria, LOASACEa.

\section{Chiliasm. See Millennium.}

Chilkoot Pass, a difficult pass through the coast range of the Rocky Mountains, on the main route from the South Alaskan strip of coast to the Canadian north-western district of Yukon, includ. ing Klondike and other rich gold-bearing regions in the upper basin of the Yukon river.

Chillan, capital of the Chilian province of Nuble (pop. 16,000), with bathing establishments, near the extinct volcano of Chillan (9445 feet).

Chillesford Beds. See Pliockne.

\section{Chillies. See Capsicum.}

Chillianwalla, a village of the Punjab, 5 miles from the enst bank of the Jhelum, and 85 miles NW. of Lahore. It was the scene of an indecisive but sanguinary battle during the second Sikh war, 13th January 1849, and is the site of an obelisk erected to the memory of the British officers and men who fell in the engagement.

Chillico'thé, capital of Ross county, Ohio, pleasantly situated on the Scioto River and on the Ohio Canal, 50 miles $\mathrm{S}$. of Columbus by rail. It has manufactures of "paper, leather, farning implements, Sc., and was from 1800 to 1810 the eapital of the state. Pop. (1880) 10,938; (1890) 11,288.

Chillingham, a village in the north of Northumberland, on the river Till, 8 miles SW. of Bel. ford. To the south is Chillingham Castle, seat of the Earl of Tankerville, built in the reign of Edward III. In the park, as at Cadzow, are preserved a herd of wild white cattle. See CATTLK.

Chillingworth, WILLIAM, one of the greatest of English controversial theologians, was born at Oxford in 1602 , the son of a prosperous citizen, who afterwards became mayor. Laud, then Fellow of St John's College, was his godfather. In 1618 he became a scholar of Trinity College, and in 1628 was elected to a fellowship in his college. Aubrey's story that he acted here as a kind of spy for Laud rests on Sir William Davenant's dubious authority slone, and may safely be neglected. His great parts soon securerl him the intimacy of Sir Lucius Carey, afterwards Lord Falkland, John Hales of Eton, and Gilbert Sheldon, afterwands Archbishop of Canterbury; 
and his restless intellect soon turned to the question of chief interest at that time in his university -the controversy between the Church of England and the mother Church of Rome. The arguments of an able Jesuit, known by the name of John Fisher, at length convineing him of the necessity of an infallible living judge in matters of faith, he embraced the Romish communion 'with an incredible satisfaction of mind.' In 1630 he went to Douay, and here being urged to write an account of the motives of his conversion, a fresh examination of the whole questions at issue, and a series of letters from Laud, at length brought him from doubt of the soundness of his recent conclusions to a complete renunciation. But although he had become convinced that the claims of the Church of Rome to an infallible judgment on matters of faith had no real foundation, he adhered alone to Scripture as interpreted by the light of reason, and for a time declined to take orders in the Church of England, regarding her Articles as themselves a needless 'imposition on men's consciences.' Meantime he had become involved in a succession of controversies with John Lewgar, a Catholic convert; Floys, a Jesuit, who went under the name of Daniel; and White, the author of Rushworth's Dialogues. His papers in answer to these-mere preliminary studies for the great work that was to follow-are contained in his Additional Discourses, published in 1687. Another Jesuit, known as Edward Knott, having published in 1630 his Charity Mistaken, doc., which was answered by Dr Christopher Potter, provost of Queen's College in Oxford in 1633, rejoined in 1634 with Mercy and Truth, dce. This second book Chillingworth undertook to answer, and with that view retired to the quiet of Lord Falkland's house and library at Great Tew in Oxfordshire. Meantime, Knott hearing of his intention, hastened to take an unfair advantage of his antagonist, by an attempt to prejudice the public mind beforehand. In 1636 he issued in a forty-two page pamphlet a series of mere scurrilous insinuations, the main drift of which was that Chillingworth was a Socinian, whose opinions tended to the overthrow of all supernatural religion no less than of Catholic doctrine. At length, in 1637, appeared Chillingworth's famous book, The Religion of Protestants a safe Way to Salvation: or an Answer to a Booke entitled Mercy and Truth, dcc. This great work suffers from its being necessarily to some extent an answer to a now completely forgotten book, and being thereby weighted with a great mass of extraneous matter. Indeed, it is only after the author has demolished. the arguments of his temporary antagonist that he is at liberty to follow the unembarrassed course of his own thought, and it is evident that only a writer of consummate talent could so have surmounted the disadvantages of such a form, as to make a book of enduring interest and value Yet it is all this and more, for we have here not only a masterly demonstration of the sole authority of the Bible in the essential matters relating to salvation, but an assertion of the free right of the individual conscience to interpret it, laid down once for all with perfect confidence and fullest plainness - the freedom of religious opinion and the right to toleration for honest difference of opinion placed on its true basis, and this two centuries and a half ago. The great question at issue is that of the basis of religious certitude, or 'the means whereby the truths of revelation are conveyed to our understanding, whether this is to rest on the infallible authority of the Church, or ultimately on the authority of the Scriptures alone.

Here Chillingworth's conclusion is, in his own oft-quoted words: "The Bible, I say, the Bible only, is the religion of Protestants." The great principles of religion, and everything of faith essential to salvation, are herein clearly revealed patent to the 'right reason' and judgment of every man. Religious certitude can thus be reached by every honest mind, from the plain interpretation of the Bible, which is necessarily itself intelligible and sufficient, without need of any medium to transfer it or judge to interprek it. Indeed, the measure of the responsibility of faith is just the measure of the elearness and sim. plicity of the divine revelation. Seripture and the candid mind acting together, under the quickening grace of God and the guidance of the Holy Spirit, are thus the sole factors of religious certitude, which is necessarily based on rational personal conviction. The simplest creed is the best creed, and the only possible basis on which to reconstruct the divided church is such a simple, assured, and accepted religious minimum as the apostles' creed, with full freedom to individual opinion in every: thing supplementary and unessential. 'For why,' he asks, "should men be more rigid than God? Why should any error exclude any man from the Chureh's communion, which will not deprive him of eternal salvation?' It may be that Chilling. worth's ideas carried out would have made any kind of church polity or even successive organised religious life impossible, but at least they would have preserved something perhaps quite as precious -an intellectual conception of toleration, that would have saved England years of misery and blood; and which need not necessarily have eliminated also the religious enthusiasm of the individual, together with his confidence in the alosolute infallibility of his own opinions.

The reasoning throughout the great work of Chillingworth is marked by strong and clear intellect; singularly simple but direct and straightforward style, warming at times into a suppressed but vehement eloquence, and informed throughout with an honesty, an earnestness, and, above all, a fairness but rare in controversial literature. Locke, in his Thoughts concerning Reading and Study for a Gentleman, commends 'the constant reading of Chillingworth, who, by his example, will teach both perspicuity and the way of right reasoning better than any book I know.' Chillingworth left little besides his masterpiece-nine sermons, the 'Additional Discourses' already referred to, and a brief fragment on the apostolical institution of episcopacy forming the whole. The rest of his life is soon told. At length he found himself able to give a general assent to the Articles, and in July 1638 he was made Chancellor of Salisbury, with the prebend of Brixworth in Notts annexed, and soon after master of Wigstan's Hospital in Leicester. In 1640 he was elected proctor to convocation by the Chapter of Salisbury. At the outbreak of the Civil War he accompanied the king's forces, though his heart sank within him to see 'publicans and sinners on the one side, against scribes and Pharisees on the other.' He was with the royal army before Gloucester, where, we are told, he devised an engine for purposes of assault after the pattern of the old Roman testudo. At Arundel Castle he was taken ill, and when the garrison sur. rendered to Waller, being too ill to be carried to London, was lodged in the bishop's palace at Chichester, where he died, 30th January $1643 . \quad H i s$ last hours were pestered by the ill-timed and cruel exhortations of one Cheynell, an ignorant and rabid Puritan preacher, who, at his burial in Chichester Cathedral, flung a copy of the noblest theological treatise of the age into the grave, that it might 'rot with its author and see corruption.' The Chillingworthi Novissima, \&c. (1644), in which this Westminster divine did such dishonour to 
himself, is one of the most melancholy monuments that exist of fanatical and unchristian bigotry. It was Chillingworth's fate to be sesailed with 'great asperity and reproaches' all his life, and throughout to be misunderstood by blind Papist and blind Puritan alike.

See the Life by Des Maizeanx (1725), and that by Rev. Thomas Birch, prefixed to his edition of the works (1742). Of these the best edition is that published at Oxford in 3 volu in 1858 See chapter $v$. (vol. i.) of the late I'rincipal 'Tulloch's Rational Theology in Eingland in the Seventeenth Century (2 vols. 1872).

Chillon, a celebrated castle of Switzerland, at the eastern end of the Lake of Geneva, 11 mile SSE. of Montreux. It stands on an isolated rock, 22 yards from the shore, and connected therewith by a bridge, though the strait between them is dry. Dating perhaps from the 8th century, it seems to have been partly rebuilt in 1238, by Amadeus IV. of Savoy, and it long served as a state prison. Here for six years (1530-36) Bonivard (q.จ.) endured the captivity immortalised by Byron's Prisoner of Chillon (1821). Among the thousands of names inscribed on the pillars of the dungeon are those of Byron, Georges Sand, and Victor Hugo. The castle is now used as a magazine for military stores.

Chiloe, the insular province of Chili, consists of the island of that name on the west coast, which is separated from the mainland by a narrow strait on the $N$., and by a gulf 30 miles wide on the E., and has a length of 115 miles, and an extreme breadth of 43 miles, and of a number of neighbouring islets, mostly uninhabited; total area, $3980 \mathrm{sq}$. m. ; pop. about 83,000 , slmost all Indians living on the principal island. Chiloe proper is hilly in the interior, and everywhere covered, except imme diately along the shores, with nearly impassable forest. The climate is mild and not unhealthy, although inordinately wet. The Indians belong to a subdivision of the Arancanian family; they are a gentle and honest race, mostly engaged in fishing and in lumbering, timber being at present the chief export from the island, although immense deposits of coal have been reported. The capital, Aneud, on the north coast, has a good harbour, but is meanly built ; it is the seat of a bishop, and has a population of 6000 .

Chilog'natha, Chilop'oda. See MYrI DPODA.

Chiltern Hills, the southern part of the low chalk range which runs north-east, about 70 miles, from the north bend of the Thames, in Oxfordshire, through Bucks and the borders of Herts and Beds. In Oxford, Herts, and Beds the Chiltern Hills are 15 to 20 miles broad, and the highest point is near Wendover (950 feet). In his sketch of Jolin Hampden's home, Mr Green paints finely 'the quiet undulations of the chalk country, billowy heavings and sinkings as of some primeval sea suddenly hushed into motionlessness, soft slopes of gray yrass or brown-red corn falling gently to dry hottoms, woodland flung here and there in masses over the hills. A country of fine and lucid air, of far shadowy distances, of hollows tenderly veiled by mist, graceful everywhere with a flowing unaccentuated grace, as though Hampden's own temper had grown out of it.

Chiltern IIundreds. In former times the beech-forests which covered the Chiltern Hills were infested with robbers, and in order to restrain them it was usual for the crown to appoint an officer, who was called the Steward of the Chiltern Hundreds. The hundreds in question (see HUN. DRED) are those of Bodenham, Desbornugh, and Stoke, in Buckinghamshire. The stewardship, which has long ceased to serve its primary purpose, now serves a secondary one. A member of the House of Commons cannot resign his ment unless disqualified either by the acceptance of a place of honour and profit under the erown, or by some other cause. Now, the stewardship of the Chiltern Hundreds is held to be such a place, and it is consequently applied for by, and granted, usually as a matter of course, to any nember who wishes to resign, though it has been refused in a case of lrilwery. As seron as it is obtained, it is amnin resigned, and is thus generally vacant when required for the purpose in question. The granting of the Chiltern Hundreds to this end began in the year 1750 ; the vift lies with the Chancellor of the Exchequer. The powers, duties, and remuneration are equally things of nounht. Nortlasteml in lorkshire has been used in the same way since 1841 ; and other manors formerly so used were Old Shoreham in Sussex (1756-99), East Hendred in Berks (1763-1840), Poynings in Sussex (1841-43), Hempholme in York (1845-65). See Quarterly Review, Jan. 1894, and Foster's Chiltern Hundreds (1897).

Chimaera, a fire-breathing monster, described by Homer as having a lion's head, a goat's body, and the tail of a dragon. In Hesiod's account a daughter of Typhaon and Echidna, she devastated Lycia until killed by Bellerophon. Gigantic carvings of the chimæra on rocks have been found in Asia Minor, representing the monster as a lion, out of the back of which grows the neck and head of a goat. It is frequently depicted on shields as a heraldic charge.

Chimaera, a genus of cartilaginous fishes, and type of a distinct order, Holocephali, which is often ranked along with the sharks and rays, or Elasmobranchs. The chief distinctions are the presence of a fold of skin covering the (4) gill-clefts, the nakedness of the skin, the fusion of the upper jaw to the skull, the separation of anal, urinary, and genital apertures. There are no 'spiracles,' nor 'spiral-valve' Except in the above particulars, and $a$ few others of a more technical nature, the members of this small order agree with the ordinary Cartilaginous Fishes (q.v.). There are only two living genera-Chimæra and Callorhynchus. The best-known species of chimrera ( $C$. monstrosa) is often called the King of the Herrings, and is occasionally taken in herring-nets in British seas.

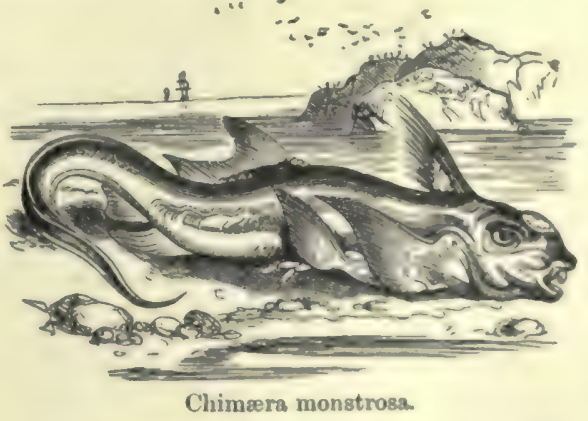

It is found on the cossts of Europe and Japan, in North Atlantic, and at the Cape of Cood Hope. In the United States it is called Sea Cat. It is an ugly fish, seldom over 3 feet in length, of a whitish colour, spotted with brown above. The males have clasping organs; the large eggs are inclosed in a leathery case. The $C$. Colliei is found on the west cosst of North America; and the $C$. Affinis on the const of Portugal. In the other genus, Callorhynchus, in the Sonth Pacifie, the snout bears an appendage, and the tail is not symmetrical as in the above, but slightly shark-like. 


\section{Chimaphila. See Winter-GREeN.}

Chimbora'zo, a conical peak of the Andes, in Ecuador, 20,517 feet above the sea, but only about 11,000 above the level of the valley of Quito, to the north. The 'silver bell' of perpetual snow and glacier was long erroneously regarded as the loftiest mountain not only in America but in the whole world. In $1745 \mathrm{La}$ Condamine ascended to 16,730 feet; no complete ascent had been made, till Whymper in 1880 twice reached the summit.-The peak gives name to the province of Chimborazo, to the south, with an area of 5523 sq. m., and a pop. of 120,000 .

Chimbote, a port of Peru, 85 miles SE. of Truxillo. Pop. 1500.

Chimere, a bishop's upper robe, to which the lawn-sleeves are attached. That of Anglican bishops is of black satin, that of English Roman Catholies is of purple silk.

Chimes. See Bell.

Chimney, a flue constructed in the thickness of a wall or in a separate 'stalk' for the purpose of carrying off the smoke from a fireplace or furnace. The heated air being lighter than the atmosphere which maintains the fire, presses the smoke upwards, and rises with a rapidity proportioned to the difference in weight, assuming that the chimney is of proper construction and size. It has been found in practice that a diameter of from 9 inches to 12 inches is suitable for the fireplaces of ordinary rooms, but in the case of kitchens and other large fires a greater width is required. In olden times it was usual to build fireplaces of great size, with very large chimneys, but as these admit a great quantity of air at the ordinary temperature, the draught is thereby checked, and the chimneys are apt to smoke. Experience has taught that the 'throat' or entrance to the chimney from the fireplace should be made as small as possible compatible with its task of carrying off the products of combustion from the fire. $\AA$ proper draught depends also on the height of the chimney, which ought to be sufficient to be above the interference of swirls of air cansed by surrounding buildings or other objects. The higher the chimney, the greater the draught.

Chimneys are of comparatively modern origin. Only traces of them are found in classic antiquity ; but there must have been some such means of discharging the smoke from the fires which heated the hypocausts of the Roman baths. In medieval times, the earliest examples of fireplaces with chimneys, such as those in the Norman castles of Rochester and Castle Hedingham, erected in the 12th century, have only a short flue ascending a few feet, and discharging by an oblong aperture in the outer face

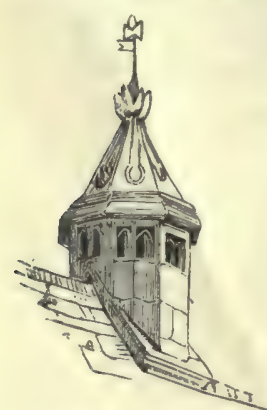
of the wall. These were no doubt found very smoky and inconvenient, and ultimately the chimneys were carried to the roof. In Gothic buildings they are often detached, and the outlet is ornamented with trefoil and other openings. In the English balls the centre hearth was long retained, without any chimney, the smoke being allowed to find its way out through an opening in the roof called the Louvre (q.v.). In Scottish mansions and castles the

Chimney, Tisbury, Wilts.

(From Parker's Glossary.)

hall has always a large fire. place and capacious chimney, while those of the bedrooms are smaller. In the late Gothic and Elizabethan styles the chimneys are amongst the most striking features of the design, being carried up in lofty and highly ornamented stalks, frequently built in brick.

In modern times the external appearance of chimneys has been greatly neglected, to the sad disfigurement of our houses, but a better taste is now beginning to prevail. In one direction, however, modern chimneys have received a great development in connection with furnaces and steam-engines. In order to create a draught, and so cause the fire to burn with intense heat, these chimney-stalks are carried to a great height. The difference of pressure of the atmosphere between the top and bottom, added to the lightness. of the air caused by the heat, acts as the motive power to the 'draught,' which thus increases with the height of the stalk. Amongst the highest existing chimneys may be mentioned the following: (1) the Townsend shaft, Port Dundas, Glasgow, which is 468 feet in total height, and has a diameter of 32 feet at base, and 13 feet 4 inches at top; weight, about 8000 tons. (2) St Rollox shaft, Glasgow - total height, 455 feet 6 inches; diameter at base, 50 feet; at top, 13 feet 6 inches.

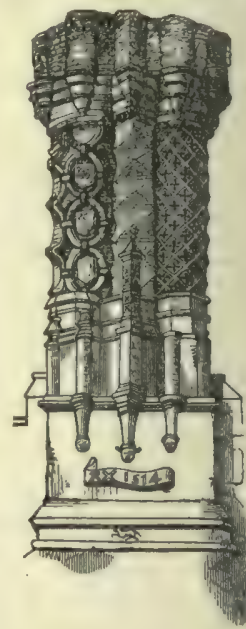

Chimney, Thornbury Castle, Gloucestershire, 1514.
From Parker.)

(3) Mechernich shaft, Cologne-total height, 441 feet; diameter (square) at base, 39 feet; at top (round), 11 feet 6 inches; weight, about 5459 tons.

An act to regulate chimney-sweeping was passed as early as 1789 ; and in 1842 , to prevent the fearful cruelties practised on young chimney-sweepers, it was rendered penal to compel or knowingly allow any person under the age of twenty-one, to ascend or descend a chimney or enter a flue for the purpose of cleaning or curing it; and no child under sixteen could be thereafter apprenticed to the trade. The act was extended and made more stringent in 1864 and 1875.

To extinguish a chimney on fire, it is only necessary to hang over the fireplace a piece of wet carpet or blanket: some handfuls of salt thrown into the fire at the same time will greatly aid the extinction. It is also recommended to scatter a handful of flowers of sulphur over the dullest part of the burning coals, the vapour arising from which will not support combustion, and will consequently extinguish the flames. Throwing water down from the top is a clumsy expedient, by which much dam. age is frequently done to furniture; so also is stopping at the top, by which the smoke and suffocating smell of the burning soot are driven into the apartment. If every fireplace were provided with a damper, or shutter of sheet-iron, sufficiently large to choke it thoroughly, fire in chimneys would become of little consequence, as it would only be necessary to apply this damper to extinguish them. All good modern grates are furnished with such dampers. To set chimneys on fire with a view to clean them is highly objectionable, even where there is no danger of fire to be apprehended, as the intense heat produced rends and weakens the walls. For other connected subjects, see SMOKE, VENTILATION, WARMiNG.

Chimpanzee (Troglodytes niger), one of the highest of the anthropoid or more manlike apes, 
belonging to the same genus as the gorilla ( $T$. gorillie).

Ilistory. - The finst historical notice of the chimpanzee seems to be that given in an account of a Carthaginian exploration of the north-west of Africa, conducted by Hanno in 470 B.C. Along with other anthropoid apes, it was known to the Romans in their varied communications with Africa. The first thorough investigntion of the anatomy was made by Tyson in 1699 . Various travellers gradually gathered information in regard to its habits, and captured specimens were known in France and England by the 18th century. The structure of the animal has been studied by several famous anatomists, such as Owen, Duvernoy, Bischoff, and Huxley ; and much information, both historical and anatomical, will be conveniently found in Professor R. Hartmann's Anthropoid Apes (Inter. Se. Series, 1885). To this naturalist much of our knowledge as to the exact anatomy of the chimpanzee and related forms is due. For more general considerations, Huxley's work en. titled Man's Place in Nature may be profitably consulted. See also his Anatomy of Vertebrate Animals.

Characteristics. As the general features of Anthropoid Apes (q.v.) have been already sketched, it will be enough to sum up the more striking -characteristics of the chimpanzee. The animal stands about four feet high, has very dark, all but black hair, a broad, leathery, reddish-brown face, small nose, large mouth, protruding lips, large browridges, and small ears. The face has an angle of 70 degrees. The head hangs down upon the chest.

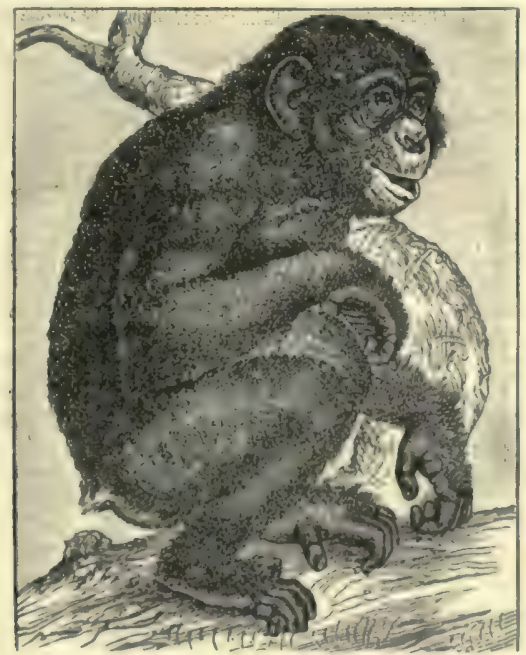

Chimpanzee (after Hartmann).

There are no cheek-pouches. The arms are very long, and reach the knee; their span is about half as much again as the height. The hand is narrow, but as long as the foot. The sole of the foot can rest flatly on the ground, and the animal readily stands or walks ereet. But his favourite attitude is leaning forward, and supporting himself on the knuckles of the hand. The backbone begins to exhibit the curves characteristic of man, and the chimpanzee is alone among anthropoids in having the spine of the second neck vertebra bifurcated as in man. It has one pair of ribs in addition to the twelve possessed by man. There is of course no tail, nor are there any sitting-pads or ischial callosities. The volume of the brain is about half the minimum size of a normal human brain. All the gyri ( ridges) of the human brain are represented in the cerebral heminpheres of the chimpanzee; but they are simpler and more symmetrical, and larger in proportion to the brain.

Ilabits. - The chimpanzee is found on the coest of Guinea and farther inland. It occupies a wider area than the gorilla, and is even said to have been found in East Africa, to the south of Abymainia. It lives in forests, is an adept climber, but keepa a good desl to the ground. The diet consists manly of wild fruits: but animal food seems to be occa. sionally eaten. The chimpanzees live in families or in small societies. They construct pent-houses in the thick forest darkness, and the males are said to jass the night below the family nest. 'They make a great deal of noise, of a dreary and horrible character, especially when provoked by other monkeys. Though they generally flee at the sight of man, they can with hands and teeth make themselves in extremity most formidable antagonists. The natives shoot them with arrows or javelins, or in recent days with firearms. The flesh is eaten by the natives of some parts of Africa; the skulls may serve as fetiches.

There is considerable dispute as to the species or varieties of chimpanzee. Hartmann discusses the question at length in the work already referred to, describing one distinct variety in addition to the typical Troglodytes niger, and admitting the possibility of hybrids. Chimpanzees are occasionally brought to European zoological garlens, but rarely stand the climate for more than two or three years. They are known to exhibit great cleverness, and admit of some education.

China. The Chinese Empire, consisting of China Proper and Manchuria (q.v.), with its dependencies of Mongolia, I-li, and Tibet (q.v.), embraces a vast territory in Eastern Asia only inferior in extent to the dominions of Great Britain and Russia. The dependencies are not colonies, but subject territories: and China Proper itself, indeed, has been a subject territory of Manchuria since 1644. It will be convenient, however, to confine ourselves in this article to the former.

China is not known among the people them. selves as the designation of the country, and the use of the term is spreading among them only through its all but universal employment by other nations. In the oldest classical writings the country is called Hwa Hsia, "The Flowery Hsia.' Chung Kwo, 'The Middle State,' or kingdom, grew up in the feudal period as a name for the royal domain in the midst of the other states, or for those states as a whole in the midst of the uncivilised states around them. The idea of its being ' in the middle of the earth' did not enter into the designation, though the assumption of universal sovereignty, de jure if not de facto, that has been 80 injurious to the nation, appears in the very ancient names Tien hsid, "all beneath the sky, and Sre Hai, 'all within the four seas." In the treaties with western nations concluded in the present century the empire is called by the title of the reigning dynasty, 'the Kinglom of the Great Pure (dynasty):' and this is in aceordance with the practice of Chinese writers, who are fond of calling their country 'the Land of Han,' and 'the Hills of T'ang, from the two great dynasties so named.

Serica, Sera, and Seres, in Ptolemy and other ancient geographers, indicate China and the Chinese as the country and people prolucing silk, being taken from sze (silk), originally the pictorial symbol of a packet of cocoons.

Cathay, a poetical name with us, and still apparent in the Russian name for China (Kitai), came into use as a designation for the northern part of the empire through Marco Polo and other medieval writere. It was the Persian deagnation of the Tartar $K^{\prime}$ itan tribes which contended with 
the Sung dynasty for the supremacy of the empire, then merged in the dynasty of Chin $(K i n)$, and were extinguished by the Mongol conquest. The country south of the Yang-tsze River was then styled Manzi or Manzy, from the old name of Man for all the southern aboriginal tribes.

The name China has come to us from India through Buddhism. In a conversation (apocryphal probably), related by Nien Ch'ang in his History of Buddhism, between the Han emperor who wel. comed them to his capital and the first two of the Buddhist missionaries, there appear the names of Chi-na and Chin-tan ('the Land of Chin'). We do not know how long before our first century the name had obtained in India, nor how it originated. If it had begun with $t s$ instead of $c h$, the view of many that it was derived from the great state of Ts'in, whose fortunes culminated in the first but short-lived imperial dynasty (221-209 B.C.), might have been considered as certain. This question must be left as hardly capable of determination; as also how it is that we find the empire called by other Asiatic peoples Sin, Tsin, T'sinistan, and the inhabitants Tsinisto. "The land of Sinim, in Isa. xlix. 12, is another denomination.

ChINA Proper was divided in the $\mathbf{K}^{\prime}$ ang-haî reign (1662-1722) into eighteen provinces; from 1887 to 1895, when it was ceded to Japan, Formosa, detached from $\mathrm{Fa}$-chien, was a separate province under the name of 'T'âi-wan; and the constitution of Sin-chiang or Sin-tsiang as a new province on the extreme west of the empire raised the number of provinces again to nineteen. One of the easternmost portions of the Asiatic continent, bordering on the Pacific Ocean, China Proper lies, if we include the island of Hai-nan, between $18^{\circ}$ and $49^{\circ} \mathrm{N}$. lat., and $98^{\circ}$ and $124^{\circ} \mathrm{E}$. Iong. Its area is given at $1,298,000 \mathrm{sq}$. m., being more than twenty-five times that of England; but if we include outlying parts of Chih-lî and Kan-su, the total area is not much, if at all, short of $2,000,000$ sq. m. (The whole empire, without Corea, has an area more than twice as large.)

On the north there are four provinces-Chih-lî, Shan-hsî, Shen-hsî, and Kan-sú ; on the west, twoSze-ch'wan (the largest of all) and Yun-nan; on the south, two-Kwang-hsî and $K$ wang-tung; on the east, four-Fu-chien (Kien-the initial ch used to be pronounced $k$ ), Cheh-chiang, Chiang-sú, and Shan-tung. The central area enclosed by these twelve provinces is occupied by Ho-nan, An-hui (Gan-and Ngan-hwei), Ha-pei, Hu-nan, Chianghsî, and Kwei-châu (parts of which are largely occupied by tribes of aboriginal Miâo-tsze). The province of Sin-chiang, Sin-kiang, or Sin-tsiang, recently constituted, includes Easteru Turkistan (q.v.), Western Kan-sú, Ili, and Zungaria (q.v.). Formosa, till then Chinese, was ceded to Japan in 1895 ; and Manchuria, one of the most valuable of the outer provinces, is, since it came under Russian supremacy in 1898, Chinese only in a very limited sense. (See below at page 194).

The population of these provinces has been so variously estimated as to justify $\mathrm{Dr} \mathrm{S}$. W. Williams in holding that, "until there has been a methodical inspection of the empire' guaranteed by the government, questions concerning the population must be held in abeyance. The Almanach de Gotha for 1900 gives for the provinces of China Proper a population of $346 \frac{1}{4}$ millions, and for the whole empire, including Manchuria, Mongolia, and Tibet, but without Corea, 3574 millions. It is probably safe to say that 400 millions is hardly an overestimate of the population of the Chinese empire. Of the twenty-two ports open to foreign commerce, only five have a population under 50,000 . That of Canton was in 1890 estimated at
$2,500,000$; of T'ien-tsin at 950,000 ; of Han-k'au at 750,000 ; of $\mathbf{F u}$-chau at 650,000 ; of Shang-hai at 450,000 ; of Ning-po at 250,000 . The total number of foreigners resident in the open ports was in 1897 stated by the Customs authorities at 11,667, of whom 4929 were British subjects, 1564 American, 1106 Japanese, 975 Portuguese, 950 German, 698 French, 439 Swedish and Norwegian, and 362 Spanish.

As to the physical features of China Proper, the whole territory may be described as sloping from the mountainous regions of Tibet and Nepa] towards the shores of the Pacific on the east and south. The most extensive mountain-range in it is the Nan Ling or Southern Range, a far-extending spur of the Himalayas. Commencing in Yunnan, it bounds Kwang-hsî, Kwang-tung, and Fa-chien on the north, and, passing through Chehchiang, enters into the sea at Ning-po. It thus forms a continuous barrier, penetrated only by a few steep passes (of which the Mei Kwan is the best known) that separates the coast-regions of South-eastern China from the rest of the country. This great chain throws off numerous spurs to the south and east, which, dipping into the sea, appear above it as a belt of rugged islands along the seaboard. Of this belt the Chusan Archipelago is the most northerly portion.

North of this long range, and west of the 113th meridian, on to the borders of Tibet, the country is mountainous, while to the east and from the great wall on the north, to the Po-yang lake in the south, there is the Great Plain, comprising the greater part of the provinces of Chih-li and Shan-tung, Ho-nan, An-hui, and Chiang-sa-an area of about 210,000 sq. m., estimated to support a population of $177,000,000$.

In the provinces west from Chih-1i-Shan-hsî, Shen-hsi, and Kan-sa-the soil is formed of what are called the loess beds, which extend even to the Koko-nor and the head-waters of the Yellow River. The name loess is adopted from that of a Tertiary deposit which appears in the Rhine Valley-a brownish coloured earth, extremely porous, crumbling easily between the fingers, and carried far and wide in clouds of dust. It covers the subsoil to an enormous depth, and is apt to split perpendicularly in clefts which render travelling difficult. And yet by this cleavage it affords homes to multitudes of the people, who live in caves excavated near the hottoms of the cliffs. Sometimes whole villages are so formed in terraces of the earth that rise above one another. But the most valuable quality of the loess is its fertility, the fields composed of it hardly requiring any other manure than a sprinkling of its own fresh loam. The husbandman in this way obtains an assured harvest two and even three times a year. This fertility, provided there be a sufficient rainfall, seems inexhaustible. The province of Shan-hsî has borne the name for thousands of years of 'the Granary of the Nation ;' and it is no doubt to the distribution of this earth over its surface that the Great Plain owes its fruitfulness.

The rivers of China-called for the most part ho in the north, and chiang (kiang) in the south, are one of its most distinguishing features. Two of them stand out conspicuous among the great rivers of the world; the Ho, Hoang-ho, or Yellow River, and the Chiang, generally misnamed the Yang-tsze. They rise not far from each other ; the $\mathrm{Ho}$, in the plain of Odontala, called in Chinese the 'Sea of Stars'-i.e. of springs or lakelets, in $351^{\circ} \mathrm{N}$. lat., and $96^{\circ} \mathrm{E}$. long.; and the Chiang (Kiang), from among the mountains. of Tibet. The Ho pursues a tortuous eastward course to Kan-s $\mathrm{t}$, and the Chiang with a southern inclination enters China at Batang, in Sze-ch'wan. From the prefecture of Lan-chau the Ho flows north-eastmore or less along the Great Wall, till it arrives. 
.

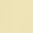

(1)

.

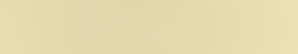




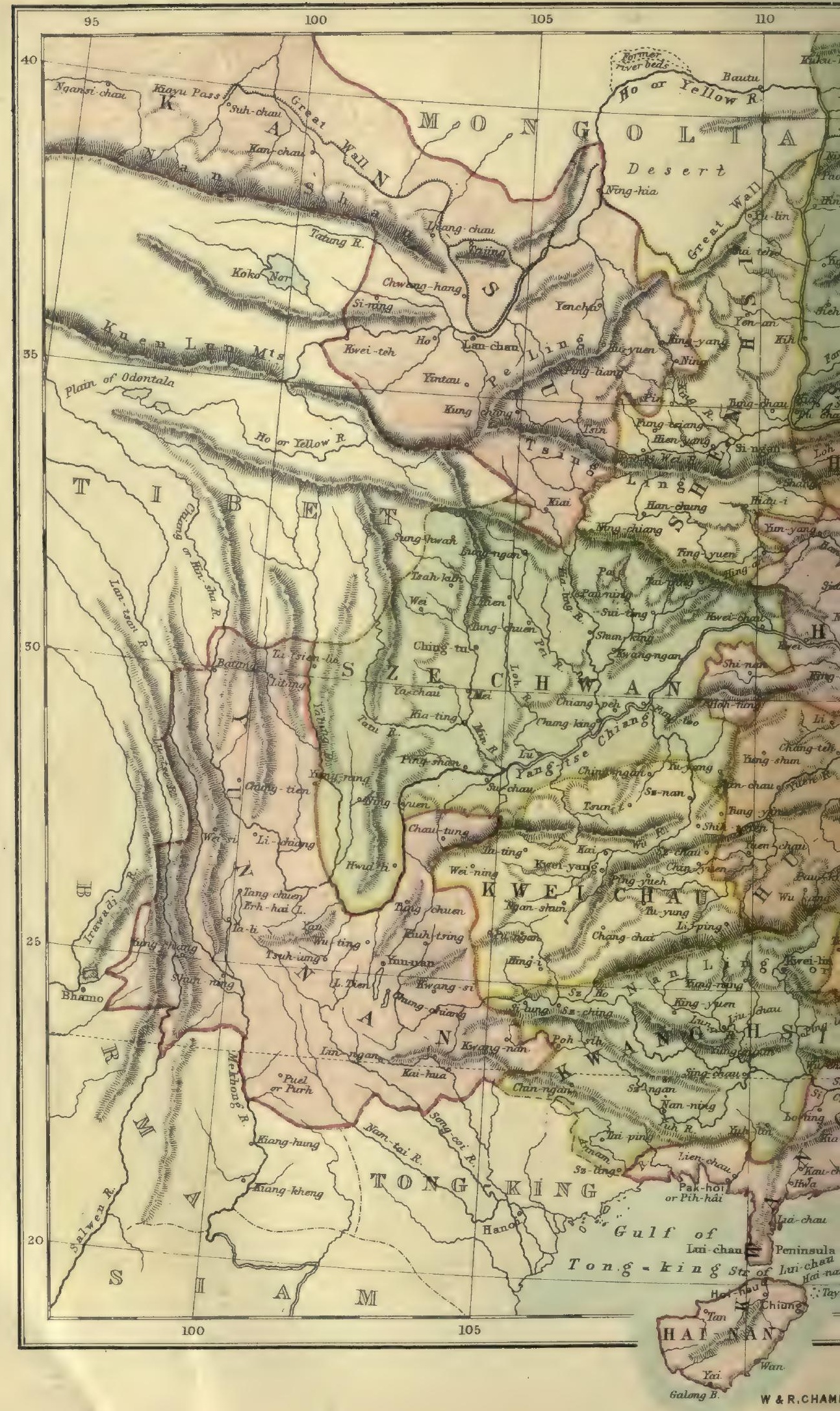



nearly at the northern limit of Shen-hss, when it turns direetly south, and fowing for s00 miles hetween that province and Shan-hol, comes to the edge of the Great Plain, and pursues an eastward course. The Chiang on the contrary flows south from Batang, between Sze-ch'wan and Y un-nan, till it reaches the southern limit of the former province. Then it turms north, and holds its way eastward through Sze-ch'wan and the other intervening provinces till it enters the ocean in lat. $32^{\circ}$. The Ho does not pursue so regular a course. It direction indeed from the edge of the plain is eastwards, but in the course of time it has ever and anon changed its channel. Chinese history opens, in the Sha King, in the 24th century B.C., with an account of one of its inundations, described in terms which have suggested to some students the Noachian deluge, and the labours on it of the Great $Y u$. The terrible calamities caused by it so often have procured for it the name of 'China's Sorrow.' So recently as 1887 it burst its southern bank near Chang Chau, and poured its mighty flood, with hideous devastation and the destruction of millions of lives, into the poyulous province of Ho-nan. It is now the task of the Manchu rulers of the empire to remedy this disaster, and regulate the terrible river for the future. Both the Ho and the Chiang must have a course of more than 3000 miles. These two riverg are incomparably the greatest in Chins, but there are many others which would elsewhere be accounted great. And among those rivers we may well account the Grand Canal, intended to connect the northern and sonthern parts of the empire by an easy water communication; and this it did when it was in good order, extending from Peking to Hang-châu in Cheh-chiang, a distance of more than 600 miles. The glory of making this canal is due to Kublai, the first sovereign of the Yuian dynasty, of whom Marco Polo says: 'He has caused a water communication to be made in the shape of $a$ wide and deep channel dug between stream and stream, between lake and lake, forming as it were a great river on which large vessels can ply.' Steam communication all along the eastern seaboand from Canton to T'ien-tsin has very much superseded its use, and portions of it are now in bad condition, but as a truly imperial achievement it continues to be a grand memorial of Kublai. Even Barrow wrote of it in 1806 : 'In point of magnitude, our most extensive inland navigation in England can no more be compared to the grand trunk that inter. sects China than a park or garden fish-pond to the great lake of Winandermere.

After the Grand Canal a few sentences may be given to the Great Wall, another vast achievement of human labour, especially as in 1887 there were paragraphs in many of our newspapers representing its existence as merely a myth. Not so useful as the canal, and having failed to answer the purpose for which it was intended-to be a defence against the incursions of the northern tribes, there it still stands, while the walls of Hadrian and Antoninus in our own country have crumbled to the ground, and their course can only be indistinctly traced here and there. It was in $214 \mathrm{~B} . \mathrm{C}$. that Shih Hwang Tî determined to erect a grand barrier all along the north of his vast empire. The wall commences at the Shan-hai Pass $\left(40^{\circ} \mathrm{N}\right.$. lnt. $119^{\circ}$ 50 ' $\mathrm{E}$. long.), where it was visited by a squadron of Her Majesty's vessels of war in 1:339, and was seen, as Lord Jocelyn leseribes it, 'scaling the precipices, and topping the craggy hills of the country.' From this point it is carried westwards till it terminates at the Chia-yu barrier gate, the road through which leads to the 'Western Regions,' Its length in a straight line would be 1255 miles, but, if measured along its sinuosities, this distance must be increased to 1500 . It is not bailt so grandly in its weatern portions after it has met the fo River, nor should it he supposed that to the east of this point it is all solid masonry. It is formed by two strong retaining walls of lorick, rising from granite foundations, the space between being filled up with stones and earth. The breadth of it at the base is about 25 feet, at the top 15, and the height varies from 15 to 30 feet. The surface at the top was covered with bricks, and is now overgrown with grass. What foreigners go to visit from Peking is merely a loop-wall of later formation, inclosing portions of Chih-1f and Shanhisi.

The lakes are very many, but not on 80 great a seale as the rivers. It will be sufficient to mention three-the 'T'ung-ting $\mathrm{H}$, the largest, having a circumference of 220 miles, and entering into the names of the provinces Ha-pei and Ha-nan; the Po-yang $\mathrm{H} \hat{n}$, in the north of Chiang-hsi, the seat of the manufactories of the best porcelain ; and the T'ai $\mathrm{Ha}$, partly in Chiang-su and partly in Cheh. chiang, famous for its romantic scenery and numerous islets.

The country is rich in the products necessary for the support and comfort of the people, and for the adornment of their civilisation. There is in it every variety of climate; but the average temperature is lower than in any other country in the same latitude. The Chinese themselves consider Kwangtung, Kwang-hsî, and Yun-nan to be less healthy than the other provinces; but foreigners using proper precautions may enjoy their life in every province.

Wheat, barley, maize, millet, and other cereals are chiefly cultivated in the northern regions, and rice in the southern. The writer once had a bag of oatmeal sent to him from Kalgan, north of the loopwall mentioned above. Culinary or kitchen herbs, mushrooms, and aquatic vegetables, with ginger and a variety of other condiments, are everywhere produced and largely used. From Formosa there comes sugar, and the cane thrives also in the southern provinces. Oranges, pummeloes, lichis, pomegranates, peaches, plantains, pine-apples, mangoes, grapes, and many other fruits and nuts, are supplied in most markets. Tea is noted below. Opium has been increasingly grown of late within the country. The Chinese are emphatically an agrieultural people. From time immemorial the sovereign has initiated the year, which begins with the spring, by turning over a few furrows in the 'sacred field;' and in each province the highest authority performs a sinilar ceremony - to impress on the people the importance of husbandry. The hoe holds the place of our spade; the plough retains its primitive simplicity; irrigation is assiduously and skilfully employed. The tsing, or well, which was anciently in the centre of the plots of land assigned to the families which cultivated them, is still seen in the north and where the canal or river-beds are below the level of the fields much ingenuity is displayed in raising the water to them by wheels and scoops. Noother people show such a sense of the value of human ordure as manure. Nothing that comes from man or beast is allowed to be lost. All is preserved and prepared for use. This does not conduce to the cleanliness of the towns or the fragrancy of the country ; but it largely increases the productiveness of the field and the garden.

The horae, the ox, the sheep, the fowl, the dog, the pis:

These are the six animals which men breed for frod,

are well-known lines; but we do not now hear of horses being eaten; and though dogs are to be seen in baskets in the markets, or cut up on the stalls, they are such as have been carefully fed. Fowls, including ducks and geese, are abundantly bred and consumed; of ducks, immense numbers 
are artificially hatched. Comparatively little beef is eaten, not so much because of the prevalence of Buddhism, which forbids the taking of life, as from a feeling of gratitude to the animal which renders the most important service in tilling the ground. Pork is the most used of all flesh meat, and the number of pigs is enormous. In addition to these animals, the seaboard, rivers, lakes, and ponds supply an immense quantity of excellent fish taken by the net. Angling is not much practised; but a boat with its complement of cormorants, trained to dive for the fish and bring them to their masters, is a pleasant sight. Shellfish also yield their quota to the food of the people. An idea is prevalent that the Chinese are gross feeders, but this is true only of the very poor. A first-class Chinese dinner with its twenty-seven courses may hold its own with most luxurious tables. The famed birds'-nest soup is a misnomer. Nests of the Collocalia esculenta, brought from the Indian Archipelago, are sliced into other soup, and supposed to impart to the compound an invigorating and stimulating quality, but the writer never felt that it added either to its flavour or piquancy.

For beverages the use of tea has nearly superseded every other. The plant does not grow in the north, but is cultivated extensively in the western provinces and in those south of the Great Chiang. The infusion of the leaves was little, if at all, drunk in ancient times, but now its use is universal. Fa. chien, Ha-pei, and $\mathrm{Ha}$-nan produce most largely the black teas; the green comes chiefly from Cheh-chiang and An-hui; both kinds come from Kwan-tung and Sze-ch'wan. Next to silk, if not equally with it, tea is China's most valuable export; and by nothing does it contribute more to the comfort and well-being of the rest of the world. To the people themselves its use has been invaluable, and more than anything else has promoted the temperance that is characteristic of them. They are acquainted with distillation, and from rice and millet produce alcoholic liquors. Their literature abounds from the 12th century B.C. to the present dynasty with warnings against the injury of strong drink; but more effectual than the proclamations of authority has been the habit of drinking tea. As compared with the populations of western nations, the Chinese are sparing in the use of strong drink, and it is rare to see one of them intoxicated. They do not sit down to tea as a special meal, nor do they make it so strong as we do, or add sugar or cream to it, but they have it at hand, and offer it to visitors, all day long. The ordinary name of the plant is $c h^{\prime} d$; but the leaf was first imported into England from Amoy in Fa-chien, where the dialectical pronunciation of the name is $t^{\prime} a y$, which the Irishman still retains. The use of opium will be discussed in a separate article.

The next essential to food and drink in the economy of life is clothing, and for this China has abundant provision in its stores of silk, linen, and cotton. It was no doubt the original home of silk. From the $23 \mathrm{~d}$ century B.C. and earlier, the care of the silkworm, and the spinning and weaving of its produce, have been the special work of woman. As it is the duty of the sovereign to turn over a few furrows in the spring to stimulate the people to their agricultural tasks, so his consort should perform an analogous ceremony with her silkworms and mulberry-trees. The tree grows everywhere, and in alt the provinces some silk is produced; but Kwan-tung, Sze-ch'wan, and Chehchiang furnish the best and the most. The manufactures of silk are not inferior or less brilliant than any that are produced in Europe, and nothing can exceed the embroidery of the Chinese. Indigenous to the country also are hemp and other fibrous plants, such as the Boehmeria nivea, from which the grass-cloth is made. The cotton-plant, though not indigenous, appears to have been introduced from Khoten (Eastern Turkestan) in the 11th cen. tury, and is now found everywhere, but is cultivated most extensively in the great basin of the Chiang. The well-known nankeen is named from Nanking, a centre for its manufacture. The Chinese cotton is inferior to the imported cloth in its finish, but is heavier and more durable. (For the flora of China, see AsIA, Vol. I. p. 491.) Of woollen fabrics the production is not large; but we meet with felt caps, rugs of camels' hair, and furs of various kinds. As the houses have no fireplaces, people keep themselves warm in cold weather by increasing the number of garments which they wear. On the whole China has more resources in itself for the comfortable support and clothing of its vast population than most other countries.

For building materials the Chinese use, like ourselves, timber, bricks, and stone; but in the south inexpensive houses are often made of a kind of concrete called 'sifted earth,' a compound of decomposed granite and lime, with the addition sometimes of a little oil, pounded in a wooden framework, which is shifted till the walls have reached their intended height. Anciently, as we learn from the Shih King, the largest structures were raised in this way. The walls, if well protected by overhanging eaves and plaster against wet, are strong and durable. Granite and limestone are found in many places, and the largest rocks are ingeniously split and wrought into building blocks. The architecture of China is defective, however, in the grandeur and grace which mark that of some other countries; the best specimens of it are seen in the marble bridges and altars of Peking, and in the Buddhistic buildings on the ' Hill of Longevity' and other places in the neighbourhood. No one who has seen them can ever forget the gigantic figures of animals and the statues lining the road that leads to the tombs of several of the Ming emperors, a considerable distance north from the capital. In the country, houses are seldom of more than one story. Even in the eities the public offices and large business establish. ments are not remarkable for their height, but for their depth, as you pass from one series of rooms to another through intervening courts. Rising conspicuous above the other buildings are the pawnbrokers' establishments, whilst the most substantial and elegantly finished structures are the guildhalls belonging to the various trades, or to the merchants congregating in them from the different provinces.

The most picturesque buildings are the pavilions and pagodas. Of the former the most striking is one in what has become famous by being miscalled the 'Summer Palace' at Peking, about 14 feet squáre and 20 high, made of pure copper. The pagodas are Buddhistic structures, borrowed from the topes of India, where they were built at first as depositories for the relies of Buddha and distinguished Arhats. In China they have taken a peculiar form, and are supposed to exercise mysterious geomantic influences. They are the most remarkable objects in the landscapes of the country, and there are few cities which cannot boast of one or more, always of an uneven number of stories. The most cele. brated of them, the Porcelain Tower of Nanking, is now a thing of the past, having been blown up by the iconoclastic 'T'âl-p'ings in 1856. It was of an octagonal form, and was intended to be of thirteen stories, rising to a height of 329 feet; but only nine stories were completed, the building of which took nineteen years (1411-30). It was built mass. ively of brick and faced with slabs of glazed porcelain-green; red, yellow and white; with lamps hanging outside from the projections of the 
different stories-one of the architectural wonders of the world.

In the cities, and studding the country also, are many $P^{\prime}$ di-lanes or Honorary Portals, which often carried the writer's thoughts to the old Temple Bar, though not of so subatantial a construction as it was. They are tokens of imperial favour, erected n hosour of distinguished persons, and many of them aignalising the virtue of widows who steadfastly refused to be married a second time.

The streets of the cities, espe. cially in the south, are not wider than so many lanes, and the streams of people hurrying through them give the stranger an idea that they are more populous than they really are, though against this hasty assumption must be set the rarity of the appearance of women in them. They are paved with slabs of stone, but badly drained, and the heat and stench render a promenade through them anything but agreeable. Most of them have high-sounding names, such as 'The Street of Benevolence and Rightcousness." As in the old Roman

cities, tradesmen of the same pursuits are found very much together in the same street. The streets are wider in the northern cities, till we arrive at Peking, where the wide ways of the Manch portion combine with the imposing walls and their lofty towers to make the visitor think for a time that he has arrived at the grandest city of the world.

When you enter the house of a well-to-do family, you find the furniture sufficient, though somewhat seanty and not luxurious. The floor may be covered with matting, but not with a carpet or rugs. The tables and straight-backed chairs are of a dark, heavy wood resembling ebony. A few pictures, not works of art, are hung on the walls, along with serolls of tine writing, expressing moral sentiments or historical and topographical references, while some jars and other specimens of fine porcelain are put down here and there. There may be a couch or two made of bamboo and rattan, and stools of the same materials. The bamboo, that queen of the Arundinacere, deserves especial mention. A clump of bamboos adds a graceful charm to the scenery, and there seems to be no end to the uses which the plant serves. The sehoolmaster employs it for his ferule, and the mandarin or magistrate for his most common instrument of punishment. The writing-paper is made from it. Its young shoots are used for food, and for comfits and pickles. Its stems, according to their size, are employed for pencil handles, for canes, and for poles, Fans, eages, baskets, and fish-creels are all constructed with it. Its roots are carved into grotesque figures, and fashioned into blocks of a peculiar shape to be used in divination. China would not be China without the bamboo.

The eountry is too thickly peopled and well cultivated to harbour many wild and dangerous animals, though one occasionally hears of a tiger that has ventured from the forest and been killer or eaptured. The lion was never a denizen of China, and is only to be seen rampant in stone in front of temples. The rhinoceros, elephant, and tapir are said still to exist in the forestr and swamps of Yun-nan; but the supply of elephants at Peking for the carriage of the emperor when he proceeds to the great sacrificial altars has been decreasing for several reigns. Both the brown and black bear are met with, and several varieties of the deer family. The musk-deer in greatly valued. Among the more domestic quadrupeds, the breed of horses and eattle in dwarfish, and no attempts seem to be made to improve them. The ass in 8 nore lively animal in the north than with us, and

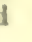

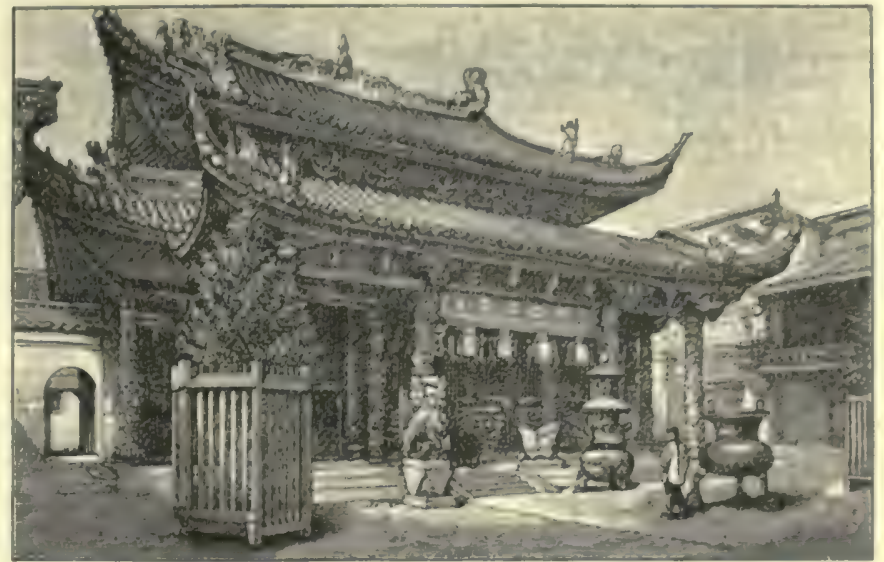

Temple of the Goddess Ma Tru-pu, Ning-po.

rom The Middle Kingdom, by 8 . W. Williams, LL.D.)

receives more attention. About Peking one is struck by many beautiful specimens of the mule. Princes are seen riding on mules, or drawn by them in elegant litters, while their attendants accompany them on horseback. The camel is only seen in the north. One of the first things that strikes a stranger in the capital is the troops of the shaggy animal lying or feeding about the walls, with their Mongol keepers, looking as uncouth as their charge.

The birds of prey are many. Minos, crows, and magpies abound. The last are 'sacred birds, which it is not safe for the traveller to shoot. The people are fond of song-birds, especially the lark, the thrush, and the canary. The song of the nightingale is familiar. The smaller birds are not 80 afraid of man as with us. Buddhism, with which life is sacred, has done much to secure for birds, both with old and young, immunity from moles. tation and death. The lovely gold and silver pheasants are well known, and also the Yüan-yang (Anas galericulata), or mandarin duck, the emblem to the Chinese of conjugal fidelity.

The people are fond of flowers, and make excellent gardeners. You look in vain, however, in the gardens of the wealthy for the gay parterres which so please the eye in England. They cultivate their favourites mostly in pots; and the 'willowplate pattern,' with its arbours, bridges, and ponds, glowing often with the large and brilliant flowers of the nelumbium, supplies a good pieture of a Chinese garden of a superior order.

While the Chinese have, as we have seen, done justice to most of the natural capabilities of their country, they have greatly failed in developing its mineral resources. The skill which their lapidaries display in entting erystal and other quartzose minerals is well known, and their work in jade, which they so highly prize, is very fine. But a mineral more valuable than any other has been comparatively neglected. The coalfelds of China are enormous-more than twenty times the extent of those of Great Britain; but up to this time the majority of them can hardly be said to have been more than acratched. Immense quantities of iron ore, moreover, must have been extracted from the earth during the millenniums of its history, but a much greater amount is still untouched. Copper, lead, tin, silver, and gold are known to exist in 
many places, but little has been done to make the stores of them available. More attention has been directed to their mines since the government and companies began to have steamers of their own; and a scheme has been approved by the government for working the gold-mines in the valley of the Amoor River. The government has become conscious of its mineral wealth, and there is no calculating the resources to which it may attain.

A gold and silver currency is one of the first things which it has to provide. Thus far the only currency has been the copper cash, cumbrous and often debased, varying in its relative value in every district, and the source of endless trouble to the traveller. Even foreign silver coins are treated as bullion, and taken by weight. What is called 'sycee silver' is made from them. After they have been defaced and broken to pieces, they are melted and cast into ingots of different sizes called 'shoes.' Much inconvenience is caused by the necessity of keeping small fine scales or steelyards to weigh every outlay and receipt. Since 1890 silver dollars have been coined at Canton. Paper money is indeed in circulation, but the banking system exists as yet only in a rudimentary condition.

Another want in China is that of good roads and comfortable conveyances. The necessity for good roads first presented itself to Shih Hwang Tî (214 B.C.), who, after he had extended the empire to nearly its present limits, ordered the preparation of them seven years before he commenced the building of the Great Wall ; and it has been said that there are now 20,000 roads in China; but according to the reports of travellers in the present century, the good roads among them are very few. The government couriers perform their journeys on horseback. Where communication by water is abundant the want of roads is not so much felt; but in their absence in times of scarcity it is a most difficult thing to convey supplies to starving populations, as in the famine which prevailed in Shan-hsî and other northern provinces a few years ago. It is owing doubtless to the want of roads that the wheelbarrow is so much used as the chief vehicle of communication and commerce from the Chiang northwards. The writer once had an experience of this, when, along with a companion, he was conveyed 280 miles on one of those 'cany wagons light' in about 8 days. Slow as the journey was, the fatigue was much less than if they had been jolted over the same distance in a springless mulecart in half the time. Even at Peking roads once paved with marble slabs have been allowed to fall into such a state of dilapidation as to be full of dis. comfort and danger; and the route and conveyances from the capital to $T^{\prime}$ 'ien-tsin, its port, are disgraceful to the government.

Social Habits. - The dress of the poor is very much alike in both sexes; and though it is regulated for all classes by sumptuary laws, it is varied among the wealthy by the richness of the materials and the various ornamentation. The most striking thing in the appearance of the men to a foreigner is the queve or plaited tail from the hair of the erown, all the rest of the head being shaved. This was not the old fashion of doing up the hair, but was enforced on the Chinese by the Manchuts in 1627, when they had commenced the conquest of the empire. Inscriptions on stone tablets in old temples in Japan, erected by refugees of the 17th century, mention this degrading requirement as one of the reasons why they had fled from their country. All dislike to the custom, however, has now disappeared. A foreigner is surprised in the same way by the small feet of the more respectable women. These were not enforced upon them by the Manchu conquerors, whose women allow their feet to grow to the natural size, nor was it a very ancient practice in the country, though it seems to have prevailed since our 6 th century. The distortion is produced by bandaging the feet in early

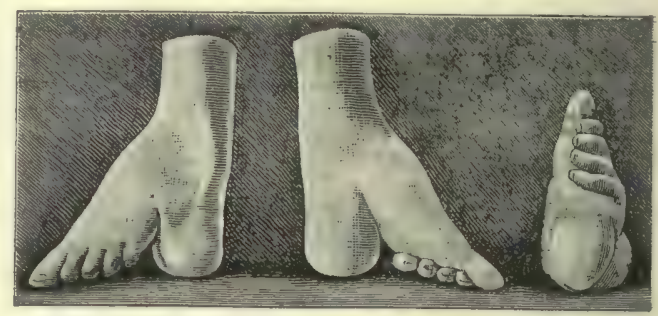

Foot of Chinese Girl (aged 16 Years), in three positions? Copied from a cast in Trinity College, Dublin. (Length of foot, 4 es inches.)

years, so as to prevent their further growth. The very poor and servants are not subjected to this torture, but such is the force of fashion that we have known humble girls of twelve or thirteen vainly try to reduce the size of their feet, thinking thereby to make themselves more attractive.

The separation of the sexes until marriage has been a feature of the social life from the earliest. times. In the old feudal period, 'at the age of seven, boys and girls of the same family did not occupy the same mat, nor eat together, and at the age of ten a girl ceased to appear outside the women's apartments. Her governess taught her the arts of pleasing speech and manners, to be docile and obedient, to handle the hempen fibres, to deal with the cocoons, to weave silks and form fillets, to learn all woman's work, how to furnish garments, to watch the sacrifices, to supply the liquors and sauces, to fill the stands and dishes with pickles and brine, and to assist in setting forth the appurtenances for the ceremonies. At fifteen she assumed the hairpin (as a token that she had arrived at woman's estate), at twenty she was married, or if there were occasion for the delay, at twenty-three.' We read nothing of any literary training for the danghtens then, nor is there any now, though Chinese history is not without instances of learned women and distinguished authoresses. In the important event of marriage the parents exercise a supreme control; and this has given rise to the class of match-makers or gobetweens, who are consulted by the parents, make inquiries, and by an examination of the horoscopes of the parties and other methods of their profession determine the question of the mutual suitability of the match. When a marriage has been agreed upon, it is carried through with a great variety of ceremonies, the parties most concerned being supposed never to have previously seen each other. In the majority of cases the husband and wife thus brought together seem to take to each other very well. Notwithstanding its defects and differences from our ideal, its result. seems to be a fair amount of peace and happiness. When the wife becomes a mother she is treated as a sort of divinity in the household.

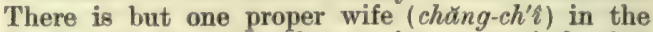
family, but there is no law against a man's having secondary wives or concubines; and such connections are common wherever the means of the family are sufficient for their support. Many of the greatest names in the nation's history are stained with this practice, and the evils of it have been and are very great. There are seven legal grounds for divorcing a wife: Disobedience to her husband's parents; not giving birth to a son; dissolute conduct; jealousy (of her husband's attentions-i.e. to the other inmates of his harem); talkativeness; 
thieving; and leprosy, Theae grounds, however, may be nullified by 'the three considerations:' If her parents be dead; if ahe have passed with her husband through the years of mourning for his parents; and if he have become rich from being poor. In muny exwess the letrothment of children is made at an early age, leading often to injurious and melancholy issues.

The charge of infanticide has been brought agrinst the fanily life in China, the vietims in the vast majority of instances being the female children. That it is stained by this crime, though not to the extent that has often been alleged, cannot be denied. It is among the very poor that the barbarity is chiefly perpetrated, and their poverty is the renson of it. From the ancestral worship which prevails among the perple, the desire for male children is greater in China than perhaps in any other country. In one case the wife of a professing Christian asked the writer whether her husband might not be allowed, like any other person, to bring a concubine to the house, as children were denied to herself, and she would bring up any boy that might be born on her knees as her own child. Public opinion is certainly against the erime of infanticide; the government is to blame in that it does not address itself to punish the deed and put it down. Even the public opinion against it is not so emphatic as it ought to be. Foundling hospitals and asylums for the aged are to be found in most of the large towns, but their cleanliness and management ure not satisfactory.

The complexion of the Chinese inclines to yellow -is, as they say themselves, of 'the colour of the olive.' The same coarse black hair and apparently oblique eyes, with high cheekbones and roundish face, belong to them all from the Great Wall to the island of Hai-nan. They are stout and muscular as compared with other eastern peoples, temperate, industrious, cheerful, and easily contented. They are addicted to gambling, and are generally held to be given also to mendacity and larceny. Many of them are so; and where is the country where there are not many such? The longer one lives among them, however, the better he likes them, and the better he thinks of them.

They bury their dead in graves which are built round in the form of a horseshoe, and often with much display and at great expense. The mourning rites are tedious, and embrace a variety of sacrifices and other observances. No subject occupies so larcre a portion of the Classic of Ritual Observances.

There is no weekly day of worship and rest like our Sunday. At the New Year the government offices are shut for about a month. New-year's Day is the one universal holiday, and at this time shops are closed for several days. The whole nation seems to be dissolved in festivity and joy. The people dress in their best; the temples are visited; gambling tables are surrounded by crowds; the noise of fireworks or 'crackers' is incessent. Throughout the year every month has its festivals, of which the most general are that of 'Lanterns,' on the full moon of the first month ; of the 'Tombs,' later on in the spring; of 'Dragon Boats,' in the fifth month; and of 'All Souls,' in the seventh month, for the benefit of departed relatives and hungry ghosts in the world of spirits. Theatrical representations are immensely popular. 'Strolling companies' can easily be hired; with the bamboo and matting, sheds, often very large, can be readily erected for the exhibition. Individual actors become celebrated as with us, and their services are well remunerated. Females do not appear on the stage. Their parts are performed by boys got up for the purpose.

History. - The chronology of China is measured not by centuries, but by sexagenaries, the first cycle being made to commence with the wixtieth year of Hwang Th in 2637 B.C. But this is morr.ly a conventional arrangement. There were Chinesie in China before Hwang $\mathrm{T}$, and the cycle names for the years prior to 827 B.C. cannot be fully relied on. The documents of the Sha King begin with the reigns of Yao and Shun (2356-2206 B.C.); and from various intinations in that work we are brought to conclude that the nation then consisted of a collection of tribes or clans of the same race, ruled by a sovereign, nominated by his predecessor, and approved by the people as the worthiest man to reign over them.

With $\mathbf{Y u}$, the successor of Shun, and the hero of Yao's deluge to which we have already made reference, there came a change in the principle of succession to the throne. As it is expressed, 'He familied the kingdom.' Then commenced the Feudal State, which lasted under three dynasties (Hsia, 2205-1767 B.C.; Shang or Yin, 1766-1123 B.C.; and Chau, 1122-255 B.C.) for a period of nearly two thousand years. The feudal system of China was very similar to that which prevailed in Europe during what we call the middle ages. At a grand durbar held by Yü after his accession there were, it is said, ten thousand princes present with their jade symbols of rank. But the feudal states were constantly being alsorled by one another. On the rise of the Shang dynasty they were only somewhat over three thousand, which had decreased to thirteen hundred when King W0 establiahed the sovereignty of the Chau. In 403 B.C. we find only seven great states, all sooner or later claiming to be 'the kingdom,' and contending for the supremacy, till Ts'in ('Ch'in) put down all the others, and in 221 B.C. its king assumed the title of Hwang Ti, or Emperor, and determined that there should be no more feudal principalities, and that, as there is but one sun in the sky, there should be but one ruler in the nation.

From that year dates the imperial form of the Chinese government, which has thus existed for more than 2100 years. The changes of dynasty have been many, two or more sometimes ruling together, each having but a nominal supremacy over the whole nation. The greater dynasties have been those of Han (206 B.C.-220 A.D.), T'ang (618-906), Sung (960-1279), Yuian (the Mongol, 1280-1367), the Ming (1368-1643), and the Ch'ing (Manchu-Tar. tar, 1643 to the present date).

The long and persistent existence of the Chinese nation has been owing partly to its geographical position keeping it apart from other great nations, and partly to its educational culture and training. Where the race came from at first takes us beyond the footsteps of history. The Chinese were not the earliest inhabitants of the country. They made their way from the north and west of China proper, pushing before them the older inhabitants, exterminating them or absorbing them, or leaving portions of them within their own ever-enlarging borders, as wrecks of tribes still subeisting here and there, and apparently mouldering to extinction. From the first appearance of the Clinese we find among them written characters (see the next article), and certain elements of intellectual and moral culture and religious beliefs. (The connection of Chinese culture with that of ancient Babylonia has been suggested but not proved.)

The Ruler and the Sage confront us in the earliest records of the nation; the Ruler to govern the people, and the Sage or Man of Intelligence to assist and advise him, and spread abroad among them the lessons of truth and duty. It is said in a document of the 18th century B.C., 'Heaven gives birth to the people with such desires that without a Ruler they will fall into all disorders, and heaven again gives birth to the Man of Intelligence to 
regulate them.' 'Thus the sovereign and the sage are both the ordinances of heaven; and it has been the rule in the various stages of the nation's history that officers of the government should possess whatever educational culture its institutions could supply. The same written character (shih) serves to designate both a scholar and an officer, and of the 'four classes of the people, scholars or officers, agriculturists, mechanics, and merchants,' the first has always been held to be 'the head.' Even in the feudal times the system of examinations for the selection of the officials existed in a rudimentary state, though it was not till our 7 th century that it began to assume its present form, open to all, excepting 'monks, play-actors, and menial servants.

This competitive system, as now existing with all the necessary machinery, is organised in three principal gradations-the provincial, the metropolitan, and the palace examinations. The students of each provinee who have attained at the district examinations to the style of $H$ siu $T s^{\prime} A i$, or ' men of talent,' assemble at the provincial capital, where as a rule every third year special examiners from Peking conduct the examination for the degree of Chü (Kü) jan, or 'men for promotion,' which perhaps three in a thousand of them may obtain, and which entitles them to some minor appointments. To take the third degree of Ts'in shih, or 'men to be presented to the emperor,' the successful Chï-jan from all the provinces must proceed to the metropolis, perhaps about six thousand in all, and there, also as a rule triennially, pass a test examination, the successful candidates at which then go in for the palace examination, conducted within the precincts of the imperial palace itself ; after which the lists are published in three classes, the first being a tripos of the three best men, who become for the time the heroes of the day. They and a proportion of the others are admitted to the ranks of the members of the Han-lin, the "Forest. of Pencils,' or 'Grand Academy of Literature." The remainder receive appointments in the provinces or at the capital, according as vacancies oceur. Such is an outline, as large as our space will allow, of the competitive system of examina-

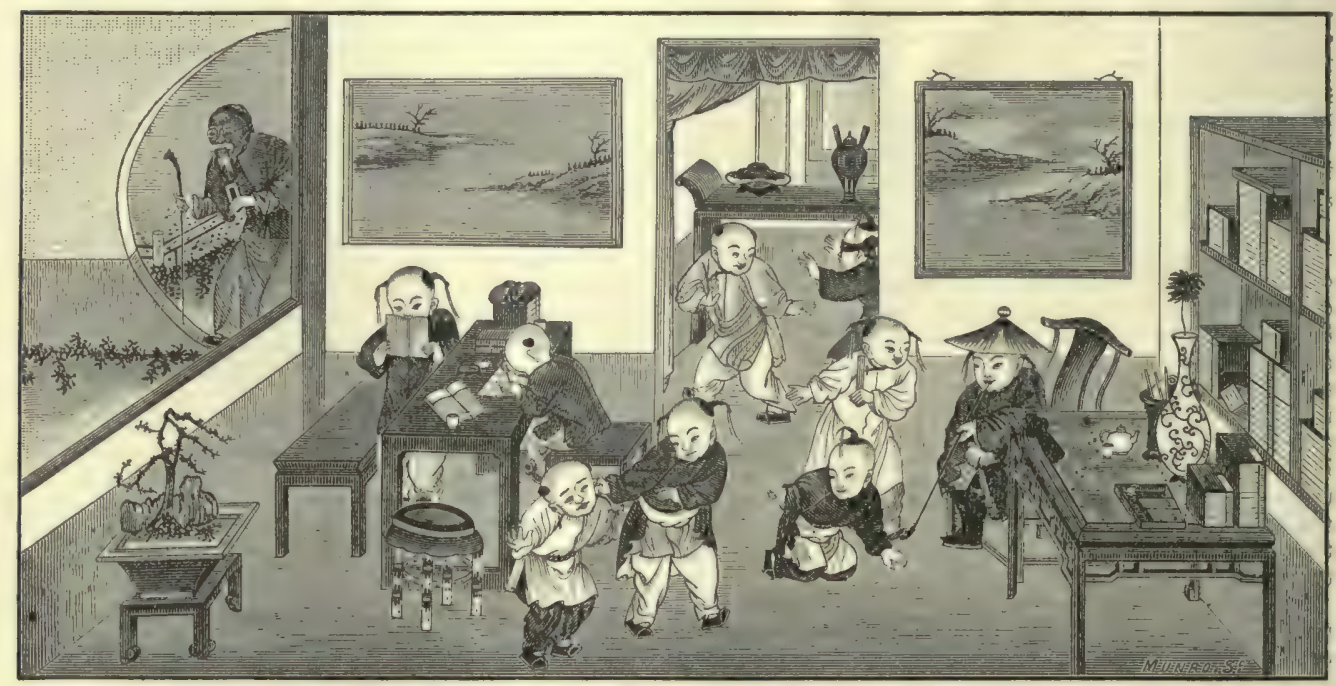

A Chinese School when the master has gone out (Peking). (From a Chinese Picture.)

tions by which the government of China seeks to secure the ablest men of the empire for its service. The examinations are testing and fairly conducted. The subjects are taken from the literature of the country itself. There are already indications not a few that the system will undergo the modifications made necessary by the new relations with other countries which have arisen in our own time ; mathematics became a subject of examination in 1888. The system has tended to impress the people with the value of education; but it must not be supposed that as a whole they are highly edueated. Everywhere indeed there are primary schools, not governmental, but maintained by the people themselves. A smattering of education is widely diffused; but apart from the official classes, those who can read freely or write readily are few.

The three religions of China are Confucianism, Taoism, and Buddhism. Most writers represent the first not so much as a religion, but as a morality; but there always underlies its teachings a recognition of the religion which prevailed in the country from the most ancient times-the beief of a Supreme Power, expressed at first by the name 'Heaven,' which soon came to be desig. nated also by the personal names $T$, ' the Ruler,' and Shang. Ti, 'the Supreme Ruler.' The state worship of Heaven or God was, and still is, confined to the sovereign as the father and priest of the people. The will of God is to be learned from the moral principles of man's nature. Govern. ment is ordained by God for the good of the people, and as soon as a sovereign ceases to seek that good and his rule is antagonistic to it, he has forfeited his title to the throne; and thus it is that the changes of dynasty are always referred to as ' the will of Heaven,' and the sovereign professes to be such 'by the grace of God.' Associated with the worship of Heaven or God, there was the worship of heaven and earth and the powers of nature, but only as subordinate to God and fulfilling His will for the good of men; and also of distinguished men, as having by their discoveries and achievements defended, benefited, and blessed the people of their own and future times. There was also common to their sovereign and all the people the worship of their ancestors. This last was and is considered as an expression of filial piety, the perpetuation of 'the duty which every one owes to his parents-the first and chief of all virtues.' On this Confucius laid great stress, endeavouring to develop all other virtues from it. 
His great object may be said to have been the inculcation o? duty, setting forth with wondrous iteration the character of his superior or ideal man. Several times he enuneiated 'the golden rule' in a negative form, "What ye would not that men should do to you, do not do to them.' Tavism derives its name from the treatine of LI Urh, eommonly ealled Lato-taze, a contemporary of Confucius, called 'The Tao or Way and its Characteristice.' The Way is the quiet, passionless discharge of all which our nature and relations prompt or require us to do, without striving or crying, and the method of maintaining and preserving life. 'Heaven' in this 'Way' is not a ruler or leqislator as in Confucianism, but only a pattern. The system was older than Lao-tsze, and indigenous in Chine, but associated with many superstitions; and after the entrance of Buddhism into China it adopted many of its peculiarities, The recognised head of Taoism has his seat on the Lung-hô Mountain in Chiang-hsi. Lao-tsze has the merit of having formulated the grand prineiple that good will overeome evil, and should be returned for it. For Buddhism, which was introduced or rather invited to China in our first century, see the article BUDDHISM.

There is no priesthood in Confucianism; but Buddhism has its monks and nuns, and Táoism its monks. The government, while not interfering with the internal organisation of either of these systems, has established a scheme of gradations of rank and authority in order that it may have the control of them in its own hands. It would no doubt recognise Christianity in the same way, if the different missions could possibly be amalgamated, and would unitedly try to adapt themselves to the bed of Procrustes which it would prepare for them in the various departments and districts. This is not the place in which to speak of the comparative number of the adherents of the "three religions ' in China. To claim a majority for those of any one of them is very absurd. As a matter of fact, Confucianism represents the intelligence and morality of Chins; Tâoism its superstitions; and Buddhism its ritualism and idolatry, while yet it acknowledges no God.

The Govern MENT of the empire (omitting the regulation of the imperial court and family, or the special Manchô department) is conducted from the capital, supervising, directing, controlling the different provincial administrations, and exereising the power of removing from his post any otficial whose conduct may be irregular or considered dangerous to the state.

There is the Grand Cabinet, the privy-council of the emperor, in whose presence it meets daily to transact the business of the state, between the hours of four and six A.M. I Its members are few, and hold other substantive offices. There is also the Grand Secretariat, formerly the supreme council, but under the present dynasty very much superseded by the eabinet. It consists of four grand and two assistant-grand secretaries, three of them Manchus and three Chinese.

The business on which the cabinet deliberates comes before it from the Six Boards - of Civil Office, of Revenue, of Ceremonies (including all matters pertaining to religion), of War, of Punishment, and of Works. Each Board has two presidents and four vice-presidents, three of them again Manchns and three Chinese. In 1861 the changed relations between the empire and foreign nations led to the formation of what we may call a seventh Board, styled the 'Ya-man (or court) of Foreign Affains." There is also another im. portant department which should be mentioned - the Censorate-members of which exercise a supervision over the Boards, and, distributed through the provinces, have it as their duty to memorialise the emperor on all subjects connected with the welfare of the people and the conduct of the government.

In the administration of the provinces, a governorgeneral and governor are for the most part associated as colleagues; though in Chih-18, Kan-an, and Sze-ch'wan there is only the governor-general, and in Shan-hai, Shan-tung, and Ho-nan only the governor. Below these two functionsies there are the lieutenant-governor (commonly called the treasurer), the provincial judge, the salt comp. troller, and the grain-intendant. The provinces are further divided for the purposes of adminis. tration into $f a$ or prefectures (amounting in all the provinces to 191), chau or departments (in all, 58 independent of the $f \hat{u}$, within which they are comprehended, and 155 subject to it), and hsien or districts, subject to the $f a$ (in all 1288). There are also four $f u$ occupied principally by the aboriginal peoples, twenty-eight chau and four hsien. The rank of the different officials in these provinces is indicated by a knol, or button on the top of their caps. In the two highest it is made of red coral ; in the third it is clear blue; in the fourth, of lapis lazuli; in the fifth, of erystal ; in the sixth, of an opaque white stone; and in the three lowest it is yellow, of gold or gilt. They also wear insignia or badges embroidered on a square patch, in the front or back of their robes, representing birds on the civilians and animals on the military officers.

As regards the revenue of the empire we need more information than we possess at present. Each province is required to support itself and to furnish a certain surplusage for the imperial government; but both the provinces and the court are constantly finding their income insufficient. Of the income of the several provinces for local purposes we cannot speak; but we take the following estimate of the imperial revenue from a series of carefully prepared articles contributed to the China Mail of Hong-kong in 1885 :

1. Land-tax portion, payable in silver. Taels.

2. T.1.50 per pecul, and rice levy in provinces

or money commutation................ $7,000,000$

8. Balt Gabelle, and tilin or transit duty on salt $9,500,000$

4. Maritime customs under foreign supervision.. 18,000,000

5. Native customs, maritime anul inland, and first inland levy on foreign opium.

6. Lkin on miscellanenus goods and opium, both foreign and native.

Total.

In 1894 the revenue was estimated at near $75,000,000$ teals. But as the Teal (q.v.) has fallen in value to about 4s, however we stretch its value we do not obtain the amount of $£ 20,000,000$; surely a very small imperial revenue for so great an empire with so vast a population. It has been increased at times by sales of office and by forced contributions, both dangerous expedients; but the former was put a stop to by an edict in 1879. China had no foreign debt till 1874; but when in 1895 the first war loan of $£ 3,000,000$ was raised, the total external debt had grown to $£ 9,000,000$.

The imperial army proper consists of Manchns, Mongols, and the descendants of Chinese who revolted from the Ming dynasty and joined the Manchis on their invasion of the empire, the first defection taking place in 1621. These are divided each into eight corps with different coloured banners, and as a whole are styled 'The Eight Banners, Their headquarters are in Peking, and they are distributed in garrisons in most of the provinces, and also in Turkestan and I-If. Their number available for actual service amounts to nearly 350,000 , of whom 100,000 are supposed to be 
reviewed by the emperor at Peking once a year. In addition to this there is the national army, distributed in more than one thousand camps throughout the provinces, nearly twice as numerous as the imperial, and called 'The Army of the Green Standard, being in fact little more than a vast militia or gendarmerie. These forces may in times of emergency be added to considerably by patriotic gentlemen calling out bands of "braves, effective enough to cope with insurgents, but all unfit to encounter the disciplined forces of any foreign power. Of this character at first were the troops of the T'âi-p'ing rebellion, which, till its suppression in 1867, for about twenty years proved a match for the imperial and national forces, and threatened the overthrow of the Manchu dynasty. See T'ÂIP'INGs, and Gordon (Charles GEORGE). The utter inadequacy of the army system was shown by the collapse of China as a military power in the war with Japan in 1894-95, and the much vaunted navy, though fought with bravery at the Yalu and Port Arthur, effected little: five vessels -an armour-clad barbette and four cruisers - were sunk in the first engagement, and the most of the remaining ships aubsequently fell into the hands of the Japanese.

Intercourse with Western Nations and Commerce. -It was not till after the Cape of Good Hope was doubled, and the passage to India discovered by Vasco da Gama in 1497, that intercourse between any of the European nations and China was possible by sea. It was in 1516 that the Portu. guese first made their appearance at Canton; and they were followed at intervals of time by the Spaniards, the Dutch, and the English in 1635. The Chinese received none of them cordially ; and their dislike of them was increased by their mutual jealousies and collisions with one another. The Mancha sovereignty of the empire, moreover, was then in the throes of its birth, and its rulers were the more disposed to assert their own superiority to all other potentates. They would not acknowledge them as their equals, but only as their vassals. They felt the power of the foreigners whenever they made an attempt to restrict their operations by force, and began to fear them. As they became aware of their conquests in the Philippines, Java, and India, they would gladly have prohibited their approach to their territories altogether. In the meantime trade gradually increased, and there grew up the importation of opium (see OPIUM TRAFFIC) from India, and the wonderful eagerness of multitudes to purchase and smoke it. Before $\mathbf{1 7 6 7}$ the import rarely exceeded 200 chests, but that year it amounted to 1000 . In 1792 the British government wisely sent an embassy under Lord Macartney to Peking with presents to the emperor, to place the relations between the two countries on a secure and proper footing; but though the ambassador and members of his suite were courteously treated, the main objects were not accomplished. In 1800 an imperial edict expressly prohibited the importation of opium, and threatened all Chinese who smoked it with condign punishment. It had been before a smug. gling traffic, and henceforth there could be no doubt of its real character. Still it went on, and increased from year to year. A second embassy from Great Britain in 1816 was dismissed from Peking suddenly and contumeliously because the ambassador would not perform the ceremony of San kwei chiu $k^{\prime}$ au ('the repeated prostrations'), and thereby acknowledge his own sovereign to be but a vassal of the empire.

So things went on till the charter of the East India Company expired in 1834, and the head of its fretory was superseded by a representative of the sovereign of Great Britain who could not con- duct his intercourse with the Hong merchants as the others had done. The two nations were brought defiantly face to face. On the one side was a resistless force, determined to prosecute its enterprise for the enlargement of its trade, and the conduct of it as with an equal nation; on the other side was the old empire seeming to be unconscious of its weakness, deternined not to acknowledge the claim of equality, and confident of its power to suppress the import of opium. The government of China made its grand and final effort in 1839, and in the spring of that year the famous Lin Tsêh-hsì was appointed to the governor-generalship of the Kwang provinces, and to bring the barbarians to reason. Out of his measures came our first war, which was declared by Great Britain against China in 1840. There could be no doubt as to the result in so unequal a contest; and we hurry to its elose at Nanking, the old eapital of the empire, where a treaty of peace was signed on the 29th August 1842 on board Her Majesty's ship Cornwallis. The principal articles were that the island of Hongkong should be ceded to Great Britain; that the ports of Canton, Amoy and Fa-Chau (in Fa. chien), Ning-po (in Cheh-chiang), and Shang-hâi (in Chiang-8a) should be opened to British trade and residence; and that thereafter official correspondence should be conducted on terms of equality according to the standing of the parties. Nothing was said in the treaty on the subject of opium, the smuggling traffic in which went on as before.

Before fifteen years had passed away, because of troubles at Canton not all creditable to Great Britain, and the obstinacy of the governor-general Yeh Ming-chin in refusing to meet Sir John Bowring (q.v.), it was thought necessary by the British government that war should be commenced against China again. In this undertaking France joined as our ally. Canton was taken on the 29 th December 1857, when Yeh was captured and sent a prisoner to Calcutta. Canton being now in the possession of the allies, arrangements were made for its government by a joint commission; and in February 1858 the allied plenipotentiaries, accompanied by the commissioners of the United States and Russia as non-combatants, proceeded to the north to lay their demands before the emperor at Peking. There was not so much fighting as there had been in 1842, and on June 26 a second treaty was concluded at T'ien-tsin, renewing and confirming the former, but with many important additional stipulations, the most important of which were that the sovereigns of Great Britain and China might, if they saw fit, appoint ambassadors, ministers, or other diplomatic agents to their respective courts ; and that the British representative should not be required to perform any ceremony derogatory to him as representing the sovereign of an independent nation on an equality with China. Other stipulations provided for the protection of Christian missionaries and their converts ; for liberty for British subjects to travel, for their pleasure or for purposes of trade, under passports, into all parts of the incerior of the country; for the opening of five additional ports for commerce-Niu-chwang (in Shing-king, the chief province of Manchuria), Tăng-châu (with port of Chefoo, in Shan-tung), Tâi-wan (Formosa, several ports), Ch'âo-châu (with port of Swa-t'au, in Kwang-tung), and Ch'iung (Kiung-châu, in Hâi-nan)-and for authority for merchant-ships to trade on the Yang. tsze River, ports on which would be opened when rebellion should have been put down and peace and order restored. (The river was not opened to steamer traffic till 1888.) Treaties on the same lines were concluded also with the United States, France, and Russia. A revision of the tariff regulations of 1842 was to take place subsequently in the year at 
Shang-hai. This was done in October, and then (s)ium was entered among the legitimate articles of import, and the arrangement confirmed that the government should employ a foreign ofticial in the collection of all maritime duties. It might seem that these trenties secured everything which foreign nations conld require, and that the lumiliation of the Chinese government was complete. But they were neurly wrecked by one conelumling stipu. lation in all of them but that of the United States, that the ratilications of them should be exchanged at Peking within a year. The emperor and his advisers, when the pressure of the force at $T$ 'ien-tsin was removed, could not bear the thought of the embassies entering the ancred capital, and foolishly cast about to escape from the

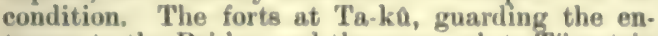
trance to the Pei-ho, and the approach to T'ien-tsin and thence to Peking, were rebuilt and atrongly fortified. When the English, French, and American ministers returned to Shang-hai with the ratified treaties in 1859 , the Chinese commissioners who hal signed them at T'ien-tsin were waiting for them, and urged that the ratifications should be exchanged there. The French and English ministers then insisted on proceeding to Peking as the place nominated for the exchange. But when they arrived at the mouth of the river, with the gunboats under their command, they were unable to force the defences. A severe engagement ensued, and the allied forces sustained a repulse with heavy loss. It was the one vietory gained by the Chinese. The British and French governments took imme. diate action. A third expedition nnder the same plenipotentiaries as before, with a force of nearly 20,000 men, was at the same place in little more than a year. The forts were taken on August 21, and on the 25th the plenipotentiaries were again established in $T$ 'ien-tsin. We can only refer to their march in September on Peking, with all its exciting details. The emperor (Hsien-fung) fled to Jeh-ho in the north of Chih-li, the imperial summer-retreat; and his brother, Prince Kung, whose name is well known, came to the front in the management of affairs. On the 13th October he :surrendered the north-enst gate of the city; and on the 24th the treaties were exchanged, and an additional convention signed, by which of course an alditional indemnity was exacted from the Chinese, and an arrangement made about the emigration of coolies, which had become a crying scandal, while a small piece of the continent of the empire, lying opposite to Hong-kong, was ceded to that colony. So it was that the attempt of China to keep itself aloof from the rest of the world came to an end, and a new era in the history of the empire was initiated.

Hsien-fung died at Jeh-ho in August 1861, leaving the empire to his young son only six years old. A cabal at Jeh-ho tried to keep the boy in their possession, but his uncle, Prince Kung, succeeded in getting him to Peking, and along with the young emperor's mother and the empress: dowager, by whom Hsien-fung had had no child, loyally and successfully administered a regency in ecordance with the new conditions of the government. The style of the reign was T'ung-chi, or 'Government in Union;' and on February 23, 1873 , the emperor announced publicly, and specislly to the foreign ministers, that he had taken the government into his own hands. This brought up the question of an audience, but, after a goul deal of protocolling and negotiation, it was finally settled on June 29 by the emperor receiving all the ministers then in Peking without the ceremony of prostration. His reign did not last long, for he died in January 1875. As he left no son, and had designated no successor, the nembers of the im117 perial house, according to the rules in such a case, apjorinted as his sucesessor Trai-t'ien, the son of Prince Shun, a younger brother of Prince Kung. The new sovereign was a chilil of four years old, and began to reign under the style of Kwang Hsú, or 'The Illustrious Succession.' He assumed the government in March 1887.

Soon after the ratification of the treaties of T'ien. tsin, the promised ports on the Great Chiang, except Nan-king, were opened-namely, Han-k'au (in Hn-pei), Chin-ehiang (Kin-kiang, in Chianghsi), and Chin-chiang (Kin-kiang, in Chiang-se). I-chang ( in Ha-pei), Wu-ha (in An-hui), Wău-chau (in Cheh-ehiang), and Pih-hai (Pak-hoi, in Kwangtun'g) were opened by the Chefor convention (1876), which also made concessions about the opium traftic. The treaty of Shimonoseki (1895), after the war with Japan, opened four additional ports-Cliung-king, Hang-clow, Soo-chow, and Sha-tsze. The foreign debt of China, contracted almost wholly in connection with the Japanese war

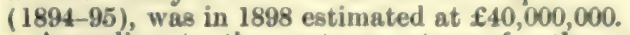

According to the customs returns for the year 1893 , the vessels entered and cleared at the various treaty ports were 37,902 (of $29,318,811$ tons) of which 19,365 (of 19,203,978 tons) were British. The total value of the imports from abroad in. creased from $110,885,000$ teals in 1889 to over $157,360,000$ in 1893 , while the value of the exports rose from $97,000,000$ teals in 1889 to $116,635,000$ in 1893. In the latter year the imports direct from Britain were $28,156,000$ teals, the exports thither $11,668,000$ teals. Most of the foreign trade is set down as with Hong-kong, which is a distributing centre for trade to and from Britain, Germany, France, Amerioa, India, \&c. After Hong-kong, the order in which foreign countries participate in Chinese trade is Britain, India, the United States, Japan, and Russia. The principal imports are opium $(31,700,000$ teals $)$, cotton goods $(45,100,000)$, metals $(7,200,000)$, oil and kerosene, seaweed and fishery products, woollens, coal, and raw cotton. The chief exports are silk $(38,115,000$ teals), tea $(30,550,000)$, straw braid $(2,430,000)$, sugar, clothing, paper, and chinaware. By the British returns, the exports from Britain to China,

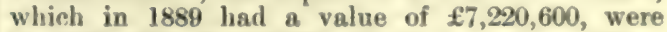
in 1893 only $£ 6,435,000$; the imports from China to Britain, which in 1889 were $£ 7,260,000$, were in 1893 only $£ 4,786,850$. The disparity between them and the Chinese reckoning is owing to the fall in the value of the silver teal (5s. 8fd. in 1882 ; 48. in 1893).

China has in the past been mainly a self-contained nation, but of late the Chinese have shown an increasing tendency to seek a livelihood abroad, especially in California, British Columbia, the Straits Settlements and Eastern Archipelago, and Australia. More than half the population of Singapore is Chinese; and in 1880 there were 200,000 Chinese in Java. In the Australian colonies there have never been more than 60,000 . From 1855 to 1867 the immigration of Chinese into the United States varied from 3000 to 7000 ; from 1868 to 1881 it was usually between 10,000 and 20,000 ; in 1882 it was 33,614 . But the imposition of prohibitory taxes on Chinese immigrants reduced this to 17 in 1886 . And in 1888 the immigration of Chinese workmen was absolutely forbidden for twenty-one years. British Columbia and some of the Australian colonies have also sought to restrict Chinese immigration by im. posing a heavy poll-tax on immigrant Chinese.

The empire has to some sniall extent taken advantage of Western civilisation-telegraphs have been established, a small beginning made with railways, and trustworthy foreigners employed in training the army, in the arsenals, and in the 
custom-houses; and a powerful navy of ironclads was arequired. But the rottenness of the military and naval systems was shown by the Japanese war of $1894-5$, arising out of the state of Corea (q.จ.). A Japanese invading force, after a battle at Ping-yang and a naval battle on the Yalu (17th September 1894), drove the Chinese out of Corea, and, entering Manchuria, took the strong naval station of Port Arthur (22d November 1894) The corresponding station and arsenal south of the Gulf of Pe-chi-li, that of Wei-hai-wei, yielded to the Japanese assaults on the 30th January 1895, the Chinese troops having nowhere made any effectual resistance. And the remaining ships of the fleet which had escaped the battle of the Yalu were, after some sharp fighting, captured by the Japanese navy. The colossal Chinese Empire was, after a few months' fighting, reduced to sure for peace. The Japanese terms included the cession of Formosa and the Pescadores Islands, the cession of the Liaotung Peninsula, including Port Arthur, and the payment of a war indenunity of thirty-three millions sterling. But Russia, France, and Germany constrained the Japanese to refrain from insisting on the cession of Liao-tung, in consideration of an increase of the war indemnity by sixteen millions. By 1898 China, become the "sick man" of the Farther East, was the object of the anxious solicitude of the European powers. Russia had arranged that its Siberian railway was to pass throngh Kirin and Moukden to Port Arthur and to Peking, and by help of garrisons and Cossack settlers had secured military and commercial control of Manchuria (q.v.), and on an extensible lease was in possession of Port Arthur and Ta-lien-wan. Germany had occupied, on a lease of ninety-nine years, the port of Kiao-chow in Shan-tung; and regarded the valley of the Hoang-ho as its special sphere of interest. Britain, insisting on full freedom of trade with China ('the open door'), had a definite promise that no part of the Yang. tsze basin (to be henceforth a British 'sphere of influence") should be alienated by China, secured the opening of additional treaty ports and the free navigation of part of some of the great rivers, and occupied Wei-hai-wei on its evacuation by the Japanese on the same terms as Russia holds Port Arthur. European diplomacy was entangled in rival schemes for giving China loans and securing (for subjects of Russia, Britain, Germany, Frunce, Belgium, and the United States) the right of making railways in China, some of them of doubtful commercial value. France secured some rectification of the Tong-king frontier, and some trading privileges in south China. Li-Hung-Chang, believed to be supporting Russian interests, fell from power, and the emperor started a brief and violent system of reforms on Western ideas, but was summarily checked in this career by the dowager empress. The innovating advisers of the emperor fled or were slain or imprisoned; the emperor, found by a French doctor to be in very poor health, was kept under strict surveillance; in 1900 large anti-foreign riots, with loss of life, broke out, necessitating the landing of foreign troops for the restoration of order.

See works on China by Du Halde ( 4 vols. folio, Paris, 1735), Sir John F. Davis (1857), A. Williamson (1870), S. Wells Williams (1883), Richthofen (1877-83), E. Simon (1887), Maule (1891), R. K. Douglas (1887), Gundry (1893 and 1895); and on the Chinese by Martin (1881), Doolittle (1887), Coltman (1891), H. A. Giles (1876-90), A. H. Smith' (1894), and Holcombe (1895); histories by Boulger (1881-84 and 1893); on the Manchu dynasty and government by John Ross (1880) and Mayers (1887); also Curzon's Problems of the Fur East, The Life of Sir Harry Parkes, Norman's Peoples and Politios of the Far Eust (all in 1894) and J. 'Thomson's Through China with a Camera (1898). On the physical geography, fauna, and flora, see also Asia and Grographical Distribution.
LANGUAGE, WRITING, aNd Literature. The speech and the written composition of the Chinese differ more widely than those of any other people. The former addresses itself, like all other languages, to the mind through the ear; the latter speaks to the mind through the eye, not. as words, but as symbols of ideas. All Chinese literature might be understood and translated though the student of it could not name a single character. The words and the names of the written characters are all monosyllabic, and are inconjugable and indeclinable, without inflection or change of any kind, and at the same time so versatile that there are few of them which may not perform the rôle indifferently, according to their position in a sentence, of most of what we call Parts of Speech. That the speech has never advanced to anything like agglutination even (see PHILOLOGY) can be owing only to the early origin and cultivation of the written characters, referred to a reign preceding that of Fu Hsi, which, on the least unlikely of the chronological sehemes, must be assigned to the 34th century B.C. We may safely say that the written characters of the Chinese existed-probably in a very rudimentary condition-more than 5000 years ago.

These characters are divided into six classes, according to the principle regulating their formation: (1) Pictorial characters (Hsiang hsing), being originally rude pictures of objects; $(2)$ Indicative characters (Chih shih), intended by their form and the relation of their parts to suggest. to the reader the idea in the mind of their makers; (3) Composite characters ( $H u \hat{\imath} \hat{\imath}$ ), made up of two or more characters, the meanings of which blend in the meaning of the compound; (4) Inverted characters (Chwan ch $\lambda$ ), formed from others by the inversion of the whole, or of parts, of them; (5) Borrowed characters (Chia tsich), used in other than their proper signification; and (6) Phonetical characters (Hsich shang), of which one part has a phonetic use, and indicates, exactly or approximately, the name of the compound, and the otherpart the category of meaning which it conveys.

The first three classes may be called origines scripturee Sinica, but do not comprehend 2000 characters; the next two are unimporiant. The sixth class is beyond comparison the most numerous, and embraces well on to 40,000 of the 43,000 characters, or thereabouts, found in the $K^{\prime}$ ang-hsi dictionary of 1704. The third class is the most interesting, bringing us mind to mind abreast of their framers, and showing us their ideas of the things represented by the characters. For example, a wife (called $f u$, 嬬) is denoted by $n \ddot{u}$, 支, 'a female,' and ch'au, 节, 'a broom:' she was the woman that used the broom. And, again, a male child (called nan, 男) is denoted by t'ion, H), 'a field,' and $l \hat{\text {, J }}$, 'strength :' his birth was welcomed as new strength for the work of the field.

The phonetical characters arose from the impossibility of framing a sufficient number of characters on the other five principles of formation to serve the purpose of a written medium. A certain number of characters, which has varied from 554 to 214 (employed in the dictionaries of the last and present dynasties), were set apart as 'ideograms' or 'mothers of meaning,' and a larger and more indefinite number were chosen, which in connection with them might express the name or sound of the compounds, and be called 'mothers of sound.' Their number altogether is large, but many are derivatives of others, and not a few of the ideograms themselves are among them. Dr Chalmers, of 
Hong.kong, published in 1878 a 'Coneise Chinese IVictionary' in which the phonetic constituents are reduced to 884 . These, with the 214 ideograms, having been learned, 1098 characters in sil, the student has mastered the elements of all the Chinese characters. Pronunciation is constantly varving, and his realing will often be far from giving 'the present truth' of the names of many charmeters; but a knowledge of these phonetic eon. stituents does much to lighten the strain upon the memory in learning Chinese.

The monosyllabic utterences, however, available to name the 43,000 characters are few indeed. In Pekinese they are only 426. Even if there were as many as 1000 diflerent syllables in the language, equally divided among the characters, more than furty mennings would belong to each. In the 'Svllabic Dictionary' of the late Dr Williams, containing only 12,527 characters, placed under 552 syllables, there are about 150 characters placed under the monosyllable $\hat{c}(=e e$ in see). To the eye there is no difficulty in distinguishing all these is ; but to the ear such discrimination, unassisted otherwise, is impossible. To assist it, there is a systen of tones, the number of which varies in different dialects. According to the tone in which the monosyllable is pronounced, its meaning is different and this renders what we call a 'good ear' desir. able in learning the speech of China. There are other devices by which the difficulty occasioned by the slender syllabary of Chinese speech is overcome, such as the combination of synonyms, and the multiplication of particles hardly to be found in the dictionaries. As a consequence, while conciseness is a characteristic of good Chinese composition, the spoken language is verbose-e.g. the fable of 'The Fox and the Grapes,' told in 131 English words, is rendered in good Chinese by 85 characters, while a version of it in Cantonese colloquial conteins 163 words. Still the colloquial speech is not difficult of acquisition. The writer had often occasion to remark that the children of Englisl families resident in China, who were not restricted from intercourse with the Chinese, spoke the colloquial more fuently and readily than the English which was spoken by their parents.

After the Buddhist missionaries came to China, and scholars got some acquaintance with the use of the Sanskrit alphahet, they began to devise a method of spelling (so to speak) their characters, dividing each monosyllable into an initial and a final sound, and then joining two other characters together, one to give the initial, and the other, always in the same tone as the character thus spelled, to give its final sound. This method, though cumbrous, might have been of use to the student if the same characters had always been employed for the same initial and the same final sounds, as in Chalmers's 'Concise Dictionary.' But every lexicographer adopted his own characters at his pleasure - e.g. the character 理 $(l l=l+\ell)$ is spelled in one dictionary by $\bar{R}(b$-iang $)$ and $I E(e h+b)$; in a

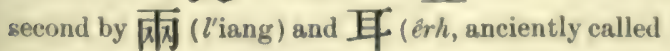
i); and in a third by ( 6 -iang) and $\mathrm{V}$ (8). The $\mathbf{K}^{\prime}$ 'ang-hsi lexicon, after reciting these three spell. ings, alds that the sound is the same as 1 , which is the phonetic element, $h$. This spelling only distracts the student; the Chinese scholars failed to apprehend the nature of the alphabetic signs or letters.

From the analysis of the characters which has been given, their inconjugable and indeclinable character, and their versatility such that one of them may perform the role of most of our "parts of speech,' it is evident that the attempt to apply to them the categorien and rules of grammar on the model of our Aryan languages must be very much 'love's labour lost;' yet composition with them has its own rules, which are not difficult to learn. As Dr Marshnan expressed it in his grammar of 1814, "the whole of Chinese grammar depends on pusition.' Under the skilful application of this principle, the Chinese characters weave the web of thought with the rapidity of engine-driven shuttles; and there has grown up an immense Chinese literature.

Before entering on a brief description of that literature, a jaramraph may be allowed to what is called 'pidgin English,' a sort of lingua franea, which grew up between Chinese on the seaboard and foreigners, for the purpose of intercommunication, while neither party had the means or the wish to acquire an accurate knowledge of the language of the other. 'Pidgin' is a Chinese attempt to pronounce our word 'business ;' and the materials of the lingo are nearly all English words similarly represented or misrepresented, and called 'broken English.' The idiom, on the other hand, is entirely that of colloquial Chinese. Foreigners get to master it in a short time, so as to carry on long conversations by means of it, and to transact important affairs of business. Dr Williams (vol. i. p. 832) gives the following example of it, taken from the Chinese Repository, vol. $x$. : A gentleman meets a Chinese acquaintance, accompanying a coffin which is being conveyed along the street, and asks him who is dead ("who hab die?'). 'No man hab catchee die,' is the answer. 'This one piecy coffin I just now give my olo fader. He likee too much counta my numba one ploper; s'pose he someteem catchee die, can usee he.'- 'So fashion, eh? How muchee plice (price) can catchee one alla same same?''I tinky can get one alla same so fashion one tousan dolla, so ; this hab first chop hansom, lo !' There is often a charming raciness about such conversa. tions, and one ocersionally sees in his Chinese interlocutor the working of the mind which has been described in the formation of the third or composite elass of characters. For instance, a Chinese boy (all servants are called boys) once came to ask the writer to intercede for him with his master, who was treating him, he thought, unjustly. 'He one sarcee (saucy = bad) man,' he said; 'he no hab topside pidgin;' meaning that his master had no religion, no dealing with the powers above. This jargon is passing away. Chinese who know English, and English who know Chinese, are increasing from year to year. See C. G. Leland's Pidgin-English Sing-song (1876).

How vast and varied the Chinese literature is may be seen from a very brief and imperfect analysis of the contents of the catalogue raisonne of the works collected by an order of the $K^{\prime}$ ien-lung reign in 1722 , to be printed or reprinted as a great national library. The catalogue is arranged in four divi. sions under the name of $K^{\prime} \hat{u}$, 'Arsenals, or 'Magazines:' the first, in 44 chapters, containing works on the classics and dictionaries necessary in the study of them; the second, in 46 chapters, works of history; the third, in 57 chapters, works on philosophy and the arts; and the fourth, in 53 chapters, works of poetry and belles-lettres.

The classics are the Confucian books, and a few others, on which an amount of commentary has been expended certainly not inferior either in voluminousness or in patient care to what has been put forth on our sacred Scriptures; and it still goes on without abatement. A collection of books on them by a multitude of scholars of the present dynasty was published at Canton in 1829 in 1400 chaptens. The histories are 
those of China itself, and are divided into four classes according to the different methods of the authors. The first place is given to the "Correct" and 'Authoritative,' or the 'Dynastic,' which now form a collection of twenty-four different works. The writer's own copy of it, bound in English fashion, amounts to sixty-four thick volumes, imperial 8vo size. In general, each dynastic history contains an account of the several reigns, followed by treatises on chronology, rites, music,' jurisprudence, food and goods or political economy, state sacrifices, astronomy, the five elements, geography, and especially topography, and the literature. After these treatises we have a host of biographies of the most remarkable individuals of the dynasty; and the history concludes with an account of the foreign peoples with which there has been any intercourse. These notices of the dynastic histories only occupy two of the 46 chapters of the division. Among the subdivisions are three chapters on 'Books on the Constitution,' embracing such works as Ma 'Twan-lin's General Examination of Records and Scholars, said by Rémusat to be 'a library in itself,' and the two continuations of it, each as voluminous as itself; and the Penal Code of the present dynasty, of which we have the translation by Sir G. T. Staunton, published in 1810.

The philosophy and arts division deals with the works of the class of the literati, both orthodox and heterodox; of writers on military affairs; on legislation; on agriculture, horticulture, and the mulberry-tree; on medicine; on astronomy and mathematics; on divination; on painting, music, engraving, and other arts; on ink and inkstones; on tea and the tea-plant; on articles of diet; on the works of several of the Roman Catholic missionaries ; and concludes with works of Tâoism and Buddhism. Five chapters are devoted to works on mythology and lighter subjects, not including, however, as we shall presently see, novels and romances.

The belles-lettres division has the general name of Tst, 'Collections' or 'Compilations.' It comprehends the various classes of polite literature, poetry, and analytical or critical works. Chinese poetry has no epie ; but it is rich in ballads, lyrical and descriptive pieces, rhythmical effusions and songs, eulogies and elegies, and monumental inscriptions. Its poets have been without number, and its poetesses not a few. One of the Confucian classics is 'The Book of Poetry;' and poetry is one of the standing subjects in the competitive examinations.

Novels and romances, dramas, and books written in the colloquial style are not admitted into such grand catalogues as the above; but the literature is not without them. There is no more pleasant reading than some of their historical romances, such as the Expanded Narrative of the Period of the Three Kingdoms (168-245 A.D.), by a raconteur of extraordinarily graphic power, written in our 13th century. Some of the best novels have been translated into European languages: The Fortunate Union, by Sir John Francis Davis; The Rambles of the Chang-Teh Emperor in Kiang-nan, under the superintendence of the present writer; Les Deux Cousines and Les Deux Jeunes Filles Lettrées, by the late Stanislas Julien; and others, as well as some of the dramas.

Great as the Chinese literature is, it would have been greater, especially in the earlier portions of it, but for the burning of the Confucian books by the founder of the 'Ts'in dynasty, and for the subsequent 'bibliothecal catastrophes' which overtook one imperial library after another down to the middle of our 6th century. Paper was made and employed for writing in our first century, and printing by means of wooden blocks, according to the fashion still prevailing, was soon practised. An edition of all the classical books was so published in $922 \mathrm{~A} . \mathrm{D}$. The invention of movable types belongs to a blacksmith called Pi Shing less than a century afterwards, though such types are only now beginning to supersede the wooden blocks. Some of the inventions claimed for China have been called in question, but about this-perhaps the most important of all inventions after the alphabet-there can be no dispute.

See Prémare's Notitia Linguce Sinice (Malacen, 1831): Rémusat's Elémens de la Grammaire Chinoise (Paris, $1822)$; Marshman's Clavis Sinica; Julien's Syntaxe Nouvelle de la Langue Chinoise (Paris, 1869-70); Gabelentz's Chinesische Grammatik (Leip. 1881); Edkins's Grammar of the Chinese Colloquial Language, commonly called the Mandarin Dialect (Shanghai. 1864); Chalmers's Structure of Chinese Characters (Aberdeen, 1882); the Dictionaries of Morrison, Medhurst, Williams, Chalmers, and others; Wylie's Notes on Chinese Literature (Shanghai, 1867): Legge's Chinese Classics, and volumes iii. xvi. xxvii. and xxviii. of the Sacred Books of the East; Biot's Le Tcheou Lh, ou Rites des Tcheou (Paris, 1851); and Zottoli's Cursus Litteraturee Sinice (Shanghai, 1879).

China, or China-ware. See Pottery.

China Bark, a name of Cinchona (q.v.) Bark, often to be met in books, and in common use on the Continent. It is derived, not from the empire of China, but from Kina or Quina, the Peruvian name of cinchona.

China Clay. See KaoliN.

China Grass, or Chinese Grass. See BaerMERIA, GRASS-CLOTH.

\section{China Ink. See INk.}

Chinandega, the capital of a department of Nicaragua, Central America, 30 miles $\mathbf{N W}$. of Leon by rail, and 13 by rail from the Preific coast. It has considerable trade, and about 8000 inhabitants.-OLD Chinandega, 5 miles to the N., has a pop. of 4000 .

China Root, the dry tuberous rhizome or rootstock of Smilax China, a climbing shrubby plant, closely allied to sarsaparilla; a native of China, Cochin-China, and Japan (see SARSAPARILlA and SMILACE ). It was formerly held in high medical repute in Europe, but is now disused; in China, however, it retains its reputation, especially in rheumatic or syphilitic cases. Various American species have been from time to time introduced as substitutes.

China Sea, the portion of the Pacific Ocean to the east of China and Siam, extending, in the widest application of the term, from Corea to Borneo. This extensive body of water falls into three divisions : the Yellow Sea (Chinese, Whang. hai), between Corea and North China, with the gulfs of Pechili and Leaotong, and Corea Bay ; the Eastern China Sea (Tung-hai), from about $32^{\circ} \mathrm{N}$. lat. to the Tropic of Cancer; and the South China Sea (Nan-hai), from Formosa to Borneo, with the Philippines on the east, and forming the great gulfs of Tonquin and Siam. Many geographers limit the term to this last division. See AsIA; and for the twin dangers, typhoons and pirates, that have combined to render the navigation of these waters notoriously perilous, see separate articles under these heads.

Chincha Islands, three bare, rocky islets, with a joint area of $6 \frac{1}{4}$ miles, rising 200 feet out of the sea off the coast of Peru, opposite the Bay of Pisco. From 1841 till 1874 they yielded millions of tons of Guano (q.v.) ; but the beds, originally some 100 feet thick, becume exhausted.

Chinchay-cocha, a lake of Peru, in the department of Junin, 13,330 feet above the sea, is 36 miles long and 7 broad, with an area of about 
$300 \mathrm{sq}$. m. It is the source of the river Janga, and abounds in fist. and wild-fowl.

Chiuchilla, a town of Spain, 12 miles SE. of Allarcete by rail, situaterl on an alsupt rocky hill, in which are numerous caves that serve as d welling. places It has gypanm and marble quarries and manufactures of earthenware. Pop. 6080.

Chinchilla ( $C$. lanigera), a South Americen rodent, well known by its soft gray fur. Two related animals (Lagidium peruanum and Lagostomus trichodactylus, the Viscacha) form along with the true chinchilla the small family Chinchillidse in the porcupine section of the Rodent orrier. All the three are somewhat squirrel-like animals, but have long hind-legs, bushy tail, very soft fur, and complete collar-bones, The chinchilla and the lagidium occur on the higher Andes

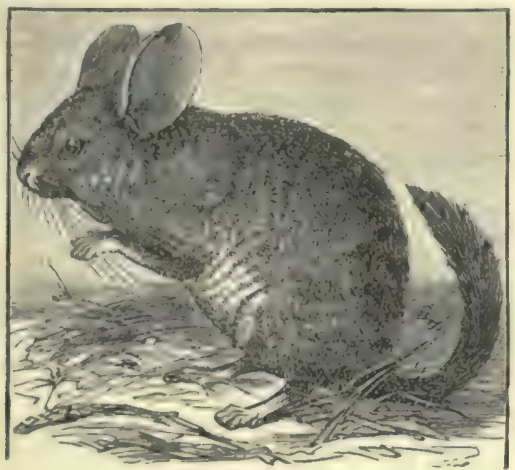

Chinchilla.

of Peru and Chili at a high elevation; the viscacha is found on the Pampas. The three genera differ distinctly, but not widely. The chinchilla proper has a body about a foot long, and the tail measures fully 6 inches. They are extremely active animals, and climb among the rocks with the greatest agility. They are killed in thousands for the sake of their fur, and prolific as they are, seem to be diminishing in abundance. The fur is used for various articles of attire, and the Peruvians are said to have formerly woven the hair into fine fabrics. See ViscacHA.

Chinchon', a town of Spain, 25 miles SE. of Madrid. Pop. 4771. After a Countess of Chinchon, wife of the governor of Peru in 1638, Peruvian bark was named Chinchona, now habitually misspelled Cinchona (q.v.).

Chindwa'ra, chief town of a district in the Central Provinces of India, on a plateau 2200 feet above the sea, 70 miles $\mathbf{N}$. by W. of Nagpur. It is the seat of a Free Chureh mission. Pop. 8220. -The district has an area of $3915 \mathrm{sq} . \mathrm{m}_{\text {, }}$, and $\mathrm{a}$ pop. of 407,494 .

Chinese Ilemp, a kind of Corchorus (q.v.).

Chinese White, a permanent white pigment used in the arts, consists of the white oxide of zine, $\mathrm{ZnO}$. Its manufacture was first attempted in 1780 , and in 1796 Atkinson patented its use as a substitute for white lead, which had previously been the only available white pigment, and was a most unsatisfactory one on account of its turning brown on continued exposure to the atmosphere. Only, however, in 1844 was a good and cheap method of preparing the pigment discovered by M. Leclaire.

Chingalpat (Chengalpat), a town of India, 36 miles SW. of Madras by rail, with district court and hospital, a public bungalow, and an old fort, now abandoned, but formerly of great strength and importance as a key of Madras. Clive captured it in 1752. Pop. 5617. - The district to which the town gives name has an area of $2842 \mathrm{~m} . \mathrm{m}$., and a pop. of $1,136,928$, mostly Hindus. It is a flat country, ent up by canals. The soil is poor. With 115 miles of coast, it has not a single harhour or anything like shelter from the surf.

Chingford, an Esaex village, 9! miles NE. of London. There is a golf course close by in Epping Forest. Pop. of parish, 2737.

Chini', a village of the Punjah, I mile from the Sutlej's right bank, on the southern slope of a lofty mountrin, 9085 feet above sea-level. It was a favourite hill residence of Lord Dalhousie.

Chin-Kiang, a Chinese port on the Yang-tzekiung, in the province of Keang-su, 40 miles ENE. of Nanking. Formerly, as the southern key of the neighbouring Grand Canal, it was both an important stronghold and a centre of traffic; but it was bombarded by the British in 1842, and nearly destroyed by the Tai-pings in 1853. Opened to foreign trade in 1861 , the commerce of the place has not greatly increased since, unless in the import of opium. Pop. 135,000.

Chinon, an antique town in the French department of Indre-et-Loire, beautifully situated on the Vienne, 31 miles SW. of Tours by rai]. Crowning a lofty rock are the ruins of its vast old castle, the 'French Windsor' of the Plantagenets, the death. place of Henry II.; and later the residence of several French sovereigns, where, in 1429, Joan of Are revealed her mission to the Dauphin. A farmhouse across the Vienne is pointed out as Rabelais' birthplace. Pop. 4397.

Chinooks, a tribe of Indians, now nearly extinct, on the Columbia River on the west coast of North America. Their language was very difficult to learn and to pronounce, and this led to the formation of the Chinook jargon, a trader's linqua Franca, consisting of words from French, English, and Hawaiian, as well as Chinook and other Indian tongues. See the dictionary by Gibls (1863) and the monograph by H. Hale (1890).

Chins. See Burma, Vol. II. p. 564.

Chin'sura, now a part of Hooghly (q.v.), originally a Dutch town, ceded in 1825 .

Chintz, a highly glazed printed calico, with a pattern generally in several colours on a white or light-coloured ground. It was chiefly used for led-hangings, for covering furniture, and other purposes where there is much exposure to dust, which does not adhere to its highly calendered surface. In Great Britain chintz is now mostly employed for babies' bassinettes. It has been long the practice in Persia to have the pattern on some chintzes partly in gold. Glue or other size is printed on the cloth, to which the gold dust or leaf adheres. See CRETONNE.

Chiococea, a genus of Cinchonacers, of which two species in particular, $C$. anguifuga and $C$. densifolia, the former a trailing herb, the latter a bushy shrub, enjoy a high reputation in Braxil as cures for snake-bites and in the treatment of dropsy. An infusion of the root is one of the most violent emetic and drastic medicines known, but it is happily no longer used in Europe.

Chioggia, or CHIozza, an important seaport town of Northern Italy, 15 miles SSW. of Venice, on an island at the southern end of the Venetian Lagoon, connected with the mainland by a stone bridge of 43 arches. It is founded on piles, and has a cathedral: its harbour, the deepest in the Lagoon, is guarded by forts and batteries. Pop., inclusive of Sottomarina, 25,084, most of them engaged in the coasting trade, lace-making, weaving, shipbuilding, and fiahing.

Chios (now called by the natives Chio, Italianised into Scio) is one of the most beantiful and 
fertile islands in the Egean Sea, belonging to Turkey, 7 miles off the coast of Asia Minor, at the entrance to the Gulf of Smyrna; about 30 miles long from north to south, by 8 to 15 miles broad, with a coast-line of about 110 miles, an area of 320 sq. m., and a pop. of about 70,000, almost all Greeks. The larger northern part is more mountainous than the southern. The climate is delightful and salubrious. Earthquakes are, however, not rare, and one in 1881 caused the death of 3558 persons, and the destruction of property to the value of three to four millions sterling. The wine produced on the north-west coast, the Vinum Arvisium of ancient times, is still esteemed. Other products are figs, also noted in classical days; mastic, silk, lemons, oranges, and olives. Goats' skins are also exported. The capital, Chios, abont the middle of the east coast, contains about 13,000 inhabitants, and has a haven touched by various services of steamers, and doing a good trade. On the west coast is a rich monastery, Nea-Moni, founded in the 11th century. In ancient times excellent marble and potters' clay were quarried in the mountains, and recently pits of antimony and ochre are worked.

Chios is one of the places which contended for the honour of giving birth to Homer. It formed in early times one of the most flourishing of the Ionian States, and contributed 100 ships to the Greek force defeated by the Persians in the sea. fight off Miletus (494 B.C.). After the Persian victory the town and temples of Chios were burnt and many of the people enslaved. In more recent times the island was taken by the Genoese (1346), and by the Turks (1566), in whose hands it has since, except for a short interval, remained. It was conferred as private property on the sultana. After a long period of prosperity, Chios suffered a terrible blow during the war of Greek independence. A number of the Chiotes having in 1821 joined the revolted Samians, a Turkish fleet and army in 1822 inflicted dreadful vengeance; 25,000 Chiotes fell by the sword, 47,000 were sold into slavery, and only some 5000 escaped. A second rising in 1827 was likewise unsuccessful. The island has since been gradually recovering.

Chip Hats. See Brazilian Grass.

Chipmunk (Tamias striatus), a kind of squirrel, common in North America. The genus includes only a few species, often called Ground Squirrels, and distinguished from the common Sciurus by the possession of capacious cheek pouches, by the longer snout but shorter tail and ears, by the constant absence of the first upper molars. They are pretty little animals, of active

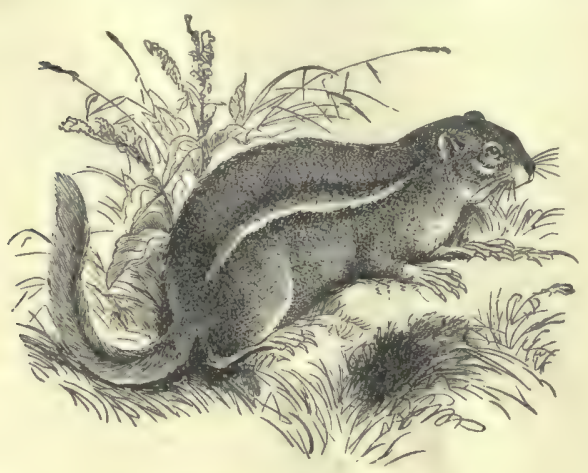

Chipmunk (Tamias striatus).

disposition, living in underground burrows, where they indulge to apparent excess their mania for storing food. The food consists of nuts, seeds, and grain; and the chipmunks plunder to no inconsiderable extent the fields of wheat and maize. They are, like many other rodents, very prolific. See SQUIRREL.

Chippendale, Tномаs, came to London from Worcestershire before 1750 , and was a successful cabinet-maker and upholsterer. The style of furniture named from him was less heavy and severe than that of his successors, and was rather elaborate, delicate, and baroque, with classical tendencies. He wrote a Cabinet-maker's Director (1752). All 18th-century furniture is often miscalled ' Chippendale.' See Clouston's Chippendale Period (1897).

Chippenham, an ancient municipal horough (mainly one well-built street) in Wiltshire, on the Avon, here crossed by a bridge of twenty-two arches, 13 miles NE. of Bath. It lost. its last parliamentary member in 1885 . Pop. 4618 .

Chippeway Indians (written also Otchipue and Ojabbeway), a tribe of American Indians of the Algonquin stock, now settled in northern Minnesota and in Canada.

Chipping Norton, a small municipal borough in the North of Oxfordshire, 85 miles NW. of London by rail, with woollen, tweed, and glove manufactures. Pop. (1881) 4167 ; (1891) 4222.

Chipping Wycombe. See Wrсомве.

Chiquichiqui Palm (Leopoldinia Piassaba), the Piassaba of the north of Brazil, and one of the palms which yield the Piassaba (q.v.) fibre so much used for making brushes.

Chiquimu'la, a small town (pop. 6000) in the east of Guatemala, which gives name to a province, and to the ISTHMUS OF CHIQUIMULA, with a breadth from the Gulf of Honduras to the Pacific of about 150 miles.

Chiquinquira, the largest town in the department of Boyacá, Colombia, near the Suarez, 30 miles W. of Tunja, was an Indian place of pilgrimage before the conquest; and the Spæniards having found here a miraculous image of the Virgin, the church where this is preserved is now visited by some 60,000 pilgrims annually. Pop. 18,000.

Chiquitos, or NaQUiÑoñaIs ('men'), an Indian stem of Bolivia, dwelling between the Paraguay and the Madeira. Bronze-coloured and well built, with large, round heads, low foreheads, and small bright eyes, they are cheerful, hospitable, fond of music and dancing, but of a low morality, and live (about 20,000 in all) in villages formerly founded by the Jesuits.

Chira'ta, or Chiretra (Ophelia Chirata), an officinal plant belonging to the order Gentianese. It is a native of the mountains of the north of India. The whole plant is intensely bitter, and has been long used in its native country as a tonic and stomachic, as also by European practitioners in India as a febrifuge.

Chiriquí, an administrative division of the department of Panama, Colombia, adjoining Costa Rica. Area, $6500 \mathrm{sq}$. m. ; pop. 43,000. It is well wooded, and has rich pasturage, especially on the Atlantic coast, where the climate is very moist. The Cordilleras that occupy the interior reach their highest point in the volcano of Chiriquil $(11,265$ feet). Chief town, David.-On the north coast is a spacious lagoon of the same name, with a depth of water for the largest ships, which receives an unimportant Rio Chiriquí.

Chiromancy. See Palmistry.

Chi'ron, or Cheiron, the most famous of the Centaurs $\left(q_{\circ} v_{\circ}\right)$, son of Cronos and Philyra, and husband of Naïs or Chariclo. He lived on Mount Pelion, and was famous for his skill in healing, 
Trinting, music, and prophecy. The great Achilles and other heroes were his pupils. He died by being accidentally wounded by one of the poisoned arrows of his friend Hercules.

Chiroptera. See Bat.

Chiru, or Panthalops (Antilope hodgroni), a species of antelope, inhabiting the pine-forest and elevated open plains of 'Tibet, in regions bordering on the snow-fine. It is much larger than the chamois, being about five feet in length, and three feet high at the shoulder. The colour is reddish. fawn with some black. The chiru lives in great herds, and seems to exceed almost all the other gregarious ruminants in watchfulness against the approach of danger. They often lie concealed in holes which they nake among the atones.

Chislehurst, a village in Kent, 11 miles SE. of London. Sir Nicholas Bacon was a native. Camden Park estate (now built over) was the residence of William Camden. Napoleon III, died at Camden Place in 1873; his remains, with the Prince Imperial's, were removed to Farnborough in $\mathbf{1 8 8 8}$. 'There are an Orphanage, a Governesses' Benevolent Institution, and a golf-course (1894) here. See History by Webb, Miller, and Beekwith (1900).

Chiswick, a suburban parish of Middlesex, on the north bank of the Thames, $7 \frac{1}{3}$ miles W. by S. of St Paul's. Here are some charming old river-side houses (one of them William Morris's home); here too are extensive market-gardens to supply London, and the gardens of the Horticultural Society. In the churchyard are Hogarth's grave and Foscolo's cenotaph; and at the Duke of Devonshire's beautiful villa, Chiswick House, died Fox and Canning. Pop. (1861) 6505; (1881) 15,975 ; (1891) 21,964. See Harper's for August 1888.

Chitaldrúg, the chief town of Chitaldrug district, Mysore, India, 126 miles NW. of Bangalore, with manufactures of coarse blankets and cotton cloth. The military cantonments have been abandoned on account of their unhealthiness. Pop. 4271. - The district is the least populous in the Mysore State, in which it is distinguished for its low rainfall (10 to 25 inches) and arid, stony soil. Area, 3994 sq. m. Pop. (1871) 531,360; (1881) 376,310 -the decrease being due to the famine of 1876-78; (1891) 413,984.

Chitin, the substance which forms most of the hard parts of jointer-footed animals (arthropods), such as crustaceans, insects, and spiders. It was discovered by Odier in 1823, but regarded erroneously as free from nitrogen; rediscovered by Lassigne in 1843; and since then recognised in all the four chief classes of arthropods and in some other types. Huxley has given an account of its formation in the erayfish. Chitin has been demonstrated in many arthropods, also in the pen of cuttle-fishes (Mollusca), and in the stalk and shell of Lingula anatina, a brachiopod. Its presence is at least probable in many other caves. In arthropods it is not confined to forming the firm and often very hard exoskeleton, but occurs internally in supportin. plates, \&c. among the tissues. In the crayfish it seems even to form the sheath of the strong ventral nerves. In arthropods the greater portion of the gut is formed as an intucking of the outer :skin (eetoderm) from in front and behind, and the resulting portions known as fore-and hind-gut are :also lined by this chitin, which frequently exhibit :special internal thickenings for food-grinding purposes. The chitinous coating or cuticle is formed from underlying skin cells. In some cases the epidermic cells probably sweat it off after the manner of other secretions ; but Huxley has shown in regard to the crayfish that the superficial portion of the cells undergoes a chitinous modification, being literally turned into chitin. The outer cont of crustaces is hardened by the addition of calcium carbonate or phosplate, especially the former; such calcareous hardening is very rare in insects, but copper has been demonstrated in some beetle cuticles.

Chitin is an amorphous white substance. It contains nitrogen, but is free from sulphur. Its resistance to acids and alkalies is very great; it is unaflected by digestive ferments, by water, hot or cold, by alcoliol or ether. It may be dissolved by strong mineral acids (hydrochloric or sulphuric), and prepared from the cleaned exoskeleton of a lobster, or better still from the pen of a squid. Chemically it is regarded as a derivative of carbo. hydrates, and may be split up into sugar and glycosanin. According to Ledderhose, its formula is $\mathrm{C}_{13} \mathrm{H}_{26} \mathrm{~N}_{2} \mathrm{O}_{10}$; according to Sund wik, $\mathrm{C}_{60} \mathrm{H}_{100} \mathrm{~N}_{8} \mathrm{O}_{20}$ $+\mathrm{HH}_{2} \mathrm{O}$. See Krukenberg, Vergleichenel-physio. logische Vorträge (1886).

Chiton, a genus of marine molluscs, type of an important sub-class which may be regarded as introductory to gasteropods. Unlike the lop-sided snails, the chitons are bilaterally symmetrical. The head is at the anterior end, the anus posterior; the 'foot' occupies the whole of the ventral surface; the heart, the gills, the excretory tubes, the genital duets, all exhibit the same symmetry. This marked. contrast to the gasteropols proper is further supported by the disposition of the two important nerve cords (pedal and visceral) which run parallel to one another along the body. In some forms there are numerous eyes, which occur, however, not on the head, but on the body. Another striking feature is the presence of a series of eight shell. plates along the back. On these and other grounds the chitons are separated from gasteropods proper, and established as a separate order, on which the

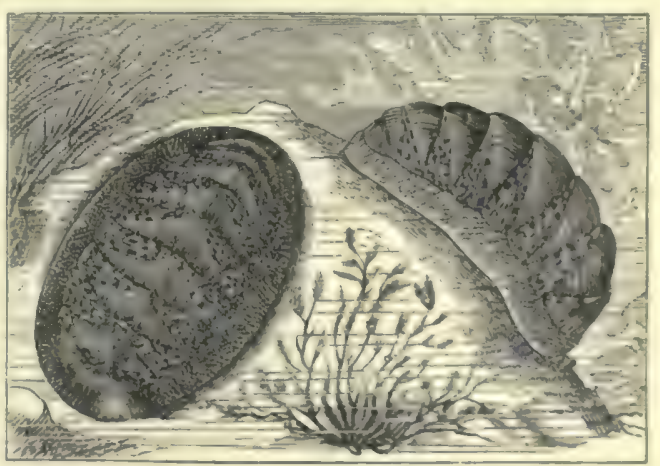

Chiton olegans.

name Polyplacophore, alluding to the multiple shell-plates, has been bestowed. Nor is the order a small one. Of the genus Chiton alone over 400 species have been recorded, and other smaller genera are also distinguished. The British species are small; those from warmer climates sometimes measure 3 to 4 inches in length. They are undoubtedly representatives of a primitive type, and include numerous fossil forms from the Silurian onwards. They are not, however, the simplest gasteropods, for a few other forms, known it is true with less fullness, exhibit the same essential features in even simpler expression. These are $(a)$ the Neomenir, including the genera Neomenia and Proneomenia, and $(b)$ the single genus Chreto. derma. The svstematic import of these last forms has been emphasised by Professor Hubrecht (Quart. Jour. Micr. Sci. 1882). Along with the chitons they 
are usually gathered together into a special subclass or class styled Isopleura or Amphineura, names referring to the equal-sided symmetry and to the double parallel nerve-cords. See GASTEROPODA; Haddon, Challenger Report, xv. (1886).

Chitral, a small mountain state in the upper basin of the Kashkar or Kunar, a tributary of the Kabul River, and bordering on Cashmere and Kafiristan, is 5200 feet above sea-level. Major Biddulph, the first European to enter it, described it in Tribes of the Hindoo Koosh (1800). The people are Moslems, but mostly speak a language closely akin to that of their pagan neighbours in Kafiristan. Upper Chitral, with its capital Mastuj, is closely connected with Gilgit. Lower Chitral enjoyed till lately undisturbed independence. But in 1894 an English resident and small body of troops were besiegred in Chitral, so in March 1895 an expedition was sent (the main body by the Swat valley, the other from Gilgit), which after sharp fighting advanced triumphantly through very difficult country, relieved the besieged, and annihilated all opposition. See Sir G. S. Robertson's Chitral: the Story of a Minor Siege (1898).

Chittagong, or IsLAmaBAD, a port of Bengal, 220 miles $\mathrm{E}$. of Calcutta, on the eastern side of the Bay of Bengal, and on the Karnaphuli River, about 12 miles from its mouth. The town is very scattered, built entirely on a number of small, steep hills, and is notorious for the prevalence of malaria. A great centre of trade under the Portuguese, it lias regained much of the commerce it lost with the rise of Calcutta. The principal imports are salt and European goods; the chief exports rice, tea, and jute. Pop. (1891) 24,069. - The district is a long narrow strip of country lying between the Bay of Bengal and the hill tracts of Chittagong and Arakan, with an area of $2563 \mathrm{sq}$. m., and a pop. of 1,290,167, two-thirds Mohammedans. - Chittagong also gives name to a division - area, 12,118 sq. m. ; pop. $4,190,081$ - and to the hill district to the enst-area, 5519 sq. m. ; pop. 107,286, three-fourths Buddhists -from whose forests a large proportion of the government elephants are obtained.

Chittagong Wood, a name somewhat vaguely used by cabinetmakens, is usually the wood of Chickrassia tabularis, a tree of the order Cedrelacer, a native of the mountainous countries to the east of Bengal. In some parts of India it is called Cedar or Bastard Cedar, names, however, which are also given to other kinds of wood. It is much valued in India, and is used like mahogany; it is often beautifully veined and mottled.

Chittim, or KIтTIM, in the Old Testament, is usually'identified with Cyprus. See also HitTrTes.

Chittor' ('little town'), a town of India, the headquarters of North Arcot district, on the Poini, 100 miles W. of Madras. Pop. 5809.

Chiusa, the name of several places in Italy, the largest being Chiusa Sclafani, a town of Sicily, 31 miles SSW. of Palermo, with oil, fruit, and sumach cultivation. Pop. 6874.

Chiusi, a town of Central Italy, 102 miles NNW. of Rome by rail, with a population of 1824 , stands on an olive-clad eminence in the Val di Chiana, not far from the small Lago di Chiusi. In ancient times, under the name of Clusium, it was one of the twelve republics of Etruria, and the residence of Porsenna (q.v.). When Italy was overrun by the barbarians, it fell into decay, the whole valley was depopulated, and became the pestilential pool described by Dante. Since the improvement of the course of the Chiana (g.v.), Chiusi has begun to flourish again along with the whole district. But it is in connection with the discovery of
Etruscan antiquities that the place is chiefly heard of. Within this century immense quantities of these remains have been found in the neighbourhood in the grottoes that served the ancient Etruscans as tombs. They consist chiefly of sun-dried black earthenware vases, ornaments, relievos, and carved stonework, and are preserved in the museums at Chiusi and Florence. See Liverani, Le Catacombe di Chiusi (1872).

Chivalry ( Fr. chevalerie, from chevalier, 'a horseman'), a social arrangement of medieval life in Christian Europe, of which knighthood formed a central feature. It included everything relating to martial accomplishments, and the relation between vassal and lord, then the chief bond of society. With regard to the position of the female sex and domestic life, it developed sentiments and manners which had a powerful and salutary effect on modern society, although it is true that the high ideal standard of purity of morals which it cultivated was not always fully exemplified in the lives of those who were trained under its influence. Though closely connected with feudalism, its germ has by some writers been traced to a much earlier age; and analogies have been pointed out between the doctrines of Boethius's Consolations of Philosophy and the ideas contained in the Testament of Love. See Feudalism, KNight.

In English Law, Chivalry is used to mean the tenure of lands by Knight's Service, which might be general or special, according as the tenant was bound to perform to the king or superior military service generally, or some particular service.

The COURT OF CHIVALRY was a military court established by Edward III., of which the Earl Marshal and the Lord High Constable were judges. It tried military offences, and decided questions of personal honour, questions as to coat-armour and the like; and sat for the last time in 1737.

Chivasso, a town of Northern Italy, on the Po, 18 miles NE. of Turin by rail, with trade in cattle and corn. Its fortifications were destroyed in 1804 by the French. Pop. 4375.

Chive, or Crve (Allium schonoprasum), a plant of the same genus with the leek and onion (see AlliUM), a perennial, $\frac{1}{2}$ to 1 foot in height, with very small, flat, clustered bulbs, increasing by its bulbs so as to form dense tufts. The leaves are tubular, eylindrical-tapering, radical, nearly as long as the almost leafless flowering-stem, which is terminated by a hemispherical, many-flowered, not bulbiferous umbel of bluish red, or, more rarely, flesh-coloured flowers. The stamens are included within the perianth. This rather pretty little plant grows wild on the banks of rivers, in marshy or occasionally flooded places, and in rocky pastures in the middle latitudes of Europe and Asia, as also. in the far north of North America. It is a rare native of Britain, being only recorded with certainty from some localities in Cornwall and Northumberland. In some of the mountainous districts of Europe a variety is found, larger and stronger in. all its parts, and with flowering-stems more leafy. Chives - the name is generally used in the pluralare commonly cultivated in kitchen-gardens, often as an edging for plots, and are used for flavouring soups and dishes, and in salads. Their properties are very similar to those of the onion. The part used is the young leaves, which bear repeated cuttings in the season. The bulbs also are by some used in preference to onions for pickling, their flavour being considered more delicate. For this purpose the clumps of bulbs are broken up in autumn or early winter, and planted in well-manured ground, in lines four or five inches apart, but standing almost close in line. In - this way they become larger and more suceulent by the following autumn, 
when they are lifted for use, the largest only being taken, and the smaller replanted for a future crop.

Chizerots and Burins form one of those peeuliar races in France that live isolated in the midat of the rest of the population, and are despised and hated by their neighbours. They are found in the arrondissement of Houry-en-Brease, in the depart. ment of Ain; and the communes of Sermoyer, Arbigny, Boz, and Ozan belong to them. According to tralition, they are descended from the Saracens. Although imlustrious and promperous, they are held in the utmost contempt and detestation by their pensant neighbours, often themselves indolent and destitute. They are looked upon as covetous and malicious, and scarcely would the daughter of a small farmer or well-to-do daylabourer become the wife of one of them, so that they mostly marry among themselves. From time immemorial, they have been field-labourers, cattledealers, butchers, and the like. Many of them are very good-looking, the young women in particular being landsome and clear-complexioned, with large black eyes. See Michel, Histoire des Races Maudites de la France et de l'Espagne ( 2 vols. Paris, 1847).

Chladni, Ernst Florens Friedrich, founder of the science of sconstics, was born at Wittenberg, November 30, 1756. He studied law in his native place, and also in Leipzig, where, in 1782, he was made Doctor of Laws. Chladni ultimately abandoned juridical stiudies altogether, devoted his mind to natural seience, and being acquainted with music, was led to observe that the laws of sound were by no means so well established as those of other branches of physics. He therefore began to spply his knowledge of mathematics and physics to acousties, and travelled for ten years (after 1802) through Germany, Holland, France, Italy, Russia, and Denmark, giving lectures on the subject, which were very successful. He died in Breslau, April 4, 1827. Chladni's writings include works on the theory of sound (1787), and on acoustics (1802 and 1817), on meteors (1820), and on the improving of musical instruments. There is a Life by Melde (1866; 2d ed. 1888). See Sound.

Chlamydo'phorus, a rare and peculiar mammal of the sloth and ant-eater order (Edentata); in its general features resembling the Armadillos, but unique in the character of its skin armour.

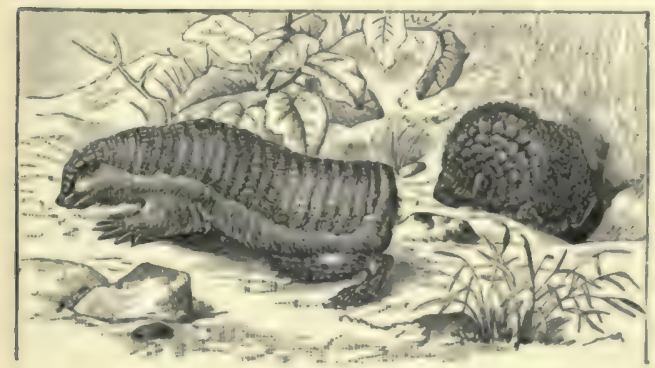

Pichiciago (Chlamydophorus truncutus).

The head and trunk are covered by about twenty movable eross bands of quadrangular horny ( slightly bony ) plates. These form an overhanging (lorsal shield, attached to the body only along the middle line of the back. The hind partis are protected by the abrupt oceurrence of a strong upright bony shield attached to the hip-girdle. The short tail, which is broadened out into a trowel shape, and tucked in between the legs, is protected by horny plates, as are also the dorsal portions of the short, clawed limbs. The rest of the body is covered with long silky hair. There are 8 teeth on each side above, and $8-9$ below. The eyes and ears are inconspicuous. C. truncatus (the Pichiciago) is a burrowing animal, living 'in the sandy plains of the wemtern part of the Argentine Repulslic: Inr. ing the day it keeps to its burrow, and is little known. It is 5 or 6 inches in length, with white hair and pinkish scales. C. retusa, from Bolivia, is larger, and the dorsal shield has a wider attachment to the body. See ANT-EATERt, Armadillo, EDENTATA, SLOTH.

Chlamydosaurus, the Frilled Lizard of Australia, is a lizard with an extraordinary frilled membrane attached to the hinder part of the head, neck, and chest, and covering its shoulders. This lies in plaits when at rest, but is expanded when the animal, which may be three feet long, is irritated or frightened. The creature, which is allied to the Iguanida, can run for forty feet with its fore-feet and tail in the air, and seens in this respect to resemble some of the extinct gigantic lizards. See a long article, with illustrations, in Nature for February 1896.

Chlamys, a short light mantle, worn as an outer garment by ancient Greek youths, and some. times adopted, even at an early period, by some Romans, as by Scipio and Sulla.

Chlopicki, JosepH, a Polish soldier and patriot, was born in Galicia in 1771. Entering the army early, he took part in the first insurrection of the Poles, next entered the French service, and served with great eredit under Napoleon in Italy, at Eylau and Friedland, in Spain, and next at Smolensk and Moskwa. After the taking of Paris by the allies in 1814, he led back to Poland the remains of the Polish troops who had fought under Bonaparte, and was well received by the Emperor Alexander, who made him a general of division. When the second insurrection of the Poles broke out in 1830, Chlopicki, who foresaw the hopeless nature of the attempt, was forced against his will to be dictator, but after six weeks of contentious opposition from the hot-headed and rashly extreme patriotic party, he resigned his office. But with a heroism all the more heroic that he knew too well the cause was hopeless, he re-entered the Polish army as a simple soldier, and fought with reckless bravery at Wawre and Grochow. Severely wounded in one engagement, he retired to Cracow, where he died 30th September 1854. (The name is pronounced Chlopitzki.)

Chloral (trichloraldehyde) is a limpid, colourless, oily liquid, with a peculiar penetrating odour, and is formed when anhydrous alcohol is acted on by dry chlorine gas. It dissolves sulphur, plins. phorns, bromine, and iodine, and is closely allied to Aldehyde (q.v.). Chloral combined with one equivalent of water forms chloral hydrate, a white crystalline substance, with a pungent odour and a bitter taste, to which the name chloral is commonly though incorrectly applied. Chloral was discovered by Liebig in 1831, and investigated by Dumas; the chloral hydrate was first used as an anresthetic and hypnotic by Liebreich in 1869 . The chief action of a molerate dose of chloral (15 to 30 grains) is the production of sleep, closely resembling natural sleep, and usually sound and refreshing. It has also a marked effect in quieting excitement, as in insanity or delirium; and in relaxing spasm, and checking convulsions and allied conditions, Its action as an anssthetic is very capricions and uncertain; medicinal doses sometimes relieve pain completely, but much more often fail to do so. It lessens the force of the heart's action, and in large doses greatly rednces the temperature of the body : and to these effects the futal results that sometimes follow its administration are chiefly due. As a 
hypnotic it is most valuable in cases where opium or morphia is dangerous or undesirable (in children, in disease of the kidneys), and where sleeplessness is combined with excitement (delirium of fevers, delirium tremens, insanity); but it may be employed in many other cases with advantage. In tetanus (lockjaw), and other diseases attended by convulsions, it is often of great value. It acts as an antidote in poisoning by strychnia and Calabar bean. It must be employed with the greatest caution, or not at all where there is any reason to suspect weakness of the heart, or embarrassment of the circulation from any other cause; in such cases dangerous symptoms are very readily produced by it. When habitually employed to procure sleep, it is generally less hurtful than opium; but sometimes "profound melancholy and enfeeblement of the will, muscular lassitude, inability to sleep without the drug, and other untoward symptoms (called collectively chloralism) result, and only disappear when its use is discontinued. Moreover, fatal accidents from its indiscriminate use are far from uncommon. Poisoning by chloral should be treated by keeping the patient warm, attempting to rouse him, administering coffee and small doses of strychnia or atropia.

When chloral hydrate is treated with caustic potash, pure chloroform is obtained; but owing to the expense, this precess has not come into use in Great Britain. It has been supposed that its anresthetic property is the result of a similar formation of chloroform in the blood, but no evidence of this is forthcoming.

Chlorantha'cea, a small group, chiefly tropical, allied to the peppers, aromatic and stimulant. Chloranthus inconspicuus is the Chu-lan of the Chinese, who use it for perfuming teas.

Chloric Acid, $\mathrm{HClO}_{3}$, is the acid corresponding to the hypothetical oxide of chlorine, represented by the formula $\mathrm{Cl}_{2} \mathrm{O}_{5}$. It is a syrupy liquid, with faint chlorine odour and acid reaction. A piece of paper dipped into it becomes charred and takes fire, and it is instantly decomposed by contact with organic matter. In itself it is not of much importance, but it forms a class of salts called chlorates, one of which at least is well known. Chlorate of potash, $\mathrm{KClO}_{3}$, is an article of commercial value, and may be prepared by pass. ing chlorine into a solution of caustic potash, heating the liquid, and crystallising out the salt. It forms pearly plates, which, when heated, melt and give off oxygen in abundance. So also when thrown on red-hot charcoal, oxygen is given off, and violent deflagration ensues. On account of this property it is used in the preparation of coloured fires, but its use is not unattended with danger, owing to their tendency to spontaneous combustion and its explosive properties when triturated with sulphur. Mixed cautiously with amorphous phosphorus, previously moistened with alcohol, it forms a mixture which, when dry, explodes if tapped with a pencil. This mixture is employed in the manufacture of some kinds of matches, which give a slight explosion when struck. If a crystal of chlorate of potash be placed on a piece of paper saturated with turpentine, and a drop of sulphuric acid added, it causes the inflaming of the turpentine with explosive rapidity. The chlorate is also used in medicine, and in a compressed form has become a popular remedy in certain forms of sore throat.

Chlorimetry is the process of estimating the proportion of 'available chlorine' in Bleaching Powder (q.v.), which may vary from 20 to 40 per cent. The term available applies only to that portion of the chlorine which is easily liberated, and which takes part in the bleaching process.
Chlorine, which is present as chloride, as in chloride of ealcium, $\mathrm{CaCl}_{2}$, has no bleaching power, and is not estimated by chlorimetry.

The process is one of volumetric analysis, and the apparatus used is similar to that described in the article on Analysis (q.v.). There are several practical methods of chlorimetry, all based on the principle of measuring the oxidising power of the bleaching powder. This is arrived at by making a solution containing a definite amount of pure sulphate of iron, arsenious acid, or other substance capable of being oxidised, running in the solution of bleaching powder very slowly, and then by suitable tests determining the exact point when oxidation has taken place. By calculation the amount of 'available chlorine' is at once obtained. Where substances other than bleaching powder are under examination, slight modifications of the process may be necessary.

Chlorine (sym. Cl ; atom. wt. 35.5 ; Gr. chtōros, 'pale green') is a non-metallic element discovered by Scheele in 1774, and named by him dephlogisticated marine air. Afterwards, in 1810, Davy proved it to be an elementary body, and gave it the name which it now bears. In nature it is always found in a state of combination. United with sodium, $\mathrm{Na}$, it occurs very largely as the chloride of sodium, NaCl-common salt-in the ocean; in large beds, as rock-salt; in all natural waters, including even rain-water; in clays, soils, limestone; in volcanic incrustations; and in the vegetable and animal kingdoms. The preparation of gaseous chlorine by its liberation from common salt, is described under HyDROCHLORIC ACID and SodA. See also BlEAching Powder, which is the form in which chlorine is prepared cornmereially. For experimental purposes the gas may be received in jars filled with warm water at the pneumatic trough, when the chlorine rises into the jar, and displaces the water. When thus obtained it is a yellowish-green gas with a peculiar and suffocating odour, is not combustible, and is a very feeble supporter of ordinary combustion. A lighted candle placed in it burns with a very smoky flame, owing to the hydrogen of the oil alone burning, while the carbon is liberated. Several of the metals, such as antimony, copper, and arsenic, in a fine state of division, or in the condition of thin leaves, at once become red hot, and burn when introduced into the gas. A piece of thin paper soaked in turpentine likewise bursts into flame. Chlorine is a very heavy gas, nearly $2 \frac{1}{2}$ times heavier than air, its specific gravity being $2 \cdot 470$ (air $=1.000$ ); it is soluble in cold water to the extent of two volumes of chlorine in one of water, and yields a solution resembling the gas in colour, odour, and other properties. The principal properties of chlorine are those of a bleacher of cotton and linen (see BLEACHING) and a most powerful Disinfectant (q.v.). The gas ean be condensed by pressure and cold into a transparent dark greenish-yellow limpid liquid, with a specific gravity of $1: 330$ (water $=1.000)$, which also possesses bleaching properties and a most powerful odour. On the animal system chlorine acts, in very minute quantity, by producing $a$ sensation of warmth in the respiratory passages, and increasing the expectoration; in large quantity, by causing spasm of the glottis, violent cough, and a feeling of suffocation. The workmen in chemical manufactories, who get accustomed to the chlorine in small quantities, are generally stout-at least, lay on fat-but complain of acidity in the stomach, which they correct by taking chalk, and also suffer from the corrosion of their teeth, which are eaten away to stumps. The antidotes to the evil effects of the introduction of chlorine into the lungs are the inhalation of the vapour of water, alcohol, ether, or chloroform ; but 
the latter two should never be resorted to except under medical supervision.

Chlorine forms with other substances a very large number of chemical compounds. Mixed with hydrogen in equal volumes, and exposed to sunlight or flame, union takes place with explonsive energy, and hydrochloric scid, $\mathrm{HCl}$, is proslueed. This acid forms an extensive class of salts called chlorides (see HYDROCHLORIC ACID), but many of these may be produced by the direct combination of chlorine with the metals, as in the experiments described above. Chlorine replaces other elements or groups of atoms in organic compounds, forming chloro-derivatives. In combination with carbon and livilrogen it forms many substances, among which Chloroform (q.v.) is perhaps chief. Chlorine forms with oxymen a series of oxygen acicls-viz. Hypochlorous, $\mathrm{HClO}$; Chlorous, $\mathrm{HClO}_{2}$; Chloric, $\mathrm{HClO}_{3}$; and Perchloric Acid, $\mathrm{HClO}_{4}$; the more important of which are referred to under separate heads.

Chlorite (Gr. chlöros, 'green'), or Ripidolite, an abundant mineral, consisting of silica, alumina, magnesia; and protoxide of ixon, in somewhat variuble proportions. It is of a green colour, and occurs now and again erystallised in minute hexagonal plates, or in aggregates of small leaflets, either singly or disposed in radial groups, which are scattered over the joint-surfaces of certain rocks, or may oceur in a thin incrustation upon other minerals. It is rather soft, and is easily broken or seratched with a knife. Before the blowpipe it is with difficulty fused on thin edges. It is readily distinguished from tale by yielding water in a closed tube. There are several other minerals included with ripidolite under the 'chlorite group' which are with difficulty distinguished from ripidolite and from each other. Chlorite enters largely into the formation of certain schistose rocks (e.g. Chloriteschist, q.v.), and is common as a decompositionproluct after such minerals as mica, augite, hornblende, and garnet.

Chlorite-schist, a green gchistose rock, in which chlorite is abundant in foliated plates, usually blended with minute grains of quartz, and often with felspar, mica, tale, or magnetite.

Chloritic Marl, a thin bed of white or paleyellow marl, sometimes indurated, containing darkgreen glauconitic grains, phosphatic nodules, and iron pyrites. It helongs to the Cretaceous system, coming between the Upper Greensand and Chalk Marl. It is characterised by the abundance of Scaphites aqualis, a species of ammonites. It is confined to the southern districts of England occupied by the Cretaceous rocks.

Chlorodyne is a patent medicine of considerable popularity, invented by Dr James Collis Browne (1819-84), but largely imitated by various chemists. It contains opium, chloroform, prussic acid, and probably Indian hemp, and is flavoured with sugar and peppermint. $A$ s it is apt to separate into two liquids on standing, it should never be taken unless it has previously been well shaken; and as, in taking a dose of chloroslyne, the patient swallows an unknown quantity of three or four of the deadliest poisons with which we are acquainted, it is always advisable to begin with small doses. It is unquestionably a compound which sometimes suceeels in allaying guin ani inducing sleep when opiates have failed; but whether a physician is justified in recommending a remedy with the composition of which he is unacquainted is a doubtful question. To meet this difficulty the Medical Council, in the 1885 edition of the British Pharmacopoin, have introduced the tincture of chloroform and morphia, which practically represents chlorodyne. Five to fifteen drope is the average dose.
Chloroform, $\mathrm{CHCl}_{\text {, }}$, was discovered a a chemical enriosity ahout the same time (1831) by Guthrie in America, Liebig in Germany, and Soubeiran in France. Soon, however, its pro. perties as a stimulant when taken internally attracted attention, and when in 1847 it was brought into prominent notice as an anxsthetic by Sir James Simpson, it was at once recognised a one of the most valuable contributions of chemical science to suffering humanity. See ANASTHESIA.

Chloroform is composed of 12 parts of carbon, 1 part of hydrogen, and $106 \mathrm{~s}$ parts of chlorine. It may be produced in several ways, but in this country at least the process by which it is obtained from bleaching powder is the only one adopted on the large scale. The materials employed are bleaching powder, alcohol, and water. The blench. ing powder and water are mixed together to form. a thin cream, the alcohol added, and the whole placed in a capacious still, connected with suitable condensing apparatus. On the application of heat the contents rapidly froth up, and even though the external application of lient be stopjed, the chemical action is so violent that the chloroform distils over rapidly along with water and any excess of alcohol. As so obtained it is very impure, and requires to be carefully treated with sulphuric acid, and then redistilled before it is fit for anæsthetic purposes. Pure chloroform is a limpid, mobile, colourless, volatile liquid, with a characteristic odour, and a powerful sweetish taste. When diluted with alcohol it enters into the composition of artificial fruit-essences, to which it gives a flavour akin to that of ripe apples. It is a very heavy liquid, its specifie gravity being about 1.500 (water $=1.000$ ), and as it does not readily mix with or dissolve in water, it falls to the bottom when poured into a vessel of that liquid, forming a distinct layer. Chloroform is readily miscible with alcohol and ether, and it dissolves camphor, amber, gutta-percha, wax, black and red senlingwax, iodine, and bromine, as well as strychnine and other alkaloids. It dissolves a small proportion of water, being also slightly soluble in that liquid. Chloroform is not combustible in the ordinary sense of the term, but when its vapour is brought in contact with flame it burns, imparting a green tint to it, and irritating fumes are produced. Pure chloroform is not met with in commerce owing to the readiness with which it decomposes when exposed to light. In onder to prevent this a small proportion of alcohol is added, the specific gravity being thus reduced from 1.500 to 1497 . When evaporated on the hand no disagreeable odour should be noticeable, and when shaken with sulphuric acid only a very slight discoloration of the acid (due to the small pro. portion of alcohol) should result. Besides its ansesthetic properties, which are elsewhere dis. cussed (see ANASTHESIA), chloroform is used in medicine both externally and internally. When applied to the skin or any of the mucous membranes it acts as a powerful irritant, producing a burning sensation, and on this account it is of value as an application in rheumatism, lumbago, and neuralgia. As an application to a decayed tooth its action is twofoli, as a stimulant and counter-irritant locally, and also to a partial extent as an anresthetic. Taken internally, diluted with alcohol, it is a powerful stimulant, and readily promluces a species of intoxieation. It is by some habitually taken as a narcotic luxury. As chloric ether, a protuet distillert from blegehing powder, and containing chloroform, it enters into the com. position of cough mixtures, pick-me-ups, \&c.

Chlorophyll, as its name implies, is leaf-green, the ordinary colouring matter of vegetation. Microseopic examination of plant tisues shows it some. 
times to tinge the whole protoplasm of the cell (though never the cell sap). Much more generally, however, it is collected into definite bodies, the so-called chlorophyll granules, or less frequently, as in some of the lower algæ, arranged in starlike masses (Zygnema) or spiral bands (Spirogyra). A brief immersion of the specimen in alcohol suffices to dissolve out the chlorophyll, and leave the form of the chlorophyll bodies unaltered; and the solution may then be conveniently studied in a fresh state, as it gradually fades on keeping. It is of a deep rich green by transmitted, but of characteristic deep red colour by reflected light; in a word, is highly fluorescent. The absorption-spectrum is quite characteristic; yet the complex nature of the substance is strongly argued for on the ground of the following experiment. Shake up the alcoholic solution with benzol, and when the two fluids have had time to separate, we find the green to have disappeared. The lighter alcohol above is now of a strongly yellow hue, while the subjacent benzol is of a distinctly bluish green. To these colouring matters the names Xanthophyll and Cyanophyll are commonly given. While their separate spectra are quite characteristic, their combined spectrum seems to restore that of chlorophyll. The latter substance resembles the blue-green colouring matter of some of the lowest algæ (Oscillatoria, \&c.), while the yellow substance recalls that of many buds and flowers. Others, however, maintain that these substances are really the result of a destructive decomposition of true chlorophyll; while Gautier has even prepared green needle-like crystals which he regards as chlorophyll in a pure state. The chemical composition of chlorophyll is also a matter of considerable difficulty, both on account of its own easy decomposability, and its being necessarily accompanied by other extractive substances; thus the question of the presence or absence of iron has been much debated, a matter which seems to indicate variability of composition. This is further borne out by the labours of spectroscopists. Thus in addition to the familiar well-detined analogous colouring matters which characterise respectively the blue-green algæ, the brown and the red (see SEAWEEDS), researches such as those of Sorby and others seem to indicate a number of varieties too numerous even for enumeration. This varietal range, however, may best be approached after considering the conditions in which chlorophyll is formed. Of the chemical factors little can be said save that the presence of iron in the soil seems to be quite indispensable; the physical conditions are, however, simpler.

A sufficient temperature is necessary to the formation of chlorophyll; for seedlings from $4^{\circ}$ to $8^{\circ} \mathrm{C}$. being a minimum, while the process is said to take place most rapidly, on the average, at about $35^{\circ} \mathrm{C}$. The most important condition is, however, the presence of light; with rare exceptions, plants cannot form any chlorophyll in darkness. The blanching of celery or leeks is a familiar instance of this, or conversely, the green coating acquired by a potatotuber where it happens to have been denuded of its covering of earth. Shoots formed in darkness form colouring matter indeed, but only of a pale-yellow hue, the so-called etiolin; after a very brief exposure to light, especially if direct sunshine, chlorophyll appears, apparently by direct transformation of the former. The other colouring matters of plants are sometimes in protoplasm granules (chromoplasts), but more frequently also in solution in the sap; and these frequently are present in such abundance, especially in the epidermis, \&c., as to mask the chlorophyll altogether, as happens especially in so many of our hothouse plants with decorative leaves. The general tendency of research is to indicate that all the phenomena of plant colour seem intimately connected with what we may term the general life-history of chlorophyll. Thus the yellows and reds of young shoots and leaves in spring may be interpreted as having some relation to the development of chlorophyll, if not absolutely stages of the process; while the same suggestion arises with regard to the colouring matters of flowers, which are similarly to be regarded as imperfectly vegetative shoots, although in this case through the onset of the reproductive function, instead of merely by reason of immaturity. Finally also with regard to the autumnal hues, in which the chlorophyll pigment seems to be disintegrating through colour-stages analogous to those of its evolution in spring, or of its arrestment in the flower. In favour of such a view evidence is forthcoming from either end of the vegetable kingdom. Thus Cienkowsky has shown that in the case of certain unicellular algæ, which like the common Protococcus of rain-water, possess red pigment as well as green when passing into the resting stage, the quantity of red may be increased in proportion as autumnal conditions are reproduced by artificially lowering the temperature, and vice versd. The same experiment may be made with the common Sempervivums, Sedums, \&c., whose leaves become more or less red in autumn or winter; those of Thuja (Arbor Vitoe) similarly become brownish, but recover themselves in spring. Among almost. all cultivated plants, variegated varieties tend to arise, that is to say, we have certain cell-areas of the leaf-parenchyma destitute of chlorophyll. The conditions of this are quite obscure (see VARIEGATION ) ; but it is noteworthy that this loss of chlorophyll may also take place in lower plants, so that there is considerable ground for regarding at least many apparent fungi as simply alga which have degenerated in this respect through parasitism. Phanerogamous parasites like Toothwort (q.v.) or Dodder (q.v.) similarly become almost completely blanched.

Chlorophyll apparently identical with that of green parts of plants, can be experimentally demonstrated in the tissues of certain animals ; and although this has in many eases been shown to be due to the presence of symbiotic algæ (see SYMBIOSIS), there remain cases-e.g. Hydra viridis, \&c., and at the very least Paramocium viride, in which we have undeniably intrinsic chlorophyll, and this of truly vegetable function.

The development of our knowledge with respect to the functions of chlorophyll is still far from complete, and may in any case be more conveniently treated under LEAF and Vegetable Physiology (q.v.); suffice it therefore to state here the elementary and essential fact that its presence is in every case constantly associated with the process of assimilation, or elaboration of new products by help of the energy of sunlight, upon which the continued nutrition of the green plant depends ; and of which the formation of starch with decomposition of carbonic anhydride and disengagement of oxygen are the most obvious chemical results. A fuller account of the state of knowledge and opinion upon this portion of the subject will be found in the articles referred to.

\section{Chlorops. See Corn Insects.}

Chloro'sis (Gr. chlöros, 'pale green '), a peculiar form of anæmia or bloodlessness, common in young women, and connected with the disorders incident to the critical period of life. It has been called the green sickness, from the peculiar dingy greenishyellow hue of the complexion; the green colour, however, is not always present. The disease is attended with very great debility, and often with breathlessness, palpitation, and other distressing or even alarming symptoms. In a few cases it is 
associated with imperfect development of the larger arteries, and is then incurable; but in the vast majority of cases it yields readily to treatment unlese complicated with some other disease. The principal means to be employed are air, exercise, often salt-water baths, with a nutritious and rather stimulating liet, and purgatives if required tugrether with sur.h special remerlies as are allupted for restoring deficient secretions, and bringing the entire fenale system of organs into a natural condition; but above all, large doses of iron, continued for some weeks or months. The tend. ency to chlorosis is often hereditary, and relapses are very apt to take pluce. For C'hlorusis in plants, see (in Vol. VIII. p. 222) Diseases of Plants.

Choate, Rurus, a scholarly American lawyer, born in Essex, Massachusetts, lst October 1799, graduated at Dartmouth in 1819, and was admitted to the bar in 1823. He sat in congress from 1830 to 1834, when he settled in Boston. Here his singular eloquence rapidly alvanced him to the place of leader of the Massachusetts bar; indeed, it has been claimed for him that he was the most eminent advocate New England, or even America, has produced. After a term in the United States senate, 1841-45, he returned to his profession; in 1859, his health giving way, he sailed for Europe, but stopued at Halifax, Nova Scotia, where he died July 13. His writings, with a memoir, were published at Boston in 1862. See Neilson's Memories of Rufus Choate (Boston, 1884).

Chocolate is a preparation of the seeds of Theobroma Cacao (see COCOA), nade by grinding the seeds to a very fine paste. The mill, heated by gas, is construeted of heavy metal rollers turning in a circular course upon a flat metal plate. A curved knife or scoop is attached to the rollers in such-wise that it shall return the paste continually to be crushed and recrushed by the rollers until it becomes almost impalpable. The object of this is to render the nut, otherwise difficult of solution, readily diffusible in water or milk when used as a beverage. The paste when unmixed is called Coeos; but when sugar and flour or other farinaceous material with flavour. ing matters such as vanilla, cinnamon, \&c. are added, it bears the name of Chocolate. The two names are much confounded commercially. Chocolate is moulded into cakes or sold in powder or flakes formed by simply cooling the paste as it comes from the mill. The seeds or nuts contain a large proportion ( 30 to 50 per cent.) of oily matter (cocoa butter). This may be partially removed or all retained in the chocolate. In the latter case much of it is mechanically adherent to the sugar or farinaceons matter. Chocolate is a favourite beverage in Spain, Italy, and other southern countries, especially for breakfast; the eake or powder is heated and diffused in water or milk with much stirring. The Italian rarely uses butter, but cuts his bread into sippets and dips them in his chocolate, the oily matter of which performs the same nutritive functions as the butter we spread on our bread. It is sometimes mixed with coffee in Italy, and there known as mis. chiata. It is also made into a paste with cream and sugar and frozen as chocolate ice. Vanilla is the favourite flavouring. The name appears to be Mexican, Chocolatl (choco, 'cocoa,' and latl, "water"). It was introduced from America to Europe by the Spaniards. It is highly nutritious, containing a large proportion of nitrogenous fleshforming material. On this account it is used as portable food by many mountaineers. An excess. ively rich food is obtained by preparing it with milk and then whisking in a raw egg. The waiters at certain Italian coffee-houses call this la gloria, and the ordinary infusion "Aurora" In the solid form, mixed with much wugar, cream, and various confections, choculate is largely used as a sweetmeat, and is introduced in pastry.

Chocolate Root. Seo Grum.

Choctaws, a tribe of American Indians, belonging to the Appalachian stock, and formerly inlabiting the central portions of Missiseippi, but now settled in the south-east of Indian Territory, where they are regarded as one of the four civilised nations, and hold 6,668,000 acres of land. They have benefited greatly by the labours of mission. aries, and have become good farmers and mechanics.

Chodowiecki, Daniel Nikolaus, German painter and copperplate engraver, was born in 1726 at Danzig, and died director of the Academy of Sciences at Berlin, 7th February 1801. He produced some 3000 plates, mostly small.

\section{Choir. See Church and Chancel.}

Choirs and Choral Singing. Choir properly denotes the body of singers who perform the musical part of a church service, but has lately been applied also to independent choral societies, such as the Bach Choir in London. The composition of a choir is so variable that only a few general principles can be indicated. The commonest and typieal form is that of the four-part choir of mixed voices-i.e. both male and female; the soprano part, however, is often taken by boys, and the next by male alto voices. While it is desirable that the individual voices should themselves be good and well trained, there are requisites over and above those looked for in solo singing. These are briefly: (1) An equal- balance of voice-power in each part; (2) adaptation of the number of voices to the size of the building where they sing; (3) an exact sense of time and rhythm in the singers, and the power of maintaining each part independent, while still in agreement with the others; (4) facility in singing at sight; and (5) frequent practice togrether. Thongh many choirs are guided by the organist alone, or have merely a leuder, a conductor is always of the greatest advantage, much of the expression and effect depending on him, and the more so in proportion as the choir and the works sung are larger. It is a much debated point whether the choir should sing alone, or guide the singing of the congregation. In not a few American churches the former principle is developed in a singular form, the quartet choir consisting merely of four solo singers, by whom alone the whole music of the service is sung.

In the Eastern Church the music is unaccompanied, and is sung by the priest and choir alone. The choir of the Imperial Chapel in St Petersburg consists of about 120 voices, men and boys, who have no other occupation. In the Church of Rome the most notable is the Sistine or papal choir in Rome. Its genealogy is traceable to the singing schools established by very enrly popes, but extensively developed by Gregory the Great. It has for a long while consisted of thirty-two choral chaplains, occasionally supplemented, and has generally possessed specimens of the rare adult male soprano voice, the leader in 1888 being one. They sing unaccompanied, but the organ is generally used in other Roman Catholic services. The effect of their singing during the Passion-week has been well described in Mendelssolin's letters. A body of some thirty-five of them were brought by the pope to the coronation of Napoleon in Notre Dame, Paris, and entirely eclipsed a large chorus accompanied by eighty harps which was expected to produce an unprecedented effect. Since 1870 this choir has been very seldom heard at all. In the
Lutheran churches in Germany, when there is a 
choir, as a rule they sing alone, and the congregation alone. The choir sing (unaccompanied) polyphonic motets, or less familiar hymus, the congregation singing the chorales in unison, with organ accompaniment. The most celebrated German choirs are those of the cathedral in Berlin and of the Thomas Church at Leipzig. The English cathedral choirs are more or less richly endowed, Durham standing at the head with $£ 2400$ a year. As a specimen, some details may be given in regard to Norwich. Here the choir consists of fourteen choristers (boys) and eight lay clerks (men). For the purpose of antiphonal singing these are divided into two sides, denominated (from the seats of the precentor and dean respectively) the Cantoris and Decani. The lay elerks are appointed by the dean; the choristers are trained by the organist, and have two rehearsals daily. A full rehearsal of all the choir is held weekly; they all attend on Sundays and festivals and (with the exception that each lay clerk is entitled to one week's absence in six) at the daily services. The precentor has the whole control of the choir, selection of music, \&c., while the organist is responsible for the accompaniments, the training of the choristers, \&c. The late Dr Buck of Norwich was perhaps the most celebrated trainer of cathedral choirs in the 19th century. Among the noted English choirs are those of the Temple Church in London and Magdalen and New College Chapels, Oxford. There is almost no literature on this subject, but much information is contained in Curwen's Studies in Worship Music (two series, Lond. 1885-88). See Chorus, Intoning, Service (Musical).

Choiseul-Amboisé, Étienne Francois, DUC DE, minister of Louis XV., was born in 1719. He served with credit in the Austrian Wars of Succession, and through the favour of the king's mistress, Madame de Pompadour, became lieutenant-general in 1748, and Due de Choiseul in 1758 . $\mathrm{He}$ was sent to Rome and next to Vienna in 1756 to arrange the alliance between France and Austria against Frederick the Great, and it was his policy that brought about later the family league of the Bourbon monarchs in Europe. He made himself very popular by the fairly favourable terms he obtained in 1763 at the close of a disastrous war, and further by his opposition to the Jesuits. He conceived, and almost carried out, a plan for the formal emancipation of the Gallican Church from papal influence, improved the army and navy, developed the trade and industry both of the nation and of the colonies, and opened up anew an intercourse with India, whose native princes were assisted by French officers in their endeavours to expel the British from the peninsula. He had spies in every European court, and so ruled all diplomatic and political cabals as to deserve the title the Empress of Russia gave him, Le Cocher de l'Europe. His power had survived the death of his patroness in 1764, but the rise of Madame Dubarry, who succeeded Madame de Pompadour in the king's affections, gradually alienated Louis from his able minister, who retired in 1770 to his magnificent estate of Chanteloup, where he lived in princely splendour. After the accession of Louis XVI. he received permission to return to Paris, and was often consulted, but never recovered his official position. He died May 7, 1785.

Choke-cherry, a name given to certain nearly allied species of Cherry (q.v.), natives of North America, having small fruit in racemes, like the Bird-cherry or Cherry-laurel (q.v.), from which latter, however, they are easily distinguished by their deciduous leaves. The fruit is at first rather agreeable, but afterwards astringent in the mouth. The species and varieties are not easily definable, but Prunus (Cerasus) virginiana, serotina, and borealis may be especially mentioned. The bark is used as a febrifuge and tonic, under the name of Wild Cherry Bark; and by distilling it with water, a volatile oil is obtained from it, associated with hydrocyanic acid, called Oil of Wild Cherry.

Choke-damp. also called after-damp or fouldamp, is the carbonic acid gas given off by coal which accumulates in coal-mines, and may suffocate those exposed to it. It is distinguished from. fire-damp, the marsh-gas or light carburetted hydrogen which causes the explosions. See CoAL, Mining.

Choking, in its slighter forms, is a very familiar occurrence, and results from a morsel of food or other solid, or even a drop of liquid, passing into the Larynx (q.v.) or upper opening of the windpipe, instead of the gullet, or in popular parlance 'going down the wrong way.' It is generally caused by a breath being suddenly drawn in coughing, laughing, \&c. while food or fluid is in the mouth; and a violent fit of coughing follows till the offending substance is expelled from the windpipe. Sometimes, however, a larger masse.g. a half-chewed piece of meat-is drawn into the opening of the windpipe, completely blocking it, and arresting respiration altogether. This condition is one of extreme danger; the sufferer becomes purple in the face, and if not at once relieved will certainly and quickly die of suffocation. The obstructing substance is usually within reach, and may often be dislodged if a bystander promptly pushes his forefinger to the back of the throat and attempts to draw it forward. A child may sometimes be saved by holding it up by the heels and shaking it, or slapping its back. If these measures fail, a sharp-pointed knife, a penknife for instance, nust be promptly pushed into the windpipe to admit air to it below the obstruction. See (under Trachea) Trachвoтомy ; see also (Esophagus, PharynX.

In cattle, the causes fall under two heads : (1) those that depend on the material swallowed; and $(2)$ those that depend on the animal swallowing. Under the first head we find sharp-pointed objects which become fixed into or entangled in the membrane lining the throat and gullet; solid masses too large to pass on to the stomach; dry farinaceous materials which clog in the passage. The second class of causes consists in inflammation of the throat, or irritation of the organs of deglutition; constrictions of the passage; ulceration of the oesophagus, which is apt to follow choking, and is the cause of a relapse; lastly, without any disease of the deglutitory organs, an animal may be choked by eating too greedily, and imperfectly masticating or salivating its food.

The symptoms vary according to the position of the obstruction. Many of the most alarming symptoms arise from the paunch becoming distended by gas. See Hoove.

Remove the obstruction with the hand when you can. Cause the animal to swallow the sub. stance, if possible, by giving it water, oil, or Belladonna solution. Carefully push the offending agent down by a probang, if it is possible to effect this, and if withdrawal by the mouth is impracticable. In some cases the gullet has to be cut into by a qualified surgeon. After a case of choking, keep the animal on soft food, and attend to its general health, in order to avoid a relapse, which is of frequent occurrence in cattle. Cattle are most frequently choked by sliced turnips and potatoes, and these should consequently be pulped or mashed.

Cholecystot'omy, the opening of the gall bladder. See CALCULUS. 
Cholera (Fr. cholera asiatique). The Greek word cholera (connected with chole, 'bile, as is also the English 'choler') was used by looth Hipjos. crates and Celsus to describe sporadic cholera (see below ). The term is now rather loosely employed to denote various forms of disense (much as chicken cholera, for which see Poultry). In this article it is used as the designation for Asiatic, Oriental, or Epidemic Cholera, otherwise called Cholera Morbus or Pestilential Cholern. This disease has been popularly believed to be a new disease which made its first appearance in Bundel. khand in 1817, when 5000 men died in five days; but there is no doubt that it has a far more ancient origin, and has visited Europe since 1500 A.D. Cholera is a specific disease characterised by violent vomiting and purging, with rice-vater evacuations, cramps, and collapse; tending to run a rapidly fatal course, and capable of being com municated from person to person by means of the dejecta of patients suffering from it. The mortality of cholera varies in different epidemies; it is always greatest at the commencement of a fresh outbreak; at the lowest estimate one-half of the persons attacked die. Cholera has been endemic for centuries in certain parts of India, especially in the valley of the Ganges, and in the 19tl century it has spread on various occasions almost all over the civilised world. In 1817-23 cholera spread rapidly throughout Bengal and other parts of India, Ceylon, Burma, and China, slaying thousands of victims. A second outbreak occurred from 1826-37, and spread via Central Asia and Russia with frightful virulence throughout Europe and America. From Riga it was imported to Sunderland (26th October 1831); from Hamburg to London (13th February 1832); and so it passed on to Paris, Quebec, Chicago, New Orleans, \&c. In 1846-63 a third epidemic oceurred, and Europe and America were again visited; 53,293 persons dying in England and Wales in 1848-49, and 20,097 in 1854. A very extensive outbreak took place in 1865-75; and in 1884-85 eholera reached France (especially Toulon and Marseilles), Italy (especially Naples), and Spain, but did not spread farther. The outbursts of cholera sre generally sudden in their advent, hundreds of people being attacked within a few days of its appearance in any locality. It is a noteworthy fact that in each outbreak of cholera, one or other of its various symptoms is especially well marked.

Certain factors determine the origin and promote the diffusion of cholera. Places having a high altitude are prone to eseape its ravages (at anyrate for a long time), whereas low-lying ground favours its spread. During the general diflusion of cholers in India in 1817-19, the hill-forts remained exempt in a remarkable way, while the lisease was prevalent in the plains around. There is no doubt too that cholera follows the rivers; and the more copious the saturation of the ground, and the greater the amount of organic matter undergoing decomposition it contains, the more exten. sive will be its spread. The drying of the soil aiter it has been soaked is very favourable for the development of cholera epidemies; and they are also favoured by certain physical characteristics of the soil, such as permeability to water and air, also by rocks that have a capacity for retaining moisture, and by organic detritus. But these are not the only factors we have to take into account, for climatic influences, such as heat and moisture, also affect its epidemic spread. Heat aids its production; a marked fall in the temperature and heavy rain stay its ravages, but rain after a prolonged drought often gives it impetus.

As to the exact nature of the morbid poison which causes cholera, authorities still differ, yet in all probability a germ found in 1883 by Koch in the dejects of cholern patients in Egypt, Caleutta, and Toulon, and named by him the 'Comma' bacillus, constitutes the morbific agent. His observations were to some extent confirmer by the resenrches of $\mathrm{Klein}$ and Gibbs in Calcutta and Bombay, and numbers of observers, notably Dr Macleod and Mr Miller at Shanghai in 1885, have since found the bacillus in the stools of eholera patients (see BACTERIA, GERM THEORY). The importance of this discovery can be estimated by the following fact. An Italian emigrant steaner arrived at New York in 188\%, having on board a case of diarrhoea, the symptoms of which were suspicious but not perfectly typical of Asiatic cholera. Cultivation experiments were made at the Carnegie Laboratory of material discharged by this patient, and in four days they manifested the characteristic appearances due to the growth of the 'Comma' breillus; and the diagnosis was subsequently confirmed by the occurrence of cases amongst the ship's passengers, in which the unmistakable symptoms of Asiatic cholera were present. It must, lowever, be said that bacilli similar to these do occur in healthy persons; they do not, however, give rise to the same appearance when cultivated by Koch's method as do the bacilli found in cholera stools. Further research is necessary to show in what way these bacilli cause cholera. The dejecta of cholera patients when perfectly fresh are innocuous, but very soon they develop the morbitic agent, and water, food, or elothing contaminated by them will communicate the disease to healthy persons. Numerous observations go to prove that the wind also is capable of conveying the poison from dried cholera stools, but how far it is impossible to say. Troops or pilgrims may carry the infection and propagate it along their line of march; if healthy bodies of men meet with infected troops or enter a tainted district, they will almost certainly suffer; or if a body of men encamp on a site recently occupied by cholera patients, they will become affected. If cholera breaks out on board ship in mid-ocean, it will be coincident with the exposure of some part of the cargo from an affected place.

Causes.-(a) Predisposing.-Fear or shock, exposure to sudden changes of temperature, intemperance in labour, pleasure, or drink, and want of proper eluthing, as well as everything which tends to derange the stomach, or the use of strong purgatives, predispose a person to an attack of cholera; and fresh arrival into an in. fected area renders a person extremely liable to an attack. (b) Exciting.-This is of counse the entrance into the body of the poison, which may be introduced into the system either by drinking. water, or by food contaminated with the discharge of a cholera patient. It may also be inhaled as dust, and enter the body through the lungs. There can be no doubt that polluted drinking-water is by far the most common source of infection; and it has been noticed, as for instance in Calcutta, that the improvement in the water-supply has greatly diminished the prevalence of cholera.

Symptoms.-After some premonitory symptoms characterised by malaise, depression, and slight diarrhoes, cholera commences by purging, to be soon followed by vomiting and painful cramps in the stomach and limls. These symptoms form the first or evacuation stage. The discharges downwards are extremely copious, and they soon become colourlese and turbid, resembling water in which rice has been boiled; hence the expression, "ricewater' evacuations. In the second stage, which is called the 'algid 'stage, there is profound collapee. In this condition the patient lies motionless and 
apathetic, except when tormented by cramps, which are of frequent occurrence. The surface temperature of the body falls to $95^{\circ} \mathrm{F}$., or even lower. The pulse becomes almost imperceptible, and the respirations are shallow and rapid, the air expired being cold, and the voice a hollow, husky whisper. The nervous system suffers severely, and muscular prostration is well marked. The features assume a leaden or livid hue; they are pinched and shrunken. The nose becomes sharp and pointed, the cheeks hollow, and the eyeballs, which are often bloodshot, sink in their sockets and are nearly hidden by the half-closed lids. The surface of the body, especially the extremities, is bluish, wrinkled and shrivelled, and bathed in cold clammy sweat. For a time the mind is clear but inactive; in fatal cases, however, stupor sets in, followed by coma ; thirst is intense. In this stage assimilation and secretion are in abeyance; all the vital processes in fact are brought almost to a standstill. This stage may last from twelve to thirty-six hours, when the third stage, that of reaction, gradually commences. Heat returns to the surface of the body, the breathing becomes regular and calm, the secretions are re-established, the pulse improves, and the patient will fall into a calm sleep. This stage may terminate in speedy convalescence, but such is not always the case, as a relapse may take place and certain complications and sequelie follow. The most dreaded of these are suppression of urine, uremia, and fever, often closely resembling typhoid, and constituting, at least in the temperate zone, one of the chief dangers in the progress of cholera. Disease of the kidneys, inflammation of the lungs, ulceration of the cornea, abscesses all over the body, and hemorrhage from the bowels may also occur. The mortality varies very much: it may be from one in four of those attacked to three in four. In some epidemics in India it is not more than 15 per cent. of those attacked; in others as high as 90 per cent. In 1885 it was announced that of 233,546 persons attacked in Spain during the recent visitation, 82,619 succumbed. One attack of cholera does not confer protection against another.

Treatment.-With regard to treatment, medicines are almost powerless, and many of the vaunted remedies undoubtedly do far more harm than good. It is, however, necessary to try to check the premonitory diarrhoes, as by so doing in many cases the disease may be cut short. The slightest symptoms of diarrhoea should be attended to ; the patient should be put to bed, a mustard plaster should be applied to his abdomen, and opium in some form or other should be administered. A favourite prescription is four grains of acetate of lead with one of opium, which may be given after each loose stool until three doses have been taken; or else thirty drops of laudanum in half a glass of brandy in hot water. In the state of collapse it is useless or even injurious to give medicine, but soda-water and ice may be administered to relieve thirst. During collapse the medicines could not be assimilated, and if given then, during reaction they would be absorbed and do harm. As soon as reaction occurs, thin waterarrowroot should be given in small quantities, and then iced milk, chicken-tea, and beef-tea, as the stomach can stand it, and enemata of beef-tea should be given every four hours.

The true remedy against cholera is undoubtedly prevention. The greatest care should be taken to secure pure drinking-water, which should be boiled before use, and uncontaminated food. Personal cleanliness, free ventilation, and thorough disinfection of the drains should be enjoined. With regard to quarantine, it is worse than useless in checking the spread of cholera; but all persons coming from an infected area who have the slightest tendency to diarrhoea should be isolated and carefully watched. It should be remembered with what ease cholera can be conveyed by clothing, and therefore the im. portation of all rags and old clothes should be prohibited. Lastly, the destruction of the dischargew from cholera patients, and of the linen soiled by them, is of the utmost importance. The dead should be buried immediately, with due precautions. A Spanish pliysician, Dr Ferran, employed preventive inoculation in 1885 ; his methods, however, were discredited. But in 1893-95 Dr Haffkine, a Russian scientist, had performed in Bengal alone 42,445 inoculations against cholera without mishap and with great preventive efficiency. In the Gangetic valley-the home of cholera-the comma baciflus is a constant feature in the malady.

Cholero Sicca is a rare form, in which symptoms of collapse occur, with great coldness and blueness of the surface, and death takes place in a few hours, without any purging.

Cholera Nostras is also called Simple Cholera, Summer Cholera, British Cholera, Sporadic Cholera, Choleraic Diarrhoea. This is an acute catarrhal affection of the mucous membrane of the stomach and small intestines, which usually occurs in late summer or early autumn. It is attended by vomiting and purging of bile, cramps and pain in the bowels, the whole system being implicated on account of the rapid loss of water from the body. This disease, although severe, is usually only fatal to young infants or to old or debilitated persons. Simple cholera is treated like Diarrhoea $(q . v$.$) .$

Asiatic Cholera is regarded as distinctly a 'dirt disease,' and the great religious pilgrimages of the East have had much to do with conveying the poison from places where it is endemic, and distributing it widely. The sanitary measures adopted at Hardwar on the Ganges have proved as strikingly effective as those employed in England to control the invasions of 1892 and 1893 . But though some attempts have been made to reduce the risks attendant on the Mecca pilgrimages (where the wells are a great source of infection), effective measures have as yet proved impossible.

See Pettenkofer's Cholera: How to Prevent and Resist it (Eng. trans. 1884); Stillé's Cholera (Phila. 1885); Bellew's History of the Cholera in India (1884); and Macnamara's Asiatic Cholera (1892).

Cholesterin, a fatty substance found in gallstones, yolk of egg, blood-corpuscles, milk, \&c., as also in peas, barley, \&c. See Animal Chemistry.

Cholet, a French manufacturing town, dep. of Maine-et-Loire, on the Maine, 32 miles SW. of Angers by rail. Pop. 15,051.

Cholu'la, a decayed town of the Mexican state of Puebla, stands nearly 7000 feet above sea-level, on the tableland of Anahuac, 55 miles ESE. of the city of Mexico. Cortes found in it 40,000 houses and 400 temples, including the great Teocalli (q.v.). Now the place only contains 9000 inhabitants. It was a great centre of the Aztec religion.

Chondrin, the substance of cartilage, is akin to the Proteids (q.v.). See Animal Chemistry.

Chondropterygii, one of the technical names by which Cartilaginous Fishes (q.v.) are known.

Chonos, a bare and sparsely peopled Chilian archipelago off the west coast of Prtagonia.

Chopin (Fr.), an old English liquid measure equal to half a pint. The Scotch chopin or chappin was nearly an English quart.

Chopin, Frédéric, virtuoso and musical composer, was born March 1, 1809, at Zelazova Vola, a village near Warsaw, in Poland, where his father, a native of Lorraine, had settled and married. Under the tuition of two professors at Warsaw, notably Elsner, the director of the Conservatoire, 
Chopin made such rapid progress that at the age of nine he plaved with success in public. As a boy and, initeerf, until his health broke down beneath. the strain of Parisian life, he possessed a great fund of high spirits, and excelled in mimicry and carica ture. In 1825 he published his first work, and by the time he was eighteen his parents acquiesced in his choice of nusic as a career. In the nutumn of 1829 he visited Vienna, gave o successful public concert, and was in much request in the salons of that eity. In the following year he left Warsaw for groul, and travelling rid Brestau, Dresden, and P'rmige, again visited Vienn3, where he sojourned for several months, and he started for Paris in July 1831. Here, after sundry vicissitudes, he took root, found fame, and lost his health; here he became the idol of the salons of the Faubourg Saint Germain, giving lessons to a select elientele of pupils, and employing his leisure in composition. Chopin rarely performed in public, for, as his biographer remarks, 'he could only play con amore when in the best society and among connoisseurs who knew how to appreciate all the niceties of his perform. ance.' But in his element Chopin, by the admis. sion of go competent a judge as Mendelssohn, was 'a truly perfect virtuoso' as well as a thorough musician, with a faculty for improvisation such as perlatps no other pianist ever possesserl. In 1836 he was introduced to George Sand (Madame Dudevant) by his friend Liszt. The intimacy which thus began lasted for geven years, when George Sand, to quote Lisat, 'gave her butterfly the congé, vivisected and stuffed it, and added it to her collection of heroes for novels.' For George Sand's version of this episode, readers may be referred to the fourth volume of her Histoire de ma Vie, as well as to the portrait of Prince Carol in her novel Lucrezia Flomiani. Chopin visited England on two oceasions-once in 1837, and again in 1848 . In the latter year he played at two matinées and at a Polish ball in London; twice in Manchester, once in Edinburgh, and once in Glasgow. His health, long enfeebled by consumption, gave way rapidly on his return to Paris, where on the $17 \mathrm{th}$ of October 1849 he passed away tranquilly, surrounded by a few devoted friends.

Of all virtuosi Chopin has achieved the greatest fame as a creative artist. Taking Slavonic airs and rhythms, notably that of the Mazur or Mazurek (Mazurka), for his groundwork, he raised upon this basis superstructures of the most fantastic and original beauty. His style is so strongly marked as to amount to a mannerism, and yet he has only been successfully imitated by men of genius like Schumann, who was amongst the first of the Ger. man critics to recognise in his early compositions gifts of the rarest order. Chopin had seldom recourse to the orchestra to express himself, and on these rare occasions treated it in perfunctory fashion, and as a mere foil to the solo instrument. But for the piano alone he wrote a great deal of music superlatively artistic in form, impregnated with subtle romance, and full of exuberant fancy music which, though it must always primarily appeal to refined and fastidious natures like his own, bears on it the unmistakable stamp of spon. taneous inspiration. Personally Chopin was of a reserved but amiable nature, singularly modest as to his merits, but unsparing in his efforts to realise the high and clearly defined aims he had set before him. His compositions, the best edition of which is that published by Carl Klindworth of Moseow, extend to 74 works with, and 7 without opus numbers; and comprise upwards of 50 mazurkas, 27 etudes, 25 préludes, 19 nocturnes, 13 waltzes, 12 polonaises, 4 ballades, 4 impromptus, 3 sonatas, 2 concertos for piano and orchestra, and a funeral amareh. Besides rendering his friend the doubtful mareh. Bes service mentioned above, Liszt is also responsible for having given eurrency in his picturesque apothessis of Chopin to a goxs many inascumate stateinents as to his education and temperament. See Lives by Karasowski (Eng. trans. 1879), Niecks (a standard work, 2 vols. 1889), and Willeloy (1892); an esary by Finck (1889); and Halow's Studies in Modern Music (1895).

Chopine (Span, chrpin), a ' high patten,'introduced into England from Venice during the reign of Elizabeth. Some chopines were half a yard high. See Shakespeare's Hamlet, II. ii. 447.

Choragus. See Chorus ; and for the Choragio monuments, see ATHEN8, Vol. I. p. 539.

Chorale. Though the name is occasionally applied to the psalm and hymn tunes of similar character used in the Protestant churches of France and Britain, it most properly belongs to the melorlies sung to the metrical hymns of the German Reformed Church, and introduced by Luther, by whon and his friend Walther the first collection of importance was produced in 1524, and entitled the Enchiridion. The settings were in four, five, or six parts, the melody, as with all the old choral hymus and psalms, being given to the tenor. Numerous other collections appeared down to the later part of the 17th century, the most prolific composer of chorales being Johann Crüger. Many of them were harmonised in the most masterly way by Bach, and were also used by him as the canto fermo, or subject, of some of his great contrapuntal workm. Some of them were adapted from the old hymn tunes of the Roman Church, others were taken from popular airs of the time, others again were original compositions; among the latter the most notable is Luther's 'Ein' feste Burg.' Whatever their source, they all possess in common a solemn, dignified, and devotional character. In Germany they are now usually sung very slowly and heavily in unison, with organ accompaniment. A few of them are well known in this country from their introduction in various collections of hymn tunes, and also in the choral works of Bach and Mendelssohn.

Choral Service, the musical Service (q.vo) celebrated by a full complement of clergymen, lay clerks, and choristers, and sung or intoned as ordered in the rubrics. See CHOIRs.

Chorasmiams, See Khiva, Palestine.

Chord. The chord of an arc is a straight line joining its two extremities; or, a chord, in a circle, ellipse, parabola, \&c. is a straight line joining any two points in the curve. If we draw a series of parallel ehords in any conic, the line through their middle points is called a dismeter, and a line parallel to the chords which passes through the extremity of the diameter is a tangent to the curve. Hence in the circle (1) a diameter is perpendicular to the chords which it bisects, and also (2) to the tangent at its extremity; (3) the three chords of intersection of any three circles meet in a point. In any conic the tangents at the ends of any chord meet in the diameter which bisects the chond. A SCALE of CHORDS on Mathematical Instruments is sometimes used for setting off angles, but has been mostly superseded by the Protractor (q.v.).

Chord, in Music, is the simultaneons and has. monious union of sounds of different pitch. The common chord is a note with its thind and fifth reckoned upwards, thus s

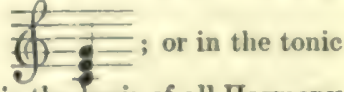
sol-fa notation, $\mathrm{m}$ : this is the basis of all Harmony d (q.v.). The subject of ehords will be found dis cussed under MUSIC. 
Chore'a (Gr. choreia, 'a dancing' or 'jumping'), a disease popularly called St Vitus's Dance, and consisting of a tendency to involuntary and irregular muscular contractions of the limbs and face, the mind and the functions of the brain generally being quite unaffected. The spasms of chorea differ from those of most other convulsive affections in being unaccompanied either by pain or by rigidity; being, in fact, momentary jerking movements, indicating rather a want of control of the, will over the muscles than any real excess of their contractions. In some cases the disease resembles merely an exaggeration of the restlessness and 'fidgetiness' common among children; in others it goes so far as to be a very serious malady, and may even threaten life. Fatal eases, however, are fortunately very rare, and in the large majority of instances the disease yields readily to treatment carefully pursued, or disappears spontaneously in a few weeks or months. Chorea is a disease much more common among children of six years old and upwards than at any other period of life; it is also more common among female children than among males. Not infrequently it follows a fright or other mental shock, or the strain of overwork. In a large proportion of cases it is associated with acute rheumatism (rheumatic fever), or with heartdisease (endocarditis). The treatment generally pursued is the use of metallic tonics, such as zine, copper, iron, and arsenic (the last, perhaps, the best), sometimes preceded or accompanied by purgatives. Anti-rheumatic remedies are in some cases very valuable. Exercise in the open air is also to be recommended; and gymnastics afford material aid in the cure. It is to be observed that the name St Vitus's Dance was applied originally in Germany to a different form of disease from that above referred to-one closely approaching in its characters the epidemic 'daneing mania,' which, in Italy, was called Tarantism. See Vitus (ST), and (under Tarantula) TARANTISM.

Chorion. See Placenta.

Chorley, a busy town in North Lancashire, 9 miles SE. of Preston by rail. It has thriving manufactures of cotton-yarn, jaconets, muslins, fancy goods, calicoes, and ginghams. Railway wagons are also built, and in the vicinity are bleach-fields, print-works, coal-mines, and stone quarries. Pop. (1881) 19,472 ; (1891) 23,082.

Chorley, Henry fothergill, musical critic, was born at Blackley Hurst, in Lancashire, 15th December 1808, and was edueated in Liverpool. He became a member of the staff of the Athenceum in 1833, and soon had entire charge of the musical department, from which he retired in 1868; he contributed also very many literary reviews. $\mathrm{He}$ published some half-dozen artificial and unsuceessful romances, three acted dramas, and some graceful verse; but it is by his Music and Manners in France and Germany (1841) and his charming Thirty Years' Musical Recollections (1862) that his name is best known to the reading public. He held very decided opinions in music (hostile to Berlioz and Wagner), and expressed them uncompromisingly ; and his insight was perhaps discriminating rather than profound. He died 16th February 1872. See the Autobiography, Memoir, and Letters, edited by H. G. Hewlett (1873).

Choroid. See Ere.

Chorus, among the ancients, meant a band of singers and dancers employed on festive occasions of great pomp, and also in the performance of tragedy and comedy on the stage. The choral dances in honour of Bacchus, which superseded the earlier ones to Apollo, were by their combination with the rhythmic recitations of the Rhapsodes, the origin of the Greek tragedy. In the plays as known to us the chorus consisted of a group of persons-boys, girls, or men-who remained in front of the stage during the whole performance as. spectators, or rather as witnesses. When a pause took place in the acting, the chorus either sang or spoke verses having reference to the subject represented, which served to increase the impression or sensation produced by the performers. At times. the chorus seemed to take part with or against the persons in the drama, by advice, comfort, exhortation, or dissuasion. In the comedy the chorus also addressed the audience. In the time of Fischylus the chorus was very large, sometimes consisting of upwards of fifty persons, but the chorus of Sophocles numbered only fifteen. Its leader was termed the Coryphæus. The charge of organising it was considered a great honour among the citizens of Athens. The person appointed for this purpose was called the choragus. The honour was very expensive, as the choragus had to pay all the expenses incurred in training the members of the chorus to perform their parts efficiently. They were, besides, fed and lodged by him during train. ing-time, and he had also to provide for them masks and dresses. At times the chorus was. divided, and spoke or sang antiphonally. These divisions moved from side to side of the stage, from which movement originated the naming of the single songs or stanzas, such as Strophe, Antistrophe, and Epode. How the musical element of the ancient chorus was constituted or composed is not known with any certainty. It was preeminently founded on rhythm, the employment of which was very varied; and it was doubtless very simple. It was accompanied by flutes. With the decline of the ancient tragedy, the chorus also fell into disuse; and only lately has there been an attempt to produce the same on the stage in the namner of the ancients, as, for example, in Schiller's Bride of Messina. The music which has been set in modern times to some of the Greek tragedies does not give the least idea of the original music, which to our ears would probably sound very bare and rude. Three fragments of a Greek hymn of a late Roman period (from a Neapolitan manuscript, and the Florentine work of Galilei), which are the only extant remains of Greek music, have been transcribed in modern notation in Rowbotham's History of Music, vol. ii., and also in Chappell's History of Music, vol. i. They are of interest as being connected with the origin of the modern opera. In his later operas Wagner professes to assign to the orchestra the functions of the Greek chorus.

In modern music the word is applied to voeal pieces in which each part is intended to be sung by a considerable number of voices; and also to. the body of singers who perform choral music. The number of parts may vary from unison to as many as forty or fifty; the normal number is four, but five and eight parts are also frequent. When the voices are divided into two choirs, it is called a double chorus. A chorus for both male and female voices is termed a mixed chorus. The forms of chorus are more varied than those of solo music, and the most characteristic are imitative, or contrapuntal, of which the fugue is the most. regular type. They may also be in simple harmony, or a combination of the two. Choral recitative is sometimes introduced; a solo voice, or even a solo. instrument, may be accompanied by chorus, or soloand chorus may answer antiphonally. A chorus. sung without accompaniment is called $a$ capella. The earliest extant form is the unisonal Plainsong. (q.v.) of the Roman Church. In oratorio music, Bach's great Passion Music may be cited as containing nearly every form of chorus, from those constructed with figured parts upon a canto fermo, 
to the dramatio turbe, the shouts of the enraged people. The double chorumess in Handel's Isritel in Egypt are also celebrated for their masterly construction and grand massive effect; and for dramatic expression those of Mendelssohn's Elijah stand in the highest rank.

In the opera as originally conceived by Peri and Caccini at the close of the l6th century, the chorns was intended to imitate that of the Greek play; and down to the time of Gluck it was arranged in two rows, without taking part in the action of the piece. Since his reforms the members of the chorus are also dramatis persone, and sometimes, as in Auber's Masaniello, play a most important part. A definite rhythm seems essential as a means of keeping the parts together in a chorus of any length; even when Wagner, who considered rhythm 'an intruder in music,' introduces choruses, which he does but sparingly, in his operas, they are at once noticeable for this feature.

Choral singing has within the last forty years obtained a widely popular development in Britain and America, greatly owing to the publication of cheap editions of classical music. The chorus singers of Yorkshire are recognised as excelling; but it need scarcely be said that in this department of singing a very great deal of the effect depends on the conductor. A remarkable feature of the Crystal Palace Handel festivals is the gigantic body of chorus, amounting in 1888 to over 3000 . See ChOIRs.

Chose in Action ( Fr. chose, 'a thing') is one of the two great classes of what the English law ealls chattels personal. The one class is 'choses in possession,' such as goods, household furniture, cattle, \&c. ; the other clase is "choses in action," such as the right to sue for a debt, a legacy, damages, \&c. The old common-law rule was ments, contracts could not be assigned so that the assignee might sue in his own name; but the assignee must bring his action in the name of the assignor or celent, so that the assignee was always exposed to every defence which might have been stated against the original debtor under the contract. This resulted from the primitive view of contract as ereating a strictly personal relation between the debtor and creditor. The Equity Courts, however, permitted the assignment of debts and equitable rights, notice being given to the debtor to preserve priority ; and in particular cases-e.g. policies of insurance under a statute of 1867 , the full right of assignment was permitted. Now, under the Judicature Act, 1873, every legal chose in action is absolutely assignable if express notice in writing be given to the debtor; and although the words of the statute do not extend to assignment by way of security, or to any assignment of what is called an equitable chose in action, there is now little practical distinction between the two.

In the United States that quality of a chose in action rendering it unassignable at common law is fast disappearing. In some states a chose in action may not only be assigned, but the assignee may bring a suit for possession in his own name; while in others the name of the assignor is used as plaintiff in the action, to the use of the assignee. Courts of law generally follow the rules of equity in this respect.

Chosün. See Corea.

Chosroes is the Byzantine spelling of the Persian KHosRO or KHƯsRU. Chosroes I. (531-579 A.D.) was the greatest monarch of the Sassanian dynasty, and was called Anísharván, 'the blessed.' He carried on war with the Roman emperor for twenty years, and at home promoted agriculture, commerce, and science. Chosroes II., his grandson (590 (328), during fifteen yestrs inflicted on the Byzantine empire disesters such as they had never experienced; Syria, Palestine, Egypt, and even Chalcedon being conquered. See PERsia.

Chota Nagpore (Chutid Nágpur), a sonth. west division or commissionership of Bengal, embracing four British districts, neven petty tributary states, and two semi-independent states, with a surface for the most part wild and hilly, Area of the British districts, 26,966 sq. m. pop. $4,628,792$. Area of the division, $43,020 \mathrm{gq}$. m. pop. $5,512,151$, of whom more than 800,000 belong to various ahoriginal tribes.

Chouans, the name applied to the royalist in. surgents who, during the French Revolution, organ. ised a reactionary movement in Brittany. The nume may very probably be due to a corruption of chat. huant ('screech-owl'), from the nocturual habits of the bands or from some special call of recognition they may have had; or it may have originated in a nickname of the instigator of this insurrection, one Jean Cottereau, a smuggler of noted sagacity and courage. In the year 1792 they began to wage a small guerilla warfare with some success, but the Chouanerie, as the insurrection was called, at first disgraced itself by drunken license and cruelty. After Cottereau's death in 1794 in a scuffle near the wood of Misdon, the thestre of his finst efforts, the brave adventurer Désoteux, surnamed Cormatin, took the lead; but after his capture there arose new leaders who extended the insurrection and lifted its aims into the region of the heroic. Georges Cadoudal and Charette soon had under their command a force of 10,000 fearless men, and their energy and daring actually imperilled for a time the security of the republican government in France. But stubborn and strong as was the old unquestioning loyalty of Brittany, it could not withstand the fiery enthusiasm that impelled the conquering legions of the giant young republic across almost the whole continent of Europe. The insurrection was stamped ont by La Hoche; its leaders Vienville and Sérent fell, Scépeaux and Cadoudal were forced to lay down their arms, Frotté fled to England and Puisaye to America. A new attempt in 1799 was soon mereilessly crushed, and henceforward Chouanerie could only smoulder on in secrecy. In 1814-15 it again made its appearance on both banks of the Loire; and after the July revolution (1830) was once more excited by the Duchess of Berri on behalf of the Duke of Bordeaux, but crushed by the energetic measures taken by Thiers.

Chough (Fregilus), a genus of birds of the crow family (Corvidre). The beak is longer than the head, strong, arched, and pointed. The tail is slightly rounded. The common European species, sonictimes called the Cornish Chough, or Redlegged Crow ( $F$. graculus), is a widely distributed but very local bird, inhabiting the Alps and other mountainous parts of the palsaretic region. In Cornish folklore King Arthur did not die, but was changed into a chough, and it is interesting to find this English belief alluded to in Don Quixote (ii. 5), though here the bird is erroneously made a raven. Shakespeare in King Lear (IV. vi.) confounds the chough with the jackdaw; and in Midsummer-Night's Dream (III. ii. ) actually speaks of 'russet-pated choughs.' The chough oceurs on some parts of the British sen-cossts, but almost exclusively confined to situations where
there are high clifts. Its long hooked claws enable it to cling easily to a rough rock, but it seems unwilling even to set its feet on turf. It lives in societies like the rook, and feeds on insects, berries, grubs, and grain. It is easily tamed, becomes very 
familiar and forward, and exhibits in the highest degree the curiosity, the pilfering disposition, and the delight in brilliant or glittering objects which also characterise others of the crow family. The

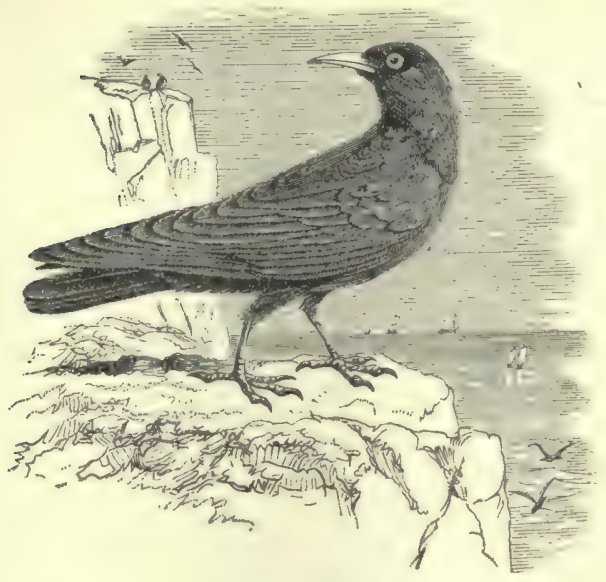

Chough.

name is sometimes extended to allied forms, such as Pyrrhocorax alpinus (Alpine Chough).

Choya. See Chay Root.

Chrestomathy (Gr. chrëstos, 'useful ;' mathein, 'to know') is a name for books of selections from foreign languages, usually provided with glossary and notes for the use of learners. See ANTHology.

Chrétien de Troyes, an old French poet of whose life nothing more is known than that he lived in the second half of the 12th century and was a favourite poet at the court of Mary, daughter of Louis VII. and wife in succession to the Counts of Champagne and of Flanders. He worked up the legends of the Round Table into numerous spirited and yet refined poems in octosyllabic verse, which had a wide literary influence, and were translated by the German minnesingers, Wolfram von Eschenbach, Gottfried of Strasburg, and others. The most important of these poems was Perceval le Gallois, or $\mathrm{Li}$ Contes del Graal (containing 50,000 verses); Li Romans dou Chevalier au Lyon; Li Contes 'd'Erec ; and Lancelot du Lac, or Le Chevalier de la Charrete. A complete collection of his works was begun by Wend. Förster (vol. i. Halle, 1884). See Paulin Paris, Les Romans de la Table-Ronde (5 vols. $1868-77$ ).

Chrism (Gr. chrisma, 'ointment') is the name given to the oil consecrated on Holy Thursday, in the Roman Catholic and Greek Churches, by the bishop, and used in baptism, confirmation, ordination, and extreme unction. There are two kinds of chrism - the one, a mixture of oil and balsam, is used in baptism, confirmation, and orders ; the other, which is merely plain oil, is used in extreme unction.

Chrisome, the name of the white linen eloth laid by the priest on the child in Roman Catholic baptism, to signify its innocence. By olden usage it was generally presented by the mother as an offering to the chureh, but if the child died before the mother was 'churched' again, it was used as a shroud. By a common abuse of words, chrisome came to mean the child itself, being first applied in the old bills of mortality to denote such children as died within the month of birth. Mrs Quickly's use of the phrase in her account of Falstaff's end will be remembered. The following from Jeremy Taylor (Holy Dying, i. 2) explains itself : 'Every morning creeps out of a dark cloud, leaving behind it an ignorance and silence deep as midnight, and undiscerned as are the phantasms that make a chrisome child to smile.'

Christ (Gr. Christos) is the word used in the New Testament and in the Septuagint as the equivalent of the Hebrew word Messiah (q.v.). Both words mean 'anointed.' When kings and priests, and sometimes prophets, were set apart for the discharge of their respective functions, it was customary to anoint them with oil in the name of the Lord (1 Sam. x. 1, xii. 3; Exod. xxix. 7, xxx. $23-33$; 1 Kings xix. 16) ; hence the term. Oil was used in the ceremony because it was regarded as emblematical of the Holy Spirit and of salvation (1 Sam. xvi. 13, x. 1, 9, 10; Isa. xi. 1, 2, lxi. 1-3; Acts $\mathrm{x} .38$ ).

In a secondary sense the word is applied to persons set apart by God for some special end, though they were not literally anointed. Thus Cyrus, the king of Persia, is spoken of as the Lord's anointed (Isa. xlv. 1), because he was Jehovah's chosen instrument for aetting free the captives in Babylon. We find it used, in the plural, regarding the patriarchs Abraham, Isaac, and Jacob (Ps. cv. 15). It is also applied to the chosen people as a whole (Hab. iii. 13, revised version).

As applied to Jesus, the word is used in a twofold sense-as an appellative, and as a proper name. At first it was used in the former sense with the article- 'the Christ'-but at a later period-e.g. in the epistles of Paul, and in 1 Peter, it is found to have passed over into a proper name. When used as a title of office it manifestly looks back to the Old Testament doctrine of the Messiah. That doctrine may be briefly indicated by a reference to three passages. We find the Messiah represented as the messenger of good tidings to men $=$ God's Prophet-in Isa. lxi. 1; as making expiation for $\sin =$ God's consecrated Priest-in Daniel, ix. 24-27; and as the King of God's heritage in Ps. ii 2. When Jesus, therefore, claimed to be the Messiah (ef. John, iv. 26), he undoubtedly meant it to be understood that the Old Testament ideals connected with the title were realised in him. In his person, that is to say, the offices of prophet, priest, and king were united and consummated. That it was thus that his disciples understood his claims is patent to every reader of the New Testament. So thoroughly filled were they with the Messianic idea of his mission that, as we have seen, the official title, 'the Christ,' came to be largely used by them, without the article, as his proper name.

When Jesus came thus to be spoken of as Christ, or Jesus Christ, it was but natural that his followers should be called after him, Christians. This name, Tertullian informs us (Apol. c. 3), was often mispronounced Chrestiani by those who were not conversant with Jewish ideas. They manifestly thought that it was derived from the Greek Chréstos $=$ good. The Christians, we are told, instead of taking umbrage at this distortion of their current name, gladly accepted it as implying an admission on the part of the heathen of the moral excellency both of their Master and of themselves. For the Life of Christ, see Jesus.

CHRIstologY is that branch of theology which treats of the Person of Christ. No attempt was made in apostolic times to formulate a Christology; the early church contenting itself with testifying to the true, yet sinless humanity, the pre-existence, the divine Sonship, the resurrection, the exaltation, and the supreme authority of its Founder. It was not till speculative minds began to broach ideas inconsistent with this accepted faith that a theological representation of the church's views was found necessary. The symbolic form in which the generally accepted doctrine 
has been 'sanded down to ns was the result of prolonged, and not unfrequently acrimonious diseus. sions. Prior to the Council of Nice (325 A.D.) various Christological theories were promulgated by the Ebionites, to whom belonged the Nazarenes, the Cerinthians, and the Gnosties of the pseudoClementine type, by the Docetre, and by the (inosties proprer. Some of these denierl the preexistence of Christ, and attributed his peculiar greatness to a supernatural endowment conferred upon him at his baptism, while others resolved lis humanity into a mere phantom, and repre. sented his person as composed of a spiritual Aon. These parties were, however, but short-lived. More formidable were the Sabellians and the Arians. The former denied the doctrine of the immanent Trinity. To them, aceordingly, the higher nature of Christ was simply absolute Deity in self-manifestation. The Arians, on the other hand, represented Jesus as the first and loftiest of God's creatures. In their view he was not, therefore, truly God. It was specially with a reference to these two opposing parties that the Council of Nice was summoned by Constantine. The results of the deliberations of this council are embodied in the well-known Nicene Creed. Both Sabellianism and Arianism were pronounced heretical, and the eternal Sonship of Christ was solemnly asserted. The question, however, remained undecided how the union between the divine and the human in his person was to be expressed. Apollinaris, Bishop of Laodicea, advanced the theory that Christ's manhood was constituted solely of an rnimal soul and body, while the Logos took the place of the mind, or spirit, in him. His true humanity was thus denied. Nestorius, Bishop of Constantinople, started a rival theory. While granting the true divinity and humanity of Christ, fie denied their union in a single, self-conscious personality. According to him the union was only moral or sympathetic. The Nestorian theory thus involved the breaking up of the personality into a duality. Eutyches of Constantinople wrote against Nestorianism, but his zeal carried him to the other extreme. His contention was that in the incarnation the human was transmuted into the divine. He thus obliterated the humanity.

At the Council of Chalcedon (451 A.D.) all these views were condemned, and the Christological formula which is still regarded as orthodox was framed. The orthodox doctrine, briefly stated, holds that in the unity of the person of Jesus Christ there are two natures, a divine and a human, each nature being complete and entire, and that these are so intimately and indissolubly united as to constitute not a third nature, but a person. It warns us against either dividing the person or confounding the natures.

Notwithstanding the adoption of this ereed, con. troversy was not by any means brought to an ead. For more than three centuries questions of extreme subtilty continued to agitate the theological world -questions pertaining to the relation of nature to personality, and of both to will. The Monophysite, the Monothelite, and the Adoptianist controversies were concerned with these abstruse points. At the Council of Constantinople (681 A.D.) it was decided that in the one person of Christ there are two natures, two intelligences, two energies, and two wills. The condemned Monothelites were consequently persecuted, and they betook themselves to the mountains of Lebanon and Anti-Lebanon, where they continued to exist as a distinct sect under the name of Maronites. During the middle nges the church as a whole acquiesced in the decisions of the above-named conncils, though individusls occasionally ventured to give expres. sion to views more or less at variance with the creeds. In our day, Iyotheletimm, or the doctrine that there are two wills in Christ, is not regarded as essential $w$ orthorloxy. In fact it in largely denied among theologians of high repute.

At the time of the Reformation Chriatology once more became a subject of keen controvens. The oceasion was a difference of opinjon hetween Luther and Zwingli regarding the presence of Christ in the elements of the ordinance of the Supper. Eventually the Lutherans accepted the doctrine of the communicatio idiomatum-i.e. the communication of the properties of the divine nature of Clirist to his humanity. By this docetrine they sought to establish the ubiquity of Christ's body. The Lutheran dogma was rejected by the Reformed theologians.

The next important movement in connection with Christology originated with Lselius Socinus (1525-62) and his nephew, Faustus Socinus (15391604). They taught that Christ was a mere man, but distinguished from all others in the following particulars: He was miraculously conceived, was sinless, was specially endowed with the Holy Spirit, was taken up to heaven prior to the commencement of his ministry, in order that he might see God and receive instructions from him, he rose from the dead and is now exalted in heaven far above all ereatures, he is invested as God's viceroy with all power in heaven and in earth. In view of his exaltation they tanght that Christ may justly be termed a God, in a sense different from that in which rulers are termed gods, and therefore he ought to be worshipped. Unitarians, who may be regarded as the modern representatives of the Socinians, speak of Christ as the Ideal Man, but probably none of them would accord him all the high distinctions above specified.

At the present day there is in vogue a Christo. logieal theory known as the doctrine of kenōsis (kenos, 'empty'), which is variously set forth by a considerable number of evangelical theologians. It derives its name from the Greek verb ekenōse which occurs in Philip. ii. 7. In its modern form the theory is probably traceable to Zinzendorf. It is advocated by such writers as Thomasius, Gess, and Godet. Its aim is to do justice to the genuine development of the Man Jesus Christ. This it seeks to accomplish by postulating an emptying of himself on the part of the Logos in the act of incarnation. He laid aside, it is said, not only his divine attributes, but even his divine self conscionsness. These he gradually regained during the course of his earthly history, and by the time that he ascended the process was complete. Such in brief is the theory. What its future may be it is vain to guess. As yet, however, the great mass of orthodox theologians look askance at it.

According to Shedd, the following four factors are necessary in order to a complete conception of Christ's Person: (1) True and proper deity; (2) true and proper humanity; (3) the union of deity and humanity in one person; (4) the distinction of deity from humanity in the one person, so that there be no mixture of natures.

The standard book on the history of Christology is Dorner's Doctrine of the Person of Christ. See also Bull's Defence of the Nicene Creed, and his Judgment of the Catholic Church dee. Bruce's Humiliation of Christ; Hagenbach's History of Doctrines: and the separate articles on the heresies (ARIUs, NestoniUs, \&a.).

Christ, Disciples of. See Campbell (Almx.).

Christadelphians, or 'Brethren of Christ,' a small religioms houly claiming to represent the true faith and practice of apostolic times, as revived by Dr John Thomas, Brooklyn, U.S., who was born in 1805 and died in 1871, and was the lead. ing advocate of their views. (After him they are 
sometimes called Thomasites.) They deny the existence of a personal devil, and the immortality of the soul, believing in 'Conditional Immortality' (q.v.), to be bestowed upon the faithful of all ages when Christ returns. They insist on the plenary inspiration of the Bible, the real death of Christ as a sacrifice for $\sin$, his resurrection and ascension; and look for his return to the earth to reign on the throne of David over the converted and restored twelve tribes of Israel and all nutions. They believe that death is a state of entire unconsciousness, terminated by a corporeal resurrection for those who have become related to Christ through faith and obedience, or are responsible for his rejection. Those accepted after the judgment reign for ever with Christ over the nations, those rejected die the second death. Communities of Christadelphians exist in the principal towns of Great Britain, Ireland, the United States, and the colonies, but no statistics as to numbers exist. Probably the members amount to a few thousands. Their leading organ is The Christadelphian, published monthly in Birmingham, and founded by Robert Roberts, whose work, Christen. dom Astray, along with Elpis Israel and Eureka by John Thomas, M.D., furnish full details as to creed.

Christchurch, a parliamentary and municipal borough of Hampshire, at the head of the estuary formed by the Avon and Stour, 24 miles SW. of Southampton by road, but $33 \frac{1}{2}$ by rail. The noble church of an Augustinian priory, founded here in 1150 , is 303 feet long by 101 across the transept, and includes every style from Norman to Perpendicular. Special features of interest are the splendid Early English porch, a monument to Shelley, a beautiful rood-sereen, and the chapel built by Henry VIII.'s victim, Margaret, Countess of Salisbury. Little remains of the domestic buildings of the monastery or of the Norman castle. Christchurch possesses one notable specialty, the making of watch and clock fusee-chains. The harbour has high-water twice every tide. The parliamentary borough, 22,350 acres in area, comprises the favourite watering-place Bournemouth. It returns one member to parliament. Pop. (1851) 7475 ; (1881) 28,535 ; of municipal borough (1881) 3260 ; (1891) 3994. The latter received a charter of incorporation in 1886.

Christchurch, capital of the provincial district of Canterbury, in New Zealand, situated on the river Avon, about 8 miles from Port Lyttelton, with which it is connected by rail, the tunnel through the Port Hills being the longest in New Zealand; it has also railway communication with Dunedin and with the north. The chief public buildings are the government offices, museum (with many specimens of the Moa, q.v.), cathedral (a reproduction of that of Caen in France), and hospital. There are numerous banks and insurance offices; and among the public schools are Christ's College, a high school for boys, and a high school for girls. The water-supply is derived from artesian wells. Two parks and the Government Domain afford ample pleasure-grounds. It is the centre of a great grazing district, and has also flourishing manufactories. Boot manufacturing is one of the chief industries; there are several newspapers published here, and the city possesses steam tramways, theaties, social and athletic clubs, and a corps of volunteers. The founders of the colony named each of the streets of its capital after an English diocese. An earthquake in 1888 damaged the cathedral and other buildings. Pop. (1888) 15,265 ; (1891) 16,223 ; with suburbs, 47,846 .

Christening, a term often used as equivalent to Baptism (q.v.).

Christian II., king of Denmark, Norway, and Sweden, was born at Nyborg, in the island of
Fuinen, in 1481, and mounted the throne of Norway and Denmark in 1513. His marriage in 1515 to a sister of the Emperor Charles V. did not extinguish his love for his mistress Dyveke (q.v.), whose sudden death he avenged with his native savagery. In 1520 he overthrew at Bogesund the brave regent of Sweden, Sten Sture the younger, and thereafter was crowned king. But his ferocious passions, and especially his treacherous massacre in the Stockholm 'blood bath' of the foremost men in Sweden (November 8-10, 1520), roused such a spirit of opposition in that country that he was speedily driven out by the young national leader, Gustavus Vasa, himself the son of one of his victims. In Denmark also a popular revolt drove Christian for refuge to the Netherlands, and placed his uncle Frederick I. upon the throne. Encouraged, however, by the Catholic party in the Netherlands, and assisted by Charles V., Christian landed in Norway in 1531, but at the battle of Aggerhuus next year was totally defeated, and spent his remaining years in imprisonment at Sonderburg and Kallundborg, where he died in 1559.

Christian IV., king of Denmark and Norway, and Duke of Sleswick-Holstein, the son of Frederick II., born at Frederiksborg, in Zealand, 12th April 1577, and elected successor to the throne in. 1588. He assumed the government of the duchy in 1593; of the kingdom in 1596. His first war with Sweden (1611-13) ended in an advantageous peace; his second (1643-45) cost him much of the territory across the Sound. Christian's share in the Thirty Years' War was brief and inglorious. In 1625 he became chief of the Protestant league, but his disasters so damped his ardour that he was fain to retire from the struggle in 1629 under cover of the peace of Lubbek to make room for the great Gustavus Adolphus. His indefatigable labours for the improvement of his country were more successful. He strengthened its maritime power; extended its commerce as far as the East Indies, where he obtained the first possessions; and by restrictions upon the Hanse towns, greatly increased the inland trade of the country. His legislative and financial reforms, together with his love and patronage of the arts and sciences, gained for him the affection of his people. Spite of his ill-success in war he became a hero; the ballad, King Christian stood by the lofty Mast, commemorates his heroism in the sea-fight with the Swedes before Kiel in 1644, and his memory is preserved in the names of the cities of Christiansand and Christiania. He died 28th February 1648.

Christian Brothers, See Schoors (BroTHERS OF CHRISTIAN).

Christian Connection, an American denomination founded early in the 19th century on the basis of the Bible as the sole authoritative rule of faith and practice, with open fellowship to all pious Christians of whatever creed. It numbers about 120,000 members, who are now mostly Antitrinitarians and Baptists.

Christian Endeavour Societies, for the promotion of Christian life amongst young people, and for making their members useful in the service of God, were first formed by Dr F. E. Clark of the Congregational church at Portland, Maine, U.S., in 1881; and by 1896 there were 45,000 societies (nearly 4000 in Britain), with 2,500,000 members. The organisation is supported by almost all the sections of Protestantism.

Christiania (Kristiania), the modern capital of Norway (the kings are still crowned at Trondhjen, (q.v.), is built at the northern end of Christiania Fiord, in $59^{\circ} 56^{\prime} \mathrm{N}$. lat. and $10^{\circ} 50^{\prime} \mathrm{E}$. long. Its population in 1891 was 151,239 , and in 
1897 (estimated) 170,000. At the heginning of the century it was but 10,000 . Christiania is named after Christian IV., who commenced building it in 1624 nfter the destruction by fire of the ancient city of Oslo, which had begun to superserte Trondhjem as eapital from the 14th century. Christiania is the neat of the national parliament (the Storthing and langtling), of the High ('ourt of Judicature, and of the National University, which has 46 pro fessors and above 1500 students who are educated free, with the exception of a small entrance-fee. Connected with this is the students' garden, \& library of about 250,000 volumes, a very wellarranged botanical garden, zoological, zootomical, botanical, and ethnographical museums, and a cabinet of coins and medals, chemical and physical laboratories, and observatory. The Meteorological Institute, established in 1866, is in systematic telegrnphic communication with British and other European observatories. The king of Sweden and Norway has two palaces here, one in the city near the university, and one, Oscarshall, beauti fully situated two miles from the city on an emin-ence overlooking the fiord, and containing Tiedmand's celebrated pictures of Norwegian peasantlife. There is a national picture-gallery, and a very interesting museum of northern antiquities. 'The Dom, or Cathedral, and the Trefoldigheds Kirke ('Church of the Trinity'), are the principal ecelesiastical buildings. The Dampkjöken ("steamkitchen ') is an interesting institution for providing oheap and substantial dinners to working-people. The old fortress Akershus Faestning still remains, and is used as a promenade, but has little military value. Among other public buildings are the Houses of Parliament, the civil and military hospitals and infirmary, lunatic asylum, penitentiary, two theatres, the Freemasons' Hall, and several banks. The staple industry of Christiania is its shipping trade; it is the central emporium for the south of Norway. Its ehief export is timber. A considerable industry has recently become developed in the brewing and export of Christiania ol, a sort of lager beer, with resinous flavour, largely consumed throughout Norway, and exported to England and other parts of the world. The minor manufactures are cotton, canvas; engineworks, nail-works, and paper-mills, the latter rapidly growing by the use of wood-tibre from :sawmill waste. There are many good hotels of recent establishment, and a considerable business is done in connection with the visits of British tourists. Cariole-making is one of the industries thus developed. There are good shops, in all of which Encrlish is well spoken; and the city has considerable printing and publishing establishments.

Christianity is the religion of which Jesus Christ is not only the founder but also the object, since it is by him and in him that man recovers his union with God by an effective reconciliation. We have thus determined in a general manner its true character, and marked the difference that exists, as we shall prove, between it and all the religions which preceded it. But first we must justify our definition. The only way to get a sure grasp of the leading thought of a.doctrine and a religion is to trace it to its origin, and to seize it at its source, before the stream has had its current troubled with the foreign elements that mingle with it. Now about primitive Christianity we possess a number of documents which are at least authentic, whatever the authority we attribute to them from a doctrinal point of view. Confining ourselves to those documents alone, whose authenticity is not disallowed by the nost negative criticism, we have in the epistles of Paul to the Corinthians, the Galatians, the Romans, and the Thessalonians, a testimony to primitive Christimuity which falls between the year 55 and the year 64 after Jesus Christ. It emanates from an apostle who had been in direct contact with the earliest associates of Christ, with those who had both seen and heard him. The finst three gospels, in which an historical basis is generally recognised in what concerns the actions as well as the discourses of Jesus, point back to the same date. We are thus led back to the very origins of Christianity. Moreover we recognise in the church of the earliest period made known to us, whether in the Acts of the Apostles or in writings as authentic as the letters of James and those of Peter, the living impress upon simple and honest hearts of the direct remembrance of Christ, like the track marking his passage across the earth. Here our concern is not more to determine the true character, the essence of Christianity, than to find out in those documents the real meaning of the religion of the gospel as it presents itself to us. It is undeniable that if it claims to carry to the world a revealed doctrine, revealing completely the true nature of God as well as that of man, and the normal relations of union between them, it attaches that doctrine to a personality considered not only as the organ of the revelation, but as its object. We have thus the right to assert that Christianity is Jesus Christ, without fearing to detract anything from the attributes of God, for Jesus Christ is his ambassador, his son, the sole mediator between God and man-in one word, the Redeemer, the Saviour, as his name implies. He has never ceased to require faith in himself as the means of again finding God by him. Fragmentary quotations on this point are vain. The whole gospel demands this faith in his person, and St Paul sums it up in the words addressed to the gaoler at Philippi: 'Believe on the Lord Jesus Christ, and thou shalt be saved '(Acts, xvi. 31).

Christianity is herein distinguished from all other religions. The revelation which it brings to the world is something other than a supernatural communication of a transcendent doctrine about God, and about our origin and purpose in the world. It consists essentially in a great work accomplished by a single person-a work which is the supreme manifestation of the holy love of God. The mere exhibition of this divine work casts a bright light upon God as well as upon man, and results in a doetrine which implies a complete metaphysic, a complete anthropology, and an entire system of ethics, as well as far-reaching views on the history of the human race in its terrestrial development and in its future destiny. For had it been otherwise, Christianity must have contented itself with communicating to us the outward fact without explaining it-without making us grasp it by its inward side in its profound significance; which would have been to alter its nature completely. It none the less remains true that for Christianity doctrine is only a secondary and complementary element-the interpretation of the fact of the great work, which is its first object. This is why it addresses itself before everything to the heart and to the conscience, although at the same time it opens up to the intellect the vastest pos. sible horizons. As soon as we deviate from this divine realism, we make Christianity fall into an intellectualism which chills it while perverting it; and we substitute for it the parching formulas of a scholasticism which at all times and in all churches has caused it to leave its banks and diverge into new and widely different channels.

Let us further consider that divine work accom. plished by Christ for the salvation of the world, which constitutes the essence of Christianity, without lingering to diseuss its proofs, which 
belong to the province of apologetics. This word salvation, if we take it in all its fullness, comes before us as its principal and even sole subject. "The son of man," says Jesus, 'is come to seek and to save that which was lost' (Luke, xix. 10). This one word contains within itself the whole gospel, and alone explains to us why it has been specially called good news. This is its true sig. nificance, if we leave aside entirely its theological development. Humanity is not in its normal condition; it is lost by its $0 *: n$ fault-through having broken by voluntary revolt the bond which at the beginning united it to God as made in his own image, and which was intended ever to become closer through the voluntary obedience it was invited to offer in the mysterious probation of its free-will. Incapable of rising again of itself, it must needs be sought out by compassionate love like a wandering and lost sheep, for the sake of being lifted up and brought back to God. This is what the Son of Man has done in agreement with the offended Father, who has had compassion upon him. Although by a saving act of his own good pleasure God has pardoned the sinner, he has not abrogated the laws of moral order. These laws demand no vengeance unworthy of God, but merely a reparation-a retractation of sin involved in an essentially moral expiation. Such an expiation can consist only in a perfect obedience, complete even to the length of accepting in a voluntary sacrifice the consequences of the original revolt. This is what the Son of Man, who was also the Son of God, has willed and has accomplished. He has died for the sins of the world, and risen again for its justification; and the cross on which he has accomplished this reparative work rises before us for ever as the symbol of a reconciliation, which each man in his turn must appropriate to himself by an act of faith uniting him to the sacred sufferer.

Christianity is thus pre-eminently the religion of redemption and of the redeemer. It has introduced into the world the grand reparative influence of a victorious love, inaugurating in Jesus himself an unceasing struggle; for that reparative influence must struggle constantly against the powers of evil, which are not magically suppressed. But this reparative work cannot consist alone in the salvation of individual souls; to be worthy of God it must strive to restore all that the original fall has blighted or destroyed-to make the fallen creature realise all his lofty destiny - that is to say, to reconstitute in man all the greatness kept in store for him, and to give him up without reserve to God, making the regenerating spirit penetrate into every sphere of his activity as into all his faculties. Hence the wide mission of Christianity to purify and raise everything that is human in the most diverse spheres of society, from the institutions which regulate the relations of men to each other to the highest culture of the intellect. This restoration of man after the divine type is the continuation and application of the redemptive work of Christ, which, after having had for its first intent to form in the Church a society of believing souls, pardoned and saved, called to
work directly for the salvation of all that is lost, next radiates outwards into all the departments of human activity. It is in this enlarged sense that we must understand the kingdom of God which the Saviour came to found upon our sinful world, and of which the progress goes on only at the price of an incessant struggle, which will continue to the end of time. But this general advance of the kingdom of God in its widely human extension is always proportionate to its internal development within his Church, which keeps and cherishes the central hearth of the divine life, whence emanate all light and heat.

We know in a general manner what the vast. influence of Christianity has been in the world for. eighteen centuries. We may say that the cross of Calvary has divided history; we find its luminous. track marked everywhere. It has renewed society in the very depths of universal decline without ever neglecting its first task, which is to lead the souls of sinners to Christ. Spiritual conquests count upon no more than this. But these victorions. struggles have not been pursued without many dangers, no little resistance and as much dark uncertainty, which have sometimes had the effect of altering Christianity for a time, at least in its historical realisations, for its high ideal has never ceased to soar with serene radiance in the eternal gospel. It may be put under a bushel, but it has never been possible to extinguish it or to change. its form. It is this inherent recuperative power. that admits of the renewal and elevation again of Christianity, however much it may have been debased. To illustrate the difficulties and the opposicion which Christianity encountered upon its. way, we must first carry ourselves back to the condition of the world at the time of its first appearance, and understand the spiritual influence of the great religions it found at that time before it. There is no better means of establishing its originality and recognising all the gains it has brought. to humanity, than to bring into the light its truerelation to the religions of the past. These religions fall into two types of very different nature and very unequal value: Judaism, and its antagonist, Paganism, comprising a considerable number. of particular religions presenting one common character in spite of well-marked differences.

The assertion is often made in our day that. Christianity was at first a mere development of Judaism, and that it was by combining with elements borrowed from the religions and the philosophies of the ancient pagan world that it. assumed its final form. But this explanation will not stand an impartial examination of the actual facts. Undoubtedly there exists a real relation between the new religion and those which preceded it. For how could it be otherwise, since on its own showing it came to accomplish that which had been asked for, expected, and longed for by the human soul under every sky, as well as positively promised on the soil of Judæa by direct revelations. If Christianity were only a religions doctrine, its originality might be disputed by adducing the basis of belief which it has in common with the an'serior religions, although here too it manifests a splendid superiority. But as has been shown, it is more than a body of doctrine-it is an immense work of reparation effected by its founder. In that respect it cannot be compared in anything with what has preceded it, and there will always be between it and the noblest intuitions of the philosophy of a Socrates or a Plato, or the sublimest oracles of an Isaiah or a Jeremiah, that insuperable distance which divides a hope and a desire from its effective realisation. If we consider somewhat more closely its relations to the religions which preceded it, stripping it in this manner of that which constitutes its essential originality, we find at once that that relation assumes a quite peculiar character when the religion of the Old Testament is concemed. Here there is direct preparation under the form of a series of positive revelations. It was necessary in the first place that the cradle of the Messiah should be deposited npon consecrated soil-consecrated indeed, although darkened under the veil of idolatry ; next, that there should be found there a chosen people to represent man in the expectation of, 
and the desire for, a true Messiah. For in order that the Saviour might nccomplish his work of reparation in the name of the human race, it was necessary that he should be waited for by a chosen veople, such as could be formed only in a nation separated from the pagan world, and subjected to a particular moral and spiritual education under special divinely sanetioned institu. tims. Greatest of these was the law of Sinai, intended to awaken in the heart sorrow and hatred for ain. Prophecy completed the work of preparation by announcing to learts pierced through by the aword of the law the coming of him who was to restore all things aggain, whose work was prefigured by the priesthond of the sons of Aaron and the sacrifices offered to God most holy. These special institutions were proper only to the period of preparation which was called the Old Covenant. Everything they contained that was exclusive and peculiar must disappear when the period of accomplishment had succeeded it.

The Old Covenant itself was aware of its transitory character, for above all its institutions there soared a promise of enlargement which God gave to the father of the chosen race on the day when he bade him leave his country and hís kindred: 'In thee shall all the families of the earth be blessed' (Gen. xii. 3); and prophecy was but one long and splendid enrichment of the promise : 'I will also give thee, he says, a Messiah 'for a light to the Gentiles, that thou mayest be my salvation unto the end of the earth (Isa. xlix. 6). As soon as the reconciliation has been consummated between man and God by the sacrifice of Calvary, the wall of separation between Israel and other nations is broken down; the barriers between a powerless priesthood and the simple faithful who participate in the priesthood of Christ fall down; and sacrifices which make no expiation disappear before the only sufficient offering. You are kings and priests, says the apostle Peter to the early Christians (1 Peter, ii. 9). The religion of humanity, which is the religion of the soul, supersedes the exclusive religion of the circumeised people-the religion of the letter which killeth; and this splendid enfranchisement is but the consequence of the redemptive work of Christ which faith assimilates. All this glorious liberty is included in the words: "The just shall live by faith' (Rom. i. 17).

It was the mission of Paul, the former Pharisee, the grand freedman of Christ, to set free the new religion from the bonds of Jewish legalism; called as he was by a divine revelation to draw all the consequences from the teaching of the Master. He formulated the charter of this freedom in two sentences, stamped with a kind of divine genius: the first, 'The law was our schoolmaster to bring us unto Christ, that we might be justified by faith' (Gal. iii. 24). Both its lofty mission and its powerlessness are here recognised together. The second is : 'Before Christ there is neither Greek nor Jew . . but Christ is all, and in all' (Col. iii. 11). Thus the religion of humanity rises on the ruins of the national religion. We see the New Covenant striking its roots deep into the soil of that Judrea whence cometh salvation (John, iv. 22), but growing like a great tree crpable of lodying in its branches all the birds of heaven; and all its liberal and blessed expansion but brings us back to the work of the Redeemer, as St Paul asserts in the words: 'Stand fast therefore in the liberty wherewith Christ hath made us free' (Gal. v. 1).

If we pass from Judaism to the religions of the ancient pagan world, at least to those developed in countries where they came into direet contact with Christianity, we find that they also had their preparation. In the first place, there is not one human soul which has not had engraved upon it the divine law, as St Paul recognises: the Gentiles, says.he, "show the work of the law written in their hearts, their conscience also bearing witness, and their thoughts the meanwhile aceusing or else excusing one another' (Rom. ii. 15). In the next place, God has not ceased to speak to them by the grand spectacle of the world itself, and of the heavens in which his invisible perfections may be seen as with the bodily eye (Rom. i. 20). Finally, if he has not granted them direet revelations, his spirit has constantly breathed upon them as it breathed upon the confused waters of chaos from which was to emerge a world. After all they belonged, as St Paul says again, to the offispring of God (Aets, xvii. 29), and there was not a single man among them who had not in him a ray of that light of the word "which lighteth every man that cometh into the world ' (John, i. 9). The need of a renewing work meets us ayain everywhere in the very heart of Paganism. There is no nation which has been without its priests and its secrifices, and which has not sought that atonement for which the human conscience has always longed. But that did not hinder the pagan world from continuing to be sunk in idolatry, for it fell under the dominion of a Nature which it deified. Hence its dreadful errors equalled only by its dreadful corruption. Yet it never ceased to seek for God, groping blindly in the dark (Acts, xvii. 27). The moral conscience which had never been stifled reacted incessantly against the deadening influence of the nature-religions ; it called for a God greater than those which Paganism had fashioned for it; it had its sublime aspirations which never ceased to re-echo through the pagan night one long penitential pealm, which, sung in the plains of Chaldrea, sometimes became a true supplication to the future Saviour. 'I turn from every side,' says the son of Vedic India to his god, "desiring to know my sin. Absolve us from the sins of our fathers, and from those which we have committed in our own bodies' (Rig Veda, vii. 86).

The preparation of the pagan nations consisted in their being made to experience their inability to find salvation in their idolatrous religions. We may consider that preparation as finished, when out of the ruius of their old idols they raised that altar to the unknown God which St Paul recognised as the symbol of aspirations all the more ardent the more they had been deceived, and the more general the decline in the world around. The converted pagans found that peace for which they longed at the feet of Christ. They gave up without difficulty their own peculiar ritesthat priesthood and those sacrifices which had availed but to express and stinulate their desire for salvation without satisfying it. For them, too, the exclusive and national character which clothed religion before the revelation of God's universal fatherhood needed to be expanded. For the religion of humanity to supersede the various religions of the soil, it was necessary not only for the Jew to renounce his exclusive theocracy, but also for the son of Paganism to recognise that the kingdom of Christ, not being of this world (John, xviii. 36), ought not to be incor. porated with the state as a thing that belonged to a particular people. We see that Paganism, nome admirable ideas alone excepted, brought nothing to Christianity but aspirations frustrated and yearnings unsatisfied. From the doctrinal point of view, even its noblest philosophies hnd been falsified ' hy the influence of the nature religions. Platonism itself with all its idealism ended in oriental dualism, for unable to triumph over evil, it identified it finally with matter under a fatalism whence man could escape only by an 
asceticism of which the Buddhist annihilation is the logical consequence. It is this which for ever distinguishes the Christian metaphysic from all the Greco-oriental speculations comprised in the system of the Alexandrian Philo. To prevent any confusion between Christianity and Hellenism it is sufficient to read these words in the prologue to the fourth gospel: 'The Word became flesh.' Presented thus according to its primitive type, the religion of Christ appears before us in its true character and its incontestable originality; and herein rests its power. Were we to see in it only a synthesis of all the anterior religions, we should have in Christ only a kind of composite idol enshrined in the last of the pagodas; and we could not connect it with that primitive Christianity which alone is true, and which remains for all time in the faithful image it has left us of itself in the sacred volume which makes it live anew in its first and authentic manifestation. Thanks to that book we can always trace it back to its source, and mark the point of departure between what it is in itself, and the superfluous accretions which have changed it.

For it was impossible that Christianity should make no deviations once it had begun to float upon the stream of history. These were rendered imperative by its being imposed by authority upon successive generations like a dead letter-the most serious of all changes to which it could possibly have been subjected, for it is before everything the religion of the spirit and of liberty. The purpose of history after its own modification through the influence of Christianity was precisely to make it penetrate to modern humanity in a free assimilation, but that assimilation involved the possibility of all its stumblings, its failures, and its obscurities ; without, however, the true Christian spirit ever ceasing to struggle against error to bring back the Church to its original type. Let us not forget that the effects of Christianity radiate outwards far beyond the immediately religious sphere; through an influence direct and indirect by turns it strives to re-establish human society upon the type of justice and love-a result which certainly forms it into a part of the kingdom of God. Mere social progress not infrequently advances religious progress, as it binds fewer burdens on the individual conscience, and appears for that reason the more easy. We cannot give more than a rapid sketch of the deviations as well as the victorious struggles of Christianity from its beginning to our own day. To explain its deviations it is sufficient for us to recall its leading thought, which is also its great power-emancipation, for these invariably tend to the alienation of the freedom in which the gospel has made us free. Christ has freed man from all the burdens under which he was bowed down, and first of all from that of sin, by his redeeming work alone. Whenever man turns aside from this, whenever he ceases to believe in a salvation which is the free gift of God, apprehended by faith, he girds on again his ancient chains, he seeks for mediators in a new priesthood, returns from the New Covenant to the Old, and restores anew the theocracy; in one word, he becomes again a Jew. This is the whole history of the formation of Catholicism, the real cause of all the slavery which it has caused anew to weigh upon the freedmen of Christ.

On the other hand, the return to Paganism takes effect whenever for the gospel of the redemption we substitute a purely philosophical speculation. The digression to the left is no better than that to the right; it is even worse, for it ends in a parching rationalism which cannot long rest on the slope downward to pantheistic naturalism. We shall limit ourselves to characterising the principal periods of the history of Christianity, in each of which we find the battle arrayed between its most faithful representatives and the promoters of tendencies whether towards Judaism or Paganism.

Already in the apostolic age the struggle had begun, for we know that it needed the apostolate of Paul to bring down the Church from its high chamber, to cast aside the swaddling clothes of its cradle, and come gradually to the point of renouncing Judaic exclusiveness. What a combat the great apostle of the Gentiles had to wage against the survivors of the synagogue who wished at any cost to hinder the grand liberation of souls, and at the close of his life against the first representatives of pagan speculation, the Gnostic hereties of Colosse and Ephesus! Beyond doubt he was victorious, and when his noble head fell under the axe of Nero's executioner, it might have been said of him that though dead he would speak until the end of time, ever uttering anew his great cry for liberty, for the freedom of the Church from all its bonds through justifying faith.

The first period of the history of Christianity after the death of the last apostles extends from the $2 d$ century to Constantine. It is an heroic age. The mission of Christ extenda over all the empire, and fashions a whole people with their own consent. Persecution rages without intermission, but the blood of the martyrs is the seed of the gospel. The struggle goes on also in the world of thought. The Gnostic heresies mark the reaction of the pagan spirit; they are refuted by $a$ powerful polemic. The apologetic writings of Justin Martyr, of Irenæus, of Clement of Alexandria, and of Origen, breathe the most living and the largest faith. The most important social reforms, as the elevation of woman, the respect due to the man in the slave, are realised at the family hearth. But the gravity of the struggles against heresy, and the questions of discipline arising ont of persecution itself for the restoration of such Christians as had wavered, tended to strengthen ecclesiastical authority in an exaggerated degree to the detriment of the primitive liberty. That tendency was aided by a certain weakening of the dogma of justification by faith, despite the struggles of Origen and Tertullian against the innovators.

The second period extends from Constantine to the establishment of the papacy. Christianity became the religion of the state when the Cresar of Byzantium granted it his burdensome protection, but it still retained within it its generous sap. In spite of the authority of St Augustine faith in the free grace of God became more and more obscured. The discussions raised by Arianism more and more gave the foremost place to a Christian theodicy which resulted in a subtle divine meta physic elaborated by the great councils of Nice, of Constantinople, and Chalcedon. These councils constituted a completed novel central authority within the Church. At the same time the old hierarchy was re-established to govern flocks cast by their birth itself into the fold of the Church. and the crook of the shepherd became the symbol of $a$ despotic authority. The Bishop of Rome acquired a primacy that ever grew greater, until when the floods of barbarian invasion had submerged the old Roman government, the papacy became incontestably the chief centralising power. It had a high regard for social progress, and the Christian mission continued its conquests; but unhappily after its union with the empire the Church began to employ forcible constraint against its enemies both without and within. Spite of many a noble protest Catholicism took the place of the primitive Christianity, and suppressed all its liberties. It was as if the dethroned Jewish theocracy had thus revenged itself for its down- 
fall yet the enslaved Church continued to pre. serve the treasures of piety. Monasticism became the right arm of the papacy, and rendered it the most precious service in the education of races still rude and indeed hardly escaped from barberism. With Gregory VII. the great transformation was completer, and the new theocratio organisation sppeared in all its glory. No one can deny that under the given conditions it rendered precious services. It was still Christianity, however disfigured, to which Europe owed its alleviation from the barbariam that weighed upon it. To it alone the weak and the oppressed owed it that they were not crushed

It is impossible to do more than characterise briefly some of the most prominent features of the micldle ages and the Reformation. In the middle ayes we mark the immoderate expansion of the religious and social omnipotence of Christianity, manifesting itself in the Crusales and the momentary subordination of the state to the Church after memorable struggles; and in consequence of that very temporal primacy of the Church we see it diverge more and more from its primitive type. It has quite decidedly become a new theocracy, and as has ever been the ease the progressive diminution of its liberties coincides with the complete subversion of the grand doctrine of justification by faith. Salvation by works replaces salvation by grace, the supposed merits of glorified saints are purcliased for the benefit of sinners, and finally indulgences from the conseguences of sin are sold for a price in money. Yet Christianity even thus disfigured and diminished still shows itself beneficent for the consolation of human misery. It produces a magnificent art. The Gothic cathedral is the symbol of its greatness and also of its formidable power. Scholasticism produces its famous theological Summas which are as it were the cathedrals of thought. The monastic orders founded in great numbers contribute at once to the relief of the wretched and to the enslavement of the faithful. Yet it was in some of these convents that there was developed that profound and touching mysticism which sought to find God beyond the sacerdotal hierarchy. From the 14th century onwards an ardent aspiration towards reform stirred the Church. It was the ferment preparing the great approaching renovation that was to shine forth after the great schism, which weakened the papacy by breaking it into factions. This need of reform was expressed officially in the councils of Pisa and Basel. The Reformation had already its forerunners in John Huss and Wyelif, while it was, as it were, realised beforehand in the valleys of Piedmont.

With Luther it burst forth with irresistible power. If its banner was victorious over great part of Europe it was because it bore the grand device of all Christian liberty: "The just shall live by faith.' The liberty of the people of God was actually reconquered in principle; it founded itself as at the first de.ys of Christianity on the certainty of salvation granted by grace and seized by faith. This doctrine of liberation dismisses all human mediators to find again the universal priesthood in the sacriticial priesthood of the Redeemer. To all tradition it opposes the sovereign authority of Christ, whom Luther calls the king of the Bible, which alone permits us to know him. Next ensued a gigantic struggle, on the one hand, between the Reformation and the ancient Catholic Church, whose usurpations linked with a mencenary concep. tion of salvation were consecrated by the Council of Trent; and on the other hand, between Christianity and a pagan culture eager to resuscitate the naturism of the ancient world without its religious aspirations. This double struggle has rerched in our day its culminating height. It is complicated whether in Catholicism or in the churches of the Reformation by an intestine struggle which brings to an issue upon narrowed ground the two opposing elementa, Thus Catholicism even after the Council of Trent saw arise within itself a movement for reform, which, rendered illustrious by the Abbs de St Cyran and Paseal, tried to elevate the doctrine of grace and to linit the papal power. That noble effort was compelled to succumb before pensecution, after having done honour to the church of France. Gallicanism contrived to lay some restriction upon the papal powers, but was speedily defeated like Jansenism, from which it had separated in the 17th century while retaining the stamp of its influence.

In the bosom of Protestantism there broke out early a struggle between a conservatism which would retain as much as possible of Catholicism and a Christian liberalism whose aim it was to bring back the Church to the apostolic type. That struggle has led to the ereation of different churches practising in both hemispheres with more or less fidelity the constituent prineiples of the Reformation, or, more correctly, continuing them and disengaging them from things inconsistent therewith. In the domain of thought the battle has been fought between the partisans of a strict dogmatism and those who would admit of theological progress without breaking in anything with the eternal gospel. We must also recognise that within the heart of historical Protestantism we have seen produced, rather more than a century since, on some questions, philosophical tendencies which are Christian only in name, and which in their extreme manifestations would introduce into the fortress the enemy that besets the walls -we mean a culture decidedly anti-Christian. The siege is being carried on to-day more vigorously than it ever was before. The struggle between Christianity and tendencies contrary to it has never been more serious. Anti-Christianity under all its forms has taken a considerable development, and seems to resuscitate in our modern so-called Chris. tian world the old Paganism, while eliminating from it the better elements, its aspirations and foreshadowings of the religion of the redemption; for this neo-Paganism in its most logical manifestations ends in an absolute naturalism which will only admit of matter and force in the evolution of all life. On the other hand, what we call the Judaising tendency so ready to appear in the Church on the morrow of the apostolic age, has reached in these last days the final stage of its course. The ecelesiastical policy which has brought about in succession the syllabus of Pius IX., the Encyclical Quanta Cura (1864), the proclamation of the Immaculate Conception of the Virgin (1854), and that of the papal Infallibility at the Vatican council of 1870, have assured the triumph of the theoeratic system, while condemning everything in the bosom of contemporary Catholicism like liberty in the Church or in the heart. Nothing is further from onr thought than to place Catholicism per $s e$ outside the pale of Christianity. We recognise in it the treasures of piety. Its charity has never expended itself over social misery more bounteously than now. Christ is loved and adored within its fold by a multitude of pious souls who find him in spite of defective forms of worship and the long chain of the sacerdotal hierarchy. We refer only to the peculiarly ecclesiastical and specific principle of Catholicism when we speak of its deplorable return to Jewish theocracy. This return is the more inexplicable as the institutions proper to the Old Covenant have no longer any reason for their existence since they have found their accomplishment in the gospel. It is impossible not to observe that there exists a real co-relation between the development of the anti-Christianity 
of this renewed theocracy which breaks with all modern progress from a social point of view by its attempt to enchain thought and the conscience to a sacerdotal power. Wherever Catholicism is the dominant religion it is taken as the true representative of Christianity itself. Hence is propagated the erroneous idea that there is an opposition between the religion of Christ and social progress, seeing that all the grand principles of justice, of law, and of brotherhood, come in reality from him who has raised man in every sense by reconciling him with God. Human brotherhood with all that it implies can come only from the divine fatherhood.

We are thus right in affirming that the victory of the Catholic theocracy has been the surest means of actually turning away recent generations from a Christianity ill understood and misrepresented, and that it has in this way facilitated the progress of anti-Christianity. Happily Christianity has had other representatives who have shown it in its true character. We must recognise that even in the bosom of Catholicism are to be found grand and lofty Christian men like Lacordaire, P. Grétry, Montalembert, and Döllinger, who have not ad. mitted the divoree of the religion of Christ from political and social progress, of the gospel from liberty. They have opposed with energy the party of religious absolutism; their eloquent testimony endures in their books, and their thought remains like leaven within the Church which they have adorned, though they failed to persuade her. We may hope that this movement for true liberty will revive sooner or later in her, all the more that the fall of the temporal power will finally bring about important moral consequences.

Whatever there may be in such forecasts of the future, really evangelical Christianity has shown itself wherever the Reformation has been planted, as the initiator and propagator of true liberalism. It is easy to prove that it was to its influence, distorted indeed and indirect, that the French Revol ution of 1789 owed everything that it contained of what was true and fertile for the future. Its first adherents had breathed the air of freedom in Anglo-Saxon countries. Besides, the French Protestants, by their resistance to the intolerable persecutions of which they had been the object, had preserved in their own persons the most important of all liberties-that of the conscience. It is more important to-day than ever, in face of the rising flood of democracy, that Christians, in order to dissipate the misunderstanding which in its opposition to the gospel and to liberty favours contemporary anti-Christianity, should delight to place themselves in the van of political and social progress, and should especially take to heart the elevation of the labouring classes. This is what true Christians are now doing more and more in every country. We gladly recognise that Catholics and Protestants are vieing with one another in their zeal for this great aocial task, which is the foremost duty of our age. We may perhaps add that the gradual disappearance of state religions, with their authoritative constitutions defining the identities between the spiritual and the temporal, need not at all tend to the disadvantage of Christianity, since it will render for ever afterwards impossible all recourse to force for maintain ing the authority of doctrine, thus putting final end to an intolerance which was the most flagrant contradiction of its most essential principle. We must not forget to make allowance for the modern cessation of compulsion in religion in our estimation of the actual manifestations of antiChristianity, which in former times was compelled to save itself by concealment or in hypocrisy, although it was possible for it to exist in large proportions within a state, though all unseen. But now the time has come for that which was whispered low to be proclaimed upon the housetops. Yet positively the truth has everything to gain in that freedom, which, however irreverent. it sometimes may be, is still due to a state of things through which the great opprobrium of a persecuting religion has been made to disappeara result for which we can hardly congratulate ourselves too highly.

The secularisation of the state entails upon us. great responsibilities, especially in what concerns. the young, who are the more judiciously intrusted to the care of the Church, because every where they are called to form their faith without any help from the state. The vast and glorious development of the natural sciences has largely contributed to. develop unbelief in the domain of speculation, under the influence of that pantheistic or materialistic philosophy which had preceded it. In the intoxication of all their scientific discoveries, men imagined that they could put God and the spirit out of the world, and recognise therein only the play of mechanical forces, the evolution of motion producing a series of existences comprising thought, conscience, and soul. The adversaries of Christianity have divided themselves more and more into two great schools: Agnostics, denying the possibility of obtaining the least knowledge of what is beyond our own consciousness, and dogmatic Materialists from whatever cause produced. We have a right to affirm that Christianity has striven victoriously against. both the one and the other. First of all, it numbers in the domain of science more than one illustrious. representative who has actually shown that wemay enrich science while believing firmly in God. Next-and this is still more important-it has. brought about the most salutary enlargement in intellects within the bosom of the most earnest. Christianity. The most eminent among Christian thinkers have proclaimed the reciprocal independence of seience and religion. They have recognised that the first is sovereign in its own sphere, that God has not revealed what man can discover, and that in consequence religion has not to link itself with such or such a conception of the past, as if it had therein a revealed system of science. By the happiest coincidence, illustrious savants with absolutely no connection with the churches, as $\mathrm{Du}$ BoisReymond and Virchow, have refused the natural sciences the right to make excursions out of their own domain, and to settle questions like those of the origin of life or of man. They have thus declared a perfectly rational scientific agnosticism about what concerns that problem of origins, which is specially the problem of religion. It follows from this that there may exist other processes of discovery and of experiment than those of the natural sciences in that which transcends their province. It is for Christians so to employ these as to establish the reality of a spiritual and divine world, and such of its successive manifestations in religious. history as come to centre themselves in Christ.

We may say that in this way a work of great. importance to apologetics has been accomplished: it has happily reflected light upon the very conception of a doctrine which is ever the more widened the less it is allowed to be shut in within any formulas of the orthodoxies of the past, in order to grasp ever the more closely the living object of belief, which is Christ, and understand the better that eternal gospel, which as we have established, is essentially $a$ fact and a person. That enlargement which we can verify in all churches freed from the yoke of outward authority, is not only favourable to the true progress of the Christian conception, but also to its preservation. One of 
the most significant characteristics of this proyreas in our age is that it makes more than ever of the human element in the gospel, without detracting in anything from its divinity. To the metaphysi. cal abatractions which effaced the original character of this great past has succeeded a really historical comprehension which makes it live again before our eyes. Thus in our conception of the very personality of Christ, he has come nearer us without ceasing to be the Son of God who saves us and lifts us up again. The heart as well as the intelleet finds its advantage in this evolution of Christian thought, which is a return to its original; and now, indeed, it is more necessary than ever that the fire of a holy enthusiasm and a fervent love for ('hrist should kindle up again in Cluristian souls, amid all the distractions of modern life, which has become so complex through the development of human activity in every sphere, artistic, industrial, commercial, or scientific.

It must not be forgotten that after all the chief struggle of Christianity is not against such or such a system, but against the power of evil, against sin which destroys us; and that it is above all a work of redemption, of restitution, and of salva. tion. It is this which distinguishes it from the two great religions which dispute with it the world. Buddhism is the religion of absolute nothingness, of Nirvana, placing salvation in death and in annihilation, and only retaining its millions of adherents by concessions ever more and more frequent to idolatrous fetichism. Mohammedanism is merely a materialisation of Judaism, making of its Allah a God at once terrible and indulgent, for he has only murderous rage for those who do not hasten on in the footsteps of his pretended prophet to the brutal conquest of the world, while at the same time he is full of indulgence to a life of sensuality, which after being largely satisfied on earth expects its final gratification in a sensual paradise. To reconquer the millions of men held within the grasp of these two great religions, and those who belong to fetichistic idolatry, which is a survival of prehistoric humanity, Christianity has spared no effort, and has never refused to pour out the blood of its martyrs. Therefore, everything brings us back to the necessity for a struggle without cessation, both near and far off, against the powers of evil which everywhere wage war against it.

If the dust of the battle sometimes casts a shadow over the true character of Christianity, it none the less remains vigorous and living as it was eighteen centuries ago. We recognise it, even under forms the least favourable, by the intensity of its religious life, by its love of God and of Christ inseparable from its love for man, who would perish withont it. Its career of conquest, far from being diminished, has increased largely during the last century throngh the magnificent development of its missions abroad and at home. Its eharity never censes to multiply works of benevolence and of relief. The eye of faith discerns across the great and tremendous struggle which sums up the whole of human history, a combatant greater than the greatest and holiest of Christian soldiers-that divine hero of whom Luther says in his immortal hymn, that he fights for us and with us. It is for this reason that we say at the conclusion, as at the commencement : Christianity is Jesus Christ.

For a list of worles on Christianity, Christian Dogma, and Church History, see the article CHorch HIBTORY and the tibliography appended.

Christian Knowledge, Society for ProMotiNG (often referred to as the S.P.C.K.), one of the great religious associations connected with the Church of England, and the oldest of them all. It was founded in 1698 , although it did not receive its present name till 1701 ; and had for its objects: '(1) To promote and encourage the erection of charity schools in all parts of England and Wales; (2) to disperse, both at home and abroad, Bibles and tracts of religion; and, in general, to advance the honour of God, and the gond of mankind, by promoting Christian know. ledge both at home and in other parts of the world by the best methods that slsould offer.' These objects it has never censed to pursue, chiefly directing its efforts to the British dominious; par. taking at once of the nature of an educational association, a missionary society, a Bilsle society. a religious tract society, and an emigrants spiritual aid society; and notwithstanding the operations of other great societies in these several departments of Christian benevolence, its revenue amounts to above $\mathbf{\epsilon 5 0 , 0 0 0}$ a year. The bookselling business shows in some years total sales of $£ 80,000$; the works published being in very various depart. ments of literature, and including several admirable series on Early Britain, Diocesan Histories, Ancient History from the Monuments, Early Chroniclers, \&e. The Protestant missionaries who laboured in the south of India in the 18th century were sup. ported chiefly by this society, and it is now fully engaged in supplying to the mission-field throughout the world needful religious literature in the vernacular. Besides translations of the Bible and Prayer-book, it provides for pioneer missionaries, grammars, dictionaries, reading-books, \&c., to instruct them in the languages which they will have to use. See a History of the Society (1898). A Scottish Society for Propagating Christian Knowledge, incorporated in 1709 , has an annual expenditure of $\$ 5000$, mainly devoted to the maintenance of schools in the Highlands and Islands.

Christian Names. See article Names.

Christiansand, sixth city of Norway in respect of population (though great part of it was burned in 1892), is situated near its southernmost extremity, on a sandy plain. Pop. 12,813. It is a garrisoned town, was built by Christian IV. in 1641, and has been the capital of its province or stift since 1684. It has several dockyards, and a good harbour much used for refuge. The steanpackets from London, Hull, Hamburg, \&e. to Christiania and the north usually call here. At the mouth of the harbour is the beautiful island of Odderö, laid out with public gardens and promenaules. Christiansand has a considerable trade in timber, pitch, stockfish (salted cod), fish-oil for curriers, salmon, mackerel, and lobsters, the latter chietly for the London market. A bout thirty lobster smacks are regularly employed between Christiansand and Billingsgate during the season. Many thousands of white ptarmigrans caught in the neighbouring districts of Lister and Mandals are shipped annually from Christiansand to England. Shiphuilding is a considerable industry. Chris. tiansand has a cathedral and grammar-school, and is the residence of a bishop and high-bailiff and of a British vice-consul. The streets are wide, straight, and regular; the houses are built of wood and detached, presenting altogether a remarkably colonial aplearance. The inhulitants are noted for their stature, said to average six feet.

Christiansfeld, a settlement of Moravian brothers in Northern Sleswick, was founded in 1772 , and has 700 inhabitants.

\section{Christians of St John. See ZABism.}

Christians of St Thomas. See Thomas.

Christianstad, the capital of a Swedish province of the same name, on the Helge, 14 miles from the Baltic, and 351 SSW. of Stockholm by rail. Formerly it was strongly fortified. It possesses an arsenal, a school, a magnificent church, and a senatehouse. Pop. (1881) 9328 ; (1891) 10,670。 
Christianstadt, the chief town of the Danish island of St Croix (q.v.), in the West Indies, on the north shore. Pop. 5500.

Christiansund $\left(63^{\circ} 10^{\prime}\right.$ N. lat., $7^{\circ} 50^{\prime} \quad \mathrm{E}$. long.), sometimes confounded with Christiansand though 350 miles farther north, is a Norwegian coast-town (pop. 10,500), built on three wooded islands, Kirkelandsö, Inlandsö, and Nordlandsö. The main thoroughfare being the sea-channels be tween these islands gives it a curionsly picturesque character, which is heightened by the irregularity of ground on which the wooden houses are built, scarcely any two being on the same level. It has a considerable trade with Spain and Italy in saltfish, and is a calling-place for the omnibus passenger steamers which now ply so numerously on the Norwegian coast. The chief public buildings are the grammar-school and custom-house.

Christina, queen of Spain. See MarIa Christina.

Christina, queen of Sweden, only child of the great Gustavus Adolphus, was born 17th December 1626, and succeeded her father in 1632, when only six years old. Distinguished equally by beauty and the possession of a lively imagination, a. good memory, and uncommon intelligence, she received a man's rather than a woman's education, and to this may partly be attributed the many eccentricities of her life." During her minority the kingdom was governed by the five highest officers of state, the principal being Chancellor Oxenstiern. In 1644 she assumed the reins of power, and in 1650 was crowned with the title of king. She had previously declared her cousin, Charles Gustavus, her successor. For four years thereafter she ruled the kingdom with vigour, and was remarkable for her patronage of learned men, such as Grotius, Salmasius, and Descartes. In 1654 , however, at the age of twenty-eight, weary of the personal restraint which royalty imposed on her, she abdicated in favour of her cousin, reserving to herself sufficient revenues, entire independence, and supreme authority over her suite and household. Leaving Sweden, she proceeded to Brussels, where she embraced the Roman Catholic religion. She next went to Rome, which she entered on horseback, in the costume of an Amazon, with great pomp. Confirmed by Pope Alexander VII., she adopted the surname of Alessandra. She next visited Paris; and there in 16507 she caused her grand equerry, Monaldeschi, who had enjoyed her entire confidence, to be executed in her own household for treason. The death of the king in 1660 caused her to hasten from Rome to Sweden; but, failing in her attempt to be reinstated on the throne, she again left the country. In 1666 she aspired to the crown of Poland. The remainder of her life was spent at Rome in artistic and scientific pursuits. Here she died April 19, 1689. See a monograph by F. W. Bain (1889).

Christison, SIR RoBerT, D.C.L., physician and toxicologist, son of the professor of Humanity in the university of Edinburgh (1806-20), was born at Edinburgh, July 18, 1797. After graduating in 1819, he proceeded to London and Paris, and in the French capital studied toxicology under the celebrated Orfila. He was in 1822 appointed professor of Medioal Jurisprudence in the university of Edinburgh; and in 1832 was promoted to the chair of Materia Medica, which he occupied till 1877, when he retired. He became famous as a medical writer, and risked his life more than once in his experiments with poisons on his own system. He was appointed physician-in-ordinary to the Queen in 1848; president of the Edinburgh Royal Society (1868-73); and created a baronet in 1871 ; and was honoured with a banquet and the degree of LL.D. in 1872 on the completion of his fiftieth year as a professor. During a vigorous old age he could walk, run, or climb mountains better than any of his contemporaries. He died 23d January 1882 . Besides contributing papers on various subjects to medical journals, Christison wrote a Treatise on Poisons (1829), recognised as a standard work on the subject; Biographical Sketch of Edward Turner, M.D. (1837) ; a treatise On Granular Degeneration of the Kidneys (1839); and The Dispensatory, a Commen. tary on the Pharmacopocias of Great Britain (1842). See his Life, edited by his sons (1885-86).

Christmas, the day on which the nativity of the Saviour is observed. The institution of this festival is attributed by the spurious Decretals to Telesphorus, who flourished in the reign of Antoninus Pius (138-161 A.D.), but the first certain traces of it are found about the time of the Emperor Commodus (180-192 A.D.). In the reign of Piocletian (284-305 A.D.), while that ruler was keeping court at Nicomedia, he learned that a multitude of Christians were assembled in the city to celebrate the birthday of Jesus, and having ordered the church doors to be closed, he set fire to the building, and all the worshippers perished in the flames. It does not appear, however, that there was any uniformity in the period of observing the nativity among the early churches; some held the festival in the month of May or April, others in January, conjointly with the feast of the Epiphany. It is nevertheless almost certain that the 25 th of December cannot be the nativity of the Saviour, for it is then the height of the rainy season in Judre, and shepherds could hardly be watching their flocks by night in the plains.

Christmas not only became the parent of many later festivals, such as those of the Virgin, but. especially from the 5th to the 8th century, gathered round it, as it were, several other festivals, partly old and partly new, so that what may be termed a Christmas Cycle sprang up, which surpassed all other groups of Christian holidays in the manifold richness of its festal usages, and furthered, more than any other, the completion of the orderly and systematic distribution of church festivals over the whole year. Not casually or arbitrarily was the festival of the Nativity celebrated on the 25th of December. One of the principal causes that cooperated in fixing this period was that almost all the heathen nations regarded the winter solstice as. the turning-point of the year-the beginning of the renewed life and activity of the powers of nature, and of the gods, who were originally merely the symbolical personifications of these. In more northerly countries this fact must have made itself peculiarly palpable-hence the Celts and Germans, from the oldest times, celebrated the season with the greatest festivities. At the winter solstice the Norsemen held their great Yule-feast (see YULE) in commemoration of the fiery sun-wheel; and believed that during the twelve nights from the 25th December to the 6th January they could trace the personal movements and interferences on earth of their great deities, Odin, Berchta, \&c. Many of the beliefs and nsages of the old Germans, and also of the Romans, relating to this period, passed over from heathenism to Christianity, and have partly survived to the present day. But the church also sought to combat and banish-and it was to a large extent successful-the deep-rooted heathen feeling by adding, for the purification of the heathen customs and feasts which it retained, its grandly devised liturgy, besides dramatic representations of the birth of Christ, and the first events of his life. Hence sprang the so-called 'Mangersongs,' and a multitude of Christmas carols (see CAROL), as well as Christmas dramas, which at 
certain times and places degenerated into farces or Fools' Fensts (q.V.), and the eustom of reciprocal presents, and of special Christmats mests and Cishes, such us Christmas cakes, dumplings, Se. The favourite dish was a boar's head. The custom of decorating churchess at Christuas, esjeceinlly with holly and ivy, is a very ancient one. Of late it has become usual for friends to forward to one another, by post, gaily illuminated Christmas cards (q.v.), benring Christmas greetings. The Christmas tree would seem to be traceable to the Roman saturnalia, and was not inprobably first imported into Germany with the conquering legions of Drusus. It is noteworthy that "the Christmas tree " with its pendent toys ind mannikins is distinetly portrayed by Víryil (Geor. ii. 389): 'Oscilla ex alta suspendunt mollia pinu." The Christmas numbers of magazines are often at great cost rendered specially attractive; they are. now issued as early as October. The Pantomime (q.v.) has a special connection with Christmas.tide. The visits of 'Santa Claus, bearing gifts, in England and America referred to Christmas, belong properly to December 6, the day of St Nicolas $(q . v$.$) . The French Noel is$ derived from the Latin natalis (dies), 'birthday." Washington Irving's Slietch Book gives a charming picture of an old English Christmas.

In the Roman Catholic Church three nasses are performed at Christmas - one at midnight, one at daybreak, and one in the morning. The day is also celebrated by the Anglo-Catholic Churchspecial psalms are sung, a special preface is made in the Communion Service, and the Athanasian Creed is said or sung. The Greek Church, the Lutheran Church, and most communions save the Presbyterian, likewise observe Christmas; while throughout England and many parts of the United States it is kept as a social holiday, on which there is a complete cessation from all business. But within the last hundred years the Christmas festivities, which at one time lasted with more or less brilliancy till Candlemas, and with great spirit till Twelfth-day, have fallen off. See Chambers's Book of Days.

Christmas Box, a small money-gift to persons in an inferior condition on the day after Christmas, which is hence popularly called Boxing-day. The term, and also the custom, are essentially English, though the making of presents at this season and at the New Year is of great antiquity. A number of interesting particulars concerning the Christmas box will be found in Brand's Popular Antiquities and in Notes and Queries. Within the memory of middle-aged persons, the practice of giving Christmas hoxes haul become such a serious social nuisance that tradesmen stuck up notices in their windows that no Christmas boxes would be given; and at the same time the public anthorities issued remonstrances to the same effect. At Christmas 1836 the Secretary of State for Foreign Affairs issued a circular to the different embassies, requesting 8 discontinuance of the customary gifts to the messengers of the Foreign Department and other government servants. Since this period the practice has greatly decreased, doubtless to the improvement of the selfrespect of the parties interested.

Christmas Cards, as now sold and distributed in millions during the festive season, in their various forms, are familiar to every one. The invention has been ascribed by gome to the late Sir Henry Cole; by others, the eredit of designing the first Christmas card in $\mathbf{1 8 4 6}$ is given to J.C. Horsley, R.A. Immense progress has been made in beanty and artistic effect since the time when the popular emblems were more or less confined to Old Father Christmas, images of flowers, the robin-redbreast, or the dove. The prize competitions for designs have alno done not a little in stimulating the art. Their production is begun often more than a year in advance; and the system of sending Christmas cards, as also New-year's, Easter, and birthday cards, has created a new trade, and a new field for artists, engravers, lithographers, and printers. The quantity of Christmas cards passing through the post-office leads to congestion for a few days in ordinary deliveries.

\section{Christuas Carols. See Carol.}

Christmas Island, in the Preific, is in $1^{\circ} 57^{\prime}$ N. lat., and $157^{\circ} 27^{\prime} \mathrm{W}$. long., with some guano deposits, and is a British possession. Another Christmas Island, annexed to Britain in 1888, lies about 250 miles SW. of Java $\left(11^{\circ} \mathrm{S} ., 105^{\circ} 30^{\prime} \mathrm{E}\right.$. $)$, is 6 miles long by 4 broad, partly volcanic, partly coralline in structure, with rich phosphate deposits (worked since 1897). There is a third Christmas Island off Cape Breton.

\section{Christmas Rose. See Hellebore. \\ Christology. See Christ.}

Christophe, Henri, king of Hayti, was born a slave on the island of Grenada, October 6, 1767. Coming to Hayti, he joined the black insurgents against the French in 1790 , and, from his gigantic stature, energy, and courage, soon became a leader among them. By Toussaint Louverture he was appointed brigadier-general. In 1802 he gallantly defended Cape Hayti against the French. He and Petion secured the overthrow of the short-lived government of Dessalines in 1806; and in 1807 he was appointed president of Hayti. Civil war cominenced between him and Petion; but in 1811 Christophe was proclaimed king of Hayti, by the name of Henri $\mathbf{1}$, and ruled with vigour and not without success. But his avarice and cruelty led to an insurrection; and deserted by his bodyguard and all his nobles, he shot himself, Oetober 8, 1820. He left a code of laws which he called the "Code Henri,' in imitation of the Code Napoléon. See HAYTI.

\section{Christopher, Herb. See Baneberry.}

Christopher (from Gr. Christophöros, "Christbearer'), a saint of the Roman Catholic and Greek Churches. According to the oldest form of the legend, he is said to have lived in Syria, and suffered martyrdom under the Emperor Decius $(249-251)$. He is said to have been 12 feet high, and of prodigious strength. In the pride of his strength he would serve only the mightiest upon earth. After being some time in the service of a king, and seeing his master's dread of the devil, he gave himself to be the devil's servant. One day, however, he saw the devil trembling before an image of Christ, and he resolved thenceforth to serve Christ only. For his penance he undertook to carry pilgrims across a broad unbridged strean. One day Christ came to him in the form of a child to be carried over, but the burden grew ever heavier and heavier, until it was almost too much for him to reach the farther shore. 'Marvel not, Christopher,' said the child, 'for with me thou hast borne the sins of all the world.' In painting and sculpture the saint is usually represented with the infant Christ upon his shoulders, leaning on a great staff, and straining every nerve to support his weight (see the Monograph by Sinemus, Hanover, 1868). The various legends of St Christopher are found in a connected form in the Legenda Aurea (lst ed. Nürnberg, 1478; new ed. by Grnesse, Leip. 1850 ) of Jacobus de Voragine, who died in 1292. The Greek Church celebrates his festival on the 9th of May, the Roman Catholic on the 25th of July.

Christ's Ilospital. Newgate Street, London, was founded on the site of the Greyfriars' Monas. 
tery, by Edward VI., June 26, 1553, as a hospital for orphans. It is usually called the 'Blue Coat School,' on account of the dress worn by the boys. This consisted of a blue woollen gown or coat with a narrow red-leather girdle round the waist, kneebreeches, yellow petticoat and stockings, a clergyman's bands at the neck, and a small blue worsted cap. The cap, however, was discontinued about thirty years ago, and the petticoat in 1865, but otherwise the dress remains unaltered. Such, with slight variations, has been the costume of the boys since the foundation of the school in the reign of Elward VI.; the persistency in it through successive generations affording a curious instance of the unchangeableness in some of the English usages. Children are admitted between eight and ten years of age, and discharged between fifteen and sixteen, according to their school position, excepting the "Grecians' (i.e. the highest class of scholars in the hospital), of whom five are sent annually on various scholarships to the universities of Oxford and Cambridge. Altogether, about 1100 boys and 90 girls are now upon the foundation. The right of presentation is vested in the governors. These are the lord mayor of London, the aldermen, and twelve common councilmen, who are ex-officio governors. Besides these, all noblemen and gentlemen who benefit the hospital to the extent of $\$ 500$ are governors, or 'donation' governors. Of these there are at present 264. The governors are the patrons of several churches, chiefly in Surrey and Essex. In 1887 the net available income for the purposes of the hospital, and for exhibitions and apprentice fees, was about $£ 58,000$, wholly from legacies and benefactions subsequent to the foundation. In addition the governors administer large pension charities, including the Rev. W. Hetherington's Charity to the Aged Blind, which is distributed in pensions of $£ 10$ a year to upwards of 700 blind persons over sixty-one years of age, resident and born in England. King Charles II. enriched it by $£ 7000$, with an additional annuity of $£ 370,10$ s. for the purpose of educating yearly ten boys for the sea-service. Most of the building perished in the Great Fire of 1666 ; but, through the generosity of the corporation of London and of wealthy Englishmen, it was soon rebuilt, under the superintendence of Sir Christopher Wren. In the course of time the new hospital fell into decay, and in 1825 a third structure was erected by Mr Shaw. The great hall of the hospital is a magnificent room, second only to that of Westminster. Christ's hospital is essentially a classical institution, Latin and Greek being the basis of education; but, to satisfy the wants arising from the changed condition of society, the modern languages, drawing, science, \&c. are also taught. In 1683 the governors built a preparatory school at Hertford, where the children are trained till they are advanced enough to be transferred to the London school. The girls, however, remain here until their discharge. It can receive about 450 of both sexes. Many eminent persons have been educated at Christ's Hospital, such as Camden, Stillingfleet, Richardson, Coleridge, Lamb, Leigh Hunt, Pugin, Sir Lonis Cavagnari, Sir Henry S. Maine, Dr Gordon Hake, and others. In 1885 a scheme of reform received the sanction of the Education Department, according to which the hospital is to be transferred to the country (a site at Horsham was acquired in 1892 , the foundation of the new buildings laid by the Prince of Wales in 1897), and a larger number of girls admitted. The boys' boarding-school will have 700 pupils, the day-school 600 ; while a girls' boarding-school will accommodate 350 , and their day-school 400. See Annals of Christ's Hospital, by a 'Blue' (new ed. 1877).

Christ's Thorn. See JuJube, Paliurus.
Chromatic, in Music (from the name of one of the Greek tetrachords or scales), is applied to notes in a melodic progression which are raised or lowered by accidentals, without changing the key of the passage, and also to chords in which such notes occur. The chromatic scale is one proceeding by semitones alone. Much irregularity prevails in the method of writing such progressions. The most strictly correct practice is to write only such chromatic notes as could occur in chords belonging to the key in which the passage is written.

Chromatic, in Opties, is that part of the science which deals with the colours of light and of bodies. See Achromatism, Colour.

Chromatophores are pigment cells (see PigMENTS) containing pigment granules of various colours, which enable animals such as chamæleons and cuttle-fishes to change colour rapidly.

Chromatype is a photographic picture in which the paper employed has been sensitized by some of the salts of chromium.

Chromium (sym. Cr, atom. weight, 52.5 ) is a metal, so called (chröma, 'colour') from the manycoloured compounds it produces. It was discovered by Vauquelin in 1797, in the chromate of lead, $\mathrm{PbCrO}_{4}$, one of its rarer ores. As chrome iron ore, $\mathrm{FeOCr}_{2} \mathrm{O}_{3}$, it is extensively distributed in America, Sweden, Hungary, \&c.

The metal has been obtained in several modifications, one of which is so refractory as to be infusible at a temperature sufficient to volatilise platinum, while it may be heated to redness without oxidation, and resists the action of most acids. Another variety is a powder which burns brilliantly when heated in air, and is readily dissolved by acids. The metal itself has not been employed in the arts, but many of the chromates are much used in painting and colouring. It has of late years been found useful for combining with the iron of projectiles. Chromium forms four compounds with oxygen, of which the chief are chromic oxide, $\mathrm{Cr}_{2} \mathrm{O}_{3}$, and chromic acid, $\mathrm{CrO}_{3}$.

Chromic oxide (chrome green) possesses a brightgreen colour, and is the colouring ingredient in the emerald. Owing to its indestructibility by heat, it is used in porcelain-painting; while, being nonpoisonous, it is now substituted for arsenical green pigments in wall-papers.

Chromic acid or anhydride, $\mathrm{CrO}_{3}$, forms darkred crystals, containing no water. When strongly heated it becomes incandescent, and is converted into chromic oxide. It forms several classes of salts : the Chromates, such as chromate of lead, $\mathrm{PbCrO}_{4}$; the Bichromates, of which bichromate of potash, $\mathrm{K}_{2} \mathrm{Cr}_{2} \mathrm{O}_{7}$, or $\mathrm{K}_{2} \mathrm{O}_{2} \mathrm{CrO}_{3}$, is an example; and the trichromates and tetrachromates, which are unimportant.

Chromate of Lead, $\mathrm{PbCrO}_{4}$, is well known to artists as 'chrome yellow.' It is readily prepared by mixing a solution of acetate of lead with one of chromate of potash. When boiled with lime, its bright-yellow colour disappears, and a scarlet basic chromate is obtained, which is used in the dyeing of calico.

Bichromate of Potash, $\mathrm{K}_{2} \mathrm{Cr}_{2} \mathrm{O}_{7}$, is prepared from chrome ironstone, by calcination with chalk and carbonate of potash, and subsequent treatment with nitric acid. It forms large red crystals, and has many uses in the arts. When added to a solu. tion of gelatine and allowed to dry, it is found that on exposure to light the gelatin becomes insoluble, and a process based on this property has been used to some extent in photography. As an oxidising agent in galvanic batteries it is very effective, while mixed with sulphuric acid it is used in the bleaching of oils.

Chromic acid and its salts are all more or less 
puisonous, owing to their corrosive and oxidising fution on organic tissues. Chrome Steel containing a small percentage of chromium is valued for its toughness and strength; and chromium is now generally used with iron for projectiles.

Chromo-lithograph. See LithogmapHy. Chromosphere. See SUN.

Chronicle (Gr. chronos, 'time') denotes a history in which events are treated in the order of time. A chronicle is understood to differ from annals in being more connected and full, the latter merely recording individual oceurrences under the succesaive years or other dates. Most of our older histories were called chronicles, such as the Saxon. Chronicle, Holinshed's Chronicle, Baker's Chronicle. The name is also given to two historical books of the Old Testament, and is not infrequently in modern days adopted by a newspaper, as the Morn. ing Chronicle.

Chronicles, The First and Second Books OF THE, an historical work standing in the third part of the Hebrew canon, and recapitulating the history of 2d Samuel and the Books of Kings, with many omissions, and many additions, genealogical and other. The Hebrew name means 'events of the days;' the Septuagint entitles it Paraleipomena ('things passed over'); Eusebius called it a 'Chronicon of the whole divine history'-whence its present name. First and Second Chronicles are one book, - of which Ezra and Nehemiah are continuations. The last three verses of $2 d$ Chronicles are the first three of Ezra, only the last verse of Chronicles ends in the middle of a sentence, which is com pleted in Ezra, i. 3. In contrast to the older histories, which were written from the prophetie standpoint, Chronicles shows a strongly Levitical tendency. Most modern scholars hold its date to be about 330 B.C. or later, at the beginning of the Greek supremacy in Asia. The most useful commentaries are by Bertheau (2d ed. 1873) and Keil (1870). See Bible.

Chronogram, or Chronograph (Gr. chronos, 'time,' gramma, 'a letter,' or grapho, 'I write'), a whimsical device of the later Romans, resuscitated during the Renaissance period, by which a date is given by selecting certain letters amongst those which form an inscription, and printing them larger than the others. The principle will be understood from the following example, made from the name of George Villiers, first Duke of Bucking. ham :

\section{GEORGIVS DVX BVCKINGAMIA.}

The date MDCXVVVIII (1628) is that of the year in which the Duke was murdered by Felton at Portsmouth. Another well-known example conveys the date in the inscription upon a medal struck by Gustavus Adolphus in 1632 :

\section{CHRISTVS DVX; ERGO TRIVMPHVS.}

See collections by Hilton (1882, 1885, and 1896).

Chronograph ('time-marker' or 'recorder '), an instrument to note, within a certain fraction of a second, the instant when a particular event oceurs. The most recent are electrical, now indispensable to astronomers, since the transit of a star can, by touching a stud, be noted to within roth of a second of time. The typical form of the chrono. graph is a cylinder which revolves once a minute, and earries on its surface a sheet of peper divided all round into equal parts, indicating fractions of a second. If, for example, the cylinder is 30 inches round, it is evident that very minute subdivisions of time are attainable.

A valuable application of the chronograph is for determining the longitude-e.g. in trigonometrical gurveys. Thus two observers note simultaneously the transit of a star, say at Vienna and Paris (and that without any reference to riglit ascension or declination), and having telegraph as well as chronograph, determine very ensily the difference of time with an accuracy never dreamt of formerly.

Benson's chronograph, by a lever movement, measures intervals of time down to tenths of a second for use at horse-races, \&c. By a special con. trivance the seconds hand on a horizontal dial carrien ink, and marks the plate beneath at the instant wher a string is pulled. Another mode of recording the exact instant of start or finish is by having a paper travel under a pencil, so that when the latter is preased a mark is made on or near one of the croes lines showing tenths or twelfths of a second.

Other forms of the chronograph are used for determining the velocity of projectiles. The most general arrangement consists in causing the bullet to pass through a series of sereens; the rupture of each screen breaks for a moment the continuity of an electric current, sets in action an electro-magnetic apparatus, and makes a permanent mark or record.

Chronology (Gr., 'time-reckoning'), the science of time, especially in regard to (1) the occurrence, recurrence, and succession of events, or (2) the duration of periods and cycles. The immense array of facts with which chronology is occupied may be distributed under two great heads-Mathematical or Astronomical Chronology, and Technical or Political Chronology. The former deals with celestial phenomena, their order and the laws of their occurrence and duration, events outside of man's sphere or influence. The latter branch deals with the whole history of our race upon this planet; and by the selection of certain fixed points in time called Epochs, refers to each of them the succession of social and political events occurring in the period immediately following it, and reckoned from it, which we term its Era. As soon as the elements of mathematical chronology were under. stood, political chronology had solid ground to build upon, and assume a systematic form: then a science of history became possible. A 'year,' for example, seems now an easy and natural unit of time-mersurement; but for long ages the only idea surgested by the word was that of a vague, intangible period. So late even as 450 B.C. we find Herodotus expressing duration of time by the phrase 'three generations' ( $=\mathbf{a}$ century) or 'five generations;' and in all languages we find 'six summers' or 'sixty winters' instead of 80 many years.

In the rudimentary stage of chrouology, a nation referred its history to the lifetime of some central figure, such as the king, the tribal chieftain, \&c.; of which custom we actually find a survival in our system of dating acts of parliament. The priestess of Juno at Argos was another instance; and in the Roman and Athenian republics, where the chiefmagistrates were chosen annually, an event was conveniently said to have occurred "when Plancus was consul," or ' in the archonship of Kallixenos.' Similar to the Roman consul and the Athenian archon was the Assyrian limu or 'eponym,' from whose name Babylonian and Assyrian documents were dated far more frequently than from that of the reigning king. Such a chronology, however, could only he of use within narrow limits inth of time and place; and at all the great centres of civilisation we find that as men's historical views widened with the national growth, they began to invent eras, some from national or political motives, others ecelesiastical, and a few seientific. Progress in astronomy, such as wo find in China and Babylonis at the dawn of history, was of notable service at this stage. To the Accadians of the latter country indeed both astronomical and political chronology owe \& lasting debt of gratitude. The Chinese, no doubt, show a 
time computation which is apparently prehistoric, and their recorded eclipse observations prove a chronology of at least four thousand seven hundred years' duration; but if they did adopt a year measurement equivalent to our Julian system some 2000 B.C., it is certain they have exerted no influence on European civilisation compared with that of the Accadians of Babylonia, or ancient Chaldeans as they used to be named. Fairly accurate chronology in ancient Babylon begins with Sargon I., king of Agade, 3800 B.C. The earliest authentic date is that inscribed on the foundation stone of the temple to the sun-god at Sippara by Naram-Sin, son of Sargon. This was dug up by Nabonidus, who began to reign over Babylon about 554 B.C., and who says that NaramSin reigned 3200 years before his time, thus giving a total of 3754 years B.C. as the date of his building of the temple. Thus by the year 4000 B.c. the nation had attained to considerable advance in literature, science, and art. Much of the greatness of Babylonia, foremost in culture for centuries, was afterwards reflected in Assyria, who inherited her civilisation and learning, as in a lesser degree also did Israel. Berosus gives a list of dynasties of 120 saroi, or 432,000 years before the Deluge, and of eight dynasties after it, and Ptolemy's canon in the Almagest gives the seventh dynasty in full from Nabonassar ( 747 B.C.) to Sinelladanos (Assur-bani-pal, 668-626). From about 2330 B.c. they used a regular calendar, with a week of seven days, and a year of twelve months, named after the zodiacal signs. Their year was of three hundred and sixty days, which probably suggested that division of all circles into degrees which we have derived from them. In astronomical chronology they had cycles of sixty years, six hundred years, and the sar (= 3600 years) - the factor sixty running through all their arithmetic. The great Babylonian work on astronomy and astrology was the 'Observations of Bel,' compiled at Acead for Sargon, and translated into Greek by Berosus. It was mostly a record of eclipses of the sun and moon, conjunctions and phases of Venus and Mars, the time of the new year, the names of the zodiacal signs and the divisions of the year. The famous Assyrian eponym canon, discovered by Sir Henry Rawlinson in 1862, fixes definitely for us the chronology of Assyria from 1330 B.C. to about 620 B.C. ; but a fairly accurate list of kings can be made out up to perhaps 1700 B.C. Thus continuing that early pre-Semitic civilisation, the more warlike Assyrians furnish many dates of importance-e.g. 720 B.C., Sargon conquered Arabia and Syria, levying contributions from Cyprus ; 705 B.C., Sennacherib conquered Phonicia and Egypt, carrying away two hundred thousand Jews; 681 B.C., building of the great palace at Nineveh, where afterwards, during the golden age of the Assyrian empire, ruled great Assur-bani-pal (long called Sardanapalus), the brilliant patron of art and letters. The discovery, in our time, of his national library almost compensates the literary world for the loss of that of Alexandria. See Babylonia, Assyria.

To the Chaldean astronomy we owe the Saros, a cycle of two hundred and twenty-three lunations, which is still of signal importance in calculating eclipses. To it also is due the era of Nabonassar, one of the most famous in the annals of chronology, the basis of all the computations of Ptolemy, and frequently referred to both by historical and astronomical writers - e.g. in connection both with Alexander the Great and Aristotle. From its epoch, 26th February 747 B.C., it maintained its ground till after the commencement of the vulgar era. In the same century, singularly enough, occur the epochs of two other eras which, though of less note in astronomical chronology, are much more familiar to historical readers-viz. the Greek era of the Olympiads, reckoned from 1st July 776 B.C., and the Roman era of the Founding of the City (A.U.C.) from $22 d$ April 753 B.C. The public games at Olympia formed an essential part of the national life to a Greek; and thus we find Xenophon refer an event to the year when Eubotas of Cyrene won the foot-race, just as in some parts of England a man will be heard saying 'Ah! that was the year Friar Tuck won the Derby!' The Olympic Games were of unknown antiquity, but the era or first Olympiad dates from the year when Corcebus was victor. Extending over a period of four years, the Olympiad (q.v.) was really a small cycle; thus the year 729 B.C. is expressed in Greek chronology as the third year of the twelfth Olympiad. The Latin epoch, the Founding of Rome, is not so accurately known as that of the Greeks; but the date assigned by Varro (753 B.C.) was accepted by Cicero and Pliny, and has been generally adopted by modern historians. Cato's date (751 B.C.) deserves note, from its use both by Livy and Dionysius of Halicarnassus : 750 was that of Polybius. Nor must we forget that all Latin writers, and many Greeks also, dated an event by naming the Roman consuls of the year. Under the empire, in 312 A.D., Constantine introduced the cycle of fifteen years, called Indiction (q.v.), of which, as an official mode of computation, there still remained some survival in France at the end of the 15th century. The old Roman era, however, as well as the Grecian, maintained some footing till after the birth of Christ; and the latter has even been traced to 440 A.D. = 304th Olympiad.

The Greeks had the honour of inventing the Metonic cycle (commencing 15th July 432 B.C.) of 235 lunations $=19$ years, and also the Calippic of 76 years. Like the Chaldean saros, both of these cycles were used to predict new moons, eclipses, \&c.

Of the Hindu or Egyptian eras there is little that affects the science of chronology. The antiquity of the Indian epics is a question purely literary; and the only epochs to record here are the descent of the Aryans on the Punjab about 2000 B.C. ; the Council of 543 B. C., which inaugurated the Buddhist era, and that of 309 B.C., when Buddhism (q.v.) became the state religion. The Indian chronology has some affinity to the Chinese; and a singular refinement in their mode of computing time was their use of the sidereal year-i.e. reckoning by the return of a meridian to the same star (see YEAR). The Egyptians, on the contrary, though their year began with the rising of the star Sirius, called a year 365 days exactly, and were, therefore, compelled to use a cycle of 1461 years $(=4 \times 365+1)$, a most cumbrous adjustment, though simple. The week of seven days was from earliest time adopted by the Brahmins in India, and the ancient Egyptians, as well as by the Accad settlers of Babylonia already referred to.

The Jewish chronology is unimportant except from its relation to religions matters, and scarcely affords examples of any era, since sacred chronology, as it is called, is only partially based upon the Pentateuch. What knowledge of astronomical chronology the Jews had was derived from the ancient Chaldeans through the Assyrians, and their calendar was mainly Egyptian. Their year, like that of the ancient Greeks and modern Turks, consisted of twelve months of alternately thirty and twenty-nine days (or twenty-nine and a half on an average-i.e. a lunation), with an intercalary month once in three years, and sometimes once in two. One peculiarity of the Jewish calendar was that they divided their year into six seasons-seed-time, 
winter, cold season, harvest, summer, and hot Beason-an arrangement due probably to their climatic surroundings. Leaving Egypt ciroe 1320 B.C. (so Bunsen, following Eratosthenes; others give 1330 ), the Jews showed some signs of national vigour in the 12th century B.C. on the decay of the Egyptian empire, and their history reached a short culnination in the reign of Solomon. When split into two small kingdoms they soon found that, although assisted by Syris and their more civilised neighbours the confederation of the Phonician cities, they were of but little avail against the might of Assyria. By the siege of Samaria in 721 B.C., and that of Jerusalem in 687 B.C., the little kingdoms of Israel and Judah were successively overthrown, and the Jewish nation finally shattered. Having no national chronology, the Jews who returned to Palestine are found using the Macedonian era, which dates from 311 B.C., the reign of Seleucus, one of the successors of Alexancler the Great. This they did in common with the Syrians and Greeks all round the Levant, and reckoned by it till the 15th century, as some Arabians are said still to do. At present the Jews, as also the Freemasons, profess to date their calendar from the 'Creation,' 3760 years B.C.

Sacred chronology, or that of Seripture, is an attempt to harmonise the suecession of events recorded in the Old Testament, especially with reference to the semi-traditional or prehistoric period preceding the Exodus, There are three accounts - the Jewish, the Samaritan, and the Greek Septuagint - and their discrepancies, though referring to the same periods and succession of events, are hopelessly irreconcilable. Sacred chronology divides all time before the birth of Jesus Christ into three great periods (as in the following table); and as to the first all the texts are at variance, while in the middle period the Septuagint agrees with the Samaritan, but both differ from the Jewish reckoning by 650 years :

\begin{tabular}{|c|c|c|c|}
\hline Period. & Jewiah. & Samarit. & Beptrang't. \\
\hline $\begin{array}{l}\text { Adam to Noah ............ } \\
\text { Noah to Abraham... }\end{array}$ & $\begin{array}{r}1656 \\
292\end{array}$ & $\begin{array}{r}1807 \\
942\end{array}$ & $\begin{array}{r}2242 \\
942\end{array}$ \\
\hline Abraham to Jesus Christ. & 2044 & 2044 & 2044 \\
\hline Oreation to Incarnation. & 3992 & 4298 & 6828 \\
\hline
\end{tabular}

The three authorities, therefore, entirely disagree as to the total period. To complicate the confusion, all those results are given differently by different interpreters; and no less than over two hundred varying computations have been made as to the date of the ereation, ranging from 3483 years to 6984. The familiar date in English books was 4004, following Arehbishop Usher's reckoning. At last it became clear through seience that man's duty is to strive to interpret uature, and to shrink from assigning any limit to her works as to either beginning or ending. The Newtonian chronology was an attempt (published posthu. mously be it remembered) to rectify some of the discrepancies in sacred and profane history, by combining a eritical examination of authors wit astronomical calculations. For example, the famous date of the Argonantic expedition was, by an ingenious application of the precession of the equinoxes, assigned by Newton to forty-three years after the death of Solomon, or 937 B.C. (Hales), a date utterly inadmissible. For the expedition, if indeed it ever took place, must have preceded the siege of Troy, which is ascribed to 1184 B.C.

The Hegira (Hedjrah) or epoch of the Moslem era is dated Friday, 15th July 622, the New.year's Day of the Arabian year, or, as others say, from the 16th. The Mohammedan year being strictly lunar-from the primitive reckoning by months instead of years - the calendar requires several adjustments from time to time ly means of tables arranged aceording to cycles of thirty years, of which nineteen have 354 days and the others 355. The principal festivals of the Moslems are the New-year, the birth of the Prophet, the taking of Constantinople, and the Grand Bairam (q.v.).

From these minor systems of chronology we at once pass to that of our present era, which, though begun as it were accidentally, unenforced by the authority and command of emperors, kings, or councils, seems destined soon to assert univensal predominance. The Christian era (or 'vulgar era' as older writens termed it) has its epoch or point of departure determined by the Gregorian ruleviz.: The years are denominated as years current from the midnight between the 31at December and the lst of January immediately subsequent to the birth of Christ, according to the ehronological determination of the event by Dionysius Exiguus.' Now as Dionysius, the obscure author of this chronological scheme, lived in the beginning of the 6th century, there was no exact determination of the epoch; and it cannot therefore be so precisely formulated as other eras of less importance. It is generally agreed that the beginning of the era should have been fixed from two to four years earlier. Another point not generally noted is that the correction of our calendar by Pope Gregory itself wanted correction because instead of ten days the papal bull should have enjoined an omission of twelve. His Holiness or some adviser proposed the Council of Nice as their starting-point in estimating the error already made, and reckoned therefore from lst January 325 A.D. instead of lat January 1 A.D. The only wonder is that his astronomers assented. It may further be pointed out that the papal reformation itself is by no means the best that could have been devised; and that long before that date, in 1079 A.D., Omar, a Persian astronomer, actually proposed a scheme which would adjust the years and days not only more exactly, but much more simply. Omar's rule, shortly, was: (1) Intercalate a day every fourth year, but (2) intercalate during the thirty. third year instead of the thirty-second. By this scheme five thousand yeans must elapse before a further correction is made-viz. of one day, whereas by Gregory's rule a correction of three days is necessary within four thousand years. In this connection may be noted the extremely ingenious mode by which the new style was adopted in Sweden-viz. by deciding to have no leap-years between 1696 and 1744 .

From the mode of fixing the epoch of the existing era as indicated above, it is manifest that, since there is no 0 A.D. and no 0 B.C., we must diminish the sum of the nominal years B.C. and A.D. by unity to find the interval. Thus the years between lst January 753 B.C. and 1st January 1888 A.D. are not 2641 but 2640 . The epoch 1st January 1 A.D. was first, as we have seen, established by measuring backwards according to the estimate of Dionysius Exiguns in 527 A.D.; and when measured forwards from other epochs we find that our era dates from lst January of the fourth year of the 194th Olympiad $=753 \mathrm{~A} . \mathrm{V} . \mathrm{C} .=4714$ of the Julian period.

That brings our subject to an era, which, theoretically at least, is the most important in the science of chronology. The epoch of our existing era is not well suited for technical purposes, as all astronomers and chronologists allow, becanse the birth of Christ is too recent an event; thus enhancing the difficulty of fixing the relation between the different systems, and of expressing a date or period of one era exactly in terms of 
another. Therefore, just as Fahrenheit chose for his zero a mark thirty-two degrees below freezing-point, in order to avoid negative measurements, so the Julian period had its epoch fixed to Ist January 4713 B.C., a point of time antecedent to all other epochs, in order that its era should be a convenient standard to which all other chronological systems can be differentially referred. Its length is 7980 Julian or Metonic years, the product of 28 (Solar period), 19 (Lunar period), and 15 (Indiction), and thus constitutes a great cycle embracing and unifying three subordinate cycles which are constantly referred to; because the year 4713 B.c. is the most recent date when those important periods began exactly all together. With the further development of technical chronology, and a more scientific treatment of history and ethnology, we may look for a much wider use and appreciation of the Julian period as a cyele comprehending all really historic time, and fulfilling certain astronomical conditions of the first importance. When the year of the Julian period is known, the corresponding date for any of the subordinate cycles is easily found, and conversely. We subjoin a table for the comparison of some selected dates :

EPOCHS AND LEADING EVENTS IN CHRONOLOGY REFERRED TO THE JULIAN PERIOD.

\begin{tabular}{|c|c|c|c|}
\hline \multirow{4}{*}{ 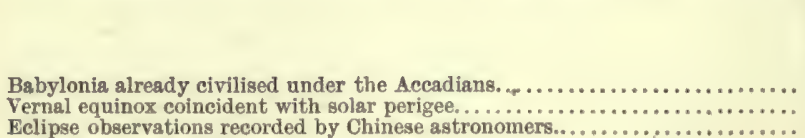 } & \multicolumn{2}{|c|}{ Julian Perlod. } & \multirow{2}{*}{\begin{tabular}{|r|} 
Common Date. \\
B.C. \\
4713
\end{tabular}} \\
\hline & Month. & Year. & \\
\hline & March 21 & 625 & 4089 \\
\hline & $\ldots .$. & 1864 & 2850 \\
\hline 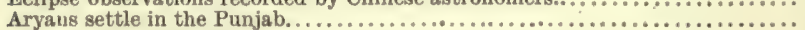 & $\because \cdots$ & 2714 & c. 2000 \\
\hline Palace built in Nineveh................. & & 3364 & 1350 \\
\hline 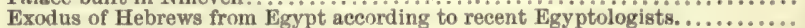 & & 3894 & 1320 \\
\hline 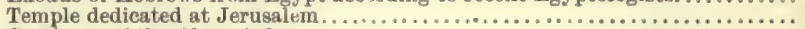 & May & 3698 & 1015 \\
\hline 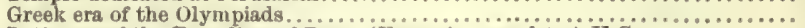 & July & 8938 & 776 \\
\hline 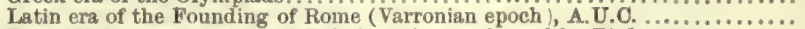 & April 22 & 3961 & 758 \\
\hline Era of Nabonassar, prince of Babylon, the epoch used by Ptolemy............ & Feb. 26 & 3967 & 747 \\
\hline Assur-bani-pal king-golden age of Assyria $\ldots \ldots \ldots \ldots \ldots \ldots \ldots \ldots \ldots$ & & 4046 & 668 \\
\hline 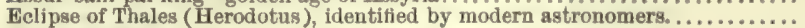 & May & 4129 & 585 \\
\hline Era ${ }^{\prime}$ Buddha. . . & & 4171 & 543 \\
\hline 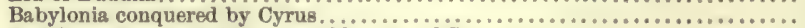 & July & 4176 & 538 \\
\hline 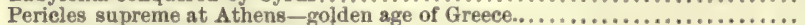 & & 4270 & 444 \\
\hline Metonic Cycle (astronomical epoch). & July & 4282 & 432 \\
\hline Reformation of the calendar by Julius Caesar. . . . . . . . . . . . . . . . . . . . . . . . & Jan. & 4660 & 45 \\
\hline Dionysian or Christian era-epoch not proposed till 527 A.D...... & Jan. & 4714 & i \\
\hline Hegira, the flight of Mohammed-epoch of the Moslem era. & July & 5335 & 622 \\
\hline 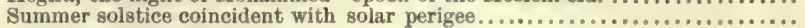 & June 21 & 5959 & 1246 \\
\hline 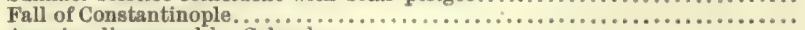 & May 29 & 6166 & 1453 \\
\hline 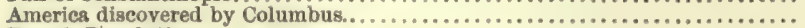 & Oct. & 6205 & 1492 \\
\hline 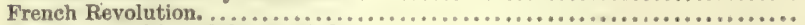 & July & 6502 & 1789 \\
\hline Completion of first julian period & Dec. & 7980 & 3267 \\
\hline 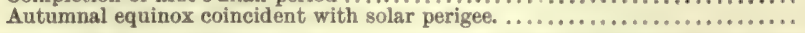 & Sept. 21 & 11196 & 6488 \\
\hline
\end{tabular}

The Julian period or cycle in its modern form was proposed by Joseph Scaliger, but the Greeks of Constantinople appear to be the authors of it. Its exact epoch is noon of 1st January 4713 B.C. for the meridian of Alexandria, which was chosen as being that to which Ptolemy had referred the era of Nabonassar already discussed. Sealiger has the best right to the title of father of chronology, often given to Eratosthenes.

The astronomer Laplace in recent times proposed another universal era not so practical in its bearing on political chronology. He calculated that about 4000 years B.C. the major axis of the earth's orbit coincided with the line of the equinoxes, and that in $1250 \mathrm{~A} . \mathrm{D}$. they were at right angles. In the latter year, therefore, he proposed to fix the universal epoch whence the whole world should reckon, the vernal equinox to be the first day of the first year, when the solar perigee coincided with the summer solstice. With Laplace's estimate may be compared the dates of coincidence with the solar perigee which are tabulated above.

There are many other instances of astronomical chronology overlapping and influeneing politieal chronology. Thus, by reckoning back we are able to identify the time and place of some remarkable eclipses, such as that of Thales (see in table above), which caused the suspension of a battle between the Medes and Persians. Another striking verification was by that of Larissa, the Nimroud of Mr Layard. Scottish history furnishes another recent instance. We read that when King Haco sailed from Bergen with his Norse fleet to punish the king of Scotland, he put in at Ronaldsvoe in Orkney, which was then subject to him, and that there the sun appeared as a thin bright ring. Sir David Brewster found by computation that there was an annular eclipse of the sun passing over Orkney on 5th August 1263, about one o'clock. Two months afterwards Haco was defeated at Largs, and Alexander annexed the Hebrides to Scotland. 'The ring at Ronaldsvoe was an evil portent.' Such verifications in chronology are dependent on the testimony of contemporary writers. Other valuable information has been derived from coins, medals, monuments, and inscriptions.

To treat adequately many of the important ramifications of our subject is here impossible, and we have therefore only passed under review the main features of the science as a whole. One department, however, of political or technical chronology deserves special attention from its interest to antiquaries and lawyers as well as to historiansviz. the method of assigning events to their respective years, or fixing their dates as it is called, either by verifying in cases of doubt, or reconciling and correcting in cases of discrepancy, inconsistency, and contradiction. How, for example, can the following dates be accounted for-all printed in the same month of the same year, 1705? In the London Gazette of 13th February is given a trans. lation of which there is an abridgment in the Edinburgh Courant of the 19th, yet the original passage is in the Amsterdam Gazette, dated $22 \mathrm{~d}$ February.

The first cause of such discrepancies is the difference of styles (see CALENDAR), which occasions seeming blunders of ten, eleven, or twelve days, according to the century. As 170 years elapsed before England adopted the new style, the chief Roman Catholic countries being followed by Poland (1586), Hungary (1587), Strasburg (1682), German Protestant States (1700), and Tuscany (1749 or 1751), all in different years, there was ample 
room left for innumerable discrepancies as to daten.

Besides differing in the atyle-i.e. Julian or Gregorian - two nations frequently began the year at different times. A Scottish writer assigned the execution of Charles I. to 1649, and his English contemporary to 1648 , though both agreeing as to the month and day; because in Seotland the year hegan with the lst of Jamury, as it hul done since 1600, and in England the 25tli March was still New. year's Day. Throughout Europe there was much variation in this respect, not only between one country and another, but even in the same country as between one time and another, as well as between its different provinces at the same time. The most common New-year's Days were these four- $(\alpha) 25$ th December; (b) 25th March; (c) Easter; (d) lst January. Thus England used both the first and second from the 6th century to 1066 ; the fourth till 1155; then the second till the day after 31st December 1751, which was called lst January 1752. Scotland used the second till 1599, when the day after 31st December 1599 was called 1st January 1600. France under Charlemagne used the first, and afterwards also the third and second till 1563. The 25th March was originally chosen by Dionysius Exiguus, the anthor of our present era, as being the Annunciation-exactly nine months before Christmas. A survival of its use in Encland appears in the annual Treasury accounts, and in preserving Lady-day as a quarter-day.

In many English documents before 2d September 1752, owing to the delay in accepting the Gregorian reformation, we find a date thus, 12 th February $170 \frac{6}{7}$ or 1706-7, meaning 1706 if the year begin on 25th March, or 1707 if it begin on the lat of January. This ambiguity of course only applies to days falling between 1st January and 24th March.

A third cause of error or uncertainty arose from dating ancient writings not only by saints' days and church festivals, but by some Latin psaln or other portion of the service which the clergy (who of course were generally the clerks) associated with the day in question. Thus we find as a date (15th century) 'the Wednesday next after Deus qui errantibus,' and (in 1610) 'the Sunday on which the church sings Reddite quae sunt Casaris Ccesari." A Scottish parliament of 1318 met at Scone 'on the Sunday next after the feast of St Andrew the A postle; ' and an English one of 1399 is only dated in a contemporary account by the phrase "on Monday the feast of St Faith the Virgin.'

A special complication arose from dating documents, and especially all state papers, by the year of the king's reign, as already referred to. Even in Rymer's Fodera, a work of the highest importance in English chronology, we find that from this cause many of the public papers from Richard I. to Edward IV. are misdated by a whole year. Our early sovereigns dated their reign from the coronation, and the writers of history frequently assumed that every king's succession was officially dated from the day of his predecessor's death. In the case of popes of Rome, moreover, scarcely any two of them in immediate succession, until recent times, dated or computed on the same principle; and some of them vary their methods even within their own reigns. In this connection may be noted a clerical error in the Scottish records of David II., where after his return from captivity every date of his reign is given one year short. Frequently too in publie documents, both English and Scottish, we read 'King Henry,' 'King Edward,' 'King Robert,' or 'King James,' without further qualification; so that for purposes of ehronology we must study the penmanship, the style and wording, the seal, and above all the names of the persons enumerated. Even then the antiquary or historian is sometimes unable to reduce the date of an instrument or letter within a narrower range than fifty or even a hundred years.

A reference to contemporary history will sometimes fix the date. For example, there are two acts in the Scottish statute-book which are thus dated-one, 'at Aberdeen in Lent next after the coming in Scotland of Vivian the Legate of the Apostolic See;' the other, at Stirling, 'on the Monday next before the feast of St Margaret the Maiden next after the first coronation of Philip king of the French.' From these data we can assign their dates as 1177 and 1130 respectively.

Biblingraphy.-Scaliger's De Eimendatiune Temprom (1583): Usher's Annales $\boldsymbol{V}$. and $\boldsymbol{N}$. Tentamenti $(1650)$; Sir I. Nowton's Chronolugy Amended (1728); L'Art de Vérifier les Dates (1818-31); Herschel's Astronomy; Ideler's Lehrbuch (1831); Clinton's Fasti, dec.; Chron. ology of History, by Sir Harris Nicolns (1838); Brinekmann's Handbuch (1882); Woodward and Cates's Encyclopredia of Chronology (1872); Whitworth's Churchman's Almanac from 1201 to 2000 (1883); Brockmann's System der Chronologie (1883); James C. Macdonald's Chronologies and Calendars (1897).

Chronometer, a time-keeper for determining the longitude at sea, is essentially a large watch with compensated balance-wheel. See HoroLogy.

Chrononhotonthologos was a burlesque by Henry Carey (q.v.), in which Aldeborontephoseophornio and Rigdumfunnidos were characters.

Chronoscope, an instrument contrived by Sir Charles Wheatstone to measure the duration of certain short-lived luminous phenomena, such as the velocity of light, or the electric spark, of which the eye itself can be no judge, owing to the persistence of impressions on the eye after the cause of sensation has ceased. The phenomenon is observed by reflection in a mirror in such rapid motion that the inage of the luminous object would appear to describe a circular are the length of which must be a measure of the duration of the light. The electric spark is found by this test to have no duration, because it image in the mirror is a mere point. The chronoscope has also been used for measuring the time of flight of projectiles. By means of it Foucault even determined the difference of the velocity of light when passing through air and water, and thus deduced the corresponding indices of refraction.

Chrudim, a town of Bohemia, 74 miles ESE. of Prague by rail. It manufactures sugar, beer, alcohol, and artificial manure, and has important horse-markets. Pop. 12,128, mostly Czechs.

Chrysalis, or CHRYSALID, a term originally applied to the golden-coloured resting stages in the life-history of many butterflies, but sonietines ex. tended to all forms of pupre or nymphs-that is, to the second stages in the history of insects which undergo complete metamorphosis. It is the stage which results from the fasting quiescence of the generally active and voracious larva or caterpillar, and also, of course, the stage which after one or rarely two moults awakens into the winged insect or imago. During the whole or part of its often prolonged existence, the pupa or chrysalid is ex. ternally quiescent; but internally most profound structural changes are going on, which amount in many cases to a thorough reconstruction, and always result in the development of wings and sexual organs. Chrysalids vary greatly in degree and duration of quiescence, in habit, in the condition of their appendages, and in the development of external covering. The colours also vary greatly, and in some cases the golden or otherwise coloured appearance is doubtless protective. They are generally found hidden away in protected corners, or underground, or suspended from the leaves of plants. The completion of the internal 
reconstruction is soon followed by a writhing restlessness, in the course of which the chrysalis frees itself from encumbrances, and emerges

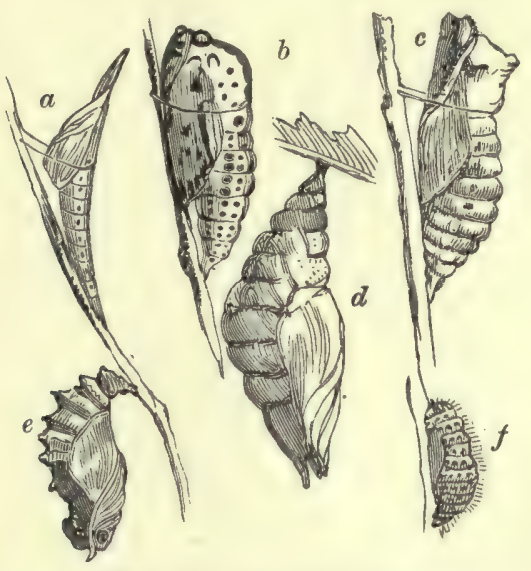

Various forms of Chrysalis :

$\boldsymbol{a}$, orange-tip butterfly ; $b$, black-veined white butterfly; $c$, swallowtailed butterfly ; $d$, purple emperor ; $e$, silver-washed fritillary; $f$, Duke of Burgundy fritillary.

into freedom and flight. Mr Poulton has made some exceedingly beautiful experiments on the effect of external surroundings on pupre, and has shown how gilded surroundings are associated with the appearance of gilded chrysalids. See Butterfly, Caterpillar, Insects, MetaMORPHOSIS.

Chrysan'themum (Gr., 'gold-flower'), a genus of plants of the natural order Compositæ, sub-order Corymbiferæ; having a hemispherical or nearly flat involucre, with imbricated scales, which are membraneous at the margin, a naked receptacle, the florets of the disc tubular and hermaphrodite, those of the ray strap-shaped and female, the fruit destitute of pappus. The species of this genus are annuals, perennials, or shrubby; and all have leafy stems. They are natives chiefly of the temperate parts of the Old World. C. leucanthemum, the Ox-eye, or Ox-eye Daisy, is abundant in fields, meadows, and grassy places of woods in Europe and North America. It has large flowers, with white ray and yellow disc. It is often a troublesome weed among hay and in pastures; being perennial, and having a creeping brittle root-stock, it is not easily extirpated. It is common in Britain, which has several other native species, $C$. segetum (Corn Marigold), a frequent weed in cornfields, which is an annual, with Iarge deep yellow flowers; $C$. inodorum (Scentless Chrysanthemum), an annual with erect branching habit, leaves like the camomile, and white flowers; and $C$. parthenium-Pyrethrum parthenium of some botanists-Common Feverfew, a perennial, probably originally spread from cultivation, but now at least apparently indigenous to a great part of Britain. Of the latter, the Golden Feather, so commonly used in designs in the flowergarden, and a compact free-flowering form with double flowers, are two useful and well-marked varieties. From $C$. inodorum has also recently evolved a variety with pure white double flowers, of great value to those who cater for cut flowers, the colour and form being desirable and the crop enormous. The Paris Daisy or Marguerites, which have recently become so popular as greenhouse and bedding plants, are forms of $C$. frutescens and C. pinnatifidum, the latter a native of Madeira, the former of the Canaries. The old-fashioned yellow and white chrysanthemum of our cottagegardens is $C$. corduarium, a native of Sicily and North Africa. C. carinatum, a pretty annual species from Barbary, is sometimes seen in gardens in this country treated as a tender annual. The most favoured speeies, however, with gardeners of this and other countries is $C$. sinense, sometimes also named $C$. indicum. It was introduced in 1764, and has increased in varieties immensely since then. In 1832 there were only about forty known; now they are to be reckoned by hun. dreds, and the num. bers are yearly being added to. Long before it was known in Europe the gardeners of China and Japan were enthusiastic cultivators of the flower; and it gives its name in the latter country to the highest order of honour-"The Order of the Golden Flower.' The colours are exceedingly various and beautiful, and the form of the flowerheads in some varieties is marked by the most perfect symmetry, while in others it assumes a medusa-like character, with numerous twisted thread-like florets of several inches in length. The circumstance that it may be had in flower dur. ing the late autumn months and far into winter, coupled with its profuse flowering

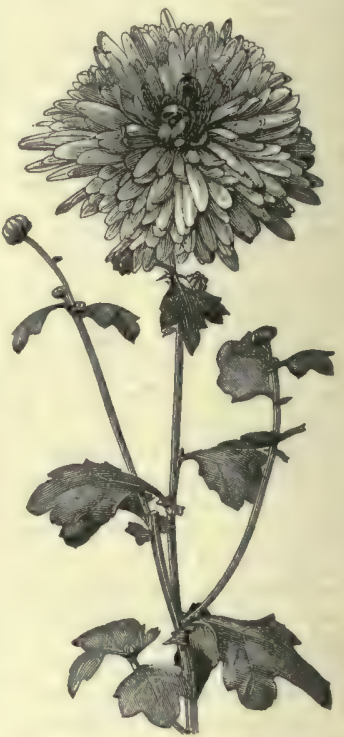

Yellow Chrysanthemum. quality and its simple cultural requirements, renders it a universal favourite. Cuttings are struck in November, December, and January. They require no heat, but merely protection from frost, and till they strike root they must be kept in a close case away from draught. The soil they delight in most is a rich loam, with decomposed manure, a third of the latter to two-thirds of the former. They should be placed out of doors from May till the time of killing autumnal frost, when they ought to be housed to protect them from freezing. See Burbidge, The Chrysanthemum: its History and Culture (1884).

Chryselephantine (Gr., from chrysos, 'gold,' and elephas, 'ivory'), the art of making statues jointly of gold and ivory, was extensively practised amongst the Greeks. It developed out of the art of wood-carving, the draperies of the wooden figures being gilded for ornament, while the faces, hands, \&c. were painted white. Then the uncovered parts of the body came to be made of marble, producing Acroliths (q.v.); and ultimately ivory was used, with gilding or gold-plating. The bulk of the figure continued to be made of wood, or wood and clay; thin gold plates were fastened over the parts intended to represent clothing, while on the fleshy parts small plates of ivory were skilfully laid. The colossal works exeeuted by Phidias in the time of Pericles are the most famous of this class, the greatest being the Athene on the Acropolis, which represented the goddess in armour, covered with a long robe, and the famous Olympian Zeus, executed in the same materials (see CoLossus). The combination of gold and ivory was chiefly used in statues of the gods; hence it was regarded as blameworthy arro- 
gance when the Macedonian kings had their family atatues made of chrysolephantine work. See SCULPTURE.

Chrysippus, an eminent Stoic philosopher, was born alnut 280 h.C., at soli in Cilicia. He came to Athens when still a youth, and devoted himaelf with ardour to philosophy. His principal master was Cleanthes, but he is said to have studied also under the aculemic teachers, Arcesilaus and Lacydes. He had the reputation of being the keenest disputant and best logician of his age, so much so that people used to say : "If the gods make une of dialectic, it can only be that of Chry. sippus.' Although he did not create a new system, and explained the physical universe like the rest of his school, in morals he modified the more ex. treme views of the earlier Stoics. Chrysippus seldom wrote less than 500 lines a day, and is said to have composed more than 700 works. Of these but a few fragments remain, which were edited by Petersen in 1827. See Zeller's great work on the history of Greek philosophy.

Chrysis ('golden-wasp'), a genus of hymenopterous insects, type of a family Chrysidre, with about 400 species. Their systematic position is not far from that of the true wasps. The French call them Guepes dorés ('gilded wasps'), and they sometimes receive the English names of Goldentailed and Ruby-tailed Flies. They delight in sunshine, and may be seen poised in the air-the motion of their wings being so rapid as to render the body alone of the insect visible.

Chrysobalanex, a sub-order of Rosacex (q.v.), presenting close affinities through Cæs. alpinere to Leguminoser. The 180 species are trees or shrubs, natives of tropical and subtropical America and Africa. The fruit of many is eatable, as the Cocoa Plum (q.v.) of the West Indies (Chrysobalanus). The kernels of some resemble sweet-almonds, notably those of Acia duleis, and other species of Guians. A useful oil is expressed from the seeds of Prinsepia utilis, a spiny Himalayan plant.

Chrysoberyl (Gr., 'golden beryl'), a gem almost as hard as sapphire, and the finer specimens of which are very beautiful, particularly those which exhibit an opalescent play of light. Lapidaries sometimes call it oriental or opalescent chrysolite. It is of a green colour, inclining to yellow, semi-transparent, or almost transparent, and has double refraction. It occurs crystallised in six-sided prisms; often in macles, or twin crystals. It is found oceasionally in granite, but more frequently in gneiss and mica-schist; sometimes it oceurs in sandstone or in alluvial soil derived from the disintegration of schistose rocks. Localities for its occurrence are the Ural Mountains, Ceylon, Pegu, Brazil, and Connecticut. It is composed of alumina, glueina, and small proportions of ferric oxide, titanic acid, and sesquioxide of chromium-the alumina being about 80 per cent. of the whole. The chrysoberyl of the ancients was a different mineral, probably the Chrysoprase (q.v.) of the moderns.

Chry socolla, an ore of Copper (q.v.).

Chrys'olite (Gr., 'golden-stone'), a mineral composed of silica, magnesia, and protoxide of iron; of a fine yellowish-green colour, with vitreous lustre; transparent, and having double refraction; in hardness, about equal to quartz; and with conchoidal fracture. It often erystallises in four-sided or six-sided prisms, variously modified. Very fine specimens are brought from Egypt and from some parts of the East, also from Brazil. Chrysolite is used by jewellers as an ornamental stone, but is not highly valued. Olivine, or com- mon chrysolite, is an important rock-forming mineral. It is dark yellowish-green in colour, and oceurs generally in somewhat rounded grains or corroded erystals in some igneous rocks, anch as the basalta. Occasionally large granular maseen, which may have a rectangular outline, are met with in lavas-some of them weighing as much as $30 \mathrm{lb}$.

Chrysolo'ras, MaNueL, the finst to transplant Greek literature into Italy, was born at Constantinople in the middle of the 14 th century A.D. About the year 1391 he was sent by the Byzantine eniperor, John Palreologus, to England and Italy to entreat assistance against the Turks, and in 1397 he left his native land and went to Florence, where, as teacher of Greek literature, he was highly esteemed and admired. Leonardo Bruno, Poggius, Philelphus, Guarinus of Verona, and other eminent scholars were among his pupils. He was afterwards employed by Pope Gregory XII. in an attempt to promote a union of the Greek with the Roman Church, and in 1413 went with John XXIII. to the Council of Constance, where he died 1415. His chief work was Erotemata, a Greek grammar (Venice, 1484). - Manuel Chrysoloras must be distinguished from his nephew, Јонк CHRYsoloras, who also taught Greek in Italy.

Chrysomela. See Colorado BeEtle.

Chrysophane, a medicament valued in the treatment of Psoriasis (q.v.), is derived from rhubarb and andira, with other herbs.

Chrysophyllum. See Star APPLE, SAPoTACEAE.

Chrysoprase is a valuable variety of chalce. dony, prized more highly as a precious stone on the Continent than in this country. It is of a fine leek or apple-green colour in choice specimens, but inferior ones exhibit other shades of green, and it is sometimes spotted with yellowish-brown. It is often set in a circlet of diamonds or pearls. Unfortunately, it is apt to lose its colour through time, particularly if kept in a warm place.

\section{Chrysops. See Cleg.}

Chrys'ostom, ST JoHN (Gr. Chrysostŏmos, 'golden-mouthed;' so named from the splendour of his eloquence), was born at Antioch about 347 A.D. His mother, Anthusa, was a pious woman, wholly devoted to her son, who grew up under her loving instructions into an earnest, gentle, and serious youth, passing through, as Neander siguificantly observes, none of those wild, dark struggles with sinful passions which left an ineffacenble impress on the soul of Augustine, and gave a sombre colouring to his whole theology. He studied oratory under the famous heathen rhetorician, Libanius, and began the eareer of an advocate; but, soon dissatisfied with this, he placed himself for three years under the instruction of Bishop Meletius, by whom in his twenty-third year he was baptised and ordained an anagnōstês or 'Reader.' After six years spent as a monk in the mountains near Antioch, an illness forced him to return in 380 to that eity, where he was ordained deacon by Bishop Meletius in 381, and presbyter by Bishop Flavianus in 386. The eloquence, earnestness, and practical tone of his preaching excited the attention of Jews, heathens, and heretics, and secured for him the reputation of the greatest orator of the ancient church. In 398 the Emperor Arcadius elevated him to the archiepiscopate of Constantinople. Chrysostom immediately began to restrict the expenditure in which his predecessors had indulged, and bestowed so large a portion of his revenues on hospitals and other charities that he gained the surname of 'John the Almoner.' He also endeavoured to reform the lives of the elergy, and 
sent monks as missionaries into Scythia, Persia, Palestine, and other lands. His faithful discharge of his duties, especially in reproof of vices, excited the enmity of the patriarch Theophilus and of the Empress Eudoxia, who succeeded in deposing and banishing him from the capital in 403. He was soon recalled, to be banished again in 404 . After a short stay at Nicæa, he was removed to the little town of Cucusus, in the desert parts of the Taurus Mountains, Even here his zeal was not abated. He laboured for the conversion of the Persians and Goths in the neighbourhood, and wrote the seventeen letters or rather moral essays to Olympias, to whom he also addressed a treatise on the proposition- 'None can hurt the man who will not hurt himself.' The intercession of Innocent I. of Rome and the Emperor Honorius only moved Areadius to order that he should be more remotely banished to Pityus on the Euxine, at the very verge of the Eastern Roman empire. Accordingly, the old man was made to travel on foot, and with his bare head exposed to a burning sun. This cruelty proved fatal. Chrysostom died on the way at Comana, in Pontus, September 14, 407 A.D., blessing God with his dying lips. A sect sprang up after his death called Johannists, who refused to acknowledge his successors; nor did they return to the general communion till 438, when the Archbishop Proclus prevailed on the Emperor Theodosius II. to bring back the body of the saint to Constantinople, where it was solemnly interred, the emperor himself publicly imploring the pardon of Heaven for the crime of his parents, Arcadius and Eudoxia. The Greek Church celebrates the festival of Chrysostom on the 13th of November; the Roman, on the 27th of January. St Chrysostom's works are very numerous, and consist of Homilies on parts of Scripture and points of doctrine; Commentaries on the whole Bible, part of which have perished; Epistles addressed to various people; Treatises on different subjects, such as Providence, the Priesthood, and the like; and Liturgies. Of these the most valuable, as well as the most studied, are the Homilies, which are rightly held to be superior to everything of the kind in ancient Christian literature. Thomas Aquinas said he would not give in exchange those on St Matthew for the whole city of Paris. Here his exegesis is sound, practical, and very 'English," in Cardinal Newman's phrase. In general he rejects the allegorical system of interpretation, and adheres to the grammatical, basing his doctrines and sentiments on a rational apprehension of the letter of Seripture. He is, however, far from being a bibliolater. He recognised the presence of a human element in the Bible as well as a divine; and, instead of attempting by forced and artificial hypotheses to reconcile what he thought irreconcilable in Scripture statements, he frankly admitted the existence of contradictions, and shaped his theory of inspiration accordingly. But his greatest excellence lay in that power, springing from the fervour and holiness of his heart, by which the conseiences of the proud, the worldly, and the profligate were awakened, and all were made to feel the reality of the gospel message. The historian Sozomen says of hin, that he was 'mighty to speak and to convince, surpassing all the orators of his time.' The surname Chrysostom was first applied some time after his death, and is first found in Isidore of Seville, who died in 636 .

The best edition of St Chrysostom's works is that of Bernard de Montfaucon in 13 vols. folio (Paris, 1718-38; reprinted by the Abbé Migne, Paris, 1863), which was largely based on the splendid edition of Sir Henry Savile, printed at a cost of $£ 8000$ (Eton, 8 vols. 1613), 'the first work of learning on a great scale,' says Hallam, ' published in England.' Some of the Homilies are translated in the Oxford Library of the Fathers.

See the older church historians; and of. the moderns, especially Neander, both in his History and in his special book on St Chrysostom, translated by J. C. Stapleton (1838). See also Thierry, Chrysostom et l'Impératrice Eudoxie (2d ed. Paris, 1874); Newman's Historical Sketches (1873); W. R. W. Stephens, St Chrysostom: His Life and Times (1872); R. W. Busk, Life and Times of Chrysostom (1885); and F. H. Chase, Chrysostom (1887).

Chrysotype, a photographic process, the result being produced mainly by a solution of ehloride of gold. See PHOTOGRAPHY.

Chub (Leuciscus cephalus), a fish of the carp family Cyprinidæ, of the same genus with the roach, dace, bleak, minnow, \&c. The colour is bluish-black on the upper parts, passing into white on the belly ; the cheeks and gill-covers rich golden yellow. The weight rarely exceeds $5 \mathrm{lb}$. It is plentiful in the rivers of England, and occurs in some of those of the south-west of Scotland, in Europe, and in Asia Minor. It spawns in April

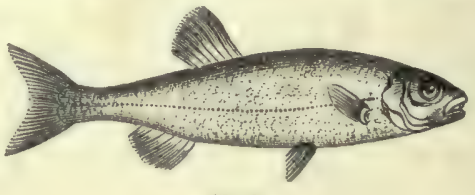

Chub.

and May, and comes into condition again by the end of June or early in July. It prefers rapid water and a clear bottom, and often hides in holes. Its diet is very mixed. It is not much esteemed for the table. The scales have been used for making false pearls. See PEARL. The common American chub is the Leucosomus rhotheus.

Chubb, Charles, locksmith, was patentee of several important improvements in 'detector' locks, originally patented by his brother, Jeremiah Chubb of Portsea, in 1818. He was in the hardware business at Winchester and Portsea previous to his settlement in London, where he died, 16th May 1845. Under his son and successor, John Chubb (1816-72), further patents were taken out and improvements made in locks and safes, and the business was greatly developed. See Lock.

Chubb, Thомas, an English deist, who wrote on religious questions during the first half of the 18th century, was born at East-Harnham near Salisbury in 1679 . His father, who had been a maltster, died early, consequently his children were poorly educated and early set to work. Thomas was first apprenticed to a glover in Salisbury, but his eyesight becoming weak, he became an assistant to a tallow-chandler, in which employment he died in 1747. He had already contrived to pick up considerable learning, when a perusal of the 'historical preface' to Whiston's Primitive Christianity Revived impelled him to write his own tract, The Supremacy of the Father Asserted, which Whiston helped him to publish in 1715. Encouraged by the patronage of Sir Joseph Jekyll and others, he continued to write, and a quarto volume of his tracts, published in 1730 , made his name known to everybody. His opinions drifted nearer and nearer to deism, yet he went regularly to his parish church and regarded the mission, if not the person, of Christ as divine. Unfortunately his learning was far inferior to his natural ability, and his teaching lacks distinctness and consistency. His principal works are-A Discourse concerning Reason . . . a sufficient Guide in matters of Religion (1731); The True Gospel of Jesus Christ Asserted (1738), followed by a defence against the critics; An Enquiry into the Ground and Foundation of Religion, where. 
in it is shown that Religion is fonnded on Nature (1738); and a Diseourse on Miracles (1741). The best statement of his views is contained in his Posthumous Works (2 vols. 1748).

Chubut, or CHupat, a colony in Patagonis, so named from a river which drains a large part of its aren. The entrance to the river, about 600 miles 8 . of the river Plate, is bad, but the bar can be crossed by vessels of from 7 to 12 feet dranght. Its principal interest lies in its Welsh settlement, which has remained almost wholly Welsh-speaking. The first settlers, 151, arrived in July 1865. Epochs in its history have been the abandonment of the colony in 1867; the subsequent return from New Bay ; a twenty months' nearly complete isolation from the outer world, terminated in 1871. The population, after dwindling to 120 , rose to 690 in 1876 , and 1286 in 1883 . The principal town, Trerawson, or Rawsonville, about 5 miles from the sea, is named after Dr Rawson, an Argentine statesman. Frosts seldom last through the day, fogs are infrequent, English grain and roots are produced, and salt of good quality is found. There are a president and council. A railway, 43 miles, was made in 1885-88 from Trelew to Port Madryn on Nuevo Bay.

\section{Chuck-Will's-widow, See Whup-Poor} WILL

Chudleigh. CAPE, is on the north coast of Labrador, at the entrance of Hudson Strait, $60^{\circ}$ $12^{\prime} \mathrm{N}$. lat., $65^{\circ} 25^{\prime} \mathrm{W}$. long.

Chumbul', a river of Central India, rising in the Vindhyan Mountains, at a height of 2019 feet above the sea, and entering the Jumna, after a generally north-east course of 650 miles.

Chunam, the Indian name for a very fine kind of quicklime made from calcined shells or from very pure limestone, and ased for chewing with Bete (q.v.), and for plaster. When ehunam is to be used for plaster, it is mixed with fine river-sand, and thoroughly beaten up with water. A little jaggery (coarse sugar) is also added.

Chumar', a town of India, on the right bank of the Ganges, 26 miles SW. of Benares. The fortress contains Warren Hastings's house. Pop. 9148.

Chunder Sen. See Brahmo SomaJ.

Chung-king, a Chinese port in Sze-chuen, on the Yang-trze, opened in 1890. Pop. 109,000.

Chupra (Chapra'), a town of Bengal, on the Gogra, a mile from the Ganges. Pop. (1891) 57,352.

Chuquisa'ca, or Sưre, capital of Bolivia, is situated on a mountain-closed tableland, 8825 feet above the sea, on a small tributary of the Pilcomayo, It is the seat of an archbishop, and though its houses are mostly of one story, is well built, and has a magnificent cathedral, a small university, a Latin school, and a hospital. Owing to its mild climate, many of the richer miners of Potosi winter here. The 27,000 inhabitants are mostly a mixture of Spaniards and Quichua Indians. Chuquisaca was founded in 1539 on the site of an ancient Peruvian town of the same name, and was for a time called Cindad de la Plata, from the rich silver-mines in the neighbouring mountains; but the Peruvian name signifying 'bridge of gold' was soon restored. The second name, Sucre, is derived from the general who in December 1824 fought and won the last great battle for colonial independence at Ayacucho.-The southern territory of the same name embraces a large portion of the Gran Chaco, which extends to the Brazilian frontier. The eastern portion of it is occupied by wild Indian tribes, and is low-lying and unwholesome; the climate of the west, among the offshoots of the Eastern Cordilleras, is healthy and pleasant. Area, 40,000 sq. m.; population (1900) 290,000, not inclnsive of some 50,000 Indians in the eastern plains.

Chuquito, a town of Peru, once capital of a rovince, on the west shore of Lake Titicace. Pop. 5000.

\section{Chur. See Corre.}

Church, the whole body of Christians; the Christian place of worship ; the clergy ; or a sect or denomination of Christians. It is derived from the Greek kyriakon, 'belonging to the Lord,' and that from kyrios, 'lord; ' the Anglo-Saxon form is circe, the Scottish kirk, the German kirche. The kyrikkon, the original name of the place of assembly, meant accordingly 'the Lord's honse.' The Christian Church, like every other aociety, must have a certain constitution and rules according to which its affairs are administered. It is disputed, however, among Christians, how far this constitution has been defined, or these rules prescribed by divine authority, and how far they lave been left to the diseretion of men. The form of church government depends primarily on the ides entertained of the constitution of the church. Episcopalians and Presbyterians agree that many congregations are to be united under a common government; but this, according to Episcopalians, should be more or less absolutely in the hands of bishops, who are superior to the mere pastors of congregations ; while according to Presbyterians it should be carried on by ministers and elders of these congregations meeting for this purpase on a footing of equality. Congregationalists, or Independents, place all church government in the hands of the members of each congregation and the officebearers whom it has elected. This theory of church government is maintained by many Baptists and others who, for various reasons, assume different denominations. See Bishop, PresbyterianISM, INDEPENDENTS, METHODISTS.

The present article is mainly devoted to church architecture. A general sketch of the history of the Christian Church will be found in this work under the head of CHurch History, while the various sections forming the great Christian communions are treated in separate articles - the Church of England at ENGLAND, as is that of Scotland at SCOTLAND; again the Church of Rome will be found at Roman CATholic CHurch, and the Eastern Chureh at GREkK. CHurch. Here we may merely note the gelf-explanatory names of the following active organisations within the bosom of the Anglican Clsurch: the Church Association (founded 1865 for the maintenance of Reformation principles); Church Congresses (annual since 1860); Church Building Society (1818): Church Defence Institution (1886, to counteract the agitation for disestablishment); Church Missionary Society (founded 1799; see Mrssions); Church Pastoral Aid Society (1836, to maintain curates and lay agents in densely populated districts); the English Church Union (1859, to uphold AngloCatholic principles).

Under BAsILICA some account is given of the mode in which the primitive form of the Chris. tian ehurch or place of assembly originated, and whence it derived its characteristic features. In course of time the numbers of the clergy increased, and a complete hierarchy, with a fixed liturgical service, became established. The simple apse was now no longer sufficient, and the presbytery or place for the clergy was enlarged. This was effected in various ways, sometimes by the erection of a low inclosure or choir extending from the presbytery or raised part in front of the apse, into the nave. This "bema" or choir served for the accommodation of the clergy and singers, and to it were attached on either side two pulpits or ambones, 
from which the Gospels and Epistles were read to the worshippers assembled round the three open sides. Such an arrangement may still be seen in the ancient basilica of San Clemente in Rome.

In other instances the apse is lengthened eastwards. so as to provide additional space. An ex-

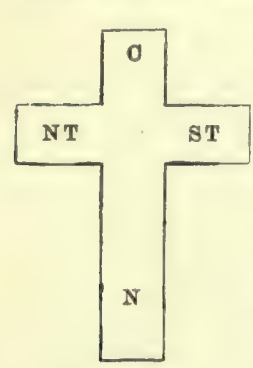
ample of this plan occurs at S. Apollinare in Classe, near Ravenna. In the Basilican churches the nave remained as at first, a long simple hall, with side aisles - in which the congregation assembled, the men on one side, and the women on the other. Meanwhile in the East the use of the dome had caused the introduction of a variety of plans, and in particular the form of the Greek cross, which was conveniently roofed by a Church :

C, Choir; $N$, Nave; S T, South Transept. large central dome and four subsidiary domes over the four arms of the cross. This plan suggested the transept or portion with high roof at right angles to the nave; and it is easy to see how the wide space in the Basilican churches between the nave and apse, in which stood the altar, might also be enlarged so as to form a transept. The above is what actually happened in the sonth of France. The Venetian merchants introduced the above Greek domed design at Périgueux, where they had reprodnced in the 11th century a copy of St Mark's of Venice; and we find in the churches of that district a transept introduced from an early period, having several apses to the east, and side aisles like the nave.

It was especially necessary in the churches of the monasteries that there should be ample accommodation for the monks in the portion of the church set apart for them. This probably led to the lengthening of the choir, but in the earlier Cistercian churches, although the transept is introduced, there is no projection to the east except the central and side apses. But when the plan of the 'cross' church, however it may have been invented, had been developed, the idea speedily claimed attention, and its symbolical significance recommended its adoption. It is remarkable, however, that during the growth and development of the early Gothic style in the reign of Philip Augustus, when most of the cathedrals and churches of northern France were rebuilt, they were almost all constructed without transepts, the object apparently being to concentrate the attention on the one important point, the high altar. It was in the monastic churches that the transept was ehiefly developed.

Along with this, another feature, which had first been introduced in the south, was worked out and perfected by the northern architects-viz. the carry. ing of the aisle round the apse, so as to convert the latter from being a simple half-cylinder, roofed with a semi-dome, into a circular or octagonal east end, supported on a screen of pillars, behind which was the surrounding aisle, with its radiating chapels, while the upper part of the apse was carried up the full height of the choir, which it terminated with a brilliant east end." Mr Fergusson supposes that this ' chevet,' or splendid eastern termination of French Gothic churches, was the result of the absorption of a circular edifice into the church. There is no doubt that the church owes several of its features to this system of absorption. Originally the group of ecclesiastical buildings consisted of the church or basilica, at the west end of which was an atrium or open court, having a circular or octagonal baptistery opening from it opposite the door to the church. In Germany the atrium was roofed in and became part of the church, while the western baptistery was also absorbed into the one chief edifice, and became the western apse so common in that country. But it had also been enstomary to build occasional churches of a circular form in imitation of the church of the Holy Sepulchre at Jerusalem. In Germany and elsewhere a choir was added to these for the use of the clergy, but in France the circular church was retained by the clergy as the choir, and a nave was constructed in connection with it for the people. The fine effect of the circular termination was thus seen, and had only to be seen to be immediately adopted. Besides the chapels radiating from the "chevet, numerous others were gradually introduced, extending beyond the aisles; the height of the main structure was increased, and great windows were inserted in the clerestory, till the interior presented a glowing vision of rich colour and endless variety of perspective.

Such was the growth of the Christian church during the middle ages, and such is the general form it still retains in Roman Catholic countries, notwithstanding the great changes of style through which it has passed from the 13th to the 19th century. Since the Reformation a new form of church has been introduced. The ancient traditions were no longer held sacred by Protestants, and a style of building adapted to the new mode of service was called for. Hence arose the arrangements of the numerous churches designed by Sir C. Wren, Gibbs, and others during the 17 th and 18th centuries. These consist of a great hall with a gallery running along the two sides and west end, with a large window or apse at the east end. During the present century the plan of the medieval church has frequently been again resorted to, both in England and the United States; but among Presbyterians, Independents, and many others, the modern plan of a hall designed with galleries so as to contain a numerous congregation, having the pulpit placed in the most prominent position, is still the most generally used.

The following table shows the comparative size of some of the great churches of the world, giving in feet their total length, breadth at transept, and height of spire or tower or dome :

\begin{tabular}{|c|c|c|c|}
\hline & Length. & Transept. & Spire. \\
\hline $\begin{array}{l}\text { St Peter s, Rome............ } \\
\text { Cathedral of Florence... }\end{array}$ & $\begin{array}{l}700 \\
530\end{array}$ & $\begin{array}{l}560 \\
323\end{array}$ & $\begin{array}{l}485 \\
380\end{array}$ \\
\hline 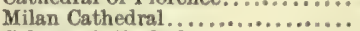 & 500 & 284 & 400 \\
\hline Cologne Cathedral................. & 445 & 282 & 515 \\
\hline Strasburg Cathedral...... & 354 & & 474 \\
\hline Antwerp Cathedral ............... & 500 & 180 & 460 \\
\hline Amiens Cathedral ................. & 442 & 194 & 223 \\
\hline Notre Dame, Paris................. & 400 & 150 & 204 \\
\hline St Paul's, London ..... . & 510 & 282 & 404 \\
\hline St Sophia's, Constantinople....... & 246 & & 183 \\
\hline Canterbury Cathedral ............. & 530 & 124 & 235 \\
\hline York Minster. & 524 & 222 & 213 \\
\hline Westminster Abbey & 500 & 189 & 199 \\
\hline Salisbury Cathedral............. & 474 & 229 & 404 \\
\hline \#........... & 319 & & 225 \\
\hline Patrick's Cathedral, New York. & 332 & 174 & 828 \\
\hline
\end{tabular}

Churches vary of course in accordance with their importance and size. The largest are the metropolitan and cathedral churches, then the con. ventual, the collegiate, and the parish churches; but although they vary in magnitude and richness, they are all constructed on the same principles, and follow one idea.

The annexed ground-plan of Durham Cathedral shows the various parts of one of the most perfect medieval structures in England, with the names attached to the different portions, which will be described under their respective headings. See Aisle, Apse, Basilica, Clerestory, Triforium, \&c. Plans, sections, or other illustrations of other important churches will be found at BYZANTINE ARchitecture, Gothic ARChitecture, LoM- 
BARD ARCHITECTURE, RENaIsSANCE, RUENISH ARCHTRCTURe, \&o., where much additional information on the developments of church building falls to be given. For the historical succession of the

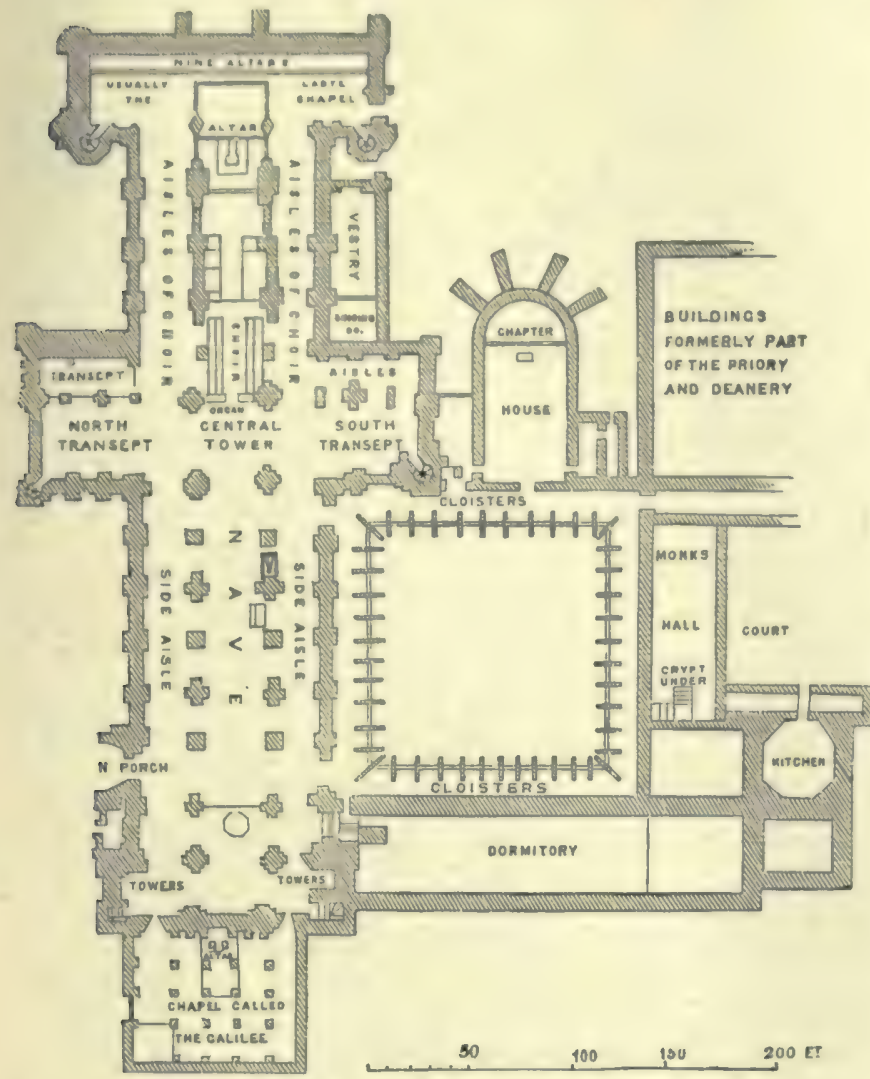

Ground-plan of Durham Cathedral.
Bimhop Andrewes, and on the Oxford movement (1891) are also very valuable. His Bacon, Spenser, St Anselm, Dante, and some of his easays were reprinted in 1888 (5 vols.). His Villorge Sfrmoms were published in 1892. He died $9 t h$ December 1890. See Life and Let. ters, edited by his daughter (1894). - He was a nepliew of Sir RICHARD ChURCH (1785-1873), born at Cork of Quaker parentage, who had become C.B. (1815) and K.C.H. (1815), and had been in the Nenpolitan service, when in 1827 he became generaliksimo to the insurgent Greeks. He died at A thens. See Lives by Lane-Poole (1890) and E. M. Church (1895).

Church, States of THE, or PAPAL STATES, stretelied from the Po to near Naples, and in 1859 had an area of $15,774 \mathrm{sq} . \mathrm{m}$. and $\mathrm{a}$ pop. of $3,000,000$. It was divided for administrative purposes into twenty districts, ineluding the Comarca of Rome; six legations, among them those of Bologna and Ravenna; and thirteen delegations, including Ancona and Perugia. More general divisions were the Romagna, Umbria, and the March of Aneona. The war of 1859 and the popular vote of 1860 left the pope only the Comarea of Rome, the legation of Velletri, and the delegations of Civita Vecehia, Frosinone, and Viterbo, $4493 \mathrm{sg}$. $\mathrm{m}$. in extent, with a pop. of about 700,000 , the rest being united with Italy. The temporal power of the popes originated in a gift of the exarchate of Ravenna by Pepin to Pope Stephen II., and it reached its greatest extent under Innocent III. (11981216). The withdrawal of the French garrison of Rome in $18 \% 0$ led to the final downfall of the pope's temporal power. See POPE, ITALY.

styles, see ARCHITECTURE; see also the articles and illustrations at AMIENs, ANTWERP, BOsTON, Burgos, Canterbury, Cologne, Durham, ExeTER, Lincoln, Moscow, Peterborough, SAlisBURY, ULM, WestMiNster, YoRK, \&c.

Chureh, Richard William, Dean of St Paul's from 1871, was born at Lisbon, 25th A pril 1815. He took a first-class at Oxford in 1836, and soon after was elected to a fellowship at Oriel. From 1853 he held the rectory of Whatley, near Frome. In 1854 he published his scholarly Essreys and Reviens. His university sermons $(1876-78)$ in a volume entitled Human Life and its Conditions (1878), the Reries of St Paul's and Oxford sermons in The Gifts of Civilisation (1880), and the five St Paul's sermons forming The Discipline of the Christian Character (1885), are profound contributions to religious thought. Other works are his Life of $S t$ Anselm (1871), an amplification of two essays in his first volume; The Beginnings of the Middle Ages (1877), an introduction to the series of 'Epochs of Modern History ;' Dante: an Essay, with a translation of the De Monarchia by his only son, F. J. Church, a young man of rare promise, who died in 1888 ; Spenser (1879), and Bacon (1884), two of the best books in the series of 'English Men of Letters.' His occasional essays or lectures on such subjects as Montaigne, Brittany, Cassiodorus, the sacred poetry of early religions, the Pensés of Pascal and
Church-ale, a kind of church festival in old England at which ale was drunk liberally. The name is obviously compounded like bridal = brideale, scot-ale, clerk-ale, bid-ale, \&c. The church-ales were usually held upon Whitsuntide, and two per. sons were chosen beforehand to preside over the feast, and divide out the vietuals and drink voluntarily contributed by the parishoners. Sometimes the drink which had been brewed from malt given by the parishioners was sold abont Whitsunday at the church for the support of orphans and poor, the practice of holding church-ales with the corresponding games was denounced by the Puritans, and is not overlooked in Stubbs' Anatomie of Abuses.

Church Discipline (Disciplina ecclesiastica), the practice of the Christian Church in dealing with such of its office-bearers and members as have by public scandal caused hindrance to its common spiritual life. Its Seripture anthority, resting on such passages as Matt. xvi. 19; xviii. 15 (et seq.), is further enforced in Paul's epistles and in the gospel and epistles of John. Under the Decian persecution there was so much apostacy that special rules became fixed for the restoration of the Lapsed (q.v.), which remained in foree till the 5th century. But the great strictness with which Penance $\left(q, v_{\text {. }}\right)$ was enforced led to the opposite extreme; it became customary for penitents to be restored repair of the church, and similar objects. The 
simply on their producing letters of recommendation (libelli pacis) from persons who had confessed Christ. The Montanists, however, maintained that those who had been once excommunicated should pass their whole life in the status ponitentice, and the Novatians denied that the Church possessed the right to assure the Lapsi of the forgiveness of sins, which only God could grant. The Donatists (q.v.) could not arrest the gradual secularisation of discipline. By the 6th century penances began to be commuted for certain fixed taxes. In the Western Church, after public penances had become rare, other punishments took their place, partly derived from the exercises of earlier asceticism, partly from the usages of Frankish law. The episcopal Missi of Charles the Great combined the functions of a civil and ecclesiastical court, and allowed church punishments to be compounded for money. From the time of Gregory the Great the doctrine of Purgatory (q.v.) had been a dogma of the Church; and Peter Lombard and other scholastics built on it the theory of Indulgences (q.v.), which was confirmed by Clement VI. in 1343. The extreme punishments in the middle ages were the Greater Excommunication (q.v.) for the individual, and Interdict (q.v.) for the community. The churches of the Reformation held that 'the power of the keys' belonged to the whole Church, by whieh it was to be intrusted to the regularly called servants of the Word. They rejected Auricular Confession (q.v.) and the whole system of Satisfactions and Indulgences; restricting the sphere of their church discipline to matters of social morality, and its enforcement simply to spiritual admonition and partial or complete exclusion from the sacraments and offices of the Church. The Lutheran Church rejected the Greater Excommunication as a merely secular punishment with which the servants of the Church had nothing to do; but retained the Lesser, simply as a means of moral training. Though Luther and Melanchthon adhered firmly to the participation of the whole congregation in the imposition of excommunication, yet, in consequence of the development of the consistorial system, it passed into the hands of the consistories in the different states. In the 17 th and 18th centuries it fell gradually into disuse. The Reformed Church laid greater stress on congregational discipline. Zwingli assigned it to the civil magistrate of the Christian state; Calvin, on the other hand, referred it to the Presbytery (q.v.). In Presbyterian churches it is exercised by the kirk-session-an appeal lying to the presbytery, and from that to the synod and general assembly. The church discipline provided for by the Canons of the Church of England has almost entirely fallen into disuse.

Church History. The history of the Christian Church includes its external history, which treats of the extension of the Church, and its relation to the state; and internal history, which is concerned with the Church's inner life, doctrine, worship, and constitution. With respect to time, the Church's history is usually divided into three periods-Ancient, Medieval, and Modern. Its Medieval History may be dated from its establishment in union with the new empire founded by Charles the Great in 800 . Modern Church History begins with the Reformation (in the view of Roman Catholic historians, with the Humanistic movement, or the discovery of America). Each of these periods may be divided into two: Ancient Church History, at the complete victory of Christianity over Greek heathenism under Constantine the Great; Medieval, at the culmination of the papal power under Innocent III.; and Modern, at the close of the Thirty Years' War by the Treaty of Westphalia.
The first of these periods extends from Christ to Constantine. The beginning of the Christian Church dates from the departure of Jesus Christ from the earth and the Pentecostal effusion of the Holy Spirit (about 33 A.D.), the time when the first confessors of Christ exceeded the limits of $a$ private society, and began to form a public com. munity. Its nucleus was the first Jewish Christian community at Jerusalem under the 'pillar-apostles" James, Cephas, and John. The spiritual conception of the Messiah which the disciples had received from the personal influence of Jesus. was sealed on their minds by their faith in his resurrection; and their comprehension of his gospel is seen in the wide aims of their first missions, in their progressive deliverance from legalism, and in the belief that faith is the essential element of salvation. As members were quickly added to the Church, especially from the Jews of the Dispersion (called Hellenists, because they spoke Greek), a beginning of its organisation was made in the appointment of seven deacons, including the
Hellenist Stephen, the protomartyr of the Church. The elements of the primitive faith were unified and systematised by the Apostle Paul, the aim of whose life was the conversion of the whole world to Christ. He succeeded in emancipating the Gentile Christian world from the ceremonial law, and in his three great missionary journeys (about $40-58$ A.D.) began the evangelisation of Europe. The destruction of Jerusalem ( 70 A.D.) completed the deliverance of Christianity from Judaism, and gave the Church the consciousness of a world-wide mission. The Judaising Christians were thenceforth an insignificant sect.

The Roman empire maintained the pre-Christian view that there could be no worship of God apart from the corporate life of the state, and, when the early Christian Church refused to take part in the state worship, it became a religio illicita, and was proseribed and persecuted as dangerous to society. To the distinguished and learned Christianity was a gloomy infatuation, to the populace the Christians contempt for the gods seemed the cause of every public calamity. The tyrannical caprice of Nero charged them with the burning of Rome (64 A.D.), and persecuted them with revolting cruelty. Under Domitian Christianity was punished as a form of high-treason. The first regular decree for legal procedure against the Christians was issued by Trajan. Under the more tolerant rule of the emperors from Hadrian to Marcus Aurelius (117161), the Christian congregations were organised as Collegia tenuiorum ('poor men's guilds'), or Collegia funeraticia ('funeral societies'), and as such enjoyed a sort of legalised existence. The vast cities of their dead in the catacombs of this period nowhere preserve memorials of martyrdom or persecution. The Christians had to suffer many a local persecution, but, apart from the temporary and thoughtless cruelties of Nero and Domitian-who, according to Tertullian, was ' a piece of Nero for cruelty'-they had the toleration, and sometimes the protection, of the emperors. Ranke ascribes such action especially to Antoninus Pius- 'the bestintentioned and most peaceable among them, and perhaps not without sympathy for Christianity'whose reign he regards as the culmination of the Roman empire. A consequence of this tolerant bearing of the imperial power was the peaceful behaviour of the Christians, who in general rejected the principles of Montanus, which aimed at the subversion of the state. This condition of affairs came to an end under Marcus Aurelius, who, no longer able to resist the popular outcry, suffered a persecution to take place in several provinces.

A bout the middle of the $2 d$ century the Christian congregations in the Roman empire were consoli- 
dating themselves into a confederacy, which caller itself the 'Great" or "Catholic' (i.e. universal) Church. By the middle of the $3 d$ century the confederation was accomplished. The Church was now organised with a hierarchical constitution and an elaborately regulated worship, while the New Testament canon was regarded as equally authoritative with the Old. From 250 the emperors whose political aims were most akin to the traditional policy of Rome struggled for life and death with the growing power. Of the times before Decius Origen testifies (Contra Celsum, iii. 8) 'fow and very easy to count are those who have died on account of the Christinn religion :' and Lactantius says (De Morte Persecutorum, ii. 4), 'after the acts of the tyrant (Domitian) had been rescinded, the Church was not only restored to her pristine state, but shone forth much more brightly ; and, times following when many good emperors held the helm of government, she suffered no attacks from enemies. . . But thereafter the long peace was broken. For after many years the accursed beast (excerabile animal) Decius arose to vex the Church.' Under Decius began the first universal and systematic persecution of Christianity as a part of the military and relicyious policy of the state. The sufferings of the Christians continued under Gallus and Valerian till 260, when Gallienus declared Christianity a religio licita. For forty years the Church had peace, and grew mightily on every side. Diocletian by four edicts of progressive severity, from February 303 to Mareh 304, when he decreed torture for all Christians, put forth a desperate effort to annihilate Christianity in the whole empire. At his abdication (May 305) the horrors of the persecution ended, except in the East, where they were continued without mercy by Maximin Daza. The victory of Constantine in 313 delivered Christendom from this its last and most relentless persecutor.

Constantine saw in the unity of the Church a new foundation for the unity of the empire, and placed Christianity on an equality with Paganism : under his sons it became predominant. The reaction under Julian ended with his death. It was the struggle with Gnosticism that had first led the Church to the remarkable development of its dog. matic system, which gives its characteristic stamp to the history of the second period of the ancient church. The simple baptismal confession had become transformed into a rule of faith giving fixity to the ecclesiastical tradition. Justin, Irenæus, Tertullian, and Hippolytus had been among its first exponents. While in the seriptures of the New Testament canon the Church possessed an abiding witness to the 'simplicity that is in Christ,' the rule of faith in the course of the $3 d$ century had been built up in the forms of the Greek philosophy of Clement and Origen. The first church synods had been held in Asia Minor in connection with the Montanist controversy about 170; and by the $3 \mathrm{~d}$ century such assemblies were common in various provinces of the empire. The institution of æcumenical councils, in which only bishops were entitled to vote, originated with Constantine. The controversy with respect to the Easter festival had disturbed the Chureh for a century and a half. The universal practice in Asia was to observe the exact day of the month (the 14th Nisan), while the usage of Alexandria and Palestine and the West was to celebrate the Passion always on a Friday, and the Resurrection on a Sunday. This controversy was finally laid at rest by the Ceumenical Council of Nicra in 325. Trinitarianism gained its first victory over Arianism at Nicsea by the combined influence of Athanasius and Constantine, and completed its triumph at the second Ecumenical Council (at Constantinople) in 381.
After this the Church was distracted with con. troversies about the views of Origen (304-438), the Apollinarian controversy (302 381 ), the dis. putes between the sehools of Antioch and Alex. andria (381-428), the Nestorian controversy (428 444), the Monophysite controvensy (444-653), the Monothelete controversy (633-680), and the lconoclastic controversy (726-842). These discussions originated in the Eastern Charch, while in the Weat the theological interest centred on the great conflict between Augustinianism and Pelagianism (412-529). The tyrannical interference of the Eastern emperors in the controversies of the Church, their supremacy in the ecclesiastical councils, and their penal enforcement of doctrinal decrees, led to infinite confusion in the relations between cliurch and state, and prepared the way for the ambitious policy of the popes, and for the final breach between the churches of the East and West.

While these age-long controversies kept the relations of church and state continually strained, Paganism was steadily suppressed. Orthodox Chris. tianity in union with the state soothed the declining years of the ancient empire; but could not prevent the conquest of Rome by Alaric the Goth. Its ad. vance in Persia was checked by political persecution before the advent of Islam, which subsequently overwhelmed the Christianity of the East. In the West, however, Christianity rose with renewed vigour from the ruins of the old empire, by the conversion of the Teutonic and Slavonic nations. The Teutonic conquerors of Gaul and Italy were Christians before their invasion of those countries. The Anglo-Saxon conquerors of England were heathens. A century and $\mathrm{a}$ half after their settlement Christian missionaries gained a footing in the south and north, and within a century from the landing of Augustine the English kingdoms had enbraced Christianity. In the general declension of political faith under the decaying Roman empire, the social power once held by the officials of Rome had gradually passed into the hands of the Christian bishops. In the lawlessness and disorder of the barbarian invasions, these representatives of the claims of moral order and human brotherhood were the trusted mediators between the conquerors and the conquered, and exercised a constant influence during peace and war. But this great authority over the new nations brought along with it much injury to religion. Discipline declined as the power and wealth of the clergy increased.

The third period of the Church's history extends from Charles the Great to Innocent III. "At the commencement of the 8th century,' says Ranke, 'on the one side Mohammedanism threatened to overspread Italy and Gaul, and on the other the ancient idolatry of Saxony and Friesland once more forced its way across the Rhine. In this peril of Christian institutions, a youthful prince of Teutonic race, Charles Martel, arose as their champion.' By his great victory of Tours ( 732 ) a final check was given to the advance of the Saracens in the West, and Christendom and civilisation were rescued from the grasp of Islam. The subjugation of the Saxons by Charles the Great was the toilsome work of thirtytwo years ( $772-804$ ), and their Christianisation was secured by the castles, towns, mission-stations, and monasteries which the conqueror planted in their country. Under the Carlovingian kings of the Franks from the middle of the 8 th century, the temporal dominion of the Papacy was founded. The legend of the 'Donation of Constantine,' bestowing imperial power and dignities upon the pope, together with the sovereignty over Rome and all Italy, and the countries of the West, was invented at Rome about 730, and embodied in the Pseudo. Isidorian decretals (about 850). It was contested by few in the middle ages, till Laurentius 
Valla demonstrated its untenability. For centuries this clumsy forgery formed one of the supports of the Papacy in its struggle for universal supremacy. The connection between the churches of the East and West had been already loosened by the schism of 484-519 during the Monophysite controversy, and by the iconoclastic policy of the emperors from Leo to Theophilos (717-842). At length the progressive centralisation of the Western Church under the Roman see, to whose authority the ' cecumenical bishops' of Constantinople could not submit, and in the 11th century the transfer by the Bulgarians of their allegiance from Constantinople to Rome, led to a final rupture. The patriarch Photius already in 867 laid down the dogmatic basis of the Schism as consisting in the western deviations from the dogmas, customs, and constitutional forms of the ancient church, especially the addition of the 'filioque' clause to the creed of Nicrea and Constantinople, teaching that the Holy Spirit proceeds not only from the Father, but also from the Son. The severance was completed on the 16th July 1054, when the papal legates laid the anathema on the altar of St Sophia in Constantinople.

The growth of Monasticism, from the beginning a lay movement in pursuit of the old ideal of Christian perfection, which men felt that a worldly priesthood no longer represented, entered at first into competition with the elergy, but gradually became subservient to Catholic aims. In the East, where the contemplative life prevailed, the best function of the monasteries was as nurseries of the priesthood, while the monks of the West christianised Germany and Britain, cultivated wildernesses, preserved the elassic treasures of antiquity, and were the diligent teachers of the common people. Above all the monastic orders, the Benedictines can claim the glory of conspicuous services to Christian missions and intellectual culture. 'In the 9th and 10th centuries,' says Gibbon, "the reign of the gospel and of the Church was extended over Bulgaria, Hungary, Bohemia, Saxony, Denmark, Norway, Sweden, Poland, and Russia. ... The admission of the barbarians into the pale of civil and ecclesiastical society delivered Europe from the depredations by sea and land of the Normans, Hungarians, and Russians. The establishment of law and order was promoted by
the influence of the clergy ; and the rudiments of art and science were introduced into the savage countries of the globe.' In the West, men held that the Holy Roman Empire, consolidated by Charles and Otto the Great, was the embodiment of the ideal state, and that God had two vicars on earth, the emperor in temporal things, and the pope in spiritual things. "The analogy of the two,' says Bryce, 'made them appear parts of one great world-movement towards unity; the coincidence of their boundaries, which had begun before Constantine, lasted long enough after him to associate them indissolubly together, and make the names of Roman and. Christian convertible. ... The Holy Roman Church and the Holy Roman Empire are one and the same thing in two aspects; and Catholicism, the principle of the universal Christian society, is also Romanism; that is, rests upon Rome as the origin and type of its universality, manifesting itself in a mystic dualism which corresponds to the two natures of its Founder. As divine and eternal, its head is the pope, to whom souls have been intrusted; as human and temporal, the emperor, commissioned to rule men's bodies and acts.' In the first half of the middle ages the Church believed herself to be coextensive with the Kingdom of God, the realisation of the noblest ethical ideal, and her servants conceived it their highest duty to labour to make the whole field of human life subject to her supremacy. Not even the moral declension of the Papacy in the centuries succeeding Charles the Great, especially during the sixty years' so-called Pornocracy (904-963), could quench the ardour of the Church's faith in that ideal; and the cloister, purged and strengthened by successive reforms, saved the authority of the Church by uniting in Gregory VII. the monastic ideal of self-renunciation with the ecclesiastical ideal of the conquest of the world.

At the great Lateran Council under Pope Innocent III. in 1215, the Catholic Church was at the zenith of its power. Innocent was the sun, and from him the princes of Christendom held their light in fee. The Crusaders, though unable to hold Jerusalem, had enhanced the prestige of the Papacy; and Scholasticism placed its skill and learning at the service of the Church. The Wald. enses and Albigenses were to be crushed relentlessly, and the Inquisition was now established for their permanent repression. No persecutions which the Church had ever suffered are to be compared for determined eruelty with those which in this period she inflicted on the heretics of southern France and of the Netherlands. Emperors and kings might contend with Rome for temporal authority; they were ready to decree the burning of heretics as much as she desired. But this unrestricted sway brought its own downfall. After the Papacy in the Avignon sojourn (1305-77) had become the tool of French policy, and after all the contrivances of pious fraud had been resorted to, during the Schism of 1378 to 1409 , to fill the coffers of rival popes at Avignon and at Rome, the people began to lose faith in the holiness of the hierarchy, and the ever louder ery for 'reformation of the Church in its head and members' became irresistible. The Schism of thirty years, during which two popes claimed the same divine prerogative, was the most direct contradiction of the doctrine that had obtained in the Catholic Church since the time of Hildebrand, that the Papacy was the unifying centre of Christendom. The conviction gained ground that even its authority was subject to that of an ocumenical council. In the development of this idea a twofold tendency presented itself. One party, that of Gerson and D'Ailly, which prevailed at the councils of Pisa and Constance, regarded the council as representative only of the hierarchy, and, while recognising the Papacy as a divine institution, aimed at restricting the absolutism of the papal see by the co-rule of a spiritual aristocracy, consisting of the bishops and the doctors of the universities. The other, mainly composed of German theologians, made the first attempt within the medieval Church to undermine the Roman Catholic conception of the Church by a distinction between the ecclesia universalis - the spiritual community of all believers-and the ecclesia Romana, of which the pope was head. The second party regarded this una catholica ecclesia alone as infallible, and held that the council represented not only all classes of the hierarchy, but all classes of Christendom; and that church reform was a duty that fell to the secular power, not only the princes, but also the entire body of the laity. But all the resolutions of the three great reforming councils were made void by the pitiful issue of the Council of Basel in the Concordat of Vienna in 1448, when the fathers of the council recognised Nicholas V., and received the holy father's forgiveness. Thus ended the last attempt towards the reformation of the Church on its old foundations.

At length the teaching of the Lollards and Hussites, the failure of the councils, and the shameless traffic in indulgences; the impotent conclusion of Scholasticism that philosophy and religion might both be true, though contradic- 
tory; the new art and learning of the RenailBance; the awakening of the spirit of nationality ; and the widespread longing of the poor for redress from the exactions of priests and nobleshal prepared men's minds for that great movement in the 16th century, which issued in the Protestant churches and in the division of the whole of western Christendom into two hostile cainps down to the present day. Luther, Zwingli, Melanchthon, and Calvin were its greatest leaders. The Reformation ealled forth a thousand changes in human existence. As it passed from country to country in all northern Europe, it broke the cloister. vow, abolished celibacy, confiscated the property of the Church, founded secular schools for the people, stripped the clergy of their privileges; and the philanthropic duties and the tasks of civilisation, which for centuries had been incumbent on the servants of the Church, it gradually transferred to the state and the community. Where it triumphed, and even where it was successfully resisted, there was no sphere of life in which its influence was not felt. The communistic movement of the Anabsptists, which had been developed in the midst of the religious perplexities of Germany, was crushed in the ruins of Münster in 1535, and with the death of 'this prodigal child of the Reformation' passed away the premature political socialism of the Reformation period. The aims of the Papacy, all centred on its political interests, were wholly irreconcilable with the Reformers' doctrine of the priesthood of all believers and the sole authority of Scripture in matters of faith. The political and humanistic period of the Papacy was succeeded by a régime of passionate zeal, under which every nerve was strained to win back the territories which had shaken off the Roman yoke. The resolutions of the Council of Trent (1545-63), subseribed by 255 prelates, separated for ever the Protestant and Catholic churches, and obtained in the latter the authority of a symbolical book.

The Counter-Reformation, led everywnere by the Jesuits, and favoured in Germany by the Peace of Augsburg ( 1555 ), went on with great success till the middle of the 17th century. It began in Bavaria in 1563, and quickly spread over southern Germany. But it was in France that the revived Roman Catholicism of the 16th century won its first great victory. The number of the 'Religionnaires' or 'Huguenots' in France had, in 1558, amounted to 400,000. From the massacre at Vasy by Francois of Guise in 1562 to the Massacre of St Bartholomew (August 23-24, 1572), four religious wars had lacerated France, and during the reign of Henry III. there were yet five of these desolating civil wars. The crafty see. saw policy of Popes Sixtus V., Gregory XIV., and Clement VIII. secured every advantage afforded by the vicissitudes of the conflict, and it was not till after Henry IV. had gone over to Roman Catholicism that the pope in 1595 recognised him as the king of France. Liberty of conscience was extended to the French Protestants by the Edict of Nantes in 1598. From 1555 the ecclesiastical position of each German territory was dependent on the religions convictions of its ruler, and the members of the Lutheran Church had political equality with 'the old religion;' but the exclusion of the Reformed from that provision led to the isolation of Lutheranism from the great struggles of Protestantism in France, the Netherlands, and England. The prineiple cujus regio, ejus religio, by which subjects should follow the confession of their rulers, unavoidably led, in the political condition of Germany in the 16th and 17th centuries, to the breaking up of the Lutheran Church into a number of small national churches, and confused the development of Lutheran theology with the dynastic and family interests of the several courts. Stability was only attained after the fearful strugule of the Thirty Years' War, when, at the Peace of Westphalia, Catholics and Protestants agreed to recounise each other's right to existence. The excellences of the Lutheran Church were the depth and power of its ascetic elements and its religious literature, especially its hymns, the noble expression of German mysticisn. But the continuation and political maintenance of the Reformation has been mainly the work of the Reformed or Calvinistic churches. "In a time,' says Hiusser, 'when, of all the creations to the Reformation, Europe presented nowhere else any solid or lasting bulwark, the little Genevan state of Calvin sent out year after year its apostles into the world, and was the most dreaded foe of Rome, when nowhere else was there any resistance to her might.' In the Lutheran Church many of the Romish ceremonies were retained, and congregational organisation was neglected; whereas in the Reformed churches the congregations were organised on a democratic basis, that had nothing akin to the traditional principles of monarchical power. "With the pas. sive resistance of Luther men could not counteract the Caraffas, the Philips, and the Stuarts; that needed a school prepared for war to the knife; the only such school was Calvin's, and it everywhere took up the glove-in France, in the Netherlands, in Scotland, and in England. Lutheranism has been established in Scandinavia and the countries along the Baltic, while the Reformed Church, which has throughout evinced a more radical character than the Lutheran, has especially prevailed in South Germany, Switzerland, France, the Netherlands, and Scotland.

In England, Edward VI., the successor of Henry VIII. - who had been recognised by the parliament in 1534 as 'the only supreme head in erthe of the Churche of England '-with the help of Cranmer, Latimer, and Ridley, completed the Reformation. The Common Prayer-book was introduced, and a confession of faith in 42 articles drawn up as the standard of the church's doctrine. After a period of persecution under Mary, the Anglican Church was established under Elizabeth in the closest union with the state. By Elizabeth all ecclesiastical disobedience was regarded as treasonable, and the legislation of her later years was directed against those who took offence at the ritual and the hierarchy, and were known as Nonconformists. English Puritanism (which may be dated from 1567, when its adherents began to separate from the Established Church) was at first only an opposition to the ceremonial elements which the Church of England still retained after its separa. tion from Rome. The principle of Puritanism was reformation through the members of the church itself, as opposed to reformation originating with the crown. It aimed at the overthrow of the episcopal system, and the establishment of a strict system of discipline in the spirit of Calvin. Under Charles I. the Puritans were severely persecuted, and many of them emigrated to America, and were the early settlers of New England. English Puritanism in alliance with Scottish Presbyterianism gained in the Great Rebellion a complete victory over the monarehy, but in England the fruits of the victory fell to the Independents, who were the most consistent section of the party. The Synod of Dort in Holland (1618-19), which was regarded as an ocumenical council of the churches of the Calvinistic Reformation, had decided the controversy between the Arminians and Calvinists entirely in favour of the latter. The Westminster Assembly (1643-49), called by the Long Parliament, drew up the confession of the Puritans, which is closely akin to the resolutions of Dort, and is still the standard in the churches of Scor 
land. Later phases of Puritanism developed a great variety of sects, the Baptists and the Society of Friends, or 'Quakers,' being the most notable.

The Reformation in Scotland had received from John Knox a strictly Calvinistic stamp. The Protestant nobles (called the 'Lords of the Congregation ') entered in 1557 for the first time into a 'Covenant,' and the Scotch Confession of Faith was ratified by the Scottish parliament in 1560 . All the efforts of Mary, Queen of Scots, to win Scotland back to Roman Catholicism were fruitless. The first National Covenant 'against all kind of Papistry' was signed by king and people in 1581, and frequently renewed. In 1592 the Presbyterian constitution was established. Yet under James $I$. and his successors determined efforts were put forth to make the Church of Scotland a province of the Anglican Church. The obtrusion of the Liturgy in 1637 was met by the Solemn League and Covenant in 1638.

During the Civil War and the Protectorate of Cromwell, Independency increased in numbers and in influence. 'Two fanatical sections of the party, the 'Fifth-Monarchy Men,' and the 'Levellers' who aimed at complete separation of the church from the state, which they maintained should preserve an attitude of religious indifference-were repressed by the iron hand of Cromwell on their attempt to establish their principles by force of arms. The declaration of faith and order issued by the Synod of the Independents in 1658 is not different in its doctrine from the Westminster Confession. After the accession of Charles II. Episcopacy was re-established both in England and Scotland. On the 24th August 1662 two thousand ministers were ejected from their livings in the Church of England, because they refused to subscribe the second Act of Uniformity, which enjoined all ministers in England to declare their unfeigned assent and consent to the entire Book of Common Prayer. In the same reign, the successive Conventicle, Five Mile, Corporation, and Test Acts increased the civil dis abilities of both Noneonformists and Catholies. The persecutions did not cease till the Revolution, when the Act of Toleration in 1689 extended religious liberty to dissenters, only requiring from them the payment of tithes to the Established Chureh.

In the 17 th century a middle party within the Church of England, known as the 'Latitudinarians,' had endeavoured to exercise a mitigating influence on the violence of the disputes between the extreme Episcopalians and the rigid Puritans. Hales and Chillingworth were in the first half of the century the leading exponents of the party, which later included the 'Cambridge Platonists,' Whichcote, John Smith, Cudworth, More, and even Simon Patrick and Tillotson. About the middle of the 17th century another movement began in England as a reaction against the religions extremes of the Great Rebellion. The principles of the English 'Deists' originated undoubtedly in the reaction from the religious excesses of the Cromwell period, but were more largely due to the progress of philosophy and the historical and natural sciences. They passed over to France, where they found a congenial soil under Louis XIV. and Louis XV., and, in presence of the Dragonnades and the persecutions of the Protestants after the revocation of the Edict of Nantes in 1685, developed into the Atheism and Materialism of the Encyclopédistes. These afterwards bore bitter fruit in the French Revolution-'the religious issue of which proved,' says Hase, 'not only the necessity of religion for a civilised people, but also the national indispensability of a church.'

In Germany the reaction from the fanatical violence of the Thirty Years' War and the lifeles: orthodoxy of the 17 th century took the form of Pietism. It began with the collegia pietatis founded by Spener about 1670 , and the similar collegia philobiblica of Francke, professor at the university of Halle from its foundation in 1694. Halle became the centre whence Pietism spread on every side, and its influence, like that of Geneva under Calvin, extended to all the Protestant countries of Europe. The church of the Moravians, in the form in which it was renewed by Zinzendorf, is a daughter of Pietism, and the founder of Methodism testified that Moravianism was the first medium of his own inspiration. Pietism, with Moravianism, which inwardly rests on the same foundation, is, says Weingarten, "the last fruit of that heart-religion, springing originally from Franciscanism, which consists in the closest vital fellowship of the indi. vidual Christian with Christ.' It laid great weight on strictness of conduct, and dwelt rather on regeneration and sanctification than on the Reformation doctrine of justification by faith. During the reign of Rationalism it appeared quiescent, but it revived in the present century, and in alliance with the orthodoxy which it formerly combated forms the predominant party in the Evangelical Church of Germany.

The founders of English Methodism did not aim at any new doctrine or order, but only sought, like the German Pietists, to deepen spiritual life, and make it more practical and fruitful. Methodist societies began to be organised in 1739 , after Wesley and Whitefield had been excluded from the pulpits of the Established Church. These two learlers separated in 1748 on the question of pre. destination, Wesley holding the Arminian, and Whitefield the Calvinistic view. Ten years after Wesley's death his followers numbered 40,000 , and in twenty years more increased to upwards of 100,000. Wesleyan Methodism and its numerous offshoots have been distinguished both in this country and in America for their evangelistic zeal and their influence over the common people; and their earnestness and success have been the means of imparting a healthful stimulus to the Church of England. About the end of the 18th century the influence of the Methodist movement extended into the Established Church, and issued in the formation of the 'Evangelical party,' which, centring in Cambridge, soon became the most energetic party in the Church of England. At Oxford, which from Laud's time had been the centre of the old 'High Church' party, began about 1833 the Tractarian movement, of which the first impulse came from the Evangelical revival; while in one of its sides, at least, it was a kind of resthetic outcome of the Romantic revival in literature and art. No fewer than 150 of the clergy and leading laymen connected with the movement followed Ward and Newman (in 1845 and 1846) into the Roman Catholic Church, but the party, held together for nearly fifty years under the leadership of Pusey, has now fully identified itself with the Anglican Church as the 'Catholic Church planted in England.' Though 'AngloCatholicism' has driven large numbers into the Roman communion, it has succeeded in doing what Methodism a hundred years before attempted, and has brought new life into the Church of England. It bears a close affinity to Roman Catholicism in ritual and doctrine, but refuses to acknowledge the universal supremacy of the Bishop of Rome. 'The 'Broad Church' party, the third in the modern Church of England, traces its beginning to Coleridge, but in spirit and to a large extent also in teaching, is substantially identical with the old Latitudinarians and the Cambridge Platonists, who, with great spiritual earnestness and honesty, maintained for over a hundred years a large and 
tolerant theology. The modern Broad Church purty agrees with the Evangelical or 'Low Church' party in minimising the importance of apostolical succesion and sacramental grace, and in attaching no intrinsie value to particular forms of ritual or clerical vestments; but unlike it demands a more liberal interpretution of dogmatie definitions, and \& greater freedon in the subseription to ereeds. In its preaching it aims at guidance rather than conversion, frankly contradicting the prevailing Evangelical teaching that attributes everything to sovereign grace and emphasises the complete corruption of unregenerate human nature. It has thronghout advocated a bolder view of the applicalility to Seripture of methods of eriticism and exegresis that have found favour in Germany. One of its earliest leaders was the famous Dr Arnold, who advocated the great Hooker's theory of the identity of church and state-a kind of spiritualised Erastianism-as the only means of fully earrying out the realisation of Christianity on earth. It has added many illustrious names to the roll of English churchmen, among them Whately, Maurice, Frederick Robertson, Julius Hare, Kingsley, Thirlwall, and Stanley.

The standard of Anglican doctrine is fixed by acts of parliament in the Thirty-nine Articles of 1571, and in the Book of Common Prayer (1552, revised in 1559 and 1661$)$. Not till the present century has the church's close connection with the state been loosened by a series of laws removing the civil and political disabilities of dissenters. The Chureh of England includes at most two-thirds (some say only one-half) of the population, and possesses the whole of the ecclesiastical endowments of the country. Its comprehensiveness is altogether unexampled; within no historic church in the world is to be found such divergency of honest opinion. Its enormous revival of activity during the last fifty years has struck its roots deeper into the religious heart of England, and though its disestablishment has often been proposed, the Church of England is so closely interwoven with the other institutions of the nation, and is so dear to the majority of the English people, that such a contingrency inust seem remote. In any event, the solidity and dignity of the Episcopal Chureh would retain for it the chief place among the eeclesiastical societies of England. Such hindrances to its efficiency as pluralities and non-residence have long been removed, the episcopate within England has been largely extended, and missionary bishops appointed to orranise and extend foreion missions, while no less than thirty millions have been spent within thirty years upon the building and restoration of churches at home. Such agencies for relieving poverty and distress as sisterhoods and specia? missions have leaped into life, and in the Church Congresses (first, 1861) and Diocesan Conferences (first, at Ely, 1864) the door has been opened to the co-operation of laymen in church work. The growing demand for greater freedom of action on the part of the church, resulted (1852, and 1856) in an attempt to revive the powers of Convocation. in abeyance since 1717. In 1867 was inaugurated the first Lambeth Conference of prelates of the Anglican rite from all quarters of the world.

James I. gave the whole ecclesiastical endow ment in Ireland into the hands of the Anglican clergy. The Irish lranch of the Anglican Church, which only embraced one-eighth part of the population, was disestablished and disendowed in 1571 by the Irish Church Act of 1869. In the census of 1891 the Catholics of Ireland numbered 3,547,307; Episcopalians, 600,103; Preslyterians, 44,974; other non-Episcopal Protestantr, 80,660.

Patronage had been abolished in Scotland in 1690, but was restored under Queen Anne in 1712 . 120
The repeated protests of the General Ansembly were disregarded, but with the gradual ancendency of the 'moderate' party in the church itwelf, were discontinued, and the dissatisfied seceded from the Establishment, forming the "Seceseion' and 'Relief' churches. In 1834 the Assembly passed the Veto Act, declaring that no pastor should be 'intruiled on any congregation contrary to the will of the people, and giving the congregation the right to veto the appointment of a presentee of whom they disapproved. After a ten years' conflict be. tween the 'non-intrusionist' and 'moderate' parties, the former seceded from the Established Church, and formed the Free Church of Scotland in 1843. The United Presbyterian Church arose from the union of the Secession and Relief churches in 1847, and is now the third in importance in Seotland.

In the United States it is a part of the con. stitution that "no religious test shall ever be required as a qualification to any office or public trust,' and that 'congress shall make no law respecting an establishment of religion, or prohibiting the free exercise thereof.' 'This separation between church and state,' says Schaff, 'is not a separation of the nation from Christianity.

The Ameriean nation is as religious and Christian as any other in the world, and shows this plainly by its voluntary support of so many churches and sects ; by its beneficent societies of every kind ; by its church-going, and respect for the elergy, who are inferior to no class in respect and influence : by its strict sabbath-keeping, which has its equal only in Scotland; by its zeal for home and foreign missions; by its reverence for the Bible; by a veritable flood of religious books, tracts, and periodicals ; and by the whole tone of its public morality. Of Protestants, the Methodists and Baptists are the most numerous, especially among the lower classes and in the southern states; while the Presbyterians, Congregationalists, and Episcopa. lians have the greatest influence among the middle and higher classes. In 1891 the Roman Catholics had 6,257,871 members; Methodists (Episcopal and non-Episcopal), 4,589,284; Baptists of various communions, 3,712,468; Presbyterians, 1,278,382 ; Lutherans, 1,231,072 ; Congregationalists, 512,771 ; and Episcopalians, 540,509.

A great development of missionary zeal took place in the Protestant churches of Europe and America during the 19 th century, leading to a vast expenditure of life and money. Anıong civilised races like the Jews, Chinese, and Hindus, the success attained has been small compared with that among races to which the Christian missionaries have brought, along with the preaching of the gospel, a vastly auperior civilisation, such as the natives of Madagasear and Polynesia. There are now a hundred missionary societies in Protestant Christen. dom, with about 5000 European and American missionaries, and about 30,000 native assistants, and raising every year more than 24 millions sterling for the evangelisation of the heathen world. The Roman Catholic Church has by its colonies and conquests in the New World endeavoured to redress the balance of the Old. In South and Central America, Hayti, and the Spanish and French West Indies, the population is almost exclusively Roman Catholic; while in British North America the proportion of Roman Catholies is $\mathbf{4 2}$ per cent., and in Australia and Polynesia about 15 per cent. The largest and most important missiousy institute of the Roman Catholic Church is the Propaganda, founded by Gregory XV. in 1622. The missions of the Benedictines, Cistercians, Premonstratensians, and especially of the mendicant orders, who penetrated Africa and North and South America, were from the 16th and 17th centuries almost eclipsed by those of the Jesuits. In the East and 
West Indies, Japan, China, and Abyssinia, they have won over thousands to their society and church. While Protestant missions have aimed at saving individual souls, they have used every possible means to effect conversions, and have counted their converts in crowds. Their constant policy has been to ingraft Catholic ideas and usages on traditional prejudices and customs. In India they commended themselves to the great as Christian Brahmins and to the poor as apostles of freedom; in Japan they sided with the native nobility against the luxurious priestly class ; in China they made their way to favour through geometry and astrology; in Spanish South America they took the oppressed natives under their protection, contended against slavery, and founded in Paraguay a socialistic theocracy of their own.

Ever since the Reformation the Roman Catholic Church has been growing more and more ultramontane, and this tendency has become most marked in the second half of the 19th century, largely through the increasing influence of the Jesuits. That order, suppressed in Portugal (1759), in France (1764), in Spain and Naples (1767), in Parma (1768), and by the bull 'Dominus ac Redemptor Noster' of 'Clement XIV. in 1773, was restored by Pius VII. in 1814. The golden days of the Jesuits were under Pius IX. (1846-78), who gradually passed entirely under their influence. The Jesuit generals, Father Roothaan (1829-53) and Father Beckx (1853-84), called the 'black popes,' reigned in Rome side by side with the 'white pope,' Pius IX. The dogma of the Immaculate Conception, which the Jesuits maintained against the Dominicans, was promulgated by the pope in 1854, and ten years later the Encyclica and Syllabus proclaimed to the world that the political and ecclesiastical theories of Jesuitism were accepted by the holy see. The Jesuits acquired considerable influence in France under Napoleon III., but were expelled in 1880 . In Italy, since the downfall of the pope's temporal power (1871), they are restricted to Rome, and they were excluded from Spain and Mexico (1868), from Germany (1872).

The famous canon expressed by Vincent of Lerinum in 434: 'Quod semper, quod ubique, quod ab omnibus creditum est,' has been the formal principle of Catholicism throughout its history. At first it fell to the bishops in the synods to decide whether any particular doctrine bore these three marks of Catholicity. Sometimes one synod set aside the resolutions of another, and even at the occumenical councils the whole Church was never represented in the same proportions. The supreme authority of the pope was the only means to secure absolute unity, and neither the defenders of the 'episcopal system' at the medieval councils nor the Gallicanism of the French clergy ( set forth in their declaration of 1682 ) were able to interpose an effective resistance. To secure the Papacy from all such opposition in future, the Jesuits persuaded Pope Pius IX. to have it decreed by the Vatican council that only the pope is the infallible head of the Church. Leo XIII. has set his seal upon the work of Pius IX. by restoring, in 1886 , to the order of the Jesuits all the privileges it enjoyed before its dissolution. The ancient conflict between emperor and pope, recently revived in the 'Kulturkampf,' ended (1883-86) in a victory for the Papacy, by the withdrawal of the 'May Laws' and the reversal of the German ecclesiastical policy pursued since 1872.

To-day Roman Catholics are reckoned at from 150 to 200 millions; Greek Catholies at from 75 to 85 millions; Protestants at from 100 to 120 millions; while non-Christians number about 1450 millions.

The primary sources of Church History are : (1) Original documents, such as the records and decrees of church councils; the official publications of bishops and popes (pastoral epistles, bulls, briefs, decretals, and constitutions); laws relating to ecclesiastical affairs, issued by sovereigns, chancellors, or parliaments ; liturgies and service-books, rules of religious orders, symbolical books and confessions of faith, sermons and treatises of theologians and ecclesiastical leaders, journals. and reports of eye-witnesses, and letters of contemporaries eminent in church or state. (2) Monuments, such as ecclesiastical buildings, pictures, sculptures, inscriptions, vessels, \&c. Among the secondary sources are calendaries, martyrologies, and necrologies; traditions, annals, and chronicles -all requiring to be sifted by criticism, the farther their date from the period to which they refer.

The earliest church historian whose writing is. extant is Eusebius of Cresarea, who made use of the earlier works of Hegesippus (about 150 A.D.) and Julius Africanus (3d century). The history of Eusebius, extending to 324 A.D., was continued by Socrates to 439 , Sozomen to 423 , Theodoretto 428 , Philostorgius to 425 , Theodore to 527 , and Evagrius to 594. The chronicle of Eutychius of Alexandria, written in Arabic, comes down to 937. Nicephorus Callisti ( 1330 ) closes the series of the Greek church historians. The Byzantine civil historians from 500 to 1500 contain valuable materials for church history. The earliest Latin historians of the Church were Rufinus, who wrote a translation of Eusebius, and brought it down to 395 ; Sulpicius Severus, 'the Christian Sallust,' extending to 400 ; Orosius to 416 ; Cassiodorus, who combined Socrates, Sozomen, and Theodoret into a text-book, the famous Historia Ecclesiastica tripartita, which was the standard down to the Reformation; and Jerome, whose translation of Eusebius, and continuation to 378 , was followed by the chroniclers Prosper of Aquitaine, Idacius, and Marcellinus. Of medieval writers of special histories the most notable are Jornandes (550); Gregory of Tours (540-595), who wrote the chronicles of the French Church in the 5th and 6th centuries; Bede, the father of English church history, which he narrated to the year 731 ; Paul the deacon ( 760$)$, author of a history of the Lombards; and Adam of Bremen, the chief authority on the northern churches from 788 to 1072 . The Dialogus Mircculorum of Cæesarius of Heisterbach throws great light on his own age (first half of 13th century). Besides the Liber Pontificalis, a history of the popes to 885 , which was probably the work of various authors, general church history was written by Anastasius of Rome and Haymo of Halberstadt in the 9th century, by the Norman monk Ordericus Vitalis, and the cardinals Petrus. Pisanus, Pandulf, and Boso in the 12th century; in the 13th, by Martinus Polonus, whose Chronica summorum Pontificum Imperatorumque was the most popular history-book of the middle ages; in the 14th, by Ptolemy of Lucea; and in the 15th, by Antoninus of Florence, whose work comes down to 1459. Laurentius Valla's attack on the legend of the 'Donation of Constantine' appeared in 1440.

The Reformation, at first more productive in exegesis than in history, awoke to the necessity of justifying itself by the Church's development in the past, as well as by the statements of Scripture. After the Peace of Augsburg, a society of Lutheran theologians at Magdeburg, headed by Matthius Flacius ( Illyricus), compiled a comprehensive history, arranged in 13 folio vols., each embracing a century. The Magdeburg Centuries was answered by the Annals of Csesar Baronius, in 12 folio vols., which was followed by the histories of Hottinger, Spanheim, and Samuel and Jaques Basnage in the Reformed Church, and of Pagi, a Franciscan monk, who also criticised Baronius. The history of the Council of Trent was written 
by Sarvi and Pallavicino. Church history was afterwards cultivated in the Roman Catholic Church chiefly by the Benedictines of St Maur and the Oratorians in France. Alexander Natalis, Fleury, Bassuet, and the Jansenist Tillemont, were the most celebrated writens. Protestant historians had been for neurly a century employed in jolemical writing, and the compilation of dry sammaries of events and dates, when Georg Calixtus gave a new impulse to the study by a series of dissertations urging the value of unprejudiced investigation. The mystic Gottried Arnold maintained the right of heretics against the Church in his 'Impartial' History (1699), and was answered by Weismann, George and Franz Walch, and S. J. Baumgarten. From the 16 th century down to the 18 th the Church of England was ably vindicated in the light of history by Jewel, Hooker, Pearson, Beveridge, Cave, and Bingham. Strype's Annals and Ecclesi. astical Memorials, and Neal's History of the Puritans, are the authorities for the Reformation and the Puritan movement in England. Of the other English writers of church history down to the present century, the chief names are those of the martyrologist Foxe and Archbishop Parker in the 16th century; Usher, Fuller, Dugdale, and Burnet in the 17th; and Jeremy Collier, Echard, Calamy, Bower, Lardner, and Milner in the 18th. Knox's History (1586) is the authority for the Reformation in Scotland. Scottish church history was written in the 17th century by Row, Spottiswood, and Calderwood; and in the 18th by Defoe and Wodrow. Mosheim was the first to establish the study of ecclesiastical history on a scientific basis, and the sceptical Semler, though, according to Hase, 'without all style and feeling for the peculiar conditions of antiquity,' founded the criticism of the sources. The huge work of Schröckh, in 35 vols., begins the so-called 'prag. matical 'school of church historians, which laboured to collect external facts and relate them to their causes, and was also represented by Spittler, the elder Henke, Stäudlin, and Planck. In the early part of the 19th century, Ernst Christian Schmidt, in 6 vols., presented an impartial statement of facts. Gieseler produced a masterpiece of scientific investigation, with the most valuable extracts from the sources accompanying the text, a method which had been previously employed by Danz, and was also cultivated by Niedner. In modern Protestant church history the greatest work is that of Neander, which, in contrast with the pragmatical histories, dwells mainly on the inner development of the Church in doctrine, worship, and religious life. He has heen followed by Jacobi and Hagenbach. Among acalemic treatises on church history the most notable are those of Guericke, $\mathbf{H}$. Schmid, Lindner, and Kurtz, all from the Lutheran point of view; those of Herzog and Ebrard in the Reformed Church; and the very able and interesting lectures of Hase, Hasse, and Rothe. Recent church history dates from F. C. Baur, who in separate treatises covered the whole field. The effect of his work on the first three centuries has been to turn the attention of many writers for more than a generation to the study of the early church. The contention of Baur, and his disciples Sch wegler and Zeller, which represented the original apostles of Christ as persistently struggling for the perpetuity of 'Petrinism' against Paulinism, and interpreted the New Testament to prove this theory, has been considerably discredited by the investigations of Ritschl, Weiszicker, Lechler, Harnack, Weiss, and De Pressensé.

In the Roman Catholie Church the study of church history has been pursued with great energy. The Acta Sanctorum of the Bollandists, begun in the 17 th century, have reached their $63 \mathrm{~d}$ volume.
Of the councils, the chief collection is that of Mansi, in 31 vols., and history that of Hefele in 7 vols. In the earlier part of the 19 th century the chief writers in Germany were Count Stolberg (whose work in 18 vols., extending to $430 \mathrm{A.D}$., has been brought down to 1300 in other 17 vols. by Kerz), Katercamp, and Mohler, who was the first of a new school of thoroughly scientifie historians, to which Ritter, Locherer, Dóllinger, Alzog, and Kraus belong, while the works of Cardinal Hergenróther and of Brück have a strong ultramontane bias.

English writers on general church history are still largely dependent on the labours of German scholars. There is no English church history worthy of a place beside the works of Neander, Gieseler, and Hagenbach.

Of other 19th-century writers may be mentioned Hinds, Burton, Kaye, T. Price, Marsden, Lathbury, Hardwick, Maurice, Blunt, Milman, Hook, Newman, Stanley, Creightor, Robertson, Wordsworth, Abbey and Overton, Haddan and Stubbs, Perry, and Stoughton in England; Cook, M'Crie, Hetherington, Welsh, Lee, Grub, Tulloch, Skene, and Cunningham in Scotland; Reeves and Killen in Ireland; Schaff, Allen, and Fisher in America; Gfrörer, Ranke, Heppe, Henke, Overbeck, Hausrath, Keim, Hausser, Kahnis, Schürer, Lipsius, Hilgenfeld, and Langen in Germany; and Matter, Bungener, Capefigue, De Montalembert, Aubé, D'Aubigné, Renßn, De Broglie, Michaud, and Chastel in France.

For the remarkable development of the literature on the life of Christ during the last fifty years, see the article on JESUS.

See the extensive bibliography in Hagenbach's Encyclo. pädie (11th ed. by Kautsch, 1884); also see Weingarten, Zeittafeln und Ueberblicke der Kirchengeschichte (3d ed. 1888); F. C. Baur, Die Epochen der Kirchlichen Geschichtsachreibung (Tub. 1852); Ter Haar, De Historiographie der Kerkgeschiedenis (Part I., from Eusebius to Laurentius Valla; Part II., from Flacius to Semler; Utrecht. 1870-71); Wattenbach, Deutschlands Geschichtsquellen im Mittelalter bis zur Mitte des 15. Jahrhunderts (4th ed. 2 vols. 1877): and Loreng, Deutochlands Geschichtsquellen seit der Mitte des 1s. Jahrhunderts ( $2 \mathrm{~d}$ ed. 2 vols, 1876-77). The reader is also referred to the various articles in this work on the subjects mentioned in the preoeding pages, and especially to the following:

\begin{tabular}{|c|c|c|c|}
\hline $\begin{array}{l}\text { Albigenses. } \\
\text { Aquinas. } \\
\text { Arias. } \\
\text { Arminius. } \\
\text { Athanasius. } \\
\text { Augustine. } \\
\text { Baptism. } \\
\text { Bishop. } \\
\text { Calvin. } \\
\text { Canonisation. } \\
\text { Celibacy. } \\
\text { Chriat. } \\
\text { Christianity. }\end{array}$ & $\begin{array}{l}\text { Confessions. } \\
\text { Councils. } \\
\text { Creeds. } \\
\text { Crusades. } \\
\text { England, } \\
\text { Church of. } \\
\text { Friends, } \\
\text { Bociety of. } \\
\text { Gallican Ch. } \\
\text { Gnosticism. } \\
\text { Greek Church. } \\
\text { Huguenots. } \\
\text { Huss. }\end{array}$ & $\begin{array}{l}\text { Independents. } \\
\text { Jesuits. } \\
\text { Jesus Christ. } \\
\text { Knox. } \\
\text { Lord's Supper. } \\
\text { Luther. } \\
\text { Lutheran } \\
\text { Church. } \\
\text { Missions. } \\
\text { Monachism. } \\
\text { Pope. } \\
\text { Presbyterians. } \\
\text { Protestantism. }\end{array}$ & $\begin{array}{l}\text { Reformation. } \\
\text { Religion. } \\
\text { Roman Cath. } \\
\text { Church. } \\
\text { Russian Chnr. } \\
\text { Sacraments. } \\
\text { Saints. } \\
\text { Scholasticism. } \\
\text { Beotland, } \\
\text { Church of. } \\
\text { Unitarians. } \\
\text { Waldenses, } \\
\text { Wyclif. }\end{array}$ \\
\hline
\end{tabular}

Churchill, Charles, satirist, was born in Westminster in 1731. After leaving Westminster Sehool, where he was contemporary with Colman, Robert Lloyd, Cowper, and Warren Hastings, he did not enter Oxford or Cambridge, being apparently disqualified by an imprudent Fleet marriage at seventeen. In 1756 he was ordained priest, 'through need, not choice,' and at his father's death in $\mathbf{1 7 5 8}$ he was appointed to the curacy and lectureship of St John's, Westminster, the poor emolu. ments of which office he strove to eke out with teaching. But he was hopelessly improvident and already dissipated; accordingly, after a bankruptey of but five shillings in the pound-and that prid only by the aid of Robert Lloyd's father-a formal separation from his wife, and a course of nnclerical inclecorum and dissipation that called forth the remonstrances of his dean and the protests of his parishioners, he slipped his neck from the orders which he wore so awkwardly, and cast himself 
entirely upon the town (January 1763). His Rosciad, published in 1761 , had already made him famous and a terror to all the actors of the time. The poem was modelled on Dryden, and had real talent and vigour, as well as scurrilous and unspar. ing personality to commend it. Later in the same year, in The Apology, he made a savage onslaught on his crities, and particularly Smollett. Night (1762), a long poetical epistle addressed to Llayd, and suggested by Day, Armstrong's somewhat unwelcome poetical epistle to 'gay Wilkes,' contained some nervous lines, but was on the whole a poor production marred by an impudent bravado of honesty, as if it were some justification of misconduct to make a eandid avowal of it. The Ghost (1762) is an incoherent and tiresome poem of over four thousand lines in octosyllabic metre, only remembered now for the attempt to satirise Dr Johnson as 'Don Pomposo' on occasion of the Cock Lane ghost-story, and the much more warrantable ridicule cast upon Whitehead the laureate. Churchill next helped Wilkes in the North Briton, and heaped timeous ridicule upon the Scoteh in The Prophecy of Famine (1763), an admirable satire, bright with wit sharpened into stinging verse-undoubtedly his best work. "It is indeed falsely applied to Scotland, but on that account may be allowed a greater share of invention,' says Boswell, with characteristically wrong-foot-foremost but whimsically ingenious reasoning. Later in the same year appeared Churchill's Epistle to Hogarth, for which the great caricaturist paid the poet by gibbeting him to all future time as a bear in torn clerical bands and ruffles, with a pot of porter, and a club inscribed 'Lies and North Britons.' Other works of Churchill's were The Duellist, an onslaught on Wilkes' assailants in the House of Lords; The Author, which pleased the critics and even Horace Walpole; The Conference, interesting especially for one redeeming feature - a singularly touching and true confession of remorse for the seduction (but not desertion) of a Westminster tradesman's daughter; Gotham, a long and ambitious exposition of his political ideas; The Candidate, a splendid attack on Sandwich; The Farewell, The Times, and Independence, the last containing an interestingly untlattering portrait of the poet by his own pen, in which he laughs at his burly frame and rolling gait-'much like a porpoise just before a storm. Meantime the satirist had prospered and gained enough not only to pay off all his old debts, but to help others, for no man was ever more faithful and unreserved in love towards his friends than this sinning and repenting prodigal. In the October of 1764 he crossed to Boulogne to see Wilkes, was seized suddenly with a fever, and died on 4 th November. Just before the end he sat up in bed to bequeath annuities of $£ 60$ to his wife and $£ 50$ to his mistress, for which, however, there proved to be no funds. His body was buried at Dover, and on a slab above his grave was inseribed with less than dubious truth the line from his poem The Candidate: "Life to the last enjoyed, here Churchill lies.' Fifty-four years later Byron, leaving England for the last time, stood beside his tomb, his mind filled with reflections on 'the Glory and the Nothing of a Name,' which he shaped into a poem scarce worthy of its theme.

Churchill left two unfinished satires-The Journey, broken off at a line of sadiy ominous significance: 'I on my journey all alone proceed;' and the severe and masterly Dedication to the arrogant Warburton. His satires are for the most part long since forgotten. Though neither "a blockhead' according to Johnson, nor 'the great Churchill' as described by Cowper with all an old schoolfellow's extravagance of admiration, he was yet a satirist of high capacity, with a happy knack of turning strong and honest thought into nervous and memorable verse. At the same time he lacked the chief essen. tials of true satire, a real insight into the heart of man and that rarest power of happy exaggeration, of preserving likeness in unlikeness and verisimilitude in distortion. A fatal volubility in rhyming, a kind of boisterous but unequal energy, and an instinctive hatred of wrong, manly and honest, although often scarce to be distinguished from the mere reflex reaction of natural spleen and obstinacy, combined to make him the hero of the hour and its ephemeral interests, but was not equipment enough for a Dryden, a Juvenal, or even a Butler. See Forster's Historical and Biographical Essays (vol. ii. 1858), and Southey's Life of Cowper.

Churchill, Lord Randolph Henry Spencer, third son of the seventh Duke of Marlborough, was born on February 13, 1849, and educated at Eton and Merton College, Oxford. Lord Randolph was first returned for Woodstock in 1874; but it was not until after the general election of 1880 that he became prominent in politics, when he appeared as the leader of a guerilla band of Conservatives known as the 'Fourth Party.' He was frequently in collision with his leaders on questions of party organisation and the conduct of the Opposition; but his vigorous attacks on Mr Gladstone's policy, both foreign and domestic, were of unquestionable value to the Conservative cause. Towards the end of Mr Gladstone's ministry Lord Randolph began to have a considerable following among the younger Conservatives, who regarded him as the future leader of the Tory Democracy. After a plucky attempt to defeat $\mathrm{Mr}$ Bright at Birmingham in 1885, Lord Randolph was returned for South Paddington. He was Secretary for India in Lord Salisbury's first ministry (June 1885-January 1886), his period of office being marked by the annexation of Burma. From July to December 1886 he was Chancellor of the Exchequer and leader of the House of Commons, when he resigned, being resolved, as he wrote to Lord Salisbury, to sacrifice himself on the altar of thrift and economy. Still on most points he spoke and voted on the Conservative side. In 1892, after a tour in South Africa, he was re-elected, and in spite of enfeebled health was recognised as one of the leaders of the Conservative party. He died 24th January 1895. In 1874 he had married Miss Jerome, a New York lady. See his Life by Escott (1885).

Churchill River, of Canada, rises between the north branch of the Saskatchewan and the Athabasca, under $55^{\circ} \mathrm{N}$. lat, and flows generally NE. through a series of lakes, first as the Beaver, then as the Missinnippi, and finally as the Churehill or English River, to Hudson Bay, which it enters near Fort Churchill, after a course of nearly 1000 miles. There is plenty of traffic during summer by canoes, which are conveyed by land portage past the largest of the stream's many rapids. The natural advantages of Churchill harbour have caused it to be regarded as a possible terminus for the railway from Winnipeg, and the starting-point of the direct sea route to England by Hudson Bay and Hudson Strait.

Churching of Women, a religious usage prevailing in the Christian church from an early period, of women, on their recovery after childbearing, going to church to give thanks. It appears to have been borrowed from the Jewish law (Lev. xii. 6); and the earliest express mention of it is in the pseudo-Nicene Arabic canons. No ancient forms for the purpose are extant, and those in actual use are of medieval date. The Greek rite is only partially concerned with the woman, being also the presentation of the new-born child in the 
church on the fortieth day after birth (s usage based apon Luke, i. 22); the Latin rite, contrariwise, is exclusively a benediction of the woman, and is restricted to such as have borne children in wedlock. It is not obligatory, nor included among strictly parochial rights, but only recommended as a pious and laudable custon. In the Church of Fncrland, also, a service for the churehing of women, differing little from the medieval rite, finds a place in the Prayer-book. By the Presbyterian and Independent churches of Britain and America it is rejected as having no Seripture warrant.

Church Music. See Anthem, Antiphony, Chant, Choirs and Choral Sivging, Gregorian Tones, Hyms, Mass, Plainsong, Service,

Chureh-rates, in England, a tax or assessment laid on the parishioners and occupiers of land within a parish, by a majority of their own body in vestry assembled, for the purpose of upholding and repairing the fabric of the church and the belfry, the bells, seats, and ornaments, the church. yard fence, and the expenses (other than those of maintaining the minister) incident to the celebration of divine service. The parishioners are convened for this purpose by the Churchwarlens (q.v.). The Chancel (q.v.) being regarded as belong. ing peculiarly to the clergy, the expense of maintaining it is laid on the rector in receipt of the great tithes, though custom frequently lays this burden also on the parishioners, as in London and elsewhere.

The church-rate was anciently a charge on parishioners in respect of their lands, according to their area and the stock thereon, but it was a personal, not a real charge; and every bishop was bound to contribute to the repair of the public 'baptismal churches' of his diocese (i.e. churches with pullic baptisteries annexed to them). The responsibility of the parishioners for the repair of their parish church is recognised as early as 1018 by a law of King Canute, enacting that ' all folk shall of right help the ehureh-lot,' which was the sum levied for repairs of churches. The care of the fabric of the church, and the due administration of its offices, are laid upon the minister and the churchwardens conjointly, and the latter may be proceeded against by citation in the ecclesiastical courts, should they neslect these duties. But there is no legal mode of compelling the parishioners as a body to provide the rate; and this circumstance has occasioned much difficulty in imposing the tax in parishes in which dissent is prevalent, and has led to many churches falling into a partially ruinous condition. The proper criterion for the amount of church-rates is a valuation of the property within the parish, grounded on the rent that a tenant would be willing to pay for it. Glebe land, the possessions of the crown in the actual occupation of the sovereign, and places of jublic worship, are not liable for church-rates; fut there is no other exception as regards immov. slble property, and in some parishes custom even extends it to stock-in-trade. It has been often decided in the courts that a retrospective churchrate -i.e. a rate for expenses previously incurredcannot be validly imposed. Much difficulty has been experienced in recovering the rates imposed by the parish on individuals refusing to pay. Previous to 53 Geo. III. chap. 127, the only mode was by suit in the ecclesiastical court. That statute, however, in all cases under $\dot{t} 10$, empowered the justices of the peace of the county where the chureh was situated, on complaint of the churchwardens, to inquire into the merits of the ease, and order payment. Against the decision of the justices an appeal lies to the quartersessions. In 1868 an end was put to all parochial contentions by enacting that no suit or proceeding should thereafter be allowed in any court to enforce or conipel payment of a church-rate, except where a local act anthorised this rate. But except so far as related to the compulsory payment of these rates, the churchwardens might, as before, make, assess, receive, and deal with wuch raten. In each district parish the inhabitants may treat their own ehureh as if it were their parish ehureh, and make and receive rates for the repair of the same. A body of trustees may now be appointed in each parish to receive contributions for ecclesiastical purposes in the parish. The result of this sut of 31 and 32 Vict. ehap. 109, is thus not to abolish church-rates, but ratler to convert them into vol. untary payments; allowing, as it does, all faithful adherents of the church to contribute, as before, to the repairs of their own churches. But it has been found practically inapplieable, and its enabling clauses are rarely acted on, so that voluntary con. tributions have in nearly all cases been substituted for rates.

In Scotland the burden of upholding extra-burghal parish ehurches is imposed on the parish heritons and where the parish is partly within burgh and partly in the country, the expense must be borne by heritors and proprietors of houses, in proportion to their real rent. See Scothand (CHurch of); also Dissenters, Parish, Heritor, Fev, Fiars. In Ireland church-rates were abolished in 1823.

Churchwardens are the modern representatives of the ancient Seniores Ecelesiastici, laymen who were custodians of chureh goods and ornaments, and agents for ecclesiastical affairs on their temporal side, but had no share in church government, nor any right of session in synods. In England they are lay ecclesiastical officers, elected yearly at Easter, sometimes by the parishioners and minister jointly, sometimes by the minister alone, sometimes by the parishioners alone, by the select vestry, by the lord of the manor, or by the outgoing wardens, but most commonly (and always in the case of new parishes) the incumbent chooses one and the parishioners the other. They are appointed for the purpose of protecting the edifice and goods of the church, keeping order in the church during public worship, seating the parishioners, and executing other parochial functions. They are admitted to their office by the Ordinary, nsually the bishop of the diocese, and are his officers, as well as re. presentatives of the lay parishioners. But their office in this respect is only one of observation and report, and they cannot interfere directly with the incumbent, if in their mind violating the laws ecclesiastical, but nust simply delate the matter to the bishop by presentment at his visitation. They are also usually appointed as trustees of sequestrated benefices. Certain classes are ineligible for election as churchwardens, such as Jews, minors, aliens, and persons convicted of felony, fraud, or perjury; and there are many exempted from serv. ing, though eligible if elected, such as peers, members of parliament, justices, clergymen, Roman Catholic ecelesiasties, dissenting ministers, officers of the army and navy, barristers, solicitors, \&e. They are generally two in number, but the oftice of churchwanden is a single one, of which each warden holds an undivided moiety, so that they cannot leyally act independently of each other. There is no officer in the Roman Catholic Church precisely corresponding to the English ehurch warden. The closest analogy is found in the trustees of the church fabric fund of the parish. These are named Marguillier (Lat. matricularius) in France, and are three in number, elected by the other members of the parish council, one of them going out of office yearly. They have the charge of the ordinary expenditure of the church, the superintendence of its minor officials, such as the 
beadle, \&c., and the general conduct of the civil part of parish business. See CHURCH-RATES, Partsh, VESTRY ; and Prideaux's Practical Guide to the Duties of Churchwardens (15th ed. 1886).

Churchyard. The churchyard in the earliest days of Christianity was often prior in time to the church itself. The Roman law so strictly protected the area within which stood monuments of the dead from violation, and even from the incidence of those acts of ownership to which other lands were subject, that the Christians found it usually feasible to obtain security for their burial-places, which would have been by no means equally ex-tended to their places of religious assembly. For this reason, and also from personal feeling, they were in the habit of assembling for worship at the tombs of martyrs, and it became usual to erect churches close to these. But where the church was prior in point of time, it was not at first usual to bury within the curtilage or precinct of the building, and the cemeteries were entirely apart. A few instances of interment within the churchyard proper appear as early as the 4th century, but it is not till after the 6 th that it became a general custom. The first direct evidence of the formal consecration of a burial-ground is in this same era (Greg. Turon., De Gloria Confessorum, chap. 6), but the usage most probably dates much earlier, because such dedication was customary in respect of all things and persons set apart for religious purposes. The belief in the efficacy of prayers for the dead had much influence in promoting burial within the precinets of churches, as those attending for worship might be expected to pray for those interred close by ; and this reason, adduced by Gregory the Great, was embodied in the Canon Law.

The introduction into England of the custom of burying in churchyards is ascribed to Cuthbert, Archbishop of Canterbury (741-758), and by common law the freehold of the churchyard belongs to the rector of the parish, qualified by the rights of the parishioners, who, in their turn, are bound to repair the fence at their own cost, unless there be acal custom for the owners of adjoining lands to repair so much of the fence as marches with their ground. The trees and grass growing in the churchyard also belong to the rector, but though he may depasture his sheep or cattle there, he is not at liberty to cut down the trees uniess to provide timber for repairing the church. Until the enactment of the statute 43 and 44 Vict. chap. 41, no form of burial service except that of the Church of England could legally be used in any churchyard; but under that act notice may be given to the incumbent or officiating minister, by the representatives of any deceased person, that they intend the burial to be either without any religious service at all, or with some 'Christian and orderly religious service' other than that of the Church of England. The widest interpretation is to be put on this definition, so as to include all services used by any society professing to be Christian, but non-Christian rites are specifically excluded from the operation of the statute. Churchyards, even if closed for purposes of burial, cannot under the existing law be converted to secular uses, and the freehold continues to vest in the incumbents of the parishes where they are situated. Any person guilty of violent or indecent behaviour in a churchyard, or disturbing any clergyman conducting a burial therein, is liable b- 22 and 23 Vict. chap. 32 , sect. 2, to a penalty of $£ 5$ or two months' imprisonment, and for damage to any monument or fence, under 24 and 25 Vict. chap. 97 , sect. 39 , to imprisonment not exceeding six months with or without hard labour. See Burial, Cemetery.

\section{Churchyard Beetle. See BLAPS.}

\section{Churl. See Ceorl.}

Churns are machines used for the production of butter from cream or from whole milk. By agitation the butter globules are thrown against each other until after a period which varies in length with the quality of the butter-fat, the temperature, and the condition of 'ripeness,' or incipient acidity of the cream. Churns are of great variety in form and dimensions, from the ladies' glass hand churn producing a few ounces of butter at a time, to one driven by water, steam, or horse-power, and churning the whole milk of a dairy at one operation. The plunge churn or thump churn is one of the oldest and most simple varieties. The common upright hand churn seen in country places is perhaps the best known form of it, but the principle is equally applicable to larger churns. The box churn, either oblong or cubical, is stationary like the latter, the action being brought about by 'dashers' or 'works' made to revolve on a horizontal spindle passing through its centre.

Revolving churns, taking the shape of a box or barrel, are supported from two points on a rigid framework, so that the whole body of the churn is turned round at the rate of forty to fifty revolutions per minute by a crank handle after the fashion of an ordinary grindstone. Sometimes the motion is a simple rotatory one, as when the barrel is supported from the centre of both ends, giving it the position of a barrel rolling on the ground. It may also be hung from two corresponding points, one on each side, and occupy an upright position while at rest. The action is then called 'end over end.' An eccentric motion is given by hanging the body unevenly. These churns also contain 'dashers' or 'diaphragms' which increase the agitation of the cream. Their great advantage is the ease with which they can be worked-a matter of first importance where hand labour is employed. Swinging or 'cradle' churns are increasing in favour, because they are so extremely easily worked, inexpensive, and simple, and because they contain no movable 'dashers,' which demand much care and labour in keeping them sweet and clean. The body, consisting of an elongated box, may be suspended by four chains or thin iron rods, or it may be carried on four flat, flexible iron supports. It is pushed so that it swings backwards and forwards, giving the cream within a course which assumes the form of the figure 8 . The Holstein churn is upright and rigid. Its dashers, which are attached to a perpendicular shaft, are worked at high speed. With these churns the temperature of a cream may be kept nearly $10^{\circ} \mathrm{F}$. lower than in ordinary ones, and churning at $50^{\circ} \mathrm{F}$. (even in summer) produces firmer and better butter. See BUTTRR, DAIRY.

Churrus, the resinous exudation found in leaves and stems of Indian hemp, the important element in the preparation of Hashish (q.v.) or bhang. See HEMP.

Chusan', the principal of the group of islands known as the Chusan Archipelago, lies about a mile off the east coast of China, opposite Ningpo. It has an area of over $230 \mathrm{sq}$. m., and a pop. of 200,000 to 250,000 ; and although mountainous in the centre, it is generally fertile, and everywhere carefully cultivated. Ting-hai, the capital, a walled town about 3 miles in circumference, is, from its position on the route between Canton and Peking, close to the great ports of Shanghai and Ningpo, a place of both strategic and com. mercial importance, and its land-locked harbour is a busy shipping centre. There are few manufactures, but its carved work and silver wares are in repute, and cordage, matting, and fans are exported. It was taken by the British in 1840, and 
held till 1841, the close of the war; and in 1860 it was again occupied by an English force. Pop. $30,(x)(0)$ to $40,(600)$. - The mont remarkable of the surrounding group is the sacred island of Pu-tu, a mile E. of Chusan, covered with Buddhist temples, pagodas, and monasteries, and inhabited by up wards of a thousend monks. The chief monastery is one of the richest in Chins.

Chutney, an Last Indian condiusent, very largety used in India, and to a considerable extent in Britain. Indian chutney is a compound of man. goes, chillies or Capsicum (q.v.), and lime-juice, with some portion of other native fruits, such as tamarinds, dic., the flavour being heightened by garlic. It is sometimes manufactured for sale in England. Families occasionally make it for their own use, and employ the following ingredients: Chillies, 1 to $1 \frac{1}{2} \mathrm{lb}$; : apples, $1 \mathrm{lb}$. ; red tamarinds, $2 \mathrm{lb}$. ; sugar-candy, $1 \mathrm{lb}$. ; fresh ginger root, 1 l $\mathrm{lb}$. ; garlic, $\frac{1}{6}$ to $1 \mathrm{l}$. ; sultana raisins, $1 \frac{1}{2} \mathrm{lb}$. ; fine salt, 1 lb. ; distilled vinegar, 5 bottles.

Chyle, Снумr. Food, having been partially digested and absorbed in the stomach, is then passed on into the small intestine. It is of a pulpy con sistency, and is termed chyme. Both digestion and absorption continue in the small intestine (see DigestroN). Of the digested chyme a portion finds its way directly into the blood-vessels of the intestine. Nearly all the fat, however, pesses into a special system of Lymphatics $\left(q . v_{0}\right)$ termed lacteals. These lacteal vessels lie in the walls of the intestine, and, during the fasting condition, are filled with a watery-looking fluid ealled lymph, which exudes from the neighbouring blood vessels. During absorption, however, the lacteals, in addition, become filled with the absorbed fat which is in a state of minute subdivision. This gives the chyle, as it is now termed, a milky appearance. The lacteals convey the chyle into a large vessel, the thoracic duct, which finally conducts it into the large veins at the root of the neck, where it mixes with the blood. One may observe the lacteals on opening the abdomen of an animal killed some few hours after a full meal containing fat. When filled with chyle they resemble white threads branching in the substance of the mesentery - a membrane stretching between the intestine and the back of the abdomen. Microscopically chyle consists of a fluid containing minute fat-globules and a few corpuseles, similar to white blood-corpuseles. Chyle is alkaline in reaction, and coagulates when withdrawn from the body. It may be looked npon as lymph plus the fat which has been absorlued. It contains (I) Proteids, such as serum-albumen, serum-globulin, and fibrinogen. Fibrin is formed during the process of coagulation. (2) Fats-palmitin, stearn, olein, and also cholesterin and lecithin. (3) Extractives, notably urea and grape-sugar. (4) Salts, especially sodium-chloride. See LYMPH, NuTrition, Digestion.

Claldini, ENrico, was born at Castelvetro, Modena, August 10, 1811. Designed for the medical profession, he studied at Parma, but by his share in the abortive insurrection of 1831 was forced to escape to France. He joined the foreign legion raised by Dom Pedro against the Miguelists, but, in 1835 passing over to the Spanish service, he fought against the Carlists, and was made colonel. When Charles Albert headed the Italian rising in 1848, he hurried to Italy ; in the struggle which ensued he received a dangerous wound, and fell into the hands of the Austrians. On his release, he was employed by the Sardinian government to reduce the volunteers to discipline, and fought at the heal of his new regiment in the brief campaign of 1849 . In the Crimes he com. manded a division of the Sardinian contingent; and on his return was appointed aide-de-camp to the king. He was intrusted by Cavour with the formation of the famous Cacmiatori delle Alpi. In the war of 1859 the victory at Palestro was his chief exploit. In 1860 he defeated the Papal army at Castelfidardo; in 1861 Gaets and Messina yielded to him. Created Duke of Greta, and for a few months governor of Naples, he had to act against Garibaldi in the second Sicilian expedition (1862). In 1864 he lrocame a senatur; and in the war of 1866 he occupied Venice almost without a blow. In 1876 he was sent as ambas. sador to Paris, but he retired in 1881, and became a general of the army. Died in 1892.

Cibber, CoLley, actor, manager, and dramatist, was born in Southampton Street, Bloomsbury, London, on 6th November 1671. He was the son of Caius Gabriel Cibber, a seulptor of some note, born in Holstein in 1630, whose best-known work is the basso-rilievo on the pedestal of the London Monument. He was educated at the free school of Grantham, in Lincolnshire; and in $1690 \mathrm{em}$ braced the profession of an sctor, joining the famous company of the Theatre Royal in Drury Lane. At this theatre, on the fortunes of which he exercised so important an influence, he re. mained, with one or two short intervals, during the whole of his theatrical career of forty-three years. At first he made very slow progress, and it was not till the secession from Drury Lane in 1695 of all the chief actors, that Cibher had an opportunity of showing how good a comedian he was. In January 1696 Cibber's first comedy, Love's Last Shift, was acted at Drury Lane, the author playing Sir Novelty Fashion. By this prodnetion his fame, both as dramatist and actor, was securely fixed; and he went on increasing in reputation till, after the secession in 1709 , he was chosen one of the managing actors of the Hay. market Theatre. In 1710 Cibber and his partners were transferred to Drury Lane, in the direction of which Steele was in 1714 associated with Cibber, Wilks, Booth, and Doggett. Various changes occurred in the personnel of the management, which was finally broken up at the retirement of Cibber in 1733. During their management the associated actors wrought a vast improvement in the condition of the stage. Plays became more decent; the dissipated loungers that were accustomed to haunt the side scenes were denied admittance, at the risk, as Cibber relates, of the managers' lives; the pecuniary affairs of the theatre were managed with regularity; and the whole atmosphere of the theatre rained in respectability. As an author Cibber contributed largely to the improvement in decency which followed Jeremy Collier's famous philippic in 1698 ; and it must always be remembered to his credit, that in his comedies he does not rely for his ludicrous effects on the outraged husband who had almost invariably been the butt of previons dramatists. His greatest work, however, is his A pology fur the Life of Mr Colley Cibber, Comedian (published in 1740 ; new ed. by $R$. W. Lowe, 1888), one of the most interesting autobiographies in our language. On the death of Eusden in 1730, Cibber, who was a devoted partisan of the Protestant succession, was appointed poet-laurente, in which office he wrote ales which were justly the object of universal ridicule. On this account, among others, he was ferociously attacked by Pope, who, in revenge for a damaging retaliatory pamphlet, elevated Cibber to the throne of Dullness in the 1743 edition of The Dunciad. The crime of dullness was, however, the last that could be charged to Cibber, who was vain, pert, a loose liver and a loose talker, but not a dullard. Cibber died suddenly on 11th December 
1757. His wife was a Miss Shore, sister of the 'Sergeant-trumpet' of England. After their marriage, about 1693 , she went on the stage, but did not attain to any great eminence.

Cibol. See ONION.

Ciborium. See Pyx.

Cibrario, LUIGI, an Italian historian and politician, was born at Turin, 23d February 1802. He studied law, entered the service of the state, and soon distinguished himself by his historical investigations. In 1848, when Italy rose against the Austrians, Charles Albert appointed him commissioner at Venice and a senator of Sardinia. In 1839 he published his Della Economia Politica del Medio Evo; in 1840, his Storia della Monarchia di Savoia; and in 1847, his Storia di Torino. In 1852 he was made Minister of Public Instruction, and ultimately, in 1855, Minister of Foreign Affairs. He published numerous other works on history, numismatics, and miscellaneous subjects. He died lst October 1870. See the Life by Odovici (1873).

Cicada, a large genus of hemipterous insects, typical of the sub-order Homoptera, with uniform wings. They are well known for the noise made

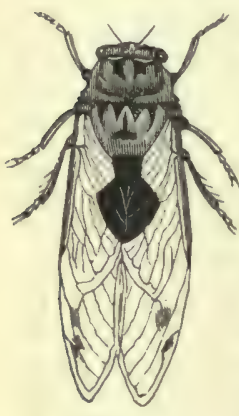

Cicada. by the males, and for the -Manna (q.v.) or sap which their incisions cause to exude from trees. Specially abund. ant in warm countries, some eighteen species of cicada oceur in the vine-bearing regions of Europe. When they do occur, their presence is not kept secret, for in the warm sunshine the males keep up a continuous and very loud, doubtless anatory, chirp-

ing. 'Their shrill 'song' has been echoed by poets from Ansereon to Byron, but seems to have sounded more sweetly in the ears of the ancients. Yet some people are so fond of the chirping that they keep the cicadas in little cages. Some large South American species are said to chirp "loud enough to be heard at the distance of a mile.' The noise is caused by the vibrations of membranes at the openings of two respiratory tubes (trachese) on the last joint of the thorax, and the volume of sound is increased by two complex resonating cavities a little farther back. The apparatus is rudimentary in the females; which in this case at least cannot be blamed for noise. The commonest South European species is Cicada orni, feeding especially on ash-trees. $C$. plebeya is a somewhat larger form. $C$. mannifera causes abundant 'manna' in Brazil. C. septemdecim is the North American 'seventeen years' locust,' or harvest-fly, said to occur in special abundance every seventeen years; though they probably appear in some part of the country every year. The males of the species perform the act of reproduction and soon die, prob. ably taking no nourishment in the perfect state. The females deposit about 500 eggs in the twigs of trees, and die immediately after. The larvae drop and bore their way into the ground, where they are supposed to remain for seventeen years, sucking the juices of the roots of trees and plants. There is also a thirteen years' variety or brood. When the pupre emerge, the ground sometimes seems honeycombed by their numbers. The larva are devoured in great quantities by birds, frogs, and owine. The damage done by the larva in their long underground career is nothing as compared with that inflicted on the foliage by the perfect insect (female) during its short life. See Bulletin

No. 8 (1885) of the United States Department of Agriculture. C. hoematodes, a small species, is recorded from the New Forest in Hampshire. The family to which the cicadas belong is often known as that of the stridulant insects, and includes about five hundred species. An even larger closely allied family is that of the Cicadellidre, including the common Froth-fly (q.v.). The name Cicada. has sometimes been applied to another hemipterous insect, a common bug named Halticus pallicornis or $C$. aptera of Linnæus. It need hardly be said that the cicadas are not crickets, or locusts, or grasshoppers. See LocusT.

Cicatrisation (Lat. cicatrix, 'a sear'), the process of healing or skinning over of an ulcer or broken surface in the skin or in a mucous membrane, by which a fibrous material of a dense resisting character, covered by a protecting layer of epithelium, is substituted for the lost texture. The new tissue in such 8 case is called the cicatrix, and usually resembles to a considerable extent the structure which it replaces; it is, however, less elastic, and from its shrinking in volume may produce an appearance of puckering. This shrinking sometimes leads to serious results, especially after extensive Burns (q.v.). The glands and other special structures of the original tissue are wanting in the cicatrix, which, however, performs perfectly well, in most instances, the office of protection to the parts below the surface. See INFLAMMATION and (under Uleers) ULCERATION.

Cicely (Myrrhis). See under Chervil.

Cicer. See Chick PEa.

Cicero, Marcus TulliUs, $106-43$ B.C., the foremost orator of ancient Rome, one of her leading statesmen, and the most brilliant and accomplished of her men of letters, lived in those stirring later days of the Roman republic, that age of revolution and civil wars, in which an old and decaying order of things was passing away. It was the age of great and daring spirits, of Catiline, Cresar, Pompey, Antony, with whose history Cicero's life is closely intertwined. Born 106 B.C. at an old Italian town, Arpinum in Latium, of a good family, and inheriting from his father, who was a man of considerable culture, a moderate estate, he went as a boy to Rome, and there, under the best teachers and professors, he learned law and oratory, Greek philosophy, and Greek literature, acquiring in fact the universal knowledge which he himself says in his essay "on the orator' (De Oratore) an orator ought to possess. An orator in the ancient world, we should bear in mind, was first and chiefly a pleader of causes, causes both legal and politicala speaker alike, as we should say, at the bar and in parliament. Hence the necessity for knowledge and information of every kind. Cicero's first important speech, in his twenty-sixth year, was the successful defence in a criminal trial of a client against one of the favourites of the all-powerful Sulla, then dictator. After a visit to Athens, and a tour in Asia Minor, where he profited by the society of eminent professors of rhetoric and men of letters, he returned to Rome, and at thirty years of age he was in the highest repute at the Roman bar.

In 76 B.C., having been elected quastor (a financial-secretary, as we may say ) by a unanimous popular vote, he held an appointment in Sicily, where he won the good opinion of two highly important interests, apt at times to conflict, the traders and the revenue collectors. To this he owed the glory of his successful impeachment of the infamous Verres in 70 B.C., which he undertook at the request of the Sicilian provincials. The bad man who had so hideously misgoverned them felt himself erushed by Cicero's ovening speech, and went into 
voluntary exile. Cicero was now a power in the state, and his rise up the official lauder was sure and rapid : in 66 в. (. The was prator, and supported in a great political speech (Pro Lege Manilia) the appointment of Pompey to the conduet of the war with Mithridateg, which in fret carried with it the supreme control of Asia and of the East. In 63 B.C., at the age of forty-four, he was consul, the highest dignity attainable to a Roman; in that memorable year he foiled, by a bold promptitude, the revolu. tionary plot of Catiline, in which many distinguished Romans - Cmasr, it was even said, among themwere implicated. He was now at the height of his fame : father of his country" he was actually called; for a brief space he was with all classes the great man of the day. But the tide soon turned; Cicero might have saved the country, but in saving it, it was said, he had violated the constitution, according to which a Roman citizen could not be cupitally punished but by the sentence of the people in regular assembly. As it was, Roman citizens guilty of complicity with Catiline had, at Cicero's instigation, been put to death simply by an order of the senate; this, it was said, was a dangerous precedent, and Cicero must be held responsible for it. His bitter enemy, Clodius, now tribune, pressed the charge against him in inflammatory speeches specially addressed to the lowest class of citizens, and Cicero in despair left Rome in 58 B.C., and took refuge at Thessalonica. That same year saw 'the father of his country' condemned to exile by a vote of the Roman people, and his house at Rome and his country houses at Formise and Tusculum plundered and ruined.

But in those revolutionary days the events of one year were reversed by those of the next; in 57 B.C., with new consuls and new tribunes, the people almost unanimously voted the recall of the exile, and Cicero was welcomed back to Rome amid an outburst of popular enthusiasm. But he was no longer a power in the world of politics; he could not see his way clearly; and he was so nervously sensitive to the fluctuations of public opinion that he could not decide between Pompey and the aristocracy on one hand, and Cresar and the new democracy on the other. His leanings had hitherto been towards Pompey and the senate and the old republic; but as time went on he felt that Pompey was a half-hearted man, who could not be trusted, and that he would have ultimately to succumb to his far abler and hore far-sighted rival, Caesar. The result was that he lost the esteem of both parties, and came to be regarded as a mere trimmer and time-server. There was all that political indecision about him which may be often olserved in eminent lawyers and men of letters. The age wanted strong men such as Cresar; this Cicero certainly was not. He was gentle, amiable, very elever, and highly cultivated, but the last man in the world to succeed in politics.

The later years of his life were spent chiefly in pleading at the bar and in writing essays. In 52 B.c. he composed one of his finest speeches in defence of Milo, who had killed Clodius in a riot, and was then standing for the consulship; in this he was acting quite against the wishes of Pompey. In the following year (51-50 B.C.) he was in Asia, as governor of the province of Cilicia, and here the best side of his character showed itself in his just and sympathetic treatment of the provincials. In 49-48 B.C. he was with Pompey's army in Greece to fight for the old cause, of which, however, he well-nigh despaired, and after the derisive hat tle of Pharsalia, at which he was not present, he threw himself on the conqueror's merey. Cresar, who had certainly nothing to fear from him, received him kindly, and was a great friend to him from that day'; but Cicero was not a happy man now that he could no longer make speeches in the nenate or in the courts; to all this Casaar's vietory had for the time at least put an end. In the years 46,45 , and 44 B.C. he wrote most of his chief works on rhetoric and philosophy, living in retirenent and brooding mournfully over his griefs and disappointments. In 43 B.C., the year aiter Crenar's death, he houl once again the lelight of liaving bis tologuence applauded by the senate. In that year his famous speeches against Antony-Philippics, as be called them after the title of Demosthenes" orations against Philip of Macedon-were delivered. These cost him his life. As soon as Antony, Octavius (afterwards the emperor Augustus), and Lepidus had leagued themselves together in the so-called triumvirate for the settlement of the state, they followed the precedent of former revolutions and published a proscription-list of their political enemies. All such were outlawed and given up to destruction. Cicero's name was in the fatal list. Old and feeble, he fled to his villa at Formix, pursued by the soldiers of Antony, and was overtaken by them as he was being carried in a litter down to the shore, where it had been his intention to embark. With a calm courage, which (to quote Macaulay's words) ' has half redeemed his fame,' he put his head out of the litter and bade the murderens strike. He died in the December of $43 \mathrm{~B} . \mathrm{C}_{\text {. }}$, in the sixty-third year of his age.

As an orator and a pleader Cicero undoubtedly stands in the first rank. Many of his speeches have come down to us. Of these the most fanous and perhaps the finest are his speeches against Verres and against Catiline. Eloquence in those days of furious faction and revolution was a greater force than it is with us. As a politician be failed because he did not distinetly realise to himself that the old republic, the government of the senate and of the nobles, had been tried and had been found wanting. He had not the courage to face the great changes which he felt were impending. Pompey, the champion of the old order, was not a leader to whom he could look up with confidence. And so he wavered, and half acquiesced in Cirsar's trimmph, even though he suspected that with that triumph the Rome which he had known and loved would pass away. To us it is as an essavist and as the writer of a multitude of letters to friends, full of miscellaneous information, that Cicero is particularly attractive; there is a gracefulness and refinement and elevation of tone ahout his writings which cannot fail to incline the reader to $8 \mathrm{ay}$ with Erasmus, 'I feel a better man for reading Cicero.' His essays on 'old age,' and 'on friendship,' his De Offictis or 'whole duty of man,' are good and pleasunt reading such as we can all enjoy; and his more abstruse writings on philosophy, his Tusculan disputations, his treatises on the nature of the gorls,' and on the 'true ents of human life' (Te Finibus), if they do not show any very original thought, at least give us an insight into the teachings of the ancient philosophical schools.

The best edition of Cicero's works is by Baiter and Kayser (1869), of his Epistley hy Trurell (6 vols. 1879 999); and the best Cicero lexicon Merguet's (Jena, 1877-84). See also works by Middleton (1741), Foreyth (1864), Jeens (1880), Trollope (1880), Lucas Collins (1871), Teuffel (1889), Weissenfels (1892), Strachan-Davidaon (1894), and Gaston Boissier (trans, 1897)

Cicero'ne (from Cicero, "the orator" or 'speaker'), a name given by the Italians to the guides who show travellers the antiquities of the country. Cicerones are to be found of all degrees of knowledge or respectability, from distinguished local archreologists to the humble laquais de place, who, though guite indispensable on a first arrival, is too often both incompetent and dishonest.

Cicho'rium. See Chicory and Exdrve. 
Cicindella; a genus of beetles in the section Pentamera, and type of a family with some 300 species. They are very active, and occur abundantly on sandy places. C. campestris is a common British species of a green colour.

Cicisbe'o, a professed gallant who waits with fantastic devotion upon a married lady. In the higher ranks of Italian society it was at one time considered unfashionable for the husband to associate with his wife anywhere except in his own house ; and in society, or at public places of amusement, the wife was accompanied by her cicisbeo. Cicisbeo is synonymous with cavaliere servente.

Cieu'ta. See Hemlock.

Cidaris, a genus of Sea-urchins (q.v.), and type of a family (Cidaridæ) with very long spines. The most of the members of the family are fossil forms, but over a score of living species are known. Dorocidaris papillata is occasionally dredged to the north of Scotland, and its beautifully marked spines in some instances measure over six inches in length, being often twice as long as the cross diameter of the shell. It is sometimes popularly called the Piper from a fanciful resemblance to bagpipes.

Cid Campeador, the name, or rather names, by which the nost renowned Spanish warrior of the 11th century is best known. By his Moorish vassals he was called 'Sid-i' ('my lord'), which the Spaniards translated by Mio Cid, and a victory in his youth over a Navarrese champion in single combat gave him the title of Campeador. His real name was Rodrigo, or Ruy, Diaz (1.e. 'son of Diego'). He was a Castilian noble by birth, seventh in descent from Nuño Rasura, who was also ancestor of the royal line of Castile. He was born either at Burgos or at Bivar near it, about the year 1040. From 1065 to 1072 he was nominally alferez, or 'ancient,' but virtually commander of the forces to Sancho II. of Castile in the wars in which that king wrested the kingdoms of Leon and Galicia from his brothers. In 1072 Sancho was treacherously slain at the siege of Zamora, and as he left no heir the Castilians had to acknowledge Alfonso, the banished king of Leon. As a conciliatory measure Alfonso gave his cousin Ximena, daughter of the count of Oviedo, to the Cid in marriage, but afterwards, in 1081, when he found himself firmly seated on the throne, yielding to his own feelings of resentment, and incited by the Leonese nobles, he banished him from the kingdom. According to tradition he never forgave the Cid for having, as leader of the Castilians, compelled him to swear that he had no hand in the murder of his brother Sancho, but there is no need to look for any cause beyond the hereditary animosity between the Castilians and the Leonese, now intensified in the latter by recent defeat and humiliation, for which they held the Cid responsible. At the head of a large body of followers the Cid betook himself to Moctadir of the Beni Hud, the so-called king of Saragossa, to whom, and to his son and grandson, he rendered important services against their enemies the king of Aragon and the count of Barcelona. In conjunction with Mostain, grandson of Moctadir, he invaded Valencia in 1088, but afterwards carried on operations on his own account, and finally, after a long siege, made himself master of the city in June 1094. The Almoravides, then in possession of south and central Spain, twice sent large armies against him, but were each time routed with great loss. For five years he reigned like an independent sovereign over the fairest and richest territory in the Peninsula, but in July 1099 he died suddenly, of grief, the Arabic annals say, at the news that some of his men had been defeated. His widow held out for two years longer, and then retired, carrying with her the embalmed body of the Cid, which for ten years sat enthroned beside the high altar at San Pedro de Cardeña, near Burgos.

The Cid's career cannot be better summed up than in the words of a contemporary and an enemy, Ibn Bassam of Seville, who wrote only ten years after his death, and could cite the testimony of one who knew him and was an evewitness of his deeds in Valencis. Of the Cidwhom he calls 'a Galician dog, one Roderic, surnamed the Canbitur, the scourge of the country' -he says: 'It was the Beni Hud who raised him out of obscurity, and they delivered over to him divers provinces of the Peninsula, so that he overran the plains like a conqueror, and planted his banner in the fairest cities. His power grew very great, nor was there any district that he did not ravage. Nevertheless this man, the scourge of his time, was, in his love of glory, strength of character, and heroic courage, one of the marvels of the Lord. Victory always followed his banner-God's curse be on him.' 'The character of the Cid was, however, a somewhat complex one. There can be no doubt of his cruelty, rapacity, and duplicity, for the statements of the Moorish authorities are substantially confirmed by the Spanish, the Cronicas, the Gesta Roderici Campidocti, and even the Poema itself. But it may ke said for him that to strike terror was one of the necessities of his position, outnumbered as he was by a hundred to one; and had he not made plunder his prime object the army he led would soon have melted away. Unscrupulous condottiere as he was, fighting for paymaster or plunder, he was nevertheless a staunch patriot at heart. Ibn Bassam had it from one who heard him that he said: "This peninsula was conquered under one Roderic, but another Roderic shall deliver it.' He was an imperfect hero; but he was a born leader of men, and it was only natural that a career like his should take a strong hold of the popular imagination, and in an age when minstrelsy flourished become a favourite theme with the jongleurs and trovadores. These, when facts began to run short, met the demand by draw. ing upon their invention, and treated the Cid precisely as they treated Charlemagne. As they invented the journey to Jerusalem, the expedition to Galicia, the Bridge of Mantible, and the Emir Balan for Charlemagne, so they devised an invasion of France for the Cid, made him defy the emperor Henry, beard the pope, cut off the head of the count of Gormaz and marry his daughter; and to allow time for all, they put back his birth twenty years, and even extended the life of his charger Bavieca to sixty. They also married his daughters to the Infantes of Carrion, princes of the bloodroyal of Leon. Historically, the Cid's daughters were married, one to a count of Barcelona, the other to a prince of Navarre, a union by which his blood passed into the royal line of Castile, and thence into the Bourbon, Hapsburg, and our own royal families. Alfonso $X$. adopted all the amplifications of the minstrels in the Cronica General, from which they found their way almost unquestioned into the history of Spain; and their inconsistencies and absurdities have in some instances led uncritical and somewhat indolent historians like Masdeu and Dr Dunham to treat the whole story of the Cid as a fable, and himself as no better than a creature of popular fancy.

Of the Cid literature it is impossible to give more than a summary here. By far the most important in every way of the works belonging to it is the Poem, written undoubtedly in the last half of the 12 th century, and probably the oldest document in the Spanish language. It is more properly an epic than a chanson de geste, and unquestionably the most Homeric piece of medieval poetry in existence. 
Editions of it have been given by Janer and Pidal in the Biblioteca de Autores Esparioles (vol. Ivii.), by Vollmöller, with introduction and notes, and by Damas Hinard, with a French prose translation. It has been translated into German by O. L. B. Wolff, and there is an English translation with introduction and notes by John Ormsby. The translated fragments by J. H. Frere do little justice to the dignity, sense, and spirit of the old Spanish poem. The Cronica Rimada, a very inferior work of a much later date, deals mainly with the apocryphal invasion of France. The prose Cronica del Cid (Burgos, 1.312) is merely that part of the Cronica General which refers to the Cid, with some additions and corrections. Southey's admirable Chronicle of the Cid is a composite work made up of portions of the Cronica and of the Poem, skilfully interwoven so as to give the story of the Cid as the old story. tellers told it. Risco's Castilla (1792) contains, besides a life of the Cid, the original Latin text of his marriage-settlement, dated 1074 , the Santiago Genealogy, and the Gesta Roderici Campidacti; both written before 1238. Of more modern works the most notable are Malo de Molina's Rodrigo el Campeador (1857), Professor Dozy's Le Cid d'apres de nouveaux Documents (1860), and $H$. Butler Clarke's The Cid Campeador (1897). The Cid ballads, so numerous in the old cancioneros and romanceros, were collected and printed in a romancero by themselves by Escobar in 1612. The fullest and best Romancero del Cid is that of Carolina Michaelis (1872), which contains no less than 205 ballads. Only a few, however, of the Cid ballads are of high excellence, or to be regarded as specimens of genuine traditional popular poetry. The greater number are comparatively modern, many are merely portions of the Chronicles put into verse, and not a few are artificial ballad imitations of the 16th and 17th centuries.

Clder, or CYDER, is the fermented juice of apples, and is extensively prepared in Devonshire, Herefordshire, Gloncestershire, and other parts of England, in the United States, and in the north. ern districts of France and Germany. The apples commonly used for making eider are by no means tempting to the palate, are in fact unfit either for eating raw or ordinary cooking. Three kinds may be used-viz, the bitter, the sweet, and the sour; but the finst are generally preferred, and are specially cultivated in the cider orchards. These bitter apples contain a considerable amount of sugar, but it is masked to the palate by the extractive matter also present. Late apples afford much better cider than early ones. The apples after gathering are left for some days to mellow or mature. This has the further advantage of showing the unsound apples, which are rejected, as giving the whole an incurably musty flavour. In the United States it is considered that a certain proportion of decaying fruit improves the flavour; probably they act by hastening or modifying the fermentation. The apples are crushed by passing them between fluted rollers, or in mills of various kinds. Some improved cider-mills grind the fruit to a perfectly homogeneous pulp. These mills give an increase in quantity, with a falling-of in quality of the product. The pulp thus obtained is placed in tubs or vats with or without a little water, and left for about a day. During this time fermentation commences and assists in breaking up the cells of the pulp. Or the pulp is more com. pletely broken up at once. The pulp is next placed in coarse canvas or haircloth bags, or on a wickerwork or perforated frame for the jnice to drain into a tub or vat. This juice is reserved for the best quality of eider. The remaining juice is removed by squeezing the bags and their contents in a press. The old process of laying up the pulp or pomace in straw for preasure gives a good quality of juice. The grenter the pressure the conser the flavour, due to that of the pips and skins, but of course the quantity is increased by additional preasure.

The next process is the full fermentation. This is usually effected in casks with large bung-holes. The casks being filled with juice, much of it froths over during fermentation, and therefore the caskis are placed over open tubs which catch it. Care is necessary to keep the casks full, so that the excens of yeast may thus be continually removed, such excess promoting acetic fermentation. This is con. tinued from three to eight or ten days according to the alcoholic strength required. It is then racked off from the sediment into clean casks and stored in a cellar or other place with cool and equable tem. perature. In the following spring this racked cider is re-racked, and is then ready for use or sale.

A weaker cider, used as a common beverage for farm labourers, is made by adding about half its weight of water to the marc or pressed pulp and fermenting this as above. The refuse pulp or 'apple cheese' is used as food for pigs and cattle.

Cider contains from 4 to 10 per cent. of alsolute alcohol-i.e. 8 to 20 per cent. of proof spirit, according to quality. This depends upon the quantity of sugar originally in the juice, and upon the care in fermentation, especially in respect to temperature, which should be about $50^{\circ} \mathrm{F}$. This is too commonly neglected, and the fermentation left to the accidents of weather. Much acetic acid is thus formed when the autumn is warm, rendering the cider rough. Sweet cider is that in which only a small proportion of the sugar has been converted by fermentation into alcohol or acetic acid. The best cider is mellow and vinous, neither sweet nor acid. The bottling of eider demands much care. Only clear samples are fit for bottling, and they should be at least twelve months old and free from hardness or acidity. Good mellow or slightly sweet cider carefully bottled before fermentation is fully completed constitutes champagne cider, and is used as a basis of factitious champagne.

Cienfuegos, a seaport city of Cuba, on the mag. nificent Bahia de Jagua ( south coast), 189 miles by rail SE. of Havana; it is also connected by rail with other parts of the island. The harbour is of the first elass, and is commercially the most important port and the centre of the sugar-trade in the south part of the island; it exports also tobacco, molasses, honey and wax, \&c. Pop. (1899) $30,038$.

Cieza, a town of Sprin, 26 miles NW. of Murcia. Pop. (1877) 10,910.

Cigars and Cigarettes. See Tовассо.

Ci'goli (properly Ludovico CARDI), a painter of the later Florentine sehool, was horn at Cigroli, near Florence, in 1559. His models were Andrea del Sarto and Correggio; but he has his own style, marked by expression and fine colour. He was invited by Clement VII. to Rome, where he died in 1613. Cigoli was also held in high estimation as an architect.

Cilia (Lat., 'eyelashes'), hair-like lashes borne by cells. They are mobile modifications of the liv. ing matter of the cell, and exhibit alternate bending and straightening. Their occurrence is very wide - e.g. on the active stages of many unicellular plants; in great perfection on the ciliated Infus. orians; on the free-swimming enbryos of sponges, Colenterates, worms, echinoderms, and molluses; on the outer surface of many lower animals such as simple worms; on the lining of the alimentary cavity, and in most of the tubular organs of Inverte. brates; and more restrictedly, though not less markedly, in some regions (such as trachea) of higher forms. They are abent throughout the Arthropods (with one possible exception), a fact 
probably to be associated with the predominance of Chitin (q.v.). In many cases, normal, pathological, and artificial cilia may sink down into less motile amoboid processes. A single lash with an undulating movement is distinguished as a flagellum and Ray Lankester emphasises the useful distinction between a flagellum such as that of a breterium, or the tail of a spermatozoon, which acts "like a tadpole's tail ' and drives the cell before it, and the motive process of a flagellate Infusorian which carries the cell behind it. See CELL.

Cilicia, an ancient division of Asia Minor, now included in the Turkish province of Adana, which lay between the Taurus range and the Cilician Sea, while the Amanus range separated it from Syria. The eastern portion of Cilicia was fertile in grain, wine, \&e. ; the western and nore mountainous portion furnished inexhaustible supplies of timber to the ancients. The pass called by the Turks Gölek Boghaz (ancientily Pyla Ciliciae) is that by which Alexander the Great entered Cilicia. In early ages Cilicia was ruled by its own kings, the people, who were probably akin to Syrians and Phoenicians, being notorious pirates. The country fell sucessively under Persian, Macedonian, and Syrian rule, and was made a Roman province by Pompey in 67 B.c. See Asia Minor.

Cimabu' $\dot{e}$, Giovanni, the first of the restorers of the art of painting in Italy, which had fallen into neglect during the barbarism of the dark ages, was born at Florence in 1240. At this time the fine arts were practised in Italy chiefly by Byzantines, though there were such native artists as Guido of Siena and Giunto of Pisa; and painting had degenerated into a worn-out mechanical conventionalism. Cimabue at first adopted traditional torms, but he soon turned to nature, painting a St Francis from the living model, 'a new thing in these times,' as Vasari tells us, infusing life and individuality into the worn-out types of his predecessors, and leading the way to the naturalism of the works of his great pupil Giotto (q.v.). In the stiff forms of his draperies he made little progress upon former practice, but he softened his outlines, improved his flesh-tints, and gave projection and a sense of rotundity to his forms. Two remarkable pictures of the Madonna by Cimabue are still preserved in Florence-one in the Academy; the other, displaying a more purely original genius, in the church of Santa Maria Novella. It is said that this latte: work in the time of Cimabue was admired as a miracle of art, and was carried to the church in a sort of triumphal procession. It is the first great production of the Florentine school which culminated in Michael Angelo, Raphael, and Leonardo. Cimabue executed several important frescoes in the south transept of the lower church of San Franceseo at Assisi, and in the north transept of the upper ehurch there; and during his later years he was appointed capo maestro of the mosaics of the Duomo of Pisa, his works in this method ranking as the finest of the period. His mosaic of Christ in glory in the apse was probably his last work; and his easel-picture of a Madonna and Child in the Louvre was executed for San Francesco at Pisa. He died about 1302.

Cimarosa, Domenrco, an Italian composer of operas, was born either at Aversa, 17th December 1749 , or more probably at Naples in 1755 . He was certainly educated at Naples, in music under Sacchini, and in the conservatory of Loretto. His first pieces were the Sacrificio di Abramo and the olympiade. When barely twenty-two he had achieved a reputation in all the leading Italian theatres. He was then called to St Petersburg as composer to the Empress Catharine II., where he resided four years. Afterwards he lived at various
German courts; thence he proceeded to Vienna, where he became imperial kapellmeister; and finally he returned to Italy. At Naples, his comic opera, Il Matrimonio Segreto, composed at Vienna, 1791, was repeated seventy times in succession. Cimarosa died at Venice, 11 th January 1801. His comic operas are remarkable for their novelty, spirit, whimsicality, and liveliness of idea, as well as for their great knowledge of stage-effect.

Cimbri, or KıмвRI, a people who issued from the north of Germany in conjunction with the Teutones, and first came into hostile contact with the Romans in the province of Noricum (Carinthia and Carniola) in 113 B.C. They were victorious in several great engagements, and were only prevented from devastating Italy by a terrible defeat they suffered from Marius on the Raudii Campi, near Verona, or, according to others, near Vercelli, in August 101 B.C. They fought with desperate courage, and when the battle was lost, their women killed themselves and their children. It is not till long afterwards, when the Romans themselves penetrated into Germany, that the name of the Cimbri again appears. Cæesar represents the Aduatici of Belgium as the descendants of the Cimbri and Teutones. Tacitus speaks of a people bearing the name of Cimbri, few in number, but of great reputation, that sent ambassadors to Augustus. This people lived in the extreme north of Germany, on the borders of the ocean; according to Pliny and Ptolemy, at the extremity of the peninsula called from them the Cimbric Chersonese, now Jutland. The ethnology of the Cimbri is doubtful. Greek writers associated them groundlessly with the Cimmerians; Sallust calls them Gauls; Cæsar, Tacitus, Plutarch, and most moderns look upon them as Germans. Some, however, have maintained that they were Celtic, and have tried to fortify their argument by a desperate analogy with the name Cymry.

\section{Cimex. See Bug.}

Cimmerians, or CrMmerI, in Homer, a legendary people dwelling 'beyond the ocean. stream, where the sun never shines, and perpetual darkness reigns.' The name was also applied to a fabulous people who dwelt in caves between Bair and Cumæ. Hence the common phrase, 'Cimmerian darkness.' The historic Cimmerii were a people whose country lay between the Borysthenes (Dnieper) and the Tanais (Don), including also the Tauric Chersonesus (Crimea). The Cimmerian Bosporus (Strait of Yenikale) derived its name from them. Being driven out by the Scythians, they migrated to Asia Minor, dwelt there for some time, plundered Sardis, failed in an attempt upon Miletus, and were finally routed and expelled by the Lydian king Alyattes, some time after 617 B.C.

\section{Cimolite. See Fullers' Earth.}

Cimon, an Athenian commander, was the son of the great Miltiades, the conqueror at Marathon. Being unable to pay the fine of 50 talents from which his father eseaped by dying, he was kept. in prison until the fine was paid by the wealthy Callias who had married his sister. Young Cimon enjoyed the patronage of Aristides, and soon distinguished himself in the patriotic struggle against. the Persians. In conjunction with Aristides he was placed over the Athenian contingent to the allied fleet, which, under the supreme command of the Spartan Pausanias, continued the war against the Persians (477 B.C.). He effected the important conquest of Eion, a town on the river Strymon, then garrisoned by the Persians. His greatest exploit was his encounter with a Persian fleet of 350 ships at the river Eurymedon (466), when he destroyed or captured 300 , and defeated the land- 
forces on the same day. He succeeded likewire in driving the Persinns from Thrace, Caris, and Lycia ; and expended much of the money which he had obtained by the recovery of his patrimony in Thrace npon the improvement of the eity of Athens. The lavish bounty with which he opened his gardens and the honours of his table, together with his cheerful temper and patience, endeared him to his fellow-citizens. At this period he nppears to have been the most influential of the Athenians. The hereditary enemy of Persin, it was his policy to advocate s close alliance with Sparta; and when the Helots revolted, he twice led an army to the support of the Spartan troops; but on the latter occasion, having lost the confidence of his allies, he was ignominiously dismissed. After his return to Athens his policy was opposed by the democracy, headed by Pericles, who procured his banishment by ostracism. He was recalled in the fifth year of his exile, and was instrumental in obtaining a five years' armistice between the Spartans and the Âthenians. He died in the year 449 B.C., at the siege of a Cyprian town.

Cincho'na (properly СнiмchONA), a most important genus of trees of the order Rubiacen (sub-order (inchonacea), yielding the bark so much valued in medicine, which has been variously known as Peruvian Bark, Jesuits' Bark, China Bark, Quina, Quinquina, Cinchona Bark, dc., and from which the important alkaloids quinine and its congeners sre obtained. "The species of this genus are sometimes trees of great magnitude; but an aftergrowth springing from their roots when they have been felled, they often appear only as large shrubs; and some of them in the highest mountain-regions in which they are found are low trees with stems only 8 or 10 feet in height. They are natives of South America between $20^{\circ} \mathrm{S}$. lat. and $10^{\circ} \mathrm{N}$. lat., and chiefly on the eastern slope of the Cordilleras. The best cinchona formerly came from the province of Loxa in Ecuador. The range of altitude of course diminishes as we recede from the equator, but may be averaged at from 8000 to 5000 feet for the best varieties. The climate of these regions is extremely variable, and this seems to have more effect upon the trees and their product than differences in soil. All the cinchonas are evergreen trees, with laurel. like, entire, opposite leaves; stipules which soon fall off ; and panicles of flowers, which, in genera appearance, are not unlike those of lilac or privet. The flowers are white, rose-coloured, or purplish, and very fragrant.

Such difficulty has been found in determining the species of cinchons and the different varieties of bark known in commerce that a voluminous apecial literature of 'quinology' has been called into existence. This difficulty is due partly to the large number and great variability of the species, and even of individual specimens of bark, as also to the difficulty of obtaining specimens of flowers and leaves along with particular kinds of bark. The most important species are $C$. officinalis of Ecuador and Peru, $C$. Calisaya of Bolivis and south-east Peru, and $C$. succirubru of the western slope of Chimborazo; but others (Carthagena Bark, Columbian Bark, \&c.) are also of importance, while the varieties are too numerous to mention. The barks of allied species which, although more or less bitter and even febrifugal, contain no quinine are apt to be used as substitutes or adulterations.

The eutting and peeling of cinchona-trees is a laborious and difficult operation earried on by Indians during the dry season. They build a hut, which serves both for their abode and for drying the bark. The trees are felled as near the root as possible, that none of the bark may be lost; and the bark being stripped off, is caretully dried and packed ; the quilled form of the thinner bark is acquired in drying.

This wasteful and costly mode of collection from almost impassuble forests, in which, moreover, the

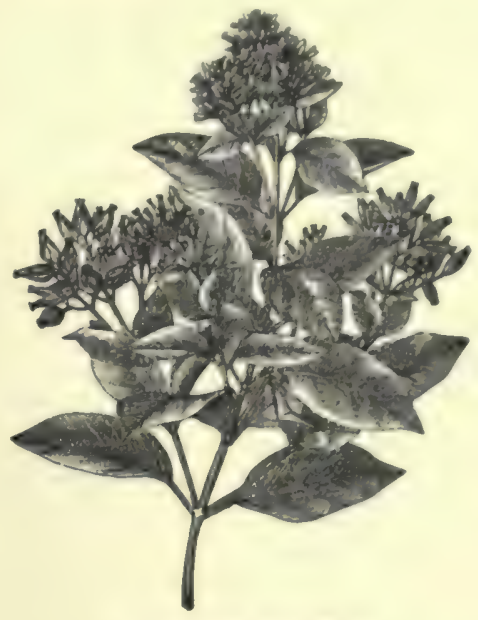

Cinchona lancifolia.

tree was becoming exterminated, and this in face of an increasing demand, gradually roused the attention of European botanists to the desirability of inaugurating a regular culture in similar regions and climates of the Old World; but the successful introduction of cinchona-seeds into Europe was only effected by Weddell in 1848 , and his seedlings were sent from the Jardin des Plantes to Algiers in 1850, and to Java in 1852. The Dutch government also imported a few living plants from Peru in 1854. The eredit of really solving the difficult problem of acclimatisation is, however, due to $\mathrm{Mr}$ Clements R. Markham. Himself going to Peru and Bolivia for C. Calisaya, he secured the services of Spruce, a well-known collector then resident in Ecuador (who was similarly successful in obtaining C. succirubra), as well as those of three other effective coadjutors. The expedition was attended by much difficulty and danger, and its narrative has a prominent place in the history of botanical travel. Plantations were formed in the Neilgherry Hills, and thence spread to Sikkim at the foot of the Himalayas, to British Burma, Ceylon, \&e. Cinchona is also being grown in the West Indies, and its acclimatisation in all suitable localities continues to make progress and to become an important industry

The Indians of Peru call the cinchona-trees Kina, from whence are derived the names Quina, China, Sc. But there is no evidence that they knew the use of the bark before the arrival of the Spaniards, nor will they even yet employ it in their native medicine. It was first imported into Europe in 1639 , by the Countess of Chinchon, the wife of the viceroy of Peru, who had been cured of an obstinate intermittent fever by means of it, and who thereafter habitually distributed it to thoee suffering from fever. Upon this account it was named C. Bark and Countess's Povoder (Pulvis comitisse). The Jesuit missionaries afterwards carried it to Rome, and distributed it through their several stations, and thus it acquired the name of Jesuits' Bark and Pulvis patrum. Cardinal Juan de Lugo having been particularly active in recom. mending and distributing it, it was also known as Cardinal de Lugo's Powoder. It attained great celebrity in Spain and Italy, being at first distrib. uted to the poor, but later sold at high prices by 
the Jesuits, by whom it was lauded as an infallible remedy, while by most of the orthodox physicians it was coldly received, and by the Protestants altogether repudiated. Falling thus into practical disuse in Europe, it was again brought into notice by Robert Talbor or Talbot, an English apothecary, who acquired great celebrity through the cure of intermittents by its use. In 1678 he was appointed physician in ordinary and knighted by Charles II., whom he next year cured of a tertian fever. In 1679 he similarly cured the Dauphin and other eminent personages on the Continent, and thus induced Louis XIV. to purchase his seeret. The adoption of the drug was henceforth assured, despite the exceeding jealousy of the profession in England and France of both the success and fortune of the irregular practitioner, who did not, however, live much longer to enjoy his reward. The Parisian faculty of medicine held out bravely, a corroboration, if any were needed, of Moliere's account of them, but the example and authority of Morton and Sydenham at length gained respectability to the side of seience. As it came into general nse, it became a most important article of export from Peru; and in order to the maintenance of a commercial monopoly, although no attention was ever paid to its culture, extraordinary methods were employed to prevent it from becoming known at a comparatively recent period of Spanish rule in America. The discovery of the alkaloids on which its properties chiefly depend constitutes a new era in the history of this medicine, and did not take place till the beginning of the present century.

The account of these alkaloids and their physiological and therapeutical action will be found under Quinine (q.v.). An excellent outline of the whole subject, with introduction to the literature of quinology, is to be found in Flückiger and Hanbury's well-known Pharmacographia, and in most manuals of pharmacology. In Markham's Peruvian Bark (1880) will be found almost all matters of general interest; and there is a Handbook of Cinchona Culture, by Van Gorkhom (trans. by Jackson, 1882).

Cincinnati, the metropolis of Ohio and seat of justice of Hamilton county, is situated on the Ohio River, by rail 263 miles

SW. of Cleveland, 270 miles SE Copyright 1889, 1897, and of Chicago, 553 miles W. of Lippineott Company.

Washington, D.C., and 757 W. by S. of New York. Steam-ferries and lofty bridges conneet the city with the Kentucky shore. Cincinnati occupies an exceedingly broken and irregular site, the more densely built parts being inclosed between the river and steep hills. This lower portion includes the principal business streets, for the most part wide and well finished; but the lowest level is devoted largely to warehouses and manufacturing establishments, and at high stages of water is sometimes liable to be flooded. A second terrace is 50 or 60 feet higher, and is densely occupied. A district between the hills and the Miami Canal is known as 'over the Rhine,' and is appropriated to the large German colony. But the most interesting portions of the city are the suburbs, which are singularly beautiful. They are built on a succession of irregular hills, by whose steepness the beantiful suburban district has been broken into a succession of com. paratively isolated villages, interspersed with parks (of which Eden Park, of 206 acres, is the largest), and approached at various points by noble winding avenues. The principal way of access, however, is by inclined steam-railways and horse-ears, or in one instance, by wagon and passenger elevators. This suburban region, and in fact a considerable part of the south-western angle of the state, is of that geological epoch in which the highly characteristic rocks of the so-called 'Cincin- nati group' were deposited. They are richly fossiliferous, and are the highest beds of what are known as the Lower Silurian rocks, corresponding nearly with the Upper Caradoc beds of British geologists. There are more than twenty-five such suburbs, most of them within the city limits; Clifton and Walnut Hills, the latter looking out over Kentucky, are especially striking, and Spring Grove has a fine cemetery of some 600 acres.

The city has an area of $24 \mathrm{sq} . \mathrm{m}$., is well built and well drained, and the water-supply from the Ohio is ample. Among the principal public buildings are the post-office, an imposing structure; a massive and very admirable new Chamber of Commerce; a large art museum (unfinished); an art school, and a college of music (1878), of deservedly high repute a large music-hall, with a noted grand organ; a commodious city building; and a court-house. There are more than 200 churches, several of them large and architecturally noteworthy, including a Roman Catholic cathedral; besides many handsome theatres, hotels, and public halls. The eity has several ample hospitals and infirmaries (public and private), a large asylum for the insane, and many other institutions for charity and correction. There are public and private schools of every grade, among them three high schools, a normal school, a school of design, and a technical school. The fourteen professional schools include six medical schools, one school of law, and two of divinity, one of which (Lane Theological Seminary, Presbyterian) has a wide reputation. Cincinnati University is free to resident youths, and to it the Cincinnati Observatory and Astronomical School are affiliated. The city has several important libraries, one of which (the Free Public Library) contains some 150,000 bound volumes and 18,000 pamphlets. There is a Zoological Garden, and the Cuvier Club and the Historical and Philosophical Society possess considerable collections. Finally, Cincinnati is well known as a centre of musical and art culture, and its decorative pottery and wood-carving have a national reputation.

Besides its large river traffic, the city transacts a great amount of business by rail. A large number of railways converge to this place, and it is a receiving and distributing centre of great importance. The Miami and Erie Canal (1827), extending northward from Cincinnati (246 miles) to Toledo, is also the channel of a considerable trade. A very large proportion of Cincinnati's staples of trade are manufactured in the city, or its near vicinity. In $1872,43,739$ persons were employed in the manufactures, and the value of the goods produced was a little over $\$ 100,000,000$; in 1890 the labourers numbered 92,000, and the products were valued at $\$ 181,500,000$. Many steamboats and barges are built here. The city has sixteen banks, a clearing-house, a board of trade, a chamber of commerce and merchant's exchange, and other similar organisations. The condition of the labouring classes is in general very good. There are numerous building associations, which greatly facilitate the ownership of houses by working-men. The book-trade is represented by several first-class and a number of minor publishing-houses. The slaughter-houses, stock-yards, and grain-elevators are very extensive.

Cincinnati was first settled by white men in 1780 , and was permanently occupied in 1788. Its name was given in honour of the Society of the Cincinnati. It is believed that a portion of its site was occupied before the historic period by a considerable aboriginal population. Mounds containing various relics appear to confirm this opinion. It was incorporated as a city in 1819, and from its prosperity and attractiveness, it early attained the name of 'the queen eity of the west.' The sobri- 
quet of 'Porkopolis' commemorates its immense trade in pork and other hog products, which has now been largely diverted to other cities. The first nteambost reached Cincinnati in 1811 , descending the river from Pittsburg; and the first railway from the city was opened in 1845. Its first Roman Catholic bishop was consecrated in 1822, and the see hecame archiepiscopal and metropolitan in 1850. In the same year the lower part of the city suffered much from a great flood. Cincinnati very early became prominent for its social culture, and for a long time it was almost the literary capital or headyuarters of the whole region west of the Alleghanies. The unuswal local development of a taste for the fine arts and for nusic was likewise noticeable at an early date, and is still a characteristic of the town. Great riots occurred in 1884, and were with difficulty suppressed by the military. Pop. in 1800, 750; in $1850,115,436$; in $1870,216,239$; in $1880,255,139$ (of whom 8128 were coloured); by the census re. turns of $1890,296,908$; and of $1900,325,902$.

Cincinnati (the Cincinnatnses), a society or order in the United States of North Anierica, established by the ofticers of the revolutionary army in 1783 , 'to perpetuate their friendship, and to raise a fund for relieving the widows and orphans of those who had fallen during the war.' It was so named becanse it included patriots, headed by Washington, who in many instances had left rura affairs to serve their country (see CincrnNatus). The baige of the society is a hald eagle suspended by a dark-blue ribbon with white borders, symbol ising the union of France and America. On the breast of the eagle there is a figure of Cincinnatus receiving the military ensigns from the senators, round the whole are the words, Omnia reliquit servare rempublicam. As this distinction was made hereditary, it was attacked as opposed to republican equality. Franklin saw in it the germ of a future aristocracy ; and at a meeting held in Philadelphia in 1784 several changes were made in the constitution of the society, the right of succession being made conditional on approval in each case by the society. After 1804 the branches in several of the states were abolished. There are still, however, several state societies, which hold a general meeting by delegates triennially. See the Memoirs of the Pennsylvania Historical Society, vol. vi.

Cincinnati Epoch, the name given in North America to a subdivision of Silurian time

Cincinna'tus. Lucrus Quinctuos, a favourite hero of the old Roman republic, regarded by the later Romans as a pattern of antique virtue and simple manners. In 460 B.C. he was chosen consul, and two years later was made dictator. When the messengers from Rome came to tell Cincinnatus of his new dignity they found him ploughing on his small farm. He soon rescued the consul Lucins Minucius, who had been defeated and surronnded by the Aqui. but Livy's acconnt of the mode in which the deliverance was effected contains inconsistencies which did not escape the eritieal eye of Niebuhr. Sixteen days after, he laid down his dictatorship and returned to his small farm on the Tiber. At the age of eighty he was once more made dictator to deal with the alleged treasonable conspiracy of the great plebeian, Sp. Mrelius.

Cinder-bed, a name given by the quarrymen to a stratum of the Middle Purbeck series of the Jurassic system, almost entirely composed of the aggregated shells of a small oyster (Ostrea distorta).

Cineas, a Thessalian, the minister of Pyrrhus (q.v.), was the most eloquent man of his time, and died about 270 B.C. Pyrrhus said his words had won him more cities than his own arms.

Cinematograph, a modification of the kinetoscope. See EDIsoN, ZoETrope.
Cinera'ria, a large and widely distributed genus of ansual or perennial herbaceous conposites, very closely allied to Senecio (Groundsel, Ragwort, \&ce) of which it is indeed often reckoned a sub. genus. Two small species are natives of the southern parts of Britain The flowers of some are very pretty. maritima, from the Mediterranean shores, is a handsome garden perennial, and many Cinerarias are also grown in green-houses in Britain

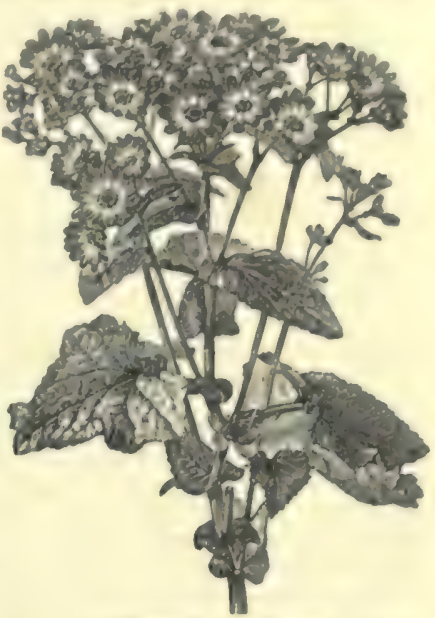

Cineraria eruents these, however, are mostly florists' flowers produced by cultivation and hybridising. The most important parent plant of these is $C$. cruenta, a native of Teneriffe.

\section{Cinerary Urns. See URN.}

\section{Cingalese. See CeYloN.}

Cinna. Lucius CoRnelius, a Roman patrician, one of the principal supporters of the faction of Marius After Sulla had driven Marius from the city, and before setting out on his expedition arainst Mithridates, he allowed Cinna to be elected to the consulship on condition of his swearing not to disturb the constitution as then existing. No sooner, however, had he entered upon that office ( 87 B.C.) than he impeached Sulla, endeavoured to form an interest among the citizens who had been added to Rome after the Social War, and agitated for the recall of Marins (q.v.). Cinna and Marius next declared themselves consuls after a cruel massacre of the Roman citizens, in which some of the most eminent citizens were slain. On the death of Marius, which oceurred within a few days of his usurpation, Cinna made L. Valerins Flaceus his colleague for that year, and C. Papirius Carbo for the two sncceeding years. In 84 B.C. he prepared to meet Sulla, who was then on his way from the East to take vengeance upon his enemies, but was slain by his disaffected troops at Brun. dusium. During his fourth consulate his daughter Cornelia had been married to Julius Cresar.

Cinnabar, an ore of mereury, from which almost all the mercury of commerce is obtained. Chemically it is a sulphide of mercury containing $86 \bullet 2$ parts of mercury and 13.8 of sulphur. It occurs both erystallised and massive, not unfrequently disseminated. Its erystals are six-sided prisms. It varies from perfectly opaque to almost transparent; has an adamantine, almost metallic lustre, and a carmine colour, with a bright scarlet streak. Its specific gravity is 8 to 82 Hepatic Cinnabar, so called from its liver-brown colour, is a variety containing a little carbon. Cinnabar sometimes oceurs in primitive rocks, but more frequently in those of the coal formation. The cinnabar mines of Almaden, in Spain, have been worked for about 2300 years, and have been surpassed in productive. ness by those of New Almaden in California. Cinnabar mines exist also in Idria, Germany, Hungary, Peru, China, and Japan. Cinnabar is used as a pigment under the name of Vermilion. 
Cinnamic Acid, $\mathrm{C}_{6} \mathrm{H}_{5} \mathrm{CH}=\mathrm{CHCOOH}$, exists in the free state in the balsams of Tolu and Peru, in liquid storax, and in gum benzoin. When oil of cinnamon (see below) is exposed to the air, it absorbs oxygen and deposits crystals of cinnamic acid. Cinnamic acid forms colourless crystals readily soluble in alcohol, ether, and boiling water, but sparingly soluble in cold water. It is not of any importance in the arts, and is chiefly interesting as being the acid corresponding to oil of cinnamon. This oil is the aldehyde of cinnamic acid, and is represented by the formula $\mathrm{C}_{8} \mathrm{H}_{5} \mathrm{CH}=\mathrm{CHCOH}$. Although isomeric with oil of cassia, it has a slightly different flavour, and is much more expensive. Both of these oils are employed in medicine as aromatic stimulants, but chiefly as pleasant adjuncts to disguise the taste of nauseous drugs. From a chemical point of view, the cinnamic acid and oil of cinnamon are related to Benzoic Acid (q.v.) and Oil of Bitter Almonds See Almonds (OIL OF). Benzoic acid is regarded as $\mathrm{C}_{6} \mathrm{H}_{5} \mathrm{COOH}$, while the oil of bitter almonds is the corresponding aldehyde $\mathrm{C}_{6} \mathrm{H}_{5} \mathrm{COH}$. On oxidation cinnamic acid is changed into benzoic acid.

Cimnamon is the aromatic bark of certain species of the genus Cinnamomum. This genus belongs to the natural order Lauracer, which includes a considerable number of species, natives of

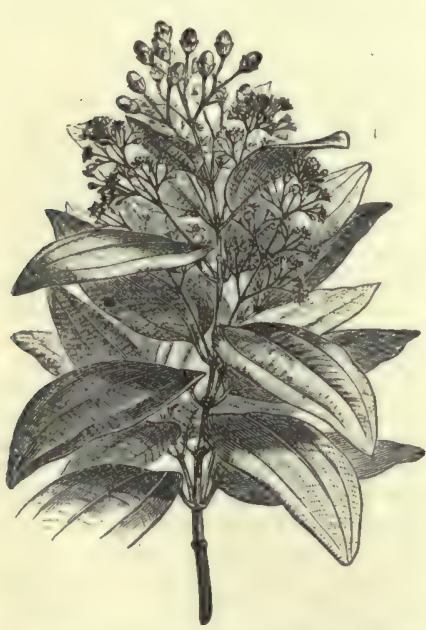

Cinnamon (Cinnanromum Zeylanicum). tropical and of subtropical parts of the East. Cinnamon has been in use from the remotest antiquity. It is mentioned in the Old Testament, and by a name almost the same as that which it still bears in most languages. The finest kind is produced by Cinnamomum Zeylanicum, or the Ceylon cinnamon-tree. It is still mainly derived from

its $n$ ative island, but was introduced into the West Indies in 1782, along with various other plants of the East, and is now cultivated there to some extent. The tree naturally attains the height of $20-30$ feet, and is sometinies 11 foot in thickness, but the cultivated trees are not allowed to grow higher than 10 feet. Its bark is of a grayish-brown colour, internally of a yellowish red. The leaves are oval, 4-6 inches long, with a blunt point, and marked with three yrincipal nerves. They have the taste of cloves. The flowers are of a silky gray on the outside, and a pale-yellowish colour internally. The fruit is somewhat like an acorn in shape; it is a small drupe, brown when ripe. There are two seasons of cinnamon-harvest in Ceylon, the first commencing in April, and the last in November-the former boing that in which the chief crop is obtained. The branches of 3-5 years' growth being cut down, the epidermis is scraped away; the bark is then ripped up longitudinally with a knife, and gradually loosened, till it can be taken off. The slices are then exposed to the sun, when, as it dries, it curls up into quills, the smaller of which are inserted into the larger, and the whole tied up in bundles of about $88 \mathrm{lb}$. each. The wood when deprived of its bark has no aroma, and is used as fuel. When the bark is first taken off it is said to consist of an outer portion, which tastes like common bark, and an inner and highly aromatic portion. In the course of drying, the oil upon which the aroma and flavour depends, is diffused throughout, and the quality of the whole is supposed to depend upon the relative quantities of these portions. Cinnamon is examined and arranged according to its quality by persons who are obliged for this purpose to taste and chew it, although in a short time it produces painful effects on their mouths and tongues. The finest cinnamon is yielded by the young branches of the tree, especially by the numerous shoots which spring up from the stump after a tree has been cut down, and which are cut when about 10 feet long, and of the thickness of an ordinary walking-stick. The smell, particularly of the thinnest pieces, is delightfully fragrant, and the taste pungent and aromatic, with a mixture of sweetness and astringency. It is used like other spices by cooks and confectioners, and also in medicine as a tonic, stomachic, and carminative. The average quantity annually imported into London is about 500,000 lb. Its virtues depend chiefly upon the essential oil which it contains (oil of cinnamon). Oil of cassia is very often substituted for this oil, as cassia is for cinnamon. The root of the cinnamon-tree contains camphor. The fruit yields a conerete oil called cinnamon suet, which is highly fragrant, and in Ceylon was formerly made into candles for the exclusive use of the king. Cassia (q.v.) is the produce of another species of Cinnamomum.-C. Loureirii, a native of Cochin-China and Japan, yields a bark which is preferred by the Chinese to that of $C$. Zeylanicum. A species of cinnamon is found at the elevation of 8500 feet in the Sikkim Himalaya.

The constituents of cinnamon are a volatile oil (oil of cinnamon), tannin, starch, mucilage, woody. fibre, resin, colouring matter, and an acid. The oil of cinnamon is generally prepared in Ceylon by grinding the waste pieces of cinnamon broken of in packing, soaking them in sea-water for two or three days, and then distilling. Two oils pass over, one lighter, the other heavier than water. Oil of cinnamon varies in colour from yellow to cherryred, the yellow variety being considered the best, and is most highly esteemed. Oil of cinnamon leaf is prepared from the leaves in Ceylon by a similar process, and is met with in commerce under the name of clove oil, which it much resembles in odour. Cinnamon water is obtained by adding water to cinnamon, and distilling a large quantity, or by diffusing the oil of cinnamon through water by the aid of sugar or carbonate of magnesia. Spirit of cinnamon is procured by acting upon cinnamon with spirit of wine and water, and distilling; and tincture of cinnamon, by soaking cinnamon in spirit of wine, and straining. The medicinal properties of cinnamon, and its preparation, are aromatic and carminative, and it is serviceable in cases of nausea and vomiting, and in cases of flatulence and spasmodic states of the stomach and alimentary canal.

The genuine Ceylon species of cinnamon is now cultivated in Guiana, St Vincent, the Cape Verd Islands, Brazil, Mauritius, Pondicherry, Guadeloupe, and Java. It yields the best bark when grown on a sandy soil. The name cinnamon is from the Hebrew qinnámón, akin to qáneh, 'a reed or cane.

Cinnamon-stone, a precious stone, of which the finer specimens are highly esteemed; it is regarded as a variety of Garnet (q.v.). Its colour varies from hyacinth red to orange yellow; and when pure it is transparent. It is composed 
essentially of silion, alumins, and lime.

It is found chiefly in Ceylon.

Cimnyris. See SUN-BIRDs.

Cinq-Ulars, Henri Colfrier dE Ruzé, MARQUIS DE, an ill-fated favourite of Louis XIII. Was the second son of the Marquis d'Eftiat, Marshal of France, and was born in 1620 . While yet a lnoy he was placed at court by Cartinal Richelien, and here his handsome figure and fascinating manners soon secured him the warm affection of the royal household. At nineteen he was chief-equerry to the king, but his ambition could not brook the delay of waiting for the further stages of the most rapid promotion, but slready in his dreams he was a duke and peer of France, and husband of the Princess Maria of Gonzaga. Finding his ambitious projeets merely alerided by Richelien, he joined with the king's brother, Duke Gaston of Orleans, in a plot to murder the great cardinal. With this was combined a wider plot with Spain for the destruction of the cardinal's power by arms. The conspiracy was discovered, and Cinq-Mars, with his friend De Thou, was executed at Lyons, 12th September 1642. His story was woven by De Vigny into the wellknown romance Cinq-Mars (1826).

Cinqué Cento (Ital. 'five hundred ; but really a contraction for 'one thousand five hundred ') is a current term for the style alike in art and in literature which arose in Italy about or after the year 1500, and which therefore belongs mainly to the 16th century. It is characterised by the revival of classical taste in all departments of culture, and is frequeníy used in the same sense as the word renaissance, especially as applied to decoration. Among the great cinquecentisti in art are Michelangelo, Raphael, Correggio, Titian, Leonardo da Vinei, and Benvenuto Cellini; in poetry the notabler names are those of Berni, Ariosto, and Traso. See ITALY, ItahiaN ARCHITECTURE, RENAISSANCE.

Cinquefoil, a common bearing in Heraldry, representing a flower with five petals borne full. faced and without a stalk. If pierced-i.e. perforated in the centre, it should be so blazoned.

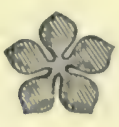

Cinquefoil : in Heraldry.

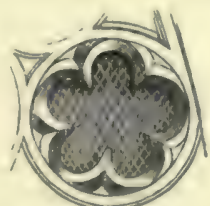

Cinquefoil :

in Architecture.
Gules, a cinquefoil pierced ermine, was the coat of the old earls of Leicester; and gules, three cinquefoils argent (sometimes ermine), that of the house of Hamilton in Scotland.-Cinquefoil, in Architecture, is an ornamental foliation in five compartments, used in the tracery of windows, panellings, and the like. The cinquefoil is often represented in a circular form, the spaces between points or cusps representing the five leaves, as in the accompanying illustration.

Cimquefoil, in Botany. See Potentilua.

Cinque Ports. The five great ports on the const of Kent and Sussex lying opposite to France -Sandwich, Dover, Hythe, Romney, and Hastings -were of considerable importance during the Anglo-Saxon period; and in a charter of Edward I. we find reference to a previous document granted them by Edward the Confessor. But it was snbsequent to the battle of Hastings that the Conqueror, in order that he might wield the resources of the seaports with grenter viyour, constituted this whole line of coast into a jurisdiction entirely separate from the counties of Kent and Sussex, and erected it into a sort of county palatine, under a warden or guardian, the seet of whose administra. tion was in Dover Castle. The warden, whose office corresponded to that of the ancient Count of the Saxon cosst (Comes littoris Saxomiei), exereised jurimliction, civil, military, and naval, unitiug in his single person the functions of sheriff, custos rotulorum, lord-lieutenant, and admiral. Privileges equal to those originally bestowed on the Cinque Ports were subseruently extended to the so-called ancient tovens of Winchelses and Rye; and all the seven municipal towns except Winchelsea had subordinate ports and towns attached to them, which were called limbs or members. In place of the Saxon terms of aldermen and freemen, those of jurats and barons were introduced, and the latter term has always been applied to the representatives of the Cinque Ports in parliament. Their chief function in early times was to furnish such shipping as was required for the purposes of the state, the crown having possessed no permanent navy previous to the reign of Henry VII. In the time of Elward I. they were bound to provide no less than fifty-seven ships, fully equipper and manned at their own cost; though the weight of this heavy burden was somewhat lessened by the provision that the period of gratuitous service should be limited to fifteen days. The ports, moreover, enjoyed in return for their services many privileges, such as exemption from tax and tallage, the right to make their own bylaws, \&e. In consequence of the warlike navy which they were thus compelled to maintain, the Cinque Ports became so confident and audacious as not only to undertake piratical expeditions, but even to make war and form confederacies as independent states. Previous to the Revolution of 1688, the lord-wardens nominated one and sometimes both of the parliamentary representatives for each of the Cinque Ports; but in 1689 an act was passed to 'declare the right and freedom of election of members to serve in parliament for the Cinque Ports.' The Acts of 1832 and 1885 reduced the number of members sent to parliament by the Cinque Ports from sixteen to three, and the Municipal Reform Act has broken up the ancient organisation of the ports, and assimilated their internal arrangements to those of other English municipalities. The ancient courts of Shepway, Brotherhood, and Guestling are still occasionally held, but their powers scarcely extend beyond matters of form. The lord-warden's jurisdiction, in relation to civil suits and proceedings, was abolished in 1835 ; but he still presides in the court of Shepway, and appoints the justices of peace within the jurisdiction of the Cinque Ports. His official residence is Walmer Castle, near Deal, a structure of Henry VIII.'s time : and here, as warden, the Duke of Wellington lived every autumn from 1829 till his death at it in 1852. See Montagu Burrows, Cinque Ports (1888).

Cintra, a small but picturesquely situated town in Portugal, in the province of Estremadura, 17 miles WNW, of Lisbon, with a population of 5500 . It stands on the declivity of the Serra de Cintra, and is surrounded by country residences. There is a palace at Cintra, a strange mixture of Moorish and Christian arehitecture, anciently occupied by the Moorish kings, and subsequently a favourite summer-resort of the Christian monarchs. On another hill-top stands La Penna, once a convent, now also a residence of the kings of Portugal. In the neighbourhood is the Cork Convent, which derives its name from the cells - which are cut out of the rock-being lined with cork to prevent damp. Cintra is historically remarkable for the 
Convention signed here, August 22, 1808, between the English and French, by which the latter agreed to evacuate Portugal, on condition of not being treated as prisoners of war, but landed on the coast of France, retaining their arms and effects. This convention excited the greatest public indig. nation both in the Peninsula and in England; and the British ministry were obliged to have the generals who signed the convention tried by a court-martial, which, however, resulted in their acquittal.

Ciotat, LA, a town in the French department of Bouches-du-Rhone, on $\mathrm{a}$ bay in the Mediterranean, 23 miles SE. of Marseilles by rail. It has a good and commodious harbour, the extensive workshops of the Messageries Maritimes Company, and a great coral fishery. Pop. (1891) 10,342.

Cipher. See Cryptography and Monogram.

Cipriani, Giambatrista, history-painter and designer, was born at Florence in 1727, of an old Pistoja family. He received some instruction from Hugford, a Florentine painter of English parentage, and he studied for three years in Rome. In 1755 he was induced by Sir William Chambers and Wilton the sculptor to settle in London, where his graceful drawings, which were reproduced by the graver of Bartolozzi, gained great popularity, and exercised a favourable influence upon the English school of figure-painters. He was a member of the St Martin's Lane Academy, and in 1768 was elected a foundation member of the Royal Academy, to whose exhibitions he contributed till 1779 , and whose diploma he designed in 1768. His pictures, of which some are preserved at Houghton, are less successful than his designs, being feeble, poor in colour, and with little expression. As an etcher he is known by a few plates in Hollis's Memoirs. He married in 1761 an English lady of fortune, and died at Hammersmith, 14th December 1785 .

Circea, a small and unimportant but widely distributed genus of rather pretty little Onagraceous herbs. $C$. lutetiana, frequent in shady situations, bears the name of Enchanter's Nightshade, and in Germany Hexenkraut (Witches' Herb). The origin of these names is not easily explained, as the plant possesses no remarkable properties, being merely a little astringent.

Circars, The Northern (Sarkair, 'a government'), is the historical name for an Indian territory lying along the coast of the Bay of Bengal, from 18 to 100 miles wide, with an area of 17,000 miles. It nearly corresponds with the present Madras districts of Ganjam, Vizagapatam, Godavari, Kistna, and parts of Nellore and Karnúl. In 1757 the Circars were ceded to the French by the subahdar of the Decean; but after a struggle, in which Lord Clive had the chief part, the Delhi court in 1766 granted the Cirears to the East India Company; but not till 1823 did they become really a British possession.

Circassia, a territory on both sides of the western Caucasus. See CaUCAsus.

Circassians, in the wide sense of the term, is the name given to all the formerly independent tribes of the Caucasus; in a narrower sense, it denotes the tribes (called by themselves Adighe, by the Turks and Russians, Tcherkesses) who inhabited the north-western wing of the Caucasus, with a government half patriarchal and feudal, and half constitutional. In 1858-65, rather than submit to Russian government, nearly the whole nation of fifteen tribes, to the number of nearly half a million persons, left their country for the Turkish possessions in Asia Minor, or the mountainous parts of Bulgaria, carrying with them their in- subordinate spirit and marauding habits, which added to the horror of the Bulgarian massacres of 1876 and 1877.

The Circassian nobles are principally Mohammedans, whilst the great mass of the people profess a corrupt Christianity, which shows strange survivals of earlier heathenism in its sacrifices and sacred trees, joined to the celebration of Easter, the sign of the cross, and processions with lights, The Circassians are proverbially handsome-for generations their daughters have adorned the harems of the wealthy Turks ; they are also strong, active, brave, and temperate. As a nation they made their first historical appearance during the middle ages. They are, however, chiefly known through their long struggles to maintain their independence against the aggression of Russia. See article Caucasus, and Ernest Chantre's mag. nificent work, Recherches anthropologiques dans is Caucase (5 vols. folio, Paris-Lyons, 1885-87). The first volume contains an exhaustive bibliography; the fifth is devoted to a detailed account of the peoples of the Caucasus as they now exist.

Circe, a sorceress of ancient Greek story, described in the Odyssey as 'fair-haired, a clever goddess, possessing human speech,' sister of 'allwise Aætes,' daughter of 'the Sun, who gives light to mortals, and of Perse, whom Ocean begot as his daughter.' Round her palace in Fæa were numbers of human beings, whom she had changed into the shapes of wolves and lions by her drugs and incantations. She changed two-and-twenty of the companions of Ulysses into swine; but that hero, having obtained from Mercury the herb Moly, went boldly to the palace of the sorceress, remained uninjured by her drugs, and induced her to disenchant his comrades. He remained with her for a year; and when be departed, she instructed him how to avoid the dangers which he would encounter on his homeward voyage. Ovid relates how, when she was jealous of Scylla, whose love was sought by Glaucus, she poured the juice of poisonous herbs into that part of the sea where her rival was accustomed to bathe, and so changed her into a hideous monster.

Circle, a plane figure bounded by a curved line called its circumference, which is everywhere equally distant from a point within it called the centre. The circumference is sometimes itself called the eircle, but in geometry that term is properly applied only to the surface or area bounded by the curve. Any line drawn through the centre, and terminated by the circumference is a diameter, which is therefore bisected in the centre (see ARC, CHORD). In Co-ordinate Geometry, the circle ranks as a curve of the second order, and belongs to the class of the conic sections. It is got from the right cone by cutting the cone by a plane perpendicular to its axis. The circle may be described mechanically with a pair of compasses, fixing one foot in the centre, and tracing out the curve with the other held at a fixed distance. The following are some of its leading properties :

1. Of all plane figures having the same perimeter, the circle contains the greatest area.

2. Of all plane curves, the circle alone has the same curvature at every point.

3. The circumference of a circle bears a certain constant ratio to its diameter. This constant ratio, which mathematicians usually denote by the Greek letter $\pi$ (perimeter), has been determined to be 3.14159 , nearly, so that, if the diameter of a circle is 1 foot, its circumference is $3 \cdot 14159$ feet; if the diameter is 5 feet, the circumference is $5 \times 3.14159$; and, in general, if the diameter is expressed by $2 r$ (twice the radius), 
then 6 (eircumference $)=2 r \times \pi$. Archimedea, in his book De Dimensione Circuli, showed that the ratio is nearly that of 7 to 22. Various closer approximations in large numbers were afterwards made, as, for instance, the ratio of 1815 to 5702 , 1010 to 3173 ; or the excellent one of Adrian Metius - viz 113 to 355 . Vieta in 1579 showed that if the dimmeter of a circle be 1000 , then the circumference will be greater than $3141 \cdot 5926535$, and leas than 3141.5926537 . This approximstion he made by ascertaining the perimeters of the inscribed and circumseribed polygons of 393,216 sides. By incrensing the number of the sides of the polygons, their perimeters are brought more and more nearly into coincidence with the circumference of the eircle; but this operose method was long ago superseded by easier modes derived from the higher mathematies. Suffice it to say that various series were formed expressing its value; by taking more and more of the terms of which into recount, a closer and eloser approach to the value can be obtained by ordinary arithmetic. We sub. join some examples :

$$
\begin{aligned}
& \text { (1) } \pi=4\left(1-\frac{1}{3}+\frac{1}{5}-\frac{1}{7}+\frac{1}{9}-\frac{1}{11}+\frac{1}{13}-\frac{1}{15}+\cdots\right) . \\
& \begin{aligned}
& \text { (2) } \pi= 8\left(\frac{1}{1.3}+\frac{1}{3.5}-\frac{1}{3.5 .7}+\frac{1}{5.7 .9}-\frac{1}{7.9 .11}+\text { \&c. }\right) \\
& \text { (3) } \pi= 16\left(n-\frac{n^{3}}{3}+\frac{n^{5}}{5}-\frac{n^{7}}{7}+\cdots\right)-4\left(m-\frac{m^{3}}{3}+\cdots\right) \\
& \text { where } n=\frac{1}{5} \text { and } m=\frac{1}{239} .
\end{aligned} \\
& \text { (4) } \pi^{3}=6\left(\frac{1}{1^{2}}+\frac{1}{2^{2}}+\frac{1}{3^{2}}+\frac{1}{4^{2}}+\cdots\right) \\
& =8\left(\frac{1}{1^{2}}+\frac{1}{3^{2}}+\frac{1}{5^{2}}+\frac{1}{7^{2}}+\cdots\right)
\end{aligned}
$$

Series (3), or one of its modifications, is the most expeditious mode yet known of extending the approximation to the ratio $\pi$. It has now been ealculated to 707 places of decimals, and verified to over 600 . The number $\pi$, though fixed in value, cannot be exactly expressed in figures, being Incommensurable (q.v.). Finally, the multiplier $(3-008-000,007)\left(1+\frac{1}{2} v\right)$ gives a close approximation, useful to the practical arithmetician.

4. The area of a circle is equal to $\pi$ multiplied by the square of the radius $\left(=\pi r^{2}\right)$; or to the square of the diameter multiplied by $\frac{\pi}{4}$; i.e. by

7854. Archimedes proved this by showing that the area is equal to that of a triangle whose base is the circumference, and perpendicular height the radius of the circle.

5. It follows that different circles are to one another as the squares of their radii or diameters, and that their circumferences are as the radii or dirmeters.

The circle is almost always employed in measur. ing or comparing angles, from the fact demonstrated in Euclid (Book vi. Prop. 33), that angles at the centre of a circle are proportional to the ares on which they stand. It follows from this, that if circles of the same radii be deseribed from the vertices of angles as centres, the arcs intercepted between the sides of the angles are always proportional to the angles. The easiest subdivision of a circumference is into six equal parts, becruse then the chord of the ares is equal to the radius, Divide one of these ares into sixty equal parts, and we thus obtain the unit of the seros. gesimal scale, called a degree. Each degree is divided into 60 seconds, and each second into 60 thirds, and so on. According to this scale, $90^{\circ}$ represents a right angle; $180^{\circ}$, two right angles, or a semicircle; and $360^{\circ}$, four right angles, or the whole circumference- the unit in the seale being the of th of a right angle. As the divisions of the angles at the centre, effected by drawing linew from the centre to the different points of graduation of the circumference, are obviously independent of the magnitude of the radius, and therefore of the circuniference, these divisions of the circumference of the circle may be spoken of as being actually divisions of angles, By laying a graduated eircle over an angle, and noticing the number of degrees, \&c. lying on the circumference between the lines including the angle, we at once know the magnitude of the angle. Suppose the lines to include between them 3 degrees, 45 ininutes, 17 seconds, the angle in this scale would be written $3^{\circ} 45^{\prime} 17^{\prime \prime}$.

The sexagesimal measurement of circumferences and angles is the most ancient, and still recommends itself universally to practical mathematicians. A second mode was proposed at the French Revolution, but though adopted by Laplace in the Mecanique Celeste, has long been abandoned even in France. By this scale, called the centesimal, the right angle is divided into 100 degrees, while each degree is divided into one hundred parts, and so on. Such a quantity as $3^{\circ} 45^{\prime} 17^{\prime \prime}$ is expressed in this notation by 3.4517 , the only mark required being the decimal point to separate the degrees frum the parts. Of course, in this illustration, $3^{\circ}$ means 3 centesimal divisions of the right angle, and $45^{\prime}$ means 45 centesimal minutes, and so on. If we want to translate ordinary degrees into the centesimal notation, we must multiply by 100 , and divide by 90 . To translate minutes in the same way, multiply by 100 , and divide by 54 ; and for seconds, multiply by 250 , and divide by 81 .

There is also a theoretical method of measuring angles, which, though indispensable in advanced trigonometry and other branches of analysis, is scarcely required in elementary mathematics. For the circular measure, as it is called, the unit angle is thus found: Let POA be an angle at the centre $O$ of a circle, the radius of which is $r$; APB a semicircle whose are accordingly $=\pi r$; and let the length of the are $\mathrm{AP}=\boldsymbol{\alpha}$. Then, by Euclid,

$\frac{\text { angle } \mathrm{POA}}{2 \text { right angles }}=\frac{a}{\pi r}$; and $\angle \mathrm{POA}=\frac{2 \text { right } \angle \mathrm{s}}{3 \cdot 14159, \& \mathrm{c}} \cdot \frac{a}{r^{\circ}}$

Now, supposing $u$ and $r$ to be given, although the angle POA will be determined, yet its numerical value will not be settled unless we make some convention as to what angle we shall call unity. We therefore choose such a one as will render the preceding equation the most simple. It is made most simple if we take 2 right angles $=1$. We shall then have (denoting the numerical value of the angle POA by $\theta) \theta=a$. The result of our convention is, that the numerical value of two right angles is $\pi$, instead of $180^{\circ}$, as in the method of angular measurement first alluded to; and the unit of angle, instead of being the ninetieth part of a right angle, is 2 right angles , or $57^{\circ} 17^{\prime} 44^{\prime \prime} 48^{\prime \prime \prime}$

nearly. Malking $\theta=1$ in the equation $\theta=\frac{a}{r}$, we

have $a($ or $\mathrm{AP})=r($ or $\mathrm{AO})$, which shows that in the circular measure the unit of angle is that angle which is subtended by an are of length equal to 
radius. Thus the circular measure of $180^{\circ}$ is $\pi$, or $3 \cdot 14159$, \&c., $90^{\circ}=\frac{1}{2} \pi, 60^{\circ}=\frac{2}{3} \pi, 45^{\circ}=\frac{1}{4} \pi$, and so on; and since $\pi$ is a fixed number, any angle is thus represented absolutely, and not as a part or multiple of another angle-i.e. an abstract number will as exactly denote an angle as it does the length of a line. If we say $\theta=3$, then in degrees $\theta=3$ $\times\left(57^{\circ} 17^{\prime} 45^{\prime \prime}\right)$; if $\phi=\frac{1}{3}$, then $\phi=\frac{1}{3} \times\left(57^{\circ} 17^{\prime} 45^{\prime \prime}\right)$ sexagesimally. For the squaring or quadrature of the circle, soe QUADRATURE; for the circles of the sphere, see Armillary SPHERE; see also MURAL Circle.

Cirele, Magic, a space in which sorcerers were wont to protect themselves from the fury of the evil spirits they had raised. This circle was usually formed on a piece of ground about nine feet square (in the East seven feet appears to have been considered sufficient), in the midst of some dark forest, churchyard, vault, or other lonely and dismal spot. It was described at midnight in certain conditions of the moon and weather. Inside the onter circle was another somewhat less, in the centre of which the sorcerer had his seat. The spaces between the circles, as well as between the parallel lines which inclosed the larger one, were filled 'with all the holy names of God,' and a variety of other characters supposed to be potent against the powers of evil. Without the protection of this circle, the magician, it was believed, would have been carried off by the spirits, as he would have been had he by chance got out of the charmed space. Another figure which, described upon the ground, could bar the passage of a demon, was the pentagram. Readers of Frust will remember its effect upon Mephistopheles.

Circles, Stone. . See Stone Circles, Standing Stones, Stonehenge, Callernish.

\section{Circuits. See Assize.}

Circular Notes are bank-notes specially adapted for the use of travellers in foreign countries; and being, in fact, bills personal to the bearer, they are believed to be more safe as travelling money than ordinary notes or coin. Circular notes of the value of $£ 10$ and upwards are furnished by or through the chief banking-houses. Along with these notes is given a "letter of indication." This letter (a lithographed form in French) is addressed to foreign bankers, requesting them to pay the notes presented by the bearer, whom they name, and to aid him in any way in their power. On the back of the letter there is a long list of foreign bankers, extending all over Europe, any of whom will cash one of the circular notes on being presented and indorsed by the bearer. In paying these notes the money of the country is given according to the rate of exchange, and free of any charge for commission. For security, the letter and the notes should not be carried together, in case of their being stolen or lost. A corresponding certificate issued by the bankers in the United States for the use of travellers, is called Letter of Credit. See CREDIT (LETTER OF).

Circular Numbers are numbers whose powers end on the same figure as they do themselves: such are numbers ending in $0,1,5,6$.

Circulating Librarw. See Library.

Circulation, in Anaromy and Physiology, is the term used to designate the course of the blood from the heart to the most minute blood-vessels (the Capillaries, q.v.), and from these back to the heart. To simplify the consideration of the subject, we shall consider-(I.) the General Anatomy, (II.) the Comparative Anatomy, (III.) the Physiology, and (IV.) the History.

I. The organs of circulation consist of the heart, arteries, veins, and capillaries. The course of the blood through these organs will be best elucidated by the aid of a diagram, which is equally applicable for all other mammals as well as for man, and for birds. The dark parts of fig. 1 represent the course of the impure or venous blood, while the lighter portions represent the course of the pure or arterial blood. Two of the four chambers of the heart ( $A$ and C) receive the inflowing blood, and are termed the auricles; while the other two chambers (B and D) drive the blood to the lungs and to the general system respectively, and are termed the ventricles. The vessels that bring blood to the auricles are termed veins, and the vessels through which the blood is driven from the ventricles are known as Arteries (q.v.). We will now trace the course of the blood, as indicated by the arrows of the diagram, commeneing with the right auricle, A. The right auricle contracting upon the venous or impure blood with which we suppose it to be filled, drives this into the right ventricle, $B$, through an opening guarded by a triple (or

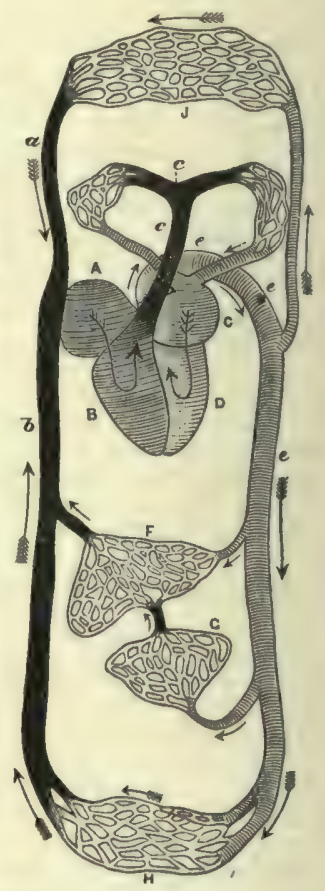

Fig. 1.-Diagram of Circulating System (from Leunis). tricuspid) valve, which almost entirely prevents the regurgitation of the blood from the ventricle into the auricle. The ventricle, $B$, being now filled, contracts, and as the blood cannot return into the auricle, it is driven along the dark vessel, $c$, which is the pulmonary artery, conveying the blood to the lungs. At its commencement it is guarded by erescent-shaped (semilunar) valves, which entirely prevent the blood which has once been propelled into the pulmonary artery from re-entering the ventricle. The pulmonary artery gradually divides into smaller and smaller branches, which ultimately emerge into capillaries freely distributed over the interior of the air-cells of the lungs. There the blood gives off carbonic acid gas, and absorbs oxygen, becoming thereby 'pure.' The capillaries, in which the blood is purified, gradually unite to form larger vessels, and finally the blood is collected into the pulmonary veins, which pour their contents into the left auricle, C. Thence it is propelled into the left ventricle, $\dot{D}$, through an opening guarded by a double (mitral or bicuspid) valve, which entirely prevents the reflux of the blood. The left ventricle contracts and drives its contents into the large artery, $e$, or Aorta (q.v.), which by means of its various branches supplies the whole body with pure blood. From the aorta and its various subdividing branches the blood passes into the capillaries, $J, \mathbf{H}$, which occur in every part of the system. In these capillaries it parts with its oxygen to the tissues, and becomes charged with the waste carbonic acid gas. The capillaries unite into larger veins, and these gradually unite to form two large trunks, $a, b$, the superior and inferior venoe cava, which pour their contents into the right auricle-the point from which we started. The diagram also shows how the venous blood from the viscera, $G$, instead of passing directly into the 
vena cava, goes through the liver, $\mathbf{F}$, in what is known as the hepatic-portal system.

Before passing to the comparative study of the eirculation, we must notice a few of the above

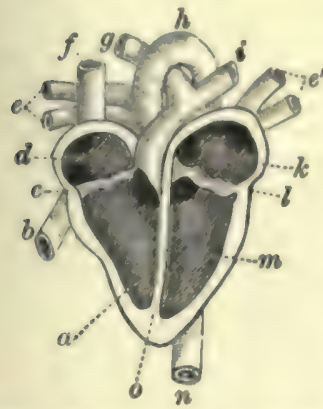

Fig. 2-Theoretical Section of the Hunan Heart:

$f, b$, the two venos cavos, opening inte $d$, the right anricle; $c$, the tricuspid vaive; $a_{1}$ the right ventricle, from which proceeds the polnonary artery, dividing into branches $a$ and $i$, goimg to the right and left lung respec. the right and left lung respoctively; $c, c$, the pulmonary veins (two from either lung), entering into the left auricle, $k ; \boldsymbol{l}$, the mitral valve; " $m$, the left ventricle, from which proceeds the aorts, whose arch is indicated by $h$, and the descend. ing portion by $n$, none of its branches being indicated in this figure; $o$, the partition, or sep. tum, between the right and left hearts.

minute networks from communicate with the capillaries. Branches which, by joining, increase in size as they pass onward towards the heart. If we except certain venous structures (called sinuses) occurring in the interior of the skull, we may divide the veins into two sets - the superficial or cutaneons, and the deep veins. The deep veins accompany the arteries, and are usually inclosed in the same sheath of tissue. In the case of the smaller arteries they generally exist in pairs, one on each side of the artery, while the larger arteries have usually only one accompanying vein. The superficial veins oceur immediately beneath the integument; they not only return the blood from the skin and adjacent struetures, but communicate with the deep veins. All the veins finally lead by two large trunks, the superior and inferior vena cava, into the right auricle of the heart. The superior vena cava is formed by the union of the veins from the head and neck (the jugulars) with those from the arms (the subclavians), while the inferior vena cava brings back the blood from the lower extremities, the trunk, and the viscera.

We must refer to the article VEIN for the structure of the walls of this part of the eirculatory system. There is only one point that imperatively requires notice here-viz. that while the arterial system presents no valves except at the points where the two great trunks leave the heart, the veins contain a great number of valves, which are formed by a doubling of their lining membrane, and resemble pocket.like folds or pouches, which allow the blood free passage toward the heart, but prevent its reflux. The veins are much less elastic than the arteries, and their total capacity is much greater.

There is one part of the venous circulation which, from its great importance, requires special notice
- vir. that of the spleen, pancreas, stomach, and intestinal canal. The blood aupplied to these organs by the coeliae and the two mesenteric arteries is not returned directly to the inferior vena cava, but passes by neveral veins into one large vessel-the portal vein, which enters the liver, and breaks up into a capillary network. There the blood undergoes important elanges associated with the bile-mereting and glyeogen. forming functions of the liver. The blood, enter. ing the liver from two sources, from the portal vein and from the hepatic artery, leaves it by the hepatic veins, which join the inferior vena cava. It is also important to notice the entirely distinct set of vessels known as lymphatics, which conduet the products of digestion into the veins (see LYMPH).

The above-described double circulation (through the lungs and through the borly) is exhibited by the blond from the time of birtl during the whole period of life. The circulation of the blood, however, begins before birth-indeed, at a very early period of intra-uterine or fotal existence; and the circumstance that before birth the lungs do not act as organs of respiration induces $\mathbf{n}$ very important molification in the course of the hlood in foetal life which will be described nnder FoETUs.

II. Comparative. - The circulatory system in man, as above described, may serve as type of the highest development, differing but slightly from that of other mammals, or that of birds. It is convenient now to begin at the other end, and to note briefty the salient steps of progress in the gradual evolution of the system throughout the animal series. In the unicellular animals the movement of the protoplasm and the special activity of 'contractile vacuoles,' represent, to some extent at least, a circulatory function before the appearance of any system. The canals which so conipletely irrigate a sponge, likewise illustrate in low expression a circulatory system not yet separated off from the others. In Coelenterates, too, the system is still unseparated : 'gastro-vascular' prolongations of the alimentary cavity penetrate the body, as may be very well seen in the dise of a conmon jelly-fish. In the lower worm-types also, where no distinct bodycavity is yet developed, the nutritive fluid simply diffuses through the body, and no vascular system is differentiated. But in higher worms there is generally a body-cavity, and with it the gradual appearance of a definite vascular system. In some we simply find a fluid moving in the body-cavity, occasionally clear, usually with corpuscles; in others, portions of the body-cavity are separated off as blood-spaces, or eventually as blood-vessels; these may remain in connection with the general eavity, or may at length form a closed system. The manifold worm-types afford abundant illustration of all the stages in this differentiation. In the bristle-footed worms (Chretopods, q.v.), and in some others, the perfecting of the blood-driving mechanism may be instructively traced. Often a dorsal vessel is diffusely contractile, less frequently the ventral ; or there may be contractile connecting loops between dorsal and ventral vessels, as in the earthworm; or lastly, a special region in the dorsal vessel may become the main seat of the vascular contractility. Such a dorsal heart is found from this point onwards throughout the Arthropods and Molluses, (The well-developed and very difficult vascular system of Echinoderms, which eo-exists with an abundant body-cavity fluid with relatively few corpuscles, has no special interest for this general survey.) In crustaceans, the dorsal heart, asually inclosed in a special space or "pericardial sinus," drives blood by more or less well-developed arteries through the body. The rest of the system is best described as lacunar. 
The venous blood passes along body-cavity spaces to the gills for purification, thence returns to the pericardial sinus, and entering the heart is redistributed. In insects a chambered dorsal heart, inclosed in a sinus as before, drives the blood forward, but as one would expect from the very efficient respiratory apparatus, the general vascular system is but slightly differentiated. The blood, purified by diffusion from the everywhere present air-tubes, passes back by venous channels into the sides of the pericardium and heart. In myriapods, scorpions, and king-crab, the system is more definitely developed, but illustrates no new advance except that of more complete establishment and wider extension of vessels. In molluses, however, some progress is observable. Except in the Elephants' Tooth Shell (Dentalium), a heart is present, and the arterial system is often very well developed, even to the extent of capillaries in some cuttle-fishes and snails. Usually, however, the venous blood travels along lacunæ, though gradual transitions oceur between these and true veins. The blood purified in the gills or pulmonary chamber passes back into a special portion of the body-cavity-the pericardium, and thence into the heart. In certain worm-types, several contractile lateral vessels may often be observed to enter the dorsal vessel ; in the Pearly Nautilus, which has four gills, four efferent vessels dilating into four indistinct auricles, enter the median dorsal heart or ventricle; in almost all bivalves the entrant dilatations or auricles are reduced to two, one on each side; while in most Gasteropods and Pteropods the specialisation has gone further, and the heart consists of a single auricle and a thicker muscular ventricle. The latter drives the blood through the body by a single or double aorta.

Passing now with equal brevity through the vertebrate series, we notice first that the heart arises as a dilatation no longer of a dorsal, but of a ventral vessel. Up to and including amphibians, the heart begins as a specialisation of the "subintestinal vein ' in the throat region; in most, if not all higher vertebrates, it arises from the fusion of two vessels. It always lies in a pericardial sac.

(1) Among the degenerate Tunicata there is considerable variety in the vascular system. In one case no heart is present; in several there are no definite vessels or blood-corpuseles. The main point, however, is that in most cases a tubular ventral heart drives blood to the respiratory pharynx. In all eases where the heart has been observed, the direction of its beats has been seen to undergo reversal at regular short intervals, a phenomenon which has also been noticed as a rarity in certain worm-types.

(2) The vascular system of the lancelet or amphioxus is of a peculiarly diffuse and undifferentiated nature. It has in one sense no heart, in another sense many; for.while there is no main centre of contractility, there are small pulsating dilatations at the bases of the vessels passing to the gill-slits, while the portal vein and ventral vessel in the anterior pharyngeal region are both said to be contractile. In general course, the cireulation is like that of a fish; the blood passes from ventral vessel to respiratory region, thence to dorsal aorta, thence to body, thence by united sub-intestinal veins to the liver crecum, and thence to the ventral vessel from which it started.

(3) In the Round Mouths (Cyclostomata) the typical fish-circulation is established. The muscular ventricle drives the blood by a ventral vessel ('ventral aorta') to the gill-sacs; thence the purified blood is gathered into efferent dorsal vessels, which form in uniting the 'dorsal aorta." The latter gives off branches to the greater part

of the body, the head-region being directly supplied from the anterior efferent branchials. The blood returns from the anterior and posterior regions into a uniting vessel behind the heart ('the sinus venosus'), thence into the receiving auricle, and from that to the muscular ventricle.

(4) It is enough after the above to notice in regard to the fishes proper, that with the exception of the double-breathing mud-fish (Dipnoi), the heart never contains anything but impure blood, that it drives this wholly to the respiratory organs, and is in no direct degree 'systemic.' The 'dorsal aorta' supplying most of the body is formed from the union of efferent branchials, and does not arise, as in higher vertebrates, from the heart. It is important to notice that the five or so arches which spring from the ventral aorta are almost all quite alike, and arise (except in Dipnoi) at slight intervals from one another. A great part of the differentiation in higher vertebrates obviously concerns these aortic arches, which are seen in Cyclostomata and fishes in primitive uniformity, but become modified in higher vertebrates into the carotids, sub-clavians, aortic arches, and pulmonary arteries. The heart of a fish consists of the sinus venosus or general junction, running transversely behind the heart (persisting hence onwards, except in adult birds and mammals), of the auricle and ventricle, and except in Teleostei of a specialised contractile portion of the latter

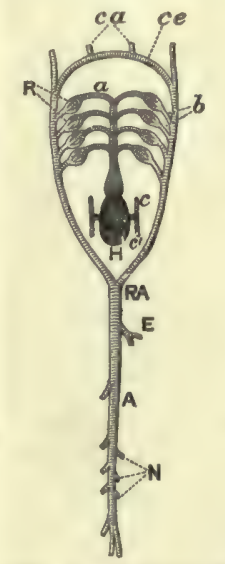

Fig. 3.-Arterial System of Fish :

$\mathbf{H}$, heart ; $c$ and $c^{\prime}$, anterior and posterior cardinal veins; $a$ branchial arteries; $\mathbf{R}$, capillaries of the branchisl ves. sels; $b$, branchial veins: $c e$, sels; $b$, branchial veins : $c e$,
head circle; $c a$, carotids ; $\mathrm{RA}$, root of the aorts ; $\mathbf{A}$, dorsal aorta ; $\mathbf{E}$, axtery to viscera (coliaco-mesenteric); N, renal arteries. (After Wiedersheim.)

known as the conus arteriosus. A dilatation of the beginning of the ventral aorta is distinguished as the bulbus arteriosus. In regard to the general system, it is worth noticing that in fishes (as in amphibians and all reptiles except Chelonians) there is a renal portal, as well as an hepatic portal system. Veins from the caudal region of the fish come into the same relations with the kidneys as the portal veins do in regard to the liver. The hepatic veins returning from the liver do not unite with the other posterior veins, but enter the sinus venosus independently. Thus fishes have no inferior vena cava. (4a) The Dipnoi are interesting as leading on to amphibians. The 
heart receives pure as well as impure blood, drives blood to lungs in addition to gills, is in part systemic (driving pure blood in Protopterus and lepidosiren through the first two pains of arches), has the roots of the aortic arches close together, and is practically three-chambered. In these respects it reaches forward to the condition seen in those amphibians which retain their gills.

(5) The heart of amphibians is three-chambered, a right auricle receiving impure blood from the boily, a left auricle receiving purified blood from the lungs or from the lungs and gills, a single ventricle which drives the blood, mingling less than might be supposed, to head or body or respiratory organs. In some cases, as one would expect, the partition between right and left auricle is imperfect. In the tadpoles at the fish-like stage there are four aortic arches, of which the first three supply gills. Where gills persist, such supply is always of course in some degree maintained. In such a metamorphosis as that of the frog, where all trace of gills is lost, the first branchial arch becomes the carotid; the second is the systemic, which forms, by uniting with its fellow, the dorsal aorta; the third dwindles away ; the fourth supplies the lungs. The same is generally true of the higher vertebrates, except that it is usually the third branchial which forms the pulmonary artery. An inferior venc cara is definitely established in amphibians; there is a renal portal as well as an hepatic portal system; special lymph hearts are sometimes present connecting the lymph system with the vascular.

(6) Among the reptiles, the differentiation of the heart goes a step further. In Chelonians, Lacertilis, and Ophidia, a strong muscular ridge forms an incomplete partition, dividing the ventricle into a right portion containing purely venous blood,

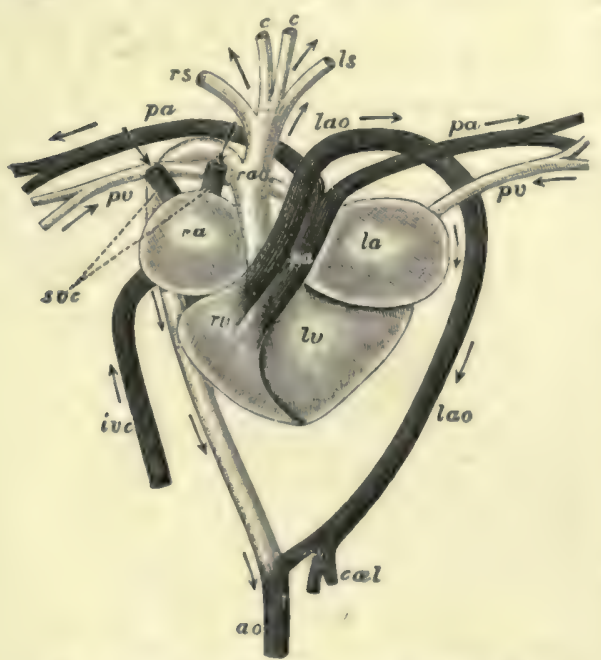

Fig. 5.-Circulation of a Reptile (Tortoise):

$r a$, right suricle: la, left auricle; rv, right (venous) portion of ventricle; Iv left (arterial) portion of ventricle; lao, left (venous) aortic arch; pa, pulnonary artery; roo, right (arterial) sortic sreh; $r, l s$, branches to fore-limbs ; $\infty$, carotids; $p \%$, pulmonary veins; swe, superior vense cave; ive, inforior vena cavs; ao, doral aorta; col, colino artery to viscera. (After Nuhn.)

and a left portion containing mixed and arterial blood. The pulmonary artery rising from the right cavity takes purely venous blood to the lungs; of the two aortic arches rising from the left cavity, the left aorta contains more venous than arterial blood, the right aorta more arterial than venous. In Crocodilis, however, there is a complete septum in the ventricle, and thus for the fint time $a$ four. chambered heart, though it is not certain that the division is exactly comparable to that of birds and mammals. From the right or venous ventricle rime the pulmonary artery and left aortic areh (taking venous, not mixed, blood to the viscera); from the left or arterial ventricle rises the right aorta, with pure blood to the greater part of the body. Though the division of arterial and venous chumbers hringw the crocodilian heart to the bird or mammal level, there are two aortic arches, one venous, the other arterial, which unite as usual, and also communicate by a foramen at their roots. In all reptiles there are two superior vene cave, an inferior vena cava formed from the union of the two efferent renals, and a renal portal system except in Chelonis. In birds and mammals a single aortic arch forms the dorsal aorta, not two or more as in reptiles. In birds the aorta goes to the right, in mammals to the left, but except in this variation and in the structure of the Heart (q.v.), the circulation in Birds (q.v.) and mammals (supra) is practically identical.

III. Physiology. - The most important conditions of circulatory function are (1) a general constancy and rapidity of flow, and (2) a power of adapting this to special needs. The conditions of the former are mainly mechanical and physical-those of the latter depend upon the nervous system.

(1) The Mechanism of Circulation chiefly depends upon the rhythmic contractility of the heart, the elasticity of the vessels, and the friction in the small arteries and capillaries. The heart is a muscular pump contracting under the influence of its automatic nervous mechanism, but also respond. ing in the nature of its beat to the conditions of the body. The human heart usually beats about seventy-two times a minute, and in the eighttenths of a second occupied by each beat, three distinct events occur-the contraction (systole) of the ventricles, a 'passive interval' of relaxation (diastole) of both auricles and ventricles, and the decidedly briefer contraction of the auricles. The pumping action of the heart is thus obviously an intermittent force which drives the blood through the closed series of elastic tubes formed by the blood-vessels. To the latter attention must now be directed.

The arteries are surrounded by muscular tissue, and are contractile as well as highly elastic. As they break up into branches from the aorta to the capillaries, the capacity for holding blood is continually increasing. The flow of blood within them, though continuous, comes in gushes corresponding to the heart-beats. The velocity of the stream is greatest the nearer the heart. The veins are much less elastic than the arteries, and have a much greater total capacity for holding blood. As they unite from the capillaries to the venre cavr, the total capacity is continually diminishing. The flow of blood within them is continuous, but with relatively little force and small velocity. The capillaries have a very small calibre, but are both elastic and contractile. They are permeable by fluids, and also allow the corpuscles to pass through their walls. The velocity of the flow is here at its minimum. The resistance to the flow of blood, due to the friction of these minute passages, works back along the arterial system to the heart, and is one of the most important factory in determining the nature of the circulation.

To return now to the actual mechanism, it is only necessary to note $(\alpha)$ that the whole system is always over-filled with blood, which consequently causes a pressure on the walls; $(b)$ that the cause of the circulation is the difference of pressure between the blood in the aorta and pulmonary arteries on the one hand and the vena cava and pulmonary veins on the other; (c) that this difference of 
pressure is due to the contraction of the heart; and (d) that the interrupted current, which would naturally arise from the intermittent action of the heart, becomes continuous because of the rapidity of the beats, the resistance in the small arteries and capillaries, and the elasticity of the arterial walls.

(2) The Control of the Circulation.-The phenomena referred to above are mainly physical and mechanical, and in their essential features can be readily reproduced on a model. But in a complex living organism there is a constant necessity for modifiability. The organs vary in their requirements, and the external conditions are frequently changing. Modifications in the circulation are brought about by changes in the heart's beat, and in the calibre and resistance of the small arteries. Both these changes are under the direct control of the Nervous System (q.v.). Modifications of less importance also occur in the eapillary resistance and in the total quantity of blood; but the important point is simply the general fact that the requirements of the organism are met by the dominion of the nervous system over the circulation.

IV. History.-Aristotle and the ancients thought of the heart as a blood-fonntain, but had no conception of circulation. Galen (131-201) disproved the prevalent notion that the arteries contained air, Calvin's contemporary Servetus demonstrated the pulmonary circulation, and various physiologists had a distinct notion of the centrifugal flow. In 1628 William Harvey published his Exercitatio Anatomica de Motu Cordis et Sanguinis in Animalibus, in which his discovery of the real nature of the circulation was expounded. Soon after, the use of the microscope revealed to Malpighi (1661) and Leeuwenhoek (1674) what Harvey had been unable to trace - the capillary connection between arteries and veins. Since those days the detailed problems of circulation, the hydraulic mechanism, the action of the heart and its valves, and the nervous control have been worked at by many of the greatest physiologists.

See AORTA, BLood, HEart, Vrin, \&c. ; the physiological text-books of Foster, Hermann, Huxley, Landois, Stirling, \&c., for human circulation; works on comparative anatomy (Jeffrey Bell, Claus, Gegenbaur, Huxley, Wiedersheim, \&c.), for the gradual evolution of the system; Willis's William Harvey, for the earlier notions on the subject.

Circulation of Sap. See Plants, SaP, Vegetable Physiology.

Circumcision (Lat., ' a cutting round'), the cutting off the foreskin, a rite widely diffused among ancient and modern nations. Three thousand years before Christ it was familiar to the Egyptians, who circumeised boys between the sixth and fourteenth year, though it is not certain whether it was extended to all males, or confined to the priestly caste and others who were connected in some special way with the religious mysteries. The ceremony is clearly portrayed on a temple at Karnak, in a drawing copied by Ebers, who adds that most of the male mummies which have been examined are found to have been circumeised. Sayce (Hibbert Lectures, p. 83) affirms on precarious grounds that circumcision was known to the Babylonians. In any case it was not generally. practised by them. It was known to the Colchians, to some at least of the Phœnicians (compare Ezek. xxviii. 10 with Herodot. ii. 104), and apparently also to the Edomites, Ammonites, and Moabites (see Jerem. ix. 25, 26). Further, it appears among Kaffirs, among many negro tribes, among Mexicans, Indians of South America, and among the islanders of the Pacific Ocean. Its original significance is uncertain, and possibly it may have arisen from different motives in different places. Sanitary reasons, considering the primitive nature of the nations in which it is found, are out of the question, and of other theories which have been advanced two only are plausible. It may have served like the tattoo to mark and stamp the circumcised person as a member of the tribe, and qualified to take part in its sacred rites, or, which is much more likely, it may have had a sacrificial character, the object being to propitiate the god or spirit by blood, and indnce him to spare the life. The former theory is illustrated and defended by Stade (Gesch. des Volkes Israel, i. p. 423), the latter by Réville (Relig. des Peuples non-civilisés, ii. p. 253). Stade's view finds some support in Ezek, xxviii. 10 , xxxi. 18, when he who dies uncircumeised is excluded from communion with the dead who have received this token of initiation. But, in fact, as Réville points out, primitive nations constantly substitute some partial mutilation for the sacrifice of the whole person. See the instructive story, Exod. iv. 24-26. We may add that in some parts of Africa an analogous operation is inflicted upon young females.

The Scripture account of the origin of circumcision amongst the Israelites is given in Gen. xvii. 7-14; but it is plain from what has just been said that circumeision could not have been in itself a sign of distinction between the Israelites and the neighbouring nations; and hence in the books of Judges. and Samuel it is the Philistines, and the Philistines only, who are taunted with being uncircumcised; while in Joshua, v. 9, it is implied that the uncircumeised state of the Israelites who had grown up in the desert was ' a reproach' to them in the eyes. of the Egyptians. But after the exile circumcision assumed a new prominence, because the nations under whose sway Israel then lived-the Babylonians and Persians-practised no such rite. A deep religious meaning was given to it. It became the sign of the covenant between God and his. chosen people, and their devotion to it grew in proportion to the contempt which it excited in their Greek and Roman oppressors.

According to the Levitical law every Jewish male must be eircumeised on the eighth day under penalty of being cut off from the congregation of Israel. The same law applied to foreign slaves bought by a Jew or born in his house. Strangers. also must circumeise their males if they wished to partake of the Passover (Exod. xii. 48). The rite was performed by the father of the house or by some other Israelite, in case of necessity even by women (1 Mace. i. 60). Modern Jews employ a mokel or official who has the requisite surgical skill. The child is brought to the door of the room and handed to the mohel, who after prayer circumeises the child, and having drunk a glass of wine, gives it its name (Gen. xxi. 3,4 ; Luke, i. 59, ii. 21), and placing his hand on its head blesses it. The Jewish ritual contains special prayers for the feast which follows. Cireumeision was excluded from the Christian community after a memorable struggle, in which St Paul was the great champion of spiritual religion. Many of the Jewish converts. wished to impose circumcision on the Gentile Christians, not only as a condition of equality, but as an essential to salvation. The result of the first struggle after a conference at Jerusalem was a mutual compromise : circumcision was not to be imposed on the Gentiles, who in return were asked to abstain from meats offered to idols, from blood, from things strangled, and from fornication. Much later, however, circumeision was urged on converts as a title of preference, and it was long before Jewish Christians could be brought to recognise the real supremacy of the gospel, itself a New Covenant in the place of the Old. St Paul speaks of his party (Phil. iii. 3) as the 'true circumeision,' and by a 
bold metaphor applies the word concision (katatome , which in the Septuagint was applied only to mutilations and ineisions forbidden by the Mosaic law, to the vaunted cireumeision of the Judaising Cluristians. The contrast of the material and wiritual eireumcision oceurs elsewhere in st Paul (liom. ii. 25-29; Col. ii. 11). The use male in the ()ld Testament of the inage of circumeision, as a metaphor for purity, had prepared the way for the apostle's application-compare the circumcision of the heart (Lev, xxvi. 41), of the ear (Jer. vi. 10), of the lips (Ex. vi. 12, 30). At the present time the Abyssinian Church alone among Christian borlies recognises it as a religious rite. It existed among the Arabs before the time of the Prophet; and though never mentioned in the Koran, circumcision is practised with much pomp and great rejoicings in all Mohammedan populations. The Arabs in the towns of Egypt have their boys eircumcised at the age of tive or six; among the peasants the age varies from twelve to fourteen. A vivid account of the ceremonies is given in Lane's Molern Egyptians. See a paper by Paul Lafargue in the Bulletin de la Société d'Anthropologie de Paris (tome $x_{0}$, 3’ série, 1887).

Circumeision, Feast or, a festival in honour of Christ's circumcision, observed on 1st January in the Roman Church since about 487 A.D., and in the Anglican since 1549. See NEW-YEAR's DAY.

Circumference, or PERIPhery, the curve which incloses a circle, ellipse, oval, cardioid, or other plane figure. In figures bounded by straight lines, as the triangle, square, and polygon, the term perimeter is employed to designate the sum of all the bounding lines taken together. The length of the circumference depends partly on the nature of the curve; thus, that of the Cirele (q.v.) $=2 \pi r=\pi d$; and that of the Ellipse (q.v.)

$$
=2 \pi a\left\{1-\left(\frac{1}{2}\right)^{2} \frac{e^{2}}{1}-\left(\frac{1.3}{2.4}\right)^{2} \frac{e^{4}}{3}-\left(\frac{1.3 .5}{2.4 .6}\right)^{2} e^{6}-\& c .\right\}
$$

where $\alpha$ is the semi-sxis major, and $e$ the eccentricity.

Circumlocution office, the name under which Dickens, in Little Dorrit, satirised the Civil Service.

Circumnavigation, the term usually applied to the act of sailing round the world, its literal meaning being simply 'a sailing round.' The eircumnavigation of the globe was at one time considered a great feat, but it is now one of the most commonplace affairs in a sailor's experience. The first to circumnavigate the globe was Sebastian d'Elcano, lieutenant of Magellan (1519-22) ; fifteen years afterwards it was accomplished by two Spanish seamen, Grijalva and Alvaradi; and in 1577-80 by the illustrious Englishman, Sir Francis Drake. The most celebrated of circumnavigators was Captain James Cook, who, between 1768 and 1779, made three voyages round the world.

Cireumstantial Evidence. See Evidence.

Circumvallation, Lises $O F$, form a chain of works surrounding an army engaged in besieg. ing a fortress, but facing outwards towards the country so as to guard against all attempts at relief by a field army. Redoubts, either isolated or connected by a line of parapet, were much used for this purpose in the sieges of the ancient and middle ages; but the greater mobility of modern armies makes it preferable to meet such attempts in the open field, many miles from the position oceupied by the investing force. At Sebastopol, owing to the smallness of the besieging force compared with that of the besieged, an outer circuit of redoubts and lines was necessary to keep off the Russian field army, which at Inkermann very nearly succeeded in penetrating this external defence. See Conthavallation, Sivoz.

Circus, in ancient Rome, was a large oblong building adapted for chariot-races and horse-races, and used also for the exhibition of athletic exercises, mock-contests, and conflicts of wild bessts. The Circensian Games were alleged by tradition to have originated in the time of Romulus; and Tarquinins Priscus celebrated a notable victory by games. The games continned to be held annually, and a permanent edifice was soon afterwards constructed. This was diatinguished, subsequent to the erection of the Flaminian and other large cirei. as the Circus Maximus. It must have been altered and enlarged at various times. Dionssius says it could hold 150,000 persons; Pliny, 260,000; and P. Victor, 385,000 . Its extent also has been variously estimated. In the time of Julins Casar it was three atadia or 1875 feet long, and one stadium or 625 feet wide, while the depth of the buildings surrounding the open space was half a stadium, or about 312 feet. The plan was oblong, rounded at one end and square at the other. Along the sides and at the curved end were ascending ranges of stone seat/s for the spectators. At the other end were the carceres or stalls in which the horses and chariots were kept, until, on a given signal, the gates were simultaneously flung open. In the centre was the spina, a long and broad wall round which the charioteers drove, terminating at both ends at the meta or goalsconical pillars which marked the turnings of the course. Julius Cæsar made an euripus or canal round the course to protect the spectators more effectually during the conflicts of wild beasts.

The circus was especially adapted for chariot-races, an amusement of which the Romans were passion. ately fond. The length of a race was seven circuits round the spina, and twenty-five races were run in each day. The number of chariots was usually four. The athletic exercises, such as boxing and wrestling, sometimes terminated fatally. A regular battle was sometimes represented (Pugna Equestri et Pedestris). By the formation of canals and the introduction of vessels, a Naumachia, or sea-fight, was occasionally exhibited; but, under the empire, this species of exhibition, as well as the Venatio, was gradually transferred to the Amphitheatre (q.v.). Animals for the Venatio or hunting were procured from every available part of the Roman empire, including Africa and Asia. The exhibition not only afforded an opportunity for the display of private munificence or ostentation, but attained the importance of a political engine, which none who aspired to popularity could afford to overlook. The turbulent classes often demanded doles of bread and circus games (panem ot circenses) from candidates. When Ponpey opened his new theatre he is said to have given public exhibitions in the circus for five days, during which five hundred lions and twenty elephants were destroyed. The Greek hippodrome was very similar in its arrangements to the Roman circus.

In modern tipes the circus survives but as the shadow of a name. It is about the same size as the modern theatre, and is employed principally for the exhibition of feats of horsemanship and for acrobatic displays. Modern cireuses are of two kinds - those that hold performances in permanent buildings, of which there are only a comparatively small number in Britain and the United States, and those that "tent" or occupy temporary erections in spring and summer, and return to buildings in winter. A circus manager on a tour must have a plentiful supply of novelties in the shape of graceful and daring riders, conjurers, and performing horses. A stud of highly trained performing horses, often of great value, is an important feature in every 
well-appointed circus. English and American equestrians are superior to those of any other nationality, and their services are eagerly sought for on the Continent, where the bulk of the performers are English. Astley (q.v.) was the most famous of English circus-managers. The Paris hippodrome is celebrated. But the circus in connection with Barnum (q.v.) and Bailey's 'Greatest Show on Earth' is probably the most important ever organised, including a whole army of performers, 'mid-air artists,' and male and female equestrians.

Cirencester, a town of Gloucestershire, amid the Coteswold Hills, on the Churn, a headstream of the Thames, and on the Thames and Severn Canal, 14 miles SSE. of Cheltenham, and 18 by rail NW. of Swindon. It has a very fine Perpendicular church (restored 1867), a public hall (1863), some remains of an abbey (1117), and, 1 mile distant, an agricultural college (1846), a Tudor edifice (see Agriculture). Near this is the handsome seat of Earl Bathurst. There is a considerable trade in wool and agricultural produce, and the town is a hunting centre. Till 1867 it returned two members; till 1885 one. Pop. (1851) 6096; (1891) 7441. Cirencester (pronounced Cisseter) was the Roman Corinium, at the junction of five Roman roads; and there is a good collection of Roman antiquities found in the neighbourhood. Canute held a council here in 1020. Rupert stormed Ciren. cester in 1642 and 1643 . The early English chronicler Richard (q.v.) of Cirencester was a native.

Cirrhosis, the drunkard's liver. See LIVER, ALCOHOLISM.

Cirripedia (Gr., 'curl-footed '), a degenerate sub-class of Crustacea, including the numerous forms of Barnacles and Acorn-shells (q.v.). Cirrho' poda was a form of the name once commonly in use.

\section{Cirrus. See Clouds.}

Cirrus, Cirrhus, in Botany, see ClimbingPLANTS and (under Plants) Movements of PlANTS. The term cirrus, in Zoology, may designate any curled filament, and has been applied to the curiously modified abdominal limbs of the Cirripedia (q.v.).

Cirta, the capital of ancient Numidia, now Constantine (q.v.).

Cis, a Latin preposition, meaning 'on this side" (as opposed to trans or ultra, "beyond '), which is often prefixed to names of rivers and mountains to form adjectives; Cisalpine, Cispadane, 'on this side of the Alps,' 'of the Po.' As most of these words are of Roman origin, Rome is usually the point of view; but in Ultramontane (q.v.) it is otherwise, as also in Cisleithania, a division of the Austrian dominions-see AUsTriA, Vol. I. p. 595.

Cisalpine Republic. After the battle of Lodi, in May 1796, General Bonaparte proceeded to organise two states-one on the south of the Po, the Cispadane Republic, and one on the north, the Transpadane. These two were on 9th July 1797 united into one under the title of the Cisalpine Republic, which embraced Lombardy, Mantua, Bergamo, Brescia, Cremona, Verona, and Rovigo, the duohy of Modena, the principalities of Massa and Cararra, and the three legations of Bologna, Ferrara, and the Romagna. The republic had a territory of more than $16,000 \mathrm{sq}$. m., and a population of $3 \frac{1}{2}$ millions. Milan was the seat of the government or Directory. The army consisted of 20,000 French troops, paid by the republic. The republic was dissolved for a time in 1799 by the victories of the Russians and Austrians, but was restored by Bonaparte after the victory of Marengo, with some modifications of constitution and increase of territory. In 1802 it took the name of the
Italian Republic, and chose Bonaparte for its president. A deputation from the republic in 1805 conferred on the Emperor Napoleon the title of King of Italy ; after which it formed the kingdom of Italy till 1814. See ITALY.

Cissam'pelos, a genus of Menispermaceæ, of which one species, $C$. Pareira, was formerly rogarded as the source of the drug known as Pareira Brava (q.v.), also called Butua Root.

Cissoid (Gr., 'ivy-like,' from the shape), a plane curve consisting of two infinite branches symnietrically placed with reference to the diameter of a circle, so that at one of its extremities they form a Cusp (q.v.), while the tangent to the circle at the other extremity is their common asymptote. It was invented by Diocles of Alexandria to solve the problem of finding two mean proportionals; but Newton first showed how to describe the curve by continuous motion. The area included between the two branches and the asymptote is exactly equal to thrice the generating circle. In later times the term has been generalised to comprise higher curves described by the same law, but where the generating curve is not a circle. When the asymptote is vertical, the circular cissoid seems to

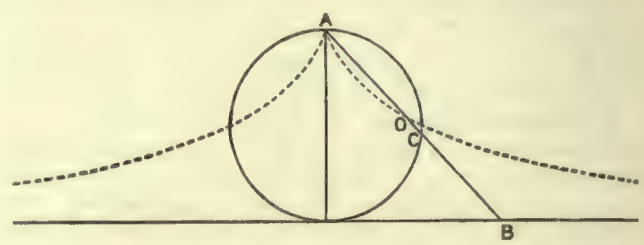

grow towards it as ivy does to a wall, \&c. Draw any straight line $\mathrm{AB}$ to the tangent. Measure $\mathrm{AO}=\mathrm{BC}$, and thus $\mathrm{O}$ traces the curve.

\section{Cissus. See VitaCEF.}

Cis-Sutlej States, a term first given to the Sikh principalities which arose south of the Sutlej in the end of the 18th century, and now includes the British districts of Umballa (Ambala), Ludhiana, Firozpur, Hissar, and the native states of Patiala, Jind, and Nabha.

Cist. See Coffin, Barrow, Burial.

Cistercians, a monastic order founded by the Benedictine abbot Robert of Champagne, in France, who, after repeated attempts-at first in the forest of Molesme-at a reformation of the secularised monastic life, established in 1098, in the forest of Citeaux (Cistercium), a small hamlet near Dijon, along with twenty companions, a monastery for the purpose of emrrying out the strictest observance of the rule of St Benedict. By command of the pope Robert returned in 1099 to Molesme, where he died in 1108; but his successor, Alberic (who died in 1109) succeeded in gaining the pope's favour and the confirmation of the order, and drew up the Instituta Monachorum Cisterciensium, which represented the new foundation as the only true Benedictinism. His successor, Stephen Harding, ruled in the same spirit, and still further stamped the order with its distinctive character of aissterity. Yet Citeaux was near extinction when the famous St Bernard, together with thirty companions, joined the Cistercians in 1113. Two years afterwards he became the first abbot of Clairvaux, which thenceforward was the centre of the influence he wielded throughout Europe. In 1119 the Abbot Stephen issued a new rule, the 'Charter of Charity,' for the monks of the order, which was already augmented by two additional monasteries. It gained great accessions in Spain and Portugal, as well as in France, where the Cistercians now also bore the name of Bernardines. Before the end of the 12th 
century the onder had 800 abbeys in different coun. tries of Europe, and by the middle of the 13th its establishments had reached the number of 1800 . But as riches increased, the old austerity and unity deesyed; the Spanish abbots seceded, and even in France and Italy arose separate congregations, auch as the Feuillans and the Trappists. The Cister. cins did little for the progress of the sciences; but they rendered valuable service in the develop. ment of agriculture, and in the 12th and 13th centuries they were consistent promoters of Gothic architecture.

The Cistercians were distinguished from the order of Clugny (q.v.) by their severer rule and stricter poverty, avoiding everything like splendour in their churches, even gold and silver crosses; by being submissive to the jurisdiction of the bishops, at least till after the death of St Bernard; by not meddling with the cure of souls; by wearing a white robe with a black scapulary; and by their peculiar form of government, which was introduced by Innocent III. in 1215 into all the monastic orders. In England theis earliest establishment was Waverley Abbey (1128), near Farnham, in Surrey. The number of Cistereian abbeys in England in the reign of Henry VIII. was 75, besides 26 Cistercian nunneries. In Scotland there were 11 abbeys and 7 nunneries. Among the English abbeys were Woburn, Tintern, Furness, Fountains, Kirkstall, and Rievaux; among the Seottish, Melrose, Dundrennan, Kinloss, Glenluce, Culross, Deer, Balmerino, and Sweetheart or New Abbey. The chief French abbeys, "the four eldest daughters of Citeaux,' as they were called, were La Ferté, Pontigny, Clairvaux, and Morimond, the last of these having itself 700 dependent benefices. Port Royal des Champs was the most celebrated of the Cistercian nunneries. Riches and indolence brought this powerful order, as well as others, into decay. Even before the Reformation many of their convents had ceased to exist. The French Revolution reduced the Cistercians to a few convents in Spain, Poland, Austria, and Saxony. The last remnant of the order in France was expelled in 1880. At Mount St Bernard, near Coalville, Leicestershire, they have a 'mitred' abbey built by Pugin the elder. See Manriquez, $\boldsymbol{A} n$.

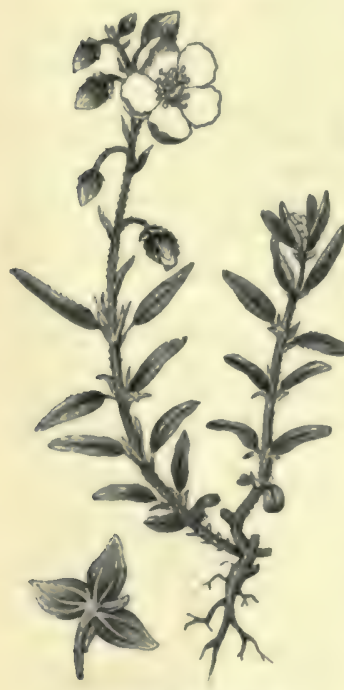

Common Rook-rose (Helianthemum vulgare). nales Cistercienses (4 vols. Lyons, 1642); The Cistercian Saints of England (ed. by Newman, 1844); Sharpe, The Architecture of the Cister. cians (1874); Janauschek, Origines Cis. terciensium (1877); also the articles Benedictines, MoNACHISM.

Cistern. See WATER.

Cistus (Gro), or Rock-Rose, a genus of thalamitloral dicotyledons, which gives its name to the Cistaces, an order allied to Cruciferne and Capparider, and containing about four genera and sixty species of shrubs and herbs, chiefly Medi. terranean. Many species are more or less resinous; and from the twigs of some mpecies of Cistns, natives of southern Europe and the Levant, particularly $C$. ereticus, $C$. cyprius, and $C$. ladariferes, the resinous substance culled Ladanum is obtained, which is used as a stimulant, chiefly in plasters, but has become obsolete in modern medical practice. Many species of Cistus are much eultivated for the beauty of their large wild-roselike flowers, which are red, white, lilac, yellow, or frequently of two colours. Most of the larger kinds require in Britain some protection in winter. The common yellow Rock-roses of our dry hillsides are species of Helianthemum, chiefly $H$. vulgare. Many pretty varieties of this and other species are grown in gardens, especially on rockwork. Several kinds are North American.

Citation, the act of calling a party into court to answer to an action, to give evidence, or to per. form some other judicial act. In England the term citation is applied particularly to process in the spiritual, probate, and matrimonial courts. In Scotland, a citation is given in the Court of Session (q.v.) by an officer of court, or by a messenger-atarms, under authority either of a summons passing the Signet (q.v.), or of a warrant by the court. Where no messenger-at-arms is resident in the district, it may be done by a sheriff-officer. Citation is made either personally, by delivery of a copy of the warrant to the party eited; or at the dwellingplace, when the party cannot be found in person. There must be one witness in every case, and in the case of poindings two witnesses to the execution of a warrant of citation. Parties resident out of Scotland, and tutors and curators of minors, are cited edietally-i.e. by delivery of the warrant at the office of the Keeper of Edictal Citation at the General Register House in Edinburgh. The officer who executes the citation returns a certificate, called the Exccution, of the manner in which it has been done. A new form of citation was introduced by the Citation Amendment Act of 1882, by which any officer authorised under the older law, or any enrolled law-agent, may execute a warrant of citation, by sending a registered letter to the known residence or place of business of the person to be cited, containing a copy of the summons or other document to be served with the citation subjoined.

In criminal cases the party cannot appear voluntarily in court; he must be cited, and can plead any omission in form, which cannot be obviated even by consent. This form of citation is regulated by the Criminal Procedure (Scotland) Act, 1887. Under this act the sheriff-clerk, for cases in the Sheriff Court, and the clerk of justiciary, for cases in the High Court, issue warrants in the form of a schedule appended to the act. Service of the indietment and citation on these warrants may be made by any macer, messenger-at-arms, sheriffofficer, or officer of police. When the accused is in prison, it may be made by a governor or warder.

Citeaux. See Cistercians.

Citharon. See ATTICA.

Cithara (Gr.), an ancient instrument closely resenbling the Guitar (q.v.). See also ZiTHER.

Citizen. See CITY.

Citric Acid, $\mathrm{H}_{3} \mathrm{C}_{6} \mathrm{H}_{5} \mathrm{O}_{7}$, is the acid to which lemon and lime juice owe their sourness. It also occurs, in some cases along with tartaric acid, in oranges, cherries, currants, gooseberries, and other fruits having a subacid taste. For practical purposes it is always obtained from lemon, lime, or hergamot juice, which contain it in large quantity. The first named of these contains from 20 to 40 grains of citric acid in each fluid ounce.

Citric acid is prepared from these juices by a very aimple process. The juice having been heated to the boiling-point to clarify it from albumen, mucilage, \&e., is mixed with chalk, $\mathrm{CaCO}_{\infty}$, which, 
combining with the citric acid, falls to the bottom as citrate of calcium. The supernatant liquid being drawn off, sulphuric acid is added to the precipitate, decomposing it, with the formation of citric acid and sulphate of lime, $\mathrm{CaSO}_{4}$. By crystallisation it may be obtained pure in the form of colourless, odourless prisms, which effloresce in dry air, and possess an agreeable acid taste and an acid reaction. It is readily soluble in water and alcohol, but almost insoluble in ether and chloroform. A solution of it in water cannot be kept owing to its tendency to ferment. Dissolved in syrup it keeps much longer, and is used largely in the manufacture of lemonade and other aerated beverages, communicating an acid, fruity taste. When heated, the crystals melt, then decompose, and are finally reduced to a combustible form of charcoal. In addition to its employment as a flavouring agent it is largely used in the manufactures. Calico-printers employ it for discharging the mordant from the cloth in patterns, and it is used in dyeing silk with safflower, \&c.

Citric acid may also be prepared artificially, but the process is too complex ever to come into practical use. Chemically it is of great interest as exemplifying that as soon as the chemical constitution is known there is a possibility of producing the substance artificially. There is a popular idea that some day quinime, morphia, and other natural products will be formed by the random mixing together of chemicals in the ehemist's beaker, but the first step towards this result must be the knowledge of their constitution, to be followed by a series of careful experiments.

Citric acid is a powerful tribasic acid (see AcIDs), and the solution in water readily dissolves zine and iron. It forms a class of salts called Citrates, many of which are employed in medicine.

The so-called Citrate of Magnesia, a granular substance, which effervesces on the addition of water, and is very popular as a gentle aperient, is not really a citrate at all, but consists of a mixture of tartaric and citric acids, bicarbonate of soda, and sugar, with perhaps a trace of some magnesium salt to justify the name. The granulating is effected by mixing the powders and placing them in a pan heated by steam, when, in proportion to the citric acid present, the powders run together into a pasty mass. This is forced through a coarse riddle, and the granules are dried by a gentle heat.

Citrate of Potash, $\mathrm{K}_{8} \mathrm{C}_{6} \mathrm{H}_{5} \mathrm{O}_{7}, \mathrm{H}_{2} \mathrm{O}$, is prepared by neutralising citric acid with bicarbonate of potash. It forms a white, granular, deliquescent powder, which acts as a cooling diaphoretic in cases of fever. Dissolved in lemon-juice it is of much value in rheumatism. It is given in doses of 20 to $30 \mathrm{gr}$.

Citrate of Ammonia can only be obtained in solution, as when this is evaporated decomposition takes place and ammonia escapes. It is employed, like the potash salt, in febrile diseases.

Citrate of Iron and Citrate of Iron and Quinine are but examples of a large number of compounds obtained in the form of brown or greenish-brown scales which are largely used in medicine. In these the medicinal value lies not in the citric acid, but in the iron or quinine with which it is associated, although the acid has doubtless a subsidiary action. A peculiarity about these 'scale preparations,' as they are called, is that the inky taste, so characteristic of iron in the form of steel drops, is in great measure removed. Citric acid also forms a series of organic salts called citric ethers, of which citrate of ethyl is an example. Lemon-juice, in which citric acid is the most active ingredient, is a most valuable medicine in scurvy, and when it cannot be obtained the acid may be used as a substitute. Citric acid in solution does not, however, appear to be nearly so effective as the juice itself.
Citron (Citrus medica), a tree cultivated in the south of Europe and other warm temperate or subtropical countries for its fruit; a native of northern India. By many botanists the lemon (C. Limonium), the lime (C. Limetta), and the bergamot $(C$. Bergamea) are reckoned varieties; but it at anyrate avoids confusion to describe these separately. The fruit is large, warty, and furrowed. The pulp is acid and cooling, and is used in the preparation of syrups, lemonade, \&c.; but the part chiefly valued is the thick and tender rind, which has a delicious odour and flavour, and is preserved or candied. From this also the fragrant Oil of Citron, or Oil of Cedrate, used by perfumers, is procured. In Germany the name cedrate is

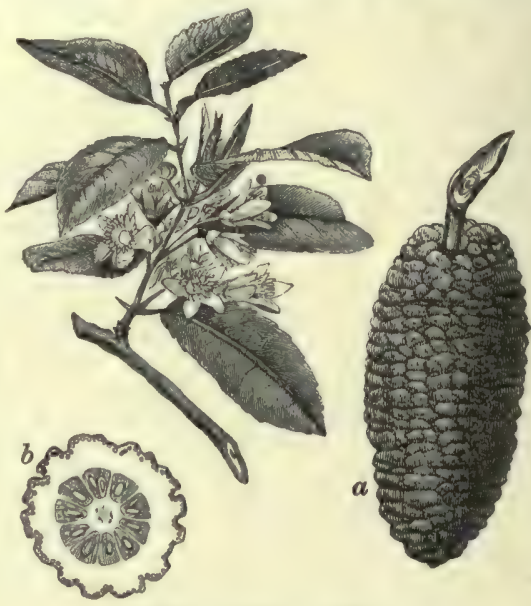

Citron (Citrus medica):

$a$, fruit ; $b$, transverse section of fruit.

extended to all kinds of citron, and the name citron is usually given to the lemon. The fruit of the largest kinds (var. macrocarpa) sometimes weighs 5 Ib. In the United States the name citron is applied to different varieties of the melon, especially one resembling the water-melon, but edible only when made into preserves or pickles. It is probable that the citron is meant in some passages of the Old Testament where the word apple is used in the English version.

Citronwood, or Citrus-woon, the most costly furniture-wood of Roman antiquity, is usually regarded as derived from Biota (Thuja) orientalis, or possibly from Callitris quadrivalvis, allied coniferous trees, both popularly known as Arbor Vitoe (oriental and African). Cicero is said to have paid an enormous sum for a table of this wood.

Citrus, a genus of Aurantiaceæ (q.v.), trees and shrubs of tropical, subtropical, and warm temperate Asia, but many of them now cultivated in all similar elimates for their fruit. To it belong the Orange, Citron, Lemon, Lime, Bergamot, Shaddock, Forbidden Fruit, \&e.

Città di Castello, a town of Central Italy, on the Tiber, 25 miles NNW. of Perugia. It has a castle, a cathedral, and several palaces rich in works of art. In the church of Santa Trinita is preserved Raphael's first commission, a guildbanner. Pop. 5433.

\section{Cittavec'chia. See Malta.}

City (Fr. cite, Lat. civitas). In the sense in which it was first used in the Romanic languages of modern Europe, the word city, like its Latin original, was probably equivalent to state (respublica) rather than to town or borough (urbs, municipium). This usage may be contrasted with 
that of the Greek term polis, which, originally denoting merely a town or collection of households, came afterwards to be frequently used as synony. mous with politeia, a state or free community. Perhaps the nesreat example in the present day to the city in the above sense is to be found in such of the cantons of Switzerland as consist chiefly of a town and its surroundings, for example, Geneva. It is difticult to find any precise meaning attached to the word city in medieval times. In his glossary of medieval Latin terms Ducange defines civitas as urbs opiscopalis, that is, a town in which there exists an episcopal see; but this restricted use of the word, though commonly accepted, rests on no sufficient ground (see CATHEDRAL). It would seem in fuct that from a very early period in English history towns have been denominated either civitas, villa, or burgum, and the inhabitants thereof cives, homines, and burgenses, indifferently. Thus in Domesday Book we find mention of the city (civitus) of Norwich, of Exeter, and of Coventry, but town of Ipswich, of Bedford, and of Shrews. bury; while Gloucester and Leicester are styled both city and borough (burgum).

In its modern sense the term eity, as used in the United Kingdom, is generally applied to all towns which are incorporated, and which either are or have been sees of bishops. See BorougH.

In the United States, a city is an incorporated town, invested with the highest municipal privileges and duties. In some states, 10,000 inhabitants are requisite to the formation of a city government, while in the new states a less number is required. A city has power to legislate upon local matters pertaining to it in accordance with the provisions of its charter, granted by the sovereign power of the people through the legislature of a state. In several of the Western States cities are organised under a general law, all having over 15,000 inhabitants being designated cities of the first class ; under 15,000 and over 2000 , cities of the second class; and all villages with less than 2000 , cities of the third class.

In the case of towns which have grown greatly beyond their original dimensions it is not unusual to give the name of eity to the space which they originally occupied-thus, we speak of the City of London, in contradistinction to the metropolis, la Cite of Paris, and similarly of other places.

A citizen (Fr. citoyen, Lat. civis) is defined by Aristotle to be one to whom belongs the right of taking part both in the deliberative, or legislative, and in the judicial proceedings of the community of which he is a member (Politics, iii. 1). A citizen, therefore, can exist only in a free state. Between a eitizen and a subject there is this distinction, that whilst the latter merely is governed, the former also governs; and thus, though every citizen is a subjeet, many subjects are not citizens. At first the rights of citizenship in Athens and other Greek communities were readily attained by those who were not born to them; but at a later period, when the organisation of Greek civic life had reached a high degree of perfection, admission to the roll of citizens was procured with great difficulty. In Rome, under the early law, there were perfect and less perfect citizens; that which peculiarly distinguished the higher class was the right to vote in a tribe, and the capacity of enjoying magistracy. All the private rights of citizenship (the jus connubii and jus commercii) belonged to the citizens of the lower class. Under these two classes, again, there were two others, originally aliens - the Latini and the Peregrini.

Roman citizenship was acquired most commonly by birth, but for this it was requisite that both father and mother should be citizens. If a citizen married a Latina or a Peregrina, even believing her to be a citizen, the children begotten of the marriage followed the status of the mother. In the earlier days of the republic, citizenship could be conferred on a stranger only by means of a lexi. e. by a vote of the people assembled either in one or other of the Comitin. When the imperial power was established, however, the public rights which formed the chief characteristic of the full Roman citizenship became little more than empty names; and the only value which thenceforth attached to it consisted in the private rights which it conferred. St Paul was 'free-born '-i.e. born a citizen. Such as it was, the constitution of Caracalla extended it to the free inhabitants of the whole Roman empire, and under Justinian the only divisions of subjects henceforth was into citizens and slaves.

In France, during the Revolution, the word citizen was adopted by the republicans as the most appropriate term to exprens the grand principle of liberté, egulité, et fraternité. It tork the place of Monsieur. Every Frenchman became Citoyen in relation to other Frenchmen, the highest in official station being so addressed by the lowest. The usage gradually died out after the assumption of imperial power by Napoleon. In its modern use, the term citizen is applied in Britain and elsewhere either specifically to a dweller in a town, or to any one who is either born in the country or has become legally naturalised in it.

In the 'Inited States, the words 'citizens' and 'people' are synonymous terms. From the point of vew of American constitutional law, a citizen being a member of the political community to which he belongs, every person born in the United States and subject to its jurisdiction falls within the definition. An alien may become a citizen by being natural. ised under the Acts of Congress. Again, a citizen of the United States residing in any state of the union is a citizen of that state. There being a government in each of the several states, as well as a government of the United States, a person may be at the same time a citizen of both, but his rights as a citizen under one of these governments differ from those under the other. Thus, although the government of the United States is supreme and paramount to the states, it cannot secure to the citizen rights or privileges which are not placed under its jurisdiction by the constitution. On the other hand, a person may be a citizen of the United States and not be a citizen of any particular state, having his residence in one of the territories, or not having a fixed residence in any state.

Citizens of each state are entitled to all privileges and immunities of citizens in the several states, and citizens of all other states have the right to go into any state and carry on business, to hold pro. perty and be protected like the citizens of that state in their rights. It may further be observed that under the existing constitutional law, children born of Chinese parents are citizens of the United States, but Chinese aliens are incapable of becoming eitizens. See Naturalisation, Alikn, Borough; and Fustel de Coulanges, La Cite antique (1864).

City of Refuge. By the Jewish law with regard to unintentional manslaughter, indicated
in Exod. xxi. 13, and fully get forth in Num. xxxv., Deut. xix., and Josh. xx., the parts of Palestine to the west and enst of the Jordan were each divided into three districts, and in each district was a city in which the manslayer should at once with all speed seek refuge. If the elders of the city of refuge recognised the manslayer's claim to the right of asylum, he was proviaionally secure from the goêl or avenger. He was then set before the community (represented by its elders) in the midst of which the deed was done, that they might decide judicially whether the right of asylum should be further extended 
to him. In that event he was free to return and sojourn in the city of refuge; and afterwards, if the goel found him outside it, he had a right (though not the duty) to kill him. Not till the death of the high-priest was he at liberty to return home. See BLOOD (AVENGER OF); and for the usage in other countries, see SANCTUARY.

Ciudad Bolivar. See Angostura.

Ciudade'la, a seaport town (formerly capital) of the island of Minorea, on the west coast, with a cathedral, ruined fortifications, and exports of cattle, wool, cheese, and building-stone. Pop. (1878) 7777 ; (1891, estimated) 8431 .

Ciudad Meal' ('royal city ;' Ciudad being Lat. civitas), a town of Spain, capital of the province of the same name-area, $6042 \mathrm{sq.} \mathrm{m}$.; pop. (1885) 280,642 - situated on a plain between the rivers Guadiana and Jabalon, 105 miles S. of Madrid by rail. It is a poor, dull place, but has a fine Gothic church, and remains of the old townwalls, with one handsome gateway. There are manufactures to a small extent of coarse woollens, linen, and table-cloths, and a trade in the agricultural produce of the district. The population has declined, and in 1897 was estimated at 13,500.

Ciudad Rodri'go ('Roderic's Town'), a fortified town of Spain, 17 miles from the Portuguese frontier, and $56 \mathrm{SW}$. of Salamanca by rail, on a steep hill above the river Agueda, which is here crossed by a fine bridge. It is a poor, dirty town, with a Gothic eathedral. It was taken by the English (1706) and French (1707) in the War of the Spanish Succession, but is chiefly of interest for its sieges during the Peninsular war. In the spring of 1810 the French under Massena invested the town, and after a gallant defence by the Spaniards, it was forced to surrender on the loth July. Meanwhile Wellington was gaining time to strengthen his lines at Torres Vedras; and in January 1812 he pouriced down on Ciudad Rodrigo, and after a siege of eleven days, took the place by assault. For this brilliant achievement he was created an English earl, and, by the Spanish Cortes, Duke of Ciudad Rodrigo. Pop. 6856.

Civet ( Viverra), a genus ố cat-like carnivores. Besides several species of Viverra proper, there are sundry other closely related forms, such as the Genettes, which some regard as separate genera.

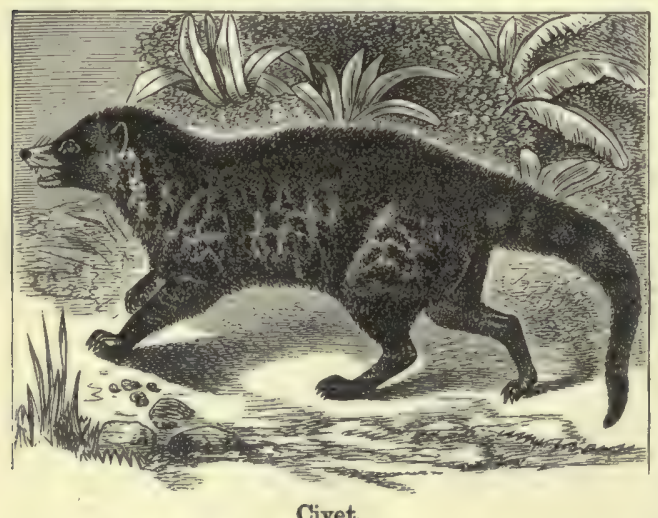

The long, thin body, the pointed head, the short legs, and small hairy feet are external characteris. tics. The larger species, such as the two first named below, are rather larger than a fox, but the Viverricula, the Genettes, \&c. are often decidedly smaller. They are active and fierce carnivores. The civets are best known in connection with the strong perfume obtained from two (per- ineal) glands near the anus. Such glands are common enough : it is only their penetrating fragrance which is peculiar. The civet perfume of commerce is obtained from $V$. civetta, the African civet or civet cat; from $V$. zibetta, the Indian civet of Bengal, China, and the Malayan region; from $V$. tangalunga, similar in distribution to the last; and from Viverricula malaccensis, the Rasse of India, China, Java, and Sumatra. Civets are often kept in confinement for the sake of the perfume, which is removed from the glands about twice a week by means of a small spatula, and is obtained most abundantly from the male, especially after he has been irritated. A dram is a large quantity to obtain at a time. Abyssinia is one of the principal seats of the trade, and Java another. The perfume is most used in the East.

Civil Damage Acts, passed in several of the United States, giving to husbands, wives, children, parents, guardians, employers, and others who have sustained injury in person or property or means of support, by any intoxicated person in consequence of such intoxication, the right of action against the person who sold or gave away the liquor which eaused such intoxication, have been held to be constitutional. In some cases the right of action has been extended to the owner of the premises where such intoxicating liquor has been obtained.

\section{Civil Death. See Death (Crvil).}

Civil Engineer. See Engineering.

Civilian is either a person whose pursuits are civil-i.e. neither military nor naval; or one who is skilled in the civil law $-\mathbf{a}$ student, professor, or doctor of the Roman civil law.

Civilisation. See Anthropology, Archa. OLOGY, ART, GOVERNMENT.

Civil Law. See Law.

Civil List. Down to the period of the Restoration in 1660, notwithstanding an attempt at negotiation between James I. and the parliament for the commutation of the hereditary revenues of the crown, the whole expenses of the government of England, civil and military, were included in one list, or rather they were defrayed ont of what was called the royal revenue. This revenue, which arose partly from crown-lands, partly from the hereditary excise and other hereditary revenues, and partly from the ordinary excise, was for a long period after the Conquest really at the disposal of the crown. Even after the supplies were provided by parliament, the specific mode of their expendi. ture continued to be free from parliamentary control. But at the Restoration a distinction was made (by statute 12 Charles II.) between the extraordinary expenses occasioned by war, and the ordinary cost of the civil establishments of the country. For the latter the needful funds were provided, partly from such crown-lands as were still unalienated, and partly from taxes which parliament voted for the purpose at the commencement of each reign. These were called the hereditary or civil list revenues, the amount of which was in 1689 fixed at $£ 600,000$ per annum. During the reign of William III. the civil list was twice raised, and in 1698, after the war with France, stood at

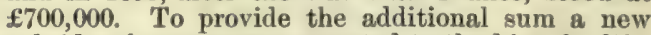
subsidy of customs was granted to the king for life. The branches of expenditure included under this head were the following: (1) The royal household; (2) the privy purse; (3) the royal palaces; (4) the salaries of the chancellor, judges, great officers of state, and ambassadors; (5) the incomes given to the other members of the royal family; $(6)$ the secret-service money, pensions, and other irregular claims. The support of the army and navy was, 
however, provided for by an annual vote of the House of Commons, and the interest of the national debt was never charged against the civil list. Dur. ing Queen Anne's reign matters remained nesily on their former footing ; the civil list remaining at

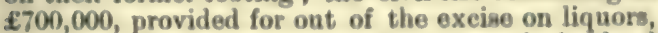
the new subsidy of customs of 1698 , and the land revenues of the crown. This was also the amount during the reign of George I., but on the accession of George II. it was raised to $£ 800,000$; and again in the fifty-fifth year of the reign of George III. it had to be further raised to $\$ 1,030,000$. George III. surrendered sume portions of the hereditary revenue of the crown which had been retained by his predecessors, and the annuities to members of the royal family were now paid ont of the Consolidated Fund (q.v.) to the amount of $£ 260,000$. When George IV. succeeded to the throne, $£ 255,000$ of expenditure was transferred to other funds, and the civil list was fixed at $\mathbf{£ 8 5 0 , 0 0 0}$ per annum. The crown enjoyed, in addition, the hereditary revenue of Scotland, amounting to about $£ 110,000$, and a separate civil list was kept up for Ireland of $£ 207,000$. Against these large sums, however, were still placed many charges which belonged to the nation rather than the crown; and it was not till the 15th November 1830 that Sir Henry Parnell, afterwards Lord Congleton, carried a motion for the appointment of a select committee for the purpose of separating the proper expenses of the crown from all other charges. The result of this measure was the act, 1 Will. IV.c. 25 , for the regulation of the civil list. The sum of $£ 510,000$ was in 1831 granted to his majesty, and exclusively devoted to the privy purse, the salaries and expenses of the royal houselold, secret-service money, and pensions. The separate list for Ireland was discontinued, and the Scotch hereditary revenues and other items were directed to be paid into the Exchequer. The change was rather a redistribution, which ensbled the country to look more closely into its expenditure, than a real reduction of the civil list.

On the accession of Queen Victoria, the civil list, which had long been of the nature of a permanent compact between the monarch and the parliament, and as such beyond the control of parliament during the life of the sovereign. was aettled by 1 and 2 Vict. chap. 2. The Queen surrendered the hereditary revenues of the crown for life, in consideration of a yearly sum of $£ 385,000$, charged against the Consolidated Fund, to be devoted solely to the support of Her Majesty's household, and the honour and dignity of the crown. The application of this sum was intrusted to the Lords of the Treasury, who were directed to pay yearly (1) to the Queen's privy purse, 160,000 ; (2) salaries and expenses of the royal household, $£ 231,260$; (3) retiring allowances and pensions to officers, \&c. of the household, $£ 44,240$; (4) for royal bounties, alms, and special services, $£ 36,300$; (5) general expenditure of the court, $£ 13,200$. This sum of $£ 385,000$ does not include the annuities of $£ 40,000$ per annum to the Prince, and $£ 10,000$ per annum to the Princess of Wales, nor the other grants made by special acts of parliament to mempers of the royal family. It is provided that if the civil list charges in any one year shall exceed the total sum of $£ 400,000$, an account of the particulars of excess shall be laid before parliament in thirty days. Besides the above sum, Her Majesty was accorded the right of granting new pensions, to the amount of $£ 1200$ every year, 'to persons who have just claims on the royal beneficence, or who, by their personal gervices to the crown, by the performance of duties to the public, or by their useful discoveries in science, and attainments in literature and the arts, have merited the gracious consideration of their sovereign and the gratitude of their country.' These pensions amount to about $\mathbf{E 2 5 , 0 0 0}$ per annum, so that the groes sum allotted to the civil lint every year is now about $\mathfrak{£} 410,000$.

Civil Service. Under this head are classed all ofticens of the crown who do not belong to the military or naval services and are engaged in the administration of the civil affains of the state, wuch as the collection of the revenue, the administration of law and justice, the performance of the executive duties of the government, and the representation of the country abroad. Originally the civil service was a body small in number and personal to the govereign, but with the growth of popular control over state affairs, the number of persons employed under government has vastly increased, and there have been many new departments called into existence to carry out fresh laws. For instance, the Education Department was established to ad. minister the grants made by parliament in aid of public education, the Poor-law Commission for the administration of the Poor-laws, and the Board of Trade for the purpose of carrying out new laws relating to shipping and railways. Posts in the civil service were originally in the gift of the min. isters of the crown, and no qualifying test was applied, though in some departments tests of competency were applied by the authorities at their sole discretion to eandidates for clerkships. Amongst these departments were the Admiralty, the Audit Office, the Customs, the Excise, the General Register Office, the National Debt Office, the Ordnauce Office, the Pay-office, the Postoffice (London), the Stationery Office, the Treasury, and the War Office. But no examination whatever took place on appointment to some of the most important offices of the state, such as the Home Office, the Foreign Office, the Colonial Office, the Board of Trade, the Office of Works, or the Office of Woods. The inadequacy of these arrangements having been foreibly pointed out in 1853 in a report by Sir Stafford Northcote and Sir Charles Trevelyan, an order in council which was issued in 1855 directed that tests of fitness should be insisted upon as regards all junior situations in all departments of the civil service, and that such tests should be appliel by a separate and independent board created for the express purpose.

A Board of Commissioners was appointed, and entered at once upon its duties. Some time, however, was required to bring under the new system all the situations and employments which it was intended to affect. Not the least important of the tests were directed to the proof of a candidate's fitness in respect of age, health, and character. The Superannuation Act, 1859, made the grant of certificates by the Commissioners an essential condition, in ordinary cases, to the receipt of a pension. In the earlier years of the Com. mission its proceedings were almost exclusively concerned with the examination of candidates nominated singly to single posts, the only ques. tion to be decided being whether the candidate reached or did not reach a minimum standard of competency. There was no rule providing for competition either open or limited. On the other hand, there was nothing to preclude competition if those who had the power of appointment to any situation should choose to nominate several candi. dates for one vacancy, or to invite applications from the public at large. The average ratio of nominees to places was about three to one. But, as many of the nominees failed to reach the minimum standard, the proportion of competent or effective candidates was lower, sometimes not more than one to one, a result of course inconsistent with the idea of competition. To remedy this defeot 
it was arranged in 1861, on the recommendation of a select committee of the House of Commons, that persons nominated to clerkships in the gift of the Treasury should first be subjected to a test examination of an elementary character, and that those who passed this test should afterwards compete in the proportion of three can. didates to a vacancy. In 1870 the plan was superseded, as far as regards these clerkships, by open competition. Limited competitions have, however, continued for various situations in respect of which the heads of departments retain the right of nomination. It was not until some years after the promulgation of the order of 21st May 1855 that the experiment of entirely open competition was tried. The first absolutely open competition occurred in 1859, when, at the instance of the then Secretary of State for India (Lord Derby), 339 candidates, having offered themselves in answer to public advertisement, were examined for eight writerships in the India Office. The advantages of open competition were formally recognised by a resolution of the House of Commons on 24th April 1856 , as well as by a select committee of that House which sat in 1860 .

The general application of the principle of open competition to the home civil service dates from the order in council of 4th June 1870, which laid it down as to certain specified departments comprising the bulk of the service that open competition for clerkships and similar situations, instead of being, as before, permissible at the discretion of the heads of departments, should thenceforth be the rule, unless expressly excluded. From that date to the present time the field of open competition has been continually extending, and it now includes several departments which, though not necessarily subject to the rule, have thought fit voluntarily to accept it. From May 1855 to June 1870 the number of competitors was 1594 for 37 appointments; and from June 1870 to December 1885 there were 108,400 competitors for 14,717 appointments. Persons seeking appointments in the civil service which are open to com. petition must pass either (1) a special examination arranged to suit the class of appointment; (2) the Class 1 examination, which is generally known as the Higher Division; or (3) the Lower Division examination. From 1870 to 1876 appointments to the clerical staff were, except in a few special cases, divided as regards examination into Class 1 and Class 2, the former of which still continues. The latter was, however, superseded after the report of a Royal Commission over which Sir Lyon Playfair presided, by the examination for the Lower Division of the service which was constituted by order in council of 12th February 1876. This order provided that no department throughout Her Majesty's civil service shall be permanently increased or regulated afresh without providing for the introduction of a system whereby such of its duties as are of a suitable character shall be performed by members of the Lower Division. The intention of this was to reduce the cost of the clerical staff in the various departments. After the system had been in force a few years it gave rise to much agitation among the clerks, and eventually a Royal Commission was appointed in 1886 to inquire into the whole administration of the service. In September 1888 the Commission presented its report on the working of the Playfair scheme, and on the scales and regulations under which pensions are granted. It recommended that the service should be divided into 'First Division' and 'Second Division' to take the place of the Upper and Lower Divisions of the Playfair system; the salaries of the 'First Division' to begin at $£ 200$ and to rise to $£ 1000$ a year, and those of the 'Second
Division ' to begin at $\mathfrak{£ 7 0}$ and to rise to $£ 350$ a year. The entire civil service was to be placed on these scales so as to secure uniformity and to facilitate transfers from one department to another. The Commissioners recommended a revision of the pension system with a view of compelling civil servants to make some contribution towards their pensions, and they suggested a deduction of 5 per cent. from salaries for this purpose. These recommendations of the Commission have never been fully carried out, and on this account there has repeatedly been much agitating on the part of the civil servants about their 'grievance."

At the census of 1891 there were 76,361 persons in the civil service, of whom 40,106 were officers and clerks, and 36,255 office-keepers, messengers, porters, and letter-carriers. Of the total 67,026 were males and 9335 were females. Appointments in the civil service as a rule are held for life, and confer the right to a pension. The pension system was instituted by the Superannuation Act, 1859, which provides that the superannuation allowance to be granted to persons who shall have served in an established capacity in the permanent civil service of the state, whether their remuneration be computed by day pay, weekly wages, or annual salary, and for whom provision shall not otherwise have been made by act of parliament, or who may not be specially excepted by the authority of parliament, shall be as follows: To any person who shall have served ten years and upwards and under eleven, an annual allowance of ten-sixtieths of the annual salary and emoluments of his office; for eleven years and under twelve years, an annual allowance of eleven-sixtieths of such salary and emoluments; and, in like manner, a further addition to the annual allowance of one-sixtieth in respect of each additional year of such service until the completion of a period of service of forty years, when the annual allowance of forty-sixtieths may be granted, and no addition shall be made in respect of any service beyond forty years. Special allowances are made in cases of the abolition of office, and these are entirely in the discretion of the Commissioners of the Treasury. By the Pensions Commutation Act, 1871, pensions may be commuted by persons entitled to them according to a scale which has been fixed by government.

In the public accounts of Great Britain the Civil Service Estimates fall under the heads of : (1) Public Works and Buildings; (2) Salaries and Expenses of Civil Departments; (3) Law and Justice; (4) Education, Science and Art; (5) Foreign and Colonial Services; (6) Non-effective and Charitable Services; (7) Miscellaneous. For the public accounts, see Great BRITAIN ; and for the Indian Civil Service, see IndIA.

Civil Service of the United States.-In January 1883 Congress passed a law to prevent the abuse of the appointing power of the officers of government. The President was authorised to appoint, with the advice and consent of the Senate, three Civil Service Commissioners, whose duty is to aid the President in preparing suitable rules which shall provide for open competitive examinations for testing the fitness of applicants for the public service, such examinations to be practical in their character, and so far as may be relating to those matters which will fairly test the relative capacity and fitness of the persons examined to discharge the duties of the service. All the offices, places, and employments arranged in classes or grades are to be filled by selections according to grade from among those graded highest as the results of such competitive examinations. The appointments to the public service in the departments at Washington are to be proportioned upon the basis of population to the several states and 
territories and the Distriot of Columbia. The law provides a period of probation before any alsolute appointment is made, and exempts all persons in the public service from all obligation to contribute to any political fund or to render any political service. It forbids any person in the public service using his official authority to coerce the political retion of any other person or body. Non-competitive examinations in all proper cases are provided for after notice given of a vacaney, the appointing power to give notice in writing to the Civil Service C'ommission of the persons seleeted for appointment among those who have been examined. Power is given this Commission to make regulations for, and to have control of, such examinations, subject to the rules made by the President. The Civil Service Commission is repuired to report annually to the President, for transmission to Congress, its own action, the rules and regulations, and the exceptions thereto in force, the practical objects thereof, and any suggestions for the more effectual accomplishment of the purposes of the law. P'rovision is made for holding examinations at convenient places twice each year in every state and territory of the United States.

The Commission punishes by fine and imprisonment all in the public service who wilfully defeat, olstruct, or deceivrs any person in respect to his or her right of examination, or who shall corruptly and falsely mark, grade, estimate, or report upon the proper standing of any person examined, or aid in so doing, or who shall furnish to any person any special or secret information for the purpose of either improving or injuring the prospeets of any person so examined being appointed, employed, or promoted. It was provided that after six months from the passing of the act, no officer or clerk was to be appointed until after passing examination, unless specially exempted by the act; and no person in the habit of using intoxicating beverages to excess is to be appointed to or retained in any office, appointment, or employment to which the act applies. This and subsequent legislation has wrought a wonderful change for the better, lessened the number of incompetent politicians who thrive upon the 'spoils system' applying for office, and secures a far better class of public servarts in all departments of the government.

Civita' Castellana, a town of Central Italy, 25 miles N. of Rome by the old Flaminian Road, on a plateau of volcanic tufa above the Treja. It has a handsome cathedral (1210), and a citadel built under Alexander VI., now a state-prison. Pop. 4251. In the neighbourhood are remains of the Etruscan Fulerii.

Civita' Vecehia, an Italian fortified port, 50 miles NW. of Rome by rail, on the Mediterranean. The harbour is both a commercial and naval one, and was originally constructed by the Emperor Trajan; the town indeed owed its origin entirely to the port of this emperor, and hence came to be known as Portas Trajani. Population, 12,300. The harbour is formed by two moles and a breakwater, on which latter is a lighthonse, The place, which became a free port under Pope Innocent XII. in 1696 , is regularly visited by steam-packets from Marseilles, Genon, Leghorn, Naples, Messina, and Malta. It suffered at the hands of Goths and Saracens, and was accupied by the French in 1849. The papal troops opened the gates of the fortress to the Italian general Bixio in 1870 .

Clackmannan, the county town of Clack. mannanshire, on the Devon, 2 miles E. by S. of Alloa. An eminence rising 100 feet above the Forth is erowned by the ruined tower of the Bruces; and there are also an old market-cross, three churches, and a public hall. Pop. 1503.
Clackmannanshire, the smallest county of Scuthud, lies between the comnties of P'erth, Fifo, and Stirling, and slopes from the green Ochil Hills th the Forth. Its greatest length is 10 miless; area, 48 sq. m. Pop. (1871) 23,747; (1891) 28,473. A ridge of high ground, with inferior soil, often resting on clay, runs west through the middle of Clackmannanshire, between the very fertile alluvial lands resting on the coal-measures in the south, and the North Devon valley in the north. The 'Hillfoots' have long been celebrated for their woollen manufactures; ale and glass bottles are largely prouluced, and there is a traule in iron and shiphuilding. Clackmannan is the county town, but Alloa is the most important place. Clackmannanshire, with Kinross-shire, returns one member to parliament; since 1895 it includes the parish of Alva, formerly attached to Stirlingshire. See Beveridge, Between the Forth and the Ochils (1888).

Clacton-on-Sea, an Essex watering-place, 15 miles SE. of Colchester; pop. 1700.

CIadium, a genus of Cyperacer, of which one species, C. Mariscus, is a native of bogs and marshes in Britain, particularly in Cambridgeshire. Its lialit is to grow in large masses, but these by no means occur frequently. It is rough-edged, and is consequently hurtful to cattle, but it is used for thatching.

Claiborne Croup, a name given in America to certain beds of clay, lignite, shelly sands, and marly limestone which occur at Claiborne, Alabama, and are believed to belong to the Eocene system.

Clairac, a town in the French department of Lot-et-Garonne, on the Lot, 18 miles NW. of Agen. Here fine white wines are made. Pop. 2197.

Clairant, Alexis Claude, mathematician, was born at Paris, 13th May 1713. He early exhibited a most remarkable aptitude for mathematics, and was considered worthy of admission to the Academy of Sciences when only eighteen years of age. Clairaut wrote a great number of scientific papers, but his fame rests principally upon his Theorie de la Figure de la Terre (1743), in which he promulgated the theorem that the variation of gravity on the surface of the earth, regarded as an elliptic spheroid, was altogether independent of the law of density ; on his explanation of the motion of the lunar apogee, a point left unexplained by Newton; and on his computation of the time of the return of Halley's comet. He died at Paris, May 17, 1765.

Clairvaux, a village of France, on the Aube, 10 miles SE. of Bar-sur-Aube, is remarkable as the site of the once famous Cistercian abbey, founded in 1115 by St Bernard, who presided over it till his death in 1153 , when he was buried in the church. The unwholesume swampy valley became the smiling Clara Vallis under the efforts of the monks, who at Bernard's death numbered 700 ; afterwards the founder's ascetic rule was disregarded, and the simple row of cells gave place to a palatial monastery, whose church was reckoned a masterpiece of architecture, but was destroyed at the Restoration. The abbey, which at one time possessed a revenue of 120,000 livres, had been suppressed at the Revolution, and the extensive buillings are now used as a central prison for the thirteen eastern departments of France.

Clairvoy'ance, the faculty, attributed to persons in the mesmeric state, of seeing objects not present to the bodily senses, whereby the clairvoyant is enabled to describe events passing at a distance. For the scientific estimate of such claims, see Animal Magnerism. The aimple 122 
elairvoyance of the professional entertainer is easily effected with the assistance of a code of signals and a good memory; generally the subject is blindfolded on the stage, while a confederate passing among the audience holds up the objects offered to him, and requires them to be named.

Clam is the common name for bivalves of the genus Chama (q.v.) and some other allied genera. The common clam, or soft clam of northern waters, is the Mya arenaria, or Chama arenaria; it is found especially in gravelly mud, sand, and other soft bottoms, especially between high and low water mark. They are largely used for bait, and in New England are a much relished article of food. Some kinds of clams rival oysters in popularity in New York. The hard clam, or Quahaug, is the Venus mercenaria. The Giant Clam, the Tridacna Gigas, found in East Indian waters, in lagoons, and on coral islands, is of enormous size, the animal (which is edible) without the shell weighing $20 \mathrm{lb}$., while with the shell it may weigh $500 \mathrm{lb}$. The shells are used as ornaments for grottoes and fountains, and as bénitiers in Catholic churches,-The BEAR's PAW CLAM is the Hippopus maculatus, a bivalve molluse of the Indian Ocean, of the family Tridacnidæ. The shell is one of the most beautiful of bivalves, alike in form, texture, and colour. It is a favourite shell for ornamental purposes. The margins of the valves are locked together by closely fitting teeth. It is 6 by 10 inches in length, broad in proportion, and transversed by ribs which are roughened by scale-like inequalities. The general colour is white, but there are beautiful spots of purplish-red.

Clan (Gael, clann, Manx cloan, meaning 'chil. dren,'i.e. descendants of a common ancestor). This word became incorporated with the English language at least as early as the 17th century, to mean a body of men confederated together by common ancestry or any other tie, and in this sense it is used both by Milton and Dryden. It came to be applied almost exclusively to the several communities of the Scottish Highlanders, as divided from each other topographically and by distinctive surnames. The word has sometimes been applied to those great Irish septs which at one time were a sort of separate states; but these, with their characteristic forms of internal government, were completely broken down by the power of the English predominance, before the word came into familiar nse in the English language. In Scotland it was used in the 16th century to designate the freebooters of the Border as well as the Celtic tribes of the Highlands; and there were two characteristics common to both-their predatory habits, and their distribution into communities. The assumption of a common surname was general, but by no means universal. Men of the most various origin were in the habit of enlisting under chiefs as men now enlist in a regiment. Very often they took the chief's name, but very often they did not. It was essentially a military organisation for defensive and predatory purposes; and the adoption of a common name became a mere survival which kept up the idea and theory of patriarchal times long after the old tribal system had in all its essentials disappeared. In the Act of the Scottish parliament of 1587, for instance, which requires landlords to find security for the conduct of their tenants, it is provided that those " who have their lands lying in far highlands or borders, they making residence themselves in the inlands, and their tenants and inhabitants of their lands being of clans, or dependars on chieftains or the captains of the clans, whom the landlords are noways able to command, but only get their mails (or rents) of them, and no other service or obedience, shall noways be subject to this act but in manner following.' Then follow provisions for enforcing the law directly on the chieftains or captains of those clans residing in territories where the owner of the soil-generally the merely nominal owner, in terms of some useless charter-had no control. It was always the policy of the old law of Scotland to require all the Highland clans to have some respectable representative -a man of rank and substance, if possible-who should be security at court for their good conduct. Clans that could find no security were called 'broken clans,' and their members were outlaws, who might be hunted down like wild beasts. The Macgregors were a celebrated broken elan, whom the law pursued for centuries with savage ingenuity. Among other inflictions their name was proseribed, and such members of the clan as endeavoured to live by peaceful industry in the Lowlands adopted derivations from it; hence we have the names of Gregor, Gregory, and Gregorson or Grierson.

The clans are never treated in the old Scots acts with any respect, or otherwise than as nests of thieves. and cut-throats. The following passage in the Act of 1581 (chap. 112), which virtually authorises any Lowlander, injured by any member of a clan, to take vengeance against all or any of his clansmen, contains a picturesque and striking account by men who knew and had suffered from the system of the Highland clans in the 16th century. "The saids clans of thieves for the most part are companies of wicked men, coupled in wickedness by oceasion of their surnames or near dwellings together, or through keeping society in theft or receipt of theft, not subjected to the ordinar course of justice, nor to ony ane landlord that will make them answerable to the laws, but commonly dwelling on sundry men's lands against the good-will of their landlords, wherethrough true men oppressed by them can have no remeid at the hands of their masters, but for their defence are oftentimes constrained to seek redress of their skaiths of the hail clan, or such of them as they happen to apprehend. Likewise the hail clan commonly bears feud for the hurt received by any member thereof, whether by execution of laws, or order of justice, or otherwise.' The Highland elans are often spoken of as a feudal institution, and it is undoubtedly true that "broken men" were settled upon lands in possession of the chiefs. on conditions of military service, just as under the more perfected system of Norman feudalism. The men receiving admission into 'rooms,' or small barns, were in the habit of binding themselves to such service by what was called 'Bonds of Manrent,' under which they engaged to follow their chief in all his feuds and quarrels. But, on the other hand, chiefship might become, and did often become, dissociated from the legal ownership of land, and in such cases the people of the clan were apt to follow their chief, against the will of their landlords. This was the survival of a far more remote system which constituted the great danger and great corruption of the clans. It dissociated the military power of chiefship from the responsibilities of property, and from subordination to settled law. This was the evil struck at and denounced by the parliament of Scotland in repeated statutes. In general the great landowners were also great chiefs, and the two powers then worked in harmony, and on the whole in the interests of civilisation under very rude conditions of society. But the severance arose not unfrequently from the more definite laws and rules applicable to the legal descent of landed property. Thus it came about, as the acts above quoted explain, that the head of a clan and the owner, according to feudal law, of the estates occupied by it, were two different persons. Clans did not acknowledge the purely feudal hereditary principle. 
and occasionally would recognise the chiefship in a brother or an uncle, in preference to the son of a decensed chief. See TriBE.

Clandestine Marriage. See Marragk.

Clanwilliam, a division of the Western Pro. vince, $\mathbf{N}$. of Cape Town, South Africa, embraces within its area the rich valley of Olifant River West, with a large stretch of mountain and karroo on each sisle. Chief village, Clanwilliam on Jan Dissels River.

Claparede, Edouard, a Swiss naturalist and professor of Comjarative Anatomy at Geneva, was horn in 1832, and died in 1871. He wrote numerous works, including those on the fertilisation of eggs (1858), on the Infusoria and Rhizopoda (1860), and the Annelida of the Hebrides (1861).

Clapham is a south-western suburb of London, lying a mile S. of the Thames. Battersea and Clapham form since 1885 one of the London parliamentary boroughs. Clapham Common is still an open common of 200 acres. Clapham Junetion, in Battersea parish, is one of the busiest and most perplexing railway junctions in the world. - Claphein Sect was a name given by Sydney Smith to the Evangelical party in the Church of England; the Rev. Henry Venn was the vicar of Clapham, and some of the most eminent EvangelicalsZachary Macaulay, Wilberforce, and the Rev. W. Romaine-lived there. Thackeray's Nevocomes has made the phrase familiac to a later generation.

Clapperton, Huar, African explorer, was born at Annan, Dumfriesshire, in 1788. At the age of thirteen he went to sea; and having after a youthful peccadillo been constrained to join a man-of-war, he ultimately distinguished himself by his services at Mauritius, and was appointed to the rank of lieutenant. In 1817 he returned to Scotland on half-pay. Government appointed him and Major Denham to accompany Dr Oudney, who was going as British consul to Bornu, in an exploring expedition. By way of Tripoli and Murzuk, they reached Kuka on Lake Tchad in 1822 ; and Clapperton proceeded westward, accompanied by Oudney, who died by the way. He still pushed on alone as far as Sokoto, but was here compelled to retrace his steps, and, in company with Denham, returned to England in 1825. The journey had done much for the know. ledge of Bornu and the Houssa country, but the great geographical problem of the course of the Niger was atill much in the same position. To solve it, if possible, Clapperton-the rank of commander having been conferred upon him-started again in August 1825, in company with Captain Pearce, R.N., Mr Dickson, Dr Morrison, and Richard Lander. They commenced their explora. tion into the interior from the Bight of Benin. His other companions died early on the journey, but Clapperton and his frithful attendant Lander reached Sokoto. Here the Sultan detained him, and vexation joined to the hardships of the journey so affected his health, that he died at Changary, near Sokoto, April 13, 1827. See the Narrative of the first journey (1826); the Journal of the second (1829); and the Records of Clapper. ton's Last Expedition to Africa, by Richard Lander (1830).

Claque (from Fr. claquer, "to elap the hands, or 'applaud') is the name given to an institution for securing the success of a public performance or production, by bestowing upon it preconcerted applause, and thus giving the public, who are not in the secret, a false notion of the impression it has made. The claque is of great antiquity, its first invention having been attributed to no less noted a person than Nero. Its suppomed origin in Rome gives the name of Romains to the clayueurs to this day, who are also named chevalier du lustre, from their position in the middle of the pit. The fint regular use of the claque as an organised and paid body seems to have been during the time of the great Napoleon, in the famoun struggle between Mademoirelle Georges and Mademoiselle Duchesnois, at the Thédre Français; and from that time its use became almost nniversal in Paris, The chief of the claque, who is named entrepreneur de succes dramatique, is an official of importance. His business is to attend the last two or three rehearsals of a new play; to arrange the points at which applause, laughter, or tears are to be forthcoming; and to communi. cate his diractions to his corps. This is divided into several classes. The main body, whose business it is to applaud, form a solid mass in the centre of the pit; and in various parts of the theatre are placed rieurs ('laughers'), pleureurs, or rather pleureuses ('weepers'), and bisseurs (whose business it is to call bis or encore /). More artistic developments of the claqueur are the sangloteure, a female who sobs hysterically; the pameuse, who faints : and the moucheur, a well-dressed gentleman who blows his nose with tact at affecting passages.

The members of the claque are generally men who are glad to earn a small sum in any way, but it is also recruited from the ranks of poor amateurs, who in return pay a smaller price for their tickets. M. Perrin, the late director of the Théatre Français, succeeded in 1878 in abolishing the claque in his theatre; and the Grand Opera followed the example of the house of Moliere.

In London there is no regularly organised claque, but in certain theatres precautions are taken on first nights which have precisely the same effect as the claque.

Clare, a maritime county in the province of Munster, Ireland, lying between Galway Bay and the Shannon. It is seventh in size of the Irish counties; length, 67 miles; greatest breadth, 43 ; average, 21; area, 1294 sq. m.-The surface is mostly hilly, with some mountains, bog, marsh, and rugged pasture. There is an undulating plain in the centre, from north to south. In the east the hills reach a height of 1758 feet. The sea-line is high and rocky, in parts precipitous, and oceasionally from 400 to 680 feet high, with many isles and fantastic detached rocks. The chief rivers are the Shannon (q.v.) and the Fergus, ranning south 27 miles through the middle plain, and by an eatuary 5 miles broad. The county has about 100 small lakes. Carboniferous limestone is a prevailing formation; the south-west third of the county forms part of the Munster coal-field. There are lead-mines, slate and narble quarries, and many chalybeate springs. The chief crops are oats and potatoes. The chief towns are Ennis (the county town), Kilrush, Ennistimon, and Killaloe. Pop. (1841) 286,394; (1851) 212,428; (1871) 147,864; (1891) 124,483 , of whom nearly 98 per cent. were Roman Catholics. The county returns two members to parliament. There are many croulechs, raths, remains of abbeys, and old castles or towers, and several round towers, one at Kilrush being 120 feet high. Till the time of Elizabeth the county was called Thomond; its present name comes from Thomas de Clare, who received part of all the land he might conquer. See books by J. Frost (1893) and Father White (1893).

Clare, one of the most interesting of the smaller towns of Suffolk, 68 miles NE. of Condon by rail, and $19 \mathrm{SSIV}$. of Bury. Pop. (1891) 1657. It has a fine old castle, and gives an earl's title to the British sovereign. See ClankNCR. 
Clare Island, an island of Ireland, belonging to County Mayo, situated in the Atlantic, at the entrance of Clew Bay. It has a length of $\mathbf{5}$ miles, with a breadth of 3 miles. On its north-east extremity there is a lighthouse.

Clare, ЈонN, English peasant poet, the son of a poor labourer, was born at Helpstone, near Peterborough, July 13, 1793. After some scanty school. ing, he began to do outdoor work in his seventh year, and for eleven months was an under-gardener at Burghley Park; mean while he studied Thomson's Seasons, and began to cultivate verse-writing. $\mathrm{He}$ enlisted in the militia (1812), associated with gypsies, in 1817 worked at a lime-kiln, but was discharged for wasting his time in scribbling, and had to apply for parish relief. His Poems, deseriptive of Rural Life and Scenery (1821), had a good reception from critics and the public. Though the Marquis of Exeter and other patrons secured him $\mathbf{E 4 5}$ a year, he continued poor and unfortunate. His Shepherd's Calendar (1827) was unsuccessful. His Rural Muse (1835) brought him $£ 40$, and he received $£ 50$ from the Literary Fund. Bro sen down in body and mind, he died in the county lunatic asylum, Northampton, 20th May 1864. See Martin's Life (1865), and Cherry's Life and Remains (1873).

Clare, ST, born in 1193 , of a noble family of Assisi, in 1212 retired to the Portiuncula of St Francis, and in the same year founded the order of Franciscan nuns, which spread rapidly through Emrope. She died August 11, 1253. Two years afterwards, she was canonised by Alexander IV.; her festival falls on August 12.-The Nuns of the Order of St Clara (also called the Poor Clares) at first observed the strictest Benedietine rule, but the austerity of this rule was mitigated by St Francis in 1224, and further modified by Urban IV. in 1265. Several convents adhered to the first and strictest rule; but the large proportion of the nuns adopted Urban's rule, and are distinguished as Urbanists. The existing convents are chiefly devoted to the education of girls.

Claremont, a mansion at Esher, Surrey, 14t miles SW. of London, originally built for himself by Sir John Vanbrugh. The present house was built in 1768 by Lord Clive for $£ 100,000$, from designs by 'Capability' Brown. When the Princess Charlotte was married to Prince Leopold of Saxe-Coburg, Claremont was assigned as their residence, and here in 1817 she died. In 1848 Leopold, then king of Belgium, placed it at the disposal of his father-in-law, ex-king LouisPhilippe, who inhabited it till his death in August 1850. At the death of Leopold in 1865, an act was passed granting it to the Qneen for life, after which it was to revert to the country. The Queen in 1882 bought the reversion of Claremont (for $£ 73,000$ ), and it became her private property.

Clarence, an English ducal title, conferred for the first time in 1362 on Lionel, second son of Edward III. and Philippa. Its origin has by some been traced to Clarence, a French name of the Greek Klarenza or Glarentsa (Ital. Chiarenza), a decayed port on the west coast of the Peloponnesus, 50 miles SW. of Patras. Before the invasion of the Turks it was an important place, and gave the title of duke to the eldest son of the prince of Achaia. That title is said to have come into England through Philippa, daughter of the Count of Hainault, and wife of Edward III. Other authorities derive it from the ancient Suffolk town of Clare (q.v.). The most notable Dukes of Clarence, all royal, are the second son of Henry IV., who fell at the battle of Beaugé (1421); the third son of Richard of York, and brother of King Edward IV. (Shake- speare's Clarence), who perished in the Tower in 1478-in a butt of Malmsey, according to three contemporary writers; William IV., who was Duke of Clarence before his accession; and Prince AlbertVictor of Wales, who was born 8th January 1864, and died 14th January 1892.

Clarenceux, or Clarencieux, the first of the two provincial Kings-of-Arms, in England, whose jurisdiction of Clarenceux extends to all England south of the Trent, that of Norroy (q.v.) comprehending the portion to the north. See HERALD.

Clarendon, Constitutions of, were laws made by a council of the nobility and prelates held at the hunting lodge of Clarendon, 2 miles SE. of Salisbury, in 1164, whereby King Henry II. checked the power of the church, and greatly narrowed the total exemption which the clergy had claimed from the jurisdiction of the secular magistrate. These famous ordinances, sixteen in number, defined the limits of the patronage, as well as of the jurisdiction, of the pope in England, and provided that the crown should be entitled to interfere in the election to all vacant offices and dignities in the church. The constitutions were unanimously adopted, and Becket, the primate, reluctantly signed them. His subsequent withdrawal of his consent, when Pope Alexander III. declined to ratify them, led to the memorable disputes between Becket and the king (see BECKET). Notwithstanding the personal humiliation to which Henry submitted after Becket's death, most of the provisions of the constitutions of Clarendon, which were part of a great scheme of administrative reform, continued to be a permanent gain to the civil power. See Stubbs, Constitutional History, and his Select Charters.

Clarendon, EDWARD HYdE, EARL oF, historian and statesman, was born 18th February 1608 at Dinton, near Salisbury, the third son of a Wiltshire squire. Destined for the church, he went up to Magdalen Hall in 1622 ; but the death of his elder brothers left him heir to the property, so in 1625 he quitted Oxford for the Middle Temple, of which his uncle, Sir Nicholas Hyde, the chiefjustice, then was treasurer. Though he rose in his profession, he loved letters better than law; for his friends he chose such brilliant spirits as Falkland, Ben Jonson, and Chillingworth, and, in his own words, "was never so proud, or thought himself so good a man, as whe' l he was the worst in the company." He married twice-in 1629, Ann, daughter of Sir George Ayliffe, whose death six months afterwards "shook all the frame of his resolutions ; ' next, in 1632, Frances, daughter of Sir Thomas Aylesbury, Master of Requests and of the Mint. She bore him four sons and two daughters; and with her, till her death in 1667 , he 'lived very comfortably in the most uncomfortable times, and very joyfully in those times when matter of joy was administered.'

In 1640 he was returned for Wootton-Bassett to the Short Parliament, for Saltash to the Long; and up to the summer of 1641 he acted heartily with the popular party. Then he drew back. Enough, he deemed, had been done; a victorious oligarchy might prove more formidable than a humbled king; nor conld he conceive 'a religion without bishops.' Charles's answer to the Grand Remonstrance was of Hyde's composing, so were most of the subsequent able manifestoes; and though in a midnight interview with the king he declined to take St John's post of solicitor-general, thenceforward, with Falkland and Colepeper, he formed a veritable privy-council. If only they had known everything, if only their advice had always been followed! but no, the attempted arrest of the five members had neither their privity nor their ap. proval. Still, Hyde headed the royalist opposition 
in the Commons, till, in May 1642, he slipped away, and followed ('harles intu Yorkshire. He witnessed Eilgehill; in 1643 wa knighted, and made Chancellor of the Exchequer; in March 1645 attended the Prince of Wales to the west of England; and with him a twelvemonth later pased on to scilly and Jersey. In Seilly, on 18th May 1646, he com. menced his history ; in Jersey he tarried two whole yeans. From November 1649 till March 1651 he was engaged in a fruitless embasay to Spain ; next for nine years he filled the oftice of a 'Caleb Balder. stone 'in the needy, greedy, factious little court of Charles II., sometimes with 'neither clothes nor fire to preserve him from the sharpness of the season, and with not three sous in the world to buy a fagot."

('harles had made him High Chancellor in 1658, and at the Restoration he was confirmed in that dignity, in November 1660 being ereated Baron Hyde, and in the following April Earl of Clarendon. To this period belongs the strangest episode in all his autobiography. In November 1659 his daughter Anne (1638-71), then lady-in-waiting to the Princess of Orange, had entered into a secret marriagecontract with the king's brother, James, Duke of York; and nine months later they were privately married at her father's house. He, on learning the news, if news indeed it was, burst into a passion of the coarsegt invective against her-it were more charitable to suppose he was acting a part, not really less jealous for his daughter's honour than for the dignity of the royal house. Anyhow, people fancied that in Catherine of Braganza he purposely selected a barren bride for the king, that so his own daughter might some day come to the throne. Nor as chief minister was he otherwise popular. A bigoted churchman, a thorough Conservative, and always a lawyer, he would fain have restored things to the status quo of twenty years earlier. He loved a Papist little better than a sectary, so would have nonght of Charles's toleration. He looked sourly on Charles's vices, yet stooped to impose Charles's mistress on Charles's queen. He could not satisfy the Cavaliers, who contrasted his ouulence with their own broken fortunes; he did more than enough to irritate the Puritans. The sale of Dunkirk, the Dutch war, the very Plague and Great Fire, all heightened his unpopularity; and though in 1663 he weathered Lord Bristol's frivolous charges against him, in August 1667 be fell an easy unlamented victim to a court cabal. The great seal was taken from him; impeachment of high-treason followed ; and on 29th November, at Charles's bidding, he quitted the kingdom for France. All but murdered at Evreux by some English seamen, at last the old man settled at Montpellier, where and at Moulins he spent nearly six tranquil years. Then moving to Rouen, ho sent a last piteous entreaty that Charles would permit him to "die in his own country and among his own chil. dren;" nay, at Rouen must he die, on 9th December 1674. No monument marks his grave in Westminster Abbey.

Men's estimates of Clarendon have varied widely. Southey calls him 'the wisest, most upright of statesmen ;' George Brodie, 'a miserable sycophant and canting hypocrite.' The truth lies somewhere between the two verdicts, but Southey's is much the truer of the two. The failings and merits of the statesman are mirrored in his great History of the Rebellion in England (3 vols. 1704-7), with its supplement and continuation, more faulty and lese valuable - the History of the Civil War in Ireland (1721), and the Life of Edward, Earl of Clarendon (3 vols, 1759). An apology more than a history, a vindication of himself and of Charles $I$., it is not, does not profess to be, impartial; it suppresees the truth, where the truth seemed unfavourable; and it is grossaly inacurate-the remult of a fallilile memory. But, $\mathrm{Mr}$ Green notwithstanding, it does not 'by deliberate and malignant falsehood' pervert the whole action of Clarendon's advensaries: care. less and ungenerous he might be, wilfully dishonest he was not. And what though his style be prolix and redundant, though it 'suffocate $u$ by the length of its periods, his splendid statelinese, his aneedotic talent, his development of motives, and, above all, his marvellous skill in portraiture (shown best in the character of his dear friend Falkland), have rendered the history a classic, imperishable where dry-as-dust chronicles have perished. The best and latest edition is that by W. Dunn Macray (6 vols. Oxford, Clarendon Press, 1889). We bave, besides, twenty-five essays by Clarendon, his Contemplations on the Psalms (begun in 1647, and finished, like the Life, drring his second exile), several controversial writings, and 3 vols. of his State Papers (1767-86; calendared, 1872-76).

See Ranke's able analysis of the History; works cited nnder Charles I and Charles II. ; the Hon. AgarEllis's Historical Inquiry respecting the Character of Clarendon (1827); Lady Theresa Lewis's Lives of the Friends and Contemporavies of Clarendon (3 vole. 1852); two articles by Mr Peter Bayne in the Contemporary Reriew (1876); and the Life of Clurendon, by T. H. Lister (3 vols, 1838).

Clarendon, Grorge William Frederick VILLIERS, EARL OF, a great English diplomatist, was born in London, 12th January 1800. He was a descendant of that Thomas Villiers, second son of the Earl of Jersey, who married the heiress of the last Lord Clarendon of the Hyde family (1752), and was made Baron Hyde (1756) and Earl of Claren. don (1776). Having studied at Cambridge, he early entered the diplomatic service, and in 1833 was appointed ambassador at Madrid, where he acquired great influence, which he employed in helping Espartero to establish the government of Spain on a constitutional basis. On the death of his uncle, the third earl of the second ereation, without issue, in 1838 , he sneceeded to the title, and in 1840 was made Lord Privy Seal under Melbourne. When the Whig ministry was broken up in 1841 he became an active member of the opposition; but warmly supported Sir Robert Peel and his own brother, Charles Pelham Villiers, in the agitation for the abolition of the corn laws. Under Lord John Russell's premiership he became President of the Board of Trade in 1846, and the following year was appointed Lord-lientenant of Ireland. He entered upon his duties in troublous times. The insurreetionary follies of Smith O'Brien and his coadjutors might have get the whole country in a blaze but for the prompt and decisive measures which the new viceroy adopted, and which soon restored general tranquillity. At the same time, his tact and impartiality contributed to allay and reconcile the exasperations of party, though it did not avert the bitter hatred of the Orangemen. He was thanked in the speech from the throne in 1848, and next year received the coveterl honour of the garter. When the Russell cabinet resigned in 1852, Clarendon was replaced by the Earl of Eglinton, but on the formation of the Aberdeen ministry next year was intrusted with the portfolio of the Foreign Office. It was thus upon his shoulders that the responsibility for the Crimean war actually fell. Mr Roebuck's resolution in 1855 cost him his office, which, however, he soon resumed at Palmerston's desire, and he sat at the Congreas of Paris. Lord John Russell was Foreign Secretary from 1859 to 1865, but became Premier on Palmerston's death, when Clarendon returned to the Foreign Office. Next year he retired with his colleagnes, to reanme the same office in Gladstone's government in 1868, 
which he retained till his death, 27th June 1870 . Lord Clarendon was a man of singularly genial and charming manners, who added by his rare tact and perfect temper an unwonted grace to the difficulty and invidiousness of diplomacy.

Clarendon Press. See Book-Trade.

Clarens, a beautiful Swiss village on the Lake of Geneva, $3 \frac{1}{2}$ miles SE. of Vevey by rail.

Claret (Fr, clairet), a term originally applied to wines of a light-red colour, but which is now used in England as a general name for the red wines of Bordeaux (q.v.). The name as used in England is unknown in France.

Claretie, Jules (properly Arsene Arnaud), a versatile French writer and popular novelist, born at Limoges, 3d December 1840. While still a schoolboy at the Lycée Bonaparte in Paris, he published a novel, and ere long his facile and clever pen made him one of the most important art and dramatic critics and political writers on the Paris press. His short story Pierrille (1863) had the honour to be praised by George Sand; and his novels, Mademoiselle Cachemire (1865), and Un Assassin, renamed later Robert Burat (1866), gained general applause. Meantime he continued his career as a journalist, although he suffered sometimes from the imperial censorship. During the Franco-German war he sent a series of remarkable letters to the Rappel and Opinion Nationale, and acquired the materials for a later series of bright and vigorous anti-German books of an historical character: Histoire de la Révolution de 1870-71 (new ed. 5 vols. 1875-76); Les Prussiens ches Eux (1872); and Cinq Ans après, l'Alsace et la Lorraine depuis l'Annexion (1876). He distinguished himself by his conduct during the siege of Paris, and showed that he possessed also high talent for affairs. His more important later novels are Madeleine Bertin (1868); Le Train 17 (1877); Monsieur le Ministre, an enormous success (1881); Le Million (1882); Michel Berthier (1883); and Le Prince Zilah (1884). He first found a firm footing on the stage with his pictures of the great Revolution, Les Muscadins (1874), Le Régiment de Champagne (1877), and Les Mirabeau (1878); and in 1885 he became Director of the Theatre Francais. In 1888 he was admitted to the Academy. His Life of Camille Desmoulins was Englished in 1876.

Claribel was the pen-name of Mrs Charlotte Alington Barnard (1830-69; married in 1854 to Charles Cary Barnard), who wrote a hundred songs and ballads, some of which, like 'Come back to Erin' and 'Won't you tell me why, Robin?' were wonderfully popular. She was buried at Dover.

Clarification is the process of clearing a fluid from a turbid condition. Natural waters containing much organic matter in mechanical suspension and in chemical solution are clarified by the addition of a little alum, which is precipitated with the organic matter, and the water then becomes healthy and refreshing. Liquids are often clarified by straining through several layers of cloth, or throngh sand or charcoal. A 'centrifugal' is a circular vessel provided with an outlet in the centre and also at the circumference, and which is capable of being made to revolve at a very high speed. When the muddy liquid is placed in the vessel, and the whole caused to revolve, it is found that the particles of dust, mud, or other matter fly to the circumference, leaving the liquid in the centre practically clear, so that it can be drawn off. See BEER, CLEARINGnUt, Filter, Gelatine, Wine.

Clarinet, or Clarionet, a wind-instrument, usually of wood, in which the sound is produced by a single thin reed. It is supposed to have been invented in 1690 by Joseph Christoph Denner, at Nuremberg, though some authorities trace its exist- ence to medieval times. Since its invention it has undergone many changes and improvements, and the modern elarinet, from the extent, quality, and variety of its tone, is one of the most perfect of wind-instruments. The tube of the instrument is cylindrical, ending in a bell, with holes to be covered by the fingers and lefthand thumb; and keys, generally thirteen in number, to supply the additional tones and half-tones.

The mouthpiece is cone-shaped, flattened on one side to form a table for the reed; in the table is a square opening about an inch long and half an inch wide $(a$ in fig.), on which the reed is fastened by the lower and thicker end $(b$ in fig.). The table being slightly curved towards the point, a gap is left between the end of the reed and the mouthpiece; and the sound depends on the vibration of the reed against this curved table. The reed is a thin slip from a tall grass (Arundo sativa) grown in Spain. The clarinet has two principal registers-viz. the lower, called the chalumeau, from $\mathbf{E}$ in the bass stave to $\mathrm{B} D$ in the treble; and the upper, of a different quality, from $\mathrm{B}$ treble stave to $\mathrm{C}$ above the stave. Another octave higher can be played by crossfingering, but beyond $\mathrm{G}$ the notes are not very effective. The difference between the lower and upper registers is an interval of a twelfth, which gives the clarinet a much greater compass than the flute, for instance, which is an octave-sealed instrument. The upper register is fingered exactly like the lower, except that the Bo key ( the highest on the tube, $c$ in fig.) is kept open

by the thumb of the left hand. The Boehm modification of fingering (see FLUTE) has been applied to the clarinet, but is not so suitable to it as to octave-scaled instruments.

The ordinary difficulties of the fingering are so much intensified in playing in keys with many sharps or flats, that in orchestras it is usual to have instruments of different pitch to simplify the key. These are usually the $\mathbf{A}, \mathbf{B} b$, and $\mathrm{C}$ clarinets, though the latter is gradually going ont of use.

In military reed-bands the $\mathrm{Bb}$ clarinet is the leading instrument, with the addition of one or two smaller clarinete in $\mathbf{E} b$ to assist in the sharper passages (see BAND). Clarinets in various other keys have been introduced but seldom used.

Mozart, Bcethoven, Mendelssohn, Weber, Meyerbeer, Spohr, and Rossini have made extensive use of the clarinet in the orehestral compositions, though some of the parts written for the instrument, especially in the overtures to Semiramide, Otello, and Gazza Ladra by Rossini, are so difficult as to be almost unplayable.

A tenor clarinet, known as the Basset-Horn $(\mathrm{g.v})$, is also used in orchestral music. The Bass Clarinet is an instrument of the same construction as the ordinary clarinet, an octave lower, usually pitched in $\mathbf{B}$. It is also used in orchestral and military bands.

Clark, SIR ANDREw, physician, was born at Wolfhill in Cargill, Perthshire, 28th October 1826, and educated at Aberdeen and Edinburgh. After a brilliant career as a student of medicine at Edinburgh, he assisted Dr Hughes Bennett and Dr Robert Knox the anatomist, and next had charge 
for four years of the pathological department at the Haslar Naval Hospital. After graluatiug at Alser deen in 1854, he settled in London, where he aciuired a high reputation for his skill in the treatment of diseases affecting the respiratory, renal, and digestive organs. Among his patients were some of the most eminent men in the political and literary world of his time, and he will live in remembrance as the 'beloved physician' of George Eliot. President of the Royal College of Physi. cians, Honorary Fellow of the Royal College of Physicians in Ireland, and Consulting Physician to the London Hospital, he was besides LL.D. of Edinburgh and Aberdeen, a Fellow of the Royal Society, and a baronet since 1883. His favourite work was clinical teaching at the London Hospital, for which Holl painted his portrait. He died (of paralysis-induced doubtless by ten years of self. devoting overwork) on the 7th November 1893. Although his professional success left him seant leisure for writing, he made numerous important contributions to medical science, both in papers contributed to the special journals and in such books as Evidences of the Arrestment of Phthisis, Lectures on the Anatomy of the Lung, The Theory of Asthma, The History of Dry Pleurisy in relation to Lung Disease, Renal Inrderuacy, The Ancemia of Girls, Neurasthenic, and Mucous Disease of the Colon.

Clark, Sir JAMES, physician, was born at Cullen, Banffshire, 14th December 1788. He took the degree of M.A. at King's College, Aberdeen, studied medicine at Edinburgh and London, and entered as a navy surgeon in 1809 \& position he held until 1815. At Rome he practised eight years as a physician; but in 1826 he settled in London. On the accession of Queen Victoria, Clark, who for two years previously had acted as physician to the Duchess of Kent, was appointed physician in ordinary to Her Majesty, in 1838 being created a baronet. He was author of a work On the Influence of Climate in the Cure of Chronic Diseases (1829), and A Treatise on Pulmon. ary Consumption (1835). He died June 29, 1870.

Clark. Thomas, chemist, was born at Ayr in 1801, and studied at Ayr Academy. He became a chemist in Glasgow, lectured on chemistry there, and in 1833 became professor at Marischal College, Aberdeen. He fell into ill-health in 1843, and died 27th November 1867. His name is specially re. membered for his discovery of the soap-test for hardness in waters, and his method of softening water by means of eaustic lime. See WATER.

Clark, William George, an eminent scholar and man of letters, was born in March 1821, and educated at Selbergh and Shrewsbury under Kennedy. He entered Trinity College, Cambridge, in 1840 , and, graduating second classic in 1844, was elected fellow of his college, where he resided till his retirement in 1873 . He had been ordained in 1853, but wrote to his bishop resigning his orders in 1869, and published his reasons in a remarkable pamphlet, The Present Dangers of the Church of England. He acted long as tutor in his college, and was public orator in the university from 1857 to 1869. He died at York, 6th November 1878, bequeathing to Trinity College property to endow a lectureship on English literature, to which Mr Gosse was appointed in 1883. Clark travelled in Spain, Greece, Italy, and Poland, during the long vacations, and published lively accounts of his experiences. In 1850 he helped to edit the Sabrina Corolla, himself contributing some of the most finished versions therein. He also edited the first series of Camibridge Easays (1855), and long acted as one of the editors of the Journal of Philology. Other works were his edition of George Brimley's Essays (1858), and Lec- tures on the Middle Ages and the Revival of Learning (1872). His greatent work whs the famous Cumbridge Shakerpeure (9 vols. 1803-66), plasuned by Clark, and jrepared in collaboration with Mr Glover and afterwards Mr Aldis Wright. Its text was reprinted in the popular "Globe Edition" (1864). Clark's projected edition of Aristophanes was unhappily left unfiuished.

Clarke, ADAM, Wesleyan divine, was born about 1762, at Moybeg in County Londonderry. Under John Wesley's influence he studied at Kings. wood, near Bristol, and began to preach in 1782 . Like his brethren, he moved from place to plare, from the Channel Islands to Shetland, but after 1805 lived mostly in London. Although peripatetic preaching is acarcely conducive to scholarship, Clarke contrived to find time for extensive study of the classics, the Fathers, oriental languages, and natural seience. Aberdeen gave him the degree of LL.D. in 1808, and many learned societies admitted him to membership. His finst work was a Bibliographical Dictionary (8 vols. 1802-6). The Board of Commissioners on the Publie Records selected him to edit Rymer's Foedera, but his health obliged him to abandon the work before he had finished the second volume. He also edited and abridged several other works, but the great work of his life was his edition of the Holy Scriptures ( 8 vols. 1810-26) with a commentary, into which were compressed all the results of his varied reading. While orthodox in essentials, Clarke had some unusual notions. Thus, he denied the eternal sonship of Christ while maintaining his divinity; held that Judas repented unto salvation, and that the tempter of Eve was a baboon, not a serpent. He died August 26, 1832. See his Life (3 vols. 1833).

Clarke, Charles and Mary Cowden, one of the most amiable among the pairs of English writers. Charles was born 15th December 1787, at Enfield, Middlesex, where his father kept a school at which Keats was a pupil. His name is imperishably linked with the dawning genius of the poet-but seven years younger than himself-who in a poetical epistle (1816) addresses Clarke as 'you who first taught me all the sweets of song.' He early imbibed a passion for the theatre, and after his parents' retirement to Ramsgate, continued to pay frequent visits to London, where he formed the friendship of Leigh Hunt, Shelley, Hazlitt, Charles and Mary Lamb. After his father's death in 1820, he became a bookseller in London, and ere long partner as music publisher with Alfred Novello, whose sister, Mary Victoria (born 1809), he married in July 1828. A year later Mrs Cowden Clarke began her famous Concordance to Shakespeare's Plays, published after sixteen years' toil in 1845 . The married life of the pair was exceptionally happy, and they enjoyed the warm friendship of most London men of letters, from Lamb and Hazlitt down to Douglas Jerrold, Macready, and Charles Dickens. In 1834 Clarke began that twenty years' course of public lectures on Shakespeare and other dramatists and poets which brought him so much celebrity and profit. He read admirably, and put the fruit of much sound study and profound thought into the preparation of the lectures. Fome of his courses of lectures were pub. lished, as his Shakespeare Characters, chicfly thase Subordinate (1863), and Molidre Charrecters (1865). In 1859 he published Carmina Minora, a volume of fair original verse, and in 1863 he edited the poems of George Herbert. The joint productions of the pair were the valuable Shakespecre Key (1879) ; an edition of Shakespeare's works with good if somewhat verbose annotations (1869), now re-iasued as Cassell's Illustrated Shakespeare; and Recollections 
of Writers (1878), a charming book, full of reminiscences of Keats, Lamb, and other famous men. In 1856 they went to live at Nice, but removed in 1861 to Genoa, where Charles died, 13th March 1877. Mrs Cowden Clarke, who died at Genoa, 12th January 1897, alone wrote novels, volumes of verse, \&e. - the best known being The Girlhood of Shakespeare's Heroines (1850) and World-noted Women (1857). See her Sketch of her husband (1887) and an Autobiographic Sketch (1897).

Clarke, EDWARD DANIEL, traveller and author, born at Willingdon in Sussex in 1769 , studied at Cambridge, and from 1790 to 1799 was employed as tutor and travelling companion in several noblemen's families, making the tour of Great Britain, France, Italy, Switzerland, and Germany. In 1799 he set out on an extensive tour with a young man of fortune; they traversed Denmark, Norway, Sweden, Lapland, Finland, Russia, the country of the Don-Cossacks, Tartary, Asia Minor, Syria, Egypt, Greece, and did not return to England till 1802. In 1808 Clarke was made first professor of mineralogy at Cambridge. He presented to the university library a number of valuable marbles collected during his travels; his manuscripts he sold to Oxford; and the university of Cambridge purchased his collection of minerals. Ordained in 1805, he held two livings from 1809 until his death, 9th March 1822. His Travels (6 vols, 1810-23) were received with extraordinary favour; his other works, chiefly on antiquarian subjects and mineralogy, are now of little value. See his Life, by Bishop Otter (1825).

Clarke, HyDE, an English financier and philologist, born in London in 1815, was employed as a civil engineer in the improvement of Morecambe Bay and Barrow, and next in the promotion of telegraph and railway service in Upper India. He became cotton councillor in Turkey, and in 1868 founded the Council of Foreign Bondholders, whose affairs he administered for years. A promoter of the Anthropological Institute and the Press Fund, he died 1st March 1895. His writings include books and pamphlets on railways, foreign loans, banking, mythology, and comparative philology, especially the native American languages and their supposed connection with those of the Old World. Unfortunately his views are much more original than sound, and most of his generalisations have failed to commend themselves to really scientific philologists. Among his books are The Pre-Hellenic Inhabitants of Asia Minor (1864), The Mediterranean Populations from Autonomous Coins (1882), \&c.

Clarke, James Freeman, theologian, was born in Hanover, N.H., 4th April 1810, and studied at Harvard and Cambridge Divinity School. He became a Unitarian pastor, and in 1841 founded the Church of the Disciples at Boston. From 1867 to 1871 he held a chair of Natural Theology in Harvard University. He died 8th June 1888. He assisted in preparing the memoirs of the Marchioness Ossoli; and among his numerous works are books on the forgiveness of sin, on prayer, and on orthodoxy, Steps of Belief (1870), Ten Great Religions (1871-83), Common Sense in Religion (1879), Manual of Unitarian Belief (1884), and Vexed Questions (1886).

Clarke, DR SAmuel, an eminent philosopher and theologian, was born at Norwich, October II, 1675, and educated at Caius College, Cambridge. The system of Descartes at that time held almost universal sway; but this failing to satisfy his mind, he, as was to be expected, adopted the views of his friend Newton, and expounded them in the notes to his edition of Rohault's Physics. Along with philosophy he pursued the study of theology and philology. Chaplain from 1698 to Bishop Moore of Norwich, in 1706 he became chaplain to Queen
Anne, and in 1709 rector of St James's, Westminster. By his work on the Trinity (1712), in which he denied that that doctrine was held by the early church, he raised a violent and protracted controversy (in which Waterland was his chief opponent). The upper house of Convocation, desirous of avoiding controversy, rested content with an explanation, anything but satisfactory, and a promise from Clarke to be silent for the future on that subject. His views were of the kind known as Semi-Arian (see ARIUs). For the rest, Clarke was a vigorous antagonist of the Deists of his time; he wrote against materialism, empiricism, and necessitarianism; and against Dodwell maintained the essential immortality of the soul. He taught that the fundamental truths of morals, arising out of the fitness or unfitness of certain relations, were as absolutely certain as the truths of mathematics. Space and time he held to be attributes of an infinite and immaterial being. His most famous work is Discourse concerning the Being and Atributes of God, originally the Boyle Lectures of 1704-5. They were expressly in answer to Hobbes, Spinoza, Blount, and other freethinkers, and contained the famous and elaborate demonstration of the existence of God, often, but inaccurately, called an a priori argument, on which his fame as a theologian largely rests. At the instigation of the Princess of Wales, Clarke entered into a keen correspondence with Leibnitz on space and time, and their relations to God, and on moral freedom. This correspondence was published under the title of Collection of Papers which passed between Dr Clarke and Mr Leibnitz (1717). He was not merely a keen dialectician and a man of great strength of mind, but was possessed of great general ability. He published several collections of much admired sermons and innumerable pamphlets, besides a posthumous Exposition of the Church Catechism and a beautiful edition of Cresar (1712); that of Homer (1729-32) was completed by his son. He died 17th May 1729. A collected edition of his works appeared in 4 vols. (1738-42), with a Life by Hoadly. His friend Whiston also wrote a Life (1741).

Clarkson, Thomas, philanthropist, the son of a clerical schoolmaster at Wisbeach, where he was born, March 28, 1760. From St Paul's School he passed to St John's College, Cambridge, where he took a good degree in 1783. His introduction to the chief interest of his life was his gaining a prize for a Latin essay in 1785, on the question, "Is it right to make slaves of others against. their will?' which, in an English translation (1786), was widely read. Clarkson henceforward devoted himself with indefatigable energy to a vigorous crusade against African slavery, both by an incessant shower of essays, pamphlets, and reports, and by visiting the chief towns of England and even Paris to form associations. Wilberforce: brought the subject before parliament in 1787 . On March 25, 1807, the law for the suppression of the slave-trade passed the legislature-the occasion of Wordsworth's sonnet: 'Clarkson, it was an obstinate hill to elimb,' and Clarkson next wrote a History of the Rise, Proqress, and Accomplishment of the Abolition of the African Slave-trade (2 vols. 1808). On the formation of the Anti-slavery Society in 1823 , for the abolition of slavery in the West Indies, he became one of its leading members, and had the happiness to see the object of its efforts attained in the August of 1833 . He took an active part in other benevolent schemes, particularly in establishing institutions for seamen in seaport towns similar to the Sailors' Homes. He was in deacon's orders in the Church of England, but all his life kept close to the Society of Friends, although he never joined its ranks. He died at Playford 
Hall, near Ipswich, September 26, 1846. See Lives by Taylor (1839 and 1876) and Elmes (1854).

Clary (Salvia sclarea), a native of southern Europe, which has been cultivated from a very early period for its aromatic and other properties, It is a biennial ( 2 feet), with clammy stem, large, heart-shaped, rough, doubly crenate leaves, and whorls of pale-blue flowers in loose terminal spikes, with large coloured bracts. Clary is antispasmodic and stimulating, and is used for seasoning soups, and in confectionery, while a fermented wine is prepared from its flowers.-A British species of Salvia (S. Verbenaca) is sometimes called Wild Clary; S. pratensis, Meadow Clary; and S. horminum, Annual Clary. See SAGE.

Classics. The term classici was originally applied to those citizens of Rome that belonged to the first and most influential of the six classes into which Servius Tullius divided the population. As early ss the second century after Christ it is applied figuratively by Gellius to writers of the highest rank, and this mode of designation has since been very generally adopted both in literature and art. Most nations have had at some one time a more than usually rich and abundant outburst of literature, and they usually style this the Classical period of their literature, and its most distinguished writers their Classics. Thus, in Latin literature the elassical period may be regarded as extending from the time of Varro, Cicero, and Lucretius, from about $80 \mathrm{B.C}$., to the time of Juvenal and Suetonius, ahout 180 A.D.; and is divided into a Golden and a Silver Age. But as the great productions of the writers and artists of antiquity have continued to be looked upon by moderns as models of perfection, the word classics has come to designate, in a narrower sense, the best writers of Greece and Rome, and 'classical' to mean much the same as 'ancient," The question of the relative value in modern education of the study of the classics in this sense has been much discussed (see Educatron). For Classicism as opposed to Romanticism, see RoMANTICISM.

Clastic Rocks (Gr. klastos, 'broken') are rocks composed of fraymental materials. The term includes all rocks of a secondary or derivative origin-i.e. rocks like conglomerate, sandstone, shale, \&c., which have been formed out of the remains of previously existing rocks. Besides the large class of sand-and-gravel rocks, it also embraces many rocks of organic origin, such as certain limestones, composed of the debris of shells, corals, \&c. ; coals, made up of the remains of plauts; and some ironstones, consisting in whole or in part of organic debris. Fragmental volcanic rocks, such as Tuff (q.v.) and Agglomerate (q.v.), come also into the same division.

Claude Lorraine (properly named Clatoe GELLÉE) a celebrated landscape-painter, was a native of Lorraine, and born in 1600. According to Baldinucei, a relative who travelled as a lace. dealer took Claude when still a boy to Italy, but deserted him in Rome. However, he soon found employment in grinding colours, and doing other menial services for Agostino Tassi, a landscapepainter, from whom he gained some knowlerlye of art. He seems next to have studied under Godfrey Wasls at Naples, and after some time spent in wandering through various portions of Europe, he finally settled at Rome in 1627 . Here he made his way slowly with the public, and it was about ten years afterwards that he received a commission from Cardinal Bentivoglio, who introduced him to Pope Urban VIII, for whom he executed four landscapes, two of which, 'La Fete Villageoise' and 'Un Port de Mer an Soleil Couchant,' both dated 1629, are now in the Louvre. His position was now assured, and his works were much sought after. During his later years he suffered from gout and other maladies, and died in Novemuler 1682.

Claude's landscapes, which number sbout four hundred, are found in the chief galleries of Italy, France, Spain, and Cermany, and in partirular England, which, according to Dr Waagen, contain fifty-four paintings by ruade. Four of his best works - the landscapes "snown as 'Morning, "Noon," 'Evening,' and 'Twalight'-are in the imperial gallery at St Petersburg. The painting on which Claude himself get the highest value is the "Villa Madama.' He kept it as a study, and refused to sell it, even when Pope Clement IX. offered for it as much gold coin as would cover the canvas. As Claude's paintings have always commanded very high prices, many copies and imitations have been imposed on buyers. This was the case even during the artist's lifetime; for he set high prices on his works. It has been stated that it was in order to stop the fraudulent trade carried on in his name that he collected the sketches of his pictures in six books titled Libri Veritatis, which are now in the library of the Duke of Devonshire; but these were probably executed simply to preserve a record of the works and of their destination. They were engraved in mezzotint by Earlom, and it was in rivalry with these prints that Turner executed his celebrated Liber Studiorum.

Claude was an earnest, indefatigable student of nature, of which, however, he possessed a far less close and scientific knowledge than is evinced by the works of many modern landscape-painters. $\mathrm{He}$ was restricted in his range of subjects and effects, and he had little sympathy with nature in her wilder and sterner moods. On the other hand, his composition, if rather formal, is always graceful and well considered; his colour is singularly mellow and harmonious; and as a sky-painter his work is full of delicacy and great tenderness of gradation and aerial quality. Claude produced about thirty etchings, the best of which are distinguished by great technical skill, refinement, and freedom. Hamerton has pronounced 'Le Bouvier' to be in many ways 'the finest landscape etching in the world.' His plates have been recently reproduced by Amand-Durand, and they are catslogued by Meaume in Le Peintre-Graveur Français of Robert-Dumesnil. His figures, in which he was sometimes aided by other painters, are in general such inferior accessories that he was wont to say he made no charge for them. See Ruskin's Modern Painters; Mrs Mark Pattison (Lady Dilke), Claude Lorrain, sa Vie et ses Euvres (Paris, 1884); Dullen, Claude le Lorrain (Lond. 1887); Grahame in The Portfolio for March 1895.

Claudianus, Cunudics, the latest of the (reat Latin poets, a native of Alexandris, flourished in the end of the 4th and beginning of the 5th century. He wrote finst in Greek, which appears to have been his native tongue, though he was originally of Roman extraction; but in Gibbon's words, he 'assumed in his mature age the familiar use and absolute command of the Latin language; soared above the heads of his feeble contemporaries, and placed himself, after an interval of three hundred years, among the poets of ancient Rome." His poems brought him into such reputation that, at the request of the senate, the Emperors Arcadius and Honorius ereeted a statue in honour of him in the forum of Trajan. The productions of Claudianus that have come down to us consist of two epic poems, Roptus Proserpina and the fragmentary Giguntomachia; besiles panegyries on Honorins and Stilicho, Eidyllia, Evigremmatu, and oceasional poems. Claudianus displays a brilliant fancy, rich colouring, with variety and distinctness in his pictures; but he is 
often deficient in taste and gracefulness. His works have been edited by Gessner (1759), Burmann (1760), Jeep (1879), and Birt (1892).

Claudius I., Roman emperor, whose full name was Tiberius Claudius Drusus Nero Germanicus, was the younger son of Drusus, brother of the Emperor Tiberius and Antonia, and was born at Lyons in Gaul, 10 B.C. He was natrally sickly and infirm, and his education was neglected, or left to be cared for by women and freedmen. His supposed imbecility saved him from the cruelty of Caligula; but Claudius, in his privacy, had made considerable progress in the study of history, and wrote in Latin and Greek several extensive works now lost. After the assassination of Caligula, he was found by the soldiers in a corner of the palace, where, in dread, he had concealed himself. The prætorians carried him forth, proclaimed him emperor, and compelled his recognition by the senate and many citizens who had hoped to restore the republic. By giving largess to the troops who had raised him to the throne, Claudius commenced the baneful practice which subjected Rome to a military despotism under the succeeding emperors. The first acts of his reign seemed to give promise of mild and just government, but in the year 42 , when a conspiracy against his life was detected, his timidity led him to yield himself entirely to the guidance of his third and most infamous wife, Messalina, who, in concert with the freedmen Pallas and Narcissus, practised cruelties and extortions without restraint. The emperor meanwhile lived in retirement, partly occupied in his studies, and expended enormous sums in building, especially in the famous Claudian Aqueduct (Aqua Claudia). At the same time he ruled well though mildly, and carried out the enlightened policy of extending citizenship to the provincials. Abroad his arms were victorious. Mauritania was made a Roman province, the conquest of Britain was commenced, and the frontier provinces in the east were settled. At home the uxorious emperor continued to be governed by his wives. Tracitus tells us that the shameless Messalina, after abusing her blind and doting husband by a series of the vilest profligacies, went so far as to marry herself publicly to a young lover, on which the emperor, at last awakened to her wickedness and his own shame, put her to death. He next married his own niece, the equally vicious and more cruel Agrippina, who procured his death by poison $(54 \mathrm{~A} . \mathrm{D}$.) in order to secure the succession of Nero, her own son by an earlier husband.

Claudius, AppIUs, a Roman decemvir (451 and $450 \mathrm{~B} . \mathrm{C}$.$) , who gained the high favour of his$ fellow-eitizens by his ability and activity. In the latter year, however, he began to show his real aims towards absolute and illegal power. The growing indignation of the Roman populace reached a height on account of his grossly tyrannous action towards Virginia, daughter of a respected plebeian named Lucius Virginius, who was abroad with the army. The proud patrician gained possession of the person of the maiden by pretending that she was the born slave of one of his clients. Her lover Icilius summoned her father Virginius from the army, but another mock-trial again adjudged the girl to be the property of the decemvir's elient. To save his daughter from dishonour, the unhappy father seized a knife and slew her. The popular indignation and the father's appeal to the army overthrew the decemviri, and the proud Appius was flung into prison, where he died by his own hand. The story is specially familiar to English readers from Macaulay's Lays. The Claudian Gens was one of the most numerous and important of the patrician tribes of Rome; and besides the sons and grandsons of the decemvir, there were numerous persons of distinction who bore the name of Appius.

Claus, KARL, zoologist, born 2d January 1835, at Cassel, became professor successively at Würzburg (1860), Marburg, Göttingen, and Vienna (1873). His principal work is the Grundzüge der Zoologie (4th ed. 1878-82).

Claus, Santa. See Nicolas (ST).

Clause. See DEED.

Clausel, Bertrand, a French marshal, was born at Mirepoix, Ariège, 12th December 1772, and obtained distinction in the Italian and Austrian campaigns of Napoleon; but more especially as commander in Spain, after the battle of Salamanca in 1812. Condemned to death as a traitor on the return of the Bourbons, he was in 1820 permitted to return from America to France; commanded the army and was governor in Algeria in 1830 ; and was made governor-general of Algeria in 1835. He returned to France in 1836, voted with the opposition in the Chamber, and died 21st April 1842. See Algeria.

Clausewitz. KARL voN, a very distinguished Prussian general, whose writings prepared the way for a complete revolution in the theory of war, was born lst June 1780 at Burg. He served with dis. tinction in several campaigns in the Prussian and in the Russian service, in 1815 became chief of a Prussian army corps, and was ultimately director of the army school, and inspector of artillery. He died of cholera at Breslau, 16th November 1831. Of his works the best known are his great book on war, Vom Krieg (3 vols. 4th ed. 1880), and his life of Scharnhorst. See his Life by Schwartz (Berlin, 1877).

Clausius, Rudolf, a great German physicist, born 2d January 1822 at Köslin in Pomerania. He studied at Berlin, and afterwards lectured on natural philosophy as privat-docent at Berlin, and as professor at the Zuirich Polytechnic School. In 1869 he was appointed to the chair of Natural Philosophy at Bonn, and here he died, August 24, 1888. He was elected a foreign member of the Royal Society in 1868, and in 1879 was given its highest honour, the Copley Medal. His scientific labours cover parts of the field of optics and of electricity, but his especial work was his contribution to the science of thermo-dynamics, the honour of establishing which on a scientific basis he divides with Rankine and Thomson. His mathematical methods he also applied to the theory of the steam. engine, the dynamical or kinetic theory of gases, and to electricity and electro-dynamics. His great work is his Abhandlungen über die mechanische Wörmetheorie (1864, and 1867), which in its second edition took a more systematic form as vol. i., Die mechanische Wïrmetheorie (1876), and vol. ii., Die mechanische Behandlung der Electrizitat (1879). Other books are Ueber das Wesen der Wäme (1857), and Die Potentialfunction und das Potential (3d ed. 1877).

\section{Clausthal. See Klausthat.}

Clavagella, or Club-SHelt, a genus of marine Lamellibranchiate Molluses of the same family with Aspergillum (q.v.). They mostly live in excavated holes in rocks or in masses of coral. The ordinary form of the bivalve shell is curiously modified. One valve (the right) is fixed to the inner surface of the chamber in which the animal lives, and is continued without interruption into a secondary shell-tube, which extends from the chamber outwards, and varies considerably in length in different species. The left valve is free and movable on the right. The mode of excava. tion is not known. Six living species of wide 
distribution are known. The fossil forms, which

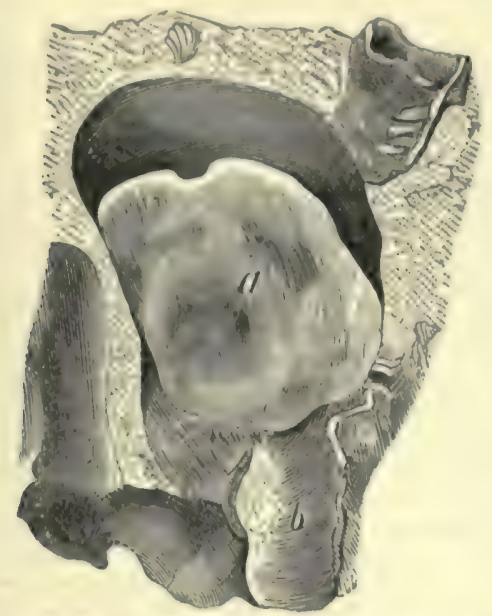

Clavagella lata, showing the cavity and fixed valve: $a$, the fixed valve; $b$, the calcareous tube.

are more numerous, were first discovered. do not occur below the Upper Chalk.

Clavaria, a genus of Fungi, of the order Hymenomycetes; family Clavariei, in which the spore-bearing tissue is produced over all parts of the surface. The species are numerous, some of them simple and club-shaped, some branched. C. botrytis, a species common in oak and beech woods, especially in Germany, growing on the ground, among moss, grass, heath, \&c., is gathered when young and used as food, having a very agreeable sweetish taste. (Botrytis is also the name of a genus of Ascomycete Fungi.) Other species of Clavaria, notably C. flava, coralloïdes, aurea, and formosa, are used in the same way. See FUNGI.

Claverhouse. See Graham (JohN).

Clavichord, an obsolete instrument of the same type as the Harpsichord $(q . v$.$) and Spinet$ (q.v.). A Claviharp is a harp struck with keys like a piano.

Clavicle, an important part of the pectoral girdle of Vertebrates, perhaps most familiarly known in the collar-bone of man and in the merry-thought of birds. It is well developed in those mammals in which the fore-leg or arm is used very strongly and freely, but is poorly developed or absent in many cases, as in Carnivores and Ungulates, In most flying birds it is strong, and often fused to the breast-bone; in the ostrich tribe it is rudimentary or absent. It is not a prominent bone in reptiles, being absent in snakes and crocodiles, apparently continuous with the scapula in tortoises, and in fact only well seen in the majority of lizards. A 'clavicle" is also to be seen in most Amphibin, though its exact relations are mnch disputed. A prominent part in the girdle of ordi. nary bony fishes is also called the 'clavicle,' but it is not certain that it corresponds to that of higher vertebrates. Of the clavicle generally it may be said that it is a paired bone superadded from the skin as an auxiliary to seapula and coracoid, that its position is ventral and anterior to the coracoid, and that it is often associated with an interclavicle. See BIRD, BONE, SKELETON; also Huxley's Anatomy of the Vertebrate Animals, and other works on Comparative Anatomy, such as those of Gegenbaur and Wiedersheim (translated by Professors Bell and Parker). There is a separate article on the human COLLAR-BONE (q.v.).
Clavicor'nia, a name sometimes applied to several tribes of beetles with club-shaped (clavate) antennas. They are included within the great Pentamerous section of Coleoptera. Burying beetles illustrate the type.

Clavije'ro, Francisco Xavier, Mexican historian, born at Vera Cruz in 1721, entered the order of the Jesuits in 1748, and became a teacher of philosophy. On the suppression of the Jeanite in 1767, he retired to Italy, where he died at Bologna in 1787. He wrote in Italisn a History of Mexico (Eng. trans, 1787).

Clavijo y Fayardo, Jose $(1730-1806)$, a Spanish publicist, who had a duel with Beaumarchais, and was made, with a character much altered, the hero of Goethe's Clavigo.

Claws, a term often applied to the chelre at the end of Arthropod limbs, but best restricted to the epidermic tips found at the ends of the digits in most reptiles, on the toes, and often on the thumb and first finger of birds, but seen in perfection in many mammals-0.g. Carnivores, Insectivores, Edentates. It is olvionsly improsible to draw any sharp line between claws and Nails (q.v.).

Clay (A.S. clogg; of the same root as 'clag,' ' claggy'), a term applied, in a vague way, to those kinds of earth or soil which, when moist, have a notable degree of tenacity and plasticity. The clays are not easily distinguished as rock species, but they all appear to owe their origin to the decomposition of various rocks, and to consist chiefly of aduminic silicate, along with other ingredients, which vary in character with the nature of the parent rock from the degradation of which they are derived. Thus common clay is a mixture of kaolin or China clay ( which is a hydrated clay), and the fine powder of some felspathic mineral, which is anhydrous and not decomposed. Clays vary much in plasticity-all being more or less plastic when moistened with water, and capable of being moulded into any form. But while many retain their shape when dried by heat, others, which in the damp state would ordinarily be called clays, tend to fall to powder when all the water is driven off. Clay is eaten by the Botocudos and other savage tribes, as also in Georgia and the Carolinas by negroes and 'poor whites.' The plastic elays are used for many purposes, as for making pottery of all kinds, bricks and tiles, tobacco-pipes, firebricks, \&c. The following are the commoner varieties of clay and clay-rocks: China clay or Kaolin (q.v.); Pipeclay (q.v.), very like kaolin, but containing a larger percentage of silica; potter's clay, not 80 pure as the preceding; sculptor's clay or modelling clay, a fine potter's clay, sometimes mixed with fine sand; plastilina, a potter's clay from Italy, supposed to be conuposed of oil, glycerine, rosin, and powdered clay, which, as it does not shrink, need not be kept wet; brickclay (see BRICK), an admixture of some clay and sand with some ferruginous matter; Fireclay (q.v.), containing little or no lime, alkaline earth, or iron (which act as fluxes), and hence infusible or highly refractory; Shale (q.v.), a laminated clay rock; clay-slate, an indurated cleaved clay-rock ; Loom (Q.V.), a non-plastic mixture of elay and sand Marl (q.v.), a clay containing much calcareous matter. Clay at the deepest sea-bottom is largely of animal origin. See PETrograpHy.

Clay Solls derive their character from the aluminic silicate which they contain in a state of mixture, as well as in chemical combination with other substances. Some soils contain so lange a proportion of alumina as 35 per cent., but generally the proportion is much smaller. The felspars which chiefly yield the alumina of clay soils con. tain also soda, potash, and lime, sabstances which 
tend to render clays fertile when under cultivation. The physical characters, however, of the different varieties of clay soils arising from the varying proportions of silica, and other substances mixed with the alumina, are chiefly concerned in their relative fertility. Calcareous matter exereises a considerable influence on their powers of producing crops. For an account of the distribution of soils in this country, see Johnston's and Cameron's Elements of Agricultural Chemistry and Geology.

Clay, Cassius Marcellus, a zealous abolitionist, born in Kentucky in 1810, graduated at Yale in 1832, and three years after was elected to the legislature of his native state. He opposed the annexation of Texas (1844); started at Lexington The True American, a vigorous anti-slavery paper, the following year; volunteered in the Mexican war (1846); supported Mr Lincoln in 1860 ; and from 1861 till 1869 was U.S. Minister to Russia. A true son of Kentucky, Clay delivered his political addresses armed to the teeth, was involved in a number of serious quarrels, and in 1877 was tried but acquitted on a charge of killing a discharged negro servant who had threatened his life. See his Life, Writings, and Speeches (2 vols. 1886).

Clay, Henry, an eminent American statesman, called, from his birthplace in the Virginia 'Slashes,' and his pursuits in early life as assistant in a grist-mill, "the Copyright 1889, 1897, and mill-boy of the Slashes,' was Lippincott Company.

born in Hanover county, Virginia, April 12, 1777. His father was a preacher, and the son received but scanty schooling, yet in manhood, with Calhoun and Webster, he formed the great triumvirate of American orators. At fifteen he became an assistant-clerk in the Virginia chancery court, and for four years was amanuensis to the chancellor, George Wythe. After studying law for one year with Robert Brooke, attorney-general of Virginia, he was licensed in 1797 to practise, though he was under age, and in the same year he removed to Lexington, Kentucky, where he soon acquired a high reputation as an orator and as a jury lawyer. In 1799, when Kentucky was framing her constitution as a separate state, he publicly advocated provisions for the gradual abolition of slavery. He was sent in 1806, and again in 1809, to the United States senate for short terms; and he entered the lower house in 1811, being chosen its Speaker, boch then and subsequently. He urged the war of 1812, and was sent to Ghent on the commission which ended the war. By his course in regard to the 'Missouri Compromise' of 1821, he won the title of 'the great pacificator.' In 1824 he was one of the strongest advocates of a high protective tariff, and in the same year was one of the four candi. dates for the presidency. No choice having been made by the electoral college, Mr J. Q. Adams was elected president by the House of Representa. tives; and Clay's acceptance of the position of secretary of state under Adams was by many held to constitute a proof of a corrupt bargain between two statesmen, neither of whom, in truth, would have been guilty of countenancing such a bargain. Clay re-entered the senate in 1831, and in the same year was renominated for the presidency; but in the following year General Jackson was re-elected to that oftice. His candidature for the office of president in 1844 was in like manner unsuccessful. The compromise of 1850 between the opposing free-soil and pro-slavery interests was largely Clay's work. He died July 29, 1852. Although he was the most attractive public speaker in his country during what is justly regarded as 'the golden age of American oratory,' his ability as a reasoner was excelled by that of Webster; while his other principal rival, Calhoun, surpassed him in intensity and fiery earnestness. No man had a larger following of devoted personal friends than Clay, and for more than forty years he had a very conspicuous share in shaping the legislation of the republic. As a public man his career was without a blemish. Of the rather numerous biographies of Clay the best is that by Carl Schurz (Boston, 1887).

Clay Cross, a town in Derbyshire, $4 \frac{1}{2}$ miles S. of Chestertield, the centre of a coal and iron district. The collieries here were begun by George Stephenson in 1838. Pop. (1891) 7143.

Clay Ironstone, a granular or compact admixture of the mineral siderite (ferrous carbonate) and clay. It occurs as nodules or in thin beds in various geological systems, but especially in the carboniferous strata. It frequently contains organic matter. When very highly carbonaceous, it passes into the variety called blackband ironstone. See IroN, Vol. VI. p. 216.

Claymore (a Gaelic term meaning' 'the great sword ${ }^{\text {) }}$ is properly used of the old Celtic onehanded, two-edged longsword, often engraved on ancient tombstones, with the guards pointing downwards. The name is now commonly given, inaccurately, to the basket-hilted sword of the officers of Highland regiments.

Claytom, JoHn MrdDletoN, statesman, was born in Sussex county, Delaware, 24th July 1796, studied at Yale, and practised as a lawyer. In 1829 he became a United States senator, and while secretary of state in 1849-50, he negotiated the Clayton-Bulwer Treaty with Britain, guaranteeing the neutrality of lines of interoceanic communication across Nicaragua or elsewhere. He died 9th November 1856. See BULWER.

Clazom'ena, one of the twelve cities of Ionia which stood on the gulf of Smyrna, westward from Smyrna. Under the Romans it was a free city, and had an extensive commerce. It was the birthplace of Anaxagoras. It is now called Vurla.

Cleanthes, a Stoic philosopher, born at Assos, in Troas, about 300 B.C. His poverty was such that he had to work all night at drawing water in order to obtain money for his support and to pay his class-fee while attending the lectures of Zenoa fact discovered only when the Areopagus called upon the ardent young student to show how he obtained his living. For nineteen years he listened patiently to the great Stoic, and, on his death, succeeded him in his school. He died of voluntary starvation when about eighty years old. Cleanthes differed from the other Stoics in regarding the sun as the governing principle of the world; but none of his writings are extant except a Hymn to Zeus, one of the purest and noblest pieces of poetry in the Greek language, showing an admirable union of religious feeling and philosophic thought.

Clear, CAPE, a headland of Clear Island, the most southerly point of Ireland, with a lighthouse and telegraph station. Clear Island, 66 miles SW. of Cork, is 1504 acres in area. Pop. 594.

Clearing-house. The business facilities afforded by bankers to their customers in collecting their bills, cheques on other firms, and similar obligations, early necessitated an organised system of interchanging such documents, whereby labour might be saved, and the cash-balances required in settlements reduced. It is claimed by a French writer that the Chambre de Compensation de Lyon, as reorganised in 1667 , was practically similar to the modern clearing-house ; and the Scottish banknote exchanges (a species of clearing) were established as far back as 1752. The present system, however, originated in London at an unknown date. It is said that the clerks, when collecting 
from the various banking.housen, began to interchange the documents of mutual indebtedness in the street, and suberuently at taverns or any hanking-office where they were tolerated. Some time previous to 1773 a special apartment was devoted by the bankens to the purpose; and in 1810 the building in Lombard Street, since known as the 'Clearing-house,' was set apart for the clearing, under the direction of a committee of bankers, and the immediate management of two insprectors. The joint-stock banks were not admitted to the clearing-house until 1854. Four vears later the country-cheque clearing was established as a department of the clearing-house. In 1864 the Bank of England entered, but it clears only against the other banks. Only twenty-seven banks, including the Southwark branch of the London and Westminster Bank, are members. Other London bankers arrange with clearing banks to represent them.

The system pursued is as follows: From time to timie during the day, each firm transmits to the clearing-house cheques and bills payable by other bankers, elassified according to the banks retirin. them, account being also taken of obligstions coming against their firm. At a certain hour the doors are closed, and the balances struck. Time is allowed for each bank to decide as to honouring the drafts upon it, after which the final adjustment of balances takes place. Subjoined is an actual balance sheet as at the close of a day's clearing.

\begin{tabular}{|c|c|c|c|c|c|}
\hline & btom & & GLXN $\mathbb{C O}$ & & editorn. \\
\hline & & & & & s d \\
\hline $\begin{array}{r}2,510 \\
12,950\end{array}$ & 8 & 6 & Alliance & & \\
\hline 12,950 & & 2 & $\begin{array}{l}\text { Barclay } \\
\text { Bank of Fngland }\end{array}$ & 254,192 & 12 \\
\hline 3,394 & 8 & 1 & Brown & & \\
\hline 51 & 17 & 11 & $\begin{array}{l}\text { Capital and Counties } \\
\text { Central }\end{array}$ & $\begin{array}{l}4,992 \\
7,904\end{array}$ & $\begin{array}{l}1911 \\
181\end{array}$ \\
\hline 6,186 & $\mathbf{0}$ & $\mathbf{2}$ & City & & \\
\hline & & & Consolidated & 72,068 & 1 \\
\hline & & & County & 128,188 & 6 \\
\hline & & & Dimsdale & 8,644 & 4 \\
\hline & & & Fuller & & \\
\hline 32,886 & 19 & 0 & Imperial & & \\
\hline 35,444 & 6 & 5 & London Joint-atock & & \\
\hline $19, \frac{10}{772}$ & 18 & $8\}$ & London and Westminster & & \\
\hline 28.492 & 2 & 9 & Lloyd's & & \\
\hline 1,938 & 2 & 4 & London and South-western & & \\
\hline 6,494 & 2 & 2 & Martin & & \\
\hline 651 & 8 & 0 & Metropolitan & & \\
\hline 4,775 & 1 & 2 & National & & \\
\hline 97 & 9 & 0 & National Provincial & 72,668 & $\mathbf{0}$ \\
\hline 13,263 & 181 & 11 & Prescott & & \\
\hline 21,246 & 19 & 8 & $\begin{array}{l}\text { Robarta } \\
\text { Southwark }\end{array}$ & & \\
\hline $\begin{array}{r}8,765 \\
63,860\end{array}$ & 14 & 8 & $\begin{array}{l}\text { Southwark } \\
\text { Smith }\end{array}$ & & \\
\hline & 7 & 0 & Union & 70,547 & 16 \\
\hline 83,605 & 18 & 8 & Williams & & \\
\hline & & & Country Clearing & 30,827 & 1810 \\
\hline 198,158 & 5 & 8 & & 646,381 & 7 \\
\hline 6,811 & 10 & 4 & Returns & 5,448 & 18 \\
\hline $\begin{array}{l}399,469 \\
252,365\end{array}$ & $\begin{array}{r}15 \\
8\end{array}$ & $\begin{array}{r}6 \\
11\end{array}$ & Balance & 651,824 & 19 \\
\hline & & & & & \\
\hline
\end{tabular}

The figures in either column are the sums due to or by Glyn \& Co. in account with each of the other members of the clearing-house, after allowing for their mutual indebtedness; the differences as they occurred that day being also shown interlined; as well as the total amount of vouchers returned unpaid. The result was that after placing all their claims on the other banks against the claims of the latter on them, there remained a sum of $£ 252,355$, 3s. 11d. due by Glyn \& Co. on the general balance. This was more than accounted for by the claims of the Bank of England, who only elear on one side. Each bank makes up a similar form. The inspectors having satisfied themselves that the general balance is correct ( all the members having agreed between themselves, and the total debtor bnlancem equalling the creditor), warrants for settling the balances by transfer at the Bank of England, certified by the inspectors, are passed between the members. Formerly these balances were settlert in cash. Thus, transactions to the amount of several millions daily are nettled without the une of a bank-note or coin. The importance of the system is illustrated by the fact, stated in evidence before the House of Commons, that the Ioudon and Westminster Bank, by getting sdmission to the clearing-house, were enabled to reduce their cash. balance by $£ 150,000$.

The record of the total amount of bills, cheques, and drafts passing through the clearing-house is regarded as an index of the state of trade; and as London is the chief centre of trade for the world, this reor yd has a world-wide range. The sums passed through the clearing-house are greatest on certain 'special days.' These are (1) the 4ths of the month, trade bills being mostly dated on the first of the month, and, with three days' grace, falling due on the 4th of some succeeding month; (2) consols settling days, once a month; (3) Stock Exchange settling days, twice a month. The following figures, commencing with the earliest record, show the magnitude and growth of the elearing-house work: (1839) $£ 954,401,600$; (1868) $£ 3,425,185,000 ; \quad$ (1873) $£ 6,070,948,000$; (1878) $£ 4,992,398,000 ; \quad$ (1883) $£ 5,929,404,000$; (1887) $£ 6,077,097,000 ; \quad(1890) £ 7,801,048,000$ (1893) $£ 6,478,013,000$. In most of the large towns in England there is now a clearing-house, and in Scotland.the system, including the separately conducted note-exchanges, has been thoroughly organised, so that clearings take place all over the country, balances being settled in Edinburgh.

The first clearing-house in America was started in New York on 11th Oetober 1853, and the system has since assumed enormous proportions throughout the United States; in 1888 there were upwards of 30 clearing-houses. The progress of the New York elearing-house will be seen from the following figures for the years ending 30th September (1854) £1,150,091,197; (1868) £5,696,857,727; (1873) $£ 7,092,210,565 ; \quad(1878) \quad £ 4,501,687,688$ (1883) £8,058,633,051; (1891) £8,513,600,000.

The system has more recently apread to the continent of Europe. La Chambre de Compensation des Banquiers de Paris was formed March 1872, the clearing-house of Berlin in 1883, and that of Vienna in 1864; but their transactions are greatly less than those of London and New York. While it was in connection with banking that the clear. ing-house system originated, the principle (in modified forms) has been adopted by other depart. ments of business. The London Railway Clearinghouse was founded in 1842, the Stock Exchange Clearing-house in 1874, and others more recently. See Howarth, Our Clearing System (1886); Francois, Clearing House et Chambres de Compensation (Lille, 1887); The New York Clearing House, its Methods and Systems (New York, 1888).

The RaIlway Clearing-house is an association institnted to enable railway companies in Great Britain to earry on, without interruption, the through traffic in passengers, animals, minerals, and goods passing over different companies' lines of railways, and to afford to the traffic the same facilities as if the different lines had belonged to one company. The arrangrements are comblueted in London by committee, the members of which are appointed by the directors of the companies who are partieg to it: and the association is regu. lated by the Railway Clearing Act, 1850. The companies are each represented on the committee by a delegate. The committee holds stated meetings four times a year, and oftener if necessary. 
Subordinate committees of railway officers also meet from time to time. The accounts of the clearing system, and the balances due to and from the several companies, are settled and adjusted by the secretary of the committee, with appeal to the committee, whose decision is final. The clerks at stations of the various companies send abstracts of all traffic monthly. The collected passengertickets are also sent monthly. Number-men are employed by the clearing-house at junctions where the lines of different companies meet, who note the number of every carriage, horse-box, wagon, van, and sheet or wagon-cover on the train going beyond the parent line, and make weekly returns. The returns from the companies' stations, together with those of the numbermen, enable the accounts of mileage and demurrage incurred to be made up by the clearinghouse, by whom the companies are debited and eredited, as the case may be. A debtor and creditor account is sent from the clearing-house monthly to each company, showing on the one side in one sum what the company has to receive from all other companies as their proportion of through passenger fares, through goods and pareels rates, and mileage and demurrage of carriages, wagons, and sheets; and on the other side, also in one sum, what the company has to pay to others out of moneys drawn by them. The balance is struck as against, or in favour of, the clearing-house (as a common debtor or creditor). In addition to declaring the balances, the clearing-house supplies to each company monthly statements of the details of the traffic of each station.

The number of companies parties to the clearing system was recently between sixty and seventy, including practically all the working railway companies of Great Britain ; and the amount of business of an intricate kind which was involved may be judged of from the foregoing particulars, and from the number of separate settlements, which amount to eleven and $\mathrm{a}$ half millions per annum, representing seventeen millions of money. The staff now numbers nearly two thousand. Regulations are published annually by the elearing-house for the guidance of the different companies in connection with the system.

The clearing-house system is made available also for the recovery of lost articles of luggage. Reports giving the description of each lost article are sent from all stations daily to the clearing house, and by this means almost all lost luggage is restored to the owners. The reports number nearly half a million per annum. The government scheme of the parcel post involves a quarterly payment by the Post-office to the whole of the railway companies of Great Britain and Ireland, and the apportionment as between the companies is effected through the machinery of the clearinghouse. There is a similar railway clearing systern in Ireland, with its headquarters in Dublin.

The general railway clearing-house has never been established in the United States, but there are several of limited extent, each embracing such lines as belong to an individual system. Thus, one at Philadelphia is a common centre for an association of lines, with about forty members. Others are at Atlanta (Ga.), Louisville (Ky.), Boston (Mass. . There are besides various railway commissions, pools, and associations partaking of the nature of a limited clearing system.

Clearing-nut (Strychnos potatorum), a small tree of the same genus with the Nux Vomica (q.v.), abundant in the forests of India, and of which the seeds are much used for clearing water. They are sold for this use in the bazaars, and travellers commonly carry some with them. These seeds being rubbed on the inside of a vessel, muddy water put into it quickly becomes clear, all impurities settling to the bottom.

\section{Clear-story. See Clenestory.}

Cleator Moor, a town of Cumberland, 4 miles SE, of Whitehaven, with coal-mines and iron-furnaces. Pop. of parish (1861) 3995 ; (1891) 9464 .

Cleats, in Shipbuilding, are pieces of wood or iron fastened to various parts of the vessel, and having holes or recesses for fastening ropes. There are several kinds, applied to various purposes.

Cleavage, or Slaty Cleavage, is a condition of rocks in which they split easily into thin plates. In true bedding the layers of rock correspond to planes of deposition or accretion, but in slaty cleavage the planes along which the rock splits may or may not coincide with bedding-planes. In point of fact they rarely do, but intersect the bedding-planes at all angles. Slaty cleavage is a superinduced structure - the result of the extreme compression which the rocks have undergone while they were being squeezed into anticlinal and synclinal folds (see ANTICLINE). When thin

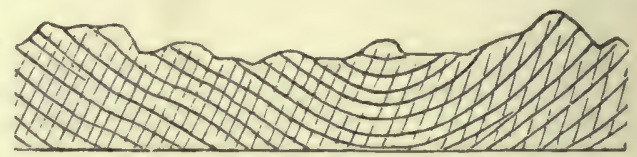

Section exhibiting Lines of Cleavage.

sections of clay-slate are examined microscopically, the grains of which the rock is composed are found to be flattened or compressed, and drawn out in the direction of the cleavage planes. Although slaty cleavage is best developed in homogeneous finegrained clay-rocks, it yet occurs in many coarsegrained rocks as well, but in these the cleavage is never so perfect as in the finer-grained clay-rocks. As induration necessarily accompanies cleavage, the cleaved clay-rocks become of great economic importance, and are familiar to every one in the common blue and purple roofing-slates.

Cleavers, or Goose-Grass (Galium Aparine), a species of Bedstraw (q.v.), a coarse Rubiaceous annual, with whorls of six to eight leaves, both stem and leaves rough with reflexed bristles, the fruit also hispid, and when ripe distributed by adhering like a bur to any animal which may brush against it. A very common weed in hedges and bushy places in Britain and most parts of Europe and North America, it was formerly of repute in domestic medicine as a diuretic. From the time of Dioscorides, and it is said still in Sweden, its prickly stems have been used as a strainer for milk.

Clef, a musical character placed on the staff, by which the absolute pitch of the notes is fixed. There are three clefs-viz. the $G$, the $C$, and the $F$ clef. The $\mathrm{G}$ clef is placed on the second line, and the stave with this clef is known as the treble stave; the $\mathrm{C}$ clef on the third line as the alto stave; and the $F$ clef on the fourth line as the bass stave. The $\mathrm{C}$ clef is a fifth below the $\mathrm{G}$ clef, and a fifth above the $\mathrm{F}$ clef, thus :

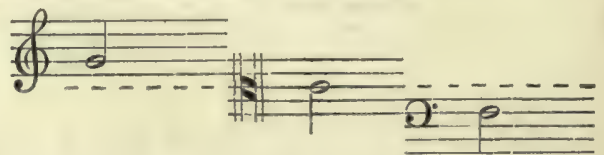

The $\mathbf{C}$ clef is also placed on the fourth line for some instruments, and for the tenor part in vocal music,

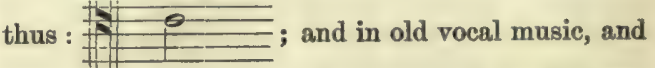

also in full scores, the $\mathbf{C}$ clef placed on the first line is used for the soprano. 
Cleg, a name given to nome insects of the dipterous family Tabanido, the females of which are in summer extremely troublesome to horses,

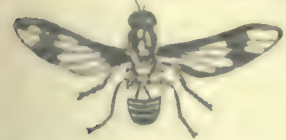
cattle, and human beings. Some of them are well known as 'breeze-flies.' The females pierce the skin of their victims by means of formidable lan-

Cleg (Chrysops cocutiens). cet-like mouth organs, and greedily suck the blowi from the wounds. The name eleg is sometimes given in England to Chrysops caecutiens, a fly frequent in most parts of Europe, but rare in Scotlind. It often attscks man, and not unfrequently inserts its proboseis through the sleeve, or some other part of the dress. It is abont one-third of an inch in length, mostly black, with yellow markings on the abromen, and very large eyes of the most beautiful green and golden colours. The insect always called cleg in Seotland is Humatopota pluvialis - a rather smaller but equally troublesome fly, mostly of a gray colour, but also remarkable for its very large and beautiful eyes, which are greenish, with waved purplish-brown bands. In England it is sometimes called the Stout. It is particularly common in low damp places.

Cleland, William (1661-89), Covenanting poet. See Cameronian Regiment.

Clem'atis ( $\mathrm{Gr}$, clèma, 'the shoot of a vine'), a genus of plants of the natural order Ranunculacese, having four coloured sepals, no corolla, and for fruit numerous one-seeded achrenia with longgenerally feathery-awns. The species are pretty numerous, herbs or shrubs, generally with elimbing stems, natives of very different climates, and much scattered over the world. They possess more or less active caustic properties. The long awns give the plants a beautiful appearance even in winter. The flowers of many species are also beautiful. $C$. vitalba, the common Traveller's Joy (fancifully so named because of its ornamental appearance by the wayside), is the only native of Britain.

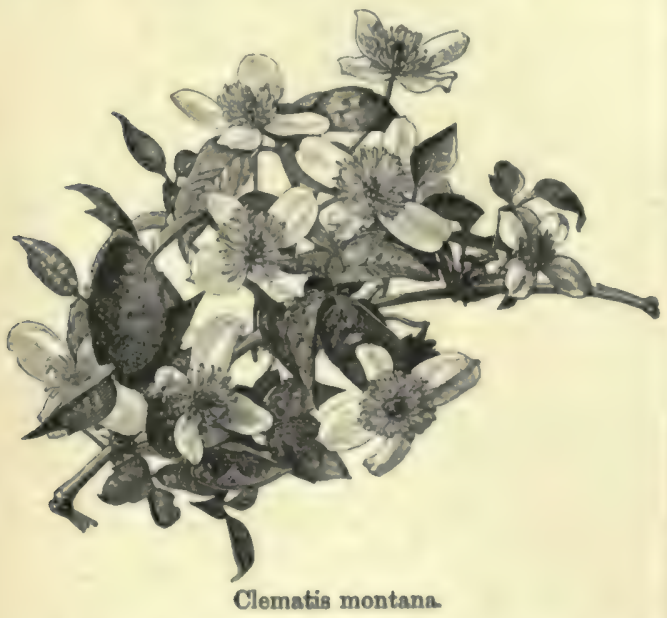

It is common in the south, but becomes rarer towards the north, and is scarcely found in Scotland. The twigs are capable of being made into baskets. It rapidly covers walls or unsightly objects. The fruit and leaves are acrid and vesicant, the leaves are used as a rubefacient in rheumatism; and those of other species are also employed in the same way. In ornamental gardening the genus is a most important one. A number of species and many garden varieties are of the greatent beanty, and mont profume in flowering. The flowers of some in different varieties attain the diameter of from 4 to 8 inches, and range in colour from pure white to pale azure, deep purple, and claret or ruby. In the United States there are many native species. A beautiful evergreen species from New Zealand, C. indivisu, with pare white flowers, is one of the handsomest of greenhouse climbers; and $C$. fammula, a native of southern Europe and northern Africa, with white flowers, which have a very strong honey-like smell, is the species known as Sweet Virgin's Bower. The garden varieties are propagated by grafting the young shoots in spring on the roots of such com. mon species as $C$. vitalba and $C$. flammult. Many are propagated by cuttings, and all may be in. creased by seeds, but the garlen varieties cannot be depended upon to come true by that means.

Clemens, Samuel Langhorne ('Mark Twain'), a popular American author, in early life successively printer, Mississippi | Copyrlet: 100, 1907, aed River pilot, and versatile hu- 1900 la the U. s. by' J.B. morous writer, was born at Lippiscott Compeny.

Florida, in the state of Missouri, November $30,1835$. From a well-known call of the man sounding the river ('Mark twain,' meaning 'by the mark two fathoms ') his pseudonym as a writer was subsequently taken. After the outbreak of the war of 1861-65, he went to Nevada, where he tried silvermining; next he edited for two years the Virginia City Enterprise, to which he had previously contributed as 'Mark Twain;' and in 1864 moving to San Francisco, became a journalist, and lectured with success there and in New York. In 1867 he joined a pleasure party going abroad, and visited France, Italy, and Palestine, gathering material for his Innocents Abroad (1869), which established his reputation as a humorist, 125,000 copies sell. ing within three years. He was afterwards an editor at Buffalo, New York, with an interest in the Express, where he married Miss Langdon, a lady of wealth. He, later, removed to Hartford, Connecticut, where he erected a unique and costly residence, and afterwards became a member of the unsuccessful publishing firm of Charles $\mathbf{L}$. Webster \& Co. He was made M.A. of Yale in 1888. His humour, however grotesque, is never laboured, never mean or ungenerous ; it is singularly direct and simple in form, and has appealed as successfully to British as to American readers. 'If the previlling spirit of Mark Twain's humour, writes Mr Howells, 'is not a sort of good-natured self-satire, in which the reader may see his own absurdities reflected, I scarcely should be able to determine it.' Mr Clemens has varied much of his work by excellent character-sketches and graphic descriptions. Among his books are The Innocents Abroad (1869); Roughing It (1872); The Gilded Age (1873), the last written with the co-operation of Mr Charles Dudley Warner, and subsequently put on the stage, where it had great success; Tom Sawyer (1876); A Tramp Abroad (1880); The Prince and the Pauper (1882); Life on the Mississippi (1874, re-issued 1883); The Adrentures of Hueklibery Finn (1885); a compilation, Librory of Humene (1888); Pudd'nhead Wilson (1894); Recollections of Joan of Are (1896); Huckleberry Finn as Detective $(1897)$; and short stories and manazine articles. The suthor lost all his money in a publishing enterprise (1884-95), and in 1898 wrote an autobiography.

Clement. Clemens, or Clement, is the name of seventeen Popes $\left(q \cdot v_{\circ}\right)$. The first of the series, CLEMENS Romanus, is accounted one of the A postolic Fathers (q.v.), and is reckoned variously as the second or third snccessor of St Peter in the see of Rome. A 9th-century legend makes him martyred in the Crimea in the year 102 . His day 
is November 23. Origen (185-254) was the first to distinctly identify Clement with St Paul's 'fellow-labourer' (Phil. iv. 3) ; but this assumption has nothing to support it, while the ancient tradition makes Clement the disciple of St Peter. Moreover, on a name so common endless theories may be built. Distinguished German scholars, such as Hilgenfeld, and Harnack (doubtfully), have identified the bishop with Flavius Clemens, cousin of the Emperor Domitian, whose sons had been named successors to the empire, and who was consul in 95 A.D., and in the same year put to death on a charge of 'atheism' and 'Jewish manners.' The most probable view is that advanced by Lightfoot-that Clement was a freedman of Jewish parentage belonging to 'Cresar's household '-strong arguments in support of which are set forth in his edition of the two Epistles. Of these, the so-called second epistle is really a homily, and is certainly not Clement's; but the first, although its genuineness has been earnestly disputed by the author of Peregrinus Proteus (Lond. 1879), is generally accepted. Chiefly hortatory and didactic, it is addressed to the Corinthian Church, in which serious feuds had arisen, and treats of social dissensions and of the resurrection, which is illustrated by a curiously circumstantial account of the phoenix. It was probably written about 95 A.D., and it was widely known and highly esteemed at an early date. Clement would appear to have had some reputation among his contemporaries as a letter-writer; Hermas (q.v.) represents himself as directed by the angel to deliver a copy of his Shepherd to him, that he may transmit it to the cities abroad, "for this function belongs to him.' To-day the epistle is chiefly of interest as the first though innocent step towards papal aggression, and for what Lightfoot calls its liturgical position. There is no respectable evidence that it was ever placed in the same catalogue with the canonical books, but in the church at Corinth it was publicly read from time to time, and by the 4th century this use had extended to other churches. For convenience of reading it would be attached to MSS. of the New Testament, as is the case in the famous Alexandrian MS. of the 5th century; but neither on this fact nor on its insertion in the forged Apostolic Canons can any argument be based; and it is only in the late Syriac MS. that it actually appears with the catholic epistles. The first edition was edited by Patrick Young in 1633, from the mutilated and incomplete Alexandrian MS., then in the king's library. This was the only copy known to the world until in 1875 Bryennios (q.v.) published a complete MS. (dated 1056) found at Constantin. ople, and in 1876 a complete Syriac MS. (1170) came into the possession of Cambridge University. See Lightfoot's scholarly and exhaustive edition (1869; appendix, 1877), where the second epistle will also be found. Quite a mass of literature has sprung up round the name of Clement, but the other works attributed to him-the Apostolic Constitutions and Canons (q.v.), two Syriac epistles on Virginity (MS. dated 1470; published 1752), the Clementina (the Recognitions and Homilies), and two epistles to James, which, with three forged Clementine letters, were in the 9 th century incorporated in the notorious Isidorian Decretalsare all undoubtedly spurious. The Clementina is a fiction of which St Peter is the hero; it was regarded by Baur and the Tuibingen school as the most notable outcome of the Ebionite party in the early Christian church, and on it much of their theory is based; the Recognitions (the Latin form, preserved by Rufinus) have been edited by Gersdorf (1838), the Homilies (the Greek form) by Schwegler (1847), Dressel (1853), and De Lagarde (1865).
For the Epistles to Virgins, see Beelen's edition (Louvain, 1856), and Funk (Tüb. 1881); for their source, see Cotterill's elaborate and convincing Modern Criticism (Edin. 1884).

Clemens, Titus Flavius, a celebrated father of the Christian church, was born probably at Athens, of heathen parents, about the middle of the $2 d$ century, and resided during great part of his life in Alexandria, whence the epithet Alexandrinus. In his earlier years he devoted himself with great zeal to the study of philosophy, and wandered far and wide in quest of truth. The date of his conversion is unknown, but it is certain that after coming to Egypt, and listening to the prelections of Pantænus, he joined the Alexandrine Church, and was made a presbyter. Afterwards he became assistant to his master, whom he succeeded, about 190 A.D., as head of the celebrated Catechetical school. In 203 the persecution of the Christians under Severus compelled him to flee to Palestine. The only later notice we have of him is as the bearer of a letter from his pupil Alexander, afterwards Bishop of Jerusalem, to Antioch; and the date and place of his death are matters of pure conjecture, some writers putting it in 213 , others as late as 220. His most distinguished pupil was Origen. Clement held a place in the Western martyrologies until the 17th century, when his name was omitted by Clement VIII. from the revised Roman martyrology; but in France, at least, he has never lost his title, his festival is still celebrated on the 4th December, and his name appears in the popular list of saints whose names may be given to children at baptism.

The chief writings of Clement that have survived, besides a practical treatise, Who is the Rich Man that is Saved, are the Missionary, the Tutor, and the Miscellanies, which form a connected series, probably continued in his lost Outlines, which was an investigation of the canonical writings. The first is an exhortation to the Greeks to abandon idolatry; the second, an exposition of Christian ethics; and the third, a collection of treatises and brief observations on Greek and Christian literature, designed as an introduction to Christian philosophy. They show that Clement, when he became a Christian, did not cease to be a philosopher. His liberal mind saw in science not a gift of devils, but of God through the Logos; Greek philosophy was part of the divine education of man, and his teaching is the result of the lofty purity of character that led him to seek the truth alike from heathen writers and from Christian heretics, believing that all that comes from God is good. The period in which he lived must also be taken into account: in his day all believers were regarded as in process of salvation; the distinction between the visible and invisible church had not yet been suggested, while Gnosticism offered to many minds an attractive solution of some obvious difficulties. Clement therefore distinguished between the ordinary believer and the Christian gnostic; above faith he placed knowledge, above salvation the more august glory and full spiritual life of the 'perfect man.' Faith implies knowledge, but imperfect knowledge; many things must be accepted in simple trust, until by contemplation and the practice of what is right the believer shakes himself free from the power of evil, and rises to intelligent sympathy with the divine will. And this system of spiritual evolution Clement extends to the future life, where the process of development is continued before the gnostic becornes as far as possible like God. Here are easily visible the germs of the later mysticism, just as his view of the Father as a pure Monad, undemonstrable, who can only be manifested through the Son, marks an important step in the progress of Neoplatonism. God and the cause of 
all things he sought to discover in the simpleat thing conceivable; and he went equally astray in making Christianity only a philosophy, and, as a means to a perfect life, the fullness of what had been partial in the Greek systems. Yet two truths he nobly taught - the present recovery of the divine likeness, and that formulated doctrine is not an end but a means to final knowledge. Clement's extant works exhibit a man of pure and gentle spirit, of sincere piety, of wide reading and of wider sympathies, and with a noble conception of the purposes of God's providence; but his learning is undigested, his quotations are often careless, and his turgid, verbose style and desultory method appear to have repelled most scholars.

The best edition of his works is still that of Bishop Potter (1715), and others based on it; there is a translation in Clark's Ante-Nicene Library (1877-79), and a bibliography at the end of Dr Westcott's article in the Dictionury of Chriatian Biography (1877). Reference should also be made to Merk, Clemens von Alexandrien (Loip, 1879), to Winter's Ethik des Clemens (Leip. 1882), to Dr Bigg's Christian Platonists of Alexandria (Bampton Lecturea, 1886), and to works by Eugene de Faye (1899) and F. R. Montgomery Hitchoock (1899).

Clement XIV.o Giovanni Vincenzo Antonio GayganelLi, born in 1705 at Sant' Arcangelo, near Rimini, at the age of eiglteen entered the order of Minorites, and studied philosophy and theology, which he afterwards successfully taught at Ascoli, Bologna, and Milan. He was the friend and con. fidant of Benedict XIV., who appointed him to the important post of counsellor to the Inquisition, and under Clement XIII. he was made a cardinal. He succeeded to the papal chair, May 19, 1769, after a conelave agitated by the intrigues of the Catholic sovereigns, who united in opposing every candidate favourable to the Jesuits. The new pope first set about reconciling these monarchs; he suspended the bull In Cona Domini, and entered into negotiations with Spain and France. After four years of deliberation, he issued in 1773 the famous lorief Dominus ac Redemptor noster, suppressing 'for ever' the society of the Jesuits. The motive nssigned in the brief is, "regard to the peace of the chureh.' From this time his strength gradually gave way, and he died September 22, 1774, of poison, it was said, although no evidence has been produced to verify this suspicion. Clement was remarkable for liberality of mind, address as a statesman, sound learning, and integrity of charscter. He cherished the arts and sciences, and was the founder of the Clementine Museum, which, by the additions of Pius VI. and Pius VII., became the chief ornament of the Vatican. See Theiner, Geschichte des Pontifikats Clements XIV. (Paris, 1853; Also in French).

Clement, JAcQurs (1564-89), the Dominican who stabbed Henry III. (q.v.) of France.

Clementi, Muzıo, in his time an eminent pianist and composer for the pianoforte, was born in 1752 at Rome, where he competed successfully for a post as organist at the age of nine. Before he was four. teen, he had composed several contrapuntal works of considerable size, one of which, a mas, had produced some sensation in Rome; he then attracter the notice of an Englishman, Peter Beckford, M.P., who brought him to England, and at whose house in Dorsetshire he studied till 1770. When he sppeared in London, his extraordinary com. mand of the pianoforte secured him an almost unprecedented success. From 1777 to 1780 he (condueted the Italian Opera; in $\mathbf{1 7 8 1}$ he visited Paris, Strasburg, Munich, and Vienna, where he engayerl in a prolonged musical combat with Mozart before the emperor, the victory being left undecided. Mozart's letters exprese the verdict that Clementi 123 was 'a mere mechanician:" but the latter had not then exchanged his brilliant execution for the melodic style of his after perfornances. He made other visits to the Continent, and amased an inde. pendence in England by teaching; and when much of this was lost in the failure of a musical firm with which he had hecome connected, he founder the business of manufacturer of pianofortes which is still carried on under the name of his associate, Collard. He died at Evesham, 9th Mareh 1832. He has left over a hundred sonatas, of which sixty are for the pianoforte alone; his ' 0 p. 2 ' (componesl in his eighteenth year) is considered the model of all modern pianofortesonatas. Of his other works, the Gradus ad Parnassum (1817) is a splendid series of 100 studies, 'on which to this day the art of solid piano-playing rests.

Cleome'des, author of a Greek treatise, in two books, On the Circular Theory of the Heavenly Bodies, which sets forth the Stoic theory of the universe, and which is remarkable as containing, amid much error and ignorance, several truths of modern science-such as the spherical shape of the earth. Nothing is known definitely regard. ing his life, but it seems most probable that he Hourished in the $2 d$ century A.D. Editions of his treatise are those of Bake (Leyden, 1820), Schmidt (Leip. 1831), and Ziegler (Leip. 1891).

Cleon. a famous Athenian demagogue in the time of the Peloponnesian war, for about six years the leader of the party opposed to peace. Originally a tanner, he grarlually abandoned his husiness, and became the champion of popular rights, a position for which his fluent speech and loud voice fitted him admirably. He first became prominent about 427 B.C. by his advocating the putting to death of the Mytilenean prisoners, but his first great success was the reduction of the island of Sphacteria, in which a Lacedgemonian force had long held out. It is by no means clear how far this exploit was not really due to the skilful dispositions of his colleague Demosthenes, but Cleon himself was highly elated with his success, and many of his countrymen must have credited him with military genius, for in 422 he was sent to oppose Brasidas, the great Spartan general, in Macedonia and Thrace. But for this task the demagogae was insufficient, and he only saved his character by falling in the battle fought under the walls of Amphipolis.

Our picture of Cleon has had the misfortune to have been painted in unfavourable colours by such masters as Thucydides and Aristophanes; and, as Grote has pointed out, it should be remembered that the great historian was full of oligarchical prejudices, while we know that Aristophanes girded at other men about whose nobility of character there is no doubt at all. Besides, it appears not unlikely that both owed the demagogue a private grudge; the former for having been lanished at Cleon's instance while holding a subordinate command, the latter because Cleon had complained to the senate that in his comedy, The Babylonians, Aristophanes had ridiculed his country's policy in the face of foreigners, and that, too, in time of war. Whether just or unjust the picture, Cleon will live in the Knights of Aristophanes as the shifty and unserupulous demasurue, lying and pandering to the mob, which he befools for his own selfish ends. In this comedy he is one of the actual dramatis persono, and this part the author played himself, not being able to find an actor bold enough to take it.

Cleopa'tra, was daughter of the Egyptian king, Ptolemy Auletes, and was born in $69 \mathrm{~B}, \mathrm{C} . \mathrm{By}$ the will of her father, who died in 51, she should have inherited the throne along with her younger 
brother, Ptolemy, who was also to be her husband, in accordance with Egyptian custom. But she was expelled from the throne by young Ptolemy's guardians, Pothinus and Achillas, whereupon she retreated into Syria to raise troops, and was just about to return to reassert her rights when the great Cresar arrived in Egypt in pursuit of Pompey. Her charms quickly touched the susceptible heart of Cæsar, who warmly espoused her cause, and, after the successful issue of the Alexandrine war, in which Ptolemy fell, placed her again upon the throne, this time with, as nominal colleague and husband, a still younger brother, of whom she soon rid herself by poison. Cleopatra bore a son to Ciesar, who was called Cæsarion (afterwards cut off by Augustus), and soon followed her lover to Rome, where she received such honours as were but ill-pleasing to the Roman populace. In the civil war after Cæsar's murder, she hesitated at first which side to take. After the battle of Philippi, Antony summoned her to appear before him at Tarsus in Cilicia, to give account of her conduct. The 'serpent of old Nile' sailed up the river Cydnus to meet him, in a gorgeous galley, arrayed as Venus rising from the sea, and accompanied with all the gorgeous and romantic splendour of the East. She was then in her twenty-eighth year, in the perfection of matured beauty, and that, from her pure descent, almost certainly of the best Greek type, spite of Shakespeare's 'gypsy's lust,' Tennyson's 'swarthy' cheeks, and Gerome's typical Egyptian features. The splendour of her beauty and her wit so fascinated the amorous heart of Antony that he at once flung away for her sake, duty, a Roman's pride, and at last all his ambition and his life. They spent the next winter at Alexandria, where they steeped their senses in the most delirious revelries of reckless love. Antony, although in the meantime he had returned to Rome to marry Octavia, the sister of Octavianus, soon returned to the arms of Cleopatra, who met him at Laodicea, in Syria (36 B.C.), and accompanied him on his march to the Euphrates. From this time his usual residence was with her at Alexandria, and here he heaped upon her and her children the most extravagant gifts and honours. His infatuated folly cost him all his popularity at Rome, and weakened his energies for the inevitable struggle. It was at Cleopatra's instigation that Antony risked the great naval battle of Actium, and when she fled with sixty ships, he forgot everything else and flung away half the world to follow her. When the conqueror appeared before Alexandria, Cleopatra entered into private negotiations with him for her own security; while Antony, who was at first indignant at her treachery, being told that she had already killed herself, fell upen his sword. Mortally wounded, and learning that the report which he had heard was false, he had himself carried into her presence, and died in her arms. Octavianus, by artifice, now succeeded in making the queen his prisoner. Finding that she could not touch his colder heart, and too proud to endure the thought that her life was spared only to grace her conqueror's triumph at Rome, she took poison, or as it is said, killed herself by causing an asp to bite her bosom (30 B.C.). Her body was buried beside that of Antony, and the good Octavia brought up the twin children she had borne to Antony as if they had been her own.

For Cleopatra, 'age cannot wither her'-the fascination of her beauty and the rare romantic interest of her story defy the touch of time. Helen of Troy and Mary Stuart alone divide with her that sovereignty over the imaginations of men that survives across the centuries. To dramatist, to poet, and to painter, she will continue to be all that she was to Cæsar and to Antony.
Clepsy dra (Gr., "water-clock'), an instrument to measure time by the trickling or escape of water. In Babylonia, India, and Egypt, the elepsydra was used from before the dawn of history, especially in astronomical observations. A Hindu form of it was that of a copper basin put to float in a vessel, so that by the gradual influx of water through an aperture beneath, it should sink in a certain time. A more common type is that referred to by Greek and Latin writers, which resembled the modern sand-glass, and was used in courts of law to limit the length of the pleadings. Julius Cresar (Com. de Bell. Gall., lib. v. 13) speaks of measuring time in Britain 'by accurate water-measures,' and some commentators infer that the clepsydra was used by the Britons. More probably, however, it was brought by the Romans, being regularly used in their armies for allotting out the three hours? watches. Pliny ascribes the invention of the clepsydra to Scipio Nasica, but he, no doubt, merely introduced it from Alexandria or Greece, where it had already been greatly improved and perfected.

The general form of the clepsydra consisted essentially of a float which slowly rose by the trickling of water from above through a small hole in a plate of metal. As the float rose it pointed to a scale of hours at the side of the water-vessel, or, in the more elaborate forms, moved a wheel by means of a ratchet, and thus turned a hand on a dial. The first great difficulty was to secure a constant and uniform supply of water. This was well and simply done by using an intermediate cistern, so that, by means of a waste-pipe near the surface, the water always remained at the same level, even when the amount poured in exceeded the average.

There remained a much greater difficulty, arising from a fact often overlooked-viz. that by the Greek and Roman calendar the hour was not a fixed space of time, being very much longer in summer than in winter. A day meant the inter. val from sunrise to sunset, and an hour being the twelfth part of it was by no means so simple and measurable a magnitude as the unit of time shown on our modern dials. The problem of measuring the hour, thus varying through the year, was solved by Ctesibius of Alexandria, who invented an elaborate self-adjusting mechanism.-Clepsydra was also the name given to an ancient musical instrument, a hydraulic or water organ, described by Athenæus.

\section{Clere, Jean Le. See Le Clerc.}

Clerestory, an upper row of windows rising clear above the adjoining parts of the building, but more probably so named as admitting clear. ness or light. The term is particularly applied to the windows in the upper part of the central nave of churches (see GoTHIC ARCHITECTURE; and for an illustration, the article BRISTOL). This mode of lighting was also in use among the Romans. See BASILICA.

Cleray (Gr. klēros, 'a lot, an inheritance'). The word cleros occurs in the Septuagint as the equivalent of the Hebrew nachalali, 'an inheritance,' applied to the Jewish nation generally as peculiarly the divine heritage (Dent. iv. 20; ix. 29), and to the Levitical office specifically, as a 'spiritual' heritage, distinguished from the temporal possessions of the other tribes (Deut. x. 9; xviii. 1-2). In the New Testament it is found in cognate senses applied to the Christian body or its several congregations (1 Peter, v. 3, where the word is plural), and to the apostolic office (Acts, i. 17, 25). Hence the term was very generally applied to the ministers of the Christian religion, as holders of an allotted office, in contradistinction to the 
term Laity. This use of the term is very ancient, being found in Clement of Alexandria (De Divite. Servemelo, 46) and Tertullian ( $D_{6}$ Monog. 12), and ajprears to have gralually become prevalent, as the ministers of religion more and more exclusively, instead of the members of the Christian church generally, began to be regarded as God's 'heritare' and 'priesthond' (1 Peter, ii. 9), consecrated to him, and peculiarly his. The distine. tion between the clergy and the laity became more marked through the multiplication of offices and titles among the clergy, the ascription to them of a place in the Chriatian church similar to that of the priests and Levites in the Jewish Church, with peculiar rights and privileges (which oecurs as early as Clement of Rome, Ep. ad. Corinth. i. 40), their assumption of a peculiar dress and of official insignia, the growth of monastic institutions, and the introduction of celibacy. In harmony with the notions on which this distinction is founded, is that of an indelible or almost indelible character derived from ordination, so that a renun. ciation of the clerical office is either viewed as an impossibility, or a sort of apostasy. These notions in their highest degree belong to the Church of Rome. In the Protestant churches, the distinction between clergy and laity is much less wide; and although the same terms are often used, it is rather conventionally than in their full signification. The employment of official robes by the clergy preceded their assumption of a peculiar ordinary dreas (indeed, for the most part, there was no direct adoption of a special garb for ordinary occasions, but the clergy did not change their fashions as the laity did, and continued to wear attire, such as the cassock, which was once commonly worn by all persons, but was discarded by the laity), and is not so intimately connected with any peculiar pretensions.

Among the privileges accorded to the clergy by the Roman emperors, and in the middle ages, was exemption from civil offices; among the rights asserted by them, and which caused much dispute, was exemption from lay-jurisdiction, even in cases of felony. With the revival of the Western Empire by Charlemagne, the clergy became one of the Estates of the empire, and the bishops were given baronial rank, and entitled to sit along with the temporal nobles in the imperial Diets. This institution survived the break-up of the Carlovingian empire, and prevailed in several parts of Europe, very noticeably in France until the Revolution. In England the clergy are still technically and constitutionally one of the three Estates of the realm, and taxed themselves in their convocations as late as 1663 . The bishops who sit in the House of Lords do so in virtue of baronies annexed to their sees, but not as prelates of the church, and it was held by parliament in Henry VIII.'s time, and later by Coke, that the right of session in convocation made the clergy of the second order ineligible to sit in the Honse of Commons. But the point remained doubtful till the Act 41 Geo. III. chap. 63, sec. 4 definitely excluded clerks in holy orders from sitting there, under a penalty of $£ 500$ per day if so sitting or voting. Those only who have formally relinguished the clerical office can sit, in virtue of the Clerical Disabilities Act of 1870 . The clergy were distinguished into the higher clergy and the lover clergy, that is, those in the 'major orders' of bishop, priest, and deacon (and, since the 13th century, sub-deacon), or those in the 'minor orders' of acolytes, lectors, exorcists, \&e. The term Secular Clergy is the designation of priests of the Latin and Greek churches who do not follow any religious rule (regula), but have the care of parishes. Monks who are in holy orders are designated Regular
Clergy. See Benefit of Cleray, Bishop, Ordens (Holy), Priest, Rector, \&e.

Clergyman's Sore Throat. See Throar. Clerieus, Johannes, See Le Clenc.

Clerk (Lat, clericus), properly a elergyman; also, in old usage, a scholar; an officer attached to courts and corporations, who keeps the reconds; s lawyer's assistant; a booking or railway elerk; and in the United States, a shopman.

The PARISH CLERK is an official in the Church of England, who leads the responses in a congre. gation, and assists in the services of public worship, at funerals, \&c. There is usually one in each parish. In cathedrals and collegiate churches there are several of these lay-clerks; and in some cases they form a corporate body, having a common estate, besides payments from the chapter. Before the Reformation, the duties of parish elerk were always discharged by clergymen in minor orders.

Clerk, JoHs, of Eldin, writer on naval tactics, was borm in 1728, the seventh son of the antiquary, Sir Joln Clerk of Penicuik, Mid. lothian (1676-1755). He prospered as an Edinburgh merchant, and by 1773 purchased the snal] estate of Eldin at Lasswade, where he devoted himself to etching, to geology, and to studying deeply both the theory and practice of naval tactics. In 1779 he communicated to his friends a new manœuvre for 'breaking the enemy's line 'in a naval battle; and during a visit to London the following year, he claimed to have had some conferences on the subject with naval officers, among whom was Sir Charles Douglas, Lord Rodney's captain of the fleet in the memorable action of April 12, 1782, when the experiment was tried for the first time, and a decisive victory gained over the French. In 1782 Clerk printed 50 copies of his Essay on Naval Tactics, for private distribution among his friends. It was reprinted and published in 1790 ; three parts were added in 1797 ; and the work was republished entire in 1804 , with a preface explaining the origin of his discoveries, Clerk died May 10, 1812. - His son, JoHN CLERK (1757-1832), was raised to the Scottish bench in 1823 , when he assumed the judicial title of Lord Eldin.

Clerkenwell, a London parish, lying within the parliamentary borough of Finsbury, and due north of St Paul's. It is largely inhabited by watchmakers, goldsmiths, and opticians. The Fenian attempt to blow up Clerkenwell prison took place 13th December 1867. Pop. (1891) 66,216.

\section{Clerk-Maxwell. See Maxwell.}

Clermont (in the middle ages, Clarus Mons, or Clarimontium) is the name of several towns in France. The most important are: (1) CLERMONT, in the department of Oise, 41 miles $\mathbf{N}$. of Paris by rail, with a large hospital and a prison for women. Pop. (1891) 3783.-(2) Clermont-FerRaND, the capital of the department of Puy-de-Dome (the Augustonemetum of the Romans, in the country of the Arverni), which is finely situated on a gentle elevation between the rivers Bedat and Allier, 135 miles S. of Paris by rail. Among the principal buildings are the old Gothic cathedral, built of dark lava from a neighbouring range of extinct volcanoes; the fine church of Notre Dame, where Peter the Hermit preached the first Crusade; the handsome Palais des Facultes; and the government buildings, formerly a convent $(1250)$. The town is the seat of a medical and a theological college, technical schools, and several scientific bodies, and has a public library with 40,000 volumes. The streets, with the exception of a number of fine squares, are narrow, tortuous, and steep. The chief manufactures are candied fruits, wax mutches, chemicals, linen, rope, lace, and machines, and there in 
an extensive traffic in the produce of the district, and in the transit trade between Paris and the south of France. There are several mineral springs in the town, of which the iron spring of St Alyre $\left(65^{\circ}\right.$ F.) has formed by deposits in the course of ages two natural bridges. The bishopric of Clermont was founded in 253 ; and seven ecclesiastical councils were held here during the middle ages, the most remarkable of which was that in 1095, at which the first Crusade was instituted by Urban'II. A statue has been erected to Pascal, who, as well as Gregory. of Tours, was a native of Clermont. Pop. (1872) 32,963 ; (1891) 41,950.-(3) ClerMonT L'HÉRAult, 33 miles W. of Montpellier by rail, with manufactures of leather and of cloth for the army. Pop. (1891) 5056.

Clevedon, a pleasant Somersetshire wateringplace, on the Bristol Channel, 12 miles by road but 16 by rail WSW. of Bristol. The historian Hallam, and Arthur, his son, lie in the old parish church; Coleridge lived a while here at Myrtle Cottage (1795); and Clevedon Court (much damaged by fire in 1882) is the 'Castlewood' of Thackeray's Esmond. Pop. of parish (1851) 1905 ; (1891) 5412.

Cleveite. See Argon.

Cleveland, a wild mountainous district, with some picturesque fertile valleys, forming the east part of the N. Riding of Yorkshire between Whitby and the Tees. In the south the hills rise 1300 to 1850 feet. An extraordinary change has been wrought in the aspect of the country by a rich discovery of ironstone in the Cleveland hills; since 1851 , lonely hamlets have become populous towns. The ironstone is chiefly an argillaceous carbonate, inferior to that of the coal-measures. See MIDDLESBorough, Iron. The title of Duchess of Cleveland was conferred in 1670 by Charles II. (q.v.) on his mistress, Barbara Villers, and her eldest son (Fitzroy) was first duke. In 1827 the marquisate of Cleveland was bestowed on William Harry Vane, Earl of Darlington (whose grandfather married a descendant of the first duke); in 1833 he became duke - a title extinct since 1891 .

Cleveland, next to Cincinnati the most inportant city of Ohio, and in population the tenth, in

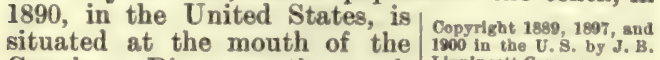
Cuyahoga River, on the south Lippineott Oompany. shore of Lake Erie, 255 miles by rail NE. of Cincinnati, $183 \mathrm{SW}$. of Buffalo, and $350 \mathrm{E}$. of Chicago. The city is built mainly upon a plain from 60 to 150 feet above the lake, and is divided into two great divisions, the east and west sides, by the tortuous valley of the Cuyahoga. The 'Hlats,' about half a mile wide, along the river are occupied by vast lumber-yards, numerous factories, iron, flour, and other mills, coal-yards, ore docks, ship-yards, \&c. A wide and massive viaduct, 3211 feet long, constructed mainly of stone, and completed in 1878 at the cost of $\$ 2,250,000$, crosses the valley at the height of " 50 to 70 feet; and another viaduct of iron (1888), 100 feet above the river and 3931 feet long, makes a second broad level highway between the two divisions of the city. The river is the harbour, and is spanned by numerous bridges. An outer harbour, safe and commodious, is completed by the construction of an immense United States breakwater, about 2 miles long and half a mile from the shore, opposite the mouth of the river, where there is a large opening for vessels. The business centre of Cleveland extends east from the lower part of the river-valley, for three-fourths of a mile along Superior Street, which is 132 feet wide, and the chief shopping thoroughfare. It embraces several parallel and intersecting streets. In this district is the Public Square, 10 acres in area. The custom- house and post-office, a large stone structure, is situated on the east side of the square, upon which front also a court-house, the fine old 'Stone' (first Presbyterian) Church, a theatre, an hotel, banks, and many business blocks. This attractive breath. ing spot contains fountains, a stone speakers' stand for public meetings, and a statue of Commodore Perry, the hero of the battle of Lake Erie in 1813. From the south-east corner of the square, Euclid Avenue, the most famous street in the city, and, according to Bayard Taylor and other travellers, the most beautiful in the world, extends nearly east through the best residence quarter of Cleveland. Four and a half miles from the square it passes Wade Park, a beautiful tract of about 65 acres, containing a lake for boating, a deer paddock, fountains, and groves of noble forest-trees.

A mile farther east, just beyond the city limits, is Lake View Cemetery, one of the finest in the country. Here, on a commanding site, 250 feet above Lake Erie, stands the stone monument to the late President Garfield, built by subseription at a cost of about $\$ 130,000$. The monument is 125 feet high, and surmounts the president's grave. Euclid Avenue is lined with stately mansions upon a gentle eminence, 200 to 500 feet from the Avenue, in a park-like stretch of shadetrees, smooth lawns, flowers, shrubbery, and winding walks and drive-ways. The same wealth of gardens and shade-trees is noticeable in a less degree throughout the 'Forest City,' except in the poorest quarters. Few houses are built in blocks, and tenements are virtually unknown. At least 20,000 families, it is believed, own the houses in which they live, and the area of the city, $26 \frac{1}{3} \mathrm{sq} . \mathrm{m}$., is about 20 per cent. greater than that of Manhattan Island, on which New York is mostly built. About $19.5 \mathrm{sq}$. $m$. lie east of the river and 6.8 miles west. The soil is light and sandy, the drainage excellent, and the water supplied from Lake Erie by a tunnel, two pumping stations and standpipes, and two large reservoirs, is pure and abundant. The climate is temperate, the average yearly rainfall being $37 \cdot 6$ inches, and the mean annual temperature $50^{\circ} \mathrm{F}$. Naturally the deathrate is low, averaging about 18 in the thousand of population. Cleveland has a music-hall capable of seating 5000 persons, 4 fine theatres and 6 of less importance, 150 churches, 8 colleges -3 of which are medical schools - 7 hospitals, and many asylums and other benevolent institutions. There are two large cireulating libraries, one, containing about 52,000 volumes, being free. The schools number about 100 ; and 60 periodicals, daily, tri-weekly, weekly, and monthly, are published in the city. Cleveland's rapid growth is due mainly to the fact that nowhere else can the rich iron ores of Lake Superior, the coal of Northern Ohio, and the limestone of the Lake Erie islands, be brought together so cheaply. The chief industries of the city are the various manufactures of iron, including steel rails, forgings, wire, bridges, steel and iron ships, engines, boilers, nails, screws, sewing-machines, agricultural imple. ments and machinery of all kinds, the refining of petroleum, wood-work, and other manufactures of endless variety. In 1880 the value of manufactured products was $\$ 48,600,000$, the number of persons employed 21,700, and the capital invested $\$ 19,430,000$. At the census of 1890 the annual value of products was $\$ 105,500,000$, and 50,000 hands were employed.

In 1880-90 the vessel tonnage constructed in Cleveland, nearly all in steamships of 1500 to 2500 tons burden, exceeded that built in the entire state of Maine. The city has a commanding commercias situation, due, primarily, to its position at the north terminus of the Ohio Canal, connecting Lake Erie with the Ohio River at the mouth of the Scioto. The start obtained when the canal was opened in 
1834 has been maintained. Seven railroads ternin. ate in the city, and two pass through it from east to west. Cleveland's lake commerce is very great, the total tonnage entered and cleared annually exceeding $3,000,000$ tons. Cleveland is the grestest iron ore receiving point in America, one of the largest lamber markets in the country, and the mercantile centre of an extensive and productive rogion. In 1796 a party under General Mosea Cleveland laid out the site of a town on this spot. In 1809 Cleveland was chosen the seat of justice for Cuyahoga county, and in 1814 the village was incorporated; the city charter followed in 1836, since which the growth has been very rapid. Pop. (1830) 1096 ; (1840) 6071 ; (1850) 17,084; (1860) 43,417, Ohio City, on the opposite side of the river, having been united with Cleveland in 1856 ; (1870) 92,829 ; (1880) 160, 146 ; ( 1890 ) 261,353; ( 1900 ) 381,768.

Cleveland, Grover, the twenty-second president of the United States, for the terms 1885-89 and 1893-97, was born ot Cald.

well, N. J., March 18, 1837. Copyriebt 1880, 1897, and In early life he removed to lipplacoti company. the state of New York. In 1859 he was ad mitted to the bar, and began the practice of law at Buffalo. From 1863 to 1866 he was assistant district attorney for Erie county, and in 1870 was chosen sheriff. After filling the office of mayor of Buffalo, he was, in 1882, elected governor of New York by an unexampled majority of more than 190,000 votes. His course as governor was ap. proved by the best people of all parties. In 1884 he was nominated by the Democrats for the chiefmagistracy of the United States. The canvass which followed was one of extreme earnestness and excitement. Cleveland received 219 electoral votes (Blaine, the Republican candidate, securing 182); and the returns of the popular vote also gave him a plurality. He took his seat as president in 1885. In a unique and forcible message to congress in Decenber 1887 regarding the reduction of the great surplus in the national treasury, he strongly advised a careful readjustment of the tariff charges on certain manufactured articles of import, and the admission duty-free of some of the raw materials of manufacture-a position which led to a well-defined issne between the two political parties. Protectionists classed the president's message as a free-trade document, but this was denied by the Democrats, and its doctrines were adopted as the basis of the Democratic platform at the convention of that party in 1888 , when $\mathrm{Mr}$ Cleveland was unanimously nominated for reelection to the presidency. In the following August, on the rejection of the proposed Fisheries Treaty with Canala by the Republican majority in the senate, the president sent a message to congress, declaring a policy of 'retaliation' against Canada now necessary. In October he demanded the recall of Lord Sackville, the British minister, for writing a letter held to trench on American politics. At the election in November, Cleveland was defeated by the Republican candidate, General Harrison, over whom, however, he secured a large majority in November 1892. His next term of office was sig. nalised by his zeal for currency reform, for the reper] of the Silver Act, and against the high republican tariff. In 1895 he suggested to the British government the appointment of a commission to determine the true boundary between British Guiana and Venezuela. On retiring from the presidency (1897), he settled at Princeton, N. J., and the same year was made LL.D. of Princeton University.

Cleveland, JонN, cavalier poet, born at Loughborough in June 1613, the son of a clergyman ousted by the parliament from the living of Hinckley in 1644 . In $1627-31$ he wasat Christ's College, Cambridge, and then migrated to St John's College, where he was elected to a fellowship in 1634, and lived nine years 'the delight and ornament of St John' mociety.' Here he studied both law and physic. Cleveland vigorously opposed Cromwell's election to the Long Parliament for Cambridge, and was for his loyalty ejected from his fellowship by the parliament in 1644. He betook himself to the king's army, was popular among the cavaliers, and was aprointed 'juilge-sulvocate' at Newark, lut was obliged to surrender with the garrison. His indignation at the Scotch army for handing over the king to the parliamentarians he expresked in some stinging verses, which, however, are too violent to be really strong. Henceforward Cleveland lived upon the hospitality of his partisans, and was forced to keep his wit in check. In 1655 he was arrested at Norwich, but was soon released by command of Cromwell, whose magnanimous spirit could admire the courageons manliness of the poor poet's letter addressed to him. In 1656 he published a small volume containing thirty-six loyal poems, consisting of elegies upon Charles I., Strafford, Laud, and Edward King, the subject of Milton's Lycidas, also some stinging satires. Cleveland now went to live at Gray's Inn, where he soon sfter died, April 29, 1658. In the year 1677 was published, with a short account of the author's life, Clievelandi Vindicia, or Cleveland's Genuine Poems, Orations, Epistles, de. Cleveland undoubtedly exercised a strong influence upon the greater genius of Butler. Thomas Fuller commends him as 'a general artist, pure latinist, exquisite orator, and eminent poet. His epithets were pregnant with metaphysics, carrying in them a difficult plainness, difficult at the hearing, plain at the considering thereof.

Cleves (Ger. Kleve, Dutch Kleef), a town of Rhenish Prussia, 48 miles NW. of Düsseldorf. It is situated on three gentle elevations, about $2 \frac{1}{2}$ miles from the Rhine, with which it communicates by canal, in the midst of a rich and beautiful country. It is well built, in the Dutch fashion, and surrounded by walls. The fine old castle, known as the Schwanenburg, partly built on a commanding rock, is the reputed scene of the legend of the Knight of the Swan, made familiar by Wagner's opera of Lohengrin. Anne of Cleves, fourth wife of Henry VIII., was born in this castle. In the collegiate church, which dates from the 14th century, are some good monuments to the counts and dukes of Cleves. Cleves has manufactures of cotton and leather goods, tobaceo, \&c. Pop. (1885) 10,170. Cleves was anciently the capital of a duchy (a countship until 1416) extending along both hanks of the Rhine, which passed by inheritance in 1609 to Brandenburg.

Clew Bay, an inlet of the Atlantic, on the west cosst of County Mayo, Ireland, about 15 miles long by 9 broad. The upper part of the bay con. tains an archipelago of fertile and cultivated islets; and at the entrance of the bay is Clare Island ( 3949 acres; pop. 62), which, as well as Inishgort (27 acres; pop. 23), has a lighthouse.

Cliché (Fr.), the impression made by a die in any soft metal. It is the proof of a medallist's or die-sinker's work, by which they judge of the effeet, and ascertain the stage of progress which they have reached before the die is hardened. The same term is applied by the French to electrotype casts from wood-engravings.

Clichy, a town of France, on the Seine, to the north-west of Paris, of which it forms a suburb. It has numerous manufactories, especially of chemicals and catgut, and is much affected by washer. women. Pop. (1886) 26,741 ; (1891) 30,561. 


\section{Click-beetle, or SkIP-JACK. See WIRE- WORMS.}

Client. See Agent and Client. See also Patron.

Clifford, a family descended from Walter, Richard Fitzponce's son, who by marriage, prior to 1138, acquired Clifford Castle on the Wye, 17 miles W. of Hereford, and who assumed the surname Clifford. He was the father of Fair Rosamond, Henry II.'s mistress, who seems to have died about 1176, and to have been buried at Godstow Nunnery, near Oxford. The legend of her murder by Queen Eleanor appears first in the 14th century; the Woodstock maze, the clue, the dagger, and the poisoned bowl belong to a yet later age. Among Walter's descendants were the soldier-judge Roger de Clifford, who by marriage with Isabella de Vipont got Brougham Castle in Westmoreland (eirca 1270); John (1435-61), the savage Lancastrian; Henry (1455-1523), the 'shepherd lord; Henry (1493-1542), fifteenth Lord Clifford and first Earl of Cumberland; George, third earl (15581605), naval commander ; and Henry, fifth and last earl (1591-1643). To a cadet branch belonged Thomas Clifford (1630-73), a Catholic member of the Cabal, who in 1672 was created Lord Clifford of Chudleigh.

Clifford, William Kingdon, F.R.S., one of the foremost mathematicians of his time, was born at Exeter, May 4, 1845. He was educated at a school in his native town, at King's College, London, and at Trinity College, Cambridge. While at Trinity he did not confine himself to examination subjects, but read largely in the great mathemati. cal writers, and came out second wrangler in 1867 , next year being elected a fellow of his college. At this time, while excelling in gymnastics, he would also solve and propound problems in the pages of the Educational Fimes, and conld discuse with ease complicated theorems of solid geometry without the aid of paper or diagram. A High. Churchman at first (though on unconventional speculative grounds), Clifford soon after taking his degree threw off all dogmatic restraints, and discussed the fundamental questions of the philosophy of religion with complete independence. In August 1871 he was elected to the chair of Mathematics and Mechanies at University College, London, which post he retained until his untimeiy death at Maderra, March 3, 1879. Clifford first established his reputation as an original thinker with the faculty of expressing scientific thought in plain and simple language by a Friday evening discourse at the Royal Institution, On Some of the Conditions of Mental Development. He was a valued member of the London Mathematical Society, contributing to the Proceedings; for a time he acted as secretary, and afterwards vice-president of the Mathematical and Physical section of the British Association; he also lectured to the Sunday Lecture Society on various physical and philosophical subjects. The versatility of his mind for philosophical and scientific discussion was further shown by his varied- contributions to periodical literature. Clifford issued in his lifetime the first part of Elements of Dynamics (1878). A further portion, edited by Mr R. Tueker, was published in 1887 . A work on the Common Sense of the Exact Sciences, which Clifford left unfinished, was completed and edited by Professor Karl Pearson in 1885. A selection from his Mathematical Papers appeared in 1881, and a series of lectures on Seeing and Thinking in 1879. Clifford's general scientific and philosophical writings are collected, with $a$ prefatory memoir, in Lectures and Essays, edited by L. Stephen and F. Pollock, 1879 ( 2 vols.; $2 \mathrm{~d}$ ed. in 1 vol. 1886). - Mrs Clifford (née Lucy Lane) has published a really striking novel, or rather tragedy, Mrs Keith's Crime (1885), Aunt Anne (1892), and two books for young children of quite unusual interest, Anyhow Stories (1884) and Very Short Stories and Verses for Children (1886).

Clifton, England. See Bristor.

Clifton (now Niagara Falls), a town and port of entry of Ontario, on the Niagara River, about 2 miles below the cataract. Here a noble suspension-bridge and a cantilever cross the river, connecting the Canadian railways with the railway systems of New York. Pop. 4000.

Climacter'ic Years (from Gr. klimaktêr, "the step of a stair or ladder,' klimax). It was long believed that certain years in the life of man had a peculiar significance to him, and were the critical points, as it were, of his health and fortunes. The mystical number 7 and its multiples with odd numbers (e.g. 35, 49) constituted crises of this kind. The most important of all was the $63 \mathrm{~d}$ year, called, by way of eminence, the 'climacteric year' or ' grand elimacter,' which was supposed to be fatal to most men; its influence being attributed to the fact that it is the multiple of the two mystical numbers 7 and 9 . An actual 'change of life' ( $\mathrm{Fr}$. Age eritique) in woman is marked by the cessation of menstruation, usually between the 48th and 52d years. Astrologers called any period which an evil conjunetion marked as threatening, a climacteric time.

Climate (from the Greek klima, 'a slope or inclination,' afterwards applied to a tract of country, with reference to its supposed inclination to the pole, and the effect of the obliquity of the sun's rays upon the temperature), a term now employed as including not merely the conditions of a place or country with regard to temperature, but also its meteorological conditions generally, in so far as these exercise an influence on the animal and vegetable kingdoms. The effect of the sun's rays is greatest where they fall perpendieularly on the surface of the earth, and diminishes as their obliquity increases; the surface which receives any given amount of the sun's rays increasing with their increased obliquity, as $a^{\prime} b^{\prime}$ is greater than $a b$ in the annexed figure; whilst

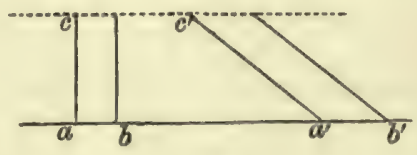

at the same time the oblique rays being subjected to the influence of a greater number of particles of the atmosphere, as $c^{\prime} \alpha^{\prime}$ is longer than $c a$, a greater amount of their heat is absorbed before they reach the surface of the earth at all. The greater or smaller extent of surface receiving a certain amount of heat, also makes important differences to arise from exposure by slope towards the equator or towards the nearest pole. Elevation is a most important cause of differences of climate. As we ascend from the level of the sea to the greatest mountain altitudes, the temperature gradually diminishes, and we nltimately reach a region of perpetual snow, as in approaching the poles. The progressive diminution of the temperature is, however, affected by many causes, so that the line of perpetual snow is far from being at the same elevation in all places of the same latitude. Thus the snow-line on the southern side of the Himalayas is depressed by the heavy rainfall brought by the winds from the Indian Ocean; and that on the northern side is elevated by the extreme drought and summer heat in the vast 
tablelands of Central Asia, thus causing setive evaporation from the snow-fields; so that the dif. ference between the two is not lese than 4000 feet in favour of the northern side of the mountain. ranges; and Humboldt says, 'millions of men of Tibetan origin oceupy populous towns in a country where fields and towns would, during the whole year, have been buried in snow, if these tablelanils had been less continuous and less extensive.

As the actual temperature of the atmosphere fepends not 80 much upon the direct rays of the sun as upon the raliation from the heated surface of the earth, the divensities in the character of that surface are productive of great effects in modifying climate. A sandy desert, a tract of country elothed with luxuriant vegetation, and an expanse of water, absorb and raliate heat in very different degrees. A newly ploughed field both alsorlos and raliates heat much more rapidly than a field covered with crass. A sandy desert heats the atmosphere alove it much more than either a fertile tract or a watery expanse, whilst a watery expanse only slightly raises the temperature; but, on the other hand, the desert cools sooner by terrestrial radiation; whilst the heat absorbed by the water being diffused through a larger mass, owing to the depth to which solar radiation penetrates and to vertical as well as horizontal currents generated by the winds to great depths, the influence of the ocean, of seas, and of great lakes, is very powerful in maintaining a greater equableness in the temperature of the air. Thus maritime places, and particularly islands and peninsulas, have a more equal temperature, with less diversity of the extremes of summer and winter, than more inland or conti nental places otherwise similarly situated. The effect of the sea is modified by many circumstances, and particularly by currents, of which the Gulf Stream (q.จ.) affords a notable instance, the heated water conveyed by it and by the general surfaceflow north-eastwards of the waters of the Atlantic, from the equatorial to the polar regions, having a great influence on the climate, particularly of the north-west of Europe. Over the world generally, atmospheric currents or prevailing winds must be regarded as exercising even a greater influence on climate than oceanic currents. The quantity of rain or snow that falls in the course of a year, and the times and manner of its falling, are circum. :stances which have the greatest possible effect on climate; these being in their turn much influenced by the distribution of land and water, and by the character and elevation of the surface of the land, according as the mountain-ranges lie across or in the line of the rain-bringing wind.

The relations of elimate to vegetation are generally determined less by the mean annual tempera. ture than by the relative duration of summer and of winter. Thus maize, which may be mentioned as an important example, succeeds well in climates of which the winter-cold is severe, the summer season alone being sufficient for its whole life; whilst, on the other hand, such plants as fuchsias, some kinds of laurel, and even the common hawthorn, which succeed well enough where maize would searcely put forth an ear, would perish from the colder winters of countries where it is profitably cultivated. The polar limit of particular species of animals, except those which hibernate, is generally determined by the degree of winter-cold which they can bear without injury

Boge and marshes exercise an unfavourable influ. ence on climate, cooling the air and generating fogs, as do clay-soils also to some extent, through their retentiveness of moisture; whilst marshes of some kinds, and in some situations, abound in malarious and other exhalations very unfavourable to health. Similar remarks apply to large tracts of forest.
The clearing, drainage, and cultivation of land have generally favourable effects on elimate; although plantations are often beneficial for shelter, and a too complete removal of natural forests may prevent the deposition of moisture from the atmosphere to such a degree an to cause droughts, a result stated to be exenplified in nome of the smaller West India Islands, and the ten. dency to which is said to be manifested on a great seale in some sections of the continent of North America.

The important and difficult subject of climate will be found further elucidated in some of the principal geographical articles (AsLA, \&c.), and in the articles Atmosphere, Geographical DistribU. tion, Glacial Period, Health-Resorts, Hyorometer, Meteorology, Monsoon, Pleistocene, RAIN, SEASONS, SNOW-LINE (under article SNOW), Storms, Temperature, W IND. See also Ramsay, Bibliography and Index of Climate (1888), and the works named under CroLL.

Climax (Gr., 'a stair,'), in Rhetoric, that artifice which consists in placing before the mind of the reader or hearer a series of propositions or objects so arranged that the least forcible strikes it first, and the others rise by successive gradations in im. pressiveness. See the example in $1 \mathrm{Sam}$. iv. 17.

Climbers (Scansores), an old-fashioned popular title for several orders of birds whose feet are mainly adapted for climbing. In many cases two toes are turned forward, and two backward; or it may be that one permanently turned backward is joined in branch grasping by another reversed for the nonce. Parrots (Psittaci), cuckoos (Coccygomorpha), woodpeckers (Picaria), \&c. are included under this wide and somewhat inexact title.

Climbing Pereh (Anabas scandens), a bony fish in the Acanthopteri division, famous for its peculisr clambering habits. It is a native of rivens and ponds in most parts of the East Indies. It is about six inches long, and in general form somewhat resembles a perch. That this fish elimbs trees, has been asserted by observers whose veracity and accuracy cannot easily be questioned; yet others, who have enjoyed ample opportunity of observation, express great doubt concerning this habit. According to circumstantial accounts, the fish suspends itself by its spiny gill-covers, and by fixing its anal fin in cavities of the bark, urges its way upwards by distending and contracting its body. There is no doubt that it often leaves pools when they are in danger of being dried up, and travels in search of water. Though these fish are sometimes

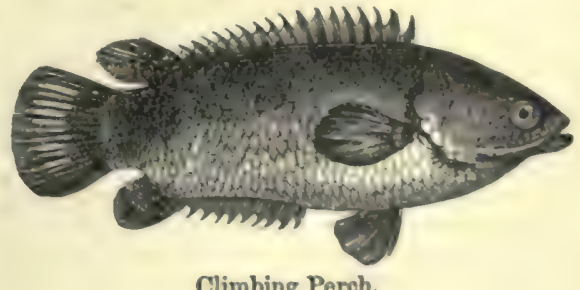

compelled in their distress to travel by day, and have been met in the glare of noon toiling along a dusty road, their migrations are generally performed at night or in early morning, whilst the grass is still wet with dew. This restless fish is aided in its peregrinations out of water by an accessory labyrinthine respiratory eavity, in which water may be retained for a considerable time. Climbing perches are plentiful in the Ganges, and the boatmen have been known to keep them for five or gix days in an earthen pot without water, uaing 
daily what they wanted, and finding them as lively as when just caught. Some related forms, such as the walking fish (Ophiocephalus), exhiloit to a less marked degree the same power of living out of water. Closely related also is the Chinese Macropod, not unfrequently kept for its beauty in aquaria. Many of the genera make nests for the eggs, over which the males frequently keep guard.

Climbing Plants, or Climbers, are, in the most extensive and popular sense of the term, those plants which, having weak stems, seek support from other objects, chiefly from other plants, in order to ascend from the ground. This, however, is accomplished in very different ways. Some elimb by means of small root-like processes growing from the stem, as the ivy; others by means of hooks (e.g. Cleavers, q.v.); others again twining round their support-e.g. hop, convolvulus, \&c.; and others, the most evolved, by help of sensitive organs, which are branches or leaves or leaf-stalks more or less modified. The subject of climbing plants has been worked out with peculiar fullness and interest in Darwin's classical monograph. See also the section Movements of PLANTs in the article Plants, in this work; also the articles Clematis, Convolvulus, HoNeYsuckle, Hop, IVy, LiaNAs, Passionflower, VINE, \&c.

Clinical Medicine (Gr. Klinē, 'a bed') is that department of the art which is occupied with the investigation of diseases at the bedside of the sick; and a clinical lecture is one delivered to students there. So with clinical surgery. Clinical baptism is baptism administered to sick or dying persons on their sick-bed; a clinical convert is one converted on his death-bed.

Clinker, the name given to the scales or globules of black oxide of iron, oltained from red-hot iron under the blows of a hammer. The same term is applied to the slags of iron-furnaces. By geologists the eindery-like masses which form the crust of some lava-Hlows are termed clinkers.

Clinker-built, or Clencher-Built. See BoAt.

Clinkstone, or Phonolite, is a greenish gray or brownish compact or very finely crystalline igneous rock, remarkable for its tendency to split into slabs, which are now and then thin enough to be used for roofing purposes. This structure is due to the parallel arrangement of plate-like or tabular crystals of sanidine felspar. The slabs give a metallic ring or 'clink' when struck with a hammer, whence its name. Its essential mineral components are sanidine and nepheline, but other minerals, such as augite or hornblende, leucite and magnetite, are usually present. The rock has often a porphyritic structure.

Clinom'eter, an instrument for the purpose of taking the amount of dip or angle of inclination of a stratum. There are various kinds in use, but the simplest consists of a strip of wood upon which is mounted a graduated are with a pendulum. When this instrument is held horizontally, the pendulum points to zero; when it is held in a slanting position, the pendulum shows the number of degrees that the upper edge or the base of the strip deviates from horizontality. The most useful form of clinometer is that which is combined with a compassboth these instruments being required in geological observations.

Clinton, (1) capital of Clinton county, Iowa, on the Mississippi, which is here erossed by an iron railroad bridge, 4000 feet long, 60 miles SSE. of Dubuque by rail. It has numerous mills, foundries, and factories, and a trade in lumber and grain. Pop. (1870) 6129; (1890) 13,619.-(2) A town of Massachusetts, on the Nashua River, 45 miles W. of Boston by rail. It has large manufactures of ginghams and plaids, carpets, combs, and machinery. Pop. (1890) 10,424.-(3) A post-village of Oneida county, New York, 9 miles WSW. of Utica, is the seat of Hamilton College (1812), a Presbyterian foundation, with about 160 students, and of several other noteworthy educational institutions. Pop. (1890) 1269.

Clinton, a distinguished American family, descended from Charles Clinton, who was born in Ireland in 1690, settled in New York state in 1731, and died there in 1773.-His third son, JAMEs, born in 1736 , served with distinction against the French, and as brigadier-general took part in several operations during the War of Independence. He died in 1812. - His brother, GEORGE, born in 1739, studied law, and from 1768 sat in the New York assembly; in 1775 he was sent as a delegate to the second Continental Congress, and in $\mathbf{1 7 7 6}$ he was appointed general of militia, serving against Sir Henry Clinton on the Hudson. In 1777 he was chosen first governor of New York, to which post he was re-elected from 1780 to 1795 , and in 1801 ; and to him was due the first conception of the Erie Canal. In 1804 he was chosen vice-president of the United States, and in that office he died at Washington, 20th April 1812.-James's son, DE WITT, born in 1769 , was admitted to the New York bar in 1788 , and was private secretary to his uncle, then governor, from 1790 to 1795 . He sat in the state legislature (1797) and in the state senate (1798-1802); and in 1802 he was elected to the United States senate, but resigned in the same year on being. appointed mayor of New York by his uncle. In this office he continued, save for two short intervals, until 1815, holding other appointments at the same time; he was defeated by Madison in the presidential contest of 1812 . It was he who pressed the adoption of the Erie Canal scheme; the bill was passed and Clinton elected governor of the state in 1817, and in 1825 he opened the canal. He was. several times re-elected in spite of the untiring efforts of his political opponents, and died in office at Albany, 11th February 1828. He published a number of addresses, some literary and historical, which will be found in his Life by Campbell (1849).

Clinton, SIR HeNRy, British general, born about 1738, was the son of the Hon. George Clinton, colonial governor of Newfoundland, and afterwards of New York. He first entered the New York militia, was gazetted to the Guards in 1751 , served with conspicuous gallantry on the Continent, and was promoted colonel in 1762 and major-general in 1772. From 1772 to 1784 he sat in parliament in the interest of his cousin, the Duke of Newcastle. Sent to America in 1775, he fought at Bunker's Hill, and in 1776 was repulsed in an attack on Charleston, but was shortly afterwards knighted for his services. under Howe. After Burgoyne's surrender in 1778 , Clinton succeeded Howe as commander-in-chief of the forces in North America, which he at once concentrated in New York. In 1780 he captured Charleston and the entire southern army; but after Cornwallis' capitulation at Yorktown in 1781, Clinton resigned his command and returned to England, where in 1783 he published a Narrative of the campaign. In 1794 he was appointed governor of Gibraltar, and died there, 23d December 1795. His two sons both rose to be generals in the army and G.C.B.'s, the younger being one of Wellington's favourite officers.

Clinton, Henry Fynes, a great classical scholar, was born January 14, 1781, at Gamston, in Nottinghamshire. He was educated at Southwell, Westminster, and Christ Church, Oxford, where he graduated B.A. in 1803. He represented Aldborough in parliament from 1806 till 1826. He 
dicd at Welwyn, Octolver 24, 1852. His great works on Greek and Roman chronology are unlikely ever to be snperseded or forgotten. These are the Fasti Hellenici (1824-34), and Fasti Romani $(1845-50)$.

Clinton Group, name given in North America to a subdivision of the Upper Silurian strata.

Cllo, in Greek Mythology, the Muse of History and Epic Poetry. She was represented as sitting with a half-opened scroll in her hand, and a casket for holding manuscripts at her feet. See Muses.

Clio, a genus of shell-less pelagic molluses in the class of Pteropods. They oceur in myriad swarms in northern ( $C$. borealis) and southern (C.australis) seas, and along with such related forms as Limacina form the principal part of the food of some species of whales. The whalers rightly call it 'whales' food.' The whale has simply to swim through a shoal with its mouth open to engulf thousands. Clio is a small animal of a spindle-shape, towards an inch in length, with distinet head, bearing six tentacle-like processes, which are sensitive and glandular, and in part used for laying hold of the prey of small animals. It is active in habit, rising to the surface when ealm, or as rapidly sinking again. It swims hy means of two locomotor expansions of the 'foot.' See Pteropoda.

Clipper is a name familiarly given to a sailing. ship built expressly for speed. Aberdeen was long celebrated for building swift tea-clippers, which since 1860 have been gradually superseded by steamers. The Baltimore clippers were also famous. As to the possible rate of speed, it may be noted that the Lightning, built at Boston, U.S., in 1854, during a voyage from Melbourne to Liverpool ran 2550 English miles in one week, or at the rate of about 15 is miles an hour during the whole period.

Clipping the Coin. See Coining.

Clitheroe, a municipal borough in Lancashire, on the left bank of the Ribble, 35 miles N. of Manchester, and $225 \mathrm{NNW}$. of London by rail. It lies on a low eminence of carboniferous limestone, at the base of Pendle Hill, which is 1831 feet high. Clitheroe has cotton and paper mills, and extensive lime-quarries are wrought in the neighbourhood. Its ruined castle, founded by Robert de Lacy in the later part of the 12th century, was dismantled by the parliamentarians in 1649. The free grammar-school dates from 1554. About 4 miles southwest of Clitheroe lies Stonyhurst College (q.v.). Clitheroe has been a borough since about 1280 . Till 1832 it returned two members to parliament; till 1885, one. Pop. (1851) 7244; (1881) 10,176; (1891) 10,815. See Whitaker's History of Whalley and Clitheroe (1801; 4th ed. 1872-76).

Clive, Caroline, novelist, was born in London, 24th June 1801, the daughter of Mr Meysey. Wigley, M.P. for Worcester. In 1840 she married the Rev. Archer Clive; and, for several years a great invalid, she died, through her dress catching fire, at Whitfield, Hereford, 13th July 1873. Between 1840 and 1872 she published eight volumes of poems by 'V.', but she is best known by Paul Ferroll (1855), a really atrong sensation novel, much superior to Why Paul Ferroll leilled his Wife (1860).

Clive, KITts, comic actress, was born in Lon. don in 1711, the daughter of William Raftor, a Jacobite lawyer from Kilkenny. She came out at Drury Lane about 1728, and chiefly at Drury Lane she continued to play till 1769 , when she quitted the stege, and retired to Twickenham. Abont 1731 she had married George Clive, a barrister, but they soon parted. She died at Little Strawberry Hill, 6th December 1785. Garrick, Handel, Horace Walpole, and Dr Johnson all liked her, the last remarking to Boswell that 'in the sprightliness of humour he never had seen her equalled.' And of him she said: 'I love to sit by $\mathrm{Dr}$ Johnson; he always entertains me.' See her Life by Percy Fitzgerald ( 1888).

Clive, RoBErT, the creator of our Indian empire, was born at the manor-honse of Styche, neas Market-Traytun, 29th September 1725. He was the eldest of thirteen children; his father, a lawyer and small landowner, of a very old Shropshire family. The boy was brought up by an uncle near Eccles. There, and at all his four schools-Lostock. Market-Drayton, Merchant Taylon', and Hemel. Hempstead-he proved a much better fighter than scholar, a thorough young dare-devil; and in $\mathbf{1 7 4 3}$ he was packed off to India as a writer in the service of 'John Company.' He reached Madras pennilesm, and the drudgery of his life there moved him to suicide. But the pistol snapped twice, and he flung it from him, exclaiming: "It appears I am destined for something ; I will live."

The eapture of Madras by the French (1746), Clive's escape thence to Fort St David (the scene of his gallant duel with the card-sharper), his share in its defence, in the iruitless siege of Ponlicherry (1748), and in the storming of Devikota (1749)these events bring us up to the August of 1751, and Clive's daring dash upon Arcot. He seized it, and held its enormous citadel for eleven whole weeks against 7000 natives and 120 French soldiers. His own little force was reduced to 80 Englishmen and 120 sepoys (splendid fellows these); but, after a last desperate assault, the siege was raised (14th Novenber), and Clive followed up his success by the victories of Ami and Kaveripak, and the cap. ture of Kovilam and Chingalpat.

In February 1753 he married Margaret Maskelyne, sister to the astronomer, and immediately after sailed with her for England, where he was presented with a diamond-hilted sword, cleared his father's estate from encumbrances, stood for St Michaels, but was unseated, and otherwise got through a very fair fortune.

So in Oetober 1755 he was back in India, and a twelvemonth later was summoned, with Admiral Watson, from Madras, to avenge the atrocity of the Black Hole. Calcutta was soon retaken; Chandernagore, the French settlement, captured; and at Plassey, on 23d June 1757, Clive's 3200 men (two-thirds of them sepoys) encountered Suraj ud Dowlah's 50,000 with 40 to 50 French gunners. The battle took eight hours to win, that truly "decisive battle of the world." But its lustre was sullied by the only two blots on Clive's memory. In his dealings with Mir Jatfier, the would-le next nawab of Bengal, he had imposed on a go-between, the merchant Omichand, with a fictitious treaty, to which he had forged his colleague Watson's signature; and now from Mir Jaffier he accepted a present of upwards of $t^{*} 200,0(0)$. Buth actiuns are defended by Malcolm, both sternly condemned by Macaulay and Malleson.

For three years sole ruler in all but name of Bengal, Clive, in 1760 , with a fortune of more than $\mathfrak{1 4 0 , 0 0 0}$ a year, returned to England, to be hailed by Pitt as ' a heaven-born general;' in India he was known as Sabat Jung, 'the daring in war.' In 1761 he entered parliament as member for Shrews. bury ; in 1762 was raised to the Irish peerage as Baron Clive of Plassey; in 1764 was created a Knight of the Bath. But meanwhile in India the Company's affairs, through the dishonesty of its servants, high and low, had fallen into the utmost disorder; and Clive was the only man who could set them right. He arrived at Calcutta in May 1765, and at once applied himself wisely and firmly to reform the civil service and re-establish military discipline. This second governorship, lasting but 
twenty-two months, marks the beginning of our Indian administration, as Plassey of our military supremacy.

Early in 1767 Clive quitted India, never to return; in all he had spent there less than a dozen years. This time he came back to England poorer than when he last left it; but this time he came back to encounter a storm of obloquy. The energy with which he had cleansed that Augean stable had raised up a host of influential enemies, who employed their influence to gratify their enmity, to stir up ill-feeling against him. His early proceedings in India were in 1772 made the subject of animadversion in parliament, and next year matter for the inquiry of a select committee. He was examined and cross-examined more like a sheepstealer than the Baron of Plassey. Indignation at treatment so unmerited found vent at last in the exclamation: 'By heaven, $\mathrm{Mr}$ Chairman, at this moment I stand astonished at my own moderation.' The censure implied in the ultimate resolution was hardly wiped out by its rider, that he 'did at the same time render great and meritorious services to his country' (21st May 1773). Sickness, opium, niental depression - on 22d November 1774 Clive died by his own hand. He is buried in the church of Moreton Say, the parish that gave him birth.

Clive's eldest son, Edward (1754-1839), was governor of Madras 1798-1803, and in 1804 was made Earl of Powis, having in 1784 married the daughter of the last Herbert Earl of Powis.

See Aroot, Dopleix, India ; Sir John Malcolm's Life of Clive (3 vols. 1836), with Macaulay's essay thereon; two works by Malleson (1882 and 1893); Sir Charles Wilson's Clive (1890): Sir A.J. Arbuthnot's Clive (1899); and Browning's Dramatic Idylls (2d series, 1880 ). For the conflicting accounts of the manner and place of Clive's death, whether by penknife, razor, pistol, or poison; whether at his mansion in Berkeley Square, or his Shropshire seat, Waleot Park, see Horace Walpole's Letters to the Countess of Ossory (i. 155); the Gentleman's Magazine for September 1848, p. 227 ; and several articles in Notes and Queries for 1888.

Cloa'ca, in Zoology, the technical name for the common terminal chamber into which the alimentary canal, the genital and the urinary ducts, all open. A cloacal chamber and aperture occurs in many fishes, in all amphibians, reptiles, and birds, and in the three lowest mammals. In all other manmals the urinogenital orifice is independent of the end of the alimentary canal or anus.

Cloa'ca Maxima, the most important of the sewers of ancient Rome, according to tradition, con. strueted by Tarquinius Priscus, or by Tarquinius Superbus, to drain off the stagnant waters of the Velabra, a swampy land between the Capitoline and Palatine hills on which the Forum and Circus Maximus also stood. Running from the valley of the Subura, under the Forum along the Velabrum, it opened into the Tiber in an archway still 11 feet wide by 12 feet high, consisting of three concentric arches, built of large blocks of peperino stone, fixed together without cement, of the uniform size of rather more than 5 feet 5 inches long and 3 feet high. The sewer was flushed by a continual stream of superfluous water from the aqueducts. Large portions of this and of the other cloacre remain entire after two thousand years, but the greater part is buried, by the accumulation of soil, at a considerable depth below the present level of the streets. During the Republic, the surveillance of the Roman cloacre was one of the duties performed by the censors. The cloaca maxima was repaired by Cato and his colleague in the censor. ship. Agrippa, when redile, obtained praise for his exertions in cleansing and repairing the cloacre, and is recorded to have passed through them in a boat. Under the empire, officers called curatores cloa- carum urbis were appointed for their supervision. So thoroughly was the city undermined by these large sewers that Pliny calls it urbs pensilis, a city suspended in the air.-Cloacina ("The Purifier") was a surname of the goddess Venus at Rome.

\section{Clocks. See Horology.}

\section{Clodius. See Cicero.}

Clog Almanac, the name given in England to a primitive kind of calerdar or almanac, called also a ' rim stock' and 'prime staff.' In Scandinavia it was called a 'Runic staff,' from the Runic characters used in its numerical notation. It was generally of wood (whence its name of 'clog'-i.e. log or block), of about 8 inches in length, but was sometimes of brass, of bone, or of horn. When of wood it was most commonly of box; but elm, fir, and oak were also employed. 'This almanac,' says Dr Plot, in his Natural History of Staffordshire, written in 1686, when it was still in use among the common people of that county, 'is usually a square piece of wood, containing three months on each of the four edges. The number of days in them are expressed by notches: the first day by a noteh with a patulous stroke turned up from it, and every seventh by a largesized notch. Some are perfect, containing the dominical letters as well as the prime and marks for the feasts, engraven upon them, and such are our prime

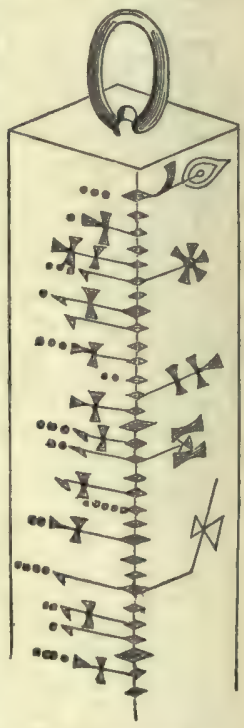

Clog Almanac for January. staves in the Museum at Oxford: others imperfect, having only the prime and immovable feasts on them, and such are all those I met with in Staffordshire.' The marks on the left side, in the figure, indicate the golden numbers of a cycle show. ing the new moons throughout the year. On the right side against the 6th January is a star, the symbol of Epiphany; against the 13th St Hilary is shown by the bishop's double cross ; 25 th, conversion of St Paul, by an axe. The mark against the first notch (or New-year's Day) symbolises the Circumcision of our Lord. Christmas was marked by a horn, the sign of health-drinking-notans cornua exhaurienda, as Dr Plot quotes. Examples of the clog almanac may be seen in the British Museum (one cut apparently towards the end of the 17th century); in the Ashmolean Museum and the Bodleian Library at Oxford ; in St John's College, Cambridge; and in the Cheetham Library, at Manchester. It is described by the Swedish historian, Olans Magnus, in the 16 th century; and by the Danish antiquary, Olaus Wormius, in the 17 th century. Some of the clog almanacs show a peculiar numerical notation. The first four digits are marked by dots; the fifth, by a sign like the Roman numeral V ; the next four, by this sign and additional dots ; and the tenth, by the sign + . See Chambers's Book of Days.

Clogher, a decayed episcopal city of County Tyrone, on the Blackwater, 15 miles SSE. of Omagh. The Protestant Episcopal see is now united to that of Armagh. The cathedral and episcopal palace are handsome edifices; but, though formerly a parliamentary borough, the place is now a mere village. Pop. 225.

Clogs are a sort of shoes, the uppers of which are leather and the soles of wood (specially alder 
wood): much used in the north of England and sonth-west of Seotlend, specially in winter.

Cloisonné. Bee ENamel.

Cloister (Fr. cloitre, claustrum, 'an enclosure'), a covered passage or ambulatory runuing round

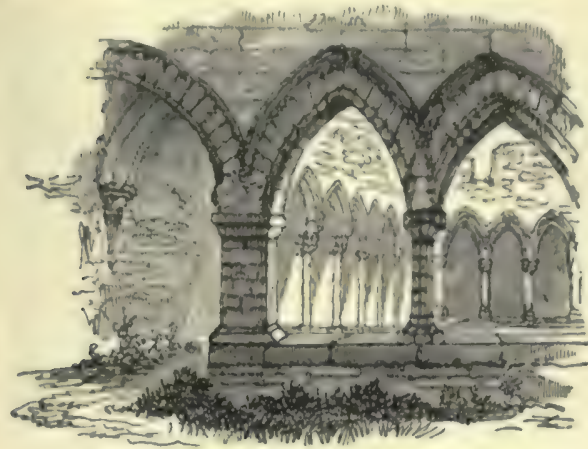

Cloister, Kilcomnel Abbey.

the walls of certain portions of monastic and collegiate buildings. The cloister usually surrounded or ran along three or four sides of a quadrangular area, which was called the cloister garth, generally situated on the south or sunny side of the church, as ahown under СнURCH in the ground-plan of Durham cathedral. That of Salisbury, one of the finest in the kingdom, is 195 feet square. The roof of the cloister, which was often vaulted, was supported on the side next to the quadrangle by pillars and arches, which were frequently oceupied by tracery. The upper portions of these arches above the mullions were often glazed; and sometimes latterly even the whole arches, so that they became a row of windows, as at Gloucester. Cloisters were used for exercise and recreation by the inmates of the religious bouses. Occasionally, when wholly glazed, they had cells or stalis for study on the inner side; and very frequently a : atone bench may still be seen, which runs along the same side. Many of the larger monasteries had more cloisters than one; and so characteristic were they of the religious houses, that the term cloister came to be used in a general sense for the whole establishment, which is still the sense of the word .kloster in German. See MoNASTERy.

Clonakilty, a seaport of County Cork, at the head of Clonakilty Bay, 33 miles SW. of Cork, with several corn and flax mills, and a considerable trade in grain. There are 'druidieal' remains in the neighbourhood. Pop. 3276.

Clones, a town of County Monaghan, 94 miles NW. of Dublin by rail, with spade manufactories, corn-mills, and the remains of an abbey and of a round tower. Pop. 2016.

Clonfert, an ancient episcopal city of Ireland, is in the extreme enst of County Galway, and has now a population of 2200 . The bishopric was founded in the 6th century, and ceased to be a separate Anglican one in 1602, being ultimately incorporated with Killaloe; but it is still the see of a Roman Catholic bishop. There is another Clonfert, a pariah in County Cork.

Clonmel', a municipal borough in Tipperary and Waterford counties, on the Suir, 135 miles SW. of Dublin by rail. It has flour-mills, and a trade in agricultural produce, especially butter. In 1650 Cromwell besieged the town, and demolished the castle. Clonmel gave birth to Sterne and Lady Blessington, and was the chief scene of Smith O'Brien's attempted rising in 1848 . Till 1885 it :sent a member to parliament. Here Bianconi (q.v.) first established his jaunting-ears; and Clonmel is still a great tourist centre. Fop. (1891) 8480.

Clontarf', a towa in Crinty Lublin, 8 miles ENE. of Dublin eity, It is much frequented for sea-bathing. Here, in 1014, Brian Boru won a great victory over the Danes. Pop. (1891) 5105.

Clootz, Jean Baptiste du Val de Grace, BARoN, better known as Anacharsis Clootz, was perhaps the most singular of all the frothy enthu. siasts brought to the surface of society by the French Revolution. He was born near Cleves in 1755 , and from his eleventh year was eduented in Paris, While still young he travensed Europe under the name of Anacharsis, lavishing his money to promote the union of all nations in one family. In the French Revolution he kaw the fulfilment of his dreams. He constituted himself the 'orator of the human race,' and wearied out the National Assembly with his endless rant, at one time leading in a tatterdemalion regiment of strangers dressed in the costumes of different nations, at another raving at Christianity and preaching in sereams the wor. ship of Reason. 'He gave his vote for the king's death 'in the name of the human race.' With all its folly his enthusiasm was honest, and he was at once hated and feared by the jealous Robespierre, who had him excluded as a noble from the Jacobin Club, and at last involved him in St Just's im. peachment of Hébert and his adherents. He was guillotined, March 23, 1794, preaching materialism to the last, and protesting against his sentence, as usual, 'in the name of the human race.' Of his absurd books, may be named : Certitude a'es Preuves du Mohammédisme (Lond. 1780), L'Orateur du Genre Humain (1791), and Base Constitutionnelle de la République du Genre Humain (1793). See his Life by Avenel (2 vols. Paris, 1865).

Close, in England, specially the precinets of a cathedral. In Scotland the word means a narrow side-street, or a passage leading to a court, or to the stair of a block of tenements.

Close Time, the time during which game, certain wild birds, salmon, and some other fish may not be shot or caught, varies for the different animals and for different places. Lists of the dates may be found in such almanacs as Whitaker's; and see WILD-FOWL, SALMON, TrouT, \&c.

Closterseven. See Cumberland (Dukg of).

Closure (formerly in the French form cloture), the name used for a power given in 1882 to the Speaker of the House of Commons, or chairman of committees, to close a debate when it seems to him that the subject has been discussed, and he is authorised to do so by a motion duly supported. For the rules of procedure, see Parliament.

Clotaire I. (Hlothar), son and successor of Clovis (q.v.), first king of the Franks in Gaul, reigned as sole king from 558 to 561 . - CLOTAIRE II., of the same Merovingian dynasty, reigned over the Franks thirty years later. See Fra NCR.

Cloth. See (under Woor) Woolen Clotu ManUfacture and Worsted MaNufacture.

Clothes-moth. See Moths.

Clotho, one of the Fates. See Fatr.

Clotho, a genus of spiders which spins a curious tent for itself and its young. See SPIDERS.

Clotilda. Sr, born in 475, was the daughter of Chilperic, king of Burgundy, and in 493 became wife of Clovis, ling of the Franks, She was the chief means of securing the conversion of her husband to Christianity, and largely influenced his life. After his death she lived a life of susterity at Tours, where she died in $\mathbf{5 4 5}$. She was canonised a few years after. Her remains were buried in the church of St Genevieve at Paris, and burnt 
at the Revolution to prevent their desecration. See Life by Professor Kurth (Eng. trans. 1899).

Cloudberry (Rubus Chamamorus), a plant related to the bramble, although of very different appearance, having a herbaceous single-flowered stem destitute of prickles. The plant is of humble growth, 8 to 10 inches in height; the leaves few, large, lobed, and kidney-shaped; the flower large and white; the fruit orange red, equal in size to a bramble-berry, and of an agreeable flavour. It is a native of the northern parts of Europe, Asia, and America In Britain it is ehiefly confined to elevated moors; in Norway and Sweden it is much more abundant, and the fruit is highly valued and made into excellent preserves.

Clouds are masses of fog, consisting of minute particles of water, often in a frozen state, floating in the atmosphere. When air has its temperature lowered below the saturation point, either by ascending and becoming rarer, or by meeting a colder current, a portion of the vapour loses its gaseous form, and becomes condensed into minute specks of water: It has been shown by Dr Aitken that this condensation always takes place round a small particle of dust. A cloud, therefore, does not consist of vapour, in the proper sense of the word, but of very small drops of water. How this waterdust is suspended in the atmosphere--why the particles do not descend as soon as formed, has never been thoroughly explained. Professor G. G. Stokes holds that the rate of fall is rendered exceedingly slow by the friction and drag of the air-particles, just as fine powders remain suspended for a long time in liquids of much less specific gravity than themselves. Besides, as Sir J. Herschel says, ascending air-currents also oppose the fall of clouds, for the air may be ascending faster than the particles of the cloud are falling through it; while at night, in the absence of rising currents, clouds often descend to, and dissolve in lower and warmer levels. The conditions under which clouds are formed, and afterwards deposited in rain, are more fully considered under Evaporation, DEW, RAIN, SNOW-LINE (under article SNow). The present artiele is confined to a deseription of the various kinds of clouds and of the weather they indicate.

A general haze of precipitated vapour covering the sky, and coming down to the earth, is termed a Fog or Mist ; and the term cloud is usually confined to masses of fog floating in the higher regions, and not descending to the ground. They are mostly within a mile of the earth's surface; and few are more than six miles above it. From observations made at Upsala in Sweden, it has been found that there are three principal eloud layers: the low clouds at from 2000 to 6000 feet; middle clouds, 12,000 to 15,000 feet; and high clouds, 20,000 to 27,000 feet. These three layers are found at apparently much the same heights all over the earth. Clouds spread and move with the wind in varied, often grand forms; they are generally disposed in beds parallel to the earth's surface; vertical clouds occur rarely, if at all.

Mr Luke Howard's classification of clouds, proposed in 1802, into three primary forms-Cirrus (Cir.), Cumulus (Cum.), and Stratus (Str.); three intermediate-Cirro-cumulus (Cir.-c.), Cirro-stratus (Cir.-s.), and Cumulo-stratus (Cum.-s.); and one compound form, Nimbus ( Nim.) - has been universally adopted, and has been shown by the Hon. Ralph Abercromby and others to hold good in all climates and atmospheric conditions.

Cirrus, or curl cloud, consists of parallel, curling, flexuous, diverging, and partly straight fibres, increasing in any or in all directions by elongation, branching, or addition of new fibres. It is the highest and least dense of clouds; varies most in extent, direction, and shape; retains longest its varied outlines; and is the longest illuminated after sunset and before sunrise. It has been com. pared to a mare's or eat's tail, a lock of hair, fine

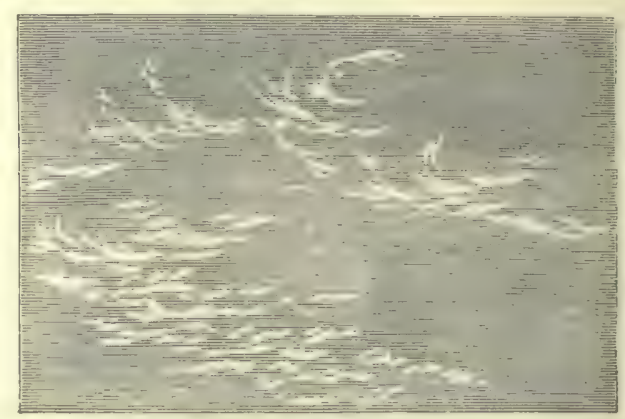

Cirrus.

trellis-work, or thin silvery streaks, and it may cover all the sky. Threads and groups of Cir., during gentle wind after severe weather, presage serene settled weather. But after a long tract of fair days, whitish filaments or parallel bands of Cir. crossing the sky, with the ends converging by perspective in each horizon, foretell a change to wet; they move with the upper currents of the atmospliere, and generally indicate by this motion a change of wind long before it is felt on the earth's surface. Cir., being so high, consists of minute ice crystals, whose refractions and reflections produce the halos, coronæ, and mock suns and moons almost restricted to this cloud and its derivatives the Cir.-8. and Cir.-c. Cir., especially with fine tails, varying much in a few hours, presages rain or snow, and windy variable weather.

Cumulus, ball of cotton, day or summer cloud, consists of dense, convex, hemispherical, or conical heaps of small roundish clouds, piled or stacked on each other. The heaps enlarge upwards from a

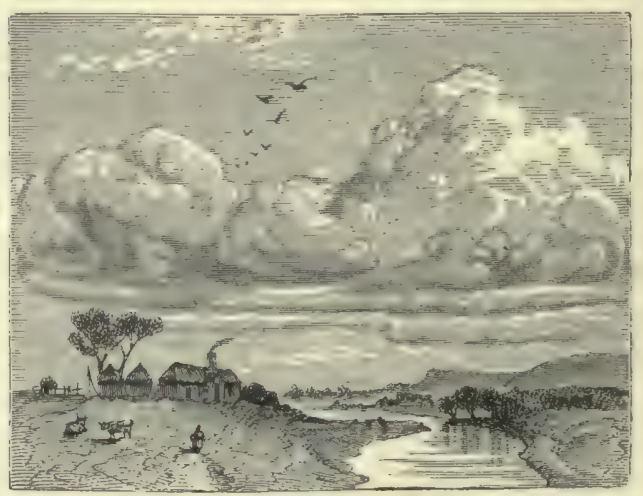

Cumulus.

horizontal base, and have rounded or rocky tops ; they sometimes unite into stupendous white-topped mountains. It is formed by the condensation of vapour in local ascending columns of air, and is generally at from 4000 to 6000 feet elevation. Cumuli often begin after sunrise as a few scattered specks in the clear sky; these specks enlarge and unite to form clouds, which nearly cover the sky in the afternoon, and generally decrease and vanish about sunset; but rain follows if they increase in number and darkness in the evening. Cum.. of 
plensing forms, dispositions, and colours, and of moderate size, presagen tine dry warm and calm days: but cold, rain, and tempest follow dark, abrupt, dense, shaggy Cum., covering the sky, and rolling on each other. Hemispherical, silvery white Cum. presages thunder.

Stratus, fall or night-cloud, the lowest of elouds, is a widely extended, horizontal sheet, of varied thickness, seldom rising above 4000 feet, and often quite close to the earth's surface. It is common in

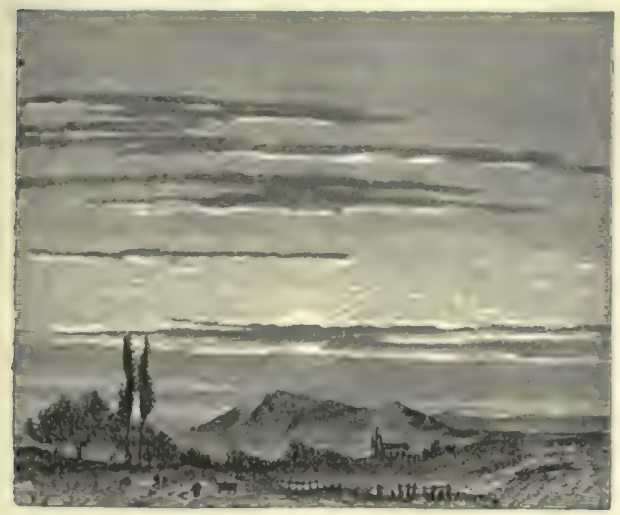

Stratus.

summer and autimn, often from sunset to sunrise, and is densest at or after midnight. It arises in calm elear evenings, after warm days, from the sinking and flattening out of Cum., from the cooling of moist air on damp ground, marshes, lakes, rivers, or from the cooling of moist air mixed with smoke enveloping great eities. From a height it is seen spreading around like a sea, and creeping up hillsides. After sunrise it rises higher, sometimes forming Cum., and sometimes entirely disappearing; but it may quietly accumulate in layers, and become Nim.

Cirro-cumulus, or sonder-cloud, consists of Cir. compressed into dense roundish-white cloudlets, or woolly irregular tufts, and is found either in the middle or high eloud layers. It forms the wellknown mackerel sky, but is also often seen through breaks in lower clouds moving differently. It may vanish or pass into Cir. or Cir.-8. Solar and lunar coronx appear in it. It occurs in warm dry weather and between summer showers, and presages increased heat. Cir.-c. very dense, round, and close, and with Cum.-8., presages a storm or thunder. In winter it precedes a thaw and warm wet weather.

Cirro-stratus, or vane-cloud, consists of long, thin, horizontal clouds, sometimes hairy, with bent or undulated edges. It is found on the advancing side of cyclonic storms, and hence is a sure prog. nostic of wind or rain. Being of great extent, but little depth, and at a great height, it is the most usual source of solar and lunar halos.

Cumulo-stratus, or twain-cloud, is a Cir.-8. mixed with Cum. heaps, or a wide flat base surmounted by a bulky Cum., with fleecy protuberances or rocky and mountain masses. It is much denser than Cum., thcugh being formed by less rapidly ascending currents, the air is not dry enough to round off sharply its tops. It often forms vast lanks of cloud, with overhanging masses. It is common towards night in dry windy weather, when it has a leaden hue. It generally arises from Cum. becoming denser, wider, and protrudiug in large irregular projections over the base. It tends to overspread the sky, and partly or wholly to become Nim., and fall in showers. Cum.-8. is intermediate between clouds indicating fair and thome indicating rongh, rainy weather, and attends sudden atmospheric changes. Distinet Cum.-1s. forms before thunder. Cum. $-\mathrm{s}$. increases the grandeur of mountain scenery, and drops on and envelop mountain. tops like a curtain.

Nimbus, or Cumulo-cirro-stratus, the black rain. cloud, is a cloud, or mixed system of elouds, with rain or snow falling from it. It is a dense, con. tinuous, horizontal black or gray sheet, with fringed edges, having rolling masees of Cum. above it and topped by Cir. Before rain, vast towrering masses of Cum. often pass into Cum. ${ }^{3}$, which, increasing in density, darkness, irregularity, and extent, become Nim. capped by Cir.-8. Thunderstorms are always accompanied by $\mathrm{Nim}$. in its most perfect forn.

The term scud has been applied to loose vapoury fragments of clouds driven by wind, and cumulonus to very shaggy cumuli.

The formation and beight of clouds depend on the quantity of vapour in the air, the course and height of air-currents, the elimate, season, tempera. ture, disposition, and extent of sea and land, and the height of land. The highest elouds yet observed were Cir. at $\mathbf{4 3 , 8 0 0}$ feet elevation. Remark. able cloud-rings prevail over the calm zones of the eruator, and over those of Cancer and Capricorn. The tops of mountains are often capped by clouds formed by the moisture in the air condensing as it is forced up and over the hill. Clouds, viewed from above in bright sunshine by the aerronaut or mountaineer, appear as dense volumes of steam or masses of white cotton.

Clouds moderate the sun's rays during day, and the earth's radiation during night. They always exhibit positive or negative electricity, but of greatest tension in thundenstorms. They are the carriers of the moisture required by plants; of the water of springs, lakes, and rivers; and of the polar, glacial, and winter snows, which cover temporarily or permanently parts of the earth.

In Britain, six or seven tentlis of the sky is on an average daily obscured by clouds. There is most cloud in winter, and about mid-day, and least in May or June, and during night. Summer and antumn nights are freest of clouds. All the forms of clonds may be seen in one day, often very much commingled.

Clough, Arthur Hugh, poet, was born at Liverpool, January 1, 1819. His father, a cotton. merchant there, belonged to an old Denbighshire family. In the winter of 1822-23 he emigrated to Charleston, in South Carolina, and there the boy mostly lived in the midst of a home-life of singular happiness, until in November 1828 he was sent back to school at Chester, and to Rugly in the summer following. Dr Arnold had already been head-master for a year, and his high ideal of Christian duty early made a profound impres. sion upon the boy. At Rugby he was foremost in athletic sports, edited for some time the school magazine, and not only worked his way to every honour open to him, but gained the warm affection of all his school-fellows. In November 1837 he entered Balliol College, Oxford, but aston. ished all who knew his powers by only obtaining a second-class in 1841. In the spring of the follow. ing year he was elected to a fellowship at Oriel. Clough's residence at $O x$ ford had fallen at a time of fierce theological controversy, and his sensi. tive spiritual nature reflected all the unrest of the atmosphere around him. For a time he fell under the spell of Newman's influence, but this was soon followed by a period of severe inward strugyle between his absolute honesty of mind and the religions prepossessions of his youth, the result of which was that he felt it his duty to withdraw in 
1848 from Oriel. A little earlier he had published his first long poem, the Bothie of Tober-na-Vuolich, a 'Long Vacation pastoral' in hexameter verse. He next spent some time in travelling in France and Italy, part of the time with Emerson, and was appointed on his return (October 1849) Warden of University Hall, London. His life here was far from congenial to him, but he found much help in the warm friendship of Carlyle. At Rome, in 1849, he had written his Amouns de Voyage, and at Venice, during a holiday in 1850, he wrote Dipsychus. In 1852 he resigned his office, and sailed to America; but an examinership in the Education Office soon recalled him to England. In June 1854 he married, and the remaining seven years of his life were spent in the calm peace of domestic happiness, free at once from the unrest of religious perplexity and the vexation of his earlier monetary liabilities undertaken for the sake of his father's business. In the spring of 1856 he was nominated secretary to the Commission for examining seientific military schools on the Continent, and the duties of this office carried him to France and to Vienna. But his health now began to give way, and he was advised by his physicians to travel. After visits to Greece, Constantinople, the Pyrenees, and Italy, he was carried off at Florence by paralysis succeeding a malarial fever, November 13,1861 .

Clough's poetry reflects with absolute sincerity all the spiritual unrest and conflict of his life, his passionate love of truth, and intense longing for reality. His few short lyrics are almost perfect in form and matter, but, as an artist in words, his best gift was perhaps his undeniable humour, which is of a rare and indeed exceptional quality. But his true significance is that pointed out with sure insight by Mr Lowell: "We have a foreboding that Clough, imperfect as he was in many respects, and dying before he had subdued his sensitive temperament to the sterner requirements of his art, will be thought a hundred years hence to have been the truest expression in verse of the moral and intellectual tendencies, the doubt and struggle towards settled convictions, of the period in which he lived.'

Clough is the subject of Matthew Arnold's elegy Thyrsis, one of the finest tributes of passionate admiration to the dead in the English language, almost worthy indeed to be compared with the Lycidas of Milton, the Adonais of Shelley, and the In Memoriam of Tennyson. No truer words have been spoken of Clough than these :

The music of his rustic flute

Kept not for long its happy country tone;

Lost it too soon, and learnt a storuy note

of men contention-tost, of men who groan,

Which tasked his pipe too sore, and tired his throst.

See Samuel Waddington's Monograph (1882), A collected edition of Clough's Poems was published in 1862, with a memoir by F. T. Palgrave, and his Poems and Prose Remains, edited by his wife, with an admirable short memoir, in 2 vols. in 1869.

Clove Bark, a name vaguely used for various aromatic drugs; some belonging to the clove, others to the cinnamon alliance. To the former class belong the bark of Eugenia caryophyllata of Ceylon, \&c.; to the latter, the Culilawan bark (Cinnamomum Culilawan) of the Moluccas.

Clovelly, a coast village of North Devon, 11 miles WSW, of Bideford. From its rude little pier it elimbs 400 feet upwards in a steep narrow combe, white house rising over white house, and all nestling in flowers and greenery. Dickens describes it in A Message from the Sea. Pop. of parish, 787.

Clover, or Treforl (Trifolium), a genus of Leguminosæ, sub-order Papilionaceæ, containing a great number of species, natives chiefly of temperate climates, abounding most of all in Europe, and some of them very important in agriculture as affording pasturage and fodder for cattle. The name clover is indeed popularly extended to many plants not included in this genus, but belonging to the same natural order, and agreeing with it in having the leaves formed of three leaflets, particularly to those of them which are cultivated for the same purposes, and sometimes collectively receive from farmers the very incorrect designation of artificial grasses, in contradistinction to natural grasses-i.e. true grasses. See MEDICK and MELILOT. The true clovers (Trifolium) have herbaceous, not twining stems; roundish heads or oblong spikes of small flowers; the corolla remaining in a withered state till the ripening of the seed; the pod inclosed in the calyx; and containing one or two, rarely three or four seeds. About 20 species belong to the flora of Britain, and many are North American.-The most important of all to the farmer is the Common Red Clover $(T$. pratense), a native of Britain and of most parts of Europe, naturalised in America, and growing in meadows and pastures. It is a perennial, but is generally treated as if it were a biennial. This plant was formerly reputed very noisome to witches; knights and peasants wore the leaf as a potent charm against their arts. The Zigzag Clover (T. medium), also called Meadow Clover, Marl. grass, and Cow-grass, much resembles the Common Red Clover, but is easily distinguished by the stems being remarkably zigzag, and more rigid than in $T$. pratense; the heads of flowers are larger, more lax, more nearly globose, and of a deeper purple colour; and the leaflets have no white spot. It is a common plant in Britain and most parts of Europe, and grows sparingly in the

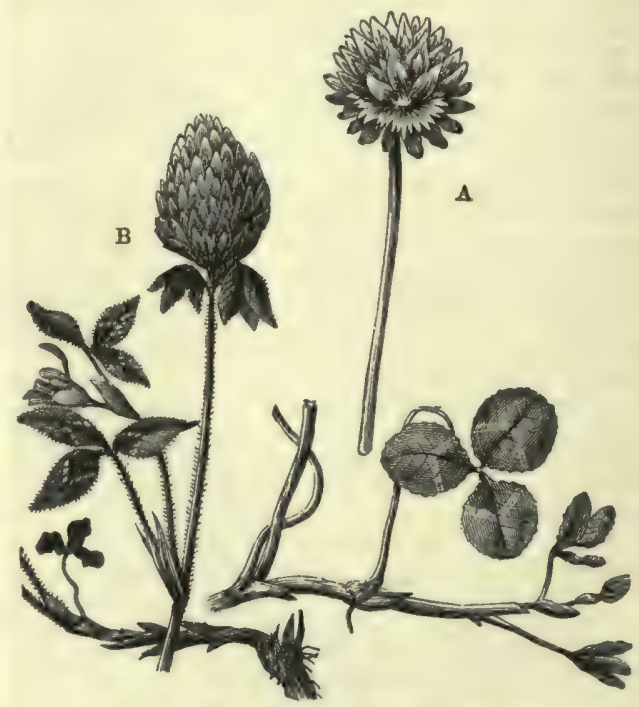

A, White Clover (Trifolium repens).

B, Red Clover (Trifolium pratense).

United States. - White or Dutch Clover ( $T$. repens) is also a common native of Britain and of most parts of Europe, and grows everywhere in North America. When a barren heath is turned up with the spade or plough, White Clover almost always appears. This is sometimes but erroneously called the Shamrock (q.v.). The flowers of all kinds of clover are the delight of bees, but those of this species perhaps particularly so. Alsike Clover ( $T$. hybridum), a perennial species introduced from the south of Sweden about 1850, 
has proved a most valunble forage plant. - Crimson Clover, or Italian Clover ( $T$. incurnutum), an annual, native of the south of Europe, with oblong or cylindrical spikes of rich crimson flowers, is much enltivated in France and Italy, and hos of late been pretty extensively grown in some parts of England, producing a heavy erop. The Crimson Clover is also sometimes employed as a decorative annual in the flower-garden.-Moliner's Clover (T. Molinevi) very much resembles Crimson Clover, lut is bienuial, and has pale flowers. It is cultivated in France and Switzerland.-Alexandrian Clover, or Egyptian Clover ( $T$. Alexandrinum), an annual species, a native of Egypt, universally cultivated in its native country, where it is the principal fodder for cattle, has been tried in Britain, but the colder climate has been found to render it less luxuriant and productive. It is aupposed to be one of the best kinds of clover for many of the British colonies. It has oval heads of pale-vellow or whitish flowers. - Yellow Clover, or Hop Trefoil ( $T$. agrarium), is very common in dry gravelly soils in Britain, and in parts of the United States, but is not much esteemed. It has smaller leaves and heads of flowers than any of the cultivated species. Its flowers are yellow.-The Showy Clover ( $T$. speciosum) is the only plant made into hay in the island of Zante, and has therefore been recommended on trial as a fodder plant in the south of England and the warmer colonies. None of the strictly native North American species have been much utilised as forage plants.

It is little more than a century and a half since elovers were introduced into field-culture in Britain. They are now universally cultivated on large farms in alternation with grain-crops. The kinds most generally sown are the Common Red, Cow-grass, Dutch White, Yellow, and Alsike, The Common Red is the finest and most valuable, but it is difficult to grow unless on naturally rich soils. Land must be thoroughly cleaned of perennial weeds before it is sown with elover, as the land cannot be subjected to cultivation while it is under this plant; clover, therefore, is always sown in the end of the rotation, or as near the fallow or turnip crop as possible. A well-manured soil greatly assists in keeping the plants from dying out in spring. Clovers, like grasses, play a most important part in restoring fertility to land which has been exhausted by grain-erops. Their leaves gather food-carbonic acid and ammonia-from the atmosphere, which they store up in their roots and stems; and these, on decomposing, afford food for cereals or other crops which are more dependent on a supply within the soil.

The eaterpillars of a number of species of moth feed on the leaves of different kinds of elover; but the insects most injurious to clover crops are weevils of the genera Apion and Sitona. See Clover-Weevil, and WeEviL.

Clover-weevil, a small black beetle of the genus A pion, which in larval and adult state infests clover and other leguminous plants. See WEEVII.

Cloves (Span. clavo, 'a nail') are the flowerbuds of the Clove-tree (Caryophyllus aromaticus). The genus to which this tree belongs is of the natural order Myrtacere; the tree is from 15 to 40 feet high, with a beautiful pyramidal head. The leaves are large, ovate-oblong, acuminated at each end, evergreen; the flowers are small, but produced in great profusion in cymes. Leaves, Howers, and bark have an aromatic odour. The ripe fruit resembles an olive in shape, but is not quite so large; it is of a dark-red colour; it sometimes appears in commerce in a dried state, under the curious name of Mother Cloves; it has an odour and flavour similar to cloves, but much weaker: the broken fruit-atalks are sometimes also used for the same purposes as cloves; but the flower-buds themeelves are the principal product of the tree. They are gathered, and are dried by exposure to the smoke of wood fires, and afterwards to the rays of the sun, or by the latter alone. When first gathered they are reddish, but lecome of a deep. brown colour. The unexpanded corolla forms little round head at the end of the calyx tube,

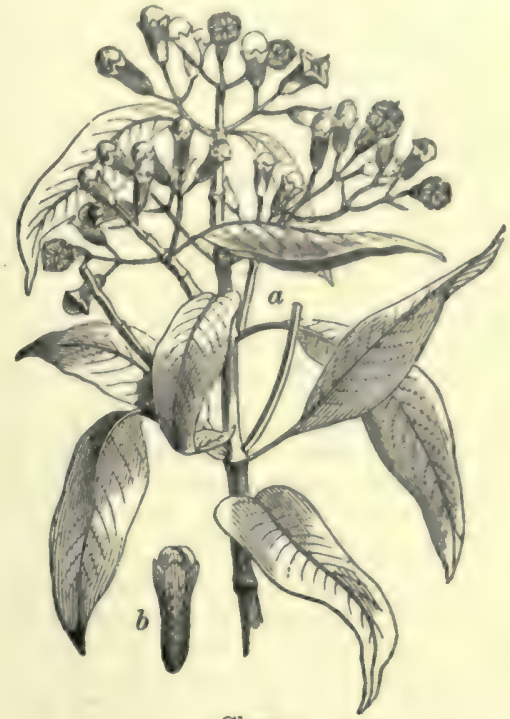

Clove :

$a$, branch with leaves, buds, and flowers; $b$, a bud.

which is about half an inch long, and thus the appearance is not unlike that of a little nail, whence the name. The clove-tree is a native of the Moluecas, and the Amboyna cloves are still esteemed the best; but the tree is now cultivated in Java, Sumatra, Réunion, Mauritius, Zanzibar, Guians, and some parts of the West Indies. The Dutch, in order to secure a monopoly and keep up the price, destroyed the trees in the other Molucca. Islands in the 17th century, and confined the culti. vation of them to Amboyna. In 1770 the French succeeded in introducing the plant into the Isle de Bourbon (Réunion). It is not deemed quite certain that cloves are the karyophyllon of the ancient Greeks; but before the discovery of the Spice Islands eastern merchants brought them from Arabia, Persia, and Egypt, to the harbours of the Mediterranean, from which the Venetians and Genoese diffused them over Europe.

The Wild Clove-tree of the West Indies is Myrcia acris. See MYrcia.

The properties of cloves depend chiefly on an essential oil, Oil of Cloves, which forms one-fifth or one-sixth of their whole weight. They are used for flavouring dessert dishes and articles of confectionery, also for driving moths from clothing, furs, \&c., by placing them in the boxes or drawers with the elothing. They are also reputed to possess febrifuge properties. They have a hot taste and a characteristic odour. The oil of cloves is obtained by repeatedly distilling eloves with water, when two oils pass over, one of which is lighter and the other is heavier than water. The oil has a hot acrid taste, is of a light yellow when pure, and brown red when not so earefully pre. pared. It has a well-known odour, and is soluble in ether, alcohol, and the fixed oils. It is useful in medicine to check nausea and griping, caused by the administration of purgatives, and has consider- 
able reputation as a cure for toothache. It is also employed in the scenting of soap, and by the distiller. Tincture of Cloves is obtained by treating cloves with alcohol for several days, and then straining, or by a solution of the ofl of cloves in spirits of wine. It is added, in medicine, to stomachic, tonic, and purgative mixtures. Cloves are adulterated by adding to the fresh spice more or less of the buds from which the oil has been distilled, and which are thereby rendered practically worthless. The exhausted buds are made to appear fresh by rubbing them between the hands moistened with sweet oil, or otherwise varnishing them with a thin coating of oil.

Clovis (old Ger. Chlodwig, modern Ger. Ludwig, Fr. Louis), king of the Franks, was of the Merovingian race, and was born $465 \mathrm{~A} . \mathrm{D}$. By the death of his father, Childeric (481), he became king of the Salian Franks, whose capital was Tournai. His first achievement was the overthrow of the Gallo-Romans under Syagrius, near Soissons. $\mathrm{He}$ then took possession of the whole country between the Somme and the Loire, and established himself in Soissons. In 493 he married Clotilda, danghter of a Burgundian prince. His wife was a Christian, and earnestly desired the conversion of her husband. In a great battle with the Alemanni near Cologne, Clovis was hard pressed, and as a last resource invoked the god of Clotilda, offering to become a Christian on condition of obtaining the victory. "The Alemanni were routed, and on Christmas Day of the same year Clovis and several thousands of his soldiers were baptised by Remigius, Bishop of Rheims. Most of the Western Christian princes were Arians, but Clovis was strictly orthodox, and, in consequence, was saluted by Pope Anastasius as the 'Most Christian King.' In 507, love of conquest concurring with zeal for the orthodox faith, Clovis marched to the south-west of Gaul against the heretic Visigoth, Alaric II., whom he defeated and slew at Vouglé, near Poitiers, taking possession of the whole country as far as Bordeaux and Toulouse; but he was checked at Arles in 507, by Theodoric, king of the Ostrogoths. Clovis now took up his residence in Paris, where he died in 511. His great aim was the subjugation of all the Frankish princes, and the union of the whole Frankish people into a single powerful kingdom. Clovis II., son of Dagobert, reigned over the Franks from 638 to 656 .

Clowes, William, an Elizabethan surgeon of distinction, was born about 1540, became surgeon at St Bartholomew's Hospital, served with Leicester in the Low Countries, and also on board the fleet that defeated the Spanish Armada. He became surgeon to the queen, and after a prosperous praetice in London retired to a country house in Essex, where he died in 1604. He wrote five books in clear and vigorous English, of which two long continued popular: A Prooved Practise for all Young Chirurgians (1591), and $A$ Treatise on the Struma (1602).

Clown. See Jesters (Court), Pantomime.

Cloyne, an ancient episcopal town of County Cork, 15 miles ESE. of Cork. The cathedral was founded in the 6th century by St Colman; opposite is a finely preserved round tower over 90 feet high. Abont 1430 the see was united to that of Cork, separated in 1678, and reunited in 1835 ; the town still gives its name to a Roman Catholic diocese. Berkeley was Bishop of Cloyne (1734-53). Pop. 1126.

Clubbing, in eabbages, turnips, and other plants of the genus Brassica, a diseased growth of tubercular excrescences in the upper part of the root or lower part of the stem, caused by the larvæ of the Cabbage-fly $\left(q . v_{.}\right)$and of other insects, by which the vigorous growth of the plant is prevented, and crops are often much injured. It is common for gardeners to cut away these excrescences, with their contained larvæ, in planting out young cablages, \&c.; and where they are not so numerous that the injury done by the knife is necessarily great, this plan succeeds very well. Dressings of gas-lime applied to the soil some time before planting is the best preventive of this evil ; but change of crop, when practicable, is of all things the most commendable. Clubbing is sometimes confounded with Anbury (q.v.), from which it is quite distinct.

Club-foot (Lat. talipes) is a distortion of the foot primarily due to shortening occurring in one or other of the groups of muscles which carry out its intricate movements; subsequently, this error in the muscular activity becomes aggravated by shortening of the ligaments which bind the bones together, and ultimately the shape of the bones themselves becomes altered so as to constitute a very serious deformity, difficult to correct. In the majority of cases the condition is congenital, and at the time of birth it is usually only the muscular structures that are affected. Thus it is of great importance to recognise its presence early in life; for until the ligaments and bones become altered, it may be remedied by very simple means, such as manipulation and electric stimulation of the affected groups of muscles. If these simple messures appear ineffectual, recourse must be had to the division of the tendons ('Tenotomy, q.v.), by which the shortened muscles are attached to the bones of the foot. The foot thus freed from the cause of the distortion, should be placed at rest in good position within an immovable apparatus, such as a plaster of Paris case, until healing of the tendons has occurred. The weakened parts should then be
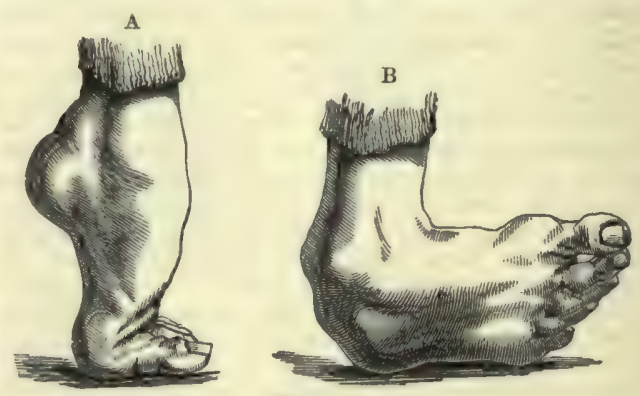

Club-feet :

A, Talipes equinus; B, Talipes varus.

exercised by suitable manipulations which restore their strength. In very bad cases it may be necessary to remove portions of the distorted bones and thus restore the natural shape of the foot.

These affections are very markedly hereditary, and they are in all probability due to disordered function in the nerves leading to the affected muscles, or in the brain or spinal cord, in which these nerves have their origin. Four chief varieties of club-foot are recognised by surgeons: (1) Talipes equinus (fig. A), in which the heel is drawn up, and the patient walks on the under surfaces of the toes; (2) Tripes calcaneus, in which the reverse condition is present, and the patient walks on the heel only ; (3) Talipes varus (fig. B), in which the patient walks on the outer border of the foot; and (4) Talipes valgus, where the inner edge of the sole alone touches the ground. See DEForMITIES.

Club-moss. See Lycopodiace A.

Club-rush. See Scirpus. 
Clubs. The word elub is from the same root as clump; and its secondary meaning of 'a collec. tion of persons' is illustrated by 'a elump of trees.' As specially applied to a select association meeting for social intercourse, it dates from the 17 th century, and the use has since been extended to other bodies having a common object, such as literature, science, amusements, politics, or the furtherance of material interests. The practice of some kind of club-life is almust universal, and ean be traced in the earliest civilisations. Modern travellers in Africa, the Pacific, and elsewhere, constantly speak of a kind of elub-houses where the men meet for gossip and recreation. Vacancies in the public tables anong the Spartans were filled up by ballot, and Aristotle refers to members of the same locality in Greece as clubling for merrymaking. Many such associations both in Greece and Rome were, however, really secret societies for the eultivation of religious mysteries; others were more of the nature of Guilds (q.v.). But there are records of social clubs more closely allied to the modern form, and Cicero tells of his pleasure in frequenting such gatherings. We also hear of a club of old soldiers belonging to the armies of Augustus, and another among the officers of an African legion. Women had their sociable collegia.

In England the history of clubs dates from the Court de Bone Compaignie mentioned by Oceleve in the early part of the 15th century. Nearly two hundred years later the symposis originated by Raleigh made the Mermaid Tavern in Bread Street famous, while Ben Jonson is said to have founded a similar gathering at the Devil Tavern. The Apollo is connected with Jonson's Leges Conviviales. The Rota (1659) and the elubs of the Pestoration were mainly political. The members of the Calves'-head Club (q.v.) were supposed to ridicule the memory of Charles I. The portraits of the members of the Kit Kat Club (1700) are still preserved. Addison, Steele, and the essayists of the Spectator and Tatler class have made us familiar with the coffee-house and tavern clubs of their time. The Royal Society Club (1743) is the earliest of the many dining-clubs associated with the learned societies. To Reynolds is due the institution of the still existing Literary Club (1762), which numbered so many distinguished members, among them Dr Johnson, who established the Ivy Lane and other clubs of a less formal character. Good fellowship and conversation were the leading features of these societies.

The present type of English club is quite different from the earlier bodies bearing the same name. It arose about the commencement of the 19th century, and is characterised by dining and other arrangements whereby members seek to preserve their independence while sharing in the benefits to which their united subseriptions contribute. The modern elub-house is generally a spacious and handsome building, with dining, smoking, billiard, newspaper, writing, and drawing rooms, \&e. Some possess libraries, the most extensive being that of the Athenreum, which owns one of the choicest collections of books of reference in London. The Garrick is famous for its theatrical pictures. Portraits of eminent members are to be found on the walls of many elub-houses. Clubs are usually managed by a changing committee who subinit their accounts and report to an annual meeting. Some are proprietary. The number of members is generally limited. They are either elected by a ballot of the whole club, a certain number of black. balls or contrary votes exeluding, or by the committee, who sometimes choose all or a select number. The revenue is derived from the sale of provisions, \&c. consumed in the house, and from an entrance fee and annual subscription paid by each 124 member. Some clubs have a dining-room to which strangens may be invited; in others a select number of honorary members are admitted. House-dinnen are a revival of a former habit. Many of the recen clubs contain bedrooms for members. Concerts and entertainments are also innovations. Muderate carl-playing is allowed, lat games of rosusce are invariably forbidien in respectable English clubs. Clubs have been instituted to unite vensons of every class, profession, and opinion. There are clubs for ladies alone, and some to which ladies are admitted on equal terms with gentlemen. In others ladies are allowed as guests. It is difficult to say where the club proper ends and the mere drinking saloon commences; some of the numerous working-men's clubs and inferior political clubs fall in the latter class. Others are developments of the old betting and gambling rooms.

The best organised and firest clubs in the world are in London, where there are over a hundred of a high class. The chief among them are the Albemarle (1875), for ladies and gentlemen; Army and Navy (1838); Arthur's (1765), social; Arts (1863); Athenæum (1824), literature, science, and art; Bachelon' (1881), ladies admitted; Boodle's (1762), social; Brooks's (1764), Liberal politicians; Burlington Fine Arts (1866), exhibitions held; Carlton (1832), for Conservatives; City Conservative (1883); City Liberal (1874); Conservative (1840); Constitutional (1883), for Conservatives; Cosmopolitan, conversation; Devonshire (1875), for Liberals ; East India United Service (1849); Garrick (1831); German Athenæum (1869), entertainments given; Grillion's (1812), breakfast parties; Grosvenor (1883), social; Guards' (1813); Hogarth (1870), artistic ; Isthmian (1882); Junior Army and Navy (1869); Junior Athenæum (1864); Junior Carlton (1864); Junior United Service (1827); Literary (1762); Lyric, entertainments given; National (1845), Church of England; National Liberal (1882); National Union (1887), for Unionists ; New Athenæum (1878); New University (1863); Oriental (1824); Orleans (1877); Oxford and Cambridge (1830); Press (1882); Reform (1836), for Liberals; St George's (1874), social ; St Stephen's (1870), for Conservatives; Salisbury (1880), ladies admitted; Savage (1857), literature, drama, \&c.; Savile (1868); Scottish (1879); Thatched House (1865); Travellens' (1819); Turf (1868); Union (1822); United Service (1815); White's (1730); Windham (1828). County clubs are to be found in all English provincial towns. At Edin. burgh the New Club (1787), and in Dublin the Kildare Street (1790), are equal to the best metropolitan elubs. The English in India and the colonies possess luxurious club-houses in which bedrooms for temporary visitors are a convenience.

Well-appointed clubs in the English style have been established in all the leading cities of the United States. Among the best in New York are the Lotos (1870), Union League (1863), Century, Manhattan, Union, Knickerbocker, and University. Gambling and the giving of dramatic and musical entertainments and exhibitions of pictures are special features of club-life on the European continent. The Jockey Club (1833) and the Union Artistique 'Cercle des Mirlitons' (1863) at Paris are representative examples. The political associations formed in Paris at the time of the first revolution exercised considerable influence on public affairs. In 1848 similar bodies in Germany and Austria were suppressed by order of the police. 'Club' is frequently used as an equivalent to society, as in benefit societies, Alpine Club (q.v.), Book-chub (q.v.), and cricket, cycling, yachting, boating, and racing clubs. The word has been adopted in most European languages, although Cercle in France and Circolo in Italy are used. 
See Ned Ward, The Secret History of Clubs of all Descriptions (1709); Ward, Account of all the most Remarkable Clubs and Societies in London and Westminster (1750) ; C. Marsh, The Clubs of London, with Anecdotes of their Members (2 vols. 1832); The London Clubs (1853); Admiral W. H. Smyth, sketch of the Royal Society Club (4to, 1860); J. Timbs, Club-life in London (2 vols. 1866); J. Strang, Glasgow and its Clubs (1857); W. Amold, The Sublime Society of Beefsteaks (1871); Col. G. J. Ivey, Clubs of the World (1880); Sir P. G. Egerton, Grillion's Club (privately printed, 1880); Club-Almanach (Paris, 1883-84, discontinued); L. Fagan, The Reform Club (4to, 1887); F. G. Waugh, Members of the Athenceum Club (1824-87 ; privately printed, 1888 ). The rights and obligations of members are discussed by A. F. Leach, Club Cases (1879), and J. Wertheimer, Law relating to Clubs (1885).

Clugny, or CLUNI, an industrial town in the French department of Saone-et-Loire, on the Grosne, 15 miles NW. of Macon by rail. Pop. 3653. The famous Benedictine abbey, founded here in 910 by the Duke of Aquitaine, had two centuries later attained a degree of splendour and influence unrivalled by any similar institution of the middle ages; at its height, Clugny stood second to Rome alone as a chief centre of the Christian world. It was the asylum of kings, the training-school of popes; its abbot took rank above all others, issued his own coinage, and was a power in the political world; it was enormously wealthy, and covered Europe with its affiliated foundations. Two hundred priors of subordinate houses assembled here in the 12th century, and in the 15th century there were said to be over 2000 religious houses that were offshoots of or connected with the abbey in France, Italy, Spain, England, Germany, and Poland; although the alphabetical list of Clugniac foundations in the 15 th century, at the end of the Bibliotheca Cluniacensis, represents only 825. In England the extension of the order dates from the Conquest; William and his successors were devoted to Clugny, and numerous foundations were shortly established, of which the priory of Lewes (1077) became the chief. At their ultimate suppression in 1539 these numbered 35, exclusive of such Scottish foundations as Paisley and Crossraguel. In the 16 th century, the conventual buildings at Clugny covered upwards of 25 acres. The grand basilica or abbey church, commenced by St Hugh, the eighth abbot, in 1089 , and dedicated by Pope Innocent II. in 1131, was, until the construction of St Peter's at Rome, the largest church in Christendom. Of this magnificent and imposing pile one tower and part of the transept alone remain; the site of the nave is traversed by a road. The abbey, over which cardinal-ministers and princes of the blood had once ruled as commendatorabbots (see CoMmendoAM), had outlived both its utility and its importance; it was no longer a great seat of learning, and its 300 monks had dwindled to 40 , when in 1790 the order to whom Pope Urban II. had said, 'Ye are the light of the world,' was finally suppressed. Its library was the richest and most important in France, and its archives are of the greatest value to monastic history and that of the early Norman kings of England. In 1562 the Huguenots sacked the abbey and scattered its records; but most of this literary treasure was afterwards wonderfully recovered. Many records were burned along with religious books by the mob in 1793, and the library was again scattered; it was generally supposed that nothing had survived, but in 1829 no fewer than 225 folio and quarto volumes of charters and MSS. were discovered in the town-hall, of which many are preserved in the Bibliotheque Nationale, Paris, and some have found their way to the British Museum. For those relating to England, see Sir G. F. Duckett's valuable Record-Evidence of Cluni (1886), and Charters and Records of Cluni (1888). See also the works of Pignot, the historian of the order, Lorain, Penjon, Cuchérat, and Champly. The aneient palace in Paris of the Abbots of Clugny became in 1833 a museum of antiquities.

Clumber, a seat of the Duke of Newcastle 3 miles SE. of Worksop. It has given name to a breed of Spaniels. See SPANIEL.

Clunes, a gold-mining township of Victoria, 119 miles NW. of Melbourne. Pop. 4717.

Clupeidae. See Herring, Sardine, Sprat.

Clu'sia, a genus of tropical trees and shrubs of the order Clusiacer or Guttiferz (q.v.), some of which are commonly called Balsam trees, from their resinous or balsamic products. They are very often epiphytes, growing on larger trees, but also take root in the ground. C. rosea, a native of the West Indies and tropical America, yields a resin, which is used as an external application in veterinary medicine, and for covering boats instead of pitch. The abundant resin exuding from the dise of the flowers of $C$. insignis, the Wax-flower of Demerara, is used to make a gently stimulating and soothing plaster. The name was given in honour of the botanist and traveller Clusius, or Charles de Lecluse (1526-1609).

\section{Clusium. See CHIUsi.}

Clwyd, a river of North Wales, rises on Craig Bronbanog, in Denbighshire, and enters the Irish Sea after an irregular course of 30 miles. Below Ruthin it flows through the fertile Vale of Clwyd, 24 miles long, and 2 to 7 wide.

Clyde (Welsh Clwyd, 'strong'), a world-famous river and firth of south-west Scotland. The river rises as Daer Water at an altitude of 1600 feet, and runs 106 miles northward and north-westward, round Tinto Hill (2335 feet), and past Lanark, Bothwell, Glasgow, and Renfrew, till at Dumbarton it merges in the firth. Its drainage area is estimated by Sir John Hawkshaw at 1481 sq. $\mathrm{m}$., of which 111 belong to the South, North, and Rotten Calders, 127 to the Kelvin, 200 to the Black and White Carts, and 305 to the Leven and Loch Lomond. Tributaries higher up are Powtrail Water, Little Clydes Burn, Douglas Water, Medwyn Water, Mouse Water with its deep gorge through the Cartland Crags, and, near Hamilton, the Avon. Of these, Little Clydes Burn, rising close to head-streams of the Tweed and the Annan, is often wrongly regarded as the Clyde's true source. In the four miles of its course near Lanark the river descends from 560 to 200 feet, and forms the four celebrated Falls of ClydeBonnington, Corra, Dundaff, and Stonebyres Linns, of which the finest, Corra, makes a triple leap of 84 feet. Above the falls the Clyde is a beautiful pure trout-stream, traversing pastoral uplands ; below, it flows through a rich fertile valley, here broadening out into plain, there pent between bold wooded banks. But its waters become more and more sluggish, begrimed, and polluted, the nearer they get in Glasgow, where experiments made with floats in 1857-58 showed that the sewage sometimes took a whole week to travel only $2 \frac{1}{2}$ miles. Since 1765 upwards of ten millions sterling has been expended on rectifying and deepening the channel from Glasgow to Dumbarton, no less than $32,261,776$ cubic yards of materials having been lifted by steam-dredgers during 1844-87. The result has been that whereas 'a hundred years ago there was a depth at low-water of 15 inches, now they have at Glasgow from 18 to 20 feet at low-water;' and that whereas even lighters could once 'not pass to and from Glasgow except it be in the time of flood or high-water at spring-tides," now a steamer has been docked at Glasgow that 
is second in size only to the Great Exstern. In 1812 Henry Bell (q.v.) lannched on the Clyile the first boat in Europe successfully propelled by stem; and since then the river's shipping and shipbuilding (the latter dating from about 1718) have both grown enormonsly, 404,383 tons having been launched from the Clyde yards in 1883. - The FIRTH, which some make begin at Glasgow (the highest point of the tide), and aome not until Gourock, extends 12 miles westward and 52 south. ward, and broadens from 1 mile at Dumbarton to 19 at Dunoon, and 37 at Ailsa Craig. It sends of the Gareloch, Loch Long, Holy Loch, and the Kyles of Bute; contains the islands of Bute, Arran, and the two Cumbraes; is bordered along its ancient sea-margin with an almost continnons fringe of seaports and watering-places (Greenock, Rothesay, Ayr, \&c.); and, like the last 14 miles of the river, is one of the world's chief commercial waterways. See the reports of Smeaton (1755), Rennie (1799), Hawkshaw (1876), and Deas (188187); Dorothy Wordsworth's Tour in Scotland (1874); W. J. Millar's The Clyde from its Source to the Sea (1888); and Pollock's Dictionary of the Clyde (1888). For the 'Clydesdales,' or famous Lanarkshire horses, see Honse.

Clyde, Lord. See Campbeld (Sir Colin).

Clyster (Gr., from kluzō, 'I wash out'), called also enema, a medicine administered in the liquid form by the rectum, or lower end of the intestine. It is used either for the purpose of procuring evacu. ation of the bowels, or of conveying stimulants (brandy, wine, \&c.), other medicines, or nourishing substances into the system. A nourishing clyster, in order to be effective, must be specially prepared or digested by means of pepsin, pancreatin, or some such agent; for the rectum, though it has the power of absorbing food already digested, is not capable of performing the functions of digestion. A nourishing or medicinal clyster must be administered in as small bulk as possible; no more than a wine-glassful should be introduced at one time, or it will probably be rejected. For the purpose of procuring evacuation, on the other hand, as large a quantity should be introduced as possible; simple warm or cold water may be employed, or in special cases, various eathartics may be used in addition, such as colocynth, aloes, eastor-oil, or turpentine made into an emulsion with yolk of egg; and sometimes carminatives, to expel air. The introdnction of a teaspoonful of glycerine is often very effectual in procuring an action of the bowels when other methods fail. Medicinal elysters should only be used under medical superintendence. An injecting syringe, with a flexible tube and a doubleaction valve, is usually employed for the adminis. tration of remedies in this way.

Clytamnes'tra, in Homeric legend, the wife of Agamemnon. See Acamemion, Eschylus.

Cnidus, or Ginidos, the chief of the cities of the Doric league in Asia Minor, stood on the promontory of Triopion (now Cape Krio), in Caria, and, with its two harbours, was long a wealthy and flourishing port. Here, in 394 B.C., a great aea-fight took place between the Athenians under Conon, and the Spartans under Pisander, in which the former were victorious. The city was a prineipal seat of the worship of Aphrodite, who was therefore sometimes called the Cnidian goddess, One of its many temples contained the famons statue in Parian marble of the naked Aphrodite by Praxiteles. Exeavations were made on the site in 1857-58, and many of the marbles then recovered are in the British Museum.

Coach-building. See Carrige.

Coach Dog. See Dalmatian Dog.
Coaching. One of the most remarkable cir. cumatances in connection with this subject is the comparatively short period in which its history is comprised. It might very reasonably have been thought that the exigencies of commerce, no less than thome of private requirements, would, even in the earliest times, have demanded a system of communication as speedy as possible, and that some steps would have been taken to necure the desired end. Such, however, scarcely appears to have been the case; and mercliants and squires contented themselves with whatever facilities for travel were afforded by the stage-wagon, a cumbrous vehicle drawn at a walk by six, eight, or more horses. Passing over all earlier attempts to organise road traffic, we may come to the year 1659 , when the first stage-cosch-that from Coventry-was started. Its pace was probably not faster than that of the Oxford coach, which went from London to Oxford in two days, at about 3 miles an hour, or that of the vehicles which occupied two days and a half in compassing the distance between London and Dover. In 1700 a week was required to go from London to York; and two days from London to Salisbury. The first mail-coach was not put on the road until 1784, when Mr John Palmer, manager of the Bath theatre, and M.P. for Bath, overcame strenuous opposition, and induced Mr Pitt to supersede Allen's system of postboys, whose contract rate of speed was 5 miles an hour, by his (Palmer's) plan of carrying the mails by mail-coach. The first experiment was made on the 8th of Angust 1784, on which day Mr Palmer entered government service as comptroller-general of the Post-office. A coach left London at 8 A.M. and reached Bristol at eleven at night. The other coach left Bristol at four in the afternoon, arriving in London at eight the next morning, the up journey thus taking sixteen hours, or two hours longer than the down journey. The scheme appears to have worked so well from the beginning, that the municipal authorities of the more inportant towns soon petitioned for the adoption of $\mathrm{Mr}$ Palmer's plan in their districts, and in nearly every instance the request was complied with. It was part of the new scheme that the mails should be timed at each stage, so that they might all reach London at about the same hour; and that the outgoing mail. coaches should start at the same time from the General Post-office. At the outset the regulation pace was 6 miles an hour; but in course of time this was increased until the coaches were rated at 10 miles per hour.

This acceleration, however, was due to causes other than the judgment and enterprise of $\mathrm{Mr}$ Palmer, the skill of coachmen and coach-builders, and the employment of better horses. At the period above mentioned the bad state of the roads precluded quick travelling, and although we find that roads were the subjects of legislation as early as 1346, it was not till the days of Macadam and Telford that road-travelling was, so to speak, revolutionised. The former returned to Ayrshire from America in the year 1783 , and after studying road. making as a science while one of the road commis. sioners in Scotland, came south to Bristol in 1816, became surveyor in that district, and was con. sulted as to the making of other roads in all parts of England. As soon as Macadam's plans were carried into effeet, good roads took the place of bad ones; quick travelling commenced, and paved the way for the palmy days of coaching, until, in 1836 , there were fifty-four mail-coaches in England, thirty in Ireland, and ten in Seotland. Meantime the stage-coaches had grown in number, travelled at a high rate of speed, and necessitated the employment of a vast amount of capital. Among the best-known London proprietors were Chaplin, 
Horne, Sherman, Nelson, and Mountain ; the two first named having the judgment to discern that the railways would eventually drive coaches off the road, threw in their lot with the London and Birmingham Railway. It was not till after George IV. came to the throne that coaching reached the zenith of its fame in respect of organisation, pace, appointments, and one may, perhaps, say coachmanship as well. The 'palmy days,' concerning which so 'much has been written, began about 1820 , and coaching was possibly at its most perfect pitch about 1836. For about four years it enjoyed this repute, and then the downward journey, far more rapid than the upward one, began; one by one coaches were taken off; coaching inns became roadside public-houses; coachmen and guards found other occupations, or migrated to the workhouse; stables were emptied, and admiration for coaching gave way to appreciation of railroad-travelling.

Of amateur coachmen and coachmanship in the last century comparatively little is known; but, when good roads were the rule instead of the exception, 'gentleman coaching' became a fashionable amusement. Mr John Warde, the famous master of foxhounds, was a renowned whip, to whom were due the thanks of the old coachmen for having originated the idea of placing springs under the coach-box. The name of Peyton has ever been connected with the annals of the road; the Messrs Walker, Sir St Vincent Cotton, the Marquis of Worcester, Mr Henry Villebois, Mr Maxse, Mr Jerningham, Mr Sackville Gw'ynne, Sir Bellingham Graham, Mr Stevenson, Hon. Fitzroy Stanhope, Hon. T. Kenyon, Colonel Sibthorpe, and Mr C. Buxton are among the number of those who patronised the road by every means in their power. Others, scarcely less enthusiastic, succeeded them, until there were no road-coaches to be driven. So far as London is concerned, the link between the past and present was broken in the year 1858, when the Brighton 'Age,' under the management of Clarke, assisted by the Duke of Beaufort and Sir George Wombwell, was given up ; and for eight years there was no road-eoach running out of London. But the love for the road was only slumbering, it was not dead; and it was on the Brighton road that the first step was taken in the coaching revival in 1866 . In that year Captain Haworth, Captain Laurie, and a few others, started the 'Old Times' to Brighton. At the end of the season the confederacy was broken up, and in 1867 the Duke of Beaufort, Mr Chandos Pole, and Mr B. J. Angel took the road, running a cosch each way daily. Between then and the present time coaches have been started to Sevenoaks, Tunbridge Wells, Virginia Water, Dorking, Sunbury, High Wycombe, Westerham, Reigate, Watford, Windsor, Rochester, Guildford, Portsmouth, Maidenhead, \&c. Some only lasted a short time, and since the revival began there have been many changes in routes and proprietors. Thus in 1884 only four coaches were left, the Brighton road being vacant ; whilst in 1888 there were eight coaches running out of London, and three of them on the Brighton road. From time to time coaches have also been put on in the provinces.

The year 1877 was a somewhat memorable one in the annals of modern coaching, as on 4th November the 'Old Times' was put on to St Albans, and has run every 'lawful day' since without a break, though not always on the same route. In 1888 it was put upon the Brighton road, and on the 11th July James Selby, its coachman since 1877, drove from Piccadilly to Brighton and back in seven hours fifty minutes, the outward journey being accomplished in three hours fifty minutes and ten seconds. This performance, though a good one, is not a 'record,' as in 1837 Israel Alexander, a pro- fessional on the Brighton road, drove down with the Queen's first speech in three hours forty minutes.

The meets of the Four-in-hand Driving Club and the Coaching Club are justly regarded as among the sights of the season. The former is the more exclusive as well as the elder, having been established in 1856, chiefly at the suggestion of $\mathrm{Mr}$ W. Morritt. The club could not entertain one quarter of the applications for membership, so in 1870 the Coaching Club was established, and has been gradually increasing in size. For the first driving club of which we have any account, we must go back to the year 1807, the date of the establishnient of the Bensington Driving Club-the B.D.C. it was generally known as-which was limited to twenty-five members. For the first sixteen years of the club's existence its members used to drive down two days in the senson to Bensington, near Wallingford, in Oxfordshire, and twice to Bedford; but in 1823 the Bensington gatherings were given up. A second. club was founded in 1808 by $\mathrm{Mr}$ Charles Buxton. The new association was called the Fourhorse Club; but it was sometimes, though wrongly, designated as the Whip Club, and the Four-in-hand Club. The Four-horse Club was broken up in 1820 , was revived in 1822, but became extinct altogether about 1829. The B.D.C. was then the only body of the kind until 1838, when Lord Chesterfield estab. lished the Richmond Driving Club, the members of which, after meeting at Chesterfield House, drove to Richmond for dinner. This club, however, came to an end after nine or ten years; and in 1852 the B.D.C. was broken up. From that time there was no driving club until the present Four-in-hand Driving Club was founded as already mentioned. See Driving, by the Duke of Beaufort (Badminton series, 1888).

Coadju'tor (Lat.), a fellow-worker, not as principal but as second, an assistant. Technically, it is applied in ecclesiastical law to one appointed to assist a bishop, whom age or infirmity has disabled. If a bishop or archbishop is too ill to execute a resignation, the crown may give the dean and chapter power to appoint a bishop-coadjutor.

Coagulation, the amorphous (q.v.) solidification of a liquid, or part of a liquid, as when the casein of milk is solidified by rennet in making Cheese (q.v.), or the white of an egg by boiling. The process varies in various substances. Albumen, or the white of an egg, coagulates at a temperature of $160^{\circ}$. Milk is coagulated or curdled by the action of rennet or by acids. The fibrin in the blood, chyle, and lymph of animals is coagulated by the separation of these fluids from the living body. See

\section{BLOOD.}

Coahui'la, a state of Mexico, separated from Texas by the Rio Grande, has an area of 59,280 sq. m., partly mountainous, and forming in the west a part of the wilderness of the Bolson de Mapimi. The climate is healthy, although extremes of heat and cold are usual. The state is rich in minerals, especially silver, and coal has been found. It has valuable pasturage, and in many parts a most fertile soil; but no district of Mexico is so little known, or has been less developed. The construction of the National Railway has, however, prepared the way for \& change, and already several cotton-factories and a large number of flour-mills are in operation. Pop. (1882) 144,594. Capital,

\section{Saltillo (q.v.).}

Coaita. See SpIDER-MoNkey.

Coal, in the sense of a piece of glowing fuel (and hence a piece of fuel, whether dead or alive), is a word common to all the languages of the Gothic stock (A.S. col, Icel. kol, Ger. kohle). The different sorts of fuel are distinguished by prefixes, as charcosl, pit-coal; but in England, owing to the 

absorbing importance of mineral or pit coal, the word coal alone has come to be used in this special signification (Ger. steinkohlen, Fr. charbon de terre)

Coal is one of the most important of all rocks ; it consists chiefly of carbon, and is univenally reurriled as of vegetable origin. Its geological relations are noticed in the article CARBoNiferous SYsTkM. It oceurs in layers or beds, and is always of a black or blackish-brown colour. Some of the varieties have a very considerable degree of vitreous or resinous lustre, while others are destitute of Justre; some have a shell-like fracture, and others have a highly cross-jointed structure, and are readily broken into cubical or rhomboidal fragments. The precise characters of coal as a rock species are not easily defined, and both in Britain and other countries important cases have occupied courts of law, in which this difficulty was strongly felt, as in the great Seottish lawsuit concerning the Torbanehill Mineral or Boghead Coal (q.v.). Coal, indeed, is rather a commercial than a scientific term, but in a general way we may define it as a fossil fuel of black colour and stony consistency, which, when heated in close vessels, is converted into coke with the escape of volatile liquids and gases. The variety known as blind coal or anthracite no doubt gives off scarcely any volatile matter, but this is because it has undergone a natural distillation through the action of subterranean heat or of the proximity of intrusive igneous rock. We may therefore divide coal into two primary divisions -namely : (1) Anthrucite, which does not, and (2) Bituminous coal, which does, flame when kindled. Anthracite (q.v.) sometimes contains as much as 94, and if we exclude the ash, 98 per cent. of carbon, and as this element decreases in amount it graduates into a bituminous coal. The term anthracite is, however, still applied to some coals which do not contain more than 80 per cent. of carbon. Various synonyms, such as stone coal, glance coal, culm, and Welsh coal, are also used to designate this substance, which is used chiefly for smelting purposes and for generating steam. In the United States it is also very largely used for domestic purposes-heating and cooking. It is difficult to kindle, but gives out a high heat in burning. Bituminous coal includes an almost endless number of varieties, one of the best marked being cannel or parrot coal. Cannel coal is probably so called from burning with a bright flame like a candle, and the name parrot coal is given to it in Scotland from the crackling or cluattering noise it makes when burned. That of different localities varies much in appearance, but it is most commonly dull and earthy, or with only a slight lustre; some examples are, however, bright and shining. In texture it is nearly always compact, and certain beds of it admit of being polished in slabs of con. siderable size, which approach black marble in appearance. Of this material vases, inkstands, boxes, \&c. are made. Cannel coal contains a large percentage of ash, but the best cannels are in some places much used for open-grate fires in houses. Cannel is for the most part consumed in making gas, of which it yields from 8000 to 15,000 euljie feet per ton. When distilled at a low red-heat it yields paraffin oil. The other varieties of bitu. minons coal are so numerous that, as an Admiralty report states, there are as many as seventy denominations of it imported into London alone. Still, among these there are three leading kinds -1. Caking coal, which cakes or fuses into one mass in the fire. It breaks into small uneven framents, and is found largely at Neweastle and some other localities. 2. Splint or hard coal, occurring plentifully in Scotland, which is hard, and breaks into cuboidal blocks. This is often called block-coal; and locally it is very valuable, be cause it can be employed in smelting without being finst coked. It is not very easily kindled, but when lighted makes a clear lasting fire. 3. Cherry or soft coal, which breaks easily into amall irregular cubes, has a beautiful shining luatre, is remdily kindled, and gives out a cheerful flame and heat. It is common in Statfordshire. Brown coal or Lignite (q.v.), though for the most part inferior to true coal, is nevertheless an inportant fuel in some countries in default of a better kind. There are, however, large deposits of lignites in some regions, as in North America, which coke well, and which are excellent sulsstitutes for true coal.

The use of coal does not seem to have been known to the ancients; nor is it well known at what time it began to be used for fuel. Some say that it was used by the ancient Britons; and at all events it was to some extent an article of household con. sumption during the Anglo-Saxon period as early as 852 A.D. There seems to be reason for thinking that Britain was the first European country in which coal was used to any considerable extent. A coal-pit at Preston, Haddington, was granted to the monks of Newbattle between 1210 and 1219 . Henry III. is said to have granted a license to dig coal in 1234. About the end of the 13th century it began to be employed in London, but at first only in the arts and manufactures; and the innovation was complained of as injurious to human health. In 1306 the parliament petitioned the king to prohibit the use of coal, and a proclamation was accordingly issued against it; but owing to the high price of wood, its use soon became general in London. It was for a long time known there as sea-coal, because imported by sea.

Several theories as to the mode of the origin of coal have been put forth from time to time. The one now generally believed in is that the rank and luxuriant vegetation which prevailed during the carboniferous age grew and decayed upon land but slightly raised above the sea; that by slow sub. sidence this thick layer of vegetable matter sunk below the water, and became gradually covered with sand, mud, and other mineral sediment; that then, by some slight upheaval or gradual silting up of the sea bottom, a land surface was once more formed, and covered with a dense mass of plants, which in course of time decayed, sank, and became overlaid with silt and sand as before. At length, thick masses of stratified matter would accumulate, producing great pressure, and this, acting along with chemical changes, would gradually mineralise the vegetable layers into coal. Microscopical examina. tion shows that coal consists principally of the cortical portions of plants-more especially of the bark of such trees as Sigillaria - commingled with the debris of various other plants, amongst which the spore cases and spores of certain lycopodiaceous trees not infrequently occur in great abundance. It seems probable indeed that many coal-seams simply repre. sent ireat swamps and marshy jungles.

As will be seen from the following table, wood, peat, lignite or brown coal, and true coal indicate by their composition the elianges which regetable matter undergoes by decay and pressure; and a table in which a considerable number of examples of each substance could be given would show how gradually these substances pass into each other

\begin{tabular}{|c|c|c|}
\hline 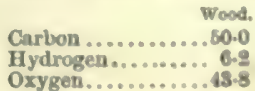 & $\begin{array}{l}\text { reat. } \\
60-0 \\
6.5 \\
82.5\end{array}$ & $\begin{array}{l}\text { Ifaite. } \\
\text { 68.7 } \\
5.8 \\
\text { 98.0 }\end{array}$ \\
\hline$\overline{100-0}$ & $\overline{100 \cdot 0}$ & $100-0$ \\
\hline
\end{tabular}

In each of these bodies there is usually a small percentage of nitrogen, which in the above table has not been separated. In passing from wood or peat 
to coal, the proportion of oxygen and hydrogen decreases, these substances being given off in the form of marsh-gas and carbonic acid in the process of decay.

On the continent of Europe, productive coal-fields occur in Belgium, France, Prussia, Spain, Silesia, and in Russia - the only important Russian coalfield being that of Donetz, on the north shore of the Sea of Azov. Coal is also found in India, China (where several extensive coal-fields occur, in which coal has been worked from a very early period), Japan, and the Malayan Archipelago, in Australia and New Zealand, and in Africa. There is evidence of promising coal-deposits in several South American countries, but, owing to the great supply of wood in their forests, there is little temptation to work them. Considerable importance already attaches, however, to the mines of Chili (q.v.). In Canada there are small, though valuable, coal. fields; but in the United States enormous fields of fossil fuel are found. The entire area of these is about $200,000 \mathrm{sq}$. m., being 83 -times greater than the area of the coal-fields of Great Britain. But although the coal-measures of the States are of vast extent, and contain many valuable coal-seams -a few of them 40 and even 50 feet thick at certain places-it has been doubted whether the amount of workable coal in them has not been exaggerated. In proportion to the extent of the seams, the quantity of coal annually raised in the States is small, and amounted to $160,000,000$ short tons of $2000 \mathrm{lb}$. each in 1892 . The distribution of the coal-fields of Britain and North America is discussed at CARBONIFERous SYSTEM.

Coal-supply of Britain.-The probable duration of the British coal-supply is a question which until recent years rarely excited any public anxiety. Early in the 19th century attention had been called to the subject by Sir John Sinclair, Mr Robert Bald, and Dr Buckland, but the existing store of coal was generally believed to be practically inexhaustible-its exhaustion at all events seemed to be relegated to so remote a date as to relieve the nation from all anxiety on the matter. In recent years, however, Professor Hull, from a more accurate survey of British coalfields than was possible before the map of the Geological Survey had been published, came to the conclusion in 1860 , that at the then rate of production we had enough coal to last for 1000 years. But as the rate of consumption was yearly increas. ing, it was obvious that our coal-supply might not last nearly so long. In 100 years, as Professor Jevons showed, if the same rate of increase continued, the annual consumption would be $415,000,000$ tons, and our coal-fields by that time would be nearly exhausted. A Royal Commission was appointed in 1866 to consider the whole question, and came to the conclusion in 1871 that at the then rate of consumption there was enough coal to last for 1273 years, but with a constantly increasing consumption this term would necessarily be reduced. The amount of coal at all depths down to 4000 feet was estimated at the date of the Royal Commissioners' Report to be 90,207 million tons, while including the coals at greater depths, the total was 146,480 millions of tons. Although, therefore, we know approximately the extent of available coal, we cannot tell how long that coal will last, for we cannot say whether the present rate of consumption will be maintained, increased, or diminished in the future. It seems most probable, however, that the rate of increase of coal used per head of the population will follow a diminishing ratio, and that it will be 300 or 400 years before the coal-supplies of these islands begin to fail.

Coal-trade.-The production and sale of coal, like every other important branch of industry, was long fettered with legislative regulations. At a very early period, the corporation of the city of London undertook the duty of either weighing or measuring the coal brought into the port, and by a series of statutes commencing with 7 Edward VI. chap. 7 , the mayor and aldermen of London, and the justices of the counties, were empowered to fix the price of coal to be sold by retail; and in case of refusal by the parties to sell at the prices fixed, to enter their wharves, or other places of deposit, and to cause it to be sold at the prices which they had set. In addition to the general supervision which they thus possessed, and the sums which they were empowered to exact for their trouble, the corporations of London and other towns have exacted, and still continue to exact, dues on coal for local purposes. These were first imposed in London in 1667, after the great fire, in order to enable the corporation to repair the ravages which it had committed; and they have been since continued as a fund for civic improvements, though, as $\mathrm{M}$ 'Culloch has remarked, no improvement could be equal to a reduction in the price of coal. In the reign of William III. a general tax, payable to government, was laid on all sea-borne coal - a tax which was in the highest degree unjust to places which were dependent for their supply on the coasting trade, and oppressive to the whole country, inasmuch as it amounted to more than 50 per cent. on the price paid to the owner at the pit's mouth. The tax varied in amount, not only at different periods, reaching its highest point of $9 \mathrm{~s}$. $4 \mathrm{~d}$. per chaldron during the great war, but also in different parts of the country, being higher in London and the south of England, and lower in Ireland and Wales, whilst Scotland for a considerable period was altogether exempt. The tax itself, with all its inequalities, was abolished in 1830 ; and the tax on coal, long collected for local purposes in London, was abolished in 1889. The repeal, in 1845, of the duty on coal exported to foreign countries was a measure of much more doubtful policy. The anuual quantity of coal exported from Great Britain during the years from 1890 to 1898 was from $25,000,000$ to $38,000,000$ tons. - For the regulation and inspection of mines, explosions, \&c., see MiNING; where also mention is made of the varying arrangements as to the proprietorship of mines. The condition of colliers and salters in Britain is discussed at Slavery. For coal-tar products, see CoALTAR, Dyeing. See also the articles FUEL, GAS and Gases, Petroleum.

Coal-whipping is the name given to a mode of unloading coal from vessels at anchor to barges, which convey them to the wharves. When the number of these men at work on the Thames was about 2000 , public-house keepers got into the habit of acting as middlemen; the trade fell into such a state, that the men were virtually slaves to the publicans. They asked for the interference of the legislature. An act was passed in 1843 , and a Coal-whippers' Board was formed, which contracted for the whipping of ships of coal, and employed the men; and other acts were passed in 1846 and 1851. But in 1856 the coal-owners agreed with the Board of Trade to maintain a Whipping Office, to give the men a refuge from the publicans, but with out interfering with the liberty of coal-shippers. The necessity for coal-whippers has been much lessened by the use of hydraulic or steam machinery in discharging.

See Green and Miall, Coal: History and Uses (1878); Galloway, History of Coal-mining in Great Britain (1882): Hull, Coal-fields of Great Britain (1880); Pameley, The Colliery Manager's Handbook (1891); Meldola, Coal and what we get from it (1891); H. W. Hughes, A Text-book of Coal-mining (1892); D. M. D. Stuart, Coal Dust an Explosive Agent (1894). 
Coalbrookdale is a distriot in Shropshire, extending 8 miles slong the river Severn; its cosl. field aupplies coal and iron as well an limestone, and manufactures iron. The village of Coalbrookdale, which gives it name, is 11 miles $8 \mathrm{E}$. of Shrewsbury.

Coal-fish (Gadus carbonarius), a species of cod, with black upper parts, common in northern seas. It occurs from $80^{\circ} \mathrm{N}$. lat. to the Mediter. ranean, and is common off North American and British coasts. In Scotland it is often called Saith. It often measures 2 to 3 feet in length, and may be considerably larger; occurs in great shoals; is exceedingly voracious. Though decidedly coane, its flesh is much eaten in northern parts. The young ones are often caught by boys fishing off the rocks, and are variously known as podleys, sillocks, cuddies, and coalseys, See CoD.

Coaling Stations. The question of coaling stations has of late engaged a large share of public attention in Britain. The necessity for maintaining a sufficient number of fortified outposts on the great lines of British trade has been recognised by successive governments, and the work of defence has, after a regrettable delay, at length been vigorously taken in hand. The inquiry by a Royal Commission resulted in the publication in 1881-82 of an exhaustive report, from which the present article has been compiled.

The Commissioners estimated the value of British ships and the freights which they carried annually at $£ 900,000,000$, British property to the value of $\mathbf{f 1 4}, 000,000$ being at all times afloat, the greater part on distant voyages. Broadly, the foreign trade of the United Kingdom may be divided into two great divisions-the trade with the Americas, and that with the Mediterranean, the East, and Australia, by the Suez Canal and the Cape. It is chielly with the latter that we are here concerned.

On the great trade-route by the Suez Canal to India and to Australia, steamships have entirely superseded sailing-ships. It is along this route that the possession of a continuous chain of coaling stations gives Britain an advantage which it is imperatively necessary to maintain. The Cape route, again, is essential to the retention by Great Britain of her possessions in India, Ceylon, Mauritius, Singapore, China, and Australia. It is by this route that reinforcements of troops and necessary supplies could, in the contingency of war, be despatched to the East with the least exposure to capture.

It must be accepted as a leading principle that the defence of harbours should be secured by forts and not by ships. The Royal Navy is not main. tained for the purpose of affording direct local protection to seaports and harbours, but for the purpose of blockading the ports of an enemy, of destroying his trade, attacking his possessions, dealing with his ships at sea, and preventing an attack in force upon any special place. It is by the effieient performance of these duties that British commerce and colonies will be best protected.

The grent fortresses of Gibraltar and Malta are maintained wholly from resources provided by the imperial exchequer. Improvements in their defences have been going forward ever since they came into the possession of Britain; and it may be assumed that Gibraltar and Malta are well prepared to resist attack. For the manning of the works strong garrisons of 6000 men are permanently maintained.

Pursuing our way throngh the Suez Canal, which, in consequence of recent political changes, has practically passed under British control, we find at Aden another commanding position. The distance from Suez is $\mathbf{1 3 0 0}$ miles, from Mauritius
1970, from Boubay 1637, and from Ceylon 2130. Aden is not only an inportant coaling ntation in peace-time for ships using the Snez Canal, but, in the event of war with any of the Mediterranean powers, it would he the only place in possession of Britain from which a fleet could prevent foreign ships of war, that had pased through the canal into the Red Sea, from gaining accens to the Indian Ocean. The Royal Commission urge strongly that Aden should be made secure against the attack of a small naval squadron.

Bombay is much more than a mere coaling station. It is the greatest port of Indis, and one of the busiest entrepots of commerce in the world. The harbour, defended by batteries and by two armoured vessels, was declared by Sir Frederick Richards, when naval commander-in-chief on the East India station, to be sufficiently secured against any probable attack.

Kurrachee is a post of immense importance as the base for the military defence of the north-west frontier of India. As compared with Bombay, Kurrachee is nearer to England by two days steaming. By skilful engineering, the entrance to the port, the anchorage, and the wharfage have been adapted to the requirements of steamships of large tonnage. The defences, both by batteries and torpedoes, are well advanced.

The distance from Ceylon to the Cape of Good Hope is 4400 miles, from Mauritius 2100, from Aden 2130, from Bombay 960, from Singapore 1510, and from King George's Sound 3400. If measures are taken to prevent an enemy's ships from coaling in the adjacent seas, Ceylon will be comparatively safe from heavy attacks. The possibility of attack by a hostile cruiser must, however, be admitted. The Commissioners carefully weighed the relative advantages of Galle, Colombo, and Trincomalee. Galle, for many years the port of call for mailsteamers, has gradually been abandoned in favour of Colombo. The latter port has a commodious harbour, already sufficiently advanced to afford well-sheltered anchorage during the south-west monsoon. For local reasons, no less than for im. perial considerations, the Royal Commission held it necessary that Colombo should be adequately protected, both by floating defences and by batteries on shore. Trincomalee is the safest and most commodious harbour in the Indian Ocean, and very capable of defence. But it is out of the course of trade, and has no facilities for the repair of ships; 80 the Commissioners did not recommend a large expenditure on fortifications at Trincomalee.

Singapore is the next important position in the possession of Great Britain. The annual value of the imports and exports of the Straits Settlements (of which it is by far the most important) is about $£ 100,000,000$. At Singapore the quantity of coal supplied to passing steamers varies from 15,000 to 20,000 tons a month. Extensive wharves, three graving-docks, and all the appliances for repairing ships have been provided by private enterprise. The colonial government has carried out a scheme of defence, planned by officers of the Royal Engineers. The torpedo defences are complete.

Hong-kong is the chief centre of British trade with China, and the only dependency from which that trade can be defended. The entries of shipping in 1890-95 included about 30,000 vessels and junks annually, of over 7,000,000 tons, and manned by 500,000 hands. Graving-docks exist in the hands of commercial companies, capable of receiving ironclads of the largest class which will be seen in the China Sea. The defence of the harbour is now heing made good at the cost of the local and imperial governments. A small ironclad is stationed at Hong-kong for the defence of the harbour.

To the Cape of Good Hope, the distance from 
England is 6000 miles. The intermediate coaling stations now used are Lisbon, Gibraltar, Madeira, St Vincent, and Sierra Leone. Lisbon, Madeira, and St Vincent being in foreign territory, Sierra Leone is the first British coaling station. The harbour is capacious and secure, and the works for its defence are nearly completed. Ascension, distant from Sierra Leone 1000 miles, from St Helena 680 miles, and from the Cape of Good Hope 2380 miles, has a roadstead, or landingplace, on its west or leeward side; there is no harbour. Ascension has been used as a depôt for stores and the supply of coals. By a wise decision of the Admiralty (1887) the stores were to be removed from Ascension, which was henceforth to be used only as a sanatorium for the benefit of ships whose crews have sutfered from fever.

St Helena, in the opinion of the Royal Commission, has many advantages over Ascension. It is larger, has a cooler temperature, more vegetation, and a better roadstead. Within a recent period $£ 30,000$ has been expended on fortifications; and it has been decided to further strengthen the defences, and to supply a modern armament.

The Royal Commission showed that the value of British trade either with the Cape of Good Hope, or passing round it, amounted to $£ 91,352,000$ annually, the whole, with the exception of about $£ 4,000,000$, being carried. on directly with the United Kingdom. Enormous, however, as is the value of this trade, it by no means represents that which, in the event of war with one or more of the great naval powers, might pass round the Cape. The annual value of British trade with India, Ceylon, China, and the East, conveyed through the Suez Canal, falls little short of the trade by the Cape route. If the long sea-route became alone available, the annual value of the traffic by the Cape would amount to $£ 150,000,000$, exclusive of that of the shipping employed. The Cape peninsula, about 32 miles in length, is a rugged mountainous district, connected with the continent by a low isthmus, 13 miles in length (see map of CAPE COLONY). Simon's Bay affords a secure anchorage, and naval establishments have been formed on its shores. The anchorage in Table Bay, the scene of many disasters in former days, has been rendered secure by a noble breakwater. Docks have been formed. The graving-dock is capable of receiving large ironclads. To make the Cape thoroughly secure, it is necessary to fortify both Table Bay and Simon's Bay. The defences at Simon's Bay have been completed at the sole cost of the imperial government. At Table Bay the works are being executed by the colony, while the armaments are provided by the imperial government.

Mauritius lies nearly midway between the Cape and India, 4440 miles apart. 'The colony has a trade of the annual value of $\$ 6,000,000$. Port Louis is a safe and commodious harbour. The Royal Commission recommended additions to and im. provements of existing defences. Mombasa (q.v.) was made a naval coaling-station in 1890 .

Having dealt with British trade with the East, we turn to the West. The trade of the United Kingdom with the United States and Canada exceeded, at the date of the Commissioners' report, $£ 119,000,000$ in annual value. The largest proportion is food and raw material supplied to the United Kingdom. War with the United States cannot be contemplated by practical British politicians. In the event of war with any other power, merchant-steamers would require protection only near the coast at either end of their voyage, trusting to their own speed for the intermediate portion.

British trade with the West Indies amounts annually to $£ 21,000,000$. The defence of this: important trade rests on Jamaica and St Lucia. The defences of Jamaica have been modernised and greatly improved in recent years. St Lucia has been selected by the Admiralty as a coaling station for the fleet in the Windward Islands.

It is not necessary to refer in detail to the land defences of the great ports of Australia. The combined expenditure of the several governments may literally be reckoned by millions. The manning of the works and the general defence of the colonies by land is guaranteed by an army of more than 30,000 volunteers, of splendid physique, well equipped, and provided with a small staff of officers from the imperial service. A considerable flotilla, for harbour defence has been created at Melbourne. Adelaide has a powerful coast-defence vessel. Brisbane has two efficient gunboats. Naval brigades have been organised both in Victoria and New South Wales.

New Zealand is secured by its geographical position from an attack in force. The defence of a few principal ports has been taken in hand, under the able advice of Sir William Jervois. A considerable body of volunteers, both for the sea and the land service, has been enrolled.

By an arrangement concluded by the administration of Lord Salisbury, a joint agreement was in 1887 entered into, with the approval of the legislatures in the Australias and at home. Under its provisions, by a colonial contribution from the several governments, a special squadron of highly efficient cruisers has been built for the defence of trade in Australian waters and on the coasts of New Zealand.

Coalition, in Polities, is applied to the union of two parties, or, as generally happens, portions of parties who agree to sink their differences, and act in common. Pitt the elder, when he took office in 1757 , coalesced with the Whig aristocracy represented by the Duke of Neweastle. The ministry always spoken of, however, as the Great Coalition was formed in 1782, when Fox, the leader of the reformers, took office along with Lord North, the leader of the opposite party. When Lord Derby's ministry resigned in 1853, there was a short coalition between the Whig party under Lord John Russell, and the more moderate of the Conservative party under Lord Aberdeen. The arrangement made between Conservatives and Liberal Unionists in $1886 \mathrm{can}$ searcely be called a coalition, inasmuch as the main responsibility of government rests on the former. while the latter give them a general support. The term is also used of alliances between separate states.

Coal-tar, or GAS-TAR, is a thick, black, opaque liquid, which comes over and condenses in the pipes. when coal or petroleum is distilled. Now usually obtained in the manufacture of gas, tar was about 1782 extracted from coal by the ninth Earl of Dundonald under a patent, expressly for the purpose of being used for protecting ships from rotting. Coaltar is slightly heavier than water, and has a strong, disagreeable odour. The amount of tar so obtained of course varies with the nature of the coal employed, but it is also dependent on the average temperature of distillation. With a low temperature, a large quantity of tar is produced, along with a small yield of a highly illuminating gas. At first this tar was regarded as a waste product, or, at most, as a source of pitch; but it soon became apparent that as a source of Benzene (q.v.), and throngh it of the aniline dyes (see ANILINE), it was a commodity of great commercial value.

When coal-tar is distilled, a large number of volatile substances pass over as the temperature 
rises higher and higher. At first varions games, ammonis and naphtia, are obtained to the extent of alwut 8 is th purt of the original tar, and then distillation censes, although the temperature gralu. ally rises. After a period of about an hour, more oils, like the former, lighter than water, are obtained, and so on the distillation proceeds, with successive intervals, yielding what are known as Creosote oils, and finally Anthracene oils, the residue in the still being pitch.

At first, when antliracene was of little importance, distillation was not pushed so far, and the anthracene oils were allowed to remain in the pitch; but since the discovery of the process for making artifieial Alizarin (q. . .), the heat is pushed as fur as possilile consistent with the production of a pitch that will sell. The first light oils yield chiefly benzol, carbolic acid, and naphtha. The ereosote oils yield creosote and naphthaline, while the anthracene oils produce anthracene and lubrieating oils.

After this enumeration of the chief coal-tar products, it will be possible to realise the great im portance of this substance. The naphtha, besides being used as a solvent for india-rubber and guttapercha, is burned to produce a fine variety of carbon for printing-ink. The benzol, including in this term many nearly allied substances, not only yields many brilliant dyes, but is used for cleaning gloves, silks, \&e., and other articles which would be injured by washing. The ereosote in its erude form is largely used for preserving wood, enabling it to be exposed in damp situations without rotting, while, when burned, its smoke yields lampblack. The naphthaline, besides being a source of many dyes, is employed in the Albo-earbon light to give to ordinary coal-gas very high illuminating power. Finally, the residual pitch is in constant requisition for making roofing felt and asphalt pavement. Besides these primary products of coal-tar, there are of course numerous compounds derived more or less remotely from it. Such are the aniline dyes, the quinine substitutes, antipyrin, antifebrin, \&c., and the sweetening substance, Saccharin (q.v.), which may be naed to replace sugar in many cases. For further references, see ANILIN ZENE, CREOSOTE, and NAPHTHALENE ; also Lunge's Coal-tar and Ammonia (1887).

Coalville, a village of Leicestershire, 16 miles NW. of Leicester by rail. Pop. 1904.

Coainza, a river of West Africa, in the Portuguese colony of Angola, flows generally NW., and enters the Atlantic about 30 miles S. of St. Paul de Loando, by a mouth over a mile broad. It is navigable for light vessels as far as the Cambambe cataracts, over 120 miles, and is regularly traversed as far as Dindo, a few miles below, by the trading vessels of a steamship company established by the Portuguese, who have many settlements on the banks.

Coast Defence. The character of the defence provided for the coosts of a state must depend on the nature of the coast and of the attack to be anti cipated. In Germany a solution of the problem has been sought mainly by means of submarine mines, associated with a strong flotilla of torpedo-boats, and, in certain spots, with powerful batteries. Italy intrusts the defence of her coasts chiefly to her very powerful fleet of ironclads, which can move from place to place as required. In France and Eng. land all these methods are employed : mine-fields, which to be effective must be protected by artillery torpedo-boat flotillas; batteries; and a strong tleet of henvy ships, some of which have been specially designed for this purpose, though their usefulness has been much questioned. In Italy the unusual feature of 120-ton guns mounted in gun-barges, to teke part in the defence of certein important harboun, is also to be noticed. As a reneral defence against an attack in force, strong hatteries in connection with mine-fieldw offer, per. haps, the best security. Against depredations by isolated ships or eruisens, well-placed guns on the disapperring system, with some fast torpedoboats, would probably be most efficacious. The question of the hest system of defence, under the great changes which have taken place in the material of warfare, must probably remain unde. cided until more experience has been gained.

Coastguard, an organisation formerly intended to prevent amuggling merely, but now constituted so as to serve as a defensive force also. The old constguardsmen were in the employment of the Customs department; they were posted along the shore at suots commanding extensive views of the beach, and were expected to be always on the lookout for smugglers. In 1856 the coastguard was transferred to the Admiralty, and under this arrangement the Admiralty may, from time to time, issue orders for the augmentation of the coastguard, not to exceed $10,000 \mathrm{men}$ in all. Lands not exceeding three acres each may be bought by the Admiralty for coastguard stations. The coasts of the United Kingdom have been divided into eleven districts. Each district is under a navy captain, who has an ironclad guardship at some port in the district. All the revenue eruisers and defence-gunboats are attached as tenders to the ships, and are manned therefrom. The able seamen, borne on the ships' books, and employed on shore in coastguard service, are in three classes - chief boatmen, commissioned boatmen, and boatmen. They receive high-sea pay, besides 18. $4 d$. per day in lien of provisions, and house-rent and medical attendance free. In war-time, all of these men may be called upon to serve as regular sailors on board ship; but their families are allowed to live rent-free during this time. The coastguard are taught naval gunnery, gunboat exercise, and the serving of land-batteries. The guardships are also employed as training ships for the navy. The whole of the coastguard now comprises some $4200 \mathrm{men}$ and the charge for their maintenance and that of their ships is abont $£ 460,000$.

Coast Range, a range of mountains nearly parallel to the Pacific Coast in California (q.v.).

Coast Survey of United States. See CHART.

Coatbridge, a thriving manufacturing town in Lanakshire, 9 miles $\mathbf{E}$. of Glasgow by rail, and $32 \mathrm{~W}$. by S. of Edinburgh. The centre of a great mineral district, it is surrounded by numer. ous blast-furnaces, and produces malleable iron, boilers, tubes, tin.plate, frebricks and tiles, and railway wagons. Coatbridge has grown very rapidly in size and prosperity - a growth largely due to the development of the Gartsherrie Iron. works of Messrs Baird (q.v.), first put in blast, 4th May 1830 . Pop. (1831) i41; (18.31) 8.564: (18\%1) 15,802 ; (1881) 18,425; ( 1891 ) 29,996. In 1885 Contbridge was made a municipal burgh. See A. Miller's Rise and Progress of Coatbridge (Glas. 1864).

Co'ati. or Contr-Mund (Nasua), a genus of the raccoon family (Procyonida), in the bear-like section of Carnivora. There are two species found in Mexico, Central Americn, and South America. They live on trees, feeding somewhat omnivorously, and grubbing with an upturned flexible snout. They are social in their habits, and readily adapt themselves to domestication. See RAcCoon.

Coat of Arms. See Heraldry.

Coatzacoalco, a river of the isthmus of Tehuantepec in Mexico, rises in the Sierra Madre, and falls into the Gulf of Mexico, 130 miles S.E. of 
Vera Cruz. It is navigable for large vessels for 30 miles, and is interesting as part of a route which was once surveyed for an interoceanic canal. Near its course was Captain Eads's projected shjp-railway.

Cobalt (sym. Co, eq, 59, from Cobalus, 'a malicious sprite' or 'gnome') is a metal the ores of which are sparingly distributed. In the metallic state it is found in meteoric stones or aerolites to the extent of one per cent., but it generally oceurs combined with arsenic as Speiss-cobalt, CoAss, or as cobalt-glance, the arsenide and sulphide of the metal, CoSAs. To obtain the metal itself from its ores is a matter of some difficulty, and although it is more tenacious than iron, yet it has not been applied to any practical use. It is of a gray colour with a reddish tinge, brittle, hard, and very magnetic. Many of its compounds are valued on account of the brilliance and permanence of their colours. The Protoxide of Cobalt, $\mathrm{CoO}$, is employed as a blue pigment in porcelain-painting. Zaffre is the impure oxide obtained by partially roasting cobalt ore previously mixed with two or three times its weight of fine sand. Smalt is the term applied to a deep-blue glass, which owes its colour to the presence of oxide of cobalt, and which, when reduced to very fine powder, is employed occasionally by laundresses to correct the yellow colour of newly-washed linen, and by paper-makers as a blue pigment for staining writing-paper. Smalt is also used in the production of the blue colours in porcelain, pottery glass, encaustic tiles, frescopainting, \&c., and forms the principal ingredient in Old Sevres Blue, Thenard's Blue, Turquoise Blue, Sc. (see BLUE). A compound containing the oxides of cobalt and zinc is of a beautiful green colour, and is known as Rinman's Green. The chloride of cobalt dissolved in much water, may be employed as a sympathetic ink. In dilute solu. tions, it is of a faint pink colour, which is not observable when it is used for writing upon paper; but when heated before the fire, it loses water, and becomes blue, and the writing is then capable of being read. On allowing the paper thereafter to lie in a damp place, or exposing it to the vapour of steam from a kettle, water is again absorbed, and the writing returns to its invisible state. The addition of a little perchloride of iron to the ink makes the writing appear green; a solution of zinc imparts a red tint; and a salt of copper, a yellow shade.

Cobán, capital of the department of Vera Paz, in Guatemala, on the fertile Tierra Templada plateau, about 85 miles $N$. of the town of Guatemala. Pop. (1895) 27,700.

Cobbe, Frances Power, author, born near Dublin, 4th December 1822, was educated at Brighton, and early had her interest aroused in theological questions. Her mother's death drove her for spiritual help to Theodore Parker, whose counsels are contained in his famous Sermon of the Immortal Life. She travelled in Italy and the East, and wrote The Cities of the Past (1864), and Italics (1864). A strong Theist, a supporter of women's rights, and a prominent anti-vivisectionist, she published her Autobiography in 1894. Among her other works are Friendless Girls, and How to help Them (1861); Broken Lights: an Inquiry into the Present Condition and Future Prospects of Religious Faith (1864); Studies New and Old (1865); Criminals, Idiots, Women, and Minors: Is the Classification Sound? (1869); Darwinism in Morals (1872); The Hopes of the Human Race Hereafter and Here (1874); Re-echoes (1876); The Peak in Darien (1882); and The Scientific Spirit of the Age (1888).

Cobbett, William, born at Farnham, Surrey, on 9th March 1762, was the son of a small farmer, and grandson of a day-labourer. From scaring crows the boy rose to be ploughman; but a visit to Portsmouth and a sight of the fleet had spoiled him for farming, when, in May 1783, a sudden freak took him to London. He reached it with just half-a-crown, and for nine months was quill-driver to a Gray's Inn attorney. Enlisting then in the 54th Foot, he first spent a year at Chatham, where he mastered Lowth's English Grammar, and read through a whole lending library-Swift's Tale of a $T u b$ had been his boyhood's delight. Next he served as sergeant-major in New Brunswick (178591), meanwhile saving 150 guineas, and studying rhetoric, geometry, logic, French, and fortification. On his return he obtained a most flattering discharge; in February 1792 married; but in March went to France to get out of a court-martial on three of his late officers, whom he had taxed with peculation. Six months later he sailed for America. At Philadelphia he taught English to French refugees (Talleyrand wanted to be one of his pupils); trans. lated from the French; and, as 'Peter Porcupine,' wrote fierce onslaughts on Dr Priestley, Tom Paine, and the native Democrats. Twice he was prosecuted for libel, and America got too hot for him, so in June 1800 he returned to England. The Tories welcomed him with open arms; and in 1802 he started his famous Weekly Political Register, which, with one three-months break in 1817, continued till his death. But, Tory first, it altered its polities in 1804, till at last it 'became the most fierce and determined opponent of the government, and the most uncompromising champion of Radicsl. ism.' A great lover of the country, Cobbett settled at Botley in Hampshire, where he planted, farmed, and went in for manly sports; a true soldiers' friend, he got two years in Newgate (1810-12), with a fine of $£ 1000$, for his strictures on the flogging of militiamen by German mercenaries. In 1817 money muddles and dread of a second imprisonment drove him once more across the Atlantic. He farmed in Long Island, writing all the while for the Register, till in 1819 he ventured back again, and came bringing Tom Paine's bones - the one really silly action of his life. Botley had to be sold, but he started a seed-farm at Kensington; and bent now on entering parliament, stood for Coventry (1821) and Preston (1826). Both times he failed; but his ill-advised trial for sedition (1831) was followed next year by his return for Oldham to the first Reformed parliament. His career there, if not quite a failure, was signalised chiefly by a crackbrained attack on Peel; anyhow, the late hours were too much for him, and on 18th June 1835 he died at Normanby farm, near Guildford. He was buried at Farnham.

Coarse, virulent, braggadocio, inconsistentCobbett was all this. He was often right, but he must have been oftener wrong, for oftener he came to abuse what once he had eulogised than vice versâ. He was a very Ishmael of politics; Lord Dalling dubs him 'the contentious man.' Still, a man he was, a genuine John Bull ; and if he wrote nonsense about Waterloo and the national debt, and more nonsense than sense about the Reformation, he wrote it in fine strong English. He loathed Whigs and 'mock gentlefolks,' but he honestly loved the poor-loved Nature, too, and could paint her dear English seenery with a freshness and insight wholly and solely his own. The Rural Rides (new edition, with notes by Pitt Cobbett, 1885) are unsurpassable. They were a reprint $(1830)$ from the Register, and followed or were followed by Poreupine's Works (12 vols. 1801), the excellent and entertaining English Grammar (1818), the savage History of the Reformation (1824-27), the Woodlands (1825), the shrewd, homely Advice to Young 
Men (1830), and forty or fifty more works. Cobbett was further the originator of Hansard's Debutes (1806), and of Howell's Strute Trials (1809). See Lord Dalling's Historical Characters (5th ed. 1876), and Edwari Smith's Life of Cobbett (2 vols. 1878).

Cobbold, Thomas Spencer, writer on parasitic worms, was born at Ipswich in 1828, studied medicine at Edinburgh, lectured in London on botany, zoology, comparative anatomy, geology, and belmin. thology, in connection with various hospitals and colleges, and died 20th March 1886. He wrote Ento. soa (1864), Parasites (1879), Taperoorms (1866), and numerous other works on kindred subjects.

Cobden, Richard, a great English politician, 'the Apostle of Free 'Trade,' was born at Heyshott, near Midhurst, Sussex, 3d June 1804. His father, a thriftleas yeoman, had to sell his farm in 1814, and relations charged themselves with the maintenance of the eleven children; Richard, the fourth, being sent to a "Dotheboys school in Yorkshire. After five wretched years there, in 1819 he was received into a wholesale warehouse in London, belonging to his uncle, where he soon showed great aptitude for business, and as a commercial traveller he visited Scotland and Ireland. In 1828 Cobden and two of his friends entered into a partnership for selling calicoes by commission in London. They set up an establishment for ealico-printing in Lancashire in 1831, and in 1832 Cobden settled in Manchester, the town with which his name is so closely associated. He wrote a comedy which was rejected by the manager of Covent Garden Theatre. In 1835 he visited the United States, and in 1836 37 travelled in Turkey, Greece, and Egypt. The result of his travels appeared in two pamphlets, England, Ireland, and America (1835), and Russia (1836); the latter intended as an antidote against the 'Russophobia' then prevalent. In these pamphlets he also ridiculed the workings of diplomacy, and asserted England's mission to be the avoidance of war and the extension of commerce. He contested the borough of Stockport unsuccessfully on free-trade principles in 1837 . In 1838 he earried in the Manchester Chamber of Commerce a motion to petition parliament for the repeal of all duties on corn. In the same year seven merchants of Manchester formed the association which soon grew into the Anti-Corn-law League. Of this League Cobden was the most energetic and prominent member. His lectures all over the country, and his speeches in parliament (to which he was returned in 1841 by the constituency which had rejected him in 1837), were characterised by clear, quiet persuasiveness; and to them was in great part due, as Sir Robert Peel acknowledged, the aboli tion of the corn laws at so early a period as 1846 .

Cobden's zeal for free trade in corn had, however, to such a degree withdrawn his attention from private business, that he was now a ruined man, and a subscription of $£ 80,000$ was raised in recognition of his great services; and with this in 1847 he re-purchased Dunford, the farmhouse in which he was born. As his health, too, had suffered, he re-visited the Continent, and during his absence was elected both for Stockport and the West Riding of Yorkshire. He chose the latter constituency, which he continued to represent till 18.5\%. He shared Mr Bright's unpopularity for opposing the policy that led to the Crimean war; and on an appeal to the country by Lord Palmerston to support him in his Chinese policy, of which Cobden was a strenuous opponent, he retired from the West Riding and contested Hud. dersfield, where, however, he was defeated. Cobden spent his leisure in a second American tour. During his absence he was elected for Rochdale.
Lord Palmenston, who was at this time forming his ministry of 1859-65, with a just appreciation of Cobden's great services, offered him a seat in the cabinet as. President of the Board of Trade; but Cobden, as the uncompromising opponent of Palm. erston's policy, felt bound to decline the honour. After his election for Rochdale, the state of his health did not permit him to take any part in par. liamentary proceedingn, but as Her Majesty's plenipotentiary, he (1859-60) arranged and concluded the treaty of commerce with France. Cobden spoke out strongly in favour of the North during the American civil war, and in 1864 strenuously opposed intervention in favour of Denmark. He died in London, April 2, 1865, and was buried at Lavington, Sussex. Few politicians have had such an honourable record as Cobden. In all the relations of life he was amiable, single-minded, and earnest. In parliament and on the platform he was a master in the art of clear, persuasive, and convincing speech. He may be regarded as the representative man of the Manchester school, and therefore as the most prominent champion of free trade, peace, non-intervention, and economy.

His Speches on Questions of Public Policy were edited by John Bright and Thorold Rogers (1870). See the articles CORN LAWs and FreE TraDE; the publications of the Cobden Club; his Life by John Morley (2 vola. 1881); Ashworth, Recollections of Cobden (1877); Sir E. Watkin, Alderman Cobden (1891); A. J. Balfour': Easuys and Addreses ; Mrs Salis-Schwabe, Rcminssences of Cobden (French, 1879; trans. 1895).

Cobet, Carel Gabriel, Dutch Hellenist, born at Paris in 1813, studied at Leyden, travelled in Italy, and in 1846 settled in a chair at Leyden, where he died 6th October 1889. He published De Avte Interpretandi (1847); collections of Varia Lectiones and Miscellanea; works on the comic poet Plato, Dionysius of Halicarnassus, and Xenophon; and editions of Diogenes Laertius, Xenophon's A nabasis and Hellenica, Lysias, and Cornelius Nepos (1881).

Cobham, Lord. See Oldcastle.

Cobi'ja, a seaport of the Chilian province of Antofagasta (q.v.), on a shallow, open bay. See ATACAMA.

Coble. See Boat.

Coblenz, or Koblexz, a eity of Rhenish Prussia, 56 miles SSE. of Cologne by rail, is beau. tifully situated at the junction of the Rhine and the Moselle, the former of which is here crossed by a bridge of boats, and the latter by a fine stone bridge, built originally in 1344. Both rivers are also spanned by railway bridges. Coblenz is very strongly fortified with a wall and a series of detached forts, including the almost impregnable castle of Ehrenbreitstein (q.v.), on the opposite side of the Rhine. In the old town, many of the streets are irregular, narrow, and dirty; but the new town, which is situated nearer the Rhine, is handsomely built, spacious, and clean. Among the prineipal buildings are the church of St Castor, the oldest Christian chureh in the Rhine district, founded in 836 , though dating in its present form from the 12th century; the Kanfhaus (1479); the Protestant Florins Kirche (12th century); the chureh of Our Lady (1250-1431); and the old Jesuit College, now a gymnasium. The extensive palace was built in 1778 86 by the last Elector of Treves, and restored in 1845 . The old archiepiscopal palace is now a factory. The favourable position of the place secures it an active commerce in wine, corn, mineral waters, \&e. It manufactures champagne (about 1,000,000 bottles annually, exported chiefly to England), eigars, japanned goods, and furniture. Pop. (1875) 29,290; (1890) 32,671. Coblenz (Fr. Coblence) was known to the Romans as Confluentes. From 1018 till 1796 it belonged to 
Trèves. In 1798 it was made the capital of the new French department, Rhine and Moselle, and by the treaty of 1815 was given to Prussia.

Cob-nut, a name given to some of the largest and finest cultivated varieties of the Hazel-nut (q.v.). - In the West Indies the name cob-nut is given to the fruit of Omphaleu triandra, a tree of the natural order Euphorbiacese. It is also called Hog-nut. The tree has a white juice, which turns black in drying, and in Guiana is used instead of ink. The albumen of the seed is eaten, after the embryo, which contains a cathartic principle, is removed.

Cobourg, a port of entry and capital of Northumberland county, Ontario, on Lake Ontario, 69 miles NE. of Toronto. It is a railway junction, and contains a Wesleyan university, and several woollenmills, foundries, and breweries. Pop. (1891) 4829.

Cobra da Capello ('hooded snake'), the Portuguese name for one of the most deadly of the poisonous Indian snakes, technically known as Naja tripudians. It belongs to the sub-order of venomous Colubrine snakes (Proteroglyphia), in which the fangs borne on the upper jaw are not perforated by a complete canal, but possess simply an anterior groove down which the poison trickles. The cobra is a large snake, 5 feet or more in length; the colour varies considerably from pale yellow to dark

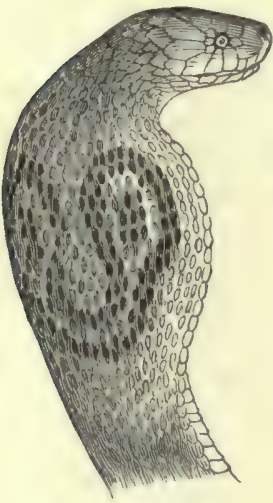

Head of Cobra. olive; one variety has spectacle-like black markings on its neck. By the dilatation of the anterior ribs during excitement the neck can be distended so as to produce a hood-like appearance. It is by preference nocturnal, and feeds on amphibians, reptiles, birds, eggs, small mammals, \&e. It does not appear to be naturally aggressive, but instinctively assumes threatening attitude when disturbed. It then dilates its neck, hisses loudly, and prepares to strike by raising its fangs in the usual snake fashion. The habits vary greatly in different

situations. It may haunt human dwellings for the sake of poultry and other food, and is said to oceur 8000 feet up the Himalayas. Though essentially land animals and fond of concealing themselves among old masonry, stone heaps and the like, the cobras can swim and climb with ease. In gracefulness of movement they excel. The head and neck are often raised above the level of the rest of the body, which remains horizontal. In spite of pictures to the contrary, they can only raise the front part of the body to a very limited extent.

The bite of the cobra is as usual accompanied by the compression of one of the salivary glands modified as a poison bag. The secretion trickles down the grooves of the fangs, and entering the wound produces rapid nervous paralysis, from which recovery is, to say the least, extremely rare. Great numbers of deaths oceur annually in India from cobra bites; but as the assailant often escapes, identification is frequently a matter of conjecture. The victims are usually natives, despite the rattles they use to warn off the reptiles. No certain remedy is known, but excision, eauterisation, ligaturing, doses of ammonia, drugging with rum, \&e. are often resorted to. The cobra is the object of animalworship, and the centre of numerous native superstitions, and is a favourite with snake-charmers.
Naja tripudians is found in India, Java, and South China; $N$. haje, an allied species, is common in Egypt and parts of Africa. The coral snake (Elaps), the rock-snake (Bungarus), the venomous water-snake (Hydrophis), are genera within the same sub-order.

See SNAKks, and works there quoted; also Professor G. Günther's Reptiles of British India (Ray Society, 1861), and Sir Joseph Fayrer's Thanatophidia of India (1874).

Cobre, a city of Cuba, 9 miles $\mathrm{NW}$. by $\mathbf{N}$. of Santiago de Cuba. In the vicinity are copper-mines. Pop. ( 1899 ) 1028.

Coburg, the capital of the duchy of Coburg, in the united duchy of Saxe-Coburg-Gotha, is picturesquely situated on the left bank of the Itz, 81 miles SSE. of Eisenach by rail. The older part of the town, which is fairly well built, is surrounded by attractive modern suburbs. Coburg is, alternately with Gotha, the ducal residence, and the palace, erected in 1549 , is one of the prin. cipal buildings in the town. Among the others are the government buildings, the arsenal, containing a public library, the town-house, and the palace of the Duke of Edinburgh. The old castle of Coburg, mentioned in 1057, beside which Coburg originally grew up, is situated on an eminence 530 feet above the town. It afforded Luther a shelter during the Diet of Augsburg in 1530, and in 1632 successfully resisted a siege by Wallenstein. In 1782 it was converted into a prison, but in 1838 it was thoroughly restored, and now contains valuable collections of engravings, zoology, \&c. Luther's apartments are preserved as he used them. Coburg has manufactures of woollen, cotton, marquetry, baskets, porcelain, furniture, and carriages, and exports beer. Pop. (1875) 14,567 ; (1895) 18,688. Prince Albert, to whom a statue was erected in the market-place of Coburg by Queen Victoria in 1865, was born at Rosenau, a ducal seat 4 miles to the north.

Coburg Peninsula, the most northerly part of Australia to the west of the Gulf of Carpentaria, runs out in a north-west direction towards Melville Island, from which it is divided by Dundas Strait. On its north side is the bay known as Port Essington, at the head of which was established, in 1831, the settlement of Port Victoria-abandoned, on account of its insalubrity, in 1850. Swamp buffa loes, originally brought from Java, have increased here enormously.

\section{Cobweb. See Spiders.}

Co'ca (Erythroxylon Coca-which has of course no connection with Cocoa or with Cocoa-nuts), a shrub of the order Erythroxylaces, of which the leaves furnish an important narcotic and stimulant. The shrub is 6 or 8 feet high, and somewhat re sembles a blackthorn bush; the leaves are ovatelanceolate, simple, and with entire and slightly waved margins, and strongly marked veins, of which two on each side of the midrib run parallel to the margin. It has been in use from a very remote period among the Indians of South America, and was extensively cultivated before the Spanish conquest. Many of the Indians of the Peruvian Andes are to this day excessively addicted to it, and its use is quite general among them, besides extending to men of European race. The dried leaves are chewed with a little finely powdered unslaked lime, or with the alkaline ashes of the Quinoa (q.v.), or certain other plants. An infusion is also occasionally used. An habitual coca-chewer takes a dose about four times daily. In soothing effect it recalls tobacco, but its influence is a much more remarkable one. It greatly lessens the desire for ordinary food, and at the same time permits of much more sustained exer- 
tion, even without sleep; it affects the nervous mechanism of respiration, so that the difficulty of breathing, so common in the arcent of long and steep slopes at high elevations, is little felt. These properties readily explain its high esteem among

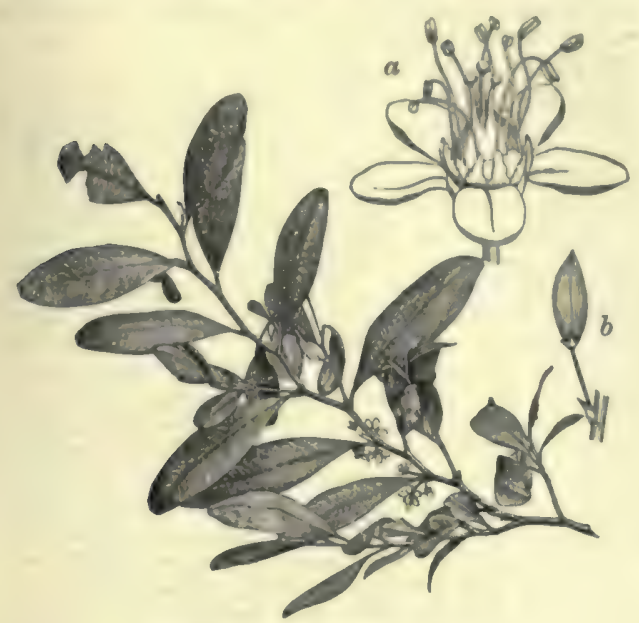

Coca (Erythroxylon Coca): $a$, s flower; $b$, fruit.

the Indians, to whom long and difficult journeys, heavy burdens, and constant privation have always been familiar.

COCAINE. - In Europe, little importance was attached to coea until the veteran pharmacologist Christison awakened interest by personally verifying in old age its sustaining powers. Investigitions followed, and the alkaloid cocaine, upın which the active properties mainly depend, has now come into regular use as a local anzesthetic, by help of which not merely some of the operations of dentistry, but much more serious surgical operations, can be performed without chloroform. To oculists it is of special value, at once dilating the pupil and removing all sensibility. Cases of intoxication and abuse are not infrequent with the leaves, and have been already recorded in connection with the more powerful extract.

Cocana'da, a seaport and headquarters of Godavari district, Madras, 315 miles N. of Madras. Its roalsteal is comparatively safe, and it exports cotton, oil-seeds, sugar, rice, and cigars. Pop. (1881) 28,856 ; ( 1891 ) 40, 533.

Cocceius, or KocH, JoHANnEs, a distinguished theologian, was born at Bremen in 1603, and studied at Hamburg and Franeker. In 1636 he became professor of Hebrew there, and in 1650 of Theology at Leyden, where he died in 1669. His chief work is the Lexicon et Commentarius Sermonis Hebrasei et Chaldaici Veteris Testamenti (Leyden, 1669 ), the first tolerably complete dietionary of the Hebrew language. Cocceius held very peculiar hermeneutical principles, which enabled him to discover the whole New Testament in the Old. The representation abundantly employed in the former of a covenant between God and man, nsurped the place of the New Testament doctrine of the Fatherhood and Sonship; and Cocceius carried the 'covenant theology, as it is called, to an absurd extreme (see CovknANT). The most complete exposition of his views is in his Summa Doctrina de Fodere et Testamento Dei (1648).

Cocceji. Heinrich Freiherr vos, born at Bremen, March 25, 1644, studied jurisprudence and philosophy in Leyden from 1667 to 1670 , and went from thence to England. In 1672 he was made professor of Law at Heidelluerg; in 1689, at Utrecht; and in 1690, at Frankfort-on-the-Oder. In 1713 the emperor named him a baron of the realm. Cocceji died in 1719. His work on civil law (Juris Publici Prudentia, 1695) was long nsed as a text-lxw). - His youngest son, SAMLEL, lworn at Heidelberg in 1679 , acquired no leas renown. He too, in 1703, became professor at Frankfort-0n. the-Oder, filled several honourable state-oflices, and was ultimately the chancellor of Frederick the Great. He died in 1755. He reformed the Prussian administration of justice, and published several works on law.

\section{Coceinella. See LadY-BIrd.}

Coceo, Coco Root, or EDDors, plants of the genus Colocasis, and of the nearly allied genus Caladium, of the order Aracer, widely cultivated in tropical and subtropical countries for their edible starchy root-stocks, of which the food-value broadly corresponds to the potato. These are deprived by roasting or boiling of the characteristic acridity of the order, which, indeed, some of them possess in a comparatively small degree. They are sometimes included under the name $Y a m$, but are totally different from the true $\operatorname{Yam}(\mathrm{q} \cdot \mathrm{v}$.$) . The$ names more strictly belong to Colocasia antiquorum, a stemless plant with ovate leaves, and flowers inclosed in a cylindrical erect spathe. This is a native of India, but was early introduced to Egypt and the Mediterranean countries, whence it has now passed even to America. $C$. esculenta, $C$. macrorhiza, or Tara (q.v.), and $C$. Himalensis are also of economic importance in different parts of the world, and many species of these and allied genera are to be seen in European hothouses, where their handsome foliage has gained them an imoportant place.

Coccoliths are small saucer-like discs found abundantly in the Atlantic ooze, probably unicellular algze. They are sometimes called coccolite, a word also used to denote a greenish kind of Augite (q.v.).

\section{Coccoloba. See Seaside Grape.}

Coccomilia, or Cocumigla (Prunus coceomilia), a species of plum, a native of Calabria, and of which the bark-particularly of the rootis used in that country for the cure of intermittent fevers.

Coccos'teus, a genus of fossil placoganoid fishes, pertaining chiefly to the Devonian and Old Red Sandstone system, but met with also in Silurian strata. The head was protected by a great shield covered with tubercles. Besides this bony cuirass there was alse a ventral shield, but the rest of the body was naked. The mouth was furnished with small teeth.

Coc'culus In'dicus (Ital. coccola, 'a berry ') is the fruit of the Anamirta paniculata, a climbing shrub found in the eastern parts of India, and in the Malayan Archipelago. It was introduced into Britain in the 16 th century for the purpose of stupefying fish so that they might be caught by hand. It acts as an acrid narcotic poison, and when the berries are thrown into a stream it quickly poisons any fish in the neighbourhood. It contains a erystalline principle called picrotoxine, which is very poisonous. It has often been asserted that as coceulus indicus imparts to beer a bitter taste, and at the same time a fullness and apparent richness, it is largely used in the manufacture of that beverage. As its effects are very deleterious, considerable attention was directed to the point, but no evidence is as yet forthcoming to substantiate the statement. In 1876 the report of the Laboratory Department of the Inland Revenue stated that in no case were 
the officers of the department able to detect it either on the brewer's premises or in the beer itself. Of the large quantity imported into England, nearly the whole is re-exported to the Continent.

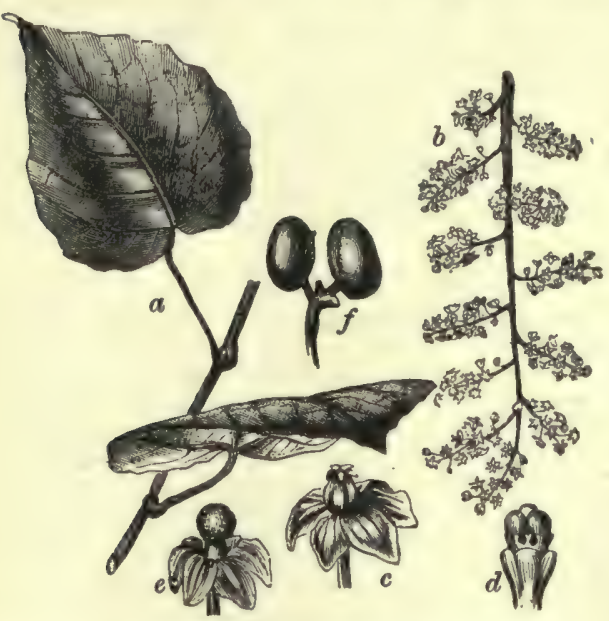

Cucculus Indicus :

$a$, branch with leaves; $b$, panicle of female inflorescence; $c$, female flower; $d$, the same with sepals removed ; $\varepsilon$, male flower; $f$, fruit. (From Bently \& Trimen.)

In Russia and elsewhere it is a popular remedy for tapeworm, lice, \&c. ; but when applied to the scalp it is not unattended with danger, as several deaths have occurred from its use.

Coceus, a genus of insects in the order Hemip. tera, and type of a family (Coccidæ), including many forms very injurious to plants, and a few others which have come to be of use to man. For the latter, see Cochineal, Lac, Manna, Wax. As general characteristics may be noted the beaded feelers, the general absence of wings in the female, the degeneration of suctorial proboseis and posterior wings in the males, and the peculiar history of both sexes. The young forms are somewhat tortoiselike, and run about on plants with some activity. The adult females attach themselves by their proboscis to a juicy part of the plant, and surrender themselves to feeding and maternity. They often become berry-like, plump, much resembling exerescences, or else very flat and scale-like. In the latter form they are often called scale-insects. The body always degenerates more or less, and after fertilisation becomes simply a case, or eventually a dead eovering for the eggs and larvæ. The young males also come to rest, and undergo a peculiar metamorphosis. From the resting larva an elegant male insect results, with developed anterior, but degenerate or aborted posterior wings. The males fertilise the females, but being without suctorial proboscis, are probably short-lived. In fact, both male and female adults seem to fall victims to the characteristies of their sex. The young shelter for a while under the dead female, and then start for themselves. For the important species and related genera, see the articles above referred to.

Coceyx. See Spinal Column.

Coccyzus. See Cuckoo.

Cochabamba, a central department of Bolivia, with offshoots of the Eastern Cordilleras, and extensive plateaus. The climate is equable and healthy, and though the department is comparatively poor in metals, its fertile valleys render it the richest as well as the most picturesque district of the republic. Agriculture and cattle-raising are the chief occupations; but here, as elsewhere in Bolivia, trade is sadly hampered by the want of roads. Area, 21,500 sq. m. ; pop. (1895) $360, \tilde{500}$. The capital, Cochabamba ( 8396 feet above the sea), on a tributary of the Guapay, was founded in 1565, as Ciudad de Oropesa. It has some fifteen churches, a so-called university and high school, and an industrious population, estimated at 25,000 , with a trade in eorn and Peruvian bark.

Cochba. See Bar-CochBa.

Cochin, a native state of India, politically connected with Madras, between the British district of Malabar and the state of Travancore, with the Arabian Sea on the SW. It contains $1361 \mathrm{sq}$. m., and (1891) 722,906 inhabitants. Its hydrography is singular. The Western Ghauts, which have here an elevation of fully 4000 feet, intercept the south-west monsoon, and render the coast one of the most humid regions in the world during June, July, August, and September. As the space between the mountains and the sea is almost on a level with the tide, the countless streams have each two contrasted sections-a plunging torrent and a sluggish river ending in a brackish estuary. Further, these estuaries, almost continuously breasted by a narrow belt of higher ground, form between them a backwater or lagoon of 120 miles in length, and of every width between a few hundred yards and 10 miles, which communicates at only three points with the ocean. The forests produce the cocos-nut, teak, red cedar, and many other woods, while the low country produces drugs, dyes, and gums. The great mass of the population $(\mathbf{4 3 0 , 0 0 0 )}$ are Hindus, but there are also $\mathbf{3 4 , 0 0 0}$ Mohammedans and 138,000 Christians (of the Syrian and Roman confessions), and 1250 Jews. The capital is Ernakolam (pop. 14,000). Cochin formed a treaty with the East India Company in 1798.

Cochin, once the capital of the principality above described, but now a seaport of the district of Malabar, in the presidency of Madras, stands on the south side of the principal channel between the open ocean and the backwater mentioned in the preceding article. In spite of the bar, Cochin is next to Bombay on this coast for shipbuilding and maritime commerce, the annual exports reaching a value of $£ 700,000$. Here the Portuguese erected their first fort in India in 1503. They were supplanted by the Dutch in 1663 ; and in 1796 Cochin was captured by the British. Pop. about 20,000 , of whom 8500 are Christians, 4500 Hindus, and 3000 Mohammedans, Half a mile south is 8 town of the same name, in the native state of Cochin (pop. 13,775).

Cochin-Chima, formerly a name for Annam, but now specifically used for French Cochin-China or Indo-Chine, a colonial possession of France, occupying the south extremity of the Indo-China peninsula, from $8^{\circ}$ to $11^{\circ} 30^{\prime} \mathrm{N}$. lat., and from $104^{\circ} 26^{\prime}$ to $107^{\circ} 30^{\prime} \mathrm{E}$. long. It is bounded N. by Cambodia and Annam; area, 23,400 sq. m. Through nearly its whole extent Cochin. China is low and almost flat. To the north and east, however, the ground rises into the hills of Cape St Jacques, Ba-ria, and Bien-hoa, and the mountain of Dienba. Cochin-China is watered in the west by two branches of the Mekhong (q.v.), the Han-giang and the Tien-giang, which follow a nearly parallel course for about 120 miles. In the east the Dong-nai River flows from north-east to south-west, receiving the Saigon River from the north-west. The Little Vaico flows parallel to and south of the Saigon River. These rivers are all connected with one another by the innumerable arroyos and canals which intersect Cochin-China in all directions. The climate alternates between the rainy season, 
from April to Oetober, when it rains almost every day, and the dry, from Oetober to April, when no rain falls. The temperature rises in the dry season to $95^{\circ} \mathrm{F}$. by day and $62^{\circ}$ by night, and in the wet geason varies between $68^{\circ}$ and $86^{\circ}$. Of all hot climates that of Cochin-China shows perhaps the least considerable variations. The elimate is trying, but its insalubrity has been much exaggerated. The soil, mostly alluvial, is exceedingly fertile, producing the best rice in the world. Sugar-cane, tobaceo, cotton, arachis, mulberry, indigo, maize, tea, betel, hemp, are raised on a small scale; and coffee, cacao, and vanilla have also been introduced. The province of Bien-hoa and the north of Saigon do not yield to the finest lands of India in the luxuriance of their vegetation and the beauty and variety of their fauna. The province of Vinhlong owes its Annamite name of vuoing ('garden') to the abundance, variety, and exquisite taste of its fruits.

The population in 1891 was estimated at 2,034 , 453, of which about 2500 were Europeans (French), 1,500,000 Annamites, 120,000 Cambojans, 60,000 Chinese, 5000 Malays, and the balance savages (Mois, Chams, \&c.). The colony is divided into four provinces. The total exports in 1892 (chiefly rice to China and Europe) amounted in value to $81,464,560$ franes, the imports to $38,255,664$ francs. A railway of 44 miles between Saigon and Mytho has been in operation since 1885, while Saigon and Cholon are also united by a steam-tramway. There are in the colony 51 miles of railway. In 1892 the lines of telegraph wire in Cochin-China mensured 1840 miles; and Cape St Jacques is joined by telegraph to Singapore, Tonkin, and Hong-kong. Though not yet paying its expenses, the colony of Cochin-China has improved financially, and with the development of its resources its ultimate profit to France is considered assured. For an account of the natives and history, see ANNAM; for a map, BURMA; and for fowls, Poultry.

Cochineal, a dyestuff employed in dyeing scarlet and crimson, and in the preparation of the pigments Carmine and Lake (q.v.).

Cochineal consists simply of the bodies of the females of a species of Coccus (q.v.), called $C$. cacti, because it feeds upon plants of the Cactus family,

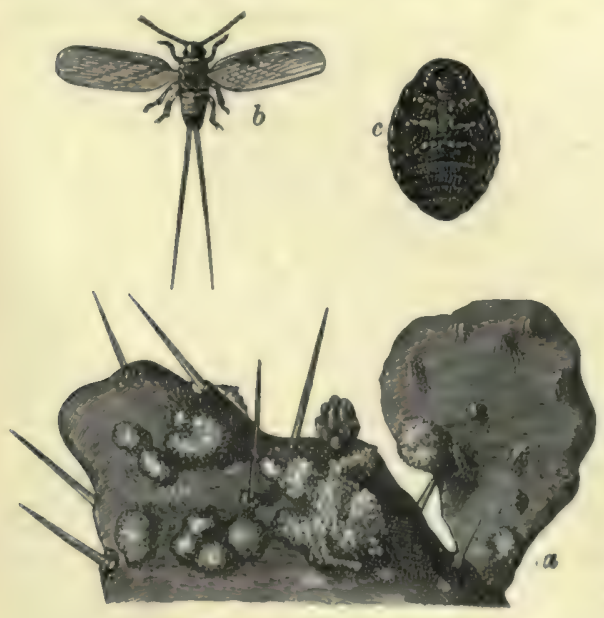

Cochineal (Coccus cacti):

$a$, living on cactus (Opuntia); $b$, male; $c$, female.

particularly on one, therefore designated the coch. ineal plant, but known in Mexico as the Nopal (Opuntia coccinelliferc), figured in the article
Cactes. This plant is nearly allied to the prickly pear, and assumes a somewhat tree-like form. The insect as well as the cactus are nativen of Mexico and other warm parts of Ameriea, bat they are now cultivated chiefly in Guatemala. This cultivation was carried on by the Mexicans. long before the country was known to Enropeans. The insect is not uncommon on wild cacti in Texas and Florida. Both plant and inseet have been successfully introduced into the Canary Islands, A Igeria, Java, and Australia. But the attempt to produce cochineal in India has been practically a failure.

The cochineal insect is a small creature, a ponnd of cochineal being calculated to contain 70,000 in a dried state. The male is of a deep-red colonr, and has white wings. The female, which is winglese, is of a deep-brown colour, covered with a white. waxy powder; flat beneath, convex above.

In some parts of Guatemsla large plantations of Nopal exist for the cultivation of the $C$. eacti. Before the rainy season commences, branches of this cactus plant covered with these insects are eut. off and stored in buildings to protect them from the weather. When the wet season is over, four or fivemonths afterwards (October), the plantations are again stocked from these supplies. Little 'nests' of some vegetable fibre, each containing about a. dozen females, are placed on the spines of the cacti. The eggs are soon deposited, and when the young. females are developed, they spread over the plants, attaching themselves to the leaves, and looking more like vegetable excrescences than insects. They become covered with a cottony substance. The first crop of pregnant females, only these being valuable for cochineal, is gathered in December, and several more crops are obtained till the follow. ing May.

In the Canary Islands the insects are reared in winter and put out on the cactus leaves from May to July. Small gauze bags containing pregnant. females are hung on the cactus plants, from which the young when developed spread over the leaves. In August and September, just before the females. are ready to deposit their eggs, they are collected in trays, and those gathered in one day are placed in the evening in an oven heated to $150^{\circ} \mathrm{F}$. They are afterwards more thoroughly dried in the sun. Hot iron and boiling water are also used in killing the insects. According to the way the insect is killed and dried, the cochineal is known in commerce as silver or black; an inferior kind being sometimes called foxy. The colouring principle of cochineal is called cochinealin or carminic acid, and the insects scarcely yield more than 10 per cent. of pure dye, although the amount is generally supposed to be much greater. Carmine has also. been demonstrated in other kinds of coccus and in aphides.

The cochineal industry has suffered very much through the introduction of aniline dyes. To see to what extent this is the case, it need only be stated that the amount of cochineal exported from the Canary Islands, where it is produced in by far the largest quantity, amounted in 1869 to $6,310,600$. lb. which was valued at $f 842,921$, while in $1885-95$ the annual export from these islands only reached about $1,500,000 \mathrm{lb}$., valued at $£ 80,000$. Meanwhile the price has fallen from eighteen or twenty shillings per lb. to about two shillings (1895).

Cochlßa. See EAR.

Cochlłaria. See Scunvy Grass.

Cochrane, Lord. See Dundonald.

Cockade ( $F r$. cocarde, or coquarde), an ornament or knot of ribbon or rosette of leather, worn either as a military or naval decoration, or as the badge of a political party. Cockades made of ribbons of the national colours were worn by 
soldiers during the wars of the 18th century, the white and red being united in the combined army of France and Spain. In 1767 an authoritative regulation was issued that every French soldier should wear a cockade of white stuff; and in 1782 cockades were prohibited to all but soldiers. From this time till the Revolution the cockade was an exclusively military badge; and, both in France and England, 'to mount the cockade' was synonymous with becoming a soldier. After the Revolution, the tricolor ribbon took the place of the white cockade.

In England, after the expulsion of the Stuart family, the white cockade became the distinctive mark of the adherents of the exiled house, in opposition to the orange of Nassau and the black of Hanover: it is a favourite theme in Jacobite songs. The black cockade, to be seen on the hats of officers' servants, was unknown in Britain till the accession of the House of Hanover, and was then introduced by George I. from his German dominions. It seems to be understood that the right to use it belongs not only to naval and military officers, but also to the holders of some offices of dignity under the -crown, including privy-councillors, officers of state, supreme judges, de., and some would extend it to deputy-lieutenants. The privilege is one of which the law takes no cognisance. See BADGE.

Cockatoo, a popular name for several genera and species of parrots (Psittaci), which may be associated in a family of Cacatuidæ or Plissolophinæ. Some of them are well known as decorative birds. The general characteristics are the tuft on the head, the strong high beak with a notch behind the point, the frequently bright colours of the plumage, the long wings, the loquacious habit. The cockatoos inhabit Australia, Tasmania, New Guinea, and the Indian Arehipelago. The word which the birds seem to say, and which is euriously represented by the English cockatoo, is said to be Malayan for 'old father,' and to have been taught to the birds by their captors. Of the genus Plissolophus, fifteen Australian and Malayan species are known-e.g. $P l$. sanguineus, $P l$. molluccensis, $P l$. cristatus. The great palm cockatoo (Microglossus aterrimus) is the strongest of the parrot tribe, and measures about two feet in length; its colour is mostly black; its special home is New Guinea. The crestless Nasiterna, the smallest of all the parrots, also inhabits New Guinea. The black cockatoos (Calyptorhynchus) form another important genus in Australia. The cockatoos feed mainly on fruits and seeds, but do not disdain insect larvæ.

Cockatrice, a fabulous monster, often confounded with the Basilisk (q.v.), and regarded as possessing similar deadly powers. To the charms of the basilisk it added a dragon's tail, armed with a sting; and it shared also its power of destroying by a glance, so often referred to in Shakespeare and other early writers. In medieval art the cockatrice is an emblem of sin generally, and the special attribute of St Vitus. The name occurs in the English authorised version of the Old Testament, where the original Hebrew word means evidently

in Heraldry. 'venomous serpent.' In Heraldry
the cockatrice is represented as a
vinged monster having the head, body, and feet of

in Heraldry. 'venomous serpent.' In Heraldry
the cockatrice is represented as a
vinged monster having the head, body, and feet of winged monster having the head, body, and feet of
a cock, the tongue barbed, and the tail of a dragon.

Cockayne. See Cockney.

Cockburn, Sir Alexander, judge, was born 24th December 1802, studied at Cambridge, was ealled to the bar in 1829 , and soon became distinguished as a pleader before parliamentary com- mittees. In 1847 he became member of parliament for Southampton in the Liberal interest, became Solicitor-general and was knighted in 1850 , was made Chief-justice of the Common Pleas in 1856, and Lord Chief-justice in 1859. He was prosecutor in the Palmer case : and among the many famous trials over which he presided were the Wainwright case and Tichborne ease. He represented Britain at the Geneva arbitration in the Alabama case. He died 20th November 1880.

Cockburn, Alison, poetess, was born 8th October 1713, the daughter of Robert Rutherford, laird of Fairnilee, Selkirkshire. In 1731 she married Patrick Cockburn, advocate, and in 1753 was left a widow, with an only son, who predeceased her in 1780. She died 23d January 1795, having for sixty years and more been a queen of Edinburgh society: in person she was not unlike Queen Elizabeth. Of her lyrics the best known is the exquisite version of The Flowers of the Forest ('I've seen the smiling of Fortune beguiling'), commemorating a wave of calamity that swept over Ettrick Forest, and first printed in 1765. Mrs Cockburn in 1777 discermed in Walter Scott 'the most extraordinary genius of a boy ;' in 1786 she made Burns's acquaintance. See Songstresses of Scotland (vol. i. 1871), and Craig-Brown's History of Selkirkshire (1886).

Cockburn, Henry, Scottish judge, was born 26th October 1779, perhaps at Cockpen, but more probably in the Parliament Close of old Edinburgh. He entered the High School in 1787, and the university in 1793 , 'being kept,' in his own words, 'nine years at two dead languages which we did not learn.' Dugald Stewart's lectures, then, 'were like the opening of the heavens,' they 'changed one's whole nature;' and through a debating club he became the companion of Jeffrey, Horner, and Brougham, from whom he imbibed Whig opinions, greatly to the annoyance of the hereditary Toryism of his family. He was called to the Scottish bar in 1800 ; and in 1807 his uncle, the all-powerful Lord Melville, gave him an advocate-deputeship-a nonpolitical post, from which, on political grounds, he 'had the honour of being dismissed' in 1810. He rose, however, to share with Jeffrey the leadership of the bar, and with Jeffrey was counsel for three prisoners accused of sedition (1817-19). His powers were better adapted for success with a popular than with a professional tribunal. Simple, clear, and impressive, at times pathetic, humorous at times, and, when he pleased, eloquent, but always unaffected, always Scotch, he would urge his case with an earnestness and candour that was all but irresistible. A zealous supporter by pen as well as by tongue of parliamentary reform, he became Solicitor-general for Scotland under the Grey ministry in 1830; had the chief hand in drafting the Scottish Reform Bill; was elected Lord Rector of Glasgow University (1831); in 1834 was made, as Lord Cockburn, a judge of the Court of Session ; and three years later a lord of justiciary. He died, 26th April 1854, at Bonally Tower, his beautiful home by the base of the Pentlands since his marriage in 1811, and was buried near Jeffrey in the Dean Cemetery, Edinburgh.

Besides five or six pamphlets, and as many articles in the Edinburgh Review, dealing mostly with legal and parliamentary reform, Cockburn was author of an admirable Life of Jeffrey (1852), and of four posthumous works-Memorials of his Time (1856), Journal, 1831-44 (2 vols. 1874), Circuit Journeys (1888), and Examination of Trials for Sedition in Scotland (2 vols. 1888). The first three of these form a kind of autobiography, into which are woven characteristic anecdotes of old-world Scottish life, and graphic sketches of the men who composed the brillant 
circle of Edinburgh society in the first four decales of the 19th century. Withal they illustrate his love of nature and veneration for antiquity.

Cockeliafer (Melolontha vulgueris), a common beetle of the Lamellicorn section, too well known in Enrope for its voracious destruction of both crops and foliage. It is a comparatively large beetle, about an inch in length; generally of a reddish-brown colour; with fine hairs, seanty on the wing covers, but thick on the brenst; and with the expanded ends of its feelers divided in the leatlet-like manner characteristic of Lamellicorns. In Seotland they are less abundant than in England.

The males appenr first, usually in the month of May, and are soon joined by their partners. They Hy with a whirring noise, and being hungry as well as active, do great damage to many of our common trees. After some weeks of flight, the femsles heavy with eggs deposit these in the ground and thereafter die. In a month or so the larve develop, but do not attrin winged life for

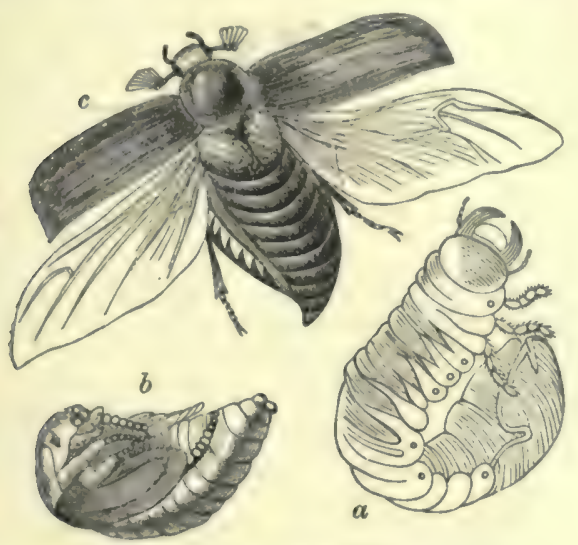

Cockchafer (Melolontha vulgaris):

$a$, full-grown larva; $b$, pupa ; $c$, perfect insect.

four years. Meanwhile they are anything but idle, are in fact most voracious, and do great damage to erops and herbage. In some years when the conditions are unlappily favourable, they commit ravages estimated in millions. In the fourth year of larval life the young beetles bury themselves, and fall for two months into the usual quiescence of the pupa stage. The liberated insect works its way to the surface, and takes its flight in the spring of the fifth year. In warm seasons and regions the period of larval life may be shortened. The adults do most of their disastrous work in the twilight. The only riddance seems to be the exposure of the larve by harrowing, and the destruction of young and old by every possible means. Rooks and other birds, insectivorous animals, and other beetles help to reduce their numbers. They have oftener been plagues on the Continent than in Britain, lut in 1574 their corpses are said to have clogged mill-wheels on the Severn, and in 1688 they clung like swarming bees on the trees and hedges in Galway. Melolontha hippocastani is another very destruetive European species. The May bug of the United States (Lachnosterna quercina) is an allied form of similar habits.

Cocker, See Spaniel.

Cocker, EDWARD, schoolmaster and anthor, was born in 1631, and died in London in 1675 . His book on arithmetic was the first English work of the kind really adapted to commercial life, and became so widely known that the 125 name of Cocker in as indismolubly anmeinted with accuracy in figures as that of Murray with the rules of grammar. He attained considerable success as a teacher of arithmetio and writing in London, and is mentioned repeatedly in Pepy's Diary, who qualities him as "very ingenious and well read in all our English poeta.' Cocker published over thirty works on writing or arithmetic, but the famous book so often reprinted, Cocker's Arithmetick, was posthumous, being dated 1678, and edited by John Hawkins. De Torgan has contended, apparently on insufficient grounds, that this book, which passed through 112 editions, was not really Cocker's work at all. Among other works published under his name are an English dictionary, and the Muses' Spring Garden, which contains some quaint verses of his own composition.

Cockerill, Jонs, manufacturer, born in Lancashire in 1790, was the son of William Cockerill (1759-1832), an inventor and machinist who in 1807 settled at Liège in Belgium. John, with an elder brother, succeeded to their father's business in 1812, established a woollen factory in Berlin in 1815, and in 1817 founded the famons works at Seraing (q.v.). He died at Warsaw, 19th June 1840 ; in 1867 his remains were brought to Seraing, where his statue was erected in 1871 .

Cockermouth, a town of Cumberland, 25 miles SW. of Carlisle, and 12 NW. of Keswick. It is pleasantly situated in an agrieultural district, and has a walk a mile long beside the Derwent. A ruined castle, founded towards the close of the 11 th century, crowns a bold height on the left bank of the Cocker, near its influx to the Derwent. It became Mary Stuart's prison in 1568, and in 1648 was dismantled by the parliamentarians, Near Cockermouth is a tumulus, Toot's Hill; and at Pap Castle are remains of a Roman camp. Wordsworth was born here in an old-fashioned house, still standing. Pop. (1881) 5354; (1891) 5464. Till 1867 Cockermouth returned two members to parliament; till 1885 (when it was incorporated in the county), one.

Cock-fighting was common among both the Greeks and the Romans, as to-day it is common in India; the Malay countries, and Spanish America. In England it flourished for fully six centuries, the cockpit at Whitehall having been erected and patronised by royalty. In 1709 a German visitor to London describes the Gray's Inn cockpit as 'round like a tower, and inside just like a theatrum anatomicum, the benches rising all round;' with the scene at $\mathrm{s}$ cock-fight Hogarth has made us familiar. Cock-fighting was prohibited in 1365, in 1654, and in 1849 ; but it is still sometimes practised in spite of prohihition. Newspaper readers are familiar with paragraphs on cock-fights interrupted by the police, and fines are from time to time intlicted.

The favourite breed of fighting-cocks is the game-fowl (see PoulTRY), and very large sums liave been given for chicks. Much art is dis. played in the training of cocks, and in trimming and preparing the cock for the combat; the fastening on of the spurs is a matter of considerable experience. Young cocks are called stags; two years is the best age. In fighting a match, a certain number of cocks to be shown on either side is agreed upon, and the day before the match the cocks are shown, weighed with the greatest nicety, and matched according to their weights Their marks are all also carefully set down to prevent trickery. The cocks within an ounce of each other in weight are said to 'foll in,' and are matched. Those which do not fall in are matched to fight what are called 'byes.' Those which do 
fall in come into the main. The main is fought for a stake upon each battle, and so much for the main, or the winner of the most battles in the main; while the byes have nothing to do with the main, and are usually fought for smaller sums. A middling size is considered the best, and from $3 \mathrm{lb}$. $6 \mathrm{oz}$. to $4 \mathrm{lb} .8 \mathrm{oz}$ is the medium. Cocks sometimes fight in silver spurs, but more often in steel. In a Welsh main the cocks fight until only one is left alive. By the Act of 1849 , a penalty of $\mathfrak{£ 5}$ may be levied on any person keeping fightingcocks, letting a cockpit, or otherwise connecting himself with cock-fighting, for every day that he shall so act.

Strange to say, cock-fighting was a specially sanctioned annual sport of public schools, the schoolmaster receiving 8 regular tax from the boys on the occasion, which was on Shrove Tuesday. It was so in the days of Henry II. ; and in his Scholemaster (1570) Roger Ascham announced his intention, never fulfilled, of writing a 'Book of the Cock-pitte,' as 'a kinde of pastime fitte for a gentleman.' As late as 1790 the income of the schoolmaster of Applecross in Ross-shire was formally said to be composed of salary, fees, and cock-fight dues. And Hugh Miller, in My Schools and Schoolmasters, gives an account of the yearly cock-fights in the grammar-school of Cromarty about 1812. The yet more barbarous custom of throwing sticks at cocks fastened to stakes, was also long practised at Shrove-tide. The slang cockshy is a survival.

Cockie-leekie is in Scotland a kind of soup made of a fowl boiled with leeks.

Cock Lane Ghost. In the year 1762 London was thrown into a state of extraordinary excitement by the reported existence of a ghost in the house of one Mr Parsons, in Cock Lane, Smith. field. Strange and unaccountable noises were heard in the house, and a luminous lady, bearing a strong resemblance to one who, under the name of Mrs Kemt, had once resided in the house, but who had died two years before, was said to have been seen. Dark suspicions as to Mr Kemt having poisoned the lady were immediately aroused, and were confirmed by the ghost, who, on being interrogated, answered, after the fashion of the spirits of our own day, by knocking. Crowds were attracted to the house to hear the ghost, and the great majority became believers. At length a plan was formed by a few sceptics to ascertain the real origin of the noises. Parson's daughter, a girl eleven years of age, from whom they supposed the sounds to proceed, was taken to another house by herself, and threatened with the imprisonment of her father in Newgate if she did not renew the rappings that evening, the noises having for some time been discontinued. She was discovered to have taken a board with her into bed, and when the noises took place, no doubt was entertained that they had all along been produced by similar methods. A prosecution was then raised by $\mathrm{Mr}$ Kemt, and Parsons was condemned to atand thrice on the pillory for imposture and defamation. Among those who visited the house was Dr Johnson, but it is not true that, with all his natural bent to easy belief in the supernatural, he was one of the dupes of this miserable imposture. Churehill's gross caricature of Pomposo's credulity in his tiresome poem of over four thousand lines, The Ghost, was mere false and malicious slander, and deserved the payment that the burly Johnson promised to give Foote upon his own stage if he persisted in taking him off in the same way. See A. Lang's Cock Lane and Common Sense (1894).

Cockle (Cardium), a large and typical genus of bivalve molluses (Lamellibranchs). The thick, ribbed, heart-shaped, equal-valved shell, and the large knee-bent "foot' are characteristics well known to every one. The shell is closed by two muscles; the hinge has large teeth; there are two minute respiratory siphons. About two hundred living species are known, and have a very wide distribution, though most abundant in the tropical seas. They live freely and gregariously, generally buried in the mud or sand. The foot is used for burrowing, but by it the cockle can also jump a few inches. $C$. edule is very largely eaten, and is often sold in great quantities on the streets of British towns. The fossil forms are very numerous, and increase from the Silurian onwards. (For figure and structure, see BIVALVEs.)

Cockle, or ConN-COCKLE (Githago-Agrostemma-segetum), of which one species, a caryophyllaceous annual weed, is common amongst crops of grain, is a native of Europe or the west of Asir, but is now found in cereal erops in almost all parts of the world. Its tall graceful habit, and large lilac-purple flowers, make it one of the most beautiful of corn-weeds; its seeds are, however, unwholesome, especially to fowls and domestic animals, and thus the undesirableness of its presence in crops is increased. A special sieve is employed for their removal in bad cases in Germany. It is an annual plant, clothed with very long hair; with large, solitary, terminal lilac flowers. The root, stem, leaves, and seed were formerly used in medicine; the seed is still sometimes sold in Germany under the name of Black Cumin (Schwartzkümmel). The corn-cockle is a very troublesome weed in some parts of Britain, and is rare and almost unknown in others.

Cockney, a familiar name for a Londoner, the earlier meaning of which was a foolish, effeminate person, or a spoilt child. The original meaning is very obscure, but in Chaucer cokenay (a trisyllabic word) had much the same meaning as this. Professor Skeat points out its obscurity of meaning in two famous passages in Piers Plowman (x, 207), and in the last stanza of the 'Tournament of Tottenham' in Percy's Reliques. The word occurs twice in Shakespeare (Twelfth Night, IV. i. 15; and Lear, II. iv. 123), and there with the meaning, according to Schmidt, of a person who knows only the life and manners of the town, and is consequently well acquainted with affected phrases, but a stranger to what every child else knows. The French Pays de Cocagne, with which the word is usually connected, denotes a Utopia-an imaginary land of luxurious abundance without labour. The true origin of the word cockney has been much debated. The explanation of Wedgwood, followed by Skeat in his 'Errata,' connected it with the French coquin, 'a rogue;' itself, according to Littré and Scheler, derived through a Low Latin coquinus from Latin coquus, 'a cook' or 'kitchenscullion.' Diez doubted this, and assumed a connection with the old Norse kok, the throat. But according to Dr Murray, the word cockeneye or cockenay means really cock's-egg, i.e. either simply a hen's egg or a diminutive hen's egg; then a 'nestle-cock,' a mother's darling, a cockered or pampered or effeminate person.

\section{Cock of the Plains. See Grouse.}

Cock of the Rock (Rupicola), a genus of South American Passerine birds in the family of Cotingida or Chatterers, beside the Cotingas (q.v.) and Pompadours, the Umbrella-bird (Cephalopterus), and the Bell-bird (Chasmarhynchus). The bill is high and strong, the tail short and straight, the sole naked, the feet are strong and stout. The male is remarkable for a lofty, laterally compressed crest. In the best-known species ( $R$. crocea), from Guiana and the north-east of Brazil, the male is 
predominantly orange-red in colonr, with a dark purple-red ereat, and decidedly larger than the solier brown female. It is about the size of a common pigeon.

Cock of the Woods. See Capercallzik.

Cockpit. in a ship of war, is the name still given to the eompartment in the lower purt of the ship where the wounded are attended to during action. The surgery and dispensary which contains the medicine chests for the ship's company adjoin the cockpit.

Cockroach (Blatta or Periplaneta), a large genus of insects, type of a family (Blattidre) within the important order Orthoptera, which likewise includes locusts, grasshoppers, crickets, leaf-insects, earwigs, \&c. Though often spoken of as beetles, cockroaches have in no sense direct connection with that order. Familiar enough as pests, cockroaches require no minute description. The antenno longer than the bodyi.e. over an inch, the bent down head (halfhidden by the large first thoracic plate), the long spiny legs compressed terminally, the flat broad segmented abdomen, the cigar-shaped anal appendages (which are supposed by some to represent a pair of rudimentary abdominal legs), are among the more striking external features. The two adult sexes in the common cockroach are readily distinguished, since the female has a somewhat broader abdomen, and only slight traces of wings. In the male, the anterior wings form stiff opaque wing-covers (tegmina), while the posterior pair are membraneous, really wing-like, and folded longitudinally; in the female, the tegmina are very small, and the posterior wings only suggested by marks. Certain cockroaches, however, are wingless in both sexes. There are complex copulatory and egg-laying structures in the respective sexes.

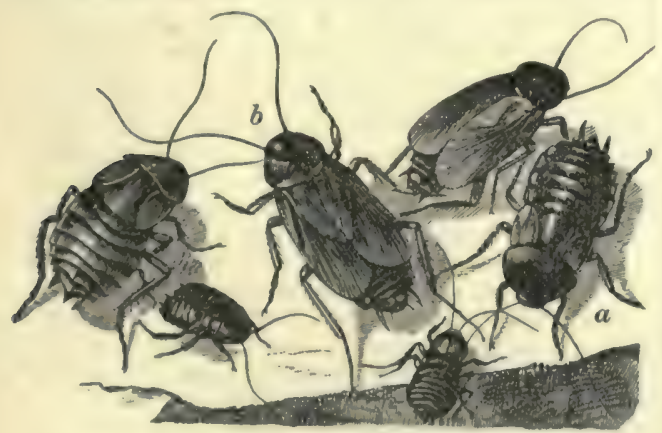

Common Cockroach :

$a$, female; $b$, male.

The essential male organs atrophy in the adult males. The egrgs are surrounded by a peculiar hard capsule, which the female carries about for a long time, but eventually attaches by a glutinous secretion to some suitable sheltering object. This cocoon, in the common species, usually contains sixteen eggs, one from each of the ovarian tubes. Like other true Orthoptera, the cockroaches have no marked metamorphosis in their life-history. The larva, when developed, appear to soften the edges of a side slit in the inclosing capsule, and emerge through this into active life. They pass through no fasting quiescent state, and when hatched, differ from the adults only in minor quantitative details. They are said to moult seven times before becoming quite adult in the fifth year of their life.

Cockroaches are voracions insects, devouring both animal and vegetable substances, which they seek out by aid of their almost certainly olfactory antenne. Their mouth organs (three pairs of jaws) are very typical, and well alsuptad for biting. The juices of the mouth leave a disgusting smeli on the objects over which the insects pase. They are nocturnal in habit, most abuudant in warm countries, fond of sheltering in houses, and notori. ously a pest to bakers and millerm. To get rid of them a tame hedgehog is often employed, or they may be caught in large numbers in a slipjery milk basin, baited with treacle, and led up to by a piece of wood which cannot be regained from the bottom. The commonest species in Britain (Periplaneta orientalis) is said to have been brought to Europe from Asia within the last two hundred years; $P$. americana has found its way hither in bales, \&c. from America. The German cockroach (Blatta or Phyllodromia germanica) is a troublesome, widely distributed form, which appears, however, to go to the wall before our common pest. Another form (Blatta or Ectobia lapponica) of smaller size, which occurs commonly in the woods of north and central Europe, is specially important in Lapland, where it sometimes does great injury by devouring the winter stores of salted fish. The largest form known is a native of South America and the West Indies, which measures about 3 inches in length, and makes a loud drumming noise. The cock. roach is an ancient insect, having been actually found in Silurian strata. As a tolerably evolved, and yet not too highly specialised type, the cockroach forms a very convenient type for the anatomical study of insects. See Miall and Denny, The Cockroach: an Introduction to Entomology (1886).

Cockscomb (Celosia cristata), an East-Indian annual of the order Amarantacex, familiar in con. servatories, often also planted out in warm borders, especially in the southern parts of Britain. It grows with an upright stem, which becomes flattened upwards, divides, expands, and forms a sort of wavy crest, covered with pointed bracts, and bearing on its surface many very small abortive flowers, so crowded as often to present a rich velvety appearance. The colours are various, and often very brilliant. In the wild species, however, the flowers are of ordinary type, and in simple spikes and panicles; while in the so-called $C$. aurea, a golden variety formerly much cultivated, only a few flowers of the base of the inflorescence are perfect, the other being represented only by bracts and scales; while in the cockscomb proper the monstrosity known as Fasciation (q.v.) has further taken place.

Cock's-foot Grass (Dactylis), a genus of Grasses, closely allied to Fescue (Festuca), but differing in habit. The Common or Rough Cock'sfoot Grass ( $D$. glomerata $)$ is a native of both palaaretic and nearctic regions, and is very abundant in Britain. It furnishes an important part of both natural and artificial pastures. In America this grass is called Orchand Grass, and is extensively cultivated. To this genus belongs also the Tussac Grass (q.v.). See Pasture, Grasses.

Cockton, Hreny, comic novelist, was born in London in 1807, and died 26th June 1853 at Bury St Edmunds, where eleven years earlier he had married and settled in business. Unless for their illustrations, all of his ten works are almost forgotten but one-Valentine Vox, the Ventriloquist (1840).

Cocon, Cacao, or Coco. The different kinds of cocos are prepared from the seeds of trees of the genus Theobrōma.

The genus Theobroma (Gr., 'food of the gods ') belongs to the natural order Byttneriacere (q.v.), and contains a number of species, trees of moderate size, with large undivided leaves and clustered flowers, all natives of the tropical parts of America. 
By far the most important species of this genus is $T$. cacao, to which the name cocoa-tree is often exclusively appropriated. It is extensively cultivated in tropical America and the West Indies, and its cultivation has been introduced into some parts of Asia and Africa. The fruit is somewhat like a cucumber in shape, is 6 or 8 inches long,

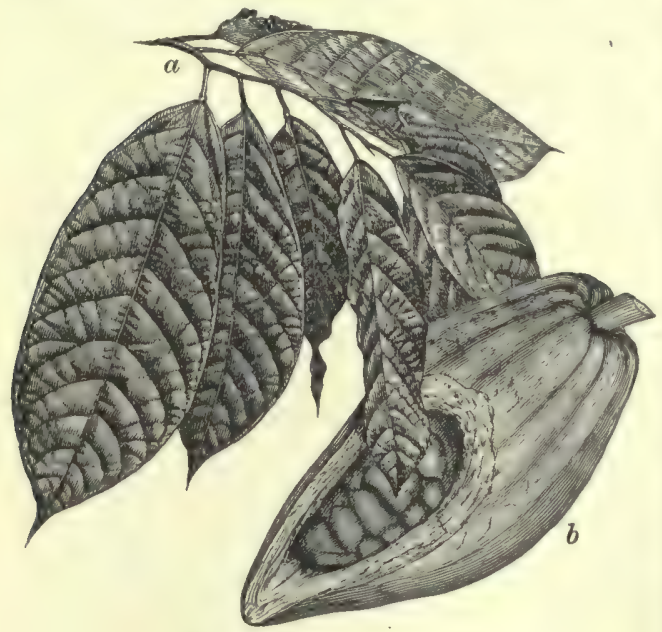

Cocoa (Theobrōma cacao) :

$a$, branch with leaves; $b$, fruit (partly in section).

yellow, and red on the side next the sun; the rind is thick and warty, the pulp sweetish, and not unpleasant ; the seeds numerous, compressed, and not unlike almonds, with a thin, pale, reddishbrown, fragile skin or shell, covering a dark-brown, oily, aromatic, bitter kernel. These seeds are the cocoa beans of commerce; when bruised so as to be reduced to small pieces, after being shelled or decorticated, they become cocoa nibs. The cocoatree produces larger seeds in cultivation than in a wild state. The tree attains its full vigour and productiveness in seven or eight years, and generally yields two principal crops in the year. When gathered, the fruit is subjected to five days' fermentation in earthen vessels or in heaps on the ground, and then opened by the hand; or it is buried for a while in the earth till the pulp becomes rotten. The latter method is said to produce the best cocoa (earthed cocoa or cacao terré). The seeds are then roasted.

The average composition of the shelled and roasted bean is, in round numbers, about as follows. There is considerable variation in different samples,

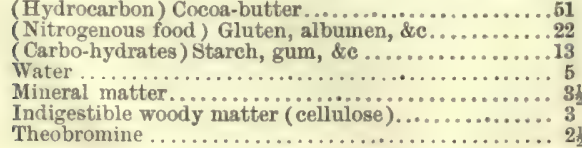

This expresses a very high nutritive value, as will be understood by comparing it with the following, which shows the proportion of corresponding constituents in lean beef -2 beefsteak, for example :

(Hydrocarbon) Fat.

(Nitrogenous food ) Gelatin, albumen, \&c............ 19

(Carbo-hydrates)

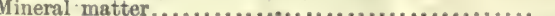

Water

$\overline{100}$

In order to render its large amount of nutritious matter digestible, the nut must be prepared. The best mode of preparation is by crushing and continuous grinding under rollers until the whole is reduced to an impalpable paste. This, when dried, adheres, and forms a hard cake. In this form it is now supplied to the navy and many merchant ships, and forms a most valuable beveragefood for sailors when scraped or pounded and boiled for a short time in water. The large amount of fatty matter and nitrogenous food renders it especially suitable for men exposed to cold and fatigue. It is a most valuable reserve food for travellers, so much of both heat-giving and fleshforming nutriment being concentrated in a given bulk and weight. It is thus used by Swiss and Tyrolese mountaineers in the form of edible chocolate. For the preparation of chocolate, see Chocolate.

An infusion of the broken and roasted shells, which are set aside in preparing the best qualities of chocolate, is used in Italy, Spain, and other countries as a cheap substitute for coffee, and bears the name of miserabile ("poverty stricken'). The pulp of the fruit is eaten in the countries in which the tree grows, and a kind of spirit is obtained from it by fermentation and distillation.

Cocoatina, cocoa essence, concentrated cocoa, are names given to preparations from which some of the cocoa-butter has been extracted to render the beverage more digestible. These, when honestly prepared, are excellent. Another mode of preparation consists in adding large quantities of cooked farinaceous material to the ground cocoa, mixing these when in a pasty condition, then drying and selling the mixture under various names-soluble coeoa, \&c. Some of them contain but a homeopathic proportion of actual cocoa, producing, when prepared by the addition of boiling water, merely a gruel flavoured with cocoa. Those who prefer such mixtures will find it economical to prepare their gruel or porridge themselves, and add genuine cocoa to it. The writer has done this by sprinkling a little powdered cocon into ordinary Scotch porridge. By using whole or ground cocoa nibs, a genuine cocoa beverage may be obtained, but for this it is necessary to subject the nibs to very long boiling; a whole day is desirable. The full and peculiar flavour of the nut comes out, and much of the butter floats on top, while the cellulose and other insoluble constituents remain as sediment.

The Theobromine or special crystallisable alkaloid of cocoa resembles that of tea and coffee, but contains a larger proportion of nitrogen, and appears to be less stimulating in its action on the nervous system. Some regard it as highly nutritious.

In South Carolina the earth-nut is roasted and used as a spurious cocoa; and in Spain the root of the earth chestnut (Cyperus esculenta) is similarly used. See Adulteration.

Cocoa-nut is the current English form of what was till Dr Johnson's time spelt Coco-nut; coco, 'mask,' being the Portuguese name given to the nut from the resemblance of its lower part to a mask. It is the well-known fruit of a species of palm, Cocos nucifera, perhaps originally a native only of the Indian coasts and South Sea Islands, but now diffused over all tropical regions, generally succeeding best in sandy soils near the sea. It is always one of the first of the larger plants to establish itself in the low islands of the Pacific Ocean, so soon as there is soil enough, its nuts being widely distributed by marine currents, while the thick husk protects the embryo from injury. It has a cylindrical stem, about $1 \frac{1}{2}$ feet in diameter, and from 60 to 90 feet high, with many rings marking the places of former leaves, and bearing at its summit a erown of from sixteen to twenty leaves, which generally curve downwards, and are from 10 
to 15 feet in length. The short racemes bear from five to fifteen or more nuts; and ten or twelve of these racemea, in different stages, may be seen at once on a tree, about eighty or one hundred nuts being its ordinary annual produce; the best trees are said to produce two hundred. The tree bears fruit in from seven to eight years from the time of planting, and continues productive for aeventy or

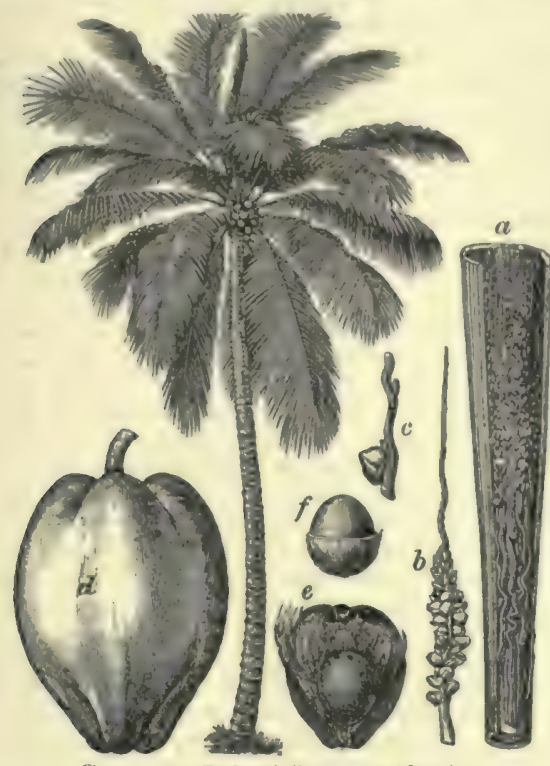

Cocos-nut Palm (Cocos nucifera):

a, portion of young spathe, with inclosed inflorescence; $b$, branch of spadix; $c$, smaller portion enlarged, showing a female flower below and male flower above; $\boldsymbol{d}$, cocos-nute husk cut open, showing hard endocarp, at $f$ opened to show the single seed.

eighty years, the fruit being gathered four or five times annually. This affords to the inhabitants of many tropical coasts and islands great part of their food; it is not only eaten as it comes from the tree, both ripe and unripe, being filled in a young state with a pleasant milky fluid, bnt it is also prepared in a variety of ways. The strueture of the fruit will be understood by reference to the article PALM.

The kernel of the cocoa-nut contains more than 70 per cent. of a fixed oil called Cocoa-nut Oil, or Cocos-nut Butter, which, however, must not be confounded with the fixed oil of the chocolate, also known as cocos butter. The oil is itself an import. ant article of commerce, being much employed in Europe, particularly for the manufacture of stecrine candles; and also of a marine soap, which forms a lather with sea-water. In tropical countries, and particularly in the East, it is much used as a lamp oil and as an unguent. It is also employed as an article of food, so long as it remains free from rancidity, to which, however, it is very liable. It has been recommended as a substitute for lard in the preparation of ointments, and in this con. nection its property of readily taking up a large quantity of water has given it a certain value. It may be used instead of cod-liver oil in consumption, for which purpose it is more palatable and less likely to cause nausea. It is obtained by pressure of the bruised kernel, or by boiling over a slow fire, and skimming off the oil as it floats on the surface. A quart, it is said, may be obtained from seven or eight cocos-nuts. It is liquid in the ordinary temperatures of tropical countries, but in colder climates becomes a white, solid, butter-like oil. It becomes liquid about 74 $\left(23.3^{\circ}\right.$ C.). It can be separated by compression in the cold into a more liquid portion ealled alein, and a more solid part termed cocosteurin, or cocosin, which is of complex constitution, and contains at least six fatty acids.

The root of the cocon-nut paim ponseases narcotic properties, and is sometimes chewed instead of the areca-nut. The terminal bud (Palm Cabbage) is esteemed a delicacy, and trees are often cut down for the sake of it; the central part of the young stem is also succulent and eatalile. - The sacchar. ine sap (toddy) of this, as of some other palms, is an esteemed beverage in tropical countries, either in the state in which it is obtained from the tree, or after fermentation, which takes place in a few hours; and from the fermented sap (palm wine) a spirituous liquor (arrack) is obtained by distillation. The juice is often also in the East Indies boiled down to yield sugar (jaggery). A variety of arrack is also distilled from the fermented milk.

The dried leaves of the cocoa-nut palm are much used for thatch, and for many other purposes, as the making of mats, screens, baskets, \&c., by plaiting the leaflets. The midribs of the leaves supply the natives of tropical corsts with oans. The wood of the lower part of the well-grown stem is very hard, takes a beautiful polish, is employed for a great variety of purposes, and is imported into Britain for ornamental joinery, under the name of Porcupine Wood.-The fibrous tissue of the less mature stems is made into cordage. A kind of gum is also frequently obtained from the stem.-By far the most important fibrons product of the cocos-nut tree is Coir (q.v.), the fibre of the husk of the imperfectly ripened nut. The husk of the ripened nut is used for fuel, and also, when ent across, for polishing furniture, serubbing floors, dic.

The shell of the cocoa-nut is made into cups, goblets, ladles, \&c., and is often polished or carved. Within the nut there is occasionally found a small stony substance, of a bluish-white colour, 'a sort of vegetable bezoar,' called in India Calappa, to which the Chinese ascribe great virtues. There are about 30 species of the genus, mostly South American, of which $C$. butyracea and $C$. coronata may be mentioned as specially important sources of oil and starch respectively. - The Double Cocon-nut of the Seychelles Islands is the fruit of a totally different palm, Lodoïcea Seychellarum. See Coco DE MER.

Cocoa-nut Beetle (Batocera rubus), a large Longicorn beetle, the larvge of which are very destructive in cocoa-nut plantations, eating their way in all directions in the stems of the younger trees. They are destitute of feet, large and pulpy, and of repulsive aspect; but are esteeined a luxury by the coolies of the East. They resemble the grugru worms of South America.

Coco de Mer (also called Sea or Maldive Double Cocos-nut) is the fruit of the Ladoiced Seychellarum palm. Its double kernel has long had an extraordinary value over a large aren in the East. As a sovereign antidote to poison, and long known only from specimens thrown up on the Maldive coasts, it was supposed to grow on a submarine tree, and had other fables attached to it. The tree on which it grows is peculiar to some of the Seychelles Islands, reaches a height of 100 feet, and has very large fern-like leaves.

Cocoon, the silken sheath spun by the larvee of many insects in passing into the pupa or resting stage. The cocoon proper is due to the secretion of special spinning glands, situated anteriorly or posteriorly, but larval hairs and foreign objects of many kinds may also be utilised. The amount of secretion, the arrangement of the threads, and the completeness of the covering vary very widely; nor is the presence of any cocoon whatever essential to the pupa stage. The most typical and pe-fect 
cucoons are those of many moths, a familiar example being that of the silkworm. The delicacy, neatness, and labour exhibited by these last silken robes make them as marvellous as they are useful. See CATERPILLAR, CHRYSAlis, INSECTS, and especially SILKWORM (under the article SILK).

\section{Cocos. See KEELING ISLANDS.}

Cocy'tus, a river of Epirus, a tributary of the Acheron, supposed to be connected with the lower world. Homer makes it a branch of the Styx; Virgil makes the Acheron flow into the Cocytus.

Cod (Gadus), a genus of bony fishes in the softrayed order (Anacanthini), and type of a family (Gadidæ) which includes some valuable food-fishes, such as Ling (Molva), Hake or 'Stockfish' (Merlucius), Burbot (Lota), \&e. The genus Gadus itself is undoubtedly the most valuable. A moderately elongated body with small smooth scales, the three dorsal and two anal fins, the distinctness of the tail from the fins, the position of the pelvic limbs on the throat, the toothed vomer and toothless palatine, are among the more important distinetive features. The genus includes about a score of species, distributed in the cold and temperate seas of the northern part of the globe, and well known to be very abundant off Newfoundland, at the Lofoden Islands, and on the Dogger Bank. They seem to follow the herring shoals. As part of oux food-supply, and as sources of cod-liver oil, the species of Gadus are of great economic importance.

Besides the cod proper ( $G$. morrhua), the following species are well known: the Haddock (q.v., $G$. oglefinus), the Whiting (q.v., G. merlangus), the Bib or Whiting-pout ( $G$. luscus), the Powercod ( $G$. minutus), the Pollack ( $G$. pollachius), the Coal-fish ( $G$. virens).

The cod itself is too familiar an animal to demand description. It attains a length of 2 to 4 feet, and may weigh as much as $100 \mathrm{Ib}$. The sensitive barbule on the chin is tolerably long. The colour varies considerably. A smaller variety (dorse) is sometimes distinguished-e.g. in the Baltic. The cod occurs between $50^{\circ}$ and $75^{\circ} \mathrm{N}$. lat. in great profusion, to a depth of 120 fathoms, but is not found nearer the equator than $40^{\circ}$ lat. It spawns from January to May, according to the climate, and it is only at this season that numbers crowd together. The cod is very voracious, and feeds at the bottom on crustaceans, molluses, worms, and even on small fishes. They are very prolific, and it has been calculated that the roe of a large female may contain towards 9 million eggs. The productiveness of the great banks of Newfoundland excels that of all others, but the cod-fisheries near the coasts of Sweden, leeland, and the north of Scotland are also important. The Dutch were engaged in the cod-fishery as early as the middle of the 14th century, and the English resorted for this purpose to the coasts of Iceland about the same period. The French have also engaged largely in the cod-fishery. The fishery is always carried on by means of lines and hooks, partly by long-lines and partly by handlines. Whelks and the like are used for bait. Une man has been known to eatch from 400 to 550 fish, on the banks of Newfoundland, in ten or eleven hours; and eight men to take eighty score in a day on the Dogger Bank. Great quantities of dried cod are carried from Newfoundland to the West Indies, and are consumed also in the Roman Catholic countries of the south of Europe. The principal seat of the cod-liver oil industry, in which other species are also utilised, is on the Norwegian coast. The preserved 'sound' or swim-bladder of the cod is esteemed a delicacy. It is also used in * dried state as isinglass. See Day's British Fishes, and Ginther's Introduction to the Study of Fishes.
Coda (Ital., 'a tail'), a passage at the end of a musical composition, intended to round it off and give a sense of completeness in form. In early music it consisted often of a few simple chords; but it was enlarged, by Beethoven more especially, into a feature of the greatest importance and dimensions, it being one of the most characteristic features in the form of his symphonies; and other composers have with rare exceptions followed his lead. See SYMPHONY.

Code (Lat. codex and caudex). The primary meaning of the Latin word was the trunk or stem of a tree; afterwards it came to signify more especially wooden tablets bound together, and covered with a coating of wax, which were used for writing on. After parchment and paper were substituted for wood, the name code was still retained. Cicero applies it to a bill; but it was not till still later, in the times of the emperors, that it was used to express a collection of laws.

In its modern sense the word code may be defined as a systematic statement of the laws of a country (either the whole law, or any special department of it) having the authority of an act of the legislature. In other words, it is the ex. pression of the law of a country in a systematic and authoritative form. This definition distinguishes it, on the one hand, from a digest, which properly signifies a collection of the decisions and rules of the common law arranged on a methodical plan, and, on the other hand, from a consolidated statute, which is nothing more than the incorporation of all the statutes relating to a particular branch of the law into one general enactment. While the digest differs from a code in so far as it wants the authority of a legislative enactment, the consolidated statute differs from it in that it does not deal with the unwritten or conmon law.

Whether it is for the advantage of a community that its laws should be expressed in the form of a code, is a question which has been much discussed both in Great Britain and abroad. On the Continent it has been practically settled in the affirmative, while in Great Britain and in some of the states of America (particularly the state of New York) the controversy is still keenly maintained. Two principal objections urged by the opponents of codification may be thus summarised: (1) That it checks the natural growth of the law and hinders its free development; and (2) that, as law is progressive, there would be no finalitythat it would be necessary to be constantly altering the code in order to adapt it to the new conditions of society. The answer usually made to the first of these objections is, that although law is a flexible and progressive seience, it is nevertheless capable of being known as it exists at any given time, and if so it must be eapable of being expressed in language. "The law of a country,' observes Mr Dudley Field, the distinguished American jurist, "may be likened to its language, and to make a code of the one is like making a dictionary of the other.' If the law is not expressed in language, it must almost necessarily be left to the fluctuating opinions of judges to say whether a particular set of facts is in any given case of legal effect or not. To the second of the above objections the answer is : Granted that a code cannot be made for all time, there is nevertheless no reason why any changes required by altered conditions of society should not be adequately met by periodical revision. A commission. of lawyers might be appointed for that purpose, and revision might take place, say, every ten years. On the other hand, the arguments specially urged in favour of codification are: (1) That it will simplify the law, thereby getting rid of a vast mass of statutes and judicial decisions, whose 
nuthority has become more or less doubtful, and which overload the book-shelves and waste the time of our lawyers and judges; and (2) that by simplifying the law it will be made accessible to and comprelsensible by ordinary citizens.

Viewing the subject histoncally, we find that the Romans were the first to realise the idea of codification. The compilation of the Twelve Tables (q.vo) in 303 B.C. Was the earliest attempt to codify the whole law, both public and private. But with the Romans the term code was confined in its applieation to the collections of the laws and constitutions promulgated by the emperors (the im. perial edicta, rescripta, and decreta), and had not the extensive meaning of the word in its modern sense.

The following is an enumeration and description of the more celebrated codes, ancient and modern :

I. ANCIENT CODEs. - (1) Codex Gregorianus et Hermogenianus. - These two collections of imperial constitutions (mainly of rescripta) were the first to receive the designation codex, and they supplied a model which was to a considerable extent followed in the subsequent codes of Theodosius and Justinian. They were both the work of private hands, although they were subsequently declared authoritative bv a decree of Theodosius and Valentinian. The first of them is supposed to have been published about the end of the $3 \mathrm{~d}$ century, and that of Hermogenianus a little later. Only fragments of each have been preserved.

(2) C'vilex Theodosianus, named after the Emperor Theodosins the Younger, during whose reign it was compiled. The original idea of Theodosius was to prepare a complete body of the law, collected from the writings of the jurists as well as the constitutions of the emperors, but his instructions to this effect were never carried out. The codex, as we have it, occupied three years in preparation, and was promulgated as law for the Eastem empire on 1st January 439, and a few days thereafter adopted and declared to be law for the Western empire by Valentinian III. This Codex Theodosianus has been in a great measure preserved. It consists of sixteen books, which are subdivided into titles, and a chronological order in the arrangement of the constitutions has been followed. All but the first five books ( containing the purely private law) have come down to us. By means, however, of the so-called Breviarium Alari. cicuum-an abridgment in great part of this code made by the order of Alaric II., king of the Visigoths - it became possible to reproduce a considerable proportion of the earlier books. Palimpsest restorations have also during the 19th century brought to our knowledge a number of the genuine constitutiones which were not to be found in the breviary of Alaric. The best editions of this code are those of Jac. Gothofredus, with his celebrated commentary upon Books VI, to XVI., originally published in 1665, and Hänel, contributed to the Corpus Juris Rom. Antejustin. (Bonn, 1842).

(3) Codex Justinianeus.-This, which is the most celebrated of the ancient codes, was named after the Emperor Justinian, in whose reign it was prepared. In the year 528 A.D. a commission of ten persons, with the famons Tribonian at their head, was appointed by Justinian to compile a code, incorporating in it the earlier codes of Gregorianus, Hermogenianns, and Theodosius, and slso the various constitutions issued subsequent to these codes. The work was performed in fourteen months, and it was then declared that the new code should supersede the older compilation. A second edition of this work, revised and having 'a number of new enactments of Justinian himself incorporated, was promulgated in 534 under the name of the Codex repetite prodectionis. This is what has come down to us, and is now known as the Codex Justinianeus, and forms purt of the corpus juris. It consints of twelve books, each of which is divided into chapters.

(4) Romano-Burbarian Codes.-Several collections were made of the laws of the barbarians of western Europe after they had become free from the domination of Rome. To three of these collec. tions the name of the Romano-Barbarian Codes is usually applied. They are (1) the Edictum Theo. dorici, compiled under Theodoric, king of the Ostrogoths, about the year 500, and consisting of 154 sections (unsystematically arranged), desling with all departments of the law, its materials being derived mainly from the Gregorian, Her. mogenian, and Theodosian Codes. (2) The Lex homana Visigothorum, prepared under Alaric, king of the Visigoths, and published in the year 506 . This collection was one of great importance, and during a considerable part of the middle ages was trented as the principal exponent of Roman law, thus exercising great influence upon the Gothic law of western Europe. It was compiled by com. missioners, appointed by Alaric, who derived their materials in great part from the Theodosian Code and the institutes of Gaius. This codex is commonly described as the Breviarium Alaricianum. (3) The Lex Romana Burgundionum, also published about the beginning of the 6th century, under Gundobald, king of the Burgundians. It was compiled from much the same sources as the code of Alaric II.

II. MODERN CoDEs.-As already observed, the idea of a code in the modern sense-viz. as a com plete statement of the whole law, or any particular department of it-was not realised by the ancients. The Roman Codex was in many respects more akin to what we call a consolidated statute than a proper code.

(1) Prussian Code. - The first of the modern codes (leaving out of view certain ordonnances of a general nature promulgated at an early date in France and some other countries, but which hardly deserve the appellation Code) was the celebrated Landrecht of Prussia-the Code Frederic-published in 1751. This work was due to the genius of Frederick the Great, and was intended by him to firmly cement the union between the various parts of his kingdom. In the introductory plan (or projet), Frederick tells what induced him to undertake the work - viz. the great uncertainty in the law arising out of the want of uniformity in the customs and statutes prevailing in the different parts of his dominions, and the excessive and costly litigations due to this uncertainty. He makes, at the same time, a violent onslaught upon lawyers generally, and hopes that one immediate result of the code will be to restrict their number to the most moderate dimensions. Out of this Code Frederic, the existing Allgemcines Land. recht of Prussia has grown.

(2) Code Napoleon. - This is the most celebrated of the modern codes. At the time of the great Revolution there was an endless variety of particular laws and enstoms (droit ecrit et droit contume) prevailing in the different parts of France, entailing great uncertainty and expense in the administration of justice, and preventing anything like true solidity and unity in the nation. Napoleon realised the necessity of the unification of the local laws by a code applicable to the whole country. No doubt, a good deal had been done towards unification by the preparation of an admirable act of ordonnances in the reigns of Louis XIV. and Louis XV., but they only went a small way in rectifying the evils. The Constitution of 1791 and Projet de Code Civil of Cambacérès (q.v.) partly anticipated the Code Napoleon, which, elaborated in four months by a commisaion com. prising Tronchet and three others, was published 
and promulgated between 1804 and 1810 . It consisted of five parts-viz. the 'Code Civil,' dealing with the main body of the private law; the "Code de Procédure Civile;' the 'Code de Commerce, dealing with the laws relating to commercial affairs ; the 'Code d'Instruction Criminelle ;' and, finally, the 'Code Pénal.' Each of these five parts was independent of the others, though prepared on the same system and governed by a uniformity of plan. In order to prevent absolutely an appeal in any case to the authority of the old laws and customs, it was expressly enacted that if cases should occur for which the code had made no provision, the judge should decide according to what he might consider to be good sense and equity or ancient custom-in this respect differing from the Prussian Landrecht, which requires that any questions unprovided for by it shall be referred by the judge to a legislative commission for decision. The Code Napolén (or, as it has been re-christened under the Republic, the Code Civil) remains in force as the law of France at the present day, and despite many defects in its original constructionnecessitating a large number of interpretative commentaries-it has, beyond doubt, proved a great hoon to that country. Napoleon (though he had, of course, no share in the legal work performed by Cambacérès, Tronchet, Pothier, \&c.) is said to have been prouder of it than of any of his victories. The best test of his excellence is that it has been (in whole or part) the model for a large number of continental codes; as, for example, those of Belgium, Italy, and Greece. So also in the Rhenish provinces, upon which it was originally imposed by foree, it remains to this day the basis of legislation.

(3) German Codes.-Prior to the constitution of the present German empire in 1871, two important codes of the German commercial law had been prepared and adopted by the North German Confederation. These were the Wechsel-Ordnung, codifying the laws relating to bills of exchange, which was published in 1848, and the Allgemeines Handelsgesetzbuch, codifying the whole commercial law, exclusive of bills of exchange and bankruptey, which was published in 1861 . Since 1871 these two codes have been made applicable to the whole of the empire, and three other departments of the law have since been codified-viz, the law of bankruptey (Konkurs-recht), the law of procedure, and the criminal law. A commission was charged with the enormous task of codifying the whole civil law of Germany, and from time to time groups of laws have been adapted for the empire.

(4) United States Codes. - In most of the states codification, either of the whole law or of particular branches of it, has been effected. At the same time it is noticeable that in one or two of the states the expediency of codifying the private law is still much controverted. This is particularly the case with New York, where in 1857-65 a draft civil code was prepared (mainly by the distinguished jurist, Mr Dudley Field), but did not receive the sanetion of the legislature. This code has, however, been adopted by California and (with modifications) the Dakotas. The penal code was adopted in 1882.

(5) British and Colonial Codes.-The only result in the way of codification achieved in the United Kingdom is in the department of the law which relates to bills of exchange (including promissory. notes and cheques). By the Bills of Exchange Act, 1882, the statute and common law of the three kingdoms relating to this important department of mercantile jurisprudence was in great measure reduced to the form of a code. This enactment is, perhaps, not a complete code in the strict sense, seeing that it does not profess to entirely shut the door of the common law in ques. tions affecting bills-decisions prior to the Act being still authoritative so far as they are not inconsistent with its express provisions. But in other respects it fulfils the proper requirements of a code. Having been drafted with much eare and skill, it has, since it came into force, proved of great value and benefit to the mercantile community in the way of diminishing litigation and otherwise. Efforts have been and are now being made by law-reformers ( prominent among them being Sir James F. Stephen) to have other branches of the law codified, and more particularly the law of evidence and the law of crimes, and criminal procedure. As regards British possessions it may just be observed that an excellent code exists in Canada, and that in India several branches of the law have been codified by the celebrated Anglo-Indian codes. The criminal code of India was drawn up in the year 1837 under the auspices of Lord Macaulay, though it was not promulgated till 1860.

Codeine, an alkaloid obtained from poppyheads. See POPPY.

Codex (Lat., 'manuscript,' pl. Codrces : see CODE), the name applied to ancient manuscripts, as of the classics or of the Scriptures. Of the latter class the four great Uncials (q.v.) are the Codex Sinaiticus, discovered in 1844 and 1859 in the monastery of Mount Sinai by Tischendorf, and the Codex Vaticanus, both of the 4th century ; and the Codex Alexandrinus (see under ALExaxdria) and Codex Ephraemi of the 5th century. All four originally contained the Old and New Testament complete, but none are perfect copies, while the last, besides having great lacunæ, is almost illegible. See PaLIMPSEST.

Codicil (Lat. codicillus, diminutive of codex), a supplement to a will, whereby anything omitted. is added, or any change demanded by the altered circumstances of the testator or the beneficiaries, is effected. A codicil is authenticated in the same manner as a will, and possesses the same privileges when holograph, or written by the hand of the testator himself. See WILL.

Codilla is the coarsest part of hemp and also of flax, sorted out and separated from the rest.

Codlin Moth (Carpocapsa pomonana), the moth whose larva cause the 'worm-eaten' apples, which fall prematurely off.

Cod-liver Oil is generally obtained from the livers of the common Cod (q.v.), but likewise from allied species, as ling, dorse, coal-fish, torsk, \&c. In these fish the Adipose Tissue (q.v.) containing oil is almost entirely confined to the liver, in which they agree with the shark tribe, whilst in other fish, as in the herring and salmon, the oil is diffused over the entire structure of the animal. The supplies of medicinal cod-liver oil used to be derived mainly from Newfoundland, but Norway now supplies the bulk of that used in Great Britain. The most famous of the Norwegian fishing-grounds is that of the Lofoden Islands. On the outer shores. of these islands immense shoals of fish begin to arrive in December, but owing to the storms to which the coasts are liable, only a comparatively small number of boats ( some 800 ) engage in the fishing. Later on, in the beginning of January, the fish pass in between the islands and enter the calmer waters of the Westfjörd to spawn. Then the fishermen, assembling in immense numbers, catch the fish by net or baited line. A good catch for a boat, with a erew of five men and a boy, is from 600 to 1200 fish ; and some idea of the im. portance of this industry is obtained from the fact that in a single year these fisheries alone employed 4000 vessels, with a crew of 27,000 men, the catch amounting to $25,000,000$ of fish. The fishing-grounds being near the shore, the 
fish are at once cleaned, and the livers re. moved. These may be treated in different ways, the various qualities of cod-liver oil being the result. The finest oil, known as 'non-freezing pale oil,' is obtained by warming the livers by means of steam heat, when the oil separates, and is either removed by straining or by allowing it to float to the surface. It is then cooled to $14^{\circ}\left(-10^{\circ}\right.$ C.), and filtered, either by mechanical pressure or in the usual way. A white tallow-like sub. stance remains in the flannel filter, and a bright cod-liver oil passes through, which is now capable of being exposed to frost without turning turbid.

In the case of those fisheries which are situated at some distance from the shore, the livers are placed in tanks, till a sufficient quantity has been collected, with the result that partial putrefaction takes place. The oil obtained in this way is of a dark-brown colour, and possesses a nauseous empyreumatic taste.

A atill coarser variety is manufactured for use in leather-making. In it the livers of the cod, herring, haddock, \&c. are indiscriminately used, a very fishy-tasted oil being the result.

It will be seen from the above that the different varieties of cod-liver oil may be produced from the same livers. Thus, that obtained by pressure or steam heat from fresh livers is the freest from taste and colour, while the oil becomes darker and darker as the livers become less fresh. It has been supposed by some authorities that the dark-brown oil is the more efficacious, but others find no difference in actual practice, while the pale oil can alone be tolerated by delicate stomachs. Cod-liver oil mainly consists of oleic, stearic, and palmitic acids, in combination with glycerine. In addition to these, galuin, a substance of biliary origin, but possess. ing no recognised medicinal virtues, is present along with iodine and bromine. Some have ascribed the virtues of cod-liver oil to the iodine or bromine, but as the iodine is only present in the proportion of 1 part in 2000 parts of the oil, this view seems untenable. Sometimes the oil is adulterated with spurious oils, to which iodine has been added, and this may be assumed if the proportion of iodine exceeds that stated above. There are unfortunately no chemical tests that can with certainty detect the presence of other oils, although there are tests which distinguish liver-oils from those of other origin. Thus with nitric acid, cod. liver oil yields a purple colour, changing to a brown; while a drop of sulphurie acid produces a violet colour, soon changing to brownish red. In order to prevent it from becoming rancid and fishy. tasted, it is well to keep it sechiled from the air.

Cod-liver oil is at present one of the most import. ant remedies in the Materia Medica. Although possessing a high reputation on the Continent, it was not till 1841, when Professor Hughes Bennet (q.v.) of Edinburgh wrote a treatise on it, that it came into genersl use in Britain. It is most valued in cases of pulmonary consumption, chronic rheumatism, and gout, besides all diseases of a gerofulous nature. In all these it is, however, useless to expect good results unless the remedy has been regularly taken for several weeks. Its mode of action is uncertain. While some hold that it merely acts as a nutrient, it is certain that pork-fat, butter, and other digestible oils, do not have the same specific action that characterises cod-liver oil. It is given in doses of from half a teaspoonful to one tablespoonful three or four times a day, and it does not seem that excessive doses, such as a cupful or more, are of any real benefit, while they are a severe strain on the digestive organs.

As its peculiar flevour is very repulsive to many patients, various devices have been adopted to render it more palatable. The addition of a trace of sulphurie ether, while rendering it more envily digested, does not improve the flavour. It may, however, be made into a jelly with ininglas, or be taken floating on the surface of porter; while in the form of Emulsion, of which many varieties are in the market, the flavour in more or less skilfully disguised. Most druggists also keep gelatin capsules, containing from one to one and a half teaspoonful, which are ensily swallowed.

Codogno, a town of Northern Italy, 17 milea SE. of Lodi by rail. Pop. 8935 .

Codrington, Sir Edward, a British admiral, was born of a good old Gloucestershire family, 27 th April 1770, and entered the navy in 1783. In 1794 he was lieutenant of Lord Howe's flagship, and took a prominent part in the action off Ushant on the glorious lst of June. At Trafalgar, in 1805 , he was captain of the Orion, and leader of a squadron. He afterwards served in the North Sea, in Spanish waters, and in North America, and rose to the rank of vice-admiral in 1821. In 1826 he was appointed commander-in-chief of the Mediterranean squadron, and in that capacity took the leading part in the battle of Navarino (q.v.), which destroyed the Turkish navy. In reward for this victory he received the Grand Cross of the Bath, with Russian and French orders; but the battle being considered an 'un. toward event,' Codrington was recalled. He attained the full rank of admiral of the red in 1837, and in 1839 was appointed commander-inchief at Portsmouth, He was M.P. for Devon. port from 1832 to 1839. He died April 28, 18.31. The 'Narrative' written to prove that at Navarino he had not exceeded his instructions, is printed in the Memoir by his daughter, Lady Bourchier ( 2 vols. 1873).-His son, GeNerax. Sir William JoHn Codrington, G.C.B. (1804-84), was commanderin-chief in the Crimea from 11 th November 1855. -Another son, ADmiral Sir Henry John CoDRINGTON, K.C.B. (1808-77), took part in the destruction of St Jean d'Acre, and served in the Baltic in 1854-55.

Codrus, the last king of Athens, was the son of Melanthus, and according to Greek legend, sacrificed his life for his country about the year 1068 B.C. A war raging between the Athenians. and Dorians, the oracle declared that the victory should belong to those whose king was slain by the enemy ; whereupon Codrus, attiring himself as a peasant, entered the Dorian camp, and having picked a quarrel with some of the soldiers, contrived to have himself slain. See Aвсноs.

Coefficient, the numerical or literal factor prefixed to an unknown quantity in any algebraic term. Thus in the expression $a x-2 b y^{3}+13 x^{2}-$ $(\alpha+5) y$ there are four terms, and the coefficients are, in order, $a, 2 b, \vee \overline{3}$, and $(a+5)$. A special and very important instance is found in the phrase Differential Coêficient of a given function with reference to one or more of the variables involved. In the theory of equations, also, coëtlicients play an important part: thus, in the cubic $x^{3}+a x^{2}+b x+c=0$, we know that (supposing the 3 roots are $p, q, r) p+q+r=-a, p q+q r$ $+r p=b$, and $p q r=-c$.

Coehoorn, or Cohorn, Mevno, Baron vas, called the Dutch Vauban, was the son of a captain of infantry, and born near Leenwarden in 1641. He studied fortification and mathematics at Franeker, and alremly captain of a company in his sixteenth year, he greatly distinguished himself at the siege of Maestricht, and in various battles. At the siege of Grave, in 1673, he demonetrated that the amall portable mortars namel after him might 
be advantageously employed. Coehoorn covered limself with honour at Senef (1674), before Kaiserswerth (1689), and at Fleurus (1690). He fortified Namur, and defended it against Vauban in 1692; besieged that fortress in 1695 , and retook it; was appointed lieutenant-general and director-in-chief of the Dutch fortifications, and fortified several towns, of which Bergen-op-Zoom was considered his masterpiece. In the war of the Spanish succession he defeated the French more than once, and took Huy and Limburg. He died at the Hague, on his way to meet Marlborough, March 17, 1704. He left two important works on fortification.

Coehorns-named from the military engineer who introduced them-are small bronze Mortars (q.v.), $\frac{8}{9} \mathrm{cwt}$. in weight, and of 48 inches calibre. Being easily carried, they are useful in sieges, to annoy working parties, and in situations where guns cannot be employed, such as the attack of hill-forts in India.

Coelenterata, the technical name for the second lowest alliance of many-celled animals, The class includes (1) locomotor types-jelly-fishes, swimming bells or medusoids, colonial medusoids such as the Portuguese Man-of-war, and extremely active organisms known as Ctenophores; (2) tubular forms or 'polyps' (mostly fixed) - the common Hydra, the compound Hydroids or zoophytes, the sea-anemones, compound sea-anemone-like types such as Dead-men's Fingers, and limy or coral modifications from all these. The two types, medusoid and polypoid, are inseparably linked together by real though not obvious resemblance in strueture, and by the facts that many swimming bells are only detached and modified reproductive members of fixed zoophyte colonies, and that a fixed polypoid stage occurs as a chapter in the lifehistory of some common jelly-fishes.

General Characters.-(1) The Colenterates are nearer the primitive two-layered sack-like ancestral form, the Gastrula (see EMBRYOLOGY), than are higher animals; (2) they are radially symmetrical in almost all cases, that is, they are the same all round, and a line drawn vertically through the body of Hydra, Sea-anemone, or Jelly-fish corresponds to the long axis of the gastrula; (3) they do not possess any body-cavity distinct from the alimentary tube; (4) they have not a distinctly developed third or middle layer of cells, as in higher animals; (5) there is an almost constant presence of offensive stinging cells; $(6)$ vegetative nultiplication by budding is very common, and division of labour is frequent in the resulting colonial organisms; (7) the life-history often illustrates Alternation of Generations (q.v.); (8) 'coral'forms occur abundantly by the formation of limy 'skeletons' in various passive types.

Classification. - (a) The Hydroids and the swimming bells often associated with them, the jelly-fish proper, colonial locomotor colonies like the Portuguese Man-of-war (q.v.), the limy Hydrocorallinæe (see MILLEPORES), \&c., are grouped together as Hydrozoa. (b) The Sea-anemone and Deadmen's Finger types, with their associated 'corals, form the division known as Actinozor (q.v.). (c) The climax of activity is represented by the Ctenophora (q.v.), such as Beröe (q.v.). For details and fossil forms, see separate articles.

Habit of Life.-Five or six Coelenterates, including the common Hydra, are fresh-water animals; the others are marine. A few are parasitic. Most of the active forms are found in the open sea, near the surface, but some live at great depths. The sedentary forms occur at all depths, and are often anchored on other animals, which they sometimes mask. The food of the great majority consists of small organisms, in the seizure of which the almost constant tentacles and stinging cells are very important.

Relationships.-For the connections between Hydra and the compound zoophytes, between the polypoid and medusoid types, between the medusoids and the Portuguese Man-of-war order, between medusoids and Ctenophores, between Seaanemones and the sessile type exhibited in the life-history of some jelly-fishes, see separate articles (ANEMONE, BeRöE, CORAL, CTENOPHORA, HYDROZOA, JELLY-FISH, \&c.).

Pedigree.-The ancestral Colenterate was proh. ably gastrula-like. Modification has taken two main directions of increasing activity and increas. ing fixedness. The class as a whole probably arose apart both from the lower Sponges and from all the higher animals. See Huxley's Anatomy of Invertebrates, and other general works of Claus, Gegenbaur, Rolleston and Hatchett Jackson, Zittel, \&c., and monographs noted under special articles.

Coelestimus. See Celestine.

Coele-Syria ('Hollow Syria'), now called by the natives El-Buka'a, 'the deep plain,' a valley of Syria, extending between the ranges of the Lebanon and Anti-Lebanon. It is 1706 feet above the sea, and is watered by the Orontes (now ElAsi). Above the valley stand the ruins of Baalbek.

Coe'liac Axis. See Aorta.

Crenobites (Gr. koinos, 'common,' and bios, 'life'), the name given to those monks who live together, in contradistinction to anchorites or hermits, who withdraw from all society, and live in a solitary fashion. See MoNACHISM.

Coenurus. See Bladder-Worm, Cestoid WORMS, TAPEWORMS.

Coffee (Turkish qahveh, from Arabic qahweh, originally meaning "wine"). This well-known beverage is an infusion of the roasted seeds of the coffee-tree (Coffea Arabica), a native of Abyssinia, Arabia, and many parts of Africa, and naturalised in many of the tropical countries colonised by Europeans. There are some twenty species of Coffea, but few of them seem to possess valuable properties; the seeds of $C$. Mauritiana, prepared in the same way, are bitter and slightly emetic. The genus belongs to the natural order Cinchonacer. It has a tubular 4-5-cleft corolla, and a succulent fruit containing two cells lined with a cartilaginous membrane, and each containing one seed.

In a wild state, it is a slender tree of 15-25 feet high, with few branches; in eultivation, it is seldom allowed to become more than 6-10 feet high, and is made to assume a sort of pyramidal form, with horizontal branches almost from the ground. The leaves are evergreen, opposite, very shining, oblong, and leathery; the flowers are small, clustered in the axils of the leaves, and snow-white; the whole appearance of the tree is very pleasing; and the smell of the flowers is delicious. The fruit, when ripe, is of a dark-scarlet colour, and the seeds are semi-elliptic and of a horny hardness. The seeds are commonly but incorrectly termed coffee beans, or, still more incorrectly, coffee berries.

The coffee-tree succeeds only in countries where the average temperature of the year is about $64-70^{\circ} \mathrm{F}$. In Peru and Quito it is acclimatised at an elevation of 6000 feet, where, however, frost never occurs ; but as it delights in a moist atmosphere, it nowhere thrives better than in tropical islands. In the hothouses of Britain the coffeetree frequently flowers and the fruit ripens. Coffee plantations are laid out pretty much in the same way everywhere. In quadrangles, bordered by fruit-trees, the coffee-trees stand in rows; they are pruned to the same height, and the ground between 
them is carefully kept clear of weeds. Where the elimate is dry, abundant irrigation is necessary, but the supply of water is eut off as the fruit begins to rijen, in order to improve the aroma of the seeds. The tree yields its first erop in the third year; from a full-grown tree it may amount to a pound of coffee beans. As the eoffee-tree continues flowering for eight months, its fruits are at uny given time of very unerual ripeness; in the Weat Indies and Brazil, three gatherings are

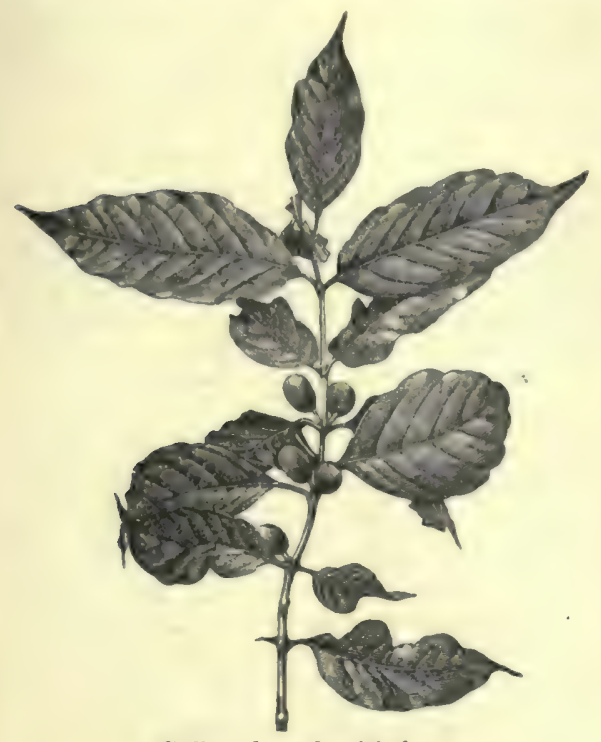

Coffee; branch with fruit.

therefore made annually. The beans are placed on mats or large floors specially aulapted for the purpose, where they are dried by the sun's rays, being meanwhile frequently turned. They are passed between rollers to remove the dried pulp of the bean, and the membrane which incloses the seeds themselves. The coffee is afterwards freed from impurities by winnowing, and conveyed in bags to the seaports. As equal care is not, however, bestowed upon the preparation of it in all places where it is cultivated, there are great differences in quality and price.

The earlier history of the coffee-tree is not very clear. Coffee was not known to the Greeks or Romans; but in Abyssinia and Ethiopia it has been used from time immemorial. In Arabia it was certainly in use in the 15th century, and over the rest of the East in the 16th century. Towards the end of the 17th century, the coffee-tree was carried from Mocha to Batavia by Wieser, a burgomaster of Amsterdam, where it was soon extensively planted, and at last young plants were gent to the botanical garden at Amsterdam, from which the Paris garden obtained a tree. A layer of this was earried out to Martinique in 1720, where it succeeled so well, that in a few years all the West Indies could be supplied with young trees.

The following sorts are particularly distinguished from each other in commerce. Mocha Coffee, which comes from Arabia, and is known by its small gray beans inclining to greenish; Java or East Indian Coffee, which has large yellow beans; Jamaica Coffee, with beans somewhat smaller and greenish; Surinam Coffee, which has the largest beans; Bourbon Coffer, with beans pale yellow and almost whitish. The devastation of the Ceylon plantations by the leaf disense (see CEYLON) has led to the introduction of a hitherto neglected variety, the Coffea Liberica, or Liberian Coffec, a native of the weat coast of Africa. It appean to resist the ravages of the disease which has been so fatal to the Arabian variety in Ceylon; but being of coarser character, it is grown only to a very mall extent.

The great demand for coffee has led to the employment of s number of chesper subatitutes, of which Chicory (q.v.) root is the best known. Of others, dandelion root, carrot, and the seeds of the common yellow iris may be mentioned. They are prepared by roasting like coflee. The seeds of Astragalus Boticus, are known on the continent of Europe as Wredish Coffee, and are said to be the best substitute for coffee yet discovered. But all these substitutes want the most important constituent of true coffee, caffeine; and are therefore very different from it in their qualities. Ground coffee is subject to great adulteration, as will be seen from the article ADULTERATION.

In France and other continental countries, ground coffee is largely mixed with caramel or burnt sngar. This is for the most part prepared by skilfully roasting the 'foots' or dregs obtained in the refining of sugar. In moderate quantities it imparts a flavour considered by many to improve the infu. sion. The so-called 'French coffee 'now so largely sold in England contains more or less of caramel-commonly much more than is desirable, its commercial value being very small. A rough test or indication of this is easily obtainable by dipping a bright silver or plated spoon into the infusion. The caramel infusion adheres to the spoon much more decidedly than the pure coffee infusion, and leaves a darker stain. Infusion of chicory behaves similarly to that of caramel.

The leaves of the coffee-tree are used in the western part of Sumatra instead of the seeds. They are prepared by quick drying in a manner similar to that in which tea-leaves are prepared; and in this state contain even a larger proportion of caffeine than the coffee beans of our shops.

Coffee owes its exhilarating and refreshing properties to the presence of three substances: (1) Caffeine (q.v.), which occurs in the rossted bean to the extent of 9 to 1 per cent. ; (2) a volatile oil, which is not present in the raw bean, but is developed during the process of roasting to the extent of only one part in about 50,000 of the roasted coffee; and (3) astringent acids, resem. bling tannic acid, but called caffeo-tannic and caffeic acids. The average composition of unrossted coffee is as follows:

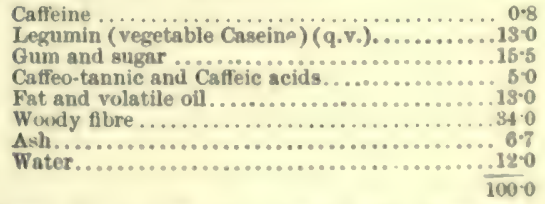

When the beans are roasted till they assume a reddish-brown colour, they lose 15 per cent. by weight, and gain 30 per cent. in bulk; when further roasted till they become chestnut brown, they have lost 20 per cent. by weight, and increased 50 per cent. in bulk; whilst if the roasting is continued till the beans become dark brown, they lose 25 per cent. in weight, and acquire 50 per cent. in bulk. When the roasting is carried too far, more or less charring is the result, and a disagreesble burnt smell is produced, which tends to overcome the natural pleasant aroma.

In Britain coffee is asually under-rossted, probably in order to escape the loes of weight, as the roaster is also the retailer. But in France, in Norway, in Germany, and other countries where it 
is roasted at home by the consumer, the roasting is carried to the dark-brown stage. The writer, who has watched the domestic roasting of coffee in many countries, attributes the superiority of the pure infusion made in these countries mainly to this and the use of the freshly roasted and ground roffee. The Norwegian peasant usually adds a very small quantity of butter to the beans while roasting in the simple apparatus, like a covered shovel or frying-pan, she uses; always shaking it while over the fire. Every tourist praises the result.

The important offices which coffee fulfils are, to allay the sensation of hunger; to produce an exhilarating and refreshing effect; and, according to some anthorities, to diminish the amount of wear and tear, or waste of the animal frame, which proceeds more or less at every moment. See DIET, Digestion, FooD.

An endless variety of apparatus have been contrived-some of them of great complexity-for preparing coffee for the table. The chief object aimed at is to obtain the liquor free from all sediment. The simplest and cheapest device is that of placing a bag or metal strainer-by means of a suitable rim-in the upper part of the coffee-pot, placing the ground coffee in this, and pouring boiling water through it. Or the ground coffee may be simply placed in a saucepan or coffee-pot, hot water poured upon it, and boiled for a few minutes. After this the grounds will settle down, and the coffee may be poured off fairly clear.

Many forms of coffee-pot have been devised in which atmospheric pressure is applied for forcing the hot water through the ground coffee resting upon a metal strainer, doing this in such a manner that the water shall all pass through while just at the boiling heat, and then shall leave it.

The question whether coffee should be boiled at all, or simply infused like tea by pouring boiling water on it, has been much discussed. The writer has observed that in countries where pure coffee is used, boiling is practically in favour. This sug. gested some experiments which have shown that pure coffee is improved by two or three minutes' boiling, while chicory is rendered bitter and unpalatable by such treatment. We therefore recommend that where a sufficient quantity of mixed coffee is prepared to render it worth while to take the trouble, the chicory should be separately infused like tea, the coffee boiled, and the two then mixed. Soyer recommends that, before the boiling water is poured in, the sancepan should be set dry on the fire, and the powder stirred till it is quite hot, but not in the least burned. In France, an equal measure of boiling milk is added to a very strong infusion in making cafe au lait. The chief effect of adding chicory to coffee is to deepen the colour. When milk is added to coffee it should be boiled; cream may be used without boiling. The Turks drink it thick with sediment; some Arabs make a tea-like beverage from the dried pulp; the Somali boil the berries in oil, and soak maize in the mixture. Raw coffee beans are improved by age. Essence of coffee is a highly concentrated infusion, mixed to the consistenc of treacle with extract of chicory and burnt sugar, which must be kept in well-corked bottles; mixed with boiling water, it makes a tolerable beverage. Of a total world's production of $12,000,000$ bags in 1894-95 (each of $132 \mathrm{lb}$.$) , Brazil produced$ $7,500,000$ bags, Java and the Dutch Indies 1,000,000. The destructive coffee-bug is a Coccus (q.v.), specifically Coccus or Lecanium adonidum.

See Lester Amold, Coffee: its Cultivation and Profit (1886) : Lock, Coffee: its Culture and Commerce in all Countries (1888); works by Hull (1877), Nietner (1880), Thurber (1881), and A. Brown (1884). Also E. F. Robinson's Early History of Coffee-houses (1893).
Cofiee-houses were first heard of in Europe at Constantinople, in the middle of the 16th century, and are spoken of as among Turkish habits. by Burton (1621) and Bacon (1627). They were introduced at Venice in 1645 . Jacobs, a Jew, opened one at Oxford in 1650. The first in London was set up about 1652 in St Michael's Alley, Cornhill, by Pasqua Rosee, a Ragusan. The Rainbow was the second $(1656)$. The first coffee-house in France was opened at Marseilles in 1671, and some years later an Armenian kept one in Paris. The Café Procope (1725), the first of the Parisian literary cafes, was founded by a Sicilian, Procopio Cultelli. The Régence became favoured in afteryears by the romantiques. Coffee-houses were established in Sweden in 1674, at Hamburg in 1679 , and at Vienna in 1683 . In 1675 an attempt was made by Charles II. to suppress them by proclamation as the resort of political agitators. For nearly a century they were in England much what they have remained in France to the present day, free and open clubs. Among the most famous were Garraway's, where tea was first retailed, and Jonathan's, both in Change Alley, the latter the stock-jobbers' resort; Dick's ; Lloyd's (q.v.); the Jerusalem, one of the earliest city news-rooms; Don Saltero's, at Chelsea, with an absurd museum of curiosities; St James's, the resort of the Whigs from the reign of Queen Anne to the close of George III. ; and Wills's, the predecessor of Button's, and the resort of Dryden. Addison and Swift patronised Button's. Other coffee-houses were Tom's in Birchin Lane, Cornhill; the Bedford, Tom King's, and the Piazza, in Covent Garden; the Chapter in Paternoster Row ; and Child's in St Paul's Churchyard. Cocoa and chocolate houses were coffee-houses under other names. The modern philanthropic coffee-tavern system was first promoted by $\mathrm{Mr}$ and Mrs Hind Smith in 1867. In 1875 a number of cocoa-houses were started in Liverpool, and at the present time about four hundred temperance coffee-houses, owned by public companies, are prospering in various towns of Great Britain. Modern coffee-houses are eatingrooms without excise licenses, and French caféschantants merely music-halls.

Cofierdam, a watertight structure used in engineering for excluding the water from the foundations of bridges, quay walls, \&c., so as to allow of their being built dry. Cofferdams are generally formed of timber piles driven close together (called sheeting) in two or more rows, according to the depth of water and the nature of the bottom; the space between the rows, which may vary from 4 to 10 feet, being spooned out, down to the solid and impervious bottom, and filled up with clay puddle. Sometimes they are made of only one row of piles of the full height, caulked above low-water, with a low or dwarf row outside to confine the puddle up to that level, or, where there is no wave or current, with a mere bank of clay thrown against the outside; and occasionally the upper work is formed of horizontal planking, fixed on open main piles, and caulked in the joints. When the bottom is rock, so as to prevent piles being driven, and is not much below low-water, cofferdams are occasionally formed of two stone walls, with a space between filled with clay. Cofferdams require to be strongly shored within, to prevent their being forced inwards by the pressure of the external water; and the rows of piles require to be strongly bolted together, to resist the pressure of the clay puddle, which otherwise would burst them. This method of founding is: now seldom practised; it is costly and obstructive to the stream.

In the construction of the Victoria Embankment on the river. Thames, between Blackfriars and Westminster Bridges, $1 \frac{1}{4}$ mile in length, the coffer- 
dams were constructed of wronght-iron Caissons (q.v.) or loxes, in substitution for ordinary timber dams; on the suggestion of Sir Joseph Bazalgette, in order to efieet a saving by using the same caiseons two or three times successively in different purts of the dam. The caissons were oval, $12 \mathrm{l}$ feet long, 7 feet wide, joined end to end, and made watertight at the joints by felting. In about twothirds of the length of the embankment, 195 caissons were employed.

Coffer-fish (Ostracion), a peculiar genus of bony fishes in the small order Plectognathi, and in the fanily Sclerodermi, which also includes the file-fishes. The body is inclosed in a firm box formed of hexagonal bony scales fitted into one

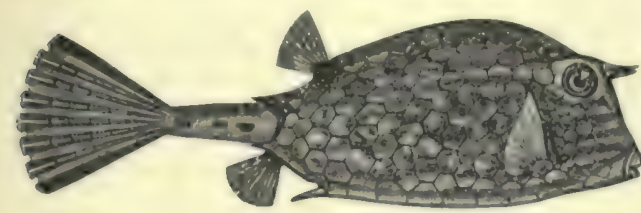

Coffer-fish.

another like a mosaic. The snout, the bases of the fins, and the end of the tail are the only softskinned parts. Over a score of species are known from tropical and subtropical seas. The bestknown form is 0 . quadricornis from the tropical Atlantic. See GLOBE-FISH, and SUN-FISH.

Coffin (Lat. cophinus, Gr. kophinos, in both languages signifying a basket, coffer, or chest, but never a coffin). Coffins for the bodies of the dead constructed of wood are known to have been used in prehistoric times in Europe. The earliest form of the wooden coffin is simply a suitable length of an oak-tree trunk split, and hollowed out for the reception of the body. Two such coffins containing the skeletons of a man and a woman of the bronze age, with their clothing undecayed, and their weapons, are preserved in the museum at Copenhagen. The wooden cotfins of the iron age were sometimes of tree trunks, and at other times of hewn planks fastened with clinker nails. From Bede we learn that the Saxons occrsionally emplover wood; but the common people, both then and in the subsequent Norman and English eras, were simply wrapped in eloth, and so put into the ground. The same eustom seems to have been followed with monks down to a comparatively recent period, and is still in use among the poorer classes in the East. See EMBALMING.

It has been keenly disputed amongst scholars, whether it was more usual with the Greeks to bury their dead or to burn them (see BURIAL); but both customs unyuestionahly prevailed. Greek coflins were called by various names (soroi, puelos, \&c.), and composed of various materials, the most common being baked clay, or earthenware. Their forms also varied. In Rome the ancient practice was to bury the dead, not to burn them; though under the Empire, and previous to the recognition of Christianity, the latter custom became almost universal. The coffin in Rome was ealled arcos or loculus, and was frequently made of stone, sometimes of a peculiar kind of stone brought from Assos, in Troas, which was said to consume all the body except the teeth in forty days, and which, from this cireumstance, was called sarcophagus - an eater of flesh (see SARCophaGUs). Roman stone colfins, both of the heathen and early Christian time, have been found in Britain. Cremation was repugnant to the feelings of the primitive Christians, who buried their dead in receptacles of stone. These were either hewn ont of the rock an in the catacombs, or were sarcophagi elahorately seulptured with scenes frum Seripture history and emblems of the faith. The simplest form of atone coffin was that used in prehistoric

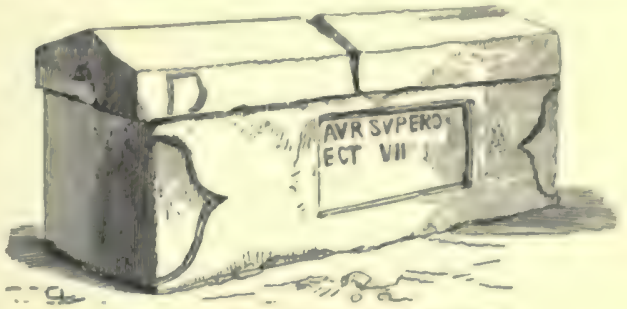

Roman Stone Coffin, found at York.

times throughout Europe, consisting of unhewn stones set on their edges, so as to cover the sides and ends of the grave, one or more flat stones being then laid over the body to form a lid. T'his form of rude stone cist or coffin was continued long after the introduction of Christianity in most European countries, and many ancient cemeteries, formerly regarded as pagan and prehistoric, are now recog. nised as Christian by the orientation of their stone. lined graves. To these succeeded stone coflins, which were commonly used for persons of the higher classes throughout the middle ages; and so late as 1686 the antiquary Dugdale was buried

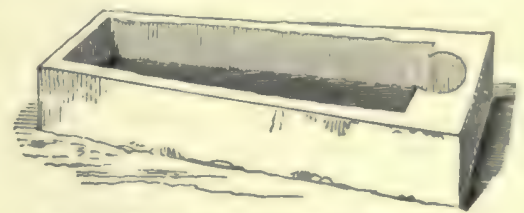

Stone Coffin, Temple Church, London.

in a stone coffin. These stone coffins were generally of a single block, commonly tapering from the upper end. In the hollow for the reception of the body, there was from the 12 th century a part pecu. liarly fitted for the head, and a hole in the bottom to allow of the eseape of moisture. Such cotfins, for the most part, were not buried deeply in the earth, and were frequently placed so near the surface that the lids were visible, which, within a chureh, often formed part of the pavement, and were covered with elaborate seulpture representing crosses and other ornaments. Sometimes they were even above the ground altogether, and thus became the originals of the table-tombs and altar. tombs of the middle ages. Leaden coffins were also occasionally used in the middle ages, as those in the Temple Church in London testify, but the slight wooden cases now in common use appear to be of comparatively recent origin. The practice of surrounding the wooden shell with a coffin of lead, and inclosing both in an oak casket, is, for sanitary reasons, to be discouraged. Even a wooden coffin, if well made, greatly retards decomposition, and keeps the process long incomplete; and to remeily this the use of wicker coftins, of white or stained osiers, has been suggested. In America, however, zine or copper lining and lids of heavy French glass are employed by undertakers to render their work as far as may be air. tight and indestructible; and of late years caskets of zine or copper, and even of iron or rolled steel, have cone into use. The modern hexagonal form of coffin is peculiar to Great Britain. The sides of the American casket are parallel, the ends either rounded or broken into three panels; the exterior is sometimes ornamonted with carved work, 
but is more commonly covered and draped with broadcloth, velvet, or satin, fringed and tasseled. Expensive woods and silvered handles and nails are frequently employed; and the lid may have a remov. able face glass. French and German coffins are of a similar shape, but plainer. The colour in Germany is usually brown. At Leipzig formerly coffins were always painted green, as a symbol of hope.

Coggeshall, a town of Essex, on the Black water, 44 miles $\mathrm{NE}$. of London. It has a school, founded by Sir Robert Hitcham (1636), remains of a Cistereian abbey (1142), a good Decorated church (restored 1868), and some manufactures of silk, velvet, and lace. It is supposed to have been the Roman Canonizm, and the remains of a Roman villa have been found. John Owen was minister here. Ralph de Coggeshall, abbot here (1207-18), wrote a Chronicon Anglicanum (of the period 1161-1224), edited by J. Stevenson in 1875. Pop. 3830. See Beaumont's History of Coggeshall (1890).

Cognac, a town of France, in the department of Charente, on an old castle-crowned hill over the Charente, 42 miles SE. of Rochefort by rail. The cultivation of the vine and distillation of Brandy (q.v.) form the chief industry of the district; in the town, casks and bottles are manufactured. Francis I. was born here. Pop. (1872) 12,950; (1886) 14,537; (1891) 16,956.

Cognate. See Agnate.

Cognizance, in Heraldry, a Badge (q.v.), in the more restricted sense of that term.

Cognoseen'ti (Ital., from Lat. cognosco, 'I know ${ }^{3}$, persons professing a critical knowledge of works of art, and of a somewhat more pretentious character than amateurs.

Cogno'vit (viz. actionem, 'he has confessed the action '), in the law of England, is the defendant's written confession that the plaintiff's cause against him is just and true. By this confession before or after issue, the defendant suffers judgment to be entered against him without trial, in which case the judgment is called judgment by confession.

Cogswell, Joseph Green, LL.D., American bibliographer, born at Ipswich, Massachusetts, in 1786, studied at Harvard and Göttingen, and was professor of Geology at Harvard from 1820 to 1823 , when he established the Round Hill School with Bancroft (q.v.). He was for some years editor of the New York Review, and, with Halleck and Washington Irving, assisted in planning the Astor Library, of which he was for many years superintendent. He died in 1871 .

Cohabitation. SeeConcubinage, Marriage.

Cohesion depends upon the molecular forces which keep together the parts of bodies, and are insensible at sensible distances. In the case of a small body these forees are much more efficient in keeping the parts together than are the mutual gravitational attractions of the parts. On the other hand, in the case of a large body, such as the earth, gravitation is much more powerful in preventing rupture than cohesion. The term adhesion is generally, though quite unnecessarily, used when the cohering particles are dissimilar-as when water clings to glass.

After the parts of a body have been separated, so as to form an incoherent mass, the force of cohesion may be again brought into action by the application of pressure sufficient to force the particles close enough together. Thus two smooth, freshly cut pieces of lead can be made to adhere by slight pressure accompanied by a screwing motion. Also two very smooth slabs of marble adhere, if pressed together, so that considerable force must be exerted to separate them. Barton made a set of cubes with surfaces so true that, if twelve of them were piled one over the other, the whole series could be fifted by raising the upper one. Lead pencils are: made by applying pressure to powdered graphite, so as to make it cohere.

Cohesion Figures. See Surface Tension.

Cohoes, a prosperous manufacturing city of Albany county, New York, on the Hudson, at the mouth of the Mohawk, 3 miles above Troy, and on the Erie Canal. It has six large cotton-mills, and some thirty knitting-mills, besides manufactures of axes, gas-piping, machines, pulp, pins, thread, \&c. Pop. (1860) 8799 ; (1880) 19,416; (1890) 22,509.

Cohort, in the ancient Roman armies, was a portion of a legion, consisting usually of 600 men. Generally, there were ten cohorts to a Legion: (q.v.).

Coif (Fr. coiffe, Ital. cuffia, 'a cap'), a covering for the head in general, but more especially the close-fitting cap of white lawn or silk, originally worn by Serjeants-at-law (q.v.). Like the Biretta (q.v.), it always represented distinct rank and dignity. Its use on all professional and official occasions was both an obligation and a privilege. Later it was the custom to wear a small skull-cap of black silk or velvet over the white coif ; and in the beginning of the 18th century, when the fashion of powdered wigs in lieu of natural hair invaded the law-courts, in order that the badge of the order might not be concealed, the peruquiers contrived a small round patch of black silk edged with white, to be worn on the crown of the wig. The notion that the coif was a device merely to conceal the tonsure of the monkish lawyérs rests only on a loose conjecture of the commentator Spelman, and, though earelessly fostered by Lord Campbell, may be consigned to the same category as the conceit, preserved in Brand's Antiquities, which derives the head-dress from a child's caul worn for luck. See Serjeant Pulling's Order of the Coif (1884).

Coimbatore, the capital of a district of Madras Presidency, on the Noyil, 304 miles SW. of Madras by rail. It lies 1437 feet above the sea, is well built and drained, and has a cool temperature that renders it a comparatively suitable residence for Europeans. Pop. (1891) 46,383 ; pop. of district (1891), 2,004,839.

Coimbra, capital of the Portuguese province of Beira, on a hill above the river Mondego, here crossed by a stone bridge, 135 miles NNE. of Lisbon by rail. Its streets are steep, narrow, and dirty, its manufactures confined chiefly to earthenware and combs, and its interest consists mainly in its historical associations. The place derives its name from the Roman Conimbria, traces of which lie to the south; it was held by the Goths, and from them passed to the Moors, from whom it was finally conquered in 1064, by Fernando the Great, aided by the gallant Cid. Coimbra was the capital of Portugal for about two centuries and a half from its erection into a kingdom, in 1139 , and many of the early kings are buried in and around the old town. Of the public buildings, the most noteworthy are the older of the two cathedrals, the church of San Salvador, and the ruined convent of Santa Clara; across the river is the Quinta das Lagrimas ('House of Tears'), where Inez de Castro (q.v.) was murdered. The university of Coimbra, the only one in Portugal, was originally established at Lisbon in 1288 , but was permanently transferred here in 1537. It has five faculties and some 900 students, and is still held in repute; attached to it are a museum, an observatory, a botanical garden, and a library of 60,000 volumes. Pop. 13,369.

Coína, a town of Spain, 20 miles WSW. of Malaga, with marble-quarries. Pop. 10,065 . 
Coining. The privilege of coining money being un exclusive prerogative of the crown, the crime of connterieiting the king's money, as it was called, was declared to be treason, both by the comimon law of England and by many statutes. In Seotland, there continued to be some differences in regard to this crime, even after the Union had exteniled the treason laws of England to that kingdom, and prosecutions were in use to be laid at common law. That practice is now abandoned, and the laws of the two countries were assimilated by a series of statutes, which are codified in the Act of 1861 passed to consolidate the law relating to offences against the coin. All such offences are now prosecuted under this statute. By this act it is a high crime and offence, punishable by penal servitude for life, to counterfeit gold or silver coin ; or to colour coin or metal with intent to make it pase for genuine gold or silver coin; or to buy, sell, or import counterfeit gold or silver coin; or unlawfully to make, mend, buy, sell, or possess instruments used in fabricating gold or silver coin ; or to convey such instruments out of the mint. To impair or diminish or lighten gold or silver coin (as by clipping or sweating) is punishable with fourteen years. It is an offence punishable with penal servitude for seven years to unlawfully possess gold or silver taken from any coin; or to counterfeit copper coin; or unlawfully to make, mend, buy, sell, or possess instruments for counterfeiting copper coin ; or to deal in base British copper coin; or to utter or import base foreign gold or silver coin. Several offences of a less heinous nature are dealt with in the act. In order to bring these offences within the limits of the statute, it is not necessary that the resemblance of the false to the true coin shall be very perfect; but if it be not such as to deceive a person of ordinary observation, the attempt to bring it into circulation is fraud, and not uttering. For false bank-notes, see ForGERY.

In the United States, the erime of counterfeiting coin or money is punishable with fine and imprisonment at hard labour for a term of from two to ten years; and includes falsely making, forging, or counterfeiting coins or notes, postal money orders, postal cards, government stamps of all kinds, and government securities, as also importing, possessing, uttering, or passing false coins or notes with fraudulent intent. Mutilating and debesing the coin is also counterfeiting, but is not so severely punished as the making of counterfeit coins.

For coinage and coins, see MiNT, NUMismatics, Money, Bullion, Currency.

Coir, or CocoA-nut Fibre, is the fibre of the husk of the cocos-nut. The husks are steeped in water, in pits, for six months, or even for a year, and then beaten with a stick till the fibre readily separates. The material is largely used on account of its strength and wear-resisting qualities for floormatting in positions where there is much traffic, and for making hall and door mats. It is also in demand for coarse brushes, for ships' fenders, and, to some extent, for ropes and eables. In the South Sea Islands, ropes of coir fibre, made by the natives, are extensively used. Coir rope, on account of its lightness, possesses some advantages for maritime purposes. The Chamrops (q.v.) is sometimes called the coir-palm.

Coire (Ital. Coira; local Romansch, Quera; ancient Curia Rhotorum; Ger. Chur), a town of Switzerland, capital of the Grisons, in the valley of the Upper Rhine, lies in a fertile plain 1940 feet above the ser, and surrounded by high mountains, It is 80 miles SE. of Zurich by rail, and stands on the Plessur, a mile and a half from its junction with the Rhine. It is of importance as standing on the great road to Italy by the Spligen
P'ass, and thus posmensing a considerable trannit trade. The bishop's palace, and the quarter around it, inhabited by 2400 Catholics, oceupy the summit of an eminence, and are separated from the rest by walls and battlements, closed by double gates. Here stands the old cathedral of St Lucius - a Romanesque edifice dating from the 8th century. It contuins singular ohd carving, paintings by Cranach, Holbein, and Durer, and also, it is said, the bones of St Lucius, a legend. ary British king. The town-hall, the Rhsetian museum, and two Protestant churches are in the lower town. Romansch is still spoken in the vicinity. Coire is a great tourist centre ; and wine, fruit, and corn are produced by the country round. Population, 9500.

Coix. See Jor's Tears.

Cojutepeque, a town of the republic of Sal vador, Central America, 15 miles $\mathbf{E}$. of the city of San Salvador. Pop. 4154.

Coke is a form of fuel obtained by the heating of coal in confined spaces whereby its more volatile constituents are driven off. Caking coal is the most suitable for the manufacture of coke, which, in its principal qualities, is approached by the hard anthracitic coals. The process of coking is conducted (1) in hesps or mounds, or (2) in ovens; but coke is also produced in gas retorts, where, however, it is merely a secondary product. Coking in mounds - a method now little practised-is done in a way similar to that employed for preparing charcoal from wood. The coal is built up into round stacks, around a wide open chimney or column, the larger masses being placed in the centre, and smanl broken coal outside, the whole being covered with wet coke-dust, except at certain air-holes. The mound of coal is ignited from above, and burns gradually downwards and ontwards, giving off at first much smoke and vapour, which consist mainly of tar-water and coal-gas. When the fire ceases to be smoky, the process of coking is concluded, all openings are covered over to exclude air and extinguish combustion, and cooling of the mound is aided by drenching it with water. The principle of making coke in cokeovens is the same, but the process is much quicker and more economical, and the resulting coke is better in quality than that made in mounds. Formerly the heat and volatile gases given off in coking were allowed freely to escape, but in modern coke-ovens arrangements are made for utilising the combustion in one retort to force the heat of another, by passing the hot gases in flues around. contiguous ovens. The whole of the gases pass from these flues into a common flue, by which they are carried away to heat steam-boilers. In a similar way the coal-gas is, from certain kinds of ovens, collected and burned, and the tar-water evolved is condensed and used as a source of ammonia and gas-tar products.

Coke is a hard, brittle, porous solid, with a steel. gray, somewhat metallic lustre, and it does not moil the fingers when being handled. It is principally valued for the intense heat which it gives off in combustion, for its freedom from smoke in burning, and because it does not becume pasty and adhesive in the fire. The process of coking also drives off a good deal of the sulphur which may be present in coal, and all these properties render coke a most valuable fuel for many metallurgical operations, and for use where intense smokeless combustion is a desideratum. The higher the temperature to which coal in coking is submitted, the harder and more valuable is the resulting coke, and the heat it gives off is relatively more intense. In chemical constitu. tion coke consists of a modified form of graphite contaminated with earthy impurities from the ash 
present in coal. Coal yields by weight about 70 per cent. of coke, which, however, increases in volume in the process of coking by about onefourth. Coke will absorb about 30 per cent. of moisture from the air, a circumstance which should be borne in mind in its purchase and its use, for such moisture in being driven off greatly reduces the calorific value of the substance.

Coke, Sir Edward, jurist, was born of a good -old Norfolk family, at Mileham, 1st February 1552. From Norwich grammar-school he passed in 1567 to Trinity College, Cambridge, in 1571 to Clifford's Inn, in 1572 to the Inner Temple; and he was called to the bar in 1578 . His rise was rapid - from recorder of Coventry (1585) to member for Aldborough ( 1589 ), Solicitor-general (1592), Speaker of the House of Commons (1593), Attorney-general (1594), Chief-justice of the Common Pleas (1606), Chief-justice of the King's Bench and privy-councillor (1613). Meanwhile he had married twice, first, in 1582, Bridget Paston, who brought him $£ 30,000$, and died 27th June 1598; next, nineteen weeks later, Lady Elizabeth Hatton, the granddaughter of his patron, Lord Burghley. The rancour shown by him in the prosecutions of Essex and Southampton, Raleigh, and the Gunpowder conspirators ( 1600 3-5) has gained him little credit with posterity; but from 1606 he stands forth as a vindicator of the national liberties, opposing, unlike Bacon, - every illegal encroachment on the part of both church and crown. He dared to cite Bracton's words to James's face, that' "the king should be subject not to man, but to God and the law; alone of twelve judges, he resisted the royal prerogative; and in the Overbury ease he showed an indiscreet zeal to come at the real truth. His removal from the bench on most trivial grounds (November 1617) was aggravated by a quarrel with his wife; and though ten months afterwards he was recalled to the council, his conduct in parliament from 1620 as a leader of the popular party, an opponent of Spain and of monopolies, estranged him for ever from the court party. In 1621-22 he suffered nine months' durance in the Tower; :still, old though he was, he carried his opposition into the next reign, the Petition of Right (1628) being largely his doing. He died at Stoke Poges, 3d September 1634, and was buried at Tittleshall in his native county.

Coke was a great lawyer, withal an honest lover - of legality, but too bitter and narrow-minded to be really a great man. His four Institutes (1628-44) deal with tenures, statutes, criminal law, and the jurisdiction of the several law-courts. The first of these, and most famous, which in 1832 reached a 19 th edition, is the so-called Coke upon Littleton (q.v.) - a commentary that, in spite of its puerile etymologies, has still a real, if mainly historical, value. Eleven of the thirteen parts of his epochmaking Law Reports were published during his lifetime (1600-15); and the whole, translated out of the original French and Latin, fills 6 vols. in Thomas and Fraser's edition (1826). Mr G. P. Macdonell mentions six minor works in his able and exhaustive article on Coke in the Dictionary of National Biography (vol. xi. 1887). See also the Lives by Serjeant Woolrych (1826) and W. Johnson (2 vols. 1837).

Coke, Thomas, Methodist bishop, born at Brecon in 1747, graduated in 1768 at Oxford, from which university he received the degree of D.C.L. in 1775 . He settled as a curate in Somersetshire, but a course of open-air preaching and cottage services, initiated after his introduction to John Wesley in 1776, brought about his dismissal by his rector, and he joined the Methodists, by whom he was attached to the London circuit. In 1782 he became first president of the Irish conference, and he was elected president of the English conference in 1797 and 1805 . In 1784 he was set apart by Wesley as 'superintendent' of the societies in America, to which country he made nine voyages, the last in 1803, and where his ontspoken opposition to slavery aroused much hostility : in 1787 he induced the American conference to alter his title to that of bishop. In 1784 Coke had drawn up the first plan of the Methodist foreign missions, and to this cause he devoted the later years of his life with untiring zeal and skill, retaining to the last the direct control of the system he had created. He died in the Indian Ocean on a missionary voyage to Ceylon, 3d May 1814. He published, besides religious works, extracts from his American Journals (1790), a History of the West Indies (3 vols. 1808-11), and, with Henry Moore, a Life of Wesley (1792), intended to forestall Whitehead's labours, with whom the two others, being joint literary executors, had disagreed.

Col (Fr., 'neck'), in Geography, is a depression or pass in a mountain-range. In those parts of the Alps where the French language prevails, the passes are usually named cols-as the Col de Balme, the Col du Gréant, \&c.

\section{Cola Nuts. See Kola Nuts.}

Colard, MAnsion, the first printer of Bruges, was of French extraction. He published twentyone works, all in French, save one Latin one; and died in 1484.

Colberg, or Kolbera, a seaport and wateringplace of Prussia, in the province of Pomerania, on the Persante, near its mouth in the Baltic, 170 miles NNE. of Berlin by rail. It stands on a hill, surrounded with three suburbs. The principal church dates from 1316. In 1102 Duke Boleslaus of Poland vainly besieged Colberg, which endured long sieges in the Thirty Years' War, in the Seven Years' War, and again in 1807, when it was most gallantly defended against the French. Colberg has manufactures of woollens, agricultural machines, and spirits; and salmon and lamprey fisheries. Pop. (1895) 18,622.

Colbert, JEAN BAP'ISTE, one of the greatest French statesmen, was born at Rheims in 1619. Before he was twenty years of age he obtained a post in the War Office under Le Tellier, and at once began a very successful career. In 1651 he entered the service of the great minister Mazarin, who soon employed him in most important affairs of state. On his death-bed Mazarin warmly recommended Colbert to Louis XIV. "I owe you every. thing,' Mazarin is reported to have said to the king, 'but I pay my debt to your majesty in giving you Colbert.' It was in 1661 that Colbert became the chief-minister of Louis XIV. He found the finances in a ruinous condition, and immediately began his reforms. Fouquet, the superintendent under Mazarin, was found guilty of impoverishing the state by his maladministration, and imprisoned for life. The farmers of the state-revenues were forced to yield up the resources of the crown of which they had fraudulently possessed themselves. The debts of the state Colbert reduced by arbitrary composition. In all the departments of finance he introduced order and economy as far as he could. So complete and thorough was the change which Colbert effected, that in ten years the annual revenue had risen to 104 million livres, of which 27 were spent in collection and administration; whereas, when the management of the finances was intrusted to him, the revenue amounted to only 84 million livres, and 52 millions were absorbed in its collection. The financial reforms of Colbert, however, only served as a 
basis for $n$ thorough reorganiantion of the entire administration. He took mensures to improve agriculture. Commeree was extended, roads and canals - including that of Languedoe-were made. In every way he sought to apjly the protective system then in vogue to promote the industries of Finnce. He organised anew the colonies in Canada, Martinique, and St Domingo, and founded others st Cayenne and Madagascar. He found France with a few old rotten ships, and in a few vears had provided her with one of the strongest ileets in the world, with well-equipped arsenals and a splendid body of seamen. Colbert improved the civil code, introduced a marine code of laws, and drew up the so-called Code Noir for the colonies.

While attending to material interests, he did not neglect the arts and sciences; all men of learning and genius found in Colbert a generous patron. The Acmlemies of Inscriptions, Science, and Archi. tecture were founded by him. In short, Colbert was the patron of industry, commerce, art, science, and literature - the founder of $a$ new epoch in France. His aim was to raise the strength of France by developing every side of the national life. In this he entirely succeeded during the early part of the reign of Louis XIV., but his work was not destined to last; the wars of Louis and the ex. travagance of his court undid all that had been accomplished by Colbert. The rigorous order and precise rules which he established might be beneficial in such hands as his own, but when abused by a selfish or incompetent despotism, could only have the most mischievous results. Colbert died in 1683 , bitterly disappointed at seeing the failure of his plans for the regeneration of France. The people were so enraged with the oppressive taxes, for which they blamed him, that his corpse had to be removed from his house by night in order to avoid their fury. Colbert had indeed carried out many measures that were arbitrary and oppressive. He had served a despotic king, who posed as the representative of all that was fair in the government, and left the disagreeable tasks of administration to his ministers. See his Lettres, Instructions et Memoires ( 8 vols. 1862-82); Lives by Clément (2 vols. 1874), Neymarck (1877), and Gourdault (6th ed. Tours, 1885); and the Comte de Cosnac's Mazarin et Colbert (1892).

Colburn, ZERAH, a mathematical prodigy, born in Vermont, U.S., in 1804, displayed such remarkable powers of calculation that in 1810 his father left Vernont to exhibit him. At this period he answered correctly such questions as 'How many hours in 1811 years ?' in twenty seconds ; and ^ few years later much more complicated problems were solved with equal rapidity. He was shown in Great Britain, and for some time in Paris; from 1816 to 1819 he studied at Westminster School at the expense of the Earl of Bristol. His father died in 1824, and he returned to America; here he was a Metholist preacher for nine years, and from 1835 professor of Languages in Norwich University, Vermont, where he died 2d March 1840. His remarkable faculty disappeared as he grew to manhood.

Colchester, an ancient municipal and parlia. mentary borough in the NE. of Essex, on the right bank of the Colne, 51 miles $\mathrm{NE}$, of London, and 12 miles from the sea. It is built on the riclge and sides of a promontory, with a port on the river at a suburb called the Hythe, which has a quay for vessels of 150 tons. It is a town of special historical and antiquarian interest. Before the Roman conquest of the island it was the British "Royal Town' of Cunobelin (the Cymbeline of Shakespeare); and when the Emperor Claudius 128 had conquered the south-eastern part of the ialand, he founded a colonia here-the fint Koman town in Britain. There are still many remain. of that town. The walls are the most perfect Roman walls in England. Immense quantities of pavements, coins, pottery, and other remains of domestic use and pensonal adomment have heen found here. A large cemetery along the principal roul out of the town has heen enrefully exploried, and $\mathrm{a}$ valuable collection of sepulchral remains found, many of which sre in the town mureum. The tower of Holy Trinity Church has all the characteristics of Saxon architecture. The castle is the largest Norman keep in England. In the Norman west front of St Botolph's Priory the Roman bricks are a striking feature; and all the old churches have an intermixture of Roman brick in their walls. The Domesday Survey is very full, and gives a complete census of the people. Two taxations of the beginning of the 13th century give not only a complete census of the inhabitants, but also an inventory of their domestic furniture and stock-in-trade, and present a complete view of an English borough of the period. The Protestant refugees from the Low Countries at the end of the 16th century introduced the bay and say (baize and serge) trade, which became an important manufacture, and spread into the neighbouring towns and villages. Colchester was one of the eight 'Dutch Congregations 'incorporated by royal license. The wars with Spain in the reign of Queen Anne elosed the markets for these goods, and the trade died ont. The only important historical event of later times was the siege of Colchester, one of the last events of the Civil War between Charles I. and the parliament. The royalists of Essex and Kent under Goring took possession of the town, and were be. sieged by Fairfax and the parliamentary army from the middle of June 1648 till the middle of August, when the town, starved out, surrendered, and the execution of Sir Charles Lucas and Sir George Lisle, by sentence of court-martial, created a great sensation.

The chief canse of the prosperity of the town throughout its history has been that it was the principal town and natural market of an extensive and fertile corn-growing district, inclosed on three sides by the rivers and the sea. It was during the great continental wars of the beginning of this century, and has again in later times become, a large military depot; and the number of troops quartered here, with their officers and their families, have contributed to its prosperity. The fishery of the Colne and its creeks has for centuries been famous for the quality of its oysters, and has been a valuable portion of the property of the corporation, to which it has belonged from, or even before, the Norman Conquest. Though always the most important town in Essex, it has never been the county town, owing probably to its being too far down in the Essex peninsula. Pop. (1851) 19,443; (1881) 28,395; (1891) 34,559. See the Rev. E. Cutts's Colchester ('Historic Towns' series, 1888), and Benham's Colchester Worthies (1892).

Colchester, Chardes ABBot, Lord, Speaker of the House of Commons, was born at Abingdon, Berkshire, 14th Oetober 1757. He was educated at Westminster School (1763-75) and Christ Church College, Oxford, and in 1779 entered the Middle Temple. In 1792 his practice was bringing him $\mathbf{\$ 1 5 0 0}$ per annum; and two years later he received the post, worth $£ 2700$, of clerk of the rules in the Court of King's Bench. Returned to parliament As a strong Tory in 1795, he effected in his first session an improvement in the legislation regarding temporary and expiring laws; and it is due to his exertions that municipal bolies receive a copy of all new acts as soon as they are printed. The country 
is mainly indebted to him for the Private Bill Office and for the royal record commission, whose proceedings he for many years superintended. But his greatest service was in the Act (1800) for taking the first census. In 1802 he was elected Speaker, the duties of which high and honourable office he continued to discharge with as much impartiality as distinction until May 1817, when ill-health compelled him to resign. He received a pension of $£ 4000$ a year, and was raised to the peerage as Baron Colchester, his father having been rector of All Saints, Colchester. He died 7th May 1829. See his Diary and Correspondence (3 vols. 1861 ), edited by his son Charles, second Lord Colchester (1798-1867), who was postmaster-general in 1858.

Col'chicum, a genus of Liliacex, sub-order Melanthaces. 'The species, which are few in number, are stemless, with flowers half subterranean like the crocus, the limb of the perianth and

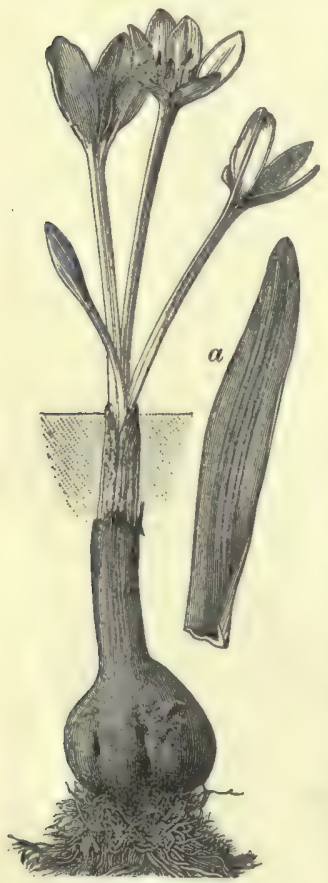

Meadow Saffiron

(Colchicum autumnale): $a$, a leaf. of alkaloid called Colchicine or Colchicia. Cattle are not unfrequently injured by it in pastures where it abounds. It is a valuable medicinal plant, and is administered, in small doses, to allay the pain of gout and rhenmatism. Repeated doses produce vomiting, purging, increase of the urinary secretion, and profuse perspiration. The parts chiefly used for medicinal purposes are the corm (popularly called the root) and the seeds. The seeds are round, brown, rather larger than mustard-seed. Other species of colchicum appear to possess similar properties. The hermodactyls of the druggists' shops, which for many centuries have enjoyed an extensive celebrity for soothing pains in the joints, and are brought from the Levant, are believed to be the corms either of C. variegatum or $C$. bulbocodioides. C. autumnale is not unfrequent in flower-borders, particularly a variety with double flowers.
Colchis, a province of ancient Asia, on the east coast of the Pontus Euxinus or Black Sea, situated north of Armenia and south of the Caucasns. Colchis was famous in Greek mythology as the land of Medea (q.v.) and the gorl of the Argonauts (q.v.); afterwards it was better known to the Greeks as the seat of some colonies of the Milesians. It was noted for its wines and fruits. The principal town was Dioscurias; the principal river the Phasis. The Colchians were at one time subject to Persia, and subsequently to Mithridates, king of Pontus, and ultimately passed under the mighty empire of Rome.

Colcothar is the name given by the alchemists to the red powder (mainly red oxide of iron) which remains in the retorts when green vitriol or the sulphate of iron is ealcined. It is used for polishing glass and the like, and is called crocus by artists.

Cold is the term by which we signify a relative want of sensible heat. There are therefore no determinate boundaries between cold and heat, and it is a mere arbitrary distinction to call the degrees of the thermometer below the freezingpoint degrees of cold. When the atmosphere, or any substance which comes in contact with our body, is at a lower temperature than the skin, it absorbs heat from it, and we call it cold. See HeAT.

The physiological action of cold on the animal organism requires a brief notice. All animals: (the warm-blooded animals to the greatest extent) have a certain power of maintaining the heat of the body, in defiance of external cold, as has been shown in the article ANIMAL HEAT. This power is mainly due to a process analogous to combustion, in which earbon and hydrogen taken into the system in food are made to unite with oxygen derived from the air by respiration. If the combustible materials are not duly furnished, or if the supply of oxygen be deficient (as in various diseased conditions), there must be a depression of temperature. Now, if the temperature of a bird or mammal (except in the case of hybernating animals) be lowered about $30^{\circ}$ below its normal standard (which in birds ranges from $100^{\circ}$ to $112^{\circ}$, and in mammals from $96^{\circ}$ to $102^{\circ}$ ), the death of the animal is the result. The symptoms indicating that an animal or a man is suffering from a depression of the temperature of the body are-retardation of the circulation of the blood, causing lividity of the skin, which is followed by pallor, in consequence of the blood being almost entirely driven from the surface through the contraction of the vessels; a peculiar torpor of the muscular and nervous systems at the same time manifests itself in an indisposition to make any effort or exertion, and in intense sleepiness. The respiratory movements become slower' (see RESPIRATroN), and the loss of heat goes on, therefore, with increasing rapidity, till the fatal limit is reached, and death supervenes.

In hibernating animals (the marmot, dormouse, bat, \&c.) the power of generating heat within their own bodies is very slight, their temperature following that of the external air, so that it may be brought down nearly to the freezing-point. See the articles Hibernation, Starvation, Dormant VITAIITY : also, for other phenomena connected with cold, Heat, Climate, Freezing Mixtures, Frost, ICE, THERMOMETER, TeMPERATURE.

Great or prolonged atmospheric cold is a most powerful depressing agent, and is a fruitful canse of disease and even of death. Whenever the temperature of the atmosphere is suddenly reduced, and particularly when it is reduced below the freezing-point, a considerable addition takes place to the mortality of the country at large. The 
effects of cold are, in ordinary cireumstances, most appurent among the aged and the very young, and among those suffering from chronic disease; but when a very low temperature is long continued, even the healthy are sure to suffer, when impoverished so as not to have sufficient means of external warmth in their homes. The most elirect effecta of cold are in the production of what is commonly called Frost-bite (q.v.).

Cold is applied in various ways in the treatment of disease. In some forms of fever, a cold bath, or cold wet pack, is the best means of reducing a very high temperature which of itself threatens life. In many inflammations relief is best obtained by the local application of ice, or of a coiled tube through which cold water circulates. The tonic and stimulating effects of a temporary application of cold are familiar in the cold morning bath, or the nse of cold water sprinkled on the frce of a person who has fainterl. The disease commonly termed a 'cold' has been already described under Catarrh.

Cold Cream is the term applied to an ointment containing rose-water which is used as a mild and cooling dressing for the skin. It may be prepared by melting together almond-oil five parts, spermaceti one part, and white wax one part. Three parts of rose-water are then added with brisk stirring, which is continued till the whole is cool, and of a soft creamy consistence. As cold cream prepared in this way is liable to turn rancid, glycerine is sometimes added, or the almond.oil is replaced by white vaseline. Cold cream is a pleasant application to irritated surfaces, protecting them from the influences of the weather, and promoting the healing of wounds and chapped hands.

Coldstream, a town of Berwickshire, 15 miles SW. of Berwick by rail, on the Tweed, over which there is a fine bridge by Smeaton (1766). At Coldstream was the famous ford by which Edward I. entered Scotland in 1296, and near which he met the Scottish nobles, to settle the dispute about the crown of Scotland. By this ford also the Scots invaded England in 1640. Being convenient as a Border town, Coldstream, like Gretna Green and Lamberton toll-bar near Berwick, was formerly celebrated for its elandestine marriages. Pop. 1616.

Coldstream Guards, a regiment in the Foot Guards (q.v.) or Household Brigade, the oldest in the British army except the 1st Foot, now ealled the Roval Scots. Raised in 1660 by General Monk at Coldstream, it was at first called 'Monk's Regiment:' but when parliament consented to give a brigade of guards to Charles II., this corps, under the nameof Coldstream Guards, was included in it. See the history of Col. Ross (1896).

Coldwater, capital of Branch connty, Michigan, 156 miles $E$. of ('hicago, on the Lake Shore Railway, has several foundries, flour-mills, and manufactories, and a public school which cost $\$ 100,000$. Pop. (1880) 4681; (1890) 5462.

Cole, Sir HExry, was lorn at Bath, 15th July 1808, educated at Christ's Hospital, and became assistant-keeper of the Records in 1838. He wrote much for the newspapers and reviews, and under the name of 'Felix Summerly' produced about twenty children's books. He was chairman of the Society of Arts, did valuable service on the committee of the Great Exhihition of 1851, was the founder of the South Kensington Musenm, and in 1860 became its director. For his services on innu. merable committees and councils, and in promoting valuable reforms, he was made K.C.B. in 1875 ; and he held several foreign decorations. He died 18th April 1882. See his Autobiography (2 vols. 1884).
Cole, Thomas, painter, born at Bolton-le-Moon in 1801, removed to Americe in 1819, where he hecame one of the best-known landscape-painterm. In 1830 two of his pictures appeared in the Royal Academy, and he afterwards made sketching toun through England, France, and Italy ; but all his best laniserupes were Anerican. He died Ilth February 1848.

Cole, Vicat, landscape painter (especially of Surrey scenes ), was born at Portsmunth, 17th April 1833 , and from 1853 was a frequent contributor to Royal Academy exhibitions. Chosen A. R.A. in 1870 , and $R$. A. in 1880 , he died 6 th April 1893. See Life by R. Chignell ( 3 vols. 1898).

Colebrooke, Henry Thomas, the pioneer of Sanskrit scholarship in Europe, was born in London, 15th June 1765, the son of Sir George Colebronke, banker, and eventually chairman of the board of directors of the East India Company. He was educated at home, and early showed a strong disposition for mathematical studies. In 1782 his father's influence procured him a writership in the Bengal service. He was a voracious reader, and his alert mind found its relaxation in the change from administrative to scientific labour. His duties as revenue officer at Tirhut led him to make a minute study of the state of husbandry in Bengal, and his Remarks thereon (Calcutta, 1795, privately printed) formed so searching a criticism of the existing policy that the work could not be published in England. At Purneah his legal functions led him to study Indian law and learn Sanskrit; and he began in 1794 publishing essays on Indian religion, poetry, and science in the Asiatic Researches of the recently founded Asiatic Society of Calcutta. His removal in 1795 to the magistracy of Mirzapur gave him the opportunity of cultivating the acquaintance of the learned men of the neighbouring Sanskrit college at Benares, and with this advantage he brought out his Digest of Hindu Law on Contracts and Successions (translated from the Sanskrit, 1798, 4 vols. Calcutta). A mission to Nagpur (1799-1801) interrupted his work, and on his return he was appointed a judge of the new court of appreal at Calcutta, and at the same time honorary professor of Hindu Law and Sanskrit at the college of Fort William. Yet he contrived during this busy period to publish the first (and only) volume of his Sans. krit Grammar (1805), based upon Pánini and the native commentators, to write his famons articles on the Vedas and on the sect of Jains, besides many other valuable essays for Asiatic Researches, and also to supplement his Digest by Two Treatises on the Hindu Law of Inheritance (1810). Before this he had reached the eminence of a seat on the governor-general's council (1807), and was using his influence earnestly in the direction of adminis. trative reform and the encouragement of oriental studies. He retired in 1814, and devoted himself to scholarly work in England, especially to eastern science. Several of his essays in Asiatic Researches related to Hindu astronomy, meteorology, mathematics, geology, and botany. He contributed also to the Transactions of the Astronomical Society, to The Quarterly Journal of Science, the Liunsean and the Geological Societies, as well as, more especially, to the Royal Asiatic Society, which he helped to found in 1823. His last vears were troubled by care, blindness, and much holily suftering, endured with fortitude; and on 10th March 1837 he died at the age of seventy-two. His translation of the Sdnkhya Karika was posthumously edited by Professor H. H. Wilson. His work as a Sanskrit scholar possessed the highest merits of extreme conscientiousness and caution, scientific aceuracy, and a stern repression of the tendency to fanciful exaggeration which marked the early theories of European 
scholars on Indian science and religion. His life has been well written by his son, Sir T. E. Colebrooke (1873), and his immense services to Sanskrit scholarship are lucidly criticised in Max Müller's Biographical Essays (1884).

Colenso, Јohn William, D.D., Bishop of Natal, the son of a Cornish gentleman, was born at St Austell, January 24, 1814. He was educated at St John's College, Cambridge, where he graduated as second wrangler in 1836, and became fellow and assistant-tutor of his college. From 1838 to 1842 he was an assistant-master at Harrow, and for the next four years a tutor at Cambridge. Appointed, in 1846, rector of Forncett St Mary, Norfolk, he published Miscellaneous Examples in Algebra in 1848, Plane Trigonometry in 1851, and Village Sermons in 1853, in which same year he was appointed first Bishop of Natal. With that energy of character which always distinguished him, Dr Colenso at once began a close study of the natives and of the Zulu language, and after a time prepared a grammar and dictionary, and made a translation of the English Prayer-book and a portion of the Bible, printing them in his own house. In 1860 he memorialised the Archbishop of Canterbury against compelling those natives who had already more than one wife to renounce polygamy as a condition to baptism, alleging that he could find no warrant for such compulsion either in the gospel or in the ancient church. In 1861 he published his. Translation of St Paul's Epistle to the Romans, commented on from a Missionary Point of View, in which he objected to the doctrine of eternal punishment. He next announced that he had become convinced of the improbability of many statements of facts and numbers in the historical books of the Bible; and in 1862 there appeared the first part of his work on The Pentateuch and the Book of Joshua Critically Examined. This treatise brought down upon its writer an avalanche of criticism and remonstrance, He had called in question the historical accuracy and Mosaic authorship of the books cited, and his work was condemned as heretical by small majorities in both Houses of Convocation of the province of Canterbury. The bishop was entreated to resign his see by his episcopal brethren, some of whom inhibited him from preaching in their dioceses. The second part of his work appeared in 1863 . Convocation censured him in the succeeding year, and he was declared to be deposed from his see by his Metropolitan, Bishop Gray of Capetown. He appealed from this judgment in 1865, when the Privy-council declared the deposition to be "null and void in law.' The bishops constituting the council of the Colonial Bishopries Fund, however, refused to pay him his income, upon which he appealed to the Court of Chancery. On October 6, 1866, the Master of the Rolls delivered an elaborate judgment, ordering the payment of the bishop's income, with all arrears and interest, unless his accusers should bring him to trial for heresy; but this they declined to do. Immediately before Dr. Colenso's return to his diocese in August 1865, his English friends presented him with $£ 3300$ as a testimonial. The Anglican community at the Cape was now divided into two camps, and although Dr Colenso remained the only bishop of the Church of England in Natal, Bishop Gray publicly excommunicated him, and in 1869 consecrated Dr W. K. Macrorie as Bishop of Maritzburg, his authority practically extending over the same diocese. In 1874 Dr Colenso visited England to report upon the affairs of his diocese to the Archbishop of Canterbury, and to consult with the heads of the church upon its relations to the new see of Maritzburg. While in England he pleaded the cause of Langalibalele, a dispossessed Zulu chief. On his return to South Africa he warmly espoused the interests of the natives against the oppression of the Boers, and the encroaching policy of the Cape officials. He opposed the attitude of Sir Bartle Frere and the home government during the Zulu war, and earnestly strove to make peace between the contending parties. Owing to his exertions, Cetywayo was allowed to visit England and plead for his rights. Dr Colenso's defence of the aboriginal claims lost him much valuable support; but the bishop and his daughter never swerved from what seemed to them to be the wisest as well as the only honourable course to pursue towards the natives of South Africa. In addition to the works already named, Dr Colenso was the author of Ten Weeks in Natal (1855); The New Bible Commentary Literally Examined (187174); Lectures on the Pentateuch and the Moabite Stone (1873); and a volume of Sermons (1873). His critical analysis of the Pentateuch extended to seven parts, the last of which appeared in 1879. This work was not without influence in modifying the views of Kuenen and other continental commentators. Bishop Colenso died at Durban, Natal, June 20, 1883. He was a man of upright and inflexible character, yet gentle in demeanour and chivalrous in controversy. His theological works still find many readers, while his treatises on algebra and arithmetic have long been text-books in the public sehools and universities. See his Life by Sir G. W. Cox ( 2 vols. 1888).

\section{Coleop'tera. See BeEtle.}

Colepeper, Јон,, was a native of Sussex, but, save that he had seen much foreign service, little is known of him till his return for Kent in 1640 to the Long Parliament. There he pursued a course much the same as Hyde's (see CLARENDON), and in January 1642 was created Chancellor of the Exchequer, a twelvemonth later Master of the Rolls, and in 1644 Lord Colepeper. With Hyde he attended Prince Charles to the western counties, and from Jersey he brought him to Henrietta Maria, to whose party he thenceforth attached himself. He lived to see the Restoration, dying on 11th June 1660. He was an able, farseeing councillor, but rough and unstable.

Coleraine, a seaport in County Londonderry, on the right bank of the Bann, 4 miles from its mouth, 33 by rail NE. of Londonderry, and 61 NW. of Belfast. It has manufactures of fine linens, pork-curing, distilling, and important fisheries in the river. The Bann is here spanned by a fine stone bridge, 288 feet long, which connects Coleraine with its suburb on the left bank of the river, Waterside or Killowen. Vessels of 200 tons can discharge at the quay - those of greater burden lie at Portrush, 61 miles off. Pop. (1861) 6236; ( 1881 ) 5899 ; (1891) 6845 . Until 1885 Coleraine returned a member to parliament.

Coleridge, HartLEy, eldest son of the great Coleridge, was born, an eight months' child, at Clevedon, Somersetshire, 19th September 1796. Very early he showed uncommon parts, and a singular power of living entirely in a make-believe world of dreams and imagination. Wordsworth's lovely and touching poem to the child at six years of age was strangely and sadly prophetic of his after-life; hardly less the concluding lines of his own father's two poems, The Nightingale and Frost at Midnight. Hartley was brought up, after the separation of his parents, by Southey at Greta Hall, and was educated chiefly at Ambleside school. In 1815 he went to Oxford as postmaster of Merton College. His scholarship was great but unequal, and not such as to lead to high distine- 
tions in the schools. His failure after no lens than three attempts to gain the Newdigate filled him with 'a passionate despondency,' from which he turned for relief to a fatal remedy. When at length he had gained with eredit an Oriel fellowship, at the close of his probationary year he was judged to have forfeited it mainly on the ground of intemperance. 'The sentence might be considered severe,' says his brother: 'it could not be satid to he unjust.' Inhappily it ruined his life, crushed his spirit, and made recovery imposaible. With $\mathrm{f} 300$ given him by the college, Hartley spent the next two years in London, then tried for four or five years taking pupils at Ambleside, occasionally writing for Blackwood's Magnzine, next lived some time at Grasmere, and then went to live at Leeds with one Bingley, a publisher, for whom he arreed to write a hiographical work on the worthies of Lancashire and Yorkshire. Of these but thirteen lives had already been written when Bingley failed. These were published under the titles of Biographia Borealis (1833) and of Worthies of Yorkshire and Lancashire (1836). Bingley also printed a small volume of his poems in 1833. Hartley next returned to Grasmere, the only remaining inter. ruptions to his ordinary life being two short and not unsucessful intervals of teaching at Sedbergh grammar-school. His father, who died in 1834, made a special provision for him in a codicil to his will, and his mother's death in 1845 made him by an annuity completely independent. He continued to write. poetry, and wrote a life of Massinger for an edition projected by Moxon. His days were spent in fitful study, lonely reverie, and wanderings over the Lake Country, with, unhappily, occasional lapses into intemperance. The dalesmen everywhere treated 'Poet Hartley' with a singularly affectionate respect, not without a kind of awe at his eerie appearance, his abstracted air, his small stature, prematurely white hair, and gentle manners. He loved children and animals, and was fondly loved by them in return. He died 6 th January 1849 , and was buried beside what was soon to be Wordsworth's grave.

Hartley Coleridge's poetry falls short of the great, but sometimes approaches it, and even nearly. It is graceful, tender, and sincere, pervaded throughout with a charm of a nature rare and almost unique, alternately wise and playful, and often perfect in the expression of the thoughts it has to convey. He is greatest in the sonneta form which seems exactly to have been the measure of his powers, or rather of the fitful periods of his poetic passion. Leonard and Susan, a narrative poem in blank verse, and Prometheus, a dramatic fragment, are the only poems of any length. His Poems were collected by his brother Derwent, with a Memoir (2 vols. 1851); also his Essays and Marginalia (2 vols. 1851).

Coleridge, LorD. John Duke Coleridge (eldest son of Sir John Taylor Coleridge, the great poet's nephew, and himself the biographer of Keble) was born in 1821, and educated at Eton and Oxford, was called to the bar in 1847, and was for some years leader of the western circuit. Appointed recorder of Portsmouth in 1855, he took silk in 1861, and from 1865 to 1873 represented Exeter in parliament. He was ancessively Solicitor-general (1868), Attorney-general (1871), Chief-justice of the Common Pleas (1873), and (1880), Lord Chiefjustice. An occasional contributor to the reviews, and a man of exceptional culture and polished eloquence, he died 14th June 1894.

Coleridge, SAMUEL TAYLOR, was born at Ottery St Mary, Devonshire, October 21, 1772, where his father was vicar, and master of the grammar-school. He was the youngest of ten children of his father's second marriage. A singu. larly precocious child, he had read the Arabien Nights in his fourth year; but he said of himself, 'I never thought as a child.' On his father' death he was sent, in his ninth year, to be educated at Christ's Hospital, where he had Charles Lamb for a sehool companion. He was poorly fed, and badly taught; but he plunged with eagerneses into a whole library of literature, and real Homer and Virgil for the mere pleasure of it. Remaining at Christ for eight years, he became head of the school, and showed a remarkable capacity for assimilating all sorts of knowledge. He was a mental rover from his boyhood onwards, with a very miscellaneous intellectual appetite. At school he translated the hymns of Synesius, studied works on medicine in Latin, on metaphysics in Greek, and fell in love with the sister of one of his companions. His last years at school, however, were years of suffering. He used to bathe in the New River, plunging into the water with his clothes on, and after a swim, resumed his games, or returned to his books, without changing his garments. The inevitable result was rheumatic fever and other ailments. While at school he had a passing attraction not only to his schoolmate's sister, but to the shoemaker's craft. This was a short-lived fancy; and in October 1791 he passed to Jesus College, Cambridge, a few months after Wordsworth had taken his B.A. degree, and left the university. During his first year at college he did good work in classics, and became one of four selected candidates for the Craven scholarship in 1793 ; but his bent not being mathematical, and having little chance of winning the chancellor's medal, he gave himself up to general literature. He also became inter. ested in politics, took a strong position on the Liberal side, and won distinction, even thus early, as a marvellous talker. He got into difficulties in Cambridge, through extravagance in furnishing his rooms, became depressed, and in a panic fled to London, where he enlisted in the 15th Dragoons, under the name of Silas Tomkyns Comberbach (a name assumed to conceal and yet reveal his identity as S. T. C.): He never could learn, however, how to manage a horse, never rose ont of the awkward squad; and a chance accident disclosing his know. ledge of classics, led to his discovery by his friends, and to his being bought out of the service. At the close of the summer term, he went from Cambridge to Oxford; and there, at Balliol College, he for the first time met Southey. In July he took a pedestrian tour in North Wales, after which he went to Bristol, and there again met both with Southey and with Robert Lovell, the latter of whom had just married a Miss Fricker, to whose sister (Edith) Sonthey had engrged himself. Coleridge at once followed his example, and became engaged to another sister (Sara); and amongst them they formed the Quixotic plan of emigration to the banks of the Susquehanna in America, where they were to form a 'Pantisocracy' - an ideal community on the prinerples of Communism. Two hours of daily abour were to suftice for providing the necessaries of life, the rest of their time being devoted to intellectual work and social converse. They were to have all things in common; and, as a result of the experiment, were to bring in a golden age, for themselves and others, It was a dream; and it passed, as dreams do.

Coleridge had left Cambridge without taking a degree. In the late autumn of 1794 he went up to London, and there renewed his acquaintance with Iamb. But in December he was brought back to Bristol by Sonthey, who fesred he might come under some new faseination in the metropolis. He had to find the means of livelihood, not on the Susquehanna, but in the west of England; and 
he began a course of miscellaneous lecturing on literary and political subjects. It was now that he made the acquaintance of Joseph Cottle, the Bristol bookseller, who became so kind a friend. Cottle offered to publish a volume of poems for him, giving him thirty guineas for the copyright; and, vexed at his delay in completing the volume, subsequently offered him a guinea for every hundred lines of verse he would write, after this first volume was printed. With this promise, and what he thought provision for life, he ventured to marry and in October 1795 Sara Fricker became Mrs Coleridge. They went at once to a small cottage, which is still to be seen at Clevedon in Somerset. Here, however, Coleridge did not long remain. We find him in Bristol in December getting his first volume of poems ready for the press (it was published in April 1796), and at the same time attempting to start a weekly journal to be called the Watchman, which was to contain general news, parliamentary reports, literary intelligence, and reviews. In his efforts to float this journal he went north to Birmingham, Manchester, Sheffield, \&c., to procure subscribers. He succeeded in starting it, Cottle being the publisher; but it only reached its tenth number, and failed-the generous publisher bearing all the loss. Coleridge next tried the experiment of preaching in the Unitarian chapels around Bristol. Cottle gives an account of his appearance in one of these at Bath on a Sunday, 'in blue coat and white waistcoat,' to discourse on the corn laws and the powder tax. This eccentricity did not last. Another friend, and a somewhat remarkable man-Thomas Poole of Nether Stowey-provided him with a small house and garden in the village of Stowey and there Coleridge went to live, in January 1797, with his wife and child (whom he had named Hartley, from his admiration for the philosophy of David Hartley). Poole also very generously raised a sum of money to provide an annuity for his friend.

Before this date Coleridge had made the aequaintance of Wordsworth. In the early spring of 1796 Wordsworth went up to Bristol from Racedown in Dorsetshire, to see both Coleridge and Southey; and, in a list of authors with whom he was acquainted, drawn up by Coleridge in March of that year, Wordsworth's name occurs. In the following year Coleridge went down from Stowey to Racedown to return the visit. As late as 1845 Mrs Wordsworth gave a graphic account to Sara Coleridge of her father's 'leaping over a gate, and bounding down a pathless field on this first visit to Racedown. In July 1797 the Wordsworths moved from Racedown to Alfoxden, partly to be nearer Coleridge; and during that winter-which William and Dorothy Wordsworth spent in Somerset-Coleridge was their almost daily companion, roaming the woods and coombs of the Quantocks with them, or spending the night at Alfoxden. Wordsworth and he discussed together the principles of poetry, and planned a joint volume of verse to illustrate these principles; Wordsworth undertaking to invest commonplace themes with an imaginative interest, by disclosing what underlay them; and Coleridge taking supernatural or romantic incidents, humanising the stories so as to give new life to them. This was the origin of the Lyrical Ballads, the little volume which more than any other marked a new departure in poetical literature at the beginning of the 19th century. To it Coleridge contributed the Ancient Mariner. The book was published in 1798 .

This meeting of Coleridge and Wordsworth was one of the most remarkable conjunctions of genius in the literary history of England, and the days they spent together in Somerset were perhaps the most joyous in their lives. While living at Nether Stowey, Coleridge kept up the practice of occasional preaching; and 'to prevent the necessity of his going into the ministry,' another admiring friend, Josiah Wedgwood, sent him a draft for $£ 100$. He returned it to the donor; but, soon afterwards, Coleridge accepted an annuity of $£ 150$ from the brothers Wedgwood, given to him on the condition that he would devote his life wholly to poetry and philosophy. In 1798 he started with the Wordsworths for Germany, crossing from Yarmouth to Hamburg; and while Wordsworth went to Goslar, Coleridge proceeded to Ratzeburg, to study the language and literature of the country. He moved on to Göttingen in January 1799. An interesting picture of his life in Germany is given in Satyrane's Letters. He returned to England in June; in August we find him at Stowey; and in September in Yorkshire with the Wordsworths. They had some idea of settling together, to renew the fellowship of the Quantock days. On the approach of winter, however, Coleridge went up to London, and there translated Wallenstein, one of the besit bits of work he ever did. He now made fresh attempts at journalism, and wrote both prose and verse for the Morning Post; but, while some of his articles were admirable, he was such an irregular contributor, that his connection with the Post lasted only for a few months. In July he went north to Keswick, and took up his residence at Greta Hall, which Southey also made his home in 1803. At Keswick he continued his poetic work, and wrote the second part of Christabel. The Wordsworths had now been settled for some time at Dove Cottage, Grasmere, and there Coleridge was their frequent guest. Dorothy Wordsworth's Grasmere journal (ed. Knight, 1897) is full of allusions to his visits, and to the wonderful friendship of these days $-a$ friendship immortalised in her brother's Stanzas written in a pocket copy of Thomson's Castle of Indolence. But during the years he spent at Keswick, Coleridge came under the influence of what was henceforward to be the very curse of his life. His health had never been robust; rheumatism and neuralgia had tortured him; and, beeoming his own doctor, he had recourse to the anodyne of opium. Little by little the habit grew, and the "Kendal black drop" at length enslaved him. It injured his constitution and killed his imagination; it enfeebled his will and destroyed his sense of truth and honour. Few things in literature are so pathetic as his own lament over the deterioration of his nature, in his Dejection, an Ode. The details of this malady; and what it led to, have not yet been fully told.

Charles Lamb came to visit him at Keswick in 1802. In 1803 he started with the Wordsworths, on their memorable Scottish tour; but left them in a fortnight, and did wonderful feats of walking alone. He now thought of many plans for the recovery of health, which were really but plans to flee from his own shadow. The frugal Wordsworth forced him to accept a loan of $£ 100$. He was befriended by others, and he sailed for Malta in April 1804. There he became secretary to the governor, Sir Alexander Ball, an office for which he was entirely unsuited. His letters from abroad were hypochondriacal, valetudinarian, and sad in many ways. From Malta he went to Sicily, to Naples, and to Rome; bnt he had to leave Italy with some abruptness, an order, it is said, having been issued by Napoleon for his arrest, on the ground of some republican utterances years before; and the vesse in which he sailed being chased by a French cruiser, he threw all his papers (which included many of Wordsworth's poems) overboard. In August 1806 he returned to England. It is unnecessary to trace his subsequent wanderings to and fro, from 
Loudon to Keswick, to Penrith, to Coleorton, to Briatol, and to Bridgwater. At London he began what might have been a very remarkable series of lectures at the Royal Institution; but the experiment failed, for the same cause as previons ones timl failed. He next thought of a fresh venture in journalism, and projected a new weekly paper, The Friend, for which he got a number of subscribers. It was priuted at Penrith at his own expense. The Wordaworthe took him into their house at Allan I3unk, Grasmere, for the winter; and while Coleridge wrote most of the papers for The Friend himself, Wordsworth supplied him with some of the articles, and Sarah Hutchinson transcribed them week by week for the preas. The paper lived from Angust 1809 to March 1810. The habit of opium-eating, which hal now obtained a fatal ascendency, could not be hidlen from his friends; and at this junc. ture the Wordsworths, with the greatest delicacy, tried their utmost to help and to befriend him. They were misumderstond. He went up to London in 1810 , and a strange cloud (the full story of which has yet to he told) obscured for a time the old relationship between the households. A partial estrangement lasted for some years, but was at length overcome by the friendly offices of Henry Crabb Robinson.

During Coleridge's later years in London he lived for four years with an old Bristol friend, John Morgan, at Hammersmith. He first tried the experiment of lecturing on Shakespeare. Occesionally his appearances were brilliant; more asually they were absolute failures. His conversationsl powers, however, seem to have increased, while his success as a lecturer diminished. All his life he had been in the habit of receiving gifts freely from such friends as the Beaumonts, and the Wedgwoods, from Stuart, and Wordsworth, and De Quincey; and though he occasionally did generous things to others, his neglect of the primal duties to his own family put a severe strain upon the tie that bound these friends to him.

The remaining years of his life were spent at Highgate with Mr and Mrs Gillman, whose kindness and consideration were unbounded. Though a wreck of his former self, the baleful opium-habit lessened, as Coleridge crew older, and he was able to do a good deal of miscellaneous writing. Some of his best prose work. was written at Highgate. Though a dreamy and often unintelligible sage, he became a sort of oracle to a circle of enthusiastic adnirers that gathered round him, and he completely fascinated the young men, who made their weekly pilgrimages to Gillman's house to hear him talk. As the years went on, his health somewhat improved, and he was even able to make occrsional visits. In 1829 he took a short tour with the Wordsworths, accompanying the poet and his daughter to the Rhine. He died on the 23d July 1834, and was buried at Highgate.

As a Poet, Critic, and Philosopher (the three functions having been combined by Coleridge as they hat never been hy any previous Englisliman he was certainly a star of the first magnitude in the firmament of letters. For originality, insight, grace, musicalness, deft subtlety of thought, natural. ness and charm of diction, he had only one rival smongst the poets of the Renainsance. It is true there have been greater poets in England, but there has been no greater poetical critic in British litera. ture. Coleridge was a critic of poets (and the poets have, as a rule, been the best critics of each other). As yet there is no estimate of the literary revival which Coleridge and Wordsworth inaugurated that is superior to what the former wrote in his Biographia Literaria; and he was a philosophical critic, because he was a philosopher amongst the pcets. He may be said to have inaugurated a new era by his poetic idealism, and by introducing the spirit of Plato alike into his poetry and his literary criticism. As a philosopher, however, he does not occupy the foremost place. He was too miscel. laneous, too asimilative, and his intellect ton meteoric and vagrant for speculative orivinality of the highest order. But he was one of the mont suggestive of critics. Though not profoundly learmed, he was very widely read; and he did more to leaven English philosophy, literature, and theolory with the depth and the free spirit of Germany than any one of his contemporaries. He vitalised whatever he discussed; and his writings will prob. ably continue to kindle successive generations, and to fascinate them, even while they fail to convince.

Coleridge's most important works are: Poeme (1876): Wallenstein (1800); The Friend (1809-10): Remorse (1813); Christabel, Kubla Khan, de. (1816); The States man's Manual (1816); Sibylline Leaves (1817); Biographia Literarin (1817); Aids to Reflectim (18\%). Posthumously published-four volumes of Literary Remains (1886-38); Confessions of an Enquiring Spirit (1840): Esay on Method (1845).

The chief authorities in reference to Coleridge are Letters, Conversations, and Recollections, by Allsop (1836). Cottle's Early Recollectione (1837); Gillman's Life (1838); Coleridge's Letters to Sir Genrge and Lady Beaumont (1886); Mrs Sandford's Thomas Poole and his Friends (1889); the Biographia Literaria (1817); De Quincey's 'S. T. Coleridge,' in his Recollertions of the Lakes (1857); Eliza Meteyard's Group of Englishmen, 1795-1815 (1871); the Memoirs of Wordsworth (1851); Southey's Life and Correspondence (1850); Lamb's Letters (1888); Mr Traill's Coleridge (1884); Brandl's S. T. Coleridge and the English Romantic School (1882): the short lives by 'Traill (1884) and Hall Caine (1887); the life by Dykee Campbell, prefixed to his admirable edition of the works (1893; separately published 1894); and the Letters edited by Ernest Coleridge (1895)

Coleridge, SARA, the gifted daughter of the great Coleridge, was born, $23 \mathrm{~d}^{\circ}$ December 1802 , at Greta Hall, near Keswick, where she was lrought up by Sonthey. Her 'depth of meditative eye' is noticed by Wordsworth in the finest lines of his rather poor poem, the Triad (1828), the other maidens of the group being Edith Southey and Dora Wordsworth. Sara early showed remarkable powers of mind, with all her father's leaning towards psychology and abstract thought. At twenty she published, to aid her brother Derwent's college expenses, a translation of Martin Dobrizhofer's Latin Account of the Abipones (1784), and three years later the 'Loyal Servitor's' memoirs of the Chevalier Bayard. In 1829 she married her cousin, Henry Nelson Coleridge, and on his death in 1843 succeeded him in the task of annotating and editing her father's writings. Her health failed early, and she died 3d May 1852. Her own works were Pretty Lessons for Good Children (1834), and Phantasmion (1837). a somewhat remarkable fairy-tale. Her Menoirs and Lettens were edited by her daughter in 1873. Her son, Herbert Coleridge, born in 1830, was educated at Eton and Balliol College, took a double. first in 1852, and was called to the bar, but devoted himself to the study of comprative philolongy. Elected a member of the Philological Society in 1857, he threw himself with enthusiasm into its ambitious project of a standard English dietionary, and was practically editor in its earlier stages His own works were a Glassarial Index to the Printed English Literature of the Thirtenth Century (1859), and an excellent esay on King Arthur, printed after his untimely death at Lombon, 23d April 1861) by the Philological Society.

Coleroon, the largest and most northerly branch from the Kaveri, flows 94 miles, chiefly hetween Trichinopoly and Tanjore, into the Bay of Bengal. It is remarkable for its two weirs of danis, the anicuts, constructed in 1856. 
Coles, Cowper Phipps, naval architect, born in Hampshire in 1819, early entered the navy, and became lieutenant in 1846 and captain in 1856 . In 1855 he constructed a gun-raft, which was favourably reported on; from 1856 he was engaged in experiments, and ultimately produced a form of turret-ship, the general idea of which had probably occurred to him independently, although its de. velopment owed much to the invention of Ericsson (q.v.). A vessel was built from his designs, with little more than 6 feet of freeboard; it was commissioned as the Captain early in 1870, and on 7th September turned bottom upwards in a gale, and sank off Cape Finisterre, almost all on board, including Coles, being drowned.

Coleseed. See RAPE.

Coleshill, a market-town of Warwickshire, 10 miles ENE. of Birmingham. Pop. of parish, 2356.

Colet, JoHn, born in London about 1467, was the eldest son of a family of twenty-two. His father, Sir Henry Colet, was twice Lord Mayor of London. Colet studied at Oxford with the view of entering the church, and about 1493 made a prolonged visit to the Continent, travelling through France into Italy. While in Italy he became acquainted with the views of Savonarola, which subsequent study and experience led him to regard with increasing approval. Having returned to England in 1496, and been ordained priest, he delivered at Oxford a series of lectures on the Epistles of St Paul, which attracted great attention, his principles of interpretation being at every point opposed to those of the scholastic theologians. In 1498 Erasmus came to Oxford, and it is one of Colet's chief claims to remembrance that he powerfully influenced that scholar's opinions on the proper methods of Scripture interpretation and on the value of the scholastic philosophy. In 1505 Colet was made Dean of St Paul's, London, and in this office still continued to deliver lectures on different books of Scripture, which gave rise to much diversity of opinion. With the large fortune he inherited on the death of his father, Colet founded St Paul's School (q.v.). At this school 153 scholars were received, whose education was conducted in a spirit far in advance of the time. On account of Colet's vigorous denunciation of the ignorance and corruption of the clergy, charges of heresy were brought against him, but Archbishop Warham refused to support them. Colet also spoke out strongly against the French wars of Henry VIII., who, nevertheless, always treated him with regard. In 1518, feeling his end approaching, Colet appointed the Mercers' Company of London as managers of his school-a step of decisive importance, as it was the first example of lay management of an educational institution. He died of dropsy, 16th September 1519.

of late years it has been conclusively shown that Colet was one of the most striking figures of his time in England. He was not a great scholar, and he left no writings that entitle him to remembrance; but by his clear view of the urgent need of reform in the church, and by the intensity of his religious convictions, he gave an impulse to men like Sir Thomas More and Erasmus, which influenced their whole life-work. At the same time, Colet, though an ardent religious reformer, never entertained the thought of a formal rupture with Rome. His foundation of St Paul's School, and the character he gave to that institution, entitles him to an eminent place among educational reformers. See Seebohm's Oxford Reformers ( $2 \mathrm{~d}$ ed. 1869), and the Rev. J. H. Lupton's Life of Colet (1887).

Colewort. See Cabbage.

Colfax, Schurler, American statesman, born ut New York, 23d March 1823, removed in 1836 to
Indiana, where in 1845 he acquired a newspaper at South Bend, which he made the most influential Whig journal in the district. He was a delegate to the Whig conventions of 1848 and 1852 ; he was returned to congress in 1854 by the newly-formed Republican party, and re-elected until 1869, being thrice chosen Speaker; and in 1868 he was eleeted vice-president of the United States, in Grant's first term. Implicated, apparently unjustly, in the Crédit Mobilier charges of 1873, he spent the remainder of his life in political retirement, making public appearances only on the lecture platform, and died at Mankato, in Minnesota, 13th January 1885. See his Life by 0 . J. Hollister (New York, 1886).

\section{Colibri. See Humming-BIRD.}

Colic (Gr. colon, 'the large intestine;' see INTESTINES ), a name employed by the later Greek and the Roman physicians to denote diseases attended with severe pain and flatulent distension of the abdomen, without diarrhoea or looseness of the bowels. The disease (commonly called gripes or belly-ache) is now generally believed to be spasmodic in character, and to be dependent upon irregular contractions of the muscular coat of the intestines : its supposed particular connection with the colon, or large intestine, however, is not usually to be made out from the symptoms. Painful disorders of the bowels are very frequent in persons who are not attentive to the regular evacuations, especially when they are exposed to cold so as to experience chill or coldness of the feet, which will often suffice to bring on an attack of colic. The disease is usually attended with Constipation (q.v.), and ceases when the regular action of the bowels is restored, although often in this case the operation of medicine is attended by continued pain for a time. Warm fomentations to the abdomen may be employed with advantage, sometimes medicated with opium, or decoction of poppy-heads; and great relief is commonly experienced from friction with a warm liniment, such as opodeldoc, or the soap and opium liniment. Pressure with the hand over the painful part commonly diminishes the suffering for the time in simple colic, but increases it in more serious diseases. Warmth to the feet, and the recumbent posture, are also to be recommended. In very severe or protracted cases opium may be taken internally. A good remedy in such cases is a full dose of castor-oil (one ounce or more for an adult), with 30 or 35 drops of laudanum, or of solution of morphia. (Opiates should not be given to children except under medical advice, and in very reduced doses.) When colic resists such mild and simple remedies as the above-when it is accompanied by tenderness of the belly, or by hard swelling in any part of it-when constipation is obstinate, or vomiting is present-when there is feverishness, or tendency to exhaustion-or when there is reason to believe that it may depend on any other cause than the mere accumulation of the products of digestion in the intestines, no time should be lost in seeking the best medical assistance that can be procured : for colic is closely allied as a symptom to several very severe and dangerous diseases. One of these complicated forms of colic is termed Ileus, or iliac passion (from the idea that its seat was in the small intestine-ileum). It is attended with obstruction of the bowels, often from mechanical twisting or involution of one part with another (hence termed volvulus). This is, of course, a disease of extreme danger. The only treatment that can be attempted without medical assistance is the employment of large injections by the lower bowel, and opium in moderate and repeated doses ( $\frac{1}{2}$ grain to 1 grain, or 12 to 20 drops of laudanum) by the mouth, care- 
fully watched, and discontinued if there is any sign of nareotism (see OPIUM). Colic pains are also present in peritonitis (see PkRTONEUM), another most dnngerous form of disease; and they form one marked symptom of the slow poisoning by leat, occasionally observed as the consequence of contamination of drinking water by leaden ciaterns, \&c. In this form the treatment is different from that of simple colic, and is treated of in the article Lead, under LEAD-POISONING.

Coligny, Gaspard DE, one of the greatest Frenchmen of the 16th century, was born at Chatillon-8ur-Loing, February 16, 1519. At the age of twenty-two he began his career as a soldier, and greatly distinguished himself in the wars which Francis I. and Heury II. carried on against Spain. By Henry II. he was appointed colonel-general of the French infantry, and the severe system of discipline he introduced gave a new character to the art of war in the 16th century. In 1552 he was made admiral of France, though he never commanded on the sea. By holding the town of St Quentin (1557) with a handful of men for seventeen days against the army of Spain, he was the means of saving his country. It was during his im. prisonment, after the eapture of this town, that he embraced the views of the Huguenots, to the furtherance of which the rest of his life was consecrated. On the accession of Francis II. in 1559, the Guises became all-powerful, and their interest and fanaticism led them to oppose all toleration of the Huguenots. To obtain this toleration, however, was Coligny's great aim, and by his high character and his abilities as a statesman and general, he succeeded in conjunction with the heads of the Bourbon family in effecting the treaty known as the 'Pacification of Amboise' (1563), by which the Huguenots were allowed freedom of worship. This concession having been gradually withdrawn by the queen-mother, Catharine de' Medicis, the second Huguenot war broke out in 1567, when, on the death of the Prince of Condé, Coliuny was appointed generalissimo of the forces of Henry of Navarre, afterwards Henry IV. of France. Both parties having grown weary of the war, peace was concluded in 1570 on the basis of the treaty of Amboise, mainly through Coligny's energy. Catharine de' Medicis, however, again becoming alarmed at the growing power of the Huguenots, and especially at the ascendency of Coligny over the young king, Charles IX., determined by one desperate stroke to regain her power. In 1572, a numerous body of the Huguenot nobles having been drawn to Paris by the marriage of Henry of Navarre with Margaret, the sister of the king, the massacre of St Bartholomew took place, when Coligny was murdered in his bed, and his boly thrown into the street by Henry of Guise and his followers.

In his personal character Coligny was one of the noblest Frenchmen of his time. His religious zeal was purely disinterested, and he had deeply at heart the welfare of his country. His great aim was to make the Huguenots a national party, and by their enthusiasm to defeat the schemes of Spain, who he asw was bent on supremacy in western Europe. Had he lived a few years longer the history of French Protestantism would have been different. Coligny's wide views are further seen in his unsuccessful attempts to found Protestant colonies in Brazil and North America. See his Life by Blackburn (2 vols. Phila. 1869), Bersier (Eng. truns. 1884), Delaborde (3 vols. Paris, 1880), and Marcks (Stuttg, 1892).

Coli'ma, a Mexican state on the Pacific coast, with an area of $2694 \mathrm{sq} . \mathrm{m}_{\text {. }}$ and a pop. (1882) of 72,591 . The soil 18 very fertile, the climate warm large quantities of coffee, mugar, rice, tobaceo, naize, and cotton are grown. The capital, Colima, 1450 feet above the sea, abont 40 miles ENE. of the port of Manzanillo, is regularly built, with narrow streets croasing at right angles, and has several large cotton-facturies. Pop. (1895) 18.977. Beyonel the state frontier, about 35 nilem $\mathbf{N E}$. of the cajital, rises the volcano of Colima $(12,750$ feet), which burst out in June 1869.

\section{Colin. See Viranian Quall.}

Coliseum. See A mphitheatre.

Coll, one of the Argyllshire Hebrides, 16 miles W. of Tobermory in Mull. It is 13 miles long, 1 to $3 \frac{1}{2}$ broad, and $30 \mathrm{sq} . \mathbf{m}$. in area. It nowhere exceeds 326 feet in height; mica-slate is the predominant rock; and more than a third of the surface is cultivated or in pasture. Pop. (1801) 1162 ; (1881) 643 ; (1891) 522 .

Collar-bone, or Clavicte (q.v.), is in man, as in most mammals, the only bone directly con. necting the upper extremity with the skeleton of the trunk. It is consequently very often broken, more often than any other bone except perhaps the radius. Under proper treatment, in children sometimes even without treatment, it readily reunites without any impairment of the usefulness of the limb. But it is very difficult to maintain such exact adjustment that no irregularity of the surface of the bone will remain; and as it lies close under the skin, the resulting deformity is often visible.

Collateral. See Consanguinity, SuccessION. Collateral Security is an additional and separate security for the performance of an obligation.

Collation. See Benefice.

Col'le, a town of Italy, on the Elsa, 24 miles SSW. of Florence. It has an old cathedral and castle. Pop. 5090.

Collect, a short form of prayer, peculiar to the liturgies of the Western Church. It consists of a single sentence, conveying one main petition, which is based on an attribute ascribed to God in the opening invocation, and closing with an aseription of praise or a pleading of the merits of Christ. Thus much for the structure of these prayers, which, whether in Latin or English, may be described, alike from their noble rhythmical harmony and from their pathos and devout simple earnestness, as models of liturgical petitions; the etymology of their name is more difficult to determine, beyond the fact that it is from the Latin colligere, "to collect.' According to some, the prayer was 80 called because, as in the Enrlish Praver.book, it collects or condenses the teachings of the epistle and gospel for the day; but this explanation applies only to the class of special collects. Accord. ing to others, the term implies that the prayer collects and sums up all the previous petitions, or gathers and offers up in one comprehensive form all the spoken and unspoken petitions of the people. Both these lerivations are open to serious oljee. tions, and neither has any historical basis; the most probable view is that which traces the name to the collecta, or assembly of the people for divine service, at which certain prayers (orationes ad collectam) were said, distinct from the later prayers of the mass (orationes ad missam). Of the collects used in the liturgy of the Church of England, some, including most of those for saints' days - since the old collects were mainly prayers for the saints' intercession-were composed at the Reformation, or even later; but most, taken from the old Roman Missal, are derived from the Sacramentaries of Popes Leo, Gelasins, and Gregory (5th and 6th centuries). The remoter source of the weekly 
collects Freeman finds in the hymns of the Eastern Church, founded on the gospels, of which these collects would thus be the 'very quintessence.' In the English Prayer-book, for every Sunday there is a proper collect, with corresponding epistle and gospel; and this collect stands for every day in the following week, except in the case of festivals and their eves or vigils, which have collects of their own. Good Friday alone has three collects; and during Advent and Lent the collect for the first day of the season is repeated after the collect for the week.

Collections at Churches. The collections which are still made at all churches in Scotlandeither at the church-doors before the service, or in the church after it-were, till a comparatively recent period, the principal fund for the support of the poor. The proceeds of these collections were originally under the control of the kirk-session, and remain so under certain restrictions. By a proclamation of the Privy-council in 1693, it was ordered that one-half of the sums so collected, and of dues received by the kirk-session, be paid over into the general fund for the support of the poor. The other half has generally been applied for the relief of sudden or temporary distress. The kirksession may be called upon by any single heritor to account for its management of this remaining half. By the Poor-law Amendment Act, 1845, it is enacted that in all parishes in which it has been agreed that an assessment shall be levied. for the relief of the poor, all moneys arising from the ordinary church collections shall in future belong to, and be at the disposal of, the kirk-session; provided, however, that they shall be applied to no purposes other than those to which they were, in whole or in part, legally applicable before the date of the act. A power is reserved to the heritors to examine the sccounts of the kirk-session, and to inquire into the manner in which the collections are applied; and the session-clerk is enjoined to report annually as to the application of the moneys, to the Board of Supervision. The collections made at Dissenting meeting-houses, under which denomination Episcopal chapels are included, are entirely at the disposal of the congregations, and do not form part of the poor's funds. The making of a collection is properly the province of the minister and elders; but when they neglect the duty the heritors have been in use to perform it. See Black's Parochial Ecclesiastical Law of Scotland (1888), p. 145.

In England there are no regular collections at churches as in Seotland. The alms collected in chapels, as well as in parish churches, during the reading of the offertory, are declared by the rubric to be at the disposal of the incumbent and church. wardens of the parish, and not of the minister or proprietor of the chapel. If the minister and churchwardens disagree as to the distribution of the alms, they shall be disposed of as the ordinary shall appoint.

Collectivism is a word of recent origin, intended to express the central idea in the economic theory of socialism, that industry should be carried on with a collective capital. It means that capital should not be owned and controlled by individuals, but by groups of associated workers, that it should be the joint property of the community or other form of social organisation. Its exact meaning depends very much on the form of socialism with which the principle is connected. See SocraLISM.

College (Lat. collegium, "a collection or assemblage'). In its Roman signification, a college signified any association of persons for a specific purpose, and was in many cases practically what we call a corporation. It required also to be incorporated by some sort of public authority, springing either from the senate or the emperor. A college could not consist of fewer than three persons, according to the well-known maxim, "three make a college' (Dig. 50, tit. 16, 1. 85). Some of these colleges were for purely mercantile purposes, but there were others which had religious objects in view, such as the colleges of pontifices and augurs, \&c., and some were political, as the colleges of the tribunes of the plebs. With us, a college is an incorporation, company, or society of persons joined together generally for literary or scientific purposes, and frequently possessing peculiar or exclusive privileges. See Physicians (College of), Surgeons (College of), Heralds' College. Very often in England a college is an endowed institution connected with a university, having for its object the promotion of learning. In this relation a college is a sub-corporation-i.e. a member of the body known as the university. For a more detailed account of college in this sense, see UNIVERSITIES, OXFORD, CAMBRIDGE. In Scotland and in America the distinction between the college as the member and the university as the body has been lost sight of ; and we consequently hear of colleges granting degrees, a function which in the English and in the original European view of the matter belonged exclusively to the university. Where there is but one college in a university, as is the case in Edinburgh and Glasgow universities, the two bodies are of course identical. Trinity College, Dublin, is practically the university. Owens College is a branch of the Victoria University. University College is a very usual name for recently founded institutions for the higher learning in the United King. dom. Some of the public schools are colleges, and many secondary schools are so called. Theological schools often bear this name, which is sometimes given to a hospital. In Germany there are no colleges in the English sense. In France the name of college is sometimes given to the local branches of the University of France (see FraNCE); as also to a school, corresponding, however, more to the Gymnasium (q.v.) of Germany than to the grammar-school of this country. The principal colleges have articles under special heads ; see KING'S College, University College (LoNdoN).

Collége de France, originally a Collége de Trois Langues merely, founded by Francis I. in 1530, is now a very important educational institution giving instruction over a very wide field of literature, history, and science. It is independent of the University of France ( $\left.\mathrm{q}_{0} \mathrm{v}_{0}\right)$, is directly under the Minister of Public Instruction, and is supported by the government. As in the Sorbonne (q.v.), the lectures are gratuitous; and for the most part are designed to attract auditors older than ordinary university students. The college comprises two faculties, one literary, one scientific ; and each has about twenty professors. Amongst the professors have been some of the most distinguished scholars and scientists in France, such as M. Renan, M. Laboulaye, M. Gaston de Paris, in the literary department; and M. Brown-Séquard in the science division. Amongst the subjects discussed are political economy, Assyrian and Egyptian archreology, Arabic, Slavonic literature, French literature; physiology, anatomy, and embryology.

College of Arms. See HERALD.

College of Justice. See Court of Session.

Collegiate Churches-so called from having a college or chapter, consisting of a dean or provost and canons, attached to them-date from the 9th century, when such foundations in large towns became frequent. They are under the jurisdiction of the bishop of the diocese in which they are situated, and he exercises visitorial powers over them. There were about ninety collegiate churches 
in England and Wales at the beginning of the 16th century, but nearly all of them were suppressed or sliswolved in Edward VI.'s reign unler the Acts of Henry VIII. which followed upon the diseolution of the monasteries, and granted the hospitals, chantries, and colleges to the crown. Those remaining in England are Westminster, Windsor, Wolverhampton, Haytesbury, Middleham; also Brecon in Wales, and Galway in Irelend. Ripon, Manchester, and Southwell have been constituted the cathedrals of new dioceses. Some churches called collegiate (auch as Beverley) have no chapters. In the Roman Catholic Church, no new collegiate chureh ean be founded without the sanction of the pope, acting on the favourable report of the Con. gregation of the Council of Trent, that the necessary conditions have all been fulfilled, such as suitable population and locality, adequate buildings, sufficient endowments, and the assent of the diocesan bishop; while a priority of rank in their elass is conceded to some such churches, distinguished by the title 'eminent' (insignis). The History of Renfrewshire (1886) contains a very full and in. teresting account of the collegiate church of CastleSemple, founded in 1504.

Collem'bola, the name given by Sir John Lubbock to a tribe of wingless insects, to which the Podura (q.v.) or spring-tail belongs; though he and other entomologists question their claim to be called insects.

Colley, Sir Grorak, major-general, was born in 1835, and in 1852 received an ensigncy in the $2 d$ or Queen's Foot, whose headquarters, then in the eastern frontier of Cape Colony, he joined in 1854. He was a border magistrate in 1857-58, surveyed the Trans-kei country, and served with his regiment in China in 1860 . He was then for some years major of brigade at Plymouth, and a professor at the Staff College. He ably managed the transport service in the Ashanti expedition, and in $1875 \mathrm{ac}$ companied Sir Garnet Wolseley to Natal, where he was for some time colonial treasurer, and prepared a valuable report and map of the Transval and Swaziland. From 1876 to 1880 , except for a short perior of service as chief of Wolseley's staff in Zululand and the Transvaal, he was private secretary to Lord Lytton, then viceroy in India. Appointed governor and commander-in-chief of Natal in April 1880, he commanded his small force against the Boers at Laing's Nek and Ingogo, and fell, shot through the forehead at Majuba Hill, February 27, 1881. See Life by Sir W. Butler (1899).

Collie. The origin of the collie is somewhat obseure, but great antiquity is elaimed for it. Buffon has gone so far as to call it the oldest known breed of dogs, an opinion not now generally entertained; though it is only reasonable to suppose that the anciente, after providing a dog for the chase, next turned their attention to obtaining a guardian for their flocks. For many years collies were confined to Scotland and the northern counties of England, until their good points as a graceful and intelligent companion attracting more attention, they were taken sonth in large numbers, and became the most popular breed of the day. Thanks to judieious breeding and a large expenditure of money, the best show collies are now all found in England. Tempted by the demand for black-andtan dogs, a cross with the Gordon setter was resorted to, producing many collies with the flat ears and open coat of the setter, a cross to be avoided at all costs. In judging the collie the fact should never be forgotten that it is meant to do work in all weathers, requiring the best of legs and feet, a close coat, and a strong active body capalule of great speed; and that a long and heautiful coat, if unaccompanied by a thick under-cost, is a lindrance, not a protection. The chief points of the collie are-head long and sharp, with bright, keen eyes, set rather clowe together, and a small ear drooping alightly at the tipn; back strong and muscular; legs with plenty of bone and not too much featber, bare below the hocks; feet

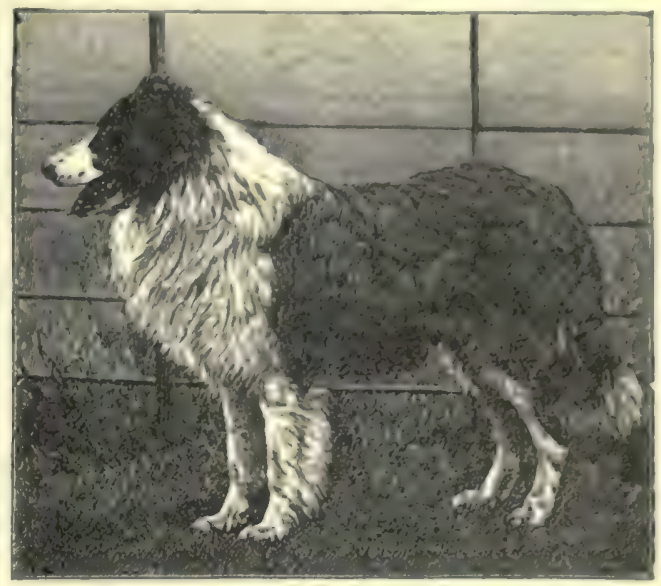

Collie.

round and cat-like. The collie should have a short dense under-cost fitted to withstand the severest wet or cold, with a long and beautiful outer-coat springing from it; round the neck this coat develops into a 'ruff' or 'frill' which sticks out in front and on each side to a great length, adding largely to the dog's beauty. Many anecdotes are told of the collie, who from his intimate association with man has acquired almost human intelligence, a good dog being able to separate the sheep under his care from those of other flocks. The collie often deteriorates in intelligence when kept merely as a companion; he is apt to get cross-tempered, a fact which the shepherd does not consider a fault, as it prevents strangers interfering with the sheep. But when not spoilt no dog makes such an agreeable conpanion as the collie, as his instinct is to attach himself to one person to whom he becomes devoted.

Collier, Arthur, metaphysician, the son of a clergyman, was born in 1680 at Langford Magna, Wiltshire, studied at $U$ xford, and became rector of the family living at Langford in 1704, remaining there till his death in 1732. At Balliol College, Collier had devoted himself to the study of Descartes and Malebranche; and his notable book, Clavis Universalis, or a New Inquiry after Truth, being a Demonstration of the Non-Existence and Impossibility of the External World (which, though published in 1713, was written ten years hefore), coin. cides in a remarkable way with Berkeley's Theory of Vision (published 1709). He was a High-Churchman, and wrote also $A$ Specimen of True Philosophy (1730) and a Logology (1732).

Collier, JERemy, nonjuror and purifier of the English stage, was born at Stow cum Quy, in Cambridgeshire, 23d September 1650. His father was a clerical schoolmaster at Ipswich, and here and at Caius College, Cambridge, he was educated, graduating B.A. in 1672. For six years he was rector of Ampton, near Bury St Erlmunds, and for some years before the Revolution he was lecturer at Gray's Inn. His reply to Dr Gilbert Burnet's Inquiry into the State of Affairs (1688) cost him some months' imprisonment in Newgate. He next waged warfare on the crown with a succession of incisive pamphlets, carrying his refusal to recog. 
nise the authority of the government so far as hardly to be persuaded by his friends to let them bail him out of prison when arrested in 1692 on suspicion of being involved in a treasonable plot. In 1696, along with two other clergymen, he outraged public feeling by solemnly pronouncing absolution, without any public confession, on the scaffold at Tyburn upon the heads of Friend and Parkyns just before their execution for a plot to murder the king. For this gross and public offence he was obliged to go into hiding, but though he was formally outlawed, no attempt was made to punish him. In 1697 he published his famous Short View of the Immorality and Profaneness of the English Stage, which fell like a thunderbolt among the wits. The boldness of the onslaught can only be understood by remembering the greatness of the odds and the might of his antagonists. 'It is inspiriting,' says Macaulay, 'to see how gallantly the solitary outlaw advances to attack enemies, formidable separately, and, it might have been thought, irresistible when com bined, distributes his swashing blows right and left among Wycherley, Congreve, and Vanbrugh, treads the wretched D'Urfey down in the dirt beneath his feet, and strikes with all his strength full at the towering crest of Dryden.' Collier's argument carried the country with it, and brought back the English drama to good morals and good sense. That excessive stage-profligacy which was a mere reaction against the rigidity of Puritanism, and had far outrun the parallel laxity of contemporary social morals, at once disappeared, and the theatre in England again became a mirror in which nature and truth were reflected without distortion. But it was not without a struggle that the wits consented to be worsted. Congreve and Vanbrugh, with many of the smaller fry, answered angrily but weakly, and were crushed anew by the redoubtable nonjuror, who was ' complete master of the rhetoric of honest indigmation." 'Contest,' says Dr Johnson, 'was his delight; he was not to be frighted from his purpose or his prey.' 'The great Dryden stood apart at first, but at length in the preface to his Fables (1700) acknowledged with a noble honesty that he had been justly reproved. 'I shall say the less of Mr Collier,' he says, because in many things he has taxed me justly and I have pleaded guilty to all thoughts and exuressions of mine which can be truly argued of obscenity, profaneness, or immorality, and retract them. If he be my enemy, let him triumph; if he be my friend, as I have given him no personal occasion to be otherwise, he will be glad of my repentance. It becomes me not to draw my pen in the defence of a bad cause, when I have so often drawn it for a good one.' But Dryden complained and fairly, that his antagonist had often perverted his meaning, that he was "too much given to horse-play in his raillery, and came to battle like a dictator from the plough.' Spite, however, of all its pedantry and overstatement of the case, and its faults of taste and of relative proportion in charges made with equal indignation, the Short View was a noble protest against evil, and was as effective as it deserved to be.

Collier continued to preach to a congregation of Nonjurors (q.v.), and was consecrated bishop in 1713. A great controversy soon rent the nonjuring community on the lawfulness of returning to certain 'usages' allowed in the communion-office of the first prayer-book of Edward VI., which Collier's party preferred to the revision of 1552. Collier at length pronounced these usages essential, and not unnaturally laid himself open to a charge of holding Romish views. He masqueraded as 'Jeremias, Primus Anglo-Britanniæe Episcopus' in some abortive attempts to form a union with the Eastern
Church. His last years were racked by the torments of the stone, from which he found relief in death, April 26, 1726. Of his forty-two books. and pamphlets, those on the stage alone are still read. The fifth edition of his famous treatise (1730) contains all the successive pamphlets which fortified the first. His largest works were the Great Historical, Geographical, Genealogical, and Poetical Dietionary (4 vols. folio, 1701-21), and $A n$ Ecclesicustical History of Great Britain . . . to the end of the Reign of Charles II. ( 2 vols. folio, 1708-14; new ed. by T. Lathbury, with Life, 9 vols. 1852).

Collier, JoHN, known under the pseudonym of 'Tim Bobbin,' was the son of the curate of Stretford, near Manchester, and from 1739 to his death in 1786 was master of a sehool at Milnrow, near Rochdale. He early wrote verse and painted grotesque pictures; his rhyming satire, The Blackbird, appeared in 1739 , and his View of the Lancashire Dialect (in humorous dialogue), his most notable production, in 1775 . It has been often reprinted. Other works are Truth in a Mask, The Fortune-teller, The Human Passions. See Life by Fishwick, prefixed to his works (Rochdale, 1895).

Collier, JoHn PAyne, Shakespearian critic and commentator, was born in London, 11th January 1789 , son of an unprosperous merchant who had succeeded as a reporter and journalist. His parents. were friends of Lamb, Hazlitt, Coleridge, and Wordsworth. The boy passed some years at Leeds, and early began to write. Still a boy, he became parliamentary reporter for the Times, next for the Morning Chronicle, and wrote regularly for the latter down to 1847. His eall to the bar was. delayed till 1829, probably through the odium he incurred by a foolish volume of satirical verse. His real literary career commenced in 1820 with the publication of The Poetical Decameron. From 1825 to 1827 he issued a new edition of Dodsley's Old Plays, and in 1831 his best work, a History of English Dramatic Poetry to the Time of Shakespeare, and Annals of the Stage to the Restoration. This opened up to him the libraries of Lord Francis Gower, afterwards Lord Egerton and Earl of Ellesmere, and of the Duke of Devonshire, the latter appointing him his librarian. From 1835 to 1839 Collier published his New Facts regarding the life and works of Shakespeare, followed by an edition of Shakespeare (8 vols. 1842-44), and supplemented by Shakespeare's Library ( 2 vols. 1844), a reprint of the histories, novels, and early dramas on which Shakespeare founded his plays. He was one of the leading members of the Camden Society from its foundation in 1838, and he edited for its issues Bale's Kynge Johan (1838), the Egerton. Papers (1840), and the Trevelyan Papers (1857 and 1863). He contributed ten publications $(1840-44)$ to the Perey Society, and twenty-one $(1841-51)$ to the Shakespeare Society, of which he was long director. In 1852 he announced his discovery of an extensive series of marginal annotations in a 17 th-century hand on a copy of the second Shakespeare folio (1631-32) he had bought-the famous Perkins. folio, so called from a name inscribed on the cover. Late in the same year he published these to the world as Notes and Emendations to the Plays of Shakespeare, and calmly lifted them into the text in his 1853 edition of Shakespeare, and again in his annotated six-volume Shakespeare in 1858. The emendations caused a great commotion in the literary world, and were furiously applauded or furiously assailed. The best Shakespearian students were more or less sceptical, but S. W. Singer and E. A. Brae were the first to express openly an unfavourable opinion. The latter also attacked Collier's alleged discovery of his suspiciously long- 
Tost notes of Coleridge's lectures on Shakespenre and Milton, delivered in 1811. Collier, in the course of abortive proceedings for libel against Brae's publisher, awore to the truth of his statements respecting both the Perkins folio and his Coleridge notes. Menntime he had been judi. cious enough to keep his folio from the eyes of experts, but at length in 1859, the Duke of Devonshire, to whose predecessor Collier had given it in 1853 , sent it, at Sir F. Madden's request, to the British Museum for examination. The result was a conclusive proof, by $\mathrm{Mr} \mathrm{N}$. Hamilton in letters to the Times, and more completely in his Inquiry (1860), that the boasted 17th-century emendations were entirely recent fabrications. Still further forgeries were later brought to light in Mr Warner's Catalogue of MSS. at Dulwich College (1883), from which Collier had prepared three publications for the Shakespeare Society. Collier replied angrily in the Times, in his long Reply (1860), the disingenuousness of which injured his reputation as much as the facts of his antagonist. The controversy widened, but every competent writer concluded against Collier, the only question that remained uncertain being whether he himself was merely a dupe or more. Unhappily for the name of a sound scholar ruined by one fatal weakness, this too was answered by the discovery after his death of some manipulated books in his own library. In 1847 Collier was named secretary to the Royal Commission on the British Museum, and in 1850 he removed to Maiden. head, where he died 17th September 1883. He had enjoyed since October 1850 a civil list pension of $\mathrm{f100}$. His later books were $A$ Booke of Roxburghe Ballads (1847), Extracts from the Registers of the Stationer's' Company (2 vols. 1848-49), The Dremetic Works of Thomas Heywood (1850-51), a good edition of Spenser (5 vols. 1862), a series of small reprints of rare 18 th and 17 th century pieces in prose and verse (1863-71), Bibliographical and Critical Account of the Rarest Books in the English Lunguetge (1865), and An Old Man's Diary Forty Years Ago (1871-72). See Dr Ingleby's Complete View of the Shakspere Controversy (1861).

Colliers and Salters. See, under Slavery, Vol. IX, page 500, section SERFDom.

Collimator, a subsidiary telescope used to detect or correct errors in collimation (i.e. in directing the sight to a fixed object) when adjusting for transit observations. When the vertical thread in the field of view exactly coincides with the vertical axis of a telescope, the instrument is collimated vertically; and when the horizontal spider's thread just covers the horizontal axis, the instrument is correct in horizontal collimation. If

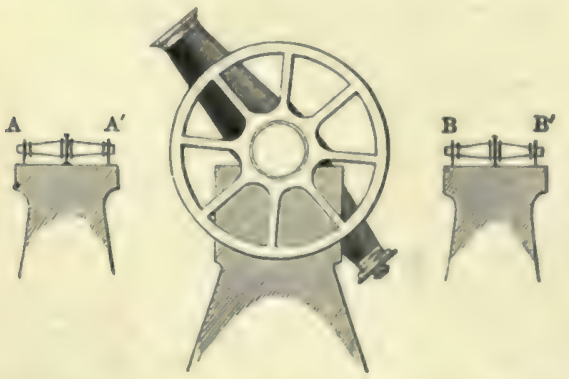

three solid piers stand on the meridian, so that the telescope to be tested can be laid between the collimators and have its axis coincident with both of theirs, the principle of correction becomes almost self-obvious. Removing the great telescope, the collimators ( $\mathbf{A A}^{\prime}$ and $\mathbf{B B}^{\prime}$ in fig.) are adjusted till the cross-wires in one coincide perfectly with thome of the other in all possible positions. Then re. placing the 'transit circle,' it is examined and tested by reference, first to one, and then the other collimator, the verification requiring that it be turned through $180^{\circ}$ till the threads in the three fields of view absolutely coincide, and the collimation is pronounced perfect.

Practical astronomers set great value on the col. limator (in the arrangement just described) for having entirely superweded the 'meridian mark.' By Rittenhouse's principle a telescope can become its own collimator, especially in determining the nadir point. When the axis is vertical over $\mathrm{a}$ vessel containing mercury, the telescope will be collimated when the cross-wires are brought to exact coincidence with their image seen in the mereury. See Telescopk.

Collingwood, a town of Ontario, on the south shore of Georgian Bay, where it connects the railways with the Huron lake steamers. It has several factories, ship-yards, and grain-elevators, and a considerable trade in lumber and grain. Pop. (1871) 2829 ; (1891) 4940 。

Collingwood, Cuthbert, Lord, admiral, was born at Newcastle-upon-Tyne, 26th September 1750. Sent to sea as a volunteer at the age of eleven, his life thenceforth, with the exception of some half-dozen years, was spent wholly on board ship. From 1778 his career was closely connected with that of Nelson, whom he followed up the ladder of promotion step by step, until Nelson's death left the topmost round vacant for himself. Among the great naval vietories in which Colling. wood bore a prominent part, were those of Lord Howe off Brest in 1794; of Lord Jervis off Cape St Vincent in 1797; and of Trafalgar in 1805, where he held the second command. In the lastnamed engagement, his ship was, by Nelson's com. mand, the first to break through the line of the com. bined French and Spanish fleets; and after Nelson had received his death-wound, he assumed the chief direction. A peerage was his reward for his gallant conduct in this buttle. He died at sea, 7 th March 1810, but was buried beside Nelson, in St Paul's. Collingwood was not the stuff great tacticians are made of, and his talents as a commander-in-chief were at best mediocre; but he was a brave and capable seaman, earnest and pious as a man, firm and mild as an officer, and admirable as a second in command. See his Correspondence and Life, by his son-in-law (1828), and shorter Lives of him by W. Davies (2d ed. 1878) and Clark Russell (1891)

Collins. Axthoyy, deist, was born 2lst June 1676, at Heston, near Hounslow, in Middlesex, and was the son of a country gentleman. He studied at Eton and at King's Collegre, ('ambridge, and became the disciple and friend of John Locke. In 1707 he published his Essay concerning the Use of Humen Reason; and in 1709, his Priesterceft in Perfection. The controversy excited by this last work induced Collins to write his Historical and Critical Essay on the Thirty-nine Articles. His next work was a Vindication of the Divine Attri. butes, in reply to King. Archbishop of Dublin, who asserted the compatilility of Divine Predestination and Human Freedom. Collins was a philoen. phical Necessitarian, and afterwands advocated his opinions more fully in his Philosoghical Inquiry concerning Liberty and Necessity (1715). In 1711 he visited Holland, where he made the friendship of Le Clere and other eminent literati. In 1713 he published his Discourse on Free-thinking, the best known, and the most important of all his works; to it Bentley made reply in his famous Remarks. In 1713 Collins made a second visit to 
Holland; and in 1718 he was made treasurer for the county of Essex. In 1724 appeared his Grounds and Reasons of the Christian Religion. The con. tention that no fair interpretation of the Old Testament prophecies will secure a correspondence between them and their alleged fulfilment in the New Testament, ereated a violent controversy, and called forth no fewer than thirty-five replies. Two years later he defended himself in his Scheme of Literal Prophecy; and in 1727 he published his last work, the Scheme of Literal Prophecy Considered. Collins died 13th December 1729.

Collins, Mortimer, a versatile writer, was born the son of a solicitor at Plymouth, June 29, 1827. He was educated at private schools, and held for some years a mathematical mastership in Guernsey, which he resigned in 1856 to devote himself entirely to literature. He settled at Knowl Hill in Berkshire, and kept up an incessant activity in the varied forms of articles on current politics, novels, and playful verses until his death, 28th July 1876. His physical was equal to his mental vigour: he was tall and remarkably strong, an athlete, a lover of dogs, flowers, and outdoor-life. His old-world Toryism and hatred of irreverence and irreligion, his humour, his wonderful facility in extemporising clever verse, his chessplaying, not to say his mathematics, made him a delightful companion, and endeared him to such friends as R. H. Horne, Frederick Locker, Edmund Yates, and R. D. Blackmore. His volumes of verse were Summer Songs (1860), Idyls and Rhymes (1865), and The Inn of Strange Meetings (1871). Of his numerous novels the chief are Sweet Anne Page (1868); The Marquis and Merchant (1871); Two Plunges for a Pearl (1872); Mr Carington, by 'Robert Turner Cotton' (1873); Transmigration (1874) ; From Midnight to Midnight (1875); and $A$ Fight with Fortune (1876). His second wife, who died March 17, 1885, collaborated with him in Frances (1874), Sweet and Twenty (1875), and in two novels published posthumously, The Village Comedy (1876) and You Play me False (1878); and wrove alone $A$ Broken Lily (1882). One of his most popular books was The Secret of Long Life (1871), a collection of essays at first published anonymously. The pious affection of his friends kept his memory green by editing from his papers Pen Sketches by a Vanished Hand, by Tom Taylor, (1879); Attic Salt, a selection of epigrammatic sayings from all his books, by F. Kerslake (1880); and Thoughts in My Garden, by E. Yates (1882). See his wife's account of his Life (1877), and his Select Poetical Works (1886).

Collins, William, a distinguished English poet, was born at Chichester, 25th December 1721. His father was a hatter in that town, of which he was several times mayor. Collins received the rudiments of his education at the prebendal sehool of his native town. At the age of twelve he was sent to Winchester School, where he remained seven years. While there he wrote his Oriental Eclogues, which in his own day, and for a considerable period afterwards, were the most popular of his productions. He was himself convinced that this preference was misplaced, and the world has long since come round to his opinion. In 1741 he proceeded to Oxford, where he was distinguished by 'his genius and indolence.' Having taken the degree of Bachelor of Arts in 1743, he shortly afterwards left the university for reasons which are not accurately known. His private means being but slender, he obtained the title to a curacy, but was dis. suaded from entering the church. As his only other alternative, he took up his residence in London, and sought to make a living by literature, a profession for which he was utterly unfitted by his desultory ways and uncertain health. He now fell into what are vaguely described as 'irregular habits," and was at times reduced to the greatest straits. On one occasion Dr Johnson rescued him from the hands of bailiffs by obtaining an advance from a bookseller on the promise of Collins to translate the Poetics of Aristotle. It was during this period, however, that he wrote his Odes, upon which his fame as a poet now rests. They attracted no notice at the time of their publication, and they were little valued even by guch contemporaries as Gray and Dr Johnson. By the death of an uncle in 1749, Collins inherited the sum of $£ 2000$, which enabled him to retire to Chichester, and apparently to pursue a regular course of study. It was about this time that he met Home, the author of Douglas, to whom he addressed his Ode on the Popular Superstitions of the Highlands of Scotland, a poem in which, aceording to Mr Russell Lowell, "the whole Romantic School is foreshadowed.' The ode was first published in the Transactions of the Royal Society of Edinburgh (1788). Before 1753, Collins felt the approaches of the mental disease to which he finally succumbed, and sought relief in a visit to France. On his return he gradually became worse, and in 1753 his reason completely gave way. He lived for six years longer in this state, though with lucid intervals. He died on 12th June 1759 , so unknown to fame that no newspaper or magazine of the day has any notice of his death.

Collins, like Gray, holds a middle position between the school of Pope and the school of Wordsworth. In his maturer work he is almost completely free from the so-called 'poetic diction' of the 18th century. He has not the passionate feeling for nature of later poets, but his feeling is at least real and not conventional. In respect of natural poetic gifts, Coleridge, and Mrs Browning, and other high authorities, place him above his contemporary, Gray. His choice of subjects, however, and his subtler modes of treatment, debar him from the popularity of the author of the Elegy. His. most highly finished ode is that To Evening, which is unsurpassed for exquisiteness of tone and diction. The ode entitled The Passions has merits of a different order, but evinces genius of even wider scope. The allegorical character of this ode and its companion pieces, To Liberty, To Mercy, and To Pity, removes them from direct human sympathy. That Collins was capable of simplicity and pathos, however, is shown by his two most popular poems, On the Death of the Poet Thomson, and his lines begin. ning 'How sleep the brave.'

Collins, William, R.A., landscape and figure painter, was born in London, September 8, 1788, of a Wicklow family. In 1807 he entered the Royal Academy as a student, and in the same year he exhibited two small landscapes. In 1812 his "Sale of the Pet Lamb' was sold for 140 guineas, and from this time his pictures became popular. He exhibited 169 works, of which the best known are the 'Blackberry Gatherers' and 'The Birdcatchers' (1814), which gained his associateship; 'Scene on the Coast of Norfolk' (1815), now at Windsor; 'The Fisherman's Departure' (1826), 'As Happy as a King' (1836), and 'Early Morning' (1846). Collins was elected R.A. in 1820 . He studied and sketched in Italy in 1836-38, and in 1839 sent to the Academy several Italian subjects. Two pietures on sacred subjects $(1840-41)$ were not particularly successful, and he wisely fell back on his green fields, his sea-beaches, his rustics, and his children at their games. A visit to the Shetland Islands. in 1842 supplied materials for the illustrations of Scott's Pirate. Collins died in London, February 17, 1847. See his Life (1848) by his elder son, William Wilkie Collins.-His second son, CHARLES Aluston Collins (1828-73), in early life painted. 
a number of pictures which are highly valued by collectors. In 1860 he married the younger daughter of Charles Dickens, and having already turned his attention to literature, produced The Eye-zoitness essays (1860), two novels, and other works, all exhibiting high promise.

Collins, Wilun Wilkie, novelist, elder gon of William Collins, R.A., was born in London, 8th Jumary 1824. He was educated partly at Highbury, but during 1836 -39 was with his parents in Italy. After his return he spent four years in business, and then entered Lincoln's Inn; but gradually rook to literature, the Life of his father (1848) being his earliest production. To it succeeded Antonina, or the Fall of Rome (1850); Basil (1852); Hide and Seek (1854); The Dead Secret (1857); The Woman in White (1860); No Name (1862); Armadale (1866); The Moonstome (1868); The New Magdalen (1873), \&e. -in all, fully a score of novels and collections of novelettes. Several of them originally appeared in Houschold Words, All the Year Round, the Cornhill, and other periodicals. The best is The Woman in White, whose 'Count Foseo' is really a creation, and in which the author's almost invariable method of unfolding an intricate plot by narratives of the chief dramatis persona had not grown hackneyed. The Moonstone also is a strong story. Died September 23, 1889.

Collinson, Peter, botanist, was born at Hugal Hall, near Windermere, 14th January 1694, and became a manufacturer of hosiery, having a large business with the American colonies. He was early distinguished as a naturalist, studied entomology and botany, and in $\mathbf{1 7 4 5}$ communicated to Franklin his first intimation of the recent advance of electrical science in Europe. But it was as a botanist he was most distinguished. He introduced the culture of numerous European plants into the United States, and introduced American trees into England. He died 11th August 1768. A genus of labiate plants was named Collinsonia after him.

Collisions. See RaIlways, Wrecks, Rule OF THE ROAD.

Collodion (Gr. kollao, 'I stick') is a solution of Gun-cotton (q.v.) or pyroxylin. Cotton itself is not soluble in alcohol or ether, but when treated, either in the form of cotton-wool, rags, or paper, with a mixture of five parts of strong nitric acid, and six of sulphnric acid, it is found that it can now be dissolved in ether, or in a mixture of ether and alcohol. To this modification the name pyroxylin is upplied. There are many varieties of collodion divisible into surgical or medicated collodions, and photographic collodions. When one part of pyroxylin is dissolved in thirty-six parts of ether and twelve parts of alcohol, 8 thickish liquid is obtained, which evaporates rapidly, leaving a thin film of pyroxylin. As an application to wounds, where it is desired to keep the edges close together, this form of collodion is of use, owing to the contractility of the pyroxylin film which it leaves, but for general purposes a flexile or flexible collodion, as it is called, is desirable. This is produced by the addition of a little Canada balsam and castor-oil to the ordinary variety. Flexile collodion is largely used as a covering for abraded surfaces, as a remedy for burns, for sore nipples, \&c., and it is also the basis for many medicated collodions, such as styptic collodion, eantharidal or blistering collodion, \&e. Salicylated collodion is well known as a popular corn cure, and it is certainly most effectual in removing hard or soft corns with but slight inconvenience. It contains, in aldition to salicylic acid, the active principle, a little extract of Indian hemp, which prevents the slight pain, which might otherwiee prove troublesome. Collodion plays a very important part in Photography (q.v.).

Collold is a name applied by Graham to any soluble substance which, when exposed to dialysis (see Osmose), does not pass through the porous membrane. Starch, gum, allumen, and gelatin are examples of colloidis; and the nane is used in contradistinction to crystalloids.

Collot d'Ilerbols, Jian Marie, a French revolutionist of infamous notoriety, was horn in Paris in 1750. Originally a provincial actor, he was attracted by the Revolution to Paris, where his im. pudence, his loud voice, and his Almunuch du Pere Gerard, secured him the public ear and his election for Paris to the National Convention. In 1793 he became president of the Convention and a member of the murderous Committee of Public Safety. Sent by Roberpierre to Lyons in November of the game year, he took bloody revenge by guillotine and grapeshot on the inhabitants for having once hissed him off the stage in the theatre. His popularity at length exciting the envy of Robespierre, Collot d'Herbois for his own safety joined in the successful plot for the overthrow of Robespierre and his party in July 1794 ; but the reaction that followed this happy event proved fatal to himself. He was expelled from the Convention, and sentenced to deportation to Cayenne, where he died in misery that deep debanches could not stupefy, January 8, 1796.

Collusion, a deceitful agreement between two or more persons to defraud or prejudice a third person, or for some improper purpose. The most common cases of collusion occur in arrangements between bankrupts and their ereditors, such as payment by anticipation to a favoured ereditor on the approach of bankruptey, arrangements for granting preferences by circuitous transactions or otherwise. Transactions in which there is evidence of collusion are reducible at common law, and many of the same nature are struck at by the bankruptey statutes. Collusion in judicial proceedings is an agreement between two persons that one should institute a suit against the other in order to obtain a judicial decision for some sinister purpose. The judgment so obtained is null. ColIusion between petitioner and respondent in a suit for dissolution of marriage bars the suit.

Collyrium is a term for various kinds of eyesalve or eye-wash.

Colman, Georgw, commonly called 'the Elder,' a dramatic author and theatrical manager, was. born at Florence in 1732 . In 1760 his first dramatic piece, entitled Polly Honeycomb, was produced at Drury Lane with great success. Next year he gave to the world his comedy of The Jealous Wife, and in conjunction with Garrick, he wrote The Clandestine Marriage, which was played at Drury Lane, 20th February 1766. In 1767 he beeame one of the purchasers of Covent Garden Theatre, and held the office of acting manacer for seven years, after which period he sold his share. In 1777 he purchased the patent of the theatre in the Haymarket from Mr Foote. In 1785 he was attacked by paralysis, which caused a gradnal decay of his mental powers, and he died in confinement on 14th August 1794. Colman was. an industrious author; besides poetry and transla. tions, he wrote and adapted upwands of thirty dramatic pieces.

Colman, GEoras, 'the Younger,' son of the preceding, was born October 21, 1762. His bent lay in the same direction as his father's, during whose illness be acted as manager of the Hay. market Theatre; and on the death of the elder Colman, George III. transferred the patent to his 
son. Colman held, till the time of his death, the office of Examiner of Plays, to which he was appointed on 19th January 1824, and in which he behaved with great arrogance. In industry he rivalled his father, and he received large sums for his dramatic writings, some of which continue in possession of the stage. He was twice married, and died on the 17th October 1836. In 1830 he published a very imperfect autobiography, which he named Records of My Life; but his most notorious work is the preface to his play of The Iron Chest, in which he furiously attacked John Kemble.

Colman, Samuel, American painter, born in Portland, Maine, in 1832, studied in Europe in 1860-62, was elected a member of the National Academy in 1862, and first president (1866-71) of the American Society of Painters in Watercolours. He has travelled extensively, and his pictures include seenes from Algeria, Germany, France, Italy, and Holland.

Colmar, the capital of the German district of Upper Alsace, stands on a plain near the Vosges, 42 miles SSW. of Strasburg by rail. Among the principal public buildings of Colmar are the church of St Martin (1263), the Dominican convent of Unterlinden, now a museum, the college, courthouse, and town-hall. Colmar is one of the chief seats of the cotton manufacture in Alsace. Other manufactures are paper, leather, ribbons, and hosiery. Colmar is an old place, having been raised to the rank of a free imperial city in 1226. It rapidly became one of the most prosperous towns in Upper Alsace. Fortified in 1552, its fortifications were razed in 1673 by Louis XIV. Pleasant boulevards now occupy their place. Colmar was formally ceded to France in 1697 , but was recovered by Germany in 1871. Pop. (1875) 23,778; (1885) 26,537 ; (1890) 30,399 .

Colne, a town in the east of Lancashire, on a high ridge near the source of the Calder, a western branch of the Ribble, 26 miles N. of Manchester by rail. It has manufactures of cotton calicoes and mousselines-de-laine; and it was formerly a seat of the woollen ind ustry. Slate and lime abound. Many Roman coins have been found at Colne. Pop. with Marsden (1881) 11,971 ; (1891) 16,774.

Colney Hateh, a village of Middlesex, 61 miles $\mathbf{N}$. of London, with a great lunatic asylum, opened in 1851.

Colocasia. See Cocco.

Coloeynth (Gr. kolokynthis), a well-known medicine, much used as a purgative, is the dried and powdered pulp of the Colocynth Gourd, Coloquintida, Bitter Apple, or Bitter Cucumber, a globose fruit about the size of an orange, of a uniform yellow colour, with a smooth, thin, solid rind. The plant which produces it, Cucumis (or Citrullus ) Colocynthis, is nearly allied to the Cucumber (q.v.). It is found very widely distributed over the Old World, growing in immense quantities on the sand hillocks of Egypt and Nubia. It is also common in India, Portugal, Spain, and Japan. It has long been known for its purgative properties, and as early as the 11th century was in use in Britain. The main supplies of the drug are obtained from Mogador, Spain, and Syria. The fruit is gathered when it begins to turn yellow, peeled, and dried quickly either in a stove or in the sun. It is chiefly in the form of a dried extract that it is used in medicine. It owes its properties to a bitter principle called Colocynthine, which is more or less abundantly present in the fruits of many of the gourd family. It is a curious fact, but to which there are many analogies, that the seeds of the colocynth plant, produced in the midst of its medicinal pulp, are perfectly bland, and they even form an important article of food in the north of Africa.-The name False Colocynth is sometimes given to the Orange Gourd (Cucurbita aur. antia), sometimes cultivated as an ornamental plant in our gardens, on account of its globose, deep-orange fruit. The pulp of the fruit possesses the properties of colocynth, but in a milder degree.

Colocynth is generally administered in the form of pills, in which the extract is associated with aloes, scammony, and in some cases with calomel or with extract of hyoscyamus. In small doses, the colocynth acts as a safe and useful purgative; and when accompanied by hyoseyamus, the latter prevents much of the pain and griping which are attendant on the use of colocynth by itself. In large doses, colocynth is a poison. Colocynth enters into the composition of some moth powders, and renders them very efficacious.

Cologne (Ger. Köln), a city and free port on the left bank of the Rhine, 362 miles by rail WSW. of Berlin, $175 \mathrm{SE}$. of Rotterdam, $149 \mathrm{E}$. of Brussels, and 302 NE. of Paris. Formerly an independent city of the German empire, it is now the capital of Rhenish Prussia. Cologne is a fortress of the first rank, forming a semicircle, with the Rhine as its chord, and the town of Deutz on the opposite bank as a tete-du-pont. It is connected with this suburb by $a$ bridge of boats, and an iron bridge 1362 feet in length, for railway and carriage traffic. Pop. in 1871, 129,233 : (1891) 282,537 ; (1895) 321,964 - one-sixth being Protestants. The old streets are narrow and crooked; but the area freed by the removal of the ancient fortifications, which dated originally from the 13th century, is laid out on a more spacious plan. This area, which doubles that occupied by the old town, was purchased in 1882 by the corporation for about $£ 600,000$; its most prominent feature is the handsome 'Ringstrasse' or boulevard, nowhere less than 60 feet wide, which encircles the entire old town. The new fortifications include a number of detached forts, planted round Cologne and Deutz, within a radius of about 4 miles from the eathedral. The ancient buildings in Cologne, both secular and ecclesiastical, are of great architectural interest; the Romanesque and Transition styles are specially well represented in the numerous churches of the 11th, 12th, and 13th centuries. The church of St Maria im Capitol, consecrated in 1049, is the earliest example in Cologne of a church with a trefoil-shaped ground-plan for transepts and choir. In the church of St Uroula are preserved the bones of the 11,000 virgins, companions of St Ursula (q.v.). The church of St Gereon boasts of the possession of the bones of St Gereon, and of the 308 martyrs of the Theban legion, slain during Diocletian's persecution. The church of St Peter contains the altar-piece of the crucifixion of St Peter by Rubens, and that of the Minorites the tomb of the famous scholastic, Duns Scotus.

The chief object of interest in the eity, however, as well as its greatest ornament, is the cathedral, one of the noblest specimens of Gothic architecture in Europe. This cathedral is said to have had its origin in an erection by Archbishop Hildebold, during the reign of Charlemagne in 814. Frederic Barbarossa bestowed upon it, in 1162, the bones of the three Magi (q.v.), which he took from Milan, and this gift greatly increased its importance. The bones are retained as precious relics to this day; but the old structure was burned in 1248 . According to some accounts, the present cathedral was begun in the same year, but others fix the date of its commencement in 1270-75. To whom the design of this noble building is to be ascribed is uncertain. The choir, the first part completed, was consecrated in 1322 . The work was carried on, 
sometimes more matively, sometimes more slowly, till 1509, when it was suspended; and during the subsequent centuries what had been already executed was not properly kept in repair. Since but a colony being planted here in 50 A.D. by Agrippins the wife of the Emperor Claudius, it received the name of Colonia Agrippina. At the partition of the Frank monarehy in 511, it was

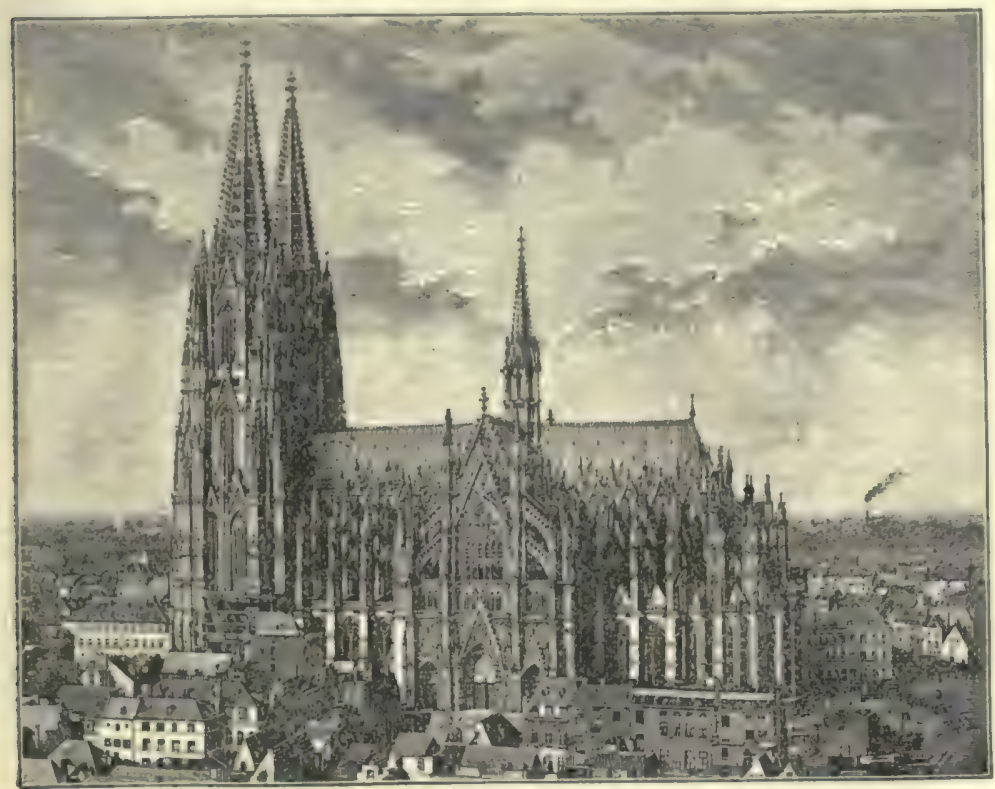

Cologne Cathedral. included in Anstrasia. and by a treaty in 870 , it was united to the Ger. man empire. It entered the league of the Hanse towns in 1201, and con. tended with Luibeck for the finst rank. The merchants of Cologne carried on conimerce far and wide, and had ware. houses in London, near the Guildhall. Cologne was at a very early period the seat of a bishopric, which was elevated, at the end of the 8th cen. tury, into an areh. bishopric. - The arch. bishops acquired considerable territories, some of them distinguishing themselves as politicians and warriors. They took their place amongst the princes and electors of the empire, but were involved in a protracted contest with the citizens of Cologne, who asserted against them the independence of the city; and the archiepiscopal resi-

the beginning of the 19th century, however, the necessary funds to repair and complete it according to the original design, have been supplied by subscriptions from all parts of Germany. The work of renovation began in 1823, and in 1842 the foundation-stone of the new part was laid. The naves, aisles, and transepts were opened in 1848; the magnificent south portal was completed in 1859 ; in 1860 the iron central fleche was added; and with the exception of the western spires, the church was completed in 1863. The spires, the crown of the edifice, were finished in 1880 , and on October 15 the completion of the work was celebrated before the Emperor William I. The body of the church measures 440 feet in length, and 240 feet in breadth; the spires rise 515 feet above the pavement of the nave. Since 1823, upwards of $£ 1,000,000$ has been expended on the building; the total cost of the whole is estimated at $£ 2,000,000$. For the 'Kaiserglocke,' see BELL. Among the chief secular buildings of Cologne are the town-house, legrun in the 14th century upon Roman foundations; the Gürzenich $(1441-52)$, the finest secular Gothic erection in Cologne, a public banqueting-hall, now containing the exchange; the modern law-courts; and the Wallraf-Richartz Museum, containing a good collection of paintings.

The educational and henevolent institutions of Cologne are numerous and well equipped. The town has recently acquired a high reputation for music The situation of Cologne is extremely favourable for enmmerce. Various branches of manufacture are carried on, of which the chief are the making of beet-sugar, tobncco, glue, carpets, soap, leather, furniture, pianos, chemicals, and spirits of wine, besides the characteristic manufacture of Eau-de-Cologne (q.v.). In 1886, 4859 craft entered, and 3190 eleared, the port of Cologne. Cologne has extensive and important railway connections. - The city was founded by the Ubii, about 37 B. C., and was at first called Ubiorum oppidum; 127 dence was therefore removed to Bonn. The arch. bishopric was secularised in 1801, when the city also lost its independence, and the congress of Vienna did not attempt to restore to it its former character, but assigned the whole territories to Prussia. The archbishop, therefore, has not now the political rights and power that belonged to his predecessors.

Colombia, a republic occupying the northwest cormer of the South American continent, and including also the Isthmus of Panamá. Its limits were officially stated in 1887 as $12^{\circ}$ $25^{\prime}$ N. $-5^{\circ} 8^{\prime}$ S. lat., and $70^{\circ} 40^{\prime}-82^{\circ} 40^{\prime} \mathrm{W}$. long., and its area was estimated at 513,938 80 . miles (nearly as large as Grent Britain, France, and Spain together), exclusive of most of its hundreds of islands and keys, which stretch as far north as the Mosquito coast. The population amounts to about $4,000,000$, including some 200,000 uncivilised Indians who inhal)it the remote forests. The situation of Colombia, washed by two oceans, with a total const-line of nearly 3000 miles, posses sing all along the Atlantic shore and on the Pacific side of Panamá commodious bays and lagnons, and with several fair harbours even on the less favoured cosst to the south, presents great commercial pos. sibilities though it has lost an expected inpulse by the stoppage of the Panamá Canal through the north-west department. The surface of the country is extremely varied, with lofty mountains in the west, and vast plains in the east scarcely above the level of the sea. For the mountains, see ANDES. This system spreads ont in three great ranges, like the rays of a fan, from the extensive platean of Prsto in the south-west; thus forming valleys running from north to south parallel to the three chains, except where disproportionate uctivity of the volcanic forces has caused an upheaval of the country near them. The fundamental formations of the country are igneous and metamorphic, and everywhere are traces of the disturbances (atill not unfrequent in the form of enthquakes) that have 
upheaved plateaus and opened fractures that now mark the courses of the principal rivers. Of the sections outside the main Cordilleras, the principal are the Sierra Nevada de Santa Marta, in the north, and the low Baudo range, along the north-west coast, which extends into Panamá. From the Central Cordillera descend the two principal rivers of Colombia, the Magdalena and its tributary the Cauca, which flow north into the Caribbean Sea, besides several affluents of the Amazon in the east, and the Patia, which forces its way to the Pacific, through a gorge between cliffs 10,000 to 12,000 feet high, and forms the only notable break in the long wall of the Western Cordillera from Darien to Patagonia. The Eastern Cordillera, by far the largest chain, consists of a series of extensive tablelands, cool and healthy, where the white race flourishes as vigorously as in Europe. This temperate region is the most thickly populated portion of the republic; and on one of its plateaus, at an elevation of 8694 feet, stands the capital, Bogotá (q.v.). Eastward from this Cordillera stretch vast llaños or plains, through which flow the Meta, the Guaviare, and other tributaries of the Orinoco. Besides these, the chief rivers are the San Juan (navigable 150 miles), on the Pacific coast ; the Atrato (q.v.) and Zulia (150 miles), flowing north; the Arauca (600), which, as well as the Meta (700) and Guaviare (850), feeds the Orinoco; and the Caqueta (1350), the Putumayo (1100), and the Napo (750), tributaries of the Amazon. The lakes are unimportant.

Climate and Productions.-In the course of one day's journey, the traveller may experience in this country all the climates of the world; perpetual snows cover the summits of the Cordilleras, while the valleys are smothered in the rich vegetation of the tropies. The mean temperature ranges from $32^{\circ}$ to $82^{\circ}$, according to the elevation. The climate of Panamá is notoriously unwholesome, and in some parts of Bolivar and Magdalena, in the north, marsh fevers abound. The rainy season falls from November to April, except among the low-lying forests of the south-east, where the rainfall is distributed throughout the year, and in the Chocó coast district of the north-west, where, shut in from the north-east winds, the heavy atmosphere hangs motionless, and mists and torrents of rain alternate. Colombia naturally vields a variety of productions corresponding to this great diversity of climate and of elevation. The hot region, extend. ing to an elevation of about 3200 feet, produces in abundance rice, cacao, sugar-cane, bananas, yams, tobacco, indigo, cotton, caoutchouc, vegetable ivory, and many medicinal plants; and the forests, with their tagua and other stately palms, their rare balsamic resins and valuable dyewoods, are ablaze with flowers and creepers, and steeped in the perfume of the delicate vanilla orchid. In the temperate zone, from 3200 to 8500 feet above the sea, many of these plants are equally common, but the cocos-nut palm gives place to the oak, the encenillo, groups of laurels, and arborescent ferns, and here flourish the coffee plant, the odorous Cherimoya (q.v.) and curibano, the fig, and the cinchona-tree. The Wax-palm (q.v.) extends beyond this region, and is found at a height of nearly 11,000 feet, and large crops of potatoes, grain, and leguminous plants are raised in the cold region; but from 10,000 feet rises the bleak paramo, with its scanty vegetation, ending in fichens at the snow-line. The fauna of Colombia is very extensive. Both coasts abound with turtles and pearl-oysters; the rivers swarm with fish and alligators, and on their marshy banks the capybara is found; the forests are the haunt of the tapir, armadillo, cavy, opossum, and deer, and during the day are alive with monkeys (of which no less than seventeen species are common), squirrels, paroquets, and numerous bright-plumaged birds, whose notes give place at night to the plaintive cry of the sloth. Beasts of prey are the jaguar, puma, ocelot, margay, and bear. The boa and numerous other snakes are common, but venomous serpents cease at an elevation of 6000 feet, the centipede and the chigoe are not met beyond 9850 feet, while the plague of mosquitoes and ants, and of other more dangerous insects, is mainly confined to the lowlands. In the northern departments, and in the immense llaños of the east, great herds of cattle, descended from those imported by the Spaniards, are reared; in the central districts, shorthorns and other English, Dutch, and Norman cattle and horses have been introdnced, and are largely raised throughout the temperate zone. Fish life ceases in the lakes at 13,000 feet; and in the solitudes above, the condor dwells alone. In minerals the country is exceedingly rich, although its scanty population, their poverty, and the absence of roads have combined to limit the exploitation of the precious metals. Nevertheless, in 1887, claims were presented to 751 mines in Antioquia; and from this department alone over $£ 400,000$ worth of gold is annually exported. The department of Tolima is the richest in silver. It is estimated that gold to the value of $£ 125,000,000$, and silver to the value of nearly $£ 7,000,000$, have been exported since the 16th century; and over 95 per cent, of this ore has been found west of the Magdalena. Iron, copper, lead, coal, sulphur, zinc, antimony, arsenic, cinnabar, rock·salt, crystal, granite, marble, lime, gypsum, jet, amethysts, rubies, porphyry, and jasper are also found; while much of the world's platinum is obtained from the upper San Juan, and the principal source of the finest emeralds is at Muzo in Boyacá, although there are other mines near Nemocon, in Cundinamarca.

Commerce, Finance, dcc.-The only industries common to all the departments of Colombia are agriculture and the rearing of cattle. Coarse cloth fabrics for the inland trade are manufactured to some extent in Santander and Boyacá, and china. ware and cardboard in Antioquia; also soap, matches, and candles are made in Bogotá, and there are two foundries and a shoe factory in Cundinamarca; but straw-hats, known abroad by the name of Panamá, although they are made only in certain parts of Tolima, Antioquia, and Santander, are perhaps the only manufactured article exported from the country. The transit trade across the Isthmus of Panamá, valued at $£ 15,000,000$ per annum, is of far more consequence than the direct commerce. The foreign trade proper is mainly with Great Britain and the United States. The imports are mostly food-stuffs, textiles, machinery, and iron. wares; the exports, coffee, gold, silver, and other ores, caoutehoue, ivory-nuts, divi-divi, tobacco, cacao, cotton, cinchona, cattle, balsams, timber and dyewoods, hides and wool. The average annual value of imports in the period 1875-84 was $\$ 9,662,806$, of exports, $\$ 13,584,890$; in 1893 the value of imports was $\$ 13,403,300$, and of exports, $\$ 14,630,330$; but it is difficult to reduce these figures to British curreney, for although the dollar has a nominal value of four shillings, the rate of exchange has since 1878 varied between five and a half and nine dollars to the pound sterling. The nation has repeatedly undergone a severe financial crisis. For the fiscal year 1895-96 the expenditure was estimated at $\$ 26,203,950$, and the revenue at $\$ 33,801,900$, showing a very considerable nominal surplus; in 1894 the internal debt, floating and consolidated, amounted to 
$\$ 9,413,000$, the foreign debt was calculated at $\$ 16,400,000$, and $\$ 26,135,600$ of goverument paper. money was in circul,tion. There appears, how. ever, some reason to expect that the measures alopted to meet the nation's liabilities may prove effectual, and the present financial condition of the republic is said to be comparatively hopeful. For the rest, the government can only look to rigid economy and the development of its rich mines, which it is endeavouring to encourage to the utmost, for relief from its embarrassments. All enterprise, however, is sadly hampered by the difficulty of communication. The Magdalena and the other great streams are the principal arteries of commerce, and a good deal of steamer traffic is carried on; but, besides that of Panama, there were in 1895 eight railways open for traffic, with only a total length of 220 miles, although several others were expected to be completed shortly. The telegraph system has 6900 miles of lines, and this and the postal service (including a parcel post with Great Britain since 1888) are worked as efficiently as the condition of the country will permit. For the railway, canal, and other information as to the Isthmus, see the article PANAMÁ.

Population. - The chief aborigines of the country, the Chibchas or Muyscas, who inhabited the plateav of Bogotá, ranked among the nations of the New World second to the Aztecs and Peruvians alone. They worshipped the sun, had a calendar, and a government closely resembling that of Japan, lived in communes, were industrious farmers, and dressed in garments of cotton. Their rich, beautiful language has been forgotten by their descendants, but is preserved in a grammar published at Madrid by the Dominican missionary, Bernardo de Lugo, in 1619. The rest of the country was occupied by a great number of tribes, with as many dialects as divisions, sinking from the grade of the Chibchas to the naked savages of the plains, who were little above the level of the brutes they hunted. Some of the intermediate races, while understanding Spanish, have preserved their primitive speech; the uncivilised Indians are now mostly confined to the eastern plains, the northern portion of Magdalena, and the district of Darien and the Atrato. The pure whites form about $a$ fifth of the entire population, and the Indian half-breeds more than half; there are now scarcely any pure negroes left in the country, but the mulattoes and zambos, resulting respectively from the union of negroes with whites and Indians, exceed a sixth of the whole. Slavery was finally abolished in 1852, and in 1870 a system of compulsory edueation was adopted which has on the whole proved successful. Parochial, secondary, normal, and technical schools are now within general reach, and all the departments boast univer. sities of more or less efficiency, except Magdalena, Tolima, and Panamá. Journalism is largely represented in most of the large towns ; and at the capital a considernble number of books are published every year. The state church is the Roman Catholic, which in the management of its own affairs is independent of the civil anthority; religious orders were suppressed in 1863, and toleration in matters of religion is guaranteed; but, by the terms of a concordat entered into with the holy see in 1888, in the universities and all educational establishments public instruction is directed in conformity with the dogmas of the Roman Catholic Chureh, religion is one of the obligatory subjects of study, and diocesans are empowered to suspend teachers or professors who neglect or disobey this order.

History. - The northern consts of Colombia were visited by Ojeda and Amerigo Vespucei in 1499, and afterwards by Bastidas; in 1502 Columbus explored part of the country, and endeavoured to found on the Jathmus of Panamá the finst Suanish colony on the American mainland. In $1513 \mathrm{Balboa}$ (q.v.) discovered the Pacific, and Pizarro and Almagro sailed along the western cosat of Colombia on their way to Peru in 1526. Ten years later Jimenez de Quesada broke the power of the Muyscan empire, and the Nuevo Remo de Granada was formed. As the country was opened up, the Indians sank, in spite of legislation designed for their protection, to the condition of serfs, and the policy of the erown, aided by the Inquisi. tion, which was introduced in 1571 , put an end to the democratic institutions of the early settlers. The region was administered by the Council of the Indies; nearly all posts were sold to Spanish speculators, who recouped themselves at the expense of the colonists; and even the commerce of the new possessions was granted as a monopoly to the merchants of Seville. The country formed a presidency (except during the years 1718 24 ) from 1564 to 1739 , a period memorable for the disastrous descents of Drake, Morgan, Dampier, and others on the coast towns ; it was then raised to a viceroyalty, which lasted until the war of independence.

On the 20th July 1810 the colony shook off the yoke of the mother-country, and entered upon the long struggle which ended in the election of Bolivar (q.v.) to the presidency of the Republic of Colombia, a term which, like the viceroyalty, embraced all that now belongs to Venezuela, Colombia, and Ecuador. Independently of the singular difficulties of communication, and of the resulting absence of anything like natural unity, this unwieldy state contained from the beginning the germs of its own dissolution in the national character of its inhabitants. So long as union was neces. sary to meet external dangers, it maintained an imposing attitude in the eyes of the world; but gradually sectional interests and political jealousies did their work, and in 1831 the ill-assorted elements of the confederation were separated for ever. What is now Colombia was then formed under the title of the Republic of Nev Granada; but in 1861 a fresh civil war led to the establishment of the United States of Colombia. In 1863 a constitution was adopted, based on that of the United States of America, with a president elected for two years; but this proved altogether unsuited to the Colombians, and, after twenty years' trial, brought about the revolution of 1884-85. In $1886 \mathrm{a}$ fresh constitution was adopted for the new Republic of Colombia, placing the central authority in the strengthened hands of the federal government, and reducing the nine former self-governing states of Antioquia, Bolivar, Boyacá, Cauca, Cundinamarca, Magdalena, $\mathbf{P a}$. namá, Santander, and Tolima to subordinate departments, which still, however, retain the management of their own finances. The executive authority is vested in a president, whose term is extended to six years, assisted by a vice-president, seven ministers, and a council of state; and the legislative power rests with a senate and House of Representatives. Capital punishment has been again established, and the members of the supreme court of justice are made immovable. The strength of the army is fixed at 6500 in time of peace, but in case of war the executive can raise this as circumstances may require.

See E, Reclus, Voyage da Sierra-Nerada de Srinte. Marthe (Paris, 1861); Colonel F. Hall, Colombia (Phila. 1871); Daguerra, Diccionario Geograffico de Colombia (Bogotá, 1879): Pereira, Les Ftuts-Linis de Colombie (Paris, 1883); Peres, Geognafla General (Bogoth, 1883); Etienne, Nouvelle Grenade (Geneva, 1887); Dr W. Sievers, Reive in der Sierva Nenada de Santa Marla (Leip. 1887); and the same author's Cordillere von 
Mérida (Vienna, 1888) contains some notes on eastern Santander. See also the Descripcion published by the Colombian government in 1887 , with the supplement on the trade with Spain, published at Barcelona in 1888; F. J'ianconi's Notice Descriptive et Carte Commerciale (Paris, 1888); and papers by F. A. A. Simons (1879, '81, '85) and R. B. White (1883) in the Proceedings of the Royal Geographical society.

Colombo, the eapital of Ceylon, is situated on the western side of the island. Since the construction of the great breakwater begun in 1875 ( improved, and commerce has largely increased; Colombo having superseded Galle as a Coaling Station (q.v.) for large steamers. It contains the government offices, is the seat of an Anglican bishop, and is an important centre of missionary enterprise. Among the chief buildings are the government house, court-house, town-hall, asylum, St Thomas's College, and Wesley College. The fortifications of Colombo were constructed by the Dutch. Colpetty, a beantiful suburb, shaded by groves of the cocoa-nut palm, is a favourite retreat. The humble, mud-constructed dwellings of the Dutch, Portuguese, Eurasians, Singhalese, Tamils, Moors, and Malays are outside the city walls. The pettah or Black Town, the only ancient quarter, extends to the river Kalany-ganga. Pop. (1871) 100,238 ; (1891) 126,926. Colombo is connected with Kandy by railway. The early name of Colombo, Kalan-totta, the 'Kalany Ferry,' the Moors corrupted into Kalambu, and by this designation it was described by Ibn Batuta about 1340 A.D. as the finest city of Serendib. The Portuguese, who fortified it 1517 A.D., wrote the name Colombo, in honour of Christopher Columbus. The Dutch succeeded to the Portuguese, and the British took Colombo, 16th February 1796. See CEYLON.

Colon, a city of Cuba, 52 miles direct SE. by E. of Matanzas, with which it is connected by rail. It is in the centre of the sugar district, and has several refineries. Pop. (1899) 7175. For Colon, Colombia, see AspinwalL.

Colon, that portion of the large intestine between the Crecum (q.v.) and the rectum. See Digestion.

Colonel (from the Italian colonello, the "leader of a column') is the grade of officer next below that of general. As designating the chief officer of an English regiment, it superseded in 1588 the title of captain, in use up to that time. In the British army, the lieutenant-colonel is commander of the infantry battalion or cavalry regiment, the office of regimental colonel being a sinecure. Regimental colonels are general officers, who have had a regiment 'given to them,' as it is called, as a reward for long service, and virtually as a retirement. The pay, except in the Guards (where it is higher), is $£ 1000$ a year. In 1888 it was decided to discontinue these appointments as soon as those who have a vested right to succeed to them have been satisfied, and it has been decided that no ofticer shall obtain the rank of colonel except by Brevet (q.v.) for distinguished conduct, or on being seleeted for certain appointments carrying with them that rank; such as aide-de-eamp to the sovereign, assistant-adjutant general, and commaniler of a regimental district. See CoмmisStons (ARMy). In the German, Austrian, and Russian armies, where the regiments are very large, the coloneleies are mostly honorary posts, held by royal and other distinguished personages.

Colonia, a department of Uruguay, on the Plata, below the Uruguay River. The uplands are barren, but in the fertile valleys and plains are numerous European colonies, engaged in agriculture and stock-raising. Area, $2185 \mathrm{sq}$. 1n. ; pop. (1895) 35,209 . The capital, Colonia del Sacramento, on the Plata, about 100 miles above Monte Video, has a good harbour, a dock for vessels of 1000 tons, ruined fortifications, and some 1500 inhabitants.

Colonial Animals, organisms which cannot be fairly regarded as unities, but consist of numerous more or less similar individuals united in a common life. Among the usually single-celled simplest animals or Protozoa, loose colonies not unfrequently occur, and are of not a little importance as suggestions of the bridge between the single-celled and many-celled animals. Such colonies arise when the original cell, instead of reproducing discontinuously, retains its daughter-cells in union with itself or with one another, just like the egg-cell of a higher animal. By sacrifice of individuality at the epoch of reproduction, a higher unity is formed. In the same way a simple cup-shaped sponge, by continuous budding, forms a colony of similar forms, which may possess more or less distinct individuality. The common fresh-water Hydra, to mount a step higher, buds off daughter Hydro, which remain for a while connected with the parent organism, and make it temporarily colonial. This becomes constant in the myriad colonies of hydra-like forms which are known as Zoophytes, or Hydroids (q.v.). The same formation of colonies is well illustrated in the higher polyps of the seaanemone type, where in dead-men's fingers and in most corals, compound or colonial organisms are beautifully illustrated. Some jellyfish-like or medusoid types also become compound, and lead on to the order Siphonophora, where, as in the Portuguese man-of-war (Physalia) or in Velella, the occurrence of compound forms is a constant character. But in this last case a further step has been made, for the individuals not only share a common nutritive life, but are bound together in a more intimate way into a true unity of a higher order. Among simple worm-like forms, chains of individuals are occasionally formed, as in Catenula, and these point to the probable origin of the higher or segmented worms which consist of a series of similar 'joints.' Even among the higher worms, temporary compound forms occasionally occur, as in the fresh-water Nais or the marine Syllis. The Polyzoa afford good illustration of colonial life as an almost constant character of a class. Finally, passing beyond the limit of invertebrate animals, we find the last examples of true colonial organisms in the Ascidians (q.v.) or Tunicata The occasional development of double or multiple forms from a single ovum is among higher animals the only suggestion of compound organisms.

From the above illustrations a few general conclusions may be drawn.' The process of asexual budding, which leads to the formation of compound organisms, is commonest in relatively passive vegetative animals, like sponges, hydroids, corals, polyzoa, and ascidians, and is an expression of their general physiological constitution. When the colonial organism is free-living, as in Siphonophora and some Tunicata, the individual members are more closely knit together, and the colony is more perfectly integrated. As above suggested, some colonial forms are of importance as illustrating in loose union an order of individuality, which in higher types becomes more firmly unified. We first find loose 'aggregates;' at a higher level these become 'integrated.' The loose colonies of some medusoid types are thus succeeded by more perfectly integrated forms in the Siphonophora. Finally, colonial organisms are of the highest physiological interest in illustrating division of labour. In a compound organism the internal and external conditions of life are not uniform for all the members ; certain 'persons," as the individuals are technically called, exhibit the predominance of one function, and others of another; 
the differenoes in function thus started bring about more or less marked diflerence of structure as its consequence; and thus division of labour and 'polymorphism' or difference in form are estab. lisherl. Stee Perrier, Le's Colonies Animales (1882).

Colonial Corps were regiments of the regular British army, paid out of imperial revenues, and located in the various colonies where they were formed. The following corps, and numbers were provided for in the Army Estimates for 1860-61 :

\begin{tabular}{|c|c|c|}
\hline $\begin{array}{l}\text { hree Weat Indla Regiments (afte } \\
\text { wards raised to flve)............ }\end{array}$ & $\mathbf{8 4 2 0}$ & Negrn. \\
\hline fewfoundland Veterans............ & 899 & British. \\
\hline eylon Rifles.... & 1686 & Native. \\
\hline Invalids & 168 & Native. \\
\hline ape Mounted Rifles........... & 1084 & Boers and natives. \\
\hline Ialta Fencibles...................... & 638 & Native. \\
\hline anadian Ritles ........................ & 1106 & British. \\
\hline Helema Regiment .................. & 488 & \\
\hline old Coast Artillery ............... & 351 & Negro. \\
\hline Falkland Islands Company.......... & 87 & British. \\
\hline 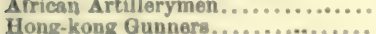 & 88 & $\begin{array}{l}\text { Negro. } \\
\text { Lascars }\end{array}$ \\
\hline
\end{tabular}

All the officers were British, except those of the Malta Fencibles. The Cape corps were mounted infantry. Though maintained out of imperial revenue, these corps were not available for the general defence of the empire, and accordingly have been gradually disbanded, their places in the colonies being supplied by levies of local militio. There still exist, besides African commissariat, ordnance store, and medical staff corps, one West India Regiment of two battalions, the Malta Fencibles, one company of Gun Lascars in Ceylon, and another at Hong-kong.

Colonial Oflice. See Secretary of State.

Colonial System, also called Commercial SYSTEM, a name for the theory long acted on by European nations, that their settlements abroad were to be treated as proprietary domains, exploited for the benefit of the mother-country, which did everything it could to import their produce as cheaply as possible, and encourage them to a large consumption of home manufactures. The system was carried to its furthest extent by Spain. See Colony, Free Trade, Mercantile System, Monopoly, Navigation Laws, United States.

Colonisation Society. See Liberia.

Colonna, CAPE (ancient Sunium Promontorium ), a headland of Greece, forming the southmost point of Attica, and crowned by the ruins of a temple of Minerva, thirteen of whose white marble columns, from which the cape derives its modern name, are still standing.

Colonna, a celebrated Roman family, which took its name from a village among the Alban Hills, 12 miles ESE of Rome, and which, from its numerous castles, vast estates, and crowds of clients, enjoyed a powerful influence from the 11 th to the 16th century. From it have sprung a pope (Martin V., q.v.), several cardinals, generals, statesmen, and noted scholars, and VITTORIA Colonna, the most celebrated poetess of Italy. She was the daughter of Fabrizio Colonna. Con. stable of Naples, at whose estate of Marino she was born in 1490. When four years old, she was betrothed to a boy of the same age, Ferrante d'Avalos, son of the Marehese de Pescara ; at seven. teen they were marriel. After her hushand s death in the battle of Puvia (1525), Vittoria Colonna found her chief consolation in solitude and the cultivation of her poetical genius. During seven years of her wilowhoul she resiled alternately at Naples and Ischia, and then removed to the convent of Orvieto, afterwards to that of Viterbo. In her later years she left the convent, and resided in Rome, where she died in February 1547. She was the loved friend of Michelangelo, admired by Ariosto (see canto xxxvii. of the Orlando), and the intimate associate of the reforming party at the papal court. Her juems belong clinofly to the period following her lusband's denth, and are remarkable for truth of mentiment and enlightened piety. They were first published at Parma in 1538 ; the most perfect edition is that of Ercole Visconti (Rom. 1840). See Mrs H. Roscoe's Vittoria Colonna, her Life and Poems (Lond. 1868), and s study by the Hon. Alethea Lawley ( 1888 ).

The family is still distinguished in Italy, three of its four lines being princely. The Colonna palace, situated at the base of the Quirinal (Rome), is celebrated for its splendid gallery and treasures of art.

Colonna, Giovanni Paolo, composer, borm about 1640, either at Brescia or Bologna, became principal of the musical academy at Bologna. Of some 44 works, nearly all were for the church; his one opera, Amilcare, was first performed in 1693. He died 28th November 1695.

Colonsay and Oronsay, two of the Argyllshire Hebrides, 16 miles NNW. of Port Askaig in Islay, separated from each other by a sound, 100 yards wide, and dry at low-water. Colonsay, which rises to a height of 493 feet, is $16 \mathrm{sq} . \mathrm{m}$. in area ; Oronsay, only 3. On the latter are a seulptured cross and a 14th-century Austin priory, with some curious effigies; whilst in the former are standing stones, a bone cave, Colonsay House (1722), and an obelisk to the memory of the lawyer, Duncan M'Neill, Lord Colonsay (1794-1874). Pop. (1851) 933 ; (1891) 381 , of whom 23 were in Oronsay.

Colony (Lat. colonia), a name somewhat vaguely applied to the foreign dependencies of a state. In accordance with its etymology (colonus, 'cultivator'), a Roman colonia ought to have been an agricultural community ; but as a matter of fact it was a military settlement, urban rather than rural, planted in subject territory. It was essential that the colonists should remain eitizens, who thus both extended and knit together the power of Rome. The name survives to this day in Cologne and Lincoln. The Greek colony (apoikia) consisted of a band of emigrants, who were impelled by political dissension or some similar cause to seek a new home beyond the sea, and who were connected with their mother-city (metropolis) by no tie stronger than that of sentiment. According to the legend embalmed by Virgil in his Aneid, Rome itself was a colony, in the Greek sense, of Troy. No Greek colonists penetrated far inland; but the shores of Asia Minor, Sicily, Southern Italy, and even the Crimea, were at an early date fringed with commercial settlements, many of which surpassed in wealth the cities of Greece proper. The Phonicians, who preceded the Greeks as the traders of the Old World, were not a colonising race. Carthage, indeed, was an offishoot from Tyre; but the wile empire of Carthage was based partly upon conquest, and partly upon a system of tradiug factories.

Colonisation is an incident of a comparatively settled state of society. The vast land migrations which have so profoundly affected the populations of Europe and Asia belong to a different eategrory. Thus it happens that, after the break-up of the Roman empire, the very ides of a colony is not heard again until the great outburst of maritime enterprise in the 16 th century. Spain and Portugal led the way, followed by Holland, England, and France. Love of adventure, thirst for gold, the miseionary spirit-all combined to attract the energies of Europe, set free by the Renaissance, to the New World and to the farther East. The long and bitter struggle for territorial aggrandisement beyond the seas went on with various vicissitudes until, at the close of the 18th 
century, the foreign possessions of the several states of Europe stood pretty much as they do now. Out of her once mighty empire, Portugal retained only a few petty settlements in India, an indeterminate authority over long strips on both coasts of Africa, and Brazil, which afterwards became independent under a scion of the house of Braganza. Spain has lost Southern and Central America within the present century; but she keeps her hold of Cuba and Porto Rico in the West Indies, and of the Philippine and Caroline groups of islands in the remote eastern seas. Holland, having been deprived by England of Ceylon and the Cape, still draws a rich tribute from Java and the adjoining Spice Islands. France, which entered last upon the struggle, has suffered most severely of all, as the result of the fortune of war with England. At one time it seemed as if half North America, and perhaps all India, would become French. But the twin stars of Wolfe and Clive influenced the fate of two continents. The acquisition of Algeria dates from 1830 ; and within the last decade France has again pushed forward in Tunis, Tonquin, and Madagascar. Italy has no foreign possessions except the port of Massowah on the African shore of the Red Sea; and those which Germany has recently acquired with so much eagerness, in Africa and in New Guinea and the adjoining islands, must be regarded rather as possible outlets for trade than as true colonies. The surplus population of Germany will doubtless continue to pour into the western states of North America, just as the Italians and Basques will continue to be attracted to the Rio de la Plata.

After this brief survey of the foreign possessions of continental states, we pass on to those of Britain, which alike in area, in population, and in promise for the future, surpass tenfold all the rest put together. If it be permissible, on historical grounds, to regard the United States as one with Britain, it may be said that the story of modern colonisation is the story of the expansion of the Anglo-Saxon race. In North America, Australasia, and South Africa, that race is already in occupation of the only large tracts of uninhabited territory where white men can work and multiply. In India, England owns the most fertile and most easily governed of tropical countries; while her minor possessions are dotted over every land and sea. These advantages abroad-gained by the valour of her children, who have known how to make the most of their good fortune-are maintained by a teeming population at home, superabundant capital, and maritime supremacy. Above all, it should ever be remembered that this great colonial empire, as it was won with no deliberate plan of aggression, so it is preserved solely through the conscious recognition of mutual rights and duties. Even in India, British rule exists by the consent of the natives and for their benefit; while the autonomous colonies of Australia are as free from British interference and as loyal to the British name as the Channel Islands or Man.

The colonial empire of England is as varied in its composition as it is vast in its extent. In the political sense, it ought to include every foreign possession or dependency of the crown. It is only by an aceident of administration that India is the charge of a distinct secretary of state, that some indeterminate protectorates (such as that of the Niger) are controlled through the Foreign Office, and that the island of Ascension is borme as a ship on the books of the Admiralty. So again, the colonies proper-i.e. those in subordination to the Colonial Secretary - vary in character from a settled country, with a civilisation more than a century old, like Lower Canada, to an unexplored wilderness of savages, like New Guinea; from the continent of
Australia to the rock of Gibraltar; from Hong-kong, the emporium of Chinese trade, to Heligoland, the favourite watering-place of Hamburgers: Adopting another principle of division, the colonies may be classified according to the modes by which they were acquired: (1) as conquered by force of arms or ceded by an independent power; (2) as occupied by settlers, where no rights were recognised in the aboriginal inhabitants. The former class would comprise the Cape and Hong-kong, the latter class Australia and British Columbia. The classification adopted by the colonial office is based upon differences of administration, as follows: (1) Crown colonies, in which the crown has the entire control of legislation, while the administration is carried on by public officers under the control of the home government. Of this class examples are Gibraltar, Ceylon, and Jamaica. (2) Colonies possessing representative institutions, but not responsible government, in which the crown has no more than a veto on legislation, but the home government retains the control of public officers. In this class are Natal, Western Australia, and Barbadoes. (3) Colonies possessing representative institutions and responsible government, in which the crown has only a veto on legislation, and the home government has no control over any public officer except the governor. This class comprises Canada, Newfoundland, the Cape, and the Australasian group. According to the Colonial Office List for 1888, the total area of all the colonies and dependencies (excluding India) is $7,475,896 \mathrm{sq}$. m., with an estimated population of $18,346,614$. Of these totals the nine self-governing colonies possess between them $5,884,020$ sq. $\mathrm{m}$. and $9,413,855$ souls. (For Cyprus, North Borneo, the Niger Protectorate, and all British dependencies, see GREAT BRITAIN.)

From an historical point of view, the expansion of the Anglo-Saxon race divides itself into three periods: (1) The 17th century, when the first beginnings were made, in rivalry with other European states which had taken the lead; (2) the close of the 18th century, when, as a result of the French wars and the command of the sea, Britain had won a preponderant position, despite the loss of the United States; (3) the 19th century, which has been a continuous period of growth and consolidation. Newfoundland boasts herself the premier British colony, having been annexed by the ill-fated Sir Humphrey Gilbert in 1583. The East India Company was incorporated in 1600 ; the first permanent settlement of Virginia dates from 1607 ; the historic Mayflower sailed from Plymouth to New England in 1620 ; Barbadoes was oceupied first of the islands in the West Indies in 1625 . The second period-a period of war-begins with the capture of Gibraltar in 1704; its decisive point was reached at the peace of 1763 , when the French yielded alike in Canada and in India; and it culminated in the Napoleonic war, when Malta, Mauritius, and many West Indian islands were captured from France, and Ceylon and the Cape from Holland, then a French dependency. The last period, which is almost co-extensive with the reign of Victoria, has witnessed the consolidation of India under the erown; the marvellous development of Australia under the stimulus of gold discoveries; the erection of Canada into a dominion of confederated provinces; the extension of British influence throughout South Africa; the commercial growth of Hong-kong and Singapore; and the gradual advance of the British flag over new protectorates and isolated Coaling Stations (q.v.). It is estimated that the population of the colonies has multiplied more than fourfold since 1837 , while the external trade has multiplied nearly ninefold.

Though colonisation is by no means synonymous 
with emigration, it is perhaps natural for the mother-country to regard her colonies primarily as affording an outlet for her own surplus popula. tion. As a matter of fact, the inhabitants of Australia are almost exclusively British; so, too, are the inhabitants of Canada, with the notable exception of the province of Quebec, which remains to this day thoroughly French in language, in religion, aud in sentiment. At the Cape, again, the descendants of the Dutch settlers still form sibout one-half of the whole population. But when the statisties of emigration are looked into, it will be found that the United States prove much more attractive than all the colonies added together. In 1853-93 the total number of emigrants from the United Kingtom, of British and Irish origin, amounted to $7,759,329$, of whom $5,194,030$ selected the United States as their new home. Of 227,179 emigrants (British and other) from Britain in $1894,159,605$ went to the United States, 23,731 to Canada, and only 11,185 to the Australasian colonies. The census returns of the United States in 1890 show $3,122,911$ persons born in the United Kingdom. The figures for Canada in 1891 are 475,456 ; and the Australasian colonies in 1891 reck. oned nearly half their total population $(4,297,889)$ as born in the United Kingdom. The home government has taken no measures to direct emigration to the colonies, beyond establishing in 1886 an Emigrants' Information Office in London, for the collection and publication of trustworthy information. Queensland alone gives free passages. Natal and Western Australia give assisted passages to farm labourers and domestic servants. See EMIGRATION.

The tie between the mother-country and the colonies is more manifest in the case of commeree. The old practice has long ago been abandoned of compelling the colonies to trade only with the mother-country; and those of them that are selfgoverning have even been allowed to impose protective tariffis against British manufactures. But, nevertheless, the trade of Britain with her colonial possessions has maintained itself more steadily than her trade with the rest of the world. During the fourteen years from 1872 to 1886 , the imports into the United Kingdom from British possessions (including India), notwithstanding the fall in

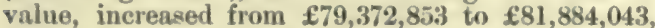
while the proportion of these imports to the total imports rose from 22 to 23 per cent. In the same period the exports to British possessions increased from $£ 65,609,212$ to $£ 82,067,711$, while their proportion to the total exports rase from 21 to 31 per cent. In the year 1893-94 the imports from British possessions into the United Kingdom had a value of $£ 91,205,462$ (20 per cent. of the total imports), and the exports from Britain thither of $£ 86,991,13 j$ ( 34 per cent. of the total). Such, expressed in dry figures, is the meaning of the maxim that 'trade follows the flag.' 'Though statistics are not so realily obtainable, there can be no doubt that the investment of British capital in the colonies, and the interest paid on it, forms a still closer bond than the interchange of commodities. In 1893-94 the aggregate public debt of all the colonies was about 312 millions sterling.

The most interesting question that remains to be considered is the political relation between the colonies and the mother-country. Not so many years ago it was tacitly assumed that the grant of responsible government to the greater colonies implied the further concession of complete independence whenever the colonies should care to demand it. History seemed to afford support for no other conclusion. Quite apart from the case of the United States, it was argued that any form of political union was impracticable between members of a state scattered over such immense distances and with such diveryent interesta. A bove all, it was doubted whether the slender link existing could stand the strain of a great European war. What concern has Canada with Constantinople, or Auntralia with Afghanistan? But there were always some to whom such calculations appreared to be a base abandonment of England's historic place among nations; and the colonists themselves have always professed the most perfect loyalty to the British connection, exactly in proportion as they have been intrusted with autonomy in their own local affairs. Canadian voyageurs tosk a prominent part in Lord Wolseley's boat expedition up the Nile in 1884; and a battalion of 800 volunteen from New South Wales fought by the side of British soldiers round Surkin in 1885. The seuse of distance has been largely obliterated by the mar. vellous progress of stean and electricity. The circumnavigation of the globe is now accomplished as easily and as frequently as was the grand tour in the 18th century. Many of the younger politi. cians make it part of their education to visit India, Australia, and Canada; the colonists, too, have ceased to be strangers in England- 'home,' as they always call it, though born thousands of leagues away. In this connection the future historian will not think it beneath his dignity to record the beneficent influence of cricket. Ân English team first went to Australia in 1862; while Australian elevens have played on equal terms with the best cricketers of England in every alternate year since 1878. The increase of intercourse has brought with it an increase of mutual knowledge and of mutual respect. The holding of a great exhibition of colonial and Indian produce at South Kensington in 1886, and the plan of commemorating the jubilee of the Queen by an Imperial Institute, have given concrete expression to the feeling of solidarity that was everywhere growing. Few persons, either in England or in the colonies, would now be found to advocate the weakening, still less the severing, of the present political ties.

With regard to the scheme known as Imperial Con. federation, less agreement is to be found. It may be suspected that many of its British supporters have been influenced chiefly by their greater dislike of separation; while in the colonies it has nowhere been received with enthusiasm. The essence of the original scheme was that the parlisment of Great Britain and Ireland should divest itself of its sovereignty in favour of a federal council, formed by election out of all the constituent parts of the empire. To this council would be delegated the initiative in foreign affairs, the power of treaty. making, the right of declaring war, with the control of the army and navy that necessarily follows therefrom. Putting aside the difficulties that would arise from the inequality of the colonies among themselves, it is easy to see that Britain must, for a long time to come, exercise the decisive pre. eminence in such a council.

In the meantime something has already been done, and more may be, to strengthen the position of the colonies in the English political system. Canada, the Australasian colonies, and the Cape, each have an agent-general resident in London, whose functions are steadily growing in dinnity. It has become the custom for every new Colonial Secretary to invite the agents-general to a ceremonious reception on his appointment; they are consulted, either singly or collectively, in all matters affecting the colonies which they represent. It is not imporsible that their status may ultimately develop into something intermediate in authority and honour between the council of the India Office and the corps diplomntique. The elastic powers of the Privy-council might easily be utilised 
so as to constitute them (with other representatives for the crown colonies) into a committee for the general control of colonial affairs.

A still more important step forward was taken in 1887, when a conference was held in London, under the presidency of the Colonial Secretary, at which delegates specially appointed by all the colonies were present. Many of the subjects discussed were of a commercial or legal character ; but a large measure of agreement was also arrived at with regard to the burning question of colonial defence. Broadly speaking, the self-governing colonies have undertaken to provide for their own defence by land by maintaining a trained force of a specified strength; while England supplies ships and guns for the protection of commeree and coaling stations. Steamers connect Canada and Australasia, and a telegraph is proposed. The "Diamond Jubilee' celebrations (1897) helped to bring closer the relation of the mother-country and the colonies. The colonial premiers and colonial troops took a conspicuous part, and were warmly received; Canada conferred fiscal favours on Britain, and Britain conceded to Canada greater commercial autonomy. During the Transvaal war in 1899-1900 the Australian colonies, New Zealand, and Canada en. thusiastically raised military corps to support the mother country ; and the difficult problem of combining colonial self-government with imperial unity seems to be brought much nearer a solution.

The colonies of the chief countries will be found under Great Britain, Franor, Grrmany, Spain, \&o. The following are some of the more impurtant books on the subject: Heeren's Manual of the Political System of Europe and its Colonies (Eng, trans. in 2 vols. 1841); Sir G. Cornewall Lewis's Essay on the Government of Dependencies (1841); Herman Merivale's Lectures on Colonisation (1841-42; new ed. 1861): Sir C. W. Dilke's Greater Britain (1863); J. A. Doyle's The American Colonies Previous to the Declaration of Independence (1869); E. J. Payne's History of European Colonies (1877); Colonies and Dependencies, by $\mathrm{Mr}$ Payne and the present writer, in the 'English Citizen' series (1883); Seeley's Expansion of England (1885) ; Froude's Oceana (1886), and The English in the West Indies (1888); the annual Colonial Office List, Colonial Year-book, and Yearbook of the Imperial Institute; Silva White's Britannic Confederition (1892); and C. P. Lucas's Historical Geography of the British Colonies (vols. i.-iii. 1888-94). Also see the articles on the various colonies.

Co'lophon, an Ionian city of Asia, about 9 miles $\mathbf{N}$. of Ephesus, and near the sea-coast. The river Halesus, noted for the coolness of its water, flowed past it. It was the native city of Mimnermus, the elegist, and claimed to be the birthplace of Homer. In its neighbourhood was the famous oracle of Apollo Clarius. The Greek proverb, 'to put the colophon to it,' meaning to terminate an affair, is explained by Strabo as arising from the belief that the cavalry of Colophon was so excellent that their charge always decided a battle. Hence, in old printed books, any device, or printer's name, or the place and year of printing, printed at the end, was called a colophon (see Book). It gave its name also to colophony, a kind of black resin. See REsins.

Coloquin'tida. See Colocynth.

Colorado (Span. for 'red' or 'reddish'), a remarkable river of North America, formed by the union of the Grand and Green rivers, in $39^{\circ} 17^{\prime} \mathrm{N}$. lat., $109^{\circ} 50^{\prime} \mid \begin{gathered}\text { Copyright } 1880 \text {, } 1897 \text {, and } \\ 1900 \text { U. }\end{gathered}$ W. long. The Green River rises Lippincott Company.

in Wyoming, and drains the south-western portion of that state; it also receives affluents from Utah and the north-west angle of the state of Colorado. The Grand River rises in Colorado, where its more common name is the Gunnison. Its main tributaries in that state are the Bunkara, or Blue, and the Dolores. Below the junction of the
Green and Grand rivers the main affluent in Utah is the San Juan, which drains an interesting region in the south-west of Colorado and the north-west of New Mexico. In Arizona the main affluents are the Colorado Chiquito or Flax River, the Bill Williams, and the Rio Gila, all from the left. The only important affluent the Colorado receives from the right is the Rio Virgen. From the junction of the Grand and Green, the general course of the stream is to the south-west, through the southern part of Utah and the north-west of Arizona ; and it afterwards separates Arizona from Nevarla and California. The lower part of its course is in Mexiean territory, where it flows into the north extremity of the Gulf of California. The most striking features of the Colorado basin are its dryness, and the deeply channelled surface of the greater part of the country. Almost every stream and watercourse, and most of all the Colorado itself, has cut its way through stratum after stratum of rock, until now it flows, in a great part of its course, at the bottom of a deep trench or cañon.

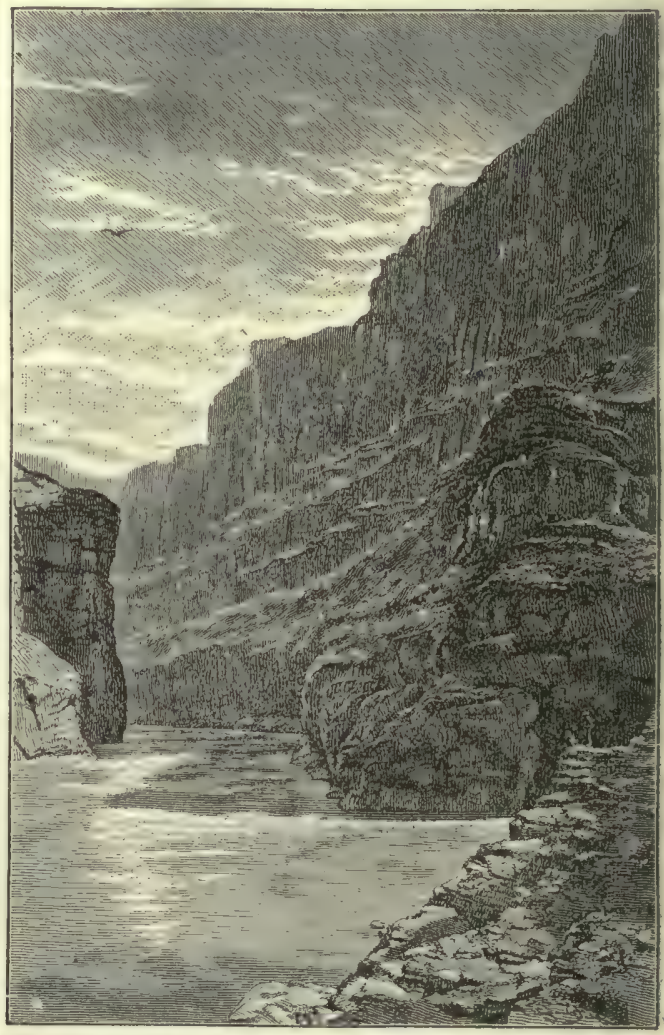

Grand Cañon of the Colorado, looking up.

(From a Photograph by E. Baer, of Prescott, Arizona.)

The main stream for nearly 400 miles below the month of the Colorado Chiquito, thus flows through a great plateau, forming what is called the Grand Cañon of the Colorado, the most extensive and marvellous example of the kind anywhere known. The cañon-walls throughout the upper part of the great cañon are from 4000 to 7000 feet in height, and are often nearly perpendicular, at some points. rising sheer from the water, while at others there. is a talus of fallen rock, or oceasionally a strip of fertile soil, on one or both banks. The fall averages from 5 to 12 feet to the mile. The river basin is 240,000 sq. $m$. in area. Its former adaptedness. 



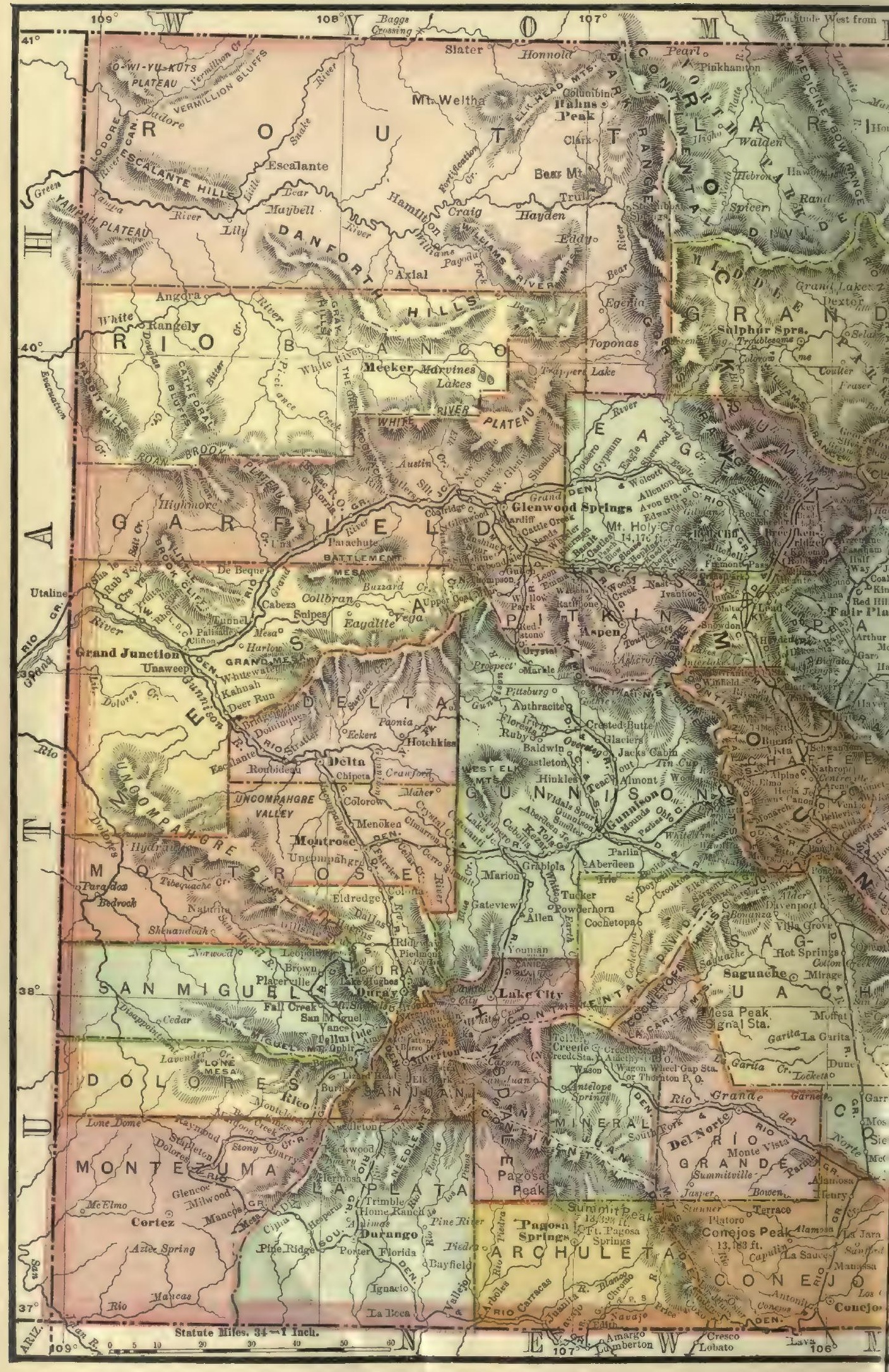


[Colorado.]

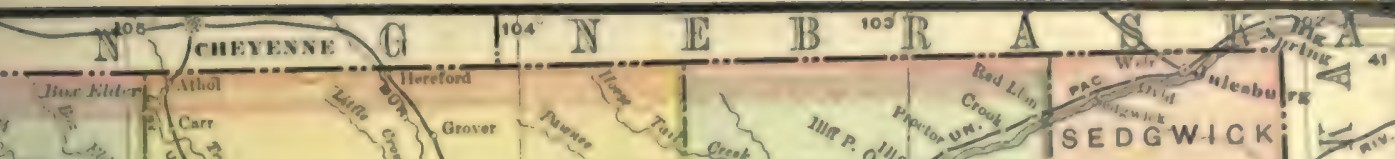

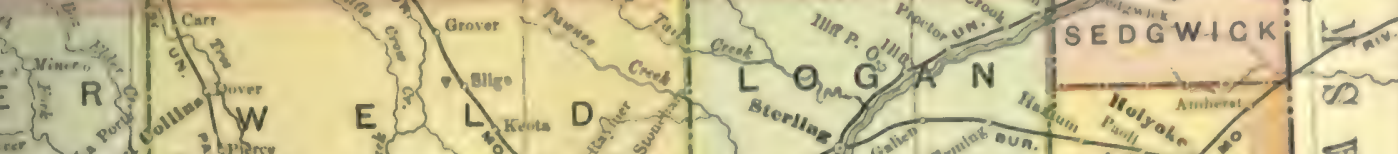

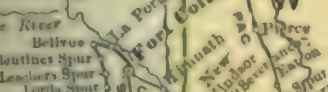
int

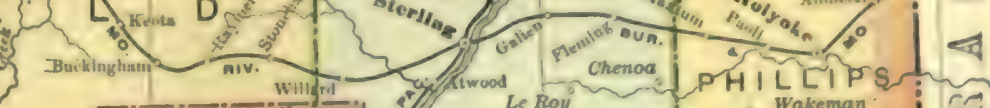

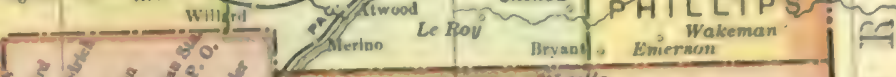

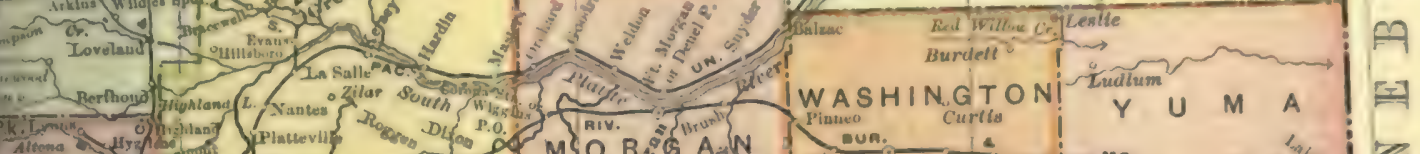

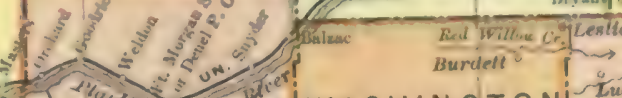
Aitiona

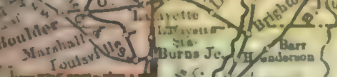

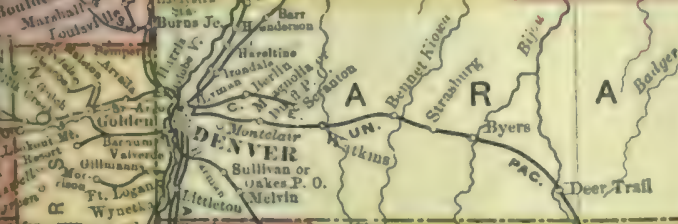

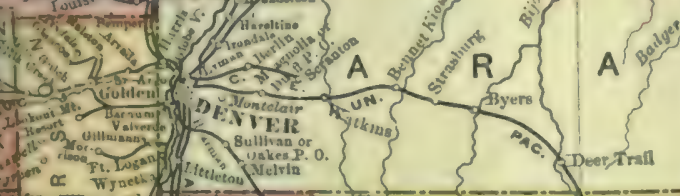

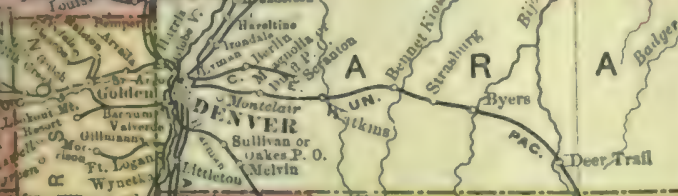

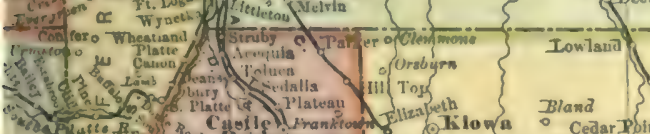

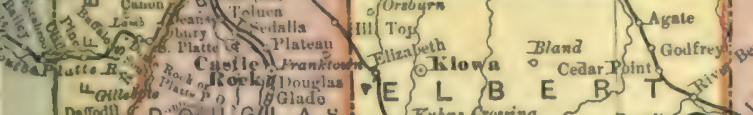

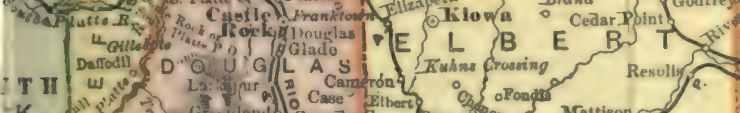
T II
$\mathrm{K}$
$\mathrm{K}$ S

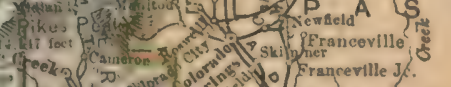
felen: $x$ Pountara

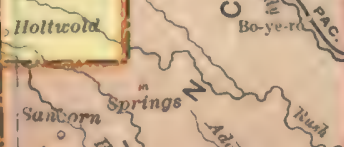
Liake JCHIt A Harrisbur $\{1$ :

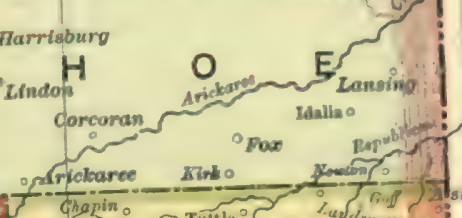



to the support of human life on a considerably grenter seule than at present, seems to he evidenced by the presence of great numbers of abandoned and prehistoric dwellings, sometimes perehed upon clifis within some canon, or on a high ridge or mear, as if for protection from hostile attack. The Moqui towns in Arizona are still inhabited by interesting tribes of semi-civilised aborigines, no doubt relics of a race once very much more widely spreal. The whole course of the river below the junction is about 900 miles; to its remotest sources it is 2000 miles. Navigation is possible for light-draught gteamers for over 600 miles. At extreme high water, steamboats sometimes go up to the month of the Rio Virgen to load rock-salt. The lower portion of the river is visited at certain seasons by bores, or high tidal waves, a phenomenon to be seen in only a very few North American rivers. The non-tidal portion of the river is subject to vast and frequent changes of volume, and except where confined by eanon-Walls, the river channel shifts to and fro in its sandy alluvial bed to a very remarkable degree. Navigation is much impeded by rocks and sand-bars.

Colorado RIver of Texas rises by many headstreams in the south part of the Llano Estacado, of North-west Texas. Its two main head-streams are the Concho or Salt Fork, and the Red or North Fork. The river takes a devious south-eastward course of 900 miles, and discharges its waters by two main outlets into Matagorda Bay. It is about 900 miles long, and its drainage area is put at $24,700 \mathrm{sq} . \mathrm{m}$. Sand-bars at its mouth impede navigation. Steambosts have ascended the river as far as Austin, the capital of the state; but the stream is not much navigated. The basin of the river is in part very level, but in some parts of the course the banks are bold and bluffy. The valley of the Colorado is fairly supplied with timber, and the soil is generally fertile; but the rains are much less abundant than in the river basins lying farther to the eastward. It is stated that this river was named Brazos by the Spanish colonists, and that the Colorado of the same settlers was what is now called the Brazos; the names having been misapplied or transposed in later times by mistake. The Colorado is the largest river wholly within the state of Texas, except only the Brazos.

Colorado, a west central state of the American Union, in $37^{\circ}-41^{\circ} \mathrm{N}$. lat. , and $102^{\circ}-109^{\circ} \mathrm{W}$. long., is traversed $\mathrm{N}$. and $\mathrm{S}$. by ranges of | Copvrigbt 1889, 1897, and the Rocky Mountrins. It takes 1900 in the U. S. by 'J. B. its namefrom the Colorado River, Ligpineot Oompany. to the basin of which all the western slope of the state belongs - as the eastern to the Mississippi valley - while part of the south is drained by the Rio Grande. The area is $103,925 \mathrm{sq}$. m., or rather more than half the extent of France ; so that Colorado ranks as eighth in area among the states and territories, being surpassed by Arizona, Alaska, California, Montana, Nevada, New Mexico, Texas. The vast ranges which traverse this region have mostly an approximate north and south direction, with many deviations. The high plains and overdrained mesas to the west are not clearly marked off from the mountain-region; and much of the western slope is actually mountainous. The eastern slope, which embraces about two-fifths of the whole state, is, apart from the foot-hills skirting the flank of the mountain-region, an open and comparatively treeless plain, with a surface singularly monotonous, and for the most part devoted to the pasturage of cattle and sheep, an interest which is of high importance in nearly all parts of Colorado. This level region averages 5000 feet in altitude, and its lowest point is 3000 feet above sea-level. The mountain-region containg many peaks exceeding 14,000 feet in height, the loftiest being Blanca
Peak (14,464 feet); while the summits exceeding 13,000 feet are stated to be more than ope hundred in number. The mountains, notwithstandisg their general parallelism, are greatly broken into short and variously named chains, there being no one ridge that can distinctly claim to rank everywhere as the main range of the system. Six passes crose mountain-ranges at points over 12,000 feet ligh ; the Argentine Pass is 13,000 feet in altitude. Rail. ways are led across many of these passes, and their construction through the valleys and caions Jus called for many brilliant displays of engineering skill and boldness. A marked feature of the mountain-region is presented in the parks, or rich mountain-valleys, often very spacious, and generally hearing evidence of being the hasins of lakes once extensive, but now nearly or quite dried up. The central mountain-region, with its parks, cañons, and hot springs, and its rich mineral deposits, has attracted most attention. The western part of the state is far less accessible and less developed, although its mineral wealth and the construetion of railways have led to the settlement of some parts of the region.

The rainfall of Colorado is small ; yet the great altitude causes a considerable local fall of rain and snow, and several important streams take their rise in the state, including several tributaries of the Colorado; the Arkansas and South-Piatte, flowing to the Misaissippi ; and the Rio Grande, the only stream which reaches the sea under its own name. Extensive and important irrigation. works are fed by some of these streams. Colorado has 8 great reputation as a health-resort, especially for persons with pulmonary disease. The dryness of the air is the great factor in the recovery of consumptive patients in this region; but some invalids only after a considerable period become so habituated to the rarefaction of the atmospliere as not to be seriously annoyed by it. The medicinal and thermal springs of the state are numerous, and are visited by large numbers. A peculiar disease called 'mountain fever' is endemic in some places, attacking principally strangers from lower levels of country.

Wheat, maize, barley, oats, hay, potatoes, fruits, and garden and dairy erops prove remunerative under irrigation. At the beginning of 1898 Colorado had 16,000 miles of irrigating eanals and ditches, furnishing water to over $3,500,000$ acres, without reckoning the ditches constructed by individual farmers; and projects were then on foot for extending the system, bringing under cultivution thousands of acres more. Visitations of insectplagues, including the well-known Colorado potatobeetle, have hitherto proved very destructive in this state; but the Rocky-mountain locust (see LocUST) has of late years been comparatively harmless. Stock and wool raising are important industries, yielding $\$ 15,500,000$ in 1897 . Lumber-cutting also enuploys a large number of hands.

Gold was first discovered in the neighbourhoor of Pike's Peak in 1858, and at Clear Creek in 1859 , leading to the great immigration in 1859 , 1860, and 1861 ; and in 1891 the famous Cripple Creek $(q . v$.$) discoveries were made; new mining-camps$ are springing up in many parts of the state. The earliest discoveries were of placer-deposits; but quartz-mining soon followed, and in more recent years a considerable proportion of gold hus been afforded by the richly urgentiferous lead-carbonate ores for which the state is famous. The introduction of the cyanide and chlorination processes has made possible the trentment of low-grade ores, which formerly could not be profitably worked, because of the high charges for smelting. In the working of the best silver ores much lead is obtained, and Colorado takes rank as the first state 
in lead-production. Vast sums of money have been invested in the construction of works for hoisting and reducing the ores; and railways have been built along the mountain-cañons, generally at a very high cost, so as to make the mines accessible. Mining and smelting operations have been much facilitated by the discovery of large beds of coal, usually of good quality, though classed as lignite; and anthracite in extensive veins has been discovered about 90 miles from Denver. Colorado led the states in the yield of both gold and silver in 1897 , producing $\$ 47,078,535$, over one-third the total. For many years from 1873, the output of silver was greater than that of gold, in 1892 about six times as much; but in 1898 the gold was estimated at $\$ 24,000,000$, silver at $\$ 14,250,000$. Copper, cement, fireclay, and manganese are wrought; iron and Bessemer steel rails are manufactured; and petroleum is found near Florence.

History. - Not quite one-half of this region was acquired by the United States from France in the Louisiana purchase of 1804 ; the remaincler was ceded by Mexico under the treaty of 1848 , together with California and New Mexico, of which last it formed a portion. The population is of mixed origin, but is largely derived from the older states of the Union, the first important settlement of English-speaking people being caused by the discovery of gold near Pike's Peak ; in the southern part is a small Spanish-speaking population, partly of Indian descent. The distinctly American traits of enterprise and progress, alike in business and education, are conspicuous. Women are admitted to the franchise. Colorado was organized as a territory in 1861, and was admitted as a state in 1876. The principal towns are Denver, the capital, Leadville, in the earbonate-mining district (altitude, 10,200 feet), and Pueblo ; and there are a number of others of considerable importance, chiefly mining centres, among them Cripple Creek (q.v.), of recent foundation and rapid growth. Pop. of Colorado (1860) 34,$277 ;(1880) 194,327$; (1890) 412, 198.

Colorado Beetle (Chrysomela or Doryphora decemlineata), a North American beetle which commits fearful ravages among potatoes. First discovered near the upper Missouri in 1824 by Thomas Say, it belongs to the sub-order of Coleoptera known as Tetramera or Cryptopentamera, and is a good type of the family Chrysomelidre. It is an oval insect, from 9 to 11 millimetres in length, of an orange colour, with black spots and lines as seen in the figure. The antennæe are clubshaped. The larva and adults live on the potatoplant, and have sometimes (as in 1859) quite destroyed the crop in certain parts of America. They pass the winter underground, and emerge from their hiding-places in the beginning of May. The

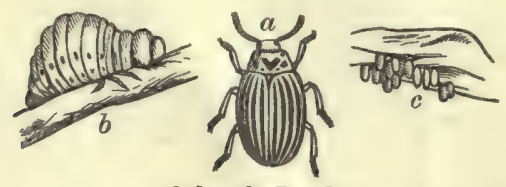

Colorado Beetle :

$a$, beetle, natural size; $b$, caterpillar : $c$, eggs. (From Miss Ormerod's Injurious Insects.)

Semaie lays many hundreds of eggs in groups of twelve to twenty on the under side of potato leaves. The larvæ, which emerge in ahout a week, are reddish and afterwards orange. They grow up quickly and produce a second generation, which may again produce a third in the same summer. Their rate of multiplication is therefore very rapid.

The home of the Colorado beetle is in the western states; 'from Nebraska and Iowa it travelled eastward, until, in 1873-76, it reached the eastern shores of America. In 1877 it was found at Liverpool in a cattle-boat from Texas." Owing in great measure to the stringent regulations of an order in council, which provides that 'it shall not be lawful for any person to sell, keep, or distribute living specimens of the Colorado beetle in any stage,' this pest has fortunately not succeeded in establishing itself in Britain. The surest remedy in case of attack is said to be a preparation of arsenic known as 'Paris Green' or 'Scheele's Green.

The genus Chrysomela ('golden beetle') to which the Colorado beetle belongs, is represented by many hundred often beautifully metallic species in temperate and tropical countries. C. cerealis, sometimes injurious to grasses and cereals, $C$. staphylea, $C$. or Lina populi, found on poplars, are common species.

Colorado Springs, a popular summer-resort of Colorado, situated in the midst of beautiful scenery on the Fontaine qui Bouille Creek, 75 miles $\mathrm{S}$. of Denver by rail, and about 10 miles $\mathbf{E}$. of Pike's Peak. Pop. (1880) 4226 ; (1890) 11,140.

Colossae. Colossæe was a town of Asia Minor, in the southern part of the province of Phrygia, situated on the river Lycus, a tributary of the Mrander, 12 miles east of Laodicea. It is mentioned by Xenophon as 'a populous city, prosperous and great,' but in the time of Strabo had become ' a small town.' It was ruined by an earthquake in 61 A.D. (Tac. Ann. xiv. 27) ; but it was again rebuilt, and in the middle ages was named Chonæ. See Colossians.

\section{Colosséum. See A mphitheatre.}

Colossians, The EPIstle to THE, an epistle sent from Rome by the Apostle Paul about the year 63, in charge of Tychicus, to the church founded at Colossæ apparently by Epaphras. Here Archippus exercised his 'ministry' (iv. 17), and Philemon, together with Apphia 'the sister,' was the entertainer of the brethren. To Philemon Paul persuaded the runaway slave Onesimus, whom he had converted to Christianity, to return. The Colossian church consisted chiefly of Gentile Christians, but was distracted by certain Judaising teachers, who laid stress on circumcision and ordinances respecting food and festivals (ii. 11 and 16), teaching a thorough-going asceticism, with angelworship, based on theosophic speculations regarding the higher world of spirits, and may be regarded as the forerunners of the Judaising Gnostics (q.v.). To counteract these was the chief aim of the epistle (see BIBLE). Its genuineness has been contested by recent criticism. Hilgenfeld, following Baur, holds that 'the Colossian letter has to do with an already fully developed Gnosticism, and this carries it not merely beyond Paul's lifetime, but beyond the first century." See the commentaries by Ellicott (3d ed. 1865), Bleek (edited by Nitzseh, 1865), and Klöpper (1882); also Holtzmann, Kritik der Epheser und Kolosserbriefe (1872); and especially Lightfoot, St Paul's Epistles to the Colossians and Philemon (8th ed. 1886).

Colossus, a Greek word of unknown origin, used to denote a statue of gigantic size. The colossal was a common feature of all ancient art, and in particular of Egyptian and Assyrian architecture and sculpture. The image set up by Nebuchadnezzar (Daniel, iii. 1) was of enormous proportions. Even Greek art, through Aristotle, laid down the principle that only the large can be noble, and carried it out in its statues of gods and heroes. Of the many colossi of which accounts have come down to us, the most famous was the bronze colossus of Rhodes, representing Helios (the Sun), the national deity of the Rhodians, which 
was reckoned among the seven wonders of the world, though it was by no means a masterpiece of Greek sculpture. It is said to have been the work of Chares of Lindus, a distinguished pupil of Lysippus, who gave twelve years to the casting, and completed his work in 280 B.C. Its height is variously given at from 90 to 120 feet. It stood near the harbour; but the legend that placed it astride the entrance is certainly apoery. phal, and probably arose from a misunderstanding of the statement that it was so high that a ship might sail between its legs. Fifty-six years after its erection it was thrown down by an earthquake, and there its ruins lay, the marvel of the place, till in 653 A.D. an Arab general sold them to a Jew from Edessa for old metal. Other famous colossi of antiquity were the Chryselephantine (q.v.) statues of Athena on the Acropolis, 37 feet, and of Zeus at Olympia, 40 feet, both by Phidias; the Zeus at Tarentum, by Lysippus, 107 feet; a bronze Apollo, 66 feet, brought from Apol. lonia to Rome by Lucullus; and a marble statue of Nero, 131 feet, set up by the emperor before the palace, but removed by Vespasian to the Via Sacra, where Commodus afterwards superseded the head by one of himself. Colossi came in again with the Renaissance, and in later times the most noteworthy have been the $\mathrm{S}$. Charles Borromeo (1697), on the bank of the Lago Maggiore, 72 feet; the 'Bavaria' national statue at Munich, 67 feet; the Arminius (q.v.) statue, 90 feet to the point of the upraised sword; the Virgin of Puy, 51 feet; the figure of Germania in the national monument on the Niederwald, 112 feet; and Bartholdi's 'Liherty enlightening the World' (1886), in New York harbour, 156 feet to the tip of the torch. There are enormous images in Japan, Polynesia, and elsewhere. See Lesbazeilles, Les Colosses Anciens et Modernes (1876); Torr, Rhodes in Ancient and Modern Times (2 vols. 1885-87).

\section{Colostrum. See Benstings.}

Colour is not a material existence; it is a sensation. The colour of an object varies slightly with the brilliancy of the light emanating from it to the eye; and where the eye is abnormal, as in the 'colour-blind,' the apparent colours of objects may differ widely from their colour as perceived by normal eyes. Light is due to waves - or other periodic disturbances whose recurrence resembles that of waves-in the ether of space; and just as air-waves of a certain definite frequency of recurrence will induce in the ear the sensation of a sound of a particular pitch, so will the impact of 'ether-waves' of a certain particular frequency induce in the eye a sensation of light of a particular coluur. We are experimentally acquainted with ether-waves whose frequencies range between $20,000,000,000,000$ and $40,000,000,000,000,000$ per second; but the eye is blind to all except a comparatively narrow range of these-viz. from 392 billion to 757 billion per second. Within that comparatively small range, however, we have a large choice of fractional and integral numbers; and each number, each frequency, has its own colour. When we look at the spectrum or rainbow we have marshalled before us a series of colours, of which the extreme visible red is produced by about 392 billion, the extreme visible violet by about 757 billion vibrations per second. Between these the eye may rest upon certain dis. tinctive colours, such as yellow, blue, and so on; and the freqnencies corresponding to these respective colours are, taking the centre of each distinctive colour as displayed in the spectrum-red, 492.4 ; orange-red, $484^{\circ} 1$; orange, 503.3 ; orangeyellow, $511^{-2}$; yellow, 517.5 ; green, 570 ; hluegreen, 591.4 ; cyan-blue, 606 ; blue, 635.2 ; violet- blue, 685.8 ; puce-violet, $740.5-$ all in billions $(1,000,000,000,000)$-per second. Light due to wave-motion of one simple frequency would be 'homogeneous" or "monocliromatic light; it would produce the mimplest colour-serasation; but no such thing is experimentally attainable. The light from burning sodium is a compound of two yellow lights, very near one another in the spectrum, and corresponding to the respective wave. frequencies of $508^{\circ} 9$ and $510^{\circ} 6$ billions per second; and this is the nearest attainable approximation to monochromatic light.

The eye takes up, singularly enough, any con. geries of several monochromatic lights impinging simultaneously upon the same spot in the retina, and the resulting sensation is always that of a single colour, not necessarily resembling any of the components. The retina is composed of numerous ultimate nerve-elements, each of which is capable of perceiving one of three physiologically primary colours. These colours are red, green, and violet (Young and Helmholtz); vermilion, emerald green, and ultramarine blue (Clerk Maxwell); or red, green, and blue (Fick). Simultaneons affection of the elements sensitive to red and of those sensitive to green produces, according to the ratio between the respective irritations, any colour of the spectrum from red through orange and yellow up to green; similarly, green and violet lights blended in different proportions produce all the intermediate blues; and when the whole three sets of nerve-elements are irritated, the sensation is still that of $\mathrm{a}$ simple colour, or, it may be by due adjustment, of white light. Coloured lights may be mixed so as to show this, either by causing coloured lights from different sources to coincide in the eye or on a screen, or else, as in the colour-top, by eausing ocular impressions of different colours to succeed one another in the eye with such rapidity that the eye or the brain blends them. But neurly every example of what we call coloured light is in reality an admixture of several monochromatic lightse.g. the light passing through a piece of green glass is composed-as will be found on trying to make a spectrum of it by means of a prism-not only of green light, but also of blue and yellow, and, often enough, of red and violet; but the resultant sensation is that of green, a simple colour.

White light is in general due to a simultaneous impact of wave-motions of all visible frequencies. But the sensation of whiteness may also be produced by the simultaneous impact on the retina of two suitable spectral colours, such as yellow and ultramarine blue; and such a pair of colours are said to be complementary to one another; other examples are red and greenish-blue, greenish. yellow and violet, orange and cyan-blue (a rather greenish blue). It will be observed that it is said that yellow and ultramarine blue lights make white light, while it is well known that yellow and blue pigments make a green pigment. The explanation of this is that the light from the yellow pigment is not pure; it contains green light; smilarly that from the blue pigment con. tains green light; when the pigments are mixed, the eye receives a simultaneous impression of blue, yellow, and green; but the blue and the yellow destroy one another, being, to the eye, complementary colours; jointly they produce white light; and thus the green alone remains, diluted with white. Complementary coloured lights may both or either be of any degree of complexity; if an aggregate impression of blue light and an aggregate impression of yellow be superimposed on the same part of the retina, whatever be the mode of their production, the result may be the same - an impression of white light. 
Colours vary in hue, in purity, and in luminosity. The hue determines the name of the colour-e.g. vermilion, scarlet; the purity or absence of admix ture with white light determines its richness - vermilion reflects 80 per cent. of red light mixed with 20 of white; the luminosity or brightness determines the shade or tone of colour. Interfere with any of these and the impression produced upon the eye is modified. Take for example a definite red light, saturated or unadulterated with white light, such a red as may be found in the spectrum; prouressively lower its purity by mixing it with white light-it becomes brighter, but passes through light rod and pink to pinkish-white tints; lower its luminosity by mixing with black-it passes through terra-cotta tones to brown, which is a dull red; interfere with both purity and luminosity by mixing with various greys-it goes through russets and maroons, the so-called tertiary colours. Any colour in nature can be matched either by a spectral colour or by a purple, treated in this way ; and for each such modification of the original colour there will be a different complementary, which when mixed with it forms not a white but a grey.

The colour of transparent objects is due to Selective Absorption. A red object seen through greenish-blue glass appears black; greenish-blue glass is opaque to the light from the red object. Hold the same piece of glass up to the sky, and the red lights, which are components of the white light of day, are cut off; what passes through produces a sensation of greenish-blue. The red, which is eut off by absorption, and the greenishblue, which passes through, are complementary to one another-both being really complex, not monochromatic. The colour of a transparent body will also apparently depend upon the thickness of the layer examined : a thin layer of iodine-vapour absorbs all the constituents of visible white light except blue and red; it therefore appears in daylight to be puiple; a thicker layer effects the complete absorption of the red but not that of the blue, and a thicker layer of iodine-vapour therefore appears blue. If looked at in red light, a thin layer of iodine-vapour appears red, while a thick layer will present the blackness of opacity.

Before a non-luminous object can be seen otherwise than by transmitted light it must reflect light; if it reflect none it will appear black; a dustless pool in a mountain-hollow, a liquid in a deep black vessel, may reflect no light to the eye of the observer, and will appear black. (Black is the negation of colour, because it implies that there is no sensation of light; gray, produced by mixing white and black, is white deficient in luminosity). Let the pool become turbid, and there will be some light reflected towards the observer. A coloured liquid in a deep black vessel will have its colour revealed by sprinkling a white powder into it. White light (daylight) enters the liquid it is reflected in all directions by the white powder; but it is in part absorbed by the liquid, which accordingly appears coloured. Of precisely the same kind is the reflection of light by $a$ solid object. Bodies allow light to traverse them to a very small depth, and then the light is, by internal reflection, turned back in all directions; absorption, meanwhile, comes into play, and the result is that the object appears to have a definite colour, the purity of which is marred by surface-reflection. The white light reflected from the surface of metal masks its true colour, which is brought out by repeated reflection. Gold is deep orange; copper, scarlet; silver, yellowish-bronze; brass, a rich golden red.

If the light supplied to an object do not contain those kinds of light which it can reflect, the object will appear black or colourless; a bunch of flowers looked at by the yellow light of burning sodium or of a spirit-lamp with common salt in the wick, will all appear black or colourless except those which are yellow. Surface-reflection modifies the result.

There is one class of cases in which colour is not due to absorption. A haze is blue if its. particles be fine enough : if it be eomposed of coarse particles it at once reflects white light in all directions; but fine particles cause repeated reflection, and at each reflection the reflected light. becomes bluer; because those rays which would have been most refracted (the blue and violet) are in fact most largely reflected. The colour of the sky is that of a haze, reflecting light downwards; if there were no dust-haze or water-haze above us, the sky would be black. The light which is not. reflected from such a haze is either transmitted through it, yellower or redder in colour, or elseit is entirely absorbed. The sun thus appears: yellower than it would do if our atmosphere did not intervene. See also DICHROISM, INTERFERENCE, IRIDESCENCE, Light, OPTICS, PhOSPHORescence, Pleiochroism, Rainbow, Spectrum, DYEING, and the articles on the several colour: and consult also Colour by A. H. Church (Lond. 1887), and Colour by C. T. Whitmell (Cardiff; 1888). For Heraldic Colours, see HERALDRY ; for the Eeclesiastical Colours, VEsTMENTs; and for Colour in Animals, PIgments of Animals.

Colour-blindness, a term introduced by Sir David Brewster to denominate a defect of vision owing to which some persons are unable to distinguish certain colours correctly. It is also called. Achromatopsia (Gr.) and Daltonism, from Dalton the chemist, who suffered from the defect, and who gave the first detailed description of it (1794). Of this defect there are several degrees, classified as. follows (by Holmgren of Upsala): (1) Total colourblindness, where there is no perception of colours as such, but only of gradations of light and shade; (2) Complete partial colour-blindness, where somebright colours, different in different cases, are confused with each other, though other colours are correctly perceived; (3) Incomplete partial colourblindness, where bright colours are recognised, but. more delicate shades are confused. The first form is rare, and generally, perhaps always, associated with other defects in the eyes; the third is probably common, though not of great importance; to the second attention will mainly be directed here.

With regard to the classification of the cases of complete partial colour-blindness authorities are not agreed; the important practical point is that in the vast majority red and green are the coloursconfused. Some confuse a bright red with a green that appears to a normal eye a much lighter colour ; some with a green that appears darker. But if suitable tests be applied it will be found that they do not distinguish red and green as such. Experience, however, and observation of the different apparent brightness of ordinary reds and greens, enables them to distinguish between them in most cases with wonderful accuracy, so that they may remain unconscious of their defect till some striking mistake, or the application of a systematictest, reveals it. Cases of colour-blindness for yellow and blue, if they occur at all, are extremely rare. Experience proves that this defect is generally hereditary, and is quite incurable. The eyes. may be, and usually are, perfect in every other respect; no difference has been detected in their structure, either during life or after death; so the cause of their defective perception remains absolutely unknown.

Numerous careful and extensive researches both in various countries of Europe and in the United States have shown that this defect is present. 
in about 4 per cent, of the males (or one in twenty-five), and less than 0.5 per cent. of the females in those countries. Now red and green are the very colours which are most largely uned for the purpose of signalling both at sea and on railways; and it must be olvious that most dis. astrous results may follow if the person whose duty it is to distinguish them from each other is unable to do so. It is then an important practical ques. vion how the defect may best be recognised. Authorities on the subject are agreed that any test which rejuires the naming of eolours is unsatisfactory, and that for two reasons. First, a person may perceive colours correctly, but may make mistakes through imperfect knowledge of their names; second, a person may be colour-blind, and yet log his perceptions of different brightness in the tests, may name the colours correctly. The most perfect test yet devised is known by the name of its introducer, Holmgren of Upsala, and consists in a number of skeins of wool of different shades. One of these is placed before the person to be tested, generally in the first instance a pale green, and he is asked to select from the remainder those which most resemble it. If colour-blind, he is sure to pick out some of the 'confusion colours,' palegrays, buffs, \&e., to match the green; and further similar tests may then be applied to determine more precisely his defect. Within recent years the importance of this defect has been recognised by the railway companies and the Board of Trade in Britain; though the tests applied are not in either case so satisfactory as is to be desired, as they consist in requiring the candidate to name coloured cards, lights, \&c. Moreover, the Board of Trade examination is required only of men applying for certificates as mates or masters of vessels; there is no compulsory examination of ordinary seamen, though one of their most important duties is to keep a lookout at night for signal-lights, many of which are red and green. This arrangement is also productive of much hard. ship to those unaware of their defect, who have spent valuable years in the drudgery of preparation for a calling to which colour-blindness should be an absolute disqualification, and only find out their unfitness when they should begin to reap the reward of their labour. Further, in certain cases colour-blindness does not prevent the granting of a certificate by the Board of Trade; the fact that its holder is colour-blind is indorsed upon it, but he is permitted to act as master or mate notwith. standing, if he can find a shipowner to employ him.

There are difficulties in the wry of substituting any other colours than red and green for signals. Blue and yellow are the only others sufficiently definite and contrasted for the purpose. But blue is much more quickly lost in passing through the air than other colours; and yellow is just the colour to which laze or distance reduces white.

Colour-blindness more or less complete may also occur as the result of disease of the eyes, particularly atrophy of the optic nerve and excessive use of tobacco. See EYE (vol. iv. p. 513), and AMAUROSIS. In the former, the distance from the direct line of sight at which colours can be recognised is diminished; in the latter, the colour of a small dise is not recognised when it is in the direct line of sight, though it may atill be perceived at a little distance from it. $A_{B}$ in the latter case, the pereeption of red and green is specially affeeted, its presence in engine-drivers, ㄷ. may cause even greater risk than the congenital form of colourblindness. For further information, see the Brit. Assoc. Report (1886); Roy. Soc. Report (1892) and works on colour-blindness and colour-vision by Jay Jefliries (Boston, U.S.), Eldridge Green (1891), and Abney (1895); and the writings of
Sir David Brewster, George Wilmon, Clerk-Maxwell, \&c.

Colour-printing. See Lithography, Pmist. ING.

Colours, Military, are the flage carried by certain regiments of the British army. Thone of the infantry were originally ealled ensigns, a name still used in the navy. In former times there was one for each company, but now there is, in each Battalion (q.v.), a "pair of colours," one (the 'Union Jack,' on a blue ground) called the royal or' queen's colour, is the more important, and of tho same pattern for all regiments; the other, or regimental colour, matches the facings of the regiment, and has in one corner the blue union, in the centre a wreath of roses, shamrocks, and thistles, with the name, crest, and motto of the regiment, and the campaigns in which it has taken part. The facings of all regiments having the title 'Royal' are blue, otherwise they are white for English, yellow for Scottish, and green for Irish. The East Kent Regiment, formerly famous as the 'Buffs,' retains the buff facings, and is the only exception. English regiments have the St George's cross in red on their white colours. All colours are made of silk, 3 feet 9 inches by 3 feet, fringed with gold, and have crimson and gold cords and tassels, on a staff 8 feet 7 inches long. They are carried on parade by the two junior sub-lieutenants (formerly ensigns), and guarded by two sergeants and two men, forming what is ealled the colonr party,' but are no longer taken into battle. Since the Franeo-German war of $1870-71$ it has been recognised that they make too conspicuous a mark. The last time British colours were taken into the field was in the Zulu war of 1880. An officer trying to save them after Isandula, was drowned in the Tugela, and the colours were found wrapped round his body. Regiments of guard cavalry have oblong 'standards,' 30 inches by 27 , and dragoon regiments have 'guidons,' 41 inches by 27 , slit in the $\mathbf{f l y}$, with the upper and lower corners rounded off at one foot from the end. These flags are all of erimson silk, with gold fringe, cord, and tassels, and bear the crest and campaigns of the regiment. The Royal Artillery, Royal Engineers, Lancers, Hussars, and Rifle regiments have no colours. When a regiment obtains new colours, they are usually solemnly presented by a royal personage or some laily of distinetion, with much military pomp, after a special religious service. The old colours are hung up in the eathedral or parish church at the territorial headquarters. A member of the Heralds' College is 'inspector of regimental colonss." Camp colours are small flags matching the facings of the regiment, to designate the part of the camp it occupies.

Colour-sergeant (so called as being a sergeant who, in addition to other duties, guardesl the colours) is the chief non-commissioned ofticer in a Company (q.v.) of British infantry. On his efficiency its good order mainly depends, as he is the channel of communication between the Captain (q.v.) and the men in almost everything. The distinctive badge consists of crossed colours worn on the sleeve above the Chevrons $\left(q_{0}, v_{0}\right)$. The pay is 3s. a day in the line, and $3 \mathrm{~s}$. 2d. in the guards. The corresponding rank in the cavalry is troop sergeant-major (corporal of horse in the Life and Horse Guards). In the United States army each hattalion has a colour-guard, composed of a coloursergeant and seven corporals. The colour-sergeant carries the national colours.

Colquhoun, Јонм, second son of Sir Јames Colquhoun of Luss, was born in Edinburgh, 6th March 1805, studied at Edinburgh University, 
served in the army 1829-34, and became a supreme authority on sport in Scotland. The famous record of his experiences, The Moor and Loch, published in 1840, was much extended and improved in the 4th $(1878)$ and 5 th $(1884)$ editions. Rocks and Rivers appeared in 1849; Salmon Casts and Stray Shots, 1858; and Sporting Days, 1866. He died at Edinburgh, 27th May 1885.

Colguhoun, Patrick, born at Dumbarton, 14th March 1745, became provost of Glasgow in 1782, went to London in 1789, and in 1792 became a police-magistrate there. He was indefatigable in forwarding administrative legislation, edueational and commercial reforms, wrote innumerable pamphlets, and published two important worksPolice of the Metropolis (1795); and Population, Wealth, Power, and Resources of the British Empire (1814). He died 25th April 1820.

\section{Colston, Edward. See Bristol.}

Colt, Samuel, inventor, born in Hartford, Connecticut, in 1814, ran away to sea in 1827, and about 1832 travelled over a large part of America, delivering lectures on chemistry by which he obtained the funds required to prosecute his invention. In 1835 he took out his first patent for a revolving pistol, which after the Mexican war was adopted as a regular weapon for the United States army, and since then has been adopted universally. Colt expended over $\$ 2,500,000$ on an immense armoury in Hartford, where he died 10th January 1862, and where his widow erected a handsome Episcopal church to his memory. See REVOLVER.

\section{Colt's-foot. See Tussilago.}

Coluber, a genus of non-venomous snakes, of almost world-wide distribution. It forms a type of the family Colubridæ, in which the common Ringed English Snake (Tropidonotus natrix) is also in. cluded. The Asculapian Snake (Coluber asculapii), so familiar from ancient times as a symbol of medicine, is the best known species. It is very common in Italy, is the species of the Schlangenbad, and is widely distributed in Europe. It is of a predominantly brown colour, attains a length of 4 or 5 feet, and is readily tamed. All the members of the family are very typical, exhibiting few deviations from the general snake structure. See SNAKE.

Columba, ST-called also ST Colum-CILle ('Columba of the Churehes,') and ST CoLM-was born (it is believed at Gartan, County Donegal) in the north of Ireland, on 7th December 521. $\mathrm{He}$ was of high descent, his father Fedhlimidh, of the powerful tribe of the Cinel Conaill, being a kinsman of several of the princes then reigning in Ireland and in the west of Scotland; and his mother, Eithne, was also of royal blood. After studying under St Finnian at Moville on Strangford Lough, and under another St Finnian at Clonard (where he had as companions St Comgall, St Ciaran, and St Cainnech), he spent some time near Dublin; but in 546, when no more than twenty-five, he returned to the north and founded Derry, and, six or seven years afterwards, Durrow, the greatest of all his Irish monasteries. The belief that he had caused the bloody battle of Culdremhne in 561 led to his excommunication by an Irish ecelesiastical synod, and practically to exile from his native land.

Setting out in 563, when in his forty-second year, and accompanied by twelve disciples, he found a resting-place in the little island of $\mathrm{Hy}$ or Ioua, now better known as Iona (q.v.), or I Colum-cille, and having planted a monastery there, he set himself to the great work of his life, the conversion of the Pictish tribes beyond the Grampians. His missionary efforts were highly successful, but unfortu- nately very little is known of the way in which he effected his purpose. Bede speaks simply of his 'preaching and example.' Adamnan, extolling his gift of miracles, tells how the gates of the Pictish king's fort near Inverness burst open at his approach, and how, as he chanted the 45th Psalm, his voice was preternaturally strengthened 80 as to be heard like a thunder-peal above the din and clamour by which the Pictish magicians tried to silence his evening prayer under the walls of the Pictish palace. We get another glimpse of his missionary footsteps from the Book of Deer (q.v.), which records how 'Colum-cille and Drostan, the son of Cosreg, his disciple, came from $\mathrm{Hy}$, as God had shown them, to Aberdour,' in Buchan; how 'Bede, a Pict, was then highsteward of Buchan, and gave them that town in freedom for evermore;' how 'they came after that to another town, and it was pleasing to Colum-cille, for that it was full of God's grace; and he asked of the high-steward Bede that he would give it to him, but he gave it not; and, behold, a son of his took an illness, and he was all but dead, and the highsteward went to entreat the clerics that they would make prayer for his son that health might come to him; and he gave in offering to them from Clochin-Tiprat to Cloch-Pette-mic-Garnait; and they made the prayer, and health came to him." In some such way as this St Columba and his disciples seem to have traversed the Pietish mainland, the Western Islands, and the Orkneys, establishing humble monasteries whose inmates ministered to the religious wants of the people. The parent house of Iona exercised supremacy not only over all those monasteries, but over all the monasteries that St Columba had built in Ireland, and over those that were founded by his disciples in the northern provinees of England. Thirty-four years appear to have been spent by St Columba in raising up and perfecting his ecclesiastical system in Scotland. But the labour did not so wholly engross him but that he found time for repeated voyages to Ireland, and for a visit to Glasgow, where St Kentigern or Mungo was restoring Christianity among the Welsh or British tribes of Cumbria and Strathclyde. The health of St Columba seems to have begun to fail in 593 , but his life was prolonged till he reached his $76 \mathrm{th}$ year, when he breathed his last as he knelt before the altar of his church in Iona a little after midnight, between the 8 th and 9 th June 597 . He was buried within the precinct of his monastery, and his bones - which were afterwards enshrined-the stone pillow on which he slept, his books, his pastoral staff, and other things which he had loved or used, were long held in great veneration.

Whether any original composition of St Columba's still survives is donbtful, though an Altus published by Dr Todd in the Liber Hymnorum, and republished by the Marquis of Bute in 1882, has been ascribed to him by unbroken tradition. Be this as it may, he was certainly eminent as a transcriber. Adamnan tells us that on the night before his death he was engaged on a transeript of the Psalter, and in the Annals of Clonmacnois it is stated that 'he (Columba) wrote three hundred books with his own hand... which books have a strange property, which is that if they or any of them had sunk to the bottom of the deepest waters they would not lose one letter, or sign, or character of them, which I have seen tried, partly by myself on that book of them which is at Dorowe.' The two existing specimens of St Columba's work, both preserved at Dublin, are the Book of Durrow just mentioned, and the Psalter known as the Cathac or Battler. This name it has received from the custom of bearing the relics of the ancient Celtic saints into battle as sacred 
vietory-bringing ensigns.

was also uned in this way.

St Columba's character was very complex, but marked in all things by enthusiasm and earnestness. Warlike and aggressive by temper and descent, as well as from the suirit of the times, he was naturally more inclined to action than to melanclioly, and yet he had a tendency to expatiate amid visions; and though his disposition was prevailingly austere, he had frequent gleams of tenderness and kindness. "Angelic in appearance,' snys Adamnan, 'graceful in speech, holy in work, with talents of the highest order and consummate prudence, he lived during thirty-four years an island soldier. He never could spend the space even of one hour without study, or prayer, or writing, or some other holy occupation. So incessantly was he engaged night and day in the unvearied exercises of fasting and watching, that the burden of each of these austerities would seem beyond the power of all human enturance. And still in all these he was beloved by all; for a holy joy ever beaming on his face revealed the joy and gladness with which the Holy Spirit filled his inmost soul.'

In the ecclesiastical system of St Columba as in that of Ireland, the church was essentially monastic with ' neither a territorial episcopacy nor anything like presbyterian parity, but the same anomalons position of the episcopal order. The bishops were under the monastic rule, and as such were in respect of jurisdiction subject to the abbot, even though a presbyter, as the head of the monastery ;' but while the power usually reserved to the episcopate was thus transferred to the abbatial office, 'the episcopal orders were fully recognised as constituting a grade superior to that of the presbyters,' and as carrying with them the functions of ordination and celebration of the eucharist according to the episcopal rite. St Columba himself, as well as his followers generally. till the year 716, kept Easter on a different day, and shaved their heads after another fashion than obtained in other parts of Western Christendom. But with these exceptions, their creed and rites appear to have been substantially the same.

The chief authority for the life of St Columba is the account written by St Adamnan (q.v.), who was abbot of Iona from 679 to 704, and who incorporated in his work an earlier life by Cuimine (abbot, 657-669). Of this Dr Reeves published an edition in 1857 for the Bannatyne Club, re-issued in the 'Scottish Historians' series (1874); and there is one by J. T. Fowler (1894). See also Smith's Life of St Columba (Edin. 1798); Lanigan's Ecclesiastical History of Ireland (1822); Father Innes's History of Scotland (Spalding Club, 1853) ; Monta. lembert's Monks of the West, vol. iii.; Forbes's Kalendars of Scottish Saints (Edin. 1872); and Skene's Celtic Scotland, vol. ii. (Edin. 1877).

Columban, or Columbanus, ST, one of the most learned, eloquent, and devoted of the many missionaries whom Ireland seut forth to the Continent during the Dark Ages, was born in Leinster in the year 543. Having studied under St Comgall, in the great monastery of Bangor, on the coast of Down, he passed over to France, in his fortieth year, accompanied by twelve companions, and founded successively the monasteries of Anegray, Luxeuil, and Fontaine, in the Vosges country. His adherence to the Irish rule for calculating Easter involved him in controversy with the French bishops in 602 ; and a few years later, the courage with which he rebuked the vices of the Burgundian court; led to his expulsion, largely at the instigation of the notorious Brunhilda, the king's grand. mother. After various travels and adventures, and having for a year or two settled at Bregenz, near the Lake of Constance, he passed into Lombardy, and in 612 founded the famous monostery of Bobbio, in the Apennines, where he died on the 2lst November 615. His life, written within a century after lis death, by Jonas, one of his successors in the abbacy of Bobbio, has been repeatedly printed. The writings of $8 \mathrm{t}$ Columban, which are wholly in Latin, consist of a rule for the government of his monastery, six poems on the vanity of life, several letters on ecelesiastical affairs, seventeen short sermons, and a commen. tary on the Psalms (finst published at Rome in 1878). The most complete edition of his works is in Patrick Fleming's Collectanea Sacra (Augsburg, 1621; Louvain, 1667), followed by the Bibliotheca Patrum, and Migne's Patrologiae Cursus (1844). The town of San Colombano, in the province of Milan, takes its name from the Irish monk, as St Gall (q.v.), in Switzerland, perpetuates the name of the most favoured of his disciples. See the Vita by his successor Jonas of Bobbio (tr. by D. C. Munro, 1896), Montalembert's Monks of the West, and Wright's Biographia Literaria.

Columba'rium (Lat.), a dovecot or pigeonhouse, which probably differed little in form from those in modern use, but was sometimes built on a much larger scale, as we read in Varro of as many as five thousand birds being kept in the same house. The same name was applied to the niches or pigeon-holes in a particular kind of sepulchral chamber in which the urns (ollar) containing the ashes of dead bodies burned were deposited. Each niche usually contained two urns, and the four walls of the sepulchre sometimes contained as many as one hundred niches or more. The names of the persons were inscribed underneath. Tombs of this description were chiefly used by great families for depositing the ashes of their slaves and dependants.

Columbia, the name of nearly thirty places in the United States, of which the most important are: (1) The capital of South Carolina, at the head of navigation on the Congaree River, 130 miles NNW. of Charleston by rail. The town is regularly built, with several handsome streets, and contains a fine granite state-house $(\$ 3,000,000)$ and other official buildings. It is the seat of a Presbyterian theological seminary, and of the university of South Carolina (1806). Pop. (1890) 15,353. - (2) A borough of Lancaster county, Pennsylvania, on the Susquelianna, which is here crossed by a railway bridge, 80 miles W. of Philadelphia, with several iron-furnaces and rolling-mills, and manufactures of machinery, flour, \&c. Pop. (1890) 10,597.-(3) The capital of Maury county, Tennessee, on the Duck River, 45 miles SSW. of Nashville by rail, with manufactures of ploughs, furniture, and flour. Pop. (1890), with suburbs, about 7000.-(4) The capital of Boone county, Missouri, 24 miles $\mathrm{E}_{\text {. }}$ of Boonville, with manufactures of flour, tobacco, and woollens, It is the seat of the state university (1840), which is open to both sexes, and has some five hundred students and fifteen professors. Pop. (1890) 3985.

Columbia, or OREgoN, after the Yukon the largest river on the west side of America, rises in British Columbia, on the west slope of the Rocky Mountains, near Mounts Brown and Hooker, in about $50^{\circ} \mathrm{N}$. lat., has a very irregrular coune, generally south-west, through Washington, forms the northern boundary of Oregon for about 350 miles, and enters the Pacific by an estuary 35 miles long and from 3 to 7 wide. Its estimated length is 1400 miles. The area drained by this stream and its affluents, of which the largest are Clarke's Fork and the Snake River (with very remarkable cañons), has been computed at 
$298,000 \mathrm{sq} . \mathrm{m}$. The river is broken by falls and rapids into many separate portions, and the ingress and egress are embarrassed by a surfbeaten bar. Still, it is open to steamboat navigation from its mouth to the Cascades ( 160 miles), and goods are carried past the obstruction, for 6 miles, by railway; the next reach, of 50 miles, extends to Dalles, where another railway, of 14 miles, has been constructed past the Great Dalles channel; and immediately above this are two sections, of 185 and 250 miles respectively, navigable for small steamboats. The extraordinarily abundant salmon-fisheries of the Columbia have been largely developed. There are a number of canneries, mostly near the mouth of the river (where a great jetty now makes a good harbour), the annual export of canned salmon exceeds 500,000 cases.

Columbia, British, is a province of the Dominion of Canada, bounded in the $\mathrm{N}$. by the 60 th parallel of latitude; on the $\mathrm{S}$. by the United States; on the W. by the Pacific Ocean and part of Alaska; and on the $\mathbf{E}$. by the provisional districts of Alberta and Athabasca (Northwest Territories). The area of the province is recorded as 383,300 sq. m., including Vancouver Island $(14,000 \mathrm{sq} . \mathrm{m}$.$) and Queen Charlotte Islands$ $(5100 \mathrm{sq} . \mathrm{m}$.$) . The last named consist of a group$ of about 150 islands, their united length being 156 miles, lying about 200 miles north-west of Vancouver Island. British Columbia was practically under the control of the Hudson Bay Company until 1858, when owing to the discovery of gold, and the consequent immigration of miners, it was made a crown colony. Vancouver Island was made a crown colony in 1849, and leased to the Hudson Bay Company for ten years. The two colonies were united in 1866, and the province joined the Canadian Confederation on 20th July 1871.

The scenery is rugged and picturesque, being diversified with mountain, lake, and river. Between the western slopes of the Rocky Moun tains (highest peaks, Mount Brown, 16,000 feet, and Mount Hooker, 15,700 feet) and the sea the whole of the space is occupied to a considerable extent by spurs and outlying groups belonging to that chain. In the immediate vicinity of the coast these form a nearly continuous line of mountains of moderate elevation, known as the Cascade Range. The territory is well watered by rivers which have their origin in the highlands, and find their way into the Pacific Ocean. Of the rivers the most important is the Fraser, 800 miles long, and 600 yards wide at its principal outlet in the Gulf of Georgia, the arm of the sea which separates Vancouver Island from the mainland. Other rivers in British Columbia are the Columbia (which has only its upper portion within the province), the Stickeen, the Skeena, and the Finlay.

Many varieties of climate are found in this province. That of Vancouver Island and the coast of the mainland is very similar to that of the south of England. The interior of the mainland is divided as to climate into three zones-the south, the middle, and the north. The south lies, for the most part, between the 49th and 5lst parallels $\mathbf{N}$. lat., and the fall of rain and snow in this district is slight. It contains a good deal of grass or pasturage lands, but for arable purposes the land requires irrigation. Between $51^{\circ}$ and $53^{\circ}$ N. lat. is the middle zone; it includes the high mountains west of the Columbia, contains dense forests, and the rainfall is considerable. The north zone lies between $53^{\circ}$ and $60^{\circ} \mathrm{N}$. lat.

Population.-In 1891 the pop. according to the final official enumeration was 98,173 (including 39,000 Indians), it having increased from 33,586 in
1871 and 49,459 in 1881. The principal towns on Vancouver Island are Victoria, the capital (pop. 22,000 , increased from 5925 in 1881 ), and Nanaino ( 5000$)$; on the mainland there are New Westminster ( $\$ 000$ ), formerly the capital of British Columbia, and Vancouver $(30,000)$, the terminus of the Canadian Pacific Railway. The Indians of British Columbia are as a rule law-abiding and industrious. The coast Indians live largely by hunting and fishing, and are also employed in connection with the lumber industry and the salmon-canneries.

The province is represented in the Dominion Senate by three members, and in the House of Commons by six. The provineial government is administered by a lieutenant-governor, appointed and paid by the Dominion, and a Legislative Assembly of 33 members, elected by the inhabitants. Education is compulsory and free between the ages of seven and twelve.

The province is not likely to become an agricultural country, but there is a considerable area of land available for arable and pastoral farming both on Vancouver Island and on the mainland in the river-valleys. On the west of the island but little arable land is to be found. The principal settlements are upon the east and south coasts, but good land is still to be found on the east coast, and also on the north. The rich valley of the lower Fraser, or New Westminster district, is the largest compact agricultural area on the mainland. There are large tracts of alluvial soil farther up the Fraser and along some of its most important tributaries. Of the total area (say $250,000,000$ acres ) only about 500,000 acres are as yet occupied. The fruit-growing industry is expected to become important, but it is still in its infancy. The principal industries of the province are connected with the mines, the fisheries, and the forests. The minerals form one of its chief resources. Gold, coal, silver, iron, copper, galena, mereury, platinum, antimony, bismuth, molybdenum, plumbago, mica, and other minerals have been diseovered in different parts, copper being very widely distributed. The value of gold produced in $1898-99$ was $\$ 2,844,563$; of silver, $\$ 2,375,841$; of lead, $\$ 1,077,581$; and of copper, \$874,781. The quartz-mines have hardly been touched; all the metal hitherto secured has come from the alluvial deposits. Coal and lignite are known to exist in many parts of the mainland. At Nanaimo, on Vancouver Island, there is a large coalfield, and the mines are the most important on the Pacific coast; in $1898,1,117,915$ tons were raised, of which the greater part was exported to the United States. Nanaimo is connected by rail with Esquimalt, the headquarters of the Pacific squadron and the site of a large graving-dock. Iron is found in many localities. The fisheries are rapidly growing in importance, the annual value of the produce being $\$ 4,000,000$. The seas, bays, gulfs, rivers, and lakes of the province swarm with food. fishes. There are numerous salmon-canneries in operation. The fur-sealing industry in the Pacific is also a valuable one. But little timber has yet been eut, notwithstanding the immense forests of magnificent trees that abound in British Columbia. The important commercial trees are the Douglas pine, Menzies fir, yellow cypress, and maple, and the shipments so far have been chiefly to Australia, South America, the Cape, and China. The annual output of timber is about $500,000,000$ feet, the produce of about 60 mills. The total value of the exports of the province in 1898-99 was $\$ 14,748,733$, and of the imports $\$ 8,414,738$, a great portion of the trade being with the United States. The annual revenue was $\$ 1,439,623$, and the expenditure $\$ 2,001,031$.

Until the completion of the Canadian Pacific Railway in 1885, British Columbia was isolated 
from the rest of the Dominion; now everything points to a rapid development of its resources. It oceupies a favourable position for trading with the weat of South America: and it is hoped thut it may become the entrepot for a through trade between Canada, China, and Australia. Lines of steamers now connect Vancouver, Hong-kong, and Australasian ports; the route for a Pacific telegraph cable between British Columbia and Australia Fats been discussed, and an 'all. British' route between the two was being surveyed in 1897-98. The recent discovery of gold in the $Y$ ukon gave a fillip to trule. See Begg, History of British Columbia (1896); Maenab's Brilish Columbia for Settlers (1898).

Columbia. District of, in the United States. See District of Columbia.

Columbia Collere, in New York eity, was founded in 1754 as King's Culiege, and reincorporated under its present title in 1784. The first elass, of eight, met in the vestry of old Trinity Church, July 17, 1754. From 1760 to 1857 the col. lege was located near the city-hall, whence it removed in the latter year to 49 th and 50th Streets and Madison and Fourth Avenues. In 1896 it assumed through its trustees the title of "Colunbin University in the City of New York," the institution embracing Columbis College with its faculty of academic arts, Barnard College for Women estab. lished in 1889 and now controlled by officers of the University, the Tenchers' College for the training of professional teachers, now a part of the university system, and faculties of Law, Medicine, Philosophy, Political Seience, Pure Science, and A pplied Science. There were in 1896 in the University about 300 offi. cers of instruction and 1858 students. The University is located on a plot of ground recently acquired, bounded S. by 116 th Street, N. by 120th Street, E. by Amaterdam Avenue, and W. by the Boulevard. Presilent Low's gifts to the University during his presidency aggregate $\$ 6,000,000$. See the (anonymous) Four American Universities, Harvard, Yale, Princeton, and Columbia (N. Y. 1895).

Columbida. See Pigeon, Bird.

Columbine (Ital. colombina, "little dove'), the female mask of the Italian improvised plays, variously figuring as the attendant of Pantaloon's rianghter, or, occrsionally, as the daughter herself. She is the betrothed of Harlequin, and frequently is called Arlechinetta. In some cases she appears in the garb of a elımbermaid. See PANTOMimk.

Columbine (Aquilegia), a genus of plants of the natural order Ranunculaces, having five coloured sepals, which soon fall off, and tive petals

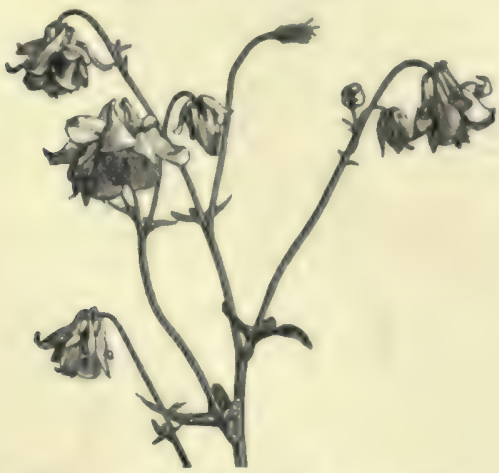

Common Columbine (Aquilegia vulgaris).

each terminating below in a horn-shaped spur or nectary. The name (from Lat. columba, 'a dove') is derived from the resemblance of the nodding flower to a cluster of doves, of which the convergent 128 nectaries suggest the heads and necks, and the divergent sepals the fluttering wincm. They are natives of the temperate and colder regions of the northern hemishere. One, the Common Colum. bine (A. vulgaris), in found in woods in some parts of Britain, and has long been familiar as an inmate of flower-gardens. It is a perennial, generally 2 to 3 feet high, with flowens of considerable beauty. Columbine was formerly much esteened for medi. cinal virtues. - Some of the other species are ornamental, and are common in flower-borders.

\section{Columbium. See Tantalum.}

Columbus, a thriving city of the United States, the capital of the state of Ohio, is situated on the Scioto River, 116 miles NE. of | Copyrigtt 18as, נ6อ7, and Cincinnati and 138 miles SSW. 1900 in the $\mathrm{C}$. \& s. by $\mathrm{J}$. of Cleveland. Its site is level, / Lppineor Compasy. its streets are broad, and in the centre of the city is a public square of 10 acres, in which stands the state capitol, a fine stone structure 304 feet long by 184 feet wide. Among other noted edifices are the city-hall, containing a public library and city offices; a court-house erected at a cost of $\$ 400,000$; United States government and Board of Trade buildings; a large state penitentiary; a hospital for the insane, with a farm of 300 acres, and accommodation for 900 patients, erected at a cost of \$1,52(1),980; and institutions for the blind, the deaf and rlumb, \&c. Here also are located the Ohio Stale University, with its grounds of 320 acres, and the Capital University (Lutheran), both liberally endowed; and the public schools have a seating eapacity of about 15,000 . Fourteen railway lines raliate from the Union Depôt in this eity in all directions, which, added to the natural advantage of its proximity to the great coal and iron fields of the state, tend to a rapid development of its manufacturing industries. The annual product of its manufactories reaches a value of more than $\$ 15,000,000$, giving einployment to many operatives. Columbus was founded in 1812. Pop. (1870) 31,274 ; ( 1880$) 51,647 ;(1890) 88,150 ;(1900) 125,560$.

Columbus is also the name of some twenty other places in the United States, the most important leing: (1) Capital of Muscogee county, Georgia, situated on the Chattahoochee River at the junetion of several lines of railroad, 100 miles SSW. of Atlanta. It has a large trade in cotton, and extensive manufactures of cotton, woollen, and iron goods. Pop. $(1880) 10,123$; (1890) 17,303, in cluding suburbs, about 31,000.-(2) Capital of Bartholomew county, Indiana, 41 miles $\mathrm{S}$. by $\mathrm{E}$. of Indianauolis, with which it is connected by railway. Pop. (1890) 6719.-(3) Capital of Lowndes connty, Mississippi, on the Tombigbee River, and on a branch railroad about 150 miles $\mathrm{NE}$. of Jack 8on. Pop. (1890) 4559.-(4) Capital of Colorado county, Texas, on the Colorado River, about 95 miles SSE. of Austin by rail. Pop. abont 3000 .

Columbus, Christopher (Ital. Cristoforo Colombo, a great navigator, especially distinguished as the discoverer of the New World / Coprrigen 1009 , $10 \%$ -and the Spanish form of whose 1900 to toe $U .8$. by J.8. name, Cristobal Colon, is some. Lipplnoots Company.

times Latinised into Colonus), was born in all prob. ability in the city of Genoa in the year 1447. His father, Domenico Colombo, seems to have been a eloth-weaver or wool-comber, ultimately very pros. perous, and it would appear that in early youth his son Christopher worked at the same trate; but he spent some time, probably not much, at the university of Pavia When fourteen years old he went to sen. The mariners of those days were firhting men, and we find notices of the young Columbus in an expedition against Naples while in the service of the good King Rene, Count of Provence, who, on one occasion, sent the young 
man to Tunis, to cut out a captured galley. It is not a little remarkable that on this occasion his men, like so many of his later crews, refused to obey his orders; and he was obliged, as more than once in later years, to deceive them as to his real course. The accounts of his early voyages are obscure and of doubtful accuracy. About 1470 he was wrecked in a sea-fight off Cape St Vincent, and reached the shores of Portugal on a plank. In Lisbon he married Filippa Moniz, a lady who had been connected with the convent of All Souls there; she was related to one Perestrello, an Italian navigator, who had governed Porto Santo, off Madeira, for the Portuguese king.

As early as 1474 he had conceived the design of reaching India by sailing westward; and in this intention he was encouraged by Toscanelli, a Florentine astronomer. In 1477, he tells 18 , he 'sailed 100 leagues beyond Thule,' probably to or beyond Iceland ( where he may have got some hint of the old Norse adventures in Vinland, q.v.); he seems also to have visited the Cape Verd Islands and Sierra Leone. Columbus soon after this began to seek a patron for his intended expedition. He applied once or more to King John II. of Portugal ; later by letters to Henry VII. of England; then to the rich and powerful dukes of Medina Sidonia and Medina Celi, in Spain, of whom the last named at length referred him to Isabella the Catholic, queen of Castile. His application to the queen was submitted to a body of jurors, most of them ecclesiastics, who reported adversely to the project of the Genoese mariner. Finally, through the intervention of Juan Perez de Marchena, a monk who had been the queen's confessor, he was brought in contact with their Catholic majesties, Ferdinand and Isabella. His plans and demands were once more rejected, but afterwards reconsidered; and finally, after seven years of alternate encouragement and repulse, his proposals were accepted by the monarchs, in the camp of Santa Fé, April 17, 1492. On Friday, August 3, 1492, Columbus, now an admiral, set sail from the bar of Saltes, an island near Palos, in command of the small ship Santa Maria, with 50 men, and attended by two little caravels, the Pinta and the Niñ $\alpha$, the whole squadron comprising only 120 adventurers. He first made the Canary Islands, whence, on the 6 th of September, he set sail westward. On the 13th a variation of the magnetic needle was observed, a circumstance which struck terror into the hearts of his followers. From this and various other causes he found it hard to keep up the courage and patience of his crews. On Friday, October 12, land was descried. There is no doubt that this first landfall, named San Salvador by Columbus, was one of the Bahama Islands; and the more general recent opinion would appear to be that it was what is now called Watling's Island; but this is not by any means certain. He then visited Cuba and Hayti, which he named Hispaniola or Little Spain, and where he planted a small colony of Spaniards. He set sail on his return with his two caravels (for his flagship had been wrecked), and after an exceedingly tempestuous voyßge, the Niña alone cast anchor in the Tagus. He re-entered the port of Palos, March 15, 1493. On the very same day the Pinta also, which had parted company from him more than a month before, entered the same port, having been driven out of her course to Bayonne. The voyagers brought back with them some gold, varions plants, birds, and land animals, and six natives of the West Indies. Columbus was received with the highest honours by the court, then at Barcelona, and was hailed as admiral of the sea and a grandee of Spain.

He sailed on his second voyage on the 25th of September, with three carracks and seventeen small caravels, and on the $\mathbf{3 d}$ of November sighted the island of Dominica in the West Indies. His remaining eareer presents one long series of failures, vexations, and miseries. After a succession of wretched quarrels with his associates, and a long and desperate illness in Hispaniola, he returned to Spain much dejected in 1496 . His third voyage, begun in 1498, resulted in the discovery of the South American mainland. In 1499 Columbus and his brother were sent home in irons by a newlyappointed royal governor; but the king and queen repudiated this action, and restored Columbus to favour. His last great voyage (1502-4), along the south side of the Gulf of Mexico, was accomplished in the midst of great hardships and in many distresses of body and mind. Spanish jealousy of the foreigner and of his well-earned honours worked against him on sea no less than at court. Columbus died at Valladolid, in Spain, May 20, 1506. He was buried at Valladolid; but in 1513 his remains were translated to Seville, whence in 1536, with those of his son Diego, they were removed to Santo Domingo, in Hispaniola. In 1796 they were, it is stated, transferred to the eathedral at Havana; but there is some reason to believe that by mistake it was the bones of Diego Colon, and not those of his father, which were so transferred. Anyhow, from Havana the outgoing Spaniards removed the 'remains' to Granada in 1899.

A man of ardent impulses and strongly poetical imagination, Columbus was hardly the stuff that leaders are made of ; consequently he failed to control the turbulent and adventurous spirits among his followers. Although an honestly and earnestly religious and truly conscientious. man, he was not seldom guilty of acts which subsequently brought him many compunctions of conscience. Irritable and impetuous, he was, nevertheless, magnanimous and benevolent. His conduct in the capture and sale of slaves, though justified by the jurists and divines of the time, was. indignantly condemned by the queen, and can only be explained by the desire of Columbus and the crown to obtain some revenue from his new discoveries, and by the expectation that while detained in slavery the natives might become christianised.

His brother BARTHolomew, who died in Cuba. in 1514, was a man of high character and excellent. abilities, and assisted Columbus effectively in his labours. - Another brother, Giacomo (called in Spain DrEGo), who also assisted him in his West Indian government, was a man of gentle and pacific disposition, but was no match for the turbulent. adventurers he attempted to control, - Christopher's eldest son, Diego (about 1480-1526), was the heir to his honours, merits, and misfortunes. The great discoverer left also a natural son, Don Fernando (1488-1539), who wrote an important Life of his father, preserved only in an Italian translation (published at Venice, 1571; Milan, 1614; and London, 1867). In 1578 the last legitimate descendant of Columbus in the male line died.

It is doubtful if any of the portraits of Columbus are authentic. Las Casas says: 'He had a figure that was above medium height, a countenance long and imposing, an aquiline nose, clear blue eyes, a light complexion tinged with red, beard and hair: blonde in youth, but early turned to white."

Among the biographies of Columbus the best in English are those of Irving (1831), St John (1850), Crompton. (1859), Helps (1868), Winsor, (1890), Elton (1892), Sir Clements Markham (1892). See also The Narrative and Critical History of America, edited by Winsor, vol. ii.; Harrisse, Colomb (Paris, 1884); Varaldo, Christoforo Colombo (1887 : The Select Letters of Columbus, edited by Major ( $2 \mathrm{~d}$ ed. London, 1870 ); the Jourmul of his first. voyage ed, by Markham (Hakluyt Soc. 1893); Stevens' Columbus's Book of Privileges (1894); and the monu- 
montal Spanish work by Asensio, published at Barcelona in 1891, in view of the 400th anniversary of the discovery of Ameries by Columbus, which was celebrated with enthusiaem at Huelva, Genon, Madrid, and Now York in $18: 92$.

Columella. I. Junius Moderatus, the most learned of Roman writers on practical agrienlture, was born at Gades, in Spain, and flourishert in the earlier part of the first century of the Christian era. For some time he resided in Syris, but lived chiefly at Rome, and died most probably at Tarentum. His grest work, De Re Rustica, in 12 books - the tenth upon gardening, written in dactylic hexameters

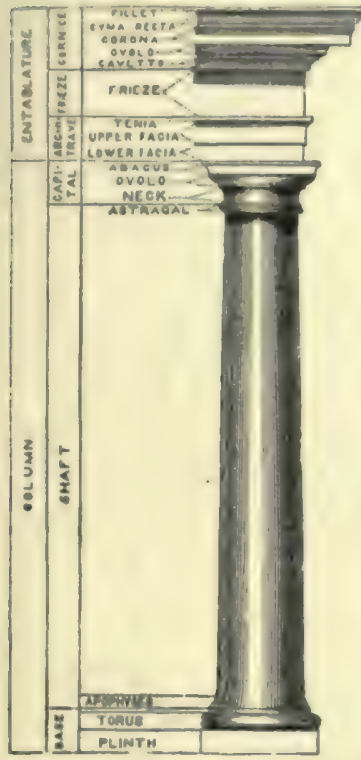

Fig. 1.-Tuscan Column. -is addressed to one Publins Silvinus, and treats of arable and pasture lands, culture of vines, olives, \&c., care of domestic animals, \&c., respectiveduties of masters and servants, \&c. A supplementary treatise relates to trees. This ancient 'Book of the Farm' is written in good Latin, and the information is copious, though not precise, and in some points of questionable accuracy. The best edition is that by Schneider in the Scriptores Rei Rustica (4 vols. Leip. 1794-97).

Column, a round pillar, usually provided with a base and capital, employed in architecture for the support of an Entablature (q.v.) or other superstructure. Fig. 1 shows in detail the names of the different parts of a column. Columns are doubtless derived from the primitive use of stems of trees in a similar position. Thus the early Egyptian columns are evident imitations of bundles of reeds bound together, or of the stems of palm-trees (figs. 2 and 3). A flat stone laid

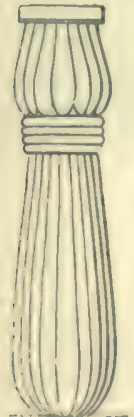

Fig. 2.
Fig. 3.

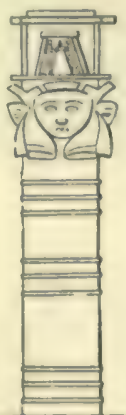
beneath to prevent the column from sinking, and another on the top to receive the lintel, would naturally suggest the base and capital. In the Classic 'orders' thecolumn played an important part, the proportions of all the different members being regulated by the diameter of the column. In Greek Doric the height of the column varied from 5 to 8 diameters, and the other orders from 8 to 10 diameters. Columns invariably taper from base to cap, with a slight swelling

in the centre called the entasis, and they were fre. quently carved with flutings or channels (see FLUT. ING). The most conspicuous distinction was the capital. The characteristics of the three Grecian orders, with the plain Doric capital, the Ionic volutes, the Corinthian leafage, will be seen from the accompanying cuts (figs. $4,5,6$ ), and will be further dealt with in Grecias Archrtвctcre; the Tusean column is also shown in fig. 1. The com. posite column retained the general proportions of the Ionic, with the Corinthian capital. For a Byzan. tine capital, see BYzAxTINe ARChтtectere. In Gothic, columns are also much nsed, but their variety is infinite, and not regulated by any fixed

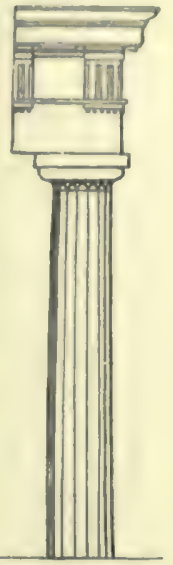

Fig. 4.-Doric.

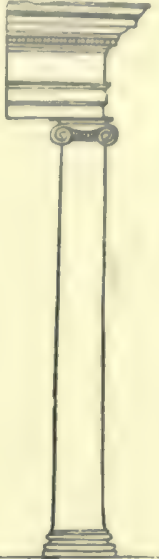

Fig. 5. -Ionic.

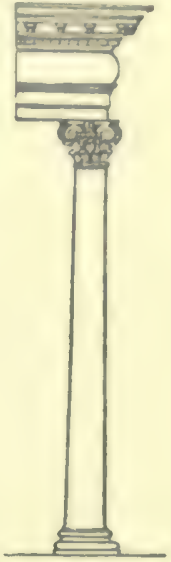

Fig. 6.-Corinthian. proportions like the Classic columns. The articles on the various styles of architecture show many forms of columns. A single column was sometimes erected to commemorate some remarkable event or great personage, such as Trajan's Column in Rome.

Column is a military formation several ranks in depth, and of any length of front, adopted for convenience of movement; line formation being only two ranks deep and suited for actual fighting in consequence of the wide front of fire that can be developed. Previous to the introduction of the breechloading rifle, and the consequent increase in the advantages of a wide front of fire, most European nations fought in column, and especially the French, who, under the first Napoleon, sometimes formed very heavy columns of infantry by ranging many battalions in line, one behind the other. British infantry always fought in line. A thin single rank formation is now universal for the leading troops in battle; but the supports move in column until obliged, by hostile fire, to deploy into line.

A British battalion in column has its companies each two deep, one behind the other, at distances equal to the front of one company, so that on wheeling into line to either flank, no gaps are left. In half-column these distances are halved, and in quarter-column they are reduced to six paces.

Cavalry may be formed in columns of four squadrons, or eight troops; or each squadron may be formed into a column of two troops, the wheeling distance in each case being preserved or reduced as for infantry. Artillery form in columns of batteries, half-batteries, or divisions-i.e. with a front of six, three, or two guns at wheeling distances, which are reduced to four yards in quarter-column.

Column of fours is the formation adopted for marching along a road and for mancuvres. Infantry are then four abreast, cavalry eight-i.e, each rank is four horses abreast. In column of sections (the cavalry route formation) the rear rank fours follow behind those of the front rank, instead of march. ing in line with them. Column of route for artillery and transport is one gun or wagon followed by another at four yards' distance, and so on.

In the United States, besides the column of fours, there is a double column of fours. Other columns 
are the column by platoons, by companies, the column by divisions (of two companies each), \&c.

Colure. See Armillary Sphere.

Colvin, Sidney, was born at Norwood, Surrey, 18th June 1845. He was educated at Trinity College, Cambridge, where in 1865 he gained the chancellor's medal for English verse, and graduating in 1867 as third classic, became a fellow of his college in 1869. He was elected Slade professor of Fine Art in the university of Cambridge in 1873, and director of the Fitzwilliam Museum in 1876, appointments which he resigned after succeeding G. W. Reid as keeper of the Department of Prints and Drawings in the British Museum in 1884. His numerous contributions to the periodicals, marked by accurate scholarship and poetic feeling, include a valuable series of papers on 'Albert Durer, his Teachers, his Rivals, and his Scholars' (published in the Portfolio for 1877) ; and his separate works are : Notes on the Exhibitions of the Royal Academy and old Water-colour Society (reprinted from the Globe, 1869), A Word for Germany by an English Republican (1870), Children in Italian and English Design (1872), Drawings by Flaxman (1876), and Landor (1881) and Keats (1886) in the 'English Men of Letters' series. He has also edited Selections from Landor (1884). As R. I. Stevenson's literary executor, he superintended the Edinburgh edition of his works (1894 et seq.), and edited his Samoan Letters (1895) and Letter's (2 vols. 1899).

Colza, a variety of cabbage. See RAPE.

Coma, a state of more or less profound insensibility allied to sleep. In coma the patient lies on his back, and is either simply insensible to external impressions, or has a confused and dull perception of them, with restlessness and low Delirium (q.v.). The former kind of coma occurs in apoplexy and epilepsy, and also in many other organic diseases of the brain and its membranes, of which, indeed, it may be said to be the natural termination. It is also seen in narcotic poisoning, and most characteristically in poisoning by Opium (q.v.). In the most fatal forms, the breathing is very slow and noisy (snoring or stertorous), accompanied with puffing of the cheeks; the pulse is at first strong and regular, afterwards feeble; there is often lividity; and the pupils are either contracted or excessively dilated, but in either case immovable, and totally insensible to light. In the second variety of coma, there is perpetual restless delirium, without enough of sensibility to lead to spontaneous and regular voluntary movements; the patient mutters slightly, and grasps feebly and without purpose at any object in his way; the pupils are commonly contracted, and the tongue is apt to be dry and brown. This kind of coma is mainly seen in many fevers, and forms one of the modes of their fatal termination. The treatment of coma is that of the disease or accident leading to it. Where there is a reasonable chance of recovery, the patient must be roused to consciousness as much as possible, either by frequent movements or strong impressions on the skin, or by the use of galvanism, so as to maintain the respiration (see OPIUM). Blistering of the head is also sometimes resorted to with good effect.

Comac'chio, a walled town of Italy, 30 miles ESE. of Ferrara, on an island in the east of the Valli di Comacchio, a shallow lagoon, about 90 miles in circumference, shut out from the Adriatic by $a$ belt of land, 3 miles wide. It is a bishop's see, and has several fine churches. There are large salt-works and extensive fisheries, the fry of the eel and mullet being admitted to the lagoon in spring by canals opening to the sea, and exit after the fish are grown being prevented by nets and sther contrivances, which are referred to both by
Tasso and Ariosto. Over 2,000,000 lb. of fish are caught annually. Pop. 7535.

Comanches, a tribe of American Indians, belonging to the Shoshone family, and roaming for the most part over the prairie-lands of Texas and Mexico. Splendid horsemen, warlike, and fond of plunder, they have until very recently been troublesome neighbours; but they are now among the most tractable and progressive of the Indians called 'blanket Indians." Honesty, truthfulness, selfrespect, and regard for chastity are marked characters of this tribe. They are to some extent addicted to intoxication, which they procure by means of a species of cactus which has narcotic qualities. Their numbers were estimated at 12,000 in 1847 ; now they are about 4000 .

Comat'ula. See Crinordea.

Comaya'gua, a city of Honduras, Central America, is situated in a fertile valley, 1935 feet above the sea, on the Rio Humuya, 190 miles $\mathbf{E}$. of Guatemala. Founded in 1540 , it has a handsome cathedral and a college, and before 1880 was capital of the state. Pop. about 10,000.

Comb (Saxon camb). This well-known toothed implement has been used in every age and by all peoples for dressing and keeping clean the hair. Combs are also used for fastening the hair when dressed, and as head ornaments. In early times the bodkin (acus), equivalent to the modern hair-pin, was employed for the latter purpose, but in medieval times elaborately ornamented combs, sometimes of precious metal, were used for ornamental hair fastening. An allusion to this practice we have in the ancient Scottish ballad of Sir Patrick Spens:

O lang, lang may their ladyes sit, Wi' their gowd kames in their hair.

Fig. 1 represents an ancient Irish long rack comb in the museum of the Royal Irish Academy.

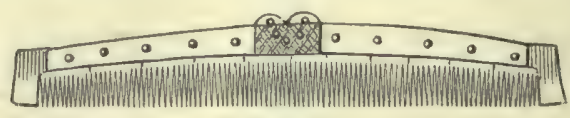

Fig. 1.

Fig. 2 is an example of an ancient Scottish double-edged comb of bone from the Broch of

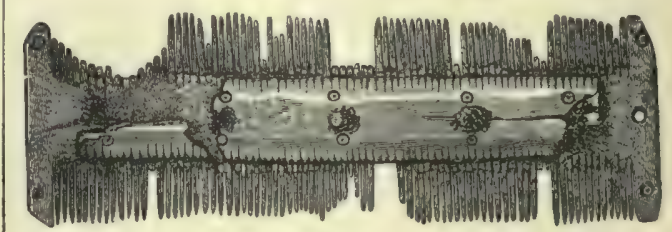

Fig. 2.

Burrian, Orkney, drawn to half the size of the original.

Combs of ivory or of boxwood have been frequently found in early Christian tombs, it being a common practice of antiquity to inclose in the sepulchre objects, especially those of the toilet, that had been used by the deceased. For a late instance, see the article on ST CUTHBERT. Combs also figure commonly in inventories of articles belonging to the medieval churches, and, being made use of by the priests prior to service, that they might approach the altar with the more decency, these instruments became in some sort sanctified by their employment.

Combs are made of horn, tortoiseshell, ivory, wood, bone, metal, india-rubber, and of a com- 
ponition ealled xylonite isee CrLLuloID). In fenling with horn, which is the prineipal comb. making material, the horns are eut into rectangular pieces in a manner which involves the least posible loss. These segments are damped and heated till they become soft, when they are opened out and preseed quite flat. The plates are next squared, smoothed, and trimmed preparatory to the tooth-cutting, which formerly was done with a stadda, or louble saw, having two blades of steel set parallel to each other, with a space between them equal to the thickness of the intended tooth. Tooth-entting is now done by small circular saws to which the plates are automatically applied, the horn moving the space of a tooth after each eut. In this way 70 or 80 teeth may be ent in an inch of ivory for fine-toothed combs. The teeth are then thinned, smoothed, and finished by means of thin wedge-shaped files. Saw-cutting is the only process available for bone, ivory, and wooden combs, and it is used for the finer kinds of horn combs also.

A rreat economy of material and time, however, is effected by making horn and tortoiseshell combs by the method of 'twinning' or parting. By saw. cutting, the material corresponding to the spaces between the teeth is of course wasted; by the vrocess of parting, this is made available to form

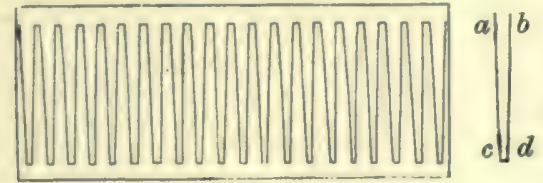

Fig. 3.

the teeth of a second comb. The annexed figure will show how this may be effected. The prepared horny plate is cut through by means of a stamping-cutter, consisting of two thin chisels inelined to each other, as $a c$ and $b d$, which represent their edges; between these, and connecting the ends, $c, d$, is a small eross-chisel. When this compound eutter descends with sufficient force upon the plate, it will cut one of the teeth shown in the figure. By simple machinery, the table carrying the plate is made to advance a dis. tance equal to the thickness of one tooth while the cutter is rising, and thus the successive cuts are made as represented. A slight pull is now sufficient to part the plate into two combs, the teeth of which only require filing and finishing.

India-rubber combs, now so extensively used, are manufactured by pressing the caoutchouc to the required form in moulds, and 'vulcanising' or combining it with sulphur afterwards. Xylonite combs are similarly made by moulding; but comb teeth of these materials are not so strong and elastic as those of horn and ivory.

Comb, a erest of skin, usually brightly coloured, found on the crown of the head in many birds, especially in the males. Like the analogous wattles, combs probably owe the perfecting of their development to Sexual Selection (q.v.).

Combaconum (Kumbhakonam), one of the oldest and most sacred cities of India, in the centre of the fertile Kaveri delta, 193 miles NE. of Madras, with Hindu temples, $n$ government college, \&c. Pop. (1881) 50,098; (1891) 54,307.

Combat, Tral by. See Batrle (Wager of).

Combatants, soldiers whose duty it is to fight both in attack and defence, are either cavalry, artillery, engineers, or infantry. Non-combatants, on the other hand, perform administrative duties, and fight only in self-defence, though soliliers and armed, as in the commiseariat, transport, ordnance store, medical, pay, and veterinary departments. bee Francs-TiRevirs.

In the navy, all seamen are combatants, but engineers, doctors, paymasters, and chaplains are non-combatants.

Combe, Avdrew, M.D., physicinn and phyniologist, was born in Kdinburgh, October 27, 1797. $\mathrm{He}$ studied medicine there and at Paris, and in 1823 commenced to practise in his native city. In 1836 he received the appointment of physician to the king of the Belgians, but his health failing, he returned to Scotland, where in 1838 he became one of the physicians to Queen Victoria. Mild, benevolent, and wise, Andrew Combe obtained the esteem and admiration of all who could appreciate purity and excellence of character. By patient adherence to physiological principles in the treatment of a delicate constitution, he combated a serious pulmonary disease for nearly thirty years at home and abroad. His death was probably hastened by exposure to the poisonous air of an emigrant ship, in which he made a voyage to America : he wrote to the Times on the urgent necessity of a law regulating the sanitary arrangements in emigrant vessels, and in 1849 an act provided a remedy for the evil. He died at Gorgie, near Edinburgh, August 9, 1847. His principal works are: Observations on Mental Derangement (1831), Principles of Physiology (1834; 15th ed. 1860), The Physiology of Digestion (1836; 10th ed. 1860), and The Management of Infuncy (1840 ; 10th ed. 1870). See his Life by his brother, George Combe (1850).

Combe, Grorar, phrenologist and moral philosopher, the son of a brewer, was born October 21, 1788, in Edinburgh. He became a Writer to the Signet in 1812, and continued to practise until 1837, when he resolved to devote himself to popularising his views on phrenology and education. As early as 1816, he had made the ac. quaintance of 'Spurzheim, and become a convert to his system of phrenology. The result was his Essays on Phrenology (1819), and his Elements of Phrenology (1824), which reached a ninth edition in 1862. But his most important production is The Constitution of Man (1828; 9th ed. 1879), in which he endeavours to demonstrate the essential harmony of the nature of man with the surrounding world, and the necessity of studying the laws of nature. Combe's doctrines were violently opposed, being considered by many as inimical to revealed religion. He numbered amongst his friends Cobden, Robert Chambers, and Miss Evans (George Elliot). Combe contributed largely to the Phrenological Journal (20 vols. 1824-47) and to Chambers's Journal and the Scotsman. He travelled and lectured in the United Kingdom, Germany, and America, and published Notes on the United States (1841). He died 14th Augnst 1858. Combe married, in 1833, Cecilia (17941868), daughter of the celebrated Mrs Siddons. Besides the works mentioned, he wrote Lectures on Popular Education (1833), Moral Philosophy (1840). Principles of Criminal Legislation (18.4), Phrenology applied to Painting und Simlpture (1855), The Currency Question (1855), The Rela. tion between Science and Religion (1857). His writings roused popular interest in the gcience of healthy living, but the phrenological works are obsolete. Combe's ideas on popular education were put into experimental shape in a secular school which he founded in Edinburgh in 1848, where the sciences were taught, including physiology and phrenology; but it was too much in advance of its time, and after a few years had to be abandoned. All his subjects, save phrenology, are now 
taught in every well-appointed board school. physiology lectureship was founded by the trustees of George and Andrew Combe. See the Life by C. Gibbon (1878); and Combe's views and articles on Education, collected by Jolly (1879).

Combe, William, author of Dr Syntax, was born at Bristol in 1741, and educated at Eton and Oxford, which he quitted without a degree. "God. son' (or natural son) of a rich London alderman, who died in 1762 , leaving him $£ 2150$, he led for some years the life of an adventurer, now keeping a princely style at the fashionable watering-places, anon a cook at Douai, and a common soldier. The last forty-three years of his life were passed mostly within the 'rules' of the King's Bench debtors' prison; but he died at Lambeth, 19th June 1823. In the Dictionary of National Biography (vol. xi., 1887 ) Professor Tout enumerates eighty-six works by Combe, published between 1774 and 1824 ; of these, the Three Tours of Dr Syntax (1812-21) alone are remembered, and even they owe much to Rowlandson's illustrations:

Combermere, Viscount (Stapleton Stapleton-Cotton), a British field-marshal, son of Sir Robert Salusbury Cotton, Bart., of Combermere Abbey, Cheshire, was born in 1772 at Llewenny Hall, Denbighshire. Educated at Westminster School, he entered the army in 1790, and in 1794 was made lieutenant-colonel of a new regiment of light dragoons, with whom he served in India for several years. In 1808 he proceeded, with the rank of major-general, to the Peninsula; in 1809 he succeeded to the baronetcy; and in 1810 he was appointed to the command of the whole allied cavalry. He was present at the battles of Talavera, Llerena, Salamanca, the Pyrenees, Orthez, and Toulouse, and was raised to the peerage in 1814 as Baron Combermere; although not at Waterloo, he had the command of the cavalry of the army of occupation in France. He was commander of the forces in the West Indies, 1817-20 ; commander-in-chief in Ireland, 1822-25; and commander of the forces in India, 1825-30, where he captured Bhartpur. Raised to the rank of viscount in 1827, he succeeded Wellington as Constable of the Tower in 1852, and was made a field-marshal in 1855. He died February 21, 1865. See his Correspondence (2 vols. 1866).

Combination. A combination to commit a crime is, in English law, an indictable Conspiracy (q.v.). A combination to commit an act which is injurious, immoral, or contrary to public policy, is in some but not in all cases held to amount to conspiracy. Combinations of workmen to raise the rate of wages were formerly unlawful; but the law was amended in this respect in 1825 , and now such combinations are freely permitted, provided they effect their purposes by lawful means. See Conspiracy and Trade UNions.-For the Laws of Combinations in Chemistry, see A Tomic Theory, Chemistry ; for Combinations in Mathematics, see Permutations and Combinations.

Combing, of wool, cotton, \&c. See CoTTon, WOOL, SPINNING.

Combretaceae, a tropical sub-order of Myrtifloræ, including about 240 species of trees and shrubs, mostly astringent.

Combustion is the term commonly applied to those chemical processes which are accompanied in a marked degree by the production of heat and light. The most familiar of such processes are those in which oxygen of the atmosphere combines chemically with the constituents of what are ordinarily spoken of as combustible substances, such as wood, coal, fats, oils, \&ce. Chemical com. bination is, as a rule, accompanied by the evolution of heat and frequently of light (see CHEMISTRY); but every case of chemical combination is not called combustion, because in many cases the quantity of heat evolved is inconsiderable.

When we speak of the combustion of, for instance, coal or wood, we mean the chemical process which consists, in general terms, in the combination of the oxygen of the air with the carbon and hydrogen which constitute the greater part of the combustible portion of either of these substances, and in the production of carbonic acid and water. Many instances are known to chemists in which the oxygen required for a combustion is not derived directly from the atmosphere, but from some oxidising (or oxygen-yielding) agent, and frequently the place of the oxygen may be alto. gether taken by some other element, as, for instance, when metals, such as antimony in powder, burn in chlorine.

The combustion of every combustible substance is accompanied by the evolution of a quite definite quantity of heat, which is invariable for each substance, whether the combustion takes place rapidly or slowly. A piece of phosphorus, for instance, as is well known, glows in the dark. This is a process of very slow combustion, and is never accompanied by much rise of temperature. When moderately heated in air, a piece of phosphorus bursts into flame, and the combustion is rapid and is accompanied by a considerable rise of temperature; whilst if the phosphorus be burned in pure oxygen, the combustion is an extremely brilliant spectacle, and a high temperature is attained. In each case the actual quantity of heat given out is identical for the same weight of phosphorus, but the time occupied by the combustion varies, and consequently the temperature at any given instant must also vary.

The quantities of heat given out by the combustion of the same weights of different substances vary greatly. The measurement of quantities of heat produced by combustion and in other ways is called calorimetry (see HEAT).

The name combustion is applied to a particular process in the analysis of organic compounds. See (under Analysis) ORganic ANALYsIS. See also SPONTANEOUS Combustion.

\section{Comédie Francaise. See Thúâtre Fran.} ÇAIS.

\section{Comedy. See Drama.}

Comenius, John Amos (properly Komenski), a distinguished educational reformer of the 17th century, was born 28th March 1592, in Moravia, either at Comna or at Nivnitz. His parents belonged to the Moravian Brethren. He studied at Herborn (1612), and then at Heidelberg, becarne rector of the Moravian school of Prerau (1614-16), and minister at Fulnek, but lost all his property and library in 1621, when that town was taken by the Imperialists. He became a wanderer, and settled at Lissa, Poland. Here he worked out his new theory and method of education, wrote his Didactica Magna, and was chosen bishop of the Moravian Brethren in 1632. In 1631 he published his Janua Linguarum Reserata, which was translated into many European, and even into some oriental languages, There is a trilingual edition, with woodcuts, in the Advocates' Library, Edinburgh. In this work he points out a method of learning languages new at that time, which has been called the intuitive or perceptive system, in which the pupils were taught by a series of lessons on subjects easily understood or appreciable by the senses - such as natural history, the sciences, different trades and professions, \&c. The Vestibulum, an introduction to the same, appeared in 1633. Comenius also published about the same time the Ratio Disciplince Ordinisque 
Ecelesice in Unitate Fratrum Bohemorum (1632; republished 1702); and his Ponsophice Prodromus (1639), un attempt at a complete stutement of the circle of knowledge. In 1641 Comenius was invited to England by parliament, through the philanthropiat Hartlieb, to assist in reforming the system of public instruction; but as the bresking out of the Civil War prevented the execution of this design, he went to Sweden (1642). There he was patronised by Oxenstiern, who gave him a commission to draw up 凡 plan for the organisation of schools in Sweden; and this he completed at Elbing, four years afterwarls. He alvo put to press (1643) a treatise on Pansophia. He returned to his Polish home at Lissa in 1648, and elaborated his work there. $\mathrm{He}$ next went $(1650)$ to Saros-Patak, Hungary, for a similar purpose. Here he composed his celebrated Orbis Sensualium Pictus, or The Visible World (Nurem. 1658), the first picture-book for children, which has been often reprinted and imitated. Finally, he settled in Amsterdam, where he published several other works. He died at Naarden on the 15th November 1671. Bacon's speculations sppear to have stirred the imagination of Comenius to the conception of universal and systematised learning, to which he gave the name of Pansophia or Encyclopredia.

His educational and pansophic works were pub. lished at Amsterdam (4 vols. 1657), and dedicated to the city of Amsterdam in recognition of his hos. pitable treatment there. In education he was a realist; he was also fervently evangelical, and his whole system was intended to lead up to know. ledge, virtue, and piety. Late in life a mystical tenciency was apparent in his works. Whatever may be thought of his educational system, he first fully developed educational method, made important reforms in the teaching of languages, and introduced into schools the study of Nature. See Laurie's Comenius, his Life nnd Work (1881), a German Life by Kracsala (1892), and Keatinge's translation of The Great Didactic (1896).

Comet. The word comet is derived from the Greek korme, ' hair,' a title which had its origin in the hairy appearance often exhibited by the haze or luminous vapour, the presence of which is at first sight the most striking characteristic of the celestial bodies called by this name. The general features of a comet are-a definite point or nucleus, n nebulous light surrounding the nucleus, and a luminous train preceding or following the nucleus. Anciently, when the train preceded the nucleusas is the case when a comet has passed its perihelion, and recedes from the sun-it was called the beard, being only termed the tail when seen follow. ing the nucleus as the sun is approached. This distinction has disappeared from afl modern astronomical works, and the name tail is given to the appendage, whatever its apparent position. Neither the tail nor the nucleus is now considered an essential cometary element, but all bodies visilsle in interplanetary space, which describe orbits round the sun of an extremely elongated form, are classed as comets. There are several plain points of difference between comets and planets. The planets move all in the same firection, from west to east, which is astronomically ealled 'direct motion;' but the movements of comets are often from east to west, or retrograde. The orbits of all the planets are confined to a zone of no great breadth on either side of the ecliptic; but the paths of comets eut the ecliptic in every direction, some being even perpendicular to it. The orbits of all the planets are nearly circular; or, more properly speaking, are ellipses of very sniall eccentricity. The orbits of comets, on the other hand, present every variety of eccentricity, some of them being ellipses or elongated closed orbits of various degrees of elongation; others, hyperbolas; while the majority lave a form of orbit not differing sensibly from the parabola, which is the limitug form of curve to which ixsth the ellipse and hyperbola approximate under given conditions.

Let $p$ be the point of perihelion passage of $\mathrm{a}$ comet, and let the direction of its motion be in the direction indicated by the arrow. There in a certain velocity of motion at this point which would give the orbit the form of a parabola, $p a^{3}$, the direction of motion always tending to parallel. ism with the straight line through ps. Any

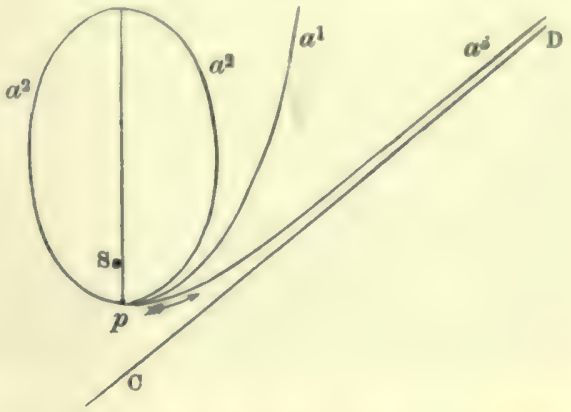

velocity less than this would cause it to describe a closed curve, $p a^{2} a^{2}$, any greater velocity would cause it to describe the hyperbola, $p a^{3}$, in which case it would approximate to the direction of the straight line, CD, and would never return. This would he the case if there were no disturbing force to interfere with the sun's attraction; and conversely, comets approaching the sun along the various paths above described would pass the perihelion with the various velocities above indieated. Any attraction, however, of an extraneous body interfering with the attraction of the sun might change the orbit from the ellipse to the hyperbola, and vice vers $\hat{A}$, or from the parabola to either. As, however, there is only one parabola corresponding to infinite sets of ellipses and hyperbolas, an interfering cause is not likely to change the orbit from an ellipse or hyperbola to the parabolic form.

There are twenty known periodical comets, eleven of which have been observed at more than one perihelion passage. These latter have periods in vears as follows: Encke's, 3.3 ; Winnecke's, 5.6 ; Bronsen's, 5.5; Tempel's I, 6; D'Arrest's, 6.4 ; Biela's, 6.6 ; Faye's, $7 \cdot 4$; Tuttle's, 13.8 ; Halley's, 76 ; Tempel's II, $5 \cdot 2$; Swift's, $5 \cdot 5$.

The orbits of forty-three comets appear to be ellipses. These are probably periodical. The paths of about two hundred cannot be distingnished from parabolas. These are passibly periodical, as the ellipse, when very eccentric, cannot near perihelion be distinguished from a parabola. Only six or seven have orbits possibly hyperbolic.

Elliptic comets in a large majority move directly -i.e. from west to east. Parabolic comets usually move in the contrary direction. But, on the whole, there is no general tendency in these bodies to move either way. Periodic comets have orbits but little inclined to the ecliptic; but, on the whole, cometary orbits show a tendency to gather round a plane inclined $50^{\circ}$ to the ecliptic. The perihelia gather about two opposite regions, in longitude $60^{\circ}$ to $120^{\circ}$, and $240^{\circ}$ to $300^{\circ}$. The nodes of the orbits gather also about two regions, not, however, directly opposite.

The discovery that comets are celestial bodies, extraneous to our atmosphere, is due to Tycho Brahé, who measured the parallax of the comet 
of 1557. Newton succeeded in demonstrating that they are guided in their movements by the same principle which controls the planets in their orbits; and Halley was the first, by determining the parabolic elements of a number of comets from the recorded observations, to identify the comet of 1682 with one which had been observed in 1607 and the observations recorded by Kepler and Longomontanus, and also with a comet observed in 1531 by Apian, at Ingoldstadt, and thus confidently to predict the return at the end of 1758 or beginning of 1759 , of 8 comet which would have the same parabolic elements. These parabolic elements are elements of a parabola nearly coincident with the elongated elliptic orbit of the comet. They are : (1) The inclination. (2) The longitude of the node. These two determine the plane of the orbit. (3) The longitude of the perihelion, or point of nearest approach to the sun. (4) The perihelion distance, or nearness of approacb to the sun. (5) The time of perihelion passage. (6) The direction of motion, whether direet or retrograde.

To determine these parabolic elements, three observations of the comet are sufficient; and by a table of such elements deduced from the recorded observations, it is possible at once to ascertain whether any newly observed comet is identical with any that have been previously observed. To predict, however, with accuracy the time of the return of a comet, a much more elaborate calculation must be made of the orbit, taking into account the perturbations of the planets to whose influence it is subject. This diffieult problem was solved, in the case of Halley's comet, by the joint work of Laland, Madame Lepante, and Clairaut, who announced, in November 1758 , just as astronomers began to look out for the return of the comet, that it would take 618 days more to return to the perihelion than on the preceding revolution. The peribelion passage was fixed about the middle of April 1759 ; but Clairaut distinctly forewarned the world that, being pressed for time, he had neglected small values, which collectively might amount to about a month in the seventy-six years. The comet passed the perihelion on the 12th March 1759 , exactly a month before the time aunounced, but within the assigned limits of divergence from that date. The elements of its orbit proclaimed it to be the comet of the former periods by their similarity. For the next perihelion passage, the different calculations executed by MM. Damoiseau, Rosenberger, Lehmann, and De Pontécoulant, fixed respectively the $4 \mathrm{th}$, the $26 \mathrm{th}$, the $11 \mathrm{th}$, and the 13th November 1835. Subsequently, observations indicated the $16 \mathrm{th}$ - that is to say, a deviation of only three days from what turned out the most accurate calculation, and a deviation of twelve days from the most remote. We have adverted to the perihelion passages of this comet in 1531, $1607,1682,1759$, and 1835 . It is also now identified with a comet observed in 1456, and one in 1378 , recorded by Chinese observations. There are no sufficiently reliable European observations previous to 1456 , sut it is conjectured by Arago that this comet is the same with the comet of 1305 ; that of 1230; a comet mentioned in 1006 by Hali Ben Rodoan ; that of 885 ; finally, a comet seen in the year 52 before our era.

This account of Halley's comet has been given at length to illustrate the principles on which the calculations are made. A simple method, due to Albers, enables the elements of cometary orbits to be calculated in a comparatively short time, and almost all comets discovered have now their paths roughly determined soon after they become visible.

There are two other periodical comets of peculiar interest: (1) That of Encke, with a short period of 1204 days. Its orbit does not extend so far as the orbit of Jupiter, and a slight acceleration in its periodic times of return was regarded until lately as suggesting the possibility of the space, within our solar system at least, being occupied by a resisting medium, though of extreme rarity. (2) That of Biela or Gambart, having a period of six years and three-quarters. During the visit of this comet in 1846, it was seen first at New Haven, U.S., by Messrs Herrick and Bradley, on December 29,1845 , in the act of separating into two distinct comets, which kept moving side by side till they disappeared. On the return of the comet in the autumn of 1852, the distance between the two nuclei had much increased. Since then, although repeatedly due, it has not again been seen.

The celebrated comet of 1680, which furnished Newton with the occasion for proving that comets revolve around the sun in conic sections, and that, consequently, they are retained in their orbits by the same force as that which regulates the movements of the planets, appears to have been about the most remarkable for brilliancy of any of which we have authentic accounts. This comet is supposed to be identical with the one that appeared about the time of Cæasar's death (44 B.C.), with that which was seen in the reign of Justinian in the year 531, and with another in the year 1106, in the reign of Henry II., the period of revolution, according to the orbit calculated for it by Whiston, being about 575 years. There is, however, some doubt among astronomers as to the real form of its orbit, the one assigned to it by Encke giving it a period of 8813 years.

This comet approached nearer to the sun than any known, ex. cept that of 1843 . The conmet of 1680 approached the sun within the $163 \mathrm{~d}$ of the semi-diameter of the earth's orbit. The annexed diagram shows a part of its path; the same diagram shows the direction of the tail.

In the first half of the 19th century, the comets chiefly notable are those of 1811 and 1843. The former was a most brilliant object for many weeks in the northern heavens. It is periodic, though travelling at aphelion to the enormous distance from the sun of $40,121,000,000$ miles. The latter was also remarkable for its brilliance, but chiefly for its very near approach to the sun, passing so near that a trifling change in its direction of approach would have caused a collision. Not more than 32,000 miles separated their surfaces when nearest. Its tail also was enormous, reaching in length $200,000,000$ miles. Since 1850 many brilliant comets are recorded: Donati's in 1858 ; and the great comet of 1861, through the tail of which our earth passed on June 30th of that year, 
with searcely a sign observable of the passage; also Coggia's comet in 1874, remarkable for the series of envelopes of luminous matter which seemed to combine to form its tail. The great comet of 1880 astonished astronomers by follow. ing the same track as that of 1843, slnuost grazing the sun. That of 1881 iii followed the track of that of 1807 , for a return of which it was at first mistaken. These two examples demonstrated that in some cases several comets travel on the same orbit, at great distances, however, from one another. The comet 1881 iii was the first anceess. fully photographed, Janssen obtaining a picture including $2 x^{\circ}$, and Dr Henry Draper of New York one including $10^{\circ}$, of its tail. Dr Huggins and Dr Draper were also both successful in photographing its spectrum, with results confirming what eye observations already had revealed. Dr Schaberle at Ann Arbor, Michigan, discovered another bright comet, the fourth for the year 1881, which for a time accompanied 1881 iii, both being in the northern heavens together. At Dudley Observatory, U.S., a comparatively small comet was discovered soon after by $\mathrm{Mr}$ Wells, remarkable as the first in whose spectrum the sodium line was seen. In 1882 the surprise of 1880 was repeated. Another bright comet appeared in September, following the tracks of the 1843 and 1880 comets, making the third in an orbital procession in space. It was seen in New Zealand on September 3, at the Cape of Good Hope on September 8, and at Rio de Janeiro on the lith. Mr Common at London had been seeking for a short time to eatch a bright comet near the sun in the daytime. Independently, on September 17, he discovered this one, close to and rapidly nearing the sun. Clouds prevented him from seeing the passage, but it was observed at the Cape of Good Hope by Messis Finlay and Elkin, who were watehing at the time. Passing in front of the sun, it disappeared from view, overpowered by the solar brilliance, to reappear shortly passing off the other edge of the disc. All next day it was clearly seen, only surpassed in brillianey by the sun itself. Though it had passed so elose to the sun, it experienced no retardation of apeed, proving that very near the solar surface there can be no resisting medium of density to affect such $\mathrm{a}$ body. It was followed with the telescope to a distance from the earth of $470,000,000$ miles. This long observation enabled its period to be well ascertained as about 700 years. It exhibited in a marked degree a ten dency to disruption. 'Space appeared,' says Miss Clerke, "to be strewn with the filmy debris of this extraordinary body all along the track of its retreat from the sun.' Its tails corresponded to types 1 and 2 (see post), and there was a vast outburst of luminous matter in October towards the sun, having a diameter of $4,000,000$ miles. Its spectrum showed the sodium line in addition to the usual cometary bands. The year 1883 was barren in cometary results; 1884 saw three new comets discovereil respectively in Tennessee, Australin, and Europe by Barnard, Ross, and Wolf. In 1885, on the $27 \mathrm{tl}$ November, there was a grand display of the meteor into which Biela's comet is now generally considered to have broken up; 50 to 60 a minute being recorded. Brooks, of Phelps, New York, discovered a comet on August 31 in that yenr. But in the nexi year (1886), within two months, three comets

rewarded thi diligent observer, a record equalled in 1887 by Barnard, of Nashville, Tenneanee. In 1868 comets were discovered by Bawerthal on February 18, and by Brooks, New York, on August 7. The returns of Encke's comet and of Fave's comet also marked that year, as they again did the year 1805, in which De Vico's comet was seen for the finst time since 1844. Seven new comets were seen for the first time between Nov. 1895 and Nov. 1896.

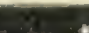


sweep them out into space with enormous rapidity, producing the splendid phenomena of the tail. The researches of Olbers, Bessel, Norton of Yale College, U.S., C. F. Pope, Zöllner, and especially Professor Bredichin, late of Moscow Observatory, have gone far to establish the existence of this force, and to identify it with electric repulsion. Professor Bredichin has divided comets' tails into three classes, those of hydrogen, of hydrocarbons, and of iron, due respectively to a repellent force (1) of ' 12 times solar gravity, (2) equal to it, and $(3) \frac{1}{6}$ of it. "The first material and force give straight, the second slightly curved, and the third strongly curved tails. The comet, $1886 \mathrm{f}$, showed three tails, one corresponding to each of these types. Observation and calculation have verified these conclusions as to the forces, and forms of tails, but not yet as to the electric nature of the forces. The light of comets is mainly due to electric discharges; a part, however, is reflected solar light, and a part perhaps due to incandescence. The tenuity of comets' tails is inconceivable to us, stars, which the slightest fog would conceal, shining clearly through a thickness of millions of miles of their material. Hence, although so great a display is caused by the matter swept away from the comet at perihelion, it loses but little in apparent bulk, though in the course of centuries the loss is abundantly perceptible. Some comets, Professor Kirkwood suggests, are probably asteroids, thrown out of their proper track by the disturbing force of Jupiter.

Comets have been alternately regarded with terror and with welcome in the popular mind. The :appearance of Halley's comet in 1456, just as the Turks had become masters of Constantinople, and threatened an advance into Europe, was regarded by Christendom with a superstitious dread, and to the Ave Maria was added the prayer: "Lord save 'us from the devil, the Turk, and the comet.' At Constantinople the occurrence of a lunar eclipse at the same time increased the portentousness of the event. The discoveries of science of the magnitude of the space filled by their bodies, and their prodigions velocity, together with the confessed impossibility of always predicting their approach, pro-duced fears of another kind, which have sometimes been, especially in France, extravagantly exaggerated in the public mind. The groundlessness of : such alarms, from the extreme improbability of collision with the nucleus, the innocuousness of a -contact with the extremely attenuated surrounding matter, and, possibly, to the greater part of the world, of a collision with the nucleus itself, will be sufficiently evident from what has been said above. It is certain that already, on many occasions, some of the attenuated vapour in the tail of comets must have come within the earth's attraction, and been absorbed in its atmosphere. Whether the effect is deleterious or salubrious, or whether it has any perceptible influence at all, is only matter of speculation. The salubrity of cometary influence is now .a popular idea; and the vintages of 1811 and 1858 were favourable seasons, whose produce has been advertised as the comet wines. It is scarcely worth while, however, to follow further speculation on these subjects, and it has been considered preferable to confine this article chiefly to the description of the general characteristics of comets, and the facts respecting them afforded by science.

Comfrey (Symphytum), a common palrearctic genus of Boraginacere, somewhat coarse perennial herbs, although occasionally to be seen in flowerborders. $S$. officinale (blue) and $S$. tuberosum (yellow) are frequent in shady and moist places. S. officinale was formerly much esteemed as a vulnerary. Its young leaves and its blanched shoots are still occasionally used as boiled vegetabies. The Prickly Comfrey ( $S$. asperrimum), a native of Siberia, 6-10 feet in height, has been recommended for feeding cattle. The stamens are covered in this genus by five awl-shaped processes pushed in from the outside of the corolla, and meeting so as to form a false bottom impassable to ants, flies, and other small honeythieves, but which can be thrust aside by the

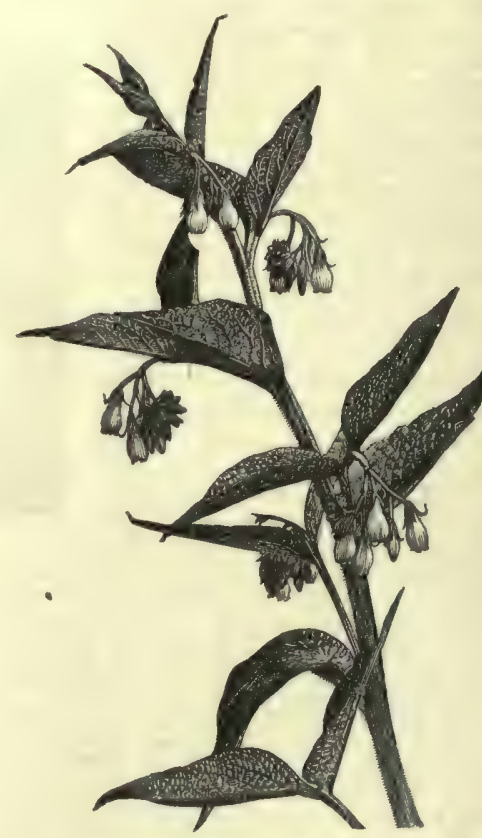

Comfrey ( Symphytum officinale).

humble-bees which alone fertilise the flower. Many bees, however (especially $B$. terrestris and one or two others), prefer to bite a hole in the side of the corolla below this cover, and the flowers may thus be seen to be visited both in the legitimate and illegitimate way. See, under FLowER, Fertilisation of the Flower, vol. iv. p. 692.

Comines, a town on the borders of Belgium and France, 15 miles SW. of Courtrai by rail, divided by the Lys into two parts, of which that on the left (pop. 4381 ) belongs to Belgium; the other, on the right (pop. 6355), to France. The town has some manufactures, and was the seat of the family of Comines.

Comines, Philippe DE, Sieur d'Argenton, a French statesman and historian, who was born about 1445-at Renescure, in the neighbourhood of Hazebrouck. His ancestors had been citizens of Ghent. He joined the court of Burgundy, and was sent by Charles the Bold on important missions to France, England, and Spain. In 1472 he forsook Charles and entered the service of Louis XI. of France. He was rewarded with the rich fief of Talmont, and became one of Louis's most trusted advisers. On the accession of Charles VIII. he was deprived of Talmont, and cast into prison for having incurred the displeasure of the regent, Anne of Beaujeu. He accompanied Charles VIII. on his Italian expedition, was present at the battle of Fornovo, and had an interview with Machiavelli in Florence. $\mathrm{He}$ held sundry places and pensions under Louis XII., and died in 1509. His Mémoires consist of seven books, six of which deal with the reign of Louis XI., while the seventh treats of Charles VIII.'s wars in Italy. They are the earliest example in 
French literature of the history as distinguished from the chronicle. Unlike the chroniclers, Conines cares little for the mere spectacle of courtly and military life. His sympathies are with the king against the nobles; his interest is centred in statecraft; he takes a keen delight in seeing the game of politics well played. His reflections on men and affairs are always dispas. sionate, and often pregnant and acute. His Lettres et Negotiations were published in 1867-68. The best edition of the Memoires is that by Chantelauze (Paris, 1881). The English translation by Danett (1596) was re-edited by Whibley in 1897.

Comi'so, a town of Sicily, 37 miles WSW. of Syracuse, with manufactures of soap and pottery. Cutton is largely grown here. Pop. 19,333.

Comitia were the legal or constitutional meet. ings of the Roman people, convened by a magistrate, msually for the purpose of putting a question to the vote. According to the constitution of the several gatherings, they were comitia curiata, comitia centuriata, or comitia tributa respectively. See RoME.

Comity of Nations-more frequently mentioned by its Latin equivalent, comitas gentiumis the international courtesy by which effect is given to the laws of one state within the territory and against the citizens of another state. 'In the silence of any positive rule,' says Story, 'affirming, or denying, or restraining the operation of foreign laws, courts of justice presume the tacit adoption of them by their. own government, unless they are repugnant to its policy or prejudicial to its interests.' See Story's Conflict of Laws; and INTERNATIONAL LAw.

Comma, in the mathematical study of sound, is a small interval, generally corresponding to the vibration-ratio $81: 80$, which occurs between the true pitches of two notes, which on the piano, organ, and other tempered instruments, are represented by one only. See TEMPERAMENT.

Commandant is the officer, of whatever rank, in command of a fortress or military post of any kind-e.g. a station on the lines of communication of an army. The title is also given to an officer commanding a larger body of troops than is proper to his rank, as captain-commandant, lieutenantcommandant, \&c., and to the senior lieutenantcolonel of a volunteer battalion in the British army, where there are two or more on its establishment. There are also commandants to most military schools.

Commander, in the British navy, is an officer next under a captain in rank, and serves either as second in command in a large ship, or in independ. ent command of a smaller vessel. In matters of etiquette, he ranks with a lieutenant-colonel in the army, but junior of that rank; and he bears the title of captain by courtesy. There were, in 1888, 160 commanilers employed, with pay of $\mathfrak{f l}$ per day ; while there were 69 on half-pay, but eligible for re-employınent, and $\mathbf{3 4 7}$ on retired pay; but the whole list of those employed, or eligilile for employment, is to be raised to 270 . Retirement is optional at the age of forty-five; and compulsory at fifty, or after five years without emplovment. In the United States navy, communders have a rank next below that of captain, and next above that of a lieutenant-commander, and rank with lieutenent-colonels in the army.

Commander-in-chief is the highest stafl appointment in the British army. After the denth of the Duke of Wellington in 1852, this title, which had been borne by him for many years, was allowed to lapse, and the administration of the army was placed under a general on the staff who was styled the general (or field-marshal, if of that rank) com- manding in clief. In 1887 the title of coumander. in-chief was revived; and in 1895 (on the resignation of the Duke of Cambridge) effect was given to the recommendations of the Hartington Commis. sion, by a more perfect organisation of our national defences under one supreme authority - though nom. inally since 1855 the commander-in-chief has been strictly subordinate to the Secretary of State for War. His office, technically called the Horse Guards, is the military department of the War Office (q.v.). At its head is the adjutant-general, and its several branches are presided over by the quartermaster-general, the military mecretary, the inspector-general of fortifications, the directors of artillery, of military intelligence, of the army medical department, and of military education, the chaplain-general, and the princijal veterinary surgeon. All promotions and military appointments are recommended by the commander-in-chief, those of great importance being supervised by the war minister, and, if necessary, discussed by the cabinet. He is responsible for recruiting opera tions, the technical education of officers and men, and everything connected with the efficiency, distribution, and mobilisation of the troops, together with the construction and armament of fortifications, He exercises an inspectionsl control over the men who are under the immediate command of the general officers commanding the various districts. See WoLSELEY.

There is also a local commander-in-chief in India, under whom all the forces there are placed, and in many of the colonies the governor bears this title. It would also be given to the officer in command of any large army engaged in active operations. The powers of these officers extend only to those troops that may be placed under them by orders from the commander-in-chief at the Horse Guards.

A naval commander-in-chief is the chief admiral at any port or station. In the United States the president is ex officio the commander-in-chief of the army and navy.

Commandery, the district under a commander, specially used in connection with the Templans (q.v.), the Hospitallers (q.v.), and other religious orders.

Commandite, Société en, or Partnership IN, an expression used for at least two cerituries in France, to express a partnership in which one may advance capital without taking part in the management of, or incurring further liability in connection with the business. The term 'sleeping partner' used in this country would nearly express the same idea, were it not for the attendant unlinited liabil. ity. The phrase is derived from the old meaning in the commercial nomenclature of France of the word commande, which was applied to the authority given to one person to transact business for another. The working partner had a commande from him who merely advanced capital. The term has acquired importance in political econoniy, hecause the law of France exempts the sleeping partners from responsibility beyond the amount they agree to be responsible for. On the other hand, by the law of the United Kingdom, every member of a partnership is liable for all its debts; limitation of liability being only obtainable by incorporation under the Companies Acts. Hence, in the discnssions about the question, whether it would be prudent to relax this law, and permit persons to invest money in trading companies without undergoing this responsibility, such companies were called 'partnerships in commandite." Proposals have from tinı to time been made in Britain to establish a system of limited partmerships intepentently of the Companies Aets. The Aet 28 and 29 Viet. chap. 86, 5th July 1865 , permits loans to trading firms in consideration of a 
share of the profits, without involving partnership liability. The contract must be in writing, and the lender ranks in a bankruptcy after other creditors.

Commelyna'ceae, an order of petaloid monocotyledons, all herbaceous, chiefly neotropical, of which a few species are cultivated in herbaceous borders on account of the beauty of their flowers, notably spiderwort, or Tradescantia (Virginica, and other species), Commelyna coelestis, \&c. Others are grown in hothouses, notably the peculiar Cochliostemma.

Commemoration, or ENCENIA, the great festival of the Oxford academic year, usually takes place on the third Wednesday after Trinity Sunday. It is of very ancient date, public exercises and recitations having been held from time immemorial in honour of the Act, or period when Masters of Arts and Doctors complete their degrees. The proceedings consist of a Latin oration in honour of founders and benefactors; the presentation of the honorary degree of D.C.L. to strangers eminent in science, politics, \&c.; and the recitation of the Newdigate or English prize poem, the Latin prize poem, and the Latin and English prize essays. The more strictly academic and solemn portion of the proceedings was frequently wont to receive seanty attention from a great part of the audience; and the noisy humours of the gallery have often encroached on the stately periods of the public orator. In 1876 the undergraduates were removed from the special gallery they had hitherto occupied, and distributed amongst the general audience, which includes ladies and strangers as well as members of the university. "Commencement' is the corresponding festival at Cambridge, where, however, it is of less general observance.

Commendam, an ancient manner of holding ecclesiastical benefices. When a living fell vacant by the preferment of its holder, it was commended by the crown to the care of a clerk, usually a bishop in one of the poorer sees, to hold till a proper pastor was provided for it. Such a living was ealled an ecclesia commendata, and was said to be held in commendam. A commendam in ecclesiastical law may be defined as the power of receiving and retaining a benefice contrary to positive law, by supreme authority. Holdings in commendam were abolished in 1836. -COMMENDATORS, in Scotland, in Roman Catholic times, were stewards appointed to levy the fruits of a benefice during a vacancy. They were mere trustees; but gradually the pope assumed the power of appointing commendators for life, without any obligation to account. This abuse led in 1466 to a prohibition of all commendams except those granted by bishops for six months and under. See Аввот.

Commensalism (literally, 'at the same table'), the intimate, but never parasitic association of two different kinds of organisms, for the benefit of one, or very often of both. Of such advantageous partnerships there are so many different forms and degrees, that no precise jefinition of the term can be given. (1) Every one who has looked at shore animals must have observed how often molluse shells, for instance, are covered with sponges, hydroids, worm-tubes, acorn-shells, and the like. But this is a purely external association, and depends simply on the fact that the shells afford convenient anchorage for the free-swimming embryos. In many cases no great advantage can accrue on either side. The habit is comparable to that of vegetable epiphytes upon trees. This grade might be spoken of as mainly external and unadvantageous association. (2) In other cases, however, the association, though probably acci-
dental, brings its reward. When one sea-mat (Polyzoa) grows entangled with another of greater vigour, or when different kinds of polyps are similarly associated, and that is often, there may be distinct advantage to the weaker form, since without becoming a parasite it enjoys the privileges. of a messmate. Or the advantage may take another form, when the associate is carried about. by its bearer. Thus, Cirripedes are common upon whales, and have evidently an advantage both. in security and continual freshness of feedingground over those which adhere to fixed objects. This grade might be distinguished as that of fixed external associates with the advantage on one side. (3) It is, however, evident that if a crab be covered with acorn-shells, or polyps, or sponges, there is no longer a one-sided, but a mutual advantage. It is well for the sedentary growth to be carried about continually to new pastures; but it is well also for the erab to be masked. Covered with a rich growth, either vegetable or animal, the crabs must appear all innocence, and like walking-woods of Birnam, can steal unnoticed upon their victims. A gasteropod may be similarly masked by polyps, and doubtless gives and reaps similar advantages. This grade may be described as that of fixed associates with mutual advantage, to this extent, at least, that the weaker animals are borne about, and the bearers are masked. (4) But a higher stage of fixed association is sometimes exhibited, that, namely, where the partnership is deliberate, where the masked bearer is not passively benefited, but is an active accomplice. Probably the most striking case of such deliberate partnership is that referred to (and illustrated) under the article ANEMONE-viz. the habit which some hermit crabs have of bearing about seaanemones on the molluse shell which they inhabit, or even upon their claws. It would appear that in some cases the crustacean deliberately chooses its ally, induces it to fix itself on the shell or claw, and takes care not to leave it behind at the epochs of shell-changing. When deprived of its commensal, the crab is said to be restlessly ill at ease until another of the same species is fortheoming. Off some parts of the British coast, the beautiful sea-anemone (Adamsia palliata) is found enveloping the molluse home of a hermit crab (Eupagurus prideauxii). The use of the sea-anemone as a mask, and also as equivalent to a stinging organ, is obvious enough, while the hermit crab returns the benefit by carrying about the sea-anemone and giving it a share of the spoil. This grade may therefore be described as deliberate partnership with mutual advantage.

So far only fixed commensals have been spoken. of, but organisms may be constantly associated without being attached. Sometimes different. organisms, both plant and animal, are found in almost constant association without any obvious. connection obtaining between them. In many cases this companionship may be simply due to the fact that similar environmental conditions suit. both. Small fishes are sometimes found as free commensals within sea-anemones; the Remora (q.v.) attaches itself temporarily to sharks and other fishes; the little crabs (Pinnotheres, \&c.). found living freely inside various bivalves are probably true messmates, and similar habitual partnership is very common among crustaceans; a brittle. star is known to live as a free messmate on a. crinoid; many worm-types are found in constant though free associations with other animals; and the same habit is exhibited by some Coelenterates and Protozoa. Many of the insects which frequent plants are in strict sense commensals, feeding not on their hosts, but on other visitors, \&c. In some cases they form an actual bodyguard.

Commensalism must, of course, be distinguished from Parasitism (q.v.), whether external or internal, 
for in parasitism the one organism more or less directly preys upon the other. Yet it is evident that a commensal may readily degenerate into a parasite. Commensalism must also be distin. guished from that most intimute kind of partner. ship known as Symbionis (ๆ.v.), and illustrated by the union of alyoid and fungoid organisms to form a lichen, or by the oceurrence of alyw as constant internal associates of Radiolarians, some Coulenterates, and some worm-types.

As part of the animate environment, commensals have influenced one another in very direct ways. See Environarex: P. J. van Beneden's Animal Parasites and Messmates (1876); and Semper's Animal Life (1881).

Commensurable. Two quantities or numbers are said to be commensurable which are of the same kind, and each of which contains a third quantity or number a certain number of times without remainder; or when both can be measured exactly by the same unit, however small.

Commentrey, a town in the French depart. ment of Allier, 211 miles $\mathrm{S}$. of Paris by rail, is close to a great coal-field, and owes its rise to coal and iron works, Pop. 9316.

Commerce, Chamber of. See Chamber of Commerce, Mercantile Law. - For the so-called Commercial System, see MERCANTILE SYSTEM.

Commercial Travellers. A commercial traveller ('C. T.') is a person whose occupation is to transact business as the aceredited travelling representative of a trading house to other trading houses. A further qualification is insisted upon by benevolent institutions connected with the body, in the rule that a traveller must have been ' on the road' for two years before he can claim benefit. A 'townsman' or 'town traveller' is one who confines his efforts to a single town. In thirty years a fourfold increase in the nnmber of commercial travellers is shown by the annexed sta tistics: In 1851 there were in England, 8378; in scotland, 1017; in Ireland, 339; total, 9734. In 1881 there were in England, 35,570; in Scotland, 4793 ; in Ireland, 1558 ; total, 41,921. In the latter year, 878 of the total number were European foreigners; but at the present there is doubtless a much larger proportion. The death-rate of commercial travellers in 1881, though it shows a considerable improvement on that of 1871, was high (34 per 1000), or nearly 50 per cent above that of persons engaged in agricultural pursuits. A very large proportion of deaths was due to diseases caused by intemperance. To this terrible scourge must also be attributed the fact that the number of suiciles is higher in this than in any occupation save one. Happily, of late years a marked improvement is noticeable, owing to the spread of temperance principles and an increased number of temperance hotels.

Of the later half of the 18th century in Britain ' many districts remained completely excluded, so that foreign products never reached them at all,' and 'even at the beginning of the 19th century the Yorkshire yeoman was ignorant of sugar, potatoes, and cotton.' It has been the work of the commercial traveller to materially assist in altering this atnte of things, and to bring about 'equality of distribution of produce, and corre. :sponding equality of prices, and generally to promote that 'facility of exchange which is the very soul of industry.' Commercial travelling in the specific sense is not an old institution. The 'commercial traveller,' 'bagman,' or 'rider' (in the United States, 'drummer') was the successor to the 'chapman' or travelling merchant, who carried with him not samples merely, but stock. Chaucer tells us that :
In Surrye whylom dwelte a cunpanye

Of chapmen riche, and therto made and trewe That wyde wher menten her spycerie.

Clothes of gold, and astins riche of hewe.

The application of steam to machinery, the conse. quent rise of the factory system, increased facilities in benking, and improved means of lncomotion, have made the commercial traveller an important factor in the commercial world. Within recent years a formidable competitor has entered the field in the person of the foreigner, whose superior education ard commercial training have hitherto placed the British commercial traveller at a disadvantage. A further development of commercial travelling is before $\mathrm{us}$; there is room especially for men possessing a thorough knowledge of foreign and colonial trade, and above all of modern languages.

There are several excellent institutions connected with the body, owing largely to the efforts of men like George Moore and George Stockdsle. The Commercial Travellens' Schools for destitute orphans and necessitous children were founded in 1845 : the school at Pinner accommodates 360 chil dren. The Commercial Travellers' Benevolent Institution was founded in 1849 for the relief of necessitons commercial travellers over the age of fifty-five years, being members, and for their widows. The relief is given in the form of an annuity of $£ 50$ to members, and $£ 30$ to their widows. The Commercial Travellen' Society of Scotland was founded in 1838 for the relief of memleers incapacitated by disease, accident, or infirmity, and for securing a payment at death. The British Commercial Travellers' Provident Society, like the last named, is based on the Friendly Societies Act. There is also a Commercial Travellers' Christian Association (1882) ; and the United Kingdom Com. mercial Travellers' Association (1883) has done good work in pushing forward hotel and railway reforms, and in promoting social intercourse among commercial travellers. A newspaper, On the Road, devoted entirely to the interests of commercial travellers, was established in 1883.

In the United States the number of commercial travellers has increased rapidly, till in 1890 it was computed that there were between 230,000 and 300,000 . Amongst their benevolent associations are the Commercial Travellers' Association of New York (2000 members); the North-western Travelling Men's Association of Chicago $(4000)$; one at St Louis (2100); an Order of Commercial Travellens, a secret society organised in 1888 ; also a Travellers' Protective Association (9000 members), for providing against overcharges by railroads and hotels, \&c. The organ of the travelling salesmen is The Merchant Traveller, published at Chicago.

Commination (Lat., "threatening'), the 'denouncing of God's anger and judgments against sinners," read in the Anglican Church on AshWednesday (q.v.). A solemn service, at which penitents were expelled from the church, after instructions and prayers for their amendment, appears to have been held on the first day of Lent irom a very early date, perhaps from the beginning of the 6th century ; but the commination oftice used in the Chureh of England is rather a continuation of the medieval practice of reciting the 'articles of the sentence of cursing,' which were at one time resul in the parish churches four times a year; only the opening exhortation to repentance was composed by the English Reformers. The present oftice is nearly the same as those found in the Sarum and York uses. The curses contrined in Deut. xxvii. are read as statements, not as prayers; and the congregation answer "Amen " to every sentence, as acknowledying the truth of what has heen stated, rather than as confirming the curse. The American 
Prayer-book omits this office, but several prayers taken from it are appointed to be said on AshWednesday, at the end of the litany.

Commissariat is a name for the organised system whereby armies are provided with food, forage, fuel, quarters, and all other necessaries except warlike stores. In feudal times, soldiers were mainly dependent for food on their lords; but they lived very much by plunder. During the wars of the Crusades, the commissariat was so utterly neglected that thousands died of starvation.

The first germ of the modern British commissariat appeared in the office of proviant-master in the time of Queen Elizabeth. Under Charles I., commissaries were stationed in the different counties. Marlborough's troops were supplied by contract; he received a percentage, and peculation was very common. After many changes during the 18th century, a commissary-general was appointed in 1793 to superintend all contracts for food and forage. The dire experience of the Crimean war showed how inadequate the small existing establishment was to bear the strain of a campaign. In 1858 and 1859 the commissariat was newly organised; and remained, until 1870 , a War-office department, under a commissary-general-in-chief.

In 1870 it was merged with other supply departments in the great 'Control Department,' which, under the Surveyor-general of the Ordnance, performed all the civil administrative duties of the army, until its abolition in 1875. The 'Commissariat and 'Transport Department' was then formed, and administered by the Director of Supplies, an officer on the staff of the Surveyor-general at the War Office, the supply of warlike stores being placed under the Ordnance Store Department (q.v.). The reorganisation of the War Office in February 1888, while leaving the duties of these two departments unaltered, has placed them under the Quartermastergeneral. In India this has always been the case so far as the commissariat is concerned, which is officered by appointments from the combatant branch. The present British staff consists of 2 commissaries-general ranking as major-general, 10 deputy-commissaries-general with honorary rank of colonel, 62 assistant and 111 deputy-assistant commissaries-general with honorary rank of major and captain respectively, 40 quartermasters (honorary lieutenants), 3 adjutants, 1 paymaster, and 2 riding-masters. Their pay varies from 98. 6d. a day in the lowest ranks to $£ 1500$ a year in the highest. There are 37 companies, having each a peace establishment of 2 officers, 123 of other ranks, 63 horses, and 12 wagons.

The war establishment laid down in 1888 for a commissariat and transport company with an infantry brigade is 5 officers, 192 non-commissioned officers and men, and 234 horses, and if with the headquarters of a division of infantry, 7 officers, 157 of other ranks, and 184 horses. The establishment for an Army Corps (q.v.) in the field, with three days' rations for the men, and two days forage for the horses, is 60 officers, 2494 non-commissioned officers and men, 2796 horses, and 438 carriages. The wagons of the Army Medical and Ordnance Store Departments are horsed by the Transport Department. Camp equipment, fuel, forage, food, \&c. are supplied by the commissariat, the actual cooking being done by the regimental cooks. Clothing is supplied by the government factory at Pimlico, and, like all other stores, brought to the army, if in the field, by the transport branch of this very important department.

The Indian commissariat is, as indicated above, a local department, varying in strength with the requirements of the moment. There is also a small local staff of 1 commissary, 3 deputies, and 1 assistant on the west coast of Africa.
In the United States the army commissariat is: administered by a commissary-general of subsistence, having the rank of brigadier-general ; five assistant commissary-generals, ranking as colonels. and lieutenant-colonels; eight commissioners of subsistence, ranking as majors, and twelve as captains. Their salaries are from $\$ 5500$ to $\$ 2000$.

Commissary, in general, is any one to whom the power and authority of another is committed. An ecclesiastical commissary is an officer of the bishop, who exercises spiritual jurisdiction in distant parts of the diocese. A military commissary is an officer charged with furnishing provisions and clothes to an army.

When the papal authority was abolished in Scotland, a supreme commissary court was established in Edinburgh in 1563, by a grant of Queen Mary. This court had jurisdiction in actions of divorce, declarators of marriage, nullity of marriage, and all actions which originally belonged to the bishops' ecclesiastical courts. Its powers were gradually conjoined with those of the Court of Session, and it was finally abolished in 1836, the small remains: of its once important jurisdiction being united in the sheriff of Edinburgh. See Alexander on Practice of the Commissary Courts in Scotland (1858), and Fraser on Husband and Wife.

Commission. As a commercial term, commission is sometimes taken to be synonymous with Brokerage, but there is a distinction. Brokerage is the percentage paid to a passive intermediary in a transaction, who incurs no responsibility; commission is the percentage paid to an active agent in a transaction, who usually does incur some pecuniary and always some moral responsibility.

A commission as a certificate of rank is granted. by the highest authority of a state. All military and naval commissions in Britain must be signed by the sovereign: but in the United States $a$ commission may be issued by a governor of a state as well as by the president of the republic, commissions in the volunteers (or militia) being generally granted by state governors. The appointment of justices of the peace in the United Kingdom is also made by $\mathrm{a}$ "commission of the peace,' issued under the great seal. The great. seal itself is in charge of a Lord-keeper, but is put. 'into commission' when a change of ministers is. taking place. This means that certain persons are appointed to exercise jointly, but without individual powers, the functions of the office. Another instance of the functions of a great public officer being delegated to others 'in commission' is that of the Lord High Admiral, who formerly had control of all naval affairs. This, however, is a permanent. commission, although commissioners of Lords of the Admiralty change with every change of the ministry.

An office in commission is an office in suspense. Yet, curiously enough, the phrase has a directly opposite meaning in naval affairs, for when a ship is ordered to be placed 'in commission,' it means that she shall be fully equipped and prepared for active service.

Permanent commissions are also constituted, not merely for the delegation of existing duties, but. also for the execution of duties with which no person had been previously charged. As instances we may take the Civil Service Commission in 1855 (see Civil Service); the Railway Commission, appointed in 1873 to carry out the act for the better regulation of railways passed in 1854, and to otherwise act as a sort of court of arbitration or appeal in disputes between railway companies; the Irish Land Commission, appointed to carry out some of the provisions regulating the land laws in Ireland; the Crofters Commission, appointed for five years from 1886 to fix fair rents for the Scotch. 


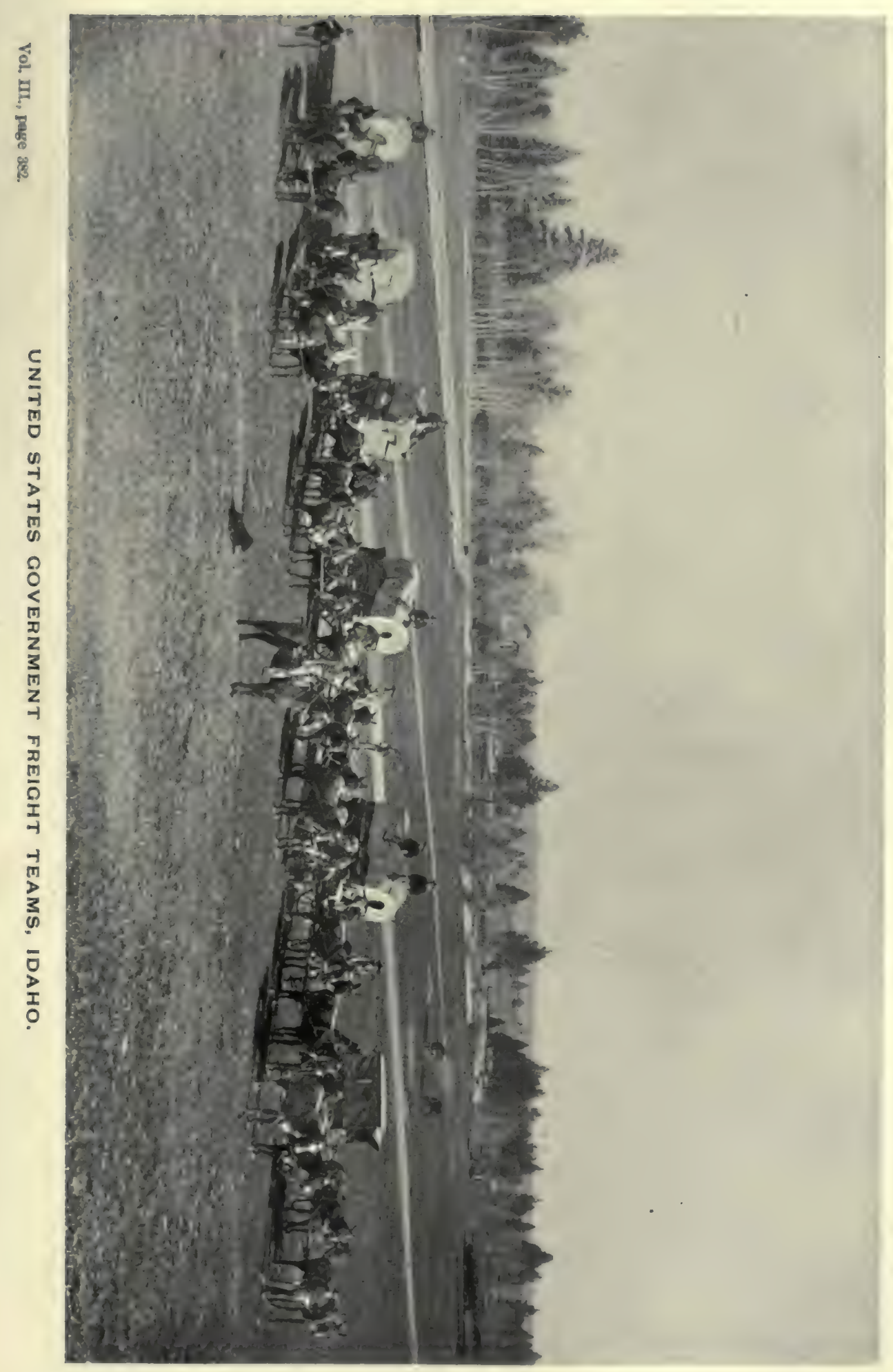



crofters. The members of these are nominated in terms of special acts of parliament.

Other permanent conmissions are the Charity Commission, ereated 1853 (of four memben, one of whom is unpaid), to examine into all the charities and the management of them, in England and Wales; the Commission for the management of the National Debt; the Ecclesiastical and Church Estates Commission: the Land Commission of England; the Public Works Loan Commission; the Thames Conservancy Commission; and the Commission for the adjustment of Cases under Income-tax Assessments. These are all hodies commissioned to execute certain specified functions, more or less administrative, and partaking to some extent of the character of public departments.

In law, a commission may be issued by mandate of a court to take evidence from parties residing abroad or incapacitated from apyearing in person. A Commission in Bankruptcy is issued for the purpose of taking charge of the effects of an insolvent for behoof of his creditors. A Commission in Lunacy is appointed by the Court of Chancery to inquire into the mental condition of an alleged lunatic whose property may be in question. There are now permanent commissioners in lunacy whose duties include visitation and supervision of asylums.

In governmental relations, commissions are some. times constituted where Britain exercises protectorate but has not formed complete colonial establishments, as in Cyprus, South Africa (see CAPE Colovy), New Guinea, and some islands of the western Pacific. The commission in such cases is a delegation, with certain limitations, of the authority of the crown. In India (q.v.) the administrative head of a province is sometimes called chief-commissioner (assisted by district commissioners), who is responsible to the viceroy of India. Sometimes commissions are international -i.e. composed of representatives of various nations for international purposes. A conspicuous example of such was the commission in 1871 on the Alabama question (see Alabama); more recent was the commission for Eastern Roumelia, appointed under the Treaty of Berlin of 1878 .

Again, a commission may take the form of a temporary embassy for certain specific purposes. The appointments are then made by the prime. minister and cabinet, as when Mr Gladstone was sent to the Ionian Islands in 1858, or Lord Dufferin to Egypt in 1883. Somewhat different in eharacter was the commission given to $\mathrm{Mr}$ Chamberlain in 1887 to proceed to America, to confer with delegates of Canada and the United States upon matters in dispute concerning the fisheries.

In its parliamentary sense, a commission may be either Special or Royal. In the former case it is appointed usually, and in the latter case invariably, in response to a motion in one or other of the Houses. A royal commission is appointed only by the crown; but a special commission may be appointed by a department of state. The expenses of a commission of this kind are usually defrayed by the parties requiring it, but those of a royal commission are included in the estimates for the enrrent year. The commissioners may be paid by fees regulated by government. When a commission sits in London, it has the power of authorising the payment of witnesses on the scale recognised in courts of law; but when a commission sits in the country, witnesses are not paid.

A royal commission is appointed by motion in parliament, and is issued by a royal warrant nominating certain 'trusty and well-beloved cousins and counsellors ' to undertake a specitied incuiry. Of such was the royal commission to inquire into the condition of the crofters (1882), which was a wholly different body from that appointed by act of parliament in 1886 to carry out certain legislative decreen. The former was one of inquiry; the latter, one of administration. The royal commissions appointed to inquire into the causes of the depression of trale (1886-87), and into the recent changes in the relative values of the precious metals (commonly called the Silver Commission), also in 1886, are among the most prominent of recent appointments of this kind.

When a royal commission is nominated by royal mandate, a secretary is appointed, and such clerical assistance as may be necessary is provided out of some of the departments. The commissioners are empowered to call and hear evidence (although not on oath), to examine documents, localities, \&c. The evidence is reported in extenso-question and answer duly numbered-and is submitted, along with the formal report, to the sovereign' and to parliament. The whole is then incorporated in a. blue-book. The multiplication of royal and special commissions has become rather a legislative nuisance and a financial burden. Royal commissions. always include members of the House of Lords or of the House of Commons, or of both.

The cost of parliamentary and royal commissions. varies much. In 1896-97 the Charity Commission cost $£ 42,869$ (a small decrease on the preceding year), the Civil Service Commission $£ 39,700$ (decrease). In 1888 the figures for all were:

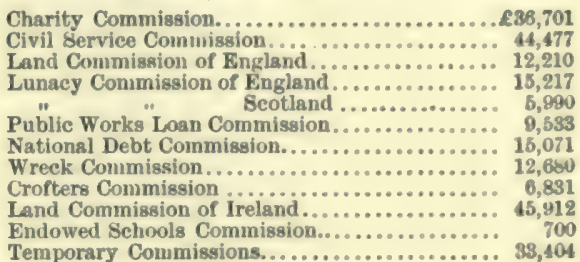

Another kind of commission is that sometines given to two or more judges to inquire into certain alleged erimes, such as the commission (1867-69) to inquire into the Sheffield trales-union outrages, and that (1888-90) of three judges appointed by act of parliament, to inquire into the 'charges and allegations' brought in the Times newspaper against Mr Parnell and others.

It should be added that the sovereign, who nominally presides over the annual deliberations of the General Assembly of the Church of Scotland, delegates the duty to a Scotch peer as Lord High Conmissioner, a fresh commission being issued every year. For the ecclesiastical court created by Queen Elizabeth, see HigH Commission.

Commission Agent, or MERCHAxt, is a person employed to sell goods consigned or delivered to him by another who is called his principal, for a certain percentage, commonly called his commission or factorage. See BRokER.

Commissionaires is a name given a class of attendants at continental hotels, who perform certain miscellaneous services. Employed to attend at the arrival of railway trains and steamboats to secure customers, they wait to take charge of buggage, see it passed through the hamls of the customhouse officers, and send it on to the hotel; for all which service they charge a fee.

In 1859 the Corps of Commissionaines was established by Sir Edward Walter in England, with divisions in London, Edinburgh, Glasgow, Leeds, Liverpool, Manchester, and other large cities in the United Kingdom. The corps has recently extended its operations to the principal cities of Australia, and purposes to continue its further development throughout the colonial empire. The corps is composed of picked men from every branch of Her 
Majesty's naval and military service, and in the London division alone there are 1200 men. They can be engaged by the day or any other period, and for any duty where honesty, sobriety, and intelligence are required. The wages range from twenty to forty shillings per week.

Commission del Créderé. See DeL Cre. DERE COMMISSION.

Commissioners of Supply. See SUPPLY.

Commissions, ArMy, are warrants from the thead of the state for holding various military offices, whether combatant or non-combatant. The latter class comprises the various departments of the army, such as chaplains, commissariat, transport, veterinary, ordnance store, \&c., in which, so far as the British army is concerned, commissions, carrying honorary or relative military rank, are obtained by direct examination, by nomination coupled with special professional qualifications, or by transfer from other branches of the service. Candidates for the Medical Staff (q.v.) pass through a course of instruction at the Army Medical School attached to the Royal Victoria Hospital, Netley, before being commissioned as surgeons. As regards the combatant officers, a first commission as sublieutenant can be obtained by any British subject of proper age, character, and physieal qualifications, either by entering one of the Military Schools (q.v.) as a Cadet (q.v.), or by passing both a literary and a military examination (similar to that mentioned below for a lieutenant's promotion), after having served two trainings as an officer in the militia. All correspondence regarding first commissions or cadetships is conducted by the military secretary at the War Office. Commissions in the Royal Marines are obtained by direct competitive examination. Two or three sub-lieutenants' commissions are given each year to cadets from the Royal Military College of Canada. It is also possible to obtain such a commission by enlisting; but only two or three specially selected sergeants are promoted each year to the rank of sub-lieutenant in the cavalry and infantry (135 officers now serving have risen from the ranks), though all quartermasters, riding-masters, or officers of the Coast Brigade Royal Artillery, and Coast Battalion Royal Engineers, are commissioned, as lieutenants, from the ranks.

Subsequent commissions up to that of lieuten. ant-colonel are given, as vacancies occur, to the senior officer of the next lower rank, provided that he has been favourably reported on, and, in the case of a lieutenant or captain, has passed an examination for promotion in regimental duties, drill, fortification, tactics, military law, and topography. To assist officers in passing this test, a deputy-assistant adjutant-general for instruction is appointed to the staff of each military listrict, and classes are held under him for the study of the four last-mentioned subjects. The rank of colonel is only conferred by Brevet (q.v.) for distinguished service, or on appointment to certain positions carrying that rank, such as aide-de-camp to the Queen, assistant adjutant-general, or commander of a regimental distriet. Promotion to majorgeneral, lieutenant-general, and general, is by selection, as vacancies occur. The establishment in these ranks has been much reduced, and only those who are eminently qualified, professionally and physically, are eligible for commissions in them.

Previous to 1st November 1871 all combatant commissions were purchased, except in the Royal Artillery, Engineers, and Marines, and a few given as prizes to those cadets who passed out of the Royal Military College at the head of the list. It was then also possible to qualify for a commission by purchase, by passing a direct non-competitive examination. The lowest price of a first commission in the line was $£ 450$, the highest (in the Life Guards) was $£ 1260$. Large sums had also to be paid for each step in rank, so that the interest of the money thus invested sometimes exceeded the pay of the rank.

The entire abolition of the purchase system (by royal warrant in 1871 ) has at the same time increased the actual value of commissions as a means of livelihood, and the number of those who are in a position to compete for them. The competition has in consequence become very severe at the examinations, which are held usually twice a year, for admission to the two military colleges and for militia candidates for army commissions. To meet this, a large number of special educa tional establishments have been formed, devoted entirely to the work of preparing candidates for these tests, and most of the large schools have special army classes. The expenses thus entailed are often not much less than the cost of a first commission under the purchase system, but no further payment is incurred by promotion.

The subjects of examination for cadetships are seleeted, so far as the number of marks allotted to each is concerned, so as to encourage boys who have received the usual classical education, to come up direct from school without having to undergo a course of eramming at a military tutor's, where the influences are not always desirable. See CADET.

Commissure, an anatomical term applied to nervous connections between adjacent parts of the nervous system. Though it is not always used in quite the same way, the general signification of the term, and the physiological import of the structure, is that of a uniting bridge. See BrAIN, NERVOUS System.

Commitment. See Criminal Law.

Committee (Fr. comité), a portion, generally consisting of not less than three members, selected from a more numerous body, to whom some special act to be performed, or investigation to be made, is committed. But though a committee usually consists of several members of the body by which it is appointed, it may consist of one member, or, what is more frequent, of the whole of the members acting in a different capacity from that which usually belongs to them. For the committees of parliament, whether 'select,' 'of the whole house,' 'grand,' or 'standing' committees, see PARLIA-

\section{MENT.}

Commodore, in the royal navy, is a rank intermediate between an admiral and a captain. It is not permanent, but is bestowed for a time on a captain. Usually a commodore commands more ships than one, detached from a fleet on some special service; he hoists at that time a white broad pennant, with a red cross, at the main if a commodore of the first class, at the fore if of the second class. A commodore is privileged to have a commander under him in his ship, in the same way as an admiral is privileged to have a captain. The commodore, in matters of etiquette, ranks with a brigadier-general in the army. When in independent command, a commodore of the first class receives $£ 7,108$, a day, and a commodore of the second class about $£ 4$, 10 s.

Until 1862 the title of commodore, without any commission as such, was given in the United States navy to such captains as commanded, or had commanded, a squadron. In 1862 the rank of commodore became a commissioned one. A commodore ranks higher than a captain and lower than a rear-admiral. His rank is assimilated to that of a brigadier-general in the United States army. 
Commodus, Lucius Aurelius, a Roman emperor, born at Lanuvium in 161 A.D., was the son of the great Mareas Aurelius and his profligate wife, the younger Faustina. He was earefully educated under his father's care, but lived to become one of the most worthless and bloody wretches that ever disgraced a throne. At his father's death in the spring of 180 , he was successfully fighting the Marcomanni and other tribes on the upner Danube, but he at once concluded a treaty with the barharians, and hastened to Rome to enjoy the pleasures of power. After the discovery of his sister Lucilla's plot against his life in 183, he gave unemtrolled vent to the senseless suvagery of his nuture. Nearly all who, by virtue, ability, and learning, had risen to honour during his father's lifetime, were sacrificed to appease his savage jeal. onsy of the good and the great. Proud of his own physical strength, he demeaned himself by exhibiting it in gladiatorial combats, and besides used, in juiblic, to sing, dance, play, and act the louffoon. Though a glutton and a shameless debauchee, who wallowed in the most sensual abominations, he yet demanded to be worshipped as a god, and assumed the title of Hercules Romanus. Many unsuccessful plots were devised against the life of this mingled monster and madman, until at length his mistress, Marcia, finding her own name marked down in his tablets for death, in concert with two confederates, tried first to poison him, then caused him to be strangled by Narcissus, a famous athlete, on the 31 st of December 192. LAW.

Common Bench. See Bench, and Common

Commoner, one under the rank of nobility; also a member of the House of Commons. For the Commoners at Oxford, a class of students esting st the common table, see OXFord.

Common Forms are the ordinary clauses which are of frequent occurrence in identical terms in writs and deeds.

\section{Common Good. See Borough.}

Common Law, in England, is the ancient customary law of the land. Before the Norman Conyuest, the rights of an Encrishman were determined mainly by the customs of the manor, borough, or shire in which he lived. After the Conquest, the king's judges began to go their circuits in every part of the country, doing justice according to the custom of the realm or the common law. In some points they kept to the ancient local customs, in others again they introduced new rules. Primogeniture, e.g., is a rule introduced by the influence of the judges; the ancient English rule of equal division survives only as the 'eustom of Kent' under the name of Gavelkind (q.v.). The custom of certain ancient boroughs, which gave the land to the youngest son, survives under the name of Borough English (q.v.). The eustom of a place, or of a body of persons, is allowed to supplement or modify the common law if it has been observed from a time "whereof the memory of man runneth not to the contrary.' Legal memory does not go lack beyond the first year of the reign of Richard I., bat evidence may be given to impugn the 'im. memorial ' character of a local custom by showing that it had its origin later than that year.

Even in making new rules, the judges never assumed to legislate; they professed to expound the good eustoms of the realm, and in applying the rules of common law, each generation of juilges was guided by the decisions of its predecessors, Decisions followed in a series of subsequent cases acquired special authority, and were quoted as lealing cases. The law fixed by custom and by judicial decision could only be set aside or amended by an act of parliament. But without aetting aside the law, courts of equity, and expscially the Court of Chancery (q.v.), framed rules of their own, which enabled them to prevent the stricter rules of common law from being nsed in defence of injustice. By the Judicature Acts (q.v.), courts of common law and equity were made parts of one supreme court; the two systems are administered conenr. rently ; where there is any conflict between equity and common law, the rules of equity prevail. See EQurT Y.

English settlers going to an uncivilised country take with them 'as much of the common law as the nature of things will hear.' In Canada, Anstralia, \&c., and in the United States, the his. torieal basis of the law is the same as in England. In Scotland, and in some other countries, the term common law is used in a sense analogous to its English meaning.

The Courts of Commox LAw. - The superior conrts of Common Law in England had their origin in the Curia Regis of the early Norman kings, the chief officers of which were the Chiefjusticiar, the Chancellor, and the king's justices. The justices sat in the King's Bench to supervise the proceedings of inferior courts and corporations, and to deal with criminal matters directly concerning the erown. In the Common Bench or Common Pleas they held pleas between subject and subject. In the Exchequer they sat, as Barons of the Exchequer, to decide revenue cases. At first all these courts followed the king, to the great inconvenience of suitors. The Common Pleas were fixed at Westminster by Magna Charta; and in course of time the three superior courts of Common Law were all established on one side of Westminster Hall, each court having its own chief and four (afterwards five) puisne or junior judges, who were called justices in the King's Bench and Common Pleas, and Barons in the Exchequer. On the passing of the Judicature Acts (1873-76), the three courts became divisions of the High Court of Justice. The offices of Chief-justice of the Common Pleas and Chief-baron of the Exchequer are now abolished, and the three divisions are consolidated in the Queen's Bench Division. The Lord Chiefjustice of England is the presiding judge; he is appointed by the crown on the advice of the prime minister, and his salary is $£ 8000$. There are fourteen puisne justices, appointed by the crown on the advice of the Lord Chancellor, each of whom has

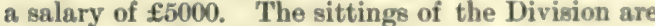
held at the Royal Courts in London; the judges also try cases on their circuits and at the Central Criminal Court. The jurisdiction of the Division includes all special authorities formerly belonging to any of the old Common Law Courts. It takes, e.g., appeals from Revising Barristers (q.v.) which formerly went to the Common Pleas, and revenue cases which belonged to the Exchequer. Appeals from any of the old Common Isaw Courts went to the judges of the other two conrts, sitting in the Exchequer Chamber, and from them to the House of Lords. Appeals from the Queen's Bench Division now go to the Court of Appeal, and thence to the House of Lords.

Besides the superior courts, there are many inferior courts which exercise a limited common. law jurisdiction. Each manor has its own courts, lut exeept in regard to Copyholds (q.v.)., manoria? jurisdiction has been superseded by local courts of modern origin. The same remark applies to the Hundred Conrt and the ancient County Court. The Court of Common Pleas in Lancaster and the Court of Pleas in Durham, now form part of the High Court. The modern County Court (which ought more properly to be called a district court) has a common.law jurisdiction; and several statutes contain provisions for remitting the less important 
class of common-law actions to the County Court for trial.

Of Borough Courts some (as, e.g., the Court of Hustings in London) are obsolete; others (as, e.g., the Mayor's Court in London and the Court of Passage in Liverpool) are still of importance. The City of London Court is framed on the model of the modern County Courts. The Court of the Cinque Ports is held before the mayor and jurats of each port; from them appeals are taken to the Lord Warden's Court, and thence to the Queen's Bench Division. Courts of Request for the recovery of small debts existed in several boroughs; they are now obsolete, as also is the Court of Pie Poudre, or dusty foot, held by the steward of a manor to which a market belongs, for the immediate decision of questions arising in the market. There are still courts of some importance, established for the benefit of privileged bodies of persons. See, as to miners (under Stannaries), STANNARY Courts ; as to Oxford and Cambridge, see UNIVERSITIEs.

Common Pleas. See Common Law.

Common Prayer, Book of. See PrayerBOOK.

Common-riding is the Scotch equivalent of Beating the Bounds. See Bounds.

Common Room, an apartment in a monastery in which a fire was constantly kept burning for the use of the monks, and which was presided over by a monk called the master. It was the prototype of the common rooms in the colleges of the English universities, where the dons take their wine after hall.

Commons, the dinner provided in English colleges and inns of court for their members. In the inns of court it is provided only during term. Separate tables are appointed for the benchers (see BENCH), for the barristers, and for the students and other members of the inn.

Commons, House or. See Parliament.

Commons and Enclosures. This is one of the numerous instances in which a different mean. ing is attached to the same term in the legal systems of England and Scotland. In England the property in the common land belongs to the lord of the manor; although rights over the common land are possessed by certain persons who hold land in the manor, and are known as commonens. Thus Blackstone defines a common as ' a profit which a man hath in the land of another, as to feed his beasts, to catch fish, to dig turf, to cut wood and the like.' But in Scotland, where the law has adopted the divisions and followed the nomenclature of the civil law and of the legal systems of continental Europe, all these profits, or rights to derive profit, are known as Servitudes (q.v.), whereas a common, or commonty, as it is more frequently called, is a common right of property existing in several individuals, frequently the inhabitants of a whole village, in a piece of ground. In each individual the right of course is limited, so as in reality to amount to little more than a servitude; but there is no over-lord, the land is not the land of another, but the land of the community as a body.

The nature and origin of rights of common have been the subjects of elaborate investigation, but are still obscure. They are probably derived from the old Germanic rights of common pasture on the Folkland (q.v.). In England at present almost the only land subject to common rights is waste land; but formerly rights of joint cultivation extended over a great part of the arable land. These are not yet quite extinct. So long as the lands subject to rights of common were extensive and fertile, their enclosure was a source of wealth both to lords of manors and to the nation as a whole. Accordingly enclosures began to be frequent in the 16th, and were continued on a great scale to the end of the 18th century. Formerly the enclosure of a common required a private act of parliament. The conmmoners, who were generally poor and unable properly to represent their case, often suffered by enclosure, obtaining inadequate compensation. By the Act 6 and 7 Will. IV. chap. 115, and subsequent acts, the necessity for a private act of parliament is abolished. By the Act 8 and 9 Vict. chap. 118, which has been often amended, a Board of Commissioners is appointed to inquire into the propriety of any proposed enclosure or partition, and to report to parliament, which may then pass a public act authorising their proceedings. This is the course generally adopted.

In Scotland, commonties or commons were made divisible by an action in the Court of Session, at the instance of any person having an interest by the Stat. 1695 , chap. 38.

The lands still subject to rights of common are for the most part such as could not be cultivated with advantage. The increase of population, however, has made them valuable as places of exercise and recreation. This value has been clearly stated by Mr J. S. Mill (Dissertations and Discussions, vol. ii. p. 213): "We must needs think, also, that there is something out of joint, when so much is said of the value of refining and humanising tastes to the labouring-people-when it is proposed to plant parks and lay out gardens for them, that they may enjoy more freely nature's gift alike to rich and poor, of sun, sky, and vegetation; and along with this a counter-progress is constantly going on of stopping up paths and enclosing commons. Is not this another case of giving with one hand and taking back more largely with the other? We look with the utmost jealousy upon any further enclosure of commons. In the greater part of this island, exclusive of the mountain and moor districts, there certainly is not more land remaining in a state of natural wildness than is desirable. Those who would make England resemble many parts of the Continent, where every foot of soil is hemmed in by fences, and covered over with the traces of human labour, should remember that where this is done, it is done for the use and benefit, not of the rich, but of the poor; and that in the countries where there remain no commons, the rich have no parks. The common is the peasant's park. Every argument for ploughing it up to raise more produce applies a fortioni to the park, which is generally far more fertile. The effect of either, when done in the manner proposed, is only to make the poor more numerous, not better off. But what ought to be said when, as so often happens, the common is taken from the poor, that the whole or great part of it may be added to the enclosed pleasure-domain of the rich? Is the miserable compensation, and though miserable not always granted, of a small scrap of the land to each of the cottagers who had a goose on the common, any equivalent to the poor generally, to the lovers of nature, or to future generations, for this legalised spoliation ?'

Acting apon the principles expressed in this extract, the legislature in the 19th century has regulated enclosures with reference to the enjoyment of the general public, as well as to the rights of the lord of the manor and of the commoners. Restraints have been placed on the enclosure of commons in or near towns, and provision has been made for laying them out and maintaining them as places of recreation. Near London especially, many commons have thus been secured to the public. See Miss Octavia Hill, Our Common Land (1878); EIton, 
The Law of Commons: Commons and Common Fields.(18\%7) ; and works by Serutton, Chambers, Conke, Hall, Willimus, Slıw-Lefevre (1894), and Sir R. Hunter (1897). Lord Thring's act against unlawful enclosures was passed in 1893.

In the United States 'common' in one sense signifies the common or general fields aet apart as pasture-land at the foundation of towns or villages the idea of such common fields may probably have been suggested by those of semi-fendal England. Common fields also existed in the villages of French and Spanish settlers. The title to these lands was confirmed to the inhabitants by act of congress. Unappropriated lands in Virginia have similarly been contirmed as common lands by statute, and the constitution of Illinois sets apart certain lands as commons. Unlese the statute expressly forbids, commons in this sense may be divided at the instance of individuals interested, if they think tit to take legal proceedings for that purpose. In the other sense, the term' common' is applied to a public park which may belong to the municipality or to the nation-e.g. the Yellow. stone Park - respecting which no individual or individuals can claim a division. Such parks are under the direct control of the authorities. As applied to a school, the epithet 'common' means public, supported by taxation, and open to all children of a certain age. It has no reference to the studies of the school.

Common Sense, The Philosophy of. There are certain beliefs that have been current among men in all ages, which by some philosophers have been declared to be groundless illusions. Of these, the most remarkable instance is the belief in an external, material world, independent of any mind to perceive it. Berkeley's doctrine (see BERKELEY) seemed to his contemporaries to contradict this belief, and affirm that there is no such thing as a material world; and Hume, carrying the same principles to their full length, disintegrated the world of spirits, and left nothing in nature but isolated ideas and impressions.

A dead-lock in philosophy was the result of these doctrines of Berkeley and Hume; and the solution offered by Reid consisted in setting up common sense as an arbiter from which there could be no appeal-that is to say, the universally admitted impressions of mankind were to be taken as corresponding to the fact of things without any further scrutiny. It is only the same view otherwise expressed, when it is declared by other philosophers that the deliverance of consciousness nust be presumed true. According to Sir W. Hamilton, in the most elaborate vindication of the common-sense philosophy that has ever been produced (in his edition of Reid's works), consciousness assures us that, in perception, we are immediately cognisant of an external and extended non-ego (not-self); and that the testimony of consciousness must he viewed as entitled to prompt and unconditional assent.

The conclusiveness of this reasoning is disputed by many, who say that it is an abnegation of the tasks of philosophy, and may establish mere prejudices as dictates of consciousness. Consciousness (q.v.) is a very wide word, comprising indeed everything that we call mind. Suppose, it is argued, we were to maintain that the veracity of each one's memory was beyond all question or dispute, it would be apparent at once how the case really stands. But there must be a standard truth. Experience is the criterion how far the memory is to be trusted; and possibly the same may be true of the larger fact named consciousness. See PHILOsoPHY, Psychology.

The truths of common sense, assumed to be those of consciousness, are such as these: the laws of Identity, Contradietion, and Excluded Middle; the axioms of Mathematics; the law of Causality (q.v.); the doctrine of an innate moral sense (see article EтHICs); the doctrine of man's Moral Liberty (see FrEE-WILL); the exintence of an external world independent of every vereipient mind. Some of these truths, which however by no means atand all on the same footing, are termed Intuitions, Intuitive Cognitions, Instincts, Feelings, Beliefs, Principles, Ultimate or Primordial Elements, Truths a priori. Kant's mission was to investigate the origin of such of those truths as might be accounted a priori; see KANT, A Priori. The philosophy of common aense, as pronulgated by Reid, bore reference espe. cially to the denial by Berkeley of the received view of the material world; see PERCEPTION.

Commonty. See Commons and Enclosures.

Commonwealth (practically, a translation of Lat. respublica, 'republic') is used in a special sense for the form of government established in England after the execution of Charles I. in January 1649. Usually the Commonwealth is held to extend till the Restoration in 1660 ; and in the Calendar of State Papers this is the usage of the word. But the Commonwealth is sometimes limited to the period 1649-53, ending with the establishment of Cromwell's Protectorate. See Cromwell, ENgland. Several states of the American Union (as Massachusetts, Pennsylvania, Virginia) are officially called commonwealths.

Commune is the unit or lowest division in the administration of France, corresponding in the rural districts to the English parish or township, and in towns to the English municipality. In France there are about 36,000 communes, with a considerable measure of self-government, with the power of holding property, \&c. Each commune has a council elected by universal suffrage, and the council is presided over by a maire and one or more adjoints or assistants. In the larger communes the maire is selected by the central government out of the members of the council; in others he is appointed by the prefect of the department. The central government through its officials exercises generally a very large control over the affairs of the commune. For the Russian commune, see MIR, and Russia.

The rising of the commune of Paris in 1871 should not be confounded with Communism (q.v.). It was a revolutionary assertion of the autonomy of Paris, that is, of the right of self-government through its commune or municipality. The theory of the rising was that every commune should have $a$ real autonomy, the central government being merely a federation of communes. The movement was based on discontent at Paris, where the people found themselves in possession of arms after the siege by the Germans. The rising began on the 18th Mareh 1871, and was only suppressed ten weeks later after long and bloody fighting between the forces of the coumune and a large army of the central government; 6500 Communists having fallen during $20-30$ th May, and 38,578 been taken prisoners. See FRANCE; and see histuries of the Paris commune by Lissagaray (trans. 1886) and Thomas Mareh (1896).

Communion signifies, in ecclesiastical languare, that relation, involving mutual claims and duties, in which those stand who are united by uniformity of belief in one religious body or church. To exclude from this relation and its involved rights is to excommunicate. The most visible symbol of this relation being the partaking together of the Lord's Supper, that rite is often called the Communion. See Lord's SUPPER, PRAYer-BOok, LrTuraY; and for Communion Table, see Altak. 
Communism is a system of society in which common property is the recognised form. In later times it is an attempt to prevent or remedy the evils arising out of the inequalities of private property by holding property in common. But in primitive societies, in the hunting and pastoral stages of civilisation, communism was universal. It was only when the transition was made to a settled life and to agriculture that private ownership in land began to appear, and even then it was slowly introduced. Long after the private use of land had been established, the common ownership of it by the tribe or clan was still recognised and enforced, and the arable land of the community was subject to periodical redistribution with the view to eultivation. Survivals of this system still exist in various countries of the world, notably in Russia under the Mir.

In the ancient world a partial communism prevailed in Crete and Sparta. Towards the decline of Greece more systematic speculations and experiments in communism appeared. The most eminent example of the former was the republic of Plato, in which a community of goods and also of wives was taught, as the form of society among the ruling and military class. These were to be supported by the industrial classes, whose form of life is not indicated. In Palestine, about the Christian era, the Essenes were a society of recluses with celibacy and the community of goods.

A most remarkable instance of community of goods is that of the early Christians at Jerusalem, recorded in Acts, iv. 32. Under the influence of Christianity the rigorous and often merciless ideas and rights of private property developed in the ancient world, especially among the Romans, were greatly modified. Denunciations of wealth tending to communism are not infrequent in the church fathers. Not to mention the corporate property of the church itself, which in medieval times embraced about one-third of the land in the conntries where it was established, many of the monastic institutions were based on the community of goods. During the middle ages, sects holding the community both of goods and women appeared, like the sect of the Giovannali in Corsica.

At times of social and spiritual change or fermentation communistic ideas usually grow up with apecial vigour. Such was the case at the Reformation, when the anabaptists Münzer and Bock. holt set up communism in Germany, and similar notions had a wide diffusion in other countries (see ANABAPTISTS). The most eminent literary form of it, combined with the noblest humanitarian ideals and practical suggestions for reform, which even yet have not been realised, was the Utopia of Sir Thomas More (1516). In that great work, besides the institution of common property, we have the most advanced views on toleration, universal education, a mild criminal code, sanita tion, and a working-day of six hours. Campanella's Civitas Solis (1623) has a similar community of goods under the despotic rule of the wise men, with a working-day of four hours.

At the discovery of America the Spanish conquerors found a system of agricultural communism under a central despotism both in Mexico and Peru. Like the partial communism of Crete and Sparta it may have been a survival or continuation of the primitive communism. In the earliest English settlements in America, both Virginia and New England, a system of common property was attempted, but soon abandoned. During the fermentation which preceded and accompanied the French Revolution communistic ideas again emerged in the writings of Morelly and Mably. They are also found vaguely expressed in the works of Roussean, and through him they to some degree affected the principles of Robespierre and St Just; but the general tendency of the Revolution was to consolidate individual rights and private property. The conspiracy of Babeuf was intended to establish a systematic communism by revolution.

Socialism is a vague phenomenon which must not be identified with communism. Yet the movement is largely coloured with communistic conceptions, and in some of its schools a thoroughgoing com. munism is taught with lax notions as to the relation of the sexes. In the anarchist, as also in the Marx school to a considerable degree, socialism takes the form of a systematic community of property, associated with vague theories of the emancipation of women (see SocralisM). Different both from socialism and this aggressive communism are the communistic societies still existing in the United States. The latter are simply quiet efforts to realise for their members a happier state of things by community of property, but without a revolu. tionary propaganda and remote from the main current of modern social development. See BRook Farm, Perfectionists, Shakers ; Nordhoff's Communistic Societies of the United States (1875): and for the rising of the so-called Communists at Paris in 1871, which was a political and not an economical moverment, see CoMMUNE.

Commutation. See Trthe, Pensions.

Commutator, an apparatus attached to many electric machines for reversing the currents. See ELECTRICITY.

Comne'nus, the name of a family, originally Italian, of which many members occupied the throne of the Byzantine empire from 1057 to 1204 , and that of Trebizond from 1204 to 1461. See Byzantine Empire, Trebizond, Alexius, IsaAC. -AnNa Comnena (q.v.), who lived in the first half of the 12th century, was a high literary as well as historical celebrity.-DAvID CoMnENus, the last representative of the imperial race in Trebizond, was executed at Adrianople in 1462, with all his family, by command of Mohammed II. The attempt to trace the descent of the Bonaparte family from a branch of the Comneni settled in Corsica is not supported by valid evidence.

Como, a city of Lombardy, Northern Italy, beautifully situated at the south-west extremity of the Lake of Como, 30 miles $\mathbf{N}$, of Milan by rail. It lies in a valley, surrounded by hills, clad with luxuriant gardens, olive plantations, and orange groves, with here and there an old ruin cropping out. The city is surrounded by old walls flanked with towers, the gateways by which the walls are pierced being fine specimens of medieval military architecture. Among the principal buildings of Como are the cathedral (1396-1732), and the townhall, built of marble, dating from the beginning of the 13th century. The chief articles of manufacture are silk, satin, gloves, and soap. By means of its port, Como carries on extensive trade in the produce of the district with Switzerland. Pop. with suburbs (1893) 32,600. Como, the ancient Comum, was the birthplace of Creilius Statius, the two Plinys, of several popes, and of the physicist Volta. In 1107 it began to war with Milan, and in the course of twenty years was utterly destroyed by its antagonist. As an important headquarters of the Ghibelline party, it was rebuilt in 1158 by Frederick Barbarossa, and remained a republic for two centuries, when it fell into the hands of the Viscontis, its history since that time being bound up with that of Milan.

Como, Lake of (Ital. Lago di Como, or Il Lario, ancient Larius Lacus), a sheet of water, in Northern Italy, lying at the foot of the Bernine Alps. It is chiefly formed by the river Adda, which enters it at its north, and issues at its south-eastern 
extremity. The total length of the lake from Como to Hiva is about 30 miles. Fifteen miles from its northern extremity, the promonury of Bellawgio divides it into two branches, the shorter of which is called the Lago di Lecco. The greatest breadth of the lake is 21 miles, but throughout the greatest part of its length it is much less. It is 663 feet above rea-level, has a mean depth of 870 feet, and is 1352 feet deep at the deepest part. The benuty of the surroumling seenery and the salubrity of the climate have made the Lake of Como the most celebrated and most resorted to in Italy, its shores being everywhere studded with noble villas. See Lund, Como and the Italian Lakes (1887).

Comorin', Cape (Kumari), the most southerly extremity of the peninsula of India, being, in fact, a sandy accretion to the termination of the Western Ghats. The low headland is in the state of Travancore, and its lat. and long, are $8^{\circ} 4^{\prime} 20^{\prime \prime} \mathrm{N}$., and $77^{\circ} 35^{\prime} 35^{\prime \prime} \mathrm{E}$.

Co'moro Isles, a group of four islands belong ing to France, in the Mozambique Channel, be tween Africa and Madagasear. The islands, which are of voleanic origin, are mountainous, and have an extremely fertile soil, are called Angaziya or Great Comoro, Anjouan or Johanna, Mohilla, and Mayotta. Great Comoro is $\mathbf{3 5}$ miles long, and has a population of 35,000 ; its highest point is 8500 feet. Johanna, next in size, with 12,000 . inhabitants, has a British consul and a British coaling station. Mohilla, the smallest, is $\mathbf{1 5}$ miles long, and has 6000 inhabitants. These became French in 1886. Mayotta or Mayotte, 21 miles long, and with a pop. (1885) of 10,049 , has been a French possession since 1841. At the capital, Dsaudsi or Nzaondzi, are government buildings, a few hundred French soldiers, and numerous officials. The annual imports and exports of the island have each a value of over $2,000,000$ franes. In all the islands the blood of the natives is partially Arab, partially Malagasy; the Sakalavas having occupied part of Mayotte after the conquest of Malagasear by the Hovas. See Madagascar.

Company, although it may be applied to every kind of partnership, is generally used in connection with the law of joint-stock companies. These differ from the ordinary Partnership (q.v.) chiefly in the fact of the shares of the eapital stock being transferable, generally apart from the consent of the remaining partners, although power is often reserved to object to a transferee; and also in the fact that full powers of management are devolved on directors and other officials to the exclusion, more or lese complete, of the shareholders. An unincorporated joint-stock company at common law, such for instance as the famous Carron Iron Company, is really a partnership in many respects, its partners being liable without limit for the debts of the company. Under the Letters Patent Act, 1837, however, it may obtain several privileges of incorporation.

It is not lawful for more than ten persons to carry on a joint-stock banking company at common law, nor for more than twenty persons to carry on any other kind of joint-stock company at common law: all such concerns must register under the Companies Acts. Unincorporated companies may be made bankrupt and wound up in the ordinary way by sequestration, but it is also competent by a liquidation petition to apply to them the usual machinery for recovering the contributions due by members of registered companies, and adjusting the rights and liabilities of contributories inter se. Of course, the constitution of such common-law companies varies indefinitely with the provisions of the agreement under which they act. There is also in existence a large class of companien created by royal charter, which have a legal corporate existence apert from their in. dividual members, and a perpetual succession and a common seal. In wuch canes the cliarter defines, more or less elearly, the objects and the powens of the corporation and the mode of management, but the majority of members have within these limits considerable powers of framing bylaw. Where the charter is silent on the subject there is no direet liability of the membens to the public at all, and their liability is limited to the unpaid balance of their shares. But the crown was empowered by statute to expresis in such charters that the liability of members is unlimited; and such until 1882 was the position of most of the large Scottish banks. The royal power to ereate corporations by charter was in certain cases delegated to burghs in Scotland, who exercised it by granting seals of canse. Of course, the validity of the pro. visions even of a royal charter may be questioned in a court of law.

Still another class of companies consists of those incorporated by act of parliament. Here no objection can be raised to the act of an all-powerful legislature. Such statutes, besides conferring the ordinary privileges of incorporation, generally give further parliamentary powers required for the particular undertaking-e.g. a right to levy tolls. All such particular statutes, which can be obtained only on giving the guarantees required by the practice of parliament in private bills, are all now subject to the general provisions of the Companies Clauses Acts of 1845, 1863, and 1869 . These general acts deal not only with such matters as the issue of new capital, the creation of debenture stock, the change of name, but also with the general administration of the company, the powers of directors, the transference and forfeiture of shares, \&e. Such statutory companies may also be placed in liquidation under the Companies Act of 1862.

The great mass of joint-stock companies, however, in this country owe their incorporation not to royal charter or statute, but to registration under the Limited Liability Acts, which began in 1855, but which are now all merged in the great statute of 1862, supplemented on various occasions down to 1880 . As a general rule the provisions of the Act of 1862 apply, without fresh registration, to the companies formed and registered prior to that date. The new procedure is that any seven people, by subseribing a memorandum of association which states the name, place of business, and general objects, and delivering it to the registrar (there is a separate registrar for England, Scotland, and Ireland), may obtain a certificate of incorporation with or without limited liability. The great majority of these companies have been limited by shares-viz. the shareholders are liable only for the amount uncalled upon their shares. But cases of unlimited liability are not nncommon, and both banks and insurance companies bave frequently availed themselves of the facilities afforded by registration; in the case of banks, the liability remaining unlimited as regards the note issue, while the liability of shareholicers for other obligations of the bank is restricted in the usual way. An insurance company requires to make a deposit of $\$ 20,000$ before registration. It is sufficient if each of the seven subseribers of the memorandum of association subseribes for oneshare. Companies not formed for commercial profit may be registered by license of the Board of Trade. After the memorandum come the articles of association, which in most cases are, slightly modified, one of the sets of model regulations known as Schedule A and B of the statute. The general effect of registration is to make the applicants and 
other members a corporate body with perpetual succession, a common seal, power to hold lands without intervention of trustees, and a liability of members for the time to pay calls on the shares, and a liability of all members, past and present, to contribute the amount of the uncalled capital in the event of a liquidation, excluding such members as have been a year out of the concern before the winding up commences. Past members only contribute if present members cannot make up the deficiency. Hence the lists $\mathbf{A}$ and $\mathbf{B}$ of contributories so unpleasantly known in the mercantile world. Contributories cannot 'set off'" or deduct from their liability debts due to them by the company. But the constitution, so defined by the memorandum and articles of association, is elastic. By special resolution of the shareholders-i.e. a resolution passed by three-fourths and afterwards confirmed, which is also registered-capital may be increased, the amount of shares altered, the liability of directors made unlimited. With the consent of the Board of Trade, the company may even change its name.

It is common to reserve to the directors power to object to a transferee of shares, but where this is not done, the directors are powerless to prevent the common practice of transferring shares to persons of no means just before a liquidation arrives, at least where such transfer is out and out. After liquidation no change can be made on the register of shareholders, which decides the liabilities of parties. Mistaken entries, however, may be rectified by petition to the court, even after liquidation, but it is then too late to raise an action to set aside a contract to take shares on the ground of fraud or misrepresentation. The liquidation of the City of Glasgow Bank (1878-82) called attention to the fact that in Scotland, differing in this respect from England, notice of trusts was taken in the registers of companies, but this did not prevent the trustees and executors who were so entered from being held personally liable for the full amount of the calls made. The necessity of keeping a register of mortgages is a useful provision, and every shareholder is entitled to obtain copies of the annual accounts and of any special resolutions passed. General meetings must be held at least once a year. The Board of Trade have power to order a systematic inspection of the books and accounts of a company, if they are asked to do so by one-fifth of the shareholders. The strongest security reserved to the management of a company for payment of calls is the stringent power of forfeiture which is often exercised with unfaimess and severity.

Upon the whole the statute of 1862 has been beneficial in the development of trade; but it has also producerl a great mass of dishonest speculation, with which the common-law doctrines of fraud and misrepresentation have not been adequate to deal. The law will shortly be amended so as to take further securities for the substantial character of business and for the punishment of dishonesty. For further information on this subject, see Liquidation. Alse see Corporation, GUILD, LIVERY, and RAILWAYS.

Company, in Military Organisation, is that part of a Battalion (q.v.) which constitutes a captain's command. In the British service there are 8 companies in an infantry battalion on the war establishment, each consisting of 3 officers -Captain (q.v.), lieutenant, and sub-lieutenant5 sergeants, 2 drummers and buglers, 5 corporals, 108 privates, and 1 driver with 2 horses for the company general service wagon. The men of the Army Service Corps are also grouped in similar companies (see Commissariat). The company is both a tactical and administrative unit, and is divided into two subdivisions of two sections each.
Each company has its own arm and accoutrement chests, and keeps its own books.

In the Engineers the field company is commanded by a major, with a captain and 4 lieutenants under him, and a surgeon, all mounted. It also has 2 sergeants, 1 artificer, 1 trumpeter, and 26 drivers, who are mounted, and 154 dismounted noncommissioned officers and men. In a cavalry regiment a captain's command is a Troop (q.v.) ; but the corresponding artillery unit is a Battery (q.v.). In the United States service an infantry battalion consists of 2 or more companies, each officered by a captain, a first and a second lieutenant, 5 sergeants, and 4 corporals. On a war footing a full company of infantry consists of 101 officers and men; in time of peace of 3 commissioned officers and 54 inen. In the German army a company comprises 249 combatants and 3 non-combatants, under a captain, who is a mounted officer, and 3 subalterns. There are 4 such companies in each battalion. The French, Russian, Austrian, and Italian companies are similar in strength to the German. See also Bearer Company.

Company, of a ship, is considered to include the whole of the persons engaged on board, and paid for specific duties-exclusive, therefore, of troops and passengers, but including naval officers as well as crew. See CREW.

Comparative Anatomy, as distinguished from special anatomy (see ANATOMY), is the science which examines and compares the structure of two or more different kinds of animal, so as to discover their points of resemblance and unlikeness; and as such it is a most important department of the science of Biology (q.v.; see also CUVIER). In this work the articles in the various groups of animals (see Bird, Mammals, Reptrles, \&c.) deal with the resembling and contrasted features of these groups. 'Comparative' is used in an analogous sense in connection with philology and physiology.

Comparetti, Domenico, philologist, was born 27 th June 1835 at Rome. He studied the natural seiences and mathematics, next held a post in a library, and in 1859 was appointed to the chair of Greek in the university of Pisa, which he exchanged a few years later for the same chair in the Instituto di Studii Superiori at Florence. His studies bore fruit in frequent articles in the learned journals, and in a series of learned works, among them one on Greek dialects in South Italy (1866), on Virgil the Magician (1872; trans. 1895), and on Homer and Pisistratus (1881). With D'Ancona he edited the Canti e Racconti del Popolo Italiano (1870-90), and lee settled in Rome. To English folklorists his name is known from his Researches concerning the Book of Sindibad (Folklore Society, 1882).

Compartment, a term in use in the Heraldry of Seotland, applied generally to the panel or other ornamental work placed below a shield on which the supporters stand, with which is sometimes intertwined the escrol in which the motto, or a second motto, is placed. Great latitude is allowed as to its form.

Compass, Marixer's, is a magnetic instrument used by mariners to indicate the direction of the ship with respect to the magnetic north and south lime, or, in other words, to give the azimuth of the ship with respect to the magnetic meridian. That the mariner may know his direction with respect to the geographical meridian, he must know the angle between the magnetic and geographical meridians (see DECLINATION), and as this angle is different in different years and at different places on the surface of the globe, the mariner must be able at any time to determine his position, when his charts will give him the necessary data to supplement his compass reading. 
The directive property of the magnet seems to have been unknown in Europe till the 12th century. It appears, however, on very good anthority that it was known in China and throughout the East generally at a very remote period. The Chinese annals assign its discovery to the year $2634 \mathrm{~B} . \mathrm{C}$., when they say an instrument for indicating the south was constructed by the Emperor Ho-ang-ti. The enrliest reference to the making of magnets is in $\mathbf{a}$ Chinese dictionary of 121 A.D., where lodestone is defined as 'a stone with which an attraction can be given to the needle;' but this property of the lexlestone could not fail to have beeu observed at a very much earlier time. At first the Chinese would appear to have used the compass exclusively for guidence in travelling by land, and we hear of their using it by sea only somewhere about 300 A.D. According to one account, a knowledge of the compass was brought to Europe by Marco Polo on his return from his travels in Cothay ; but as against this, the late Mr William Chappell, in a letter to Nature (June 15, 1876), produced evidence to show that we owe the sppearance of the compass in Europe in the 12 th century to independent discovery, and not to importation from China.

The ordinary mariner's compass is made up as follows: The needle is a magnetised strip of steel, or in the better compasses a number of thin strips nagnetised separately and then bound together. This is balanced so as to swing horizontally on a fine pivot. Fastened to the upper surface of the needle and swinging with it is a circular card marked with the thirty-two 'points,' and having the point marked $\mathbf{N}$ immediately over the end of the needle that is attracted to the north. The pivot on which the needle swings stands up from the bottom of a copper bowl, which has a glass covering to protect the contents from wind and weather. The compass-bowl is made of copper (a good conductor of electricity) in order to damp the vibrations of the needle. For the needle in moving induces eurrents of electricity in the

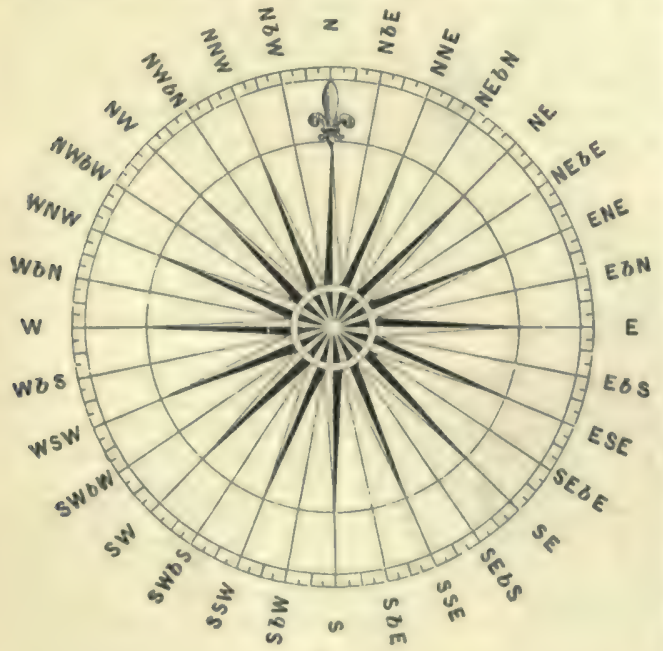

Fig. 1.

copper bowl, the electro-magnetic forces of which tend (according to Lenz's Iaw ) to oppose the motion vroducing them. For the same purpose also the com- pass-bowl is sometimes filled with spirit, but the additional friction of the liquid interteres with the sensitiveness of the needle. The bowl is supported in Gimbals (o.v.) so as to remain horizontal in all positions of the ship. The whole arrangement is placed in the binnacle, situated when possible in the fore and uft line, and having provision for the placing of lamps to illuminate the compass-card by night.

The compass-eard is represented in fig. 1. The four cardinal directions or 'points' are marked N. E. S. W., and there is a convenient notation for intermediate points. Tlus the point midway be-

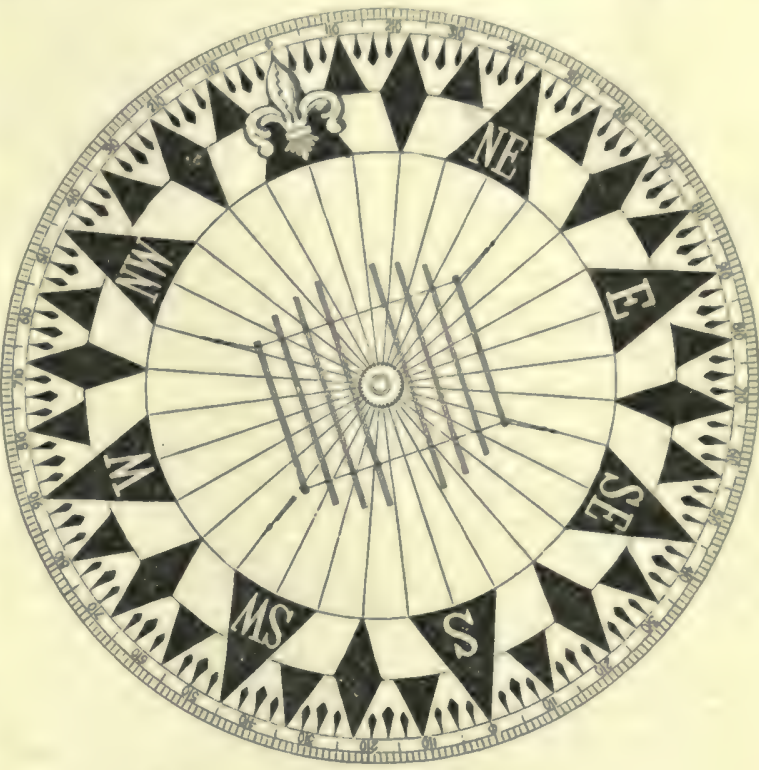

Fig. 2.

tween $\mathrm{N}$. and $\mathrm{E}$. is called NE., that again between N. and NE. is called NNE. (read north-north-east), and so on. The remaining sixteen points, such as $\mathrm{N} b \mathbf{E}$. (read north by east), are named on a plan which will be readily made out by an examination of the figure. These thirty-two points are often further subdivided into halves, quarters, and even eighths, and then we have N+E., and so on. When the ship lies in the magnetic neridian, and pointe to the north, the $\mathrm{N}$. point on the card is directed towards a black line, called the lubber's line, marked on the inside of the compass-bowl. Boxing the compass means reading off from memory the thirty-two points in order going round either way.

Modified forms of the compass are in use on land by surveyors and miners, and need not be further alluded to here.

By way of summarising the qualifications of a good compass, we shall deseribe the best conpass in use-Sir William Thomson's, patented in 1876 : A thin aluminium ring (fig. 2) is connected by silk threads with an aluminium boss, which rests on an aluminium cup having a centre piece of apphire poised on an iridium point (fig. 3). Instead of a single needle there are eight thin strips of steel fastened to the silk threads as shown in the figure. The thin paper rim bearing the points is divided at intervals so that the contractions and expansions due to change of temperature may not produce warping of the aluminium. The whole arrangement weighs only 200 grains or so, and thus there is very little tendency to flatten the point of the 
supporting needle. Hence the 'friction error' can be made very small -in fact, if it is found that a card can be made to rest even half a degree out of the magnetic meridian, the supporting point is rejected for a sharper one. The weight, such as it is, being mostly in the rim, the period of vibration of the card is long ( 40 seconds, or so), which makes the cand very steady. The bowl is saved from violent oscillation by having in the bottom a quantity of castor-oil. The gimbals are supported on knife edges, and their being made of brass wire-rope dispenses with the not very durable india-rubber pads otherwise used. A simple device prevents the card from jumping off the pivot when heavy guins are fireda matter of some importance in an engagement. The bin. nacle has complete provision

Fig. 3.

for stowing away the magnets, soft iron bars, and spheres used to counteract the magnetism of the iron of the ship.

Along with Thomson's compass is supplied a piece of apparatus for converting it into an azimuth compass, which is a compass for finding the angle subtended at the observer's eye by the projections of two objects on the horizontal plane.

For the earth's action on a magnetised needle suspended free to move horizontally and vertically, see the articles MAGNETISM, Declination.

The great difficulty connected with the use of the compass arises from the disturbing influence of the ship's magnetism, of which part is considered permanent, and part-dne to the soft iron -is temporary, and varies with the position of the ship. Various methods are in use to regulate this difficulty, which in iron vessels is sometimes so great as to make an ordinary compass almast useless. The principal are (1) counteracting the permanent induced magnetism by properly placed permanent bar magnets; and (2) supplying about the compass soft iron masses in such a way that, however the ship turns, the transient induced magnetism on the left of the compass shall be exactly equivalent to that on the right. Many of the best ships carry a standard compass placed as far as possible from the iron of the ship, especially from vertical masses like iron masts and funnels. When it is mentioned that an error of one point $\left(114^{\circ}\right)$ in steering means an error of about one mile in five, the necessity for the various precautions will be readily recognised. For details on this subject, see the Admiralty Manual on the Deviations of the Compass, and the references there given.

Compasses, instruments for transferring and marking off distances, or for drawing circles, \&c. The common compasses are simply two rods or 'legs' joined together at one end by a pivot-joint, and pointed at the other; when nsed for draw. ing circles, the lower part of one of the legs is replaced by a pen or pencil. Spring dividers are much in use by workmen; in these, the legs are united by a strong steel spring, the action of which is to stretch them open; but half-way down, a serew passing between the legs, regulates by means of a nut, the degree of opening. The value of these depends upon the permanency with which they retain any degree of opening given to then, pivot compasses being liable to slip. A more delicate variety of the spring dividers is also made for use in mechanical and architectural drawing.

Beam Compasses consist of points sliding on a long bar, to which they may be clamped at any distance from each other. They are used for greater openings than pivot compasses can safely span, and, when delicately made, for more accurate dividing. See GRADUATION.

Proportional Compasses have a point at each end of each leg and the pivot between, thus forming a double paix of compasses opposite to each other, end to end. The pivot is a clamping serew moving in an elongated slit in the legs, by means of which any proportion between the ends may be attained. They are usually provided with scales of proportions for lines, solids, cubes, and cireles. They are very useful in making reduced or enlarged copies of drawings, especially mechanical drawings.

Triangular Compasses have three legs, so that the points of a triangle may be all transferred at. once. For Calliper Compasses, see CALLIPERs.

Compensation is used in both English and Scottish law to denote the claim which arises to the owner or occupier of land which is taken for the purposes of a public undertaking under statutory powers, or which is injuriously affected by the execution of public works. The question is generally referred to arbitration, under the Lands Clauses Act, and the award is final as to the amount of damage. The claim includes such matters as loss of profits from shop, interference with access and amenity, nuisance from smoke, \&c. Formerly, fifty per cent. used to be added for compulsory purehase, but latterly awards have been more moderate. Compensation is also the name given in recent statutes to the right of an outgoing tenant. in respect of certain classes of unexhausted improvements which are scheduled to the acts. See Agricultural Holdings ACT. The word is loosely applied to any claim of damages arising in respect of injury. Thus in event of legislation interfering with the business of the publicans (in the way of limitation or prohibition), it is strongly affirmed by some, and as strongly denied by others, that the publicans are entitled to compensation. In Scots law its proper meaning is that mutual creditors and debtors may set off one debt against another. This applies, as it did in the eivil law, to most pecuniary obligations, but in order that one debt may extinguish another, so as to stop interest, \&c., compensation must be pleaded. Even where an unliquidated claim of damages is opposed to an ascertained debt, time will be given to constitute, if the claims arise under the same contract.

Compensation of Errors, in Physies, a. method of neutralising errors which cannot be avoided, by introducing others into the experiment or observation, of an opposite nature, and equal in amount. The compensation pendulum illustrates the principle. See PENDULUM.

Competition (Lat., 'a seeking together') has. been well defined by Dr Johnson as 'the act of endeavouring to gain what another endeavours to gain at the same time." In political economy it is simply the form taken by the struggle for existence as applied to industry. Formerly, prices and generally the economic relations of men to each other were regulated by custom or authority. The growth of freedom has now brought it about. that these relations are determined by individual effort. The general rule is that each man must be responsible for his own economic well-being. Theworkman brings his labour to the market and gets what he can for it. The capitalist engages labour on the terms most favourable to himself, and sells his produce at such price as it can bring. The 
owner of land generally takes the highest rent he can obtain. In short, the industrial world is a world of contlicting or competing interests.

As we have said, this syutem of competition is an outcome of modern freedom, and the rime of it may be historically traced. In medieval times the relations of men were fixed by custom or anthority. But the restraints of custom and authority were felt to be vexatious, oppressive, and injurious, and in the various spheres of human activity, in religion, politics, and economics, the free individuality of men sought and found wider room to develop itself. This great movement began with the revival of learning, the discovery of America, and the Protestant Reformation, and has been continued through the revolutions of the $17 \mathrm{th}, 18 \mathrm{th}$, and 19th centuries. In the industrial sphere it means that whereas in former times a man's calling, place of residence, and the remunera. tion of his industry were fixed for him, he is now at liberty to decide them for himself as best he can. Each man is free to do the best he can for himself, but as he finds numerous individuals who exercise the same freedom within a limited field, there arises the prevailing system of competition.

No one conversant with the facts will deny that the system of free competition has been attended with enormous progress, and that it has acted as a powerful stimulus to human energy and the spirit of improvement. But the development of the system has brought with it most important limitations, some of which may be noted. While such a system must always be limited by law and justice, and the necessities of political union, legislation has been obliged to provide special safeguards against the evils of competition, notably in the English Factory Aets. The English trades-unions are an attempt to regulate competition in the interest of labour. Employers' combinations have a like object in the interest of the capitalist. In America especially the development of 'trusts' tends to make competition a dead letter. These trusts are combinations of capitalists with a view to regulating prices. The protective system of countries like France, Germany, and the United States is intended to maintain native industries against British competition. Lately France and Germany have imposed duties on cereals in order to protect their agriculture against American competition. It should be noted also that even yet eustom is largely influential in many spheres, and that not a few of the evils of competition are mitigated by the kindly feeling which prevails in all the relations of life. Employers do not generally bring wages down to the lowest level attainable by competition. Thus in actual experience the competitive system is modified by a great variety of influences. On the other hand, the 'sweating system,' by which starvation wages are given for long hours of hard work, is rendered possible by the keen competition of many, otherwise unemployed, for such unremuner. ative laloour.

Competition for eituations in the public service is very different from the system above described. Competition as applied to the public service is regulated by the state. The salaries in the various graules, and the conditions of employment, are fixed by authority. The chief material stimulus is the hope of promotion. See Civil SERvick. For the advantages and disadvantages of competitive examinations in education, see EDUCATION; also the Nineteenth Century, the Universal Revievo, \&e., for 1888.

Compiegne, a quiet and old-fashioned but picturesyue town in the French department of Uise, on the river Oise, a little below its junction with the Aisne, 52 miles NNE. of Paris by rail. Of its churches three deserve notice, St Germain (15th century), St Antoine (12th century), and St Jacquen (13th century). The hotel-de-ville is a late Gothic edifice with a fine central belfry. But the chief pride of Compiène is its palece, built anew by Louis $X V$., and splendidly fitted up by Napoleon, who often oceupied it. Its facade towards the forest is 624 feet long. From the gardens an arbour walk, 1600 yards long, leads towards the benutiful forest of Compiegne, which was a favourite hunting-ground of many of the kings of France. It extencs to wor 30,000 acres, and contains some fine oak timlier. The inhabitants of Compiège manufacture canvas, cordage, and sugar. Pop. (1872) 11,859; (1891) 12,353. Compiegne is mentioned in the times of Clovis under the name of Compendium. It was at the siege of this town, in 1430, that the Maid of Orleans was captured; and here, in 1810, Napoleon first met Maria Louisa of Austria, on occasion of their marriage.

Complement of an angle is what it lacks to make up $90^{\circ}$; of an arc, to make up a quadrant; and hence, in Astronomy, the complement of a star is its zenith-distance. In Music, two intervals, which together make up an octave, are called complementary (see Inversion). In Arithmetic, if any number is subtracted from the next higher power of ten, the result is its complement. 'Tluss 7 and 3 are complementary; so are 63 and 37 ; 881 and 119 ; and 1.4384386 is the complement to 8.5615614. In Chromatics, red is the complement of green, orange of blue, and yellow of violet.

Complexion. See SkiN.

\section{Compline. See Breviary.}

Complutensian Bible. See Alcala dE HENARES and XIMENES.

Compony, or Gobony. See Bordure.

Compositae. This is the richest of all natural orders in species, these numbering about 10,000 ; it is also the most widely distributed through all regions of the globe, although most abundant in temperate and subtropical climates; and, furthermore, the richest in individuals, it having been reckoned that about every tenth plant on the earth's surface is a composite. The rationale of this may be broadly seen (at least if we grant an individual constitution and structure especially well adapted to both vegetation and reproduction), for we can see that the consequent great number of healthy individuals must be associated with active local competition and survival of the fittest, and with distribution of these over a wide area; while this again is at least one condition of considerable differentiation of varieties, and so ultimately of species.

While popularly a daisy or dandelion is regarded as a simple flower, the roughest examination suffices to analyse this into an orderly assemblage, technically a capitulum of small but distinct florets; hence the beginner is apt, without more aulo. to refer all similar aggregates, say a head of Scabious (Dipsacacere) or Seapink (Plumbaginacere) to the Compositre. We find, however, such aggregates arising in all alliances, and naturally so; racemes, spikes, or umbels of flowers wholly distinet in structure may all be shortened down into heads or capituln, since reproductive development is tending everywhere to check vegetative growth. We are thus led to inquire of what forms are the composites to be regarded as the reduced members, and the evidence of comparative anatomy goes to prove their relationship to Campanulaces and their irregular forms the Lobeliacere; in a word, to view the yellow 'tubular' florets of our daisy as a head of tiny bells, while the white strap-shaped or 'ligulate' ones of its ray, like all those of a dandelion, resemble the flowers of lobelia. 
In shortening down, or less figuratively, in arresting the inflorescence into a head, the bract of each separate Hower remains in place; and in a Zinnia, or sunflower, we find each floret with its separate bract throughout the whole capitulum; in most cases, however, these disappear. Those of the outermost florets, however, together with the immediately lower leaves of the flower-axis (which bear no florets, and are thus in strictness not entitled to their common name of bracts) become usually crowded into an involucre. This subserves in bud the protective purposes of a calyx to the whole inflorescence at once, and thus the caly $x$ of the separate florets becomes unnecessary. In its place we find at most a circle of fine downy hairs, which may be characteristically serrated or feathered, and which only reach full development and usefulness when the fruit has to be distributed. On account of its merely epidermic nature and late appearance, its calycine nature has been denied, and the term pappus substituted; the evolutionist need, however, feel little hesitation in regarding the pappus as simply representing the epidermic fringe of a reduced calyx, nor is veriticatory evidence wanting. The stamens grow upon the united corolla and themselves unite by the anthers, thus forming a ring or rather pollen-bearing tube, up through which the style grows, all much as in bells. The style bears two stigmas, indicating an originally twocarpelled arrangement, but the ovary is one-celled, and contains only a single ascending ovule. The ovary hardens as a nutlet, which is commonly floated away upon the wind when ripe by help of its pappus; it may be anchored where it descends by its minute grappling-hooks or serrations, In this way it is conveyed to new soil, it may be at a great distance, an obvious advantage, alike to the species or the individual, when germination takes place.

The classification of so many closely related genera and species into larger groups is one of the most difficult problems of the systematist, and all attempts must as yet be admitted to be largely artificial. The method of Jussieu is to separate (1) those in which the florets are all tubular, as in the thistles (even though the outer be enlarged as in corn-flowers- see CENTAURY), as Cynarocephalæ; (2) those in which, while the inner florets are tubular, the outer are ligulate as in daisy, sunflower, \&c., as Corymbiferse, and (3) those in which all the florets are ligulate, $a s$ in dandelion or chicory, as Cichoraces. The more recent method of $\mathrm{De}$ Candolle is now more generally adopted : his distinctions are (1) Tubuliffore, including those which have mainly tubular florets, although the ray be ligulate, thus abandoning the attempt to separate the first two divisions of Jussieu; (2) Ligulifloræ, with florets all ligulate, corresponding to Cichorace»; (3) Labiatifloræ, with florets all bi-labiate, a small South American group. But while this last group has unquestionable distinctness, the value of both preceding classifications in other respects is shown to be somewhat superficial by the familiar faot that in cultivation tubular florets tend to become ligulate (in inaceurate popular phrase, double). Thus we see the wild daisy, dahlia, chrysanthemum, \&c., alike practically passing into the ligulate group on cultivation.

Although many composites are cultivated and useful plants, none attain the highest economic importance: yet the artichoke, and Jerusalem artichoke, salsafy, lettuce, endive, \&c., are familiar inmates of the kitchen-garden, while chicory is extensively cultivated as a substitute for coffee, and even sometimes, as well as Jerusalem artichoke, for the purpose of feeding domestic animals. A very few, like safflower and saw-wort, yield dyestuffs ; from the seed of others-e.g. sun. flower, a bland oil is expressed, while many are of time-honoured repute for their medicinal properties -e.g. chamomile, arnica, wormwood, elacampane, \&c. A still greater number-e.g. headed by dahlias and sunflowers, asters and chrysanthemunis -are esteemed ornaments of our flower-gardens, particularly in the latter part of summer and in autumn. Being mostly herbs, or rarely shrubs, the order is quite unimportant as regards timber the Siriehout (Tarchonanthus camphoratus), a small tree of the Cape of Good Hope, is, however, closegrained and beautiful.

For detailed information, see systematic works such as Luerssen, Med. Pharm. Botanik; Baillon, Histoire des Plantes; or Engler's Pflanzen-familien.

\section{Composite Order. See Column.}

Composition. Under the title Composition and Resolution of Velocity and Forces, we deal with one of the fundamental problems in mechanies - viz. to compound two velocities (or forces) into a single velocity (or force) which shall be their equivalent. We shall consider it as applied to velocities in the first place.

If a point is moving with two independent velocities in any direction, it moves in some one definite direction with a definite speed. This single velocity (for the term includes the idea of direction as well as speed) is equivalent to the two component velocities, and is termed their resultant. A good example is afforded by a ball thrown up in a moving railway carriage; it partakes of the train's motion horizontally, while it also simultaneously moves vertically upwards.

When the two components are in the same straight line, their resultant is in all cases equal to their algebraic sum. In the case of velocities in different directions, the magnitude and direction of their resultant is obtained by the following theorem. known as the Parallelogram of Velocities: If a point A move with two velocities, represented in magnitude and direction by $A P$ and $A Q$ respectively, their, resultant will be similarly represented by $A R$, the diagonal of the parallelogram of which $A P$ and $A Q$ are conterminous sides. For, let the point move along $A Q$ with velocity $A Q$, and let the page bein motion in the direction AP with velocity $A P$. After a unit of time

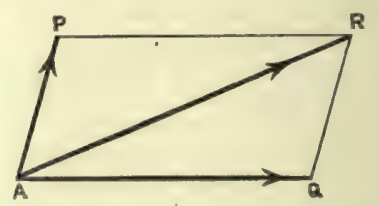
has elapsed, the point will have moved from $\mathbf{A}$ to $\mathrm{Q}$ along $\mathrm{AQ}$, but, owing to the motion of the page, the line $\mathrm{AQ}$ will have moved into the position $\mathrm{PR}$, so that the point will really be at $\mathbf{R}$; hence its motion has been in the direction $A R$, with a velocity whose magnitude is represented by AR.

Similarly, we may compound any number of velocities in one plane into a single resultant. In the case where three components are not coplanar, a corresponding theorem, the Parallelepiped of Velocities, is used to find the resultant.

The resolution of velocities is exactly the converse problem; for where a directed length such as AR can be made the diagonal of a parallelogram, then the conterminous sides are the components. of course, in this manner, an infinite number of pairs of components can be obtained, each having the given velocity as their resultant. But the resolutions usually required are those in which the components are at right angles.

Since forces can be graphically represented in the same manner as velocities, all that has been said of velocities applies equally well to forces; and obvious changes in the terminology at once give 
the means of compounding and resolving forces. See Dynamics, Kinematics, Statics.

Composition, in Bankruptoy, a certain percentage which creditors agree to receive from a bankrupt in lieu of full payment of his debts, and the acceptance of which operates as a discharge to the bankrupt. See BANKRUPTCY.

Compos Mentis. See Insanity.

Compostella. See Santiaco de Compo. STELLA.

Composts are a kind of Manure $\left(q, v_{0}\right)$, consisting of mixtures of substances adapted to the fertilisation of the soil, which being allowed to ferment, and undergo chemical changes for a considerable time in heaps, become more valuable than they were at first, or ever could have been if applied separately. Composts were formerly male of farm-yard manure, and earth or lime in addition. Rond-scrapings, peat-moss, leaves, and clearings of ditches also formed materials for the purpose. By allowing these to lie for six months in heaps of from three to four feet in depth, food was prepared for plants. The mass was usually applied to the turnip-crop, and when artificial manures were unknown, considerable benefit arose from such dressings. The use of guano and other light manures has superseded in a great measure the necessity of this laborious process, and composts for the turnips or barley-crops are now little used. The wonderiul effects that have resulted from the application of small doses of artificial manures have impressed farmers in general with the truth that the most energetic elements bear a small proportion in weight to the whole mass of farm-yard lung or composts, and that the mixing of manures in hesps with earth does not so much add to its virtues as to repay the labour expended in the process. More eare is now rightly bestowed in preserving manure from washings by rain. Composts formed of leaves, ditch-scourings, road-scrapings, or any earthy substance containing a large percentage of vegetable matter, with the addition of lime, may still be used with benefit for pastures that are deteriorating, or where the soil is stiff. Indeed there should still be a compost-heap at every farm. Wherever tidy and careful management prevails, there is a good deal of road-scrapings, ditch-scourings, and other rubbish to be disposed of, and the compost-heap is a handy and useful receptacle for all such matter. The value of well-made compost for the top-dressing of pasture-land is greater than is generally understood or acknowledged, and it can be carted ont and spread at odd times when there is a lull in the more urgent farm-work. Where moss prevails, lime should enter largely as a component. On the other hand, where the soil is of a strong and clayey nature, earthy substances containing vegetable matter in larger proportions should be nsed. Vegetable matter has the effect of imparting a softness to the surface that is particularly conducive to the free growth of pastures. Compost made of turf, leaves, earth, and bone-dust is used with great benefit by gardeners for vines and fruit-trees which are injured by too concentrated manures.

Compound (corruption of Portuguese campenha, "yard or court') is the usual name in India for the inclosure in which a house stands, with its outhouses, yard, and garden.

Compound Animals, See Colontal AnIMALS.

Compounding of Felony, in England, is the oflence of taking value for forlyearing to prosecute a felony, and is punishable with fine and imprisonment, The offence is also known as agreement not to prosecute, and is equally committed where the agreement is only to show favour to the person accused. It practically amounts to misprision of felony. Compounding of informations upon penal statutes, and compounding of misde. meanours, without order or consent of the court, are punishable in a lighter degree, and that whether any offence has been committed or not. But in misdemeanours affecting some private rights, the court will often permit the prosecutor to accept pecuniary amends, and withdraw the prosecution. Advertiang a reward for stolen property, coupled with worls implying that no questions will be asked, or that no prosecution will be instituted, or that a pawnbroker returning the property will be paid what he has advanced on it, is punishable by a fine of $£ 50$ each on the advertiser, publisher, and printer. And any one taking money or reward for restoring a stolen dog is liable to imprisonment for eighteen months.

\section{Compound Interest. See INTEREsT.}

Compressed-air Bath, a strong chamber of riveted iron plates in which two or more persons can sit, and into which air is driven by a sterm. engine to any required pressure, as notified by the attached barometers. The inflow of fresh air and the escape of the foul air are regulated by valves. Patients remain in the bath from one to three hours, and the pressure is generally increased to an atmosphere and a half. Another appliance for using either compressed or rarefied air consists of a mask tightly covering mouth and nose, and connected by a tube and suitable valves with some form of air-cistern in which the pressure can be varied as desired. By this appliance patients can either inspire compressed or rarefied air, or can breathe out into either of these. Practically only the first and fourth of these possible methods are used. Treatment by Aerotherapeutics has long been a favourite study, but the results have varied much, and have lacked exactness. The general effects of compressed air are to lessen the frequency of the movements of the chest, and of the heart or pulse beats, while allowing the absorption of more oxygen, and increasing the blood-tension. Rarefied air produces the opposite effects. Many disensed conditions therefore should benefit by this treatment, especially asthma, chronic bronchitis, and catarrh under compressed air, and emphysema by rarefied air; while in the treatment generally we have a useful system of lung gymnastics, which increase the power of the respiratory muscles and the vital eapacity of the lungs.

Compressed-air Motors. One mode of employing air as a motive power has been described under AIR-Engine (q.v.). Another obvious way is to compress the air and then apply it in the manner of high-pressure steam. But the great loss of power, due principally to the diseipation of the heat which results from the high compression of the air, will always render the employment of such in motive power very wasteful. There are, however, many conditions under which the use of compressed air is convenient and advantageous. The air-gun, although more a toy than a useful weapon, is one of the oldest examples of a com. pressed-air motor. Partly by compression and partly by exhaustion of air, pneumatic tubes are worked in connection with central post-offices for the transmission of letters and messages to and from various districts in large cities. In boring in mines, and in blasting and tunnelling operations, compresed air is an exceedingly useful agent, the power being easily carried by tubes into confined areas where the air when liberated, after it performs its primary duty, is of great value for aiding the ventilation of the spaces (see BorINa). In the application of automatic brakes to passenger trains, 
compressed air has also been found to be the most convenient power (see BRAKES). Air compressed and stored in a reservoir under the vehicle has also been proposed as a motive power for tramway cars. In a different direction the agency of compressed air is important in the artiticial production of cold for chilling-houses for meat-preservarion on land, and for frozen-meat chambers for preserving fresh meat on board vessels (see REFRIGERATION).

Compression and Compressibility. When a body is subjected to the action of any force which causes it to occupy less volume, it is said to be compressed, and the diminution of volume is termed compression. The term compressibility is frequently used to signify that property of bodies whereby they yield to that particular form of stress known as pressure; but more strictly it is employed to denote the measure of this property as possessed by different substances. Under the same pressure it is obvious that the same volume of various substances will diminish by different amounts; and, to measure this change, the compressibility is defined to be the ratio of the amount of compression per unit volume to the compressing force applied. It thus may be determined by measuring the amount of compression of a known volume when under a certain pressure; dividing this by the product of the original volume and the pressure gives the average compressibility (per unit pressure) of the substance throughout the range of pressure employed. 'The unit of pressure generally used is one atmosphere, which is defined in this country as being the weight of a column of mercury, one square inch in section, 29.905 inches in height, at the temperature of $0^{\circ} \mathrm{C}$., and weighed at sea-level in the latitude of London. Its actual value in pounds-weight per square inch is nearly 14.7 ; so that 152.3 atmospheres of pressure is equivalent to a pressure of one ton per square inch.

In gases the relation between pressure and volume is given by Boyle's Law (see GASES)-viz. the volume of a given mass of gas is inversely proportional to its pressure. From this it follows that the compressibility is inversely proportional to the pressure-i.e. the diminution of volume due to a given increment of pressure is correspondingly small as the pressure is great. The behaviour of a gas under pressure is elosely related to the proximity of its temperature to the critical point (see Critical Temperature); for if below this temperature the gas ean, and if above it, cannot be liquefied by pressure alone. It is only since 1877 that liquefaction has been effected in those gases formerly termed permanent.

From the first attempts to compress liquids it was concluded that they were incompressible, but Canton in 1762 , by a comparatively simple experiment, showed that the compressibility of water though small is quite appreciable, and that it is less at higher than at lower temperatures. The measurement of the compressibility of liquids is usually made in a glass vessel (see fig.) termed a piezometer. A tube, $A B C D$, open at one end, $D$, is bent upon itself between $C$ and $D$, widened at one end into a eylindrical bulb, AB, and at the other into a cistern, D. The liquid experimented on fills the bulb and stem to $\mathrm{C}$, from which point to $D$, mercury fills the tube. On the surface of the mereury at $\mathrm{C}$ an index floats. The instrument is placed in a larger and much stronger vessel containing water to which pressure (measured by an attached gauge) is applied. The contents of the piezometer being thus compressed, the mercury column ascends in the stem, and when the pressure is relieved the index is left at that point to which the mercury rose under the highest pressure applied. The actual amount of compression, and the original volume, as well as the pressure, being known, the comipressibility can be thereby calculated, a correction being finally added for the compression of the glass piezometer itself. From experiments made with such apparatus, the following conclusions (see Report on some of the Physical Properties of Fresh Water and Sect-water, by Professor P. G. Tait; Challenger Expedition Commission Reports, Physics and Chemistry, part iv.) seem now to be well established regarding the compressibility of liquids, more especially of water. The compressibility of water decreases as both the temperature and pressure are raised; under moderate pressures (e.g. one or two atmospheres) it has a point of minimum value about $60^{\circ} \mathrm{C}$., while its actual value at $10^{\circ} \mathrm{C}$. and at a pressure of one ton per square inch is very nearly इоำ. Sea-water is less compressible than fresh water; the ratio of the compressibility of the former to the latter being 915 . Solutions of common salt are less compressible as they are stronger; the compressibility falling off uniformly with increased strength. Both sea-water and salt solutions diminish in compressibility with temperature and pressure in the same manner as fresh water. It has also been proved that the maximum-density point of water is lowered by pressure; the actual amount of this lowering being $3^{\circ} \cdot 1 \mathrm{C}$. per ton-i.e. water under a pressure of one ton per sq. in. has its maximum density point at $0^{\circ} \cdot 9$, instead of at $4^{\circ}$, as under ordinary atmospheric pressure.

The compressibility of solids is generally very niuch smaller than that of either liquids or gases. It is best measured by noting the shortening of a rod or fibre of the material tested while subjacted to hydrostatic pressure; the linear compressibility thus obtained is, to a sufficient degree of approximation, one-third the cubical compres. sibility. For glass it is 00000265 per atmosphere.

Compulsion. The effect of compulsion on the validity of obligations and payments, and on criminal responsibility, is noticed under CONTRACT, Crime, Force aND Fear, and DURess.

Compurgators were twelve persons whom Anglo-Saxon law permitted the accused to call in proof of his innocency, and who joined their oaths. to his. - They were persons taken from the neighbourhood, or otherwise known to the accused. It was rather in the character of witnesses than of jurymen that they acted, though the institution has. been spoken of as the Anglo-Saxon jury; what they swore to was not so much their knowledge, as. their belief. The number of compurgators varied with the rank of the parties and the nature of the accusation, but was usually twelve. The system of compurgators was adopted even in civil actions for debt. Compurgation, which was a custom common to most of the Teutonic races, fell into disuse after the conquest; but the ceremony of what was called canonical purgation of clerks-convict, was not abolished in England till the reign of Elizabeth. See (under Jury) JURY Trial.

Comrie, a pleasant and sheltered village of Perthshire, on the Earn, 7 miles W. of Crieff. It has often been visited by earthquakes, notably in the Oetober of 1839 and January of 1876 . These are apparently due to its geological position on the great line of fault between the Highlands and the Lowlands. Here George Gilfillan was born in 1813. The Free church, built in $1879-81$, cost over $£ 10,000$. The railway hither was opened in 1893. Pop. 870. 

Comstock Lode, a ledge of silver, to which Virginia City, Nevada, largely owes its prosperity. Diseovered in 1850, the linle has since yielded at times over ton million dollars annually. The shaft is 2300 feet deep, but work is now confined to the upper levels, the workmen having been driven from the depths by the heat $\left(120^{\circ} \mathrm{F}\right.$.) and by the steam generated through the action of the air on the sulphurous rock penetrated by the different levels.

Comte, Auauste, the founder of Positivism (q.v.), was born 19th January 1798, at Montpellier, where his father was treasurer of taxes. At the Lycee of his native place he was distinguished equally for his aptitude for mathematics and his resistance to official authority, characteristics which did not desert him on his entering the Ecole Poly. technique at Paris in his seventeenth year. Here he took the lead in a protest of the students against the manners of one of the tutors, and was expelled, after a residence of two years had obtained recognition of his abilities from the professors. A few months were spent with his parents, and then Comte returned to Paris, where for a time he made a scanty living by teaching mathematics. It would seem that, some years before, he had completely freed himself from the influence of all existing social and religious theories, and a reforming zeal was beginning to possess his mind, when in 1818 he came into contact with St Simon, by whom his inclination towards the reconstruction of thought and life was confirmed and strengthened. A definite relation was established between them, by which Comte remained for six years the disciple and collaborator of the older thinker; but there gradually became apparent a disagreement of aim and method, and the necessity felt by Comte of asserting the independence of his own conceptions led to a violent rupture. In 1825 Comte married, but the union proved unhappy, and after seventeen years of inter. mittent diseord, ended in a separation. In the following year Comte began a course of lectures in exposition of his system of philosophy, which was attended by several eminent men of science, but the course was soon interrupted by an attack of insanity, which disabled the lecturer for a few months. His labours were afterwards resumed, and the six volumes of his Philosophie Positive was published at intervals between 1830 and 1842, during which period his livelihood was ehiefly obtained from the offices of examiner and tutor in the Ecole Polytechnique. After these positions were taken from him, owing to the prejudices of his colleagues, he resumed the private teaching of mathematics, but in his later years he was supported entirely by a 'subsidy' from his friends and admirers. In 1845 Comte became acquainted with Clothilde de Vanx, and until her death within a year afterwards, a close intimacy was maintained between them. On Comte's side it was a passionate attachment, the purity of which was happily preserved, and its influence is clearly shown in his later works, especially in the most important of these, the Politique Positive. Comte died in his sixtieth year on 5th September 1857. He was buried in the cemetery of Pere-la-Chaise. A full account of his system will be found in the article PosirivisM. His works are Cours de Philosophie Positive (6 vols. Paris, 1830-42; freely translated into English, and condensed by Harriet Martineau, 2 vols. 1853), Traite Elementaire de Gémetrie Analytique (1843), Traite d' Astronomio Populcire (1845), Disconrs sur l'Ensemble du Pasi. tivisme (1848), Systeme de Politigue Positive (4 vols. 1851-54; Enc. trans. 1875 et ser., Longmans), and Catéchisme Positiviste, ou Sommaire Exposition de la Religion Universelle (1 vol. Paris, 1852). Comte's Testerment was published with a good many of his letters in 1884.
Comus, in later antiquity, a divinity of fentive mirth and joy, represented as a winged youth, sometimes drunk and languid as after a debauch, of slumbering in a standing posture with legs erosaed. Comms thus beeme the representative deity of riotous merry -making, of tipsy dance and jollity, and as such figures in Milton's noble poetic tribute to chastity, the mask of Comus; though here the poet, as elsewhere, has devised his own mythology, and made him the child of Bacchus and of Circe, 'much like his father, but his mother more."

Comyn, Cummina, or Cumys, a family which rose to great power and eminence in England and Scotland. It took its name from the town of Comines, near Lille, on the frontier between France and Belgium. While one branch remained there, and in 1445 gave birth to the historian Philippe de Comines (q.v.), another followed the banners of William of Normandy to the conquest of England. In 1069 the Conqueror sent Robert of Comines, or Comyn, whom he ereated Earl of Northumberland, with 700 horse to reduce the yet unsubdued provinces of the north. He seized Durham, but had not held it for 48 hours when the people suddenly rose against him, and he perished in the flames of the bishop's palace, leaving two infant sons. The younger, William, became Chancellor of Scotland about 1133, and nine years later all but possessed himself of the see of Durham. The chancellor's grandnephew, Richard, inherited the English possessions of his family, and acquired lands in Scotland. By his marriage with Hextilda, the granddaughter of Donald Bane, king of the Scots, he had a son William, who was Great Jus. ticiary of Scotland, and about 1210 became Earl of Buchan by marrying Marjory, daughter and heiress of Fergus, the last Celtic Earl of Buchan. Their son, Alexander, Earl of Buchan, married Isabella or Elizabeth, second daughter of Roger de Quenci, Earl of Winchester, and with her acquired the high office of Constable of Scotland, with great estates in Galloway, Fife, and the Lothians, By a previous marriage with a wife whose name has not been ascertained, William Comyn was father of Richard-whose son John (Red John Comyn) became Lord of Badenoch-and of Walter, who by marriage became Earl of Menteith, and was one of the guardians or regents of Scotland during the minority of Alexander III. Through other marriages the family obtained, for a time, the earldoms of Angus and Athole, so that, by the middle of the 13th century, there were in Scotland 4 earls, 1 lord, and 32 belted knights of the name of Comyn. Within seventy years afterwards this great house was so utterly overthrown that, in the words of a contemporary chronicle, "there was no memorial left of it in the land, save the orisons of the monks of Deer' (founded as a Cistercian monastery by William Comyn, Earl of Buchan, in 1219). The Comyns perished in the memorable revolution which placed Bruce on the throne of Scotland. Their chief, Black John Comyn, Lord of Badenech, great.grandson of William, Earl of Buchan, had, in 1291, been an unsuccessful competitor for the crown, as a descendant of the old Celtic dynasty through the granddaughter of King Donald Bane. His son, also called Red John Comyn, was one of the wardens of Scotland, and distinguished himself by his gallant resistance to the English. Suspected by Bruce of betraying him to Edward, Comyn fell under Bruce's dagger, before the altar of the Franciscan friars at Dumfries in 1306 ; and his kindred went down, one after another, in the struggle to avenge him. John Comyn, Earl of Buchan, the son of Alexander and Isabella de Quenci, was deferted by Bruce in a pitched battle, near Inverury, in 1308 , when his earldom was wasted with such relentless severity, that-we are told by the poet 
who sang the victories of Bruce-for sixty years afterwards men mourned the desolation of Buchan. Such of the Comyns as escaped the sword found refuge, with their wives and children, in England, where, although they were so poor as to be dependants on the bounty of the English court, they married into the best families, so that, in the words of $\mathrm{Mr}$ Riddell, "their blood at this day circulates through all that is noble in the sister kingdom." See M. E. Cumming-Bruce, Family Records of the Bruces and the Comyns (Edin. 1870).

Conncre is the custom of letting land in Ireland in small portions for a single crop, the rent being paid either in money or in labour.

Conant, Thomas Jefferson, D.D., American biblical scholar, born in Brandon, Vermont, in 1802, graduated at Middlebury in 1823, and afterwards filled chairs of Languages in various colleges and seminaries. In 1856 he published a translation of the book of Job, and in 1857 he was appointed by the American Bible Union to revise the Scriptures. On this work he was engaged until 1875 , and he was also a member of the American committee of the Old Testament Company who prepared the revised version. His works include translations of Gesenius' Hebrew grammar and critical English versions of both Old and New Testament books. Died April 30, 1891.

Concarneau, a village of Brittany, on the east coast of Finistere, 15 miles by rail SE. of Quimper. Its inhabitants are largely engaged in the sardine fisheries and in pisciculture. Pop. (1886) 5496.

Concealment is a technical expression in the criminal law of both England and Scotland; as in concealment. of pregnancy and birth, concealing treasure-trove, concealing ore from a mine, concealment by a seller from a purchaser of any instrument material to the title with intent to defraud, \&c. The concealment of another's crime may expose to a charge of misprision, or it may amount to a charge of accession after the fact-e.g. where the body of a murdered person is concealed. In bankruptcy, concealment of debtor's property is a serious offence. In civil transactions, but especially in particular contracts, such as insurance and suretyship, where a high measure of good faith is expected, the concealment of a material fact may often invalidate an obligation.

\section{Concealment of Birth. See BirTH.}

Concepcion, (1) a province of Chili, stretching from the Andes to the coast north of Arauco. It is an important agricultural and cattle-raising district, and has valuable coal-mines. Area, $3535 \mathrm{sq} . \mathrm{m}$.; pop. (1885) 182,459. - CONCEPCION, the capital, near the mouth of the Biobio, is one of the most regular and handsome towns of the republic, although it has suffered severely from earthquakes. Its cathedral and several of the other public buildings are noteworthy, and its port, Talcahuano, on Concepcion Bay, is the safest and best harbour in all Chili, and ranks next to Valparaiso as a mart of foreign trade. Pop. 19,000.-(2) CONCEPCION DEL URUGUAY, the former capital of the Argentine province of Entre Rios, on the Uruguay, 180 miles SE. of Paraná by the Entre Rios Railway, with large slaughter-houses and active rivertrade. Pop. 10,000.-(3) ConcePcION, a town of Paraguay, on the Paraguay River, about 260 miles above Asuncion, with trade in maté. The official pop. (1879) 10,697 , includes the surrounding districts; the town has less than 2000 inhabitants.-(4) The name of several places in Bolivia, the largest being CONCEPCION DE APOLOBAMBA, capital of the province of Caupolican, formerly a Franciscan mission. Its Indian popula- tion cultivate coca and cacao, and collect medicinal barks from the surrounding forests.-(5) CoNCEPCION, a town of Mexico, 50 miles W. of Chihuahua, in the upper Yaqui valley, famous for its apples.-(6) CoNCEPCiON DE LA VEGA, a town of San Domingo, 5 miles SE. of Santiago, with 9000 inhabitants.

Conception, in Psychology. See IDEA.

Conception, Immaculate. See Immaculate Conception.

Conception of Dur Lady, an order of nuns, founded in Portugal in 1484 by Beatrix de Sylva, in honour of the immaculate conception. It was confirmed in 1489 by Pope Innocent VIII. In 1489 Cardinal Ximenes put the nuns under the direction of the Franciscans, and imposed on them the rule of St Clara. The order subsequently spread into Italy and France.

Conceptualism. See Nominalism.

\section{Concert. See Music.}

Concertina, a musical instrument invented in 1829 by Sir Charles Wheatstone, the sounds of which are produced by free vibrating reeds of metal, as in the accordion. The scale of the concertina is very complete and extensive, beginning with the lowest note of the violin, $G$, and ascending chromatically for four octaves. Violin, flute, and oboe music can be performed on the concertina with good effect, and it has an extensive repertoire of music specially written for itself. Every sound in the scale is double, and can be produced either by pulling the bellows open, or by pressing them together. Concertinas are now made in France and Germany, but not so perfectly as in England. The keys in the German concertina are constructed on the same principle as those in the accordion, which play one note when the bellows are expanded, and another when contracted.

Concerto, a musical composition for a solo instrument, with orchestral accompaniments, calculated to give the performer an opportunity to display the highest mechanical skill, as well as intelleetual cultivation in the art. The concerto consists of three movements, each of which, like the whole, has a certain character, and like the symphony or the somata, to which it approximates in form, requires a clear development and treatment of the motives, and a strict adherence to the rules of form. A peculiar feature, usually introduced in the first movement, but frequently also in the last, is the Cadenza (q.v.). When the form is in any way abridged, it is then called a concertino. From the beginning of the last century to the present time, the pianoforte and the violin are the solo instruments mostly used for the concerto. The oldest violin concertos are those by Torelli, the first being published in 1686. The form was developed by Corelli, Tartini, Bach, and Handel, and reached its modern shape under Mozart, though some important modifications were introduced by Beethoven, whose violin concerto and pianoforte concertos are regarded as the highest achievements in this form. Concertos for wind-instruments have been less regarded, and are generally written by the performers themselves, and seldom deserve to be called classical works. Weber's clarinet concerto may be mentioned as one of the few exceptions. There are also concertos for various combinations of solo instruments, such as Bach's for two or more pianofortes, or Beethoven's for piano, violin, and violoncello.

Conch (Gr. konchè, 'a shell'), a marine shell, especially of the Strombus gigas (see STROMBIDAs); and, in art, a spiral shell used by the Tritons as a trumpet, and still used by some African peoples in war. The native whites of the Bahamas are called. 
'Conchs' from the commonneas of the shells on their coasts.

Conchifera (Isat., 'shell-bearing'), a term applied by Lamarek to bivalve molluses and the very different Brachiopoda (q.v.), but now rarely used.

Conchoid (Gr., 'shell-like,' from the shape), a plane curve invented to solve the problem of triseoting a plane angle, doubling the cube, \&c. Given any straight line and a point without it, we can describe two companion eurves which are dissimilar, but have the straight line as their common Asymptote (q.v.) between them. Thus both branches extend in either direction to infinity, and can never meet though continually approaching each other. The conchoid is obviously symmetrical with respect to the straight line drawn perpendicular to the given line from the given point. This eurve has been utilised in architecture to give a waving outline to tapering columns. Through $\mathbf{A}$ the fixed

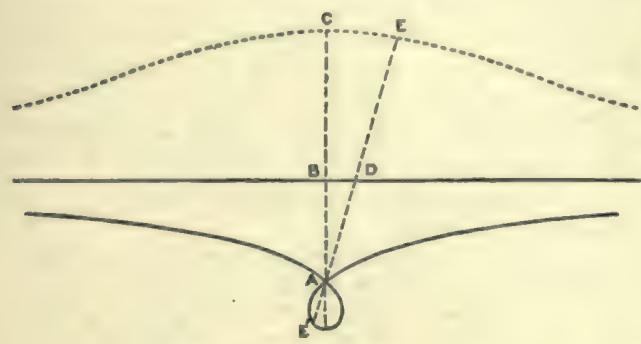

point draw any line $\mathrm{ADE}$, measure $\mathrm{DE}$ and $\mathrm{DE}^{\prime}$ each $=\mathbf{B C}$, then $\mathbf{E}$ and $\mathbf{E}^{\prime}$ trace the two branches of the conchoid. When $\mathbf{B C}=\mathbf{B A}$, there is a cusp at $\mathbf{A}$; when $\mathbf{B C}$ is greater than $\mathbf{B A}$, the inferior branch has a loop as in the figure.

Conchology, that branch of natural history which deals with the shells of molluses. From the time of Aristotle the beauty and variety of these structures have made them favourite objects of study, and few zoological subjects have excited so much popular enthusiasm. The study often became unscientific, and sometimes a craze, as when extravagant sums were paid for rare forms of no particular beanty or interest. Since the shells are only external coverings, and were seldom considered in relation to their tenants, or in connection with the internal and external influences to which they owe their shapes, conchology has been somewhat barren of seientific results. It is, however, possible that with the accumulation of knowledge in regard to the constitution and conditions of molluses, the study of their shells may come to have fresh scientific interest and dignity. See Brvalves, Mollusca, Shells, \&c.

Concierge is the French name for a doorkeeper or janitor of a house, hotel, or public edifice. In French towns, where a large portion of the population lives in flats, the common door by which many households have access to their several tenements is very nsually under the charge of a concierge, who exercises a general supervision over all who pass his conciergerie. The ancient Paris prison, known as the Conciergerie, is still standing; though Marie Antoinette's cell, converted in 1816 into a chapel, was destroyed by the Communists in 1871 .

Conclave (Lat.), the place where the cardinals of the Roman Catholic Church assemble in private for the choice of a pope, or that assembly itself. See Pope.

Concord, capital of New Hampshire, U.S., on the Merrimac River, 73 miles NNW. of Boston by rail. It extends two miles along the river, with wide streets, and contains a fine granite state. house and other public buildings. Its quarries of white granite are celebrated; and with abundant water-power, it has manufactures of cotton, woollen, leather, and wooden goods, machinery, enrriages, organs, \&c. Pop. (1870) 12,241; (1890) 17,004.

Concord, a town of Massachusetts, in the county of Middlesex, 23 miles by rail NW. of Boston. It is the seat of a large prison and reformatory. As early as 1767 the people of Concord opposed the measures of the British government, and in the revolutionary war a skirmish took place here, 19th April 1775. The place is notable as having been the honne of Emerson, Hawthorne, Thoreau, and other men of letters. Pop. (1880) 3922 ; (1885) 3727 ; (1890) 4427.

Concord, in Music, is a combination of notes which satisties the ear, without requiring any others to follow-e.g. the comnon chord, or combination of a note with its perfect fifth and major or minor third. See Music.

Concordance (Low Lat. concordantia), originally a system of harmonising things that differ or appear to differ. Thus there is a concordance of the Gregorian and Julian calendars, and of passages in the Bible that do not seem to agree. Subsequently it came to be used for a book arranged so as to form an alphabetical index of all passages, or at least of all the more important words in any work. For writings of universal import, from which passages are continnally being adduced to prove or support principles affecting nur daily life and action, such a handbook is indispensable. The necessity of a concordance for the Bible seems to have been felt at an early period. The tirst regular concordance of the Vulgate was made about 1244 by Hugo de Sancto Caro, with the assistance of many other Dominican monks. This work was frequently printed (e.g. Lyons, 1540, 1551), and led to Hugo's division of the Bible into chapters being universally adopted. Amended editions were prepared by Arlotto de Prato (about 1290), and (in the 14th century) by Konrad of Halberstadt. Concordances to the Vulgate were published at Basel in 1521 and 1561, by Rob. Stephanus (Paris, 1555), by Fr. Lucas (Antwerp, 1617), and by the Abbé F. P. Dutripon (Paris, 1838). A Greek concordance of the New Testament and Septuagint was prepared by Euthalios of Rhodes about the year 1300 , but has been lost. Concordances of the Septuagint were compiled by Conrad Kircher (Frankfort, 2 vols. 1607), by Abraham Fromm (2 vols. Amsterdam, $1718)$ and by Dr Hatch (6 parts, 1889-92). Xystus Betuleius published in 1546 the first printed concordance of the Greek New Testament, which was republished and amended by Stephens (Paris, 1594; Geneva, 1600). A better concordance was compiled by Erasmus Schmidt (1638), whose work, as revised and enlarged by Bruder (1842; new ed. 1880 ), is now of standard value. An abridgment was issued by Schmoller (1869). The first Helvrew concordance was drawn up by Rabbi Isaac Nathan ahout 1438 , and by Johann Buxtorf (edited by his son Johann Buxtorf, Basel, 1632). On the work of Buxtorf the later concordances of J. Fürst (1840), Bernhard Barr (1861 et seg.), and Davidson (Lond. 1876) are based. The chief concordances for Luther's Bible are those of Lankisch (1718), Buichner $(1740 ; 17$ th ed. 1885), Beck (1770), Wichmann (1782), Sehott ( 1827), Hauff (1828), Bernhard $(1850)$. The first concordance of the New Testament in English was by Thomas Gybson (Lond. 1535), and of the whole Bible in English by John Marbek (1550). The best known of the numerous concordances for the authorised English version of the Bible was compiled by Alexander Cruden, and first published in 1737 (3d ed. with his 
corrections, 1769); Dr R. Young's (1884) and Rev. J. B. R. Walker's (1894) are more recent. The Englishman's Hebrew and Greek Concordances (1860) deserve mention. The first Concordance of the Koran appeared at Calcutta in 1811 , but was superseded by that of Flugel (1842). The Complete Concordance to Shakespeare, compiled by Mrs Cow. den Clarke (1845; new ed. Lond. 1881), and that by John Bartlett (1894) are admirable. Concordances have also been prepared to Pope, Milton, Cowper, Tennyson, Dante, Chaucer, and Shelley.

Concordat (Lat. concordatum, 'a thing agreed upon'), though sometimes used of secular treaties, is generally employed to denote an agreement made between the pope, as the head of the Roman Catholic Church, and a secular government, on matters which concern the interests of its Roman Catholic subjects. Such concordats may take either of two forms. The pope may, after consultation with the government in question, issue a bull regulating the affairs of the Roman Catholic Chureh in the country, the contents of the said bull being afterwards ratified by the government and ineorporated in the law of the land. Or again, a formal treaty may be drawn up and signed by plenipotentiaries on both sides. Various theories have been held on the obligation of such contracts. Secular jurists have denied that they impose any real obligation on the state, which may annul them at pleasure. Extreme Ultramontanes, on the other hand, have regarded concordats as privileges which the pope grants for the time without entering into any contract properly so called, while the more moderate of Roman canonists recognise a contract binding both sides. As a matter of fact, no modern government can engage that its stipulations with the pope will be respected by its successors in oftice. Thus the Austrian concordat was secured by the clerical party in 1855 and swept away by their opponents in 1870. The famous and more enduring concordat by which the church in France was re-established after the Revolution was concluded by Napoleon (as first consul) and Pius VII. in 1801 .

Concordia, \& town of the Argentine state of Entre Rios, on the Uruguay, 302 miles N. of Buenos Ayres by river. It has a custom-house, and a river-trade exceeded only by that of Buenos Ayres and Rosario, exporting salted meat and Paraguay tea. It has railway connection with Paraná, Uruguay, and South Brazil. Pop. 12,000.

Concordia Formula. See Augsbura Confession, Confessions, Chemnitz (Martin).

Concrete. There is but little difference between concrete and coarse mortar. The mortar used in the masonry of castles and churches erected during the middle ages is in fact a conerete with small pebbles instead of the larger ones used in modern conerete. Any mixture of lime, sand, and water, with broken stones or bricks, bits of slag, gravel, or other hard material, is called a conerete. The hard lumps are termed the aggregate, and the mortar in which they are embedded is called the matrix. The mixture varies with the nature and quality of the materials, but it often consists of 1 part of quicklime, 2 of and, and 5 of gravel. It is better to use such a material as broken stone rather than water-rolled gravel, which has often too smooth a surface. Lime concrete, as the kind above described may be termed, is used principally for foundations, that is, a thick bed of it is formed below the lowest course of stones or bricks in walls, in cases where the ground itself is not sufficiently firm and solid. Not unfrequently, in some countries, walls themselves are formed of concrete, by laying a font or two of it in height at a time between boards, and giving it some time to harden. It then forms an artificial stone. Other methods of building walls of concrete are in use (see BUILDING).

Portland cement concrete is made either by mixing it with gravel alone, or more generally by using the cement along with sand and broken stones. The concrete used at Portland Breakwater Fort and at Cork Harbour have nearly the same composition. The cubic yard of it at the former place was made by using of Portland cement 5 cubic feet, of sand 10 cubic feet, and of broken stones (not more than $3 \frac{1}{2}$-inch gauge) 28 cubic feet, along with $23 \frac{1}{2}$ gallons of water. A concrete with these materials in much the same proportion has been used at other places, but different proportions are also employed. Portland cement being the binding material in this concrete, the question arises whether there is sufficient experience of its durability, especially where it is exposed to the action of sea-water, to warrant its employment in structural works of great or even of moderate size.

\section{See Cements.}

Concrete made of the hydraulic lime from Teil in France, which contains 66 per cent. of silicate of lime, has been employed in the construction of breakwaters and similar works at Cherbourg, Marseilles, and other places. The Teil hydraulic lime is one of the strongest known, and the concrete made with it has resisted the action of seawater for many years. Ordinary lime concrete does not set under water.

A concrete is made of broken stones and tar, about 12 gallons of the latter being used for every cubic yard of concrete. Bitumen or asphalt is better than gas-tar for this purpose, and either may be hardened by the introduction of dried and pounded lime, clay, or brick-dust. The materials should be heated before being mixed with the tar or bitumen. For backing armour-plates in forts a concrete of cast-iron turnings, asphalt, and pitch has been used. Gravel mixed with rather more than a thirtieth part, by bulk, of iron borings, was successfully used as a concrete at Stranraer pier.

Concrete, a term in logic opposed to abstract. A concrete notion is the notion of an object as it exists in nature, invested with all its qualities, as any particular flower, leaf, or tree; an abstract notion is the notion of any attribute of that flower, leaf, or tree, such as its colour, form, or height; qualities which may be thought of independently of the objects in which they inhere, though they cannot so exist. - The abstract method of handling a subject is adapted to speculation and reasoning; the conerete, to poetic effect and impressive illnstration.

Concretion, in Medicine, a formation of solid unorganised masses within the body, either by chemical precipitation from the fluids, or by the accidental aggregation of solids introduced into the system from without. In the former case, a concretion is termed a Calculus (q.v.); in the latter, the concretion may be either wholly composed of solids foreign to the body, or these may be mingled with the elements of the secretions, as with mucus, or calculous matter. Thus beans, peas, needles, \&c., introduced into the cavities of the body, have become the nuclei of concretions, by attracting around them mueus, or crystalline deposits from the urine. The most remarkable forms of concretion, however, are perhaps those formed in the stomach and intestines of man and the lower animals, from the more solid and indigestible parts of the food, or of substances improperly swallowed. Thus, young women have been known to acquire the habit of swallowing their own hair to a great extent; and very large concretions have been thus formed, which have proved fatal, by obstructing the passage of food. The 
nse of ontmeal in large amount has also been found to lead to concretions, especially when eaten coarsely ground and unboiled; such concretions have commonly been found in the intestines. The excessive domestic use of mognesia in the solid form as a laxative has been known to have a sinilar effect. In certain animals, intestinal coneretions are not uncommon, and grow to an immense size; they used 2 ) be grently prized as antidotes, and were used in medicine under the name of Bezoars (q.v.). In certain forms of morbid deposits, such as fibrons tumours (see TUMOUR), and in Tuberele (y.v.), concretions not unfreinently form; they are for the most part composed of phosphate of lime.

Concretionary Structure is a condition in rocks produced by molecular aggregation subsequent to the deposition of the strata, whereby the material of the rock is formed into spherules or balls, as in the concretions of magnesian limestone and the somewhat similar structures occasionally seen in certain tufis and crystalline igneous rocks. Concretions are nodules, balls, or irregular masses of various kinds which occur scattered through the body of a rock, and consist of mineral niatter which was formerly diffused through the material of the rock. Some of these concretions are erystalline, as gypsum in clay; others may be spherical, and have an internal radiating structure, as iron-pyrite in shale. Fantastically shaped coneretions are not uncommon in certain fine clays; such are the "fairy stones' of the country people here, and the 'löss puppen' of Germany.

Concubinage, the state of cohabitation of a man and woman without the sanction of a formally legal marriage. We find examples in the Old Testament, showing that it was permissible as a relief from a childless marriage. The Roman concubinatus was a permanent relation affording freedom from many of the severe marriage restrictions of the eivil law. It was a perfeetly respectable arrangement, and the woman had a footing in law, although a less dignified position socially than a wife. The offspring, called natural children, came to have limited rights of succession, and could be completely legitimated by subsequent marriage. Augustus, with a view to promote regular marriages, and check the growing licentiousness, enacted a comprehensive marriage-law (Lex Julia et Papia Poppoea), which confined conenbinage to women of low rank or who had lost their station. Christianity required the complete sanctity of marriage, although the civil law long continued to tolerate separation at pleasure. In the eastern enipire concubinage was entirely prohibited by the Emperor Leo. The ancient laws of the Germans recognised, along with regular marriage, a similar informal connection of the :sexes still not unknown as Morganatic Marriage (q.v.). The barragania of medieval Spain and the hand-fasting of our own ancestors were merely forms of concubinage. See CELIBACY and MARRIAGE.

Concurrent is a technical term for the penson who accompanies a sheriff's officer as witness or assistant.

Concussion of the Brain, in Medicine, is me form of Shock (q.v.) - that, namely, where the symptoms are due to an injury which has shaken or jarred the brain, and stunned the patient, without producing any mechanical injury, so fai as can be ascertained, to the brain or skull. It is generally loelieved that eoncussion alone can produce severe symptoms and even death, though conclusive proof of this has not yet been riven. It is apt to occur from a severe blow or fill on the head, from railway accidents, \&c. The symptoms 130 are those which charncterise shock-pale and cold skin, feeble pulse and respiration, with the addition of unconsciousness. This condition may last a few minutes, and be followed by rapid recovery, or may terminate in death. But in most cases it is succeeded by a period of reaction after an lour or more (often ushered in by vomiting, which is thus a favourable symptom), when the skin becames warmer, the pulse stronger, and consciousness gradually returns. During reaction, congestion or inflammation of the brain is apt to occur. Recovery is usually complete; but sometimes loss of memory, weakening of mental power, undue excitability, or some other sign of impairment of the nervous mechanism, remains for a long time or even permanently.

In regard to treatment, the patient should as quickly as possible be put to bed in a well-sired room, with warm bottles or blankets applied to the body and limbs, and should have injuries to other parts attended to; but beyond this, the less he in interfered with the better. In particular, brandy and other stimulants should on no account be given, except by medical direction; for though occasionally necessary, they do much more harm than good in the great majority of cases. During the period of reaction the patient must be kept very quiet; and for some days at least after apparent recovery he must abstain from alcohol and other causes of excitement, and from mental exertion.

Concussion of the Spinal Cord is due to similar causes acting upon the vertebral column instead of the head. The symptoms vary much with the site and severity of the injury. In many cases they are altogether absent or quite trivial at first, and only attract attention after some hours or days have elapsed; yet, and probably for this very reason, the injury not being treated at first, serious after-effects are much more common than in cases of concussion of the brain. Here also, however, complete recovery is the rule. The treatment must be in the first instance the same as in concussion of the brain.

Concussion of the spinal cord has attracted special attention in recent times owing to its frequent occurrence as a result of railway accidents. The slow and insidious nature of the symptoms presented by many such cases, and the difficulty of deciding whether those symptoms are real, and whether they have resulted from the alleged injury, have given rise to much litigation with respect to damages. The subject is very fully treated by Erichien, Concussion of the Spine, de. (Lond. 1875).

Condé, in the French department of Nord, situated at the contluence of the Haine and Scheldt, 7 miles NNE of Valenciennes by rail, is a fortress of the third rank, and gives name to the famous family. Pop. 4067.-CondE-sur-Nolreau, a town in the department of Calvados, 23 miles SSW. of Caen by rail. Pop. 6590.

Condé, louis I. DE Bourbon, Privce DK, younger brother of Antony of Bourbon, king of Navarre, was born 7 th May 1530, representative of an ancient and famous race taking their name from the town of Condé. During the wars between Henry II. and Spain, Condé distinguished himself by his gallantry, winning especial honour at the siege of Metz, the battle of St Quentin, and the capture of Calais from the English-the chief military events of the time. On the accession of Francis II. (1559), the family of the Guises became all-powerful in the state, and Condé and his brother Antony, partly from jealousy of the Guises, and partly from sincere religions conviction, joined the Huguenots, who were now 
struggling for legal recognition. To destroy the power of the Guises, and further the interests of the Huguenots, Condé was induced to join the Conspiracy of Amboise (1560). The plot miscarried, and Condé escaped execution only by the death of the king, which by necessitating the regency of the queen-mother, Catharine de Médicis, the bitter enemy of the Guises, changed the policy of the country. Concessions were now granted to the Huguenots, and Condé was made governor of Picardy. The massacre of Huguenots at Vassy by Guise (1562), however, led to the first civil war, and Condé and Coligny gathered an army of Huguenots. At the battle of Dreux, Condé was defeated and taken prisoner, but the assassination of Guise soon afterwards made possible the Pacification of Amboise (1563), by which Condé was released, and the Huguenots were granted liberty of worship. This concession being gradually withdrawn by Catharine de Médicis, the second Huguenot war broke out in 1567. In the south of France Conde had coins struck with the inscription: 'Louis XIII., first Christian king of France.' But at the battle of Jarnac (1569) Condé was defeated and taken prisoner, and immediately after his surrender, shot dead by his bitterest enemy, the Baron de Montesquiou. Condé was a brave leader, and exceedingly popular with his soldiers, but he had neither the lofty character nor the genius of Coligny. His great-grandson :-

Louis II. DE Bourbon, Prince dE Conde, known as 'the Great Condé,' was born September 8,1621 . Carefully educated by the Jesuits in their college at Bourges, Condé acquired a taste for literature, which he retained all throngh his life. In his seventeenth year he was introduced at court, and the year following was intrusted by his father with his government of Burgundy. By his marriage, much against his will, to the niece of Richelieu, he gained the support of that minister, and for a time of Richelieu's successor, Mazarin. At this period the Thirty Years' War was still raging, and since 1635 France had been engaged in a protracted struggle with Spain. In 1643, when he was only twenty-two, Condé was appointed to the chief command of the French forces, and in his first campaign defeated the Spaniards at Rocroi in the most brilliant of all his victories. As for more than a century the Spanish armies had been deemed al but invincible, this victory placed Condé at once in the first rank of commanders. In 1644, with his great rival Turenne as his subordinate, in a series of engagements he inflicted at Freibourg a severe check on the Bavarian general, Mercy; and in the following year again defeated the same general at Nordlingen. These successes were gained at an immense cost of life, and in the matter of strategical skill have been disapproved by subsequent military authorities. By the death of his father in 1646 , Condé, who had hitherto been known as the Duc d'Enghien, became the head of the house, and was theneeforth addressed as Monsieur le Prince. The capture of Dunkirk in 1646, and a great victory at Lens in 1648, in which the famous Spanish infantry were again completely beaten, were the other achievements of Conde during this the first period of his career. The war of the Fronde, occasioned by the quarrels of the court and the parliament, had now broken out, and Condé was required to support the power of the queen and Mazarin. With the aid of Condé the court party came to terms with the Fronde; but Condé himself, who after this service expected to be chief in the state, gave such offence to the queen and Mazarin by his arrogant conduct, that they had himself and his hrothers arrested and imprisoned for a year at Vincennes, a proceeding approved alike by the Fronde and the people of Paris. Popular feeling, however, soon changed in his favour, and grew so strong against Mazarin that he was forced to leave Paris and set Condé at liberty. But Mazarin's power over the queen was still absolute, and Condé, disappointed once more in his ambition, and finding the queen, Fronde, and people once more all against. him, retired to Guienne, and raised an army on the plea of rescuing the young king, Louis XIV., from bad advisers. Thus began what is known as the third war of the Fronde. At Bleneau he defeated the royal troops, but was at length forced by Turenne to make for Paris. Here in the Faubourg St Antoine he sustained a defeat which deprived him of all hope of ultimate success, and a peace was concluded in 1653. The terms of this peace, however, were such as Condé wonld not accept, and deprived of all support in France, he went over to Spain, and for six years served in all the campaigns against his country. Hampered in his action by the Spanish generals, he could effect little against the strategy of Turenne. The battle of the Dunes, near Dunkirk, where Turenne, aided by 6000 of Cromwell's Ironsides, inflicted a severe defeat on the Spaniards, put an end to the war. At the peace of the Pyrenees (1659) which followed, it was said that the affairs of Condé were more difficult to settle than those of Europe. So formidable was he deemed, that the young king found it advisable to restore him to all his honours and estates, and even to his government of Burgundy. Retiring to his estate at Chantilly, Condé remained here till his services were required in another war between France and Spain, when at his suggestion and by his action, Franche Comté was overrun and conquered (1668). The next year, on the resignation of Casimir, king of Poland, Condé would probably have been chosen his successor but. for the jealousy of Louis. In 1674 he fought his last battle. This was at Seneffe in Belgium, where he had for his opponent William, Prince of Orange. The battle lasted seventeen hours, and both sides elaimed the victory. On the death of Turenne in 1675, Condé succeeded him in the command of the army on the Rhine, but his health was now such as: to render him unfit for active service. Retiring again to Chantilly, he lived there till his death on 11 th December 1686, associating much with the great. men of letters of the period, Moliere, Racine, Boileau, and La Bruyère. Condé had all his life been noted as a scoffer at religion, but the year before his death he publicly announced his conversion. He took especial pleasure in the sóciety of Bossuet, whose oration on his death, regarded as one of the masterpieces of French literature, has served ever since to throw a deceptive lustre round the name of Condé. $\mathrm{He}$ had no political genius, and even as a commander he owed his successes more to the fiery energy of his character than to sheer military talent. There is no ground to suppose that in his public career he was influenced by any other motive than selfish ambition; and in his private character, though he could on occasion display a certain magnanimity, he was in intense degree. self-willed and overbearing. When all deductions have been made, however, Condé still remains in the first rank of the Frenchmen of his century.

See Mahon's Life of Conde, Fitzpatrick's The Great Conde and the Period of the Fronde; Histoire des Princes de Condé, by the Duc d'Aumale ( 7 vols. 1862-95); also the various Mémoires of the period, such as those of Cardinal de Retz, Madame de Motteville, \&c.

Condenser is an apparatus in which aqueous or other water is condensed into a liquid form either by the introduction of cold water, as in the condensing Steam-engine (q.v.), or as in distillation, by placing the condenser in another vessel, through which a current of cold water passes. When the water-supply is deficient at sea or on the 
coast, salt water may be distilled and condensed. See Distillation, Gas and tiases.

The ELkCTRIC CONDENSER is an apparatus consisting essentially of two parallel conducting plates, separated by a layer of non-conducting material or dielectric, employed to receive and retain quantities of electricity greater than either or both of the plates would do alone. The aimplest and typical form of condenser is that which was first used by Franklin. It is simply a sheet of glass, C (see fig.), both sides of which, excepting a margin at

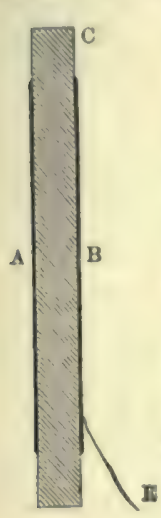
the edges, are covered with tinfoil, $A$ and B. To charge such a condenser, one of the sheets of tinfoil. say B, is connected with the ground, $\mathbf{E}$ (either by some metallic connection or by being placed on the hand of the experimenter), while the sheet, $\mathbf{A}$, remains insulated. If $\mathbf{A}$ be now charged with electricity, positive for example, a negative charge is induced on that side of $\mathrm{B}$ nearer A, while an equal quantity pusses to the ground. Increasing the charge in $\mathbf{A}$ induces $\mathbf{a}$ corresponding increase in B. This process, although by means of it large quantities of electricity may be accumulated, eannot go on indefinitely; for on reaching a certain limit, depending on the dimension, \&c. of the apparatus, the nature of the dielectric used, and the difference of potential of the two conducting plates, either a dismuptive discharge (see ELECTRICITY) takes place, or the charge passes off through the insulating supports of the condenser.

All the various forms of condensers satisfy the definition given above. One useful form is that in which the two conducting plates are fixed on the ends of brass rods which pass through brass knobs on the tops of two glass pillars, the dielectric in this case being air. The more common form, how ever, is the Leyden Jar (q.v.). Another is made up of sheets of tinfoil and paraftined paper, placed alternately in layers; the first, third, fifth, \&c. sheets of tinfoil are connected to one terminal, and the second, fourth, sixth, \&c. to another.

The capacity of a condenser is defined to be that quantity of electricity with which one plate must be charged in order to raise its potential by one unit. It can be shown that, in the case of condensers of the Leyden jar form, the capacity is numerically equal to the product of the outer and inner radii of the coating, divided by the difference of the radii-i.e. is greater as that difference is less. Hence the thinner (within certain limits) the glass between the two coatings of such a condenser, the greater is its capacity.

Condescendence, in the judicial procedure of Scotland, is an articulate statement annexed to a summons, setting forth the allegations in fact upon which an action is founded.

Condillac, bitenne Bonnot de Mably de, philosopher, was born of a noble family at Grenoble, 30th September 1715. His life was uneventful. As a child his delicate health delayed his progress in education; but in youth he numbered among his friends Rousseau, Diderot, Duclos, \&c. Many of his works were composed for his pupil, the Duke of Parma, grandson of Louis XIV.; aml he was titular Abbé de Mureaux. He was chosen a member of the French Academy of Sciences in 1768. He died on his estate of Flux, near Beangency, on August 3, 1780.

A great part of the Essai sur l'Origine des Connaissances Humaines (1746), and nearly all the Traité des Systemes (1749), are occupied with a molenic agrinst innate ideas and uhutract symtons. He expounds his analytic method in the Logigue (1780) and the Art de Raisonner (part of the Cours d'Etudes, in 13 vols. 1755). The Langue des Cal. culs appeared in 1798.

In the Traite des Sensations, Condillac uses his analytic method to solve the problem of the origin of our ideas and the formation of the mental faculties. He divided philosophical systems into three classes--(1) Abstract systems, (2) hypothesis, (3) the 'true' system of Locke, which rests on the facts of experience. But in confounding sensation and perception, and endeavouring to base all thought on sensation, he departed from Locke, and became the founder of Sensationalism. To Condillac all reasoning is only a variation of the form of expression. He beld that all idens and mental operations are only transformations of sensation. So he was compelled to put into the primary sensation all that he sought to develop out of it. His curious device of the statue, gradually endowed with the various senses and mental faculties, was for the purpose of isolating sensations. He substituted for the Cartesian test of truth his own criterion of identity. He recognised three kinds of evidence - of fact, of feeling, and of reason; and he affirmed that the same method of analysis is common to all the sciences. Unlike his scholars and followers, the encyclopxdists Diderot, D'Alembert, Holbach, Condillac was not a materialist.

Le Commerce et le Gouvernement, published in 1776 , treats economy as the science of exchanges, and has much influenced later economists. Condillac was a strong believer in Free Trade. The first of several editions of his Euvres Completes appeared in 1798. See monographs by Robert (Paris, 1869) and Réthori (1864), and Lewes's History of Philosophy.

Condiments, or seasoning agents, are those substances which are employed at table for the purpose of imparting a flavour or seasoning to the ordinary solid or liquid food. The prineipal condiments are saline substances, such as common salt; acidulous bodies, such as acetic acid or vinegar; oily condiments, anch as butter and olive-oil; saccharine substances, such as sugar and loney; and aromatic and pungent condiments, such as mustard, ginger, pepper, and pickles. See DIET,

Condition means in law a declaration or provision that upon the occurrence of an uncertain event an obligation shall come into force, or shall cease, or that the obligation shall not come into force until a certain event. Such conditions are known respectively as precedent or subsequent, resolutive, and suspensive. Physically impossible, and unlawful conditions in matters of contract annul the obligation to which they are annexed, but in questions under settlements and wills the opposite rule holds, and such conditions are ignored. Conditions in restraint of marriage are considered unlawful only where they are absolute and imposed on persons otherwise entitled to succeed. A potestative condition is the technical name for a condition in the power of one of the parties. It is an important doctrine of contract law that if a debtor does anything to prevent the accomplishment of a condition, he becomes liable as if the condition had occurred. Many most important conditions are merely implied-o.g. in a marine policy that the ship is seaworthy. In hankruptey, dividemis are set aside to meet conditional obligations. Again, in sales on credit, solvency is an implied condition, and where the buyer is declared insolvent, the seller may refuse to proceed. A good instance of a suspensive condi. tion is that of sale on approbation, or on sale and 
return. The doctrine of condition in feudal grants is in the law of Seotland very simple. Apart from entails, which were authorised by statute, such conditions must be intended to protect some valuable interest of the superior. Such are the clauses of pre-emption, the now obsolete clause prohibiting subinfeudation, clauses to preserve the plan of a town, or to prevent nuisances. Probably a condition against public-houses is valid, as in the case of the Grangemouth feus by Lord Zetland. If properly inserted and recorded in the titles, such clauses may entitle the superior not merely to refuse an entry under the old law, but to reduce the vassal's title.

Conditions of sale is the name used in England for what are ealled articles of roup in Scotland. These are generally printed along with the particulars of sale and distributed among those attending the auction. They provide what sort of title the purchaser is to accept. Similarly, conditions are prefixed to catalogues of furniture and books.

Condition, in Logic, denotes that which must precede the operation of a cause. It is not regarded as that which produces an effect, but as that which renders the production of one possible-to some logicians, however, a distinction without a difference. For instance, when an impression is made on wax by a seal, the seal is said to be the cause; the softness or fluidity of the wax, a condition.

The Philosophy of the Conditioned was a phrase brought into use by Sir W. Hamilton to express the inability of the human mind to conceive or reason respecting the Absolute and the Infinite. Our thought, according to him, can only be of the relative and the finite, of which these terms are but the negations; relativity and finitude are the conditions under which the human intelligence operates. In one of his dissertations on this, he criticised and endeavoured to refute the opposite position as maintained by Cousin $-a$ modification of the previous doctrine of Schelling-that 'the Unconditioned, the Albsolute, the Infinite, is immediately known in conscionsness, and this by difference, plurality, and relation.' Dean Mansel, in his Bampton Lectures (1858), brought Hamilton's doctrine into special prominence, and dwelt on the relativity of knowledge as a great fundamental law of the human mind.

Conditional Immortality is a tenet held by a theological school which denies the inherent immortality of the soul, and the consequent doctrines both of eternal misery and of Universalism as contrary to the teachings both of nature and of revelation. Its advocates maintain that the Bible sets immortality before men as something to be sought after (Rom. ii. 7), as a divine gift offered on certain conditions (Rom. vi. 23; John, iii. 15 , 16 ), and as a matter of hope and promise in the present life (Titus, i. 2); that this immortality is not a present possession (Mark, x, 30), and is to be realised by the assumption of a spiritual body at the resurrection of regenerate men from the dead (Luke, $\mathrm{xx} .35,36$ ), an event synchronous with the second coning of Christ ( 1 Cor. xv, 51, 52). Divine testimony, no less than experience, they say, declares unequivocally that man has the same natural life as all other animals (Eccles. iii. 19), and only those who by faith and obedience are united to Christ have the promise of immortality. The Calvinistic doctrine of eternal misery is untenable, the punishment of sin being death or everlasting destruction, to be inflicted subsequent to a judgment after the Lord returns (2 Thess. i. 9, 10). The dogma of Universalism, the only alternative to endless torment if the soul must live for ever, is also, they maintain, unfounded, since the punishment of sin (death) is said to be everlasting, like the life which is the reward of the righteous (Matt. xxv, 46). It is claimed that a succession of eminent and pious men have upheld this doctrine from apostolic times, among whom may be mentioned Justin Martyr, Clement of Alexandria, Irenæus, \&e.

Conditional immortality has received considerable impulse in recent years from many able and zealous advocates, notably the late William Leask, D.D., editor of the Rainbon, and Rev. Edward White. The Conditional Immortality Mission started in Britain in 1878 has done much, by means of lectures, publications, and annual conferences held in various cities, to disseminate this view. It has an organ, The Bible Standard, published monthly by the secretary. Many churches have been organised in Great Britain and it colonies, as well as in America, having conditional immortality as part of their doctrinal basis. The best modern works on the subject are Life in Christ, by Edward White; The Life Everlasting and The Unspeakable Gift, by J. H. Pettingell ; Hades, by Henry Constable; Duration and Nature of Future Punishment, by the same author.

Condom, a town in the French department of Gers, pleasantly situated on a height above the confluence of the Baise and the Gele, 20 miles SW. of Agen by rail. It has one fine church, once a eathedral; and was formerly the capital of the extensive Gascon district of Condomois, now included in the departments of Landes and Lot-et-Garonne. Bossuet was Bishop of Condom for a year (1669). Pop. 5070.

Condonation, in the legal phraseology both of Great Britain and the United States, means forgiveness granted by the injured party, and may be urged by the guilty party as a defence against an action of divorce on the ground of adultery. See DIVORCE.

Condor (Sarcorhamphus condor or gryphus), the great vulture of the Andes, one of the largest and most remarkable birds. Among the wide order of Accipitres, or Birds of Prey, the condor is the grandest representative of the family Cathartidæ,

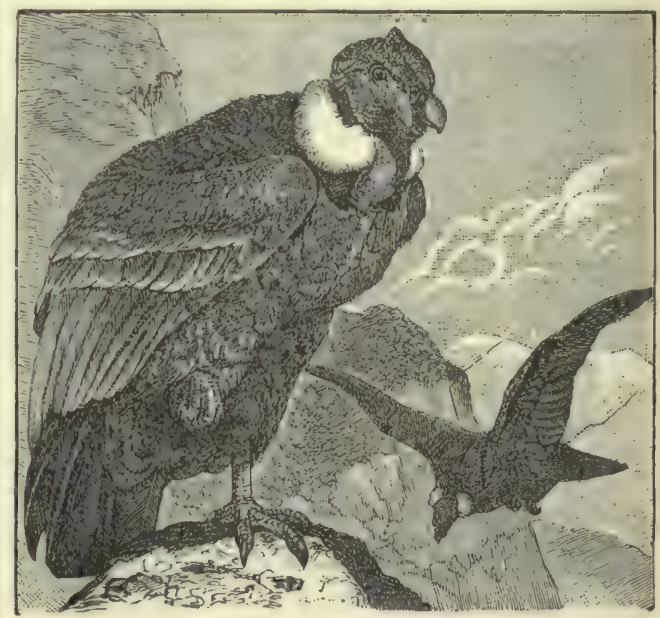

Condor.

or New-World Vultures. These may be at once distinguished from Old-World forms by the incompleteness of the partition between the nostrils, by having, to put it more plainly, ' $a$ hole through their nose." The beak is also constricted at the end of the 'cere,' and the feathers have no 'after. shaft.

Among these New-World vultures, the condor is chief. Though its size and strength have been often exaggerated, this magnificent bird is probably 
the largest of the vultures. The only rival which could dispute this claim is the famous Lammergeier (Gypotus burbatus) of the Alps. The male condor may measure alout $3 \frac{1}{2}$ feet in length, the female is slightly smaller. The expanse of each wing (said to be 15 feet from tip to tip) is more than twice the length. The general colour is black with a steel-blue sheen, and some of the fenthers verge into gray ; there is a downy white ruff round the dull-red naked neek. The young birds are covered with whitish down. The beak is long, hooked at the apex, black at the root, yellow at the point and on the sides. The head is naked, and in the male bird henrs a large lleshy comb. The eyes look sideways; the 'perforated' nose is characteristic of the family. The voice is limited to a weak sort of snorting. The feet are not well suited for grasping, the hind-toe being very small and hardly reuching the ground. The stories about condors lifting their prey in their feet from the ground are mythical. These birds have their central home in the Andes, but extend to some other mountainous parts of South America. They breed on the heights, laying their two eggs on bare ledges in the months of November and December; the young are unable to fly for a whole year. They descend to the plains to feed on carrion, tearing carcasses with their strong bills; they may also attack lambs and calves, or several together may venture on an adult animal. Their boldness and voracity seem to have been exagrerated. Their voracity is, however, great: Tschudi mentions one in confinement at Valparaiso, which ate $18 \mathrm{lb}$. of meat in a single day, and seemed on the morrow to have as good an appetite as usual. The condors have great powers of flight, and can soar to immense heights, till, in fact, they are lost in or far above the clouds. They are readily kept in confinement, and may be seen in many zoological gardens.

In the same genus is the rarer King of the Vultures ( $S$. papa), inhabiting the wooded plains of South and Central America. It is a smaller bird, reddish-yellow above, white beneath, with bluishgray rutf, black quills and tail. Its head and neck are covered with variously coloured roughnesses. It owes its name to the way in which it bullies other vultures. Closely allied is the Turkey Vul. ture (Cathartes aura) of North America. This bird, useful as a carrion destroyer, is about $2 \frac{1}{\text { feet }}$ in length, black in colour with a purplish sheen, well marked by its carmine and bluish-red head, fleshy neck, and white feet. C. atratus is another species from South America.

Condorcet, Jean Antoine Nicolas de CariTAT, MARQUIS DE, an eminent French author, was born, the son of a cavalry officer, in the little town of Ribemont, near St Quentin, in the department of Aisne, on September 17, 1743. In childhood he breathed the closest atmosphere of clerical and aristocratic exclusiveness, with the result of making him in after-years the enemy of all privilege and a thoroughgoing sceptic. Condorcet, after distinguishing himself in the Jesuit school at Rheims, began his mathematical studies at the ace of thirteen, at the College of Navarre in Paris. His success was rapid and brilliant; and the high approval of Clairaut and D'Alembert determined his future. His Essai sur le Calcul Integral (1765) obtained for him a seat in the Academy, and he became perpetual secretary in 1777. He took an active part in the Encyclopedic. On the ontbreak of the Revolntion he made eloquent speeches and wrote famous pamphlets on the popular side, was sent by Paris to the Legislative Assembly in 1791, and in 1792 became president of the Assembly. He voted that the king should receive the most severe punishment except death, and as deputy for Aisne in the National Con- vention, he voted usually with the (iirondintm. Accused and condemned by the extreme party, he found refuge in the house of a generous lady. Madame Vernet, for eight months; but driven to change his place of concealment, he was recognised and arrested. Imprisoned in the gmol of Bourg-laReine on the 7th April 1794, he was found dead the next morning, whether by divease or poison was never known.

His profession of faith, in a letter to Turgot, which was written when he left college at seventeen yeans of age, lays stress on moral sympathy as the source of all virtue. His constancy in moral principle was fitly associated with perfect consist. eney in politics. He raised a great commotion by his attempt to apply the calculus of probabilities in the domain of jurisprudence, and of the moral and political sciences. In his Progres de 'l'Esprit Humain, written in hiding, he insisted on the justice and necessity of establishing a perfect equality of civil and political rights between the individuals of both sexes, and proclaimed the indefinite perfectibility of the human race. Complete editions of his works have been issued in 1804 (21 vols.) and 1849 (12 vols., containing a biography by Arago). See Morley's Critical M̂iscellanies, Comte's Philosophie Positive, and Flint's History of the Philosophy of History.

Condottie'ri (Lat. conducti, 'hired'), the name given in the 14th and 15th centuries to the leaders of certain bands of 'free lances' or mili. tary adventurens who, for booty, offered their services to any party in any contest, and often practised warfare on their own account purely for the sake of plunder. These mercenaries were called into action by the endless feuds of the Italian states during the middle ages. Among the most celebrated of their leaders were Sir John Hawkwood at Florence (1390, originally an Essex tailor); Francis of Carmagnola (about 1412); and Francis Sforza, who in 1450 became Duke of Milan. The Com pagnies Grandes in France, during the 14th century, resembled the bands led by the Italian condottieri. They originated in the long bloody wars between France and England, did enormous mischief, and became powerful enongh to rout the king's forces in 1361; but ultimately Du Guesclin persnaded them to seek their fortune in the Spanish service. See O. Browning, The Age of the Condottieri (1895).

Conductivity. See Heat, Electricity.

Conductor, the director of the modern orchestra. Though from the earliest days of the orchestra abroad he has always performed his duty by beating time with the baton, the practice was unknown in this country till introduced by Spohr in 1820 , at a concert of the Philharmonic Society of London. Previously the orchestra was kept together by the leader of the violins, the conductor simply sitting at the harpsichord or piano with the score before him, occasionally putting in a few chords, or accompanying; but the result was clearly unsatisfactory, and the condueting stick had only to be introduced to gain general acceptance at once. The art of conducting as now practised requires 80 many qualifications that it may be considered rather as a special gift than an acquirement to be learnt. But few eminent composers have also distinguished themselves as conductors. The greatest recent conductors are Costa, Von Bülow, and Richter.

Conductors and Non-conductors of Electricity. When an electrified body is placed upon a metallic stand, so that it is in metallic connection with the earth, all traces of electrification disappear; but if placed upon supports of glass or ebonite, its charge is still retained, the body then being said to be insulated. In the former case, the electric charge having passed to the ground through 
the metallic support, the metal is termed a conductor of electricity; in the latter, the glass or ebonite is termed a non-conductor or insulator, since by its means the charge is prevented from leaving the body. This distinction is somewhat artificial, since no substance is known to be either a perfect conductor or an absolute insulator. The substances in frequent use as conductors and nonconductors may be arranged in the following order of their conductivity, beginning with the best : Silver, copper, gold, brass, zine, platinum, iron, tin, lead, mercury, German-silver, graphite, red phosphorus, mineral acids, saline solutions, seawater, pure water, alcohol, wood, ice, vegetable oils, lime, chalk, camphor, porcelain, wool, hair, silk, glass, wax, sulphur, resin, amber, gutta-percha, shellac, paraffin, ebonite, air and other gases.

It is found that the efficiency of a non-conductor, when used as an insulator in electrostatic experiments, depends very largely on the state of its surface. In a damp atmosphere, glass becomes coated with a thin film of molsture which considerably lessens its insulating power. Hence these experiments succeed better in dry weather; otherwise the apparatus requires to be heated, or the glass insulators employed to be coated with shellac varnish, upon which moisture does not so readily deposit. In metals, conducting power decreases when the temperature is raised; on the other hand, glass, wax, sulphur, and some other bodies which are extremely. bad conductors at ordinary temperatures, conduct very much better when raised to a sufficiently high temperature. It has been observed that a series of metals arranged in order of their electrical conducting powers, exhibits the same order as when similarly arranged for their thermal conducting powers ; in other words, metals which conduct electricity well, conduct heat well. Also, that when two specimens of the same metal differ in electric conductivity, they differ in thermal conductivity, and in the same wry. See LIGHTNING CONDUCTOR.

Condurango is the name of several South American Asclepiadacen (q.v.), whose bark affords a drug used as a remedy for venomous bites.

Condyle, a protuberance on the end of a bone, serving for articulation with another bone; especially that by which the occipital bone of the skull is articulated to the spine.

\section{Condy's Fluid. See Manganese.}

Cone. In general, the term cone is applied to any surface described by the motion of a straight line which always passes through a fixed point and

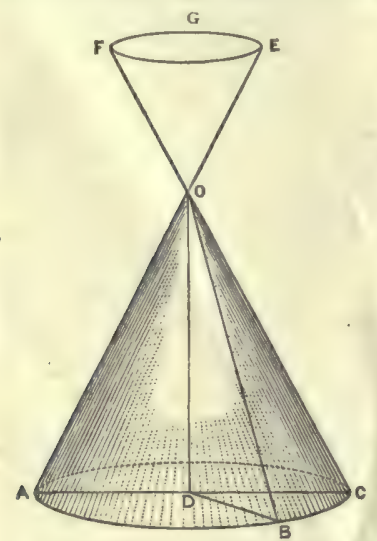
also intersects some curve in space. But more particularly, the word is used to denote a right circular cone-i.e. the solid produced by the revolution of a right-angled triangle round one of the sides containing the right angle. Thus (see fig.), let ODC be a triangle with a right angle at $D$; if it revolve round $\mathrm{OD}$, then in moving through successive positions, OC will trace out the cone, OABC. The point, $O$, is termed the vertex; the height, OD, the altitude; the line, $\mathrm{OD}$, the axis; and the circle, $\mathrm{ABC}$, the base of the cone. The line, OC, by whose motion the cone is produced, is termed a generating line, or generator. In the oblique cone, the axis is inclined to the base at an angle other than a right angle. A truncated cone is the lower part of a cone cut by a plane parallel to the base.

The lateral surface of a right circular cone is obtained by multiplying half the circumference of the base into the slant height of the cone; the solid content, or volume, is equal to one-third of the area of the base multiplied by the altitude.

In considering the different possible sections of a cone by a plane, it is necessary to remember (as is indicated in the figure) that a cone is really produced in duplicate; that the generators, after passing through the fixed point, $\mathrm{O}$, form another cone, such as OEGF. Different positions of the sectional plane produce different curves, according as it is parallel to the base, a generator, the axis, or parallel to none of these ; so, consequently, we have a circle, parabola, hyperbola or ellipse, respectively. See articles Circle, Ellipse, Hyperbola, PARABOLA.

Cone is a term used in Botany, with considerable latitude and variety of application. The growing point or bud of any ordinary higher plant is of more or less acutely conical shape, and the young leaves at first arise in close succession upon it. But while in vegetative growth the axis usually lengthens and the leaves develop and expand, the onset of reproductive functions may check these changes. In the simplest cases the leaves may become partially modified for pollen or ovule bearing, as stamens or carpels, while the leaf apices do not wholly lose their leafy character and arrangement ; thus we have the cone-like male and female flowers of Cycads (q.v.). In the allied conifers, which include the most characteristic conebearing trees, the leafy character of the crowded stamens composing the male flower may be almost entirely lost; but in the female the structure of the familiar cones (e.g. Scotch fir, spruce, larch) has been the subject of enormous controversy ; since from one point of view it is regarded as a single flower composed of many carpellary leaves (each bearing a biovular placenta on its upper surface); while from the other it must be viewed as an in. florescence of which the crowded bracts bear axillary biovular branches (see GyMNOSPERMS). The cones of Coniferæ may vary greatly from their typical shape, witness the almost spheroidal cones of Araucarias, while the number and crowded succession of the leaves in ordinary cones may be much reduced and simplified-e.g. cypress.

The apparent cones which oceur in some orders of dicotyledonous plants are always due to a crowding of the inflorescence. Thus, the so-called cone of Casuarina (q.v.) is simply produced by the crowding of the fruit; that of Hop or Gale (q.v.) by the overlapping of the leafy bracts which conceal the small reduced flowers. But the term is with advantage disused by most botanists outside the linits of the Gymnosperms.

Coneglia'no, a picturesque town of Northern Italy, 31 miles $\mathrm{NE}$. of Venice by rail. It was the birthplace about 1460 of the painter Giambattista Cima, called often Conegliano. Pop. 4682.

Cone-shell (Conida), a family of Gasteropod molluscs, with substantial conical shells. The last whorl of the spiral is much larger than those which precede it and simply form the apex of the cone. The aperture is long and narrow, with a sharpedged outer lip. The head of the animal has a long proboscis ; the 'foot' is long and narrow as the aperture suggests; the respiratory siphon is short and thick. In the living state the shell is covered by a yellowish epidermis, and it is only when this is rubbed off that the great beauty 
of the colour and marking is diaclosed. During life the inner layer of the shell and the internal partition of the second last whorl undergo more or less absorption. The principal genus, Conus, includes some 500 living species, runging from the

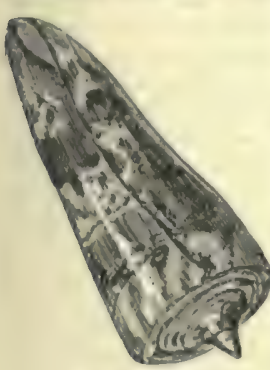

Cone-shell. Mlediterranean to the Cape, but especially at home in the eastern equatorial seas. They ereep in relatively shallow water among the rocks and coral reefs, and prey upon other molluses. Among the numerous species, some are rare, and have been favourite objects of collectors' mania. Many pounds have been paid for single specimens, and Conus gloria-maris is said to be "worth ten times its weight in gold." $C$. cedo nulli is in Its finer varieties a much prized treasure, and $C$. ammiralis is another favourite, though much commoner form. Numerous fossil species are known from the chalk onwards. Some of the animals are eaten, and the shells often form ornaments, or are worn down into rings and the like. The augurshell (Terebra), the latticed shell (Cancellaria), the tower-shell (Pleurotoma) are nearly allied genera, often regarded as types of separate families.

Coney Island, barely separated from the south-west angle of Long Island, at the entrance to Now York harbour, is a narrow strip of sand, 5 miles long, by t mile broad, with a fine beach. It is a crowded place of summer resort, and is conneeted with New York and Brooklyn in summer by a number of railways and steamboat lines. On the edge of the dunes stand a long row of enormous wooden hotels, and farther inland is the Brooklyn seaside home for invalid poor children. Other structures are a tubular iron pier (1000 feet), a look-out tower ( 300 feet), and a great number of bathing pavilions, some nearly as large as the hotels, In winter the place is nearly deserted.

Confarreation, a peculiar mode of marriage in use among the Romans, which consisted in the employment of certain words in the presence of ten witnesses, and in the performance of a religious ceremony in which panis farreus ("bread made of spelt') was partaken. Various priestly offices, such as that of the Flamen Dialis, were open only to those who were bom of parents thus married.

Confederate States, the name adopted by the confederacy formed by the eleven southern and slaveholding states which seceded from the American Union in 1860-61, and established a government which lasted till the close of the great civil war in 1865. See UNITED STATES. The Confederate States were South Carolina, Alabama, Florida, Mississippi, Georgi̊, Louisiana, Texas, Virginia (without West Virginia), Arkansas, Tennessee, and North Carolina.

Confederation, Imperial. See Colony and CANADA.

Confederation of the Rhine. During the war of 1805, so disastrous for Austria, several German princes, too weak to remain neutral, were forced to ally themselves with France. The first to do so were the Electors of Ravaria and Würtemberg, who, in recompense of their services, were elevated to the dignity of kings by the peace of Presburg, 26th December 1805. Finally, at Paris, on the 12th July 1806, 16 German princes formally signed an act of confederation, dissolving their connection with the Germanic empire, and allying themselves with France, under the protectorate of Napoleon. The more important of these 16 princes were the kings of Bavaria and Wirtemherg, the areh-chancellor, the Elector of Baden, the new Duke of Cleves and Berg (Joachin Murat), and the Landyraf of Hesse-Darmstadt; later, other princes followed their example, including the king of Saxony, the new king of Westphalia, and the Elector of Wurzburg. In 1811 the unpatriotic confederation comprised 4 kingdoms, 5 grand-duchies, 11 duchies, and 16 principalities; covering an area of $125,000 \mathrm{sq} . \mathbf{m}$., with a population of $14,608,877$, and an army of 119,180 men. The utter ruin which overtook the French army in the Russian campaign acted like a solvent on the confederation, and the year 1813 saw it vanish like mist in the sudden outburst of German patriotism. See Germany.

Conference, a meeting of the representatives of a number of states for political or diplomatic purposes. It is usually distinguished from a Con. gress (q.v.) as having only the power to discuss and prepare arrangements; while a congress has the power of deciding and concluding. But it is difficult to draw a precise line between the two; thus the Congo Conference at Berlin in 1884 was practically a congress. - Conference is also the name of the supreme synod of the Methodists (q.v.).

Conferva, a genus of lower fresh-water Algre, forming slimy masses or tufts in ponds and stagnant pools, easily recognised by their unbranched filaments, each consisting of a simple row of cells, which are destitute of spiral bands or other distinet differentiation of the contained protoplasm. The filaments do not conjugate, and multiplication appears to take place by rejuvenescence of swarm spores only. See ALGE, and Cooke's Handbook of

\section{British Algae.}

Confession, in Roman Catholic theology, means a declaration of sins to a priest in order to obtain absolution. The word, however, has borne very different meanings at different times, and the changes in sense mark important stages in the development of discipline and doctrine. St James (v. 16) speaks of that spontaneous confession which Christians make 'one to another' out of humility and brotherly love; and, much in the same spirit, Origen (Ḧom. in Ps. xxxvii.) recommends the sinner to seek out a physician "learned and merciful,' to whom he may diselose his wounds, and from whom he may get advice. In all this there is no question of strict obligation on the one hand, or of priestly power upon the other. Still, even before Origen's time, the word had acquired a new signification. From the close of the $2 d$ century at latest the ehurch marked ont for special reprobation those sins which were called 'mortal'viz. murder, idolatry, and adultery. The guilty person was required to make public confession, he was subjected to penitential exercises, and was either excluded during life from the communion of the church, or readmitted, after long discipline, by the bishop, who imposed his hands upon him. The list of 'mortal offences' was extended during the 5 th and the following centuries to all crimes which the Roman law punished with death, exile, or grave corporal penalty, and Leo I. (440-461 A.D.), in a famous letter to the Bishops of Apulia (Ep. 168), substituted private confession to the priest for public confession to the congregation. But the essential points of difference between ancient and modern or sacramental confession remained. In the former, the church only required confession to man of certain enormous offences, and left the mass of sins which are now called mortal to the judgment of God; and she exercised the power of 'binding and loosing' by excluding sinners from, and readmitting them to, her communion. Such power is really inherent in every society, though 
of course the church claimed to hold it by divine commission (Matt. xvi. 19, xviii. 18; John, xx. 22, 23 ), and insisted on the serious consequences which it involved. We can trace the faint beginnings of the modern system in the practice which prevailed in monasteries and nunneries of confessing breaches of the rule to the superiors (Jerome, De Req. Monachorum; Basil, Reg. Brev.), and in the growing habit of seeking advice from priests by secret confession. The thirty-third canon of the Council of Chalons, which was held 813 A.D., throws great light on the state of things then existing. Some, the council says, maintain that 'sins should be confessed to God alone,' others to God and to the priest. The council finds no fault with either view, and remarks that confession to God purges the conscience from sin, while confession to the priest teaches the penitent 'how his sins are to be purged.' Even Peter Lombard, the great theological authority of the 12th century (In Sentent. lib. iv.), occupies the same ground as the Council of Chalons; and Aquinas (Supplement to the Summa) admits that in Lombard's time the necessity of confessing all mortal sins to the priest was an open question. Meantime, the fourth Lateran Council in 1215 (can. xxi.) had required all the faithful who have come to the years of discretion to confess their sins at least once a year to their parish priest, or with his leave to another priest. The doctrine received its final form in the Couneil of Trent (Sess. xiv.). The council explains 'mortal sins' to mean all sins, 'even sins of thought" which separate the soul from God. It declares that for mortal sin after baptism, confession to an approved priest, in act if possible, in desire if a priest cannot be had, is by divine institution the one and only remedy. This confession must embrace every mortal sin which can be recalled after careful self-examination. Further, it declares that the secret confession of mortal sins has always been practised in the church, and whereas in Peter Lombard's time Roman Catholics were free to hold that absolution was no more than a declaration of forgiveness by God, the council condemns this opinion under anathema. But it is careful to add that confession and absolution, in order to avail, must be accompanied by sincere sorrow before God for sin past, and a firm purpose of amendment. By the present canon law, Roman Catholics living in the world may choose any priest approved by the bishop as their confessor. The confession of slight or venial sins remains a matter of counsel and not of precept.

Confession to a priest is prescribed by the Greek and most of the Oriental churches, and the Church of England recommends private confession in the case of the sick, though it has never enforced the use of it. In 1873, 483 Angliean elergymen presented a petition to Convocation for the education, selection, and licensing of duly qualified confessors. That petition fell flat; but confession is regularly practised among a consilerable section of the English communion. The Lutherans at first were inclined to retain some sort of private confession, but they were content with confession of a general kind, and have allowed it to fall into disuse. It is entirely rejected by Presbyterians, Methodists, Congregationalists, Baptists, \&c.

The 'seal of confession' is the obligation which binds the priest to make no use whatever outside of the confessional of the knowledge acquired there. It is imposed under severe penalties by the fourth Lateran Council. See CoNFIDENTIALITY, and Lea's History of Auricular Confession (3 vols. 1896).

Confession, in eivil procedure by English law, is a formal admission or avowal of a fact, as when a defendant alleges a ground of defence which has arisen since the commencement of an action, and the plaintiff confesses the defence-i.e. admits the truth of the defendant's allegation. In Scotland, a party to an ordinary eivil action may be called on to confess or deny any relevant matter of fact, and if he refuse, he will be held as confessed. Where a statement within the opposite party's knowledge is averred upon one side, it is held as confessed by the other unless specitically denied. In criminal law, a confession is an admission of guilt. In England, a confession by a criminal made in the course of a judicial proceeding is sufficient, if plenary, to found a conviction, as where a prisoner pleads guilty. An extra-judicial confession, if freely made, may be admitted as evidence. In Scotland, a confession made by a criminal in presence of a judge will be admitted as evidence; but; is not held as equivalent to a confession by the panel in presence of a jury, which is conclusive evidence against him. In the United States also confession is evidence, if voluntary and made without promise of reward or threat of punishment, and that whether made before or after apprehension and commitment; generally confession without eorroboration is insufficient, but in one or two states the jury may convict without corroboration. As to confession on trial, see PLEAD. ING, TRIAL; as to confession before the examining magistrate, see DECLARATION ; and for Judgment by Confession, see CogNovit.

Confession AND Avomance, in pleading at common law, in England, is the admission of the allegation of the opposite party, but with the addition of some circumstance which deprives it of legal effect, as, for instance, the admitting that an assault was committed in self-defence. Since the passing of the Judicature Acts of 1873 and 1875, pleas in confession and avoidance have technically fallen into desuetude. See (under Plea) Pleading.

Confessional, the seat or recess in which the priest sits to hear confession in a Roman Catholic church. It is probable that the confessionals in English churches, previous to the Reformation, like those still often found in Catholic use, were slight wooden erections, because they have so entirely disappeared that their form is a matter of dispute among ecclesiologists. It would seem that confessionals were not always used, as in an old painting on the walls of St Mary's Chapel, Winchester, a woman is represented kneeling to a priest, who is seated in his stall. The confessional commonly has a door in front for the priest to enter by, and an opening on one or both sides, like a small window, with a grating of wire or zinc, for the penitents to speak through.

Confessions of Faith are generically identical with Creeds (q.v.). If any distinction be made, it is the merely accidental differentiation that creeds are shorter, and that confessions of faith are generally polemical as well as didactic in their character and aim. Such a distinction, it is found, actually obtains in practice, and confessions of faith, as thus distinguished from creeds, are so numerous and varied as to call for separate attention.

Confessions of faith may be defined as anthorised summaries of a church's belief, and standards of its faith and doctrine. In all Protestant churches, however, they are regarded as subordinate standards, ranking under the Scriptures, which are recognised as the only supreme "rule of faith and life. Their object is to present the cardinal truths of revelation in a connected and logical form, especially if these be controverted; while at the same time they afford a basis of association and a bond of unity for Christians. As they are the result of the conflicts of a church with error, confessions of faith vary in their doctrinal comprehensiveness, are more or less gradual in their 
growth, and are signifieant and important features in it history.

Prior to the era of the Reformation in Europe, the public formularies of the Christian ehureh were genernlly terned creeds. It was the rise of Protestantism that evoked confeseions of faith as we now understand the name. Among the first to formulate these were the Swise at Zurich, where, in 1523, Zwingli wrote his Sixty-seven Articles or Condusions. To Luther and Philip Melanchthon, however, is due the honour of drawing up the finst authoritative evangelical formulary, the Augsburg Cimfession (q.v.), by the adoption of which the Lutheran princes, with their states, in 1530, finally broke with Rome. It was followed by the Apology of the Augsburg Confession, drawn up by Melanch. thon, and recognised as a confession in 1532 . Later confessions of that church are the Articles of Smal. cald, prepared in 1537, the Saxon Confession, and the Würtemberg Confession, both published in 1551. But these were superseded in 1580 on the adoption of the Form of Concord (Formula Con. cortia), which is the most representative symbol of the Lutheran Church.

The German Reformed Church, which sprang up side by side with the Lutheran, and stood midway between it and the Calvinistic bodies, issued in 1530 the Tetrapolitan Confession, so called because sent forth in name of the four cities of Strasburg, Constance, Memmingen, and Lindau. It was written chiefly by Bucer. Among other confessions ofticially recognised by this church, or local portions of it, were the Confession of Anhalt (1581); the Confession of Nassau (1578); the Consensus of the Ministry of Bremen (1598); the Hessian and Heidel. berg Confessions (1607); and the Declaration of Thorn (1645).

In Switzerland, the labours of Zwingli were followed by the publication in 1534 of the First Confession of Basel, prepared by Ccolampadius and Myconius. To it succeeded in 1536 the Second Confession of Basel, better known as the First Helvetic Confession. It was superseded in 1566 by the more comprehensive Second Helvetic Confession, which was written by Bullinger, and obtained official sanction in Scotland, Hungary, France, and Poland. Calvin left his mark on confessional literature in, among others, the Consensus of Zurich (1549); in the Consensus of Geneva (1552), which is a treatise written mainly in defence of the doctrine of predestination; and in the Gallican Confession, which he prepared in conjunction with his pupil, Antoine de la Roche Chandieu (Sadeel). The latest Swiss confession is the Helvetic Consensus Formula, written in 1675 , by Heidegger of Zurich. It is thoroughly Calvinistic, and was drawn up in defence of the conclusions of the Synod of Dort.

The Gallican Confession, was adopted by the French Reformed Church in 1559, and after revision was ratified at the Synod of Rochelle in 1571, whence it is sometimes called the Confession of Rochelle.

The Belgic Confession, drawn up principally by Guiclo de Bres in 1561, has since then been, and still is, the authoritative standard of the Dutch and Belgian Reformed churches. The Arminian controvensy occasioned the meeting of the Synod of Dort in 1618, and the issuing of the Canons of Dort in the following year. These canons were adopted as symbolical by the Dutch and French Reformed churches.

But confessions have not been peculiar to the Protestant Church. Influenced by the Reformation, the Greek Church adopted the Orthodox Confession of Mogilas, the metropolitan of Kief (died 1647), who drew it up in a catechetical form as a protective mensure against both Protestant and Roman Catholic churehes. Recast by Syrign, the metropolitan of Nicrea, it became in 1672 the confen. sion of the whole (ireek Church. At the same time the anti-Calvinintic Confession of Dositheus was promulgated by the Synod of Jerunalem. Similarly, the Roman Catholic Church published the Canons and Decrees of the Council of Trent in 1.564, to which were added in 1854 the decree of Pius IX. on the Immaculate Conception, and in 1870 the Vatican Decrees, See Homas CATHOLIC CHURCH.

In Britain the chief confessions are the Scots Confession, consisting of twenty-five articles, drawn up by John Knox in 1560, and aslopted by the Church and kingdom of Seotland; the Thirty-nine Articles of the Church of England, adopted in 1562 ; the Irish Articles, one hundred and four in number, prepared by Archbishop U'sher, and adopted by the Irish Church in convocation at Dublin in 1615 , but superseded by the Thirty-nine Articles of the Church of England in 1635 (see ARTICLES); and the Westminster Confession of Faith, emitted in 1647 by the Westminster Assembly of Divines (see WESTMINSTER). This confession has become identified with Presbyterianism among all the Englishspeaking populations of the globe. Its theology was also adopted with some modifications by the Congregationalists and a section of the Baptists. It was ratified by the English parliament in 1647 , but in England its influence waned with the de cline of Presbyterianism during the Commonwealth and the reign of Charles II. By Scotland, in furtherance of the uniformity agreed upon in the Solemn League and Covenant, the Westminster Confeseion was cordially received and adopted in place of that of 1560 . It was approved by the General Assembly in 1647, with the modification of but one section regarding the magistrate's power circa accos, was ratified by parliament in 1649 and again in 1690 , and continues to be the common symbol of the Church of Scotland and of the churches which have seceded from her communion, save in the case of the United Presbyterian Church, which in 1879 modified its acceptance of the Confession by a Declaratory Statement regarding certain of its doctrines.

The Westminster Confession consists of thirtythree chapters, is thoroughly Calvinistic in its teaching, and is in many parts stated in terms designed to counteract the principal errors of the time. Beginning with the canon of Scripture, it surveys the entire field of theology, deals also with the relations of the state to the church, the constitution of the ehurch itself, and concludes with the topics of death, the resurrection, and the last judgment. Its precise logic, its clear, dignified and powerful diction, and its constant reference to Scripture in proof of its statements, tended greatly to beget that influence to which it attained.

Confessions of faith are now the subject of a voluminous literature which is fully utilised in the History of the Creeds of Christendom (3 vols. 1876), by Dr Philip Schaft of New York, and his IIarmon! of the Reformed Confessions (1877). A valuable historical appendix, with special reference to the Presbyterian Church, is given in the Report of the Second General Council of the Preshy terian Alliance (1880). See also under CREEDS.

\section{Confessor. See Canovisation.}

Confidentiality, in Law. The most common instance of confidentiality is in the case of those communications between a elient and his legal adviser which neither of them can be called on to produce in a suit, and upon which no action of damages can be founded. The privileyre applies to letters written by the lawyer to his client relating to a suit which is either pending or contemplated; but to what extent it covers other business communications is a question on which there are 
conflicting authorities in Scotland. In England the rule is not qualified by reference to impending litigation. The same privilege is extended to the conimunications of several parties, or of their counsel and agents engaged on the same side of a canse, and made with a view to their joint prosecution or defence. Where a party placed in such circumstances is examined as a witness, he will be entitled to decline answering questions as to such communings, and even bound to do so, unless the privilege is waived by the other party interested. Such confidential communications cannot, as a rule, be made the ground of an action for libel or slander, because there is a presumption against malice, which may, however, be rebutted. It is on the same principle that a master is protected who, when called upon for the character of a servant, charges him with a theft. With a view to preserving the freedom of domestic intercourse, and from a belief that the testimony of near relatives in favour of each other was worthless, it was formerly the habit to reject them as witnesses. The practice in England for a long time, however, has been to admit, and even to exact their evidence, making allowance, in appreciating its value, for the circumstances in which they are placed. The same principle has latterly been followed in Scotland; and the only exceptions which have been retained by the Evidence Acts of 1853-54 are, that neither the parties themselves, nor their husbands or wives, shall be competent or compellable to give evidence in criminal proceedings in which they are accused, nor to answer questions in a civil suit tending to criminate themselves or each other, or to reveal matters which they have communicated to each other during marriage. But where the issue for trial involves the terms on which the spouses lived, \&c., they may be examined. Such com munications remain confidential, although the marriage has been dissolved by death or divorce.

From the 4th and 5th centuries the 'Seal of Confession' was held to be inviolable, and no priest could be called upon, under any circumstances, to reveal facts which had been confided to him under its sanction. To this the case of treason was an exception in England, even in Roman Catholic times. The capitularies of the French kings and some other continental codes of the middle ages prohibited the attendance of clergy as witnesses in court. In Roman Catholic countries the privileges of the confessional remain unaltered, although a priest may state that the accused has submitted to penance. The duty of disclosure, however, is enforced in all cases in which the confession has reference to a future crime. In England no special privilege whatever is extended to the Roman Catholic confessional ; and the question as to how far a confession made to a clergyman for the purpose of obtaining spiritual comfort and consolation is protected was long considered doubtful. The rule has, however, been settled for some time that clergymen are not entitled to the same privilege as legal advisers; though it has often been advocated as advisable to extend the rule to clergymen, including Roman Catholic priests. In Scotland the point has never been decided, evidence of the kind in question, when not indispensable for the ends of justice, being generally either withheld or withdrawn. It has been decided in England that communications to a medical man, ven in the strictest professional confidence, are not protected from disclosure; and the same is the case in Scotland. Factors, bankers, and intimate friends are certainly not within the protection of the rule. Confidentiality exists as to the great majority of official reports and state papers.

In the United States, members of the legal profession are privileged, and, as a rule, what a client says to them cannot be disclosed except the right of confidentiality be waived. Interpreters stand in the same relation as attorneys. Confessions made to a clergyman or priest in some states are privileged by statute, but generally it is otherwise. By a statute of the state of New York, ministers of the gospel and priests of every denomination are forbidden to disclose confessions made to them in their professional character; and in the course of discipline enjoined by the church, similar statutes exist in Missouri, Wisconsin, Michigan, and Iowa. Communications made to a physician are not as a rule privileged; but in some states confidentiality is recognised. Communications between a husband and wife are privileged from disclosure, on the grounds of public policy and the good order of society. See Privilege.

Confirmation, a Latin word which signifies 'strengthening.' In the ancient church, the rite so named was administered immediately after bap. tism, if the bishop happened to be present at the solemnity; and in the Greek Church it is still made part of the baptismal rite, being administered then by the priest by means of unction with chrism preconsecrated by a bishop. In the Roman Catholic Church, for the last 300 or 400 years, the bishops have interposed a delay of seven years after infant baptism ; in the Lutheran Church, the rite is usually delayed for from thirteen to sixteen years; and in the English Church, from fourteen to eighteen years. There is, however, in the latter church no limitation of age, other than such as is indirectly implied by the exaction of a specified amount of religious knowledge as a qualification for the rite. Confirmation may be administered at an earlier period, if a family is about to emigrate; and persons are confirmed up to sixty or seventy, if they choose. The ceremony consists in the imposition of hands by the bishop, accompanied by an invocation of the Holy Ghost as the comforter and strengthener. But both in the Lutheran and in the English Church, the ceremony is made the oceasion of requiring from those who have been baptised in infancy, a renewal in their own persons of the baptismal vow made for them by their godfathers and godmothers, who are thereby released from their responsibility. Properly, none can par. take of the Lord's Supper, in these churches, unless they have been confirmed. In the Roman Catholic Church, confirmation is held to be one of the seven sacraments, and in its administration chrism and the sign of the cross are used; and instead of the imposition of hands, the person confirmed receives a slight blow on the cheek, to remind him that he must in future suffer affronts for the name of Christ. Catholics usually take a new name at confirmation, which should be the name of some saint whom they choose for their special patron. In the Thirty-nine Articles of the Church of England, confirmation is declared not to be one of the sacraments, and the above ceremonies have been discontinued since the Reformation.

Confiscation, in Scottish law, has been applied to the forfeiture of lands or goods to the crown, as part of the punishment for certain crimes, such as murder and treason. But more commonly the word is used in international law to signify the appropriation of goods or ships belonging to a hostile state, or its subjects, generally as a punishment for an attempted breach of blockade.

\section{See Escheat.}

Confliet of Laws. On the breaking up of the Roman empire into separate kingdoms, as many systems of jurisprudence, more or less dissimilar, arose, and were administered side by side. But owing to commercial intercourse and intermarriage many persons held property in more 
countries than one; many possessed two nation. alities by birth, and more than two-if nationality could be acquired by residence and interest in a foreign atate. In such eireumstances it often became an object of the utmost importance to indi. viduals to ascertain, and of the greateat difficulty to lawyers to determine, whether the laws of one state or of another were to govern questions of sale, succersion, status, and the like. As no state could vindicate its jurisdiction beyond its own bonndaries without being guilty of an act of aggression, it became absolutely indispensable that certain general rules should be fixed upon in order to prevent the danger of national hostilities on trifing occasions. The elaboration of these rules constituted a new branch of juriaprudence, to which the title of Private International Law has been given. Many of the elassical treatises on the subject-e.g. Huber and Story-are entitled the Conflict of Laws. Other writers, such as Savigny, Bar, and Foelix, nse the term 'Private International Law.' From the partially independent character which belongs to the different states which constitute the American Union, the labours of the continental jurists in international jurisprudence have been carefully adapted to the requirements of that country ; and it is consequently to America and to continental Europe, rather than to British writers, that we must look for systematic works on this subject. See INTERNATIONAL LAW.

Conformable Strata are beds which lie parallel to each other, the accumulation of the upper strata having followed the deposition of the underlying beds without any break or prolonged interruption. Conformity thus points to a continuity of the same physical conditions.

Confraternities. See Brotherhoods and GuILDs.

Confronté, in Heraldry, is a term applied to two animals facing or fronting one another.

Confucius, the name by which the great Chinese sage is known, is a Latinised form of the

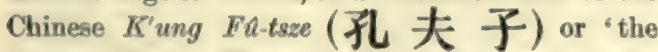
Master K'ung,' K'ung being his clan or family name, and Fu-taze the denomination applied to him by his disciples after he had become a teacher, and gathered around him a school of ardent and inquiring spirits, to whom he communicated his views on the ancient literature and history of their country, and on the principles of human duty. As a child, he received the postnomen Ch'it, and when urown up he was called Chung-ni, mark. ing his place in the honsehold. His birth took place, according to the most authoritative account, in 551 B.C., in the village of $\mathrm{Ch}^{\prime}$ ieh, in the state of La, a part of the present province of Shan. tung.

The K'ung family had migrated to La from the dukedom of Sung, and were a branch of the ruling house of Sung. The lineage of Confucins is thus traced through the dukes of Sung to the kings of the Shang or Yin dynasty, and through them again, up among the mists of antiquity, to the sovereign Hwang $\mathrm{Ti}$, whose reign is said to have commenced in 2697 B.C. His father, known to us by the name of Sha Liang-heh, was commandant of Tsau, and a soldier distinguished for his strength and daring. In his old age he contracted a second marriage with a young lady of the Yen family, and of her was born the sage in 551.

Liang-heh died in the child's third year, leaving his mother and him in straitened circumstances. He has described his own mental growth till he was' seventy;' when he 'could do whatever his heart prompted, without transyreasing what wa right,' and tell us that 'at fifteen his mind was set on learning, and st thirty he stood firm in his convictions.

At nineteen he married, going for his wife to the Chien.kwan family in his ancestral state of Sung, and in the year after, his son Ll was born. Besides this son Li, Confucius had two daughters.

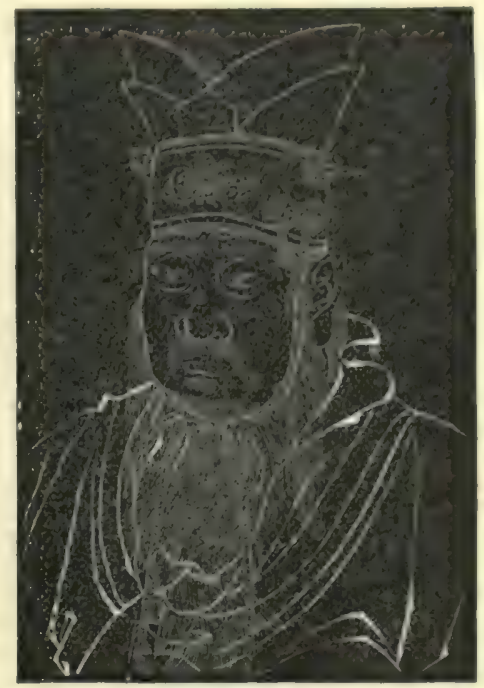

Confucius.

(Reduced fac-simile of a rubbing from a marble slab behind his temple at Kio-foo-hien).

About the time of his marriage we find him in humble offices, in eharge of the public stores of grain, and of the public herds, performing efficiently his functions, and allowing nothing beyond or higher than them to occupy his attention. In 531 B.C., when he was in his twenty-second year, he commenced in Ch'tieh-li his career as a teacher. He continued in his native state till 517 B.C., with the exception of a short visit to the capital at Loh, where he is said to have net with Lhotsze (q.v.). In 517 La fell into great disorder. The Duke Châo being worsted in the struggle, fled to the neighbouring state of Ch'1, and thither Confucius also for a time repaired.

Returning to $\mathbf{L} \hat{a}$, he remained there for sixteen more years without being called to any official emplovment. Duke Châo died in exile in 510 B.C. ; and his younger brother and successor, Duke Ting, in 501 B.C. appointed Confucius governor of the town of Chung-ta, where a marvellous reformation in the manners of the people speedily took place. The next year saw him first minister of works for the state, and next minister of crime. Tle government was now couducted for three years according to his counsel. 'He strengthened,' we are told, 'the ruling house, and weakened the ministers and chiefs. A transforming government went abroad. Dishonesty and dissoluteness were ashamed, and hid their heads. Loyalty and good faith became the characteristics of the men, and chastity and docility those of the women. Strangers flocked to Lo from other states.' Confucius was the idol of the people. But this success did not last long. The prosperity of the state awakened the jealousy and fears of its neighbours, The marquis of Ch'f cunningly sent to Duke Ting a present of beautiful courtesans and fine horses, and a breach was made between Confucius and his ruler. His counsels were no longer sought. He determined to leave LA and visit other states. Accordingly in 497 B.C., when he was now 
in his fifty-fifth year, he went forth from $L \hat{u}$, nor did he return to it till 485 or 484 B.C.

During this long period he visited many states, attended always by a company of his disciples. His fame had gone before him, and many of the princes would have received and supported him, but he would not settle where he could not obtain free course in carrying out his principles. Repeatedly he and his companions were in straits, and even in peril of their lives. Once they wère assailed by a mob, who mistook him for an officer by whom they had been oppressed. But while the others were alarmed, he calmly said: "After the death of king Wan, was not the cause of the right way lodged in me? While Heaven does not wish this cause to perish, what can the people of $K^{\prime}$ wang do for me?" Another time, in somewhat similar circumstances, he said: 'Heaven has produced the virtue that is in me; what can any man do to me?' Such was his belief concerning himself and his mission. He never pretended to be anything more than man, but he knew the right way, the way for the individual to perfect himself, and the way for the highest ruler to rule, so as to make men happy and good. One of the princelets through whose territory they passed asked his disciple Tsze-la how he would describe the Master, and the disciple gave him no reply. When he told the Master of the question, Confucius said: "Why did you not tell him that I am a man who in his eager pursuit of knowledge forgets his food, and in the joy of its attainment forgets his sorrows, and who does not perceive that old age is coming on!' He was then probably in his sixty-fifth year.

Duke Ting of Lu died in 495 B.C., and was sncceeded by his son Duke Âi, who in his tenth year sent a message of recall to the sage in Wei. The ruler and his ministers received him respectfully, but he can hardly be said to have re-entered political life. Only a few more years remained to him, during which he is said to have put the finishing hand to his labours on the ancient writings, and been specially assiduous in the study of the Yiking. He tells us himself that he reformed the music to which the ancient odes were sung, and digested the odes themselves, giving to the pieces in the principal parts of the collection their proper places. He must have occupied himself also with the composition of the only classical work which is assigned to his own pencil-the $C h^{\prime} u n C h^{\prime} i t$, embracing the events in the history of La from 722-481 B.C. The latest entry in the work is that in Duke Âi's fourteenth year (481 B.C.). He died on the 11 th day of the 4th month in 479 B.C.

In the Confucian Analects, or memorabilia com. piled soon after his death from the reminiscences of his disciples, we have abundant information of the Master's Sayings and Doings, and they can be added to from the supplements to the $C h^{\prime}$ un $C h^{\prime} i n$, the Narratives of the School, portions of the Books of Ritual Usages, and the memoir by Sze-ma Ch'ien. There are other works about him, but all containing more or less of the legendary element, evidently introduced after the Buddhistic literature became known to the Chinese. Of no ancient personage do we have fuller information than we possess of Confucius, and no other can we fashion more completely to ourselves. One whole book of the Analects is oceupied with his personal characteristics, his deportment, his eating, his dress. It shows him to us at his ruler's court, in his intercourse with his disciples, in his earriage, at his table, in his bed. The disciples tell us that there were four things from which he was freeforegone conclusions, arbitrary determinations, obstinacy, and egoism ; that there were four subjects which he avoided in talking with themextraordinary things, feats of strength, rebellious disorder, and spirits ; that there were four things which he taught them-letters, ethies, leal-heartedness, and truthfulness; that there were three things of which he seldom spoke-profitableness, the appointments (of Heaven), and perfect virtue; and that there were three things in regard to which he thought the greatest caution should be exercised-fasting (as preliminary to sacrifice), (going to) war, and (the treatment of) disease.

It is often said that Confucianism is a system of morality without religion. That he was emphatically a moral teacher is indeed true; and his greatest achievement as such was his formulating the golden rule, 'What you do not wish done to yourself, do not do to others.' He acknowledges in one passage that he himself failed in taking the initiative in obeying it. But this high morality was not without a religious sanction. If it be the requirement of man's nature on a correct analysis, yet that nature is the distinguishing endowment conferred on man by Heaven or God, and obedience to its requirements is obedience to the will of God. The first sentence of the Chung Yung, the treatise written by Confucius' grandson, is this : "What Heaven has conferred is the Nature; an aceordance with this nature is what is called the Path; the regulation of this path is what is called the Teaching.

But how is it that we do not find in the utterances of Confucius the expressions of a fervent piety, and that in his many exhibitions of the character of the Chün-tsze, his superior, model, or ideal man, he does not show him to us communing with God, confessing his own unworthiness, and imploring his forgiveness? These defects in his teaching we must admit. The explanation of them lies probably in this, that the direct worship of God was confined in the ancient religion of China, as it still is, to the sovereign as the parent and priest of the people. Speaking of the greatest religious services of the ancient sovereigns, Confucius, as is recorded also by his grandson, delivered the important judgment that in those services, 'in the ceremonies of the sacrifices to heaven and earth, they served God.' He probably thought that it was not for him as a subject to be taking on his lips the Great Name; he was, as he said, merely a 'transmitter and not a maker.'

It has been said that Confucius discountenanced prayer; but the passage referred to in support of the charge is not sufficient to bear it out. Equally reticent and enigmatic were his replies to the well. known question of the same disciple about the services offered to the spirits of the departed, and about death itself. He did not rise to the acknowledgment of the principle enunciated by Lao-tsze, that kindness is to be returned for injury, and evil overcome with good, but laid down to his disciples the dictum that they should 'recompense injury with justice, and return good for good.' And his own special work, the $C h^{\prime} u n C h^{\prime} i t$, is evasive and deceptive; according to Kung-yang it often 'conceals (the true nature of events) out of regard to the high in rank, to kinship, and to men of worth." The person in the past to whom he looked back with the greatest reverence was the Duke of Chau, the legislator and consolidator of the dymasty of Chan (died 1105 B.C.).

He died lamenting the failure of his life; but he was hardly gone when his merit began to be acknowledged. Duke Â $i$, who had been unable to follow his counsels, caused a temple to be built, where sacrifices, or offerings, should be presented to the sage from generation to generation. In one aspect of it, the brief reign of Shih Hwang-Ti, the first imperial sovereign of China, was a contest between him and Confucius, in which the latter prevailed. The first emperor of the Han dynasty, 
in 197 B.C., in pasaing through La presented to him "i grent offering." Succeeding dynasties have done houour to him by titles and offerings; and by none has this been done so much as by the present Mancha-Tartar dynasty, intending thereby, it is believed, to reconcile the Chinese people to their sway. The Klıang-hat emperor, the greateat of its monarehs, after visiting his temple, and presenting the offerings, prostrated himself three times before the sage's image, bowing his head each time thriee to the ground. The law requires that there shall be a temple to Confucius in every prefecture, sub-prefecture, district, and market-town in the empire. These temples are not to Confucius alone. They are not pantheons, for he has never been deified; but the worship paid to him in them is extended to several of his disciples and a crowd of his most distinguished followers, amounting to more than one hundred and fifty names in all, selected by imperial decree from the literati and ofticers in all the course of time.

Twice a year, on a certain fixed day, the emperor goes to the imperial college in Pekin, and does homage to Confucius. The words of the principal prayer or sddress on the occasion are the following: 'On this month of this year, I, the emperor, offer sacrifice to the philosopher $\mathbf{K}^{\prime}$ ung, the ancient Teacher, the Perfect Sage, and say, o Teacher, in virtue equal to heaven and earth, whose doctrines embrace both time past and present, thou didst digest and transmit the six classics, and didst hand down lessons for all generations! Now in the second month of spring (or autumn ), in reverent observance of the old statutes, with vietims, silks, spirits, and fruits, I offer sacrifice to thee. With thee are associated the philosopher Yen, Continuator of thee; the philosopher Tsang, Exhibitor of thy fundamental principles; the philosopher Tsze-sze, Transmitter of thee; and the philosopher Mang, second to thee. Mayest thou enjoy the offerings!' Confucius' descendants are nany. His lineal representative has the title of king or duke, and large landed property - his by imperial grant-and is considered next in rank to the members of the imperial house. So is the Sage's honour perpetuated.

See Mŕmoires concernant $C$ 'Histoire et les Sciences des Chinois (Paris, 1776-1814); Legge's Chinese Classics, vol. i. (1861), and Confucives Life and Tenching (6th ed. 1887 ); Plath's Confucins und seine Schuler (1867); and Alexander's Confucius the Great Teacher (1891).

Congé d'élire (Norman-French), the name given in England to the king's warrant or permission to a dean and chapter to proceed to the election of a bishop to a vacant see. Since the act of Henry VIII. in 1534, the congé d'élire has always been accompanied by a letter-missive from the sovereign, mentioning the person to be elected by name, so that in reality it is a nomination by the crown. If the dean and chapter delay the election beyond twelve days, the nomination is effected by letters-patent from the crown; if they delay beyond twenty days, or elect another than the person named, they incur the penalties of a Promunive (q.v.). See Bishop.

Conger, or Conger-EEL, a marine bony fish in the eel family (Mursenidæ). The body is eel-like, without pelvic fins, with a continuous dorsal fin heginning very far forward, and without scales. The length varies from 3 to 6 feet, or even more; the colour is dark gray or bluish above, whitish below; the mouth is wide; the tongue free; the teeth in rows, one elosely packed series forming a sharp edge. Four species occur widely distributed in temperate and tropical seas. Conger vulgaris is common on the British cossts, especially off Cornwall. Giant specimens, 10 feet in length, 18 inches in girth, over $100 \mathrm{lb}$. in weight, are recorded; and even ordinary specimens left aground among the rocks, or landed unexpectedly on board a bout, are awkward eustomern to deal with. They are very museular and voracious fishes, feeding on comparatively large prey, and have rentarkalsly atrong biting powers. They often rotate rapidly on their

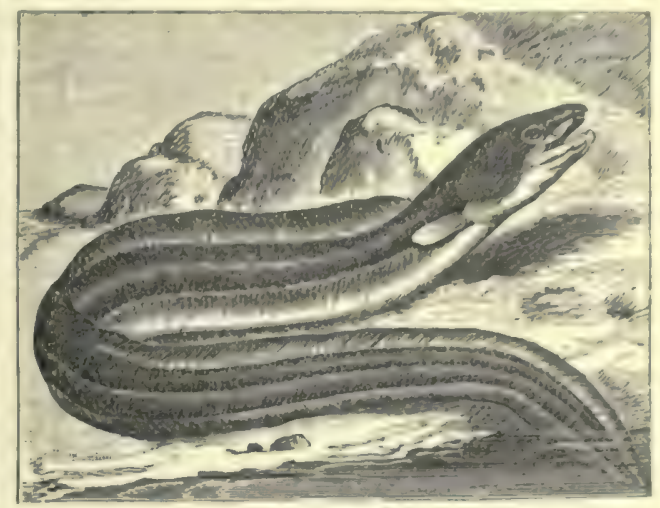

Conger-eel.

own axis, and have a certain degree of grasping power with their tails. The colour seems to vary with habitat, since those from rocks are blacker than those from sand-banks. They occur from the shore down to about 50 fathoms, and are extremely prolific. The flesh is coarse, but is often enough eaten. What is called turtle soup is believed to be often made mainly of conger-eel. See Day's British Fishes.

Congestion may be defined to be excess of blood in the vessels of a part, and is to be regarded not as an independent disease, except in a very small proportion of cases, but as one stage or one manifestation of some other disease. It is, however, of such importance and of so irequent occurrence as to require a separate notice. Congestions are divided into two groups-viz. active, due to dilatation of the arteries of the affected part; and passive, due to some canse interfering with the return of blood by the veins. In active congestion the flow of blood is usually inereased, and the excess is chiefly in the arteries. Familiar instances are the phenomenon of Blushing $(q, v$. and the effeet of heat, especially moist heat, in increasing the redness of any part to which it may be applied. But the most important active congestions are those which occur in connection with Inflammation (q.v.), of which they constitute the first stage. In passive congestion the flow of blood is always diminished, and the excess is chiefly in the veins. It may be due either to direct obstruction to the return of blood through the veins, or to general enfeeblement of the circulation.

Congestion from venous obstruction is easily illustrated by tying up the arm, as is done before opening a vein, when the veins are compressed more than the arteries. If the ligature is kept on for a sufficient time, the veins swell, the fingers become red, and then livid, and the whole linb is swollen. Cold applied to the surface of the boty acts similarly on it, and contracts the veins more rapidly than the arteries, which lie deeper; and the purple colour of the hands and face after exposure to cold shows the congested state of the capillaries. 'Congestions,' says Dr C. J. B. Williams, 'are caused in internal organs by an obstruction of the veins leading from them. Thus, congestion of the brain may be produced by a tight cravat or by a tumour pressing on the jugular veins. Efforts of straining, coughing, holding the breath, and asthmatic paroxysms which impede the flow of 
blood through the lungs, cause congestion in various parts. Tubercles in the lungs cause congestion of that organ. Obstruction to the transit of blood through the liver causes congestion in the abdomen, hemorrhoids, \&c.

Congestion from weakness of the circulation includes a numerous class of cases. Here gravitation comes into play very much more forcibly than in the healthy body in determining the distribution of the blood to different parts and organs, though it always produces some effect. Diseases of the valves of the heart are almost always accompanied. by congestion of other internal organs at some stage of their progress. In extreme debility, certain fevers, \&c., there is general congestion of the parenchymatous organs-the lungs, liver, \&c. -and the blood gravitates to the lowest parts, giving rise to what is termed hypostatic congestion of the posterior parts of the lungs, the skin of the back, dc. In other cases the effect is more local, as when the feet swell after long standing, in consequence of over-distension of the veins. Congestive affections of this kind are often mistaken for inflammation, and instead of being treated by tonics, are treated by depletion, which, although affording temporary relief, usually aggravates the evil.

Active congestion, when it requires treatment, must be dealt with in the same manner as inflammation. With regard to passive congestion, the end to which treatment must be directed is the removal of its cause. This can be effected in some cases by measures having a local effect, either completely, as by the loosening of a ligature, the disuse of too tight articles of clothing, or by the removal of a tumour compressing veins, or partially, as by elevation of the head in affected brain, and the recumbent position in congestion of the hemorrhoidal or uterine vessels. Uniform gentle pressure, by supporting the weak vessels, and friction, by increasing the onward movement of the blood in the veins, are often of great use in superficial parts. Where the heart-power is at fault, strengthening remedies must be given-ammonia, cinchona bark, digitalis, \&c. The American Witch-hazel (q.v.) when administered internally seems to have the power of diminishing the size of dilated veins, and is sometimes useful in varicose veins, hemorrhoids, \&c. . Various remedies are supposed to have a special power of removing the congestion of certain organs; thus, mercurials are recommended for congestion of the liver; digitalis and cantharides for congestion of the kidneys ; squills, benzoin, and the balsams for bronchial congestion.

Congleton, an ancient municipal borough in the east of Cheshire, picturesquely situated in a deep valley on the banks of the Dane, an affluent of the Weaver, 26 miles $\mathrm{S}$. of Manchester. It has a handsome town-hall (1S64), manufactures of silk, and neighbouring coal-mines. Pop. (1851) 11,505; (1891) 10,744. See book by R. Head (1887).

Conglomerate, or PLUMPUDDING-STONE, a rock consisting of varions-sized, round, water-worn stones cemented together, the binding material being generally of a calcareous, siliceous, or ferru. ginous character. Now and again the stones are held together by simple compression without any cement. Conglomerate is evidently gravel compacted into a more or less coherent mass. Like coarse gravel and shingle, some conglomerates are very tumultuous in appearance, and show no lines or planes of deposition. Generally, however, rocks of this kind exhibit rudely alternating layers of finer and coarser materials. The included stones Inay consist of any kind of rock or mineral, but the harder species, such as quartz-rock and quartz, are supt to preponderate. Conglomerates are generally beach-deposits, either marine or lacustrine; sometimes they are of fluviatile origin.

Congo. The earlier history of the Congo, the great equatorial river of Central Africa, may be brietly summed up as follows. In the year 1484-85 Diogo Cam (q.v.) discovered the mouth of a large river in $7^{\circ} \mathrm{S}$. latitude while sailing along the West African coast in command of an expedition having for its object the diseovery of the East Indies. He erected a pillar on the south bank, and gave it the name of Rio Padraxo, or Pillar River. The country in its vicinity, and for some distance to the south, as far as Cape Negro, was known by the name of Congo Land. During the 15th and 16th centuries several attempts were made by the Portuguese to penetrate into the interior, but they never reached farther than San Salvador. The Jesuits established a large missionary station at this place, and made it the capital of the Congo. At the outset this attempt to convert the nations met with considerable success, but towards the end of the 17th century, ravaged by native wars, it had almost ceased to exist. At this time the Portuguese called the great river the 'Zaire,' which is only a corruption of Nzari, Nzadi, Nyali, Niadi, all of which mean 'river' in the many dialects spoken within the limits of what was then ealled the kingdom of the Congo. The native name for the river was Moenzi Nzadi, or the 'Receiver of all the Waters;' and the European map-makers give it the name it at present enjoys of "the Congo."

In 1816 an expedition under Captain Tuckey was despatched by the British government to solve the question which then agitated the minds of geographers, whether the Congo was one of the mouths of the Niger. Captain Tuckey penetrated with his boats to the head of the navigable portion of the lower river-a distance of 110 miles-and he then proceeded by land to a place called Issangila, about 52 miles farther on; but his expedition had a most melancholy result, for within three months-the period which they remained in the river-eighteen out of fifty-six Europeans succumbed to the climate. This great mortality gave the river a bad name, and, with the exception of slave-traders, it was little frequented by Europeans for some years. Valuable additions to geographical science, however, resulted from Captain Tuckey's expedition, as it proved that the Congo was the outlet of some vast riverine system, and it dispersed much of the fable and myth with which the imaginations of earlier writers had surrounded this region.

From 1867 to 1871 Dr Livingstone, in his researches between Lakes Nyassa and Tanganyika, and from thence to Nyangwe, proved the existence of a large river flowing to the north under the native names of Luapula and Lualaba, which he imagined to be the Nile, and this opinion was shared by many men of science on receipt in England of the maps and journals recording these explorations. In October 1876, five years later, $\mathrm{Mr}$ H. M. Stanley, despatched to Central Africa under the auspices of the New York Herald and Daily Telegraph, to complete Livingstone's explorations, arrived at Nyangwe, and he too gazed on that mighty stream with its waters flowing ceaselessly to the north. $\mathrm{He}$ determined to follow its course, and in 1877 news was received of the successful accomplishment of his adventurous journey, and the establishment of the fact that the Luapula, Lualaba, and the Living. stone (the name given by Stanley to that part of the river below Nyangwe) are in reality the Congo-the great equatorial river of Central África, the second largest river of the world.

The Lake of Bangweolo noticed by Lacerda in 1795 , and by other earlier Portuguese explorers, of 
which the Chambeze, traced by Livingstone, is the largrest feeder, and into which also flow numerous streams from the Lokinga Mountains on the south, is the reservoir from which this grent river issues under the name of the Luapula. Flowing in a northerly direction, it expands into Lake Mnero, on lesving which it is called, as far as Nyangwe, the Lualalia ; from Nyangwe to Situnley Falls (Arab name for which is Zingatini) Stanley christened it the Livingstone; and from Stanley Falls to the mouth it is known by the name of the Congo.

Its length has been calculated at over 3000 miles ; it drains an area of more than $1,300,000$ aq. $\mathrm{m}$. ; and it discharges a body of water into the ocean second only to the Amazon. Such is the power and foree of this mighty stream that no delta exists at its mouth. Vessels take in fresh water at its entrance into the sea, and, during the rainy season, when the river is at its highest, vessels approaching the Congo enter discoloured water, and pass through floating debris more than 300 miles from land. The two largest tributaries of the Congo are the Kassai from the south, whose waters were thoroughly explored (1885) by Lien. tenant Wissmann of the German army; and the Mobangi, from the north, explored (1884-85) by the Rev. Mr Grenfell, who penetrated beyond the 4th degree of $\mathrm{N}$. lat., and whose explorations were afterwards continued by Lieutenant Vangele of the Belgian army. This officer reached $21^{\circ} 53^{\prime}$ of $\mathrm{E}$. long., or within about 60 miles of Dr Junker's lowest point on the Makua-Welle, thus proving that the Welle of Schweinfurth is the same as the Mobangi of Grenfell. Besides these two great affluents, the Congo has many other tributaries. The most important of these are the Kwa or Kwango, the Juapa and Bosira, the Ikelemba, the Lulongo, and the Lumami rivers on the south or left bank; and the Aruwimi, the Mbura, the Loika, the Ngala, the Lokinga Nkundji, \&c., on the north or right bank.

As regards commerce and navigation, the Congo may be divided into three parts-Lower, Middle, and Upper. The lower region extends from Banana at the mouth to the foot of the first rapids, a distance of 110 miles. Ocean stesmers, drawing not more than 18 feet, can safely navigate this portion. The middle or cataract region extends from Vivi to Stanley Pool, a distance of about 235 miles - a portion of this part of the river-viz. from Issangila to Manyanga, a distance of 70 miles, is navigable for small steamers or iron whaleboats. The upper region from Stanley Pool to Stanley Falls has an extent of 1068 miles of navigable water for steamers of a draught not exceeding four feet. The length of navigable tributaries which enter in this section of the river has been calculated at over 3000 miles, forming a unique system of waterways.

These discoveries by $\mathrm{Mr}$ Stanley led, in 1878, to the formation of the Association Internationale nnder His Majesty the King of the Belgians, and this subserquently expunded into the Congo Free State, which, recognised by the European powers assembled at the conference at Berlin in the year 1885, has the following boundaries: The northern bank from the mouth, with a strip of territory averagring ahout 60 miles in wilth, as far as Manyanga, situated about 240 miles from Banana, the entrance part of the river. At Manyanga the French territory commences and continues along the north bank, passing Stanley Pool as far as the Mobangi. The territory of the Congro Free State recommences at this river, and the boundary line runs along the left bank as far as the fourth parallel of $\mathbf{N}$. latitude, which then becomes the northern boundary of the central portion of the state.
North-east it extends to the watenhed of the Congo basin, eastwards to $30^{\circ} \mathrm{E}$. long. and Lake 'Tanganyika, south-east to Lake Bangweolo and the southern watershed of the Congo basin as far as Lake Dilolo, south-went to the Kasmai river, is $7^{\circ} \mathrm{S}$. lat., the Kwiln, the Kwango, and the parallel of Nokki. These boundaries were only finally settled by the neutrality declarations of 1894 and 1895 , after a series of treaties. The area is stated at $900,000 \mathrm{sq}$. m., the pop. at $30,000,000$.

The Congo Free State is governed by an admin. istrative bureau at Brussels, consisting of three secretariats-Control, Finance, and Foreinn Aflairs, under the direet supervision of His Majesty the King of the Belgians; also by an administrator on the Congo who has his headquarters at Boma, 60 miles from the sea, on the right bank of the river. The state las stations at Banana, Vivi, Boma, and Matadi on the Lower Congo; at Iukuncru, Issangila, Manyanga, Lutete on the Middle Congo; and at Leopoldville, Kinshassa, Kwamouth, Lukolela, Equator, Bangala, and Stanley Falls on the Upper Congo. Besides these the state las erected two stations on the Kasai, Luebo, and Luluaberg. All imports are free, and only snch export duties are levied as are necessary to carry on the work of administration. It has a coinage and postal service, and has entered into the Postal Union. A road has been surveyed between Matadi and Leopoldville, and by the introduction of ox-wagons the facilities for transport will be largely increased. It is intended to follow this up by a railway. Its present income is derived from an endowment of $\mathbf{1 0 , 0 0 0}$ a year bestowed upon it by His Majesty the King of the Belgians, and such other sums as are produced by its export dues.

The inhabitants of the Congo basin belong to what has been termed the Bantu race. They are a happy, inoffensive people, not so dark as the Fan or Ethiopian. Split up into numberless tribal communities, they can offer but slight resistance to the advance of civilisation; and as they are born traders, they take very readily to commerce. The dialects throughout the country are very numerous, but many of them would appear to have a common origin (see BANTU). Even the Swaheli language, spoken by the natives of Zanzibar (who come as porters, \&c. into this region), has much in common with the Kishi Congo, or language spoken on the west coast. Of this typical member of the Bantu family, the Rev. W. Holman Bentley has furnished an excellent Dictionary and Grammar (Lond. 1888). The religion is mainly fetichism; and domestic slavery exista everywhere. The name of French Congo is now given to what was known as the Gaboon (q.v.) territory; and Portuguese Congo is the coast country to the south of the independent state.

The elimate of the Congo State is tropical, the average temperature ranging between $78^{\circ}$ and $82^{\circ}$. Malarial fevers, esuecially on the eoast, are not infrequent; but with eare and attention to diet Europeans ean remain in the country for several years without change. The interior is more healthy than on the coast. The principal products are ivory, palm-oil, palm-kernels, india-rubler, various gums, ground-nuts, camwood, beeswax, orchilla; also coffee, tohacco, hill rice, maize, and soryhum. Tropical fruits, such as bananas, pine-apples, and mangos, abound. The total value of the special ex. ports of the independent state proper vary in value from $5,000,000$ to $8,000,000$ frunes; the general exports from $8,000,000$ to about $15,000,000$ francs. About 50 miles of the railway, past the rapids to Léopoldville ( 250 miles), are open. In 1889 the king of Belgium bequenthed his rights in the state to Belgium; and in 1890 Belgium reserved the right of annexing the state. 
The introduction of eivilisation into new and wild countries demands time and patience, and the progress of the State has not been so rapid as its friends hoped. The European officers have been few in number, and some of them not well chosen. And gross cruelties seem to have been practised by native functionaries and troops, especially in foreing the collection of caoutchoue for the government.

See map of Africa in Vol I., and the articles AFricA, StANLEY; also Stanley, Through the Dark Continent (1878), and The Congo and the Founding of its Free State (1885); H. H. Johnston, The River Congo from its Mouth to Bolobo.(1884); Bentley, Life on the Congo (1887); works in French by Wauters (1885 and 1893), Coquilhat (1888), Alexis (1888), Dupont (1889), Jeannent (1889), Chapaux (1893); Ward, Five Years with the Congo Cannibals (1890); E. G. Glave, Six Years in Congoland (1893); German works by Pechuel-Loesche (1887) Büttner (1890), and Raab (1892); S. L. Hinde, The Fall of the Congo Arabs (1897).

\section{Congo Snake. See Aмpнiuma.}

Congregation (Lat. con, 'fogether ;' grex, 'a flock'), an assembly, generally a religious assembly; in its most ordinary use, an assembly of Christians met in one place for worship (see CHURCH ). - In the Roman Catholic Church, it often designates a sort of board of cardinals, prelates, and divines, to which is intrusted the management of some important branch of the affairs of the church. Thus the Congregation of the Index examines books and decides on their fitness for general perusal (see InDEx). The Congregation de Propaganda Fide is instituted for the propagation of the Roman Catholic faith and the government of the church in non-Catholic countries (see Propaganda). The Congregation of Relics inquires into the genuineness of supposed relies. The Congregation of the Holy Office takes cognisance of heresies, \&c. (see INQUISITION). The Congregation of Rites regulates the festivals and offices of new saints. 'Ihere are numerous other congregations. The word is also used in the Church of Rome to describe communities of ecclesiastics who live together under rule, but without being bound by vow, or at least by solemn vow. Such are the Congregation of the Oratory, the Congregation of the most Holy Redeemer, usually called Redemptorists, \&c.

\section{Congregationalists. See INDEPENDENTs.}

Congress, an assembly either of sovereign princes, or of the delegated representatives of sovereign states, for the purpose of considering matters of international interest. Even in America, though the term has now a different meaning, it had a similar origin, the first congress being that of the delegates from the various British colonies, who met on the 7th October 1765, for the purpose of considering their grievances. Previous to signing a treaty of peace, a meeting of plenipotentiaries usually takes place, to which the name of a congress is sometimes applied, though it seems more properly to be reserved for those more important meetings at which extensive schemes of future policy are determined on, and the balance of power anongst the various European states readjusted. To this class belonged the famous Congress of Vienna in 1815; that of Carlsbad in 1819, for regulating the affairs of Germany; that of Paris at the end of the Russian war of 1854-56; and that at Berlin after the Russo-Turkish war of 1877-78. There is scarcely any difference between a congress and a diplomatic Conference (q.v.).

Congress of the United States. The legislative department of the government of the United States is ealled the Congress, and $\mid$ Copyrigh 1889, 189\%, and consists of a Senate, elected by 1900 in the 0.8 .8 .67 , J. B. the legislatures of the several Lippincott Company. states, and a House of Representatives, elected by the direct votes of the people. It is supreme within its constitutional limits, deriving its powers directly from the people. By constitutional provision congress has certain direct, express powers, and such implied powers as are necessary to carry these into effect. It convenes on the first Monday in December in each year, and receives from the president of the United States his annual message, giving information of the state of the Union, and containing such suggestions and recommendations as he may judge expedient and necessary.

Express Powers.-Congress has power to impose and collect taxes, duties, imposts, and excises, to pay the debts and provide for the common defence und general welfare of the United States. This grant of sovereign power is independent of state control, and is limited only by the provision in the constitution that the duties, imposts, and excises shall be uniform throughout the United States.

Congress has power to borrow money on the credit of the United States, to regulate commeree with foreign nations, and among the several states and with the Indian tribes. It has the exclusive power to establish a uniform rule of naturalisation, and uniform laws on the subject of bankruptcies throughout the United States; to coin money, regulate the value thereof and of foreign coin, and fix the standard of weights and measures; to provide for the punishment of counterfeiting the securities and current coin of the United States; and to establish post-offices and post-roads. Congress has power to promote the progress of science and useful arts, by securing for limited times to authors and inventors the exclusive right to their respective writings and discoveries; to constitute tribunals inferior to the Supreme Court; to define and punish piracies and felonies committed on the high seas, and offences against the law of nations.

Congress alone has power to declare war, grant letters of marque and reprisal, and make rules concerning captures on land and water. It can raise and support armies, may provide and maintain a nary, and make rules for the government of the land and naval forces. Congress has power to provide for calling forth the militia of the several states for the purpose of executing the United States laws, to suppress insurrections, and repel invasions, and to provide for organising, arming, and disciplining the militia, and for governing such part of them as may be employed in the service of the United States; reserving to the states respectively the appointment of the officers, and the authority of training the militia, according to the discipline preseribed by congress.

Congress exercises exclusive legislative control in all cases whatsoever over the District of Columbia (the seat of government of the United States), and over all places purchased for the erection of forts, magazines, arsenals, dockyards, and other needful buildings. Congress has power to dispose of and make all needful rules and regulations respecting the territory or other property belonging to the United States, and to make all laws which shall be necessary and proper for carrying into execution all powers vested by the constitution in the government of the United States, or in any department or offices thereof.

Constitutional Limitations. - Congress cannot pass a bill of attainder or any ex post facto law. Neither can it lay any tax or duty upon articles exported from any state, or give preference to the ports of one state over those of another, by any regulation of commerce or revenue; nor can it compel vessels bound to or from one state to enter, clear, or pay duties in another. It cannot enact a law taking from the eitizen his private property for public use without compensation therefor.

Congress cannot make any law respecting an 
establishment of religion, or prohilsiting the free exercise thereof, or sbridging the freedom of speech or of the press, or denying the right of the people jeruerably to asemble, and to petition the govern ment for a redreas of grievanoes. Congreas cannot enact any law that will render the people insecure in their persons, houses, papers, and effects from unressonable searches and seizures; or authorise any warrants to issue but upon probable eause supported by oath or aftirmation, particularly describing the place to be searched, and the persons or things to be seized. Congreas has no power to take from a person accused of crime his right to a speedy and public trial, by an impartial jury of che state or district wherein the crime was committed; or his right to be informed of the nature and cause of the accusation, to be confronted with the witnesses against him, and to have compulsory process for obtaining witnesses in his favour; or his right to be defended by counsel. It cannot enset \& law requiring excessive bail, imposing excessive fines, or inflicting cruel and unusua punishments.

Senate. - The senate is composed of two senator from each state, chosen by the legislature thereof for a term of six years, so arranged that one-third of all the senators shall go out every two years. No person is eligible for the office of senator unless he is thirty years of age, has been a citizen of the United States nine years, and is an inhabitant of the state for which he is chosen. The senate is presided over by the vice-president of the I'nited istates, but in case that officer is acting president of the United States, or is unable to preside, the senate elects a presiding officer pro tempore. It chooses all its other officers. The senate has the sole power to try impeachments presented by the House of Representatives, and when sitting in that capacity the senators are sworn or affirmed. Should the president of the United States be on trial, the chief-justice of the Supreme Court of the United States presides, and two-thirds of the senate may convict, upon which judgment of removal from office and disqualification to hold any office of honour, trust, or profit under the United States mav be pronounced.

House of Representatives. - The House of Repre. sentatives is composed of members chosen every second year by the people of the several states. It elects a Speaker to preside over its deliberations, and all its other officers. No person can be a representative in congress who has not attained the aye of twenty-five years and been seven years a citizen of the United States, and he must be an inluabitant of the state in which he is chosen.

The representatives are apportioned among the several states according to the number of their inhabitants respectively, counting the whole num. ber of persons in each state, excluding Indians not taxed. But when the right to vote at any election for the choice of electors for president and vicepresident of the United States, representatives in congress, the executive and judicial officers of a state, or the members of the legislature thereof, is denied to any of the male inhabitants of such state, being twenty-one years of age and citizens of the United States, or is in any way abridged, except for participation in relvellion or ot her crime. by constitutional provision the basis of representation is reduced in the proportion which the number of such male citizens bears to the whole number of male citizens twenty-one years of age in such state. The first article of the United States Constitution provides that there shall not be more than one representative to every 30,000 inhabitants ; but the increase in population necessitated an increase in the unit of population, to prevent the House from becoming unwieldy, and the reapportionment after the census of 1900 guve 194,000 inlubitantw as the unit, or 336 members in all. Each oryanized territory nends one delegate to the House of Kejresentatives; he may debate, but cannot vote.

The House of Representatives has the sole power of impeachment of the executive and judicial officers of the United States, and must present the charges on which it rests to the menate for trial. Ench lonse is judge of the elections, returns, snd qualifications of it own members, and a majority constitute a quorum to do business; but a less number may adjourn from day to day, and may be anthorised to compel the attendance of absent members.

Each house determines the rules of its own pro. cedure, and may punish its members for disorderly behaviour, and also may compel the attendance of witnesses before its committees, and inflict punishment for contempt of its authority.

Each house must keep a journal of its proceed. ings, and must publish the same (excepting such parts as may in their judgment require secrecy), and at the desire of one-fifth of the members present, the yeas and nays of the members voting on any question must be entered on the journil. But neither house, during the session of congress, without the consent of the other, can adjourn for more than three days, nor to any other place than that in which the two houses shall be sitting.

No senator or representative may be apjointed to any civil office under the authority of the United States which shall have been created during the time for which he was elected, and no person hold. ing any office under the United States can, during his continuance in oftice, be a member of either house of congress.

Members of congress are privileged from arrest, except for treason, felony, and breach of the peace, during their attendance upon their public duties.

Two-thirds of the senators present must concur in any treaty which may be made, and in all appointments by the president of ambassalors, or other public ministers and consuls, judges of the Supreme Court of the United States, and such other officers whose appointments are not otherwise provided for.

By the amendments to the Constitution of the United States, abolishing slavery, guaranteeing civil rights, the validity of the public debt of the United States, and forbidding the denial or abridg. ment of the United States citizen's right to vote on account of race, colour, or previons condition of servitude, congress is empowered to enforce these provisions by appropriate legislation.

When any person, having taken an oath to support the constitution of the United States, as an executive or judicial officer of the United States or of any state, or as a member of congress or state legislature, is, by article xiv. of the United States constitution, ineligible to the position of senator or representative, or elector of president and vicepresident of the United States, or to any office, civil or military, under the government of the United States, from having engaged in insurrec. tion or rebellion against the same, congress is empowered to remove this disability by a twothirds vote of both houses.

ACTs OF CONGRESs are the legislative enactments of the two houses of conyress. Bills may originate in either house (except bilis for raising revenue, which must originate in the House of Representatives ), and be introlued by any memler, and may be amended in either house. They are usually referred to the appropriate standing committee for examination and report; and are read a first, second, and third time before being put upon their final passage, being subject to modification or amendment and discussion, according to the rules in each house. 
After a bill has been passed by both houses, it is presented to the president of the United States for his approval and signature. If he approves and signs it, it becomes a law. If he does not approve it, the president returns it, with his objections, to the house in which it originated; and that house must enter his objections at large upon its journal, and proceed to reconsider it. If after reconsideration it is passed by a two-thirds vote, it is sent to the other house with the president's objections, by which it shall likewise be reconsidered, and if approved by two-thirds of that house, it becomes a law; the vote in both houses must be taken by yeas and nays, and the names of the voters for or against are entered upon the journal of each house respectively. If the bill is not returned by the president within ten days (Sundays excepted), it becomes a law. in the same manner as if he had signed it, unless congress by adjournment prevents its return, in which case it does not become a law.

Every order, resolution, or vote to which the concurrence of both houses is necessary (except adjournment) must likewise be presented to the president after passage, and in case of his dis approval (or veto) must be repassed by a twothirds vote in the same manner as bills, in order to become a law notwithstanding his objections.

Congress is usually in session during several. months, but can adjourn at any time by the concurrence of a majority in both houses. A special session may be called by the president of the United States, however, in cases of emergency, or if congress has adjourned without passing the appropriation bills necessary for the expenses of government. Each congress ends on 4th March, every second year, at twelve o'clock noon. See J. W. Moore, The American Congress (1895).

Congreve, Richard, Positivist, born at Leam ington, Sept. 4, 1818, and educated under Arnold at Rugby, becume a scholar, fellow, and tutor of Wadham College, Oxford, but resigned after having become definitively a disciple of Comte. He died July 5, 1899. In 1855 he published a good edition of Aristotle's Politics. Later works are Lectures on the Roman Empire of the West (1855); Elizabeth of England (1862); The Catechism of Positivist Religion (1858); Essays: Political, Social, and Religious (1874); besides many propagandist sermons and addresses.

Congreve, William, the greatest master of the English comedy of repartee, as distinguished from the humoristic or Jonsonian comedy which it replaced, was born at Bardsey, near Leeds, and baptised on February 10, 1669 (1670). As a schoolboy he was educated at Kilkenny, and as an undergraduate at Trinity College, Dublin. And if this does really make an English gentleman an Irish one, as certain writers learned in 'racial mixings' have generously assumed, Congreve's genius may be taken as another proof that English wit, like English poetry, is the onteome of that mysterious 'Celtic element,' or breath of the 'Celtic Titan' discovered by the late Matthew Arnold. After the completion of his education, Congreve returned to England, and began life in London, where, like Wycherley, and, indeed, like many another man of letters, he entered upon the study of the law-an arid study, as is generally supposed, for a wit, and yet one which (being the study of the practical logic of life) does more than any other, it has been said, to solidify and strengthen the disparate forces of the intellect in whatsoever field those forces may afterwards come to be exercised. Entered at the Middle Temple, but finding, as Leigh Hunt says, that ' having family as well as wit and scholarship, he could 'make way in life without a profession,' Congreve invaded very early the literary arena where 'family and wit and acholarship' were in. those old days of more account than would now seem possible. His first publication was Incognita, or Love and Duty Reconciled, a novel of cross-purposes and disguises, based partly on reminiscences. of the method of Shakespeare's fancy-plays, and partly on reminiscences of a very different dramatic method, that of the new prose comedy which, invented by Etheredge, had been very greatly strengthened by Wycherley. When Dr Johnson said of this novel that he 'would rather praise it than read it,' he spoke with his usual sagacityindeed, he may be said to have marked out a course of criticism which has found high favour among succeeding critics of fiction-a course which is, no doubt, as wise as amiable in regard to nine novels out of any given ten. But whether the tenth, the novel to be read as well as praised, should properly be Rasselas or Incognita seems to depend, now as then, on the temper and the constitution of the praiser. If Rasselas is the more instructive, Incognita is the more amusing. For though to langh with the author is difficult, to laugh at him is easy enough, and laughter is certainly good. Congreve's. novel is rich in 'cultismo' of that highly ornate kind which has at intervals illuminated modern literature from Gongora to Dr Chivers. Such a passage as that in which Congreve talks about his heroine's employing one of Cupid's pen-feathers 'to pick her teeth" would have satisfied even such masters of style as the author of Polyphemus and the author of Eonchs of Ruby.

That a story so full of that silly mock-sentiment then in vogue - stuff which would now make even school-girls laugh-should have been written by the great wit and humorist of Love for Love - that the story should have had a very great success among those same cynical beaux and brazen belles who were in the hubit of sitting out She Would if She Could and the Country Wife-would be incredible did we not remember the still more astonishing fact that the love-passion-the passion which Shakespeare and Ford and the rest of the Shakespearians. had delineated so powerfully-was, judging from the literature of Congreve's time, wiped out as by a sponge from the English character. It is not enough to say that as soon as the wits of the coffee-houses attempted to touch the love-passion their sense of humour straightway fled: their common sense fled too; they became idiots, positive idiots. As far as date of publication goes, Congreve's novel was followed by his translation of the eleventh satire of Juvenal. This appeared in Dryden's Juvenal and Persius, dated 1693, but actually published in 1692. From Dryden, to whom he had been introduced it is said by Southerne, Congreve received unvarying kindness -kindness which was answered by unvarying gratitude, or rather by that generosity of recognition among fine spirits - the sublimation of gratitude-which is said to be undreamed of by smaller souls. In January 1693 appeared Congreve's comedy the Old Bachelor, under the auspices of Dryden'then as now a living and immortal witness to the falsehood of the vulgar charge which taxes the greater among the poets with jealousy or envy, the natural badge and brand of the smallest that would claim a place among their kind.' But if Dryden was free from envy, the disease which, according to the above skilful diagnosis by Mr Swinburne, afflicts poetasters and criticasters alone, not less: free from this literary leprosy was Congreve himself. This is what makes him, notwithstanding his rank-worship, so interesting as a personality ; this is what also makes the other comic dramatists Etheredge and Vanbrugh interesting, so interesting, that we would fain, if we dared, condone even such sins against the sanctities of art as theirs; they 
were free from the disease which it seems foeds the lower slopes of Parnansus with poisonous air. No three writers were ever more generally belovednone were ever beloved more deservedly than these. And even Wyeterley-he whose literary sins were the most grievous of all-was, on account of his fine social qualities, called 'Manly Wycherley.' That a corrupt court should have spoiled such men as these is, among all the heavy impeachments of the Restoration, the heaviest.

Congreve's freedom from the fussy egotism of the literator served him in good stead in regard to the Old Bachelor. Dryden, while declaring that he 'never maw such a first play in his life, hinted at the same time that a great deal of skilful manipulation was required before it could be safely placed upon the boards. And he and Southerne and Maynwaring, who set about manipulating it, seem to have had from Congreve carte blanche to do with it as they liked. The brilliant success of the Old Bachelor - a play whose merits were of entirely a literary kind-is evidence of the enormous change that has come over play-goers since those days. Congreve's second comedy, the Double Dealer, which appeared in the November of 1693, was more firmly knit, and in every way stronger than the Old Bachelor, but the satire on the morals of the time -especially on the meanness and heartless treachery in sexual relations which had become the fashion of the court, was administered in too serious a temper to please an audience composed largely of the very people satirised. The empty-headed beanx and callous women who went to the theatre went there to be amused, not to be sermonised. But besides this repellent quality, the play suffered from a want of dramatic illusion greater in a certain sense than even the Old Bachelor had displayed. An audience can scarcely be interested in the doings of a villain who every few minutes comes to the footlights in order to assure them what a consummate villain he is, and on what admirable psychological principles his creator has fashioned him, nor yet in a hero who lets a villain do what he will in order that the dramatiat's plot may be conveniently worked ont. In stage-eraft Congreve was always weaker than Vanbrugh and Wycherley, but the weakness made itself specially conspicuous here.

It was to this play that was prefixed Dryden's famous verses 'To my dear friend, Mr Congreve,' verses whose generosity passes into pathos. Congreve's next publication was the Monrning Muse of Alexis, a poetic dialogue upon the subject of Queen Mary's death, as full of artificial conceits as his novel. Love for Love, the finest prose comedy in the English language, finished in 1694, was produced at the 'theatre in Little Lincolns Inn Fields' in 1695. It has an abandonment of humour, an irresistible rush of sparkling merriment, such as Congreve's previous plays had not promised. In judging of its qualities we must not forget that in comedy as in tragedy-in prose as in versenothing is really informed by artistic vitality which lacks the rhythmic rush born of creative enjoyment. To him who is really and truly organised to write, whether in verse or in prose, there is always in the genuine exercise of his faculty a sense of sport as delightful as it is deep, an exhilaration that cannot be simulated and that cannot be sup plierl to the nervous system of the true writing man by any other stimulant. Not all the Paradis artificiels summoned up by the genii of Opium, Hashish, or Alcohol, can compete with the true paralise which the Genius of the Inkhorn throws open to the born literator when the impulse is really upon him. And as surely as the hilarity of artistic creation is seen in Aristophanes, in Lucian, in Rabelais, in Shakespeare, in Swift, in Dickens, is it seen in Congreve's Love for Love. No wonder then that of all his plays it was the lant to be banished from the stuge. So late as 1842 Macrealy revived it (umsli. fied of course) at Drury Lane, and this was followed by atill later revivals, the last of all being a verwion of the play in three acts, compressed by Mr John Hollingshead at the Gaioty Theatre in November 1871, with Miss Cavendish in Angelica and Mins Farren in Prue. In Lowe for Love culminated the prose comedy of England. Abundant and brilliant as is the wit, the coruscations do not, as in Congreve's other plays, outilazale the sweeter and softer light of the humonr. The characterisa tion is true, true under the conditions which, as he himself admirably said in his letter to Dennis, the comedian must always work under. 'The distance of the stage,' says he, 'requires the figure represented to be something better than the life; and, sure, a picture may have features larger in proportion and yet be very like the original. If this exactness of quantity were to be observed in wit, as gome would have it in humour, what would beeome of those characters that are designed for men of wit? I believe, if a poet should steal a dia logue of any length from the extempore discourse of the two wittiest men upon earth, he would find the scene but coldly received by the town.

Some of the characterisation, such as that of Angelica, is really beutiful, while some, like that of Sir Sampson Legend, in its genial breadth passes from the comedy of artifice into absolute comedy, and is almost Shakespearian. In 1697 Congreve's one tragedy, the Mourning Bride, appesred. The honours it received in the 18th century were as excessive as the contempt it met with in the next. No doubt it is full of improbabilities, but it shows a considerable power of invention of melodramatic if not of tragic incident. The purely theatric and scenic qualities of the second act are of a most original, if not of high order, and with the scenic appliances of our own day might be made theatrically effective. Of course, however, it is coldcold as those 'monumental caves of death' which 'ghot a chillness' to the 'trembling hearts' of Drs Johnson and Blackmore-and nothing could really warm it.

Between the date of the Mourning Bride and that of Congreve's last comedy, the Way of the World, he was busily oceupied, in company witl several others, in the famous Jeremy Collier controversy, defending the morality of the new stage. The great mistake of Congreve's life was thisof defending his plays on moral grounds. To "let well alone' is wise : to let ill alone is perhaps wiser still. Of all sins, that of producing harmful litera. ture is the blackest. It is the peculiar glory of letters that stronger than king or kaiser is he who writes strongly. It is so to.day : it was so when the warrior kings of Nineveh went ont to reap glory-i.e., to slay and flay-in order to furnish the seribe with subjects-in order that the seribe should, in bas-relief and euneiform character, record their doings. Hence, in the truest and deepest sense, to write is, as Bishop Butler has said, to act ; and if, as he declares, 'endeavouring to force upon our minds a practical sense of virtue, or to beget in others that practical sense of it which a man really has himself, is a virtuous act,' what, on the other hand, was the act of him who wrote certain scenes in the Double Dealer and Love for Love?

And yet even this new stage was not without one saving grace till Congreve defended it ; it had a frankness in sin: that was something at least. Its place was not alongside those filthy French fictions of our own time which, while pandering to the bestial side of man, set up an impudent vretence of doing 80 for the good of his sonI. But Congreve in his lame defence condescended to 
the part of the hypocrite-condescended to exploit Aristotle's paradox about comedy being an imitation of bad characters - an imitation with an ethical end; as if such comedy as his had anything to do with ethical ends! Notwithstanding the conventional tags at the end of Congreve's plays -tags which had no serious meaning, and were meant to have none-the 'Seventh Hell' of the Hypocrite could never claim the author of Love for Love until he set about defending that play. Better to leave ill alone, we say.

Congreve's last play, the Way of the World, was produced in 1700 . Though quite as full of intellectual brilliance as Love for Love, and evidently written with more care, not to say labour, it lacks the humorous impulse which we have seen in Congreve's masterpiece. The glitter is that of icicles in the sunlight. The wit of the dialogue is not sufficiently held in hand to work out the characters and the plot. In a word, it comes more completely than does any other of Congreve's plays within the scope of the Duke of Buckinghamshire's strictures upon the comedy of repartee :

$$
\begin{aligned}
& \text { Another fault, which often does befal, } \\
& \text { Is when the wit of some great poet shall } \\
& \text { So overflow, that is, be none at all, } \\
& \text { That ev'n his fools speak sense, as if possest, } \\
& \text { And each by inspiration breaks his jest, } \\
& \text { If once the justness of each part be lost, } \\
& \text { Well may we laugh, but at the poet's cost, }
\end{aligned}
$$

This play was received with comparative coldness, and Congreve wrote no more for the stage; but he lived till January 1729. Socially his life was one unbroken success. Physical suffering he had, but most of it was the result perhaps of his own youth. ful indiscretions. Kneller's portrait shows him to have been a handsome man with dark eyes. His career shows him to have been a man of fine genius who, smitten with the English canker of rankworship, succeeded in half-misprising his endowments and living and dying genteel. He amassed a fortune, and left it not to his greatest friend Mrs Bracegirdle, a woman of genius, of surpassing beauty, and most lovable nature, who had sacrificed everything for him, but to the Duchess of Marlborough, who, after his death, had a waxen statue of him made-a statue which sat at her table in his very clothes, and nodded mechanically over the dinner at Her Grace's smallest joke, even as he had nsed to nod in the flesh.

See the Comedies, edited by W. E. Henley (1895); the edition by Knight; the short Life by Gosse (1888); and essays by Hazlitt, Swinburne, and others.

Congreve, Sir William, was born 20th May 1772, the son of William Congreve, Comptroller of the Royal Laboratory at Woolwich. Young Congreve passed through the Royal Academy at Woolwich, and in 1808, after a long series of experiments, contrived the Congreve rocket. It was tried in the Basque roads in 1809, and at Leipzig in 1813, seareely with the suecess that was expected. Honours were heaped on Congreve; he was elected F.R.S., and returned to parliament in 1812. Two years later he succeeded to the baronetey and his father's place. He died at Toulouse, 16th May 1828. See RockET.

Coni, or CUNEO, capital of an Italian province, stands in a fruitful district, 48 miles SW. of Turin by rail. It has a fine cathedral, lately restored. It was once strongly fortified, and a place of great strategic importance. Its chief manufactures are silk, cotton, and paper. Pop. 13,500.

Conic Sections. See Cone, Circle, Ellipse, Parabola, and Hyperbola.

Coniferze. This important and interesting order of dicotyledons attained its maximum import. wnce during past geological periods; its world-wide geographical distribution and strongly marked family and generic differences being in this way explained-i.e. when we regard the existing forms as the survivors of a larger and once predominant coniferous flora, which has been in good part dis. placed by the more recent and higher monocotyledonous and dicotyledonous (angiospermous) forms. About 300 species, included in about 33 genera, now remain. Leaving the questions of floral morphology and minute structure which separate the conifers (along with Cycads and Gnetacese) from the remaining phanerogams or 'angiosperms' to the article GYMNOSPERMS, it may be most profitable here to make a rapid survey of the most important groups of the order, with their principal types. Various systems of classification have been propounded; an old and widely adopted one recognises three sub-orders, the pines (Abietineæ), eypresses (Cupressineæ), and yews (Taxinex). Since, how. ever, the first two of these are much less widely separated from each other than from the third, later systematists are returning to the classification of Lindley, and regard these as making up a single sub-order (Pinoidere) equivalent to the yew (Taxoides). On account of the exceptional importance of this order, alike in forestry and horticulture, a brief enumeration of the families of these sub orders, with mention of their most important species, may now be given.

Commeneing with the Abietinese division of Pinoider, we find three families, the pines proper (Abietina), Araucarias (Araucariina), and Taxodiums (Taxodiina). The genus Abies (including Picea) consists of evergreen trees, or sometimes shrubs, in which the linear and always more or leas completely needle-shaped leaves arise singly, and are never clustered in branchlets, while the scales of the cones are not thickened at the tip. The list may be headed by the Spruce Fir, or Norway Spruce ( $\boldsymbol{A}$. excelsa), one of our commonest trees, while A. Douglasii, A. nobitis, and other Californian species are of special beauty as trees and value as timber, with other species too numerous to mention. The old Linnean genus Pinus (from which the firs, larches, and cedars have been separated off as Abies, Larix, and Cedrus respectively) still includes about 100 species, easily distinguished from Abies by the grouping of the leaves upon arrested branchlets, the thickening of the tips of the cone-seales, and other characters. Among the more important species, $P$. sylvestris (the Scotch fir), $P$. austriaca (the Austrian pine), $P$. Laricio (the Corsican pine), $P$. Pinaster (the cluster pine), and $P$. Pinea (the stone pine of southern Europe), may be first mentioned, alike on account of their frequency of occurrence in forests and plantations in Europe, and as agreeing in having usually only two leaves on each branchlet. A large and chiefly Californian series agrees in having three leaves on each sheath. Of these, $P$. insignis (the Oregon pitch pine), $P$. Benthamiana, and $P$. radiata may be mentioned; finally a series, usually five-leaved, includes the Weymouth Pine and White Pine of North-east America ( $P$. Strobus), the Siberian Stone Pine (P.Cembra), \&tc. Of the allied genus Larix (see LARCH) only $L$. europoa (decidua) need here be mentioned, while of Cedrus (see CEDAR ) C. Libanus and C. Deodara are of special importance. The Araucariinæ are familiarly represented by the A. imbricata of Chili, so common in suburban gardens (see ARAUCARIA), and other more graceful but usually less hardy species; as also by the important Kauri pine and other species of Dammara. See DAMMAR.

The Taxodiina include $a$ number of very important trees, notably the surions umbrella pine (Sciadopitys) of Japan, Cunninghamia sinensis of China, and the colossal Sequoia (Wellingtonia gigantea) 
of Californin, with its allierl species (see Szquora). In addition to these we may mention also the Japanese Cedar (C'ryptomeria jupenien, the Virginian Bald Cypress (Taxodium distichum).

Anong the Cupressines we have first the eypresses proper, which includes besides the well. known genus Cupressus (see CYPRkss) the closely allied Retinospora of Japan. Juniperus (see JUNIPER) alone forms another sub-family; while Thuja (see Arbor VIT E) with its immediate allies Thu jopsis and Libocedrus constitute a third; and Cillitris with Actinostrobus and Fitzroya make up the fourth.

Passing now to the sub-order of yews (Taxoidere) we have again two main divisions, the yews proper or Taxere, and the Podocarper. Among the latter we shall only mention the oriental genus Podocarpus, and the beantiful Dacrydium cupressinum of New Zealand: but the former are of much greater variety and importance (see $\mathrm{YLW}_{\mathrm{kW}}$ ). Besides the species of Taxus, we have especially the Chinese and Jrpanese Cephalotaxus, the curious Ginkgo (Salisburia) adiantifolia of the same region, together with the Chinese and Californian species of Torreya.

In addition to the general article GYMNOSPERMS, and to those devoted to particular genera or species of conifers, the reader should especially consult Engler's Pfanzenfamilien, both for a full summary of our present knowledge and copious references. For the purposes of the English horticnlturist Veitch's Manual of Conifero is most exhaustive, while Gordon's Pinetum, and Hemsley's Handbook of Hardy Trees, doc. (Lond. 1877), will be found of service to the amateur.

Conington, Jorn, a great classical scholar, was born at Boston, 10th August 1825. He was educated at Beverley, and for tive years at Rugby, obtained a demyship at Magdulen College, Oxford, in 1843, and next year carried off, in the same term, the Hertford and Ireland scholarships. In 1846 he betook himself to University College, where he was elected to a fellowship two years later. Other distinctions he won were the chancellor's prize for Latin verse, for an English essay, and for a Latin essay. Determining not to take orders, he tried the study of law, but soon abandoned it in disgust. In 1854 he was appointed to the newly-founded chair of Latin Language and Literatnre at Oxford, which he filled until his untimely death at his native place, October 23, 1869. The impulse that Conington's lofty and contagious enthusiasm gave to clasaical scholarship and real culture in England was far more considerable than anything he was able to effect in the way of performance. His unique personality and the singular charm of his simple but serions nature made a profound and permanent impression upon his friends and pupils. His greatest work is his edition of Virgil ( 3 vols. 1861-68), with its singularly subtle and suggestive essays. His edition of the Agamemnon (1848) and C'woephori (1857) of Eschylus are of less moment, though indeed the latter is admirable. In his last vears he gave himself much to translation, the results of which were his metrical version of the Udes of Horace (1863); the Eneid (1866), in Scott's ballad-metre; the Iliad (1868), in the Spenserian stanza; and the Satires and Epistles of Horace (1869), in the eomplet of Pope. Of these the last is without doubt the most valuable. His edition of Persius was published in 1872, and in the same year his Miscellaneous $W$ ritings (2 vols.), with a short Life by Professor H. J. S. Smith.

Conirostres, a term often applied to a section of Passerine birds, characterised by a strong conical beak. It includes numerous families, and such types as weaver-birds, finches, sparrows, and larks.
The character referred to is too external and adap. tive to be of much importance, and the term is too wisle in its application to be of much use. It is better disused.

Coniston Grits and Flags, a merien of sili. ceous sandstones, grits, flags, and conglomerates, belonring to the Silurian system of Cumberland, \&c. They take their name from Coniston in Laneashire, and attain a naximum thickness of probably not less than 7000 feet. They are characterisedthe finer grained leeds (flays) expesially-lyy the presence of many species of graptolites and other fossils. They are believed to be on the same geological horizon as the Denbiglushire grits and flags of Wales. See SiLURIAN SYSTEM.

Coniston Lake, in the English Lake District, lies in North Lancashire, at the east foot of the Coniston Fells, 9 miles W. of Bowness on Windermere, and 10 by rail NNE. of Foxfield Junction. It is 5 miles long, th mile brosd, 147 feet above the sea, and its greatest depth is 260 feet. Its waters abound with trout and perch. On the east shore stand Ruskin's home, Brantwood, and Tent House, once Tennyson's. The Old Man of Coniston, to the north-west, is 2633 feet high. See LAKE DISTRICT.

Conium. See HemLock.

Conjeveram (Kanchivaram), "the Benares of South India,' 45 miles SW. of Madras by rail, with three old pagodas, ancient tanks, and Free Church missions. Here Hyder Ali defeated the Britich in 1780. Pop. (1881) 37,275 ; ( 1891 ) 42,548.

\section{Conjugal Rights. See Marriage.}

Conjugation of Cells, a mode of reproduc. tion in which two apparently similar cells unite, as in Amceba, Diatoms, Spirogyra, \&e. See Algas, Desmids, Diatoms, and Reprovuction.

Conjunction. in Astronomy, is one of the Aspects (q.v.) of the planets. Two heavenly bodies are in conjunction when they have the same longitude-that is, when the same perpendicular to the ecliptic passes through both. If they have, at the same time, the same latitude - that is, if they are both equally far north or south of the ecliptic-they appear from the earth to be in the same spot of the heavens, and to cover one snother. The sun and moon are in conjunction at the period of new moon. In the case of the inferior planets Mercury and Venus, there is an inferior conjunction when the planet is between the earth and the sun, and a superior when the sun is between the earth and the planet. In general, a heavenly body is in conjunetion with the sun when it is on the same side of the earth, and in a line with him; and it is in opposition to the sun when it is on the opposite side of the earth, the earth being in a line between it and the sun. Planets are invisible when in conjunction with the sun, except in rare cases when an inferior planet passes over the sun's dise, and may be seen as a speck on his surface. Conjunctions are either geocentric or heliocentric, according as they are actually witnessed from the earth, or as they would be witnessed if observed from the sun. In observing a conjunction from the earth's surface it is usual to reduce the observation to what it would be if made from the earth's centre; by this means the exact times of conjunction are more accurately fixed, and the observations of one astronomer made available to every other, wherever he may be on the earth's surface. Grand conjunctions are those where several stars or planets are found together. Chinese history records one in the reign of the Emperor Tehuen-hin (2514-2436 B.C.), which astronomers calculate to have actually taken place.

Conjuring, as understood at the present day, signifies the production of effects apparently miraculous by natural means. 
The art of producing apparently supernatural phenomena has been cultivated from remote an. tiquity. The earlier professors of the art claimed bona-fide supernatural powers; and in ages when the most elementary principles of physical science were unknown beyond a very limited circle, it was not difficult to gain eredence for such a pretension. The modern conjurer makes no such claim, but tells the public frankly that his marvels are illusory, and rest either on personal dexterity or on some ingenious application of natural principles. Of the conjurers of remote antiquity we have few reliable records; though it is a tolerably safe conjecture that the prestige of the ancient mysteries rested in no small degree upon effects of natural magic. It may also be gathered that the conjurers of old were familiar with certain forms of optical illusion, in which the use of plane and coneave mirrors, and a partial anticipation of the principle of the magiclantern, played prominent parts. Chaucer mentions illusions of his own day of which the above seems the most probable solution. In the accounts of very early writers, however, large deductions must be made for the comparative ignorance of the observer, and the desire, common to all narrators of extraordinary occurrences, to make the marvel as marvellous as possible. Perhaps the earliest really trustworthy authority is Reginald Scot, who in his Discoverie of Witcheraft (1584) has enumerated the stock feats of the conjurers of his day. The list includes swallowing a knife; burning a card and reproducing it from the pocket of a spectator; passing a coin from one pocket to another; converting money into counters, or counters into money; conveying money into the hand of another person; making $\mathrm{a}$ coin pass tlırough a table, or vanish from a handkerchief; tying a knot, and nudoing it 'by the power of words ;' taking beads from a string, the ends of which are held fast by another person; making corn to pass from one box to another; turning wheat into flour ' by the power of words ;' burning a thread and making it whole again; pulling ribbons from the mouth; thrusting a knife into the head or arm; putting a ring through the cheek; and cutting off a person's head and restoring it to its former position. Strange to say, many of these feats, which were doubtless already old in the time of Scot, are still performed, with more or less variation of detail, by conjurers at the present day.

The conjurers of Scot's time, and even of much later date, were acenstomed, in order to facilitate the substitutions on which a great part of their tricks depended, to wear an apron with pockets, known (from its resemblance to a game-bag ) as the gibéciere. A later school suppressed this tell-tale article of costume, and used instead a table, with cover reaching nearly or quite to the ground. This table concealed an assistant, who worked most of the required transformations, \&c., either handing the needful articles to the conjurer as he passed behind the table, or pushing them up through traps in the table-top. Conus the elder, a French conjurer who flourished at the close of the 18th century, made a further improvement by discarding the concealed assistant, and using an undraped table with a seeret shelf (now known as the servante) behind it, on which his substitutions were made. His immediate competitors did not follow his example, a whole generation of later conjurers, including Comte, Bosco, and Philippe, retaining the suggestive draped table. Its death-blow, however, was struck by Robert Houdin (1805-71), with whom about 1844 a new era began. His miniature theatre in the Palais Royal was remarkable for the elegant simplicity of its stage arrangements, and in particular for the complete suppression of the boute a compere ('wooden confederate'), as Robert Houdin sarcastically terms it. The new style took with the public, and by degrees Robert Houdin's contemporaries found themselves compelled to follow his example.

To Robert Houdin belongs the credit of devising some of the best-known and most ingenious pieces of magical apparatus, as also that of the application of electro-magnetism, then little understood, to the production of magical effects. The wellknown magie drum, that beats without visible drumsticks, the magic clock and bell, and the chest, light or heavy at command, are all fruits of his inventive genius.

The most modern school of conjurers, following the lead of Wiljalba Frikell, and at present repre. sented by Hartz, Hermann, Buatier de Kolta, Ver. beck, Lynn, Bertram, \&c., generally aim at producing their magical results with the minimum of visible apparatus. There are, however, signs of a reaction in favour of more spectacular illusions, such as those of Messis Maskelyne and Cooke, in which the resources of optical and acoustic, as well as mechanical seience, are laid under contribution in aid of conjuring proper. See the articles MAGrC and JUGGLERS.

For practical information as to the methods of conjurers, see Hoffmann's Modern Magic (6th ed. 1886) and More Magic (1889); Sleight of Hand, by Edwin Sachs (2d ed. 1885); Robert Houdin's Secrets de la Prestidigitation et de la Magie (1868; reprinted in 1878 under the title of Comment on devient sorcier) and Mavie et Physique Amusante (1877); and an anonymous work, Recueil de Tours de Physique Amusante (published by De La Rue of Paris). The three last-named works have been translated into English by Hoffmann, under the titles of The Secrets of Conjuring and Magic, The Secrets of Stage Conjuring, and Drawiny-room Conjuring respectively.

Conkling, Roscor, American politician, born in Albany, New York, 30th October 1829, was admitted to the bar in 1850 , sat in congress as a Republican in 1858-62 and 1864-66, and was elected to the United States senate in 1867, 1873, and 1879. He was now an influential member of his party ; in 1876 he received ninety-three votes for the presidential nomination, and, in 1880 , by his support of Grant, and his personal opposition to Blaine, divided the Republicans into two sections. In 1881 he and his colleague suddenly resigned from the senate, owing to a dispute with President Garfield on a question of patronage, and songht re-election; but after a warm canvass, both were rejected, though vigorously supported by Vice-president Arthur. Conkling afterwards practised low in New York city. He died 18th April 1888.

Conn, Lough, a picturesque Irish lake in the north of County Mayo, together with Lough Cullin (from which it is separated by a narrow neck of land), 13 miles long, and 1 to 3 broad. It lies in a wild romantic region of hills, glens, rocky slopes, precipices, broken ground, and bogs, contains many islets, and has bold shores.

Connara'ceae, a sub-order of 'Terebinthacez, including about 25 species, all tropical, of which the most important is Omphalobium Lamberti of Guiana, the source of the zebra-wood of cabinetmakers.

Connaught, the most westerly and the smallest, both in extent and population, of the four provinces of Ireland. It is bounded N. and W. by the Atlantic; $\mathbf{E}$. by Ulster and Leinster, from the latter of which it is separated by the Shannon; and S. by Munster. It contains the counties of Galway, Leitrim, Mayo, Roscommon, and Sligo. Greatest length from north to south, 105 miles; greatest breadth, not including Achil Island, 92 miles. Area, $6863 \mathrm{sq}$. m. The west coast has many fine bays and harbours, and the surface, especially in the western half, is mountainous and 


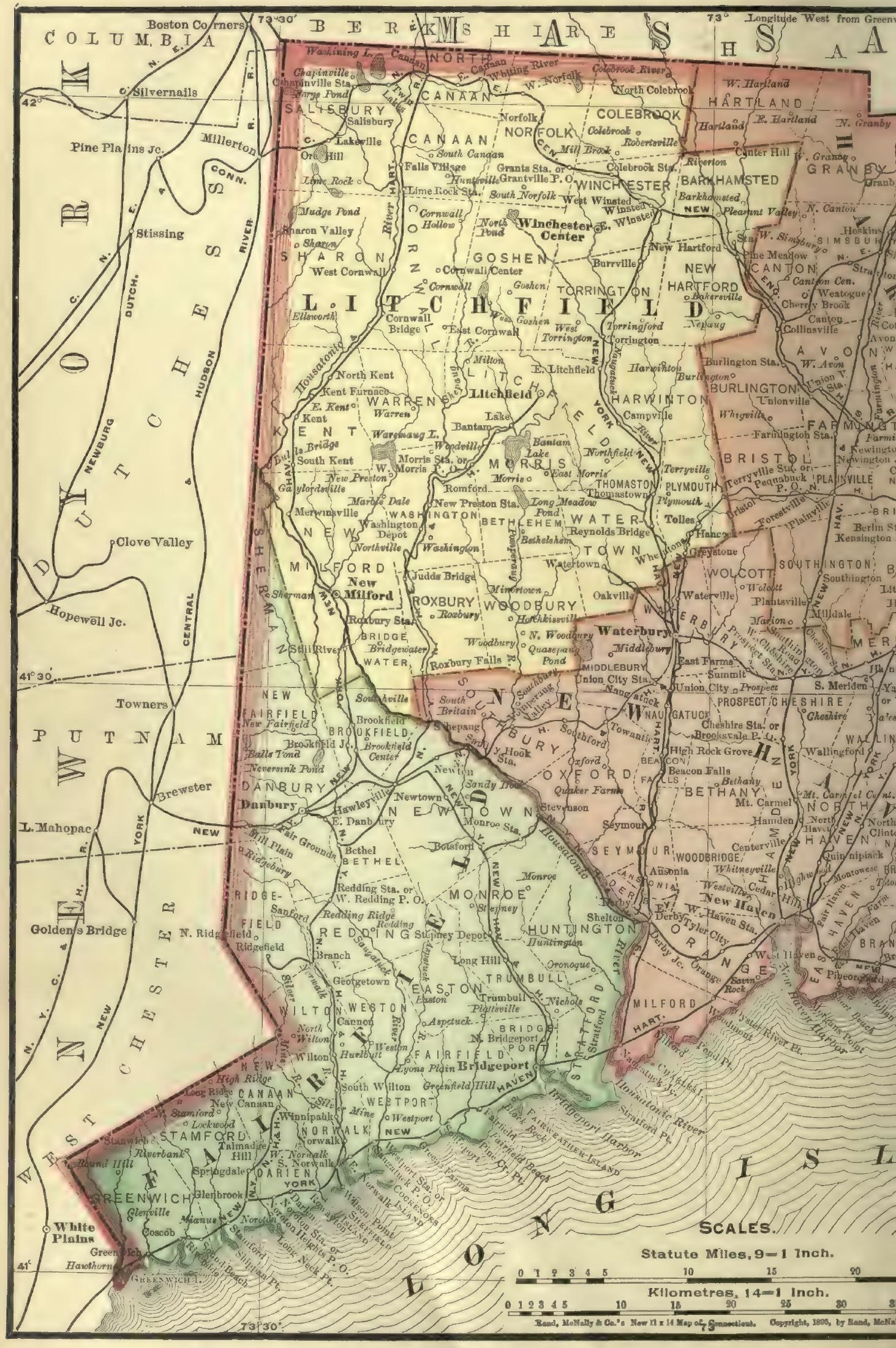


[Connecticut.]

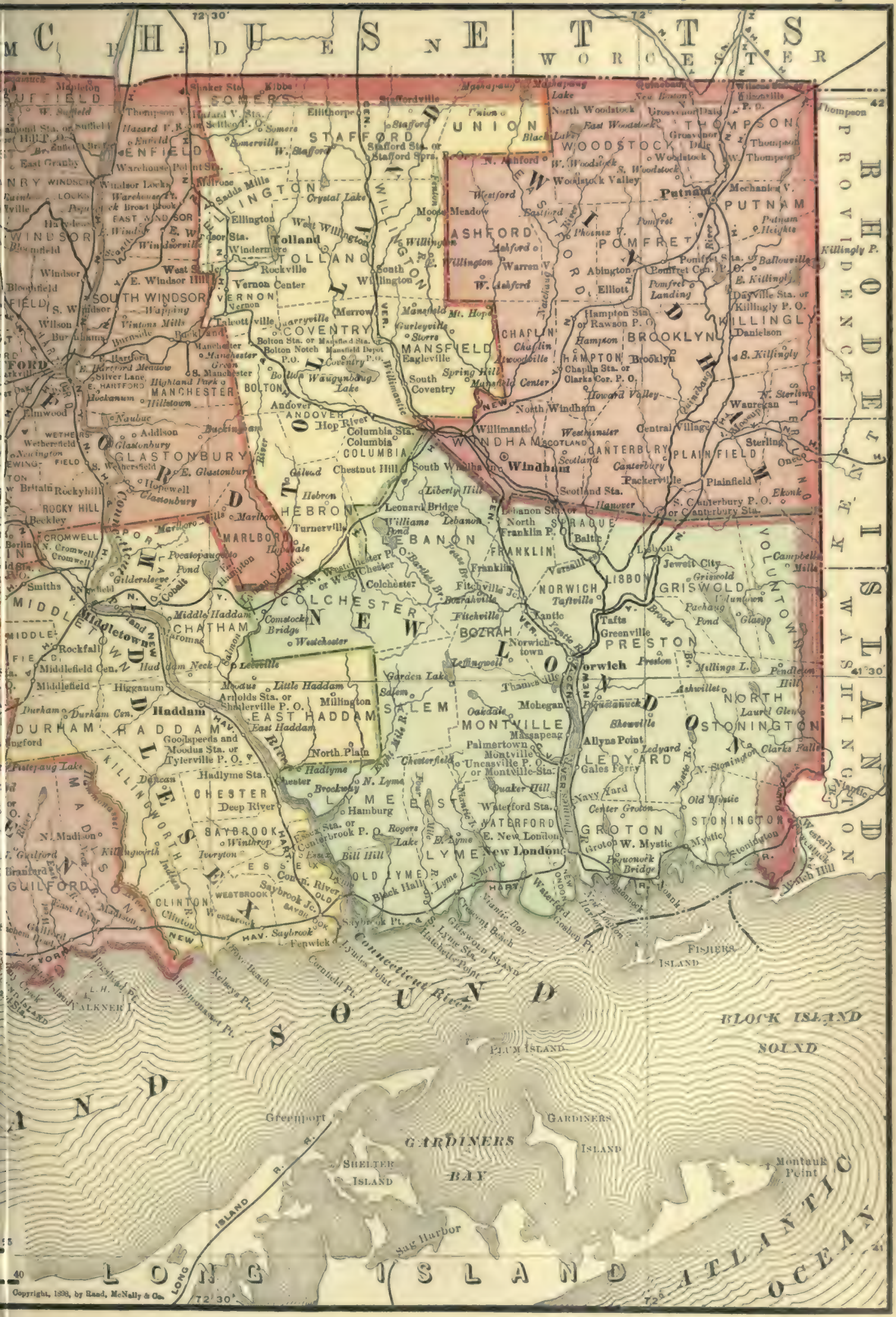



rugged, forming remarkably grand and pieturemue seenesy. The peosple are still almost purely Celtic. In ancient times the O'('onnors were kinger of Connumbt. In 1560 the province was divided by the English into six counties, ita prosent five, with Clare, afterwards joined to Munster. In 1874 the title Duke of Connaught was conferred on Prince Arthur, third son of Queen Victoria. The territorial regiment, the Connaught Rangers, once the 88th foot, now comprises the old 88th and 94th regiments (with four battalions of militia). Pop. (1841) 1,420,703; (1851) 1.015,479; (1861) 919,135; (1881) $817,19 \%$; (1891) 723,573 , a lecrease due to famine and emigration.

Connecticut (kon-net'-i-cut), a state of the Anerienu Union, colebrated for its matufacturing imlustries, is lumuded N. by Massachusetts, F. liy Rhorle 1900 in the U S. by J. B. Island, \&. by Long Island Sound, Elpodneott Oompany. W. by New York. It is the smallest in area of all the states, excepting Rhode Island aud Delaware; but there were in 1880 ten states smaller in population than Connecticut. Its area is $4845 \mathrm{sq}$. $\mathrm{m}$., or nearly two-thirds that of Wales. It is one of the most alensely peopled states of the Union. A great part of the surface is rocky and uneven, and the fireen and Taconic Mountains of the Appalachian system occupy a considerable part of the western extremity of the state; but the mountains here are all insigniticant in respect of height. Much of the surface is not easily cultivated, and rather unfertile; but a considerable part of the valley of the Connecticut River is very productive, tobacco being a leading product of this section. Hay, potatoes, maize, oats, and rye are the principal crops. Grazing and milk farms, orchards and market-gardens, are profitably sustained in all parts of the state.

The Connecticut River, which, rising in New Hampshire, forms the boundary between that state and Vermont, and flows south through Massachusetts, crosses Connecticut also, and after a course of about 450 miles enters Long Island Sound, 30 miles east of New Haven. It is navigable for vessels of light draught as high as Hartford. In the east part is the River Thames, and in the west the Housatonic, both of which afford some naviga. tion. But the greatest value of the very numerous streams is as a source of water-power. In 1880 over one-half the power employed in the manu. factories of the state was water-power; and the atilised water-power was returned by the United States census as $12 \cdot 63$ horse-power per 89. $\mathrm{m}$. The surface-rocks are mostly Azoic, with the principal exception of a strip of Triassic sandstone or paammite running along the Connecticut River. This brown sandstone is largely quarried at Portland and East Haven, as are excellent red and plain granites and gneissoid building-stones at many points; valuable serpentine and verdesntique exist near New Haven. Some quarries yield excellent flagstones of gneissoil charucter: the so-called 'trap' rock, here really a diabase of "Triassic date, is also wrought; and in the northwest good limestones of Lower Silurian age are quaried. Brown hematites are extensively wrought in the north-west section, and yield excellent iron. Deposits of lead, copper, and cobalt have been locally mined. Userul mineral-ivaters oceur at various points. The elimate is very changeable, and is rather severe in winter, but generally healthful. Nearly the whole surface was once richly forested; but no very extensive areas are now covered by large timber; still the aggregate production of wood for building purposes and for fuel is very considerable. The sea-const affords a number of good harbours. Most of the maritime enterprise is now directed to the coast-wise trade, the whale and seal fisheries having declined. Oyster-fishing is engaged in largely and very systematically, as is the taking of fish for oil and fish.gunno. The manufactures of Connecticut are carried on upon a very extensive scale, and are of excesedingly varied character; and notwithstanding its smal) area, the state atands in the firat rank as re. spects the amount and aggregate value of manu. factured goods. Clocks, hardware, india-rubluet goods, firearms, silks and other textiles, and small. wares in great variety, are produced on a large scale. Life, fire, and accident insurance, and the publication of subscription books, receive great attention. Thestate is well supplied with railways, Few parts of the world do more for popular education than does this state. The public-school system dates from 1644, and is supplemented by private, denominational, and parochial schools of every grade. The public librariesarenumerous. Yale L'niversity at New Haven comprises collegiate and post-graduate courses, besides medical, theologicul, scientific, law, and art schools, and takes a very high place among the seats of learning in the country. Mention should be made of Trinity College, Hartford, and of the Wesleyan University at Middletown. There are also divinity schools at Hartford (Congregationalist) and Middletown (Episeopalian). The state is divided into 8 connties: Fairfield, Hartford, Litclifield, Middlesex, New Haven, New London, Tolland, Wintham, and anıong the princiual cities and towns are Hartford (the enpital), New Haven, Brilgeport, Norwich, Norwalk. New Britain, and New Loudon.

The old stock of inhabitants were of English Puritan origin, but of later years there has been a large immigration of Irish, German, English, and others. The colony of Connecticut may be said to date from 1634, when the movement began in which Hartford, Wethersfield, and Windsor were settled by persons removing from Massachusetts, and displacing a slender colony of the Dutch. This movement was in reality the secession of the more democratic element from Massachusetts. Saybrook, named in honour of Lord Say-and-Sele and Lord Brooke, was the nucleus of a separate colony which in 1644 was united to Connecticut, as was in 1662 the New Haven colony, founded in 1638. The Connecticut colony adopted a constitution in 1639 , "the first written democratic constitution on record.' The royal charter of 1662 was exceedingly liberal, it being essentially a confirmation of the older constitution ; and it continued in force even after the independence of the American states, but in 1818 was replaced by the present state constitution. A large part of Long Island was for a considerable period under the government of the colony. Prom. inent events in Connecticut history have been the bloody war with the Pequot Indians, 1637; the governorship of Sir Edmund Andros, during a part of which (1687-88) the colonial charter was in abeyaneo, and according to the very doubtful but commonly received account was only saved from destruction by being hidden for a time in a hollow tree, the Charter Oak at Hartford. Slavery was abolished in 1818. Pop. (1870) 537,454; (1880) 622,700 (of whom 129,992 were foreign born) : (1890) 746,258. See Alex. Johnston's Connecticut (1857).

Connema'ra is the name of the wild and picturesque district which forms the westernmost division of County Galway. Its interesting scenery, its lakes, streams, and inlets abounding in fish, attract many fishers and tourists. Connemara is also called Ballynahinch.

Connoisseur, a term borrowed from the French, to designate persons who, without being themselves artists, are competent to pass a eritical 
judgment upon the merits of works of art, especially in painting and seulpture. The Italian equivalent for connoisseurs is Cognoscenti.

Conodonts, minute fossils met with in Palæozoic strata. They are variable in form, and look very like the teeth of different kinds of fishes, some being simple slender pointed sharp-edged cones, while others are more complex, resembling in form the teeth of certain sharks. Their affinities are very uncertain-some maintaining that they are really the minute teeth of fishes allied to the living hag-fishes and lampreys-others suggesting that they have more analogy with the hooklets or denticles of annelids and naked molluscs.

Comoid, a solid formed by the revolution of a conic section round its axis; such are the sphere, paraboloid, ellipsoid, and hyperboloid.

Conolly, John, physician, born at Market Rasen, Lincolnshire, in 1794, graduated at Edinburgh in 1821, and in 1827 settled in London, where he was for two years professor of the Practice of Medicine in University College. In 1839 he was appointed resident physician to the Asylum for the Insane at Hanwell; this post he held till 1844 , and afterwards he was retained as visiting physician. Here, under Conolly, all forms of mechanical restraint were from the first entirely discontinued; and although his views were admittedly not original, it is mainly to his earnestness and eloquence that the revolution in asylum managenient in England is due. His best works are those on the Construction and Government of Lunatic Asylums (1847), and kindred subjects. He died 5th March 1866. See the Memoir by Sir James Clark (1869).

Conquest. In the law of succession in Scotland heritable property acquired during the lifetime of the deceased, by purchase, donation, or excambion, was called Conquest, in opposition to that to which he has succeeded, which is called Heritage. The distinction was abolished by the Conveyancing Act, 1874. Conquest, in a marriage-contract, is property acquired by the husband during the marriage as distinguished from what he possessed before the marriage. Such property was frequently but is now rarely settled either on the heir or on the issue of the marriage.

Conquistado'res (Span., 'conquerors') is a collective term for the Spanish conquerors of America, such as Cortes, Balboa, Pizarro. See the articles under their names; as also Mexico, PERU, \&c.

Conrad, or Konrad I., king of the Germans, was the son of the Count of Franconia, and the nephew of the Emperor Arnulf. He was elected king (practically emperor of Germany) on the extinction of the direct line of the Carlovingians in 911 A.D. He gradually re-established the imperial authority over most of the German princes, carried on an unsuccessful war with France, and at last fell mortally wounded at Quedlinburg (918), in a battle with the Hungarians, who had repeatedly invaded his dominions. See GERMANY.

Conrad II., king of the Germans, and Roman emperor, was elected after the extinction of the Saxon imperial family in 1024. He was the son of Henry, Duke of Franconia, and is by many considered as the founder of the Franconian dynasty. Immediately after his election he commenced a tour through Germany to administer justice. In 1026 he crossed the Alps, chastised the rebellious Italians, was crowned at Milan as king of Italy, and he and his wife Gisela were anointed emperor and empress of the Romans by the pope. $\mathrm{He}$ was soon recalled to Germany to put down four formidable revolts, in which he succeeded so well that by 1033 peace was restored. In 1032 he had succeeded to the kingdom of Burgundy, which he annexed to the empire. In 1036 a rebellion in Italy again compelled him to cross the Alps; but his efforts to restore his authority were this time unsuccessful, and he was forced to grant various privileges to his Italian subjects. Shortly after his return he died at Utrecht, 4th June 1039. Conrarl was one of the most remarkable of the earlier monarchs of Germany. He reduced the dangerons power of the great dukes of the empire, and defended the rights of the humbler people against oppression by the nobility.

Comrad III., king of the Germans, the founder of the Hohenstaufen (q.v.) dynasty, was the son of Frederick of Swabia, and was born in 1093 . While under twenty years of age, Conrad, with his elder brother Frederick, had bravely supported Henry V. against his numerous enemies, and in return that monarch granted Conrad the investiture of the duchy of Franconia. He subsequently contested the crown of Italy with the Emperor Lothaire of Saxony, but was compelled to resign his pretensions. On the death of Lothaire, the princes of Germany, fearing the increasing preponderance of the Guelph party, and attracted by his brilliant courage, moderation, and goodness, offered Conrad the crown, and he was accordingly crowned at Aix-la-Chapelle, 2lst February 1138. $\mathrm{He}$ was immediately involved in a quarrel with Henry the Proud, Duke of Bavaria and Saxony, and head of the Guelph party in Germany ; and the struggle was continued under Henry's son and successor, Henry the Lion (q.v., and see GUELPHS AND GHibeluines). While Germany was thus convulsed, the state of Italy was not a whit more peaceable. The several belligerents besought Conrad's assistance, but he well knew the natural inconstancy of the Italians, and determined to stand aloof. Soon after this St Bernard of Clairvaux commenced to preach a new crusade, and Conrad, seized with the general infatuation, set out for Palestine at the head of a large army (see Crusades). A new attempt by the Duke of Bavaria to regain his dukedom was defeated by the nephew of Conrad, whose health had broken during the crusade. Conrad died at Bamberg in 1152. See GERMANY.

Conradin of SWABIA, the last descendant of the imperial House of Hohenstaufen (q.v.), was the son of Conrad IV. (1237-54), and was born in 1252 , two years before his father's death. His uncle Manfred (q.v.) had assumed the crown of Sicily on a rumour of Conradin's death, though he declared himself ready to give it up to the rightful heir. But Pope Clement VI.'s hatred of the Hohenstaufens led him to offer the crown of the Two Sicilies to Charles of Anjou, a consummate warrior and able politician. Charles immediately invaded Italy, and met his antagonist at Benevento, where the defeat and death of Manfred, in 1266 , gave him undisturbed possession of the kingdom. But the Neapolitans, detesting their new master, sent deputies to Bavaria to invite Conradin, then in his 16 th year, to come and assert his hereditary rights. Conradin accordingly made his appearance in Italy at the head of 10,000 men, and being joined by the Neapolitans in large numbers, gained several victories over the French, but was finally defeated near Tagliacozzo, 22d August 1268, and. taken prisoner along with Frederick of Baden and other comrades. The two unfortunate princes were, with the consent of the pope, executed in the market-place of Naples on the 20th October. A few minutes before his execution, Conradin, on the seaffold, took off his glove, and threw it into the midst of the crowd as a gage of vengeance, requesting that it might be carried to his heir, Peter of 
Aragon. The tragic tale has furnished materials for many poete. See SicILIAN VESPERs; also Del Giudice, La Condanna di Corradino (Naples, 1876).

Conrad von Wurzburg, one of the most colebrated poets of the middle ages, died at Basel in 1287. Conrad is fertile in imagination, learned, and-although marking the decline of Midcle High-fermatn pretry hy his prolix and artificial style-prohably the imost perfect master of German versification that had apueared up to his own day. His last poen, which he left in an unfinished con. dition, has for its subject The Trojan War. But ('onrad appears to most advantage in his smaller narrative poems, of which the best are Engelhart, Otto, Der Welt Lohn, Silvester, Alexius, Der Schwanritter, and Die Goldene Schmiede. His Lieder have been edited by Bartsch (1870).

Consalvi, Ercole, Cardinal, a distinguished reformer of abuses in the Papal States, was born at Rome, June 8, 1757. He was made eardinal and secretary of state by Pope Pius VII., and in this capacity concluded the concordat with Napoleon in 1801. His staunch maintenance of the rights of his own sovereign against the insidious eneroachments of France offended Napoleon. He was the papal representative at the Congress of Vienna, and secured the restoration of the Papal States, As papal secretary he reformed numerous abuses, suppressing all monopolies, feudal taxes, and exclusive rights. $H_{e}$ was a liberal patron of science, but especially of the fine arts, and employed his leisure in the study of literature and music. In diplomacy he displayed great address, and was generally successful. He died in Rome, January 24, 1824 .

Consanguinity (Lat. con, 'together,' and sanguis, 'blood'), the relationship which subsists between persons who are of the same blood. It is either direct, which is the relationship between ascendants and descendants, or collateral, between persons sprung from a common ancestor. In the direct line, a son is said to stand in the first degree to his father; a grandson, in the second degree to his grandfather; and so on. - Affinity (q.v.) is the relationship brought about by marriage between a hushand and the bloot-relations of his wife, or between $\mathrm{s}$ wife and the blood-relations of her lıushand.

Consanguinity and affinity have been in all parts of the world more or less looked on as impediments to marriage between the parties related. Among the ancient Persians and Egyptians, marriages were sometimes sanctioned between brother and sister, and even father and daughter; and in the book of Genesis we read of Abraham marrying his half-sister.

The Roman law prohibited marriage between ascendants and descendants, a prohibition extended to relations by adoption. In the collateral line, the prohibited degrees included brother and sister, and all cases where one party stood in loco parentis to the other, as uncle and niece. Marriage between cousins-german, at one time prohibited, was de. clared lawful by Areadius and Honorius. The degrees prohibited in consanguinity were by Constantine also prohibited in affinity.

By the old canon law and early decretals, mar. riages were prohibited between persons as far removed as the geventh degree of consanguinity or affinity. The fourth council of Lateran, 1215 A.D., narrowed the prohihition from the seventh to the fourth degree; i.e. the grandchildren of cousinsgerman. A marriage between persons related in any of these ways was accounted incestuous, and the children bastards. The pope assumerl the right of granting dispensations from impedinients to marriage arising from consanguinity and aflinity, a (w)wer which seems to have been finst exercised in the 12th century.

In the countries which embraced the Reformation, a general relaxation took place in the pro. hihitions to marriage from consanguinity and nftinity. In England, an set of 1547 allowed all jersons to marry who were not prohibited by the fevitical law; and according to the interpretution put on this statute, the prohibitions included all relations in the direct line, brother and sister, and collaterals, when one party is brother or sister to the direct ascendant or desceudant of the other; the degrees prohibited in consanguinity beimg equally prohibited in affinity. In Scotland, acts of 1567, professing to take the Levitical law as the standard, assimilated the prohibitions from consanguinity and aftinity to those of England. In France, the Code Napoleon prohilbits marriage between ascendants and descendants lawful or natural, and persons similarly connected by affinity and in the collateral line between brothers and sisters lawful or natural, and persons similarly connected by affinity. Marriage between uncle and niece, and aunt and nephew, is also prohibited. In various countries of Europe, as Denmark, no prohibitions from affinity, except in the direct line, are recognised. In most of the United States of America, marriage is allowed between uncle and niece. See AfFinity, Deceased WrFE's Sister; and for exogamy and curious savage methods of counting relationship, MARRIAGE.

On the much-vexed question whether the marriage of relations tends to injure the constitution of their offspring, either by the intensification of hereditary taint or more directly, see The Marriage of Near Kin (2d ed. 1888), by A. H. Huth (who takes the negative view), and the bibliography there given of works on both sides of the question. See also Breed, Cattle.

\section{Conscience. See Ethics.}

Conscience, Hendrik, a popular Flemish novelist, was born December 3, 1812, at Antwerp. His father, the inspector of the dockyards there, was a native of Besançon, but his mother was of Flemish birth. At fifteen the boy had to shift for his living as an under-master in a school, but at the outbreak of the revolution in 1830 he joined the Belgian ranks, and served till 1836. Patriotism and poverty together impelled him to write, and between them produced in 1837 his first volume in Flemish, In't Wonderjoer, 1566. Wappers the painter finally got him appointed in 1841 to an othice in the Antwerp Academy, which he con. tiuued to fill until 1854. Three years later he received a place in the local administration of Courtrai, and became in 1866 director of the Wiertz Museum at Brussels. Here he died, September 10, 1883. His Phantasy (1837), a fine collection of tales, and his most popular romance, De Lecuro van Vlaenderen (1838), early made his name dear to his fellow-countrymen; but it was his series of charming pictures of quiet Flemish life, beginning with the little book, Hoe men schilder wordt (1843), that, through French, German, and English translations, carried his fame over Europe. Amongat those translated into English, besides the Lion of Flanders, are Blind Rosa, Ricketicketack, The Poor Gentleman, The Miser, and The Demon of Gold. The historical securacy of his Geschicdenis van Belgien (1845) was somewhat impaired by his Catholie predilections. The vast popularity of Con. science's novels depremled mainly on the untlagring vigour and interest of the incidents in which they abounded, although these often enongh defied all historical consistency and verisinilitude alike. It should be remembered to his credit; as, indeed, it 
was his own proudest boast, that in his hundred volumes he had never painted vice in seductive colours. A complete collection of his works appeared at Antwerp in 10 volumes, 1867-80; a German translation of the same at Munster in $\mathbf{7 5}$ small volumes, 1846-84. See his Life, in French, by Cekhoud (Brussels, 1881).

Conscience, Courts of, in England. These were courts for the recovery of small debts, constituted by special local acts of parliament in London, Westminster, and other trading districts. The county courts have superseded them. See, under County, County Courts, vol. iii. p. 522.

Conscience Money, money paid to relieve the conscience, is a not inapt term for money sent to the Chancellor of the Exchequer in payment of a tax that had previously been evaded, and in regard to which a tender conscience feels that something remained to be done. The conscience money is often sent anonymously.

Consciousness. This is the most comprehensive term employed in designating the mind. In the widest and most unexceptionable meaning consciousness is a term which includes all mental states, operations, or processes, and, as has been truly said, it is not strietly susceptible of definition, :seeing that we can have no experience of the unconscious. We may specify different modes or varieties of consciousness, such as thoughts, feelings, and volitions; but the quality in which they all agree, and which constitutes them mental facts or states of consciousness, cannot be otherwise explained than by a mere reference to the constant experience of every human being. Consciousness, in this its strict sense, thus embraces the whole field of mental experience, and the expression 'facts of consciousness' is frequently used as synonymons with psychical facts or facts of mind to designate the subject-matter of psychology.

Popularly, therefore, when we are mentally alive, or performing any of the recognised functions of the mind, we are said to be conscious; while the total cessation of every mental energy is described by the term 'unconsciousness,' among other phrases. In dreamless sleep, in stupor, fainting, and under the influence of the anzesthetic drugs, we are unconscious; in waking, or rallying into renewed mental activity, we are said to become conscious.

The difficulties of the subject, however, have prevented a perfectly definite and uniform usage from being adhered to. As the mind in its waking or active condition may be more or less excited, or vary in the intensity of its manifestations, there are degrees of consciousness; and, accordingly, the name is apt to be applied to denote the higher degrees in opposition to the lower. Thus, in first learning to write, to east up sums, to play on an instrument; or to ride a bicycle, our mind is put very much on the stretch; in other words, we are very much excited or highly conscious. But when years of incessant practice have consummated the process into a fullformed habit, a very small amount of mental attention is involved; and we may then be said to perform the work all but unconseiously. Such habitual actions are frequently designated second. arily automatic, and Sir W. Hamilton, for example, speaks in this connection of 'unconscious mental moditications.' But as he has previously defined consciousness as co-extensive with all mental phenomena, such a phrase evidently involves a contradiction in terms, being equivalent to unconscious consciousness. It is explained, though not justified, by the (unavowed) double use of the term consciousness just adverted to. Later writers have sought to escape from this inconvenient terminology by speaking of the more obscure mental processes as 'sub-conscious.' Stress is laid by them upon the infinite gradations of consciousness, and some amount of consciousness, however infinitesimal, is postulated so long as we can speak with propriety of mental phenomena at all. This sub. conscious region is understood to include not only the phenomena of habit referred to above, but the mass of organic or bodily feelings which, though intellectually unanalysed, are constantly present as a kind of background to our more distinet consciousness, and mainly determine both our habitual temperament and our varying moods. The hypothesis is also employed to explain the phenomena of memory as well as that instinctive basis of human life to which, under the name of the Unconscious, Hartmann (q.v.) has of late assigned such important philosophical funetions.

Consciousness is sometimes used in a special sense to denote the mind's cognisance of itself, as opposed to the cognisance or examination of the outer world. Hence, in studying our own minds, we are said to be using consciousness as the instrument; but in studying minerals or plants, we resort to external observation by the senses. A contrast is thus instituted between consciousness and observation, which contrast gives to the former word a peculiarly contracted meaning; for in the wide sense above described, observation is truly an act of consciousness. But such a usage is confusing and undesirable, and has been generally abandoned by accurate writers. The study of our own mind may be more appropriately expressed by such phrases as 'self-consciousness,' 'reflection,' or 'introspection."

Important philosophical points are involved in the determination of the conditions of consciousness, or the circumstances attendant on the manifestation of mental energy. The most general and fundamental condition of our becoming conscious is difference or change. The even continuance of one impression tends to unconsciousness; and there are a number of facts that show that if an influence were present in one unvarying degree from the first moment of life to the last, that influence would be to our feeling and knowledge as if it did not exist at all. This condition of our mental life has been formulated by Professor Bain as the Law of Relativity. For the varieties or divisions of our conscious states, see Psychology. See also Personality.

Conscription has been defined as the call to military service by the drawing of lots, a certain annual contingent of men for the army being selected by lot from the youths who have reached military age, while a man with sufficient means has the right to buy himself off, or pay for a substitute. This system obtained in France, with intervals, from 1798 until 1872, when substitutes were abolished and personal military service made obligatory upon every Frenchman not physieally incapacitated. All such must enter the army at the age of twenty ; but those who choose to enlist may do so at eighteen. The term, originally twenty years, was extended by the Military Bill of 1888 to twenty-five-viz. three in the regular army, six and $a$ half in the army reserve, six in the territorial army (militia), and nine and a half in the territorial reserve. At forty-five years of age liability to service ceases. A register is kept of the number of youths in France who reach the age of twenty in each year (about 280,000). All under 5 feet 2 inches in height are exempt; also any whose natural infirnities unfit them for active service; the eldest of a family of orphans; the only son of a widow, or of disabled fathers, or of fathers above seventy years of age; and the pupils at certain colleges. Moreover, if the younger of two brothers is efficient, the elder is exempt; and if of two only brothers one is already in the army, or 
has retired through wounds or infirmity, the other is exempt. Culprits and felons are not allowed to enlist.

A similar law of univensal service has existed in Prussia since 1813, and in 1887 it was made even more severe than formerly throughout the whole fermun empire. Russia, Italy, and all the chief Furnean nations have also alopted this method of recruiting.

In the United Kingdom a form of conseription was erested by the Ballot Act of 1860 which pro. vides for all inales over $\boldsymbol{b}$ feet $\mathbf{2}$ inches between the ages of eighteen and thirty being called upon to serve in the militis, but is held in abeyance by an annual act of parliament. In the Channel Islands, service in the militia is always compulsory for all natives, tradesmen, and owners of real vroperty, who are plysically fit, from sixteen to forty-five years of age. Breaches of discipline are punished by the eivil magistrate by fine or imprisonment.

Consecration is the act of solemnly dedicating a person or thing to the service of God. In the Jewish law, rites of this nature are frequently enjoined, the Levites and priests, the tabernacle and altar, \&c. being specially dedicated or consecrated to Goul; and analogous forms occur in most pagan nations. Among Christians the word consecration describes-(1) the ordination of bishops. The Nicene Council (can. 4 ) requires the ceremony to be performed by not less than three bishops. This rule is maintained by the Chureh of England. Among Roman Catholics the pope may permit consecration by one bishop and two priests. (2) The hallowing of the elements in the eucharist, by the words of institution according to Roman Catholics and Anglicans; by the invocation of the Holy Spirit according to the Greeks, (3) The dedication of churches; first mentioned by Eusebius, Hist. Eccles. x. 3. The rites, originally very simple, have become long and elaborate in the Church of Rome, though the present form is in substance as old as the Sacramentary of St Gregory. In the English Church the bishop chooses his own form. Tint most generally used was drawn up by the Anglican episcopate in 1712. In the American Episeopal Clumeh a form was appointed in 1799. (4) The benediction of abbots and abbesses accord. ing to forms prescribed in the Roman Pontifical. It is nsually performed by a bishop. (5) The consecration of altars, chalices, and patens by the bishop with the chrism or hallowed oil. The consecration of altars is mentioned by councils of the 6th centurv, that of chalices and patens in the Gregorian Śacramentary.

Consecutive, a term in Music. In part writing consecutive octaves or consecutive fifths, according to the rules of harmony, are strictly forbidden, though there are many exceptions to this in modern music.

Consent is the foundation of all contracts ancl legal obligations. The doctrine that the free consent of the parties bound, and not the will of any earthly legislator, or the form in which that will is expressed, constitutes the binding element in con. tracts, flows as an inevitable logical consequence from the doctrines of personal and political freedom. All that either civil or ecclesiastical anthority can do is to ascertain, at the instance of one or other of the parties, whether consent has or has not been given.

Conservation of Energy. See Exergy.

Conservative, as applied to one of the two great parties in English politics, was first used by J. W. Croker in an article in the Quarterly for January 1830 , and was by Macaulay in the Edin. burgh for 1832 referred to as a 'new cant word.'
Conservative accordingly began to mpersede Tory about the time of the Reform Bill controvernies. See TORY.

Conservatoire, or Conservatorium (Ital. conservatorio). forms of a name given by the Italians to mehools instituted for the purpose of advancing the study of music and maintaining its purity. In the enrliest times these schools were partly attached to benevolent institutions and hospitals; others, again, were supporterl by opulent private individuals. They were originally intended for foundlings, orphans, and the chíldren of poor parents. Some trace their origin to St Ambrose, Bishop of Milan, in the 4th century, or St Leo, who flourished in the 5th. They were largely developed by Gregory the Great. The scholars, male and female, all received free board, loklging, and elothing, and were taught to sing and play. Extra boarders were also admitted on paying a fee. In Naples there were at one time four such schools, while in Venice there were four expressly for females. In 1808 the Neapolitan conservatoires were reduced to one, under the name of Reale Collegio di Musica. The Venetian conservatoires shared in the down. fall of the Venetian republic. A new grand conservatoire was founded at Milan in 1808, which still exists. In France the necessity of a school for educating singers gave rise to the Rcole Royale de Chant et de Déclamation in 1784. During the French Revolution, in consequence of the scarcity of instrumental musicians for the army, the government decreed the erection of an Institut National de Musique in 1793 , which was changed into the present establishment in 1795 under the name of the Conservatoire de Musique. The yearly expenses of this conservatoire were fixed at 240,000 francs, the number of masters was 125 , and the pupils of bath sexes amounted to 600 . In 1802 the expense was reduced to 100,000 francs, with a corresponding reduction in the number of masters and pupils, but the original sum and number of pupils has now been nearly reached again; the professors are at present 77 in number. The tuition is divided over more than seventy different classes, in which all pertaining to music and also declamation is taught by the best masters. The elemen. tary works published by this conservatoire for all instruments are known over the whole world, and it possesses a library and museum of the first import. ance. The post of director has been held by an illustrious succession-Cherubini, 1822-42 ; Auber, 1842-71; and then, M. Ambroise Thomas. Other important conservatoires are those of Brussels (founded 1833), Prague, Vienna (1816), and the great conservatorium of Leipzic, extablisherl in is42 under the auspices of Mendelssohn; also those of Cologne, Munich, Stuttgart, Berlin, \&c. The Royal College of Music in London, which received a charter in 1882, is designed to rival the conservatoires of the Continent. There are several of note in the United States, especially the Boston Con. servatory of Music (1867), the New England Conservatory of Music (1870), also in Boston, and the Cirand Conservatory of Music of the City of New York (a corporation); and there are reputable schools of music, termed conservatories, in slmost all the principal cities. The name conservatoire is used for other than musical schools in France. There is thus a Conservatoire des Arts of Metiers at Paris.

Conservators of the Peace, a title usually applied to knights eleeted in each shire from the 12t. century onwards for the conservation of the peace. They were in fact the predecessors of the Justices of the Pence $\left(\mathrm{q} . \mathrm{v}_{\mathrm{o}}\right)$, by whom they were superseded.

Conservatory. See Plart-house. 
Conserves. See Preserved Provisions.

Considérant, Victor-Prosper, a French Socialist, was born in 1808 at Salins, in the department of Jura. After being educated at the Polytechnic School of Paris, he entered the army, which, however, he soon left to promulgate the doctrines of the socialist Fourier. On the death of his master (1837), Considérant became the head of his school, and undertook the management of the Phalange, a review devoted to the spread of their opinions. Having gained the support of a young Englishman, Mr Young, who advanced the required sum of money, Considerant established, on a large estate in the department Eure et Loire, a socialist colony or Phalanstere; but the experiment failed, and with it the Phalange fell to the ground. Thereafter he continued to promote his views in the Démocratie Pacifique. Among his numerous writings, the chief is the Destinee Sociale, dedicated to Louis-Philippe. In 1849 Considérant was accused of high treason, and fled from France. La Réunion, his socialistic community in Texas, flourished temporarily, but has since come to nothing. He returned to France in 1869 , wrote occasional political pamphlets, and died 27th Dec. 1893. See Fourier, SocialisM ; and Life by Coignet ( 1895 ).

Consideration, in Law, the thing given, or done, or abstained from by agreement with another, and in view of that other doing, giving, or abstaining from something. An obligation in. curred without consideration is, in England, termed voluntary, in Scotland gratuitous ; if for consideration, it is so styled in England, but in Scotland it is ealled onerous. Considerations are divided in England into good and valuable, the former being affection for a near relative, the latter a pecuniary or other tangible benefit, or marriage. But 'good' as distinguished from 'valuable' consideration has now no legal effect in England. There is no corresponding division in Scotland, but the fulfilinent of a natural obligation, such as that of aliment, is often recognised as supporting a transaction which would otherwise be inoperative against creditors. In Seotland, however, there is, as a general rule, no need for consideration to make a contract valid, while in England no action lies for breach of a contract not under seal, unless there has been valuable consideration, and the courts never enforce specific performance of a gratuitous contract, even though it is under seal. This doctrine does not mean that consideration must be adequate in view of the court. But the excess of consideration is an important fact in the setting aside of obligation obtained by means of pressure or undue in. fluence. The English doctrine of unconscionable bargains is not, however, recognised in Scotland. Where the consideration for an obligation totally fails, an action of repetition lies.

'There are some circumstances which, in both countries, warrant the setting aside of obligations without consideration, whether made by deed or not. In England they are void as against bona-fide purchasers, and void as against ereditors where the grantor is indebted to such creditors at the time to the extent of insolveney. A similar rule to the latter, with respect to ereditors generally, is estab. lislied in Scotland by the Act 1696, chap. 5, and by 1621 , chap. 18, without proof of insolvency when the deed is granted to a near relation, or a person in a confidential situation. As regards sales of land in Scotland, these are made on the faith of the records, and the first registered conveyance prevails. And all obligations for which the consideration is illegal or immoral are in both countries void.

In the United States, consideration in law has the same general signification as in England, and is subject to the same general divisions, 'good' or 'meritorious' and 'valuable.' A consideration is: an essential element enforceable in law, and must be actual and expressed, or the instrument must be such as to bear evidence of a consideration. By common-law statutes re-enacted in the United States, negotiable paper and sealed instruments are declared to bear this evidence; but in some states by usage, and in others by statute, courts of equity are empowered to set aside these instruments for want of, or a failure of, a valid and legal consideration upon the ground that the instrument was executed upon a promise or stipulation not fulfilled.

Consignment, in Mercantile Law, is the term applied to goods which are placed in the hande of an agent or factor for sale, or for some other specified purpose. If the consigner fails, the consignee has generally a lien on the unsold goods for advances ; if the consigner has to pay bills granted by consignee for advances, he may generally get back his consignment so far as unsold.

Consistory (Lat. consistorium), properly a place of assembly, but in the later Latinity the word came to signify the particular place where the privy-council or cabinet of the Roman emperor met, and after the time of Diocletian and Constantine, the council itself. The form of the imperial consistory passed over into the early Christian church. The bishops established their consistories; and the highest ecclesiastical court, composed only of cardinals (the College of Cardinals), which meets in the Vatican, under the presidency of the pope, to determine all such matters as the appointment of cardinals, archbishops, bishops, \&c., still bears this name, as do also the private councils which the pope can call at will. The Protestant Church of Germany perpetuated the consistorial courts, chiefly because the territorial princes who came into episcopal authority were unfamiliar with ecclesiastical affairs. The Lutheran consistories (the first was established at. Wittenberg in 1542) exercise supervision and discipline over religion and education, the clergy and the schoolmasters, regulating divine worship, administering church property, and examining theological candidates on their trials for license and ordination; they had formerly a certain jurisdiction in regard to marriage. In the French Protestant churches their jurisdiction is more re. stricted. The word denotes in England the court Christian or spiritual court. Every archbishop or bishop holds in his cathedral or other convenient place a consistorial court before his chancellor or commissary, for ecclesiastical causes. In Scotland the consistorial courts have lapsed into the commissary-courts. See COMMISSARY.

Consolación del Sur, a city of Cuba, 13 miles by rail ENE. of Havana. The finest of tobaceo is grown in the vicinity. Pop. (1899) 3062 .

\section{Consolato del} Ma'ré. See MERCANTILE LAW.

Console (Fr.), in Architecture, a projection resembling a bracket, frequently in the form of the letter $\mathrm{S}$, used to support cornices, or for plac.

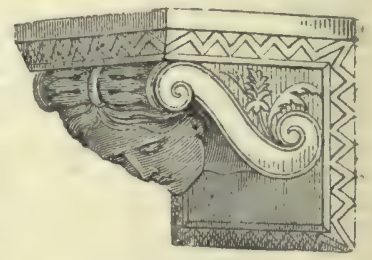

Console. ing busts, vases, or figures on. Consoles were often. richly ornamented in the under part. The illustration, from Parker's Glossary, is from the palace of Diocletian at Spalatro.

Consolidation Aets, acts of parliament which combine or consolidate into one general. statute the enactments of several special measures, 
such as the Railways Clauses Consolidation Act, 1845, the Titles to Land Consolidation Act, 1868, Se.

Consols, a contraction of Consolidated Annuities. In incurring the national debt, government borrowed money at different periods on special conditions, being generally the payment of an annuity of sn much per cent, on the sum borrowed. Grest confusion arose from the variety of stocks thus crented, and it was thought expedient to consolidate them into one fund, kept in one account at the Bank of England. The Consolidated Anuuities Act was passed in 1749-50, consolidation being completed in 1757. For consolidation of the Funded Debt subsequent to that period, see NationaL DEBT.

Consonance is a combination of notes which can sound together without the harshness produced by beats. See SoUnd, MUsic.

Consonant. See LETTERs.

Consort, literally, one who throws in his lot with another. In English constitutional law, the term is applied to the husband or wife of the reigning sovereign, viewed not in a private but in a public capacity, as participating to a certain limited extent in the prerogatives of sovereignty. A queen-consort is speeially so named in distinetion from a queen-regnant, who holds the crown in her own right, as Queen Elizabeth and Queen Victoria, and from a queen-dowager, the widow of a king. A queen-consort is in all legal proceedings looked upon as a feme-sole, independent of her husband's control, as if she were a single woman. Coke gives as the reason for this that the common law would not have the king, whose care is for public affairs, troubled with the domestic concerns of his wife. The queen-consort has also a particular revenue and peculiar exemptions and privileres. One curious and ancient perquisite is that, when a whale, which is a royal fish, is taken upon the coast, it by right should be divided between the king and the queen, the head only being the king's property, and the tail the queen's. The consort is in all respects a subject of the sovereign ; accordingly the husband of a queen-regnant is her subjeet, and may be guilty of treason auainst her. Up to the year 1857 the husband of Queen Victoria possessed no distinetive English title, and no place in court ceremonial except such as was conceded to him by courtesy. In that year the title of PrinceConsort was conferred upon him by letters-patent.

Conspiracy, a combination between two or more persons to perpetrate an unlawful act, or to do a lawful act by unlawful means. A person injured by conspiracy has an action at law for the damage done, as when a man is falsely indicted of a crime. In criminal law, conspiracy is a misdemeanour punishahle by penal servitude. Few things are left so doubtful in law as the point when a combination for a common object becomes unlaw. ful. Formerly, combinations by workmen to raise the rate of wages were conspiracy, but this is no longer so; and till lately, prevailing judicial opinion was that a trade-union was a 'conspiracy in restraint of trade.' See Combination.

Conspiracy was defined in the reign of Eslwarl I. by the Ordinance of Conspirators, which was aimed at persons binding themselves together to lay false indictments, and otherwise to obstruct the course of justice. But the word came in time to have a wicler meaning, and almost every combination to do a criminal or even an unlawful act is now an indictable conspiracy (see CoMBINATION). The vagueness of the law has placed considerable power in the hands of juries. Almost any act, however innocent, may be treated as a crime if the jury choose to impute it to some motive connected with an unlawful combination. Again, in proving a charge of conspiracy, the prosecution may begin by giving evidence of the existence of a general con. spiracy, amd such evilence may consist of acts of third parties with which the person aceused had no connection. The judges also have exercised their own diseretion in deciding whether the objects of a combination were 'contrary to good morals and public policy or not. But if juries and judges have not always exercised their diseretion wisely. it is to be remembered that such diseretion must of necessity form part of the law of conspiracy. Acts which are comparatively harmlese when done by one or two persons may become intoleralily oppressive when they are committed by a large number of persons acting in concert. See PLOT, SEDITION.

Conspiracy Bill. See Polmical Offenczs.

Constable (Lat. constabulus), the title of an ancient officer, originally of high military rank, but now generally an officer of the peace. The older writers, as Coke and Selden, fancifully derive the word from koning-stapel, 'staff and stay of the king. It represents, however, the Latin comes stabuli, ' count of the stable,' an officer who in the later Roman empire was at first charged with the care of the stables, and afterwards became captain of a military force, and chief officer of the army. The title was borrowed from the Romans by the Franks. The Constable of France rose gradually in import. ance from the comparatively modest position of an officer of the household, till at last he became $e x$ officio the commander-in-chief of the army in the absence of the monarch, the highest judge in mili. tary offences and in all questions of chivalry and honour, and the supreme regulator and arbitrator in all matters connected with tilts, tournaments, and all martial displays. The office was suppressed by Louis XIII. in 1626. Under Napoleon, the constable was the fifth of the great dignitaries of the empire. The office was again abolished on the restoration of the Bourbons, But besides the Constable of France, almost all the great vassals of the crown had constables who filled analogous offices at their minor courts.

The Lord High Constable of England appears shortly after the Conquest as the seventh great officer of the crown, and formerly a judge in the Court of Chivalry. The office went by inheritance to the Earls of Hereford and Essex, and afterwards in the line of Stafford. When Edward Stafford, Duke of Buckingham, was attainted in 1521, the office became forfeit, and has never since been granted except for a special ceremony of state, as when it was conferred on the Duke of Welling: ton for the coronation of Queen Victoria. The High Constable of Scotland was an ofticer very similar to the Constable of France and England. The office, now purely honorary, in 1314 was made hereditary in the noble family of Erroll, and is reserved both in the Treaty of Union and in the statute of (ieorge II. aludishing hereditary jurisalietions. The High Constalile is ly birth the first subject in Scotland after the bloodroyal.

The governor of a royal castle was often ealled Constable; see Tower of Loxdon. The Constables of the Hundred, and of the Vill, were the predecessors of the high and petty constables of later times. The statute of Winchester (1285) ordains that in every hundred or franchise there shall be chosen two constables, to make the view of armour, and to see to the conservation of the peace. The petty constable exercised similar functions within the narrower limits of the township or parish, and was subordinate to the high constableof the hundred. The high constables were formerly appointed by the 
courts leet of the franchise or hundred over which they preside; or, in default of such appointment, by the justices at their special sessions. An act of 1869 made provision for the abolition of the office of high constable throughout England and Wales. The appointment of petty constables is made by the justices, who are directed annually to require from the overseers of parishes a list of those within the parish qualified and liable to serve as constables. When not specially exempted, every ablebodied man, between twenty-five and fifty-five years of age, resident in the parish, and rated to the poor, or a tenant to the value of $£ 4$ per annum, must be included in this list. - SPECIAL CoNstabLES are persons sworn in by the justices to preserve the peace, or to execute warrants on special occasions, as in 1848 on account of the Chartists, and in 1887 on account of the 'unemployed 'riots in Trafalgar Square, London. Any two justices of the peace who shall learn that a tumult, riot, or felony has taken place, or is apprehended, may swear in as many householders or others as they may think fit, to act as special constables. The lord-lieutenant may also, by direction of one of the principal secretaries of state, cause special constables to be appointed for the whole county, or any part of it. In Scotland, constables are the officers of the justices of the peace charged with the execution of their warrants and orders, and appointed at quartersessions. In royal burghs they are appointed by the magistrates. It is their duty, without warrant, to apprehend rioters and breakers of the peace, and bring them before the nearest justice. In the United States they are generally elected by the people, but special constables may be appointed by the authorities in emergencies. The title of High Constable is in some American cities given to the principal police officers. For county constabulary, see POLICE, and for the Irish constabulary, IRELAND.

Constable, Archibald, publisher, was born at Carnbee, Fife, 24th February 1774, and became a bookseller's apprentice in Edinburgh (1788-95). He then started as a bookseller at the Cross of Edinburgh, and speedily gathered round him the chief book-collectors of the time. He gradually drifted into the publishing business, secured the copyright of the Scots Magazine in 1801, and was chosen as the publisher of the afterwards famous Edinburgh Review. He published for all the leading men of the time, and his quick appreciation of the merits of the works of Sir Walter Seott became the envy and wonder of the book-trade. There were several business partners in the career of Constable \& Co. but Archibald Constable was from first to last the mainspring of the concern. Had painstaking business qualities kept pace with his shrewdness and large-minded literary transactions, business calamities might have been averted. "Among all his myriad of undertakings, I question,' says Lockhart, "if any one that really originated with himself, and continued to be superintended by his own care, ever did fail.' In 1812 he purchased for between $£ 13,000$ and $£ 14,000$ the copyright of the Encyclopodia Britannica. In the commercial crisis of 1826 Constable \& Co. failed, the liabilities amounting to upwards of a quarter of a million. The only noteworthy publishing scheme of Constable after this failure was the issue of his celebrated Miscellany. He died July 21, 1827. See Archibald Constable and his Literary Correspondents, by his son, Thomas Constable (1873).

Constable, Henry, poet, was born in 1562, son of Sir Robert Constable of Newark, a soldier who was knighted by Essex in 1570. At sixteen Henry entered St John's College, Cambridge, early turned Roman Catholic, and betook himself to
Paris. He was pensioned by the French king, and seems to have been often employed in confidential missions to England and to Scotland. He died at Liège, 9th October 1613. In 1592 was published his Diana, a collection of twenty-three sonnets; two years later, the second edition, containing seventy-six, but some of these by his devoted friend, Sir Philip Sidney, and other poets. Constable's sonnets are quaint, and sometimes laboured, but they are instinct with fancy and the tremor of genuine poetic feeling. Constable contributed to England's Helicon (1600), and sixteen 'spiritual sonnets' to Park's Heliconia. See editions by W. C. Hazlitt ( 1859 ) and John Gray ( 1897 ).

Constable, JoHn, R.A., landseape-painter, was born at East Bergholt, Suffolk, where his father was a well-to-do landowner and miller, 11th June 1776. At the age of eighteen he assisted his father for about a year in the mill; but his love of art was irrepressible, and it was encouraged by Sir George Beaumont, who prevailed upon his family to send him to London. Here he arrived in 1795 ; and, after an interval of a year spent in his old employment, he returned in 1799, and entered the schools of the Royal Academy, to whose exhibition he sent a work in 1802 . Hitherto he had been carefully studying the methods of other painters, poring over Sir George's great Claude, and copying Ruysdael, seeking, as he says, 'truth at second-hand.' He now turned exclusively to nature, resolving to free himself from conventionality, to paint the very fact, to 'adopt a pure and unaffected manner of representing the scenes that may employ me.' But the public, trained to admire an artificial and pseudoclassical adaptation of nature, cared little for his simple renderings of common subjects, and he was. nearly forty before he sold a single landscape beyond the circle of his relatives and personal friends. Meanwhile he supported himself by painting likenesses; he copied portraits by Reynolds for the Earl of Dysart, and executed altar-pieces for the churches of Brantham and Nayland in Suffolk.

In 1816 he married Mary Bicknell; and in 1828, on the death of her father, solicitor to the Admiralty, an inheritance of $£ 20,000$ placed the family in easy circumstances, and enabled Constable to devote himself quite exclusively to his beloved but unremunerative landscape work. In 1821 he had won the best artistic triumph of his life, in the applause which greeted the appearance of his ' Haywain' (then titled 'A Landscape-Noon'), when it was exhibited in the Paris Salon by a French purchaser. Not less marked was the impression produced by his 'White Horse,' at the Lille Exhibition in 1825. Each work gained a gold medal, and the former in particular won the warmest enthusiasm of Delacroix and the other leaders of the romantic school, and exercised a definite and powerful influence upon the future of landscape art in France. Appreciation of this sort was more precious to a true artist than such formal academic honours as Constable won in England, than his election as Associate in 1819, and his tardy and ungraciously awarded promotion to membership in 1829. His later years were saddened by the deaths of his wife and his friend Archdeacon Fisher, by illhealth, and by great depression of spirits; but he worked steadily at his art, though his landscapes still were frequently unsold, producing 'Salisbury Cathedral from the Meadows' (1831); 'Waterloo Bridge, then titled 'Whitehall Stairs' (1832); and 'The Valley Farm' (1835). He was engaged upon 'Arundel Mill and Castle' at the time of his death, which occurred suddenly, on the 30th of March 1837.

The art of Constable marks the first definite departure in the history of English landscape from the conventional treatment of our earlier painters, 
the breaking away from the traditions of Claude and the Dutch masters, the return to direot and personal impressions of nature. With a broad and rapid touch he renders all the force and variety of colouring that full-leafed English landscepe presents; entehes, with singular skill, her passing effects of rain-eloud and sunlight; suggests, with swift and unsurpassable power, her sense of glitter and motion. Mr Ruskin's eriticism has, alike in its general scope and in most of its specific references, done much to disparage Constable's art in the estimation of the public of the time that is just passing; but already there is a recoil on the part of both painters and crities from the detailed intricacy of pre-Raphaelite methods; Constable's works are assuming their true place in the sequence of our national art; and their painter is being recog. nised as one of the very foremost figures of English landscape-painters. Three of his most important and most powerful landseapes, 'The Valley Farm, 'The Cornfield,' and 'The Hay-wain,' were already in the National Gallery in 1888, when five more were gifted by the painter's family. His 'Salisbury Cathedral' is at South Kensington, where, as also in the British Museum, his work in water-colour and pencil may be studied.

The most important of the engravings after Constable are the mezzotint plates by David Lucas, many of which were supervised with especial care during their progress by the painter himself. See his Life by C. R. Leslie (1843; new ed. 1896).

Constance, or Kostnitz, a city of Baden, once a free imperial city, is situated on both sides of the Rhine, at its exit from Lake Constance, 91 miles E. of Basel by rail. One of the most ancient towns of Germany, Constance owed its prosperity to its linen industry, for which it was already famons in the 12th century; but five centuries later this had sunk greatly, and it has only been partially revived since the establishment of railways. Its manufactures include linen, cotton, jute, and waterproof fabrics, canvas, carpets, and chemicals; and other industries are bell-founding, printing, and publishing. Beside the picturegallery, library, and town-hall, with a valuable collection of archives, the most noteworthy build. ings are the cathedral (part of which dates from the 1 ith century), the old Dominican convent (now an hotel), and the present market-hall, in which three places the sessions of the great council were held. Pop. (1890) 16,235, - The most notable event in the history of Constance is the meeting of the ecclesiastical council here in 1414-18 with a view to put an end to the disorders in the popedom and in the election of popes, and also to prevent the spread of the doctrines of Huss. There assembled with the Emperor Sigismund and Pope John XXIII. 3 patriarchs, 33 carlinals, 47 archbishops, 145 bishops, 124 abbots, 750 doctors, and about 18,000 priests and monks, besides numerous princes and counts of the empire, and representatives from all the monarehs of Catholic Christendom: and the retinues of these members of council swelled the number of strangers resident in the town to over 50,000 . The three rival popes, John XXIII. Gregory XII., and Benedict XIII., were deposed, and Martin V. was elected. Huss (q.v.) and Jerome of Prague (q.v.) were condemned and burned. The emperor was, however, disappointed in his hope of a thorough reform of the church (causa reformationis), in spite of the efforts of such advocates of reform as Peter d'Ailly and Gerson (q.v.); and the Conncil of Basel (q.v.) was afterwards called to carry on the work which the Council of Constance had failed to accomplish.

Constance. LAKE (called by the Germans Bodensec or Bodmansee-the Lacus Brigantinus of the Romans), lies between Switzerland and Germany, and on the north side of the Alps of Switzerland, and forms a meeting.point of the five territorieg-Baden, Wurtemberg, Bavaria, Vorarl. berg (Austria), and Switzerland. It has an eleva. tion of 1306 feet above the wer. Lake Constance is traversed by the Rhine from east to weat ; it grentent lenuth is about 44 milem, and utmont breadth 9 miles, the ares being 208 sq. miles; the mean depth is 490 feet, while the greatent depth is 906 feet. The southernmost of the two western extremities is called the lower lake, and is separsted from the main lake by a narrow channel two miles long, and lies full $\mathrm{a}$ yard below the level of the lake. The shores are formed by hilly lands, with low tracts at the mouths of the Khine and smaller rivers. Cornfields, vineyards, pastures, orchards, and wooled declivities, with here and there the ruins of old castles interspersed, surround the lake. The water has a dark-green hue, often rises suddenly some ten or twelve feet during a thaw, and rolls in high waves during the prevalence of a strongsouth, north-west, or east wind. Without visible cause it sometimes rises and falls to a considerable degree. Usually the level rises from June onwards to August, when it sinks again. It is seldom frozen, except in very severe winters. The fisheries of this lake are important. Since 1824 stean-navigation has added to the facilities of commerce across the lake, and its commercial importance has been greatly increased by the connection of the chief towns on its shores with the railways of South Germany and Switzerland. The chief towns are Constance, Bregenz, Lindan, and Friedrichshafen. See Capper's Shores and Cities of the Bodensee (1881).

Constans, youngest of the three sons of Constantine the Great, received Illyricum, Italy, and Africa as his share of the empire. After the defeat and death of his elder brother Constantine, in 340 A.D., Constans became sole ruler of the West till his death in 350 .

Constant, BENJAMIN, subject-painter, was born in Paris, 10th June 1845. He studied in the Ecole des Beaux-Arts and under Cabanel, and began to exhibit at the Salon in 1869 , with his 'Hamlet and the King,' a work purchased by the French government. He soon turned to those Eastern subjects for the treatment of which he is best known, producing 'Prisoners in Morocco' (1875): 'Mahomet II.' (1876); 'The Harem' (1878); 'The Favourite of the Enir' (1879): 'The Day after a Victory in the Alhambra' (1882); and 'The Vengeance of the Cherif' (1885). His works are characterised by direct and powerful but frequently most repulsive realism, melodramatic feeling, bold portrayal of the nude, and vivid colouring. He is one of the most popular of contemporary French painters, and received medals in 1875 and 1876 , and the decoration of the Legion of Honour in 1878 .

Constant de Rebecque, Henri Benjamin, author and politician, was borm of French Huguenot ancestry at Lausanne, 23d October 1767. He was educated at Oxford, Erlangen, and Edinburgh, where he became acquainted with Mackintosh and Erskine. In 1795, settling in Paris, he quickly gained reputation as a publicist. He entered the Tribunate in 1799, but was banished from France in 1802, for having denounced the despotic acts of Napoleon. After travelling over Germany and Italy, in company with Madame de Stael, he lived for a number of years in Götingen. On Napoleon's fall in $\mathbf{1 8 1 4}$ he returned to Paris, and issued several pamphlets advocating constitutional liberty; during the Hundred Days he became one of Napoleon's Councillors of State, thourh previously he had styled Napoleon a Genghis Khan, and his government a goverument of Mamelukes. After 
the second restoration of the Bourbons, Constant wrote and spoke consistently in favour of constitutional freedom. He was returned to the Chamber of Deputies in 1819, and became the leader of the Opposition. He was the ablest controversialist among the Doctrinaires, the French Whigs. The greater number of his very able political pamphlets were collected under the title of Cours de Politique Constitutionelle (4 vols. 1817 20) ; his Discours were published in 1828 . He died 8th December 1830. His powerful intellect had many sides. In De la Religion (5 vols. 1824-31) he maintained that the spirit of religion, as it grows loftier and purer, casts off the various forms in which it has been embodied, and which obstruct its expansion. He was likewise the author of a remarkable novel, Adolphe (1816), a short story of love and disillusion, in which Constant forestalls the method of the modern school of analytic novelists. His Correspondence appeared in 1844, his Euvres Politiques in 1875 , his Letters to Madame Récamier in 1881, and his Journal Intime in 1894.

Constantia, a district of Cape Colony, in South Africa, lying on the eastern and north-eastern slopes of Table Mountain range, and distant from Cape Town 7 miles by rail. Constantia consists of only three estates, High, Great, and Little Constantia, which have long been famed for the quality of the wines produced upon them. The wines are sweet wines of delicious aroma, both red and white. For wine-growing at the Cape, see CAPE Colony, Vol. II. p. 734 .

Constantina, a town of Spain, in Andalusia, situated in a mountainous district, 40 miles NNE. of Seville, with silver mines, and a trade in wine and vinegar. Pop. 10,988.

Constantine, capital of the easternmost pro vince of Algeria, is very picturesquely situated on a nearly isolated chalk rock with flat summit, three sides of which are washed by a small stream, flowing through a deep and narrow ravine, and the fourth is connected by a narrow ridge with the adjoining mountains. It is 830 feet above the river, and 2160 feet above the sea; it is connected by rail with its port Philippeville, 40 miles NE., as also with Algiers and with Tunis. It is surrounded by walls constructed by the Arabs out of Roman sculptured stones. There are practically two cities, the French and the Arab, though the running of wide streets through the Arab town has taken away much of its primitive oriental look. Constantine was anciently the capital of Numidia, called Carta by the Carthaginians, Cirta by the Romans; and near it many notable events occurred in the wars with Jugurtha. It was destroyed about 311 A.D., but was soon rebuilt by Constantine the Great, from whom it derives its present name. It held out against the Vandals and other besiegers, but was taken by the Arahs in 710. Subsequently, it shared in general the fortunes of Algeria (q.v.). Constantine manufactures woollen cloths, saddlery, leather goods, and carpets ; it is a great trade centre, being the chief grain market of Algeria, and exports oil and wool. Pop. (1886) 36,536 ; (1891) 46,581, of whom 12,006 were French and 3321 Jews.

Constantine I., Roman emperor, 306-337 A.D. Flavius Valerius aureius Constantinus, 'surnamed 'the Great,' was born in $\mathbf{2 7 4}$, at Naissus, in Upper Moesia. He was the eldest son of Con stantius Chlorus and Helena, and first distinguished himself as a soldier in Diocletian's famous Egyptian expedition (296), next under Galerius in the Persian war. In 305, the two emperors, Diocletian and Maximian, abdicated, and were succeeded in the supreme rank of Augustus by the two Cresars, Constantius Chlorus and Gal erius. Galerius, envious of young Constantine's brilliant genius and popularity among the soldiers, took every means of exposing him to danger, and it was now that he acquired that mixture of reserve, cunning, and wisdom which was so conspicuous in his conduct in after-years. At last, extorting a reluctant consent from the jealous Galerius, he made his way hastily to his father, who ruled in the West, and joined him at Poulogne just as he was setting out on an expedition against the Picts in North Britain (306). Constantius died at York in the same year, having proclaimed his son Constantine his successor. The latter now wrote a conciliatory letter to Galerius, and requested to be acknowledged as Augustus. Galerius did not dare to quarrel with Constantine, yet he granted him the title of Crsar only. Political complications now increased, until in 308 there were actually no less than six emperors at once-Galerius, Licinius, and Maximin in the East; and Maximian, Maxentius his son, and Constantine in the West. Maxentius having quarrelled with his father, forced him to flee from Rome; he took refuge with Constantine, who had married his daughter Fausta at Arles in 307 , but was ungrateful enough to plot the destruction of his benefactor. This being discovered, he fled to Marseilles, the inhabitants of which were just about to give him up to the conqueror, when he anticipated his fate by suicide (309). Maxentius professed great anger at the death of his father, and assembled a large army, with which he threatened Gaul. Constantine anticipated his movements by crossing the Alps by Mont Cenis, and invading Italy. Already twice he had defeated Maxentius, when he finally crushed his power by the great victory of the Milvian Bridge, near Rome, 28th October 312. Maxentius himself was pressed by the thronging crowd of fugitives over the bridge into the river, and drowned. Constantine now entered the capital, disbanded the Prætorian guards, and destroyed their camp. During his short stay in Rome he assumed the title of Pontifex Maximus. It was during his final struggle with Maxentius that the famous incident occurred that is said to have caused Constantine's conrersion, and which Euse. bius gives us an account of from the lips of the emperor himself. At noon there appeared in the sky a flaming cross inseribed 'Ev roúr $\varphi$ vixa ('By this, conquer'). Again, the night before the final battle, a vision appeared to Constantine in his sleep, bidding him inscribe the shields of his soldiers with the sacred monogram of the name of Christ. Hence the well-known labarum or standard of the cross, which Constantine, however, did not give his army, according to Gibbon, till 323 . Whatever the story of the conversion be worth, one satisfactory consequence was the edict of Milan (March 313), issued conjointly with Licinius, and giving eivil rights and toleration to Christians throughout the empire.

Constantine was now sole emperor of the West. Similarly, by the death of Galerius in 311 , and of Maximin in 313, Licinius became sole emperor of the East. In 314 a war broke out between the two rulers, in which Licinius had the worst, and was fain to conclude a peace by the cession of Illyricum, Pannonia, and Greece. Constantine gave Licinius his sister Constantina in marriage, and for the next nine years devoted himself vigorously to the correction of abuses in the administration of the laws, to the strengthening of the frontiers of his empire, and to chastising the barbarians, who learned to fear and respect his power. In 323 he renewed the war with Licinius, whom he defeated, and ultimately put to death. Constantine was now at the summit of his ambition, the sole governor of the Roman world. He chose Byzantium for his capital, and in 330 solemnly inaugurated it as the seat of 
government, under the name of Constantinople or City of Constantine. In 326 be committed a deed that has thrown a dark ahade over his memory. His elclest son (liy his tirst wife), Crispus, a gallant and accomplished prinee, who was very popular, he put to death on a churge of trenson; and next year his own second wife, Faunta, mother of the three sons anongst whom he divider his empire. In 325 was held the great Council of Nicen, in whicls he opunsed the Arims on prolitionl gromnds, a. the weaker party; lut not being theologienlly interested in the diswensions, refrained from active persecution of them. In 324 Christianity became the state religion, the pagan temples were climed, and sacrifices forlidilen. Yet it was only a short time before Constantine's death, which oceurred 22 July 337 , that he would allow himself to be baptised by the Arian bishop, Ensebius of Nicomedia. The story of his baptism at Rome by Pupe Sylvester in 326, and of the so-called Dona. tion of Constantine thereafter, alluder to in Dante's Inferno, and often in the past gravely argued as giving an historical basis for the temporal power of the papacy, may safely be dismissed (see CANON Law). For other Constantines, gee BYzantine EMPIRE.

Constantine Nikolaeviteh, Grand-duke of Russin, the second son of the emperor Nicholas I., and the brother of Alexander II., was born 2lst September 1827. During the Crimean war he commanded the Russian fleet in the Baltic, and directed the defensive preparations which held the English and French armaments in check before Cronstadt. The leader of the Muscovite or national party, he strenuously opposed the concessions made to the western powers, but through. ont gave, although contrary to expectation, steady alleriance to his elder brother from his accession to his unhappy death. On the outbreak of the Polish insurrection in 1862 , he held the office of viceroy of Poland for three months, was appointed in January 1865 and reappointed in 1878 president of the council of the empire. In 1882 he was dismissed from this dignity, as well as the command of the fleet, on the suspicion of having intrigued with the revolutionary party, while his eldest son, Nicholas, was banished. Died January 25, 1892.

Constantinople, $49^{\circ}$ N. lat., $28^{\circ} 59^{\prime}$ E. long., the capital of the Ottoman empire, was founded in 330 A.I). by ('mstantine the Great, from whom it derives its name, on a site partly oceupied by the ancient Bvzantium. The Turks call it Istambol or Stambol, which they pretend is a corruption of Islambol ('Islam abounding'), a name which was formerly engraved upon the coinage in lieu of Kus. tantiniya, the Arabic form of Constantinopolis. European writers have fancifully derived Istambol

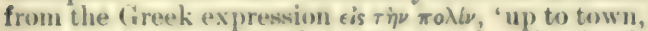
but a more probable derivation makes it simply a Turkish mispronunciation of Constantinopotis. The original Byzantium was a colony (about 658 B.C.) from Megarn, with an Argive mixture, however, to which the worship of Hera, and the introduction of the myth of Io, represented upon the earliest coins, may probably be ascribed. It was built on the apex of the triangular peninsula which juts out towards Asin on the sonthern side of the Golden Horn, where the present Eski Serai or 'Old Seraglio' stands, and its commanding position made it an object of strife among the nations-Persians, Gauls, and Greeks, In the middle of the 4 th century B.C., the Athenians under Demosthenes, coming to the assistance of the Byzantines, repelled the siege of Philip of Macedon, aided, according to the legend, by the supernatural appearance of a crescent in the sky, which revealed the presence of the invaders, and 132 was forthwith adopted as the badge or creat of the city, as it is to this day. After ite snbmiemion, the Roman emperors long recognised its virtual independence, and in $\mathbf{3 3 0}$ A.D. impresused by its mag. nificent site, Constantine the Great abandoned the old capital on the Tiber, and founded in the place of Byzantium a new metropolis on the lumporus, which he called Constantinople. Its walls and public luildings ware enlatured and lesutifiod by Justinian in 527-65. Since then it las undergone many sieges by Sassanians, Penians, Avars, Saracens ( ix times), Ruseians (in 9th to 11 th century), Latins, and Turks ; and of its twenty-mix sieges and eight captures, that of the Latins under Bald. win and Dandolo in 1204 was by far the most disastrous, barbarous, and spoliating. The chief adornments of the city, the treasures of the churches, and even the bodies of the great dead, were not re. spected by these vandal 'crusaders.' In comparison, the Turkish sieges were humane and chivalrons: the first took place in 1356; Murad II. made the

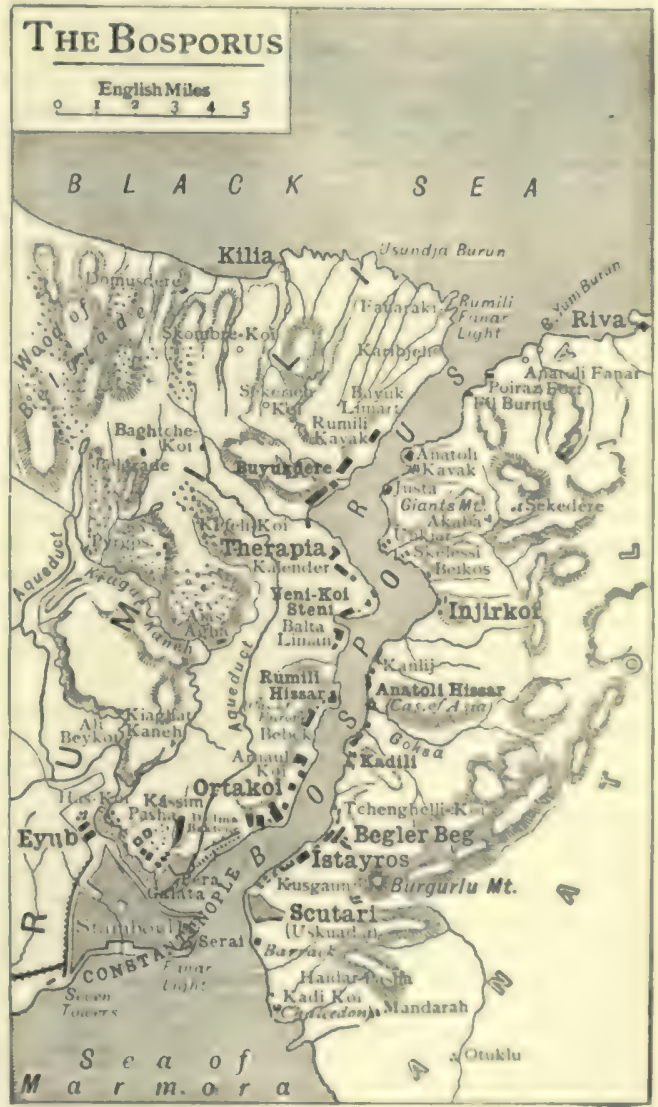

attempt agrin in 1422 ; and Mohammed II. carried the city agninst the resolute resistance of Constan. tine Palaeologus and Fiustiniani in 1453. Since then such has been the renown of the Turks or the jealousy of the Powers, that the inperial city has witnessed no fresh siege (see TVRKEY).

Constantinople consists of two distinet parts, besides more distant suburb-Constantinople proper or Stamlul, and what may he termed Christian Constantinople (Pera, Galata, Top-hana), because it is there thint the Christian colonies chiefly congregate. The two are separated by the Golden Horn, a creek alwont five miles long and half a mile wide at the entrance, so called prohably from its famous fisheries, a veritable horn of plenty 
to the ancient inhabitants; in the present day a safe harbour, capable of accommodating 1200 sail, and so deep that the largest ironclads of the Turkish navy, which may be seen there during a great part of the year, find enough water for their draught quite close to the shore. Stambol or Turkish Constantinople lies on the southern side of the Golden Horn, and Christian Constantinople lies on the north side : the two are connected by a couple of rude but convenient bridges, from the larger of which steamers start for various points on the Bosporus and Sea of Marmora. Stambol is on the site of Byzantium, and the old walls, in courses of stone and red brick, which Constantine built and Theodosius and others restored, show that the modern Turkish city occupies much the same area as the capital of the first Christian emperor. The walls run a circuit of 14 miles from the grim but now ruined and disused castle of the Seven Towers-where many sultans met their deaths at the hands of their mutinous soldiery, and where foreign ambassadors were imprisoned upon declaration of war-to the Golden Horn, then along its southern shore to Seraglio Point, and so back to the Seven Towers close along the margin of the Propontis. Within these walls the city rises, like Rome, upon seven low hills, crowned by noble mosques, with a wilderness of picturesque, tumbledown, filthy, wooden houses, and lane upon lane of even more picturesque and scarcely less dirty bazaars, climbing up their sides from the Golden Horn to the Hippodrome. Years ago Stambol was more beautiful and more filthy, but fire, the great purifier of the East, has so repeatedly laid low its thousands of dwellings, that the old streets are becoming few, and their place is being taken by more sanitary but not equally pleasing thoroughfares and brick or stone houses. In the bazaars and some of the less reformed byways there is quite enough of the old Mussulman leaven to make one's eye and one's nose aware of the charms and the drawbacks of an oriental city. Very few of the goods, however, which the admiring tourist carries away from the bazaars are made there; many come from Vienna, and not a few from Manchester, whither they are faithfully brought back by the travelled citizen.

In Stambol are nearly all the monuments and antiquities worth seeing in Constantinople. In the row of some half-dozen mosques, whose conglomeration of domes, like a clustered jelly-mould, and tall and exceedingly slender minarets, erown the summits of the hills, we see some of the most famous and magnificent monuments of Christian and Saracenic art. First, next the Seraglio, stands Agia Sophia, Saint Sophia, the church dedicated by Constantine to 'Eternal Wisdom, and rebuilt with added splendour by Theodosius (415) and by Justinian (538-568), and now converted into a cathedral mosque. Outside it is not worth a second glance; but within, the airy grace of its stupendous dome, and the beauty of its marbles and mosaics, despite all the ravages of Moslem, and, worse than Moslem, tourists desecrations, fascinate and amaze the vision (see Byzantine Architecture). Next, but not less beautiful, is the Suleymaniya, the mosque which the Great Suleyman and his architect Sinan erected in $1550-5$ on the model of St Sophia, but with Saracenic ornament and a loftier though not quite so expansive dome. Some of the monolithic columns are remarkable for their size and beauty, and the general effect is even more im. posing than that of St Sophia. Searcely less stately is the mosque of Sultan Ahmed I. in the Hippodrome; distinguished without by its six minarets (instead of the usual four), and within by the four gigantic columns, 36 yards round, which support the dome : here the official celebrations and formal processions take place at the great festivals. The mosque of the conqueror Mohammed II. is also worth seeing, though it has been greatly altered in restoration. There are over two hundred other mosques in Constantinople, and an even larger number of chapels (besides hundreds of medreses or mosque colleges, and mektebs or elementary schools); but very few of them present features of special interest, except sometimes in the beauty of their wall tiles, of the Rhodian style, for the manufacture of which the suburb of Eyyab was famous.

The remains of the Greek churches are more interesting, and the Fanar, or Greek quarter of Stambol, recall the memories of many distinguished Fanariote statesmen; but among the relies of ancient Constantinople none is more striking than the Hippodrome (now called At-Meydan, or 'Horse Manège ), originally a circus surrounded by marble seats, long since removed, but still showing remains of antiquity, such as the famous column of the Three Serpents which once stood at the Temple of Delphi, and supported a gold tripod made out of the spoils taken by the Greeks at the battle of Platee, but was removed to his new capital by Constantine. The serpents' heads are broken off; one was said to have been struck off by the scimitar of Mohammed the Conqueror, and one is still preserved in the museum of antiquities. In the Hippodrome also stands an obelisk brought from On (Heliopolis) in Egypt, and re-erected by Proclus the Protor in the reign of Theodosius; hard by are the Burnt Column, the column of Theodosius, and the Seraskier's Tower, whence watchmen survey the city and give. warning of conflagrations. Among the remains of Mohammedan splendour the Old Seraglio (Eski Serai) is the most important, though it has not been a royal residence since the days of Mahmud II. Its first gate, Bab-i-Humayan or 'Sublime Porte,' has given its name to the Turkish government in its foreign relations. Within its three spacious courts, full of beautiful trees and picturesque in their gray decay, are various stables and offices of the court, the old council chamber, the armoury (once the Church of St Irene), the museum, mint, and the celebrated treasury, where uneut jewels, gold-embroidered vestments, and gorgeously mounted arms are preserved in fabulous value. In the neglected gardens overlooking Seraglio Point, whence a lovely view is gained of the Bosporus, the Asiatic shore, and the Sea of Marmora, are various kiosks, one of which, ealled that of Baghdad or Murad IV., is lined with exquisite tiles, another contains the imperial library, and a third is the ominous Kafes or 'cage' where the unhappy princes who menaced the peace of sultans were immured for all their lives.

Christian Constantinople, on the north side of the Golden Horn, comprises Galata, Pera, and Top-hâna. Galata is pre-eminently the merchant quarter, the seat of customs, and the steam companies' agencies; it was founded by a colony of Genoese merchants in 1216, and originally was inclosed by walls of 4 miles' circuit, now destroyed. Traces of Genoese architecture may still be found in the narrow dirty streets, and in the Tower of Galata, a Genoese erection, which serves the samepurpose as the Seraskier's Tower on the opposite side in giving alarms of fires. Of late years Galata. has been considerably improved; stone and brick houses have superseded the dangerous wooden constructions of the past; a good thoroughfare provided with a tramway extends for a mile to Beshiktash, and a tunnelled railway drags passengers up the steep ascent to Pera. Pera is the aristocratic quarter; here are all the embassies: and legations and consulates, and here every one of position has his town-house. Two-thirds of 
this quarter were burned down in 1870 , including the English embassy, and 40,000 persons were left homeless. The result was a considerable inurovement in the architecture and ventilation of Pera. The ateep and badly paved Grande Rue, which traverses the whole quarter, and is continued along the shore of the Bosporus for many miles, is, however, still in parts little better than a lane; but it is lined with fair if expensive shops, and boasts a rude opera-house, many cafés and restaurants, besides most of the principal hotels, and probably the worst morals in Europe. In Pera is the English Memorial Church, erected in honour of those who fell in the Crimean war. Turks preponderate at Top-hana, which is a named from its cannon-foundry, and is chielly famous for its market, its Circassian slave-dealers, its caiguebuilding, and its beautiful marble fountain. Close by is the magnificent palace of Dolmabagché, on the brink of the Bosporus.

duong the other suburbs may be mentioned Kasim Pasha, extending beyond Galata, along the north shore of the Golden Horn, the seat of the admiralty; continued by Hasköi, inhabited by a Jewish and Armenian colony ; and at the head of the Golden Horn the picturesque village of Eyyab, a green medley of gardens and grave. yards surrounding the celebrated mosque where every sultan must gird on the sword of Osman ere he may ascend the throne. No Christian is allowed to approach the holy place. Along the European shore of the Bosporus are many villages used as summer resorts by the Perotes, among which Therapia, the chief sumner residence of the ambassadors, and Biyukderé are the most important. The Asiatic shore is also lined with settlements, from Scutari, which is the Asiatic suburb of Stambol (where is the chief Turkish burial-place, as well as the great Crimean cemetery), to Candili, where is a large European population, chiefly of the trading classes, and Beikos (see Bosporus). Numerous palaces of past sultans and ministers line both shores, Dolmabagché on the European and Beglerbeg on the Asiatic being the largest; but the present sultan resides in a new palace called Yiluliz Köshki, at the top of the hill of Beshiktash, beyond Pera. Famous among pleasure resorts are the Sweet Waters of Europe, at the head of the Golden Horn; Kiahat-hana, near the Castle of Asis; the forest of Belgrade; and the Princes' Islands in the Sea of Marmora, not far from Kadikoi, the ancient Chalcedon.-The population of Constantinople is estimated at about 875,000 , of whom half are Mohammedans. The trade, chiefly in the hands of Europeans, is much below what it might be if properly developed. The burden of vessels entering and clearing the port is placed at $4,000,000$ tons. The eity has great strategical importance, and is fortified on the land side. The first through train from Paris reached Constantinople in 1888; there are also railways to Salonika and Uskub, and to Bourgas.

See BrzanTine EMPIRE and TURKEY, and books there quoted; Broulribb and Besant, Constantinople and its Sierses (1878); E. Pears, The Full of Constantinople (1885) ; and books on the topography and history by E. de Amicis (trans. 1896), Ars Minto Elliott (18:2), Paspates (1893), Coufoproulos (Black's Guides, 1895), F. Marion Crawford (1895), E. A. Grosvenor (1895); and on Santa Sophia by Lothaby and Swainson (1894). For the Counoils of Constantinople, see Councis.

Constantius Chlorus, nephew of the emperor Clandius II., became Cresar in 292 A.D., received Britain, Gaul, and Spain as his government, and after re-establishing Roman power in Britain and defeating the Alemanni, became one of the two Augustuses in 305 , bot died at York in 306. Constantine the Great was his son.-(2) Constantuus, third son of Constantine, was Roman emperor, 337-361 A.D. He fought with the Persians: and after the death in 350 of his brother Constans (who in $\mathbf{3 4 0}$ had defented their elder brother Constantine), became sole emperor till his death in 361 .

\section{Constanza. See KU'stexdJ.}

Constellation (Lat. con, 'together,' and stella, 'a star'), a group of stans. The stars which stud the firmament have, from a time earlier than authentic records can trace, been formed into artiticial groups, which have received names borrowed from fancy or fable, mainly from Greek mythology. These groujs are called constellations. Though quite devoid of anything like systematic arrangement, this traditional grouping is found a sufficiently convenient classification, and still remains the basis of nomenclature for the stars among astronomers. They are divided into northern, southern, and zodiacal constellations. In old authors, 'constellation' is used to signify the relative positions of the planets (see AsPECTs) at a given moment. See Strars, Orion, Ursa Major, Zodiac.

Constipation, or irregular and insufficient action of the bowels, is one of the most common of ailments; there are few persons in fact who have not at some time or other suffered from it It may be due either to deficient secretion of fluids in the digestive organs, or to imperfect muscular action of the bowels (see DIGESTION), or most often to both these cruses combined. The retention within the organism of matters which should be regularly evacuated as they are formed, and their consequent absorption into the blood and tissues of the body, often leads to a whole train of unpleasant symptoms : headache, or pain in other regions, irritability, lassitude, and debility, and many other discomforts may be due to this eause. In prolonged and severe cases of constipation, actual obstruction of the bowels (ileus) may result; and often the bowel becomes so distended and its muscular power so enfeebled that the restoration of a healthy condition is impossible.

Constipation is especially apt to occur in those who lead sedentary lives, or whose diet consists too exclusively of animal food and starchy substances. It may often be avoided by judicious regulation of habits and diet; and the hygienic treatment is of far more importance than the medicinal.

In perfect health, the lower bowel should be evacuated every day, or at the furthest every second day. This process, like many others in the body, tends to reeur at the same period every day, and every one should do all he can to aequire a habit of regularity in this respect. Moderate regular exercise, especially in the open air, is often of great importance; where the liver is at fault, riding is specially nseful. A daily cold bath, or in the case of those with whom this does not agree, brisk rubbing with a rough towel, may be helpful. A favourite remedy with some is the use of a eloth wrung out of cold or tepid water and applied to the abdomen; this, as used at hydropathic establishments, is called an 'abdominal compress,' and is worn nuder a bandage of macintosh cloth, to keep the moisture from escaping, dnring the earlier part of the day.

Attention to diet is of prime importance. In Britain very many persons live almost entirely on animal food, white breal, and potatoes, a diet extremely apt to lead to constipation. There are many easily obtainable foods the habitual use of which would in many cases correct this tendeney. Oatmesl, especially in the form of porridge, brown 
or 'whole-meal' bread, or gingerbread; almost all vegetables (except potatoes), either cooked or uncooked; olive-oil, which may be used in salads; treacle, eaten with bread or made into puddings fruit of all kinds, particularly prunes and figs, which can be obtained all the year round-all tend to increase the activity of the bowels. If such forms of food were more generally used, the rest of the community would gain even more than the many vendors of 'liver pills,' and other quack medicines would lose.

The amount of fluid taken in the day is also of importance. Many persons, especially those in whom much fluid taken with meals interferes with comfortable digestion, do not imbibe enough for the needs of the body. In such cases a stated amount of fluid should be taken at other times. A tumbler of water, either cold or hot, slowly sipped during the process of dressing in the morning, is sometimes efficient in relieving constipation.

Lastly, the use of medicinal remedies must be shortly considered. Compared with the measures already noticed, they must be regarded as an evil, though often a necessary one. Constipation may be seriously aggravated by their injudicious employment. Often a large dose of some purgative is taken and produces very free action of the bowels with temporary relief; but increased constipation is almost sure to follow. The condition to be remedied is a chronic and habitual one, and must be combated by patient and persevering treatment. The medicine selected should be taken every day, but the dose must be the very smallest which will produce the desired effect.

It is impossible to enumerate all the drugs which may be used, or to define the conditions in which each is most likely to be beneficial. A few of those in most general use only must be enumerated. Natural mineral-waters (Friedrichshall, \&c.) are in much repute at present: a dose should be taken on rising in the morning. Epsom or Glauber's salt, if dissolved in plenty of water, is much cheaper and almost as satisfactory. Etfervescing salines (seidlitz powder, magnesia, and many much-advertised patent medicines) are more pleasant to take, and have a similar action. Castor-oil in small doses at bedtime is objectionable only on account of its flavour. Compound colocynth pills, or colocynth and hyoscyamus pills; compound liquorice powder (containing senna and sulphur, one of the best preparations); Gregory's powder (containing rhubarb and magnesia); podophyllin, euonymin, and other drugs from America, are all useful aperients, and should be taken at bedtime. Nux vomica is a useful addition to other aperients, as it acts specially upon the muscles of the intestines, increasing their activity. A word of caution is necessary regarding mercurial preparations, which are most valuable in certain cases, but most dangerons if used habitually. The indiscriminate use of calomel and gray powder in the nursery, where they are very popular owing to their tastelessness, cannot too strongly be condemned. The most generally useful of all aperients at present in use is Cascara Sagrada, the bark of a North American species of buckthorn (Rhamnus Purshiona). The liquid extract is the preparation in most general use, of which from 15 to 40 drops taken daily, either in one dose at bedtime or still better in several doses after meals, is generally sufficient. It increases the secretions, but especially the muscular power of the intestine; and in very many cases can be given up altogether after being used for a few weeks (see also A PERIENTS). In some cases a Clyster (q.v.) is the most satisfactory means of procuring an evacuation.

Constipation in the lower animals depends, as in man, on imperfect secretion from, or motion of, the intestinal walls. In the horse it is usually accom- panied by Colic (q.v.), and when long continued leads to Enteritis (q.v.). The appropriate remedies are soap and water clysters given every two hours; smart friction and cloths wrung out of hot water applied to the abdomen, with three drachms of aloes and one of calomel given in gruel, and repeated in sixteen hours, if no effect is produced. Give, besides, walking exercise; restrict the amount of dry solid food, but allow plenty of thin gruel or other fluids, which may be rendered more laxative by admixture with treacle or a little salt. Similar treatment is called for in dogs, cats, and pigs.

In cattle and sheep, digestion principally takes place in the large and quadrisected stomach; the bowels, accordingly, are little liable to derangement ; and constipation, when occurring in these animals, generally depends upon impaction of dry hard food between the leaves of the third stomach, fardel-bag, or moniplies. The complaint is hence called fardelbound. It results from the eating of tough and indigestible food, such as ripe vetches, ryegrass, or clover; it prevails in dry seasons, and on pastures where the herbage is coarse and the water scarce. It occurs amongst cattle eating freely of hedgecuttings or shoots of trees, hence its synonym wood-evil. From continuous cramming and want of exercise, it is frequent in stall-feeding animals; whilst from the drying up of the natural secretions, it accompanies most febrile and inflammatory diseases. The milder cases constitute the ordinary form of indigestion in ruminants, are accompanied by what the cow-man terms loss of cud, and usually yield to a dose of salts given with an ounce or two of ginger. In more protracted cases, rumination is suspended, appetite gone, constipation and fever are present. There is a grunt noticeable, especially when the animal is moved, different from that accompanying chest complaints, by its occurrence at the commencement of expiration. By pressing the closed fist upwards and forwards beneath the short ribs on the right side, the round, hard, distended stomach may be felt. This state of matters may continue for ten days or a fortnight, when the animal, if unrelieved, becomes nauseated, and sinks. Stupor sometimes precedes death, whilst in some seasons and localities most of the bad cases are accompanied by excitement and frenzy. In this, as in other respects, the disease closely corresponds with stomach-staggers in the horse.

Give purgatives in large doses, combining several together, and administering them with stimulants in plenty of fluid. For a medium-sized ox or cow, use $\frac{3}{4} \mathrm{lb}$. each of common and Epsom salts, ten croton beans, and a drachm of calomel, with three ounces of turpentine; and administer this in half a gallon of water. If no effect is produced in twenty hours, repeat the dose. Withhold all solid food; encourage the animal to drink gruel, sloppy mashes, treacle and water; and give exercise, clysters, and occa. sional fomentations to the belly.

Constitution, in Politics, signifies a system of law established by the sovereign power of a state for its own guidance. Its main objects are to fix the limits and define the relations of the legislative, the judicial, and the executive powers of the state, both amongst themselves and with reference to the citizens of the state, regarded as a governed body. In continental countries, since the formation of the federal government of the United States of America, or, at all events, since the first French Revolution, the idea of a constitution has been generally that of a body of written public law, promulgated at once by the sovereign power. In Great Britain it is the whole body of the public law, consuetudinary as well as statutory, which has grown up during the course of ages, and is continually being modified by the action of the general will as interpreted and expressed by the 
parliamentary representatives of the nation. A constitutional monarchy is one in which the sovereign is restricted in his powen by chambers of the representutives of the people; the 'granting of a constitution' mecordingly means the transforming of a monarchy more or less nearly absolute into a constitutional state. The constitutions of the varions countries will be found under FRANCE, GERMANY, \&c., and see the list of articles appended to Politics.

Constitutions, Apostolic. See Apostolic Constitutions.

Consubstantiation, as opposed to Transubstantiation $\left(q . v_{0}\right)$, is the Lutheran doctrine that in the eucharist the body and blood of Christ are, in a way not to be explained, in, with, and under the unchanged bread and wine. See LonD's SUPPER.

Consuetudinary or Customary Law is an unwritten law eatablished by usage and derived by immemorial eustom from remote antiquity. When universal, it is called common law; when particular, it is called custom in a narrower sense, as the custom of a trade or of a district. See Custom, Common Law.

Consul, the title of the two highest ordinary magistrates in the Roman republic. The idea of two supreme magistrates or joint-presidents of the state seems to have been interwoven with the earliest conceptions of political organisation in Rome. After the expulsion of Tarquin, Lucius Junius Brutus and Lucius Tarquinius Collatinus were chosen joint heads of the state; but the title of consules seems first to have been introduced about 300 B.C. At first, the consuls seem to have differed from the kings in little else than their limited tenure of office, and the power which their fellow-citizens retained of calling them to account at its termination. They never assumed the golden crown, but their dress in almost every other respect was regal. They made peace and negotiated foreign alliances, had the supreme command of the army, and appointed the public treasurers. They likewise exercised the judicial functions of royalty. Dates were always determined by naming the consuls of the year. The symbol of their authority was the bundle of rods (fasces), with the axe in the centre, which was carried before them by twelve lietors. For a considerable period the con. suls were chosen exelusively from the populus or patricians, as opposed to the plebs. At length, however, two pletweian officers called tribuni plebis were appointed as a sort of democratic rivals to the aristocratic consuls. The result of this rivalry was that the consulship was opened to plebeians, the famons Lex Licinia (367 B.C.) ordaining that one of the consuls should belong to that order. This law was more stringently re-enacted in 342 , and from that time it was customary for one of the consuls to be a plebeian. This same law prohibited any individual from holding the same office within ten vears, but the enactment was often suspended. The appointment of Censores (443) and of Pratores (367) relieved the consuls of many of their judicial functions. In the government of the provinces, the aid of the former consuls was called in, the consul thus appointed having the title of pro-consul. In sudden and critical emergencies, the consuls were either superseded by a Dictator (q.v.), or absolute power for the occasion was conferred on them by the decree of the senate, which ran in the famous formula: Videant consules ne quid respublica detrimenti capiat - Let the consuls look to it that the state take no harm.' The consuls were in augurated by a great procession to the Capitol and a sacrifice to Jupiter Capitolinus. The shadow of the consulate survived the downfall of liberty ; but the election of the consuls was taken from the people and conferred on the venate. Then their number was increased; they were divided into classes : till at last the oflice became a mere honorary appointment conferred by the emperor.

The title of consul was revived in the French republic after the revolution of the 18 th Brumaire, and lasted till the coronation of Napoleon as emperor, 18th May 1804.

Consul, Mercantile, the name given to thome officers whom the state maintains in foreign countries for the protection of its trade and vindication of the rights of its merchants, and to whom the further duty is assigned of keeping the home government informed of all facts bearing on the commercial interests of the country. The practice of appointing such officers originater among the trading communities of Italy about the middle of the 12th century, and gradually extended itself; and in the 16th century had been adopted by all the countries of Europe. In aldition to their commercial duties, others of a more strictly political kind were frequently confided to consuls in places in which there was no ambassador or political agent. In almost all civilised countries consuls are divided into consuls-general, consuls, vice-consuls, and consular agents. The consul's first duty on his arrival is to exhibit his commission to the authorities of the country to which he is accredited, in order that he may obtain their sanction to his appointment. This sanction is communicated to him in a document called an exequatur, which secures to him the enjoyment of such 'privileges, immunities, and exemptions as have been enjoyed by his predecessors, and as are usually granted to consuls in the country in which he is to reside."

The general duties of English consuls are communicated to them in printed instructions. In these the consul is ordered to make himself conversant with the laws and general principles which relate to the trade of Great Britain with foreign parts, and with the language and municipal laws of the country wherein he resides. Further, it is his duty to protect his countrymen in the lawful exercise of their trade, to quiet their differences, to obtain the redress of injuries done them-fail. ing which, to report the matter to the English ambassador at the capital of the country-and to forward to the Secretary of State for Foreign Affairs an annual return of the trade carried on at the different ports within his consulate, as well as a quarterly account of the market prices of agricultural produce during each week of the quarter, the course of exchange, \&c. The consul must afford relief to British seamen or other subjects wrecked on the coast, and endeavour to procure them the means of returning to England. The commanders of British war-ships touching on the coast are entitled to call on him for intelligence, and aid in procuring supplies of water, provisions, and the like; and it is his duty to endenvour to recover all wrecks and stores, \&c. of queen's ships, whether found at sea and brought into the port at which he resides, or thrown on the coast. As regards his 'privileges and immunities,' a consul engaged in trade is amenable to the civil jurisdiction of the state to which he is accredited, but B consul sent out from this country, and not engaging in trade, has always been exempted from the taxes of the country in which he resicles. A consul en perform all the acts of a notary. public, all deeds executed by him being acknow. ledged as valid by our courts of law. The fiction is, that the consulate is the territory of the country from which the consul is sent, and, consequently, that deeds and acts done within it, or under the consul's seal, are done in England. Hence the 
marriage of British subjects recorded in the books of a British consul is a valid ceremony.

Consuls in various foreign countries have special powers regulated by what are called 'capitulations.' They act as judges in consular courts to whose jurisdiction all subjects of their nation are amenable, to the exclusion of the native tribunals. Such privileges are enjoyed by English consuls in Turkey and the Levant, Morocco and other parts of Africa, China, Corea, Muscat, Siam, and the Western Pacific. In Egypt there are mixed international courts as well as consular courts. In Japan the capitulations were abolished in 1895, and in Madagascar when the island became French.

The first care of every Levantine trader is to obtain the protection of some foreign power, so that he may set at defiance the local courts, and, to some extent, the local executive authority. 'To obtain letters of nationalisation as a British subject is rightly made somewhat difficult; but this is not the case with most other European nations. The eapitulations are especially injurious in Egypt, where the native authorities and their English advisers are constantly thwarted in their endeavours to promote order and good government by the ill-defined and jealously-asserted power of the foreign consuls.

Of late years attempts have been made to establish $a$ body of trained men from among whom the consular service in the Levant, as well as in China and Japan, could be recruited, and student interpreterships have been founded. The student interpreters are selected by competitive examination in England, and are sent to Constantinople or to the far East, as the case may be, with a salary of $£ 200$ a year. Their advancement 'depends entirely on the ability which they may show after their arrival at their destination, and on their general steadiness and good conduct.'

Consuls who are permitted to trade are not required to pass any examination, but members of what may be called the regular service are supposed to do so. The limit of age for appointments is twenty-five to fifty.

In the United States, literary and scientific men are frequently appointed to important consulships abroad, Hawthorne and Bret Harte having, for example, been consuls in Britain. In the British service the names of Charles Lever, Mr Stigand, Gifford Palgrave, and Sir Richard Burton are modern examples of such appointments.

The salary of British consuls varies from $£ 2500$ (chief-justice of the Supreme Court for China and Japan), to the nominal salary of many vice-consuls. Among the more important posts are the consulgeneral at Shanghai, $£ 1600$; consul-general at New York, $£ 2000$; consul at Boston, $£ 1200$; New Orleans, $£ 1100$; Zanzibar, $£ 2150$; Honolulu, $£ 1100$; Sofia, $£ 1200$; Beyrout, £1250; Manila, £1100; Old Calabar, $£ 1200$; the consul-general and judge at Constantinople, $£ 1600$. The United States consuls at London, Liverpool, Paris, and Rio Janeiro have euch, apart from fees, a salary of $\$ 5000$; the consul at Havana receives $\$ 6000$.

Consumption, in Political Economy, is that department of the subject which treats of the use of wealth. It is the converse of production, which refers to the making or creating of wealth. As production is the first stage in economics, consumption is the last. Consumption is the chief end of industry, for everything that is produced and exchanged is intended in some way to be consumed. Consumption is usually divided into two heads - reproductive and non-reproductive. Wealth consumed in reproduction is simply Capital (q.v.). Wealth consumed as capital, while it is the final stage in one process of industry, becomes an item in a further process of industry. A shopkeeper who, having made a thousand pounds in his business, afterwards uses it in farming, proposes thereby to apply his money to a new kind of reproductive employment. Industry is to a large degree simply a continuation of this process. Wealth which is produced to-day will to-morrow be consumed in fresh production.

But consumption is pernaps more properly regarded as non-reproductive, as that use of wealth which has no fresh production in view, or is simply applied to the satisfaction of human needs. The wants of men, as well as the means of satisfying them, have varied greatly at different periods of history, and do still greatly vary in different countries and different states of society. As regards wealth applied to consumption, we may recognise three stages : (1) Necessaries; (2) comforts; (3) luxuries. The commodities which were once a luxury are now in civilised countries merely a comfort or even a necessity. In the middle ages a linen shirt was a luxury even at royal courts. In fact, nothing perhaps so marks the development of comfort as the general use of underclothing, whether woollen, cotton, or linen. In the economics of all ages the question of luxury has claimed great attention. The extravagance of the wealthy was both in ancient and medieval times considered so dangerous to society, that Sumptuary Laws (q.v.) were passed to repress it, often without the desired effect. On the other hand, the luxury, extravagance, and even prodigality of the rich have been justified on the ground that such expenditure was necessary to provide labour for the industrial classes; but this notion is exploded among competent economists. It should be clearly understood that consumption should be both rational and moral, and that the just and rational needs of men have the first claim on society.

As all wealth is produced in order to be consumed, and as there can be no consumption without production, it will be obvious how the great processes of production and consumption are correlated to each other. If there be insufficient production, consumption is checked and suffering ensues through human wants not being satisfied. On the other hand, over-production frequently tends to bring about commercial crises. When the effective consumption is unable to absorb the mass of commodities, the market becomes overstocked and the industrial process is deranged.

Consumption, Dechre (in medical language, Phthisis, Tuberculosis), is a condition well recog. nised by the laity as by the physician. Strictly speaking, the name includes a group of affections, but it is generally used to indicate pulmonary consumption (phthisis pulmonalis) - -i.e. a more or less rapidly advancing process of lung destruction, associated with progressive emaciation and other characteristic signs and symptoms. This is a disease of grave importance, from its frequency and fatal tendency. It has been estimated that consumption is responsible for nearly one-seventh of the total mortality of Europe. Consumption appears to have committed its ravages from the earliest times, and its distribution is probably universal, though far from equal. Thus, statisties show consumption to be less common in the Hebrides and Shetland Islands than on the mainland of Scotland, while the unanimous verdict of Icelandic physicians has been that consumption occurs relatively seldom in their island. It is not easy to propose any fixed rule regarding its distribution. Latitude as such seems of less insportance than might be expected. The mean level of temperature has little connection with its occurrence, though apparently, in tropical countries, the course of the disease is more rapid. The most probable explanation of the comparative immunity of certain 
districts and countries is to be found rather in the minimal amount of moisture present. Wet ness of the soil is a factor of the greatest impurtance, as was shown by the researches of Buwditeh in Amerien, Buchanan in England, and Milroy in Scotland. Their united testimony was that the number of cases of consumption varied directly with the degree of dampness of the soil. Elevation also exercises an important influence; and, other things being equal, the more elevated the district, the leas favourable will it be to the accurrence of consumption. The explanation of this is probably to be found in the combined purity and rarity of the atmosphere.

Though consumption was early recognised as a definite disease, and its clinical course fairly well studied, much obseurity has rested over the question of its causation. A bout no disease has opinion so) persistently fluctuated. Definition was first rigidly attempted by Bayle and Laennec, who held that consumption was essentially due to the presence in the lung of little granular masses of varying size and claracter, which were named Tubercle (g.v.). On the other hand, Andral, Virchow, and Niemeyer maintained that only a limited number of cases were to be so explained, and that consumption was most frequently induced by a process of ehronic inflammation of the lung. This view gave scientific basis to the popular belief in the effects of neglected cold. Medical opinion was divided between those main lines until 1882, when Koch announced the fact that he had discovered an organism, which he believed to be present in all cases of consumption proper. This organism-the Bacillus tuberculosis-is a minute rod-like structure, capable of cultivation outside the human borly, and easy of demonstration in the expectora. tion of consumptive patients (see BACTERIA). Clinical and experimental evidence has since corroborated the truth of Koch's assertions, and the bacillar origin of ensumption has been pretty generally accepted, so that the oller teaching has been subjected to much modification. Although this is 80 , considerable difference of opinion remains as to the relation of other factors to the bacillus. Some observers are even yet inclined to think that certain eases of consumption may be satisfactorily explained apart from the bacillus. This view is very questionable.

As regards the lung itself, the resultant condition is more or less uniform, varying in degree according to the stage of the disease. The process is one of gradual disintegration, in which two phases may be recognised : (1) Consolidation, when the affected lung feels relatively solid, and the normal vesicular structure can be but imperfectly distinguished; (2) excavation, when the consolidated mass in part breaks down, leaving irregular spaces, varying in size, presenting an uneven, secreting surface. The cavities (vomica) tend to be largest towards the upper part of the lung. Associated with these changes in the lungs, grave disturbance appears in other organs, notably in the stomach and intestines, the liver, and the kidneys.

While aceepting the baeillar origin of consump. tion, it is impossible to overlook the predisposing infuence exerted by certain conditions. The list of such factors is a large one. Pre-eminent among them is Heredity (q.v.). Undoubtedly there exists in many families a tendency to weakners-i.e. a less power of resistance - of the respiratory organs. This may be transmitted through several generations. This want of vital balance in the respiratory apparatus is manifested by recurring 'colds,' with. out apparently sufficient cause. It is not difficult to realise how the bacilli take root, and Hourisly more readily under such conditions. It is a Disthesis (q.v.) or disposition which is inherited, rather than the disease. Greater difficulty is ex. perienced when the question of actual transmission of the disease is considered. Though certain facts, indeed, point to the conclusion, it cannot be said that a congenital infection of child by mother has yet been demonstrated in man. The so-called serofulous diathesis, in which there in a tendeney to $\mathrm{n}$ low form of glandular inflammation and degeneration, has been eited in favour of this view. The inter-dependence of serofula and consumption cannot be denied. Sex seems to have little bearing in reference to consumption. Similarly of little value is the popular belief that the disease is more frequent in the offspring of consanguineous mar. riages. It is, however, to be borne in mind that such unions necessarily double the chance of a particular family taint being reproduced. Age is a factor of greater moment. It may be said that consuniption makes its appearance most frequently between the ages of fifteen and thirty. It frequently attacks persons beyond thirty, but in very young children it is not common. $A$ most important part in the causation of consumption is undoubtedly plaved by improper sanitary conditions. This is evidenced by the much greater prevalence of consumption in towns and other crowded centres. The statistics of mortality in England illustrate this, In the counties whose industry is chiefly agricultural, the death-rate from consumption is comparatively low, while in Lancashire and other more largely manufacturing counties the rate is high. Badly built, overcrowded dwellings and workshops, with insufficient ventilation and damp, afford the most suitable conditions for the development of consumption. All physicians are agreed that 'perhaps no cause exerts such a decided influence on the production of consumption as the privation of fresh air and exercise.' No better illustration of this can be cited than the excessive mortality from consumption which was at one time recorded in British and foreign prisons. Thus at Millbank Penitentiary, during the seventeen years from 1825 to 1842 , the annual mortality from consumption was reckoned at 13 per 1000 . The vicious influence of these factors is, of course, increased enormously when, in aldition, poverty and want are present. It must be admitted, too, that sedentary oceupations generally predispose to consumption. Thus tailors, seamstresses, and similar workers are especially prone to the disease. More especially is this true of occupations whose performance necessitates the inhalation of dust particles-e.g. stone-masonry, knife-grinding, metal-polishing, wood-carving, \&c. The dust particles act as irritants of the fine structures which line the air passages and vesicles, indueing chronic changes, which, in turn, are liable to lead to consumption.

The bacillar doctrine has given fresh impetus and scope to the important inquiry as to the contagious. ness of consumption. On this subject the evidence is conflicting. The large experience of consumption hospital physicians, such as that of the Drs Williams at Brompton Hospital, points decidedly towards the negative view. On the other hand, the statements of most careful observers, who have again and again recorded cases of infection, are strong in the opposite direction. An unprejudiced review of the facts seems to justify the conclusion that, although consumption is a communicable disense, it is so within certain limits-i.e. the contact and intercourse which, apart from other causes, expose to risk, must be of an ex. tremely close nature. Probably the expectoration of phthisical patients affords the best means of transmission.

There remains the interesting question, whence do the bacilli make their appearance? This is a difficult problem. The faet that the organs of 
respiration are more especially affected, seems to point to the conclusion that the bacilli are present in the air. But their presence there is not easily proved. On the other hand, the expectoration of consumptive patients is found to be loaded with the organism. It has further been demonstrated that the bacillus oceurs abundantly in the milk of cows suffering from tubercular disease of the udder ; and meat obtained from the carcasses of tubercular animals, particularly the liver, kidneys, and glands, cannot be regarded without suspicion. The prevalence of abdominal consumption in young children has been attributed to the ingestion of the bacilli by means of milk. It has further been shown that tubercular disease may be induced through an open wound, to which the bacilli have obtained access.

The symptoms of consumption cannot be fully discussed in the present article. As seen in advanced cases, they are pretty generally appreciated by the non-professional eye; but at first they are treacherous and frequently remain undetected. The early symptoms vary much. There may be nothing but a gradual loss of strength, it may be of flesh ; there may be a slight discharge of blood from the throat or chest; there may be a more or less persistent, tickling cough ; there may be breathlessness, with or without pain in the chest; or there may be little save an increased tendency to take cold easily, with but tardy power of throwing it off. Or again, the slow beginnings may be expressed by a gradually progressing pallor, and, in the female, by diminution or cessation of the menstrual discharge. Any of those conditions, especially when they show themselves in the adolescent or young adult, are to be viewed with suspicion, and regarded as a sure indication that medical help is necessary. The more experience physicians have in the treatment of consumption, the stronger becomes the conviction that many lives might be saved, if only an opportunity were afforded of arresting the disease at an early stage. It is peculiarly at this point that the greatest skill and prudence are required from the physician. The appreciation of the signs which indicate the presence of consumption, both at this early stage and later, must be left in his hands, and cannot, of course, be treated of here. The later symptoms of consumption are better defined, and are, unhappily, too well known. They are, more particularly, cough, expectoration of a more or less thick, opaque substance, of varying colour, from whitish-gray to green, sometimes of blood, shortness of breath, pain in the chest, gradually advancing emaciation and loss of weight and strength, profuse sweating, especially in sleep, feverishness, diarrhoea. As the disease advances further, there frequently occur swelling of the feet and sores about the mouth. Accompanying these symptoms, grave changes oceur within the lungs. These are appreciated with ease by the trained observer. It should be added that all the abovementioned symptoms must not be looked for in every case of consumption. The type varies endlessly, and some cases run towards a fatal issue with relatively few signs or symptoms, while anatomically the disease is the same.

The duration of consumption varies greatly. In a certain proportion of cases the destructive process is very rapid, and, if unchecked, may lead to death within $\mathrm{a}$ few weeks. To this variety the name Galloping Consumption has been applied. The great majority of cases are extremely chronic, and the disease seems from time to time to become stationary. Consumption may terminate fatally only after many years.

As to the curability of consumption opinion has differed much. For long-and, unfortunately, to a considerable extent at the present day - con. sumption was regarded as incurable, and treatment adopted in the direction of palliation. More recently, however, the view of its curability, maintained both by Laennec and Niemeyer, leaders of opposite schools of pathology, has received fresh life through Koch's discovery. During the last few years many cases of recovery have been recorded. If those who have reported such have sometimes been affected with that peculiar hopefulness-spes phthisica-which is a frequent attribute of the consumptive patient, it must be regarded as a more pleasing indication than the apathy which was formerly too often displayed in respect of such patients, as evidently appointed to die. There is, moreover, reason to hope that we are on the eve of greater possibilities. Never was attention so keenly directed to this once neglected problem. In illustration of this may be eited the institution at Paris in 1888 of an International Congress, which is to meet once in two years for the consideration and elucidation of all questions relating to consumption, with a view to its prevention and treatment. Meanwhile, it may be affirmed that consumption, if suitably treated in the early stage, is curable; that occasionally more advanced cases are cured, and that for all cases much may be done in the way of prolonging life and relieving suffering. The popular mind must be disabused of the idea of the hopelessness of consumption.

The treatment of consumption is one of the most complicated problems which the physician has to face. In its wide sense, it involves a consideration of some of the largest questions relating to social and individual hygiene. From the prophylactic point of view, it includes the study of all points bearing on the causation of consumption. Only thus can the attempt be made to cope effectively with the evil on the large seale. A knowledge of the dependence of consumption on overcrowding, vitiated air, improper ventilation, and other insanitary conditions, ought to lead the responsible authorities to adopt and enforce such regulations as will remedy the evil. Within recent years much has doubtless been effected in this direction. The legislature has taken in hand several departments of this work; and employers, in many instances, have shown a proper interest in the welfare of their employees. But more remains to be done. There is need of increased popular instruction, so that working-people and others may themselves appreciate the dangers which they run by neglect of simple precantions. Further, having regard to the communicability of consumption from the lower animals to man, means should be devised whereby the milk from tubercular cows may be excluded from the market, and the flesh of tubercular animals condemned, These provisions have been embodied in the recommendations of the Paris congress (1888), that tuberculosis in animals should be included in the list of contagious diseases, the animals seized and destroyed, and dairies and milk-houses be subjected to strict scrutiny by competent officers. The danger of phthisical expectoration as a means of transmission has been already alluded to. It is therefore advisable that this, whenever possible, be destroyed by burning, or rendered innocuous by scalding or other satisfactory method.

In respect of the treatment of individuals, much may be expected from prevention. Though lacunx exist in our knowledge of the life-history of the tubercle bacillus-more especially as regards its access to, and development in, the human bodythere is good ground for believing that general depreciation of the system is a favouring factor of much importance. Hence all measures are to be adopted which will place the body under as good conditions as possible, more especially when there is suspicion of a family tendency towards consump. 
tion. Open-air exereise, varied according to circum. stances, light gymnatics, friction of the skin, and lathing, unless contra-indicated, are to be commender. Sufticient sleep, abundant and regular meals of simple nourishing food, and warm light clothing are essentiul. Exposure to chills or damp must be strictly avoided, and the utmoat care taken that no 'cold' be allowed to persist. If a cough continue, or any other symptom of consumption show itself, medical advice should be obtained at once.

When consumption is distinctly present, there are two lines open to the physician - the defensive and the offensive-and rational treatment should combine these. In carrying out the former, an attempt must be made to improve the general condition, so that effective resistance may be oflered to the invasion of the bacillus. For this purpose all means of fattening the body should be adopted; and of these, par excellence, cod-liver oil, which has come to be regarded almost as a specific for consumption. As Dr C. J. B. Williams says : 'The beneficial operation of cod-liver oil extends to every function and structure of the body.' Fatty foods, butter, cheese, cream, milk, koumiss, glycerine, sc. are similarly of service. Care must be taken to maintain the appetite. The moderate use of alcohol, in one form or another, is advisable. Attention should be bestowed on the carrying out of those general hygienic rules which have been indicated. The chest should be gently expanded by such means as reading, singing, and regulated open-air exercise. Disadvantageous climatic and atmospheric conditions are to be removed, where possible. This is specially of importance in our moisture-laden climate. Often a change of residence from seaside or eity to the highlands proves beneficial, or, where the disease is pronounced, removal from the northern to a more temperate zone. Where comparatively short journeys can alone be contemplated, Bournemouth, Hastings, Ventnor, Torquay, Penzance, and other places on the southern shores of England may be thought of. Where longer ones are possible, the variety is immense, from the Mediterranean and Atlantic stations to the slopes of the Rocky Mountains. In many cases a sea voyage is best; but this is contra-indicated under certain conditions, and should never be undertaken without medical advice. In connection with all these plans, wise consideration will be given to the fact that apparent advantages are unfortunately counterbalanced by disalvantages which are less easily gauged. While much benefit is to be expected in suitable cases, it is unnecessarily eruel to send a patient to die away from home. The offensive method of treatment rests on the hypothesis of the opposition offered by certain drugs to the life and development of the bacillus. The first vague feeling after such a system found expression in the various respirators, whose efficacy has from time to time been vaunted. There are, however, grave objections to the use of these. Firstly, such instruments of necessity render the movements of respiration less easy ; and secondly, it is questionable whether, in the diseased state of the lungs, much of the antiseptic influence reaches the diseased portion. More recently an attempt has been made to introduce into the body certain drugs, which experiment indicated as antagonistic to the life of the bacillus. These have been administered by the mouth, by the rectum, subcutaneously, and by injection into the air passages directly. Thus ereosote, iodoform, terebene, sulphurous acid, menthol, and other drugs, have been exhibited. The method is still on trial. Most encouraging reports have been published from time to time, but it cannot be said that certainty of result has yet been attained. For the relief of suffering and the palliation of distreming symptoms, an endless number of remedies might be named. No disease taxes more fully the patience and resource of the physician, and, apart from the general lines indicated, each case must be regarded individually.

Consumption in the Lover Animals - The con. sumption of the lower animals has been proved to be essentially the same disease as that occurring in man. Its immediate dejendence on the tuherele bacillus has been estallished. It affects the bovine species more especially. It is comparatively rare is: the sheep, and very rare in the horse and dog. Pigrs, rabbits, and poultry are extremely susceptible to the disease. The same class of causes appears to give rise to it. Its extreme frequeney in cows is probably referable to the more or leas confined life which these animals lead in comparison with the horse and dog. The udders of the tubercular cows frequently exhibit signs of the disease, and in those cases the Bacillus tuberculosis has been demon. strated in the milk. It is a question whether the bacillus is found in the nilk of tubereulous animals apart from such local disense. But tho probable communicability of the disease from the lower animals to man makes it desirable that consumption should be included among the contagious diseases, so that tubereular cattle may be destroyed. The symptoms presented by tubercular animals are in the main similar to those seen in man, and in the later stages are recognised without much difficulty. At first, however, consumption is less easily distinguishable - a fact which renders legislation on the subject extremely difficult.

Contagion, the communication of a disease from the sick to the healthy, either by direct contact of a part affected with the disease, or through the medium of the excretions and exhalations of the body. The term is sometimes used of all methods by which disease is communicated, but more generally of those in which direct contact has taken place between the healthy body and the diseased one, or some object which has tonched it; more subtle means of transference, especially through the air, being termed "infection." This distinction, though it cannot be considered a fundamental one, is practically convenient; for some diseases (e.g. syphilis, ringworm) are always, or all but always, propagated by contact; others (e.g. measles, influenza) much more often through the air; while in some (e.g. anthrax) the symptoms and course of the disease are much moditied by the method of communication. See INFECTION, and Germ Theory of Disease, in Vol. V. p. 168.

Contagious Diseases Acts were passed in 1865, 1867, and 1868 for the seaport and military towns, Aldershot, Canterbury, Chatham, Colchester, Dover, Gravesend, Maidstone, Plymouth and Devonport, Portsmouth, Sheerness, Shorncliffe, Southampton, Winchester, Windsor, and Woolwich; and in Ireland, the Curragh, Cork, and Queenstown. To a certain extent they also applied in other towns, and similar acts were largely adopted in the British colonies. The main features of this legislation were (1) the registration and police supervision of prostitutes; (2) the perionlical examination of these women, which might be compelled; (3) their detention in hospital when necessary. The acts were from the first strongly opposed as contrary to constitutional freelom and public morality, as giving undesirable safety to vicious practices, as dangerons to virtuous women, as treating unequally the two sexes, and as encouraging elandestine prostitution. Their operation was inquired into by a Royal Commission 
in 1870 , which was generally favourable to their retention; and by a Select Committee in 1882, which reported that the acts had diminished venereal disease, and had increased the efficiency of the army. The army returns, however, leave this fact in some doubt; and while medical and sanitary principles support the acts, and the opinion of the clergy and the police in the garrison towns credited them with good results, they were condemned by a wave of strong public feeling in 1883 , and have since been repealed. This repeal, however, has not yet been adopted in the colonies.

Contagious Diseases (Amimals) Acts. This legislation was begun in 1869, but now stands on acts passed in 1878, 1884, and 1886. These acts, and the orders issued under them by the Privy-council, constitute a most important code of administrative regulations for the protection of cattle, sheep, goats, and all other ruminating animals, and also swine, against cattle-plague (or rinderpest), contagious pleuro-pneumonia, foot and mouth disease, sheep-pox, sheep-scab, glanders, farcy, swine-fever, and anthrax. The Privycouncil have also issued an order relating to rabies in dogs. Since 1888 the acts are administered by the county councils in counties, town councils in boroughs over 10,000 , and by the police authorities in smaller towns in England; and in Scotland by certain mixed boards for the counties, and by the town councils in parliamentary burghs. The method of working is that on the report of a local veterinary inspector, the Privy-council declare a place to be infected, and direct all animals suffering from cattle-plague to be slaughtered, compensation being given to the owners out of money provided by parliament. As regards pleuro-pneumonia, the local authority may take the initiative in declaring a place infected, and they provide the compensation for slaughtered cattle out of a local assessment. The same process is followed as regards foot and mouth disease, but the power of slaughter does not exist in this case. 'The place 'declared' is often only a field or a cow-shed, but may be indefinitely extended. The Privy-council have a general power of making orders with reference to the transit or movement of animals affected with pleuro-pneumonia or foot and mouth disease; and a large part of the administration consists in carrying out these 'movement orders,' which are numerous and modified frem time to time. It is the duty of every person having a diseased animal to give immediate notice to the police. For the purposes of these acts the Privy-council has a large jurisdiction over markets, exhibitions, landing wharves, the treatment of cattle by railway companies and on board ship, \&c. They are responsible for the regulations connected with the landing of foreign animals, which is allowed only at prescribed places. In connection with this the local authorities have power to provide wharves, lairs, sheds, \&e., for the landing, reception, and slaughter of foreign animals.

The Act of 1886 transferred to the Local Government Boards of England and Ireland and the Board of Supervision in Scotland the power of issuing orders relating to dairies, cow-sheds, and milk-shops, and to local sanitary authorities the power of making regulations under such orders. These regulations may deal with the lighting, ventilation, cleansing, drainage, and water-supply of dairies and cow-sheds in the occupation of persons following the trade of cow-keepers or dairymen; the cleanliness of milk-stores, milkshops, and of milk-vessels used for containing milk for sale by such persons; and may prescribe precautions to be taken by purveyors of milk and persons selling milk by retail against infection or contamination. The result of this transfer of powers has been to place milk-selling under stricter supervision than hitherto, as it is unlawful for any person to carry on the trade without being duly registered.

\section{Contango. See Stock Exchange.}

Contari'ni, the name of a noble family in Venice, one of the twelve that elected the first Doge. Between 1043 and 1674, eight Doges were furnished by this family, which also counted amongst its members four patriarchs, and a large number of generals, statesmen, artists, poets, and scholars (see Venice).-Cardinal Gasparo Contarini (1483-1542) distingnished himself as Venetian ambassador at the court of Charles V., and was papal legate at the Diet of Ratisbon (1541), where he displayed great moderation, seeking by concessions to bring about the reunion of the Protestants with the church.-SIMONE (1563-1633) was Venetian ambassador at several Italian courts, in Spain, in Constantinople, \&c., and was a Latin poet.-LUDovico (1629-1653) was ambassador in Paris.

Contemporaneity, in Geology, has a somewhat more extended signification than the word bears in ordinary language. When a geologist speaks of the Silurian systems of America and Europe having been accumulated contemporaneously, he does not infer that they were precisely synchronous, but merely implies that each occupies the same relative position in the succession of systems. Each was preceded by a Cambrian and succeeded by a Devonian system; but for aught he can tell, the Silurian period may have commenced earlier or endured longer in one area than the other. Professor Huxley has suggested the term homotaxis ("similarity of order") as a substitute for contemporaneity. According to this view we should apply the term homotaxial instead of contemporaneous to widely separated systems which contain the same assemblages of fossils - all that the proposed term indicates being this, that the order of organic succession was the same in both regions. All the evidence, however, goes to show that in the earlier ages of the world the climate of the earth was not differentiated into zones as it is now, so that faunas and floras were enabled to extend themselves readily in every direction. Hence, although it is impossible to say that any particular bed of palæozoic or mesozoic limestone in Europe is of precisely the same age as a similar limestone in America, yet it seems in the highest degree probable that the great system to which both these limestones happen to belong was accumulated during one and the same long-continued period. Geologists seem to be justified, therefore, in describing the successive systems of the Old and New Worlds as actually contemporaneous.

Contempt of Court, a disregard of the rules or an offence against the dignity of a court which has power to punish for such offence. Contempts, according to the law of England, may be classed as (1) disobedience to the Queen's writ; (2) contempts in the face of the court, as when a witness refuses to be sworn or prevaricates in his evidence, or where jurymen refuse to give a verdict; (3) contemptuous words or writings concerning a court; (4) refusing to comply with the rules and awards of a court; (5) abuse of the process of a court; and (6) forgery of writs, or any deceit tending to impose on \& court. Any act which insults or resists the power of a court or the persons of the presiding judges, or which plainly tends to create a disregard of judicial authority, may be a contempt, as unseemly behaviour, applauding, talking boisterously and obstreperously while the business of a court is proceeding, intimidating a suitor to discontinue his action, kidnapping or corrupting witnesses or 
jurors, obstructing officers of court and the like. Contempt is ocoasionally punished by fine $(6 . \mathrm{g}$. of $\mathbf{f} 500$ during the Purnell Commismion), but oftener by commitment to prison for an indefinite period. Similar powers are exereised by judges in Scotland, where contempts may be punished arbitrarily by censure, fine, or imprisonment, either by the court of its own instance or under a summary complaint by the public prosecutor. In the United States also, the courts have power to fine and imprison all such contempt of their tuthority, every court being the exclusive judge of its own contempt, and having power to preserve its own dignity. Motions and affidavits for attachments in eivil suits are on the civil side of the court, but as soon as the attachment issues, the proceedings are on the criminal side. For Contempt of Parliament, see PARLIAMENT.

Conti, House of, a younger branch of the Bourbon House of Condé ( $\left.\mathrm{q} . \mathrm{v}_{\mathrm{.}}\right)$. Its founder and first prince was Armand de Bourbon Conti, brother of the great Condé. He was born at Paris in 1629 , and took his title from the little town of Conti, near Amiens, Though feeble and deformed, and set aside for the chureh, he took with ardour to the career of arms, but after 1657 retired from the world, and died at Pézenas in 1666.-Lovis ARMAND, eidest son of the preceding, was born in 1661. After a short but promising career in arms, he died childless in 1685.-FraxçoIs LouIs, Prince de la Roche-sur-Yon et de Conti. brother of the preceding, and the most remarkable of the family, was born at Paris in 1664. Educated under the eyes of the great Conde, he early conceived a passion for war, and already in his first campaign in Hungary covered himself with glory. Falling into disgrace with the court, he was banished to Chantilly, but pardoned by the intercession of the great Condé before his death. Subsequently Conti served under the Due de Luxembourg, who was warmly attached to him, and took a brilliant part in the victories of Steinkirk and Neerwinden. In 1697 he narrowly escaped being made king of Poland. On his return to France he was still coldly received by Louis, who, however, was at last forcel by disaster to employ him. He received the command of the army of Flanders in 1709, but died on the 22d February of the same year. SaintSimon, in his Mémoires, thus speaks of him: ' $\mathrm{He}$ was the delight of armies, the divinity of the people, the hero of officers, the darling of parliament, and the almiration of the most learned savants.'-The last member of the House of Conti was Lours FrancoIs JosePh, who was born 1734, and died at Barcelona, 1807.

Contiguity, Law of. See Association of IDEAS.

Continent. This name, originally applied to a great division of the earth's surface containing a number of countries, has latterly come to have a more precise seientific meaning. Six contiments are recognined by geographers-Asia and Europe (which, strictly speaking, form but one continent, the division between the two being arbitrary and uncertain); the three great triangular peninmulas. Africa, North America, South America; and the vast islands Australia and Antarctica. Antaretica has never been explored, but the evidence of the gradual shoaling of the gea on all sides within the Antaretic circle, and the nature of the rocks. dredged in the far south, make the existence of $a$ continent and not an archipelago of oceanic islandw round the south pole practically certain.

The earth's surface is divided by the 1000 fathom ( 6000 feet) line of ocean soundings into two equal parts, one a region of depression surrounding the south pole and stretching porthward in three wide branches or ocean-basins, the other a region of elevation surrounding the north pole and stretch. ing southward in three great arms crowned by the continents. All the land rising above ser-level forms collectively the continental area, and amounte to $\frac{5}{16}$ of the earth's surface. Geological evidence shows the extreme probability that the continental and abysmal areas have never changed places, lut are permanent features of the earth's surface. Continental rocks, granite, gneiss, schist, and their derivatives, differ entirely from those of oceanic islands. Detached portions of the continents, though now far from the mainland, may therefore be readily recognised (see IsLAND). Around all continents the action of waves has carved out a ledge or terrace, the continental shelf, of variable width, on which the bottom slopes gently from the land to soundings of 100 fathoms, and then abruptly plunges to the oceanic depression (see SEA). The absolute elevation of continents or mountains above mean sea-level cannot easily be determined, on account of the permanent distortion of the sea surface by the attraction of the projecting mass of land. This heaping up of the sea has been calculated at 300 feet for the vicinity of the Himalayas at the Bay of Bengal, and 2000 feet for the Chilian Andes. Sir John Murray calculates the average height of continental land above sealevel as 2200 feet, and gives as probable estimates the mean heights represented in the diagram. Particulars of each of these continents will be found under their respective names.

The continents occur in north and south pairs, united by a narrow isthmus or archipelago, or separated only by a shallow strait. They are directed south-south-eastward, tapering from the north in all cases, and frequently ending in a series of south. pointing peninsulas, which are often partially submerged so as to form archipelagoes of small islands on the eastern side. Each continent has an axis or backbone of high land, usually a platean contain. ing an area of internal drainage, and serving as a

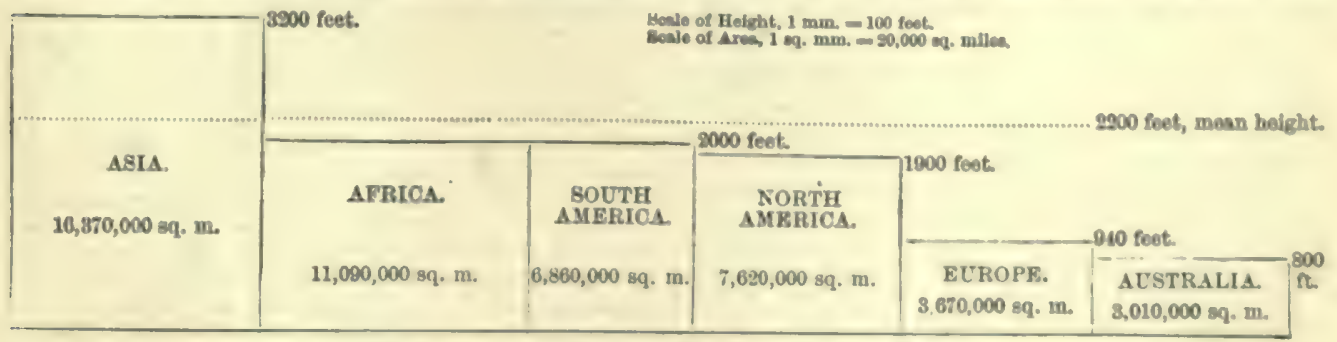

Relative Arens and Average Heights of the Continents.

watershed for rivers flowing to all sides. This high land is situated towards the south, and runs east and west on the whole in Enrasia, giving the north-flowing rivers long slopes, and the sonth-flowing streams a short and rapid ran. Africa is a transition type, the watershed being on the whole 
nearer the east; Australia, more extreme, has the main watershed lying close to the east coast. In the two Americas there is a high western mountainridge or plateau running from north-west to southeast, and a low range on the eastern coast, leaving great central low plains watered by large rivers. The interior of a continent has usually a very low rainfall (see DESERT), and is subject to great extremes of temperature between summer and winter, and between day and night, hence the term continental climate. Land and sea breezes and the monsoons of tropical coasts (see MoNsoon) result from this circumstance.

Continental System, the name given to Napoleon's plan for shutting England out from all connection with the continent of Europe. This system began with Napoleon's famous 'Berlin Decree' of November 21, 1806, which declared the British Islands in a state of blockade, and prohibited all commerce and correspondence with them; all merchandise belonging to an Englishman became a lawful prize, and all trade in English goods entirely prohibited. No ship coming direct from Britain or from a British colony was allowed to enter any port.

Britain was not long in making reprisals. By an 'Order in Council,' issued January 7, 1807, all neutral vessels were prohibited from entering any port belonging to France or her allies, or under her control. Every neutral vessel violating this order was to be confiscated with its cargo. Still more oppressive for neutral commerce was a second order in council of November 11, 1807, by which all harbours and places of France and her allies in Europe and the colonies, as well as of every country with which England was at war, and from which the English flag was excluded, were placed under the same restrictions as if strictly blockaded. These orders were followed by new French measures, By the Milan Decree of December 17, 1807, strengthened by a second of January 11, 1808, from the Tuileries, any vessel, of whatever nation, that had been searched by an English ship, had sub. mitted to be sent on a voyage to England, or paid any duty to the English government, was to be declared denationalised, and treated as English.

Most of the countries of Europe were coerced by Napoleon into joining the continental system. The great war of 1812 against Russia was largely owing to her refusal to adhere to it anv longer. It was a violent interruption of human intercourse, which could not last long, and could only serve to strengthen the hatred of Europe against French tyranny. Accordingly, with the breaking up of Napoleon's power, the continental system fell to the ground. The policy of England in connection with the continental system can be justified only on the ground that it was necessary to avert a supreme national danger. It was not without its mischievous results, for the measures adopted in regard to neutral commerce led to the American war of 1812

Contorted Strata are beds which are highly folded, plicated, and twisted - the folds being extremely irregular, and giving rise to rapid changes in the direction and angle of inclination. Contorted strata are frequently crumpled and puckered - the fossils and pebbles which they may chance to contain being compressed, flattened, and distorted-facts which show that the beds have been subjected to great crushing and squeezing.

Contour. When, on a map of any district or country, a line is drawn through points on the earth's surface which are all at the same height above mean sea-level, the curve so obtained is termed a contour-line. For equidifferent altitndes a series of such lines may be drawn. It is obvious that they may be ideally laid down by projecting orthographically on the map the sections of the earth's surface made by a series of horizontal planes. at equal distances apart; or (what is the same thing) were the sea-level to rise 100 feet, then to 200 feet, and so on, above its normal level, the seamargins made at each successive rise would be the contour lines of the district for 100 feet, 200 feet, \&c. These lines, which are drawn on British Ordnance Survey maps for intervals of usually 50 feet. however they may vary in form in different cases, have certain common properties which render them of assistance to the surveyor, engineer, and geographer. Suppose, for example, the case of a hemispherical hill be taken (see fig.), and that the contours (which are, in this case, concentric circles) are drawn for each 100 feet of altitude. It will be noticed that where the distance between the two successive contours is least, there the hill is the steepest; for, in ascending the hill at that part, a given length inwards horizontally is accompanied by the greatest

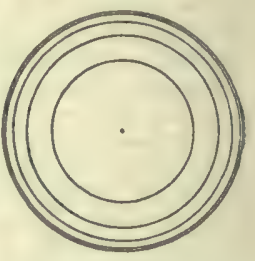

vertical ascent. In other words, the steepness of slope or gradient at any point in any given direction is inversely as the distance between the contours at that point in the given direction. The line of steepest slope at any point is therefore the shortest line which ean be drawn to the next contour which it cuts at right angles. This is the course which would be taken by water running down the hillside, and hence is termed a stream line. Thus in any given system of contour-lines the corresponding system of stream-lines can be obtained by drawing a system of orthogonal curves.

The method of contours has found many applications in science besides the one already detailed. Especially in meteorology has it been of service here isothermals and isobars drawn on a map are simply lines drawn through points having the same temperature and barometric pressure respectively the corresponding stream-lines being lines of flow of heat or of atmospheric pressure. Similarly, lines of equal magnetic dip, variation, and intensity are examples of applications in terrestrial magnetism.

The method is also applicable to other dimensions. in space than those we have dealt with. The contours of a curve are points; of a surface (exemplified above), curves; while those of a solid are surfaces. From the examples given it may be seen that a contour is a point, line, or surface at, along, or on which some physical property or characteristic is constant. Generally the advantage of the method is that by its means the mutual variations of three quantities may be represented by lines in two dimensions.

Contraband of War (Lat. contra bannum 'against the proclamation') is a name applied to certain commodities during hostilities between states which acknowledge what are called the laws of nations. One such law is, that neutral nations must not carry on, for the advantage of either of the belligerent powers, any branches of commerce from which they are excluded in time of peace. Another is, that the name of contraband of war shall be given to such articles as pertain to military or naval warfare-guns, ammunition, and stores of all kinds. Unless there are special treaties, defining exactly what articles are contraband of war, the interpretation of this law often leads to much embarrassment. Another law insisted on by England during the Napoleonic war was, that each belligerent shall have a right to visit and examine neutral ships, to 
aee whether they carry any articles which are contraband of war, and which seem likely to be intended for the enemy. A neutral state may carry on ordinary trade with either belligerent except when prevented by blockade (see BLOCKADE) ; but the ships, according to the above rules, must not contain articles contraband of war; nor must a conterminous land frontier be crossed by such commodities. If a merchant evades these rules, he does so at his own risk; his merchandise may be seized, and his own government will not protect him. By the law and practice of nations, it is for the Admiralty Court of the capturing power to decide what is or what is not contraband of war. Upon such questions it is the province of this tribunal to adjudieate, and from its final judgment there is no appeal. At various times discussions have arisen whether corn, hay, or coal can ever be included in the list of articles contraband of war ; they are obviously articles of peaceful commerce, but they are also essential to the maintenance of an army, and sometimes a supply would give one belligerent a great advantage over the other. Especially is this the case in reference to coal in the present age of war-steamers. - Contraband in commerce depends upon the special laws of each country. See SmuggliNa.

\section{Contra-bass. See Double Bass.}

Contract. The law of contract occupies a prominent place in all modern systems of jurisprudence, and different nations are in closer agreement as to its principles than in regard to any other department of law. A contract may be defined as the voluntary agreement of two or more persons, by which something is to be given or done upon the one side, for a valuable consideration, either present or future, upon the other side. English lawyers usually adject to this definition the qualification that the agreement is enforceable by law, an agreement not enforceable by law being reirariled as void. Every contract requires a consideration, a quid pro quo, but as a general rule any consideration, adequate or inadequate, will be sufficient. For the making of a contract there must be a communication between the parties of their intention-i.e., in one shape or another, there must be offer and aceeptance of distinct terms. An offer or proposal can be revoked at any time before it is accepted; and in strict law, silence does not give consent. When silence is taken to constitute acceptance, it must be silence under such circumstances as to amount to acquiescence. An acceptance must be unqualified, otherwise there is no contract. As the validity of a contract rests upon the consent of parties, persons legally incapable of giving consent cannot be parties to a contract. Contracts made by a person under the age of twenty-one are as a general rule voidable, unless they have been made for his benefit, or, as in England, for his 'necessaries,' And persons in a state of absolute drunkenness cannot contract, although a lesser degree of intoxication may be compatible with legal consent. Similarly, contracts made by a lunatic are voidable when it can be shown that his state was known to the other contracting party. Further, the consent given must be genuine, and a contract will be void if there is mistake or error in either of the parties with regard to any essential particular. Thus, if $\mathbf{A}$ sell to $\mathbf{B}$ $a$ bar of brass in the belief that it is a bar of gold, and $\mathrm{B}$ buy in the same belief, the contract is bad by error. Misrepresentation, or innocent misstatement of fact, and fraud, or wilful misstatement of fact, will also vitiate a contract, as will force or fear or undue influence exercised to compel the con-sent of either of the parties. A contract may also be void by impossibility - e.g. when the thing agreed to be done is naturally inpossible, as in the case of a pianoforte player who is prevented from performing his agreement by dangerous illness; or imporsible by construction of law, as when a change in the law of the country mupervenes upon and contradicts a private agreement. Besides these, the law refuses to recognise contract to per. form any illegal act, as to burn a house or steal a horse; and such an agreement may be in itrelf a crime, as conspiracy. Contracts against good morals, as, e.g., an agreement to pay the price of prostitution, are denied legal recognition and enforcement, as also are agreements against the public policy of the country where they are made. Examples are agreements in frand of the revenue, as in smuggling transactions; or contracts in restraint of marriage, which are held to be against jublic policy as tending to decrease the population. Thus a contract not to marry is void.

Contracts are variously classified. The law of Scotland adopts the old division of the civil law into Nominate Contracts and Innominate Contracts. The nominate contracts are loan, commodate, deposit, pledge, sale, permutation, location, society or partnership, and mandate. The law of England distinguishes between Contracts of Record and Contracts under Seal-both of which are formal, or dependent for their validity upon their form-and simple contracts, which depend for their validity upon the presence of consideration. Contracts of record are the judgments of a court; recognisances, as contracts made with the crown in its judicial capacity; and the obsolete acknowledg. ments of debt known as Statutes Merchant and Staple. Deeds and bonds may be taken as examples of contract under seal. Of simple contracts, some require no specialties of form; others are by law required to be in writing, as, e.g., a bill of exchange or an assignment of copyright. Contracts are distinguished into express or implied accordingly as they are based upon formal state. ments in words, spoken or written, or upon matter of inference and deduction either from the conduct of the parties or from the provisions of law. They are also distinguishable into executed contracts, where the transaction is completed the moment the agreement is made, as where an article is paid for and delivered over the counter, and executory contracts, where some future act is to be done after the arrangement is completed, as where an agreement is made to build a house in six months. A contract of benevolence is one made for the benefit of only one of the contracting parties, as mandate or deposit. See BrEach, Damages.

The remedy for breach of contract is an action for a certain sum due by the defaulter or for damages, ascertained by a jury ; but where the remedy of damages is inadequate or unsuitable, the courts will enforce a contract by decree for specific per. formance of the thing agreed to be done, or by injunction forbidding an act agreed not to be done.

Contractility. See Muscle.

Contractions. See Abbreviations, Palao-

\section{GRAPHY,}

Contract Notes, also called BOUGHT AND SOLD NoTES, or AIVICE Notks, are notes of a purchase or sale signed by a broker, and delivered to his principals, by which the bargain through him is completed. They are used by all kinds of brokers, and the following is the form of a stockbroker's contract and note

2 OLd Brond Btakit, LoNDox, 20th Deomber 1888. Bovarr by order and on account of $A$. B. Esq. (subject to the rules and regulations of the London Stoek Krehsnge) 20 Loudon Street Tramway Shares, at $216 \ldots . .28 \& 0$ 0 Brokerage.

$\operatorname{seg} 120$
C. D. \& $\mathrm{Co}$. Sworn Brokers. 
These notes are, in fact, transcripts from books in which it is the practice of brokers to enter or register their transactions. The bought notes and the sold notes are respectively delivered to the principal parties; and as they contain the essential parts of the bargain, they will suffice as evidence, in the absence of a corresponding entry in the broker's books ; but if they describe the particulars differently or incorrectly, as one species of goods for another, or erroneously state the terms, no contract arises, and a variation of this nature cannot be corrected by a reference to the broker's book.

In England, such written notes are required by the Statute of Frauds ( 29 Charles II. chap. 3) to prove a contract; while in Scotland, except in certain cases, any kind of evidence will be admitted in proof (see PAROLE EvIDENCE; see also BROKER, SALE).

Contralto is the deepest or lowest species of musical voice in boys, in eunuchs, and best of all in women, where its beauty of tone gives it the preference. This quality of the human voice was too much neglected by the French and German composers and singing-masters. Rossini and the Italians have, on the other hand, abundantly utilised its capabilities, and it is now one of the normal parts in the choral music of all nations. The powers of expression which it possesses are quite peculiar, and cannot be supplied by any other kind of voice. Its tone-character (timbre) is serious, spiritual, tender, and romantic. The low contralto in particular has a fullness of tone combined with power in the lower range. The high contralto has generally the same range of compass as the mezzosoprano, but differs from it in the position of the cantabile and in its character of tone. Contralto voices generally consist of two registers, the lowest beginning at $\mathrm{F}$ or $\mathrm{G}$ below middle $\mathrm{C}$, and reaching as high as the A or B above it. The higher notes up to the next $\mathrm{F}$ or $\mathrm{G}$ partake more of the character of the soprano. See VoICE.

Contrat Social ('Social Contract') is the name of a famous work (1762) by J. J. Rousseau, and of the theory maintained in it that government is based on the consent, direct or implied, of the governed. See Roussead.

Contravallation, LINEs of, form a chain of works round a besieged place to resist the sorties of the garrison. See Blockade, Circumvali. TION, and SIEGE.

Contrayerva, a medicine once in much repute against low fevers, and as a mild stimulant and diaphoretic, also as efficacions against snake-bites, whence the Spanish name, consists of the rootstocks (rhizomes) of different species of Dorstenia, a tropical American plant of the natural order Artocarpacese. The genus is remarkable for the plane receptacle in which the numerous small flowers are depressed, the female flowers more deeply so.

Control Department. See Commissariat.

Convalescent Hospitals are institutions of the greatest importance. Many patients die on returning to their own unhealthy homes from our ordinary hospitals; the convalescent home or hospital supplies a valuable stage in the process of eure. Either a series of detached cottages or one large and well-appointed house may serve to secure pure air and wholesome treatment. Of the latter kind, one of the first and best models was the magnificent establishment at Vincennes, founded in 1857. It contains more than 400 beds; permits an average stay of from twenty to thirty days; and in three years received 14,000 convalescent artisans.

Convallaria. See LILY of the Valley.
Convection. See Heat.

Convent. See Monachism.

Conventicle (Lat. conventiculum, a diminutive of conventus) originally meant a cabal among the monks of a monastery. The word was given as an appellation of reproach to meetings of the English and Scottish Nonconformists in the 17th century. Severe statutes were often passed for the suppression of these conventicles, especially the Conventicle Act of 1664 , which was repealed by the Toleration Act of 1689.

Convention, in Diplomacy, is a kind of treaty (especially military) of a temporary kind.

In Polities, it is a branch of the royal prerogative of Britain that no parliament shall be convened by its own authority, or by any other authority than that of the sovereign. Where the crown is in abeyance, this prerogative cannot of course be exercised, and the expedient of Convention Parliaments has been resorted to, the enactments of which shall afterwards be ratified by a parliament summoned in accordance with the provisions of the constitution. The convention parliament. which restored Charles II. to the throne met five weeks before his return, and was afterwards declared to be a good parliament, notwithstanding the absence of the king's writs. In like manner, at the Revolution of 1688, the Lords and Commons, on the summons of the Prince of Orange, met in convention, and disposed of the crown and kingdom, and this convention was subsequently declared to be really the two Houses of Parliament, notwithstanding the want of writs and other defects of form. Under the name of Convention there also took place a meeting of the Estates of Scotland, called by the Prince of Orange on the same occasion. The word convention was frequently used in the United States during the struggles with the British authorities which preceded the revolutionary war. For the French National Convention, see France. For the Convention of Royal Burghs, see BorougH.

Conversa'no, a town of South Italy, 18 miles. SE. of Bari. It has a fine cathedral, and a trade: in wine, oil, almonds, and cotton. Pop. 11,006.

Conversion, a theological term applied to the conscious change of heart prompting the repentant. sinner to a new life, which is part of the process. of regeneration. Popularly the name means the sensible experience. of this, and obviously there will be as much variety in its intensity and immediateness in individual cases as there was in their temperaments and antecedent spiritual conditions. The man who really knows something of the human heart will no more sneer at the grotesque expression of his experience from the lips of an awakened collier than he will smile at its intensity in the pages of a St Augustine or a Bunyan. The word is applied also to a change of religion or of creed, as that of John Henry Newman from the Anglican to the Roman Catholic Church. By those who disapprove the change, such a conversion is called perversion.

CoNvERSION, in Logic, signifies that one proposition is formed from another by interchanging the subject and predicate. Thus, 'No $A$ is $B^{2}$ has for its converse, by simple conversion, ' No B is A.' For the rules of conversion, see any handbook of formal logic.

Conveyancing. A conveyance may be defined as the form prescribed by law or custom for transferring property from one person to another. In the earliest stage of society, before written titles and contracts were in use, property was transferred by symbolical acts, performed in the presence of witnesses. Thus, in Ruth, iv. 7, a person surrendering his rights binds himaelf by plucking off his. 
shoe and giving it to his neighbour: 'and this was a restimony in Israel.' Among the ancient Goth and Swedes, the conveyance of land was made in the presence of witnessess, who extencled the cloak of the buyer, while the geller threw into it a clod of land. Similar to these symbolic forms are the old English and Scottish modes of conveyance by nolemn delivery of seisin, sasine, or possession. Goods have always been transferred with less ceremony than land; but the eustoms of ancient markets provided in certain cases for delivery in presence of witnesses, that frauds and disputes inight be avoided.

Written forms of conveyance are almost as old as the art of writing. An early example is given in Jer. xxxii. 9-12, where the prophet describes his purchase of the field of Hanameel, and the book or written evidence of the purchase subscribed by the parties and their witnesses. The Romans carried the art of conveyancing to high perfection. They had public recristers in which formal documents might be recorded; and the same legal forms were used by notaries and lawyers throughout the empire. The Roman law favoured freedom of alienation, and applied the same principles to movable and immovable property. When the barbarians broke into the empire, they brought their primitive customs with them; and Sir H. Maine has shown that barbarian custom and Roman law combined to form the feudal system. The great aim of feudalism was fixity of tenure; but the church men, who were also the lawyers and conveyancers of the period, were led by their own interest, and also by their superior education, to favour free alienation, both inter vivos and by will.

In England and in Scotland feudal ideas so far prevailed, that for some centuries the owner of land was hampered in dealing with it by the incidents of his tenure. $\mathrm{He}$ was liable for military or other service, and his land was subject to many inci dental claims of a vexatious nature (see COPY hold, Escheat, Feudalism, Fine, Freehold). The church lawyers were driven to devise a whole system of conveyancing, the object of which was to enable corporations and private persons to evade the strict rules of the common law. Political insecurity led to the invention of other forms of secret conveyance. In England by the end of the 17 th century the art of convevancing had become a complicsted mystery, and all dealings with land, in the way of commerce or of family settlement, were attended with expense and difficulty. Modern conveyancing has been rendered more simple and reasonable, and, on the whole, less expensive, by a series of reforms extending from the acts prepered on the advice of the Real Property Commissioners in 1832-33 to the Conveyancing Act, 1881, and the Settled Land Act, 1882.

In Britain it is not necessary to employ a professional person to prepare a conveyance; but the risk run by those who trust to a deed or will drawn by an unskilled person is considerable. Con. veyancing is part of the ordinary work of solicitors, and in Scotland of writers to the Signet. In England many members of the bar devote themselves entirely to conveyancing; and there is also a special class of practitioners known as convey. ancers who are members of the Inns of Court, but not called to the bar. Like solicitors, conveyancers are required to take out an annual certificate. In some of the large cities in the United States, companies have been formed to andertake convey. ancing, and to guarantee titles to real estate. In learning and practising his art, the conveyancer is much assisted by collections of precedents, which contain the styles and forms which have been found most safe and useful. By turning over any of the books of precedents now in ase, even the ordinary realer may obtain some notion of the variety and the importance of modern couvey. ancers work. In the United States the laws of conveyancing are not uniform; but in general the essentials of a conveyance of land are that it shall be in writing, signed and sealed by the grantors, acknowlerlged before the officer appointed by law, and delivered and recorded in the oflice appointed. In most states conveyancing is done by memlers of the bar, but elsewhere by skilled conveyancers wh. are not otherwise lawyers. See DEED.

Convict. See Prisung, Criminal Law.

Convocations (from Lat, convocure, 'to call together') were originally provincial synods of the clergy or the ancient erclesiastical councilss of the archbishop, but became incorporated into the Eng. lish constitution of church and state, and endued with certain parliamentary privileges. Some writers distinguish between councils and convocations - the former as being for spiritual purposes, and summoned without authority from the crown; the latter as being for civil purposes, and by command of the crown. This distinction, however, has no foundation in fact, the truth leing that the same assemblies discharged ecclesiastical functions, such as the enactment of canons, and civil functions, as the voting of subsidies to the crown, since the clergy were not subject to taxation save that levied by themselves in their provincial synods. The circumstances attending the famous assembly at Northampton in 1282, in the reign of Edward I., helped to settle the form which convocations have since assumed. In England the provinces of Canterbury and York have each their convocation. Previous to the Reformation these were sometines convened into a National Synod; but since then, matters have usually been concluded in the con. vocation of Canterbury, and transmitted to York for concurrence.

A convocation consists of three elements - (1) the archbishop; (2) the suffragan bishops of the province; (3) the clergy of the second order. They originally met in one assembly, but since the beginning of the 14th century the clergy in the provinceof Canterbury have retired into a distinct chamber, presided over by a prolocutor, with officers and journals of their own. These two bodies are called the Upper and Lower Houses. In the Convocation of York the same distinction exists, but on the occasions of their meeting, the business has been generally conducted in one assembly. The archbishop has the sole power of summoning, presiding, and proroguing; he has also 8 veto upon ali measures. He cannot, however, summon withont authority from the erown. The Upper House is the proper locus synodi, where the bishops have a right to sit and vote, and hefore the Reformation the mitred abbots had place there also. The Lower House consists of the lesser dignitaries, as deans and archdeacnns, and the proctors sent by capitular bodies and by the parochial clergy. In Canterbury the beneficed clergy only elect, and they send one proctor for each diocese; in York all the clergy elect, and send one proctor for each arehdenconry. The Lower House delilorates on matters proposed by the archbishop; it may present petitions to the Lpper House and state grievances, be with it in judicature on persons convened, and dissent from and so hinder the passing of any synodical act. Till 1534 the provincial synods or convocations. conld enset canons at pleasure, but in that year was enacted the statute 25 Henry VIII., chap. 19, making a license from the crown necessary before any new canons could be framed or published.

The passing of subsidies in convocation ceased in 1665 , and the reconds were destroyed in the fire of London in the following year. Meetings of convo- 
cation fell into abeyance in 1717 , being indefinitely prorogued as a punishment for the synodical condemnation of a book by Bishop Hoadly, who was high in favour with the government. They have been revived (in 1852 for the province of Canterbury, in 1856 for York) with considerable advantage to the church, but their action has been and is greatly restricted. In Ireland the convocations of the four provinces assembled at Dublin, all together, and were on the model of those in England. From the Union downwards, the Irish convocations never assembled. Since the disestablishment the legislative assembly of the Protestant Eviscopal Church is called the General Synod. An act of parliament was passed in 1663 for regulating the meetings of convocation in Scotland; but shortly after the Revolution of 1688, the Episcopal Church ceased to be the national establishment; and ever since the meetings of the Presbyterian Church, embracing clergy and laity, have been called General Assemblies. See Assembly, Synod.

The position of the Church of England as respects its convocations is exceedingly anomalous, but is incidental to certain eireumstances in the constitution and polity of the country. As practically interwoven with the state, the church possesses little independent action; its articles, liturgy, organisation as to benefices, \&c., are all affected by civil statutes; while its discipline falls within the scope of the ecclesiastical courts, a class of tribunals apart from the ministering elergy. The church, therefore, in its capacity as an institution to teach certain doctrines of religion, is left little to do in the way of jurisdiction. It is further urged, as a reason for restricting the power of con. vocation, that being purely sacerdotal, it might be apt to rum into excesses, and put forth claims adverse to the prevailing tone of sentiment on religious matters; that, in short, as things stand, it is safer for the public to be under the authority of parliament than to be subject to the ordinances of a body of ecclesiastics. At the same time it is generally allowed that some kind of reform is desirable, though how this should be effected in a manner satisfactory to all parties it would be

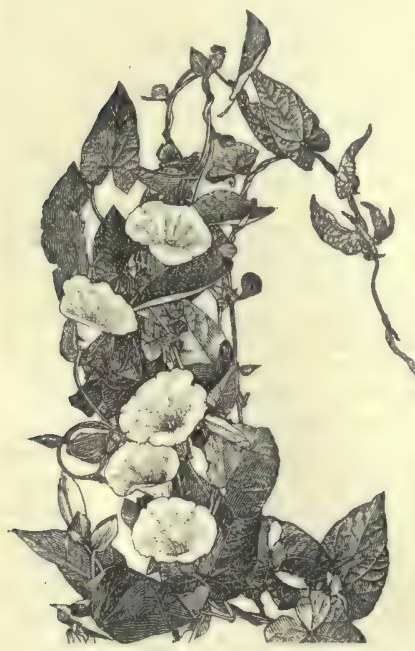

Convolvulus (Calystegia sepium). difficult to say. The convocations of Canterbury and York assemble annually at the opening of parliament, each keeping up its own distinctive customs. See Trevor's Convocations of the Two Provinces; Cardwell's Synodalia, and Documentary Annals; Lathbury's History of the Convocation of the Church of England.

\section{Convol'vu-}

lus (Lat. convolvere, "to twine together'), a

genus of plants, the type of the order Convolvulaceæ. This order contains about 800 known species, herbaceous and shrubby; generally with a twining stem and milky juice, chiefly tropical. Many are cultivated as ornamental plants, particularly species of Convolvulus and Ipomœa.
The acrid milky juice is often strongly purgative; and jalap and scammony are products of this order. Some species, however, have large farinaceous roots, capable of being used as food, of which the Batatas or Sweet Potato (q.v.) is the most important. A few are natives of Britain, and are known by the name of Bindweed. A common name in the United States is Morning Glory. $C$. arvensis is a troublesome weed in some sandy soils in England, and Calystegia sepium in richer soils. The wood of $C$. scoparius, a shrubby species, native of the Canary Isles, called 'Rosewood,' or Lignum Rhodii by apothecaries, has so strong a smell of roses that the essential oil it yields on distillation is employed to adulterate the attar of roses.

Convoy ( Fr. convoi) is the name given to one or more ships of war appointed to protect a fleet of merchant-vessels against the attacks of an enemy or of pirates. If a merchant-ship parts company with the convoy, or neglects to obey the convoy's instructions or signals, all claims of insurance are forfeited. The name is sometimes applied to the merchant-vessels so escorted. In the military service a convoy is a train of wagons or canal boats laden with provisions, treasure, or warlike stores, and escorted by a detachment of troops.

Convulsion, in Medicine, is sometimes used of any involuntary contraction of the voluntary muscles of the body; but especially of seizures in which the body is thrown into violent spasmodic contractions, the sensibility and voluntary motion being for a time suspended. In adults convulsions almost always indicate the presence of grave disease, either of the brain (particularly Epilepsy, q.v.) or of the kidneys. In children, especially before the age of three years, they are of much more common occurrence, and, though serious in them. selves, may be due to temporary and comparatively trifling causes. The following description applies chiefly to the convulsions of children. A fit of convulsions may last from a few minutes to some hours, and may readily prove fatal, if not relieved within a short period. The first symptom observed is often a twitching of particular muscles or groups of muscles, and a change in the habitual expression or colour of the face, with distension of the features, and turning of the globes of the eyes suddenly upwards. The fingers are sometimes clenched in the palm, and the feet turned inwards sometimes, however, convulsions occur absolutely without warnings of this kind, and even in the midst of perfect apparent health. Their cause is usually to be found in some source of irritation, especially in the digestive organs; as, for instance, disordered dentition, worms in the intestine, indigestible or unsuitable food, \&c. Mnst epidemic fevers are also apt to be attended, in children, by convulsions in their early stages, and if severe, particularly in the case of whooping-cough, during their progress as well ; and diseases of the brain and its membranes at every stage. Convulsions are greatly promoted by bad ventilation and injudicious feeding, with deficient exercise; and a great part of the cure consists in discovering and removing the causes of the disease.

When a child is suddenly seized with a tendency to spasm, such as twitching of the features, or contractions of the fingers and toes, it should be placed at once in a very free current of air, with its feet towards the fire; the extremities should be kept warm, and a cold lotion may be applied to the head, especially if there is much flushing of the face; a little castor-oil may be given unless the bowels are loose; and if there is flatulence, the belly may be rubbed with a warm hand, or with some simple stimulating liniment, such as camphorated oil. If an actual convulsion occur, the feet, or if 
possible the whole body, should at once be put in hot water to which a little mustard hos been added, and eloths wrung out of cold water frequently spplied to the heml. If there is any suspicion that worms or undigested food may be the cause, 凡 purgative Clyster (q.v.) should be given; and sperient medicine by the mouth as well, if the child be able to swallow. Nothing more should be attempted without medical advice. The further treatment generally consists in the administration of nerve sedatives, especially bromide of sodium or potassium and chloral, and in obstinate cases chloroform, with careful attention of course to any canse of irritation that may be present.

Convulaions are rare amongst horses and cattle. In young dogs, however, they frequently oceur from intestinal worms, disordered digestion, or in comnection with distemper or other delilitating diseases : they usually disappear when their special causes are removed.

Convulsionaries, the name given to a fanatical sect of Jansenists who sprang up in France about 1730. Their meeting-place was the churchyard of St Médard, in a suburb of Paris, where was the tomb of a certain Francis of Paris, who died in 1727 , and was reckoned very holy by the Jansenists on account of his extravagant asceticism. At this tomb a multitude of people poured forth fanatical prayers, preachments, and prophesyings. Miracles are also alleged to have been performed, for proof of which we are referred to a work written by $\mathbf{M}$. Montgeron, a French senator, and entitled La Vérite des Miracles opérés par IIntercession de François de Paris (Paris, 1737). After 1731 the fanaticism of the convulsionaries increased to utter madness. "They threw themselves into the most violent contortions of body, rolled about on the ground, imitated birds, beasts, and fishes, and at last, when they had completely spent themselves, went off in a swoon.' In 1733 the king issued an order for the imprisonment of these fanatics, but it was found impossible to put a complete stop to the mischief. They took to predicting the downfall of the throne and the church, which propheey the French Revolution appeared to fulfil. They were not much heard of in Paris after the middle of the 18th century, but have occurred in country-places at various times within the present century. They brought Jan. senism into 80 much disrepute, that Voltaire declared the tomb of Francis to be the grave of Jansenism. See Mathieu, Histoire des Miracules et des Convulsionnaires (1864).

Conway, a river in North Wales, famous for the bold romantic scenery along its higher, as well as for the richly beautiful scenery along its lower course. It rises in a small mountain-lake round which meet the three counties of Merioneth, Denbigh, and Carnarvon; and it runs 30 miles northward past Llanrwst and Conway to Beaumaris Bay. In its last ten miles, a smoothly-flowing if winding stream, it is navigable for vessels of 100 tons. At Conway it is half a mile broad at spring. tilles, which rise here from 21 to 24 feet. Pearl. mussels are found at its mouth.

Conway, or Aberconway, an ancient and picturesque little seaport town of North Wales, in Carnarvonshire, situated on the left bank of the river Conway at its estuary, $45 \frac{2}{2}$ miles NW. of Chester by rail. The river is crosed by a fine tubular bridge constructed by Stephenson in 1848 , ss well as by a suspension bridge built by Telford in 1826 (see BRIDGE). The town is triangular in form, and is surrounded by a high wall 12 feet thick and 1 mile in circumference, piercel by four Moorish looking gates, and crowned by twenty-one round towers. In its south-eastern corner are the magni. ficent remains of Conway Castle, riving proudly from a rock above the river. It was finst built by Hugh Lupus, Earl of Chenter, and rebuilt in 124 by Edward I., to check the Welsh. Its walls are 12 to 15 feet thick, with eight vast towers, four of which are each surmounted by a slender turret. The Plas Mawr ('great mansion') is a noble timber house erected in 1585, its exterior and interior profusely covered with ornament. A Cistercian abbey was founded here by Llywelyn ab Jorwerth, prince of North Wales, in which Llywelyn the Great was buried. The Castle Hotel now occupies its site. Pop. (1881) 3179. Conway (a chartered borough since 1876) is one of the six Carnarvon boroughs. It is still visited by vast numbers of tourists, but as a place of resort it has been left far behind by Llandudno, 4 miles to the north.

Conway, Hugh, the pseudonym of Frederick John Fargus, who was born in 1847, the son of a Bristol auctioneer. He adopted that pseudonym from the school frigate Conway, stationed on the Mersey, which he entered when he was thirteen for the purpose of training for a seafaring life. His father set his face against this, so young Fargus entered the auctioneer business, employing his leisure in writing clever newspaper verse and occasional tales. Some songs of his were accepted and published in 1878 , a volume of verse in 1879 ; but it was the issue and rapid sale of his melodramatic story, Called Back, as vol. i. of Arrow. smith's Bristol Library (1884), which made him famous. Within five years 350,000 copies of this book had been sold. Fargus sold his share in the auctioneer's business in Bristol, and went to London, where he adopted the profession of authorship. His Dark Days followed, and just as in A Family Affoir, and other works which he now produced in rapid succession, he had begun to show higher capabilities as a novelist, he died of malarial fever at Monte Carlo, 15th May 1885.

Conway, Moncure Daniel, American author, born in Virginia in 1832, entered the Methodist ministry in 1850 , but, after a course at the Cam. bridge divinity school, settled as a Unitarian preacher in Washington in 1854, and in Cincinnati in 1857. He was a strong opponent of slavery, and in 1863 came to England to lecture on the war. In London he became head of the South Place Institute (for advanced religious thought), and pub. lished The Rejected Stone (1861), The Golden Hour (1862), Republican Superstitions (1872), Idols and Ideals (1877), Demonology and Devil-lore (1879), Thomas Carlyle (1881), Pine and Palm (1887), and A Life of Paine (1892), whose works he also edited (2 vols. 1892). He returned to Americs in 1897.

Conway, Sir William Martin, born at Roch. ester in 1856, was professor of Art in University College at Liverpool (1885-88), wrote on the Dutch wood-engravers, and on his own mountaineering in the Karakoram (1894) and his exploration of Spitzbergen (1897). He was knighted in 1895 .

Cony. See Hyrax, Rabbit.

Conybeare, WILLIAM JoHs, joint-author with Dean Howson of a widely known Life and Epistles of St Paul (1851), was born 1st August 1815, 8on of William Daniel Conybeare (1787-1857), the eminent geologist, who in 1844 became dean of Llandaff. He was educated at Westminster and Trinity College, Cambridge, of which he became a fellow. In 1842 he was appointed principal of the newly-founded Liverpool Collegiate Institution, which ill-health compelled him to exchange for the vicarage of Axminster. He died at Weybridge in 1857. Essays, Ecclesiastical and Social (1856), and a novel, were his only other works.

Cony'za, an unimportant genus of Compositre (sub-order Corymbiferw). C. squarrosa is known 
as Fleabane and Ploughman's Spikenard, and has a strong peculiar smell, traditionally said to drive away fleas and gnats.

\section{Cooch Behar. See BeHar.}

Cook, Dutron, dramatic critic and author, the son of a solicitor, was born in London, 30th January 1829, spent four years in his father's office, then entered a railway office, which he left to follow the full bent of his literary and artistic tastes. $\mathrm{He}$ studied painting and engraving, wrote a successful melodrama, acted as dramatic eritic for the Pall Mall Gazette, 1867-75, and then for the World till his death, 11th September 1883. He wrote for various newspapers and magazines, including Temple Bar and Chambers's Journal, and his eight novels, and others, were always interesting and well written, bat sometimes failed in catching the average novel-reader. He wrote the dramatic and theatrical lives for the first two volumes of the Dictionary of National Biography, was also author of A Book of the Play (1876), Hours with the Players (1881), and On the Stage (1883).

Cook, EuIzA, a favourite minor English poetess, daughter of a London tradesman, was born at Southwark in 1818. She contributed poetical pieces to various magazines from an early age, and Issued her Melaia and Other Poems in 1838, which, along with the issue of volumes in 1864 and 1865 , established her reputation as a meritorious verse writer of sound morality, and clear, sensible, and simple treatment. She conducted Eliva Cook's Journal (1849-54) till ill-health obliged her to relinquish it; in 1864 a pension of $£ 100$ a year was conferred upon her by government. She also wrote Jottings from $M y$ Journal (1860), and La. conics (1865). Died September 25, 1889.

Cook, James, one of England's greatest navigators and maritime explorers, was born at Marton, in Cleveland, Yorkshire, where his father was an agricultural labourer, on October 28 (according to another authority, November), 1728. After a meagre education, Cook was apprenticed at the age of thirteen to a haberdasher at Staithes, 10 miles north of Whitby. After a short experience of this life, he was bound apprentice to Whitby shipowners, and spent several years in the coasting and Baltic trade. In 1755 he entered the royal navy as an able seaman, and in four years rose to the rank of master. For about ten years after this he was mostly engaged in surveying about the St Lawrence and the shores of Newfoundland, and the results as embodied in his sailing directory (1766-78), are of value even at the present day. During this period he devoted himself to the study of mathematics, and otherwise qualified himself for the highest rank in the navy. In 1768 he was raised to the rank of lieutenant, and placed in command of the Endeavour, appointed to convey the expedition for the observation of the transit of Venus in the Pacific. The Endeavour sailed on August 25, and arrived at Tahiti in the following April, the transit being successfully observed on June 3. On the return, New Zealand was for the first time circumnavigated, and its coasts charted; the east coast of Australia was surveyed and taken possession of in the name of Great Britain. The strait which separates Australia from New Guinea was sailed through, and the distinction of those two islands established beyond doubt. Continuing his voyage by Java (Batavia) and the Cape of Good Hope, Cook anchored in the Downs on June 12, 1771: One important result of the voyage was to disprove the existence of the 'great southern Continent,' which had been supposed to extend from the Antarctic as far north as $40^{\circ} \mathrm{S}$. Cook was promoted to the rank of commander, and given the command of a second voyage of discovery in the Resolution and Adventure, which sailed from Plymouth, July 13, 1772. This expedition was out for three years. The great object was to discover how far the lands of the Antarctic stretched northwards. For this purpose Cook sailed round the edge of the ice, and penetrated as far south as possible, his farthest south point being $71^{\circ} 10^{\prime}$, in long. $110^{\circ} 54^{\prime} \mathrm{W}$. During the intervals between the Antarctic royages, Cook cruised in the Southern Pacific, visiting Tahiti, exploring the New Hebrides, discovering New Caledonia, and many of the island groups in the Pacific. Plymouth was reached on July 29, 1775. One important feature of the second voyage was that, owing to the precautions taken by Cook, there was only one death among his crews during all the three years-a marked contrast to the fearful losses sustained during other voyages of this: period.

Cook, who had been promoted to eaptain, and received an appointment in Greenwich Hospital, had scarcely been home for a year before he was appointed to the command of another expedition, the main object of which was to discover a passage round the north cosst of America. from the Pacific. Cook sailed from Plymouth in the Resolution, July 12, 1776, followed by Captain Clarke in the Discovery. Leaving the Cape on November 30 , the expedition visited Tasmania and New Zealand, and spent the year 1777 cruising among the Pacific Islands. In the beginning of 1778 the Sandwich Islands were discovered, when Cook made for the west coast of North America. This he followed and surveyed from $45^{\circ} \mathrm{N}$. as far as Icy Cape on the inside of Behring Strait, where he was compelled to turn back, reaching Karakakoa Bay in Hawaii, Sandwich Islands, January 17, 1779. At first the expedition was treated in the most friendly way by the natives. For some reason their attitude changed, and on February 14, when Cook landed with a party to recover a stolen boat, the natives set upon them with sudden fury, Cook being clubbed and stabbed to death at the edge of the water. Part of the body was recovered and buried, and in 1874 a monument was erected near the spot where he fell. Many varied accounts have been given of Cook's death, and many reasons adduced for the changed attitude of the Hawaiians; but the probability is that he simply fell a victim to a sudden outbreak of savage fury. Cook did more than any other navigator to add to our knowledge of the Pacific and the Southern Ocean; his observations have stood the test of modern investigations ; in character he was honest and just, both to his own men and to the natives with whom he came into contact, and who almost invariably became greatly attached to him. A pension of $£ 200$ was granted to his widow (whom he married in 1762 ), and $£ 25$ to each of his: three children.

An account of the first voyage originally appeared as vols. ii. and iii. of Hawkesworth's Voyages (1773); the narrative of the second was written by Cook himself, 2 vols, with 1 vol of plates (1777); that of the third appeared in 3 vols. and an atlas (1784), partly by Cook and partly by Captain James King. See Kippis's Life and Voyages of Captain James Cook (1788; reprinted 1883): Professor Laughton's article in the Dict. Nat. Biog.; Besant's monograph (1890); and the unabridged. reprint of Cook's Journal of his First Voykge, by Captain Wharton (1893).

Cook, JosEpH, lecturer and author, born at Ticonderoga, New York, in 1838, graduated at Harvard and Andover, and after three years' preaching went to Europe in 1871, where he studied in Germany, and made a tour of the Mediterranean countries. In 1873 he commenced a series of 'Monday Lectures' in Boston, which, endeavouring to harmonise science and religion, 
and dimeuming social and political questions, hecame very popular; and in 1880 he began an extended lecturing tour around the world. Hesides his leetures, he has published a number of works on such subjects as Biology (1877), Heredity (1878), Marriage (1878), Labor (1879), Socialism $(1880)$, \&c.

Cook, Тномаs, railway excursion and tourist pioneer, was born at Melbourne, Derbyshire, November 22, 1808. His educational advantages were few, and his early days were spent in gar. dening pursuite, and then in wood-turning and cabinet work. In his twentieth year he became a village missionary, and whilst thus occupied his sympathies were actively enlisted in the cause of temperance and free trade. But from 1841 his time and toil were engaged chiefly in the initiation and promotion of railway excursions. His first trip was from Leicester to Longhborough in 1841, his aim being the furtherance of the temperance cause. The Midland Railway was for some years the centre of his operations, and the town of Leicester his home. But overcoming the great diffieulties, he extended the business not only through all Great Britain, but throughout the world, and the tourist-tickets of Thomas Cook \& Son are found everywhere. In connection with the previous wars in Egypt and the Soudan, the English and Egyptian governments were largely aided by their enterprise; and the firm undertake on behalf of the Indian gov. ernment the conveyance of Mohammedan pilgrims from India to Mecea. He retired in 1878 in favor of his son, and died July 18, 1892.

Cooke, George Frederick, actor, born in Westminster in 1756, made his first public appearance at Brentford in 1756 , and in the period between 1784 and 1800 became very popular in the English provinces and in Ireland, attaining a front rank in his profession, in spite of drinking habits that increased with his years. From 1801 to 1810 he played at Covent Garden both in eomedy and in tragedy, and rivalled Kemble in the public favour; although here, also, from 1803 , when he was hissed off the stage for drunkenness, his intemperance was a notorious thing, and a matter for jesting apology. His best characters were Richard, Shylock, Iago, Sir Giles Overreach, and Sir Pertinax MacSycophant. In 1810 he visited America, and appeared before enthusiastic audiences in the chief northern cities, where admiration for the actor secured indulgence and pity for the extravaganees of the drunkard. He died in New York city, 26th September 1811; a monument marks his grave, erected in 1821 by Edmand Kean, who regarded Cooke as the greatest of actors. See his Life by William Dunlap (Lond. 1813 ).

Cooke, Sir William Fotheramu, electrician, born at Ealing in 1806, served in the Indian army from 1826 to 1831 , and after studying medicine at Paris and Heidelberg, abandoned this for telegraphy, and in 1837 entered into partnership with Profesanr Wheatstone. After experiments on vari. ous railway lines, they patented the single needle apparatus in 1845. In 1846 Cooke formed a company, which paid $£ 120,000$ for the partners' earlier patents, In 1867 Cooke and Wheatstone received the Albert gold medal; Wheatstone was knighted in 1868, and Cooke in 1869. He died 25th Jane
1879 .

Cookery. The art of cookery, like other arts and handicrafts, is one which cannot be tanght in an encyclopredia article, but the general principles which underlie the operations of cookery may be briefly expounded. This part of the subjectthe chemistry and physics of cookery-has been much neglected until very lately.

The chief agent in cookery is heat, and therefore a large part of our subject is the consideration of the cliemical and physical changes which oceur in food materials when subjected to the agency of heat. We may apply this agent either by bringing the food into direct contact with the source of heat, or by exposing it to radiations from the nource of heat. Roasting, toasting, grilling, and to a partial extent, baking, are examples of the latter; while stewing, frying, and the so-called 'boiling' of food -i.e. Immersion in hot water-are examples of herting by contact. The verm 'boiling' is commonly misapplied in a manner that leads to confusion of ideas. Thus we speak of boiling a leg of mutton, boiling fish, boiling potatoes, \&e. quite improperly. The food in question is not bolled, should not be boiled; it is merely immersed in water, which is conveniently used as a heating agent. As will presently be shown, even the water itself should not in most cases boil. Frying, properly conducted, is another example. Here a wath of fat is used to convey the heat.

What are the changes effected on the food by the action of cookery? is the fundamental question to be answered in treating cookery as a branch of applied science. What is the difference between a raw and a cooked potato? What is the difference between a raw and a cooked leg of mutton? and other such questions throughout. We all know the difference in flavour, but the chemical and mechanical changes are but little understood. To answer these questions we must first know something of the composition of the uncooked viands.

For this purpose the old-fashioned division of the elements of organic substances into proximate and ultimate is very convenient. The ultimate elements - carbon, oxygen, nitrogen, hydrogen, \&c. -are not cookable, and in their uncombined state do not concern our subject; but the proximate elements, or more properly proximate constituents, such as albumen, gelatin, starch, cellulose, \&c., are altered, and the whole subject will be best understood by considering separately the alterations which occur to these in the course of cookery.

Taking first the constituents of vegetable food, the largest of these is the material of the cell walls of the vegetable, cellulase, or woody fibre. The next in quantity, as existing in ordinary articles of food, is starch, or fecula, or farina. Both of these are carbohydrates-i.e. compounds of carbon with water, or the elements of water, and they contain these elements in the same proportions, but their structure and digestibility are very different. Starch in its raw state consists of small granules (see STARCH) which, placed in cold water, sink to the bottom without any degree of solution or other change by union with the water. In this condition they are practically indigestible in the human stomach, but when cooked, starch is the most exsily digestible of all human food.

The changes that take place in the cookery of starch are considerable. If pure starch (arrow. root is such) be placed in water raised to the temperature of $140^{\circ} \mathrm{F}$., the granules swell considerably, and the mixture becomes pasty or viscons. A little stirring breaks up the distended granules, and we obtain a glairy paste such as used by the lanndress, and seen in cooked arrowroot. If the heat be now raised from $140^{\circ}$ to the boiling-point, and the boiling continued, the gelid mass becomes thicker and thicker; and if there are more than 50 parts of water to 1 of starch, a separation takes place, the starch settling down with its 50 parts of water, and the excess of clear water standing above. We have here a case of hydration or combination with water fls the result of cookery, and the probable cause of the improved digestibility. Dry starch may be raised to $300^{\circ}$ without becoming thus semi-soluble. 
The hydrate once formed may be dried by'evaporation, and still retains some water and the same degree of solubility. Many farinaceous preparations, such as corn-flour, \&c., consist chiefly of starch in this condition. This, however, is not the limit of starch cookery. If it is heated to about $400^{\circ}$, it is converted into dextrin, which is completely soluble in water at all temperatures, the solution being mucilaginous but not pasty. Dextrin differs from starch in other properties (see DEXTRIN), but is composed of the same elements in the same proportions, $\mathrm{C}_{6} \mathrm{H}_{10} \mathrm{O}_{5}$-i.e. six equivalents of carbon to five of water, or its elements. This change of starch into dextrin is of great practical importance as an operation of cookery, inasmuch as it anticipates the first stage of the digestion of starch.

The saliva, the pancreatic juice, and one of the intestinal secretions contain a peculiar principle which has received the name of animal diastase, from its resemblance to the diastase of malt. This converts the starch of food into the completely soluble dextrin, a change absolutely necessary for its assimilation as nutriment. In some animals the supply of this is so small that starch is almost worthless to them as food. It passes through the body nnaltered. Such is the case with the carnivora. Human infants, when suddenly deprived of their mother's milk, have not sufficiently developed the power of salivary, pancreatic, and intestinal secretion of diastase to digest starch, and therefore demand assistance. Such assistance may be afforded by carrying the cookery of starch to what we venture to call the second stage-viz. its complete or partial conversion into dextrin. Thus, ordinary flour or oatmeal, simply heated in boiling water or milk, is merely subjected to the first stage-viz. hydration of the starch; but if the flour or oatmeal be well baked, a considerable proportion of its starch is converted into dextrin. A knowledge of this is of great importance to mothers, and also to nurses preparing food for dyspeptics, as adults vary greatly in their powers of diastatic secretion.

The reader will now understand why bread is rendered more digestible by toasting, and why crust of bread is more digestible than the crumb, in spite of greater hardness. In the ordinary baking of bread a variable amount of the starch is converted into dextrin. Well-baked bread is more digestible than under-baked. In the cookery of oatcakes, bannocks, scones, and all kinds of biscuits, this should be understood. The writer enjoys the luxury of hot rolls without their indigestibility, by simply moistening stale crusts of bread and reheating them in a kitchen oven. They thus become softened like new bread, and more digestible than before on account of the dextrinisation of a larger proportion of the starch. Baked and fried potatoes have a similar advantage.

The diastase of malt (see MALT) may be used for the dextrinisation of farinaceous food by adding malt flour or extract of malt to it; or the grain itself may be malted. The temperature at which malt diastase acts most vigorously is about $140^{\circ}$. At lower temperatures it acts more slowly; at much higher, its eurious property is destroyed. To illustrate its action, make some oatmeal porridge very thick, then add about $\frac{1}{10}$ th part of dry malt flour at about $140^{\circ}$, and stir. In a few minutes tine thick pudding becomes quite sloppy owing to the greater solubility of the dextrin into which the starch has thus been converted.

The cellulose-i.e. the stalks and the cell walls, such as the fleshy part of leaves, \&c.-are more or less digestible, according to their looseness of structure and their interfluidity or succulent character. Thus we may digest a raw lettuce more easily than a raw cabbage, or the inner leaves of either more readily than the outer leaves or stalks. The action of cookery on cellulose appears to consist in the loosening of its fibres, and rendering them more soluble. It is therefore advantageous that the water in which green vegetables, such as cabbages, are cooked should boil vigorously, the agitation of the steam bubbles assisting in the loosening of the fibres. Cellulose, like starch, may be converted into dextrin and sugar by the combined action of moderate heat with moisture and an acid. This change is aided by a little diastase. Sawdust and old rags may thus be converted into digestible and nutritious food, but not with commercial profit at present. An example of such conversion in Nature's laboratory is afforded by the ripening of a pear. Many varieties which are hard, woody, and sour when full grown in autumn, become gradually softer and sweeter, and finally delicious by simple storage. The action of ensilage (see ENSILAGE) of cattle food probably includes some degree of such conversion of cellulose.

The nitrogenous constituent of grain, the gluten, is not so greatly altered by cookery. The writer's investigations of this neglected subject lead him to the conclusion that the alteration which does occur is that of a partial hydration rendering the gluten more soluble, but this hydration is not so decided and definite as in the case of starch. There is one constituent of vegetable food which demands no cookery. This is pecten (otherwise pectose and pectin)-i.e. vegetable jelly. It exists most abundantly in fruits, and is familiar to all in the form of currant jelly, apple jelly, \&c., which are pecten plus sugar. The cookery of vegetable casein will be discussed with that of the casein of milk.

Of the proximate elements of animal food the most abundant is gelatin ; it constitutes about half the weight of the body of most animals. It exists in two forms-soluble and insoluble. Its cookery consists in the hydration of the insoluble form and rendering it soluble, as in the stewing of bones; tendons, skin, \&c. in a stock-pot until their gelatin becomes soluble jelly. The muscular fibre itself, which with its enveloping membranes form lean meat, is subjected to a similar change, but less completely, in the course of cookery.

The cookery of albumen differs materially from any of the preceding. Albumen exists in raw flesh meat as one of its juices, being a glairy liquid which is distributed between the muscular fibres and the joints, and around the bones, forming a lubricant, and probably conveying material of growth and renewal. It is typically seen in the white of eggs. When heated to about $134^{\circ}$, white fibres begin to appear within it. If the heat is continued, and gradually increased, they increase, until at about $160^{\circ}$ the whole mass becomes white and nearly opaque. It is now coagulated into a tender, delicate, jelly-like substance, easily digestible and highly nutritious. If the heat is further raised, it becomes harder and harder, up to $212^{\circ}$. If this heat is continued, it shrinks, and becomes tough and horny, losing some of its water of composition, and its easy digestibility.

Ignorance of these particulars, and further ignorance of the fact that water has the same temperature, whether 'simmering' or boiling violently, causes the spoiling of vast quantities of food and wasting of much fuel in this country. The cooking temperature for all animal food is from $160^{\circ}$ to $180^{\circ}$. When maintained for any length of time at the temperature of boiling or 'simmering' water, it is spoiled. To prove this, take a beefsteak and cut it in half. Place one half in water in a common saucepan, and boil or 'simmer' it for half an hour or more. Place the other half in water in an open-mouthed jar (such as a gallipot), and 
place the jar in a saucepan of water so that only the onter water shall loil; cosk it thus, and com. pare with the first. At a continued temperature of $212^{\circ}$ not only does the alloumen become toughened, but the gelatin also becomes dehy. drated, hardened, and indigestible. All stewing operations should, therefore, be conducted at $30^{\circ}$ or $40^{\circ}$ below the boiling-point. When the exposure to a higher temperature is but for a short period, little or no mischief is done. This is the ease in frying and grilling of animal fool. These operations should always be rapidly conducted.

Besides the above-named constituents of animal and vegetable food, there are the saline juices necessary for supplying the saline constituents of the blood, and upon which the flavour of food largely depends. These are not altered by cookery, but are too frequently sacrificed. Potatoes, for example, contain a certain proportion of potash salts. The writer has examined the water in which potatoes have been cooked and that which is condensed when they are steamed, and finds that if the potatoes are peeled, a large proportion of the salts pass into the water. If they are cooked 'in their jackets, 'much less is lost; but when baked or fried, all is retained. The complete retention of the juices is one of the reasons why roasted and grilled meat has more flavour than that which is cooked in water.

The changes which cookery effects on fat appear to consist in partial dissociation of its proximate elements. It is composed of a fatty acid combined with glycerine. These are partially separated by heat.

Another constituent of both animal and vegetable food is casein. It does not exist in the flesh of animals, but is an important component of milk; is the solid basis of the curd which is separated by the action of rennet or acids (see CASEIN). It also exists in peas, beans, and other seeds of leguminous plants. It is highly nutritious. There are two forms of casein-the soluble and insoluble. It is soluble as it exists in milk, but insoluble after precipitation by acids or rennet, as in making cheese. An infant that digests the casein of milk cannot digest it after separation as cheese.

The writer has succeeded in partially reconverting the insoluble to the soluble form by adding bicarbonate of potash in the proportion of 4 th to $z d$ of an ounce to $\mathrm{I} \mathrm{lb}$. of cheese ; the potash dissolved in about a teacupful of water, and the cheese, grated or sliced, added to the solution, which is boiled until the cheese dissolves, forming a custardlike result. This may be added to oatmeal porridge and a multitude of other preparations. The theory upon which this method of treating cheese was founded is, that the curding of milk is due to the combination of an acid with the natural alkali of the soluble casein, chiefly consisting of potash. The artificial addition in the proportion named not only renders the cheese more digestible, but restores the saline constituent of the original milk, which in the course of cheese. making, passed into the whey. The importance of thus rendering cheese more digestible, and supplying its saline dietetic deficiency, will be understood by the fact that $20 \mathrm{lb}$. of cheese contain as much nutriment as a sheep weighing more than $60 \mathrm{lb}$. Lean beef and mutton contain from 721 to $73 \frac{1}{3}$ per cent. of water, cheese alwut 30 per cent. and no bone. Cheese may be stored and carried almost as easily as coal.

A multitude of cookery books exist, too many to name. These consist mainly of instructions in the preparation of particular dishes. The philosophy of cookery has a very limited literature. In the third, sixth, and tenth essays of Benjamin Thompson, Count Rumford (1796), The Chemis- try of Cookery, by W. Mattion Williams (1885), and Cantor Lectures on The Scientife Basis of Cookery, by the same suthor, the subject in treated as a branch of applied science. Count Rumford's essays also include his remarkable achievements in economic feeding of the poor in Munich, and his improvements of cooking apperratus. Of late, much more attention lias freen bestowed on cookery in Grent Britain, and the board-schools in the principal towns now make provision for instrueting their girl pupils in this important subject. The processes of rossting, stewing, \&c. will be treated under their respective titles. See also DIKT, DigEsTion, and the articles on Brillat-Sayarin and Soyer.

Cook Islands, otherwise known as the Hervey Archipelago, lie about midway between the Society and Navigator groups, near $20^{\circ} \mathrm{S}$. lat., and $158^{\circ} \mathrm{W}$. long., and are some voleanic, some coralline. The principal members of the cluster are Mangaia, Atiou, and Raratonga. The natives, mainly of the brown Polynesian stock, are about 10,000 in all, of whom 6000 are in Raratonga, which is mountainons but fertile. Formerly cannibals, they are now all Christians, and dress after the European fashion. The islands were annexed by Britain in 1888 .

Cook, Mount, the highest peak of Australasia, is one of the Southern Alps near the centre of the range, on the western side of the South Island of New Zealand. It is 12,349 feet high, is covered with perpetual snow (the snow-line being 3500 feet lower than in Switzerland), was scaled for the first time to near the summit by Mr. Green in 1882. See Mannering, With Rope and Axe in the New Zealand Alps (1891)

Cookstown, a town in County Tyrone, Ireland, 53 miles W. of Belfast by rail, with manufactures of linen, and bleach-works. Pop. 3841.

Cook Strait, discovered by Cook on his first voyage, separates the north and south islands of New Zealand, and is 20 to 80 miles wide.

Cooktown, a port (dating from 1873) in the north of Queensland, on the Endeavour River, 1050 miles NNW. of Brisbane, and 122 by rail NW. of the Palmer gold-field. There are handsome public buildings and a monument (1889) to Captain Cook, who beached his ship, the Endeavour, here in 1770. Near there are gold-diggings and tin-mines, pearlfisheries, and fislieries of trepang. Pop. (1891) 2482; at one timeit was 10,000 , three-fifths of them Chinese.

Cooler. See Beer, Refrigeration.

Coolgardie, a mining station in Western Australia, 270 miles NE. of Perth, where, especially since 1893, rich finds of gold have been made. In 1895 a telegraph was established, and in 1896 a railway from Perth was opened.

Coolies (Hind. kuli, 'labourer'), Indian and Chinese lnbourers who emigrate to foreign lands, whether at their own charge or at the expense of the foreigner whom they bind themselves by con. tract to serve for a fixed term of years. Labourens who migrate from one part of India to another, as for instance from Bengal to Assam, are also called coolies. The European and American residents in the treaty ports of China give the same name to the lower class of Chinese labourers in their service.

The natives of India having a strong repugnance to erossing the ocean, free coolie emigration is almost entirely Chinese. Although until recent years emigration from China was illegal, and the strong ties of family affection, the love of country, and ancestral worship, made it unpopular, the pressure of population produced a continual outflow during the 18th and 19th centuries, chiefly from the southern provinces of Fuh-Kien and Kwang. tung. The emigrunts swarmed over the archi- 
pelago, settled by thousands and tens of thousands in Java and in the Straits Settlements, and threaten eventually to displace the natives in Siam and the Malay Peninsula. The discovery of gold attracted large numbers of Chinese to California and Australia. The first railway across the Rocky Mountains was partly made by Chinese labour, and M. Lesseps invited their help for the excavation of the Panama Canal. In spite of his utility, the coolie has become an intolerable offence to the working-classes of America and Australia. $\mathrm{He}$ is accused of gambling, opium-smoking, and immorality ; but the head and front of his offending is his working for low wages, and lowering the market value of labour. In 1881 the United States negotiated a treaty with China, by which restriction of Chinese immigration was secured to the States in return for American prohibition of the opium trade on the coast of China. Another treaty between the two powers in 1888 , prohibiting the entry of Chinese labourers into the United States for a period of twenty years, has been refused ratification by the Peking government. In British colonies the attempt has been made to exclude the obnoxious coolie by the imposition of a polltax. The legislature of British Columbia passed an act in 1884, by which every Chinaman was obliged to take out a license, and pay a fee of \$10. A Chinese, named Wing Chong, refused to pay the fee on the ground that the act was unconstitutional, and an infraction of the existing treaties between Great Britain and China. A judge of the Supreme Court of the colony decided in Wing Chong's favour, and though the colonial government initiated an appeal to the Privycouncil, they failed to prosecute it; so the act became a dead letter. In Australia, similar acts, though quietly submitted to, failed to secure the desired end, Chinese immigrants continuing to arrive, in spite of the heavy poll-tax of $£ 10$ a head. In 1888 the New South Wales legislature passed an act to prohibit the landing of Chinese immigrants; but this ease also the law-courts decided against the legislature. At a conference of delegates from the governments of all the Australian colonies, it was unanimously agreed to endeavour to secure the exclusion of the Chinese, through the negotiation of a new treaty between the British and Chinese governments. The existing treaties which promise protection to the Chinese immigrant are the Treaty of Nanking (1842), the Treaty of Tientsin (1858), and the Convention of Peking (1860).

The coolie in the United States and in some British colonies is an uninvited and unwelcome visitant. At the same time his services have been eagerly sought in other colonies, the governments and planters of which have borne all the expenses of his passage, paid him a small advance, and in addition paid head-money to the agent who obtained him. To recoup this expenditure, the planter required the coolie to bind himself to serve for a term of years at a fixed rate of wages. Coolies thus indentured occupy a similar position to apprentices, soldiers, and sailors. Theoretically the system is quite justifiable, but practically it has shown itself liable to the grossest abuse. The dark story of coolie emigration to Peru and Cuba, carried on from Macao (q.v.), rivals in atrocity the horrors of the slave-trade and slavery. This branch of the coolie traffic was brought to an end in 1873 by an enactment of the Chinese government, requiring that in the contract a clause should be inserted securing to the coolie a free passage home at the expiration of his term. The planters were not willing to incur this obligation; and coolie emigration from Chinese ports ceased. During the years between 1847 and 1873 , there was a fearful loss of life, some perishing on shipboard in vain attempts to recover their liberty, others dying of ill-treatment or disease, or by suicide. The only redeeming feature in this sad business was that some time or other it came to an end. The slave was a slave until death : the coolie could look forward to the end of his contract. In 1878 Consul-general Cowper reported to Lord Salisbury that out of 116,267 coolies actually landed in Havana, about 50,000 were then in Cuba.

Coolie emigration under contract to British and French colonies is mainly Indian, with a small percentage of Chinese in its ranks. Both the Indian and the colonial legislatures have taken great pains to prevent abuse of the system, and with considerable success, although there is evidence that constant watchfulness is necessary. Every step of the process, from the first solicitation of the labourer, until the ship carries him out of port, is regulated by the Indian government. The agents who collect the coolies, the depôts where they are lodged, the contracts they sign, the ships in which they embark, are inspected, licensed, supervised by government. Protectors of emigrants are appointed in Calcutta, Madras, and Bombay, from which ports only the emigration is lawful. In like manner the colonial governments have enacted regulations and appointed protectors, to secure to the coolie limitation of his task, sufficient food, suitable lodging, and medical care in sickness. The imperial government has intervened by conventions entered into with foreign governments, with France in 1861, with the Netherlands in 1870 , to secure the fair treatment of the coolie in foreign colonies. That all this legislation is neither unnecessary nor unfruitful is proved by the case of Réunion. In 1880 M. Rougon reported to the French government that the coolies in this island "were badly clothed, badly fed, badly paid, and badly cared for when sick." The Indian government receiving similar reports, put in force a provision of the Emigration Act, and prohibited emigration to Réunion. The British consul at Cayenne reported that the coolies in French Guiana suffered 'barbarous and inhuman treatment; ' and in 1876 emigration to that colony was stopped. According to the Indian Emigration Act of 1883 , at present in force, emigration under contract is lawful to the following places: British colonies-Mauritius, Jamaica, British Guiana, Trinidad, St Lucia, Grenada, St Vincent, Natal, St Kitts, and Fiji; French colonies-Martinique, Guadeloupe; also to Dutch Guiana, and the Danish island, St Croix. In 1886 the Jamaica government suspended immigration from China and India to that colony. In Trinidad the coolies, about 55,000, are one-third of the population. They are usually well fed, not overworked, and are well treated in sickness. A large proportion elect to remain in Trinidad when they are entitled to a passage back to India; and of those who go, a large number take sums of money with them, and not a few, having gone back to India, return again to Trinidad. Some coolies, too, remain on particular estates for many years. Occasional cases of injustice or illtreatment no doubt occur, but on the whole the coolie is well used (Governor Norman's report, 1885). On the other hand, there are unfavourable reports from Mauritius, where the Indian coolies number in round figures 150,000 . There are about 25,000 in Natal, 13,000 in Jamaica, and 70,000 in the French colonies.

Coolie contract labour in India is regulated by the Inland Emigration Act of 1882, which relates to 'emigration from other parts of India to the labour distriets of Bengal and Assam.' Its provisions are similar to those of the Indian Emigration Act. of 1883. Every possible precaution which a government can take appears to have been taken 
nevertheless complaints of unfair and even eruel treatment of the coolies are heard from time to time. The coolie traffic between the southern ports of Indis and Ceylon is constant and mutually advantageous; about 70,000 go from India every year, of whom three-fourths return, and the rest settle in the island.

The islands of the Pacific have been the scene of a so-called labour trale, in respect to which Sir Arthur Kennedy, governor of Queensland, wrote in 1881 : 'I have never concealed my opinion of the trattic in Polynesian savages, and I feel assured that scandals exist which do not reach the public.

I have had many years' experience in the West African slave-trade and the Clinese coolie-trade, and I cannot divest myself of grave fears that the Polynesian labour-trade partakes of many of the evils of both.' A Royal Commission of Inquiry was appointed in 1884; the existence of kidnapping was proverl; and 404 kidnapped islanders (called 'Kanakas') were restored to their homes.

The literature of this subject consists chiefly of parlismentary papers and government reports. Besides those referred to above, the following may be named: Corre spondence, Papers, or Reports on the Macao Coolie Trade (1871 to 1875); on Coolie Emigration from India (1874); on the Coolies in Assam (1867), in Surinam (1877), in Trinidad (1885); on Coolie Importation from India to French Guiana (1878); and on Chinese Immigration into the Anstralasian Colonies (1888). The West Indies and Spenish Main, by A. Trollope (1860); The Corlie: his Rights and Wrongs, by E. Jenkins (1871); In Quest o Coulies, by J. I. A. Hope (1872); Charles Kingsley's At Lout (1872), and Churchyard's Blackbirding in Southern seas (1888), may be consulted.

Coomassie, the capital of the kingdom of Ashanti, Western Africa, is situated about 120 miles NNW. of Cape Coast Castle. It occupies the side of a rocky hill, and is abont four miles in circuit. The walls of the houses are mostly formed of stakes and wattle-work, the interstices being filled up with clay; the roofs are of palm-leaves. The king's palace was burned by Wolseley in 1874, but has been rebuilt (see AsHANTI). Pop. stated by natives to be 100,000 ; but other reports, including observations during the war, say 20,000 . See Reade's Coomassie (1876).

\section{Cooper, Ashley. See Shaftesbury.}

Cooper, Sir Astuey, surgeon, was born, a clergyman's son, at Brooke Hill, Norfolk, 23d August 1768. In his seventeenth year he went to London, and became a pupil of Mr Cline, one of the most noted surgeons of his day. He devoted himself with ardour to his profession, and was a constant attender at the dissecting-rooms, and also at the lectures of the famous John Hunter. In 1789 he was appointed demonstrator of anatomy at St Thomas's Hospital; and two years after he assisted in the lectures on anatomy and surgery. In 1793 he was appointed lecturer on anatomy at the College of Surreons, in 1800 surgeon to Guy's Hospital; anl in 1813 professor of Comparative Anatomy in the College of Surgeons. Meanwhile, Cooper had heen enriching medical literature by various contributions. An eseay on the effects resulting from the destruction of the membrana tympani gained him, in 1802, the Copley medal of the Royal Society, of which he was elected a fellow three years afterwards. In 1804-7 appeared his great work on Hernia, with life-size illustrations, a contribution of the utmost value to melical science, though in a pecuniary point of view it proved very unurofitable to himiself. The practical part of his profession was not neglected during this time. He was the first to attempt the tying of the earotil artery, an attempt which, though unsuccessful in his hands, has since proved effectual in the hands of other practitioners. His annual income, which in the fifth year of his practice only amonnted to 2100 , had in 1813 risen to the enormous sum of $£ 21,000$. In 1817 he tried what has been considered the boldent experiment ever attempted in surgery, the tying of the morts, which did not prove successful. In 1820 Conper removed a tumour from the heal of George IV., who conferred a baronetey upon him some six months after. In 1827 he was elected President of the College of Burgeons, in 1828 became sergeant-surgeon to the king, and in 1830 was made vice-president of the Royal Society. Other honours flowed in upon him. He was made a member of the French Institute, and correspond. ing member of the Royal Acrulemy of Sciences, a D.C.L. of Oxford, and an LL.D. of Elinburgh. Ever busy with his pen as with his knife, he in 1822 published a great work on Dislocations and Fractures. His treatise on the Anatomy and Diseases of the Breast (1829-40) was characterised by all the care, research, and originality which dis. tinguished his previous works; so likewise was his Anatomy of the Thymus Gland (1832). Cooper died 12th February 1841, and was buried in the chapel of Guy's Hospital. A colossal statue to his memory is erected in St Paul's Cathedral, London. As a teacher, Cooper possessed the faculty of communicating knowledge in a manner at once easy and agreeable; and he elevated medical surgery, the operations of which before his time had been described as a series of 'frightful alternatives, or hazardous compromises,' into a science. See his Life ( 2 vols. 1843 ).

Cooper, James Fenimore, a distinguished American novelist of Quaker descent, was Gorn as Burlington, N. J., Sept. 15, 1789.

His father was a man of wealth and Federalist member of con.

Ooprright 19as, 18en, and 1900 in the U.S. by 2.

gress. In 1790 the family removed to Cooperstown, N. Y., then in a wild frontier region of great natural beauty. Cooper entered Yale College in 1802, a boy of thirteen. After remaining there three years, he was dismissed for some minor act of alleged misconduct. In 1806 he shipped as a common sailor, and in 1808 entered the navy as a midshipman. He rose to the rank of a lieutenant, but in 1811 resigned his commission, and married Susan, a sister of Bishop De Lancey of New York. His first novel, Precaution (publislied anonymously in 1819), was a failure. It was followed by thirty-two tales of extremely unequal quality. Among those of merit we may name. The Spy (1821), The Pilot (1823), The Last of the Mohicans (1826), The Prairie (1826), The Red Rover (1831), The Bravo (1831), The Pathfinder (1840), The Deerslayer (1841), The Two Admirals (1842), Wing-and-Wing (1842), and Satansto (1845). His other writings include a meritorions Naval History of the United States (1839; abridged edition, 1841), and Lives of Distinguished American Naval Officers (1846). His works of fietion have long enjoyed great popnlarity ; and his best productions, in spite of conspicuous faults, well deserve all the favour they have received. His sea-tales and stories of frontier life are in all respects his best. Cooper's descriptive talents were of very high order; and some of his characters, such as 'Natty Bumpo,' 'Long Tom Coflin,' 'Birch,' 'The Big Serpent,' and especially 'Leather-Stocking,'are drawn with as much strength and life as almost any in the whole range of fiction. The peace of many of the later years of his life was much disturbed by literary and newspaper controversies and actions for libel, in nearly all of which he was snceessful. He conducted his own lawsuits, and usually pleaded his own cases with admirable tact and ability. One good result of these suits was to put upon the newspaper press of his own time and country some degree of restraint from the scandalously savage and virulent freedom of speech 
which then prevailed. On either side of the Atlantic Cooper's own severity of language won him no small amount of personal unpopularity; yet no man loved his own country better than he; and his high regard for the nobler side of the English character, and his appreciation of the grand achievements of British history, found frequent expression in his writings. These writings, other than the best of his novels, contained much to excite opposition, and they brought upon him, not altogether undeservedly, the reputation of being a proud, contentious, and somewhat wrong-headed man; yet there was in his real character much sweetness, as well as great strength, purity and dignity, and unqualified honesty. His pride was large, but it was not mixed with personal vanity. It has been well said that his faults were those of temper and judgment, rather than of character. He died at Cooperstown, September 14, 1851. The best biography is by Lounsbury (1882).

Cooper, Peter, manufacturer and philanthropist, born at New York, 12th February 1791, assisted his father in his successive occupations of hatter, brewer, and brickmaker, and served an apprenticeship to a carriage-builder, 1808-12. He next made independent ventures as a machinist, cabinetmaker, and grocer, and established a glue factory on Long Island. He erected large ironworks in Baltimore in 1828, and in 1830 constructed there, from his own designs, the first locomotive engine ever built in America. He afterwards built an iron-wire factory in New York, and large blast-furnaces in Pennsylvania; and he was largely instrumental in bringing about the laying of the Atlantic cable. To provide the working-classes with educational advantages, of which he himself had enjoyed so few, he erected and endowed the Cooper Union (1854-59), one of the most useful institutions in New York, where free lectures, reading-room, art collections, and technical schools have been provided. In 1876 he received the Independent nomination for president. He died in New York, 4th April 1883. See Life by Mrs Carter (1889).

Cooper, Thomas, the Chartist poet, born at Leicester in 1805, was apprenticed to a shoemaker at Gainsborough, taught himself Latin, Greek, Hebrew, and French, and became a schoolmaster at twenty-three, and at the same time a local Methodist preacher. After reporting for some of the newspapers in the Midlands, he became leader of the Leicester Chartists in 1841, and was an active editor of tracts. He lectured in the Potteries during the riots in August 1842, was arrested on a charge of conspiracy and sedition, and sentenced to two years' imprisonment in Stafford gaol. Here he wrote The Purgatory of Suicides, a poem in the Spenserian stanza, and Wise Saus and Modern Instances, a series of tales, which were both published in 1845. Next year appeared his Baron's Yule Feast, a Christmas Rhyme, and a series of papers headed 'Condition of the People of England" in Douglas Jerrold's Newspaper. In 1848 he began to lecture on history and polities in London, and set up the Plain Sueaker and Cooper's Journal, two short-lived penny weeklies. He published two novels, Alderman Ralph (1853), and The Family Feud (1854), and about the end of 1855 relinquished the sceptical opinions he had held since his imprisonment, and became an active lecturer on Christian evidences, In $1867 \mathrm{a}$ number of his friends purchased for him and his wife an annuity of $£ 100$. Cooper published his Autobiography in 1872, and Poetical Works in 1878. Died July 15, 1892.

Cooperage, the art of making vessels of pieces of wood bound together by hoops. It is a very ancient art, such vessels having been in use among the Romans at the period of the Christian era. The upright pieces forming the sides of a barrel or cask, or other cooper's work, are called staves; and as casks are usually larger in the middle than at the top and bottom, this swelling, called the belly or bulge, is formed by skilfully shaping each stave so that it shall form part of the required double conoid, and that, when all are built and hooped together, their edges shall coincide perfectly ; for this purpose each stave is made broadest in the middle, and narrowed down in a curved line towards each end. A skilful cooper can work this curve so accurately, that no further fitting or alteration shall be needed when the staves are put together. The staves are made to meet at their inner edges, and by driving the hoops very hard, the inner part is compressed until the slight gaping outside is closed, and thus slight inaccuracies of fitting are remedied.

There are several branches of cooperage. The wet or tight cooper makes vessels for holding liquids. The $d r y$ cooper does inferior work, such as barrels for containing dry goods, where an inferior degree of accuracy is sufficient. The white cooper makes churns, pails, \&c., which for the most part have straight sides.

The best work is made of oak, which must be thoroughly dried before being put together. In warm countries, the drying of the sun is sufficient, and casks are therefore mounted in summer only; but in Britain, artificial drying is commonly resorted to. The hoops are hammered down from the narrow to the wide part of the cask, by means of a mallet striking a piece of wood held against the hoop. Iron hoúps are sometimes put on hot, in order that their contraction on cooling may bind the work together. Most ingeniously constructed machinery is now generally used in barrel-making.

Cooperage, on the North Sea, is that demoralising system of selling or bartering strong drink, tobacco, or other articles, to fishermen or sailors, from Dutch or other foreign vessels called copers (Ger. kaufen, Dut. kopen). They ostensibly cruise with the English fishing-fleets to sell foreign tobacco on which no duty has been paid, and what on shore would cost four shillings per pound is sold for eighteenpence. The trade began more than fifty years ago by foreign vessels from Dutch ports trading with English smacksmen in articles of clothing, which grew into the more profitable barter and sale of tobacco and spirits. An English smack, until the insurance company refused to insure her, has been known to take ont $£ 500$ worth of grog and tobacco, and clear another $\mathfrak{f 5 0 0}$ in two months in the traffic. To counteract the evils of the system, Mr E. J. Mather, in 1882, started a mission for the deep-sea fishermen, which in 1888 had at command eight mission ships, stored with good literature, woollen clothing, tobacco, and medicine, and a staff of twelve clergymen as honorary chaplains. The Customs Commissioners refused the necessary concessions for the sale of tobaceo at a cheap rate in 1885 , but granted the same in 1887 , and now the ordinary drawings of a voyage may be $£ 100$ for tobacco. The Queen became the patron of the mission, and it is duly registered by the Board of Trade. As a result of an international conference at the Hague between the six fishing powers, a convention was signed in 1887, one of the provisions of which contemplated the absolute prohibition of the sale or barter of spirits on the North Sea. The North Sea Fisheries Bill (1888) gave effect (as far as Great Britain is concerned) to the recommendation of the convention. The sale of spirits to fishermen and others on board fishing-vessels is prohibited; fishermen are forbidden to buy spirits at sea ; the exchange or barter for spirits of any article, especially the fish eaught, 
nets, or gear of the fishing-hont, is also pro. hibited. Vessels trading in provisions, \&e. must be licensed, and penalties from $£ 10$ to $£ 50$ are exigible for oflences against the convention. See E. J. Mather's Nor'ard of the Dagger (1887).

Co-operation. In the social and economic sense of the word, co-operation generally mems the association of work-people for the management of their own industrial in terests, in store, workshop, or other undertaking, and the equitable distribution of profits among those who earn them. In Great Britain it has succeeded best in distribution, that in, in the form of co-operative stores for the supply of the domestic wants of the workmen's families; in Germany and Italy it has flourished chiefly under the form of people's banks, for furnishing mutual credit to workmen and also small tradesmen. Co-operative production has not yet made correxponding progress. The co-operative movement acquired vitality with the foundation of the lioch. dale Society of Equitable Pioneers in 1844. Before that date there had been instances of co-operative industry among English miners, New England fishermen, and the Greek sailors of the Levant. In Great Britain there exist even yet co-operative societies, which were founded prior to 1844 ; one at Govan, eaid to have been established in 1777, and another at Hull, started in 1795. The earliest in England, however, was that founded in 1794 at Mongewell, in Oxfordshire, by Shute Barrington, Bishop of Durham. During the Owenite agitation from 1820 to 1845 , the movement began to assume national importance, hundreds of societies rising up, which for the most part rapidly disappeared. By general consent it is agreed that the movement took practical and permanent form with the Roch. dale Pioneers (1844). The founders were twentyeight weavers, nearly all of whom were socialists of the Owen school and Chartists ; and their original eapital was $£ 28$, painfully collected by subseriptions of twopence, afterwards raised to threepence a week. With this capital they opened a store for supplying themselves with provisions, but at first they had only four articles to sell-flour, butter, sugar, and oatmeal. Their success, which was steady and rapil, was chiefly due to their device of limiting interest on shares to 5 per cent. and dividing profits among members in proportion to their purchases. By 1857 they had a membership of 1850, a capital of $£ 15,000$, and annual sales to the amount of $£ 80,000$. Their society, its organisation and methods of conducting business, became a model to the working-men in the north and centre of England, as also in Scotland. In this way the movement rapidly spread, and the societies are now over 1400 in number, with nearly a million members. In 1864 the Wholesale Society for the supply of commodities to the varions stores was established at Manchester, and a second at Glasgow in 1869; but the two work in harmony, and may be considered as one institution. In 1871 the Co-operative Neves was started as the organ of the co-operators. Since 1869 national congresses of co-operative aocieties have been held every year in one or other of the large towns of Great Britain. These may be regarded as the annual parliaments of co-operators. The efforts after organisation culminated in the consolidation of the Co-operstive Union with a regular constitution drawn up in 1873. Subject to the congress, the Union is governed by a U nited Board of twelve members, representing the six sections into which the union is divided. The sectional boards have monthly meetings of their own. The Central Co. operative Board, consisting of all the members representing the six sections, comes together for business only at meetings of congress.

Having thus sketehed the general development of English co-operation, we shall now more speci. fically indicate the rules and organisation of the societies. Any one may become a member on paying an entrance fee of one shilling, and memleers may pay up their shares at the rate of threepence a week. Shares are uxually one pound each, and one or two of these shares, trans. ferable but not withdrawable, constitutes all the capital a member is required to hold. The other ahare capital that a member may hold is withdrawable. The interest on eapital is limited to 5 per cent. Goods are sold at the prices eurrent among respectable shopkeepers in the neighbour. hood, and after paying expenses the nett profits are diatributed quarterly among the members in proportion to their purchases. These dividends may be allowed to accumulate in the store, but no member is permitted by law to hold more than £200. The general rule is that payments be made in ready money, a system to which co-operation largely owes its success, but which is not yet nniversal. At the congress of 1888 complaints were made that the credit system is to some extent permitted. Irrespective of the amount of his investments, each member has only one vote. The members elect a committee for the management of the business. The committees have frequent meetings, and control the employees of the store. The members themselves hold guarterly and in many cases monthly meetings. The Wholesale Society is a federation of retail societies, which have to take up shares, and they participate in the management in proportion to their membership. The Wholesale is a large and growing organisation for the supply of goods to the various societies composing it, with purchasing and forwarding depots not only in England and Ireland, but in New York, Hamburg, Copenhagen, Calais, and Rouen. It owns five steamships, which ply between England and the Continent. It has also extensive productive works, as boot and shoe factories at Leicester, soap-works at Durham, woollen-cloth works at Batley, \&c. Besides the productive works thus conducted by the Wholesale Society, there are a number of societies for production alone, societies for working corn-mills, and a number of retail societies which carry on eorn-mills and various branches of domestic production. The annual production by societies adhering to the Co-operative Union may probably be estimated at about $\$ 5,000,000$. In addition to the societies already mentioned, there is a co-operative fire and life insurance society, and the $\mathrm{Co}$ operative Nevos Society, started in 1871 for carry. ing on the organ of the co-operators. It should also be mentioned that the societies spend considerable sums in edueation.

Statistics of English (o-operation, taken from the report of the Co-operative Congress for 1888: Connected with the Co-operative Union, were (in 1887 ) 1432 societies, with a membership of 945,619 , a share capital of $£ 10,012,048$, and sales to the amount of $£ 34,189,715$, on which profits to the amount of $£ 3,193,178$ were made. In 1895 the membership was $1,414,158$, the share enpital $\mathbf{f 1 6}, 164,667$, the sales $£ 52,512,126$ (with a net profit of $£ 5,397,582$ ). Co-operative manufacturing as well as co-operative distribution was steadily extending-the latter type, however, much more slowly than the other. Ábout one-sixth of the population of Great Britain have their wants in whole or in part supplied through co-operative stores.

Co-operation in England is thus already one of the established institutions of the country, the importance of which has been recognised alike by statesmen and economists. Though essentially a workmen's movement, it should be said that is owes much to the enlightened and philanthropic guidance of men of other classes, to Robert Owen, 
Maurice, and Kingsley. Messrs Neale, Holyoake, Hughes, Ludlow, and the Marquis of Ripon have also powerfully aided in promoting it.

In the United States of America co-operation has not made such progress as might have been expected from the energy and spirit of initiative prevalent among the people. Though co-operation had previously existed among the fishermen of New England, the Brook Farm (q.v.) experiment may, be regarded as the starting-point of the movement. Co-operative business in New England may in an average year reach the following figures: In distribution, $£ 600,000$; productive co-operation, exelusive of dairies or creameries, $£ 200,000$; creameries, $£ 150,000$; banks, $£ 800,000$-in all, about $£ 1,750,000$. In Philadelphia, co-operative building societies have provided the workmen with from 80,000 to 100,000 homes. The same form of co-operation flourishes in other parts of the country. A notable and thoroughly successful effort in productive cooperation has been made in the coopering trade at Minneapolis since 1874. In 1882 the students of the university of Harvard formed a cooperative society for supplying themselves with books, stationery, and other articles. The movement has been a success, and has been imitated by the universities of Yale and Michigan. The general result, however, of a study of co-operation in America is that while the experiments have been numerous, varied, and in many cases successful, its influence has been on a limited scale. The rewards offered to every kind of exceptional capacity in private enterprise are so enormous, the scope for the development of individual energy in all directions is still so great, that the workmen have not yet widely realised the necessity for industrial association among themselves. Many important firms have, however, successfully introduced the system of sharing profits with their work-people. Complaints are made that the laws of some of the states do not offer reasonable facilities for the formation of co-operative societies.

In France the industrial partnership system, by which the capitalist gives his workmen a share in his profits, has made greater progress than the co-operative movement properly so called. At the revolution of 1848 the government gave some scanty subsidies to co-operative production, but only a few of the societies prospered. Even yet cooperative stores, co-operative banks, and societies for co-operative production have only had a limited success. See Profit-SHARING.

In Germany co-operation has flourished greatly in the form of people's banks. These originated in 1849 under the auspices of Schulze-Delitzsch, at the little town of Delitzseh in Saxony. In 1885 there were 3822 societies belonging to the SchulzeDelitzsch system, of which 1965 were credit societies, 678 for distribution, 493 for the purchase of raw material, \&c. The societies had an aggregate membership of $1,500,000$, a share and reserve capital of $£ 15,000,000$, a loan capital of $£ 25,000,000$, and did an annual business of $£ 150,000,000$. Since 1859 they have held annual congresses. Schulze-Delitzsch was salaried counsellor (anwalt) or general manager of the societies till his death in 1883 . In 1885 there were 145 productive associations in Germany. While there were in 1873 only 6 co-operative dairies in Germany, there were 226 of them in 1885. In addition to all these, in 1884 there were 800 societies (called after Raiffeisen, their founder), whose function it is to provide mutual eredit for the small farmers of Germany. In 1895 there were (including the last-named) in all Germany 11,141 societies, of which 647 were credit societies. Austria had in 1894,2050 associations, besides some 500 in Hungary.

In Italy co-operation is making great progress, chiefly in the form of people's banks. In 1883 there were 250 such banks. At the end of 1885 their number had increased to 423 , with $£ 2,500,000$ of share capital and about $£ 13,000,000$ of loan capital. In 1895 there were 950 . Co-operation in other forms also is rapidly making way-there are co-operative dairies, and besides there are many co-operative bakeries, established with a view to checking the ravages of Pellagra (q.v.) by the supply of wholesome bread. Such institutions receive the support of the Italian government.

In Belgium the co-operative movement has established itself on a very considerable scale at industrial centres such as Ghent, in stores, bakeries, and in co-operative fisheries.

In Denmark co-operative dairies have recently been making wonderful progress (see DAIRY).

The various Professional and Civil Service stores are simply a result of the application of the co-operative system for the supply of the wants of the middle classes, especially the professional classes and clerks, begun in 1864; and these stores now do a very large business, the largest being the Army and Navy Stores in Victoria Street, London. The salient difference between this middle-class cooperation and that of the working-men is that the former admits of the system of privileged shareholders, whereas all the benefits of the latter are open to every one who pays an entrance fee of one shilling.

From the above facts it will be apparent that the purpose and tendency of the co-operative movement is that the workmen, through the principle of associated industry, by means of a joint capital, should equitably manage their own aftairs so far as they can. Such management, we have seen, has been applied on a large seale to distribution and to people's banks, and has had a considerable success also in various forms of domestic production, as in corn-mills, bakeries, boot and shoe factories, dairies, \&c. In the large and staple branches of manufacture it has as yet done very little. But so far as it has gone, the movement has been a real and effectual training for the intelligence, business capacity, and moral character of the workmen. It has taught them thrift, foresight, self-control, and the habit of harmonious combination for common ends; and it has opened up an unlimited field for peaceful, hopeful, and successful effort in the future.

See Holyoake's History of Co-operation (2 vols.), and his Self-help a Hundred Years Ago (1888); the reports of the Co-operative Congress; Working-men Co-operators, by A. H. D. Acland and B. Jones (1884); Reports on Co-operation in Foreign Countries, a blue-book issued in 1886; English Associations of Working-men, by Dr Baernreither (1888). See also History of Co-operation in the United States, published under the auspices of Johns Hopkins University (Baltimore, 1888).

Cooper's Hill, a ridge on the borders of Berks and Surrey, commanding a beautiful view of the Thames valley. It was the scene of a famous poem by Denham (q.v.), and is now known in connection with the Cooper's Hill College, an important institution established in 1870 for the education of engineers for the Indian Works Department, to which a forestry school (1885) is attached.

Co-ordinates. See Geometry (Analytical).

Coorg (a corruption of Kodagu, 'steep mountain'), a province under the government of India, on the eastern slope of the western Ghats, and bordering on Mysore. Area, 1583 sq. m.; pop. (1881) 178,302 ; (1891) 173,055-a decrease. The capital is Merkara (pop. 8500). Coorg is mainly within the basin of the Kaveri River; great part of its area is 3000 feet above the sea. The yearly rainfall is 122 inches, and hence the temperature is humid. Nearly the whole of this rugged 
region is covered with forests, which form the main natural wealth of the country, though gold and iron are found. The natives, a branch of the Dravidian stock, speaking a language akin to Kanarese, are handsome and athletic mountaineers. Agriculture is linited to the valley. Coflee (injured recently by diserase), cardamom, and cinchona are grown. Polyandry used to be the rule. Cairns and dolmens are common, and the country is intersected by earthen ramparts, which are from 15 to 25 feet in height, with deep ditehes.

Coot (Fuliur), a water-bird in the same family as the rails (Rallidre), and in the old order Grallæ. The members of the genus are well marked by $\mathrm{B}$ sealloped fringe round the long toes, which thus show sn approsch to the webbed condition. The leak is straight and short, but expands in a curious swollen patch on the front of the forehead. The tail is very short. The coots are essentially aquatic, almost always afloat, and especially frequent still waters. They feed on water-plants and small animals. The European species generally migrate southwards in winter.

The Comnon Coot ( $F$. atra) is widely distributed in Central and South Europe, and in Western Asia. It is about 16 inches in length, and has a

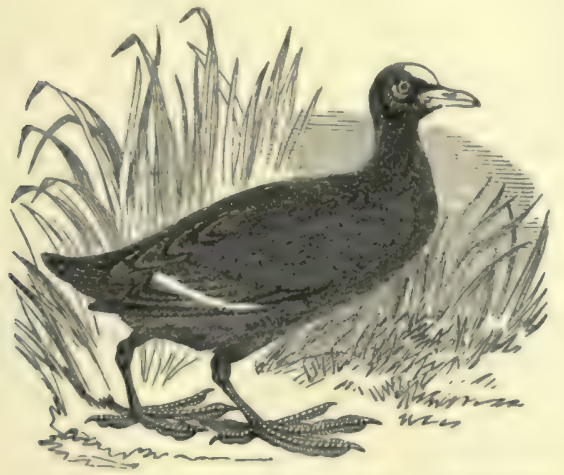

Common Coot (Fulica atva).

predominantly slaty black colour, with a narrow white band across the wings. The bill and the bald forehead expansion are bright white, the feet more or less green. Coots make a large rough nest of water-plants and stems among the rushes, or on a rock in the middle of the stream. They are not much exteemed for eating, but are readily and often shot in large numbers when congregated thickly on the mud-banks. In the north of Scotland the cont is only a summer bird, but in the south of England they stay all the year. The American Coot ( $F$. americana) is common in all parts of North America.

Coote. Sir Eyre, soldier, born in County Limerick in 1726, entered the army at an early age, and from 1754 to 1762 served in India. It was by his arguments that Clive was induced to risk the battle of Plassey, and for his services in this and other engagements, Coote was in 1759 given the command of the newly-raised 84th regiment. In 1760 he defeated Lally-Tollendal $(q . v$ ) at Wandiwash; and his capture of Pondicherry in 1761 completed the downfall of the French in India. Coote returned to England, and was knighted in 1771. In 1779 he assumed the command-in-chie in Indin, with the rank of lientenant-general, and in 1781 he routed Hyder Ali at Porto Novo; his victory here, with the successes that followed, a second time saving the presidency. He died at Madras, 26th April 1783.
Cootehill, a town in County Cavan, Ireland, 88 miles NW. of Dublin. Pop. 1589.

Copaiba, or Coparva, Balsam or, a valuable drug, consisting chietty of a resin (resin of copaiba) and a volatile oil (oil of copaiba). It flows from incisions in the stems of various species of copaifera trees, natives of the American tropics, which belong to the natural order Leguminose. When these treen become old or surcharged with copaiba, it is no un. usual thing for the stems to burst with a loud booming sound. The balsam has a peculiar, aromatic, but not disagreesble odour, which, however, is highly persistent, while its taste is decidedly acrid. It has stimulant properties, is diuretic, laxative, and in large doses often an active purgative. It is, however, mostly on account of its powerful action on the mucous membrane that it is used, and it is accordingly much employed in affections of the urino-genital system, in chronic catarrhs, \&c. The resin itself has been found efficacious given in the form of a cough-pill. Balsam of copaiba is sometimes adulterated with castor-oil or volatile oils. The former of these is readily detected if any milkiness is produced when the balsam is shaken with ten times its volume of petroleum benzin. The volatile oils may be recognised by shaking the balsam with a little alcohol, when, being more soluble, they are removed first.

Copais, Lake. See Boeotia.

Copal, a resinous substance used for a variety of purposes in the arts. It appears in conmerce in smooth rounded masses, colourless or lemonyellow, translucent or transparent, rather brittle, and in a cold state, almost without smell or taste. It is readily fusible and inflammable, is insoluble in water, and only partially soluble in alcohol and oil of turpentine, but becomes entirely soluble in them when it has been for a short time melted. Various useful pale-yellow or almost colourless varnishes and lacquers are made by dissolving melted copal in alcohol, oil of turpentine, or boiled linseed-oil. The chief sources of copal are the East Indies, Africa, and South Ameries, but the varieties derived from these countries differ in their origin. The East Indian is the exudation of a large tree, Vateria Indica, and possibly also of different species of Hymenea, which probably yield the Brazilian variety. Zamzibar supplies unst of the best copal. Gum Anime is the name applied to copal frequently found in rounded masses embedded in sandy soil.

Copalchi Bark, a bark resembling Cascarilla Bark (g.v.) in its properties, and produced by a shrub of the same genus, Croton niveus, a native of Central Americn (see CrotoN). The bark is in quills a foot or two in length, and has a thin corky epidermis Copalchi Bark is much used as a sub. stitute for cinchons in Mexico, where it goes by the name of Quina blanca, and is injported, al though not to a large extent, into Europe. It contains a minute proportion of a bitter alkaloid resembling quinine.

Copan, an Indian village in the south-western comer of the Central American state of Houduras, in a mountainons region, the site of a city still populous at the time of the conquest, and of which magnificent ruins still remain, first described by Stephens.

Coparcenary, an estate in England orig. inating in descent to two or more persons, called thence coparcenans or parcenars. It generally arises under the rule of law which makes the daughters of one dying without male heirs inherit equally, but it may also arise by local custom, as in the case of Gavelkind (q.v.). Although the property remains undivided, yet each parcenar is entitled to a dis- 
tinct share of it, and consequently there is no benefit of survivorship as in joint-tenancy, but the right of each descends to his or her heirs. The rule of descent is also per stirpes, so that the heirs of one who has predeceased the common ancestor take only the share which would have come to their iminediate ancestor had he or she survived, and thus in the rare case of gavelkind a grandson of the common ancestor will also exclude his own sisters. Division may be carried through by voluntary agreement, or by a suit in Chancery. Such parts of the property as cannot be divided (such as the manor-house, \&c.) pass to the eldest sister or her issue, but an equivalent in value is assigned to the remaining sisters. These principles resemble closely the law of common property in Scotland, as to which the right of individual management extends only to necessary operations, not to extraordinary use of the subject. Each pro indiviso owner may sell his right, and, except in the case of conjunct rights to husband and wife (which are considered indivisible), may insist on an action of declarator and division. If the subject is naturally indivisible, as a brewery, it may be sold and the price divided. In the case of heirs. portioners in Scotland, also, such things as a peerage, a public office, or a mansion-house with accessories form a procipun for the eldest sister. Where the procipuum comes under a settlement, compensation is generally due to the younger sisters. An Advowson (q.v.) is exercised in turns, according to seniority.

\section{Co-partnery. See Partnership.}

Cope (Lat. cappa, pluviale), an ecclesiastical vestment worn in the Latin Chureh during processions, solemn lauds and vespers, and other

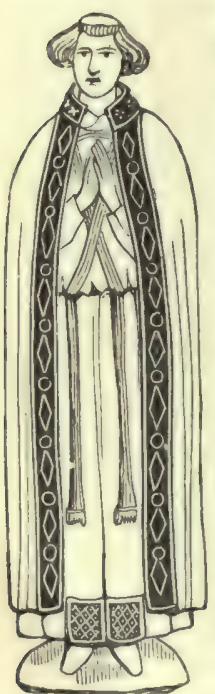

Cope. solemnities, but not by the celebrant at mass. The Greek form of the cope ( manduas) is restricted to archimandrites and bishops. The cope of the former is plain, that of the latter with a pattern of wavy stripes. The Armenians alone use the cope as the vestment for mass. In the Church of England the cope was allowed as an alternative to the vestment or chasuble by the Common Prayer-book of 1549. Both were forbidden by that of 1552, but legally revived under Elizabeth in 1559. By Canon xxiv. of 1603 , the principal minister at the Holy Communion in cathedral or collegiate churches, together with the epistoler and gospeller, is directed to wear the cope, and at Durham it was so worn till Bishop Trevor's episcopate (175271), when one of the prebendaries disused it, finding it interfered with his wig. The cope, however, has been customarily worn by the clergy officiating at coronations; while some further revival of its use has taken place of late years. The cope was originally a cloak worn for ordinary purposes. In form it is a semicircle, without sleeves and with a hood. It is fastened across the breast with a clasp or morse. Copes soon began to be ornamented with embroidery, and even with jewels; and so early as the 13th century they became the most magnificent and castly of all the vestments of the priesthood.

Cope, Charles West, R.A., subject-painter, was born at Leeds in 1811, the son of a landscapepainter. He attended the schools of the Royal
Academy, and studied for two years in Italy. He began to exhibit in the Academy in 1833, and produced a long series of sacred, historical, and domestic subjects. In 1843 his eartoon, "The First Trial by Jury,' gained a $£ 300$ prize at the Westminster Hall competition; and in 1844 he was selected to execute, in the House of Lords, a mural painting of 'The Black Prince,' which was followed by 'Prince Henry,' and in the Peers' Corridor a series of eight subjects from the Civil War, completed about 1865. He was elected an A.R.A. in 1843 , and an R.A. in 1848 ; and from 1867 to 1874 he held the professorship of Painting. He retired in 1883. He was an original member of the Etch ing Club, and his plate of 'The Lifo Class of the Royal Academy' (1865) ranks as one of the most vigorous figure-subjects ever etched by an Englishman. Died August 21, 1890.

Cope, Edward Drinker, American naturalist, born in Philadelphia, 28th July 1840, was professor of Natural Sciences at Haverford College, 1864-67, and afterwards appointed palrontologist to the United States Geological Survey. His numerous papers and works on palæontology are highly valued; and to the discussion of the theory of evolution he contributed over a dozen works of importance. He was a member of numerous scien. tific societies in America and in Europe, and among other recognitions of his services to science, he, in 1879, received the Bigsby gold medal of the Royal Geological Society. Died April 12, 1897.

Cope, Sir JoHn, an English general, was a cornet in 1707, and, having been made a Knight of the Bath, in 1742 commanded the troops sent to the assistance of Maria Theresa. On the landing of Prince Charles Edward in 1745, Cope was commander-in-chief of the government forces in Scotland. After a fruitless march to the Highlands, he returned with his troops by sea to Dunbar, and on 2lst Sept. was totally defeated at Prestonpans. His defeat is celebrated in the Jacobite song, 'Hey, Johnnie Cope, are ye waukin' yet?' Cope died 28 th July 1760. See Life by Cadell (1899).

\section{Copec. See Kopeck.}

Copenhagen (Ian. Kjöbenhavn, 'Merchants' Haven'), the capital of Denmark, and headquarters of the national commerce, literature, and art, is situated on the low-lying eastern shore of the island of Zealand, in the Sound, which is here about 12 miles broad; an outlying portion, Christianshavn, stands at the north end of the island of Amager or Amak, which is separated from Zealand by a narrow arm of the sea. The channel forms a fine and capacious harbour, which is bridged over so as to connect Christianshavn and the main part of the city at two points. The fortifications on the land side have been removed since 1863; so that the city has now practically incorporated the suburbs Österbro, Nörrebro, Vesterbro, and Frederiksberg. The total population in 1735 was 60,000 ; in 1835 , 120,000 ; in $1880,235,254$; and in 1890 it was, with suburbs, 375,215 . To counterbalance the expected injury to the city's commerce from the opening of the Baltic Canal, a great free port (free from customs. dues) was constructed in 1890-94 to the north of the harbour. The business quarter stretches from the harbour in a north-east direction towards the principal and central square, Kongens Nytorv, which in itself forms the focus of the life of the city. Farther north and east of this point lies the aristocratic quarter, with the handsome Amalienborg Square and its royal and ministerial palaces; this district is bounded in the extreme north by the citadel and the adjoining public gardens and walks on the shores of the Sound.

Amongst its few buildings of historical interest or intrinsic beauty, the metropolitan cathedral 
ehureh, known as Vox Frue Kirke, rebuilt after the bombardment of 1807 , possesses statues of Christ and the Apostles, and a baptismal font, designed and in part executed by Thorwaldsen. Trinitatis. kirke is remarkable for its round tower, which is ascended by a winding causeway instead of steps; and Holmens' Kirke contains interesting monuments to the great naval heroes, Juel and Tordenskjold. An English church, built at a cost of $\mathbf{f 1 0 , 0 0 0}$, was consecrated in 1887 . The royal palace, called ('tristiansborg, was rebuilt be tween 1794 and 1828, but was never remarkable for architectural beauty. The principal part of the vast builling was destroyed by fire in 1884 , when many precious works of art were destroyed. Happily most of the pictures in its great art gallery were saved. The castle of Rosenborg (1610-24), where the regalia are kept, contains interesting collections of objects of art; and the palace of Charlottenborg (1624) is now used as an academy of arts. The univensity was founded by Christian I. in 1479, has five faculties, 40 professors, and is attended by 1200 students. Comnected with the university are a surgical aca demy, an observatory, a botanical garden, a zoological museum, a polytechnic institution, and a library of 250,000 volumes, containing also a great collection of ancient Persian MSS., and another of ancient northern MSS. Copenhagen is the centre, not only of Danish, but of northern literature and art, and is the seat of a number of societies for the advancement of these in all their branches, amongst which the most important are the Royal Society, founded in 1742; and the Royal Society for Northern Antiquities, founded in 1825; as well as agricultural, geographical, and other societies. The roval library contains 500,000 volumes, besides great treasures of Sanskrit and other MSS. The Museum of Northern Antiquities in Prindsens Palais, is unrivalled in its kind, having been made what it is mainly by Worsaae. The Thorwaldsen Museum, opened in 1846, consists of works of art by that sculptor himself, and others left by him to the Danish nation, for which a separate building has been erected. Copenhagen contains also a number of well-supported benevolent institutions, banks, theatres, an exchange, \&c. There are statues of several of the Danish kings, of Tycho Brahe, and of the poets. The chief exports of Copenhagen are grain, rape-seed, butter, cheese, beef, cattle, wool, hides, bones, and grain-spirit. Poreelain, pianos, clocks, watches, mathematical instruments, chemicals, sugar, beer, and tobacco are manufactured.

About the middle of the 12th century, Copen. hagen was but a fishing-village, in the neighbourhood of which Bishop Axel, or Absalon, built a castle. In 1254 the village obtained the privileges of a town, and in 1443 King Christopher made it the capital of the kingdom. It was several times attacked by the Hanseatic League; was besieged by the Swedes in the 17th century; was bombarded by the English, Dutch, and Swedes in 1700; suffered grievously by fires in 1728, 1794, and 1795; witnessed a great sea-fight in its roads on 2d April 1801, when the English, under Sir Hyde Parker, with Nelson as his second in command, destroyed the Danish fleet; and (to prevent the Danish fleet from falling into the power of Napoleon) was bom. barded by the English from the $2 d$ to the 5th of September 1807, when great destruction was wrought, both in houses and public buildings, and hundreds of persons lost their lives (see DENMARK). In 1888 an international exhibition was held here.

Copenhagen Fields, in North London, noted as the meeting-place of an immense gathering of labour unionists on 21st April 1834, with the object of overawing the ministry. But the crowd, nee. ing the military and other preparations made to receive them, dispersed quietly witlout attempting to carry out any of the violent design with which they were eredited. Since 1885 the site bas been occupied by the Metropolitan Cattle Market.

Copépoda, an order of minute marine and fresh-water crustaceans, belonging to the Entomostraca $\left(\mathrm{q}, \mathrm{v}_{\mathrm{o}}\right)$.

Coper'nicus, Nicolas, founder of the modern astronomy, was born 19th Feluruary 1473, at Thorn, in West Prassia, lately belonging to the order of the Teutonic Knights (q.v.), but then a part of Poland. His father, a Polish subject, was apparently a Germanised Slav, and his mother of pure German extraction. Copernicus seems to have spoken German as his mother-tongue ; but Poland and Germany still dispute with each other the honour of producing him. Brought up under the guardianship of his uncle Lucas, prince-bishop of the great Prussian diocese of Ermland, he matriculated at Cracow 1491, and there studied mathematics, optics, and perspective. Leaving without taking a degree, he enrolled himself in 1496 in the 'Natio-Germanorum' of Bologna University as a student of canon law, and was next year appointed canon of Frauenburg, the cathedral eity of the diocese of Ermland, standing on the shores of the Frisches Haff. The year 1500 he spent at Rome, where he lectured on astronomy, and (6th November) "observer an eclipse of the moon." The following year he began the study of medicine at Padua, medicine in that age being essentially dependent on astronomy, and was at Ferrara, in 1503 , invested with the doctorship of canon law. In 1505 he left Italy never to return to it, and settled in his native Prussia. 'Scholasticus' of Breslau till 1538, and canon of Frauenburg, yet Copernicus never became a priest. Appointed permanent medical attendant on his uncle, he lived with him from 1507 till 1512 in the princely castle of Heilsberg, 46 miles from the town of Frauenburg, where, besides thinking out his new astronomy, he had toilsome administrative and other duties to perform, involving him in frequent journeys. After his uncle's death in 1512, he lived at Frauenburg with an income as canon caleulated at about $\mathbf{1 4 5 0}$ of present money, not merely to study the stars in his tower Curia Copernicana, but to execute difficult and multifarious offices as bailiff, military governor, judge, tax-collector, vicargeneral, and physician. These offices he fulfilled with vigour and success, even while his difficulties were increased by the intrigues and wars which ultimately led to the restoration of West Prussia to the Teutonic Knights, and its incorporation with the Protestant state of Brandenburg. The coinage having been grossly debased by the Teutonic Knights and the three leading commercial towns of Prussia, Copernicus set himself strenuously to the task of its reform, and advocated the establishment of a single mint for the whole of Prussia. In 1523 he was appointed administrator-general of the diocese. The De Reculutionibus he completed in 1530 , but could not be prevailed on to give it to the press till just before the end of his life. In 1542 he was seized with apoplexy, accompanied by paralysis on the right side. On the 24th May 1.54 the first printed copy of the work arrived at Franenburg, and was touched by his dying hands only a few hours before he expired. His memory gone, and his faculties all obseured, it could only be said he seemed to know what it was he touched.

Besides the De Revolutionibus, Copernicus wrote and published at Cracow a Latin translation of the Epistles of the Byzantine author Theophylactus Simocatta, and a treatise on trigonometry. His 
life was written by Gassendi; more recently by Von Hipler (1873), and Polkovski (Warsaw, 1873). By far the most complete account of Copernicus's life and labours is, however, the great biography by Dr Prowe ( 2 vols. Berlin, 1883 ; volume of documents, 1884). Copernicus's family name of Kopper nigk is derived from a village so called in Silesia, and was Latinised by himself as Coppernicus, and indeed by him generally so spelt.

The Copernican System is that which represents the sun to be at rest in the centre of the universe, and the earth and planets to move round it as a centre. It got its name from Copernicus, who (although some vague general notion of the system seems to be due to Pythagoras) first distinctly drew the attention of philosophers to it, and devoted his life to its demonstration. For the rest, the glory of developing on the lines he broadly laid down, belongs to Kepler, Galileo, and others, and to Newton, who finally marked out the form of modern theoretical astronomy. Many who reverence the name of Copernicus in connection with this system, would be surprised to find, on perusing his work, how much of error, unsound reasoning, and happy conjecture combined to secure for him in all times the association of the system with his name; yet, with all its faults, that work marks one of the greatest steps ever taken in science.

Entitled De Revolutionibus Orbium, and dedicated to Pope Paul III., it consists of six books. The first contains the following propositions: 1. That the universe is spherical. This is established by such arguments as that the sphere is the most perfect figure, \&c. 2. That the earth is spherical, which flows from the same kind of considerations: 3 . That the earth and sea make one globe. 4. That the motions of all the heavenly bodies must be uniform and circular, or compounded of uniform and circular motions. Here, again, we meet with singular reasons. A simple body must move circularly, and nothing but circular motion could give periodicity to phenomena. 5. That, supposing the distance of the stars to be immense, there is no reason why the earth should not have a motion round its axis as well as a motion in its orbit. 6. That the sphere of the stars is immensely distant. The proof is fanciful, and shows he had no notion of a universe of stars pervading space. 7 and 8 . The ancients were wrong in placing the earth at the centre of the universe. The arguments under this head are as fanciful as those which they were designed to refute. The falling of a body to the earth he deduces from the assumption, that it is only given to wholes to move circularly, while it is of the nature of parts, separated from their wholes, to move in right lines. That there must be a centrum mundi, an entity unknown to modern science, is admitted, the question being as to its position. 9. It is possible for the earth to have several motions. 10. He establishes the order of the planets, and draws a diagram of the system much as it is now represented. Following the old systems, such as the Ptolemaic, he lays down a sphere for the fixed stars. It is clear, also, that he had no idea of the motions of the planets other than that they were such as would be caused by their being fixed in immense erystal spheres revolving round the sun.

The sum of Copernieus's astronomical achievements is, mainly, the shifting of the centre of the solar system from the earth to the sun, and the consequent explanation of the alternation of day and night by the earth's rotation round itself, and of the vicissitude of the seasons by the earth's revolution round the sun. This complete transformation in astronomy was due in the first instance to the sense of order in Copernicus's own mind, which, ever more clearly, protested against the inverse conception of a much smaller body at the centre, and a far greater at the circumference, and all the repugnant notions regarding the movements of the planets which such a conception involved. Discriminating motion as an attribute of matter, and space as the scene but not the subject of motion, Copernicus explained how the celestial sphere was but a limitation of space, and its movement only apparent; and how the 'backward loopings' of the paths pursued by the planets were only the perspective result of their real movements in conjunction with the real movements of the earth. Such was the comprehensive scheme of astronomy conceived by Copernicus; but it was impossible for him, with the instruments and ascertained facts then at his disposal, to master all the details. Instead of grasping the idea of elliptic orbits, he still abode by that of uniform circular motion, and had therefore to retain the 'epicycles' to account for 'irregularities,' though he reduced this apparatus of checks and balances to the number of thirty-four. It was reserved for Kepler to dispense with the epicycles (see PToLEmaic System, Astronomy, KEPLER). Catholic churchmen received Copernicus's work with much favour; the only theological objections came from the Protestants. Luther denounced Copernicus as an arrogant fool who wrote in defiance of Scripture, and Melanchthon urged the suppression of such mischievous doctrines by the seeular power. The conduct of the De Revolutionibus through the press having been delegated by Copernicus's friend, George Joachim von Lauchen (Rheticus) to Osiander (q.v.), the latter, by way of conciliating existing prejudices, foisted on the work a preface (Prafatiuncula) quite foreign from Copernicus's intentions, in which the doctrine of the earth's rotation is represented as a mere hypothesis, which has been attributed wrongly to Copernicus himself.

Copiapo, capital of the Chilian department of Atacama (q.v.).

Copland, JAMES, physician, was born at Deerness, in the Orkneys, in 1791. He graduated M.D. at Edinburgh in 1815 , and settled to practice in London in 1820, where he soon began to make his name known by his papers in the medical journals on yellow-fever, hydrophobia, cholera, and the like. His largest work was the Dictionary of Practical Medicine (3 vols. 1832), a monument of enormous industry ; others were on palsy and apoplexy (1850), and on consumption (1861). He died 12th July 1870.

Copley, John Singleton, R.A., portrait and historical painter, was born 3d July 1737, at Boston, U.S. His parents, both of English extraction, had emigrated from Ireland in the previous year. It has usually been asserted that Copley was a self-taught artist; but $\mathrm{Mr}$ W. H. Whitmore of Boston has shown that he was instructed by his stepfather, Peter Pelham, the portrait-painter and engraver, and probably also by John Smibert. At the age of sixteen he was executing portraits of considerable merit; and in 1755 Washington sat to him. In 1766 and 1767 he sent over works for exhibition in the rooms of the Society of Incorporated Artists ; and in June 1774 he left for Europe. In London he was well received by Reynolds, West, and Strange, and he was commissioned to paint the king and queen for Governor Wentworth. Passing to the Continent in August, he studied in Italy, returning to London in the end of 1776 . His first important subject-picture was the 'Youth reseued from a Shark, presented by the artist to Christ's Hospital School; which was followed by 'The 
Denth of Chatham' (1779-80), an impresaive aub. ject, in which the portraits of the peers were carefully studied from life, and the still finer 'Death of Major Pierson' (1783), Both are in the National (iallery; the former was engraved by Bartolozai, the latter by Heath. In 1789-90 he executed the immense 'Siege and Relief of Gibraltar,' now in the Guildhall. Among his numerous other popular worka may be named 'The Surrender of Admiral de Windt to Lord Duncen:' 'Charles I. demand. ing the Surrender of the Five Members,' now in Boston; 'Charles I. aigning Strafford's Death. warrant;' and 'The Assassination of Buckingham.' Till the end of his life he was unwearied in the pursuit of his art. In August 1815 he was attacked by paralysis, and died on 9 th September, leaving a son, the future Lord Lyndhurst.

Copley's historical subjects are more original, spirited, and realistic than those of his friend and countryman West, with whom he is commonly classed; and they are distinguished by far richer and finer colouring. His composition is simple and effective, and his draftsmanship careful and aceurate. In religious and poetical subjects he was less succeseful. His portraits, full of individuality, excellent in modelling and colour, are in themselves enough to justify a great reputation; and in artistic qualities the finest of them may be said to approach the works of Reynolds and Gainsborough. See Lives by Perkins (1873) and Mrs Amory ( 1882).

Copper. This appears to have been the first metal employed by man both in war and the peace. ful arte. Like gold and silver, it is found native, but, except in one or two districts, only to a small extent. It can, however, be extracted from its ores at a comparatively low heat, and it is not altered by exposure to dry air; although in moist air, in the presence of carbonic acid, it soon takes on a costing of the green carbonate of copper. The use of copper by ancient nations is well known, through the weapons and other objects of Bronze (q.v.) - that is, copper mixed with a small quantity of tin, \&c. - which have been so largely collected by archreologists. Some prehistoric inıplements are, however, of unalloyed copper. It was obtained by the ancients from various places, but especially from Cyprus-whence the name. Copper has a characteristic fine red colour and takes a brilliant polish. It is nearly nine times heavier than water, its specific gravity being from $8 \cdot 8$ to $8 \cdot 95$. Next to silver it is the best conductor of heat and electricity, hence its many nseful applications. Its point of fusion lies between silver and gold, but unlike these metals, it absorbs oxygen when strongly heated in the air, and scales of black oxide form rapidly on its surface. Copper is moderately hard, and is highly malleable, ductile, and tenacious, although not so strong as iron. When held, in the form of sheet or wire, in a flame, it communicates to it a highly characteristic green colour. Whereas steel is hardened by being heated to redness and suddenly cooled in cold water, copper is softened by the same process. Copper forms two important com. pounds with oxygen-cuprons and cupric oxides.

Cuprous Oxide (red oxide, sub-oxide), $\mathrm{Cu}_{2} \mathrm{O}$. This is obtained by heating to redneas the black oxide with nearly its own weight of finely divided copper in a well-covered crucible, to protect the mixture from the oxidising action of the air. It is got as a hydroxide by adding grape-sugar to a solu. tion of sulphate of copper, and then caustic soda, till a blue precipitate, which is first formed, is redissolved. The solution, on being gently warmed, deposits the hydroxide as a rich orange-yellow powder. On continuing the heating till the liquid has reached the boiling-point, and maintaining the ebullition for some time, the powder changes into the red anhydrous oxide. This oxide is need in colouring glass a fine ruby tint. It is not acted on by air or moisture, and for this reamon is produced on copper surfaces as a bronze to keep the metal itself from becoming stained. The salts of this oxide are generally colourless, but they are liable to absorb oxygen and pass into the blue-coloured cupric salts. Cuprous ehloride is the most im. portant salt, being used for absorbing carbonic oxide in gas analysis.

Cupric Oxide (copper monoxide, black oxide), $\mathrm{CuO}$, is the scale or rust of copper which peels off the surface of the metal when heated. It is got for chemical purposes by heating nitrate of copper to redness in a crucible with occasional stirring, and carefully avoiding any possible admission of coaly matter. By the use of cupric oxide Liebig established the method by which the composition of all organic substances has been determined, as it readily gives up its oxygen at a red heat to carbon and hydrogen, converting them, respectively, into carbonic acid and water, from the weight of which the composition of the organic body is calculated. This oxide is used for staining glass, to which it imparts a green colour; and its solution in ammonia. has the remarkable property of dissolving cotton fibre. The Hydroxide, $\mathrm{Cu}(\mathrm{OH})_{2}$, is obtained as a blue precipitate by adding caustic soda to sulphate, or other salt, of copper, which, as in the case of the cuprous oxide, becomes anhydrous on boiling, the blue precipitate becoming black and granular. The salts of cupric oxide are readily obtained by dissolving it in the necessary acids; for example, in sulphuric acid for the sulphate, and in nitric acid for the nitrate of copper.

Cupric Sulphate (sulphate of copper, blue vitriol), $\mathrm{CuSO}_{4}$, occurs native in veins of copper and iron pyrites, and is manufactured on a large seale by gently roasting native copper sulphide (copper pyrites), when oxygen is absorbed from the air, the anhydrous sulphate thus obtained being dissolved in water, and from this solution the salt as found in commerce crystallises out. The crystals are large, transparent, and have a fine blue colour. They are much used by the dyer and calico-printer, in electroplating, and in the preservation of organic materials.

Cupric Nitrate, $\mathrm{Cu}\left(\mathrm{NO}_{3}\right)_{2}$. The erystals of this salt are of an intense blue colour and deliquescent. It is much used in calico-printing as an oxidising agent.

Cupric Cyanide, $\mathrm{CuCy}_{2}$, along with eyanide of potassium, gives the solution from which copper is deposited on an iron surface. It is not, however, necessary to prepare pure cupric cyanide, as the sul. phate in excess of potassium cyanide serves the purpose.

Cupric Arsenite, $\mathrm{CuHAs} \mathrm{O}_{3}$ (Scheele's green), is a well-known green pigment, got by adding an alkaline arsenite to cupric sulphate, and washing the precipitate till free from sulphate, and drying. This colour has been much used for wall-papers, but has been supposed to have insanitary effects. See ARSENIC.

Copper Acetate, $\mathrm{Cu}\left(\mathrm{C}_{2} \mathrm{H}_{3} \mathrm{O}_{2}\right)_{9}$, is got by adding copper hydroxide, or carbonate, to acetic acid. It forms dark blue prisms. If acetic acid is allowed to act on metallic copper in the presence of air and moisture, a basic acetate is slowly formed termed verdigris; this has less acetic acid than the previous compound, and is much less soluble. It has a bluish. green colour. Verdigris and arsenious acid boiled together in water form the fine colonr termed emerald green-an aceto-arsenite of copper.

Copper Stearate is obtained by adding stearate of soda to sulphate of eopver in hot solutions. It is a light bluish-green powder used for colouring candles.

The pigment, Brunsucick green, used in the arts, is an oxychloride of copper. 
Copper in any liquid is easily discovered by placing in it a plate of polished iron, when it will be oluserved coating the metal with its well-known reddish tint, making its appearance over the part of the plate immersed in the fluid. If the quantity of copper is very small, the liquid should be concentrated till it half fills a watch-glass, and a bright steel needle used in place of an iron plate. Solutions of cuprie salts have a blue or greenish-blue colour, but this on addition of ammonia in excess becomes an intense purplish blue.

Native Copper, although frequently met with wherever copper ores occur, is yet rarely discovered in sufficient quantity to admit of its being systematically worked. It is found crystallised in cubes and in modifications of this form; also in arborescent pieces, in thin laminæ, and in irregular lumps or masses. Sometimes it forms a nucleus with first a layer of red oxide and then a second layer of carbonate of copper around it. The largest masses of native copper are obtained from mines in Russia and from copper-bearing strata in the neighbourhood of Lake Superior. One mass was mined at Minnesota in 1859, weighing 500 tons, which required the work of forty men for a year to extract it. The largest yet obtained was got in 1866 at the Central mines, Lake Superior, and weighed 800 tons.

The ores of copper are numerous. Cuprite, ruby copper, cuprous oxide, or red oxide of copper, is the richest ore. It contains, when pure, nearly 90 per cent. of copper. Malachite (q.v.), or green carbonate of copper, consists, when pure, of 57 per cent. of the metal. This ore occurs largely in Russia, South Australia, and in some localities in South America. Chessylite, azurite, or blue carbonate of copper, in a pure state contains 55 per cent. of copper. Chalcopyrite, copper pyrites, or yellow copper ore, a sulphide of copper and iron, is, from its abundance, the most important of copper ores. Although containing, when pure, 35 per cent. of copper, yet on account of impurities, what is mined in England does not yield, on an average, more than 8 per cent. of the metal. Some of the auriferous copper pyrites of the western states of America and elsewhere is worked as an ore of gold (see GoLD). Erubescite, or purple copper ore, is also a sulphide of copper in which the proportion of the metal varies from 60 to 70 per cent. Tetrahedrite, or gray copper ore, is a sulph-antimonite of copper of very variable composition, but often containing from 30 to $\mathbf{4 0}$ per cent. of copper, \&c. Atrcamite (q.v.) is an oxychloride of copper mined in Chili, and found in other countries. Melaconite, or black oxide of copper, and Chrysocolla, a silicate of copper, are sometimes smelted as ores of the metal.

COPPER-SMELTING.-In practice, the process of smelting copper from ore (eopper pyrites) like the Cornish is somewhat complicated, but in theory it is comparatively simple. The main impurities of the ore are quartz, iron, sulphur, and very commonly arsenic. The process is conducted with the view of separating the iron and quartz as a fusible slag, and of dissipating the sulphur and arsenic, by converting them into sulphurous and arsenious acids, through oxidation in the furnace. At Swansea, which is the chief seat of copper-smelting in this country, leverberatory furnaces are used, and these are of two kinds, called respectively calciners and melting furnaces. Gas, along with Siemens' regenerative apparatus, is now to some extent used in different parts of the world for supplying heat to copper furnaces, but at some places it has been given up, after a short trial, owing to the costly repairs which it causes. There are never fewer than six operations in the Welsh process of copper-smelting, and when so limited, a favourable admixture of ores, such as copper pyrites and copper carbonates, is necessary. In the first, the ore is calcined in a furnace for at least twelve hours, by which time the greater part of the sulphide of iron is decomposed, and much sulphurous and other acids have formed and escaped in fumes -i.e. a partial oxidation of the iron and sulphur

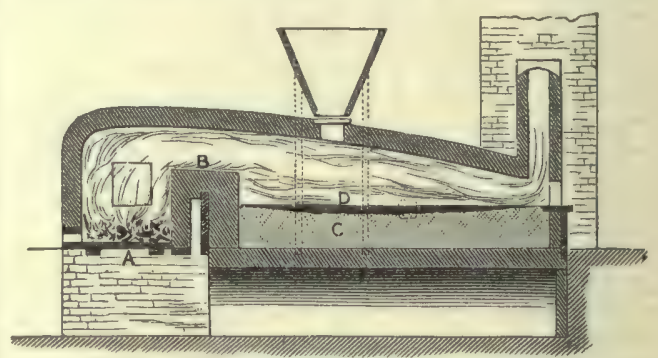

Fig. 1-Section of a Reverberatory Copper-melting Furnace:

A, fireplace ; B, fire-bridge; C, bed of sand ; D, melted copper.

takes place. In the second, the calcined ore is melted along with siliceous slags obtained in later stages of the process. Here a fusible slag, consisting in great part of silicate of iron, is formed, and the sulphides of iron and copper are run off as a regulus, termed coarse metal, and granulated in water. A section of a melting furnace is given in fig. 1. In the third, the coarse metal is calcined again for twenty-four hours, during which time most of the sulphide of iron is converted into oxide. In the fourth, the calcined coarse metal is melted with slags rich in oxide of copper, and also with rich ores, as oxide and carbonate. These oxidise any sulphide of iron remaining, and a regulus called white metal is formed, consisting almost entirely of sulphide of copper, and containing about 75 per cent. of the metal. In the fifth, called ' roasting,' the regulus is very slowly melted, so as to allow of the gradual and thorough reduction of the sulphide by heated atmospheric air through the formation of oxide of copper. When oxide and sulphide of copper are heated together, they decompose each other, the sulphur escapes as sulphurous acid, and impure metallic copper, called blister copper, is produced, while other foreign bodies are for the most part removed in the slag. In the sixth, the copper from the previous operation is refined. To effect this, it is melted in a furnace, and exposed to the oxidising influence of the air for from fifteen to twenty hours, by which time it is full of dioxide, and this is in turn reduced by throwing pure coal on the surface of the molten metal, and then stirring it with a pole of green birch-wood.

At those smelting works where the sulphurous acid produced in the calcining or roasting of copper pyrites is saved for the manufacture of sulphurie acid, peculiar furnaces, such as Gerstenhöfer's, Hasenclever and Helbig's, and Maletra's, are used for roasting the ore. Shaft or cupola furnaces, instead of those of a reverberatory kind, are used in some countries, for smelting copper ores where these are highly ferruginous, or oxidised, or comparatively poor. Coke, anthracite, or charcoal is used as fuel in cupola furnaces, which require a blast of air at a moderate pressure.

Wet Copper Extraction Process. - Soon after iron pyrites (sulphide of iron) began to be used about thirty years ago as the source of sulphur for the manufacture of sulphuric acid, it was thought desirable to recover the copper, amounting to a small per cent. of the pyrites used. The burnt pyrites, consisting chiefly of oxide of iron, along 
with 4 or 5 per cent. of copper, is mixed with from 12 to 15 per cent. of crushed rock-nalt and the mixture properly calcined, when the whole of the copper is converted into a soluble chloride. The roasted mass is then lixiviated, and the copper con. tained in the solution thrown down as metal by sermp iron. This precipitate contains about 75 per cent. of pure copper, and is mixed with the copper of the later stages of purification got in the dry process.

A PPLICATIONs of CopPER. - The metal is used for a great variety of purposes. It is most largely consumed along with zine in the production of Brass (q.४.). To a less, but still considerable extent, it is made into bronze and gun-metal, in which it is alloyed with tin and other metals (see Brovze). Alone it is employed for hoilers, stills, cooking vessels, aeamless and other pipes, wire and wire cloth, nails, and spikes. In the form of thin plates it has long been in demand for engraving and etch. ing upon, and in the shape of strong rollens it is extensively employed for a like purpose by the calico-printer. Copper does not cast very well, but it is almirably alajted for producing works of art in electro-deposit instead of casting them. This process is extensively employed, and does even for objects as large as life-sized statues. In this way engravings and pages of type are also copied for the printing-press. For its use in coating other metals, see Brovzing. Copper is the metal usually chosen for lightning conductors. Writing.pens are made of an slloy consisting for the most part of copper, and for some purposes are better than those made of steel, as they do not corrode nearly so soon. These pens are usually white in colour. An alloy of copper, 'yellow metal,' is used for sheathing the bottoms of timber ships, so as to prevent molluscs and seaweeds from encumbering them. Copper, owing to its duetility, may be made into pipes, tubing, \&c., by high pressure alone, without heat.

The copper-mines of the United Kingdom appear to have first risen into importance in the early part of the 18th century. According to Sir C. Lemon (Journal of the Stratistical Society, vol. i.), the prodnce of the Cornish mines in 1771 was 27,896 tons of ore, yielding 3347 tons of copper. In 1856 (Hunt's Mineral Statistics for 1856) the returns were-Cornwall, 163,245: Devon, 42,025 tons of ore; together yielding 13,500 tons of metallic copper. Since 1860 , the year of their maximum yield, the grantity of copper obtained from mines of the United Kingdom has steadily and rapidly declined from 236,696 tons of ore, and 15,968 of metal, to 5346 and 426 tons respectively in 1893.

The copper ore mined in other parts of the country besides Cornwall and Devon is compara. tively trifling. Copper is chiefly smelted at Swansea and its neighbourhood, but to some extent also in Lancashire. The English smelting works are now most largely supplied with ore from Spain, South Africa (see CAPE Colovy, Vol. II. p. 735), Venezuela, the United States, and Australia (q.v.). The entire quantity of metallic copper smelted and refined in the United Kingdom annually varies from 25,000 to 30,000 tons.

The production of copper in the United States has increased rapidly since 1872 . In that year the quantity of this metal obtained was 12,500 tons, while in 1897 it was as nuch as 212,000 (long) tons, and the United States is now the largest producer of copper. The richest mine in the world is said to be that at Calumet (Mich.), on Lake Superior, in which region copper was mined by the ancient Indian or pre-Indian inhabitants. Arizona and Montana (United States) are also productive; but copper occurs in several other parts of the Union. $A$ very large quantity of copper wire is used in 134 that country for electrical purposes. The enormous increase in the output of copper between 1880 and 1884 , and its fall in price, led to the formation of a powerful syndicate to regulate the total produc. tion and control the price; which for a time succeeded, but by 1880 collapsed. T'ise price of copper, which in 1890 was about 265 a ton, sank to $\mathfrak{f 1 1}, 2 \mathrm{~s}$, 6d. in the end of 1895 , but rose to $\mathbf{f 4 9}$ in the middle of 1896 .

Copperas, or sulphate of iron, is used in dyeing black, in making ink, and as a dressing for erops. See IroN, p. 214.

Copperhead (Trigonocephalus contortrix), a venomous snake, allied to the rattlesnake, found in eastern North America, It has a thick body from 2 to 3 feet long, and a short tail without rattles, and is slow and clumsy in its movements ; but, lurking in dark and moist places, and giving no warking, is more dreaded than the rattlesnake. The term was given to the peace party during the American civil war.

Coppermine River, so named, in common with the Copper Mountains to the west of it, from the metallic products of the vicinity, rans through the North-west Territory of Canada, and after a course of 250 miles, enters a bay of the Arctic Ocean about $68^{\circ} \mathrm{N}$. lat, and $116^{\circ} \mathrm{W}$. long. It was discovered by Hearne in 1771. Its course is continually interrupted by falls and torrents.

\section{Copperplate Printing. See Engraving.}

Coppet, a village of Switzerland, 8 miles N. by E. of Geneva by rail, with a chateau, where Necker and his daughter, Mme, de Staèl, are buried, and where the latter spent much of her life.

Coppice. See Copse.

Copra, or CopperaH, is the commercial name for the kernel of the cocoa-nut broken into small pieces and dried in the sun. From $500 \mathrm{lb}$, of copra 25 gallons of cocoa-nut oil should be obtained. See CocoA-NuT.

Coprolites (from Gr. kopros, 'dung,' and lithos, 'a stone") are the fossilised excrements of animals found in Palnozoic, Mesozoic, and Tertiary strata. Their true nature was first inferred by Dean Buck. land (1829), from their occurrence in the bodies of several species of Ichthyosaurus, in the region where was situated the intestinal tube. It has been since shown that they are the voidings chiefly of saurians and of sauroid fishes. They often con. tain portions of scales, bone, teeth, and shells, the indigestible parts of the food on which the animals lived. Occasionally, they may be found exhibiting the spiral twisting and other marks produced by the conformation of the intestinal tube, similar to what is noticed in the excrement of some living fishes. These peculiar markings obtained for them the name, when their true nature was unknown, of "larch-cones" and "bezoar-stones." Coprolites are found to contain a large quantity of phosphate of lime; and as this forms a valuable manure, the deposits containing them have since 1846 been largely quarried by the manufacturers of artificial manures.

Copse, or Coppice, a natural wood or plantation, of which the trees are cut over from time to time, without being allowed to attain the size of timber-trees, sending up new shoots from their roots or stools. Some kinds of trees-as the firsare incapable of being treated in this manner, refusing to send up new shoots; but many-as the onk, birch chestnut, ash, elm, maple, alder, hazel, and willow-very readily do so, at least if they have not been allowed to attain too consider. able a size before being cut over. Copse-woods are sometimes planted chiefly to rary and beantify the landscape, but more generally with a view to profit. 
It often happens that, owing to scantiness of soil or to unfavourable subsoil, oaks and other trees, after growing vigorously for a number of years, are arrested, and remain almost stationary in their growth. In such eircumstances, it is advantageous to cut them over early, and to treat the plantation as a copse. Oak is much planted as copse-wood, in consequence of the demand for its bark : in some parts of Herefordshire, the trees are cut over every twelve years; but in the Highlands of Scotland, twenty-five or thirty years are often necessary for sufficient growth. The largest pieces of the wood are used for making wheel-spokes, and for other purposes of timber; the smaller portions for charcoal and firewood. Ash-coppice is serviceable for handles of implements, hurdles, hoops. Chestnut copses are planted in England to supply hop-poles. Hazel is in great demand for making crates, \&c. Besides the cultivation of different kinds of willow or osier for basket-making, in which they are cut over annually, some of the species are cultivated as copse, and cut every five, six, or seven years, for hoops, crates, \&e. (see Willow). In some countries, copse-wood affords a valuable supply of fuel.

Coptis, a genus of Ranunculacer. C. trifoliata, called Gold Thread on account of the appearance and colour of its rhizomes, is a native of swamps in the colder northern regions of both hemispheres. It has ternate leaves and solitary white flowers. The bitter rhizomes are used in America as a tonic, and as a yellow dye. That of C. teeta of Assam is used in India as a bitter tonic.

Copts, the Christian descendants of the ancient Egyptians. The name (in Arabic, $K u b t$ ) is most probably derived from the same root as E-gypt. The Copts are in number about 300,000 , only oneeighteenth of the population of the country. A large proportion live in Cairo, but there are numerous populous settlements of Copts in Upper Egypt, notably at Girga, Negáda, Luksor, Asyât, Dendera, and Ikhmim, where 40,000 are said to reside. They are essentially townsmen, engaged as clerks on account of their undoubted mathematical talents; or employed in the finer handicrafts, such as goldsmithery; and their occupations account for their paleness as compared with their Moslem neighbours. The few Copts who work in the fields do not differ perceptibly from the Moslems, and the resemblance to the ancient Egyptians is visible in both, though the inbreeding of the Copt has perhaps retained the ancestral lineaments more faithfully. They are of middle stature, have black eyes, and black curly hair; dress like the Moslems, but are generally distinguished by a black or blue turban; the women are veiled. Their character is in general gloomy, deceitful, and avaricious; they are ignorant, drunken, and sensual. In religion they are Monophysites (q.v.) of the Jacobite sect; but a few are united to the Greek and Roman Catholic churches. When the Council of Chalcedon in 451 pronounced the Jacobite opinion heretical, some of the Copts supported the verdict, and bitter jealousies ensued between these 'royalists' and the Jacobite Copts. The latter did not scruple to welcome the Moslem conquest in 640 in order to expel the Greek faction. They ascribe their conversion from heathenism to St Mark, whom they regard as the first patriarch of Alexandria. Their highest dignitary is the patriarch of Alexandria, whose residence, however, is in Cairo. Their other orders of clergy are twelve bishops, and archpriests, priests, deacons, and monks. The patriarch is named by his predecessor, or chosen by lot from among the monks of the convent of St Anthony. $\mathrm{He}$ is not permitted to marry, and when he sleeps it is necessary to waken him every quarter of an hour. He nominates the metropolitan of Abyssinia (see ABYSSINIA).

The Copts are very strict in some of their religious observances, and hate other Christian sects even more than they hate the Moslems. They maintain the seven sacraments-baptism by trine immersion; confirmation; penance or confession; orders; matrimony ; unction; and the eucharist, administered in both kinds to all, even young children, and formed of leavened bread which has been dipped in wine. They keep Wednesday and Friday with great strictness as fast-days, and have besides an onerous fast of Nineveh, lasting fifty-five days, and lesser fasts of the Nativity, the Apostles, and the. Virgin. Each fast is followed by a feast. Pilgrimage to Jerusalem is prized highly. Priests may be married to one virgin provided the ceremony takes place before ordination; if the wife die, he may not marry again, nor may the widow of a priest remarry. The Copts seldom marry outside their own sect the wedding ceremonies are very peculiar, and may be read in L. Oliphant's Land of Khemi; the bride is expected to remain at home until confined, or for a year if barren (see Lane's Modern Egyptians). The Coptic ritual, liturgy, vestments, $\mathrm{dc}$. are specially interesting as preserving unchanged very ancient Christian forms. The churches, of which the most celebrated are those built in the Roman fortress of Babylon at old Cairo, and those in the Nitrian valley, are remarkable for peculiari. ties of construction and plan, and for exceedingly beautiful carved ivory screens. An admirable account of them is given by $\mathrm{Mr}$ Butler. They have many schools, but only for boys, who learn the psalms, gospels, and apostolic epistles in Arabic, and then the gospels and epistles in Coptic. The Coptic, however, is not grammatically taught, and is not now a spoken language, having been everywhere supplanted by the Arabic. It has not been spoken in Lower Egypt since the 10th century, but lingered for some centuries longer in Upper Egypt. It is, however, still used by the Copts in their religious services, but the lessons, after being read in Coptic, are explained in Arabic. The Coptic language is the descendant of the ancient Egyptian, but the alphabet is Greek uncial, probably introduced soon after their conversion to Christianity. 'The romance of language could go no further than to join the speech of Pharaoh and the writing of Homer in the service-book of an Egyptian Christian" (Butler). There are two principal dialects of the language-the Sahidic or Upper Egyptian, and the Memphitic or Lower Egyptian, which is sometimes exclusively called Coptic. $\mathbf{A}$ third dialect, the Bashmuric, of which only a few remains exist, was spoken in the Delta, and is interesting from its points of resemblance to the language of the hieroglyphics. The literature is wholly religious. See the article EGYPT; and The Ancient Coptic Churches of Eqypt, by Alfred J. Butler ( 2 vols. Oxford Clarendon Press, 1884).

Copula (Lat., ' a band ') is a term employed in logic to designate the word which unites the two notions of a sentence-the subject and predicateinto one judgment or thought.

Copyhold, a species of estate or right of property in land, in Ireland and England, nearly resembling in many particulars the feu-rights of Scotland. Copyhold is expressed technically as 'tenure by copy of court-roll, at the will of the lord, according to the custom of the manor.' This means that it is tenure of land, being part of a manor, the title being evidenced by the courtrolls of the manor, and the right of the owner being in conformity with the immemorial customs of the manor. The addition, 'at the will of the lord,' 
serves only as a memorial of the derivation of this species of estate from the estates granted in old times to the bondsmen or Villeins (q.v.), which were of course resumable at the pleasure of the lord. But the will of the lord is now absolutely controlled by the cuatom of the manor, which forms the law of the tenure; and as this custom must he immemorial -i.e. extending to the reign of Richard II. - no copyhold can now be created.

The custom of each manor may vary in important particulars. In some the lands are held for life only, generally, however, with a customary right to renewal or to appoint the successor; in some they descend according to particular rules; in most, however, they descend according to the ordinary rules of succession. But the custom, whatever it may be, cannot be altered. The tenant cannot, for instance, entail his land unless the custom warrants him. The freehold remaining in the lord includes a right to minerals and timber, but in the alsence of special eustom he cannot remove these without the consent of the tenant. The tenant also in the general case cannot lease his land for more than one year. This tenure makes the intervention of the lord necessary in every act of alienation, which therefore resembles the Scottish procedure of resignation of a feu, and is called a surrender and admittance.

Various money-payments are due by the copyholder to the lord. These are divided into the rents, an annual payment of the nature of the Scottish feu-duty; fines, payments on particular occasions, such as alienation or succession, like the Scottish composition to the inferior; and heriots, or the best piece of personal property, to which, on the death of the copyholder, the lord becomes entitled. As to fines, it may be observed that the courts of law have fixed the extreme amount that can be exacted at two years' rent of the land.

In the case of an heir succeeding there is no surrender, but there is admittance only upon pay. ment of the customary fine, and it is enforced by a customary penalty. A mortgage is effected by a surrender, upon condition that the money is repaid, and the admittance takes place only in event of failure of payment. A copyhold may, in like manner, be devised by will, the devisee being admitted on the death of the devisor.

The inconveniences and loss accruing through the variety of customs to which copyright lands are subject have led the legislature to make provision for their gradual extinction. By the copyhold commissioners all the services due to the lord of the manor may be commuted for a fixed rent. The lord is also authorised to enfranchise or convert into freehold the lands by agreement with their owners. Since 1853 either the lord or the tenant so admitted may compel enfranchisement on pay. ment, either of a fixed sum where it is at the instance of the lord, or of an annual rent where it is at the instance of the tenant, fixed in both eases by the commissioners. The copyhold commissioners are now incorporated with the Inclosure Commissioners and the Tithe Commissioners, under the name of the Land Commissioners for England, who publish an annual blue-book. Upwards of 16,000 enfranchisements have been made, the compensation amounting to considerably above $£ 2,000,000$.

Copying is a term in general use for a great many difterent processes, lut may be described generally as the reproduction, usually either on an enlarged or reduced scale, of any drawing, map, or other work of art. A few of the methods employed may be shortly described. If the copy is to be the aame size as the original, the easiest way is to trace it. A piece of tracing-paper (which may be bought at any stationer's) is put over the drawing, and the principal lines gone over with pencil. The back of the tracing is then rublued with hlack lesul or ruddle, and put on the clean paper on which the copy is to be made; the truced lines are gone over with a hard point, and thus indiented fuintly on the paper. Guided by the traced lines, the copy can then be drawn in. It is usual to have the ruddle or black lead on a separate piece of thin paper, and interposed hetween the tracing and the paper. When the copy is required of a different size from the original, the simplest way is to sketch it by hand and eye, but where more mechanical accuracy is required, the method of squares is very useful. The original is covered with squares of any convenient size by pencil lines or threads; a piece of paper for the copy is prepared with a cor. responding number of squares, of a smaller or larger size, according as the copy is wanted smaller or larger. These squares must bear the same proportion to the squares on the original, as the copy is to bear to the original. It is then a comparatively easy matter to copy in each square the part of the original in the corresponding square. To avoid confusion if the squares are small, it is well to number them along each side of the drawing. If it is not convenient to cover the original drawing with pencil lines, or to tie threads over the face of it, a very good way is to draw the squares on a piece of tracing-paper, and put that over the original; the same tracing-paper will do any number of drawings. A pair of proportional compasses (see CoMPASSES) will be found very useful for fixing the proportional size of the squares. Any drawing consisting principally of straight lines, such as a plan, can be conveniently reduced by constructing a scale to suit the reduced size required. The lines of the original are measured by its scale, and the same proportion of the smaller scale gives the necessary measurement. The Pantograph (q.v.) is another means of making a reduction or enlargement, but is very seldom used now. It is only accurate in a general way. Perhaps the simplest and most exact method is to get the original photographed to the required size; the copy can then be traced on to clean paper as already described.

The copying of letters and other documents for commercial purposes is usually done by means of the ordinary copying-press, which is so familiar in every counting-house as to need no detailed deseription. A letter written with specially prepared ink is transferred to another piece of paper by means of damp and pressure. Common ink thickened with a little sugar will serve as copving.ink. Many modifications of this arrangement have been devised for producing a number of copies of circulars, \&c. from one written copy, and are known as 'graphs' (hektograph, \&c.). A document written with the ink prepared for the purpose is transferred by pressure with the hand to a gelatinous slab, from which as many as fifty or sixty copies, more or less distinct, ean be retransferred by rubbing with the hand. A very useful method of manifold writing is largely employed in telegraphic news work, and for duplicating invoices by retail tradesmen. Carbonised paper is put between two or three or more sheets of thin paper ('flimsy'), and thus, whatever is written on the top sheet by a hardish pencil is duplicated on the others. When an indefinite number of copies of any drawing or other subject is required, there are many printing processes which may be employed. Letters or circulars, if written with lithographic ink, ean be transferred to stone, and any number printed. Engineers' or architects' drawings, or any other drawing executed in line, can be very successfully reproduced in any size by the photo-lithograph process, which will be deseribed under LITHOCRAPHY. If required for block or letterpress printing, then 
any of the zincotype processes may be employed. By this process, also, plates to reprint steel-engravings can be produced from any printed engraving (see ENgRaving). For reproducing drawings executed otherwise than in line, photographs from nature, or paintings, there are many processes which will also be described in the same article.

Copying in photography, that is, the method of copying pictures and other drawings by the camera, will be deseribed under Photography.

Drawings for wood-engravings are now seldom made directly on the wood, but executed on paper or eardboard, and copied by photography on to the wood. By this means the drawing need not be so minute as the required engraving, but may be of any convenient size. The process employed will also be described under PhotogRAPHY.

Copyright is the exclusive right to multiply copies of a written or printed composition, or of a work of art. Such rights were claimed by authors even before the introduction of printing. After the invention of the printing-press, the right to publish books became the subject of licenses and patents. In. Chambers's Domestic Annals of Scotland, under date November 9, 1699, may be seen a warrant of the Privy-council authorising George Mossman, stationer in Edinburgh, "to print and sell the works of the learned Mr George Buchanan, in one volume in folio, or by parts in lesser volumes, and forbidding all others to print, import, or sell the whole or any part of the said Mr George his works, in any volume or character, for the space of nineteen years.' Similar privileges were granted in England; but all such monopolies were regarded with suspicion by common lawyers. The common law affords a certain measure of protection to works unpublished, or published only for a limited purpose. The writer of a letter, for example, transfers his property in it to the receiver; but the receiver has no right to print it for sale or distribution without the writer's consent. The copyright in published works is the creation of statute : the first Copyright Act was passed in 1709, and by virtue of its provisions authors acquired the sole liberty of printing their books during a term of fourteen years from first publication, and, if the author should be living at the end of that time, during a further term of fourteen years. While this act was in force, Thomson sold the copyright of his poems to Millar, a London bookseller. Millar claimed the right to prevent the issue of reprints by Donaldson (of Edinburgh) and others, even after the statutory term had expired, on the ground that an author had, at common law, the sole right of printing his works. Out of this dispute arose the famous cases of Millar $v$. Taylor, and Donaldson $v$. Beckett. which led to a remarkable difference of opinion among the judges. The House of Lords decided that, if any common-law right existed, it had been taken away by the statute.

At the union with Ireland, the Copyright Act was extended to that country, and the trade in cheap editions, printed in Dublin and secretly imported into Great Britain, came to an end. In 1814 the term of copyright was extended to twentyeight years, and the residue of the author's life if he were living at the end of the term. The impetus given to literature at the beginning of the present century, and especially the popularity attained by the works of Scott and Byron, greatly increased the market value of copyright, and ultimately led to further legislation in the interest of authors and publishers. The basis of the existing law is the Copyright Act of 1842, commonly known as Talfourd's Aet or Lord Mahon's Act. Macaulay's speech in the House of Commons on the second reading of this measure is one of his most successful parliamentary efforts. The law of copyright is still far from being settled; the acts which relate to the subject are extremely ill drawn. In 1878 a Royal Commission recommended 'that the law on this subject should be reduced to an intelligible and systematic form.' Pending the execution of this useful design, the provisions of the existing British law may be summarised as follows.

Books. - The term of copyright in books is forty. two years, or the life of the anthor and seven years, whichever of the two terms is the longer. No copyright can be enjoyed in seditious or immoral publications, or in books first published out of the United Kingdom. A register of proprietors of copyright is kept at Stationers' Hall, in which the owner of a copyright may make an entry on payment of a fee of 5. Assignments may be made by entry in the register. Non-registration does not affect the copy right, but only the right to sue in respect of the infringement thereof. In case of infringement, the owner of copyright may obtain an injunction from the High Court (in Scotland, an interdict from the Court of Session) to restrain the issue of unauthorised copies; he may also bring an action and claim damages. In such proceedings the defendant frequently pleads that he has made only a fair use of the plaintiff's work. The question, what is a fair use, is a question of common sense, rather than of law. An author may resort to previous works for facts and ideas; he may extract or abridge the copyright composition of another, provided he does not actually copy it, or an unreasonably large part of it, into his own book. Authors complain that the law as it stands does not sufficiently protect them against unfair use of their materials and ideas. The crown is said to have the sole right to authorise the printing of Bibles, copies of the Book of Common Prayer, the Westminster Confession of Faith and Catechisms, and acts of parliament. The universities are permitted to enjoy perpetual copyright in works bequeathed to them. For government publications, see BLUE-Books.

Encyclopocdias and Periodicals.-Articles contributed to publications of this class, and books published in parts or series, belong to the proprietor. But the proprietor may not publish them separately without the writer's consent, and after twentyeight years the copyright reverts to the author.

Dramas and Musical Pieces.-These, if first published in book-form, are subject to the same rules as books. But if they are performed in public before appearing in print, the author retains the sole right of permitting them to be represented during the term of eopyright; and this right is distinct from the copyright he acquires if his drama or piece is published as a book. By an Act of 1882 the proprietor of a piece of music, desiring to reserve the right of performance, must give notice to that effect on the cover. Verses may not be taken from a copyright work and set to music, for sale, without permission: A novel may be dramatised without the author's permission; but if copies of the drama are published containing passages borrowed in substance from the novel, the author of the adaptation is liable to an action. In the 'Little Lord Fauntleroy Case' (1888), the right to dramatise was admitted, but it was held that the authoress could restrain the publication of copies containing passages which were taken from the novel without alteration. Even distribution of copies to the Lord Chamberlain and the actors was held an infringement of her rights; so that the right to dramatise can only be exercised with precautions which must greatly restrict it in practice.

Lectures and Speeches.-If a person delivers an address to the general public, he has probably no cause of action against any one who publishes a report of what he says. But a person addressing a 
limited audience for a limited purpose (as e.g. a protessor instructing his class) may prevent the publication of unauthorised reports.

Letters. - The copyright in a letter, an alrealy mentioned, is retained by the writer, unless he in. dicates his wish that it should be published.

Neospapers registered under the Copyright Acts are copyright, and even the adoption of an exist. ing newspuper title is a gorl cause of action.

Engravings, Maps, dec. - Copyright in these is for twenty-eight years. Each plate and print must bear the name of the proprietor. Copyright in paintings, drawings, and photographs is secured to the artist during his life and seven years after. A register of proprietors of eopyright in paintings, \&c. is kept at ritationers' Hall.

Colonial Copyright. - Since 1842 the copyriglst of books printed in the United Kingdom is extended to all the colonies thereof, and in 1847 the Foreign Reprints Act enabled the colonies to import foreign reprints of British books, on making dne provision for the rights of authors. In 1874 the Canadian Copyright Act euabled a British author to obtain copyright in Canada for twenty-eight years, provided his work be published in the colon

International Copyright.-Foreign anthors and artists are able to secure copyright in Britain for their works, provided due protection has been secured by the country in which such works were produced for the benefit of those interested in similar works published in Her Majesty's dominions. The term of copyricht in France is life and fifty years; in Belgium, life and twenty years; in Germany, life and thirty years; in Italy, life and forty years (with a further term of forty years) ; in Russia, Spain, and Portugal the term is life and fifty years; in Holland, life and twenty years.

Copyright in designs is protected in Englend by the Patents Act of 1883, and in the United States designs are patentable. See Patents, TradeMARKS.

COPYRIGHT IN THE UNITED STATES.-The copyright law of the United States of America, in force in January 1898, provides that authors, artists, artisans, and other proprietors of copyrightable articles may secure a first copyright of the same for a term of twenty-eight years, with a renewal on the expiration of the term for an additional fourteen years, the renewal to be by the author of the book or other work if he be then living, or if he be dead, by his widow or children. No person, however, is entitled to a copyright unless he shall on or before the day of publication of his work in this or any foreign country deliver at the office of the Lilorarian of Congress or deposit in the mail within the Uniterl States addressed to the Librarian of Congress at Washing. ton, D.C., a printed copy of the title of the book or other article on which a copyright is desired, or in ease of a painting, drawing, or other work of art, a description of the same; nor unless he shall also, not later than the day of publication thereof in this or any foreign country, deliver at the office of the Librarian of Congress, or deposit in the mail within the United States addresend to the Librarian of Congress at Washington, D. C., two copies of such copyright book or other printed product on which a copyright is desired, or if it be a painting or drawing, or other work of the fine arts, or a design for a work of the fine arts, a photograph of the same; and to render the copyright defendable he must insert in the several copies of every edition of the work pub. lished, on the title-page or the page immediately following, if it be a book, or if any other copyrightable work on some visible portion thereof, a copyright notice, which notice may be in the following words: "Copyright 18 .. by A. .. B. and he must also send to the Librarian of Congress a copy of every subsequent edition of his book wherein substantial changes have been male; and in case of the failure of the proprietor of any copyright to deliver to the Librarian of Congreas the books or other articles as herein specified for the completion of said copyright, he shall be liable to a penalty of twenty-five dollars, to be collected by the Librarian of Congress in an action in the dis. trict court of the United States.

Copies of books, photographs, chromos, and lithographis deposited for copyright purposes must have been printed from type set within the limits of the United States, or from plates (whether electrotypes, negatives, drawings on stone, or transfers) made therefrom; and in case of the renevul of the copyright by the author or his widlow or children as provided, the printed title of the book or other work, together with the two copies of the same, or the plotograph if it be a work of the fine arts, must be again deposited with the Librarian of Congreas as in the case of the first copyright, the said deposit to be male within six months before the expiration of the first copyright; and the party securing the renewal must within two months from the date of said renewal cause a copy of the record thereof to be published in one or more newspapers printed in the United States for the space of four weeks, and shall comply with all other regulations the same as in the case of original copyrights.

The fees of the Librarian of Congress are : (1) For recording the title or description of any copyright book or other article, fifty cents; or in the case of the description of a production of a person not a citizen or resident of the United States, one dollar. (2) Every copy of such record, fifty cents. (3) Record. ing any instrument for the assignment, one dollar. (4) Every copy of such assignment, one dollar.

See G. H. Putnam, The Question of Copyright (New York, 1891 ; new ed. 1896) ; works by Serutton, Copinger, Shortt, Bowker, and A. Birrell (1899); and Constant's Code Ginéral des Droits d Auteur (1888).

Coquelin, Benoit Constant, actor, born in 1841 at Boulogne, admitted to the Conservatoire in 1859, and made his début at the Thétre Francais, 7th December 1860, as Gros-René in the Dépit Amoureux, After a quarter-century of unbroken success, in classical pieces, in rôles created by himself, and in the broader aspects of comedy, he left the Théatre Francais in 1886, appeared in London in 1887, and in South America and the United States in 1888.

Coquerel, Athanase Laurent Charles, an eloquent minister of the French Reformed Church, was bom in Paris in 1795. He studied theology at Montauban, and beeame in 1818 minister of the French church in Amsterdam, but came to Paris in 1830 , on the invitation of Cuvier, and preached here until his death, 20th January 1868. In 1848 he was elected a delegate to the National Assembly by the department of the Seine. His writings, all marked by earnestness and liberal sympathies, include a reply to Strauss (1841), six collections of sermons (1842-56), and Christologie (1858).-His son. ATHa Nase Josué LaURENT, also a Protestant pastor of liberal tendencies, was born at Amster. dam in 1820. A still more 'advanced' theologian than his father, he found himself at variance with the Protestant Consistory and the predominating intluence of Guizot in his somewhat rigidly orthodox old age. He died at Fismes, in Marne, 25th July 1875. Among his works were an edition of Voltaire's letters on toleration (1863), and Jean Calas et sa Famille (1857).

Coquilla Nut, the fruit of a Brazilian palm, Attule funifirt. On aceount of their large size ( 3 to 4 inches long) and the hard texture and bean. tiful mottling of their dark brown endosperm, they are imported by button-makers and turners. 
Coquimbo, also called LA SERENA, capital of a province of Chili, stands near the mouth of the river Coquimbo, on three terraces. It is a handsome town, with a new cathedral, seminary, lyceum, and hospital. Pop. 14,000. The port of Coquimbo is on a toay, 6 miles SW., and has a population of 5000. It exports copper, silver, and manganese ores, wool, cattle, hay, and cobalt.-The province of Coquimbo occupies the entire breadth of the country from the sea to the Andes. Its area is 12,855 sq. m. ; pop. (1885) 176,244 . The rainfall is small, save in the south, where some farming is carried on. The main occupation is mining of copper, as also silver and gold. See CHILI.

Coqui'to (Juboea spectabilis), a beautiful Chilian palm, of which the sap is boiled down as syrup (miél de palma).

Coracias. See Roller.

Coracle, Currach, or Courach (Celt. comog, curach; Lat. curuca, carrocium, carabus), the name given in the British Islands to a canoe or boat made of a slender frame of wood or wicker-work, and covered with skins. Skiffs of this sort, as well as canoes hollowed out of the trunks of oaks, were in use among the Britons in the earliest times of which we have record. Julius Cresar, who built some of them after the British model, tells us that the keel and gunwales were of light wood, and the

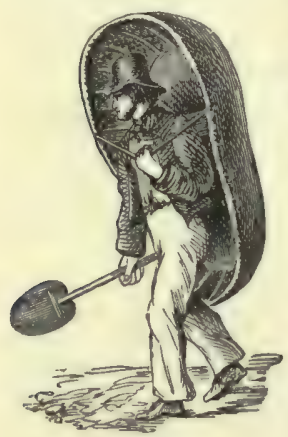

Coracle. sides of wicker covered with hides. The first occurrence of the name seems to be in Gildas, who wrote in the 6th century; he speaks of the coracle as in use among the Scots and the Picts. A long voyage in the North Sea, made in a coracle, during the same century, by one of the companions of St Columba, is commemorated by Adamnan, who died in 704. In 878 three Irish missionaries sailed in a coracle from Ireland to Cornwall; the voyage occupied seven days; and the size of the coracle is indicated by the remark that it was one of two skins and a half. An old Life of St Patrick speaks of a coracle ' of one skin, with neither helm nor onr. The coracle of a larger size had a mast and sail. The coracle, often now covered with tarpaulin, is still used on the Severn, the Dee, and on the Irish coast (Clare and Donegal). The last coracle known to have been used in Scotland is in the museum at Elgin. It was employed on the Spey towards the end of the 18th century. Shaw's History of Moray (1775) describes the coracle, which had then become rare, as ' oval in shape, near 3 feet broad and 4 long; a small keel running from the head to the stern; a few ribs placed across the keel, and a ring of pliable wood around the lip of the machine. The whole is covered with the rough hide of an ox or a horse ; the seat is in the middle; it earries but one person, or, if a second goes into it to be wafted over a river, he stands behind the rower, leaning on his shoulders. In floating timber, a rope is fixed to the float, and the rower holds it in one hand, and with the other manages the paddle. He keeps the float in deep water, and brings it to shore when he will. In returning home, he carries the machine on his shoulders, or on a horse.' One who figures in the Dunciad-Aaron Hill the poet-by showing the Strathspey Highlanders how to make their timber into a navigable raft, hastened the disappearance of the coracle from Scotland. A boat of bison skin, essentially the same with the
British coracle, is in use among some of the Indians of North America.

Coracoid, an important paired-bone in the breast-girdle, forming along with the scapula the articulation for the fore-limb, and always lying ventrally. In the lower fishes the entire girdle is cartilaginous ; in the bony fishes distinct coracoids first appear; they are well seen in Amphibia and in all reptiles except snakes; they are very large and strong in birds; but become mere processes of the scapula in mammals. They very often exhibit a special anterior portion known as the precoracoid. See BIRD, SkEleton, Huxley's Anatomy of the Vertebrates, and such comparative anatomy text-books as those of Gegenbaur and Wiedersheim (translated by Professors Bell and Parker).

Corais (Fr. Coray), Adamantios, a learned Hellenist, was born at Smyrna, 27th April 1748. He early abandoned hereditary mercantile pursuits to devote himself to letters at Paris, where he lived till his death, 6th April 1833. He published editions of many ancient Greek authors, as the Athiopica of Heliodorus, and laboured all his life to promote Greek learning and the feeling for Greek patriotism. His Atakta, ou Mélanges sur la Littérature Grecque Moderne (5 vols. Paris, $1828-35$ ) is a work of great value. His autobiography was published at Paris in 1829-33; his papers and letters at Athens (8 vols. 1881-91). See Koraës, a monograph by Thereianos (Trieste, 1891 ).

Coral, a term loosely applied to any animal in the class Cœlenterata which forms a hard skeleton. The tubular organ-pipe coral, the noble or red coral of commerce, and the reef-building madrepore corals, are familiar examples. Presuming an acquaintance with the general features of the class, as summed up in the article Carenterata, we may notice at the outset the fact that the formation of hard supporting structures is exhibited in very varied degrees, in manifold styles of architecture, and in widely separated forms.

Different Kinds of Coral.-(1) Among the Hydrozoa the skeletal investment of the polyp

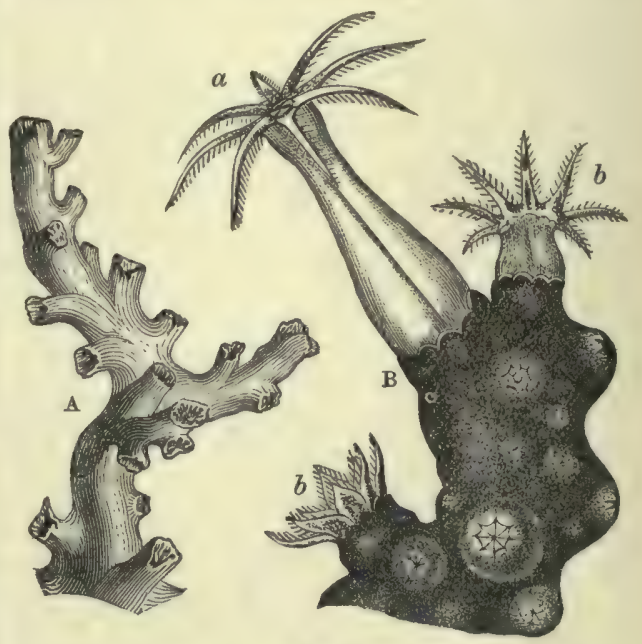

Fig. 1.

A, branch of Dendrophyllia; B, part of a stock of red coral, with $(a)$ fully extended polyp, and $(b, b)$ two polyps, partly extended.

types, when present, is usually horny. In one subdivision, however, the supporting framework is limy, and to these forms-Millepores $(q, v$.$) and$ Stylasterids-the title Hydrocorallina is fitly applied. (2) It is, however, in the other sub-class 
of Coelenterates-the Actinozoa-that the formation of coral structure becomes emphasised and perfected. In many aimple and in most colonial forms, a skeleton is formed, as isolated spicules or continuous. When continuous it may be horny, or limy with an organic basis, or to all appearance entirely limy. (a) Among the Aleyonaria, of which Alcyonium $\left(q . v_{\text {. }}\right)$ is a convenient type, Tubipora, with the spicules united to form tubes and crossing platforms ; Corallium, with a branched axis of fused spicules; Isis, with a jointed axis alternately limy and horny; Heliopora, with limy cups inclosing the individual animals, and traversed as they grow by successive horizontal floors at slight intervals, are examples of different forms of coral occurring in distinet groups. (b) Among the Zoantharia, of which Actinia or any sea-anemone is a familiar example, the Actiniaria have no skeleton, and therefore include no coral forms; the Antipatharia have a varied non-calcareous supporting skeleton, and include some forms known as 'black corals;' the third subdivision, the Madre. poraria, always have a continuous limy skeleton, and include the best-developed corals. Most madrepores are colonial, and the common connecting skeleton is either solid (apart from mere gaps) or perforated by canals which establish community of life between the individual members. Hence it is usual to distinguish two sections of Madrepores as Aporosa and Perforata. (3) The earliest corals of Palrozoic strata-the Rugosa or Tetracorallaare distinguished by four primary partitions.

General Structure.-In discussing further the general structure, it will be convenient to leave the widely separated Hydrocorallina out of account. The most general fact that can be stated at the outset is, that with the possible exception of the ses-pens, the cells which form the skeleton are at leat originally epidermic. Free spicules, connected lattice works, solid cups, illustrate various degrees of lime deposition; while supporting axes, ensheathing tubes, and what look like tolerably

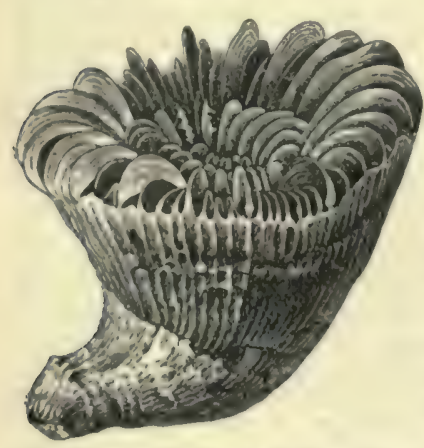

rig. 2.-Caryophyllia borealis, single individual. complete casts of the entire animal, are the main types of coral architecture. In detail, however, those main types vary widely, and in the cup-corals especially, the structure is often very complex. In a simple madrepore coral, repre. senting s single individual, the following structures are at once obvious. The main eup-like mass, known as the theca, is usually attached by its base to some foreign object. A terminal depressionthe calyx-contains the animal, the soft parts of which extend more or less over the lips. Within the cup, when the animal has died away, radial partitions are seen, forming various systems of septa. Some of these often meet in the middle of the cup to form a central pillar or columella. When the coral is colonial, as is generally the case, complications arise by the fusion of individuals. The deeper parts of growing corals are sometimes separated off by cross partitions (tabula), but this is rare in-the Zoantharia. In large masses of madrepore certain portions of the skeleton are often left behind by the animals, and being exposed to the water, become corroded and altered. In regand to the development of corals, it is hardly powsible yet to make any uneful general statementa. For the animals themselves, it nust be enough here to refer to the articles on ALCYONIUM and ANEMONE. which, though not themselves 'coraln,' are gool examples of the two sub-classes to which most cornls belong.

General Life. Corals are predominantly pasoive forms, and are much moditied by their environ. ment (currents, \&c.); the great majority are permanently fixed, except in embryonie life. Flabellum may be noted as an instance of a coral. cup which becomes free as an adult. The liny material which forms the skeleton seems, in many cases at anyrate, to be derived not from the water. but from the minute animals which constitute the food. The great majority are colonial, yet cases of division of labour are very rare. Many corals are richly coloured, but the meaning of the numerous pigments is still imperfectly known. Masses of corals furnish browsing ground for crowds of animals, not a few of which intrude into the colonies, while others have become established parasites. Some corals also include parasitic Algro (see Sy MBIosis). Semper describes some very interesting cases of the constant association of worms and corals, and notes how the guest has permanently modified the host (see CoMMENSALISM). It is interesting to notice, apart from actual modi. fieation of form, how various worm-organisms act upon the 'sea-meadows of coral' much as earthworms do upon land-meadows (see Huxley's Inverte. brates, p. 171).

In most corals the sexes are separate, and even the colonies may be entirely male or female. In Corallium, hermaphrodites may occur, or different branches be of either sex. As is common in sessile passive organisms, asexual or vegetative reproduction is a marked feature. Semper considers the budding of the Fungia colony as illustrating "alternation of generations."

Distribution. - Of the madrepore corals, the "solitary" forms, which never form great masses, are for the most part widely distributed deep-sea animals, while the reef-builders are as markedly dwellers in shallow water, from the low-tide mark to abont 20 fathoms, and are limited to warm waters. They are not found on the western coasts of Africa and America. In the waters of the Central Pacific reef-corals are found in greatest profusion and variety; but those of the Red Ser, Indian Ocean, and East Indies are not far behind. Over eighty fossil genera of the Palseozoic Rugosa are known, and of the other Actinozoan corals, about 1800 fossil, and as many living species. Of these, the vast majority are madrepores, and only a small number Aleyonarian. Both sets begin in Silurian times, but were for long outnumbered by the Rugosa. Most existing genera date only from the Tertiary period. The 'areas of past distribution of coral-reefs in no way correspond with those distinctive of the modern seas,' See Heilprin, Distribution of Animals (1887).

Important Forms. The most important corals are the reef-builders (Porites, \&c.). The deliente colour, exquisite architecture, and lahyrinthine complexity make the limy skeletons beautiful objects. Yet more benutiful, however, is the wealth of colour often exhibited by the living forms. Caryophyllia is a simple and solitary eup-coral found on the south cosst of England. Bathyactis and Deltocyathus are almost worldwide. Antipathes the black coral-has a valu. able hard axis like ebnny. Fungia is worth noting on account of its flat mushroom-like shape and Semper's observation (see above) in regand to alternation of generations; among Aleyonarian 
forms may be noted the blue coral (Heliopora corvelea) of many Pacific coral-reefs, the horny and beautifully coloured sea-fan (Gorgonia flabellum), and the familiar organ-pipe coral (Tubipora musica).

More important, however, in practical interest is the red coral (Corallium rubrum) of commerce. In this coral the limy spicules are fused to form the familiar solid axis. The most important banks are those of Algiers and Tunis, and off the Sardinian, Sicilian, and Balearic islands. Great quantities are fished near Naples, and at Sciacea in Sicily. The coral is roughly dredged, freed from its rind, assorted according to colour, and manufactured in Naples, Leghorn, Genoa, \&c. Pale rose-coloured coral, not spoilt by the boring of worms and other intruders, has fetched $£ 12,10 \mathrm{~s}$. per ounce. The industry is a very important one, though in recent years it has seriously declined. The most important markets are in Asia, Africa, parts of Russia, Japan, and South America.

CORAL ISLANDS is the name given to certain low islets which are composed for the most part of the calcareous skeletons of various kinds of corals. An atoll or typical coral island consists of a somewhat ring-shaped reef inclosing a lagoon. Such reefs vary in size from less than a mile up to 90 miles long and may be 10 miles wide-the breadth of the annular reef being on an average about a quarter of a mile. Barrier-reefs, which have a similar breadth, are found surrounding islands or bordering mainlands, from which they are separated by a navigable channel. Fringing-reefs, on the other hana, extend outwards from the shore, with no separating lagoon-channel. In the case of atolls and barrier-reefs there is generally a navigable passage through the reef into the lagoon or lagoonchannel, which is kept open by the scour of the tide. It is upon atolls or barrier-reefs that islands occur. Only very rarely, however, are these islands coextensive with the reef-generally they appear as longer or shorter belts, forming a series of islets straggling along its surface. As reef-building corals do not flourish in water having a lower temperature than $68^{\circ} \mathrm{F}$., they are necessarily restricted to tropical and subtropical seas-from many regions of which, however, they are excluded by the presence of cold currents coming from extra-tropical latitudes, by the muddy character of the water opposite the mouths of large rivers, and by other causes.

The rock of a coral-reef is a white limestone com. posed chiefly of masses of corals, coral debris, and sand, together with the hard parts of molluses, echinoderms, bryozoans, and calcareous algæ. Not infrequently this rock has been changed by the chemical action of percolating water into a compact or crystalline mass, which has lost all, or nearly all, trace of its organic structure. Chamisso (q.v., known also as a poet), the naturalist who accompanied Kotzebue the Russian navigator in his voyage of discovery into the South Sea in 1815-18, appears to have been the first to show how such reefs are converted into dry land. He describes how the polyps cease to grow when they reach the surface of the sea, and how the reef, exposed at low-tide, by and by becomes disintegrated, while broken coral debris is heaped up by the action of the breakers so as eventually to form a high bank which can only be covered during spring-tides. This bank of coral blocks and debris solidifies in time, and remains exposed to the fierce heat of the sun, so that the mass shrinks and cracks, and flakes are detached from it, and raised one upon another by each returning tide. "The always active surf throws blocks of coral (frequently of a fathom in length and 3 or 4 feet thick) and shells of marine animals between and upon the foundation-stones; after this the calcareous and lies undisturbed, and offers to the seeds of trees and plants cast upon it by the waves a soil upon which they rapidly grow to overshadow its dazzling white surface. Entire trunks of trees, which are carried by the rivers from other countries and islands, find here at length a resting-place after their long wanderings: with these come small animals, such as lizards and insects, as the first inhabitants. Even before the trees form a wood, the real sea-birds nestle here; strayed land-birds take refuge in the bushes; and at a much later period, when the work has been long since completed, man also appears, builds his hut on the fruitful soil formed by the corruption of the leaves of the trees, and calls himself lord and proprietor of this new creation.' According to Professor L. Agassiz, the large blocks torn off by the breakers. are loosened not by shrinkage under the sun's heat, as Chamisso supposed, but by the innumerable perforations of various boring molluses.

The origin of coral-reefs is a question which has at various times given rise to discussion. Accord. ing to Chamisso, the corals commenced to grow on shoals in the sea- on the tops of submarine mountains in short. The circular form of the atoll and its basin-shaped lagoon he believed to be due to the natural growth of the coral. The most vigorous growth took place upon the outward edges of the reef, where the largest and most massive corals flourished. In the interior the coral growth was hindered by the accumulation of shells, coral debris, and sand swept forward by the waves. The reef, therefore, as it approached the surface would gradually assume a basin-shape-the outer edges, or peripheral and actively growing portion, forming the reef-the interior part, where growth was retarded or prevented by sediment, \&c., forming the lagoon. Other writers attempted to account for the annular form of atolls by supposing that the reefs had grown upwards from the crests of submarine volcanic craters. The not infrequent oecurrence of voleanoes and volcanic islands in the coral regions of the Pacific Ocean was thought to favour this supposition, but the enormous diameter of many atolls seemed to preclude the possiloility that these larger atolls, at all events, could be founded on the lips of submarine craters. And when at length it was discovered that reef-building corals flourish only in comparatively shallow water, this hypothesis was rejected, since it was extremely unlikely that so many submarine volcanic mountains should rear their summits just to the limits within which the corals could begin their superstructures.

Darwin, during the famous voyage of the Beagle, was naturally fascinated by the problem of the origin of these remarkable reefs, and while he admitted that certain atolls might very likely have been formed in the manner described by Chamisso, yet he could not believe it possible that a broad mountain-summit lay buried at the depth of a few fathoms beneath every atoll, and nevertheless that throughout the immense areas occupied by many of those reefs not one point of rock should project above the surface. The theory of subsidence which he subsequently advanced seemed to account for all the phenomena, and until recently it commanded nearly universal assent. According to Darwin, each atoll has passed through the suecessive stages of fringing-reef and barrier-reef. Since reef-building corals do not thrive at greater depths than 100 feet or thereabout, it is evident that the foundations of a coral reef could not have been laid in deeper water. And as such moderate depths occur only round islands and off the shores of continents, the reef-builders would begin their work by forming at first a fringing-reef. Slow subsidence of the sea-bottom is supposed to have supervened; but while the foundations were being carried down, the corals continued to grow upwards, the 
rising of the reef keeping pace with the sinking of the sea-bottom. Thus by-and-by the fringing-reef is converted into a barrier-reef. We have now only to suppose that the movement of subsidence and the labours of the corals continue until the reefencircled island disappears below the waves, and a complete atoll will be the final result. Darwin's views were illustrated and strongly supported by Professor J. D. Dana, who accompanied the Wilkes exploring expedition round the world in $1838-42$, while MM. Couthouy and Beete Jukes likewise upheld the hypothesis of subsidence. The researches of Professors L. Agassiz and Le Conte amongst the reefs of Florida have shown that Darwin's views are there inapplicable. They attribute the formation of the southern portion of Florida, which consists of a series of concentric barrier-reefs, to the natural growth of the coral alone aided by the mechanical action of the seaa view which, stated generally, is the same as that held by Chamisso. Professor Karl Semper like. wise, after examining the reefs of the Pelew Islands, came to the conclusion that the form of these reefs had been determined by the natural growth of the corals, modified by local conditions, which is just Chamisso's explanation. But Darwin had already expressly stated that some reefs might have originated in the manner suggested by Chamisso; and geologists apparently recognised that the conditions of the great Florida reef were hardly analogous to the isolated atolls which rise from profound depths in the open ocesn.

In 1880, however, Dr (afterwards Sir) John Murray of the Challenger expedition, published another explanation which has given rise to considerable discussion. He returns to the old views of Chamisso, maintaining that reefs have grown up from the tops of submerged and partially submerged banks and mountains. To the objection that it is hard to believe that so many banks and cones should occur just at the proper depth from the surface, Dr Murray replies that it is not necessary to suppose that all the submarine emin. ences were of equal or nearly equal height. Some may have risen at first above the level of the sea, and subsequently have been reduced by the waves and breakers to the condition of shoals; while others that did not reach to the limits within which reef-builders live may have been brought up to that zone by the accumulation upon them of the hard parts of pelagic organisms. For these forms of life flourish in extraordinary numbers in the surface. waters of the tropics where reefs abound, and as they die, their hard parts falling to the bottom will accumulate there along with the exuviæ of ereatures living at such depths, until they come to form considerable deposits. This levelling-up of submarine banks to the zone within which coral-builders thrive is the most marked feature in Dr Murray's hypothesis. His further account of the mode in which atolls and barrier-reefs have been formed is a more particular and scientific development of Chamisso's explanation. The growth of a reef is regulated by the food-supply of the corals; those growing on the external parts of the reef are most favourably placed in this respect, consequently they thrive best, and have the advantage over those that are growing in the centre of the reef; and this difference in the rate of growth of the outer and inner areas will be intensified as the reef approaches the surface. Eventually the corals of the interior die, and the dead coral rock is gradually removed by the solvent action of the sea-water which contains carbonic acid. In this manner the reef assumes a basin-shaped form. Fringing-reefs, according to Dr Murray, are converted into barrierreefs by the simple ontward growth of the coral apon a talus of its own debris, forced off from the edge of the reef by the breakers. The lagoon. channel that eventually separates the reef from the lend is formed in the same way as the lagoon of an atoll-namely, by the dissolution and removal of dead coral rock. Professor A. Agassiz published in 1882 an account of his detailed examination of the Tortugas and the Florida reefs, in which he shows how the bottom of the sea in those regions has been gradually raised by the accumulation of the exuvire and skeletons of massive organimms which flourish in prodigious numbers on the seafloor, forming the submarine plateaus known as the Florida, Yucatan, and San Pedro banks. He thinks it is by the gradual upward growth of such aceumulations that the sea-bottom was eventually raised to the zone in which reef-builders thrive. He thus arrived independently at the same general conclusion as Dr Murray.

As recently as 1887 Dr Guppy (q.v.) has given the result of his investigations in the Solomon Islands, and has vigorously supported the hypo. thesis advocated by Murray. He shows that in those islands we have elevated reefs which exhibit the very structure which we should expect to find if the new view of coral-reef structure is correct. He found some of those islands largely composed of earthy calcareous deposits having the same character and origin as the various volcanic muds and organic oozes which the Challenger expedition dredged at depths varying from 100 to 2000 fathoms. These deposits reached to heights of over 1000 feet, and in some cases denudation had exposed an underlying nucleus of volcanic rock. The earthy calcareous beds were covered with a comparatively thin erust of true coral rock. The phenomena described by Dr Guppy thus lead to the belief that many other atolls may have a similar structure. Dr Guppy thinks that the various agencies insisted upon by Semper, Murray, and A. Agassiz - such as currents and tidal scour, solution and the distribution of food-supply, the repressive influence of sediment and the action of the breakers-have each played a part in determining the form of coral reefs. To the objection that some lagoons are deeper than the zone in which reef-corals live, Dr Guppy replies that where the submarine slope is moderate, the water clear, and breakers of no great size, reef-corals may be found flourishing at depths of 50 and even 60 fathoms. Whether the explanation advocated by Murray and Guppy is destined to lead to the total collapse of Darwin's hypothesis, is likely to remain for some time an unsettled question-some writers holding that while Murray's view may be the true explanation of the origin of many atolls and barrier-reefs, it does not forbid the possibility or, as others would say, the probability that many other reefs may really have been formed, as Darwin supposed, during slow subsidence of the bottom.

See Coglenteratzs, Ankmone, Aloronium; textbooks of Zoology-Huxley, Claus, \&e.; Darwin, Dana, Murray, Guppy, de on Coral-reefs, and 'Semper's Animal Life; Moseley and Queloh Challenger Rep., vols ii. and xvi.; for skeleton, Von Koch, Morphologisches Jahrbuch (1879-86); for red coral, Lacase-Duthiers, Hiatoine Naturelle du Corail (1864); for fossil forms, Zittel's Palceontologie; cystematio works-Dana, Zoophytes (1848-49); Milne-Edwands and Haime, Hist. Nat. des Conalliares $(1857-60)$; Koren and Danielssen, Nye Aleyonider, Gongonider of Pennatulider (1883); Koch, Monograph on Gongonida (Naples Station, 1887).

Coral Fishes (Squamipennes), a name applied to a family of bony fishes in the spiny-rayed or Acanthopterous order. They are tropical forms, abundant about coral-reefs, usually small, with short, deep, often brightly coloured bodies. The family includes the Archer-fish (q.v.), the very beautiful Chretodons, the genus Chelmo with 
peculiarly elongated snout, and other interesting forms.

Coral Flower, or Coral Tree (Erythrina), a tropical and subtropical genus of papilionaceous trees and shrubs, with long racemes of beautiful flowers of a rich dull crimson or a scarlet colour, resembling coral. Some species are thorny, and are hence used for hedges, notably $E$. corallodendron in the West Indies, and E. indica in the East. The wood is so light and spongy that it is used not only for portable objects, such as ladders, but even as a substitute for cork.-Jatropha multifida, a totally different plant, of the order Euphorbiacer, is also sometimes called Coral Tree.

Coralline (Corallina officinalis), a linıy seaweed, exceedingly common on British coasts, where it adds much to the beauty of the rocky pools. It is a hardy perennial plant, and envelops the rocks and almost any object between tide marks with its beautiful branching fronds. In spring it appears as a thin crust, with a fresh delicate pinkish or purplish colour. With the increasing sunshine it grows into prettily jointed and branched tuftis, spreading like brushwood over the surface of the rock. Its purple colour increases in depth, till the plant grows old and begins to die; then the brightness pales, and the limy incrustation finally remains

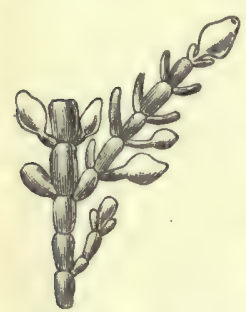

Portion of Branch of Corallinaofficinalis magnified.

(From Landsborongh.) as a white skeleton. The purple colour soon fades on exposure; a bright white light is produced by holding a piece of the alga in a candle flame; an unpleasant smell lingers for years about the dried specimen. The coralline was formerly regarded as an animal. "since all lime,' Linnæus said, 'is most truly a product of animals. But neither for this, nor for its supposed medicinal (vermifuge) virtues was there any warrant. Technically, the com mon coralline, along with a few other species, forms a genus of alga in the family Corallines,

the section Rhodospermea, and the group Floridere. Melobesia is an allied form of similar stony character. It is sometimes used for manuring fields, and is said to have been one of the principal con. stituents in the mortar of. Iona cathedral. The name coralline is sometimes extended vaguely to certain Zoophytes or Hydroids (q.v.). See Landaborough's British Secweeds, Harvey's Phycologia Britannica, Johnston's British Sponges and Corallines.

Coralline Crag. See Crag and Pliocene.

Coral Rag, or CoralliaN, a group of the Oxford or Middle Oolites. See JuRAssic System.

Coral Sea is that section of the Pacific which stretches between Australia on the west and the New Hebrides on the east. In 1874 the Challenger expedition found parts of it to be 14,700 feet deep. See Pacific.

Coral Snake (Elaps), small venomous snakes in the same family (Elapidre) as the Cobra (q.v.). The typical species ( $E$. corallinus) frequents woods and thickets in South America. Their very small mouth makes them less dangerous. The usual colour is rich red with black and yellow transverse hands, and it is an interesting faet that besides the venomous Elaps, at least two other genera occur which are quite harmless. These, Mr Wallace suggests, probably derive advantage from their close resemblance to the venomous forms.

Coram, THомAs, philanthropist, was born at Lyme Regis, Dorsetshire, in 1667 or 1668 . He was bred a seaman, and rose to be a merchant captain. Already in 1694 we hear of him as settled at Taunton, Massachusetts, and engaged in benevolent work of various kinds. A few years after he seems to have returned to sea, and to have settled in London, after suffering shipwreck off Cuxhaven in 1719. In London he interested himself in the settlement of Georgia, and in planting English artisans in Nova Seotia; but he soon began his long agitation for the foundation of a foundling hospital. Children were first admitted in 1741 . Coram's portrait was painted by Hogarth, a warm patron of his scheme. More thoughtful for others than for himself, Coram fell into poverty, from which he was relieved in $\mathbf{1 7 4 5}$, by an annuity of 161 contributed by his friends. He died 29th March 1751.

Cor Anglais, a wind-instrument of the reed species, similar in construction to the Oboe $(q . v$.$) ,$ to which it has the same relation as the Basset-horn (q.v.) has to the Clarinet (q.v.). It is usually made in the key of F, a fifth lower than the ordinary oboe, and has the same range-viz. from $\mathbf{E}$ in the bass stave to $\mathrm{B}$ b above the treble stave.

Cora'to, a large town in Southern Italy, on a fertile plain, 25 miles west of Bari. Pop. (1881) 30,428 ; (1891) 30,798 .

Corban, properly an offering to God in fulfil. ment of any vow. This might either be of some possession devoted to God, redeemable by an equiv. alent in money, or it might be a pledge to deprive one's self of something lawful in itself, as wine, for a longer or shorter period. A man might so interdict himself by vow, not only from enjoying anything himself, but also from giving it to others, and thus many of the old Jews juggled their consciences into getting rid of natural responsibilities, as the support of decayed parents, and the like. It was this miserable selfishness, under the thin garb of religions hypocrisy, that our Lord rebukes in the Scribes and Pharisees (Matt. xv. 5 ; Mark, vii. 11).

Corbeil, a town in the French department of Seine-et-Oise, on the Seine, 21 miles $\mathbf{S}$. of Paris by rail, with manufactures of clocks, cotton, and paper, and large flour-mills and granaries for the supply of Paris. Pop. (1881) 7541 ; (1891) 8047.

Corbel, in Architecture, a projection of stone or wood from the face of a wall, used for supporting pillars or other superincumbent weights. Corbels proper were originally plain on the sides and carved on the front only. Such were the Romanesque corbels, which are so numerous and so richly ornamented. The carving at first resembled the end of wooden beams, but gradually all sorts of figures were introduced, chiefly heads of men and

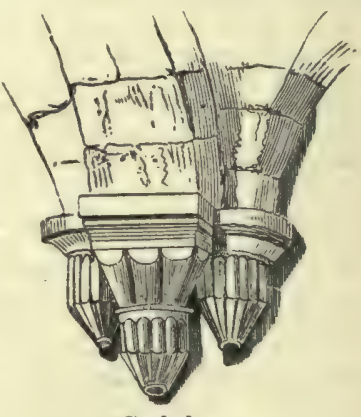

Corbel :

Kirkstall Abbey. animals. Corbels of great size were likewise used to carry the projecting parapets of castles.

Corbet, Richard, poet and bishop, was born in 1582, son of a gardener in Ewell, Surrey. From Westminster School he passed to Broadgates Hall (now Pembroke College), next to Christ Church, Oxford. He took orders, and had already enjoyed preferments at Cassington, Oxfordshire, and Stewkley, Bucks, as well as a prebend in Salisbury, 
when in 1620 he was made Dean of Christ Church at thirty-aeven. In 1624 he was appointed to the see of Oxford, and translated to that of Norwich in 1632. Here he died in 1635 , and was buried in his euthedral. Corluet's poretry reflects the cheerful and genial temper of the man. His longest piece is Iter Boreale, an account of the holiday. tour of four students; the best, as well as the best known, is the Fairies' Farevell. Corbet was famous throughout life for his conviviality and wit.

Corbey, or Corbiz. See Corver.

Corbie-steps, or Crow-strps, the stepped slopes of gables. This is a Scottish term, derived

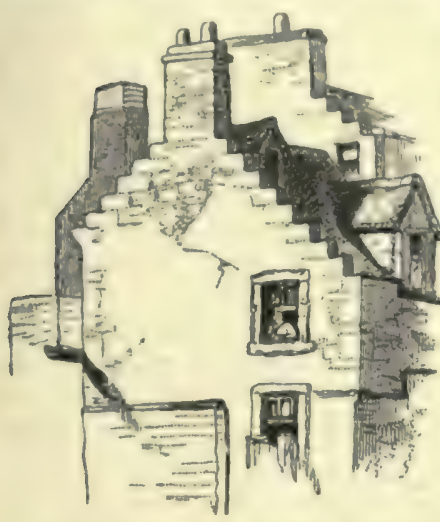

Corbie-steps, from a house formerly in the Castle-wynd, Edinburgh. nodour the corbelled or projectin character of the steps, and af terwards corrupted in to erow-steps from the resemblance of corbelled to corbie or crow. The origin of this mode of finishing a gable probably arose from the steps used for passing from one side of the roof toanother - the parapet defending the passage being stepped in conformity with the slope of the stairs. Crow-steps were the almost invariable finish of Scottish gables from the 14th to the 17th century, and they were also much used on the Continent, especially in the Low Countries.

Cor'chorus, a genus of Tiliacer. $\quad C$. olitorius is widely diffused in tropical countries, being cultivated both as a pot-herb (Jew's Mallow) and on account of its fibre. More important, however, in the latter respect, is the closely allied $C$. capsu laris, which has long been cultivated for its fibre in China ('Chinese Hemp'); also in India for making Gunny Bags (q.v.), and is now of great importance in European manufactures as Jute (q.v.). The Japanese shrub, common in gardens on account of its pretty double yellow flowers, and still frequently ealled by gardeners $C$. japonicus, really belongs to the Spirtea family of Rosacere, and is correctly known as Kerria japonica.

Corcyra is the ancient name for Corfu $(q . v)$.

Corday d'Armans, Marie Charlotte, known as CHARLOTTE CORDAY, was born at St Saturnin, near Sées (Orne), 27th July 1768. The descendant of a noble family, with Corneille's blood in her veins, she yet welcomed the Revolution, for from Voltaire she had imbibed 'philosophic' theories, from Plutarch ideas of antique heroism. But she was horrified at the monstrosities of the Jacobins; and her hatred of their acts was intensified by converse with a party of proscribed Girondists, who had tled to Caen in Normandy. She resolved to rid her country of one of the heads of the Jacobins, and came with that view to Paris. Whether to slay Robespierre or Marat was an open question; but while she debated the matter with herself, a demand of the letter for two hundred thousand more vietims, marked him out for her weapon. Twice she failed to obtain an audience, but on the evening of 13th July 1793 she was admitted on the plea that she had important news from Caen to communicate. She found Marat in his bath, and her pretended denunciation of the fugitive Girondists, nome of whom were her own friends, called forth the remark: "They shall re. ceive their reward; I will have them all guillo. tined at Paris.' Straightway she drove her knife to his heart; he died with a stifled ery. Charlotte was at once arrested, and brought before the Re. volutionary Tribunal, where she gloried in the act. In the Conciergerie she sat to the artist Hauer: on the evening of $17 \mathrm{th}$ July she was guillotined. The executioner held up her head to the multitude, and slapped it; in the sunset the beantiful deal face seemed to blush. See works on her by Vatel (3 vols. 1872), Mrs Van Alstine (1889), and $R$. Focke (1895); also Austin Dobson's Four French. women (1890).

Cordeliers ('cord-wearers'), the name applied in France to the strictest branch (see OBsERV. ANTIST8) of the Franciscans on account of their wearing a girdle of knotted cord. During the Revolution the name was applied to the nembers of a political elub which was instituted in 1790 , and assembled in the chapel of a Franciscan monastery. Its leaders included Danton, Hébert, Camille Desmoulins, and Marat, and for a time it rivalled the more famous club of the Jacobins $\left(q, v_{0}\right)$. The height of its influence was the period of Camille Desmoulins' journal, Le Vieux Cordelier. Soon after the fall of Danton, the Cordelier clul, lost its influence, and it was insignificant when closed by the Convention in August 1795 .

Corderius, the Latinised name of Mathurin Cordier, grammarian, born in Normandy in 1478, who taught at Paris (where he had Calvin for a pupil), and, becoming a Protestant, settled at Geneva. There he died, famous as a skilful tencher of youth, on the 8th September 1564. He wrote a long series of grammatical works, of which the best known throughout Europe was the Colloquia Scholastica (1564).

Cordia'cese are simply drupaceous Boraginacese. Some species are valued for their fruit, others for their timber.

Cordierite, Dichnorrk, or IoLITE, a natural silicate of magnesia, alumina, and ferric oxide. It crystallises in stout orthorhombic prisms, and is of various shades of blue, sometimes with a tinge of gray or brown. It exhibits the property of dichroism very clearly, often appearing deep blue when viewed in the direction of the vertical axis, but red or yellow when seen by transmitted light at right angles to that direction.

Cordille'ras (lit. 'chains ') a name applied in America to various chains of mountains. The Cordilleras of South America are described under ANDES; and the Rocky Mountains are the Cordillers of North America. Those of Central America extend from Darien to the north of Mexico. See America, Mexico.

Cordite, a smokeless powder (see GUN-COTTON) invented by Sir Frederick Augustus Aleel, and used in the British Army since 1889, is made of a mixture of gan-cotton, nitro-glycerine, and vaseline; and is named from its string-like or cord-like appearance. See RIFLEs.

\section{Cordoba, in Spain. See Cordova.}

Cor'doba, a central province of the Argentine Republic, mostly paupa land, rising to the Sierras de Cordoba and de Pocho in the west. Area, 55,350 sy. m. ; pop. 380,000 . Cattle-raising is the chief industry. The climate is healthy, lut very dry ; the temperature ranges from $18^{\circ}$ to $107^{\circ} \mathrm{F} .-$ The capital, Cordoba, lies 246 miles WNW. of Rosario by rail. It has over 10 miles of tramways, a cathedral, a handsome city-hall, the old university 
building, with walls from 4 to 6 feet thick, a national observatory, and noble baths. The university (1613) sank greatly after the expulsion of the Jesuits (1767), until in 1870 several German professors settled here. The town possesses also a national college, a school of art, and an academy of sciences, which publishes a valuable Boletin. Founded by Cabrera in 1573 , the town was famous during the Spanish occupation as a seat of learning and the centre of the Jesuit missions in South America. It was afterwards falling into decay, but the opening of the railway in 1870 , with the transit trade which this brought, has greatly restored its prosperity. In the hot months of December, January, and February, however, the place is a very trying residence. Pop. (1869) about 28,500 ; (1895) 42,700.

Cor'doba, a town of Mexico, 66 miles WSW. of Vera Cruz by rail, in a fruitful valley, 3045 feet above the sea. Formerly important, it sank greatly after the revolution; but in later years it has in some degree recovered its trade. It is surrounded by rich coffee-plantations. Pop. about 12,000.

Cordon, in military operations, is a line of sentries within sight of each other inclosing or guarding any particular space of ground, to prevent the passage of unauthorised persons. If intended to guard against contagious diseases, it is called a cordon sanitaire.

Cordon Bleu, originally the 'blue ribbon' which in France supported the insignia of the Order of the Holy Ghost; but playfully transferred to good cooks, who after examination received a medal, also suspended from a 'blue ribbon.'

Cor'dova, or CóRDoBA, a city of Spain, capital of the province of Cordova, 81 miles ENE. of Seville by rail. It stands on the right bank of the Guadalquivir, here crossed by the Moorish 'Puente Viejo " of sixteen arches, and occupies a slope connected with the Sierra Morena. The old turreted walls inclose gardens and vineyards; but the interior shows narrow and dirty streets. Cordova was from the 9 th to the close of the 12th century a Moorish town of the first rank, renowned for its rich mosques and palaces, and still more for its university. Among the principal buildings is the cathedral, built as a mosque in the 8th century, the most magnificent Mohammedan temple in Europe, and converted (1236) into a Christian church. Cordova was at one time celebrated for its manufacture of goat leather, called cordovan, whence the term cordwain, but that industry is now almost entirely gone from it. Cordovan, still prepared in the Levant, is used in bookbinding and for finer boots and shoes. Cordova has a bishop's palace, a lyceum, a theatre, a fine casino, museum, \&e. It manufactures silverware, silk fabrics, paper hats, \&c. Called by the Carthaginians the 'gem of the south,' Cordova was (152 B.C.) founded by the Romans as Corduba. Taken by the Goths in the 6th century, it fell (711) to the Moors, in whose hands it remained till 1236, when Ferdinand III. of Castile struck it a blow from which it has never recovered. In 1808 Cordova was taken and plundered by the French. Cordova was the birthplace of the poet Lucan, and the philosophers Seneca and Averroes. Pop. (1895) 57,450.-The province of Cordova has an area of $5190 \mathrm{sq}$. m., and a pop. of 420,000. See Andalusia.

Corduroy, a ribbed kind of fustian, a cotton stuff made after the fashion of velvet. See Fustian.

Corea (native name Chosön, 'Morning Calm'), a kingdom on the east coast of Asia, stretching as a peninsula from $34^{\circ} 30^{\prime}$ to $43^{\circ} \mathrm{N}$. lat., and from $124^{\circ}$ $30^{\prime}$ to $130^{\circ} 30^{\prime} \mathrm{E}$. long., between the Sea of Japan and the Yellow Sea, and separated by the Strait of Corea from the Japanese Islands. It has a coastline of about $\mathbf{1 7 4 0}$ miles, and a total area of about $90,000 \mathrm{sq} . \mathrm{m}$. The north boundary line is formed by the river Tu-man flowing north-east, and the Am-nok flowing south-west from the watershed of Paik-to-san. The Tu-man, for the last 5 miles of its course, separates Russian Asia from Corea. A belt of land, $5600 \mathrm{sq} . \mathrm{m}$., on the north side has for the last three centuries been constituted a neutral zone between Corea and Manchuria, but is now being gradually encroached upon both from the Chinese and Corean side. The east coast is high, monotonous, and but slightly indented, with very few islands and harbours. The south and west shores are deeply and manifoldly scooped, and beset by numberless picturesque islands. From these island-fringed shores, especially on the west cosst, mud-banks extend out to sea beyond sight. While the tide on the east coast is very slight-only 2 feet at Gensan-it increases on the south and west coast in a north direction, rising to 33 feet at Chemulpo. The rapid rise and fall of tides and the vast area of mud left bare at low-water cause frequent fogs, and render the numerous inlets little available except for native craft. On the west coast the rivers are frozen in winter, but the east coast is open the whole winter through. Quelpart, the largest island, 40 by 17 miles, lies 60 miles $S$. of the mainland. Port Hamilton, between Quelpart and Corea, was for a time an English possession, but in 1886 was given to China. The Russians have been credited with a desire to possess the magnificent harbour of Port Lazareff on the Corean mainland. See the map of CHINA.

Occupying about the same latitude as Italy, Corea is also like Italy hemmed in on the north by alpine ranges, and traversed from north to south by a branch chain. From the north the chain runs close to the coast, till, about the 37 th parallel, it trends inland. The chain rises in elevation from the north to the centre, throwing out feelers to the west which break up the country into a series of narrow valleys debouching on the ses. Precipitous on the east, the chain slopes towards the broader west side, which is accordingly the more developed part; though Kyöng-sang province in the southeast is one of the richest in Corea. Corea is on the whole very mountainous. Among the summits are Hien-fung, measured from sea at 8114 feet high, though later travellers deem this height an exaggeration ; Mount Popoff, at 37th parallel; Coxcomb, north-east of Seoul (Söul), rises to 4800 feet. The mountains are mostly of primary rock; those of Hwang-hai-do are, however, mesozoic, and about the centre are lava and voleanic rocks. The chief rivers on the west coast are Keum, navigable for boats drawing $4 \frac{1}{2}$ feet 30 miles up ; Han, navigable to a little above Seoul, 80 miles; Tai-dong, navigable to Phyöng-yang, 75 miles; Am-nok, far the greatest, navigable to above Wi-wön, 175 miles. Flowing through beautiful well-timbered mountains, the Am-nok has many affluents, and in the summer floods its waters rise to full $\mathbf{4 0}$ feet even where a mile or more wide. In the south-east the Nak-tong is navigable for boats drawing $4 \frac{1}{2}$ feet for 140 miles up.

The climate is healthy, bracing in the north, but colder in winter and hotter in summer than in corresponding European latitudes. The heat is tempered by sea-breezes, but in the narrow inclosed valleys becomes very intense. The Han is frozen in winter so as to be available at Seoul, where it is 400 yards broad, for cart traffic three months in the year. The Tu-man is usually frozen five months in the year. Various kinds of timber-trees abound, except in the west, where wood is searce, and is sparingly used; and in other parts the want of coal 
has cansed the wasteful denudation of many hillsides. The fauna is very comsideralile, and hesides tigers, leopards, deer, includes pigs, tiger-cats, ludgrers, foxes, beavers, otturs, martens, and a great variety of birds. Among the products are rice, wheat, beans, cotton, hemp, naize, millet, sesume, perilla. Ginseng grows wild in the $\mathbf{K}$ unge mountains, and is also much cultivated about Kai-söng, the duties upon it, notwithstanding much smuggling, yielding about half a million dollars annually. The domestic animals are fow. The cutcle are excellent (the hul! heing the usual beast of burden), the ponies very small but hardy, fowls good, pigs inferior. Iron ores of excellent quality are mined; and there are copper-mines in several places. The output of silver is very small; in some years a good deal of goll is exported. The principal industries are the manufacture of paper, mats woven of grass, split bamboo blinds, oil-paper, and silk. The total value of the foreign imports in some years has amounted to abont f500,000, twothirds representing cotton goods ; the native exports renched $£ 136,666$, chiefly beans and cowhides. The foreign vessels entering the treaty ports number between 500 and 600 in an average year, witl a total tonnage of 150,000 tons or more. Three-fourths of the trade is with Japan, and over a fifth with China; British goods go by way of these countries. Business has hitherto been done chiefly by barter, imports being exchanged largely for gold dust, and Japanese silk piece goods being a current exchange for trade inland; but in 1888 the mint at Seoul was approaching completion, and a beneficial effect on commerce is anticipated from the introduction of a convenient and sufficient coinage. Seoul is connected with Taku and Port Arthur by telegraph.

The population is variously estimated at from eight to ten millions, of a mainly Mongrolian type, though some assume that there is a Caucasic element is the stock. Hair not quite black, and even blue syes and an almost English style of face are met with. The language is intermeliate between Mongolo-Tartar and Japanese, polysyllabic and rgglutinating. It has an alphabetic system of its own; but Chinese characters have taken the place of Corean in official writing and correspondence. A grammar and dictionary by Ridel were published at Yokohema in 1879. The philosophy of Corea is Confucian, but in spite of great restrictions on Buddhism there are numerous Buddhist monasteries. Evidence of other religion exists in the miriok, half. length human figures carved in stone. The government is an hereditary and absolute monarchy, and carried on through three ministers, besides whom are ministers of six departments. Caste is very powerful, and no office of even only local importance is held by others than a noble. There is strictly no well-to-do middle class, those who are not officials being cultivators. In some districts the lower classes live in a very squalid condition, and mud. hovels thatched with straw are the usual houses everywhere; but beggars are rare, and absolute distress is seldom met with. Cores is divided into eight provinces or Do; three on the east and five on the west coast. Seoul, the capital, has a pop. of about 240,000. Phyöng-yang, 36 miles from the sea, on the Tai-dong, has a pop. of over 20,000 . It is the centre of a silk industry, and 20 miles off, at Keum-san, are gold-washings. Kai-söng is important as the capital of the old dynasty, and for its cultivation of ginseng.

The earliest records of Corea carry us back to 1122 B. C., when Ki-tze with 5000 Chinese colonists brought to Corea Chinese arts and polities. Down to modern times Corea has remained perfectly secluded. Almost the first knowledge of Corea obtained by Europe was through the shipwreck of some Dutchmen on the cosst in 1653 . The mis. sionary De Cespedes had, however, entered Corea at the end of the 16th century, and from 1777 other nissionaries followed. In 1835 M. Maubant gained a footing in Corea, but in 1866, after thousands of converts had been put to death, the only three Catholic missionaries left had to flee for their lives. To avenge the death of the Catholics the French sent an expedition, which was, however, repulsed. Corea was tributary to China, thomoh uracti. cally independent. But Japan stealily increased its influence in the country, especially after 1876 . and in 1894 made internal dissensions in the Coren state a reason for proposing to China a joint inter. vention. China declining (as Japan had hoped) to interfere with its vassal state, the Japanese thereupon invaded and occupied Coren, defeated the Chinese at Phöng-Yang and in a naval battle on the Yalu, and, invading China, forced the Chinese to submit to a humiliating peace (1895). Russian influence is now dominant. See CHINA.

See Dallet, Histoire de l'Églize de Corbe (1874): Oppert, A Forbidden Land (1880); J. Rosa, Bistory of Corea (1880); two works by Griffis (New York, 1882 and 1885); and other works on Corea by Lowell (1886), Carles (1888), Gilmore (1893), Captain Cavendish (1894), A. H. Savage Landor (1895), and Mrs Bishop (1898), besides Curzon's Problems of the Far East (1895). There are Corean Dictionaries by Underwood (Shanghai, 1890) and Scott (Shanghai, 1891). And see JAPAN.

Core'gonus, a genus of fishes in the salmon family, including numerous species found in fresh water and sometimes in the sea, especially near the const. The body is compressed, the scales are of medium size, and the teeth are small or degenerate. They inhabit Aretic and north temperate regions, ranging from North America to Siberia. They are good for eating. $C$. Oxyrhynchus in the Baltic and the south-east of the North Sea, C. lavaretus in the Baltic, $C$. fera in Swiss lakes, $C$. clupeoides in British lakes (the 'powan' of Loch Lomond, or Gwyniad, q. v.), C. pollan (the 'pollan') in Ireland, $C$. lucidus, \&c. (the 'herring-salmon'), and C. sapidus or albus (the much-esteemed 'white fish') from North American lakes, are common representatives of the genus.

Corelli, Arcangelo (1653-1713), composer, was born at Fusignano in the Bolognese, and died at Rome. His pieces, especially for the violin, mark an epoch in chamber music, and influenced later composers, as Bach.

Corelli, Marie, novelist, a step-daughter of Charles Mackay (q. v.), was horn in 1864, and has written A Romance of Twoo Worlds (1886), Vendetta (1886), Thelma (1887), My Wonderful Wifo (1889), Wormuood (1891), The Soul of Lilith (1892), Barabbas (1893), The Sorroves of Satan (1895), The Mighty Atom (1896), The Munder of Delicia (1896), Ziska (1897), \&c. - works that have enjoyed a most astonishing vogue.

Corentyn, a river of South America, flowing northward to the Atlantic between British and Dutch Guiana (q. v.), navigable for 150 miles.

Corfe Castle, a village-borough of Dorset. shire, in the 'Isle' of Purbeck, 4 miles SE. of Wareham. Its famons castle, dating from early Norman times, is the traditional scene of the murder of King Edward the Martyr, by his stepmother Elfirida (979); and more than twenty knights, 'most noble and valorous in arms,' were done to death within its walls by King John. In 1643 it was gallantly defended by Lady Bankes for six weeks against 600 Roundheads. Taken through treachery two years later, it was dismantled; and its beantiful ruins, with their 'hanging towers,' cover nearly 33 acres Pop. of parish, 1777. See histories of Corfe Castle by G. Bankes (1853) and T. Bond (1884). 
Corfu, the most northerly and largest of the Ionian Islands, at the entrance to the Adriatic Sea, separated from the coast of Albania by a channel from 2 to 12 miles broad, is 40 miles long from north-west to south-east by $3 \frac{1}{2}$ to 20 miles broad; area, 270 sq. m.; pop., mostly Greeks, 114,535. The island is traversed by mountains, bare and rocky in their upper slopes, culminating in Pantocrator, 2997 feet high, at the north-east end. The surface is largely covered with luxuriant groves of olive, eypress, and ilex. The winters are rainy, the summers hot and dry. The principal products are olives and wine, oranges, citrons, figs, carob, silk, and honey. Maize is the chief cereal, but yields only about a quarter of the consumption. Goats are numerous, but there are no cattle and so no butter, the substitute for which is olive-oil, the principal export of Corfu. Wine is also exported to Austria-Hungary and Italy. There is no proper agriculture. Fishing, too, is left to the Albanians and Italians. The minerals are sulphur, salt, coal, and marble. The principal town, Corfu, having 19,025 inhabitants, is finely situated on the east coast, and has a good harbour in direct steam communication with Alexandria, Athens, Trieste, Italy, and England. Corfu is the seat of a Greek archbishop and of a Catholic bishop, and has a royal palace, an Ionian academy, founded by Lord Guildford in 1823, with a library of 35,000 volumes, a gymnasium, theatre, \&c. The town underwent great improvements during the British protectorate, but there is still room for improvement. The ancient name of the island is Corcyra, but from its shape it was also called Drepane, or 'sickle.' It has been incorrectly identified with the Homeric Scheria. About 734 B.C. the Corinthians planted a colony here, which, by its commerce, growing rich and powerful, fought with the mother-country (665 B.c.) the first sea-battle on record. After many vicissitudes, Corfu fell under the Roman dominion (229 B.C.). For the more modern history, see IONIAN ISLANDS.

Cori, a town of South Italy, 30 miles SE. of Rome, with a population of 5500 . It preserves the name and occupies the site of Cora, one of the oldest cities of Latium. The ancient remains still existing include those of the old walls, temples of Hercules and of the Dioscuri, and a fine bridge.

Coriander (Coriandrum sativum), an annual plant of the natural order Umbelliferse, with branching stem, 1 to 2 feet high, the lower leaves bipinnate, the upper leaves more compound, and globose fruit. It is a native of the south of Europe and of the East, and has long been cultivated for the sake of its fruit; and has thus become naturalised in some parts of England, although its fruit (coriander seed) is much less used in Britain than in Germany and some other European countries. The whole plant, when fresh, has a very offensive smell; but the ripe and perfectly dry fruit has an agreeable aromatic smell and a sweetish aromatic taste. It is used in medicine as a carminative, and as a corrective of certain purgatives; also in domestic economy as an aromatic, being very often mixed with bread in the north of Europe; spirituous liquors are flavoured with it; and confectioners cover it with sugar to make a well-known kind of comfit. In the south of England it is common to sow coriander and caraway together, the coriander yielding a crop in the first year, and the caraway in years following. Coriander delights in a rich soil, and is much cultivated and used in India.

Corigliano, $a$ town in the Italian province of Cosenza, on the slopes of a castle-crowned hill, 4 miles from the Gulf of Taranto. Pop. 12,271, mostly employed in cultivating the vine and corn.
Coringa, a seaport in Godavari district, Madras, stands at the northern mouth of the Godavari River, 8 miles S. of Cocanada. It has declined much owing to the obstruction of its harbour by a bar, and to its having been twice overwhelmed by a tidal wave-in 1787 and 1832. Pop. 4397.

Corinna (surnamed $M u i a$, "the fly'), a Greek lyric poetess, a native of Tanagra, in Boeotia, who flourished about 500 B.C. She is said to have instructed Pindar, and to have vanquished him in a poetic contest. Only a few fragments of her work remain, collected by Bergk in his Lyrici Poetoe Graeci (Leip. 1843).-Madame de Staël's Corinne was an Italian improvisatrice. For her, see Vernon Lee's Studies of Italy in the 18th Century.

Corinth, a city of Greece, celebrated in antiquity, situated on the rocky isthmus of Corinth ( $3 \frac{2}{s}$ miles wide, and 262 feet high), which connects: the Peloponnesus with the mainland. The city lay under the northern declivity of the mountain (1886 feet high, and forming one of the strongest. natural fortifications in the world) on which stood its citadel (Acrocorinthus), and had three harbours, Lechrum, to the west, on the Gulf of Corinth; Cenchrere and Schoenus, to the east, on the Saronic Gulf. Its position, midway between the Agean and Adriatic Seas, was exceptionally advantageous for trade. It was as easy to transport goods across. the narrow isthmus - called by Pindar " the bridge of the untiring sea'-as it was difficult to round the Peloponnesus. In its western harbour lay the ships of Italy, Sicily, and Spain ; and to Cenchreæ came Egyptian papyrus, Libyan ivory, Syrian perfumes, Phonician dates, Euboan fruits, and. Phrygian slaves. The exports of Corinthian manufacture were chiefly productions of art, such as statues, pictures, vases, pillars, and vessels of metal and earthenware. Syracuse, Molyeria, Sollium in Acarnania, Ambracia, Anactorium, Lencas, Corcyra, Epidamnus, Apollonia, and Potidrea were among the colonies of Corinth. At its most flourishing period it is said to have had a population of 300,000 , with more than half a million slaves employed in the fleet and in the colonies in the Mediterranean. It was at Corinth that the first triremes were built, and the first naval battle of the Greeks was fought between the fleets of Corinth and its colony Corcyra (see CoRFU).

According to legend, the city of Corinth (anciently called Ephyrê) was founded about 1350 B.c. by the Eolian Sisyphus, whose descendants ruled the country round till conquered by the Dorians under the Heraclid Aletes in 1074. Monarchy was abolished in 748, and an oligarchy of 200 families lasted till 657, when it was overthrown by Cypselus. He and his son Periander (629-585) greatly extended the eity's industry and trade. In 582 the old Dorian constitution was restored. Corinth, which had formerly been the ally of Athens, after the Persian wars became jealous of the increasing power and commerce of the Athenians, and joined the league of the Dorian states. It waged an unsuccessful. war on Athens in 458, and incited the Peloponnesians to begin (431) the Peloponnesian war (see GREECE). In 395, at the instigation of Persia, it entered into an alliance with Thebes, Athens, and Argos against Sparta, and the 'Corinthian War' began, which ended with the Peace of Antalcidas. (387), dividing the supremacy of Greece between Persia and Sparta. Timophanes made himself master of Corinth in 366 , but was overthrown and murdered by his patriotic brother Timoleon. The assemblies of the Greeks that appointed Philip and Alexander of Macedon the leaders against Persia, were held at Corinth in $\mathbf{3 3 8}$ and $\mathbf{3 3 6}$. Under the Macedonian supremacy it was occupied by a strong garrison. After the expulsion of the Macedonians it 
joined the Achreun leagne (243), of which it formed part down to 146 B.C., when it was utterly destroyed by the Romans under Mummius. Exactly a century afterwards Corinth was rebuilt by Julius Casaar, new-named Colonia Julia Corinthus, and jerspled with veterans and the descendants of irerimen; and under Augustus and his successors it quickly became once more 'the citadel and star of 'Greece.' It reached almost its old importance as a trading and manufacturing town, and centred in itself the traffic that had formerly belonged to Athens and Delos. A bout sixty or seventy years before its completion by Hadrian, it was visited by $8 t$ Paul, who, during a sojourn of a year and a half, plaated a Christian church in Corinth, to which he addressed two of his epistles. The city was (from 27 A.D.) the seat of the pro-consul of the Roman province of Achaia, and the restoration of the Isthmian Games brought to it multitudes of Greeks from all parts of the Roman empire.

The Corinthinns were devoted to the worship of the deities of love and of the sen. Aphrodite's temple was the oldest and the holiest in Greece. In her rites at Corinth, Phoenician influence is distinctly traceable. According to Strabo, in the most flourishing period of the eity more than 1000 hiercdouloi were kept there-'a source of much danger to strangers as of lustre and credit to the service of the goddess,' It was at Corinth, where unbridled licentiousness received such religious consecration, that the Apostle Paul wrote his description of heathen corruption in the Epistle to the Romans. Nowhere in the Hellenic world was licentiousness so prevalent. "The vices of the Greeks were notorious in the Roman empire, the Corinthian vices even in Greece. With all the artistic skill and culture of the Corinthians, and the lavish expense at which they adorned their wealthy city, they showed but little creative power in art, and 'among the illustrious writers of Greece, not a single Corinthian appears. Yet Corinth produced the painters Ardices, Cleophantus, and Cleanthes; the statesmen Periander, Phidon, Philolaus, and Timoleon; Arion, the inventor of the dithyramb; and was the abode in his later life of the cynic philosopher, Diogenes.

Corinth was spoiled by Gothic hordes at the end of the $3 d$ century, by Alaric in 396 , and by the Slavs in the 8 th century. In 1205 it was taken by the Franks, and from them it fell back into the hands of the eastern emperors, from whom in 1459 it was wrested by the Turks. It was held by the Venetians from 1699 to 1715 , when it was retaken by the Turks, under whom it sank to a miserable village. After being delivered from Turkish domination in 1822, Corinth slowly inereased from 1830 till the 218 t February 1858, when it was utterly destroyed by an earthquake. The town has since been rebuilt in a more convenient position, 3 miles to the north-east. Its population is now 3000. A mile and a half east-north-east of New Corinth, on the Gulf of Lepanto (anciently Gulf of Corinth), is the western mouth of the canal throngh the isthmus. Two new towns have been sau out at its east and west mouths, the eastern named Isthmia, the western Posidonia. See CANaL, Vol. II. p. 699.

Corinth, capital of Alcorn county, Mississippi, on two railways, 93 miles $\mathrm{E}$. by $\mathrm{S}$. of Memphis. Here General Rosecrans gained a decisive victory over the Confederates, October 3-4, 1862. Pop. (1880) 2275 ; (1890) 2111.

Corinthians, First and Skcond EpIstues TO THE, two writings forming part of the New Testament Canon, addressed by the Apostle Paul to the Christian church which he had founded at Corinth (q.v.) during his sojourn there, in part of
52, the whole of 53, and part of 54 A.D. Paul had been succeeded at Corinth by Apollos, and Apollom by certain Judaising teachers, and the church had become divided into four parties (1 Cor, i. 12). The First Epistle-which contains a reference to another epistle which precerled it, but has not been preserved (1 Cor. v. g, 10)-was written from Ephesus in the spring of 57 or 58, and was occasioned by the reports which Paul had received from 'those of the household of Chloe' (1 Cor. L 11) about these divisions. It was intended also to correct various abuses, and answer certain ques. tions which the Corinthian Clurch had asked him by letter ( 1 Cor. vii. 1 ; viii. 1 ; xii. 1 ; \&c.).

The reports brought by Titas of the condition and disposition of the Corinthian Church, and of the impression made on it by the previous epistle, induced Paul to write the Second. In this he ap. pears to many scholars to refer to a second visit he had paid to Corinth ( 2 Cor. xii. 14 ; xiii. 1 ) some time between the first visit and our Finst Epistle-though by others this supposed second visit is much disputed-urges a collection for the mother-chureh at Jerusalem (2 Cor. viii. and ix.); endeavours to remove certain acandals that still existed, and to re-establish his apostolic authority, which had been contested by the schismatic teachers; and expresses his intention to pay another visit to Corinth. The epistle was written from Macedonia in the autumn of the same year ( 57 or 58 A.D.). The two epistles are unquestionably genuine, and show in the clearest light the personal character of the writer and the inner life of the primitive Gentile Church. 'We are here,' says Stanley, ' and (as far as the epistles are concerned) here only, allowed to witness the earliest conflict of Christianity with the culture and vices of the ancient classical world. . . It is the Apostle of the Gentiles, as it were, in his own peculiar sphere -in the midst of questions evoked by his own peculiar mission-watching over churches of his own creation.

The best of the special commentaries on both epistles are those of Meyer (6th ed. 1881), Holsten, Das Evangelium des Paubus (vol. i. 1880); Godet (English trans. in Clark's Series, 2 vols.); Stanley (5th ed. 1882); and Beet (3d ed. 1885); on the First Epistle, those of Heinrici (1880) and Lias (1886); on the Second, of Klöpper (1874).

\section{Corinto. See Nicaragua.}

Coriola'nus, Carus or CNaus Marcius, a Roman patrician, surnamed Coriolanus from his heroism at the capture of the Volscian town of Corioli (493 B.C.). Of a proud and haughty spirit, he was strongly opposed to the plebeians, who refused to elect him when a candidate for the consulship. After this, during a time of famine, he argued in the senate against a gratuitous distribution of the corn which had arrived from Sicily, unless the plebeians should give up their tribunes, but lately instituted. For this he was impeached, and banished. He took refuge among the Volscians, whom he aided in their war with the Romans. His victories at the hend of his Volscian troops alarmed the Romans, who, on his approach to their city, sent a variety of deputations to plead with him. He was deaf to every entreaty. At last, the noblest matrons of Rome, headed by his old mother Veturia, and his wife Volumnia, leading her two children, came to his tent. (Shakespeare follows Plutarch in ealling the mother Volumbia, while the wife is Virgilia.) Their tears cooled his fierce desire to be revenged on those who bad dis. honoured him, and he led back the Volsci to their own territories. Shakespeare's Coriolanus is a stately and impressive drama, its hero a magnifcent ereative realisation of the haughty but noble aristocrat of Plutarch's story. 
Cork (Span. corcho, from Lat. cortex) is the extraordinarily developed corky layer (see below, and article BARK) of the bark of the Cork-tree or Cork-oak (Quercus suber) of the Mediterranean. Spain and Portugal chiefly supply the world with cork. The cork-tree is not of great size, generally 20 to 60 feet high, the trunk often 3 feet in diameter, much branched, with ovate-oblong evergreen leaves, entire or serrate. The acorns are edible, and resemble chestnuts in taste. The tree is usually twenty or twenty-five years old before it yields a gathering of cork, and attains an age of 150 years. The first produced (Virgin Cork) is of little value, hut is removed in order that the next production may be better, for every successive formation is superior to that which preceded it, and it is not till the third gathering that cork of the highest quality is obtained. About every eight or ten years a crop is taken; but the improvement is being introduced of leaving the loosened cork-layer for some months as a protective jacket upon the tree. The cork-cambium is thus protected from the sun and the attacks of insects, and the new growth is thus both more rapid and of finer quality. In stripping off the cork, longitudinal and transverse incisions are made to the proper depth, and each piece is then cut away from the tree by a curved knife with two handles, like that of a cooper. The pieces are soaked in water, pressed flat, dried, and superficially charred, to remove decayed parts and conceal blemishes, before they are packed in bales for the market. Besides the use of cork for stopping bottles, casks, \&c., it is much used, on account of its lightness, for tloats of nets, life-belts, \&c.; and on account of its impermeability to water, and its being a slow conductor of heat, inner soles of shoes are made of it. All these uses are mentioned by Pliny; but the general employment of corks for glass bottles appears to date only from

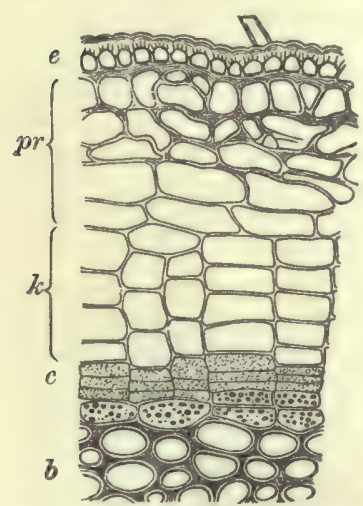

Formation of Cork in a branch of Black Currant, one year old (man. 350 diameters):

$\ell$, epidermis ; $b$, bast-cells ; $p r$, cor tical parenchyma; $k$, the corkcells formed from $c$, cork-cambium. (Sachs.)

\section{or Alligator Apple) in the West Indies, \&c.}

the 15th century. The Spanish Black used by painters is made by burning cork-parings in closed vessels. Cork-waste is also utilised for many objects, and most largely in the manufacture of linoleum.

The cork-tree is occasionally planted in England; it has been found to do well in some parts of the United States.

The wood of some trees possesses the cellular sponginess, lighiness, and elasticity of cork in such a degree as to be sometimes substituted for it in many of its uses, as that of the Anona

As, already mentioned under Bark (q.v.), cork is by no means botanically the exceptional product it seenis from the practical or popular point of view. The epidermis being usually only a single layer of definitely formed cells, it is insufficient either for covering or protection in almost all conditions of continuous growth and exposure to climate (the mistletoe being rather a less developed type than a true exception among woody plants, since its deeper ordinary epidermic cells never lose the power of multiplication). In sections of the young shoots of dicotyledonous trees or shrubs this provision for replacing the epidermis can be beautifully traced; a layer of cells just outside the cellular envelope, the so-called cork-cambium, is seen to have already formed an appreciable thickness of cork-cells, easily recognised by their prismatic shape, tolerably regular vertical series, and thin walls. As the stem grows older the epidermis wears off and the cork-layer thickens, while the access of air to the living cellular envelope below is permitted by the occurrence of spaces empty or filled only witi looser tissue, the Lenticels (q.v.), which, of course, become represented by the deep air-channels so obvious in the inferior quality of cork.

CoRK-CUTTING.-The bark, after being cut into square pieces or sheets, is pressed to remove its natural curvature and flatten it. If it is found that simple pressure has not flattened it sufficiently, it is heated on the convex side, and the contraction thus produced straightens it. It is then cut into slips, and these slips into squares, according to the required size of the corks. These are rounded by the cork-cutter by means of a broad sharp knife; the cork is rested against a block of wood, and the knife pushed forward, its edge at the same time being made to describe a circular curve. The knife requires continual sharpening; the workman has a board before him on which the knife is rubbed on each side after every cut. But cork-cutting is now largely done by machinery; in the United States the process has been carried to great perfection. Corking-machines are ingeniously contrived to force the cork into the neck of the bottle, and, if necessary, to wire it down. For rock cork, see Asbestos.

Cork, a maritime county in Munster, the southmost and largest of the Irish counties. Greatest length from east to west, 110 miles; greatest breadth, 70 ; average, 34. Area, 2890 sq. miles. Cork is hilly, with great variety of surface. The west part is rocky, mountainous, wild and boggy ; the east and south, rich, fertile, and picturesque. The ranges run east and west, except the Boghra Mountains, between the Lee and Blackwater. The coast is bold and rocky, and from its indenta. tions, 250 miles long; the bays, which run 3 to 25 miles inland, admitting large vessels. The chief bays are Bantry, Dunmanus, Baltimore, Glandore, Clonakilty, Kinsale, Cork Harbour, and Youghal. There are many isles off the coast, including Cape Clear Island, which lies in $51^{\circ} 25^{\prime} \mathrm{N}$. lat., and $9^{\circ} 30^{\prime} \mathrm{W}$. long, and, with the exception of a rock 4 miles to the SSW., is the southmost point in Ireland. In the west, Cork is divided from Kerry by a range of Silurian clay-slate running north-east and north, the chief points being 1200 to 2240 feet high. This range sends offshoots to the east, which divide the county into the parallel basins of the three chief rivers of Cork, the Blackwater, Lee, and Bandon: the lower parts of these basins are well cultivated and productive. The Lower Carboniferous limestone forms the largest lowland tracts and valleys of the county. Part of the Munster coalfield occupies 400 sq. m. in the north-west. Cork has many small lakes in the west. One of these lies at the source of the Lee, amid wild, picturesque scenery, with the ruins of a chapel on an islet frequented by pilgrims. The chief mineral productions are coal and iron, copper, barytes, limestone, fine dark-gray and also red marble rich in fossil shells, fullers' earth, brickclay, marl. There is a thermal magnesian spring at Mallow. The climate is moist, but genial. The soils are calcareous, loamy, and moory. The dairies are extensive, and Cork butter stands in high estimation. The eattle are small in size, but yield large quantities of milk. Of the total area, about 30 per cent. is under crops. The chief manufactures 
are leather, tweed, whisky, porter; and the chief exports provinions. Pop. (1841) 854,118; (1851) $63.3,180 ;(1871) 517,076$; (1891) 436,641, of whom 90.8 per cent. are Catholics. Formerly Cork county sent two members to parliament, besides two for the city, and four for minor boroughs. Since 1885 the county returns seven members, the city two; and Bandon, Mallow, Kinsale, and Youghal have been absorbed in the county. The antiquities of Cork are stone circles and altars, two round towers, circular earthworks or raths ; ruins of abbeys and churches, chiefly built by descendents of the English invaders under Henry II.; and many ancient castles or square towers.

Cork, a city and parliamentary borough of Ireland, capital of County Cork, and a county in itself, on the Lee, 11 miles above its mouth, and $166 \mathrm{SW}$. of Dublin by rail. Standing in the centre of $n$ picturesque valley, it is built in part on an island, or group of islands, formerly a swamp, which the word Cork, Corcoch, or Corcaig implies: in part, on the north and south slopes of the river-banks. The houseg are generally of old red sandstone. Nine bridges cross the river to the central islands. There is a spacious public park of about 400 acres, the chief use of which is as a racecourse, and a walk known as the Mardyke, above a mile long, lined by noble elms, on the west of the city. There is also a beautiful public cemetery. Cork has a pleasant picturesqueness from its uneven ground, irregular streets, intersecting river, and overhanging lieights. The chief buildings are St Anne Shandon's Chureh, with a tower 170 feet high ; the Protestant Cathedral, Early English in style, erected since 1865 at a cost of $£ 100,000$; several Catholic churches ; 4 monasteries; 2 nunneries; the bishop's palace; the Queen's College, a fine Tudor-Gothic quadrangular building, opened in 1849; the Schools of Science and Art, erected mainly through the munificence of a citizen, Mr W. H. Crawford. The banks of the Lee above and below Cork are richly planted, and studiled with villas. The Lee in both branches is navigable to about a mile above the city, and a large sum has been expended on the improvement of the navigation by the harbour commissioners. The extent of the quays is now above 4 miles, and ships of 2000 tons reach them. Cork harbour, noted for its size and safety, is a basin of 10 sq. m., formed by the estuary of the Lee. It could contain the whole British navy, and has been the main source of the rise and progress of the city. It is the port of call for the transatlantic stermers plying between Liverpool and New York, the vessels of seven different lines touching each week to embark or discharge mails and passengers. The estuary contains several large isles, rising abruptly and high above the water, with narrow channels between them. The entrance is by a channel two miles by one, defended by batteries. Carlisle Fort on the esst side, and Camden Fort on the west, while Spike Island, now called Fort Westmoreland, commands the entrance. In these forts some of the heaviest ordnance in the kingdom may be found, Camden in addition possessing a torpedo and submarine battery of immense destructive power. Spike Island has ceased to be a convict establishment, and is used now as a military depot. Adjoining the island of Hrulbow. line, on which are erected extensive government stores, is a large government dock, where vessels of the British fleet may be repaired. On the shores of the estuary are the towns of Passage and Queenstown, formerly Cove of Cork. Cork har. bour is much frequented by wind-bound ships and ships waiting orders. In the years $1894-98$ inclu. sive, an average of 2402 vessels, with a total tonnage of 563,319 , entered the port annually, and an 135 average of 2382 vessels, with a total tonnage of 619,413 , cleared. The chief manufactures are leather, iron, gloves, ginghams, friezes, flour, malt liquorw, and whisky. The chief exports are grain, provisions, butter, live-stock, leather, and tweeds, valued at several millions sterling yearly. Pop. (1871) 78,642 ; (1891) 75,070; parliamentary borough, 96,891, of whom five-sixths are Roman Catholics Cork returns two members to parliament, Cork grew up around an abluey founded in 600 by St Finbar. The Danes in the 9th century built the city walls. Dermod Macearthy, king of Cork or Desmond, surrendered it to Henry II. in 1172. Cromwell besieged and took it in 1649, and Marl. borough in 1690. James II. landed at Cork in 1688. In Cork, William Penn, the founder of Pennsylvania, became a Quaker. There is a statue of Father Mathew (q.v.), who laboured here many years. See Miss Cusack's History of the City and County of Cork (Dublin, 1875). For the Earls of Cork, see BoYLE.

Corkwing (Crenilabrus melops), a species of Wrasse (q.v.).

Corleo'ne, a town of Sicily, 21 miles S. of Palermo. Pop. (1881) 15,441 ; (1891) 16,072.

Corm (Gr. kormos, 'a stump')-sometimes called a solid bulb - the short and bulb-like subter. ranean stem of many monocotyledonous plants e.g. crocus, gladiolus; tuberose, and arising through the annual storing of starch to be consumed by the next year's bud and flower. In functions, as in general appearance, the corm resembles the Bulb (q.v.); a vertical section, however, shows that while in each we have indeed a stem and leaves, the thickening is confined in the former case to the stem, in the latter to the leaves. Transitional forms occur, indeed, in most bulbs; the thickened leaves arise from a more or less thickened and shortened-i.e. corm-like-base. While a section of a corm shows the origin of its usually membraneous leaves, and many corms produce new subterranean buds in the axils of their leaves, in either case they arise on the upper surface or sides of the parent corm, and there thicken as new corms. When borne on the upper surface, the new corms then gradually approach the surface of the ground as in crocus.

Cormorant (Gr. Phalacrocorax, 'bald-headed raven'), a genus of web-footed birds in the order Steganopodes, beside pelicans, solan-geese, and frigate-birds. They are familiar birds, frequenting islands in most parts of the world. They vary

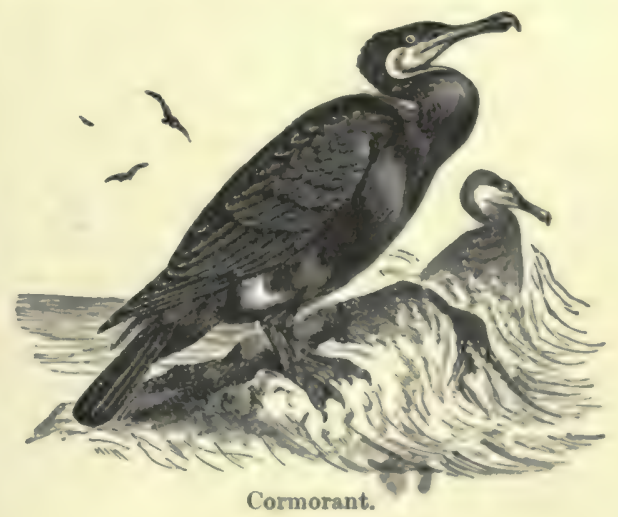

greatly in size, but have the following characters in common. The head is relatively small, and is naked behind the eyes and at the root of the beak. At the breeding season some forms exhibit a crest 
and wattles. There is a dilatable membrane beneath the lower jaw, showing incipiently what becomes exaggerated in the pelicans. The bill is moderately long, straight, rounded above, and strongly hooked at the end; the nostrils are linear and inconspicuous. The neck is long, snake-like; and naked on the throat. The wings are of moderate length; the tail is rather short and rounded, but with stiff feathers, which are used as aids in progression. The unfeathered lower leg is very short; all the toes are united in a web; the middle claw is serrated and apparently used in trimming the plumage.

The numerous species live on the shores of islands, or sometimes inland by rivers-e.g. the Danube -and lakes. They feed exclusively on fishes, and are proverbial for their voracity. They do not dive when in flight, but from the surface of the water. The smaller of the two British species has been caught in a crab-pot at a depth of 120 feet. When the prey is inconveniently seized, it is often tossed in the air and more adroitly recaught. Eels are said to form a favourite prey. Their haunts are often peculiarly dirty. The nests are usually built of seaweed, and are strong though rude; they are sometimes found on mangrove and other trees. The egg is bluish-green, but the coloux is much obscured by thick incrustations of lime. When attacked, the larger species, at anyrate, fight vigorously and to purpose. The flesh is dark and fishy, but that of the young birds of some species is said to be eatable.

The Common British Cormorant $(P$. carbo) is an almost cosmopolitan bird about 3 feet long, for the most part of a blackish-green metallic colour, with brownish feathers on the shoulder region. When in full breeding plumage it has a crest on the head, white plumes on the throat, and a white patch on the lower flanks. The bill is black, the face yellow, the feet also black. It was formerly trained in England, as still in China, for fishing purposes. At first a ring is put round its neck to keep the bird from swallowing the fish it catches, but it soon learns to bring its prey to its master, being afterwards allowed to fish on its own account. The smaller species ( $P$. cristatus or graculus) found on our coasts has a more decided green colour. The Dwarf Cormorant ( $P$. pygmaus), from Southeastern Europe, North Africa, Southern Asia, and the Florida Shag ( $P$. floridanus) are other wellknown species. Along with the genus Urile, the cormorants form a family (Phalacrocoracida) ineluding about three dozen species.

Corn, a general term for the seeds of cereal plants, thus including all the kinds of grain which form the food of men or horses. But it has also a specific sense, and denotes in any country that grain which furnishes the prevalent bread-stuff of the people. Thus, in England, corn generally means wheat ; in the United States, maize; and in Scotland, oats. The word not only occurs in all the Teutonic tongues, but is seen also in Lat. granum, and Russian zerno. See Cerealita, and special article WhEAT, \&e. See CoRNS for a different word.

Corna'cese, the cornel or dogwood order, are calyeifloral dicotyledons, nearly allied to Umbelliferæ, containing about eighty species, mostly trees and shrubs, chiefly natives of the north temperate zone. The fruits of some are eatable; the bark and leaves of some are medicinal; some are valued as ornamental ferits. See CoRNeL, DogwOoD, Aucuba.

Cornaro, the name of a Venetian noble family, of which the most illustrious members were: (1) Caterina (1454-1510), married King James II. of Cyprus in 1472, after whose early death she was kept in mild imprisonment by the Venetians until
1489, when she set up a kind of court for poets and scholars at Assolo, near Bassano. - (2) Luigi, born 1467 , an instructive example of temperance. Delicate by constitution, at forty he found his health so much impaired by his intemperance that an immediate change of life was absolutely necessary. He at once adopted strict rules of temperance both in meat and drink, by which means he prolonged a cheerful old age almost to a hundred years, dying in 1566. At eighty-three he published his famous Discorsi della Vita Sobria (Padua, 1558), which was translated into most European languages (Eng. 1779).

Cornbrash, a member of the Lower Oolites. See JuRAssic SYsTEM.

Corn-cockle (Agrostemma Githago), a tall beautiful caryophyllaceous weed, well known on account of its large purple flowers. It is often so common in cornfields as to be mischievous, especially on the Continent, and this not only because of its rankness and abundance, but also because of the deleterious nature of its seeds, which are injurious to man and poisonous to most domestic animals, and which sometimes require to be separated from the grain by a special kind of sieve.

Corn-crake (Crex pratensis), one of the true rails, in the old order of Grallatores, whose cry at least is very familiar in Britain. The bird itself is seldom seen ; it is about a foot in length, and has colours varying from brownish-gray to red. The bill is shorter than the head, and slightly bent, the tail is very short, the legs are long and powerful. As a summer visitor to Britain, coming in May and leaving in antumn, the bird is well known by the harsh ery of the male, which is sometimes imitated for decoy purposes by running the thumbnail along the teeth of a small comb. The cry is

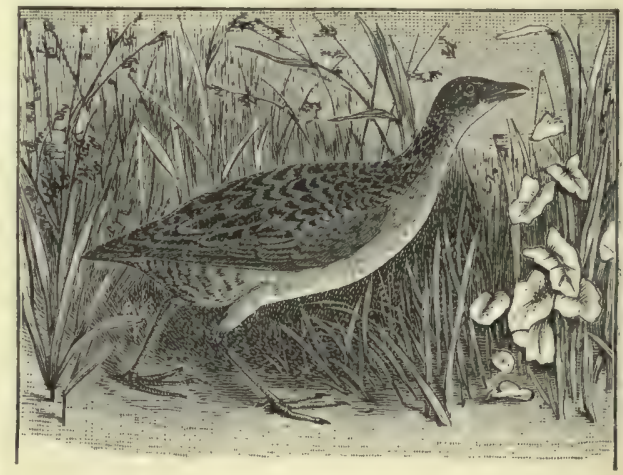

Corn-crake (Crex pratensis).

mostly uttered in the evening and throughout the night, and is much less frequent after the young are hatehed. Unlike the nearly related waterrails, the corn-crake frequents dry corn and hay fields. It can, however, swim well on occasion. Its running powers are very great, but it flies rather heavily. It is very prone to trust to concealing itself rather than to flight. The females are very faithful to the young birds, which are covered with black down when hatched. The species is widely distributed in Northern Europe and Central Asia, but its headquarters are in Africa. The flesh is very good eating. See RAIL.

Cor'nëa, one of the coats of the eye ; so called from its resemblance to horn (Lat. cornu). See EYE.

Corneille, Pierre, the greatest tragic dramatist of France, and the forerunner of Moliere in genuine comedy, was born at Rouen on June 6, 
1606. The son of a legal official, he was trained for the bar, and for some time tried with but slight suceess to obtrin a practice in his birthplace. In 1629 be removed to Paris, where his comedy Melite, which had already been performed at Rouen, proved so successful as to be run at the same time in two theatres, the Marais and the Hotel de Bourgogne. It was followed by Clitandre, La Veuve, La Galerie du Palais, La Suivante, and La Place Royale. In these early pieces intricate and extravagant plots are handled with considerable ingenuity, but the writer's poetic genius only flashes out in occasional verses. For some time Corneille was numbered among Richelieu's 'five poets,' the others being Rotrou, Colletet, Hois-Robert, and L'Etoile. These writers were engaged to compose plays on lines laid down by the cardinal. Each of the five wrote an act, which was then criticised, altered, and paid for by their employer; among the pieces thus produced being Les Tuileries, $L$ Aveugle de Smyrne, and $L a$ Grande Pastorale. Corneille, however, was too independent to retain Richelieu's favour, and his dismissal followed at once on his proposing to alter a plot of the carclinal's devising. Médée, a tragedy which appeared in 1635, showed a marked advance on his earlier works, both in dramatic power and in style; and in 1636 the $C i d$, his most famons if not his best play, took Paris by storm. Richelieu ordered his literary retainers to write down the piece, and Seudéry called on the Academy to vindicate French letters in the eyes of Europe by passing formal censure on Corneille. The Academy, which had lately been founded by Richelieu, thereupon issued a hostile excumen of the play ; but adverse eriticism was powerless against the general enthusiasm, and the phrase beau comme le Cid passed into the language. The result of the struggle between the minister and the dramatist is happily summed up in Boileau's famous couplet:

En vain contre le Cid un ministre ge ligue,

Tout Paris pour Chimene a les yeux de Rodrigue.

The story of the play was taken from Las Mocedudes del Cid, a Spanish work by Guillem de Castro (q.v.), but Corneille's treatment of the sub. ject was thoroughly original. With the appearance of the Cid the poetic drama took possession of a stage hitherto occupied by broad and shapeless farces, wooden imitations of Senees, and the extravagant and off-hand pieces of Hardy. The graceful and heroic figures of the lovers, Rodrigue and Chimene, the nobility of the sentiments, the power and harmony of the verse, justify the enthusiasm which the play excited. It may not be its author's greatest effort, but there is a charm in the spirit of youthful ardour and tenderness which animates it such as is hardly to be felt again in Corneille's work, until we come to the exquisite lyric love-scene which he contributed in his old age to the opera of Psyche.

The Cid was followed in 1639 by Horace, a play which was founded on the story of the Horatii and Curiatii as told by Livy, and which contains, in the tirade spoken before her death by Camille, the most maynificent burst of invective in the French classical irama. Cinna appeared in 1639; Poly. eucte, one of Corneille's nohlest tragedies, in 1640 and La Mort de Pompee in 1641. Le Menteur, which was produced in 1642, entitles Corneille to be called the father of French comedy as well as of French tragedy. The play is a masterpiece. The character of Dorante, the liar, is drawn with admirable humour and insight, and the style, at once easy, graceful, and pointed, reaches a level of excellence which Molière did not surpass in his ear'ier works. Theodore was brought out in 1645 , and Rodogune, perhaps the most impressive and thrilling of Corneille's tragedien, in 1646. Between 1647 - when lie was male ил sudernjoin- and 1653 Corneille produced Heraclius, Don Sanche d'Aragon (an imitation of Lope de Vega's Palacio Confuso), Amiromede, Nicomede, and Pertharite. These pieces, of which the last named was damned, show a decline in dramatic and poetic power. After the failure of Pertharite in 1653, Corneille ceased for a time to write plays, and occupied himself with making a vense translation of the Imitatio Christi. He returned to the stage in 1659 with Edipe, which had considerable success, and which was followed by $L a$ T'oison d'Or, Sertorius, Sophonisbe, Othon, Agesilas, Attila, and Tite et Bérénice (1670). In 1671 he joined Moliere and Quinault in writing the opera of Pryche, and the loveliest verses which he ever penned are to be found in the scene between Psyche and Cupid (act iii. scene 3). His last works were Pulcherie (1672) and Suréna (1674).

His work did not bring him wealth, for he never received more than 200 louis for a piece. His private fortune was not large, and the pension which was granted him was not regularly paid. After his marriage in 1640 he lived habitually in Rouen until 1662, when he settled in Paris. His domestic life seems to have been a happy one. He and his brother Thomas married two sisters, and dwelt for \& long time in contiguous houses. During his later years he had to compete with Racine, an inferior poet but a more dexterons playwright, and one who could cater more shrewdly for the public taste. The veteran dramatist spoke contemptuously of his rival's "sighs and flames," but his popularity waned before that of the younger writer, whose cause was espoused by Boileau and the king. Corneille died in Paris in the Rue d'Argenteuil on October 1, 1684.

Corneille and Racine are the chief dramatists of the classical school which held command of the French tragic stage from the middle of the 16th century down to the Romantic movement of 1830 . The works of this school were modelled on the plays of Seneea-that is to say, on plays cast in the mould of Greek tragedy, but having even less action and more diffuse moralising. The writer who adopts this form of drama is bound down by a set of rigid rules which allow him to present only a few idealised personages in certain stereotyped situations. He cannot exhibit the development of character and the interaction of human passions. $\mathrm{He}$ is almost denied the use of incident, and the slow progress of his play to its climax is mainly brought about through the agency of messengers and confidants. Before Corneille the classic school had failed to produce a single good acting play ; its adherents, nevertheless, succeeded in diverting him from the path on which he had entered when he produced the Cid, and in thereby cramping his rich and vigorous genins. 'Corneille,' says Mr Walter Pollock, "was one of the first to make a move in the direction of the romantic drama, and wanted nothing but courage and self-sacrifice to carry out his intention.' (See his admirable articles on Victor Hugo and Romanticism in French Poets, 1879). Unfortunately, instead of disregarding the academic criticism of his day, Corneille turned from Spain to a 'Castilian Rome,' remote from the world of romance, and set himself to compose plays of so severe and uneventful a type that he failothsave in one or two cases, to invest them wipl song sustained interest. In reading these $\hat{A}$ - we yield alternately to admiration and fatigue. The characters have a simplicio and grandeur which recall the work of the sculptor, but they have also something of its immobility. We can grasp them at once; they are not developed in the course of the drama. Corneille's heroes bear their fate with an inflexible 
self-reliance which seems more than human, and therefore moves us the less. His heroines, his 'adorable furies,' resemble one another closely. 'Their love,' says Sainte-Beuve, 'springs from the head rather than the heart. We feel that Corneille knew little of women." Where he excels his rivals is in the grandeur of his morality, in the eloquence and passion of certain scenes and speeches, in the splendid flashes of poetry with which he illumines the pale world of classic tragedy, in the power and music of his verse. Victor Hugo alone has made the Alexandrine move with the same swelling harmony and variety of cadence. The monotony which so often weighs on Corneille's readers was not due to any coldness or narrowness inherent in his genius. To be convinced of this it is enough to recall the brilliant comedy of the Menteur, the martial stir and glowing passion of the Cid, the lyric grace and chastened ardour of the central lovescene in Psyche. But his powers were in a measure misdirected. His place in literature must always be a very high one ; but readers-other than French readers, at least-can hardly doubt that it would have been still higher had he been free to select and develop his characters at will, to exercise his humorous faculty and give full scope to his tragic powers in the fields of romantic drama.

See Guizot's Corneille et son Temps (1852; Eng. trans. 1857 ); Jules Taschereau's Histoire de P. Corneille (1828; new ed. 1855); Sainte-Beuve's Portraits Littéraires (tome i.) and Port Royal (tome i.); Bouquet, Points obscurs de la Vie de Corncille (1888); Trollope, Corneille and Racine (1881); and Prof. Lodge, A study in Corneille (Balt. 1891). The best editions are those by Lefèvre (12 vols. 1854), and Marty Laveaux (12 vols. 1862-67). See M. E. Picot's Bibliographie Cornélienne (1875).

Corneille, Thomas, younger brother of the great Corneille, was born at Rouen on August 20, 1625. He was a dramatist of considerable merit, was made a member of the Academy in 1685, and died at Andelys on December 17, 1709. His tragedies, Camma, Laodice, Pyrrhus, Bérénice, Timocrate, Ariane, Bradamante, \&c., are in general superior to his comedies. He also wrote a verse-translation of Ovid's Metamorphoses.

Cornel, or Cornelian Cherry (Cornus mas), the Cornus of the ancients, a small tree of the order Comacer, is a native of the middle and south of Europe, and of great part of Asia. It is not found wild in Britain, although it is common in shrubberies, and was formerly much eultivated as a fruit-tree, as it still is in Germany and other parts of Europe. It has oval leaves, and small yellow heads of flowers, which appear before the leaves in spring, and which are much frequented by bees. The fruit is oblong, a little larger than a sloe, shining, red, or rarely yellow or white. It is late in ripening, and until quite ripe is very austere; but when perfectly mellow has an agreeable vinous acid taste; it is also made into a preserve, or gathered unripe and pickled like olives. It was formerly also fermented for a beverage. In Turkey it is much used in making sherbet. The wood of the cornel is extremely hard and tough, and was used by the ancient Greeks for lance-shafts; it is still valued by joiners, turners, and instrumentmakers.-Dwarf Cornel (C. suecica), a native of mountain-pastures and bogs throughout the north of Europe and in Britain, is a herb about 6 inches high, with its umbels surrounded by four white bracts. and is said

Gaelic name Frant of Gluttony. Dogwood (q.v.) belongs to the same genus.

Cornelia, mother of the Gracchi. See Gracchus. Cornelian. See Carneliar.

Cornelisz, LuCAs, a Dutch subject and portrait-painter, was born at Leyden in 1495 , the son of Cornelis Engelbrechtsen, the master of Lucas van Leyden. He was instructed in art by his father, but found little patronage in his own country, and was obliged, for the support of his large family, to act as a cook, whence his usual sobriquet of Kok ('the cook'). He visited England, probably in 1527, and was appointed by Henry VIII. royal painter. There is ground for believing that, after remaining some five years in England, Cornelisz passed to Italy, and between 1535-47 was employed by the court of Ferrara. He is stated to have died in $\mathbf{1 5 5 2}$. Several of his works are in England.

\section{Cormelius Nepos. See Nepas.}

Cornelius, Peter von, one of the first masters of the modern German school of painting, was born at Disseldorf, 23d September 1783, and studied in the academy of his native town. When only nineteen years of age, he painted some remarkable frescoes for the old church of Neuss. Four years later he gave still more unmistakable proofs of a creative fancy in his illustrations of Goethe's Faust and the Nibelungen Lied. In 1811 he went to Rome, and joined the group of Veit, Schadow, and other Germans who were there at work, Overbeck being his chosen friend. This journey exercised a profound influence on the whole of his future career. The great importance of the early masters became ever clearer to him as he studied their choicest productions. While at Rome he aided in the decoration of the Casa Bartoldi, and gained wide reputation by two cartoons, 'Joseph's Interpretation of the Dream' and 'Joseph's Recognition of his Brethren.' From Rome he passed to Disseldorf, where he became director of the academy, which he remodelled; in 1819 he was called to Munich, and entered the service of the then crown-prince of Bavaria. Here he remained till 1841, and executed those grand works on which his fame mainly rests, and which may be divided into two classes, Pagan and Christian, the former of which comprises the large frescoes in the saloon of the Glyptothek, all illustrating stories of the Greek gods and heroes; while the latter, or Christian series, begun after the completion of the former in 1830 , consists of frescoes of New Testament scenes, extending from the 'Incarnation ' to the 'Judgment,' and decorates the 'Lud. wig's Church' in Munich, which was built for the purpose of affording scope for the genius of Cornelius. The 'Judgment' is the largest fresco in the world, larger even than Michael Angelo's "Judgment" in the Sistine Chapel. In 1841 Cornelius was invited by the king of Prussia to Berlin, where he was appointed director of the Berlin Academy. Among his productions in the Prussian capital are the frescoes for the Campo Santo, or royal burial-place, where his "Four Riders of the Apocalypse' display an impetuous and daring power which he had not hitherto evinced. Opinion is divided regarding the merits of Cornelius. By his own countrymen he is much admired; and certainly the importance of the impetus which he gave to mural decorrtion in Germany cannot be overestimated. French critics, on the other hand, regard him as more a thinker than an artist. He is admitted to have been a profoundly creative genius, but without mastery in manipulation or great power as a colourist. He formed, however, a school, from which have gone forth many illustrious pupils; but he lived to see it losing hold on public sympathy. A series of his cartoons is preserved in the National Gallery, Berlin, and his works have been reproduced by Amsler, Schoefer, Eberle, and the best German engravers. He died in Berlin, 6th March 1867. See his Life by Förster ( 2 vols. Berlin, 1874). 
Cormell University, named from ita founder, Exra Cornell (1807-1874), is situated in the eity of Ithaca, N. Y., and was opened in 1868, on a thoroughly unsectarian besis. By the terms of its charter it must elucate, free of all fees, one student annually from each of the 128 assembly districts of the State of New York, besides providing instruetion in "agriculture and the mechanic arts," in return for the income derived from the sale of 989,000 neres of public lands, which was transferred to it by the State. The endowment funds now (1898) amount to over $\$ 6,300,000$. Bexiles the four general courses of four years each in arts, philosophy, letters, and science, the university provides instruction in many lines of graduate work, in architecture, in eivil, electrical, mechanical, and marine engineering. There is a flourishing school of law. There are 39 fellowships and graduate scholarships and $\mathbf{3 6}$ scholarships for undergraduates, all of which are aivarded for excellence in attainments. The libraries are fively equipped for the most advanced and special work in all lines, containing over 200,000 volumes and receiving over 400 eurrent periodicals. Among its numerous well-appointed buildings is Sage College, a dormitory for women. In 1897-98 the number of instructors was 191 , and of students 2042.

Cornet (Ital. cornetto, Fr. cornet a piston), a brass treble wind-instrument, with a cup mouthpiece, is a comparatively modern modification of the Trumpet (q.v.). The tube, which is more tapered than in the trumpet, is less so than in the Bugle (q.v.), giving the cornet a tone intermediate between these, and more in harmony with other brass instruments of the trombone and saxhorn kind. It has the usual open notes, $\mathrm{C}$ (below the treble stave), G, C, E (stave), G, Bo, E (above the stave). It has also four higher notes, D, E, F, G, and a fundamental note, C (octave below the stave), but they are almost never used. To provide the connecting notes and half notes of the scale, it has three slides (1, 2, 3 in the fig.), the first, lengthening the tube to the extent of one tone; the second, a semitone; the third, three semitones. In playing. the air is diverted through these slides by means of three valves or pistons, which are depressed by the fingers of the performer, singly or in combination.

Although the cornet, from its recent invention, has not a place in classical music, it is sometimes nsed to play trumpet parts; and in modern orches. tral music, it is an indispensable and popular solo

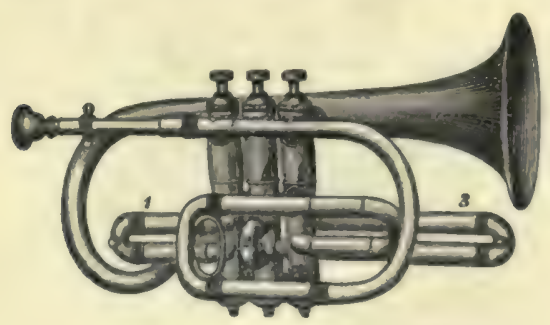

Cornet.

instrument. In military reed and brass bands it is a solo and leading instrument respectively.

Originally the cornet or cornopean, as it was then called, was provided with 'crooks' (pieces of tube to insert between the instrument and the mouth piece), to alter the pitch, which is naturally Bo, to $\mathrm{A}, \mathrm{Ab}, \mathrm{G}$, and others, lut it is now only used in Bo and A. Smaller cornets in Eb and Do are sometimes used in military brass bands. The cornet-stop in the organ is named after an obsolete wind-instrument of the oboe species.
Cornet (Ital. cornetta, 'a small flag') was, until 1871 , the lowest grade of comminsioned officer in the cavalry, equivalent to envign in the infantry, one of his duties being to bear the standard, which, however, is only carried by heavy cavalry regiments in the British army. With the lientenant he assisted the captsin in the daily duties connected with the troop to which he belonged. Before the abolition of purchase in 1871 a conet's commission used to cost $\mathbf{f 4 5 0}$; but much larger sums were habitually paid in celebrated or fashionable corps. The pay was 8s. per day, with ls. or In 6d. extra for field allowance. In 1871 cornets were aholished, sub-lieutenants (who are merely probationary lieutenants) being substituted.

Corneto, a picturesque, medieval-looking town of Central Italy, 12 miles $\mathrm{N}$. of Civita Vecchis by rail, 3 miles from the Mediterranean. Pop. 6175. Corneto rose out of the ruins of the Etruscan city of Tarquinii, whose remains, within a mile and a half of Corneto, are amongst the most importent for the student of Etruscan history. The painted tombs, of which some twenty are specially interesting, were known in the 18th century; but it is mainly since 1842 that they have been examined; valuable new discoveries were made during excavations in 1881-82. See ETruria.

Corn-flour is the name applied to the finely ground Hour of Maize (q.v.) or Indian corn.

Corn-flower (see Centaurea) is a well-known composite weed of cornfields, universally known

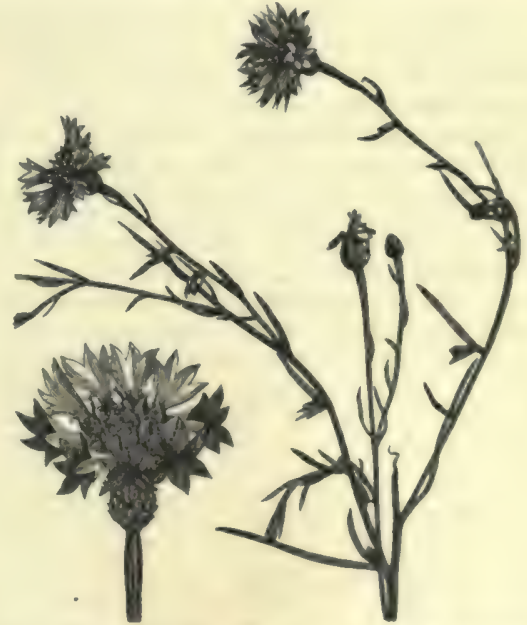

Corn-flower, or Blue-bottle (Centarrea cyanus).

and admired for the beauty of its wreath-like circle of outer barren florets, and the splendid deep asure of their hue. It was formerly of some little medicinal repute, and its blue flowers were used in domestic dyeing; from early times, too, it has been used for decoration in wreaths and garlands. This use became specially prominent in Germany after 1870 , on account of its being the Emperor William's favourite flower.

Cornice. In classical architecture the cornice is the uppermost member of the entablature, surmounting the frieze. Each of the orders has its peculiar cornice; but these, yineir relation to the other portions of the eny e, will be better understood when explained-n injunction with that term (see ENTABLATURE). In the Gothic styles the form of the cornice varies greatly. In Provence and countries where Roman work abounded, the classic cornice was elosely imitated (see Romaneseur Architbcture). In other 
districts a row of corbels, carved in the grotesque Teutonic spirit, and bearing the parapet, forms the cornice. A series of small arches frequently rests on the corbels. This is the prominent style of cornice in all Rhenish and Lombardic structures.

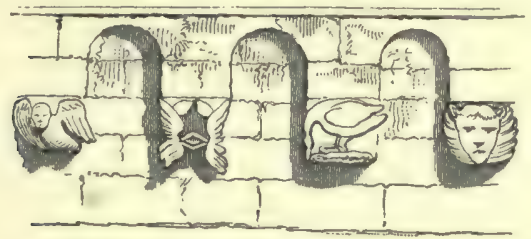

Corbel Table.

In Early Gothic the small arches become orna mental-taking the form of trefoils with moulded edges, and the corbels become less uncouth. The decorated and perpendicular cornices are chiefly horizontal mouldings, with flowers or heads inserted

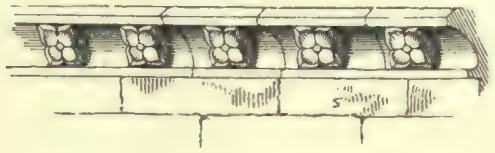

Cornice:

Eynsham Church, Oxon, circa 1450.

as enrichments. The term cornice is also applied to the plaster mouldings seen round the ceiling of rooms at its junction with the walls.

Corniche. See Riviera.

Corniferous Period, name given in North America to the lowest division of Devonian time. It embraces the Corniferons epoch, the Schoharie epoch, and the Cauda-galli epoch. The name corniferous (Lat. cornu, 'horn,' fero, 'I bear') has reference to the common occurrence in the limestones of a quartzose mineral called hornstone.

Corn Inseets. While numerous insects are of great importance in carrying the fertilising

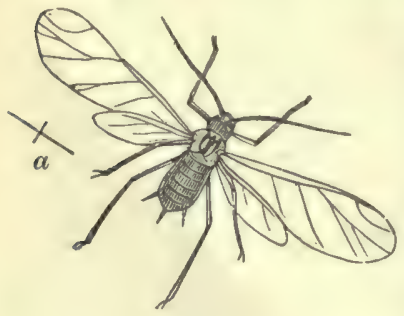

pollen from one Hower toanother, and others are in themselves of directuse to man there remains a vast erowd of more or less in. jurious forms. Of these some attack man and domestic mammals, others do damage quite as effectively by in-

Corn Aphis :

$a$, natural size.

juring fruit and

forest trees, vegetables and crops. A convenient account of these injurious insects will he found in Miss E. A. Ormerod's Manual of Injurious Insects and Methods of Prevention, and fuller details may be gathered from other works mentioned below. It is here proposed simply to give a brief list of the more important insects injurious to corn crops. First then (following Leunis), we may notice some of those which re berably wide in their destructiveness : (1) Zdoreus vibbus (Coleoptera, Carabidæ), a dark bronzed beetle, abundant in Central Europe, less common in England, ravaging wheat-fields, the adults devouring the grain, the larva the leaves. (2) Melolontha vulgaris, Cockchafer (q.v.). (3) Rhizotrogus solstitialis, Midsummer Chafer, a beetle nearly related to the last, of generally similar habit, the larvæ sometimes injuring the seed. (4) Agriotes lineatus, \&c. (Coleoptera, Elateridæ), Skipjacks, Click-beetles, Wireworms (q.v.), injuring root, grain, and fodder crops. (5) Chrysomela cerealis, in the same genus as the Colorado Beetle (q.v.), common in Europe on grasses, and occasionally on cereals. (6) Cephus pygmoeus, Corn Saw. fly (Hymenoptera, 'wood-wasps'), a long, thin-bodied, minute insect, of a brilliant black colour, the larvæ injurious to wheat and rye, feeding on the inside of the stalk, and eventually cutting it through near the ground. (7) Agrotis tritici, \&e., 'cut-worms' (Lepidoptera, Noctuidæ), common moths whose caterpillars feed upon the roots of grasses and other crops. Neuronia

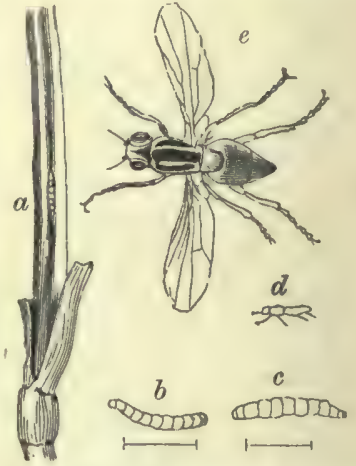

Corn-fly (Chlorops toeniopus): $a$, a portion of a culm or stem of wheat with a swollen joint, caused by larva of corn-fly ; $b$, larva; $c$, pupa; $d$, fly, natural size; $e$, fly. magnified. popularis is a similar form also injurious to grasses and the like. (8) Cecidomyia destructor, or Hessian Fly (q.v.). (9) Diplosis tritici and aurantiaca, allied to the last, infesting wheat, rye, \&c. (10) Anthomyia coarctata (Diptera, Muscidæ), a fly whose eggs are laid in seed, which the larvæ devour in spring. (11) Pachytylus or Oedipoda migratorius and cinerascens (Orthoptera, Acridide), locustlike insects, which, like some other members of the order, do great damage when they appear in hosts. Acridium egyptium and Caloptenus italicus are allied forms not infrequently doing great damage to vegetation (see CRICKET and LOCUST).

Wheat crops are specially liable to be attacked by the following insects: (12) Chlorops treniopus and lineata (Diptera, Muscidæ), flies which deposit their eggs on the ears of corn. The development of the maggots checks the growth, and causes the ears to abort. In Britain barley is oftenest attacked by $C$. tocniopus, which has received the
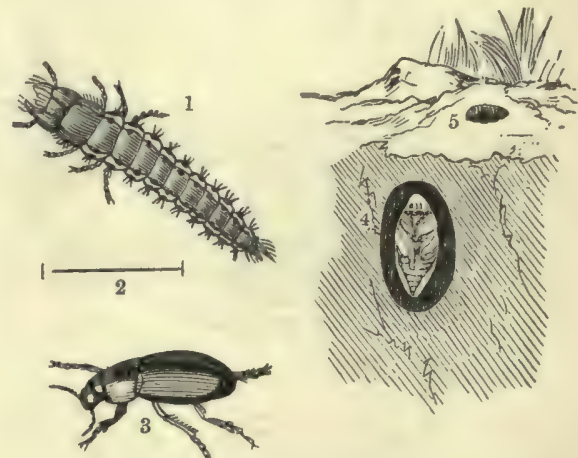

Corn Ground Beetle :

1, larva, magniffed; 2 natural size of larva : 3 , perfect insect, female, slightly magnified; 4 , a cell containing pupa; 5 , a burrow.

name of Gout-fly from the swollen distortions which appear at the joints of infected plants. Towards the end of summer the insects leave the ears as two-winged flies, about the eighth of an inch long, thick and stumpy in shape, yellow, with 
three black stripes along the back between the wings, and the abromen of a greenish-black, with black eroes-bands. C. lineata often does great

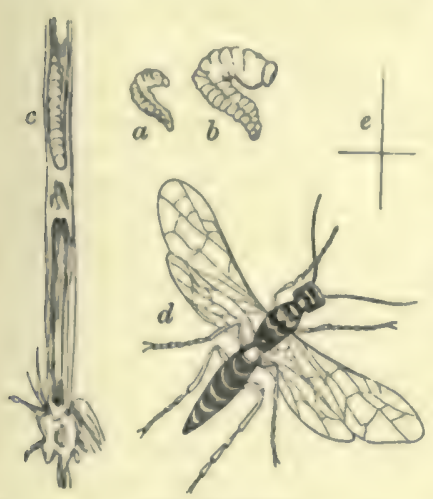

Corn Saw-fly :

*, maggot, natural size; b, maggot, magniflet ; $c$, the maggot in its ear in the stem of the eorm; $d$, remale insect, magnifled; 6. fetrale insect, natural aine.

(Hemiptera. cereals, and sometimes does much damage (see APHIs). (15) Thrips cerealium, Corn-thrips (Thysanoptera, Thripsidæ), a very minute, hardly distinguishable insect, which sucks the sap from wheat ears and canses the seed to shrivel. (16) Tipula oleracea, or Daddy Long-legs (q.v.), or Crane-fly, often does great damage to corn and other crops.

Oats, like barley, are very often damaged by some of the alove, and especially by Chlorops taniopus and $C$. frit, Aphis cerealis and A. avene, and Thrips cerealis. Rye is also subject to these and some other devastating insects.

Of a somewhat different habit from the above is Tinea granella, the Corn-moth (Lepidoptera, Tineidr), in the same genus as the Clothes-moths. This form lays its very small eggs among stored grain or on the sheaves. The larvæ, or Cornworms, appear among the grain on the granary floor, and when care is not taken to keep things clean and the grain well shovelled, often does much damage. From its voracity it is known as the wolf. It spins a web round several grains, and gradually devours them. Another of the granary pests is Calandra granaria, the Corn-weevil or brown Corn-worm (Coleoptera, Cureulionidre), a small reddish-black insect, not quite two lines long, and without wings. It seems to have come to Europe from the East, but is now common in the southern regions. The female lays an egg in each of a number of grains, the larva soon develop, and a second brood is produced the same summer. The most successful method of arresting the mis. chief is said to be that of leaving a small heap of corn undisturhed, while the great mass is well shovelled. The weevils shift to the unstirred heap, and may then be destroyed. See WEEVIL.

For the remedies used, Miss Ormerod's work should be consulted. See also Bulletins of U.S. Entomological Commision; Journal of Royal A gricultural Society; John Curtis, Farm Insects; Kaltenbach, Die Pflanzenfeinde aus der Chrse der Insekten (1874): Traschenbers, Praktische Insekten-kunde (1880); Schmid-Goebel, Die Schddlichen und nutalichen Inaekten in Forst, Feld, und Garten (1881).

Corn Laws, the name popularly given to cer tain statutory enactments which had for their object a restriction of the trade in grain. The English corn laws date as far back as the year 1360 , in the reign of Edwand III. Before this period, there seems to have been a general rule carried into effect by the erown against the exportation of any grain; and the Aet of 1360 enacts the prohibition, but at the name time excepts certain places which the king may appoint by license. An Act of 1436 permitted exportation when the price of wheat did not exceed 6s. 8d. per quarter. Hitherto, there seem to have been no prohibitions against importation; but in 1463 an act was passed prolsibiting it oo long as the price at home was below the 6s. 8d. at which there was free exportation. The next change was in the reign of Henry VIII., when an Act of 1534 prohibited all exportation except by license specially granted under the great seal. This act was not found to work well; and twenty years later the previous arrangement was adopted of allowing exportation when the price atood below a certain point. In 1562 exportation was permitted when the price was under 10s. a quarter. Export duties of varying amounts were imposed from 1570 to 1689 , when they were altogether abolished. The subsequent legislation for some time merely changed the price at which exportation might begin, generally enlarging it. After the Restoration, the policy of increasing the duties on importation, for the protection of agriculture and the landed interest at home, begins to be perceptible. At the same time the effect of that event on the relations of Scotland and England towards each other forms a curious illustration of such fiscal regulations. Under the Protectorate they were one country, with free intercommunion of trading privileges. Scotland was increasing in wealth nnder this arrangement; but the countries were separated by the restoration of Charles II., and became the same to each other as foreign nations. The English duties restricted the importation of grain from Scotland; and in 1663 the Scotch parliament, in retaliation, laid heavy duties on the importation of English and all other foreign grain. Had not the union of 1707 made the two countries one again, England and Scotland would probably have continued a corn-law contest against each other, as was the case with the French provinces under the old regime.

The agricultural interest continuing powerfully to control this department of legislation, an act was passed in 1670 for virtually prohibiting importation into England until the home price had reached 53s. 4d., and laying a heavy duty on it above that point. This law had, however, little effect in favour of the landed interest, from the cireumstance that then, and for long afterwards, Britain was an exporting, not an importing country -that is to say, it generally proluced nore corn than its population required. A new device was alopted at the Revolution of 1689 , a bounty being awarded on exportation-i.e. a sum of 58. was paid for every quarter of wheat sent abroad when the price fell below $48 \mathrm{~s}$., so that if the price in the foreign market would not indnce people to export corn, the bounty, in addition to that price, might. For upwards of a century the numerous enactments in this department will be found to be a mere shifting, according to circumstances, of the incidence of the bounty on the one hand, and of the inport duty on the other. In 1773 a permanent adjustment was supposed to be reached by Burke's act, which provided that the lxounty should cense when the price reached $44 \mathrm{~s}$, prohibited exportation when the price was above that figure, and allowed importation at a nominal duty 'of 6d. at a price of 485 . In 1791, and during the wars of the French Revolution, further alterations in the corn laws favourable to the landed interest were effected. The bounties, however, were abolished in 1814. In 1815 , after the conclusion of the wars, a law was 
passed prohibiting importation of foreign corn when the price was below 80 s. a quarter.

The principle of the sliding-scale which had been more or less followed in previons enactments was systematically carried out in the year subsequent to the great wars, in 1822, and particularly in 1828, when Wellington's sliding-scale was passed. The object of the device called the sliding-scale was to reduce the import duty as the price of grain increased, for the purpose of virtually prohibiting the importation when the price was low, and encouraging it when the price was high, so that at famine-prices grain might come in duty free. By the Act of 1828, the price of $62 \mathrm{~s}$. a quarter on wheat was taken as the turning-point. At that price the import duty was $£ 1,4$ s. 8d. For every shilling less in the price a shilling was added to the duty. When the price rose above this point a different gradation ruled, the duty decreasing by a larger ratio than the rise. Thus, when the price was $69 \mathrm{~s}$. the duty was $15 \mathrm{~s} .8 \mathrm{~d}$.; and when it rose to $73 \mathrm{~s}$. the duty sunk to its minimum of 1s. The effect of such fluctuation in rendering the trade a gambling one is obvious, and yet this was not acknowledged until it had been proved by a series of ruinous instances. Thus, an importer who, when the price of grain was 73s. a quarter, bought a cargo, if the price sunk $4 \mathrm{~s}$. before he could accomplish a sale, had not only to sell at that reduced price, but with a further reduction of $14 \mathrm{~s} .8 \mathrm{~d}$. a quarter paid as duty. What was still more important, the supplies to this country being so eapricious and irregufar, foreign countries did not grow corn habitually for the British market. In 1842 Sir Robert Peel tried a modification of the sliding-seale, which did not in the least degree mitigate the growing hostility to the corn laws.

The basis of this hostility to the corn laws was found in the population which had now grown up in the large towns. The effect of the industrial revolution connected with mechanical invention and the utilisation of steam had been to transform Great Britain from an agricultural into a manufacturing and commercial country. The new interests thus ereated were rapidly rising to supremacy. But the nation did not, till the very last, earnestly unite in calling for repeal. There was a powerful party who defended the corn laws, and represented, with great plausibility, that these restrictive statutes were for the public good. Their arguments might thus be summed up: (1) Protection was necessary, in order to keep certain poor lands in cultivation. (2) It was desirable to cultivate as much land as possible, in order to improve the country. (3) If improvernent by that means were to cease, we should be dependent on foreigners for a large portion of the food of the people. (4) Such dependence would be fraught with immense danger; in the event of war, supplies might be stopped, or our ports might be blockaded, the result being famine, disease, and civil war. (5) The advantage gained by protection enabled the landed proprietors and their tenants to encourage manufactures and trade; so much so, that if the corn laws were abolished, half the country shopkeepers would be ruined; that would be followed by the stoppage of many of the mills and factories; large numbers of the working-classes would be thrown idle; disturbances would ensue; capital would be withdrawn; and what would happen then, the wisest could not foresee. Such arguments had great weight with the labouringclasses, the small-town shopkeepers, almost all the members of the learned professions, and an immense majority of both Houses of parliament. Those who endeavoured to represent the impolicy of a restricted trade in corn were generally set down as little better than mischief-makers. In the House of Lords in 1839, Lord Melbourne, a Liberal premier, said, "To leave the whole agricultural interest without protection, I declare before God that I think it the wildest and maddest scheme that has ever entered into the imagination of man to conceive.'

Meanwhile the ANTI-CORN-LAW LEAGUE concentrated the efforts of the free-trade party in Britain, and ultimately enabled them to carry the repeal of the corn laws, and to establish in practice the principle of free trade. In 1836 a number of philosophical radicals, among whom were Grote, Joseph Hume, and Roebuck, had formed an association for repealing the corn laws. In 1838 seven Manchester merchants formed an association of the same kind. The latter was soon joined by Cobden, who threw all his energy into the agitation, and secured for it also the eloquent advocacy of John Bright. Charles Villiers, who led their canse in the House of Commons, moved in February 1838 that the House resolve itself into a committee of inquiry on the corn laws. The motion was rejected by 342 to 195 ; and immediately the famous League was formed, with a central office at Manchester, its constitution dating from the 20th March 1839.

This was the beginning of a remarkable agitation, supported by lectures, verses, pamphlets, and popular oratory, which had a great influence on the economic and political education of the country. Large sums of money were raised, and a vast mass of popular literature bearing on the corn laws was diffused. In 1843 the League raised $£ 50,000$; in $1844, £ 100,000$; in 1845 , $£ 250,000$, for continuing the agitation. At a great meeting at Manchester in $1845, £ 60,000$ were subscribed in an hour and a half.

The opposition to the corn laws steadily increased. Roused by the addresses of Mr Cobden, Mr Bright, and other leaders of the League, the people poured in petitions to parliament. The failure of the potato erop and the famine imminent in Ireland gave an overwhelming weight to the arguments of the League. At length the Conservative premier, Sir Robert Peel, became a convert to Free Trade (q.v.), and in 1846 carried a measure to put an end to the corn laws. By this act, the duty on corn was at once greatly reduced, and was to cease altogether in 1849, with the exception of a registration duty of 1s. a quarter, which terminated in 1869.

The repeal of the corn laws did not lead to a very great fall in the price of corn, nor did it result in the ruin of the agricultural interest. The vast expansion of industries, attended with a large increase of population and the growing demand for food, kept prices up to a tolerably high level. A markedly increased consumption of butcher-meat specially tended to enhance prices in that department and to raise the rent of land. With the development of American competition, about the year 1976, however, a new period set in. English agriculture has suffered severely, a fact which has largely contributed to the formation of a Fair-trade Party demanding among other things what they consider a moderate and reasonable protection for our landed and cultivating classes.

The pressure of American competition has also of late years led to the establishment of a corn-law system for the protection of agriculture in Germany. In 1879 protective duties on the importation of foreign grain were passed by the imperial parliament, and these have since been considerably increased. In France, trade in grain has long been subject to government regulation. During the course of the 19th century the duties on importation had been greatly reduced, but within the last few years things have followed the same course as in Germany. Slightly raised in 1881 , the duties on grain were 
increaser fivefold in 1885. See BRICHT, and COBDEN, and works there cited.

Corno, Monte. See Gran Sasso d'Italia.

Cornounille, a distriet forming part of Brittany, included within the modern department of Finistere. It is one of the most barren and desolate parts of France; the chief town is Quimper. The slentity of the name with Cornwall is obvions. See Brittany.

Corns (Lat. cornu, 'horn,' through the French) are small hard growths, resulting from an increase in the thickness of the cuticle or epidermis, which is generally caused by the irritation of some ex. cessive preasure or friction on the part. They occur most commonly on the feet as a result of tight or ill-fitting shoes. Corns are either hard or soft; the structure of both classes is essentially the same. A hard corn begins as an ill-defined thickening of the epidermis st one point. As irritation con. tinues the excessive growth of epidermis increases, and the papillse (see SKIN) beneath also enlarge, giving the deeper part of the growth a fibrous appearance, popularly described as the "roots" of the corn. Pressure upon the sensitive nerves of these papillse causes the usual pain of corns. Old corns often have a bursa or sac developed beneath them, which in part protects the underlying structures. Excessive irritation sometimes causes this burse, or in its absence the connective tissue beneath a corn, to inflame and suppurate; and the little abscess thus formed, confined by the hardened epidermis, gives rise to intense suffering. In socalled fibrous corns, more allied to warts, the enlargement of the papillæ predominates, and the pain is greater than in ordinary hard corns. Soft corns oceur between the toes, where the warmth and moisture promote early separation of the epidermis, and growth of the papillæ; they are therefore more vascular than the other forms, and often extremely painful.

The treatment of corns consists in the removal of all undue pressure or friction, either by removing the shoe altogether, or protecting the corn by surrounding it with a border of some soft material, as Amadou (q.v.) or soft leather; or the hardened cuticle may be pared or filed away, the central part most deejly. Of late years a simple and convenient remely has been introduced, now sold everywhere as a 'certain and painless cure for corns,' It consists of a solution of salicylic acid in collodion, one drachm to one ounce, with a small proportion of extract of Indian hemp. It is painted over the corn once or twice daily, and allowed to dry, with the effect of so softening the epidermis that, usually after six or eight applications, it can readily be peeled off with the aid of hot water. Soft corns should be freely dusted with oxide of zinc powder, and the affected toe isolated from its neighbours by means of medicated cotton-wool. If suppuration occur beneath a corn, the matter must be let out by a puncture, after the corn has been pared down. Those subject to corns should avoid patent leather boots, or even eschew leather altogether, and use 'pannuscorium' or some other more porous sub. stitute.

Corns affect horses as well as men. In the foot of the horse they occur in the angle between the bars and outer crust, and consist in a bruise of the sensitive secreting sole. Some forms of feet are especially subject to them. Corns constitute unsoundness ; cause \& short, careful, tripping gait; are the most frequent source of lameness amongst roadsters: abound in badly-shod horses, and usually occur in the inside heels of the fore-feet, these being more especially subjected to weight, and hence to pressure. The discoloured spot indicating the recent corn must be carefully cut into with a fine drawing-knife; any serum or blond is thus allowed free vent. If the bruise has been extensive, a poultice will have the twofold effect of allaying irritation and relieving the sensitive parts by softening the hard unyielding horn. When the injury has been of some standing, and soft faulty horn is secreted, a drop of diluted nitric acid may be applied. On no account must the bans or outer crust be removed; they are required for bearing weight, which may be further kept off the injured part by the use of a bar-shoe. In horses subject to corns, harden the feet by putting on tips or slippens instead of full shoes, thus bringing the heels into contact with the ground; this will cause a rapid and strong growth of horn, not liable to be bruised.

Corn Salad, or Lamb's LeTTuce (Valerian. ella), a genus of Valerianaces, humble annual weeds, of which some are used as spring salads, especially in France and Germany. The commonest species is $V$. olitoria, which is naturalised in the Lnited States, and often called Fetticus or Vetti. cost. There are several native American species.

Cornstone, an arenaceous or siliceous lime. stone, often mottled, and not infrequently concretionary. It usually ocenrs in those systems which are largely composed of reddish sandstones.

Cornucopia (Lat. cornu, 'a horn,' and copia, "plenty '), in classical antiquities, the horn or symbol of plenty placel in the hands of emblematical figures of Plenty, Liberality, and the like, who are represented as pouring from it an abundance of fruits or corn. It is frequently used in architecture, sculpture, and heraldry.

Cornwall, a maritime county, forming the south-western extremity of England, and the southernmost part of the British Isles. It is peninsular, tapering westward from Devonshire to the Land's End, bounded on the E. by Devonshire, on the $\mathrm{N}$. by the Bristol Channel, on the W. by the Atlantic, and on the S. by the English Channel. No part of the county is more than 20 miles from the sea. The total length from Welcombe to the Land's End is 81 miles, and the extreme breadth. from Morwenstow to the Rame Head 45 miles. The Scilly Isles, 24 miles W. of the Land's End, form part of the county. The aren is $1365 \mathrm{sq} . \mathrm{m}$., of which 63.4 per cent. is under cultivation. There are very extensive stretches of moorland, much rocky and barren, but a large proportion useful as mountain pasture. The surface of the county is very irregular, and a ridge of rugged, bleak, rocky hills, interspersed with moors, stretches from the Tamar to the Land's End, a continuation of the Dartmoor upland, and forming the watershed. Brown Billy (1368 feet) is the loftiest point in the county. As this range is nearer the north of Cornwall than the south, the principal rivers are on the southern side, and empty themselves into the English Channel. With the exception of a few unimportant ereeks, there are only two harbours on the north const-the estuary of the Camel, on which is Padstow, and the bay of St Ives. For nearly the whole of its length this north coast is formed of bold and picturesque eliffs ; but at Perranzabuloe and Gwithian there are hills of blown sea-sand, which have buried much good land. The gouthern coast is also for the most part bold and rocky, but indented with many headlands and bays. Between the Land's End $\left(5^{\circ} 41^{\prime} 31^{\prime \prime} \mathrm{W}.\right)$ and the Lizard Point $\left(49^{\circ} 57^{\prime} 30^{\prime \prime} \mathrm{S}\right.$. ) is the deep indentation named Mount's Bay, from St Michael's Mount, with the harbour-works of Penzance. East of the Lizard is Falmonth Bay, into which opens Falmouth Harbour, one of the finest in Britain. On the enstern boundary of the county is another of the great havens of the kingdom, Plymouth Sound. The estuary of the Fowey also sffords a small but per- 
fectly sheltered deep-water harbour-of considerable importance in the middle ages. The chief river is the Tamar, which practically divides Cornwall from Devon, rising within 3 miles of the north coast at Wooley Barrows. It is tidal, and navigable for 19 miles (total length 59) from its embouchure in Plymouth Sound. Its principal Cornish tributary is the Notter, which enters it through the estuary of the Lynhir, and is navigable for 5 miles. The lower part of the estuary of the Tamar is called the Hamoaze. The Fowey is 30 miles long, and navigable for 6. The Fal is 20 miles long from its source to Falmouth Harbour, into which several smaller streams empty themselves through tidal creeks. The Camel (also called the Alan) is 29 miles long, 10 miles being tidal. There is a tradition that a large tract of land between the Land's End and the Seilly Isles was submerged by the sea. This is the fabled Lyonesse.

Cornwall is mainly composed of clay-slate, provincially called killas, which is broken along the higher ground by the protrusion of bosses of granite, in five larger and many smaller masses, probably connected beneath the surface. Associated with the granite are schorl and allied rocks, and there are many dikes of quartz- and felspar-porphyry, locally termed elvans. The slates are interspersed with igneous rocks, interbedded and intrusive, and there has been much alteration. The Lizard district presents the most complex series in the kingdom. Serpentine and gabbro are the most distinctive rocks here; but there are schists and gneisses and porphyries in singular variety. The stratified rocks of the east of the county are recognised as Devonian; in the central region Silurian are largely represented; the western may be still older; and the Lizard are believed to be partly Archæan. Mining has been carried on in Cornwall from prehistoric times, and the county has been regarded as the Cassiterides (q.v.) of the Phonicians and Greeks. The most profitable mines are near the junctions of the granite and killas, and the most important mining area at the present day is around Camborne and Redruth; the deepest and richest mine is Dolcoath, wrought to a depth of about half a mile. The county yields tin, copper, lead, iron, zine, silver, cobalt, antimony, manganese, bismuth, tungsten, and arsenic in commercial quantities; and a greater variety of minerals (some unique) than any other part of the United Kingdom. Gold has been found in alluvial tin works or 'streams,' the largest nugget over two ounces. Of late years mining has been very much reduced, and almost all the mines now existing are tin, of which Cornwall yields nearly all that is raised in the kingdom. The output of copper is at present small. Next to tin, the most important mineral product is china clay (kaolin), the decomposed felspar of granite which has undergone the natural process of kaolinisation. The chief centre of this industry is the district north of St Austell. Here also is found a peculiar kind of granite called china-stone (petuntze).

The fisheries of Cornwall are extensive and important, and in favourable seasons large quan. tities of pilchards are caught by seining, cured, and exported to the Mediterranean, where they form a common Lenten food. Herring and mackerel fisheries are also extensive, and enormous quantities are sent by rail to London and various inland markets. The climate is generally mild, but damp. In the extreme west of the county snow seldom lies, and the winter temperature. is such that plants live and flourish in the open air that require protection almost anywhere else in England. At Trevarrick, near St Austell, and Lamorran and Penjerrick, near Falmouth, many foreign trees and shrubs have been successfully acelima- tised. Camellias grow and flower in the open air as luxuriantly as the common laurel in sheltered localities. The gardens at Trescoe, Scilly, are quite tropical in character, from the variety and beauty of their tropical contents. This favourable climate has been turned to good account in the Scilly Isles and the Penzance district, by the development of market-gardening for the supply of early vegetables to the leading markets, particularly broccoli and potatoes, of which double crops are raised annually. With the exception of the peach, nectarine, and apricot, nearly all fruit-trees thrive and mature; and the banks of the Tamar are specially favourable to the growth of cherries and strawberries, for rail supply. As a general agricultural county (its moorlands excepted), Cornwall stands high: the soil is rich; crops are abundant, and in some localities very early.

There are very few manufactures; and most of the inhabitants, since the falling off in mining, are employed in agriculture. The population in 1881 was 329,484 ; in $1891,322,589$. Cornwall contrins one parliamentary borough - Falmouth and Penryn, and six county divisions. It returned 40 members prior to 1832, 14 till 1867, 12 till 1885 , and now 7 in all. The bishopric of Cornwall, merged in that of Exeter since Saxon times, was restored in 1876, and the see fixed at Truro.

Cornwall remained in the hands of its Celtic inhabitants, and under the rule of the British Church, with more or less completeness, until it was finally subjugated by Athelstan in 936. The ancient Cornish language belonged to the Cymric or Brythonic group of the Celtic tongues (see CELTS), and was akin to Welsh and Breton. It was generally spoken until the reign of Elizabeth, and it was not until 1678 that it finally ceased to be used in public worship. It lingered in the extreme west of the county until the early part of the 18th century; Dolly Pentreath (?1676-1778) of Mousehole is popularly regarded as the last who spoke it; while words and phrases have been handed down to the present day. The literature comprises a vocalulary dating probably from the 13th century, and some sacred dranias not earlier than the 14th. See Norris's Ancient Cornish Drama (1859); Whitley Stokes's editions of The Life of St Meriasek (1872), of The Mystery of the Creation (1864), and of the Glossary of Cormac (1864); the glossary of words still in use in Cornwall, published by the English Text Society in 1880; a paper by LachSzyrma in the Journal of the Royal Institution of Cornwall for 1883; and Jago's English-Cornish Dietionary (1887).

Cornwall abounds in rude stone and allied monuments - circles, remains of huts, menhirs, cromlechs, artificial caves or fogous, cairns and barrows, inscribed stones, and early crosses. The medieval antiquities are less important, the most noteworthy being the remains of the castles of the ancient earldom, created into a duchy in 1337 for the Black Prince. The eldest son of the reigning sovereign is Duke of Cornwall; and the revenues derived from the duchy by the Prince of Wales average $\$ 61,000$ a year. In the management of the affairs of the duchy the Prince is assisted by a council, the chief officer of which is the warden of the Stannaries, by whose vice-warden the Court of the Stannaries, which has the local regulation of mining affairs, is held. See Tregellas's Cornwall (4th ed. 1884), and other works cited there.

Cornwall. a port of entry of Ontario, at the mouth of the Cornwall Canal, and separated by the St Lawrence from New York state. It is on the Grand Trunk Railway, 67 miles SW. of Montreal, and has, among other factories, one of the principal woollen-mills in the Dominion. Pop. (1881) 4468 ; (1891 ) 6805 . 
Cornwall, Barry. See Procter.

Cornwallis, Caroline Frances, was born on the 12th July 1786, the daughter of the rector of Wittersham and Eltham, in Kent. She acquired a thorough knowledge of Latin and Greek, and making herself conversant with nearly every study which occupies thoughtful men, from an early age she carried on a correspondence with many emi. nent persons. Her refusal to accept the hand of Sismondi dicl not forfeit his friemlship, and she lived mueh in Italy. Her finst work, Philosophical Theories and Philosophical Experience, by a Pariah (1842), was the first of a series of twenty 'Small Burs on Great Subjects,' the said subjects including the Connection of Physiology and Intel lectual Science, Ragged Schools, Criminal Law, Greek Philosophy, and the History and Influence of Christian Opinions. Miss Cornwallis also pub. lished in 1847, Pericles, a Tale of Athens. She died at Lidwells, in Kent, 8th January 1858. See her Letters and Remains (1864).

Cornwallis, Charles, Marquis, an English general and statesman, son of the first Earl Cornwallis, was born in London, December 31, 1738, and was educated at Eton and the Military Academy of Turin. He served as aide-de-camp to the Marquis of Granby during part of the Seven Years' War; in 1766 was made a colonel; four years later, governor of the Tower of London; and the year after a major-general. In 1760 he had been returned to parliament for the family borough of Eye. Though personally opposed to the policy of forcing taxes upon the American colonists, he accepted a command in the war, and with an inferior force gained a victory over General Gates at Camden in August 1780, and more than held his own against General Greene at Guilford, March 1781. But his operations were hampered by the incapacity of his superions, Howe, and after him, Clinton; and at length he was forced to surrender with all his troops at Yorktown, Virginia, 19th October 1781. This disaster proved the ruin of the British cause in America, and was the occasion of much dissatisfaction, resulting in a change of ministers at home. Cornwallis, however, who was high in favour with the king, escaped censure. In 1786 he was appointed governor-yeneral of India and commander-in-chief, and in this double capacity distinguished himself by his victories over Tippoo Saib, and by unwearying efforts to promote the welfare of the natives, that proved less successful than they deserved. He returned from Indis in 1793, when he was raised to the rank of Marquis. As lord-lieutenant of Ireland, with Castlereagh as his secretary, he crushed the '98 rebellion, and showed a rare union of humanity and vigour in his measures for the pacification of the country. As plenipotentiary to France he negotiated the peace of Amiens in 1802, but showed little skill in diplomacy. Reappointed governor-general of India in 1804, he died at Ghazipur, in the province of Benares, October 5, 1805, on his way to assume the command of the army in the Upper Provinces. See his Correspondence, ed. by Charles Ross (1859); and the Life (in 'Rulers of India') by Karr (1890).

Coro, a town of Venezuela, in Falcón state, lies about 210 miles W N W. of Carácas, near the Golfete de Coro. It has a fine aqueduct, and a college; but it has greatly declined since the period $1527-78$, when it was the capital of the Spanish provinee. Pop. 9100. There are valuable coal-nines near. The port is La Vela, 7 miles NE. by rail.

Corolla. See Calyx, Flower.

Cor'ollary, a proposition the truth of which appears 80 elearly from the proof of another proposition as not to require separate demonstration.
Coromandel Coast is a name used vaguely for the major part of the eastern coat of what in now the province of Madras, on the west shore of the Bay of Bengal. It has hardly a single safe place of refuge for large vessels. The name is probably a corruption of Cholamandalam, 'country of the Cholas,' an old Dravidian people.

Coro'na, or Crows, in Botany, an appendage of the corolla in some flowers; sometimes developed as a crown-like circlet witlin the petals, as in the common white narcissus, or prolonged like an in. ternal united corolla, as in the daffodil. Much discussion has taken place as to its morphological nature, at first as to whether it was to be regarderl as composed of modified stamens or supernumerary petals. But in many Caryophyllese (e.g. Lychnis) each petal is seen to bear a ligule, so called from its resemblance to that of a grass-leaf (see Grasses). These are regarded as of stipular origin; and in this way we come to look at the corona of a narcissus as composed neither of modified petals nor stamens, but of the united petaline stipules. See Narcissus.

Corona (Lat., 'a crown'), in Architecture, the drip, or lower member of the projecting or upper part of a classical cornice (see ENTABLATURE). The term corona is also applied to the apse or semicircular termina. tion of the ehoir. Corona is also applied in ecclesiological no-

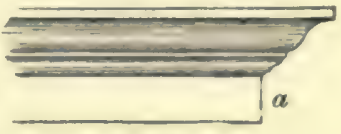

$a$, the Corona. menclature to a chandelier, in the form of a crown or circlet, suspended from the roof of a church.

Corona. See Sun.

Corona Boreialis, a small and bright con. stellation near Hercules.

Coronach, a name formerly used for the funeral dirge amongst the Irish and the Scottish highlanders. The dirge, disused in Scotland, is in Ireland now commonly known as the keen.

Coronation. The practice of placing a crown on the head of a monarch at the commencement of his reign is very ancient, and there is probably searcely any country in which it has not been followed in one form or another. Generally it has been accompanied by what was regarded as the still more solemn rite of anointing with oil, a ceremony which, from the times of the ancient Hebrews to our own, has been peculiarly significant of consecration or devotion to the service of God. In England, before the Norman Conquest, the term was more usually 'hallowing' or consecration than coronation; but it would seem that the ceremony as then performed at Kingston-on.Thames or Winchester was in all essentials the same as that which now takes place in Westminster Abbey, though now the ceremony is a mere pageant. Detailed accounts of many English cononations, from Richard I. downwards, have been preserved.

There have been considerable variations from time to time in the oath. Originally the king pledged himself to three things-peace and reverence to God and the ehureh, justice to the people, the upholding of good and abolition of bad laws. In Elward II.'s time it became more precise, and assumed the form of question and answer. The present form was settled after the Revolution of 1688. By it the sovereign, in a series of responses to questions by the Archlishop of Canterbury, sweare to govern the people of the United Kingdon accord. ing to the statutes in parliament agreed on; to cause law and justice, in mercy, to be executed; and to preserve and maintain the Protestant religion established by law. This oath was held 
both by George III. and George IV. to prevent them from granting Catholic Emancipation, and was also by many regarded as an obstacle to the disestablishment of the Irish Church (see Bishop Phillpotts, The Coronation Oath, 1828). The treaty of Union between England and Scotland provides that the oath of the preservation of the

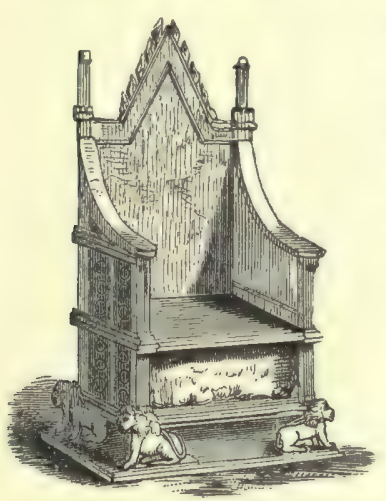

Coronation Chair of the Kings of England. government, worship, and discipline of the Church of Scotland should be taken not at coronation but at the accession of the sovereign. For the ceremonies connected with coronation, see CHAMPION ; Chapters on Coronation (1838); Planché, Coronations of Queens of England (1838); Jones, Crowns and Coronations (1883); and Lives of Queen Victoria by Holmes (1897) and others.

The Scottish coronation stone, the Lia Fail or 'Stone of Destiny,' was said by tradition to have been the stone which Jacob used for a pillow, and to have been brought to Ireland, and from Tara to Scotland, where it found a resting-place at Scone, till in 1296 Edward I. carried it to Westminster. It now forms part of the coronation chair, occupying the space beneath the seat. Skene, in his monograph (1869), asserts it to have been originally quarried from the rocks near Scone.

Coronation Gulf, an inlet connected with the Arctic Ocen, south of Victoria Land, in $68^{\circ} 30^{\prime}$ N. lat., and $110^{\circ} \mathrm{W}$. long.

Coronea, a small town of Boeotia, SW. of Lake Copais, where in 447 B.C. the Bootians defeated the Athenians, and in 394 Agesilaus (q.v.) defeated the allied Greeks.

Coronella, a genus of non-venomous snakes in the family Colubrida, to which the English Ringed Snake (q.v.), Tropidonotus natrix, also belongs. The genus is welf represented in dry regions in Europe and North Africa. C. lavis or austriaca is a very common European species between two and three feet in length.

Coroner (Lat. coronator, corona, 'a crown'), a very ancient officer, in England, at the common law. The coronator is mentioned in a charter of King Athelstan, 905 A.D. ; and the office is said to be of Saxon origin. But Bishop Stubbs (Constitutional History, vol. i. chap. 17) finds the origin of the office of the modern coroner in an ordinance of 1194 A.D. for the election in every shire of officens to keep the pleas of the crown, whence the name. In this light, the Lord Chief-justice of the Queen's Bench is the principal coroner in the kingdom, and may exercise jurisdiction in that capacity in any part of England. There are, however, particular coroners in every county in England, and in some counties three or four, or even more. Every borough having a separate court of Quarter Sessions has a coroner; but since 1888 boroughs have ceased to have a separate coroner unless the population amounts to 10,000 . Coroners were formerly paid by fees on each inquest, but now by salary out of the county rate. The coroner is chosen for life, and the election, which formerly lay with the freeholders, rests, under the Local Government Act of 1888 , with the county-council, or with the town-council of a borough having the right to appoint one. A coroner may, however, be dismissed by the Lord Chancellor for inability or misbehaviour in his office. By the statute of Westminster the first ( 3 Edw. I. chap. 10), it was enacted that none should be chosen but lawful and discreet knights; and in the time of Edward III. there is an instance of a man being removed from the office because he was merely a merchant. Subsequently it was thought sufficient if a man had lands enough to entitle him to be made a knight; and Blackstone complains that in his time it had come to be sought for the perquisites, and not for the honour of serving the country. This motive has now ceased. The coroner is now usually a professional man, frequently a solicitor or a medical man.

The office of coroner is to some extent the only one in England charged with the investigation of crime. When the coroner cannot act, there is no authority to examine witnesses until a suspected person has been actually charged or accused before a magistrate. But even the coroner's duties are very limited. They are defined by 50 and 51 Vict. chap. 71, which consolidates most of the previous statutes. The coroner can inquire only into the causes of violent or sudden death, and into these only when the body has been found. When such a death happens, it is the duty of the constable to give notice of it to the coroner, who then summons a jury from the body of the county for the purpose of making an inquisition into the matter. The coroner presides over the inquisition, and the court thus constituted is a court of record. The jury consists of twelve men at least, who are sworn and charged by the coroner; and the verdict must be found by twelve. The inquest is to be held before the coroner in whose district the body shall be 'lying dead.' If any be found guilty by such inquisition of muxder or other homicide, the coroner is to commit them to prison or take bail for their appearance at the assizes, according to the gravity of the offence, and he nust certify the inquisition under his own seal and the seals of the jurors, together with the evidence thereon, to the court in which the trial is to take place. The accused may thereupon be put on his trial without other indictment. The coroner is empowered to summon medical witnesses, who are liable to a penalty for non-attendance. He has power to pay a medical witness one guinea for a simple examination, and two guineas if a post-mortem examination of the body has been made. Coroners are empowered to appoint deputies in case of absence from illness or other reasonable cause. Another branch of the coroner's office was to inquire concerning shipwrecks and treasure-trove; but this has been nearly superseded by the provisions of the Merchant Shipping Act, 1854. He is a conservator of the king's peace, in which capacity he is mentioned in the oldest treatises on the common law. As such, he may cause suspected felons to be apprehended, whether an inquisition has found them guilty or not. The coroner has likewise ministerial functions as the sheriff's substitute, in making out the panel of jurors, and in executing process in suits in which the sheriff is related either to the plaintiff or defendant. Latterly, the office of coroner has been the subject of consideration with a view to certain reforms of administration.

Coroners or crowners, as they were also called in England, are mentioned in many old Scottish statutes; and there is no doubt that the office, as well as that of alderman and mayor, existed in those parts of the country that were peopled by persons of Teutonic race. But it was abolished or fell into desuetude, probably in consequence of 
the succession war and the French connection; and in Scotland the duties are now chiefly performed by an officer appointed by the crown, styled the Procurator-fiscal (q.v.). In Ireland the office of coroner is regulated by 9 and 10 Vict. chap. 37. See Jervis, Office and Duties of Coroner (new ed. 1880).

In the United States the coroner is generally elected for a specified term by the voters of each county. He is authorised to employ deputies, assistants or clerks, as well as a legal adviser, and a physician to examine the cases which come before him. His powers and duties relating to the inquiry into cases of sudden or violent death are substantially the same as those of an English coroner. But he is confined to this function. Nor does the inquisition found before the coroner dispense with the necessity of an indictment found by the grand jury, as in England. In cases where the sheriff is absent or disabled, the coroner may sometimes act as an executive officer in his stead. He must in each term make a report under his official seal to the Court of Common Pleas of the state.

Coronet, an inferior sort of crown worn by persons of princely or noble rank, as a crown properly so called is worn by a sovereign. In England, coronets were worn by peers as far back as the reign of Edward III. ; but the definite form given to the coronets of the different orders of the peerage is of later date, as is also the practice of placing within the coronet a cap of crimson velvet lined with ermine and surmounted by a gold tassel. The use of coronets by barons began in the reign of Charles II. Peerg wear their coronets on the occasion of the coronation of a sovereign; and they are placed over representations of their arms, this being done even in the case of peers by courtesy. In 1665 Charles II. granted warrants to the Scottish and Irish kings of arms for the peers of those kingdoms to wear coronets similar to those of peers of England.

The following are the distinctive forms of the coronets in use in the United Kingdom: The coronet of the Prince of Wales differs from the royal crown only by the absence of one of the

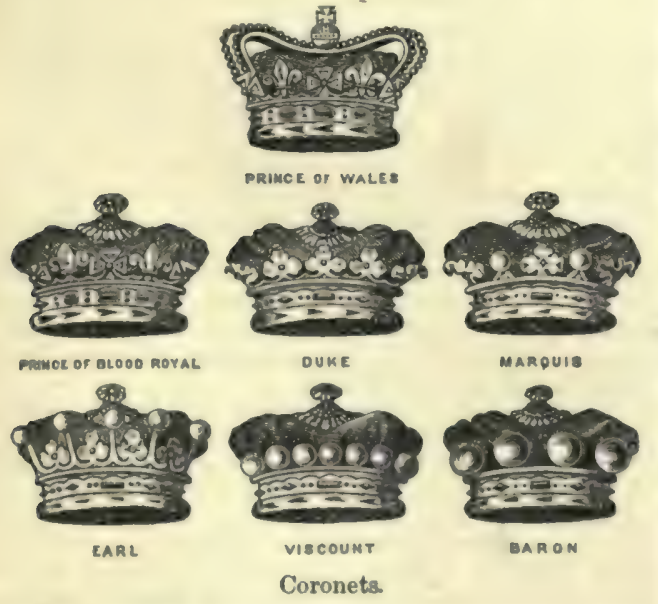

arches. The coronets of other princes, sons of the sovereign, are without arches. Princes, sons of the above, have a similar coronet, with strawberry. leaves substituted for fleurs-de-lis. The coronet of a duke has above the rim of gold eight strawberry. leaves, of which five are shown in pictorial representation. That of a marquis has four strawberry * leaves, alternating with as many large pearls upon short points. The coronet of an earl has eight points of more considerable height, with a pearl set on each, alternating with as many strawberry. leaves on the rim below. A viscount's coronet has sixteen, and a baron's six pearls set directly on the rim. The co-called pearls are always made of silver. No coronet belonging to a peer not of the royal family should be adorned with jewels.

The term ducal coronet is sometimes applied in heraldry to $a$ decorative coronet like that of a duke, but with only three leaves, and without the cap, out of which (in place of out of a wreath) the crest issues.

The coronets of continental nohility are without caps, and otherwise differ somewhat from those in use in Great Britnin. They are only used in blazonry, and are not worn on state occasions. The coronet of a French duke is like that in use in England, that of a marquis has three strawberry or parsley leaves alternating with three pearls, while a count's coronet has nine pearls. German dukes arch their coronets, and German counts often elevate their pearls. The coronet of the Dauphin of France was heightened with fleurs-de-lis, and arched with four or sometimes eight dolphins.

Corot, Jean Baptiste Camille, landscapepainter, was born at Paris, 28th July 1796, the son of a hairdresser who became a draper. Educated in the Lycée at Rouen, he became an assistant in a drapery establishment in Paris, and it was not till his twenty-sixth year that he was able to yield to his natural inclinations and begin the systematic study of art. He was instructed by Michallon and Victor Bertin, and in 1825 he settled in Rome, his small view of the Coliseum in the Louvre bearing that date. Here he studied under Aligny, 'I' Ingres des arbres,' and in 1827 he returned to Paris, and contributed his 'Vue prise à Narni,' and his 'Campagne de Rome' to the Salon, where he constantly exhibited till the year of his death. His main sketching ground was at Barbizon, in the forest of Fontainebleau; but he made two other visits to Italy in 1835 and 1843 . His earlier productions are careful and precise in execution, and it was not until about 1840 that he asserted his full individuality, and developed that style, characterised by grent breadth and delicacy, and sacrificing accuracy of detail to unity of impression and harmony of general effect, which marks the works of his maturity. He was not an artist of great variety or of very extended range in subject and effect. He was the painter of misty lakes and vaporous rivers, of the quiet of moonlight, of the tender moments of pure sunrise, or of softly coloured evening; and these he has treated in the spirit of a true poet, introducing very appropriately his figures of peasants, or more frequently of nymphs and classical personages, who take their place most fittingly in scenes like his which tend towards the ideal and the idyllic. His works made their way slowly with the public, but werlth and fame came to him in the end. At the Salon he won medals in $1833,1848,1855$, and 1867 . In 1846 he received the Cross of the Legion of Honour, and in 1867 he became an officer of the order. He exercised a most powerful and clearly marked influence upon the younger French artists, with whom his genius, his frank kindliness, and his openhanded generosity rendered him the most popular of men and painters. In 1874, when the medal of honour of the Salon, which they expected to be bestowed on him, was awarded to Gerôme, they subscribed for a medal of their own, which they presented to 'le pere Corot," as they were fond of calling him, only three months before his death, which occurred at Paris, 22d February 1875. Among his masterpieces may be named 'Danse de Nymphes,' 'Macheth,' 'Homere et les Bergers,' 'Orphée,' 'Souvenir de Montefontaine,' 'Joueur de Flate,' 'Un Matin à Ville 
d'Avray,' 'Dante et Virgile.' He is well represented in public and private collections in Britain and the United States. See Lives by Dumesnil (1875), Robaut (1880), Rousseau (1884), and Roger-Miles (1891); and the Monograph by D. C. Thomson (1892, reprinted from his Barbizon School, 1891 ).

Corozo. See Ivory (Vegetable), Button.

Corpora Quadrigemina. See BraIN.

Corporal, in the British army, is the grade of non-commissioned officer next below that of sergeant. When the regiment is on parade he falls in as a private soldier, but in barracks or camp he exercises certain disciplinary control over the privates, commands small guards, and does orderly duty. The distinctive badge is two Chevrons (q.v.) on the sleeve. The pay varies from 1s. 8 d. to $2 \mathrm{~s} .4 \mathrm{~d}$. a day. There are 4 corporals to each troop of cavalry, and 5 to each Company (q.v.) of infantry. A lance-corporal is an acting corporal, who remains on private's pay, and wears one chevron only. In the artillery there is a special grade of non-commissioned officer below that of corporal, called a bombardier, with pay equal to the lowest rate of corporals in the infantry. The badge is one chevron, and there are acting bombardiers, but no lancecorporals. In the engineers the corresponding rank is that of second corporal. In the Household cavalry the title of corporal of horse is given to the non-commissioned officers corresponding to the troop sergeant-majors of other cavalry regiments (see Colour-SERGEANT). The pay is 3s. a day. A ship's corporal in the navy is a petty-officer under the master-at-arms, to aid in teaching the use of small-arms, guard against the smuggling of spirits on board, extinguish the fires and lights, and keep order below at night.

Corporal (Lat. corpus, 'the body'), a name given to the linen cloth, also called pall and chaliceveil, with which the celebrant covers what is left of the consecrated elements in the Holy Communion until the service is concluded.

Corporal Punishments. See Flogarng.

Corporation. This, in England, is either aggregate or sole. A corporation aggregate is a society of persons anthorised by law to act as one person, and to perpetuate its existence by the admission of new members. Without such legal authority the acts of the society would be regarded only as the acts of the individuals, and the property of the society would descend to the heirs of the individual members. A corporation sole consists of one person, the holder of a public office, and his successors, such as the sovereign, a bishop, the vicar of a parish, and most perpetual curates. The only Scottish instance is the minister of the parish. A singular modern instance is the Treasury Solicitor. As regards property, however, some of the public departments represented by their chief -e.g. the Secretary of State for War-are also corporations sole-i.e. property transmits without conveyance to each holder of the office. There are also quasi corporations aggregate, such as the churchwardens in England, the Commissioners of Supply in Scotland, the heritors of a Scottish parish, who cannot hold land in succession, and have no common seal. An intermediate class consists of parochial boards and school boards, which can hold land, but have no common seal.

A corporation could formerly be established only by charter from the crown or act of parliament, unless, indeed, it existed by immemorial prescription; but of late years the exigencies of commerce have led to the passing of various enactments, by compliance with which any society of persons may acquire for themselves the character of a corporation (see CoMPary). Many important municipal charters were granted by ecclesiastical authoritye.g. till 1835 Newcastle had only a charter from the bishop of Durham. Boroughs, too, had frequently delegated from the crown, or some subject superior with royal rights, the power of incorporating trades or crafts within their own territory. The freedom of the crafts or of the merchant guild may in general be acquired by apprenticeship or by services in the army or navy (see GuILDS). A corporation always receives a corporate name, by which it sues and is sued, and it must possess a common seal, which is the proper evidence of its intentions and obligations. The majority of the members are entitled to act within the powers of the corporation, and may, by a bylaw, even delegate -except in the case of municipal corporations-the power of acting to a certain number of the members. For these acts none of its members are personally liable.

Corporations, whether aggregate or sole, are divided into ecclesiastical and lay, and the lay are subdivided into civil and eleemosynary. The ecclesiastical are such as are composed wholly of clergymen in their ecelesiastical capacity, and are chiefly for the purpose of holding ecclesiastical property. Civil corporations include municipal corporations, the universities, the colleges of physicians and surgeons, learned societies, and many trading companies incorporated. Eleemosynary corporations are for the administration of funds for charitable and pious purposes, such as hospitals, the colleges in universities, which, unlike the universities, the English law holds to be subject to visitation, \&c. An important consequence of these distinctions is the effect it has on the right of visiting a corporation, or exercising a legal superintendence over its proceedings. The crown is the visitor of the archbishops, each arehbishop is the visitor of his suffragan bishops, and each bishop is the visitor of all the ecclesiastical corporations in his diocese. Civil corporations have no visitor, but in both England and Scotland they are of course liable to be restrained by the courts where anything ultra vires is attempted. Eleemosynary corporations in England are visited by the founder and his heirs, or such persons as the founder appointed to be visitors, and in default of such persons, by the Court of Chancery. To some extent similar functions have devolved on the Charity Commissioners. See under CHARITIEs.

A corporation may be dissolved by the death of all its members, or of such number as leaves not enough to make new elections in the way the charter requires; by forfeiture of the charter through breach of its conditions; by surrender of the charter ; or by act of parliament. In all such cases the lands of the corporation revert to their several donors; the creditors, however, if any, being entitled in the first place to insist on a sale and distribution of the property, whether in a sequestration or otherwise.

Corporations, as has been pointed out in the American Civil Rights Act of Congress, are liable to the ordinary laws and treaties of the country, but are not eitizens in the sense of exercising a political or municipal franchise. The American law has also had occasion to emphasise the distinetion between public corporations which may be affected by legislation, while the written constitution of America prohibits any interference with the rights of a private corporation. Further, according to American law, the franchises of a corporation are treated as realisable assets for creditors. The amount of property which may be held by a corporation in the States is frequently limited in the act or charter; and as regards charitable and religious purposes, a general law forbids the holding of more than $\$ 50,000$, or $£ 10,000$ worth. In the States less 
anportance is attached to the use of the common geal of a corporation than in Britain. For trade corporations, see the article GuILDS.

Corps d'Armee. See Army Corps.

Corpse Candle. See Candur.

\section{Corpulency. See OвesrTy.}

Corpus Christi Festival, the most splendid festival of the Roman Catholic Church. It was instituted in 1264 (see BoLsENA), in honour of the Consecrated Host and with a view to its adoration, by Pope Urban IV., who appointed for its celebration the Thursday after the festival of the Trinity, and promised to all the penitent who took part in it indulgence for a period of from forty to one hundred days. The festival is chiefly distinguished by magnificent processions. In France it is known as the Fete Dieu; in Germany, as the Fronleichnamsfest.

Corpuseles, Blood. See Blood.

Corpuseular Theory. See Liant.

Corpus Delicti, a criminal law term used in Scotland to signify the body or substance of the crime charged. To make out the corpus delicti is to prove that the crime charged has been committed ; as, when a person is charged with murder, it must be proved that the deceased came by his death in consequence of the injury libelled, and not, for example, by natural causes.

Corpus Juris Civilis is the whote body of the Roman or Civil Law, as comprised in the Institutes, the Digest (or Pandects, q.v.), the Code, and the Novellæe (see CoDE, LAw). In like manner the juris canonici is the body of Canon Law (q.v.).

Correction, House or, a prison for the reformation of petty offenders. See PRIsons, REFORMATORIES.

\section{Correction of Proofs. See Proors.}

Correggio, ANTonio Allegri DA, was so styled from the place of his birth, a small town 20 miles E. of Parma, where he was born in 1494. Morlern research has proved the inaceuracy of Vasari's highly coloured account of his struggles and poverty. His father, a well-to-do merchant or tradesman of Correggio, seems to have designed him for a learned profession; but he turned to art, studying under his uncle and three other masters. He is believed to have gained some idea of foreshortening and perspective from the works of Mantegna at Mantua, which he visited in 1511, and to have been influenced by the grace. ful colouring of Lorenzo Costa. At the age of about twenty he returned to his native town, where in 1514 he painted an altarpiece for the Franciscan convent, a work, now in the Dresden Gallery, distinguished by more gravity, restraint, and religious feeling than characterise his later productions. In 1518 he began his great series of works at Padua by a besutiful fresco series of mythological subjects for the decoration of the convent of San Paolo, which are still in an excellent state of preservation. From 1521 to 1524 he was engaged upon his subject of 'The Ascension' in the cupola of the Benedictine church of San Giovanni, a fresco in which the master's power is fully visible. His next great monumental work was the decoration of the cathedral of Parma, commissioned in 1522. The subject chosen for the interior of the main dome was 'The Assumption of the Virgin.'

During the execution of these frescoes Correggio was also much occupied with easel-pictures in olls. Among these are his very celebrated Adoration of the Shepherds, known as 'La Notte' or "The Night,' commissioned in 1522, now in the Dresilen Gallery, a work of marvellous softness and delicacy. Five years later he painted 'Il Giorno,' an exquisite picture, now in the Parma Gallery.
In 1530 Correggio removed from Parma to his native town, where, in the anme year, he purchaed an estate, and in 1533 some additional land. The production of the 'Jupiter and Antiope' of the fouvre, 'The Education of Cupid' of the National Gallery, London, of the 'Danae of the Borghese Gallery, and of the 'Leda' of the Berlin Museum, has been assigned to the painter's later years; and the 'Reading Magdalene,' of which the picture in the Dresden Gallery is now regarded as merely a 17th-century copy, was completed in 1528. He died at Correggio, at the early age of forty, on the 5th of March 1534, and was buried in the cloister of the Francisean church of the place.

The art of Correggio is distinguished by its grace and gaiety, by its sunny sensuous charm. His figures are rendered with a bounteous sweeping outline, and he delineates rapid motion and momentary attitudes and expressions with singular power. His colouring possesses the finest delicacy and luminosity; his foreshortening is bold and skilful, if sometimes rather extravagant ; and, above all, he was unrivalled as a master of subtle and refined chiar-oscuro. His works present the strongest possible contrast to the gravity and restraint, to the reverential feeling and the accurately balanced compositions, of the earlier devotional painters of Italy.

His only son Pomponio, by his wife Girolama Merlino (whom Correggio married in 1520, and who died in 1529), was born in 1521, and was alive in 1593. He also was a painter, and an altar-piece from his hand is in the Academy at Parma.

See, besides Julius Meyer's article in the $\boldsymbol{K}$ in Lexicon (1870; Eng. trans. 1876), and J. P. Richter's in $\boldsymbol{K}$ unst und $\boldsymbol{K}$ unstler (1879), the fully illustrated Life by Corrado Ricoi (trans, by Simmonds, 1896).

Corregidor is the name given in Spain to the principal magistrate of a town, appointed by the king. Readers of Gil Blas will remember his functions and the terror of his name to evil-doers. The Portuguese corregidor has administrative but not governing powers.

Correlation of Forces. See Eneray, ForCE.

Correlation of Organs, the close mutual dependence between different systems and structures within the organism. A three- or fourchambered heart is correlated with the development of lungs; animals with an allantois never have gills; the development of a placenta is all but co-extensive with the presence of milk-glands. So among plants parallel venation of the leaves is alnuost constantly correlated with monocotyledonous structure; and a restriction of the vegetative leaf-organs will show itself in a counterbalancing moditication of flowers and fruit. From the time of Ariatotle such correlations have been noticed; but it was not till after the work of Cuvier, Geoffroy St-Hilaire, Goethe, and their contemporaries, that the fact was alequately apureciated. It was only then, in other words, that the organism began to be really understowl as a unity of mutually dependent parts. The general proposition that all the organs are partners in the general life, that if one member suffer all the nembers are more or less influenced, is sufficiently self-evident. But beyond this there are the special facts which show that certain organs are knit together by closer physiological bonds than others, that certain strue. tures stand or fall together, that certain characters have $\mathrm{A}$ contemporaneous appearance in the his. torical evolution. The facts are well known; their explanation in many cases is difficult or quite obscure. See Evolution, Variation.

Correspondence Classes, a method of instruction first fully developed in the United 
States by the Chautauqua Literary and Scientific Circle (1878), and since adopted in England-e.g. under the Oxford University Extension (1889). See Chautauqua.

Correze, a French department, formed out of part of the old province of Limousin, and taking its name from a river, the Corrèze, flowing 52 miles south-westward to the Vezère. Area, $2265 \mathrm{sq} . \mathrm{m}$. ; pop. (1872) 302,746; (1891) 328,119. The chief rivers of Corrèze are the Dordogne, the Vezere, and the Correze. The surface of the department is mountainous, especially in the north and east, where it is broken in upon by offsets from the Auvergne Mountains, which, in Mont Odonze, attain a maximum altitude of 3129 feet above the sea. The lower slopes are clad with forests, but the district is in general sterile. Minerals, particularly coal, iron, lead, alabaster, and granite of various colours, are found. The department is divided into the three arrondissements of Tulle, Brive, and Ussel. Tulle is the chief town.

Corrib, Lough, a lake of counties Galway and Mayo, the second largest in Ireland. Lying only 30 feet above sea-level, it is of very irregular shape, 25 miles long from NW. to SE., and 1 to 6 broad, with an area of $68 \mathrm{sq} . \mathrm{m}$. From its south end, 4 miles north of Galway, it discharges its surplus waters by Galway River into Galway Bay. It receives the waters of Lough Mask, at its north end, through the Pigeon Hole and other caves, as well as those of the Clare and other smaller rivers. It contains many islets, and to the west are moúntains 3000 feet high, whilst near it are many stone-circles.

Corrichie, a moor on the borders of Kincardine and Aberdeen shires, 15 miles W. of Aberdeen. Here on 28th October 1562 Queen Mary's halfbrother, the Earl of Moray, defeated the Catholic Gordon, Earl of Huntly, who himself fell in the battle, while his two sons were taken prisoners. There is a rather poor ballad on the subject, in broad Aberdeenshire dialect, quite at variance with the facts of history, and first printed in Evans's Old Ballads (1777).

Corrie (Gaelic coire, 'a caldron' or 'large pot'), a term applied in Scotland and Ireland to semicircular recesses or cirques in mountains, generally flanked by steep and lofty eliffs. They vary in character according to the nature of the rocks. In some the declivities are rounded and smooth, but generally they are broken and rugged, the bounding cliff's rising to heights of 1000 or even 2000 feet. Similar features are recognised in many mountainregions all the world over. The origin of corries has been a subject of some controversy by geologists. There can be no doubt, however, that they are due in the first place to denudation - to the action of torrents and springs and frosts, aided and directed by the natural division-planes of the rocks. Many of the corries in Scotland and other mountainous countries have been occupied by glaciers-the grinding action of which has tended to modify the form of the ground. Not a few corries are occupied by mountain-tarns.

Corrientes, a province of the Argentine Republic, between the Paraná and Uruguay rivers, extending from Entre Rios to Misiones territory, with an area of $40,000 \mathrm{sq}$. $\mathrm{m}$. The surface is generally flat, with numerous lakes and swamps, but has undulating stretches along the Parana and in the east, and is heavily wooded in parts. Lake Iberà, a group of lakes and gwamps covering some 1800 sq. m., is surrounded with a jungle, in which the 'tacuara' bamboo ( 30 feet) is conspicuous; and here jaguars and alligators abound. The mean temperature $\left(72^{\circ} \mathrm{F}.\right)$ is the highest in the republic, but the extremes $\left(44^{\circ}-98^{\circ}\right)$ are not so excessive.
As in Paraguay, Guarani is the common language, Spanish being employed only by the official and educated classes. Cattle-raising is the chief occupation; agriculture is very backward. Pop. (1895) 239,344. - The capital, Corrientes, is almost hidden among orange-groves, 15 miles below the confluence of the Parana and the Paraguay, and takes its name from seven currents formed by points of rock above the city; vessels of 9 feet draught can reach the town at all seasons. Steamers from Buenos Ayres (832 miles) touch here almost daily, and in 1887-95 railway connection was made with the south by way of Monte Caseros. Pop. 18,000.

Corrievrekin (Gael., 'Brecan's cauldron'), a whirlpool or dangerous passage scarcely a mile broad, off the west coast of Argyllshire, in the strait between Scarba and Jura isles. It is caused by the meeting of tides (running 13 miles an hour) from the north and west, in the narrow passage into the Sound of Jura, round a pyramidal rock, which rises with rapid slope from a depth of 100 fathoms to within $\mathbf{1 5}$ feet of the surface.

Corroboree is the Australian name for a gathering of aborigines, generally in large numbers, at which dances and other exercises are gone through with much excitement. They usually take place on moonlight nights, and may last the whole night through.

Corrosive Sublimate, the popular name of the highly poisonous bichloride of mercury (mercuric chloride). See MERcurY.

Corrugated Metal. Iron and other metals in sheets and plates have communicated to them enormously increased rigidity and power to resist buckling and collapse by being corrugated. The process is merely an application to metallic substances of the old contrivance of 'goffering' or 'piping,' by means of which frills are stiffened and kept in shape. The metal to be corrugated is passed between pairs of rollers with ridged surfaces, the ridges of one fitting into the hollows of the other, and the sheets or plates operated on are bent and compressed into the wavy outline of the rolls. Walls and roofs of light and temporary buildings are extensively made of corrugated galvanised iron-i.e. sheet-iron first corrugated and subsequently coated with zinc by dipping the sheets into a bath of the liquid metal. The most important mechanical application of corrugated metal has been for the flues of large steam-boilers. About 1878 a system of annular corrugated iron flues was introduced, which increased the resistance of the flue to collapse, and saved fuel because of the greater heating surface presented by the corrugations. A spiral corrugated flue gives the greatest amount of strength.

Corruption of Blood. See Atrander, TREASON.

Corrupt Practices Aet. See Bribery.

Corry, a town of Erie county, Pennsylvania, situated at the junction of several railways, 37 miles SE. of Erie. It has machine-shops, saw. mills, and oil-refineries. Pop. (1870) 6809; (1880) 5277 ; (1890) 5671.

Corsair, a pirate or sea-robber, and specially any of those rovers who in former times cruised from the Barbary ports, as Algiers, Tunis, or Tripoli, and became the terror of merchantmen in the Mediterranean and the Atlantic Ocean, ravaging the coasts and seizing shipping, as far north as Cornwall, Baltimore in Cork, and even Iceland. Though piracy on a small scale had long prevailed, the immediate canse of the sudden development of corsair states and fleets at the beginning of the 16th century was the persecution of the Moors in Spain : the exiles looked for vengeance, and their necessities 
compelled thieving; and when they were joined by adventurers from the Levant and not a few Cliristian renegades, who were attracted by the spoils of the Indies, then coming to Spain, they soon became a formidable power, and founded citadels and state (see Algiers, TUNis, Tripoli, Sallke). Their grentest leaders were the brothers U raj and Kheyred-din Barbaroses, the finst pashas of Algiens. Kheyr-ed-din rose from a mere captain of a galley to be high admiral of Sultan Suleyman (Soliman the Magnificent), and defeated the combined imperial, papal, and Venetian fleets under Doria off Prevesa in 1538. Other famous consairs were Dragut (Torghud), a Sardinian who died at the siege of Malta; Ochiali (Ulaj 'Ali), who fought in the battle of Lepanto, 1571; Ailin Reis, or Drub. devil ; Sinan of Smyrna; Salih Reis; Ramadan Ali Pichinin, \&e. Many attempts were made to put down the corsairs, from Sir Robert Mansel's expedition in 1621 to the very important expedi. tion against Algier by the United States under Decatur (q. . ) in 1815 - the first serious attempt to put an end to the long established evilfollowed by Lord Exmouth's victory in 1816; but the jealousies of the European powers conspired to assure the pirates' immunity, and the Deys of Algiers levied bluckmail upon Christian governments who wished to protect their trade. Nothing less than the French conquest could lave suppressed so long-seated i disorder, which had infected the Mediterranean for more than three centuries, and even carried off captives from Ireland. See Barbarossa, Galleys, Piracy, Slavery; and Corsairs of the Mediterranean, by Stanley Lane-Poole ( 1889 ).

\section{Corsets. See Tight-LAcing.}

Corsica, the fourth largest island of the Mediterranean and a French department, is 114 miles long by 52 miles broad, with 300 miles of coust-line. Area, 3378 sๆ. m. ; pop. (1872) 258,507; (1896) 290,168 . Corsica is separated from the twin island of Sardinia, double its size, to the south, by the Strait of Bonifacio. It is 54 miles SW. of Leg. horn and $98 \mathrm{~S}$. from Genon. Though now part of France, the island belongs geographically, his torically, and linguistically to Italy. The promontory into which the north coast projects runs 23 miles north beyond the general north const-line, and is 6 to 9 miles broad. The interior is a labyrinth of mountains, in which, however, a principal ehain traverses the whole island from north to south, dividing Corsica into two regions, an eastern and a western zone. These regions are each divided by transverse chains into parallel valleys deeply hol lowed by watercourses plunging from the high sum mits. The highest elevations are about the middle Cinto (8898 feet); Rotondo (8607); Pagli-Orha (8283). On the west side the mountains reach to the coast, but on the east, between mountains and sea, there extend alluvial plains, edyed seawards with lagoons and swamps, highly fertile but malarious, so that in summer the occupants have to escape to the mountains. In the time of the Romans these plains were densely peopled, and recently eucalyptus plantations are beginning to overcome the malaria. The west zone is occupied mostly with primary strata, granite, and schistose rock; on the east side the mountains are cretaceous, with serpentine and porphyry. Corsica is watered by numerous streams, none navigable, with cascales glittering in all directions. On the enat const are the Tavignano, 47 miles long, from lake Nino; and the Golo, 52 miles long. On the west the longest is the Taravo, 34 miles long.

With the exception of the malarious coasts in the east the climate is highly salubrious. The soil is very fertile, and over 43 per cent. of the entire 136 area is returned by official statistics as arable land; yet in 1887 over 35,000 tons of flour, and large guantities of whent and hay, wore imported. Corsica presents a succession of climates and vegetation zones, $O n$ the lower slopes are olives, oranges, citrons, laurels and vines. Higher, up to 6250 feet, are magnificent chestnuttrees; higher still rise virgin forests of oak, pine, larch, \&e. These again are overtopped by pastures. The highest sunmits are snow-clad for half the rear. About one-sixth of Conica is estimated to he covered with forest, but this includes in many places only confused thickets (mucchie) of green osk, arbutus, myrtle, and broom, often serving as the hiding-place of bandits. Canıo dell' Oro around Ajaccio and the country north of Bestia are among the most fertile districts of the Mediterranean. The muftlon or wild sheep is found; also wild boars, large foxes, and small deer, but no wolves or bears. The venomous ant, innafantato, is peculiar to Corsica, where are also the Malmig. nata spider and the tarantula. The minerals of Corsica are yet little worked. Copper and silverlead mines near Calvi are now being worked by an English company. Sulphide of antimony is successfully worked in Cape Corso. There are also iron and manganese ores. Among the valuable stones are red and blue granite, porphyry, jasper, alabaster, and marble; and the Orezza mineral waters have a high medicinal value. Agriculture is backward. In many parts tillage is carried on almost exclusively by Italian labourers ('Lucehesi'). The chief industries are fishing and rearing of cattle. Raw silk is raised to the amount of about $500 \mathrm{cwt}$. of cocoons annually. The principal ports are Bastia, Ajaceio, and Calvi; in 1891-1900 an average of 2060 ships, with a total tonnage of 471,800 , entered, and 1642 cleared, with a tonnage of 312,000 . The chief imports are corn and other food-stutis, building materials, coals, metal wares, salt, cattle, cheese, fodder, brandy, pottery, glass wares, and paper; and the chief exports, wine, wood, bark for tanning, olive-oil, chestnuts, and fruits fresh and preserved. There is a railway from Ajaccio to Bastia, with branches to Calvi and Orbo. Corsica is divided into tive arron. dissements : A jaccio, Bastir, Calvi, Corte, Sartène. The capital is Ajaccio, but the nost important town is Bastia. The language is a corrupt Italian. Though not industrious, the Corsicans are patriotic and brave.

In early times known as Cyrnos, Corsica in the 8th century fell to the Saracens, who in the 11th yielded it to Pisa. Thence it passed to the (ienoese. Genoese towers, that defended the bays against Saracen incursions, still add a picturesque trait to the landscape. The Genoese, unable to subdue the Corsicans, who had risen under General Paoli, sur. rendered Corsica to the French, who conquered it in 1768 ; since then it has willingly united with France.

See Boswell's Account of Corsion (1768); Ortoli's Contes popul. de l'lle de Corse (1845); Paul Burle's En ('orse (1887); J. W. Barry, Studies in Corsicu (1893); L. H. Caird's History of Corrica (1899); and for 'the Corsican," BoNAPARTE, NAPOLEoN. For the Corsican blood-feud, see VENDETTA, and Prosper Merimée's powerful picture of Corsican life, Colomba (1841)

Corsite, a variety of Diorite (q.v.), composed of anorthite-felspar, hornblende, and a little quartz.

Corslet, a kind of cuirass, formerly the usual body-covering of pikemen. It was made chiefly of leather, and was pistol-proof.

Corsned. See Ordeal.

Corso, an Italian word used to express not only the racing of riderless horses, but also the slow driving in procession of handsome equipages through the principal streets of a town, such as almost always takes place in Italy on festivals 
This custom has given a name to many streets in almost all the larger towns of Italy. The best known of these is the Corso in Rome, which is the scene of the celebrated diversions of the Carnival.

Corssen, Wilhelm Paul, a great German philologist, was born at Bremen, January 20, 1820. After studies in philology at Berlin, especially under Boeckh and Lachmann, and two years spent in teaching in a gymnasium at Stettin, he was called in 1846 to lecture at Schulpforta, and there he remained till 1866, when ill-health compelled him to retire to Berlin. There, however, he continued his arduous studies until he died, a martyr to learning, June 18, 1875. His earliest great work is his treatise, Ueber Aussprache, Vokalismus, und Betonung der Lateinischen Sprache (2 vols. 1858-59; $2 \mathrm{~d}$ ed. 1868-70). It was followed by Kritische Beiträge zur Lateinischen Formenlehre (1863) and Kritische Nachträge zur Lateinischen Formenlehre (1866). His second masterpiece is Ueber die Sprache der Etrusker (2 vols. 1874-75), in which he labours with great ingenuity and vast learning to prove against the world that the Etruscan language was cognate with that of the Romans. $\mathbf{H}$. Weber edited from his papers Beiträge zur italischen Sprachkunde (Leip. 1876).

Cort, Cornelis, known in Italy as Cornelio Fiammingo, a famous Dutch engraver, was born at Hoorn in 1533 or 1536 . He studied under Hieronymus Cock, and his early plates bear that master's name. In 1572 he went to Venice, and was hospitably received there by Titian, some of whose finest works he engraved, as well as those of other Italian masters. Cort next settled at Rome, where he founded an engraving school ; and from this school sprang the most excellent Italian and Venetian engravers. He died at Rome in 1578.

Cortes, the name given in Spain and Portugal to the assembly of representatives of the nation, the origin and history of which varied greatly in the different kingdoms out, of which modern Spain is formed. See Aragon, Castile, \&e.; also Spain and Portugal.

Cortes, Hernando, the conqueror of Mexico, was born at Medellin, in Estremadura, in 1485, of a noble but decayed family. The longing for adventure which early filled his heart was not cured by two years' study at Salamanes. He sailed for San Domingo in 1504, and ere long accompanied Velazquez in his expedition to Cuba. After the island had been subdued he came into serious disfavour with the governor, but was reconciled, and became alcalde in the capital, Santiago. The discovery by De Córdova of Yucatan, and of New Spain (Mexico) by Grijalva, had already fired the ambitious mind of Velazquez, when Pedro de Alvarado, who had been despatehed by Grijalva, arrived at Cuba; and his glowing accounts filled the governor with a fresh thirst for gain and glory. He hastened to fit out a new expedition, the command of which he gave to Cortes. Cortes sailed 18th November 1518, and one of the most romantic chapters in the history of the world began. The armament with which he entered on the conquest of a vast and civilised empire consisted, according to Bermal Diaz, of five hundred and fifty Spaniards, two or three hundred Indians, twelve or fifteen horses, with ten brass guns and some falconets. Scarcely had he touched at Trinidad when orders from Velazquez to supersede him reached the island. These Cortes refused to obey, and thus cut himself off from all hope save in success. He landed first in Yucatan, and entered New Spain at the river of Grijalva. Proceeding inland he reached Tabasco, and here he fought his first battle with the natives. His victory gave him his invaluable interpreter, the beautiful and faithful Donna Marina. At San Juan de Ulua messengers from Montezuma, the king of Mexico, reached him, bringing rich presents, but objecting to his ex. pressed desire for a visit to the king. Here when the faction of Velazquez within his little force began to express openly their hesitation about pro. ceeding farther, Cortes adroitly got his men te entreat him to change the purpose of the expedi. tion into colonisation and conquest instead of mere trade, and was thereupon formally appointed captain-general and justicia-mayor.

He now founded Vera Cruz, and sent messengers to Charles V. He next united all opposing interests in that of the common safety by burning his ships behind him, and marched to Tlascala, whose warlike inhabitants, subdued after some hard fighting, became henceforward his ever-faithful allies. After some delay he started on his memorable march to Mexico, attended by some thousands of his Tlascalan allies; and at Cholula a treacherous attempt, by orders of Montezuma, to entrap the Spaniards, was frustrated by his sleepless vigitance. On the 8th November 1519 he reached the capital, which Bernal Diaz says appeared when they first saw it like something in a dream, or like one of the enchanted castles in the book of Amadis. The city was situated in a great salt lake communicating with a fresh-water lake, and was approached by three causeways of solid masonry, one two leagues long, with wooden drawbridges at the ends. At the lowest estimate its inhabitants exceeded 300,000 . Cortes had not been a week in the city before he had determined to seive the august person of the king, and hold him as a hostage; his pretext being a treacherous attack upon Vera Cruz Montezuma was paralysed at the heroic audacity of his proposal, and was carried to the Spanish quarters, from which he was never to return. Seventeen of the king's officers brought from Vera Cruz were burned to death in his presence, and Montezuma himself put in irons the while. In general, however, but little apparent restraint was put upon him, and he was allowed to go to his temple accompanied by a guard of one hundred and fifty Spaniards. At length he was constrained to submit to a public act of vassalage to Spain, and to give gold to the value of 100,000 ducats.

But Cortes was far more than an ordinary conquistador: he inquired about the mines and the methods of cultivation, and made wide explorations into the country; while with characteristic religious zeal he destroyed the more hideous Mexican idols, and sternly forbade human sacrifices. Meantime, however, the Mexican hatred for the conquering invaders was beginning to surmount their fear, as they began gradually to discover that they were merely mortal men spite of the strange wonder of their horses and cannon, and moreover were miserably few in numbers. In the sixth month of his imprisonment Montezuma asked Cortes to depart. The conqueror craved delay, and learned a few days after the request that eigliteen ships had arrived in the bay of San Juan. These ships had been despatehed by Velazquez under Pamphilo de Narvaez, who sent a favourable message to Montezuma. Cortes left Alvarado in command, and hastened with but a handful of men to meet Narvaez, whose force numbered 800 men; and at Cholula, amid a blinding storm, surprised him in an unexpected night-attack in which but three of his own handful of heroes fell. The defeated troops gladly embraced the cause of the conqueror.

Fourteen days after the defeat of Narvaez came the news from Alvarado that the Spaniards were besieged in their quarters in Mexico. Cortes at once collected all his men, marched to his lieutenant's 
relief, and reached the city, 24th June 1520. He found himself face to face with a whole nation in arms under Montezuma's brother as popular leader. A ceneral attack was soon made upon him, and not repulsed without a demperate struggrle. On the third ilay the unhappy Muntezuma appeared on a battlement with the view of pacifying his people, but was wounded by a shower of stones-an indignity which broke his heart. Cortes burned the two great idols of the city, but this did not terrify the Mexicans, and he now saw that he must leave the city. His dispositions were quickly made; the start was made at midnight, Ist July 1520. The first bridge was croseed safely by a pontoon which lie had prepared for this purpose, but at once the lake was covered with a multitude of canoes, and so furious an attack made that it proved impossible to raise the pontoon to cross the second bridge. Soon the water was choked with a crowd of strug. gling horses and men, and the retreat became a confused and hopeless rout. The second and third bridgeways were both broken down, but it was at the third that the greatest loss occurred. In the horrors of that awful night ( $l a$ noche triste) were lost 450 Spaniards, forty-six horses, his artillery, 4000 Indian allies, and most of the Mexican prisoners. At Otumbs, whither the miserable hand. ful of survivors had retreated, Cortes found himself encompassed with an innumerable host, and there was a desperate battle, in which every individual Spaniard performed prodigies of valour. The exhausted victors were kindly received by their Tlascalan allies, and Cortes at once began preparations to repair his disaster.

On the 26th December 1520 Cortes reviewed his troops. He had still 550 foot-soldiers, with forty horsemen, and eight or nine cannon. Taking with him 10,000 Tlascalans he marched to Tezcuco, and contrived to form alliances with some of the surrounding Indian tribes. At length his brigantines, built at Tlascala, arrived, carried by a host of Tlascalans; and, after a perilous expedition round the lake, and many ineffectual attempts to come to terms with the Mexicans, he began the formal siege of the city. He himself, with three hundred men, took command of the brigantines, as, in his own words, 'the key of the whole war was in the ships.' After defeating the Mexicans on the lakes, and destroying innumerable canoes, he made a series of simultaneous incursions along the causeways. The Mexicans fought with the fury of despair, and the triumph of the Spaniards proceeded only at the cost of the gralual destruction of the buillings in the city. Meantine the Spaniards themselves suffered desperate hardships from the ambuseades of their sleepless enemy, and becoming impatient, they demanded a general attack, in which they suffered a gevere repulse. Although famine and pestilence fought for the Spaniards-as many as fifty thousand Mexicans dying of these during the siegethe city had to be destroyed before it could be taken. It fell at length, 13th August 1521, after a siegre of seventy-five dnys, hardly to be surpassed in the history of the world for obstinacy and valour. Scarce any booty was obtained, the ruined houses were filled with heaps of dead, and almost the entire eity had to be rebuilt.

Cortes now showed his wislom by attempting to restore the native institutions. He rewarded his men with encomiendas or grants of Indians for labour and assistance in colonisation. He was formally appointer governor and captain-general of New Spain in 1522. He next sent out Alvarado on an expedition which led ultimately to the conquest of Guatemala, Sandoval to the north, and Christoval de Olid to Honduras. The last, unfaithful to his trust, rebelled, and the indefatigable Cortes at once set out on a perilous journey to subdue him; but finling his rebellious lieutenant assassinated before his arrival, he returned to New Spain (1526) to find Ponce de Leon invested with the powers of govern. ment. In May 1528 he arrived in Spain, was received with marked honour by the king, and ereated Marquis del Valle de Guaxaca. He returned in July 1530 as captain-general, but to his disappointment was not appoiated also civil governor of New Spain. He was poor and broken in health, and henceforward had the continual mortification to see the government nuddled by envious and incom. petent men. During ten years he was constantly engaged in making new discoveries to the north of Mexico, but now, says Bernal Diaz, 'everything turned to thorns with him;' and in 1540 he re. turned to Spain. He accompanied the emperor in his unhappy expedition to Algeria, and was mortified by having his offer to take Algiers, if given the command, slighted and despised. Vol. taire's story of his proud speech to the emperor as he stood on the step of his carriage: 'I am a man who has given you more provinces than your ancestors have left you cities,' is true in spirit, if not in fact. Cortes wished to return to Mexico, but was not allowed till his impending suits were settled. His last years were darkened by neglect, deepened by the domestic vexation of his daughter Donna Maria's repudiation by a great Spanish noble to whom she had been betrothed. He went to meet her at Seville, fell ill, and died in a small village near that city, 2d December 1547. His lody was first buried at Seville, ufterwards at Tezcuco, and lastly (1629) in Mexico.

The great conquest of Cortes ranks as one of the most splendid achievements in the world's history, and indeed it is more like romantic fable than sober fact. Its hero was no common adventurer or mere courageous soldier, but a captain of admirable sagacity and resource, a statesman of rare penetration and foresight. To the reckless audacity of a Rupert he added the astuteness of a Hannibal-a combination that marks only the highest order of military genius. His whole character was constructed on heroic lines, and is marked with a certain conspicuous grandeur throughont. He was passionate, yet patient; fond of splendour, yet simple in diet; eruel sometimes, yet sincerely religious; silent and reserved, yet capable of inspiring the most devoted as well as the tenderest personal affection. In many things he resembles Cresar, and like him he possessed that rarest power of knowing, as De Solis says of him, "how to be a superior without ceasing to be a comrade,' See Prescott's History, and the admirable Life by Sir Arthur Helps (2 vols, 1871).

Cortona (Lat. Crotona), a town of Central Italy, 69 miles SE. of Florence by rail. It stands 2130 feet above sea-level, looking down on the Valle di Chiana and the Trasimene Lake, and is one of the oldest cities in Europe, with mighty cyclopean walls of Pelasgic origin, Etruscan and Ruman remains, numerous handsome palazi, a fine cathedral, and half a dozen churches. These are rich in paintings by many old masters, includ. ing Luca Signorelli (q.v.) and Pietro Berrettini or da Cortona (1596-1669). The Accademia Etrusea (1726) has its seat here; its museum contains a multitude of Etruscan sarcophagi, vases, \&c. Pop. 3605 .

Coruña, LA (ordinarily in English, Corunna, among seamen, Groyne), a fortified seaport of Spain, and capital of a province of the same name, situated about midway between capes Ortegal and Finisterre, on a peninsula in the Bay (ria) of Coruna, 263 miles NW. of Leon by rail. The town divides itself naturally into the upper portion and the lower, called Peseaderia, which, formerly 
a haunt of fishermen, is now the centre of wealth and trade. The harbour is commodious and protected by forts; and in 1888 a long-desired quarantine harbour was completed. There are large cavalry and infantry barracks, and a handsome new college, preparatory for the university of Santiago; but few of the other buildings are striking. To Englishmen the most interesting object is the tomb of Sir John Moore, in the centre 'of the gardens of San Carlos. One mile northwest of the town stands the famous Torre de Hercules, restored by Trajan, which serves as a lighthouse, and is nearly 100 feet high. Coruña has still a considerable commerce, but its cattle trade, which once employed a small fleet to carry oxen to Portsmouth and Plymouth for the British army and navy contracts, has fallen off. The chief imports are sugar from the colonies, and American raw petroleum, dried cod, hides from Argentinia, cheap German spirits, and English coal. The industries of the town include the manufacture of cigars, glass-wares, and canned meats and fish, as well as cotton-spinning. Pop. (1885) 34,202 . Coruña dates its origin from the Phonicians, from whom it was taken by the Romans in the Ist century B.C. To Englishmen Coruña has rare historic interest. Here in $1386 \mathrm{John}$ of Gaunt landed to claim the crown of Castile in right of his wife, daughter of Pedro the Cruel ; in 1554 Philip II. embarked here for England to marry Queen Mary ; and in 1588 the great Spanish Armada, which had been refitted at this port, set sail for the conquest of England. Here also fell gloriously Sir John Moore (January 16, 1809), after having with but 14,000 travel-worm men defeated no less redoubtable an antagonist than Soult at the head of 20,000 Frenchmen, fresh and flushed with the expectation of victory. Few exploits in English history are prouder than his memorable retreat, closed by the brilliant victory that covered the embarkation of the British troops.

Corundum, a mineral consisting essentially of mere alumina, yet of great specific gravityabout four times that of water-and of remarkable hardness, being inferior in this respect only to the diamond. Mineralogists regard the Sapphire (q.v.) as a variety of corundum, and along with it the gems popularly known as Oriental Ruby, Oriental Topaz, Oriental Emerald, and Oriental Amethyst; but the name corundum is more usually limited to the coarser varieties. These, instead of exhibiting the brilliancy of gems, are in general of a dull and muddy appearance, and the crystals-which are usually six-sided prisms and six-sided pyramidsare externally dull and rough. The colour is various, often green, blue, or red, inclining to gray. Corundum is found in many parts of the world, and has long been used in India for polishing all gems except the diamond, which is too hard for it. Emery (q.v.), so well known as a polishing substance, is a variety of corundum.

Corvée is the name usually given to the obligation on the inhabitants of districts to perform gratuitous labour (such as the maintenance of roads) for the sovereign or feudal lord. The forced labour for the aristocracy was one of the grievances of the French peasantry, which led to the Revolution. See France.

Corvei (Corbeia nova), a Benedictine abbey on the Weser, near Höxter, the oldest and most famous in early Saxony, founded in 822 . It was a colony from the monastery of Corbie in Picardy, then part of the country of the West Franks. It received rich endowments; was the centre of great agricultural improvement and prosperity during the earlier part of the middle ages; and the seat of a school, founded by Ansgar, the Apostle of the North, which flourished greatly in the 9th and 10th centuries, and was next in reputation to Fulda. Its abbots were numbered amongst the spiritual princes of the German empire. In 1794 it was made a bishopric by Pius VI. Its territory then extended to about 20 square miles, with 10,000 inhabitants. In 1803 it was annexed to Nassau, from which it was transferred in 1807 to Westphalia, and in 1815 to Prussia. The Gothic church has a magnificent interior, and contains \& multitude of princely monuments. The library and archives of the cloister, which contained most valuable records of the early ages of German history, were mostly destroyed - the Chronicon Corbejense, an alleged record of this abbey from its foundation to the end of the 12th century (pub. 1823), being a forgery; but there are some genuine though meagre Annales Corbeienses (648 to 1148) printed in the Monumenta Germanio Historica.

Corvette was a term applied to a flush-deck vessel, ship or barque rigged, having only one tier of guns, either on the upper or main deck. The term is no longer used in the royal navy. This class of vessels are now called cruisers. See NAvy.

Corvidae, a family of crow-like birds, in the old order of Passeres, among which they are the strongest. The family is widely distributed, and includes towards 200 species. Their family features may be best learned from those of the individual members. See CHOUGH, Crow, JACKDAW, JAY, MAgPIE.

Corvi'mus, MatThias, king of Hungary (145890). See Matthias.

Corvo, the most northerly of the Azores (q.v.).

Corwen, a town of Merionethshire, North Wales, on the right bank of the Dee, at the foot of the Berwyn Mountains, 12 miles NE. of Bala by rail. It is a great resort of anglers, and boasts traditions of Owen Glendower. Pop. of parish, 2708.

Coryate, Thомas, was born at Odcombe, Somersetshire, about 1577, entered Gloucester Hall, Oxford, in 1596, but left like many better men without a degree, and after James I.'s accession lived by his wits, or rather his wit, about court. In 1608 he set out on a rambling journey on the Continent, passing through Paris, Lyons, Turin, Venice, Zurich, and Strasburg, and returning five months later with a record of 1975 miles, mostly on foot. His entertaining journal was at last published in 1611, with a huge collection of commend atory verses, as Coryat's Crudities: Hastily gobled up in Five Moneth' Travells in France, dc. Next year, after dedicating his travel-worn shoes in his native church, he started again on his travels, visited Constantinople, Greece, Smyrna, Alexandria, and the Holy Land, and found his way by caravan to Mesopotamia, thence through Persia and Afghanistan to Agra, where he arrived in October 1616. In the December of the following year he died at Surat. Letters of his were printed in 1616 and in 1618.

Corybantes, the priests of Cybele (q.v.) in Phrygia.

Corygaum, a village in the presidency of Bombay, 16 miles $\mathrm{S}$. of Poona, the scene of the last of the three battles which eaused the subjugation of the Peishwa of the Mahrattas. Captain Staunton, with a native force of but 300 horse and 500 foot and 24 European artillerymen, fought with suceess the whole day long against 3000 infantry and 20,000 cavalry (January 1,1818 ).

Coryla'ceae. See Cupulifere.

Cor'ymb, a form of Inflorescence (q.v.) which may be regarded as a raceme in which the main 
axis las been more or less arrested in development, while the lower flower-8talks are lengthened so as to bring their flowers almost to the level of those of the upper. As fauiliar examples may be cited hawthorn, eandytuft, \&c. After flowering, the main axis of a corymb often elongates into an ordinary raceme, as un many crucifers.

\section{Corymbiferze. See Composita.}

Coryphar'us ( (ir. koruphe, 'the head'), the lemier of the chorus in ancient Greece. The name is now used to signify those of the highest distinction in any art or science. The French coryphee is generally used of the principal danseuse in the ballet.

Coryphene (Coryphana), a genus of bony fishes, remarkable for the brilliancy of their colours. They are nearly allied to mackerels, belonging to the same family, Scombridre. For some not very evident reason they are often popularly called 'dolphins.' The body is somewhat elongated, and is laterally compressed; the scales are very small; the head of the adults bears a sharp crest. The colours of silver, blue, and yellow have great beauty and metallic brilliancy, whether the fish be darting with extreme rapidity in the sunlit water, or lie dying on the shore. Apart from their marvellous beaty, the coryphenes are well known for their habit of pursuing shoals of flying-fish. Sailors often catch them with a glittering bit of metal for bait. They are frequently seen in the Mediterranean (four species), and also in the Atlantic, Indian, and Pacific Oceans. The most familiar species is Coryphana hippurus.

\section{Coryza. See Catarrh.}

Cos (often called by the Italian name of Stanko), an island of the Archipelago belonging to Turkey, off the coast of Asia Minor. It is 23 miles long and 5 broad, with a population of 20,000 , mostly Greeks. Cos consists mostly of fertile and welltilled plains, partially of hilly country ; and exports lemons, grain, wine, cotton, and silk to an annual amount of about $£ 50,000$. Many ancient Greek remains are scattered over the island. The chief town, $\mathrm{Cos}$ or $\mathrm{Co}$, is situated on the north-east coast. In early times Cos was famous for its wine, its amphore, and its fine 'Coan garments.' It was the birthplace of Ptolemy Philadelphus, of the painter Apelles, and the physician Hippocrates.

Coscinomancy, an ancient mode of divination by means of a sieve (Gr. leoskinon) and a pair of shears. It appears to have been chiefly employed for the discovery of thieves. The sieve was supported or suspended by means of the shears, in some way not easily understood; a certain mystical form of words was then used, and the names of the suspected persons being mentioned in succession, at the name of the thief the sieve moved or turned round.

Cosenza, a town of Italy, capital of the province of the same name, formerly called Calabria Citeriore. It is situated 12 miles $\mathrm{E}$. of the Mediterranean, and $262 \mathrm{SE}$. of Naples by rail, in a mountain-closed valley at the confluence of the Crati and the Busento, and suffers in summer from malaria. It is the seat of an archbishop, and has a cathedral, a fine court-house, and trade in oil, wine, silk, hemp, grain, earthenware, and iron and steel wares. Pop. 16,686. The ancient Consentia, a city of the Bruttii, was captured by the Carthaginian general, Himilco, and was forced to surrender (204 B.C.) to the Romans, who afterwards colonised it. Alaric (q.v.) died here, 410 A. D.

Coshery, or Coshering, in Ireland, was the ancient feudal right of a chief to guarter himself and his retainers on his tenantry at his own diseretion.
Cosin. JoHs, a famous bishop of Durham, wa born in 1594 at Norwich. Educated there and at Cnius College, Cambridge, he became fellow of his college and secretary to Bishop Overall of Lich. field, next in succession chaplain to Bishop Neill of Durham, prebendary of Durham, rector of Elwick, archdeacon of the Enat Riding, rector of Brancepeth, master of Peterhouse, Cambridge (1634), and dean of Peterhorough (1640). An int: mate friend of Laud, he had already come into collision with the Puritans about his ritualistic reforms, and been denounced by Smart, a brother prebendary of Durham, as 'our young Apollo, who repaireth the Quire, and sets it out gayly with strange Babylonish ornaments.' In later invectives his antagonist did not spare his pluralism and even his fondness for tobaceo. Prynne denounced also his chapel services at Peterhouse. Cosin was soon deprived of his benefices by the House of Commons, whereupon he retired to Paris, and for nineteen yeans of exile kept up there a Church of England service. At the Restoration he recovered his preferments, and in December 1660 was consecrated Bishop of Durham, and soon by his splendid energy, enthusiasm, munificence, and administrative ability, made his a model diocese. His personal dignity and commanding presence were perfectly in keeping with his conception of the part of one who was not only a bishop, but a prince-bishop. During his first seven years he spent no less than $£ 34,500$ upon his two castles, his cathedral, the library at Durham, and deeds of general benevolence. Imperious in temper, he sternly repressed Puritan and Roman Catholic recusancy alike; for, however devoted to ancient ritual and order, he hated Popery, and never ceased to regret the perversion of his own 'lost son' who had 'forsaken his mother, the Church of England.' He differed too from the rest of his party in his Puritan-like support of the strict observance of the Sabbath. During his last years Cosin earned great unpopularity by his opposition to the desire of the people of the Palatinate to be represented in parliament. He died in London, 15th January 1672. All Cosin's writings are inconsiderable, save his Collection of Private Devotions ( 1627 ), which was denounced by Prynne in his Brief Survey and Censure of $M r$ Coren's Cozening Devotions. A lasting service to the church was his contribution, invaluable from his profound liturgical learning, to the final revision (1661) of the Book of Common Prayer. Bishop Cosin's works were collected in 5 vols. in the 'Library of Anglo-Catholic Theology' (1843-55). His Correspondence was edited for the Surtees Society by Canon Ornsby (2 vols. 1868-70).

Co-sine, Co-tangent, \&c. See TrigonoMETRY.

Cosmas, surnamed Indicopleustes, a merchant of Alexandria, who lived in the middle of the 6th century, and after having travelled much, returned to Egypt, where in monastic retirement he wrote in Greek a work of greater interest than value, in twelve books, on Christian Topography, extending to countries as far as India. An annotated transla. tion of the work was edited in 1898 for the Hakluyt Society by Dr M'C'rindle.

Cosmas and Damian, SAINTs, Arabinn brothers, who practised as physicians at Agrea in Cilicis in the 3rd century A.D., and who were cast into the sea as Christians, but, according to the legend, rescued by an angel. Thereafver, burn ing and stoning having proved ineffectual, they were heheaded in 303 . Their relies were translated from Bremen to Munich in 1649, and their names commemorated in the Canon of the Mass.

Cosmeties (Gr. kosmeō, 'I adorn') are chemical preparations employed for improving the appearance of the skin and hair. Several of the 
cosmetics in use are comparatively harmless, such as perfumed starch and chalk (see RoUGE); whilst others, such as pearl white (the subnitrate of bis muth, see BISMUTH), are more or less poisonous, and dangerous to use. At all times, the employment of cosmetics is to be discouraged, as the minute particles tend to fill up and elog the pores of the skin, and prevent the free passage of gase and vapours, which is so essential to the preservation of any animal organ in a thorough state of liealth.

\section{Cosmic Dust. See Dust.}

Cosmo de' Medici. See MEDICI.

Cosmog'ony, a theory of the origin of the universe (Gr. kosmos) and its inhabitants, such as is found in the mythologies of all peoples except those in the very lowest stages of culture. There is the utmost variety in the explanations given, the only idea that is at all widely spread being that in the beginning all things were held in solution by water. Other prevailing conceptions are those of the Phoenician and Egyptian generative world-egg; of the Hindu tortoise which supports elephants, themselves the actual bearers of the world; of the Polynesian air-god, Tangaloa, hovering over the waters. A very elaborate cosmogony is given in the Pehlevi Bundehesh, ascribing creation to the free-will of a personal deity, as distinct from primordial matter, and this more elevated conception the religion of Zoroaster shares with the Jewish alone.

In the Sanchoniathon we have presented in a Greek version a fragment of an interesting Phoni. cian eosmogony, which explains the origin of organic matter as due to a series of spontaneous emanations. But the most interesting cosmogonies we possess are the ancient Babylonian, of which one form is preserved in the Greek of Berosus, while another was deciphered by George Smith from the cuneiform inscriptions. These present startling identities with the ereation story in the first chapter of Genesis.

Modern cosmogonists arrange themselves mainly according to their attitude to Theism (q.v.). Theists explain the world of matter and order as having come into existence at the omnific fiat. Pantheism (q.v.), again, holds the universe to be the very body and being of Deity, and as such to have been from all eternity. Most men of science, in modern times, stopping short of an actual cosmogony or genesis of the world, have pushed their inquiries into the order of development of its present state. Some assume the necessary existence of matter; with these there is no proper beginning of things, but an eternal round, under fixed laws of growth and decay.

In cosmogonical speculations, heat, air, atoms with rotatory motions, numbers-have all in turn been recognised as the fountain and causes of things. Of hypotheses as to the formation of our own rotating globe, of our system, and of all similar systems in space, the most notable is that of Laplace, founded on observation of the mutual relations of the planets, their common direction in rotation and revolution, their general conformity to one plane, \&c., taken in connection with such facts as the rings of Saturn and the fundamental unity of the asteroids. Laplace had in some measure been anticipated by Kant. Thus arose the Nebular Theory (see NERULE), the evidence for which was earefully marshalled by Sir W. Hersehel; and which is still regarded by some physicists as indicated by the general tendencies of the laws of nature. M. Faye has given his theory of the origin of the earth from meteorites, and discussed other cosmogonic theories in Sur l'Origine du Monde (1880). Following up this view of a formation of the planetary globes by natural causes, there have been speculations as to the commencement and progress of organic life upon them, and communication of it from one planet to another (as by Sir William Thomson ; and see Professor Tyndall's presidential address to the British Association in 1874). Darwin's work has completely altered the face of biological research and theory (see EvoLU. tion, Darwinian Theory, and Spencer). For the cosmogonies of the various nations, philosophies, and religions, see MATERIALISM, Theogony, Hegel, AdaM, Creation; as also the articles on the Seandinavian Mythology, on the Greek Religion, on Spontaneous Generation, and on various aspects of Indian speculation.

Cosmological Argument. See GoD.

Cosmos. See Cosmogony.

Cosne, a town, with iron manufactures, in the French department of Nievre, and on the right bank of the Loire, 122 miles SSE. of Paris by rail. Pop. 6684.

Cosquin, Emmanuel, an eminent French folklorist, was born at Vitry-le-Francois in Marne, where his father was a notary, as well as maire for nearly twenty years, 25th June 1841. He made his studies at the college of his native town, taking at the close of his course the diploma of licentiate in law, and here he has lived ever since. He has contributed many articles on religious questions to the Conservative and Catholic journal, Le Francais (since November 1887 incorporated with $L_{e}$ Moniteur Universel), as well as numerous articles on more general questions to other newspapers and magazines, and has translated La vraie et la fausse Infallibilité des Papes (1873), and Le Concile du Vatican (1877), two works by Mgr. Fessler, geheral secretary of the Vatican Council. But his most important work was a series of articles from 1876 to 1881 in the pages of Romania, which at once arrested the attention of scientific folklorists everywhere. These were collected into two volumes, issued in 1886 as Contes populaires de Lorraine, perhaps the most really important contribution made to storiology since the classical collections of J. F. Campbell (1860-62) and Von Hahn (1864). The stories were taken from a limited region, and were for the most part poorer in detail than parallel versions found elsewhere, but they possessed in their scientific accuracy a value which belongs unhappily to but few collections of folk-tales avail. able to the student. The theory of the origin and transmission of such stories that M. Cosquin supports in his admirable introduction and in his no less luminous than learned notes, is a development of that put forth by Benfey in the famous introduc. tion to his translation of the Panchatantra (1859), that not only the bases of these stories but their combinations have been carried from India within the historical period. M. Cosquin's position has been vigorously assailed by $\mathrm{Mr}$ Lang and others, but has been as vigorously defended by himself. See FOLKLORE.

Cossacks (Russ. Kasak), a race whose origin is hardly less disputed than that of their name. The latter has been variously derived from words meaning, in radically distinct languages, ' an armed man, a sabre, a rover, a goat, a promontory, a coat, a cassock, and a district in Circassia, The Cossacks are by some held to be Tartars, by more to be of nearly pure Russian stock; but the most probable view is that they are a people of very mixed origin. Slavonic settlers seem to have mingled with Tartar and Circassian tribes in the regions to the south of Poland and Muscovy, in the Ukraine and on the lower Don, and to have given to the new race, first heard of as Cossacks in the 10th century, a predominantly Russian character. On the conquest of Red Russia by Poland, numerous Russian 
refugees fled to the Cossack country; and more on the Tartar conquest of Muscovy. The numbers of the Cossacks were also recruited from time to time by adventuress or fugitives from Poland, Hungary, Wallachia, and elsewhere; but in phys ique, as in language and religion, the Consacks have always been mainly Russian. They distin gruished themselves in war against Turks and Tartass, and were known as a powerful military confederacy in the loth century. The kings of Poland and the czars of Muscovy employed them largely to defend their frontiers, especially Against nomadic neighbours; but the connection between the Cossacks and their lords paramount was always very elastic, and was frequently repu. diated to suit the convenience of either party. The Coseracks are still the ontposts of Russian suthority in Siberis, Central Asia, and the Caucasus, Living near, or, as "free Cossacks" amongst, hostile peoples, they developed their peculiar military organisation-either forming a cordon of military settlements along the confines of oceupied territory, or isolated camps in the nomad country beyond. Agriculture they eschewed; self-reliance and readiness at all times for defence or assault were their chief characteristics; thongh such of them as inhahited the banks of the Don and Dnieper, and their islands, became and still are skilful boatmen and fishers. Their political constitution was completely democratic all offices were elective for one year only, and every Cossack might be chosen to any post, in cluding the supreme one of Attaman or Hetman. This organisation they have in great measure re tained, though the office of Hetman was abolished by the Emperor Nicholas, except as a title hereditary in the imperial family. There have been two main branches of the Cossacks-the Little Russian, or Ukraine, and the Don Cossacks. To the first belonged the Zaporogian Cossacks, those dwelling near the Porogi or falls of the Dnieper. From them again are descended the Tschernomerian Cossacks, those of the Kuban Valley and of Azov. From the Don Cossacks apring those of the Folga or of Astrakhan, of the Terek Valley, of Orenburg, of the Ural, and of Siberia. They furnish a large and valuable contingent of light cavalry to the Russian army, and are very patient of fatigue, hunger, thirst, and cold. The Don Cos sacks give name to a province with an area of 61,886 8q. $m$., and a population of over $1,450,000$ inhabitants, of whom 20,000 are Kalmucks. Though the Cossacks have generally been represented in the west of Europe as little better than fierce savages, they have left a very favourable impression on those who have dwelt amongst them. Jonas Hanway found them in 1743 ' $\mathrm{A}$ eivilised, and very gallant as well as sober people;' and many more recent travellers agree in asserting that in intelligence, cleanliness, refinement, and enterprise they are greatly the superiors of the average kins sians. See Springer, Die Kosaken (Vienna, 1877) Wallace Mackenzie's Russia (1877); and Erckert, Der Ursprung der Kosaken (Berlin, 1882).

Cossimbazar (Kasimbazdr) is a decayed eity, which at the end of the 17 th century was the chief English agency in Bengal. It stood on the Bhagirathi near Murshidabad (q.v.); but its site is now a swemp.

Cossus, See Goat Moth.

Costr, Isano Da. See Da Costa.

Costa, Sir Michael, a popular musical conductor and composer, was born at Naples, 4th February 1810. As he early showed a decicter talent for music, he was sent to the Royal Academy in his native city for education, where he greatly distinguished himself and produced varions compositions (1825-29). He settled in England, and in 1831 his ballet of Kenilworth was produced with sucerems. He was conductor at the King's Theatre (1832), at Covent Garden (1846), to the Philharmonic Concerts (1846), and to the Sacred Harmonic Society (1848). His great work. the oratorio Eli, produced at the Birmingham Festival of 1855 (where he conducted till 1879), raised him to eminence as a composer. Nuaman, which was leas successful, was finst anng in Bir. mingham in 1864. From 1857 till 1877 he con. ducted at the Handel Festival, and in 1871 he became director of Her Majenty's Upera. He war knighted by the Queen in 1869 . Costa was the author of several ballets, and of some opveras, including Malek Adhel (1838) and Don Curlus (1844). As a composer he bolds a respectable place in the second rank, but it is as a conductor that he will be longest remembered, Meyerbeer, in 1862, styling him 'the greatest chef $d$ 'orchestre in the world.' He died 29 th April 1884.

Costa Rica, the most Boutherly of the five republics of Central America. It is divided into six provinces, and occupies the entire breadth from sea to sea between Nicaragua on the one side and Colombia on the other, with an area of 21,495 miles, or about two-thirds that of Ireland. The population, which is mostly concentrated in a central plateau of about $3500 \mathrm{eq}$. $\mathbf{m}$., was in 1885 officially estimated at 213,785 , including some 10,000 uncivilised Indians; but in 1886 , again, an ofticial estimate gave only 196,270 . The whites are mostly of pure Spanish descent. Except on the coast, the country is generally mountainous, with many volcanoes, all under 11,500 feet; on the Atlantic slope dense forests prevail, but wide savannals are more frequent on the Pacific side. The climate is mild and temper. ate in proportion to the elevation, and the soil of the valleys and uplands is very fertile. Prior to the discovery of gold in 1823, Costa Rica was a land of poverty, owing its title of "The Rich Coast" solely to the anticipations of its first Spanish settlers; since then, foreign capital has opened up much of the country, and brought its products within reach of a market. Althongh rich in gold, silver, copper, and other metals, its chief industry is agriculture; but the population is very scanty, and only a twentieth part of the land is under cultivation. Besides valuable timber and dye-woods, it yields tobacco, sugar, bananas, cacao, caoutchouc, sarsaparilla, and vanilla, which, with hides, tortoiseshell, and mother-of-pearl, are largely exported. But the staple of trade is coflee, to which is princi. pally due the reviving prosuerity of 'the Coffee Republic.' Of a total annual export of $£ 1,131,845$ (1898) coffee represents four-fifths. The imports, chiefly manufactured goods from Great Britain, and wheat and other products from the United States, amounted in the same year to $£ 851,780$. The clief ports are Punta Arenas and Limon (q.v.); the other places of any note are San José, the capital, and the cities of Cartago, Alajuela, and Heredia.

Discovered by Columbus in 1493, and probably first settled on his fourth voyage, in 1502, Costa Rica has had much the anne history as its veigh. bours: pronunciamientos have been frequent; its present constitution is the ninth since the declaration of independence in 1821; and for the ten years preceding 1883 that constitution was practically suspended. The government is now, however, accounted the best and most libeml in Central America. The president is chosen every four years, and the members of congress are electeil for the sume term. There is a small standing army of 600 men, besides 12,000 militia, which embraces all males between the ages of eighteen and thirty, while those from thirty to fifty-five form the 
reserve; and while the Roman Catholic is the state church, religious liberty is guaranteed. The annual revenue (1898-99) was $£ 1,682,640$, mainly derived from the government monopoly of spirits and tobaceo, and just about balanced the expenditure. The foreign debt, $£ 2,100,000$, was rearranged in 1897 on a basis of $2 \frac{1}{2}$ and 3 per cent, and an arrangement made to pay off part of the large arrears of interest by instalments. There are in all about 170 miles of railway and 920 miles of telegraph.

See Peralta, Costa Rica, its Climate, \&c. (Lond. 1873) Costa Rica, Nicaragua, y Panama, en el Siglo XVI. (Madrid and Paris, 1883); and Costa Rica y Colombia (Madrid, 1886); also Calvo, República de Costa Rica (San Joøé, 1887 ; English ed., Chicago, 1890).

Costello, Louisa STuART, a voluminous English authoress, was born in 1799. In Paris, and afterwards in London, she painted miniatures, and enjoyed the patronage of the Burdett family. From 1852 she received a civil list pension of $£ 75$ until her death, which took place at Boulogne, 24th April 1870. Her first production, at least of any note, was Specimens of the Early Poetry of France (1835), but it was her bright descriptions of travel in Auvergne, Béarn and the Pyrenees, North Wales, Venice, and Tyrol, that made her really popular. Her semi-historical novels on Catharine de' Medici, Mary of Burgundy, and Anne of Brittany were read in their day.

Coster, the usual name of LAURENs JANszoon, according to the Dutch the inventor of printing, who was born at Harlem about the year 1370. He is supposed to have made his great invention between the years 1420 and 1426, to have been sacristan (Koster) at Haarlem, and to have died of the plague about 1440. No question has caused more discussion than that between Coster and Gutenberg; an account of this controversy is given under Printing. It is unpatriotic not to argue for the native hero, whose relics are exhibited and to whom monuments have been raised. Yet the most thoroughgoing assault on the claims of Coster and of Haarlem, as being founded on local legends, was made in 1870 by a Dutchman, Dr A. van der Linde. See, however, Hessels, Haarlem the Birthplace of Printing (1888).

\section{Costiveness. See Constipation.}

Costmary (i.e. costus or aromatic plant of the Virgin Mary), or ALE-Cost (Balsamita vulgaris), is a herbaceous perennial composite of southern Europe. It was introduced from Italy in 1568 , and is cultivated in gardens (as in Britain, and in the United States) for the fragrance of the leaves. The leaves were formerly put into ale and negus, and are still occasionally used by the French in salads.

Costs, the technical name in English law for the expenses incurred in legal proceedings. (In Scotland they are called Expenses, q.v.). Costs are either (1) between solicitor and client-i.e. the charges which a solicitor is entitled to recover from the person employing him as remuneration for professional services; or (2) between party and party -i.e. those which are allowed to the party succeeding in an action against his adversary. As a general rule, costs follow the event, and the costs of the successful party are paid by the loser; but the rule is subject to important exceptions. (1) A party suing or defending in formá pauperis does not pay costs, though he is entitled to receive them if successful. (2) In actions in which the plaintiff recovers damages under $10 \mathrm{~s}$, he is, in certain cases, not entitled to costs, unless the presiding judge certifies that he ought to have them; and in all other cases, he is not entitled to them, if the pre. siding judge certifies that he ought not to have them. (3) A plaintiff who might have brought his action in the county court is not entitled to costs if he sues in the higher courts, and recovers not more than $£ 10$ in certain actions, or $£ 20$ in others, unless the judge who tries the case certifies that it was proper the action should have been brought in the higher court. (4) A party who is successful in the main, and therefore entitled to the 'general costs,' may be unsuccessful upon some minor point, and therefore bound to pay the costs which belong properly to it. (5) A party who has tendered the amount recovered, and who pays the sum into court, and pleads the tender, is not bound to pay costs. (6) The payment of money into court in the course of an action relieves the party paying from costs of subsequent proceedings, if no greater amount be ultimately recovered.

In suits by and against the crown, the same rules concerning costs apply as in the case of private suits. In administrative proceedings, such as actions for the execution of trusts, or proceedings to ascertain the construction of a will, executors, trustees and others, who have properly or neeessarily taken part in the proceedings, are allowed their costs out of the fund or estate involved. When any step in an action is put off at the request of one of the parties, that party is usually required to pay to the other the costs of the particular step. These are called "costs of the day." By the Judi. cature Act, 1875, it was enacted that the costs of all proceedings in the High Court shall be in the discretion of the court; and that where any action is tried by a jury the costs shall follow the event unless for cause shown the judge shall otherwise order.

Costs are taxed (i.e. the items allowed or disallowed) by the officer of the court appointed for the purpose under the name of the taxing-master; and any party may have, if he choose, his own attorney's or solicitor's bill taxed by the same officer.

In criminal cases, the prosecutor's costs may be allowed by the judge, and in that case are paid out of the county rates, the county being reimbursed by the Treasury; and on acquittal of a person indicted who has not been committed or held to bail, the court may order the prosecutor to pay costs to the accused if it think the prosecution unreasonable.

The English doctrine of allowing costs to the successful party generaily prevails in the United States. The right to costs, and the rate of costs, is dependent upon statutes which must be strictly construed. The Federal Courts allow costs according to the rates allowed by state law, unless contrary to some act of congress, in which case the latter will prevail as against the state law. By act of congress in 1853 a Fee Bill was established regulating the costs in the Federal Courts. This act, by implication, denies costs to the losing party, which in some cases are allowed by the state laws. The rule of one state as to costs cannot be applied to cases involving contracts of that state litigated in another forum. If the cause is removed from the state to the Federal Courts, the parties are entitled to costs according to the state law prior to removal, and after removal under the act of congress.

Costume. See Anthropology (Vol. I. p. 312), FASHION.

Costus, or Costus Arabicus, an aromatic: much esteemed by the ancients, is the dried root of Aplotaxis auriculata, a composite plant, and is not derived from the plant Costus Arabicus, as was at one time supposed. It is a native of the moist open slopes surrounding the valley of Cashmere. The roots are there burned as incense. They have a strong aromatic pungent odour, and are employed in protecting bales of shawls from moths. It is alse 
used in India as a hair-wash, as a stiuulant in cholern, and as a stimulating ointment.

Cosway, Richard, R.A., miniature-painter, was born in 1740, son of the master of Tiverton school in Devonshire. He early displayed a taste for painting, and studied in London under Hudson, in Shipley school, and in the Royal Academy, of which he became an associate in 1770 , and a mem. her in 1771. He painted oil-subjects, aiming at the siveetness and softness of Correggio; but it was in portraiture that he made his mark, and soon his miniatures were 'not only fashionable, but the fashion itself.' Having gained the personal friendship of the Prince of Wales, he was appointed his painter-in-ordinary, and Mrs Fitzherbert and all the beauties of the coterie sat to him. His small female full-lengths with the faces finished in watercolour, though slight in execution, are full of exquisite grace; and his ivory miniatures are also delicate and valuable. Personally Cosway was vain and eccentric. He died 4th July 1821. In 1781 he married MARIA HADFIELD, a skilful musician, also known as an artist; she executed subjects for Boydell's Shakespeare, and Macklin's Poets. She separated from her husband, and is believed to have died in a convent at Lyons.

Côte-d'Or, a department in the east of France, formed of purt of the old province of Burgundy, with an area of $3383 \mathrm{sq}$. m., and a pop. (1891) of 376,866 . The surface is in general rather elevated, and is traversed by a chain of hills forming the connecting link between the Cevennes and the Vosges. A portion of that range, called the Cote-d'Or ('golden slope'), receives its name, which it gives to the department, from the excellence of the Burgundy wines produced on its slopes. Much of the surface is covered with forests. The valleys and plains are fertile, and there is good pastureland. Cote-d'Or is watered by the Seine, which rises in the north-west, and by several of its affluents; by the Saone, and by the Arroux, a tributary of the Loire. By means of canals it has watercommunication with the German Ocean, Mediter. ranean, English Channel, and Bay of Biscay. The climate is temperate ; iron, coal, marble, gypsum, and lithographic stones are found, the first in large quantities. Cote-d'Or is divided into four arrondissements: Beaune, Chatillon-sur-Seine, Dijon, and Semur, and has Dijon for its capital.

Cotentin, THE, the peninsula projecting from the north-west of Normandy into the English Channel, between the Bay of St Michel and the Gulf of Carentan, now forms the northern part of the department of Le Manche. It is about 55 miles long and 25 broad. Under the dukes of Normandy, the Cotentin became the seat of numerous powerful barons and rich abbeys. Many of the former followed William the Conqueror to England in 1066, and the names of several of the aristocratic families of England may be traced to humble towns and villages on this peninsula (e.g. Beaumont, Bruce, Carteret, Neville). The Cotentin is highly fertile, and is famous for its herds of fine cattle. The ehief town in the peninsula is Cherbourg, though the old capital is Coutances.

Cotes, Roger, a mathematician, whose remark. able promise was ent short by untimely death, was born at Burbage, near Leicester, July 10, 1682. He had his education at St Paul's School, London, and Trinity College, Cambridge, where he was elected fellow in 1705 , and next year, through the influence of Newton, Whiston, and Bentley, Plumian professor of Astronomy and Natural Philosophy. He was elected F.R.S. in 1711, and took orders in 1713 . His principal work is the admirable preface explain. ing the Newtonian philosophy, and answering objections to gravitation, prefixed to the second edition (1713) of Newton's Principia, Varions original mathematical papen, tending preatly to the development of logarithms, were edited after his death, which took jare 5th June 1716. "Himl Cotes lived,' said Sir Isanc Newton, "we might have known something.'

Côtes-du-Nord ('northern coasts '), a French department forming part of Brittany, and bounded $\mathbf{N}$. by the English Channel, in which are neveral small islands belonging to Cotes-du-Nord, Area, 2659 sq. In. ; pop). (1872) 622,295; (1891) 618,65:? The Menez Mountains, 16 miles broad, and 1115 feet high, cross the department from east to west, and chiefly consist of granite and clay-slate. There are several short but navigable rivers. Though a great portion of the south and the higher plains is occupied by heath and woods, there ure also fertile tracts. The cultivation of flax and hemp, with pasturage and iron-mining, supply employment in the hill-districts; while in the sheltered valleys and on the const-levels grain, pears, apples, \&c. are produced. The department is divided into the five arrondissements of St Brieuc, Dinan, Loudéac, Lannion, and Guingamp. The chief town is St Brieuc.

Coteswold, or Cotswoup HiLs, a range of oolitic limestone bills, running through the middle of Gloucestershire, from Chipping Campden in the NE., by Cheltenham and Stroud, to near Bath in the SW. The range is over 50 miles long, with an average height of 500 or 600 feet, and separates the Lower Severn from the sources of the Thames. The highest point is Cleeve Hill, 1134 feet. For the Coteswold Games, see ATHLETIC SPorts.

Cotgrave, RANDLI, author of our earliest French dictionary, but of whose life little is known save that he was a native of Cheshire; was: adnitted scholar of St John's College, Cambridge, in 1587; became secretary to William Cecil, Lord Burghley; and was alive as late as 1632, in which year he carried the second edition of his dictionary through the press. The first edition had appeared in 1611, and editions revised by James Howell were issued in 1650, 1660, and 1673. Cotgrave's dictionary was a really remarkable book for its time, and is still invaluable to the philologist, not only as a storehouse of older English words, but because it fixes the actual forms of French wordsthough it is inevitably erowded with mistakes.

Cöthen. See Köthes.

Cothurnus. See Buskin.

Cotillon (Fr., 'petticoat'), the name of a brisk dance, of French origin, performed by eight persons. The quadrille may be regarded as a modífication of it.

Cotinga, a genus of Passerine birds, represented by six species in Central and in tropucal South America. The family (Cotingidre) to which they belong is often called the Chatterers of South America, though the name Chatterers (q.v.) is by others confined to the Ampeliclac. They are fruit. eating birds, and the males are very beantifully adorned in blue or violet at the breeding season. See Cock of THE Rock.

Cotise, or CosT, in Heraldry, one of the diminutives of the Bend (q.v.).

Cotman, Jонर SELL, an artist of the 'Norwich. School,' was born 16th May 1782, and educated at Norwich grammar-8chool, till, about 1798, he went up to London to study art, and there made Turner's acquaintance. In 1807 he returned to his native city, where he taught drawing and published etchings and engravings of local architecture, brasse's, \&.c. In 1334 he obtained, through Tumer, the post of drawing-master in King's College, London, but his later years were elouded by much 
suffering. He died 24th July 1842. Cotman's fame as a water-colour landscapist has grown steadily; indeed $\mathrm{Mr}$ Cosmo Monkhouse opines that 'taken altogether he was the most gifted of the Norwich School, wider in range, a finer draughtsman, and of more refined and cultivated individuality, than "Old Crome." His second son, Joseph John Cotman (1814-78), was also a landscape-painter.

Cotoneaster, a genus of Rosaceæ, sub-order Pomer, closely allied to the hawthorn and medlar. The species are shrubs or small trees, some evergreen; with simple entire leaves, more or less woolly beneath; small flowers in lateral cymes; and small, unpalatable, but bright-coloured fruit, persistent in winter. C. vulgaris (said to be found wild in a single locality in Wales) and other species are common mountain plants of central Europe and Asia, but have been largely introduced as ornamental shrubs, the evergreen species ( $C$. rotundifolia, \&c.) being especially used for covering walls and rockwork.

Cotopaxi, the loftiest active volcano in the world, is in Ecuador, in the eastern chain of the Andes, and about 50 miles $\mathrm{S}$. of the equator. Humboldt gave the height at 18,880 feet; Reiss, the first to ascend it (in 1872), at 19,500 feet Whymper, who ascended in 1880 to the edge of the crater, at 19,550 feet above the sea. The valley at its foot, however, is itself 9000 feet high. The upper part of Cotopaxi, a perfect cone of 4400 feet, is entirely covered with snow, save that the verge of the crater is a bare parapet of rock. Below the snow is a well-marked barren belt covered with lichens and shrubs, below which again is forest. Smoke issues from the summit; sounds as of explosions are occasionally heard; and above, a fiery glow is often visible by night. Lava rarely flows even during eruptions, but flame, smoke, and immense volumes of ashes are then ejected; and when the heat melts large masses of the snow lying on the sides, destructive floods are occasioned in the valleys beneath. The first eruption recorded was in 1533 . Others followed in $1698,1743,1744$, and 1768 , the most terrible of all. On the latter occasion ashes were carried 130 miles distance, and thickly covered an extensive area. Cotopaxi was quiet till 1851 . In 1854, 1855, and 1856 there were again eruptions of more or less violence.

Cotroné, a fortified town of Italy, 35 miles NE. of Catanzaro by rail, built on a point of land projecting into the sea. Pop. 9649.

Cotswold Hills. See CoteswoLD.

Cotta, a publishing-house established at Tübingen in 1640, and still one of the mout flourishing in Germany. The family came originally from Italy. Its most prominent members have been (1) Johann Friedrich (1701-79), a learned writer and theological professor at Tubingen, Göttingen, and Jena; (2) his grandson, Johann Friedrich, Freiherr Cotta von Cottendorf, born at Stuttgart in 1764, educated at Tuibingen, and for some time an advocate. In 1787 he undertook the family business; and in 1795 established the famous Horen, a literary journal, under the editorship of Schiller, with the friendly co-operation of Goethe and Herder. Already in 1793 he had sketched ont the plan for the Allgemeine Zeitung, which has appeared since 1798. The Almanach für Damen (1798) and other periodicals were no less successful. Cotta now began likewise to publish the works of Schiller, Goethe, Herder, Fichte, Schelling, Jean Paul, Tieck, Voss, the Humboldts, \&c., establishing thereby a claim to the gratitude of the wide literary world. In the seventy years ending in 1864, the house had paid to Schiller and his heirs no less a sum than 528,966 marks, to Goethe and his heirs in the same period, 865,554 marks. In 1810 he changed his residence to Stuttgart, and in 1824 introduced the first steam printing-press into Bavaria. He died 29th December 1832. In the diet of Wütemberg, and afterwards as president of the Second Chamber, he was ever the fearless defender of constitutional rights; he was, too, the first Wuirtemberg proprietor who abolished servitude on his estates. He was succeeded by his son, Georg (1796-1863); and he by his son Georg Astolf (1833-76).

Cottage, a small dwelling-house, especially of labourers, varying greatly in size, appearance, and comfort. Since 1860 especially, public attention has been called to the deplorable state of the cottages in many parts of Great Britain, and the desire to secure their improvement has led to the publication of many works on Cottage Architecture, including those of Birch (1872), Young (1872), Bicknell (1877), Shand (1878), Bruce (1886), and Menzies (1886).

Cottbus, or KoTTBus, a town of Prussia, in the province of Brandenburg, situated on the Spree, 71 miles SE. of Berlin by rail. It is an important railway junction and $\mathbf{a}$ busy mercantile town, with manufactures of woollen cloth, carpets, hats, linen, jute, leather, and tobacco. Pop. (1875) 22,642 ; (1885) 28,249 ; (1890) 34,910.

\section{Cotters. See Crofter.}

Cottin, Sophre (née Ristaud), French authoress, born at Tonneins, in the department of Lot-et-Garonne, in 1773, married at seventeen a Parisian banker, who left her a childless widow at twenty. For comfort she turned to letters, wrote verses and a lengthy history, and in fiction won unfading laurels. She had already written Claire d'Albe (1799), Malvina (1800), Amélie Mansfield (1803), and Mathilde (1805), when in 1806 she wrote Elisabeth, on les Exiles de Sibérie, a story stamped with such real unsought pathos that it has been translated into most European languages. Madame Cottin died 25th A ugust 1807.

Cottle, JosEPH, bookseller and author, born in 1770, was well read in English literature when he started business in Bristol in 1791. He took kindly to Coleridge and Southey, to whom he was introduced by Robert Lovell, and offered them each 30 guineas for their poems ; and in addition 50 guineas for Southey's Joon of Arc, with $1 \frac{1}{2}$ guineas to Coleridge for every additional 100 lines of poetry he might write. The poems thus arranged for appeared in 1796. Cottle also became responsible in a business, and partly in a pecuniary, sense for Coleridge's Watchman; and an introduction to Wordsworth led to his publication of the afterwards famous Lyrical Ballads (1798). Cottle was intrusted with the delicate duty of handing over De Quincey's generous donation of $£ 300$ to Coleridge, to whom he also addressed some serious expostulations as to his indulgence in opium, which drew replies from the poet. Cottle's injudicious and unmereiful exposure of Coleridge in his interesting but sometimes inaccurate Early Recollections (1837) has been condemned. He wrote several volumes of verse the fourth edition of his Malvern Hills (1829) contains several prose essays. He retired from business in 1799, and died 7th June 1853.-His elder brother, Amos Simon CotTLE (1768-1800), educated at Bristol and Cambridge, wrote various works, including Icelandic Poetry (1797), which contains a poetical address to him from Southey.

Cotton, an important vegetable fibre, extensively cultivated in various parts of the globe within the 35 th parallels of latitude.

(1) Botanical and Commercial Classifications.Cotton is the produce of all the species of the 


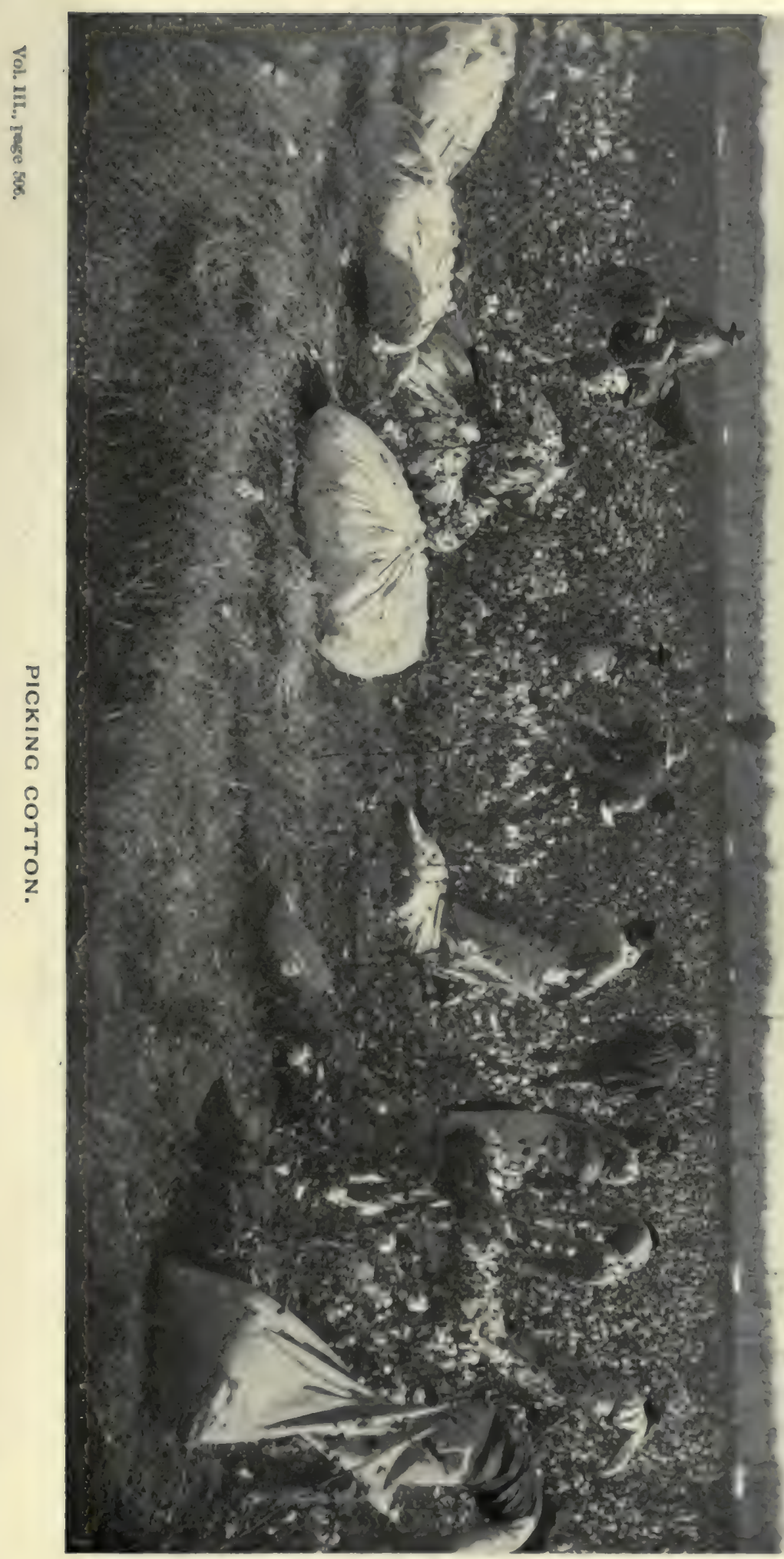



genus Gossypium, which belongs to the natural order Malvucese, and is thus sllied to Mallow, Hollyhock, Hibiscus, \&c., the general resemblance to which is very apparent both in the foliage and flowers. The species are partly shrubs, partly herbaceous, and either perennial or annual; they are natives of the tropical parte of Asia, Africa, and America, but their cultivation has extended far into the temperate zones. They all have leaves with three to five lobes, which in a very young state are often sprinkled with black points, and rather large flowers, which are mostly yellow, but sometimes in whole or in part purple; the flowers very soon fall off; they grow singly from the axils of the leaves, and are surrounded at the base by three large, heart-shaped, cut or toothed, involucral leaves or bracts, partially growing together as one. The fruit is a 3-5-celled capsule, springing open when ripe by $3-5$ valves, and containing numerous seeds enveloped in cotton, which is generally white, but sometimes yellow, and issues elastically from the capsule after it has burst open. The fibres are long cylindrico-spiral tubes of from $-\frac{1}{6} \sigma^{\text {th }}$ to $\bar{g}^{1} \delta_{0}$ th of an inch in breadth, which when platted adhere firmly together. The wool is also very sus. ceptible of dyeing. The figure shows the manner in which the cotton escapes from the capsule. Some

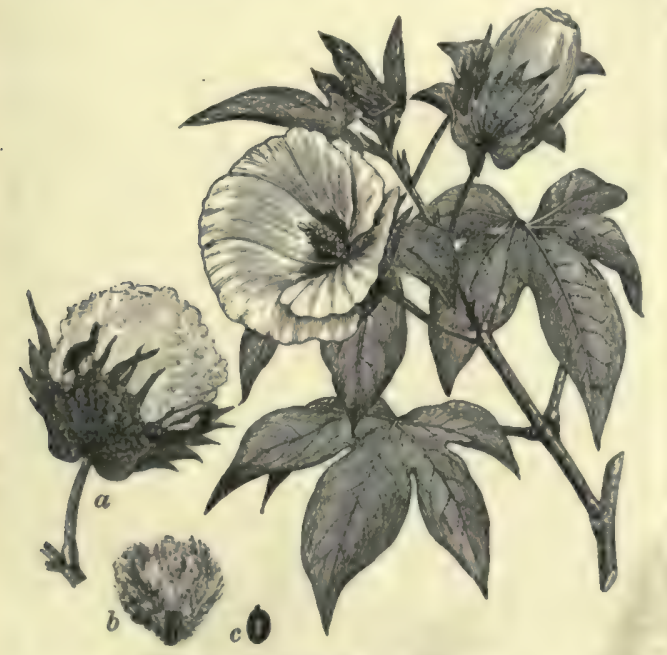

Cotton (Gossypium Barbadense) :

c, ripe capsule after dehiscenco; $b, a$ seed; $c$, the same deprived of its hairs. (From Bentley \& Trimen.)

of the kinds have the flowers larger in proportion, and the leaves divided into more numerous and much deeper and narrower lobes, but the general appearance of all is very similar.

Difference of opinion exists among botanists as to the number of distinct species, and there are very many varieties in cultivation, the number of which, through climatic influences and other causes, is continually increasing; but there are certain leading peculiarities on sceount of which some botanists and planters reduce all, at least of the cultivated kinds, to four primary speciesvix. (1) Gossypium Barbadense; (2) G. herbaceum or indicum; (3) G. peruvianum; and (4) G. arboreum. The produce of the first species is the most valuable. The beautiful long-stapled (11 to 22 inches) silky wool known as 'Sea Island" is a variety, and is grown exclusively upon the islands and a portion of the mainland of Georgia, South Carolina, and Florida; the saline ingredients of the soil and atmosphere being indispensable elements of the growth. The plant, 6 to 12 feet in height, hears a yellow flower, and the meseds are small, black, and quite smooth, and the wool is easily separated therefrom; but when sown far inland, away from the saline influences of the cosst, the seeds increase in size, and become covered with innumerable short hain. A large percentage of the crope raised in Alabama, Louisinna, Mississippi, Texas, \&c., are also varieties of this species, though, owing to elimatic influencen, the plant is smaller ( 4 to 6 feet in height), and the wool is shorter in staple (\& to $1 \frac{1}{1}$ inch), and less easily separated from the seeds than Sen Island. In 1888 the commercial value of the latter kind varied from 10d. to 2ld, per lb., rare specimens sometimes realising $2 \mathrm{~s}$. 6u. to $3 \mathrm{~s}$, per fh. The better descriptions of Egyptian cotton belong to $G$. Barbadense, and bring $9 \mathrm{~d}$. to $18 \mathrm{l}$. per $\mathrm{lb}$. in the Liverpool market (staple 1 to 1 inch). The short-staple varieties, known as New Orleans, Mobile, Uplands, \&c., sell at from 4d. to 7d., extra qualities sometimes bringing $9 \mathrm{~d}$. to $10 \mathrm{~d}$. per lb. $G$. herbaceum is found in India, China, Africa, \&c. The prineipal commercial varieties are those known as Surat, Madras, Bengal, \&e. It is a small shrubby plant ( 2 to 4 feet high), bears a yellow flower, the seeds are covered with short grayish down, and the staple produced, though not long ( $\frac{8}{8}$ to 1 inch), is very fine. Its price varies from 3d. to $51 \mathrm{~d}$. per $1 \mathrm{~b}$. The cotton known as nankeen is thought to belong to this species. $G$. herbaceum can be profitably cultivated in colder countries than any other species of cotton-plant. The third species ( $G$. peruvianum) is a native of South America, and the 'green seed' cotton of the United States appears to be a variety. The stem reaches 10 to 15 feet in height, the flowers are yellow, and the capsules contain eight or ten black seeds firmly attached together in a cone-like mass. The wool is long. (1 to 11 inch) and strong-stapled, and in value stands next in order to Sea Island and Egyptian. Pernambuco, Maranham, Bahia, Maceio, and Peruvian are varieties which sell in Liverpool at from 5 5 d. to $61 \mathrm{~d}$. ; extra qualities of Peruvian bring 6dd. to 8d., and Sea Island Peruvian is worth $9 \mathrm{~d}$. to $12 \mathrm{~d}$. per $\mathrm{lb}$. $G$. arboreum is found in India, China, \&c., and, as its name imports, is a large tree-like plant. It bears a red flower, and produces a fine yellowish-white wool. Varieties of it have been long cultivated in the United States, and with the requisite soil and climate, are said to produce a wool somewhat resembling Sea Island.

The finer kinds of yarn are spun from Sea Island and long-stapled Egyptian, and from them are fabricated our muslins, laces, se. From Brazil and the better classes of short-stapled American come our cambrics, calicoes, shirtings, sheetings, \&c. and from the inferior qualities of American and Surat are spun the coarse yarns required for fustians and other heavy fabrics. Yorkshire broadcloths are sometimes half cotton. From warps of eotton, and wefts of wool or worsted, are formed varieties of Orleans cloths, Coburgs, mousselines de laine, \&'c. There are also fabrics composed of silk and cotton, linen and cotton, alpaca and cotton, \&c.

(2) Cultivation. - The plant is a very delicate organism, and requires a peculiar soil and climate for its due development. The method of cultivation is much the same in the various countries where the fibre is grown; lut the most perfect system is that which obtaing in the United States of America. Although the plant is not, strictly speaking, an annual, it is found more profitable to destroy the shrub, after the crop is gathered, and sow new seed every year. The preparation of the land takes place during the winter months. After the ground has been thoroughly ploughed, and as soon as all symptoms of frost have disappeared, the soil is laid 
off into rows varying in width from 3 to 4 feet, according to the situation and quality of the soil. The seed is then sown along the centre of the beds in a straight furrow made with a small plough or opener; but in some plantations the seed is sown in holes from 12 to 18 inches apart. The sowing commences in March, and generally continues through April ; but sometimes, owing to late spring frosts, the planting is prolonged to May. The young shoot appears above ground in about eight to ten days, and is then and subsequently weeded and thinned. Blooming takes place about the beginning of June-in early seasons, towards the latter end of May; the average date is about June 5. For ploughing, the planter requires just sufficient rain to give the soil a moist and spongy texture. During the early stages of its growth, the crop flourishes best with a warm steamy. sort of weather, with an occasional shower until blooming; too much rain being productive of weeds and wood at the expense of wool, whilst a severe drought produces a stunted plant, forced into too early maturity, and resulting in a small and lightstapled crop. A great deal, however, depends upon the position of the plantation; lands situated in hilly or upland districts obviously requiring more moisture than those lying in the plains and riverbottoms. From the date of blooming to the close of the picking season, warm dry weather is essential. Picking generally commences in August, occasionally in July, and continues until the occurrence of frost-about the end of October or beginning of November-puts a stop to the further growth of the plant. Uccasionally, in the absence of a killing frost, picking extends to December or January, and even into February, but the cotton is inferior in grade and quality. All the available hands of the plantation, young and old, are called into full employment during the harvest. The cotton is gathered into baskets or bags suspended from the shoulders of the pickers, and when the crop has been secured, it is spread out and dried, and then separated from the seeds.

The latter process was formerly performed by hand-a tedious operation, by which one hand could elean only a pound or so a day; but since the invention of the saw-gin by Eli Whitney in 1793, the process of cleaning has been both rapid and effectual. This machine is composed of a hopper, having one side formed of strong parallel wires placed so close together as to exclude the passage of the seeds from within. The wool is dragged through the apertures by means of circular saws attached to a large roller, and made to revolve between the wires, the seeds sinking to the bottom of the hopper. This process is adopted only' in eleaning the short-stapled varieties of American cotton, the wool of which adheres so firmly to the seeds as to require a considerable amount of force to separate them. The Sea Island variety is cleaned by being passed through two small rollers which revolve in opposite directions, and easily throw off the lard smooth seeds. In India, though the saw and other machine-gins have been introduced in some districts (notably the Macarthy-gin in Broach, and the saw-gin in Dharwar), the wool is mostly cleaned by means of the primitive roller. Prior to the American war the roller-gin was in exclusive use in Egypt and the Brazils, but the cotton famine led to the invention of the Macarthy-gin (which in principle is an improved roller-gin), and to its introduction into Egypt, and to the adoption of the saw-gin by the planters of Brazil ; the effect in both cases being a considerable extension of the culture. The cotton cleaned by the roller-gin, being uninjured thereby in staple, realises the better price; but the deterioration caused by the saw-gin is compensated for by the greatly increased quantity cleaned : the latter turning out four or five times as much wool as the former in an equal space of time.

In India, throughout the greater portion of the Bombay Presidency, the North-west Provinces, the Central Provinces, and the Berars, sowing generally takes place between the middle of June and the middle of July, but in Dharwar and other southern districts of Bombay, and in the Madras Presidency, not until August or September-in some places later still. In the first-named districts picking commences in November, but in some portions not until January or February, and in Madras not until March or April. The extension of the railway system brings cotton which formerly went to other ports to Bombay (q.v.), and 80 per cent. of the total export from India is now from that port, while the bulk of the shipments takes place in the first six months of the year. In Egypt sowing commences in March or April, and picking in October-continuing until January. The busiest export months are November to February. In Brazil planting takes place as early as January or as late as May, according to district, and picking six months later. The chief shipping months are October to May.

(3) Production and Distribution.-The oldest cotton-producing country is India, in which empire the plant has been grown and manufactured from time immemorial. The first notice of it in connection with China dates no further back than the 11 th century, but it is exceedingly probable that the plant was cultivated there long prior to that period, as cotton fabrics were known in China before the Christian era. Early mention is made of it in the annals of Egypt, and it is believed to have a high antiquity in all parts of Africa. It has for many centuries been produced in Asia Minor, in several of the Mediterranean islands, in Greece, and Southern Italy. In the western world, it was found by Columbus in the West Indies, and in Mexico and South America by his immediate successors, but was not so extensively cultivated as in the East; though during the past half-century the culture there has outstripped, both in quantity and quality, the produce of the Old World. Down to the commencement of the 19th century the cotton consumers of Europe were dependent upon the East and West Indies and the Levant for their raw material; but the inventive genius, superior farming, and greater energy of the planters of the southern states of America had, prior to the civil war, almost secured the monopoly of supplying the manufactures of Great Britain and the European continent with this valuable fibre. The following table gives at a glance the movements for a century back. The figures represent the annual imports into Great Britain from the chief sources of supply, in bales of the uniform weight of $400 \mathrm{lb}$. each, in quinquennial averages, except that the last column is based on the average imports for two years only :

\begin{tabular}{|c|c|c|c|c|c|}
\hline $\begin{array}{c}\text { British West... } \\
\text { Indies....... }\end{array}$ & $\begin{array}{c}1786-90 \\
45,000\end{array}$ & $\begin{array}{c}1816-20 \\
23,800\end{array}$ & $\begin{array}{r}1846-50 \\
1,910\end{array}$ & $\begin{array}{r}1876-80 \\
1,670\end{array}$ & $\begin{array}{r}1886-87 . \\
660\end{array}$ \\
\hline Mediterranean... & $.13,000$ & 1,030 & 31,310 & 402,190 & 435,590 \\
\hline Brazil ............ & $.-5,000$ & 55,760 & 67,860 & 85,330 & 126,040 \\
\hline East Indies...... &.$\quad 500$ & 93,710 & 186,140 & 510,800 & 601,710 \\
\hline United States.... & 100 & 166,310 & $1,297,230$ & $2,589,070$ & $3,186,790$ \\
\hline Sundries........ & . & 10,970 & 2,870 & 51,710 & $32 ; 310$ \\
\hline Total. & 3,600 & 351,580 & $1,587,320$ & $3,640,770$ & $4,388,10$ \\
\hline
\end{tabular}

At the close of the 18th century the British West Indies supplied 70 per cent. of the cotton imported into Great Britain, but owing to the competition occasioned by the rapid expansion of the culture in the southern states of the American Union, the imports gradually decreased; the planters finding it more profitable to employ their labour and capital 
in the production of sugar and other articles. In the thirty years ended 1820 , the quantity fell off nearly 50 per cent., while the proportion of West Indian in the total importa from all countries fell from 70 per cent. down to barely 7 per cent. Thirty years later it was only about one-tenth of 1 per cent. louring the American war there was an increase to about 10,000 bales. After the close of the war the import fell rapidly away. In 1870 it was about $(6 x)$ bales; in 1886, only 150 bales; in 1887, 1160 bales.

After the West Indies, the chief sources of supply a century ago were the countries bordering on the Mediterranean-Asia Minor, Cyprus, \&e. The large increase in the imports from the Mediterranean since 1820 is due to the development of the cotton industry in Egypt. The cotton-plant has been in existence in Egypt from time immemorial, but the cotton known as Egyptian is the product of an exotic plant introluced by the French alout the heginuing of the present century from the Isle de Bourbon, into which it had been introduced from Barbadoes. M. Jumelle, a French mechanician, saw the plant in a garden at Cairo in 1821, and at his suggestion Mehemet Ali gave instructions that as much seed as could be obtained should be planted in Lower Egypt. The first crop produced about 1000 cantars of $93 \mathrm{lb}$. net, and with the seed from this about 35,000 cantars were raised in the succeeding season (1822-23), say about 8000 bales of $400 \mathrm{lb}$. In 1824-25 the erop reached 228,000 cantars, or 53,000 bales of $400 \mathrm{lb}$. During the subseruent ten years the culture was more or less interrupted, owing to political disturbances, and at times seriously reduced in consequence of the withdrawal of a large number of labourers to carry on the wars of the Pasha in the Soudan, Syria, \&c. From 1867 to $1879-80$, with occasional fluctuations owing to unfavourable seasons, there was a gradual increase, until the total reached $3,168,000$ cantars, since which but little progress has been made, partly in consequence of the fall in prices, and partly owing to the slower increase in the demand for long-stapled cotton, compared with that of the shorter stapled growth of America. In 1884-85 (a good year) the area planted was 912,000 English acres, and the product $335,000,000 \mathrm{lb}$; in $1887-88$ (a poor year) $1,060,000$ acres produced $282,700,000 \mathrm{lb}$.

There are several varieties of cotton produced, but they are all from one species. Out of a total crop of $3,000,000$ cantars, about $2,500,000$ consist of Asimouni and similar varieties. The staple is good and the colour brown. About 100,000 cantars consist of Gallini, which is long and silky in staple, and competes with Ser Island. The remaining 400,000 cantars will consist of white cotton similar in staple to the brown, and not unlike extra-stapled Orleans. Gallini was (1888) quoted 8 g. to $11 \mathrm{~d}$. per lb., lrown $39 \mathrm{~d}$. to $8 \mathrm{l}$. per 16 , and white 5 g. to $7 \mathrm{~d}$. per $1 \mathrm{~b}$. ; against $11 \frac{1}{3} \mathrm{~d}$. to 2ld. per lb. for Sea Island, and $49 \mathrm{a} d$, to $6 \mathrm{~d}$. for the current grades of Orleans.

In 1860 the total import of cotton into Europe from Turkey and other Mediterranean countries, except Egypt, was only 21,000 bales of $400 \mathrm{lb}$. In 1865 it rose to 239,000 bales, fell to 129,000 in 1867 , and rose to 207,000 in 1869 . Since 1880 it has fluctuated between 24,000 and 50,000 bales of 400 1b. During the height of the cotton famine (1863$65)$, Italy and Greece produced 100,000 to $120,(000$ bales of $400 \mathrm{lb}$., a large part of which is included in the imports of these yeans, but they do not now produce more than 10,000 bales.

The first import from Brasil arrived in 1781. In the five years $1786-90$ the receipts averaged 5000 bales of $400 \mathrm{lb}$. In thirty years they were increased tenfold; but with a plentiful supply from the United States there was little further progress during the thirty yearm ended 1850. The cotton famine led to an extensive expansion in production. In 1879 there had been a reduction to 47,000 bales; but by 1887 there was a recovery to 207,000 bales. From other places in Central and South America the imports into Great Britain in the five yeans (1883-87) from Peru fluctuated from 3,050,000 to $7,411,000 \mathrm{lb}$; from Chili, 284,000 to 1,560,000 lb. from Venezuela and other portions of South America, 310,000 to $1,549,000 \mathrm{lb}$. Mexico uses about 180,000 bales of $400 \mathrm{lb}$, of which 130,000 bales are home-grown, and 50,000 imported from the United States (44,000 bales of $456 \mathrm{lb}$.).

In their search for the increased supply of cotton requisite to meet the wants of the rapidly growing industry of a hundred years ago, the spinners of Lancashire naturally directed their eyes towards India, where the plant had been cultivated and the nanufacture carried on from time immemorial; and at their suggestion the Fast India Company imported a small parcel in 1789-about $5000 \mathrm{lb}$., which was followed by about $400,000 \mathrm{lb}$. in 1790 . The venture, however, was not satisfactory, and in 1791 the arrivals fell to about $3000 \mathrm{lb}$, and in 1792 to nothing. But high prices brought renewed supplies, and in 1880 the imports reached $6,630,000 \mathrm{lb}$., or about 16,000 bales of $400 \mathrm{lb}$. In 1790 West India cotton was selling at $12 \mathrm{~d}$. to $21 \mathrm{~d}$. per $1 \mathrm{~b}$, but in 1798 the quotation ranged from $25 d$. to $40 d$. per 1 b., in which year American was quoted at $22 \mathrm{~d}$. to $45 \mathrm{~d}$. per lb. Thence to the end of the Napoleonic wans there were very wide fluctuations (nee next page). These variations in prices led to considerable tuctuations in the imports of cotton from India, but the general tendency was in the direction of increased figures; the arrivals in $1806-10$ averaged 25,000 bales of $400 \mathrm{lb}$. per annum ; in 1816-20 they rose to nearly 94,000 bales, but in $1826-30$ fell to 55,000 bales. The large import between 1816 and 1820 became so unsaleable that 10,000 bales (Bengals) were shipped frcm London to China! Since 1830 the imports have been large or small, according to the outturn of the erops in the United States. This was especially the case prior to the American war, but the impetus given to the industry by the cotton famine incidental to that event, led to such greatly improved methols of gimning and handling the crop, that the supply from India is no longer merely supplementary to that from America. The quality is greatly superior to the imports of a quarter of a century ago, and of recent years the consumption in Europe has averaged 1,500,000 bales, against only 500,000 in 1860 , and only about 200,000 in 1850. The total crop of Indis is about $2,600,000$ bales of $400 \mathrm{lb}$, of which $1,000,000$ bales are consumed in India, and 1,600,000 bales exported. Considerable changes have taken place in the distribution of the crop during the past quarter of a century. Prior to the opening of the Suez Canal (November 1869), the bulk of the cotton received into Europe from Indin came in the first place to England. Half the imports were also spun in Great Britain; but since the opening of the canal, continental spinners have taken the bulk of their requirements direct, while the quantity consumed in England is only about one-sixth of the total consumption of Europe. These changes are set forth in the following account of the imports into Europe, and the deliveries for consumption in the years named in 1000's of bales as imported (360 lb. to $393 \mathrm{lb}$.)

\begin{tabular}{|c|c|c|c|c|c|c|}
\hline & \multicolumn{3}{|c|}{ IMPOnT-direat. } & \multicolumn{3}{|c|}{ Consumprion. } \\
\hline & Great Britain. & Continent. & Totel. & Great Britase. & Contineat. & Total. \\
\hline 361 & 886 & 13 & 900 & 848 & 488 & 770 \\
\hline 186 & 1452 & 193 & 1646 & 801 & 889 & 1660 \\
\hline 78 & 1988 & 408 & 1606 & 687 & 942 & 1699 \\
\hline 8 & 1052 & 721 & 1778 & 105 & 1188 & 1608 \\
\hline 87 & 6018 & 984 & 1602 & 200 & 1208 & 1627 \\
\hline
\end{tabular}

The variations in the two totals arise from varia- 
tions in the stocks at the end of the year. The consumption in India in 1887 was about $1,000,000$ bales, including about 700,000 to 750,000 used by mills containing machinery imported from England, and built and worked as in Lancashire.

The first import of cotton from the United States took place in 1784, and consisted of eight bags weighing about $1200 \mathrm{lb}$. Occasional small shipments had been received from the American colonies prior to this date, but they consisted chiefly of West Indian produce transhipped, and as the colonies were now independent, the eight bags just mentioned were detained by one of the customs' officials, on the ground that as West Indian produce it was a breach of the then existing navigation laws to import them in a foreign vessel. But the parcel was liberated on proof being forthcoming that the cotton was really the produce of the United States. In 1791 about 189,000 lb. were exported, but in 1792 only $138,000 \mathrm{lb}$. In 1793 Eli Whitney invented the saw-gin, and the cultivation of the plant increased so rapidly that the exports bounded from less than $500,000 \mathrm{lb}$. in 1793 to over $6,000,000 \mathrm{lb}$. in 1795 , to more than $9,000,000$ in 1798 , and to $20,000,000 \mathrm{lb}$. in 1801 , or in eight years from about 1200 bales of $400 \mathrm{lb}$. to 50,000 bales. What has since taken place is shown at a glance in the following table, which gives the erops of the various states, the total quantity exported, and the balance left for consumption and stock in various years from 1800 to 1887 , in 1000 's of bales of the uniform weight of $400 \mathrm{lb}$. :

\begin{tabular}{|c|c|c|c|c|c|c|c|}
\hline & 1800. & 1820. & 1840. & 1860. & 1870. & 1880. & 1887. \\
\hline Virginia.......... & 12 & 20 & 25 & 55 & 8 & 65 & 57 \\
\hline Tennessee....... & 8 & 45 & 60 & 297 & 182 & 372 & 828 \\
\hline North Carolina.. & 10 & 25 & 130 & 146 & 145 & 438 & 400 \\
\hline South Carolins. & 40 & 110 & 154 & 353 & 224 & 587 & 677 \\
\hline Georgia .......... & 25 & 100 & 408 & 702 & 474 & 916 & 965 \\
\hline Alabama....... & .. & 50 & 293 & 990 & 429 & 787 & 873 \\
\hline Mississippi..... & .. & 26 & 488 & 1208 & 565 & 1088 & 1080 \\
\hline Louisiana........ & $\cdots$ & 25 & 381 & 778 & 351 & 571 & 523 \\
\hline Florida ........ & . & $\cdots$ & 30 & 65 & 40 & 62 & 68 \\
\hline Arkansas........ & . & .. & 15 & 367 & 248 & 684 & 791 \\
\hline Texas............ & .. & . & $\cdots$ & 431 & 351 & 905 & 1763 \\
\hline Total crop...... & 90 & 400 & 1993 & 6387 & 3012 & 6470 & 7425 \\
\hline Exported ...... & 50 & 320 & 1653 & 4419 & 2016 & 4550 & 5130 \\
\hline Consumed ...... & 40 & 80 & 840 & 968 & 996 & 1920 & 2295 \\
\hline
\end{tabular}

The Virginian figures for 1880 and 1887 include some cotton raised in Missouri. Alabama was admitted into the Union in 1819, Mississippi in 1817, Louisiana in 1811 (purchased from France in 1803), Florida in 1845 (ceded by Spain in 1819), Arkansas in 1836, and Texas in 1845. The reduced crop of 1870 shows the extent to which the agricultural industry of the South had been thrown back by the war of 1861-65. Even in 1887 the crops of several of the states were still below those of 1860 , in consequence of the transference of labour farther west to Texas and Arkansas. Of the total increase of $1,083,000$ in 1880 over $1860,791,000$ belonged to these two states, which also figure for $1,756,000$ bales out of the $2,038,000$ increase in 1887 over 1860.

As the crops increased prices declined, especially as the cost of production was gradually reduced by improved methods of cultivation and eleaning. The cost to consumers in Europe was also dimin. ished by cheapened freights and carriage, and by other economies brought about by the competition amongst the various middlemen who had the handling of the crop from the plantations to the spindles. At the opening of the century the aver. age price of middling American was about $18 \mathrm{~d}$. per lb. In 1803 it fell to $12 \mathrm{~d}$., but in 1814 it stood at $30 \mathrm{~d}$., and during the year was as high as 36d., owing to the partial cessation of imports caused by the war. Thence (with fluctuations) the tendency was downwards until 1829, in which year the average was only 5id. Production had outrun consumption, and the stock of American cotton in Great Britain at the end of 1827 was equal to thirty. eight weeks' requirements. The low prices retarded production and stimulated consumption, and by 1835 the stock of American was reduced to only ten weeks' requirements, while the average price advanced to $104 d$. per lb. During the subsequent ten years, production again overtook consumption, and in $\mathbf{1 8 4 5}$ the stock of American in England was equal to thirty-three weeks' requirements, while the average price was only $4 \frac{1}{d} d$., after having in the course of the year touched $31 \mathrm{~d}$. per lb. These prices were repeated in 1848 owing to disturbed politics. In 1850 there was a rebound to $7 \mathrm{~d}$., but thence to 1852 a fall to $5 \frac{5}{16} \mathrm{~d}$, owing to increased crops. Thence to 1860 the average price fluctuated between 5 s. and $7 \frac{1}{\mathrm{~g}} \mathrm{~d}$., ending in $64 \mathrm{~d}$. The war between North and South eut off supplies, and prices rapidly advanced, until in 1864 the average reached $27 \frac{1}{2} \mathrm{~d}$., while as high as $31 \frac{1}{2} \mathrm{~d}$. had been touched in the course of the year. In 1865, with peace, the average fell to $19 \mathrm{~d}$., and it was thought that values would rapidly decline to the ante-war level. But the war, and the abolition of slavery incidental to it, had so thoroughly disorganised the industrial system of the Sonth, and so completely impoverished the planters, that the average price of 1860 (61d.) was not touched until 1876, while the crop of $1860(4,824,000$ bales $)$, though almost repeated in $1876(4,660,000$ bales $)$, was not actually exceeded until $1879(5,073,000$ bales). Between 1876 and 1879 the average price ranged from $6 \frac{1}{8} \mathrm{~d}$. to $6 \frac{5}{16} \mathrm{~d}$. Since then the tendency has been downwards. In 1886 it fell to $5 \frac{1}{8} \mathrm{~d}$., but in 1887 rose to $5 \frac{1}{2} \mathrm{~d}$. The decline in prices which has taken place within the past ten years has been due mainly to reduced cost of production, to diminished land and ocean freights, and to lessened intermediate charges brought about by the elimination of unnecessary middlemen, though part of the fall is, no doubt, traceable to the currency changes, which have affected values in general.

The variations in the outturn of the crops were due to climatic causes. In 1881-82 the plant suffered from severe drought; $1882-83$ was a phenomenally perfect season; 1883-85 were drought seasons; 1885-87 were average seasons; $1887-88$ was better than an average, but not so good as that of 1882-83. The 6,514,000 bales produced in 1886-87 weighed $2,970,384,000 \mathrm{lb}$. net, equal to $7,425,000$ bales of $400 \mathrm{lb}$, as given in the table above, containing particulars of the crops of each state separately.

Particulars of the extent of land planted, and of the weight of cotton produced, are given in the following table:

\begin{tabular}{|c|c|c|c|}
\hline \multirow{2}{*}{ Beswon. } & \multirow{2}{*}{$\begin{array}{c}\text { Area Planted, } \\
\text { acreas. }\end{array}$} & \multicolumn{2}{|c|}{ Pound of Cotton. } \\
\hline & & & Per nere. \\
\hline $1881-82$ & $16,711,000$ & $2,424,456,000$ & $145^{\circ} 0$ \\
\hline 1882-83 & $16,277,000$ & $8,216,320,000$ & $197 \cdot 5$ \\
\hline 1883-84 & $16,778,000$ & $2,582.728,000$ & $158 \cdot 9$ \\
\hline $1884-85$ & $17,426,000$ & $2,556,719,000$ & $146 \cdot 6$ \\
\hline $5-86$ & $18,379,000$ & $2,980,250,000$ & $162 \cdot 1$ \\
\hline-87 & $18,632,000$ & $2,970,884,000$ & $159^{\circ} 4$ \\
\hline $1887-8$ & $18,790,000$ & $8,192,735,000$ & $169 . \mathrm{g}$ \\
\hline
\end{tabular}

The production per acre varies considerably-from less than $100 \mathrm{lb}$. per acre in the poorest upland soils to $500 \mathrm{lb}$. per acre in the rich bottom lands of the south-west. The average produetion per season, for the entire cotton-growing region, has for the past seven years ranged from 145 to $197 \frac{1}{2} \mathrm{lb}$. per acre. The average for the seven seasons was $162 \mathrm{fb}$., or about one-third of a bale. The crop of 1886-87 was worth at the plantations about $£ 51,800,000$, according to the annual report of the Department of Agriculture.

The following is an account of the imports of 
cotton into all Europe (in bales of the uniform soeight of 400 (b.) in and since 1860 :

\begin{tabular}{|c|c|c|c|c|c|c|c|c|c|}
\hline & 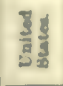 & मี่ & $\frac{5}{3}$ & 造 & 进。 & $\frac{8}{8}$ & है & $\frac{1}{3}$ & 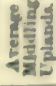 \\
\hline 1860 & 4088 & 18 & 185 & 21 & 23 & 658 & * & 4897 & $6 t$ \\
\hline 1861 & 8076 & 46 & 181 & 36 & 18 & 919 & & 4248 & $8 \%$ \\
\hline 1868 & 108 & 68 & 188 & 68 & 20 & 1010 & 2 & 1490 & $17]^{\prime \prime}$ \\
\hline 1863 & 108 & 67 & 294 & 197 & 36 & 1179 & 81. & 1947 & 237 \\
\hline 1864 & 241 & 187 & 427 & 188 & 89 & 1874 & 289 & 2686 & $27 ?$ \\
\hline 1868 & 892 & 150 & 640 & 289 & 84 & 1281 & 88 & 2860 & 19 \\
\hline 1866 & 1665 & 292 & 279 & 161 & 77 & 1706 & 18 & 4015 & 15 \\
\hline 1867 & 1659 & 820 & 305 & 189 & 108 & 1389 & 1 & 8806 & 10 \\
\hline 1508 & 1946 & 809 & 355 & 145 & 85 & 1476 & . & 4816 & 10 \\
\hline 1569 & 1583 & 881 & 858 & 207 & 92 & 1578 & .. & 4094 & 12 \\
\hline 1870 & 2946 & 217 & 879 & 186 & 70 & 1057 & 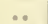 & 4218 & 9f: \\
\hline 1871 & 809 & 281 & 896 & 119 & 180 & 1381 & .. & 6719 & $80^{\circ}$ \\
\hline 1872 & 8284 & 877 & 489 & 188 & 121 & 1526 & & 4845 & $10 P_{8}$ \\
\hline 1873 & 2908 & 248 & 484 & 148 & 105 & 1155 & . & 6038 & $9^{\circ}$ \\
\hline 1574 & 3177 & 258 & 582 & 98 & 98 & 1817 & . & 5469 & 8 \\
\hline 1875 & 8112 & 216 & 652 & 88 & 69 & 1420 & . & 6467 & 78 \\
\hline $18 i 6$ & 8461 & 169 & 749 & 89 & 55 & 1134 & & 5657 & of \\
\hline 1877 & 8163 & 140 & 625 & 89 & 87 & 980 & & 4993 & 63 \\
\hline 1878 & 8006 & 68 & 468 & 51 & 78 & 818 & .. & 5818 & 61 \\
\hline 1879 & 4329 & 47 & 616 & 81 & 48 & 868 & . & 6933 & 63 \\
\hline 1880 & 4520 & 78 & 688 & 24 & 88 & 1074 & . & 6312 & of \\
\hline 1381 & 4815 & 135 & 726 & 26 & 88 & 1098 & & 6843 & 67 \\
\hline 1882 & 4457 & 106 & 597 & 88 & 82 & 1677 & .. & 6067 & 6 \\
\hline 1683 & 5104 & 164 & 620 & 84 & 80 & 1520 & & 7452 & 6 . \\
\hline 1884 & 4681 & 130 & 708 & 62 & 30 & 1658 & . & 7159 & 6 \\
\hline 1885 & 4371 & 99 & 808 & 65 & 29 & 943 & & 6815 & $5)$ \\
\hline 1886 & 5026 & 96 & 709 & 46 & 30 & 1306 & .. & 7212 & 5. \\
\hline 1887 & . 6920 & 208 & 734 & 41 & 28 & 1575 & $\cdots$ & 7915 & $6 \frac{1}{2}$ \\
\hline
\end{tabular}

Of the total quantity of cotton imported into Europe in 1860 , no less than 83.9 per cent. came from the United States. For a number of years it had averaged about 75 per cent. This virtual dependence of a vast industrial system upon one source of supply for the raw material necessary to keep its labour and machinery fully employed, had long been regarded with considerable anxiety; the more so as it was known that sooner or later a great crisis would, for a period of more or less duration, dislocate the agricultural industry of the South; but all attempts to escape from so undesirable a state of things were frustrated by the one important fact that no other cotton-producing country had been able successfully to compete with America in either quality or price. The war, by raising values to a famine level, led to a largely increased production of cotton in India, Egypt, South America, \&c.; but even after the conflict had lasted four years, scarcely half of the decrease in the imports from the South had been made up by increaserl receipts from all the world besides. The average import from America in the two years 1860-61 Was $3,566,000$ bales of $400 \mathrm{lb}$., but in $1864-65$ only 381,000 , showing a loss of $3,185,000$ bales. The average import from all other sources in $1860-61$ was 976,000 , and in $1864-65,2,366,000$, showing a gain of only 1,390,000 bales, or barely 46 per cent. of the delicit in the supply from the States. After peace had been restored, and cottonplanting at the South had been resumed, prices rapidly declined; but for ten years after the war they remained considerably above the rates current prior to 1861, and yet the import of cotton into Europe from countries other than America never exceeded $2,651,000$ bales of $400 \mathrm{lb}$. (1872), while the annual average for the ten years ended 1875 was only $2,309,000$ bales, against $2,366,000$ in $1864-65$. Between 1875 and 1880 , with a fall to ante-war prices, the imports from countries other than the United States fell to an average of only 1,767,000 bales, while those from the South rose to $3,875,000$ bales, and in 1881 the receipts from Ameriea repre. sented 70 per cent of the total imports into Europe. In 1886 the proportion was 693 per cent, and in 1887,67 per cent.

Prior to the American war, very exaggerated notions prevailed respecting the quantity of cotton produced in Indin: the current estimates being $5,000,000$ to $6,000,000$ bales of American weiglit (450 lb.), while some computations ran as high as $10,000,000$ bales. But the fret that famine prices attracted to Europe only about a million and a quarter bales per annum in the three years ebuled 1865, proved that the crop was much smaller than had previously been calculated upon, and the investigations and inquiries made by the govern. ment in 1867-68 showed that the annual yield could not at any time have exceeded 24 to 24 million bales of $400 \mathrm{lb}$. The consumption of cotton goorls in India is about $2 \mathrm{~b}$ 1b. per leaul per annum, or a total of $650,000,000 \mathrm{lb}$. for a population of $260,000,000$. In the three years ended 1887 , the weight of goods and yarm imported into India averaged $390,000,000 \mathrm{lb}$., of which about $70,000,000$ lb. were re-exported, leaving $320,000,000 \mathrm{lb}$. for consumption. The consumption of native-made gords would therefore be alout $330,000,00011$. This item, added to $90,000,000 \mathrm{lb}$. Indian yarn and goods exported, and $550,000,000$ raw cotton exported, gives a total of $970,000,000 \mathrm{lb}$. as the probable extent of the cotton crop in 1885-87. This calculation cannot be far astray inasmuch as the area under cotton did not exceed $14,000,000$ acres, which at $70 \mathrm{lb}$. per acre (the estimated average yield) gives a total of $980,000,000 \mathrm{lb}$., or $2,450,000$ bales of $400 \mathrm{lb}$.

No cotton was received from China (except occasional small samples) until prices had risen to about 2s. per $1 \mathrm{~b}$., and even this extravagant figure brought to Europe only 380,000 bales of $400 \mathrm{lb}$. dur. ing the four years of the famine, a proof that the cotton crop of China is much smaller than even that of India. Assuming the consumption of cotton fabrics to be at the rate of $2 \frac{1}{2} \mathrm{lb}$. per head, and allowing for yarns, goods, and raw cotton imported, the crop cannot exceed 1,500,000 bales of 400 lb. A similar calculation for Japan, Java, \&c., gives a crop of 130,000 bales.

Small imports of cotton are received every year from $A$ frica, but they rarely exceed a few hundred bales. The plant is cultivated throughout the continent, and if the per capita consumption averages only half that in India and China, the $200,000,000$ inhabitants will require $250,000,000 \mathrm{lb}$. of cotton fabrics; but as $100,000,000 \mathrm{lb}$. of goods are imported, the crop required would be only $150,000,000 \mathrm{lb}$., or 375,000 bales of $400 \mathrm{lb}$.

The crops of the various countries and districts of the world in 1887 were, as nearly as can be ascertained, as follows (in bales of the uniform weight of $400 \mathrm{lb}$.) :

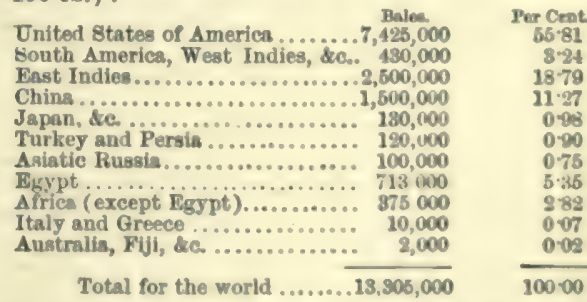

It will be observed that the United States produce more than half the cotton grown in the world, although they only commenced the business about one hundred years since.

(4) Consumption. - Great Britain.-It is not possibie to ascertain with certainty the finst beginnings of the trade in Europe. It existed in Spain in the loth century, and no doubt quite as early in Italy and Greece. The first reconded import of cotton into England was in the 13th century, and quite as early imports took place into France through Marseilles. The first mention of the industry in connection with Germany, Holland, and Switzer- 
land was in the 16th century, and in Russia in the 18th. But until the close of the last century, the cotton used was either for candle wicks or for mixture with flax or wool. The first piece of Britishmade calico-i.e. a fabric all cotton-was produced in 1783. Prior to that date cotton-yarn had been used for weft only, the warp being supplied by flax or wool. Hargreave's 'spinning-jenny' (invented 1764, patented 1770) could not produce a yarm strong and hard enough for warp; but this difficulty was overcome by Arkwright's ' water-frame' (spinning by rollers), brought out in 1769 , and further improved in 1775. Hargreave's 'spinningjenny', was virtually superseded by Crompton's 'mule' (so called from the circumstance that it combined the principles of both Hargreave's and Arkwright's inventions), patented in 1779. It was also called the 'muslin-wheel,' because it produced a finer and more uniform yarn than was possible by either the 'jenny' or the 'water-frame.' Up to the date of Crompton's invention, the progress of the industry had been very slow; the import of cotton in that year being only about $6,000,000 \mathrm{lb}$, against nearly $4,000,000 \mathrm{lb}$, in 1764 , and nearly $3,000,000$ 1b. in 1751. In 1785 Arkwright's patents, which comprised improvements connected - with carding, drawing, roving, and spinning, were thrown open, and the industry at once advanced by leaps and bounds - the import of cotton reaching $18,000,000$ lb. in 1785 , and $31,000,000 \mathrm{lb}$. in 1790 , or 45,000 bales of $400 \mathrm{lb}$., and 77,000 bales respectively. There was now a plethora of yarn, but this was overeome by improvements in weaving. Dr Cartwright invented the power-loom in 1785, and added to its utility in 1787 . These were the first improvements since Kay's 'fly-shuttle' (1738) and 'dropbox' (1760). Between 1790 and 1797 the ery was for more cotton; prices advancing from a range of $12 \mathrm{~d}$. to $22 \mathrm{~d}$. per $1 \mathrm{~b}$. to one of $25 \mathrm{~d}$. to $40 \mathrm{~d}$. The spinners looked to India, but the invention of the 'saw-gin' in 1793 brought relief from America, and the import in 1800 reached $46,000,000 \mathrm{lb}$. In the meantime Bell had invented 'cylinder printing' (1783), which enabled one man and a boy to do the work of 100 men and 100 boys; and in the same year oxymuriatic acid was first applied to bleaching, whereby work which had previously taken up several months could now be done in a few days. Watt's steam-engine was invented in 1769 , improved in 1781, and first used in connection with cotton-spinning and manufacturing in 1785 . Vast improvements have been made upon the original inventions of Arkwright, Crompton, and Cartwright during the present century; but the improvements in spinning were for many years much more rapid than those in weaving. The 'self-acting mule' was brought out by Messrs Sharp \& Roberts in 1825, and further improved in 1830 , about which time, too, considerable improvements were made in the 'water-frame:' but in the lastnamed year there were still only about 80,000 power-looms at work against about three times the number of hand-looms. In 1841, however, Messrs Kenworthy \& Bullough brought out a power-loom, which, while reducing the labour of the weaver nearly one-half, produced a greater quantity, as well as an improved quality of eloth. Still further improvements have since been made, all tending towards augmented outturn and diminished cost of production. Hargreave's first ' jenny' contained only 8 spindles, but the number was increased by degrees until it reached 120 . At the opening of the present century the 'mule' contained about 200 spindles; it now contains from 1000 to 1200 , while within quite recent times the speed at which the spindles run has been increased from 7000 revolutions per minute to 10,000 revolutions. Fifty years since the speed of the loom varied from 90 to 112 picks (throws of the shuttle) a minute; now it ranges from 180 to 200 picks a minute, and in some instances still more. At the Oldham Exhibition there was shown a light calico loom capable of running as high as $\mathbf{4 0 0}$ picks per minute.

The leading economical results of the inventions of a century ago, and of the subsequent improvements are briefly set forth in the following table, which gives the weight of cotton consumed in Great Britain, the weight of yarn, and the quantity of piece-goods exported in millions of $1 \mathrm{bs}$. and yards, and the value of all kinds of cotton products exported in various years, commencing with 1779, the year in which Crompton's 'mule' was brought out, followed by 1785 , the year in which Arkwright's patents were thrown open. Figures in millions of lbs., yards, and $E^{\prime}$ ' :

\begin{tabular}{|c|c|c|c|c|c|c|c|}
\hline \multirow[t]{2}{*}{ Tears. } & \multicolumn{2}{|c|}{$\begin{array}{c}\text { Cottnn } \\
\text { Consumed. }\end{array}$} & \multicolumn{2}{|c|}{$\begin{array}{c}\text { Yarn } \\
\text { Exported. }\end{array}$} & \multicolumn{2}{|c|}{$\begin{array}{l}\text { Piece-goods } \\
\text { Exported. }\end{array}$} & $\begin{array}{l}\text { Value of all } \\
\text { kinds Cotton } \\
\text { Products } \\
\text { exported. }\end{array}$ \\
\hline & th. & $\begin{array}{l}\text { Average } \\
\text { per } 1 \mathrm{~b} .\end{array}$ & 1b. & $\begin{array}{l}\text { Average } \\
\text { per llb. }\end{array}$ & Yarils. & $\begin{array}{l}\text { A verage } \\
\text { per yd. }\end{array}$ & \\
\hline 1779 & 6 & 18 & .. & .. & .. & क. & 0.8 \\
\hline & 11 & 20 & $\ldots$ & .. & .. & .. & 0.8 \\
\hline & 30 & 17 & .. & .. & & .. & $1 \cdot 6$ \\
\hline 1800 & 52 & 18 & 5 & $\ddot{\theta}$ & 77 & & 5.8 \\
\hline 1820 & 120 & $11 \frac{1}{6}$ & 23 & $29 \mathrm{~A}$ & 351 & 129 & 16.5 \\
\hline 1840 & 469 & 6 & 118 & $14 \frac{3}{8}$ & 790 & 445 & $24 \cdot 6$ \\
\hline 1860 & 1084 & 67 & 197 & 12 & 2776 & 3. & 52.0 \\
\hline 1880 & 1373 & 6) & 215 & 132 & 4474 & 8) 18 & $75 \cdot 5$ \\
\hline 1887 & 1487 & $5 \frac{1}{3}$ & 252 & $10 \frac{4}{8}$ & 4904 & $28^{8}$ & 70.9 \\
\hline
\end{tabular}

The complete particulars from 1779 to 1800 are not obtainable. The average price of cotton is for West Indian from 1779 to 1790 ; but for 1800 and since it is for middling American. The value of goods, \&c. exported from 1779 to 1800 is the 'official 'value; since then, the real or declared value. The average prices of yarn and goods exported are those of the Board of Trade. The effect of the continued improvements in machinery is shown still more strikingly in the following statement of the cost at various dates of producing yarn of forty hanks to the pound. The first line of figures represent the selling-price of the yarn, the second the cost of the cotton used ( $18 \mathrm{oz}$. in weight), and the third the balance left for labour and capital :

\begin{tabular}{|c|c|c|c|c|c|}
\hline 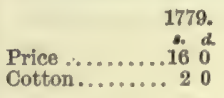 & $\begin{array}{rl}1784 & \\
10 & d \\
2 & 0\end{array}$ & 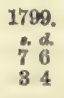 & $\begin{array}{ll} & \\
8.2 . & \\
2 . & 6 \\
2 & 6 \\
1 & 6\end{array}$ & $\begin{array}{ll}1830 . \\
3 & 2 \\
1 & 2 \frac{1}{1} \\
0 & 71\end{array}$ & 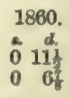 \\
\hline abour, \&c.... & 811 & 12 & 10 & 0 & 0 \\
\hline
\end{tabular}

The cost of weaving has also been vastly reduced. A species of calico selling at $6 \mathrm{~s}$. per yard towards the close of the last eentury ean now be had for as many pence! The decline in the price of calicu since 1815 is greater in proportion than the fall in the price of yarn : 40 's yarn, for instance, is only worth about one-third the price current in 1812 , but calico is not worth more than one-sixth or oneseventh.

The rapid increase in consumption between 1785 and 1790 was due to the spread of Crompton's and Arkwright's inventions. The great increase in the volume of trade, and the material decline in the prices of yarn and piece-goods, between 1820 and 1840, was owing chiefly to the invention of the 'self-acting mule." The still more important developments between 1840 and 1860 were due chiefly to the improvements in the power-loom, but in a great measure also to the opening up of the trade with China. The progress made in the export branch of the industry is shown more fully in the following account of the shipments of piecegoods and yarn from Britain to the leading districts of the world at various periods from 1820 onwards, in millions of yards and $\mathrm{lbs}$. 


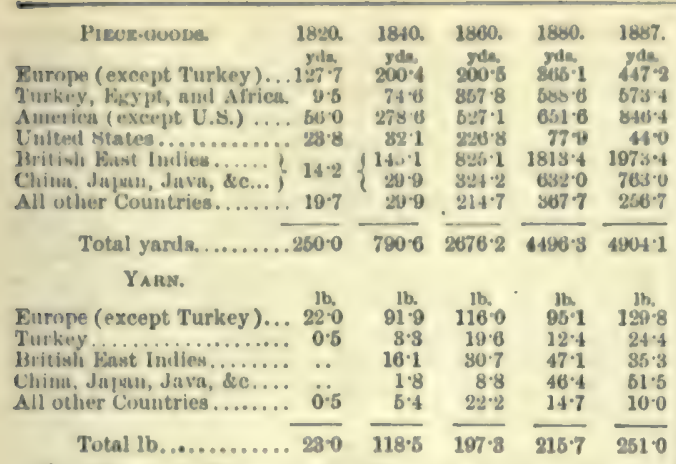

Continental Europe was the principal outlet for both goots and yarn in 1820, and is so still in respect of yarn. Next followed Ameriea. There was a considerable incrense in the exports to both districts between 1820 and 1840 , but between 1840 and 1800 the business with the Continent was almost stationary, owing to the large inerease in domestic cotton industries of the various countries. The trade with the United States increased considerably down to 1860 , but since then the highly protective tariff introduced during the war has reduced the business to an insigniticant compass. The low prices brought about by diminished cost of production (1840 to 1860 ) led to a large increase in the trmie with Turkey, and there has since been an almost constant, though more gradual, movement in the same direction. One hundred years ago, about the time when Arkwright's patents were thrown open, Manchester complained loudly of the injurious conipetition of calice imported from India, and from time to time the duties were increased. About fifty years later (1831) the manufacturers and dealers of Bengal asked for the removal of these duties, on the ground that the native industry was being seriously injured by the import of cotton fabrics from England, although the shipments from this side had not yet assumed important proportions. Even in 1840 they were only 145 million yards, but in 1860 they reached 825 million yards, thanks to the improvements in the power-loom already mentioned. The same circumstance, and the opening of the ports in $1841-42$, led to a similar expansion in the trade with China. Since 1869 (except the temporary interruption occasioned by the cotton famine), the business with the East has been largely augmented, and now more than half the piece-goods and more than one-third of the yarn exported from Great Britain go to India and China.

'ilue following statement gives the weight of yarn produced, number of spindles at work, number of hands employed, and the production per spindle and hand in Great Britain, at various dates:

\begin{tabular}{|c|c|c|c|c|c|}
\hline & Yan & Spindles at & Hand & Prodee & on pe \\
\hline & $\begin{array}{c}\text { Produesd. } \\
\text { Ib. } \\
106,500,000\end{array}$ & $\begin{array}{c}\text { Work. } \\
\text { No., } \\
7,000,000\end{array}$ & $\begin{array}{c}\text { Eunployed } \\
\text { Non } \\
110,000\end{array}$ & $\begin{array}{l}\text { Sylndis. } \\
\text { ib. } \\
\mathbf{1 5 2}\end{array}$ & $\begin{array}{l}\text { Hin } \\
\text { Ib. } \\
96\end{array}$ \\
\hline & $210,500,000$ & $10,000,000$ & 140,000 & 210 & 154 \\
\hline & 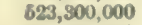 & 19 & 19 & & \\
\hline & 00,000 & Do, & 248 & $80^{\circ} 0$ & \\
\hline$B-8$ & $1,415,000,000$ & $48,000,000$ & 245,000 & 827 & 00 \\
\hline
\end{tabular}

A portion of the yarn produced is exported; the balance is woven into piece-goods. The particulars compare as follows:

\begin{tabular}{|c|c|c|c|c|c|}
\hline & Boods & Looms & Banda & \multicolumn{2}{|l|}{ Prodes } \\
\hline 181 & $\begin{array}{l}\text { Produced. } \\
1 \mathrm{~b} . \\
80.620 .000\end{array}$ & $\begin{array}{l}\text { at Work. } \\
\text { No, } \\
\text { 2025,000 }\end{array}$ & $\begin{array}{l}\text { Eusployed. } \\
\text { So. } \\
250.000\end{array}$ & $\begin{array}{l}\text { Loom } \\
\frac{\mathrm{m}}{885}\end{array}$ & $\begin{array}{c}\text { Band. } \\
\text { ih. } \\
849\end{array}$ \\
\hline 18 & $\begin{array}{r}80,020,000 \\
142,000,000\end{array}$ & 805,000 & 275,000 & 470 & 821 \\
\hline $2844-46$ & $848,110,000$ & 282,000 & 210,000 & 1234 & 1681 \\
\hline $2-61$ & $660,870,000$ & 400,000 & 208,000 & 1627 & 820 \\
\hline $18=6-87$ & $1,162,000,000$ & 580,000 & 265,000 & 2003 & 1559 \\
\hline
\end{tabular}

There were 240,000 hand-looms and 15,000 powerlooms at work in 1819-21; 225,000 and 80,000 respectively in $1829-31$; and 60,000 and 220,000 137

rexpectively in 1844-46. In 1850-61 the hand-loom had practically dissappeared.

The factory returns for $184^{5}$ gave the number of spindles in the United Kingdom as only $44,348,521$ agrainst $44,208,690$ in 1878 , of which $40,121,451$ rgainst 39,527,920 were spinning-npindles, but tlome figures were defective. The number of mpinningmpindles actually in existence was certainly litte if any less than $43,000,000)$, as alsout $3,(000,(000)$ had been put up in the Oldham district alone hetween 1878 and 1885. The number of looms is stated as 560,000 , but this is also too small. In 1888 it was said by those in the trade that about 600,000 were at work, and 580,000 is a fair estimate for 1886-87. The eapital employed in the industry may be stated as follows:

43,000,000 spinning - spiniles and $5,000,000$
doubling-spindles. Protuale cost 24s. per doubling-spindles. Probable cont 24s. per
spindle, present value abriut 1ss. per spindle, \& $\& 8,200,000$ 880,000 looms. Probable cost $\mathbb{E 2 4}$ each, present value about $£ 20$ each.

$11,600,000$

Foating capital requisite to carry on the busines. $25,000,000$ Capital employed in printing, bleaching, and other works.

$18,000,000$

Capital employed in the manufacture of coston. lace, and hosiery.................... 7,000,000 Total.................... $\overline{\text { el04,800,000 }}$

According to the census tables for 1881 there were 686,000 operatives and others employed in the cotton industry. In 1889 there were about 700,000 . The average rate of wages is about $\mathfrak{£ 4 2}$ per annum, or a total of $£ 29,400,000$. The amount paid for raw cotton in 1887 was $£ 34,460,000-$ viz $1,486,855,000 \mathrm{lb}$. at $5 \frac{1}{6} \mathrm{~d}$. per $1 \mathrm{lb}$. The value of all kinds of cotton products exported was $£ 70,957,000$, and the value of the produets consumed at home $£ 30,440,000$. These figures compare as follows with those for 1859-61 :

1859-61.

Value of products exported.......... $449,029,000$

Value of home consumption......... 27,971,000

Total value of products . . . . .... $877,000,000$

$\begin{array}{ll}\text { Paid for cotton. . . . . . . . . . . . . . . . . . } & 29,290,000 \\ \text { Paid for wages ................. } 20,995,000\end{array}$

Total as above. .

$277,000,000$ Balance for all other exp. and profits $26,715,000$

1887.

$\mathbf{2 7 0}, 957,000$

$80,440,000$

$\overline{\varepsilon 101,597,000}$

$84,460,000$

$29,400,000$

97,587,000

$\overline{\mathbf{e 1 0 1 , 9 9 7 , 0 0 0}}$

Taking into consideration the persons employed in the building of the mills and making of the machines, and in the buying and selling of the raw and manufactured articles, it will be found that something like 4 to 5 million individuals are dependent upon the prosperity of the cotton trade for their livelihood.

The earnings of the work-people have upon the whole steadily increased from year to year. The following table furnishes the rates current in 1839 , 1849,1859 , and 1887 . It will be obeerved that the proportionate advance during the last-mentioned period was on an average much greater in the lowest than in the highest paid hands

\begin{tabular}{|c|c|c|c|}
\hline \multicolumn{4}{|c|}{ AVERAGE WEEKLY WAGE } \\
\hline \multirow[b]{2}{*}{ Cariting Department - } & \multicolumn{2}{|c|}{$\begin{array}{c}1849.1860 . \\
60 \text { Hours }\end{array}$} & $\begin{array}{l}1887 . \\
\text { s6t Hours. }\end{array}$ \\
\hline & a. 2 & 2. 2 & $=2 \quad 2<$ \\
\hline Seutchers (1)...... & 76 & 80 & 180 to 150 \\
\hline 8tripuers (2)..... & 120 & 140 & $168 \sim 10$ \\
\hline Overioukers........ & & & 280 " 60 \\
\hline \multicolumn{4}{|l|}{ Mule-Spinuing- } \\
\hline Minders .......... & 180 & 200 & 280 " 400 \\
\hline Piecers (8)........ & 90 & 10 & 110 " 20 \\
\hline Overlookers ...........200 0 & 980 & 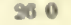 & 280 n 670 \\
\hline \multicolumn{4}{|l|}{ Throutle Spluning - } \\
\hline Spinners (4) $\ldots \ldots \ldots \ldots 40$ & 46 & 80 & $90 \div 14$ \\
\hline (women)... & 76 & 90 & $140 " 20$ \\
\hline Overlookers........... & 500 & 240 & 200 " 550 \\
\hline \multicolumn{4}{|l|}{ Weaving- } \\
\hline Winders (\$) ....... & 96 & 06 & $100 * 20$ \\
\hline Sizers (nen) ..........280 & so 0 & 250 & $800 " 45$ \\
\hline Three-loom weavers $(6) .180$ & 130 & 150 & $160 * 19$ \\
\hline toom " & 160 & 190 & 200 " 25 \\
\hline Six-loom & . & 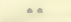 & 290 " 82 \\
\hline
\end{tabular}
AVERAGE WEEKLY WAGES. 1889. 1849.1860 60 Hours 7680 190140 980280 180200

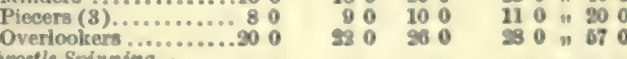
Spunners (4) $46 \quad 80$

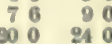
140 i 0 Overlookers .............180 nementera $(6) .180$ (4) girls 14 to 18 years: (6) young women; (6) wounen and wen 
The average rate of wages paid in 1887 was about 80 per cent. more than in 1839,69 per cent. more than in 1849 , and 55 per cent. more than in 1859 . In the meantime, the hours of labour have been reduced from 69 per week to 56 s per week.

Continental Europe.-Up to within about fifteen years from the close of the last century, the quantity of cotton consumed on the Continent was certainly larger than the weight spun in England; but at the close of the century, thanks to the mechanical inventions to which reference has already been made, England unquestionably stood first. Severe penalties were inflicted upon any one found guilty of either enticing cotton operatives or of exporting cotton machinery to foreign countries. Nevertheless, both operatives and machinery found their way to various portions of the Continent ; and cotton-spinning on the English plan was introduced into Russia in 1799 , Switzerland in 1800, Belgium in 1801, and France in 1803. Germany, Holland, Spain, Italy, and Austria followed later on. Between 1801 and 1821 France increased its consumpt from 42,000 bales (of $400 \mathrm{lb}$.) to 80,000 , and the rest of the Continent from 33,000 to 80,000 .

The chief increase on the Continent between 1811 and 1821 was gained after the peace of 1815 . The consumption in France in 1816 was only about 65,000 bales. France held the lead on the Continent until the war of 1870 , since which she has been passed by Russia and Germany. The following table shows the progress made by each country since 1830. It gives the consumption of cotton in the years named in 1000 's of bales of the uniform weight of $400 \mathrm{lb}$. each.

\begin{tabular}{|c|c|c|c|c|c|c|c|}
\hline Countries. & 1830. & 1840. & 1850. & 1800. & 1869. & 1880. & 1886. \\
\hline Russia.......... & 10 & 36 & 119 & 218 & 243 & 550 & 660 \\
\hline Sweden.......... & 2 & 4 & 20 & 40 & 40 & 62 & 70 \\
\hline Germany ........ & 40 & 66 & 115 & 850 & 367 & 715 & 890 \\
\hline Austria ........ & 50 & 85 & 145 & 235 & 240 & 350 & 460 \\
\hline Switzerland.... & 22 & 45 & 60 & 76 & 98 & 122 & 130 \\
\hline Holland........ & 5 & 10 & 12 & 16 & 24 & 50 & 60 \\
\hline Belgium ......... & 20 & 40 & 55 & 72 & 88 & 125 & 130 \\
\hline France......... & 170 & 291 & 350 & 565 & 650 & 500 & 600 \\
\hline Spain .......... & 15 & 35 & 85 & 130 & 125 & 220 & 275 \\
\hline Italy. . . . . . . . . . & 10 & 20 & 40 & 65 & 66 & 160 & 260 \\
\hline Total. & 344 & 632 & 1001 & 1767 & 1841 & 854 & 35 \\
\hline
\end{tabular}

The large increase between 1840 and 1850, especially in Russia, was partly due to the repeal (1843) of the enactment which prohibited the export of cotton machinery from this country. The figures for 1869 are given instead of those for 1870 , because the movements of trade in the last-named year were disturbed by the Franco-German war. The small general inerease between 1860 and 1869, compared with that in the previous decade, was due to the cotton famine incidental to the American war. In 1871, 1,500,000 spindles (those of Alsace) were transferred from France to Germany. This accounts for the decrease in the quantity of cotton consumed in France in 1880 as compared with 1869 , and for part of the exceptionally large increase in quantity consumed in Germany. The total number of spindles in France in 1869 was $6,120,000$; in 1870 , $4,620,000$. As less than $1,600,000$ people had been transferred along with the $1,500,000$ spindles, the $4,620,000$ remaining spindles had to supply yarn

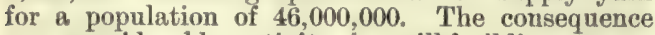
was considerable activity in mill-building or enlarging, and by 1872 the number of spindles had increased to $5,011,000$. During the subsequent ten years there was very little change, except the substitution of new for old spindles, which enabled the spinners to turn off a greater weight of yarn. In 1884 there were in France 5,111,000 spindles, of which 227,000 were idle, against $5,011,000$ and 385,000 respectively in 1872 . The number at work in 1884 was $4,884,000$ against $4,626,000$ in 1872 . The cotton industry of Switzerland has been almost stationary of late years, owing to the adverse influ. ence of foreign competition and hostile tariffs, and there are no more spindles at work than there were ten years ago, while the number in existence is smaller owing to mills burned down not having been rebuilt. The figures for Italy are exclusive of cotton grown in Italy itself, of the extent of which there are no authentic records. The quantity has been quite small, however, during the past fifteen years. Besides the countries mentioned above, there are about 24,000 bales of $400 \mathrm{lb}$. used in Portugal, and about 18,000 bales spun in Greece.

The following is a statement of the number of spindles and the weight of cotton spun in each country in 1886 :

\begin{tabular}{|c|c|c|c|}
\hline Conntry. & Nuraber of & \multicolumn{2}{|c|}{ Cotton Consumed. } \\
\hline & Spindles, & & Per Epindle. \\
\hline Russia ............... & $4,400,000$ & $264,000,000$ & $60^{\circ} 0$ \\
\hline Sweden................. & 320,000 & $28,000,000$ & $87 \cdot 5$ \\
\hline Germany............. & $5,150,000$ & $356,000,000$ & $69 \cdot 1$ \\
\hline Austria........... & $2,085,000$ & $184,000,000$ & $88 \cdot 2$ \\
\hline Switzerland.. & $1,850,000$ & $52,000,000$ & $28 \cdot 1$ \\
\hline Holland............... & 260,000 & $24,000,000$ & $92 \cdot 3$ \\
\hline Belgium ............ & 840,000 & $52,000,000$ & $61 \cdot 9$ \\
\hline 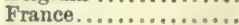 & $4,900,000$ & $240,000,000$ & $48 \cdot 9$ \\
\hline ............ & $2,085,000$ & $110,000,000$ & $54 \cdot 0$ \\
\hline Portugal ............. & 140,000 & $10,000,000$ & $71 \cdot 4$ \\
\hline Italy................ & $1,210,000$ & $104,000,000$ & $85 \cdot 1$ \\
\hline Greece............... & 65,000 & $7,150,000$ & $110 \cdot 0$ \\
\hline Tota1.......... & 0 &, 000 & 011 \\
\hline
\end{tabular}

The Russian figures are exclusive of cotton received from Asia, estimated at 100,000 bales of $400 \mathrm{lb}$. per annum. The variations in the average weight of cotton per spindle are occasioned by the differences in the counts of yarn spun, or in the number of hours worked per day. Switzerland consumes only a small weight of cotton per spindle because she produces very fine yarns, similar to those spun at Bolton.

America.-The first cotton-mill built in the United States was put up in 1793 . Others followed at short intervals, but the progress was not very rapid until during the war of 1812-14, which led to such an extraordinary rise in prices, that cotton goods similar to those which had been imported from England at 20 cents per yard rose to 75 cents per yard. This stimulated mill-building to such an extent, that when the war was over, and importations resumed, prices fell back to a lower point than ever, and the new domestic industry suffered so severely that an agitation was at once com: menced in favour of increased import duties. Hitherto the tariff on imported textiles had been only from $7 \frac{1}{2}$ to 10 per cent. ; but in 1816 the duties were raised all round to 25 per cent, and henceforth the protected industry made rapid progress: the consumption of cotton advancing from 80,000 bales of $400 \mathrm{lb}$. in 1820 , to 340,000 in 1840 , and 968,000 bales in 1860 . Thence to 1870 there was only a slight increase; the quantity consumed in that year being only 996,000 . In 1880 it reached $1,920,000$ bales; and in $1887,2,795,000$ bales. The census returns of 1880 gave the amount of capital employed in the cotton manufacturing industry as $\$ 41,756,000$, including $£ 3,533,000$ in the South ; the number of spindles as $10,678,516$, including 583,696 in the South; the number of looms as 227,156 , including 12,194 in the South. In 1887 there were $13,500,000$ spindles in the States, including $1,225,000$ in the South. The consumption of cotton represented 30 per cent. of the crop against about the same in 1880 , but against only 18 per cent. in 1860 , and 17 per cent. in 1840. The New England manufacturers have hitherto been unable successfully to compete with the old country in the outside markets of the world; the value of the entire exports of cotton products in 1887 being only $£ 2,986,000$, against $£ 1,996,000$ in $1880, £ 757,000$ in $1870, £ 2,187,000$ in $1860, £ 947,000$ in 1850 , and $£ 710,000$ in 1840 . 
The cotton industry of Canada has recently gained in importance. The consumption in 1887 was sbout 80,000 bales of $400 \mathrm{lb}$, against about 40,000 bales in 1881 , and only about 15,000 bales in 1877. There are alout 300,000 syindles at work. The consumption of cotton in Mexico in 1887 was about 130,000 bales of $400 \mathrm{lb}$., and there were about 500,000 spimlles at work. The native consumption of Brazil and other parts of South America is estimated at about 100,000 bales of $400 \mathrm{lb}$., but it probably exceeds this figure.

Asia.-One hundred years ago Lancashire complaines that her then new iudustry was being injured by the competition of goods imported from India ; fifty years later Indian manufacturers complained of the injurions influence of imports from England; and now Lancashire is once more in fear of the competition of India ; not on account of imports into England (these, so far, being only slight), but on account of the extensive shipments of Indian-spun yarn and Indian-made goods to China, Japan, and other markets in the East. This competition is only of recent growth, and has arisen from the extensive erection of cotton-mills in Bombay and elsewhere, on the Lancashire plan. In 1861 there were only 338,000 spindles at work in all Indin, and as late as 1874 the number was only
593,000 ; but there are now $2,420,000$ at work. The movements for the past eleven years, as shown in the figures for 1877,1882 , and 1887 , compare an follows :

\begin{tabular}{|c|c|c|}
\hline $\begin{array}{c}1877 \\
.88,600,000\end{array}$ & $\begin{array}{c}1882 \\
154,400,000\end{array}$ & $\begin{array}{c}1887 . \\
28,390,000\end{array}$ \\
\hline Yarn exported, ib.......8 8,706,000 & $88,280,000$ & $01,808,000$ \\
\hline Gensls exporteai, yards. $18,54,000$ & $28,(600,000$ & $63,405,000$ \\
\hline Weight of exports, 1b. ..11,906,000 & 89.211 .000 & $102,465,000$ \\
\hline
\end{tabular}

In arriving at the total weight of yarn and goods exported, it is assumed that 5 yards of goodis are equal to $1 \mathrm{lb}$. of yarn.

The cotton crop of China, as already stated, is about 1,500,000 bales of $400 \mathrm{lb}$. The wliole is con. sumed at home, along with about 100,000 bales imported from India. Japan produces about 100,000 bales, of which only trifling quantities are exported. Japan is imitating Bombay, and there are now about 200,000 spindles at work. Of these, 120,000 were put up in 1888 .

Recapitulation.-The following statement shows the relative importance of the cotton industries of Great Britain, continental Europe, the United States, and India, as exhibited in the quantity of cotton consumed in each of the various seasons named since that of $1860-61$, in $1000^{\prime} \mathrm{s}$ of bales of $400 \mathrm{lb}$ : :

\begin{tabular}{|c|c|c|c|c|c|c|c|c|c|c|c|c|c|c|}
\hline \multirow[b]{2}{*}{. } & \multicolumn{2}{|c|}{$1800-11}$. & \multicolumn{2}{|c|}{$1802-69}$. & \multicolumn{2}{|c|}{$1870-72}$. & \multicolumn{2}{|c|}{$1876-77}$. & \multicolumn{2}{|c|}{ 1882-es. } & \multicolumn{2}{|c|}{ 1888-87. } & \multicolumn{2}{|c|}{$1537 \times 2}$. \\
\hline & Bales. & $\begin{array}{c}\text { Pex } \\
\text { cont. }\end{array}$ & Bales. & $\begin{array}{c}\text { Pex } \\
\text { cent. }\end{array}$ & Balea. & $\begin{array}{c}\text { Pox } \\
\text { cent. }\end{array}$ & Bales. & $\begin{array}{c}\text { Por } \\
\text { cent. }\end{array}$ & Balea. & $\begin{array}{c}\text { Pert } \\
\text { cent. }\end{array}$ & Inles. & $\underset{\text { Peat. }}{\text { Per }}$ & Bales. & $\begin{array}{l}\text { Per } \\
\text { enent. }\end{array}$ \\
\hline Grest Britain. .... & 2814 & $48 \cdot 3$ & 1161 & $49 \cdot 2$ & 3013 & $48 \cdot 8$ & 3182 & $42 \cdot 8$ & 8770 & $37 \cdot 7$ & 3691 & $35 \cdot 2$ & 3841 & $85 \cdot 2$ \\
\hline Continent ......... & 1723 & 818 & 782 & $81 \cdot 0$ & 1962 & $81 \cdot 7$ & 2460 & 88.0 & 8487 & $84 \cdot 4$ & 8640 & $84 \cdot 7$ & 3770 & 246 \\
\hline United states..... & 1009 & 187 & 435 & $18 \cdot 4$ & 1116 & 181 & 1571 & $21 \cdot 1$ & 2360 & 23.6 & 2448 & $23 \cdot 8$ & 2528 & $23 \cdot 2$ \\
\hline India. ........... & 65 & 12 & y2 & $1 \cdot 4$ & 87 & 1.4 & 281 & 81 & 481 & 4.8 & 710 & $6 \cdot 8$ & 771 & 70 \\
\hline
\end{tabular}

The figures for 1862-63 are inserted as showing the effect of the American war. As respects the general movement, Great Britain held her own between 1860-61 and 1870-71; but since then her competitors have made relatively and positively much greater progress, but so far without encroaching upon our export trade. The diminished consumption in Great Britain in 1886-87 as compared with 1882-83 was due partly to 'short-time' in the summer, and partly to the circumstance that the American crop was less wasty than that of 1882-83. The increased production on the Continent is almost entirely consumed at home, and is due partly to the improved economical condition of the people, and partly to the cireumstance that cotton gools are overtaking linens and woollens. The increased production in the United States is also mostly consumed at home. Lancashire's only formidable competitor in the ontside narkets of the world is India, but even in this respect nothing serious has yet taken place. The increase in the Indian mills has, so far, been chiefly at the expense of the old native hand industry, which is rapidly disappearing.

A recapitulation of spindles compares as follows :

\begin{tabular}{|c|c|c|}
\hline Great Britain........80,300,000 & $\begin{array}{l}1877 \text {. } \\
89,500,000\end{array}$ & $\begin{array}{c}1887 \\
43,000,000\end{array}$ \\
\hline $.10,000,000$ & $19,600,000$ & $28,750,000$ \\
\hline United States....... $6,000,000$ & $10,000,000$ & $18,600,000$ \\
\hline lia.............. 848,000 & $1,280,000$ & $2,400,000$ \\
\hline - & $70,350,000$ & $0 x, 000,0$ \\
\hline
\end{tabular}

Cotton-seed Oil. - Pulp is now made from cotton stalks, and converted into the finest writing-paper, an enormous saving of waste being thus effected. Cotton seed is remarkably rich in oil, now used for a variety of purposes. The crop of cotton seed in the United States amounts to about $3,500,000$ tons. The bulk of this is returned to the ground. In 1887 about 500,000 tons were crushed at the oil-mills of the United States-produeing 175,000 tons of cake, 75,000 tons of oil, and 6250 tons of linters (the short fibres left on the seed after ginning); the remaining 243,750 tons being waste. The total cotton-oil product is estimated at from $15,000,000$ to $17,000,000$ gallons, most of which is consumed in the manufacture of lard, which it is said to equal for culinary purposes. Cottonseed cake or meal is especially rich in nutritious matter for farm-stock, causing cattle to fatten rapidly, and producing very rich milk (though the butter is not improved). Boiled cotton seed with hay or straw is admirable feeding. The seed is worth in America about £4, 108. per ton; the oil, 1s. 3d. per gallon ; the cake, f3, 10s. per ton; and the linters, $2 \mathrm{~d} \mathrm{~d}$. per $\mathrm{lb}$. A bont 300,000 tons of Egyptian cotton seed are crushed in Great Britain per annum.

The Cotton Famine.-The American civil war broke out in 1861, and in 1862 our import of cotton fell to 524 million lb., against 1257 million in 1861 , and 1391 million in 1860 . Increased supplies from India and other sources brought the arrivals up to 669 million in 1863,893 million in 1864 , and 978 million in 1865 . The war closed in 1865 , trade with America was resumed, and the imports in 1866 rose to 1377 million $I b$, and the cotton industry shortly afterwards resumed its former dimensions. At the crisis of the famine the mills were not working more than half-time, and in December $1862,247,000$ cotton operatives and others connected with the trade were out of employment, and 165,000 others only partially employed. In the same month, 234,000 persons, or 24 per cent. of the total population of the districts affected, were in receipt of charitable relief. In 1863 the average number of persons out of work was 189,000 , and that of those only partially em. ployed, 129,000 ; in 1864 the figures were 134,000 
and 97,000 respectively : and those for the first five months of $1865,107,000$ and 68,000 . During the course of the famine the losses of the trade amounted to between $£ 65,000,000$ and $£ 70,000,000$, including from $£ 28,000,000$ to $£ 30,000,000$ loss of wages to operatives.

Recent Statistics. - In the five years 1894-98 an average of 16,334,211 cwt. of raw cotton, of the value of $£ 33,193,300$, was imported. The imports for 1898 were in excess of the average, amounting to $19,004,896$ ewt., of which $16,119,077$ ewt. came from the United States, 2,463,657 cwt. from Egypt, 244, 194 cwt. from India, 87,808 ewt. from Peru, 53, 769 ewt. from Brazil, and small quantities from Canada, British West Indies, and Australasia. Of the total average imports for the five years mentioned, $1,884,189$ ewt. were re-exported in a raw state, leaving 14,450,022 ewt. to be manufactured for home use and exportation. The following gives the different forms in which it is exported, with the annual quantities and values, the figures giving in all cases the average for the five years 1894-98: Yarn and twist unbleached, and bleached and dyed, $246,752,340 \mathrm{lb}$., of the value of $£ 9,294,910$, the principal quantities going to Holland and Belgium, $43,900,000$ lb. ; Germany, $43,150,000$ lb. : India, 42,000,000 lb. ; Japan, 20,130,000 lb. ; and Turkey, $20,000,000 \mathrm{lb}$. Piece goods, unbleached and bleached, $3,458,208,820$ yards, value $£ 28,647,309$; piece goods, printed, 977,416,020 yards, value $£ 10,455,289$; piece goods, dyed or manufactured of dyed yarn, $698,408,860$ yards, value $£ 9,181,744$ : the principal quantities of these combined items going to India, $2,118,000,000$ yards ; China, $387,000,000$ yards; Turkey, 371,000,000 yards; Brazil, 183,000,000 yards ; Egypt, 175,000,000 yards; Australasia, $148,000,000$ yards ; Java, 128,000,000 yards ; Argentine Republic, 98,000,000 yards; Holland and Belgium, 97,000,000 yards; Hong-kong, 92,000,000 yards ; Japan, 92,000,000 yards ; Chili, 73,500,000 yards; British West Africa, 72,000,000 yards; British West Indies, 67,500,000 yards; Columbia, $62,000,000$ yards; United States, 54,000,000 yards; Germany, 53,000,000 yards; West Africa (foreign possessions ), 45,000,000 yards ; Mexico, 41,000,000 yards ; Venezuela, 39,000,000 yards ; Cape of Good Hope, 37,500,000 yards; Morocco, 35,000,000 yards; Persia, 26,500,000 yards; Portugal, 23,000,000 yards; the remainder going in smaller quantities to nearly every region in the hubitable glote. Piece goods of mixed material, cotton predominating, and other unenumerated kinds, to the value of $£ 2,143,416$; lace and patent net, value $£ 2,090,492$; hosiery of various kinds, value $£ 390,570$; sewing thread, 24,060,980 lb., value $£ 3,209,803$ - the total value of the exports of manufactured cotton thus amounting to $£ 65,413,933$; the three greatest consumers being India, China, and Turkey. Besides the imports of raw cotton, there were imported $5,710,1501 \mathrm{lb}$. of cotton yarn, mostly from Germany; $49,483,867$ yards of muslin and other piece goods, four-fifths coming from the United States and Holland and Belgium; and hosiery, \&c., to the value of $\$ 2,284,845$, of all which nearly one-half was re-exported. In addition to the manufactured cotton goods exported by Great Britain given above, there were retained for home consumption manufactured goods to the value of nearly $£ 40,000,000$. In 1897 the comparative amount of raw cotton consumed in various countries was: Great Britain, 1,570,000,000 lb. ; United States, 1,340,000,000 lb. ; Germany, 640,000,000 lb. ; India, 480,000,000 lb.; Russia, 430,000,000 lb.; France, 400,000,000 lb.; Austria, 270,000,000 lb. ; Italy, 240,000,000 lb. ; Spain, 160,000,000 1b.; Japan, 160,000,000 1b.; Brazil, 120,000,000 lb. ; and various, 110,000,000 lb. ; -representing a total estimated value of about $£ 130,000,000$; while the estimated total value of the manufactured goods amounted to $£ 360,000,000$. The United States is still the largest producer of the raw material, the total produce in 1898 being $50,689,965$ cwt. In the same year the States exported raw cotton to the value of $\$ 230,442,215$, and manufactured cotton to the value of $\$ 17,024,092$. Egypt exported in 1897 raw cotton

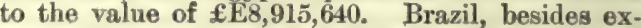
porting 319,920 ewt. of raw cotton in 1897 , has 155 mills for its manufacture, employing about 200,000 persons. Peru exported 111,720 ewt. of the raw material in 1897. In British India a large amount of cotton is grown, $9,458,842$ acres being under its cultivation; and there are over 150 cotton-mills in operation, containing about 38,000 looms and $4,000,000$ spindles. The number of cotton factories in Great Britain is above 2530, with about 650,000 power-looms and 4,500,000 spindles, giving employ ment to about 550,000 operatives. In Germany there are in operation 7,880,000 spindles; in Austria, $2,070,000$; in Switzerland, 1,710,000; in Belgium, 610,000 ; and in Poland, 510,000 spindles.

For the manufacture of cotton, see SPINNING, W BAV ing, Calico-Printing, Fustian, Vklvet, Gun-CotTon, CELLULOID, \&c. And see for further information Ellison, The Cotton Trade of Great Britain (new ed. 1886); Marsden, Cotton Manufacture (new ed. 1886); Forbes Royle, Cotton in India (1851); and Dana, Cotton from Seed to Loom (New York and London, 1878); Lister, A Practical Manual of Cotton Manufacture (1894) Taylor, Cotton Weaving and Designing (1893); French works by Reybaud (1863) and Alcan (1875), and German books by Fritz (1889) and Kuhn (1892).

Cotton, Charles, the friend of Izaak Walton and translator of Montaigne, was born at his father's estate of Beresford in Staffordshire, 28th April 1630. His father, himself a man of great ability, was a warm friend of Ben Jonson, Selden, Donne, and other illustrious men. The boy travelled on the Continent, devoted himself from youth to a life of letters, and early wrote verses which were handed about among his friends. In 1656 he married his cousin Isabella, sister of the famous Colonel Hutchinson. Though a sincere loyalist, he seems to have lived securely enough under the Commonwealth, and the decay of his father's estate was due mainly to unprosperous lawsuits. In 1664 Cotton issued anonymously his burlesque poem, Scarronides, or the First Book of Virgil Travestie, added to in later editions in grossness as well as in bulk. Later books, somewhat of the same cliaracter, are his Voyage to Ireland in Burlesque (1670), and his Burlesque upon Burlesque, or the Scoffer Scoft, being some of Lucian's Dialogues (1675). H His Planter's Manual (1675) testifies to his zeal and taste for horticulture. Next year he contributed a treatise on fly-fishing to the fifth edition of Walton's Compleat Angler, and here he commends his old friend and master, its author, as 'the best and the truest friend ever man had.' Further marks of affection were his commendatory verses in the 1675 edition of Walton's Lives; his poem, The Contentation, as well as an earlier one of invitation to Walton to visit him; and the twisted cipher of his own and his master's names above the door of his fishing-house on the Dove. In 1685 Cotton published his translation of Montaigne's Essays - a masterpiece on which his fame still rests securely. He died in 1687. Cotton's verses are full of rare felicities of thought and phrase, and are more really poetical than much far more pretentious poetry. His prose is simple and clear, direct and vigorous. His character was eminently lovable; his only troubles, his debts; his only enemies, his duns.

Cotton, Georan EDward LYNCH, D.D., bishop, born in 1813, was educated at Westminster and Cambridge, and from 1836 to 1852 was a master at Rugby under Arnold and Tait; in Tom 
Brown's School Days he appears as 'the young master,' For six years he was at the head of Marlborough College, which he raised to a position among the first achools of England. In 1858 he was convecrated Bishop of Calcutta, where he suc. cessfully alministered his immense diocese, and where his schools for the children of the poorer Anglo-Indians and Eurasians are monuments of the services he rendered to education. He was drowned in the Ganges, 6th Oetober 1866.

Cotton, Јонs, olergyman, born at Derby in 1585, was a tutor at Cambridge, and from about 1612 held a charge at Boston, in Lincolnahire. Cited to appear, for his Puritan views, before Laud at the high commission court, he in 1633 fled to Boston, in New England, where he preached until his death in 1652. Cotton was reputed a profound geholar, and was the author of nearly fifty works, including a catechism, forms of prayer, and a defence of the interference of the eivil anthority in religious matters, in a famous controversy with Roger Williams.

Cotton, Sir Robert Bruck, an English antiquary, was born at Denton, Huntingdonshire, 22d January 1571. From Westminster School, where he had the famous Camden for master, he passed to Jesus College, Cambrilge, where he graduated B.A. in 1585. He soon settled in a house in Westminster on the site of the present House of Lords, and here he commenced to accumulate books, manuscripts, coins, and other articles, and to practise that large hospitality that made Cotton House the meeting-place of all the scholars of the kingdom. His papers read before the Antiquarian Society spread wide the reputation of his learning King James knighted him in 1603, ereated him a baronet in 1611, and frequently consulted him on political matters. But he kept the scholar in prison for eight months in connection with the Overbury case. He had been returned to parliament in 1604 , and soon identified himself completely with the policy of constitutional opposition to the crown. His protest against the proposed debasement of the coinage (1626), his frank eriticism of kingeraft in his History of Henry III. (1626-27), his outspoken review of the present political situation in his tract, The Dangers wherein the Kingdom now Standeth, and the Remedye (1628), and the frequent meeting in his honse for deliberations of Eliot, Pym, Selden, and Sir E. Coke, marked him out to the court as an enemy to be crushed. The occasion was soon found. An ironical tract, entitled A Proposition for His Majesty's Service to Bridle the Impertinency of Parliaments, having fallen into the hands of Wentworth, it was found on inquiry that the original was in Cotton's library, from which a copy had been made, though without his knowledge, for the preas, Cotton and others were flung into prison, but proceedings were stayed and the prisoners released on the occasion of the birth of an heir to the throne (29th May 1630). But Cotton's library was not restored to him in spite of his pathetic petitions, and as his heart was bound up in his books, he pined and died less than a year after (6th May 1631). Fourteen of his tracts were collecter and publisher as Cotton's Posthuma in 1657. His son, Sir Thomas Cotton (1594-1662), had the books restored to him; and his grest-grandson, Sir John Cotton (1679-1731), bestowed the library on the nation.

The CoTtoniaN LiBRaRY was accordingly removed to Ashburnham House, Westminster, in 1730. In the following year a fire occurred in the house, in which about 114 out of the 958 volumes of MSS. which the library contained were reported as 'lost, burned, or entirely spoiled: and 98 damaged so as to be defective." The library was transferred to the British Museum (see Vol. IL. p. 462) in 1753.

Cotton-grass ( Eriophorum), a genus of (yper. acer, in which the perigone or covering of united bracts, which in this order inclose the ripening ovary, is developed into long silky or eottony hairs, which used to be employed for candle. wicks, stuffing pillows, \&c. A more recent attempt to employ these as a substitute for cotton has naturally failed, nor is the herbage willingly eaten by sheep or cattle. Two species are common in Britain, and give a characteristic appearance to bogs and wet moors.

Cotton-wood. See Poplar, SilK-COTTON.

Cotton-worm is a common name for the caterpillar of an owlet moth (Aletia xyliria), which is in some years very destructive to the cotton erop of the United States. The caterpillar is green, with yellow stripes and black dots, and grows to a length of Common Cotton-grass (Erio an inch and a half. The phorum Anyustifolium). boll-worm, the caterpillar

of an allied form (Heliottus armigera), is also very destructive to cotton-buds and other crops.

Cottus, a genus of acanthopterygious fishes, comprising the Bulliead ( $C$. gobio) of British rivers, the marine Father Lasher ( $C$. scorpius), and the closely akin C. bubalis, found on the coasts of California and Georgia. See BullhEad.

Cotylédon (Gr., 'a cup or cup-shaped hollow') is the technical term applied by botanists to the seed-leaves of the embryo. Their morphological importance was formerly somewhat exaggerated, as they were supposed to be quite unrepresented even in the higher cryptogams ( see FER Ns, \&c.), to which the term acotyledonous, now disused, was therefore applied. The number of cotyledons is, however, nsually of high systematic importance; for although in Gymnosperms it varies from a whorl of eight, ten, or even more in conifers, to usually two in cycads, it is almost constant among the higher Angiosperms, the old division of monocotyledons and dicotyledons having few exceptions to its literal accuracy. Every one is familiar with the two cotyledons of so many seedlings of the latter group; but a more extended study shows that many never emerge above ground, or even leave the seed. The form and structure of the cotyledons depends largely on whether they have pre. cociously absorbed and stored the nutritive contents of the endosperm; in this case, of which the leguminous seeds of pea, bean, \&c. Afford the most familiar example, they become more or less fleshy, and frequently do not appear above ground in germination. The mode of packing the cotyledons in the bud also presents many differences in detail of high systematic constancy, and therefore importance. See OVULE, SEED, Embryo, and Germination.

Coucal (Centropus), or LARK-HeELED CUCKOO, a genus of conmon bush-birds in Afrien, Indis, and through the Malayan Archipelago to Australia. The hind-toe is prolonged into a very long spur. 
Their call is loud and in some cases apparently ventriloquistic. They build their own nests. See Cuckoo.

Couchant. In Heraldry, a beast lying down, with his head up, is couchant. If the head is down, he is dormant.

Couch-grass (Triticum repens), also called Wheat-grass, Dog-grass, Quickens, and Squitch or Quitch, a grass which, although of the same genus with wheat, is a widespread and troublesome weed. Its perennial creeping root-stocks render it extremely difficult of extirpation; they are carefully gathered out of land under cultivation; but in times of scarcity have been employed as human food, as a source of beer, as a domestic medicine, and more frequently as fodder. They are sometimes useful in binding sand into pasturage of inferior quality. Cut early, couch-grass makes very good hay.

Couching. See Cataract.

Coucy, Raoul or Renault, Castellan de, was a French court poet or Trouvere (q.v.) of the 12th century; to whom twenty-three poems are ascribed. He was named after the Château de Coucy, near Laon. See Gaston Paris in Romania (1872).

Coughing, considered physiologically, consists (1) in a long inspiration which fills the lungs to a greater extent than usual; (2) in the closure of the glottis, or narrow opening in the organ of voice (see LARYNX), at the commencement of the act of expiration; and (3) in the sudden forcing open of the glottis by the violence of the expiratory movement. In this way, a blast of air is driven upwards from the lungs through the mouth, which carries with it. any sources of irritation that may have been present in the air.passages. Coughing may occur from irritation in the back of the throat, in the larynx, trachea, or bronchial tubes, and may be excited by acrid vapours, by irritant gases, or by articles of food or drink - such as even a drop of water or a crumb of bread-making their way into the air-passages instead of into the pharynx, or by excessive or morbid secretion from the walls of the air-tubes, or even by the entrance of cold air, when the lining membrane of the air-passages is abnormally irritable. More rarely it results from irritation of other parts, as the ear, and possibly the stomach.

The object of coughing in the animal economy is unquestionably to guard against the danger of the entrance of mechanical and chemical irritants into the air-passages; and accordingly the mucous membrane, especially of their upper part, is endowed with a most exquisite sensibility which, when aroused by irritation or by a state of disease, provokes incessant coughing until the irritation be allayed or removed. Cough is an exceedingly common symptom of all diseases of the respiratory organs. The treatment of coughing must first be directed to the removal, if possible, of the canse which excites it. But besides, when once begun, coughing frequently becomes excessive, and so irritating or exhausting to the patient, from too great sensitiveness of the nervous mechanism which produces it; and this tendeney, when injurious, must also be combated. The remedies suitable to most cases of cough are therefore Expectorants (q.v.) and nervine sedatives, especially opium, morphia, and bydrocyanic acid; 'congh mixtures' generally contain both. Such household remedies as liquorice, jujubes, black-currant jelly, or linseed tea are often of service. See also under names of diseases in which cough occurs.

Cough occurs amongst the lower animals under similar conditions. From continued breathing of a close foul atmosphere, the bronchial mucous membrane becomes unduly irritable, hence the prevalence of chronic congh amongst the cows in our overerowded town-dairies. Chronic cough also occurs in horses, usually as a sequel to an attack of cold. It constitutes unsoundness, is best treated by repeated doses of belladonna and camphor, but often requires for its entire removal a run at grass.

Cough is an accompaniment of teething, and is also common in diseases of the digestive organs. See Pneumonia, Consumption, Bronchitis, Catarrh, \&c.

\section{Couguar. See Puma.}

Coulmiers, a French village, some 12 miles WNW. of Orleans, where Von der Tann and his Bavarians were defeated by an overwhelming force under D'Aurelle de Paladines, 9th November 1870.

Coulomb, Charles Augustin de, famous for his experiments on friction, and the invention of the Torsion Balance for measuring the force of magnetic and electrical attraction, was born at Angoulême in 1736. In early life he entered the engineers, and served some time at Martinique. In 1777 he gained an Academy prize by a work on magnetic needles, and again two years later by his Theorie des Machines simples. For speaking the truth about a projected canal in Brittany, he was for some time imprisoned, but earned the hearty approval of the honest Bretons, as well as his own conscience. Coulomb lived in retirement during the Revolution, became a member of the Institute in 1804, and died August 23, 1806.

Coulter. See Plough.

Coumarin $\left(\mathrm{C}_{9} \mathrm{H}_{6} \mathrm{O}_{2}\right)$ is a fragrant crystalline substance, analogous to volatile oils and camphor, which is present in the well-known Tonka bean. It is identical with the odorous principle of many other plants, including the Woodruff, Melilot, and Vernal grass.

Council, or Synod, an assembly of ecclesiastics met to regulate doctrine or discipline. We first hear of such assemblies during the Montanist controversy, about 150 A.D. Ecumenical councils are convoked from all parts of Christendom, and claim to regulate the affairs of the whole church. Other synods have represented the East and West respectively. Patriarchal, national, and primatial councils represent a whole patriarchate, a nation, or the several provinces subject to a primate, while the bishops and other dignitaries of a province constitute a provincial; the clergy of a diocese under the presidency of the bishop, a diocesan council. Mixed councils during the middle ages dealt with civil as well as ecclesiastical affairs, and were composed of secular persons as well as churchmen. Sometimes, but not always, the lay and ecclesiastical members voted in separate chambers.

The first eight general councils were convoked by the emperor, all the later ones by the popes, and the fifth Lateran Council asserts (Sess. xi.) the modern principle that the right of convoking, removing, and dissolving general councils belongs to the pope. The right of voting was reserved in early times to bishops and priests, or deacons who acted as representatives of absent bishops. From the 7 th century onwards this right was sometimes extended to abbots, and from the end of the medieval period to cardinals who were not also bishops. At the Vatican Council the members entitled to vote were cardinals, bishops (even if only titular bishops), mitred abbots, and generals of religious orders, Priests acting as proxies of bishops were not admitted. The presidency at the early wecumenical councils followed no fixed rule. In a certain sense it belonged to the emperor, who 
had convoked the bishops, and was responsible for peace and order. 'It was not,' says Harnack (Dog. mengeschichte, ii. p. 101), 'till the fourth general council that the papal legates gained a unique fusition, and learned Catholics have almitted that the presidency of the papal legates at Nicas does not adunit of positive proof.' This is true even of Catholic theologians writing after the Vatican decrees. Thus Krans (Kirchengeachichte, p. 147) contents himself with maintaining 'the probability' that the papal legates presided at Nican, and Hefele (Coneil. i. p. 38, 2d ed.) aulmits that the question is 'not without difficulty.' The modern theory that a council is then, and then only, to be counted genersl when its acts have been ratified by the pope, is of still later origin. Even medieval theologians, such as Thomas of Walden, maintained that the decisions of general councils did not acquire binding force till they had been accepted by the whole church. And although it was an estab. lished principle in the 6th and the following centuries that the definitions of couneils, indisputably cocumenical, could not be called in ques. tion, it is certain that St Augustine had heen of another mind. He asserts ( De Bapt. contra Donat. ii. p. 3-4) that Scripture alone has final and irreformable authority, but that even 'plenary councile, assembled from the whole Cliristian world,' may be 'corrected' (emendari) by the accession of knowledge and experience. Moreover, the fact that the decisions even of provincial councils are sometimes attributed, in the 4 th century, to the 'suggestion' of the Holy Spirit, shows that caution is needed in interpreting the rhetoricp.l language of early writers.

I'\%, Greek Church recognises seven general councils-viz.: (1) The first of Nicren, 325 A.D. ; (2) the first of Constantinople, 381 ; (3) Ephesus, 431 ; (4) Chalcedon, 451 ; (5) second of Constan. tinople, 553; (6) third of Constantinople, 680 ; (7) second of Nicrea, 787. To these Roman Catholics add : (8) fourth of Constantinople, 869 ; (9) first Lateran, 1123; (10) second Lateran, 1139 ; (11) third Lateran, 1179 ; (12) fourth Lateran, 1215; (13) first of Lyons, 1245; (14) second of Lyons, 1274; (15) Vienne, 1311; (16) Constance, 1414-18, of which Ultramontanes accept only the decrees prssed in sessions $42 \mathrm{~d}$ to 45th inclusive, and such decrees of earlier sessions as were approved by Martin V.; (17) Basel, 1431 and the following years, wecumenical according to Ultramontanes only till the end of the twentyfifth session, and even then only in respect of such decrees as were approved by Eugenius IV.; (18) Ferrara-Florence, $1438-42$, really a continuation of Basel; (19) fifth Lateran, 1512-17; (20) Trent, 1545-63; (21) Vatican, December 8, 1869, to July 18,1870 , and still unfinished.

The best collections of councils are by Hardouin (12 vols folio, Paris, 1715), and that of Mansi (31 vols. folio, Florence, 1759), which is by far more complete than Hardouin's, but inferior to it in correctness of typoyraphy. An excellent account of the councils, with the text of the most important decrees, will be found in Bishop Hefele's Konziliengeschichte $(7$ vols. $1853-74$; continued by Hergenröther and then Knöptler, vols. viii.-ix., 1887-90 ; Eng. trans, vols. i. -iv., 1871-95). For the more important councils, see NICAs, BASEL, \&c.

Council Blufrs, a city of Iowa, capital of Pottawattamie county, 141 miles WSW. of Des Moines by rail, on a plain backed by the high bluffs from which it takes its name. The Missouri River, 3 miles to the west, is crosed by a grand railway brilge to Omaha, and five milways form a junction at the town, which has manufactures of paper, iron, carriages, nnd a rricultural machines. Pop. (1870) 10,020; (1880) 18,063; (1890) 21,474.
Council of $\mathbf{W}$ ar is a conference of military or naval officen, to consider a plan of campaign, determine the order of battle, or give their opinions on some matter in which the commander wishes to fortify his julgment by an appeal to that of others. The senior officers and heads of departments meet him in the consultation whenever he thinks it desirable; and their opinions are placed upon record. Thus the conmandant of a fortress generally solicits the opinion of a council of war hefore surrendering to besiegers. The British military code leaves its assembly to his discretion, but the French make a special provision for a council of defence. In the navy, a council of war consists usually of flag-officers only; but officens of lower rank occasionally assist.

\section{Counsel. See Advocate and Barrister.}

Counsellor is the term which in the United States most nearly corresponds to Barrister $(q . v$. in England, and Ádvocate (q.v.) in Seotland. But in the United States there is no such well-marked distinction between counsellor and solicitor as in the United Kingdom obtaing between barrister or advocate and solicitor. See LAWYER.

Count (Lat. comes, in Fr. comte, Span. conde, Ital. conte), the name of a dignity in medieval and modern Europe, to which Earl (q.v.) is in one view supposed to be analogous, the Latin equivalent of each being the same, and the wife of an earl being a countess. On the various significations of the comes of classical times it is unnecessary to enter. Under Constantine the term became an honorary title; and the comites became a sort of council of state both in the eastern and western empire, each having his separate office in the household. The counts under the first two races of Frankish kings were (like those of the lower empire) of various degrees. The count of the palace (comes palatii nostri) was the highest dignitary in the state after the maire of the palace; and in the 11th century he had already acquired a rank apart from that of the other counts. He presided in the court of the sovereign in his absence, and possessed sovereign jurisdiction. The habit of instituting counts-palatine (comites palatii) was adopted by Spain and England. Those counts, again, who, at a later period, as rulers of provinces, had attained to something appronching to sovereign power, exercised also the right of appointing countspalatine under them-e.g. the Counts of Chartres, of Champagne, of Blois, Toulouse, \&e. ; and the ancient houses of Chartres and of Blois contiuued to claim in perpetuity the title of count-palatine as that of their eldest sons. Counts of this sovereign class owed their origin to the feebleness of the later Carlovingian kings, under whom they contrived gradually to convert the provinces and towns which they hud governed as royal ofticers into principalities hereditary in their families. It was then that the counts came to be known by the names of their counties. Down to the middle of the 14th century they wielded a most formidable power, somewhat broken by the eventually successful struggle of the towns of Northern France to throw off their yoke. In later times there were numernus mere titular counts, and even before the first revolution many titles of count, believed to be pure arsumptions, were recognised by the courtesy of society.

The German word graf, akin (like reeve, grieve, and sheriff) to the Anglo-Saxon gerefa, governor,' in time came to be identified with the comes or count, the pfalzyraf being the German equivalent of the comes palatio. In Germany there have been in modern times two classes of counts. one belonging to the Dymastien-adel, or higher nobility-i.e. those families whose head had a seat in the diet or estates of the realm; the other 
forming the highest class of the lower nobility. Of the former class the larger number, as the price of their acquiescence in the abolition of the old German empire, received the title of prince, and very few now exist. The merely titular counts belonging to the lower nobility are very numerous.

Counterfeit. See Corning.

Counterforts, the buttresses or arches behind the revetments or retaining walls of the ditches of permanent fortifications. They help to support the earth above them and make it more difficult to form a Breach (q.v.).

Counter-guard is a low outwork designed to cover the revetment of a bastion or ravelin from the fire of the enemy's breaching batteries. It is separated from them by a narrow ditch, and lest the enemy should establish a battery on it when captured, the terre-plein, or flat space behind its parapet, is made very narrow. See ForTIFICATION.

Counter-irritants, agents applied to the skin so as to redden (rubefacients), to vesicate (vesicatories or Blisters, q.v.), or to produce pustules, purulent issues, or even sloughs of skin and of the subcutaneous textures. The milder counter-irritants are mustard (see CATAPLASM), turpentine applied on warm cloths, and spirit or acetic acid in lotion. The stronger are blisters of Cantharis (q.v.) or of ammonia; of Croton-oil (q.v.) or Tartar Emetic (q.v.), in ointment; setons, caustic or pea-issues, and the moxa; and above all, the actual Cautery (q.v.) or hot iron. None of the stronger counter-irritants should be used without careful consideration and medical advice; great mischief is often done by their careless or improper use. Counter-irritants relieve internal pain, check inflammations, and tend to promote the absorption of morbid effusions. Their effeet is probably due mainly to reflex action, produced by the impression they cause upon the nerves of the skin to which they are applied.

Amongst horses, counter-irritants are much used for strains and diseases of the joints, but should never be applied, as they too often are, in recent cases, or whilst the part is hot or inflamed. Cantharidine preparations, or ointment of biniodide of mercury, are the most convenient. For cows, use fomentations, followed by the smart infriction of mustard-paste; for dogs, soap-liniment, strengthened, if required, by ammonia or turpentine.

Countermine, a subterranean way to counteract besiegers' mines. See Mines (Military), SiEge.

Counterpoint, in Music, has been defined as 'the art of combining melodies.' The name arose from the early system of notation by points. When another part or melody was added to one already represented by a row of points, this was called punctum contrapunctum. A single melody is usually taken as the 'subject,' and the part or parts added are called the 'counterpoint." When this is done according to the numerous and strin. gent rules of the old authorities, it is called strict counterpoint; but in modern music these rules are much relaxed. The devices of counterpoint are, however, still largely relied on; Wagner, the greatest innovator of our time, being also one of the greatest practical contrapuntists. The aim of Beethoven in his later works to make every part sing, and not be a mere filling up of the harmony, may be referred to as illustrating the object of these devices; and there is no doubt that as used by the classical writers, they are the source of some of the grandest effects in music.

In simple counterpoint the parts are written above or below the subject without regard to their capability of being transposed. It is divided into different species, according as the added parts contain one, two, or four notes against each note of the subject, or are written in syncopated notes, or have a combination of all or any of these, when it is called 'florid.' The so-called 'rules' are in effect limitations of the degrees in which the parts may progress - e.g. the prohibition of consecutive octaves and fifths. The general prineiple of them is to secure complete independence of melodic motion in the parts, while at the same time the laws of harmony are observed. When the parts reach the number of eight or more in vocal music, they are sometimes divided into different choirs, which sing alternately together and in antiphony. A famous example of this class is Tallis's motet 'Spem in alium non habui,' for forty voices, in eight choirs, each of five voices. In double counterpoint the subject and counterpoint are so written that each may form the bass to the other. When in this transposition the upper part is taken to the octave below, or vice versa, it is called double counterpoint at the octave; but it may also be at any other interval, the fourth, fifth, \&c., or even at two different ones. In treble counterpoint each of three melodies can be put as the bass to the others; and similarly in quadruple and quintuple counterpoint ; but counterpoint beyond double can only be at the octave, as the other intervals are impracticable. One or more free parts may be added to fill in the harmony. The following instance of quintuple counterpoint is taken from the finale of Mozart's 'Jupiter' Symphony :

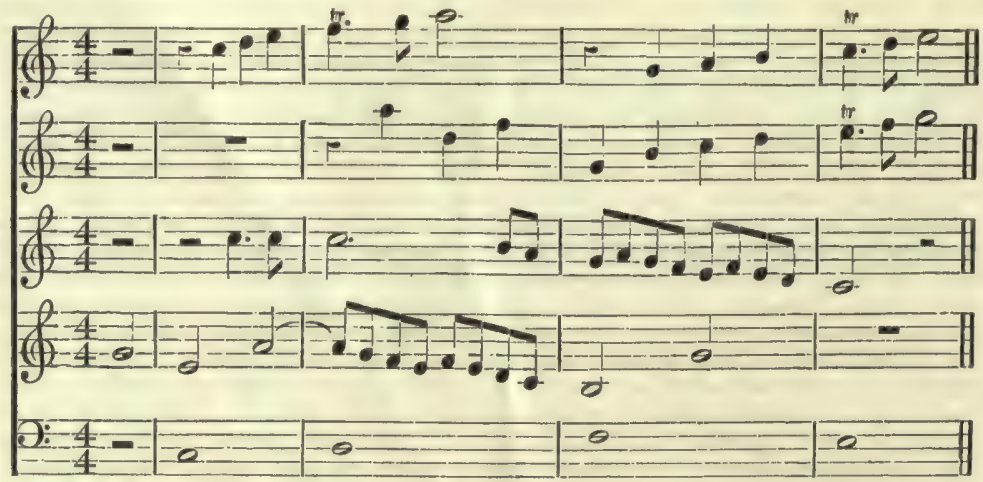

Among the other devices of counterpoint may be mentioned those of contrary motion, angmentation, and diminution, the latter two referring to the time-values of the notes. See IMITATION.
The history of the art of counterpoint can be traced step by step from its beginnings in the rude efforts at part-writing, called organum, barbarous to modern ears, in medieval church music, of which 
the enrliest known aceount we have is by Huchald, 2. Flemish monk, who died in 930 . The earliest existing specimen of part-music is an English one - B rota or round, written by a monk of Rearling in 1226 to worls beginning 'Sumer is icumen in, the MS. of which is in the British Museum. The Poly. phonie schools of composition in Flanders, England, (iermany, and Italy, of the four succeeding centuries, reaching their culnination in Palestrina, were based pre-eminently on counterpoint. Bach is, however, usually considered its greatest master. There is an enormous number of treatises on the subject in moet European languages; it will be sutticient to refer to that of Sir F. A. G. Ouseley, based on Cherubini, and to the primers published by Novello \& Co.

Counterscarp is that side of the ditch of a fort which is nearest to the besiegers; the other side being called the escarp or acarp.

Countersign, in military affairs, is a watchword used to prevent unanthorised persons passing a line of sentries whose orders are to stop any one unable to give it. It is fixed each day by the commanding officer, but may be changed at any moment if necessary, and is only communicated to those entitled to know it.

Counter-tenor, the highest adult male voice, the same as Alto $\left(q \cdot v_{\circ}\right)$. See also Contralto, TEYOR.

Country-dance ( $\mathrm{Fr}$. contre-danse, of which the English term is a corruption), a dance in which as many couples can take part as there is space to accommodate them; the gentlemen being ranged at the commencement on one side, and the ladies on the other. The dancers are constantly changing places, leading one another back and forward, up and down, parting and uniting again. 'Sir Roger de Coverley' is the best known example. See DANCING.

County (derived from Fr. comte; Lat. comitatus) is now the recognised subdivision of the three kingdoms for judicial and local government purposes.

History. - The term 'county' corresponds with shire (Saxon, seir, from sciran, 'to divide'), a word which, however, it has now to a great extent superseded. It means a division of a kingdom immediately superior to the hundred, and its first nse was in connection with the assignment of jurisdiction for judicial business. Some counties, snch as Essex, Kent, Mildlesex, Surrey, Sussex, were ancient Saxon kingdoms, but other counties or shires were formed by the subdivision of Mercia, Wessex, Northumbria, and the other Saxon king. domis, The shire represented in its constitutional machinery either the national organisation of the several divisions created by West Saxon conquest, or that of the early settlements which united in the Mereian kingdom as it advanced westwards, or the rearrangement by the Weat Saxon dynasty of the whole of England on the principles already at work in its own shires. The division of England into shires, which was begun before the time of Alfred, was probably not completed till the Danes, Angles, and Saxons were united into one kingdom under Edgar. In the government of the shire there were two officers, the ealdorman and the scir-geréfa, or sheriff. The ealdorman (the princeps of Tacitus, the satrapa of Bede, the dux of the Latin chron. iclers, and the comes of the Normans) was originally elected by the Witan, but in course of time the oflice tended to become hereditary, though in all cases down to the Norman Conquest the consent of the king and the Witan was necessary to each fresh nomination. The ealdorman shared with the sheriff and the bishnp the administrative functions of the county in the shire-moot. The sheriff was the representative of the king alone, and was the chief judicial officer of the shire, on whom was imposed the duty of executing the law and seting as steward of the royal demesne. Each county or shire comprised a number of bundreds, and just in the same way as the hundreds had their moot, so each county or shire had its moot, which was attended by the representatives of the hundreds and townships, and by a representative body of witnesses to give validity to its proceedings. According to the laws of Edgar, the shire-moot was held twice a year. After the Conquest the shire. moot continued to be held in each county, but its independence was much interfered with by the exercise of the royal prerogative. Between the reigns of Henry I. and Henry III. these courts began to meet more frequently, and eventually as county courts, or sherifr's courts, met once a month, and continued to be held, though under varying conditions, until comparatively modern times.

Constitution. - The organisation of a county in England comprises the following officers: (1) A lord-lieutenant, who is the military representative of the crown, and whose dnty it is to select persons for the commission of the peace; (2) a custos rotulorum (keeper of the records); (3) a sheriff; (4) a coroner; (5) justices of the peace, qualified by an estate in possession of $£ 100$ a year, or in reversion of $£ 300$ a year, or by two years' assessment to the inhabited house duty at $£ 100$. All the justices for a county hold the general and quarter sessions as prescribed by law. A single justice may act in petty aessions. (6) A clerk of the peace, who is appointed by the custos rotulorum, but may be removed by the justices; (7) a county treasurer; (8) a surveyor, and other minor officers. The duties that now belong to the county justices are mainly of an imperial eharacter, and relate to the maintenance of the militia, to the local administration of the criminal law, and to the carrying out of certain matters connected with parliamentary representation, licensing, assessment, appeals, and so forth.

County Councils. - By the Local Government Aet, 1888 , all duties purely relating to matters of local government in England and Wales that were performed by the justices in quarter sessions were transferred to county councils which were newly established by the act. These councils are elected by the inhaluitants of the county, who are enrolled as 'county electors 'for the purpose. A county elector may be a man or woman, but must be of full age and not subject to any legal incapreity, and must not have been in receipt of parochial relief. Such a person must have been an occupier of some building or land in the county for a certain term, and must have paid all rates due and complied with certain conditions as to residence, \&e. For the purposes of the establishment of county councils in England and Wales what are termed administrative counties are formed. Of thene there are sixty, and the number of county councillors and county aldermen for each county couneil is as follows, the aldermen forming one-fourth of the total in each case, viz. : England-Bedford, 68 ; Berks, 68; Bucks, 68; Cambridge (exclusive of the lsle of Ely), 64; Cambridge (Isle of Ely Division), 56 ; Chester, 76; Cornwall, 88; Cumberland, 80 ; Derby, 80 ; Devon, 104; Dorset, 76 ; Durham, 96 ; Essex, 84; Gloucester, 80 ; Hereford, 68; Herts, 72 ; Hunts, 52 ; Kent, 96 ; Lancaster, 140 ; Leices. ter, 72; Lincoln (Holland), 56 ; Lincoln (Kesteven), 64; Lincoln (Lindsey), 76 ; London, 137 ; Middlesex, 72; Monmouth, 64; Norfolk, 76; Northampton (exclusive of the Soke of Peterborough), 68 ; Northampton (Soke of Peter. borough), 40 ; Northumberland, 80 ; Notts, 68; Oxford, 76; Rutland, 28 ; Salop, 68 ; Somerset, 
88 ; Southampton, 100 ; Stafford, 100 ; Suffolk (Eastern Division), 76 ; Suffolk (Western Division), 64; Surrey, 76; Sussex (Eastern Division), 68; Sussex (Western Division), 60; Warwick, 72; Westmoreland, 56; Wilts, 80 ; Worcester, 76 ; York (East Riding), 68; York (North Riding), 80 ; York (West Riding), 120. Wales-Anglesey, 56 ; Brecknock, 60; Cardigan, 64 ; Carmarthen, 68 ; Carnarvon, 64; Denbigh, 64; Flint, 56 ; Glamorgan, 88 ; Merioneth, 56 ; Montgomery, 56 ; Pembroke, 64; and Radnor, 32. These are distinct from the aldermen and councillors in boroughs, who take no part in county administration.

The powers and duties which are given to the county councils by the Local Government Act, 1888, relate to county finance, rating and assess. ment, county buildings, bridges, lunatic asylums, reformatories, registration and polling of parlia mentary electors, contagious diseases (animals), the appointment of coroners, maintenance of highways, preventing the pollution of rivers, and numerous minor matters. The control of the police is vested in the courts of quarter sessions and the county councils jointly. As regards its finances, each county council is empowered to make and levy county and other rates, and it will also receive its share of the income derived from certain license duties collected by the imperial government, to gether with a proportion of the probate duty col lected in the United Kingdom.

County Rate.-The county rate is made under an Act 15 and 16 Vict. chap. 81, and is assessed, not on individual properties, but on the various parishes, and a precept is issued to the guardians of each union requiring them to pay to the county treasurer the aggregate amount of the sums pay. able by the parishes in their union. It can be expended only for 'county purposes,' which the county council is required to provide funds for in the execution of its powers as above enumerated.

County Boroughs.-By the Local Government Act, certain boroughs are exempted from the jurisdiction of the county councils of the counties in which they are situated, and are enabled to retain their independence, subject to certain special regu. lations for the adjustment of their financial relations with the counties. These boroughs are called 'county boronghs,' and are such as either were counties in themselves before the passing of the Local Government Act, 1888, or on the 1st of June 1888 had a population of not less than 50,000. They are as follows: Barrow, Bath, Birkenhead, Birmingham, Blackburn, Bolton, Bootle-cum-Linacre, Bradford, Brighton, Bristol, Burnley, Bury, Canterbury, Cardiff, Chester, Coventry, Croydon, Derby, Devonport, Dualley, Exeter, Gateshead, Gloucester, Halifax, Hanley, Hastings, Huddersfield, Hull, Ipswich, Leeds, Leicester, Lincoln, Liverpool, Manchester, Middlesbrough, Newcastleupon-Tyne, Northampton, Norwich, Nottingham, Oldham, Plymouth, Portsmouth, Preston, Reading, Rochdale, St Helens, Salford, Sheffield, Southampton, South Shields, Stockport, Sunderland, Swansea, Walsall, West Bromwich, West Ham, Wigan, Wolverhampton, Worcester, Yarmouth, and York.

County Courts are sixty tribunals which have been established in the different counties of England for the hearing of cases of a minor importance relating to civil matters only. They are now regulated by the County Courts Consolidation Act, 1888, and under that statute can exercise jurisdiccion in questions of law and of equity. Since their establishment in 1846 their powers have been gradually enlarged, and the tendency is to transfer cases in which the matters in dispute are not great from the higher courts to these courts. The registrar has power to take all undefended and admitted cases by leave of the judge. In every action or suit of whatever nature where more than $£ 5$ is claimed, and in all other actions, by leave of judge, a jury may be demanded. The number of jurymen to try a cause in county courts is five. There is a right of appeal in all cases where more than $£ 20$ is claimed, and by leave of judge in all other cases. The judge only may commit to prison in cases where he is satisfied the debtor has the means to pay the debt or instalment thereof. There is no other ground of imprisonment for debt in county courts. A dehtor may be committed for any period not exceeding forty-two days, and can be imprisoned only once for the same default.

In Seotland the tendency of the constitution under the feudal system was towards English methods of administration, and this brought about, among other innovations, the division into counties or shires. Its introduction seems to have begun early in the 12th century, and to have proceeded northwards. The crown at an early period adopted the practice of appointing Sheriffs (q.v.) in Scotland, and local judges for each county, and the system of appointing justices of the peace was introduced by James VI. There are now thirty-three counties in Scotland. The county organisation comprises a sheriff-principal (see SHERIFF), sheriffsubstitutes, and justices of the peace. A system of local government by county councils essentially similar to that of England was extended to Scotland in 1889; superseding commissioners of supply, road trustees, \&c. See Scothand.

In Ireland the division into counties was begun in the time of King John, and it was not completed till that of James I. There are now thirty-two counties, each of which is divided into baronies. Its county organisation comprises the sheriff, the grand jury, justices of the peace, and officials. The grand jury consists of twenty-three persons, and is appointed under the Act 6 and 7 Will. IV., chap. 116. It is the principal county authority for purposes of local government, and its powers end with each of the assizes. The system of county government is thus seen not to be based on popular representation, as is the case in England and, to some extent, in Scotland. See JuRY.

In the United States the county is a creation of the legislature of each state, and is not a thing of gradual growth, as in England. Each county is invested with certain corporate rights and powers to enable it to perform the duties required of it in the machinery of government, and its affairs are managed by a board of commissioners or supervisors, who can levy and collect taxes and hold real and personal property for the benefit of the inhabitants. In every county there is a sheriff, coroner, treasurer, recorder of deeds, and registrar of wills. All officers are elected by the people. New counties are created by the subdivision of the existing counties. County courts exist in each county, but their powers vary according to the state they are in, some having very extensive common-law and equity jurisdiction, while others ean deal only with small suits, and are limited to chancery jurisdiction and matters affecting trust properties.

For authorities, see Stubbs, Constitutional History (1874-78); Hallam, Constitutional History (1827; new ed. 1866) : Freeman, Norman Conquest (1867-79); Gneist, English Constitution (trans. 1886) ; also LOOAL GOVERNMENT, and works there eited.

Cowp is a French word signifying ' a stroke, used in certain phrases that have become current in Europe. A coup d'etat ('stroke of state ") means an arbitrary encroachment suddenly effected by the governing authorities upon the constitution of the state, altering or setting aside the prerogatives of other parts of the body politic. The term is applied particularly to the treacherous but successful attack 
upon the liberties of his fellow-conntrymen by Louis Napoleon, 2d December 1851. Coup de main ("a stroke of the hand ') is a sudden and successful attack; coup d'oeil ("a stroke of the eye') is a summary view of a compliceted matter; coup de thedre is a trick of the stare; and coup de grace is the merciful blow that puts a victim ont of pain.

Compar-Angus, a town of Perthshire (till 1891 partly in Forfarshire), near the left bank of the Isla, a tributary of the Tay, 13 miles NNE. of Perth, and $15 \mathrm{NW}$. of Dundee. Here are remains of a Roman camp, within which is the fragment of a Cistercian abley, founded by Malcolm IV. in 1164, and forming the subject of a monograph by Rogers and Allan (2 vols. 1879-80). Linen is manufactured. Pop. (1841) 1868; (1881) 2154; (1891) 2106. See also CUPAR.

Couped, or Coupk, in Heraldry, is used to deseribe the heml, or any limb of an animal cut off in a straight line. It is distinguished from erased-i.e. forcibly torn off, and therefore ragged and uneven.

Couple is the name given in statics to a pair of equal forces acting on the same body in opposite and parallel directions. The effect of a couple is to rotate the body about a certain definite line (the axis) perpendicular to the plane in which the forces constituting the couple lie.

Couplet. Any two lines which rhyme together may be called a couplet; but the term is more frequently used to denote two lines which contain the coniplete expression of an idea, and are therefore to a certain extent independent of what goes before or what follows. The poetic wits of the age of Queen Anne excelled in this kind of aphoristic versification. Pope, as has been said, reasons in couplets. For example :

"Tis with our judgments as our watches, none

Go just alike, yot each believes his own.

However effectively epigrammatic short aphorisms may be expressed in rhymed couplets, a long poen in this rhythm becomes wearisome to the ear. Not all the alert genius of Pope, nor the sonorous strength of Dryden could avert from their favourite rhythm the damning sin of monotony.

Coupon (Fr., and from couper, 'to cut'), a term signifying any billet, cheque, or other slip of paper cut off from its counterpart. It is, however, applied chiefly to a dividend or interest warrant, which is presented for payment by lolders of debentures. Coupons in Great Britain require to be stampecl. The term is also applied to one of a series of tickets which are vouchers that certain payments will be made or services be performed, at various times or places, in consileration of money paid.

Courant ( Fr.), the heraldic term for 'running.'

Courbet. Gustave, painter, was born at Ornans, Franche-Comté, on the 10th of June 1819. In 1839 he was sent by his father, a well-to-do farmer, to study law in Paris, but all the bent of his singularly strong and self-assertive nature was turned towards art, $\mathrm{He}$ made himself acquainted with the Flemish, Florentine, and Venetian schnols; but amid all he was careful to preserveas he plurases it-his 'own intelligent and independent individuality." In 1841 he took to landscape work, painting in the forest of Fontainebleau. In 1844 he began to exhibit at the Salon: and his works created a great sensation when shown in the Salon of 1850. Marred by frequent coarseness, and by defects of drawing, Courbet's works possess fine and powerful colour, and are valuable for their firm basis in actual fact, for their truth to an individual and personal impression of nature. His hunting scenes and animal subjects are especi ally vigorous and spirited. In 1869 he accepted the
Cross of the Order of St Michael from the king of Bavaria, and after the revolution of 1870 be was appointed Director of the Fine Arta. In the follow. ing year he joined the Commune, and was concerned in the destruction of the Vendome Column $(16 \mathrm{th}$ May), for which, in the following September, he was sentenced to six months' imprisoument, and to be tined for its restoration, his pictures being sold in 1877 towards that purpose. On his release he retired to Vevey in Switzerland, where he died, 31st December 1877. An exhibition of nearly two hundred of his works was brouglit together in the Ecole des Beaux Arts, Paris, in 1882. See the Century for February 1884.

Courbevoie, a town of France, on the left bank of the Seine, opposite the north-western suburbs of Paris. It has many handsome villas, a large barrack, bleaching-fields, and a carriage factory. Pop. (1886) 15,937 ; (1891) 16,150.

Courier, PAul Lours, one of the most powerful and brilliant of French writers, was born in Paris on January 4, 1772. His boyhood was spent in Touraine, and he afterwards studied at the College de France and the School of Artillery at Chalons. He then served for some eighteen years in the army, but his interest lay wholly in study, and especially in the study of the Greek language. His military experiences ended in 1809 on the field of Wagram, from which he was carried insensible to Vienna. Thenceforth he devoted himself to letters. He lived for some time at Florence, where he became embroiled with the lihrarian of the Laurentian Library, in regard to a manuscript of Longus. The quarrel led to the publication of the Lettre \& M. Renouard, in which Courier's incomparable ironic faculty was for the first time revealed. He removed to Paris in 1812 , and in 1814 settled on his estate in Touraine. In 1816 he issued the first of his famous pamphlets, the Petition aux Deux Chambres, a scathing exposure of the wrongs inflicted on the peasantry by the government of the Restoration. The Pétition was read by high and low, and its anthor was thenceforth recognised as a political power in France. Courier continued the attack in a series of admir. ably witty letters in the Censeur, and in 1821 there appeared the inimitable Simple Discours de Paul Lonis, Vigneron de la Chavonniene. In this pamphlet the scheme to purchase the estate of Chamhord for the Due de Bordeaux by a 'national offering,' wrung from the peasantry, was mercilessly derided and laid bare. The Simple Discours is Courier's masterpiece. It was made the subject of a government prosecution, and its author underwent two months imprisonment in Sainte Pélagie, where he formed the acquaintance of Berranger. On his release he was again tried, but escaped with a reprimand, for his Petition pour les Iillagrois qu'on empéche de danser. His subsequent writings were published anonymously at Brussels. They comprised Reponses aux Lettres Anonymes, the Gazette du Village, the Livret de Paul Louis, the Piéce Diplomatique-n imaginary letter from Louis XVIII. to the king of Spain-and the Pamphlet des Pamphlets, a vindication of pamphleteering, which appeared in 1824, and which Armand Carrel called 'the swan-song of Courier.' On Sunday, May 10, 1825, Courier was found shot dead a little before sunset in the grounds of his honse at Varetz.

With the exception of Pascal, Courier is the greatest master of irony in the ranks of French authors. A deadly controversialist, he was at the same time an exquisite artist, whose style is characterised by anstere simplicity of diction. See the notice of Courier in the edition of his works edived by Armand Carrel (4 vols. Paris, 1834), and an 
admirable essay by $\mathrm{Mr} \mathrm{H}$. Traill in the Fortnightly Review of February 1877.

Couriers are persons hired to accompany travellers abroad, whose special duty is to make all arrangements for the journey, and relieve their employers as far as possible of all anxiety about passports, exchange of money, hotel negotiations, and the like. The speaking of several languages is one of many important qualifications in a good courier.-King's or Qneen's Messengers are sometimes calked Foreign Office couriers.

Courlan, an American wading-bird of the genus Aramus, usually placed among the Rails (q.v.). The North American courlan or cryingbird ( $A$. giganteus) is $27 \frac{1}{2}$ inches long, with long bill and short wings, is a rapid runner, and has a cackling note. It inhabits Florida and the West Indies. The nest is usually attached to reeds. The flesh of the young is good eating. The South American courlan (A. scolopaceus) is larger.

Courland, or Kurland, a Russian government, and one of what are called the Baltic provinces. It was formerly an independent duchy -properly, indeed, consisting of two duchies, Courland and Semgallen-and belonged, along with Livonia, to the Teutonic Knights. The difficulty of resisting the Russians led to the acknowledg ment in 1561 of the feudal sovereignty of Poland. The country was long distracted by the contentions of two parties, one Russian and the other Polish; and after being for some time very completely under Russian influence, it was finally united to Russia in 1795. Biron (q.v.) was made Duke of Courland in 1737. It contains about 10,540 sq. m., with a population in 1895 of 713,800 , mostly Protestants. It is generally a level country, with ranges of low hills, and contains many lakes, bogs, forests, and sand-dunes, but some parts have a very fertile soil. Cattle-breeding is on the increase; game abounds; and bears, boars, elks, and wolves are met with occasionally. The proprietors of land are mostly German ; the peasantry, who constitute the bulk of the population, of Lettish extraction, are chiefly engaged in husbandry. The Russians do not amount to 2 per cent. of the population. There is little manufacturing industry, but trade is rather increasing. The capital is Mitau, but the most flourishing town is Libau.

\section{Courses. See SaIL.}

Coursing is defined by Dr Johnson as 'the sport of hunting hares, foxes, and sometimes deer with greyhounds.' From the sportsman's point of view foxes and deer must be eliminated from the definition, for coursing is now understood to be the pursuit of hares by a brace of greyhounds. 'The saying that 'a gentleman was known by his hawk, his horse, and his greyhound,' is a very ancient one; and King John is recorded to have accepted greyhounds in lieu of a noney fine; but in those times it was generally deer that were coursed. In Elizabeth's reign the sport attained a fashion and celebrity previously unknown, and has since that time been followed up with undiminished zeal.

Late in the 16 th century we have a record of some laws of the leash framed by the then Duke of Norfolk on principles which have been largely adhered to since. To Lord Oxford, the lordlieutenant of Norfolk, the sport of coursing is much indebted. Indeed, by some he is called 'the father of modern coursing;' and he it was who founded the first society, as it was then called, in 1776 at Swaffham in Norfolk. Other clubs were noon organised, Lord Craven founding one at Ashdown Park in 1780, and this was followed by the Malton Club in Yorkshire and the Bradwell and Tillingham Club in Essex, besides many others starting soon after the opening of the 19th century.

After the passing of the Game Laws in 1831 coursing became much more general, and the sport was taken up by the public, meetings prior to that time being principally supported by members of clubs, of which there were a large number spread over the kingdom. From that date up to 1875 the growth of coursing was very great, and all the chief meetings throughout England, Scotland, and Ireland were attended not only by those who owned dogs, but also by many who simply went for the love of the sport. It was feared by many that the Ground Game Act of 1880 would greatly interfere with public coursing, and this fear naturally caused coursers to follow the example of $\mathrm{Mr}$ Case, of Plumpton, who originated the inclosed system, the first ground being made over his farm in Sussex. Up to this time coursers as a body had looked rather askance at the new method of carrying on the sport; but the Ground Game Act caused more inclosures to be formed, and then the fact of their being so easy of access added greatly to their popularity.

The real sport of coursing can only be obtained at the open meetings, so called in distinction to the inclosed, notwithstanding that these latter fixtures have been for a time in favour with those who prefer the 'ease and comfort' obtained from commencing the day some time between eleven and twelve and finishing at four, whilst all the courses run can be witnessed from a grand-stand. At the inclosed fixtures the betting as a rule is far higher than when the coursing takes place in some open country where the slipper and dogs have to be followed from one end of the day to the other, for this would be far too much work for the ordinary betting-man.

At a coursing-meeting two Greyhounds (q.v.) are slipped together, and the judge who has been appointed by the committee or by the votes of the nominators decides which is the winner of the trial upon the one uniform principle that the greyhound which does most towards the killing - though he may not actually kill - is to be declared the winner. The judge has a recognised code of points to go by, these points being speed, for which one, two, or three points may be allowed; the go-bye, two or three points; the turn-that is, bringing the hare round at not less than a right angle-one point; the wrench-bringing the hare round at less than a right angle-half a point; the kill, one or two points or even less; and the trip-where the hare is thrown off his legs-one point.

Those fixtures held over the downs have always been looked upon as amongst the very best of the open meetings. The Amesbury meeting has always been held over the splendid range of Wiltshire downs belonging to the Antrobus family. The village of Amesbury, which is the headquarters for this fixture, is $7 \frac{1}{2}$ miles north of Salisbury. The Ashdown Park Club was established by the then Eari of Craven in 1780, and the stakes up to 1850 were confined to its members; but since that date open meetings have taken place in addition to others held by the South of England Club. The Berkshire village of Lambourn is the headquarters for the Ashdown meetings, Another favourite meeting is held over the Stockbridge Downs, a short distance from the well-known racecourse. The Waterloo Cup meeting takes place over the so-called Plains of Altear (belonging to the Earl of Sefton) in Lancashire, and here, too, the Altcar Club holds its fixtures. The Ridgway Club meeting is another of the large and old-established Lancashire fixtures, but the running there is confined to members. The Clifton Arms Hotel at Lytham is the headquarters. Two meetings 
are annually held at Southport. In Yorkshire the beat meetings take place under the North of England Club, several estates being lent by the owners for their fixtures: and in aldition Scar. borough and other places annually hold open meet. ings. Lincolnshire has a well-managed fixture at Sleaford. In the Midlands Lichifield is the best supported meeting, the Marquis of Anglesey allowing the coursing to take place over his estate at Beandesert. Newmarket-the turf metropolisannually boasts of a large and well-attended meeting. Farther south the Cliffe and Hundred of Hoo Club and the Essex Club both hold open fixturesthe former over the Cliffe marshes beyond Gravesend, the Essex Club at Southminster.

The Border Union ranks as the best meeting held in the north, and this fixture, which now takes place in November, is much looked forward to by both northern and southern coursers. Longtown, 91 miles north of Carlisle, is the headquarters. The principal meetings in Scotland are Carmichael and Corrie. In Ireland, Mourne Park may be said to be the chief meeting (though really coming under the head of 'inclosed '), many English dogs heing sent across the Channel to compete, and the coursing season is always opened there. Other fixtures are held by the Northern Club and the Leinster and Limerick clubs.

The first ground over which 'inclosed' coursing took place in 1876 was at Plumpton in Sussex. Here originally there were three fields, with plantations for letting the hares out from and escape coverts made at the farther end; but the smallest of these inclosures was soon done away with, and the sport took place over the Station Field, which was 800 yards long by 300 yards wide, and the Hill Field, 700 yards by 300 yards. Since 1886, however, the Station Field only has been used; and this is on an incline from one end to the other, affording good trials, and fairly well testing both the speed and stamina of the greyhounds. In connection with High Gosforth Park an inclosure was made 5 miles from Newcastle-on-Tyne. The coursing-ground is slightly down hill from the slipping station for about 150 yards, and from that point a very easy rise to the escape covert. At Haydock Park, near Newton Bridge station, on the Liverpool and Manchester Railway, are two fields quite distinct, which are used on alternate days, so that the same hares are not coursed two days in succession.

Kempton Park, the nearest inclosed ground to London, is situated in the Vale of Sunbury, 16 miles from the metropolis. Two meetings a season are held here, and the champion meeting which annually takes place in January holds the lighest rank in this style of coursing. All the fastest dogs in the United Kinglom are bronght together, for, as a rule, it is to the dog with the most speed that the chief prizes in the inclosures fall, the working qualities of the greyhound not being sufficiently brought into play.

At Wye, near Asluford in Kent, an inclosure has been established, and meeting after meeting takes place here throughout the season, with at times a very small interval between them. Here the ground is on the incline nearly all the way, and this, as a rule, gives the slower greyhounds a better chance of gaining the judge's verdict, as, though generally led, they when once in possession go the better with their game. The average num. ber of points made in a course here are certainly greater than at the other inclosures. The inclosure at Four Oaks Park, about a mile from Sutton Coldfield, is another that is almost all on the incline, but the meetings here are now few and far between. The coursing arena is 700 yards in length, and 400 yards in width.
Court, Presentation at. Fomial presenta. tion to the sovereign of persons whose status entitles them to that honour, taken place either at St James's Yalace, at a levee, intended for gentlemen only, or at Buckingham Palace, a draw. ing-room, where both ladies and gentlemen appear. The days when levees and drawing-rooms are to be held are always announced some time beforehand. It is difficult in the present day to define exactly who may and who may not be entitled to be pre. sented. Members of families of the nobility and landed gentry, diplomats, members of the House of Commons, persons holding high offices under the crown, judges, magistrates, ehurch dignitaries, officers in the army and navy, persons who have attained distinction by eminence of any kind, and the wives and daughters of the same clasees, form the larger number of those presented at levees and drawing-rooms. Persons are often presented on entering on some office, or attaining some dignity. Any one who has been once presented is entitled to appear at any future levee or drawing-room without a new presentation. The whole arrangements con. nected with presentations are under the supervision of the lord chamberlain, in whose office in St James's Palace information is given to all persons wishing to be presented. The names of ladies and gentlemen desiring presentation, and of the ladies, noblemen, and gentlemen who are to present them, have to be submitted to the govereign for approval, and there is a strict excln. sion of persons of damaged reputation, whatever their rank. Court dress or official uniform must be worn. A British subject who has been presented at St James's may on any after occasion elaim to be presented by the British minister at any foreign court. As to court dress both of ladies and gentle. men, court etiquette, court mourning, \&c., reference may be made to Old Court Customs and Modern Court Rule, by the Hon. Mrs Arnytage (1883).

Courtallum (Kuittalam), a town of the district of Tinnevelli. Madras, stands amongst the Ghats near the southern end of the peninsula; and though only 450 feet above sea-level, serves as the sanatorium of the district, deservedly enjoying a reputation for salubrity of air, richness of vegeta. tion, and beauty of scenery. Pop. about 1500 .

Courtesy, or Curtesy, in Law, is the life interest which the surviving husband has in the real or heritable estate of the wife. Both in England and in Seotland this customary right has been regarded as a national peculiarity. Littleton speaks of it as tenure 'by the curtesie of England because this is used in no other realine but in England onely.' In Scotland it is called the courtesy or curiality of Scotland. It was probably introduced into both countries from Normandy. The four circumstances which are requisite to make a tenancy by courtesy in England aremarriage, seizin of the wife, living issue, and the wife's death. The rule that the child must have been heard to ery, which at one time was followed in England, is still adhered to in Scotland. It is not necessary, however, in either country, that the child survive; it is enough that it was once in existence, although it should have died imme. diately after its birth. In both countries, the child must be the mother's heir, and it is consequently said that courtesy is due to the surviving husband rather as the father of an heir than as the widower of an heiress.

Courtesy Titles are titles allowed to certain near relations of peers by understood ueage and the courtesy of society, bnt to which the users have no legal right The subject of conrtesy titles, though tolerably familiar in its general outline to persons resiclent in Britain, is complicated 
enough to be a frequent source of perplexity to Americans and foreigners, and may be thus explained: Dukes, marquises, earls, and even viscounts are often in possession of a number of titles belonging to an inferior grade in the peerage, which have in many cases been gradually accumulated by the ancestors of the peer in the course of his upward progress in the peerage. Some peers have as many as sixteen inferior titles-e.g. the Duke of Atlole, who has one marquisate, fout earldoms, three viscounties, and eight baronies. While in ordinary parlance a peer is known by his highest title (or titles, if he holds two of the same degree), his eldest son bears by courtesy one of his inferior titles. Thus the eldest son of the Duke of Devonshire is Marquis of Hartington; of the Duke of Buccleuch and Queensberry, Earl of Dalkeith ; of the Marquis of Bute, Earl of Dumfries. There is no rule as to which inferior title should be assumed, a lower one being occasionally preferred to a higher; and the courtesy title may be different in one generation from another. The inferior title of a viscount who is also a baron is never borne as a courtesy title by his son; but a usage prevails anong viscounts and barons (more properly 'lords') in the peerage of Scotland, of the eldest son designing himself 'master ;' thus the eldest sons of Viscount Arbuthnot and Lord Lovat are known as the Master of Arbuthnot and Master of Lovat. Courtesy titles are allowed to the eldest sons of courtesy marquises and earls. Thus the eldest son of Earl Percy, himself eldest son of the Duke of Northumberland, is Lord Warkworth. There are various instances of titles borne by heirs. apparent or grandsons of peers which have no existence among the family honours, or are derived from them by some modifications. While Earl Nelson's inferior titles are Viscount Merton and Baron Nelson, his eldest son is known as Viscount Trafalgar. There are a few cases where, in consequence of the inferior title being identical with the higher one, the eldest son substitutes the family surname for the title. The Earl of Gosford, whose family surname is Acheson, is also Viscount Gosford and Baron Gosford; and his son adopts the courtesy style of Viscount Acheson. The holders of courtesy titles, not being legally peers, can sit in the House of Commons.

The younger sons of dukes and marquises have the courtesy title of 'Lord' prefixed to their Christian name and surname-e.g. Lord Charles William de la Poer Beresford, second son of the late Marquis of Waterford; and the daughters of dukes, marquises, and earls, have 'Lady' followed by their Christian name and surname, the surname being that of their husband if married, or his courtesy title if he be a courtesy peer. But if a lady enjoying such courtesy title marry a peer (not by courtesy), she only takes her husband's peerage title. Thus the fifth Duke of Buccleuch's second daughter, by her marriage with Donald Cameron of Lochiel, became Lady Margaret Elizabeth Cameron, while the same duke's eldest daughter is Marchioness of Lothian. Lady Emily Somerset, daughter of the Duke of Beaufort, on marrying Viscount Dupplin, eldest son of the Earl of. Kinnoull, was known as Lady Emily Dupplin; but on her husband sueceeding his father as Earl of Kinnoull, she became simply Countess of Kinnoull, this change of designation involving, curiously enough, a loss of precedency, inasmuch as the rank of a duke's daughter is higher than that of a countess. When, as often happens, a royal warrant is granted to the brothers and sisters of a peer whose father has never been in possession, giving them the precedence of the sons and daughters of a peer, they enjoy the corresponding courtesy titles. The title 'Honourable, used by sons of earls, viscounts, and barons, and daughters of barons, belongs, not of courtesy, but of right, to them in common with all sons and daughters of peers.

The widow of a peer or a knight is allowed by courtesy to retain the title she acquired from her husband, notwithstanding a second marriage; the widow of a baronet is legally entitled to do so.

Along with courtesy titles may be ranked the appellations of the judges of the Court of Session in Scotland, who prefix 'Lord' either to their surname or to a territorial designation. These titles, though given in general society as well as on the bench, are not used in subscribing the judge's name, even to official papers. Hence Lord Medwyn's signature, 'J. H. Forbes,' and Lord Mure's, 'David Mure.' The wives of judges do not par. ticipate in their husband's titles. See ADDRiss, FORMS OF.

Court-fool. See Jesters.

Court-hand, a name given in England to a modification of the Norman handwriting, as distinguished from the modern or Italian handwriting which was in use in the English law-courts from the 16th century till abolished by law in the reign of George II. See Writing.

Court-martial, a court for the trial of all persons subject to military law or to the Naval Discipline Act. In the army, before the institu. tion of a standing army in 1660 , military discipline was maintained by articles of war issued by the crown, to remain in force only so long as the campaign continued. These ordinances were administered by the Court of Chivalry (q.v.), of which the judges were the Lord High Constable and the EarI Marshal. In 1689 the first Mutiny Act (q.v.) was passed by parliament, and, with the articles of war, made by royal prerogative, constituted the law under which discipline in the army was maintained. This law, which is now embodied in the Army Act of 1881, provides for the assembly of courts-martial for the trial of offences which are of too grave a character to be dealt with summarily by the regimental commanders. They are of five kinds - general, district, regimental, field-general, and summary. The sovereign issues a warrant authorising each general officer to convene the two first named, and every regimental commander has power, in virtue of his office, to convene the third. The fourth can only be convened in countries beyond the seas, and to try offences against the person or property of an inhabitant when an ordinary general court. martial cannot conveniently be assembled. The last can only be convened on active service under similar conditions, and, with the fourth, has the same powers as a general court-martial.

A general court must consist of five officers (nine in the United Kingdom, India, Malta, and Gibraltar), including the president, who must be the senior and a field-officer, except in special circumstances, when a captain may preside, and each member must have held a commiasion for three years. Similarly, a district court must consist of three or five officers of two years' service, and a regimental court of three officers of one year's service; if no captain is available, $\mathrm{a}$ lieu. tenant may preside over either of them. All members must be strictly impartial, and may be chal. lenged by the prisoner on that point. A fieldgeneral court must consist of three officers, of any rank, and a summary court of the same number, if available, otherwise two are sufficient; but in that case it cannot pass sentence of death, and, with three members, all must concur in such a sentence.

Any of these courts is competent to try any offence, but not any offender; thus an officer or 
a civilian subject to military law, and on the same fonting as an oflicer (e.g. a newspaper correspond. ent) can only be tried by a general, field-general, or summary court-martial, and a warrant-ofticer cannot be tried by a regimental court. Their jowery of punishment vary also, from forty. two days' imprisonment to death. An officer may be centenced to eashiering, dismissal, forfeiture of rank, or reprimand; a non-commissioned officer to reduction to the ranks, and like a private soldier, to discharge with ignominy, forfeiture of service, medals, \&c., fines and stoppages of pay; all runks and civilians, if subject to military law because accompanying a force on active service, may be sentenced to imprisonment, penal servitude, or death.

All sentences must be confirmed before they are carried out-those of general, field-general, and district courts by the sovereign, or officer authorised to confirm by warrant from Her Majesty; those of regimental and summary courts by the convening officer. The confirming authority may commute, mitigate, or remit the whole or part of a sentence, and may order both finding and sentence to be revised (unless the prisoner is ac. quitted), but cannot, nor can the court on revision, increase the sentence.

The procedure is similar to that of civil courtsthe court is public, and the same rules of evidence are in force; but the members of a court-martial act as both jury and judge-i.e. they find the facts and allot the sentence. All are sworn, and each votes, commencing with the junior, both on the linding and sentence, as well as on any question that may arise, the majority deciding. The witnesses are also sworn. An officer is appointed as judgeadvocate in important trials, to assist the court on points of law, see that the proceedings are regular, and, with the president, take care that the prisoner is treated with strict fairness. Counsel may appear on both sides at general courts, and, if barnsters or officers subject to military law, may address the court, and examine and cross-examine witnesses; or before any court the prisoner may be assisted in his defence by a 'friend,' who may make suggestions to him, but is not allowed to address the court or the witnesses. The prosecutor must be an officer and not a member of the court; he is sworn, and eharged with the duty of eliciting the truth, but not necessarily of obtaining a conviction. The proceedings are all written, except those of summary courts, which have a necessarily abbreviated form of procedure, like the drum-head court-martial for which they have been substituted.

Contempt of a court-martial by persons subject to military law is punishable by the same or another court-martial, and, in the case of civilians, by a civil court, to which the offence is certified by the president. Witnesses are snmmoned by the convening officer or the president, and, if civilians, their travelling expenses must be tendered. Sometimes courts of inquiry are held instead of a courtmartial, not to try or to punish, but to make an investigation; the members not being on oath. Such a court occasionally precedes a court-martial.

On board a man-of-war no military court-martial may sit except a regimental court, with the sanction of the captain of the ship, for the trial of a non-commissioned officer, and it may only sentence him to reduction to the ranks. Marines are liable to trial by military court-martial when not borne on the books of a man-of-war, in which case they come under the Naval Discipline Act. Naval courts-martial consist of admirals, captains, and comnianders, who try offences against the Naval Discipline Act. The chief admiral of the fleet or squadron appoints the members; but all captains on the station have a right to sit, if not implicated.
The court-martial is open to all the crew and other as spectators. The nentence in find, and needs no confirmation.

Courtney, Leonard HeNry, was born at Penvance, in Cornwall, the son of a lunker there, July 6, 1832. Educated at Penzance and St Jolin's College, Cambridge, he grauluated second wrangler and firat Smith's prizeman in 1855, and became fellow of his college the year after. In 1858 he was called to the bar, and from 1872 to 1876 he filled the chair of political economy at University College, London. He early began to write for the Times, and his pamphlets and articles to monthly magazines placed him among the ablest and most advanced doctrinaire Liberals in England. He early became an eager advocate for proportional representation and a wide extension of local goverument. He was returned for Liskeard in 1876 and 1885 ; in 1886, 1892, and 1895 for South-east Cornwall. He was Under-secretary of State first in the Home and next in the Colonial Otfice, and in May 1882 succeeded the ill-fated Lord Frederick Cavendish as Financial Secretary to the Treasury. He was appointed chairman of committees in both the purliaments of 1885 and 1886-92.

Court of Session, the supreme court of civil jurisdiction in Seotland, was constituted in 1532. The credit of its origin is generally ascribed to the Duke of Albany, who when regent had submitted a scheme for the establishment of such a court to Pope Clement VII. ; and the details of the scheme were carried out by Archbishop Dunbar of Glasgow, who was then Lord Chancellor. Its constitution was principally modelled on that of the parliament of Paris, of which body the Duke of Albany was at that time a member. French influence was clearly seen in many features of the Court of Session, and to this day may be recognised in the names of its officers-president, king's advocate, advocates, dean of faculty, procurators, \&c. The judges of the Court of Session originally consisted of the Lord Chancellor, Lord President, and fourteen ordinary judges or 'senators of the College of Justice,' together with an indefinite number of extraordinary lords, who represented the peerage. At first, half the number of the judges were laymen appointed by the king, and half ecelesiastics appointed by the church. In 1584 all clergymen were declared disqualified from holding judicial office, but so late as 1664 the Archbishop of Glasgow was made an extraordinary lond. The extraordinary lords themselves were abolished in 1723 , and the Court of Session then consisted of the Lond Presi. dent and fourteen ordinary judges, the oflice of Lord Chancellor having been abolished at the Union. The Court of Session finst sat in the Tolbooth or prison of Edinburgh, but in 1639 was accommodated in the buildings of the Parlia. ment House, which was then erected. It sat as one chamber, one of the ordinary londs going by rotation weekly to sit in what was called the Onter House. Here all cuses, with certain exceptions, were in the first place heard and deciled by the Lord Ordinary, but an appeal lay from his judgment to the whole conrt. Fresh changes were made in 1808 and 1810 ; and in 1830 the total number of judges was reduced to thirteen, the two divieions each consisting of four, including the Lord Presi. dent and Lord Justice-clerk, whilst the number of the Outer House judges remained as before: this is the present constitution of the court. In 1850 , moreover, the office of president was united with that of Lord Justice-general or president of the High Conrt of Justiciary (q.v.), the supreme criminal court in Scotland. Prior to 1887 five of the judges were aplointed Lords Com- 
missioners of Justiciary, but by the Criminal Procedure (Scotland) Act of that year all the judges are now members of that court. Since the Union in 1707, several courts which had a separate existence, and in some cases an exclusive jurisdiction, have been merged in the Court of Session. These are the Court or Commission of Teinds (though this still sits nominally as a separate court), in which questions relating to the law of teinds or church tithes were decided; the High Court of Admiralty, dealing with maritime cases; the Court of Exchequer, having jurisdiction in all matters relating to crown rents, customs, \&c.; and the Commissary Court of Edinburgh, which had to do with wills. The judges of the Court of Session are appointed by the erown from the bar, and hold their offices ad vitam aut culpam. See APPEAL, Justiciary Court.

Court-plaster. See Plasters.

Courtrai (Flem. Kortrijk), a town of Belgium, in the province of West Flanders, 54 miles SW. of Brussels by rail, and 6 miles from the French frontier. Courtrai, which is built on both sides of the Lys, is surrounded with ancient walls, and has a fine old bridge flanked with Flemish towers, a noble town-hall (1526), belfry, and a beautiful Gothic church, founded in 1238 by Baldwin, Count of Flanders. Table damask, linen, and lace are the principal articles of manufacture, and employ 5400 hand-looms and several large factories. There are extensive bleachinggrounds in the vicinity, and the neighbouring plains supply fine flax in large quantities to many Europenn niarkets. Pop. (1875) 27,076; (1893) 31,319 . In 1302 the Flemings, citizens of Ghent and Bruges chiefly, won a splendid victory over the chivalry of France beneath the walls of Courtrai, called 'Battle of the Spurs,' from the number of gilt spurs afterwards gathered from the dead by the victors, Henry VIII.'s 'Battle of the Spurs' was fought at Guinegate (q.v.) in 1513 .

Courts of Law. See Common Law, CHanCERY, EQUiTy, APPEAL, High COURT OF JUSTICE, Court of Session, County Courts, Admiralty Courts, Divoree, \&c.

Cousin (Fr., from Low Lat. cosinus; for Lat. consobrinus), a kinsman; more specifically the son or daughter of an uncle or aunt. The children of brothers or sisters are cousins-german (german being the Lat. germanus, "brother"). The children of cousins-german are second cousins; and if A and $\mathbf{B}$ are cousins, $\mathbf{A}$ is a first cousin once removed to the children of $\mathbf{B}$, as $\mathbf{B}$ is to the children of $\mathbf{A}$. See Consanguinity.

Cousin, VICTOR, the founder of systematic eclecticism in modern philosophy, was born in Paris, November 28, 1792. He studied with brilliant success at the Lycee Charlemagne and the Ecole Normale. He was attracted to the study of philosophy by Laromiguière, a disciple of Locke and Condillac; but appointed in 1815 assistant-professor to Royer-Collard at the Faculty of Letters, he threw himself heartily into the reaction against the sensualistic philosophy and literature of the 18th "entury. Following the path of his senior, he became an exponent of the doctrines of the Scottish metaphysicians, but exhibited far more brilliancy than the original anthors of these doctrines. In 1817 Cousin visited Germany, and already introduced to its bolder speculative systems, he now zealously studied Kant, Jacobi, Fichte, Schelling, and Hegel. For his liberalism he was in 1821 deprived of his offices; and in a second visit to Germany in 1824-1825, suspected of carhonarism, he was arrested at Dresden, presumably at the instigation of the French police, and sent to Berlin, where he was detained for six months.
He took advantage of his compulsory residence in the capital of Prussia further to study the philo. sophy of Hegel. On his return to France he took a decided stand against the reactionary policy of Charles $X$, and in 1827 was reinstated in his chair at the Sorbonne. Meanwhile he had appeared as an author. During 1820-27 he published his editions of Proclus and Descartes and part of his celebrated translation of Plato. It has been said that to find an audience as numerous and as passionately interested as were those of Cousin, it would be necessary to go back to the days of Abelard. Cousin threw great moral earnestness into his work; his doctrines were for the most part new to his hearers, bold, and in harmony with the spirit of the time. The finest qualities of the national genins appeared in his lectures, a wonderful lucidity of exposition, a beauty of style such as few philosophers have equalled, and a power of co-ordinating the facts of history and philosophy in such a manner as to make each illustrate the other. At this period Cousin was one of the most influential leaders of opinion in Paris ; and consequently, after the revolution of 1830 , when his friend Guizot became prime-minister, Cousin was made a member of the Council of Public Instruction; in 1832 a peer of France; and later, Director of the Ecole Normale. The great success of his efforts for the organisation of primary instruction was largely a consequence of those valuable reports which he drew up, from personal observation, on the state of public education in Germany and Holland. In 1840 he was elected a member of the Academie des Sciences Morales et Politiques, and in the same year became Minister of Public Instruction in the caloinet of Thiers. The revolution of 1848 found in Cousin a friend rather than an enemy, and he aided the government of Cavaignac. After 1849 he disappeared from public life. In his last years he lived in a suite of rooms in the Sorbonne, and he died at Cannes, 13th January 1867.

His philosophy is eclecticism, but not mere syncretism. He has a definite criterion of truth, and a definite method of observation, analysis, and induction; his system comprises psychology, ontology, and an eclectic history of philosophy. Psychological observation gives three great factors - sensibility, activity or liberty, and reason, the latter being impersonal. Cousin repudiates pantheism, with which he has often been charged; and criticising the opposing systems of sensationalism, idealism, scepticism, and mysticism as incomplete rather than false, he holds that each expresses a real order of phenomena and ideas. Cousin's influence revived the study of philosophy in France, and especially renewed interest in the history of philosophy. Amongst his pupils more or less influenced by his teaching are Jouffroy, Rémusat, Barthélemy St Hilaire, Jules Simon, and Janet.

Cousin's chief works (besides those already mentioned) are Fragmens Philosophiques (1826), Cours de l'Histoire de la Plizlosophie (1827), Cours d'Histoire de la Philosophie Moderne (1841), Cours $d^{\prime}$ Histoire de la Philosophie Morale au XVIII' Siecle (1840-41), Leçons de Philosophie sur Kant (1842), Études sur les Fernmes et la société du XVII' Sidcle (1853), his famous $D u$ Vrai, du Beau, et du Bien (1854; 23d ed. 1881), works on Aristotle, Locke, Kant, and Pascal, and his editions of Abelard and Pascal's Pensées. See Sir W. Hamilton's eritique in the Discussions; Janet, Victor Cousin et son Euvre (1885); Jules Simon's Monograph (1887; trans. by Masson, 1888); and Barthélemy St Hilaire, Victor Cousin, sa Vie et Correspondance (3 vols. 1895).

Cousins, Samuel, engraver, was born 9th May 1801 at Exeter, and was apprenticed to $\mathrm{S}$. W.
Reynolds, the excellent mezzotinter, in many of 
whose plates he had a chief hand, while some fific-live of the suall mezantints after Sir Josluna, which bear his master's name, were his work. Alsout this period he also executed portraits in pencil. In 1820 he started on his own account as an engrnver, and produced the 'Master Lamb. ton' after Lawrence, a mezzotint which at once established his reputation. It was followed by a long series of admirable plates after Reynolds, Lavrence, Landseer, Leslie, Millais, Leighton, and other eminent painters. His 'Marie An. twinette in the Temple,' after $\mathbf{F}$. M. Ward, he was accustomed to rank as one of his finest works, He was elected an Associate-engraver of the Royal Academy in 1835, and a Royal Academician Engraver in 1855, and he retired in 1880. To the Acalemy he presented a sum of $£ 15,000$ to found annuities for poor and deserving artists. He died 7th May 1887. His works were catalogued by Algernon Graves in 1880 .

Coutances, a town in the French department of La Manche, 5 miles from the English Channel, and $57 \mathrm{~S}$. of Cherbourg by rail. It stands on a hill crowned by the cathedral (dating from the 13th century), one of the finest specimens of ecclesiastical architecture in the Early Pointed style in Normandy. Pop. 8108 .

Couthon, Georaes, a fanatic of the French Revolution, was born in 1756 at Orcet, near Clermont, in Auvergne. An advocate at the outbreak of the Revolution, he was sent by Puy de Dôme to the National Convention, where, spite of his crippled limbs, he made himself conspicuous by his shrieking hatred of the priesthood and the monarchy. He voted for the death of the king without delay, became a devoted and blowithirsty partisan of Robes pierre, and was appointed in July 1793 a member of the Comite de Salut Preblic. At Lyons he erushed the insurrection with mereiless severity, and outdid himself after his return to the Convention, with his frothy ravings against Pitt and the English nation. The fall of Robespierre brought down Couthon also. Accused by Fréron, he was thrown into prison, delivered by the mob with whom he was popular, recaptured by the soldiers of the Convention, and executed 28th July 1794, along with St Just and Robespierre.

Coutras, a town in the French department of Gironde, on the leit bank of the Dronue, 32 miles NE. of Bordeaux by rail, with some trade in flour and wine. Here, in 1587 , Henry of Navarre gained a bloody victory over the forces of the League, under the Duc de Joyeuse, who perished. Pop. 2302.

Coutts, Thomas, banker, was born in 1735 in Edinburgh, the son of a merchant and banker, who was lord provost in 1742-44. With his brother James he founded the banking-house of Coutts and Co, in London, and on the latter's death in 1778 became sole manager. Keen and exact in matters of business, although charitable and hospitable in jrivate, he left a fortune of some $£ 900,000$ at his leath in 1822. By his tirst wife, who had been a servant of his brother's, he had three daughters, who married respectively the Earl of Guilford, the Marquis of Bute, and Sir Francis Burdett, Bart. in 1815 he married Miss Mellon the actress. See BURDETT-COUTTS.

Couvade, a singular and widespread custom anong savages in many parts of the world, and regulating the conduct of a father in connection with the birth of a child. In Guiana, even before the child is born, the father alstains from some kinds of animal food. The mother works up to a few hours before the birth, and retires alone, or with some women, to the forest for the birth. In a few hours she returns and resumes her ordinary work. 138
Meanwhile the father has taken to his hammock, and alsstains from every kind of work, from meat and all other food except weak gruel of ensanva meal, from smoking, from washing himself, and especially from touching weapons of every kind. During this time, which may extend for weeks, he is fed and cared for by the women. The explanation is unattainable; but the custom appears to imply a mysterious magieal and sympa. thetic connection between father and child, such that if the father infringe the rules of couvade the child suffers. If he eat capybara flesh, the child will have protruding teeth like those of that animal ; if he eat an animal with spotted skin. the child will be spotted too. In Guina the child is not weaned till the third or fourth yen. Indians often allege in explanation that the child descends more directly from father than from mother. Some recent anthropologists find the origin of the custom in the transition from the original matriarchal system (see TRIBE), in which descent and inheritance were reckoned through the mother alone, to the patriarchal system. In some places still the father has to buy the child from the mother; among the ancient Komans, the father had to lift the child from the ground. The couvade may therefore be a ceremony by which the father secures and proclaims his property in the new-born child. Diodorus records the custom as in use among the ancient Corsicans; and it has been found by ancient and modern travellers in parts of China, Borneo, Africa, North and South America. The name, now commonly used by anthropologists, is French, being from couver, 'to hatch eggs.' See Tylor, Eurly History of Mankind (1878); Giraud-Teulon, Les Origines de la Famille (1874).

Covenant (Lat. convenire, "to come together"), a contract or agreement; a term much used by theologians, and in its ordinary signification, as well as in its theologieal use, nearly if not always exactly equivalent to the Hebrew berith of the Old Testament and the Greek diatheke of the New. Applied to relations established between God and men, the term covenant must be understood with a certain modification of the meaning which it bears when employed concerning the relations of men to one another, when two independ. ent parties enter into a covenant, which they have equal right to make or to refuse to make; and is sometimes employed as equivalent to dispensation, and the Jewish dispensation is enlled the old Covenant (or testament, by another translation of diathelke), in contradistinction to the Christisn, which is called the New (see BIBLE). The 'Covenant' or 'Federal' system of theology was developed by Cocceius (q.v.). God, in his supremacy, is regarded as appointing certain conditions for his creatures, which they cannot but accept, yet their willing consent to these conditions gives to the relation established the nature of a covenant; and thus God is commonly said to have made two covenants with man-the first covenant, or cotenant of voorks, with Adam, as the representative of the whole human race, pronising life (with perfect happiness), upon condition of perfect obedience, whilst death was threatened as the penalty of trans. gression; the second covenant, or covenant of grace, Preing that on which depends the whole hope and alvation of man since the first covenant was broken, and in which life is freely offered to sinners, and they are simply required to believe in Jesus Christ that they may be saved. This covenant God is regarded as having made with Christ, as the representative of his people, and with them in him. The older theologians often speak of the covenant of redemption between God and Christ, employing the term covenant of grace rather to designate the whole dealings of God with men in 
giving effect to the covenant of redemption; but the term covenant of grace has long been almost universally employed to include all that was comprehended under both terms. The Abrahamic covenant is the covenant of grace as declared to Abraham, in its particular relation to him and his seed. God is represented in Scripture as sustaining a covenant relation to his own people, to the Jews under the Old Covenant, to believers in Christ under the New; and doctrinal theology consists not a little in tracing ont the nature of this relation, and the consequences which flow from it. As the people of God collectively sustain a covenant relation to him, so do believers individually; and it has not been an uncornmon thing for pious persons to endeavour to reduce to writing their sense of this covenant obligation, under the notion of a personal covenanting with God; and of binding themselves by a stronger obligation to what they believed to be good and their duty. It has also been common for men, from the earliest ages, to enter into covenants with one another with more or less of religious solemnity; and this has in particular been done among those who have suffered persecution, or have been engaged in contests concerning matters of religion, for which the authority of certain passages of the Old Testament is strongly pleaded. Instances occur in the history of the Waldenses, and of some of the Reformed ehurches, particularly in Scotland.

The Covenants, known in Scottish history and tradition, originated in the Reformation movement of the 16th and 17th centuries. The first Reformation, in 1560 , was preceded by several religious bonds among the Reformers themselves; but the work of reformation was crowned in both first and second periods by the whole nation engaging in public religious covenanting. These public national covenants are two in number-the National Covenant, and the Solemn League and Covenant.

The National Covenant, which is sometimes called the 'Scots Confession' and the 'Short Confession,' to distinguish it from the more elaborate Confession of Faith enacted and placed on the statute-book by parliament in 1560 , was drawn up in 1580, at the command of James VI., by one of his chaplains, John Craig (q.v.), to counteraet attempts which were being made by the Roman Catholies to regain their lost hold of Scotland. It contains a profession of adherence to the "true Christian faith and religion' more particularly expressed in the Confession of 1560, an explicit renuneiation of the tenets of popery, which are detailed at length, and a pledge of obedience to the Presbyterian discipline of the church as then established, and of allegiance to the king in the defence of the gospel, all being ratified by solemn oath. By the ordinance of the king, the Privy-council, and the General Assembly, this Covenant was sworn and subseribed by all ranks and classes in 1581; renewed in 1590 in a bond specially directed against the machinations of the Holy League, which had in 1588 despatched the Armada ngainst the British Isles; again renewed in 1596, and still again in 1638. In the last-mentioned year it was renewed in a bond directed against the attempts of Charles I. to enforce the Laudian service-book and Episcopacy upon Scotland. The swearing and subscribing of the Covenant throughout the country was inaugurated in the Greyfriars' Churchyard at Edinburgh, on 28th February ; numerous copies were then sent out over the country, and of these many are still extant both in private and public custody. In the library of the Faculty of Advocates at Edinburgh alone, no fewer than five parchment copies are preserved with the original signatures of Rothes, Montrose, Loudoun, and many others of the nobility, gentry, commissioners of counties and burghs, and ministers. Only one of these, however, is connected with the year 1638. At the meeting of the General Assembly in Glasgow, on 21 st November of that year, the Covenant was ratified and appointed to be again sworn, while in pursuance of the object of the Covenant, the assembly deposed the whole of the Episcopal hierarchy which had been established by James VI. The other four copies of the Covenant above referred to were subscribed in 1639. The Covenant was further ratified by the parliament of Charles I., held at Edinburgh, June 11, 1640; and it was subseribed by Charles II. on his landing in Scotland, at Speymouth, on June 23, 1650, and again at his coronation at Scone, on January 1, 1651.

The Solemn League and Covenant was in effeet an international treaty between Scotland and England, for the object of securing the civil and religious liberties of these kingdoms. In 1643 commissioners were sent by the parliament to Edin. burgh to solicit the assistance of the Scots on the basis of a treaty between the two kingdoms. To this the Scots Convention of Estates and also the General Assembly cordially assented, on condition that the treaty was drawn up in the interests of their religious as well as their eivil liberties. Com. mittees of both were appointed to meet with the English commissioners, and the result of their deliberations was the Solemn League and Covenant. It is believed to have been largely the work of Alexander Henderson. It was hailed by both the representative bodies of the Scots with joyful unanimity, and sent to England for approhation, with their warmest recommenilations and assurances that it would prove 'the most powerful means, by the blessing of God, for settling and preserving the true Protestant religion with perfect peace in all his majesty's dominions, and propagating the same to other nations, and for establishing his majesty's throne to all ages.' It was received with almost perfect unanimity by the English parliament and the Westminster Assembly of Divines, both of whom forthwith swore and subseribed it, and sent copies over the kingdom, with their ordinance that it should be subseribed and sworn by all. Zachary Crofton gives a list of 793 ministers in twelve only of the counties of England, the West Riling of Yorkshire, and the city of London who subscribed their allerence to the Covenant. As soon as intimation of its acceptance by England was received in Scotland, the Solemn League and Covenant was enjoined to be sworn there by all ranks and classes; and being sent to Ireland was embraced by the Protestants there with like eagerness and satisfaction.

The prime object of the Solemn League and Covenant, as stated in the preamble thereof, was 'the preservation of ourselves and our religion from utter ruin and destruction,' and the Covenanters pledged themselves, in their places and callings, to endeavour the preservation of the reformed religion in the Church of Scotland, and the reformation of religion in England and Ireland, in the way of securing a uniformity of religion in the three king. doms, in doctrine, worship, discipline, and government. There can be little doubt that Presbyterianism was intended, as prelacy, which had just been abolished by both English and Scottish parliaments, was specially marked for extirpation along with popery. The Covenanters also pledged themselves to 'preserve the rights and privileges of the parliaments,' to ' defend the king's majesty's person and anthority in the preservation and defence of the true religion and liberties of the kingdoms,' to endeavour that the three kingdoms might 'remain conjoined in a firm peace and union to all posterity,' and finally, to evince a thorough and real reformation of life both in public and in private. The 
Solemn League and Covenant was reriewed in Seotland in December 1648, and along with the National Covenant was sworn to and subscribed by Charles II. at Speymouth and Scone, In tigliting for his succession arainst Cromwell, the Scots in 1650 enaeted that the motto on all their colours and stendards should be 'For Covenant, religion, king and kingdom,' and their watchword at the buttle of Inuluar was 'The Covenut.' After the Restoration, parliament decreed that the Covenants were not obligatory on the lieges; in 1662 they were declared unlawful oaths, and all acts ratifying and approving them were annulled; in $1682 \mathrm{an}$ onth was imposed specially renouncing the obligations of the Covenants, and in $\mathbf{1 6 8 5}$ it was declared to be treason to take them.

During the period, however, between the Restoration and the Revolution, the Covenants were ad. hered to by many who, upon this account, were called Covenanters. They maintained that these Covenants, notwithstanding all acts of parliament to the contrary, were binding upon the nation, and great numbers of them suffered and died in this testimony. Their heroic resistance was justified by the Revolution of 1688 , when the nation united in one final effort for the restoration of civil and religious freedom. . The Covenants, however, found no place in the polity of the reconstructed Chureh of Scotland, and so far as it and the nation in general is concerned, they remain a dead letter. They are nevertheless printed along with the authorised standards of the church-viz. the Westminster Confession of Faith, and Catechisms, \&c. But their continued obligation upon the entire nation remained a prominent principle of the Original Secession and Reformed Preshyterian churches, both of which have frequently renewed them from the Revolution down to the present day. See Scotland (Chureh of), Cameronians.

Covenant, in English Law, an agreement by Deed (q.v.) in writing, signed, sealed and delivered. A special action of covencent lay where a party claimed damages for breach of a covenant; but since the passing of the Judicature Act, 1875, this is no longer a technical expression. A covenant may also be implied. 'Covenant running with the land,' is a covenant affecting the land into whosesoever hands it comes. In the United States, the term covenant is used with the same sense as it has in England. The action of covenant is not there in use, a eovenant being enforced by an ordinary civil action. The covenant running with the land is almost universally replaced in the United States by a covenant of warranty, by which the granter of the deed, and not the land itself, is bound.

Covent Garden, corrupted from Convent Garden, from having been originally the garden of the Alobot of Westminster, is a spacions square in Condon, celebrated for a great market held within it of fruit, vegetables, and flowers. The square was formed about 1631 from the designs of Inigo Jones, and has the areade or piazza on the north and north-east side, Tavistock Row on the south, and the church of St Paul's on the west. In the 17th century Covent Garden was a very fashionable quarter of the town. The scene of one of Dryden's plays is laid here, and frequent allusions are made to the place in plays of Charles II.'s time. The market, now so famous, appears to have originated about 1656 in a few wooden sheds and stalls. Covent Garden is for a stranger one of the sights of London, and is seen to greatest advantage about three o'clock on a summer morning; Tuesday, Thursday, and Saturday being the principal days.

Coventry, a city, parliamentary and municipal borough, and manufacturing town in the north of Warwickshire, on the Sherbourne, an affluent of the Avon, 18 mlles ERE. of Birmingham, and 94 NW. of London. It atands on a gentle eminence in a valley, with a ridge of hill on the south, and still contains some old houses, with timbered fronts projecting into the atreets, and which belomg to the Sth and 16th centuries. Town improvements in recent years have necessitated the removal of many old houses and the construction of new streets, the area of the city being greatly extended. The morlern buildings include a corn exchange, market. hall, baths, Free Public Library, School of Art, new grammar and other schools, churches, chapels, and hotels, many tricycle and bicycle works, the Cov. entry and Warwickshire Hosuital, and the Coventry Provident Dispensary (about 20,000 members being connected with the last-mentioned institution). Coventry is rich in benevolent and charitable institutions, which have been greatly augmented by the benefactions of the late David Spencer. In $1887 \mathrm{Mr}$ Spencer provided a building for a technical school; a few years earlier he had given four thousand guineas for a public recreation ground and at his death (June 9, 1888) he bequeathed about $f 100,000$ for benevolent purposes. A beau. tiful approach to the city from the London and North-western Railway Station has been made by the opening of the Coventry Park for building purposes, and the laying out and ornamentation of Grey Friars' Green. A statue of Sir Thomas White has been erected, and a memorial of James Starley, the inventor of the modern tricycle. At a cost of many thousands of pounds the principal streets have been widened, and a steam tramway now runs through the eity. During recent years upwards of $\mathbf{f 7 0 , 0 0 0}$ has been expended in eliurch restoration, and during 1887-89 all of Tennyson's 'three tall spires' were in the restorens' hands. Large sums liave also been expended by the various noneonformist congregations in the erection of new, and the restoration of existing places of worship. The chief buildings are the ancient churches, with imposing spires, that of St Michael's rising to a height of 300 feet. St Michael's Church, built $1230-1395$, is said to be the largest parish ehurch in England, and is one of the noblest of the lighter Gothie structures. St Mary's Hall, bnilt in the 14th century, for the Guild, is one of the finest specimens of ornamental work in England, with gro. tesque carved oak roof, ancient tapestry, and great painted window. The ancient walls, three miles in circuit, round Coventry were demolished by Charles II. Coventry returns one member to parliament. The chief manufactures are ribbons, watches, bieycles and tricycles (see CYCLING), cotton, worsted and woollen goods, and art metal works (the Albert Memorial, Hyde Park, London, being of Coventry manufacture). There are large silk-dyeing works. Coventry is nearly in the centre between the four great English porta, London, Bristol, Liverpool, and Hull, and has extensive canal communication with other parts of the country. The city is in an excellent sanitary state, its sewage being treated by an improved system of precipitation, at works erected at Whitley, about one mile from Coventry. The gas and water works both belong to the corporation. Under the Local Government Bill (1888), Coventry is reconstituted a county, and thus reverts to an ancient privilege which it enjoyed from 1451 to 1842 . The ancient 'Coventry Great Fair' (formerly eight days) is now held annually, for five days, commencing on Whitmonday. Pop. of parliamentary borough (1841) 30,743 ; (1861) 41,647; (1881) 46,563. A county boruugh since 1885, it had in 1891 a pop. of 54,743 .

The name Coventry has usually been interpreted 'Convent-town,' but as the form in Domesday is Coutentrev, it is more likely "town on the Couen" -Cowen being the ancient British name of the 
Sherbourne, and trev being ' town.' It is certainly a place of ligh antiquity. In 1043 Earl Leofric and his wife, Lady Godiva, founded here a magnificent Benedictine monastery. In memory of the noble deed of Godiva (q.v.), curious and splendid processions were formerly held in Coventry. In the 15th century religious mysteries or plays were often acted here by the Grey Friars before kings. Henry VIII. demolished the beautiful cathedral of Coventry. Here occurred the famous meeting for the intended trial by battle between the Dukes of Norfolk and Hereford, immortalised in Shakespeare's Richard II. Two memorable parliaments were also held in the monastery of Coventry in the 15th century. The one contained no lawyers, while the other passed attainders against the Duke of York and others. In the 15th, 16th, and 17th centuries, Coventry was famous for woollens, broadclotlis, caps, and blue thread bonnets. 'George Eliot' lived in Foleshill Road during 1841-42. See local histories by T. Sharp (Birm. 1871) and M. D. Harris (1898).

Coventry, SIR JoHs, a staunch cavalier who had sat in the Long Parliament (1640), and who at the coronation of Charles II. was made a Knight of the Bath. Elected for Weymouth in 1667, he asked, during a debate on playhouses (October 1670), a question which reflected on the king's amours. Charles and his minions were furious, and one December night Coventry was pulled from his coach by Sir T. Sandys and other rutfians, and his nose slit to the bone. Parliament took notice of this atrocious outrage, and by its 'Coven. try Act' made cutting and maiming a capital offence; but they had not the courage to bring the king's bravoes to trial. Coventry died in 1682.

Coverdale, MrLes, translator of the.Bible, was born in Yorkshire in 1488. He made his studies at Cambridge, was admitted priest at Norwich in 1514, when he joined the Austin Friars at Cambridge, and probably imbibed his liking for the new doctrines from Robert Barnes, who became prior about 1523, and whose Protestantism led to his being tried and ultimately burned in 1540 . Before long Coverdale went abroad. According to Foxe he was at Hamburg with Tyndale in 1529. His own translation of the Bible appeared in 1535, with a dedication by himself to Henry VIII., and secured the royal license in the quarto and folio editions of 1537. The Psalms of this translation still form the psalter in the Book of Common Prayer, and many of the finest phrases in our authorised version of 1611 are directly due to Coverdale. The original issue of the book is a folio volume, 'faithfully and truly translated out of Douche and Latyn into Englishe,' printed in German black letter, in double columns, with woodeuts and initials, and containing the Apocry. pha. Its place of publication is very uncertain, and attempts have even been made to degrade Coverdale from its translator to a mere proofreader. In the prologue to his own second edition (1550) he states that the translation was his own work, although not at his own cost, and that it was made 'out of tive sundry interpreters,' most likely the Vulgate, Luther's version, the Zuirich or German-Swiss Bible of 1531, and Tyndale's Pentateuch and New Testament. In 1538 Coverdale was sent by Cromwell to Paris to superintend in Regnault's press another English edition of the Scriptures. Francis I. had granted a license, but in spite of this, before the printing was finished, an edict was issued prohibiting the work. Many of the sheets were burned, but the presses and types were saved and hastily carried over to London, whither also some of the workmen soon came. Grafton and Whitchurch, the noted printers of that day, were thus enabled to bring out in '1539, under Coverdale's superintendence, the 'Great Bible,' which was presented to Henry VIII. by Cromwell. The second 'Great Bible,' known also as 'Cranmer's Bible' (1540), was also edited by Coverdale, who found it expedient to leave England on the fall of his patron Cromwell. While abroad he married, received the degree of D.D from Tülbingen, and acted as Lutheran pastor for some years at Bergzabern, in Rhenish Bavaria. In March 1548 he returned to England, was well received through Cranmer's influence, and in 1551 was made Bishop of Exeter, discharging the duties with great diligence and zeal. On the accession of Mary he was deprived of his see, but was suffered to leave the country, at the earnest intercession of the king of Denmark, whose chaplain, Dr Macchabæus (MacAlpine), was Coverdale's brother-in-law. From Denmark he passed to Wesel in Westphalia and to Geneva, where he may have assisted in the preparation of the famous Geneva version (1560), the favourite Bible of the Puritans. Returning to England in 1559, he did not resume his bishopric, but was made D.D. by Cambridge in 1563, and the following year was collated by Grindal to the living of St Magnus, near London Bridge, which he resigned from growing Puritan scruples about the liturgy in 1566. He continued, however, to preach, but died early in 1568, and was buried in St Bartholomew's Church, and on its demolition in 1840 to make room for the New Exchange, was reburied in the south aisle of the church of St Magnus. The tercentenary of his Bible-the first complete English translation of the Scriptures-was celebrated October 4, 1835, when medals were struck in honour of the venerable translator. Most of Coverdale's works, including his letters, were edited for the Parker Society by Rev. George Pearson ( 2 vols. 1844 46). See Memorials of Myles Coverdale (1838), H. R. Tedder's article in the Dictionary of National Biography (vol. xii. 1887), and F. Fry's The Bible by Coverdale (1867).

Covered-way is a space 11 yards wide in most parts, outside the ditch of a fortress, between the Countersearp (q.v.) and the Glacis (q.v.). The latter is arranged for musketry in the usual manner, and gives cover to soldiers standing upon the covered-way, which, being also protected from enfilade fire by traverses, is convenient for sentries, and for the passage of troops to the enlarged portions, called places of arms, where they assemble for making sorties. See FonTIFICATION.

Covilhão, a town in the Portuguese province of Beira, on an eastern spur of the Estrella Mountains, with some manufactures of brown cloth, and a pop. of 10,986. - Pedro de Covilham (or Covilhão), sent by the king of Portugal in 1486 to visit Prester John's country, reached Calicut overland in 1487 , and Abyssinia in 1490 .

Covington, a city of Kentucky, U.S., on the Ohio River, opposite Cincinnati, with which it is connected by a fine suspension bridge. Many of the inhabitants transact their business in Cincinnati, but Covington is itself a thriving place, with distilleries, as well as manufactures of glassware, nails, and tobacco. Pop. (1830) 715 ; (1850)

9408 ; (1880) 29,720 ; (1890) 37,371 ; (1900) 42,938.

Cow. See Cattle, Dairy.

Cowbane. See HemLock.

Cowberry. See Whortleberry.

Cow-bird (Molothrus pecoris), also called Cow. pen Bird, Cow Blackbird, \&c., a native of North America, nearly allied to the Troupials, remarkable for its cuckoo-like habit of utilising the nests of other birds for its own eggs. The latter are 
hatched sooner than those of the riglitful owners, which fall victim to this lofty form of parasitism. The cow-bird is about 7 inches in length, predom. inantly brownish-bleck in colour, and has a short but sharply pointed beak. "It utters a peculiarly liquid April sound.' The females are far more numerous than the males, and polygamy is therefore in vogue. The malea have deeper, glossier coats than the females. It is said to damage the fields of sown maize, but feeds largely on insects. The name refers to its habit of frequenting cow. pens for the sake of the attracted insects. Seven other species of Molothrus are known, occurring from La Plata to the United States.

\section{Cow-boy. See Ranchina.}

Cowbridge, a municipal borough of Glamor. ganshire, on the Ddaw, 12 miles W. of Cardiff (17 by rail), with which and Llantrissant it returns one member to parliament. It has an old gateway and a grammar-school (1678). Pop. (1891) 1377.

Cow-catcher, a kind of barred iron cone or beak shaped arrangement, about 6 feet long, projecting from the front of locomotives, cluse over the railway track, and attached to the buffer-beam by strong bolts. It is generally used upon American lines where unfenced. Sometimes it is sheathed with iron plates in winter, when it acts as a snowplough. Despite its nane, it catches no cows, but generally throws any animal struck up on the buffer-beam, or clears the line by shoving forward and tossing aside.

\section{Cowdenknowes. See Earlston.}

Cowell, Edward ByLes, a learned Sanskrit scholar, was born at Ipswich, January 23, 1826. He was educated at Ipswich grammar-school and Magdalen Hall, Oxford, and in 1856 sailed for Calcutta, to fill the chair of History in the newlyestablished Presidency College, becoming also soon after principal of the Sanskrit College. He returned home in 1864, and was elected in 1867 professor of Sanskrit at Cambridge, and in 1874 to a fellowslip in Corpus Christi College. He has pub. lished a long series of Sanskrit texts and translations, alone or in collaboration with other scholars, and edited Colebrooke's Essays (1873). He was a contributor to this work.

Cowen, Frederic Hymen, composer, born at Kingston, Jamaica, 29th January 1852, was brought as a child to Enerland. He enrly sliowed decided musical talent, which was cultivated by a course of stuily under Benedict and Goss, as also at Leipzig ani Berlin. Among his works are the operas Pauline (1876), Thorgrim (1890), Signa (1893), and Harold (1895); the cantates The Kose Maiden, Sleeping Beauty, The Water Lily, and others; two oratorios (including Ruth, 1887); half-r-dozen symphonies, one of which, No. 3 (Scandinavian), is esteemed throughout Europe; a number of overtures, pinnoforte pieces, and minor works, and over 250 songs. In 1888-92 he was conductor to the Philharnonic Society, in 1896 succeeded Hullé at Manchester and Liverpool.

Cowes, a seaport and watering-place in the north corner of the Isle of Wight, 11 miles SSE. of Southanpton by water, and $4 \mathrm{~N}$. of Newport by rail. It consists of West and East Cowes, lying on opposite sides of the mouth of the estuary of the Medina, and connected by steam-ferry. Standing on a hill-slope, West Cowes has a striking aspect from the ses, and is the seat of much trade, being the chief port of the island, and the headquartens of the Royal Yacht Club (1815), whose regattas are held here. Their club-house was originally a fort, built by Henry VIII. in 1540. Yacht-building is the great speciality of Cowes, which has a fine promenade (1864), excellent hotels, baths, villas, lodging-houses, \&ce. Slatwoods at East Cowes was the birthplace of Dr Armold, and in the vicinity are East Cowes Castle (1798), Norris Castle (1799). and Osborne House (1845). The last, built by Cubitt as a marine residence for Queen Victoris, is an Italian edifice, with a tlag-tower 112 feet high, and beantiful groumds. Pop. of West Cones (1851) 4786; (1881) 6772; (1891) 7768; of East Cowes (1861) 1954; (1881) 2615; (1891) 2880.

Cowhage, Cowagr, or CowrTCH, consiats of short, slemier, hrittle hains, which cover the pods of species of Mucuna, a papilionaceous climber, particularly $M$. pruriens of the West Indies and $M$. urens of the East. These hairs readily stick in the skin and cause intolerable itching, and were hence formerly used (as still in their native country) as a vermifuge. They are administered in syrup, and of course act mechanically. The unripe pods are eaten like kidney-beans.

\section{Cowl. See Benedictines.}

Cowley, Abraham, in his own day considered the greatest of English poets, was born in London, 1618. His father was a stationer in that city, and died before his son's birth. By the exertions of his mother, Cowley received a learned education. At an early age he was sent to Westminster School, where he displayed an almost unparalleled precocity. It was by the reading of the Faëry Queen, a copy of which lay in his mother's window, that his mind was turned to poetry. He wrote excellent verses at the age of ten, and published a volume of poems at fifteen. In 1637 he proceeded to Cambridge, and while here wrote, among many other pieces. a large portion of his epic, the Durideis, on the subject of the life of King David. On the outbreak of the Civil War, he was ejected (1644) from Cambridge for refusing to take the oath tendered to all the members of the university. At Oxford, however, the headquarters of the king's party, he continued his studies for other two years. On the queen's flight to Paris, Cowley followed her, and did effectnal service to the royalist canse by various missions, and by carrying on the secret correspondence in cipher between the queen and Charles. In 1656 he returned to England, but was arrested and only allowed at large on a bail of £1000. To conoiliate the party in power, he qualified himself as a doctor of medicine, by way of proving that he had abandoned all political connections. On Cromwell's death, Cowley again went to Paris, but retumed to England at the Restoration. He was disappointed in the hope of preferment, especially of the mastership of the Savoy, which both Charles and his father had led him to expect. By the gen. erosity of the Duke of Buckingham and Cowley's lifelong friend the Earl of St Albans, he at length received a confortable provision. Cowley died at Chertsey, London, 28tlı July 1667.

Cowley's most ambitious works are the Davideis, the Pindarique Odes, written in supposed imitation of Pindar, and the Mistress, a series of love poems. His fate as a poet is one of the noat singular in literature. Deemed unapproachable in his own day, he has ever since sunk steadily in popular estimation. Dr Johmson's explanation is still accepted as the best that can be suggested. Cowley wrote for the court and the reigning taste, and not for the general heart of men. What he is still admired for is his astonishing ingenuity and agility of mind. Moreover, though the bulk of his verse can never again have any living interest, he has not a few passages characterised by delicacy and power. By his small collection of eseays, Cowley takes rank with Goldsmith and Addison as one of the masters of simple and graceful prose style. It is by these essays that Cowley is now best known to modern readers. They are included in Grosart's 
complete edition (1881). See Sprat's Life of Cowley (1668), and Johnson's Lives of the Poets.

Cowley, Hannah (1743-1809), wrote thirteen lively dramatic works, including The Belle's Stratagem (1782), and several volumes of feeble verse. She was attacked along with the other Della Cruscans by Gifford in the Baviad and Moeviad.

Cowley, Henry Richard Charles WellesLEY, EARL, diplomatist, was born June 17, 1804. His father, the first Baron Cowley, was a younger brother of the great Duke of Wellington. He was educated at Eton, and at twenty began a long career as a diplomatist by becoming an attaché at Vienna. He was in succession secretary and ambassador at Constantinople, ministerplenipotentiary to Switzerland (1848), to the Germanic Confederation (1851), and in 1852 succeeded the Marquis of Normanby as ambassador at Paris, a position which he held with rare tact and temper throughout all the difficulties that occurred until his resignation in 1867 . With Clarendon he represented Great Britain at the Paris Congress of 1856, and in 1860, with Cobden, he arranged the commercial treaty between France and England. He succeeded to his father's title in 1847 , was created Viscount Dangan and Earl Cowley in 1857 , and made a K.G. in 1866. He died July 14, 1884.

Cow-parsnip (Heracléum), a genus of Umbelliferae, of which one species (H. Sphondylium) is a common and rank wayside weed, which, however, when cut early in the season, affords a wholesome fodder to pigs and cattle. $H$. sibiricum, a much larger species, has been recommended for cultivation on account of the great quantity of herbage it yields very early in the season, and with other species (H. giganteum, \&c.) it is also used with much effect as a decorative plant. $H$. lanatum is very common in North America.

Cowper. William, surgeon and anatomist, was born at Petersfield, in Sussex, in 1666, settled as a surgeon in London, and died 8th March 1709. He made some new anatomical observations, notably discovering the glands beneath the male urethra ealled 'Cowper's glands,' and published The Anatomy of Humane Bodies (1698) and other works.

Cowper, William, was born in 1731 at the rectory of Great Berkhampstead, in the county of Hertford. He was sent to Westminster School at so early an age that all his impressions were painful, and he thus conceived a hatred of public schools which was never modified. He complains that there he became an adept 'in the infernal art of lying, an art which we could hardly assert either to be extinct in our public schools at the present time, or to be or ever to bave been entirely confined to them. Among his schoolfellows were Churchill the poet, and Warren Hastings; and for these two at least he seems to have maintained a lasting affection. On leaving school he was articled to an attorney named Chapman, with whom he idled away his time for several years. One of his fellow-pupils there was Thurlow, who in a jesting mood promised to give Cowper an appointment when he should be Lord Chancellor. The boyish ambition was verified, as every one knows; but not the promise. Cowper was called to the bar in 1754, and lived for some time the ordinary life of a young man, not uncheerful, though with occasional fits of depression. He belonged to the 'Nonsense Club,' founded by Bonnell Thornton and George Colman, and is supposed to have contributed some short articles to the Connoisseur, a paper started by them. He also fell in love, during this period, with Theodora, the daughter of his uncle Ashley Cowper, a lady who seems to have had for him a far deeper feeling than his essentially recipient nature could return. Certainly he appears to have made no particular effort to overcome his uncle's opposition to his suit. In those days a well-connected young man was more easily provided for than now, and a sinecure appointment, as 'Commissioner of Bankrupts,' gave Cowper a certain independence, which he enjoyed tranquilly, relying on the influence of his relations to promote him further, an expectation which they on their side did all they could to fulfil. His cousin, Major Cowper, had the right (extraordinary to hear of nowadays) of appointing to the office of Clerk to the Journals of the House of Lords, and also to the joint offices of 'reading clerk and clerk of the committees' to the same august assembly, All these appointments happened to fall vacant at the same time (1763). Major Cowper wished his cousin to take the latter and more valuable office, but Cowper in one of his tits of self-depreciation, preferred the other, which was found eventually to involve a so-called examination as to his fitness for the office, meaning in fact only an appearance before the bar of the House. The idea of this appearance unmanned him altogether. A fixed idea, the well-known forerunner of madness, that every one was hostile to him, gradually took possession of his mind; and the horror grew by continual brooding, until suicide seemed the only way of escape. He several times attempted to make away with himself, and on one occasion at least was only saved by a fortunate accident. When his friends were finally made aware of his condition, they gave up at once a project so evidently impracticable ; but Cowper's mind was permanently unhinged. He fell into a state of religious despair as to the consequences of the crime he had almost committed, in the height of which his misery found vent in the composition of a copy of Sapphics, in which he describes himself as 'damned below Judas, nore abhorred than he was,' and again, 'man disavows and Deity disowns me.'

It was found necessary to remove him to a private asylum at St Albans, where he was gradually restored to health by judicious treatment. After this, in June 1765, he drifted to the quiet town of Huntingdon, where he made acquaintance with an amiable and religious family to which he was at once attracted, and in which he was soon accepted as an inmate. The head of the family, Mr Morley Unwin, was a clergyman, but retired from active work, and with his wife and two children lived a life of almost perpetual devotion, into which Cowper plunged, spending most of his time in religious exercises of various kinds, and corre. spondence on religious subjects. Cowper continued to reside with Mrs Unwin after her husband's death (July 1767), but they soon removed to Olney in Buckinghamshire, where the famous John Newton was curate. This remarkable man soon acquired the most complete influence over the gentle invalid; and, under Newton, Cowper worked among the poor of his friend's parish, devoting his whole time to pious exercises and good works. Owing, perhaps, to these exertions, and to the unbroken monotony of the atmosphere, signs of his former madness began to reappear, and in 1773 it burst out. He was at the time in Newton's vicarage, and here he remained for more than a year, refusing to return to his own house though it was but next door. After his recovery (which was never complete) he lost-we might almost say, though it seems cruel, he was delivered from-the companionship of Newton, who was presented in 1779 to the rectory of St Mary Woolnoth. The effect of his departure on Cowper was miraculous; whether Newton, in his intense enthusiasm miscalculated his friend's powers, or whether he was only ignorant 
of the delicate nature of the mind on which he was working, it is evident that the constant intercourse with him, aided perhaps by the wearying sameness of the life, had an oppressive and erushing effect npon Cowper. Even after Newton's departire, the old gloom appean in letters addressed to him, while in correspondence with Hill or Unwin, Cow per is always cheerful, full of graceful playfulness, entering into a pleasant record of his amusements and occupations, his hares and garden and greenhouse. To the quiet of this period of his life we probably owe the tranquillised condition of mind which makes the tone of Cowper's poetry contrast 80 strangely with the sentiments of his early experiences. An astonishment almost smounting to incredulity fills our mind when we find the madman, the religious fanatic, who despaired of salvation, and on several occasions attempted suicide, luxuriating in the quiet of nature, which he fully appreciated and enjoyed, and changing his abject fenrs of Giol's wrath for a tender delight in and love of the ordinary works of His hands.

He was, however, as yet no poet at all. Mrs Unwin was the first who had the wisdom to perceive that a variety of occupation was necessary to Cowper, and that something to occupy his mind during the gloomy months of winter was of the highest importance to his well-being. No power of initiation seems to have existed in his mind, but he followed with docility his friend's suggestions, and when she bade-him write poetry, did so. His first volune (1782) was in the fashion of the time, and consisted of several poems on alostract suljects, a poetical dialogue called 'Table Talk' heing added to lighten and enliven the book. Probably Cowper himself was not conscious at the time how much higher he was capable of flying and was destined to fly ; but once more a happy suggestion came to his aid. In 1781 he accidentally made the acquaintance of Lady Austen, a woman full of intelligence, and of a gay and happy disposition, bringing sunshine with her. The acquaintance rapidly grew into a warm friendship, and Lady Austen settled in Newton's deserted viearage, next door, it will be remembered, to Cowper's house. The inhabitants of the two houses soon, of course, grew intimate, with the happiest results to the poet. It is to Lady Austen's playful commands to write a poen for her on any subject, "this sofa for instance," that we owe Cowper's greatest work, The Task. She has also the eredit of having told him the story of Joln Gilpin, reproduced in the immortal ballad the next morning: and there can be no doubt that this lady was his better angel, and made the happiest revolution in the too-serious house. His position between his old friend and his new one, both being women, has been the subject of many, and we think somewhat vulgar comments. That Cowper was engagel to marry Mrs L'nwin, that this project was defeated by a dawning love between the poet and Lady Ansten, and that jealousy and passion came in to disturb their relations is an oft-repeated tale. It surely, however, requires but little reflection to see how unneceseary such a theory is. Cowper was in every way calculated to arouse a more than passing interest in the heart of an intellectual woman, but neither in his past nor his present was there anything that could inspire such a woman with the desire of marrving him. He had the gift of making friends and ealling forth symyatly in an unusual degree, and the influence of this tender sympathy not only saved but made him what he grew to be. If Lady Austen had never said to Cowper, "Why not try blank verse?" that grand revolt against the smoothness and artificial perfection which Pope had established as essentials of poetry might have been indefinitely postpoued. Against a style which repelled him,
Cowper was the first to protest by the effectual reproduction of a more excellent way. He took that polished and splendid instrument from the hand of Milton, witliout his grandeur of tone, yet with a sweetness and serious power not unworthy of it. His schoolfellow, Churehill, had struck a rougher and more vigorous note, yet had not been bold enough to return to the old ways. But the timid poet in his seclusion, under the influence of his domestic muses, with unexpected boldness, seized on his inheritance. Worlsworth carried on both style and subjects, but he, like Gray, put of his own into the theme, and deseribed less Nature herself than the thoughts which she inspired. In Cowper, on the contrary, we have Nature's very face, the calm description of a quiet scene painted by one who loved her for herself, not peopled with fancies by a poetical observer.

How his friendship with Lady Austen came to an end has never been clearly known, but at the end of 1783 she retired to Bristol, and Cowper writing to Unwin declared the connection at an end. It is a commonplace to talk, of course, of jealousy between Lady Austen and Mrs Unwin, and it is easily comprehensible that the latter lady may have objected to see her place as Cowper's friend and adviser taken from her by a stranger. However, as regards our poet, Lady Austen had done her work; The Task was published in 1785, and its power and the greatness of the old-new method very soon made themselves apparent. Whether Cowper has retained the high place which was accorded to him in the surprise and delight of the new movement, is a question which will be answered according to individual tastes and opinions, but there can be no doubt that the publication of The Task had a most powerful effect upon the literary tastes of the time.

It is characteristic of Cowper that on the departure of Lady Austen, he fell for some time into a little of his old melancholy, until in 1786 Lady Hesketh appeared upon the scene, and the poet accepted the new comforter in lieu of her who was gone. His translation of Homer was carried on under the influence of this new adviser, who was a relation of his own, and consequently escaped the imputation of wishing to marry him. She procured the removal of the sad poet and his ailing companion to Weston-Underwood, where they made acquaintance with the Throekmorton family, and received much comfort and consolation in their waning days. This move, as well as the translation of Homer, Newton, with whom Cowper still kept up a correspondence, eondemned with almost brutal violence of language, and it is an evidence of his temporary recovery of strength, that Cowper defended himself without, however, losing his temper. Agrinst Newton's advice he continued his translation, which brought him in at least a little money if not much fame: and the money was by this time much needed. In 1787 he had another attack of his old ailment, and again attempted suicide. From this attack he never seems to have completely recovered, and when he was almost at his worst, Mns Unwin had a stroke of paralysis which cast a gloom over this devoted pair from which they never emerged. In 1794 a pension of $f 300$ a year was assigned to him, but too late to confer much comfort or relief. When Mrs Unwin died in $\mathbf{1 7 9 6}$ he heard the news without emotion, and growing gradually weaker, died peacefully at East Dereham. Norfolk, on the 25th of April 1800. Curiously enough, out of the gloom of his last waning vears came two of his most leautiful and tonching poems, the lines 'Addressed to $\mathrm{My}$ Mother's Picture,' and those entitled 'My Mary.

Hayley's Life first appeared in two volumes in 1803 . The later editions $(1806,1809,1812)$ were in four volumes 
The Life by T. Wright appeared in 1892 . The standard edition of Cowper's works is that edited by Southey, with a memoir (15 vols. 1834-37), and reprinted in Bohn's 'Standard Library' (1853-54). Others are those of Grimshawe ( 8 vols. 1835), the Aldine edition, with a good life by John Bruce (1865), and the Globe edition, with a memoir by Rev. W. Benham (1870). There are selections of the poems, by Mrs Oliphant (1883), and of the letters, by Rev. W. Benham (1884) in the 'Golden Treasury' series. For criticism, see Ste. Beuve's Causeries du Lundi (vol. xi. 1868); Stopford-Brooke's Theology in the English Poets (1874); Goldwin Sinith's monograph in the 'English Men of Letters' series (1880); Leslie Stephen, in series iii. of 'Hours in a Library' (1882); and Mrs Oliphant, in The Literary History of England (1882).

Cow-plant (Gymnema lactiferum), a perennial Asclepiad of Ceylon, which has aequired a factitious celebrity from the oft-repeated statement that its milky juice is used as milk, and that its leaves are boiled to supply the want of eream! But this, according to Sir J. E. Tennent, arises entirely from the appearance of the juice, which indeed probably contains a share of the poisonous principles so general in this order.

Cowry (Cyproa), a large genus of Gasteropods in the Prosobranchiate section, including over a hundred species, some of which are very familiar as decorative objects and as furnishing a medium of exchange with uncivilised peoples. The shell has more or less of an oval form, and is usually thick, polished, and beautifully coloured. The young shells are delicate and more typically snail-like, but in the adults the large last whorl more or less conceals the others, and has its outer lip bent in towards the inner. The internal axis may be wholly absorbed. The animal has a broad head, a protrusible proboscis, eyes associated with the long horns, and a broad foot protruded through the elongated aperture. The mantle or skin fold, which forms the shell as in other molluses, extends over the whole or most of the surface, and thus conceals during life what gives the dead shells half their charm. In habit the cowries are predominantly sluggish animals, creeping slowly on rocks and coral reefs. They are mainly carnivorous in diet. Though widely distriluuted, they thrive best in the tropical seas. Fossil forms occur abundantly (about 80 species) from the chalk onwards. The nearest relations of the cowries are the two genera Ovulum and Trivia. The former includes the Poached Eggs and the Weaver's Shuttle (Ovulum volva); two species are found on British shores. The genus Trivia includes the little 'cowry' (Trivia europcea), not uncommonly found on British coasts-e.g. near John o' Groat's House.

The cowries proper are well known in several practical connections. The money cowry ( $C$.

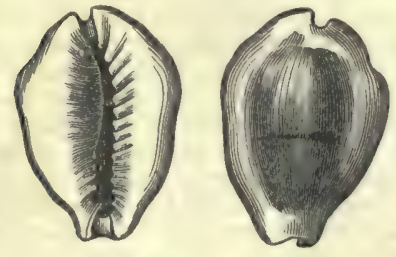

Money Cowry. especially in the Maldive Islands, was long used as currency, and is still so used in Africa from Guinea to the Central Soudan. In Siam over 6000 cowries were re quired to make a tieal worth 18. $8 \mathrm{~d}$. Cowries are familiar in England as counters in games of chance. From prehistoric times they have been used to form necklaces and other ornaments of the person. In some cases they are worn as charms, and their bright colours, so attractive to human eyes, have also been utilised in catching cuttlefishes. Cowries have had their share in later days in the conchological craze, and 'small fortunes' have been spent in gathering that wealth of varied colour which a good cahinet displays. A single shell of C. princeps has been sold for $£ 40$.

Cowslip (Primula veris; see PrIMrose), a common native of pastures in England and many other parts of Europe, although rare in Scotland, a delicate and modest little flower, a universal favourite, both for its beauty and its fragrance. It differs from the common primrose conspicuously in having umbels of flowers on a seape; it is sup. posed to be the original of the garden polyanthus. Darwin holds the common oxlip to be a cross between the cowslip and the common primrose. Its bells were long supposed to be the haunt of fairies, and the name of Fairy Cups is still given to them in some parts of England. The flowers are sometimes fermented with sugar to make cowslip wine, which is not unpalatalile. It was once a favourite domestic soporific. The leaves are by some used as a salad and pot-herb, and also as food for the silkworm before those of the mulberry have expanded. The American cowslip (sometimes also called Shooting-star) is Dodecatheon Meadia, a very handsome spring flower. This and other species are also well known in cultivation.

Cow-tree, a name given to a number of trees of different natural orders, the bland milky juice (Latex, q.v.) of which is used instead of milk. The most famous of these is the Palo de Vaca of the Cordilleras and Caraccas (Galcuctodendron (Brosimum) utile), an artocarpaceous tree, with large laurel-like leaves and very small flowers. The milk is obtained by piercing the bark of the trunk or branches, and flows so freely that an ordinary bottle may be filled in half an hour. The milk has an agreeable creamy odour and taste recalling that of cow's milk, but is slightly viscid and soon becomes yellow, gradually thickening into a somewhat cheesy consistency. Its chemical composition, of course, widely differs from that of milk, but its nutritive value is considerable. It is much used by the negroes and Indians.

The cow-tree or Hya-hya of Demerara is Taber. nomontana utilis, a tree belonging to the Asclepiadacese. In this order the milky juice is usually acrid and poisonous, and even that of other species of the same genus is of sharp and burning taste. In this case, however, the latex is agreeable and wholesome, although somewhat sticky, owing to the large proportion of caoutchouc.

Cow-wheat (Melampyrum), a genus of Scro. phulariaces, of which the deep-furrowed two-celled capsule somewhat resembles a grain of wheat. They are annual weeds, growing in woods, cornfields, and pastures, and are eaten by cattle. Being root-parasites, they grow on the roots of other plants. M. pratense is common in Europe and North America.

Cox, David, landscape-painter, was born at Deritend, a suburb of Birmingham, 29th April 1793. His father was a blacksmith, and he worked at the forge for a time; and after trying various employments and studying drawing under Joseph Barber, he was scene-painter in the Birmingham, Swansea, and Wolverhampton theatres, and oceasionally appeared upon the boards in minor parts. He next took lessons in London from John Varley; in 1805 and 1806 visited North Wales, which to the end of his life was his favourite sketching. ground; and taught as a drawing-master, mainly in Hereford, publishing A Treatise on Landscape Painting and Effect in Water-colours (1814), and other educational works, illustrated by soft-ground etchings by his own hand. In 1813 he joined the Society of Painters in Water-colours, to whose exhibitions he was a regular contributor. From 1827 till 1841 his headquarters were in London, but he was constantly sketching in the country, 
and occasionally he male brief visits to the Con. tinent, exeenting water-colours of noble quality which slowly but steadily made their way with the public, and are now recognised as entitling their painter to a place among the very first of English lundsenpists. In 1839 he turned his attention seriously to oil-painting, a medium which he had hitherto used only for sketching, and soon he had mastered the process. He executed in all alout a hundred works in oil. These are less widely known than his water-colours, but they are of at least equal quality. In 1841 he settled at Harborne, near Birmingham, where he resided for the rest of his life. It was during this period that he produced his greatest works, those most rapidly synthetic in execution, and most deeply poetic in feeling. They mainly owe their inspiration to the scenery of North Wales, and especially of Bettws-y-Coed ( $\left.q_{0} v_{0}\right)$, which he visited every autumn. He died at Harborne, 15th June 1850. The manliness and simplicity of the painter's own character is reflected in his direct, faithful, and forcible art. His works are distinguished by great breadth, purity of tint, truth of tone, and brilliancy of effect, and they are admirable in their rendering of atmosphere, and in their suggestion of the sparkle and breezy motion of nature. Among the more celebrated of his oil pictures are 'Lancaster Castle' (1846); 'Peace and War' (1846), a small picture 18. by 24 in., for which Cox received $£ 20$, but which fetched $£ 3602$ in 1872 (his lifelong ambition had been 'some day, D.V., to get $£ 100^{\text {? }}$ for a picture); "The Vale of Clwyd' (1846 and 1848); 'The Skylark' (1849); 'Boys Fishing" (1849); and 'The Chureh of Bettws-y-Coed.' Among his very numerous watercolours are 'Lancaster Sands ' (1835); 'Ulverston Sands' (1835); 'Bolton Abbey' (1847); 'Welsh Funeral" (1850); and 'Broom Gatherers on Chat Moss' (18.4). His water-colour titled "The Hayfield, fetched $£ 2950$ in 1875 . His works have been frequently brought together in exhibitions, and he was admirably represented by forty-six examples in the Manchester Exhibition, 1887. See the Memoir by N. N. Solly (1875), and the Biography by William Hall (1881).-His son, David Cox the younger (1809-85), was also known as a water-colour painter.

Cox, Sir Grorae, an eminent mythologist, was born in 1827, and educated at Rugby and Trinity College, Oxford. He took orders in 1850 , and after holding curacies in Devonshire, and an assistant-mastership at Cheltenham, became vicar of Bekesbourne in Kent, and afterwards rector of Scrayingham, York. In 1877 he succeeded to his uncle's baronetcy. An industrious man of letters, he has written much on ancient history and on mythology. His Tales of Ancient Greece (1868) was a collected edition of several admirable earlier volumes of Greek history. His most importent work, The Mythology of the Aryan Nations $(2$ vols. 1870$)$, was an uncompromising develop. ment of the solar and nebular hypothesis as the key to all mythologies. It is learned, lacid, and courageous; but the extreme to which a serviceable enough theory has been pushed in an attempt to account for the unaccountable, and to reconcile the irreconcilable, has exposed its real weakness. His History of Greece (2 vols. 1874) was a work of great learning, and his Introduction to the Science of Comparative Mytholugy and Folklore (1881) showed its anthor's old ingenuity and erudition, but none the less the singular limitation of his knowledge, Other works are Latin and Teutonic Christiunity (1870), The Crusades (1874), History of British Rule in Indin (1881), and Lives of Grech Statesmen (2 vols. 1886), and concise History of England (1887). With W. T. Brande he edited the useful Dictionary of Science, Literature, and
Art (3 vols. 1865-67). His Life of Bishop Colenso appeured in 1888.

Coxe, Henay Uctavius, librarian, was born at Bucklebury vicarage in Berkshire, Septenber 20, 1811. He had his education at Westminster and Worcester Collegre, Oxford, and entered the manuscript department of the British Museum in 1833, soon after taking orders. In 1838 he be. came attached to the Bodleian Library, in 1860 its head, and here his marvellous knowledge and patient kindliness made him the very ideal of the librarian. Already in 1857 he had been ment by Sir G. C. Lewis to the East on a tour of discovery, which reaulted indeed in his finding many codices, though the grasping greed of the ignorant monks, at last awakened to their value, made it impossible to buy them. Coxe held in succession several curacies near Oxford, and in 1868 became rector of Wytham. He was Select preacher in 1842, Whitehall preacher in 1868, and in 1878 presided at the first annual meeting of the Library Association at Oxford. Coxe died July 8, 1881 . Although himself an excellent palseographer and ripe scholar, Coxe did much more for others' reputations than his own. The most important of his own works were an edition of Roger of Wendover's Chromicle (5 vols. 1841-44), and of Gower's Vox Clamantis for the Roxburghe Club (1850), and his Catalogues of MSS. in the colleges and halls of Uxford (1852), and of the Bod. leian MSS. (1853-54). See Dean Burgon's Lives of Twelve Good Men (1888).

Coxe, Wrluam, historical writer, was born in London, 7th March 1747, and from Eton passed to King's College, Cambridge, of which he became a fellow in 1768. As tutor to the sons of four persons of quality, he spent much of twenty years on the Cuntinent, where he neglected no opportunity of collecting information about the countries which he visited. The result appeared in fourteen works of travel and history, careful but dull, the best known being his History of the House of A ustria (1807). He died, a prebendary of Salisbury and Archdeacon of Wilts, at Bemerton rectory, 16th June 1828 .

Coxswain, or CockswaIN (pronounced cosn, and often abbreviated to cox), on board ship, is the steersman of a boat, and commander of the boat's crew. In boat-racing, the coxswain should always by preference be a very light weight. See RoWING.

Coxwell, Henry Tracey, aèronaut, born in 1819 , at Wouldham, near Rochester, was educated for the army, but settled as a surgeon-dentist in London. From boyhood he had taken a keen interest in ballooning; in 1844 he became a pro. fessional aèronaut, and in 1845 established the Aerrostatic Magazine. Since then he made some 700 ascents, the most remarkable being that of 1862 , when he reached, with Mr Glaisher, a height of seven miles. He publisherl My Life and Ballowning Adventures ( 2 vols. 1887-88), and died in January 1900. See BALLOON.

Coyote. See WouF.

Coypu (Myopotamus coypu), a large rodent in the porcupine section of the order. It is the only known species of its genus, is common in South America on both sides of the Andes, lives (in pairs) in burrows near water, and feeds on aquatic plants. The animal measures from one to two feet in length, not including the long scaly tail; the general colour is brown varying towards yellow; the hind-feet are webbed and enable the coypus to swin well. The mother-aninal swims with her young on her back, and this halit may have some. thing to do, it is suggested, with the peculiar position of the teats, which are high up on the 
flanks. The coypu is much hunted for its flesh and fur. The latter is best known under the

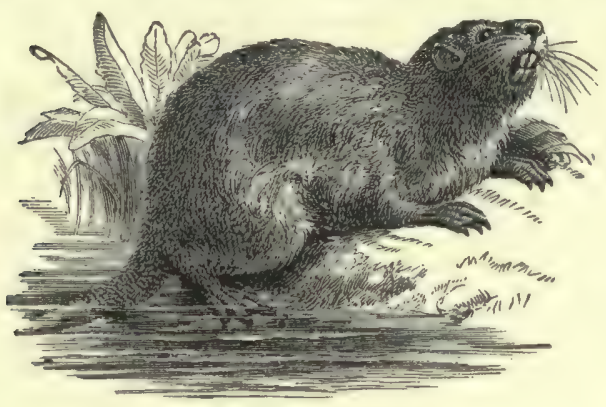

Coypu (Myopotamus coypu).

Spanish name of Nutria, and forms an important article of commerce.

Cozens, JoHs Robert, water-colour painter, was born in England in 1752 . He was instrueted by his father, Alexander Cozens, also known as an artist in water-colours, who was one of the two natural sons of Peter the Great, by a woman from Deptford who accompanied the Czar to Russia. In 1776 he visited Switzerland, with $\mathrm{R}$. Payne Knight, and in 1783 returned from an extended tour in Italy with William Beckford, who commissioned many of the washed drawings which he then executed. Among his English subjects are some fine studies of trees made in Windsor Forest. In 1794 the artist's mind gave way, and in his later days he was befriended by Sir George Beaumont and Dr Munro. The date of his death has been usually stated as 1799, but there is reason to believe that he was alive after 1801. The great qualities of his art have commanded the enthusiasm of brotherpainters. Turner and Girtin copied his drawings, and Constable pronounced that 'his works were all poetry,' that he was 'the greatest genius that ever touched landscape.' He to some extent extended the very limited colour-scheme of previous painters in the medium, introducing greater force and variety of tinting; and he substituted for their topographical treatment of landscape a rendering more imaginative and more perceptive of the delicacies of atmospheric effect. In composition, his works are singularly large and harmonious, and they evince an especial sympathy for nature in her moods of placid sublimity. There is a fine series of his works in the British Museum Print Room.

Crab, a popular name legitimately applied to any of the short-tailed (Brachyura) division of decapod Crustaceans (q.v.). The body is usually short and counpressed; the abdomen is short and is tucked up beneath the relatively large cephalothorax; there are 1 to 4 reduced abdominal appendages, but seldom any tail-paddles; the antennse are short. In the common Shore-crab (Carcinus monas) the carapace is a wide shield, broader than long, and bent inwards at the sides; the eyes are stalked, and lie as usual above and in front of the antennules, though apparently rather external to them; the antennules have the ear-sac lodged in their dilated base; the bases of the antennze are immovable, and the opening of the excretory organ at their base has a curious movable plate. The hindmost of the foot-jaws or maxillipedes is in part expanded into a broad plate which covers the neighlouring appendages. The great claws are generally larger in the male than in the female, and thus the market value of the male Edible Crab (Cancer pagurus) is said to be five times as great as that of the female. The reduced abdominal appendages of crabs are solely nsed for reproductive purposes. The two anterior pairs are copulatory in the males; those that persist in the females have the eggs attached to them. The abdomen is always larger and broader in the females. The nervous system is peculiar in the centralisation of the thoracic ganglia into a single mass. The alimentary, circulatory, and exeretorv systems do not present any important peculiarities. The gills are always fewer than in the crayfish, never exceeding nine on each side. The gill-cavity is large, especially in the land-crabs. In the common shore-crab, the larva leaves the egg as a zoæa, after repeated moults becomes a sort of hermit-crab-like form known as a Megalopa, and gradually with broadening shield, loss of abdominal

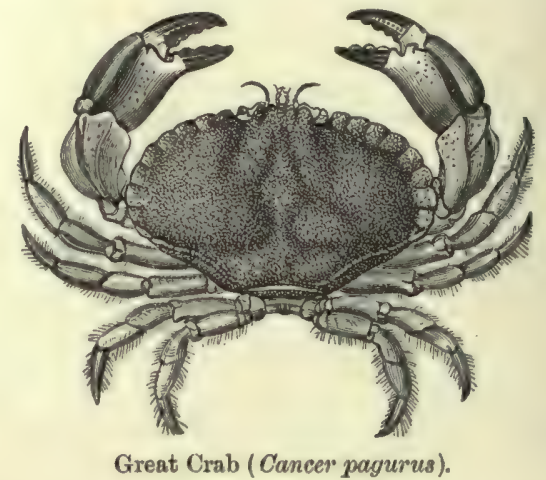

appendages, bending up of the abdomen, and modification of the anterior limbs becomes a miniature adult.

General Life. - Crabs feed chiefly on other animals both alive and dead. The Swimming Crabs (Portunus) - e.g. P. pelagicus, attack fishes. Cardisoma carnifex, found in the mangrove swamps of the West Indies, is fond of the fruit of a species of Anona, but is also notorious for burrowing in the cemeteries. The well-known Land-crab (Gecarcinus ruricola) damages sugar-canes. Many crabs are very rapid runners, especially the sand and land forms; othens are powerful burrowerse.g. the Calling Crab (Gelasimus), which has one of its great claws much exaggerated, and carried during locomotion over its head in such a way that it looks as if it were beckoning; others again are expert swimmers-e.g. our British pelagic Polybius henslowii, which has a light shell, and four of its thoracic appendages flattened for swimming. In regard to respiration it is worth noticing that the land-crabs are so far terrestrial that they are liable to be drowned in water. The male crabs are usually larger, and sometimes fight with one another as well as with other species. In some cases (Gelasimus) the bright colour is only acquired at the period of reproductive maturity. The sexes of the common Shore-crab (Carcinus moncs) are said to unite just after the female has moulted her hard shell. In all but the land-crabs the female carries about the eggs till they are hatched.

Habitat.-Almost all crabs are strictly marine forms, and the majority frequent shallow water. Among the terrestrial forms the best known are the species of Gecarcinus, swiftly moving nocturnal crabs in tropical regions of both hemispheres, chiefly vegetarian in their diet, migrating in companies to the sea for egg-laying purposes. The genus Ocypoda includes some land forms, and some which produce a shrill noise by rubbing the ridged surface of the second-last joint of 
the right great elaw againat a sharp edge of the second joint. The Calling Crab) (ielusimus) makes large burrows, and the male closes the mouth of the hole with its exaggerated great claw. The Pea-erabs (Pinnotheres) live inside bivalves (Pinua, Mytilus, Mactra, \&c.). One species ( $P$. veterum) was said by the ancients to nip the molluse when danger threatened, and to receive its share of food in return. There is no doubt as to the share of food, but no evidence that the crab rewarls its host. In the genus Telphusa all the species live in fresh water in the warm parts of the globe. The European species ( $T$. fluvictilis) is tolerably common in southern Europe, was known to the ancients both in its habit and edibility, and is often figured on Sicilian coins. As regards geological distribution, the Brachyura do not certainly appear before the upper Jurassic, and become gradually more numerous in Cretaceous and Tertiary strata.

Moulting and Amputation.-Like other ernstaceans, crabs periodically cast their chitinous and limy shells. The moults are most frequent in youth, when the rapid growth of the body conflicts with the rigidity of the armature. Extra feeding may accelerate the process, Before moulting the old shell becomes virtually dead, reserve stores are used in fresh growth, a new shell begins to form within the old, and finally with considerable, and sometimes fatal effort, the shell is cast. It is left in apparent intactness, a very image of its lost tenant. The new suit, which is at first soft, requires several hours or days to acquire firmness. The loss of internal linings, of stomach mill, of the outer covering of the eyes, \&c., as well as of the entire outer armature, leaves the crab very much hors de combat. The period is one of great disadvantage to the crabs, not only from the fatigue and often fatality of the process, but from the state of defenceless helplessness in which they are temporarily left. In many cases erabs lose their limbs in fighting, and they may voluntarily resign them (as in Porcellana platychelys) to save their bodies. Sudden panic or injury is said to lead to similar self inflicted amputation or 'sutotomy.' Like many animals lower in the scale, crabs are able to make good their injuries, though geveral moults are regnired to regenerate a limb.

Masking. - A common habit among crabs is that of masking themselves with foreign objects. Thus both the European species of Maia ( $M$. aquinado and $M$. verrucosa) are usually overgrown by Algre, Hydroids, and Polyzon; the same is true of Pisa; in Inachus the long feet are especially well concealed by sesweeds; our common Stenorhynchus is often covered by a sponge growth; the Mediterranean Dorippe lanata uses its hind-loge to carry some living or deal object upon its back, and thus very emphatically asserts its innocence; the conmon Dromia ( $D$. vulgaris) holds sponges on its back in similar fashion. See CoMmensalsm.

Intelligence. - As in several features of their structure, so in their intelligence, crabs appear to hold the highest place among crustaceans. Moseley observed how a sand-crab (Ocypoda ippeus), which dreals the sea, dug itself into the sand and held on against the undertide of each great wave. liomanes refers to the alleged habit of the common crab in stationing a hard-shelled individual as sentinel during the moulting season. There seems to be not a little of the intelligent in some cases of crab-commensalism. Darwin has, however, given a crowning instance of intelligence which is worth many less emphatic. Some shells were thrown towards the hole of a burrowing shore-crab (Gela. simus). One rolled in, three reniained a few inches from the mouth. In a few minutes the crab came out, hearing the shell which had fallen in, and re. moved it to the distance of a foot. 'It then saw the three other shells lying nour, and evidently thinking that they might likewise roll in, carried them to the spot where it had laid the finst.

Common British Furms.-The Common Shorecrab (Carcinus manas); the Great Crab (Cancer pagurus), so much eaten; the Slender Spider-erab or Slender-beaked Crab (Stenorhymchus tenuirus. tris), with very long spider-like legs and bright

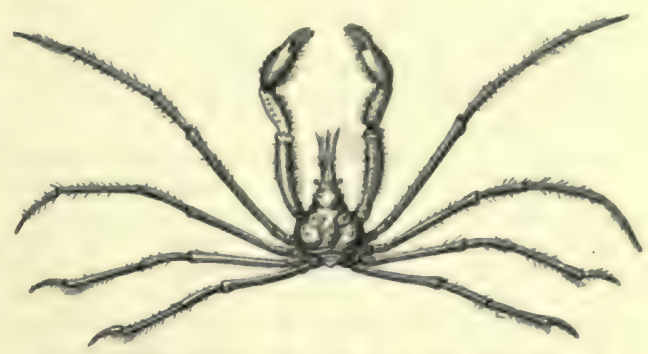

Slender Spider-crab (Stenorhynchus tenuirostrie).

pink triangular body; the large Thorny Spidererab (Maia squinado); the Common Swimming Crab (Portunus variegatus), common on Seotch coasts, with the last pair of legs flattened like oarblades; the Velvet Fiddler-crab or Devil-crab (Portunus puber), with a brown hairy shell; the Masked Crab (Corystes cassivelaunus), with a carapace marked so as to suggest a mask, often found buried in the sand of English and Welsh coasts; the small Four-horned Spider-crab (Pisa tetraodon); the little Pea-crab (Pinnotheres pisum, \&c.), inside bivalves, are familiar British species.

Classification.-Crals are generally classified according to the shape of their cephalothorax into five families : (1) Catometopa, usually quadrangulare.g. Ocypoda, Grapsus, Pinnotheres, Gecarcinus ; (2) Cyclometopa, usually broad, narrowed behind, bow-shaped in front-e.g. Telphusa, Cancer, Portunus, Carcinus ; (3) Oxyrhyncha, triangular, pointed in front-e.g. Maia, Pisa, Hyas, Stenorhynchus, Inachus; (4) Oxystomata, nsually round e.g. Calappa, Ilia; (5) Notopoda, with the last or last two pairs of limbs more or less turned back -e.g. Dorippe, Porcellana, Lithodes, Dromia.

See Crustacka, Craypish, Hermit-crab, Lobster. Besides general works mentioned under Crustacea, see Balfour's Embryoloyy; W. K. Brooks, Handbook of Invertebrate Zoology (Boston, 1882); Fréderiog, Archiv. Zoologie Expér. (1883); Huxley's Invertebrates; Romanes, Animal Intelligence (Inter. Se. Series, 1886); Carus Sterne, Werden und Vergehen (1886); Woodward, in Cassell's Natural History.

Crab. Roger, hermit, was born about 1621 in Buckinghamshire, and served for seven years (1642-49) in the Parliamentary army. He then set up in business as "a haberdasher of hats" at Chesham, in his native county. He had imbibed the idea that it was sinful to eat any kind of animal food, or to drink anything stronger than water and in 16.51, determined to follow literally the injunction given to the young $\operatorname{man}$ in the gospel, he sold off his stock-in-trade, distributing the proceeds among the poor, and took up his residence in a hut. His food consisted of bran, turnip-tops, dock-leaves, and grass. The persecutions the poor man inflicted on himself caused him to be persecuted by others, endgelled, and put in the stocks. He was four times imprisoned for sabbath-loreaking and other offences, yet still he persisted in lis course of life. He puhlished The English Hermite, Dagon's Dounfall, and a tract 
against Quakerism; and he died at Bethnal Green, 11th September 1680 .

Crab-apple is a term applied somewhat vaguely to any sour and uncultivated variety or species of apple. Thus Pyrus spectabilis of shrubberies is known as the Chinese Crab, $P$. prunifolia as the Siberian Crab, $P$. coronaria as the American Crab, and $P$. baccata of North Asia (including cerasifera) as the Cherry Crab. More strictly, lowever, the term is applied to the wild varieties of the true apple ( $P$. Malus, var. sylvestris). Of this, again, two main varieties are distinguished, one smooth-leaved and sour (var. austera), the other more or less woolly-leaved and sweeter (var. mitis). The former of these may therefore be considered as the crabapple proper.

Crabbe, Georar, poet, was born on Christmas Eve of 1754, at Aldeburgh, on the Suffolk seaboard. His father, 'salt-master' and warehousekeeper, was a clever, strong, violent man; the mother, a meek, religious woman; and of three brothers, one perished captain of a slaver, another was lost sight of in Honduras. George, the eldest, got some schooling at Bungay and Stowmarket, then ofrom 1768 to 1774 was surgeon's apprentice at Wickham-Brook and at Woodbridge. In his first place he had to help the ploughboy; in his second he fell in love with Sarah Elmy ('Mira'), who lived with her uncle, a wealthy yeoman, at the old moated hall of Parham. A spell of drudgery in his father's warehouse-nine months in London, picking up surgery cheaply - some three years' struggling practice at Aldeburgh - at last in April 1780 , with $£ 3$ in his pocket, he sailed again for London, resolved to try his fortune in literature. Eight years before he had written verses for Wheble's Magazine; he had published Inebriety, $a$ Poem (Ipswich, 1775); and now his Candidate soon found a publisher, unluckily a bankrupt one. A season of penury, dire as Chatterton's, was borne by Crabbe with pious bravery; he had to pawn clothes and instruments; appeals to Lords Thurlow, North, Shelburne, met no response; and early in 1781 he saw himself threatened with arrest for debt, when he made his case known to Burke. Forty-one years later he told Lockhart at Edinburgh, how, having delivered the letter at Burke's door, he paced Westminster Bridge all night long until daybreak. Burke proved a generous patron; from the hour of their meeting Crabbe was a 'made man.' He stayed at Beaconsfield; he met Fox, Johnson, and Reynolds; Thurlow gave him a bank-note for $\$ 100$; Dodsley brought out his Library; and the very next winter he was ordained to the curacy of his native town. He resided as domestic chaplain to the Duke of Rutland at Belvoir Castle (-1782-85); married Miss Elmy (1783); held four livings in Dorset, Leicester, and Lincoln shires, but spent thirteen happy years in Suffolk, at Parham, Great Glemham, and Rendham (17921805); returned to Muston, his Leicestershire rectory; and his wife having died there in 1813, exchanced it the next year for Trowbridge in Wiltshire. His gentle, kindly life, in which botanising had given place to fossil-hunting, was broken now and ugain by visits to London and its best society lie witnessed the Bristol riots (1831), as fifty-one years before he had witnessed those of Lord George Gordon; and on 3d February 1832 he died at Trowbridge.

Three novels, a treatise on botany, and poems untold all perished in grand yearly 'incremations; but still, Crabbe published The Village (1783), The Newspaper (1785), The Parish Register (1807), The Borough (1810), Tales (1812), and Tales of the Hall (1819), for which last and the earlier copyrights Murray paid him $£ 3000$. Of these poems Words. worth wrote in 1832, " They will last full as long as anything expressed in verse since first they made their appearance;' and Jane Austen said Crabbe was the only man whom she would care to marry. Byron, too, Scott, Jeffrey, Wilson, Lord Tennyson, Sivinburne, Cardinal Newman, ana, above all, Edward Fitzgerald, must be reckoned among his few votaries. 'Though nature's sternest painter, yet the best,' Byron's verdict upon him, is truer than Horace Smith's, 'a Pope in worsted stockings,' for this refers but to the accident of metre--the rhyming heroics, which, thirty per diem, Crabbe ground out anywhere. Their subject-matter, though, is all Crabbe's own. He is as much the poet of East Anglia as Seott of the Borderland or Wordsworth of the Lake Country. Its scenery and the life of its fisher-folk and peasantry he described with a realism greater than Zola's, if sometimes almost as tedious, Zola! nay, Crabbe has closer kinship to Balzac; and his strong, sombre pictures of sin and suffering are ever and again lit up with homely pathos and shrewd, Dutch-like humour. 'The tragic power of Crabbe,' Mr Swinburne says, ' is as much above the reach of Byron, as his singularly vivid, though curiously limited, insight into certain shades of character.' And in old John Murray's words, 'Crabbe said uncommon things in so common a way as to escape notice;' surely he claims notice from such as rank thought higher than expression.

An admirable Life by his son, the Rev. George Crabbe (1785-1857), for twenty-three years vicar of Bredfield, Suftolk, is prefixed to Crabbe's Works (8vols. 1834). See also Mr Leslie Stephen's 'Hours in a Library' (2d series, 1876) : Mr Fitzgerald's Rendings in 'Tales of the Hall' (1882); the essay on Crabbe by $\mathbf{M r}$ W. J. Courthope in vol. iii. of Ward's English Poets (1884); and T. E. Kebbel's Craube (1888).

Crab-stones, or Crab's Eyes. See Cray. FISH.

Cracked Heels. From careless grooming, washing horses' legs and imperfectly drying them, permitting them to stand in accumulatious of filth or exposed to dranghts, the skin becomes inflamed, tender, itchy, thickened, and by-and-by cracked. An ichorous and fetid discharge exudes, and lameness often results. In animals with round gummy legs it is sometimes constitutional ; underbred horses with rough hairy fetlocks present the majority of cases; white heels, being more delicate, are especially affected; whilst the hind limbs, exposed as they are to filth and cold, suffer most frequently. Cleanse carefully with tepid water; wash with a diluted solution of Goulard's Extract, or any other mild astringent; or dress occasionally with oxide of zinc ointment. Give, besides, 8 half-dose of physic, and a few mashes, afterwards carrots, swedes, or such laxative food, and where the ailment is persistent, use Diuretics (q.v.). When the skin is dry and irritable, poultice and apply glvcerine before proceeding with astringents. In cold weather, and especially when the horse is heated, interdict washing the legs; but allow them to dry, and then brush off the dirt.

Cracovienne (krakoviak), the national dance of the Polish peasantry around Cracow. It has a very marked rhythm in $\frac{2}{4}$ time, and is often accompanied by singing. The Poles have a multitude of little ditties of two lines each, adapted to this music and dance.

Cracew (Pol. Krakov, Ger. Krakau), a city of the Austrian crown-land of Galicia, 259 miles NE. of Vienna by rail. It stands 672 feet above sea-level, in a wide, hill-girt plain on the left bank of the Vistula, which here becomes navigable, and is spanned by a bridge (1850) leading to Podgorze. 'The old walls have been converted into promenades, 
and $a$ line of detached forts now defends the city. It older portion is a labyrinth of narrow, dark, and deserted streets, but contains many fine specimens of Gothic architecture in its churches and other editices; and some handsome buildings are also to be seen in the more modern sulsurbs. On the Wavel rook, in the midst of the houses, rises the old castle of the Polish kinga, degraded now to a barrack. The neighbouring eathedral (1320-59) is a splendid pile, containing the graves of John Sobieski, Poniatowski, Kosciusko, and many more heroes, with Thorwaldsen's statue of Christ. The university was founded in 1364 , by Casimir the Grent, and reconstituted under the Jagellons in 1394. Long the centre of light for Poland, it had decayed under Jesuit influence, but was reorganised and reopened in 1817, and now is attended by more than 800 students. It possesses a library of 150,000 volumes, and many MSS. of great value in connection with Polish history. Cracow has important fairs, and its trade and manufactures (chemicals, tobacco, beer, agricultural implements, \&c.) have of late years greatly revived. Three miles west of the city is a grassy mound, 150 feet high, reared in 1820-23 to the memory of Kosciusko. It is composeal of earth taken from all the patriotic battle-fields of Poland. The population has varied much at different periods, from 80,000 in the 16th century to 10,000 at the end of the $18 \mathrm{th}, 49,835$ in $1869,66,095$ in 1880 , and 76,025 in 1890 , of whom 20,600 were Jews.

Cracow was foinded by Krak, Prince of Poland, from whom it derives its name, about the year 700 , became the capital of Poland in 1320, and continued such till 1609, when that honour was transferred to Warsaw. It was taken by the Bohemians in 1039, by the Tartars in 1241, by the Swedes in 1655 and 1702, and by the Russians in 1768. On the third partition of Poland, in 1795, it was assigned to Austria. From 1809 to 1815 it formed part of the duchy of Warsaw. The congress of Vienna established it as a republic, with a territory of $425 \mathrm{sq} . \mathrm{m}$., and containing about 140,000 inhabitants, under the protectorate of Russia, Prussia, and Austria. Internal dissensions between the nobles and the common people afforded a pretence for interference, and the sympathy shown for the cause of Polish independence was marle the ground of the annexa. tion of Cracow to the Austrian dominions (1846). See Pol.AND.

Craddock. Charles Egbert, is the pen-name of Miss Mary Noailles Murfiee, born near Murfreesborough, in Texas, about 1851, and early disabled by paralysis. She is known as anthor of In the Tennessee Mountains (1884), Where the Buttle was Fought (1884), Down the Ravine (1885), The Prophet of the Great Smoky Mountains (1885), The Despot of Bromsedge Cone (1888), and other stories.

Crag and Tail, a term used to designate a peculiar hill conformation, in which a bold and precipitous front exists on one aspect of a hill, while the opposite is formed of a sloping declivity.

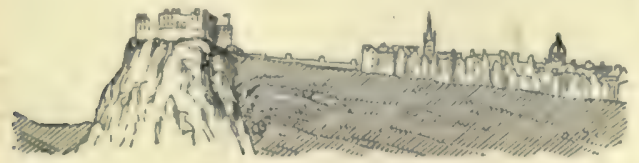

Castle Rock, Edinburgh.

Fine examples of this structure occur in and around Edinburgh, where the bold ' erag' faces the west and the 'tail' slopes towards the enst; as, for example, the Castle rock, precipitous and unap. proachable on every side except to the east. The structure owes its origin to the juxtaposition of rocks of variable degrees of durability - the harder and more durable rocks having resinted denudation, and so protected the more rendily eroded rocks that oceur on the lee side of the former. The crag and tail phenomena of central Scotland and other regions which have been subjected to extreme glacistion (see Glacial Peroo) is due to glacial erosion and accumulation. The crng fuces the direction from which the ice came, and thus by opposing its advance induced excessive erosion upon the ground immediately in front. A hollow has thus usually been scooped ont in this place, and continued along either side of the olustruction for some little distance. This somewhat crescentshaped hollow is well seen on the west side of Edinburgh Castle rock, sweeping round on the north by Princes Street Gardens (the old Nor' Loch), and on the south by the valley of the Cowgate. The morainic material dragged along underneath the ice accumulated in the rear of the erag, so that the strata in that position are usually covered to a greater or less depth with boulderclay, \&c. The High Street of Edinburgh is thus built upon morainic materials.

Craig, JoHr, Scottish Reformer, was born in 1512, next year lost his father at Flodden, and was educated at St Andrews. He joined the Doninicans there, but fell under suspicion of heresy, and after a brief imprisonment (1536) went to Rome. Through Cardinal Pole he gained admission to the Dominican convent of Bologna, where be became the master of novices; next a copy of Calvin's Institutes fell in his way, and converted him to Protestantism. On 18th Angust 1559 he was lying in the dungeon of the Inquisition, condemned to suffer next morning at the stake, when Pope Paul IV. died, and the mob broke open the prisons, and set the prisoners at liberty. A bandit befriended him; a dog brought him a purse of gold as he was wandering helpless through a forest; he escaped to Vienna, and there preached in his friar's habit, one of his hearers being the Archduke Maximilian. Presently the new pope, learning his whereabouts, demanded his surrender; but Maximilian gave him a safe-conduct, and in 1560 he returned to Seotland. In 1563 he was appointed coadjutor to Knox, and with him was accused by the Earl of Bedford of having been privy to Rizzio's murder; in 1567 he incurred some censure for proclaiming, under strong protest, the banns between Queen Mary and Botliwell; and in $\mathbf{1 5 7 2}$ he was sent to "illumin. ate the dark places' in Angus and Aberdeenshire. He came back to Edinburgh in 1579 as a chaplain to James VI., took a leading part in the cliurch's affairs, and had a share with Melville in the Second Book of Discipline. He was the author of the 'Confession of Faith' or first National Covenant, 'subscribed by the king's majesty and his household and sundry others' at Edinburgh, 28th January 1580. He withstood the restoration of prelacy; hut his comparative moderation was not seldom displeasing to the 'popes of Elinburgh.' He died 12th December 1600. His Short Summe of the whole Catechisme (1581) has been reprinted in fac-simile, with a valuable introductory Memoir by T. G. Law (Edin. 1883).

Craig. Tнома8, writer on fendal law, was born in 15.38, either at Craigfintray (Aberdeenshire) or in Edinburgh. From St Andrews he passed in 1555 to the university of Paris, and in 1563 was adnitted an advocate at the Scottish bar, being next year appointed justice-slepute of Scotland, and in 1573 sheriff-depute of Edinburgh. Whilst head of the criminal judicature, he did not neglect the muses, as was evidenced ly an epithalanium on Queen Mary's marriage with Darnley and a poem on the 
birth of James VI. Besides several more Latin poems, and the masterly Jus Feudale (1608; 3d ed. 1732 ), by which he is chiefly remembered, he wrote three other Latin treatises-on James VI.'s right to succeed to the English throne; on the advisability of a union between the two kingdoms, and on the homage controversy between Scotland and England. He stood high in favour with James, who wanted to knight him in 1603 , and, on his declining, dispensed with the ceremony, but gave him the title. He died 26th February 1608. See his Life by P. F. Tytler (1823).

Craig-fiuke (Pleuronectes cynoglossus), a flat fish in the same genus as Dab, Plaice, and Flounder (q.v.).

Craigleith Stone, a siliceous sandstone belonging to the lower carboniferous series, quarried at Craigleith, 2 miles W. of Edinburgh, and largely used for building in that eity, for which it is admirably adapted by its purity and durability.

Craik, George LirLie, a versatile and industrious author, born at Kennoway, Fife, in 1798, was educated for the church at St Andrews University, but, preferring a literary career, came to London in 1826, and formed a connection with Charles Knight. His first work of importance was the Pursuit of Knowledge under Difficulties (1831). He also contributed largely to the Penny Magazine and Cyclopaedia, and in 1839 became editor of the Pictorial Histary of England, some of the most valuable chapters of which were written by himself. From these his Sketches of the History of Literature and Learning in Eng. land ( 6 vols. 1844) and his History of British Commerce (3 vols. 1844) were reprinted. In 1849 Craik was appointed to the chair of History and English Literature in Queen's College, Belfast, a situation which he oecupied till his death on 25th June 1866. His other works include Spenser (1845), Bacon (1846-47), Romance of the Peerage (1848-50), The English of Shakespeare (1856), History of English Language and Literature (1861; 9th abridged ed. 1883). - His youngest daughter, Georgina Marion (Mrs May), born in 1831, began to write at nineteen, and had at her death in 1895 published some thirty novels and stories.

Craik, Mrs. Dinah Maria Mulock, well known as the author of John Halifax, Gentleman, was born at Stoke-upon-Trent in 1826. She early took the burden of supporting an ailing mother and two younger brothers, and wrote stories for fashion-books, as well as for graver publications. Her first serious appearance as a novelist was in 1849, with her story The Ogilvies, which was followed by Olive, The Head of the Family, and Agatha's Husband. But she never surpassed or even equalled her domestic novel John Halifax (1857), which has had, and still continues to have an extraordinary popularity, and has been translated into French, German, Italian, Greek, and Russian. The scene is laid at Tewkesbury, where a marble medallion has been placed to her memory in the abbey. A pension of $£ 60$ a year, awarded to her in 1864, she set aside for anthors less fortunate than herself. In 1865 she married Mr George Lillie Craik, a partner in the publishing house of Macmillan \& Co. (nephew of the subject of the preceding article), and spent a period of quiet happiness and successful literary industry at her home, Corner House, Shortlands, Kent, where she died 12th October 1887. Much of Mrs Craik's verse is collected in Thirty Years' Poems (1881). She wrote a good deal for the magazines, and produced in all forty-six works, viz.--fourteen more novels, and several volumes of prose essays, including $A$ Woman's Thoughts about Women (1858), and Conrerning Men, and other Papers (1888).
Mrs Oliphant's sketch in Macmillan's Magazine (1887).

Crail, an antique little coast-town in the 'East

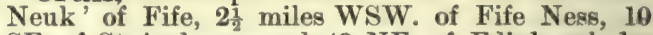
$\mathrm{SE}$. of St Andrews, and $43 \mathrm{NE}$. of Edinburgh by rail. There is a fragment of a castle of David $I$. ; and the church, which was made collegiate in 1517 , is an interesting Second Pointed structure. John Knox here preached his 'idolatrous sermon,' 9th June 1559; and in 1648, James Sharp was appointed minister. The fishing is not what it once was, and the harbour has little trade; but Crail is a pleasant summer-resort. It was made a royal burgh in 1306, and unites with the other six St Andrews burghs to return one member to parliament. Pop. (1861) 1238; (1881) 1148; (1891) 1115.

\section{Crake. See Corn-Crake.}

Crambé, a genus of Cruciferæ, having a pod (silicula) of two unequal joints, of which the upper is globose and one-seeded, the lower abortive. C. maritima is well known as Seakale (q.v.). C. tartarica, of Eastern Europe, with much divided leaves and a great fleshy root, is cultivated in Roumania as cauliflower, and its root is eaten either boiled or in salads.

Cramer, Johann BAptist, pianist, was born at Mannhein in 1771, the son of Wilhelm Cramer (1745-99), a musician of repute, who settled in London in 1772. From 1788 the son undertook concert tours on the Continent, and gained a high reputation as a facile and expressive performer. He founded the musical publishing firm which hears his name in 1828, and after some years residence in Paris, died in London, 16th April 1858. Most of his compositions are now forgotten, but his series of Studies is a work of importance.

Cramp is a word applied to muscular contractions of an irregular kind, in a somewhat variable way.

(1) In its common use, it denotes an involuntary and painful contraction of a voluntary muscle or group of muscles. It is most apt to occur when a muscle has been fatigued; though any muscle may be affected, those of the calves most often suffer. It is especially common in pregnant women and persons of a gouty diathesis, and is a prominent feature in some diseases, especially cholera. There is no specific for preventing it; each case must be treated on its merits. The contraction and accompanying pain is usually cut short if the affected muscle be stretched-e.g. in the case of the calfmuseles, the knee must be straightened and the foot bent up as far as possible towards the front of the leg, to lengthen the affected muscles to the utmost, and similarly with other cases.

(2) Writer's Cramp is the commonest and best known of a group of diseases called trade spasms. The person affected can use his fingers for any purpose, even the most delicate manipulations, so long as he does not attempt to write; but whenever he does so, the muscles refuse to obey his will, and the pen either drops from his hand or executes spasmodic purposeless movements. Similar conditions may occur in telegraphists and pianists - in fact; in any case where frequent and continued use of particular muscular actions is necessary. These distressing and troublesome affections have recently been cured in some cases by means of Massage (q.v.) and systematic gymnastic exercises of the affected parts.

(3) Bather's Cramp.-A good swimmer, while bathing, is seen to throw up his arms, perhaps is heard to cry out once, and then sinks to rise no more. It is said that 'bather's cramp' has been the cause of his death. This phrase, however, is merely an apology for ignorance: what has happened, and whether it is the same in all 
apparently similar cases is as yet quite uncertuin. Crump, in the ordinary sense, of one or more limbs, though very embarrassing and alarming. would not be so dinastrous to a practimed swimuer as to make him sink without a struggle; and, though common in bathers, cannot be accepted as the cause of all the fatal aecidents like that described above. Of other theories advauced, the most probable is that sudden failure of the heart's action, a partial or total faint, is the cause of the calamity, at least in very many casen. A sudden plunge into cold water by itself causes some strain upon the lieart; and swimming, about the most severe of all forms of exercise, increases its work very grently - sometimes, it is easy to believe, beyond safe limita. The recorded experience of gome who have narrowly eacaped death from this cause makes it appear extremely probable that it is the renl explanation of at least some of these sad accidents. No one when out of practice should attenpt a long swim in cold water; and persons with weak hearts should he especially careful to avoid fatiguing themselves when bathing.

Cramp Rings were rings which were sup posed to cure cramp and the 'falling-sickness.' They are said to have originated as far back as the middle of the 11th century, in a ring presented by a pilgrim to Edward the Confessor, which, after that ruler's death, was preserved as a relic in Westminster Abbey, and was applied for the cure of epileusy and cramp. Hence appears to have arisen the belief that rings blessed by English sovereigns were efficacious in such cases; and the custom of blessing for distribution large numbers of cramp rings on Good Friday continued to exist down to the time of Queen Mary. The accomplished Lord Berners, ambassador to Spain in Henry VIII.'s time, writes from Saragossa to Curdinal Wolsey: 'If your grace remember me with some crampe ryngs ye shall doo a thing muche looked for; and I trust to bestow thaym well with Goddes grace.' The metal the rings were composed of was what formed the king's offering to the cross on Good Friday, usually either gold or silver. The superstitious belief in the curative property of eramp rings made out of certain pieces of silver obtained in particular ways still lingers in some districts of England.

Cran (Gaelic), a measure of eapacity in Scotland for herrings when just taken ont of the net. It amounts to $37 \mathrm{f}$ imperial gallons, and comprises about 750 herrings on an average.

Cranach, LucAs, a celebrated German painter, so named from Kronach in the bishopric of Bamberg, Upper Franconia, where he was born, 4th October 1472. Little is known of his early life, but he seems to have been instructed by his father, and, possibly, by Matthew Grundewald; to have resided in Gotha, where he married Barbara Brengbier; and to have accompanied Frederick the Wise, Elector of Saxony, to the Holy Land in 1493. Certainly he was befriended by that prince, and was his court-painter at Wittenberg, an appointment which he received in 1508, slong with patent of nobility, and the 'motto,' or kleinod, of a crowned and winged serpent, with which he marked his subsequent works, instead of (sometimes in combination with) the initials which he had previously used. Monopolies for printing and the sale of medicine were also bestowed npon him. The house in which he carried on his manifold oceupations was standing at Wittenlerg till $187 \mathrm{l}$, and his inportance in the town may be gathered from the fact that in 1537, and again in 1540 , he was elected a burgomaster. In 1509 he accom. panied an embassy to the Emperor Maximilian, and while in the Netherlands he portrayed the prince, afterwards Charles $V$, then a boy of nine. After the death of the Elector Frederick in 1805 . he was continued in his ofticial ponition by his brother, and also by his successor, John Frederick the Magnanimous, whose captivity at Augsburg the artist shared, and whose release he is believed to have procured from the emperor in 1552. He returned with his master to Weimar, and died there on 16th October of the following year. The superiority of his earlier works, both in painting and engraving, is doubtless to be accounted for by the fact that in later life the preasure of numerous commissions necessitated the assistance of his sons, and of many other pupils. His paintings, executed in oils on panel, include sacred and a few classical subjeets, hunting-scenes, and portraits.

His drawing is commonly hard and defective, but his colouring is rich, warm, and effective, and a certain homely earnestness, sometimes mingled with humour, characterises his productions. A quaint portrait of a girl in an elahorate costume from his hand is in the National Gallery, London. He was closely associated with the German Reformers, many of whom were portrayed by himself and his pupils. Figures of Luther and Melanchthon, and the painter himself, are introduced in his 'Crucifixion' in the Stadtkirche, Weimar, a work engraved in Waagen's Handbook of Painting (ed. of 1874 ), and usually regarded as the artist's most important composition. Three of his copper engravings, dated 1519, 1520, and 1521, represent Luther; and among lis other principal works with the burin are "The Penitence of St John Chrysostom ' (1509), and a portrait of the Eleetor Frederick. His wood-engravings are nore numerous, including 'The Passion,' 15 cuts ; 'The Martyrdom of the Apostles,' 12 cuts; and 'The Wittenberg Hagiology,' 119 cuts. He had three sons, all of whom were painters. - The second of them, LuCAs, the younger, born 1515, was a burgomaster of Wittenberg. He painted in the manner of his father, and their works are difficult to distinguish, especially as both artists used a similar mark. According to Schuchardt, however, in the productions of the son the crowned serpent appears with the wings folded, instead of erect as in those of the father. His 'Crucifixion,' or 'Nativity,' and a picture of 'The Lord's Vineyard,'symbolical of the progress of the Reformation, are in the Staultkirche at Witten. herg, and his works may also be studied in Berlin, Munich, and at Dresden, where are his portraits of the Electors Maurice and Augustus, and a 'Crucifixion.' He died at Wittenberg in $\mathbf{1 5 8 6 .}$

Cranberry (Oxycoccus), a north temperate and aretic genus of small evergreen shrubs of the order Ericacese (sub-order Vaccinen). The only British species (O. palustris, formerly Vaccinium Oxycorcus) grows in peaty bons and marshy grounds, and is a small wiry shrub with creeping thread-like branches, and small oval leaves rolled back at the edges. Large quantities of the fruit, which is chiefly used for making tarts, are collected in some parts of Britain, as also in Germany and other European countries, although the draining of bogs has now made it scarce where it was once plentiful. The berries are an excellent antiscor. hutic, and hence furnish an excellent addition to sea stores. Wine is made from them in Siberia, and a beverage made from them is sold in the streets of St Petersburg. - The American Cranberry ( 0 . macrocarpa) is of similar distribution, hut is a larger and more upright plant, with higger leaves and berries. The berries are not now col. lected by means of a rake, bnt by hand, as the former method bruises them. Large quantities are exported to Europe, and the berries are also im. ported into Britain from Russia and other parts of northern Europe. Both kinds may be cultivated in 
gardens, in a peat-soil kept very moist or round the margin of a pond. - The herries of the Red Whortleberry or Cowberry (Vaccinium Vitis-Idoen) are sold under the name of cranberries in Aberdeen and

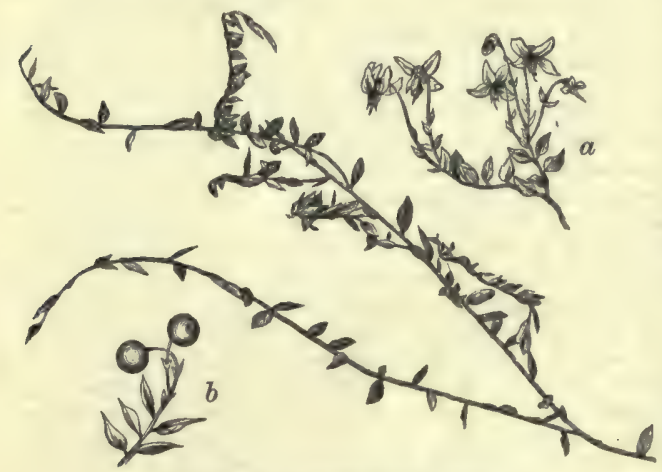

Cranberry (Oxycoccus palustris): $a$, flower; $b$, fruit.

other places, and are used in the same way.-The Tasmanian Cranberry is the fruit of Astroloma humifusum, a pretty little trailing Epacridaceous shrub; while in Australia the same name is given to other plants of the same order, notably Styphelia ascendens and Lissanthe sapida.

Cranborne, VISCOUNT, the courtesy title of the eldest son of the Marquis of Salisbury.

Cranbrook, a plessant little market-town in the Weald of Kent, 46 miles SE of London. It has a fine Perpendicular church, and a large trade in hops. From the 14 th to the 17 th century it was the centre of the broadcloth manufacture introduced by the Flemings. Pop. of parish about 5000 . See Tarbutt's Annals of C'ranbrook (1875).

Cranbrook, Gathorne Gathorne-Hardy, EARL (1892), was born Ist Oetoher 1814, at Bradford, the son of John Hardy, Esq., of Dunstall Hall, Staffordshire. Educated at Shrewsbury and at Oriel College, Oxford, where he took his B.A. in 1837, he was called to the bar in 1840 , and in 1856, after unsuccessfully contesting Bradford nine years earlier, was returned as a Conservative by Leominster. In 1865 he defeated Mr Gladstone in the celebrated Oxford University election; in $\mathbf{1 8 7 8}$ he was raised to the peerage as Viscount Cranbrook. He was Undersecretary of State for the Home Department (18.58. 59), President of the Poor-law Board (1866-67), Home Secretary (1867-68), War Secretary (1874 78), Secretary of State for India (1878-80), and Lord President of the Council (1885-92).

Crane (Grus), a genus of birds in the order Grallatores, the type of the family Gruidre. This family differs from herons, storks, \&c., in having the hind-toe placed higher on the leg than the front ones, and in certain characters of bill and skull. The members are also less addieted to marshy places, and feed not only on animal, but, to a considerable extent, on vegetable food. The cranes are all large birds, long legged, long necked, long billed, and of powerfal wing. Some of them perform great migrations, and fly at a great height in the air. Some twelve species are known, mostly th the palrearctic region, but also in Asia, Australia, and America. Unlike other Grallatores, the young cranes are helpless and require to be fed. Only two eggs are laid.-The Common Crane (G. cinerea) breeds in the northern parts of Europe and Asia, retiring in winter to tropical or subtropical regions. Flocks of cranes periodically pass over the southern and central countries of Europe, uttering their lond harsh cries in the air, and occasionally alighting to seek food in fields or marshes. The crane, when standing, is about four feet in height; the prevailing colour is ash-gray; the head bears bristly feathers, and has a naked crown, reddish in the male; the bill, which is longer than the head, is reddish at the root, dark green at the apex; the feet are blackish; the tail is short and straight. They are very stately birds, though their habit of bowing and dancing is often grotesque. The covering feathers of the wings are elongated, reaching beyond the ends of the primaries, and their webs are unconnected; they are varied and tipped with bluish-black, and are the well-known plumes once much used in ormamental head-dresses. The visits of the crane to Britain are now very rare, although in former times they were comparatively frequent. It feeds on roots, seeds, \&c., as well as on wormis, insects, reptiles, and even some of the smallest

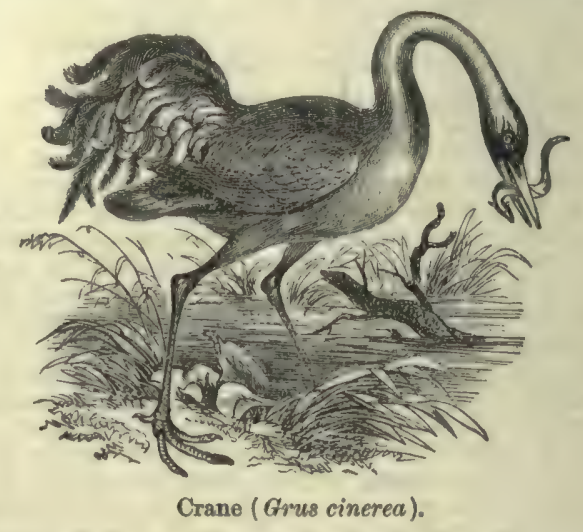

quadrupeds. The flesh is much esteemed. Cranes use their bill as a dagger, and when wounded are dangerous to the eyes of a rash assailant. They may be readily tamed in captivity and exhibit great sagacity.-The Whooping Crane $(G$. americana) is considerably larger than the eommon crane, which it otherwise much resembles except in colour; its plnmage, in its adult state, is pure white, the tips of the wings black. It spends the winter in the southern parts of North America. In summer it migrates far northwards, but rather in the interior than the eastern parts of the continent. - To the crane family belong also the Demoiselles-e.g. Anthropoides virgo, from southern Europe to central Asia, and the Ethiopian Balearic Cranes-e.g. Balearica pavonina. See Blyth, Natural History of the Cranes (1881).

Crane, a machine for lifting weights, worked either by hand, or by steam, or by hydraulic power. The most common hand form consists of an upright revolving post and a projecting arm (usually at an angle of about $45^{\circ}$ ), the jib with a fixed pulley at its extremity. The lifting chain or rope is secured to the weight, passes over the fixed pulley, and then round a drum or cylinder; suitable toothed-wheel gearing worked by a handle revolves this drum, and thus winds up or unwinds the rope or chain, and so raises or lowers the weight, while at the same time the effort applied by the men at the handles is greatly magnified-namely, distegarding frictional losses, in the same proportion that the peripheral speed of the handles is reduced by the gearing interposed between handle axis and drum axis. The revolving motion of the upright post enables the load to be deposited at any point within the sweep of the jib. It is often arranged that the jib shall be hollow; the chain then passes down it, and thero 


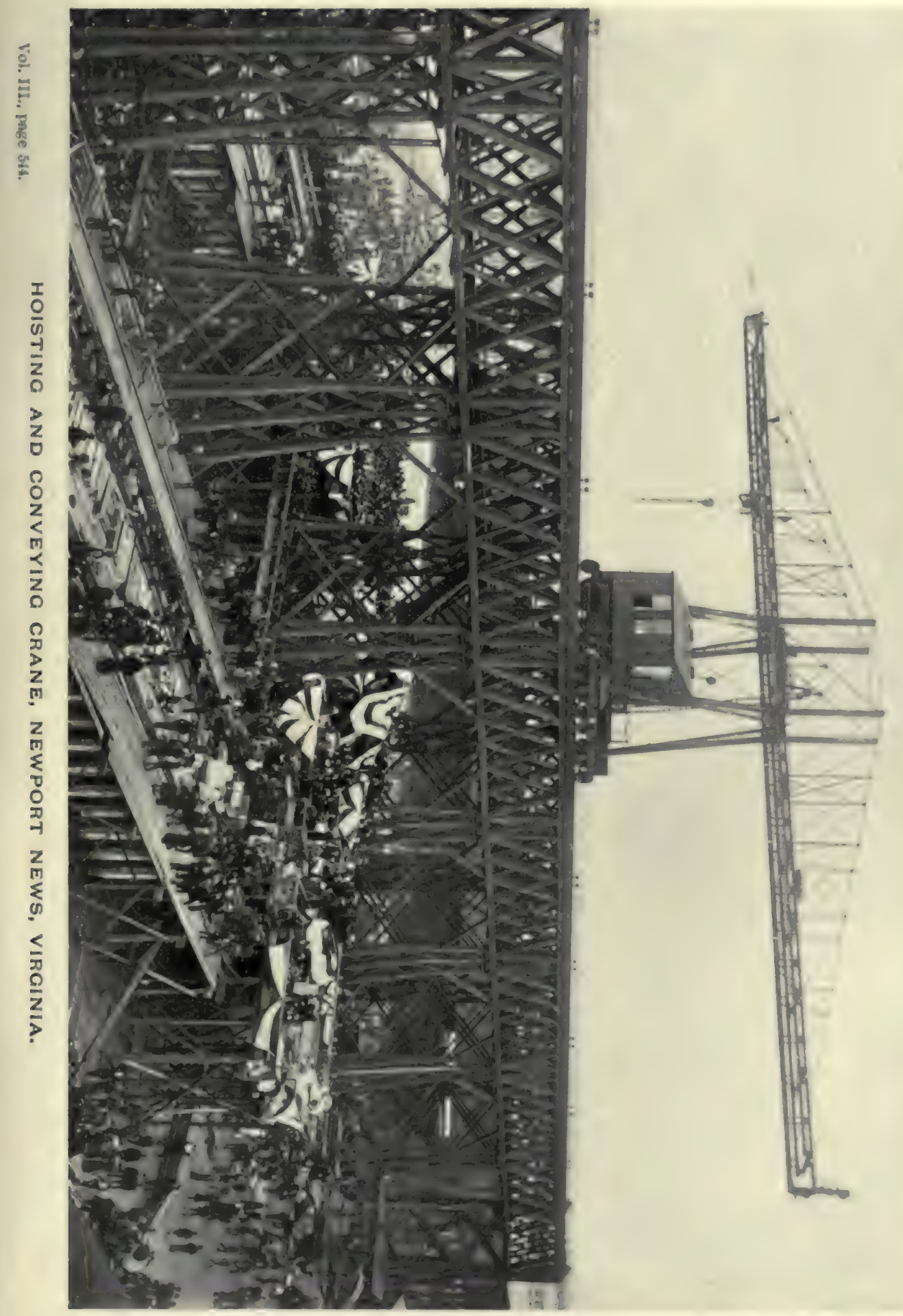



is no fear of fouling; if also the jib is of a curved form, we obtain the full benefit of the lift, while in

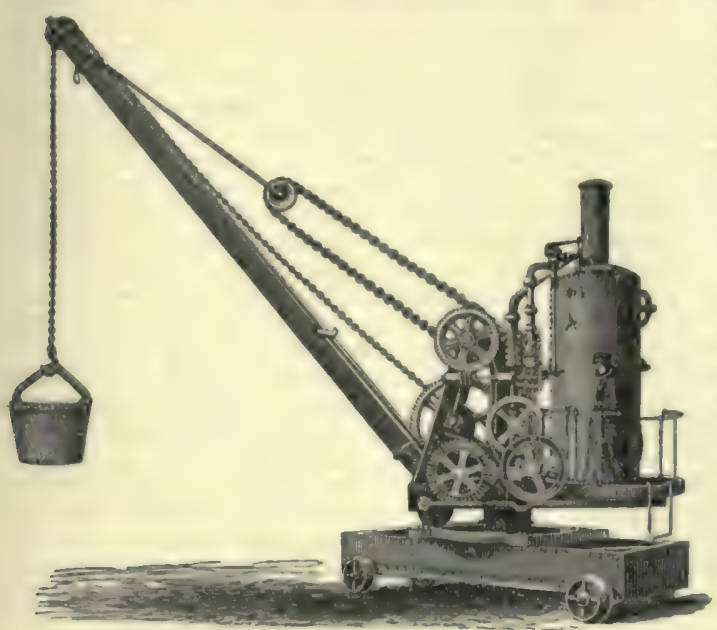

the ordinary crane the form of the jib or the tie interferes with the usuál height of lift.

Whenever much hoisting or heavy work has to be done, steam or hydraulic power is always used; the cranes are then either stationary or portable, the latter type being used whenever it is more convenient to move the crane to its work than the con. verse. The stationary power eranes differ from the hand ones mainly in their vastly greater power, and consequently greater size and complexity of gearing; where steam is used there are generally two direct-acting steam-cylinders, which replace the two handles worked by hand. The very powerful stationary cranes used in docks eapable of lifting 50 to 75 tons are examples of this kind; they are always mounted on massive foundations, and 80 arranged as to sweep a whole circle. Hydraulic power is very largely used in cranes for these places and in great steel-works; they are simpler in construction, a good deal of gearing being done away with; the water in the operating cylinder is always under great pressure, usually $700 \mathrm{lb}$. on the square inch. In the hydraulic cranes originally introduced by Sir William Armstrong \& Co., the power given ont by the hydraulic cylinder is reduced by using systems of pulleys in the inverse order, the lifting chain being attached to the eylinder, then passing over a pulley fixed to the head of the ram, then round other fixed pulleys, and 80 up to the fixed pulley at jib end, the effect being to increase the motion of the ram, and so secure very rapid lifts at the expense of using more power. In one very ingenious stem-crane (Morrison's) the poet of the erane is hollow, and forms the steam-cylinder, in which works a piston with flexible piston-rod-namely, the lifting chain ; this form is very steady and very readily slewed.

Portable eranes are mounted on plain railway trucks, either of wood or iron. This truck carries firmly attached to it a central post, the whole of the rest of the crane being carried on a strong baseplate capable of revolving round this post as a pivot, the boiler being so placed (often standing on its own feed-water tank) on this base-plate that it forms a counterbalance to the weight to be lifted. The boiler is always of the vertical type, and very simple in its internal arrangements of tubes (gee fig.), because it often has to work with very dirty feed-water. The gearing is usually carried by $A$ frames bolted to the base-plate; the engine, having generally two amall direct-acting steam. 139 cylinders, is ensily revenued; by mesum of gesring and elutches, which are operated by the man in charge of the crane by hand or foot levers, the engine can perform the following operations: (1) Jower or raise the outer end of the jib; (2) slew the crane-i.e. the base-plate and all it carries; (3) propel the truek along the rails; (4) hoist the loads. For the last three operations the gearing is generally so arranged that there are two speeds, a quicl: and a slow, either of which can be used, depending on the work to be done. The figure shows a very common type of this kind, which will lift from 5 to 7 tons, according to the position of the jib. For the maximum load the chain end is often attached to end of jib, and then round a hanging-block, and so up to fixed pulley at jib end, thus doubling pull on chain. For the same purpose as the ordinary crane are used contrivances known as derricks, which consist essentially of a mast or tripod with a long cross-boom at the top, tied to the mast by guys; pulley-blocks attached to one arm of the boom form the means of lifting. They are a good deal used in America for very heavy work, such as raising wrecks, bridgebuilding, \&c. They readily lend themselves for use as floating-cranes, since by making the vessel carrying them in watertight compartments which can be filled, it is easy to counterbalance the load. Electric eranes are also now in use.

Crane, Thomas Frederick, a leamed folklorist, was born in New York city, July 12, 1844. He was educated at the public school and academy of Ithaca, New York; and graduated at the college of New Jersey (Princeton) in 1864; A.M. in 1867 ; and Ph.D., causa honoris, in 1874. He was appointed assistant-professor of Modern Languages in Cornell University in 1868, professor of Spanish and Italian there in 1872, and professor of Romance Languages in 1881. Professor Crane has contributed a large number of articles to the North American Review, International Review, Harper's Magazine, Lippincott's Magazine, and The Nation on folklore and the literary history and philology of the Romance languages, especially during the period of the middle ages. Since his article on Italian folk-tales in the North American Review for July 1876, he has devoted much attention to the subject of the origin and diffusion of popular tales, and was one of the founders of the American Folklore Society (1888). Among his books are Italian Popular Tales (Boston, 1885); Le Romantisme Francais (New York, 1887); and an edition (1890), for the English Folklore Society, of the Exempla or illustrative stories contained in the sermones vulgares of Jacques de Vitré, Bishop of Acre (died 1240), containing the Latin text, trans. lation into English, elaborate notes on the origin and diffusion of the individual stories, and an introduction on the life of the author, and the use of illustrative stories in medieval sermons, \&c. Professor Crane's Italian Popular Tales forms, from its extent, its scientific accuracy, and the wide learning of its notes, one of the most important of recent contributions to storiology.

Crane, WALTER, painter and socialist, was born at Liverpool, 15th August 1845, the son of an artist, Thomas Crane (1808-59). He himself was trained as an artist, and his earlier as well as much of his later work consists of bonk-illustrations. Among these may be named his series of 'Toy. books '(1869-75), 'The Baby's Opern' (1877), and 'The Sirens Three,' in which last the poem as well as the designs was his work. In 1862 he began to exhibit paintings at the Royal Academy, showing in that year 'The Lady of Shalott ;' and he was a constani contributor to the Grosvenor Gallery from 
its foundation in 1877 till 1888. His pictures nearly always deal, in a somewhat decorative and archaic fashion, with subjects of an imaginative nature, such as 'The Riddle of the Sphinx' (1887). He has also produced many very delicate landscape subjects in water-colours; has designed wall-papers; and has published poems, illustrated by himself, Queen's Summer (1891), and The Claims of Decorative Art (1892). Since 1888 a member of the Royal Society of Painters in Water-colours, he was in 1893 appointed art director to the city of Manchester.

\section{Crane-fly. See DADdy-LONG-LEGS. \\ Crane's-bill. See Geranium.}

Cranganore (properly Kodungalúr), a town in Cochin state, on one of the openings of the great Cochin backwater, 18 miles N. of Cochin town; pop. about 10,000 . It is the traditional scene of St Thomas's labours. The Syrian Christians were established here before the 9th century, and the Jews' settlement was probably still earlier. It was taken from the Portuguese by the Dutch in 1661 ; was seized by Tippoo in 1776 , retaken, sold, and destroyed and abandoned by Tippoo in 1789.

\section{Craniology. See Skull, Eтhnology.}

Crank, in Machinery, is a lever or arm on a shaft, driven by hand (e.g. a winch-handle), or by a connecting-rod, its object being to convert reciprocating motion into rotary motion. Engine-cranks which convert the to and fro motion of the piston into continuous rotation of crank-shaft are connected to the piston-rod end by the connecting-rod. They are, when single, of steel, wrought-iron, or cast-iron, the crank in this case being either a simple arm, enlarged at one end to fit over the shaft, and with a pin at the other end embraced by the rod end (fig. 1); or else a disc centred on the shaft, with crank-pin as before (fig. 2). This last form is well balanced. When double, as is usual in large engines (fig. 3), they are now often built up

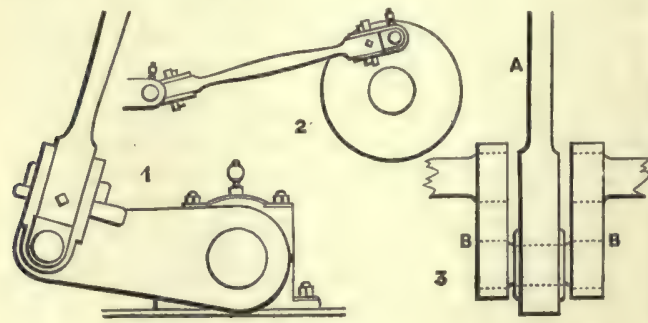

of steel, the two arms being shrunk on to the shaft, and pin on to them. In two positions during each turn, a connecting-rod exerts no power of rotation. These are when rod $\mathbf{A}$ and crank-arms $\mathbf{B}$ are parallel (as in fig. 3 and opposite position), and are the dead centres; all the push or pull of the rod only causes pressure on shaft-bearings. To carry the crank over these points either a heavy wheel (flywheel) is attached to the shaft, which stores up energy during other parts of the revolution, and gives it out at these points, or else two or more cranks are so placed on the shaft that when one is on its dead centre, the others are exerting nearly their maximum effort, which is when rod and crank are at right angles.

Cranmer, Тномаs, Archbishop of Canterbury, was born of a good old family at Aslacton, Nottinghamshire, 2d July 1489. He learned his grammar of 'a rude parish clerk,' a 'marvellous severe and cruel schoolmaster,' who seems to have permanently cowed his spirit; still, his father trained him in all manly exercises, so that even as primate he feared not to ride the roughest horse, and was ever a keen hunter. By his widowed mother he was sent in 1503 to Jesus College, Cambridge, where in 1510 he obtained a fellowship. He forfeited it by his marriage with 'black Joan' of the Dolphin tavern, but regained it on her death in childbed before the year's grace was up; and taking orders in 1523, proceeded D.D., and became a divinity tutor. During the quarter of a century that he resided at Cambridge he did not greatly distinguish himself; Erasmus never so much as mentions him; he was just a clever, hard-reading college don.

But in the summer of 1529 the plague was raging in Cambridge, and Cranmer removed with two pupils to Waltham. Here he met Fox and Gardiner, the king's almoner and secretary; and their talk turning on the divorce, Cranmer suggested that Henry might satisfy his conscience of the nullity of his first marriage by an appeal to the universities of Christendom. The suggestion pleased Henry; he exclaimed, "Who is this Dr Cranmer? I will speak to him. Marry! I trow he has got the right sow by the ear.' So Cranmer became a counsel in the suit. He was appointed a royal chaplain and archdeacon of Taunton; was attached to the household of Anne Boleyn's father (Anne at the time being Henry's paramour); penned a treatise to promulgate his view; and was sent on two embassies, to Italy in 1530 , and to Germany in the middle of 1532. At Rome the pope made him grand penitentiary of England; at Nuremberg he had married a niece of the Reformer Osiander-a marriage uncanonical but not. then illegal--when a royal summons reached him to return as Warham's successor in the see of Canterbury. He sent his wife secretly over, and himself following slowly, was consecrated on 30th March 1533, four days after the arrival of the eleven customary bulls from Rome. He took the oath of allegiance to the pope, with a protest that he took it 'for form sake, and with, as was usual, a contradictory oath of allegiance to the king.

That Henry looked for a pliable judge in Cranmer no man could doubt, least of all Cranmer himself, who in May pronounced Catharine's marriage null and void $a b$ initio, and Anne's, four months earlier, valid; and who in September stood godfather to Anne's daughter Elizabeth. It was the same through. out the entire reign. Cranmer annulled Henry's marriage with Anne Boleyn ( 1536 ), divoreed him from Anne of Cleves (1540), informed him of Catharine Howard's prenuptial frailty, and strove to coax her into confessing it (1541). Sometimes he raised a voice of timid entreaty, on Anne Boleyn's behalf, on Cromwell's; still, if Henry said they were guilty, guilty they needs must be. He did what he dared to oppose the Six Articles (1539), naturally, since by one of them the marriage of priests was rendered felony, punishable with death; but he failed to stick to his opposition, and sent away his own wife to Germany, whence he did not recall her till 1548.

A kindly, humane soul, yet he was not ahead of his compeers-More, for instance, or Calvin-in the matter of religious toleration. We cannot acquit him of complicity in the burning of Frith and Lambert for denying the doctrine of Transubstantiation (1533-38), of Friar Forest for upholding the papal supremacy (1538), of two Anabaptists, a man and a woman (1538), of Joan Bocher for denying Christ's humanity (1550), and of a Dutch Arian (1551). In the death, however, of Anne Askew (q.v.) he seems to have borne no part; nor is there one word of truth in Foxe's legend that he coerced Edward VI. into signing the warrant for Joan Bocher's execution. With the dissolution of the monasteries he had little to do; but he 
bestirred himself in promoting the translation of the Bible (y.v.) and a service-Ixwk, in curtuiliug the number of holy clays, in the supuression of the cult of St Thomas of Canterbury, and in negotiating an eirenicon with foreign Reformen. On the path, inleed, towards Protestantism, he was ever in advance of Henry VIII., though to Henry he surrendered his right of private judgment as completely as ever Ultramontane to Pope. Thus, writing in 1540 on the sacraments, he could wind up \& thesis with 'This is mine opinion and sentence at this present, which nevertheless $\mathbf{I}$ do not temerariously define, but remit the judgment thereof wholly unto your majesty.' Henry repaid him with implicit confidence, and twice saved him from the plots of his enemies (1543-45).

On 28th Jamuary 1547 Henry died, and Cranmer sang mass of requiem for his soul. He had been slowly drifting into Protestantism; but now the inrushing tille swept him onward through all those religious changes by which the mass was converted into a communion-changes stereotyped in the Second Prayer-book of 1552. See ENGLAND ('HL'RCh of), Prayer-book, Articles, Homily, CATECHISM. During this as during the preceding reign he meddled little with affairs of state, though he was one of the council of regency. What he did do was not too creditable. In gross violation of the canon law he signed Seymour's deathwarrant; he had a chief hand in the deposition and imprisonment of Bishops Bonner, Gardiner, and Day; and won over by the dying boy-king's pleading, he reluetantly subseribed the instrument diverting the succession from Mary to Lady Jane Grey (1553). Herein he was guilty of conscious perjury, yet, the twelve days' reign over, he made no attempt to flee. On the contrary, he was roused to an outburst of indignation, rare with him, by a report that he had offered to restore the mass, had indeed restored it at Canterbury. In the heat of the moment he dashed off a letter, denouneing that report as a lie of the devil, which letter, unrevised, being prematurely circulated, on 14th September Cranmer was sent to the Tower, on 13th November was arraigned for treason, and, pleading guilty, was condenmed to die. If he had been executed on that sentence, little could have been urged against his executioners, but he was reserved to be tried as a heretic, and, perchance, to recant his heresy. In March 1554 he was removed with Ridley and Latimer, to Bocardo, the common gaol at Oxford. He bore himself bravely and discreetly in a scholastic disputation, as also upon his trial before the papal commissioner, whose jurisdiction he refused to recognise. In Oetober from the gaol he witnessed Latimer's and Ridley's martyrdom; in December judgment was pronounced against him; and on 14th February 1556 he was formally degraded, stripped of the mock vestments in which they had arrayed him. And now in rapid succession he signed form after form of recantation, seven in all, each more submissive than its predecessor. The last he transcribed on the morning of 21st March, and forthwith they brought him to St Mary's Chureh. If not before, he learned at least now from the sermon that he must burn; anyhow, when they looked for him to read his recantation, instead he retracted all that 'for fear of death' his hand had written 'contrary to the truth.' With a cheerful countenance he then hastened to the stake, and, fire being put to him, thrust his right hand into the flame, and kept it there, crying: "This hath offended! Oh this unworthy hand !' Very soon he was dead.

Among Cranmer's forty-two writings, the chief of which have been edited by the Rev. $\mathbf{H}$. Jenkyns (4 vols. 1833) and the Rev. J. E. Cox (2 vols. Parker Society, 1844-46), may be noticed his prefaces to the Bible (1540) and the Fint Prayer. bouk (1549); the Reformatio Legum Ecclesiast: carum-his revision, happily abortive, of the Canon Law (q.v.)-tirst jullished in 1571 ; and $A$ Defence of the True and Catholic Doctrine of the Sacrament (1550).

See Narratives of the Reformatim, edited by J. G. Nichols (Camden Society, 1859), with a sketch of Cran. mer by Kalph Morice, his secretary; Yoxe's Acts and Monuments; Cooper's Athena Cantabrigiensee (1868); Mr Gairdner's artiele in the Dictionary of National Bio. yraphy (vol. xiii. 1888); Strype's Ecoleviantical Memoriale (1721); Shakespeare's Henry VIII. am 'Tenny yon в Queen Mary; and Lives of Cranmer by Strype (1694), Gilpin (1784), Todd ( 2 vols. 1831, with fine portrait), Le Bus (2 vols. 1833), Dean Hook, Lives of the A rehbishope ( vola. vi.-vii. 1868), Collette (1887), and Mason (1898).

Crannog, from the Gaelic crann, 'a tree,' a modern term employed to designate a species of lake-dwelling common in Scotland and Ireland, which consisted of an islet wholly or partially built up from the bottom of the loch by masses of brush. wood, steadied by piling, and consolidated by stones and gravel, the whole being surmounted above the level of the water by a platform of timber, earth and stones, on which were wooden huts, often surrounded by palisades for better security. The earliest occurrence of the word in historical docu. ments is in the Register of the Privy-council of Scotland in 1608, when the 'Crannokis of the Ylis' are classed with 'houssis of defence and strongholds' to be given up to the king. See LAKEDWELLINGS.

Crape, a thin fabric made of silk, which has been tightly twisted, without removing the natural gum with which it is covered when spun by the worm. It is woven as a thin gauze, then boiled to extract the gum, which causes the threads partially to untwist, and thus gives a waved and rough appearance to the fabric. It is usually dyed black, and used for mourning apparel. The nature of the finishing processes in the making of crape is kept secret by European manufacturen. In Japan, crape is manufactured by nsing alternately weft threads twisted in opposite directions, and these are of a much closer twist than ordinary threads. When the piece is woven it is dipped in cold, then in hot, and again in cold water in rapid succession, and afterwards rolled and dried. The effect of these operations on the weft threads produces the crisp surface. Chinese and Japanese crapes are often white, with coloured designs, or in single colours, and used for shawls, scarfis, \&c.

Crashaw, Richard (circo 1613-49), an English religious poet, was the son of a clergyman in the English Church, and was born in London about 1613. He was educater at the Charterhouse, and at Cambridge, where he obtained a fellowship at Peterhouse in 1637. His leanings towards Roman Catholicism prevented him from receiving Anglican orders, and in $\mathbf{1 6 4 4}$ he was ejected from his fellowship by the parliament for refusing to take the Covenant. He went to Paris, adopted the homan Catholic faith, and suffered great pecuniary distress, until about 1648, through Cowley's influence, he was introduced to Queen Henrietta Maria, who recom. mended him to certain dignitaries of the church in Italy. He obtained a humble office in the household of Cardinal Palotta, but in April 1649, a few months before his death, he became sub-canon of the church of Our Lady of Loretto. In 1634 Crashaw published a volume of Latin poems, Epigrammatum Sacrorum Liber (2d ed. 1670), in which appeared the famous line on the miracle at Cana:

'Nympha pudioa Dewm vidit of erubuit'

(The modest water saw its God and blukhed).

In 1646 appeared his Steps to the Temple; Sacral Poems, with other Delights of the Muses-in which 
there is much fervid poetry. The title of this collection, which is due to the editor, not the author, refers to its affinity with George Herbert's Temple. An edition (the third) was published at Paris in 1652, under the title Carmen Deo Nostro, with 12 vignette engravings designed by Crashaw. A collective edition of Crashaw's works was published in 1858, at London, by W. D. Turnbull, and a fuller edition in 1872 by Dr A. B. Grosart. Crashaw greatly resembles George Herbert in his cast of thought, and is not inferior to him in richness of fancy, though his conceits are more strained, and less under the control of taste. His devotional strains are nobly worded. Tutin's selections (2 vols. 1887 and 1900 ) are almost a complete edition.

Crassulacea, an order of calycifloral dicoty. ledons, allied to the Saxifrages, are herbaceous or sometimes shrubby plants, always more or less suceulent. About 400 species are known in the genera, chiefly from warm and temperate countries and in dry, sunny situations. South Africa and Mexico are peculiarly rich in species. Sedum (stone-crop) and Sempervivum (house-leek) are the most familiar genera. These and allied forms, such as Echeveria, are largely used for bedding-out purposes, grown on rockwork, or cultivated in the 'succulent-house.' Crassula coccinea, which, like nearly all its very numerous (150) congeners comes from the Cape, is in general cultivation on account of the beauty of its flowers. See Succulent Plants.

Crassus, the surname of several old Roman families, among which that of the Licinii was most remarkable.-(1) LUciUs LiciniUs, born in 140 B.C., was the best orator of his age, and was as distinguished for his wit as for his rectitude in the capacity of proconsul of Gaul. In 95 he was elected consul, along with Quintus Scævola, who had been his colleague in all his previous offices. During their consulship was enacted a rigorous law banishing from Rome all who had not the full rights of eitizens, which imbittered the feelings of foreigners toward Rome, and was one of the chief causes of the Social War. As censor in 92 Crassus closed all the schools of the rhetoricians, believing that they exercised a bad influence on the minds of young men. He died in 91 B.C., a few days after vigorously opposing in the senate the democratic consul L. Philippus. Crassus is one of the speakers in Cicero's De Oratore, and indeed is the representative of the writer's own opinions.-(2) MARCUs Licinius, surnamed Dives, the triumvir, was born sometime before 115 B.C. His father was a partisan of Sulla, and on the return of Marius and Cinna to Rome in 87 made away with himself. Cinna spared the boy's life, but subjected him to a jealous and dangerous surveillance, to escape which he went to Spain. He afterwards joined Sulla (83), and distinguished himself in the battle against the Samnites at the gates of Rome. As prætor he crushed the Servile revolt by the conquest of Spartacus at the battle of Lucania (71), and in the following year was made consul with Pompey, a colleague whom he hated. On the other hand, Cresar valued the friendship of Crassus, the most wealthy of Roman citizens. He was a keen and far-seeing speculator, and devoted his entire energies to the accumulation of money. We are told that he even bought clever slaves, and had them taught lucrative arts that he might enjoy the profits. During his consulate, Crassus gave a feast to the people, which was spread on 10,000 tables, and distributed to every citizen a provision of corn for three months. Plutarch estimates his wealth at more than 7000 talents, and Pliny states that his lands were worth 8000 talents (say $£ 2,000,000$ ). About 60, Cresar, Pompey, and Crassus entered into a private arrangement for their common benefit, which paction is known as the first triumvirate. In 55, as consul with Pompey, Crassus had Syria assigned him for his province, and began to make preparations of war against the Parthians, hoping both for glory and for gain. The latter end he effected in the meantime by plundering the towns and temples in Syria. At length, however, he set out, but was misled by a treacherous guide, and utterly defeated in the plains of Mesopotamia by the Parthians. Crassus now retreated to the town of Carrhæ, intending to pass into Armenia; but was beguiled into a conference with the Parthian general, Surenas, and was slain at the appointed place of meeting. His head was cut off and sent to Orodes, who is said to have poured melted gold into the dead lips, saying: 'Sate thyself now with that of which in life thou wert so greedy.' His quæstor, Cassius, with 500 cavalry, escaped into Syria; but the remaining Romans were scattered and made prisoners, or put to death.

Cratagus, a genus of Rosaceæ, sub-order Pomer, very nearly allied to Mespilus (Medlar) and Pyrus (Pear, Apple, \&c.), but distinguished by the acute calycine segments, and by the round or oval fruit, closed at the apex, and concealing the upper end of the bony cells. The species are pretty numerous, natives of the temperate parts of the northern hemisphere, and in general have flowers in beautiful terminal corymbs. They are all large shrubs or small trees, more or less spiny, whence the name Thorn has been very generally applied to them. The only native of Britain is the common Hawthorn (q.v.), (Cratagus Oxyacantha). Most of the species resemble it considerably in habit, size, form of leaf, \&c. A number of them are now fre. quent in plantations and shrubberies in Britain, of which perhaps the most common is the Cock's-spur Thorn ( $C$. crus-galli), a native of North America from Canada to Carolina. Its leaves are not lobed; its fruit rather larger than that of the hawthorn. The Azarole (C. Azarolus), a native of the south of Europe, and the Aronia (C. Aronia), a native of the Levant, are occasionally cultivated for their fruit, which is about the size of the Siberian crab, and is used either for dessert or for pies. $C$. orientalis (or odoratissima) and C. tanacetifolia have also fruit of considerable size. The latter is much eaten in Armenia. C. mexicana has a large fruit, like a small apple, but not eatable. It is, however, very ornamental. The wood of most of the species much resembles that of the hawthorn. It is common to graft the rarer species on the hawthorn.-C. Pyracantha differs much in appearance from most of the genus; being a pretty evergreen shrub, with lanceolate crenate leaves, and rich clusters of red berries, which remain on it all winter; a native of rocky places in the south of Europe and the Caucasus. It is often employed in Britain as an ornamental covering for walls, and is known as the Pyracantha.

\section{Crater. See Volcanoes.}

Cratinus, a Greek comic poet, born about 519 B.C., who did not begin to exhibit till sixty-five, and who died in 424. Next to his younger contemporaries, Eupolis and Aristophanes, he best represents the Old Attic comedy. He changed its outward form considerably, limiting the number of actors to three, and he was the first to add to comedy the interest of pungent and personal attack. The habits, manners, and institutions of his fellowcitizens he considered a legitimate mark for censorious satire. Even the great Pericles did not escape. Aristophanes repaid him in kind, but his allegation of habitual intemperance Cratinus hinself admitted and defended humorously in his Pytine. His style was very metaphysical and 
Ingeniums. Of his twenty-one comelies, nine of which obtained the first prize in the public competitiuns, we posseas only some fragments, collected by Meineke in his Frammenta Comicorum Gre. corum (Berlin, 1840). - There was also a younger C'RaTisus, an Athenian contemporary of Plato, who belonged to the school of the Middle Comedy.

Cratippus, a Peripatetic philosopher, a native of Mitylene, and a contemporary of Cicero, whose son Marcus he instructed at Athens in 44 B.C. Pompey visited him after Pharsalia, and Brutus turned aside to Athens to hear him, even while making preparations to meet Octavian and Antony. Nothing that Cratippus wrote has survived.

Crawford. Tномаs, sculptor, born in New York eity in 1814, in 1834 went abroad for his studies, and settled in Rome, where he at first worked under the guidance of Thorwaldsen. Many of his earlier groups have found a place in Boston collections; his later works include the fine group known as the Washington monument, in the envitul park at Richmond, and the bronze figure of Liberty, surmounting the dome of the capitol at Washington. Stricken with blindness in 1856, Crawford died in London, 10th October 1857.

Francis Marion Crawford, novelist, son of the foregroing, was born in Tuscany, August 2, 1853. He had his education at Concord, New Hampshire; Trinity College, Cambridge; Karlsruhe, and Heidelberg. At Rome he devoted himself to the study of Sanskrit, and during 1879-80 was engaged in press work at Allahabad, where he was admitted to the Catholic Church. He was selected by the government eommittee to write the national ode at the centennial of the American Constitution, September 17, 1887. His first novel, Mr Isaacs (1882), was a book of striking and quite unusual merit, securing a new romantic element in certain of the aspects and contrasts of modern oriental life. Among its successors have been Dr Claudius, and To Leeward (1883); $A$ Roman Singer, and An American Politician (1884); Zoroaster (1885); The Story of a Lonely Parish, and Saracinesca (1886); Marzio's Crucifix, and Paul Patoff (1887); With the Immortals (1888): Sant' Ilaro (1889); A Cigarette Maker's Romance, Khaled, und The Witch of Prague (1891); Don Orsino (1892); Pietro Ghisleri, Marion Darche, and The Children of the King (1893); Katherine Lauderdule, Love in Idleness (1894); The Ralstons (1895); Taquisara (1896); Corleone (1897); Constantinople (1898), a description of the city; and Via Crucis (1899).

Crawford, William Harris, born in Virginia in 1772, practised law, and was elected to the United States senate in 1807 and 1811. Appointed minister to France in 1813, and secretary of the treasury in 1816, he was a Democratic candidate for the presidency in 1824; but none of the candidates securing a majority, the House of Representatives cliose John Quincy Ailams. Crawforl returned to Georgia, where he was thrice elected circuit julge, and died 15th September 1834.

Crawford and Balcarres, ALExANDER William Crawford LiNdsay, EarL of, born in 1812, was educated at Eton and Cambridge, and succeeded his father in 1869. He gained a high reputation for his works on religion, philosophy, and art; and his researches into the annals of his own house enabled him in 1848 to prepare the case for his father's (Lord Balcarres) claims to the premier earldom of Scotland, as 24th Earl (cre. 1398). Besides Lives of the Lindsays (1849), and the Earldom of Mar (1882), he wrote Letters from the Holy Land (1838), Progression by Antagonism (1846), and Sketches of the History of Christian Art (1847), by which he is best remembered. His dominant idea, however, was the formation of a perfect library, to which for nearly lialf a century he devoted great industry and learning; and the library at Haigh Hall, near Wigan, is probably unrivalled among private collections, He died in Florence, 13th December 1880; his body, which for over seven months had been missing from the mausoleum at Dunecht, near Aberdeen, was found in a wood close by in July 1882, - His son and successor, JAMEs Li bovic: Lisisay, lorm in 1847 , was elected president of the Royal Astronomical Society in 1878-80, and F. R.S. in 1878, and received the degree of LL.D from Edinburgh University in 1882. In 1888 he presented to the nation the admirably equipped observatory at his seat of Dunecht, 12 miles W. of Aberdeen; and the ap. paratus, with the magnificent astronomical library, have been transferred to a new observatory (1895) on Blackford Hill, near Edinburgh.

Crayer, Caspar DE, a Flemish historieal and portrait painter, was born at Antwerp in 1584. He lived first at Brussels, and afterwards at Ghent, where he died in 1669. The churches at Ghent contain many of his paintings, which are also common all over Flanders.

Crayfish (Astacus, Fr. écrevisse), a large freshwater crustacean, in the long-tailed (Macrura) division of the order Decapoda. The body consists of two great divisions, the head and thorax protected by a rigid shield, and the abdomen or tail of six separate rings. The integument exhibits the characteristic Arthropod combination of lime and Chitin (q.v.). There are altogether twenty segments and nineteen pairs of appendages, not including the eves. The sensitive antennules and antennæ, the six appendages crowded round the mouth, the great claws, the fourwalking legs, the little swim. merets under the tail, and the pair of large terminal paddles make up the series. These appendages, 80 different in form and function, are all homologous.

The muscles are well developed for working the tail, the appendages, and the stomach mill. The nervous system consists of brain and ventral chain of ganglia. The eyes are stalked and compound; the ear-sacs with their fringes of auditory hairs and inclosed foreign particles floating in a gelatinons fluid lie at the bases of the antennules, which also bear olfactory bristles. The most remarkable feature in the alimentary system is the gastric mill, a comples masticating apparatus in the fore-sut, the essential mechanism of which consists in the rapid clashing of three teeth-one dorsal and two lateral. On the walls of the stomach there are two limy coneretions (gastroliths) which store lime preliminary to monlting. There is a large digestive gland opening into the small mid-gut; the hind-gut is long and straight. The circulatory system consists of a dorsal heart, whence the blood passes by arteries and capillaries to the body, thence 
by venous channels to the gills, and thence back again to the heart. The respiratory system includes twenty pairs of feathery gills lying under the shelter of the sides of the great shield. The ceaseless baling movement of one of the mouth appendages secures a current of water. The excretory system is represented by a ' green-gland' or kidney, lying behind the base of the antennæ, on which its opening, shielded by a prominent knob, may be readily seen. The reproductive system consists of three-lobed essential organs with paired ducts opening on the thoracic legs.

The eggs are laid in November or December, and are glued by a secretion to the abdominal legs of the mother. The young are hatched in May to July. They do not differ in any important features from the adults, and the crayfish has thus very much abbreviated the typical life-history. The young escape from the inclosing egy-cases, to which they, however, adhere for a while by means of the strongly incurved claw-tips. The female with its crowd of attached young presents a curious and interesting appearance. The young crayfish moults eight times during its first year of life, five times in the second, twice in the third. The male is adult in its third year, and continues for some time at anyrate to moult twice a year. The female is mature in the fourth year, and has only one annual moult. The moulting is in part the result of the fact that the inclosing armature does not grow with the growth of the body. Reserve products of lime and glycogen accumulate before moulting; the old shell virtually dies; a new armature (at first soft) begins to be formed; the animal grows; the old husk, including the hard structures of the stomach, is cast; and the crayfish is left perfectly limp and helpless. The fatigue of the process is shown in the great mortality.

The crayfish is exclusively a fresh-water form, barring the fact that some related genera (Engreus, Cambarus, Parastacus) appear to be for the most part terrestrial. They usually make burrows by the sides of streams, and often lie at the mouths of their holes in wait for passing prey. They are chiefly nocturnal. In their diet they are strikingly oinnivorous, eating most things available, from worms to water-voles. Dead animals, molluses, worms, and insect larvæ form their chief sources of supply. In captivity they may be kept for a while on bread crumbs. In certain cases they do not refrain from eating one another. Their chief enemies are said to be eels and otters.

Crayfishes, though fresh-water forms, have a peculiarly wide distribution. The English and Irish crayfish is a variety of A. Auviatilis, and is by authorities designated $A$. torrentium. It occurs all over Europe, except in Seandinavia and Seotland, but is locally limited by the presence of suffi cient lime in the water for shell-forming purposes. Another variety of $A$. Auviatilis, $A$. nobilis, is also widely distributed on the Continent. This variety is much cultivated in France and elsewhere for the sake of its dainty though not abundant flesh. They are in best condition from May to August. In ponds for artificial breeding, the animals often fall victims to disease, probably of a fungoid character. In rivers they are sometimes netted, sometimes lured by a light in the darkness. Numerous other species occur both in the old and New World, and along with the southern forms (Parastacidø) may be fairly called cosmopolitan. In the United States, where they are very common, their burrows sometimes cause crevasses or ruptures in the artificial dykes of rivers. The largest species measures over a foot in length. Crayfish-like forms appear in the Middle Mesozoic times, and a some what doubtful Astacus (A. philippi) has been found in the carboniferous limestone of Ireland. It is probable that they were originally marine. The term crayfish is often extended to the nearly related marine form, the Norway Lobster or Nephrops norvegicus (see LoBsTER). See Huxley's Crayfish: an Introduction to Zoology (Inter. Sc. Series, 1877).

Crayon (Fr., 'a pencil'). Though used in French, and occasionally in English, to designate pencils generally, including those made of lead, the word crayon is more frequently applied in England to those small cylinders of charcoal, or of pipeclay or chalk coloured with various pigments, which are used for drawing. Cohesiveness is given to the paste of which the cylinders are formed by means of gum, wax, soap, \&c. Crayon drawings are often remarkable for the delicacy and softness with which objects are represented, but they ara deficient in power. See Pencil, Chalk.

Cream is the fat of Milk (q.v.). It exists in minute globules throughout the bulk of milk as it comes from the cow. In virtue of being lighter than the watery portion of milk, cream gradually rises and forms a thin yellowish greasy layer on the surface. Devonshire cream, or clouted (i.e. clotted) cream, is obtained by heating milk in a shallow wide pan on a liot plate or over a slow charcoal-fire. The milk should stand in the pan for twenty-four hours before heating. It usually takes from half an hour to three-quarters of an hour to heat the milk completely; but it must not boil. It then stands for twenty-four hours, when the eream is skimmed off, and a little sugar thrown on the top. Whipped cream is cream or milk beat up with white of egg by means of a whisk. Lemon cream, Vanilla cream, \&c. are made with milk, white of egg, and sugar, and flavoured. Cream cheese may be made of rich cream, or cream, milk, and rennet, tied up in a clean wet cloth, and kept for some days in a cool place, then put in a finer cloth, and placed for a day or two in a mould, with a weight upon it. The term cream is used frequently for anything superior in quality; thus the French, in referring to persons in the height of fashion, speak of La crême de la crême, "the cream of cream.

Cream Separators (Centrifugal). -The bestknown forms are the 'Laval,' the 'Danish,' and the 'Victoria'-the latter a recent invention of a Glasgow firm. Though they differ in form and in detail, the principle involved in the work of separating the butter is common to all. Advantage is taken of the difference existing between the specific gravity of cream and the watery part of milk. While yet warm the milk coming from the cow is run into a strong, spherical, steel vessel revolving at high speed. As the milk is carried round within the vessel (whether revolving horizontally or vertically) it rises up the sides and stands as a wall, thus forming a lining of milk while the speed is maintained. The heavier part inclines outwards, and the light cream is forced inwards and forms an inner layer. From the positions indicated the separated cream and milk are conducted into different channels, and finally into different vessel receptacles. The advantages, as compared with the old method of flat setting (see MrLK), are that the cream is got off immediately ; no time is allowed for the development of acidity in either the skim milk or cream, and more of the cream present can be removed-the proportion being as $\mathbf{1 3}$ is to 11 . Small machines driven by hand, costing $£ 13$, and separating 12 gallons of milk an hour, do not give quite so good results as those driven by steam. Prices range, for those of sizes capable of separating 45 to 150 gallons of milk an hour, from $£ 24$ to $\mathfrak{£ 4 5}$. A steam turbine has recently been adopted as the means by which power is communicated. The 
cost of a turbine separator, eapable of doing 90 gallons per hour, is t46. See BuTTKR, DArr.

Creau of Tartar exists naturally in grape juice, but heing insoluble in alcohol, it is gradually teposited, in the form of aryol, as the sugar of the juice becomes converted into alcohol by fermentation. In the preparation of eream of tartar the argol is dissolved in hot water, to which charcoal or fine clay is added, to take up the colouring matter; by boiling and filtering a clear colourless solution is obtained, from which, on cooling, the cream of tartar separates as erystals. These erystals, after being exprosed on linen for several days, become whiter and constitute the crystals of tartar, or, when ground to powder, the cream of tartar. Although cream of tartar is, practically speaking, the bitartrate of potash, $\mathrm{KHC} \mathrm{H}_{4} \mathrm{O}_{6}$ (see TARTARIO ACID), yet it usually contains from 5 to 10 per cent. of tartrate of lime, while adulterants, properly speaking, may also be present. The tartrate of lime is derived from the clay added to purify it, and is more or less present in all commercial samples. In 1888, however, eream of tartar was offered in the market containing 99 per cent. of bitartrate of potash, so that it may be assumed that in future a purer article will be fortheoming. Crean of tartur is readily soluble in hot water, though it takes 60 parts of cold water to dissolve one part of it. Soluble cream of tartar is prepared by dissolving together 2 parts of Borax (q.v.) and 5 parts of eream of tartar, evaporating to dryness and powdering. Cream of tartar hus an acid taste and gritty feel. When taken repeatedly in small doses of a scruple to a drachm, it acts as a refrigerant and diuretic; in doses of one to two drachms, it is useful as an aperient; and in larger doses of from two to three drachms it acts as a purging agent, accompanied by flatulence and griping. Imperial liquid is prepared by dissolving about a drachm of cream of tartar in a pint of boiling water, and adding a little lemon-peel and sugar to flavour it; when an agreeable refrigerant drink is obtained, which is highly serviceable in allaying thirst in feverish cases. Cream of tartar whey is obtained by adding two drachms of the salt to a pint of milk.

\section{Crease, a Malay weapon. See Kris.}

Creasote (Gr. kreas, 'flesh;' sōzō, 'I preserve') is an oily substance obtained from the tar produced by the destructive distillation of wood. When Coal-tar (q.v.) is distilled, a certain portion called creasote oils passes over, and from this much of the creasote of commerce is obtained. This, although similar in some respects to wood creasote, is quite distinct chemically. The coal product consists largely of carbolic acid, along with ereasol and xylenol, while the wood product, to which alone the name creasote rightly belongs, con. sists of guaireol, creasol, and phlorol. As it contains several substances, so its boiling-point ranges from $392^{\circ}$ to $428^{\circ}\left(200^{\circ}-220^{\circ} \mathrm{C}\right.$. ). The leading char. seter of wood creasote is that it instantly coagulates albumen, but does not coagulate Collodion (q.v.), in this respect differing from carbolic acid. It has a very remarkable power of arresting the decay of meat or wond, and when meat is treated with so small a proportion as one-hundredth of its weight of creasote, and exposed to the air, it does not putrefy, but becomes hard and dry, assuming the taste and odour of smoked meat. Indeed, there can be no doubt that hams cured by means of wood smoke owe their preservation and flavour to some extent to the volatile creasote in the smoke. Railway sleepers and wood liable to be frequently wet are often saturated with the coal-tar creasote; or, where economy is not so essential, with the wood ereasote, and are thereby preserved in definitely. In toothache, where the enuse of pain is a carious tooth with an exposed, inflamed nerve. a drop of creasote, carnfully inserted, after previ. ously cleansing the cavity, will often give relief. In this case it acts by coagulating the alloumen and destroying the nerves, Creasote acts power. fully on the skin, producing a white stain when applied to it. A few drope added to a pint of ink preserve it from mouldiness. Medicinally, it is given in doses of one or two drops, and has been found efficacious where there is a tendency to fermentation of the contents of the stomach and bowels. Owing to its action on the skin it acts as an energetic poison when taken in large doses. The Creasote Plant (Larroea mexicana), growing abundantly on the borders of the Colorado Desert, emits a strong odour of creasote. The odour arises from an exudation similar to Indian gum-lac, and is caused by the punctures of an insect, Carteria Larroea.

Creasy, Sin Edward Shepherd, born at Bexley in Kent, in 1812, from Eton passed to King's College, Cambridge, in 1832, and in 1834 was elected a fellow. Called to the bar in 1837, he went on the home circuit for upwards of twenty years, and presided for three or four years as assist. ant-judge at the Westminster Sessions Court. In 1860 he was appointed chief-justice of Ceylon, and knighted. Ten years later he came home invalided on a year's leave of absence, after which he went out again, but was obliged to return home finally after struggling with his malady for two years more. He died at London, January 27, 1878. In 1840 he was appointed professor of History in University College. Creasy was the author of The Fifteen Decisive Battles of the World (1851), Invasions of England (1852), History of the Ottoman Turks (1854-56), \&c.

Creatin, or Kreatin (Gr. kreas, 'flesh'), a constant and characteristic constituent of the striped muscle of vertebrates. It was discovered by Chevreul in 1835 , but little was known about it till Liebig published his researches on the Chemistry of Food in 1847. Its chemieal formula is $\mathrm{C}_{4} \mathrm{H}_{9} \mathrm{~N}_{3} \mathrm{O}_{2}$ Except in one doubtful case, it has always been found as above indicated ; it is very uncertain if it ever occurs in unstriped muscles, and it has never been demonstrated in invertebrates. A dehydrated form, known as Creatinin, $\mathrm{C}_{4} \mathrm{H}_{7} \mathrm{~N}_{3} \mathrm{O}$, occurs as a constant constituent of urine, and has also been demonstrated in fish muscles. Under the influence of acids, ereatin becomes creatinin, and by hydration the transformation may be reversed. Ás these changes may readily occur during extraction, there is often doubt whether creatin or creatinin is present in a given case. See Appendix to Foster's Physiology; Krukenberg, Unters. Physiol. Inst. (vols, iii-iv. 1880-81).

Creation. For the scientific discussion of the method by which ereation has been effected, reference must be made to the articles DARWINIAN Theony, Evolution, Mas, Species, \&e. ; but it may be desirable to make a brief statement here regarding the controversy between Genesis and science. In reality, so far as modern scientific theology is concerned, this controversy is now practically at an end, so that only the briefest historical sketch will be necessery to show the nature of the problem and the steps by which the final conclusion has been reached.

To theology, Genesis had for centuries seemed to affirm that the world was created in six days by successive divine commands. To modern science, on the other hand, the rocks disclosed accumnlating evidence that the earth and its forms of life were not 'ereated' in this sense at all, but 
slowly built up or evolved by secondary causes under the control of natural laws. The new scientific position did not traverse the biblical view of the origin of matter or of life ; nor did it deny that the laws of nature might be "the hands of the Living God.' But it claimed that the creation of the world was an ordinary problem for scientific investigation, and that so far as that had gone, some form of development was probably the means by which creation had been brought about. Frankly recognising the right of science to deal with this question, and accepting on certain points the overwhelming evidence of geology, theologians found themselves compelled to reconsider their ground. The first difficulty was that of time. And here they yielded at once by substituting 'periods' for the 'days' of Genesis-an expedient which, what. ever literary objection may be taken to it, was certainly allowed by the original Hebrew. Efforts were next made to reconcile these "periods' with the formations of geology and with the succession of life as revealed by palæontology. Devont men of science worked out these harmonies with great learning and ingenuity, and as new discoveries of science threw their labours aside, fresh workers by further manipulation of the data on either side continued the attempt to bring the apparently rival records once more into line. Prominent among these attempts were the Universal Pre-Adamite Chaos theory of Dr Chalmers; the Partial Chaos theory of Dr Pye Smith; the Vision theory of Hugh Miller; and the cognate though not identical theories of Kurtz and Guyot. Such attempts were at that time perfectly admissible, and even inevitable-inevitable because the true direction from which the solution was to come was not yet suspected. But one by one these efforts failed. An attempt by Mr Gladstone, so recently as 1885, elicited a reply from $\mathrm{Mr}$ Huxley, who, in the name of modern science, not only repudiated the immediate theory but made it obvious that no reconstruction along that line was ever likely to square with acknowledged facts of science. It is of course always possible to challenge the current reading of a growing science, and the harmonist may still take refuge if he chooses in the fallibility of contemporary interpretations of nature. But on the general question of gradual development versus specific creation, the consensus of mature scientific opinion is now so pronounced that any one still clinging to the latter would find it impossible to impress his views upon his age. In some other way, then, the educated mind will seek to reconcile to itself the apparent want of reconciliation between the teaching of nature and the teaching of Scrip. ture.

Stated in a word, the explanation is to be sought for in the fact-recently brought into prominence by the young science of biblical criticism-that the Scriptures really contain no teaching at all upon matters of science. It is an elementary canon of literary eriticism that any interpretation of a part of a book or of a literature must be controlled by the dominant purpose or motif of the whole. And when one investigates that dominant purpose in the case of the Bible, it is found to reduce itself to one thing-religion. The books of the Bible, respectively, can only be read aright in the spirit in which each was written, with its original purpose in view, and its original audience. Bearing that in view in the ease of Genesis it soon becomes evident that a scientific theory of the universe formed no part of the original writer's intention. Could any one with any historical imagination for a moment expect that it would have been? There was no science then. Scientific questions were not even asked then. And to have given men science would not only have been an anachronism, but a source of mystification and confusion. If the Bible had really aimed at science-teaching, geology would have been one of the last things upon which it would have enlightened mankind. Why was not physiology taught to physicians, or the use of chloroform to surgeons, or of the stars to navigators-matters which would have affected the well-being and actual life of man? In fact it is a first principle of revelation-involved in the very meaning of the word and proved by its whole expression-that matters which are discoverable by human reasoning and observation should find no place in it, that its subject matter is that alone which men could not find out for themselves. Men could find out for themselves the order in which the world was made. What they could not find out was, that God made it. That therefore was the object of Genesis-theology, not geology. Genesis is a presentation of one or two great elementary religious truths to the childhood of the world. Dating from the infancy of the world, written for children, and for that child-spirit in man which remains unchanged by time, its literary form takes colour and shape accordingly. It is not dedicated to the reason but to the soul. It is a sublime theology, clothed in the most memorable and impressive dress, utilising, purifying, and transfusing with the religious spirit some material at least which was common to the cosmogonies of all nations. Now from this point of view the problem of the reconciliation of Genesis with geology simply disappears. The question becomes as irrelevant as when it is asked what the Paradise Lost is meant to prove. Science and Genesis are no longer in competition as to which shall be the accepted authority regarding the process of the creation of the world. Genesis does not even enter the field. And in ceding this position it is only to assume, with even greater authority, its legitimate and much higher function.

The strength of this attitude is that it is quite independent of all conclusions of science. Evolution may be true or false, science may change its ground, new discoveries may arise; but these cannot affect the literary and theological province within which wholly this question is now seen to lie. Hence the attack of science is for ever disarmed. And those who assent to evolution, and the many who in its present form do not yet see their way to accept it, may hold an equal truce with Genesis.

As regards the material utilised by the writer in Genesis, it is sufficient to remark that most of it is a common property of the older cosmogonies. The mythology of Persia describes six creative periods of a thousand years; the cosmogony of the Chaldeans is similar; while that of the Etruscans agrees still more elosely with the order of Genesis. Thus the Bible did not create this material, nor reveal it. It incorporated it, inspired it, and so made it the vehicle of a revelation.

Crébillon, Prosper Jolyot DE, a French dramatist, was born at Dijon, on January 13, 1674 . His parents belonged to the middle class, and he was educated in Paris for the law. He soon abandoned a legal for a literary career, and his tragedy of Idomenée was successfully produced in 1703. It was followed by Atrée et Thyeste (1707), Electre (1709), and Rhadamiste et Zénobie (1711). The last is his best play, the character of Zenobia being drawn with remarkable power. After writing several other pieces, Crébillon fell into neglect. and produced nothing for more than twenty years. He was then pushed forward as a dramatic rival to Voltaire by Madame de Pompadour and other enemies of the great writer, elected to the Academy, awarded a pension of 1000 francs, and appointed royal censor, and one of the royal 
Jibrarians. His tragedy of Catilina, for which the king furnished the properties, was brought out with great success in 1748. Among his other works were Xeraes, Semiramis, Pyrrhus, and Le Triumvirat, the last of which was written when he was eighty one years old. He died on June 17, 1762. He was a very unequal writer. An oppressive gloom pervades the tragedies which he founded on Greek legend; but occasionally he writes naturally and powerfully. 'Not a few of his verses bave a grandeur which has been said to be hardly discoverable elsewhere in French tragedy between Corneille and Hugo' (Saintsbury). Next to Vol. taire, he was the best tragic dramatist of his age in France. There are editions of his works by Perelle (2 vols. 1828) and Vitu (1885).-Claude Prosper Jolyot de CrébilloN, the younger son of the dramatist, was borm in Paris on February 14, 1707. He was educated at the Jesuit College of Louis le (irand, and after writing a number of slight pieces for the stage, acquired great popularity as an author of prose fiction. In 1740 he married an Englishwoman, Lady Stafford. One of his books, Le Sopha, conte moral, having given offence to Madame de Pompadour by its indecency, he was banished from Paris for five years, but on his return in 1755 was appointed to the censorship. He was believed by his friends to be dead long before he died on April 12, 1777.

Crèche (Fr., 'manger'), a sort of public nursery where, for a small payment, the children of women who have to go out to work are fed, nursed, and taken care of during the work hours of the day.

Crécy-en-Ponthieu, or Cressy, a village in the French department of Somme, on the Maye, 12 miles $\mathbf{N}$. of Abbeville. Crecy is celebrated on account of the brilliant victory obtained bere, 26th August 1346, by Edward III., with 40,000 English soldiers, over a French army amounting, according to Froissart, to 100,000 men under the command of the Count of Alencon. In this great battle, one of the most honourable to English prowess recorded in history, perished the Hower of the French chivalry, as well as the blind king of Bohemia, who was fighting on the side of France. Altogether about 30,000 of the French soldiers bit the dust. In this battle the Black Prince distinguished himself greatly, and gained his spurs (see the article ICH Dien). Pop. 1382.

Credence, a small table placed near the altar or communion-table, at its south side, on which the bread and wine intended for consecration are placed in readiness. In the Greek Church this is called the trapera protheseos, or simply prothesis, but is always placed north of the altar, usually in a structural side-chapel. Archbishop Laud was a great stickler for the credence, and pleaded the suthority of Bishop Andrewes and other bishops for its use. There are ancient credences in various Anglican churches; among others, in the Collegiate and St John's churches, Manchester, and in the parish church at Ludlow, where they have been in use from time immemorial. Sometimes the place of the credence was supplied by a mere shelf across the Fenestella, or a niche in the south wall of the chancel. The term was also used for a buffet, or sideboard, at which the meats were tasted in early times before being presented to the guests, as a precaution against poison. Hence the origin of the word, which is derived from the Ital. eredenzare, to taste meats and drinks before they were offered to another, an ancient cont practice, which was performed by the cup-bearers and carvers, who for this reason were called in Ger. eredenzer. The usage is still observed at Rome when the pope celebrates mass, come of the wafers and of the wine to be offered being tasted by the assigtant ministers before they are brought to him a oblation. The introdnetion or restoration of eredences is one of those restitutions of old usages which marked the Oxford movement in England; and they have been judicially pronounced legal ornaments of the chureh, as sulwidiary or auxiliary to the celebratiag of Holy Communion, in order to compliance with the rubrics in that part of the Common Prayerbook.

Credentials, papers or lettens given to an ambassador, or other public minister, to a foreign court, in order to enable him to elaim the confidence of the court to which he is sent.

Credit, in Political Economy, may be defined as the power to make use of another man's wealth. It rests on the simple fact that when one man has more wealth than he proposes to use himself, he is ready, for a consideration, to lend it to another. The wealth thus lent may be used for purposes either of production or consumption, thougl the great function of eredit in modern industry is to furnish the means of production to those who are in need of them. Credit of course is not capital, but it enables one man to utilise the capital of another. The credit system is an elaborate system of appliances and institutions, by which facilities for lending and borrowing are provided. Bills and bank-notes are well-known instruments of eredit. Banks are the most notable institutions of eredit, which is further facilitated by companies of every kind, designed to transmit superabundant capital to the most distant colonies and to all the ends of the earth. Credit is thus a mighty organ of industry, whose operations are co-extensive with the world, but it has attained to this far-reaching and cosmopolitan position only in comparatively recent times. Yet it is also one of the oldest phenomena in the his. tory of society, marked by usages and laws, which are of the highest interest and importance. Credit is found in the earliest communities, one of its most striking forms being in the relations of the primitive farming class to the money-lender. It was considerably developed in ancient Greece and Rome, as also in the commercial Phcenician states on the Mediterranean. During the middle ages it grew up in the Italian republics, and afterwards in the cities of Germany and the Netherlands. But its vast extension dates from the great development of commerce and industry connected with the United States, India, and the colonies, combined with the utilisation of ste $\mathbf{m}$ and the electric telegraph. In short the development of the credit system has gone hand in hand with the development of modern industry. While the credit system has thus go powerfully aided the development of industry by supplying capital to those who have ability and opportunity to utilise it, it is needless to say that it has led to many abuses. In early communities the creditor had power to enslave, maim, or even to slay the debtor. In modern times, by rendering capital accessible to adventurens of every class, it has occasionally given scope for the wildest and most dishonest speculation.

\section{Credit, Cash. See Cash Account.}

Crédit Foncier ('landed eredit'), a system of lending money on the security of landed property, established in France by an edict of 28th February 1852. Its peculiarity is that the loan is repayable by a terminalile annuity, the amount and currency of the annuity being so calculated that when the last payment is made, the loan and the interest on it will be extinguished. Or it may be deseribed as a loan repayable by instalments. The borrower, however, has the right of anticipating repayment. The system is precisely regulated by the edict, which prohibits an advance to more than one-half of the value of the property pledged or hypothecated. 
Three companies were established by the French government in Paris, Marseilles, and Nevers. They were all formed in 1852, and on 10th December of the same year were amalgamated as the Crédit Foncier de France, with the privilege of making such advances. The Crédit Foncier stands relatively to real estate as the Crédit Mobilier to personal property. The companies formed in Britain to advance money for improvements on landed properties are of a similar character. The Crédit Foncier (Limited), formed in London in 1864, was a general finance company. It speculated largely in the promotion of public works at home and abroad, met with heavy losses, and was several times reorganised.

Credit, LetTer OF. This is the term applied to a letter addressed to a correspondent at a distance, requesting him to pay a sum therein specified to the person named, or to hold the money at his disposal, and authorising the correspondent to reimburse himself for such payment, either by debiting it in account between the parties, or by drawing on the first party for the amount. This arrangement may take place between merchants or others, but in general it occurs between bankers residing in different places-e.g. between a banker in London and his correspondent in New York; and it is designed to enable any one who has money lodged at one place to obtain the use of it at another for a small charge, or commission, without the risk or trouble of actually carrying money between the two cities. It is thus a sort of primitive or informal Bill of Exchange (q.v.), though not, like a bill, a negotiable instrument. Sometimes the letter is addressed to all or several of the correspondents of the bank issuing it, in which case it is termed a Circular Credit; and any of them may pay the sum mentioned, or sums to account as desired, taking the holder's receipt, or his draft on the granter, in exchange; and the sums so paid are indorsed on the letter, to show how far the credit has been used. Even where the granter has no correspondent, the holder of an authentic letter will usually have little difficulty in obtaining money upon it; and the system is thus productive of much convenience to all who have occasion to travel.

Sorne bankers, having an extensive correspond. ence abroad, issue what are called Circular Notes, usually of the value of $£ 10$ or $£ 20$ each, which any of the granter's correspondents, or indeed any one else, may cash to the holder, on his indorsation and production of a letter of indication. In this kind of eredit, the notes are bought outright; whereas for the ordinary letter of credit, the banker debits the drafts under it only when they are advised to him. The introduction (about 1770) of these notes, which have proved of great convenience to travellers, though of little direct profit to the banks, is due to Mr Herries, the founder of the eminent banking. house of Herries, Farquhar, \& Co., London.

A marginal credit is one in which the due payment of the bills or drafts under it are guaranteed by a third party interested in the transaction; the guarantee being usually expressed in a marginal note on the bill. See Circular Notes.

\section{Crédit Mobilier. See MobILIER.}

Crediton, or KIrkTon, a borough in the middle of Devonshire, on the Creedy, a tributary of the Exe, 7 miles NW. of Exeter. It lies in a narrow vaie between two steep hills, and, having suffered much by fire in 1743 and 1769 , is mostly modern. Its church, however, is a fine old cruciform structure. The birthplace of St Boniface (q.v.), the apostle of Germany, Crediton was the seat of a bishopric from 910 to 1050 , when it was tranisferred to Exeter, and from 1897 has a bishop suffragan under Exeter. Its woollen manufactures belong to the past. Pop. (1851) 3924 ; ( 1891 ) 4207.

Creditor. See Debtor, Bankruptcy.

Creech, William, Edinburgh bookseller, born 21st April 1745, learned his trade in Edinburgh and London, and spent some time on the Continent before beginning business in 1771. For more than forty years he issued the chief literary productions of that period in Edinburgh, including the first Edinburgh edition of Burns, and the works of Blair, Beattie, and Dugald Stewart, and Mackenzie's Mirror and Lounger. He was Lord Provost (181113), and died 14th January 1815. His newspaper letters and odd writings collected in Edinburgh Fugitive Pieces (1791; new ed. with memoir, 1815), contain much curious information about old Edin. burgh, and the way of life of a past generation.

Creedmoor, a village of Long Island, 12 miles E. of New York by rail, with an extensive riflerange.

Creeds, the authorised expressions of the doctrine of the church at large, or of the several main sections into which it is divided. Such statements of doctrine sprang up naturally in the conrse of the church's progress. As the doctrines taught by Christ became the subjects of thought, of argument, of controversy, they could not fail to receive a more defined intellectual expression, and to be drawn out into more precise dogmatic statements; and the great creeds, as they rise in succession, and mark the climax of successive controversial epochs in the church, are nothing else than the varying expressions of the Christian consciousness and reason, in their efforts more completely to realise, comprehend, and express the originally simple elements of truth as they are recorded in Scripture. Accordingly, the creeds of Christendom grow in complexity, in elaborate analysis and inventiveness of doctrinal statement, as they succeed one another.

What has been called the Apostles' Creed is probably the earliest form of Christian creed that exists, unless we give the precedence to the bap. tismal formula at the close of St Matthew's Gospel, out of which many suppose the Apostles' Creed to have grown. There were in the early church differing forms of this primitive creed: that which is received and repeated in the service of the Church of England has come to us through the Latin Church; and some of its clauses, as, for instance, 'He descended into hell,' and again, 'The communion of saints,' are at anyrate additions to the earliest known forms, even if they are not developments of doctrine. A great variety of opinions has been held as to the origin of this creed. It has not only been attributed to the apostles directly, but a legend has professed to settle the clauses respectively contributed by the several apostles. The earliest account of its origin we have from Rufinus, an historical compiler of the 4 th century. His statement is, that the apostles, 'when met together, and filled with the Holy Ghost, composed this compend of what they were to preach, each one contributing his share to the one composition, which they resolved to give as a rule of faith to those who should believe. But Rufinus is no great historical authority, and even learned Roman Catholics (as Wetzer and Welte) regard the story as a legend. It is not improbable in itself, how. ever, that even in the age of the apostles some formula of belief existed. The exact form of the present creed cannot pretend to be so ancient by four hundred years, but Irenæus repeats a creed not much unlike the present; and Tertullian also affirms that a similar ereed had been "prevalent as a rule of faith in the church from the beginning of 
the goopel.' The same thing is proved by the creseds alministered to the candidates for baptism in the ad and Id centuries. They correspond, with slight variations, to the Apostles Creed. The true view of this formula of church belief, therefore, seems to be that which regards it as the Roman or Latin form of the ereed which prevailed in all the early churches. It is not strictly apostolic; but it is substantially apostolic-fairly representative of the different elements of Christian faith as handed down from the apostles.

The Nicene, or rather the Niceno-Constantinopolitan Creed is the next great expression of doctrinal truth that we meet with in the history of the church. It sprang ont of the conflict, which had heirun even in the $2 d$ century, as to the dignity and character of Christ. (For the varions Christo. lomical doctrines, see (Hrist, Church History.) These debates continued more or less throughout the 3 d century; and early in the 4th Arius denied that Christ was 'of the substance of God,' or "without beginning;' he was only the highest of created beings, in a sense divine, but not the same in substance with the Father, nor equal with him in power and glory. Athanasius came forivard as the opponent of Arius, and the contest raged throughout the church. The Council of Nierea was summoned in 325 by Constantine, with the view of settling this controversy, and the Nicene Creed was the result. There were these three parties in the council-the Atha. nasians, or extreme orthodox party; the Eusebians, or middle party; and the Arians, or heretical party. The hereties were few in number, and possessed but little influence; but the Eusebians were a strong party, and for some time resisted certain expressions of the orthodox or Athanasians, which seemed to them extreme and unwarranted. At length the Homöousians, as the Athanasians were called, prevailed; and Christ was declared not merely to be of like substance (homoiousios), but of the same substance (homoousios) with the Father. At the later Council of Constantinople (381), the additional tenet of the divinity of the Holy Spirit was added, and the creed completed in the form in which it is familiar in the mass and in the communion service in the Book of Common Prayer, except the memorable phrase 'and from the Son' (filioque). This phrase, teaching the procession of the Holy Spirit from the Son, which was destined to be the subject of controversy between the Eastern and Western Churches (see Greek Church), seems to have been added by the Western Churches in the 5th and 6th centuries.

The next remarkable monument of doctrinal truth in the chureh is what is ealled the Athanasian Creed, a product probably of the 5th century, much later than Athanasius himself, but representing, with great formal minuteness and fidelity, his doctrine of the Trinity, as apprehended and elaborated by the Western Church. Seg AтHA. NASIAN C'REED.

The Apostles', the Nicene, the Athanasian, may be said to form the great catholic ereeds of the church. After the time of the last-mentioned formula, there is no general symbol of faith that claims our attention till the period of the Reformation. When the eye of free criticism and argument was turned upon Seripture, new creeds, or rather confessions, began to spring up; these are treated at Confessions. The Professio Fidei Tridentina, commonly known as the Creed of Pope Pius, arose out of the Decrees of Trent, and is practically the Confession of Faith of the Roman Catholic Chureh (q.v., and see TrENT). This was published in 1564, but some important additions to it were made in 1870 , in consequence of the decision of the Vatican Council.
It is remarkable that the oriental churches have never formally accepted any ereed except the Nicene, without the insertion of the word fliogue in connection with the Procession of the Hoiy Spirit (q.v.).

Soe Smith's Dictionary of Chriatian Antiquities; the Encyclopsedia of the Buman (atholion Wetzer and Welte; the works of Dr Heurtley of Oxford: of the Lutheran Dr Caspari: and the three volumes of the Preshyterian Dr Schaff (Lond. 1877). A mong patristio treatisen may be specially named the Catechetical Lectures of St Cyril of Jerusalem, in the 4th century, and somewhat later the tractates of St Augustine, De Fide et Symbolo; De Symbolo ad Catechumenos. In the 17th century an English prelate, Bishop Bull, received the thanks of the Gallican Church, led by Bossuet, for his Defensio Fidei Nicene, and Bishop Pearson and Dean Jackson won lasting fame by their respective volumes on the Apostles' Creed. On the Roman Catholic side the learned Jesuit Petan (Petavius) is conspicuous, and in 1832 Möhler published two volumes entitled Symbolik, which treated of the Reformed and Roman Confessions. Seo ARticles, athanasian Creed, Conprgsions, Theology.

Creek, in Geography, is a small inlet on a low coast, and in rivers formed by the mouths of small streams. In America and also in Australia, the term creek is applied to small rivers.

Creeks, or Muscogees, a formerly powerful tribe of American Indians, of the Appalachian stock, who, reduced by war to some 25,000 , were in 1836 removed from Georgia and Alabama to Indian Territory. In 1895 their number was estimated at 10,000 .

Creeper (Certhia), a genus of Passerine birds, the type of the family Certhialse. The bill is long, much eurved, laterally compressed, and pointed; the tongue is long, narrow, sharp-pointed, and jagged near its tip; the tail is rather long, and the tips of the tail-feathers are firm and pointed, extending beyond the webs. The feet are rather slender; the hind-toe about as long as the others. The feet are well adapted for tree-climbing, and the stiff feathers of the tail are also employed for support. There is probably more than one species, but this is doubtful, and the distribution is somewhat wide. The Common Creeper ( $C$. familiaris) is

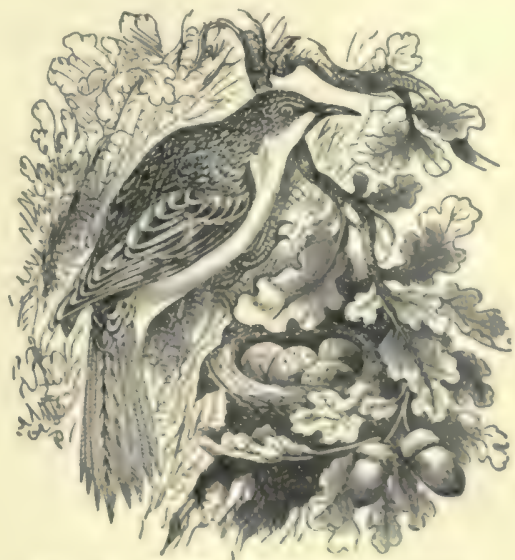

Common Creeper (Certhia familiaris).

found in all temperate parts of the northern hemi. sphere, wherever woods abound. It is a permanent resident, but is never numerous or gregarious. It is not so well known as many other birds, in consequence of its restless habits, its rapid movements, and prompt retirement to the farther side of the tree from the spectator. The Scoteh name, Bark-speeler ('climber'), describes its almost con- 
stant habit, as it searches for insects and their larvæ in the erevices of the bark. 'The nest is usually in a hole of a decayed tree. The creeper is one of the smallest of British birds, although larger than the wren. Its prevalent colour is dark gray above, with spots of yellow and white; the under parts are white. -The Wall Creeper (Tichodroma muraria) of the south of Europe frequents walls and the faces of roeks. - The Nuthatch (q.v.) is a closely allied genus.

\section{Creeper. See Climbing Plants.}

Creighton, Mandell, historian, born at Carlisle, 5th July 1843, from Durham School gained a postmastership at Merton College, Oxford, in 1862 , and was elected a fellow in 1866 . He became vicar of Embleton, Northumberland, in 1875, first professor of Ecclesiastical History at Cambridge in 1884, Bishop of Peterborough in 1891, and of London (1896). His chief works are Simon de Montfort (1876). History of the Papacy during the Reformation Period (5 vols. 1882-94), and the sumptuous Queen Elizabeth (1897).

Crema, a town of Lombardy, 27 miles NW. of Cremona, with a cathedral (1341). Pop. 8500.

Cremation, the reduction of the dead human body to ashes by fire, was a very early and widespread usage of antiquity. The early Aryans-as opposed to the non-Aryan aborigines of India-the Greeks, Romans, Slavs, Celts, and Germans, burned their dead, so that cremation may be regarded as the universal custom of the Indo-European races. The graves of North Europe throughout the 'bronze age' contain only jars with ashes. It was Christianity that gradually suppressed the practice of cremation. In India it is still a usual method for disposing of corpses, and is also practised by numerous uncivilised peoples of Asia and America (see BuRIAL). A return to the practice has been strongly insisted on by many in modern Europe. This is opposed mainly on grounds of kindly feeling for the dead, and for religious reasons connected with the belief in the resurrection of the dead. Advocates of cremation assert that these are prejudices founded on misapprehension, and allege that the question is solely a sanitary one. The damage to the health of such as live near churchyards and cemeteries, from the exhalations of noxious gases and the poisoning of water supplies, is an indisputable fact, and is in many cases quite inevitable. By burning, the body is reduced more swiftly to its constituent elements, without disrespect to the dead or hurt to the living. The ashes of the body of an adult after due incineration weigh from 5 to $7 \mathrm{lb}$. Others allege as the juridicocriminal difficulty that cremation might be made to destroy the evidence of murder (as by poisoning); but advocates of cremation answer that a properly organised system of medical inspection would obviate this objection. In Italy cremation has been legal since 1877, and is not unusual at Milan, Lodi, Cremona, Brescia, Padua, Varese, and Rome, and at these places crematory furnaces, on the Gorini system, have been erected. About 1000 cremations have taken place in these and other Italian towns. In Berlin, Dresden, and Leipzig there has been strong agitation in favour of crema tion; and at Gotha there is a large mortuary and crematorium, where between 1878 and 1888 more than 550 bodies had been eremated and lodged in the Columbaria of the crematory temple. Societies for securing the legalisation of the process exist in nearly every country in Europe, and in some the rite of cremation is permissible. At present this is not so in Belgium, Russia, or Austria. Two crematory furnaces were erected in 1888 by the municipality of Paris at Père-la-Chaise. The movement found for long but little favour in the United
States; there were but 20 cremations in 1875-82, but in $1885-93,1282$ bodies were cremated. Interest in this movement was awakened in England in 1874 by Sir Henry Thompson: the council of the society established in that year purchased ground at Woking, and in 1885 erected a crematory, which by 1893 had cremated 458 bodies: The number of cremations in England is now 130 annually. There are crematories at Manchester, Glasgow, and elsewhere. For each cremation about seven shillings' worth of wood fagots and coal are needed. The time occupied in the reduction of an adult varies from $1 \frac{1}{4}$ to $1 \frac{3}{4}$ hours, and the ashes weigh, as before stated, from 5 to $7 \mathrm{lb}$. Cremation having been declared legal in England, it is expected that some of the large cities will very shortly possess these media for destruction of the body by fire. The human body consists of 60 per cent. of water and 40 per cent. of solid matter; and quickly to reduce this to ashes requires a strong furnace. A special form of Siemens' regenerator furnace is that which has found most favour in Germany, but elsewhere only the Gorini form of apparatus is used. The Gorini crematory furnace consists of a receiver, a furnace, and a chimney. The receiver is a flatbottomed chamber open at each end, one of which communicates with the upper part of the furnace, and the other with the lower part of the chimney. The furnace, which discharges its heat into the receiver, is somewhat spacious, sufficiently so to produce the necessary heat by means of wood fuel only if found requisite. The chimney is also of sufficient sectional area to remove the products of combustion from the receiver as well as the furnace, and high enough to permit the draught to keep above the gases pervading the receiver, and prevent any dispersion of heat or smoke through the apertures around the receiver or cremation chamber. In order to perfectly overcome the idea as to any organic molecules escaping from the shaft, a grating is placed near the base of the chimney, and upon this a portion of coke is kept burning. The products of animal combustion which issue still highly heated from the receiver, are subjected to higher temperature in passing through the burning coke, and any organic matter which may have resisted or escaped the first combustion is destroyed by the second, and mixes harmlessly with the atmosphere. The literature of the subject. began with Thompson's Treatment of the Body after Death (1874); Erichsen's Cremation of the Dead (1887); Ullersperger's Urne oder Grab (1874); and some works by Italian doctors. The Transactions (annual) of the Cremation Society of England contain a complete bibliography on the subject up to date. Since 1874 upwards of 3000 works and pamphlets have been published on this subject in various countries.

[While this volume was passing through the press, the author of the above article died, and his body was cremated at Woking. - ED.]

Crémieux, IsaAC Adolphe, jurist and politician, was born of Jewish parents at Nimes, 30th April 1796, and became an advocate in Paris in 1830. In 1842 he entered the Chamber, and in 1848 was a member of the provisional government. Imprisoned at the coup d'état, he subsequently confined himself to professional work, till 1870 . when he was a member of the government of national defence. He was made a senator in 1876 , and died 10th February 1880. He was the founder of the Alliance Israélite Universelle.

Cremona, a decayed city of Northern Italy, on the north bank of the Po, 60 miles SE. of Milan by rail, and $46 \mathrm{E}$. of Pavia. Cremona has some fine buildings-the principal the eathedral (1107-1606), with gorgeous interior; the neigh- 
bouring octagonal Baptistery; the Palazso Publico (1245); the so-called Campo Santo; and the famous Torrazzo (1288) or belfry - the loftiest campanile in Italy, being 396 feet high, and commanding mag. nificent views over the fertile plains of Milan. By means of the Po, Cremona carries on a considerable trade in the produce of the district; and it has manufactures of silk, eotton, earthenware, and chemicals. In the 16th, 17th, and 18th centuries it was greatly celebrated for its manufacture of violins, the most famous makers being the Amatis, the Guarneris, and Stradivari (see VioLIN). Pop. 31,930. Cremona is the capital of a province of the same name; area, 632 sq. m. ; pop. (1886) 314,755.

Cremorne Gardens, near Battersea Bridge, on the north side of the Thames, a very popular place of amusement for Londonery down to 1877, when they were closed.

Crenelle, a Battlement (q.v.), or an embrasure in a battlement.-CRENELLE, in Heraldry, em. battled, signifies that any ordinary is drawn like the battlements of a wall.

Creole (Span. criollo), in general an indi. vidual born in the country but not of indigenous blood, a term applied, especially in the former Spanish, French, and Portuguese colonies of America, Africa, and the East Indies, to natives of pure European blood (sangre azul), in opposition to immigrants themselves born in Europe, or to the ofispring of mixed blood, as mulattoes, quadroons, Eurasians, and the like. In Brazil the native whites call themselves Brasileiros. Creole dialects are corruptions of French, Spanish, Portuguese, English, or Dutch, arising in various colonies, and may be studied in such formal treatises as Thomas, The Theory and Practice of Creole Grammar (Port of Spain, 1869), and Quentin, L'Histoire de Cayenne et de la Grammaire Creole (Paris, 1872). Mr Cable's stories revealed to English readers the singularly quaint charm of the phraseology and manners of the Creole population of Lovisiana.

Creosote. See Creasote.

Crescendo, in Music, means a gradual increas. ing of sound, or changing from piano to forte and fortissimo. It is marked thus or with the abbreviation cresc. The converse is decrescendo. The swell of a good organ produces a most perfect crescendo.

Crescent. A representation of the half-moon with the horns turned upwards, called a crescent, is often used as an emblem of progress and success. It was the emblem of the Greek before it became that of the Turkish rule (see ConstantiNOPLE, p. 433); but it was not adopted by the Turks from the Greeks - it had been used by them hundreds of years before in Central Asia. Genghiz Khan's Tartars had the crescent on their banners, and so had the Jauisaries of Sultan Orchan.

Crescent, a decoration, sometimes called order of, in Turkey. In 1799, after the battle of Aboukir, the Sultan Selim III. testified his gratitude to Nelson by sending him a crescent richly adorned with diamonds. It was not intended as an order, but Nelson wore it on his coat; and Selim, flattered by the value attached to his gift, resolved that a similar decoration should be conferred on foreigners who have done service to the state. There was an old Order of the Crescent, instituted by René, Duke of Anjou, in 1464.

Crescentia. See Calabash Tree.

Cress, a name given to many plants belonging to the order Crucifers, which have in common, in greater or less degree, a pungent mustard-like taste, and antiscorbutic, diaphoretic, and other medi. cinal qualities. They are very generally distributed abundantly over the temperate and northern countries of the earth, and much used as salad and medicinally by the peoples of those countrien. In Britnin the most commonly used is the Common Cress (Lepidium sativum), of which there are several

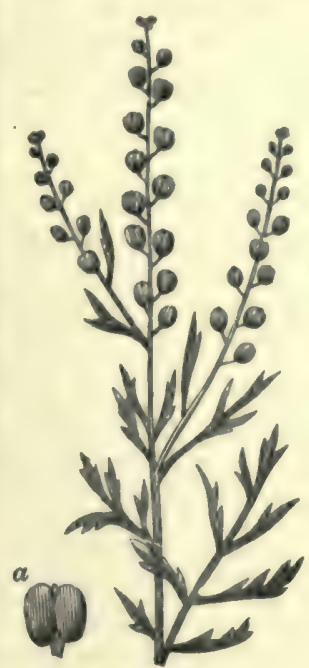

Commen Cregs

(Lepidium sativum) : $a$, silicule.

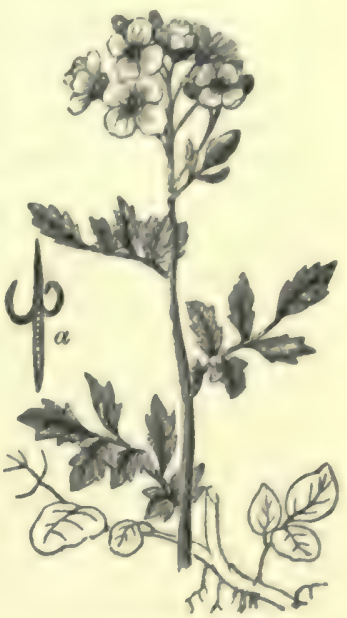

Bitter Cress

(Cardamine amara) : $a$, sllique, opening. varieties, the most favoured being that known as the Curled Cress. Sown thickly in soil in moderate heat under glass, this may be raised during winter in a few days; and the seeds spread out thickly on flannel, which is kept saturated with warm vapour, as from a boiler or tank of boiling water, will vegetate and yield a crop within 48 hours after sowing. In this way it has been found invaluable during aretic voyages as an antiscorbutic. The Poor Man's Pepper is the Broad-leaved Cress ( $L$. latifolium), a native of Britain, and formerly used as a condiment by the poor. The Virginian Cress ( $L$. virginicum) has similar properties to the Common Cress, and is cultivated in Britain, in North America, and in the West Indies for use as a salad. L. piscidium, a native of the South Sea Islands, is there used to stupefy fish, and by sailors as an antiscorbutic. The allied genus Barbarea supplies the Winter Cress or Yellow Rocket of gardens ( $B$. vul. garis), a native of Britain, and the American Cress (B. prazcox), by some regarded as merely a variety of the preceding, is also a native of Britain, the European continent, and America, where both are used for the

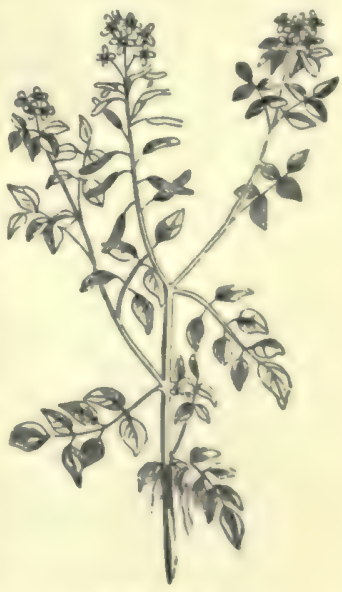

Water Cress

(Nasturtium officinale). purposes already de. scribed. The Bitter Cress (Cardamine amara), the Lady's Smock or Cnckoo-flower ( $C$. pratensis), and the Hairy Cress ( $C$. hirsuta), are all natives of Britain and of other temperate and northern countries of the globe, but being more bitter than 
pungent, are less used in salads in this country than on the Continent and in America. Water Cress (Nasturtium officinale) is an aquatic perennial species of the same natural order, largely cultivated in England and on the Continent in slowly running brooks and ditches, where the water is pure and the bottom gravelly. In stagnant water and a muddy bottom the plant soon perishes. For the so-called Indian Cress, see NAsturtium.

Cressida. See Troilus.

Cressy. See Creçr.

Cresylite. See SHeld, Vol. IX. p. 386.

Crest (Lat. crista, 'a comb or tuft'), a heraldic figure or ornament, which in its original use surmounted the helmet. Though often popularly regarded as the most important part of the heraldic insignia of a family, it is, in the eyes of heralds, an accessory without which the bearing is complete. The practice of ornamenting the helmet with a capriciously assumed figure existed in classical times; but no such usage is found in the early middle ages, or at the time when heraldry had its rise. Crests first appear occasionally on the helmets of knights in the 13th century, and were a mark of dignity and estate beyond what was implied by the use of arms. Edward III. was the first English king who assumed a crest; and crests are found in use by the early Knights of the Garter. The practice gradually spread, particularly in England, till the crest became the almost indispensable adjunct of a shield of arms, as it now is. On the Continent there are still many families of distinction who have never used a crest. The crest is generally placed on a Wreath (q.v.) of the principal metal and colour of the shield; sometimes, however, it is (by permission of the sovereign or king-at-arms) allowed to issue out of a ducal coronet, mural crown, or cap of maintenance. Different crests are, in modern times, often assigned to separate branches of the same family, and there are many crests which so many families have in common that they are hardly distinctive. No ladies except sovereign princesses can, with any propriety, attach a crest to their arms. The assumption of crests by churchmen is equally objectionable. Corporations occasionally use them, a practice for which precedent may be shown from the 15 th century. Crests are not to be confounded with family badges, which were never placed on a helmet, and ought not to be borne on a wreath. See BADGE ; Fairbairn's Crests (2 vols. new ed. 1893), and Knight and Butters' Crests (2 vols. 1885 ).

Creste, in Architecture, an ornamental finish ing, either in stone, or of tiles or metal, running

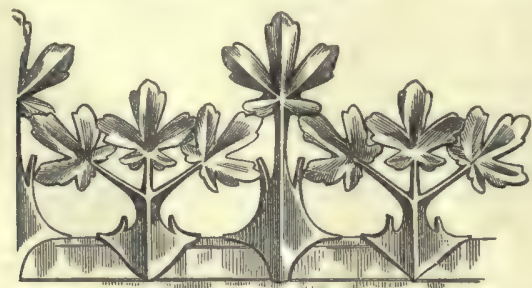

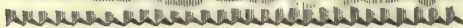

Creste, 13 th century (from Viollet le Duc).

along the top of a wall or the ridge of a roof. Such crestings were adopted by the Romanesque architects from the East, but the designs were soon made after their own style. Elaborate ornaments of this kind were frequently used in Gothic buildings. In modern times cast-iron has been greatly used for such ornaments, many roofs being covered with gilded iron rails or crests.

Cresswell, Sir Crasswell, judge, born in Newcastle in 1794, was educated at Charterhouse and Cambridge, and called to the bar in 1819. Between 1822 and 1830 he issued, with Barnewall, a valuable series of Reports; in 1830 he was appointed recorder of Hull, and in $1834 \mathrm{a}$ king's counsel. He was returned to Parliament by Liverpool in 1837 and 1841, and in 1842 Peel made him a puisne judge. He sat in the Court of Common Pleas till 1858, when he was appointed first judge of the newly-created Probate and Divorce Court, the success of which was mainly due to him. $\mathrm{He}$ was especially distinguished in will cases and cases in mercantile and navigation law. He died shortly after a carriage accident, 29th July 1863.

Crestien de Troyes. See Chrestien.

Creston, a town of Union county, Iowa, 115 miles W. of Ottumwa. It is connected by railway with Burlington, Chicago, and St Joseph, and has large machine-shops and railway-carriage works. Pop. (1870) 411 ; (1890) 7200.-There is a smaller town of Creston in Wyoming, and a third in Illinois.

Creswick, Tномаs, R.A., a popular landscapepainter, was born at Sheffield, 5th February 1811. He early exhibited a taste for drawing, and removed to London in 1828, where two of his pictures during that year found a place in the Royal Academy's exhibition. Creswick loved to paint the beautiful streams, and glens, and wooded dells of his native land; and these, which, along with some coast scenes, form the subject of his best paintings, are represented on his canvas with great delicacy of finished detail and truth of aerial perspective, the figures introduced being frequently from the brush of Ansdell, Cooper, Frith, and other artists. He was well known as a book-illustrator by his drawings for the wood-engravers, and he contributed to the publications of the English Etching Club. He was elected an A.R.A. in 1842, an R.A. in 1851 . He died 28th December 1869. More than a hundred of his works were collected in the London International Exhibition of 1873.

Cretaceous System, the highest division of the Mesozoic or Secondary strata, rests conformably upon the Jurassic System (q.v.), and is overlaid unconformably by the oldest deposits of the Eocene System (q.v.). The cretaceous strata of Britain are confined chiefly to the east and south-east of England. They form the Yorkshire Wolds, extend over large parts of Norfolk, Suffolk, and Hertford, and compose the Chiltern Hills, Salisbury Plain, the Downs, and the south part of the Isle of Wight. On the Continent the cretaceous rocks have a considerable development. They form a broad basin in the north of France, and stretch eastward from Belgium, Holland, Denmark, and the south of Sweden, through the great plains of northern Europe to the south end of the Ural Mountains. But over extensive regions within that wide area they lie more or less concealed under younger formations. There is another extensive development of cretaceous strata in southern Europe, where they enter largely into the composition of many of the Mediterranean coast-lands. The chief petrological feature of the cretaceous strata of western and northern Europe is the great development of white chalk in the Anglo-French area, and its gradual replacement, when followed eastwards into Germany, \&c., by earthy limestones, shales, sandstones, \&c. The most marked characteristic of the cretaceous system in southern Europe is the great development in that region of massive marine limestone (hippurite limestone).

In North America cretaceous strata likewise occur in force, especially in the western states and 
territories. They also occupy wide tracts in the Gulf states, whence they extend up the Mississippi valley to the Ohio: they put in an appearance at intervals on the Atlantic borders between South Carolina and New Jersey ; and we meet with them again on the Pacifie boriler and in the coast-range. Strata of the same age ocenr also in the far west of British America, at the month of the Mackenzie River, and in Greenland. In India the system is marked in the Decean by a masaive series of basaltrocks, $400(0)$ to 6000 feet thick, and covering an area of $200,000 \mathrm{sq}$. m. In Australia and New Zealand there is a considerable development of cretaceous rocks, such as the 'desert sandstones' of Queensland, and a small coal-bearing group of beets. In New Zealand the system likewise contains cosls, gome of which are lignites, while others are bituminous coals of fair quality. The following is the succession of cretaceous strata in England:

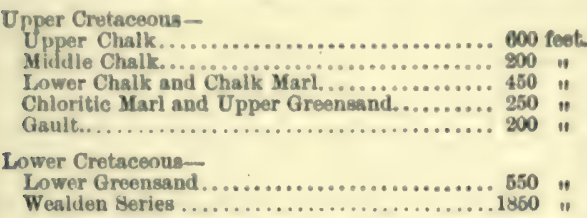

The Wealden Beds consiat largely of elay and sand, and are almost entirely of fresh-water origin. In Yorkshire, however, the strata which occur on the same horizon as the Wealden beds of the south are of marine origin, as seen in the Speeton clay near Bridlington. The Lower Greensand, consisting of sand, clay, \&c., are marine. The Gault (q.v.), a tough blue clay, is likewise marine, and so also are the shallow-water sands of the Upper Greensand, and the thin layer of chalky marl called Chloritic Marl (q.v.), which is characterised by the presence of glauconitic grains and phosphatic nodules. The most characteristic rocks of the system, however, are the chalk beds. The basement of these beds is the argillaceous chalk known as Chalk Marl. The lower chalk is a grayish-white chalk, while the middle chalk is a pure white chalk, containing in its upper portions layers of flint nodules. A hard layer of yellowish limestone called Chalk-rock lies at the top of this division. The upper white chalk is a thick massive white chalk, containing numerous layers of nodules and occasional tabular sheets of flint. All these chalks are of marine origin. The following are the divisions adopted by continental geologists, and now largely used by geologists in Britain :

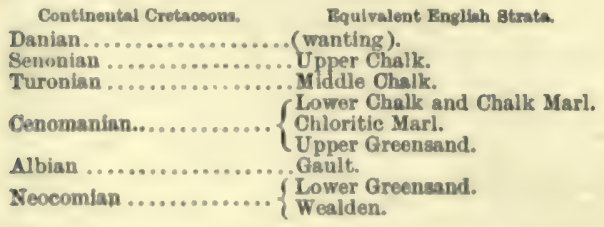

The cretaceous strata of Britain being almost exclusively of marine origin, it is not surprising that land-plants seldom occur, and that they are met with chiefly in the fresh-water beds near the base of the system. They consist chiefly of ferns, cycads, and conifers - a flora resembling that of the preceding Jurassic periol. The upper cretaceous rocks of Germany, however, have furnished many plant remains. Amongst those are the oldest known dicotyledons, such as extinct species of maple, oak, walnut, beach, laurel, magnolia, de., also several protesceous plants. A similar admix. ture of forms occurs in the eretaceous strats of North America. Amongst animals the Protozos played a very important part-the white chalks and enrthy limestones heing very largely compomed of the minute shells of forminifera, such as Globigerina, Rotalia, and Textularia, which atill swarm in the ooze of the Atlantic. Sponges, such as Ventrieulites, Siphonia, \&c., were very abundant, and sea-urchins also oceurred in great numbers. Star-fishes and bryozoans were fairly common, as were also, amongst brachiognels, Terebratula and Rhynchonella. But the brachiopods as a class were feebly represented as compared with their abundance in the earlier stages of the world's history. Ordinary bivalves, however, were very numerous, such as Inoceramus, Hippurites, Spondylus, Lima, Pecten, \&c. In the Danian beds carnivorous gasteropods begin to abound, and they include a number of existing genera. Cephalopods are not only the most abundant, but also the most characteristic fossils of the cretaceous rocks. Amongst them are a great variety of Ammonites, and many forms of Belem. nitidre. Amongst the fishes were ganoids, and various kinds of the shark tribe, together with the earliest representatives of the Teleostei-which include most living genera of fishes. The waters of the period seem also to have swarmed with reptiles, such as Ichthyosamrus and Plesiosaurus. Winged reptiles were also present, such as Pterodactylus. Amongst dinosaurs were Cetiosaurus, Megalosaurus, and Iguanodon. Another remarkable reptile was the serpent-like Mosasaurus. Besides these, there were lizards, chelonians, and crocodiles. The American cretaceous system is likewise characterised by the presence of huge dinosaurs and other reptiles-some of them being European types, while others are peculiar. One of the most remarkable features of the American rocks, however, is the occurrence in them of the toothed birds-Ichthyornis and Hesperornis. (Separate articles deal with most of these various forms.)

No break separates the Jurassic from the eretaceous system-there is a gradual passage from the upper beds of the former into the lower beds of the latter. At the beginning of cretaceous times most of the British and Irish area existed as dry land. Over the south-east of England lay the estuary of a large river, flowing probably from the north. The Wealden beds are the delta-deposits of that river the English and French beds of this division covering an area of $20,000 \mathrm{8q}$. $\mathrm{m}$. The sea into which that river flowed occupied a considerable area in the north of France, spread over the Low Countries into Hanover, filled the basin of the North Sea, and overtlowed a portion of eastern England. Wealden beds occur in north-west Germany, and indicate the delta of a river, like that of the British area, flowing from the north. While land-conditions predominated in northern and middle Europe, an open sea covered vast areas in southern Europe. Gradual subsidence of the sea-bottom took place during the deposition of the Wealden series, and eventually the great deltas became submerged, and a wide sea covered most of what are now the low grounds of the British area, and passing eastwaris, submerged vast regions of middle Europe up to the glopes of the Ural Mountains. The depreesion was greatest in the western areas, where in the deep clear waters there gradually accumulated the calcareous matter which subsequently formed our white chalk. There is no deposit forming at present which is quite analogous to white chalk. The calcareous oozes of existing seas which most resemble it are of abysaal origin, but the sea in which the chalk accumulated probably did not exceed 1000 or 2000 feet in depth. The extreme purity of the chalk, consisting as that rock does of 95 per cent. and more of carbonate of lime, is difficult to account for on the supposition that the sea in which it formed was comparatively shallow. 
The sea of western Europe may have been dotted with small islands-from none of which large rivers descended; and possibly the formation of the chalk was not so slow a process as many geologists suppose. Professor Prestwich even suggests that it may to some extent be of the nature of a chemical precipitate thrown down under special and peculiar conditions prevailing at the time. However that may be, the shells of foraminifera and other organic remains certainly enter very largely into its composition. In the Mediterranean basin, a deep open sea would seem to have persisted all through the cretaceous period. It was in this sea that the massive hippurite limestone was formed. Open water appears at this time to have extended through the Mediterranean area into Asia, covering there also vast tracts of what is now dry land, and communicating with the Indian Ocean. The conditions of clinate seem to have been remarkably uniform over vast regions of the earth's surface. Ferns, cycads, and conifers flourished in the lands within the Arctic Circle, and the waters of the same region were tenanted by cuttlefish, ammonites, and huge reptiles.

Crete (Ital. Candia, Turk. Kirit, Gr. Krētè), a Turkish island in the Mediterranean, is the most southerly portion of Europe. It is 60 miles $\mathrm{S}$. of Cape Malea in Greece, $110 \mathrm{SW}$. of Cape Krio in Asia Minor, 100 SSW. of Rhodes, and 300 W. of Cyprus. Its length is $\mathbf{1 5 6}$ miles; its breadth varies from 30 to as little as 7 miles; and its area is $3326 \mathrm{sq}$. m., or twice the size of Hampshire. The climate, inferior only to that of Rhodes, is excellent, and has always been celebrated for its salubrity. The air is pure, fresh, and bracing; the rainfall about 27 inches. In July, August, and September it is hot in the plains, but the seabreezes temper the heat, especially at night, and during the rest of the year the climate is delightful.

Crete is for the most part mountrinous, especially in the west, where the White Mountains form the most important range. In the centre Mount Ida, now called Upsiloriti, the loftiest in Crete, rises to a height of 8055 feet. The east is less mountainous, and everywhere numerous small valleys are exceedingly fertile. The rivers are unimportant, being almost invariably dry in summer, and in winter and spring rushing down to the sea as torrents. The country is, however, fairly well watered, even in the dry.season, as springs abound all over the island.

The coast-line, deeply indented on the north, includes some good harbours: Suda Bay, on the north, is one of the finest anchorages in the Mediterranean, and now well known by name as the resort of the British fleet at interesting political crises; and on the south is the small but wellsheltered Kaloi Limenes, or the Fair Havens, by which name it is spoken of in Acts, xxvii. 8. In the immediate neighbourhood of Crete are three islands: Clauda, the modern Gavdo, off the southwest coast, with an area of about 15 sq. m., also spoken of in Acts, has a lighthouse. Dia, north of Candia, and Grabusa, at the north-west, were fortified by the Venetians. In Homer, Crete had 'a hundred cities;' now there are but three of importance-Canea (q.v.), the chief town; Candia (q.v:) ; and Retimo (q.v.).

Wheat and fruit are the most important products; oranges and lemons flourish. The grapes are good, but the wine, though abundant, is of inferior quality. In the middle ages the wine made at Malevesi, near Canea, was celebrated under the well-known name of Malmsey (Fr. Malvoisie). The forests, as usual in the Levant, have almost entirely disappeared. But on the hills the cypress grows; on the plains the olive is cultivated ; and chestnuts, valonia oak, and carobs also grow. The principal exports are olive-oil, soap, carobs, wool, cheese, valonia acorns, and fruits. Sheep are largely bred, but the wool is not of fine quality. Sponges are found upon the coast. The most important wild animal is the Cretan ibex. The population, numbering about 295,000 , are, with the exception of few Turks in the larger towns, almost wholly of pure Greek descent; though about 90,000 of them are Mohammedans, descendants of renegades, but they too speak Greek as their mother tongue.

The early Cretans were seafaring Greeks, rivals of the Phoenicians. The island was the favourite resort of colonists from every part of Greece, and was celebrated at once for its climate, its laws, and its great lawgiver, judge, and king, Minos. Crete was subdued by the Romans in 67 B.C., and was held by the Greek emperors (with an interval of Saracen rule in 823-961), until the capture of Constantinople by the Crusaders (1204). A year or two afterwards the Venetians established themselves here, and kept possession till-after the terrible siege of the then capital, Candia, which lasted three years - the Turks conquered the island. The Cretans are a turbulent race, of proved and proverbial mendacity, bold, independent, and hard to govern ; and, except after defeated rebellions, their subjeetion to the Porte was more nominal than real. They shared in the Greek rising of 1821, but were subdued by Ibrahim Pasha in 1824; and from 1830 till 1841 'the Powers' left it under the administration of the Viceroy of Egypt. A really serious rebellion against Turkish rule took place in 1866 , suppressed with difficulty by Omar Pasha in 1867, Greek assistance and European sympathy prolonging the native resistance; and in 1869 a convention at Halepa, a suburb of Canea, made important concessions to the islanders, never fully carried into effect. After repeated risings and nominal concessions, a very resolute rebellion broke out in 1896 , which brought the whole Eastern Question into an acute phase. The Greek intervention here led to the short but disastrous war of the Greeks with the Turks in April and May of 1897, when the Turkish victory made it difficult for the 'Concert of Europe,' hampered by international jealousy, to secure for the Cretans the promised autonomy, with a Christian prince of their own. Prodigious difficulty was experienced in keeping the peace on the island by mears of a large body of men and ships belonging to the various Powers. A serious and fatai Moslem attack on a British force in Candia led to an ultimatum by Britain, Russia, France, and Italy, which was arcepted by the Sultan in October 1898, and the Turkish troops were withdrawn ; and in December, Prince George of Greece reached Crete as High Commissioner for Europe.

See books on Crete by Spratt (1865), Raulin (Paris, 1869), Stillman (New York, 1874), and Edwardes (1887) H. F. Tozer, The Islands of the Aggean (1890); and R. A. H. Bickford-Smith, Cretan Sketches (1898).

Cretinism (Fr. crétin, 'an idiot;' probably from chrétien, 'a Christian,' an 'innocent'). Idiocy or defective mental development, associated with bodily deformity or arrested growth, occurring alony with Goitre (q.v.) or enlargement of the thyroid gland, in the lower mountain valleys of the Swiss and Italian Alps, of the Pyrenees, of Syria, India, and China. In Europe it is rarely found above 3000 feet, and haunts chiefly valleys surrounded by high and steep walls of rock, which exclude the light, and limit the free circulation of air. In some such localities it is extremely prevalent. Cretins are always pitiable and frequently repulsive objects; they are generally dirty, shameless, and obscene; their appetite is commonly voracious; the mouth is large and open, the tongue often protruded, the eyes small, the nose flat and broad, the skull flattened above and 
expanded at the sides, the forehead retreating, the complexion cadaverous; in addition to which, the whole body is dwarfish, the skin thick and coarse, the hands and feet large, the limbe often rickety, the belly protuberant. Recent investigations have shown that the connection between eretinism and goitre is an extremely close one. The disease callerl Mrxielema (१. v.) closely resembles cretinism, except that it comes on during adult life; and it has been proved to be always aseociated with destruetive change of the thyroid gland. A similar conclition has also been found to follow the removal of the thyroid gland by surgical operation in a large proportion of cases. It is, therefore, probable that loes of the function of the thyroid gland is the assential factor in the production of cretinism, while goitre consists in its enlargement. It is as yet quite uncertain, however, why the inhabit. ants of particular districts are so liable to disease of this organ. Many attempts have been made to improve the condition of the eretin in childhood, by removing him from the locality of his birth, and by careful training; the institution founded by Dr Gurgenbihl on the Alendberg, near Interlaken in Switzerland, having been the prototype of many others on the Continent, and of some in England and Scotland, for the education of idiots.

Cretonne, originally a white cloth of French manufacture, is a name now applied to a printed cotton fabric used for curtains or for covering furniture, which was introduced about 1860. Chintz (q.v.), so much employed for the same purpose in former years, is a comparatively thin printed cloth usually highly glazed. Cretonne, on the other hand, is generally thick and strong for a cotton fabric, and with a twilled, crape, basket, wave, or other figure produced on the loom. When a pattern is printed on this uneven surface (it is sometimes plain), it has a rich, soft appearance. A cretonne is rarely calendered or glazed. The thick weft threads of inferior qualities are commonly formed of waste cotton, and the patterns upon these, though often bright and showy, are as a rule printed in more or less fugitive colours. Some cretonness are now printed on both sides with different patterns.

Creuse, a river and a department in the centre of France. The river rises near Féniers, on the northern slope of Mont Odouze, and flows 146 miles north-westward till it falls into the Vienne, a tributary of the Loire, 12 miles $\mathbf{N}$, of Chatellerault. -The department, with an area of $2150 \mathrm{sq} . \mathrm{m}$., had a population of (1872) 274,663 ; (1891) 284,660 . Low mountains and chains of hills, 2000 to 3000 feet high, occupy the greater part of the land. The climate is moist and variable, and the soil thin and light, interspersed with stretches of heath and pasture in the southern hilly district, but better in the lowlands of the north-east. The rearing of cattle forms the chief industry, and large quantities of chestnuts and frnit are grown. Coal is mined at Ahun. Creuse is divided into the arrondissements of Aubusson, Bourganeuf, Boussac, and Guéret, with Guéret for capital.

Creusot, or Creuzot, LE, a town in the French department of Saone-et-Loire, 14 miles SSE. of Autun, and 236 SSE of Paris. Situated in the midst of a district rich in coal and iron, it owes its importance to the establishment here in 1837 of the great ironworks of Schneider \& Co., which rank amongst the largest in Europe. They have their own collieries and coke furnaces, have large smelting furnsces and rolling-mills for armourplates, execute military engineering work of all kinds, especially cannon, and employ over 13,000 people. Pop. (1846) 4012; (1891) 18,467. See 140
Vadot, Le Creusot, son Histoire, son Industrie (1875), and works by Hennebert ( 1890 ) and Weyl ( 1889 ).

Creuzer, Friedrich, a learned German philo. logist, was born at Marburg, March 10, 1771, and studied there and at Jena. In 1802 he was called to a chair at Marburg, and in 1804 to that of Philo. logy and Ancient History at Heidelbery, which he filled till his retirement in 1845. Here he died, 15th February 1858. Creuzer's first and greatest work was his perversely ingenious and learned Symbolik und Mythologie der alten Volker, besonders der Griechen (4 vols. Leip. 1810-12). His symboli cal explanation of ancient mythologies was asailed by Hermann, Voss, Lobeck, and Pott. His next work in importance was a complete edition of the works of Plotinus (3 vols. Oxford, 1835). With G. H. Moser, Creuner edited several of the philosophical works of Cicero. Most of his writings are collected in the series of Deutsche Schriften (1837-54), which contains also his autobiography, under the title Aus dem Leben eines alten Professors, subsequently divided and arranged into Deutsche Lehr- und Wanderjahre and Paralipomena. In 1854 appeared his Opuscula Selecta.

Crevasse. See Glacier.

Crevecour (Fr., 'heart-breaker'), a once famous Dutch fort in the province of North Brabant, at the confluence of the Meuse and the Dieze, 4 miles NNW. of Bois-le-Duc. It figures in history from 1587 to 1794 .

Crevillenté, a town of Spain, 20 miles WSW. of Alicante. Pop. 8683.

Crew, of a ship, is a collective name for all the persons employed therein, but usually limited to designate petty-officers and seamen only. In men-of-war, the entire erew are divided into five groups : (1) Commissioned and warrant officers ; (2) chief petty-officers; (3) first-class petty-officers; (4) second-class petty-officers; (5) able seamen, ordinary seamen, non-combatants, and boys. In the royal navy there are upwards of 180 different ranks, grades, or offices among the crew, excluding officers and marines.

In the case of a merchant-ship abont to proceed on a foreign-going voyage from'a British port, the erew sign the agreement between the shipowner and themselves (usually called 'the articles') in the Mercantile Marine Office in the presence of the officers of the Board of Trade; and on returning to the United Kingdom, the master must lodge the articles at the Mercantile Marine Office within forty-eight hours of his arrival, and the crew are discharged there. Seamen leaving the vessel abroad must be discharged before the British consul, and new engagements abroad must bo made before the same official. In the case of vessels in the coasting trade, the crew sign articles on board the vessel, but the agreements are handed over to the Mercantile Marine Oftices every June and December. Vessels under 80 tons hand over their erew-lists only, in the same manner. There is no statutory scale for manning British ships, but the Passengers Act requires that a ship carry. ing emigrants shall be manned with an 'ellicient' crew to the satisfaction of the enigration officer clearing her. Owing to improvements in masting and rigging, the use of bettermechanieal appliances, and the necessity for economical working, merchant-ships' crews are now smaller than in former years, except in the best class of passenger vessels.

Crewe, a town of Cheshire, with a great railway junction and the huge works of the London and North-Western Railway, to which it owes its present importance. It is 158 niles $\mathrm{NW}$. of London, $43 \mathrm{SE}$. of Liverpool, 31 SSW. of Manchester, and $53 \mathrm{NW}$. of Birmingham. Abont 1810 
there were only two or three houses where Crewe now stands; but since then its population has grown to 4491 in 1851,8159 in $1861,17,810$ in 1871 , and 24,385 in 1881 - chiefly employed in the railway stations, and in the world-famous locomotive and carriage works, which were commenced in 1843 . Naturally, Crewe is not an attractive place, though the London and North-Western Company have erected a good many handsome buildings, done much in the way of sanitation, and in 1887-88 presented the town with a beautifully laid-out park of 40 acres. Crewe was incorporated in 1877. Lord Crewe's seat, Crewe Hall, by Inigo Jones, was destroyed by fire in 1866 , but has been since rebuilt. Pop. of Crewe in 1891, 28,761.

Crewel-work is a kind of embroidery in fine worsted or silk. See EMpRoIDERY.

Crewkerne, a market-town of Somersetshire, in the fertile valley of the Parret, 15 miles SE. of Taunton. It has a cruciform Perpendicular chureh, with a splendid west front; a grammar-school (1499), occupying commodious new buildings; a railway station (1860); and manufactures of sailcloth, girth-web, hair-seating, \&c. Pop. of parish (1891) 4946; of town, 3500. See Pulman's Book of the Axe (4th ed. 1875).

Cribbage, a game at cards, probably of English origin. It does not appear in foreign treatises on games, and in the Academy of Play (1768), translated from the French, eribbage is called an English game. Cribbage is played with a pack of fifty-two cards; the scores accrue in consequence of certain combinations in play, hand, and crib (for an account of which see any treatise on the game). The scores are marked on a cribbage board pierced with holes. Cribbage was formerly called noddy. It is mentioned under that name in an epigram by Sir John Harrington (1615). Nares (Glossary) says noddy was not played with a board ; but Gayton (Festivous Notes upon Don Quixot, 1654) speaks of noddy-boards. The earliest description of the game is in The Compleat Gamester (1674). Under cribbage it is stated that the game was sixty-one, 'set up with counters;' and that knave-noddy is one in hand and two to the dealer-i.e. if turned up. In 1791 Anthony Pasquin (pseudonym) published a treatise on the game of cribbage; and in 1800 cribbage was added to revised editions of Hoyle's Games. The most comprehensive work on the game is Walker's Cribbage Player's Handbook, long out of print, but republished in great part in Bohn's Handbook of Games.

Crib-biting is a bad habit and an unsoundness met with especially in the lighter breeds of horses, and those spending a considerable amount of leisure in the stable. The act consists in the animal seizing with his teeth the manger, rack, or any other such object, and taking in at the same time a deep inspiration, technically called windsucking. Crib-biting springs often from idle play, may be first indulged in during grooming, especially if the operation is conducted in the stall, and the animal be needlessly teased or tickled; is occasionally learned, apparently, by initation from a neighbour; and in the first instance is frequently a symptom of some form of indigestion. Its indulgence may be suspected where the outer margins of the front teeth are worn and rugged, and will soon be proved by turning the animal loose where he can find suitable objects to lay hold of. It usually interferes with thriving and condition, and leads to attacks of indigestion. It can be prevented only by the use of a muzzle or throat-strap; but in those newly. acquired cases resulting from gastric derangement, means must further be taken to remove the acidity or other such disorder.
Crichton, JAMES, surnamed the 'Admirable," son of Robert Crichton of Eliock, Dumfriesshire, Lord Advocate of Scotland, was born on 19th August 1560. He was educated at St Salvator's College, St Andrews, where George Buchanan was his tutor, and where he graduated M.A. in 1575. In 1577 Crichton left Scotland. He was for two years in France, where he seems to have served in the French army. There is no trustworthy evidence that he distinguished himself as a disputant at the university of Paris. In July 1579 he was at Genoa, and addressed the senate in a Latin oration, which was printed. Next year he reached Venice, and printed a Latin poem addressed to the scholar Aldus Manutius, grandson of the founder of the Aldine press. Aldus took the youth under his patronage, and issued a printed handbill announcing a great scholastic disputation in which Crichton was to take part. The young Scotchman was there described as a skilled athlete, scholar, poet, linguist, with unparalleled powers of memory. In 1581 (according to Aldus) Criehton went to Padua and overeame all the scholars there in public disputations. At the end of 1583 Aldus issued an edition of Cicero's De Universitate, dedicated to Crichton's memory, and asserted there that his versatile protégé died on 3d November 1583. No details are given, and although Aldus's date has been widely adopted, it is clearly an error. In 1584 Crichton visited Milan. There late in that year he published an elegy on the death of the archbishop, Cardinal Borromeo, and two gratulatory odes-one addressed to the cardinal's successor, Gasper Visconti, and the other to Charles Emmanuel, Duke of Savoy, on his marriage. Early next year (March 1585) he issued a collection of scattered Latin poems dedicated to the chiefmagistrate of Milan. This is the latest date at which he is known to have been alive. In 1591 Crichton's younger brother Robert had become owner of his father's property in Scotland. Hence Crichton died between 1585 and 1591. In 1601 one Thomas Wright, in Passions of the Mind, related that when in Italy he heard that a young (unnamed) Scotchman, 'of most rare and singular parts,' was attacked by an (unspecified) Italian prince in disguise; that the prince, running some risk from the Scotchman's sword, announeed his name; that the Scotchman, who was previously acquainted with the prince, handed him his sword, and the prince thereupon basely ran his opponent through the body. John Johnston, in Heroes Scoti (1603), states that Crichton was killed at Mantua by a son of the duke in a nocturnal brawl, and that he was buried at Mantua. Crichton's early 17th-century biographers combine Wright's and Johnston's stories, adding such doubtful details as that Crichton was tutor to his assailant, the Duke of Mantua's son, on the recommendation of Pope Clement VIII. Wright and Johnston were practically contemporaries of Crichton, and the outline of their story is doubtless true. But the fatal encounter at Mantua must be dated at least two years later than the date of Crichton's death supplied by Aldus. John Johnston in 1603 first used the epithet 'admirable ' in describing Crichton ('omnibus in studiis admirabilis'), and it was again employed in David Leitch's Philosophia illacrymans (1637). But Criehton chiefly owes his popular reputation, as well as his designation of "the Admirable,' to Sir Thomas Urquhart of Cromarty, who wrote an extravagantly fantastic account of the scholastic and athletic prowess which he displayed at Paris and Mantua in his Discovery of $\alpha$ most exquisite Jewel (1652). There is little that is historical in Urquhart's fables, although they have been largely accepted by later biographers, including P. F. Tytler, the first edition of whose biography of 
Criohton appeared in 1819 , and the second in 1825 . Aldus's testimony to Crichton's vereatility is alone worthy of serious consideration. Aldus was in the habit of praising extravagantly promising young strunfers at the Italian univermities, and aseriben to a Polish contemporary of Crichton, Stanislaus Niegrosenski, almost the identical scomplishments with which he credits Crichton. That Crichton's power of menory was extrumlinary, is, however, independently corroborated by a physician of Treviso near Venice, named Bartolomeo Burchelati, in his Epitaphiorum Dialogi Septem (1583). And there is no reason to doubt his linguiatic facility or his skill as a fencer. But the numerous Latin verses and prose exsays which Crichton printed indicate no special eapacity. Harrison Ainsworth wrote a novel on Crichton's apocryphal career in 1837. For a critical and bibliographical account, see articles in Dictionary of National Biography, and in Centlemen's. Mugazine for Mareh 1858 (both by Sidney L. Lee). A genealogical paper by John Stuart in Proceedings of Society of Antiquaries of Seotland (1855), ii. 103-18, is also nseful. Unique copies of most of Crichton's publications are in the Grenville Library of the British Museum.

Cricket. Like that of most games played with a ball, the origin of cricket may be said to be lost in obscurity. Numerons researches have been marle in the hope of fixing a date, but no really satisfactory conclusion has been arrived at, though it is tolerably certain that the game, in some shape or form, existed at a very remote period of antiquity. Various attempts have been made to prove that the birthplace of ericket was outside the fimits of Great Britain; but the weight of evidence favours the popular view that to England alone the world is indebted for this manly and universally liked game. It is considered highly probable that the word ericket is a corruption of ereag, a variation of an old Saxon word signifying a game played with a crooked bat; if so, it would appear that cricket was known amongst us nearly 600 years ago, as the worl is found to have been in use during the reign of Edward I. (1300). This, however, is supported only by material of slender character. Strutt, one of our best authorities on ancient sport, adduces some evidence to show that 'club-ball,' played in the 14th century, may have been the parent of cricket, but both 'cat-and-dog' (mention of which occurs in the 16th century) and "stool-ball" (frequently referred to in the 17th century) have a closer affinity. It is stated in Russell's History of Guildford that cricket was plaved in that well-known Surrey town in the middle of the 16th century, but for fifty years subsequently no trace has been found; and indeed history tells us really little or nothing of the game that is not speculative until the opening of the 18th century, from which period its growth may be readily followed, though scarcely anything of a definite character is to be gleaned even at that time as to the mode of playing the game. While it was then generally admitted to be healthful, it was condemned on account of the amount of gambling associated with it.

There is some evidence of a match having been played between Kent and All England previously ; but the earliest matches of which copies of the seores have been preserved were those of Kent v. All England, decided on the Artillery Ground, Finsbury, in 1746, and of Hambledon (a club started about 1750 , and which held a somewhat similar position to that afterwarls taken up by the Marylebone Club, inasmuch as the Hambledonians played matches in different parts of England, and generally promoted the interests of the game) against Kent, which took place at Bishopsbourne Paddock, near Canterbury, August 19, 1772.
Nearly two year after the latter match-viz February 25, 1774 - a committee of noblemen and gentlemen met at the Star and Garter, in Pall Mall, London, and formally drew up a set of laws for the government of the game, and these are helieved to have been the first written laws. They have from time to time undergone extensive alteration and addition. In those days the runs scored were recorded by means of notches made on the edge of a strip of wood; the wickets were placed, as now, 22 yards apart, with a popping-erease, 3 feet 10 inches (now 4 feet) in front of each; the stumps, two in number, were 22 inches long, and the bail 6 inclses (a previous wicket having been 2 feet wide, with a hole dug out of the ground in the centre, and 1 foot high); the ball weighed from 5 to 6 ounces. Towards the end of the 18 th century a third stump was added to the wicket, which then became 2 inches higher and 1 inch broader, and the only change made since has been a further inerease both in height and width. There was at first no limit to the size of the bat, and the early instru. ments were curved at the end, so that little else than hitting could have been attempted; but as the character of the bowling changed and became more destructive, alterations were made in the in. strument of defence, which even at the beginning of the 19th century was inelegant compared with that now used. The later portion of the 18th century was remarkable for the formation of the Marylebone Club, which took place in $\mathbf{1 7 8 7}$ on the dissolution of the White Conduit Club, which had had an existence of several years, and had played matches in the fields from which the club took its name. The new club, destined to become the con. troller of cricket, located itself in Dorset Square, in the parish of Marylebone, for about a quarter of a century; then went to North Bank, Regent's Park, but after a brief period had again to make a move, and finally in 1814 settled down in the St John's Wood Road, its present quarters. 'Lord's,' as the home of the M.C.C. has always been known, is the best-appointed cricket ground in the kingdom.

To John Nyren (born in 1764) and Lambert (born in 1779) we are indebted for the earliest printed instructions as to how to play the game; but these cricketers of vast experience had many imitators, and the comparatively large amount of cricket literature that sprung up at this period furthered the interests of the game in a marked degree. Round-arm bowling was introduced during the lifetimes of these two famous cricketers, and both viewed it with disfavour, Lambert declaring that if continued it would have a degenerating effect. Two counties claimed to have introduced the new style, Kent averring that Wills was the discoverer, and Sussex that the honour rested with Broadbridge. Wills was perhaps the first to reully put into practice the style of bowling identical "with that now so universally adopted, though the delivery then was not nearly so high as it subsequently became. Round-arm bowling was not allowed to have an uninterrupted career. The delivery increased in height as the advantage of so doing was observed, and so suspicionsly like throwing was some of this bowling thought, that after it had been practised for eight or ten years the Marylebone Club discarled it altogether. It was revived, however, about 1825 , and on the hard and uneven surfaces upon which cricket was then frequently played, it became so dangerons that recourse was had to leg-guards and batting-gloves, articles which had had no previous existence. During the second quarter of the 19 th century the game made rapid strides, and grew in popularity with the middle and upper classes. The celebrated I Zingari, consiating entirely of gentlemen, was 
formed in 1845, and cricket began to be taken up by other countries in a slight degree.

County cricket, too, which is at the present time the mainstay of the game, was becoming general, though the interest in many of the matches was discounted by some of the players being found in the ranks of two or three counties in one season. Several of the counties played matches early in the 19th century and even before; but properly organised county clubs did not exist for many years afterwards, as the following dates of formation show: Surrey, 1845; Sussex, 1857 (having been conducted by a committee from 1842): Kent, 1859 (re-formed in 1879); Notts, 1859 ; Yorkshire, 1863; Lancashire, 1864; Middlesex, 1868; Gloucestershire and Derbyshire, 1870. In June 1873 rules were passed respecting the qualification of county plavers, and since then county cricket has left little room for the elevens which were wont to perambulate the country under the respective titles of All England, United All England, and later still the United South. Even the matches between the Gentlemen and Players, and North $v$. South, which at one time were the most attractive of the season, have in a measure had to take a secondary position, for the increased demands of the counties have made it almost impossible for such contests to be of a thoroughly representative character. International cricket dates back as far as 1859, when George Parr took a team out to America. This was followed two years later by the visit of a team to Australia under the captainey of H. H. Stephenson, and up to 1876 three teams had visited America, and four Australia, while in 1868 England welcomed a party of aborigines. Then 1878 was signalised by the arrival in England of Conway's Australian eleven, the first of its kind, but destined to be followed by many others. The latest development in the game was the two new M.C.C. rules (1889), increasing the number of balls in an over from four to five, and allowing a eaptain to declare an innings closed.

So much for its history and the variety of opinions held by its historians. As to the merits of the game as now played but one opinion exists. By general assent cricket stands pre-eminent amongst the many outdoor pastimes pursued during the summer months. All classes play it, and at im. portant matches the company of lookers-on includes representatives of all grades of society. The keenest interest, too, is shown in connection with the leading fixtures of the season, and the results of many matches are telegraphed to all parts of the world. One of the great reasons of the remarkable popularity of this game is its uncertainty. Cricket is not solely an affair of skill; chance is also a factor to a very large extent. Conditions of ground and weather exert such a remarkable influence on the game that in many cases a side which apparently possessed little hope of success has come out of a match victorious. A mistake in the field, an act of carelessness on the part of a batsman, may change the character of the whole game, and indeed 'never lost till won' may with greater reason be applied to cricket than any other pastime. Within the reach of almost every one, cricket is, as a most enthusiastic lover of the game has put it, a health-giving, glorious amusement, calculated to bring out all good qualities, trying alike temper, patience, and courage. To excel at cricket it is necessary that the study of the game should be commenced at an early age, as a great deal of patience and practice is requisite. At nearly all, if not all, of our public schools, a cricket ' coach' or tutor is engaged, and as many of the masters are capable and only too willing to give good advice, the youth of the middle and upper classes have splendid opportunities of cultivating a good style, a most essential element towards success.
Instruction from old cricketers given at practice time is the best of all instruction, and this should always be remembered by those less fortunately placed than public-school boys and university men, from whose ranks the best amatei- talent is drawn. In speaking of practice, Dr W. G. Grace, the most famous cricketer of this age, says, "that the more nearly the practice-game approaches to a match, and the more steady and painstaking the player is, the better. One of the best methods of practice I know of is for sixteen people to play amongst themselves; eleven to go into the tield, two to go to the wickets, two to the umpiring, and one scoring. An afternoon's practice, to last for four hours, will thus give a quarter of an hour in each position to every player, and each player will gain experience in every department of the game, getting half an hour's batting (fifteen minutes at each wicket, no matter how often out), half an hour's bowling (fifteen minutes at each wicket), half an hour's umpiring (fifteen minutes at each end), a quarter of an hour's scoring, and two and a quarter hour's fielding, being fifteen minutes at each place ; overs of four balls being bowled, and discipline kept up thoroughly as in a match. . . The advantage of having eleven in the field when you are practising is that you thereby best learn how to judge the runs, and there is nothing so important to a cricketer as to be able to do this well.

The game of cricket can be played either at single-wicket or double-wicket, but matches at the former have become very rare. For the latter, two wickets must be pitched opposite and parallel to each other at a distance of 22 yards, each wicket to be 8 inches in width, and to consist of three stumps (of equal and sufficient size to prevent the ball from passing through, 27 inches out of the ground) with two bails ( 4 inches in length, and when in position not to project more than half an inch above the stumps) upon the top. In a line with the wicket and extending three feet on either side of it, is the bowling-crease, beyond the limits of which the bowler must not go. He uses a ball measuring in circumference not less than 9 inches, nor more than 94 inches, and weighing not less than 51 ounces, nor more than 5\% ounces; and he bowls either round-arm or underhand, and at what pace he pleases. Four feet in front of the wicket and parallel with it is the popping-crease, which defines the batsman's territory. Anywhere behind the popping-crease the batsman is in his own ground. The bat used must not exceed $4 \frac{1}{4}$ inches in its widest part, and must not be more than 38 inches in length. A match is played between two sides of eleven players each, unless otherwise agreed to ; each side has two innings, taken alternately, unless the side which goes in second scores eighty runs (sixty in a one-day match) less than the opposing side, in which case it follows its innings (i.e. has to play again). The choice of innings is decided by tossing. Two members of one side go in to bat, and the rival eleven take up various positions in the field, the ball being bowled in overs from each wicket alternately. The score is reckoned by runs, and a run is obtained each time the batsmen, after a hit, or at any time while the ball is in play, eross and make good their ground from end to end; also by means of a no-ball (the penalty for delivering the ball unfairly or from the wrong position), wide ball (a ball that in the opinion of the umpire is not within reach of the batsman), and in the event of the fieldsman stopping the ball otherwise than with any part of his person. The side which scores the greatest number of runs wins the match. The batsman may be bowled, caught, stumped, or run out; he may be out leg before wicket, for obstructing the field, for hitting the ball twice (except for the pur- 


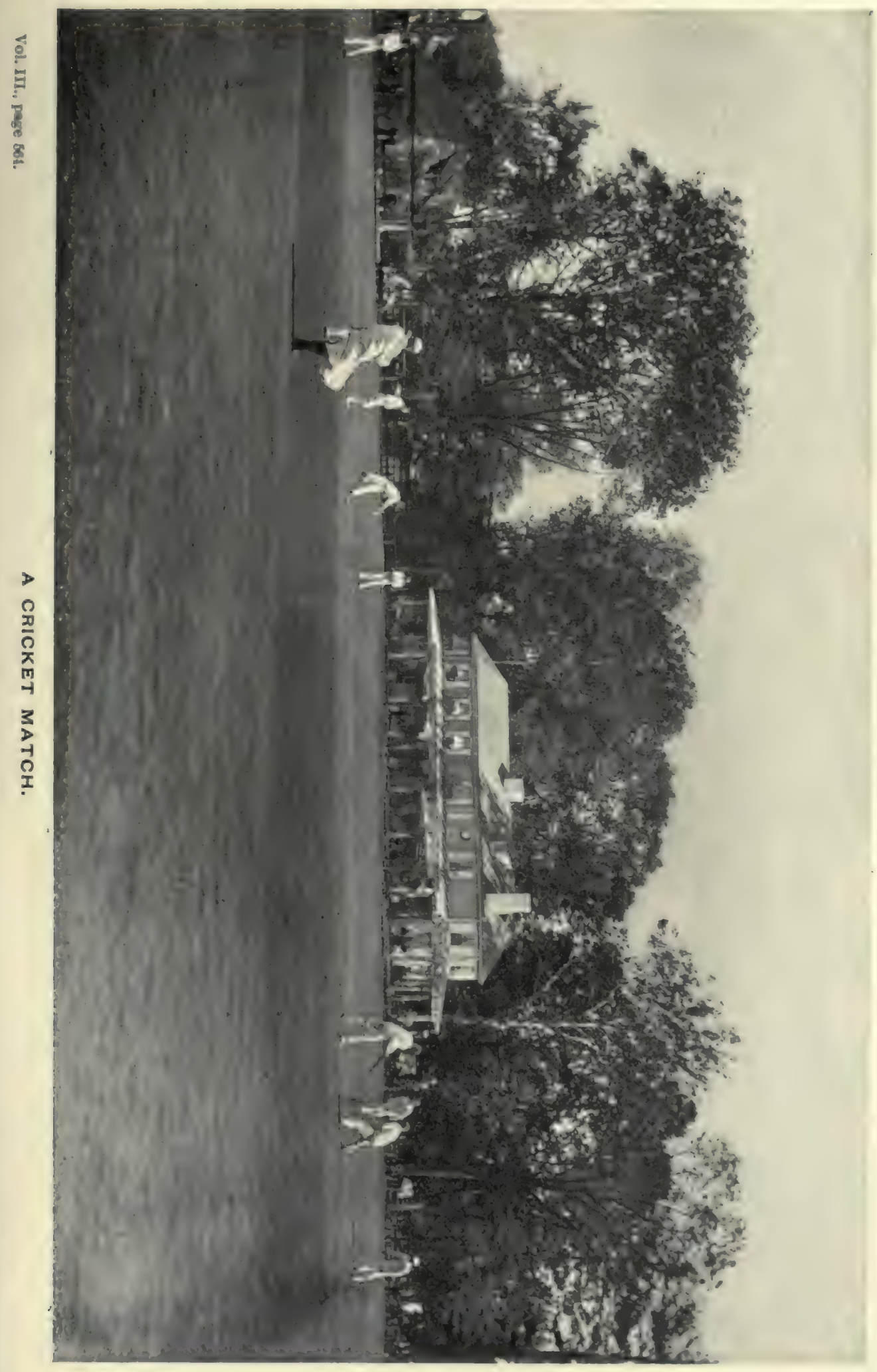



unse of guarding his wicket), or for handling the hall while in play, unless requested to do so by the opposite side. It is the duty of the fieldsmen to save as many runs as possible, and to do this they should not only wateh every ball that is bowled, but they should endeavour, if possible, to anticipate
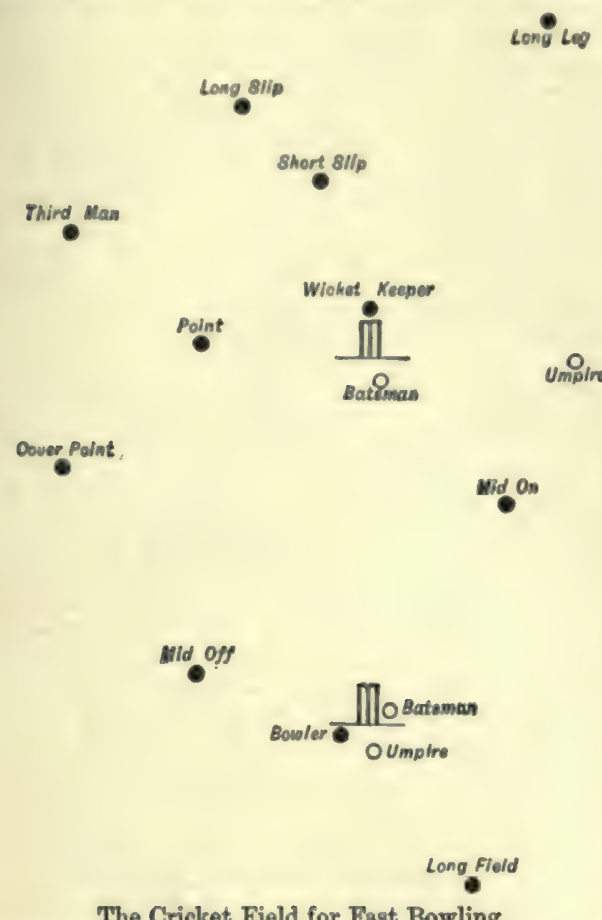

The Cricket Field for Fast Bowling.

where the bataman intends to hit the ball. The positions of the fieldsmen vary with the bowling, but for fast bowling may be given as wicketkeeper, point, cover-point, short-slip, long-slip, third man, long-field, mid-on, mid-off, long-leg, bowler. The bowler as a rule takes slip at the end he bowls from, for the simple reason that little running about is required of him. For point and cover-point great smartness is necessary, and both long-slip and long-leg are places which are not easy to fill satisfactorily; while the long-fields should be good at throwing, and able to judge a eatch well. It is necessary to have two umpires and a scorer.

See C. Box, The Engliah Game of Cricket (1877), and Chronicles of Cricket (1888); Lillywhite's Cricket Seores and Biographies (1862); Daft's Kings of Cricket (1893); bouks on the game by Gale (1888), Bligh (1889), W. G. Grace (1891), and Nyren (1893); the 'Badminton' manunl, by Steel, Lyttleton, and others (1889); and The Jubilee Book of Cricket, by the 'Black Prince of Cricketers,' Prince Ranjitsinhji (1897).

Cricket (Gryllus), a genus of orthopterous insects akin to grasshoppers. Long feelers, a rasping organ on the wing-covers of the males, wings closely folded lengthwise, but often along with the wing-covers degenerate, great powers of leaping, and \& retiring, more or less subterranean habit of life, are some of the more important char. acteristics of the family (Gryllidis) of which the cricket is a type. The females are fertilised by means of peculiar spermatophores, and as in allied Orthoptera there is no marked metamorphosis in the life-history. In the genus Gryllus the head is blunt, the antennse are long and thin, the wings are always present, the hind-legs are very broad and strong, and the females have a straight protruding egg.laying organ. - The Field Cricket ( $G$. campestris) is very common throughout Europe in felds and meadows (local in England), and is very well known from the sound, by means of which the male captivates his mate. The body is compressed, the head is black and shining, the wing-covere are brown and yellow at the roots. As in otfier erickets, the noise of the males is made by rubbing the wing. covers against one another. The under side of one of the nervures bears over a lundred sharp transvence ridges or teeth. These insects hide in burrows in the ground, and sometimes do much damage to vegetables, The female lays numerous egge in the burrow, and the larva remain as such through the winter.-The House Cricket ( $G$. domesticus) has a lanker, yellowish-brown body an inch long. A recent arrival in the United States, it is common throughout Europe in houses, is said to occur in the open air in Madeira, and even in Britain occasionally wanders out of doors in summer. It hides in nooks and crevices, and loves the neighbourhood of the fire, especially in winter. Its merry note has become associated with ideas of domesticity (as in Dickens's Cricket on the Hearth).

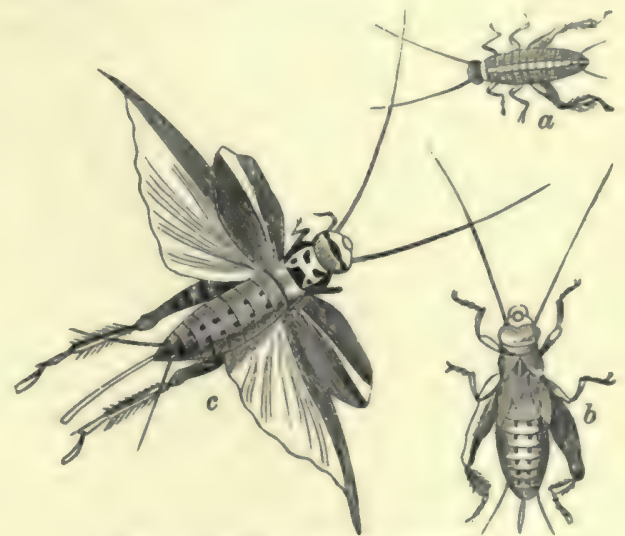

Honse Cricket (Gryllus domesticus) :

$a$, full-grown larva; $b$, pupa ; $c$, perfect insect.

Without the heat of the fire, it becomes more or less dormant in winter. It remains quiet during the day, but hunts about actively at night

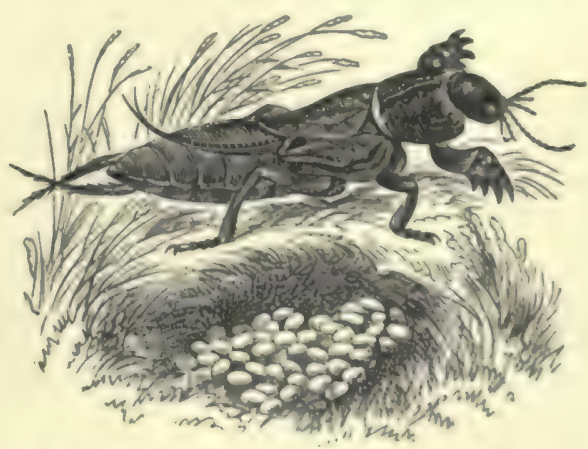

Mole Crioket and eggs (Gryllotalpa velgaris).

for crumbs and other sersps both animal and vegetable. For the sake of both food and warmth it often frequents bakehouses. The larvo are wingless, and the pups have only radimentary wings. The loudest noise made by a cricket is probably that of a Sicilian species $(G$. megalo. 
cephalus), which is said to make itself heard 'at a distance of a mile.' Closely allied to the above genus is Myrmecophila, a wingless cricket with extremely strong hind-legs. Only the females are known, and these live parasitically in ants' nests. The Mole Cricket (Gryllotalpa) belongs to the same family, and is distinguished by the enormous burrowing fore-legs, by the large size of the anterior ring of the thorax, and by the absence of an ovipositor in the females. The only European species (G. vulgaris) is a large and formidable insect, sometimes attaining a length of two inches. It is of a grayish-brown colour, with a silken sheen. It burrows like mole in fields and meadows, but is sometimes seen in flight in the evenings. Numerous eggs, inclosed in a cocoon, are laid underground. The larvæ are long in becoming adult. The mole cricket often does damage by biting at the roots of vegretable crops. Like the field cricket, however, it feeds very largely on ground insects and the like. A South American and West Indian species ( $G$. didactyl $\alpha$ ) damages the sugar-eanes.

Cricklade, a town in Wiltshire, on the Isis or Thames, 7 miles NNW. of Swindon. Enfranchised under Edward $I_{\text {, }}$ it returned two members to parliament till its disfranchisement in 1885 , the 'borough' since 1782 having included forty-four parishes and parts of six others, with a population of 51,956. Pop. of town, 1680.

Criefi, a town of Perthshire, on the Earn's left bank, 26 miles NNE. of Stirling, and $18 \mathrm{~W}$. of Perth by two branch lines opened in 1856-66. It is situated in the midst of exquisite seenery, enjoys a pure dry climate, has a large hydropathic (1867), two old market-crosses, some handsome new churches, and Morison's Academy (1859). Its famous cattle fair was transferred about 1770 to Falkirk; the manufacture of woollens was introduced in 1812. Of many seats in the neighbourhood, Drummond Castle (1491), Lord Willoughby de Eresby's, is famous for the beauty of its gardens. Pop. (185̃1) 3824 ; (1881) 4469 ; (1891) 4901.

Crillon, Louis des Balbes de Berton de, surnamed 'Le Brave,' was born at Murs in Provence in 1541. Under Francis of Lorraine, Duke of Guise, then the model of military chivalry, he was trained for war, and, still a boy, covered himself with glory at the siege of Calais, and at the capture of Guines. His heroism was rewarded with a number of church benefices, which he intrusted to the eare of learned clerks. $\mathrm{He}$ distinguished himself further at Dreux, Jarnac, and Moncontour. Wounded at Lepanto (1571), he was yet sent to carry the news of the victory to the pope and the French king. His noble heart abhorred the treachery and horrors of St Bartholomew, but he took part in the siege of La Rochelle in 1573. Faithful to his king in his struggle with the Catholic League, after his death he gave hearty allegiance to Henry IV. When the peace with Savoy was concluded, Crillon retired to Aviguon, and, after the fashion of a true Catholic warrior, ended his days 'in the exercise of piety and renance,' December 2, 1615. A somewhat melodramatic story is told how once when listening at church to an account of the crucifixion, the old hero, brandishing his sword, cried out: "Where wert thou, Crillon?

Crime, in its legal, as opposed to its moral or ethical sense, is an act done in violation of those duties for the breach of which the law has provided that the offender, in addition to repairing, if it be possible, the injury done to the individual, shall make satisfaction to the community. A private wrong, or civil injury, on the other hand, is an infringement on the rights of an individual merely, for which compensation to him is held to be suffi- cient. Legal criminality is not a permanent characteristic of actions as such, but one decided by considerations of expediency. Without changing its absolute moral character, the same action may, and very often is, criminal in one country or generation, and no crime in another country or generation. It cannot, however, be supposed that the criminality or non-criminality of an action does not exercise an important reflex influence on the moral judgment of the community with respect to the particular action. Malice or evil intention is essential to the character of most crimes, for though there may be an immoral act which it is inexpedient to punish, it can rarely be expedient to punish what is not an immoral act. But it is not necessary that the evil intention shall have had reference to the party injured. If the offender acted in defiance of social duty, a crime has been committed, though not the particular crime intended. For example, it is murder if $\mathbf{A}$ kill $\mathbf{B}$ by mistake for $\mathrm{C}$, unless the killing of $\mathrm{C}$ would have been justifiable, or excusable. But the absurd doctrine of versans in illicito, according to which A shooting at his neighbour's poultry, and killing his neighbour, is guilty of murder, is now generally abandoned. The law can take no cognisance of a bare intention which has not ripened into any sort of act. How far Attempts (q.v.) are punishable is always a question of difficulty. The general rule seems to be that if such acts can be unequivocally connected with the criminal intention, they are punishable, though not to the same extent as the completed crime - e.g. if the act is one of a series which, if not interrupted, would result in the commission of the crime, even though the accused voluntarily desisted from further attempts. Pupils under seven years of age, and insane persons, as being incapable of design or intention, are regarded in the eye of the law as incapable of crime; as regards children between seven and fourteen it must be shown that they had capacity to know their act was wrong. In the case of persons under sixteen, otherwise known as juvenile offenders, magistrates have a large discretion to substitute for ordinary punishment confinement in a reformatory school. The legal definition of insanity is well settled in England and Scotland, but is totally inadequate from the medicopsyehological point of view. The law of responsibility in drunkenness and delirium tremens also requires amendment. Ignorance of law is no defence -e.g. a foreigner, killing his opponent in a duel in England, is guilty of murder. In some cases ignorance of fact is inportant-e.g. where bigamy is charged against a woman who had reason to believe her husband dead. The defence of compulsion, if completely established in fact, is generally sufficient in law. The subjection of a servant to a master, or of a wife or child to a husband or parent, will be no defence, but in the latter case few juries would convict, except in extraordinary circumstances. Magistrates acting bond fide, and soldiers and policemen acting under their officers in the ordinary line of duty, are not liable to a criminal charge. Extreme want is no excuse in law, though it furnishes a ground for an appli cation for mercy, as in cannibalism at sea.

In the technical language of the law of England, the term offence has a wider signification than crime, the latter including only such of the former as are punishable by Indietment (q.v.). Crimes are divided into Misdemeanours (q.v.) and Felonies (q.v.), the latter being a higher species of offence than the former. The Criminal and Judicial Statistics give annual data as to the number of trials and convictions, as to police, prisons, and prisoners, the number of the criminal classes $(29,226$ in England and Wales in 1886), \&c. See Criminal LAW. 
Crime'a (Tartar Krym, anciently the Tauric Chersonese) a peninsula of South Russia, compris. ing live of the eight districts of the government of Tuurida, between the Black Sen and Sea of Azov, joinerl to the continent of liussia ly the Isthums of Perekop, 18 miles long by 51 miles broad at its narrowest part (for a proposed canal across the isthmus, see CANAL). The peninsula is about 200 miles from esst to west, by 125 miles from north to south, with about 625 miles of cosst-line, and an area of about $10,000 \mathrm{~Bq}$. $\mathrm{m}$. In shape it is an irregular quadrilateral, projecting eastwards into the penimsula of Kerteh, which terminates at the Strait of Yenikale. Along the Siwash or Putrid Sea on the north, and the Sea of Azov, the coaste sre tlat and open. To the west of the wide bay of Katfa or Theodosin the south cosst becomes rocky and elevated, and forms a succession of cajes and small gulfs. Balaklavs, and more especially Selastopol, have fine harbours.

In the character of its surface, the north, and much the larger part of the Crimea, is only a continuation of the South Russian steppe. The southern part, from Cape Chersonese to the Strait of Yenikale, only about one-fifth of the whole peninsula, is highland, traversed by a mountain-chain. the continuation of the Caucasus - a region geologically, climatically, and botanically distinct from the rest of Russia. The limestone mountains from Cape Chersonese to Baffa Bay show deep erosion, presenting the ruins of a vast tableland, sloping gently northwards into the steppe, but hanging in abrupt precipicee southwards. Chatir Dagh or Tent Mount (anciently Mons Trapezus or Table Mount), 5450 feet, is a quadrilateral mass of over 8 sq. in., isolated on all sides, and seems to be exceeded in height by Roman Kosh. In the hilly district alout Kerteh are thermal and naphtha springs, and mud voleanoes. There are some fifty small rivers and rivulets, all fordable except after the melting of the snows and heavy rains. There are about four hondred salt lakes, rich in salt. The climate is healthy, and generally mild. But in winter the steppe is exposed to cold vinds, frost, and snowstorms, while the south coast is sheltered and warm. The steppe, though not fertile, yet grazes innumerable herds of cattle, and yiehls porphyries and various coloured marbles. The northern mountain-slopes are laid out in pastures, thickets, orchards, and gardens watered from the rivers. In the uplands are still magnificent forests of oak, beech, elm, ssh, willow, \&c. On the southern slopes grow sea-pine; lower down is an Italian vegetation of laurel, pomegranate, fig, arbutus, and vine. Here are famous health-resorts, with Livadia and other imperial residences. Good wine is largely produced, and some exported. Though the Crimea was once famous for its corn, it has suffered much from drought, and much good land is now uneultivated. The fauna is not rich. Of wild quadrupeds are the hare, fox, and small rodents. All the domestic animals of the Russian steppe have been introduced, as also the two-humper camel. The Crimea has a highly prized oyster. The limestone mountains contain porphyry, diorites, and greenstone. Good coal is mined; an extensive field was opened in 1888.

The population numbers about 250,000 , of whom 80,000 are Tartars, 130,000 Russians, and 40,000 Greeks, Jews, Bulgarians, Germans, \&c. The capital is Simferopol (q.v.), the old Tartar eapital being Bakehiserai (q.v.). The Crimes is connected by railway with Russia, the main line running from Alexiejevea to Sebastopol. In the Black Sen, between Europe and Asia, of fine climate and rich in products, the Crimea has from earliest times been a bone of contention for successive nations, and the double or more manifold names of many places, Greek, Tartar, Turk, Russian, record the dominations they have successively undergone. For the early history of the Crimea, see Bosponus. In the 13th century came the Tartars, the last of the Ghirei dynasty abdicating in favour of Russia, 1787. See J. B. Telfer, The Crimea and Transcaucasia (1876).

Crimean War. For close upon forty years Britain had beeu at peace with all the grent powen of Europe, but in 1853 a war-cloud aroee on the eastern horizon. Russia had long cast a covetou. eye upon Constantinople and the Sultan's prosess. sions, and had contrived in various treaties to lay the foundation of a elaim to something like a pru. tectorate over the Christians of the Greek Church in Turkey, amounting to three-fourths of the Sultan's subjects in Europe. As early as 1844 the Emperor Nicholas had proposed to divide with Britain the inheritance of the 'sick man,' so he called Turkey; and in 1853 he began to urge his claims in a form which Turkey could not accept without ceasing to remain an independent state. The other great powens intervened as mediators, but in vain; and meanwhile a Russian srmy took possession of Moldavia and Wallachia. After nearly a year of fruitless diplomacy, negotiations were broken off, and Britain and France agreed to support Turkey by armed intervention. War was proclaimed against Russia on 28th March 1854.

The war thus undertaken lasted two years. At first, England and France stood alone in their support of Turkey; but early in 1855 Sardinia boldly joined the alliance, and sent a contingent to the seat of war. The other powers remained neutral throughout the contest. The chief scenes of opera. tion were the Black Sea and the Baltic. In the spring of 1854 a powerful British and French fleet appeared in the Gulf of Finland; but the Russian fleet declined the combat, and kept safe behind the granite fortresses of Cronstadt and Sveaborg, which, owing to shallow water and difficult navigation, could not be attacked by the large vessels composing the allied fleets. The only thing of im. portance effected, besides imprisoning the enemy's navy and ruining his commerce, was the destruction of the fortress of Bomarsund, and the capture of the Aland Islands, on which it was situated. The second Baltic campaign, in 1855, was a repetition of the first. Sveaborg was bombarded and partially destroyed, but again the want of gun boats confined the real services of the fleet to a strict blockade of the Russian coaste.

In the Black Sea the Russian fleet followed the same tactics as in the Baltic, and took refuge in the fortified harbour of Sebastopol, sinking vessels across the entrance to keep out the enemy. On land, the Turkish forces, under Omar Pasha, had sustained during the winter of $1853-54$ an heroic contest on the Danube rgainst the Russian invaders. The French and British troops sent to the aid of the Sultan were landed at first in European Turkey, chiefly at Varna (April and May 1854). But the valiant defence of Silistria by the Turks themselves rendered our advance in that direction unnecessary ; after using every effort for six weeks, the Russians had to retire baffled from before the place. The allies having sufiered great loss fmm cholera at Varna, it was resolved to carry the war into the Crimea; and on 14th September an army of 25,000 British under Lord Raglan, as many French under Marshal St Arnaud, and 8000 Turks, landed on the west coast, 30 miles north of Sebas. topol. On the 20th they attreked and completely defeated a Russian army strongly posted on the steep heights above the river Alma; then taking up position near Balaklava, to the south of Sebastopol, they commenced the siege of that vast fortress. The Russians made repeated attempts, 
with overwhelming masses of troops, to force the allied position, which led to the sanguinary battles of Balaklava (25th October) and Inkermann (5th November).

Balaklava was mainly a cavalry action, and did far more credit to our soldiers' gallantry than to their commanders' generalship. It will ever be memorable for the glorious charge of the Light Brigade, who, in obedience to a bungled order, rode a mile and a half beneath a murderous fire against the Russian army in position. Faster and faster grew the pace, until with a cheer that was many a hero's death-cry, they broke right into the battery, sabred the gunners, and burst through a column of infantry. Then they paused, and cut their way back; but out of the six hundred who had ridden forth, not two hundred returned. 'It is magnificent, but it is not war,' was the comment of a French general. Inkermann, known as the Soldiers' Battle, was fought on a dark and drizzly morning of autumn. Taken unawares, and short of cartridges, 8000 British sustained for several hours a hand-to-hand fight against six times that number of Russians, till 6000 French came to their aid, and completed the rout of the enemy.

Thronghout the ensuing winter, the allies, especially the British, suffered terrible hardships, owing partly to the rigour of the climate, but more to the shameful breakdown of the system for provisioning the army. The supplies of food, clothing, and other necessaries were often sent where they were not wanted. The hospitals, too, were frightfully mismanaged; barely 12 per cent. of our total loss in the war $(20,656)$ dying in battle, the rest in hospital. To Florence Nightingale, a lady of gentle birth, was due the establishment of proper nursing in the military hospitals, not merely then, but thereafter.

The prodigious extent and strength of the fortifications of Sebastopol (q.v.), together with the skill and obstinacy of its defence, protracted the siege for nearly a twelvemonth, and rendered it well-nigh the greatest in history. In March 1855 died the Czar Nicholas, whose ambition was the cause of the contest; but under his son and successor, Alexander II., Russia continued to sustain the enormous drain on her population and resources. The trenches, or lines of attack, had drawn closer and closer to the Russian works, till at one point the foes were well within speaking distance; at last, on 8th September 1855, after a three days' tremendous cannonade by the allies, the French stormed and carried the Malakoff fort, the key of Sebastopol. That night the Russians evacuated the city, or rather its blazing ruins. Except for the surrender of Kars in Circassia, after its gallant defence by the Turks under Colonel Williams, a British officer, the war ended with the fall of Sebastopol. In March 1856 a treaty of peace was signed at Paris, by which Russia lost all she had gained or attempted to gain; but the article prohibiting Russia from building arsenals or having war-ships on the Black Sea $(q . v$.$) was abrogated in 1871. See Kinglake's$ Invasion of the Crimea (8 vols. 1863-87), and books on the war by Sir E. Hamley (1891), Sir D. Lysons (1895), Sterling (1895), and Sir W. H. Russell (1855 and 1895).

Criminal Conversation. See Adultery.

Criminal Law is that branch of law which deals with crimes and their punishment, and is in use in one shape or another wherever human society exists. The earliest form of penal law seems to have rested on a principle of private vengeance, and to have taken shape in the lex talionis, the law of retaliation formulated in the familiar passage in Exodus which lays down as a fit punishment an eye for an eye and a tooth for a tooth. The severity of this doctrine was mitigated when the right of persona vengeance was satisfied by a money payment, a custom which can be traced in the early laws of the Hebrews, Greeks, and Romans, and which is par. ticularly characteristic of early Teutonic systems of penal law. According to these a family is made pecuniarily responsible for the offences of its members, or accepts a fine as a compensation for the life of a lost kinsman (see WEREGILD). When a man was killed, a part of this fine was paid to the king or head of the community to compen. sate the clan's loss of a fighting member; and in the distinction established between injuries done to the individual and injuries done to the community, the foundation of a system of criminal law was laid. The sovereign power in a community or state took up the wrongs of private persons, and exereised a right of public vengeance. Legislation upon this principle had for its. object the intimidation of the wrong-doer, and was specially characterised by the great variety and severity of its punishments. It was not until the 18th century that a more enlightened jurisprudence: prevailed. Beccaria's work, On Crimes and Punishments, published in 1764, has exercised a strong influence on the criminal legislation of Europe by urging the claims of criminals to humane consicleration, and examining the basis in morals npon which criminal law rests. The principle which Becearia. opposed to the older theory of public vengeance was that of a legitimate defence restrained within the limit of the common interest. The true object of criminal law was set down as the amendment of the criminal, and the restoration to him of the rights of a free man. From this point of view many jurists have opposed Capital Punishment. (q.v.), and some go so far as to oppose all forms of corporal punishment on the ground that they degrade the eriminal. The modern view gains ground that crime is to be looked upon as a disease of the social body, and that the remedy is to be looked for rather in improved education and social well-being than in a repressive system of arbitrary punishments. The criminal law of a particular state is the body of legal rules affecting the commission and prosecution of crimes. See Crime, and the several articles on MURDer, THEFT, PERJURY, \&e., also JUDGE, WARRANT, \&c.; and for the criminal courts, see CoMMON LAw (CourTs of), Assize, Justice (High Court of), Justiciary Court, JuRY, Justice of the Peace.

The proced ure in criminal cases differs in England and Scotland. In England the prosecution is at the instance of the private person injured, and the trial resembles an ordinary civil litigation to a greater degree than is nsual in other countries. The proceedings begin before justices by an 'information,' upon which the justices issue a summons directed to the party charged, or grant a warrant for apprehending him. When the person charged appears, the witnesses for the prosecution are examined in his presence, and he is at liberty to put questions to them, either personally or by counsel. After the examination the accused may say anything he desires in answer to the charge, but what he says is taken down, and may be given in evidence against him at his trial. After the statement of the accused, he may call witnesses, and the justices are bound to take the statement of these. Thereafter the justices may, according to their opinion of the evidence, either discharge the accused, or commit him to gaol, or admit him to bail. The commitment is for trial, either at quarter sessions or at the assizes. The first step in the trial is the presentment of an indictment to the grand-jury, who are chosen from gentlemen of standing in the district. The grand-jury having been charged by the judge, and having heard the 
witnesses, find a 'true bill ' if they are satisfied that there is a prima fucie case. The case then goes to trial in open court before a judge and jury. The prisoner is entitled to be represented by counsel, although there is no provimion of law in England, as in Scotland, to find counsel for prisoners who cannot afford the eustomary fee. The order of proceeding at trial is as follows: When a jury has been sworn, and the defendant has pleaded not guilty, the counsel for the prosecution opens the case, and then examines the witnesses for the prosecution, who are afterwards cross-examined and re-examined according to the rules of evidence. Counsel for the prisoner then states the defence, and examines witnesses, and may sum up the evidence to the jury if there sre no witnesses for the defence; counsel for the prosecution sums up the evidence against the prisoner. When evidence is given for the prisoner, the counsel for the prosecution has the right to reply; but in practice it is hardly ever exercised. After the reply, the judge sums up the case, and the jury consider their verdict, which must be unanimous. If the verdict be not guilty, the prisoner is discharged; if guilty, he is sentenced. The prisoner has a right to be present throughout the trial, though the court may probably proceed in his absence if he so misconducts himself as to make it impossible to try him with decency. See Sir J. F. Stephen's Digest of the Law of Criminal Procedure (1883), and his History of that law (1883).

The procedure in Scotland has been altered and simplified by the Criminal Procedure (Seotland) Act, 1887. The first step is a petition for warrant to arrest and commit, which may be granted by any magistrate. A person arrested is entitled at once to have intimation sent to any law-agent he may name that his services are required; and to have a private interview with his legal adviser before the examination, and the legal adviser may be present at the examination. The declaration of the accused is then taken by the magistrate, whose duty it is to warn him that the déclaration may be used against him. The next step is the preeognition or inquiry into the facts of the crime, which is conducted as a rule by the procurator-fiscal. The accused is then committed for trial on a warrant specifying the offence charged. $\mathrm{He}$ is then served with an indictment. Where the trial is by jury, all public prosecution is conducted on indictment in name of the Lord Advocate. The old form of indictment was a lengthy and cumbrous document, and the strictness of the rules as to its form laid it often easily open to technical objections. A simpler and shorter form was introduced by the Criminal Procedure Act. On the day fixed, the trial proceeds in the presence of the prosecutor, who may appear by deputy, and that of the prisoner, which is indispensable. The panel is first called ou to state objections to the relevancy of the libel; these being disposed of, to plead. If he pleads not guilty he is remitted to the knowledge of an assize i.e. his case is laid before a jury of fifteen. Evidence is led, first for the prosecution, and then for the defence, and counsel for the parties address the jury, the accused's counsel having the last word. The presiding judge then sums up the evidence, and directs the jury in law. The jury then return their verdict, which need not be unanimous, if a majority agree. If the verdict be not guilty, or not proven, the accused is dismissed from the bar. If it be guilty, the prosecntor moves the court for sentence, which is pronounced; and can only be reviewed by way of pardon. See Macdonald's Criminal Lavo of Scotland (1877) and N. Mac. donald's Manual of the Criminal Procedure (Scot. land) Aet (1887).

The criminal law of the United States has closely followed that of England. But in the United States there are pullic prosecutors - the district-attorneys. In some states there may also be private prosecu. tion.

Criminology is a recently invented term denoting a new science-the branch of anthropol. ogy which deals with crime and criminals, some. times called "criminal anthropology." The science is largely based on the resenrches and views of Dr Cessre Combroso, born of Jewish sturk at Verona in 1836, who, after serving as an army surgeon and holding posts as professor of mental diseases at Pavia and director of a lunatic asylum at Pesaro, was appointed profoseor of forensic medicine and psychiatry at Turin. $\mathrm{He}$ has written numerous works on insanity, eriminal insanity, the anthropometry of eriminals, and the close connection between insanity and genius (The Man of Genius, trans. 1891); but his great work is L'Uomo Delinquente (1875; 4th ed. 1889), in which bis theory of criminology is expounded. 'The criminologist holds that the congenital habitual criminal is marked by conspicuous physical and mental defects. Arrested cranial development and deformity, heavy jaws, ugly features, and many other minor abnormal physical characters, are associated with moral insensibility, low intelligence, vanity, and irregular emotional peculiarities verging on insanity. The occasional criminal who yields to gevere or special temptations is treated as belonging to a wholly distinct category. The acceptance of these anthropological views would naturally lead to somewhat sweeping ehanges in the treatment of criminals, with a view to their reclamation somewhat on the lines of the treatment in use at Elmira.

See, besides the works of Lombroso, the Archives de $l$ Anthropologie Criminelle, and The Criminal by Have. lock Ellis ('Contemp. Science' geries, 1890); also the articles Prisons, ReformatoriEs AND INDUstrial. Schools, Insanity, Capital Punishment.

Crimp, a person who usually keeps a sailors boarding-house, and who professedly occupies himself in finding employment for seamen. Crimps, or 'runners' as they are often called, and the disreputable persons who are associated with them, live by pandering to the follies and vices of the lower and less provident class of seamen. Their object is to get hold of the sailor and his effects, keep him by means of drink or drugs in their power until his wages are paid; and fleece him of his money, and even of his elothes.

Crinan Canal, an artificial waterway, 9 miles long, in the west of Argyllshire, between Loch Gilp, a branch of Loch Fyne, and Loch Crinan, in the Sound of Jura, at the head of the peninsula of Kintyre. Constructed in 1793-1801 at a cost of $£ 183,000$, to avoid the eircuitous passage of 70 miles round the Mull of Kintyre, it is 24 feet broad and 10 deep, has 15 locks, and admits vessels of 200 tons. In 1859 the three reservoirs feeding it burst, and government had to repair the damage at a cost of $£ 12,000$. The receipts seldom cover the year's expenditure.

Crinoidea (Gr., 'lily.like'), a class of Echinodermata, sometimes called feather-stans or sealilies, and well known in fossil form as encrinites or stone-lilies. While agreeing in general strueture with starfishes and other Echinoderms, the Crinoids present many peculiarities. They are fixed permanently or temporarily, mouth upwards, by 2 stalk, which is usually jointed. The visceral mass is inclosed in a cup at the apex of the atalk. As in most other Echinoderms, there are numerous limy plates, forming the stalk, the supporting eup, the framework of the arms, fe. The anus lies near the mouth. The 'arms,' thongh typically five in number, may be very much multiplied (towards 
200 ) by branching; they usually bear lateral pinnules, which produce a feathered appearance. The water-vascular ring does not communicate directly with the ex-

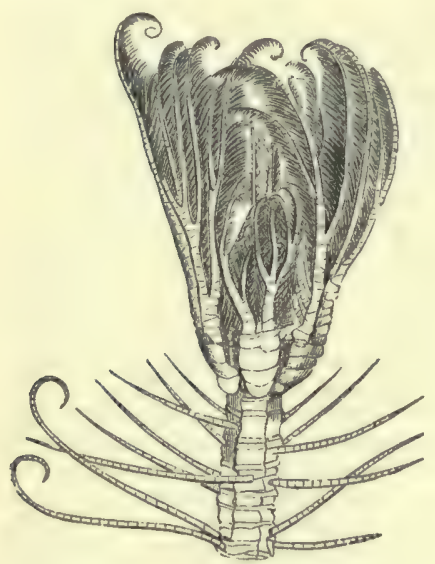
terior, but is in connection with the body-cavity. The radial water-vessels give off lateral groups of 'tube-feet, which have the form of tentacles, and are respiratory in function. There is a double nervous syst e m, the upper system a c companying the watervessel being wholly motor; the lower system, with

Fig. 1.-Pentacrinus. a central mass and radial extensions, being both sensory and motor. The sexes are separate and similar. The ciliated larval form (known in the case of Antedon) is not as divergent as that of the other classes of Echinoderms.

Mode of Life.-The Crinoids are typically stalked and more or less fixed, but the modern family of Comatulidæ break off from their stem at a certain

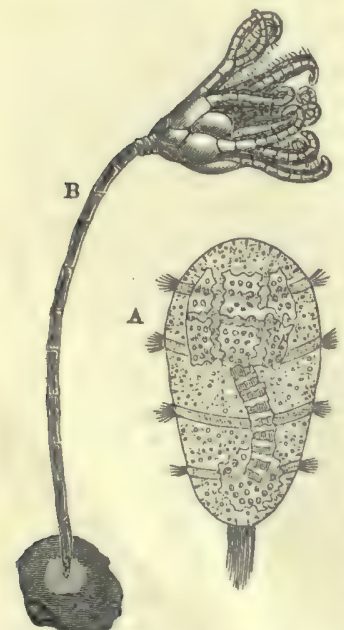

Fig. 2. stage. The stem of the stalked forms is usually anchored to a rock or other foreign object, but in some cases the animal grows more loosely on a muddy bottom. Like the extinct forms, the modern stalked Crinoids grow in masses, forming beds of sealilies on the ocean floor. Over a hundred specimens have been dredged in a single haul. When they move about, as in the Comatulidæe, they do so by alternately bending and straight ening the arms. The food, which consists of minute organisms (protozos, diatoms, small crustacea, \&c.), is A, free-swimming larva, with wafted down ciliated skeleton of adult forming in. grooves on the pinside; B, fixed stalked young nules and arms to the (Pentacrinus-like) stage.

mouth. The known larvæ are actively freeswimming by means of cilia. Comatula and some others are the hosts of curious parasitic Chætopod worms (Myzostomidæ), which cause deformities on the arms. Like many other Echinoderms, the Crinoids have the power of regenerating lost parts. Broken-off arms may be replaced, and even the renewal of the visceral mass has been observed.

Important Forms and Classification.-The bestknown genus is the cosmopolitan Antedon or Comatula, of which $A$. rosacea is the most abundant species, frequently dredged off British coasts. Along with the large genus Actinometra and some others less important, Antedon represents the family of Comatulids, which differ from other Crinoids in being stalked only in their youth. Professor J. Vaughan Thompson has the eredit of having discovered the young stalked stage of $A$. rosacea, and thus revealing the existence of a most interesting habit. The free Antedon swims gracefully by bending its ten arms, and then settles down again for

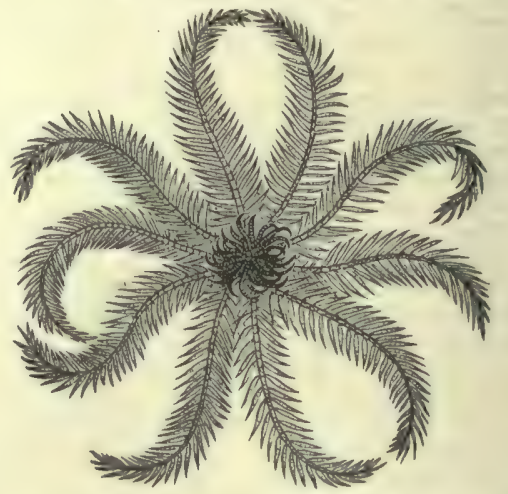

Fig. 3.-Free Adult, showing wreath of anchoring hooks,

a while, anchoring itself by means of an inferior wreath of clawed attaching processes. Among permanently stalked Crinoids may be mentioned the genus Pentacrinus (e.g. P.asterius), from the Atlantic and Pacific, often at great depths; Rhizo. crinus (e.g. $R$. lofotensis), from the Atlantic, usually abyssal ; Holopus, from the Caribbean Sea, with very massive arms, and only a single extant species. These and others, being of more recent origin, are distinguished as Neocrinoidea, from the wholly extinct Palæozoic forms, the Palæocrinoidea or Tesselata. In the latter the eup does not invariably show that fivefold symmetry which is constant in the former.

Distribution.-Though recent deep-sea explorations have greatly increased the catalogue of living forms to a total of over 400 species, distributed in twelve genera, these nevertheless represent but a small fraction of the extinct Crinoid fauna. Over 200 genera and 1500 species are known from fossiliferous strata. These begin to appear in the Cambrian, and attain maximum development in Silurian, Devonian, and Carboniferous times. Recent Crinoids never attain the size exhibited by some of the fossil forms. Extinct species have been found with stems 50 and 70 feet in length.

Many of the stalked Crinoids are found at great depths, and some of the Challenger dredgings revealed the continuance in the deep sea of types which had previously been regarded as extinct. Thus the pear-encrinites (Apiocrinidæ) are continued in the abyssal genera Rhizocrinus, Bathycrinus, and Hyocrinus, Bathycrinus gracilis has been dredged from a depth of 2435 fathoms, an Antedon from 2900 fathoms, Holopus and Hyocrinus from 1200 to 2500 fathoms. The majority, however, and especially the free forms, frequent shallower water. Antedon is a cosmopolitan genus; Holopus is confined to the Caribbean Sea; stalked Crinoids are found between the parallels of $68^{\circ}$ N. and $46^{\circ} \mathrm{S}$. lat. ; Comatulidx between $81^{\circ}$ $\mathrm{N}$. and $52^{\circ} \mathrm{S}$. lat.

Relations.-There seems little doubt that the Crinoids, Ophiuroids, and Asteroids are more closely linked to one another than to Echinoids and Holothurians. In some ways the Crinoid type is struc. 
turally the lowest, and probably appeared first. With the primitive Crinoids two entirely extinct classas must be associated-the Cyatoids and Blas. toids. The former were aesile or shortly stalked, with oval or globular bodies, and very limy. The Blastoids had a short stalk and ovate body, and were also heavily weighted with lime.

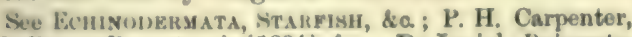
Challenger Reporta, xi. (1884), de.; De Loriol, Palcento. loyie Frumsetise (Paris, x. 188:-84); H. Ludwig, Anat. der Crinoiden (Leip. 1877); I. Perrier, La Comatula rosaces (Archiv. Zool. Expér., ii. 1872) ; C. Wachsmuth and F. Springer, Revirion of Palaoerinoidea (Phila. 187y85); Zittel, Handbuch der Paldontologie (1876-80).

Crinoline, the name originally given by the French modistes to a fabric of horse-hair (Fr. crin, ' hair'), capable of great stiffness, and employed to distend women's attire. It was applied in a general way to those atructures of steel wire or hoops, by means of which women between 1855 and 1866 attained enormous dimensions-12, even is feet in circumference. The fardingale of Queen Elizabeth consisted of a cuirass of whalebone for the upper part of the body, uniting at the waist with an equally stiff fardingale of the same material, which descended to the feet in the shape of a grent drum. The hoop petticoat, differing from the fardingale in being gathered at the waist, was a novelty in 1711 ; by 1744 hoops were so extravagant that a woman occupied the space of six men. An elongated oval form, raised at each side to show the high-heeled shoes, also came into fashion. Dis. carded in private life by about 1796, hoops were still the mode at court until abolished by royal command during the reign of George IV.

Crinum, a genus of bulbous-rooted amaryllids (sometimes included under Sternbergia), chiefly tropieal, and frequently cultivated in hothouses๑.g. C. amabile of India, C. scabrum of Brazil, \&c. C. capense of South Africa is a fine hardy species, with large, fragrant, rosy-white flowers, remarkable for the depth and slenderness of their tube. The bulbs of C. asiaticum are powerfully emetic.

Cripple Creek, a city, capital of Teller county, Colorado, 40 miles by rail N. by. W. of Florence. It is a gold-mining centre, and has a stock exchange. Pop. (1899) 20,000; or, within 36 sq. m., 45,000.

Cris-cross Row. See Hornbook.

Crispi, Francesco, statesman, was born 4th October 1819 at Ribera in Sicily, and was ealled to the bar in Palermo, but joining in the revolutionary movement of 1848, had to flee to France. He organised the successful movement of 1859-60, and re-entered Sicily with Garibaldi. He has been conspicuous in the history of the restored kingdom of Italy as deputy, president of the chamber, minister, and in 1887-90, and again in 1894-96, premier. He represented the Left, was strongly anticlerical, and maintained the alliance with Germany even at the cost of the alienation of France. In 1895 strenuous efforts wers made by his enemies to discredit him by connecting him with a series of bank scandals. See Life by W. J. Stillman (1899).

Crispin, saint and martyr, about the middle of the $3 d$ century, under the reign of Diocletian, fled, along with his brother Crispian, from Rome into Gaul, where he worked as a shoemaker in the town which is now called Suissons, and dis. tinguished himself by his exertions for the spread of Christianity, as well as by his works of charity. In A.D. 287 he and his brother suffered martyrdom by being thrown into a caldron of molten lend. Both are commemorated on the 25th October. Crispin is the universally recognised patron saint of shoemakers.

Cristo'fori, or Cristofali, Bartolommeo, harpsichord-maker, was born at Padna in 1653, and died at Florence in 1731. He is regarded as the inventor of the pianoforte.

Critchett, Gronar, ophthalmic surgeon, born in London in 1817, became F. R.C.S. in 1844, and was assistant-surgeon and (1861-63) surgeon to the London Hospital. He early devoted his attention to ophthalmology, and was attached to the hoopi tal at Moorfields from 1846; in 1854 he published a course of lectures on Diseases of the Eye, and from 1876 he was ophthalmic surgeon and lecturer at the Middlesex Hospital, where his operations acquired a European fame. He died lat November 1882.

Critias, one of the pupils of Socrates, bnt unfortunately one who was rather a hearer than a doer of his word. On his return to Athens from banishment, he put himself at the head of the oligarchical party, and was afterwards the most rapacious and cruel among the thirty tyrants set up by the Spartans (404 B.C.). In the same year he fell at Munychia, resisting Thrasybulus and the exiles. Critias had a high reputation as an orator, and besides wrote poetry.

Critical Temperature is that temperature below which a substance may, and above which it cannot, be liquefied by pressure alone. This tem. perature for carbonic acid gas, for example, is $30 \cdot 9^{\circ} \mathrm{C}$. -i. $\mathrm{e}$. below that temperature, the liquefaction of the substance may be easily effected if sufficient pressure be applied; but above it the substance cannot be liquefied, no matter how great be the pressure to which it is subjected. The discovery of the eritical temperature by Dr Andrews in 1869 first gave the means of distinguishing between a true gas and a true vapour; for the former is a substance above, the latter one below, its critical temperature. When any substance is at this temperature it is in the critical state-i.e. its passage from liquid to gas, or vice versat, is one in which the two parts, liquid and gaseous, so merge into one another as to render them optically indis. tinguishable. The critical temperatures of oxygen, hydrogen, and nitrogen (formerly termed 'perman. ent'gases ) are all extremely low, and hence lique. faction can only be effected (as it has already been by the application of intense eold as well as considerable pressure. On the other hand, such vaporous bodies as sulphurous anhydride, alcohol vapour, ether vapour, dc. can, provicled the pressure be sufticiently great, be liquefied at ondinary air temperatures, since these are much below their critical temperatures. See GAs AND GAsks, VA. POUR, and (under Matter) STATES OF MATTER.

Croaghpatrick, a celebrated Irish mountain where St Patrick is said to have begun his missionary work. It stands about 4 miles SW. of Westport, in the south of County Mayo, and is 2510 feet high.

\section{Croatia and Slavonia (Hung. Horvdt} Szlavonorszig) form, together with their former 'Military Frontier,' a crown-land belonging to the Hungarian section of Austria (q.v.), lying between the Adriatic Sea on the SW., where Croatia has a seaboard of abont 84 miles, and Hungary on the NE. Area, 16,352 sq. m., of which 5246 is Croatian, 3707 Slavonian, and 7399 belongs to the district of the military frontier. Pop. (1881) 1,892,499, Croatia having 816,802, Slavonia 377,613, and the former Frontier 698,084 inhabitants; in 1890 the total population had increased to $2,184,414$. The surface of Croatia falls mainly into the wooded mountain district to the north of the Kulpa, with offshoots from the south. enst Alps, and a calcareous platean, belonging to the Karst region, to the south. To the Alpine system belong the Matzel, Ivincica, and Kalnik groups in the north; to the Karst system belong 
the Liburnian Karst (5007 feet), along the coast from Fiume to Novi, and the Velebit Mountains to the south-east, with the peak of Sveto Brdo (575l feet) near the Dalmatian frontier. The province belongs to the basin of the Danube, its most important rivers being the Drave and Save, with their affluents; the Gatschka, Likka, and others belong to the Karst, and the Zermanja, in the south-west, flows into Dalmatia. In Slavonia extensive marshes are found along the main rivers. Warm mineral springs are numerous, and earthquakes, especially about $\operatorname{Agram~(q.v.),~are~frequent.~}$ The Adriatic coast is poorly supplied with harbours, and exposed to the blasts of the Bora (q.v.). The climate along the coast and in the north is mild, Fiume and Agram having respectively a mean temperature of $60^{\circ}$ and $52^{\circ} \mathrm{F}$.; in the Karst the yearly mean is from $43^{\circ}$ to $46^{\circ} \mathrm{F}$.

The soil is in general very productive. Corn, maize, pulse, millet, flax, hemp, tobacco, and grapes are cultivated; large quantities of wood are exported, the rich forests being for this industry recklessly despoiled; and horses and cattle are successfully raised, while the oak-forests of Slavonia support great droves of swine. Silk-culture is progressing, and bees are largely kept in the heath districts. Only in ores and minerals is the province poor ; iron, silver, copper, lead, zinc, sulphur, and coal are all worked, but in small quantities. Much of the weaving is done at home, and the other manufactures are not important. The trade is chiefly in land products, Slavonia exporting also a brandy made from plums. The bulk of the people are Slavs; both Croats (originally Chorvats, 'mountaineers,' from chora or gora, 'a mountain') and Slovenes are tall and strong, honest, and goodnatured, holding much of their land in common, and dwelling for the most part in scattered hamlets. In the west the religion is Roman Catholic, em. bracing 71 per cent. of the entire population; in the east, that of the Greek Church. Education is very backward; in 1890,40 per cent. of the male inhabitants could neither read nor write. A number of railways, however, now penetrate the country, and the interest in education and in the national language and literature is visibly increasing.

Croatia and Slavonia were for the most part included in the Roman province of Pannonia; in the 7th century the territory was taken possession of by the Slavonic races. The Croats shook off the Byzantine yoke about 900 , and in the following century extended their rule over Dalmatia, built a strong fleet, which they employed first for piracy, and afterwards for trade, and had their king, Dirzislav, recognised by the Eastern court in 994 . His son, Crescimir Peter, one of the greatest national heroes, was acknowledged as king of Dalmatia, as were also his successors until 1091, when the kingdom was taken over by Hungary. Slavonia was made a province of Hungary about the same date, but in the 17th century a great part of the land was held by the Turks, who only in 1699 resigned all territory north of the Unna. Croatia, Slavonia, and Dalmatia were united as the kingdom of Illyria from 1767 to 1777 . Afterwards Croatia and Slavonia were regarded as part of the kingdom of Hungary; but among the Croatians a feeling of hostility to the Magyars grew up, which asserted itself in 1848-49. In reward for Croatia's services during the Magyar revolt, it was declared independent of Hungary, and practically so remained until 1868 , when the connection with Hungary was restored, Croatia sending deputies to the Hungarian diet. There must be a Croatian in the Hungarian ministry; there is a natioual diet at Agram, and the official language is Croatian. In 1883 there was a popular move- ment, with riots, directed against the subordination to Hungary. The Military Frontier, established along the Turkish border in the 16th century, arose out of the necessity of perpetual defence. It was inhabited by military colonists who enjoyed special privileges, maintained regular armed posts, and were able to raise a force of 100,000 men on the briefest notice. This region was in 1881 finally incorporated with Croatia and Slavonia. See BAN ; and for language, SERviA.

Crochet (Fr., 'a hook'), a species of fancy work in worsted, cotton, or silk, which may be described as an extensive system of looping, by means of a small hook made for the purpose.

Crocidolite, a mineral consisting of silicate of iron and sodium, in asbestos-like fibres, and sometimes called 'blue asbestos.' See CAPE Colony, Vol. II. p. 735.

Crockets are ornaments used in Gothic architecture since the 12th century, when they were introduced on capitals of columns in the shape of incurved bunches of leaves springing from stems in place of the classic volutes employed before that date. Similar projecting erockets were soon applied to cornices, gables, spires, \&c. In the Early English style they stand up in a detached manner, with the foliage at the point; but in the Decorated and Perpendicular styles the leaves are more developed and cling to the copes or ramps, to which they are applied as ornaments. Animal forms, specially modified, are sometimes utilised for crockets. See the articles on the various styles.

Crockett, SAMUel Rutherford, novelist, was born of farmer stock near New Galloway in Kirkeudbright in 1859, and educated at CastleDouglas and Edinburgh University, becoming in 1886 Free Church minister at Penicuik, near Edinburgh. He resigned his charge for a purely literary career in 1895 . From his college years, and during a residence abroad as tutor, he contributed to the periodicals, especially verse. A volume of poems, Dulce Cor, appeared in 1886, and in 1893 their author attained, to fame by the sketches collected under the title of The Stickit Minister (illustrated ed. 1894). The Galloway story of moors, mountains, outlaws, kidnapping, and adventure, The Raiders, achieved great success in 1894, and was followed by Mad Sir Ughtred, The Lilac Sunbonnet, The Play Actress, Bog Myrtle and Peat, The Men of the Moss Hags (1895), Sweetheart Travellers, Cleg Kelly, The Grey Man, Lad's Love, Lochinvar (1897), \&c. He is a copious contributor to the magazines.

Crocodile (Crocodilus), a large saurian reptile, the name being originally applied to the erocodile of the Nile only. The term is now used for a whole genus of reptiles, as well as for the small order

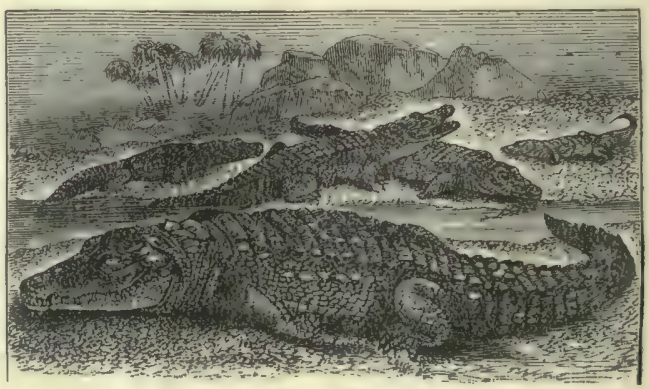

Crocodile.

(Crocodilia) to which it belongs. The order in cludes the largest living reptiles-viz. the crocodile 
proper, the Alligator (q.v.), and the (iavinl (q.v.). The most diatinctive characters are as follows:

Externals. - The body, which is provided with a Iong, laterally compreseed, erested tail, is covered with an armature of seales and dorsal bony 'sentes.' The latter exhibit a sculptured appearance. There are four short, strong limbs, with five fingers and four toes, which are wobbed in various degrees of completeness. The three inner digits bear elaws. Glands with a musk-like secretion are found on the margin of the lower jaw, at the sicle of the clomeal aperture, and on the posterior margin of the dorsal shields. The musky odour is strongest during the season of love. The nostrils lie close together at the point of the snout, and can be closed by valves; the eves possess third eyelids, and the pupil is a vertical slit in nocturnal species; the tympanum of the ear is overhung by $\mathrm{n}$ fold of skin which closes during diving; the cloaca has a longitudinal aperture.

Skeleton.-Between the skull and the hip-girdle there are always twenty-four vertebrz, and behind the sacrum a large and variable number of caudal vieres. The vertebrie are procielous-that is to say, hollow in front-and bear ribs in the neck as wel as in the thoracic region. The ribs are provided with two heads for articulation with the vertebre, and those in the middle of the thorax give off hook-like, backward-turned (uncinate) processes which also oceur in Birds (q.v.). A breast-bone, with which the thoracic vertebre are connected, is always present, and behind this a number of posterior rib-like processes ( 'abdominal ribs ') form a further support. These arise from ossification of septa between the muscles. In the breast-girdle the clavicle is absent; the hip-girdle is normal. In the large skull the chief peculiarity is the formation of a closed bony palate. By the internal union of premaxillæ, maxille, palatines, and pterygoids, the roof of the mouth is complete, and the posterior aperture of the nostrils is thus shunted back to the very beginning of the glottis. The development of the skull has been studied by Parker. The mouthopening is very large, and the jaws hear numerous, usually conical, hollow teeth, implanted in distinct sockets, with reserve germs, at first on the inner side, and afterwards within the pulp cavities of the old ones.

The nervous system calls for no special remark. The peculiarities of nose, eye, and ear have been noted above. The animals have large lachrymal glands, and their 'tears' are proverbial. The tympana communicate with the mouth by three Eusta. chian tubes, one median and two lateral. As regards the alimentary system, the flat tongue is fixed to the floor of the mouth, the mouth-cavity is bounded behind by two soft transverse membranes. These meet when the crocodile is drowning a vietim, and prevent water rushing down the throat. The stomach is in several respects like that of birds. The circulatory system is of importance, since in crocodiles for the first time the heart is four-chambered (see Cinculation). The partition between the ventricles is here complete, but as two sortic arches remain, mixed blood still goes to the posterior body. The left aortic arch carries only venous blood to the viscera, whereas in other reptiles it earries mixed arterial and venous. The pulmonary arch carries purely venous, the right aortic arch purely arterial blood. The right and left wortic arches communicate at their roots just outside the heart by a small aperture-the foramen Panizze. The respiratory system presents no special peculiarity except in the backward shunting of the internal opening of the nostrils. When drowning its prey, and with its half-shut mouth in consequence open to the water, the crocodile keeps the tip of its snout on the surface, the glottis is pushed a little forward to meet the posterior open. ing of the nostrila, a complete air channel is thus mide, and respiration can go on unimpeded. The air is drawn into the lungs when the ribs expand, and an incipient diaphragm is also of une. The lungs are inclosed in pleural saca. There is no urinary bladder.

Mude of Life.-Crocoliles are predominantly aquatic animals, and move rapidly by means of their powerful tail strokes. They are clumsy when ashore, and suffer from being stiff-necked. The body drags somewhat on the ground. They feed on fishes, especially in their youth, and on quadrupeds, which they catch by the river-side, and kill by drowning. If the prey cannot be readily torn, it is often buried till it begins to rot. For their shore work they prefer the darkness, but they also like to bask in the sun. They very often float in the water with their snout and upper back above the surface. The eggs, which are firm, though not thick-shelled, are laid in layers in holes on the benks. They are about the size of goose eggs, and the disproportion between the newly-hatched young and the adults is very striking. The females of some species are said to guard their young. Crocodiles are on the whole sluggish animals, and are very remarkable in the long continuance of the slow growth, which hardly seems to reach a limit as in other animals.

The crocodile has acquired in literature a character for deceitfulness which is largely undeserved. The conceit of 'crocodile's tears' (the animals have large lachrymal glands) was common in Shake. speare's time. Spenser describes (Faerie Queene, I. v. 18) the Doth weepe full gore, and sheddeth tender teares,

Another quotation given by Richardson (see Kitchin's edition of the Faerie Queene, Clarendon Press) is still more libellous, "as cursed crocodile most eruelly can tole with truthlesse teares unto his death the silly pitieing soule.' Kitchin refers also to the invention of the adjective "crocodilian" to express a depth of deceitfulness.

Different Forms. - The order of erocorliles includes twenty-five living species, distributed in three families and a doubtful number of genera. They are all found in tropical and warm regions. The three types may be thus contrasted:

\begin{tabular}{|c|c|c|}
\hline Alligator. & Crooodile. & Cavial. \\
\hline $\begin{array}{l}\text { Nasal bones form } \\
\text { part of nasal aper- } \\
\text { ture. }\end{array}$ & As in alligator. & Do not. \\
\hline $\begin{array}{l}\text { Head hort and } \\
\text { brosd. }\end{array}$ & Longer. & Very long. \\
\hline Teeth very unequal. & Unequal. & Almost equal. \\
\hline $\begin{array}{l}\text { First and fourth } \\
\text { lower teeth bite } \\
\text { into upoer pits. }\end{array}$ & $\begin{array}{l}\text { First into a pit, } \\
\text { fourth into a }\end{array}$ & $\begin{array}{l}\text { First and fourth } \\
\text { bite into }\end{array}$ \\
\hline $\begin{array}{l}\text { Union of lower jaws } \\
\text { does not extend } \\
\text { beyond filth tooth. }\end{array}$ & Not beyond eighth. & $\begin{array}{l}\text { At least to } \\
\text { fourteenth. }\end{array}$ \\
\hline $\begin{array}{l}\text { Neck scutes distinet } \\
\text { from hack. }\end{array}$ & $\begin{array}{l}\text { Sometimes distinet, } \\
\text { sounetimes nnited. }\end{array}$ & Continuous. \\
\hline $\begin{array}{l}\text { Bouth Ameries and } \\
\text { south of North } \\
\text { America. }\end{array}$ & $\begin{array}{l}\text { Africa, Indis, North } \\
\text { Australia, Cuba, } \\
\text { South Amerien. }\end{array}$ & $\begin{array}{l}\text { Ganges, Borneo, } \\
\text { North Austra- } \\
\text { lin. }\end{array}$ \\
\hline
\end{tabular}

There are altogether a dozen different forms of Crocodile proper, some of which have been dignified as separate genera. The erocodile of the Nile $(C$. vulgaris) is a well-known species, not now found farther north than Thebes, but occurring abundantly farther sonth and east. Several varieties are known. It is said sometimes to attain a length of 30 feet, though half that is considered large. It often fatally attacks man, and feeds very largely on smaller mammals. It grows very slowly and continuously, and, with the exception of man, has few formidable antagonista after 
it has survived its youth. Some two or three score of eggs, with delicate rough limy shells, about the size of those of geese, are laid in sandy cavities in the bank. The young crocodiles are often happily destroyed by the ichneumon, and by a species of lizard. The adult crocodile lives in amiable partner. ship with a little bird (Pluvianus agyptius). As Herodotus relates, this watcher warns the crocodile by its cry when danger threatens, and it also cleans its body of small animals which fix themselves there. The crocodile was worshipped and even mummified by the ancient Egyptians, and it occasionally bore a part in the Roman gladiatorial combats. It is now hunted for the perfume of its musk-glands, and also for its skin and fat. Crocodile-hide has lately increased in value as an article of commerce. The eggs are esteemed as dainty morsels. The most widely distributed species is $C$. biporcatus, or por: osus. It occurs from the Mascarene to the Fiji Islands, from Farther India to Corea, and also on the north coast of Australia. It lives not only in fresh water, but ventures sometimes into the sea. A very large specimen in the British Museum measures $17 \frac{1}{1}$ feet in length. C. frontatus, in equatorial West Africa; C. acutus, in the north-west of South America, in Central America, and in the West Indies; C. cataphractus (often placed in a special genus, Mecistops), from the west coast of Africa, are other important species.

History.-These giant reptiles, like other large forms, have in recent ages been continuously on the wane. They date from the Triassic period (Belodon, Parasuchus, and Stagonolepis-the last from the Elgin sandstones). In the Jurassic age they are very numerous, forty species having been recorded from British strata alone. In the Chalk, the first Crocodilia with anteriorly concave vertebra appear in contrast to the Triassic, the Jurassic, and in part the Cretaceous forms, which had biconcave vertebræ. Among these Cretaceous forms are true Crocodiles and Gavials, which are also abundant in Tertiary strata. Professor Huxley has worked out the 'almost unbroken' series of gradations from the ancient Triassic forms down to the modern erocodiles, but where this series takes origin among the ancient reptiles is still obscure.

See alligator, Gavial, RePtilis; ; also Duméril et Bibron, Erpétologie Générale (Paris, 1834-54); J. E. Gray, Synopsis of Recent Crocodilians (Trans. Zool. Soc. Lond. vi. 1867); A. Heilprin, Distribution of Animals (Inter. Sc. Series, 1887 , pp. $327-30$ ); C. K. Hoffman, Bronn's Thierreich, vi.; Huxley, Anatomy of Vertebrates (1879) Journ. Linn. Soc. iv. (1860) \&c.; Nature, xxxiii. (1885$86)$, p. 331 ; A. Strauch, Synopsis der lebenden Krokodiliden (Mém. Acad. St Petersburg, x. 1866).

Crocus, a very beautiful genus of Iridaceæ, all palrearctic, and particularly abundant in the Mediterranean countries and Asia Minor. Crocuses have long been cultivated in flower-gardens, particularly C. vernus, the purple crocus, with its many violet, white, Spring Crocus (Crocus vernus). or striped varieties; and $C$. luteus, and other yellow species; all so welcome in early spring. The saffiron crocus ( $C$. sativus, see SAFFroN) and other species flower in autumn. These must not be confused with the meadow saffron, often called autumn crocus (Colchicum, q.v.), which is a liliaceous plant, from which the true crocuses can at once be distin. guished by their inferior ovary, and three instead of six stamens. Bulbocodium vernum is a pretty spring flower, also much resembling crocus, but closely akin to colchicum. Two species of crocus occur wild in England, $C$. nudiflorus and $C$. vernus, but the latter at least is merely naturalised. The tlowers of one or two species are fragrant. Owing to the shortening and thickening of the stem, the ovary is subterranean, hidden among the leaf-bores, but in ripening it grows out upon a long thin procumbent pedicel, and thus deposits its seed at a sufficient distance from the parent plant. The thickened axis is a Corm $\left(q_{.} v_{0}\right)$. It is necessary frequently to take up crocuses and plant them anew, on account of the manner in which the corms multiply. See CoRM; and Mard, Monograph of the Genus Crocus (1887).

Crocus of Antrmony is the oxysulphide of Antimony (q. $\left.v_{0}\right)$. Crocus of Mars is the finely divided red oxide of iron.

Croesus, the last king of Lydia, succeeded his father, Alyattes, in 560 B.C. He made the Greeks of Asia Minor his tributaries, and extended his kingdom eastward from the Agean to the Halys. From his conquests, his mines, and the golden sand of the Pactolus, he accumulated so much treasure that his wealth has become a proverb. He gave himself up in his court at Sardis to a life of pleasure and sumptuous extravagance, deemed himself the happiest man in the world, and was. displeased when Solon, on a visit to his court, told him that no man should be called happy till his death. He soon found how uncertain was a happiness such as his ; for his beloved son Atys was killed while hunting, and there was left to him only one son, who was dumb; whilst in his war with Cyrus he was totally defeated, his kingdom conquered, and himself made prisoner and condemned to be burned (546). At the funeral pyre, his repeated exclamation of " $O$ Solon!" struck the conqueror, who, when told the reason of it, spared his life and treated him with great kindness. As to his death, nothing is known.

Croft, William, musician, born in Warwickshire in 1677, was a chorister in the Chapel Royal, of which he became joint-organist in 1704, and sole organist in 1707. In 1708 he succeeded his old teacher, Dr Blow (q.v.), as organist of Westminster Abbey and choirmaster of the Chapel Royal ; and in 1713 he took the degree of Mus. Doc. at Oxford. From 1704 Croft wrote a number of anthems for state ceremonies and public thanksgivings, thirty of which appeared in two folio volumes in 1724 ; and it is by these that he is now chiefly remembered. He died in $172 \%$.

Crofter. The term crofter is commonly used in Scotland to designate a small tenant of land who derives a substantial portion of his livelihood from cultivation or the raising of live-stock. By the Crofters' Holdings Act of 1886, it is defined to mean the tenant of a holding who resides on his holding, the annual rent of which does not exceed $£ 30$ in money, and which is situated in a crofting parish.

Crofters may be broadly divided into two classes: (1) Those who occupy arable land in separate tenancy, and mountain pasture in joint tenancy; (2) those who occupy land in separate tenancy only. The first class may be denominated 'township erofters,' the second 'independent crofters.' The township crofters are by far the more numerous class, so much so that the joint tenancy of pasture is a characteristic feature of crofting life. They 
are seattered over the whole surface of the Western Highlands and Islands, and over the whole of Sutherland. They are found in Caithness, Orkney, Shetlend, and in the interior of Roseshire and Inverness-shire, but leas frequently on the eastern seaboard. The township crottens hold directly from the landlord, pay money rents, have had a preponderant share in the construction and maintenance of the buildings on the holding, and have been the authors of the grenter part of the simple improvements on the holding and the township. They have preserved some marks of a primitive community in common rights and common obligations, and in the election of township officens who, by the custom of the estate, exert some anthority in regulating the relations of the occupiers among themselves, and the relations between the occupiers and the landlord. The crofting township of the Highlands is a partial survival of a system of land. tenure once common to the whole of Scotland and prevalent in other countries. It has in all times existed in direct relations with the chief or landlord, yet the greater number of extant township crofters are the descendants of sub-tenants to the tacksman of a former period, and were brought into immediate dependency from the proprietor in the 18th century. The township crofter has always been in the eyes of the law a tenant at will, whether holding under the landlord or the tacksman, except in the case of a specific covenant to the contrary, but it is probable that during the prevalence of the clan system the mutual interests and affections of chief, tacksmen, and people, procured for the crofters the actual status of permanent tenure. While the crofters derive a material share of their livelihood and even of their food from the holding, their existence would be impossible without other sources of support. Among these fishing holds the first place and often affords the chief means of subsistence; but other local employments, domestic crafts, itinerant rural labour in the south, the earnings of a seafaring life, and remittances from relatives at home and abroad, all contribute to the crofters' maintenance.

The grievances from which the great mass of the township crofters have suffered may be enumerated as follows: The restricted area of holdings, and especially the reduction of common pasture land high rents in exceptional cases; disturbance withont due compensation; the molestation of deer and other game; the imposition of excessive local rates: the inereasing burden of cottar dependents; want of harbours and defective means of transport to the centres of consumption. To these may now be added an unexampled depression in the value of agricultural proluce, and a disastrous change in the methods previously used in the management of the fishing trade. The causes which have brought about such unhappy reanlts are not far to seek. They exist in the covetous or mistaken policy of proprietors in the beginning of the present century, manifested by eviction and excessive consolidation of land; in the necessities of their successors; in the potato disease; in the too great subdivision of crofts; in the failure of the kelp manufacture; in the precipitate application of the Education Act in districts to which it was unsuited; in the apathy and improvidence which prevail among the crofters themselves; and, finally, in foreign competition in every department of inlustry. Such are the errors and neglects of the past; such the misfortunes of the present, which conspire to de. press the crofting people. These hostile influences are intensified by the stormy climate, ungrateful soil, dangerous sea, and rugged irregular configura tion of the Western Highlands. It remains to be proved in what degree such obstacles can be sur. mounted by legislative provisions conceived in the interests of a class who with seriou defects of character possess attractive and estimable qualities.

The independent crofters, who may be recognined as a distinet order among the crofting population, are found in all the Highland counties. They appear in considerable numbers in Argyllshire, in Caithness, in Orkney, in Shetland, and in the eastern parts of Inverness-shire and Rose-shire. They are more rare in Sutherland, on the western seatoard, and in the Hebrides. These laborious tenants have been recruited from the working-classes in ad jacent districts, and from the members of broken townships dispersed by the forniation of sheep farma. Established, for the most part, on waste lands under improving leases or stringent estate regulations, favoured in the eastern districts by a drier climate and soil, surrounded by the examples of a superior husbandry, and encouraged by assistance from the landlord, they have attained a higher condition than the crofting communities, both in regard to dwellings and tillage. The allegerl grievances of the independent crofters have reference mainly to high rents, inseeurity of tenure, and confiscation of improvements. Against such abuses they are now protected by the Act of 1886 , from which they will derive substantial benefit.

In recording the diversities of erofting tenure it is necessary to mention the exceptional examples of freehold crofts with common pasture in the united parishes of Harray and Birsay in Orkney. These minute estates exhibit a marked superiority over yearly tenancies elsewhere. Belonging to a vigorous race of cultivators whose families prosecuted their fortunes in the colonies and on the sea, the Orkney freeholds have not suffered from excessive suli. division, and illustrate the advantages attached to stability and possession. It would be rash, however, to affirm that the institution of similar tenures would succeed equally well among the Celtic inhabitants of the western coast.

The comparative condition of the crofting people in the present and the past has been the subject of angry controversy. It seems not improbable that their state is now, in some respects, inferior to what it was in the age immediately following the fall of the clan system in 1746 , while in others it is certain that the contemporary crofter possesses immunities and advantages of which his forefathers never dreamed. In favour of the older time may be alleged a larger share of the land, with a corresponding abundance of the necessaries of life in seasons of plenty, more unrestricted access to the use of fish and game, freedom from local taxation, the existence of a graduated social order more harmonious and more congenial to the greatest number, the enjoyment of recreations native to the race, and that spirit of contentment or resignation which is associated with ignorance and isolation. It may, on the other hand, be contended, on behalf of the present, that the crofter is exonernted from personal services of an oppreasive nature, that he obtains relief in scarcity, remedies in sickness, public support in infirmity and old age, elenentary instruction, access to external labour markets, facilities for emigration, and that he possesses those aspirations and opjortunities which helong to an expanded horizon of intelligence. When to the humane innovations of modern civilisa. tion are added reduced rents and enlarged holdings, the crofting people will have little to envy in the precarious advantages claimed for their ancestors a century ago.

Moved alike by the recent sufferings, former wrongs, and threatening agitation of the crofters, the government of $\mathrm{Mr}$ Gladstone in 1883 nominated a Royal Commission to inquire into their condition. The commission conducted its investigations in the course of that year, and submitted its report in the 
beginning of 1884 . In May 1885 a remedial measure was introduced into the House of Commons which proved abortive, owing to the political incidents of the time; but the question was resumed in a more liberal spirit in 1886, when the Crofters' Holdings Act received the sanction of parliament and the crown. This statute embodies in substance the following provisions: The recognition of the 'crofting parish' as the area within which the, act is applicable ; security of tenure ; fair rents ; faculty to renounce tenancy; compensation for improvements ; right to claim the enlargement of holdings ; concession of testamentary powers in relation to the holding. And under this statute, three Commissioners were nominated to determine the areas within which the act shall be applicable, and to carry its provisions into effect.

In addition to these legislative enactments, the government has, in the appropriate administrative departments, initiated measures for the emigration of families from congested districts, the supply of fishing-boats and gear, the development of telegraphic communication, and the mitigation of the :school-rate by increased grants.

The measures referred to, whether legislative or administrative, have been formed with an equitable consideration of the interests and rights of all parties concerned, and with a genuine desire to do good. The conditions by which they are surrounded are so complex, and the financial advances hitherto contemplated so restricted, that no immediate results of importance can be expected. A still graver impediment unhappily exists in the extreme poverty of the class whom it is desired to benefit.

Closely associated with the crofters by origin, avocations, and distresses, are the cottars. These people are occupiers of dwellings and small patches of ground, holding rarely from the landlord, more frequently from the farmer, the township, or the individual crofter, sometimes mere squatters, paying no rent and owning no allegiance. They exist by fishing, by casual employments on the land, and by public charity. Cottars are intermingled with their better-endowed kindred in all quarters of the crofting country, but they are most numerous and most miserable in the Long Island. Their claims are recognised by the Act of 1886, which grants them compensation for improvements in the case of arbitrary and voluntary removal.

The crofter and cottar population in the six counties to which the Act of 1886 applies were roughly computed by the Royal Commission of 1883 to comprise about 40,000 families, or 200,000 souls.

The Crofters Act of $\mathbf{1 8 8 6}$ is applicable in crofting parishes only within the counties of Argyll, Inverness, Ross and Cromarty, Sutherland, Caithness, and Orkney and Shetland. Crofters' tenancies are diffused in other counties, especially in Aberdeenshire and Perthshire, but as they are subject to more favourable economic conditions, it was not considered necessary to admit them to the benefits of special legislation. Further legislation has been repeatedly proposed, but a government bill of 1894 was withdrawn.

Croisic, LE, a small port on the Atlantic, in the French department of Loire-Inférieure, 20 miles W. of St Nazaire by rail. It has a sardine-fishery, and is a popular watering-place. The name is familiar from Browning's Two Poets of Croisic. Pop. 2291.

Croker, JoHn Wilson, politician and man of letters, was born at Galway, 20th December 1780 the son of the surveyor-general of customs and excise in Ireland. After four years at Trinity College, Dublin, in 1800 he entered Lincoln's Inn, but in 1802 was called to the Irish bar. Two satires on the Irish stage and on Dublin society (1804-5) proved brilliant hits; so did his Sketch of Ireland Past and Present (1807), a pamphlet advocating Catholic emancipation. In 1809 he published a poem on the battle of Talavera, which Wellington pronounced 'entertaining,' and during the same year helped to found the Quarterly, to which up to 1854 he contributed 260 articles. He had entered parliament for Downpatrick in 1807 ; and now in 1809 he was rewarded with the lucrative post of Secretary of the Admiralty for his warm defence of the Duke of York, who was charged with conniving at and sharing in the sale of army commissions by his mistress. That post he held till 1830 , and then retired with a pension of $£ 1500$ a year. On the passing of the Reform Bill (1832), he refused to re-enter parliament, unable 'spontaneously to take an active share in a system which must subvert the church, the peerage, and the throne-in one word, the constitution of England.' He would not even take office under Peel, his old friend (1834); and with Peel he broke utterly on the repeal of the Corn Laws (1846). He died 10th August 1857. Among the seventeen works that he wrote or edited were his Stories for Children from English History (1817), which suggested to Scott the Tales of a Grandfather; the Suffolk Papers (1823); his Boswell's Johnson (1831); and Essays on the Early Period of the French Revolution (1857). By some Croker is chiefly remembered for his onslaught on Keats, and Macaulay's onslaught on him (Macaulay 'detested him more than cold boiled veal'); or as the originator of the term Conservative (q.v.); a founder of the Athenseum Club, and the "Rigby" of Disraeli's Coningsby - the jackal of 'Lord Monmouth' (the Marquis of Hertford). But in Sir Theodore Martin's nine-page eulogy in the Dictionary of National Biography (vol. xiii. 1888), he figures as a 'debater of the first rank,' a master of 'rhetoric that eclipsed Macaulay's,' the 'friend and confidant of many of the best and ablest men of his time,' a pattern of 'sincerity,' 'consistency, 'devoted loyalty and unselfishness.' See also his Memoirs, Diaries, and Correspondence, edited by Louis J. Jennings ( 3 vols. 1884).

Croker, Thomas Crofton, Irish folklorist, was born at Cork, 15th January 1798, and in 1814 was apprenticed to a Quaker merchant, but four years later got a clerkship in the Admiralty through John Wilson Croker, a friend, though no relation. of his father's. He retained this post till 1850, and died at Old Brompton, 8th August 1854. As a boy of fourteen he had begun to collect songs and legends of the Irish peasantry; in 1818 he sent Moore nearly forty old Irish melodies; and in 1825 published anonymously his Fairy Legends and Traditions of the South of Ireland, a work which charmed Scott, and was translated into German by the brothers Grimm (1826). A second series fol. lowed in 1827, and the whole reached a 6 th edition in 1882. Of nearly twenty more works of which Croker was either the author or editor, the best were Researches in the South of Ireland (1824) Legends of the Lakes (1829), illustrated by his friend Maclise, and re-issued as Killarney Legende (1876); The Adventures of Barney Mahoney (1832); A Memoir of Joseph Holt, General of the Irish Rebels (1837); and Popular Songs of Ireland (1839; new ed. by Professor H. Morley, 1885). Croker was a zealous antiquary, a member of many learned societies. See the Life by his son, prefixed to the 1859 edition of the Fairy Legends.

Croll. JAMEs, physicist, was born in 1821 near Coupar-Angus, in Perthshire. He received an elementary school-education, but in science was wholly self-trained. Successively millwright, insuranceagent, and keeper of the museum of Anderson's College, Glasgow, in 1867 he joined the staff of the 
(iendogionl Survey of Seotlanul, lunt retired in 1881. An I.R.S. and L.L.D. sinee 1876, he died $15 \mathrm{th}$ Decenber 18100 (nee his Life by J. C. Irons, 1896). Besides many papers in the scientific journals, he wrote The Plilosophy of Theism (1857), Climate and Time (1875), Discussions on Climate and Cosmology (1886), and Stellar Evolution (1889). Climate and Time, one of the nost in. portant contributions to geologienl climatulngy, worked ont in detril the view with which Cmil's name is identified, that, contrary to the opinion of most ploysicists, changes of the earth's climate, such as the glacinl perionla, are due to the necular variations in the eccentricity of the earth's orbit, together with conreqnences arising ont of them, such is the deflection of ocean eurrents. See Climate, Glactal Period, Precession.

Croly, George, poet, romance-writer, biographer, and prencher, was born at Jublin in 1780, and educated at Trinity College there. He took orders in 1804, and in 1810 came to London, where, after twenty-four years of literary labour, he in 183.5 lecame rector of St Stephen's, Wallorook. He died 24th November 1860 . Between 1817 and 1858 Dr Croly published some forty works-the best known being the romance of Salathiel. See the Memoir prefixed to his Book of Job (1863).

Crom'arty, the county town of Cromartyshire, on the southern shore of the Cromarty Firth, 2 miles from its entrance, and 19 NNE. of Inverness. Nothing remains of the old stronghold of the Urquharts, the most famous of whom was Rabelais' translator, Sir Thomas. From him the estate came to the second son of that Sir George Mackenzie who in 1685 was ereated Viscount Tarbat, and in 1703 Earl of Cromarty - a title forfeited by the third earl for his share in the ' 45 , but revived in 1861 in favour of his descendant, the Duchess of Sutherland, who, dying in 1888, was succeeded therein by her second surviving son, Francis. In 1859 a statue was erected of Hugh Miller (q. . .) The population has dwindled from 2215 in 1831 to 1308 in 1891 , though with Wick and four other burghs Cromarty still returns a member to parliament.-CromarTy FIRTH, a land-locked inlet on the north-enst coast of Scotland, extends 19\% miles north-eastward and eastward to the Moray Firth, and is inclosed by the counties of Ross and Cromarty. It forms a moble harlour, 1 mile to 79 miles broad, and 5 to 35 fathoms deep; receives at its head the Conon; and narrows at its entrance to 7 furlongs, between the beetling North and South Sutors, 400 and 463 feet high. On its shores are the towns of Dingwall, Invergordon, and Cromarty (the last has declined with the rise of the second ); the old red sandstone near its mouth is classic as 'Hugh Miller's huntingground. - CROM'ARTYSHIRE, once a Scottish county, 369 sq. $\mathrm{m}$. in area, consisting of ten detacher por tions seattered up and down Foss-shire ( $\mathrm{q} . \mathrm{v}$.$) ,$ with which it was incorporated by the Cocal Government Act of 1889. It compriseil the ancient sheriffilom of Cromarty, and outlyiug bits annexed thereto towards the close of the 17th century at the instigation of Viscount Tarbat, who wished thus to hold jurisdiction over every part of his estates Pop., with Ross-sliire (1891), 77,810. See Sir W. Fraser's Earls of Cromarty (2 vols. 1876).

Cromdale, a place in Elginshire, on the right bank of the Spey, on miles NE. of Grantown. Here, on 1st May 1690, 800 Jacobite Highlanders were surprised and routed by a body of King William's dragoons. This encounter is celebrated in a song called The Haughs of Cromdale.

Crome, Jонर (known as 'Old Crome'), land. scrpe painter, the chief member of the "Norwich School' of artists, was born in that city, the son of a poor weaver, $22 d$ December 1768. After serving th an erraml-lwy to a phymician, he was apprenticed to a house-painter: but, showing a strong predilection for art, he was befriended by Mr T. Harvey, of Catton, who proeured him enployment as a drawing-master, and permitted him to study works by Gainsborough and the Dutch masters in his collection. He also received some instruction from Beechey and Opie. He was mainly influential in founding, in 1803, the Norwich Society of Artists, which helil exhibitions from 1805, and of which he was president in 1808. He occasionally visited London, where he exhibited in the Academy and the British Institution; and a tour through Belgium and France in 1814 resulted in 'The Fishmarket on the Beach, Boulogne, and 'The Boulevard des Italiens, Paris.' But his subjects were nearly always derived from the scenery of his native county, which, thongh found ing in practice upon that of the Dutch landscapists, he treated in a singularly direct and individual fashion, painting trees, and especially the oak, with exceptional fidelity and beauty. His works realised only most moderate prices during the artist's life; but he is now recognised as one of the great names among English landscapists, and fine examples of his art fetch very large sums. Several of his oil-paintings, includ. ing the great 'Mousehold Heath,' are in the National Gallery ; and among his other masterpieces may be mentioned 'Carrow Abbey,' 'View of Chapel Fields, Norwich,' 'Oak at Poringland,' 'The Willow,' and in the Fitzwilliam Museum, Cambridge, the 'Clump of Trees, Hautbois Common.' He also practised as a water-eolour painter, but his works in this medium are rare; and a series of his etchings of 'Norfolk Picturesque Scenery' was published in 1834, and has been repeatedly re-issued. The earlier impressions are fine and valuable. He died, 22d April 1821, at Norwich, where, in the following year, a collected exhibition of his works was brought together, and he was fully represented in the Royal Academy Old Masters Exhibition, 1878. His eldest son, John Bernay Crome (1794-1842), painted landscapes in a style similar to those of his father, as whose productions they are frequently sold.

Cromer, a pleasant watering-place on the coast of Norfolk, 23 miles $\mathbf{N}$. of Norwich by a railway opened in 1877 . The sea has here made great eneroachments on the eliffs since 1350, though the town itself is now protected by a seawall, formed in 1877, with an esplanade and $\mathrm{B}$ jetty, at a cost of nearly $\$ 10,000$. There are capital sands and golf-links (1887), and the church has a noble flint-work tower of 160 feet. Pop. of parish (1891) 2197. It gives a peer's title to Sir Evelyn Baring (q.v.). See Rye's Cromer (1889).

Cromlech (from the Gaelic crom, 'enrved,' and leac, "a stone") is a modern term, formerly applied by British archreologists to a clnss of megalithic monuments, consisting of one flat stone supported on two or more upright stones, and forning a kind of open chamber with a roof. It is now generally recognised, however, that these are merely the denuded or uncovered chambers of chambered cairns (see CAIRN) or harrows (aee BARROW), for which another moiern term, Doluen (q.v.), is now generally substituted. The French archreologists retain the use of the word eromlech, but they have always applied it to those groujs of standing stones which in Britain and Seandi. navia are called Stone Circles (q.v.).

Crompton, SaMukL, whose invention of the spinning-mule entitles him to rank as one of mankind's greatest benefactors, was born, the son of a small farmer, at Firwood, near Bolton, Ianca- 
shire, December 3, 1753. Like his father, Crompton was brought up to the loom and the farm. His mother, a woman of great energy, perseverance, and stern independence, when left $\mathrm{a}$ widow struggled hard to give him and her two daughters the best education the district afforded. When he was old enough, he assisted her in the farm, and wove, and earned a little money by playing the violin at Bolton theatre. At the arge of twenty-one, he was so much annoyed at the breaking ends of yarn and the difficulties in getting it to weave that he set to work to invent a spinning-machine which should produce better yarn than Hargreaves', one of which his mother possessed. For five years he laboured to realise his idea, sitting up late at night to overcome the successive difficulties, and resuming his labour for daily bread early in the morning. In 1779 he succeeded in framing a machine which produced yarn of such astonishing fineness that the house was beset by persons eager to know the secret. He was rendered miserable. All kinds of devices were tried to gain admission; even ladders were placed against the windows. His machine was such that if a mechanic saw it, he could carry away the leading features of it. He could not leave the house for fear of his discovery being stolen from him. He had spent every farthing he had in the world upon its completion; he had no funds wherewith to obtain a patent, and his shy and unbusiness-like temperament prevented him profiting as he should have done by his invention. A Bolton manufacturer persuaded him to disclose the invention to the trade, under the promise of a liberal subscription, but all that he got was 467,6 s. $6 d$. Soured by this treatment, in the course of time he saved money enough to begin manufacturing on a small scale at Oldhams, near Bolton, and latterly at Bolton, but not till his rivals had a hopeless start of him in the business. After the use of the mule had told distinctly on British manufacturing prosperity, a sum of between $£ 400$ and $£ 500$ was raised for him by subscription, through Mr John Kennedy, his earliest biographer. Efforts were made to procure for him a national reward. Five thousand pounds was all he obtained in 1812, and he returned to Bolton almost broken-hearted. He began the bleaching trade at Over Darwen, then became a partner in a cotton firm, but was unsuccessful in both. Some friends latterly purchased an annuity of $£ 63$ for him. He died June 26, 1827. Crompton's was soon by far the most used of all spinning-machines, and in 1811 the number of spindles on his principle was $4,600,000$, while there were only 310,516 of Arkwright's, and 155,880 of Hargreaves'. A monument was placed over his grave, and in 1862 a bronze statue of him erected at Bolton. See Kennedy's Memoir in vol. v, of Memoirs of Literary and Philosophical Society of Manchester, and French's Life of Crompton (1860).

Cromwell, Oliver, Protector of the Common. wealth of England, Scotland, and Ireland, was born at Huntingdon, April 25, 1599. He was the son of Robert Cromwell, younger son of Sir Henry Cromwell, descendant of a nephew of Cromwell, Earl of Essex, and was a younger brother of Sir Henry Cromwell of Hinchinbrook. His mother was Elizabeth, daughter of Thomas Steward of Ely, afterwards knighted by James I., who, when she married Robert Cromwell, was the widow of William Lynne. He was first-cousin to John Hampden. He was educated at Huntingdon grammar-school, the master of which was the Puritan Dr Beard, and at Sidney-Sussex College, Cambridge, and seems to have carried away a modest share of classical and general culture. He went to London to study law, but never entered an Inn of Court. In June 1617 his father died, leaving him a moderate estate at Huntingdon. In August 1620 he married Elizabeth, daughter of Sir James Bourchier, a London merchant. Of the wildness of his youth there is no proof beyond his own remorseful confession after his conversion that before he knew God he had been the chief of sinners. He was, however, under medical treatment for hypochondria. He embraced Puritanism in its most enthusiastic form, attended and supported the ministry of its proseribed preachers, and beeame a zealous adherent of the cause, and opponent of its archenemy and persecutor Laud.

In 1628 he sat as member for Huntingdon in the stormy third parliament of Charles, and raised his voice against Romanising ecclesiastics. The parliament dissolved, he returned to farming at Huntingdon, whence he removed to St Ives and afterwards to Ely, where property had been left him by his uncle. He appears to have come into collision as a local patriot with the king's com. missioners for the drainage of the Fens. He sat for Cambridge in the Short Parliament and in the Long Parliament (1640). In the Long Parliament, though no speaker, he was active and veliement on the Puritan side. Sir Philip Warwick describes him at this period in 'a plain cloth suit, which seemed to have been made by an ill country tailor his linen was plain, and not very clean; and I remember a speck or two of blood upon his little band, which was not much larger than his collar. His hat was without a hat-band; his stature was of a good size; his sword stuck close to his side; his countenance swollen and reddish; his voice sharp and untunable; and his eloquence full of fervour.' Sir Philip adds: 'It lessened much my reverence unto that great council, for this gentle. man was very much hearkened unto.'

When war broke out (1642) he was sent down to organise his district for the parliament, which he did with the greatest vigour and success, He also sub. scribed $£ 500$ to the cause. Becoming captain of a troop of parliamentary horse, he fought at Edge. hill. After Edgehill, he warned his friends that the parliament must have soldiers of a better stamp, and that to the spirit of a chivalrous gentry must be opposed that of a God-fearing yeomanry. On this principle he formed his unconquerable Ironsides. With strict morality and organised enthusiasm he combined in the famous corps a rigid discipline, which enabled him always to keep his troopers well in hand, and thus to turn the wavering tide of more than one battle. While the cause of the parliament was depressed elsewhere, his constancy, capacity, and courage upheld it in the eastern counties, which had formed themselves into an association, of which he was the soul. A brilliant action near Gainsborough marked him for high command. In the summer of 1644 he. under Manchester, led the forces of the associated counties to join the Scots and the troops of the Fairfaxes before York, and in the battle of Marston Moor the charges of his cavalry decided the day. He now stood forth as the leader of the Independent and thoroughgoing party against the Presbyterians and moderates. After the second battle of Newbury he impeached the conduct of Manchester in parliament. While the Presbyterian and aristocratic generals were set aside by the Self-denying Ordinance, Cromwell was retained in command. Under Fairfax he led the new model army, of which he no doubt was the chief organiser, to decisive victory at Naseby, June 14, 1645. Fairfax being no politician, Cromwell became the representative of the army in its contest with the Presbyterian parliament, which desired to disband it. The Presbyterians proving intractable, 
he resorted as nsual to strong measures, marched on London, and coerced the parliament. He was never revolutionary, but he eared not for forms when they stond in the way of what he thought right. It was no doubt under his directions that Joyce carried off the king from Holmby. It seems that Cromwell desired, had it been possible, to make terms with the king; but Charles was in. eurably possessed with the idea of recovering his power by playing off one party against the other. Whether it was by Cromwell or by the Scotch onvoys that Charles was induced to fly from Hampton Court is a question on which authorities differ.

As a prisoner in the Isle of Wight, the king, while he was negotiating with the parliament, was carrying on intrigues with his partisans in England and Scotland, which brought on the second Civil War and the invasion of England by Hamilton. Again Cromwell was called to take the field for his cause, which was once more in extreme peril. After swiftly quelling the insurrection in Wales, he marched northwards, attacked the invading army of Hamilton at Preston and totally destroyed it. The soldiery now clamoured for justice on the king; and Cromwell, probably sharing their wrath and despairing of any arrangement with the faithless Charles, complied with their demand, brought the king to trial, sat in the High Court of Justice, and signed the death-warrant (January 1649), Had ambition been his motive for this deed we should hardly have found him at the same time treating for the marriage of Richard, his heir, with the daughter of Mr Mayor, a private gentleman. The Commonwealth having been established, the first service rendered by Cromwell to it was the suppression of the formidable meeting of the Levellers, which he accomplished by a characteristic union of vigour with mercy. He was next sent to Ireland to end the civil war still raging there. This he did effectually, and on the whole humanely, though it cost some strokes of sanguinary severity, the necessity for which he himself deplored.

On his return from Ireland he (Fairfax having declined) took the command against the Scots, who had declared against the regicide republic and called in Charles II. With his usual daring he assumed the offensive and invaded Scotland. But he was out-generalled by Leslie, and was in extreme peril, when a false move of the Scots, by affording him battle, enabled him once more to display the superiority of the soldiery which he had trained and to win the decisive victory of Dunbar. The image of militant Puritanism was never more vividly presented than by Cromwell's bearing on that scene. With the defeated Covenanters he dealt as with estranged friends. The rovalists proper, who still held the field in Scotland, having eluded his strategy and marched into England, he followed, and on September 3, 1651, at Worcester, gained the victory which he ealled his erowning mercy and which ended the Civil War. Returning to London in triumph, he declared for a constitutional settlement and an amnesty. The parlia. ment, now reduced by revolutionary expulsions to the 'Rump,' was hent on perpetuating its own power. After fruitless negotiations Cromwell turned it out with unwise violence and contumely. Supreme power being now in his hands and those of the other chiefs of the army, he called the con. vention of Puritan notables, nicknamed the Bare. bones Parliament, for the settlement of the nation. The Barebones Parliament proving too visionary and revolutionary, was dismissed, and supreme power reverted to Cromwell and his officens.

Cromwell was now declared Protector under the instrument of government, which provided for a government by $\&$ single person with one House of parliament elected on a reformed basis of representation, and a Council of State, in the appointment of which nomination by the Protector was combined with election by the parliament (Decem. ber 16, 1653). A power of legimlating by ordinance till parliament should meet was reserved to the Protector, and was largely used by Cromwell for the purposes of reorganisation and reform. His aim evidently was to restore in substance the ancient constitution of the realm, with a Protestant protectorate or monarchy, and full securities for liberty, especially for the religious liberty which had been in his mind at least the main object of the Civil War. But when parliament met, though elected under his writs, it fell to questioning his authority, and he was compelled to exclude the disaffected by a test. His second parliament, from which the recalcitrants were exclucled at the outset, offered him the title of king. Cromwell wavered; but the stubborn resistance of the republican soldiers decided him to decline the offer. The Uper House of parliament was, however, restored, and the Protector was empowered to name his successor. A fixed revenue was also voted to him. He was now installed as Protector with a ceremonial resembling a coronation. When the parliament met again, its two House fell into a collision which compelled Cromwell to dissolve it; and his power thenceforth rested upon the army, thongh it was his constant desire to revert to constitutional government, and he was preparing to call a new parliament when he died.

His protectorate was a perpetual conflict with republican resistance on the one hand and with royalist plots and risings on the other, while his life was constantly threatened by royalist assassins. To keep down the rovalists he for a time put the country under major-generals, supplying his treasury at the same time by an impost on the property of the cavaliers. He was, nevertheless, able to inaugurate a great policy, home and foreign. He reorganised the national church on the principle of comprehension, including all but Papists, Prelatists, and Antitrinitarians, while the ministry was weeded by commission, the result being, as Baxter, an opponent of the government, testifies, a ministry very acceptable to the people. Personally tolerant, Cromwell upheld toleration as far as he could, especially in the case of the Sectaries, and curbed the persecuting tendencies of parliament. For law reform he did his best, but professional interests were too strong for him. He united Scotland and Ireland to England, giving them both representation in parliament. Scotland, hav. ing free trade with England, enjoyed great prosperity under his rule. Ireland he souglit to make a second England in order and industry, and if his measures were high-handed it must be remembered that the native Irish were then in an almost savage state. It was his aim to enlist ability, without distinction of party, and youths of promise from the universities into the service of the state. He saved the universities from the fanatics, pat good men at their head, and encouraged letters.

But it is his foreign policy that has brought him most renown. Under him the Comnonwealth be came the head and protectress of Protestant Europe. He made peace with Holland and tried to form a league of all the Protestant states. He protected the Waldenses of Pieslmont arainst their persecutors, using the pen of Milton in his protest. In the interest at once of religious liberty and commerce he allied himself with France, as the more liberal power, against Spain, the power of persecuting Roman Catholicism and the tyrant of the Western waters. He failed in an attempt on Hispaniola, but took Jamaica, and thus gave British enterprise a foothold in those seas. The 
victories gained by his fleet under Blake over the Spaniards brought him at once glory and treasure. His troops, with those of France, won the battle of the Dunes, and he obtained Dunkirk as his share of the spoil. He sedulously fostered British commerce, and by the hand of Blake chastised the pirate-states of Barbary. His boast that he would make the name of Englishman as respected as that of Roman had been, was, so long as he reignied, fulfilled; and his bitterest enemies could not deny the impression which he had made on the world, or the height to which he had raised his country, His court was simple and frugal, yet dignified; and though there was a strain of coarseness in his character (as illustrated in occasional horseplay), his bearing in public upheld the majesty of the state.

Cromwell had always been a most loving husband and father, and the palace of the Protector was a virtuous English home. His speeches are very rough and unmethodical as compositions, but they are marked by sense, force, and intensity of purpose. He was fond of music, and not without regard for art. It seems that his government was striking root, since people of rank were beginning to ally themselves with it, and his heir succeeded without the slightest opposition. But disease and care, together with grief at the death of his favourite daughter, Lady Claypole, cut short his life. He died September 3, 1658, and the fabric of government which his mighty arm had sustained fell speedily to the ground.

The records of Cromwell's life are very imperfect. Of his greatness as a soldier and statesman there can be no question, but it is difficult across two centuries and a half to see into his heart and pronounce how far amlition mingled with higher motives. That the religious enthusiasm which sent him out to expose his life in war at the age of forty-three was sincere cannot be doubted; but religious enthusiasm is often associated with fanaticism and self-deception. One who knew Cromwell well has described him as 'in body compact and strong, about five feet ten in height, with a head which you might see was a vast treasury of natural parts, with a temper exceeding fiery but under strong moral restraint, and compassionate even to an effeminate measure.' 'A larger soul, I think, hath seldom dweit in a house of clay than his was.' He was laid with great pomp in the tomb of the kings at Westminster, but after the Restoration his body was exposed on the gibbet at Tyburn and afterwards buried under it.

See Noble, Memoirs of the Protectoral House of Cromwell (1787); Cromwell, Life of $O$. Cromwell and his Sons (1820); Carlyle, Cromwell's Letters and Speeches (1846); Sanford, Studies of the Great Rebellion (1853); Goldwin Smith, Three English Statesmen (1867); Jas. Waylen, The House of Cromwell (1892); books on the Protector by F. Harrison (1888), R. F. D. Palgrave (1890), S. H. Church (1894), Horton (1897), S. R. Gardiner ( 1897 and 1899 ), Baldock (1899), and Paterson (1899); and works cited at CHARLES I. and II.

Cromwell, Richard, third son of Oliver, was born October 4, 1626. By the deaths of his two elder brothers, Robert and Oliver, he became his father's heir. He was an amiable and popular but weak man, devoted to field-sports and fond of pleasure. He lived for some time in com. parative privacy, but when the Protector had been empowered to nominate his successor, Richard was brought to the front, and an effort was made to train him to the work of government, but in vain. Searcely had he entered on his office, when the forces of anarchy, both parliamentary and military, broke loose, and he found himself utterly unable to restrain them. It was probably with little reluctance that he quitted Whitehall and retired into private life. After the Restoration he lived for a time abroad under a feigned name; but he returned to England about 1680 , and passed the remainder of his life at Cheshunt, where he died July 12, 1712, and was buried in the ehureh at Hursley, Hampshire.

Cromwell, Thомаs (malleus monachorum, 'the hammer of the monks'), was born about 1485 , the son of a Putney blacksmith, cloth: shearer, brewer, and innkeeper. His youth was turbulent and adventurous. During eight or nine years passed on the Continent (1504-12), he seemis to have served as a common soldier, to have been befriended at Florence by Frescobaldi the banker, to have acted as clerk at Antwerp and to a Venetian merchant, to have visited Rome, and to have traded on his own account at Middelburg. Anyhow, by 1513 he was back in England and married; there, step by step, he rose to wealth and importance as a wool-stapler and a scrivener, half usurer, half lawyer, having originally been bred to the law. Wolsey employed him as early as 1514; through Wolsey, probably, he got into parliament (1523); he was Wolsey's chief agent in the unpopular work of suppressing certain smaller monasteries for the endowment of his colleges at Ipswich and Oxford (1525); and finally he became his factotum and secretary. He stepped to meatness over his fallen master. Cavendish tells how on All-Hallows Day, 1529 , he found 'Master Cromwell saying of Our Lady matins-which had been since a very strange siglit in him'-and bewailing his own misadventure, lut intending to ride from Esher to the court, 'where,' quoth he, 'I will either make or mar.' And Pole tells how, a few months earlier, Cromwell bade him take Machiavelli for his guide. Both stories illustrate the very man.

He was cheaply faithful to the cardinal, aiding him not only by quick-witted advice, and by plead. ing his cause in parliament, but even with $£ 5$ out of his own savings. Withal, he made himself friends of Wolsey's enemies; and his fidelity ingratiated him with Henry VIII. Him Cromwell promised to make the richest king ever in England, and counselled him to cut the knot of the divorce by declaring himself supreme head of the church. Counsel and promise were carried into effect by the Act of Supremacy (1534) and by the dissolution of the mouasteries (1536-39). To abolish papal authority, break the power of the eliurch, humble the nobility, and make the king absolute, were Cromwell's aims in their accomplishment he stuck at nothing. At heart, it would seem, still a Catholic-for so late as 1535 he bequeathed $£ 46$ for a priest to sing mass for his soul-he yet did his utmost to Protestantise the English Church, whose 'polity,' in the words of Mr Froude, Cromwell's admirer, 'remains as it was left by its creator.' It is often hard to determine whether he was tool or instigator, to dissever his actions from those of Henry ; both must be treated under Henry's reign. But here may be noticed his winning manners and ungraceful person, his venality and profusion, his purposeful ruthlessness and ubiquitous industry, his army of spies and vast correspondence-above all, the fact that that English 'Terror,' in which perished More and Fisher and hundreds of lowlier victims, set in with Cromwell's rise, and ebbed with Cromwell's fall. Among the posts and honours showered on him were those of privy-councillor (1531), chancellor of the exchequer (1533), secretary of state and master of the rolls (1534), vicar-general (1535), lord privy seal and Baron Cromwell of Oakham (1536), kniglit of the Garter and dean of Wells (1537), lord great chamberlain (1ن39), and finally, on 17th April 1540, Earl of Essex. 'He had,' says Professor Brewer, 'engrossed in his own hands powers such as no subject and no sovereign in this country had ever 
possessed lnofore or will ever posmess again.' But the hand that had so exalted could equally abase him. The hatred all men bore him, the Catholic reaction, and Henry's aversion to Anne of Cleves, the coense Lutheran consort of Cromwell's choosing, combined to effeet his ruin : less than eight weeks after his elevation to the earldom he was arreated and lodged in the Tower. His abjeet entreaties for 'Mercy, mercy !' availed him nothing; as little did his filthy revelations of Henry's discourse with him touching Anne of Cleves. Condemned under n bill of attainder, his own favourite engine of tyranny, he was bunglingly beheaded on Tower Hill, 28th July 1540. See Mr Gairdner's article in the Dictionary of Natiomal Biography (vol. xiii. 1888); Dean Hook's Lives of the Archbishops of Canterbury (vol. vi. chsp. 1, 1868); Professor Brewer's article on 'The Royal Supremacy' in Kimplish Studies (1881); works cited under HENRY VIII. ; and two articles in the Antiquarian Maga. zine for 1882 by Mr Jolın Phillips of Putney.

Cronje. PIET, a Transvaal general, born in 1835, took a leading part in the wars with Britain in 1881 and in 1899-1900. After a skilful and determined resistance to Lord Methuen ut Magersfontein, he surrendered with 4000 of his army to Lord Roberts on the Modder River on 27th February 1900. He was sent with other Boer prisoners to St Helena.

Cronstadt, a strongly fortified Russian seaport, 20 miles W. of St Petersburg, on a narrow island 7 miles long, at the moutli of the Neva. Cronstadt is at once the greatest naval station and the most flourishing commercial port of Russia. It was founded by Peter the Great in 1710, after taking the island from the Swedes (1703). Its fortifications command every approach to St Peteraburg. They are all built of granite, and armed with the heaviest ordnance. The place, indeed, was considered by Sir Charles Napier, who reconnoitred it during the Russian war of $1854-55$, so impregnahle that it would have been utter madness to niake any attempt upon it. Cronstadt, which is the seat of the Russian Admiralty, has three harbours: the enst, intended for vessels of war, and eapable of acennmodating thirty ships of the line; the midrlle harbour, where vessels are fitted up and repaired, and which is connected with the former by a broad canal; and the west or Merchant's Harbour, for the merchant-shipping, with capacity for 1000 vessels. Since $1884 \mathrm{St}$ Petersburg is connected with Cronstadt by a ship-canal 200 feet wide and 22 feet deep. Cronstudt contains a cathedral, a statue of Peter the Grent, and a British senmen's hospital (1867). In 1891 a 135-ton Krupp guu was put in position. Pop. 42,683.

Cronstadt, in Hungary. See Kronstadt.

\section{Cronus. See Saturn.}

Crook, George, American soldier, born in Ohio in 1828, graduated at West Point in 1852 , served in California till 1861, and was actively engaged throughout the civil war, in which he rose to the rank of major-general. He served againat the Indians in Idaho (1866-72), in Arizona (1872-75), and crushed the great rising in Wyoming and Montana in 1875-77. In 1882 he returned to Arizona, where he controlled the Indians on the southern frontier, and induced them to take up farms and become peaceable. Died March 21, 1890.

Crooked Island. See Baнamas.

Crookes, Sir William, a great physicist and chemist, born in London in 1832, was a pupil and assistant of Hofmann at the Royal College of Chemistry, next superintended the meteorological department of the Radeliffe Observatory, and lectured on ehemistry at the Science College,
Chester. In 1859 he founded the Chemical News, and in 1864 became also editor of the Quarterly Journal of Science, He was elected F. R.S. in 1863, vice-president of the Chemical Society in 1876, member of council of the Royal Society the year after, and in 1880 was awarded by the French Academic des Sciences an extraordinary prize of 3000 francs and a gold medal. He is an authority of the first rank on sanitary questions, especially the disposal of the sewage of towns, and his method of producing extreme vacua gave a great impulse to incandescent electric lighting. His original resenrches in chemistry and physics led to the discovery of the metal thallium in 1861. of the sodium amalgamation procens for separating gold and silver from their ores in 1865, and of important discoveries in molecular physics and radiant matter, besides the invention of the Radiometer $\left(q_{*} v_{*}\right)$. He is the author of Select Methods of Chemical Analysis (1871), and of works on beetroot sugar munufacture, dyeing, ealico-printing, and sewage, and has trauslated books on chemistry and metallurgy'. 'Crookes Tubes' are Vacuum Tubes (q.v.); and see RUNTGEN, GAs. For Crookes's spiritualistic views, see SPIRITUALISM. Crookes was made a K.C.B. in 1897, and was President of the British Association in 1898.

Crookhaven, a fishing village of County Cork, 30 miles SW. of Skibbereen, on a fine bay.

Cropredy Bridge, near Banbury, gives name to a royalist success (29th June 1644).

Croquet, an open-air game, in which two or more players endeavour to drive wooden balls, by means of long-handled mallets, through a series of arches set in the ground according to some pattern. The object of each player is to make the complete circle of six to ten hoops or arches; but during the course of the game lie may have the progress of his ball retarded by his opponents, or assisted by his partners; and these friendly aids and hostile attacks constitute the chief interest of eroquet. The game seems to be substantially $\mathrm{a}$ revival of the old game of Pall Mall, which gave its name to what is now the well-known London street, and to other places in England. Pall Mall, played with ball (Ital. palla) and nailet (Ital. maglia), came from France into England early in the 17th century, and died out in the 18th. Croquet (Fr. croquer, 'to erack') became a popular game about 1850 , was the great summer social game during $1860-70$, but was after alrout 1875 superseded by lawn-tennis, to revive about 1897. A croquet-ground should be a well-rolled level grass plat or lawn, not less than 30 yarils long by 20 yarils wide; a full-sized croquet-ground measures 40 yards by 30 yards.

Crosier, a staff 5 feet long, surmounted by a cross, and borne by or before an archbishop on solemn occa. sions. It is generally hollow, gilt, and richly ornamented. 'The crosier differs entirely from the Pastoral Staff (q.v.), with which it is often nevertheless confounded-the latter having a circular head, in the form of a crook. The illus. tration is of Archbishop Warham's crosier, from Canterbury Cathedral.

Cross. The cross was a common instrument of capital punishment among the ancients; and the death of the cross was esteemed so dishonourable that only slaves end 
malefactors of the lowest class were subjected to it by the Romans. Among the Carthaginians, and probably also among the Phonicians and allied races, it was employed as an instrument of sacrifice to Baal. Thus the Carthaginian general, Malcus, invested his son, Cartalo, in royal raiment, with a crown on his head, and crucified him to obtain a special favour from Baal. It has been suggested that there may be some allusion to these crucifixions to the sun in Num. xxv. 4 ; Josh. viii. 29 ; x. 26 . Among the Gauls, as shall be noted later, a cross of equal arms was a solar symbol. It was customary among the Romans to proclaim the name and offence of the person crucified, or to affix a tablet (album) to the cross, on which they were inscribed. Malefactors were sometimes fastened on a simple upright stake, and so left to die, or they were impaled upon it, and to this upright stake the Latin name crux was originally and more strictly applicable; but very generally a crosspiece (patibulum) was added to the stake, to which the arms of the criminal were tied, or to which his hands were nailed. When the cross-piece was fastened at right angles below the summit of the upright stake, the cross was called crux immissa; when the cross-piece was fastened at right angles across the top of the upright stake, the cross was crux commissa; and when it was formed of two beams crossing one another obliquely, it was crux decussata. There was often a projection, on which the body rested, as on a seat. The cross was erected without the gates of towns, but in places of frequent resort. The person crucified often lived for days upon the cross.

The death of Christ by crucifixion led Christians to regard the cross with peculiar feelings of reverence, and to make use of the sign of the cross as a holy and distinguishing sign. The custom of crossing one's self in honour and commemoration of Christ, can be traced back to the $3 \mathrm{~d}$ century. It was customary, probably from apostolic times, for the Christians to pray with extended arms; and Justin Martyr and Origen explain this attitude as representing that of Christ on the cross. In this manner Christians are represented in the early paintings in the catacombs as praying. The Emperor Constantine, after obtaining the victory over Maxentius, through the influence, as he believed, of the sign of the cross, caused crosses to be set up in public places and upon public buildings; but the so-called cross of Constantine, or Labarum, was not really a eross, but a circle containing the XPI, the first three letters of the name of Christ in Greek, and was merely an adaptation of a symbol of a Gaulish solar deity (see Gaidoz, Le Dieu Gaulois du Soleil), which consisted of a wheel of six spokes, or sometimes of four. After the Invention of the Cross, or finding of the alleged true cross of Christ in Jerusalem, which was supposed to have taken place in a search made on Calvary by the Empress Helena (q.v.) in 326 A.D., a surprising quantity of the relics of the cross were distributed through all parts of Christendom. When a portion of the cross was given to St Radegund by Justin II., emperor of the East, and she desired to have the relic received with honour into the eity of Poitiers, the Bishop Maroveus peremptorily refused to allow it. She was obliged to appeal to King Sigebert, and he ordered the Archbishop of Tours to receive the relic. Maroveus left the town rather than countenance what he regarded as a superstitions act. For this occasion Venantius Fortunatus wrote the famous hymn 'Vexilla regis,' and it was first sung on the introduction of the relic processionally into Poitiers, circa 580. Various other protests were made against the extension of the worship of the relies, but in vain. The sign of the cross is made not onlv by Roman Catholies, but by the members of the Eastern churches also; by the Westerns from left to right, by the Easterns from right to left. It is admitted by the Lutherans as a commemorative sign of the atoning death of Christ, but by many Protestants is rejected as a human invention in worship, and as tending to superstition. It was very generally used during the middle ages, and still is among the less enlightened peasantry in some Roman Catholic countries as a sort of charm, or as affording some security, like an amulet, against all evil, and particularly against evil spirits and witchcraft. The festival of the Invention of the Cross is celebrated on the $3 d$ of May; that of the Elevation of the Cross conmemorates the re-erecting of the cross at Jerusalem by the Emperor Heraclius in 628, after it had been carried away by the Persians. See Legends of the Holy Rood, edited by Richard Morris for the Early English Text Society (1871); and the Legendary History of the Cross, by Ashton and Baring-Gould (1887).

The earliest mention of representations of the crucifixion are by two writers in the 6th century. Gregory of Tours relates that such a picture was in one of the churches of Narbonne, and gave offence because it was nude; and the rhetorician Choricius says that in a church at Gaza was a representa. tion of Christ crucified between two thieves. See CrUCIFIX. As neither of these writers remarks on the novelty of such representations, it may be supposed that they were not infrequent in the 6 th century. Early crucifixes were, in contradistinction to that mentioned by Gregory, clothed to the feet. In the treasury of Monza are two such, one given by Gregory the Great in 599 to Adalwald, son of Queen Theodolinda, and another of the 6 th century with a Greek inscription. The use of the cross without a figure of Christ is much earlier. As already mentioned, it was employed as a sign made with the hand, or by extension of the arms, at an extremely early Christian epoch; but no crosses are found represented in the catacombs of Rome before the 5th century, excepting the so-called eross of Constantine, $a$, which is not a cross but a monogram. This symbol is found first in the beginning of the 4th century. It also took the form $b$. Then it became a plain cross, $e$. A very complete list of all the representations of the cross in its various forms in the Roman catacombs and other Christian monuments of the first five centuries will be found under the heading 'Kreuz,' in Kraus, Realencyclopädie d. Christlichen Alterthumer (1886)

It appears that the sign of the cross was in use as an emblem, having certain religious and mystic meanings attached to it, long before the Christian era; the crux ansata, or cross with a handle to it, $c$, is common on Egyptian monuments. It was the symbol of immortality. The cross with equal arms, and the cross with re. turned arms or fylfot, $d$, is a symbol found on prehistoric relies in Italy and elsewhere (see Mortillet, Le Signe de la

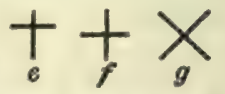

Croix avant le Christianisme, 1866). The Spanish conquerors were astonished to find it an object of religious veneration among the natives of Central and South America, where it was a symbol of the god of rains.

The forms given to crosses in art are endless; but the two lcading types are the Latin cross, $e$, or crux immissa, supposed to be that on which Christ suffered, and the Greek cross, $f$, both of which are subject to many fantastic variations. The Greek cross forms the well-known cross of St George, which was the national ensign of the English 
previsus to the union with seotland. The ernss of St Andrew, g, differed entirely in form from the Latin or Greek croes. This cross, or erux decussata, eon. sisted of two shafts of equal length croned diagonally at the middle, as in the annexed cut. Accord. ing to the legend, this was the form of cruss on which St Andrew, the national saint of Scotland, suffered martyrdom (aee ANDREW). As the Scottish ensign, it is now blended with the cross of St George in the Union Jack.

The Cross of the Resurrection is a floriated cross ; and is usually represented as heading a lance, to which is fastened a banner upon which a cross is depicted. The earliest and hinest floriated cross is that in the mosaic of San Ponziano, where, how. ever, the flowers spring from the shaft, and on the arms stand two lighted candles. The idea of the floriated eross seems to have been to connect it with Aamn's rod that budded, and so to signify the eternal priesthood of Christ.

In medieval times a cross, the Rood, stood over the screen hetween the nave of a church and the chancel. This was always veiled in Lent. The crutehed crose, like the letter $T$, was the symbol of St Anthony the Hermit. Processional crosses are those carried in processions (see Crosier); pertoral crosses, those worn on the breast by ecelesiastics of rank. Many orders have distinetive crosses, See LEgIoN of Hovour.

The Order of the Cross, originally a spiritual order of knighthood, sprang up in Palestine in the time of the Crusades, and was then called the Bethlehemite Order. Pope Gregory IX. confirmed the order in 1238. Its principal seat was in Bohemia. There is also a Brazilian Order of the Cross.

Sanctuary, Boundary, or Monumental Crosses, as they are called, consist of an upright flat pillar or obelisk, covered with sculptural devices, and set

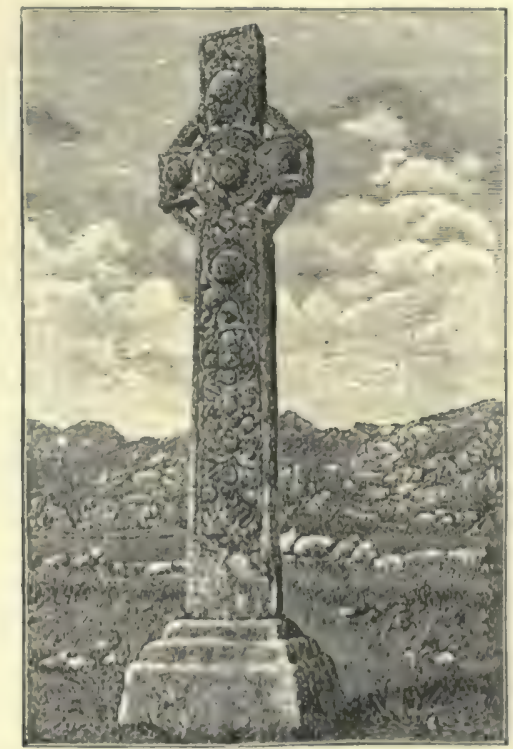

St Martin's Cross, Iona.

in 8 socket level with the ground. Occasionally, they appear to have marked boundaries, but more frequently were monuments over the graves of heroes, kings, bishops, \&c. A vast number of extremely rude and early crosses of granite occur in Cornwall and Devon : some of these have apparently been fashioned out of prehistoric monoliths. In sonie instances, they probably marked the verge of a sanctuary. A characteristic type of cross is the
Celtic Cross, most frequently found in Ireland and in the north and west of scotland. Such eromem vary much, from a croses incised on a flat slab to an elaborate cruciform monument. The majority of the latter seem to belong to the period between the 12th and 15th centuries. One of the best known in that at Iona called st Martin's Cross, standing in the grounds of the cathedral. It is a column of compact mica schist, 14 feet high, 18 inches broed, and 6 inches thick, and is fixed in a pedestal formed out of a massive block of red granite, about 3 feet high. In connection with certain ancient religious houses in Ireland, there were very fine Celtic crosses. Some crosses of this type show Scandinavian workmanship; hence they are often called Runic crosses. The cross of Kuthwell $\left(q_{0} v_{0}\right)$ in Dumfriesshire, and that at Bewcastle $\left(q_{0} v_{0}\right)$ in Cumberland are interesting samples.

Churchyard Crosses seem to have existed in all churchyards before the Reformation: some still exist, and the remains of others are numerous. In France, in connection with the cemetery crose, in some parts, a perpetual lamp was kept burning, and the contrivance for the lamp remains in some of them.

Many very beautiful crosses exist in England, upon the points of gables of ehurelıes, or grave. stones, and in other situations, as also in heraldry. Among these, the cross most commonly seen is called the cross crosslet (see below).

Memorial Crosses are such as are erected in memory of a beloved object, or in commemoration of some event of local importance. In England there sre some superb crosses of this kind; they are popularly called Norman Crosses. This species of cross resembled a Gothic turret set on the ground, or on a base of a few steps, and was decorated with niches for figures and pinnacles.

The best.

known ex. amples are those erected by Edward I. $(1290)$ in memory of his queen, Eleanor; being placed on the spots where the body rested in its funereal progress to Westminster. The crosies at Wa $l$ t h a m, Cheapside, and Charing were of the number. That at Charing was removed by the parliament in 1647 ; a modern re. production now oceupies its site. The W a lt h a m

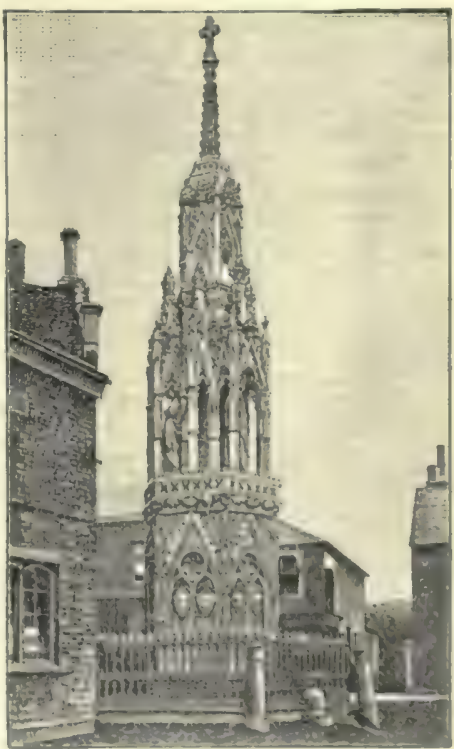

Waltham Cross, restored.
Cross, repaired in 1890 , remains as a testimonial of the affection and piety of the greatest of the Plantagenets.

Village Crosses stood in the centre of most vil. lages in ancient times. In the west of England a good many remain.

Town or Market Crosses were erected as stands to preach from, or in commemoration of events regarding which it was deemed proper to evoke pious 
feelings. As these structures were incorporated with or surmounted by a crucifix, the term cross was so indelibly associated with them that it survived the religious character of the fabrics. The earliest examples of this kind consisted, probably, of tall crucifixes of wood, such as are still seen by the waysides in some continental countries. Afterwards, stone shafts would be substituted; and according to the increase of market revenues, or progress of taste, these town-crosses assumed that imposing character which they latterly possessed. The crosses at Cheddar in Somersetshire and at Malmesbury in Wiltshire, are open vaulted structures, with a commodious space beneath as a refuge for market-folks during rain, and surmounted with a kind of Gothic turret. At Chichester, Bristol, and Winchester, the marketcrosses, while similar in form, are of a higher architectural quality. Adjoining St Paul's in London stood Paul's Cross, a structure which we read of as early as 1259, in the reign of Henry III. At this preaching-cross, by order of Henry VIII., preachers delivered sermons in favour of the Reformation, and here Queen Elizabeth attended to hear a thanksgiving sermon for the defeat of the Spanish Armada; but in 1643 the cross incurred the displeasure of the Puritans, and was demolished by order of parliament. See The Ancient Stone Crosses of England, by Alfred Rimmer (1875).

Scotland offers no specimens of memorial or Norman crosses, unless it be the modern Scott Monument, at Edinburgh, which is essentially a Norman cross of a gigantic order. The simpler kind of Scottish market-cross consisted of a shaft of stone, standing on a flight of circular or octangular steps - the grander market-cross consisted of a tall stone shaft, on an imposing circular, hexagonal, or octagonal substructure, 10 to 16 feet high. The top formed a platform, which was surrounded with an ornamented stone parapet, and was reached by a stair inside. Losing their religious character, the

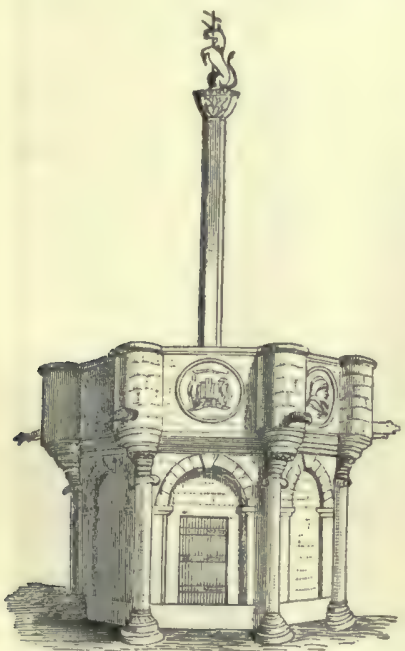

Scottish marketcrosses were employed for royal and civic proclamations, and as places where certain judicial writs were executed. The oldest cross of Edinburgh stood in the centre of the High Street, but was removed in 1617 . A new market-cross was then erected farther down the street, on the south side, which consisted of an octangular brse, with a stone shaft of about 20 feet in height; its removal in 1756 , by the civic authorities, is in-

Edinburgh Market-cross, 1617-1886.

dignantly referred to by Scott in Mormion. The shaft, which had been preserved, was re-erected on a similar substructure near the same site in 1885, at the expense of $\mathrm{Mr}$ Gladstone.

Cross, in Heraldry, is one of the ordinaries, and is represented with four equal arms, and considered to occupy one-fifth of the field if not charged, and one-third if charged. Argent, a cross gules, is the cross of St George. Like other ordinaries, the cross may be engrailed, invecked, \&c. When its central square is removed, it is said to be quarter-pierced; and when it does not extend to the margin of the shield, it is called humettee. But the cross of heraldry is often found varied in other ways, the varieties having each separate names. Thirty-nine varieties are enumerated by Guillim, and 109 by Edmonson. Those most frequently occurring are here mentioned; and it may be remarked that they st George's Cross. have rather the character of com-

mon charges than ordinaries not extending to the margin of the shield, and being often borne in numbers as well as singly. The cross moline (fig. 1) has the ends turned round both ways; the cross fleury (fig. 2) has each end terminating in a
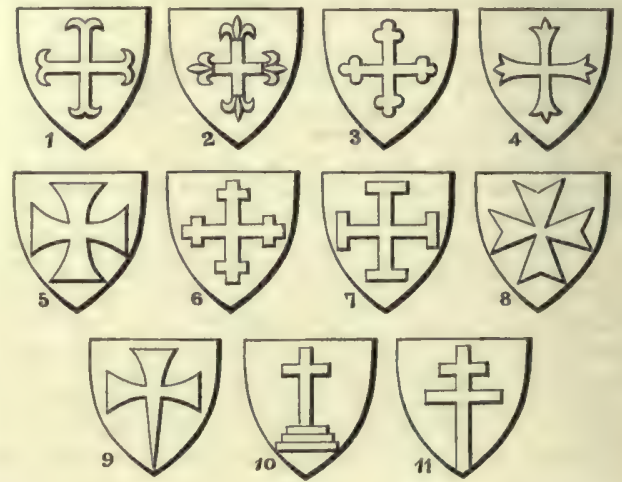

fleur-de-lis ; the cross botonnée (fig. 3) has each end terminating in a trefoil; the cross patonce (fig. 4) has three points to each limb; the cross patee (fig. 5 ) is small in the centre, but widens towards the ends; the cross crosslet (fig. 6) is crossed at each end; and the cross potent (fig. 7) is erutch-shaped at each end. The Maltese cross (fig. 8), which converges to a point in the centre, and has two points to each limb, though not frequent as a heraldic charge, derives importance from being the badge of the Knights of Malta and other orders. Any of these crosses is said to be fitchee when the lower limb terminates in a point, as in fig. 9, representing a cross patée fitchée. Besides these and other crosses with equal limbs, there is the cross Calvary (fig. 10), being the cross of crucifixion elevated on three steps, and the patriarchal cross (fig. 11) with two horizontal bars.

Cross, Mary Ann. See Eliot, George.

Cross, Southern. See Southern Cross.

Cross Bill, a bill of exchange or promissory note given in consideration of another bill or note.

Crossbill (Loxia), a Passerine bird in the finch family (Fringillidæ), well known for the curious way in which the points of the upper and lower bill-halves cross one another. There seems to be no constancy in the direction of crossing, for in different individuals, even of the same species, the upper and lower portions are found variously directed to right or left. This peculiarity is probably for the most part a directly mechanical adaptation to the food-habit of the bird, which consists in tearing up the cones of firs and pines for the sake of the seeds. Bringing the two points together, the crossbill inserts its beak into the cone, then opens it with a strong lateral movement, and with its scoop-like tongue detaches and 
captures the seed from the loosened cone. In a similar way, the croesbill ean soon tear an ordinary cage to bits; or, which is more important, may rapidly do great damage by cutting up the apples in an orchard. It is interest. ing to compare two common s pecies, $L$. $p$ ityopsit $t a$. cus and $L$. cror. virostra, since in the former the crossing of the bill is seen in a much less enphasised de. gree. The lastnamed species is of frequent, though incon.

stant oceur.

Crossbill (Loxia curvirastra). rence in Britain, and two other species lave been recorded as visitors. Altogether, seven species are known, from the northern regions of both hemispheres, and always found gregariously in conifer forests. The erossbill has become associated with a sacred legend, familiar to many from Longfellow's translation of a German poem on the subject. The bird was fabled to have sought, by pecking at the nails, to free Christ from the cross.

Crossbow, or Arbalest, a weapon used in war and sport in medieval times. It consisted of a wooden stoek, with a bow made of wood, iron, or steel, erossing it at right angles to the end; the bowstring was pulled down towards the other end of the stock by a lever (which

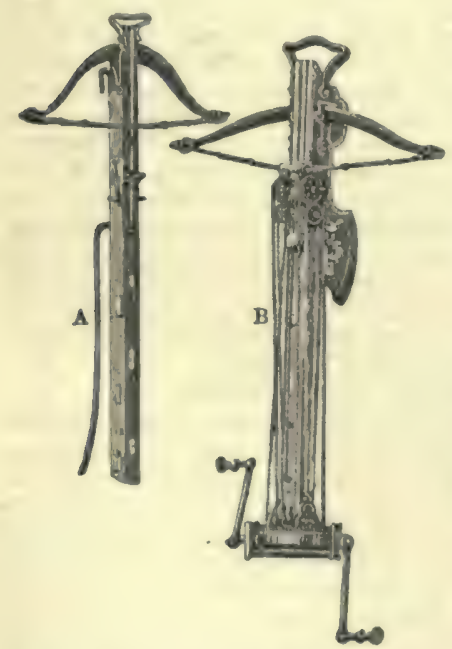

in the simpler kinds was worked by hand or foot), and retained in position sometimes in a noteh by a catch or trig. ger. The bolt or 'quarrel' was then laid in a groove on the top of the stock, and the trigger being pulled, it was shot with a considerable Bmount of power. The atter, of course, de. pended on the size of the bow, some of

A, Hand Crossbow ; B, Rolling-purchace the weapons Crossbow.

being com. paratively

small and easily handled, while others were of large dimensions, and required a machine of the nature of a windlass, called a 'moulinet' or 'gaffle, 'to enable the bow to be properly bent. The crossbows of the 14th century were almost all thus equipped. The 'quarrels' emploved varied with the size of the bow, but generally they were short stout shafts about 18 inches long, winged with horn or leather, and having a metal point, which was sometimes sharp, but often lozenge-shaped, obtuse, and indented at the sides. Some crossbows had a tube or barrel, with a slit for the bowstring, and dis- charged balls of elay, marble, or lead with sneh force that they were more formidable weapons than the earlieat frearms. The larger erowshows were really military engines, which required neveral men to work them, and threw proportionally heavy missiles (see BALLISTA). The cross bow was used in England chietly during the 13th century ; after that it gave place to the longbow, which was found to be the more convenient and easily handled weapon of the two. Its use, however, was general among the continental nations of Europe after the $12 \mathrm{th}$ century; though the Lateran Council of 1139 forbade its use as being too murder. ous a weupon for Christians to employ against one another.

\section{Cross-breeding, See BREED.}

Cross-buns, a small cake specially prepared for Good-Friday, and in many towns of England eried about the streets on the morning of that day as 'hot cross-buns.' Bun is, according to Skeat, ultimately of Seandinavian origin. There is an Old Fr. word bugne, 'a swelling,' which may be the immediate source of the English word. Good. Friday buns were appropriately marked with the cross, and hence the name. The origin of the practice is obscure. Most probably it is a relic of some heathen observance, to which the early church gave a Christian significance. At Chelsea, there were formerly two celebrated bun-houses, besieged on Good-Friday from morning until night by hundreds of eager purchasers, but they have long since disappeared.

Crosse, Andrew, electrician, born at Fyne Court, Somersetshire, 17th June 1784, was edu. cated at Bristol and at Brasenose College, Oxford. His principal researches in science were as to the artificial formation of minerals by processes of electrical deposition and the application of electricity as a means of improving wines, cider, \&c. In 1837 be announced that under certain circum. stances, organisms (of the genus Acarus) appeared in solutions of inorganic substances; a discovery which attracted much attention, but which exposed him to the ridicule of opponents. He died 6th July 1855. See Memoir (1857) by his second wife ; and her Red Letter Days of my Life (1893).

\section{Cross-examination. See Evidence.}

Crossley, Sir Fravcis, manufacturer and philanthropist, was born at Halifax, October 26 , 1817. His father was the founder of the Dean Clough Carpet Mills. Sir Francis encouraged the inventor George Collier to produce a greatly im. proved carpet-foom; the mills increased till 6000 hands were employed; while carpets were much cheapened in price, and their use greatly extended at home and abroad. 'Anıongst Sir Francis's bene. factions to Halifax were a public park (1857) at a cost of $\mathbf{f 4 0 , 0 0 0}$, almshouses, and orphan homes, besides large donations to the London Missionary Society and to the Congregationalists. A baronetcy was conferred on him in 1863, and from 1852 till his death on 5th Jan. 1872 he represented Halifax and the West Riding as a Liberal.

Crossraguel ('Cross of St Regulus'), a roined abbey in Ayrshire, 2 miles $\mathrm{SW}$, of Maybole. It was a Clugniac foundation, a daughter of the Paisley abbey, and dates from 1244. A notable 'disputation took place in 1562 between John Knox and the abbot, Quentin Kennedy; and in 1570 the commendator was 'roasted ' or severely tortured by fire by the Earl of Cassilis, to force him to resign certain lands. The charters of the abbey have been edited by F. C. Hunter Blair ( 2 vols, 1886 ).

Crotalaria (Gr. krotalon, 'a rattle'), a tropical genus of papilionaceous Leguminoss, deriving its 
name from the inflated pods in which the seeds rattle when ripe. The species are annual, perennial, and shrubby plants, some of which yield valuable fibre, particularly $C$. juncea, the Sunn, or Hemp Sana, or Janupa Hemp of India, an annual species. The perennial C. tenuifolia (Jubbulpore Hemp) is grown in Southern India, and other species or varieties are in cultivation. Several species are North American.

\section{Crota'lidae. See RatTlesnake.}

Crotch, William, composer, was born at Norwich in 1775. His musical genius was quite as precocious as that of the great Mozart. When little more than two years old he could play God save the King with chords, and in 1779 he was performing in London as a musieal prodigy. When only twenty-two he was appointed professor of Music in Oxford University, and in 1822 he obtained the principalship of the Royal Academy of Music. Crotch composed a large number of pieces for the organ and piano, two oratorios, ten anthems, \&c.; and he was author of Elements of Musical Composition (1812) and Styles of Music of all Ages (1807-18). He died at Taunton, December $29,1847$.

\section{Crotchet. See Music.}

Croton, a genus of plants of the natural order Euphorbiaces, with numerous species, which are mostly tropical or subtropical trees or shrubs, a few herbaceous. The nost important is the Purging Croton (C. Tiglium), a small tree, a native

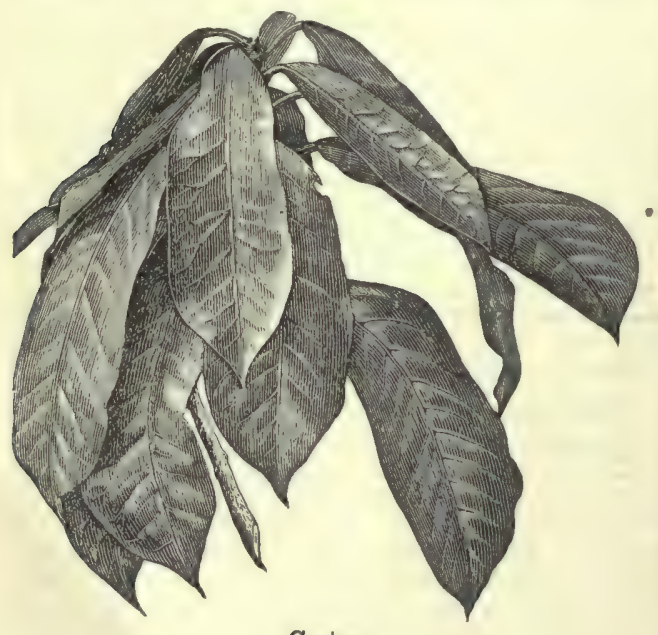

Croton.

of India and the more easterly tropical parts of Asia. The leaves are extremely acrid; the wood in a fresh state is a drastic, and in a dried state, a more mild purgative; and the seeds (Croton Seerls, or Tilly Sceds) are a very powerful drastic purgative, formerly much employed in Europe, but latterly disused on account of violence and uncertainty of action, although still valuable as vielding croton-oil. They are oval or oval-oblong, about the size of field-beans. So great is their acridity, that dangerous effects have ensued from working for some hours with packages of them. The oil is obtained mostly by expression, and partly by treating the cake with alcohol. The wood and seeds of $C$. Pavana are employed in some parts of the East in the same way as those of $C$. Tiglium. Other species possess similar properties. Very difforent are the properties of the species which yield Casearilla (q.v.) and Copalchi (q.v.) barks. Other species are still more aromatic, and some delightfully fragrant, containing in great abundance a thickish balsamic sap. The sap of $C$. gratissimus is employed as a perfume and cosmetic at the Cape of Good Hope; that of $C$. origanifolium is used in the West Indies as a substitute for Balsam of Copaiva; that of $C$. bulsamiferum, also West Indian, furnishes Eau de Mantes by distillation; and the balsamic sap of some South American species is dried and used as incense. The $C$. Draco and other species yield a blood-red juice, which, when dried, forms the finest kind of dragon's-blood, and is possessed of astringent properties.

CROTON-OIL is the oil expressed from the seeds of the C. Tiglium, and is a sherry-coloured, viscid liquid, with an acrid taste, a somewhat rancid smell, and a fluorescent appearance. It contains a number of oily bodies, none of which have as yet been definitely shown to be the cause of its purgative and vesicating properties. Croton-oil is a violent purgative, in most cases a single drop being sufficient to remove constipation. When rubbed upon the skin it produces rubefaction and pustular eruption, and thereby tends to relieve some affections of the internal organs. It is used either by itself in the unmixed state, or diluted with oliveoil, soap liniment, alcohol, \&e. It is not to be employed except under the advice of a doctor.

Crotona, a city of Lucania in ancient Italy, owed its origin to a colony of Achrans, as far back as 710 B.C. It soon became one of the most prosperous, wealthy, and powerful cities of Magna Gracia. Its walls measured 12 miles in circumference, and the territory over which it extended its sway was considerable. Its inhabitants were celebrated for athletic exercises, and they carried off most of the prizes at the Olympic games. Pythagoras settled here about the middle of the 6th century B.C., and beeame a very important member of the body politic (see Pythagoras). About 510 B.c. Crotona sent forth an army of above 100,000 men, under Milo, its most renowned athlete, to fight the Sybarites; the latter, though three times as numerous, were utterly defeated, and their city destroyed. The war with Pyrrhus completely ruined the importance of Crotona, and in the $2 d$ century B.C. it had sunk so low that a colony of Romans had to be sent to recruit its well-nigh exhausted population. It never afterwards recovered its prosperity. Some ruins belonging to the old exist in the vicinity of the modern eity (called Cotrone, q.v.); and very fine Greek coins have been found. Cortona (q.v.) was also anciently called Crotona.

Croton River. See Aqueduct.

Crotophaga (Gr., 'tick-eater'), a genus of birds in the cuckoo family and order Coccygomorphre. They are also known by the names Ani and Keelbird, the former referring to the cry, the latter to the blade-like ridge on the compressed arched beak. The best known of the three species $(C$. ani frequents South America to the east of the Andes, and is often called the Savanna Blackbird. They are distinguished from other cuckoo-like birds by the tail, which has only eight steering feathers. The beak is as long as the head, and the keel is said to be used in unearthing their insect prey; the wings are long and pointed; the tail is long, broad, and rounded. They are social birds, and several females lay their eggs in a common nest. They are fond of keeping about herds of horses and cattle for the sake of the insect larva which they find on their skin. In this connection they are obviously of some importance.

Croup, a term used in Scotland from an early period to describe a certain train of laryngeal symptoms, was first applied by Dr Francis Home, in 1765 , to an acute inflammatory and non-contagious affection of the Larynx (q.v.), in which there is the 
formation of a false membrane or fibrinous deposit on the mucous surface of the windpipe. The.invasion of the disense resembles that of sinaple Catarrh (q.v.), and may be very insidious. The child is languid, feverish, and thirsty, and a dry, shirill cough is gradually developed, but these symptoms sooner or later give way to those of the second stage. Here the respiration becomes difficult, the drawing of each breath having a hissing and 'eroupy 'sound; the voice is almost inaudible or greatly modified, and accompanied by a harsli, brassy, or may be stifled cough; the face is red and swollen, and covered with sweat; and the nostrils are rapidly working. If the little patient is not relieved by coughing or vomiting up some membraneous shreds and glairy mucus, a state of greater dyspnoea ensues; the lipa become livid and the nails blue; the fever is hiyher, the pulse quicker but iveaker; and the child's efforts to relieve the increasing obstruction to the breathing are most distressing to witness. A period of extreme restlessness and suffering is (unless relieved by imme. diate treatment - see below ) soon followed by death from inereasing coma, syncope, or exhaustion.

Croup seems to be caused by a damp atinosphere of low temperature, and is got in exposed situations. It is most frequently met with between the years of two and ten, although all ages and classes are liable to sufter from it. It is commoner in boys than girls. Croup requires to be distinguished from simple catarrh of the windpipe; from so-called false croup, a spasmodic affection of the larynxthe Laryngismus Stridulus of Dr Mason Good; and from Diphtheria $(q . v$.$) , an infectious disease in$ which a false membrane is usually found on the pharynx or palate, as well as in the larynx. As eroup is an acute and very fatal disease, the treatment requires to be active and decided. If the case is seen early, apply an ice-bag to the throat and give ice to suck, but if you suspect the presence of false membrane, give a full dose of an emetic, such as ipecacuanha, sulphate of copper, or sulphate of xinc, which should be repeated in three or four hours if necessary and effectual in relieving the breathing. The child should at intervals be placed in the hot lath, and inhalations of steam or medicated vapours administered. An inhalation of lactic acid is often of great use in the first stage. If these means fail, Tracheotomy (q.v.) must be at once resorted to, to save the life of the patient, as recommended by Trousseau.

Crow (Convus), a genus of Passerine birls, and type of a family Corvida, which also includes Magpies (Pica), Nuterackers (Nucifraga), Jays (Garrulus), Choughs (Fregilus), and other genern. The erow family is included in that division of Passeres known as Acromyouli, from peculiarities in the voeal organs, and its members share the following characters : the bill is moderately long, strong and thick; bristles at the base cover the nostrils; the wings are of medium size and rounded; the tail is not prominent; the feet are strong. On the whole they outdo the other Passeres in size and strength, and are represented by towards two hundred species.

Keeping first to the crow genus proper (Corvus), we need give little description of the general characters of these familiar birds. The long black bill, the large gape, the tail all but eovered ly the wings, the black feet, \&c. are well-known cliaracteristies. The genus is distributed in moat parts of the world except South America and New Zealand. They are essentially tree birds, and almost always luild their nests there. In diet they are predominantly vegetarian. It is important to distinguish the four British species of erow. (1) The Raven (Corves corax) is a well-known species in Europe and North Asia. Its black plumage has a bluish sheen; the upper portion of the bill is hent over the lower; the wings reach the point of the tail. It is a hungry bird, devouring inier alia field. mice and small birds ; it is not unfrequently tamed, and can be readily taught to ejaculate and play tricks. See RAvEN.

(2) The Rook (C. frugilegus) is a commoner smaller species of gregarious habit. There is the same metallic shimmer, the wings again reach the tail, but the upper bili is not elongated over the lower. The face becomes curiously lare during the finst winter, and so remains. It is of use in destroying injurious insects, but its omnivorous appetite includes eggs, young birds, fish, walnuts, corn, \&c. See Rook. The accompanying figure

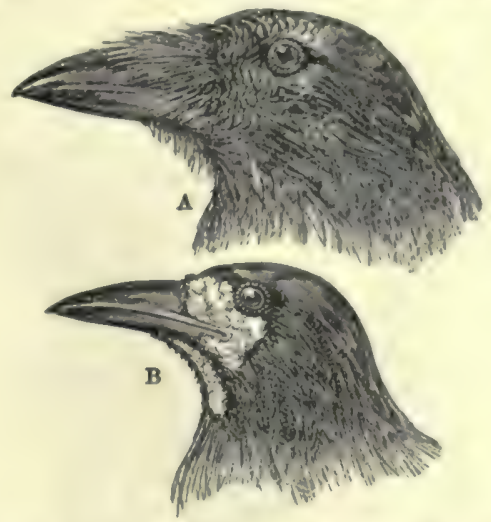

shows the heads of the raven, A, and the rook, $B$, and illustrates well the prevalent characters of the lill in this genus. It shows also in the raven the bristles which, as in most of the species, surround its base, but which are wanting in the rook. Noteworthy, too, is the greater strength of neck head, and bill of the more carnivorous as compared with the more frugivorous species.

(3) The Hooded Crow ( $C$, cornix) derives its name from the fact that while the general colour is ashen gray, the head is black. The under throat, the wings, and the tail are also, however, black. Like the next species, the hooded crow is fond of carrion, and both are often shot by gamekeepers on account of the damage they do to young game-birds, \&c.

(4) The Carrion Crow ( $C$. corone, or Corone hiemalis), which is of the same size as the rook, has black pluniage, with a steel-blue shimmer on back and liead, and wings which do not reach the tip of the tail. The bases of the feathers are gray in the rook, white in the carrion crow. It is nseful in destroying mice and insects. It is said to interbreed with the preceding species. The name is given in America to a Vulture (q.v.). In some parts of Scotland the carrion crow is called the Hoody. There is considerable dispute as to the specific dignity of some of the crows. A few other forms in addition to the above four may be noticed. The crow of North America ( $C$. americanus) is very similar to the carrion erow, but rather smaller, and, after the breeding season is over, congregates into great flocks; it is aleo partially migratory, great numbers from the more northerly parts mov. ing to the south on the appronch of winter. Its habits are otherwise intermediate between those of the carrion erow and the rook. - The Fish Crow (C. ossiframus) frequents the consts and sonthern rivers of the United States, feeding chiefly on fish, which it catches with great dexterity. It also sometimes assails gulls, and compels them to disgorge their prey. - The Jabhering Crow (C. jamaicensis) of the Blue Mountains of Jamaica 
is renarkable for the resemblance of its voice to human speech. Sir J. E. Tennent gives an interesting account of the small glossy gray-necked crow of Ceylon ( $C$. splendens), which frequents the towns, feeding on offal, and boldly enters rooms through open windows, to snateh some morsel from the dinner-table. See also CHOUgH, JAckdAw, JAY, MAGPIE.

Crowberry, or Crakeberry (Empetrum nigrum), a small procumbent shrub, with characteristically inrolled leaf-margins, of the order Empetraeeæ, a native of the colder northern parts of the world, abundant in the moors of Scotland and the north of England, and common throughout Canada, Alaska, and Siberia. The order consists of a few heath-like shrubs, which, however, are usually associated with Euphorbiacere (Spurges, \&c.), with small trimerous unisexual flowers, the fruit a small

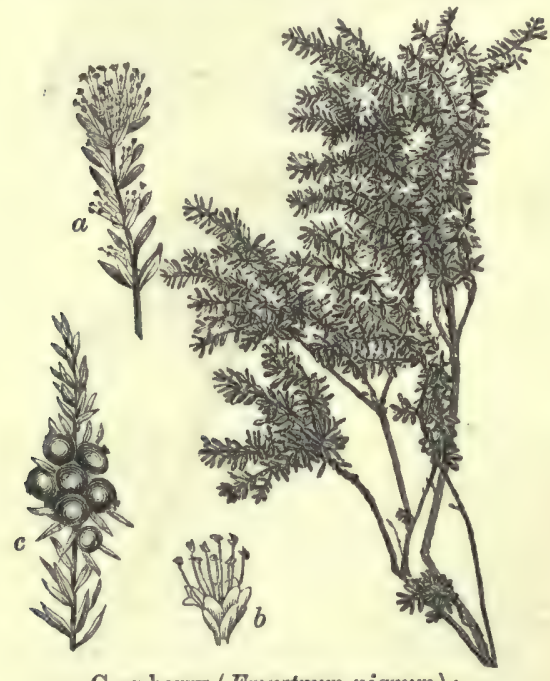

Crowberry (Empetrum nigrum):

$a$, flowering branch; $b$, flowers enlarged; $c$, fruit.

berry seated in the persistent calyx. The berries of the crowberry are nearly black, surround the branches in crowded clusters, and each contain six to nine bony seeds and a watery acidulous juice. A fermented liquor is prepared from them in some northern countries. They are a favourite food of game. E. rubrum of Cape Horn differs little, except in having red berries. The berries of the Camarinheira (Corema alba) are employed in Portugal for the preparation of an acidulous drink in fevers. The plants of this order, especially $E$. rigrum, have taken considerable part in the formaion of peat.

Crowe, Mrs Catherine (née Stevens), authoress, was born at Borough Green, in Kent, in 1800. In 1822 she married Lieutenant-colonel Crowe, and spent great part of her after-life in Edinburgh. She died in 1876. Her mind was morbid and despondent, ever hovering on the border-line of insanity, which it crossed once in one violent but brief attack. Her translation of Kerner's Seeress of Prevorst ( 1845 ) prepared the way for her well-known Night Side of Nature (1848), a great collection of supernatural stories, told, indeed, with vigour and verisimilitude, but hopelessly credulous and uncritical. She wrote also tragedies, juvenile books, and novels; of the last, the best, Susan Hopley (1841) and Lilly Dawson (1847). Her Spiritualism and the Age we live in (1859) has no value, save as autobiography.
Crowe, Joseph Archer, C.B., art-writer, born in London in 1825, studied and travelled widely on the Continent, where in 1847 he met Cavaleaselle; their joint works will be found in the article CAvALCASELLE. Crowe was a special correspondent in the Crimean war, the Indian mutiny, and the Franco-Austrian war; and in 1857-59 was director of the School of Art at Bombay. In 1860 he was appointed British consul-general at Leipzig, and afterwards at Disseldorf; in 1882 he was named commercial attaché at Paris. Made a C. B. in 1885, he was raised to the dignity of K.C.M.G. in 1890 . He contributed the article RAPHAEL to this work. He died 6 th September 1896. See his Remiviscences (1895), mainly of his eareer as journalist.

Crowfoot. See Ranunculus.

Crow Indians, some 4000 in number, of the Dakota stock, live on reservations in Montana.

Crowland, or CROYLAND, an ancient markettown in the south of Lincolnshire, on the Welland, in the Fens, 10 miles NNE. of Peterborough. Here in $716 \mathrm{King}$ Ethelwald founded a monastery in honour of the hermit St Guthlac, which, burned by the Danes in 870 , and again destroyed by fire in 1091, was restored in 1113 , and thereafter became a mitred Benedictine abbey of singular magnificence. The north aisle of its church now serves as the parish church, and part of the west front also remains. Ingulph (q.v.) was abbot of Croyland. Pop. of parish, 2929. See G. Perry's Croyland 'Abbey (1867). The 'Triangular Bridge' is described in our article BRIDGE, Vol. II. p. 436.

Crown (Lat. corona). The crown of classical times was a circular ornament of metal, leaves, or flowers, worn on festive and solemn occasions, and as a reward of worth, talent, and military or naval prowess. Among the Greeks the crown (stephanos) was sometimes used as an emblem of office, as in the case of the archons; sometimes as an ornament for the heads of the victors in the public games; and sometimes as a mark of distinction for citizens who had merited well of their country. The Romans made great use of crowns as rewards for valour. The most highly prized was the corona obsidionalis, which was bestowed by a beleaguered garrison or army on the general who rescued them. It was made of grass or wild-flowers, gathered from the place which had been beset by the enemy. Next in order was the corona civica, a garland of oak leaves and acorns, which was given as a reward to any soldier who had saved the life of a Roman citizen in battle; the corona navalis, a gold circle decorated with beaks of ships, was the reward for naval services ; the corona muralis, a similar circle surrounded with battlements, was bestowed on him who first scaled the walls of a besieged city; and the corona vallaris, a circle ornamented with palisades, on the first soldier who forced his way into the enemy's camp. There was also the corona triumphalis, bestowed upon a general when he obtained a triumph.

Other crowns were emblematical, such as the sacerdotal, funeral, convivial (of roses, violets, myrtle, ivy, and even parsley), and nuptial crowns. The eustom of wearing bridal wreaths or even bridal erowns of metal is not unknown in modern Europe as in Germany and Norway and medieval England; and the bridal wreaths of young brides are still suspended in some Derbyshire churches. (1) Corona sacerdotalis, worn by the priests and bystanders when engaged in sacrifice. (2) Corona funebris or sepulchralis, with which the dead was crowned, a custom which prevailed both among the Greeks and Romans. In Greece, these erowns were commonly of parsley. (3) Corona convivialis, worn by guests on festive occasions. 
As the emblem of sovereignty in modern Europe, the crown was borrowed less from the erowns of antiquity than from the diadem, a flllet of silk, linen, or woollen. This decoration was originally oriental. Alexander the Great alopted it from the kings of Persia; and Antony assumed it during his luxurious intercourse with Cleopetra. In modern states, crowns have been of various forms, and undergone various changes. The royal erown of Encland in the 12th and 13th centuries was a jewelled circlet of gold, heightened with struwberry-leaves or trefoils, sometimes alternatel large and small. In the very costly and magnifi. cent erown of Henry IV., the strawberry-leaves, eight in number, alternated with as many fleursde-lis, the whole alternating with sixteen small groups of pearls. The same crown was worn by Henry $\mathbf{V}$. in the beginning of his reign, but on undertaking his French campaign he ordered it to be broken up, and the fragments distributed as security for the lonn required by him to earry on the war. The crown that succeeded it was probably an arched one; for although no arched crown appears on the Great Seal of any monarch before Elward IV., the arched as well as the unarched form of erown is found occasionally in sculptures and illuminations of the reigns of Henry $\mathrm{V}$. and Henry VI. The crown of Edward IV. (which was probably also worn by Henry $\mathrm{V}$. and Henry VI.) differs from previons erowns in being arehed over with jewelled bands of gold, closing under a mound ensigned by a cross patée, while crosses patée are substituted for the strawberry-leaves, and roses or tleurs-de-lis for the clusters of pearls. During succeeding reigns down to that of Charles II., the crown underwent various minor changes of form.

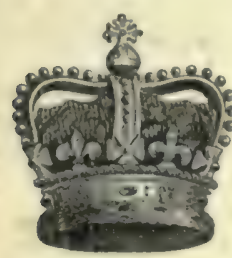

Fig. 1. There were sometimes three complete arches, gometimes two as at present, and these were at first very acute, afterwards more and more de. pressed; but the erown of the first Stuarts (weighing $7 \mathrm{lb} .6 \mathrm{oz}$, and worth $£ 1110$ ) was broken up in 1649 . From the reign of Charles II. till that of William IV., the same actual crown was used, its form being what is still nsually known in this country as the imperial crown, and represented in fig. 1. It has four erosses patée and four fleurs-de-lis set alternately

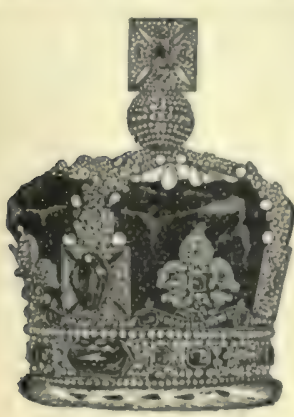

Fig. 2. on the circlet, while two complete pearl-gtudded arches rising from within the erosses patée carry at their intersection the mound and cross. A new state crown was made for the coronation of Queen Victoria, differing some. what from the imperial crown. Its arches rise almost perpendicularly, are elevated rather than depressed at their intersection, and assume the form of wreaths of rose, thistle, and shanırock, formed of brilliants; and the crown itself is covered with diamonds and studded with costly gems (fig. 2 ). In official representations of the royal arms, they are ensigned by the imperial crown, but a graceful modification of that crown is sometimes made use of instead of it with Her Majesty's sanction (fig. 3). For the coronets of the members of the royal family and of the nobility generally, see CORONET.
The crown of Seotland, long lost sight of, was in 1818 discovered, along with the other Regalis (q.v.), in a cheat in Edinburgh Castle. Its gold circle, richly jewelled and enamelled, is heightened with ten feur-de-lis, alternating with os many crosses fleury, each adomed in the centre with a great diamond between four large pesils put erossways. Four gold arches, added in the reign of James IV., close under a mound, on which rests a large eross patee, with four pearls at the extremities, and as many in the angles. Excepting the arches, the crown is probably of the date of Rolert Bruce.

In the crown of the kings of France the circle was heightened with fleurs-de-lis; and from the time of Francis I. it was closed with eight arches,

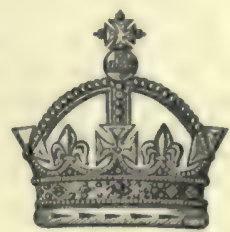

Fig. 3.

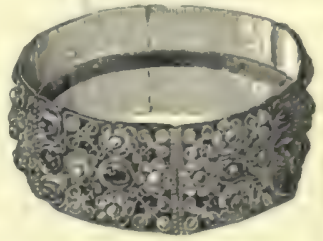

Mig. 4. from whose intersection arose a fleur-de-lis. The erown of the former German emperors, now of the Anstrian emperors, is cleft in the centre, so as to present an appearance suggestive of a mitre. The adoption of this erown by Charles V. seems to have resulted from the kings of France having, in enulation of the emperors, assumed a close crown. The iron crown of the ancient Longobardic kings (fig. 4)-restored to the king of Italy by the Emperor of Austria in 1866 - is alleged to have been bestowed by Pope Gregory the Great on Queen Theodolinda, and with it Henry of Lnxemburg and succeeding emperors were crowned. It is a gold circle with enamelled flowers and jewels, within which is a thin fillet of iron, which has been asserted to have been hammered from a nail of the true eross. The crown of the new German empire is shown in fig. 5 .

The crown with which

the king of Roumanis

was crowned in 1881 was

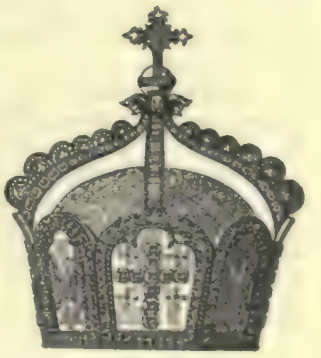

Fig. 5. made of bronze from the cannon captured in the Plevna redoubts.

The crown of an English King-at-arms is of silver gilt, with sixteen oak-leaves, each alternate leaf higher than the others. Since 1727 that of the Scottish Lyon King-at-arms is gimilar in form.

Crowns frequently occur as heraldic bear. ings; of these there are three of the classical crowns noticed in this article-

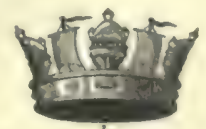

b

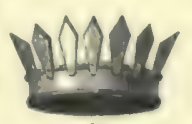

$c$

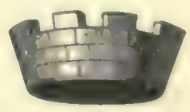

$\ell$

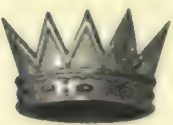

$d$
Big. 6.

viz. the crovons mural, $a$ (fig. 6 ), naval, $b$, and vallary, $c$, also the eastern or antique crown, $d, a$ circle with high points rising from it, and the celestial crown, differing from the last in having a star on each point. 
The Crown is a term often employed to signify the state and the matters under control of the executive authority. Thus, in the interests of the state there are crown-ministers, crown-lawyers, crown-officers, erown-lands, \&c.-the term, in no instance, having any special connection with the sovereign personally. In Scotland, certain high crimes are technically called Pleas of the Crown. These are four in number-murder, robbery', rape, and wilful fire-raising-and fall within the jurisdiction of the High Court of Justiciary. Likewise, in Scotland, there is a functionary styled crown-agent. $\mathrm{He}$ is a practising law-agent or solicitor, who, under the Lord Advocate and his deputes, takes charge of criminal proceedings. His duty is to receive from the procurators-fiscal of the different counties the precognitions which they have taken, and to lay these precognitions before the lawyers for the crown, that they may determine whether there is ground sufficient to call for a prosecution. $\mathrm{He}$ also expedes indictments and criminal letters, and otherwise discharges the duties of an agent in preparing and assisting in the conduct of trials before the High Court of Justiciary. The appointment of the crown-rgent is with the Lord Advocate, and cerses with the administration.

Crown Cases Reserved, Court for. See APPEAL.

Crown-soliction, the solicitor to the Treasury, who, in state prosecutions in England, acts as solicitor for the crown in preparing the prosecution. In Ireland there are crown-solicitors attached to each circuit, whose duties correspond in some degree to those of the Procurators-fiscal (q.v.) and crown-agent in Scotland. In England there are no analogous officers, and prosecutions are conse. quently conducted by solicitors appointed either by the parish, or by private parties bound over by the magistrates to prosecute. But in cases of great importance to the public, such as unusual or monstrous crimes, it is of frequent occurrence that the Solicitor to the Treasury takes charge of the case and instructs counsel.

Crown DEBTS.-It is a prerogative of the crown to take precedence of all other creditors, and in England, to recover its debts by a summary process called an extent. By 33 Henry VIII., chap. 39 , this preference is given over all creditors who have not obtained judyment (meaning in Seotland, the execution of diligence) for their debts before the commencement of the crown's process; and the Act 6 Anne, chap. 26, extended the law of England in this respect to Scotland, the old writ of extent being abolished in 1856. The rule in Scotland was limited to movable or personal property, and the erown has no privilege over a subject in a competition for heritage. It obtains, however, as opposed to the landlord's Hypothec (q.v.). Mercantile sequestration does not discharge crown debts except with consent of the Treasury; and in a sequestration the erowu has a statutory preference for one year's arrears of income and property tax, and assessed taxes, A similar preference is given for local rates. See EXTENT, EXCHEQUER.

'ROWN-LANDS must be distinguished from such rights as that in the seashore, which are merely held by the sovereign in trust for the people; and also from that portion of the royal patrimony which consists of such reserved rights as mines, salmonfishings, \&c. The crown-lands are called annexed property in Scotland, and demesne lands in England, and are of course also distinct from the private estate of the person who happens to be sovereign. They are now contracted within narrow limits, having been almost entirely granted away to subjects. King William III. so impoverished the crown in this manner, that an act was passed in 1703 voiding all grants or leases from the crown of royal manors, or other possessions connected with land, for a period exceeding thirty-one years. At a much earlier period ( 1455 , chap. 41) a Scottish statute had rendered the consent of parliament necessary to the alienation of the property of the crown, but the policy adopted of extensive subinfeudation to encourage agriculture had the effect of greatly diminishing the relative value of crown. lands not actually given away; and in Scotland they now consist mainly of a few castles, palaces, and feu-duties. The superintendence of such property as still belongs to the crown is now vested in commissioners appointed for the purpose, called the Commissioners of Woods, Forests, and Land Revenues. See Woops AND Forests. In some British colonies unallotted ground is nominally crown-land. Thus the sale and settlement of land in New South Wales was regulated by the Crown Lands Act of 1884.

Crown, in Architecture, a species of spire or lantern, formed by converging flying-buttresses. Familiar examples in Scotland are the erowns of St Giles's, Edinburgh, and King's College, Aberdeen; south of the Tweed the only old crown is that of St Nicholas's Cathedral at Newcastle.

Crown Imperial. See Fritullary.

Crown Pieces of silver, of the value of five shillings, were introduced into the English coinage by Henry VIII. They have a standard weight of 436.56 grains. None were coined from 1861 till 1887 , but since then they have again been struck. The name crown is also used as the translation of the French ecu, which varied in value from 6 francs (or livres) to 3 francs.

Crown Point, a post-village of New York, on Lake Champlain, near the site of a British fort of the same name surprised and captured by Colonel Ethan Allen in 1775.

Crown-work, in Fortification, is an ontwork consisting of two Bastion (q.v.) fronts connected with the main work by long flanks, so that its plan resembles sumewhat the outline of a crown.

Crow's-feet. See Caltrop.

Crow-stone, the top stone of the gable-end of a building. See CorbIE STEPS.

Crowther, Samuel Adjar, Bishop of the Niger territory, whose native name is Adjai, was born in Ochugu, to the east of the kingdom of Dahomey, in 1812, was carried off as a slave in 1819 , and after having been bartered and sold more than once, was taken by a British man-of-war and landed at Sierra-Leone in 1822 . He was placed under a missionary for training at Bathurst, and in 1825 professed his adherence to Christianity, taking his present name after a London vicar. He was next placed in charge of a mission school at Regent's Town; was with the first and second Niger expeditions (1841, 1854); visited London in 1842 , when, as the result of some further training, he was ordained by the Bishop of London, entered with enthusiasm upon his missionary labours, and was consecrated Bishop of the Niger territory in 1864. He was D.D. of Oxford, author of several na. tive tracts, and translated the Bible into the Yoruba langunge. Died in 1891. See his Life (1888).

Croydon, a town in Surrey, $10 \frac{1}{2}$ miles S. of London Bridge, yet practically a suburb of London. It lies on the edge of the chalk and plustic clay, near the Banstead Downs, at the source of the Wandle, hence its name Croindene (Fr., 'chalkhill') in Domesday. The archbishops of Canterbury had a palace here from the Conquest till 1757. Its Perpendicular hall (1452) and chapel (1633-63) were purchased by the Duke of Neweastle in 1887 and presented to the Sisters of the Church Extension 
Assoctation. Addington Park, 31 miles FSE., has since 1807 been the summer seat of the arehbishope. Addiscombe House, at one time the residence of the first Earl of Liverpool, was converted in 1812 into the East India Military College, but was pulled down in 1868. The fine old Perpendicular parish church wns destroyed by fire in January 1867, with the exception of the tower, but was rebuilt by Sir (vilbert Seott, and retains the monument of Archbishop Sheldon, with fragments of that of Archbishop Grindal. That of Archbishop Whitgift was restored in 1888 at a cost of ff60. Whitgift's Hospital (1596) is a red brick pile, restored in 1860; his grummar-school now oceupies buildings of 1871, besides a large Whitgift middle school. A new town hall, with law-courts and free library, was oprened by the P'rince of Wales in May 1896. Croydon was one of the first towns to grapple effectually with the economical disposal of town-sewage. A system of disposing of sewage by irrigation was inaugurated in 1858, and the corporation now possess two sewage farms, comprising 680 acres. In 1868 new water-worlks were completed, the water, which is of great purity, being obtained from an artesian well, yielding nearly $3,000,000$ gallons per diem; and a further supply of $2,000,000$ gallons per diem was introduced in 1888 at a cost of $£ 50,000$. The deathrate in 1848 , the year before the adoption of the Public Health Act, was 28.16 ; in 1887 it was $14 \cdot 71$. There are thirteen railway stations, Till the 18th century Croydon was famous for its 'colliers' or charcoal-burners; now its chief specialty is the manufacture of church clocks and carillons. It was made a inunicipal borough in 1883, a parliamentary one in 1885, and a county borough in 1888 . Pop. (1851) 10,260 ; (1881) 78,953 ; (1891) 102,697. See J. C. Anderson's Short Chronicle (1882).

Crozet Islands, a group to the south of the Indian Ocean, almost on a line between the Cape of Gow Hope and Kerguelen's Land, in lat. $46^{\circ} \mathrm{S}$., and long. $52^{\circ} \mathrm{E}$. Except four or five, they are mere rocks, and are all uninhabited, though shipwrecked sailors have lived for a time on them. They were visited by the Challenger expedition in 1873-74.

Crozier. See Crosier.

Crucian (Carassius vulgaris), a fresh-water fish, nearly related to the carp, from which it differs in the absence of barbules, in the singlerowed arrangement of the pharyngeal teeth, and in a few other minor pointe. It is found in uumerous varieties in rivers, ponds, and lakes in Europe and Asia; and is sometimes, though rarely, caught in the Thames. The food chiefly consists of dead vegetable and animal matter. The flesh is less esteemed than that of carp. The fish spawn in May or June, and then assemble in great numbers. See Carp.

Crucibles (Low Lat. crucibulum; from the root of Old Fr. cruche, 'a pot ') are vessels made of materials capable of being exposed to high temperatures without altera.

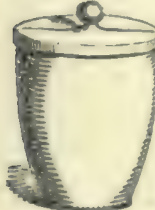

Crucible. tion, and used for fusing substances together, such as the materials for glass.making, or metallic ores, with various fluxes to obtain the several metals they yield. Crucibles should resist the corrosive action of the substances brought into contact with them, and are generally made of fireclay, porcelain, graphite, iron, platinum, and, for some special operations, of silver. See Assayina.

Cruci'fere (Lat, 'cross-bearing, from the $\mathbf{X}$. wise position of the four petals ), an important order of thalamifloral dicotyledons, including ahout 1200 known species, mostly palsestretic, and specially abundant in Europe. No order is incleod more familiar or more widely represented ; the Mustand, Shepherd's Purse, \&c., are among the commonest weeds of enltivation, while the Turnip and Cab. bage, the Radish and Cress, \&c, are no lese familiar and widespread in usefulnesa An wild flowers, they are mostly inconspicuous, but the pretty Cuckoo-flower or Lady's Smock (Carda. mine pratensis), and not a few others, might be mentioned as contributing oome characteristic feature to marsh or eliff or copse; while a large number of genera are of the greatest value to the florist, for whom the exuberant masses of Iberis, Alyssum, Arabis, and Aubrietia are among the most admired resources of the rock-garden. Besides the Stocks and Wallflowers, \&c., the old-fashioned Honesty and Gillyflower are among the most familiar inmates of every cottage-garden. The general character of the order is antiscorbutic and stimulating, with more or less acridity; the familiar flavour being due to the presence of a characteristic ethereal oil. Striking examples of these properties are given by the Scurvy-grass of our shores, 80 important to mariners in the days of long voyages and salt provisions; or more familiarly by the Common Water-cress; while a wide range of variation of flavour is presented by the flesh, rind, and leaves of the Common Turnip, especially in different varieties, soils, and seasons. A tixed oil is largely present in the seeds (see RAPE, CoLzA), and the Woad Plant (Isatis, see WOAD) has been used from the earliest times as a source of indigo. The order was conveniently subdivided by Linnsens by the nature of its fruit as long and short podded (Sili. quosæ and Siliculosæ), while later systematists have derived important characters from the mode of folding of the cotyledons within the seed. See Engler's Pflanzenfamilien, or other systematic work, and separate articles-e.g. CABBAGE, \&c.

Crucifix (Lat. crux, 'the cross,' and figo, 'I fix'), a cross with the effigy of Christ fixed to it. The principal crucifix in Catholic churches stands in the centre of the high-altar. It overtops the tapers, and is ouly removed to make place for the host in the service of Benediction. well-ap pointed churches, the altar crucifix is gener. ally either of gold or silver. Cruci. fixes are used in Lutheran churches, and in Prussia they are often made of Berlin iron. The crucifix first began to take the place of the plain eross in the time of Con.

stantine, but it was never publicly acknowledger by the Greek Church, and did not come into yeneral use in the East till towards the end of the 8th century. It was not till the Carlovingian age that it became general in the Latin Church. On the earlier crucifixes, Christ is represented as alive, with open eves, and generally clad, and fastened with four nails. On later ones he is represented as dead, naked, except for a cloth round the loins, and fastened with three nails-i.e. the two feet pierced by a single nail. See Cross.

Cruden, Alexaxder, bom at Aberdeen, 31st May 1701, from the grammar-school passed to 
Marisehal College, where he took his M.A., but, having shown symptoms of insanity, was for a short time placed in confinement. On his release he left Aberdeen, and, after spending ten years as a tutor, in 1732 established himself as a bookseller in London. In 1737 appeared his Complete Concordance of the Holy Seriptures, a really admirable work. It was dedicated to Queen Caroline, who graciously promised to 'remember him,' but unfortunately died a few days later. Cruden now relapsed into insanity, and for ten weeks was kept in a mad. house, as again for a fortnight in 1753. Earning meanwhile his livelihood as a press-reader, he assumed the title of 'Alexander the Corrector,' and in 1755 began to go throngh the country, reproving by voice and pen the nation's sins of Sabbath-breaking and profanity. But many a good and kindly action was interwoven with his crack-brained courtships, his dreams of knighthood and a seat in parliament. He was just back from a visit to his native city, when he died at his prayers in his Islington lodgings, 1st November 1770. See the Life by A. Chalmers, prefixed since 1824 to many of the numerous editions of the Concordance. See CONCORDANCE.

Cruelty. See Animals (Cruelty to), ChilDREN (CRUELTY TO).

Cruikshank, George, one of the most gifted of English pietorial satirists, was born in London, September 27, 1792, the son of Isaac Cruikshank, who, as well as his eldest son, Isฌac Robert Cruikshank, was also known as a caricaturist. Cruikshank at first thought of the stage as a profession; but some of his sketches having come under the notice of a publisher, he was induced to engage in the illustration of children's books and songs. A publicaticn, The Scourge (1811-16), afforded scope for the display of his satiric genius, and from that time forth he continued to pursue with remarkable success this his true vein. His illustrations for Hone's political squibs and pamphlets, and especially those dealing with the Queen Caroline trial, attracted much attention, and sent some of them through no less than fifty editions. But in the exquisite series of coloured etchings contributed to the Humorist (1819-21), and in the etchings to the Points of Humour (1823-24), did his true artistic power begin to be visible. This second, and in many ways finest, period of his art, represented by these works, culminated in the etchings to Peter Schlemihl (1823), and to Grimm's German Popular Stories (1824-26), which in the siniple directness and effectiveness of their execution, and in their fertile and unencumbered fancy, rank as the artist's masterpieces. The latter series, now extremely scarce, was reproduced in 1868, with a laudatory preface from the pen of Mr Ruskin. Similar in artistic aims and method are the spirited little woodeuts contributed to the Italian Tales (1824), Mornings at Bow Street (1824-27), and Clark's Three Courses and a Dessert (1830); and the plates to Scott's Demonology and Witchcraft (1830) may be regarded as the last examples of his earlier and simpler method as an etcher. His numerous plates in Bentley's Miscellany mark a third period of his art, in which he aimed at greater elaboration and completeness, introducing more complex effects of chiar-oscuro, and frequently attaining great power of tragic design. The finest of these are the great series to Dickens's Oliver Twist, and to Ainswortl's Jack Sheppard in Bentley's Miscellariy, and The Tower of London, and in the same class are to be ranked the plates to Windsor Castle, and The Miser's Daughter, of which, as of Oliver Twist, he thirty years afterwards claimed the chief authorship. Among the best productions of his later years are the large and elaborate etchings to Brough's Life of Sir John Falstaff, published in 1858. His last illustration was the frontispiece to Mrs Blewitt's The Rose and the Lily (1877), 'Designed and etched by George Cruikshank, aged eighty-three, 1875.' As a water-colourist he left work marked by con. siderable skill and delicacy. In his late years he devoted himself to oil-painting, and in this province showed perhaps more humour, fervour, and inven. tive ability than artistic power. His most import. ant picture was 'Worship of Bacehus' (1862), which has been engraved partly by his own hand, a vigorous and earnest protest against the evils of drunkenness; and to the cause of temperance he also devoted many of his designs, especially the tragic and powerful series of The Bottle (1847), which, reproduced by glyptography, attained an immense circulation. He died lst February 1878. There are excellent collections of his works in the printroom, British Museum; the Royal Aquarium, Westminster ; and the South Kensington Museum. The last named, presented in 1884 by the artist's widow, numbers 3481 items. See G. W. Reid's Catalogue (3 vols. 1871), and Lives by Bates ( 2 d ed. 1879), Jerrold (2d ed. 1883), and Stephens (1891); and Marchmont's The Three Cruikshanks (1897).

Cruiser, formerly an armed ship employed to protect commerce or capture enemies' ships. See Privateer, Frigate; and for what are now called 1st and $2 d$ class cruisers, see NAVY.

Crusades is the name given to the religious wars carried on during the middle ages between the Christian nations of the West and the Mohammedans. In time, however, the name came to be applied to any military expedition against heretics or enemies of the pope. The first of the regular crusades was undertaken simply to vindicate the right of Christian pilgrims to visit the Holy Sepulchre. On the conquest of Palestine, how. ever, the object of the crusades changed, or at least enlarged, and the efforts of the subsequent erusaders were directed to the recovery of the whole land from the Saracens, who had repossessed themselves of it. From an early period in the history of the church, it was considered a pious act to make a pilgrimage to the Holy Sepulchre, and to visit the various spots which the Saviour had consecrated by his presence. When Palestine was conquered by the Arabs in the 7th century, that fierce but generons people respected the religious spirit of the pilgrims, and allowed them to build a church and a hospital in Jerusalem. Under the Fatimides of Egypt, who conquered Syria about 980 A.D., the position both of the native Cliristian residents and of the pilgrims becane less favourable; but the subjugation of the country in 1065 by brutal hordes of Seljuk Turks from the Caucasus rendered it intolerable. These barbarians, but recently converted to Mohammedanism, were nearly as ignorant of the Koran as of the Scriptures. They hardly knew their fellow-religionists, and are said to have wreaked their vengeance on the Mussulmans of Syria as well as on the Christians. The news of their atrocities produced a deep sensation over the whole of Christendom. The first to take alarm were, naturally enough, the Byzantine monarchs. In 1073 the Greek emperor, Manuel VII., sent to supplicate the assistance of the great Pope Gregory VII. against the Turks, accompanying his petition with many expressions of profound respect for $\mathrm{His}$ Holiness and the Latin Chureh. Gregory-who beheld in the supplication of Manuel a grand opportunity for realising the Catholic unity of Christen. dom-cordially responded; but circumstances prevented him from ever carrying the vast designs which he entertained into execution, and the idea of a crusade died gradually away. It was, however, 

revived by his successor, Urban II., an alle and humane nian, whose sympathies were kindled by the burning real of Peter the Hermit, a native of Amiens, in Franee, who had made a pilgrimage to the Holy Land, and witnessed the eruelties perpetrated by the Turks. He was now traversing Europe, preathing everywhere to crowds in the open air, and producing the most extraordinary enthusinsm by his impassioned descriptions of how pilgrims were murlered, robbed, or beaten; how shrines and holy places were desecrated; and how nothing but greed restrained the ruffian Turka (who made the Christians pay heavy taxes for their visits to Jerusalem) from destroying the Holy Sepulchre, and extirpating every vestige of Christianity in the land. As soon as the feelings of Europe had been sufficiently heated, Urban openly took up the questiun. Two councils were held in 109\%. At the second, held at Clermont, in France, a crusade was definitely resolved on. The pope himself delivered a stirring addreas to a vast multitude of clergy and laymen, and as he proceeded, the pent-up emotions of the crowd lourst forth, and eries of Deus vult ('God wills it') rose simultaneously from the whole sulience. 'This tumultuous cry,' says Hallam, ' which broke from the heart and lips of the assembly at Clermont, affords at once the most obvious and most certain explanation of the leading principle of the crusades.' These words, Deus vult, by the injunction of Urban, were made the war-cry of the enterprise, and every one that embarked in it wore, as a badge, the sign of the cross; hence the name Crusade (Fr. croisade, from Lat. crux, 'a cross').

First Crusade.-From all parts of Europe thousands upon thousands hurried at the summons of the pope to engage in the holy war. "The most distant islands and savage countries,' says William of Malmesbury, "were inspired with this ardent passion. The Welshman left his hunting, the Scotehman his fellowship with vermin, the Dane his drinking-party, the Norwegian his raw fish." It is said that in the spring of 1096 not less than $6,000,000$ souls were in motion towards Palestine. This, however, must be a huge exaggeration. What we do know positively is, that previous to the setting out of the great hosts of European chivalry, four armies-if disorderly multitudes deserve that name-amounting in all to 275,000 persons, had departed for Palestine. The first consisted of 20,000 foot, and was commanded by a Burgundian gentleman, Walter the Penniless. It marched through Hungary, but was cut to pieces by the natives of Bulgaria, only a few, among whom was Walter himself, escaping to Constantinople. The second, consisting of 40,000 men, women, and children, was led by Peter the Hermit. It followed the same route as its predecessor, and reached Constantinople grestly reduced in numbers. Here the two united, crossed the Bosporus, and were utterly defeated by the Turks at Nicea, the capital of Bithynia. A third expedition of a similar kind, composed of 15,000 Germans, led by a priest named Gottschalk, was dispersed with ter. rible slanghter in Hungary; which also proved the grave of the fourth, a horde consisting of about 200,000 wretches from France, England, Flanders, and Lorraine, who had swept along through Germany, committing horrible ravages, especially against the Jews, whom they murdered withont mercy. Now, however, the real crusaders made their appearance : the gentry, the yeomanry, and the serfs of feudal Europe, nnder chiefs of the first rank and renown. In this, the most successful of the crusades, neither the emperor nor any of the kings of the West participated; and to this cireumstance was doubtless due its more fortunate termination. Six srmies sppeared in the field, marching separately, and at considerable 142 intervals of time. Their respective leaders were Godfrey of Bouillon, Duke of Lorraine; Hugh the Great, Count of Vermandois, and brother of Philiple, king of Frunces; Rolvert Curthome, Iuke of Nornandy, the son of William the Conqueror: Count Robert of Flandens; Bohemond, Prince of Tarentum, son of the famous Guiscard, under whom was Tancred, the favourite hero of all the historians of the erusade; and lastly, Count Raymond of Toulouse. The place of rendezvous was Constantinople. The Greek emperor, Alexius, afraid that so magniticent a host-there were in all not less than 600,000 men, exclusive of women and priests-might be induced to conquer lands for themselves, eajoled all the leaders, excepting Tancred and Count Raymond, into solemnly acknowledying themselves his liegemen as long as they remained in his territory. After some time spent in feasting, the crusaders crossed into Asia Minor accompaned by the nnfortunate Peter the Hermit. Here their first step was the siege and capture of Nicrea, the capital of Sultan Soliman, 24th June 1097. This monarch was also defeated by Bohemond, Tancred, and Godfrey, at Dorylæum. Baldwin, brother of Godfrey, now crossed into Mesopotania, where he olotained the principality of Edessa. After some time, the crusaders reached Syria, and laid siege to Antioch. For seven months the eity held out, and the ranks of the besiegers were fearfully thinned by famine and disease. Many even brave warriors lost heart, and began to desert. Melancholy to relate, among the deserters was the poor enthusiast who had inspired the enterprise. Peter was actually severa] miles on his way home when he was overtaken by the soldiers of Tancred, and brought back to undergo a public reprimand. At length, on the 3d of June 1098, Antioch was taken, and the inhabitants were massaced by the infuriated crusaders, who were in their turn besieged by an army of 200,000 Mohammedans sent by the Persian sultan. Once more famine and pestilence did their deadly work. Multitudes also deserted, and escaping over the walls, carried the news of the sad condition of the Christians back to Europe. But again victory crowned the efforts of the besieged. On the 28th June 1098 the Mohammedans were utterly routed, and the way to Jerusalem opened. It was on a bright summer morning (1099) that 40,000 erusaders, the miserable remnant of that vast array which two years before had laid siege to Nicren, obtained their first glinpse of Jerusalem. On the 15th of July, after a siege of rather more than five weeks, the grand object of the expedition was realised. Jerusalem was delivered from the hands of the infidel. $A s$ on the occasion of all the triumphs of these first crusaders, a horrible massacre ensued. Religious enthusiasm, evoking the intensest and most strangely mingled passions, naturally led to these excesses on the part of men reared in the fiercest times of feudalism. Eight days after the capture of the city, Godfrey of Bouillon was unanimously elected king of Jerusalem. His kingdom, at first comprising little more than the mere city of Jerusalem, was gradu. ally extended by conquest until it included the whole of Palestine. A languacre resembling Norman French was established, a code of fendal laws drawn up-Jerusalem was erected into a patriarchate, and Bethlehem into a bishopric. The best part of Asis Minor was restored to the Greek empire, while Bohemond became Prince of Antioch. For nearly fifty years, the three Latin principalities or kingdoms of the EastEdessa, Antioch, and Jertsalem-not only maintained themselves against the attacks of the Mohammedans of Egypt and Syria, but greatly increased in size, power, and wealth. At Jern. 
salem were founded the two famous orders of the Knights Hospitallers of St John and the Knights Templars.

Second Crusade.-In 1144 the principality of Edessa was conquered by the Emir of Mosul, and the Christians slaughtered. His son, Noureddin, advanced to destroy the Latin kingdoms of Syria and Palestine. Europe once more trembled with excitement. A second crusade was preached by the famous St Bernard, abbot of Clairvaux, in Champagne; and early in 1147 two enormous armies, under the command of Louis VII., king of France, and Conrad III., emperor of Germany, marched for the Holy Land. Their united numbers were estimated at $1,200,000$ fightingmen. The expedition, nevertheless, proved a total failure. The Greek emperor, Manuel Comnenus, was hostile; and through the treachery of his emissaries, the army of Conrad was all but destroyed by the Turks near Iconium, while that of Lonis was wrecked in the defiles of the Pisidian Mountains. After a vain attempt to reduce Damascus, the relics of this mighty host returned to Europe.

Third Crusade.-The death-blow, however, to the kingdom of Jerusalem, and the power of the crusaders, was given, not by Noureddin, but by Salah-Eddin, commonly called Saladin, a young Kurdish chief, who had made himself sultan of Egypt, and who aspired to the suzerainty of the Mohammedan world. He invaded Palestine, took town after town, and finally, in October 1187, compelled Jerusalem itself to capitulate, after a siege of fourteen days. The news of this led to a third crusade, the chiefs of which were Frederick I. (Barbarossa), emperor of Germany; Philippe Auguste, king of France, and Richard Cour-deLion, king of England. Barbarossa took the field first in the spring of 1189 , but lost his life by fever caught from bathing in the Orontes. His army, much reduced, joined the forces of the other two monarchs before Acre, which important city was immediately besieged. In vain did Saladin attempt to relieve the defenders; and after a beleaguerment of twenty-three months, the place surrendered. But the crusaders were not united ámong themselves. Philippe soon after returned to France; and Richard, after accomplishing prodigies of valour, which excited the admiration of the Saracens, concluded a treaty with Saladin, by which 'the people of the West were to be at liberty to make pilgrimages to Jerusalem, exeinpt from the taxes which the Saracen princes had in former times imposed.' 'This, as has been previously noticed, was $a l l$ that had been claimed by the first erusaders. On the 25th of October 1192, Richard set sail for Europe.

Fourth Crusade.-Crusading unfortunately now became a constituent of the papal policy; and in 1203 a fourth expedition was determined upon by Pope Innocent IIf., although the condition of the Christians was by no means such as to call for it. It assembled at Venice; but how entirely secular crusading had become, will be seen from the fact that the army never went to Palestine at all, but preferred to take possession of the Byzantine empire. The leader of this host of pseudo-cruscuders, Baldwin, Count of Flanders, was seated on the throne of the East in 1204, and thus founded the Latin empire of Constantinople, which lasted for fifty-six years. Nothing was achieved in this crusade for the recovery of Jerusalem, but Innocent had his reward in the temporary supremacy of the papal see over the Eastern Church.

Fifth Crusade.-This was commanded by Frederick II., emperor of Germany. It began in 1228, and terminated in a treaty between that monarch and the sultan of Egypt, by which Jerusalem (with the exception of the Mosque of Omar), Jaffa, Beth. lehem, and Nazareth were ceded to Frederick, who, after being crowned king of Jerusalem, returned to Europe, leaving his new possessions in a state of tranquillity. Frederick, however, who had been excommunicated by Gregory IX. for his tardiness in embarking in this crusade, was denounced in the most violent language by the same pope for having thus made terms with the infidel.

Sixth Cruscde.-In 1244 the Khorasmians, driven from Tartary by Genghis Khan, burst into Syria, and made themselves masters of Jerusalem. This was made, by Pope Innocent $1 \mathrm{y}$., the occasion for another crusade; and in 1249 Louis IX. (St Louis) of France headed an expedition against Egypt, which was now regarded as the key of the Holy Land. The expedition was an utter failure. Louis was defeated and taken prisoner by the sultan, and obtained his liberty only on the payment of a heavy ransom.

Seventh Crusade.-This also was primarily undertaken by St Louis, but he having died at Tunis (where he had gone in the hope of baptising its king) in 1270, on his way to Palestine, Prince Edward of England, afterwards Edward I., who had originally intended to place himself under the command of St Louis, marched direct for Palestine, where his rank and reputation in arms gathered round him all who were willing to fight for the cross. Nothing of consequence, however, was accomplished; and Edward soon returned to England, the last of the crusaders. Acre, Antioch, and Tripoli still continued in the possession of the Christians, and were defended for some time by the Templars and other military knights; but in 1291 Acre capitulated, the other towns soon followed its example, and the knights were glad to quit the country, and disperse themselves over Europe in quest of new employment, leaving Palestine in the undisturbed possession of the Saracens.

Besides the great expeditions above enumerated, there were many others on a lesser scale. These, however, from the unimportance of their results, and the limited numbers engaged in them, do not call for special mention. Of the pseudo-crusades, three deserve notice for the important results that followed from them. Firstly, in 1209, there was that against the Albigenses (q.v.). Secondly, on the principle that it was binding on the servants of the church to do battle with all ontside its pale, in 1230 the Teutonic knights were called on by Gregory IX. to undertake a crusade against the heathen Prussians on the shores of the Baltic. The result was the complete subjugation of the Prussians, and the establishment in their country of the Teutonic military order till its extinction at the battle of 'Tannenberg in 1410. Thirdly, in 1262 Urban IV., jealous of the growing power of Manfred, king of Sicily, son of the Emperor Frederick II., offered Manfred's crown to Charles of Anjou, brother of St Louis of France, and gave to this dispossession the name of a crusade. A protracted war ensued, which resulted in the House of Anjou gaining the kingdom of Naples, and the House of Aragon the kingdom of Sicily. The terrible wars of the 16th century between France and Spain for supremacy in Italy were the direct consequence of this pseudo-crusade.

Effects of the Cruscides.-While we cannot help deploring the enormous expenditure of human life which the crusades occasioned, it is impossible to overlook the fact that they indireetly exereised a most beneficial influence on modern society. They secured for humanity certain advantages which it is difficult to see could have been otherwise obtained. Guizot, in his Lectures on European Civilisation, endeavoured to show their design and function in the destinies of Christendom. "To tho 
first chroniclers,' he says, 'and consequently to the finst crusulers, of whom they are but the expres. sion, Mohammedans are objects only of hatred : it is evident that those who sperk of them do not know them. The historians of the later crusades sperk quite differently : it is clear that they look upon them no longer as monsters; that they have to a certain extent entered into their ideas; that they have lived with them; and that relations, and even a sort of sympathy, have been established hetween them." Thus the minds of both, but particularly of the crusaders, were partly delivered from those prejudices which are the offspring of ignorance. A step was taken towards the enfran. chisement of the human mind.' Secondly, the crusaders were brought into contact with two civilisations, richer and more advanced than their own-the Greek and the Saracenic; and it is beyond all question that they were mightily struck with the wealth and comparative refinement of the East. Thirdly, the close relationship between the chief laymen of the West and the church, occasioned by the crusades, enabled the fornier ' to inspect more narrowly the policy and motives of the papal court.' The result was very disastrous to that spirit of veneration and belief on which the church lives, and in many cases an extraordinary freedom of judgment and hardihood of opinion were induced $\rightarrow$ such as Europe had never before dreamed of. The immediate results of the crusades, however, went altogether to strengthen the power of the -church. Through their means the popes found an easy method of ridding themselves of refractory monarchs; and by the exorbitant taxes levied in the name of the cross they practically rendered all the kingdoms of the West their tributaries. Fourthly, great social changes were brought about. A commerce between the East and West sprang up, and towns-the early homes of liberty in Europe-began to grow great and powerful. The crusades, indeed, "gave maritime conmerce the strongest impulse it had ever received.

See Gibbon's Bistory of the Decline and Fall of the Roman Empire; Milman's Latin Christianity; Hallam's History of the Middle Ages; Mill's History of the Crusades ; Cux's History of the Crusades ; Heeren's Esay on the Influence of the Crusoudes; the great Recueil des Historiens des Croiscules, issued by the Académie des In. scriptions; and Archer and Kingsford, The Crusoules ('Nations Series,' 1894); and the articles BaLdwin, Goljprey, Jrbusalem, Richard I., Saladiv, Willay or TrRe, \&c.

Crusea, Accademia della. See Academy, Della Cruscan school.

Crusenstolpe, Magrus JakoB, Swedish political writer, was born at Jinköping, 11th March 1795. He wrote novels, elaborate historical works, pamphlets, and contributed to the newspapers. His Stälningar och Förhollenden, carried on from 1838 till 1865 , spplied vigorous and unspr. ing criticism to the questions and persons of the day. His bitter opposition to government cost him three years' imprisonnent (1838-41). He died 18th January 1865.

Crustacea, a large and important class of Arthropod animals, including erabs, lobsters, shrimps, sand-hoppers, wood-lice, water-fleas, barnacles, acorn-shells, \&c. The class contains such variety of structure that general charncters arc hard to find. They are almost all aquatic, but a few (e.g. wood-lice and land-crabs) are terrestrial. The majority are marine, but great numbers is. habit fresh water. The form of the body is very variable, as may be seen by contrasting crab and barnacle. A head with five pairs of appendages, a limb-bearing thorax more or less united to the former, and a segmented abdomen with or without limbs, are very generally distinguishable. The segmentation is never developed in the Ostracod water-fleas, and is often lost in degenerate forms. $\mathrm{By}$ the development of shields (A pus), bivalve shells (water-fleas), and mantlea (Cirripedes), the real form is often obecured. As to appendages, the head usually bears two pair of antenne, a pair of mandibles, and two pairs of maxillue; the thorax is always limb-bearing except in utter degeneracy; and the abdomen of the majority sho carrien appendages. The typical form of limb, on which so many changes are rung, consists of a basal piece and two more or less jointed forks. The cuticle varies greatly in degree of firmness, but is always chitinous (see CHITIN) and often much calcified. Glauds open on various parts of the surface, and may le of use for preliminary digestion, for eggattachment, for mooring the animal, \&c. The colouring of the bxly is often very brilliant and beautiful (see PrgmenTs). It is sometimes like that of the surroundings, and is occasionally associated with sexuality. The power of colour-change is also not uncommon. Sapphirina is said to rival the humming-bird in its splendour. While the nervous system in general retaing the Arthropod charac. teristics, the ventral ganglia are often concentrated (as in crabs). The majority possess compound eyes, which in one large division are stalked. Eyes are absent in some subterranean forms, and are lost during the development of Cirripedia (q.v.) and many parasites. In the Euphausidre there are very numerous eye-like structures or luminous organs over the body. Smelling hairs usually occur on the first antennx, and anditory hairs have been frequently observed, usually more or less inclosed in sacs. The alimentary system, which consists of fore, mid, and hind gut, is usually simple, except as regards the hard masticating parts often developed on the cuticle of the anterior portion. In some parasitic forms the entire system degenerates. The body-cavity is usually a good deal filled up by the muscles and viscera; it contains the blood fluid, which is occasionally faintly coloured with hremo. globin, tetronerythrin, and other pigments, and includes amoboid elements. A heart is usually present in the thoracic region, and is often inclosed in a special part of the body-cavity - the pericardium. In higher forms the blood passes by distinct arteries to the bodies, is gathered up in venous spaces and sinuses, is purified in the gills, and returns to the pericardial sac and heart. The respiratory system is typically represented by distinct gills variously attached; in many cases water flows in and ont at the anus, and probably effects an anal respiration; in many lower forms the blood is simply puritied by being exposed under the skin. The excretory system is never very marked. The green glands of higher forms, the shell.glands of Phyllopods and Copepods, and certain other structures, are exeretory. The reproductive system presents many variations. The sexes are usually separate, but most Cirripedes are hermaphrodite. "In the Cymothoidre (Isopoda) the sexual organ of the young animal is male-of the old, fenale-in function." The glands are usually thoracic, and the ducts double. Some of the appendages are often modified for copulation or egry-retaining. The spermatozon are peculinr in being usually non-motile. The eggs are in most cases carrier alout by the female, but are occa. sianally laid on water-plants, \&e., or in the water. According to Bates. Podocerus copillatus builds a nest of interlaced seaweed. Parthenogenesis (q.v.) has been observed in some of the lower forms. 'Complemental' males oceur among the hermaphrodite Barnacles and Acorn-shells (q.v.).

Life-history. - The development of Crustaceans is usually indirect-that is to say, the newly. 
hatched young is unlike, often very unlike, its parent. Even when there is no metamorphosis after hatching, traces of transformation, as opposed to continuous development, are sometimes to be detected in the earlier history while the embryo is still within the egg-case. (a) The crayfish (Astacus) has a very much abbreviated life-history, for the newly-hatched form is almost quite like the adult. (b) The newly-hatched lobster (Homarus), however, begins life a little further back, in what is known as the Mysis stage, in which the thorax bears two-branched swimming appendages. (c) Most other higher Crustaceans (e.g. crabs) begin at a still lower level, in what is ealled the Zocea stage, with a short unjointed thorax and a segmented abdomen without limbs. (d) The

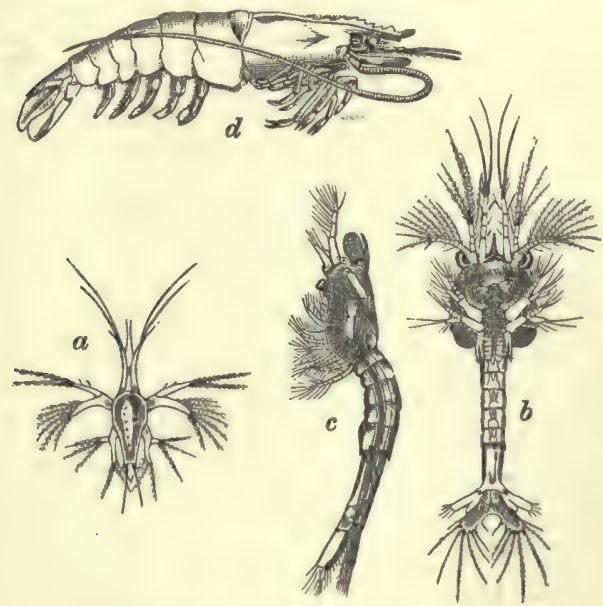

Development of a Prawn (Penceus):

$a$, Nauplius ; $b$, Zoæa ; $c$, Mysis ; $d$, adult.

Decapod Penzeus, a shrimp-like creature, has its life-history still more drawn out. It quits the egg as a Nauplius, an unsegmented larva with three pairs of appendages, the first unforked, the other two pairs double-branched. These correspond to the first three appendages of the adult. The median eye is also a distinctive feature in the Nauplius larva. The Penæus Nauplius has with successive moults first to become a Zora, and then a Mysis, and then an adult. It is as a Nauplius that the majority of lower Crustaceans leave the egg, but then they do not climb so high. To understand the circuitous life-history of a form like Penæus, we have to note that it begins in the Nauplius stage, at the level of the lowest Crustaceans, and gradually climbs through a series of higher and higher stages, each of which is represented permanently by some division of Crustaceans which have not risen higher. If the various grades from Nauplius up to Decapod adult represent successive historic levels, now exemplified in the classification of Crustaceans by those which were left behind at each lift, what the Penrus does is to recapitulate in its individual life-history the historic evolution of the class. This idea has been beautifully applied to Crustaceans in Fritz Müller's Facts for Darwin. The various grades of Nauplius, Zoæa, Mysis, and adult Penæus (overlooking intermediate ones) may be compared to stations which mark the gradual extension of the Crustacean line of advance. Penrus has to travel along the rails laid down by the ancestral history, and has to stop for variable periods at the successive stations between the starting-point and the terminus. Crabs skip over the Nauplius station, and like most other Decapods start at the Zoxa point; lobsters abbreviate still further, and begin as Mysis forms; the crayfish has found the shortest eut of all. Some of the lower Crustaceans never get far past the Nauplius stage, while others remain practically on the Zoxa grade. The life-histories of Crustaceans vividly illustrate how the individual life-history is a rehearsal of the historic evolution of the kind, or more technically, how ontogeny recapitulates phytogeny.

Habit of Life. - The acorn-shells fastened to the rocks, wafting in their food by their curled feet; the barnacles moored to floating logs and shipbottoms; such extremes of parasitism as are illus. trated by Sacculina on hermit-crabs; the hermitcrabs themselves, stealing the shells of Gasteropods, or entering into partnership with sea-anemones; the thousand minute and active water-fleas; the wood-lice, quite terrestrial; the brine-shrimps in the salt-pools; the fresh-water crayfish; the giant marine lobsters; the land-crabs, habituated to inland life, sufficiently suggest how varied are the habits of Crustaceans. Some Crustaceans form masking shelters for themselves out of Tunicates, or get covered over by a concealing growth of seaweed, sponge, hydroids, \&c. A few forms are known to make a stridulating noise. The general intelligence of the class is probably considerable (see CrAB). On the whole the members of this class are active animals, but on each side of the medium activity of the majority there are extremes. Thus, not a few active marine forms are phosphorescent, while parasitism (to the extent of some 700 species) occurs in most of the subdivisions. Many of the parasites are very striking in the contrast between the free-swimming young and the ne plus ultra of degeneracy in the adults (see Degeneration, Parasitism). Some of the interesting cases of Commensalism (q.v.) have been referred to under that title; while some of the external parasites show in the castration, \&e. which they effect on their hosts, how real in such cases is the direct intluence of the animate Environment (q.v.). The diet of Crustaceans is very varied; the majority are carnivorous and aggressive; many feed on dead creatures and organic debris in the water; others depend largely upon plants. They often lose limbs in fighting or otherwise, and have the power of replacing what they have lost.

Classification (after Claus).--(A) Entomostraca. Lower forms, small, simple, with variable number of rings and appendages, with not more than three appendages concerned in mastication, usually leaving the egg as a nauplius. (1) Phyllopoda: $(\alpha)$ Branchiopoda e.g. Brine-shrimps (q.v.), Apus, Estheria, \&c. ; (b) Cladocera-the common "waterflea' Daphnia, Moina, \&c. (2) Ostracoda-common Cypris (q.v.), Cypridina. (3) Copepodacommon Cyclops (q.v.), Lernaea, \&c. (4) Cirripedia-Acorn-shells, Barnacles (q.v.), Sacculina, \&c.-(B) Malacostraca. Higher, larger forms, with nineteen segments, with more than three appendages concerned in mastication, usually quitting the egg at a higher level than the Nauplius : (1) Leptostraca, Nebalia, a primitive form with bivalve shell; (2) Arthrostraca, with free thorax, and no cephalothoracic shield, eyes sessile: (a) Amphipoda-Sand-hoppers (q.v.), Caprella, \&c.; (b) Isopoda-Wood-lice (q.v.), Asellus, Tanais, \&c. (3) Thoracostraca, with all or part of thorax fused to head, and with a cephalothoracic shield, eyes mostly stalked: $(a)$ Cumacea, sessileeyed-Cuma; $(b)$ Stomatopoda, with gills on abdominal feet-Squilla; (c) Podophthalmata, with stalked eyes and large shield: (i) Schizopoda, with eight pairs of double thoracic feet-Mysis; (ii) Decapoda, with thorax fused to head, and last five thoracic feet not double; long-tailed 
(Macrura) - e.g. Crayfish (q.v.), Lobater ; shorttailed (Brnchyura), Crabe.

Distribution in Spme and Time.-(re) Deepsea forms are very abundant, and often remarkable 'for their colossal size, their bizarre forms, and brilliant red colouring.' Blind species are known to oceur in the depths, and others are brilliantly phosphorescent. (6) Pelagic surface Crustaceans (especially Schizopods and Entomostraca) are very abundant, and often form a large part of the food of fishes. They are often beantifully transparent, and hardly to be seen in the water. Less frequently they are brilliantly coloured (as in Supphirina) or phosphorescent. Some of them are remarkable for their large eyes. One Amphipod Crustacean presents a curions mimicry of a Medusoid form. Deeapods are most abundant in the warmer waters. (c) Crustaceans form an important part of the relatively sparse and uniform fauna of lakes. They occur both on the surface and at the bottom, the latter being generally more sluggish. The surface forms, at anyrate, are usually perfectlv transparent, with the exception of the eve. (d) The catulogue of terrestrial Crustaceans, which includes species of Amphipods, Isopods, and Decapods, is relatively a very short one.

The Crustacea date back to Cambrian times, but the highest forms (Decapods) were not firmly established till the Tertiary period. Some 800 fossil species, as against over 5000 living forms, are known. Some of the genera-e.g. Estheria-from the Devonian, ure marvellously persistent, and survive from ancient epochs as still very successful and widely distributed forms. The Trilobites (३.v.) are not now regarded as true Crustaceans. (For distribution, see Heilprin, Inter. Sc. Series, 1887.)

Pedigree. - It is usmally believed that Crustacen are descended from a primitive Phyllopod-like ancestor, and this from a segmented worm-type. The very constant occurrence of a Nauplius larva has led zoologists to regard it as representing a remote ancestor. The lines of differentiation chiefly consisted in the development and manifold modifi. cation of the fundamentally similar appendages, and in the perfecting of the exoskeleton as a base for muscular attachment. (See Herdman's Classification of Animals, Lond. 1885.)

Economic Importance. - Crabs, lobsters, crnyfish, shrimips, prawns, \&e. form part of our food-supply. Others are indirectly useful as important parts of the food of herrings and other fishes. Many are doubtless useful in purifying the water from organic debris, while others are the hosts of im. portant parasites e.g. the Cyclops species, which contains Drucunculus mulinenis.

See Acors-8hrll, Bahnache, Brine-shrimp, Ctrktprdia, Copepoda, Crab, Cratrish, Crprrs, Crclops, Lobster, Prawn, Shrimp, Water-rlea, \&o. ; aloo Colfmensalism, Parasttisy, Parthenogrvesis, \&c., and references under above articles. For further details, consult general text-books of Brooks (Boston, 1882), Clans, Gegenbaur, Huxley, Rolleston and Hatchett Ja"lsson; also Baird, Britieh Entomostraca (Ray Soc. 1850); Balfour's Embryoloyn: Bell, Britiah stalk-ened Crustacea (Lond. 1856); Challenger Reports (several); Clans, Gencalomy of Crustacen (1876): Dana, Crustacea of U.S. Axp/nring Expedition (Phila. 1852); Gerstwooker in Bronn's Thierreich; Huxley's Cranfieh (1881); MilneEdwards, Histoire Nuturelle des Crustanés (Paris, 1834 40): the Munouraphs of the Naples Station (several) F. Müller, Facts for Darwin (1869); Sars, Fresh-water Crustacea of Norwody (Christiania, 1867); Spence Bate and Westwool, British Sessile-eyed ('rustucea (1863-68) Stebbing, $\boldsymbol{A}$ History of Crustaced (1893).

Crutched Friars, an order of friars, carry. ing in their hand a staff, on the top of which was a cross, received the name of Croisiers (Fr. zroix, 'cross '), corrupted into Crouched' or Crutched
Friars. They came to England in the 13 th century, and had monasteries in London (which still gives name to a street), Oxford, and Reigate.

Cruvelhier, JRax, physician, born at Limoges in 1791, became professur of Pathology at Montpellier in 1824, and of Pathological Anatomy in Paris in 1836. Besides his great work, Anatomie Pathologique du Corps Humain $(2$ vols. 1828-42), he published several other works on anatomy, which were for many yeans the most valuable French contributions to their subject, and also a Life of Dupuytren (1840). He died 6th March 1874.

Crwth (pronounce the $w$ as French $u$ ), an old Welsh stringed instrument. Four of its six strings were played with a bow, the other two being twitched by the thumb.

Cryolite, a mineral which exists in great abund. ance on the coast of Greenland. It consists mainly of a fluoride of aluminium in combination with Fluoride of Sodium, $6 \mathrm{NaF}, \mathrm{Al}_{2} \mathrm{~F}_{6}$. The metal Aluminium (q.v.) was formerly largely obtained from it, but it is now most important as a source of alum and of soda bicarbonate; much of it, also, is nuelted and made into a kind of glass.

Cryophorus (Gr. kryos, 'cold,' and phero, 'I carry ${ }^{\prime}$ ) is an instrument consisting of a glass tube with a bulb at both ends, used for showing the diminution of temperature in water by evapora. tion. In constructing it the whole of the air is extracted, leaving practically a vacuum inside. A little water is present in one of the bulbs, and when the second bulb, containing only watervapour, is placed in a freezing nixture, the vapour condenses, which causes more vapour to rise from the water in the first bulb. The result of this vaporation from the first bulb is the alstraction of much heat, and ultimately the remaining water passes into a frozen state.

Crypt (Gr. krypto, 'I hide'). In the early days of persecution the Christians were accustomed for security to worship in the catacombs or erypts where they buried their dead (see CAтAcombs). When persecution ceased, this custon led to the erection of churches over the graves of martyrs and saints; but at a later date the bodies of the saints were transferred to chambers, constructed to resemble the catacombs, under the sanctuary or altar of the new churches, in order to add to their sanctity. These erypts and their sacred shrines were visited by numerous pilgrims, and were frequently constructed for the accommodation of the devotees, of sufficient size to admit a number at a tinse, who descended by one stair, and ascended by another. In other cases the erypts were so placed that the shrine of the saint could be seen from the aisles of the choir, the floor of which was necessarily raised considerably above the level of the nave. Crypts of these kinds were usual in the early centuries, and many examples of them have been preserved in Italy and France, even where the churches over them have been rebuilt. The erypt of the Circular church of St Benigne at Dijon was one of the largest. There a great circular apertnre in the centre of the floor of the upper church enabled a very large congregation of pilgrims, including those in the erypt, to see the shrine of the saint, and witness any ceremony taking place there.

After the 13th century crypts were not so much in use. The great cathedrals were regarded as much in the light of civil as of ecclesinstical edifices, and the floor of the choir was brought down to the level of the rest of the building. It sometimes happened that owing to the slope of the site considerable underbuilding was required under the choir, in which case an under church was constructed, which was called by the old name of the 
crypt, and was generally used for sepulchral purposes. The crypt of Canterbury is one of the finest of this kind. The erypt of Glasgow Cathedral is

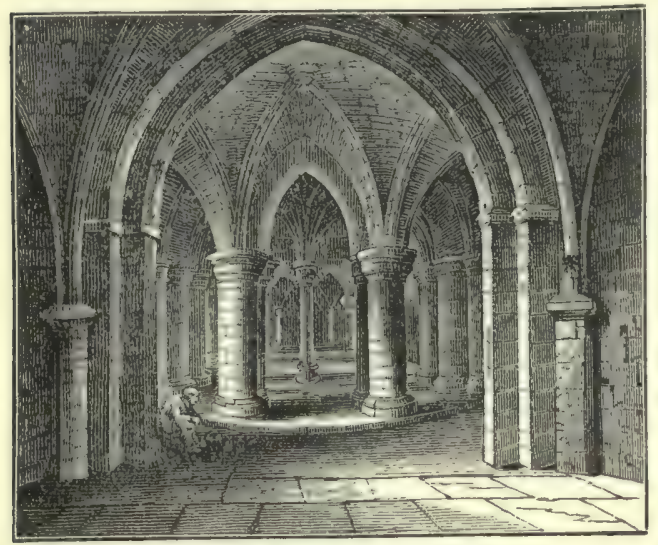

Crypt, Canterbury Cathedral.

also a very beautiful example, the vaulting over the shrine of St Mungo being pointed out by Sir Gilbert Scott in his lectures as one of the best specimens of its class.

Cryptogamia. This term was introduced by Linnreus as the twenty-fourth and last class of his system of classification, and broadly with its present contents. The name, however (Gr. kryptos, 'concealed,' and gamos, 'marriage'), in opposition to flowering plants (Phanerogamia, q.v.), records its donor's well-founded expectation that sexual reproduction would one day be discovered. Jussieu proposed to distinguish them as Acotyledones from monocotyledons and dicotyledons; but the term has necessarily lapsed for many reasons. De Candolle distinguished them into two great groups, Cellulares and Vasculares; while EndJicher's separation of the vegetable kingdom into Thallophytes and Cormophytes still further recognised their vast morphological range. Armed with the microscope more recent investigators have determined the life-history and mode of reproduction of all the leading types, so not only anply confirming the hypothesis of Linneus, or even still further increasing their morphological importance as compared with Phanerogams, but entirely revolutionising our interpretation of the flowering plants themselves, since leading us to view them as more profoundly cryptogamic than the eryptogams. The separate groups of cryptogamic plants are outlined in the articles ALGE, Seaweeds, Bacteria, Fungi, Lichens, Mosses, Ferns, Rhizocarps, Horse-TaII, Lycopodium, Selaginelua ; while their relation to higher plants is explained under Phanerogamia, Flower, Gymnosperms.

Cryptography, the art of secret writing, also called Writing in Cipher, Hieroglyphic Writing, Secret Writing, Steganography, Polygraphy, has been in nse from an early date in correspondence between diplomatists and others engaged in important affairs requiring secrecy. Every government used to employ its staff' of decipherers, who availed themselves of extraordinary means for interpreting despatches which (fairly or unfairly) came in to their possession. The cipherers and the decipherers waged a constant struggle to outwit each other; the one by constructing new difficulties; the other by conquering the difficulties as soon as constructed. How often we hear of a courier being murdered and his despatches carried off! And without the key to decipher letters so written, ts what purpose would they be intercepted by such a deed? In these modern times, however, there has been so great an improvement in the morals of governments that the custom of killing foreign-office messengers for the sake of their despatch-bags is entirely obsolete in diplomacy, and statesmen have ceased to pillage post-offices or rifle portmanteaus for cryptographic messages.

Most of the odd knacks, contrivances, decoys, blinds, now employed by cryptographers were to some extent known to and employed by the ancients. Substituting points for vowels; arranging threads, knots, or ink-spots at determinate distances; substituting one letter for another; inventing new arbitrary characters for whole words or even sentences-now made use of extensively in telegraph codes; abbreviating words in their prefixes and affixes; writing a long sentence of nonsense, with a clue to find the words which gave the proper sense-all were brought into requisition. Perhaps the most amusing of all eryptographs was the one mentioned by Herodotus. Histiæus, a Greek at the Persian court, being desirous of sending a secret message to Aristagoras at Miletus, selected a slave who was afflicted with bad eyes, and shaved his head, pretending that it was necessary for his recovery. In performing this, Histireus inprinted his secret intention in legible characters on the man's head, and kept him in close confinement till his hair grew again, when he sent him to Aristagoras for a perfect cure. Aristagoras repeated the shaving, read the writing underneath, and thus obtained the desired information by means of the unconscious mes. senger.

One of the simplest methods of cryptography is to use instead of each letter of the alphabet a certain other letter at a regular interval in advance. Such was a mode of secret writing adopted by Julius Cæesar, As a variety of this plan, the alpha. bet is used invertedly, $z$ for $\alpha, y$ for $b, x$ for $c$, and so on; or, while the first seven letters are represented by the second seven, the next six may be represented by the last six. And many other variations may be adopted. But the deciplierment of such messages is naturally not difficult, and with a little consideration of the peculiarities of the English language, all the ups and downs of many an interesting love story related in cipher in the columns of the Times can be followed from start to finish with comparative ease. It is known that $e$ is the most frequent letter; that the is the commonest word; that $e a$ and $o u$ are the double vowels which most frequently occur; that the consonants most common at the ends of words are $r, s$, and $t$, \&c. We also know that a word of a single letter must be either the pronoun $\mathrm{I}$, or the vowels $\alpha$ or 0 ; that $a n, a t$, on, to, of, and in are the most common words of two letters ; that the and and are the most frequent words in three letters; that the most usual doubled letters are $e e, 00, l l, s, f f$; that double vowels are mostly followed by $l, m, n, r$; that the letter $a$ begins three two-letter words in very extensive use - an, $a s$, at ; that the letter $o$ begins or ends eight two-letter words in very common usedo, go, no, so, to, of, on, or ; that more words in a sentence of average English begin with $t$ than with any other letter; that in about three-fourths of all the words in a sentence, either the first or the second letter is a vowel ; that among consonants, $d$ and $h$ are most largely used, after which come $n, s, r, t$; that the letter $q$ is always followed by $u$; that no English word of two letters or more ends with $i$. All these considerations will guide us to the solution of any simple cipher, enabling a skilful decipherer to read almost any ordinary piece of cryptographic writing in a very short time. 
In British listory, oryptography has at no time heen in grenter reguisition thun durisy the ('ivil War. Cliarles I.'B celebrated letter to the Earl of Glamorgan (afterwards Marquis of Worcester), in which he male some compromising concessions to the Catholies of Ireland, was composed in an alphahet (sometimes supposed to be Churles's own, but more probably Worcoster's invention) of twenty-four short strokes varionsly situated upon a line (see OGAM), Other letters hy the same monareh are to appearance a mere series of numbers of two or three figures divided by semicolons. In such cases it was necessary that the two parties engaging in the correspondence should have previously concerted what words ench number was to represent.

In the reign of William III. the Jacobites in. vented many curious ciphers to enable them to communicate with their exiled king. All the Jacobite clubs had distinct methods of their owntheir great aim being to write in such a manner that the very ciphers themselves should pass through their enemies' hands without suspicion. This they accomplished by means of sympathetic inks. A favourite Jacobite cipher was the use of parables, conveying, by means of ordinary language, a double meaning, which only the person acquainted with the writer's views would think of. The use of eryptography for purposes of state in England ended, it may be said, with the Peace of 1815. During the Peninsular war the government attached a eryptographer to the othice of the Minister for Foreign Affuirs to read and write the ciphers received and despatched. It is said that on more than one occasion the minister was unable to comprehend his own eipher.

The earliest elaborate treatise on writing in cipher is the Steganographia (Frankf. 1606) of the abbot John Trithemius, a MS. copy of which was bought for a thousand crowns at Antwerp by Dr Dee in 1563. Lord Bacon, who esteemed cryptography one of the most useful arts of his time, framed what he believed a not easily penetrable cipherin which he employed only $a$ and $b$, arranging each of these letters in groups of five, in such collocations as to represent all the twenty-four letters. Thus $a a b a b, a b a b a, b a b b a$ conveyed the word $f y$. In his De A ugmentis he styled this an omnia per omnia cipher, believing that in this case preconcertment would be necessary; but in reality any clever molern decipherer could have read any letter composed in such a manner if it were of any length.

Mr Donnelly, in his work The Great Cryptogram, endeavours to prove that Bacon inserted a cipher in the Shakespearian plays - which he claims is the work of the great philosopher-but the cipher is of so elaborate a kind that nobody but $\mathrm{Mr}$ Donnelly has been able to follow its intricacies. The unfortunate Earl of Argyll used a mole of secret writing which consisted in setting down the words at certain intervals, which he afterwards filled up with other words, making of the whole something intelligible, but of no use to any one else reading the message. The Marquis of Worcester invented a cipher composed of dots and lines variously ordered within a geometrical figure; while Dr Blair made one of three dots, placed over, under, or on the line, by which he could represent no fewer than eighty-one letters, figures, or words. The Doctor, in his able article in Rees's Cyclopedia, declares this cipher to be as nearly as possible undecipherable by strangers; but two years after. wards, Mr Gage, of Norwich, published a pemphlet on purpose to solve Dr Blair's riddle. As he devoted fourteen closely printed octavo payes to the explanation, any description of the cipher is beyond the limits of this article. Mr Thicknesse, a weil-known expert of the 18th century, also devised a plan of conveying information in the disguise of music, the notes, rests, expresaion. marks, \&e., standing for letters.

All the methouls, however, of cryptography may thus be summarimed: (1) liy invisille ink; (2) by superfluous words; (3) by misplaced words; (4) by vertical and diagonal reading; (5) by arti. ficial word-grouping; (6) by stencil-plates cut out os to show certnin words benenth; (7) by using two letters (Lord Bacon's cipher); (8) by transposing the letters; $(9)$ by substitution of letters ; (10) by counterpart tabulations; (11) by mixed symbols; (12) by a printer key and code-look, used chiefly in telegrams; (13) by the employment of numerals.

The present century has seen the decline of cryptography for all practical purposes, and the art is now only regarded as a enrious study, closely connected with the history of all nations.

Cryptomeria, or Japanese Cedar. This lofty and besutiful hardy coniferous tres ( $C$. japonica) is widely distributed in mountain dis. tricts of Japan and China, as well as cultivated in many varieties. It was introduced by Robert Fortune in 1842, and has since passed into cultiva. tion. Although originally confused with the cypresses, it is nearly allied to Sequoia and Taxodium. See Conifer.e.

Cryptoprocta, a fierce carnivorous animal of Madagascar, forming a genus and species by itself. Semi-plantigrade, and with beautiful fur, it resembles a large polecat, three feet long, and attacks the largest animals with great ferocity.

Crystalline Rocks, a name given to all rocks having a crystalline structure. The crystalline texture may either be original or superinduced. Thus some erystalline rocks, such as certain calcareous masses, owe their origin to chemical precipitation from water, while others again, such as lavas, have consolidated from a state of igneous fusion. There is another large class of erystalline rocks, the crystalline granules of which present a remarkable foliated character-that is, they are arranged in more or less parallel layers (see ScHISTs). This peculiar schistose structure appears to have been superinduced-the original rocks having been either fragmental or crystalline or both-and the result of great heat and pressure. Such highly altered rocks ocenr in the neighbourhood of masses of granite, and cover wide regions, where there is abundant evidence to show that the strata have been subjected to enormous compression, crushing, and crumpling-having been folded and fractured and pushed violently over each other for distances of sometimes 15 miles and more. It is therefore believed that pressure and the heat engendered by great earth-movements, and the intrusion of plutonic igneous matter, are among the most potent agencies in the production of schistose structure.

Crystallites, minute non-polarising bodies (the result of incipient erystallisation) occurring in the vitreous portions of igneous rocks. See lGNEous Rocks.

Crystallography (from the Greek krustallos, 'ice," an idea among the ancients being that rock-crystal, which may be taken as a type of erystalline minerals, resulted from the subjection of water to intense cold). Minerals, salts, and inorganic boclies generally (examples, rock-crystal, fluor-spar, alum, and sugar) exist in the crystalline state: and when we exanine all crystals, whether occurring naturally or obtained artificially, certain laws have been discovered, and phenomena observed, and these laws and phenoniena constitute the science of erystallography. The following are the more important laws and principles of the science :

(1) Law of Constuncy of Ang.es. - Crystals of tho 
same substance may differ much in general appearance, but when the angles between their faces are measured these angles are found constant. Thus the crystals $\mathbf{A}$ and $\mathbf{B}$ (fig. 1), when cut through in

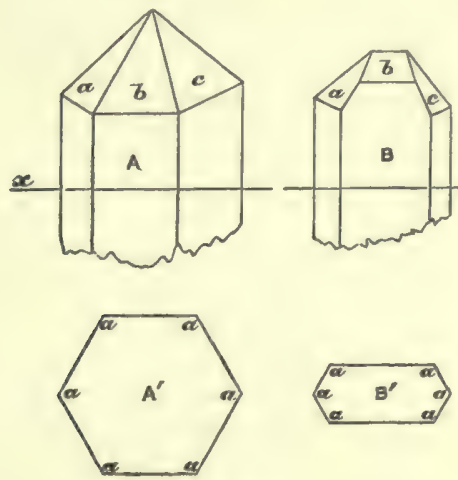

Fig. 1.

Drawings of two crystals differing much in appearance, but with angles at $a$ shown to be constant when similar sections are made.

the direction $x y$ at right angles to the prism, give the sections shown at $\mathbf{A}^{\prime}, \mathbf{B}^{\prime}$; and in each section the angles $a$ will be found the same-viz. $120^{\circ}$; or again, if the angles between the faces $a b, b c$, or $a c$, be measured, they will be found identical in both crystals.

(2) Law of Symmetry.-Suppose we cut a crystal in two, and then place the two parts with their cut surfaces on a mirror. The mirror will reflect each part, and may or may not produce the appearance of the original crystal. If the mirror will produce the appearance of the original crystal, we have severed the crystal in a plane of symmetry. Thus with a cube, if we cut it in either of the planes $a b c$, def, ghk, lmn, opq, $r h m, n h g, l k n, g m k$, and

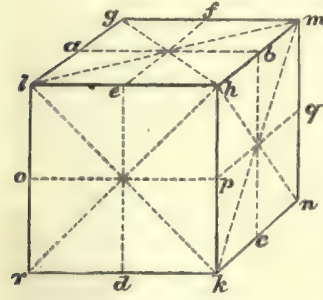

Fig. 2.

Each of the planes represented by dotted lines is a plane of symmetry.

planes of symmetry, while with other forms varying numbers of planes of symmetry may be found, until with a sphere there are an infinite number of planes of symmetry, for it is obvious that if a sphere be cut anywhere by a plane passing through its centre, and the half thus obtained be laid upon $a$ mirror, the appearance of a complete sphere will be produced. Now examining all (holohedral) erystals, it is found that they fall into one of the following six eategories or systems: (1) Anorthic System.-No plane of symmetry-examples, copper sulphate and anorthite. (2) Oblique System.-One plane of symmetry-gypsum and washing-soda. (3) Prismatic System. - Three planes of symmetry at right angles to each other-barytes, saltpetre, and native sulphur. (4) Rhombohedral System.-Three planes of symmetry at $120^{\circ}$ to each other-calcite, quartz, and ice. (5) Pyramidal System.-Five planes of symmetry-cassiterite, zircon, and idocrase.
Cubic System.-Nine planes of symmetry-fiuorspar, galena, and alum.

(3) Law of Rationality of Indices. - The various planes of crystals, as explained below, are indicated in the Millerian system by three numbers, which together form the symbol of the plane. Thus we have planes represented by 123 , by 111 , by 110 , \&c. Now the law of rationality asserts that the symbol of a plane must be represented by numbers which are rational-i.e. numbers which can be expressed exactly, not those like $\downarrow \overline{2}, \sqrt[3]{4}$, \&c., which can only be obtained approximately. Thus by the law of rationality, no plane of a crystal can have such a symbol as $1 \sqrt{3} 5,1 \sqrt{2} 0$, \&c.

Crystallographic Notation.-Several methods of representing planes of crystals by symbols are in use. Two of these only need be mentioned-viz. Miller's notation and Naumann's notation. In both systems the planes are referred to three axes corresponding in direction to three edges of the crystal.

Let $a b c$ (fig. 3) represent parts or parameters cut off from three axes $x y z$, then in Miller's

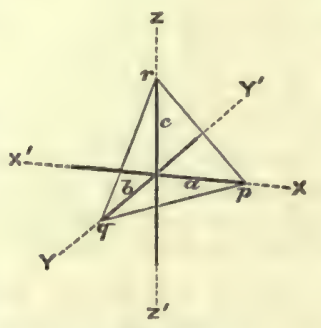

Fig. 3.

The plane 111 in Miller's notation.

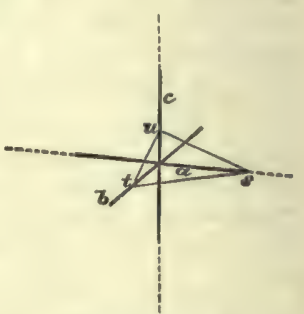

Fig. 4. notation.
The plane 128 in Miller's

system the plane 111 represents a plane which cuts the $x$ axis at one-oneth of $a$, the $y$ axis at one-oneth of $b$, and the $z$ axis at one-oneth of $c$. Such a plane is indicated by $p q r$. The plane 123 means a plane which cuts the $x$ axis at one-oneth of $a$, the $y$ axis at one-half of $b$, and the $z$ axis at onethird of $c$, Such a plane is represented by $8 t u$, fig. 4. The plane 110 means a plane which cuts the $x$ axis at one-oneth of $a$, the $y$ axis at one-oneth of $b$, and the $z$ axis at one. noughth of $c$-i.e. does not cut $c$ at all, or is parallel

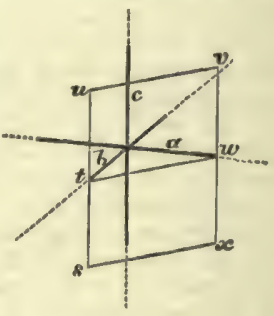

Fig. 5.

The plane 110 in Miller? notation. to it. Such a plane is represented by uvxs in fig. 5 .

In Naumann's system some form is selected as the fundamental pyramid of the crystal, and his pyramid, which corresponds to Miller's form, 111 , is represented by the letter $\mathbf{P}$ in all systems but the cubic (in this system it is called $O$ ) and the rhombohed. ral (in this system it is called R). Thus the planes marked $\mathbf{P}$ (fig. 6 ) form the fundamental

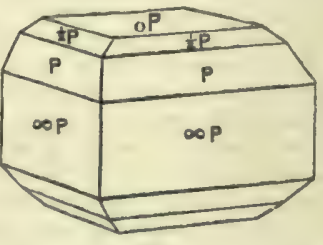

Fig. 6.

$A$ crystal with the faces inariked in Naumann's notation. 
of no height, while the planes $\infty \mathrm{P}$ represent a pyramid of infinite height.

Draving and Mupping of Crystals.-Various modes of representing erystals have been adopted. Perspective drawings are made by projecting the axes aceording to the rules of Projection (q.v.), then the various planes are indicated, and from these their intersections are known, and these intersections form the drawing of the erystal. Fig. 7 represents one octant of the form 211

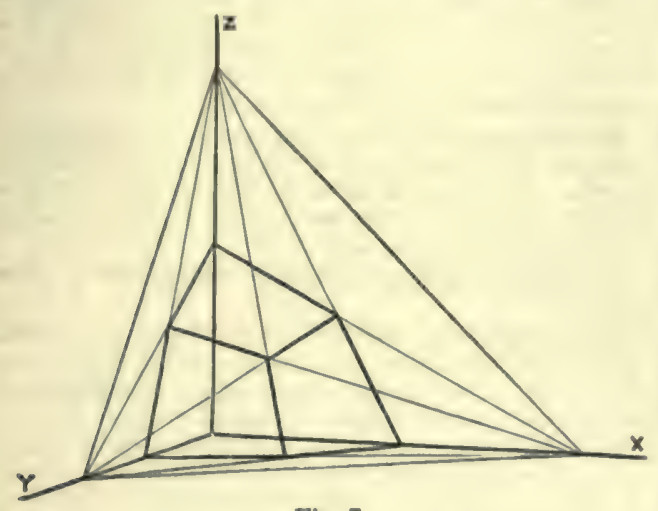

Fig. 7.

Mode of drawing a crystal from projection of axes.

drawn by this method. Some writers represent crystal forms by orthographic projections-that is, represent them in plan and front elevation. Of alf methods, however, of representing erystals from measurements made with the goniometer, the most elegant and convenient is that of spherical projections. Two kinds of spherical projec. tion are in nse-viz. the gnomic and the stereo. graphic. Imagine a glass sphere placed within a erystal, as in fig. 8 , and suppose the faces of the

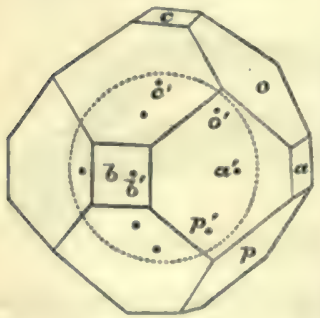

Fig. 8.

Bphere within a erystal. When plaues are moved they touch the sphore where dots are marked. erystal to move paralle to their original positions until they touch the sphere, and where the faces touch let dots be marked on the sphere. Thus the face $a$ will produce the dot $\alpha^{\prime}$, the free $o$ the dot $o^{\prime}$, and 80 on. When the sphere is thus marked with dots corre. sponding to the several fnces, the next thing is to make a map of the dots in their proper position. If the map is to be made on the gnomic projection. the sphere is supposed to be placed on the paper on which the map is to be made, and the eye is then placed at the centre of the sphere. The various dots when projected on to the paper as seen by the eye placed at the centre of the sphere produce the map. If the map is to be made on the stereographic projection, suppose a piece of rlass to pass through the centre of the sphere as in fig. 9, and let the eye be placed touching the aphere at $\mathbf{E}$, then the dots as they appear on the gliss to the eye at E form the map. Such a map of the orystal of fig. 8 is given in fig. 10. In the atereographic projection all great circles on a sphere are represented on the map by either straight lines or ares of circles, wherens in the momic projection they are represented by straight lines. The map (fig. 10) shows not only the prosition of the dots or poles, but also great circles passing through the sphere, Thene great circles correspond to the planes of symmetry of the cube (bg. 2) and other forms of the cubie system. Thene stereographic maps, as will be seen by reference to treatises on

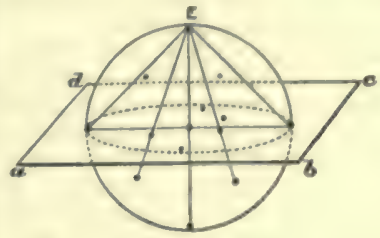

Fig. 9.

The eve placed at $\mathbf{E}$ sees the dots on lower part of sphere projected on the plane a b c d.

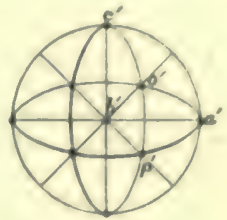

Fig. 10.

Stereographic map of the eryntal of $\mathrm{ng}$. 8 as obtained by method in fig. 9 the subject, convey a good deal of information respecting the erystals they portray.

Planes of crystals form a zone when the inter. sections of the planes (i.e. the edges) are parallel to each other. Thus, in fig. 6 the faces oP, \& $P$, $\mathrm{P}$, and $\infty \mathrm{P}$ form a zone. Now in Miller's notation these forms have the indices $001,112,111$, 110 , and it will be noticed that all these symbols have a common ratio-thus, the first and second index are equal to each other. It may be shown that this is universally true; hence, knowing the indices of a plane, we can say whether it is on a particular zone, or knowing that a plane lies in two zones, we can determine its indices. Thus, the planes 123 , 124,125 , \&c., are all in one zone, as the symbols have the common ratio $1: 2$, and the plane 345 cannot be on this zone, because its symbol does not contain the ratio $1: 2$.

Holohedrism and Hemihedrism. - Crystals which have all faces present as required by the law of symmetry are termed holohedral. Where, as is often the case, only one-half of these faces are present, the crystal is said to be hemihedral ; while if only one-fourth of the full number of faces are present, the erystal is said to be tetartohedral.

Physical Crystallography. - The physical properties of crystals have some interesting relations to the symmetry and form of the crystal, and these vroperties are included generally with ervestal. lography. Thus, if in the regular system a face is striated or has any peculiarity, this striation or peculiarity will be found on each face which is present by the law of symmetry. Again, most erystals cleave (i,e. break easily) in certain direc. tions, and the cleavage planes follow the law of symmetry. Again, when examined by polarised light, other properties of crystals in relation to symmetry are brought out. Thus, erystals of the regular system (except in a few certain cases) do not doubly refract light, no matter in what diree. tion the light is incident. With crystals of the rhombohedral systen and the pyranidal system light is not doubly refrneted when it falls parallel to the vertical axis, but in other directions it is doubly refracted; while in the remaining systems two directions can be found in which the crystals of these systems do not doubly refract light, though they do so in all other directions. Agnin, heat is conducted differently in different systems of crystale. Suppose crystals turned in a lathe into spheres, and that the centre is uade suddeuly hot, then in the regular system the heat spreads equally, and after a time the surface of the sphere is uniformly raised in temperature; with other sys. tems the effect is different; with the pyramidal and rhombohedral systems a similar experiment would result in the surface of the sphere being heated uniformly over belts corresponding to an squacor and parallels of latitude, but the tempera. 
ture of the different belts would be different; thus showing that heat is propagated in two directions at right angles to each other with different velocities. With other systems more complex results would be obtained owing to heat being propagated in three directions with different velocities.

When soluble crystals are placed in a solvent the faces are eaten out differently, producing figures termed by German writers 'aetzfiguren." These figures will often indicate the symmetry of the crystal, and have been nseful in such determination. As physical properties generally are related to elasticity, Groth states that the best way to define a crystal is that it is a solid body, the elasticity of which is the same in all parallel directions, but on the contrary is different in different directions.

See A Tract on Crystallography, by W. H. Miller (Deighton, 1863);A Treatise on Crystallography, by W. H. Miller (1839); Introduction to Mineralogy, by William Phillips (ed. by Brooke and Miller, 1852); Cryslallography, by H. P. Gurney (S.P.C.K.); A Guide to the Mineral Gallery of the British M I seum, by L. Fletcher; N. S. Story Maskelyne, Crustallography (Oxford, Clarenron Press, 1895); "W. J. Lewis, A Treatise on Crystallography (1899). In most treatises on mineralogy a portion of the work is devoted to crystallography.

Crystalloid is a name given by Graham to a class of substances which when in solution pass easily through membranes; as opposed to colloids. Metallic salts, sugar, oxalic acid, are crystalloids. See Diffusion, Osmose.

Crystallomancy, a mode of divination by means of transparent bodies, at one time very popular. A precious stone, crystal globe, or other transparent object was employed, but a Beryl (q.v.) was deemed most effective. In using it, the operator first muttered over it certain formulas of prayer, and then gave it into the hands of a youth or virgin-none others were pure enough to discern its revelations-who beheld in it the information required. Sometimes the wished-for knowledge was conveyed by means of written characters on the crystal; sometimes the spirits invoked appeared in the erystal to answer the questions asked. Dr Dee was a great adept at Crystallomancy, and two of his magic mirrors - cannel coal and smoky quartz, polished -are now in the British Museum. Even in the middle of the 19th century Lady Blessington's 'magic crystal' was in great repute in the upper circles of London; it figured in the libel case of Captain Morrison, R.N. ("Zadkiel '), v. Sir Edward Belcher (1863).

\section{Crystal Palace. See Sydenham.}

Csaba, a town of Hungary, 7 miles S. of Bekes by rail. It has a trade in grain, flour, wine, hemp, and cattle. Pop. (1890) 34,243.

Csanad, a village in Hungary (pop. 3000 ), on the Maros, 22 miles E. of Szegedin.

\section{Csardas. See Czardasch.}

Csoma de Körös, Alexander, a Hungarian traveller and philologist, born 4th April 1784 in the Transylvanian village of Körös, was educated first at the college of Nagy-Enyed, and subsequently at Göttingen, where Eichhorn the Orientalist inspired him with a passion for philology. In 1819 he studied Slavonic in Croatia with his customary ardour, and next year started on his pilgrimage to Central Asia, finding his way in Asiatic dress with the most indomitable perseverance by Bagdad and to Cashmere and Tibet. He soon began to devote himself to a study of the Tibetan language under the patronage of the English government. Early in 1827 he started on his third journey thither, and remained in the country for three years, completely absorbed in study, and indifferent to the extreme cold of winter and to privation of every kind. Early in 1831 he arrived at Calentta, where he completed his Tibetan grammar and dictionary. He was appointed librarian to the Asiatic Society, but no comforts could wean him from his love for travel. In January 1836 he started on another journey to Tibet, but died of fever six days after arriving at Darjeeling in Sikkim, 30th March 1836, a veritable martyr to science. His Life was written by Dr Theodore Duka (1885), who disposed of the assertion so often made, that the traveller's zeal, at least after the years of mere boyhood, was due to a devout imagination that somewhere in the heart of Asia it was possible still to discover the original home of the Magyar race.

Csongrad, a town of Hungary, at the confluence of the Theiss and the Körös, 75 miles SE. of Pesth. The inhabitants, 17,837 in number, are chiefly engaged in the rearing of cattle, fishing, making of wine and soap.

Ctenoid Seales (literally, 'comb-like'). See SCALES.

Cteno'phora (literally, 'comb-bearers'), a subclass of Coelenterates (q.v.), representing the climax of activity in that series of animals. The Common Berỏe and Pleurobrachia are good types. Venus? Girdle (Cestum veneris) is a well-known aberrant form, which has been elongated sideways to a yard or more in length. They are beautifully delicate, free-swimming marine organisms, generally globular in form, moving by means of comb-like plates. These are composed of numerous agglutinated cilia, and disposed along eight meridional rows. The mouth is at one pole of the sphere, two excretory or anal apertures lie at the other, which also exhibits a sense organ and a probable steering mechanism usually known as the "otolith." There are numerous alimentary vessels regularly disposed in relation to the main central cavity. In most

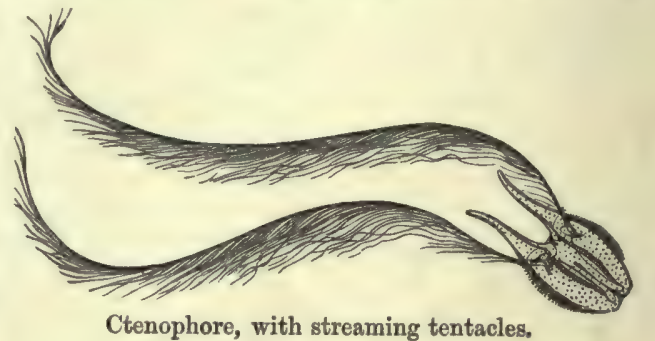

cases there are two retractile tentacles; the stinging cells so characteristic of Colenterates are usually modified into 'adhesive cells.' The Ctenophores are hermaphrodite, carnivorous in diet, ex. tremely active in habit, and often phosphorescent. They are connected with the veiled (Craspedote) medusoids by the transitional genus Ctenaria, a medusoid which in some ways looks like a Ctenophore in the making. Some would place them along with Hydromedusæ rather than allow them the rank of a distinct sub-class. Lang has suggested the derivation of some of the lower wormtypes from Ctenophora, but other authorities do not regard such a connection as at all probable. See Beröe, Celenterata.

Ctesias, a Greek historian of Persia, was private physician of Artaxerxes Mnemon, and accompanied him in the expedition to crush the revolt of his brother Cyrus, 401 B.c. His Persika was a history of Persia in twenty-three books, written in the Ionic dialect, but unhappily only a meagre fragment can be recovered in an abridg. ment in Photius, and in some portions preserved by Diodorus and other writers. The first six books 


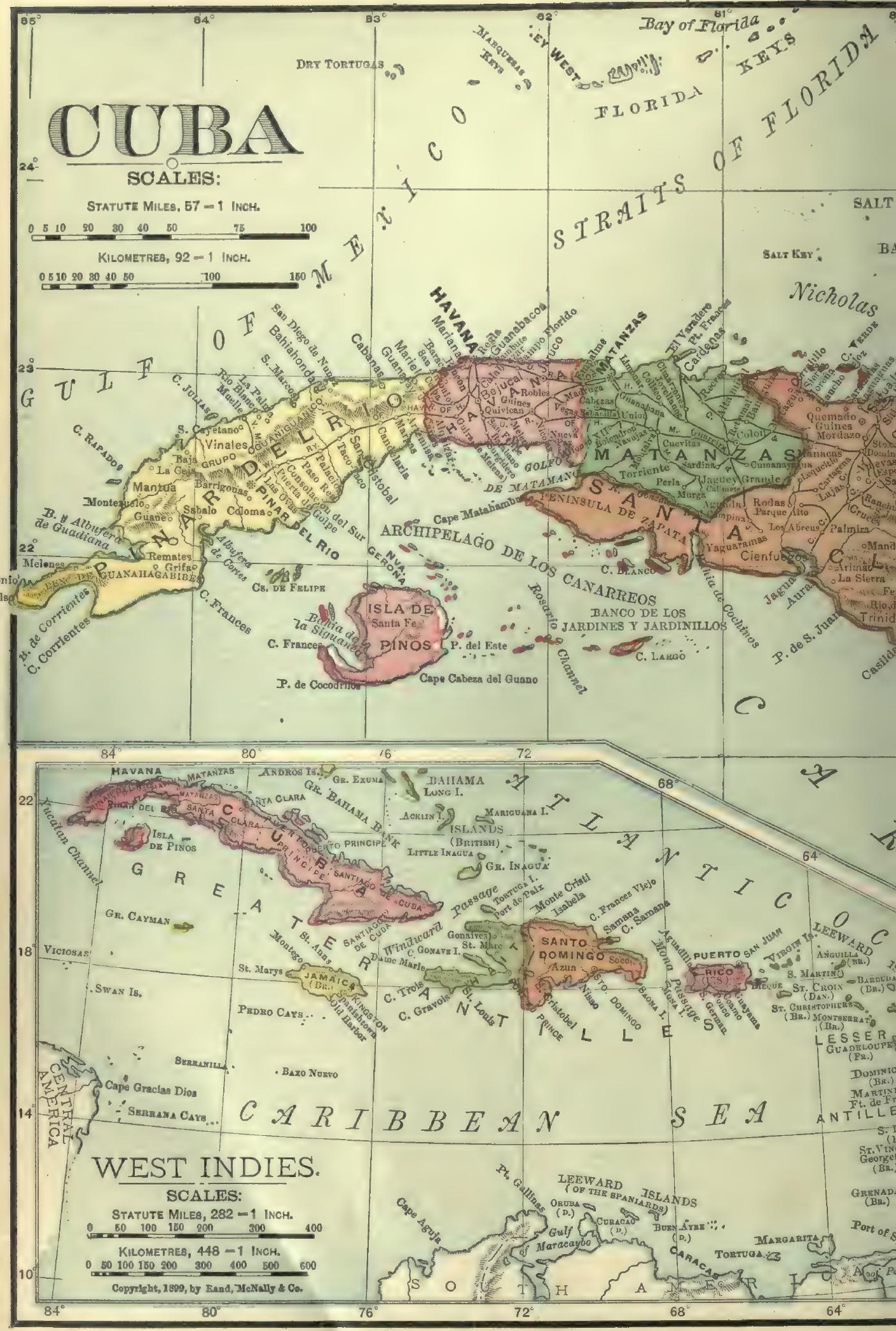


[Cuba.]

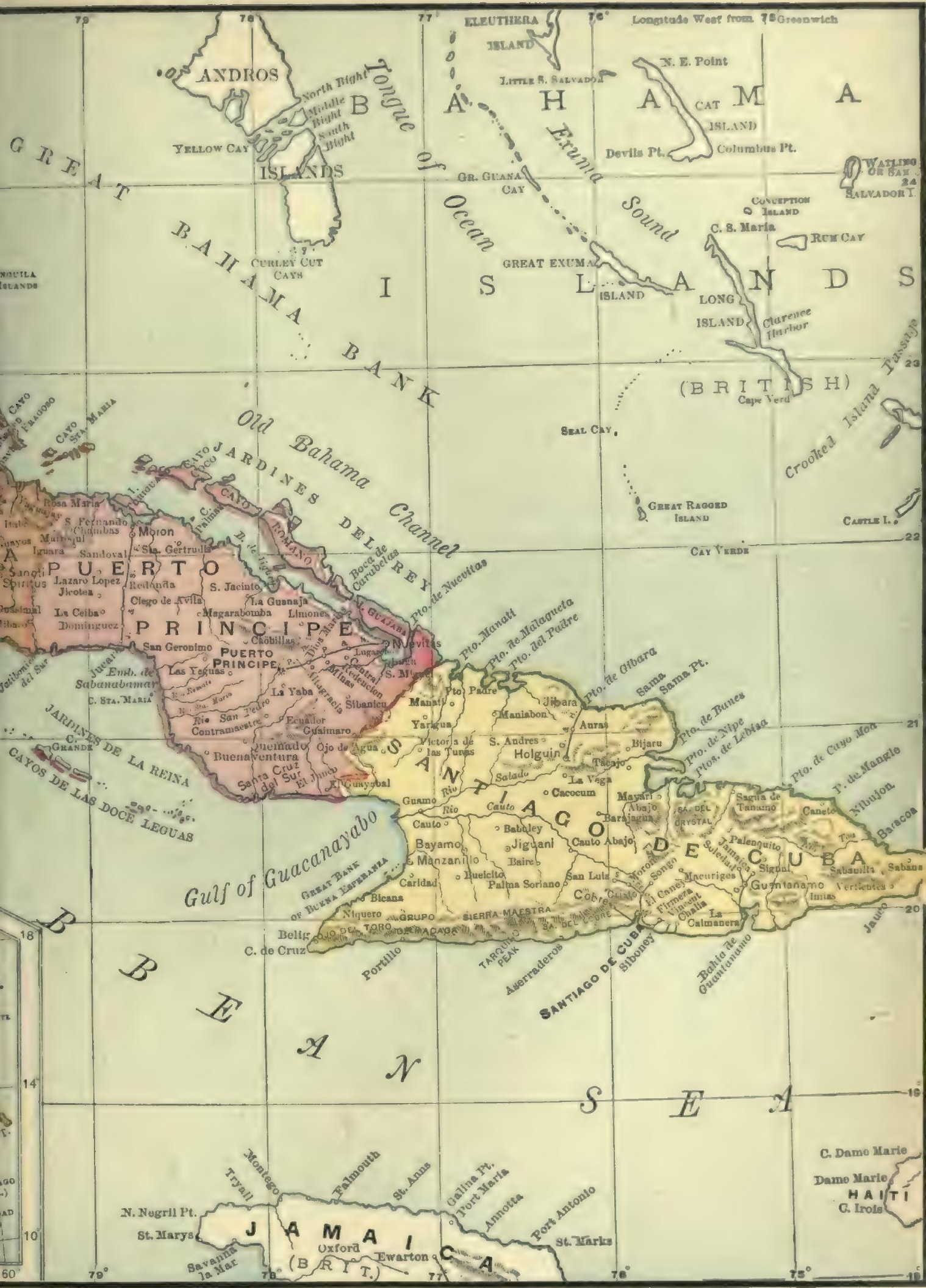



contained the history of the Assyrian monarchy down to the foundation of the kingdom of Pensia; the next seven continued the history of Persin down to the end of the reign of Xerxes; the remaining ten carried it down to 398 , the year in which Ctesias left Persia. Ctesias compiled his history from oriental sources, and it is not wonderful that his statements often contradict those of Herodotus. Of his Indika also only an abridgment by Photius is extant. See Gilmore's edition of The Fragments of the Persika of Ktesias (1888).

Ctesibius, a Greek who flourished under Ptolemy Philadelphus and Euergetes, at Alex. andria, about 250 years B.C., and was famous for his inventions in mechanics. We owe to him and his pupil Hero Alexandrinus, the pump, the bent siphon, and also the discovery of the elastic force of air, and its application as a motive power.

Ctesiphon, a city of Babylonia, on the eastern bank of the Tigris and opposite Seleucia, the common winter residence of the Parthian kings, and finally the eapital of the Parthian kingdom. It was conquered by the Romans in $115 \mathrm{~A} . \mathrm{D}$., and destroyed by the Arahs under Omar in 637. Its ruins still attest its former magnificence.

Cuando, a name of the Chobe, a tributary of the Zambesi (q.v.).

Cuango, or Kwango. See Congo.

Cuba, the most westerly and largest island of the West Indies, till 1898 the principal colony left to Spain, stretches in the form of a long narrow crescent, convex on the north side, at the entrance of the Gulf of Mexico, which it divides into two channels - the north-west, 124 miles wide, and the south-west, $97 \frac{1}{2}$ miles at its narrowest part. Cuba is 759 miles long from Cape Maysi on the east to Cape Antonio on the west, with a breadth varying from 27 miles to 110 miles, and a const-line of about 2000 miles. According to the census of 1899 , the area of Cuba is approximately $44,000 \mathrm{sq}$. m., the Isle of Pines being included in Havana province. Only about one-third of the coast-line is accessible to vessels, the remainder being beset by reefs and banks. The shores, low and flat, are liable to inundations, but there are numerous excellent havens. A watershed running lengthwise through the island rises into mountainous heights only in the southeast, where are the Sierra de Maestra shooting up in the Pico de Turquino to 8400 feet, and the Sierra del Cobre (copper). The mountains, composed of granite overlaid with calcareous rocks, and containing minerals, especially copper and iron, are clothed in almost perennial verdure, wooded to the summits. Carboniferous strata appear in the west, schistose rocks on the north coast. The limestone rocks abound in caverns, with magnificent stalactites. Mineral waters are plentiful. The rivers, running north and south, are navigable for only a few miles by small boats, but are very serviceable for irrigation of the plantations, and supply excellent drinking water. The climate, more temperate than in the other West Indian Islands, is salubrious in the elevated interior, but the coasts are the haunt of fever and ague. No month of the year is free from rain, the greatest rainfall being in May, June, and July. Earthquakes are frequent in the east. Hurricanes, less frequent than in Jamaica, sometinies cause widespread desolation. A hurricane in 1846 demolished 1872 houses, and sank 216 vessels.

The soil of Cuba is eminently fertile, a large part still covered with virgin forest containing magnificent mahogany, cedar, ebony, ironwood, dyewoods, and pine. The vegetation of Cuba also includes lignum-vitæ, tamarind, palms, ferns, lianas, \&c. Among the cultivated products are sugar, tobacco, coffee, cacao, rice, maize, cotton, eseulent roots, and tropieal fruita. Among the ani. mals are a species of tail-less rat peculiar to $\mathrm{Cuba}$, grent abunlance of birils, inclurling the mocking. bird, a species of vulture (valuable as a maversger), woodpecker, partridge, flamingo, alluatrose. of noxious animals there are the crocodile, scorpion, and mosquitoes. The rivers and seas are well stocked with fish. the turtle abounding in the shallows and sandy places of the beach.

Sugar, for which soil and elimate are peculiarly favourable, has long been the chief pruduct of Cuba, though it had suffered much from the low prices even before the insurrection ruined trade. The total production of sugar in the year 1894-05 was 1,004,264 tons. About nine-tentlus of the sugar and nearly all the molasses are exported to the United States. Of tobacco, of excellent guality, the yield is abont 300,000 bales anuually. In 1893 the export of tobaceo was 227,865 bales, besides 147,365,000 eigars; in $1895,156,513,000$. The mining industry of Cuba has as yet received little attention; but one iron company has exported to the United States in some years 200,000 tons of iron ore. Manganese and copper are also found. There are some 1600 sugar plantations in Cuba, 8500 toliaceo plantations, and 700 coffee plantations. The total imports into Cuba in 1892 are stated at $57,000,000$ pesos or dollars, and the exports at $90,000,000$. But for war, the revenue should be about $25,000,000$ pesos. The debt is now much over $40,000,000$.

The census taken ( 1899 ) under the American military administration showed a total population of $1,572,797$, as against $1,500,000$ in 1879 (De las Peñas, Havana, 1881); the Chinese have decreased to 14,857. The principal towns, Havans, Puerto Principe, Matanzas, Santiago, Nuevitas, and Cienfuegos, are united by railway, of which there are about 1100 miles; the telegraph system aggregates (1898) about 2300 miles. Under Spanish rule the captain-general was highest military and civil commander; and all state offices were held by Spaniards from Spainone of the great grievances of the Cubans.

After the war (see below) and the conclusion of peace (1899) between the Uniter States and Spain, Cuba became practically a dependency - in the first instance a military protectorate- of the United States; and though it was intended that the island was to be governed in the interests of the Cubans, and as soon as possible by Cuhans, the formal status of Cuba was not definitely settled. Many American statesmen regarded with serions 'misgivings a colonial expansion that absorbed Puerto Rico, annexed Cubn, and took over the Philippines at once. But the Americans proceeded to reorganise the administration on a provisional footing, to make roads and railways, to improve docks and harbours, and to impose hitherto unheard-of sanitary precautions. Many burdensome taxes were abolished and a fair customs tariff was established.

Cuba, spoken of as the 'Queen of the Antilles,' was first discovered by Columbus in 1492 , the discoverer calling it 'the most beautiful land that eyes ever beheld. It was first settled by Spaniards at Baracoa in 1511. Havana, first settled in 1519 , was reduced to ashes by the French in 1538, and agrin in 1554. For about one and a half centuries Cuba was in constant danger from French, English, Dutch, and Weat Indian filibusters. In 1762 the English under Lord Albemarle (q.v.) took Havana, which, however, was by the Treaty of Paris next year restored to Spain. Hitherto the whole Spanish trade with the colonies had been in the hands of a single privileged company. During the ten months' English occupation, Havana, open to free trade, showed in its port, instead of ten to twelve ships yearly as formerly, more than one thousand, and agriculture made rapid progress. In 1818 Cubs 
was opened to the world's trade, and soon reached unexampled prosperity. The civil war in the United States ruined its sugar industry and so benefited Cuba; but the suppression of slavery by the Spanish government (1880-86) without compensation ereated discontent not abated by the constitution of 1884 . A serious insurrection took shape in 1895. A bsolute freedom from Spanish rule was demanded, a Cuban Republic was proclaimed, and soon a bloody grierilla war was in progress. In their efforts to crush the rebellion the Spanish government sent to Cuba upwards of 200,000 soldiers, of whom a very large proportion died in hospital. The savage and destructive character of the war, and the cruelties believed to have been shown by the Spaniards even towards non-combatants, provoked very pronounced sympathy with the insurgents on the part of the United States, and American intervention was repeatedly threatened. The destruction of an American war-ship by an explosion in Havana harbour embittered American feeling, and in April 1898 the United States and Spain were at war. The harbour of Havana was blockader; but the centre of military operations was Santiago, where there was sharp fighting. The total destruction of the Spanish fleet in August ended the short war, and the Spanish troops were deported from the island. By the terms of the peace negotiationsat Paris(1898), Spain relinquished her sovereignty in $\mathrm{Cuba}$, which thus became independent, though occupied in a military way by the United States during the formation of a stable autonomous civil government.

See Gallenga, The Pearl of the Antilles (1873); other books on Cuba by Hazard (New York, 1871) and Ballou (Boston, 1885), Larrinaga (1881), Piron (Paris, new ed. 1889), R. H. Davis (1897), Richard Davey (1898), R. P. Porter (1899); and works cited at WEST INDIES.

Cubango. See NGami.

Cube, a solid bounded by six equal square faces, opposite pairs of which are parallel; the three edges meeting at any point being at right angles to one another. This form frequently occurs in nature, especially among crystals (see Crystallography). In arithmetic, the cube of a number is the product of its multiplication three times by itself; if the edge of a cube be a line of 4 inches, its solid content is 64 cubic inches. The cube root of a number is that number which, mul. tiplied three times by itself, produces the first number. See Involution, Root, Doubling THE CUBE.

Cubebs, or Cubeb PePper, the dried berries of Piper Cubeba, a climbing shrub, a native of Sumatra, Java, and Southern Borneo. The fruits of other species of Piper are sometimes substituted for the true cuheb. Although known to the Arabs in the middle ages, cubebs fell gradually into disuse, till at the beginning of this century all reference to it was omitted in medical books, and its importation into Britain ceased entirely. It is again, however, coming into use. As a stomachic and carminative in indigestion it nas a certain value, while in piles and in sore uhroats its administration is attended with benefit.

Cubebs contains a volatile oil, a crystalline substance called cubebin, and resinous bodies, one of which is cubebic acid. The cubebin is inactive, while the volatile oil is not believed to have the full virtue of the cubebs. It enters, however, into the composition of a well-known voice lozenge, to which it imparts highly stimulating properties. The diuretic properties are held by some to be entirely due to the resinous bodies, but on this point there is difference of opinion. The dose of powdered cubebs is from one to three drachms, that of the volatile oil ten drops, and of the oleoresin five to thirty drops.
Cubic Equations. A cubic eouation in a given quantity is an equation in which the highest exponent of that quantity in any term is $\mathbf{3}$. Every such equation can be reduced to the form $x^{3}+p x+q=0$, where $x$ is the variable and $p$ and $q$ are constants. Every equation of this form has three roots, all of which may be real, or one may be real and two imaginary. An equation containing any number of variables in which the greatest sum of the exponents of the variables in any term is 3 is called a cubic equation. Thus $x^{2} y+5 y^{3}$ $+6=0$ and $x y z+z^{2}=0$ are cubic equations in $x$, $y$, and $x, y, z$ respectively. See EQuATIONS.

Cubit (Lat. cubitus, 'fore-arm'), a Roman measure of length, supposed to equal the length of the fore-arm from the ellow to the tip of the middle finger. It was $1 \frac{1}{3}$ Roman feet ( $17 \frac{1}{2}$ English inches). The English eubit is $1 \frac{1}{2}$ English feet. The cubit of Scripture is generally estimated at 22 inches.

Cubitt, Sir Wrlliam, engineer, born at Dilham, in Norfolk, in 1785, was a niller, cabinetmaker, and millwright until 1812, when he became chief-engineer in Messrs Ransome's works at Ipswich, where he was a partner from 1821 to 1826. In 1823 he joined the Institution of Civil Engineers, and removing to London, was afterwards engaged in most of the public undertakings of his day. The improvement of the Severn and of Boulogne port, the Bute docks at Cardiff, and the water-works for Berlin are among his works. He also invented the treadmill, and constructed the South-Eastern Railway; and for his services in connection with the erection of the Great Exhibition buildings he was knighted in 1851. He died 13th October 1861.

Cueking-stool. See Ducking-STOOL.

Cuckoo (Cuculus), a well-known genus of birds in the order Coccygomorphre, or, according to others, Picariæ, and type of a large family (Cucnlidre). The common cuckoo (Cucülus canōrus) is a widely distributed bird, breeding in summer in the northern parts of Europe and Asia, and migrating in winter to Africa, as far as the Cape, or to India. It is best known for the 'con-coo' cry with which it announces its arrival and that of spring, and for its habit of utilising for its own family the nests and the brooding of other birds. The enckoo is slightly over a foot in length; the bill is as long as the head, slender and slightly curved; the wings are long and pointed; the tail is also long and rounded; the upper part of the shank is feathered.

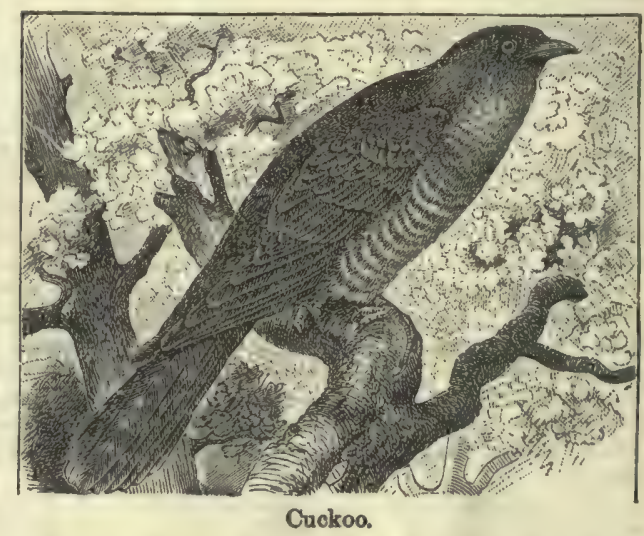

The upper surface is ashen gray, the belly and legs are whitish with undulating transverse brown lines, the tail is spotted with white above, and the root of the bill and the feet are yellow. The young birde 
are blaskish, and mottled with yellow and gray. A roddish variety oceasiomally ocenrs. The bird arrives in North Europe in April or May, and leaves again in Auguat or September. Its cheerful call carses to be heard about the middle of June. Predominantly an arboreal bird, it is rare in treeless distriets. Fuch cuckoo neems jealonsly to 'presorve' is certain territory for itself. Like the wher species of Cueulus, it is a shy, restless, unsocial birl. It is extremely valuable on account of its insatiable appetite for caterpillars. The luiry forms are especially delighted in, and the incligestible hairs form a felt-like coating in the stomach. The female lays its eggs singly (sometimes to the number of eight), each in the nest of some suitable bird, chonsing such as feed their own young on insects-in order of preference, hedgesparrow, water-wagtail, titlark, yellow-hammer, green linnet, and whin-chat. The young cuckoo, unconsciously reared by its foster-parents, manages to secure the bulk of the food-supply, and in the struggle for existence completely monopolises the nest, ousting the rightful brood. Stories of the ungrateful young bird devouring its foster-parent are entirely mythical. Nor has it been shown that the adult ever sucks the eggs of other birds. The males greatly outnumber the females. The latter have somewhat darker feathers, and a somewhat less emphatic note. The males are said to be very passionate in their love-making, but there is no regular pairing or continued attachment. The musical interval between the cuckoo's two notes is not uniform, and varies from a minor to a major third (the latter being that adopted in Beethoven's reproduction). See Nature, voL. xxxvi. p. 344 .

The genus Cuculus includes about a score of other species, restricted to the eastern hemisphere. In the sanie family as the true cuckoos are several important genera : The Honey-guide (Indicator), of Ethiopian distribution, feeding chiefly on wild bees, and directing attention to their nests; the Golden Cuckoo (Chrysococeyx); the Jay-cuckoo (Coecystes), utilising the nests of erows and magpies; Eudynamis, of similar habit; Scythrops, a very large form in Australia, New Guinea, and the Celebes; the swift 'Road-runner' or 'Ground Cuckoo' (Geococcyx), of California; the grub-eating Anibird (Crotophaga, q.v.); the Coueal or Spurred Cuckoo (Centropus), with the claw of the inner toe prolonged into a grent spur. An East African cuckoo (Tepe-tepe) is a delightful song-bird. The American Cuckoo (Coccyzus cmericanus) is particularly interesting, since it makes but a very rudimentary nest, has a very irregular way of laying, and exhibits an unnatural indifference to its young. Its egg is occasionally found in the nest of other birds. These facts, secording to Burrourhs, raise the question whether the American cuckoo 'is slowly relapsing into the habit of the European species, which always foists its egg upon other birds; or whether, on the other hand, it be not mending its manners in this respect.'

The parasitic habit of our common cuckoo demands further attention, as one of the strangest of bird habits. The facts, which are very hard to explain, may be thus summarised: (1) The habit of utilising the nests and brooding patience of other birds is not common to the genus. It is also the practice of an Australian species, and of some related genera, and is occasionally exhibited by the American representative. Professor Newton notes that a few of our common birds, 'whether by mis. take or stupidity, not unfrequently lay their egge in the nests of others.' In the genus Molothrus, allied to starlings, and far separated from cuckoos, the various species exhibit a gradual perfecting (if we may use the term in such a connection) of the parasitic habit. (2) The modus operandi of the habit is usually as follows: The enckoo selects the nest of an insect-eating bird, mueh smaller than herself, and often with eggs approximately like her own. Into this, say of a hedge-sparrow, she lifts her egg with her bill, having previously laid it upon the ground. After an interval of two or three days, she repeats the process in another nest. The hedge-sparrow or other bird, all nuaware apparently of what has happened, sits on the cuekoo-egg along with her own. The young cuckoo is generally hatched first, and is restless and uneasy until it has got rid of the other eggss or young Lirds. This it does with considerable exertion, and sometimes with a real struggle, by lifting the living burden upon its back and throwing it over the side of the nest. Thereafter it remains sole though wrongful possessor, and is reared in peace. (3) Among the facts which make the habit a success, the following should be noted. The relatively small size of the cuckoo's egg is striking. "The egrg of the cuckoo is not any larger than that of the skylark, although an alult cuckoo is four times the size of an adult skylark.' This makes the duping of the small birds easier, if, indeed, they have any suspicions. The laying of the egg in a small bird s nest makes the ousting work of the young cuckoo an easier task. In many cases, as already noted, the cuckoo's egg is coloured approximately like those of the victimised foster-parent. Till the young cuckoo is about twelve days old, when the disposition for turning out its companions begins, according to Jenner, to decline, its broad back has a curious depression in the middle. The presence of this cavity makes it easier for the restless and still sightleas nestling to bear up and toss over the eggs or young birds which interfere with its desire for sole pessession. (4) The alvantage to the young bird, which earns by its exertions plenty of growingroom and an extra portion of food, is obvious enough. The individual parent is also saved both time and trouble, as well as all the patient sacrifice of brooding. Jenner has pointed ont that the advantace to the species is probably this, that by leaving their eggs to other birls to incubate, the cuckoos are able to have a numerous progeny reared in the short period of their stay in northern Europe. Or, to put it in another way, the parasitic habit enables the cuckoos to migrate earlier. Hence Darwin believed the constant parasitic habit of our cuckoo to have been derived from its occasional occurrence (as in the American form) through the action of natural selection. Those cuckoos which fell in with the trick succeeded better than their neighbonrs, till gradually only those survived in whom the trick had become habitual.

It is interesting in this connection to note the occasional reversion of a cuckoo to parental re. sponsibilities. Mr Romanes has given a detailed discussion of the subject in his work on Animal Intellagence, and also comes to the conclusion that " we are justitied in setting down the instinct to the creating influence of natural selection.' It ought not, however, to be overlooked that all the cuckoos are solitary, unsocial birds; that the American genus is said to be immorally uninterested in the fate of the young; that the species of Molothrus, which has most completely developed the parasitic habit, is extremely careless about the brood, and often drops its eggs on the bare gronnd. The haloit nay be regarded not so much as requiring special explanation, an an expession of a general constitution or habit of life. Brehm describes the cuckoo as a greedy, discontented, ill-conditioned, passionate, in short, decidedly unamiable bird. It seems plausible, therefore, to suggest that one dominant "physiological tendency " or mood shows itrelf in the restless selfishness of the nestling, in the 
jealous, solitary individualism of the adult, in the preponderance of males, in the very note, in the relatively small size of the egg, and in the parasitic habit as the most striking nutcrop.

The folklore of the cuckoo is almost inexhaustible in every country of Europe. It has the gift of propheey as the herald of spring and of long life, the prelude of storms, of prosperity, and of speedy marriage to maidens. Countless superstitions, and those of the most varied character, are connected with its origin, the cause of its cry, its winter transformation into a hawk, as well as with the first hearing of its call, the hearer's occupation at the moment, and the direction from which it comes; while as many proverbs play upon the monotony of its note, its supposed stupidity, and its obvious connection with euckoldom, from its habit of depositing its offspring with alien parents. It has only been by a strange transference of meaning that the name cocu or cuckold has been transferred from the paramour to the unsuspicious husband, unless cuckold means, as explained by Littré, one who has been cuckoo-ed or treated after the manner of the cuckoo. The earliest English song extant (13th century) is an expression of the joyousness of the first cuckoo-call.

For details of Cuckoo folklore, see Mannhardt in the Zeitschrift für Deutsche Mythologie, vol. iii. pp. 209298; Jaines Hardy's 'Popular History of the Cuckoo,' in Part II. (1879) of The Folklore Record; and Swainson's Folklore of British Birds (1886).

Cuckoo-flower. See Cress.

Cuckoo-pint. See Arum.

Cuckoo Spit. See Froth-Fly.

Cucumber (Cu'cumis), a genus of Cucurbitaceæ. The Common Cucumber ( $C$. sativus), distinguislied by heart-shaped, acuminately pentangular leaves, which are rough with hairs

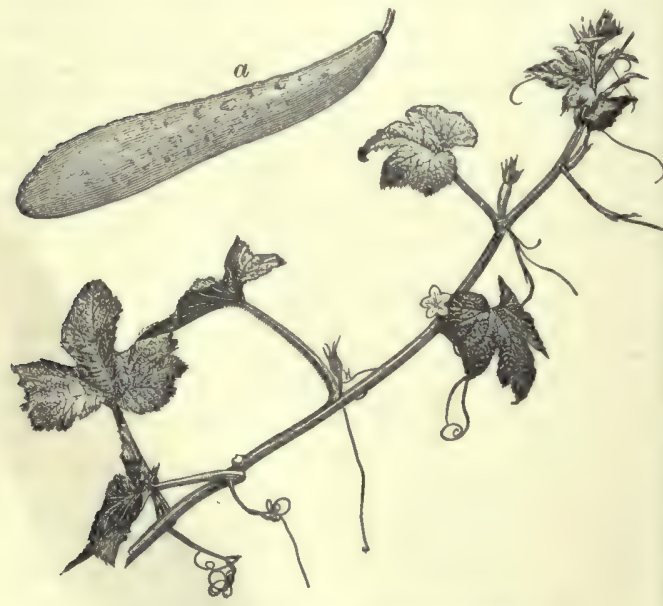

Common Cucumber (Cucumis sativus):

$$
a, \text { fruit. }
$$

approaching to bristles, and oblong fruit, is a native of the middle and south of Asia, and has been cultivated from the earliest times. Its fruit forms an important article of food in its native regions, the south of Europe, \&c., and an esteemed delicacy in colder countries, where it is produced by the aid of artificial heat. Many varieties are in cultivation, with fruit from 4 inches to 2 feet long, rough, smooth, \&c. Young cucumbers are much used for pickling, and are called gherkins; a small fruiting variety is selected for this purpose. The cucumber is cultivated in fields even in the south of England, for the supply of the London market; but in all parts of Britain the plants required for the purpose of growing either in the open or under glass must be reared in a hotbed in spring. In the northern parts it ean only be successfully cultivated in frames during summer. A large trade is now done in winter crops of encumbers, which are grown in well-heated, specially constructed glass-houses. In many parts of the United States it will, if planted late enough to escape the frosts, grow well with almost no care. But it requires rich soil, much moisture, and heat. To this genus belong other species valued for their edible or ornamental fruit, but all that are popularly named cucumber are not properly Cucumis, but merely species or varieties belonging to allied genera. Dudaim (C. Dudaim) is a highly fragrant, handsome fruit, with insipid flavour and flaceid flesh, often grown in this country by gardeners under the name, Queen Anne's Pocket Melon, simply for its attractive appearance, the fruit being about the size of an ordinary orange, and beautifully barred with green and orange or deep orange-red. (Dudaim is the Hebrew name rendered Mandrake in Scripture.) Connemon is the fruit of $C$. conomon, which is grown everywhere in Japan, and preserved and sold as an article of food. C. auguria, a West Indian species, with fruit about the size and shape of a pullet's egg, is esteemed as an ingredient in soups, and is also eaten raw, but considered inferior in that state to the common cucumber. The Snake Cucumber (C. flexuosus) has fruit of great length which is eaten either pickled or raw, and has similar qualities to the common encumber. A number of species of Cucurbitacere are natives of the United States, but they are all of small economic importance. For other representatives of the natural order Cucurbitacen, see ColocyNth, Elaterium, Melon, \&c. See, too, May's Cucumber Culture (1880).

Cucurbita'ceae, an important order of corolli. floral dicotyledons, of which the 500 species are mostly herbaceous climbers, inhabiting the warmer regions of the globe; only one, the Common Bryony (q.v.), reaching the south of England. The young shoots and leaves of many species are used as potherbs, and the persistent rhizomes or roots of others are sometimes esteemed on account of their store of starch. Acridity, however, is a common characteristic of the order; and Bryony, Elaterium, and especially Colocynth (q.v.), are of old medicinal repute. But the central importance of the order is due to the characteristic fruit, which is technically known as a pepo, but which may be regarded as a large and many-seeded berry, with its more or less succulent pulp protected by a hardened wall. The many specific and varietal forms are known as Cucumbers, Melons, Gourds, Pumpkins, Squashes, Vegetable-marrows, Bottle-gourds, \&c., and are described under separate articles. The seeds of some species are medicinal, others edible, while the fibro-vascular skeleton of the fruit of an Egyptian species of Luffa (loofah) is a familiar adjunct of the bathroom.

Cúcuta, San José DE, a town in the Colombian department of Santander, on the Rio Zulia, 35 miles S. of Puerto Villamizar by rail. It is the third commercial town of the republic, a centre of coffee and cacao cultivation. It was destroyed by earthquake in 1875, but has been well rebuilt. Pop. 13,000.-Rosario DE Cúcuta, to the SE. was the seat of the first Colombian congress in 1821, and the birthplace of the patriot General Santander (1792-1840). It has large plantations of coffee and caca.o. Pop. 6000.

Cud, the sodden bolus of hastily swallowed fodder which ruminants drive from their pauncl and honeycomb stomach back again into the 
mouth. There the eud is leisurely chewed, and the semilluid result passes down again into the stomach, usually into the manyplies. One bolus is driven upwards after another until the greater part of the eropped herbage has been clrewed. Bee RUMinanss.

Cudbear. The lichens from which, and the process by which, this dyestuft is obtained, are described under the heal ArCH1L, cudbear being simply archil paste dried and ground. It is very useful to the wooldyer for producing, in conjunction with indigo, logwood, fustic, and other colomring materials, rich shales of brown and choculate. The preparation of archil, known as French purple, was used for a short time in calicoprinting, and produced fine and delicate shales of purple, but its employment for this purpose ceased soon after the introduction of aniline mauve as a dyestuff. The ancient Cretan purple was probably obtained from the same source as archil. The name cudbear is a corruption of Cuthbert, and is derived from that of Dr Cuthbert Gordon, under whose management the manufacture of this dyestnff was begun in Leith about the year 1777, by $\mathrm{Mr}$ Macintosh of Glasgow.

Cuddalore (Kudalier or Gudulur), the chief town in South Arcot, Madras, on the Coromandel or east corst of Hindustan. It is situated on a backwater formed by the confluent estuaries of two rivers, 16 miles S. of Pondicherry, and 127 8. of Madras by rail. It has a large trade by land with Madras in oils, indigo, and sugar, and exports grain by sea. Though the river itself is silted up, and admits only native craft, yet there is good anchorage off-shore at the distance of a mile and a half. Cuddalore was at one time a place of great strength; and in that respect it was frequently an object of contention in the wars which, during the later half of the 18th century, so long desolated this neighbourhood. In 1758 it was taken by the French from the British, who had held it for 77 years; and was finally ceded to the British in 1785. Pop. (1891) 47,355.

Cuddapah, a town in the province, and 161 miles NW. by rail of the city, of Madras. It stands, at the height of 507 feet above the sea, near the south bank of the northern Pennar, which flows into the Bay of Bengal. Till 1868 it was a military cantonment. Pop. (1891) 19,120.-The district of Cuddapah, partly lowland and partly highland, has an area of $8745 \mathrm{sq}$. m., and a pop. (1891) of 1,272,072. It has heen British since 1800 .

Cuddesden, a village of Oxfordshire, 6 miles ESE of Oxforil. Here is the palace of the bishops of Uxford, rebuilt by Bishop Fell in 1679, with a chapel added in 1846 by Bishop Wilberforce, to whom the adjoining theological college (1854) also owes its existence. 'The church is a fine old cruciform building.

Cuddy was the name first applied in East India trading ships to a cabin under the poop, where the men messed and slept. The same name was afterwards given to the only cabin in very small vessels, and sometimes to the cooking-room.

Cudweed, the popular name of many small inconspicuous species of composite weeds of the genera Gnaphalium, Filago, and Antennaria, the stems and leaves of which are more or less covered with a whitish cottony down. The heads of the flowers consist, in great part, of dry involucral seales, and may he kept for a long time without undergoing much apparent change, so that they may be reckoned among Everlasting Flowers (q.v.). Antennaria dioica (also called Cat's-foot) is very frequent in dry mountain-pastures. All the three genera are represented in the United States, where Gnaphalium polycephalum has some repute in domestic medicine.

Cudworth, RaLPH, the chief figure in the group of 'C'smbriclge I'latonists,' was Pxm in 1617 at Aller, in Somensetshire, and admitted pensioner of Emmanuel College, Cambridge, in 1632. He grauluated B.A. in 1635 and M.A. in 1639, and was in the rame year elected fellow of his college, where he became a popular tutor. In 1645 he was appointed by parliament Master of Clnre Hall, and in the same year regius professor of Hebrew. In 1650 he was presented to the college living of North Cadbury, in Somersetshire, and in 1654 was elected Master of Christ's College, an appointment the confirmation of which at the Restoration his acquiescence with the rule of the Commonwealth did not prevent. In 1662 he was presented by Archbishop. Sheldon to the rectory of Ashwell, Hertfordshire; and in 1678 he was installed pre. bendary of Gloncester. He died at Christ's College, July 26, 1688. His daughter Damaris, who became the second wife of Sir Francis Matcham of Oates, in Essex, was a friend of Locke, and herself wrote a well-reasoned Discourse concerning the Love of God (1696).

Cudworth's great work, entitled The True Intel. lect ual System of the Universe, was published in 1678. It is a learned, ample, and discursive work, singu. larly large-minded and sagacious; but its logical consistency as a consecutive argument is somewhat marred oy discussions on such subjects as the true meaning of the pagan mythology, and the relation of the Platonic and Christian trinities. Its aim was to establish the reality of a supreme divine Intelligence against the materialism of Democritus and Epicurus, the 'atheism of atomicism;' to vindicate the eternal reality of moral ideas against the old nominalists and their successors; and to prove the reality of moral freedom and responsibility in man as against pantheistic naturism and stoicism. The only basis for a philosophy of religion rests on the conception of man as a free moral subject, capable of choosing good or evil. The portentous erudition of this famous treatise, and the redundant fullness of its endless digressions, with its strange Alexandrian amalgamation of fancy and speculation, have tended to obseure its real merits. Perhaps its most honourable distinetion is the marvel. lously honest and impartial statement of the best arguments of his antagonists, which, indeed, laid him open to the charge of having fallen into the same heresy with Milton and with Clarke, and even into atheism, simply for being just to the arguments of atheistic writers. "He has raised,' says Dryden, 'such strong objections against the being of a God and Providence that many think he has not answered them'- "the common fate,' adds Shaftesbury, 'of those who dare to appear fair authork."

Cudworth's admirable sermon, preached before the House of Commons in 1647, shows the best features of that much-abused Latitudinarian school to which he belonged, and, says Mrckintosh, "may be compared even to Taylor (Liberty of Prophesying, published the same year) in charity, piety, and the most liberal toleration.' In its insistence upon the co-ordinate relativity of all knowledge, and the connection of religion with life and morality, the author lays down a sound basis for a harmony between philosophy and religion, between reason and faith. Many of Cudworth's MSS. still lie unprinted. His Treatise concerning Eternal and Immutable Monality was published in 1731, and is a contribution of real value to ethics. See Tulloch's Rational Theology in England in the XIII. Century (18\%2), Dr Martineau's Types of Ethical Theory (1885), and monographs by Lowrey (New York, 1884) and W. R. Scott (1891). 
Cuenca, a picturesque decayed city of Spain, 85 miles ESE. of Madrid. It stands on a rocky hill-girt eminence, 2960 feet above the sea-level, at the confluence of the Jucar and Huecar-the latter spanned by the noble bridge of San Pablo (1523), 150 feet high and 350 long. Of Moorish origin, Cuenca has narrow, erooked streets, and a very interesting cathediral (1177-1669). Pop. 7549. -Cuenca gives name to a mountainous, wellwatered province, yielding excellent timber, honey, wine, and grain, with good pasture, and various minerals, including iron, coal, copper, and silver. Area, 6726 miles. Pop. 242,460.

Cuenca, a city of Ecuador, on the Rio Paute, 190 miles SSW. of Quito, stands on a fertile tableland, 8469 feet above the sea, and enjoys a perpetual spring, with mean temperature of $58^{\circ} \mathrm{F}$. Its streets are wide, and several canals intersect the town ; the principal buildings are the cathedral and high school. There is some trade in cheese and grain, and manufactures of hats, woollens, earthenware, and candied fruits. Pop. (including the Ejido, or Indian quarter ) 30,000 .

Cuernaváca, capital of the Mexican state Morelos, lies in a lovely and fruitful valley, about 40 miles S. of Mexico city. It has a church built by Cortes, an agricultural school, and refineries of sugar and brandy. Pop. 17,000. Near by is the famed teocalli of Xochicalco, with five terraces.

Cuevas de Vera, a town in the Spanish province of Almeria, situated on the Almanzora. It has an old Moorish castle, and a considerable industry in connection with the silver-mines of the neighbouring Sierra Almagrera. Pop. 20,644.

Cufic. See KuFic.

Cui Bono? ('for whose advantage?'), a Latin phrase not infrequent in Cicero and elsewhere, and very common in modern newspaper English, usually in a somewhat erroneous sense, as if equivalent in meaning to "what 's the good?'

Cuirass. See Breastplate, Armour.

Cuirassiers are heavy cavalry wearing the 'cuirass' and helmet. They represent the troopers of the 16th and 17th centuries, who were similarly protected. In the British army no regiments are officially styled cuirassiers, but the two regiments of Life Guards and the Royal Horse Guards were riven steel cuirasses in 1821 , which, however, they do not wear on active service. The price of one is $₫ 3,6 s$. See GUARDS. There are twelve cuirassier regiments in the German army, the cuirass being of white metal with a brass plate. The French lave also twelve regiments of euirassiers, having steel cuirasses with a brass plate. Russia has four regiments of cuirassiers, whose cuirass of iron, with a thin layer of copper, weighs 30 lb. From $13 \frac{1}{2}$ to $16 \mathrm{lb}$. is the welght of those of other armies. Napoleon III. at one time main. tained a bodyguard of cuirassiers, called 'Centgardes,' who wore cuirasses of aluminium, much lighter than steel ones, but, like them, not proof against a rifle-bullet striking them directly.

Cujacius, properly JACQUES DE CUJAS or CuJAUS, jurist, born in 1522, was the son of a tanner of Toulouse. After studying law, he lectured on the Institutes at Cahors, Bourges, and Valence (1554-67); lived at Turin and Grenoble; and after repeated changes, finally settled in 1577 as professor at Bourges, where he resided till his death, October 4, 1590. His great reputation as a jurist was founded on a lucid exposition of Roman law, based on conscientious study of the original authorities. He had in his library 500 MSS. on Roman law, and by his emendations contributed greatly to remove the obscurities of jurisprudence. A complete collection of his works was edited by
Fabrot (10 vols. Paris, 1658), and frequently republished. See Spangenberg's Cujacius (1822).

Culbin Sands. See DrIFr.

Culdees, or Keldees (Celt. Ceile De, 'a com. panion of God;' Lat. Colidei, Culdei, Calledei, Keldei, Keledei), the name given to an ancient order of ecclesiastics with monasteries in Scotland and Ireland, those in the former country being best known. In England and Wales only two instances of their occurrence seem to be authenticated-the first, where the canons of St Peter's at York were called Culdees in the reign of Athelstan (924-31), and the second, where Giraldus Cambrensis, writing about 1190, describes the island of Bordsey on the coast of Carnarvon as inhabited by "most devout monks called celibates or Culdees.

The origin and early history of these bodies is involved in almost hopeless obscurity. The name is not mentioned in the works of Adamnan, Eddi, or Bede, and makes its first appearance only abont the 8th century. The conclusion at which Dr Skene arrives is 'that the Culdees originally sprang from that ascetic order who adopted a solitary service of God in an isolated cell as the highest form of religious life, and who were termed Deicola: that they then became associated in communities of anchorites or hermits; that they were eleries, and might be called monks, but only in the sense that anchorites were monks; that they made their appearance in the eastem districts of Scotland at the same time as the secular clergy were introduced, and succeeded the Columban monks, who had been driven across the great mountain-range of Drumalban, the western frontier of the Pictish kingdom; and that they were finally brought under the canonical rule along with the secular clergy.'

When the Culdees appear clearly in history in the 12 th century each monastery was evidently an independent community, connected with the others by no ties whatever, and owning no control except that of its own abbot, in this and other respects resembling the secular canons or monastic 'families' of England, Ireland, and the Continent in the 11th century. The monasteries seem indeed to have undergone a similar secularising process to that which took place in the Northumbrian Church after the withdrawal of the Columban clergy, when, according to Bede, false monks, under pretext of founding monasteries, purchased for themselves territories, and caused "these to be assigned to them by royal edicts for an hereditary possession.' 'There seem to have been at this period two sections in each oommunity, one still performing divine service - and other religious duties pertaining properly to the body; while the other had become thoroughly lay, and so free from monastic discipline as to marry. Indeed, if a tradition of the 16th century can be received as authority for what passed in the 12th, the Culdees of Dunkeld were all married; but, like the priests of the Greek Church, lived apart from their wives during their period of service at the altar.

According to the records of the see of St Andrews, the state of the Culdee monastery there (and it may probably be taken as typical of all the rest) was in the middle of the 12th century far from satisfactory. They tell that there were thirteen Culdees holding their office by hereditary tenure, and living rather according to their own pleasure and the traditions of men, than after the rules of the holy fathers; that some few things of little importance they possessed in common; that the rest, including what was of most value, they held as their private property, each enjoying what he got from relatives and kinsmen, or from the benevolence granted on the tenure of pure friendship, or 
otheriwise ; that after they become Culdees they were forbiciden to have their wives in their houses, or any other women of whom evil suspicion could arise; that the altar of St Andrew was left without a minister, nor was mass celebrated there except on the rare oceasion of a visit from the king or the hishop, for the Culdees said their own oftice after their own way in a corner of the church. The first attempt to reform this state of matters was made by Queen Margaret, and her efforts were followed up by her sons, Alexander I. and David L; so that from the time of the appointment of Turgot to the see of St Andrews, when we are told that 'the whole rights of the Keledei over the kingdom of Scotland passed to the bishopric of St Andrews," the history of the Culdees is simply that of a vain resiatance to foes backed by all the weight of the royal power.

If tradition could be trusted, the first appearance of Culdees in Seotland was later than in Ireland, and should be placed about the middle of the 9th century. A leaf of the Register of St Andrews, written about 1130 , relates that Brude, the son of Dergard, the last king of the Piets (who ceased to reign about 843 ), gave the island, since called $\mathrm{St}$ Serf's Inch, in Lochleven, to God, St Servan, and the Culdee hermits serving God there. They were governed by an abbot; and about the year 1093 , Suring the rule of Abbot Ronan, they gave up their island to the Bishop of St Andrews on condition that he should find them in food and raiment. On this island they renained in peace, receiving grants of lands or immunities from all the kings of the Scots from the time of Macbeth till that of David I. but in 1144, Robert, Bishop of St Andrews, gave their island, and all their possessions, including their church vestments and their books (a conıplete list of which is given in the charter), to the newly. founded Canons Regular of St Andrews, in order that a priory of that rule might supplant the old abhey of Culdees on St Serf's Inch. The lishop's grant was enforced by a charter from King David, in which it was ordered that such of the Culdees as chose to live canonically and peacefully under the new canons should remain in the island. We hear no more of the Culdee hermits of Lochleven.

The Culdees of St Andrews were of more import. ance than those of Lochleven, and when the Canons Regular were established there, the members of the older body were treated much more considerately than their unfortunate brethren of St Serf's Inch, those who refused to become Canons Regular being allowed to retain a liferent of their revenues. Not only was this so, but they had sufficient influence to manage to remain a distinct community down to the early part of the 14th century, and were even able to asert their right to take part in the election of the bishop till 1273. In that year they were excluded under protest, and in 1332 they were excluded entirely, and thereafter the name seems to have disappeared.

The Culdees of the church of St Mary at Mony. musk, in Aberdeenshire, appear to have been settled by the Bishop of St Andrews towards the end of the 11th century. In the beginning of the 13th century they are found making a claim to be regarded as Canons Regular, which was, after an appeal to Rome, settled by a compromise.

Culdees are found at A bernetliy, in Strathearn, about 1120. In the end of that century part of their possessions passed to their hereditary lay. abbot (the founder of the noble family of Abernethy), and in 1273 they were transformed into Canons Regular. After a similar division at Brechin, the prior and his Culdees were absorbed into the chapter of the new bishopric, founded by King David I. about 1145, and in less than a hundred years the name of Culdee disappears. The snme 143 silent change of Culdees into secular canons took place during the 13th century at Dunblane, at Dunkeld, at Lismore, at Rosemarky, and at Dor. nox.h. At Dunkeld, as at Brechin and at A her. nethy, great part of the Culdee revenues was held by a lay-abbot, whose office was of such mark as to be hereditary in the royal family. The father of ' the gracious Duncan,' and the son of St Margaret, were Culdee abbots, Culdees are found holding land at Monifieth, near Dundee, about 1200 : at Muthil, in Strathearn, in the beginning of the 13th century ; and at Iona in the middle of the 12th.

The Culdees of Armagh, dissolved at the Refor. mation in 1541, were resuscitated for a brief space in 1627. Their old possessions-among which were seven town-lands, containing 1423 acres, seven rectories and four vicarages, were in 1634 bestowed upon the vicars-choral of the cathedral. There were at least seven other houses of Culdees in Ire. land-vir, at Clonmacnois, Clondalkin, Devenish, Clonés, Popull, Monanincha, and Sligo.

Such is a concise recapitulation of all that is certainly known of the Culdees. Before their history was ascertained, opinions were held regarding them which now find few if any supporters among archreologists. It was believed that they were our first teachers of Christianity ; that they came from the East before corruption had yet overspread the church; that they took the Seriptures for their sole rule of faith; that they lived under a form of church-government approaching to Presbyterian parity ; that they rejected prelacy, transubstantiation, the invocation of saints, the veneration of relies, image-worship, and the celibacy of the clergy ; and that they kept their simple worship and pure doctrines undefiled to the last, and were suppressed only by force and fraud, when the Roman Catholic Church triumphed over their older and better creed. For all this it is now clearly seen that there is no foundation. There is no reason to suppose that the Culdees differed in any material point of faith, discipline, or ritual from the other elergy of the British Islands and Western Christendom.

See Reeves in the Proceedings of the Roval Irish Academy for 1860, and his Culdees of the British Islands (1864); and Skene's Celtic Scot/and, vol. ii., whose views have tound acceptance both with Catholies and Presbyterians. The opinions formerly held regarding the Scottish Culdees (controverted by Pinkerton and Chalmers) will be found in Selden's preface to the Decem Historice Anglicance Scriptores, and Jameson's Bistorical Account of the Ancient Culdees (1811).

Cu'lenborg, or Kuilenburg, a town of Holland, 11 miles SSE. of Utrecht, on the left bank of the Lek, which is eroesed here by a railway viaduct 1420 yards long. Pop. 6798.

Culiacan', an ancient city of Mexico, on the Rio de Culiacan, 30 miles from the W. coast, and $100 \mathrm{SE}$. of Sinaloa. Pop. 7878.

Culilawan Bark, also called Clove BARK, an aromatic bark, the product of the Cinnamomizm. Culilawan, a tree of the same genus with the Cinnamon (q.v.) tree, growing in the Molucea Islands. It has an odour resembling that of nutmeg and cloves, and was formerly employed to some extent for cases of indigestion, diarrhoen, \&c.

Cullen, a fishing-town of Banfishire, on the Moray Firth, 67 miles $\mathrm{NW}$. of Alwerdeen by rail. way (1885). Backed by the conical Bin Hill ( 1050 feet), it has a harbour formed in 1817-34, and a criciform parish church, which was founded by Robert Bruce, whose second queen died here, and which in 1543 was made collegiate. Cullen House, a seat of the Earl of Seafield, is a Scottish baronial pile, enlarged and remodelled in 1861 . Cullen has been a royal burgh since about 1200 , and unites with Elgin and five other places to 
return one member to parliament. Pop. (1841) 1423 ; ( 1881 ) 2033 ; ( 1891 ) 2100.

Cullen, PaUt, a great Irish churchman, was born near Ballitore, in County Kildare, April 27, 1803. After a brilliant course in the Collegio Urbano of the Propaganda at Rome, he was ordained priest in 1829, and filled in succession the offices of vice-rector and rector of the Irish College in Rome, and rector of the Propaganda College. During the period of Mazzini's power in Rome in 1848, Cullen astutely saved the property of his college by placing it under American protection. At the close of 1849 the three names sent up to the pope having been passed over, Cullen unexpectedly found himself nominated to the arehbishopric of Armagh and primacy of Ireland. He was consecrated early in the following year, and at once commenced a vigorous and uncompromisingly ultramontane reign of eight-andtwenty years, in which he established lasting memorials to his memory in new churches, schools, convents, and hospitals, such as the Mater Misericordix. He denounced mixed education in every form, and from the outset opposed all revolutionary and anti-constitutional opposition to the crown. His vigorous denunciations of Fenianism made him many enemies among the more hot-headed Irishmen, but greatly increased the respect of English Protestants for a church that would make no terms with erime, even when committed by its own children. At the Synod of Thurles in 1851, principally by Cullen's persuasion, the establishment of a Catholic university in Ireland was recommended. Translated to Dublin in 1852, he was ereated a cardinal priest in 1866, the first Irishman who had reached that elevated rank. One of the majority at the Vatican Council, he long enjoyed the familiar friendship of Pope Pius IX. He died at Dublin soon after his return from a journey to Rome, October 24, 1878.

Cullen, Wrluam, M.D., physician, was born at Hamilton, Lanarkshire, on 15th April 1710, his father being factor to the Duke of Hamilton. After learning his profesiion, first as apprentice to a surgeon-apothecary in Glasgow, next as surgeon on board a West Indian trading ship, and then as assistant to an apothecary in London, he returned to Scotland in 1731, and commenced practice in his native county. Feeling the necessity of more systematic study, he spent two winters at Edinburgh University under Munro primus, and then removed to Hamilton, where he soon secured a good practice. One of his articled pupils was William Hunter (q.v.), to whom he became extremely attached; and it was agreed that one of them should be alternately allowed to study during the winter, while the other carried on the practice. Cullen spent the first wirster at Edinburgh, and it is at this time that he appears to have taken an important part in founding what is now known as the Royal Medical Society. It being Hunter's turn next year he went to London, and having attracted attention there, did not return, Cullen generously cancelling the articles. In 1740 Cullen graduated M.D. at Glasgow University, gave up surgical work, and soon after established himself in Glasgow as a physician. At that time there was not in Glasgow any regular course of medical study, and Cullen occupied himself much in the foundation of a medical school, himself lecturing on various subjects. One of his pupils was the famous Dr Joseph Black (q.v.). Cullen's labours resulted in his appointment to the chair of Medicine in the university, which be occupied four years. In 1755 he was persuaded to leave Glasgow for Edinburgh, and for the next thirty-five years was one of the mainstays of the Edinburgh medical school. During this long period he oceupied successively the chairs of Chemistry, Institutes of Medicine, and Medicine, besides teaching clinically in the Royal Infirmary all the time.

Living as he did in what might be termed the renaissance period of the history of medicine, Cullen was essentially a man of his time, and did much to advance the science. For many centuries all disease had been referred to disorders of the fluids of the body. Just before Cullen's time, Boerhaave had added to this a pathology of the 'fibres 'still strongly tinctured with the old fluid or humoral pathology. To Cullen is largely due the recognition of the important part played by the nervous system both in health and disease. He denied the theory supported even by Boerhaave, that the brain was an excretory organ and the nervous influence a fluid. Many of his speculations as to reflex nervous action, the possible presence in a single nerve of both sensory and motor fibres, and the connection of sensory and motor nerves with the anterior and posterior nerve roots, have now been proved to be facts. He had a singularly open and candid mind, and while himself introducing the use of several new drugs, as oxide of antimony and tartar emetic, was careful to distinguish between the action of drugs and the curative operations of nature. It may be said of him in his own words when speaking of Sydenham, "that he rather sought for theory to connect his frets, than for facts to support his theory.'

In the later years of his life arose the contro. versy on the Brunonian system (see BRown, JOHN, M.D.), which system Cullen bitterly opposed. Brown's specious division of diseases into sthenic and asthenic was obviously a deduction from Cullen's theories of nerve influence, and was only one instance out of many where a reputation was built on ideas borrowed from Cullen.

Cullen died on 5th February 1790 at his small estate of Ormiston Hill, having nearly completed his seventy-ninth year, and having been actively engaged in teaching and consulting practice till within a few months of his death. Cullen's most important works are First Lines of the Practice of Physic (Edin. 1777), Synopsis Nosologia Methodica (1785), Institutions of Medicine (1777), A Treatise on the Materia Medica (1789). See Biography, vol. i. by Dr John Thomson (1832), vol. ii. by Cullen's son and Dr David Craigie (1859), also an article by Sir W. Hamilton in the Edinburgh Review (1831).

Cullera, a town and port of Spain, near the mouth of the Jucar, 25 miles SSE. of Valencia. It exports rice, pistachio-nuts, oranges, wine, and oil. Pop. 11,050.

Cullod'en, or Drummossie Murr, a broad flat sandstone ridge, 300 to 500 feet high, 6 miles ENE. of Inverness. Planting and culture have changed its aspect much since 16th April 1746, when it was the scene of the total rout of 5000 Highlanders under Prince Charles Edward by 12,000 regulars under the Duke of Cumberland. Since 1881, a cairn, 20 feet in height, with an inscription, marks the spot where the battle was fiercest, and where many of the slain lie buried. Within 2 miles stands Culloden House, the seat of Duncan Forbes and his descendants.

Culm, a kind of impure Anthracite (q.v.). In some districts the culm obtained from the pits in a broken and erumbling condition is used as fuel, being made up into balls, with one-third of its bulk of wet viscid clay. It burns without flame, producing a strong and steady heat, well adapted for cooking (see BRIQUETTE). The term Culmmeasures is applied to the carboniferous strata of Devonshire, on account of the workings for culm near Bideford, and other places. 
Culm, the peculinr cylindrical hollow and jointed atem of (irassen (q.v.).

Culmination, an astronomical term, signify ing the passage of a star acrose the meridian. The star is then at the highest point (culmen) of its course; hence the name. The sun culminates at mid-day, or twelve o'clock, apparent solar timewhich seldom agrees exactly with mean time, as shown by a wateh or elock. The full moon eulninates at midnight.

\section{Culna. See Kalna.}

Culpa simply means fault (generally the omission of some ret) which leads to legal liability for the immediate consequences. It may arise under a contract, especinlly where many of the obligations of the parties are left to implication-e.g. in the contract of carriage of passengers; or from the mere relative position of parties, as where a member of the public, or a neighbour, is injured by the neyligrent use of property. The distinction between culpa and brench of contract, while theoretically clear, is practically difficult; and accordingly the opinion of a jury is constantly required to ascertain whether fault has been committed in the execution of a contract.

Culpable Homicide. See Homicroe, and

\section{MURDER.}

Culpeper, JoHn. See Colepeper.

Culpeper, Nicholas, was born in London in 1616 , and after studies at Cambridge and elsewhere, started in 1640 to practise astrology und plysic in Spitaltields. In 1649 he published an English translation of the College of Physicians' Pharmacopoeis under the title A Physical Directory, or a Translation of the London Dispensatory, renamed in 1654 as Pharmacopocia Londinensis, or the London Dispensatory. This infringement upon a close monopoly, together with his sturdy and uncom promising support of Puritanism and the parlia. ment, broucht Culpeper many enemies and much obloquy. In 1653 he published The English Physician Enlarged. Both books had an enormous sale, and both are included in Dr Gordon's collective edition of his Works (4 vols. 1802). Culpeper wrote numerous other books, many of which were left unprinted, and died worn out before his time, 10th January 1654.

Culpeper, Sir Thomas, was born of good Kentish fanily in 1578. He studied at Hart Hall, - Oxford, and at one of the Inns of Court, next bought Leeds Castle in Kent, where, or at Green. way Court, near Hollingbourn, he mostly lived till his death, which took place in 1662. He was knighted by James I. in 1619. His Tract against the high rate of Usurie, published in 1621 , contended for the reduction of interest to six per cent. - His thind son, Sir Thomas CulPePER, born in 1626, made his studies at University College, Oxford, and after making the grand tour, and leing knirgted soon after the Restoration, retired to his estate of Greenway Court, where he died in 1697. Besides editing and prefacing his father's treatise on exorbitant usury in 1668, he limself published many pamphlets on the same subject, repeating his father's arguments. He wrote also Essayes or Moral Discourses on several Subjects (1655 and 1671).

Culross, an old-world village of Fife ( $t$ ill 1890 in a detached portion of Perthshive), on the north shore of the Firth of Forth, 7 miles W. by S. of Dunferm. line. With memories of St Serf and St Kentigern, James VI., and the Elgin and Dundonald families, it has remains of a Cistercian abbey (1217), but lias lost it manufacture of 'girulles,' its saltworks, slipping, and submarine coal-mines. A royal lurgh since 1588, it unites with. Stirling and three other towns to return one memler to parlimment. P(n). 373. See Beveridge's C'ulrous and 'T'ulliullan (1885).

Cultivated Plants, That the history of material progress is directly connected with and measured by man's increasing utilisation of the vegetable and animal, no less than of the mineral world, is an idea of conmon experience, which the researches of archeologiats in all parts of the world have amply contirmed. The whole subject forms, indeed, ove of the most fascinating aspecte of the history of eivilisation. Primitive man, acquiring his acquaintance with useful plants by slow and often bitter individual experience at the very margin of subsistence, offers a striking contrast with the experimental organiser of new and in every sense remotely productive cultures like that of the cinchona-tree in the Himalayas, -a contrast which spans the whole range alike of the practical resources and the scientific culture of the human race.

Without speculation as to the precise steps by which man passed from the hunting or merely pastoral to the agricultural state, we find positive evidence of the existence of agriculture long before written records. Thus, though the 'kitchenmiddens' of northern countries contain no trace of cultivated plants, the deposits of Swiss lakedwellings have yielded remains of fruits, of cereal and other seeds, and of linen fabrics, showing the existence of a considerable agriculture before the use of metals. Ancient traditions and ceremonials of China also bear witness to the remoteness of cultivation there. The earliest Egyptian picturewritings and the greater number of cultivated species have arisen in that central cradle of civili. sation which may be broadly marked off by draw. ing lines from the delta of the Nile to the head of the Persian Gulf, and from the Dardanelles to the Caspian-i.e. between $30^{\circ}$ and $40^{\circ}$ lat. From this region the majority of European plants are derived. Another great centre of ancient agriculture, how. ever, is China; while the third is intertropical America, where the ancient Mexicans and Peruvians practised the culture of not a few plants, of which some have become almost cosmopolitan since the epoch-making voyage of Columbus.

Since the rise of modern botany (see BoTANY), our knowledge of species at least possibly useful has been greatly extended, yet there seems little risk of displacement of the established cereals, fruit-trees, sc., since these have the advantage of an enormous past of artificial selection, which has in many cases practically transformed them into new species, apparently distinct from their wild congeners, and incapable of continued existence in the uncultivated state-e.g. wheat, barley, maize, pea, sugar-cane, yam, \&e., and probably also bean, tobacco, manioc, \&c. Moreover, such long cultivated plants usually exhibit greater variability than naturally wild species, and thus in every way new cnltures tend to be unremunera. tive. Hence the majority of species of primary nutritive importance to man at present are annong those which have been in cultivation for the past 2000 years; and the progress which is now being made is essentially on lines which merely supplement these: the newer plants, cultivated for less than 2000 years, being, according to De Candolle, chiefly artificial fodders, which the ancients scarcely knew; then bulbs, vegetables, medicinal plants (cinchons): plants with edible fruits or nutritious seeds (buckwhent), or aromatic seeds (coffee). Here, of course, the demand for variatious in fool and drink, for narcotics and medicines, for textiles and timber, all combine towards progress; in most of these the demant is at buttom more largely asthetic than utilitarian, 
while this becomes exclusive in the newest but extending department of flower gardening.

See the articles Agriculturk, GarnkNing, Fruit, Pasture, Plants (Mmdicinal), \&c. ; those on special plants-o. BARLEY, COCA, DATK, MAIZk, \&c.; also De Candolle, Origin of Cultivated Plants (Inter. Sa. Series, 1884); and Hehn's Wanderings of /lants and Animals (1886).

Cultivator, a farm implement. See GrUBBER.

Culverin, one of the earlier forms of Cannon (q.v.), of great length, generally an 18-pounder, weighing 50 cwt.; the demi-culverin being a 9.pounder, weighing $30 \mathrm{cwt}$.

Culver's Root, the rhizome of Veronica virginica, used medicinally as radix leptandros of U.S. Pharmacopœia.

Culvert is the name given to ais arched channel of masonry for the conveyance of water underground or beneath an embankment.

Culverwel, Nathanael, one of the Cambridge Platonists, was born in Middlesex, and entered Emmanuel College in 1633. He graduated B.A. in 1636, M. A. in 1640, was elected fellow in 1642 , and died not later than 1651 . In 1652 was published An Elegant and Learned Discourse of the Light of Nature, with several other treatises-viz. the Schism, the Act of Oblivion, the Child's Return, the Panting Soul, Mount Ebal, the White Stone; Spiritual Optics; and the Worth of Souls. An edition of the Light of Nature was issued in 1857, edited by Dr John Brown of Edinburgh, with a critical essay by Principal Cairns. It is a treatise of great power and learning, written in a vivid and vigorous style, and is a work not unworthy of the college that produced Cudworth, Whichcote, and John Smith. See Tulloch's Rational Theology, vol. ii. (1874), pp. 410-26.

Cumae, an ancient city on the coast of Campania, founded conjointly by colonists from Chalcis in Eubœa, and from the Eolian town of Cyme in Asia Minor. The date of its foundation is uncertain, but according to Strabo it was the earliest of all the Greek settlements either in Italy or Sicily. It soon attained to wealth and power, built several harbours or port-towns of its own, kept a tolerably large fleet, extended its influence over the native tribes of the neighbouring territories, planted colonies in Italy and Sicily, at Puteoli, Neapolis, and Zancle (Messina). Spite of attacks from the Etruscans and Umbrians without, and dissensions within, for the two hundred years before 500 B.C. it was the most important and civilised city in Southern Italy. In 474 its ally, Hieron, king of Syracuse, defeated the combined fleets of the Etruscans and Carthaginians, who had attacked it by sea. Cumæ at length lost its independence $(417$ B.C.) when it was conquered by the Samnites, who killed or enslaved most of the citizens. It ultimately became a Roman municipium and colony, but continued to decline. It re-assumed a momentary importance during the wars of Belisarius and Narses. Its strong fortress, garrisoned by the Goths, was the last place in Italy that held out against the Byzantine army. Few remains of the ancient city exist. - Cumr is famous as the residence of the Sibyl (q.v.), whose cave was identified with one of the many subterranean passages in the rock on which the citadel stood. Most of these are now choked up.

Cumana, a town of the Venezuelan state of Bermudez, on the Manzanares, a mile above its mouth, where the port of Puerto Sucre lies on the Gulf of Cariaco. It has a national college, and some export trade, but is chiefly of interest as the oldest European town on the South American mainland, having been founded by Christopher Columbus's son Diego as New Toledo in 1521. It has suffered much from earthquakes, and was almost entirely destroyed in 1853. Population about 10,000 .

Cumania is the name of a region in Central Hungary divided into Great Cumania, east of the Theiss, and Little Cumania, Jetween the Danube and the Theiss, now incorporated in the adjoining Hungarian provinces. The inhabitants, the Cumans, are the descendants of a race of nomad invaders of the Turkish stock, who forced their way into Hun. gary from beyond the Volga in the lith century. They long held their own in alternate alliance and war with the surrounding states. They maintained their heathenism and their barbarous customs, till in 1278 a crusade was proclaimed against them by Pope Nicholas IV., and they were compelled to accept Christianity and adopt the ways of their Magyar neighbours. They are now wholly Magyarised.

Cumberland, a Border county of England, washed on the $W$. by the Irish Sea and the Solway Firth, and elsewhere bounded by Dumfries and Roxburgh shires, Northumberland, Durham, Westmoreland, and Lancashire. Eleventh in size of the English counties, it has a maximum length of 75 miles, a maximum breadth of 45 , a coast-line of 75 , and an area of $1564 \mathrm{sq} . \mathrm{m}$. The surface is mountainous in the south-west and east; the middle consists of hills, valleys, and elevated ridges; and the north and north-west districts, including the vale of Carlisle, are low, flat, or gently undulated. The mountains in the south-west are high, rugged, and sterile, with deep and narrow valleys, lakes, rivers, waterfalls, and woodlands. The chief mountains are Scaw Fell Pike (3210 feet), Scaw Fell (3162), Helvellyn (3118), Skiddaw (3058), Bow Fell (2960), and Cross Fell (2892). The largest lakes are Uliswater, Derwentwater, Bassenthwaite, Thirl. mere, Buttermere, Wastwater, and Ennerdale. Six of the ehief waterfalls are 60 to 156 feet high. The chief rivers are the Eden, the Esk, and the Derwent. The Lancaster and Carlisle railway route from London to Edinburgh crosses the north-east part of Cumberland.

The Lake district, or nearly the south-west half of Cumberland, consists of Silurian slates, with protrusions of granite and trap rocks, and with New Red sandstone along the coast south of St Bees Head. In the north is a semicircular strip of carboniferous limestone; then follow strips of coal strata and Permian rocks; then the new red sandstone plain of Carlisle, with carboniferous limestone on the north-east, including a trap-dike 30 miles long. Cumberland abounds in mineral wealthsilver, ccpper, lead, iron, plumbago, gypsum, limestone, coal, slates, marbles, marl, and several of the rarer minerals.

In the mountainous parts the clintate is wet and variable, especially from July to October; on the coast it is nild. There is an annual rainfall of 50 inches at Whitehaven, and of 59 at Keswick; while at Styhead Pass, at an altitude of 1077 feet, the rainfall has been as much as 243.98 inches. Half of the cultivated soil consists of dry loam. Much of the subsoil is wet clay. The chief crops are wheat, barley, oats, turnips, and potatoes. There are many small dairies. Sheep and eattle are reared in the mountains. The estates are generally small, and farmed by the owners, or held under the lords of the manors by customary tenure. Many of the small proprietors, or 'statesmen,' have had their lands in their families for centuries, and have a high spirit of independence. There are manufactures of woollens - much being domestic cottons, linens, earthenware, and glass. The chief towns are Carlisle, Cockermouth, Whitehaven, Workington, Maryport, Wigton, Penrith, Keswick, 
Eyremont, Under the Distribution of Seats Act, 1885. Cumberland returns one member for each of the four divisions, North or Eskdale, Mid or Penrith, Cockermouth, and West or Eyremont. Pop. ( 1801 ) 117,250; (1841) 178,038; (1871) 220,253; (1891) 206,550. Near Keswick and Kirkoswald are two tine stone circles; and many Roman relics have been fouml, such as altan, coins, and inserip. tions. For centuries part of Cumbria or Strathclyde, the present county was finally annexed to England in 1157. For three hundred years prior to the union of the crowns, it was the constant scene of war and devastation, from incursions of the English and Scotch; and it suffered again in both the '15 and the '45. Cumberland had formerly several monasteries and hospitals; and on the Border, many towers or peel-houses; and it has still some fine old clurches. See BORDERs, LAKE District ; and K. S. Ferguson's Hist. of C. (1890).

Cumberland, a river, rises in Kentucky, flows into Tennessee, and returning to Kentucky, enters the Ohio at Smithland, after a course of about 650 miles, of which nearly 200 are navigable for steam. boats.-For Cumberland Mountain, see APPALAchisas.

Cumberland, capital of Alleghany county, Maryland, on the Potomac River, 178 miles W. by N. of Baltimore by rail. It is a canal terminus and an important railway centre, and has manufactures of brick, cement, flour, and leather, and an extensive trade in coal. Pop. (1890) 12,729.

Cumberland, DR RICHARD, was born in London, July 15, 1631. Educated at St Paul's School and Magdalene College, Cambridge, he was preferred to the rectory of Brampton, Northamptonshire, in 1658; in 1667 to the living of All Hallows, Stamford; and in 1691 to the bishopric of Peterborough. Cumberland was a man of great acquirements, and of sincere and simple piety ; his frequent saying, 'a man had better wear ont than rust out, explaing his unusually birh ides of episcopal duty. He wrote several works, of which one is still read, his Inquiry into the Lavs of Nature, written in reply to Hobbes, and remarkable as placing the foundation of morality on a utilitarian basis. His Essay on Jevish Weights and Measures was dedicated to his old college friend Pepys, as president of the Royal Society. As an instance of Cumberland's insatiable thirst for knowledge, it is mentioned that he learned Coptic after the age of eighty-three. He died Oetober 9, 1718.

Cumberland, Richard, a dramatic writer and essayist, was born on the 19th February 1732, in the lodge of Trinity College, Cambridge. He was the great-grandson of Bishop Cumberland, and grandson, by the mother's side, of Dr Richard Bentley. From Bury St Edmunds and Westminster, where he was contemuorary with Cowper, Churchill, and Warren Hastings, he passed to Trinity College, Cambridge, and here was elected to a fellowship at twenty. Becom. ing private secretary to Lord Halifax, he gave up his intention of entering the church, and, after passing through several subordinate offices, was appointed secretary to the Board of Trale. $\mathrm{He}$ held that office siter his return from an unfortunate secret mission to Spain (1780), which cost him as much as $£ 5000$, a sum that ministers refused to reimburse, when the Board was suppreseed. Having obtained a compensation allowance of about half his salary, Cumberland retired to Tunbridge Wells, where he devoted himself to literature, and wrote incessantly farces, tragedies, comedies, pamphlets, essays, and novels, two at lesst of merit, Arundel and Henry. Many of his comedies were successful at the time of their appearance, although they' have not kept poseeseion of the stage. Among them may here be namerl The West Inelicn, The Bruthers, The Fashionable Lover, The Jew, and The Wheel of Fortune, Cumberland is alluded to in Goldsmith's Retaliation with not unkindly atire as 'the 'Terence of England, the mender of hearts:' in Sheridan's Critic he is gibbeted as 'Sir Fretful Plagiary,' Cumberland's essays and translations from the Greek poets are long forgotten. He died at Tunbridge Wells, 7th May 1811. His inaceu. rate Memoins of himself were published in 1807.

Cumberland, William Augustug, Duke of, second son of George II., was born in 1721. He adopted a military career, was wounded at Dettingen in 1743, and defeated, not ingloriously, at Fontenoy, by Marshal Saxe, in 1745 . He was next sent to crush the Young Pretender's rebellion. which he did effectrally at Culloden (1746); and by a series of severe measures against the broken and dispirited Highlanders he earned for himself the lasting title of 'the Butcher,' to set off against his reward of $£ 25,000$ a year and the thanks of parliament. In 1747 he was defeated by Saxe at Lawfeldt, and in 1757 had to surrender and disarm his army at Kloster-Zeven ; after which he retired into private life, and died 31st Oct. 1765. See the military Life by Kev. A. N. CampbellMaclachlan based on the duke's General Orders of 1745-47 (1876).-For other dukes and earls of Cumberland, see Havover and Clifford.

Cumberland Island (so called) is a peninsula of Baffin Land, extending into Davis Strait.

Cumberland Presbyterians, a religious denonination which sprang up in 1810 in the state of Kentucky, in consequence of a dispute between the presbytery of Cumberland in that atate, and the Kentucky Synod of the Presbyterian Church in America, concerning the ordination of pensons who had not passed through the usual educational curriculum, but whose services the presbytery regarded as demanded for the ministry by the exigencies of the times. In 1887 this church had 26 synods, 1538 ministers, 150,000 members, and several colleges and seminaries. Their form of government is presbyterian, though they have added a system of itinerating like the Methodists. Arminian in doetrine, they deny unconditional election and predestination, and believe in the universality of the atonement.

Cumberland Valley. See Pennsyluania.

Cumbrae, Big or Great, an island of Buteshire, in the Firth of Clyde, 24 miles $\mathrm{E}$. of Bute at the narrowest, and 1 mile WSW. of Largs. With the shape of a shark's tooth, it is 39 miles long, 2 broad, $10 \mathrm{~d}$ in circumference, and $5 \mathrm{gq} . \mathrm{m}$. in area. It rises to a height of 417 feet, and consists of Old Red sandstone, with wall-like trap-dykes intersecting it. The Marquis of Bute is sole proprietor. Millport, on the south shore, 19 miles SSW. of Greenock (via Wemyss Bay), is a crowded resort in summer. Pop. (1801) 506; (1891) 1784, of whom 1668 were in Millport. - LITTLE CuMBRAE, is mile SSW. of Millport, is barely 1 sg. $\mathrm{m}$. in area. It rises 409 feet, and has a lighthouse (1826). Pop. 23.

Cumbria. See Cambria and Strathclyde.

Cummin, or Cumin (Cuminum), a genus of Unbelliferse, containing only one known species (C. суminum), common in Egypt and the neigh bouring countries, sometimes as an annual weed, but more frequently in cultivation, as also in southern Eumpe and India. It is referred to in Seripture (as in Matt. xxiii. 23). The fruit-lobes separate in the way characteristic of the order, and are thus popularly called seerls; their odour and properties resemble those of Caraway (q.v.). 
but are stronger, and therefore to some palates more pleasant. It is employed as a carminative flavouring in many parts of the world; but its strictly medicinal use (as in plasters) is now chiefly confined to veterinary practice. In Germany, it is often put into bread; in Holland, sometimes into cheese. It contains a peculiar volatile oil. (Oil of Cummin). Cummin-seed is brought to Britain mostly from Sicily and Malta. - The fruit of Lagoecia cuminoides, another umbelliferous plant, a native of the Levant, is similar in its qualities and ases to that of cummin. The Black Cummin of the ancients is sometimes identified as a species of Nigella (q.v.).

Cumming, Constance Frederika Gordon, a well-known traveller, was born 24th May 1837, and was the sister of the lion-hunter (see below). She has travelled extensively, having resided for two years in Ceylon, and two in Fiji. She has also visited Tahiti, China, Japan, California, Hawaii, New Zealand, and Australia, and has written various sprightly and entertaining volumes of travel, including From the Hebrides to the Himalayas (1876); At Home in Fiji (1881); A Lady's Cruise in a French Man-of-war (1882); Fire Fountains-Hawaii (1883); Wanderings in China (1885); Two Happy Years in Ceylon (1891).

Cumming, ЈонN, divine and author, was born in Fintray parish, Aberdeenshire, loth November 1807. He was educated at King's College, Aberdeen, where he took his degree of M.A. in 1827 , and in 1832 was oriained to the Scotch Church, Crown Court, Covent Garden, London, where he preached with great popularity and success till 1879. Edinburgh University gave him the degree of D.D. in 1844. He was active in philanthropic projects, and as a controversialist and lecturer both against the party that formed the Scotch Free Church and in the 'anti-Popery' cause; but his celebrity was chiefly due to his writings on the interpretation of prophecy. His andacity in this perilous enterprise drew upon him mueh ridicule. In 1868 he asked the pope if he might attend the Ecumenical Council, but his application was declined through Archbishop Manning. After some years of ill-health, Cumming died 5th July 1881. His works number over a hundred various publications. Among them are Apocalyptic Sketehes (three series, 1848-50), Prophetic Studies (1850), Signs of the Times (1854), The Millennial Rest (1862), Ritualism the Highway to Rome (1867), The Sounding of the Last Trumpet (1867), and The Seventh Vial (1870).

Cumming, Roualern-George Gordon, the African lion-hunter and the second son of Sir William-Gordon Gordon-Cumming, was born 15̃th March 1820 , and was educated at Eton. He became a cornet in the Madras Cavalry in 1838, served for a time in Canada, and joined the Cape Mounted Rifles in 1843; but he soon resigned his commission, and, till his return to England in 1848 , engaged in those famous hunting exploits narrated in his Five Years of a Hunter's Life (1850), of which he issued a condensed edition, entitled The Lion-hunter of South Africa (1858). He died at his residence, Fort Augustus, 24th March 1866.

Cummins, Maria Susanna, American novelist, born at Salem, Massachusetts, April 9, 1827, began to write in 1850 , contributing presently to the Atlantic Monthly and other magazines. Her first novel, The Lamplighter (1854), had a phenomenal sale, 40,000 copies being sold in two months; its entire sale in America alone has exceeded 120,000 copies. Her other books include Mabel Vaughan (1857), El Fureidis (1860), and Haunted Hearts (1864). She died at Dorchester, October 1, 1866.
Cumnock, OI, a town of Ayrshire, on Lugar Water, 18 miles by rail $E$ of $A y r$, and $43 \mathrm{NW}$. of Dumfries. The manufacture of wooden snuff-boxes was many years since transferred to Mauchline, and mining is now the chief industry. The Covenanting 'prophet,' Peden (1626-86), lies in the churchyard. Dumfries Honse, a seat of the Marquis of Bute, is 2 miles W. Pop. 3104. See History by Warwick (Paisley, 1899).--NEw CuMNock, on the Nith, $5 \frac{1}{2}$ miles SE. of Old Cumnock, has 1514 inhabitants.

Cumulative Voting. See Representarion.

Cunard, Sir SAMuer, was born 21st November 1787 at Halifax, Nova Scotia, where his father, a Philadelphia merchant, had settled. Becoming early a successful merchant and shipowner, Cunard came to England in 1838, joined with George Burns, Glasgow, and David M'Iver, Liverpool, in founding (1839) the British and North American Royal Mail Steam Packet Company, and obtained a contract from the British government for the mail service between Liverpool and Halifax, Boston, and Quebec. The first passage was that of the Britannia in 1840, the time occupied being fourteen days eight hours. Iron steamers were first used in 1855, and paddle-wheels gave way entirely to the screw after 1862 . From its small but suecessful beginning, Cunard's undertaking soon developed into one of the vastest of private commercial concerns. In 1878 it was made into a joint-stock company. Created a baronet in 1859 , Cunard died at London, 28th April 1865.

Cunaxa. in Babylonia, east of the Euphrates, about 60 miles N. of Babylon, noted for the battle (401 B.C.) between Cyrus the younger and his brother Artaxerxes Mnemon, in which the former was killed.

Cundinamarca, a central department of Colombia, extending east to Venezuela. It is the second largest department of the republic, with an area of $8500 \mathrm{sq}$. m., excluding the territory to the south-east of the Meta, which is about as large as Italy. The population is about 570,000 (including 17,000 wandering Indians). The western part is mountainous, with fertile valleys and plateans; in the east are vast plains. It is well wooled, and rich in minerals. The capital is Bogotá (q.v.), also capital of the republic.

Cune'iform, Cuneatic, Wedge-shaped, Arrowheaded (Fr. tête-à-clou, Ger. keilformig), are terms for a certain form of writing, of which the component parts resemble a wedge. It was used by the ancient peoples of Akkad, Babylonia, Assyria, Armenia, Elam, and Persia; and was inseribed upon stone, bronze, iron, glass, and clay. Cuneiform inscriptions were chiselled upon stone and iron, but they were impressed upon soft clay with a pointed stylus having three unequal facets; the smullest to make the fine wedge of the cuneiform signs, the middle-sized to make the thicker wedges, and the largest to make the outer and thick wedges of the characters. The first date that can be assigned to the use of cuneiform writing is about $3800 \mathrm{~B}, \mathrm{C}$., and its use was continued until after the birth of Christ. The earliest inscription at present known is that inscribed upon the porphyry whorl in the time of Sargon of Agade; the latest is a tablet preserved at Munich, which may have been written about 83 A.D. Cuneiform writing was first used in Mesopotamia, and from thence it spread to Persia and to the districts north of Nineveh. For nearly 1600 years after its extinction its very existence was forgotten. The immense ruins found all over that ancient kingdom, and especially those of ancient Persepolis, had at all times attracter the attention of eastern travellers; still no one seems to have dreamed that those strange wedges which com. 


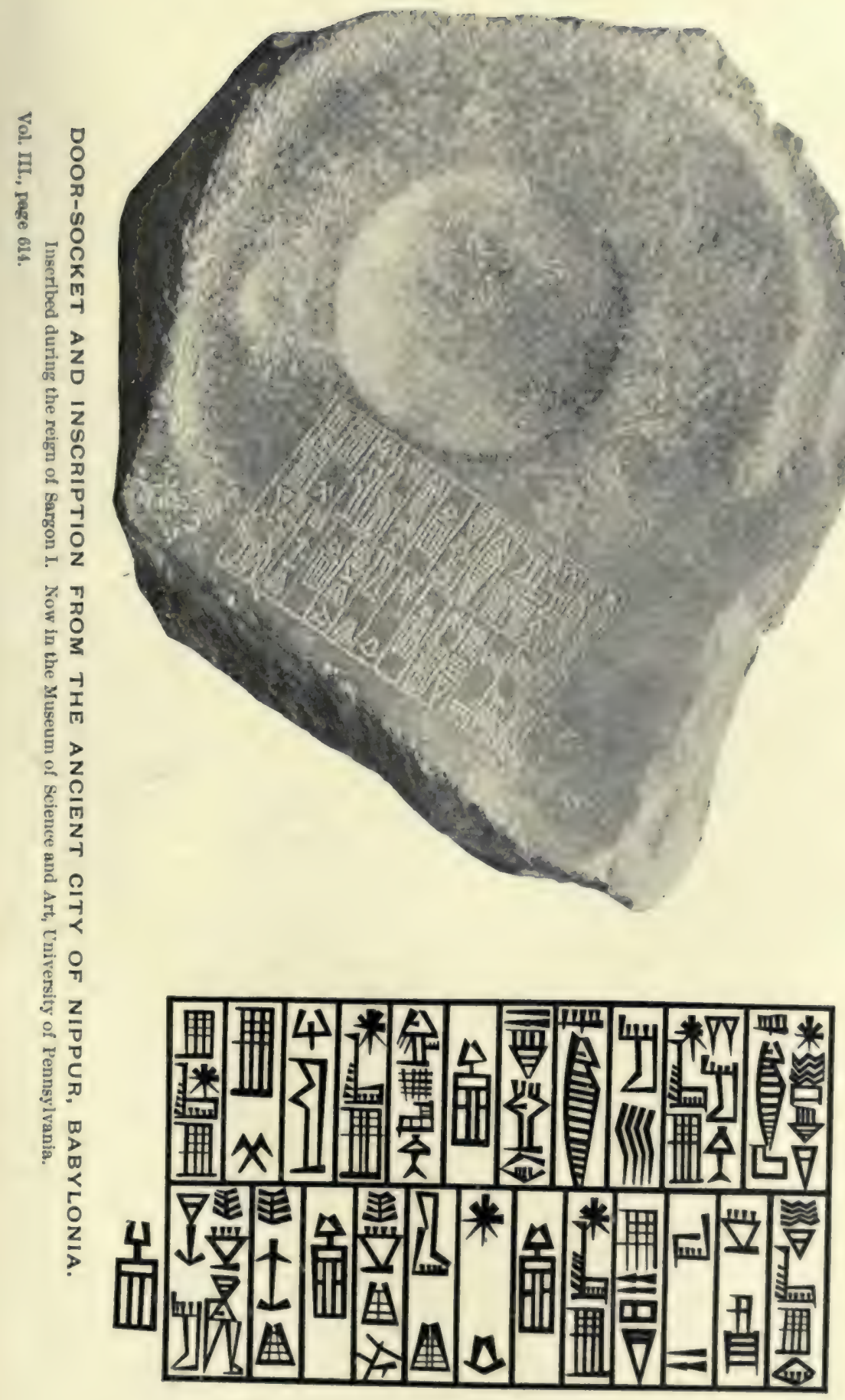



pletely covered some of them could have any meaning. It was Garcia de Sylva liguểroa, anbaswador of Philip III. of Spain, who, on a visit to Persepolis in 1618 , finst became possessed with the firm conviction that these signs must be in. seriptions in nome lost writing and, perlaps, language, and hal a line of them copied. Amongst subsequent travellers whose attention was attracted to the subject, Chardin, after his return to Europe in 1674, published three complete groups of cuneiforms, copied by himself at Pensepolis, together with a comparatively long and minute account of the mysterious character. He likewise declared it to be 'writing and no hieroglyphs: the rest, however, will always be unknown.' Michaux, a French botanist, sent, in 1782, a boundary stone, found at Baydlad, to Paris, covered with inscriptions. Ever since, the materials for the investigation of a subject the high importance of which by that time was fully recognised have been rapidly acemulating. Sir H. Jones, Ker Porter, Robert Stewart, Sir W. Ouseley, Bellino, Dr Schultz-up to Rich and Botta, Flandin, Rouet, Layard, Oppert, Smith, Rassam, Budge, and, above all, Rawlinson, each in his turn brought back more or less valuable materials from his eastern travels; and, naturally enough, those explorens were among the foremost to engage in the study of the records they had brought to light.

Now that we are able to explain so much of these inseriptions, it is highly interesting and instructive to notice the opinions first entertained of them by the wise and learned in Europe. In the Transactions of the Royal Society of June 1693, they first appeared from a copy made by Flowers, and they are held to be "the ancient writing of the Gaures or Gebres,' 'Thomas Hyde, the eminent Orientalist, declared them, in his learned work on the religion of the ancient Persians (1700), to be nothing more or less than idle fancies of the architect, who endeavoured to show how many different characters a certain peculiar stroke in different combinations could furnish. Witte, in Rostock, saw in them the destruetive work of generations upon generations of worms. Generally, they were pronounced to be talismanic signs, mysterious formulæ of priests, astrological symbols, charms which, if properly read and used, woulil open immense vaults full of gold and pearls - an opinion widely diffused among the native savants. The next step was to see in them a species of revealed digital language, such as the Almighty had first used to Adam. Lichtenstein read in some of then certain passages from the Koran, written in $\mathrm{Kufic}$, the ancient Arabic character; in others, a record of Tamerlane; and was only surprised that others should not have found this, the easiest and clearest reading, long before him. Kampfer was not quite sure whether they were Chinese or Hebrew characters. That they were Runes, Oghams, Samaritan, or Greek characters, were some of the soberest explanations.

It was Karsten Niebuhr who first showed the way, to the more sensible portion of the learned, out of this labyrinth of absurdities. Without attempting to read the character itself, he first of all established three distinct cuneiform alphnbets
instead of one, the letters of which seemed to outnumber those of all other languases together. The threefold inseriptions found at Persepolis he rightly took to be transcripts of the same text in three alphabets, in a hitherto unknown language. Tychsen of Rostock (1798), and Minter of Copenhagen (1800), affirmed and further developed this conjecture. The latter went 80 far as to divide the characters and inseriptions into alphabetical, syllabic, and monogrammatical, and to assume two different languages-Zend for inscriptions of a religious, Pehlevi for those of a political character.
The real and final discovery, however, is due to Grotefend of Hanover, and dates from 1802. On the $7 \mathrm{th}$ of September of that year he laid the finst cuneiform alphabet, with its equivalents, before the Academy of Góttingen-strangely enough, in the very same sitting in which Heyne gave an account of the firat reading of hieroglyphs. The process by which Grotefend arrived at that wonderful result is so supremely interesting, that we can. not omit to sketch it briefly. He fixed upon a Persepolitan inseription of what was called the first class, and counted in it thirty promiscuously reeurring groups or combinations of cunciforms. These groups he concluded to be letters, and not words, as a syllabary of thirty words could not be thonght of in any language. Then, again, a certain oblique wedge, evidently a sign of division, which stood after three, four, five, up to eight or nine such groups or letters, must show the beginning or end, not of a phrase, but of a word. Tychisen and Münter had already pointed out a certain combina. tion of seven characters as signifying the royal title. Grotefend adopted this opinion. The word occurred here and there in the text, and after the first words of most of the inseriptions, twice; the second time with an appendage, which he concluded to be the termination of the genitive plural, and he translated these two words, without regard to their phonetic value, 'King of Kings,' He then, in comparing the words preceding the royal titles in two tablets, found them repeated in what he assumed to be a filial relation; thus: There were three dis. tinct groups, words, or names, which we will call X, $\mathrm{D}$, and $\mathrm{H}$, and this is how they occurred: (1) $\mathrm{X}$, King of Kings, son of D, King of Kings; (2) D, King of Kings, son of $\mathrm{H}$; but the (3) H was not followed by the word King. $H$, therefore, must have been the founder of the dynasty. Now the names themselves had to be found. Grotefend, unlike his predecessors, had recourse not to philology, but to archeology and history. The inscriptions in question were by that time proved to belong to the Achæemenian dynasty, founded by Hystaspes = group H. He was followed by Darins, 'King of Kings, son of Hystaspes,' or Darius Hystaspes = group D; he, again, by Xerxes, King of Kings, son of Darius, King of Kings = group $X$-and the problem was solved. It could not have been Cyrus and Cambyses, as the groups did not begin with the same signs (C); nor Cyrns and Artaxerxes, the first being too short for the group, the second too long-it could only be Darius, Xerxes, Hystaspes - of course in the orthography of their, not of our time; and wherever in these names the same letters recurred, they were expressed by the same combinations of signs. A further proof of the correctness of the reading was furnished by a vase in Venice, bearing a cuneiform and a hieroglyphical inscription, which were both read at the same time independ. ently : 'Xerxes.' Innumerable difficulties, however, remained, and remain up to this moment. Grotefend had, aiter all, only read-and not altogether correctly - three names, which did not contain more than twelve letters-the rest being mere conjecture -and there were many more in this alphabet. The other two alphabets, with an infinite variety of letters, had hardly been properly approached yet. Moreover, the discovery of Grotefend was in itself so startling, so extraordinary and bold, that no one ventured to follow it up for the next twenty years, when H. Martin found the grammatical flexions of the plural and genitive case. We cannot now specify his further discoveries, or those of Rask, Iurnouf, Lassen, Westergaard, Beer, Jacquet, and others who followed; we will only say that they mostly secured for thenselves fane and name by rectifying or fixing one or two letters. The last and greatest of investigators of this first alphabet 
is Rawlinson, who not only first copied, but also read, the gigantic Behistun inscription-containing more than 1000 lines-of which more anon.

Inscriptions in the 'Persian cuneiform character are mostly found in three parallel columns, and are then translations of each other in different alphabets and languages, called respectively Persian, Median, and Babylonian; the Achrmenian kings being obliged to make their decrees intelligible to the three principal nations under their sway, as in our days the Shah of Persia would use the Persian, Turkish, and Arabic languages, in order that he might be understood in Bagdad and Teheran.

The first of the three, the Persian, consists of thirty-nine to forty-four letters, and is the most recent, the most ancient being the Babylonian. It is distinguished by the oblique stroke which divides its wonds. Its letters are composed of not more than five strokes or wedges placed side by side horizontally or perpendicularly, or both, but never - with one exception-crossing each other. The language is pronounced by all investigators to be as near Zend (q.v.) as possible, and to be the mother-language of modern Persian. It is only twice found by itself; all the other inscriptions are trilingual, The time of its use is confined to the years $570-370$ B.C. The oldest instance of its employment is an inscription of Cyrus the Great at Pasargadre; the most recent, that of Artaxerxes Ochus at Persepolis. The most important is that of Darius Hystaspes, in the great inscription of Behistun (q.v.), which contains, besides genealogical records, a description of the extent of his power, the leading incidents of his reign, prayers to Ormuzd and the angels, and reference to the building of the palaces. Most of these inseriptions occur at. Persepolis, Behistun, Naksh-i-Rustam, and Hamadan.

The second kind is called the Median, because it takes the second place in the trilingual inscriptions, under the conquering Persians, but over the conquered Assyrians, and as the Medes stood somewhat in that relation to these two nations, that name was selected. Another name, 'Scythic,' has been proposed, or, by way of compromise, 'Medoscythic,' and the language-supposed to have been spoken by those innumerable Tartaro-Finnic tribes which occupied the centre of Asia-has been pronounced to be a Turanian dialect. But the process of constructing out of such slender elements as Samojed and Ostiak words, a so-called 'Scythic,' is somewhat similar to the attempt of reconstructing Sanskrit from some detached and very doubtfu French and English words. These inscriptions never occur by themselves (one instance again excepted), and being translations of the Persian records, about ninety names have been ascertained, and an alphabet of about one hundred characterscombinations of a syllabic nature-has been established. The principal investigators of this charac ter are Westergaard, De Saulcy, Hincks, Norris, and Oppert. Gobineau holds the language to be Huzvaresh, a mixture of Iranian and Semitic.

The third and most important is the Babylonian portion of the cuneiforms. The trilingual records gave the first clue to the deciphering of this character; but many original documents, more than three thousand years older, have since been found in Babylon, Nineveh, and other places near the Euphrates and Tigris, and even in Egypt. On one occasion, the Asiatic Society submitted a cylinder of 'Tiglath-pileser to four prominent investigators of the suhject, and they independently read it nearly alike, with the exception of the proper names, where they widely differed. As a proof of the enormous importance of this character for history, grammar, law, mythology, archæology, and antiquities generally, we name some of the records which Rawlinson began to publish (now in progress): Babylonian Legends, such as the Fight between Marduk and Tiamat, the Descent of Ishtar into Hades (2000-1500 B.C.); Bricks from Kilehshergat of the early Kings of Assyria (1350-1100 B.C.), in a character much complicated; Annals of Tiglath-pileser I. (1120 B.C.); Annals of Assur-nasir-pal, of Shalmaneser I. and II., Sargon, Sennacherib, Assur-bani-pal, son of Esarhaddon: Inscriptions of Nebuchalnezzar I. and II. ; Cylinders containing the name of Belshazzar, \&c, ; besides syllabaries, vocabularies, mathematical and astronomical tablets, calendars, and a selection from the mythological tablets.

In order to give the reader some idea of the appearance of the cuneiform character, we subjoin the name of Darius, written in the Persian, Scythic, and Babylonian characters.

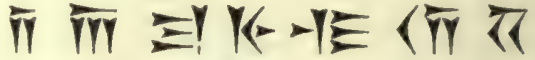 Persian.

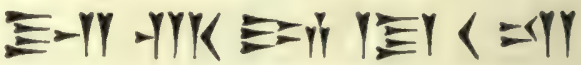 \\ Seythic.

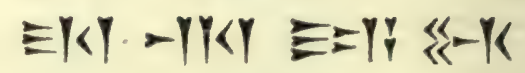 \\ Babylonian.}

The cuneiform signs were originally pictures of objects. It appears that they were first drawn in outline upon some vegetable substance, called in the native documents likhusi. Whether the supply of this material failed it is impossible to say, but it is quite certain that at a very early period in the history of Babylonia, clay was adopted as a substance for writing upon. On substances like papyrus and leather it is quite easy to draw in outline a picture of any object; but it became more difficult to do this when ciay was used, because the outlines of the object represented had to be pressed into it. The necessary result of this was that the shapes of the objects became altered. Thus a circle (1) represented the sun, but when inseribed upon clay it became 2 ; and $a$ star $(3)$ became 4 : in process of time, as scribes became busier, these signs were represented by 5 and 6 respectively.

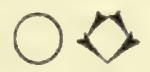

12

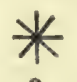

3

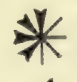

4

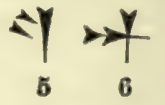

6
The use of clay as a writing material completely modified the shape of nearly every character in the cuneiform syllabary. The signs inseribed upon stones of the early empire are most complex, and in many of them it is difficult to see what object they are intended to represent. As time went on, these complex signs became simplified, and wedge after wedge was discarded, until the character was reduced to its simplest form. Lenormant, Hyde Clark, and others adopting their theory, have tried to prove that the Babylonian and Chinese signs are related. In the time of Esarhaddon and Assur-bani-pal, it became the fashion to write inscriptions in the ancient complex character, and special syllabaries of such signs were drawn up. Fragments of these are now in the British Museum. The cuneiform syllabary contains about two thousand signs of a phonetic, syllabic, and ideographic nature. Each sign originally represented an object, but no attention was paid to its ideographic signification when its 
syllabic or phonetie value was employed in a word. Before the name of a king, town, city, or private persun, \$e., a cuneiform sign, being the ideograph for the word following, was placed; after names of placess like Bubilu (Balyylon), a suftix hi, meaning 'earth' or 'laud,' was placed. It is the opinion of some that the cuneiform characters were invented by the primitive Akkadian inhabitants of Chaldrea (who spoke an ngglutinative language). See the articles Assyria, BaBylon, Writing.

See Sir H. Rawlinson, The Cuneiform Ineoriptions of Weatern A sia ( 6 vols. folio, ed. by E. Norris, G. Smith, and T. O. Pinches, 1861-80); Grotefend, Die Keilinsohriften aus Bchistun (1854); Lassen u. Westergaard, Ueber die Keilinsehreften (1845); Hinoks, On the Firat and Second Kinds of Persepolitan'Writing ('Transact. Roy. Ir. Soc. 1816) : Norris, Memoir on the Scythic Version of the Behistun Inseription (Jourual As. Soc. 1853); Rawlinson, $A$ Connmentary on the Cuneiform Inscriptions of Babylon and Assyrie (1850); and works by Benfey, Oppert, Renan, Spiegel, Sohrader, Delitzsol, and others,

Cune'ne, an African river, rises on the heights which bound the interior platean of South Africa in the W. and after a course of 600 miles southward and westwarl, forming the boundary partly between the Portugnese and German dominions, reaches the sea 60 miles north of Cape Frio. It is shallow and nearly useless for navigation.

Cuneo. See Coni.

Cumningliam, ALLAN, poet and industrions man of letters, was born in the parish of Keir, Dumfriesshire, 7th December 1784. His father was factor or land-steward to Miller of Dalswinton, and therefore neighbour to Burns at Ellisland; and Allan, a boy of twelve, followed at the great poet's funeral. At eleven he was apprenticed to a stone-mason, but continued to give all his leisure to poring over native songs and stories. His first publications were his verse and prose contributions to Cromek's sham-antique Remains of Nithsdale and Galloway Song (1810). These, while they did not of course deceive the learned, or apparently even Cromek himself, procured the clever young mason the aequaintance of Hogg and Sir Walter Scott. With the latter, 'Honest Allan' was always a great favourite. He now removed to London, and became one of the best-known writers for the London Magazine, as well as secretary and manager in Chantrey's studio, a post which he held till Chantrey's death in 1841. Though thus busily employed all day, Cunningham maintained an in. defatigable literary activity, writing tales, novels, magazine articles, poems, songs, and biographies. His best works were his Traditional Tales of the English and Scottish Peasantry (1822); The Songs of Scotland, Ancient and Modern (1825); Lives of the Most Famous British Painters, Sculptors, and Architects (6 vols. 1829-33); and his edition of Burns, with Life (8 vols. 1834). His Life of Sir David Willie appeared posthumously. He died in London, 30th October 1842. Cunningham was a remarkably worthy and kindly man, whose 'stalwart healthy figure and ways ' pleased even Carlyle -but then he was from Dumfriesshire. As a Seotch poet, he ranks, perhaps, after James Hogg. $\mathrm{His}$ songs, although marred by defects in taste, have the true lyrical impulse and movement. See Life by the Rev. David Hogg (Dumf. 1875).

Of his sons, the eldest, Joseph Davey (1812-51), rose in the Indian service, and wrote a good history of the Sikhs (1849); Major-general Sir Alexander (1814-93) wrote on Indian arelasology and statis. tics; Peter (see below) became a well-known man of letters; Francis $(1820-75)$, also an Indian soldier, edited Marlowe, Massinger, and Ben Jonson.

Cunningham, PETER, son of Allan Cunning ham the pret, was born in Pimlico, April 1, 1816. He was educated at Christ's Hospital, London, entered the Aucit Office through Peel's influence in 1834, and ultimately became chief elerk. He retired in 1860, and died at St Albens, 18th May 1809. His name is chiefly remembered by his Handbook of London (1849), a book stored with out-of-the-way facts, and informed with true literary Havour. He contributed largely to the literary journals, edited books for both the Shakespeare and the Percy Societies, as well as Horace Walpole's Letters (1857), Drummond of Haw. thornden, Goldsmith, Johnson's Lives of the Poets, and Pope. Other books are Modern London (1851) and the Story of Nell Groynn (1852).

Cunningham, WiLliam, a distinguished Scotch theologian, was born at Hamilton in 1805 educated at Duns and Elinburgh, and ordained minister at Greenock in 1830. He was called to Trinity College Church, Edinburgh, in 1834, and soon became one of the foremost leaders, alike on the platform and in the pamphlet, on the 'Nonintrusionist' side in the great controversy that pre. ceded the Disruption of 1843. He was appointed professor of Theology in the Free Church College in 1843, of Chureh History in 1845, and its principal on Chalmers's death in 1847. His D.D. degree was given him by Princeton in 1842. He was moderator of the Free Assembly in 1859, when he received a testimonial amounting to over $£ 7000$. He died at Edinburgh, 14th December 1861. His literary executors published from his MSS. Historic Theology: a Review of the Principal Doctrinal Discussions in the Christian Church (1862), Reformers and Theology of the Reformation (1862), and Discussions on Church Principles (1863). See his Life, by Rainy and Mackenzie (1871).

Cunninghamia, a genus of the Taxodium family of Coniferre (q.v.), of which the only species (C. sinensis) is a lofty evergreen tree of southern China and Cochin China, with sessile leathery leaves, somewhat resembling those of an Araucaria. It is too tender for the climate of Britain, save in peculiarly favourable localities.

Cup is a name for a refreshing beverage, made usually of wine, soda-water, ice, and flavouring ingredients. Thus claret eup may be made of one quart of claret, one bottle of soda-water, half a pound of pounded ice, four tablespoonfuls of pounded sugar, a little grated nutmeg, a liqueur glass of Maraschino, and a sprig of green borage. Champagne cup may be made of one quart of chan. pagne, two buttles of sola-water, one glass of brandy, one pound of pounded sugar, with borage or cucumber rind. Cider cup is similarly compounded.

Cup, Divination BY, a mode of foretelling events, practised by the ancient Egyptians, and still surviving, though with but little eredit, in some of the rural districts of England and Seotland. One of the eastern miethouls consisted in throwing in small pieces of gold or silver leaf into a cup of water, in which also were placed precious stones, with certain characters engraved upon them. The infernal powers were then invoked, and returned answer, either in an intelligible voice, or by signs on the surface of the water, or by a re. presentation in the cup of the person inquired about. By the modern method, \& person's fortune is foretold by the disposition of the sediment in her teacup after pouring out the last of the liquid.

Cupar, or Cupar-Fife, the county town of Fife, on the Eden, 10 miles W. by S. of St Andrews, $30 \mathrm{NNE}$ of Edinburgh, and $13 \mathrm{~S}$. of Dundee. In the 12th century a enstle of the Macdufle, Earls of Fife, crowned the 'School Hill,' whose northern slope was afterwands the show-place of mystery. plays and moralities such as the Thrie Estaitis 
(1535) of Sir David Lyndsay (q.v.). Cupar has a handsome new Free Church (1877), the Duncan Institute (1870), and a public park (1871-72). Brewing, tanning, \&c. are carried on; and there is a large corn-market. Lord Campbell was a native. The place has been a royal burgh since at least 1363, and it unites with St Andrews and five other towns in returning one member to parliament. Pop. (1851) 5605; (1881) 5010 ; (1891) 4729. 'See also Coupar-ANgus.

Cupellation. See Assaying.

Cupid (Lat. cupido, 'desire'), also AMOR, the Latin name for the Greek Eros, the god of love. Eros is not mentioned in Homer, but occurs first in Hesiod, whose conception of him is that of a cosmogonic force uniting, as it were, in harmony and love, the conflieting elements of primal chaos. Thus Plato, in his Symposium, speaks of him as the oldest of the gods. Quite different, however, from this venerable and somewhat impersonal deity is the Eros of the epigrammatic and erotic poets, the Cupid of Horace and Ovid. The genealogy of this meddlesome divinity is rather confused. $\mathrm{He}$ is variously represented as the son of Aphrodite (Venus) by Ares (Mars), Zeus (Jupiter), or Hermes (Mercury). He appears as a wanton boy, playful and mischievous, with bow, arrows, sometimes a torch, quiver, and wings. The eyes are often covered, so that he shoots blindly. His darts could pierce the fish at the bottom of the sea, the birds in the air, and even the gods in Olympus. The immensity of space was his home, but like his mother, he specially loved the flowery thickets of Cyprus. Later poets make a number of Erotes (Amores and Cupidines), with the same attributes as the prototype. We find also an Anteros ('return love'), whose function it is to punish those who do not return the love of others. Thespire in Boeotia was the chief seat of the worship of Eros; here was held the Erotidia, a quinquennial festival. Eros or Cupid was a frequent subject for Greek and Roman works of art. The most celebrated statue was that by Praxiteles at Thespiæ.

The beautiful fable of Cupid and Psyche, as given by Apuleius, is a literary version of one of the best-known stories in the world. Of course it is merely an ordinary household tale, with nothing but the names to connect it with the recognised Greek mythology. Here Cupid is merely the invisible bridegroom of scores of stories the world over, with the added name and attributes of the winged son of Aphrodite. See a study of the myth by Andrew Lang, in the introduetion to his reprint (1887) of Adlington's translation (1566) of the story as told by Apuleins.

Cup-markings on rocks and CUP-MARKED STONEs belong to a peculiar class of archaic seulpturings which have recently attracted much attention among archreologists. Cup-markings on rocks are chiefly of two varieties-circular cavities or 'cups' pure and simple, and cups surrounded by circles. The circles round the cups are shallow indentations, varying in number up to five or six. Both cups and circles often show the marks of a pointed tool, as if they had been formed by picking, but frequently they appear as if weathered or abraded to a perfectly smooth surface. The cups vary in size from about one inch to three inches or more in diameter. Sometimes they are confluent at the edges, but more usually separate, and occasionally two or more are connected by a shallow groove or duct. They usually occur in groups, sometimes to the number of several hundreds. In such groups the majority are plain cups, intermingled with occasional cups and circles. The circles placed concentrically round the cups are occa- sionally incomplete at one side, and a radial groove or duct passes from the central cup ont through the circles. The circles are only approximately circular, sometimes oval, and oceasionally even roughly quadrangular. These groups of eups, mingled with cups and circles, and occasionally with imperfect spirals and other rude and irregular sculpturings, are found on the stones of sepulchral structures of the stone and bronze ages, on rock-surfaces and earth-fast boulders, and on loose stones of small size in the neighbourhood of sites of early habitations or strongholds over nearly all Europe. They are still subjects of superstitious regard in Scandinavia, and while they are found in connection with the megalithic monuments of Europe and India, Mr Rivett Camac has traced a resemblance to them in the conventional symbols of Siva in the modern temples. On the other hand Dr Veckenstedt found recent cup-markings ( but without the characteristic circles) on the walls of churches in Prussia. Dr Rau has described a considerable number of ex. amples from various parts of America, but few with circles. Many of the smaller cupped stones he attributes to the Indian custom of cracking hickory nuts, by laying them in such eavities and striking them with another stone. The larger-sized cups and basin-shaped cavities in earth-fast boulders and rocks he classes as mortars. But the more elaborate sculpturings on rock-surfaces present the central cup, the surrounding circles and the radial groove of the European and Indian examples, and the inference is that they belong to the religious or ceremonial symbolism of primeval man. The most remarkable examples of rock-surfaces sculptured with cups and circles in Seotland are those at Achnabreac in Argyllshire, described by Professor Sir J. Y. Simpson, and at High Banks in Kirkeudbrightshire, discovered in 1887 and 1888, and de. seribed by $\mathrm{Mr}$ George Hamilton in the Proceedings of the Society of Antiquaries of Scotland.

See Archaic Sculpturings of Cup8 and Circles, dec., by Sir J. Y. Simpson (Edinburgh, 1867) ; Incised Markings on Stone, dc., from drawings made for the Duke of Northumberland (Lond. 1869); Skandinavien's Hallristningar af A. E. Holmuberg (Stockholm, 1848); and Observations on Cup-shaped and other Lapidarian Sculptures in the Old World and in America, by Charles Rau (Washington, 1881).

Cu'pola (Ital., from the root of cup), a spherical vault, or concave ceiling, on the top of a building; the internal part of $a$ Dome (q.v.). The term is also sometimes used for a dome which is ogival (not hemispherical or semi-elliptical) in outhine, or for a small dome. Cupolas are often wholly or partially of glass. 'There are cupola-furnaces; see IRON.

Cupping is one of the simplest and most popular methods of producing local depletion, by the application of partially exhausted cupping-glasses to the surface of the skin. By this means the blood is diverted from deeper structures to the surface of an affected part, whence it may be removed by scarifying the skin (wet cupping), or where it may be allowed to remain exuded in the subcutaneous tissues like a Bruise (q.v.), until it be removed by absorption (dry cupping).

Cupping has been a part of surgical practice from the earliest times, and instruments for performing it have been found in use among the least civilised nations. Of old, the cups were either small horns, open at both ends, from which the air was withdrawn by suction at the narrow extremity, or glasses of various shapes, with a small hole in the bottom of each. This hole was plugged with wax, the air exhansted by heat, and when the operator wished to remove them, he withdrew the plug, and allowed the air to enter. The modern cuppingglass is a beaker containing 3 to 6 fluid ounces, 
with a finely.ground rim, which adheres closely to the surface of the skin.

The principal improvements have been in the methods of incising the skin. This used to be effected with a common lancet or narrow kuife, with a short blade and convex edge, set in a long elastic handle, which the onveratur struck rapilly with his finger, $8 n$ as to drive the blade 20 or 30 times into the skin. This was so tedious an operation, that a number of similar blades came to be used at once. These are contained in a box, which has slits pierced in it correaponding to the number of blates; the latter can be caused to emerge by setting free a spring, which eauses them to revolve suddenly, and in doing so they protrude at the slits more or less, recording to the regulation of the instrument by the operator. This apparatus is known as a 'scarificator.' A scarifieator, glasses, a torch, some spirits of wine, and a lighted candle are placed ready at hand; the part is sponged with hot water, so as to cause an increased llow of blood into it; then dried with a warm towel; the torch, previously saturated with the spirits of wine and lighted, is held for an instant in one of the glasses. By this means the air in the glass is quickly expanted, and when the glass is then rapidly applied to the smooth damp surface of the skin, the rapid rarefaction of its contained air causes it to adhere tiglitly, and gives rise to determination of blood to the part to which it is applied. When the skin under the glass has become red and swollen, the cupper removes it, applies the scarificator, and as rapidly as possible agrin exhausts the air from the glass, which he re-applies. The blood will now How into it; and when enough has been taken, the glass is removed, and some lint applied to the wounds. The number of glasses applied depends on the quantity of blood it is thought desirable to alostract; each one will probably withdraw from 3 to 5 ounces. This apparently simple proceeding requires considerable skill. The difficulties consist in regulating the depth of the cuts; for should they be either too deep or too shallow, the blood will not flow; in the one case, because the deeper vessels of the true skin are not opened; in the other, becuuse the skin being completely cut through, the fat which lies beneath it is draivn up into the wounds, which it plugs, and stops the flow of blool. If, on the other hand, the glasses be completely exhausted of air, their rims press so firmly on the surface as to prevent the flow of blood to the part from surrounding areas of the skin, and as a result, very little blood flows from the wounds.

There are many modifications of the ordinary cupping apparatus, but all act on the same principle; and it need scarcely be added that extempore cups may be found in tumblers, finger-glasses, or any air-tight vessel with a smooth rim.

Dry Cupping is simply applying the cups as described, but not wounding the skin. A hard mass of extravasated blood is found occupying the skin at the site of this operation. The mass, at first cherry-red, becomes in a few days a dead black colour, then greenish, and finally yellow, following the usual course observed in the healing of a bruise.

Cupule (Cupula), in Botany, a shortened axis with a number of more or less cohering bracts, numerous and crowded in the acorn, or three in the beech-nut, which more or less completely inclose the ripening fruit. The husk of the liazelnut may be regarded as an incipient cupule.

Cupuli'fera (i.e. 'cupule-bearing'), an old order of dicotyledonous trees and shrubs, more naturally separated into (1) Betulnces or Corylaces, the birch and hazel family, including $(a)$ the birch and alder, (b) the hornbeam and hazel; and (2) the Fagacere or Cupulifera proper, including $(a)$ the beeches, $(b)$ the chestnuts and naks. See the articles on theme separate trees.

Cur, a name sometimes applied indiscriminately to small dogs of any kind not highly valuesl, and in this way often particularly appropriated to dogn of mongrel breed, but also used by naturalists as the common designation of many ruces, of which the Terrier (q.v.) may be considered as the type. See $\mathrm{DOG}$.

Cura, Ciudad DE, a town in the state of Miranda, in Venezuela, lies 60 miles SW. of Carácas, to the soutl of Lake Valencis, has a good deal of industry, and extensive cotton plantations, and a pop. of 12,200 .

Curaça'o (also spelt Curacoa and Curassou) is the most important of the Duteh West India Islands. It lies about 40 miles from the const of Venezuela, is 36 miles long by 8 broad, and lans a population (1890) of 26,245 . The eapital of Curacao is Willemstad, a very handsome town, situated on the bay of St. Anna, with 10,000 inhabitants. The soil of Curaço and its dependent islands is less productive than that of other tropical lands. The chief produce is salt, and a rock rich in valuable phosphates, but careful cultivation produces sugar, tobaceo, maize, figs, cocoa, cocosnuts, lemons, and oranges. The Curacao orange, Citrus Aurantium curcssuviensis, is a peculiar variety. Willemstad is the headquarters of the colonial government, which has authority not merely over the neighbouring islands of Aruba and Bonaire, but also over St Eustache, Saba, and the Dutch part of St Martin. Altogether the Duteh West Indies have a population of alout 120,000. The trade is mainly with the United States. Curacao was discovered by Spain in 1527, taken by the Dutch in 1634, conquered by the Englisb in 1807, and restored to Holland in 1815 .

Curacoa is a well-known and esteemed liqueur, usually made in Holland with the dried peel of the Curaça orange, the peel being macerated with water, and then distilled with spirit and water. The result is sweetened with sugar, and a little Jamaica rum is often added. A palatable imitation can be made from the fresh peel of bitter oranges and whisky.

Curati, Urari, Woorali, or Woorara, is a celebrated poison used by some tribes of South American Indians for poisoning their arrows. It is by means of this poison that the small arrows shot from the Blowpipe (q.v.) become so deadly. It is brought to Europe as a black, brittle extract, resinous in appearance, and encrusting the sides of little gourds containing it. The source of this deadly poison was for long unknown, owing to the natives jealously guarding the secret. The process of manufacture has now, however, been witnessed and described by several travellers, and in each case some species or other of Strychnos has been recognised as the source of the poison. There seem to be four distinet varieties of curari, each characteristic of a different tract of country, and prohally varying in their physiological action; but for our purpose we may confine onrselves to that kind which is used in physiological experiments. Curari is one of those poisons which have little action when taken into the stomach, owing to the difficulty with which they are absorbed, but when introduced into a wound it acts with great promptness. The symptoms caused are loss of muscular power, feeble respiration, and death by suffocation. By means of artificial respiration it is possible to sustain life for a lengthened perioul, although the animal is apparently insensible to pain. In this 
way it is employed in vivisection experiments as an anresthetic.

At first it was supposed that curari contained strychnine, but as its action was so entirely different, this view was soon abandoned. Prolonged research has separated a special alkaloid, Curarine, which possesses the leading properties of the poison itself. Curarine differs from all other crystallisable alkaloids, save one, in containing no oxygen. It forms salts, and is said to be twenty times as strong as curari. In medicine curari is very little used. It has been proposed to employ it in lockjaw, hydrophobia, and as an antidote in poisoning by strychnia; but although it quiets the spasm, it has no direct curative effect, and it may cause an equally fatal paralysis.

Besides curari proper, there are two other arrowpoisons called Corroval and Vao. These, which are brought chiefly from Colombia, have an entirely different action on the body, as they primarily stop the beating of the heart, whereas with curari the heart continues to beat after breathing has ceased.

Curassow, or Hocco (Crax), a genus of large game-birds inhabiting the forests of Central and South America. Their most distinctive features concern the head. This is adorned with a crest of feathers, eurled forwards, and capable of being raised and depressed; while the often brightly coloured cere is enlarged into a prominence at the root of the high beak. Eight species are found from Mexico to Paraguay, predominantly arboreal, living mostly on fruits, but in general habit like poultry. They are very unsuspicious of danger, especially careless at the love-making season, and are very readily tamed. The best-known species is $C$. alector-the Royal Pheasant of the Mexicans.

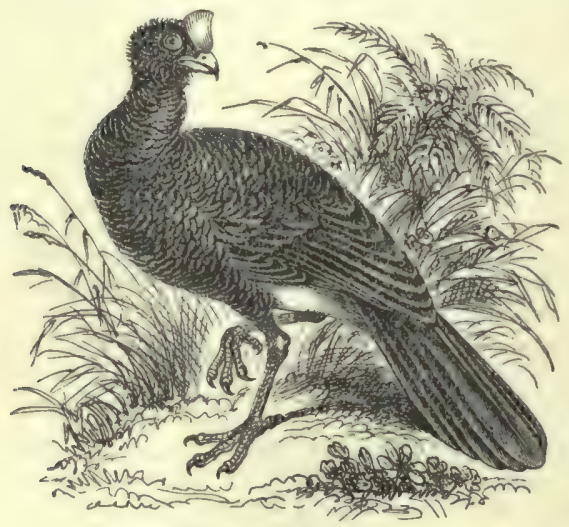

Crested Curassow.

It is a very sombre bird, about the size of a turkey. It is oceasionally domesticated, and a stock imported into Holland at the end of last century seemed to become acclimatised. It was, however, lost amidst the troubles subsequent to the French Revolution. Though their love-making is keen, the birds are not very productive, and it is probable that the natives have discovered that this apparently very profitable bird will not breed readily under domestication. Closely allied, and of similar distribution and habit, are the fierce Guans and Penelopes (Peneloping), and the rare Mountain Curassow (Oreophasis derbianus). The Turkey (q.v.) is also a near relative.

Curate, literally one who has the cure (Lat. cura, "care") of souls, in which sense it is used in the Church of England Prayer-book, 'all bishops and curates;' as the cognate word curé is used in French to denote the incumbent of a parish. It is, however, generally used now to denote the unbeneficed parochial clergy in the Church of England, more exactly styled 'assistant curates,' Formerly, such curates were usually the deputies of non-resi. dent incumbents, but now they are mostly helpers of resident pastors. A curate, in this sense, is a minister employed by the incumbent of a church (rector or vicar), either as assistant to him in the same church, or else in a chapel of ease within the parish belonging to the mother-church. He must be licensed and admitted by the bishop of the diocese, or by an ordinary having episcopal jurisdiction, who also usually appoints his salary. Any curate that has no fixed estate in his curacy, not being instituted and inducted, is liable to removal on six months' notice from the incumbent, and to summary withdrawal of his license by the bishop. In the latter case, an appeal to the archbishop of the provinee is open. But there are perpetual curates as well as temporary, who are appointed where tithes are impropriate and no vicarage was ever endowed : these are incumbents, and not removable, and the impropriators are obliged to maintain them. Their title in new district parishes has been changed to that of vicar.

\section{Curator to a Minor. See Guardian.}

Curb. See BrIDLE. - The disease in horses so called consists of strain of the straight ligament which runs down the back of the hock; is most common in animals with straight small hocks and that conformation known as sickle hams: whilst like other strains it occurs from sudden and violent exertion, often proceeding in the lighter breeds from leaping or galloping in heavy ground, and in the heavier, from the effort of keeping back a load whilst going down a steep incline. Swelling appears on the outer and back part of the joint, about 5 or 6 inches below the point of the hock, generally causing lameness, which is most apparent in trotting, and, in slight cases, usually decreases after the animal has been out for ten minutes. Fomentations must first be used to allay the irritation and inflammation, and a high-heeled shoe put in; when heat and tenderness disappear, cold applications will be advisable; after which the enlargement still continuing, a blister may be necessary; whilst, from the first, all work must be forbidden.

Curcas. See Physic Nut.

Curcu'lio. See WeEvil.

Cur'cuma (Arab. kurkum), an Indian genus of Scitamineæ, the ginger and cardamom order. C. longa is widely cultivated in Southern Asia, its rhizomes (radix curcuma longo of pharmacists) being the source of Turmeric (q.v.). Young plants also yield a kind of arrowroot, but this is especially prepared from $C$. leucorhiza, with colourless rhizomes. $C$. zedoaria yields a tonic medicine (radix zedoarioe officinalis or zedoary of pharmacists), and is also used as food. C. amada is the mango ginger of Bengal.

Curé, the name applied in France to a priest with a cure of souls, properly the priest of a regular parochial as opposed to a succursal church, but commonly applied to any pastor with spiritual functions.

Cures, an ancient town of the Sabines, 25 miles NE. of Rome, whence the Romans, after the people of Cures united with them, came to be called Quirites. See Rome.

Cureton. William, Syriac scholar, born at Westbury, Shropshire, in 1808, studied at Oxford, and was ordained in 1831 . In 1837 he entered the British Museum as assistant-keeper of manuscripts, and here his labours brought to light a Syriac version of the Epistle of Ignatius (q.v.), remains 
of a Syriac recension of the fiospels, and other MSS. of more or lees value, which involved their ditor in long eontroversies. In 1849 Cureton was rppointed canon of Westminater and rector of St Mirguret's. Among other honoun, he received the degree of LL.D. from Oxford and of D.D. from Halle, and was a Fellow of the Royal Society and a foreign assnciate of the Institute of France. He died 17th June 1864.

Cur'few (Fr. convre-feu, 'cover fire'). To William the Conqueror is ascribed the introduction of the curfew-bell into England, the object of which was to warn the people to cover up their fires, and retire to rest. The time for ringing these bells was sunset in summer, and about eight o'elock in winter; and certain penalties were imposed upon those who did not attend to the signal. The practice of ringing the curfewbell, however, appears to have prevailed throughout Europe long before the era of the Norman Conquest, its olject being the prevention of fires, which, owing to houses being chiefly composed of wood, were then both frequent and destructive. The custom of ringing the curfew-bell at eight or nine o'clock is still continued in many parts of England, though its original significance is of course lost, and a list of the various places where the custom has been kept up will be found in Notes and Queries for 1883 and earlier years. The name has passed into literature as a current synonym for nightfall-it oceurs in the opening line of 'Gray's Elegy. The curfew survives in some parts of New England. See BELL.

Curia. See Rome, also Aula Regis.-The Papal Caria, or Curia Romana, the functionaries forming the court of the pope, including the congregations of cardinals, the secretariat of state, the functionaries through whom the holy see has relations with foreign powers. See PoPE.

Curia Muria. See Kuria Muria.

Curico, a town of Chili, capital of a province of the same name, lies near the Rio Lontué, 140 miles SSE. of Valparaiso. Pop. 10,110.

Curlew (Numenius), a genus of birds of the order Grallatores, and of the same family (Scolo. pacida) with the snipe, sandpiper, avocet, stilt, de. The bill is much longer than the head, slender, curved, and compressed; the face and head are feathared; the legs are slender, and part of the tibia is naked as well as the shank; the tail is short, and the folded wings extend about as far as the tail. The plumage is lark-like. The genus is cosmopolitan in its distribution. The Common Curlew ( $N$.arquatus), the Whaup of the Scotch, frequents the seashores in winter, and elevated moors in summer. Its peculiarly weird and plaintive cry is familiar to every visitor of the uplands. It feols on worms, molluses, and in. sects, and its long bill enables it to reok its food is marshy or boggy ground. A slight nest of leavea or other dry materials is built in some tuft of rushes or anong long grass or heath, and uaually contains four eggs. The curlew is good enting. -

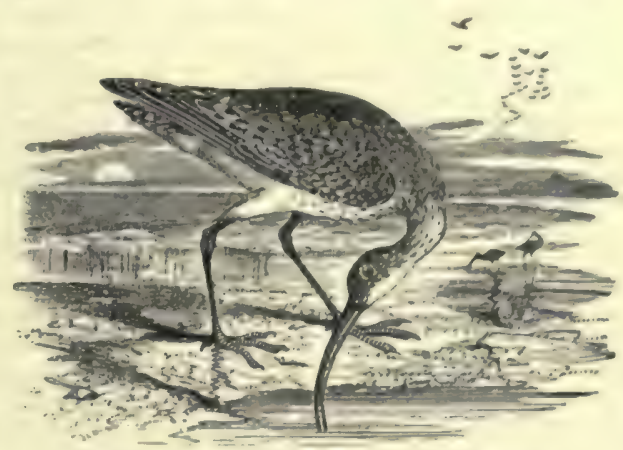

Common Curlew (Numenius arquatus).

The Whimbrel ( $N$, phacopus) is a smaller spectes, much resembling the common curlew. Like the latter it is very widely distributed in the Old World, and frequently occurs on the shores of Britain, though apparently breeding only in the most northerly moors. North America has several species of curlew, some of which extend their summer migrations to very northerly regions.

Curling, a sport on the ice common in Scotland, where it is played by all classes of people in winter. Frozen-over lakes and rivers answer for the purpose, but under the auspices of curling clubs, artiticial shallow ponds are maintained for the sake of this popular national sport; and the bonspiels, or set matches, are contested with great spirit. The sport is regulated by a body of rules issued by a central association called the Royal Caledonian Curling Club, which has grand matches in which hundreds are engaged once, if possible, every winter, and which awards medals to pro. vinces and parishes for competition. The remarkable and pleasing peculiarity of curling is, that it produces for the

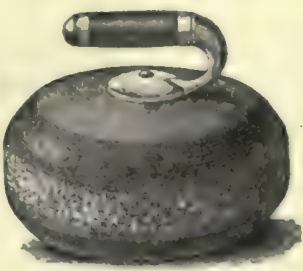

Curling-stone. time a thorough mingling of ranks - peers, peasants, clergymen, farmers, country gentlemen, and trades. men, all meeting familiarly and hilariously for the

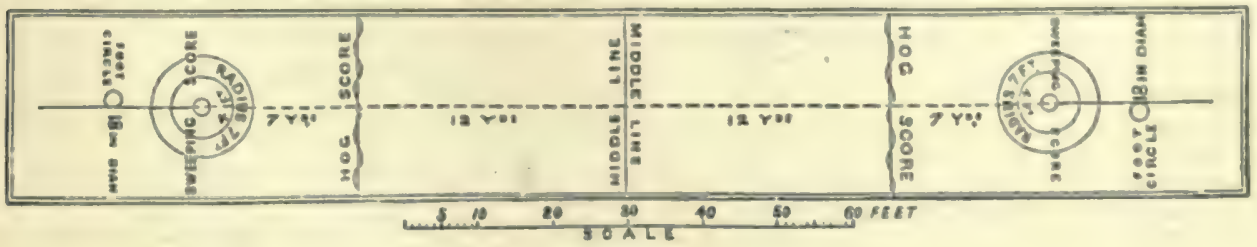

The Rink.

occasion. Latterly, curling has migrated to England, Canada, and other countries where Scotchmen can find ice of sufficient strength and keenness, and in Southport Glaciurium (1878-89) the game was played in summer on artificial ice. Curling is played with flattish round stones, about 9 inches in diameter, prepared by curling-stone manufacturers, each stone weighing from 30 to 50 Ib. Each of the playen has a pair. The stones are provided with handles, to enable the player to hurl them on the ice with the proper degree of force. As at bowls, the stones are hurled to an axaigned point or mark. The game is as follows: Sides are made up, usually consisting of fou 
against four, with a director styled skip for each ; after which a certain length of ice is chosen on which to play. This is called the rink. Certain marks are then made at each end of the rink, consisting of several concentric rings, called broughs, and a centre, called the tee. The game is decided by time, or by one party first attaining a certain number of shots, such. as 21 or 31 ; and the keenness displayed by rival sides in competing for victory is perhaps withont a parallel in any other pastime whatever. One on each side plays alternately. The chief object of the player is to hurl his stone along the ice towards the tee, with proper strength and precision; and on the skill displayed by the plavers in placing their own stones in favourable positions or in driving rival stones out of favourable positions, depends nearly all the interest of the game. At a certain distance from each of the tees, a line-the hog-score-is drawn across the ice; and any stone not driven beyond this mark counts nothing, and is laid aside. In country places, a dinner composed of 'beef and greens,' the well-known curler's fare, generally concludes the day's diversion, which, taking place when outdoor labour is suspended, is felt to be no encroachment on rural oceupations.

For laws of curling, and general remarks on the game, see The Channel-stane (four series, 1883-84), the last series of which contuins an ample bibliography; Descriptive and Historical Sketch of Curliny (1828), reprinted as The Kilmarnock Treatise (1883); Curling, Ye Glorious Jastime (1882), a reprint of the Acrount of the Game of Curling (1811); Curling, by Dr James Taylor (1884). There are, besides, the Annuals of the Royal Caledonian Curling Club, 1839-88. This club in its jubilee year (1888) undertook the preparation of a volume-the Rev. J. Kerr's History of Curling (1890).

Curll, EDmund (1675-1747), a notorious London bookseller of the first half of the 18th century. His connection with Court Poems (1716) led to his first quarrel with Pope, who afterwards made the bookseller figure in the Dunciad. He earned an unenviable reputation for the publication of indecent literature, which afterwards received the brand of Curlicism. He was twice (1716 and 1721) at the bar of the House of Lords for publishing matter regarding its members; was tried and convicted for publishing obscene books (1725), fined (1728) for the issue of Nun in Her Smock and De Usu Flagrarum, and spent an hour in the pillory for his Memoirs of John Ker of Kersland. His announcement of $\mathrm{Mr}$ Pope's Literary Correspondence (1735) led to the seizure of the stock, and furnished Pope (who has been proved to have instigated its publication) with a sufficient excuse for the issue of an authentic edition (1737-41). Curll did not deal solely in garbage, as is shown in a list of his containing 167 standard works, including Swift's Meditation on a Broomstick (1710), Dr South's works, \&c. His Curliad (1729) is styled a 'hypercritic upon the Dunciad Variorum.' It was of Curll's biographies that Arbuthnot wittily said they had added a new terror to death.

\section{Currach. See Coracle.}

Curragh, a large undulating down in the centre of County Kildare in Ireland, 2 miles $\mathbf{E}$. of Kildare town. It is the property of the erown, and in it is a large camp of exercise, established in 1855, with accommodation for 12,000 troops (see CAMP). The Curragh of Kildare is even better known as a famous racecourse.

Curran, JoHs Philpor, Irish orator, was born at Newmarket in County Cork, son of the seneschal of the Manor Court there, July 24, 1750. At Trinity College, Dublin, he was as idle and reckless as he had been at school, but spite of his dissipations he contrived to learn soniething of law, and the boisterous taproom debates of his life in Dublin and London shaped him into an orator. After two years at the Middle Temple, London, he was called to the Irish bar in 1775. Here his conviviality, his wit, and his vehement eloquence, soon made him a prominent figure, and led to his being employed in many of the greatest causes of the time. In 1782 he became King's Counsel, and next year was returned to the Irish parliament for Kilbeggan. He became a strong supporter of Grattan, but his eloquence proved less effective on the floor of the House than before an Irish jury. His sareastic retorts led him into several duels, of which, in the course of his career, he fought no less than five, all fortunately without serious harm. Although a staunch Protestant like so many great Irish patriots, Curran had a warm sympathy with his suffering Catholic countrymen, and was eloquent and constant in his unavailing appeals to the government to change a policy which was driving the Irish into rebellion. With his defence of Archilıald Hamilton Rowan in August 1792 commenced the long series of defences in state-trials which have shed such a lustre on his name. The insurrection at length broke out in 1798, but was speedily suppressed, whereupon the prosecutions of its leaders at once began. Curran flung himself into their defence with a heroic energy that rose above the browbeatings of the bench and insured him an im. mortality of affection in the hearts of his fellow. countrymen. The last of his defences was that of Napper Tandy in May 1800 . Then came the Union, which Curran had always opposed as 'the annihilation of Ireland.' His own health was now shattered, and soon domestic troubles followed to darken his later years. His wife eloped with a clergyman, and his youngest daughter, Sarah, pined away and died in Sicily, a few months after the hap. less fate of her bright young lover, Robert Emmett (1803). Her story is immortalised in Moore's well-known lines, 'She is far from the land where her young hero sleeps.' After the death of Pitt (1806) and the accession to power of the Whigs, Curran was appointed Master of the Rolls in Ire. land, an office which he held till his retirement in 1814. He died in London, 14th Octolser 1817. His remains were re-interred in Glasnevin Cemetery, Dublin, in 1834. Curran's little figure, ugly face, bright black eyes, and intense vivacity, formed a sufficiently unique personality; but his brilliant wit, his quickness in repartee, his mental acuteness, and the astonishing felicity of his ready language were altogether unparalleled, and made him easily the master of his company. He well deserved O'Connell's epitaph: 'There never was so honest an Irishman.' See Lives by his son, W. H. Curran (1819), A. Stephens (1817), and O'Regan (1817); also Ch. Phillips, Curran and his Contemporaries (1850). His Speeches were edited, with a Life, by Thomas Davis, in 1855 .

Currant, a name originally belonging to a small kind of grape (see CURRANTs), and transferred, in consequence of the similar size of the fruit, to many species of Ribes (order Saxifragacere, sub-order Grossulariacese). The species known as currants are destitute of spines, and have the flowers in racemes: the spiny species are known by the name Gooseberry (q.v.). Among the fruit-shrubs most generally cultivated in our gardens is the Red Currant ( $R$. rubrum), Grosseille of the French, a native of woods and thickets in the south of Europe, found also in some parts of Asia and of North America, perhaps rather a naturalised than a truly native plant in Britain. It has long been cultivated, although it does not appear that it had a place in the gardens of the ancient Greeks or Romans. The berries, besides being used for dessert, and to a much greater extent for pies, and for making jelly (eaten with mutton and hare), are used 
also for making an agreeable and refreshing beverage, enlled in France Eau de Grosseilles (made of the juice of the fruit, water and sugar, strained and iced), and a well-known fermented liquor called Currant Wine (q.v.).-The White Currant is a mere variety of the red, the result of cultivation, with fruit less acid, and more fit for

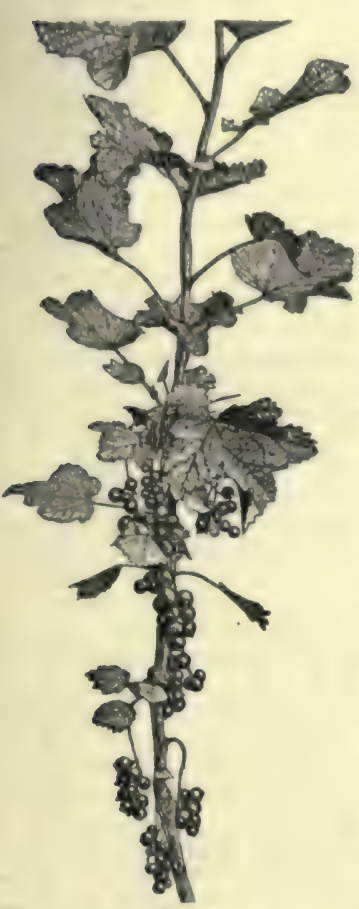

Red Currant. dessert, generally also rather larger. There are many sub-varieties, and many intermediate shades of col. our. Both the red and the white currants are either trained as stan. dard bushes, or against walls, the latter treatment producing larger and finer fruit, and both are sometimes trained on a north wall, to retard their ripening till after the ordinary season. They grow readily, like the shrubs of this genus in general, from cuttings. Unlike the black eurrant, the red and the white grow in clustered bunches. The Black Currant ( $R$. nigrum), Cassis of the French, grows in moist woods, and on the banks of streams in Europe and the north of Asia." The fruit is much larger than the red currant, and cultivation has lately produced varieties remarkable for size. There is a variety found in Russia with yellow berries. The jelly and preserve made from it are very useful for sore throats, as is also black currant vinegar, made in the same manner as raspberry vinegar. In Russia, the berries are gathered in large quantities in the woods, and drier in ovens, to be used in pies. They are tonic, and also slightly diuretic and sudorific. A liquenr, ealled Liqueur de Cassis, is prepared in France from the black currant, and it has been suggested to introduce this manufacture in the Helorides and Shetland Islands. Those who are fond of the flavour of green tea in mixture with black, but to whom it is injurious, may effectually gratify their taste by dropping one or two leaves or a bud or two of black currant into the teapot during the process of infusion.-Many other species, some of them probably deserving of cultivation, are found in temperate and cold climates in almost all parts of the world. One with large beautiful red berries, nceurs on the Himalaya at an elevation of 13,000 feet. - $R$. oxyccenthoides, a native of North America. is much like the common gooseberry in flavour, and the colour is red or green in different varieties. $-R$. lacustre, also a North American species, produces its fruit in bunches, a fruit like that of the black currant. - The fruit of $R$. fragrans is sweet, bat the species is more remarkable for the production of a pleasant balamic reain which exudes from the under side of the leaves in yellow drope and has the smell of black currants. - The Kiod. flowered Currant ( $R$. sanguineum), now so com. mon as an ornamental bush in shrubberies, and trained on walls, producing in April a profu. sion of deep-red flowers in large drouping racemes, is a native of the north.west of America, and was introduced into Britain in 1826. Its bluikh-black, mucilaginous, insipid berries are not, $\mathrm{s}$ is popularly believed, poisonons. - The Golden Currant $(R$. aureum), also a very ornamental shrub, from the same regions, has a tubular calyx and long goldenyellow flowers. Its fruit, which is either yellow or black, and of fine tlavour, is not freely produced in Britain. - The name Native Currant, or Australian Currant, is given in Australia to the berries of different shrubs, particularly the white berries of Leucopogon Richei (order Epacridacen). Other fruits bearing the same name are produced by species of Coprosma (order Cinchonacese), but they are very inferior.

Currants, a small kind of raisin, are the dried red or blue berries of a small-fruited seedless variety of the common vine, which is cultivated in the East, and especially the Ionian Islands and in Greece. The name, originally Ruisins de Corinthe, is derived from the city of Corinth, in the neighbourhood of which they were first cultivated. They are very small, round, with a thin skin, without seeds, and very sweet. Those brought from the island of Zante are most esteemed. The grafting, pruning, trimming, and irrigating of the vine-stocks, which of late have suffered from the phylloxera, involve much labour. As the grapes ripen, the bunches are dusted with sulphur, to keep off the dreaded Oidium (q.v.); rain at this period always injures and sometimes ruins the crop. The vintage is in August. The currants when ripe are spread out on drying-grounds in layers half an inch thick, and frequently turned. The currants, now loosened from the grape-stick, are tightly packed in barrels for exportation, and are an important Greek export. In a few districts of Greece, a very sweet wine is uude from cnrrants. The duty on eurrants imported into Britain fell from 44\%. per ewt. Before 1834 to 78 . in 1860. Onr import is abont 128,000 tons per annum. In 1877-91, when the vines were sutfering from the pliylloxern, France imported enormous quantities for wine-making.

Currant Wine is made of the juice of red or white currants, to which is added about one pint of water for every four pints of berries employed. About a pound and a half of sugar is afterwards added to each pint of the liquor, a little spirits being generally also added, before it is set aside to ferment. A larger quantity of sugar is sometimes employed, and no water, and a stronger and sweeter currant wine is thus produced. Fermentation requires several weeks, and the wine is not fit for use for at least some montlis afterwards. Black currant wine is made in the aame way from black currants, but the fruit is put on the tire in as small a quantity of water as possible, and heated to the boiling. point before it is bruised.

Curreney means originally the enpacity of being current, or, as Johnson defines it, "the power of passing from hand to hand.' It is applied in practice to the thing that is so current, and generally to whatever, by being current among any nation or class of persons, serves as the money with which they buy conmodities or pay their delis. It is necesary to be content with a practical explanation, withont venturing on a scientific definition of the term, because, among the many disputed points in political economy, there is none productive of more exciting controversy than the proper regulation of the currency; and the advocate of each theory is apt to defne the term sccording to the view he takes of the functions of government regarding currency. Whether correctly or not, it is applied in practice to everything that is received for payment. It differs from the word money, in its popular accoptation, in as far as it includes various 
sulustitutes for the metallic money of a country, especially bank-notes. The leading question among political economists regarding currency is, how far it should be restrained. The most effectual method of restraining it is by confining it to the precious metals. If it were law that none but a gold currency should be used in any country, and if, at the same time, there were no effort to tamper with this gold currency, and give it an artificial value, the currency of that country would always be adjusted to the general level of prices throughout the commercial world, and if it were redundant would be at once exported, and if deficient at once imported in exchange for commodities.

A country which does not produce gold must pay for its gold with commodities, and consequently it is a very expensive currency, and therefore, ever since man's ingenuity was turned to trade, methods have been devised for superseding gold or the other precious metals by something cheaper. Unless, however, law or custom intervenes to give it efficiency, this cheaper material will only be worth its own (so-called) intrinsic value. A tive-pound Bank of England note is worth so little in its intrinsic value as a picture upon thin paper, that such a value can hardly be expressed. It derives its power as currency from the obligation it fixes on a great rich corporation to make good its professed amount to the holder. We thus pass from a purely bullion currency to the next step of restraint, which is generally called a mixed currency. Here some maintain that no note should be issued unless the banker or other person issuing it has in his possession as much bullion as will pay it. Others say it is sufficient that he is bound to pay its amount in bullion on demand without his actually possessing the bullion throughout the whole period of the currency of the note. A third party, again, are for a currensy entirely free of a metallic basis; they hold that naturally paper money, passing from hand to hand, will represent transactions, and will therefore come in the end to be made good in some shape or other; and they further hold, that if some losses should thus occur, these will be more than compensated by the rapid increase of trade and enterprise, caused by a free trade in currency, as it is termed-that is to say, by every man issuing his own notes or promises to pay to whoever will take them. As a matter of fact, every nation beyond the first stage of civilisation has always regulated its currency, and Adam Smith carefully points out that this is no real intringement of natural liberty and free trade. Through a succession of practical measures, reached with considerable caution, the English have come to a mixed currency, resting on a compromise between the two classes of mixed currency above referred to. In the theory of the measures brought to completion under Sir Robert Peel in 1844, it is admitted that, to a certain extent, a currency can be based on transactions and the property of those concerned in them, but that a limit must be drawn, to prevent the power of creating such a currency from running to excess, by the issue of notes which cannot be immediately made good by those who issue them. Accordingly, the several banks in existence were allowed to continue their note circulation; but they were permitted to increase it only on the condition of having bullion in their coffers to pay the additional notes issued by them.

A currency which is not worth its nominal value in bullion is called a "depreciated currency.' During the period of the restriction of cash payments (1797-1821), the notes of the Bank of England were at one time (1816) depreciated 168 per cent. Before the resumption of cash payments, the notes of the bank of England had sunk to be worth but 16s. in the pound; as compared with gold. During the civil war in the United States, the paper dollar sank in 1864 to 38 cents ; it did not reach par ( 100 cents) till 1879. A depreciated currency may be created by a government calling notes or any other form of money a legal standard, and issuing a greater quantity of it than the real transactions of the country and the property passing from hand to hand require ; or it may be created by private persons aeting under laws by which the right of issuing a currency is not duly limited. This faculty which a currency has of becoming depreciated without being repudiated, is the real source of danger in all proposals for an unfettered currency, or a free trade in the issue of money. If the bank-notes for which bullion cannot be immediately obtained were repudiated, there might be a natural chesk on over-issues; but it is their nature, on account of the difficulty of getting bullion for them, or the chance that it may never be got, that they pass at a discount or reduction of their value. Hence such a currency wonld be ever shifting there would be no permanent standard, and the person incurring a debt before a depreciation which he pays afterwards would, in reality, be paying his creditor a dividend only. A 'token' currency, the material of which is avowedly overvalued, and which is issued in limited quantities for use in small payments, must be distinguished from a depreciated currency. In the silver currency of Britain, a pound is worth little more than fourfifths of a sovereign, even at the old valuation of silver, at about $60 d$. per oz. If a person due $£ 100$ could pay it in silver, he would get off with a dividend of from 16s. to $18 \mathrm{~s}$. in the pound; but by law, silver is not a legal tender for more than $40 \mathrm{~s}$. The copper currency is so far below its real value, that it has not been thought worth while to give it a permanent weight--the pence and halfpence now issued are little more than half the weight of those of former mintages; but they are only a medium for small sums, and the royal stamp establishes reliance. See Bimetallism, Bullion, Money, and W. A. Shaw's History of Currency (1895).

Currents, OcEanic, are treated in the articles on the oceans to which they belong-ATLANTIC, Pacific, \&e. See also Gulf STREam, Sea, and the Map of the Atlantic in Vol. I.

Currie. JAMES, the earliest editor of Burns, was born at Kirkpatrick Fleming manse, in Dumfriesshire, 31st May 1756. He spent five years at Cabin Point, Virginia, in a mercantile situation (1771$76)$, then studied medicine at Edinburgh and Glasgow ; and settling in Liverpool in 1780, soon obtained a good practice. His chief medical work was the able Reports on the Effects of Water in Febrile Disease (1797); but he is best remembered by his edition of Burns (1800; 7th ed. 1813 ), with a. Life and criticism of the poet's writings, which he undertook solely for the benetit of Burns's family, and which was long the basis of all subsequent editions. Dr Currie died at Sidmouth, 3lst August 1805. See the Life by his son ( 2 vols. 1831 ).

\section{Currying. See Leather.}

Curry Powder, or CuRry Paste, is a com. pound of turmeric, coriander, pepper, ginger, and various spices; it is used to a large extent in India and elsewhere as a seasoning for a variety of dishes.

Curse of Scotland, a term popularly applied to the nine of diamonds in a pack of playing-cards. Perhaps the least worthless of the many explana. tions offered is that it involves a reference to the detestation entertained in Scotland towards John Dalrymple, first Earl of Stair, on account of his activity in promoting the Union, and especially for his share in the Massacre of Glencoe. His herulase 
benrinus, 'or, on a maltire azure, nine lozenges of the field,' bore a fanciful resemblance to the nine of dimunemes.

Cursing. See Sweariva.

Cursitor, an old name for clerks of the Court of Chancery who made out writs. The Cursitor Burun used to administer oaths to sheriffs, bailiffs, dic.

Curtain, in Fortification, is the portion of rampert connecting one Bastion (q.v.) with another.

Curtesy. See Courtesy.

Curtis, George Wrllam, American author, born in Providence, Rhode Island, in 1824; in 1850 joined the staff of the New York Tribune, and was one of the elitons of Putnam's Monthly from 1852 to 1869. He commenced the 'Editor's Easy Chair' papers in Harper's Monthy in 1853, and became principal leader-writer for Harper's Weekly on its establishment in 1857. A novel, Trumps (1862), and most of his books appeared first in these journals. Until 1884 he was a Republiean; then he supported Cleveland. He died at New York, 3lst August 1892. See Life by E. Cary (1894).

Curtius, Ervst, a distinguished German classical archwologist and historian, born September 2, 1814, at Lubeck. He studied philology at Bonn, Göttingen, and Berlin, visited Athens with Brandis in $183 \%$, and next accompanied his teacher, Ottfried Miiller, in his travels through Greece. For some time he taught in two Berlin gymnasiums, next became extraordinary professor at the university there, and (1844-49) tutor to the Crown Prince of Prussia. In 1856 he succeeded Hermann as professor at Göttingen, whence he was recalled in 1868 to become ordinary professor at Berlin. From 1853 a menber of the Reyal Acrdemy of Sciences, lie was in 1871-93 one of its permanent secretaries. His earlier works were Klassische Studien (1840), Anecdota Delphica (1843), Inseriptiones Attica Duodecim (1843), and Die Akropolis von Athen (1844). The fruits of his repeated visits to Greece and Asia Minor-last in the spring of 1874 , to make preparations for the intended excavations at Olympis at the instance of the German government-appear partly in the memoirs of the Gottingen Society of Sciences and of the Berlin Academy, and partly in his books, Nascos (1846), Olympia (1852), Die Ionier (1855), Die Topographie Kleinasiens (1872), and Ephesos (1874). His orations, delivered at Göttingen in the crpacity of 'Professor Eloquentire,' were colleeted in 1864; those at Berlin, under the title, Altertum und Gegenwart (2 vols. 1875-82). Besides these and numerous papers in the special archatogical and philological journals, Curtius published Peloponnesas (2 vols. 1851-52), a luminous deseription of that part of Greece, and Griechische Geschichte (3 vols. $1857-61$; 6 th ed. $1887-89$; trans, by $\mathrm{A}$. W. Ward, $1868-76$ ), a work uneyualled for its insight into the artistic growth and development of the Greek race, With Kaupert he prepared the Atlas ron Athen (1878); earlier, with Adler and Hirsel.. feld, Die Ausgrabungen zu Olympia, the official account of the excrvations at Olympia (3 vols. 1877-78). He died 11 th July 1896.

Curtius, Gzora, a distinguished clessical scholar, the brother of the preceding, was born at Lübeck, April 16, 1820, and studied at Bonn and Berlin. After teaching some time at Dresden and Berlin, he became in 1849 extraordinary, in 1851 ordinary, professor of Classical Philology at Prague, and settled as such at Kiel in 1854, at Leipzig in 1862. He died August 12, 1885. One of the soundest Greek scholars in Germany, Curtius was the first philologist of the generstion that succeeded the giants Bopp and Benfey. His most important works were Griechische Schulgrnmmatik (1K52; 20th ed. 1890), translated into many lauguages (into English in Dr Suith's series in 1863); next the Er. lauterungen to the foregoing (1863; 3d ed. 1875), translated into English by Abbott in 1870 ; Grundzüge der Griechischen Etymoloyie (18:8s; 5 th ed., with the collaboration of $\mathrm{A}$. Windisch, 1879), translated into English by $\mathbf{A}$. S. Wilkins and E. B. England, 1875-76; and Das Verbum der Griechisch. en Sprache (1873-76; 2d ed. 1877-80), translated by Wilkins and England, 1880. Other works were De Nominum Gracorum Formatione (1842), Die Sprachvergleichung in ihrem Verhultniss zur Klassischen Philologie (1845), Sprachergleichende Beiträgs zur Griechischen und Lateinischen Grammatik (1846), Philologis und Sprachvissenschaft (1862), Zur Chronologie der Indogermanischen Spruch forschung (1867; 2d ed. 1873), and Zur Kritik der neuesten Sprach forschung (1885), his last work, in which he vigorously assails the theories of the "new grammarians,' and to explain the word-changes in a language maintains the necessity of a third principle of varying or sporadic change, in auldition to invariable phonetic law and the operation of analogy. In the famous Studien zur Griech, und Lat. Grammatik (10 vols. Leip. 1868-77) Curtius united his own papers with those of his pupils and others, including Brugmann, Fick, G. Meyer, and Windisch. The ninth volume contajned Brugmann's famous paper on the 'nasalis sonans,' which first marked the revolt of the 'neogrammatici' against the master and traditional philology. Curtius founded in 1878, with $L$. Lange, $O$. Ribleck, and H. Lipsius, the Leipziger Studien zur Klassischen Philologie.

Curtius, Metrus or METTIUs, a noble Roman youth who heroically sacrificed his life for the welfare of his country, 362 B.C. A yawning chasm had opened in the forum, and the soothsayers declared it could only be filled by throwing into it the most precious treasure of Rome; whereupon Curtius appeared on horseback in full armour, and exclaim. ing: "Rome has no greater riches than courage and arms,' leaped into the abyss, which at once closed over him.

Curtius, Quixtus (Quintus Curtius Rufus), author of the work De Rebus Gestis Alexandri Magni, in ten books, of which the first two have been lost, and the text of the remainder has come down to us in an imperfect condition. Some critics have placed him in the reign of Augustus against the evidence of his style, which is moulded on that of Seneca, and would naturally suggest a writer contemporary with Claudius and Nero; others, as Niebuhr, under Severus; and others again much later. Curtius was poorly equipped as a historian. and his book has but little value as history ; but its style, if mannered and declamatory, is elegant and pleasing. The editio princeps was published at Fenice ahout 1471. Molern editions are those of Mùtzell (1841), Zumpt (1849), and Vogel (1875-80).

Curule Chair (sella curulis), the chair of honour of the old Roman kings, and later of con. suls, protors, "curule sediles," and some of the other higher magistrates of the repullic having senatorial rank. It was a folding-stool originally of ivory, then of metal, with curved legs crossing.

Curvature. For Curvature of Strata, see Anticline, Geology, Mountains; for Curvature of Spine, see SpINal Columa.

Curve. a line described by a point moving so that the direction changes at every instant; and in mathematics the term curvature is restricted to lines that follow some law in their change of direction. Thus, the law of the circle is, that all points of it are equally distant from a fixed point, called the centre. The law of a plane curve is generally 
expressed by an equation between the co-ordinates of any point in it referred to a fixed point; and thus the doctrine of curves becomes matter of algebra (see Co-ORDINATES). When the equation of a curve contains only powers of $x$ and $y$, the curve is algebraic; when the equation contains other functions, logarithms, for instance, of $x$ and $y$, the curve is called transcendental. The cycloid, e.g., is a transcendental curve.

'There are also curves, like some spirals, that do not continue in one plane; these are called curves of double curvature, and require, in analysis, three co-ordinates and two equations. - Curves are said to be of the first, second, third, \&c. order, according as their equations involve the first, second, third powers of $x$ or $y$. The circle, ellipse, parabola, and hyperbola are of the second order of curves. There is only one line of the first order-viz. the straight line, which is also reckoned among the curves.The higher geometry investigates the amount of curvature of curves, their length, the surface they inclose, their tangents, normals, asymptotes, evolutes and involutes, \&c.

The number of curves that might be drawn is of course infinite. A large number have received names, and are objects of great interest to the mathematician - in some cases, for their beauty, in others, for their geometrical properties. Among the most interesting are the following : (1) Circle; (2) ellipse; (3) hyperbola ; (4) parabola ; (5) cissoid of Diocles; $(6)$ conchoid of Nicomedes ; 7 lemniscata ; (8) cycloid ; (9) harmonic curve ; (10) trochoid ; (11) the witch; (12) eardioid; (13) curves of cirenlar functions-e.g. curve of sines; (14) the logarithmic curve and other plane spirals, such as that of Archimedes, the lituus, the reciprocal or hyperbolic, and the involute (q.v.) of the circle; (15) the catenary ; (16) the tractory; (17) the tractrix ; (18) the ovals of Cassini.

Curwen, JoHs, the apostle of the Tonic Solfasystem of teaching music, was the son of an Independent minister, and was born at Heckmondwike, Yorkshire, 14th November 1816. He was trained for the ministry, and after having served as assistant in various charges, was settled as minister of the Independent chapel at Plaistow. In 1841 he began to advocate the Sol-fa System (q.v.); in 1843 his Grommar of Vocal Music appeared; in 1864 he resigned his ministry and gave himself wholly to the cause. He died 6th May 1880. See Memorials of John Curwen (1882).

Cur'zola, a Dalmatian island, 30 miles by 5 , with a pop. of 15,000 , of whom 2000 are in the town of Curzola.

Cusa, Nicolaus of (1401-64), born at Cusa or Kues on the Moselle, studied at Deventer with the Brothers of the Common Life and at Padua. As archdeacon of Liége he took the anti-papal side at the Council of Basel ; but was ultimately Bishop of Brixen in Tyrol, cardinal, and papal legate to Constantinople. He exposed the false Isidorian decretals, denounced perverted scholasticism in De Docta Ignorantia, taught that the earth went round the sun, and in pantheistic tendencies and otherwise was a precursor of Giordano Bruno. See German monographs by Düx (1848), Scharptf (1871), and Glossner (1891).

Cuscus, a marsupial akin to the Phalanger (q.v.).

Cush, the son of Ham (q.v.), and father of the Cushites. See Ethiopia, Semites.

Cushing, Caleb, American statesman, born in Salisbury, Massachusetts, in 1800 , was admitted to the bar in 1821, sat in the state legislature and senate, and was elected to congress in 1835-43. He arranged the first treaty between China and the United States in 1844 ; raised and commanded a regiment in the war with Mexico; and was United
States attorney-general in 1853-57, counsel for the United States at the Geneva Conference in 1872 , and minister to Spain in 1874-77. He died in 1879 .

Cushman, Charlotte Saunders, a distinguished American actress, born in Boston in 1816, appesred first in opera in 1834, and as Lady Macbeth in 1835. Miss Cushman played sometimes in high comedy, but her name is identified with tragie parts. In 1844 she accompanied Macready on a tour through the northern states, and afterwards appeared in London, where she was well received in a range of characters that included Lady Macbeth, Rosalind, Meg Merrilees, and Romeo-her sister Susan (1822-59) playing Juliet. Miss Cushman retired from the stage in 1875 , and died in Boston, 18th February 1876.

Cusk. See Torsk.

Cusp (Lat. cuspis, 'a lance-point'). If we conceive a curve to be generated by a moving point, then a cusp is where the point suddenly stops and

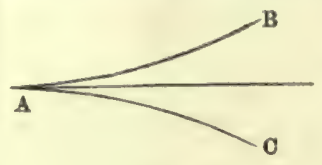

Fig. 1.

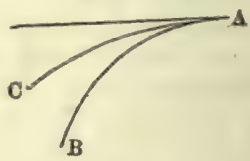

Fig. 2. returns for a time in the same general direction as that in which it was moving when it reached the cusp point. A later name is 'spinode.' When two branches (as BA, CA) meet a common tangent without extending further, the point of contact is a cusp. Fig. 1 is an example of the first species, and 2 of the second.

Cusparia. See Angostura Bark.

Cusps, curved projections or featherings in Gothic tracery, arches, panels, \&c. They began in the Early English period, when they projected from the flat soffit of the arch; but they were soon comprised in the mouldings, and generally spring from the inner splay or cavetto. In Decorated and Perpendicular work the points were length-

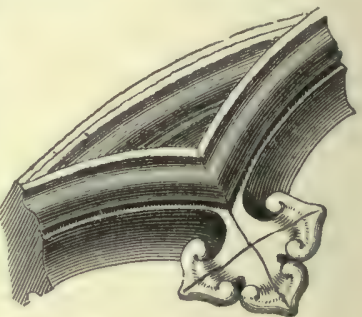

Cusp. ened, and were frequently ornamented with flowers, heads, dic.

Cusset, a small town in the French department of Allier, 2 miles NE. of Vichy, with two mineral springs. Pop. 5356.

Cusso, Kusso, or Cabotz (Brayera anthelmintica), a small Abyssinian tree of the order Rosaces, sub-order Spirseaces, the dried flowers of which have been long infused in Abyssinia as an anthelmintic, and have been found so efficacious in the removal of tapeworm, that they were in 1874 introduced into European pharmacy as Flores Kusso.

Cust, Robert NeedhaM, was born in 1821, at Cockayne-Hatley, Bedfordshire, studied at Eton, and entered the Indian civil service. He held varions important administrative and judicial posts in North India, in 1864-65 was a member of the legislative council, and returned to England in 1869. He is a member of many learned societies at home and abroad, has contributed extensively to their Transactions, and has published works on the 
modern languages of the East Indies (1878), of Afrien (1882), and of Ocennia, as well as Linguistic and Oriental Esacys and Sketches of Anglo-Indian Life.

Custard, a composition of milk or cream, eggs, Sc., sweetened with sugar, and Havoured according to taste. Custards are of various kinds, such as plain, buked, lemon, orange, almond, coffee enstards, \&c. For a plain custard, take four eggs and beat them well with two tablespoonfuls of flour and a little cold milk. Seuson this with sugar, ground cinnamon, grated lemon-peel, and pour on a pint of lwiling milk, stirring all the time. It may be either baked or boiled. If more eggs are used, the flour may be omitted. Flavouring ingredients may be added according to taste.

Custard Apple, the name commonly given in the West Indies and other tropical countries to the fruits of certain species of Anona (order Anonacer, allied to Ranunculacere). Some of the fruits of this genus are among the most delicious prosluced in tropical countries, as the Cherimoya (A. cherimolia), and even the Common Custard Apple (A. squamosa or reticulata), which is a native of America, but is now very conmon throughont the East Indies. It is a large, greenish, or darkbrown, roundish fruit, sometimes from its size and appearance called Bullock's Heart in the West Indies; the tree is of considerable size. Sonie other American species and varieties are sometimes called custard apples, and two or three which are natives of Western Africa, A. muricata, the soursop, A. (Asimina) triloba, the pappaw-tree of the warmer parts of North America, and A. palustris, the dog or alligator apple of the West Indies, may also be mentioned. A. laurifolia grows in Florida and the West Indies; its large fruit is hardly eatable.

Custer, George Armstrong, American soldier, born in Ohio in 1839, graduated at West Point in 1861, and served with distinction through the eivil war, retiring with the rank of majorgeneral. He afterwards held various eavalry commands in the west, and several times defeated the hostile Indians. On 15th May 1876, with a force of 1100 men, he attacked a body of Sioux. afterwards found to number some 9000 , encamped on the Little Big Horn, in Montans, and he and his entire command were destroyed. See his Life by Whittaker (New York, 1878).

Custom, in English Law. This is either general or particular. For the principal doctrines relating to general customs, вее СоммоN LAW. In order to establish particular customs as law, they must be proved by verdict of a jury, except the custom of the city of London, which is proved by certificate by the lord mayor, aldermen, and recorder. A particular custom must, like a general custom, be established as in force for a time whereof the memory of man runneth not to the contrary. A eustom must have been uninterrupted and peaceable, reasonable, and certain ; compulsory - i.e. not in the option of every person whether he will use it or not-and consistent with other customs.

The customs and usages of England were adopted by the United States government at its foundation as far as applieable to the condition of the country, and have the effect of positive law. They cannot be set aside by implication, but only by statutes. Customs and usages are frequently invoked in the interpretation of positive law, particularly when a conservative interpretation is required. A marked instance of this is found in the interpretation of generic words nsed in the federal and state constitutions and laws, so as to deprive women eitizens of the right to the elective franchise in a govern. ment founded upon equality of citizenship, and to restrict their industrial sphere.

Seo Customs DuTiks.

Customs Duties, the portion of the revenue derived from a tax on imports. In some countries, customs duties are imposed on certain exports also. The origin of the term is connected with the long conflict between the crown and parliament as to the right of taxation, although the practice it signifies is as old as the Roman empire, and is even to be traced among the ancient Greeks. To meet the claims made by the House of Commons to the exclusive right to vote all supplies, it used to be maintained that there were certain duties on exportation and on importation to which the crown had acquired a right by custom (although it is certain that enstoms duties existed in England prior to the Norman Conquest), and after the power of parliament over this branch of taxation had been fully established it retained its old name. This tax, which originally was a sort of premium of insurance for protection from robbery, after the excise came in force was always applicable dis. tinctively to goods changing place. There were customs not only upon things leaving and things coming to the British dominions, but also upon commodities transferred from one part to another. In Scotland the duty on commodities imported. into any town from a foreign country was called the great custom; and the duty charged by a burghal corporation on commodities coming within its walls from the country districts was called the small or petty customs. After 1707 the Seotch customs duties became the same as those of England. At present the term eustoms duties applies in the United Kingdom solely to the tax levied on commodities imported from abroad.

The tax on imports was of old a simple percentage, familiarly known to the readers of English history as 'tunnage and ponndage,' from the method in which it was levied on the tun of wine, or the pound ad valorem of other mercliandise. These were subsidies granted first to the crown, and then for the maintenance of the authority and dignity of the state. That is to say, they were forms of public revenue; and many complications arose by the additions and alterations of successive governments. Out of this confusion, no doubt, arose the belief that customs duties might be utilised for fostering domestic industries and discouraging foreign competition. When it came to be held as an established principle, with regard to any trade, that the eustoms should be adjusted in such a nianner as either to aid or to impede it, the regulations regarding that trade alone would have complexity enough for a whole code of customs laws, the original object of which was mere revenue. The more complex the arrangements, the more open were they to the operations of the smuggler or defrauder, and, consequently, regula. tion had to be added to regulation, till the whole became a chaos. Frequently the duties were such as to act as a prohibition to importation, and they always added a heavy increase to the price. Sometimes there would be relaxations in favour of the produce of British colonies, and sometimes of some favoured country with which Britain had a treaty of reciprocity. Then, to encourage trade and manufactures, it was considered politie to allow goods to be imported for re-exportation abroad, or to be imported for the purpose of being worked up into a manufacture, and there would be a difference between the extent of encouragement granted to that manufacture if it were for home consumption or for exportation. The method in which such relaxation was accom plished was at first by charging the duty on the importation, and afterwards repaving it by what was called a 'drawback;' and this was subse- 
quently accomplished in an easier method for the importer, by allowing him to 'bond' the goods in the government warehouses until the duty was paid, or the conditions which dispensed with it fulfilled. An ordinary importer was also allowed to 'bond' his goods, instead of being compelled, as in the old times, to pay duty on arrival of the vessel whether he had sold his cargo or not. See BONDED WAREHOUSES.

In the year 1825 the laws of the British customs were consolidated into some half-dozen statutes. It will give a conception of the confused and cumbersome condition into which the system had merged, to note that the number of acts repealed on the occasion of the consolidation was 443 , and it was afterwards discovered that several had been omitted. There was still a long list of customs duties; but the free-trade legislation of 1846 cleared away a great mass of this burden on the commerce of the country, and there has been steady abbreviation of the list of duties or Tariff (q.v.). One by one, articles of food have been exempted; and nearly the whole customs revenue is now derived from spirits, wine, tobaceo, tea, coffee, and dried fruits. The tendency has for some time been to concentrate the customs duties on a few articles, and yet they supply an enomnous amount of revenue. The British revenue for the year ending 31 st Mareh 1895 was $£ 94,684,000$, and to this amount the customs contributed $£ 20,115,000$. Down to 1845 the tariff included some 1200 articles.

The defects which, according to the doctrines now prevalent in Great Britain, are to be avoided in a code of customs, are-1. The prohibition or discouragement of the importation of useful com modities; 2. Encouragement to the smuggler; and 3. Loss of revenue by raising the duty to the height which discourages importation. Under the first head, see Corn LAws, and Free Trade. The second is connected with the view that on stimulants the duty cannot be too high, even though it should greatly impede their importation: but on the other hand, if the smuggling trade be encouraged, the stimulant is not only obtained with out any contribution to the revenue, but the people become demoralised and trained to crime. Under the third head a memorable example was furnished by the old sugar-duties of France, which were so high that the native agriculturists could make sugar from beet-root cheaper than the dutypaid foreign sugar.

The collection and general management of British customs duties is under one great central department of the government in London. The office of receiver-general was in 1871 united with that of the comptroller-general, and there is a fourfold division into the paymaster's, examiner's, accountant's, and auditor's branches. The annual cost of collecting the customs dues and managing the necessary establishments is about $£ 952,000$, although the tariff contains now only twenty dutiable imports.

In the United States, the number of dutiable articles is large. Of the total imports the dutiable have nearly double the value of the free goods. In 1890-95 the total insports had a value of from $\$ 655,000,000$ to $\$ 870,000,000$; and in the years of largest imports the customs duties reach a value of $\$ 200,000,000$, being by far the largest item in the total national revenue-say, from $\$ 300,000,000$ to $\$ 400,000,000$. The very large surplus from customs has led to keen debate. See also TAX, Excise.

Custom House (Fr. douane, Ger. Zollamt), the office at a seaport or frontier where the customs duties are paid, vessels entered and cleared, \&c. In England the custom-house officer has the right of personal search only when he has good cause to suspect that contraband goods are concealed about the person. See Smugaling.
Custos Rotulorum (Lat., 'keeper of the rotuli or rolls') is the person appointed by the crown to keep the records of the county sessions. The office is an ancient one, and can only be held by a justice of peace. In fact it is usually held by the lord-lieutenant. In practice the rolls are kept by the elerk of the peace, an officer appointed by the Custos Rotulorum.

Custozza, a village 10 miles SW. of Verona, where the Italians have twice been utterly defeated by the Austrians. On 23d-25th July 1848 Charles Albert was routed after severe fighting by Radetzky with a smaller force, and forced to retreat behind the Mincio; and on 24th June 1866, Victor Emmanuel with 130,000 men was defeated by the Archduke Albert with 75,000 men.

Custrin. See Küstrin.

Cutch (Kachchh), a protected principality under the government of Bombay, stretches along the Gulf of Cutch and the Indian Ocean between Gujarat and Sind. Excluding the Rann of Cutch, it is 160 miles long from $\mathrm{E}$. to $\mathrm{W}$., and 30 to 70 broad from N. to $\mathrm{S}$. The state, exclusive of the Rann, consists of 6500 sq. m., is the belt on the seashore, touching Sind, of which it may be regarded as a physical continuation, on the north-west, and being separated by a detached portion of the Rann from Gujarat on the south-east. While the southern edge of this belt is merely a sandy desert, the northern section, traversed lengthwise by two parallel ranges of hills, presents, amid much sterility, many fertile tracts, which yield cotton, rice, \&c., and feed a large stock of horses, kine, buffaloes, and camels. The grand defect of the country is the scarcity of water. The mineral productions are coal, iron, and alum. The traces of volcanic action are numerons, and earthquakes also have recently occurred, as in 1819 , $1844,1845,1864$; that of 1819 , besides shaking every fortified city to its foundations, and destroy. ing many hundred lives, changed the level of part of the Runn. The population of the state, according to the census of 1891 , was 558,415 , being 86 individuals to a square mile. The ruler is styled the Rao; and the feudatory chieftains under him are about 200. The capital is Bhúj.

The Rann or Runn of Cutch-subdivided into two parts, the smaller, of nearly $2000 \mathrm{sq} . \mathrm{m}$., on the east, and the larger, of $7000 \mathrm{sq}$. m., on the northis a desert, being mainly caked, hard ground during the dry season, and then in turn a sort of shallow lake formed by the heavy rains and pentup tides of the south-west monsoon. It is supposed to have been originally a permanent inlet of the ocean, and to have had its level raised by some such convulsion of nature as that which marked the year 1819. The periodical disappearance of the waters leaves behind it one continuous erust of salt. This dreary waste has a few elevated spots on which a little vegetation grows. Herds of wild asses and clouds of flies are its only inhabitants. The sea is at present advancing into the little Rann year by year. For the substance called Cutch, see CATECHU.

Cuthbert, St, of Durham, was one of the three great saints of England in the middle ages, the other two being St Edmund of Edmundsbury, and St Thomas-à-Becket of Canterbury. St Cuthbert was born about 635 . A legend, which was long generally believed, tells that he was born in Ireland, and drew his lineage from one of the petty kings of that country; but another tradition fixes his birth in what is now Berwickshire. When the light of record first falls upon him, he was a shepherd boy in the kingdom of Northumbria, which then stretched northwards to the Forth. In 651, while watching his flock by night on the heights of Lauderdale, he believed that he saw the heavens 
open, and a company of angels descend upon the earth, and again ascend to heaven, carrying with them the soul of St Aidan, the pious Bishop of Lindisfarne, or Holy Island. The vision determined him to become a monk, and in the anme year he entered the monastery of Old Melroee, of which St Boisil was then provost or prior, and St Eata abbot. When the latter removed to the newly. founded monastery of Ripon, Cuthbert sccom. punied him, and was appointed to the oftice of superintendent of the guests. In consequence of the dispute as to the keeping of Easter, which was then raging, Eata returned to Melrose, and Cuthbert, having accompanied him, was on the death of St Boisil in 661 elected prior of the monastery. While in this office, he distinguished himself by his assiduity in visiting the strrounding country, and especially the remoter mountain hamlets, sometimes on horseback, but oftener on foot, and labouring by his teaching and example to reclaim the people from the superstitious or pagan rites into which they had fallen. After a few years spent in this way, he left Melrose for the island monastery of Lindistarne, of which he became prior, his old master, St Eata, being abbot. Long. ing for an austerer life even than the monastic, he quitted Lindisfarne in 676 , to become an anchorite, or solitary recluse, in a hut which he built with his own hands on House Island, one of the Farne group. Here, in 684, he was visited by Eegfrid, king of Northumbria; Trumuine, ex-bishop of the Picts, and other great men of the north, who came at the request of the synod of Twyford to entreat that he would accept the bishopric of Hexham. He reluctantly complied with their wishes, but shortly after exchanged the see of Hexham for that of Lindisfarne. Still thirsting after solitude, at the ond of two years he resigned his bishopric, and returned to his hut, where he died ou the 20 th of March 687. The anniversary of his death was a great festival in the early English Church, which commemorated also the 4th of September, as the suniversary of the day on which his body was translated to Durham. The influence which St Cuthbert exercised upon his age seems to have been due chiefly to his fervent piety and extraordinary asceticism. The gift of a persuasive tongue is ascribed to him, and he would seem to have had skill and prudence in the management of affairs, but nowhere is there any trace of his learning.

The fame of St Cuthbert had been great during his life; it became far greater after his death. Churches were dedicated to him throughout all the wide country letween the Trent and Mersey on the. south, and the Forth and Clyde on the north. It is stated that when his tomb was opened at the end of eleven years, his body was found incorrupt, and so, for more than 800 years, it was believed still to continue. It remained at Lindis. farne till 875 , when the monks, bearing it on their shoulders, fled inlanil from the fury of the Danes. After many wanderings it found a resting-place at Chester-le-Street in 883 . It was transferred to Ripon in 995, and in the same year it was removed to Durham. Here, inclosed in a costly shrine, and believed to work daily miracles, it remained till the Reformation. The grave was opened in 1826, when a cotfin was found to inclose another, which there was reason to suppose had been made in 1104; and this again inclosed a third, which answered the description of one made in 608, when the saint was raised from his first grave. This innermost case contained, not, indeed, the incorruptible body of St Cuthbert, but his skeleton, still entire, wrapped in five robes of embroidered silk. Fragments of these, and of the episcopal vestments, together with a comb and other relics, found beside the bones, are to be seen in the cathedral library.
The asceticism which distinguished St Cuthhert in life, long lingered round his tomb. Until the Reformation, no woman was suffered to approach his shrine. His wrath, it was believed, was equally prompt to avenge every injury to the honour or posseswions of his church. A cloth said to have been used by St Cuthbert in celelsrating mass was fashioned into a standard, which was believed to insure victory to the army in whose ranks it was carried. Flodden was only one of many fields in which the defeat of the Scots was ascribed to the banner of St Cuthbert.

The Life of St Cuthbert was twice written by the Venerable Bede. Other ancient authorities are Bymeon of Durham, and Reginald of Durham. See Kaine's $8 t$ Cuthbert (1828), Archbishop Eyre's Bistory of Bt Cuthbert (1849; 8d ed. 1887), and Fryer's Cuthberht of Lindie. farne (1880).

The name St Cuthbert's Beads has been popularly given to single joints of the stems of fossil Crinoidea (q.v.), which being hollow could be strung on thread, and 80 made into a rosary.

Cuticle, a sheath formed outside a layer of cells, either by their secretory activity or by a modification of their external portions. In the strict sense, a cuticle is not in itself cellular, but consists of the products or of the modified portions of underlying cells. The thin envelope which may be rendily stripped off a leech or earthworm when killed in spirit supplies a convenient example. A cuticle is usually formed outside relatively passive cells, bnt even ciliated Epithelium (q.v.) may have its cuticular outer layer through the pores of which the cilia emerge. By continuous modifications of the cells considerable thickness of cuticle may be developed-as e.g. the hard lining of the gizzard in many birds. By chemical modification of a well-developed cuticular formation very varied protective and offensive skin-structures often result. Thus the peculiar gelatinous, cellulose. containing tunic of Ascidians is for the most pert a cuticle; the shells of molluses are cuticular formations plus lime; the raspers of snails are formed from cuticle; the hard armour of Arthropods is a cuticle associated with the formation of Chitin (q.v.); the bristles, jaws, and firm sheaths of many worms are also cuticular, and so on. For the use of the term in special connections - e.g. the cnticle of the hair or of the teeth, see special articles. The term must not be confused with cutis, one of the names for the under skin or dermis; nor should it ever be used as equivalent to skin. See CELL, EPITHELIUM, SkiN.

Cutlass, a sword nearly 3 feet long, broad and nearly straight, mostly used by seamen of the royal navy. Those of the converted pattern of 1871 were pronounced utterly inefficient and unfit for service by a commission in 1887. See SwORD.

Cutlery, the general name given to such cutting instruments as knives, forks, scissors, razors, \&c. The making of larger objects of this nature, such as axes, chisels, and saws, is rather the business of the tool-maker than of the cutler. Shells, flints, and other sharp-elged stones formed the rudest and most ancient eutting instruments, and the earliest traces of buman existence in Britain and elsewhere are associated with stone 'celts' and other weapons and cutting implements. These were followed by bronze weapons and other articles, including reaping-hooks. In the museum of Bologna there are ancient Etruscan bronze knives carved in form somewhat like modern reaping. looks, and in the great Naples collection of oljects from Pompeii and Herculaneum, there are sickles, bill-hooks, knives, lancets, and spring-shears, some of which are made of iron or steel, as well os of bronze. These are of course ancient Ruman. 
Bronze, like steel, can be hardened, but by opposite means, since it is softened by sudden and hardened by slow cooling. The ancients appear to have been great experts in the tempering of bronze.

The Anglo-Saxons had knives somewhat resembling a razor-blade. They had forks also; but it would appear that these were employed for serving, not for use in feeding. The custom of using forks for eating with came from Italy, and was not known in England till the reign of James I. Before that, people fed themselves with their fingers, as is still the practice in the East. The Persians so much prefer this custom that they contemptu. ously call a fork a claw. Up to the end of the 15th century knives do not appear to have been much used at table, but as in those days everybody carried a knife in his girdle, it probably served to cut meat with as one of its applications. Springshears of the ancient Roman form were the only kind known up to Norman times, and probably even till the 15 th or 16 th century.

The London cutlers obtained a charter of incorporation in 1417 from Henry V.; but long before that knives were made at Sheffield, as the 'whittle' of that town, or village, as it would then be, is incidentally mentioned by Chaucer. Knives, sickles, shears, and scissors are named as being made in Sheffield, when the Hallamshire cutlers were incorporated in 1624. Cutlery was not then however an English specialty; and England still imported iron and steel goods largely from the Continent; and in England, Birmingham was in the 17th century regarded as the home of smiths and cutlers. The vast increase in the size of Sheffield since 1800 shows that it is chiefly during this century that its cutlery wares have expanded from being a mere inland into that of a world-wide commerce.

Table-knives.-Of these the best kinds are made by hand, and have the blade of steel, while the shoulder and tang, to which the haft is fitted, is of malleable iron. From the end of a thin bar of steel, which has been carefully brought to a proper heat, the blade is roughly forged, cut off, and welded to a piece of iron for the tang and shoulder. 'The latter, usually called the 'bolster,' is formed by crushing the hot iron between a pair of dies, and the tang drawn out by some strokes of the hammer. After reheating, the blade is again hammered and the maker's name stamped upon it. The next stage, that of hardening and temper. ing, is all-important in every kind of steel cutting instrument. Raising the blade to a dull red heat and then plunging it in cold vater hardens it, but at the same time makes it brittle. The brittleness is removed and the steel made flexible by the process of tempering, which consists in again heating the blade till it aequires a bluish colour, and at this moment putting it back into the water. After tempering, the knife passes to the grinder, who smooths the bolster and works the blade a little on the grindstone. But the blade still requires to be made quite straight in the smithy, and again ground. The finishing processes of lapping, glazing, and polishing follow, in which different wheels are used along with emery and polishing-powder. The lap is covered with an alloy of tin and lead, and the glazing and polishing wheels with leather. Bone, ivory, horn, and other materials are employed for the hafts, but these are prepared by a different set of workmen.

Machinery is now used for the manufacture of blades of common table-knives, in which case blade, bolster, and tang are made of one piece of steel. A few strokes of a steam-hammer shape the blade, and without reheating the shoulder is formed, but it requires to be heated again for drawing out the tang. The blade is next reheated and lammered thin, and then the whole of the metal portion of the knife is pressed into dies to give it the exact shape and size. Grinding and the finishing processes now follow.

Very cheap knives are made by simply 'flying' (i.e. pressing into dies) the blade and tang out of a cold sheet of steel at one operation, and dispens. ing with a shoulder.

forks.-These are made from a bar of steel threeeighths of an inch square. The forger begins by forming the tang, shoulder, and shank. He then beats out flat a square piece left at the end for the prongs. In the next stage the whole is heated till it is soft, and pressed with some force between two halves of a die, which roughly form the prongs. The fork is afterwards filed, ground, brightened, and hafted. Forks of an inferior kind are cast.

Spring-knives.-Pocket-knives are of much more modern date than those used at the table. The earliest piece of cutlery made at Sheffield, or perhaps in England, was called a thwytel or whittle, and served for a weapon as well as for other purposes. At a later time the jack-knife appeared, which was made to shut into a groove in the handle, but had no spring. Some springknives are believed to have been made as far back as the beginning of the 17th century; but it was not till about 1820 that a spring-knife of the type now so much in use was invented by the first Lord Wharncliffe, or at least was named after him. The process of making the blade of a spring-knife does not differ much from that already described for a table-knife. Sometimes the springs are forged, but others are 'flied'-i.e. formed at a single blow out of a piece of steel. The inner scales of the haft are made of brass or iron, and sometimes of a more expensive metal ; while a still greater variety of material, such as hard wood, horn of various kinds, ivory, bone, and tortoiseshell, is used for the outer scales.

Razors. - The use of the razor goes back to a very remote period. It is referred to in the book of Numbers, and was used by the ancient Egyptians as well as by the Greeks and Romans. The blade of a razor is forged from a piece of steel of the thickness of its back, and half an inch wide, the concave sides being formed on the rounded edge of the anvil. In the smithing process which follows, the workman hammers it to make it compact, and at the same time shapes it into proper form. It is next ground, hardened, and tempered; after which it is once more ground, and then lapped, glazed, and polished. The best qualities of razors are made of the finest cast steel, and are manipulated with great eare in every stage of their manufacture. But there is always some uncertainty about the quality of a razor even when made with the utmost skill and care and from the best material. Perhaps this explains why high-priced razors are not in great demand, at least in Great Britain.

Scissors. - A blade is forged from a flat bar of steel, and this, including $\mathrm{a}$ bit for the shank and bow, is then cut off. Next a hole is punched for the bow to admit of its receiving the point of a small anvil upon which it is roughly shaped. After reheating, the bow is further shaped, the shank formed, and both filed. The joint is now squared, and the hole bored for the rivet or serew. Grinding and smoothing of the blade follow, and then the two are screwed together. If they work smoothly, they are ready for hardening and temper. ing, but the serew is first removed and the two halves wired together. Afterwards the scissors are gronnd and passed through the finishing processes already described.

In describing briefly the manufacture of the several articles of cutlery noticed above, only the 
more imjortant procensen have been mentioned. The subdivision of labour is very fully carried ont in the cutlery trade, so much so, that the man who forgen the pen-blules does not forge the larger blailes for the same knife. It is the same with those who grind the blades. Including those of 8 comparatively trivial nature, an orlinary three. bluled pocket-knife goes through more than a hundred processes.

The grinders in former years suffered so much from the fine particles of stone and metal which pervaded the atmosphere of the workshopa that their average age did not exceed twenty-nine. This was especially the case with those engaged in dry-grinding, which, for example, was that used for forks. The evil has been lessened in recent yenrs by the adoption in some establishments of wet-grimling, the water on the stone preventing the escrupe of particles of matter through the room. Another plan has been a good many years in usenamely, the application of a fan with a properly construeted flue, which withdraws by guction the grit und steel dust as it is prodnced.

A few of the leading manufacturers at Sheflield prepare hafting material such as iyory, wood, and horn on their own premises; but the manufacture of 'scales,' as these hafts are called, is to a large extent a separate trade. Ivory was long so popular a material for knife-handles that Sheffield has in some years consumed the tusks of 20,000 elephants ; but owing to its increasing scarcity and price, various substitutes are now employed. In trading with savage people it is curious how they wil sometimes unexpectedly reject a useful article on account of its colour. For example, the Fiji Islanders a few years ago, if not now, would on no account accept in barter a white-handled knife, but would readily take one with a black handle.

In eutlery France and Germany are now competing with England in many foreign markets; but the trade has again shown a tendency to increase in Sheftield. The manufacture is now also extensively carried on in the United States. In France the headquarters of cutlery are at Thiers, Langres, Nogent, Chatellerault, and Paris, where the finest surgical instruments are made. Solingen is called "the German Sheffield;" but Remscheid, Suhl, Sehmalkalden, and many other towns produce. knives and the like. Swedish razors are famous. See also SworD.

Cuttack (Kataka, 'the fort '), the capital of a district in Orissa, Bengal, stands immediately below the bifurcation of the Mahanadi, thus oecupying the apex of the delta of that river, a position advantageous both in military and commereial respects. The eity, which is 220 miles $\mathrm{SW}$. of Calcutta, is chiefly notable for its filigree-work in gold and silver. Pop. (1891) 47,186, of whom over 8000 were Mohammedans. - The district is the central one of the Orissa division, and lias an area of 3633 sq. m., and a pop. (1891) of $1,937,671$.

Cutter is a name given to two kinds of small vessels. The cutters used by vachtsmen and revenue cruisers, and which are built with esplecial reference to speed, have a single mast, and a straight running bowsprit that can be run. in on board occasionally. They are much like sloops in rig, but have larger sails. Such small vessels occasionally venture on long voyeges. In 1857 the Charter Oak, a cutter of 23 tons, crossed the Atlantic from New York to Liverpool. In 1865 the Alert, a cutter of 56 tons yacht measurement, made the voyage from England to Sydney (Aus. tralia) in 108 days, including 5 days' detention at tha Cape of Gond Hope. From that time to this, long voyages with vessels of this class, especially across the ........... have been matters of common occurrence. Soe Yachт; for the other kind of

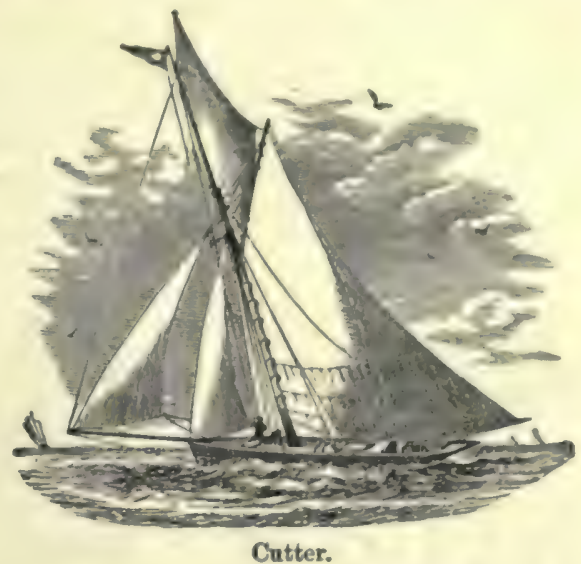

cutters, see BoAT.-In the United States, very long sleds, for coasting, are called cutters.

Cuttings are branches or portions of branches of trees or shrubs, employed to produce new plants, by burying the lower end in the earth so that new roots may arise from the nodes. Nothing is more easy than to propagate willows, fuchsias, pinks, geraniums, currants, gooseberries, \&c. in this way; but many other plants, commonly propagated by cuttings, require greater attention on the part of the gardener, warmth, a uniform damp atmosphere, and shade. The term cutting is, however, usefully extended by most horticultural writers to any part of a plant which can be separated to become an individual similar to its parent; thus some plants may be propagated most readily from simple leaves or portions of leaves, others from a segment of stem bearing a single leaf with a bud at its base, others from offshoots at the base of the parent plant, some again from the younger shoots, and others from partially ripened wool, and so on. Hence there is room for considerable experience and skill, and detailed instructions should be sought by the amateur florist in works on horticulture (e.g. Johnson's Dictionary of Gardening). The most convenient general method, however, is to strike cuttings in well-drained shallow pots or boxes of silver sand overlying a little sandy peat or loam shade and water being applied with diseretion, and bottom heat only in special cases, which of course include the majority of stove plants Hardy fruittrees may be best propagated by euttings taken after the fall of the leaf, and planted on the north side of a wall, but not so close as to be constantly in shade.

Cuttle-fish (A.S. cudele), strictly speaking, a member of the genus Sepia, more generally applied to any Cephalopod (q.v.). A brief account is herc given of the structure, life-history, and habits of the common British species (Sepia officinalis, Linn.), with a tabular indication of its relationships.

The Sepia (fig. 1) measures from six to ten inches in length, and its colour varies from pale gray to dark brown or neutral tint. The body is oval, flattened from above downwards, and contained in a tough muscular aac (mantle), which expands along the whole of either margin into a narrow fin. The integument consists of a single layer of cells, lving upon connective tissue, in which are imbedded 'chromatophores,' or cells charged with variously coloured pigment-granules. By expansiou of the cell the pigment is diffused, and by its cortraction concentrated, hence the rapid Hashes of changing 
colour for which the cephalopoda as a whole are so remarkable.

The head is broad, and contains a cartilage of complex shape which protects the central nervous system, and forms a socket on either side for the large eye; this has a bright green lustre during life, the black pupil is shaped like the Greek letter $\omega$, and there are two eyelids, the upper coloured, the lower white. The front of the head is oceupied entirely by the bases of the arms and the mouth. The former are ten in number, eight of

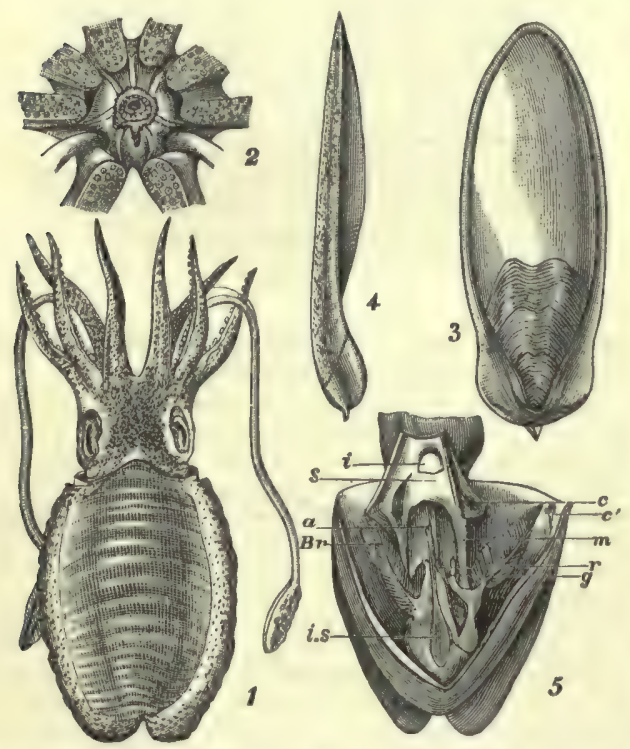

1, Sepia officinalis from the dorsal aspect; 2, view of the Mouth, showing its Lip and the bases of the Arms and Tentacles; 3 , the Shell seen from the ventral surface; 4 , the same in lateral view; 5 , the Animal with the Mantle divided in the middle line to expose the Branchial Cavity :

e, siphon; $i$, its valve; $c$, pit in the base of the siphon ; $c$, prominence on the mantle which fits into it; $m$, muscle passing backwards from the siphon to the mantle; $a$, termination of the intestine; $B r$, gill: $r$, renal opening; $g$, genital opening; $i$. s., ink sae. At the base of the right gill a portion of the membrane has been removed to show the branchial heart.

them being alike, oblong in transverse section and tapering off to slender extremities; they have the surface which is turned towards the mouth covered with suckers in four longitudinal rows. The suckers consist of a museular periphery, strengthened by a horny ring; a fleshy pad acts like a piston in the base of this latter. Each sucker is mounted on a short flexible stalk. The two remaining arms, known as 'tentacles,' occupy the interspaces between the ventral arms and those next to them. They are twice as long as the others, and have a cylindrical stem, slightly expanded at the extremity into a club farnished with larger and smaller suckers. They can be withdrawn into pockets situated beneath the eyes, and are carried in this position when not in use. The mouth (fig. 2), situated in the centre of the roots of the arms, is surrounded by a lip with seven prominent angles, which bear small suckers in some species, and have been compared to rudimentary arms. Projecting from it may be seen the two black horny mandibles, shaped like those of a parrot, but with the lower overlapping the upper.

On the lower aspect of the animal, between the muscular sac and the body proper which contains the viscera, is a hollow space, the 'branchial' or 'mantle-cavity.' When this is opened by a longitudinal incision it is seen to contain the following structures (fig. 5). Anteriorly is the base of the 'siphon,' or 'funnel,' $s$, a conical tube containing a valve, $i$, through which water can be forcibly expelled by the contraction of the mantle. At its posterior margin on either side is an almond-shaped depression, lined with cartilage, $c$, into which fits a prominence on the inner surface of the mantle, $v^{\prime}$, an arrangement which largely contributes to the solidarity of the body as a whole. Lying along the middle line is the terminal portion of the intestine, $a$, furnished with two small flap-like appendages of uncertain function, and on either side, a little farther back, is a small papilla, $r$, upon which the kidney opens, and on the left side only, the genital orifice, g. Two large gills, $\mathrm{Br}$, are situated in the lateral recesses of the mantle-cavity, each consisting of an arterial stem running up the attached side, and a venous stem passing down the other aspect, the bulk of the organ being made up of a series of folds passing transversely from one to the other, and richly supplied with vessels contrining the blood to be aerated. Respiration is carried on by rhythmic contractions of the mantle, in consequence of which water enters at either side, passes over the gills, and is expelled by the siphon; this takes place abont seventy times in a minute.

On the dorsal side of the animal, immediately beneath the integunent, is a closed sac which contains the internal shell (cuttle-bone, sepiostare, figs. $3,4)$. Speaking generally, this may be said to be of an elongated spoon or boat shape; it consists of a horny lamina, which gives it its characteristic outline, extending also into the small cone at the back, which in many species is much larger than in the one now under consideration, and has been compared with the guard of the Belemnites (q.v.). On the dorsal surface is a granular calcareous deposit; while the concave ventral aspect of the spoon is occupied by a series of layers of calcareous matter, which are deposited in succession and do not entirely cover each other, so that the hinder portion of this surface presents a striated appearance due to their parallel margins. This part of the shell is porous and extremely light, the interstices being filled with air. These shells are im. ported into Liverpool in some quantity, and ground into fine powder to form a dentifrice.

The Digestive Organs.-Within the beak above alluded to is a solid muscular mass (buccal cone), part of which is devoted to its movements. Through its centre passes the gullet, the lower wall of which bears a most remarkable organ, the toothstrap or 'radula;' this consists of seven longitudinal rows of horny teeth, which are secreted by certain special cells of the epithelium, and whose apices are directed backwards. They can be moved to and fro by appropriate muscles. Behind the buccal cone the osophagus bears the salivary glands, and still farther back it opens into $a$ round saccular stomach with muscular walls. A large bilobed gland, commonly called 'liver,' but having the functions of a pancreas, is situated on the œesophagus. Lying parallel to the terminal portion of the intestine is the 'ink-bag,' $i, 8$, a hollow gland opening near the anus, and furnishing a deepbrown fuid, which is ejected by the animal when alarmed in order to conceal its retreat. When genuine, the pigment known as 'sepia' is prepared from it.

The Circulatory Organs.-The heart is situated posteriorly, and consists of a pear-shaped sac which receives on either side a vein from the gills, dilated just before its termination into a muscular con. tractile antechamber or auricle. It gives off an artery anteriorly to supply the head and arms, and one posteriorly to the abdominal organs. The 
boond, after being distributed throughout the borly, is collected in veins which travene the walls of the kidneys and pericardium, and eventually pass to the gills, at the base of which a muscular dilatation (branchial heart) is situated, nerving to eflect the circulation of the blood through the gills.

The Nervous System consists of the three pairs of ganglia common to the Mollusea concentrated round the cosophagus. One pair (pedal) supplies the arms and siphon: a second (plenro-visceral) the gills, viscera, and mantle; a third (cerebral) the head and eyes. In the mantle on either side is a large nervous mass (ganglion stellatum) situated on the pleural nerve, and supplying the mantle. In addition to these parts, and connected with them, there is a system of so-called 'enteric' nerves, springing from the buceal ganglia, which lie on the vesopliagus just in front of the cerebral ganylia.

Of the Organs of Sense the eyes are the most conspicuous. They occupy depressions in the head cartilage, the hinder part of which is occupied by the optic ganglia, ocular muscles, and a white glandular substance of unknown function. The retina consists of an inner layer of rods with swollen bases, and an outer layer of nucleated cells with a limiting membrane between them. The retinal chamber is elosed in front by a spheroidal lens, made up of an inner and onter portion, which are secreted separately by an epithelial structure necupying a groove round its equator. In front of the lens is the iris, supported by a cartilage and containing a sphincter muscle; the outer surface of the whole organ is formed by the transparent cornen, which, though continuous in the Sepia, is perforated in the members of a large group of Cephalopoda (Egopsida).

The ears are a pair of small closed vesicles, imbedded in the head-eartilage, and supplied by nerves which, though apparently springing from the pedal ganglia, really have their origin in the cerebral. A ciliated pit, usually considered to be olfactory in function, lies behind each eye.

Generative Organs.-The sexes are separate. The testis and ovary are both single and situated in the hinder part of the body; the latter lies in the visceral sac or pericardium above deseribed, the former in an almost closed diverticulum of it. 'The eggs have a tough capsule, with a projection at one end and a kind of handle at the other by which they are attached in bunches to a twig of seaweed or other similar substance. As in the hen's egg, the proportion of nutritive to formative yolk is very large, and the embryo, as it develops, comes to stand head downwards on the former.

Habits. - The animals are found in littoral regions or in moderately deep water; ordinarily they rest horizontally on or near the bottom, the fins gently undulating, the tentacles retracted, and the arms depressed (see cut at Cephalopoda). Progression may take place by means of the fins with consider. able rapidity in either direction, the funnel being turned so that the stream of water issuing from it assists in propulsion; rapid darts backwards when the aninual is alarmed are brought about either by the sudden ejection of water through the siphon, or by spreading out and reuniting the arms. When feeding, the Sepia remains motionless till its prey is within striking distance; then the dorsal arms are raised, the others open out sideways, the tentacles are shot forth with the rapidity of lightning, and the victim seized between their terminal clubs (see cut at CEPHALOPODA).

Distribution. - Fifty-eight recent species of Sepia have been described, of which some forty or fifty may be regarled as valid. By far the greatest number belong to the Indo-Malayan region, whilst, with one doubtful exception, none occur on the shores of the New World. Abont a dozen fonsil forms have been recorded from Tertiary deposita For large and fabulous Cephalopods, nee OcTOPUs, SEA-SERPENT.

Cutty Stool. See Stool, or Repextaxcl.

Cutworm, a term used loosely of worms or grubs destructive to cabbage, beans, \&c.

Cuvier, the chief of modern comparative anatomists, the first to unite the palseontology of extinct forms with the anatomy of the extant, inportant also as an educationist. Leopold Christian Frédéric Dagobert Cuvier, better known by his adopted literary title Georges Cuvier, was born on the 24th August 1769, in the town of Montbeliard, at that time belnnging to Wuirtemberg. His ancestors were Proteatant refugees from the Jura. He was destined by his parents for the church, but early exlibited a predisposition for natural history. In his education at Stuttgart, he came under the happy influence of the botanist Kerner and the zoologist Kielmeyer. At the age of eighteen he became tutor in a fumily living near Caen, in Nornandy. There the abundant fossil Terebratule of the shore, the cuttle-fish and other molluses landed by the waves, excited his eager interest, and became subjects of close study. There too he was introduced to Geoffroy St-Hilaire and other Parisian savants. Genffiroy at once recognised his abilities, and invited him to Paris. Cuvier accepted the invitation, became first assistant, and then professor of Comparative Anatomy in the Jardin des Plantes. Elected a member of the French Institute in 1795, he became in 1803 permanent secretary of the Academiy of Sciences. In 1808 he undertook the reorganisation of public instruction, and shortly before the fall of Napoleon was admitted into the Council of State. After the Restoration he was made Chancellor of the Uni. versity of Paris. Afier a visit to England in 1818, where he was received with great honour, he was, in 1819, admitted into the cabinet by Louis XVIII. and in 1826 was made grand-officer of the Legion of Honour. His decided opposition to the royal measures for restricting the freedom of the press lost him the favour of Charles $X$. Under Louis. Philippe he was made a peer of France (Baron Cuvier) in 1831, and in the following year he was nominated Minister of the Interior. Then his career was terminated suddenly from an attack of paralysis of which he died, May 13, 1832.

Cuvier's life was characterised by extraordinary activity. In his plans for the extension and int. provenient of national education, in his efforts for the welfare of the French Protestant Church, and in his scientific work, he was alike zealous and indefatigable. On every hand he gave evidence of gigantic intellect, and of honest, resolute character. He was conspicuous for an unsurpassed grasp of conerete facts, rather than for originality of suggestion or power of generalisation, and remained a vigorous and formidable opponent of the Theory of Descent.

In several departments of zoologv, Cuvier's indefatigable industry and giant intelligence achieved grent progress. (1) By marvellous energy in cul. lecting, examining, and dissecting, he vastly incrensed the circle of acenrately known forms, both living and extinct. (2) This was done, however, in $\mathrm{a}$ way which combined depth of insight witl increasing breadth of view. He penetrated bolow external form to the internal structure, and not content with empirical dissection, rationalised his results in the first systematic comparative anatomy. His profound anatomical studies led him further to appreciate more clearly than heretofore the unity of the organiom and the mutual dependence of its parts. In olearly defining the principle of tin 
correlation of organs, he recognised, to quote his memorable words, that "the organism forms a connected unity, in which the single parts cannot change without bringing about modifications in the other parts.' (3) In his hands classification became more natural, being more thoroughly based on real similarities of structure, and less on superficial resemblances. He recognised the existence of four great types-Vertebrate, Molluse, Articulate, and Radiate, a classification independently confirmed by the embryological researches of Von Baer. Although his four types are now known to give a false simplicity to nature, the establishing of structural classification, followed out in his subdivisions, introduced a new order in the aninal kingdom. (4) Before his work, fossil forms had been very scantily known, and still less understood. His researches, however, especially among vertebrate remains, not only revealed an undreantof wealth of entombed forms, but disclosed to some extent the relation between the living and the dead. For the first time palreontology was linked to comparative anatomy, and the new contact brought fresh light. Yet it must be remembered that to him the Linnean dogma of the constancy of species seemed unassailable. Clear as he was in regard to the existence of fundamental and recurrent types, he was as determinedly opposed to the suggestion of Buffon, Lamarck, and others, that animals were connected by common descent.

Among Cuvier's more important works are the following : Lecons d'Anatomie Comparée (1801-5); L'Anatomie des Mollusques (1816); Recherches sur les Ossements Fossils des Qucudrupedes (1821-24); Discours sur les Révolutions de la Surface du Globe (introduction to the last); Histoire naturelle des Poissons (1828-49), written in concert with Valenciennes. Better known perhaps than any of these is the work which has passed through so many editors' hands-Le Regne Animal distribué d'après son Organisation (1817), more familiar in the enlarged and elaborated form which it received under the editorship of Cuvier's school. Important too for the history of zoology are numerous eloges and historic reports delivered on various oceasions throughout Cuvier's life.

See Mrs R. Lee's Memoirs of Baron Cuvier (Lond. 1833 ); Pasquier's Eloge de Cuvier (Paris, 1833); Carus's Geschichte der Zoologie (Munich, 1872); Haeckel's History of Creation (Lond. 1876).

Cuxhaven, a pleasant little German watering place, on the southern bank of the Elbe, at its mouth in the German Ocean, 72 miles NW. of Hamburg by rail. The port whence the Hamburg steamers ply when in winter the Elbe is frozen over, Cuxhaven has an old castle and a safe harbour. Pop. (1890) 4905-in summer doubled by visitors.

Cuyaba, the capital of the Brazilian state of Matto Grosso, occupies pretty nearly the centre of South Ameriea. It stands on the left bank of the Cuyabá River, 980 miles NW. of Rio de Janeiro. Founded by gold-diggers in 1719, and wrecked by an earthquake in 1746, it is now a well-built place, with a cathedial and 8000 inhabitants. It can be reached by the rivers Paraná and Paraguay, a voyage of 2500 miles from Buenos Ayres.

Cuyp, or KUyp, JACOB Gerritse, commonly called the Old Cuyp, was born at Dordrecht in 1575. Jacob Cuyp's representation of cows and sheep, battles and encampments, are clever, but his fame rests principally upon his excellent portraits. His colouring is warm and transparent his manner, free, and spirited. Cuyp was one of the four founders of the Guild of St Luke at Dordrecht, and died after 1649.-ALBERT CUYP, Jacob's son, was also born at Dordrecht, in 1620 .
He excelled in the painting of cattle grazing or reposing, moonlights, wintry landseapes, still waters with ships, horse-markets, hunts, camps, and cavalry-fights; and in rendering effects of warm golden sunlight he is without a rival. During his lifetime and long after, Albert's pictures, although in many respects equal to those of Claude, were held in little estimation. Opinion, however, has now changed regarding them, and a fine example of his art has realised over $\$ 5000$. England is particularly rich in his works, the National Gallery possessing eight of his subjects. He died at Dordrecht, 1691.-BENJAMIN CUYP, a nephew of Albert, was born at Dordrecht in 1608, and be. came a member of the guild there in 1631 . He painted biblical pieces in Rembrandt's style, and familiar scenes of country life. His best works are in the manner of Teniers. His aeashores have less repute.

Cuzco, a city of Peru, stands 11,440 feet above sea-level, in a valley of the Andes, 345 miles ESE. of Lima. It was the ancient capital of the Incas (in whose language, says Garcilaso, Cuzco signifies 'navel '), and at the time of its conquest by Pizarro (1533) had 200,000 inhabitants. Now it has only some 18,000, but it is one of the finest cities in the republic, with a cathedral (1572-1654), a so-called university (1598), and some remunants of Cyclopean architecture.-Cuzco gives name to a department, with 238,445 inhabitants. See PERU.

Cyanite, Kyanite (Gr. kyanos, 'blue'), DISTHENE, or SAPPARE, a mineral composed of alumina and silica. It often occurs crystallised, and generally in broad prisms. It is sometimes colourless, red, yellow, \&c., but more frequently of a fine sky-blue, slightly tinged with violet; it is transparent, and sometimes beautifully opalescent.

Cyanogen, $\mathrm{CN}$ or $\mathrm{Cy}$, although intrinsically of little importance, is one of the most interesting compounds of carbon. It was the first known compound body which was proved to be able to unite with elements in the same way as these substances unite with each other. Thus hydrogen, H, unites with chlorine, $\mathrm{Cl}$, to form hydrochloric acid, and sodium, $\mathrm{Na}$, unites with chlorine to form chloride of sodium, $\mathrm{NaCl}$. Like these elements, $\mathrm{H}, \mathrm{Cl}$, or $\mathrm{Na}$, each a single substance, the group $\mathrm{CN}$, consisting of 12 parts of carbon and 14 of nitrogen, enters into combination, acting as if it also were for the time being an element; thus it forms cyanide of sodium, $\mathrm{NaCN}$, or $\mathrm{NaCy}$, and hydrocyanic acid, $\mathrm{HCN}$, or $\mathrm{HCy}$. There are now many thousands of such radicals known, of which the groups methyl, $\mathrm{CH}_{3}$, ethyl, $\mathrm{C}_{2} \mathrm{H}_{5}$, \&c. may be taken as other examples.

Cyanogen is a colourless, poisonous gas, which burns with a purplish flame. It is soluble in water, and can be condensed to a liquid, under a pressure of about four atmospheres $(60 \mathrm{lb}$. per sq. inch). It may be obtained by heating the cyanide of mereury, $\mathrm{HgCy}_{9}$, when the cyanogen passes off in the gaseous state.

Cyanogen forms poisonous compounds with metals called cyanides, of which the best known is the cyanide of potassium, a salt of much importance in photography. With hydrogen it forms the deadly prussic or hydrocyanic acid, while it is united with oxygen in eyanic acid. For the pro. perties of cyanides, see HYDROCYANIC ACID.

Cyanic Acid, $\mathrm{HCyO}$, is a compound of eyanogen which can hardly be prepared in the free state, owing to its great tendency to decompose. It forms a class of salts called cyanates, of which the chief is the eyanate of potash, $\mathrm{KCyO}$, produced when cyanogen gas is passed into solution of potash? - For the cyanide process of gold-extraction, see Potassium. 
Cyano'sls ( Cir. kyonos, 'blue '), lividity of eomplexion, with fullness of the capillaries and minute veins, especially of the face and lips. A name charncteristically applied to the colour in certain cases of congenital disease or malformation of the heart. See HEART.

Cyanotype is a photograph obtained by the nse of a cyanide. See Photography.

Cyathea. See Trez-FER.

Cybele (called also Agdistis and Dindymène), an ancient goddess whose worship was universal in Phrygia, and widely spread in Western Asia as that of 'the great mother' or 'the niother of the gods. She seems to have been a nature divinity, whose worship was attended with wild orgiastic rites, many of which were adopted by the Greeks from the eastern nations. The Greeks, moreover, identified the oriental Cybele with their ancient earth goddess Rhea, whose worship seems to have originated in Crete, where she is associated with the Curetes. Among the Romans she was considered as identical with Ops, the wife of Saturn, and mother of Jupiter. In Phrygia her priests were the Corybantes, who worshipped her noisily with drums, cymbals, and horns, dressed in full armour. The Roman priests of Cybele were often called Galli. In art Cybele is usually represented seated on a throne, adorned with a mural crown, with lions erouching to the right and left, or sitting in a car drawn by lions. See RHEA.

Cyeads, or CyCADACE , an order allied to Coniferos (see GYMNosPERMs), but in vegetative appearance rather resembling ferns and palms. The stem, which is externally covered with leafscars, may be so short that the crown of leaves arises little above the surface of the ground; more frequently, however, it rises to a height of a few feet, then resembling a tree-fern; and in exceptional cases (e.g. Cycas media of Australia) may

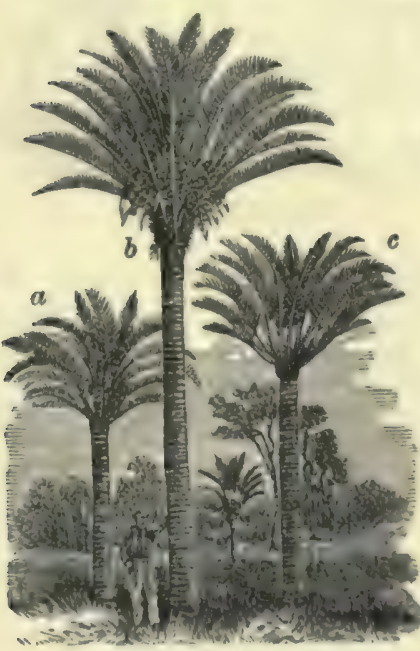

Fig. 1. attain a height of 50 or 60 feet. The foliageleaves, which develop under the protection of reduced budleaves, are usu. ally pinnate, and mostly parallel-veined; but in Cyeas we have a middle vein only, and in the curiously fern-like Stangeria a mid-vein with lateral branches. The leaves are always of more or less leathery consistence, and sometimes bo come very hard and spiny at the a, Cycas Nornanbyana; $b, c$, Cycas media. tips and on the edge. In Cycas the pinnas are circinate in bud as in ferns, although the midrib is straight: conversely in Zamia, the leaf itself is inrolled, although the pinne are straight; in others, however, where both are straight, the pinnve overlap each other from above downwards, as in the moon-wort fern (Botry. clium). The stem is of complex internal struc. ture, but is thickened by permanent cambium. It may hear lateral bude on the axils of old leaves. especially in unhealthy plants; and these may fall off and propagate the plant. In some cases, bow. ever, we have an apparent dichotomy, although probably due to branching. Uichotomy of the roots has also been deseribed; this, however, not as a normal development, but due simply to irrita. tion by a fungus-mycelium or a nostoe-like alga, which commonly invests the root, and even pene. trates the tissue (see SYмBiosis). Yet among those who admit the pathological nature of this, some still regard it as an atavistie reappearance, the last surviving trace of the dichotomy eo com. mon among the ancestral cryptogams (see FERNs, LYCOPODIACEA ).

The exceedingly primitive flowers are found on separate plants, and are respectively composed simply of staminate or pistillate leaves, in both cases usually spirally aygregated as cones. The stamens are reduced and undivided leaves hearing on their dorsal surfaces a usually indefinite number of pollen-saes, so furnishing a perfectly intermediate form between the sporangium-bearing frond of a fern and the stamens of higher plants. The pollen-grains show a very distinct remnant o the male prothallium.

Passing to the female flowers, we find those at least of Cycas to be terminal on the axis, which
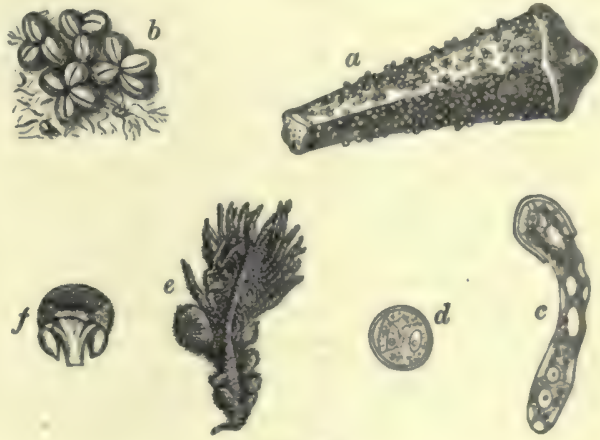

Fig. 2.

$a$, Stamen of Cycas circinalis, under surface; $b$, group of pollensacs (Microsporangia); $d$, pollen-grain of Ceratoramia ; $a$, the same germinating; e, carpellary leaf of Cyous revoluta, with lower pinne reduced and bearing ovules; $f$, stamen of Zavia integrijolia.

after flowering resumes vegetavive growth, a condition which occurs only as an anomaly or rever. sion in higher plants (e.g. proliferous roses). The separate carpellary leaves retain more or less distinct traces of vegetative character; thus in Cycas the ovules (microsporangia) represent the reduced lower pinnse; more frequently, however, only two are developed (Zamia, fg. 2); but the carpellary leaf is always open, and shows no trace of that still more precocious development of its ovules and arrest of its opening altogether, which would give us the ovary of the higher flowering. plants (see Ovary). On ripening, the cone may fall to pieces, liberating the ovules; in the simpler Cycas the separate naked seeds become molified and enlarged into large fruit-like bodice, with an outer fleshy and an inner stony wall. The nucellus is crushed into little apace by the growth of the endosperm, which contains the straight embryo with its one (Ceratozamia) or two, often nnequal (Cycas, Zamia), cotyledons.

The more vegetative character, both of the flowering axis and of the carpellary leaves, which dis. tinguish Cycas from all the other genera, explains the separation of the orler by systematists into Cycadere and Zamies. Among the latter, Stangeria of Port Natal is at once distinguished by its pinnate venation; and Bowenia of Queensland by its bipinnate 
leaves. Dioon (Mexico) is characterised by the origin of its ovules on cushion-like modifications of the two parent pinnze, instead of being simply sessile as in the remaining genera, which are merely distinguished by slight differences in the shape of their cone-leaves. The thirty species of Zamia range from Mexico into the Antilles and far into South America. Ceratozamia is Mexican, and Microcyças Cuban, while Macrozamia is distributed over Eastern Australia, and Encephalartos is characteristically South-east African. But the widest distribution is that of Cycas itself. The best-known species, C. revoluta of Japan, is not only widely found both wild and in cultivation in many parts of the Old and New World, but C. circinalis of the East Indies, C. media and Normanbyana of Australia, C. Seemani of the Fijis, may also be mentioned as of importance.

Schimper enumerates no less than thirty-four fossil genera, with 278 species. The group appears to have attained its maximum in Triassic and Jurassic times. They are familiar to English palreontologists in the Lias and Oolite especially.

The stem of many cycads contains an abundant starchy deposit, which is used as food in many countries. It resembles sago, and so has frequently led to the confusion of cycads with the true Sagopalms (q.v.). C. revo'nta yields a coarse sago in Japan and elsewhere; trom Dioon edule a kind of arrowroot is prepared in Mexico, and from Zamia pumila, \&c. in the Antilles and Florida; while Encephalartos is often called Kafir Bread.

Cyc'lades. See Archipelago.

Cyc'lamen, a genus of Primulacer, including about eight highly variable species, mostly natives of southern Europe. Their thickened and compressed perennial stem half immersed in the ground, their heart-shaped leaves, peculiarly twisted and reflexed corolla-lobes, and spirally reverted fruit-stalks give the genus a peculiar and highly characteristic appearance. They are commonly cultivated on account of the beauty of their flowers: which mostly appear in spring. C. persicum is the

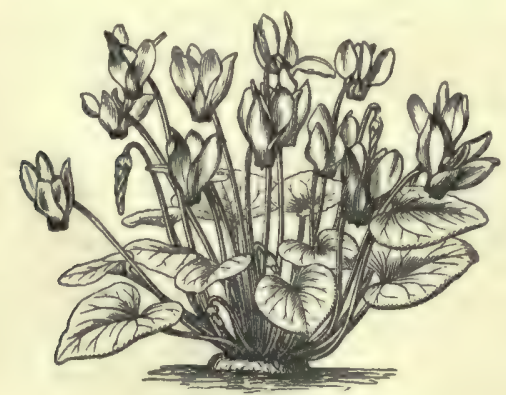

Cyclamen persioum.

one chiefly grown in our conservatories; $C$. europoum, not uncommon in gardens, flowers in autumn. The turnip-like stem, despite an extreme acridity which long gave it medicinal repute, is largely eaten by swine in southern Europe, especially Sicily; hence the English name of Sowbread.

Cy'cle (Gr., 'a circle'), in Astronomy and Mathe. matical Chronology, a period or interval of time in which certain phenomena always recur in the same order. There are two great natural eycles, that of the sun and that of the moon. The solar cycle is a period of twenty-eight Julian years, after which the same days of the week recur on the same days of the year. The lunar or Metonic cycle consists of nineteen years or 235 lunations (see CHRONOLOQY), after which the successive new moons happen on the same days of the year as during the previous cycle. The number of the year in the cycle of the moon is called the Golden Number (q.v.). The cycle of Indictions (q.v.) is purely arbitrary, its years being fifteen, a conventional number; and the Julian Period, which combines and harmonises all the three others, might be termed the cycle of cycles. The term 'cycle of eclipses' is an instance of the more general use of the word, meaning the period of 223 lunations, within which seventy eclipses recur in the same order and magnitude-viz. twenty-nine of the moon and forty-one of the sun.

Cycling. The early history of cycling-in which generic term the use of all classes of manuand pedo-motive carriages is now by general consent included-is, like that of ancient Britain, involved in obscurity. As long since as 1818 something in the nature of a bicycle was introduced into England by Baron von Drais, a Frenchman resident at Mannheim, and was known as the Draisnene or Célérifère; while velocipedes or manumotive machines with three or more wheels were in occasional use in England even before that date, one of the earliest being an invention of Richard Lovell Edgeworth (circa 1767). The Draisnene consisted of two wheels, about 30 inches in diameter, running one in the wake of the other, and connected by a beam of wood, upon which, midway from each end, was placed a saddle or perch. At the fore-end of the beam an arm-rest was secured, and this, roughly completed the apparatus. The mode of propulsion was singularly simple: the rider placed his leg over the beam, got into the saddle, and, resting his arms upon the support

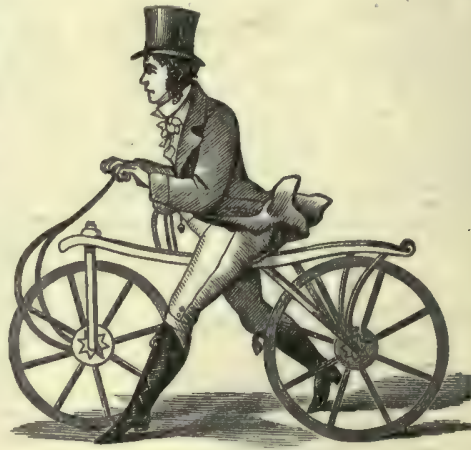

The 'Dandy-horse.' referred to pushed the 'dandy-horse' ahead by kicking the ground with his right and left foot alternately; when a certain impetus was attained, he could, were he a skilful rider, cease the kicking process, and allow the machine to proceed until the momentum was exhausted, when he had to commence de novo. The satire of Cruikshank and his contemporaries effectually killed the quaint and comical holliy-horse of 1818 .

The fashioning of the first practical bicycle (circa 1846) is currently credited to Gavin Dalzell, a cooper at Lesmahagow in Lanarkshire. It went by the name of the 'woorlen horse,' being constructed chiefly of wood; the saddle was low, and the pedal movements or 'stirrups,' which moved backwarls and forwards alternately, were connecter by iron rods with the cranked uxle of the driving. wheel. But it seems that Kirkpatrick Mremillun, a blacksmith in the parish of Keir, Dumfriesshire, was six years earlier on the road with a hobby-horee completely equipped with cranks and levers.

The next revival of cycling may. be said to date from 1867. A few years previous to this it occuryed to an inventive genius, one M. Michaux, to fit to the hobby-horse a pair of pedals by which the front wheel might be revolved with the feet. This, of course, meant that the rider must depend for his balance upon some means 
whereby the relative positions of the two wheels might toe vuriesd at will; in other words, sume methorl whereby the buse of the machine might be clanged at plensure. To this end, a transverse handle was affixed to the front wheel, which asmitted of its being turned even to a right angle. This new-eomer was known as the bicycle, but is now irreverently alluded to in all quarters as the 'boneshaker' - probably because it was made of wood, and shod with iron tyres insterd of rubber, while springs were often conspicuous by their absence.

The boneshaker craze was a serious one; it affected all classes of society, but chiefly - in con. sequence of the cost of the article-the middle and upper ranks; in witness whereof, the illustrated papers of 1867-69 contained more than one wood. eni showing the Prince Imperial upon his boneahaker in the Tuileries. One of the earliest of Michaux's bicycles found its way to $\mathrm{Mr}$ Charles Spencer's gymnasium in London in 1868. So little was to be gained, and so much was to be lostparticularly in the way of appearances-by 'boneshakerism, that in a few years it promised to become a lost art, when, happily, the inventive genius of an Enerlishman, whose identity is open to question, supplied the missing link-the rubber tyre-which, with the suspension wheels and steel framing introduced at a later period, made the modern bicycle. From the bicycle the tricycle was early evolved, chiefly through the instrumentality of James Starley (died 1881), of Coventry ; a further impetus was given by the pneumatic tyre, and now the types of machine are practically endless.

The utility of the cycle is proved beyond all question. It is asserted on the best authority that a person of average capalilities can upon it travel at least three, and frequently six, times as far as he can walk in a day, and this with even less fatigue; while the possibilities of the machine in able hands will he admitted, when it is pointed out that a nile has been ridden upon a bicycle in less than two minutes and a half, and that 32 miles have been traversed in an hour, 616 miles in the 24 hours, on the racing track. The twenty-four hours road record is in England 414 miles; in Scotland, $314 \frac{1}{2}$ miles; and in Ireland, 248 miles. The rom from Land's End to John o' Gront's - roughly, 900 miles by road-has been accomplished in three days four lours forty-six minutes!

But the utility of the eycle is further proved by facts other than those given; it has become the poor man's carriage, and the rich man's hobby in more senses than one. Royalty disports itself, at anyrate in quasi-publicity, upon it, and the nobility and gentry make no seeret of their love of the wheel. Clergymen visit their parishioners; medieal men their patients; and tens of thousands of the middle classes transact their business or follow their pleasures by its means; while it is next to impossible to pass through any of the streets of our chief towns withont seeing that the cycle, in some one of its numerous shapes, is ably ministering to the wants of the community. It was estimated that in 1895-96 the anmual British ontput was about 750,000 machines, while that of America was already over 1,000,000. Cycle-making has become a very important industry.

So general has cycling become, that there are in existence in Great Britain alone at least twenty cycling publications, varying from weeklies to annuals, while roadbooks and handbooks innumer able have already been put npon the market.

As with most other sports or pastimes, eycling in strong in a clubdom of its own. Hundreds of local clubs exist in different parts of the country, while acting in concert with them is the largest of all, the Cyclists' Touring Club, whose headquarters are at 47 Vietoria Street, London. The C.T.C., as it is familiarly called, was not the forerusner of the local clubs to which reference has been made, for some of these existed three or four years before it, but it was called into existence in 1878 for the purpose of encouraging and promoting touring, as its name implies. To this end it has appointed at one fixed tariff some hotel-often the leading onein every town as healquarters. It has also appointed a member in nearly every town to act as consulin other words, to be a guide to visiting elubmen ; in addition to which it has nominated the most competent mechanic the place possesses to repair machines at moderate prices in case of breakage. By the introduction of a specially suitable and durable uniform; by the compilation of roadbooks and maps for the Continent, as well as for Great Britain; by agitating for better roads, for fingerposts and milestones; and in countless other ways it has benefited cyclists and cycling; and that its programme is popular, will be apparent when it is explained that it at present possesses orer 45,000 members. It publishes an official Gazette, which, consisting of some forty to fifty pages, is sent gratis to every member once a month, as well as an ofticial handbook with full details of the arrangements made in the different parts of the country for the convenience of its members. The benelits of membership are all obtainable for a nominal sum annually. The C. T. C. is international in its character, nearly a dozen prosperous divisions having already been established in the United States, in Canada, and upon the Continent.

Cycling possesses also a. National Cyclists' Union that looks after the legislative side of the sport; that frames and endeavours to uphold the amateur lefinition; that pledges itself to oppose the introduction of prohibitive restrictions; that holds the amateur championships; and that in many other ways does a large amount of good for wheeldom. The headquarters of this body are at 57 Basing. hall Street, London, E. C., and the sulscription for nembers not belonging to a local club affiliated en masse is five shillings. There are hranches of the N. C. U. in Scotland, and Ireland has its Cyclists' Association.

For many years cycling was practised in England in the face of much ridicule from the general public, and hostility from other sections of the road-using community; while ingress to the parks was denied its votaries. These prejudices have, however, happily been overcome; by the instrumentality of the C. 'T. C. and the N. C. U. before referred to, nearly all these restrictions have been removed, and, speaking broadly, a cycle is at liberty to enter and use the inclosures to which other public vehicles are given access Similarly, through the exertions of the C. T. C., the powers hitherto possessed by courts of quarter session and corporations under the Highways Amendment Act of 1878, and the Municipal Corporations Act of 1882, have by the Local Government (England and Wales) Act, 1888, been taken from them. Cyeles have been declared to be carriages within the menning of the Highways Acts, entitled to all the benefits, and subject to all the penalties (taxpaying excepted) applicable to other carriages, while the anomalous and conflicting bylaws hitherto in force were, on 1st April 1889, superseded by a statute law which runs as follows:

Local Government (England and Wales) Act, 1888, sect. 85. - (1) The provisions of sect. 26, subsect. 5, of the Highways and Locomotives (Amend. ment) Aet, 1878, and seet. 23, sub-sect. 1, of the Municipal Corporntions Aet, 1882, in so far as it gives power to the council to make bylaws regulating the use of carriages herein referred to, and all other provisions of any other public or private acts, 
in so far as they give power to any local authority to make bylaws for regulating the use of bicycles, tricycles, velocipedes, and other similar machines, are hereby repealed; and bicycles, tricycles, velocipedes, and other similar machines are hereby declared to be carriages within the meaning of the Highway Acts; and the following additional regulations shall be observed by any persan or persons riding or being upon such earriage: $(a)$ During the period between one hour after sunset and one hour before sunrise, every person riding or being upon such carriage, shall carry attached to the carriage, a lamp, which shall be so constructed and placed as to exhibit a light in the direction in which he is proceeding, and so lighted and kept lighted, as to afford adequate means of signalling the approach or position of the carriage. (b) Upon overtaking any cart or carriage, or any horse, mule, or other beast of burden, or any foot-passenger, being on or proceeding along the carriage-way, every such person shall, within a reasonable distance from and before passing such eart or carriage, horse, mule, or other beast of burden, or such footpassenger, by sounding a bell or whistle, or otherwise, give audible and sufficient warning of the approach of the carriage. (2) Any person summarily convicted of offending against the regulations made by this section, shall, for each and for every such offence, forfeit and pay any sum not exceeding forty shillings.

Cycle-racing, by both amateurs and professionals, has developed into a fine art, and bids fair to rival in popularity all but horseracing. Cinderpaths specially constructed for the purpose exist in nearly all the more important centres, and amateur race meetings are of frequent occurrence during the summer season; but Leicester, Wolverhampton, North Shields, and Coventry are the places chiefly noted for contests among the professional fraternity.

The practice of camping out under canvas is one which seems to have commended itself to cyclists in a marked degree. The habit originated at the North of England Cyclists' Meet, held annually at Harrogate; and it has been perpetuated not only by Northerners, but by Southerners as well, the latter usually selecting Mid-Surrey as their camping ground.

Apart from the marvellous modern records to which previous reference has been made, some notable distances were covered even upon the earlier and more imperfect forms of machines. Among them should be mentioned the one from London to Bath by David Stanton, who was credited with covering the 106 miles in 8 hours 28 minutes on the 17th August 1874, as also the year's record of $\mathrm{Mr} \mathrm{E}$. Tegetmier of the Belsize Bicycle Club, London, who claimed to have ridden over 10,000 miles in a single season.

The development of the pastime of bicycling in all classes of the community, ineluding ladies, was especially marked in 1895-96; and this led to a rapid increase in the number of companies for manufacturing bicycles, or parts of them. In 1896 alone companies with a capital of $£ 11,000,000$ were floated in Britain-one of them, the Dunlop Pneumatic Tyre Company, with a capital of $£ 5,000,000$. The Americans, though comparatively late in entering the field, had by 1897 incrensed their export of bicycles to $\&$ value of about $£ 1,000,000$ a year. Chainless driving gear and English and American roller gear were being cautiously introduced; bamboo spokes and aluminium machines were no longer novelties; machines constructed on the cantilever principle were in use, hardened paper for bicycle tube frames were commended. As against many of the chainless cycles, it is alleged that by the bevelled cog-wheels friction is increased, while the ore wheel is spread or pushed away from the other. One kind of chainless machine is worked by means of roller-bearing pegs, which engage each other at right angles; another by means of a self-coiling and self-uncoiling band from the driving sheave to the driven sheave (both smooth like belt sheaves), the ends of the band being screwed to the sheaves. The longpronised electric tricycle has not yet appeared, the difficulty being the inevitable weight involved in carrying a series of accumulators (but see T'RACTION-ENGINES)

The crypto-dynamic gear manufactured by the Crypto Cycle Company (serviceable on rough roads and on steep gradients) marvellously lightened the labour of eycling in the case of elderly persons and invalids, but as a rule a muscular rider is content with one speed affixed to a light machine, upon which he is able to make even better progress than upon the necessarily heavy crypto-geared article. A simple method of ascertaining how a machine is geared is to nultiply the diameter of the drivingwheels by the number of teeth in the lower cog. wheel, and then divide by the number of teeth in the cog upon the main axle-e.g. a 40-inch wheel has twenty teeth upon its lower cog-wheel, and fifteen upon the upper; this gives a gearing of $53 \mathrm{~b}$ inches.

'Trick riding' is an art which American riders assiduously practise, and in which they naturally excel; so much so, that many "professors' thereof have from time to time visited Great Britain and continental Europe to exhibit their prowess to the multitude. Trick riding aside, however, it is generally conceded that the typical Englishman makes the most enthusiastic cyclist; partly because the bicycle was first systematically made and ridden here, and partly because he possesses an inbred love of athleties. Coventry, Birmingham, Nottingham, Wolverhampton, London, and to a smaller extent other important places, are interested in the manufacture of machines, while the first named has happily been enabled to sub. stitute for the fast-decaying or depressed industries of ribbon-weaving and watchmaking, for which she was long celebrated, the designing and manufacturing of cycles, which find employment for thousands of liands. The Pneumatic Tyre Company is said to be able to turn out about 12,000 tyres per week.

The types of machines in current use are the ordinary bicycle, the dwarf rear-driven safety bicycle or some modification thereof, the front-steered tricycle, the carrier or tradesman's tricycle, tandem bicycles, both ordinary and dwarf, tandem front-steered bicycles, and invalid pedo-or manu-motive cycles ; but numerous machines coming within none of these categories are met with from time to time. The fashion in this respect has necessarily changed with great rapidity, seeing that it is only within the last few years that really skilled and competent engineers and mechanics have turned their attention to the perfecting of the cycle. The numerous improvements, together with the impracticable ideas of the ever-present visionary, are generally shown annually at the Stanley exhibition, a fixture which takes its name from the London club bearing this title.

Among recent developments in connection with the cycle have been its adoption by some of the leading London dailies to convey special editions to the various railway termini, and the use of the cycle by the postal authorities; while pregnant with much greater import to all concerned is the official adoption of the two-wheeled machine by the military authorities. With this object in view, the various volunteer corps at present in existence 


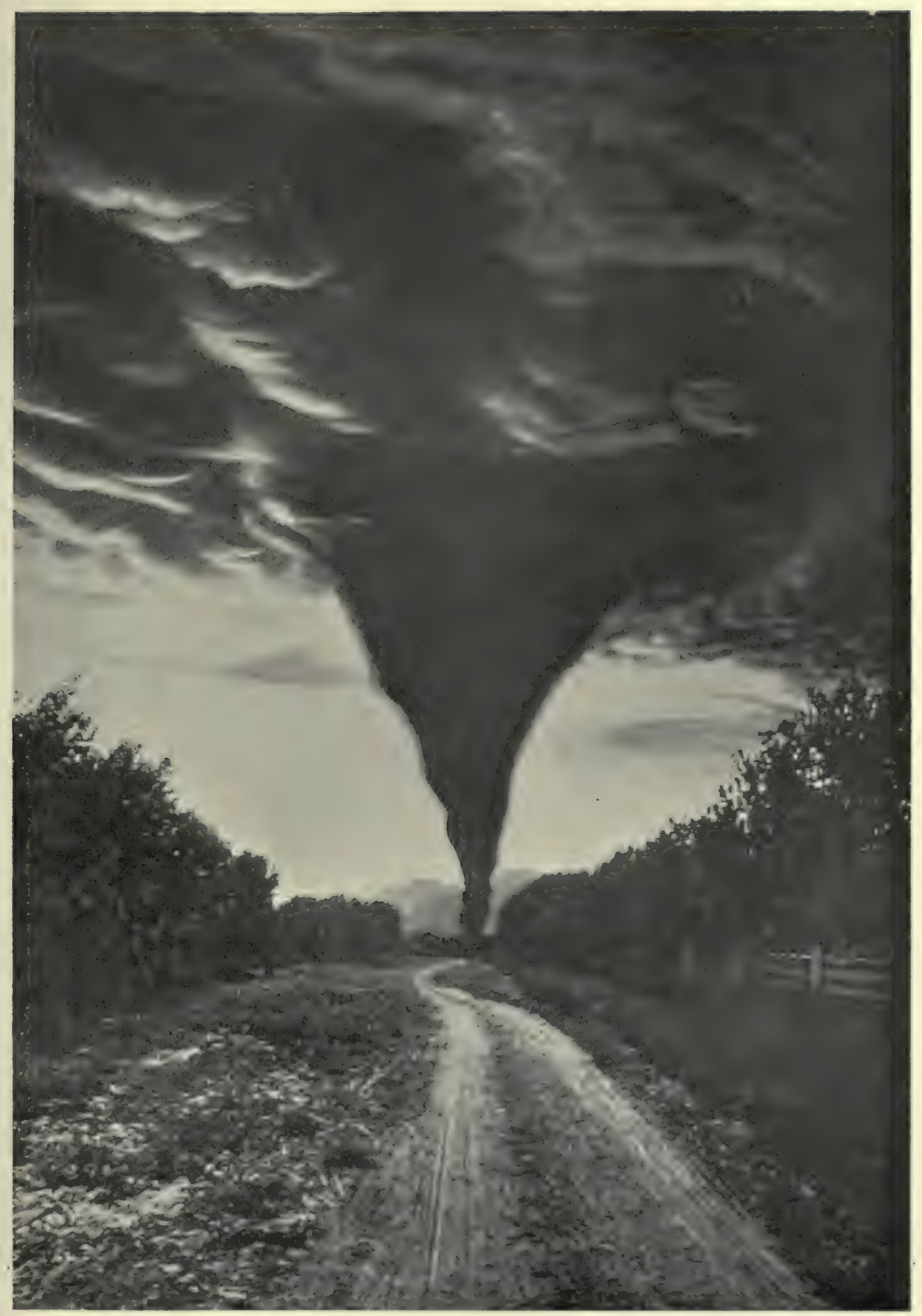

Vol. III., page 639.

CYCLONE, OKLAHOMA. 

were in 1887 anthorined by the War Office to form eycle contingents within their ranks, while a special cycliat corps, known as the 26th Middlesex, lias been culled into existence. These various formations ean hardly be eonsidered to have as yet wos the place they seem destined to oceupy, but they have sufficiently demomatrated their capabilities to cause the highest military authorities to entertain a very hopeful opinion of their value in the near future.

In America, where cycling is becoming increas. ingly pupular, there are a large number of flourishing cyclist clubs in the large cities, such as New York, Brooklyn, Philadelphia, Chicago, and Washington; and the club-houses there are more complete and better equipped than in Great Britain. Une American eyclist is credited with having ridden 8000 miles in a year, and another 7000 miles. Mr Thomas Stevens, starting from San Francisco on the 22d of April 1884, travelled to Boston, then shipped to England, again embarked for the Continent, and passent thromgh Cermany, AustriaHungary, the Balkan Peninsula, Asia Minor, Armenia, Persia, Afglianistan, Inllia, anil China, whence he sailed for his starting-point. 'This was a ride oceupying three years, and involving an enormous amount of endurnce, pluck, and energy. Two American students, T. Allen and L. Sachtleben, oceupied three years in riding round the world, 15,044 miles. The popularity of cyeling has led to proposals for a tax on cycles; in France $£ 80,000$ a year comes from this source.

Cycling, if rationally pursued, is so exhilarating and healch-giving that leading medical men recommend its adoption by both sexes in nearly all cases where organic disease is absent.

See Cycling, by Viscount Bury and G. L. Hillier (Badminton series; new ed. 1895); Spencer's Bicycles and Tricycles, Past and Present (1883), and his Cycle Directory; Sir B. W. Richardson's Tricycle in Relation to Health and Recreation (1885); Stahles's Henlth upon Wheels (1885); Plensures and Adrantanes of Cyoling (1887) : Mecredy and Stoney, Art and Pastime of Cycling (2d ed. 1893); Stevens, Around the World on a Bicycle (1887): Baudry de Saunier, Histoire Generale de la Velocipede (1891); Hillier and Bramson, Amateur Cycling (1893); O. Jennings, Cycling and Health (new ed. 1893); Allen and Sachtleben, Across Asia on a Bicycle (New York, 1894): A. C. Pemberton, The Complete Cyclist (1897); Bicycles and Tricycles, an Elementary Treatise on their Conatruction, by Archibald Sharp (1897); the C.T.C. Road Books and Inglis's Contour Road Books (1896-97).

Cy'cloid (Gr., 'circle-like'). If a circle roll along a straight line in its own plane, any point on the circumference describes a curve which is called a cycloid. This is the most interesting of what are called the transcendental curves, both from its geometrical properties and its numerous applications in mechanies. In dynamics, for example, we find that a heavy particle descends from rest from any point in the are of an inverted cycloid to the lowest point in the same time exactly, from whatever point of the curve it starts. This is sometimes expressed by saying that the cycloid is the isochron. ous (Gr., 'equal-time') curve. The body having

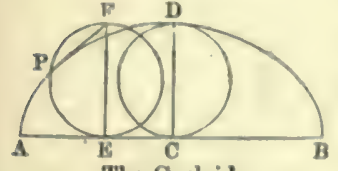

The Cyoloid. reached the lowest point, will, through the impetus received in the fall, ascend the opposite branch of the curve to a height equal to that from which it fell, and it will employ precisely the same time in ascend. ing as it did in descending. It is clear that if a surface could be procured that would be perfectly smooth and hard, the cycloid would thus present a solution of the perpetual motion. The line AB, which is called the base of the cycloid, is equal to the circumference of the generating eircle; the length of the curve ADB is four times CD, the dianeter; the evolute of any cycloid is a similar curve of equal length; and the surface between the curve and its base is three times the aren of the circle CD. In any position EPF of the generating circle, $\mathbf{A E}$ is equal to the are $\mathbf{E P} ; \mathbf{P E}$ is the normal at $\mathbf{P}$ and $=$ half the radius of curvature; $\mathrm{PF}$ is the tangent to the curve at $P$.

Cycloid-scales, fish-scales with a round untonthed posterior margin and concentric lines parallel to the latter. See Scales, Fishes.

Cyclone ( Gr. kyklos, 'a circle'), a circular storm of yreat foree, which, extending over an area of perhaps 500 miles, and revolving round a calm centre, advances at the rate of from 20 to 30 miles an hour. See STORMS.

Cyclopadia. See Encyclopada.

Cyclo'pes (Gr. leukloppes, 'the round-eyed '), in the incoherent traditions of a gradually developing mythology, fall into three groups. (1) The Homeric Cyclopes, a wild, lawless, and impious race of giants, inhabiting the sea-coasts of Sicily, the most prominent of whom is Poly phemus (q.v.). Althongh Homer does not directly call them one-eyed, yet he expressly terms Polyphemus such, and the later poets attribute his peculiarity to the rest. (2) The three Cyclopes mentioned by Hesiod: Brontes, Steropes, and Arges, each having one eye in the middle of his forehead; these were sons of Uranus and Gra, belonged to the race of Titans, and forged thunderbolts for Zeus. Hurled into Tartarus by their father, but delivered by their mother, they helped Kronos to usurp the government of heaven. Kronos, however, in his turn, threw them back to Tartarus, from which they were again released by Zeus, whose servants they now became. Finally, they were slain by Apollo, because they forged the thunderbolt with which Zeus killed Esculapius. Later tradition placed their workshop in Mount Etna, or in the volcanoes of Lemnos and Lipari, and made them the slaves of Hephrestus. (3) The Cyclopes mentioned by Strabo as a people who had come from Thrace or Lycia to Argolis, and were distinguished for their skill as builders.

Cyclopean Walls is a name given to masonry built of large, irregular stones, closely fitting, but unhewn and uncemented. They were attributed to Strabo's Cyclopes, who were probably mythical, and many of them still exist in Greece (as at Mycenae and Tiryns), Italy, and elsewhere. More probably the so-called Crelopean walls were built by some ancient race, perhaps the Pelasgians (q.v.), at a period long anterior to the historical civilisa. tions of Greece and Rome.

Cyclops, a genus of small fresh-water crustaceans, type of a family (Cyclopidæ) in the order Copepoda. They are popularly included under the wide title of 'water-fleas. Various species are common as active swimmers in fresh.water pools or slow. flowing brooks, and a few forms have heen recoriled from the ser. Like other copepods, cyclops has an elongated body, without a shell, with four forked thoracic feet and a five-jointed abdomen. The head-region is not distinct from the first ring of the thorax; there is a pear-shaped segmented body and a long abdomen; both pairs of antennre are long, and in the male the anterior pair form claspers; the mandibular and maxillary palps are legenerate; and a heart is said to be awsent. The average length of the commonest species is from 2 to 3 millimetres; the males are generally smaller than the females. A very marked fenture, to which the name refers, is the single median eye, usually bright crimson and sparkling like a gem; 
and not less noticeable are the two large egg-bags carried by the females. They eat both animal and vegetable matter, and are very prolific. See CRUSTACEA, WATER-FLEA.

Cyelop'teris, a genus of fossil ferns met with in Devonian and Carboniferous strata. The leaflets are somewhat rounded or wedge-shaped, and have no midrib, the nerves spreading from the point of attachment.

Cyclorama. See Panorama.

Cyclosis (Gr., 'circulation'), the name employed to designate certain movements of the contents of cells in plants. See Vegetable Physiology.

Cyclostomata (literally, 'round mouths'), a class of vertebrates often included along with fishes, but separated from them by some fundamental divergences. Hag-fish (Myxine) and Lamprey (Petromyzon) are the two most familiar examples, and are types of the two orders into which the Cyclostomata (or Marsipobranchii) are divided.

Cydnus, a river of Cilicia, rising on the south side of the Taurus range, and flowing through a rich and level country, past the city of Tarsus, and a broad lagoon, now choked up with sand, into the sea. Its water was famous for its clearness and coldness, and was supposed to be efticacious against gout and nervous diseases. Alexander nearly lost his life through an illness brought on by bathing in it when overheated.

Cydonia. See Quince.

Cygmet, a young Swan (q.v.).

Cylinder (Gr., 'a roller'), a well-known solid whose cross-section at any point of its length gives always the same circle; or, mathematically, a solid generated by the revolution of $a$

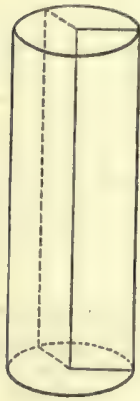
rectangle about one of its sides, which line is called the axis of the cylinder. That, the typical cylinder, is frequently called right, and if cut by two parallel planes not perpen. dicular to the axis, the result is an oblique cylinder, with elliptical ends or sections. The term has also been generalised to include a solid generated by a line moving parallel to a fixed direction while tracing any fixed closed curve. In all cases the content of the cylinder is found by multiplying the number of square units in the base by the number of linear units in the altitude, which is the perpendicular distance between the two ends. The area of the convex surface is equal to the product of the circumference of the end, and the length of the generating line. To this must be added the areas of the two ends, to get the whole surface of the eylinder.

Cyma. See Mouldings.

Cymbals are a pair of thin round metal plates, with a hollow part in the centre, in which a leather strap is fastened for holding in the hand. They are instruments of percussion, which, when struck one against the other, produce a loud harsh sound of no fixed pitch. They are of very ancient origin, and were used by the Greeks in the worship of Cybele. The best eymbals are those made in Turkey and in China. Attempts to discover and imitate the composition of the metal have all failed, the nearest approach to . it hitherto discovered being an alloy of 80 parts of copper to 20 of tin. The cymbals generally play the same part as the bass drum, and in orchestras they are played on by the same performer, one cymbal being fixed on the drum, the other held in one hand, while the other hand wields a drumstick. Cymbals are, however, essentially military instruments.
Cymbeline, an ancient king of Britain in a well-known play of Shakespeare called by his name. By his first wife he had a daughter, Imogen, who married Posthumus Leonatus. His second wife had, by a former husband, a son named Cloten. Shakespeare borrowed the name from the half-historical Cunobelinus in Holinshed's Chronicle, of whom several coins are extant.

Cyme, a term employed in Botany to designate those forms of inflorescence which are definite or centrifugal-i,e. in which the main axis ends in a flower, but bears one or more lateral branches which again terminate in flowers, but not before producing secondary branches which continue the same process as far as growth permits. The various forms and varieties of cyme, which are not only of great morphological interest, but frequently also of systematic importance-e.g. Caryophyllaceæ, Labiatse, \&c., are described under Inflorescence (q.v.).

Cymry. See Celts and Wales.

Cynanchum, a genus of Asclepiadacese, of which some species have been used medicinallye.g. C. monspeliacum as a violent purgative, the so-called Montpellier Scammony, and C. vincetoricum, formerly in repute as an antidote to other poisons. The Indian $C$. extensum yields fibre, and C. ovalifolium of Penang, caoutchoue.

Cynewulf, an Anglo-Saxon poet of whom almost nothing is known. He has handed down his name wrapped up in runes in his poems Christ, Juliana, and Elene. It seems most probable that he was a Northumbrian, but Wiileker holds that there is no sufficient evidence for this belief. Dietrich identifies him with Cynewulf, the Bishop of Lindisfarne (737-80), but Ten Brink refuses to admit the identity between the two. Cynewulf's principal works niay be referred with some degree of confidence to the second half of the 8th century. He belonged to the guild of wandering glee-men, possessed some learning, and was popular with his contemporaries. His poems are aglow with fervid Christian feeling, and show rich imagination and power of language. The influence of Aldhelm is distinctly traceable both in the themes and in their treatment. The chief works are a collection of poetical riddles; the Christ (ed. by Gollanoz, 1892), a subjeet borrowed from the old Latin homilies, in which His birth, His ascension, and the judgment are described, the last being particularly effective ; Andreas and Elene, religious epies; Guthlac and Juliana, versified lives of those saints.

Cynics, the name applied to a school of Greek philosophers, who were distinguished mainly for their morose and snarling ethics, and their ostentatious contempt of the ordinary pleasures of life. The name is due either to Cynosarges, the place where Antisthenes, the founder, taught; or to their dog-like (kynikos) contempt for conventional manners. For their peculiar opinions, see articles Antisthenes, Diogenes, Menippus, \&e.

Cy'nips. See Gall-Fly.

Cynodon, a genus of grasses of which one apecies, $C$. dactylon, is of peculiarly widedistribution, not only ranging from its British habitat on the sandy shores of Cornwall to fringe those of North America and the West Indies, where it is known as Bermuda grass, but also forming (on aceount of its great power of resisting drought) the most important fodder and pasture grass of India, where it is known as Dhob, Doorba, sc. Its ereeping roots, and those of its congener, $C$. lineare, have medicinal virtues, and are sometimes used as a substitute for sarsaparilla.

Cynomorium, a genus of the curious parasitic order Balanophorere (see PARAsitic PLANis). 
Cynomurinu coccineum, a plans of a strange funguslike appearance, is found in the islands of Malta

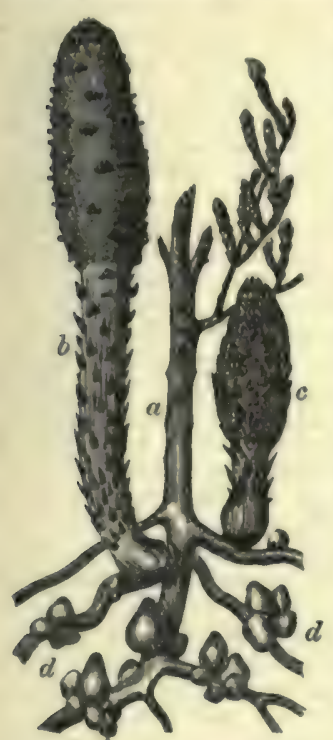

Cynomorinm ooccineum, growing upon the roots of $(a)$ its phanerogamous host; $b, c, d$, different atages of development. and Gozo, It was long known as Fungus Mel? tensis, and enjoyed the highest reputation as a styptic, besides being used as an astringent in dysentery and other maladies. These uses, however, depended on the doctrine of signatures alone, its scarlet colour and blood-like juice being interpreted as providential indications of its curative destination for all injuries or diseases accompanied by bleeding. So high a value was set upon this plant, that the knights of Malta took it under their particular care as one of their choicest possessions; it was carefully gathered and deposited in a government office, from which the grand-master sent it to friendly sovereigns, and to the hos. pitals of the island. Up to a recent date a keeper of the rock which most abundantly produces the plant was still appointed by the British government.

Cynomorpha (literally, 'dog-shaped'), the lower division of Old.World or Catarrhine mon keys, Baboon (Cynocephalus) and Magot (Macacus) are good examples. See MoNkEY.

Cynoscephalae ('dog's heads '), two hills near Scotussa, in Thessaly, where Flaminius defeated Philip of Macedon, 197 B.C.

Cy'nosure (Gr. kynosoura, literally, 'the tail of the dog '), the Greek name for the constellation of the Little Bear, which contains the pole star, by which the Phonician mariners steered their course, while the Greeks steered by the Great Bear. The name is metaphorically applied to anything that attracts attention, or to which all eyes are turned. Its use, with this meaning in reference to a lady, in Milton's classic poems L'Allegro and Comus, will be remembered. In the Greek mythology, Callisto, danghter of Lycaon, king of Arcadia, was changed into the Greater Bear (called also Helice), and her son, Arcas, into the Lesser (called also Cynosura). -The Dog's-tail Grass is called Cynosurus.

Cypera'cea, the order of reeds and sedges, are nearly akin to grasses, but easily distinguished by their solid, uhjointed, generally triangular stems, undivided leaf-sheaths, and absence of palese. There are alout 2000 species, widely distributed throughout all climates, but more especially in temperate and cold regions, and in marshy soils, of which they often take almost entire possession. Dry and rough in texture, they furnish only the very poorest constituent of fodder or hay, nor with few exceptions (see Bulrush, Cyperus, Papyrus, Carex, REED) have they any other economic uses

Cyperus, a large genus of Cyperacea, chiefly tropical. The tubers or root-stocks of some species are edible, notably $C$. esculentus, cultivated in sonthern Europe for its amandes de terre. C. longus and others are used in medicine and perfumery. C. textilis of South Africa yields fibre. In America,
C. hydra, a tuberous species, is an exceedingly tromblesome weed in cultivated lands, such as cotton-fields.

Cy-pres, which, roughly translated, means 'as near as possible, is applied to a well-known doctrine in the law of charitable trusts in England. This doctrine is to the effect that where a truster mentions a general purpose to which money is to be applied-ag. higher education, and slso some particular method-e.g. payment to an institution which ceases to exist, the court will direct the application of the money in some other particular method, as near as possible to the one mentioned, and consistent with the general purpoese. The doctrine is elosely connected with another-viz. that where only a general charitable intention is expressed-e.g. relief of the poor, the court will devise some particular scheme, and will not hold the trust void for uncertainty. These doctrines also exist in Scots law, though not under the name of cy-près. The expression is also applied to a principle on which the conrt acts, so as to avoid illegality in settlements of property. In the United States it is held that the equity courts cannot make valid charities which are uncertain, but where charitable trusts have once been set agoing, they will prevent the trust from being defeated by change of circumstances.

Cypress (Cupressus), a genus of evergreen coniferous trees or shrubs, with small generally appressed and imbricated leaves, and with almost globular cones, the peltate woody scales of which bear numerous hard winged seeds. The bestknown species is the Common Cypress ( $C$. semper. virens), a native of the Mediterranean countries, Asia Minor, and Persia, whence it has been introduced into mild localities in Britain. It has two main varieties, one (var. horizontalis) with spreading or drooping branches, forming a flat-topped tree, the other (var. fastigiata) with elosely appressed branches like a Lombardy poplar, and capable of attaining a height of 100 feet. On account of its sombre colour yet upward aspect, this variety has been planted since classic times around temples and

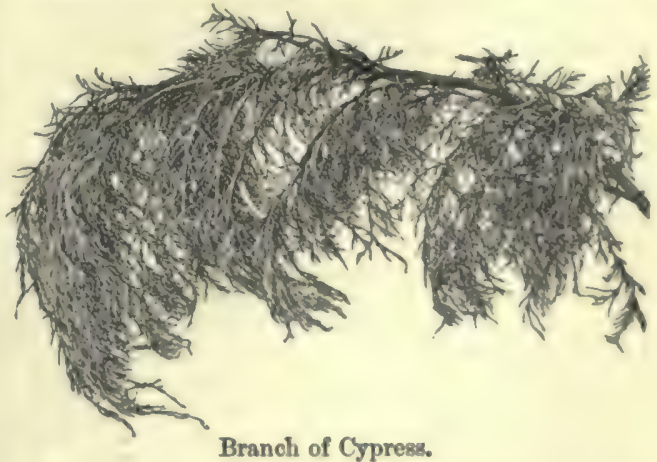

tombs; in this latter aspect, the drooping variety often took a marked place. The Greeks and Romans put its twigs in the coffins of the dead, they used it to indicate the house of mourning, and planted it about burial-grounds, as is still the custom in the East. The vast Turkish cemeteries, of which European and American cemeteries may be regarded as imitations, are thickly planted with the poplar-like variety, and are often growing into sombre forests. The wood of the cypress is yellow or reddish, and has a pleasant smell. It is very hard, compact, and durable; the ancients reckoned it indestructible; and the resin which it contains gives it the property of resisting for a long time the action of water. It is not liable to the attacks of 
insects, and being also of beautiful colour and easy polish, was formerly much esteemed for the finest kinds of work in wood, even Cupid's arrows being traditionally made of eypress-wood. Some believe that the cypress is the true cedar-wood of Scripture, and it has also been identified by commentators as the gopher wood of Noah's ark. In any case, cypress and cedar have been prized for shipbuilding in the East from the earliest times. The doors of St Peter's at Rome, made of cypress, lasted from the time of Constantine the Great to that of Pope Eugene IV., above 1100 years, and were perfectly sound when at last removed, that brazen ones might be substituted. Medicinal virtues were formerly ascribed both to the wood and seeds of the cypress, and oriental physicians have long been wont to send patients suffering from chest-diseases to breathe the air of cypress-woods, thus curiously anticipating the western practitioner. The resin has also had medicinal repute from classic times, while the Turks still use also the fruit and bark. The ethereal oil of cypress-wood was also used by the ancients for embalming, and the coffins of mummies were made of the wood.

More common in cultivation in Britain is the extremely hardy $C$. Lawsoniana, a native of Upper California, but of which there are now many varieties. $\quad C$. fragrans and macrocarpa, from the same region, are also often cultivated, together with C. thyoides, the White Cedar of Canada, and C. nutkaensis (Thujopsis borealis), the valuable Yellow Cypress of Alaska and Oregon. Among tenderer species are occasionally seen $C$. lusitanica, the Portugal Cedar, or Cedar of Goa, a native of Goa naturalised in Portugal ; C. torulos a, from the Himalaya; $C$. excels $\alpha$ and others, from Mexico. The pretty little Retinosporas of Japan, now so common in cultivation, forms for some authors only a sub-genus of cypress, or with some of the preceding (e.g. C. nutkaensis) are separated on aceount of their two-seeded fruit-scales, as the genus or sub-genus Chamæcyparis.

Cyprian, ST. Thascius Cæcilius Cyprianus, one of the most illustrious Fathers of the church, was born about 200 A.D., probably at Carthage, of heathen parents. After being a teacher of rhetoric at Carthage, he became a Christian, and was baptised probably in 245 or 246 . Immediately afterwards he gave to the poor the greater part of his corsiderable fortune, and devoted himself assiduously to the study of Scripture and the writings of the church's teachers, especially Tertullian. After being successively a deacon and presbyter, he was made a bishop in 248. His zealous efforts for the restoration of strict discipline soon brought him a host of enemies. In the Decian persecution, which at Carthage was especially severe, the heathen people cried incessantly 'Cyprianum ad leonem!' but Cyprian sought safety in flight, in his retire. ment still caring for his flock with the help of two vicarii, and distributing large sums of money among the poor. He returned to Carthage in 251, and the rest of his life was a constant struggle to hold the balance between the two extreme parties-the adherents of Felicissimus and Privatus on the one hand, who favoured laxity in the treatment of the Lapsed (q.v.), and those who would exercise the utmost severity, such as the followers of Novatianus, on the other. Cyprian was excommunicated by the Roman bishop Stephanus for his opposition to the Roman viow of the validity of lay baptism. He rejected this doctrine as making the sacrament merely mechanical, and laid stress on the personal piety of the priesthood and their special authority for its administration, asserting that baptism could only be a reality when accompanied ' with the full and entire faith both of the giver and receiver.' At a synod at Carthage in 256, he maintained that the Roman bishop, spite of the primacy of Peter, could not claim a judicial authority over other bishops. His principle, that 'a priest of God, holding the gospel and keeping the commandments of Christ, may be put to death, but cannot be overcome,' Cyprian himself illustrated, on the 14th September 258, when he suffered martyrdom under the Emperor Valerian.

His character and conduct have been very variously judged. Both in his own and later times he has been accused of cowardice and pride. His zeal, fidelity, and self-denial were undeniable, and his courageous martyriom frees him from the reproach of cowardice. His writings are all directed to practical ends. The earliest complete editions of his works are by Erasmus (Basel, 1520), Pamelius (Antwerp, 1568), and Bishop Fell (Oxford, 1682); and the best is that of Hartel (3vols. Vienna, 1868-71). They consist of a collection of Epistles, and a series of treatises, which are them. selves pastoral epistles of a bishop to his flock (see the translation by Wallis, 2 vols. 1869). His best-known work, De Catholica Ecclesioe Unitate, laid the foundation of the hierarchical conception of the church. Cyprian holds that the unity of the ehurch is founded upon the episcopate, not of Rome, but of the universal Church. In the Church alone can salvation be obtained ('he cannot have God for his Father, who has not the church as his mother'). See the Lives by Poole (Oxford, 1840), Peters (Ratisbon, 1877), and Fechtrup (Munich, 1878) ; and Archbishop Benson's Cyprian: his Life, his Times, his Work (1897).

Cyprinida ('carps'), a large family of freshwater bony fishes in the order Pliysostomi, with open swim-bladders. Barbel, Bream, Carp, Chub, Dree, Gold-fish, Gudgeon, Minnow, Roach, Tench, are familiar examples. They are distinguished from their neighbours by their small toothless mouths, naked head, usually sealed body, and by the absence of the adipose fin. The family includes over a hundred genera, and eight times as many species. They are widely distributed, most abundant in north temperate regions, absent from Australia and South America. They are voracious, very fertile, and frequently hibernate. See CARP, \&c.

Cyprinodontidae ('toothed carps '), a family of small bony fishes in the order Physostomi, with open swim-bladders. They are allied to carps (Cyprinidr), but the mouth bears teeth, the head and body are scaled, and there are never barbules. The family includes twenty genera and over a hundred species, widely distributed in the warm and tropical zones, both fresh-water and marine. They are in most cases viviparous, and the males are generally smaller than the females. The majority are carnivorous, but several forms are known as mud-eaters. Cyprinodon, Fundulus, Anableps (q.v.), and Poecilia are the more important genera.

Cypripedium, or Slipper-orchis. See ORCHIDS.

Cypris, a very common small fresh-water crustacean, type of a family (Cypridre) in the order Ostracoda. Like other ostracods, this small 'Water-flea' (q.v.) has an unsegmented body, seven pairs of appendages, a rudimentary abdomen, and a bivalve molluse-like shell inclosing all. The shell of cypris is dainty and elastic; the posterior antennæ bear a long turt of bristles on their second joint; the second pair of maxillæ have a small gill. appendage; the posterior limbs are very irregular, Various species of cypris are readily found in freshwater pools, in which they swim very actively; the largest form ( $C$. puber $\alpha$ ) measures 27 millimetres in length. The reproductive relations are of some general interest. Some species-e.g. C. 
fusea and $C$. pubera, reproduce parthenogeni. cally in summer and autumn, the males being rare and transient; while in others- $\mathrm{gg}$. C. ovum, the males are found throughout the year, and partheno. genesis seems not to reeur. The eggs are usually laid in masses on stones and water-plants; in $C$. pubers the egg remains as such throughout the winter. The males are remarkable for a peculiarly long and complex syringe-like modification of the reproductive duct. The adults are said to be able to survive desiceation, and this is certainly true of the egga. Some spevies are very abundant as fosails in fresh-water strata-0.g. C. valdensis, in the English Woalden. See Crustacea.

Cyprus ( (Gr. Kupros, Turk. G'br's, Fr. Chypre, Ital. Ciprol is situated in the north-east of the eastern basin of the Mediterranean, S. of Asia Minor, and W. of Syria, between $34^{\circ} 30^{\prime}$ and $35^{\circ} 41^{\prime}$ N. lat, and $32^{\circ} 15^{\prime}$ and $34^{\circ} 36^{\prime} \mathrm{E}$. long. The distance from Cape St Andreas, the north-easternmost point of the island, to the mainland of Syria near Latakis is about 52 geographical miles, while Cape Kormakiti on the north of the island is onty 35 miles from Cape Anamúr in Cilicia. Larnaca is nearly 1000 miles east of Malta, and fittle over 200 from Port Said and the entrance to the Suez Canal, while Limassol is somewhat nearer to both. The familiar shape of the island was likened by the ancient Greeks to that of a deer's skin, of which the long and narrow peninsula of Carpas represented the tail. The extreme length is ahout 140 miles, of which 40 consist of this Carpas peninsula; the extreme brealth is 60 miles; and the area is 3707 sq. m., or a little larger than Norfolk and Suffolk together. There are two principal ranges of mountains which form the most remarkable natural feature of the country. The northern range extends from Cape St Andreas, at the extreme east of the island, almost as far as Cape Kormukiti, some 20 miles to the west of Kyrenia. The highest mountains of this range, Buffavento (3240 feet), St Hilarion (3340), and Pentedaktylon (2480), are situated almost immediately north of Nicosia, and appear, owing to the extreme clearness of the atmosphere, to rise almost from the outskirts of the town, from which they are distant fully 12 miles. To the south of this range, and extending from Salamis to Morfu Bay, is the great Messaorian plain, once famous for its erops of cereals. Of late years, owing to the abandonment of irrigation-works, the decay of wells, and the absence of any system of water storage, its fertility has greatly fallen off, and in 1887, owing to a deficient rainfall, there was a scarcity almost amounting to fanine. The western range occupies the greater part of the western and south-western districts of Cyprus, and extends to the east as far as the isolated peak of Santa Croce or Stavrovouni, only 12 miles to the west of Larnaca. The highest mountain of this range is Mount Trobdos (6352 feet), of which one of the peaks bears the classic name of Olympus.

On the slopes of Troodos, under gigantic pinetrees, is pitched the camp where troops from Limassol spend a part of the summer months under canvas, and where the brigade of guards recruited their strength in the autumn of 1885 after their sufferings in Eyypt. Cyprus has practically no harbours; Larnaca and Limassol, the chief seaport towns, are open roadsteads, unprotecter against al but northerly winds, with such shallow water that steamers are obliged to anchor at a considerable distance from the shore. Moreover, a dangerous surf is raised in stormy weather which renders landing difficult. At Kyrenia there is a little harbonr fit only for small eraft, and unprotected in northerly' winds ; and in days gone by there were harbours at Salamis, at Papho, and Famagusta.
The restoration of the last would greatly increase the strategic value as well as the commercial importance of Cyprus, but so far nothing has been done.

The rivers only flow after beavy rain or the melting of the snow in the hills. There are no lakes of any importance save that of Paralimni near Famagusta, which is noteworthy chiefly on account of the fact that whereas it becomes entirely dry in summer, it abounds in fish during the winter, a phenomenon which has never been explained, but which certainly cannot be called in question. The chief towns are Nicosia (the capital), Larnaca, and Limassol. Famagusta is a ruin'; Papho, a site; Kyrenia and Morfu, villages on the northern coast. Until 1885 the topography of Cyprus was by no means accurately known, a state of things now put an end to by the issue of the great map of the trigonometrical survey of the island. This map, which was published in 1885, has been engraved by Messry Stanford on a scale of one inch to the statute mile.

A census taken by order of government in 1891 showed the population to be 209,291 , of whom 161,247 profess the Orthodox or Greek religion, and 48,044 the Mohammedan. Dividing the popula tion according to language, 140,000 speak as their mother-tongue a form of the Romaic or modern Greek, and 46,000 the Turkish. The Cypriot Greek dialect is a poor'as well as a corrupt idjom, neither expressive nor harmonious. The language of the Cypriot Moslens, on the contrary, is remarkably pure, and is said to be the best Turkish spoken out of Stamboul.

History.-Cyprus was colonised at a very early period by the Phoenicians and subsequently by the Greeks, who gave to the island the name Kupros, and substituted the worship of Aphrodite (the Cyprian goddess, 'Paphian Venus'), to whon Cyprus was considered sacred, for that of the Phonician Ashtaroth or Astarte. The ancient Cypriote syllabary was derived, according to Sayce, from the writing of the Hittites (q.v.). Early in the 6th century B.C. Cyprus was conquered by the Egyptian king Amasis; and a little later by Cambyses, who annexed it to Persia, 525 B.C. After the battle of Issus, Cyprus became a part of the Macedonian empire, but on the death of Alexander it passed into the possession of the Egyptian Ptolemy. In 58 B.c. Cyprus became a Roman province, and was administered by Cato the Younger and Cicero. The Cypriotes were one of the first Gentile peoples to embrace Christianity, and Cyprus was visited not only by St Paul but by many saints of the early church. At the division of the empire Cyprus naturally passed into the hands of the Enstern or Byzantine emperors, to whom it continued subject for over seven hundred years. In consequence of the supposed discovery by a shepherd of tha body of St Matthew and part of his gospel near Salamis, in the 4th century, Cyprus was constituted by the empire a sepurate autonomous church, and to the archbishop was accorded the privilege, enjoyed only by the emperor himself, of signing his name in red ink, a privilege which has been uninterruptedly exercised to the present day. In 646 Cyprus was taken by the Saracens, under Othman, and again in 802 by Haroun al Rashid; but on each occasion it remained but a very short period under the sway of the Moslem. In 1195 Richard I., on his way to Syria for the thind crusade, took the island from Isaac Comnenus, the representative or duke of the eastern emperor, and gave it to Guy de Lusignan, king of Jerusalem, in whose family the sovereignty of the island remained until 1487, when it passed under the dominion of the republic of Venice. In 1570 the Turks under Belim II. invaded Cyprus, and after long sieges and terrible massacres at 
Famagusta and Nicosia, took possession of the country and ruled it for three hundred years. On the 10th July 1878 Cyprus was occupied by the British, under the provision of the celebrated Turkish Convention, by the terms of which the island is to be occupied by Great Britain until Batoum, Kars, and Erzeroum are restored to Turkey by Russia, England paying $£ 92,440$ a year to the Porte as quit rent. By a subsequent arrangement this "tribute" is paid by Cyprus to England, and England pays one-half to France, or rather to the French bondholders of the 1854 Turkish Loan. The surplus revenue of Cyprus did not till 1892 reach $£ 92,000$; the deficit is made up by an annual grant by parliament. In 1880 the administration of Cyprus was transferred from the Foreign to the Colonial Office, and in 1882 a constitution, with a (partly elected) council, \&e., was granted to Cyprus.

Although under the convention the English maintain the Molımmedan religious tribumals, an admirable judicial system has lately been introduced, and English barrister-judges preside over courts which are highly appreeiated by the people. The fiscal system, however, is well-nigh unreformed, and is most unsatisfactory, as is the system of land tenures. The Eastern Telegraph Company have stations throughout the island, the calle connecting with Alexandria and Syria. Postal communication with England is slow and unsatisfactory; within the island it is efficient. The police, 215 horse and 460 foot, under English officers, is an admirable force. Half a regiment of Euglish infantry is quartered at Polymedia camp, 4 miles north of Limassol. There is no artillery in the island. The Cypriotes are peaceable, orderly, and easily ruled. Englishmen, almost exclusively ofticials, are popular. There are three higlı schools, over 200 Christian elementary schools, and 120 Moslem schools.

Cyprus produces wheat, barley, cotton, silk, flax, tobacco, carobs, madder, wool, gypsum, oranges, pomegranates, sponges, gum-mastic, and immense quantities of wine. Carobs, or locust beans, are perhaps the most important export; the annual value being from $£ 75,000$ to $£ 105,000$. Next in importance comes wine, of which some $3,500,000$

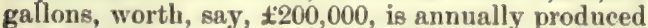
(as well as 200,000 gallons of spirits), and $£ 66,000$ exported; next cotton, about $£ 28,000$. The export of wheat varies from a value of $£ 10,000$ to over $£ 30,000$, though the amount grown in the country is of the value of over $£ 200,000$. Barley is grown in very large quantities for home consuniption, both as grain for horses and cattle, and as spring fodder, in a green state in place of grass, of which none grows in the island, The export of madder has entirely ceased since the adoption of aniline dyes. Wool and silk (cocoons) are each exported to the extent of about $£ 8000$ a year, but a good deal of hoth is spun and woven in the country. The total value of all exports in 1890-95 varied from $£ 470,000$ to $£ 550,000$; but only $£ 60,000$ worth of produce was shipped to Great Britain in consequence of the want of good communication.

Cyprus was once celebrated for its copper-mines, which were worked by the Phoenicians and Romans; indeed the word copper is derived from the name of the island. At the present day a concession granted to Messrs Knowles and Foster to mine copper at Limni, in the extreme west of Cyprus, is being worked by a company. Gypsum or plaster of Paris is manufactured at Larnaca in large quantities and exported chiefly to Alexandria. Salt was produced, under the Turks, to the value of $t 40,000$ a year, by evaporation at the salines, near Larnaca, whence that town is sometimes called Salinas. At present, owing to prohibitive duties in the neighbouring countries, no salt is exported and only a very small amount for island consumption is made by the British authorities. Cyprus imports (to the value of from $£ 240,000$ to $£ 350,000$ ) wheat, barley, olive-oil, sngar, textile fabrics, iron and copper goods, rice, dried fish, coal, timber, cotton-yarn and piece-goods, tobacco, petrolenn, and gonts.

The revenue varies from $£ 175,000$ to $£ 220,000$, of which about a sixth is produced by customs, and a little less by excise, while of the remainder, part is derived from land-tax, but by nuch the greater portion from the tithe on produce, an oppressive, antiquated, and expensive form of taxation. The tithe on grapes was abolisher in 1884. The expen. diture in the island, curtailed from year to year since the occupation, amounts now to from $f 105,000$ to $£ 120,000$, leaving a considerahle surplus to be sent to England for the 'tribute.' The climate of Cyprus has been unduly vilified. When the English troops landed in the hot autumn of 1878 they were encamped in malarious situations and kept without appropriate shelter, food, or occupation, and it is true that most of them sickened and that many died. But for people who live regular lives and take reasonable precautions, the climate of Cyprus is not only healthy but very pleasant. The deathrate is low. Ophthalmia and intermittent fever of a mild type are the commonest forms of disease. Throat, chest, and lung complaints are exceedingly rare, but leprosy is not uncommon. The people are healthy and well grown; the men, as a rule, handsome, the women rarely so.

The flora and fauna are with few exceptions the same as those of the neighbouring coasts of Syria and Asia Minor. Among wild animals the moufflon or Cyprus sheep is the most interesting, but is becoming very scarce. Mules of peculiar excellence are bred in Cyprus and command large prices. Goats are amongst the pests of the island. The forests (for which Cyprus was once famous) have well-nigh disappeared, and the climate and fertility of the country have greatly suffered in consequence. Nothing is being done to re-afforest the island, and the flocks of goats prevent any natural growth of trees on the mountains, by biting off the tops of the young shoots as fast as they appear. A still greater scourge has commanded the attention of the authori. ties, and the locusts are now almost exterminated. The work of destruction has been thoroughly as well as economically performed (especially 1880-84), upon a system invented by a Cyprus gentleman, Mr Richard Mattei, C.M.G.

Since the English occupation something has been done for the roads (till then few and bad), and a little for re-afforesting the hills and restoring the timber supplies. In 1897 a railway conmecting Nicosia, Larnaca, and Limassol was being laid, and both the English government and the local administration made large grants for irrigation and drainage of swamps. A company was trying to revive silk-culture (once very famous, as good Cyprus cocoons are the best known) and to iniprove agriculture.

See works on Cyprus by Cesnola (1877), J. Thomson, Iang, Hepworth Dixon, Sir S. Baker, Mrs Scott Stevenson, Miss Agnes Smith, W. H. Mallock (1889), and Mrs Lewis (1894); Macheras, Chronique de Chypre (Paris, 1891); vol. iii. of Perrot and Chipiez, History of Ancient Art (trans. 1885); M. O. Richter, Kyprus, the Bible, and Homer (1894); and pamphlets and articles in the magazines by Professor Geddes in 1897.

Cyrenaica, the name of the district in northern Africa whose capital was Cyrene (q.v.). In its widest limits it stretched from the borders of Carthage to the Chersonesus Magna or northern headland of the Gulf of Platra (Gulf of Bomba). The productions of Cyrenaica mentioned by ancient writers are corn, oil, wine, honey, fruits of all kinds, cucumbers, truffles, cabbage; flowers yielding the richest perfumes; a rare plant called 
silphium (still abundant), from which was obtuined a famous medicinal gum-resin; and its horses. The first settlements in Cyrenaica were made by a Spartan colony in 631 B.C. The earliest cities were Teuchira and Hesperis, then Barca, a colony from Cyrene; and these, with Cyrene itself, and its port Apollonia, formed the original Libyan Pentapolis; sutsequently, Hesperis became Berenice; Teuchira, Arsinoë; while Barca was eclipsed by its port, which became a city with the name of Ptolemas. Cyrenaica at length became Roman, and under Constantine was constituted into a province as Libya Superior. In the 7th century it was overrun by the Arabs, and now nearly corresponds with Barea (q.v.).

Cyrené, the capital of Cyrenaica (q.v.), founded in 631 B.C., by a colony of Spartans under Battus, whose dynasty ruled for nearly two centuries, and was replaced by a republic, which was far from prosperous, until the Roman rule at length gave it rest from party conflicts. During its prosperity Cyrene carried on a great commerce with Greece and Egypt, and to a less extent with Carthage. Its extensive ruins still attest its former magnificence. It is repeatedly mentioned in the New Testament. Here were born the philosophers Aristippus (q.v., founder of the Cyrenaic School), Anniceris, and Carneades, the poet Callimachus, the astronomer Eratosthenes, and the Christian rhetorician and bishop, Synesius.

Cyrenius, a Grecised form of Publius Sulpicius Quirinus, named in Luke ii. as governor of Syria. He received his appointment as governor in 6 A.D., but the difficulty in harmonising this with Luke is got over by admitting that he had been governor also at an earlier date-according to Zumpt, from $4 \mathrm{~B} . \mathrm{C}$. to $1 \mathrm{~B}, \mathrm{C}$.

Cyril and Methodius, apostles of the Slavg, were brothers, and natives of Thessalonica. Cyril was the name adopted as a monk by Constantine, born in 827. He had been a disciple of Photius, and for his learning was surnamed 'the philosopher.' The Khasars, a Tartar people who inhabited the country from the north-east of the Black Sea to the lower Volga, having about the year 860 asked the Emperor Michael III. to send them Christian mis. sionaries, Cyril was sent in answer to their appeal, and made many converts. The Bulgarians of Thrace and Musia were evangelised by Methodius, who baptised their king Boyoris in 861. At the request of Ratislav, Duke of Moravia, the brothers then turned to the countries on the March and Danube. They prepared a Slav translation of the Scriptures and chief liturgical books (which became the foundation of the literature of the Slavs), and by their services in the mothertongue won the hearts of the people from the Roman missionaries. The two brothers were summoned to Rome to explain their conduct, and Cyril died there in 869. Methodius, who in the same year was consecrated at Rome Bishop of the Moravians, completed the evangelisation of the Slavs. Called to Rome a second time in 879 to justify his celebration of the mass in the native tongne, he succeeded in gaining the approval of Pope John VIII., returned to his dincese in 880 , and (according to the most probsble account) died at Hradisch on the March, 6th April 885. Bohemia and Moravia celebrated the millenary festival of their two apostles on the 5th July 1863 . Both brothers are recognised as saints by the Roman Catholic Chureh, after having been condemned as Arians by several popes (including Gregory VII.). Their festival falls in the Roman Catholic Church on the 9th of March, in the Greek Church on the 11th of May. The Cyrillic alphabet, modified out of the Greek by Cyril, superseded the more ancient Slavonic alyhabet over a wide area. The history of Cyril and Methodius is still very obscure. The source are collected by Schafarik in vol. ii. of his Slavische Alterthumer (Ger, trans, 2d ed. 1863), and more completely by Ginzel in his Geschichte der Slawenapostel Cyril and Method (Leitmeritz, 1857). See also Dimmler and Mik. losich, Die Legende vom Heiligen Cyril (Vienna, 1870 ).

Cyril of Alexandria, ST, one of the Fathen of the church, was born at Alexandria, and brought up under the care of his uncle Theophilus, whom, after some years spent as a monk in the Nitrian desert, he succeeded as patriarch of Alexandria in 412. Cyril forthwith closed the churches of the Novatians, and in 415 expelled the Jews from the city. With the shameful nurder of Hypatia (q.v.) he was at least indirectly connected. The latter part of his life was spent in his relentless persecution of Nestorius (q.v.), against whom, in the name of a synod held at Alexandria in 430 , he hurled twelve anathemas for his refusal to apply to the Virgin Mary the epithet Theotokos ("Mother of God"). The ceumenical council of Ephesus in 431 condemned Nestorius, with his doctrine of the two natures in Christ. After this, John of Antioch, with his adherents (numbering from 30 to $\mathbf{4 0}$ bishops), who had arrived at Ephesus too lato to take part in the discussion, constituted a synod of their own, which condemned Cyril. The emperor confirmed both of these depositions, but Cyril, notwithstanding, kept his patriarchate till his death in 444. On hearing of his death, Theodoret wrote, 'Envy is dead, and heresy is buried with her.' Among the extant works of Cyril are a defence of Christianity, in 10 books, written against the Emperor Julian in 433; a series of homilies and dogmatic treatises on the Trinity, the Incarnation, and on the Worslip of God in spirit and in truth ( 17 books, written against the Anthropomorphites). The best edition of his works is that of Aubert (7 vols. Paris, 1638). See Neander's Church History, Newman's Historical Sketches (vol. ii.), Kingsley's Hypatia, Hefele's History of the Councils (vol. ii.), and Kopallik, Cyril von Alexandria (Mainz, 1881).

Cyril of Jerusalem, ST, was born probably about 315, but his descent and birthplace are unknown. About 334 he was ordained a deacon, and about 345 a presbyter. During the Arian con: troversies he endeavoured to maintain a neutral attitude, and in 351 was ordained Bishop of Jerusalem by Acacius, Bishop of Cresarea, who was an Arian. Cyril having repeatedly disregarded citations by Acacius, his metropolitan, wes deposed by him in 358, and by a synod at Constantinople in 360 ; but on the accession of Julian in 361 he re. turned to his flock, which he ruled in peace till 367 , when, by order of Valens, he was again expelled. $\mathrm{He}$ returned to Jerusalem on the death of Valens in 378, took part in the second ceumenical council at Constantinople, and died on the 18th (acconding to other accounts, on the 11th or 20th) March 386. The ganuine writings of Cyril are his Katecheseis (or instructions to catechumens), eighteen of which are addressed to candidates for beptism, and five to the newl:- baptised. They are not in the form of question and answer, but are connected lectures, written in a style of great simplieity and clearness, and making constant reference to Scripture. The articles of the creed (called by Cyril Pistis, or the 'Faith') on which the teaching is based can be gathered with tolerable certainty from the last thirteen of the first series of the Katechèseis, and are distinguished from those of the Nicene Creed by the avoidance of its distinctive word Homoousios ('of the same substance'). The best editions are 
by Tonttée (Paris, 1720 ; new ed. 2 vols. 1844) and by Reischl and Rupp (2 vols. 1845-60). There is an English translation by Dean Church in the Oxford Library of the Fathers (vol. iii. 1838). See also works on Cyril by Plitt (1855), Gonnet (1876), and Mader (1891).

Cyrus The Great (Kurus, perhaps from kur, 'a mountain'), the founder of the Persian empire. He was the fourth in a line of kings of Anzan or Susiana (called by the Hebrews Elam) who formed a branch of the royal dynasty of the Achrmenides (q.v.). According to Herodotus, Cyrus was the son of Mandane, daughter of Astyages, king of Media, and the Persian Cambyses. Moved by superstitious fears, Astyages attempted to destroy him in his infancy, but the child was saved by a herdsinan, who brought him up as his own son. Being recognised in his boyhood by Astyages, he was sent to his parents in Persia. Cyrus in course of time rose against Astyages and conquered him. This narrative and the greatly varying accounts of Xenophon, Ctesias, Nicolaus of Damascus, Diodorus, and Trogus Pompeius, formerly regarded as the authorities for the life Cyrus, have been superseded by the evidence of recently discovered monuments. A new light has been thrown on his history by the discovery of his own cuneiform records on a clay tablet and cylinder recently brought from Babylon to England. Cyrus was the son of Cambyses I., grandson of Cyrus I., and great-grandson of Teispes, conqueror of Elam, who was also the great-grandfather of Hystaspes, the father of Darius (q.v.). From the tabletinscription we learn that in the sixth year of Nabonidus, king of Babylon (549 B.C.), Cyrus, 'king of Elam,' conquered Astyages, king of Media, made him a prişoner, and took his capital, Ecbatana. By the year 546 he had become 'king of Persia." Year after year was idly spent by Nabonidus at Tema, a suburb of Babylon, while his son (doubtless Belshazzar) was with his army in Akkad (Northern Babylonia). In 538 Cyrus, favoured by a revolt of the tribes on 'the Lower Sea,' or Persian Gulf, advanced on Babylon from the south-east, and, after giving battle to the army of Akkad, took Sippara (Sepharvaim) and Babylon itself 'without fighting.' The account of the siege of Babylon by Cyrus recorded by Herodotus must therefore be erroneous. The Greek historian seems to have transferred to the reign of Cyrus events which took place in the reign of Darius. On the eighth day after Cyrus entered Babylon in person, he appointed Gobryas its governor, and that very day Nabonidus died. Nabonidus in his distress had biought the images of many local gods to Babylon, so as to proteet it from the invader ; and the cylinder-inscription shows very clearly that Cyrus was a polytheist and an idolater, for he there says, "the gods dwelling within them left their shrines in anger when [Nabonidus] brought them to Babylon,' and, after telling how he had restored them all to their sanctuaries, prays them to intercede before Nebo and "Merodach my lord,' for himself and Cambyses his son. Cyrus at once began a policy of religious conciliation. The nations who had been carried into captivity in Babylon along with the Jews were restored to their native countries, and allowed to take their gods with them. The empire of Lydia had fallen before the army of Cyrus two years before (in 540), and after the conquest of Babylonia he was master of all Asia from the Mediterranean to the Hindu Kush. The conqueror's hold over Asia Minor and Syria was much strengthened by his friendly relations with the Phonicians and also with the Jews, who received the news of his triumphs with enthusiastic sympathy as the confirmation of the prophetic aspirations for their national deliverance. In the
Old Testament he is ealled the Shepherd and the Anointed of Jehovah, because in 538 he gave the Jews who were living in captivity in Babylon permission to return; yet it is expressly said of him: 'For Jacob My servant's sake, and Israel My chosen ... I (Jehovah) have surnamed (or titled) thee, though thou hast not known Me ... I will gird thee, though thou hast not known $\mathrm{Me}^{\text {? }}$ (Isa. xlv. 4, 5). The favour which he showed to the Jewish people awoke the hope that he might be won over to faith in Jehovah as the one true God; but doubtless he was less moved by religious than by political motives to allow the Jews to return to their own land. After the great king had extended the boundaries of his empire from the Arabian desert and the Persian Gulf in the south, to the Black Sea, the Caucasus, and the Caspian in the north, he died in 529according to Herodotus and Diodorus, during an unsuccessful struggle with Tomyris, queen of the Massagetre, on the Jaxartes ; according to Ctesias, of a wound which he had received while conquering the Derbicci on the upper Oxus. The empire of Cyrus was organised under satraps and minor governors, after the manner of the second empire of Assyria. Three years before his death, Cyrus made his son and successor Cambyses "king of Babylon.' His own title was ' king of the world.' The chief seat of his court was Ecbatana; during the spring months it was held at his old capital, Susa, or Shushan, in Elam. Cyrus takes a high rank among Asiatic conquerors; he was a wise and considerate ruler, whose aim was to soften by his clemency the despotism which he was continually extending by the sword. But he did little to con. solidate the empire which he founded, contenting himself with a declaration of allegiance, and leaving the government nearly every where in the hands of native rulers. He brought the greater part of the Old World (Egypt excepted) under his sway, but left the organisation of his conquests to his successors. The Cyropadia of Xenophon is obviously an historical romance. See Professor Sayce's Introduction to Ezra, Nehemiah, and Esther (2d ed. Lond. 1887); also his Fresh Light from the Ancient Monuments (1883).

Cyrus the Younger, the second of the sons of Darius Nothus (or Ochus) and Parysatis, was born in 424 B.C. He conspired against his brother Artaxerxes Mnemon, who harl succeeded to the throne (404 B.C.). The plot, however, being discovered, he was at first sentenced to death, but afterwards pardoned, and even restored to his dignity as satrap of Asia Minor. Here he employed himself in making arrangements for war against his brother, although he concealed his purposes to the very last. In the spring of 401 B.c. he left Sardis at the head of 100,000 Asiatics and 13,000 Greek mercenaries, under pretence of chastising the robbers of Pisidia. Artaxerxes being warned of Cyrus's perfidy, made preparations to oppose him, and the two armies encountered each other in the plains of Cunaxa, 500 stadia from Babylon. Cyrus was defeated and slain, although the Greeks fought with the greatest courage, and even routed that portion of Artaxerxes' troops immediately opposed to them. The fortunes of the Greeks, on their retreat through the highlands of Armenia, in severe winter-weather, are recorded by Xenophon in his Anabasis (q.v.).

Cyst (kystis, 'a bladder'), a word sometimes used in the original sense as applied to hollow organs with thin walls, as the urinary bladder and gall-bladder; but commonly reserved for the designation of pathological structures or new forma. tions within the body having the bladder form. Cysts may arise in two different ways: (1) either 
by the sccumulation of products within cavities nurmally present, or (2) by the independent formation of a cavity. Of the first, wens, collections of secretion in a sebaceous gland of the skin, are the commonest example; instances of the second are eystic tumours of the Ovary $\left(q, v_{\text {. }}\right)$ and the sacs leveloped in connection with certain parasites ('bladder-worms;' see Hydatid, EnTozoA). The structure of their walls is still more variable than their mode of origin; sometimes they are thin and transparent, sonetimes dense and fibrous. They are either simple or compound, unilocular or multilocular; they are sometimes small, numerous, and separate; in other cases they yrow to an enornous size, and are very complex. Some cysts are present at birth, and remain through life almost unchanged; some increase rapidly in size, and form large and dangerous tumours. For Cystic Worms, Cysticereus, see BLADDER-WORM, CESTOID WORMS, TAPEWORMS.

Cystin, or Cystic OxIDE, forms a rare variety of urinary Caleulus (q.v.). Its chemical composition ie $\mathrm{C}_{8} \mathrm{H}_{7} \mathrm{NSO}_{2}$, and it forms a whitish or dirty yellow deposit consisting of six-sided crystalline tablets. It is soluble in ammonia, and is thereby distinguished from the similar crystals of uric acid.

Cystitis, inflammation of the Bladder (q.v.).

Cystoidea (Gr. cystis, 'a bladder'), a group of fossíl echinoderms, so called from their spherical or bladder-like form. The spherieal body was inclosed by calcareons plates, and resembled that of the crinoids in general form. It was borne on a short stalk, or was sessile. See CRINOIDEA.

Cythe'ra. See Cerigo.

Cy'tisus, a large genus of Leguminosæ, suborder Papilionacere, small trees or shrubs, with temate leaves, and yellow, white, or purole flowers, natives chiefly of the warmer temperate parts of the old World, but frequently introduced on account of the beauty of their flowers (see LABURxUM). In its widest sense the genus may include the common Broom (q.v.)

Cyzicus, the ancient name of a peninsula of Asia Minor, projecting into the Sea of Marmora, which lies immediately to the SE. of the island of Marmora, and is about 9 miles in length. It was at oue time an island. In early times Cyzicus was a Milesian colony, and the city of Cyzicus, which was not finally ruined till its conquest by the Arabs in 675, is deseribed by Strabo as one of the first eities in Asia, alike for extent and splendour.

Czar, more properly Tsar, Tzar, or Zar, the title of the emperors of Russia. The word occurs early in Old Slavonic, equivalent to king or keiser. and is connected with the Latin C'usur, continued in the Roman empire as a title of honour long after the imperial house itself had becone extinct. In the Slavonic Bible the word basileus is rendered by ezar; Cwsar (kaiscer) by Cesar. In the Russian chronicles also the Byzantine emperors are styled czars, as are also the khans of the Mongols who ruled over Russia. The title of the Russian princes was kniaz ('prince') and veliki kniaz ('great prince'): and the princes of Moscow took the title of czar as rulers of the Mongolians. As individual sub. khans made themselves independent of the king. dom of the Golden Horde, they also assumed the title of ezar; thus, there were czans of Siberia, of Kasan, and of Astraklian. The conquest of the Golden Horde by the khan of the Crimea in 1480 made the grand-princes of Moseow completely independent; and upon them devolved the absolute power which the czars had exercised over all Russia. Ivan IV. the Terrible first caused him- self to be crowned ezar in 1547 ; from that time the title of czar became the chief title of the Muscovite rulers, and became practically the equivalent of emperor. The wile of the car was named tzaritza (ezarina); the sons, tzare. witch; the daughters, tzarevna; but after the death of Alexei-Peter I.'s son-these titles were abolished, and the imperial princes were called grand-dukes, and the imperial princesses grandduchesses. In 1799 the Emperor Paul I. introduced the title of cesarewitch (not czarewitch) for his second son, the Grand-duke Constantine. The heir-apparent and his wife are still called cesarevitch and cesarevna. Among the Russian people themselves, the emperor is more frequently called Gossudar (Hospodar, 'Lord') than czar. The term White Czar, bèlyj zar', comes down from Mongol times, and is merely equivalent to an in. dependent, non-tribute-paying czar. See Russia.

Czardaseh, or CsÁrdAs, a Hungarian national dance, consisting of two sections - a slow move. ment called a lassu or lassan, and a quickstep, the friss or friska. Both are always in $f$ or a time, and in the same key. Examples on an extended scale occur in Liszt's 'Rhapsodies Hon. groises.'

Czartoryski, Adam Geonge, son of Prince Adam Czartoryski (1734-1823), was born at Warsaw, 14th January 1770. Edueated at Edin. burgh and London, he returned to Poland, and took part against Russia in the war of 1794 . Sent to St Petersburg as a hostage, he gained the friendship of the Grand-duke Alexander and the confidence of the Emperor Paul, who made him ambassador to Sardinia. When Alexander ascended the throne, he appointed Czartoryski assistant to the Minister of Foreign Affairs; and he took an active part in oflicial life until after the peace of Tilsit. As curator of the university of Wilna (1803) he exerted all his influence to keep alive a spirit of nationality; and when some of the students were sent to Silheria on a charge of sedition, Czartoryski resigned his office. His successor reported to the emperor that the amalgamation of Russia and Lithuania had been delayed a century by Czartoryski. Russian favours could not deaden or even dull Czartoryski's - pure patriotism. Into the revolution of 1830 he threw himself with all his heart. He was elected president of a provisional government, and in this capacity summoned a national diet, which in January 1831 declared the Polish throne vacant, and elected Czartoryski head of the national government. He inmediately devoted half of his large estates to the public service, and adopted energetic measures to neet the power of Kussia. In August he resigned his post, but continued to fight as a common soldier. After the suppression of the rising (see PoLAND), Craxtoryski-specially excluded from the general amnesty, and his estates in Poland confiscatedescaped to Paris, where he afterwards resided, the liberal friend of his poor expatriated countrymen, and the centre of their hope of a revived nation. ality. In 1848 he liberated all his serfs in Galicia, and during the Crimean war he ineffectually en. deavoured to induce the allies to identify the cause of Poland with that of Turkey. He refused the amnesty offered to him by Alexander II., and died 15th July 1861. See his Memoirs, translated by Gielgud (1888).

Czaslau (Bohemian Cdslav), a town of Bohemia, 40 miles ESE. of Prague by rail, with nanufactures of beet-sugar and alcohol. Its church, in which the Hussite leader Ziska was buried, is surnounted 'by the highest steeple in Bohemia (290 feet). The place was the scene of 
an important victory gained over the Austrians by Frederick the Great, 17th May 1742. Pop. (1890) 8396.

Czechs (also spelt Tzechs, Tschechs, Cesks, Cheskians, \&c.), the most westerly branch of the great Slavic family of nations. In the latter half of the 5th century A.D. the Czechs migrated from their lands in Carpathia, on the upper Vistula, to the country now known as Bohemia. Other Slavic tribes came too; but in the course of time the Czechs gained such an ascendency that, in the 9th century, their name was commonly applied to the whole Slavic population of Bohemia (q.v.). Here, in Moravia, and in other parts of Austria, the Czechs now number in all some 7,000,000.

Czeoled, a market-town of Hungary, 47 miles SE. of Pesth by rail. The inhabitants (1890), 27,549 in number, are employed principally in agricultural pursuits, the district around yielding much grain and red wine.

Czenstochau, or Czenstochowa, a town of Poland, 148 miles SW. of Warsaw by rail. A Catholic monastery, founded here about 1382 , is visited yearly by fifty to sixty thousand pilgrims, as possessing the famous 'Black Virgin,' a murky painting of Byzantine origin, but ascribed by fegend to St Luke himself. In 1655 Czenstochau was the only place in Poland which offered resistance to Charles Gustavus of Sweden, when 70 monks and 150 soldiers for 38 days held out against 10,000 men. The inhabitants, 15,500 in number, carry on a considerable trade in sacred pictures and rosaries.

Czermak, JoHANN NePOMUK, physiologist, was born, 17th June 1828, in Prague, studied at Vienna, Breslau, and Würzburg, was professor successively at Cracow, Pesth, Jena, and Leipzig, and died 16th September 1873. He was the founder of laryngoscopy. His principal work is Der Kehlkopfspiegel (2d ed. 1863), and his collected works were published in 1879 .

Czerno'witz, the capital of the Austrian province of Bukowina, stands 720 feet above sea. level, near the right bank of the Pruth, 165 miles SE. of Lemberg by rail. Among its buildings are the palace of a Greek archbishop (1875); his cathedral (1864), on the model of St Isaac's at St
Petersburg; the Armenian church (1875); the synagogue (1877); and the 'Austria Monument" (1875). The university, founded in 1875, has 36 instructors and some 225 students. The manufactures and trade are steadily developing. Pop. (1869) 33,884 ; (1880) 45,600 , of whom 14,449 were Jews; $(1890) 57,403$.

Czerny George (Turkish Karadjordje)-i.e. Black George, the leader of the Servians in their struggles for independence, was born of poor parents, 21st December 1766, near Kragujevatch. He took part in a rising against the Turks in 1787, and was subsequently a cattle-dealer. In August 1801, a band of janizaries broke into his dwelling, and plundered it. Czerny fled, vowing vengeance. He soon collected a band of mal. contents, and commenced a sort of guerilla war. Gradually his numbers increased, and in 1804 he captured the fortress of Schabaz. Subsequently, he invested Belgrade, and in the beginning of 1806 routed the Turks at the rivers Drina and Morawa. Assisted secretly by Russia, he captured Belgrade in December 1806. After the treaty of Slobosje (8th July 1808), he was elected governor by the people, and recognised as Prince of Servia by the sultan. The French invasion of Russia in 1812 compelled the latter country to let Servia shift for itself. Hostilities recommenced; the Turks were successful, and Czerny had to flee to Austria, where he lived for some time. Meanwhile, the freedom of Servia had again been secured through the leadership of Miloseh Obrenowitch ; and when, in July 1817, Czerny returned, he was murdered at the instigation of Prince Milosch.

Czerny, KarL, pianoforte teacher and com poser, born at Vienna in 1791, was the pupil and friend of Beethoven, and also gained much from Clementi and Hummel. Besieged by pupils, he would teach only those who showed especial talent; among these were Liszt, Thalberg, and Döhler. Living in great retirement, he devoted much of his time to composition; a mass of MS. is preserved in the archives of Vienna, while his published works number over 900 , of which his Theoretical and Practical School is the best known, and probably also the most valuable. He died 15 th July 1857. 


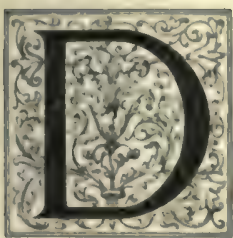

is the fourth letter in our own alphabet, as well as in the Phoenician, Hebrew, Greek, and Latin, from which last it was immediately derived. The original symbol in the Egyptian hieroglyphs was the picture of $a$ hand. When taken over by the Phonicians, this sion was called daleth ' the dnor,' from a fancied resemblance to the curtained aperture of a tent, rather than to the wooden quadrangular door of a house. This resemblance may be traced in the Greek letter $\Delta$, whose name delta was derived from the Semitic daleth. In Phoenician and the oldest Greek, the letter had a short tail, 4, but as this form differed very little from that of $B$, and hardly at all from that of $\mathbf{R}$, the three letters were differentiated, $\mathbf{B}$ acquiring a second loop, $\mathbf{R}$ a tail, while D lost the downward prolongation of the stem.

In cursive Greek the letter was rounded, and acquired the form $\delta$, which is due to the ligature connecting it with the following letter. These changes are shown in the table given in Vol. I., page 187, which also explains the singular process whereby, in the minuscule form $d$, the loop of $D$ has been transferred from the right of the stem to the left. In the Aramean alphabets the loop opened out, as is seen in the Hebrew 7 .

The sound of D is the soft dental mute. It has, like $t$, an affinity for $n$, and is often brought in as a sort of shadow to facilitate the utterance of this letter. It is intrusive in such words as sound, compound, lend, riband, gender, thunder, kindred. Sometimes it disappears, as in the case of cruel from erudelis, or winnow from windewe. It is often assimilated to the following consonant, especially in compounds derived from the Latin, as in the words accept, attain, allocution, appear, aftirm, arrogant, gossip. It is sometimes replaced by $l, r$, or $b$, as in the words lacrima, Ulysses, lingua, arbiter, meridies, bellum, bonus, bis. By Grimm's Law a primitive $d$ becomes $t$ in English, and $\approx$ in German : as in the words decem, ten, zehn; or duo, two, swei. A primitive $d h$ becomes $\theta$ in Greek, th in Gernian, $f$ in Latin, and $d$ in English; as the words $\theta$ n, thier, fera, and deer. Di followed by a vowel sometimes becomes $j$, as in journal from diurnal.

D, the Roman numeral for 500 , arose out of ID, the half of CID, which was the old way of writing $\Phi$, the primitive sign for 1000 , which was afterwards written $M$.

$D$, in Music, is the second note in the natural scale. See Music, Scale.

Dab (Pleuronectes limanda), a species of Flounder (q.v.), common on European coasts, but not occurring in the Mediterrsnean. It is distinguishable from plaice and flounder by its lightbrown, or ashen-gray colour, with small irregular dark spots, by the roughness of its small, close-set scales, and by its more arched lateral line. Its length is from 8 to 16 inches. It is common all round Britain, and in the Firth of Forth is known as the Salt-water Fluke. Its flavour excels that of flounder. A rather larger species, of even more northern distribution, is the Lemon or Smooth Dab ( $P$, microcephalus). It may be distinguished from

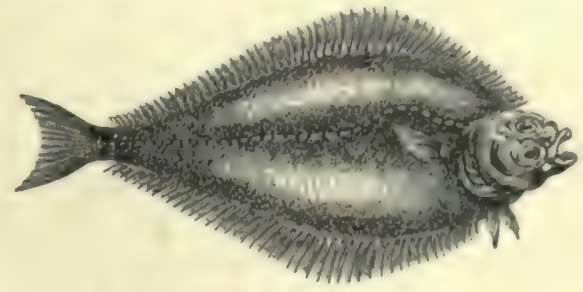

Dab (Pleuronectes limanda).

the common dab by the fact that the first ray of the anal fin is not spiny. The brownish colour is sometimes prettily mottled.

Dabchick. See GrebE.

Da Capo (Ital., 'from the beginning'), a term in Music, frequently placed at the end of a part or movement, indicating that the performer must return to the beginning of the movenent, or (dal Segno) to some other part of it marked with the sign :S: and finish where the word fine is placed. The words are generally abbreviated thus, D.C., sometimes D.C. al fine.

Dacea, a city of Bengal Proper, 150 miles NE. of Calcutta, on the north bank of the Buriganga. occupies an area of $8 \mathrm{sq} . \mathrm{m}$., and consists of a dull esplanade and one long street meeting at right angles, with a complementary network of narrow, crooked lanes. Its position commands the principal waterways of the delta, and it thus enjoys singular facilities in the way of inland navigation. On this account it was chosen, about 1610 , as the seat of the Mohammedan government of Bengal, which rank it retained, except during an interval of twenty years, until 1704. The suburbs extended 15 miles northward, where mosques and brick buildings are still found buried in thick jungle. In the isth century it became widely celebrated for the delicate texture of its muslins, and in connection with this manufacture the French and the Dutch, as well as the English, had extensive estab. lishments in the place. After 1817, however, the annual value of the trade declined, under the competition of Manchester piece-goods, and the aspect of the city changed with the disastrous decay of its staple industry. Its busy marts were deserted; in many quarters the streets, with their desolate, abandoned honses, were overgrown with jungle; and the population fell from 200,000 in 1800 to 69,212 in 1872 . Since then the fortunes of Dacca have somewhat brightened; the general develup. ment of trade throughont the presilency has brought back a share of its former prosperity, and the opening of the Dacea and Maimansingh State Ruilway in 1886 has notably increased the transit trade. A small colony of muslin-weavers still survives, and other manufactures are coarse cotton eloth, embroidery, silver-work, shell-carving, and pottery. Besides the Dacea College (1835), with about 300 students, there are many good schools, and a fine 
hospital; in 1878 a system of water-works was opened, and the sanitary condition has since improved. Pop. (1891) 82,321.-DACCA District has an area of $2797 \mathrm{sq}$. m., and consists of a level plain, interseeted by a network of rivers and artificial watercourses. Two-thirds of the district is under cultivation; food-crops, oil-seeds, jute, cotton, saftlower, and sugar-cane are grown. Trade is carried on chiefly by water, and the rivers are crowded at all seasons with steamers and native craft; the adventurous boatmen of the district have a name throughout Bengal. Floods, blight, or drought never seriously affect the district, but earthquakes are of common occurrence. Outside Dacca eity sanitation is unthought of; fevers, dysentery, and goitre are among the endemic diseases, and epidemics of cholera and smallpox are not infrequent. Pop. (1872) 1,852,993; (1881) $2,116,350$; (1891) $2,420,656$ - over 60 per cent. Mohammedans.

Dace, DARE, or DART (Leuciscus vulgaris), a fresh-water fish in the carp family Cyprinidæ (q.v.), and of the same genus as the roach, chub, minnow, \&c. It chiefly inhabits the deep and clear water of quiet streams. It is found in Italy, France, Germany, \&c., and in some of the rivers of England, but is very local. In form it is not unlike the roach, but rather more elongated; the mouth is rather larger, the scales smaller. The upper parts are dusky blue, becoming paler on the sides, and

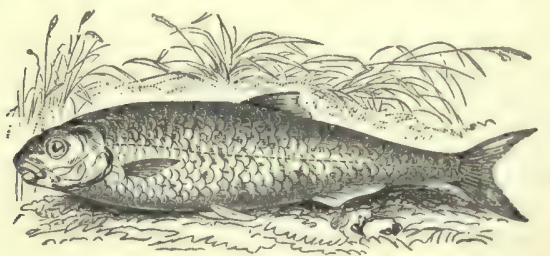

Dace (Leuciscus vnlgaris).

passing into white on the belly, the cheeks and gillcovers silvery white. It measures about 8 inches in length, and never exceeds a pound in weight. The dace is gregarious, and swims in shoals. It spawns in early summer. Its flesh is preferred to that of the roach, but is not highly esteemed. The dace is perhaps the liveliest and most active of the Cyprinidx, and affords the angler fair sport both with fly and bait.

Dachshund, a name adopted from the Ger man, signifying 'badger-dog.' 'The dachshund has been common in Germany for many years, but was unknown in England until introduced by the late Prince Consort towards the middle of the 19th century; it then became very fashionable and popular, but is not now so common. The dachshund is a small dog, weighing about $20 \mathrm{lb}$., with short crooked fore-legs, and an extremely long body, its head rather resembling that of a miniature bloodhound. Its strong, large paws enable it to dig rapidly. Its colour should be black and tan, or brown. On the Continent the dachshund is extensively used for covert-shooting, but rarely so in Britain, as his headstrong disposition somewhat spoils his usefulness. The dachshund is closely akin to the old English Turn-spit, employed to drive a wheel by which roasting-spits were turned.

Dacia, the land of the ancient Daci or Getre, including the country between the Danube, the Theiss, the Carpathians, and the Pruth. The Dacians were the most valiant of all the tribes of Thracian origin (see THRACE). In the reign of Augustus they began to molest the Roman allies, and indeed from this time there was almost continual fighting between the Romans and the Daci, who actually, under their brave king, Decebalus, compelled their civilised enemies, in the reign of Domitian, to purchase peace by paying tribute. In 101 the Emperor Trajan cressed the Danube, and after five years' desperate fighting, conquered the whole country, and formed it into a Roman province. Roman colonists were sent into the country, great roads were opened up, and a bridge was built over the Danube-the ruins of which are still extant. Under Aurelian the Danube was made the boundary of the empire, and Dacia was resigned to the barbarians, its Roman colonies being transplanted to Moesia.

Dacier, ANDRÉ, a French scholar, born of Protestant parents at Castres, in Upper Languedoc, 6th April 1651, studied at Saumur under Tanneguy Lefèbre; and in 1672 came to Paris, where in 1683 he married Anna (1654-1720), his old preceptor's daughter, and two years later was admitted with her to the Roman Catholic Church. Dacier subsequently became royal librarian, nember of the Academy of Inscriptions and of the French Academy, and perpetual secretary of the latter. He died 18th September 1722. His works include a Delphin edition of Festus and Verrius Flaccus (1681), as well as indifferent translations of Horace, the Poetics of Aristotle, some of the Dialogues of Plato, Epictetus, and Plutarch's Lives. His wife's works include Delphin editions of Florus, Aurelius Victor, Eutropius, Dictys Cretensis, and Dares Phrygius; and translations of Anacreon, Sappho, some plays of Plautus and Aristophanes, Terence, the Iliad and the Odyssey. Her admiration of Homer was more unbounded than discriminating, and involved her in many controversies.

Dacoits, a name used for brigands herding in gangs in various parts of India, and living by dacoity or robbery with violence. According to the report of the general superintendent of the Thuggee and Dacoity Department in 1887 , there were over 9000 men practising dacoity in India, which in some districts is earried on with great ferocity. In the Gwalior territory forty-six persons were killed by dacoits: and of the seventy-five villages in the Chanderi district, thirty-six had been dacoited since 1880. Dacoity was long prevalent in Burma. See Thugs ; and Hervey, Some Records of Crime (1892).

Da Costa, IsAac, a Dutch poet, born at Amsterdam, the son of a Portugnese Jew, 14th January 1798. He studied at Leyden; and in 1822, a year after receiving the degree of doctor of philosophy, he embraced Christianity. His poems speedily gained him such reputation that, on the death in 1831 of Bilderdijk, whose warm friendship he had enjoyed, Da Costa succeeded him in the first place among the poets of Holland, which he lield till his death, on 28th April 1860. His principal works are to be found in his Poёzï (2 vols. 1821-22), Politieke Poëzy (1854), and Hesperiden (1855). His Battle of Nieupoort, the last of his poems, is one of his masterpieces. Da Costa also made essays in the domain of history and theology, the most important of which, his Israel and the Gentiles, has been translated into English.

Dacotahs. See Sioux, American Indians.

Dacry'dium, a genus of coniferous trees of the yew family, but more allied to Podocarpus. There are twelve species-Malayan, Tasmanian, and of New Zealand. Dacrydium cupressinum of New Zealand is best known in Britain, on account of the beauty of its pendulous foliage. $D$. frank. linii, the so-called Huon Pine, and D. taxifolium, the Kakaterra tree, yield valuable timber.

Dactyl (Gr. dactylos, 'finger'), the name of a measure or 'foot' in Greek and Latin versifica. 
tion, emsisting of a long and two short oyllables, as in the word ömnibus. It was so called from its resemblance to the finger, which consists of three joint:-one long and two short. The same name is sometimes applied to a trisyllabic measure in Eng. liah verse, consisting of one accented syllable and two unaccented syllables, as in destiny (see VERSE). Dretylic verse eonsists of dactyls ind spondees, and includes both hexameter and pentameter verse.

Dactylology, the art of communicating thoughts by the fingers. See DEAF AND DUMB.

Daddy-long-legs, or Crave-FLY (Tipulce oleverea), a familiar insect in the order Diptera, and a good type of its family Tipulidre. The body, the leiss, and the antennse are very long. Tho latter have an arched curvature, and are longer in the males; the front of the head projects promi. nently; the posterior body, which is connected with

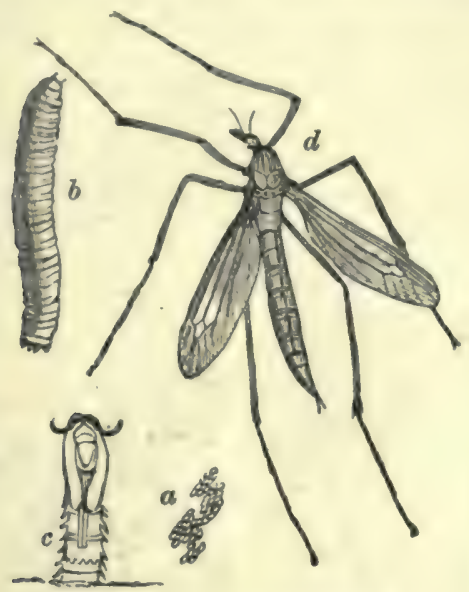

Daddy-long-legs (Tipula olevacea) :

$a$, eggs ; $b$, larva; $c$, pupa case as left by the insect sticking out of the earth ; $d$, perfect insoet.

the thorax by a very thin bridge, is brosder in the females. The middle of the body is gray, with brown stripes, the abdomen reddish-brown, the legs brownish-yellow, and in part blackish, the wings brown, varying to red and white. This common European insect is towards an inch in length, is abundant from July to October in meadows and gardens, and is familiar to every one. 'The female is often seen laying her numerous eggs in damp places on the ground; the eggs are small, black, and shining; the larvæ, known as 'leather-jackets,' live in the ground, and often do damage in vegetable gardens and fields; the pupre have spines on their abdominal segments, by which they push their way out of the ground. Of the genus Tipula about ninety European species are known. The largest form ( $T$. gigantea) measures over an inch, and is not uncommon in Britain. T. hortulana is very common in gardens. The genus Ctenophora, commoner in wooded districts, is nearly allied. They have stouter bodies, and usually brighter colours. See MIDGE.

Dado (Ital., 'a die '), in classical Architecture, the term applied to the cubic block which forms the body of a pedestal. It is also applied to the plane face and the series of mouldings which, in the interiors of buildings, form, as it were, a continuous pedestal. The interior dado is formed of wood, and, running round the bottom of the walls of a room, serves to protect the plaster or paper from injury. Dados and wall-linings were much used in Elizabethan and subsequent styles till this century, when, under the classic regime, they were dispensed with. The recent revival of the 'Queen Anne' taste, however, has led to the reintroduction of dalos not only in the form of wooden panel. lings, but also in the painting and papering of the walls.

Dre'dalus, a figure in Greek Mythology who personified the beginning of the arts of sculpture and architecture. He was of the old Athenian royal race of the Erechtheida. Having killed his nephew and pupil in envy at his growing skill, he had to flee to Crete, where he made the well. known cow for Queen Pasiphae, and afterwards for King Minos the famous labyrinth to confine the Minotaur. Minos next inurisoned Dsedalus, but he escaped with the help of Pasiphae, and formed wings for himself and his son learus, with wlich to fly across the sea. He himself flew safe across the Aigean, but unhappily Icarus flew too near the sun, the heat of which melted the wax that fastened his wings to him, so that he dropped into the sea, and left his name to be borne by that part of the Agean into which he fell. Dredalus made his way to Sicily. Some accounts made him first alight at Cumæ in Italy, where he dedicated his wings to A pollo. Works of art were freely ascribed to Dredalus in Greece, Italy, Libya, and the Mediterranean islands. The name Doedala was applied to the earlier painted and gilded wooden stutues of the gods.

Daendels, Herman Willem, a great Dutel general, was born in 1762 at Hattem, in Gelder. land, took part in the revolutionary disturbances that broke out in Holland in 1787, and was in consequence compelled to seek refuge in France. In the campaign of 1793 he rendered important service to Dumouriez, and was elevated to the rank of a general of brigade. In 1799 he commanded one of the two divisions of the army of the Batavian republic, and in 1806 took service under the king of Holland. From 1808 to 1811 he was governorgeneral of the Dutch East Indian possessions, and published a work on them. On the overthrow of Napoleon, the new king of Holland, William I., intrusted Daendels with the organisation of the Dutch colonies on the coast of Africa, and there he died in June 1818.

\section{Daffodil (eor} rupted from Lat. asphodelus), the Eng. lish name of those species of Narcissus which have a large bell-shaped corona. The Common Daffodil ( $N$. pseudo-narcissus) is a native of England and of most parts of Europe, growing in woods and hedges, and often cultivated in gardens, where it not unfrequently becomes double. It is natural. ised in many places in Seotland and Ireland, but seems scarcely indigenous, From Herrick's lament to Wordsworth's dancing verse we have widely varied recomitions of the familiar golden cups of the daffodil as a source alike of poetic wealth and inspiration. See NARcissus.

Das, a hand-gun or thick pistol, used in the 15th and 16th centuries, It oceurs in the Spanish Tragedy (1603); it sometimes means a dagger. 
Dagger, a weapon resembling a sword, but considerably smaller, being used for stabbing at close quarters. Daggers are generally two-edged, and very sharp towards the point. The dagger of lath was the weapon given to the Vice in the old moralities.

Daghestan ('mountain-land'), a triangular territory of Ciscaucasia, between the Caucasus and the west const of the Caspian Sea. Area, $11,425 \mathrm{sq}$. m.; pop. (1895) 610,000. The surface is generally mountainous, being traversed by offsets from the Caucasus; the level tracts are chiefly near the coast, and here and in the valleys the land is very fertile. The country is well watered, the climate generally mild in the lowlands, and dry, except along the coast, where the rainfall is considerable. In the highlands large flocks of sheep are herded. The chief town is Derbend (q.v.). See Caucasus, and Shamyl; also Cunynghame's Daghestan (1872).

Dago, an island near the entrance of the Gulf of Finland, forming pert of the Russian government of Esthonia, and separated by the narrow channel called Sele-sund from the island of Oesel on the south. Area, $367 \mathrm{sq}$. m. ; pop. 15,000, of whom one-third are Swedes and Germans. The coast is rugged, and the soil fertile only in the south and south-west; inland there are large forests and swamps (54 sq. m.).

Dagoba, the common name in Ceylon for a Buddhist tope. See TopE.

Dagobert was the name of several of the Merovingian kings of France, the first of the name reigning from 631 to 638 . See FRANCE.

Dagon, the national god of the Philistines, half-man, half-fish, is mentioned in the Old Testament as having temples at Gaza and Ashdod. Several names of places prove that the worship of Dagon existed also in other parts of Palestine. It seems to have come to Canaan from Babylonia, the Assyrian monuments presenting a figure with the body of a man and the tail of a fish, and the cuneiform inscriptions containing the name of a god Dakan or Dagan, which is probably identical with Dagon. Baudissin favours the old derivation of the name from dag ("fish"), with the formative syllable -on. Dagon and the fish-goddess Derketo or Atargatis probably answered to each other as male and female water-deities.

Daguerreotype is the name of the photographs fixed on a plate of copper thinly coated with silver by the successive action of the vapours of iodine, bromine, and mercury. Louis Daguerre, after whom the invention is named, was born in Normandy in 1789, was a scene-painter in Paris, made a famous diorama in 1822, and devoted the rest of his life mainly to perfecting the processes of photography, from 1826 till 1833 in conjunction with M. Niepce. $\mathrm{He}$ wrote two works on the subject, and died in the neighbourhood of Paris, 12th July 1851. The history of the invention is given at PHOTOGRAPHY.

Dahabeeah, a boat used by voyagers on the Nile, which varies in size, has one or two masts, and accommodation for from two to eight passengers, including a raised cabin on the after-deck. The boat sails, is rowed, or is dragged by ropes, according to circumstances.

Dahl, Johann Christian Clausen, a Norwegian landscape-painter (1788-1857), who from 1821. onward was professor of Painting at Dresden.

Dahlak, a group of three islands, with many smaller rocks, in the Red Sea, off the Bay of Massowah. They were famous in Roman times for their pearl-fisheries, but the beds have long since been exhausted and abandoned. The inhab. itants number about 1500 , are under the rule of a sheik holding authority from Egypt, and carry on a trade with the Arabian coast.

Dahlgren, KarL FREDRIK, Swedish poet and humorist, born at Stensbruk in Ostergötland, 20th Jume 1791, studied at Upsala, and acted from 1815 as preacher at Stockholn, where he died, $2 \mathrm{~d}$ May 1844. As a writer he made his début in Atterbom's Phosphorus, and afterwards published novels, humorous tales, poems, and dramas. His works fill 5 vols. (1847-52).

Dahlgren Gun is so called after John Adolph Dahlgren (1809-70), an officer in the United States navy, by whom it was introduced in 1850 . It is a muzzle-loading, cast-iron, smooth-bore gun, with great thickness of metal at the breech. Many Dahlgren guns are still in the United States service. In 1883 six of 10 -inch calibre and muzzleloaders were converted into 8 -inch breech-loading rifle guns, by lining and strengthening them with wrought-iron coils.

Dahlia (Dahlia Georgina)-after Dahl, a Swedish botanist, and pupil of Linnæus-a genus of large perennial composites (sub-order Tubulifloræ, family Asteroidere). It was first brought from the botanic garden of Mexico to that of Madrid in 1784, whence it reached England in

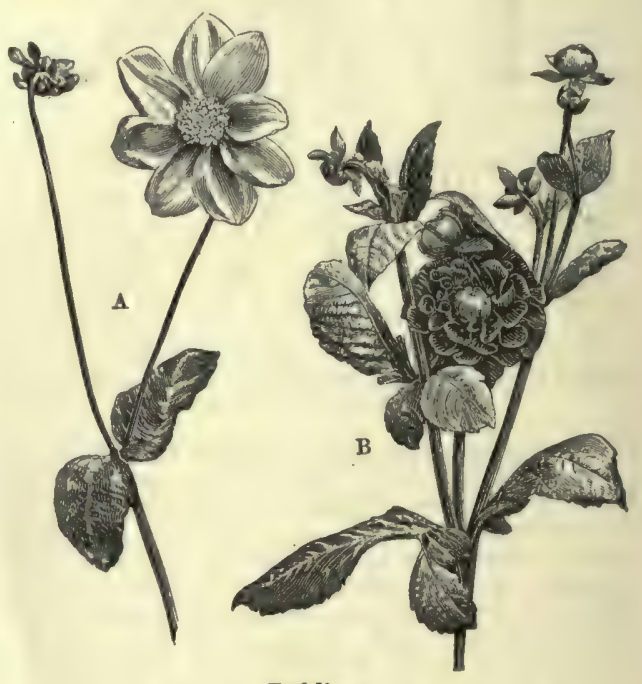

Dahlia

A, single; B, double varieties.

1789, and France in 1802, while in 1804 Humboldt sent a fresh supply of seed to Berlin. Its extraordinary variability soon attracted the attention of florists, who brought to bear on it all the resources of selection and crossing, with so much success that by about the middle of the present century no fewer that 2000 varieties had been described, all from $D$. variabilis or $D$. coccinea or their hybrids, and chiefly from the first named. For a long time only 'double' dahlias were cultivated, but of late years the single dahlia, in which the florets of the dise remain tubular, has again come into fashion; while among double dahlias the less regular cactus dahlia is highly esteemed. They are easily cultivated, and propagated by seeds, cuttings, or tubers ; but the tubers require to be taken up and stored in a dry place out of the reach of frost. They flower luxuriantly in autumn, until cut off by the first frosts. On account of the quantity of inulin in their tubers, they are cultivated for food in Mexico, but similar attempts in Europe have failed 
because of their unpalatablenens. See Nicholson's or other Dictionary of Gardening, also any Horist's eatalogue.

Dahlmann, Friedrich Chrigtoph, German historian, was born May 13, 1785, at Wismar. His earlier studies in Copenhagen and Halle were devoted to archaology and philology; but his sttention was subsequently directed to the study of politics and the history of the middle ares. From $1813 \mathrm{on}$, he filled the chair of History at $\mathrm{Kiel}$, and in 1829 was appointed to that of Political Seience in Göttingen, where he published (1830) his invaluable Quellenkunde der deutschen Geschichte. Banished in 1837 by King Erust August of Hanover, on account of his protest arainst the abolition of the Hanoverian constitution, he went to Leipzig, next to Jens, where he wrote his historical masterpiece, Geschichte von Dänemark (3 vols. 1840-43). In 1842 he became Professor of History at Bonn, and took a prominent part in the political affairs of Germany after the movement in 1848, heading the constitutional liberals, who were unfortunately too reasonable to be successful. At the close of the struggle, he returned to his acculemic duties, to which he devoted himself till his death, 5th December 1860 . See Life, by A. Springer ( 2 vols. Leip. 1870-72).

Dahn, Júus Sophus Felix, publicist, historian, and poet, was born at Hamburg, 9th February 1834, the son of a well-known actor and actress. He studied law, philosophy, and history at Munich and Berlin, became extraordinary professor at Munich (1862), next year ordinary professor at Würzburg, and in 1872 was appointed to the chair of German Jurisprudence at Königs berg. Among his contributions to public law are Das Kriegsrecht (1870), Handelsrechtliche Vorträge (1875), Deutsches Rechtsbuch (1877), and Deutsches Privatrecht (1878). Of his historical works the chief are Prokopius von Cäsarea (1865), Die Könige der Germanen (1861-71), Westgotische Studien (1874), Langobardische Studien (1876), Urgeschichte der germunischen und romanischen Völker (3 vols. 1881-84), and Geschichte der deutschen Urzeit (1885). Dahn's versatility is as remarkable as his erudi. tion is profound. He has written a series of popular historical romances, and of lyrical and dramatic poems. Of the former may here be naned Ein Kampf um Rom (1876), a powerful novel, Odhins Trost (1880), and Die Kreuzfahrer (1885). See his Erinnerungen (1892-93).

Dahna. See Arabia, Vol. I. p. 362.

Dahomey (the native name of the people being Dauma or Dahome) is since 1892-94 a French protectorate in Western Africa, between Lagos (British) and Toyoland (German), with an area stated at 4000 miles. But the frontiers of the 'hinterland, always vague, were matters of disagreement and debate between Britain and France as Inte as 1897, the French elaiming a territory continuous to Borgu and beyond. The corst strip is not Dahomey proper, but, as the Slave Coast, is part of French Gumea (comprising (irand Popo, Cotonu, and Porto Novo). The long lagoon which, shut in from the ocean by a protecting liank of sand, affords an ensy ronte along nearly the whole of this coast, extends in Dahomey, from its western frontier almost to the Denham lagoon, in the east. Abont midway is the port of Whydah, whence a road extends inland to Abomey, a distance of 65 miles. Dense forests and dismal swamps cover nearly two-thirds of this distance, but from the Great Swamp of Agrime vast undulating plains rise for many miles, in the direction of the Kong Mountains, The Avon and Denham lagoons receive the rivers of the country, none of which are very important. The soil is a rich, red-coloured clay, and is extremely fertile.
Groves of oil-palms encircle each town, and palm. oil is made in lnge quantities. Maize, beans, and peas, as well as cussava, yarns, sweet potatnes, limes, oranges, pine-apples, and other tropical fruits, grow in splendid luxuriance; cotton, sngar, and spices of all kinds are also grown, and sheep, goats, swine, and poultry are raised, though not in large numbers. Cotton eloth is male, and weapons and tools are forged from native iron.

The people are negroes, of the Ewe group, generally of small stature, but very robust and active. They are sociable, equally fond of dancing and of rum, but warlike and prone to theft. The Daho. man kingdom dates from the beginning of the 18th century, and reached its zenith under Gezo, who ruled from about 1818 to 1858 . Since then its power has declined, and even its population has iallen off; but little reliance can be placed on the estimates of the numbers, which range from 150,000 to 900,000 , the former number being probably most correct. The army may be taken at 10,000 men; the Amazons (devoted to celibacy), who are distinguished for their bravery and ferocity, may perhaps be limited to 1000 . Fetich-worship prevails, taking the form of serpent-worship along the coast; a temple with over a hundred of these sacred snakes exists at Whydah. The king is the most absolute of despots. Wholesale murder is one of the chief features in religions and state cere. monies ; but, according to Sir Richard Burton, who visited Dahomey in 1863 , the number of the victins has been greatly exaggerated, and they are principally foreign captives. Still, as many as 500 human victims have been sacrificed at one of the grand 'customs' which take place every October. 'The revenue formerly depended greatly upon the sale of slaves; but the vigilance of the cruisers employed to prevent the traftic has ruined the trade. Hence the monster slave-hunts which periodically took place are a thing of the past. In 1876 the coast of Dahomey was placed under a strict blockade by Great Britain, on account of an outrage on a British subject, for which the king of Dahomey refused satisfaction.-ABOMEY, the capital, stands on a rolling plain, nearly surrounded by marshes. It is about 8 miles in circumference, and is surrounded by a deep ditch and clay walls, pierced by six gates. There are three palaces belonging to the king here, several large squares, and a number of farms, which are cultivated within the city. Pop. about 30,000 . Whydah has a pop. of about 12,000 ; and Cana, where is the king's country residence, 8 miles SE. of Abomey by a good road, about 5000 . See Burton's Mission to Gelele, King of Dahomey (new ed. $1864)$; Skertchly, Dahomey as It is (1874); and Bouche, La Cote des Esclaves et le Dahomey (Paris, 1885 ).

Dahra, a distriet of Algeria, to the east of Mostaganem. In June 1845 Pélisaier (q.v.) suffocated 500 refugee Kabyles in caves here.

Daimiel, a town of Spain, 28 miles ENE of Ciudud Real by rail, with uanufactures of woollens, brandy, \&c. Pop. 9652.

Daimler Motor, a specially modified petro. leum oil-engine (see GAS-ENGINE, Vol. V. p. 109), perfected by the inventor, Gottlieb Daimler of Cannstatt in Wurtemberg (who assisted Otto of Deutz in perfecting his gas.engine), for use in auto. cars (see TRACTION-ENGINEs). Such carriages could, even when, noisy and smelly, they were first put upon the roads, ensily do twelve and a half miles an hour, and carry snpplies of petrolenm for four or more honrs' running. Experiments - which involved several days' running-were successfully carried ont between Paris and Bordeaux in June 1895. Similar experiments were subsequently repeated in England.

Daimyos, the old nobles of Japan (q.v.). 
Dairy is a word used in speaking of a number of cows kept for milking purposes, or to indicate the buildings in which Milk (q.v.) is sold or manufactured into Cheese (q.v.) or Butter (q.v.). The byre or cow-house should be connected by a covered way with the milk-house proper, and the arrangements for ventilation made so perfect that it should not be possible to detect in the vicinity of the milk any smell from the cows, pigs, or other source. The milk-house should on no pretext be made a common storeroom for meat, game, onions, or any material which will taint the air and then the milk and the cheese or butter, as the case may be. The first essential in a dairy is the absolute cleanness not only of the floors and walls of the building, but of all its furnishings. This is secured by daily washing and by the scalding or steaming of all vessels or implements which come in contact with milk or its products; the object being to destroy the microbes which live and multiply in milk and bring about its acidity and decay. The thermometer in the dairy should stand at $55^{\circ} \mathrm{F}$. in sum. mer, and $60^{\circ} \mathrm{F}$. in winter. At temperatures higher than these milk is liable to spoil, owing to the greater activity of the above-mentioned germs; many degrees below this it gets chilled, and will not manipulate satisfactorily. An abundant supply of pure water is necessary, and means for boiling water must also be provided, not only to secure scalding water for washing, but to raise, when necessary, the temperature of the products of milk during manufacture, or maintain a suitably high temperature in the air of the cheese-room or the milk-house. A small steam or gas engine is frequently employed in a dairy conducted on a large scale, to supply the power necessary for a centrifugal Cream Separator (q.v.), also for churning whole milk or cream, and at times for driving the compressed-air refrigerator. The latter is used to lower the temperature of vaults in which fresh, summer-made butter is stored until the winter season, when the prices for good 'grass' butter are high. As the cost of the necessary machinery is considerable, the method can only be made to pay when the business is extensive.

Dairying has developed much within recent years. The growing demand for milk in large towns has increased the volume of the milk-trade, and modified the system of management. Summer dairying, while suitable for the making of cheese, and so far for butter also, must be supplemented by winter dairying to keep up the supply of milk and fresh butter throughout the year. For summer dairying it is usually arranged that the cows calve during March, April, and May, so that they go to pasture when they are coming to the period at which, with a proper supply of succulent food and suitable surroundings, they should develop their greatest yield of milk. They lie out day and night, and have the whole summer and early autumn before them-the period in which grass, the most natural food of a cow, is most abundant, best, and cheapest. In some instances the grass is supplemented by 2 or $3 \mathrm{lb}$. a day of cotton-seed or other cake, and when the grass begins to fail in autumn, some variety of green food, as cabbages, rape, vetches, \&c. As frost begins to appear the cows are housed at night, and in spite of liberal and careful feeding, fall off in their yield of milk. Nevertheless, it is the better practice to house them in good time, because they keep in better condition during winter than if left out too long, and for the few remaining weeks of the milking period they give $\mathrm{a}$ larger average return. All naturally 'dry off,' some more rapidly than others. Milking should be stopped abruptly at the end of the year-experience points to this being the best and simplest nethod of drying off cows at this season. After two or three months of rest, the cows calve, and this goes on year by year from the age of two or three (depending upon size and condition) until ten years old, when all should, without exception, be replaced by heifers. A ring appears on the horn to mark each year after the third year, and by this the age can be determined.

Where winter dairying is also practised, the cows are made to calve at all times of the year, so that a. number come in possibly every week, to replace others that have ceased to milk satisfactorily. The temperature of the cow-house has to be maintained at such a high point, to keep up the full flow of milk during winter, and the feeding is made so foreing and unnatural that the constitutions of cows would show the effects of this high-pressure system if they were kept to calve another year. In consequence, few farmers who adopt this system of management retain their cows more than one milk. ing period. They shut them in the house both summer and winter, and give a full supply of food all the while, to maintain their condition. Some send them to auction as soon as the yield of milk falls to the net cost of its production. Others attempt to feed the cows after this until they put on flesh, so that they command a higher total price and a higher rate per stone in the fat market than ordinary milking cows. Unquestionably the system of changing cows after one milking period pays farmers who are favourably situated for the disposal of milk to private families, better than keeping them for a number of years and 'bringing them round ' to calve each season; yet there is one serious drawback as regards the suspension of the improvement of dairy cattle, by neglecting the selection of calves for rearing from the best milking mothers. The system is only possible, without doing serious injury to the breeds of cattle, because it is not general throughont the country, but confined to dairies supplying milk to large centres of population.

Eight to ten cows is a sufficient number for each milker, and the operation should be performed as quietly and as expeditiously as possible. Men are usually employed in England, and women in Scotland. When cows give a large flow of milk, or when it is wanted for town consumption, milking is done thrice daily; but in the great majority of cases throughout the country it is only performed morning and evening. Heavy milking cows consume a large quantity of water, which should be supplied to them at least twice daily. Cows not in milk are often allowed to drink only once a day, though it would be better to let them do so twice. To offer tepid water to a cow immediately after calving is an unnatural and altogether unnecessary precaution; she should have cold, but not iced, water in small quantities, and given frequently until she is satisfied. Cows consuming a large amount of sloppy food and roots do not require much water.

It is important that the water should be pure and clean. Outbreaks of typhoid fever among children have been traced to cows drinking water contam. inated with the germs of this disease. Though sewage irrigation grass is extensively used, under the 'soiling' system, by cowfeeders near to towns (Edinburgh, for example), no injurious results have been traced to this practice. Irrigation grass has been largely superseded within recent year's by supplies of better quality got from immense crops of Italian ryegrass (Lolium italicum), grown without irrigation by means of heavy and repeated dressings of nitrate of soda. In no place can this system he seen to greater perfection than around Edinburgh. In some parts clover and vetches take the place of ryegrass. Succulent food is essential for the production of large returns of milk. As the grass season ends in October, the succulent portion of 
food may be derived from brewers' and distillers' grains ( 1 bushel per day being a full allowance for is large cow), and from turnips - a favourite variety at present being the Fosterton hybrid. Turnips, when given in excessive quantities, produce an objectionable taste in the milk and butter, but as an ingredient in a liberal and well-balanced diet they may be used with impunity, where milk is the prowluct wanted. Swedes and mangels are not so liable as common turnips to taint cow products, and as they keep well when stored, they are reaerved for use during the winter and spring months. Cows in full milk require a daily allowance of perhaps 5 to $8 \mathrm{lb}$. of concentrated food $-\mathrm{a}$ mixture of various farinaceous meals and oil-seed cakes along with bran, which acts as a corrective as well as a food sub. stance. Bean meal is prominent among the meals for encouraging a flow of rich milk and at the same time maintaining the condition of the cow. Turnips, unless liberally supplemented, are liable to reduce the condition. The ingredients in the food mixture should be determined by their market prices from time to time. There is a decided advantage in giving a mixed food, as compared with one variety, provided a proper proportion is secured between the albuminoids and the carbohydrates - one to five is a good ordinary average to sim at under ordinary cireumstances, hav. ing estimated oil as equivalent to two and a half times its weight of starch. Not only must the proportion of the components of a food mix ture be adjusted, bnt the total bulk of the food must be great enough to distend the stomach sulficiently to promote healthy action in the diges tive system. About $30 \mathrm{lb}$. of dry food substance is a good allownnce for a healthy milking cow of one of our large breeds. If that were given entirely in the form of concentrated food, such as meal and cake, the animal conld not chew the cud, and impaction of the rumen would result. The practice of chaffing straw into very short lengths is associ. ated with the sause danger. Dry fodder, more especially straw, is vastly improved for milk cows by cooking - either steaming it, or throwing warm water over it, and covering it up for a few hours. In spring, before the grass comes, the flow of milk in newly-calved cows is often largely developed and maintained by treating hay in this fashion, and supplying them with the hay tea and the solid residue mixed with meal. When very large quantities of concentrated food are used, it is safer to add to the daily allowance of each cow from 1 to $2 \mathrm{lb}$. of molasses, which supplies not only a valuable in. gredient of food, but maintains a healthy action in the organs of digestion. Without some such precaution the percentages of ailments and deaths, in the case of cows kept under a high-pressure system of feeding, are likely to be considerably above an average. Epsom salts should never be given to a cow in milk, as they permanently reduce the yield for the season; 8 to $10 \mathrm{lb}$. of warm treacle is more rapid in its action, safe, and free from injuri nus after-consequences. Bought concentrated food has another function than the above to perform. Its ash ingredients which pass away in the manure make good to the land the considerable loss of boneeurth and other valuable substances which are removed in dairy products-more especially milk. See Catrue, Butter, Cheese, Milk.

Duiry Factorles. As a special business dairy. ing has been extensively developed in America (the United States and Canada in.

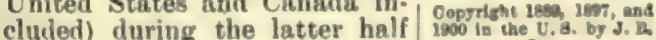
of the 19th century, mainly Hpptseots Dewpasy. through the introduction of the peculiarly Aneri. can factory system, or associated dairying. The first factory was organised in the state of New York, by Jesse Williams, in 1860, and the result being exceedingly favourable in regard to the quality and increased market value of the product (which was then cheeve only), many other factories were organised, until in 1846 there were nearly 500 of them in operation in the state mentioned, the cost of these being about $81,000,000$ $(£ 200,000)$, with a stock of cows worth, at the then low valuation, at least $\$ 10,000,000$. The farms thus associated were then worth, for the million acres covered by them, not more than

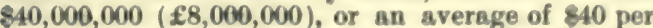
acre. Five years later there were factories in several of the states and also in Canada; the list comprising 946 in the state of New York, 103 in Ohio, 46 in Illinois, 5 in Kentucky, 4 in Minnesota, 34 in Wisconsin, 26 in Massachusetts, 32 in Vermont, 14 in Pennsylvania, 7 in Iowa, 2 in Indiana, and 1 each in Virginia, North Carolina, Tennessee, Kansas, and Connecticut. This associated industry became known in foreign countries as the "American system of dairying, and was quickly introduced into England, Sweden, Denmark, Switzerland, Holland, and other countries where the dairy business was carried on extensively, but it has not increased to anything like the extent it has in America. Very soon the manufacture of butter was introdnced into the factories, as well as into special establishments for butter-making alone, the latter being called creameries, in contrndistinction to the factories where cheese only was made, or where butter and skim-milk cheese were made, or where the skim-milk was adulterated with fats and oils of various kinds, as substitutes for cream. It was about this time (1872) that the French oleo-margarine (a preparation of beef-fat) was introduced into the American dairy as a substitute for pure butter fat in the manufacture of eheese. It is a disagreesble truth to confess that this fraudulent 'dairy (?) product,' as it is called, still maintains a firm hold upon American dairying, and largely as a distinct fraud, made use of for the purpose of making and selling adulterated cheese, and butter as well, for a pure product. And in addition to the fat of beeves, lard and cotton-seed oil are extensively used. Laws recently passed in several of the states and in the United States congress forbid under heavy penalties the sale of butter so adulterated, but cheese has not yet been so protected. This stigma upon the American dairy (from which Canada is happily free) is a reproach and severe pecuniary damage to the dairy business; the unnual export of cheese decreased 40 per cent, between 1893 and 1898 .

American dairy cheese is made under the wellknown Cheddar system, so called, which is prevalent in parts of England, and in Ayrahire and other localities in Scotland. This is the American cheese which is so well known and highly regarded in Great Britain, when purely made under the best system of management. But a considerable variety of cheese is now made in imitation of foreign kinds, and is used by the foreign-born citizens, who have not forgotten their acquired taste for the old homemade cheese.

Creameries, or butter-factories, came into use with the cheese-factories, but were not numerous until a way was found to utilise the sim-milk by adding artificial fats to it. Then the combined butter and cheese factory turned out its lutter and its full-milk cheese together. This questionable method of business, however, became nnpopular, and actual creameries came into vogue after 1880 . The clseese and butter factory system has been introduced into various countries (Denmark, Holstein, \&c.) with great success, and success. ful experiments have leen made in Ireland and Britain. In the creamery, the cream gathered from 600 or 800 cows is worked up by one skilled 
butter-maker, and the product is a good article of even quality all through; it is made in sufficient quantity for shipment and sale under the best conditions, and hence it commands a higher price than the best ordinary farm-dairy butter. It is made with the best apparatus, is packed and shipped in cold-storage or refrigerator cars, and reaches the domestic consumer within a week after it is made; and the foreign purchaser may have it upon his table within two weeks of the churning in the creamery, more than 4000 miles distant. These are advantages which the solitary buttermaker cannot secure; hence he can only get the creamery price by securing special customers near his dairy. A few so-called fancy dairies are able to secure 40,50 , or even 75 cents (1s: $8 d$. to $3 s_{\text {s. }}$ ) per pound for their butter, but even the best ordinary farm-dairy butter sells at a lower price than creamery butter, and fully three-fourths of it sells for less than half the price of the other.

American creamery butter is made by the deep setting system, borrowed from the Swedish method, and improved by American ingenuity. The milk is strained from the pail into cans 9 inches in diameter and 20 inches deep. These are set in tanks of water conled by ice to $45^{\circ}$. At the end of twelve to twenty-four hours the cream has separated, and the milk is drawn off by a tap in the bottom of the can, view being given by a strip of glass let into the side of the can. The cream is then drawn off by itself. For the use of the creamery the quantity of cream is measured by the inch, and is paid for on the basis of so many inches to the pound of butter. One hundred and thirteen cubic inches of cream is taken as the standard in this respect. The creamery gathers the cream once a day, and secures it perfectly sweet, while the skim-milk is also left sweet for the feeding of calves, for sale for consumption, or for the making of pork. The cream is kept until it is slightly acid before it is churned, making thus a quality of butter which keeps better and longer than that made from sweet cream. The churns most popular are those without any dash, being a cubical box turning on an axis passing through diagonal corners; or a barrel turning on an axis passing through its centre sidewise; or an oblong square box oscillating endwise in swinging supports. The action of churning thus consists of a dashing of the cream violently against the sides or ends of the churn, and, by concussion, eausing the globules, of fat in the cream to adhere together, and gradually coalesce and form small grains of butter. When these grains are as large as wheat-grains, or peas at the largest, the buttermilk is drawn off, cold water or weak brine is poured into the churn, and the churn is moved gently, to agitate and wash the butter. When the butter has been conpletely freed from milk, and no longer clouds the water, it is drained, and salted with finely-ground pure salt, at the rate of from $\frac{1}{2} \mathrm{oz}$. to $1 \mathrm{oz}$. to the pound of butter. The salt is easily incorporated with the small grains of butter, and after a rest of a few hours for the salt to absorb the excess of moisture from the butter and become completely dissolved, a butter-worker is used to press the butter, make it solid and even in texture, and as dry as possible. It is then packed in new spruce or oak tubs, or pails, of 20 to $50 \mathrm{lb}$., for domestic sale, or in 100 -1b. firkins for export.

The dairy interest has reached vast proportions in America and Canada. At least 1,500,000 farms, with $10,000,000$ cows and $100,000,000$ acres of land, are devoted more or less closely to the various branches of the industry. In the most populous of the states, where the dairy is the principal agricultural employment, good dairy farms are valued at $\$ 100$ ( $f 20$ ) per acre and up. wards, as the buildings may be more valuable than the average. The land held to be most suitable for the dairy is a rich limestone loam or gravel, that is productive of the best variety of grasses, especially the so-called blue grass (Poa pratensis), which affords the best pasturage. The best dairy districts are in the states of Vermont, New York, Pennsylvania, Ohio, Iowa, Wisconsin, Illinois, and the province of Ontario, in Canada.

The cows mostly kept upon dairy farms are the Dutch or North Holland, commonly called Holstein or Holstein-Friesian, Shorthorns, Ayrshire, the half or higher bred grades of these, and the common 'native' cows, the descendants of the promiscuous mixture of the various races of eattle brought into America. The most popular of these is the grade shorthorn, which may be purchased when in fresh milk; the Dutch cow is next in popular estimation, but it is scarce and high-priced, and is much less used. The average yield of these cows varies from 6000 to $8000 \mathrm{lb}$. of milk per year, or between calves, where calves are bred; the largest yield of the shorthorn and its grades averages $50 \mathrm{lb}$. daily, that of the Dutch cows is somewhat greater, and a few of the best have a record of more than $24,000 \mathrm{lb}$. of milk between calves and within a year. These cows can be kept with profit only upon high feeding and the best of pasture. For the butter-dairy the Jersey breed and its grades are the most profitable, and American pastures are now quite thickly sprinkled with the Jersey colours. Ayrshires come next, and the Devon follows in favour; but of necessity the common native and much cheaper cow forms the rank and file of the dairy herds.

In America the whole of the work of caring for the cows, feeding and milking them, is done by men. The feeding consists of pasturing wholly; pasturing with partial soiling, or full soiling in the summer; and feeding upon hay and meals of various kinds with pulped roots or silage in the winter. A large number of dairies are devoted to making butter in the winter, by which a higher price is obtained for the product, and leisure is secured in the summer for the growth of the feeding crops for use in the winter. With the rapid rise in the value of farms suited to the dairy, pasturing is found to be too costly for the largest profit, and partial soiling is almost universally resorted to. Complete soiling, by which one cow nay be kept on the product of one acre of land all the year, is practised in some of the best of the fine-butter dairies, where land is worth $\$ 200$ per acre or more, and where pure-bred Jersey, Guernsey, or Ayrshire cows of high value are kept, a yield of 12 to $14 \mathrm{lb}$. of butter per week being obtained by the high feeding of these cows. One of these cows, a Jersey, recently produced $49 \mathrm{lb}$. of butter in a week, under a forced test, while from $14 \mathrm{lb}$, to $24 \mathrm{lb}$. of butter weekly has been given by more than 100 Jersey cows now living. This, however, is an example of what is known as fancy dairying, which is closely connected with breeding cows for' sale at high prices. In a good working dairy a cow is required to yield 7 to $10 \mathrm{lb}$. of butter weekly in the height of the season, and at lenst 200 to $250 \mathrm{lb}$. in the season.

The average feeding of a dairy cow in the sum. mer consists of the best pasture that can be afforded, with some fresh green fodder as soon as the great heat of the summer hardens the grass, and from 2 to 12 quarts of ground feed-ground corn and oats, bran, cotton-seed meal, or linseed meal. A very common method of feeding is to give $\mathbf{2}$ or $\mathbf{3}$ quarts of mixed corn meal and bran, with a quart of cotton-seed meal at each milking time, the cows generally being brought to the barn to be milked. In winter, hay of clover and timothy grass mixed, with the same quantity above mentioned of meal and a peck of brewers' grains, is 


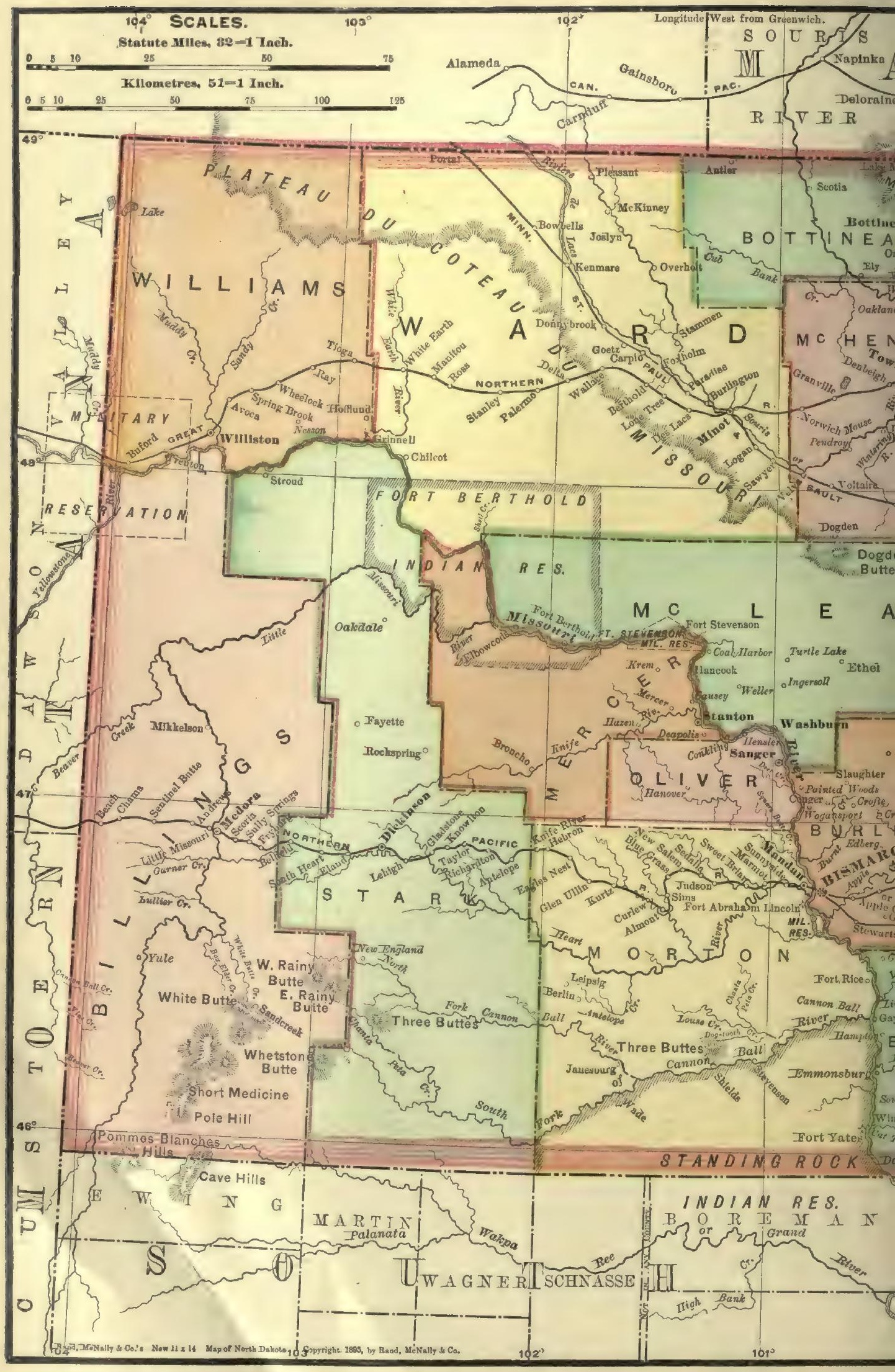


[North Daknta.]

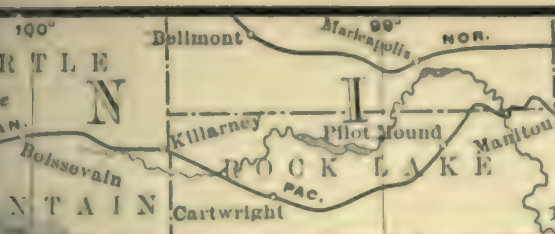
titramiont
Plomery
Sirmina $\mathrm{IN} M \perp L \mathrm{~T} O \mathrm{~N}$
$3 \int^{2} 1:$

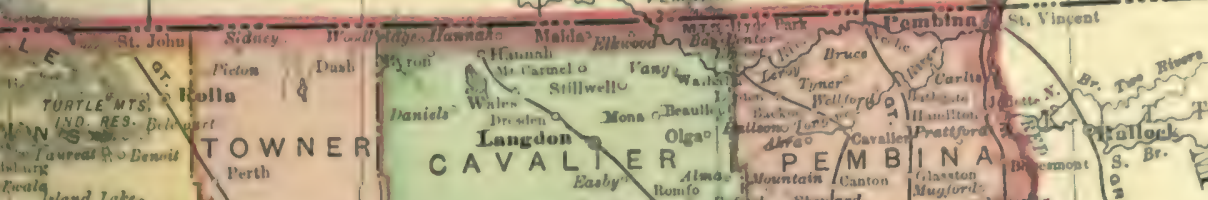

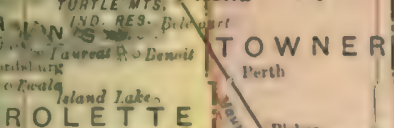

Sinhoure

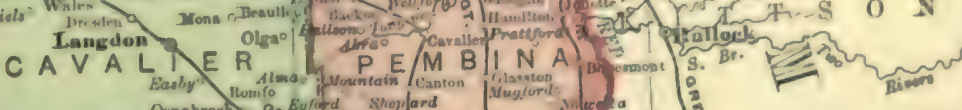
Osnabroct

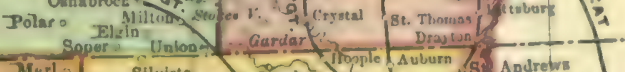

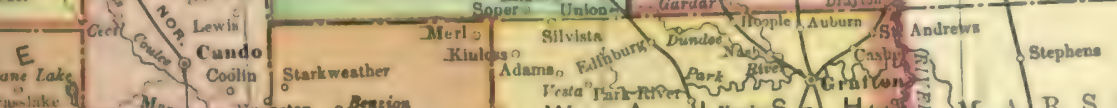

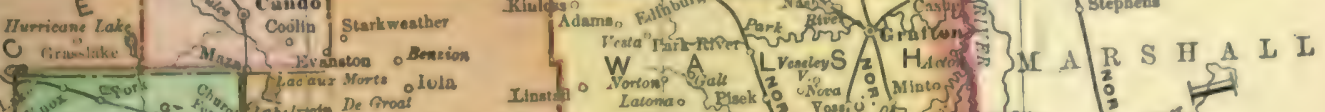

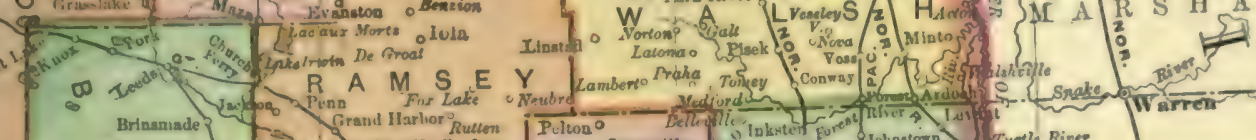

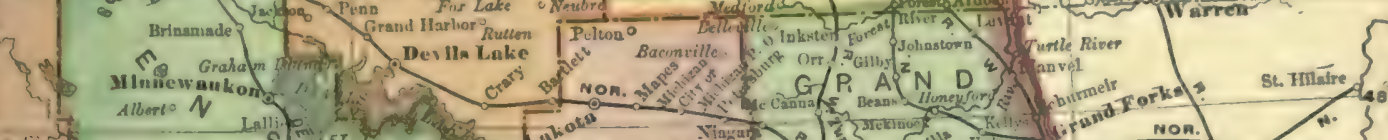

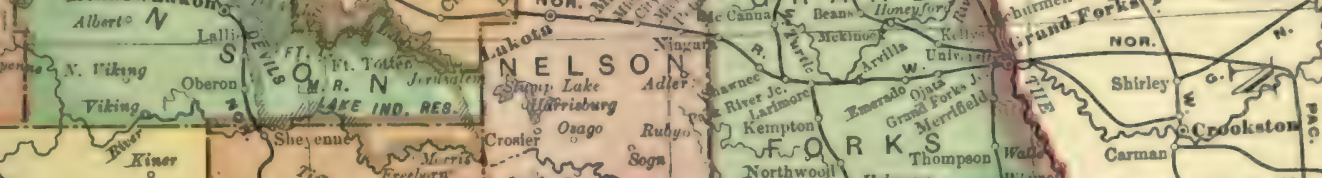

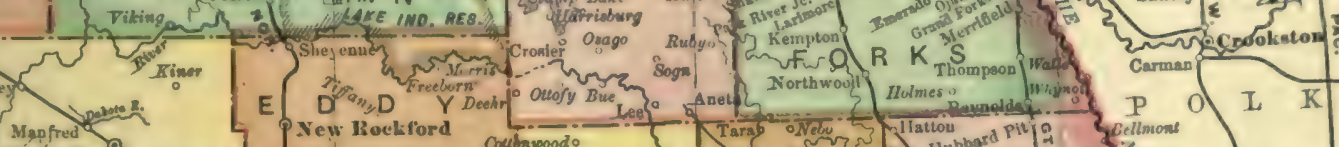

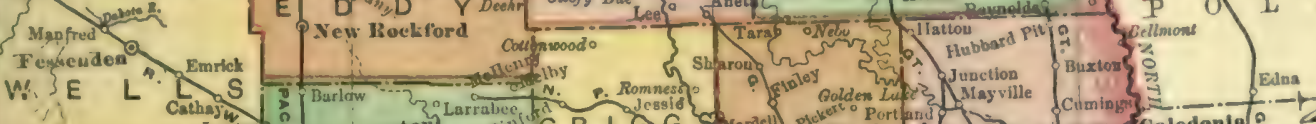

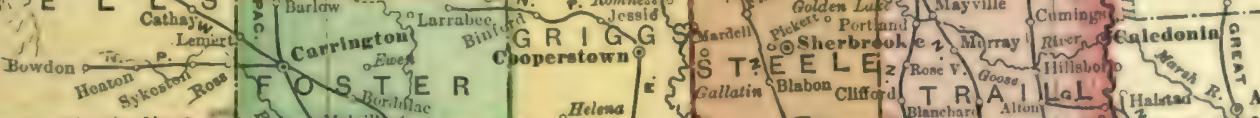
- Hawke Noes

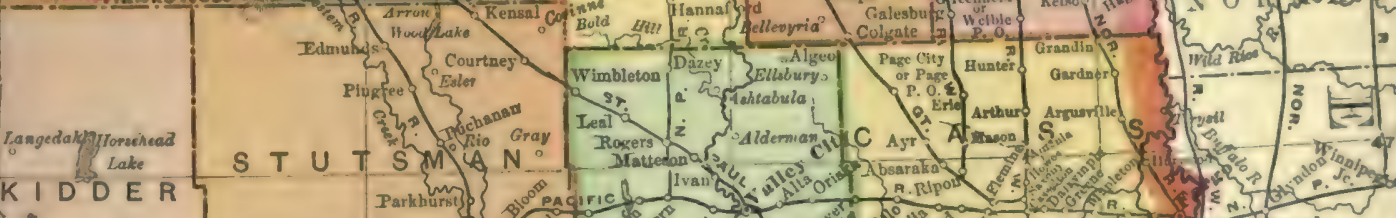
- TIDDERT

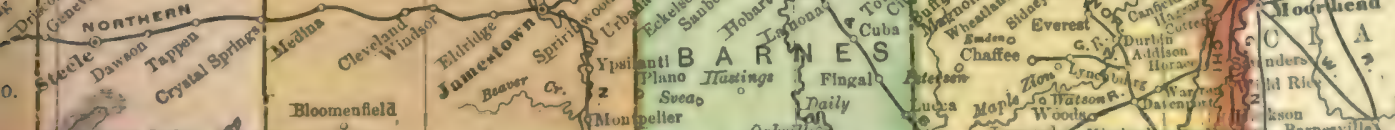

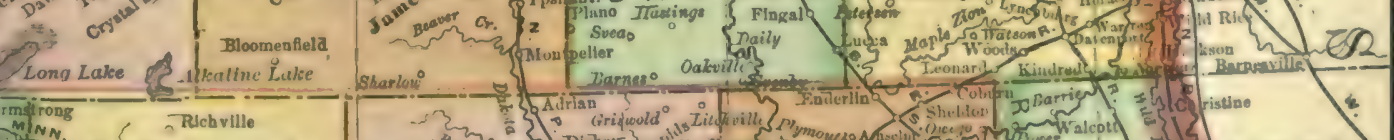

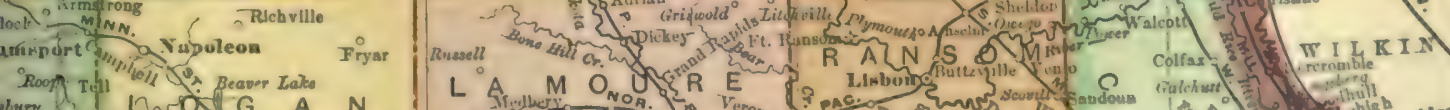
ibury L L L

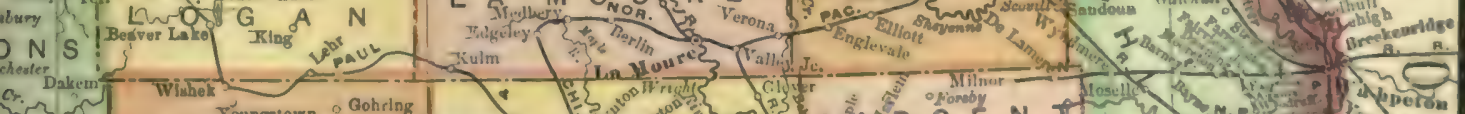

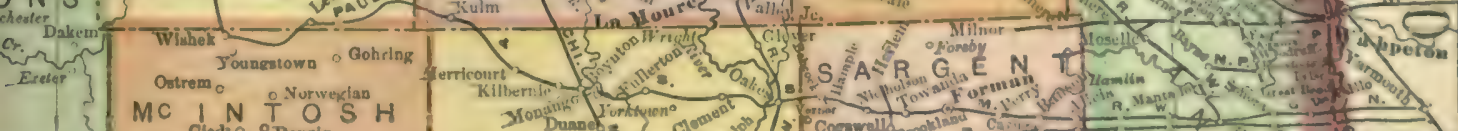

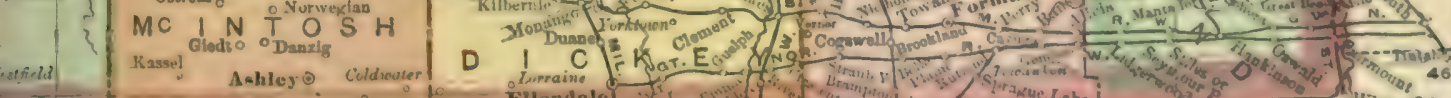
MP B L L | 

a common ration for cows kept in milk-dairies; brewers' grains are not thought favourably of in cheene or butter dairies, where any food that resudily becomes sour or tainted is scrupulously avoided, and is wholly prohibited by the owners of factorios or ereameries, and by condensers of milk. Roots of various kinds are rarely used in Americn, the hot, dry summer elimate and the greater ease of growing the equally valuable feeding crop, maize (commonly called corn), combining to make rout-crops unpopular. When roots are grown, the long res or the yellow globe mangels are preferred.

The use of ensilage has been found very convenient in the dairy, and this practice is rapidly extending. In the dairy districts of Wisconsin at least 2000 silos were built in 1888, the serious damage to the feeding erops by the dry season of the previous year having induced dairymen to secure ample feed by growing corn-which suffers little from drought, and to some extent enjoys dry, hot weather-and preserving it green in silos. It is quite certain that the cheapness and ease of production of this grand folder crop has given a greater stimulus to the Ameriean duiry than any other favourable circumstance. The abundance and cheapuess of the grain (corn), and alsu of bran, enable American dairymen to produce cheap milk, cheese, and butter; and there is no other class of American farmers who enjoy equal comfort, and even wealth.

IDais (Old Fr. deis, dois, from Lat. discus, 'a quoit," 'platter ;' in late Lat. 'a table'), a term used with considerable latitude by medieval writers. Its most usual significations are the following: (1) A canopy over an altar, shrine, font, throne, stall chair, statue, or the like; the term being applied to the canopy without regard to the materials of which it was composed, which might be cloth, wood, stone, metal, or other substance; (2) the chief seat at the high table in a hall, with the canopy covering it; (3) the high table itself; (4) the raised portion of the floor, or estrade, on which the high table stood, and which divided the upper from the lower portion of the hall

cloth of state for covering a throne or table.

Dnisy (Bellis), a genus of tubulifloral com. posites (family Asteroidere) characterised by its conical receptacle and absence of pappus. The seven or eight species are palrarctic, save $B$. integrifolia of Tennessee and Arkansas. The familiar species, $B$. perennis, needs no description, nor can any one have failed to notice its habit of elosing at night. Double varieties, crimson, pink, white, or striped, are common in gardens, and are frequently of such exuberantly vegetative habit as to produce smaller heads in the axils of the involueral bracts of the main capitulum, whence the popular name of Henand-chickens. A handsome variegated variety is ealled aucubafolia. The characteristic beauty and almost perennial profusion of blossom have made this commonent of flowers the prime favourite alike of childish and poetic garlands, and invested its many naures (Eng. Day's eye, Seot. Govoun, Fr. Marguerite, \&e.) with such an unequalled wealth of associations that it must here suffice only to name Chaucer and Burns as foremost laureates of a ceaseless tribute of admiring song. The Ox-eye Daisy is a Chrysanthemum (q.v.).

Dak, or DAWK, the mail-post of India; also, travelling by Palanquin (q.v.). See Bungalow.

Dako'ta, NorTH and SouTH, two states of the American Union embracing the former territory of Dakota, and having respectively areas of 70,795 and 77,650 square 1900 to the $\mathrm{V} . \mathrm{s}$. by ' J. Bs. miles. The territory from which Impineou Compang.

they were formed was bounded N. by Assiniboia and Manitoba (Canada); E. by Minnesola and 146
Iowa; S. by Nebraska; and W. by Montana and Wyoung. Four-fifths of the aurface is an undu. lating plain. A belt of high platenn, the Cotenu du Missouri, traverses the tract from nortl.west to wouth-east; and a similar but smaller ridge or divide lies east of the James River valley. The great river Missouri flows south-esstward acrosm the Dakotas; and the country west of that stream is more broken and better timbered than the rest. In South Dakota lie the Black Hills, a rugged and mountainous region $(3200 \mathrm{sq} . \mathrm{m}$.$) , and well$ wooded. Their highest point, Harney Peak, is 8200 feet high. The Turtle Mountains in the north are erossed by the Canadian boundary, south of which their area is but $800 \mathrm{sq} . \mathrm{m}$., and their highest ele. vation 2300 feet. The geological features of the Dakotas are full of variety and interest. A very large proportion of the surfuce is covered by glacial and alluvial drift, and much of the country bears evidence of having heen more than once submerged. During the Silurian age a shallow sea or saline lake must have rolled over it; while there is evidence that at about the end of the rlacial period it was either the bed of a great lake, or at least was very largely covered with lacustrine waters. At present the lakes are all relatively small, except Devil's Lake, or Minniwaukon, in the north, which, like many others of this region, has no outlet. Its waters are therefore saline, but it is inhabited by fishes of various fresh-water species. About one-third of the area of the tract, chiefly towards the northwest, is believed to be underlaid with beds of workable lignite, well adapted to use as a domestic fuel ; and the spontaneous firing of the lignite beds has probably been a large factor in the development of the so-called 'bad lands,' which are covered with rocks of most fantastic shapes. Natural fuel-gas has been obtained by boring at several points. Among the building-stones are quartzite, jasper, and granite in the south-east, and sandstone, marble, and granite in the south-west. Fictile clays, gypsun, cement, chalk, mica, and other useful minerals are found in many places. Medicinal and thermal springs are found in the south-west, where the Black Hills afford much gold and silver, as well as tin, antimony, lead, mica, copper, and other minerals. The tin-mines are the only ones of any extent ever worked in America; and some of the gold-mines are among the most extensive in the world. In the ten years 1877-87 the gold and silver production of the Black Hills amounted to $\$ 33,770,000$.

The climate of the Dakotas presents some remarkable features. The winters are cold, but so dry and sunny that the cold is usually borne without great suffering, except during the blizzards (see BLIzzaRD) which are occasionally experienced. The summer days are warm and often windy, but the nights are ordinarily calm and cool. The climate is everywhere remarkably healthful; malarial diseases are nearly unknown. The rainfall is relatively low, but the copious saline elemente in the soil, with the generally level surface and the coolness of the climate, tend to the retention of moisture; hence the rainfall is usually ample for the production of all the ordinary crops. The planting of forests has been greatly encouraged by local and national legislation. The Missouri River is the principal stream; it is usually navigable for eight months in the year. The other important rivers are the James, noted for the fertility of its valley; the navigable Red River, famous for its rich alluvial basin; the Big Sioux, Vermilion, White, Cheyenne, Bad, Moreau, Grand, Cannon Ball, Heart, Little Missouri, Maple, and the Mouse or Souris. The north-east section of North Dakota is tributary to Hudson Bay through the Red River: 
but the far greater part of the Dakotas belongs to the Mississippi valley. The leading agrieultural products are spring wheat of high grade, the staple product of the Red River basin; maize, which does well throughout a large part of the states; flax, raised chietly for the oil of its seed; oats, rye, barley, buckwheat, potatoes, and hay. Fruit-growing is receiving a rapid development. Hops grow wild and of good quality in certain sections. The rearing of live-stock is very important, the cattle-ranch system prevailing in the less settled districts; the Bad Lands, formerly regarded as worthless, are now specially valued as suitable for cattle-raising. The Indian reservations occupy a total of $21,328 \mathrm{sq}$. m., of which 15,371 sq. m. are in South Dakota; tota Indian population, 26,995 in 1898 . The area still open for settlement is about $30,000 \mathrm{sq}$. $\mathrm{m}$. in North Dakota, and about $20,000 \mathrm{sq} . \mathrm{m}$. in South Dakota. Immigration has gone on at a rapid rate, the larger proportion of the settlers coming from the older northern states and Canada; but many come from Scandinavia, Britain, and Germany, and not a few (Mennonites) from Russia. The construction of railways has been pushed, preceding, rather than following, the settlement of the country. The aggregate mileage in 1897 was 5346, of which 2547 miles were in North Dakota and 2799 miles were in South Dakota. Abundant provision has been made for the educational needs of the country : beside the district free-schools, each state has a state normal school for the training of teachers, a state university, an agricultural college, a school of mines, and a system of teachers' institutes, and other universities and colleges. North Dakota has 39 counties, and South Dakota 69. Among the principal towns of North Dakota are Bismarck, the capital, Fargo, Wahpeton, Grand Forks, Pembina, Jamestown, \&c. ; of South I)akcta, Pierre, the capital, on the Missouri River, Deadwood, in the Black Hills, Sioux Falls, Yankton, Watertown, \&c.

Pop. of the territory of Dakota (1860) 4837 ; (1870) 14,$181 ;(1880) 135,177$. Area of North Dakota $70,795 \mathrm{sq}$. m. ; pop. in 1890, 182,719. Area of Soutl Dakota 77,650 sq. m. ; pop. in $1890,328,808$.

History. - The first real and permanent white settlement in Dakota was probably estahlished by French Canadian settlers near Pembina about 1780. Lord Selkirk in 1812, by a mistake, built his fort of Pembina south of the Canadian line; there were fur-trading posts established at least as sarly as 1808. By a treaty with the Dakota Indians in 1851 a large part of the country was opened to white settlement. The territory was established and organised in 1861. Yankton was the capital until 1883, when Bismarck became the seat of government. During the congressional session of 1888-89 provision was made to admit it into the Union as two states-North Dakota and South Dakota.

\section{Dalai'-Lama. See LAMAISM.}

Dalbeattie, a town of Kirkeudbrightshire, near Urr Water, 15 miles SW. of Dumfries. Founded in 1780 , it owed its importance to the neighbouring Craignair granite-quarries (now to a large extent exhausted), and to its polishing-works, which furnished granite for the Liverpool and Odessa Docks, the Thames Embankment, and many more works, both at home and abroad. Pop. (1841) 1430 ; (1881) 3861 ; (1891) 3149.

Dalberg, the name of an ancient and noble German family which long held by hereditary right the office of chamberlain to the archbishopric of Worms. So great was the renown of the Dalberg family, that at every coronation of a German emperor the royal herald exclaimed: 'Is there no Dalberg here?' whereupon the representative of the family kneeled, and received from the new emperor the dignity of 'first knight of the empire.'
One of the most eminent members of this family was Karl Theodor (1744-1817), the last prince-bishop of Mainz, who, trained for the church, held numerous high offices, and ultimately became elector of Mainz, chancelior of the empire, and primate of Germany. He was a friend of Wieland, Herder, Goethe, and Schiller, and wrote works on history, philosophy, and restheties.

Dalbergia, a tropical genus of papilionaceous trees and climbers. Some of them are valuable timber-trees, particularly the Sissoo of Bengal (D. Sissoo) and $D$. melanoxylon of Senegal (Senegal Ebony, q.v.). D. monetaria, of Surinam, yields a resin very similar to Dragon's Blood.

Dale, DAvID, was born 6th January 1739 at Stewarton in Ayrshire. Early apprenticed to a Paisley weaver, he afterwards travelled some time round the country, buying up the homespun linen yarn, next became clerk to a silk-mercer, then an importer of French and Dutch yarns. On Arkwright's visiting Scotland it was agreed that he and Dale should engage in cotton-spinning together at New Lanark near the Falls of Clyde. There Dale built mills, and became prosperous. In 1799 he sold these mills to a Manchester company whose manager was the famous Robert Owen, husband of Dale's daughter. Dale spent his last years in active works of benevolence in Glasgow, and in preaching to a church of his own which called itself the 'Old Independents.' He died at Glasgow, 17th March 1806.

Dalecarlia, or DALARNÉ (signifying 'valleycountry'), an old province of central Sweden, now forming the län or county of Kopparberg. The Dalecarlians are celebrated for the part they took under Gustavus Vasa in freeing their country from the yoke of Christian II. of Denmark.

D'Alembert, JEAN LE ROND, mathematician and encyclopredist, was born in Paris, November 16,1717 , and was found the day after his birth near the church of St Jean-le-Rond, from which he derived his name-the surname he himself added long after. He was the illegitimate son of Madame de Tencin and the Chevalier Destouches, and wrs brought up by the wife of a poor glazier; but his father, without publicly acknowledging the paternity, secured to him an allowance of 1200 francs a year. At twelve the boy entered the Collegge Mazarin, where he soon showed his lifelong passion for mathematical studies. On leaving college, he returned to the humble home of his kind fostermother, where he continued to live and pursue his favourite studies for thirty years, broken only by two ineflectual attempts to earn a living by law and medicine. 'You will never,' said his foster-mother, 'be anything but a philosopher; and what is a philosoplier, but a fool who torments himself during his life that people may talk about him when he is dead?" His first distinction was admission at twenty-three to the Academy of Sciences. Two years later appeared his Traité de Dynamique, which reduces all the laws of motion to the consideration of Equilibrium, thereby making an epoch in mechanical philosophy. Later works were Réflexions sur le Cause générale des Vents, which gained the prize of the Academy of Berlin, 1746, and which contains the first conception and use of the Calculus of Partial Differences; Traité de l'Équilibre et du Mouvement des Fluides (1744); Recherches sur la Précession des Équinoxes et sur la Mutation de l'Axe de la Terre (1749); and Recherches sur Differents Points Importants du Système du Monde (1754). His Opuscules Mathématiques ( 8 vols. 1761-80) contain an immense number of memoirs, some on new subjects, some containing developments of his previous works.

But D'Alembert did not confine himself to 



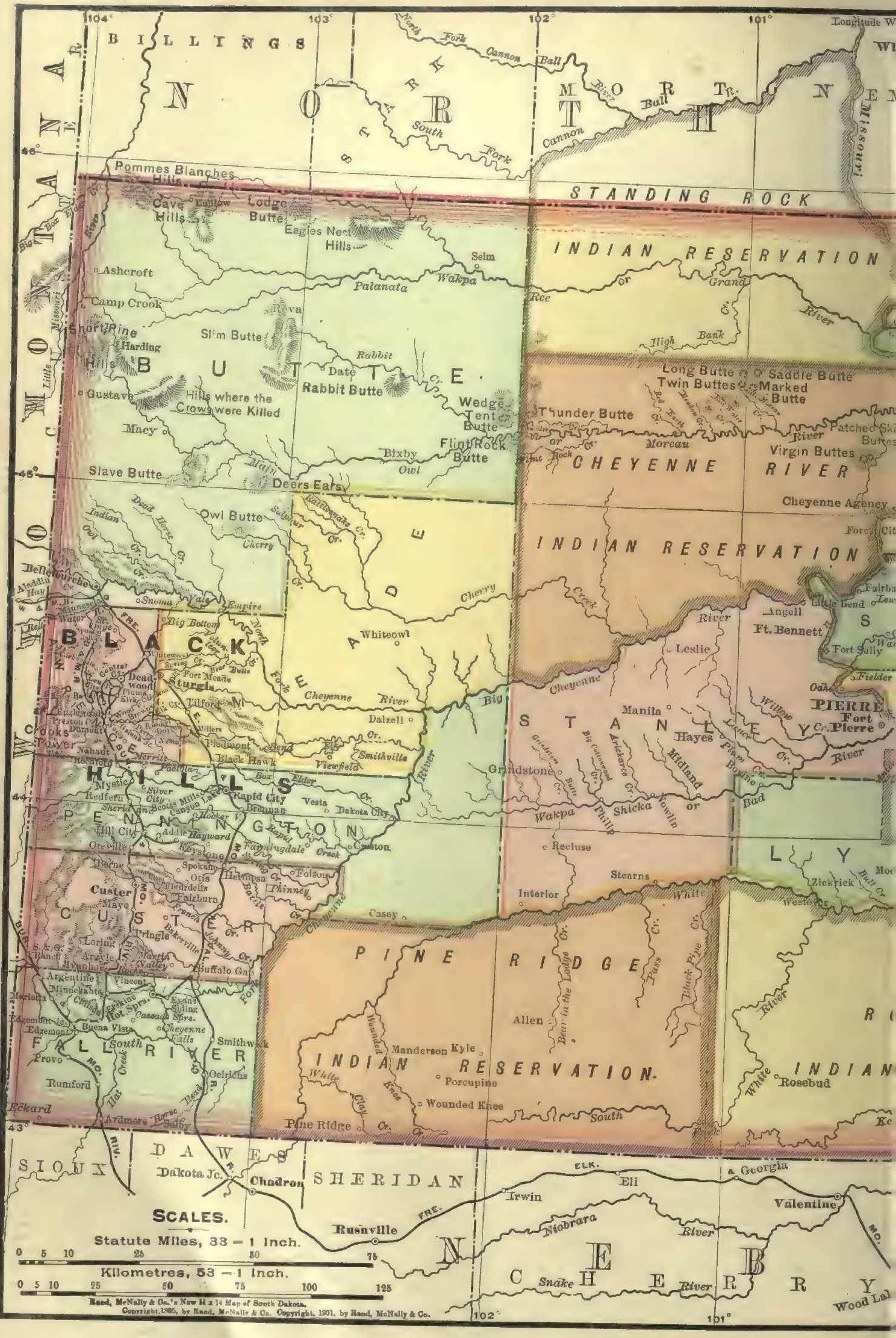



physical science, For the great Encyclopedie planned by Diderot he wrote the famous Discours Preliminuire, a noble tribute to literature and philosophy, a model of lucid and elorguent exposition, although its classitication of the sciences is open to question. Besides numerous articles in the Eneyclopertie (the muthematical portion of which he edited), he published books on philosophy, literary criticism, the theory of music, and a treatise, Sur la Destruction des Jesuites (1765), which involved him in controversy. He became secretary to the Academy in 1772, and there. after he wrote the lives of all the members deceased between 1700 and that year-one of the most pleasing of his works. His literary works have been published in a collected form, new edition, by Bossange (Paris, 5 vols. 1821). This edition contains his correspondence with Voltaire and the king of Prussia. His scientifie works have never been colleoted.

So genuine was D'Alembert's love of independence that wealth and rank had no fascination for him. Frederick II. of Prussia offered him the presidency of the Academy of Berlin in 1752, but he declined to leave France, and only accepted a subsequent offer of a pension of 1200 franes. The king of France granted him a similar sum. In 1762 Catharine II. of Russia invited him, through her ambassador, to undertake the education of her son, with a salary of 100,000 franes; and when he declined, she wrote him an autograph letter, urging that to refuse to contribute to the education of a whole nation was inconsistent with his own principles; and inviting him, if he could not reconeile himself to the breaking-off of his pursuits and friendships, to bring all his friends with him, and she would provide both for them and for him everything they could desire. But he remained steadfast. 'D'Alembert never married. He was tenderly attached for many years to Mademoiselle Lespinasse (q.v.), with whom he lived in the aame house in Platonic affection for nearly a dozen years, but who was searce worthy of his devotion. Her death in 1776 was $\Omega$ crushing blow to the philosopher. He died October 29, 1783. See his Euvres et Correspondances inédites, edited by Charles Henry (Abbeville, 1887), and the Life by J. Bertrand (Par. 1889 ).

Dalgarno, George, an almost forgotten but very able author, was born at Aberdeen about 1626, studied at Marischal College, and afterwards kept a school in Oxford for thirty years, where he died August 28, 1687. He deserves to be remembered for two remarkable works-the Ars Signorum, vulgo Character Universalis et Lingua Philosophica (1661), and Didascalocophus, or the Deaf and Dumb Man's Tutor (1680). The former is a very ingenious attempt to represent and classify ideas by specific arbitrary characters irrespective of words. It contains the germs of Bisliop Wilkins's subsequent speculations in his work, $A$ Real Charneter and a Philosophical Lenguage (1668). Leibnitz has repeatedly alluded to it in complimentary terms. The latter work has for its design "to bring the way of teaching a deaf man to read and write as near as possible to that of teaching young ones to speak and understand their mother-tongue."

Dalhousie, James Andrew Broun-Ramsay, MARQUIS OF, Governor-general of India, and 'greatest of Indian proconsuls,' was the third son of the ninth Earl of Dalhousie, and was born April 22, 1812, at Dalhousie Castle, Midlothian. He was educated at Harrow, and graduated at Christ Church, Oxford. In 1832, by the death of his only remaining brother, he succeeded to the courtesy title of Lord Ramsay. In 1835 he stood unsuccessfully for Edinburgh in the Conservative interest: in 1837 was elected for Haddingtonshire. On the death of his father in 1838 he entered the House of Peem as Earl of Dalhousie. In 1843 Sir Hobert Peel appointed him Vice-president of the Board of Trade, and in 1845 he succeeded Mr Gladstone as President of the Board. The 'railway mania' threw an immense amount of labour and responsibility upon his department; but the energy, industry, and administrative ability he displayed in his office, no less than his readiness and Huency in parliament, marked him out for the highest oflices in the state. When Peel resigned office in 1846 , Lord John Russell paid the Earl of Dalhousie the rare compliment of asking him to remain at the Board of Trade, in order to carry out the regulations he had franied for the railway system. In 1847 he was appointed Governor-general of India, as successor to Lord Hardinge, and arrived in Calcutta, January 12, 1848 - the youngest governor-general ever sent to that country. His Indian adminis. tration was not less splendid and successful in regard to the acquisition of territory than in the means he adopted for developing the resources of the country, and improving the auministration of the East Indian government. Pegu and the Punjab were conquered; Nagpur, Oudh, Sattara, Jhansi, and Berar were annexed-altogether, four great kingdons, besides a number of minor prineipalities, were added to the dominions of the Queen. Railways on a colossal scale were planned, and partly commenced; 4000 miles of electric telegraph were spread over India; 2000 miles of road between Calcutta and Peshawur were bridged and metalled; the Ganges Canal, the largest of the kind in the country, was opened ; important works of irrigation all over India were planmed and executed; and the department of public works was reorganised. - Among other incidents of his beneficent ad. ministration may be mentioned his energetic action against suttee, thuggee, female infanticide, and the slave-trade; the organisation of the Legislative Council ; the improved training of the civil service, which was opened to all natural-born subjects of the British erown, black or white; the succersful development of trade, agriculture, forestry, mining ; and a great reform in the postal service of India. In a minute which he drew np on resigning office, he reviewed with pardonable pride the events of his eight years' governor-generalship. His constitution had never been strong, and it gave way under the incessant lahour and responsibility imposed upon him by his noble ambition. Meanwhile, honours had been showered upon him by his Queen and country with no sparing hand: in 1848 he was made a Knight of the Thistle; in 1849 he receivert the marquisate, the thanks of both Houses of Parliament and of the East India Company for the 'zeal and ability' displayed in administering the resources of British Indis in the contest with the Sikhs; in 1852 , on the death of Wellington, he was nominated by the then prine-minister, the Earl of Derby, to the office of Constable of Her Majesty's Castle of Dover and Lord Warden of the Cinque Ports. Dalhousie sailed from Calcutta in March 1856. On his arrival in England he was unable to take his seat in the House of Lords; and the remainder of his days was spent in much physical suffering and prostration of strength. On 19th December 1860 he died at Dalhousie Castle in his 48th year, leaving behind him a name that ranks among the highest in the roll of Indian viceroys for statesmanship, administrative vigour, and the faculty of inspiring confidence among the millions eubjected to his sway. As he died without male issue, his title of marquis became extinet, the earldom of Dalhousie and other Scottish honours reverting to his cousin, Baron Panmure. His policy of annexation has been blamed for the 
mutiny which broke out ere his death : but though, in Justin M'Carthy's words, 'he was a man of commanding energy and indomitable courage, with the intellect of a ruler of men and the spirit of a conqueror,' he was also of a most sensitive conscience, and entered on the Sikh and Burmese wars and embarked on a policy of annexation against his will. See the articles India, OUDH, PEgU, PUNJAB, SIKHS ; the Duke of Argyll's India under Dalhousie and Canning (1865); and Captain Lionel 'Trotter's Dalhousie in the "Statesmen' series (1889).

Dalias, a town in the Spanish province of Almeria, at the foot of the Sierra de Gador, with a pop. of about 9500, who are employed chiefly in mining and smelting.

Dalkeith, a town of Midlothian, 6 miles SE. of Edinburgh, on a tongue of land between the North and South Esks. There is a large corn exchange (1855); of nearly a dozen places of worship the only old one is the parish church, collegiate once, of which Norman Macleod was for three vears minister. The chief glory of the place is Dalkeith Palace, a seat of the Duke of Buccleuch (see ScoTT). Standing near the end of the High Street, in a beautiful park of 1035 acres, it is a Grecian edifice, built in 1700 by Sir John Vanbrugh for Monmouth's widowed duchess. The castle, its predecessor, was the seat first of the Grahams, and then of the Douglases from the 14th century till 1642, when the ninth Earl of Morton sold it to the second Earl of Buccleuch. Dalkeith thus has memories of the Regent Morton (the 'Lion's Den' the castle was called in his day), of General Monk (1654-59), and of visits from James IV. James VI, Charles I., Prince Charles Edward, George IV., and Queen Victoria. It is the scene, too, of Moir's Mansie Wauch. Pop. (1841) 4831; (1881) 6931 ; (1891) 6952.

Dallas, capital of Dallas county, Texas, on Trinity River, 265 miles NNW. of Houston by rail. It is a flourishing place, with colleges for boys and girls, a nedical institute, a number of flowrmills and grain-elevators, several foundries, and manufactures of woollens, soap, \&c. Pop. (1880) 10,358 ; (1890) 38,067.

Dallas, Georen Mifflin, an American diplo. matist and statesman, was born in Philadelphia, July 10, 1792. His father, A. J. Dallas (17591817), was a distinguished lawyer of West Indian birth and Scottish descent, who filled with eredit the positions of secretary of the treasury and acting-secretary of war under President Madison. The younger Dallas graduated at Princeton College in 1810. In 1813 he was admitted to the bar, and soon after entered the diplomatic service. In 1831 he was sent to the United States senate by the Pennsylvania legislature. He was United States minister to Russia from 1837 to 1839 , and in 1844 was elected vice-president of the United States. In 1846 his casting-vote as president of the senate repealed the protective tariff of 1842 , though he had previously been considered a Protectionist. His course on this question aroused much indignation in Pennsylvania. He was sent to Great Britain as United States minister at St James's from 1856 to 1861 . He died at Philadelphia, December 31, 1864. His principal published writings were posthumous; they include a very readable and entertaining Series of Letters from London (1869), and a Life of $A . J$. Dalles (1871). His life was marked by assiduous devotion to official duties, which left him little leisure to look after his own private interests, and he lived and died \& poor man.

Dalles. See Columbia River.

Dalling, LORD. See BULwer.
Dalmatia, a narrow strip of Austrian territory extending along the Adriatic Sea, and bounded on the N. by Croatia, on the $\mathbf{E}$. by Bosnia, Herzegovina, and Montenegro. Area, $4940 \mathrm{sq.} \mathrm{m}$. pop. (1890) 527,426. The coasi of Dalmatia and numerous adjacent islands is everywhere steep and rocky, and the chief towns, all of which are on the coast, are Zara, Sebenico, Lissa, Spalato, Brazza, Ragnsa, and Cattaro. The country is moun. tainous, chiefly dry moorland, with numerous small lakes and rivers, most of which dry up in summer. The highest mountain is Orjen, near Cattaro, 6235 feet. The climate is uncertain; mean temperature about $60^{\circ}$; rainfall about 28 in. The Bora (q.v.) wind is much dreaded. About one-ninth of the land is arable, and produces wheat, barley, oats, maize, rye, and potatoes. Wine and olives are also produced. Nearly half of the land is in pasture, and wood occupies about a third. The islands are not very fertile, but supply good timber for shipbuilding. Cattle-rearing, seafaring, and the fisheries are the chief industries. The annual value of the exports and imports is $£ 1,500,000$. The exports consist principally of wine, oil, brandy, hides, wool, wax, honey, and fruits. Of the whole population, it is computed that about 55,000 are Italians, 1000 Albanians, 1000 Germans, 500 Jews, and the remainder consists of Southern Slavonians-chiefly Dalmatians and Morlaks. The Dalmatians are a fine race of men, bold and brave as seamen and soldiers, and formerly were the main support of the military power of Venice.

In ancient times Dalmatia was a considerable kingdom, and, after many unsuccessful attempta, was first subjugated by the Romans in the time of Augustus. On the fall of the Western Empire, Dalmatia, which had formed the most southern part of the province Illyricum, was captured by the Goths, from whom it was taken by the Avari $(490)$, who in their turn yielded it to the Slavonians about 620 . The state founded by the Slavonians continued until the beginning of the 11 th century, when King Ladislaus of Hungary incorporated a part of Dalmatia with Croatia, while the other part, with the title of duchy, placed itself under the protection of the Venetian republic. The Turks afterwards made themselves masters of a small portion; and by the peace of Campo-Formio (1797), the Venetian part of Dalmatia, with Venice itself, became subject to Austrian rule. When Austria, in 1805, had ceded this part of Dalmatia to Napoleon, it was annexed to the kingdom of Italy; afterwards (1810) to Illyria. Since 1814 Dalmatia forms part of Austria; the commune of Spizza being added by the Congress of Berlin in 1878.

See Sir Gardner Wilkinson, Dalmatia and Montenegro (1848); Paton, Highlands and Islands of the Adriatic (1849); Wingfield; Tour in Dalmatia (1859); Yriarte, Les Bords de l'Adviatique (1878); Freeman, Sketches from the Subject and Neighbouring Lands of Venice (1881); Henri Cons, La Province Romaine de Dalmatie (1882); and Jackson, Dalmatia, the Quarnaro, and Istria (1887).

Dalmatian Dog, or CARRIAGE-DOG, a variety of dog closely resembling in size and shape the modern pointer. It is often kept in stables, becomes attached to the horses, and may be seen running after carriages. Its colour should be white with black spots not more than an inch in diameter regularly distributed over its body, including its ears and tail. Its origin is uncertain; the name Dalmatian is probably altogether misleading; and it is supposed that it may have been brought from Indis, where a very similar kind of dog exists.

Dalmatic (Dalmatica), the deacon's robe in the Roman Catholic Church. The most ancient form of the dalmatic is exhibited in the annexed 
woodent, after an early Christian painting on a wall in the catacombe at Rome. It was originally

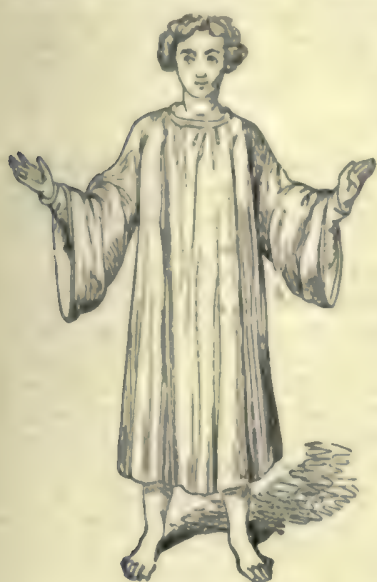

Dalmatio. of linen, but it is now generally made of the same heavy silk as the Chasuble (q.v.).

Dalmau, a city of Oudh, on the left bank of the Ganges, 60 miles $\mathrm{NW}$. of Allahabad, with a magnificent Hindu temple. Pop. 5367.

Dalmelling. ton, an Ayrshire village, near the river Doon, 15t miles SE. of Ayr by rail. In its vicinity are many active collieries and ironworks. Pop. of the village alone, about 1500 .

Dalri'ada ('the home of the descendants of Riada'), the ancient name of a territory in Ireland, comprehending what is now called 'the Route,' or the northern half of County Antrim. Its inhabitants were Scots of Grelic race living in the midst of a Pictish population, and a number of them crossed over to Argyll in 498 and founded there another kingdom of Dalriada. More than twenty kings of this state are enumerated before Kenneth MacAlpin, who, about 843, united under one sceptre the Dalriads or Scots and the Picts, and thus became the first king of Alban, which about two centuries afterwards began to be known as Scotia or Scotland.

Dalry, a town of Ayrshire, on the Garnock, 23 miles SW. of Glasgow. Pop. (1851) 2706 ; (1891) 4572 , this growth being due to the establishment of neighbouring ironworks in 1845. - For the skirmish at Dalry, near Tyndrum, see BRUCE.

Dalrymple, Alexander, hydrographer, was a younger brother of Sir David Dalrymple, Iord Hailes, and was thus a member of an old and illustrious Scottish family (for its chief members, see StaIr and HaILes); he was born at New Hailes, near Edinburgh, 24th July 1737. At fifteen he sailed for Madras as writer in the East India Company's service, and after a few years' dreary work besan to attract the notice of his superiors hy his industry and intelligence. In 1759 he made a voyage of observation among the eastern islands, and after returning to Madras in 1762 , was sent to open up the trade with Sulu, reaching Canton late in 1764. In 1775 he went to Madras as a member of council, but was recalled two years after on an unfounded charge of misconduct. $\mathrm{He}$ became hydrographer to the East India Company in 1779, and to the Admiralty in 1795, and died, three weeks after his summary dismissal from the latter office, 19th June 1808.

Dalrymple. SIR JAMES, was the second son of Sir James Dalrymple, baronet, afterwards first Viscount Stair. He was called to the Scottish bar in 1675, and ultimately became one of the chief clerks of the Court of Session, and a Nova Scotia baronet in 1698. He was a sound antiguary, and his work entitled Collections concerning the Scottish History yreceding 1153 (Edin. 1705) is still of value.

Dalton, ЈонN, chemist and physicist, was born 6th September 1766, at Eaglesfield, near Cockermouth, in Cumberland, and was the son of a Quaker weaver. He received his early education at a
Quaker school in his native place, and, after 1781, in a boarding-school kept by a relative in Kendal, of which three years later he and a brother became the proprietors. Here his love of mathematical and physical studies was first developed. He wrote several mathematical essays, and in $1787 \mathrm{com}$. menced a journal of meteorological observations, which he continued throughout his whole life, recording in all 200,000 observations. He collecter butterflies, and gathered a great hortus siccus and herbarium. In 1793 he was appointed teacher of mathematics and the physical seiences in New Col. lege, Manchester: after the removal of the college to York in 1799, he supported himself in Manchester by private tuition. In 1803 he lectured at the Royal Institution. His Meteorological Obserivations (1793), dealing largely with auroras, contained the germs of many of his future discoveries. In 1794 he first described the phenomena of colour-blindness, observed by him in his own case and that of his brother, and often called Daltonism. In 1808-10 he published his New System of Chemical Philo. sophy, to which he added the first part of a second volume in 1827. In 1817 he was appointed president of the Manchester Philosoplical Society. He was also a member of the Royal Society, and an associate of the Paris Academy, and of several other foreign societies. In 1833 he received a pension of $£ 150$, afterwards raised to $£ 300$. In the same year Dalton's friends and fellow-townsmen collected $£ 2000$, to raise a statue to his honour, which was executed by Clantrey, and placed at the entrance of the Royal Institution in Manchester. Oxford gave him its D.C.L., and Edinburgh, LL.D. He was twice a vice-president of the British Association. In 1837 he had a shock of paralysis, and he died, universally respected, at Manchester, July 27, 1844. His chief physical researches were on the constitution of mixed gases, on the force of steam, on the elasticity of vapours, and on the expansion of gases by heat. In chemistry, he distinguished himself by his development of the atomic theory, as also by his researches on the absorption of gases by water, on carbonic acid, carburetted hydrogen, \&c. Dalton was un. questionably one of the greatest chemists that any country has produced. Profound, patient, and intuitive, he had precisely the faculties requisite for a great scientific discoverer. His atomic theory elevated chemistry into a science. In his habits, Dalton was simple ; in manners, grave and reserved, but kindly, and distinguished by his truth. fulness and integrity of character. $\mathrm{He}$ 'never found time' to marry. See Lives by Angus Smith (1836); Henry (1854); Lonsdale (1874); and Sir H. Roscoe (189.5); and the article ATOMC 'THEOR.

Dalton-in-Furness, a town of Lancrshire, 16 miles WNW. of Lancaster, communicating with the sea by a canal (31 miles). It has extensive malting and ironworks; and the ruins of Furness Abbey (q.v.) are in the vicinity. Romney was a native. Pop. (1861) 2812 ; (1890) 13,300.

\section{Daltonism. See Colour-Blindeness.}

Dalyell, or Dalzell, Thomas, a Seottish general famed for his zeal in the repression of the Covensnters, was born ahout 1599, the son of Thomas Dalyell of Binns, Linlithgowshire. Entering the army at an early age he was made a general major of foot by Charles II. in 1650; and excluded from Cromwell's Act of Grace, he entered the service of Russis and distinguished himself in the wars against the Tartars and Turks, At the request of Charles II. he was permitted to return home, and in 1666 was appointed commander-in. chief in Scotland with the view of repressing the Covenanters. On 28th November he defeated them at Rullion Green, in the Pentlands, and, in Burnet's 
words, 'acting the Muscovite too grossly,' made his name a byword of terror. A very devoted royalist, he is said never to have shaved his beard after the execution of Charles I. He died 23d August 1685.

Dam. See Water, Vol. X. p. 570; Cofferdam.

Damages, in Law, are the pecuniary reparation due for loss or injury sustained by one person through the fault or negligence of another. Where a sum ascertained in amount is due, the action is one not properly for damages, but of debt. But where the sum is not ascertained, as where an injury has been done to a man's character or property, the action can in general only be for damages the amount of which the injured party estimates, and which is determined by the judgment of the court or verdict of a jury. When parties to a contract agree that if the contract be broken, a specified sum of money shall be paid, this sum is spoken of as liquidated damages, a sum agreed upon to save the trouble of ascertaining the actual damage done. Nominal damages are those given to a plaintiff who establishes his right, but has not shown that he has suffered actual loss. Exemplary or vindictive damages are given not only to compensate the injured party, but to punish the offender, as in actions for damages by fraud, seduction, and the like. Damages ultra are additional damages claimed by a plaintiff over and above those paid into court by a defendant. Every person is liable in damages for injuries caused by culpable neglect or ignorance. Professional persons are liable to make reparation of loss occasioned through their want of ordinary skill in their calling. Railway companies and steamboat owners are liable for injuries to person or property caused by the fault of themselves or their servants. The principal rules according to which danages are awarded are, that the damage is measured by the actual pecuniary loss, when ascertainable; that the injury suffered must be the immediate consequence of the faulty act or omission; and that all the parties concerned in committing a wrong are liable each for the full amount of damages to the injured party.

In the United States, the same general principles apply as in England. But the tendeney of modern legislation, instead of restricting actions for damages to cases in which the restitution of property and the enforcement of rights are involved, is gradually being extended to cases involving civil injury arising from eriminal negligence. This has been made necessary from the great powers granted corporations by law. Damages for the infringement of patents and copyrighits may by act of congress be double or treble the verdict of a jury, at the discretion of the court. See Costs, LiabiLity.

Daman', an outlying portion of the Punjab, extending along the right bank of the Indus, and as far back as the Suliman Mountains.

Daman', a Portuguese settlement and port in the province of Gujarat, on the Gulf of Cambay, 100 miles $\mathrm{N}$. of Bombay. The settlement consists of Daman proper (22 sq. m.), and the parganá of Nagar Havili (60 sq. m.), to the east. Pop. of the former, 56,084; of the latter, 12,636, nearly all Hindus. The climate is generally healthy, the soil moist and fertile. The magnificent teak forests of Nagar Havili provide excellent timber for shipbuilding, for which Daman has some celelority. The port, guarded by two forts, stands at the mouth of the Daman-Ganga, a deep, navigable stream, with a bar at its mouth, while outside is an excellent roadstead. Although the Portuguese have held Nagar Havili since 1780 only, Daman has been occupied by them since 1558. It formerly was noted for its weaving and dyeing, and exported its own fabries to the coast of Africa, besides large quantities of opium to China. The opium trade, however, has been stopped, and the chief industry, beyond the weaving of cotton cloth, and of bamboo mats and baskets, is now the deep-sea fishing, in which about $\mathbf{4 5 0 0}$ men are engaged.

Daman. See Hyrax.

Daman-i-Koh ('skirts of the hills'), a tract of hilly country in Bengal, reserved for the Santals and other equally primitive races. Area, $1366 \mathrm{sq}$. m. ; pop. 360,000 .

Dam'araland, a territory in the west of South Africa, between Namaquáland and Ovampoland proper, extending from tho. Atlantic to about $10^{\circ}$ $45^{\prime} \mathrm{E}$. long. Behind the waterless coast region (100 miles) rises a mountain district, with peaks over 8500 feet above the sea; and farther inland stretch wide prairies. The mountains are rich in minerals, especially copper; vegetation is confined to their valleys, and to the prairie region, which in the north enjoys a fine rainfall. The produce of the interior consists of ivory, feathers, skins, \&c. The Damaras, properly Herero, a Bantu (g.v.) stem, number about 80,000 , of whom 50,000 live in the mountain distriet; they are nomads, and own large flocks and herds. The Hawkoin, or Hill Damaras, in the north-east, however, who are a much lower type, now speak Hottentot. The only harbour in this part of the coast is Walvisch Bay $(q, v$.$) , which$ properly belongs to Namaqualand; it was annexed to Cape Colony in 1884. In the same year the desert region along the coast was made a German protectorate.

Damascening, or DAMASKENING, is a name which is given (1) to the watered or striated structure seen in certain sword-blades and other weapons, and (2) to the ornamental incrustation with gold and silver of steel and iron surfaces. The term in both its applications originates from the eity of Damascus, whence the erusaders brought into Europe swords and other weapons of remarkable strength, elasticity, and keenness of edge, the surfaces of which were beautifully striated with waved dark and light lines. The hilts of such weapons, and the wholesurface of defensive armour from the same source were in many cases elaborately ornamented with incrusted gold, and hence one term came to be applied to the peculiar structure of the metal, and to its ormamental treatment. It is probable that even in the crusaders' times the making of the so-called Damascus blades and the art of damascening were Persian, and to this day they remain characteristic of that country, the practice having spread thence eastward into India, while the Persians still supply the Turks on the west with their best and most highly ornamented weapons. The production of a watered or damascened surface is illustrated by the manufacture of 'Damascus twist' barrels for sporting-guns. The metal for the barrels is prepared from rods of iron and steel, piled alternately and forged and welded together into a single solid rod of small section. Three of these composite rods are used in forming a barrel. They are separately twisted in contrary directions till each has the appearance of a fine threaded screw, then they are welded together into a solid ribbon, which in its turn is spirally wound and welded by the edges till the requisite length and bore of barrel are formed. The result of the intertwisting of fine laminge of steel and iron is a beautifully damascened surface which shows itself when the barrel has been treated with acid. The incrustation of arms, armoux, and other objects of steel and iron with gold, and more rarely with silver, is very extensively praetised in the Northwest Provinces of India, as well as in Persia. In India it is known as Kuft work or Kuftgari. The 
design to be worked eut is undercut in the metal, into this the gold or silver wire is laid, and the scarp edge is ineaten down with a hammer, thus securiug the wire in its position. Another method eonsists in scratching the surface, and beating into the seratehed lines the gold or silver wire, after which the whole surface is burnished to remove the incisions. See GuN.

Damascenus. See Joannes Damascenus.

Damaseus is the capital of Syria, and the largest town in Western Asia. It is called by the natives Dimashk es-Sham, or simply es-Sham, the name which is generally applied to all Syria. The city stands $1 \mathrm{~h}$ mile from the mouth of the gorge, through which the Barada, the Chrysorrhoas of the Greeks, forces its way into the plain ; and it is now connected with Beyrout on the Mediterranean by an excellent French road about 70 miles long. The plain of Damascus, $500 \mathrm{sq}$. $\mathbf{m}$. in area, is dotted by over a hundred towns and villages. It is bounded on the north-west by the Antilibanus range, on the south by the Black Mountains, beyond which are the hills of Bashan, and on the east by the marshes of the plain. Damascus is situated on the western side of the great plain at an elevation of 2260 feet above the level of the sea, and immediately to the north-west of the city the Anti-Libanus rises to a height of 3840 feet. This elevated part of the mountain, called Jebel Kasyun, is erewned by the Kubbet en-Nasr ('Dome of Victory'). From the base of this dome the best view of Damascus is obtained. Its exquisite beauty, as seen from the mountain, is greatly enhnnced by contrast. Towards the west there are the bare chocolate sahara and the stormbleached, lime-streaked mountains. But the Barada, having forced its way through the mountain, spreads fan-like by seven rivers over the plain of Domascus, 'and everything lives whither the river cometh.' A beautiful green meadow, the joy of all orientals, extends almost from the mountain to the eity; gardens, in which all the trees of the forest and the field blend their many shades, extend for many a mile and hold the desert at bay. From out this bower of soft green the city lifts to heaven its forest of minarets towering above pearly domes. The rivers of Damascus are the constant source of the city's perennial existence. According to trudition, Abraham on his westward march lingered by the erystal waters, and ruled the city in peace.

The seven canals by which water is drawn off from the central Barada are called rivers. The most important on the right side is Nahar Abanias. This is the river Abana, and it flowed through the fashionable west-end suburb in the palmy days of Damascus. The most important canal on the left sicle of the Barada is Nahar Taura - the Pharpar of 2 Kings, v. 12. Both rivers flowed through the residential parts of the city, and were largely used for bathing purposes.

The appearance of Damaseus as viewed from the mountain resembles a tennis-racquet. The handle, which lies in a south-westerly direction, is the Meidan, a suburb which extends along the Mecca pilgrim-route for about a mile, and ends at the Bawabat Alla ('Gate of God'). The other part is concentrated on the rivers, and is inclosed within ancient walls and encompassed by luxuriant gardens which seem to surge around and over the pearl. coloured city like s sea. At the western side of the city within the walls stands the citadel. It is a large quadrangular structure about 300 ) yards long and 250 wide, with projecting towers, and surrounded by a most. It was ereeted in 1219 by Melik-elAshraf, and has a massive appearance, but it is a good deal dilapidated. The palace stands ontside the walls west of the citadel, and about 400 yards enat of the citadel stands the Great Mosque, burnt in Octolver 1893. The Monque was erected by Walid 'Abrl-el-Melik at the heginning of the sth century on the site of the church of St John, just as that church had been erected by Arcadius about the beginning of the 5th century on the site of a uagan temple, which probably occupied the site of the ancient Beit Rimmon. The cliurch was con. structed from the splendid material of ancient temples, and the mosque is made up of the materials of ancient churches. The old walls and many of the columns of the church are still in position, and on a portal, older than Mohammedan or Christian times, is carved a cross, followed by the 13th verse of the 145th Psalm in Greek, from the Septuagint, with the abbreviation Xe added. The mosque is adorned by three minarets, one of which, ealled the minaret of Jesns, rises to a height of 250 feet, and on this minaret, according to Mohamniedan tradition, Jesus will appear when he comes to judge the world. Near to the pulpit there is a richly gilded dome, beneath which the head of John the Baptist is said to rest, and in the conrt there is another dome which contains precions fragments of Kufic, Syriac, and other manuscripte. Damascus contains 70 other mosques, and more than 150 chapels for prayer and instruction. The churches and synagogues have no architectural pretensions, and their internal decorations are gorgeous but tawdry. The tomb of Nur ed-Din is one of the ornaments of the eity, and the walls of the best baths are decorated with beautiful Kishani tiles, and the floors with parian marble. The public cafés, though picturesque when lighted up, are dirty and sodden.

The religious communities occupy different quarters of Damascus. The Jewish quarter ( Harat el-Yahoud) lies to the south of the 'street called Straight,' which runs east and west for about a mile, with Roman gateways at either end. The course of the Via Recta can be traced by the columns in situ. The Christian quarter (Harat-enNasara) lies north of the street ealled Straight in the eastern part of the city, and the renainder of the city is occupied by Mohammedans. It is spoken of as Harat-el-Islam. The Christians are superior in physique, in education, in enterprise, in skill, in industry to their Mohammedan neigh. bours.

The different industries are also carried on in separate quarters. There is the silversmiths' bazaar, where rough but very effective personal ornaments are made; the saddlers' bazaar, where scarlet saddles and horse-trappings are gaily deeorated with gold and silver thread; the shoemakers' bazaar, where red and yellow slippers of gondola-form and gorgeous top-hoots are made; the Greek bazar, where imitation 'Damasens blades' and 'antiques' newly made are offered to the unwary. The book bazaar ( the Paternoster Row of the East), the cloth bazaar, the seed bazaar, the silk bazaar, and all the other trades and commodities, have their distinct locations. The narrow and badly paved streets of Damascus are dusty in summer and muddy in winter. On either side are the rows of arched niches which are the shops of the place. Each shopkeeper sits cnoss-legged in his dukkan, with his spices or Manchester goods piled up around him, awaiting customens, whom he serves with great statelines of manner. Behind the mud walls and mean entmnces there are splendid houses in Damascus. On entering, one is dazzled by the barbaric grandeur - white marble pavements, tesselatel with coloured stone; showy fountains where the constant music of falling water mingles with the cooing of doves from their nests in the lemon-trees or trellised vines; walls frescoed and decorated with mosaics and Persian tiles, and slabs inlaid with coloured pastes and 
precious stones; arabesque ceilings set with Venetian mirrors, and adorned with. blue and purple and gold-all that oriental art and lavish expenditure can do has been done to attract and charm the eye.

Great and steady progress is being made in Damascus in education, especially by the Christians ; but the Jews and Mohammedans are also awaking to the necessity of a higher standard of civilisation. For many years the Irish Presbyterians have conducted successful educational establishments in the city and neighbouring villages as auxiliary to their mission work. The British Syrian schools have also an establishment, and the London Jews' Society.

One of the sights of Damascus is the Hajj (q.v.). When it is starting for Mecea the whole city turns out to see the procession. For miles around there is a surging sea of human beings, dressed in the brightest and most striking colours. Circassians and Afghans, Kurds and KaImucks, Turkomans and Tekkes, Bedouins from the desert, and shepherds from the steppes, and all the heterogeneous tribes and peoples of the East, are represented in that brilliant procession. Damascus is also one of the meeting-places between the East and West. Enormous caravans of camels pass to and fro between Bagdad and Damascus, exchanging the dates and tobaceo and spices and carpets of the East for the produce of the looms and workshops of Europe. The chief exports are grain, flour, native cotton and silk manufactures, wool, apricot paste and stones, raisins, and liquorice-root; the imports include textiles, indigo, tobacco, coffee, sugar, and leather. The exports have an annual value of $£ 350,000$, and the imports of about

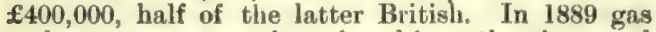
and tramways were introduced into the city; and since 1892 two railways lither (from Haifa and from Beyrout) were begun, but not finished. Pop. about 150,000 , of whom 20,000 are Christians of various sects ; 6000 are Jews.

Damask. This name, long given to certain fabrics with ornamental patterns, appears to have originated through Damascus having become, as early as the 12 th century, so celebrated for its figured silks that they were sought for everywhere. The term damask is now applied to stuffs made for table-covers, window curtains, and furniture coverings, with floral, scroll, heraldic, or partly geometrical patterns woven in the loom, but not to printed designs. There are silk, woollen, linen, and cotton damasks. Some are of two materials, usually dyed of different colours, such as silk and linen, or silk and wool, while many old damasks are of silk and gold. There are other figured textiles more or less resembling damask, such as Brocade (q.v.) and figured Velvet (q.v.), but on these the pattern is generally, at least slightly, raised, while in damask the surface is flat, and the pattern is distinct on both sides of the cloth. The structure of damask, like diaper, is merely a variety of twilling. It is by the order $n$ which the warp threads are raised and depressed for the interweaving with the weft that the pattern is produced; the weft, as a rule, intersecting the warp from every fourth up to every eighth thread. This is accomplished by a Jacquard apparatus attached to the loom. The pattern is first painted on a specially prepared paper, and then 'read off' and perforated on cards by a cutting machine made for the purpose, each card being made to control the arrangement for one shot or weft thread. These cards, which may be from 200 to 2000 in number, are laced into an endless chain, and made to revolve on a eylinder forming part of the apparatus. The holes in the cards correspond to a certain number of cross 'needles,' into which are looped upright wires terminating in hooks for lifting the warp threads. The mechanism for raising such of these wires, and with them the warp threads as are required for each throw of the shuttle, is explained under JACQUARD-LOOM. It requires four Jacquardmachines to complete some patterns of damask, and a greater number if the design is exceptionally elaborate.

Table-linen damask is perhaps the kind most largely made. In Great Britain, the principal seats of this manufacture are Dunfermline in Scotland, Belfast in Ireland, and Barnsley in Yorkshire. At some of the linen damask mills in England and Scotland, coloured union damask, of wool and linen, is also made on a large scale. Cotton damasks, both dyed and undyed, are woven extensively at Manchester and its neighbourhood, as well as at Glasgow and Prisley. The mills where all-wool damasks are chiefly manufactured are situated at or near Halifax and Bradford, where a new kind, consisting of mohair, or of mohair and silk, has been recently fabricated. Silk damasks are principally made in the neighbourhood of London. Since 1860, largely through the labours of Dr Bock of Aix-la-Chapelle, one or two very interesting collections of European damasks and other figured stuffs, ranging in date from the 13th to the 16 th century, have been made. A catalogue with some illustrations of the specimens in the South Kensington Museum was prepared some years ago by the Rev. Dr Daniel Rock. Since then some remarkable examples have been added, and the authorities of that institution are now publishing large coloured illustrations of these. The original pieces, even though many of them are much faded, give $a$ vivid idea of the beanty of the products of the looms of Sicily, of Florence, Venice, Lucea, and Genon, and of some Spanish towns, during the middle ages. The materials of which they are made are silk alone, silk and gold, silk and linen, and silk and cotton. When flowers or animals are represented on these damasks, they are conventionally, not realistically, treated, and the designs of most of them are so appropriate and effective, that even the chromolithographs of them are of great value not only to the textile designer, but to students of every branch of decorative art.

Damasns, the name of two popes of Rome. DAMASUS I. was born in 306 , probably at Rome, became archdeacon of the Roman Church in 355, and pope in 366. The party of Ursinus, the rival of Damasus, were overpowered after a sanguinary struggle of three days in the streets of Rome, and afterwards in the Basilica Liberiana (S. Maria Maggiore), from which 137 corpses were carried out in one day, the 25th October 366. The Emperor Valentinian I. decided in favour of Damasus, and twelve years later, the schism still continuing, an edict of Gratian (378) made him the judge in the case of all the clergy of the hostile party who still lived in Rome. He was a zealous opponent of the Arians, and condemned the Illyrian bishops Ursacius and Valens at a synod which he held at Rome in 368, and Auxentius, Bishop of Milan, at a second synod there in 370 . Damasus induced his friend Jerome to undertake the revision of the Italia (in 383 and 384 ), which led him to the preparation of the Vulgate version; and he did much for the preservation and adornment of the Roman catacombs. He died in 384, and was canonised. His festival falls on the 11th December. The writings of Damasus, which are ehiefly letters and epigrams, were published at Rome in 1638 (new editions, Rome, 1754, and Paris, 1840). See Langen, Geschichte der römischen Kirche (vol. i. Bonn, 1881), and Rade, Damasus, Bischof von Rom (Freiburg, 1882).-Damasus II., previously Poppo, Bishop of Brixen, was elected pope in 1048, through the influ. 
ence of the Emperor Henry III., and died twenty. three days after his accession.

Dambula, or DAMBUL, a vast Buddhist rock. temple in Ceylon, 40 miles $\mathbf{N}$. of Kandy, containing, among a profusion of carvingm, figures of Buddha of extraorlinary magnitude. See CEYLON.

Dame (Lat domina, 'a mistreas'), a title of honour which long distinguished high-born ladies from the wives of eitizens and of the commonalty in general, and which still is the accurate title of a knight's wife (see also BAnoNer). In the age of chivalry, it was enstomary even for a queen to be so called by her ehosen knight ('the dame of his heart, of his thoughts,' \&e.). In conse. quence of the greater courtesy shown towards women of higher rank, arose the custom of prefixing the word ma to dams, as a special proof of veneration and homage. Hence, too, the Virgin. mother was ealled in France Notre Dame ("Our Lady ; as if no single Chriatian could exclusively claim the privilege of serving her with the homage of his heart). The daughters of the king of France, as goon as they came into the world, were called Madame; and this ivas also the sole title of the wife of the king's eldest brother. In England, the word Dame, though not much used, is now applied to married women of all classes; but has recently acquired a special significance in connection with the Primrose League (q.v.). It is also applied specially to the mistress of a small elementary school, especially if elderly and ignorant. Mudame is shortened into Madam, a usual term of address for ladies in general, but still also a wond of honour, applicable, in particular cases, to majesty itself. Thus Tennyson in dedicating his poems to Queen Victoria, speaks as a chivalrous troubadour might have done-

\section{Take, Madam, this poor book of song.}

Dame's Violet (Hesperis), a genus of Crucifero, closely allied to stock and wallflower; natives chiefly of the

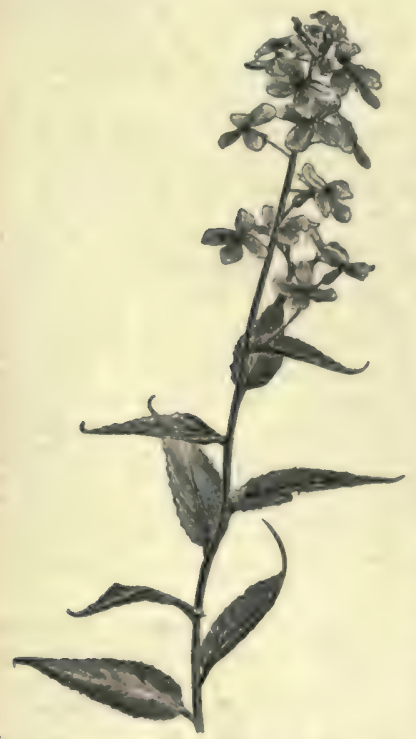

Common Dame's Violet (Hesperis matronalis). middle and south of Europe, and temperate Asia. One only, the Common Dame's Violet or Rocket ( $H$. matronalis), oceurs wild in Britain as a garden escape. The usually lilaccoloured flowers are scentlees by day, but very fragrant at night, on which account this plant is enl. tivated in flower. pots by German ladies. The cus. tom appears to have been an old English one also, and from it the plant derives its technical name. The Night. scented Rocket ( $H$. tristis) is also a favourite flower in Germany.

There are many florist's varieties ranging on each sicle of the faniliar lilge tint to purple or white, often also variegated, and single or double.

Damianl. PIETro, a grent Italinn eceleniastic of the 11th century, was born in 1007 at Ravenna, herded swine in his boyhood, but rowe by his learn. ing and devotion to the interests of the chureh to be cardinal and Bishop of Ustis (1057). Не sup. ported with vigour the ecelesiastical policy of Hildebrand (afterwards Gregory VII.), without sharing his arrogance and ambition, and was em. ployei in many important mismions. He died at Faenza in 1072. His letters, speeches, and other writings were collected by Carlinal Cajetan, and often reprinted (bost ed. 4 vols. Ven. 1743). See the Life by Neukirch (Gött. 1875).

Damianus, ST. See Cosmas.

Damien, FAtrer. Joseph Damien, born at Louvain, 31.January 1841, in 1873 devoted limself to the awful duties of spiritual guide to the lepers confined to the Hawaiian island of Molokai. Sent on a misaion to Honolulu, where he heard from the bishop the neglected state of the lepers, some 700 or 800 in number, who lived on that smull island, he volunteered to establish himself amongst them; and from 1877 onwarls became physician of their souls and borlies, their magistrate, teacher, carpenter, gardener, cook, and even graveligger at need. For long he worked on single-handed at his nohle laloours, but was ultimately joinet by another priest. For twelve years he escrped all contagion of the fatal disense, though in constant contact with the sick and dying: lut in 1885 the malsdy appeared in him; yet lie continued unabated his heroic labours till near his denth, 10th April 1889. There are lives by Clifford (1889) and Cooke (1889).

Damiens, Robert Frascois, the would-be murderer of Louis XV., was born in 1714 near Arras. Already known in his youth as Robert le Diable, he was by turns a soldier and a servant in Paris; in 1756 he was forced for a robbery to flee to Belgium, but ventured to return to Paris about the end of the year. Already he had formed the plan to murler the king, either, as he him. self allegred, on Hccount of his conduct towards the parliament, or because, as was generally asserted, he was instigated by the Jesuits. On 4th January 1757 he went to Versailles, next day followed the king and his courtiers about every. where, and about six o'clock at night, when the king was entering his carriage to leave Trianon, managed to stab him. Damiens was seized before he could finish the deed, and was nearly three months later adjudged by the parliament to a horrible death. The hand which had attempted the murder was burned at a slow fire; the fleshy parts of his body were then torn off by pincers, and melted resin and oil poured into the wounds; finally, he was torn to pieces by four horses. The fragments of his body were burned, the houme in which he was born pulled down, and his family banished from France for ever.

Damietta (Arab. Dimyat), a town of Lower Egypt, situated on the right bank of the chief eastern mouth of the Nile, about 8 miles from its mouth in the Mediterranean. It is irregularly but well built, and has some handsome mosques and marble baths, and of course several bazaars. Its commerce has been much injured by the prosperity of Alexandria, but it still carries on a considerable trade in exporting rice, fish (from Lake Menzala), coffee, and dates ; and imports charcoal, soap, and manufactured coods. It is the terminus of a branch. railway from Cairo. The cambric (kasab) known as dimity received its name from Damietta, where it was first manufactured, but it is so no longer (Lane. Poole, Art of the Saracens), and the leather-work for which it was famous has alan declined. A bar at the month of the river prevents vessels of more than fifty or sixty tons burden from ascending to the eity. Pop. about 30,000. The existing town was erected arter 1251, but, prior to that, a eity of 
the same name (more anciently Tamiáthis) stood more to the south. It was strongly fortified by the Saracens, and formed on that side the bulwark of Egypt against the early crusaders, who, however, succeeded in capturing it more than once. It was razed, and rebuilt farther inland on the site it now occupies, by the Mamluk sultan Beybars.

Dammar, or Dammar PINe (Agathis, Dammara 1, a genus of Coniferr, of the family Araucaring, distinguished from Araucaria by its laterally winged seeds not being adherent to the carpellary leaf. There are four species, all oriental or Australasian, of

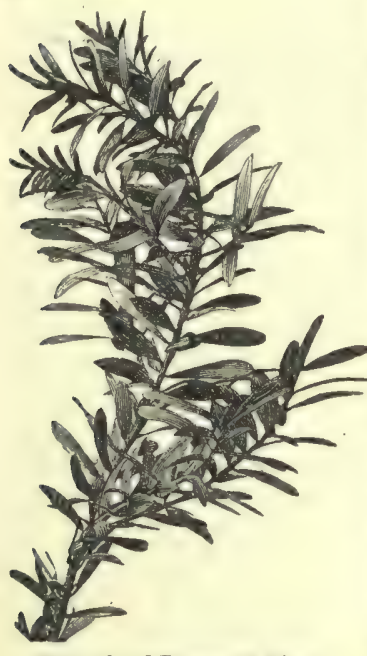

which the most familiar is $A$. ( Dam mara) orientalis or alba of the lower mountain-regions of the Malay Archipelago, Borneo, and the Philippines, a lofty tree with stout, leathery, lanceolate leaves. The timber is light, but the tree is chiefly valuable for its extraordinary abundance of resin, which is not only obtained in quantity from incisions which are best made in the large knot-like prominences of the lower part of the stem and the root, but which naturally exudes so freely as to form large lumps underground, and

foot-lnng icicles or stalactite-like masses hanging from the branches. According to Miguel it even drips from the branches in Sumatra in such quantity as often to form incrustations and rock-like masses on the banks of streams. At first semifluid and of pleasant balsamic odour, it soon hardens into an inodorous transparent mass, of no great hardness, but of glossy appearance and conchoidal fracture. It is soluble in cold ether, and at all temperatures in ethereal and fatty oils; but not entirely in boiling alcohol. It is of great value in the preparation of transparent and rapidly drying varnishes. The name signifies in Malay, 'light.' The Kami Pine (q.v.) of New Zealand is A. australis. D. ovata of New Caledonia has also similar properties.

The same name is applied in commerce to the resin of other and unrelated trees. Thus the dammar of shipyards is derived from a species of Canarium, an Amyridaceous tree, while Black Dammar is a kind of pitch derived from the allied Marignia. Shorea robusta, a dipteraceous tree, yields pitch and resin used in Indian dockyards, and sometimes also called dammar. Dammar is also occasionally confused with kinds of copal; thus the resin of Vateria indica (Dipteracer) is sometimes known as Dammar or Piny Dammar. It is the source of the Piny Varnish of India. See Copal.

\section{Damnatory Clauses. See Athanasian}

\section{Creed.}

Damocles, one of the courtiers and flatterers of the elder Dionysius, tyrant of Syracuse. Cicero tells how Damocles, having extolled in the highest terms the grandeur and happiness of royalty, was reproved by Dionysius in a singular manner. The Bycophant was seated at a table, richly spread and surrounded by all the furniture of royalty, but in the midst of his lnxurious banquet, on looking upwards, he saw a keen-edged sword suspended over his head by a single horse-hair-a sight that at once altered his views of the felicity of kings.

Damodar, a river of Bengal, rises in the Chutia Nagpur watershed, and after a south-easterly course of 350 miles, enters the Hoogly from the right. The valley of the Damodar abounds in coal and iron; and some 40,000 tons of coal are brought down yearly in native boats, strengthened to resist the strain cuused by frequent grounding on sandbanks.

Damoh, a town of India, in the Jabalpur division of the Central Provinces, 50 miles $\mathrm{E}$. of Ságar, with 8800 inhabitants, -The district of Damoh has an area of 2831 sq. m., and a pop. of 325,613 .

Damon and Pythras (more correctly Phintias), two noble Pythagoreans of Syracuse, remem. bered as the models of faithful friendship. Pythias having been condemned to death by the elder Dionysius, the tyrant of Syracuse, begged to be allowed to go home, for the purpose of arranging his domestic affairs, Damon pledging his own life for the reappearance of his friend at the time appointed for his doom. Dionysius consented, and Pythias returned just in time to save Damon from death. Struck by so noble an example of mutual affection, the tyrant pardoned Pythias, and desired to be admitted into their sacred fellowship.

Damper, a door or valve which, by sliding, rising and falling, tuming on a hinge, or otherwise, diminishes the aperture of a chimney or airflue; this lessens the quantity of air that can pass through a furnace or other fire, and thus 'damps' or checks the combustion. - The damper of a pianoforte is that part of the mechanism which, after a key is struck, and the finger is lifted up from the key, immediately checks or stops the vibration of the string (see PIANo).-Damper is also the name given in Australia to a simple kind of unleavened bread formed of wheat-flour. It is made while travelling in the bush, and baked among the ashes of a fire often kindled for the purpose.

Dampier, the name of several places in Aus. tralasia: (1) Dampier Archipelago, a cluster of about twenty small rocky islands off the NW. coast of Australia, in $21^{\circ} \mathrm{S}$. lat., and $117^{\circ} \mathrm{E}$. long., divided by the Mermaid Strait in two groups; in the eastern is Rosemary, the largest island.-(2) Dampier Island, off the NE. const of New Guinea, with a volcano about 5250 feet high.-(3) Dampier's Land, a peninsula of Western Australia, fertile and well watered, lying between King Sound and the Indian Ocean.-(4) Dampier Strait, hetween New Guinea and the archipelago of New Britain, forming, with Goschen Strait to the SE., the shortest route from Eastern Australia to China by some 300 miles.-(5) Dampier Strait, separating the island of Waygiou from the NW. extremity of New Guinea, the safest and easiest passage between the Indian and Pacific oceans.

Dampier. WILIIAM, a celebrated English navigator and hydrographer, was born near Y eovil in Somersetshire in 1652. He went early to sea, saw much hard service, and gained a great knowledge of hydrography in voyages to Newfoundland, Bantam, Jamaica, and the Bay of Campeachy. After spending a few years among the lawless log. wood-cutters on the coast of Yucatan, where honest trade was pleasantly varied with private piracy, he joined in 1679 a regular party of bnccaneers who crossed the Isthmus of Darien, sacked Santa Marta, and ravaged the coast as far south as the island of Juan Fernandez. In 1683 he engaged in another 
buccaneering expedition, in which he consted along the shores of Chili, Peru, and Mexico, sailing thence across the Pacific, and touching at the Philippine Islands, China, and New Holland. Put nshore on Nicobar Islands, May 1688, after a dispute with his comrades, he made his way by sheer seamanship in a native eanoe to Atcheen, and after two years trading in the neighbouring seas, made his way to England (1691), where he pub. limhel his vigorous and interesting Voyage round the World (1697). He was afterwurds deputed by government to conduct a voyage of diseovery to the South Seas, in which he explored the west and north-west coasts of Australia, also the consts of New Guinea and New Britain, giving his name to the Dampier Archipelago and Strait. On the return voyage his vessel was wrecked off Ascension, and Dampier with his crew lived on turtles and goats on that island for over two months, until relieved. The old buccaneer was more skilful as a pilot than successful as a commander, and his overhearing cruelty to his lieutenant led to himself being court-martialled. Yet soon after he was again appointed to the command of two vessels in a privateering expedition to the South Seas. He was as unfortunate as before. According to an account published by Fummell, one of his sailors, Dampier was guilty not merely of drunkenness and brutality, but even of cowardice, which at least is hard to believe of an old buccaneer. The master of one of his two vessels was that Alexander Selkirk who wae marooned at Juan Fernandez, and was yet to be made immortal as Robinson Crusoe. Dampier returned home at the close of 1707 , poor and broken, nor did his angry Vindication re-establish his reputation. Next year he sailed again to thSonth Seas as pilot to a privateer, which rescued Selkirk, and returned in 1711 after a prosperons voyage. Dampier died in London early in March 1715. See Life by Clark Russell (1889).

Damping off, in Horticulture, the death of plants from excess of moisture in the soil and atmosphere. Young seedlings in stoves and hotbeds are particularly liable to it. Although the cause is sufficiently obvious, prevention is not always easy; not only because some plants are very sensitive as to moisture, but also because the necessity of keeping sashes closed on account of temperature often stands in the way of the ventila. tion which would otherwise be desirable, and it is when a moist atmosphere stagnates around them, and the temperature is not very low, that plants are most liable to damp off.

Damson, a rather small oval-fruited variety of the common plum, much esteemed for preserving, and not wholly unfit for dessert. The tree grows to a considerable height, but has a bushy, sloe-like sppearance. It is extremely fruitful. There are many sub-varieties, with fruit of difterent colours, dark purple, bluish, black, yellow, \&e. Damsons are produced in great quantities in some parts of England. Damson pies and damson cheese-made somewhat in the nianner of fig-cake-are well known. The name is a corruption of Damascene, from Damascus. - The Mountain Damson or Bitter Damson of the West Indies is the Simaruba (q.v.).

Dana, Chartes Anderson, an American man of letters, was born at Hinsdale, New Hampshire, 8th August 1819, spent two years at Harvard, and was a member of the Brook Farm (q.v.) coinmunity. From 1848 to 1862 he was the managing editor of the New York Tribune, which he was largely instrumental in making the leading organ of the party opposed to the extension of slavery to new territories; and from 1863 to the close of the war he was assistant-secretary of war. In 1867 he purchased the New York Sun, and commenced the anccess $f u l$ suanagement of that journal on democratic lines. He published severn! translations and anthologies, collaborated in a Life of Grant (1868), and, along with George Ripley, an ansociate at Brouk Farm, planned and edited the $N$ ew American Cyelo. podia (1857-63), and its revised edition, the Amer. reen Cyclopadia (1873-76). See ENcycLopdeDIA. Died Oetober 17, 1897.

Dana, JAmes Dwight, an American mineralo. gist and geologist, was born at Uticn, New York, 12th February 1813. He graduated at Yale College in 1833 , and was sent out in 1838 as a scientific observer in the United States exploring expedition, under Wilkes, visiting the Antaretic and Pacific. During the course of this expedition Dana's ship was wrecked. He was afterwards associated with his father-in-law, the elder Silliman, in the editor. ship of the American Journal of Science. In 1846 he was elected professor of Natural History and Geology in Yale College. Among his works are a System of Mineralogy (1837), a Manual of Mineral. ogy (1848), two treatises on Corals, a Text-book of Geology (1864), Hawaiian Volcanoes (1890), and many highly rulued reports on geolugical, mineralogical, and zoological sulijects. He died on the 14th April 1895. Dr Dana's labours gained him world-wide clistinction, and he was made an honorary member or fellow of many of the prominent scientitic societies of Europe and America.

Dana, Richard Henry, an American poet and prose writer, was born at Cambridge, Massachusetts, 15th November 1787. He was educated at Harvard College, and was admitted to the bar at Boston in 1811. In 1818 he became associate editor of the North American Review, to which he contributed largely. Some of his poems, such as The Dying Raven (1821), and The Buccaneer (1827), were warmly praised by critics on both sides of the Atlantic. The American public, however, reeeived them coldly, partly because it was not at that time educated up to the standard of Dana's work, but chiefly because that work, with all its literary merita, such as learning, neatness of execution, and precision in verbal expression, lacked the elements which most appeal to the popular feelings. Dana's best literary work was done in the field of criticism. His abilities as a critic were very decided; and though many of his best efforts were not duly appreciated in his day, they did much to educate and ele. vate the literary taste of New England. A collection of his prose and verse appeared in 1833. He was for a time in 1821-22 connected with The Idle Man, a meritorious though ill-supported literary periodieal. He died at Boston, 2d February 1879. His son, Richard H. DANa, anthor and lawyer, was born 1st August 1815, and graduated at Harvard College in 1837. During an interval in his collegiate career, occasioned in part by a troublesome affection of the eyes, he shipped as a common sailor, and made a vovage to California and back. This voyage he described in Two Years before the Mast (1840), the best book of the kind in the language; in 1840 he was admitted to the Massachusetts bar. As a lawyer he attained great distinction, especially in the department of maritime law. Among his works are The Seaman's Friend (1841) and To Cuba and Buck (1859). He also published an edition of Wheaton's International Law, and was prominent as a Free-soiler and Republican. In 1879 he was nominated minister to England, but after a long contest the senate failed to confirm the appointment. Hedied in Rome, 7 th Jan. 1882. See Life by C. F. Adams (2 vols. 1890).

Danaë, the danghter of Aorisius, king of Argas, himself the great-grandson of Danaus. An oracle had announced that she would one day give birth to a son, who should kill his grandfather. Acrisius, 
for safety's sake, shut her up in a dungeon, where, nevertheless, she was visited by Zeus in a shower of gold, and so became the mother of Perseus. Acrisius next put both the mother and child into a chest, and exposed them on the sea. The chest, however, drifted ashore on the island of Seriphos, and Danaë and her child were saved. She remained in the island until Perseus (q.v.) had grown up and become a hero famous for his exploits; afterwards she accompanied him to Argos. On his arrival, Acrisius fled, but was subsequently slain accidentally by Perseus at Larissa.

Danakil (singular Dankali), the Arabic and now general name for the numerous nomad and fisher tribes inhabiting the coast of north-east Africa, from Massowah south to Tajurrah Bay, and from there south-west to Shoa. They belong to the Ethiopic Hamites, and are well built and slender, with features indicating an intermixture of Arab blood. In a country of waterless plains, they are generally nomads, living partly by caravan traffic and the slave-trade, but mostly on the milk of their flocks. For the language, see Isenberg's Vocabulary (Lond. 1840) ; see also Scaramucei and Giglioli, Notizie sui Danachili (1884).

Danalis, in Greek Mythology, the son of Belus and twin-brother of Egyptus, originally ruler of Libya. Fearing his brother, he fled to Argos, with his fifty daughters, the Danaides, and here he was chosen king, in place of Gelanor. The fifty sons of Agyptus followed him, and under the pretence of friendship, sought the hand of his daughters in marriage. Danaus consented, but on the bridal night he gave his daughters each a dagger, and urged them to murder their bridegrooms in revenge for the treatment he had received from Egyptus. All did so, except one, Hypermnestra, who allowed her husband, Lynceus, to escape. The poets tell how in the under-world the Danaides were compelled, as a punishment for their crimes, to pour water for ever into a vessel full of holes. From Danaus, the Argives were called Danai.

Danbury, one of the capitals of Fairfield county, Connecticut, 69 miles NNE. of New York; has a sewing-machine factory, and over a dozen manufactories of hats, entploying $a$ capital of $\$ 1,500,000$. Pop. $(1870) 8753$; (1880) 11,666; (1890) 16,552 .

Danby, Francis, A.R.A., landscape-painter, was born near Wexford, Ireland, 16th November 1793. In 1812 ire began to exhibit in Dublin; in 1813, with $O$ Connor and George Petrie, afterwards president of the Hibernian Academy, he started for London, but at Bristol the means of the party were exhausted, and Danby resolved to settle in that city, where he resided till 1824. His 'Upas Tree,' a large and impressive work, now in the South Kensington Museum, was exhibited in the British Institution (1820); his 'Disappointed Love,' in the Academy (1821), as also his 'Delivery of the Israelites ont of Egypt' (1825), which gained him his election as an associate. In 1828 his 'Opening of the Sixth Seal' won a preminm of $£ 200$ at the British Institution; in the following year two other important subjects from the Apocalypse appeared in the Academy. At this time $\mathrm{a}$ disagreement arose between the artist and the Academy, which, along with other reasons, led to his leaving England. For eleven years he resided on the Continent, mainly in Switzerland, painting little, and amusing himself with boating. On his return to England, he took up his residence at Exmouth, and contributed very regularly to the Academy till his death on 9th February 1861. His 'Fisherman's House, Sunset' (1846), is now in the National Gallery. His works, of which several have been engraved, are distinguished by imagination and poetic feeling. His three sons, Johu, Thomas, and James Francis, were all land. scape-painters. The last named was born at Bristol in 1816, and died in London, 22d October 1875 .

Danby, Lord. See LeEds (DUKE OF).

Dance, Georat (1700-68), architect, designed the Mansion House (1739) and many other London buildings. - His son, GEORGE DANCE, the younger (1741-1825), rebuilt Newgate $(1770-83)$, and was one of the original Royal Academicians.

Dance of Death (Lat. Chorea Machaboorum, Fr. La Danse Macabre), a name given to a certain class of allegorical representations, illustrative of the universal power of death, and dating from the 14th century. When the introduction of Christianity first banished the ancient Germanic conception of a future state, a new description of death-nythology arose, partly out of biblical sources, partly out of the popular character itself, wherein the Last Enemy was represented under simple and majestic images, such as that of $\mathrm{g}$ hushandman watering the ground with blood, ploughing it with swords, sowing it with corpses, rooting out weeds, plucking up flowers, or felling trees; or of a monarch assembling his arnies, making war, taking prisoners, inviting his subjects to a festival, or citing them to judgment. But with a gradual change in national manners came a change in the mode of treating the subject, and it was associated with everyday images, such as the confessional, chess. playing, and above all, with the adjuncts of a festiva - viz. music and dancing. This tendency to familiarise the theme increased during the conrusion and turmoil of the 14th century, when the national mind alternated between fits of devotion and license, or blended both elements in satire and humour. Such a mood as this naturally occupied itself with personifying Death, and adopted by preference the most startling and grotesque images it could find-that of a musician playing to dancingmen, or a dancer leading them on; and as the dance and the drama were then intimately connected, and employed on religious oecasions, this particular idea soon assumed a dramatic form.

This drama was most simply constructed, consisting of short dialogues between Death and four-audtwenty or more followers, and was undoubtedly enacted in or near churches by religious orders in Germany during the 14th century, and at a rather later period in France. It would appear that the seven brothers, whose martyrdom is reeorded in the 7th chapter of the 2d Book of Maccabees, either played an important part in the drama, or the first representation, which took place at Paris in the Monastery of the Innocents, fell upon their festival, and hence the origin of the ancient name, Chorea Machabæorum, or La Danse Macalore. As early as 1400 , the dramatic poem was imitated in Spain, and appears there in seventy-nine strophes of eight lines each ( La Dança General de los Muertos), but it did not spread; while the French, having a love for pictorial representation, very early affixed an illustration to each strophe, and in 1425 painted the whole series on the churchyard wall of the Monastery of the Innocents, where the Dance of Death was habitually enacted. We find the subject treated in painting, sculpture, and tapestry, in the churches of Anjou, Amiens, Angers, Rouen, to say nothing of the numerous woodcuts and accompanying letterpress which succeeded the invention of printing. From Paris, both poem and pictures were trans. planted to London (1430), Salisbury (about 1460), Wortley Hall in Gloucestershire, Hexham, \&c.

But nowhere was the subject so variously and strikingly treated as in Germany. A picture in one of the chapels of the Marienkirche, at Liibeck, 
still, in wpite of repented re-paintingm, learing the unmiatakable impreses of the 14th century, exhibits the very simplest form of the drama, and has some Low.German venses attached to it. Here we see twenty-four figures, partly elerical, partly lay, arranged in a descending senle, from the pope himself down to a little child, and between each of them a duncing figure of Denth, not in the form of a skeleton, but a shrivelled corpse, the whole being linked in one chain, and dancing to the musie of another Death. This representation in almost the same as a very ancient one at La Chaise-Dieu, in Auvergne, and points to the identity of the original dramatic spectacle in both countries.

The celebrated Dance of Death on the eloister walls of the Klingenthal, a convent in Basel, though painted probably not later than 1312 , exhilited a leparture from the simplest form-the number of persons exceeding the original twenty-four, and the chain being broken up into separate couples. But both alike are only to be regarded as scenes from a drama, and cannot, therefore, be justly compared with a painting in the Pisan Campo Santo, the 'Triumph of Death,' ascribed to Andrea Orcagna. And the acted drama enduring till the 15th cen. tury, we find that while there were varieties in the printings, the poem, which was the most important feature, remained almost unchanged.

A bout the middle of the 15th century, however, the drama being altogether laid aside, the pictures beeame the main point of interest, the verses merely subsidiary. Accordingly, we find from this time the same pictures repeated in different places, with different verses, or no verses at all, till at length both verses and pictures entirely change their original character. The Dance of Death being transferred from the quiet convent walls into public places, gave a new impulse to popular art. Duke George of Saxony had, in 1534, the front of his Dresden castle ornamented with a life-size bas-relief of the subject, and other representations are to be found at Strasburg and Bern. There was a Dance of Death painted round the cloister of old St Paul's in London, in the reign of Henry VI. ; and there is a sculptured one at Rouen, in the cemetery of St Maclou. But Holbein has the credit of availing himself most effectively of the original design, and giving it a new and more artistic character. Departing from the idea of a dance, he illustrated the subject by fifty-three distinet sketches for engravings, which he called 'Imagines Mortis.' The originals of these are at St Petersburg, and impressions of them have been frequently repeated under different names.

See Peignot's Recherches mu les Danses des Morts (1826); Massinan's Buseler Todtentänze (1847); and Douce's Dance of Death (1833).

Dancette, one of the lines of partition in Heraldry, which differs from In. dented in the greater width and

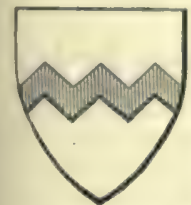

Fess Danoetté. depth of the indentations. A fess dancetté has but three indentations, as in the subjoined figure.

Dancing, a form of exercise or amusement in which one or more persons make a series of more or less graceful movements with measured steps in accord with music. In its earliest forms among simple races it is a mode of outward expression for strong emotions of joy and sorrow, love and rage, and even for the most solemn and impassioned religious feelings ; in more civilised strata of hunan society it becomes a mere frivolous amusement with no high signification whatever. Dancing corre. lsponds to a universal primitive instinct in man.
It is still practised by the South Sea Islanders, the forest Indians of Braxil, the Zulus, the negroes of Central Africa, and the native Australians, exactly as it was in the earlier stages of every civilined modern race. Many of the rude courting dances of modern savages, like the native Australian corro-borec, are themselves refinements of more ancient dances, in the survivals of which we can guess at their original grossuess and obserenity. Ferocious war-dances were constantly practived by savage warriors, as the North American Indian braves, who worked themselves up into frantic mechanical intoxication capable of carrying them irresistibly on to victory. The Zulu war-dance is still a noble exercise for warriory, like the Pyrrhic dance of the ancient Spartans: and the dancing and spinning dervishes in the East, who work themselves into spasms of physical excite. ment, are still highly esteemed for devoutness and piety. Into savage dancing, moreover, the idea of magic always enters. Thus the Mandan Indians dance buffalo to bring game when supplies of food are low, the rain-doctors of Central Africa dance mystic dances to bring down rain, and the wives of Gold Coast negroes dance a battle-dance to give their absent husbands courage in the battle. Everywhere in ancient religions is dancing one of the chief acts of worship. Religions processions went with song and dance to the Egyptian temples; the Cretan chorus, moving in measured pace, sang hymns to the Greek god, Apollo ; and one of the Muses (Terpsichore), themselves daughters of Zeus, was the especial patroness of the art. The Phrygian Corybantes danced in honour of Rhea to drum and cymbal; at Rome, during the yearly festival of Mars, the Salian priests sang and danced, heating their shields; among the ancient Jews, Miriam danced to a song of triumph-itself an net of worship, and David danced in procession before the Ark of God. A survival of religions dancing is still seen even within the pale of Christendom, where during the Corpus Christi Octave a ballet is danced every evening before the high altar of Seville Cathedral, by boys from twelve to seventeen years of age, in plumed hats and the dress of pages of Philip III.'s time.

Dancing and imitative acting in the lower stages of eivilisation are identical, and in the sacred dances of ancient Greece we may trace the whole dramatic art of the modern world. Aristotle ranked dancing with poetry, and Pindar applies the name of the dancer even to A pollo. The dancing. master in Le Bourgeois Gentilhomme asserts that the destinies of the nations devend on the science of dancing; and Lucian, in a well-known dialogue, proves that the art is superior to tragedy, and coeval with the world itself. Sir John Invies, in his long poem, the Orchestro, illustrates the origin and importance of dancing, tracing in it all the motions of nature :

For what are breath, apeech, echoes, music, winds, But daneings of the ayre in sundry kinds.

The Spartans practised dancing as a gymnastic exercise, and mate it compulsory upon aff children from the age of five. Cicero srys, "No one dances sober unless he chances to be mad;' and indeed sedate Romans in general considered it disgraceful for a free citizen to dance, except in connection with religions ceremonies, but willingly enough witnessert the performances of professional dancers, like the Almé of modern Egypt, and the Baraleres or Nanteh girls of India. The early Christians practised choral dances, which came into discredit with the love-fensts or Agapoe. St Augustine says, "it is better to dig than to dance," and many of the Fathers condemned the practice as vigorously as our Puritan ancestors, who 
saw deadly sin in 'proniscuous dancing.' St Chrysostom says dancing came first from the devil, and Father Mariana tells us the famous saraband worked more mischief than the plague. The fandango was hotly condemned by the clergy, but when danced before the Sacred College, who wished to see it before finally prohibiting it, so charmed the grave judges that they gave it their unanimous approval. Many of the medieval dances were solemn and stately in character, like the danses busses, which were danced to psalm-tunes at the court of Charles IX. of France; while it was not uncommon to see the princes of the church themselves treading a measure, and it is said the whole august Council of Trent danced at a ball given in 1562 to King Philip II. of Spain. The more lively galliarde and volta were introduced into France from Italy by Catharine de' Medici, but it was not till the reign of Louis XIV., himself an enthusiastic dancer and performer in the court ballets until cured by some verses about Nero in Racine's Britannicus, that dancing reached its height in France. A Royal Academy of Dancing was founded in 1662, at the head of which was the famous Beauchamps, from whom the king took a dancing lesson every day for twenty years. Later great dancing-masters in France were Pécour, Marcel, and Noverre. Among dances that suceessively were paramount in society in France were the graceful minuet, the favourite for a century ; the quadrille or contre-danse, often connected erroneously with the English country-dance; the Ecossaise, first introduced in 1760; the galop, a death-blow to the 'poetry of motion,' introduced from Germany; the cotillon, fashionable under Charles. X.; the polka, first danced at the Odéon in 1840 by a daneing-master from Prague; the polka tremblante, or schottisch, also of Bohemian origin, first brought out in Paris in 1844 ; the lancers, introduced by Laborde in 1836 ; and the waltz, originally Bavarian, and which, now considerably modified from its original form, promises to maintain its supremacy. The French provide the world with fashions, and society everywhere in Europe has followed their lead. The people, however, have preserved their own old national dances, and these are still danced in every corner of Europe, stamped everywhere with as distinct an impress of nationality as the grave Basque mutchiko, or the cachucha, the fandango and bolero of southern Spain. Characteristic again of particular races or merely of classes of people are such forms of the dance as the Scoteh reel, Highland-fing and strath. spey, the Irish jig, the negro break-downs, sailors hornpipes, step-dances, the can-can, morris-dances, and the like. Skirt-dancing became popular about 1891 ; and between that date and 1898 the American daucer Loie Fuller, by means of voluminous draperies deftly managed and skilfully illumiued, revealed new possibilities in the art.

See BalikT, Waltz, Strathspey, \&c.; German books by Czerwinski, Voss, Angerstein, Zorn, and Freising; Desrat, Dictionnaire de la Danse (1896); Soria, Histoire de la Danse (1897); E. Scott, Dancing as an Art (1893), and Dancing in all Ages (1899); Mrs Grove, Dancing (Badminton Library, 1896); Gaston Vuillier, The History of Dancing (trans. 1897).

Dancing Mania, an epidemic disorder allied to Hysteria (q.v.). Imposture was often present, and the consequences often clearly showed impure motives; but there is also evidence that in many cases the convulsive movements were really beyond the control of the will, whatever may have been the original character of the motives that prompted them. Epidemics of this sort were common in Germany during the middle ages, and are formally described as early as the 14 th century ; in Italy, tarantism, a somewhat similar disease, was ascribed to the bite of a spider called the Tarantula (q.v.); and similar convulsive affections have been witnessed in Abyssinia and India, and even in comparatively modern times and in the most eivilised countries in Europe, under the influence of strong popular exeitement, especially connected with religious demonstrations. But the true dancing mania of the middle ages had its theatre chiefly in the crowded cities of Germany.

In July 1374 there appeared at Aix-la-Chapelle assemblies of men and women, who, excited by the wild and frantic, partly heathenish, celebration of the festival of St John, began to dance on the streets, screaming and foaming like persons possessed. The attacks of this mania were various in form, according to mental, local, or religious conditions. The dancers, losing all control over their movements, continued dancing in wild delirium, till they fell in extreme exhaustion, and groaned as in the agonies of death; some dashed out their brains against the walls around. When dancing they were insensible to external impressions, but haunted by visions, such as of being immersed in a sea of blood, which obliged them to leap so high, or of seeing the heavens open, and the Saviour enthroned with the Virgin Mary. The frenzy spread over many of the towns of the Low Countries. Troops of dancers, inflamed by intoxicating musie, and followed by crowds, who eaught the mental infection, went from place to place, taking possession of the religious houses, and pouring forth imprecations against the priests. The mania spread to Cologne, Metz, and Strasburg, giving rise to grave disorders, impostures, and profligacy. These countries were generally in a miserable condition; and arbitrary rule, corruption of morals, superstition, and insecurity of property, had already prepared the wretched people, debilitated by disease and bad food, to seek relief in the intoxication of an artificial delirium. Exorcism had been found an efficacious remedy at the commencement of the outbreak; and in the beginning of the 16tl century, Paracelsus, that great reformer of medicine, applied immersion in cold water with great success. At the heginning of the 17 th century it was already on the decline; and we now hear of it only in single cases as a sort of nervous affection. See CHOREA, Convulsionaries, Vitus (St), and Hecker's Epidemics of the Middle Ages (Eng. trans. 3d. ed. 1859).

Dancourt, Florent Carton, a French drama. tist, born in 1661. At one time an actor and 8 favourite of Louis XIV., he became devout in his old age, which he spent in retirement in the country. He died in 1725. He was a prolific author, and excelled in depicting the stupidity of the peasantry and the follies of the bourgeoisie. Of his plays the best are Les Bourgeoisies de Qualité, Le Chevalier a la Mode, Le Galant Jardinier, and Les Trois Consines.

Dandelion (Taraxacum officinale, formerly Leontodon Taraxacum) is a ligulifloral composite, common in several varieties or sub-species throughout Britain and the whole of Europe, in pastures and by waysides, and now also so perfectly naturalised in many parts of North America as to be there one of the most familiar spring-flowers. The names Dandelion and Leontodon (Fr. and Gr., 'lion's tooth') both have reference to the form of the leaves. The whole plant abounds in a milky juice, containing a peculiar erystalline principle called Taraxcucin; has a bitter taste, and valuable medicinal properties. Roasted and ground, dandelion-root is sometimes used as a substitute for coffee. Dandetion Coffec, however, is usually a mixture of ordinary coffee and the powder or extract of dandelion-root; and Dandelion Chocolate is composed of 
one part of eommon ehocolate and four parts of the puwiler of dandelion-root. The young leaves, when blanched, are a goud salad, resembling lettuce or endive.

Dan'dolo, a famous Venetian family, which gave four doges to the republic. The most illus. trious of its memlers was Eurico, born about 1110 or 1115 A.D. Eminent in learning, eloquence, and knowledge of atfains, he ascended from one step to another, until, in 1173, he was sent as ambassador to Constantinople, and in 1192 was elected doge. In this latter erpacity he extended the bounds of the republic in Istria and Dalmatia, defeated the Pisans, and, in 1201, marched at the head of the crusaders. He sublued Trieste and Zara, the consts of Albania, the Ionian Islands, and Constantinople, 17th July 1203. When the Emperor Alexius was murdered by his own subjects, Dandolo laid siege to Constantinople, and took it by storm, 13th April 1204. He established there the empire of the Latins, and cansed Count Baldwin of Flanders to be chosen emperor. By his exertions Venice obtained possession of several Greek islands and large territories in Greece. Dandolo died at Constantinople, lst June 1205. See Crusades, VENICE - Giovanni Dandolo was doge, 1280-89; Francesco, 1328-39; Andrea, 1342-54.

Dandy Dinmont. See Terrier.

Dandy Fever. See Dengue.

Dan'ebrog ("the Danish banner') is the name of the second in dignity of the Danish orders instituted by King Waldemar in 1219.

Danegeld, a tax levied on land, originally to buy off the Danes. It was first raised by Ethelred II., was abolished by Edward the Confessor, reimposed at a higher rate by the Conqueror, and finally abolished under Henry II.

Dane-lagh (Danelaw or Denalagu), the name applied to that part of England in which Danish intluence was at one time paramount, and which still shows in the blood of the natives and in popular place-names a distinct Danish impression. At various times it ranged along the coast counties fron Yorkshire to Essex. The southern part of the old province of Deira was the most thoroughly Danish part of the whole district, and here the typical Danish endings for place-names, thorpe, caster, and by, are still the most common. Next to Yorkshire came Lincoln, with Lindsey for its centre. The least Danish part of the Dane-lagh was East Anglia and Essex. Deira and Lindsey were divided into ridings or trithings, and these ayain in to wapentakes, like the hundreds of southern counties. See Northmen, Englanv.

Danes' Dyke. See Flamborough Hzad.

Dangerfield. Tномаs (1650-85), an accom. plice of Titus Oates (q.v.).

Dángs, THE, a hilly tract within the limits of the presiclency of Bombay, in $20^{\circ} 22^{\prime}-21^{\circ} 5^{\prime} \mathrm{N}$. lat., and $73^{\circ} 28^{\prime}-73^{\circ} 52^{\prime} \mathrm{E}$. long., with an area of about 1000 sq. m., and a population of 50,000 , belonging almost entirely to the wild forest tribes. Densely wooled and slut in by steep hills, with a heavy rainfall and a close atmosphere, the country is aingularly unhealthy. It is ruled by fifteen petty chiefs, with from 134 to 14,205 subjects respectively. The Bhils (q.v.) are the most important tribe; they have charge of the police and of the district treasuries. The only inportant products are the teak and other timber-trees.

Daniel (Heb., 'God is judge') is mentioned by Ezekiel (6th century B.C.), along with Noah and Job, as a great example of righteousness and wisdom (Ezek. xiv. 14, 20, and xxviii. 3), According to the book which bears his name, he was one of the Jews carried away to Babylon in the reign of Jehoiakim, king of Judah, and gained a high position at the court of Neluchadnezzar, which he maintained also nnder Darius and Cyrum, notwithstanding all the intrigues of houtile courtiens. The book stands in our Bible, as well $a$ in the LXX. and Vulgate, immediately after Ezekiel, while in the Hebrew canon it is not included in the collection of the Prophets, but appears anong the miscellaneous "Writings" (see BIBLE). Delitzasch points out that the lwok nowhere claims to be written by Daniel, and that its position in the canon shows that it is not properly a prophetic book, but an apocalypse. It is written partly in Hebrew, partly in Aranaic, but forms a coherent whole, which is now divided into twelve chapters, the first half consisting of narrative, the second half of predictions. 'Jliese predictions are not prophetic speeches like those of the other prophetic scriptures, rebuking the sins of contenporaries, foretelling judgment on the impenitent, and promising Messianic salvation to the repentant and believing; they are minutely detailed apocalyptic visions embracing the history of four successive world-empires-the Chaldean, the Median, the Persian, and the Greco-Macedonian-culminating in the establishment of the eternal kingdom of the saints of the Most High. Oljections to the Danielic authorship of the book were made by the Neoplatonist Porpliyry as early as the 3d century A.D., but first found support in the eritical investi. grtions of Bertholdt (1806-8), followed by those of Bleek, De Wette, Langerke, Ewald, Luicke, and others. These investigations have led to the view that the book was not written till the time of the religions persecution of Antiochus Epiphanes, about $168-165$ B.C. But the book is certainly of great importance, and 'has exercised,' says Schiirer, 'a profound influence upon the form of the Messianic idea. ... In this book (xii. 2) the hope in a resurrection of the body is for the first time plainly and decidedly expressed. The Messianic hope is here the hope of a glorious future for the nation, but with the double modi. fication that the future kingdom of Israel is conceived of as a universal kingdom, and that all the saints who have died will share in it.' Accord. ing to Delitzsch, our Lord's testimony in Matt. xxiv. 15 proves' that Dan. ix. 26, et seq., is a prophecy of the desecration of the temple in the Roman war, not that it is a prophecy then fullilled for the first time.' See Hilgenfeld, Die Jüdische Apokalyptik (1857), and the special commentaries by Hitzig (1850), Auberlen (3d ed. 1874), Hilgenfeld (1863), Caspari (1869), Pusey (1864), Despres (1879), and Rotinson (1882).

Daniel, SAMuEL, poet, was the son of a music-naster, and was born in 1562 near Taunton, Somersetshire. He entered Magdalen Hall, Oxford, in 1579, but 'his glory being more prone to easier and smoother studies than in peck. ing and hewing at logic,' quitted the university withont taking a degree. He was some time tutor at Wilton to Willian Herbert, son of the Earl of Pembroke and Sir Philip Sidney's sister; afterwards at Skipton to Anne Clifforl, daughter of the Earl of Cumberland. In 1603 he was appointed to read new plays, and twelve years later he had for some time charge of a conıpany of young players at Bristol. In 1607 he became one of the queen's grooms of the privy chamber. Towards the close of his life he retired to a farm which he possessed at Beckington, in his native county, where he died in Oetober 1619. Daniel was highly praised by his contemporaries, as Lodge, Carew, Drummond of Hawthornden, although Ben Jonson deseribed him as 'a good honest man ... bnt no poet,' and Drayton quotes the opinion of some wise men that he was 'too much historian in verse," 
besides saying for himself that ' his manner better fitted prose.' Of modern crities, Coleridge, Lamb, and Hazlitt unite in praising him. As a sonneteer Daniel is altogether admirable. Some of the 'Delia' series rank near the best examples of this form in English. Daniel is indeed an elegant if not a great poet. His writings are pervaded by a moral thoughtfulness and purity of taste remark able indeed, but lacking that vital energy of move. ment and memorableness of expression which spring from genuine inspiration. The "welllanguaged Daniel' is therefore not the most interesting of the Elizabethans, although his style is quite modern. His works inclnde sonnets, epistles, masks, and dramas; but his chief production is a poem in eight books, entitled a History of the Civil Wars between York and Lancaster. His Defence of Ryme (1602) is written in admirable prose. Dr Grosart reprinted Daniel's works in the Huth Library (3 vols. 1885-87).

Daniell, JoHN FrEDERIC, scientist, was born in London, March 12, 1790. He was for a time engaged in a sugar-refining work, but was elected a Fellow of the Royal Society in 1814, and devoted himself to chemistry and meteorology. In 1823 he published his Meteorological Essays, and in 1824 the Horticultural Society awarded him their silver medal for an essay on artificial climate. In 1831 he was appointed professor of Chemistry in King's Collège, London; and in 1839 published his Introduction to Chemical Philosophy. In 1843 he received the degree of D.C.L. from the university of Oxford, and obtained all the three medals in the gift of the Royal Society. $\mathrm{He}$ invented a hygrometer (1820), and a new pyrometer (1830), as well as the electric battery known by his name; and he wrote many valuable papers on chemistry, especially on voltaic combinations and electrolysis. He died suddenly, March 13, 1845.

\section{Danish Literature. See DEnMARK.}

Danites, or Destroying ANGELs, a secret society of Mormon devotees organized in 1838, professedly for the defence of the Mormon sect against the mob, and supposed by the "gentiles" to have acted under the authority of the Mormon officials. Historians of that sect, however, claim that the band was organized by one Sampson Avard on his own responsibility for purposes of plunder, and that as soon as the practices of the band became known Avard and all who persisted in them were cut off from the church. The members, originally some 300 in number, were bound by terrible oaths and penalties to sustain one another in all things, and assassinations and other outrages were laid to their charge. Remembrance of the society's operations was revived by the trial, conviction, and execution of John D. Lee, in 1877, for the massacre of a train of 140 non-Mormon emigrants at Mountain Meadow, near Pinto, Utah, twenty years before.

Dannecker, JOHANN HEINRICH voN, a German sculptor, was born at Waldenbuch, in the dis. trict of Stuttgart, 15th Oetober 1758. His parents were in the humblest circumstances; but through the favour of the Duke of Würtemberg, he received a good education at the military academy at Ludwigsburg. His artistic talents were rapidly developed. In 1780 he obtained the prize for the best model of 'Milo ;' and in 1783 went to Paris, where he studied for two years; after which he returned to Rome, where he met Goethe, Herder, and Canova, to the last of whom he was indebted for much valuable instruction. At Rome Dannecker remained till 1790 . Here he executed in marble his statues of 'Ceres' and 'Bacehus.' On his return to Germany, the Duke of Wirtemberg appointed him professe of Sculpture in the Academy of Stuttgart, in which city he resided till his death, 8th December 1841. Dannecker was undoubtedly one of the best of modern seulptors. His forte lay in expressing individual characteristics, in which respect he has not been surpassed. This gives a great value to his busts of distinguished persons, such as Schiller, Lavater, and Gluck. His earlier works are chiefy pagan in their subjects, while his later ones are Christian, and are pervaded by a pensive idealism. ' Ariadne on the Panther' (1816; at Frankfort) ir his masterpiece.

Dannevirke ('Danes work'), the rampart built by the Danes about 808 across Sleswick (q.v.), just north of the Eider; the scene of fighting in 1849 , and razed by the Germans in 1850 .

D'Annumzio, GABRIELE, an Italian realist poet and novelist, born in 1864 on board ship in the Adriatic. His novels slow great gifts as a story-teller, and combine decadentism, restlieticism, pessimism, and egoism. They attracted notice outside of Italy in French translations before they were translated into English (The Triumph of Death, 1896, \&e.).

Dante Alighieri (also written ALdiGHIERI, ALAGHIERI, and otherwise), 'that singular splendour of the Italian race,' as Boccaccio, his first biographer, calls him, was born in May 1265, the exact day being unknown. The house in which he was born is still shown in the Piazza di San Martino at Florence. His father was a lawyer, his mother, who was his father's second wife, was named Bella, but her surname is not known. The future poet was baptised with the Christian name of Durante, afterwards contracted into Dante, in the beautiful baptistery of Florence, towards which in his later years the tenderest thoughts of the hopeless exile turned (see Inf. xix. 17; Par. xxv. 1-12). The fancy of the old biographers loved to divell on the appropriateness of both names, 'the much-enduring,' and 'the giver.' As with many other great men, a halo of legend surrounds the circumstances of his birth and early years. But the curtain is first lifted on his actual history, and that by himself, in his Vita Nuova, the New (i.e. probably Early) Life, when he relates how he first set eyes on 'the glorious lady of his heart, Beatrice,' he being then about nine years of age, and she a few months younger. To Boceaccio, and to his statement alone, we owe the generally accepted fact that she was the daughter of Folco Portinari, for Dante himself never gives the slightest clue as to her family name. Owing to his reticence on this point, combined with the extraordinary and, to modern notions, almost unintelligible amount of idealisation in Dante's language about her, some crities have (as might be expected) denied that she was a real person at all. That chance meeting in May 1274 determined the whole future conrse of the poet's life. The story of his boyish but unquenchable passion is told with exquisite pathos in the Vita Nuova. There is no evidence that any similar feeling was aroused in thes heart of Beatrice Portinari. She was married at an early age to one Simone de' Bardi, but neither this nor the poet's own subsequent marriage interfered with his pure and Platonic devotion to her. This became even intensified after her death, which took place on June 9, 1290, when she was in her 24th year. Shortly after this Dante married Gemma Donati, a member of one of the most powerful families of the Guelph faction at Florence. According to Boccaccio, this marriage was recommended by his friends, alarmed at the condition of his health through overmuch sorrow. It has commonly been assumed that the marriage was an unhappy one. This, however, is merely a conjecture, supported mainly by the fact that after Dante's exile in 1301 he never appears to have seen, or cared to see, his wife again. 
In 1289 Dante took part in the battle of Cam. paldino, in which the Florentines and their Guelphic allies defeated the Ghibelline league of Arezzo. The thight and death of Buonconte, who fought on the opposite side, is the subject of one of the most splendid episodes in the Divine Commedia ( l'u\%. v.). Later in the same year he was present at the eapitulation of Caprona, as he himself tells $n s$ in Inf. xxi. 94. With these experiences his military life seems to have closed. Soon after, we find him beginning to take part in politics, and accorling to the custom of the times, he first beeame registered in one of the eity guilds-viz that of the Apothecaries, he being then thirty years of age. It is interesting to note that he is there entered as 'Dante d'Aldighieri, poeta.' It should, perhaps, have been mentioned that we know little of his early education, except that he is said to have studied at the then celebrated. university of Bologna, and that he was certainly for some time a pupil of Brunetto Latini, of whom he speaks with the utmost veneration and affection, though a stern sense of justice compels him to place him in $\mathrm{Hel}$ (Inf. xv.). At the outset of his public life his sympathies were with the Guelph party, to which he would naturally have been attached by family ties both through his father and his wife. After filling minor public offices, and possibly going on some embassies abroad (though, doubtless, not all of those which later writers in their admiration have attributed to him ) in the ever-memorable year 1300 , the mezro canmino of his own life, when he was thirty-five years old, the beginning of a new century, the year of the first Jubilee at Rome, the assumed year of the great poetic vision of the Com. media, he attained to the dignity of one of the six priors of Florence. That singular office, lasting for only two months, seems (as Mr Lowell suggests) to have been invented by the Florentines apparently to secure at least six constitutional chances of revolution in the year.' It should be explained that this was a very eritical and stormy period at Florence. Not only was the eternal feud of Guelph and Ghibelline in full force, but a new excuse for party hatred had been found in the distinction of Black and White Guelphs, t's latter being the more moderate party, who tended to verge towards the Ghibellines, and under certain eireumstances to make common cause with them. So far as Dante could be ealled ' $\Omega$ party man' at all (see Par. vi 100-3; xvii. 68-69), it was towards this section that his sympathies tended. His office as prior lasted froni June 15 to Augnst 15 in the year 1300. He distinguished his brief tenure of office by procuring the banishment of the heads and leaders of the rival factions by which Florence was torn asun. der. He carried out this process with characteristic sternness and impartiality on Guelph and Ghibelline, White and Black alike, unmoved by any considerations of relationship, friendship, or political sympathy. Shortly afterwards the leulers of the Whites were permitted somehow to return. The partiality thus shown was a prominent feature in the accusation against Dante; but he had a com. plete answer in the fact that he was no longer in ollice at the time that it occurred.

In the following year, 1301, and probably in the autumn, in alarm at the threntened interference of Charles of Valois, who had now emesed the Alps, Dante was sent on an embassy to Rome to Pope Boniface VIII., under whose instigation Charles was acting. From that embassy he never returned, nor disl he ever agnin set foot in his native city. For mean while had occurred the dreaded advent of Charles, nominally as percemaker, on November 1, 1301. He espoused the side of the Neri or Blacks, and for three days the iight raged in the streets of Florence, Finally, the victory of the Neri was complete, their opponents were slain or banished. and their houses sacked. Soon after, in January 1302, the sentence of banishment went forth againas Dante and others, nominally on the charge, an utterly baselese one, of barateria, or malvenwation in the oflice of prior in 1300 . This was followed by a yet severer sentence on March 10, condemning them to be burned alive if ever caught, which was repented again on September 2,1311 , and yet once more on November 6, 1315. We need not attempt here to follow the wanderings of his exile of twenty years. He made at finst one or two hopelesus attempts to return, but abandoned them, partly in disappointment at their failure, partly in discust at the kind of associates with which such proceedings linked him (see Par. xvii. 61-69).

His principal halting-places seem to have beenfirst Verona, under the protection of one of the Della Seala family, described by him as "gran Lombardo' with much eulogy in Par. xvii. 71 . Then in succession he sojourned in Tuscany (with Count Salvatico), in the Lunigiano (with Moruello Malaspina), near Urbino (with Uguccione della Faggiuola), and then at Verona again. During this period he is said to have visited Paris; but though there seems little doubt that he was actually there at some time of his life, yet some of his biographers connect this visit with the period of his early education. Among these is Serravalle, who wrote, it should be noted, as late as 1417, and who is also the sole authority for Dante's allegred visit to England and Oxford. Those who, like Boccaccio, take him to France duriug his exile, suppose him to have been recalled to Italy and politics by the election of Henry of Luxemburg as emperor, and his visit to Italy, where no emperor had set foot for more than fifty years (see Purg. vi. 105, \&c.). The exile's hopes were now roused to the highest pitch, and he addressed an epistle to Henry, couched in language borrowed largely from Scripture, which to our ears sounds extravagant. His hopes were once more and finally crushed by Henry's unexpected death on August 24, 1313, after which Iante took refuge in Romagna, and finally in Ravenna, where for the most part he remained, under the protection of Guido Novello da Polenta, until his death. This took place on September 14, 1321. The precise canse of it is unknown. He was no doubt utterly broken in spirit and in health. He had been employed by his patron in an embasey to Venice, which proved unsuceessful, and he died very soon afterwards, as some biographers say, from grief and annoyance at his failure at Venice, and as others, with more probability, assert, from the effects of a fever, aggravated if not originally caused by the unhealthy manshes which he hail traversed on his return to Ravenna by land, the Venetians having harshly refused to allow him to make the journey by sea.

He was buried with much pomp by his friend Guide at Ravenna, and there he still lies. At some unknown period, by unknowr hands, and from a motive still unexplained, his body was removed from the rarcophagus in which it lay, and was walled up in the neighbouring church of St Francis, in a rough box, inseribed Dantis Osac. There it was discovered by pure accident on Mav 27,1865 , and after the bones had been identitied leyond possibility of donbt, they were replaced in the sarcophagus, from which it was found they had been abstracted. Dante had seven children, six sons and one danghter, Bentrice, who was a nun in a convent at Ravenna. His family, however, be. came extinct in the 16th century. His personal appenrance is too well known to need much deseription. Fortunately, a cast was taken from his face after death, so that we have an absolutely 
authentic record of his features. Boccaccio also, writing not very many years after his death, has preserved numerous personal details, such as that he was of moderate stature, stooping when he walked, slow and dignified both in gait and speech, reserved and taciturn in habit, but, when he spoke, keen, sarcastic, and often contemptuous. That he was devoted to music and painting appears from many passages in his works, as well as from current tradition.

The dates and sequence of his various works are a matter of conjecture, and are still very much disputed. Doubtless the Vita Nuova is the earliest. By far the most celebrated is the Divina Commedia, the pre-eminent greatness of which has tended to eclipse his other writings, which do not generally receive the attention they deserve. In this poem he purposes, and assuredly fulfils his purpose, 'to say of Beatrice that which never yet was said of any woman' (end of Vita Nuova). In this vision of Hell, Purgatory, and Heaven, we have, as it were, an encyclopedic view of the highest culture and knowledge of the age on philosophy, history, classical literature, physical science, morals, theology. All this, moreover, is expressed in the sublimest and most exquisite poetry, and with consummate power and beauty of language. The Divina Commedia, indeed, may be said to have made the Italian language, which was before so rude and unformed that Dante himself hesitated to employ it on such a theme, and is said to have commenced his poem in Latin. No work probably in the world, except the Bible, has given rise to so large a literature. To say nothing of nearly six hundred MSS. in which it was copied before printing became common, there have been published about three hundred editions; it has been no less than a hundred times translated into various European languages; and of commentaries, introductions, essays, and monographs there is no end. About fifty years after Dante's death, a public lectureship on the Divina Commedia was established at Florence, to which Boccaccio was first appointed.

The next most important work (and one throwing much light on the Commedia) is the fragment called the Convito, or Banquet. It takes the form of a commentary on some canzoni, or short poems, of the author, of which there are only three, though the work, if completed, would have contained fourteen of these 'courses,' as the author calls them. Its contents are almost as encyclopedic as those of the Commedia. The De Monarchia (written in Latin) expounds Dante's theory of the right, and, as he held, divinely-intended, government of the world, by a universal emperor acting in harmony with a universal pope, respectively administering, without conflict or interference, the temporal and spiritual affairs of mankind. Another work, again unfinished, since it consists of two books only, when four were promised, is the De Vulgari Eloquio. It also is written in Latin, and is a discussion of the origin of language, the several divisions of languages, and the numerous dialects of Italian in particular. A considerable collection of short poems, canzoni, sonnets, \&c., is also preserved under the title of the Canzoniere, and finally, we have about a dozen epistles addressed mainly to leading statesmen or rulers, and dealing with the most urgent political problems of the day. There are also some Eclogues and other minor works, as well as several of doubtful authenticity which are sometimes assigned to him.

The editions most to be recommended are as follows: For the Commedia, Brunone Bianchi, or Fraticelli, are the most serviceable for ordinary students; for a more thuruuyh and critical study, Scartazaini ( 3 vols.) is indispeusable; for the De Monarchia and the Vita Nuova, also the Commedia, the editions of Witte; for all the works, Fraticelli; for all except the Conimedia, Giuliani. The Uxford Dante, a complete text (3 vols.), was published in 1894 by the present writer, who has also written Dante and his Early Bioyraphers (1890). Scartazzini's Prolesomeni della Divina Commedia (1890) represents the labours of fifteen years; and on it is based the German Dante Handbuch, translated by Butler (1894) as A Comvanion to Dante. Butler has also published Dante, his Times and his IIork (1895). The invaluable Bibliourafia Dantescn of Colomb de Batines wascontinued by Carpellini (1845-65) and by Petzholdt (1865-80). L. G. Blanc's Vocabolario Dentesco is very valuable; and for a ceneral introduction to the life, character, and works of Dante, A Shadow of Dante, by Maria Francesca Rossetti, is strongly to be recommended. The principal English translations in verse are by Cary, Wright, Cayley, Pollock, Longfellow, Plumptre, Hazelfoot, Rossetti, Sibbald, and Musgrave (the last three the Inf. only); and in prose by Dr John Carlyle (Inf, only), Butler, and C. E. Norton.

Danton, GEORGes-J ACQUes, was born of good farmer-people, at Arcis-sur-Aube, 26th October 1759. The outbreak of the French Revolution found him a quiet and studious man, practising as an advocate in Paris, but ele long its fever filled his veins. It was not till 1792, however, that he became a great leader, as we find no trace of his influence in such movements as the destruction of the Bastille and the forcible removal of the court from Versailles to the Tuileries, Mirabeau quickly de tected Danton's genius, and hastened to attach him to himself, but his death in the spring of 1791 removed the last stay to the speedy downfall of the monarchy and the onward progress of a turbulent and infatuated democracy. Along with Marat and Camille Desmoulins, Danton instituted the Cordeliers' Club, which soon became the rallying-point of all the hotter revolutionists. There the tall brawny man-a born Tribune-with harsh and daring countenance, beetling black brows, and a voice of enormous power, thundered with vehement eloquence against the aristocrats, till the passions of the populace rose into ungovernable fury. Meantime the unhappy king stumbled into ever new blunders - most fatal, the attempt to flee from Paris (June 1791), and the affair of the Champ de Mars (July 2, 1791). Assertions have been made that Danton was after these events corrupted by the court, but there is no trustworthy evidence of this, and it is certain that his hostility to the monarchy remained as implacable as ever. 'The Mirabeau of the Sansculottes' was, indeed, says M. Claretie, 'a kind of bourgeois Mirabeau, equally powerful, but neither dissolute nor venal.' Danton's share in the insurrectionary march on the Tuileries (10th August 1792) is very doubtful, but it is certain that immediately thereafter he appears as Minister of Justice. And now the gigantic personality of the man seemed to overshadow all the surrounding figures. He stood forth as the incarnate spirit of the Revolution, manifesting alike its heroic audacity in the presence of danger fron without, and its mad suspicion and terror of danger from within. The advance of the Prussians seemed for a moment to strike a panic to the heart of France. On the 2d of September Danton mounted the tribune, and addressed the Legislative Assembly in a speech of tremendous power, which closed with the famous words regarding the enemies of France: - Pour les vaincre, pour les atterrer, que faut-il ? De l'audace, encore de l'audace, et toujours de l'audace.' The heart of Paris was moved with resistless enthusiasm : she poured forth army atter army of her sons, whose fiery valour quickly drove the invaders from the sacred soil of France. But the excitement of Paris was not all heroic-the Sep. tember murders in the prisons were merely an out burst of cowardice and fear. Danton had no shire 
in this atroeity, for which Marat was mainly responsible, but he admitted that such excesses were incidental to a revolution, and condoned them as merely morbid and passing ebullitions of forces that would yet flow freely in healthy channels.

Danton voted for the death of the king (Junuary 1793), was one of the nine original members of the Committee of Public Safety, and frequently went on missions to Dumouriez and other republican generals. In the Convention he now bent all Piis giant strength to erush the Girondists, or mixlerate party, on whose fall the extremists found themselves supreme. But he could not re. strain the forces he had ereated, and his heart filled with ineflectual pity when the heads of opponents against whom he had thundered in debate fell under the merciless guillotine of the triumph. ant Mountain (Octuber 1793). Danton was chiefly instrumental in setting up a strong central authority in the Committee of Public Safety and investing it with dictatorial powers, but he elected not to belong to it himself. Henceforth all his energies were devoted at once to fire the hearts of Frenchmen against the foreign enemy, and to conciliate domestic hatreds. He strove with all his might to abate the fanatical and pitiless severity of the revolutionary tribunal, but although Hébert and his party were cut off, Danton's policy of elemency failed to commend itself to the Mountain, whose ferocious instincts saw a more promising leader in the narrow and acrid Rolvespierre. A fruitless attempt was made to reconcile the two, but their interview left them worse friends than before. Meantime Danton was strangely careless of his fate. He went awhile for rest to his native Arcis, and forgot all the machinations of his enemies in the quiet of domestic happiness with the wife he had just married. 'I prefer being guillotined to guillotining, he said to a friend - a great saying which history will remember. Soon his friends summoned him to return to Paris. When news was brought him that the warrant for his arrest was made out, he said merely, 'They dare not,' and calmly went to sleep as usual. Arrested at last, he carried his head high until his doom :- "I leave the whole business in a frightful welter. Not one of them understands anything of government. Robespierre will follow me; I drag down Robespierre. Oh, it were better to be a poor fisherman than to meddle with governing of men.

On the 2d April 1794 he was brought with Camille Desmoulins and a group of his friends before the bar of the Revolutionary Tribunal he had formed a twelvemonth before. Asked his name formally by Fouquier-Tinville, the attorneygeneral, he replied with more than his customary greatness of phrase: 'My name is Danton : a nane tolerably known in the Revolution: my abode will soon be annihilation: but I shall live in the Pan. theon of history.' His defence was sublime in its audacity, its incoherence, its mixture of heroism and magnificent buffoonery. 'I sold to the enemy !' he exclaimed, "A man of my stamp is priceless." 'Do I look like a hypocrite?' was his only answer to one of the absurdest of the charges. The first two days of his trial his mighty voice and passionate eloquence moved the people so greatly that the Committee of Public Safety in terror hastily concocteal a decree that the months of men who had 'insulted Justice' should be shnt; and only with this shameful outrage upon justice were his enemies able to send to his dooin the greatest figure that fell in the Revolution (A pril 5, 1794). At the fout of the scaffold the thought of his much-loved wife filled his lreart, but with the woris, 'Danton, no weakness,' he nerved his heart to die' as he had lived. To the headsman he said, "Thon wilt show my head to the people; it is worth showing.
The outlines of the Titan of the Revolution in Carlyle's glowing pagen are none too beroie; his story is written large on the ennal of bim time.

See alao French works by Robinet and Bougeart, and English worka by Belloe (1889) and Beesly ( 2890$)$.

Dantsie. See Danzig.

Danube (Lat. Danubius; in the lower course, Ister; Ger. Donau; Hung. Duna; Slav. Dunai), the second river of Europe, inferior only to the Volga, has its origin in the Brege and Brigach, two mountain-streams rising in the Black Forest, in Baden, and uniting at Donaueschingen, 2264 feet above sea-level. The Danube has a total length, including windings, of 1740 miles, and drains an area estimated at $315,000 \mathrm{sq}$. $\mathrm{m}$. It flows first $\mathrm{SE}$. to Gutmadingen, and then NE. to Ulm (1519 feet above sea-level), which may be taken as the limit of its upper course. A few miles above Ulm it receives on its right bank the Iller, from which point it is navigable for boats of 100 tons. At Regens. burg (Ratisbon) the river reaches its most northerly point $\left(49^{\circ} \mathbf{Z}^{\prime}\right)$, and from thence its course is generally SE. to the northern frontier of Bulgaria. Between Ulm and Passan, where it leaves German territory, it receives, among other tributaries, the three large alpine streams, the Lech, Isar, and Inn, on the right, and the Altmuhl and Regen on the left bank. At Passan its width is 231 yards, and its depth 16 feet. The erystalline rocks of the Bohemian Forest mountains follow the stream into Austria, and as far as Aschach its banks are wild and picturesque. It flows $\mathbf{E}$. to Presburg with little variation of course, receiving the Ens from the S., and the March or Morava from the N. : and it passes from the Austrian dominions through an opening, called the Carpathian Gate, between the Leitha chain and the Lesser Carpathians, where its width is 320 yards, and its depth 20 feet. Between Presburg and Komorn the stream divides, and forms the Great and Little Schuitten, or alluvial islands. Near Waitzen it turns directly S., and enters upon the Hungarian plain, a vast sandy alluvial flat, in which it is con. tinually forcing new channels and silting up old ones; it maintains this course for 230 miles, receiv. ing from the $\mathbf{N}$. the Warg and the Gran, while the Drave from the W. adds considerably to its volume.

After this last accession, the Danube turns again SE., and, increased by the waters of the Theiss and Temes from the N., sweeps past Belgrade, where it is joined by the Save, and forms the boundary between Hungary and Servia. At Semlin, near Belgrade, it is 1706 yards wide and $\mathbf{4 6}$ feet deep, but the width is greatly contracted by spurs of the Transvlvanian and the Servian mountains for 75 miles beyond Ujpalanka. Within this stretch are eight distinct rapids, shnt in by lofty walls, and strewn with rocky shoals of limestone, crystal. line sehists, and granite. The lower Klissura is the most strikingly picturesque of these, but the most difficult passage is the shortest ( 1 , mile) of the eight - the 'Iron Gate,' properly so called, below Orsova, where the middle course of the river ends. Here the stream has a breadth of only 129 yards, and the piled-up waters attain a depth of 28 fathoms; ledges of rock lift their tooth-like points above the surface, and all around a seething stretch of whirlpools, cataracts, eddies and countereddies, combines with the river's rapid fall to present a serious and formerly impassable obstacle to navigation. Many attenipts have been made to improve the bed here, which, under article 57 of the Berlin Treaty, Anstria bonnd herself to clear; but prior to 1889 little had been effected: only. when a depth of at least 8 feet covered the obstructions could steamens drawing 5 feet make the pasage. From here the Danube enters on the Wallachion depression, and flows in a 
wide stream, through a district fertile indeed, but solitary and poorly cultivated, constantly broadening into a lake, or overspreading its banks with swamps. It drains the country between the Transylvanian mountains and the Balkans, forming the northern boundary of Bulgaria as far as Silistria; and from here it turns northward, skirting the Dobruja, and flows between marshy banks to Galatz, receiving on the way the Jalomitza and the Sereth. From Galatz it flows E., and, after being joined by the Pruth from the N., SE. to the Black Sea. The delta, which begins 5 miles W. of Tuldja, is a vast wilderness, covering an area of $1000 \mathrm{sq} . \mathrm{m}$., and resembling an immense green sea of rushes; it is cut up by numerous channels and lakes, and is the haunt of sea-birds, wolves, and buffaloes. The farthest mouths are 60 miles apart. Two-thirds of the Danube's volume passes through the Kilia, but this arm forms a secondary delta near its outlet, and the southern or St George branch also forms two channels ; it is consequently by the middle or Sulina mouth that ships enter, although it discharges only of of the river's waters. The iinprovements (1858-95) of this mouth have increased the depth over the bar from 7 or 11 feet (according to the season) to a minimun depth of 23 feet. And cuttings (1890-94) have shortened the course of the Sulina branch by six nautical miles. To defend Vienna against risk of inundation, the course of the Danulue skirting it was, in 1868-81, diverted into an artificial channel, and the bed has since been iniproved, alove and below the city, from the mouth of the Isper to that of the March. Similar works have been carried out nen Pesth, and a new channel, cut at rast expense, to avoid the inpediments to navigation at the lron Gate, was opened in 1893. Until then any effectual improvements of that passage had never advanced beyond the stage of projects, while throughont Hungary and along the lower course inundations had caused great damage. The operations were actually begun by the Hungarian government in 1890. A great steel cantilever railway lididge across the Danulve at Tchernavoda in Rommania (with its appronches, 11,800 yards long) was opened in 1895. It partly rests on the island of Balta. The Danube has ahout 400 tributaries, 100 of them navigable, and the Danube Steam Navigation Company (1830), which has done much to increase the conimerce, possesses nearly 200 steamers and over 700 iron tow-boats; other companies also have placed steamers on the upper portions of the river. Nevertheless, owing to the obstructions and to the shifting course of the stream, the tonnage of the Danule trade is inferior to that of the Elbe. The Danube is connected with the Rhine by means of the Ludwigs-Canal (1844), and with the Elbe by means of the Moldau and Mühl, and canals.

The InTERnationaI, DanuBE Navigation CoMmission was constituted in 1856 , when at the Peace of Paris the navigation of the river was declared free to all nations, and was composed of delegates of all the great powers, to whom a representative of Roumania has been added since 1878. It was appointed on the express condition that it should dissolve in 1858 , but such was its usefulness that it was informally continued till 1866, when the Conference of Paris formally prolonged its powers for five years. In 1871 the Conference of London continued the Commission for twelve years, and in 1883 a second London conference extended its existence for other twenty-one years. It exercises almost sovereign power on the mouths of the Danube, where it has conducted the great engineering works already referred to ; it has its own flag, uniform, and revenue, and has raised loans, made laws, and maintained its own small army of police. Its jurisdiction, originally limited to the river between Isaktcha and the sea, was extended at the Congreas of Berlin (1878) as far as Galatz, and afterwards to the Iron Gate; but in the last-named portion of the stream its authority is exercised only by delegation to the Riverain Commission of the states on the bank (also constituted in 1856), or on appeal from its decisions.

Danubian Principalities, a name applied to Moldavia and Wallachia. See Roumania.

Danvers, a post-village of Essex county, Massachusetts, 4 miles NW. of Salem, with nanufactures of shoes, carpets, bricks, \&c. It is the seat of a state asylum for the insane, Pea. body, 3 miles to the south, was formerly South Danvers. Pop. (1885) 7048 ; (1890) 7454.

Danville, (1) capital of Vermilion county, Illinois, on the Vermilion River, 132 miles $S_{\text {o }}$ of Chicago by rail. It is an important railway junction, and contains railway-shops, besides a number of steam-mills and foundries, and organ and chair factories. Bituminous coal is mined near by. Pop. (1890) 11,491.-(2) Capital of Montour county, Pennsylvania, on the north branch of the Susquehanna, 68 miles $\mathrm{N}$. by $\mathrm{E}$. of Harrisburg by rail. The place was first settled in 1768 , and the Pennsylvania Ironworks here is the oldest establishment in the United States for the manufacture of railroad iron. There are also numerous blast-furnaces, foundries, and rolling-mills, and the annual value of the iron forged and rolled here has sometimes reached \$5,000,000. Pop. 9073.-(3) A flourishing town of Virginia, on the Dan River, here spanned by an iron bridge, 141 miles SW. of Richmond by rail, with a female college, large cotton and other mills, and a very important trade in tobacco. Pop. (1880) 7526 ; (1890) 10,305, with suburbs, 15,000 .

D'Anville, JEAN Baptiste BourguignoN, a geographer and map-maker, was born at Paris, i1th July 1697, and levoted himself to mathematical and geographical studies with such zeal and success that in 1719 he was appointed geographer to the king. He died 28th January 1782. He published in all 211 maps; the most notable collections were the Atlas General (1737-80), and the Atlas Antiquus Major, with its accompanying three volumes of Geographie Ancienne (1769).

Danzig (Polish Gdansk), an important seaport and capital of West Prussia, and fortress of the first rank, is situated on the left bank of the western branch of the Vistula, 284 miles NE. of Berlin by rail, and about 4 miles from the river's mouth in the shallow Gulf of Danzig, an inlet of the Baltic. Danzig was an important town in the 10th century, and its possession was contended for by Danes, Pomeranians, Prussians, Brandenburgers, Poles, and the Teutonic Knights, the last of whom held it from 1308 to 1454 , when it became a free city under Poland. In 1793 it fell to Prussia, in whose hands, except during the years 1807-1814, when it existed as a separate dukedom under Napoleonic rule, it has since continued. It is surrounded by a wall with twenty bastions, and by wet ditches, and possesses works for laying the surrounding country under water on three sides; its works are strengthened by outlying forts, and a chain of batteries extends to the mouth of the river. The eity is traversed by the Motlan and Radaune, tributaries of the Vistula, the former of which has been deepened to 15 feet, and admits vessels up to the Speicherinsel, an island forming one of the quarters of the town, retained for the storage of grain. The principal port, however, is at the mouth of the Vistula, below the sand-bars across it. Many of the streets are narrow and crooked, but the Langgasse, intersecting it from east to west, presents a most picturesque appearance, with its lofty gable houses of the 16th 
and 17th centuries; and there are good nuburbs to the weat, with wide thoroughefares. Among the most noteworthy buildings are the large church of St Mary (1343-1502), with a noble 'Last Judgment,' painterl probably by Memling. and a finely-carved altar of wood; the churel of St Catharine (1326-30); the fine old Gothic town-hall; the old exchange; and the Franeiscan monastery, now used as a museum and sclusol. Dauziy was at one time a prominent memler of the Hanseatic League, and is still one of the chief commercial cities of northern Europe. Of the aeaward trade in 1884 , nearly $£ 2,850,000$ represented the imports (chiefly herrings, cotton, iron, drugs, conl, coffee, and hides), and $£ 3,162,000$ the exports (sugar, wheat, timber, spirits, \&c.). The river and railway trade is also important. The manufactures include beer, spirits (Danzig Goldwasser), sugar, tobacco, flour, iron-wares, machinery, amber, gold and silver ormaments; and there are also an imperial dockyard employing 1580 men, and an artillery arsenal with over 800 work men. The town has a library of 100,000 volumes, and is well supplied with hospitsls, asylums, schools, museums, \&e Pop. (1880) 108,55̄! ; (1885) 114,805; (1890) 120,338-two-thirds Protestants.

Daoudnagar. See Daudragar.

Daphne, a nymph who, chased by Apollo, changed herself into a laurel. The myth is a point dappui of the solar mythologists. Dapline was the name of a famous grove of cypresses and laurels near Antioch, with a temple of Apollo.

Daphne, a genus of Thymeleacer, all shrubs or small trees, deciduous or evergreen, acrid and with poisonous berries, but often with deliciously fragrant tlowers. The deciduous Mezereon (D. Mezereum), well known both for the fragrance of its pink winter flowers and for its medicinal uses, is naturalised in some places of England. The only species certainly a native of England is the Spurge Laurel (D. Laureola), an evergreen shrub, 3 to 4 feet high, with large, leathery, tufted leaves,

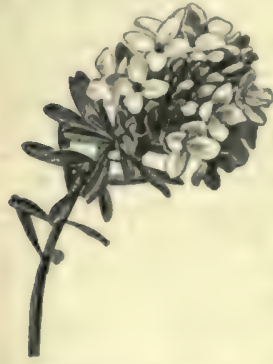

Daphne Cneorum. and greenish-yellow axil. lary flowers. It grows well under the shade of trees, and flowers in February, while the nearly allied $b$. pontica, introduced from Asia Minor, flowers a month later. Upon the three species are grafted the rarer or less hardy species. Easily recognised by its trailing and branching habit, with persistent smooth, linear, obtuse, mucronate (box-tipped) leaves, and its frngrant profusion of terminal flowers in early spring, $D$. Cneorum is the best of all species for small gardens; while $D$. alpina, with its varieties Dauphin and Verloti, is a pretty deciduous form for rock-work. $-D$. japonica, from Japan, has lemon-scentied leaves. From the bat of some species of Daphne, and nearly allied genera, useful tibre is obtained, and paper is made in different parts of the East, particularly Nepul paper from that of $D$. cannabina. In Tibet $\mathrm{Cdg}$. worthia Gardneri is employed in the same way.

Daphnia. See WATER-FLRA.

Dapsang. See Asia, Vol. I. p. 485.

Darabyherd, or DARAB, a town of Persia, in the province of Farsistan, 115 miles SE of Shiraz. Pop. 4000.

Daraganj, a suburb of Allahabad, from which it is 2 miles distant, on the right bauk of the Ganges. Pop. 13,159.
Darbhangah, the chice tuwn of Darbloangah district, in BeTar province, on the Little Baghmet. Kiver, 78 miles $\mathrm{NE}$. of Patna by rail. It has larye bazaar and a handsome market-place, extenuive tanks, a hospital, and the malsarajal's palace, with fine gardens, menagerie, and avisry. There is an active trade in oil-seeds, food-grains, timber, malt, iron, lime, \&o. Pop. (1891) 73,561.-The district has an area of $3665 \mathrm{sg}$. m., forming one large alluvial plain, intersected by a network of streams, and eovered with wide rice-fields, bamboo, and mango-groves. The rivers flood extensive areas, and fever is endemic. Rice, indigo, linseed, mustard. and tolaceo are the chief erops; the manufactures include indigo, sugnr, saltpetre, pottery, eloth, and tobaceo. Pop. (1872) 2,139,298; (1891) 2,801,955.

D'Arblay, MADAME, better known as a novelist by her maiden name of Frances Burney, was born at King's Lynn, 13th June 1752, the second daughter and the third child of the six children of Dr Burney, then organist there. Her father removed to London to teach music in 1760 , and on his wife's death next year sent his daughters Esther and Susannah to a school in Paris, but kept Fanny at home from a fear that her great affection for her maternal grandmother, then in France, should make her a convert to Catholicism. Dr Burney's second marriage in 1766 gave her a kind step-mother, but did not disturb her daydreams nor her incessant seribbling of atories, plays, and poems, begun at ten, although but two years before she was ignorant of her letters. On her fifteenth birthday, in $\mathbf{a}$ fit of repentance for snch waste of time, she burned all her papers, but she could not erase from her brain the plot of the story which grew later into Evelina, or a Young Lady's Entrance into the World. This was sold for $£ 20$ to Lownes, and published anonymously in January 1778, not even her father having seen the manuseript, although he had been dutifully told beforehand of the project. Dr Burney. at once recognised his daughter's touch, and soon confided the secret to Mrs Thrale, who, as well as Dr Johnson, petted and flattered the gifted young authoress to her henrt's delight. The praises showered upon the book by Johnson, Reynolds, Burke, and the whole world of fashion, might well. have turned her head, and are told in delightful detail in her diary. Urged to write a comedy, she had the sense to suppress it in deference to the criticisms of her father and Samuel Crisp, a sagacious old critic, soured to the world but not to her, the 'daddy' of so many of her letters. In 1782 she published Cecilia, which was no less successful than her first novel. At Windsor, in the house of her friend the venerable Mrs Delany, she becane known to the royal family, and soon received (July 1786) the appointment of second keeper of the robes at court, with a salary of $\mathcal{E 2 0 0}$ a year. She soon found her menial dutics intolerably tedious, and her health began to decline, but her veneration for the queen kept her froni resigning until compelled by the remonstrences of Burke, Boswell, Windham, and others of her father's friends. At length in July 1791 she was permitter to retire with a pension of $£ 100$ s year, and soon recovered her health and spirits by travelling in England. At Mickleham, near Dorking, she met General D'Arblay, a French refugee, and married him on nothing more than her pension in July 1793. Her third novel, Camilla, was published by subscription in 1796, and brought her, it is sup. mesel, about 3000 guinens, with which she built Canilla Cottage, near Mickleham. It was, however, nothing more than a pecuniary success, while her tragedy, Edwoy and Elvina, had already been damned in 1795 , spite of the acting of Mrs. Siddons and Kemble. From 1802 to 1812 she lived at Passy in France with her husband, who 
had procured eivil employment there, then returned to England with her son, tended her father till his death in April 1814, and in the beginning of the same year published her last novel, The $W$ anderer, another literary failure. At the first Restoration she joined her husband in Paris, was at Brussels during the battle of Waterloo, and soon after returned finally to $\mathbf{E}$ gland with her husband, who died 3d May 1818. Her son was tenth wrangler at Cambridge that year, took orders, became minister at Ely ehapel in 1836, and died of rapid decline the year after. In 1832 Madame D'Arblay published her nemoirs of her father, written in pretentious style; she died 6th January 1840. Five vol. umes of her Letters and Diaries were published in 1842, two more volumes in 1846, and the Early Diary in 1890 . Spite of its tedious triviality this work is invaluable from the insight it gives us into the very heart of the dull decorous court of George III., and much more for its revelation of English manners towards the end of last century. Its stories of Dr Johnson and his group will live in hiterary history. Croker's ill-tempered attacks on her veracity for allowing an impression to go abroad that Evelina had been written at seventeen, printed in the Quarterly Review for April 1833 and June 1842, were satisfactorily answered by Macaulay in the Edinburgh Review for January 1843. As a novelist, Frances Burney's greatest merit is that she conceived the idea of representing modern society in a manner realistic without ceasing to be feminine and completely artistic. She was the forerunner of Miss Edgeworth and Jane Austen, who were both greater than herself. The latter's admiration for her model is imperishably written in a passage in Northanger Abbey.

Darboy, Georges, an ill-fated Archbishop of Paris, was born 16th January 1813 at Fayl-Billot, in Haute-Marne. He was educated at the seminary of Langres, and four years after his ordination as priest (1836) was appointed a professor there. In 1845 he came to Paris, where his reputation as trans lator of Dionysius the Areopagite had preceded him. In 1854 he was made protonotary apostolic, in 1859 Bishop of Nancy, and in 1863 Archbishop of Paris. He strenuously upheld the Gallican theory of episcopal independence, and waged a long struggle with the Jesuits that lost him the favour of the holy see. At the Vatican Council he opposed with vigour the declaration of the papal infallibility, but when the dogma was finally adopted, was one of the first to set the example of submission. During the German sioge of Paris he was unceasing in labours of benevolence, and during the brief but dreadful triumph of the Commune he refused to leave his flock. Arrested as a hostage by the Communists, 4th April 1871, he was shot in the court of the prison of La Roquette on the 24th of May. He died with the heroic courage of the Christian martyr, words of forgiveness on his lips, and his hands lifted in blessing as he fell. His two im. mediate predecessors had likewise died a bloody death-Sibour murdered during the celebration of a religious rite (January 3, 1857) ; Affre shot down on the barricades (June 1848). Darboy's body was reinterred in a stately public funeral, 5th June 1871. See Foulon's Vie de Darboy (1889).

Darbyites, a name often applied to the Plymouth Brethren (q.v.) from their principal founder, John Nelson Darby (1800-82), of whose collected writings thirty-two volumes have appeared (186783). See his Personal Recollections (1881).

D'Are. See JoAn of Arc.

Dardanelles ( the ancient Hellespont), a narrow channel separating Europe from Asia, and uniting the Sea of Marmora with the Archipelago. The name is derived from the ancient city of Dardanus in the Troad, on the southern shore; and Dardanus was named from the Dardani, an ancient people' farther inland. The strait extends from north-east to south-west, and has a length of about 40 miles; and a breadth varying from 1 to 4 miles. From the Sea of Marmora a strong current runs through the strait to the Archipelago. Both sides are strongly fortified. A treaty concluded between the five great powers and Turkey in 1841 arranged that no ship of war belonging to any nation save Turkey should pass the Dardanelles without the express consent of Turkey; all merchant-ships being also required to show their papers to the Ottoman anthorities. These provisions were confirmed at London in 1871 and at Berlin in 1878 , in the February of which year a British fleet had sailed into the Sea of Marmora. The Dardanelles is celebrated in ancient history on account of Xerxes and Alexander having crossed it, the former in $480 \mathrm{~B} . \mathrm{C}$. to enter Europe; and the latter in 334 B.C. to enter Asia. The point at which Xerxes crossed, by two separate bridges, was in the neighbourhood of Abydos, on the Asiatic shore, opposite to Sestos. Alexander crossed at nearly the same place; and here also young Leander nightly swam across to visit Hero-a feat performed in 1810 by Lord Byron.

Dardanus, a son of Zeus and Electra, the mythical ancestor of the Trojans, and through. them of the Romans. Originally a king in Arcadia, he migrated to Samothrace, thence to Asia, where King Teucer gave him the site of his town, Dardania. He married a daughter of Teucer, and his grandson was the eponymous hero Tros, who removed his grandfather's Palladium to 'Troy.

Dardistan is the name given to a region of Central Asia, bordering on Baltistan, the northwestern portion of Cashmere. The country, which consists of lofty mountains and high-lying valleys, is little known, and its limits are varionsly given. But its interest depends mainly on the fact that its inhabitants, the Dards, are an Aryan people, speaking a Sanskritic tongue mixed with Persian words. They had been called 'Stray Aryans in 'Tibet,' and are Moslems converted from Buddhism at a comparatively recent period : the rajah of Cashmere is constantly endeavouring to subject them completely to his anthority. The chief districts are Hasora, Gilghit, and Tassin ; some would also include Chitral (q.v.) in Dardistan. See Leitner's Tour in Dardistan (1867-70), and CASHMERE.

Dar-es-salaam, a seaport of German East Afriea, 45 miles S. of Zanzibar. Pop. 4000.

Dares the Phrygian. See Troy, X, 309.

Dar-fertit is the name of the thinly peopled territory south of Dar-Fur, beyond the Bahr-el-Arab, and north of the Niam-Niam country. Scliwein. furth was here in 1870 .

Dar-Fur, a country of Central Africa, one of the divisions of the Sndân or 'Land of the Blacks,' situated approximately in $10^{\circ}$ to $16^{\circ} \mathrm{N}$. lat., and in $22^{\circ}$ to $28^{\circ} \mathrm{E}$. long.; but its limits are not clearly defined. It is hilly in parts, and traversed by a mountainous ridge called Marra, which is the source of numerous streams. Towards the north it is level, sandy, and almost destitute of water. During the rainy season (June-September) it exhibits a rich vegetation. The principal products are wheat, millet, rice, maize, and sesame. Tobaceo, which is used by the natives in every form, abounds. Water-melons, slso, are abundant during the rainy season. Among the fruits are tamarinds and dates. The chief minerals are copper and iron. The wealth of the inhabitants consists principally in cattle. Horses, sheep, camels, 
and game abound. The $3,000,000$ or su of inhabi. tunts are mainly Fulahs (q.v.). Dar.For, long a centre of the slave-trade, was annexed to Eigypt in 1874-75, but sulfered with the rest of the Soudan from the desolating tyranny of the Maluli (q.v.) and his successor the Klalifa, till the defent of the latter in 1898. By the treaties witl Germany and Italy in 1890-91, and with France in 1899, it is recognised as part of the Egyptian Soudan and under British influence. See EOYPT, SOUDAN.

Dargal, a platean in the Afridi country on the NW. Indian rrontier, taken in a foglt in which Gurkhas and Gordon Highlanders specially dis. tineruisherl themaelves, 21st October 1897 .

Dargan, WrLlaM, railway projector, was born at ('arlow, 2xth Felıuary 1799, spent some time in a surveyor's oflice, and for a time was employed under Telford. He was a successful contractor, and became one of the first capitalists in Ireland. It was he who in 1831 contracted for the first railway ever executed in Ireland the Dublin and Kingstown), and he was afterwards connected with most great Irish undertakings, such as the making of railways, canals, tunnels, and embankments. He was also an extengive holder of rail. way stock, a stermboat proprietor, flax-grower, farmer, and the main promoter of the Dublin exhibition of 1853, when he declined a baronetey. He died 7th Folvruary 1867.

D'Argens, Jean Baptiste de Boyer, Marquis, born at Aix, in Provence, 1704, at the age of fifteen entered the army, but disabled in 1734 by a fall from his horse, and disinherited for his follies, he went to Holland and tried his fortune in author. ship. Frederick the Great, then erown prince of Prussia, was attracted by his writings, and on his accession invited him to the court of Prussia. The king appointed him chamberlain and a director of the fine arts. When almost a sexagenarian he renewed the adventures of his youth by again fall. ing a victim to the charms of an actresa, whom he married without Frederick's permission. Deprived of his pension, he returned to Provence, and died near Toulon, 1771. His works fill 38 volumes. See his Memoires (new ed. Paris, 1807).

D'Argenson, Marc Pierre, Comte, a cele. brated French statesman, was born in 1696, the younger son of the Marquis d'Argenson (1652-1721) who created the secret police and established the lettres de cachet. After holding a number of inferior offices, he became war minister in 1743 , at a time when the very political existence of Frunce was imperilled, and by his vigour and lucky choice of generals elaanged the fortunes of the war in the course of a single year. After the peace of Aix-laChapelle (1748), he devoted himself to the improvement of the military system, and in 1751 established the Ecole Militaire. He was an illustrious patron of literature. Diderot and D'Alembert dedicated to him their great Encyclopédie; and to Voltaire, whose fellow-student he had been, he furnished materials for his siecle de Louis XIV. In 1757 he was banished to his estate by the machinations of Madame Pompadour; but on her death he returned to Paris, where he died in 1764.

Daric, a Persian gold coin named after Darius, weighing rather more than a movereign.

Dariel. See Caucasus.

Darien, a name formerly applied to the entire isthmus now generally known as Panamá (q.v.). It is now more properly confined to the heavilywooded lill-country lying between the Gulfs of Uraba on the north and San Miguel on the south. The former, a principal inlet of the Caribbean Sea, is commonly called the Gulf of Darien; and the Colombians distinguish San Miguel as the Darien of the South. The southern extremity of the northern gulf forms the Bay of Choco, into which the river Atrato $\left(\mathrm{q}_{0} \mathrm{v}_{\text {e }}\right)$ debouches; the southern gulf receives the Tuira, after a course of 190 miles, of which over 100 are navigable. Little of the district, which is rich in gold, has yet been explored. There is, however, an active trade in tortoiseshell, pearls, and gold-dust, which the Indians readily burter for firearms and rum. These natives are said to number 20,000 , are un. civilised, and as expert with the gun as were their ancestors with the bow. The capital of the district is Yaviza ( 3000 inhabitants).

Darien Scheme, a disastrous speculation projected by William Paterson ( $\left.\mathrm{g} . \mathrm{v}_{\mathrm{c}}\right)$, the founder of the Bank of England, was established by act of the Seottish parliament, and was sanctioned by royal authority in 1695. Its object was to plant a colony on the Atlantic side of the Isthmus of Panamn, and so form a commercial entrepot between the eastern and western hemispheres. An entire monopoly of the trade of Asia, Africa, and America, for a term of thirty-one years, was granted to the Company. At that time, the foreign trade of Scotland had been ruined by the English Navigation Act of 1660 , which provided that all trade with the English colonies should be conducted in English ships alone, so that when Paterson opened his subseription-list, the nobility, the gentry, the merchants, and people, royal burghs, and public bodies in Seotland all hastened to subseribe. No less than $\$ 400,000$ was immediately put down on paper, of which $£ 220,000$ was uetually paid up. Deputies in England received subseriptions to the amount of $\$ 300,000$; and the Duteh and Hamburgers subseribed $£ 200,000$. The English parliament, however, actuated by a feeling of national antipathy, and the jealous clamours of trading corporations, gave its unequivocal condemnation to the scheme. The British resident at Hamburg, probably with the concurrence of William III., also made varions insinuations against it. The result of this interference was the almost total withdrawal of the Dutch and English subseriptions, It must now be admitted that there was one fatal objection to the schene -viz. the danger of settling on ground claimed by Spain, withont coming to a proper understanding with that country beforehand. Unable, however, to see any sort of obstacles, incited by the vehement eloquence of Paterson, and dazzled hy the magnificent proportions of the scheme, the Scotch hurried forwart their arrangements. Five ships, with 1200 men on boand, set sail from Leith for Panana on the 25th July 1698. They reached their destination in four months, near what is still called Puerto Escoces (in $8^{\circ} 50^{\prime} \mathrm{N}$. lat.), and having bargained with the natives for a country which they called New Caledonia, the colonists fixed the site of what was to be their capital, New Edin. burgh, and built a fort in its vicinity, which they named New St Andrews. Having thus constituted their colony, they issued a proclamation of perfect freedom of crade and universal toleration in relivi. ous matters to all who should join them. For the first few months they seemed to be on the hishway to success. But the climate, which was tolerable in winter, became unbearable in summer, and many sickened under it ; their supplies failed before they could derive a return fron the soil; and on rending to the British colonies in Ameriea for provisions, they learned with the deepest indignation rnd despair that the British Aneriean colonies, hnving been informed that King William had not given his sanction to the expedition, had regolved to hold no intercourae with the new colony at Panamá.

Sickly and desponding, they waited long for supplies from the mother-country; but the Company at home was not aware of their wretehed 
condition, and none came. At length, having waited eight months for assistance, the colony broke up. In the meantime, 1300 colonists had set sail from Scotland, but ere they arrived the pioneers had fled. A Spanish force of 1500 men, and a squadron of 11 ships, immediately threatened the new-comers. Captain Campbell marched by night with a body of 200 Scots upon the Spanish camp, which he broke and completely dispersed. On returning to the fort, however, he found it invested by the Spanish squadron. The ammunition of the colonists had now become exhausted, and they were obliged to capitulate, the Spaniards granting honourable terms. Not more than thirty of the colonists, among whom was Paterson, who was rendered for a time insane by his dreadful misfortunes, ever came back to Scotland. The scheme and its collapse cansed unprecedented excitement in Scotland from 1695 till 1703, when the last of the adventurers reached home, and contributed to render the union of the kingdoms highly unpopular. It has been faily contended that, but for the hostility of the king and the jealousy of the English companies, the scheme night have led to enormous extension of British commerce and British territory. And it should be remembered that a Panamá Canal was included in the plans of the far-seeing projector. The books and other documents which had belonged to the Company are preserved in the Advocates' Library; the most complete account of the scheme is J. H. Burton's Darien Papers, printed by the Bannatyne Club (1849). See also his History of Scotland, vol. viii., and Warburton's novel Darien.

Dari'us (Daryavus, Heb. Darĕyavesh), the name of three kings of Persia. Darius I. (Hystaspis), born in 548 B.C., was the son of Hystaspes (Vishtâspa, in the Babylonian cuneiform Ustaashpi), of the family of the Achremenides (q.v.), and succeeded to the Persian throne in 521, after putting to death the Magian Gaumata (the Pseudo-Smerdis of the (Greeks), who gave himself out to be Bardes, brother of Cambyses. We possess accurate accounts of his reign through a contemporairy monument, the great trilingual inscription on the rock of Behistun (q.v.). He is there represented with his foot on the body of Gaumata, and with nine conquered rebels in front of him, the first three from Susiann, Babylon, and Media, the ninth a Sacian, with the characteristie pointed hat mentioned in Herodotus, vii. 64. The inscription states that his father, Hystaspes, was the great-grandson of Teispes, who was the son of Achremenes. Darius had for several years to contend with revolts in all parts of his empire. Babylon resisted him with especial obstinacy under Nidinta-Bel for nearly two years (520-19), and revolting a second time, under Arakha, was again taken (514). He then reorganised the Persian empire, removing the seat of government to Susa, dividing his dominions into more than twenty satrapies, establishing a regular system of taxation, and providing facilities for communication and trade; while he also pushed his conquests as far as the Cancasus and the Indus. The Indian province paid into the exchequer $£ 1,290,000$ a year; Babylonia, $£ 290,000$; while other eighteen satrapies contributed altogether

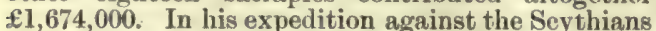
in 515, after carrying 700,000 men aeross the Bosporus on a bridge of boats, and subduing Thrace and Macedonia, he was led on by the retreating Seythians as far as the Volga, and returned to the Danube with the loss of 80,000 of his warriors. He returned to Susa, leaving Megabazos in Thrace with a large part of his army. His first expedition against the Athenians miscarried through the wreck of his fleet at Mount Athos in 492; the second was decisively defeated at Marathon (q.v.) in 490. He died in 485, before the Egyptian revolt (487) had been subdued, and in the midst of his preparations for a third expedition against the Athenians, and was succeeded by Xerxes (q.v.). Darius was a Persian by birth, and bred in the Zoroastrian faith, which under him and his successors became the state religion of the empire. $\mathrm{He}$ is mentioned in the Old Testament as permit. ting $(520)$ the erection of the second temple at Jerusalem, which was completed in the sixth year of his reign (515).

DariUs II. (Ochus, called by the Greeks Nothos, ' bastard '), illegitimate son of Artaxerxes I., in 424 B.C. snatched the crown from Sogdianus, his also illegitimate brother, who had put to death the rightful king, Xerxes II. He was entirely under the influence of the eunuchs and women of his harem, especially his cruel and depraved aunt and spouse Parysatis; and his reign was a lcng series of miseries and crimes. The numerous revolts were cruelly put down, except that of Amyrtæus, satrap of Egypt, who was independent from 414 to his death in 408. After the failure of the Sicilian expedition of the Athenians in 415, Darius seized the opportunity to break the humiliating treaty of 449. Through Tissaphernes, satrap of Asia Minor, and his successor Cyrus, younger son of Darius and Parysatis, he gave so much support to the Spartans against the Athenians in the Peloponnesian war as turned the scale to the side of the former. He died at Babylon in 405 , and was succeeded by his eldest son, Artaxerxes II.

DARIUS III. (Codomannus), the last king of the Persians, son of the Achremenid Arsanes by Sisy. gambis, daughter of Artaxerxes II. (q.v.). He is briefly designated as 'Darius the Persian' in Nehe miah, xii. 22, and in the lst Book of Maccabees is called 'King of the Persians and Medes.' Artaxerxes III. had been poisoned by Bagoas in 338, and the speedy death of his son and successor, Arses, prepared the way for Darius III., who began to reign in the same year as his conqueror Alexander the Great (336). Defeated at the Granicus (334), at Issus (333), and at Arbela (331), the handsome and gentle kirg was betrayed and slain during his Hight by one of his satraps (330). See AlEXANDER THE GREAT.

DARIJS THE MEDE, mentioned in the Book of Daniel, cannot with certainty be identified with any historical king.

Darjeeling (Dárjiling), a sanitary station in the Lower Himalayas, and administrative headquarters of Darjeeling district, is situated on a narrow ridge, at an elevation of 7167 feet above the sea. It has a fine sanatorium (1883), a good watersupply, and is an increasingly popular summerresort for visitors and invalids. The fashionable month is October, after the rains, when the clear atmosphere shows at its best a view of unsurpassed extent and grandeur. Pop. 7018.-DARJEELING is the most northerly district of the Kuch Behar division of Bengal, divided from Independent Sikkim by a series of rivers and mountain-torrents. Area, 1234 sq. m. Pop. (1872) 94,712 ; (1895) 250,000 , mostly Nepalis and other aboriginal or semi-aboriginal tribes, attracted to the district by the increased demand for labour on the railway and in the tea-gardens. With a surface divided between the Lower Himalayas and the marshy sub-montane strip, the scenery of the district is magnificent; up to 12,000 feet the ridges are clothed witl valuable forests, and on the higher slopes the rhododendron grows in gorgeous luxuriance. The climate is excessively humid, but not unhealthy. Food-crops are raised, and there is a trade with Tibet and Nepal; but the staple industry is the cultivation of tea, of which the 
yield steadily increaned in 1875-95. The district auffered from earthquake in 1899.

\section{Dark Ages. See Agr.}

Darley, Frix Octavius Carr, an Ameriean artist, was burn at Philadelphia, June 23, 1822. He early gave himself to drawing with such success as to encouruge him to devote himself exclusively to nrt, especinlly in the form of book illustrution. His earliest important work was a series of drawings for the Library of Humorous American Works, after producing which he went to New York (1848), where his ontline drawings to Washington Irving's Legend of Sleepy Hollow ani Rip Vin Winlile soon spread wille his reputation. Later works, not less popular, are his illustrations of Judd's Margaret, and to Cooper's, Dickens's, and Simms's novels. In 1868, after some yeurs' residence in Europe, he published both illustrations and letterpress of Sketches Abroad with Pen and Pencil. Died March 27, 1888.

Darling, a name applied to a river, a mountainrange, and two districts in Australia, is derived from Lieutenant-general Sir Ralph Darling (1775-1859), who was governor of New South Wales (182.5-31). (1) The river Darling, a tributary of the Murray River, is formed by the union of several head-streams, all of which rise in the great Dividing Range. The chief of these head-streams are the Barwon and Gwydir. Farther down, the Darling receives the Culgos and the. Warrego from the north, and the Bogan from the south. Its length, with affuents, is stated at 1160 miles, and it and its tributaries are estimated to drain an area of $198,000 \mathrm{sq}$. $\mathrm{m}$. It joins the Murray at Wentworth, on the border between New South Wales and South Australia, having received no tributary in its lower course. Much of the district traversed by it is an arid plain, save near the river-bank ; the river is subject to floods. (2) The Darling Range, in Western Australia, rums parallel to the west coast, at a distance of 10 to 25 miles inland, from the southwest corner of the colony to a point some 250 miles farther north. The range has a height of from 1500 to 2000 feet; and in Mount William attains an elevation of 3000 feet. (3) The Darling district at the south-western corner of New South Wales, seantily watered, has an area of $50,000 \mathrm{sq}$. m. (4) The Darling Downs form the richest pastoral district of Queensland, in the southern part of the colony. This is an upland district on and about the summit of the Dividing Range. It was discovered by Allan Cunningham, the botanist, in 1827 , and has an area of $6080 \mathrm{sq}$. $\mathrm{m}$. There is also much fine agricultural land in which the cereals, potatoes, anil all kinds of vegetables grow well. The western railway traverses the north, and the southern line the extreme east of this district.

Darling, Grace, a name famous in the annals of heroism, was the daughter of William Darling (1795-1860), lighthouse-keeper on Longstone, one of the Farne Islands, and was born at Bamborough, 24th November 1815. On the morning of the 7th September 1838, the Forfarshire, bound from Hull to Dundee, with sixty-three persons on board, struck the Harker's Rock, among the Farne Islands, and in fifteen minutes forty-three persons were drowned. The vessel was seen by Grace Darling from the lighthouse at a quarter to five lying broken on the rocks. Darling and his daughter agreed that if they could get to her, some of the shipwrecked crew would be able to assist them in getting hack. By wumlerful strength and skill, they brought their boat to where the sufferers ( nine in number) crouched. The solitary, woman and four men were safely taken to the Longstone; two of the men returned with Darling, and succeeded in bringing the remainder off by nine o'clock A.M. Such an undertaking, =o daring in itself, and so successfully carried out, filled every one with the warment alusiration. 'The lighthouse at Iongstune, solitary and unknown no more, was visited by many of the wealthy and the great. Presents, testimonials, and money were heaped at the feet of Grace Darling; but she did not long survive her change of circumstances. She died of consumption, after a year's illness, on 20th October 1842. See Grace Darling, by E. Hope (1876), and the Journal of William Darling (1886).

Darlington, \& parliamentary and municipal borough in the south of the connty of Durham, on a slight elevation overlooking the Skerne near its junction with the Tees, 23 miles S. of Durham, and $45 \mathrm{NNW}$. of York. The chief industry of the place is connected with the extensive locomotive works, which give employment to many workers. There are iron and steel works in the north end of the town; brewing and tanning are carried on; and there are wonl-mills. Pop. (1821) 6551; (1851) 11,228 ; (1871) 27,730 ; (1881) 35,102 ; (1891) 38,060 , of whom many belong to the Society of Friends, long a prominent and influential element amonyst the inhabitants. Darlington was created a parliamentary borough, sending one member to parlia. ment, in 1867. Its prosperity dates from the opening, on 27 th September 1825, of the Stockton and Darlington Railway, which was the first passengerline on which a locomotive-engine was employed; and that locomotive now stands on a pedestal outside the station. From the 11 th century onwards the town belonged to the bishops of Durham, and till 1867 a borough bailiff, appointed by the bishop, managed its affairs; in that year it obtained a charter of incorporation. St Cuthbert's collegiate church, a very fine specimen of Early English, was founded in 1160 by Bishop Pudsey, and was restored by Sir G. G. Scott in 1869 . It has three beantiful sedilia, and a tower 180 feet high. Among the chief modern erections are the other churches (Anglican, Presbyterian, Roman Catholic, and Nonconformist), the spacious new railway station (1887), a grammar-school, a high school for girls, a British and Foreign School Society's college for female teachers, and the banks of Backhouse \& Co., and Pease \& Co. A free library was opened in 1885 , for which Mr Edward Pease had bequeatlied

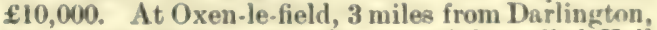
are curious cevities of unknown origin, called Hell Kettles; and near Darlington was the seat of George Allan the antiquary (1736-1800).

Darlingtonia, a genus of remarkable Anerican Pitcher-plaits, belonging to the order Sarraceniacese; and like its congeners, is insectivorous. See INSECTIVOROUS PLANTS.

Darmesteter, JAMBs, orientalist, was born in 1849 at Chateau-Salins (in the part of Lorraine now German), of a Jewish family originally $-a s$ the name indicates - from Darmstalt. He was educated at Paris, in 1875 wrote a thesis on the Avesta, crowued by the Institute, and hecame a conspicuous unember of the Société Asiatique. He was professor of Zend at the Ecole des Hautes Etudes (1877) and at the Collége de France (1885). In 1883 he published Etudes Iraniennes, followed by works on the Mahdi, on Persian popular poetry, and on Afghan fulk-8ongs (the fruits of a government mission to India). His principal works were a series of books on the Zend-Avesta, including a translation of the great part of it in The Socred Books of the East. He held Lnat much of the Avesta has a late origin (see ZR..D). In a volume on the Hebrew Propliets, he advocated a return to Hebrew monotheism. He also wrote Essais de Litterature Anglaise, edited two volumes of 
philological articles by his brother Arsène, and translated into rhythimical French a selection of his wife's poems. He died 19th October 1894. His wife, Agnes Mary F. nee Robinson in 1857, has written a long series of books of admirable poetry, lyrical and other, translations from Euripides, a novel (Arden), and Lives of Emily Brontë (1883) and Renan (1897).-ARsene (1846-88), trained to be a rabbi, passed to the study of mediaval French, in which he soon became the recognised authority; and began the great dictionary in collaboration with M. Hatzfeld.

Darmstadt, a town of Germany, capital of the grand-duchy of Hesse-Darmstadt, is situated on the small river Darm, 15 miles S. of Frankfort-on-Main. The streets of the old town are narrow, but those of the new town exhibit many imposing specimens of architecture. Darmstadt has several public squares, and fine public gardens and promenades. Besides the arsenal, the barracks, and the various religious edifices, it possesses two palaces. One of these, the old ducal palace, contains museums of painting, natural history, and archæology, and a library of 500,000 volumes; in the other, Prince Charles's palace, is Holbein's famous 'Meyer Madonna." The handsome post-office dates from 1881, the theatre from 1871. There are manufactures of chemicals, hats, machinery, tobacco, playing-cards, carpets, and beer; and a trade in iron, petroleum, fruit, flour, and wine. But the place depends more on its ducal court and government offices than on its industries. Pop., with suburb (1875), 44,088; (1890) 56,399 (including 9038 Catholics, 1498 Jews).

Darnel (Lolium temulentum), an annual grass of the same genus with Rye-grass (q.v.), common as a weed in cornfields in England and many parts of Europe. Probably the tares of the parable, it is reputed (thongh some authorities deny the fact) to have a narcotic poisonous seed. See Raphania.

Darnétal, a town in the French department of Seine-Inférieure, $2 \frac{1}{2}$ miles E. of Rouen, with manufactures of cotton, linen, and cloth goods. Pop. 6532.

Darnley. See Mary Queen of Scots.

Darter (Plotus), a genus of birds nearly allied to Cormorants (q.v.), but very heron-like in gait and gesture. The four species are severally restricted to the warm parts of America, Africa,

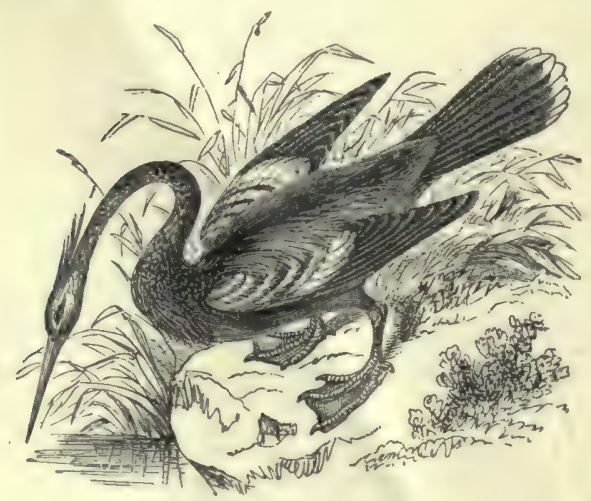

Darter (Plotus anhinga).

Asia, and Australia. The head is small, with naked cheeks and throat; the neck is very long, thin, and flexible; the bill is long and straight; the tail and the toes are also long. The darters catch fish voraciously and with great dexterity; the name 'snake-neck' well describes them.
Though aquatic in habit, they rest and nest on trees. The American species figured is over three feet in length.

Dartford, a thriving market-town of Kent, in the narrow valley of the Darent, 2 miles above its intlux to the Thames, and 17 ESE. of London. Edward III. here founded an Augustinian nunnery (1355); St Edmund's chantry was a great place of pilgrimage; and at Dartford Wat Tyler commenced his rebellion (1381). The ehurch, with a Norman tower, was restored in 1863 ; among its interesting monuments is one to Sir John Spielman, Queen Elizabeth's jeweller, who in 1588 established at Dartford what is said to have been the first papermill in England. Paper is still manufactured, besides steam-engines and machinery, gunpowder, \&c. The modern buildings include a county courthouse (1859), assembly rooms (1860), and, in the neighbourhood, the City of London lunatic asylum (1866). Pop. of parish (1851) 6224; (1881) 10,163 ; (1891) 11,962. See the local histories by Dunkin (1844) and Bayly (1876).

Dartmoor is a great granitic upland in Devonshire, the source, with two exceptions, of all the principal rivers of the county, remarkable alike for its wild and rugged scenery, its antiquities, its wide, solitary, trackless wastes, and its mineral products. It is upwards of 130,000 acres in extent, the extreme length from north to south being 25 miles, and the extreme breadth from east to west 20 miles. The outline is irregular. The central portion is the ancient royal forest of Dartmoor, and this is surrounded by a belt of open country, once known as the 'Commons of Devonshire,' but portions of which have been inclosed. The attempts to cultivate Dartmoor itself have been very few, and the northern quarter for miles shows no trace of man, but the val. leys through which the rivers descend to the lowland country are singularly fertile, and at times full of beanty. The moor itself affords valuable mountain pasture to eattle, sheep, and large numbers of half. wild ponies. The forest rights belong to the duchy of Cornwall; but there are rights of pasturage exercised by holders of what are called venville tenures in certain parishes bounding the moor, which date prior to the Norman Conquest.

The average height of Dartmoor above the sea is upwards of 1200 feet, but its highest point, High Willhayes, is 2039 feet; and the next, Yes Tor, 2030. The hills are commonly called tors, and for the most part have granite erests, weathered into grotesque and picturesque shapes. The whole of Dartmoor is of granite, protruded between the close of the Carboniferous and the opening of the Triassic periods. Devonian rocks mantle round its southern extension, and Carboniferous round its northern, associated at various points with gabluros, dolerites, and other intrusive rocks. The granite is chiefly gray, but there are rich red varieties, as at Trowlesworthy. Large quantities of the ordinary stone have been quarried, especially at Hey Tor and King Tor. Dartmoor is rich in minerals. Tin has been raised for many centuries, long before the dawn of history, by streaming in the valleys, and vestiges of the ancient mining operations of the 'old men" abound. Copper, iron, and manganese have also been worked, but mining is now carried on at a few points only. Gold has frequently been found in the river-beds. The tinners of Devon had a quasi-corporate existence in Saxon times, and their rights were confirmed by King John and other monarchs. The Stannary Parliaments, in which they managed their affairs, were held in the open air on Crockern Tor. The most important mineral product of Dartmoor at the present day is china-clay, or kaolin, which is the result of the decomposition of the felspar 
of the granite. The largest china-clay works in Emylum are at Lee Monor, and are comnectod by a tramwy with wharves at Pymouth.

The faina and flora of Dartmoor have many points of interest. Trees are very rare; but there is a very singular group of gnarled and stunted osks on a slope overlooking the West Dart, near Crockern Tor, of high antiquity and weird aspect, which las been ealled one of the "wonders of the moor'-'Wistman's Wood.

The chief rivers rise at a height of over 1800 feet ahove the sea, in a wide stretch of peat-bog around Cranmere Pool-the Dart, Teicn, Trw, Okement, Lyd, Tavy, and Walkham. From the morasses of the southern quarter spring the Plym, Yealm, Erme, and Avon.

Dartmoor is unrivalled in England in the extent and character of its prehistoric and rude stone antiquities - earthworks, barrows, kistvaens, menhirs, lines or avenues, cyclopean bridges, circles, eromlechs, trackways, and pounds or inclosures of stones, sometimes containing the remsins of villages. Many stone implements have been found. On several of the tors there are rock basins, formerly ealled Druidical, but now assigned to the operation of natural causes.

The chief centre of population is Prince Town, named after George IV. when Prince Regent. Here a prison was built (1806) during the war with Napoleon, for the reception of prisonens of war. When the war ended it was abandoned, and was at one time used for the manufacture of naphtha from peat, which failed, as all attempts to utilise the Dartmoor peat beyond the supply of local wants have done. In 1855 the buildings were adapted to their present purpose of a convict prison. Attached is a fertile reclaimed farm. A very picturesque railway runs to Prince Town, See Rowe's Perant. bulation of Dartmoor (1856 ; 3d ed. 1896).

Dartmouth, a seaport and municipal borough (till 1867 also parliamentary) in the south of Devonshire, 32 miles S. by W. of Exeter. It is built in picturesque terraces on a steep slope 300 to 400 feet high, on the right bank of the romantic estuary of the river Dart, at a short distance from the sea. The streets are narrow, and many of the houses very old, with overhanging stories, projecting gables, and wood-carvings. St Saviour's Church (eirca 1372) has a richly seulptured, painted, and gilt stone pulpit, and a beautifully carved mod-loft. A battery, and the remains of a castle built during the reign of Henry VII., stand at the entrance to the harbour. Pop. (1891) 6038. Dartmouth is a quarantine port of the Eng. lish Channel, and has a considerable trade with the Mediterranean, and in the Newfoundland tisheries. It is the port of departure of the 'Castle' line of mail steamers to Sonth Africa, and a favourite yachting station-the harbour being deep and landlocked. At Dartmouth, in 1190, the Crusiulers, under Richard Cour-de-Lion, embarked for the Holy Land. The French hurned it in Richard's reign, but were repulsed, chiefly by the women, in an attack in 1404. In 1346 Dartmouth furnished 31 ships for the siege of Calais. In 1643 Prince Maurice besieged and garrisoned it; but in 1646 Fairfax stormed and took it. Newcomen, the in. ventor of the steam.engine, was born here; Sir Humphrey Gilbert was born at Greenway, on the opposite side of the Dart; and anotlier great Elizabethan worthy, John Davis, at Sandridge.

Daru, Pierre Antorne, Comte, a French writer and financier, was born at Montpellier, 12th January 1767. At sixteen he entered the army, and rose rapidly, but was flung into prison during the Terror, where he amused himself by translating Horace. Under Napoleon he was Intendant. general in Austria and Prusais, and a conneillor of state, while in 1818 Louis XVIII. male lim a peer. Thenopforth he devoted himelf enclunisely to letters. He died a member of the Inmtitute and of the Academy of Sciences, 5th September 1820. Of his many books the chief are Cleopedie (1800), a spirited poen ; Hidoire de la Republique de Venise (7 vols. 1819-21); and Histoire de la Bretaque (3 vols, 1826). - His son, NAPOLEon DARU (1 $\left.80^{\circ}-90\right)$, opposed the coup d'etat, and was proseribed; lant becane a member of the National Assembly in 1871 , of the senate in 1876.

\section{Darwaz, See Bokнara.}

Darwen. a municipal borough of Lancrshire, on the river Darwen, 3 h miles $\mathbf{S}$. of Blackburn, and $9 \mathrm{~N}$. of Bolton. Cotton is the staple manufacture; then come paper-making and japer-taining ; and to these and other industries, with its water facilities, and the neighbouring coal-mines and stone quarries, Darwen owes its rapid growth and its well-being. It was incorporated in 1878. Chief buildings are the free library, market hall, co-opera. tive hall, and the public baths, erected in memory of Sir Robert Peel. Pop. (1851) 7020; (1881) 29,744 ; (1891) 34,192 . See History by Slaw (1891).

Darwin, Charles RoBert, naturalist, the discoverer of the principle of uatural selection, was born at Shrewstury, February 12, 1809. His grandfather was Dr Erasmus Darwin, and his father Dr Robert W. Darwin, F.R.S. His mother was a daughter of Josiah Wedgwood, the celebrated potter. Darwin was educated at Shrewsbury grammar. school, studied at Edinburgh University for two sessions in 1825-6-7, and entered at Christ's College, Cambridge, in 1828. Already at Edinburgh he had become a member of the local Plinian Society; he took part in its natural history excursions, and read before it his first scientific paper $-\mathrm{a}$ new contribution to our knowledge of the Flustra or sea-mats. It was at Cambridge, however, that his biological studies seriously began. Here he became acquainted with Professor Henslow, the well-known botanist, who encouraged his interest in botany and zoology. His chief taste at this time was for geological research. In 1831 he took his degree of B.A., and shortly after was recommended by Henslow as naturaliat to the expedition of H.M.S. Beagle, under Captain (afterwards Admiral) Fitz. roy, R.N., then about to start for a scientific survey of South American waters. He sailed on December 27, 1831, and did not return to England from his long eruise till October 2, 1836. Nlean. while he visited Teneriffe, the Cape de Vercle Islands, the Brazilian coast, Monte Video, Tierm del Fuego, Buenos Ayres, Valparaiso, and the Chilian region, the Galapagos Archipelago, 'Tahiti, New Zealand, Tasmania, and the Keeling Islands, in which last he laid the foundation for his famous theory of coral reefs. It was during this long expedition that Darwin obtained that intimate knowledge of the fauna, flora, and geological conditions of many tropical, subtropical, and tem. perate climates which so admirably equipped him at last for the great task he was afterward to per. form in settling the factors of biological evolution.

On his retum to England in 1836, he set to work to co-ordinate the resulis olotainesl luring his voyacre. He formed the friendship of Sir Charles Lyell and other scientific leaders, by whose aid he was ap. pointed secretary of the Geological Society in 1838. A year later, he was elected to the fellowship of the Royal Society, and early in 1839 he married his cousin, Miss Wedgwood. In the same year he pub. lished his Journal of Researches into the Gealogy and Natural History of the varions Countries visited by H.M.S. Beagle. From 1840 to 1843 Durwin was occupied with the publication of the Zoology of the 
Voyage of the Beagle, under government auspices, to which great work (complled by the leading specialist authorities of the day) he himself contributed an introduction and many notes. In 1842 appeared his work on The Structure and Distribution of Coral Reefs; in 1844, Geological Observations on Volcanic Islands; and in 1846, Geological Observations on South America. These works placed him at once in the front rank of contemporary scientific thinkers. In 1851-53 appeared his valuable treatise on barnacles, $A$ Monograph of the Cirripedia.

Three years after his marriage Darwin settled at Down, near Beekenham, in Kent, where for the rest of his days he passed his time as a country gentleman among his conservatories, his pigeons, his garden, and his fowls. The practical information thus gained (especially as regards variation and interbreeding) was of invaluable use to him in his later researches. Private means enabled him to devote himself unremittingly henceforth, in spite of continuous and distressing ill-health, to the pursuit of science. It was at Down that Darwin began to occupy himself with the great work of his life-the problem of the origin of species. In 1837 he had already set out to accumulate facts and observations for this purpose. After five years' unremitting work, he 'allowed himself to specnlate 'on the subject, and drew up some short notes, which he enlarged in $\mathbf{1 8 4 4}$ into a sketch of conclusions for his own use. These conclusions embodied in embryo the famous principle of natural selection, the germ of the celebrated Darwinian Theory (q.v.) With constitutional caution, however, Darwin de layed publication of his hypothesis, which was only at length precipitated many years later by an recidental circumstance of a romantic character. In $1858 \mathrm{Mr}$ Alfred. Russel Wallace, the distin guished explorer, sent home from the Malay Archipelago a memoir addressed to Darwin himself, for presentation to the Linnean Society. On opening this packet, Darwin found to his surprise that it contained in essence the main idea of his own theory of natural selection. Sir Charles Lyell and Sir Joseph Hooker, to whom he communicated the facts, persuaded Darwin to read a paper of his own concomitantly with Wallace's before the Linnean Society, which was accordingly done on July 1, 1858. Urged forward by this strange coincidence, Darwin set to work seriously at once to condense his vast mass of notes-the labour of a lifetimeand put into shape his great work on The Origin of Species by means of Natural Selection, published in November 1859. For an account of the main ideas there promulgated, see DARWINIAN THEORY. The book itself, an epoch-making work, was received throughout Europe with the deepest interest, was violently attacked and energetically defended, but in the end succeeded in obtaining recognition (with or without certain reservations) from almost all competent biologists. From the day of its publication Darwin continued to work on unremittingly at a great series of supplemental treatises, in which his main principles were still further enforeed and enlarged, while minor corollaries were brought prominently into view. The Eertilisation of Orchids appeared in 1862, The Variation of Plants and Animals under Domestication in 1867, and The Descent of Man in 1871. The lastnamed work, hardly less famous than the Origin of Species, derives the human race from a bairy quad. rumanous animal belonging to the great anthropoid group, and related to the progenitors of the orangutan, chimpanzee, and gorilla. In this bo,$k$ Darwin also developed his important supplement; theory of sexual selection, which on the whole has been received by scientific thinkers with less favour than his other ideas. His later works are The
Expression of the Emotions in Man and Animals 1873), Insectivorous Plants (1875), Climbing Plants (1875), The Effects of Cross and Self Fertilisation in the Vegetable Kingdom (1876), Different Forms of Flowers in Plants of the same Species (1877), and The Pover of Movement in Plants (1880). His last work, The Formation of Vegetable Mould through the action of Worms, appeared in 1881. In it Darwin showed grounds for believing that the vegetable mould which covers a large part of the globe is mainly due to the castings of earth-worms, without which the greater portion of the land surface of the world must necessarily consist of barren rock or thirsty sand.

It is, however, as the great leader of evolutionary biology that Darwin will be mainly remembered among men. Though not (as is commonly, but erroneously, believed) himself the originator of the evolution hypothesis, nor even the first to apply the conception of descent with modification to plant and animal organisms, Darwin was undoubtedly the first thinker to gain for that conception a wide acceptance among biological experts. By adding to the crude evolutionism of Erasmus Darwin, Lamarck, and others, his own specific idea of natural selection, he supplied to the idea a sufficient cause, which raised it at once from the level of a hypothesis to the grade of a verifiable theory. His kindliness of character, honesty of purpose, devotion to truth, and attachment to his friends, rendered him no less remarkable on the moral and emotional than on the purely intellectual side of his nature. For many years his health had been extremely feeble, and he had worked under the severest physical disadvantages. He died suddenly, after a very short illness, April 19, 1882, and was buried with unusual honours in Westminster Abbey. See his Life and Letters by his son, Francis Darwin (1887).

Darwin, Erasmus, physician, natural philosopher, and didactic poet, was born 12th December 1731, at Elston Hall, near Newark, in Nottinghamshire ; entered St John's College, Cambridge, in 1750 , graduated B.A. in 1754, and afterwards studied medicine at Edinburgh. After an unsuceessful attempt to establish a practice at Nottingham, he removed to Lichfield, where he married and became a popular pliysician and prominent figure from his ability, his radical and free-thinking opinions, his poetry, his eight-acre botanical garden, and his im. perious advocacy of temperance in drinking. After his second marriage in 1781, he settled in Derby, and then at Breadsall Priory, where he died suddenly 18th April 1802. Darwin had once a great reputation as a physiologist, but his system is, for the most part, inconsequent, baseless, and untenable. At the same time, many of his ideas are original, suggestive, and contain within them the germs of important truths. His strength and his weakness lay in his faculty for seeing analogies in nature. Sometimes he is exceedingly happy in his discoveries; at other times he is quite fantastical. The same remarks hold good as regards his verse, where, amid the frequent extravagance and incomprehensibility of his notions, there burst forth strains of genuine poetry. The Loves of the Plants (1789), a part of his chief poem, the Botanic Garden, was happily burlesqued in the 'Loves of the Triangles' in the Anti-Jacobin. Interest in Darwin's speculations has been revived by the recognition of his partial anticipation of Lamarck's views on evolution, and so of his own famous crandson's. His chief works are Zoönomia, or the Laws of Organic Life (1794-96); and his Phytologia, or Philosophy of Agriculture (1799). See his Life by Krause, trans, by Dallas (1879). By his first wife he was grandfather of Charles Darwin; by his second, of Francis Galton. 
Darwinian Theory, the explanation of the ovolution of torms of life on our planet, offered by the great naturalist, Charles Darwin $(q . v$.$) .$ From the very outset we must carefully guard against the confusion, still widely popular, of 'Evolution' with 'Darwinism.' Evolution nust clearly be retained to denote the entire drama of cosmic change; Darwinism, therefore, must as clearly be reatrieted to one particular interpretation of the mechanism and plot of this cosmic drama, of many which have been thrown out by reflective spectators. Darwin expressed the mode of the evolutionary process in a classic phrase, the title of his great work-The Origin of Species by means of Natural Selection, or the Preservation of Fuovured Ruces in the Struggle for Life. That explanation is not only in itself peculiarly shrewd and well reasoned, luminous and widely applicable, but has been of the very greatest importance in awakening biologists and students of all other sciences, and thus ultimately the intelligent public, to the facts of the case-to the conscious. ness of this evolutionary drama. On the promulgation of this new hypothesis as to the mode of occurrence of evolutionary changes in the organic world, the whole discussion as to the occurrence of evolutionary change at all speedily came to centre round it; although in view of the powerful arguments for the occurrence of evolution which had been independently adduced by Spencer and others, it may be admitted this was not quite logical. The fret, however, remains. Moreover to the new standpoint afforded by the clear acceptance of both ideas -evolution and this through natural selection-and to the energetic application of these, first by Darwin himself, but soon by a multitude of zealous workers, we owe a progress which it would as yet be premature to estimate, but which has pervaled the whole field of biology, and even the fields of all the higher sciences, montal and social, which so largely utilise biological methods and generalisations. Whatever may be the subsequent development of our evolutionary conceptions, the epoch-making importance of the Darwinian theory will be unaltered. Hence the expediency of the present comparatively full exposition of its main positions and of their bear. ings, apart from the larger and more general argument under EvoluTioN.

To the statement of Darwin's thenry, therefore, we may at once proceed, postulating no more than that general acquaintance with the aims and results of biology which is now becoming so commonly current, or which may readily be gained by help of the articles Blology and Botany. Nor need any statement of the general doctrine of evolution, or of evolutionary theories before Darwin, here detain us, since these find more fitting place in the general article Evolution.

The failure of pre-Darwinian theories to gain any very general acceptance among naturalists was no doubt largely attributable to established prejudice, backed as this was by the predominant authority of Cuvier. This was by no means the whole explanation. For while those theories rendered it extremely prohable that modifieation had oceurred, they all fell short, as Darwin pointed out, in one most important particular. They failed to show how the modification of one species from another could take place, 'so as to acquire that perfection of atructure and co-adaptation which justly excites our admiration;' since the hypotheses of the potency of external conditions of habit, of the volition of the organism itself, and so on, alike successively broke down.

Darwin was especially struck by the distributional phenomena he witnessed during his 'Naturalist's Voyage,' and thereafter devoted himself primarily to the problem of the origin of species, specially concentrating himself upon what seemed to him the weakest point of the preceding theories, the explanstion of adaptations. Con. meneing in 1837, "after five years" work, I allowed myself to speculate on the subject, and drew up some short notes; these I enlarged in 1844 into a sketch of the conclusions which then seemed to be probable; from that period to the present day I have steadily pursued the same object.' This was written as late as 1859 , and even then because he had received a paper from $\mathrm{Mr} \mathbf{A}$. $\mathrm{R}$. Wallace (at that time exploring the Malay Archipelago), in which views identical with his own were expressed, and thus was compelled to proceed to the publica tion of his results. He did so first in a brief out line read, by advice of Lyell and Hooker, simul. taneously with Wallace's paper (see Jour. Linn. Soc., 1858); and in the following year in that fuller abstract, as at first he merely regarded it, which soon became so famous-the Origin of Species. Its subetance may with advantage be briefly sum. marised, to far as further compression of such 'intellectual pemmican' is possible. For details and explanations the reader luust consult the work itself (7th ed. 1880 ).

Outline of 'Origin of Species.' - In order to gain insight, then, into the means of modificution, Darwin commences with a study of the variation of plants and animals under domestication (later expanded into a separate work ; 2 d ed. 1876).

Variation and Heredity. - While all plants and animals exhibit some degree of variation, this is greatest among domesticated species, owing to their new and less uniform conditions of life. These may act directly on the whole oryanisation, or on separate parts, and the variation, though rarely, is sometimes definite, as when size inerenses with quantity of food, or colour changes with its quality ; or the conditions may act indirectly by influencing the reproductive system, which is peculiarly sensitive. Changed habits produce an inherited effect-e.g. the leg-bones of the common duck weigh proportionally more, and its wing-bones less, than in the wild variety, becanse it flies less and walks more. So, too, tame mammals acquire drooping ears, since these are rarely pricked in alarm. One variation is nsually correlated with others, thus long-beaked pigeons have small feet, and conversely. All variations tend to be in. herited. The popular belief that domestic races simply revert to the aboriginal stoek is unsupported by facts.

Save that domestic varieties are less uniform than wild species, often differ more widely in some single part, and are fertile when crossed, there is no well-marked distinction between there and 80 . called true species. If, therefore, such varieties as the different breeds of the dog can be shown to be descended from a single wild species, there neces. sarily arises great doubt as to the inmutability of closely allied natural species, such as the foxes. While, however, the many breeds of dog appear to have arisen from several wild speeies, aud those of cattle also from two or three, our fowls, ducks, rabbits, Ke, all certainly urise from a single ances. tral species. The case of pigeons is of peculiar inportance, aince ponter, carrier, fantail, and tumbler differ so thoroughly, externally and internally, that any ornithologist would be compelled to ansign to them not merely specitic but generic distinctness, if he had discovered them in the wild state. There is at least as much difficulty in believing that such breeds can have proceeded from a common ancestor, as there is in the ense of any group of birds in nature; and every breeder of these has been firmly convinced of their descent from distinet species. Yet all these breeds are proved to come from the common rock-dove (Culumba livia; see Piasos), 
and thus those who admit the unity of domestic races should be cautious in deriding the unity of wild ones.

Domestic races all exhibit adaptations to man's use or fancy, rather than to their own good. The key to this is man's power of selection: nature gives successive variations, man accumulates these, so making for himself useful breeds, and often, (e.g. in sheep, cattle, roses, dahlias) profoundly modifies their character even in a single. human lifetime; so that in all characters to which he attends, they may differ more than the distinct species of the same genera. Again, that unconscious selection which results from every one trying to possess and breed the best animals is yet more important than conscious selection. Two flocks of Leicester sheep, kept equally pure, appeared of quite different varieties after fifty years. Such slowly accumulated change explains why we know so little of the oricin of domestic races; and its absence in regions inhabited by uncivilised man explains why these yield no plants worth immediate culture. Human selection is facilitated (1) by the keeping of large numbers, since variations will be more frequent, and (2) by preventing free-intercrossing; some species vary, however, more than others.

Variation under Nature.-All similar organisms in nature present individual differences, more con. siderable than is usually supposed. No two blades of grass are alike, and far more marked differences often vecur, several castes or varieties sometimes existing in the same sex. Between these castes, and much more frequently between forms which systematic botanists and zoologists rank as true species, perfectly intermediate forms may oecur. No agreement about the definition of species (the amount of difference necessary to give any two forms specific rank) has ever been come to ; thus, in the British flora alone, there are nearly two hundred disputed forms, and individual opinion is in these cases the only criterion. As long as a genus is imperfectly known, and its species founded upon few specimens, they appear clearly limited. But with fuller knowledge, intermediate forms come in, and doubts as to specific limits augment. The terms species and variety are thus arbitrarily given to sets of individuals more or less closely resembling each other. Ste VARIATION, SPECIES, Genus.

Individual differences are thus of the highest importance, as the first steps towards the slightest varieties worth recording, these in turn towards more distinet and permanent varieties, these varieties again towards sub-species, and in the next stage to species; though extinction may often arrest the process.

The species which present most varieties are those which have the greatest geographical range, or the widest diffusion in their own territory, or which possess the greatest number of individuals.

the larger genera of each country the species vary more frequently than in the smaller genera; and in many respects the species of large genera present a strong analogy with varieties, which analogy is alone intelligible on the view that they once existed as mere varieties themselves.

Struggle for Existence.-All organic beings tend to increase with extreme rapidity, so that if they were not kept down, the earth would soon be covered by the progeny of a single pair. This is evidenced not merely by calculation, but by actual observation of the extraordinary rapidity with which plants and animals have spread, when in. troduced into new and favourable circumstances (e.g. thistles and rabbits into Australia).

Since organisms then are reproducing themselves so rapidly, and since all their offspring cannot escape their enemies, get food, and live, much less leave progeny in turn-since, in other words, the doctrine of Malthus applies to animals and plants with manifold force (for these can have no artificial increase of food, and no prudential restraints on re. production ) - there must in every case be a struggle for existence, either of one individual with another of the same species, or with the individuals of distinct species, or with the physical conditions of life; often, indeed, with all these at once, and that more or less intensely throughout the whole of life.

The checks which prevent increase are most obscure, and vary in each case. In all cases the amount of food, of course, gives the extreme limit. The youngest organisms generally suffer most; seedlings, for instance, are destroyed in vast num. bers. Thus, even in a patch of ground purposely dug and cleared, where no choking from other plants could take place, 295 out of 357 seedling-weeds were destroyed, chiefly by slugs and insects. So, too, the stock of game on an estate depends chiefly upon the destruction of vermin. Climate, however, is highly important, and periodic seasons of extreme cold and drought seem the most effective of all checks - a severe winter sometimes destroying fourfifths or more of the birds of a locality. Epidemics, too, may occur, especially where numbers have inordinately increased. On the other liand, a large number of individuals of the same species is essential for its continued preservation.

The complex relations of all animals and plants to each other require illustration. The planting of part of a heath with Scoteh fir leads to a profound alteration of its flora and fauna, while the growth of these firs again is wholly dependent upon the exclusion of eattle. Many flowers depend for fertilisation on the visit of a special insecte.g. red clover on humble-bees. But bees are destroyed by field-mice, and consequently protected by cats; hence, not only no bees, no clover, but also the more cats, the more clover! The struggle for life is most severe between individuuls and varieties of the same species, and between the species of the same genus, since these tend to fill the same place in the economy of nature; hence we see the brown rat supplanting the black, and the hive-bee supplanting its Australian congener. The structure of every being is related to that of the others with which it conipetes, or from which it seeks to escape, or on which it preys; as is alike eviclent in the structure of the tiger and of the parasite which clings to his hair. So, too, the albumen of a seed is chiefly useful in favouring the young plant's struggle for light and air against the adult plants around.

Natural Selection.-But how will the struggle for existence act with regard to variation? Can the principle of selection, so potent in the hands of nian, apply under nature? Most efficiently so. Let us bear in mind (1) the constant occurrence of variation; (2) the infinite complexity of the relations in which organisms stand to ench other, and to the pliysical conditions of life; and consequently (3) what infinitely varied diversities of structure might be useful to each being under changing conditions of life. Can it then be thought improbable, seeing that variations useful to man have undoubtedly occurred, that other variations useful in some way to each combatant in the great and complex battle of life should also occur in the course of many gerrerations? And if such do oceur, can we doubt (remembering that many more individuals are born than can possibly survive) that individuals having some advantage, howevel slight, have the best chance of surviving and of reproducing their kind, while injurious variations are destroyed? This preservation of favourable variations, and the destruction of injurious ones, 
is termed Natural Selection, or less liguratively, the Survival of the Fitteat.

Taking the cawe of a country undergoing a change of climate, the proportional numbers of its denizens would change, some species probably becoming extinet-and theae chauges would in many ways affect the survivors. $\boldsymbol{A}$ further dis. turbance would come from the immigration of new forms: or if that were prevented, we should have places in the economy of nature which miglit be fretter filled up. Any slight favourable modifica. tion of the old species would tend to be preserved, and we have seen that changed conditions increase variability.

Nor are such changes neceasary in order to leave places for natural selection to fill. No country can be named where the native inhabitants are perfectly adapted to their conditions and competitors, for as some foreigners have taken firm possession in every country, we may safely conclude that the natives might have been moditied with advantage to resist then.

And when human selection has produced such great results, why may not natural! Human selection acts only for man's own good, on mere external and visible characters, and irregularly throurhout a short period; natural selection acts for'the good of the being itself, on the whole machinery of its life, and incessantly on the species, throughout almost infinite time. (It is important here to remember that the objection to this agency on the ground of its presumed insignificance, is identical with that so long but unsuccessfully employed against Lyell's explanation of the origin of the physical features of the globe by summing up the existing natural ehanges.

Natural selection thus leads to the improvement of each creature in relation to its organic and inorganic conditions of life, and consequently in most cases to what must be regarded as an advance in organisation. Nevertheless, low and simple forms will long endure, if well fitted for their simple conditions.

Natural selection may modify the egg, seed, or young, as easily as the adult, and these moditications may effect through correlation the structure of the latter, and conversely.

Besides Natural, we have to consider Sexual Selection-i.e. not merely do individuals struggle for existence, but the males struggle for the females, and the most vigorous thus tend to leave most progeny. Special weapons, offensive and lefensive, like the cock's spurs, the stay's horns, or the lion's mane, are used in this struggle, and the most useful variations are those which are transmitted. Ayain, just as man can in a short time give beauty to his domestic birds, so there is no yood reason to doubt that female birds in thousands of generations, by selecting, as they are observed to do, the most melodious or beauti. ful males, might produce a marked effect, and many sexual differences are thus explained.

The theory of natural selection may be applied in special cases-e.g. (1) to explain the evolution of sivift yreyhound-like varieties of wolves; (2) to explain the origin and the excretion of nectar in flowers, its use to insects, the action of insects in transferring pollen from flower to flower, with its alvantage in intercrossing; and the resultant molification and adaptation of flower and insect to each other by the preservation of advantageous variations.

The circumstances favourable to the production of new forms through natural selection are also reviewed. These are chiefly, great variability; large numbers of individuals; the complex effects of intererosaing ; isolation in small men, yet aloo extensiun over continental ones, esjeciully if these vary in altitude; and considerable lapee of time. Rare species are shown to be in procens of extine tion. The divergence of character in domestic breeds, largely due to the fact that fanciers do not, and will not, admire a medium atandard, but like extremen,' applies throughout nature, from the circumstance that the more divensified the descend. ants from any one species become in mtructure, constitution, and habits, by so much will they be better enabled to seize on many and widely diversified places in nature, and so to increase in numbers. Thus, taking a carnivorous animal which has reached the maximum numbers its territory will support, it is evident that it can succeed in increasing only by its varying descendants seizing places hitherto occupied by other animsls. This must hold equally of all species, and is separately demonstrated for plants. The greatest amount of life can be supported by help of proportionally great diversification of structure; hence, in small areas where competition is severe, the inlabitants are extremely varied.

The probable effects of the action of Natural Selection, through divergence of character and extinction, on the descendants of a commun ancestor are then discussed in detail by $\mathrm{Mr}$ Darwin with an illustrative diagram. This takes the form of a genealogical tree- the great tree of life, which fills with its dead and broken branches the crust of the earth, and covers the surface with its everbranching and beautiful ramifications.'

Lave of Variation (see VARIATION). - Of the cause of most variations we are still ignorant, but the same laws appenr to have acted in producing the lesser differences between varieties of the same species and the greater difierences between species of the same genus. Changed conditions sometimes induce definite and permanent effects : habit, use, and disuse are potent in their effects. Specific characters are more variable than generic, and varietal than either. Rudimentary organs and secondary sexual characters ure highly variable. Species closely related of similar constitution and similarly influenced, present analogous variations, and frequently exhibit characters which can only be explained as reversions to those of their ancient progeniturs-e.g. zebra-like stripes on horses, or wood-pigeon's markings on fantails, tumblers, \&c.

Difficulties and Objections, - In four chapters all the miscellaneous objections raised against the theory between 1859 and the appearance of the latest edition are successively stated, weighed, discussed, and met, as well as the much more serious difficulties pointed out by Darwin himself. These latter are, (1) the definiteness of species and the rarity of transitional forms; (2) the enornous degree of moditication in habits and structure assumed by the theory, and the seeming improbability that Natural Selection should produce on the one hand an organ of such trifling importance as the tail of a giraffe, and on the other, an organ 60 wonderful as the eye; (3) the acquirement and moditication through Natural Selection of such marvellous instincts as those of the bee; (4) the sterility of crossed species, and the fertility of crossed varieties. For these dikcussions, however, the reader muat consult the work itself.

Imperfection of the Geological Record.-On the assumption of the extermination of an enormous number of intermediate varieties, which were the links between existing and remote ancestral forms -why, then, is not every geological formation charged with such links? Why does not every collection of fossils afford plain evidence of the gradation and mutation of the forms of life? Geology, assuredly, does not revenl any such finely graduated organic chain, and this is one of the most obvious and plausible objections to the 
theory. The explanation offered is the extremethe almost incredible -imperfection of the geological record. Only a small portion of the globe has been geologically explored with care; only certain classes of beings have been fossilised; and the number, both of specimens and species yet discovered, is absolutely as nothing compared with the number which must have passed away during even a single formation. The Malay Archipelago equals in area the formations best known to us; its present condition represents that of Europe while Europe's strata were being deposited; its faina and flora are among the richest on the globe, yet, even if all the species were to be collected which ever lived there, how imperfectly would they represent the natural history of the world! Only few species are preserved at all, and most of these in an imperfect manner; moreover, subsidence being almost necessary for the accumulation of rich deposits, great intervals of time must have elapsed between successive formations, so that during periods of elevation, when variation would be most frequent, the record is least perfect. Moreover, geological formations have not been continuously deposited; the duration of specific forms probably exceeds that of each formation; migrations have largely taken place; widely ranging species are most variable, and oftenest give rise to new species; varieties have been at first local ; and finally, it is probable that periods of modification are short as compared with periods of permanence. Hence we cannot find innumerable varieties, and any linking variety between two forms is, of course, ranked as a distinct species, for the whole chain cannot be permanently restored. Thus the geological record is a history of the world indeed, but one imperfectly kept, and written in a changing dialect; of this history we possess the last volume only, relating to two or three countries. Even of this volume only here and there has a short chapter been preserved, and of each page only here and there a few lines.

Geological Succession of Organic Beings (Distribu. tion in Time). - The preceding difficulties excepted, the facts of palatontology agree admirably with the theory. New species come in slowly and successively ; they change in different rates and degrees; old forms pass through rarity to extinction, and never reappear ; dominant forms spread and vary, their descendants displacing the inferior groups, so that after long intervals of time the productions of the world appear to have changed simultaneously. The most ancient forms differ most widely from those now living, yet frequently present characters intermediate between groups now widely divergent, and they resemble to a remarkable extent the embryos of the more recent and more highly specialised animals belonging to the same classes. These laws, and, above all, the important law of the succession of the same types within the same areas during the later geological periods, and most notably between the Tertiary period and the present time (e.g. fossil and recent marsupials in Australia, and edentates in South America), cease to be mysterious, and become at once thoroughly intelligible on the principle of inheritance, and on that alone.

[Since the publication of the Origin of Species in 1859 , palæontological research has been constantly furnishing the most triumphant verification of these views. The imperfection of the geological record was so far from overestimated that Huxley (Science and Culture, 1880), in comparing our present knowledge of the mammalian Tertiary fauna with that of 1859 , states that the results of the investigations of Gaudry, Marsh, and Filhol are 'as if zoologists were to become acquainted with a country hitherto unknown, as rich in novel forms of life as Brazil or South Africa once were to
Europeans:' Gaudry has found the intermediate stages by which civets passed into hyrenas; Filhol has disinterred still more remote ancestral carnivores; while Marsh has obtained a complete series of forms intermediate between that, in some respects, most anomalous of mammals, the horse, and the simplest five-toed ungulates (see MAMMaLs). Again, Darwin's belief that the distinctness of birds from all other vertebrates was to be accounted for by the extinction of a long line of progenitors connecting them with reptiles, was in 1859 a mere assumption; but in 1862 the long-tailed and intensely reptilian bird Archæopteryx (q.v.) was discovered, while in 1875 the researches of Marsh brought to light certain cretaceous birds, one (Hesperornis) with teeth set in a groove, the other (Ichthyornis) with teeth in sockets, and with bi-concave vertebræ. Besides these reptilian birds, bird-like reptiles have similarly been fortheoming, and the hypothesis of Darwin is thus admirably verified. Considerable light, too, has been thrown on the pedigree of crocodiles; ammonites, trilobites, and other invertebrates have been arranged in series, while important collateral evidence is also furnished by 'persistent types' such as Ceratodus, Beryx, Nautilus, Lingula, \&c., which have survived-we must assume by ordinary generation-almost completely unchanged since remote geological periods. On such grounds, therefore, Huxley asserts (op. cit.) that ' on the evidence of palrentology, the evolution of many existing forms of animal life from their predecessors is no longer an hypothesis, but an historical fact; it is only the nature of the physiological factors which is still open to discussion.']

Geographical Distribution.-Neither the simi. larity nor the dissimilarity of the inhabitants of various regions, whether of land or sea, can be accounted for by identity or differences of climate, or other physical conditions, but both are related in the most striking degree to the absence or presence of barriers to migration between those regions. Within the same area there exists the most marked affinity among the species, though these differ from place to place. Species appear to have arisen in separate definite centres, the few apparent exceptions being accounted for by migration and dis. persal, followed by climatic and geographical changes. But for a summary of our knowledge of the existing mode of distribution of organic life, and of the way in which that distribution has been effected, as well as of the very important bearing of these facts upon the theory of evolution, which they may be said, indeed, more than any other class of facts, to have suggested, see the article Geographical Distribution.

Morphological Arguments.-The physiological and distributional lines of argument being summarised, those furnished by morphology, although not less numerous and hichly important, can only be very briefly outlined. These are mainly four, and are derived from $(a)$ Classification, $(b)$ Homologies, (c) Embryology, (d) Rudimentary Organs.

(a) Classification. - Naturalists arrange the species, genera, and families in ench class, on what is called the Natural System. But what is meant by this system? Is it, after all, merely an artifieial scheme for enunciating general propositions, and of placing together the forms most like each other? or does it, as many believe, reveal the plan of creation? The grand fact of classification is, that organic beings, throughout all time, are arranged in groups subordinated under other groups-individuals under varieties, and these again under species; species under genera; genera under subfamilies, families, and orders; and all under a few grand classes. The nature of all these relationships-the rules followed and the difficulties met 
hy naturalists in their classifieations-the high vulue set upen conetant and prevalent structures, whether thesse be of great or little une, or, as with rudimentary organs, of none at all-the wide opposition in value between such misleading remenblances of adaptation, as, for instance, the fishlike form of whales, and such characters of true aflinity as are afforded by the structure of their eireulatory or respiratory system-all these receive a simple and natural explanation on the view of the common descent of allied forms with modification through variation and natural selection; while it is to be noted that no other explanation has ever even been attempted. The element of descent, too, is atready used in linking all the sexes, ages, forms, and varieties of the same species, widely though these (e.g. Cirriperles) may differ from each other in structure: and we have only to extend it to understand the meaning and origin of the Natural System.

(b) IIominlugy. - The members of the same class, independently of their habits of life, resemble each other in their general plan of oryanisation. Thus, the hand of man, the digging-paw of the mole, the ley of the horse, the paddle of the porpoise, and the wing of the bat, are all constructed on the same pattern, bone corresponding to bone. Similarly with the hind-limb. Again, the mouths of insects are of innumerable varieties of form and usewitness the long spiral trunk of $\mathrm{a}$ moth, and the great jaws of a beetle-yet these are formed by modifications of an upper lip, mandibles, and two pairs of maxillse. And so it is with the limbs of crustaceans, or the flowers of plants; in fact, with the organs of every class of beings.

This conformity to type is "powerfully suggestive of true relationship, of inheritance from a common ancestor:' it admits, in short, as no one indeed denies, of a simple explanation in terms of the evolutionary theory, and thus strengthens that theory not a little. Attempts have been made to explain this unity of plan in two other ways-first, by assuming it due to utility, which is negatived by the facts, since organs of identical use (e.g. the wings of a bird and those of a buttertly) very frequently de not conform to the same type at all; secondly, by attributing it to a unity of design, which, however, $(\boldsymbol{t})$ instead of being always maintained, as it should be, on the theory, is not unfreguently quite lost in highly sprecialised forms and which, even if it always existed, (b) would directly suggest the unity of descent, the design thus serving only to mislead the anatomist.

Serial Homology, too, las to be accounted forthat unity of type which is found on comparing the dillerent parts and organs in the same individual, so that the wonderfully complex and varied jaws and legs of a lobster, or the widely different leaves, sepals, petals, stamens, and pistils of a flower, are all found to be modifications of a simple limb, and a simple leaf-organ respectively. Not only are such metamorphoses apparent on comparison, but they can be actually observed to occur during the - development of each individual; is then the term metamorphosis to have a mere metaphorical meaning when applied to the species, or has it not actually arisen in past time, through the natural selection and transmission of advantageous varia. tions?

(c) Development.-It has been already indicated that the serially homologous parts in the same individual are alike during an early embryonic period, as also are the homologous organs in animals which, like bat, horse, and porpoise, may be widely differentiated in adult life. So closely, too, do the embryos of the most distinct species belonging to the same class resemble each other, that even Von Baer wrs unable to distinguish whether two un- labelled specimens were lizards, hirds, or mammals. This law of enbryonic resemblanee holds very widely - e.g. with voung crustacesns. The essubyos often retains witlin the egg or womb structure which ars of no service to it, either at that or at a later period of life, like the transitory gill-nrehes of birds or manmals; while, on the other hand, larva (e.g. of insects), which have to provide for their own wants, undergo complete mecondary adaptation to the surrounding conditions. The process of development goes from the general 10 the special; thus there is generally an advance in organisation. In peculiar conditions, however, degeneration may occur. All these facts are resulily explained on the principle of successive slight variations not necessarily or generally supervening very early in life, and inherited at a corre. sponding period; hence it is in the highest degree probable that most embryonic stages show us more or less completely the progenitor of the group in its adult state; and embryology thus rises greatly in interest. See EмвRYoLOGY.

(d) Rudimentary Organs.-Rudimentary, atro. phied, and abortive organs, bearing the plain stamp of inutility, are so extreniely common that it is impossible to name a higher animal in which none oceurs. The mammæ of male mammals, the hindlegs of boas, the wings of many birds, or the teeth of foetal whales, and the upper incisors of unborn calves, are familiar instances. Such organs are intelligible on the evolutionary theory, and on that theory alone.

Recapitulation and Conclusion. After tersely summing up the preceding mass of evidence, Darwin coneludes by pointing out $(a)$ that the theory of evolution by natural selection is no more inimical to religion than is that of gravitation, to which the same objection was strongly raised; $(b)$ its revolutionary influence on the study of all departments of natural history; $(e)$ on Psychology $\left(q . v_{0}\right) ;(d)$ on the origin of man and his history (see MAN); (c) on our theories of fnture progress.

Envoy.- It is interesting to contemplate a tangled bank elothed with many plants of many kinds, with birds singing on the bushes, with various insects flitting about, and with worms crawling through the damp earth, and to reflect that these elaborntely constructed forms, so different from each other, and dependent on each other in so complex a manner, have all been produced by laws acting around us. These laws, taken in the largest sense, being Growth with Reproduction; and Inheritance, which is almost implied by reproduction; Variability from the indirect and direct action of the conditions of life, and from use and disuse; a Ratio of Incrense 80 high as to lead to a Struggle for Life, and as a consequence to Natural Selection, entailing Divergence of Character and the Extinction of less improved forms. Thus, from the war of nature, from famine and death, the most exalted object which we are capable of conceiving, namely, the production of the higher animals, directly follows. There is grandeur in this view of life, with its several powers, having been originally lreathed by the Creator into a few forms, or into one; and that, whilst this planet has gone cyeling on sccording to the fixed law of gravity, from so simple a beginning endless forms most beantiful and most wonderiul have been, and are being, evolved.

The stormy reception of the Origin of Species, the controversies to which it gave rise, itis rapid and widespread acceptance, helped as it was by the independent support, yet generous self-abnega tion, of Mr Wallace; and the powerful advocacy of Huxley, Hooker, Asa Gray, and others, are all recorded in Darwin's Life. Of the proposed expan-. sion of the Origin, only the finst chapter actually 
appeared, as Variation of Animals and Plants under romestication (see VARIATION); but in Fertilisation of Orchids, Forms of Flowers, Insectivorous Plants, Climbing Plants, Movement in Plants, we have a series which not only greatly developed Darwin's favourite study of adaptations, and with it enormously strengthened his general theory, but gave to the arid field of botany the interest and freshness of a new intellectual spring (see BOTANY). Again, the very difficulties which he felt to be presented to his theory by the complex phenomena of bee and ant society led him onwards, till he reached the problems of mind and language; the obvious and burning question of the origin of man had also to be faced, and thus we had the Descent of Man and the Expression of the Emotions.

Before conclusion, justice demands, if not discussion, at least mention of some of the more im. portant criticisms which have been urged against Darwin's theory. That which Darwin himself seems to have felt as most serious was made by Fleeming Jenkin, who laid stress on the tendency to swamping any individual variation, however advantageous, through intererossing. Mr Mivart's Genesis of Species next engaged him most; but Darwin's replies to these and other criticisms up to 1872 will be found in the final edition of the Origin of Species. In his essay in Darwin's Life, Huxley says, 'I venture to altirm that so far as all my knowledge goes, all the ingenuity and all the learning of hostile critice have not enabled them to adduce a single fact of which it can be said this is irreconcilable with the Darwinian theory ;' while Mr Ray Lankester still more recently assures us that 'sinoe its first publication in 1859 the history of Darwin's theory has been one of continuous and decisive conquest, so that at the present day it is universally accepted as the central, all-embracing doctrine of zoological and botanical science.

As a matter of fact, however, this 'universal acceptance' is not without its universally dis tributed exceptions. Some of Darwin's contemporaries have withheld their adhesion-e.g. Virchow in Germany, Owen and Cleland in Britain, and the older French naturalists; nor can the critical and controversial writings of Mivart, the Duke of Argyll, Samuel Butler, and others, be thus wholly ignored. Constructive criticism is also busy, On one hand certainly we have the ultraDarwinian speculations of Weismann, warmly accepted by Lankester and others; but on the other, attempts are again being made, and with increasing frequency, to restate the theory of evolu tion more or less completely in non-Darwinian terms. Thus, following up the doubt which oceasionally troubled Mr Darwin's recent years, that he had assigned too little importance to the modifying factors of use and disuse, of environment, \&c., we have Mr Spencer re-entering the field; in America an active Neo-Lamarckian school has also arisen, which lacks neither knowledge nor thoughtfulness; in Germany. we owe new constructive efforts to Nägeli and Semper, and more recently to Eimer; while in Britain, complementary hypotheses have been propounded by Romanes, Sutton, Gulick, Geddes, dc. But such proposed positive contributions to the evolutionary theory fall rather to be treated under EvoLUTION.

See Biologr, Botany, Evolution, Environment, Heredity, Geographical Distribution, Zoology, and other articles. Besides the works of Darwin himself, and those of Alfred Russell Wallace (from Natural Selection in 1870 to Damoinism in 1889), with the special treatises referred to under the above-mentioned and minor articles (e.g. Fertilisation), see F. Darwin's Life of Charles Darvin ; also minor Lives by Grant Allen and Bettany, Of other expository literature may be menti ned Haeckel's Generelle Morphologie and Natural History of Creation; Huxley's Lay Sermons, American Addresses, Science and Culture, Anatomy of Invertebrated Animals; also his essay On the Reception of the Oriynn of Species in Darwin's Life, vol. ii. ; Obituary Notice of Charles Darwin in Proc. Roy. Soc. (Lond. 1888); and Struggle for Existence, a Programme (Nineteenth Century, 1888). Weismann's studies in the Theory of Descent (1880-82), and for more recent developments his subsequent papers (see HEREDTY and WRISMANN), must also be noted. Rousanes' Scientific Evidences of Organic krolution, Lankester's Degeneration (both Nature ser.es), Schmidt's Doctrine of Descent and Darwinism, Fiske's Darwinism and other Essays, are examples in English of an abundant and more popular literature, in which the writings of Mr Grant Allen and Dr A. Wilson are also specially known, and which is likewise abundant in Germany, France, and Italy.

Of controversial writings may be cited Mivart's Gencsis of Species, Lessons from ${ }^{-N}$ ature, \&c.; the Duke of Argyll's Unity of Nature, as well as the review articles of both writers. See also Butler's Erolution, Old and New, and Luck or Cunning. For the literature of the more constructive attempts referred to, see EvoLUTion. For general bibliography Bettany's Life of Daruin is most accessible; also Seidlitz, Die Darw. Theoric (Leip. 1875), the Naples Jahresbericht f. Zoologie, and the Zoological Record; Osborn, From the Greeks to Darwin (1895); Poulton, Darvin and Natural Selection (1896).

Darwin Sound and MOUNT DARWIN are on the SW. side of King Charles's South Land, Tierra del Fuego. The mountain rises 6800 feet.

Dasent, SIR GEORGE WebBe, was born in 1820 at St Vincent in the West Indies, of which island his father was attorney-general. He was educated at Westminster School and King's College, London; graduated B.A. at Magdalen College, Oxford, in 1840; and was called to the bar at the Middle Temple in 1852, in which year also he received his degree of D.C.L. He was for twenty-five years $(1845-70)$ an assistant-editor of the T'imes, and married a sister of its editor, $\mathrm{Mr}$ Delane. An accomplished linguist, especially in Scandinavian, he acted as examiner in English and morlern langunges for the Civil Service; he was a Civil Service Commissioner in 1872-92, whs kniglsted in 1876, and died 11th June 1896. In 1842 he published a translation of The Prose or Younger Edda, which was followed by an essay, "The Norsemen, in the Oxford Essays (1858); Popular Tales from the Norse, with an Introductory Essay on the Origin and Diffusion of Popular Tales (1859), and Tales from the Fjeld (1874), both from the Norwegian of Asbjörnsen; translations from the Icelandic of the Saga of Burnt Njol (1861), and the Story of Gisli, the Outlaw (1866); and an Introduction and Life of Cleasloy, prefixed to Vigfusson's completion of Cleasby's untinished Icelandic-English Dictionary (1874). Sir George Dasent also wrote several fair novels. His famous introduction to Asbjörnsen's Popular Tales was a solid contribution to folklore, being an admirable exposition of the Aryan theory of story-transmission as advocated by Grimm and Max Müller.

Dash, Countess, the name under which Gabrielle Anna Cisterne de Courtiras, Vicomtesse de Saint-Mars, published a series of novels, many of which were readable, if of but slender literary merit. She was born at Poitiers, August 2, 1804, of a noble family, married early, and took to literature for a living after the loss of her property, writing sometimes as many as five or six novels a year. She died 11th September 1872 . Her stories deal almost exclusively with the aristocratic world and its more or less illegitimate liaisons. They have a certain brightness and vigour, but lack reality, and are peopled by a crowd of stilted puppets rather than living men and women. Of her numberless books may only be mentioned 
Les A mours de Bussy-Rubutin (1850), La Pumme ¿' Eve (1853), Le Galanteriea de la Cour de Louis X'V. (1861), Comment Tombent les Femmes (1867), and Les Aventures d'une Jeune Marile (1870).

Dashkof, Princess Ekaterina Romanovna dsughter of Count Voronzoff, was born 28th Mareh 1743, at St Petersburg, and from her earliest youth received a careful truining. She married Prince Dashkoff when only fifteen years old, but was left a widow three years after. She was an intimate friend of the Empress Catharine II., and one of the heads of the conspiracy formed against Peter III. the success of which secured the throne to Catharine. Soon afterwards quarrelling with Catharine, she obtained permission to travel, and visited Germany, Englaud, France, and Italy, making the acourintance of many eminent men (among others, Garrick, Dr Blair, and Dr Rohertson). The empress and she were reconciled to each other, and the princess was appointed Director of the Academy of Arts and Sciences; and in 1783, President of the Russian Academy, established at her own suggestion in imitation of the French Academie. On the death of Cathariue in 1796, she was deprived of her offices, and ordered by Paul III. to retire to her estates at Novgorod. She died 16th January 1810. Besides writing several comerlies and occasional papers, the Princess Dashkoff was mainly instrumeutal in inducing the Russian Acadeny to draw up a dictionary of the Russian language, and herself executed part of the work. See her very interesting autobiogrinpliy (trans. 1840).

Dasyprocta. See Agoutr.

Dasyure (Dasyurus), a genus of carnivorous marsupials, including forms which in the Australian and Tasmanian fauna take the place filled in other regions by carnivores. The large sharp canines, the sharp-pointed cusps on the back teeth, and the clawed toes are among the adaptive camivorous features, and there are others of a more technical nature. The dasyures, are nocturnal and savage animals, and as one would expect, peculiarly untamable. One of the most pronounced is the Tasmanian Devil (D. ursinus), a savage animal, about the size of a badger, with a disproportionately large and broad head, and massive crowded teeth. The body is plump; the fur is coarse and brownish-black, with a white band on the chest, and another at the end of the back; the tail is

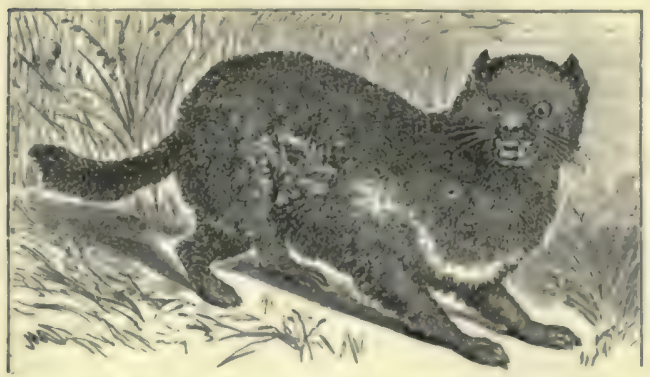

Tasmanian Devil (Dasyurus urainus).

thick, and about half as long as the body. In Tasmania these 'devils' used to commit great havoc among poultry and even sheep, but are being driven into more and more remote haunts. The Spotted Dasyure (D. maculatus ), also Tasmanian, is a much smaller animal, about the size of a cat. Another 'wild cat' of the same country and Victoria is Mauge's Dasyure (D. maugei or viverrinus). Other species occur in Australia and New Guiner. Nearly allied to the dasyures are two genera,
Thylaoinus and Phascogale. The former, the Thylacine $(q, v$,$) or Tasmanian wolf, is the largest$ carnivorous marsupial; the latter is insectivorous. See Marsupials.

Date. See Chronology.

Date Palm (Phonix), a genus of palms, the most important species of which is the Common Date Palm, the Pulm I'ree of Seriuture ( $P$. ductyliferu), a native of the northern half of Africa, the south. west of Asia, and some parts of Indin, and of which the cultivation is no less wide, and still extending.

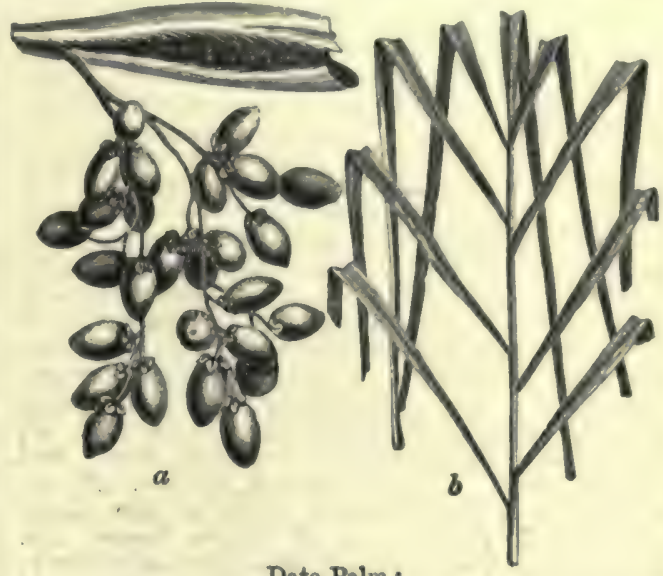

Date Palm :

$a$, bunch of dates dependent from their spathe; $b$, portion of leaf.

Some parts of China produce large crops, Thestem, which is straight and simple, reaches a height of 30 to 60 feet, and bears a head of 40 to 80 glaucous pinnated leaves, of 8 to 10 feet long, and a number of branching spadices, each of which on the female tree bears 180 to 200 fruits (dates, dactyli). A bunch of dates weighs 20 or $25 \mathrm{lb}$, , so that an average year's crop may be reckoned at 300 to $600 \mathrm{lb}$. per tree, and the yield per nere at about twelve times that of corn. From the earliest times fertilisation has been artificially aided by cutting off the male inflorescences just before the stamens ripen, and suspending them among those of the female tree; so avoiding the risks and losses of ordinary windfertilisation. In a palm grove there may be but one male stem to forty or fifty fruit-bearing ones. The Arabs seldom raise palms from seed; to make sure of the sex they take suckers from female trees known to bear good fruit. The tree begins to beas about the eighth year, reaches maturity at abour thirty years, and does not decline until about the age of one hundred. This is one of the most im. portant and useful of all the palms. In Egypt, and generally in North Africa, Persia, and Arabia, dates form the principal food, and date palms the principal wealth of the people. The fleshy part of the fruit contains 58 per cent. of sugar, accompanied by pectin, gum, \&c. The fruit is eaten either fresh or dried, and in the latter state becomes an article of commerce. Cakes of dates pounded and kneaded together, and so solid as to be eut with a hatehet, are the store of food provided for African caravans on their journey through the Sahara. A sweet juice (date-honey) can be expressed from the fruits, from which a kind of wine is obtained by fermentation; also a sort of vinegar; an ardent spirit is of course also distilled from the fermented juice. Palm-wine is also made from the sap after the terminal bud is removed. The bnd is eaten as palm-cabbage, similarly also the undeveloped panicles of flowers. The date 
'stones' or seeds are roasted in North Africa as a substitute for coffee, and have also been introduced into Britain for the same purpose. They are also ground and pressed for oil, and the residue used for feeding cattle. From leaf-stalks of the common date palm, all kinds of basket and wicker work are also made, and walking-sticks, fans, \&c. The leaves themselves are made into bags, mats, \&c. the fibres of the web-like integuments at the base of their stalks into cordage. The wood is used for building, fences, \&c.-The Toddy Palm of the north of India, or Wild Date Palm ( $P$. sylvestris), so nearly resembles this species, that it is doubtful if it is distinct. In some places, the trees present a curiously distorted and zigzag appearance, from the practice of yearly tapping the alternate sides for the sixp or toddy. This forms a grateful and wholesome beverage; readily also fermenting into palmwine, and by distillation yielding $\operatorname{Arrack}\left(\mathrm{q} . \mathrm{v}_{\mathrm{.}}\right)$; whilst if boiled down it yields the syrup called jaggery, from $4 \mathrm{lb}$. of which $1 \mathrm{lb}$. of sugar is obtained, a single tree producing about 7 or 8 lb. of sugar annually. The operation of tapping for toddy spoils the fruit of the tree, which is small and much inferior to the African date. It is, however, eaten.-Another species, $P$. paludosa, the most gregarious of Indian palms, growing only 6 or 8 feet high, covers the landscape of the Sunderbunds with the liveliest verdure. $P$. acculis and $P$. farinifera are also dwarf and closely allied common Indian species. $P$. reclinata is a characteristic palm of the Natal coast, and $P$. spinosa of Sierra Leone, \&c. Some derive the origin of the colonnade pillar in architecture to the regular mode of its planting and the use of its stem in building, while in symbolic interest it stands second to no other plant. The symbol of beauty and of victory alike to Hebrews and Hellenes from the earliest times, it passed readily to the suggestion of victory over death and glorious immortality; hence alike the name Phonix from the fabled bird, and the habit of representing angels and the blessed with palms in their hands. It was largely used also for decoration of festivals, and for strewing in processions. Christ's triumphal entry into Jerusalem is still commemorated on Palm Sunday (q.v.).

Date Plum (Diospyros), a genus of Ebenacer, important for timber (see EBONY, IRONwOOD) and fruit. The Common Date Plum or Pishamin, also called the European Lotus and the Date of Trebizond ( $D$. lotus ), is a tree of 18 to 30 feet in height, with oblong shining leaves and small reddish-white flowers, a native of the coasts of the Caspian Sea, Northern Africa, \&c., but cultivated and naturalised in the south of Europe. It can also be grown in the south of England. Its fruit is of the size of a cherry, and in favourable climates larger, yellow, sweet, and astringent. It is eaten when over-ripe, like the medlar, or is used for conserves. - This fruit has been supposed by some to be the Lotus (q.V.) of the Lotophagi. The Virginian Date Plum, or Persimmon ( $D$. virginiana), is a tree of 30 to 60 feet high, with ovate oblong leaves and pale-yellow flowers, a native of the southern states of North America, where one tree often yields several bushels of fruit. The fruit is about one inch in diameter, with six to eight oval seerls. It is not palatable till mellowed by frost, and is sweet and astringent. $A$ kind of beer or cider and an ardent spirit are made from it. $D$. Mabola is cultivated as a fruittree in Mauritius. D. Kaki, sometimes called the Keg-fig, is a native of Japan, which occasionally is kept in greenhouses in France and England. The sweetmeat called Figues-caques is made from this fruit in France. The fruit of some other species is also edible-e.g. $D$. decandra of CochinChina.
Datholite (Gr. dathos, 'turbid'), a mineral, colourless or inclining to grayish, greenish, white, or yellowish-gray colour, occurring both masivive and crystallised in rhombic prisms, the edges and angles of which are commonly replaced by planes. It is composed of boracic acid, silica, and lime, with a little water. It has been found both in schistose and crystalline igneous rocks; and occurs near Edinburgh, in Norway, Italy, Connecticut, \&c.

Datia, a native state of Bundelkhand, with a pop. of 186,440 . The clief town, Datia, 125 miles SE. of Agra, on a rocky eminence, has a pop. of 27,566 . It has several palaces, some now untenanted.

Datiscacea, a very small order allied to Begoniacer, including ouly four species, of remote distribution. Datisca cannabina, a plant much resembling hemp, is cultivated in Crete and Asia Minor for its hemp-like fibre, also as a source of yellow dyestuff. It has tonic properties.

\section{Dative. See Declension. \\ Dat'ura. See ThorN APPLE.}

Daub, KARL, a speculative theologian, was born 20th March 1765, at Cassel, studied philosopliy and theology at Marburg, and became in 1795 professor of Theology at Heidelberg, where he died 22d November 1836. An earnest and singularly open-minded seeker after truth, although defective in the true historical sense, and not a robust and independent thinker, Daub laboured incessantly to find a sound basis for a reconciliation between religion and philosophy, and his suceersive writings reflect the whole development of prevailing philosophy from Kant to Hegel. Thus his Lehrbuch der Katechetik (1801) rests completely on Kant's fundamental principles; again, dominated by the influence of Schelling's 'philosophy of identity' are his Theologumena (1806) and Einleitung to Christian dogmatics (1810); while Schelling's transition to theosophy and to "positive philosophy" is mirrored in Daub's Judas Ischarioth (1816), despite its eccentricities his best work. Hegel was called to Heidelberg in 1816, and henceforth it was his influence which was dominant over the receptive mind of Daub. In his Dogmatische Theologie (1833) and Prolegomena (1835), he attempts in the darkest language of the Hegelian dialectic a philosophical restoration of the dogmas of the church. Daub's Theol.-philos. Vorlesungen were colleeted by Marheineke and Dittenberger in seven volumes (1838-43). See Rosenkranz's eulogistic but uneritical Erinnerungen (1837), and D. F. Strauss, Charakteristiken und Kritiken (2d ed. 1844).

Daubenton, LoUIS JEAN MARIE, naturalist, was born at Montbar in Burgundy, 29th May 1716. He studied theology at the Sorbonne, but soon gave himself up to medicine and anatomy. In 1742 his old schoolfellow, Buffon, invited him to assist him in the preparation of his great work on Natural History, and Daubenton contributed richly to the first fifteen volumes of the Histoire Naturelle, until the jealousy of Buffon led to an estrangement. Daubenton now devoted himself almost entirely to his duties in the Jardin du Roi, where he was professor of Mineralogy. He was also for a time professor of Natural History in the College of Medicine. He contributed largely to the first Encyclopédie, and wrote many valuable mémoires. He died 31st December 1799.

Daubeny, Charles Giles Bridle, chemist and botanist, was born at Stratton in Gloucester. shire, 11th February 1795. He devoted himself chiefly to the elucidation of natural phenomena by the aid of chemical science-his great work being A Description of Active and Extinct Volcanoes (1826). He also wrote on thermal springs. He 
became professor of Chemistry at Oxford in 1822, of Botany in 1834, and was an F. R.S. Other works are an Introduction to the Atomic Theory (1831), Lectures on Agriculture (1841), and Lectures on Climate (1862). Daubeny died December 18, 1867.

D'Aubigné, Jean-Hexri Merce, a popular ecclesiastical historian, was born at Eaux-Vives, mear Geneva in Switzerland, 16th August 1794, studied there and at Berlin-under Neander-and in 1818 became pastor of the French Protestant Church in Hamburg. In 1823 he was appointed court-preacher at Brussels; lnt after the revolu. tion of 1830, he declined the post of tutor to the Prince of Orange, and returning to Geneva, took part in the institution of the new evangelical church, and filled the chair of Church History in its theolourienl seminary until his sudden death, in the night of Oetober 20-1, 1872. With the exception of some visits to England and Scotland, where he had numerous readers and admirers, and where he received the degree of D.C.L. from Oxford and the freedom of the city of Edinburgh, he remained constantly at Geneva. The work which has given him a widespread reputation is his Histoire de la Reformation au Seizieme Sidcle (1835-53); it has been translated into most European tongues, and has attracted more notice abroad than at home; it is written with a devout, fervid sympathy that is often eloquent, although the narrative is too graphic to be everywhere exact. Its popularity has been immense. Among his other writings are Germany, England, and Scotland (Lond. 1848); a vindication of Cromwell (1848); Trois Siecles de Lutte en Ecosse (1849); and Histoire de la Réforma. tion en Europe au Temps de Calvin (1862-78).

D'Aubigné, ThÉodore AgripPa, a famous French scholar, was born on 8 th February 1550 , near Pons in Saintonge. At an early period he exhibited a remarkable talent for the acquisition of languages. Although born of a noble family, he inherited no wealth from his father, and consequently chose the military profession. In 1567 he distinguished himself by his services to the Huguenot cause, and was subsequently rewarded by Henry IV., who made him vice-adniral of Guienne and Brittany. His severe and inflexible character frequently embroiled him with the court; and after Henry's assassination (1610), he betook himself to Genevs, where he spent the remainder of his life in literary studies. He died April 29, 1630, leaving a worthless son, Constant, who was father of Madame de Maintenon. D'Aubigné's best-known work is his Histoire Universelle, 1550-1601 (Amsterdam, 1616-20), which had the honour of being burned in France by the common hangman. D'Aubigné was possessed of a spirit of biting satire, as is proved by his Confession Catholiyue du Sieur de Sancy, and his Aventures du Baron de Freneste. See his Histoire Secrete, ecrite par lui méme (1731); also French studies by Réaume (1883) and Morillot (1884).

Daubigny, Charles Francots, landscapepainter and etcher, born in Paris in 1817, studied under his father, who was a miniature-painter, Panl Delaroche, and others, and from $1838 \mathrm{ex}$ hiloited in the Salon, although his full recognition came only after the artist had reached his fiftieth year. He devoted himself to close and sympathetic study from nature, working much on the Seine in a house-boat, and developed a style of landscape art narked by aingularly unaffected fidelity and originality. In 1853 he gained a first-class medal with his 'Pool of Gylien.' In 1857 he produced his 'Springtime;' in 1861, 'The Banks of the Oise ; ' in 1872, 'Windmills at Dordrecht;' and in 1877, his large and very impressive 'Rising Moon." His 'Sluices in the Valley of Optevos ' (1855) and his 'Vintage
(1803) are in the Luxemhourg Gallery. He is also known as a book-illustrator and is a vigorous etcher, having produced over a hundred plates, some reproductions, other direct from nature, marked by great frankness of method and free painter-like quality. He died in Parin, 19th February 1878.

D'A ubusson, Pierre, Grand-master of the order of St John of Jerusalem, surnained 'the Shield of the Church,' was born of a noble French family in 1423. At in early age he entered the service of the Emperor Sigismund, and served under the Archduke Altrecht of Austria against the Turks. Returning to France, he served with the Armagnacs against the Swiss, and covered himself with glory at their defeat near St Jacob (1444). He next joined the order of the Knights of Rhodes, and rose rapidly into power, becoming grand-master in 1476. He laboured to bring about a conferleration of all the Christian powers to counteract the triumph of the Turks that followed the fall of Constantinople. Mohammed II.'s career of conquest, which threatened to spread over Western Enrope, was stayed alone by the obstinate bravery of $D^{\prime}$ Aubusson and his little colony of Christian soldiers in the island of Rhodes. In May 1480 an army of 100,000 Turks invested the town, but were forced to raise the siege after a month's desperate fighting, leaving behind them as many as 9000 derid. Mohammed was filled with fury, and a second attack wrs only arerted ly his dentli in 1481 . D'Aubusson died.in 1503. See Hospitallers.

Daudet, AlPHONSE, was born at Nimes on May 13, 1840. His family had been in trade, but were not in good circumstances. He was, however, well educated at the Lyons Lycee, and was able when quite a boy to take the place of usher in a school at Alais, an employment of which, in Le Petit Chase and others of his works, he has given no cheerful reminiscences. He was only seventeen when, giving up his ushership, he set out for Paris with his elder brother, Ernest, who himself became a journalist and novelist of some mark. Alphonse (as also did Ernest) obtained an appointment as elerk or private secretary in the office of the Duke de Morny, of whom he has drawn a famous portrait in Le Nabab. Indeed, one of the main characteristics of M. Daudet's method, and one of the main reasons of his popularity with some, and his un. popularity with other readers, is the manner in which he seems to have utilised almost every circumistance and almost every acquaintenceship of his life in his books. M. Daudet's literary efforts, however, began with poetry; and his first book. in 1858, was entitled Les Amourenses. He also devoted some not too successful years of experi. ment to theatrical work, writing by himself, or with a collaborator, La Derniere Idole (1862), L'Eillet Blane (1865), Le Frere Aine (1868), Le Sacrifice (1869), Lise Tavernier, and $L^{\prime}$ Arlésicnue (1872), pieces of which the earlier were more successful than the later. Besides this, he contributed to many journals, especially the Figaro. In this form appeared some of his best work, the Lettres de Mon Moulin (collected 1869), Robert Helmont (1871), the Contes du Lundi, and others; and it was in these years that he conceived the charming extravaganza of Tartarin de Tarascon, a most amusing satire on the charscteristics of the natives of the south of France (1874), which he followed up with Tartarin sur les Alpes (1886) and Port Tarascon (1890).

It was not, however, till many years after his literary beginnings that $M$. Daudet hit on the style which has made him popular and famous. He had sketched something of the kind early in $L_{6}$ Petit Chose, a book full of pathos anci of reminio. 
cences of his own early struggles. This pathetic quality is still further developed in Jack (1873), the story of an illegitimate child, part of the interest of which turns on the half-malicious sketches of certain literary Bohemians; and in Fromont Jeune et Risler. Aine (1874), where the devotion of a man of business to his firm, his wife, and his brother, meets in all three cases with an equally evil return. These have been followed by Le Nabab (1877), a transparent caricature of Morny and other well-known personages under the empire; Les Rois en Exil (1879), the chief parts in which are supposed to have been played also by actual persons : Numa Roumestan (1882), the hero of which was supposed to have some resemblance to Gambetta, and which at anyrate is as remarkable in the serious way as Tartarin in the comic amongst satires on the 'meridional' type ; L'Evangéliste (1883), in which the then new craze of the Salvation Army was introduced; Sapho (1884), a book somewhat out of M. Daudet's usual line, in which the mutual infatuation of a young man and a courtesan and artist's model is drawn with remarkable if not very wholesome power; and L'Immortel (1888), in which all the author's powers of ridicule, and all lis practised skill in attacking individuals under a thin disguise, are employed to throw discredit on the French Academy. The vigour, and within certain limits, the versatility, of this series of novels is not denied by any one; but in addition to the personality already noticed, there has been charged against the earlier ones at least a following of Dickens, which ean hardly be accidental, though it has been asserted to be so.

M. Daudet married early a lady of talent, who rendered him much assistance in his literary work, and he formed for some time part of a coterie of remarkable literary characters, which included the Russian novelist Turgenief, Gustave Flaubert, the brothers Goncourt, and M. Zola. He published autobiographic papers, collected as Trente Ans de Paris (1887), and Souvenirs d'un Homme de Lettres (1889). Long a sufferer from locomotor ataxy, he died 16th December 1897. See R. H. Sherard's Daudet (1894) and the Memoir by his son, Léon (Eng. trans. 1898), who is also a novelist.

Daudnagar, a mean-looking town in the Gaya district of Bengal, on the Son, 90 miles SW. of Patua. It possesses, however, a considerable river trade, and manufactures coarse fabrics both of wool and of cotton. Pop. 9870.

Daulatabad ('fortunate city'), a town and fort in the Deccan, within the Nizam's dominions, 28 miles NW. of Hyderabad. The fortress consists of a conical rock, 600 feet high, with a wide ditch and an outer wall nearly 3 miles in circumference. The place surrendered to the Mohammedans in 1294, and Shah Muhammad Tughlak (1324-51) thrice attempted to remove the seat of government hither from Delhi. The fortress has not been garrisoned now for many years, and the town has greatly decayed. Pop. 1243.

D'Aulnoy, Marie Catherine Jumelle de Berneville, Countess, was born about 1650 , and died in 1705. She wrote many tedious and longwinded romances long consigned to safe oblivion. Of these may here only be mentioned Hippolyte, Comte de Douglas (1690). Equally worthless are her historical memoirs. But her fame rests securely on her Contes des Fees, which are written in a simple, bright, and charming style, not altogether unworthy of the inmitable ruaster, Perrault. The White Cat, the Yellow Dwarf, Finette Cendron, and Le Mouton have for two centuries been naturalised in the nurseries of Europe, and are still familiar figures in pantomime.

D'Aumale. See AUMALE, (DUC D').
Dawmer, GEORG FrIEdRICH, an able but in 1800 at Nuremberg, where for a time he was a professor in the gymnasium, and where Kaspar Hauser (q.v.) was committed to his care. Abandoning the pietism of his student days, he passed through Schelling's philosophy to a position of bitter antagonism to Christianity, which he wished swept from the face of the earth ; but in 1859 he joined the Ultramontane party, and became one of its foremost champions. His many philosophical writings reflect his varying positions; so late as 1847 he endeavoured to prove that among the ancient Jews and the Christians of the first century human sacrifice obtained; from 1859 he expounded and defended the faith. His poetical works, especially Mahomet (1848) and the Liederblüten des Hafis, two graceful imitations of Persian poetry, have gained a high reputation. Daumer died at Wirrburg, 14th December 1875.

Daumier, Henri, a celebrated French caricaturist, was born at Marseilles in 1808. Fashion, tittle-tattle, scandal, politics, blemishes of figure, and oddities of character in turn inspired his inexhaustible genius for mockery. Few among his illustrious contemporaries escaped his pencil, and his caricatures had always some strikingly truthful feature about them. He made his debut in the Charivari, in a series of sketches from Robert Macaire; and the revolution of 1848 suggested two of his most remarkable series-Idylles Purlementaires and Les Représentants Représentés. In old age Daumier became blind, and was befriended by Corot. He died at Valmondois, 10th Feb. 1879. See monograph by A. Alexandre (Paris, 1888).

Dawn, LEOPOLD JOSEPH, GRAF VON, com: mander-in-chief of the imperial troops during the Seven Years' War, was the son of Count Wierich Philipp von Daun, a distinguished officer in the Austrian service, and, was born at Vienna, 24th September 1705. Entering his father's regiment, he acquired a reputation during the Turkish campaigns (1737-39). The war of the Austrian Succession also afforded him many opportunities of dis. playing that combination of valour and prudence for which he was famous. After the peace with Prussir in 1745, Daun fought against the French in the Netherlands $(1746-48)$, and in 1754 received the dignity of field-marshal. Before this, he had, in spite of many obstacles, introduced into the imperial army a new military system, and reorganised the Military Academy at Vienna. At the commencement of the Seven Years' War he commanded the army of Moravia in 1757, and neutralised the defeat of the Austrians under General Browne near Prague, by driving Frederick the Great, who had beleaguered that city, as far as Kolin, and forcing him, after a hard-fonght battle, to evacuate Bohemia. On the 14th of Octoher 1758 he gained another victory over Frederick at Hochkirch, and came near to annihilating the Prussian army. In 1759 , at Maxen, he compelled Fink, the Prussian general, with 11,000 men, to surrender. After this, however, he gained no important successes; Frederick began to understand the tactics of 'the Anstrinn Fabins Cunctator,' and to conduct uis campaigns accordingly. Daun died 5th February 1766.

Dauphin (Lat. Delphinus), formerly the title of the eldest son of the French king, was originally that of the sovereign lords of the province of Dauphiné, who bore a dolphin as their crest. The last of these, the childless Humbert III., in 1343 bequeathed his possessions to Charles of Valois, grandson of Philippe VI. of France, on condition that the eldest son of the king of France should bear the title of Dauphin of Vienne, and govern the province. As late as the time of Louis 
$\mathrm{XI}$, the dauphin exercised almost sovereign rights: but after his time these were gradually alorilgresl, until Dauphine was placed under the same faws as the rest of the kingdom, and the title became merely honorary. After the revolution of 1830 , it was abolished altogether. See DelpuIN Classics.

Dauphine. formerly a frontier province in the south-west of France, now forming the departments Drome, Isère, and Hautes Alpes. Its capital was Grenoble, and it hoasted its 'seven wonders' remarkable caves, mountain-peaks, \&e. Once the territory of the Allobrogi, after the fall of the Roman empire Dauphine formed the southern. most part of the kingdom of Burgundy. It then passerf under the dominion of the Franks, and after the disinemberment of the Carlovingian monarchy, it became a portion of the new Burgundian king. dom of Arles It then passed by legacy into the possession of the German emperor in 1032, and remained united with Germany till 1343, when it was presented to France (see DAUPHIN). There is a listory by Chorier (2 vols, 1883).

Daurat. JEAN, a gifted French scholar, who played an important part in determining the course which his country's literature took at the time of the Renaissance. He was born about 1510, and became president of the College Coqueret, where he superintended the studies of Ronsard, Du Bellay, Baif, and Belleau. These poets, with whom he was united in the famous coterie of the Pléiade (q.v.), he carefully trained for the task of reforming the vernacular, and ennobling French literature by the imitation of Greek and Latin models. He wrote nothing of importance in French, but devoted himself to guiding and stimulating the other members of the Pléiade, in whose works his learning and enthusiasm bore rich and enduring fruit. He died in 1588 .

Dauria, a mountainous region of south-eastern Siberia, between Lake Baikal and the river Argun, on the Chinese frontier.

Dauw. See Horse, Quagga, Zebra.

D'Avenant, Sir William, English poet and playwright, was born in 1606 at $0 x$ ford. where his father kept the Crown Tavern, a house at which Shakespeare was in the habit of stopping when on his journeys between London and Stratford. A story arose later that D'Avenant's lirth was due to an intrigue between his mother and the great dramatist, but for this there seems to be no foundation, though apparently D'Avenant himself was willing enough to barter his mother's reputation for the crellit of such a parentage. Aubrey tells us that D'Avenant would often say, when pleasant over a cup of wine, that it seemed to him that he wrote with the very spirit that Shakesperre did, and 'seemed contented enough to be thought his son.' In his twelfth year the precocious boy penned an Ode in Remembrance of Master Shakespenre, not printed, however, until 1638 . After a short period of study at Lincoln College, he became page to Frances, Duchess of Richmond next passed into the household of the agred poet, Fulke Greville, Lord Brooke, and in 1628 took to writing for the stage. During the next ten year. he produced many plays, the least poor of which were The Cruel Brother (1630) and The Wits (1636). In 1638, at the request of the queen, he was appointed poet-laureate in succession to Ben Jonson. About the same time he lost his nose through an illness - a calnmity which laid him open to the merriment of such wits as Suckling, Denham, and Sir John Mennis. He afterwards became manager of Drury Lane Theatre, but became embroiled in the intrigues of the Civil War, and was apprehended and flung into the Tower. He soon escaped to France, and returning, distin- guished himself.. so much in the royalist cause, that he was knighted by Charles at the siege of Gloucester (September 1643). D'A venant again got into difficulties, and was confined in the Tower for two years, when he was relensed, it in said, on the intercession of Milton. Once more he set about establishing theatrical representations, and in 1658 succeeded in opening a theatre. Two year earlier he had given what was practically the first opera in England, with Mrs Coleman as the first actress that ever appeared on an English stage. After the Restoration, D'Avenant was favoured by royal patronage, and continued to write and superintend the performance of plays until his death, April 7, 1668. His epic, entitled Gondibert, a feeble reaction from the romantician of the Elizabethan poets, consists of fifteen hundred four. line heroic stanzas with alternate rhymes-a metre which the genius of Gray's Elegy can scarce save from the damning sin of monotony ; much bepraised by its contemporaries, it now sleeps securely in the same oblivion with the anthor's Madagascar, and his great opern The Siege of Rhodes. A col. lected edition of his plays, with memoir, was edited by Logan and Maidment (Edin. 5 vole. 1872-74). CharLes D'AVENANT, his eldest son, was born in London in 1656, was edueated at Balliol College, sat in parliament under James II. and William If̂., was commissioner of excise and joint-licenser of plays, under Anne secretary to the Commissioners for Union with Scotland, next inspector-general of imports and exports. He died 6th November 1714. Among his writings are Discourses on the Publick Revenues and the Trade of England (1698), and $A$ Discourge upon Grants (1700).

Davenport, capital of Scott county, Iowa, on the Mississippi, opposite Rock Island (q.v.), 183 miles $W$. by $S$. of Chicago by rail. It is the seat of Griswold College (1859) and of several Catholic institutions, has extensive manufactures of flour, wooden and iron wares, and woollen goods, and is the shipping depot of a large grain trade. Pop. ( 1880 ) 21,831; (1890) 26,872; (1900) 35,254.

Daventry (pronounced Daintry), an ancient municipal borough of Northamptonshire, at the sources of the Avon and Nene, 12 miles W. of Northampton, and 4 NW. of Weedon by a branch line opened in 1888. It is well built on an eminence, and has two principal streets. Cliarles I. spent six days here in 1645 before the battle of Naseby. Pop. (1851) 4430; (1881) 3859; (1891) 3939. A mile to the east is Danes or Borough Hill, one of the largest Roman camps in the kingdom.

David, capital of Chiriqui $\left(q, v_{0}\right)$ in Panamá, lies in a fertile plain on the Rio David, which enters the Pacific 8 miles to the south. Stock. raising and the cultivation of tobacco are extensively engaged in, and there is a considerable trade. Pop. 9000 .

David (Heb., 'beloved '), the second king over Israel. He sprang from a family of Judah, and was the youngest son of Jesse, a man of some substance at Bethlehem. He is described as a hand. some youth, 'red.haired, with beantiful eyes, and fair of face," when he first distinguished himself in Israel by slaying the Philistine giant Goliath. After this heroic deed, Sasl took him to his court, and appointed him to a military command. According to another account (1 Sam. xvi. 14-23) it was his skill in playing the harp, and his being sent for to banish the melancholy of Saul by that means, that first led to his coming into contact with the mooly king. He had som to flee from Saul's court, as the king's jealousy of his supposed rival led him to seek David's life; but, by the eraft of his wife Michal, Saul's daughter, and the friendslip of Jonsthan, Saul's son, he escaped, and fled to the 
country of the Philiatines, where, however, he found refuge only for a short time. In the cave (or hillfort) of Adullam, near Gath, he gathered a troop of 400 freebooters, which afterwards increased to 600 , and with which he ranged throngh the country between Philistia and the Dead Sea, never attacking his king or countrymen, but always their enemies on the west and south, and levying contributions from the people of Judah for his protection of their flocks. The expeditions which Saul led against him frequently put him to great straits, and the difficulty of controlling his irregular force without assuming the offensive against 'the Lord's anointed 'becoming ever greater, David left Judah, and became a vassal of the Philistine king of Gath, occupying for a year and four months the town of Ziklag in the desert to the south. After the death. of Saul and Jonathan at Gilboa, he reigned seven and $\mathbf{a}$ half years in Hebron over the tribe of Judah, while Ishbosheth, Saul's son, ruled the rest of Israel with the help of Abner-probably as a vassal of the Philistines. On the death of Ishbosheth, all Israel chose David as king. He conquered the independent city of Jebus (Jerusalem), the strongest natural fortress in the country, and made it the political and religious centre of his kingdom, building, with the help of Tyrian artificers, a palace for himself on its highest hill Zion (the 'city of David'), and placing the Ark of the Covenant $\left(q . v_{b}\right)$ there under a tent - to be replaced under his successor by a temple, for which large collections of materials were made in David's reign. The nucleus of his army consisted of his old bodyguard of 600 gibbôrim (or 'heroes'), from which the officers of the general levy were drawn. A plan is described in Chronicles by which 24,000 were put under arms each month out of the 288,000 able-bodied men who were the fighting strength of the country. There was an additional regiment of lifeguards, mostly foreigners. ('Crêthi and Plêthi'). In the course of a few years the conquest of the Philistines, Moabites, Arameans, Edonites, and Ammonites reduced the whole territory from Egypt to the Euphrates. During the siege of Rabbah, the Ammonite capital, David committed the greatest sin of his life, his adultery with Bathsheba and indirect murder of her husband. Henceforward 'the sword never departed from his house.' The last years of his long reign of thirty-two years in Jerusalem were troubled by popular disaffection, of which his favourite son Absalom availed himself to attempt a revolution, which nearly succeeded in placing him on the throne, but cost him his life, to David's excessive grief ; and shortly before David's death-which was at earliest 1018, at latest 993 B.C. - another such unsuccessful attempt was made by another son, Adonijah, who was aggrieved at the choice of Solomon as his father's successor.

David is by far the greatest of the kings of Israel. The spirit of his rule is beautifully expressed in his 'last (poetic) words,' in 2 Sam. xxiii. 1-7. His personal courage, his skill and unvarying success in war, his foresight and circumspection in government, and his readiness to sacrifice merely personal ends to the welfare of his whole people are especially conspicuous. $\mathrm{He}^{\mathrm{e}}$ 'exeeuted judgment and justice unto all his people.'. The foundation of his rich and complex character was his strong faith in Jehovah his Goa.. It was this that distinguished him from Saul as 'the man after God's own heart.' He was no saint in the Christian sense, and in his lapses from veracity, his polygamy, and his eruel treatment of conquered enemies, he followed the customs of his time. But the same unvarnished history which is the sole authority for the dark sides of his character is equally to be believed in its presentation of the brighter sides, and does not.support the unfavourable judgment of David expressed by
Bayle, Voltaire, Renan, and others, who would make him out either a licentious, cruel, and hypocritical despot, or simply a child of nature gifted with an equal share of great virtues and great vices.

The historical picture of David fully supports the tradition that 'the sweet singer of Israel' was the greatest poet of his time, and the founder of the sublime religious lyric poetry of the Hebrews, though many of the Psalms are rather productions of the Davidic spirit than of David's own pen. 'At an earlier date,' says Cheyne, 'much labour was rather unprofitally spent in defending the Davidic authorship of psalms transparently nonDavidic. An opposite tendency now prevails. Of the three most distinguished writers, Ewald acknowledges only eleven entire psalms and some fragments of psalms as Davidic, Hitzig fourteen, and Delitzsch forty-four. All of these agree as to the Davidic authorship of Psalms iii., iv., vii., viii., xi., xviii., xix. 1-7, and two out of three as to that of Psalms ix., x., xii., xiii., xv.-xviii., xix. 8-14, xxiv., xxix., xxxii., ci. Kuenen, however, will admit no Davidic psalm, though Davidic passages may have been inserted. In any case, it is quite certain that there are none in the last three books, and the probability is that Ewald's is the most conservative view of the headings at present tenable.'

The reign of David not only determined the political life of Israel, but also its conception of ideal glory. As the succeeding ages grew darker and more troubled, believing hearts in Israel turned back to those days of the kingdom's glory; men felt that only a king like David could restore the theocracy ordained of Jehovah; he formed the prototype for the Messianic hope that Jehovah would send a son of David, who should redeern Israel.

David, or DEwI, ST, the patron saint of Wales, first mentioned in the Annales Cambrio (10th century) as having died in 601, Bishop of Moni Judeorum, or Menevia, afterwards. St David's. He presided over two Welsh synods, at Brefi and at 'Lucus Victoriæ.' A rich legendary history supplements these meagre but authentic details. Rhygyfarch tells that he was grandson of King Ceredig, and a pupil of Paulinus, that he journeyed through Wales preaching and working miracles, visited Jerusalem, and denounced Pelagianism at Brefi with such triumphant loudness that he was made by acclamation metropolitan Archlishop of Wales. Giraldus follows Rhygyfarch in his life, and Geoffiey of Monmouth supplements it further by making David the unele of King Arthur, and locating the metropolitan see first at Caerleon, whence it was transferred by David, with the sanction of Arthur, to Menevia.

David I. (often called ST DAVID), king of Scotland, was the youngest of the six sons of Malcolm Ceannmor and St Margaret (q.v.). Born in 1084, he was sent in 1093 to England along with his sister Matilda (who in 1100 married Henry I. of England), and remained for several years at the English court - a residence that powerfully affected his after career. There, as his contemporary William of Malmesbury puts it, he was 'polished from a boy' until he 'had rubbed off all the rust of Scottish barbarity.'

In 1107, when his elder brother Alexander succeeded to the throne, David, by express bequest of Eadgar, became Prince of Cumbria, a territory which, besides part of the morlern shire of Cumberland, included the whole district between the Tweed and Solway and the Firths of Forth and Clyde, except the shires of Haddington, Edin. burgh, and Linlithgow. Over the greater part of this domain he appears to have held absolute sway. Alexander seems at first to have been inclined to 
dispnte David's right to the district, but the suc. cess of his elaim was secured without contest by the influence of the great Norman barons who hid by this time acquired extensive possessions in the south of Sentland, and to whom David's English truining rendered him peculiarly acceptal,e. By David's marriage in 1110 to Matilda, widow of Simon de Senlis, and heiress of Waltheof, Earl of Northumberland, he still further inereased his power, becoming Earl of Huntingdon and Earl of Northampton.

In 1124 he succeeded his brother on the Scottish throne, but had in 1130, and again in 1137, to light for his crown against the heirs of the old Celtic dynasties supported by the wild tribes of the north and west. On both ocersions the Anglo-Norman ehivalry which David had gathered around him gave him decisive victories. Having sworn, along with the other great barons of England, to maintain the right of his niece, Matilda, to the English erown, David took up arms on her behalf in 1135 when Stephen mounted the English throne, and penetrated into England as far as Durham, where at a meeting between him and Stephen perce was restored by the grant of the earldom of Hunting. don, and the promise of the earldom of North. umberland, to David's son Henry. In 1138 the war was, however, renewed, and the king of Scots, deserted by Bruce and others of his Anglo-Norman vassals who owned large estates in England as well as in Scotland, was signally defeated at the 'Battle of the Standard,' near Northallerton. The next year, a second peace was concluded, when the promised earldom of Northumberland was bestowed on Prince Henry.

The rest of David's reign-which marks the end of Celtic and the beginning of Feudal Scotlandwas devoted to the accomplishment of the great designs begun by his father and mother, and continued by his two predecessors - the union of the different races of Scotland into one nation, and the civilisation of the people. How well he succeeded may be traced in the two centuries of prosperity that followed his reign. By the introduction of the feudal system, and the promulgation and vigorous personal superintendence of the working of wise laws, he endeavoured to secure the peace and safety of the country; and he looked for aid in this work to the Anglo-Normans whom he had brought from the south. By the erection of burghs he promoted the trade, manufactures, and commerce of the nation, and laid the foundations of its freedom. In his civilising efforts he depended also largely on the church, the extension and influence of which he greatly fostered and encouraged. Immediately after he became Prince of Cumbria he restored the fallen bishopric of Glasgow, and after his accession he founded and endowed the bishoprics of Ross, Aberdeen, Caithness, Brechin, and Dunblane; besides enriching the previously established 800 of St Andrews, Moray, and Dunkeld, and re. viving the old see of Galloway (Whithorn). He aiso founded or restored the abbeys of Kelso, Jed. burgh, Melrose, Newbattle, Hoiyrood, Cambus. kenneth, and Kinluss, as well as a number of minor religious establishments. So far indeed dicl this process of endowment go, that according to Bellenden, "the croun was left indegent throw ampliation of gret rentis to the kirk, a state of matters that led James I. (of Scotland) to remark, while standing by David's tomb at Dunfermline, that 'he was ane sair sanct for the crown.' On the other hand one who was a hard judge of monarchs-Gieorge Buchanan-said with much more truth, that 'if men were to set themseives to draw the imare of a good king, they would fall short of whut David showed himeelf thrunghout the whole course of his life.' Though King David is often called St David, he was never formally canonised; but his name was inserted in the calendar prefixed to Land's Yrayer-book for Scotland, printed at Edinburgh in 1637.

King David died at Carlisle, 24th May 1153. Hin son Henry had died in the previous June, and he was succeeded by his grandson, Malcolm, then in his twelfth year.

The oldest Scottish painting now known to exist - an illuminated charter to the monks of Kelso, written in 11 hy - preserves rude miniatures of the young king Mal. colm and his saintly grandfather. It is preserved st Floors Castle, and engraved in fac-simile in the Liber 8 . Murie de Calchou (Bannatyne Club, 1846). Bee also Innes's Scotland in the Muldle Ages (1860); Robertson's scotland under her early Kings (1862); and Skene's Celtic Scotland (1876). The remains of David's legislation, including the interesting colle of the Leyes Bur. yorsm, have been carefully collected in the firat volume of The Acts of the Parliaments of Scotland (1814).

David II., only son of King Robert Bruce, was born at Dunfermline, 5th March 1324, and was married in 1328 to Edward II.'s daughter, Joanna. In June 1329 he succeeded his father, and in November 1331 was crowned, with his child-queen, at Scone. In 1334 the success of Edward Baliol (q.v.), and Edward III.'s victory at Halidon Hill, forced David's guardians to send him and his consort to France, whence by the triumph of the national party he was permitted to return in 1341. Five vears later, in fulfilment of his alliance with France, he invaded England, but at the battle of Neville's Cross, near Durham, was utterly routed by the Archbishop of York, 17th Octolier 1346. For eleven years he remained a prisoner, in or near London, and at Odiham, in Hampshire; at length, in 1357, he was released on promise of a heavy ransom $(100,000$ merks), whose non-payment involved him in shameful dependence on England. In 1363 he actually proposed to his parliament that Edward III.'s second son should succeed him on the Scottish throne; and though the proposal was curtly rejected, the intrigue between the two kings was ended only by David's death at Edinburgh Castle, 22d February 1371. He was not forty-seven years old, yet his reign had lasted more than forty-one years - a reign as inglorious as it was long, but still of great moment to Scotland, since, 'from a war of conquest and patriotic resist. ance, the struggle had died into a petty strife between two angry nations, a mere episode in the larger contest which it had stirred between England and France.' Queen Joanna dying in 1362, David next year had married Margaret Logie, a comely widow, whom he divorced in $1369 . \quad \mathrm{By}$ neither marriage had he any issue, so was succeeded by his sister's son, Robert II.

David. Félicrex, a French composer, was born 8th March 1810, at Cadenet, in the department of Vaucluse. He was first a chorister in the cathe dral of Aix, then at the age of twenty entered the Paris Conservatoire. He threw limself earnestly into the social speculations of his day ; became an ardent diaciple of St Simon, and afterwaris of Enfantin; and finally, on the break-up of the brntherhood in 1833 , he betook himself, along with several of his fellow-dreamers, to the East. The little knot of enthusiasts renched Constantinople, whence they made their way to Snivrna and Cairo. As they had no means, they ouffered greatly from want, sickness, and ill-usaye. In 1835 he returned to Paris, and published his Melodies Orientales for the pianoforte. They were unsuccessful; and David remained in obscurity till 1844, when he brought out at the Conservatoire his Desert, a grand Ode-symphonie, as he called it, the words of which were furnished by his friend and fellow. wanderer, Anguste Colin. Ito success was sudden 
and complete. David was declared a master at once, and his Désert was performed in all the theatres. Subsequently, he travelled through Belgium and Germany, and was everywhere greeted with applause. Less successful works were-Moïse sur le Sinaï (1846), Christophe Colombe and Le Paradis (1847), La Perle du Brésil (1851), Herculaneum (1859), and Lalla Rookh (1862). He composed also a quartette for strings, a nonette, a symphony, and songs. Appointed an officer of the Legion of Honour in 1862, and in 1869 librarian to the Paris Conservatoire de Musique, David died 29th August 1876.

David. Ferdinand, a distinguished violin virtuoso, born 19th June 1810, at Hamburg, was from thirteen a pupil of Spohr at Cassel, and hecame in 1836 concertmeister at Leipzig, which place he kept till his death at Klosters in the Grisons, 19th July 1873. His remarkable talent for teaching his instrument he showed after the establishment of the Leipzig Conservatorium, and many of the best violinists of his time were his pupils. His compositions were equally esteemed.

David, GerharD, painter, born about 1450, at Oudewater in Holland, in 1484 entered the Painters" Guild of Bruges, of which he became dean in 1501. He died in Bruges in 1523. The National Gallery, London, contains an admirable example of his work in 'A Canon and his Patron Saints, a wing from an altarpiece; and among his other pictures are a Madonna, in the museum at Rome; a Crucifixion, in Berlin; and a Baptism of Christ and a Descent from the Cross, both at Bruges.

David. JACQUes LouIs, historical painter, was born at Paris, 31st August 1748. He received his first instruction from Boucher, his uncle, and at the age of twenty-one became a pupil of Vien. After several unsuccessful attempts he gained the "prix de Rome' in 1774, and in the following year he settled in Rome, where Vien had been appointed director of the French Academy. Here he produced little in colour, but devoted himself to making accurate drawings from the antique. Six years later he returned to France, and his 'Belisarius' (1780) procured his admission to the Academy. Soon afterwards he married, and again visited Italy and also Flanders. It is in the works executed during this period, such as the celebrated 'Oath of the Horatii' (1784), 'The Death of Socrates' (1788), 'The Loves of Paris and Helen' (1788), and 'Brutus condemning his Son' (1789), that the classical feeling-founded upon sculpture and possessing much of its hardness as well as its clearcut accuracy of form which was the painter's chief characteristic-is first clearly visible. During the Revolution David entered with enthusiasm into the political conflicts of the period. In 1792 he became a representative for Paris in the Convention. He voted for the death of Louis XVI. and was a member of the Committee of Public Safety; and he was the artistic director of the great national fetes of the republic, which were founded on classical customs. After the death of Robespierre he was twice imprisoned, and narrowly escaped with his life. On his release in 1795 he devoted himself to his art, producing 'The Rape of the Sabines' (1799), which is usually ranked as his masterpiece. He was an original member of the Institute, and in 1804 was appointed court painter by Napoleon. After the restoration of the Bourbons, he was banished in $1816 \mathrm{as} \mathrm{a}$ regicide, and retired to Brussels, where, having declined an invitation to undertake the directorslip of Fine Arts at Berlin, he died, 29th December 1825 .

David's productions are distinguished by a certain austere dignity of conception and by elaborate accuracy of form. On the other hand they are often cold and unreal in sentiment, unpleasantly monotonous in colouring, and defective in their arrangements of light and shade. His art and example exercised the most powerful effect upon the French school of painting; among his pupils were Girodet, Gros, Léopold Robert, Ingres, and Gérard; and the classicism which he introduced reigned supreme until the rise of the Romantic school headed by Géricault and Delacroix. The influence which in his later days he exereised upon the school of Belgium was hardly less marked and powerful. Fourteen of his works are in the Louvre, and five-including 'Bonaparte crossing the Alps' (1805) - are at Versailles. See Le Peintre David, by his grandson, J. L. Jules David ( 1880 ).

David, Pierre Jean, a French sculptor, known as David d'Angers, was born at Angers, 12th March 1789. In spite of the opposition of his father, a talented wood-carver, he resolved to become an artist; and after studving in the art sehools of his native town, he made his way on foot to Paris in 1808, and placed himself under Jacques Louis David, the painter. In 1811 his 'Death of Epaminondas' gained the 'grand prix,' and David proceeded to Rome, where, though he became intinuate with Canova, he preserved his own individuality, and produced works modern in feeling and full of strongly marked character. In 1816 he returned to France. A statue of the Great Condé, which he executed about this time, established his reputation. In 1826 he was named a member of the Institute, and appointed a professor in the School of the Fine Arts; in 1828, and again in 1834, he visited Germany. During the July revolution, David fought in the ranks of the people, and in consequence he was employed by the new govern. ment to execute the pediment of the Pantheon (1835-37). By many it is considered his chef d'auvre. In 1848 the well-known republicanism of the artist procured for him the honour of a seat in the Constituent Assembly. After the coup d'etat he was sent into exile, and went to Greece, but soon after returned to France. $\mathrm{He}$ died 5th January 1856. In the museum of Angers about two hundred of David's works in relief and the round are preserved, as well as some four hundred of his medallions and many of his drawings. Besides its artistic value this collection possesses the greatest historical interest, as including portraits of the most eminent of the seulptor's contemporaries. See his Life by Jouin (1878).

Davidson, ANDREW BRUCE, D.D., LL.D. born in Aberdeenshire in 1831, was educated at Marischal College, Aberdeen, and at the Free Church College, Edinburgh, where in 1863 he was appointed to the chair of Hebrew and old Testament exegesis. In this capacity he has since laboured quietly, but has exercised a quite nnusual personal influence upon his students, and through them has done much to leaven the Free Church with a critical spirit that is fearless in method, but reverent in spurit, and in the best sense conservative of the real essentials of faith. With a singular reticence and self-repression, Dr Davidson, beyond an occasional sermon or article in the Expositor, has seldom spoken outside his lecture-room, and has published little, and that rather suggestive than demonstrative of his power as an exegete. He was throughout a member of the Old Testament Revision Committee. His books are a short treatise on Helorew accentuation (1861), an untinished commentary on Job (1862), a thoroughly serviceable Introductory Hebrew Grammar (1874), and admirable short school Com. mentaries on Job, the Epistle to the Hebrews, and Ezekiel. 
Davidson, SAMuel, D.D., LL. D., one of the ablest of English exeyetes, born near Ballymena in Ireland in 1807, edncated at the Royal College of Belfast, entered the Presbyterian ministry, and was called in 1835 to the chair of Biblical Criticism in his own eollege. Beoming a Congregntionalist, he was ealled in 1842 to the cliair of Biblical Litera. ture and Oriental Languages in the Congregationalist College at Manchester; a position which he was compelled to resign in 1857 on the publication of the volume which he contributed to a new edition of Horne's Introduction. He was a member of the Old Testanent Revision Committee. He died Ist April 189x, and his Autobiography, edited by his daughter, apjeared in the next year. His works are Scered Hermeneutics (1843), Lectures on Ecclesiastical Polity (1848), An Introduction to the New Testament (3 vols, 1848-51), Treatise on Bibli. oul Criticism ( 2 vols. 1852), The Hebrew Text of the Old Testament revised (1855), Text of the old Testament, and the Interpretation of the Bible, for the new edition of Horne's Introduction (1856); Introduction to the Old Testament (3 vols. 1862), An Introduction to the New Testament (2 vols. 1868). On a fresh Revision of the English Old Testamient (1873), The Canon of the Bible (1877), The Doctrine of Last Things (1883); besides trans. lations of the New Testament from Tischendorf's text, of Gieseler's Church History, and Fürst's Hebrew Lexicon.

Davies, Sir JoHs, poet and statesman, was born of a good family at Tisbury, Wiltshire, in 1569. At sixteen he entered Queen's College, Oxford, whence he passed to the Middle Temple. He was called to the bar in 1595 , but was disbarred three years later for breaking a stick in the dining-hall over the head of a wit whose raillery had provoked him. He returned to Oxford, and there wrote his long didactic poem on the immortality of the soul, Nosce Teipsum, dedicated to Queen Elizabeth, in 1599. Spite of the difficulties of a formal poem upon such a theme, it is a fairly successful perform ance, clear, vigorous, and sincere, though quite devoid of passion or imagination. The verse is that of the Annus Mirabilis and Gray's Eleyy. Davies had already published in 1596 his Orchestra or a Posme of Dancing, 'a sudden rash half-capreol of my wit.' It is written in seven-line stanzas in imitation of Spenser, and is a graceful and harmonious poern on the conceit that all natural phenomena are subject to a regulated motion here called dancing. In 1599 Davies published also his Hymns to Astriea, a collection of clever acrostics each making the name Elizabeth Regina. He contributed also to England's Helicon and to Francis Davison's Poetical Rhapsody. In 1601 , after ample apologies, Davies was readmitted to the sonietv of the Middle Temple, and was returued to parliament for Corfe Castle. On the death of Elizabeth he accompanied Lord Hunsdon in his journey to the Seottish court, and quickly came into favour with James I., who sent him in 1603 as solicitor-general to Ireland. Three years later he was appointed Irish attorney-general and serjeant-at-law, and was raised to the honour of knighthood. He sent many statesmanlike letters and reports to Cecil, supported severe anti-Catholic and repressive measures, ánd took an important part in the plantation of Ulster. He sat in the Irish parliament for Fermanagh, and was for some time its speaker; but was returned to the English parliament in 1614 for Newcastle-under-Lyne, and resigned his office at Dublin in 1619 , continuing to practise as king's serjeant in Englani. He was nominated chief-justice in November 1626, but died suddenly of a fit of apoplexy about a month after. He collected his three clief poems into one volume in 1622. His complete works were collected by Dr
Grosart in the 'Fuller Worthies Library' (3 volk. 1860-76).- - His widow, Eleanor Touchet, daughter of Baron Audley, whom he laad married in 1009 , married again and survived till 1652. She was crazy enough to imagine herself a prophetewa; but her exercitations brought her nothing aave fine, imprisonment, and ridicule (see A NAGHAM). - With Sir Jolin Davies must not be confounded John Davies of Hereford (1565-1618), poet and writingmaster, whose poetry is not without merit, although prolix and tedious. His ehief long poems are Mirum in Modum, Microcosmus, and Summa Totalis. In his collection of three hundred poor epigrams ( about 1611 ) is one addressed "To our English Terence, Mr Will. Shake-speare.' His works were collected by Dr Grosart in two volumes in 1873.

Davila, EnRIco CATERINo, a celebrated Italian historian, was born at Pieve di Saceo, in the vicinity of Padua, in 1576. When seven years old, he was taken to France for his education, and at the age of eighteen he entered the service of Henry IV., which he afterwards exchanged for the mili. tary service of Venice. In 1631 he was shot by an assassin on his way to Crema, to take command of the garrison. Davila has been rendered famous by his great work, entitled Storia delle Guerre civili di Francia (1630; best ed. Milan, 1807), a history comprising that eventful period from the death of Henry II. (1558) to the pence of Vervins in 1598. There is a translation by Aylesbury and Cotterell (1647). See Balboa, Avili.

\section{IDa Vinci. See Leonardo da Vincr.}

Davis, JEFFErson, president of the Confederate States, was born in Christian county, Kentucky, June 3, 1808. He studied at Transylvania College, and at the United Strtes military academy at West Point, where he graduated in 1828. Entering the army, he served in several frontier campaigns, but resigned his commission in 1835 . He entered congress in 1845 as a representative from Mississippi, and served in the Mexican war $(1846-47)$ as a colonel of volunteers, in which capacity his bravery won high commendation. He was appointed to the United States senate in 1847 , and re-elected in 1848 and 1850 ; in 1851 he made an unsucceseful canvass for the governorship of Mississippi. From 1853 to 1857 he was Secretary of War under the presidency of Franklin Pierce. After this he returied to the senate, where he succeeded Calhoun as the leader of the extreme State Rights party. He was the author of the seven resolutions passed in May 1860 by the senate, in which it was virtually asserted that neither congress nor the legislature of any territory could prohibit slavery in such territory, but that both were bound to protect property in slaves; that the people of no territory could prohibit slavery until after the adoption of a state constitu. tion; snd that congress could neither prohibit nor permit the iustitution of slavery in any state apply: ing for admission into the Union. The refusal of the lower house of congress to concur in these resolutions led to great popular agitation in the South. The failure of the Democratic National Convention at Charleston to adopt resolutions embodying substantially the same ideas had already (May 1, 1860) caused the disruption of that body and of the Democratic party ; and the election of Lincoln, the Republican candidate, to the presidency was an immediate result of this division of the Democrats. In January 1861 the state of Mississippi seceded from the Union, and as a consequence Davis left the senate. A few weeks later he was chosen president of the Confederate States under their provisional form of government. In the November following he was without opposi. tion elected president of the confederacy for a term of six years. The history of his presidency is that 
of the war of 1861-65 (see UNITED STATES). In May 1865, after the collapse of his government, Davis was captured by a force of Union cavalry. After two years' imprisonment in Fort Monroe he was released on bail, and though he had been indicted for treason, was never brought to trial, a nolle prosequi being entered in his case in 1868 . After 1879 he resided on an estate bequeathed to him in Mississippi and in that yem he was specially excepted in a bill to pension veterans of the Mexican war. In 1886 he dedicated a Confederate monument in Montgomery. He published The Rise and Fall of the Confederate Government (2 vols. 1881). Died Dec. 6, 1889. See his Life by Alfriend (1868) and Pollard (1869); also Craven, The Prison-life of Jefferson Davis (1866).

Davis. JoHN, an English navigator, was born at Sandridge, near Dartmouth, about 1550, and is principally distinguished for having undertaken in 1585 and the two following years three voyages to the Aretic Seas in search of a north-west passage. In the last voyage, he sailed with a bark of apparently not over twenty tons, as far north as the $73 \mathrm{~d}$ degree of latitude, and discovered the strait which bears his name. He next made two ill-fated voyages towards the South Seas, and as pilot of a Dutch vessel bound to the East Indies. In his last voyage as pilot of an English ship of 240 tons he was killed in a brush with some Japanese pirates at Bintang, near Singapore, 30th December 1605. His writings, The World's Hydrographical Description (1595) and The Seaman's Secrets (1594), were edited for the Hakluyt Society in 1878 by Captain A. H. Markham, with a biographical introduction. Here it is pointed out that Davis is often confounded with John Davis of Limehouse, a navigator to the East Indies, who died at Batavia in 1622, and published in 1618 A Ruter or Briefe Direction for Readie Sailings into the East India, which will be found in Part I. of Purchas his Pilgrimes.

Davis, Thомas, Irish poet and patriot, was born at Mallow, 14th October 1814, the son of an army surgeon. At Trinity College, Dublin, he read hard and graduated, and, after spending nearly three years in London and on the Continent, was called to the bar after his return to Dublin in 1838 . Next year, though a Protestant, he joined the Repeal Association, and in 1841 became for a short time joint-editor with John Dillon of the Dublin Morning Register. In the July of 1842 , with Dillon and Dutfy, he founded the famous Nation newspaper, the chief aim of which was 'to direct the popular mind and the sympathies of educated men of all parties to the great end of nationality.' It was the first time that conspicuous literary ability had been devoted to the cause, and ere long its bright vigorous articles and stirring as well as pathetic songs, many of them from the pen of Davis himself, made the pages of the Nation dear to Irishmen all over the island. Davis started a projected series of Irish orators with the Speeches of Curran (1844), and wrote a good 'Essay on Irish Songs' for Barry's Songs of Ireland (1845). But his bright and promising career was soon closed by his premature death of fever, in Dublin, September 16, 1845. His Poems were published in 1846 in 'Duffy's Library;' his Essays in 1847. See the Memoir by Sir C. G. Duffy (1890).

Davis Strait washes the western coast of Greenland, and connects Baffin Bay with the Atlantic Ocean. At its narrowest point, immediately north of the Arctic circle, it measures about 200 miles across. In 1888 the identity between Ginnunga Gap, referred to in the Sagas, and the present Davis Strait was demonstrated.

Davits, on shipboard, are upright columns of forged iron, curved at their upper ends, which pro- ject, or may be made to project, over a vessel's side or stern, and are used as a kind of crane to hoist, suspend, or lower a boat. They are arranged in pairs, one for each end of the boat. See BOAT. LOWERING GEAR.

Davitt, MichaEL, founder of the Irish Land League, the son of a Mayo peasant, was born near Straid, County Mayo, in 1846. Evicted from their small holding, the family emigrated to Hastingden in Lancashire (1851); and here six years later the boy lost his right arm through a machinery accident in a cotton-factory. In 1866 he joined the Fenian movement, the result being that he was sentenced in 1870 to fifteen years' penal servitude. He was released in 1877 ; and, supplied with funds from the United States, began some two years later an antilandlord crusade in Ireland, which culminated in the foundation of the Irish Land League (October 21, 1879). Davitt was thenceforward in frequent collision with the government, and from February 1881 to May 1882 was imprisoned in Portland for breaking his ticket-of-leave. His Leaves from a Prison Diary were published in 1885. The views of the 'Father of the Land League' on the subject of land therein take a Socialistic form, and accordingly, though a strong Home Ruler, on the question of land nationalisation he found himself in opposition to the Parnellites. After the split in the party, he opposed the continued leadership of Mr Parnell (q.v.), and was returned to parliament in 1892 as anti-Parnellite, but unseated on petition, on the ground of clerical and other intimidation. $\mathrm{He}$ was returned unopposed for South Mayo in 1895, but resigned in 1899.

Davōs' (Romansch Tavau) is a small valley lying amongst the Alps of the Eastern Grisons, 16 miles SE. of Coire. The village of Davos-Platz stands 5105 feet above sea-level; but the valley, inclosed by lofty hills, has become famous as a health. resort in winter, especially for such as suffer from chest disease. 'The air is still and dry, and throughout the winter there is a great deal of bright, warm sunshine. Till lately mere out-of-the-way hamlets, the villages of Davos-Platz and DavosDörfli have now eight or ten hotels, numerous villas and chalets, several doctors, and daily posts. The 3561 inhabitants of the valley, which till 1848 was one of the 26 independent republics of the Grisons, are mostly German Protestants. See works by Wise (1881) and Muddock (1884); and J. A. Symonds, Our Life in the Swiss Highlands (1892).

Davoût (not DAvoust), Louis Nicolas, French marshal, was born 10th May 1770, at Annoux, in Burgundy; was educated along with Bonaparte at the military school of Brienne; and in 1788 became lieutenant in a cavalry regiment. During the revolutionary wars he rose-to the rank of general. He accompanied Bonaparte to the East, where he mainly contributed to the victory at Aboukir, and otherwise distinguished himself both in Upper and Lower Egypt. On his return to France, he was named general of division in 1800 , commanderin-chief of the consular grenadier guards in 1800, and marshal of the empire in 1804. He acted a brilliant part in the great victories obtained by the French at Austerlitz (1805) and Auerstädt, and was created by the emperor Duke of Auerstädt (July 2, 1808). On the renewal of the war with Austria in 1809, Davout rendered useful service at Eckmühl (22d April); and at Wagram, where he commanded the right wing, he succeeded in turning the eneniy's left, and so first checked the Austrians attack. In 1811 he was created Prince of Eckmiihl. Appointed governor of Poland, he ruled that country in a spirit of the harshest despotism, and provoked the reproaches of the emperor, buts 
neverthelens, did not forfeit his esteem. In the Ruмwian compaign of 1812 he grathered fresh laurels on the fielils of Mohilev and Vitebsk (27th July). After the retreat from Moseow, Davont became guvernor-generul of the Hanse towns, and at Ham. lurg, though hated for his eruelty, resulutely maintained himself till the restoration of the 13isurbons. On the return of Bonaparte from Elba, Davont was appointed war-minister, and as such showed a remarkable genius for the rapid orgmisation of tronps and supplies. After the battle of Waterloo, he received the command of the remnant of the French army under the walls of Paris. He would have continued the contest had he not been ordered by the Provisional Government in the capital to conclude a military convention with the Allies. In 1819 he was made a peer of France. His death took place June 1, 1823. Firmness of character and dauntless courage were Davoat's leading chamcteristics; but his military severities often went the length of harsliness, and even cruelty, while his rapacity had in it something akin to barbarism. See his Correspondance (4 vols. 1885), and his Life by Chénier (1886), by his daughter, the Marquise Bloequeville (3 vols. 187980 ), and by Montegut (1882).

Davy, Sir HuMPHRY, one of the greatest chemists, was born 17th December 1778, at Penzance, Cornwall, where his father was a carver in wood. At the school at Penzance, and afterwards at Truro, he developed a taste for story. telling, poetry, and angling, and for experimental science, in which he was aided by Dunkin, a saddler. In 1795 he became apprentice to a surgeon and apothecary in Penzance, wrote verses, and indulged in chemical experiments. He at the same time entered upon a course of study all but universal. 'Speculations on religion and politics, on metaphysics and morals, are placed in lis notebooks in juxtaposition with stenzas of poetry and fragments of romance.' The study of natural philosophy brought him near to that department which was to be his own; but it was not till he had reached his nineteenth year that he entered seriously upon the study of chemistry. He was then introduced to the notice of Dr Bellioes (q. . .), who in 1798 establisher a Pneumatic Institute at Clifton, and took him as his asistant. Here he made the acquaintance of the Earl of Durham, of Coleridge, and Sonthey, and carried on a course of experiments on the respiration of different gases, in which he had more than once nearly sacrificed his life. He thus discovered the singular exhilarating effect of nitrous oxide when breathed. The account which he published in his Researches Chemical and Philosophical (1799), although afterwards regretted, established his reputation, and led to his appointment, at the age of twenty-two, as lecturer to the Royal Institution of London. He delivered his first lecture in 1801 ; and his eloquence, and the novelty and variety of his experiments, soon attracted crowded and brilliant audiences. In 1803 he liegan researches connected with agriculture, on which he delivered a course of epoch-making lectures, which were published under the title of Elements of Agricultural Chemistry (1813). The discoveries, however, on which Davy's fame as a chemist chiefly rests, took their origin in the views which he deChemical Agencies of Electricity. This essay was universally regarded as one of the must valuable contributions ever made to chemical science, and obtained the prize of the French Institute. Fol. lowing out his principle, he was led to the grand discovery that the alkalies and earths are conpound substances formed by oxygen united with metallic bases. It was potash that he first suc- ceeded in decomposing, on the 19th Octoher 1807. When he finst saw the globules of the new metal, potassium, his delight is said to have been so ecstatic that it required some time for him to com. pose himself to continue the experiment. He next decomposed soda and the alkuline carths, baryta, strontia, lime, and magnesia ; and discovered the new metals, sodium, barium, strontium, caleium, and magnesium. With regard to the earthe proper, he succeeded in proving that they consist of metals united to oxygen. It was reserved for Wobluler and others to exhibit the metals by themselves. He lectured in Dublin in 1808-9, and received the honorary degree of LL.D. from Trinity College.

On 8th April 1812 Davy was knighted; he married Mrs Apreece, a laciy of considerable wealth, daughter and heiress of Charles Kerr of Kelso, and resigned the chemical chair of the Royal Institution, April 1813. In order to mark the high sense of his merits, he was elected honorary professor of Chemistry. He discovered the talents of Farsulay $(q, v$,$) , for whom he secured the appoint-$ ment as assistant in the laboratory of the Royal In. stitution. That he might investigate his new theory of voleanic action, he received permission from the French government - though the two countries were then at war - to visit the Continent, and was re. ceived with the greatest distinction by the scientific men of France. He was accompanied by Faraday. On returning to England in 1815 , he entered on the investigation of the nature of fre-damp, which is the cause of explosions in coal-mines. This resulted in the invention of the Safety-lamp (.$v$.$) . A$ public subscription of about $£ 1500$ was collected as a testimonial by those interested in 1817 , and he was entertained to dinner, and presented with a service of plate. He was ereated a baronet, 20 th Oetolser 1818. On the death of Sir Joseph Banks in 1820, Sir Humphry Davy was elected President of the Royal Society. In 1820-23 his researches on electromagnetism were communicated to the Society. He invented an ingenious plan for preventing the corrosion of the copper-sheathing of ships by altering the electric condition of the copper by means of bands of zine; but the bottoms of the vessels became so foul from the alhesion of weeds and shells that the plan had to be abandoned.

Early in 1825 Sir Humphry Davy had hegun to complain of the loss of strength, and in 1826 he had an apoplectic attack. He made two journeys to the Continent for the recovery of his health, and died at Geneva on the 29th May 1829, at the early age of fifty-one. The Genevan government evinced their respect by a pnblic funeral. He was a nember of almost all the scientific institutions in the world. Cuvier, in his Éloge, says: 'Davy, not yet fifty. two years of age, occupied, in the opinion of all that could judge of such labours, the first rank among the chemists of this or of any other age." Another critic has said: 'He was not only one of the greatest, but one of the most benevolent and amiable of men.' His widow placed a tablet to his memory in Westminster Abbey, and a statue was erected to him in Penzance. Besider the works alrealy mentioned, and a great number of contributions to the Philosophical Transactions, Sir Humphry Davy was author of Elements of Chemical Philosophy (1812); On the Safety-lamp in Coal. mines (1818); Sulmonia, or Days of Fly.fishing (1828); and Consolations in Travel (1830)-all included in his Collected Works (9 vols. 1839-40).

See Memoirs of the Life of Sir Humphry Davy, by his brother, John Davy (1836); his Fraymentary Rcmains (1858); the Life by Dr Parie (1831); and that by Dr T. E. Thorpe (1896).

Davy, Јонs, musician, was born near Exeter in 1763, and died in London in 1824. Many of his songs were great favourites, and though most aro 
forgotten, 'The Bay of Biscay' has never lost popular favour.

Davy Jones, a sailor's familiar name for a malignant sea-spirit or the devil generally. The commion phrase 'Davy Jones's locker' is applied to the ocean as the grave of men drowned at sea. A dubious explanation of the name makes it consyounded from Duffy, a West Indian negre spirit name, and the scriptural prophet Jonah, in jocular allusion to his somewhat unusual adventures.

\section{Davy Lamp. See SAFETY-LAMP.}

Dawalla (Hypophthalmus dawalla), a fish of the family Siluridie, found in the rivers of Guiana, and highly esteemed for the delicacy of its flesh. It is sometimes $2 \frac{1}{2}$ feet long, and is brightly coloured. The eye is situated below the angle of the mouth.

Dawkins. WILliam Boyd, was born at Buttington vicarage, near Welshpool, Montgomery shire, 26th December 1838, and educated at Rossall School and Jesus College, Oxford. In 1862 he joined the Geological Survey, became eurator of Manchester Museum in 1839, and professor of Geology in Owens College there in 1874. In 1882 he presided over the anthropological section at the Southampton meeting of the British. Association, and in the same year was elected honorary fellow of his old college. The Channel Tunnel committee employed him in 1882 to make a special survey of both coasts; and next year he laid down the line for a tunnel under the Humber. Professor Dawkins is a fellow of the Royal and other learned societies, and has contributed numerous papers to their issues relating especially to fossil mammalia. His books are Cave-hunting: Researches on the Evidences of Caves respecting the Early Inhabitants of Europe (1874), and Early Man in Britain, and his place in the Tertiary Period (1880), the latter a work of great interest.

Dawlish, a pleasant watering.place, on the $\mathrm{SE}$. coast of Devonshire, 12 miles $\mathrm{S}$. by E. of Exeter by rail. Backed by the Great Haldon ( 818 feet), it has public baths, and a dressing pavilion connected with the sea by a small tram-car. Pop. (1861) 3505 ; (1881) 3977 ; (1891) 4210 .

Dawn. See Twilight.

Dawson, GeoreE, a busy and popular preacher and lecturer, was born in London, 24th February 1821, taught for a time in his father's academy, and studied at Aberdeen and Glasgow. He became pastor of Rickmansworth Baptist Chapel in 1843; of Mount Zion, Birmingham, in 1844, where his eloquence, breadth of view, and entire freedom from conventionality drew crowds to his services. Daw. son's doctrinal position, which did not allow of his being fettered by theological forms of belief, led to his resignation; the 'Church of the Saviour' was built for him (1847), which borrowed its ritual from many sources. He took a lively interest in politics; was extremely popular as a lecturer for thirty years; popularised the views of Carlyle and Emerson, with both of whom he was personally acquainted; taught English literature classes at the Midland Institute for six years; advocated free libraries, and was one of the founders of the Shakespeare Memorial Library, Birmingham. Since his sudden death at King's Norton, near Birmingham, 30th November 1876, other works have been published: Sermons (4 vols. 1878-82), Prayers (2 vols. 1878-83), Biographical Lectures (2 vols. 1886-87), and Every Day Counsels (1888). See the Memoir by Crosskey (1876).

Dawson, Sir John WilliaM, geologist and naturalist, was born at Pictou, Nova Seotia, Octoiner 1820. He studied at Edinburgh, and afterwards devoted himself to researches in the natural history and geology of Nova Scotia and New Brunswick, aiding Sir Charles Lyell in his investigations in Nova Scotia in 1842 and again in 1852. He was appointed superintendent of education in Nova Scotia in 1850 ; principal of M'Gill University, Montreal (1855), and afterwards vicechancellor. In 1882 he received the Lyell medal of the London Geological Society, to whose Proceedings he frequently contributed; in 1884 he was knighted; and he was an LL.D. of Edinburgh, \&c. His address as President of the Birmingham meeting of the British Association (1886) was on the geographical history of the Atlantic Ocean. His Devonian and Carboniferous Flora of Eastern North America records the discovery of what he believed to be the lowest known form of animal life, the Eozoon Canadense of the Laurentian limestone (see EozoöN). In some of his works he combated the Darwinian theory of the origin of species. He published Archria (1858), Story of the Earth and Man (1872), Dawn of Life (1875), Origin of the World (1877), Fossil Men (1878), Change of Life in Geological Time (1880), Egypt and Syria (1885), Geology and History (1894), and Relics of Primeval Life (1597). He died 19th November 1899.

Dax, a town in the French department of Landes, on the Adour, 93 miles $\mathrm{S}$. by W. of Bordeaux by rail. A fine bridge connects it with its suburb of Sablar; and it has a 14thcentury castle, now a barrack, remains of Roman walls, a cathedral and several other interesting churches. It has manufactures of pottery and liqueurs, and some trade; but it is chiefly remarkable for its hot sulphur-springs $\left(77^{\circ}-144^{\circ} \mathrm{F}\right.$. whose waters are used in cases of rheumatism and nervous complaints. A commodious bathing establishment has been construeted. The springs were known to the Romans, who called the place Aquoe Tarbelle ; in the middle ages it was called Acqs. Pop. ( 1872 ) 8154 ; (1886) 9458 ; (1891) 9927.

Day originaliy meant the space of time during which it is light, in opposition to the space of darkness or night; it now more usually denotes a complete alternation of light and darkness. It is the earth's rotation that causes the vicissitude of day and night. The earth being a globe, only one-half of it can be lighted up by the sun at once; to that half it is day, while to the other half, which is in shade, it is night. But by the earth's rotation, the several portions of the surface have each their turn of light and of darkness. This happens because the position of the earth is such that the equator is on the whole presented towards the sun; had either pole been towards the sun, that hemisphere would have revolved in continual light, the other in continual darkness.

One complete rotation of the earth does not make a day, in the usual sense. If the time is noted when a particular fixed star is exactly south or on the meridian, when the same star comes again to the meridian the next day, the earth has made exactly one rotation, and the time that has elapsed is called a sidereal day. This portion of time may be regarded as being always of the same length; for the motion of the earth on its axis differs extremely little from absolute uniformity. Hence siclereal or star-time is much used by astronomers. But the passage of a star across the meridian is not a conspicuous enough event for regulating the movements of men in general. It is not a complete rotation of the earth, but a complete alternation of light and darkness that constitutes their day. This, which is called the civil or the solar day, is measured between two meridian passages of the sun, and is about four minutes longer than the sidereal day. The cause of the greater length is 
this: When the earth lias made one complete turn, so as to bring the meridian of the place to the same pexition anong the tixed stars as when it was noon the day inefore, the sun has in the mentime (apparently) moved east ward nearly one degree among the stars, and it takes the earth about four minutes more to nove round so as to overtake him. If this eastward motion of the sun were uniform, the length of the solar day would be as simple and as ensily determined as that of the sidereal. But the ecliptic or great eircle in which the sun apparently moves, eroses the earth's equator, and is therefore more oblique to the direction of the earth's motion at one time than another; and besides, as the earth moves in her orbit with varying speed, the rate of the sun's upurent motion in the eeliptic must also vary: Tlie consequence is, that the length of the solar day is constantly fluetuating; and to get a fixed measure of solar time, astronomers have to imagine a sun moving uniformly in the celestial equator, and completing its circuit in the same time as, the real sun. The time marked by this inıginary sun is called mean solar time; when the imaginary sun is on the meridian, it is mean noon; when the real sun is on the meridian, it is apparent noon. It is olvious that a sun-dial must show apparent time, while elocks and wutehes keep mean time. Only four times in the year do these two coincide. The difference is called the equation of time, because, when added to or subtracted from apparent time, according as the sun comes too soon or too late on the meridian, it makes it equal to mean time. The mean solar day is divided into twenty-four hours, the hours into minutes and seconds. A sidereal day, we have seen, is shorter; its exact length is 23 hours, 56 minutes, 4 seconds of mean solar or common time. Astronomers divide the sidereal day also into twenty-four hours, which are of course shorter than cominon hours. In the course of a eivil year of 365 days, the earth turns on its axis 366 times, or there are 366 sidereal days. Astronomers reckon the day as beginning at noon, and count the hours from 1 to 24 . The eivil day begins at milnight, and the hours are counted in two divisions of twelve each. The ecelesiastical day was reckoned from sunset to sunset. The Greeks counted their day from sunset, as clid also the Hebrews, the Romans from midnight, the Babylonians from suurise, the Umbrians from mid-day.

The diagram will explain the variation in the relative duration of light and darkness at different times of the year and different parts of the earth's

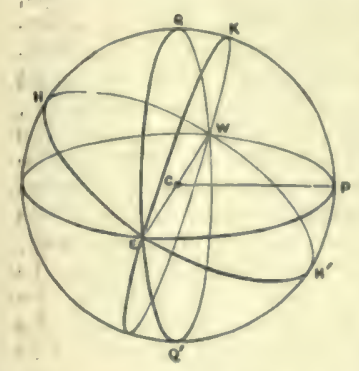
surface. C represents the position of the earth, $\mathbf{P}$ being the north pole of the heavens. $\mathbf{E}$ and $W$ represent the east and west points. EQW and EKW are the celestial equator and the ecliptic respectively. Let us suppose the observer to be in the northern hemisphere and that $\mathrm{HEH}^{\prime} \mathrm{W}$ is his hori-

zon. When the sun is on the equator it is obvious that the arcs $F Q W$ and $E^{\prime} W$ are equal-i.e. the sun is as long above the horizon as it is below it. Bnt, if the sun be in the northern half of the ecliptic, its apparent path is a circle parallel to EQW passing through the sun's position; and more of this circle is above the horizon than below it. Similarly we can explain the appearances for other positions of the sun and of the observer.

Day, as opposerl to night, varies with the latitude and the season of the year. As we go north from the equator it increases in mumer, and decreases in winter. At the equator, day is a little more, night a little leas than twelve hours; at the poles, day is a little more, night a little less, than six months. For the time of day in different countries, see Tiмk.

$A$ day, in Law, includes the whole twenty four hours from midnight to midnight. In reckoning periods of time from a certain event, the day on which the event occurred is excluded. On the other hand, if it be required to prove survival for a certain number of days, it will suffice if the person be alive for any portion, however small, of the last day. While an obligation to pay on a certain day would therefore be theoretically discharged by pay. ment before midnight, the law requires that reason. able hours be observed-e.g. if the payment (as a bill) is at a bank or place of business, it must be within business hours.

A lavful day is a day on which there is no legal impediment to the execution of a writ-i.e. all days except Sundays and fast-days appointed by government. Criminal warrants, and in Scotland warrants against debtors in meditatione fugo, are an exception to this rule, and may be both granted and executed on Sundays and fast-days. By 29 Car. II. chap. 7, all contracts made by persons in their ordinary calling on a Sunday are void. The exceptious to this rule will be explained under LORD's DAY. In England, Christmas-day and GoodFriday generally stand on the same footing with Sundays and fast-days appointed by royal proclamation; but in Seotland there is no exception made in favour of any of the feast or fast days of the chureh.

Days of Grace.-The time at which a bill is actually due and payable, except in the case of bills payable on demand or at sight, is three days after the time expressed on the face of it, and these three additional days are called days of grace. If the third day of grace full on a Sunday, Christmasday, Good-Friday, or a national fast or thanksyiving day, the bill is payable the day before. If it fall on any of the other bank holidays, or if the last lay of grace is a Sunday and the second a bank holiday, the bill is payable on the succeeding business day (see BILL). Days of grace have now been abolished in many countries, but there are still three allowed in the United States, and ten in Russia.

Day, JoHN (1522-84), a native of Dunwich, was an early London printer, his most celebrated production being Foxe's Book of Mcrtyrs.

Day, JoHN, a dramatist, of whose life hardly anything is known. He is mentioned in Henslowe's Diary in 1598 as an active playwright. But few of his earlier works have come down to ns save The Blind Beggar of Bednal Green. Day collaborated freely with contemporary writers, as Chettle and Dekker. Ben Jonson in his conversations with Drummond of Hawthornden grouped him with some other admirable gentlemen and authors as a rogue and a base fellow. His best works that have reached us are a graceful comedy, Hunour out of Breath, and The Parliament of Bees, a kind of allegorical masque in which all the characters are bees. 'The very air,' says Charles Lamb, 'seems replete with humming and buxzing melodies. Surely bees were never so berhymed before." An edition of Day's works was privately printed by A. H. Bullen in 1881 .

Day, Tномаs, the author of Sandford and Mertom, was born in London, 22d June 1748, and thirteen months later, by his father's death, became heir to $f 900$ a year. From the Charterhouse he passed to Corpus Cluristi Collere, Oxford, where he formed a close friendship with Richand Lovell 
Edgeworth (q.v.). In 1765 he entered the Middle Temple, in 1775 was called to the bar, but he never practised. A good, elever eccentric, a disciple of Rousseau, he brought up two children, an orphan blonde and a foundling brunette, one of whom should presently become his wife. That scheme miscarried ; and, admitted to the Lichfield coterie, he proposed first to Honora Sneyd, next to her younger sister Elizabeth. She sent him to France to acquire the French graces; as acquired by him, they but moved her to laughter. Finally in 1778 he married an appreciative heiress, Esther Milnes, and spent with her eleven happy years, farming on philanthropic and costly principles in Essex and Surrey, till on 28th September 1789 he was killed by a fall from a colt he was breaking in. His wife died broken-hearted two years afterwards, and both lie in Wargrave churchyard near Henley. Two only of Day's eleven works call for mentionThe Dying Negro (1773), and the History of Sandford and Merton ( 3 vols. 1783-89). The poem struck the keynote of the anti-slavery movement; the child's book, like its author, is sometimes ridiculous, but slways excellent. See Day's Life by Keir (1791) and Blackman (1862); also Miss Thackeray's Book of Sibyls (1883).

Day-fiy. See Ephemera.

Day-lily (Hemerocallis), a perennial herbaceous genus of Liliacese, so named from the ephemeral duration of its individual flowers, which, however, succeed each other freely upon the peculiar inflorescence (a helicoid cyme). Several species are cultivated in our flower-gardens, especially the fragrant Yellow Day-lily (H. flava), a native of

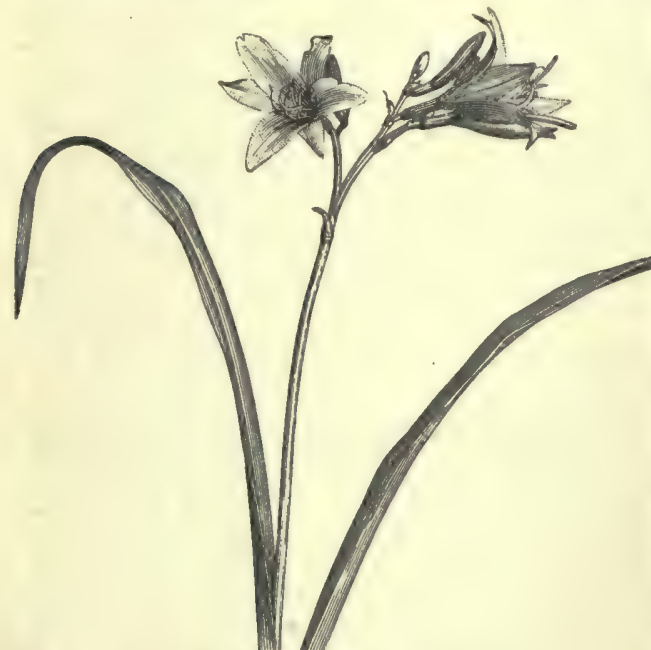

- Yellow Day-lily (Hemerocallis flava).

warmer Europe, Southern Siberia, and Northern China, and $H$. fulva, from the Levant. Both species, but particularly the latter, have been recommended as sources of green fodder for cattle.

Dayton, capital of Montgomery county, Ohio, the fifth city of the state in point of population and of wealth, is situated on the Great Miami, at the mouth of the Mad River, 60 miles NNE. of Cincinnati by rail. The streets are broad, the private residences generally handsome; the public buildings include a court-house of white marble, a large gaol, a number of schools, and about fifty churches. Standing on the line of the Miami Canal (opened 1829), the city is the terminus of eight railroads, and the water of the Mad River is brought through its streets by an hydraulic canal, supplying abund- ant water-power. It has numerous and iniportant manufactures, including railroad-cars, cotton, woollen, and iron goods, oil, flour, paper, and machinery. Dayton is the headquarters of the Gypsies in the United States. Pop. (1870) 30,473 ; (1880) 38,678 ; ( 1890 ) 61,220 ; ( 1900 ) 85,333.

D'Azara, FELIX́, naturalist, was born in Aragon in 1746, entered the army, and in 1781 was appointed a commissioner for detining the Spanish and Portuguese possessions in South America. He wrote an inportant Natural History of the Quadrupeds of Paraguay (1801 ; Eng. trans. 1838), and Voyages dans l'Amérique Méridionale (4 vols. 1809 ). He died in Spain in 1811.

D'Azeglio. See Azeglio.

Deacon, lit. a 'servant' or 'follower' (and, in that sense, found in classic and also in Hellenistic Greek), became in ecclesiastical usage the name for an office-bearer in the Christian church. In Acts vi. we read of the appointment of seven men chosen by the laity and ordained by the apostles to attend to the finances of the infant chureh, and to see that its alms are fairly distributed. The name deacon is not applied to them. They are to be spiritually-minded men; they are soleminly set apart from the rest of the congregation; and almost immediately they are found preaching and baptising (Acts, vi. vii. and viii. 38 ); and the most distinguished of them, St Stephen, dies as the first Christian martyr. In the epistle to the Philippians they are named along with the bishops, and in the pas. toral epistles they are recognised as part of the Christian ministry (1 Tim. ii. 8-13) without any special reference to financial duties. Chrysostom suggested that the appointment in the Acts was of a temporary nature, and distinct from the sacred ministry of the diaconate subsequently instituted; and this view obtained some sanction from the sixth General Council. But a great Anglican antiquary, Bingham (supported in this matter by the Roman Catholies Thomassinus and Petavius), takes the opposite side, and is able to appeal to Justin Martyr, Irenæus, Hilary, Cyprian, and other doctors, to the effect that the seven were truly deacons in the later sense, and were anthorised by the apostles to undertake these higher functions. The number seven continued to be adhered to in many churches -e.g. at Rome, until the 11th century, when the number was doubled.

During the $2 \mathrm{~d}$ and $3 \mathrm{~d}$ centuries, the duties falling to the deacons had considerably inereased; and since as confidential attendants and helpers of the bishops, they had risen into consequence, it became necessary to divide the various functions among an archdeacon, deacons, and sub-deacons. Deacons might now dispense the bread and wine at the communion, but not consecrate them. They had to receive the offerings and presents for the bishop, to keep the sacred vessels, to chant the introductory formulas of public worship, and to take the oversight of the morals of the congregation; and they were allowed, in many cases, with the leave of the bishop, to preach and baptise, and receive penitents into the communion of the church. At an early period, the offices of archdeacon and deacon were considered to belong to the higher orders of consecration (ordines majores ) : this was not the case with that of subdeacon till after the 12th century. At the consecration of a deacon, according to the Roman rite, certain sacred vessels may be handed to him as symbols of his office; but this does not seem to be regarded as essential. In the Greek rite the flabellum ( a fan for driving away flies from the sacred elements) is given to the deacon. The peculiar robes are the dalmatica and the stole, but the stole (both in East and West) is only placed over the left shoulder. 
In Protestant churches the position of deacons varies Among Presbyterians, the elders have the spiritual oversight of the congregations; while descons (as in the Free Church of Scotland) and managers in others have the care of the financial allicirs. Among Congregationalisto, the demons combine both spiritual and financial duties. The Chureh of England has retained in the main the older form of ordination. The deacon has only the hands of the bishop laid upon him, and not those of any attendant priests also; he cannot consecrate the ele. ments at holy communion or pronounce the alsolu. tion or benediction; snd he only preaches by special license from the bishop, and not directly by virtue of his office. For this, as well as for holding any benefice or church-preferment, priest's orders are necessary. The office is now regarded very much as simply one of probation before admission to priest's orders. But in ancient times it was not uncommon for a man to remain a deacon for life. The cardinal leacons at Rome sometimes remain such, especially if much occupied with secular business, Thus the late celebrated Cardinal Antonelli always re. mained a deacon. Before a person can be appointed deacon in the English Church, he must have reached the age of twenty-three, and he usually remains in this office one year at least.

DEACONESSES (ancille, ministre, vidue, virgines, episcope, presbytere), female ministers or servants of the church or Christian society in the time of the apostles (Rom. xvi. 1). At a later period, they cooperated with the deacons, showed the women their plice in the ehurch assemblies, assisted at the baptism of persons of their own sex, instructed those who were about to be baptised as to the answers they should give to the baptismal questions, arranged the agapos or love-feasts, and took care of the sick. In the $3 d$ century it seems to have been also part of their duty to visit all Christian women who were suffering imprisonment, and to be hospitable to such as had come from afar. In very early times they were consecrated to their oftice by ordination in the same manner as other ecclesiastical or spiritual personages; later, however, they were inclucted into their office by prayer without the imposition of hands. Until the 4th century, the deaconesses had to be either maidens or widlows who had been only once married, and sixty years of age; but after the Council of Chalcedon the age was fixed at forty. Their assistants were called sub-deaconesses. After the 6th century in the Latin Church, and after the 12th century in the Greek Church, the office of deaconess was discontinued; but the former has retained the name. In convents, for example, the nuns who have the care of the altar are called deaconesses. In the Reformed Cliurches of the Continent there are deaconesses who nurse the sick and tend the poor. The first deaconesses' house at Kaiserwerth on the Rhine, near Düsseldorf, was founded by Pastor Fliedner in 1836 ; and now seattered over the Protestant world there are upwards of sixty similar institutions, with fully 6000 sisters. The Church of Scotland adopted the otfice of deaconess in 1887-88. The Diocesan Deaconess Institution, London, was established in 1861; but Sisterhoods (q.v.) have struck a much deeper root in the Anglican communion. See works by Dean Howson (1886) and Cecilir Robinson (1899).

Deacon of a Trade, the president, for the time being, of certain incorporations in Scotland, where, prior to the passing of the Burgh Reform Act, 1834, the deacons of trades or crafts represented the trades in the respective town-conncils. That act enacted that the deacons shall no longer be recognised as official and constituent members of the town-council, but preserved the power of the crafts to elect deacons and other officers for the 149 management of their affairs. The deacon-convener of the trades in Ediuburgh and Glasgow is still a member of the town-council. See DEAx of GuILD.

Dead, in seafuring language, is very frequently enployed as part of a designation or phrame having, in general, a meaning somewhat opposite to that of active, effective, or real. The chief of such phrasess are the following: Dead-eyes, cirenlar, Hattish wooden blocks, without sheaves, and having eyes for lanyards, which form' a purchase or tackle whereby the shrouds or other fixed rigging are extended or set-up taut; Decud-flut, the name for one of the midship-timbens; Dead-lights, strong wooden shutters used to close cabin-windows, on the approach of a storm, to protect the glass; Dead. ropes, such as do not run in blocks; Dead-wood is the term applied to the solis blocks of timber erected upon the keel throughout the sharp portions of a ship's hull at stem and stern, the chief object being to give solidity and strength to the ends of the ship; Dead-reckoning, an estimation of a ship's place without celestial observations, made chiefly by the log-book, and liable to error on account of currents, lee-way, fluctuation of wind, \&c. To these may be added Dead-wind, a seaman's desiguation for a wind blowing directly against a ship: course.

Other compounds are Dead-lock, a position of matters when they have become so complicated that they are at a complete standstill and progress is imposisible; Dead-freight, the compensation paid to the shipmaster by the merchant who freights a whole ship for the space which he fails to oceupy; Dead language, one no longer spoken; and Deadletter, a letter undelivered and unclaimed at the Post-office (q.จ.). The Dead-points of an engine are when the connecting-rod and the crank are in one line (see Crank). The impetus of the fly. wheel is necessary to earry the engine over these points, and if it is allowed to stand at either of them, a start is impossible till the fly-wheel is turned by hand sufficiently to permit of the piston acting on the erank.

Dead, Book or THE, the great funerary work of the ancient Egyptians, who themselves entitled it Per-em-Hru, 'to go forth from (or by) day.' It is ' a collection of prayers and exoncisnis composed at varions periods for the benefit of the pilgrimsoul in his journey through Amenti (the Egyptian Hades); and it was in order to provide him with a safe-conduct through the perils of that terrible valley that copies of the work, or portions of it, were buried with the mummy in his tomb.' Such copies, hieroglyphic or hierutic according to the age when they were executed, and made gome to order, others for sale, constitute fully one-half of the thousands of extant papyri. They are mostly corrupt and faulty; but as the frit of ten years toil, a pure text at last has leen published by Edouard Naville in Dos Aegyptische Todfenbuch der XVIII. bis $X X$. Dynastie (Berlin, 1886), whose folio supplement contains 212 plates of texts, vignettes, and variants of vignettes. Dr Birch's English translation (Egypt's Place in Universet) History, vol. v. 1867) is bared on Lepsius' imperfect Turin text (1842), as also is Pierret's French trans. lation (1882). See the articles EGYPT, HueroGLYPHCS, and AMENTHEs; two works by E: A. Wallis Burge (1895 and 1897); and a masterly article on M. Naville's work by Miss A. B. Edwards in the Academy for 10th September 1887.

Dead, Prayer yor the. See Prayer, PurGATORY.

Deadly Nightshade. See BrLLadorxa. Dead-men's Fingers. See Alcyonium.

Dead Nettle (Lamium), a genus of Labiatae. L. purpureum and $L$. album, together with (Gaiv 
opsis) the closely allied Hemp-nettle, are very common British weeds. The comnoner species have been somewhat thoroughly naturalised in the long-settled parts of the United States. They are sometimes boiled as pot-herbs in Swedea. The name seems derived from the superficial resemblance to the true or stinging nettles; this is especially marked in $L$. album.

Dead Sea is the usual name, dating from the time of Jerome, for a most remarkable lake in the south-east of Palestine, called in the Old Testament The Salt Sea, Sea of the Plain, or East Sea; by Josephus, Lacus Asphaltites; and by the Arabs now, Bahr. Lut, 'Sea of Lot.' It is 46 miles long, with a

White Dead Nettle (Lamium album).

breadth of from 5 to $\mathbf{9}$ miles. Its surface, which is lower than that of any water known, is 1292 feet below the level of the Mediterranean. The depth of the greater part, the northern section, is about 1300 feet; but at the southern end the water is only from 3 to 12 feet deep. The shape is that of an elongated oval, interrupted by a promontory which projects into it from the south-east. The Dead Sea is fed by the Jordan from the north, and by many other streams, but has no apparent outlet, its superfluous water being supposed to be entirely carried off by evaporation. Along the eastern and western borders of the Dead Sea there are lines of bold, and in some cases perpendicular, eliffs rising in general to an elevation of 1500 feet on the west, and 2500 feet on the east. These cliffs are chiefly composed of limestone, and are destitute of vegetation save in the ravines traversed by fresh-water streamlets. The north shores of the lake form an extensive and desolate muddy flat, marked by the blackened trunks and branches of trees, strewn about and incrusted with salt. The sonthern shore is low, level, and marshy, desolate, and dreary. On this shore is the remarkable ridge of rock-salt, 7 miles long and 300 feet high, called Khashm Usdom ("Ridge of Sodom '). Lava-beds, pumice-stone, warm springs, sulphur, and volcanic slag prove the presence here of volcanic agencies at some period. The neighbourhood of the Dead Sea is frequently visited by earthquakes, and the lake still occasionally casts up to its surface large masses of asphalt. The basin of the sea and the valley of the Jordan seem both to be due to a great fault or crack in the earth's surface of very ancient date. The longentertained belief that the exhalations from this lake were fatal is not founded upon fact. Within the thickets of tamarisk and oleander, which here and there may be seen upon its brink, the birds sing sweetly, and they fly over and swim about on its surface. But the salinity of the waters is adverse to life, though some lower organisations are found in them.

The water of the Dead Sea is characterised by the presence of a large quantity of magnesian and soda salts. Its specific gravity ranges from 1172 to 1227 (pure water being 1000 ). The proportion of saline matter is so great, that whilst sea-water contains only 3.5 per cent. of salts, the water of the Dead Sea contains upwards of 26 per cent., or more than eight times-as much as that of the ocean. In all lakes or collections of water without any outflow, the water acquires an infusion of salt, its feeders constantly bringing in this material, while none can go off by evaporation, even when the shores do not as here abound in salt and nitre. The evaporation is great as the heat is intense, and the sea rather contracts than increases. Rain hardly ever falls; the water is nearly as blue and clear as that of the Mediterranean; and though its taste is horribly salt and fetid, a bath in it is refreshing. Owing to the great specific gravity of the water, it is almost impossible for the bather to sink in it, strive as he may. Several of those who have navigated and explored the sea have fallen vietims to a fatal fever. The story of the "Cities of the Plain," is given in Gen. xix. See Palestine; and Conder says, "It is now generally agreed that the Dead Sea and Jordan were formed by a great fault or crack in the earth's surface long before the creation of man, and that the district presents in our own days much the same aspect as in the days of Abraham. It is vain, therefore, to suppose that the "cities of the plain" were beneath the present sea, although this view was held as early as the time of Josephus' (Bible Geography, 1884). See also Ritter's Geography, and the works on Palestine by Robinson, Stanley, and Tristram; De Luynes' Mer Morte (1874); Lieutenant Lynch's Report of the United States Dead Sea Expedition (1852); and Professor Hall's Survey of Western Palestine (Palestine Exploration Fund, 1886).

Dead's Part, in Scots law, is that part of a man's movable property which he is entitled to dispose of by testament. If a man dies without leaving widow or children, the dead's part is the whole; if he leave widow but no children, or cliildren but no widow, it is a half; and if he leave both widow and children, it is a third of his movable property. 'The dead's part, however, may be increased or diminished by special provisions in a marriage-contract, or by wife and children renouncing their legal rights. This dead's part in English law is called the 'dead man's part,' and went formerly to pay for masses for the dead man's soul. Afterwards the administrators applied it to their own nse, until finally it was by statute subjected to be distributed among the next of kin.

Deaf and Dumb. Persons who are born deaf, or who lose their hearing at a very early age, are dumb also; hence the compound term deafand-dumb. But deafness is the primary defect; dumbness is only the consequence of deafness. Children ordinarily hear sounds, and then learn to imitate them-i.e. they learn to repeat what they hear other persons say. It is thus that every one of us has learned to speak. But the deaf child hears nothing; cannot, therefore, imitate, and remains dumb. Persons who lose their hearing later in life are not to be classed among the deaf and dumb. Having learned to speak before their hear. ing was lost, they can readily communicate with others: and if they are educated, there are still open to them all the stores of knowledge contrined in books, from which the juvenile deaf and dumb, ignorant of all written and spoken language, are utterly excluded. It is this latter class alone which is contemplated in our census enumerations, and for which our institutions for the education of the deaf and dumb are designed.

The term 'deaf and dumb' is somewhat unfortunate, as embodying and repeating the error that the affliction is twofold. It affects two organs, certainly, but only, as above deseribed, in the way of cause and effect. The organ of hearing is wanting, but the organs of speech are present; they merely lack the means of exercise. The ear is the guide and directress of the tongue; and when the ear is doomed 
to perpetual silenee, the tongue is included in the ban ; though, if we could by any means give to the ear the fuculty of henring, the tongue would soon learn for itself to fulfil its proper ofhee. To correct the error involved in this apparent misnomer, some authorities use the term deuf simply, others speak of the decf-dumb and deaf-mute. The latter term is common in America, as in France is its equivalent Sourds-muets. In the Holy Scriptures the same original word is translated "deaf' in some places (as in Mark, vii. 32), and 'dumb' or 'speechless' in othens (see Matt. ix. 33, and Luke, i. 22).

This affliction is very much more common than, for a long time, and up to a recent period, it was supposed to be. Happily, however, along with the knowledge of its extensive prevalence, has come the means of alleviating it, by education. It was only when the schools now in existence began their useful work, and caused inquiries to be made, that the actual numbers of the deaf and dumb began to appear. In every place where it was proposed to establish a sehool-in Paris, London, Liverpool, Manchester, Yorkshire, and in New York-the objection was immediately started that children could not be found in sufficient numbers to require such gchools. Their promoters, however, knew better than this, and persisted in their design. They goon had the satisfaction of converting the objectors into their warmest supporters. The facts thus ascertained, and the caleulations based upon them, continued to be the only statistics upon the subject of deaf-lumbness in Great Britain and Ireland until the census of 1851, when for the first time the number and ages of the deaf and dumb formed a part of the inquiry.

In 1891 the total number of deaf and dumb persons in England and Wules was 14,192, in Scotland 2125, in Ireland 3365, and in the United Kingdom 19,682 - a decrease in proportion to the total population $(38,104,975$ in the United Kingdom at the same date), as appears from the figures for earlier census years :

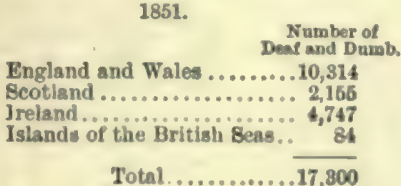

\section{1.}

Fingland and Wales .........12,286

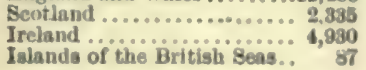

Ialand of the British 8 eas.

$$
\text { Total............ } \overline{19,848}
$$

1871.

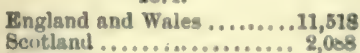

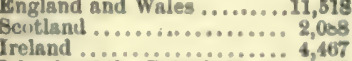
Ireland

$$
\text { Total ........... } \overline{18,160}
$$

1881.

Fngland and Wales.........18,295

Ecotland .................. 2, 148

Islands of the Britich Sens.. 88

$$
\text { Total .......... } \overline{19518}
$$

\section{Total \\ $17,927,609$ \\ $2,888,742$ \\ $6,552,386$ \\ 148,126}

$27,511,862$

$20,068,224$

$8,062,294$
$8,798,967$

148,847

$29,070,832$

$22,712,260$

$8,300,018$

$8,412,877$

81, 629, 209

$25,974,489$

$8,785,573$

$5,174,836$

188,791

$86,028,689$
Proportlon.

1 in 1738

$1 " \cdot 1840$

1 "I 1880

1 in 1590

1 In 1640

1 " 1811

1 " 1176

1 iा 1647

1 in 1484

1 in 1971

1 " 1608

1
1 1211

1 in 1749

1 in 1958

1 11 1744

$\begin{array}{r}1101296 \\ 1 \text { 1 } 1577 \\ \hline\end{array}$

1 in 1704
The increase of population in 1861 above that of 1851 was $1 \frac{1}{2}$ millions, and the number of deaf and dumb had also inereased; but although the popula. tion in 1871 had increased by $2 \frac{1}{2}$ millions alnove that of 1861 , the returns show a large decrease in the proportion of deaf and dumb. A further increase of population in 1881 of 3 millions still shows a diminution in the proportion of deaf and dumb; there was only a total increase of 1368 deaf and dumb. We can only attribute thin to more extended and improved sanitary measures, advanced knowledge in medical treatment, and more careful nursing of chilitren when suflering from thome diseases which so frequently result in deafness.

But while social seience is prosecuting its import. ant inquiries into the causes, inevitable and preventable, of deafness, Philanthropy has before her the work of educating these 'children of silence, to whom the ordinary means of instruction are obviously inapplicable, and for whom, until little more than a century ago, there existed scarcely any available means of education at all. The deaf are spoken of frequently in the writings both of the Old and New Testaments; they are alluded to by the poets, philosophers, and lawgivers of antiquity; yet we have no account of any attempt at elucating them until the 15 th century; no schicol existed for them until the middle of the 18 th ; nor could it be said that education was freely offered, and readily accessible, until within the last fifty or sixty years.

Some isolated attempts had been made before the 18th century, by different men, in different countries, and at long intervals, to give instruction to one or two deaf and dumb persons, and their endeavours were attended with various degrees of success. These several cases excited some attention at the time; but after the wonder at their novelty had subsided they seem to have been almost forgotten, even in the countries where the experiments were made. Bede speaks of a dumb youth being taught by St John of Beverley (q.v.), to repeat after him letters and syllables, and then some words and sentences. The fact was regarded as a miracle, and was classed with others alleged to have been wrought by the same hand. From this time, eight centnries elapsed before any record of an instructed deaf-mute occurs. Rodolphus Agricola, a native of Groningen, born in 1442 , mentions as within his knowledge the fact that a deaf-mute had heen taught to write, and to note down his thoughts. Fifty years afterwards, this statement was controverted, and the alleged fact pronounced to be impossible, on the ground that no instruction conld be conveyed to the mind of any one who could not hear words addressed to the ear. But the discovery which was to give the key to this long-concealed mystery was now at hand. In 1501 was born, at Pavia, Jerome Cardan (q.v.), a man of great but ill-regulated talents, who, among the numerous speculations to which his restless mind prompted him, certainly discovered the theoretical principle upon which the instruction of the deaf and dumb is founded. He says: "Writing is associated with speech, and speech with thought; but written characters and ideas may be connected together without the intervention of sounds,' and he argues that, on this principle, 'the instruction of the deaf and dumb, though difficult, is possible." All this, which to ns is obvious and familiar, was a novel speculation in the 16 th century. With us it is a common thing for a man to teach himself to read a language, though he cannot pronounce it. There are, for instance, hundreds of persons who can read French, who do not and cannot speak it. Now it is evident, in this case, that written or printed words do impart ideas independently of sounds, yet this was a discovery which the world owes to Jerome Cardan; and it was for want of seeing this truth, which to $\mathrm{ns}$ is so familiar, that the education of the deaf and dumb was never attempted, but was considered for so many centuries to be a thing impossible.

It was in Spain that these principles were first put into practice by Pedro Ponce (1520-84), a Benedictine monk, and again, in the following century, by another monk of the same order, Juan Paulo Bonet, who also published a work upon the 
subject, which was the first step towards making the education of the deaf and dumb permanent, by recording the experience of one teacher for the instruction of others. This book, published in 1620, was of service to De l'Epée a hundred and forty years later; and it contains, besides much valuable information, a manual alphabet identical in the main with that one-handed alphabet which is now in common use in the sehools where the alphabet is used, on the Continent and in America. His own system of teaching, however, like that of every teacher in every country before De l'Epée, was in the main oral. The practicability and adaptability of signs, for conversation rather than teaching, had occurred to several of the earlier teachers, but De l'Epée was the first to adopt them as a distinct medium, and the chief medium, of teaching; and so to establish them as a language. Bonet himself says of the manual and written alphabets that they 'should be associated with speech, by pointing to the letter as written with the finger corresponding with the same letter in the manual alphabet and the articulated sound.' He also describes the positions and movements of the rocal organs necessary in pronunciation, as he himself used them, and as, with little variation, Wallis and Amman used them also in later times, believing themselves to have been the original inventors of the methods they employed. From the time of Bonet there was a general awakening of the attention of intellectual men, not only to the importance of the subject, but to the practicability of instructing the deaf-mute. One of Bonet's pupils was seen by Charles I., when Prince of Wales; and the case is described by Sir Kenelm Digby, who met the prince in Madrid, during his memorable matrimonial journey to Spain (1623). Of this pupil, a younger brother of the Constable of Castile, Sir Kenelm gives an interesting account in his Treatise of Bodies, how he 'would repeat after anybody any hard word whatever'-not Spanish merely, but English, and even Welsh.

When the art died away in Spain, it was taken up by Englishmen, and began forthwith to assume an entirely new aspect. Dr John Bulwer published, in 1648, his Philocophus, or the Deafe and Dumbe Man's Friend, in which he speaks of a 'lip-grammar, which may enable you to hear with your eye, and thence learn to speak with your tongue.' Bonet also found in the course of his experience that lipreading reached a much greater utility than he had, at the ontset, thought it capable of. It has been described as the backbone of the oral system. It is the conviction arising from experience, which has in our own days, and in nearly every country, in Italy and France especially, made some of the most eminent sign-teachers the chief advocates of the oral system. Dr William Holder published his Elements of Speech, with an Appendix concerning Persons Deaf and Dumb, in 1669; and Dr John Wallis, Savilian Professor of Mathematics in the university of Oxford, both taught the deaf and dumb with great success, and wrote copiously upon the subject. In 1662 one of the most proficient of his pupils was exhibited before the Royal Society, and in the presence of the king. The Philosophical Transactions of 1670 contain a description of his mode of instruction, which was destined to bear ample fruits long after his death.

Before the close of the 17th century many works of considerable merit appeared, the chief of which are the Surdus Loquens (1692) of John Conrad Amman; a physician of Haarlem ; and the Didascalocophus, or Deaf and Dumb Man's Tutor, of George Dalgarno (q.v.). This treatise, p blished in 1680 , and reprinted in 1834 by the Maitland Club, is eminently sound and practicel, which is the more remarkable, as the author speaks of it as being, for aught he knows, the first that had been written on the subject. He is the first English writer who gives a manual alphabet. The one described by him, and of which he was the inventor, is, most probably, the one from which the present two-handed alphabet is derived. Henry Baker (q.v.) about 1720 introduced an improved system of his own; in 1765 the Abbé de 1'Epée established his little school in Paris; and five years previously, the first school in the British dominions had been started in Edinburgh by Thomas Braidwood (q. v.). He commenced with one pupil, the son of a merchant in Leith, who had strongly urged him to carry into effect the plan of instruction followed by Dr Wallis, and described in the Philosophical Transactions ninety years before. His school, the parent and model of the earlier British institutions, was visited and spoken of by many of the influential men of that day, and its history and associations are imperishable. Its local name of 'Dumbiedykes' suggested to Sir Walter Scott a designation for one of his most popular characters in the Heart of Mid. lothian. A visit paid to it in $\mathbf{1 7 7 3}$, by Dr Johnson, and his biographer Boswell, supplies one of the most suggestive and characteristic passages in the Journey to the Western Islands, in which he speaks of Henry Baker and his unpublished work. In 1783 Braid. wood removed to Hackney, near London, and the presence of his establishment so near to the metropolis undoubtedly led to the foundation of the London Asylum in 1792. Dr Watson, its first principal, was a nephew, and had been an assistant, of Braidwood; and he states that, some ten or fifteen years previously, the necessity for the establishment of a public institution had been plainly seen, and some few but insufficient steps taken towards the accomplishment of such a design. From its foundation in 1792 until 1829 , it was directed with great ability by Dr Joseph Watson, author of Instruction of the Deaf and Dumb.

The numbers of deaf and dumb children at school in the United Kingdom at the dates given, were as follows:

\begin{tabular}{|c|c|c|c|c|c|}
\hline & 1851 & 1831. & 1871. & 1881. & 1886. \\
\hline England and Wales.. & 816 & 1001 & 1200 & 1782 & 1091 \\
\hline Secoliand ............. & 250 & 240 & 801 & 386 & 412 \\
\hline Ireland.............. & 284 & 399 & 478 & 545 & \$55 \\
\hline Tota & 300 & 1640 & 1979 & 2713 & 0 \\
\hline
\end{tabular}

In 1895 the schools for the deaf and dumb certified under the Elementary Education (Blind and Deaf Children) Act of 1893 provided accommodation for 2755 deaf children (1155 day-scholars and 1600 boarders) in England and Wales, and in Scotland for 525 chililren. In Ireland the number of deaf and dumb children receiving education is somewhat larger than in Scotland.

In England and Wales there are some 25 public institutions for deaf and dumb, and several private ones. The oldest is that of Uld Kent Road, London, founded in 1792, and now at Margate; the next, that at Edgbaston, Birmingham, in 1812. In Scotland there are 8, that in Edinburgh dating from 1810; in Ireland 4, one in Dublin founded in 1816. In the United Kingdom there are about 50 schools and classes, with 250 teachers and 3800 pupils. In the United States there are over 60 schools, with 7500 pupils and 600 teachers; in Germany, 96 schools, with 5892 pupils under 595 teachers; in France, 70 schools, 3655 scholars, and 364 teachers; in Italy, 35 schools, 1500 pupils, and 238 teachers. If to these we add the schools in Austria, 18; Switzerland, 15 ; Sweden, 17 ; Norway, 8; Russia, 11; Belgium, 11; Spain, 7; Holland, 3; Canada, 7; Australia, 3; with others in New Zealand and Cape Colony, and one at Bombay (the only one in Asia), it will be evident that the schools throughout the world must be about 500 in number. 
It is to the 19th century that the honourable distinction belongs of having done so much for the deaf and dumb. This has not been by inventing the art of teaching, or by raising up the earliest lnbourers in this field of usefulness, but by founding and supporting public institutions for this purpose. De l'Epere, when he opened his sehool in 1765, ham no foreknowledge of the work he was commencing. As his labours increased, he invited others to his resistunce, and they were thus enabled to carry the light of instruction elsewhere, and to keep it alive when ho was no more. His death tork phace in 1789 , and his assistant, Sicard, succeeded him. Four years afterwards, the school was taken over by the French government, and now exists as the Institution Nationale of Paris, A pupil of this institution, M. Laurent Clerc, went in 1816 to the United States with Mr Thomas Hopkins Gallaudet (1787-1851), the founder and first principal of the American asylum, who in the New World became, like De l'Epee, 'the father of the deaf and dumb.'

There is some diversity of opinion as to which is the hest kind of school for the deaf-the boarding or the day school. And with this question is involved, to some extent, the question of systems of instruetion. Until the introduction of the oral system from Rotterdam in 1867, and the establishment in 1874 of the classes for the deaf in the ordinary sehools by the School Board for London, all the institutions in Great Brituin were board. ing-schools. Of the two systems-by congregation or by separation-the former, the boardingschool system, is upheld by its advocates for its advantages of continuous teaching, influence, and discipline. These they hold to be of special necessity for the deaf, and not to be attainable, generally, under the day-school system. The latter system is accepted by some, but only as a necessity -not the best to be hoped for, but the best which can be got. Others defend separation, and oppose congregation altogether, on the ground that with the oral system it is the best, absolutely; that the pupils, heing tanght to speck in order to prepare them for the world, ought to live in the world, and so to bring into constant exereise and practice what they have been taught. Living at home or boarding out in families is therefore advocated and adopted, on this ground, in London and in various large towns on the Continent, though in many places where the oral system finds its strongest supporters the boarding-school is still retained. The possible danger to life and limb in passing through erowded streets alone, has combined with other reasons to pronluce in Lonclon the establishment of homes for deaf children - where they are boarded, lodged, and eared for, and receive their education in a conveniently adjacent school-board class. These homes, now occupying seven separate houses, were established by the Rev. Dr Willam Stainer. They are largely made use of by Boards of Guardians and others, and are called by the founder's name.

The mental condition of the deaf and dumb is 80 peculiar-so entirely unlike that of any other branch of the human family - that it is extremely difticult, withont very close thought, to obtain an accurate conception of it. While almost every one will readily admit that there is a wide difference between a denf and a hearing child, very few, who have not had their attention specially drawn to the subject, possess any adequate notion of the difference, or could tell wherein it consists. Sometimes the deaf are compared with the blind, though there exists no proper ground of comparison between them. Except that the blind are more dependent than the deaf and dumb, the relative disadvantages of the two classes do not admit of a moment's comparison. The blind can be talked with and read
to, and are thus placed in direct intercourse with the world around them: domeatic convense, literary pleasurus, political excitement, intellectual reaearch, are all within their reach. The born.deaf are utterly exeluded from every one of these. The two afflictions are so essentially diswimilar, that they can only be considered and spoken of together by way of contrast. Each of them affects both the physical and the mental constitution; but blindness, which is a greates physical aftiction, falls leas severely on the mind; while the effect of deafneas is the extreme reverse of this-it touches only one bodily organ, and that not visibly, but the culamity which befalls the mind is one of the most desperate in 'the catalogue of human woes.' The deprivation under which the born-deaf labour is not merely, or so much, the exclusion of sound, as it is the com. plete exclusion of all that information and instruction which are conveyed to our minds, and all the ideas which are snggested to them, by means of sound; as it is through sound alone, in the first instance, that we all learn language, the medium of all knowledge. The denf know almost nothing, because they hear nothing. We, who do hear, acquire knowledge through the medium of lan. guage-through the sounds we hear, and the words we read-every hour. But as regards the congenitally deaf, speech tells them nothing, because they cannot hear; and books terch them nothing, because they cannot read; so that their original condition is far worse than that of persons who ' can neither read nor write' (one of our most common expressions for extreme ignorance); it is that of persons who can neither read, nor write, nor hear, nor speak; who cannot ask you for information when they want it, and could not understand you if you wished to give it to them. Your difficulty is to understand their difficulty; and the difliculty which first meets the teacher is, how to simplify and dilute his instructions down to their capacity for receiving them.

A class thus cut off from all communication through the ear, can only be addressed through the eye (i) by means of oljects, or representations of them, or by the visible language of pictures, signs, and gestures; $(2)$ the finger-alphahet (or I)actylology) and writing, which make them acquainted with our own uritten language; or (3) articulation and reading on the lips, which introduce them to the use of spoken language. The edueation of the deaf and dumb must be twofold-you must awaken and inform their minds by giving them ideas and knowledge, and you must cultivate them by means of language. Where the oral system is employed, the deaf child is tanght by spoken language as other children are. Where the combined system is in use, a knowledge of things is conveyed by the use of signs ; but to this must be added a knowledge of words. These pupils are therefore taught, from the first, that words convey the same ideas to our minds as pictures and signs do to theirs; they are therefore required to change signs for words until the written or printed character is as readily understood as the picture or the sign. This, of course, is a long process, as it has to be repeated with every word. Names of visible objects (nouns), of visible qualities (adjectives), and of visible actions (verbs), are gradually tanght, and are readily acquired; but the syntax of language, abstract and metaphorical terms, a copious dietion, idiomatic phraseology, the nice distinctions between words called synonymous, and those which are identical in form but of different significationthese are far more difficult of attainment; they can only be mastered through indonitable perseverance and application on the part of the pupil, in addition to the ntmost akill and ingenuity of the teacher. The wonder, therefore, surely is, seeing the point of starting, that this degree of advance 
ment is ever reached at all on the sign system; though oral teachers maintain that on their system it is attained readily, in a manner similar to that of hearing children.

Yet it has been set forth by otherwise respectable authority, that the deaf and dumb are a "gifted race ;' that they are remarkable for 'their promptitude in defining abstract terms ;' and those who ought to have known better have strengthened this delusion by putting forth, as the bond-fide answers of deaf-mutes, those brilliant aphorisms and definitions of Massieu and Clere, which are so often quoted at public meetings by eloquent speakers who know nothing of the subject. It is very well known to those who are acquainted with the subject, that the so-called definitions of Hope, Gratitude, Time, Eternity, \&c., were not Massieu's at all, but those of his master, the Abbe Sicard. The influence of these fallacies has been most mischievons ; they raise expectation to a height which is unreasonable, for it is thought that what was done by 'the celebrated pupil of the Abbe Sicard' may be done every day ; and disappointment is the inevitable consequence. The honest, laborious teacher who cannot produce these marvellous results, and will not stoop to deception, has often to labour on without that appreciation and encouragement which are so eminently his due ; the cause of deaf-mute instruction suffers; and a young institution is sometimes crippled by the frilure of support, which was first given from one impulse, and is now withdrawn from another-nac a whit more unreasonable than the first, but very unfortunate in its consequences.

In 1886 the education of the deaf and dumb was referred to the investigation of a Royal Commission which has instituted far-reaching inquiries, from which valuable results are anxiously expected. But the most striking feature of all has been the rapid diffusion of the pure oral system. Originally confined to Germany and Holland, it has since 1867 spread over western Europe and America, sometimes forming by itself the sole principle of instruction, and sometimes, though against the views and protests of its principal advocates, in combination under the same roof with the sign or manual system. It was introduced into London in 1867, at the instance of the late Baroness Meyer de Rothschild, and applied by Mr Van Praagh, at the Jews' Deaf and Dumb Home. In 1871 it was extended by the establishment of the 'Oral Association,' whose school and training college, placed under the direction of Mr Van Prangh, are in Fitzroy Square. In 1877, by the efforts and influence of Mr B. St John Ackers, the training college and school was founded which has its headquarters at Ealing, and of which one of the chief objects was the diffusion of the 'German' system in the United Kingdom. The college of teachers was established later, in 1885. It has had a successful career. Nearly every head-master in the kingdom is a member, and it has attracted $a$ large number of the younger teachers to its examinations, all of whom are required to pass in subjects set by the heads of the profession, including the ability to teach on the oral system. This method, advocated by the means already named, had been prosecuted with great zeal and much success, but was wonderfully accelerated by the international congress held at Milan in September 1880. Here the pure oral system was stamped with almost unanimous approval, and its acceptance, either wholly or partially, speedily followed in every country in Europe and some more distant regions. It was at once adopted in the three national institutions of France-the birth. place and cradle of the sign or French sy stem; and by 1884 more than 60 per cent. of all the known schools in the world had proclaimed their full adoption of it. In Germany, Austria, Hungary, Luxemburg, the Netherlands; and Switzerland its adoption was universal ; in Italy it prevailed in 34 out of 35 schools; and in Norway in 6 out of 7. In other words, it was the system in actual practice in all the schools of some countries, in nearly all of other countries, and in a continually increasing number in every country where the deaf are taught at all.

The oral system, discarding signs and the manual alphabet as instruments of teaching and as meuns of communication, employs speech and lip-reading for these purposes. The child is taught $(\alpha)$ to speak by seeing how his teacher speaks; $(b)$ to lip-readthat is, to read the speech of his teacher and others as expressed upon their lips; and to understand so much of this as is co-extensive with his own knowledge of language, to which he is of course adding daily and hourly by means of speech. Instruction comes to him by the spoken and written language of the hearing, not by the signs and gestures of the deaf. 'Thus, he speaks, he lipreads, and he has books opened to him. The first attainment, striking as it is, is as nothing to the second, and the second is inferior to the third. It cannot be too clearly understood that the greatest and most certain of all these advantages is the last-named. The acquirement of speech may be more or less perfect, therefore more or less uncertain as a means of communication; but the ability to read the lips of other persons does not depend on this, and it is much the more valuable of the two, because by this means the mind which is full is laid open for the information of the mind comparatively empty. But the ultimate attainment-the command of books and literature afforded by the mastery of language-is, in regard to intellectual eultivation and moral guidance, incomparably the most valuable acquirement of all, however gained. Nothing is to be compared with this as a means of breaking down the barrier and bridging over the gulf which separates the deaf from the hearing - the most formidable and at first sight the most impassable which can separate man from man. By way of illustration, it has been said that the iriental condition of the born-deaf, without education, is blank imprisonment in the most awful solitude; that the sign system removes this to the extent of enabling the captives to associate with each other; while the pure oral system throws open the doors of their captivity, and sends them out to take their part in the life and action of the world around them.

The modes of teaching on the oral system are not everywhere uniform, though the principles are the same. These methods vary to some extent in different countries, being influenced by the character of the language, and are essentially traditional. Some eminent authorities teach the vowels first, others the consonants; the simple combinations follow, afterwards those which are less simple, and then short phonetic words, leading on to simple sentences. The vocal organs are trained to pronounce and the eye to observe (i.e. to lip-read) simultaneously. It is gravely erroneous to suppose that teaching speech is all that is meant by teaching on the oral system. Its advocates say that, with pupils properly taught, lip-reading, articulation, and writing are simultaneous. One branch is not allowed to get ahead of the other. To acquire a new word, the pupil first reads it from his teacher's lips; he is next taught to pronounce it himself, and then to write it down. On this principle the whole course of instruction is carried out. The system, to be successful, demands its own conditions, of which a longer school term (eight years at least), an earlier commencement (at the age of seven or younger), smaller classes (of not 
more than eight or ten), teachers trained specially to the work, and the exclusion of signs and the manual alphabet are held to be indispensable, The growth and decalence of the sigu system is historie. It cume in after 1760. It then took hold and grew, and maintained its ascendency for nearly a hundred years, when the reaction began which lias marked our own times. Before 1760 there were no public schools ; all teaching was individual and private, and it was oral. After 1765 , when De l'Epée had a seloool of sixty ehildren and no assistants, it is no wonder that he gave his pre. ference to signs, whereby the pupils could help to teach each other, and he could aldress them an at once. So speech was abandoned, except in some frvourable cases as an accomplishment; sigms be. came the lunguage of deaf-mutes, teachers were few and inadequate, a large proportion of them

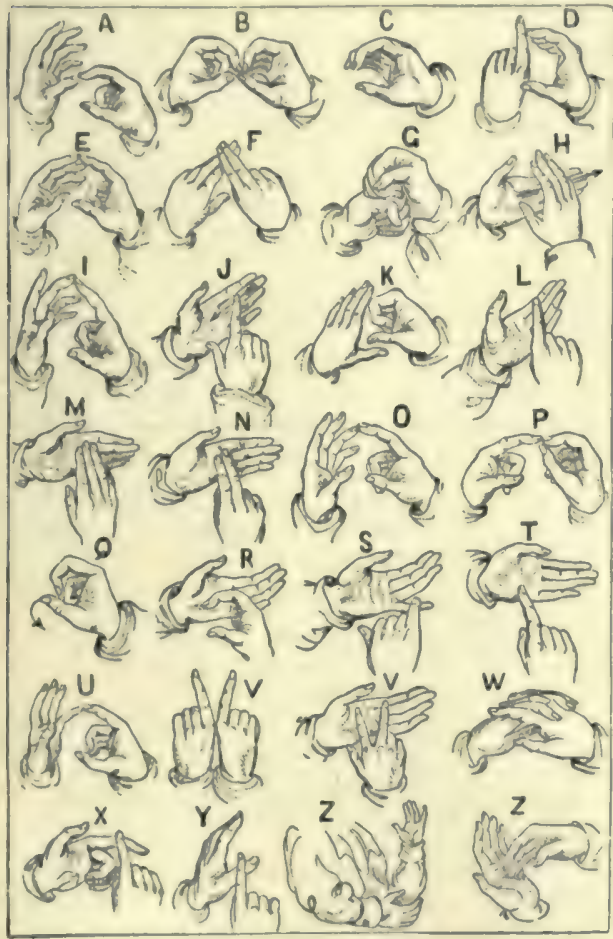

Two-handed Alphabet.

were deaf themselves, teaching deteriorated, and interest languished. Meanwhile, the best men did the best that was possible with an imperfect instru. ment. The sign system was such an instrument, and what was within its eapabilities they did devotedly and did well. But with the superior instrument, the oral system, applied with the same energy and zeal, higher results have been reached, notalily, in many instances, by the eame men.

Though they have worked on each method as it came before them, there never was in the minds of the most experienced teachers any doubt as to the superiority of speech over signs. The question was never, which system is the best? but which system is the most pructicable in large sehools? It is olvviously better that deaf persons should use the speech common to everybody than the language of nobody but themselves. Until seventeen hundred people go out of their way to lesrn the language of one, the deaf minority must stand isolated in the world, shut ap with each other. Though such as have learned to speak may not, with all their efforts, succeed in rining to the level of those that hear, yet the effurts made are themselves improving. and halsitual practice is still more 00 ; whereas the practice of signing is distinctly lowering and hindering. Those taught hy signs think in signs ; those taught by speech think in words. The mix. ture of the two is injurious; translation from eigns to words produces confusion; signs invert language, and when the two systems are placed together signs become the dominant power, and speech the lesser one; then comes in a combined system in which the oral system stands degraded, of which it has been said, to degrade it is to kill it. Natural signs-the signs which all hearing pernous under. stand-are allowed to be nsed for purposes of ex planation, and some authorities permit the use of the manual alphabet as well, because what is conveyed by the manual alphabet is identical with language, and not, like conventional signs, an imperfeet substitute for it. But the inflexible advocates of the pure oral system condemn and exclude signs and the manual alphabet altogether. Signs, they say, are at best but a 'baby language,' wedded to which the mind cannot grow, and with which, alone, intellectual maturity can never be attained.

Excellent work for the deaf and dumb has been done in the United States. The institutions there are munificently supported by grants from the states, and are aimirably managed. The staff of teachers is numerous, able, and efficient, and a high degree of stuccess is attained where the work is carried on under advantages which are unknown in the schools of Great Britain. At Washington a college was established in 1864, under the presidency of Dr E. M. Gallaudet, the youngest son of the founder of the American Asylum. It is empowered by the United States government to confer degrees, and has expressed this power by conferring the title of Doctor upon four prominent experts in Great Britain-Messis Charles Baker and D. Buxton in 1870, and R. Elliott and W. Stainer in 1887. The same honour was conferred in 1880 upon Professor A. Graham Bell. The inventor of the telephone, he is also well known by his interest in the education of the deaf on the oral system, of which he is one of the most eminent and influential advocates. That advocacy is mainly based on educational grounds, but also as a check to the evils arising from the congregation of the deaf and dumb together in institutions-their general association with each other, their frequent intermar. riacres, the consequent excess in the births of deafmute children, and the danger, by no means vision. ary, he insists, of 'the formation of a deaf variety of the luuman race.' In New York the Rev. Dr 'Thomas H. Gallaudet, vicar of St Anne's, in 1852 started services in his church in the sign langmage, and in 1872 organised a mission to promote the temporal and spiritual welfare of aduli deaf-mutes in other cities of the Union. In London St Saviour's church was built to meet the same neces. sity, and religious services have been conducted there by successive chaplains. Another clergyman and several laymen condnct similar services in various parts of the metropolis In Liverpool, Man. chester, Edinburgh, Glasgow, and Dublin, also in Birmingham, am the larye manufacturing towns of Yorkshire, special funds are raised, and special agents employed, to promote in like manner the social and religions benefit of the deaf and dumb.

The contentions hetween the rival systems have been carriel on with much vigour and spirit in numerous articles, reports, aud pamphlets; and education has been promoted by the publication of lesson-books such as those of Dr Harvey P. Peel of New York, and of Morits Hill of Weissenfuls (trans. by Stainer). See besiles the report of the Royal Commission above mentioned, the Manual 
on the education of Denf-mutes by T. Arnold (1872) and his Method (1881); W. R. Scott, The Deaf and Dumb (1870) : J. A. Seiss, The Children of Silcnce (Phila. 1888); French books by Ordinaire (1836), Dubranle (1884), Dupont (1884), Goguillot (1889), Denis (1886), and Drouot (1896); and German books by Hill (1867), Schottle (1874), Hartmann (1880), Walther (1882 and 1895), Schmaltz (1884), Gude (1880 ', Heidsiek (1889), Hedinger (1884), Vatter (1892), Mygind (trans. 1894), and Bezold (1896).

Deaf and DUmb, in Law. The Roman law held deaf and dumb persons to be incapable of con. sent, and consequently unable to enter into a legal obligation or contract. Both in England and Scotland they may make contracts or wills if they have the use of reason and understand the nature of their undertaking, and express their consent intelligibly. Although the presumption of law is that a deaf and dumb person is in the same state as an idiot, and incapable of any understanding, such a one may be subjected to a criminal trial on proof that he knows right from wrong. And, if he understands the nature of an oath, and is possessed of intelligence, he Inay give evidence as a witness by signs through an interpreter or by writing. It is always a good objection to a juryman that he is deaf and dumb.

In the United States, in general, the legal presumption of the common law as to the mental incapacity of the deaf and dumb does not exist. They are presumed to be capable of comprehending the nature of erime, the nature and obligation of an oath, and of making any contract; hence may be indicted, tried, and punished for crime, and may testify as witnesses. The federal courts have no peculiar jurisdiction as to persons deaf and dumb, but the act of congress preseribing punishment to be inflicted upon 'every person' who is guilty of certain acts prohibited, includes every person pos. sessed of sufficient mental capacity for criminal responsibility, although they may be deaf and dumb. The federal courts are governed by the practice of the states in which the cause is pending as to the competency of a deaf and dumb person as a witness, and this competency will be determined in either state or federal court by the judge before whom the cause is pending, upon examination of the individual, and upon testimony of those acquainted with the party. A deaf and dumb person is legally incapacitated to serve as a juror, or for service in the army and navy, but in other respects has the rights of citizenship.

Deafness. See Diseases of THE EAR, IV. 158.

Deák, Francis, Hungarian politician, was born in 1803 at Kehida, in the district of Szalad, where, after a course of legal study at Raab, he practised as an advocate, until returned as its representative to the national diet in 1832. Here he soon took his place as leader of the liberal opposition, and by his firm and moderate policy effected reconciliations between Hungary and the Austrian emperor as her king-temporarily in 1840 , and more permanently in 1867. After the revolution of March 1848 he became Minister of Justice in the cabinet of Count Batthyanyi, and made every effort to ward off the inevitable war. On Kossuth's coming into power (September 1848), Deák resigned his portfolio, and after the unsuccessful attempt next year at negotiation, withdrew from public affairs, and retired to his estate. He refused to return to public life till 1860, when a constitution was granted to his country.

Returned by Pesth to the diet in 1861, he again became the leader of the moderate party, while the extreme party collected round Count Téléki. The death of the latter (8th May) destroyed the only influence which could counterbalance that of Deak ; and the diet appointed him to draw up the address to the emperor demanding the constitution of 1848 , a Hungarian ministry resident in Pesth, the return, without restriction, of the exiles, and the restitution of their property. The emperor answered it by a hostile rescript, against which Deák protested strongly. Out of the humiliation of Austria in 1866 came the triumph of Deák's policy. He asked nothing more than before, and thus his wise and statesmanlike moderation effected a satisfactory constitutional relation between Austria and Hungary in the dual system of monarchy. Deák's party was all-powerful, but he lived to see the rise of $a$ more advanced party under the leadership of Tisza. He died at Buda-Pesth, January 29, 1876. See Memoir, with preface by Grant-Duff' (1880).

Deal, a municipal borough and sea-bathing place, in the east of Kent, on a bold open beach, near the south extremity of the Downs, between North and South Foreland, 89 miles by rail from London, and 6 miles SE. of Sand wich. Till 1885 it was part of the parliamentary borough of Sandwich. A fine anchorage extends 7 or 8 miles between Deal and the Goodwin Sands. Deal has mainly arisen to supply the wants of the numerous vessels which are often detained by the winds in the Downs. The chief branches of industry are connected with maritime pursuits, boat-building, sail-making, piloting or hovelling, victualling and uaval stores. The prosperity of the place now largely depends on its seabathing, on the military depôt at Walmer ( 2 miles S. of Deal), and on the shipping in the Downs. The handsome iron promenade pier was erected in 1864. Pop. ( 1851 ) 7067; (1891) 8898. It has been one of the Cinque Ports (q.v.) since the 13th century. Of the three castles built by Henry VIII. in 1539, Deal Castle is the residence of its 'captain ;' Sandown Castle (where Colonel Hutchinson died) to the north, has been blown up $(1880-95)$ as dangerous throngh the encroachment of the sea; and to the south, Walmer Castle (q.v.) is now the residence of the Warlen of the Cinque Ports. See H. S. Chapman, Deal Past and Present (1891). Some maintain that it was near Deal that Julius Casar landed in 55 B.C.-The Deal boatmen are, like some of the other boatmen on that coast, locally known as 'hovellers.' They are noted for giving assistance to ships in distress, and were formerly nuch employed in carrying off provisions to outward-bound vessels, and in bringing ashore mail-bags requiring to be forwarded by express.

Dealfish (Trachypterus), a genus of deep-sea bony fishes, in the Ribbon-fish (q.v.) sub-order of Acanthopteri. As the name suggests, the elongated body is laterally compressed, and with the exception of a small separate anterior portion, the dorsal fin is continuous along the back. The tail fin is peculiar in being turned sharply upwards. The pectoral fins are well developed. The skeleton is very brittle. Some eight species are known, on European coasts and from the west of South America. They rarely come to the surface. One form ( $T$. arcticus or bogmarus, the vaagmaer of Icelanders and Norwegians) is occasionally found on North British coasts. It is a large fish, 4 to 6 feet in length, and of a silvery colour. The dorsal and caudal fins are red. A smaller species ( $T$. tcenia) occurs along with others in the Mediterranean.

Dean. The word dean, from the Latin decanus, properly means an officer over ten subordinates, the etymon being decem, 'ten,' It is first found as a military grade, being mentioned by Vegetius in the 4 th century as an old but then disused term ( $D e R e$ Milit. ii. 8). Somewhat later it appears, still in the 4 th century, as a title of certain minor officers in the imperial household (St Ambrose, Epist. i. 20 ; St Chrysostom, Hom. 13, in Heb. vii.). With the rise and organisation of monachism, the name 
was given to a monk placed in charge of ten others, for wluse discipline or execution of aypointed tasks he was responsible (St Augustine, De Mor. Eocl. Cuth. i. 31 ); and in the legislation of Justinian the word has yet another sense, being applied to the public officers having superintendence of funerals (Novell. 43, 59). In the Visigothic and Anglo-Saxon codes the decanus is a judge of finst instance or other legal oflicer having jurisdietion within a tithing, for every hundred consisted of ten districts, called tithings, and in every tithing was a constable or eivil dean. The monastic model was adapted to colleriate and other churches having a large staff of clergy, and the dean in such churches pressiled over ten eanons or prelnendaries, though this rule of number dnes not seem to have been strictly required. In conformity with this, the spiritual governors, the bishops, divided each diocese into deaneries or decennaries (Lat. decem, 'ten '), corresponding to tithings, each of which was the district of ten parishes or churches, over every one of which a dean was appointed, who in the cities or large towns was called the dean of the city or town, and in the country, dean of Christianity, or rural deren. In the English Cliurch there are the following dignitaries who bear this name:

(1) In the province of Canterbury it is part of the dignity of the arehbishop to have prelates to be his ofticers, and of these the Bishop of London is his provincial dean; and when a convocation is assembled, the archbishop sends to him his mandate for summoning the bishops of the province. This is the sole example of the kind.

(2) Honorary Deans, as the Dean of the Chapel Royal of St James's. See CHAPEL Royal.

(3) Derins of Peculiars, as of Battle in Sussex, founded by William the Conqueror in nuemory of his conquest. There are also the Deans of the Arches in London, of Bocking in Essex, and of Croydon in Surrey, who have jurisdiction, but no cure of souls.

(4) Deans of Chapters, as at Canterbury, St Paul's, \&c., who are governors over the canons in cathedrals and collegiate churches. Their appointment is in the direct patronage of the crown, which may appoint by letters-patent: and the dean so appointed is entitled to be installed. The dean of a chapter must reside eight months in the year, and he may hold one benefice with his desnery. The income of the office is, in the case of Durham, $£ 3000$; of St Paul's, Westminster, York, and Manchester, $£ 2000$; of other cathedrals, $£ 1000$ except st Davids and Llandaft, which have $\mathbf{f} 700$. See Cathedral.

(5) Rural Deans. - This is a very ancient office of the church, but eustom gradually transferred its duties to the archdencon, as in the visitation of churches, parsonage-houses, \&c. Rural deans, however, may act as deputies to the bishop and arehdeacon; and since 1850 the office has been revived with grent advantage, and in well-ordered dioceses affords a useful channel of communication between the bishop and his clergy, and a means of joint action in matters affecting the church. There are altogether nearly six hundred rural deaneries in England and Wales.

In the universities of Oxford and Cambridge the dean is the officer who superintends the discipline of the college and the chapel services. At Christ Chureh, Oxford, which is a cathedral, the dean is master of the college.

In the Roman Curia the Cardinal-bishop of Ostia is ex officio dean of the College of Cardinals ; but while the head of foreign collegiate churehes is styled dean, the officer bearing that title in cathedral churches is inferior in rank to the provost in some cases, and in others to the vicargeneral; and in feudal times the clerks who acted as deputies for the lay-ablots of impropriated foundations were also styled deans.

Dean. Fonest or, a picturesque hilly tract, 34 sq. miles in extent, in the west of Gloucentershire, between the Severn and the Wye, and within the hundred of St Briavels, is an ancient roval forest. It was almost entirely disafforeated by Charles I. on a sale to Sir John Wintour, but was re-afforested by act of parliament very shortly after the Restoration. The greater part still remains crown property : and about one-half is appropriated for the grow th of timber for the navy. It is divided into six 'walks,' which contain woods of oak, beech, \&c. There are coal and iron mines, and quarries of stone suitable for building and making grindstones, troughs, and rollers. Persons born in the hundred, and residing and working a year and a day in the mines, become, on registration, free miners, Their ancient privileges, entitling them exclusively to grants of the crown mines (subject to the right of the erown to put on a fifth man for every four miners, now commuted for a royalty ), and, formerly, to timber for the mines, were regulated and enforced by the Mine Law Court, held at the Speech House, within Dean Forest, where the Verderer's Court is still held; but have, with some variations, been defined and confirmed by several acts and commis. sioners' awards of the present century. Dean Forest is under the control of the Commissioners of Woods and Forests, one of whom, as 'gaveller,' has the supervision of the mines, and a deputy-surveyor, deputy-gaveller, registrar, four verderers (whose office, since the extermination of the deer in 1854 is almost a sinecure), and other officials.

\section{bean of Faculty. See Advocates.}

Dean of Guild, in Scotch burghs, was the head of the mercantile body called the Guild. brethren (see GuILDS). In former times (Act 1593, chap. 180) he was a judge in mercantile and mari. time causes within the burgh, but for a very long period he has been rather what might be called a Scotch kind of Ailile (q.v.). His chief duty is now to see that buildings within the burgh are erected according to law, and, in case of their falling into a ruinous condition, to order them to be pulled down. Though in some of the larger burghs the dean of guild is still ( 3 and 4 Will. IV. chap. 76 , sect. 22) a member of the town-council ex officio, his jurisdiction is altogether separate from that of the bailie-court. In Edinburgh the Dean of Guild Court, in addition to the dean of guild, consists of five members of the town-council, and five registered electors of the city, not being councillors, of whom three must be architects, civil engineers, ordained surveyors, or master-builders. They are assisted by the law assessors of the magistrates of the city. No building can he either ereeted or demolished, or even materially altered, without a warrant from this court. Ventilution and sanitary arrangements are under the control of this court. Opposition to the granting of the warrant may be offered either by a private party or by the corporation acting for the public interest. The enforcement of the $\mathrm{Act}$ 1698, chap. 8, as to the height of buildings, the thickness of the walls, \&c., lies within the province of the Dean of Guild Court. The judgments of the Dean of Guild Court may be reviewed by the Court of Session.

Death. It is one of the fundamental doctrines of physiolngy, that every part of the organism hes its own definite term of vitality, and that there is a continuons succession of the destruction of old cells and the formation of new ones in all tissues, and especially in those in which the most active vital changes are going on, as, for example, in the nervous and museular tissues. Even the most solid portions of the animal frame, such as the 
bones and (to a less extent) the teeth are undergoing a perpetual although a slower change of this nature; and throughout the whole body there is a continuous removal of effete or worn-out tissues, and a corresponding deposition of new matter. Every blow we strike, every thought we think, is accompanied by the death and disintegration of a certain amount of muscular or nervous tissue as its necessary condition; and thus every action of our corporeal life, from its beginning to its close, takes place at the expense of the vitality of a certain amount of organised structure. This is termed molecular death, and, within its proper limits, is obviously essential to the life and well-being of the organism.

The cessation of the circulation and respiration may be regarded as constituting somatic death, or the death of the entire organism, which must obviously be shortly followed by the molecular death of every portion of the body.

We shall now briefly notice the principal modes in which death occurs. Death happens either from the natural decay of the organism, as in old age, or (and much more frequently) from some of those derangements or lesions of the vital organs which occur in the course of the diseases and injuries to which we are liable. These derangements of the vital organs may occasion various modes of dying. Dr Watson said that life rests on a tripod, whose three vital supports are the heart, the brain, and the lungs; and Bichat, that 'the mode of dying may begin at the head, the heart, or the lungs." The functions of these organs are, however, so mutually dependent upon each other, that impairment in the functions of one of them may lead to death, though the immediate cause of death is the failure of another.

Death from failure of heart may be either sudden or gradual. Sudden failure (death by syncope or fainting) may occur from disease or weakness of the heart itself, or from shock conveyed to it through the nerves. Gradual failure takes place when the whole system is enfeebled-e.g. by the action of certain poisons, and by many wasting diseases (death by asthenia, Gr., 'want of power'). When death occurs from loss of blood (anæmia), the failure of the heart may be either sudden or gradual, according to the extent of the loss; but in this case the heart ceases to contract not from inability to do so, but because the blood, its natural stimulus, is insufficient in amount to excite contraction.

Death from failure of respiration (Asphyxia, q.v.) oceurs when access of the air to the lungs is impeded, or when the actions of the muscles of respiration cease. We have examples of it in drowning, smothering, choking, strangulation, \&c. Forcible pressure upon the chest, such as sometimes happens in great crowds, or as occurs to workmen partially buried by the fall of earth, de., will cause death in a few minutes, if movement of the lungs is prevented by the pressure. Tetanus and the poison of strychnine prove fatal in this way.

Death by coma, or beginning at the brain, is caused by obstruction to the circulation through that organ by pressure (as, for example, when there is effused blood within the cranium, or when a portion of bone is depressed in a fractured skull); by clots of blood within the vessels; by various nareotic poisons, such as opium, alcohol in excessive quantity, carbonic acid, \&c.

To these forms of dying some writers propose to add necromia, or death beginning in the blood, as in typhoid fevers and in other diseases of a malignant or pestilential kind. Such cases may, however, always be referred to one of the three forms already enumerated, or a combination of them; and further complication seems unnecessary.
The signs of approaching death require a briat notice. The mind may be affected in various ways; there may be dullness of the senses, vacancy of the intellect, and extinction of the sentiments, as in natural death from old age; or there may be a peculiar delirium, closely resembling dreaming, which usually is of a pleasing and cheerful character.

Dementia or imbecility sometimes comes on shortly before death, and manifests itself by an incapacity of concentrating the ideas upon any one subject, and by an almost total failure of memory. The mental weakness is often exhibited by the pleasure which is derived from puerile amusements. Shakespeare notices 'playing with flowers' as a token of approaching dissolution. In the form of delirium, ocular spectra seem frequently to be present, the patient apparently trying to catch some imaginary object.

There is generally well-marked relaxation and incapacity of the muscular system, and the voice is usually weak and low as death approaches, often dwindling to a mere whisper. The mode in which the action of the heart declines is various ; in most diseases of long standing, the cessation of the heart's action is gradual, the rate of the pulsations being much increased, but their energy being very much impaired. In some acute affections, the failure is shown by the irregularity of the pulse, while the force is little altered. In other cases (especially in cerebral diseases) the heart, before finally ceasing to beat, contracts violently, and suddenly stops.

The respiration is sometimes hurried and panting till just before death, while in other cases it is slow, laborious, and stertorous. The accumulation of mucus, \&e. in the air-passages increases the difficulty of breathing; the sound known as the 'death. rattle " being produced by the passage of the air from the lungs through the fluid collected in the trachea and upper respiratory passages. There is also a loss of animal heat, beginning at the extremities.

The signs of actual death may be arranged under three heads : (1) Signs of the extinction of the vital functions ; (2) Changes in the tissues ; (3) Changes in the external appearance of the body.

(1) The arrest of the circulation and respiration would at first sight appear to afford decisive evidence of death ; but these functions, as in the case of hybernating animals, may be reduced to so low a condition that it is by no means easy to decide whether or not they are completely annihilated. In cases of apparent drowning, and in newly-born infants, these functions are frequently suspended and again restored; and cases like that of Colonel Townsend (see any standard work on medical jurisprudence) occasionally occur, in which the patient has the power of voluntarily suspending these functions for a considerable period. The gradual loss of animal heat is an important sign. But it is sometimes delayed; and in exceptional cases a rise of temperature may even take place after death. Loss of contractility of the museles when a galvanic eurrent is applied to them is a certain sign of death; but the period at which it takes place is very variable. The contractility of the skin is also lost after death. When a cut is made through the skin of a dead body, the edges of the wound collapse, while a similar lesion inflicted during life presents an open or gaping appearance.

(2) Among the changes in the tissues, the rigor mortis, or rigidity of the muscles, which ensues at a varying period after death, is the most important. It may appear within half an hour after death, or may be delayed twenty or thirty hours, according to the nature of the disease; and its mean duration is from twenty-four to thirty-six hours. It commences in the nock and trunk, then appears, 
according to most obeervers, in the upper, and lastly in the lower extremities, and disappean in the same orler.

(3) Various changes in the external appenrance of the body have been regarded as indieative of death by different writers; of these, the most important unguestionalaly is the altered colour of the surface. Livid spots of various sizes may oceur from locel congestions during life; but the appear. ance of a green tint on the skin of the abdomen, accompanied by a separation of the epidermis, is a certain sign that life is extinct.

The diserimination of true from apparent death is obviously not a matter of mere physiological interest. The case of Vesalius, the eminent anatomist, who opened an apparently dead bodv in which the exposed heart was seen to he still beating, is well known; as also that of the Abbe Prevost, who, having been struck down by apoplexy, was regarded as dead, but recovered his consciousness under the scalpel, and died immediately afterwards; and a French author, Bruhier, in a work On the Danger of Premature Interment (1742-45), colleeted fifty-four cases of persons buried alive, four of persons dissected while still living, fiftythree of persons who recovered without assistance sfter they were laid in their coffins, and seventy. two falsely considered dead. But when reason. able care is taken such mistakes are hardly possible. See Burial, Catalepsy.

Denth, in a legal point of view, is either natural or civil: the former being the cessation both of physical life and of the legal rights which attach to it; the latter, the cessation of the legal rights whilst the plyssical life remains. A man was said to be civilly deal in England when he had been attainted of treason or felony, or had aljured the realm, or was banished, or beenme professed in religion by going into a monastery. In these events his property devolved as if he were naturally dead. The doctrine of civil death is now abolished except as to cases of outlawry, in which it seems still to be applicable.

According to the Scottish Law of Death-hed, an heir in heritage was entitled to rerluce all voluntary deeds granted by his ancestor to his prejudice, if they were granted by this ancestor on lis denth. bed. It was necessary that at the time the deed was granted the ancestor should be snffering from the disease of which he died, and should not survive for more than sixty days. The law did not apply if, after granting the deed, the ancestor was able to go unsupported to kirk or ninrket. The law of deatli-bed was aloolished in 1871 .

The so-called Valley of Death is a specially arid tract in the MOHAVE DESERT (q.v.) - $\mathrm{n}$ depression without vegetation, and with a saline efflorescence. See also the articles AnNuity, Capital Punishment, Dance of Death, Disease, Execution, Insurance, LifE, Registration.

\section{Death Duties. See Leacy.}

Death's-head Moth (Acherontia atropos), a species of Hawk-moth $\left(q, v_{0}\right)$, in the family Sphingidre, not uncommon in some parts of England and of the continent of Europe. It is widely distributed over the world, being found in Africa, the Mauritius, and the East Indies. It is one of the largest of the European Lepidoptera, and mensures almost six inches from tip to tip of the extended wings. The general colour is dark, the woolly body yellow, with black markings, the thorax with markings which have some resem. blance to a skull, the upper wings mottled with brown, black, and yellow, the hind wings dark yellow' with two black bands. The large caterpillar is greenish-yellow, the back speckled with black, with transverse lines partly blue and partly white. The tail end bears an 8-8haped horn. In conntries where the potato is cultivated it is often to be found feeding on the leaves of that plant.

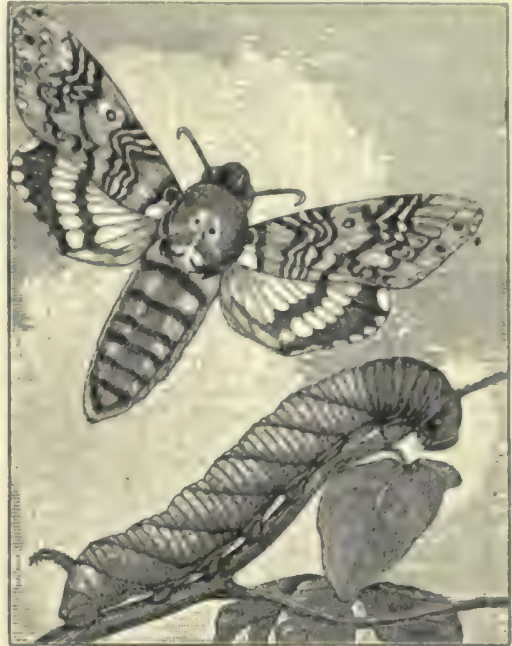

Death's-head Moth (Acherontia atropos) and Caterpillar.

In the pupa stage it is brown, and lies in a hole in the ground. The insect is nocturual in habit, and is interesting as an audacious plunderer of bee-hives. How it daunts the bees is a mystery. Even more remarkable is the much discussed shrill piping note, which is probably produced by the forcible expul. sion of air from the fore-gut through a cleft in the proboscis. The sudden appearance of large numbers is popularly regarded as ominous of evil, and in the Mauritius the insect is believed to cast from its wings a dust which produces blindness in those persons on whom it falls.

Death-wateh, a ticking or rapping noise produced by various insects in houses. Being oftenest heard in the quiet of sickness and anxiety, it has been superstitionsly recrarded as a signal of approaching death. In Britain it is generally the love-signal of the small boring beetle (Anobium, see BORER(), of a brownish colour, and about inch in fength. Various species frequent wood, furniture, Se. A. pertinax, A. tesselatum, and A. striatum are all common death-watches. Some other insects besides Anobium make tapping noises, notably the Giant Cockroach (q.v.) or drummer. Oue of the book-lice (Atropos pulsutorius), in a very different order, used to be regarded erroneously as the 'death-watch.'

Debacle, a French word, meaning in that language the breaking up of the ice in a harbour or river, but introduced into English by geologists to express any sudden flood of water, which bears before it opposing obstacles, and leaves its path marked with confused and seattered fragments of rocks, stone, and other debris.

De Bary, Heinnich Antos, an eminent botanist, horn at Frankfort-on-Main, 26th January 1831. After a course of medical studies at Heidelberg, Marburg, and Berlin, he began in 1853 to practise in his native city, but next year became a privat-docent in Tubingen, the year after was called to be professor of Botany at Freiburg, where in 1859 he was appointed ordinary profeasor. In 1867 he oheyed a enll to Halle, and in 1872 to Strasburg, where he was the first rector of the newly reorganised university. He died at Stras. burg, 19th January 1888. As a botanist, De Bary is famous especially for the contributions he 
has made to our knowledge of the morphology and physiology of the fungi and the Myxomycetre. Of his numerous works in these departments, the Comparative Anatomy of Phanerogams and Ferns has been trunslated (1885); as also the Morphology of Plonts, and Lectures on Bucteria (1888).

Debateable Land. See Borders.

Deben'ture is a deed or instrument issued by a company or public body as a security for a loan of money. It charges the property of the company with the payment of interest, and the repayment of the principal at some fixed period, usually three, five, or seven years. Debentures vary in their terms, style, and legul incidents according to the statutes under which power is given to issue them; but the most common form is that of the railway debenture, which is a mortgage issued under the Companies Clauses Act, 1843, and containing an assignment of the whole undertaking and receipts of the company. Debentures of a company registered under the Companies Act, 1862, generally create a charge on the property of the company, but are sometimes merely bonds, or in the form of promissory notes. In many cases the issue of debentures has been superseded by the issue of debenture stock, which, with the interest thereon, is a charge on the undertaking of the company prior to all shares or stock of the company. It is capable of being transferred in any amount, and does not, like a simple debenture, represent the title of the original holder by an instrument complete in itself, but requires entry in a register.

The term debenture is also used by officers of excise to denote a certificate entitling a merchant who exports goods to receive bounty or drawback.

Debit and Credit. See Book-KeEPING.

Debo'rah (Hebrew, 'bee'), the 'Mother in Israel,' a Hebrew prophetess, wife of Lapidoth, judged Israel under a palm-tree on Mount Ephraim between Ramah and Bethel. Through her patriotism the Hebrews were delivered from the yoke of the Canaanites, under which they had lain for twenty years. She united several of the tribes of northern Israel under Barak (= Carthaginian Barca, 'lightning'), who completely destroyed a great army of the Canaanites at Taanach in the plain of Esdraelon on the brook Kishon. Sisera, the Canaanite leader, fled, and was murdered in his sleep by Jael. 'The land had rest forty years." The song of Deborah (Judges, $v_{\text {. }}$ ) is an inspired utterance of the most joyful enthusiasm. See Ewald, Die poetischen Bücher des alten Testaments (vol. i. new ed. 1865), and the eloquent passage on 'this Hebrew Boadicea' in Coleridge's Confessions of an Inquiring Spirit.

De'breczin, a town of Hungary, in the midst of a wide plain, 130 miles $\mathbf{E}$. of Pesth by rail It is a large straggling place, indeed really a collection of villages. Notwithstanding its generally squalid character, Debreczin is possessed of some very handsome public buildings, including a town-hall. The Protestant college, with faculties of law and theology, has a valuable library, and physical and zoologieal collections, is the chief Reformed college in Hungary, and has 1500 students; there are also a Catholic academy, a commercial college, and an agricultural college. Agriculture is the dominant interest; enormous herds of cattle graze on the fertile plains around. There are also manufactures of soap, saltpetre, sausages, hams, and tobacco-pipes, which are famous throughout Hungary, and a great steam flour-mill. There is much trade in cattle, swine, and grain. Pop. (1891) 56,996, all Protestants but 2000. The 'Rome of the Calvinists,' Debreczin was long the headquarters of the Reformed faith, and its inhabitants suffered much for their religion. The town took a prominent part in the revolution of 1849 , and was for some months in that year the seat of the national diet.

De Brosses. See Brosses.

Debruised, a heraldic term applied to an animal having a bend or other ordinary placed over it.

De Bry, Theodor, a goldsmith and copperplate engraver, born at Liege in 1528, who settled in Frankfort-on-Main about 1570, and established a printing-house there. The most important of the works issued from his press is the collection of Voyages to the East and West Indies, published in Latin (25 parts, 1590-1634) and Ger-

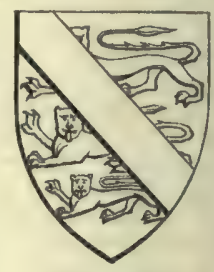

Debruised. man ( 27 parts, 1590-1630). He died in 1598, leav. ing two sons to complete the undertaking.

Debt means a definite sum of money owed by A to B. The word includes the right of the creditor as well as the liability of the debtor. It is contrasted with the liability for damages, or other unliquidated liability. In England there is, in general, no method of securing debts before they are payable (what is called a garnishee order applying only to judgment debts); but future and contingent debts may in Scotland be secured by arrestment or inhibition where the debtor's solvency is doubtful. The main division of debts in Seotland is into movable and heritable - the former being primarily chargeable only upon the debtor's personal funds, although they may, by adjudieation, be made also a charge upon his real estate; and the latter being directly a charge upon his real estate. The former have always been treated as personal estate as far as regards the creditor's succession, while until 1868 the latter were considered as heritable estate. Now, there is no distinction. In England also a debt may be secured on the debtor's real estate, as by mortgage or equitable lien; but these mortgages were always regarded as personal estate, although until 1874 the formal title was in the heir, not the executor. In England, a debt of record is one proved to exist by the records of a court. The most important are judgment dehts, which have not only certain facilities in execution and attachment, but must be paid in full out of the personal estate before any debts due on contract. A judgment debt, when delivered in execution, creates a charge on the debtor's real estate, as if he had given a mortgage. Specialty debts in England are debts by contract created by a deed or an instrument under seal. Such debts were formerly entitled to a preference over simple contract debts, such as the liability under a bill of exchange. But that was altered in 1869. In the administration of a deceased's estate, the order of preference among debts (as recognised by the Judicature Act of 1873) is (1) expenses; (2) crown debts ; (3) judgment debts ; (4) recognisances and statutes; (5) special and simple contract debts. Under the Judicature Act in England, and at common law in Scotland, in the winding up of the estates of deceased persons, provision must be made for the valuation of contingent and future liabilities or debts, very much in the same way as under sequestration or liquidation proceedings in cases of bankruptey.

In bankruptey there are certain preferential debts, such as taxes and rates, wages and salaries. In England, actions of debt, when on contract under seal, must be brought within twenty years; on other contracts, within six years. The time in both 
cases is taken from the aceruing of the caure of action-i.e. the breach of contract; hut if a nulsequent acknowledgment in writing has been made by the party liable, or he has paid the delot in part, or paid interest, the time will run from such subsequent act. In Scotland, on the other hand, obligations generally, and eapecially auch as correspond to the speecialty contracts of England, are only subject to the long negative prescription of forty years, but tradesmen's accounts and some others preserilue in three years (see PRtscription). The debtor's sumnons, commonly used in England, is a summons to pay generally a trade debt (not

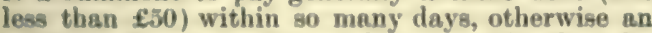
aet of bankruptey will have been committed, and a bankruptey petition will be presented.

IMPRISONMENT OF DEBTORS, - Except in the case of fraud, no debtor can be imprisoned in England for a deht below $£ 20$, exclusive of costa. But such debtors, if ordered by an insolvent or county court to pay the debt by instalments, or otherwise, may, if they make default, be committed by the court to prison for forty days. In Scotland, the limit below which imprisonment for debt is incompetent is $£ 8,6$ s. $8 \mathrm{~d}$. If a debtor escapes after arrest, and before imprisonment, the officer of the law in charge of the process is liable for the debt.

In England, imprisonment for debt was abolished by the Debtors Act, 1869, except in certain cases, the most important of which are those of a defaulting trustee and of a-judginent debtor who is able, but refuses to pay. In certain actions for $£ 50$, defendants about to leave the country may be imprisoned, and under the Absconding Debtors Act, 1870 , insolvent debtors may be arrested to prevent their evading bankruptey proceedings by going abroad. In Scotland, imprisonment for debt was abolished by the Debtors (Scotland) Act, 1880, 43 and 44 Vict. chap. 34, generally known as Cameron's Act; except in the case of taxes, fines, or penalties due to the Queen, and rates and assessments lawfully imposed, and also sums decerned for aliment. By the Civil Imprisonment (Scotland) Act, 1882 , 45 and 46 Vict. chap. 42, imprisonment was further limited, (1) in the case of assessments, to a period of six weeks ; $(2)$ in the ease of aliment, to debtors wilfully failing to pay, though possessed of means, or heing able to earn the same. These acts do not exclude imprisonment where a debtor is in medi. tatione fugos, or where he refuses to perform an obligation ad fact um prostandum. What is known in Scotland as a fugoe warrant is granted where it appears that a debtor, in a debt above $\mathfrak{E 8 , 6 8 . 8 d}$., is about to leave the country without provicling for its payment. Security must be given to present the debtor when decree is obtained, so that he may be charged to pay. It is thonght this remedy does not apply to foreigners travelling through Seotland for pleasure.

In the United States originally imprisonment of debtors was adopted as a part of the common law, but at the present time imprisonment for debt, except in case of fraul, or of an absconding debtor, is believed not to exist in any of the states. Congress, empowered by the United States Constitution to make a uniform bankrupt law, exereised this power, and subsequently repealed the law of imprisonment (see BANKRUPTCY); and now, by Revised Statutes 990 and 991 , no person can be imprisoned for debt by any process issuing out of the courts of the United States, in any state where by the laws of the state imprisonment for debt has been abolished. Most of the states, by constitutional provision ( either by Article of the Constitution, or by Declaration in Bill of Rights), have prohibited arrest or imprisonment for debt, while the other states, either by direct statutes prohibiting imprisonment for debt, or by poor debtors laws, or by insolvent laws, secure the anme result; it being held to be against public policy to deprive a man, by imprisonment, of the power to pay his debts, and make him a direct eharge upon the state. These statutes and constitutional provisions are not in con. flict with the provision of the United States Consti. tution, prohibiting the states from making any law impairing the obligation of contracts, as imprison. ment for debt is no part of the contract; but they do not in general apply to arrest in actions for tort. In some states, statutes providing for the arrest of a defendant in actions for breach of promise have been held to be unconstitutional, as in conflict with the provisions of state constitution prohibiting arrest for debt, that provision applying to mesne as well as final process. If a person in custody of the court is discharged by giving bail for the payment of a fine or other money within a certain specified time, the bail may be forfeited, but no commitnent can be made for the payment of the fine, as that would be imprisonment for debt, but a judge may imprison for personal examination in act of execution.

Recovery or DeBTs. - With respect to the

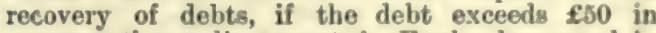
amount, the creditor must, in England, proceed in one of the superior courts of law; and, in Seotlund, he may proceed either before the superior court or before the sheriff-conrt. If the debt do not exceed $t 50$, the creditor may proceed in the English county court, or the sheriff-court; if below £25, in Scotland he must proceed in the sheriffcourt.

In England, the first step to recover a debt not exceeding $£ 50$ in the county court, is for the creditor to go to the registrar of the district within which the defender resides, or to the jurisdiction of which he is on some other ground amenable. He there fills up a printed form, called a plaint, shortly stating the elaim and the ground of it. The registrar upon this issues a summons, and gives it to the bailiff of the court, who serves a copy of it on the defendant. This summons names a day on which the parties must appear before the judge. No written pleadings are in general necessary; but if the debtor has any special defence-such as, that he has a counter-claim against the plaintiff, or that he (the defendant) was a minor at the time the delst was contracted, or that he has been discharged under the bank: ruptey acts-he must give the creditor notice in writing five days before the hearing. If he simply denies the debt, he has nothing to do but to attend the hearing, with what witnesses be may require. If the witnesses are not likely to come voluntarily, summonses to enforce their attendance (as well as the prodnction of documents) may be obtained at the registrar's office. At the hearing, the judge (unless a jury have been required) proceeds hinself in a summary way to try the cause. He examines the witnesses on oath, keeping no record of the evidence; and, on hearing the parties, gives judg. ment at once. If he decides for the plaintiff, he may make the sum payable at once, or in cases below $£ 20$, by instalments. The costs are according to a fixed scale, which may be seen in the court or in the registrar's office.

There are provisions for parties having their ense tried by jury, and also for appeal on questions of law. Either party who wishes it, may ask for a jury : and if the sum claimed exceed $f 5$, the demand must be complied with. If there be a jury, the number of jurymen is five, and their verdict must be unanimous. The party dissatisfied with the verdict may ask for a new trial, and the judge, if he thinks right, may grant it on such terms as he thinks reasonable. This power to try by jury is nsed very rarely indeed-less than one per cent. of all the casen which go to trial being tried in that 
manner. The right to appeal is against decisions in point of law, and against the admission and rejection of evidence. The appeal is to a Divisional Court of the High Court of Justice. It is taken by requiring the judge to state a case for the opinion of the higher court, and thereafter entering it for discussion there. The appellant must give security for the costs of the appeal, and (if defendant) for the amount (both of principal and costs) contained in the jurlgment. The right of appeal is not much exercised, and the parties have it in their power to agree beforehand (in writing) that there is to be none. Leave to appeal is required where the sum sued for is less than £20. Before trial, cases may be removed by Certiorari (q.v.) to the High Court of Justice, but that is in the diseretion of the superior judge.

When judgment is for the creditor, and the order for payment is not complied with, execution may issue against the goods of the debtor. Although imprisonment for debt was (in the general case) abolished in England in 1869, it still remains the law that in the county courts, in certain cases, the debtor may also be imprisoned. The debtor is summoned to show cause why he has not obeyed the judgment. At this hearing (whether the debtor attend or not), the creditor may get an order to commit, if he can show, to the judge's satisfaction, that the debtor has had since the judgment sufficient means to pay, and has refused to do so. This imprisonment may be for six weeks, but it is not held to be equivalent to payment. Of course the debtor is protected by bankruptcy or liquidation.

Although it is competent to proceed in the county courts for sums as large as $£ 50$, they are not much used for sums above $£ 20$. When the debt does not exceed $\mathfrak{E 2 0}$, there is a certain compulsion on the creditor to resort to the county court, for if he resort to a superior court, and recover no more than that sum, he will have no costs, unless he satisfies the court that he had sufficient reason for taking that course. In point of fact, there is only about one case for a sum exceeding $£ 20$, for a hundred which do not exceed it ; and the average amount sued for is between $\mathfrak{E 2}$ and $\mathfrak{f 3}$. The law upon this extremely important practical matter is now consolidated in the County Courts Act, 1888.

In Scotland, under the Small Debt Act, 1 Vict. chap. 41 , as amended in 1853 , debts not exceeding $£ 12$ may be recovered in the Sheriff Small-debt Court. The ereditor takes two copies of his account to the office of the sheriff-clerk for the circuit in which the debtor lives; from him he obtains a summons, in which the day for the trial is fixed; and this summons he takes to an officer of the court (sheriff-officer), who serves a notice, with one of the copies of the account, on the debtor, at least six days before the trial. The presence of a witness at citation was dispensed with by the Cita. tion Amendment Act of 1871, which also abolished lockhole citation; and under the Citation Amendment Act of 1882 , citation by registered letter instead of by messenger-at-arms will be allowed in the general case, it being formerly allowed only where the debtor hid himself, or refused access, or had gone for forty days. Both parties may employ an officer to cite witnesses. The ereditor must appear at the trial, either by himself or by one of his family, or by such other person as the sheriff may permit. Law-agents require special permission to appear, unless where both parties consent. If the defender intend to plead a counter-claim, he must cause a sheriff-officer to give a copy of it to the pursuer, at least one free day before the trial; otherwise, there are no written pleadings. On the day fixed for the trial, if the debtor does not appear, decree is given against him, with expenses, as a matter of course; against which he can afterwards be 'reponed' only. on consignment of the expenses and a sum of 10s. If both parties appear, the judge hears the case. If the pursuer or the defender have clearly no good ground of action or defence, he disposes of it at once; but if not, he exanines the witnesses on oath. No record of the evidence is taken. At any time before judgment, the case may be remitted to the 'ordinary court' of the sheriff, where it is conducted by agents on written pleadings and written proof. Otherwise, the whole proceedings are coneluded in one day, adjournments not being permitted, except in special cases. After judgment, there is no appeal, except on the ground of want of jurisdiction, malice, oppression, or wilful neglect of the statutory forms, in which cases there is an appeal to the Court of Justiciary. The judg. ment provides for execution against the debtor's goods. This process is often used for the recovery of sinall rents.

The Debts Recovery Act, 1867 (30 and 31 Vict. chap. 96), has extended the Scottish small-debt jurisdiction, with important alterations, to $\mathrm{f50}$. The class of debts that may be sued for between $£ 12$ and $\mathfrak{E 5 0}$ has been limited to those which most require summary proceedings - namely, those which prescribe if not sued for within three years, such as all ordinary merchants' accounts, and accounts for professional services or for servants' wages. The principal differences between this and the proper small-debt proceedings are, that agents are allowed to appear; that there are two days in court, one at which the grounds of action and defence are stated, and an adjourned one, at which the witnesses are examined; that the judge makes a note of the pleas of the parties; that a record is kept (if required) of the admissions in fact and of the evidence ; and that there is a right of appeal, if the debt does not exceed $£ 25$, from the sheriffsubstitute to the sheriff, and if it exceed $£ 25$, also to the Court of Session. If the judge be not asked to take a note of the evidence, there is no appeal in matters of fact. All the fees and costs, whether payable to the sheriff-clerk, the officers of the court, or the law-agents, are distinctly stated in the act, and must be hung up in every court. - In other respects, the proceedings are analogous to those in the Small-delit Court, and, like them, may proceed either at the principal town of the county, or at one of the towns at which sheriff's circuit-courts are held.

In England and in Scotland there are other courts which deal with the recovery of debts beside the county courts. The Sheriff's Court of the City of London has a jurisdiction similar in general to that of the English county courts; and there are local courts, such as the Court of Passage at Liverpool, and the Manor Court at Bradford, which exercise jurisdiction in small as well as other debts. In Scotland, the magistrates of royal burghs, and the justices of peace, possess a small-debt jurisdiction for debts not exceeding $£ 5$ in amount. In the latter case, the Royal Commission of 1870 recom. mended a reform, especially as regards fees and execution against goods. The widespread belief that a corpse could be attached for debt was a vulgar error.

LAWS OF DEBTOR AND CREdTTOR. - In the history of execution for debt the march of social progress may be traced in earlier times. On the one hand, lending is confounded with alms-giving; and the exaction of interest, and even of capital, is regarded as an act of inhumanity towards the poor. On the other hand, when the creditor's rights come to be recognised in a legal sense, there seem to be no limits set to them. If he is entitled to exact the debt at all, he is entitled to seize the goods of the debtor; and if the debtor has no goods, he is 
entitled to his services. But the possession of his services implies the possession of his person; and the possession of his pernon implies the posscssion of his life. The person of the individual, the father of a family, brings along with it right over his wife, his children, and his slaves. The ereditor thus becomes the absolute master of the life and liberty of his debtor, and of all those who are dependent upon him. The arrangements of the Mosaic Law are an illustration of the manner in which, in the ruder forms of society, the laws of debt thus com. bine a degree of lenity with a degree of severity which are equally alien to modern views. If an Iaraelite became poor, it was a duty to lend to him, and no interest was to be exacted either in money or in produce. If he was a foreigner, the case was different, and the taking of interest was legal (Exod, xxii. 25; Dent. xxiii. 19, 20; Lev. xxv. 35-38). When the Sabbatical year arrived-i.e. at the end of every seven years-there was a general remisaion of debts as between Israelite and Israelite; and the near approach of the year of remission was not to be recognised as an apology for declining to lend to an indigent brother (Deut. xv. 1-11). Pledges, it is true, might be taken, but even here the same humane principles prevailed. The upper millstone was sacred, for to take it would be to deprive the debtor of the means of subsistence. If raiment was the pledge, it must be returned before niglitfall, when it might be required for a covering (Exod. xxii. 26, 27); and the widow's garment could not be taken in pledge. In strange contrast to this is the provision (Lev. $\mathbf{x x v}$. 39) that a poor Israelite may be sold to one possessed of sulstance, even when modified by the special provision that he shall serve as a hired servant, not as a bond-servant, and shall he set at liberty when the year of jubilee arrives. Michaelis says that the judicial procedure for debt was quite summary, the most important causes being decided probably in a single quarter of an hour; and he remarks that Moses nowhere thinks it necessary to mention how a debt was to be proved before a judge. There was, however, an extensive system of appeal; from the jullge over 10 , the case was carried to the judges over 50,100 , and 1000, and finally to Moses himself. As every Israelite was entitled to claim the land of his fathers at the jubilee year, and thus to place matters on the footing on which they were after the settlement in Palestine, debts and burdens on land were limited to claims to the fruits of forty-two harvests; but houses, with the exception of those of the Levites, might be sold in perpetuity (Lev. xxv. 29, $30,32,33)$. Children were often given in pledge (Job, xxiv. 9), and ultimately into slavery, in pay. ment of debt (2 Kings, iv, 1). Subsequent to the Captivity, the pressure of debts upon the poor became so intolerable, that Nehemiah espoused their cause, and insisted on a general remission (Nehem. v.), exacting from the rich an oath that they would never afterwards press for pavment.

Both in Greece (Plut. Vita Solonis, i5) and in Rome (A. Gell. xx. 1, 19; Liv. ii. 23) the creditor had a clain to the person of the delstor. Previous to the time of Solon this arrangement had produced consequences at Athens closely analogous to thoee which afterwards led to the struggles between the patricians and plebeians at Rome; and his abolition of it forms one of Solon's many claims to the character of an enlightened legislator. By the Twelve Tables, it was enacted at fome that if the debtor admitted the debt, or had had judgment pronounced against him for it, thirty days should be allowed him for payment. At the expiration of that perion lie was liable to be given into the hands of his creditor, who kept him sixty days in chains, expos. ing him on three market days, and pmelaiming his dobt. If no one stepped in to rolesso him, the debtor st the end of that time ruight be sold for 8 slave, or put to death. If there were neveral creditors, the letter of the law permitted them to eut their debtor in pieces, sharing him in proportion to their claims ; but Gelliu rays this law was never enforced. To treat him as a slave, however, aud make him work out the debt, was the conmon practice; and the children in his power, in accurd. ance with the whole constitution of society at Rome, followed his condition. The Lex Potelia (326 B.C.) alleviated the condition of the debtors (nexi) by prohibiting the voluntary alienation of penonal freedom. It is uncertain whether it also put an end to the involuntary alienation by the execution of judgment debts. "During the Republic a debtor could not be taken as a slave to satisfy a judgment debt. The inprisonment of the debtor in a public prison took the place of his reduction to slavery (chap, vii. 71, 1). Great prominence was given by the plebeians to a change in the laws of debtor and creditor, on the occasion of their first secession, in 494 B.C. ; and subsequently during the whole course of the struggles between the two orders. At Rome the ereditor was not bound to maintain his debtor in prison, but it was an offence to prevent food and beclding being supplied. In 320 A.D. Constantine abolished imprisonment for debt, unless the debtor was contumacious.

During the feudal period the person in general was not attachable for debt, imprisonment being inconsistent with the duties of warlike service, to which every man was bound; and it was for the encouragement of commerce, and in consideration of the merchant having to deal with strangers and foreigners, that it was first introduced by the mercantile conmuunities of Europe.

For further information on this and oognate subjects, see other articles in this work, such as ABREsTMENT, Atrachment, Bankhuptex, Bond, Cresio Bovoluy, Contract, Diligenoz, Husband and Wifz, Infayt, SAsctuau, \&a For the history of the law of imprison. ment for debt, see, for England, Reeves's History of the 'Law, and for Scutland, Bell's Commentaries. For archaio systems of execution for debt, such as the Indian darna, or fasting at the door of the debtor, see the works of bir Henry Sumner Maine.

Debt, Natronal. See National Debt.

Debut (dobut), a French word which has been adopted into the English language, signifying generally a beginning or entrance, but specially applied to the first appearance of an actor or actress on the stage at all, or to a first appearance in a particular theatre. In these circumstances, the actor is called a debutant; the actress, a debutunte.

Deca (Gr., signifying 'ten'), a pretix of frequent occurrence: as in Decapolis, a group of ten cities; decalogue, the ten commandments; decametre, a measure of ten metres, ¿ce. From deca is formed decade, a collection or group of ten. In the calendar of the French Repulblic the term decade was used to designate their week of ten days, the various days of which were named primidi, duodi, tridi, quartidi, quintidi, nextidi, septidi, octidi, nonidi, and docadi. See CALExDAR.

Decachord, an ancient Greek instrument of ten strings (hence the name), triangular in shape; also a kind of large guitar with ten strings.

Decagon is a plane geometrical figure of ten aidles. Winen the sicles are equal, the tigure is called a regular decagon.

Decalogue (Gr. delcalogos, 'ten words' or 'sentences ', the ten commandments. The 'ten words,' as they are called in Exodus xxxiv. 28, and elsewhere, are prefixed to the collection of laws called the 'Book of the Covenant' (Ex. xx. 22 to xxiii. 39), and with it form part of the 'Prophetical Narrative' of the Pentateuch (here extending from 
Ex. xix. 3 to xxiv. 15). They are quoted at length in Deut. v. 1-21, and, besides minor differences, with remarkable extensions and variations in the fourth, fifth, and tenth commandments. The Divine rest after Creation is given as the ground of the fourth commandment in Ex. xx. 11, the first part of that verse being based on Ex. xxxi. 17b, and the second part on Genesis, ii. $2 b$, beth of which form part of the 'Priestly Narrative' of the Pentateuch. In Deuteronomy this reason for the commandment is omitted, and appended to the commandment there is a statement of the purpose of the Sabbath (based, indeed, on Ex. xxii. 12), ' in order that thy man-servant and thy maidservant may rest as well as thou,' and of the motive to keep it-viz. Israel's gratitude to Jehovah for deliverance from his own servitude in Egypt. It has been conjectured that the Decalogue in its original form was entirely without comments, and that all the commandments were expressed with the same terseness and brevity as in the first, sixth, seventh, eighth, and ninth.

The prohibitions of other gods and of imageworship being closely connected, and supported in common by the reason annexed in Ex. xx, 5, 6, were even in aneient times taken together as one of the Ten Words; the number ten being made out of the rest in various ways. The Jews commonly considered the prefatory words in Ex. xx. 2 (Dent. v. 6), 'I am the Lord,' \&c., as forming the first Word. The Lutheran Church, following another ancient Jewish division, divides the prohibition of evil concupiscence into two-the ninth and tenth commandments, making "Thou shalt not covet thy neighbour's house' (which in Ex. xx. 17, is mentioned first) the niuth. The Roman Catholic Church, following Augustine, finds the ninth commandment in the first clause of Deut. v. 21, 'Thou shalt not covet thy neighbour's wife.' In the other Protestant Churches, and in the Greek Church, as also in Josephus, Philo, and the earliest Church Fathers, the prohibitions of other gods and of image-worship are counted as the first and second commandments, and that of evil desire as one-viz. the tenth. The Catholic and Protestant Churches agree in making 'Honour thy father and thy mother' begin the second table of the Decalogue; but Delitzsch, Oehler, and other scholars hold that the ten commandments fall into two sets of five, the first including the commandments of piety to God and to those whom he has invested with natural authority; the second, the commandments of probity, or of duty to one's neighbour. See Pentateuch ; Driver's Notes on Lessons from the Pentateuch (New York, 1887) ; Stanley's Christian Institutions, chap. xvii.

Decameron, the great work of Boccaccio (q.v.).

Decamps, Alexandre-Gabriel, a celebrated French painter, was born at Paris in 1803 . great portion of his childhood was spent in a lonely part of Picardy among the peasants, which seeins to have given him a lifelong distaste for the ways of cultivated society. He studied in a desultory manner under Bouchot, Abel de Pujol, David, and Ingres, but he saw nature in his own way, and stamped the small pictures of animals which he then produced with his own individuality. His want of a thorough grounding in art, and his dis. inclination for systematic study, told against him, and prevented him from working with perfect ease and mastery. His effects were attained by repeated paintings, and his pictures exhibit a strong impasto, which he scraped with pumicestone, and again retouched. In 1824 he spent the summer in Switzerland, and in 1827-28 he travelked in Italy and passed to the Levant, where he found congenial subjects, of the class that Delacroix afterwards treated, which greatly occupied his brush, and which attracted attention in the Salon of 1831. He aspired to treat historical and religious subjects: his 'Defeat of the Cimbri' (1834) attained a great success. He was made a chevalier of the Legion of Honour in 1839, and became officer in 1851. He died at Fontainebleau from a hunting accident, 22d August 1860. His works prove him to have been a powerful colourist; they are effective in composition and the distribution of light and shade, and show a fine apprecia. tion of the wilder and more picturesque aspects of man and nature. Since his death they have realised large prices, his water-eolour of 'Children let out of a Turkish School ' (1842) fetching 34,000 francs in Paris in 1861. See his Life by Moreau (1869).

De Candolle, Augustin Pyrame, an eminent botanist, descended from an ancient noble family of Provence, was born at Geneva, 4th February 1778, and was first drawn to the study of botany by the lectures of Vaucher. In 1796-97 he studied chemistry, pliysics, and botany in Paris, where in 1797 his earliest work, on lichens, was published. Other works quickly followed, including his Astragalogia (1802), and his valuable Essais sur les Propriétés Médicales des Plantes (1804). In 1802 he was elected to an honorary professorship in the Academy of Geneva, but remained in Paris, and delivered his first botanical lectures in the Collège de France in 1804. His Flore Francaise appeared in four volumes in 1805. Employed by the government, he visited all parts of France and Italy in 1806-12, investigating their botany and agriculture. The results of his journeys are partly embodied in a supplement to the Flore. He was appointed in 1807 to a chair at Montpellier, where he lived from 1810 to 1816 ; he then retired to Geneva, where a professorship of Botany was founded for him, and where he spent the remainder of his life. He died 9th September 1841. De Candolle was an industrious writer, and the fruits of his valuable studies in systematic botany and the properties and natural affinities of plants are embodied in a considerable number of works. The greatest of these, his Regni Vegetubilis Systema Naturale (vols. i. and il. Paris, 1818-21), was commenced on too grand a scale, and was continued within more reasonable limits in the Pro. dromus Systematis Naturalis Regni Vegetabilis (17 vols. 1824-73, the last ten by his son and others). De Candolle bequeathed his collections-including a herbarium of more than 70,000 species of plantsto his son, ALPHONSE DE CANDOLLE (born 1806), on condition of his keeping them open to the public, and of his carrying on the Prodromus. That son, himself a botanist of no mean fame, published several works of note, the most important being Géographie Botanique (2 vols. 1855) and Origine des Plantes Cultivées (1883). He also edited the Mémoires of his father (1862). Died April 9, 1893.

Decapoda. See Crab and Crustacea.

\section{Decapolis. See DecA.}

Deca'tur, capital of Macon county, Illinois, on the Sangamon River, 39 miles E. of Springfield, at the junction of several railways. It has woollen, planing, and flour mills, and a number of smaller manufactories. Pop. (1880) 9547 ; (1890) 16,841.

Decatur, STEPHEN, American naval commander, was born in Sinnepuxent, Maryland, 5th January 1779 , of French descent, and obtained a midshipman's warrant in 1798 . He saw some service against the French, and was commissioned lieutenant in the following year; and at the close of the French war in 1801 he was one of the thirty-six officers of that rank retained in 
the reduced strength of the navy. In the war with Tripoli (1801-5) he gained great distinction; his brilliunt mblievenent of Insuriling und hurning the captured Philadelphia in the harbour of Tripoli, and then eseaping umler the tire of 141 guns, Nelson pronounced 'the most daring act of the age." For this he received his comminsion as euptrin in 1804; in 1810 he was aprointerl com. modore. In the war with England in 1812 he eaptured the frigate Macedonian, but in $\mathbf{1 8 1 4}$ he was obliged to surrender, after a resistance that enst him a fourth of his erew, to four British frigates, In 1815 he chastised the Algerines for their piracy, and compelled the dey to declare the American tlag inviolable; and he obtained indemnities for violating treaty stipulations from the bey of Tunis and the pasha of Tripoli. He was appointerl a navy commissioner in 1816, and was killed in a duel by Commodore James Barron, near Bladensburg, Maryland, 22d March 1820.

\section{De Caus. See Caus.}

Decazeville, a town in the French department of Aveyron, 110 miles NNE. of Toulouse by rail, with iron and coal mines near by, and extensive blast-furnaces and ironworks employing 3000 hands. Pop. (1886) 7981 ; ( 1891 ) 8871 .

Decean (Dakshin, "the sonth'), a term applied sometimes to the whole of the Indian peniusula south of the Viudhya Mountains, which separate it from the basin of the Ganges, and sonetimes restricted to that portion of the same which is rather vaguely bounded on the north by the Nerbudda, falling into the Gulf of Cambay, and on the south by the Kistna or Krishna, flowing into the Bay of Bengal. Independently of this indefiniteness of meaning, the name, like that of the Carnatic (q.v.), is rather of historical interest than of actual use.

Deceased Wife's Sister. By the laws of the United Kingdom, marriage with the sister of a decensed wife is prohibited as being incestuous. At one period this was the universal law of Christendom-both branches of the Christian church, the Eastern as well as the Western, having united in condemning it. The early canon law forbade marriages between relatives to the seventh degree (afterwards changed to the fourth degree by a council of Lateran), and declared that affinity nust be treated in the same way as consanguinity (see Consanouinity). The foundation for this was the Mosaic law respecting the intermarrying of kindrerl, as given in Levitiens xviii. As is well known, however, the canon law was not at all times stringently enforced by the ecclesiastical courta, and we find that papal dispensationsa fruitful source of revenue to the churehwere not uncommon at certain periols of history. A noted historical instance is the case of Henry VIII. and Catharine of Aragon. The opinion of the 19th century, however, tends to run counter to the canon law on the subject, as adopted by the Reformed Churches; and the law prohibiting marriages with a brother's widow or a decestsed wife's sister has been abrogated in every state on the continent of Europe, in the United States, and in most, if not all, the British colonies. Great Britain alone arlheres to the old rule.

In England, though marriage with a deceased wife's sister seems to have heen voidable at common law, it wrs first specially prohibited by the ecelesiastical courts by an act paseed in the reign of Henry VIII. ( 25 Henry VIII. chap. 22). The force of this enactment was, however, soon afterwards somewhat weakened by another statute in the same reign declaring that ' all lawful persons may marry.' The combined effect of both statutes and common law continued to be a subject of 150 dispute anong lawyers down to the pasing of Lord Lyndhurst's Act, 1835. The better opinion seems to be that down to 1835 such marriages were binding till they were annulled by decree of the ecclesinstieal courts, and therefore if either of the parties died before deeree was obtained, the children of the marriage vere legitimate, and entitled to inherit. But Lord Lyndhurst's Aet put the matter on a clear footing, for it declared all such marriages entered into after its date to be ipso facto nuIl and of no effect. And according to the construction which this statute has received, the English courts hold every marriage entered into with a decensed wife's nister to be null, provided the parties have their domicile in England, although by the law of the locus contractus the marriage might he quite legal. It was m) decided in the famous case of Brook $v$. Brook (1861), where two English people had gone to Altona in Germany to be married.

In Seotland, by the Act 1567, chap. 14, all connections expressly prohibited by the divine law in the 18th chapter of Leviticus are declared incestu. ous, and punishable by death. The declaration of the Confession of Faith follows in this matter the canon law. According to the interpretation which this Act of 1567 has received from the judges ( and the Act 1567, chap. 15, as regards civil effects), it applies to marriages with a decensed wife's sister. And there are not wanting instances where the punishment of death was inflicted for such mar. riages. Barbara Tannahill, in the beginning of the 18th century, was executed on her own judicial confession, for having had connection with the husband of her deceased sister. (See Hume on Crimes, vol. i. 449). According to the existing law of Scotland, therefore, as expressed in these old statutes, marriage with a deceased wife's sister is prohibited as incestuous, and is null for civil effects as well as punishable criminally. In punishing the offence criminally, the Scottish law is more stringent than the English, incest not being per se a crime in England.

Organiserl agitation in Great Britain for the aboli. tion of the law respecting marriage with a deceased wife's sister dates back to about the time of Lord Lyndhurst's Act. The matter was first brought before parliament in 1841, in which year leave was refused by the House of Commons for the introduction of a bill for the repeal of the law. Since then the subject has been brought before nearly every successive parliament. Its history in the House of Conmmons may be given brietly as follows: In the parliament of 1847 the bill was twice read a second time. In that of 1853 it was once read a second time, and once rejected on the second reading. In 1857 it was twice read a second time. In 1859 it was twice thrown out. In 1866 it was rejected once. In 1868 the second realing was carried four times; and in $18 \% 4$ the second rending was negatived by a small majority. Introuluced into the Honse of Lords first, in 1882 the bill was only thrown out by four votes, and in 1883 it was carried on the second reading by five votes, but lost by seven on the third. In 1884 the bill was dropped on the second realing in hoth Houses, and in 188j-86 it was lost in the Honse of Londs by a majority of twenty-two. Generally till 1893 the bills have been eurried in the Commons by a large majority, but lost in the Lords. But in 1896 the bill was earried in the Lords. Marriages of this kind have been legalised in Australia, Canada, Barlualoes. ('eylon, and Mauritius, sud progress in the same direction made in other colonies. A bill legalising in Britain marriages validly contracted in the colonies has not been carried.

In Britnin the churches oppose legislation, the existing law being based upon Leviticus xviii. 18, but 
the interpretation of this text has given rise to diversity of opinion. The better opinion is that the prohibition refers only to marriage during the lifetime of the wife; and, in particular, this view of the text has been taken by the most learned Jewish rabbis. In the Book of Deuteronomy the Jewish law seems to have allowed and even commanded the marriage of a woman with her deceased husband's brother (Deut. xxv, 5), and it seems hardly reasonable to suppose that the one should be pernitted and the other prohibited.

It should be noted that there is no distinct reference to this subject in the New Testament, it being generally admitted that the words of our Lord, 'And they twain shall be one flesh' (Matt. xix. 5), in reference to husband and wife, are used in a metaphorical sense.

The principal arguments (leaving out of view the question of seriptural authority) adduced by those in favour of repealing the law are as follows: That on grounds of social expediency such marriages are to be approved. They are desired by the poorer classes generally, amongst whom they are of frequent occurrence. When a law is out of harmony with the manners and feelings of a people it should be abolished. Secondly, it would, as a rule, be a benefit to the children of a wife who has died when they are in tender years to have their maternal aunt taking the place of mother to them, rather than a stranger. Naturally she would be least likely to act the cruel stepmother. Thirdly, the present state of the law inflicts a wrong on the offspring of such marriages, by their being thereby deprived of their rights of inheritance, and this more particularly in the case of poor parents who cannot afford to shift their domicile (an easy matter for the rich) to the Continent, or one of the colonies. Further, it may happen, in the present state of the law, that one who has been long resident and legally married in one of our colonies, and has returned to settle in Great Britain, may find his children bastardised. In regard to this, the late Lord Cairns has observed : "If a man, being domiciled in a colony in which it is lawful to marry his deceased wife's sister, do marry her, his marriage will be good all the world over; whereas if a domiciled Englishman, merely resident in such colony, do so marry, his marriage will be bad everywhere." Finally, experience is in favour of such marriages, for it is said that in other countries where the repeal of the law in question has taken place nothing but good has resulted.

This latter assertion is denied by the upholders of the law, who further assert that by maintaining the law in its present state the unity of conjugal life is cherished, the circle of sisterhood is enlarged, and the growth of domestic intimacy between allied families promoted, which could not be the case were such unions possible. Many, too, have affirmed their belief that by making this change in our marriage laws other changes of a more sweeping nature would be sure to follow (as in the case of Germany), and the sanctity of the marriage tie be thereby disturbed. But this, which is styled the thin-end-ofthe-wedge argument, ignores the fact that prior to 1835 such marriages were in England not uncommon, and that not more than one per cent. were set aside by the ecclesiastical courts.

December, the last month of the year. In the old Roman ealendar, before the time of Julius Cæasar, the year began with March, and that which is now the twelfth was then the tenth month; hence the name (decem, 'ten'). Our Saxon ancestors called it Mid-winter-month and Yule-month.

Decemvirs, the ten men appointed to codify the law, both public and private, at Rome. Commissioners were first sent to Greece to study the
Greek statute law, and on their return (302 B.C.) all the magistracies were suspended, and a commission of ten patricians (decemviri legibus scribendis) appointed with consular powers to reduce the laws to writing. By the end of the next year the code was tinished, and after being ratified by the comitia of the centuries, was erected in the Forum inscribed on ten tables of wood. Next year the decemvirate was renewed, and the result of their deliberations was to add two other supplemental tables, from which the whole code bore its official title of the laws of the Twelve Tables $(q . v$.$) . The president of both the decemvirates$ was the notorious Appius Claudius (q.v.).

Deception Island, a volcanic island belonging to the South Shetland group in the Antarctic Ocean, directly south of Cape Horn. Amidst its ice-covered rocks lies a crater-lake, 5 miles in circumference, surrounded by hot springs.

Deciduous Trees (Lat. de, and cado, 'falling off') are those which annually lose and renew their leaves. In cold and temperate countries the fall of the leaf in autumn, and the restoration of verdure to the woods in spring, are among the most familiar phenomena of nature, connecting themselves also very intimately with the feelings, habits, and circumstances of mankind. The greater part of the trees and shrubs of temperate regions are deciduous; but within the tropics the forest retains always its luxuriance of foliage, except in courtries where the dry season is extremely marked. There many trees lose their leaves in the dry season, and exhibit the same partial suspension of vegetative life. Trees not deciduous are called Evergreen (q.v.). The means of disarticulation of deciduous leaves is described under LEAF.

Decimal Fractions (Lat. decem, 'ten') are such as have for their denominator any of the numbers $10,100,1000, \& c .-$ i.e. any power of tes (see Fraction). Thus, $\frac{7}{10}, \frac{28}{100}, \frac{18}{10} 8$, are decimal fractions. In writing these the denominator is conventionally omitted, and the fractions expressed thus : 0.7 or $\cdot 7,23,019$. That these numbers do not express integers is intimated by the point to the left; and the denominator is always 1 , with as many ciphers annexed as there are figures in the decimal. In the third example a eipher is prefixed to 19 , because otherwise it would read as if it stood for 18 . The expression $\mathfrak{5 5 . 6 4 7}$ is read, Five pounds and 647-thousandths of a pound; or, Five pounds, and six-tenths, four-hundredths, and seventhousandths of a pound. That these two readings are equivalent appears from this, that $\frac{647}{1000}=\frac{1000}{1000}$ $+\frac{4}{1000}+\frac{7}{1000}=\frac{8}{10}+1^{4}-10^{7} \%$. It thus appears that the first figure of a decimal to the right of the point expresses tenths of the unit; the second, hundredths; the third, thousandths, \&c. In this property lies the great advantage of decimal fractions; they form merely a continuation of the system of notation for integers, and undergo the common operations of addition, multiplication, \&c., exactly as integers do. To explain the principles which determine the position of the decimal point after these operations belongs to a treatise on arithmetic.

The disadvantage attending decimal fractions is, that comparatively few fractional quantities or remainders can be exactly expressed by them ; in other words, the greater number of common fractions cannot be reduced, as it is called, to decimal fractions, without leaving a remainder. Common fractions, such as $\frac{1}{2}, \frac{3}{3}, \frac{1}{4}, \frac{3}{7}, \frac{9}{2}$, for instance, can be reduced to decimal fractions only by multiplying the numerator and denominator of each by such a number as will convert the denominator into 10 , or 100,1000 , \&c. (The common process is merely an abridgment of this.) But that is 
posalble inly where the denoninator divides 10 , or Poo, de. without remainder. Thus, of the sbove denomicators, 2 is contained in 10,5 times; 4 in 100,25 times; and 25 in 100, 4 times; there.

fore, $\frac{1}{2}=\frac{1 \times 5}{2 \times 5}=\frac{5}{10}=5 ; \frac{1}{4}=\frac{1 \times 25}{4 \times 25}=\frac{25}{100}=$ $25 ; \frac{9}{25}=\frac{9 \times 4}{25 \times 4}=\frac{36}{100}=36$. But neither 3 nor

7 will divide 10 or any power of 10 ; and therefore these numbers cannot produce powers of 10 by multiplication. In such cases, therefore, and in fact in the care of any vulgar fraction (in its lowest terms) whose denominator contains any other prime factor than 2 or 5 , an equivalent decimal cannot be found. If we try to find it, the result is an infinite geries, which is ealled a repenting, recurring; or circulating decimal. Thus $=6666$, \&e., where the 6 repeats for ever-i.e. $\frac{2}{3}$ ernnot be expressed as a decimal. The non-terminating result, 666 , \&c., is written $\circ$.

Decimal System. This name is applied to any system of weights, measures, money, \&c., in which the standard unit is divided into tenths, hundredths, \&c., for the denominations below it, and multiplied by 10,100 , \&c., for those above it. The nature of this method of division will be best explained by an example from the French system, where it has been most rigidly carried out. The metre ( = 39.37 English inclies nearly) is the unit of length, and the foundation of the whole system. For the higher denominations of length, the Greek words décu, herto, kilo, and myria, are prefixed to Bignify multiplying by $10,100,1000,10,000$; so that dercumetre $=10$ metres, lilometre $=1000$ metres, \&c. The Latin words deci, centi, milli, on the other hand, are used to express division by 10,100 , \&e., and thus furnish names for the lower denominations ; decimetre $=$ To of a mètre, centimetre $=$ Idr of a metre, Sc. Similarly with money; the franc being the unit, a decime is the tenth part of a frane; and a centime, the hundred th part.

In 1865 Belgium and Switzerland adopted the French decimal system of money, weights, and measures. Afterwards the Italian lira, the Greek drachme, the Spanish peseta, and more recently the Roumanian lei, and the Servian dinar, were assimilated to the frume. Other countries, though retaining each its own special unit coin, divide it into 100 parts - viz. Germany, Austria, Russia, and the adopted the metrical system of weights and measures, though rejecting the frane: Germany, the Netherlauds, Spain, Portugal, Norway, and Sweden. Engineers, too, have their own decimal systems of measurement.

The method of decimal gradation in weights and measures naturally suggests itself to the arith. meticisn, on account of the language of numbers, and the Arabic notation. Practical legislators, however, have pronounced the number ten to be most unsuitable as a basis, especially for the purposes of 'retail trade.' In France the prices 1-25, $4 \cdot 25,6 \cdot 75$, \&c. are extremely common; yet if half a yard of cloth, for example, is bought rt $1-25$ the yard, the exact price cannot be paid, and the buyer therefore suffers. He is compelled to pay more than the proper value by reason of the limitations in. separalle from the decimal system. The analogous price in English money is 18. 3d., which allows not only half a yard to be sold at the exact price, but even $a$ quarter of a yard. To estimate the loss undergone by the poorer classes in France on account of the imperfections inherent to their monetary system, the most ordinary caso will suffice-e.g. if sugar is sold at 25 centimes a poond, then any one who buys half a pound must pay exactly 4 per cent. more than the proper price. The same nerious draback in inmeparable fruin the monetary system of the United States, as colnpared with that of Great Britain. In such s case as that just quoted, the poor buyer in New York is derrauded still more than in Paris; whereas, in Edinburgh, London, or Dublin, the luyer will not only lose nothing by such a transaction, but can buy even a quarter of a pound at the proper price.

In 1821, after an able mort draw's up by John Quincy Adams, the United States government rejected the metrical system as unsuited to practical life. The question of adopting the French neheme has also been repeatedly discussed in the House of Commons, but though many, in the interests of certain scientific pursuits and international transactions, advocated a change, there seems little probability of uprosting our existing method, with its excellent aupply of binary factors, and the nuch greater ease with which it lends itself to mental arithmetic. Although proposed in $\mathbf{1 7 9 5}$, the decimal system in France required repeated legislation before it could gain footing, and though it was made obligatory from January 1, 1840, the people still retain traces of the older and less arbitrary mode of computation, just as the shilling and sixpence still exist in the United States as terms of reference. The centesimal division of the right angle was also proposed at the French Revolution, but has long been abandoned, even in France. It was also used as a basis in dividing the thermometric scale (misnamed centigrade for hectograde), but Fahrenheit's is often preferred because there are more subdivisions, and because it avoids the use of negative numbers. The application of the system to the division of time was so unworkable as scarcely to to erate even a trial. There, as elsewhere, the duodecimal mode, as compared with the decimal, is vastly and incontestably superior. For the decimal system in numerical notation, see NoT.A. TION, NuMERALs; and for the system of measurements based on the metre, see Mittre.

Decimation, a Roman military punishment, whereby when a considerable hody of troops committed some grave military offence, which would be punished with death in an individual, the punishment was awarded to one-tenth of them by lot, instead of to the whole number, that so the army might not be too much weakened. The practice was borrowed from the Romans by Essex at Dublin (1599), by the Austrinns at Leipaig (1642), and by the French at Trèves (1675); but Blicher tried vainly to employ it ayainst the mutinous Saxon battalions at Liègo (1815).

Decivs, a Roman emperor, whose name in full was C. Messius Quintus Trajanus Decius. He was born at Budalia, in Lower Pannonia, towards the close of the $2 d$ century, and was sent in 249 by the Emperor Philippus to reduce to subordination the rebellious army of Moesia. The soldiers proelaimed him emperor against his will, and foreed him to march upon Italy. Philippus encountered the forces of Decius near Vernna, lot was defented
and slain. Decius assumed the government of the empire in the end of the year 249 , but his brief reign was one of restless warring with the Goths, fighting againat whom he was killed near Abricium in the close of the year 251 . In his reign the Christians were persecuted with great severity. At Rome, Antioch, and Jerusalem the bishope were massacred, the great Origen was eruelly tortured, and dreadful eruelties were perpetruted at Alexanciria.

Deck, in ship structure, is a horizontal platform extending from one side of a vesel to the other, thereby connecting them together, and forming in addition a floorlng to the persons above it, and a 
covering to those below it. There are, as a rule, more than one deck in ships of medium size, and in steamers of the larger class-both war and mercantile vessels-there are usually three, four, and even five decks. Modern steamships of great length with three or four decks have, as a rule, two of the decks composed of iron or steel plating in addition to the usual cross deck-beams and longitudinal wood planking. All decks, especially the upper or 'weather' deck, have a slight ' cam. ber' or 'round-down' towards the sides of the ship, in order to dislodge water and contribute to their lateral strength. The several tiers of decks are supported one upon the other by solid iron pillars, and by the ship's transverse bulkheads.

Vessels are classed for various purposes, accord ing to the number of their decks, as 'single-decked, 'two-decked,' 'three-decked:' and are otherwise distinguished by terms. such as 'spar-decked,' 'flush-decked,' 'awning-decked,' according to the deck which is most typically eharacteristic. A spar deck is always the topmost or weather-deck, and stretclies flush or level from stem to stern. Below it there is the main deck, on which the heavy weights (e.g. guns in war-ships) are carried. Next comes the lower deck, and below it again, in very large ships, is the orlop deck. The space between the several tiers of decks is conventionally spoken of as 'tween or between decks. Above the main deck of two-decked, or the upper of threedecked vessels, there are frequently partial decks erected; the forecastle or top-gallant forecastle deck being at the fore end, the bridge or hurricane deck about the mid-length, and the poop or quarter deck at the aft end. An awning or shelter deck is defined by Lloyd's Register Rules as 'a light superstructure, fore and aft, on the main or upper deck proper of the vessel, intended to shelter passengers or cattle, or for the conveyance of cargo either light in its nature or limited in quantity.' Other particulars about decks, their construction, \&c., will be found in the articles SHIP. BUilding, Navy. For deck cargoes, see Plimsold.

Decken, KarL KLAUS von DER, an ill-fated African traveller, was born 8th August 1833, at Kotzen, in the Mark of Brandenburg, passed from the gymnasium of Lineburg, and the cadets' college at Hanover, into the Hanoverian army, which he left after ten years' service (1860) to follow his bent towards travel. On Barth's advice he went to Zanzibar, and started thence on a journey to Lake Nyassa, which failed through the tieachery of his Arab guide. Next year he started on a second and successful journey to the mountain-regions of Kilima-Njaro. In the following year, with $O$. Kersten, he climbed that mountain to the height of 13,780 feet. In 1863 he made an extensive voyage along the east coast of Africa, after which he returned to Europe to plan a great expedition for the exploration of East African rivers. This journey ended in disaster, and Decken was murdered by a Somali on the 25th September 1865. Only five Europeans and six negroes of his company managed to reach Zanzibar. See Kersten's Von der Decken's Reisen in Ostafrika (4 vols. 1869-79).

Decker, Sir MATTHEw, a political economist, was born at Amsterdam in 1679. He came to London in 1702, and having embarked in conmerce, attained the greatest success ; received a baronetey in 1716 , and subsequently sat in parliament. He died 18th March 1749. He published anonymously two pamphlets which were much discussed: one (in 1743) proposed to raise all the public supplies from a tax upon houses; the other, on the decline of Britain's foreign trade (1744), contained many goud arguments for free trade.
Decker, Thомas. See DEKkER.

Declaration, in Criminal Proceedings. In Scotland, the statement made by the prisone before the magistrate is called his declaration. It is the duty of the magistrate to take this declaration immediately on the prisoner's being brought to him-that is to say, if the prisoner is in his sober senses; but under the Criminal Procedure (Seotland) Act, 1887, the magistrate has power to postpone the examination to a time not later than forty-eight hours after arrest, in order to give opportunity for the legal adviser of the prisoner to appear. Before the examination the prisoner is entitled to have a private interview with his legal adviser, who may be present during the examination. The magistrate must previously inform the prisoner that it is entirely at his own option to declare or not, but that if he chooses to declare, the declaration may be used in evidence against him on his trial. In practice the examination is generally conducted by the procurator-fiscal. The declaration ought to contain the name, age, and designation of the prisoner, the parish and county in which the crime is said to have been committed, and all similar particulars. When completed it must be read over to the prisoner, who, if he is able to write, signs every page of it along with the magistrate. If he cannot or will not write, the magistrate signs it in his stead. There must, moreover, be two witnesses present, who shall sign the declaration, and who, if necessary, can speak to the manner in which it was taken. If the prisoner does not understand English, a sworn interpreter must be employed. The declaration cannot be produced as evidence if the magistrate has delegated the duty of taking it to his clerk, or to any one not a magistrate.

In the United States, when a person is arrested for a felony, the magistrate before whom he is brought takes the statement of the accused prior to the commitment if he desires to make one. The magistrate must act in person, and the prisoner must understand that he may or may not make the statement, and that it may be used against him upon his trial. If he cannot write, or refuses to write, the magistrate must not write his name for him; if he signs it he must first have the opportunity of reading it himself, but may waive his right to read it and ask the magistrate to read it to him. The magistrate may ask questions to bring out the facts. The mode of taking the statement or declaration is in general regulated by statute, and may form a part of the preliminary examination. If taken according to the prescribed forms of law, and as a spontaneous admission of guilt, it is termed a judicial confession upon which an indictment may be found.

Declaration, in Common Law, was the pleading in which the plaintiff in an action at law sets forth his case against the defendant. Since the Judicature Act of 1875, the Statement of Claim (q.v.) takes the place both of it and of the former Bill in Chancery (see BILL). In the United States the declaration still retains many of the features of the English eommon-law declaration, but this form is gradually falling into disuse in obedience to the modern tendency to simplify judicial proceedings. Many of the states having adopted one form of civil action, the courts of law have simplified the common-law declaration and adapted it to this form of action. The declaration substituted must be entitled of the court, term, and number, the venue laid, the names of the parties, and the facts necessary to show jurisdiction stated. This is followed by a concise statement in narrative form of the entire cause of action showing the right of plaintiff to recover. 
Declaration, in lieu of an oath. See A Fris. MATION, OATH. In the United States, the form of an oath is immaterial, provided it le anch as the witness believes is binding upon his conscience. It is essential that the oath, declaration, or aftirmation be administered in a manner preseribed by law. Mere technical variations do not affect the validity of an oath, and verlual deviations are immaterial. Perjury may be committed although the person was improperly sworn. No person will be permitted to make a declaration or aftirmation unless he has conscientious scruples against swear. ing or taking an oath. Declaration in lieu of an oath or affirmation is becoming very general throughout the United States.

Declaration. DYing. The rule that second. 'ary or hearsay evidence is inadmissible suffers an exception, both in England and Scotland, in the case of a declaration made by a person convinced of his impending death, and who does not survive the trial of the accused. In cases of murder, the dying declaration of the victim as to the circum. stances of the crime is always admitted as evidence on the trial of the prisoner, provided that it was deliberately emitted while the deceased was in possession of lis faculties, and that it is proved by eredible witnesses. In Seotland, the dying declaration of a witness is admissible even thongh he is not himself conscious of the danger of death, and in the United States a declaration is frequently admitted, both in civil and in criminal cases, as primary evidence, without regard to the immediate apprehensions of death. In the same country, declarations are also almitted as secondary evidence under circumstances in which the declar. ant is either actually or presumed to be dead. The principle under which the dying declaration is admitted is that the awful situation of the dying person is as powerful over his conscience as the obligation of au oath, and does away with all motive to disguise the truth. Accordingly the person against whom a dying declaration is put in evidence may be allowed to show that the deceased was not of such a character as to feel the religious obligation of his situation. A dying declaration may be adduced for as well as against a person accused of crime; and there are cases on record in which persons charged with murder have been success. fully exculpated by this kind of evidence.

Declaration of Rights. See HignTs.

Declar'ator, a form of action in Scotland. See Action.

Declension, a grammatical term applied by the ancient grammarians to the system of modi. fications ealled cases, which in many languages nouns, pronouns, and adjectives undergo to indicate the various relations in which they stand to other words. The word Case means 'falling:' Declension, a 'sloping down;' and were applied becruse that form of a noun used as the suljeet of a sen. tence was supposed to be represented by an upright line, and the other forms by lines falling or sloping off from this upright line at different angles. Hence a collection of the varions forms which a noun might assume formed the declension or sloping down of the noun. The English language has no proper declensions at all, having no cases but the genitive, and some traces of a dative, while it has no genders save in the pronouns of the third person. The Sanskrit language again had eight cases : Latin, six; and Greek, five. Groups of nouns forming their case-endings in the same way are called declensions. Thus Latin nouns are said to be divided into five declensions. The Latin cases are the Nominative, which names the subject or actor ; the Genitive, expressing the source whence something proceeds, or to which it belongs; the Dative, that to which monething is given, or for which it is done; the Accusative, the object towards which an action is directed; the Vocative, the permon addreseed or called; and the Ablative, that from which nomething is taken. The Greek has no Ablative cane, while the two additional cases of Sanukrit are an Instrumental case, and a Locative cave, In time case-endings become rubled off, and prepositions are used in their stead, thus French and Italian have lost all the Latin cases of nouns and adjec. tives. Languages of the agglutinating order have, in general, a great abundance of cases. Thus Finnish nouns have fifteen enses; and in Magyar as many as twenty cases may be reckoned. See Grammar and Philology.

Declination. If a great circle be drawn through the pole of the heavens and any star, the declination of the star is the portion of the circle intercepted between the star and the equator (see PoLK). The place of a point in the heavens i determined by its right ascension and declination, just as a point in the earth's surface is determined by its latitude and longitude.

Declination Needle, or Declinometer. The magnetic meridian pasking through any place on the earth's surface is a vertical plane whose direction is that in which a magnetic needle, free to move about a vertical axis, comes to rest under the influence of the earth's magnetic force. In general, the magnetic and geographical (or astronomical) meridians are not coincident; the angle between is termed the magnetic declination, or

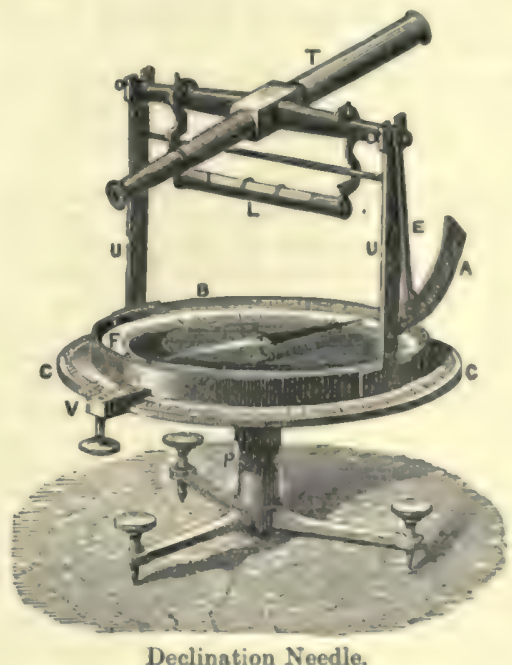

(in nantical phraseology) the variation. It is enot or west, secording as the magnetic is east or west of the geographical meridian. Any apparatus for the measurement of this angle is termed a declin. ometer, and consists essentially of a means of ascer. taining the two necessary elements-viz, the directions, at the place of observation, of the two meridians. The accompanying figure represents one such instrument, the declination needle or compass. I jon a tripol, provided with levelling screws, stands the piltar $P$, to which is fixed the graduated eircle CC. The compass-box B, with the attached vernier $\mathrm{V}$, moves on the aximuthal circle hy means of a pivot on the pillar P. Two upriglits, $\dot{U}, U$, sre fixed to the side of the compass.box, on the tops of which rests the axis of the telescope T. A gradusted are, A, is fixed to the hottom of one of the uprights, and the angle of elevation of the telescope is marked by the vernier on the arm E, 
attached to the axis of the telescope, on which is hung the level $\mathrm{L}$, for adjusting the instrument previous to making an observation. Inside the compass-box is another graduated circle F, the line joining the zero-points of which is parallel to the axis of the telescope. The compass-box and telescope thus move round together on an axis passing through the centre of the azimuthal circle. "When an observation is made, the instrument is first of all levelled, and the telescope directed to a star which is either on the astronomical meridian or whose position with respect to it is known. The reading of the inner circle then gives the declination at once, in the former case ; if the latter-i.e. if the star be not on the meridian, the reading of the inner circle has to be corrected by adding or subtracting, as the case may be, the position of the star in azimuth, in order to give the declination. In order to obviate error due to the noncoincidence of the magnetic and geometric axes of the needle, a second reading is taken with the face of the needle reversed; the mean of the two readings is taken as the true declination.

It is found, however, that this instrument only gives results approximately correct, and has in consequence been superseded in observatories and magnetic surveys by a form of the unifilar magnet. ometer. For an account of the determination of declination by this latter instrument, see MAGNETOMETER. Details as to the value and secular change of the declination at different places on the earth's surface will be found under MAGNETISM.

Decoction, the term applied in pharmacy to the solution procured by boiling an organic substance with water.

Decolorim'eter, an instrument for determin ing the power of portions of bone-black or animal charcoal to abstract colouring matter. See CHARCOAL.

Decomposition is the rather comprehensive term applied to the breaking up of complex substances, or substances of delicate stability, into others which are less complex or more stable. Such breaking up is very familiar in many chemical changes, and may result from increase of tempera. ture, the action of light, the action of ferments and micro-organisms, and so on. The ordinary process of alcoholic fermentation is a good example of decomposition, which takes place in the presence of, and is dependent upon, the life and growth of yeast in the saccharine solution. Similarly the oxidation of nitrogenous organic matters with formation of nitrates, if not dependent upon, is greatly accelerated by the presence of a microorganism.

The term decomposition is constantly applied in chemistry to the changes which compounds undergo in the most varied circumstances when subjected to change of conditions. See also CHEMistry, Fermentation, Putrefaction.

Decomposition of Forees. See CoMposITroN

Decorated Style of Gothic Architecture. This style prevailed in England during the reigns of the first three Edwards, or from towards the close of the 13th till near the end of the 14th century. Under Gothic ARchitecture it will be shown how the pointed style progressed, and was naturally and logically developed in all its elements, constructional as well as decorative, until skill in execution exceeded originality in design, after which the art gradually deteriorated. The Decorated or second pointed style occupies the position in which these two elements were in full $f$ sord and completest development. Hence this ise-variably considered the perfect period of Gothic Architecture.

In the Decorated style the simple forms of the early pointed became more complex. The simple roll is divided into two parts, the mouldings are more numerous and refined, and they are beauti. fully grouped and proportioned. The pillars con. sist similarly of clustered shafts or mouldings arranged commonly on a lozenge plan (fig. 1). The caps are usually carved in imitation of natural foliage, and partake of the character of wreaths growing round the caps, instead of springing froms the neck-moulding as in the preceding style (fig. 2 ). The buttresses are encircled with niches and

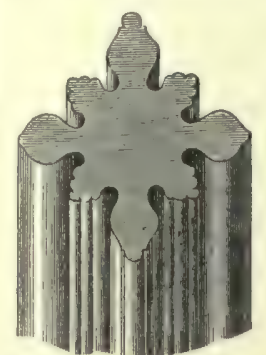

Fig. 1.-Column, Collegiate Church, Manchester, 14th century.

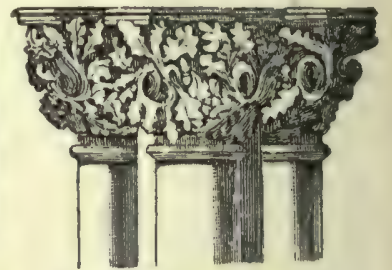

Fig. 2-Decorated Capital, York Cathedral. canopies, and the latter are more elaborately decorated than formerly. The drip-mouldings over doors, windows, niches, \&c. are crocketed and formed into an ogee curve at the top, and finished with a finial-in short, every detail is elaborated and richly decorated. But this development is most prominently marked in the tracery of the windows. In the first pointed style this feature is of the simplest character; but in the Decorated

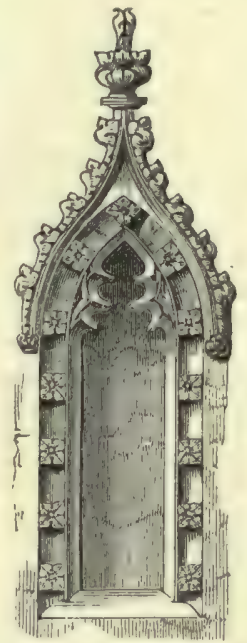

Fig. 3,-Niche, Walpole St Androws, Norfolk, 14th century.

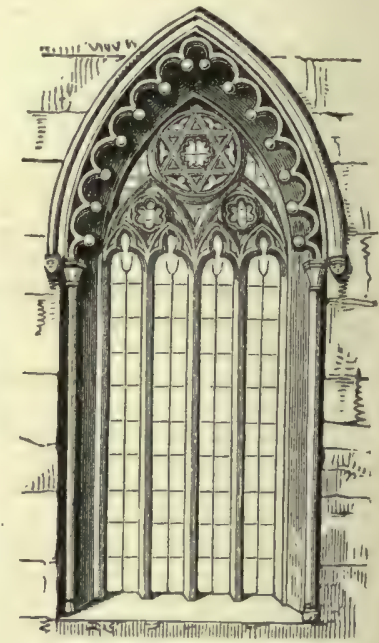

Fig. 4.-Window, Broughton, Oxfordshire, 1300 . it becomes fully developed, and forms the most prominent characteristic of the style. At first the tracery consists of geometric figures, such as circles, trefoils, \&c. ; but in the later examples it develops into flowing lines, which in France passed into the 'Flamboyant' (q.v.). This development of the tracery led to the enlargement of the windows, in order to afford space for its exhibition. Large circular windows, filled with tracery, were also introduced (see Window). The early 
ornaments became refined, as, for instance, the dog. inoth was enriched into is four-leaved flower, and the ball-flower is also of frequent use. Segmental arches and square lintels are occasionally employed. In the beginuing of the 15th century the Decorated gralually passed into the P'erpendicular atyle.

Decoration Day, or Memorial Day, in the United States, is a day set apart, on which day the graves of soldiers are visited, and decorated with Howers by surviving comrades and friends.

Decorations. See Orders, MEdA.

Decort, Frans, a Flemish lyrieal poet, born at Antwerp, 21st June 18:34. At first he was engaged in trale, later he edited newspapers, was secretary to a steamiship company, and becmme in 1861 - ecretary to the general anditor in the Cour Militaire at Brussels, where he died, 18th January 1878. Decort's poetry deals mainly with the simple joys and sorrows of the family hearth, but it does not lack passion and power. For some years he issued at Antwerp a very popular alma nac, Jan en Alleman. Various collections of his poems were Liederen (2 vols. 1857-59), Zingzang (1866), and Liederen (1868). In 1862 he published a fine Flemish translation of some of Burns's songs.

Decoy. See WILD-FowL.

Decoying of Children. See Abduction, KIDNAPPING.

Decree, or, as it is frequently called in Scotland, a Decreet, is a final judyment of a court, whereby the question at issue is set at rest. In England, it used to be commonly applied to the final judgments of courts of equity. For a decree nisi, see Divorce. Decree in absence, in Scotland, is equivalent to a judgment by default in a commonlaw court.

In the United States, a decree is the order or judgment of a court of equity, admiralty, or a common-law court with equity powers. It may be either final or interlocutory, and is conclusive if all parties in interest have been served with proper notice. It cannot he set aside by an act of congress or the state legislature. By the United States Constitution, the decrees of a competent court having full jurisdiction in one state are equally binding in every other state, and must be received in evidence in all the courts of the United States.

\section{Decree, in Theology. See Predestination.}

Decrepitation is the term applied to the crackling sound heard when a substance like common salt is thrown upon a fire. A series of minute explosions occur, owing to the water between the plates of the erystalline particles becoming expanded by the heat, and ultimately bursting them.

Decrescent, a heraldic term by which the wane of the moon is indicated. A moon decrescent is a half moon with her horns turned to the (heraldic) sinister-i.e. the right of the speetator.

becretals, collections of the Canon Law (q.v.)

Dedication. See Book, PATroN.

Deduction, in Logic, as opposed to Induction $\left(q . v_{0}\right)$, is the method of reasoning from generals to particulars, as the latter is from particulars to generals. Induction is the mode by which all the materials of knowlerlge are brought to the mind and analysed; Deduction, the process by which the knowlerlge thus acquired is utilised, and by which new and more complicated induetions are rendered possible. Thus every step in a deduction is also an induction. See INDUCTION, LoaIc.

Dee, a Welsh and English river, insuing from Bala Lake, in Merionethshire, and flowing NE.,
N., and NW. to the Irish See Near Trevor it is erosed by the Ellesmere Canal, on an aqueduct 1007 feet long and 120 high; and also by the stone vialuet of the Chenter and Shrewsbury Rail. way, of 19 arches, each 90 feet span and 150 high. Below Trevor it winds first south-east, and then north-east and north to Chester, which eity it nearly encircles, At Chester (q.v.) it is 100 yands broul, and thence runs alongmide unarsloes in an artificial tidal canal 7 miles long, which should admit shipe of 600 tonk, but which in the autumn of 1888 was reported to be rapidly silting np. Near Connah's Quay, between ('Tester and Flint, where its width is 160 yards, it is eroesed loy the great railway swing-bridge, whose finst eylinder was laid by Mr Gladstone on 16th August 1887 . The Dee ends in the Irish Sea, in a tidal estuary 13 miles long and 3 to 6 brosd, and forming at high. water a noble arm of the sea; but at low-water a dreary wate of sand and ooze (Kingsley's 'aands of Dee), with the river flowing through it in a narrow stream. Its whole course is $\mathbf{9 0}$ miles long, and its chief tributaries are the Treveryn, Alwen, Ceirog, Clyweddog, and Alyn. Canals conneet the Dee with the rivers of central England. The ancient Britons held its waters sacred; Milton speaks of its 'wizard stream,' and Spenser of the

Dee, which Britons long ygone

Did call divine, that doth by Chester tend.

Dee, a beautiful river of Aberdeen and Kincardine shires, rising at an altitude of 4060 feet among the Cairngorm Mountains, and running 87 miles eastward, till it enters the German Ocean at Aber. deen, where in 1870-72 a mile of its channel was diverted for harbour improvements. It makes a descent of 2084 feet during the finst 29 miles of its course; at the Linn of Dee, 18 miles lower down, tumbles through a chasm 300 yards long, and at one point scarcely 4 feet wide; thereafter flows by Castleton of Braemar, Balmoral Castle, and Bal. later; since 1864 has supplied A bendeen with water and is still a good salmon river, though not what it once was, - The Kirkcudbrightshire Dee issues. from Loch Dee ( 750 feet above sea-level), and flows 38 miles south-eastwand and southward, past Threave Castle and Kirkendbright, to Kirkeudbright Bay. Midway it is joined by the Water of Ken, 28 miles long, a stream of greater volume than its own. It, too, affords fine fishing.

Dee, Dr JoHN, alchemist, was born in London, $13 \mathrm{th}$ July 1527, and educated there and at Chelmsford, till in 1542 he was sent to St John's College, Cambrilge, where for three vears lve stuilied eighteen hours a day. One of the original fellows of Trinity (1546), he earned the reputation of a soncerer by his mechanical beetle in a reprenentation of Aristophanes' Peace, and next year he fetched from the Low Countries sundry astronomical instruments. This was the first of many foreign viaitsto Louvain and Paris (1548-51), where he lectured on Euclid, to Venice and Presburg in Hungary (1563), to Lorraine (1571), to Frankfort-on-Oder (1578), to Bohemia (1583-89), and even, it is said. to St Helena. He was imprisoned under Queen Mary on suspicion of compassing her denth by magie (1555); but Edwand VI. had conferred two chureh livings on hin, and Elizabeth howed him considerable favour, twice visiting him at his Mort lake home, and in 1595 making him warden of Manchester College. He was constantly in difficulties, though he claimed to have fonind in the ruins of Glastonbury a quantity of the Elixir, one grain of which transmuted into gold a piece of a warming pan. Indeed, he appears to have lreen as much dupe as deceiver, the dupe of his own resistant, Edward Kelly, during 1582-89. This knave, who had lost Doth ears in the pillory, professed to 
confer with angels by means of Dee's magic crystal (see CrYstallomancy), and talked him into consenting to a community of wives. In 1604 Dee petitioned James I. to let him clear himself by public trial of the slander that he was a "caller of divels,' but half a year later he was back at his invocations. He died wretchedly poor, in December 1608, and was buried in Mortlake church.' 'A mighty good man he was,' by Aubrey's showing, 'a great peace-maker, a very handsome man, with fair, clear, sanguine complexion, and a long beard as white as milke.' His eldest 'son, Arthur (15791651), was likewise an alchemist, a friend of Sir Thomas Browne. Of Dr Dee's seventy-nine works, only thirteen have ever been printed : the rest are in MS. at Oxford, Cambridge, and the British Museum. They deal with logic, mathematics, astrology, alchemy, navigation, geography, the 'Rosie Crucian Secrets,' and the reformation of the calendar (1583), in which at least he was much in advance of his countrymen. See his Private Diary, edited by J. O. Halliwell (Halliwell-Phillipps) for the Camilen Society (1842), and a thirteen-page article in Cooper's Atheno Cantabrigienses (vol. ii. 1861 ).

Deed, Execution of, the performance of the ceremonies required by law in order to make a deed binding and effectual. These ceremonies in England consist in signing, sealing, and delivering. Signing is usual in practice, but it is open to doubt whether it is strictly necessary in law. When a party, from any cause, is unable to write, it is usual for him to place his mark in the place of signature. But a mark is unnecessary, and signature by another, at request of the party, is enough. Sealing is the most ancient form of authentication of deeds, and comes from the Norman usage. A seal is absolutely essential to the validity of an English deer, but any species of seal is sufficient, and in practice a common wafer is usually affixed. Delivery is the third requisite. Delivery may be made either to the grantee or to another person for him. In the former case, the deed becomes absolute; in the latter, it is called an Escrow, and does not yet acquire its full effect. Witnesses are not absolutely required to a deed in England, but in practice it is usual that one witness should attest. Before execution, a deed must be read, if required, by a party to it; and if not read, it is void as to the party requesting. A will (except that of a soldier or sailor in active service) must be in writing, and signed by the testator or by some other person in his presence and by his direction; and two witnesses must attest the signature.

In Scotland, sealing was once essential, but has long fallen into disuse. A deed is now probative on the face of it (i.e. is received as the authentic act of its grantor) if it is signed by the grantor on each sheet, and attested by two witnesses who are either designated in the deed itself, or in a designation added to their subscriptions before the deed is recorded or founded on in court. In case the maker of the deed cannot write, the deed is validly executed by one notary public or justice of the peace signing it for him in his presence and by his authority, and reading it over to him, all in the presence of two witnesses. A parish minister may act in his own parish as notery for signing a will. Holograph deeds - i.e. deeds written throughout in the handwriting of the grantor, are exempted from the rules as to execution; as also, out of favour to trade, are mercantile writings, such as Bills of Exchange.

In the United States, the formalities required for the transfer of real estate are governed by local laws. Generally throughout the states, signing, sealing, attestation, acknowledgment, and delivery are the essential requisites of a valid deed of con. veyance. The usual form of attestation being 'signed, sealed, acknowledged, and delivered in the presence of us witnesses,' then follow the names of the subscribing witnesses. The grantor must himself sign the deed, or if it is signed by his agent he must adopt the signature as his own in the presence of the subscribing witnesses and the commissioner or other qualified officer. In the United States, a 'deed,' technieally speaking, is an instmument under seal ; hence a seal, although a mere formality, is essential, except in those states in which seals have been abolished by statute-Alabama, Louisiana, Texas, Virginia, Kentucky, Kansas, and Iowa. Neither wax nor wafer is necessary for a seal, although a wafer is generally used. A scroll with a pen inclosing the letters 'L.S.' is a seal within the meaning of the law, if it is the intention of the party appending it to adopt it as his seal, and by its use a specialty is ereated, the same as by the use of wax or wafer. It is not necessary to refer to the fact of sealing in the attestation clause. The number of witnesses required is governed by statutes in most of the states. Generally two are required, but in some of the states only one witness is necessary if the grantor can read; and it is believed that in any state a deed otherwise properly executed with but one subseribing witness would be good as between the parties themselves. It has also been held that independent of any statute, a deed signed, sealed, and delivered, without being acknowledged or recorded, is valid as between the parties and their privies, but the provisions of a local statute as to the execution of a deed inust be strictly followed, or the deed is inoperative. Delivery, although essential to the execution of a deed, need not be formally made in the presence of witnesses, but may be a matter of circumstance. A deed takes effect from the date of actual de livery, or the date of record. Everywhere in the United States it is the law that deeds of convey. ance must be recorded either in the proper office of the county in which the land lies-or if the convey. ance be by grant or letters patent from the state or United States, the record must be made in the land office of the state or United States. The recording of $a$ deed has the force of seisin and possession under the English law. Any estate leas than a fee may be conveyed by deed with single acknow. ledgment, but if the estate sought to be conveyed is a fee, the husband and wife must join in the deed and acknowledge it separately. Deeds of conveyance of lands sold at judicial sale, or for taxes for several successive years and unredeemed made by the sheriff of the county, and deeds made in pursuance of a decree of court by the officer appointed for that purpose, are as effectual as if made by the grantor and his heirs, and must be executed with the same formalities and recorded within fifteen days; neither is it necessary to set forth in the deed as a part of the title the proceedings which culminate in the decree of sale. Federal decisions as to the formalities necessary to the execution of a deed are apparently conflicting. This arises from the application of the principle that land or property must be governed by the law of the place in which it is situated, and the lack of uniformity of state laws upon this subject. The United States laws are applicable only to lands belonging to the United States and those located within the territories. See also CoN. veyancing, Contract, Charter, Title-deeds, WiLl, Erasure, Registration, de.

Deemster is the title of the two chief judges in the Isle of Man (q.v.). In Scotland, Dempster or Doomster was the name of an officer formerly attached to the High Court of Justiciary in Scot. land, who pronounced the dnom or sentence on 
condemned persons. The office was held nlong with that of executioner. See Scott's notes to Old Murtality and Heart of Midlothian.

Deep-sen Exploration. See Challenger Expedition, SFA, and SoUndiva.

Deer (C'ervila), a large family in the ruminant section of even-toed Ungulates. Though doubtleas of common ancestry, the antlered ruminant. or deor are definitely, though not very readily, reparated from the other great family of hornerl ruminants or cattle. The common characters of Cervidie and Hovidas will be noted under the title RUMrNaNTs (q.v.); only the chief peculiarities of the Cervides need here be noticed.

General Characters. - If appendages are present on the head, they are true bony outgrowths, famil. iarly known as antlers. Except in one genus, they are confined to the males. There are two open ings to the duct of the lachrymal gland, situnted on or inside the orbit. A large envity in front of the orbit euts off the lachrymal bone from articula. tion with the nasals. The first molar tooth is shortcrowned. There are usually upper canine teeth in both sexes, and these are often large in the males. In addition to the functional third and fourth digits, the second and fifth are very generally represented. The placenta has few cotyledons or villous patches. Except in Australia and Africa, the Cervidae are distributed over the globe, usually living in pains or herds in wooded and grassy regions, and feeding upon herbage. About 100 living and extinct species are known.

Genera.-Dr J. E. Gray classified the Cervida into two groups, according to the position of a hairtuft on the lower part of the hind-leg. Professor Farrod has divided them according to features in the skull ; Sir V. Brooke has classified them according to the state of the limbs. In their general outlines the three classifications agree; that of Brooke is here followed.

A. Upper ends of the second and fifth metacarpals remain-Plesiometacarpi- - $-g$. Cervus. B. Lower ends of the metacarpals remain-Telemetacarpi; within which the three genera Alces, Hydropotes, and Capreolus are separated by other characters from a more definite section, including Cariacus, Pudua, and Rangifer.

Important Forms. - As many of the important deer will be separately discissed under their common names, a list of the distinctive types is all that is here necessary. A. Cervulus muntjoc, from British India and the Malayan region, with large canines in the males (see MUNTJAK): Elaphodus, with very small unbranched antlers; Rusa, a subgenus of Cervus, from the Indien region, including some of the largest and smallest species-e.g. $C$. aristotelis, C. equinus; Rucervus, another Indian sub-genus, with forms of small stature-0.g. C. schomburgki; Elaphurus, Axis (q.v.), Pseudaxis, other sub-geners of Cervus ; the genus Cervus, in the restricted sense, large deer in Palwarctic and Nearctic regions, including the Red Deer $\left(q, v_{0}\right)$, or Crrvus elaphus, in Britain, Continental Europe, Algeria, Asia Minor, and the Cancasus, and $C$. canadensis, in North Americn; Dame, another sub-genus, including forms of medium size, from south-western Palnearctic regions-e.g. the Fallowdeer (q.v.), semi-domesticated in European parks. B. (1) The northern genus Alces, including the Elk (q.v.), of large size, with great antlers; the Water-deer (q.v.), or Hydropotes, without antlers in either sex; the genus Capreolus, inclading the small Roe-deer (q.v.) (Capreolus coproa), in Britain, Europe, North Palestine, Sc. (2) The genus Cariacus, in its strict usage, including the Virginian Deer of the United States (C. virgini. anus) and the Mexican Deer (C. Mexicanus); the sub-gener of Carincus - Blastocerns, Fureifer, Conssus, from South America: Pulus, from the Chilian Andes; and the Reindeer (q.v.), or Ram. gifer, with antlers in both sexes.

Antlers.-Antlers are usually present in the male deer, though alsent in both aexes in Hydropotes, and present in both in the reindeer. Their nature as true bony outyrowths, their early covering with sensitive vascular skin or velvet, the drying of this to leave the horn a hard and insensitive weapon, the basal constriction and detachment, and the regrowth in the following year, have leeen already referred to in the article Axthens $(q, v$,$) . The$ different parts receive technical names, but it is only necessary to note the permanent "pedicle " or stalk from which the regrowth starts, the main stem or 'beam,' the branches, 'tines, or 'snags,' and the not infrequent flattened or 'palmate' form. Antlers are of special importance as weapons used by the males in fighting for the possession of the females, and have doubtless been perfected by Sexual Selec. tion (q.v.). They are also of interest in the parallel they ilustrate between the life-history of the individual and the evolution of the race. The figure given of antlers at successive years in a stag's life

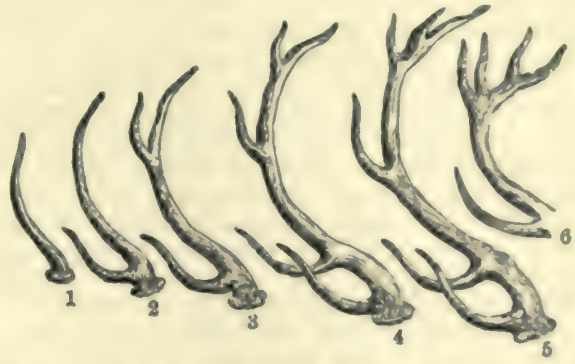

will also suit for the evolution of antlers in sncces. sive historic periods. Young deer develop in the first year small simple antlers, and the branches are added on the annual regrowths. So the errliest (Lower Miocene) deer had no antlens, the Mfildle Miocene species had simple, at most two-branche processes, as in the second year of life, while in the Upper Miocene three branches occur; and in Pliocene and Pleistocene the modern luxuriance gradually appeais. Sir V. Brooke gives full details (1) of the gradual evolution of antlers from very simple to complex forms, tracing the history from the earliest Dremotherium onwands : (2) of their constant tendency to vary, as is well known in the semi-domesticated species; (3) of "variation extending far enough to induce the partial atrophy of one part of the antler to compenate for the extra development of some other part; '(4) of the transmission and establishing of such variations by heredity. A great part of the theory of evolution can be beautifully read from antlers alone.

The fleab, skin, and antlers of deer are valuable, bat deer injure crops, eat the leaves, twigs, and bark of trees, and clamage forest trees ly rubbing their antlers against the trunks and branchea.

See articles on the various kindis of Deer (REU DEEB.

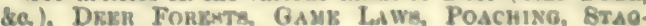
HOexD; Sir V. Brooke in Proe. Zool. Soc. (1878); J. G. Millais, British Deer and their Horne (1897).

Deer, Ord, a village of Buchan, Aberdeenshire, 38 miles $\mathbf{N}$. of Aberdeen. Here, abont 580 A.D., St Columba $\left(q . v_{0}\right)$ and Drostan, his neplew, established a monastery, which William Comva, Earl of Buchan, refounded sbout 1219 for Cistercian monks. Little remains of the monartic bnildinge; but in $\mathbf{1 7 1 5}$ a Latin MS., a small octavo of 88 pages, which had belonged to the monks of Ieer, found its way to the Cambridgo University Library, 
though not until 1860 was the attention of scholars direeted to its great importance by Mr Bradshaw, the librarian. It contains St John's and parts of the other three gospels (in mainly the Vulgate version of St Jerome), the Apostles' Creed, and a fragment of an office for the visitation of the sick, with a Gaelic rubric. On the blank leaves of the MS., in the handwriting of the early part' of the 12th century, are several Gaelic entries relating to the endowments of the Columban monastery. These notes are of the highest interest as the oldest specimens of Scottish Grelic, and only less interesting is the Gaelic ornamentation enriching the MS. See Dr John Stuart's edition of the Book of Deer (Spalding Club, 1869), and Dr Joseph Anderson's Scotland in Early Christian Times (1881).

Deer-forests, tracts of country devoted to the red deer or fallow deer, either for sporting or for breeding purposes. The requisites of a Scotch deer-forest are a great extent of quiet ground, high mountain tops and corries, plenty of moorland and pasture. There is now little wood in Scotch deer-forests, and almost all other game, and cattle and sheep, must be excluded. Onetenth of the heather in a deer-forest should be burned every year, the heather living ten or twelve years; and in each forest a sanctuary should be provided. The forest of Mar is 80,000 acres in extent; Blackmount, 70,300 ; Reay, 64,600 ; then come fourteen of from 51,000 to 30,000 ; whilst the rest are smaller, some as low as 10,000 acres. The requisites of an English deer-park, on the other hand, are wood, lawn, with sufticient underwood, rough grass and bracken, in an inclosed and undulating country of rich soil. In Scotland, deer-stalking has largely increased during the 19 th century. In 1812 there were only five forests; in 1888 there were 111. In England, since 1750 , when fox-hunting superseded deer-hunting, deer are kept chiefly for breeding and ornament, being sometimes fed in stalls. There are, however, several packs of staghounds which hunt the red deer -e.g. in the high ground of Somerset and Devon. Before the civil war there were 700 parks in England; now only 300 , of which only 30 have red deer. Among the great Scotch forests may be noted : in Aberdeenshire, Ballochbuie, Mar, Glen Tanner, Glen Muick; in Inverness-shire, Abernethy and Glenmore, Rothiemurchus, Ben Alder, Gaick and Ruthven, Glen Feshie, Glen Strath Farrar, Guisachan, Invermarkie; in Argyllshire, Blackmount; in Perthshire, Athole, Fealar, Glen Bruar, Glen Artney, Rannoch; in Ross-shire, Dundonnell, Strathconan, Torridon, Kintail, Applecross, Wyvis, Diebidale, Kinlochewe, Morsgail, Kildermorie, Glen Carron, Park ; in Sutherlandshire, Dunrobin, Glendhu, Loch Inver, Reay. The deer-forests of Scotland occupy a space of nearly $2,000,000$ acres. They are occupied chiefly by English noblemen and others, not the owners. The best-known English parks are Eridge in Sussex, Talton in Worcestershire, Northwich in Cheshire, Duncombe in Yorkshire, Eastwell in Kent, Donington in Leicester, and the royal park of Windsor. Originally, in both England and Scotland, the king's nobles and the church held special forest jurisdictions of the most oppressive kind. Thus, in Scotland, the forester might forfeit cattle and other goods found within the forest. In England, the Norman law. yers pretended that all game belonged to the king. King John had 18 forests, 13 chases, 781 parks. A chase was an open forest, not subject to special forest law; a park was an inclosed chase on the land of the owner; a purlieu was an addition made to an old forest. The Charta de Foresta disafforested large tracts of land, and prevented the arbitrary creation of forests. In Scotland, the
Stewarts passed many statutes for the protecticn of deer, and so late as 1680, in the case of Faskally, the Court of Session recommended the king not to grant new forests, as hurtful to the lieges. In 1850 the Duke of Athole claimed a right to enter on the neighbouring estates to recover deer, but this was not permitted. It is the opinion of many that deer-forests have displaced crofters and sheep in the Scotch Highlands. This was denied by a Select Committee of the House of Commons, who reported on the Game Laws in 1872. An act on the valuation of deer-forests for purposes of assessment was passed in 1887 : there was a government report showing the area and rents of the Scottish deer-forests in 1891-92.

See Shirley, Forest Lans; books on the English deer-parks by Shirley (1867) and Whittaker (1892); Macdonald's Cattle, Sheep, and Deer (1872); Macrae's Hundbook of Deer-stalking (Edin. 1880); the Report of the Crofters Commission (1884); Johnston's large map of Scottish deer-forests (1888); and Grimble's DeerForests of Scotland (1896).

Deer Mouse (Hesperomys), often called Vesper Mouse, a genus of American rodents representing in the New World the Old-World mice, from which they differ only in trivial charaeters. The whitefooted or deer mouse $(H$. leucopus $)$ is found over the greater part of North Amierica in several varieties. It is an animal about 3 inches in length, of a very variable but frequently fawn colour; sometimes arboreal, sometimes burrowing ; feeding chiefly on corn and nuts, which it stores for winter. See Mouse.

Deer-stealing. See Game-Laws, PoAching.

Deés, a town of Transylvania, on the Szamos, 37 miles NNE. of Klausenburg by rail. Pop. 6191.

\section{Defamation. See LIBEL.}

Default. A party to an action is in default when he fails to comply with the rules of procedure. If the defendant, for example, fails to appear to the writ, the plaintiff may have judgment against him; if the plaintiff fails to deliver a statement of claim, the defendant may apply to have the action dismissed. Judgment by default may be set aside, on such terms as to costs, \&c. as the court thinks just. In Scotland, a decree by default may be recalled by reclaiming note, but after the time for reclaiming has expired, an action of reduction must be brought to set it aside.

Defeasance, DeED $O F$, in English law, an instrument which defeats the force or operation of some other deed or estate; and that which in the same deed is called a condition, in a separate deed is called a defeasance.

Defender of the Faith, a title conferred in 1521 on Henry VIII. by Pope Leo $X$. as a reward for writing his Assertio septem Sacramentorum, in answer to Luther. The title was afterwards confirmed by parliament ( 35 Henry VIII. chap. 3), and has ever since been used by the sovereigns of this country. The corresponding title in Spain is 'Most Catholic,' and in France was 'Most Christian King.'

Defenders, a Catholic association in Ireland (1784-98), the opponents of the Peep o' Day Boys.

Defiand, Marie DE Vichy-Chamrond, MarQUISE DU, one of the most brilliant letter-writers of the 18th century, was a member of a noble Bur. gundian house, and was born in 1697. She was educated in a convent in Paris, and as a girl became famous for her wit, audacity, and beauty. In 1718 she married the Marquis du Deffand, from whom she shortly afterwards separated. She led a life of gallantry for a number of years, and became a conspicuous figure in the literary society of Paris, her salon in the Rue Saint Dominique being a favourite resort of the philosophes. She was a correspondent 
of Voltaire, Montesquien, D'Alembert, nnd other great men of letters of her day. In 1753 she be. came blind, and in the following year she inviterl Mulemoinelle do I'Fspinasse to live with her and help her to preside over her salon. The arrangement lasted for ten years, when a quarrel broke out through Madame dn Deffand's jealousy, and Mademoiselle de l'Espinasse departed, taking away with her D'Alembert and others of the elder laly's former admirens. Fron 1766 Madame du Deflaud carried on an interesting correspondence with Horace Walpole, who held her in the highest estimation, and pressed the use of his purse on her when she fell into peonniary troubles. "To say nothing of her extraordinary parts,' Walpole wrote, 'ghe is certainly the most generous friendly being upon earth.' As a matter of fact, however, she was as selfish and spiteful as she was witty and shrewd. She died at Paris, September 24, 1780. See Correspondunce de Madame du Deffand (new ed. 5 vols. 1865-67); her Letters to Horace Walpole and Voltaire (4 vols. Lond. 1810); and Asse, Mille. de Lespinasse et la Marquise du Deffand (1877).

Defilading, in Fortification (q.v.), consists in determining the direction and height of the rampart, so that the interior of the work may not be commanded by the fire of the enemy. To prevent the lines being enfiladed, their prolongations must avoid all places where hostile batteries could be posted, and the parapets must be of sufficient height to protect the interior from frontal fire.

Definite Proportions, Laws of, in Chem. istry, 'See ATOMIC THEORY.

Definition, the process by which we determine the common qualities of the objects belonging to any given class, so as to distinguish effectively that class from other elasses. Regarding the class as a species, we give the proximate genus and the dif. ference; genus here denoting the distinctive quali. ties belonging to all of the genus, while the difference marks ont the part of the genus in question. A good definition should state the essential attributes of the species defined, without containing the name itself, and should be exactly equal in denotation with it.

Deflagration is the term applied to the rapid combustion of ignited charcoal when a nitrate ( such as nitrate of potash) or a chlorate (such as chlorate of potash) is thrown thereon. As chlorates do not oceur naturally, it follows that deflagration with a natural salt indicates a nitrate; and if the defla. gration be accompanied by a violet flame, it is characteristic of nitrate of potash (ordinary nitre or saltpetre); and if by a strong yellow flame, it is indicative of nitrate of soda (cubical nitre).

Deflection, in Navigation, the departure of a ghip from her true course; in Optics, a deviation of the rays of light toward the surface of an opaque body.

Defiuxion (Lat. defuxio), a discharge from a nucous membrane, especially of the air-passages, as in catarrh.

Defoe, DANIsL, immortal as the author of Robinson Crusoe, was born most likely in 1661, in the parish of St Giles, Cripplegate, London. His family belonged originally to Northamptonshire, and his father, James Foe, became a butcher in St Giles's, and was living so late as 1705. It was Daniel who first changed his name to De Foe, or Defoe, abont 1703, for unknown reasons. He had a good education at a dissenting academy, but soon aliandoned his early idea of beeoming a dissenting minister, and engaged in business, apparently as a hose-factor, about the year 1685. Little is known of his early life, but it seems he was out with Mon- mouth, and it is certain that he volunteered into King William's army in 1688, travelled both in France and Spain, and became bankrupt about 1692 ; his debts, or at least great part of them, he paid up later with a serupulousnews mowt honour. able to him. He next became accuuntant to the glass-duty commissioners, and necretury tos a Til. bury pantile factory. His Essay upon Projects appeared about 1698, and towarils the clome of William III.'s reign he becrme noted as an sble and busy pamphleteer in support of the king's policy. His vigorous poem, The True-born Englishmun, a Satyr (1701), was an attempt to ajologine for the king's being a Dutchman by proving the English themselves to be a most composite race. His restless pen was active throughout the bitter struggle under Anne between the High-Church party and the dissenters, and his famous treatise, The Shortest W cuy with the Dissenters (1703), nule him a martyr in the cause. Ostensibly written by a 'high-flyer,' it advocated the extirpation of dissenters with a masterly irony (pace Mr Saintebury), which at first deceived and then infuriated his opponents, as, in his own words in The Present State of Parties (1712), it ' cut the throat of the whale party.' The House of Commons ordered the book to be burned, and a reward of $\$ 50$ was offered for his apprehension, from which fortunately we have an exact descrip. tion of his appearance as 'a middle-sized, spare man, about forty years old, of a brown complexion, and dark brown-coloured hair, but wears a wig; hooked nose, a sharp chin, gray eyes, and a large mole near his mouth.' Tried at the Old Bailey in July, he was sentenced to pay a fine of 200 marks, to stand thrice in the pillory, and to be imprisoned during the queen's pleasure. Accordingly, the 'unaloashed Defoe' stood in the pillory the last three days of July 1703, in the midst of a sym. pathetic mob that protected him from insult, and even drank his health. On the same day he suffered appeared his masculine Hymn to the Pillory, which concluded with a noble defiance to the government, expressed in some of his finest lines. During his imprisonment in Newgate he continued an incessant literary activity upon 'occasional conformity' and other points at issue in the great controversy, published a 'true collection' of his writings, and started his Reviev (19th February 1704 -11th June 1713), at first a weekly, after eight numbers a bi-weekly, and after the eighth num. ber of the second volume a tri-weekly newspaper, "purged from the errors and partiality of news. papers and petty statesmen of all sides.' This was Defoe's largest, if not his most impurtant work, and indeed forms one of the greatest monuments of literary industry ever reared by a single hand, embracing as it does in more than five thousand printed pages esays on almost every lranch of human knowledge, and these written during but nine years, in which also, according to Mr Lee, he published no fewer than eighty distinet works, themselves containing as many as 4727 pagea. Itw 'Scandal Club,' which discussed minor matters of manners, was distinctly the forerunner of the more famous Tatlers and Spectotors.

In Angust 1704 Defoe was released from prison at the instigation of Harley, who, moreover, procured for him pecuniary relief and enploy. ment, thus earning for himself the journalist's unceasing gratitude. After a short stay at Bury St Edmunds, he returned to London, niaintaining at both places his activity in his Review, end in such admirable pamphlets as Giving Alves no Charity, and Employing the Poor a Griec. ance to the Nation, a masterly denunciation of indiscriminate charity and national workshops-a kind of socialistic scheme propounded by Sir Hum. phrey Mackworth. Next year (1705) appeared The 
Consolidator; or Memoirs of Sundry Transactions from the World in the Moon, a political satire, which some have supposed may have supplied a hint for Gulliver's Travels; and the year after (5th July 1706) his masterpiece of verisimilitude and plausibility, The True Relation of the Apparition of one Mrs Veal. Mr Lee, in his life of Defoe (vol. i. pp. 127-8), disproves the old story that this fiction was a mere tour de force, written to sell an unsaleable book, Drelincourt on the Fear of Death, by showing that Drelincourt's book was already popular, being then rapidly running through its third English edition, while Defoe's pamphlet was only attached to its fourth edition by the author's consent. His next work was his Jure Divino, a tedious political satire, in twelve books of poor verse. About the close of 1705 Defoe was sent by Harley on a secret mission to the West of England, and in October of the next year we find him sent to Scotland by Godolphin, to whom Harley had recommended him as a secret agent to promote the Union, and here he lived for sixteen months. His History of the Union appeared in 1709, and in the same year Sacheverell's famous sermon gave him the opportunity of a fling at an old enemy. At the beginning of 1708 Harley's fall had made his political position somewhat precarious, but he found himself able to be a staunch Whig under Godolphin's government, until the fall of the Whigs after the error of Sacheverell's impeachment, and the return to power of his old benefactor Harley (1710), left him under the necessity of arguing that Englishmen should support the country even under a Tory ministry. In the pages of his Review he did his best to preserve the semblance of consistency, but not all his cleverness could save him from the contemporary reproach of being a time-server and a renegade. It is itself significant that his journalism was always anonymous from his second employment by Harley. He played a difficult and dubious part in the strange intrigues that preceded the accession of the House of Hanover, with the result that at length he found himself in a general discredit, which his apology, entitled An Appeal to Honour and Justice (1715), did not remove. Isetters of his found in the State Paper Office in 1864, and printed in Mr Lee's introduction, revealed the fact that in 1718 he was in somewhat equivocal government service, subediting Jacobite and High Church organs, as the Mercurius Politicus, Dormer's News-Letter, and Mist's Journal, in such a dexterous way that 'the sting should be entirely taken out, although it was granted that the style should continue Tory' (second letter). Further, in the same letter he describes his purpose more fully, that these papers 'will be always kept (mistakes excepted) to pass as Tory Papers, and yet be disabled and enervated, so as to do no $\mathrm{Mis}$ chief, or give any Offence to the Government.' He describes himself further as 'for this Service, posted among Papists, Jacobites, and enraged High Tories-a generation who, I profess, my very Soul Abhors. . . . Thus I bow in the House of Rimmon.' Defoe was not exactly serupulous in his point of honour, but it is certain he never was a Tory, and it would not be difficult for him to construet an argument by which he could persuade himself that by this dangerous and ambiguous means he was doing good service to the cause of liberty and religion.

Although Mr Lee maintains that he wrote busily in the journals almost to the close of his life, henceforward his interest for us is mainly literary. In 1715 appeared the first volume of the Family Instructor, and four years later the first volume of the immortal Robinson Crusoe, which at once leaped into that popularity which it will never cease to retain. The same year appeared the second volume, and the year after the greatly inferior sequel.
Defoe's realistic imagination worked most freely on a basis, however slight, of fact, and this was found for him in the four years' solitary residence of a marooned sailor, Alexander Selkirk, on the island of Juan Fernandez. Perhaps no man at fifty-eight in the whole history of literature ever devised $\mathrm{B}$ more splendid masterpiece of creative imagination than this marvellous story, which carries with it the irresistible conviction of very truth. In 1720his most prolific year-he gave to the world the Life and Adventures of Duncan Campbell; the famous Memoirs of a Cavalier, the most real and truthful of all our historical romances, which the great Chatham accepted as genuine history; and Captain Singleton, a book of such brillianey, vigour, and interest as would alone have given a reputation to any other writer. His next great creative year was 1722 , in which he issued The For. tunes and Misfortunes of Moll Flanders, which is at least a marvel of the novelistic art; The Journal of the Plague Year, better known by the title in the second edition, A History of the Plarue, a fresh masterpiece of verisimilitude and reality; and the History of Colonel Jack, which, though unequal throughout, and actually feeble towards its close, is in its commencement, and in episodes here and there, the most charming and, perhaps, the greatest of all his books. Later works were Roxand, or the Fortunate Mistress (1724), a weaker Moll Flanders; A Tour through the Whole Island of Great Britain (1724-26); A New Voyage round the World (1725); The Complete English Tradesman (1725-27), a glorification of mere money-getting, which Charles Lamb condemned for its "vile and debasing tendency;' The Political History of the Devil (1726), which may be grouped with his System of Magic (1726) and Essay on the Reality of Apparitions (1727). The only other works that nay here be mentioned are his Religious Courtship (1722), and The Treatise concerning the Use and Abuse of the Marriage Bed (1727), which reveal the strangely limited and vulgarly profit-and-loss character of his conception of religious duty. His Everybody's Business is Nobody's Business (1725) is an amusing diatribe upon the insolence of domestic servants - a subject to which he frequently recurs.

Meantime Defoe had been prospering in his affairs. He built himself ' $a$ very handsome house' at Stoke-Newington, where he amused himself with gardening and the company of his three daughters. A mystery not yet satisfactorily explained hangs around his last days. His affairs seem to have fallen into confusion, one of his sons had behaved undutifully, and he was under apprehensions of some trouble, which may, however, have been due merely to a degree of mental derangement. He died 'of a lethargy' in Ropemakers' Alley, Moorfields, 26th April 1731, and was buried in Bunhill Fields.

Defoe remains one of our greatest English writers, and his greatness is of a kind unlikely to be disturbed by a competitor. His immense vitality and energy, clearsighteduess, and ready power of forcing plain arguments either in prose or verse to an inresistible conclusion, make him the typical journalist-to be surpassed only by Swift at his best; but it is to a much rarer quality than this that he owes his fame-his incomparable realism and faithfulness in fiction, the secret of which must be looked for not in his singularly plain and direct language, his simple-looking but most effectively artistic digressions, or his perfect though artless preservation of dramatic propriety, but in that subtle and impalpable genius which informs his style. For his character he was shifty, and perhaps somewhat low in his moral perceptions; but with all his political inconsistencies he remained true to the principles of the Revolution. 
See the Iives by George Chalmers (1786), Walter Wileon (1890), Chadwiek (I869), Lee (1869), and Wright (1S94); the studies by Scott, Lamb, Huzlitt, Forster, Lesslie Stephen, and Profensur Minto. The best approxi. mation to complete editions of Defoe's works have been those of Noott and Hazlitt.

Deforeement, in English law, includes abate. ment, intrusion, disseisin, or any other wrong where. by he that lass the riglit to a freselush is kept out of possersion. 'Deforciant' was formerly the technical name of the defendant in the fictitious proceserling called a Fine. In Scotland, the term deforcenent is most commonly used to denote forcible obstruction of the otticers of the law : this is one of the cases in which the Court of Session has a criminal jurisdiction.

Deformities are variations in the form of the bruly as a whole, or in one or more of ita parts, constituting a departure from the normal conditions of structure, and usually implying a corresponding divergence from natural and healthy functions. They may be divided into three groups, with reference to their origin - the hereditury, the congenital and the acquired. The first group is characterised by a marked tendency to recurrence in the line of direct descent from generation to generation, as in those cases where the presence of extra fingers or toes hes become characteristic of many members of one family (for a full record of an interesting case in point, see Carpenter's Human Physiology). Such hereditary tendencies to modifiention of forn along certain lines of descent constitute local examples of the 'Natural Law of Variation,' which plays an important part in the Darwinian theory of the origin of species. According to this theory, modifications which are of value in the exigencies of the struggle for existence will become perpetuated, and supersede earlier and less favourable conditions of conformation; while modifications that do not possess such value, after repetition through one or two generations, disappear again, and these, since they are useless as well as aberrant conditions, are properly included within the group of hereditary deformities. In the second group, that of congenital deformities, occur those much more frequent abnormalities that result from disturbing influences acting on the otherwise normal embryo previous to its birth. These anomalies occur chiefly as deformities by defective development, and deformities by perverted development. Arrested development may be general, affecting the whole body, when a dwarf is produced; or local, affecting individual organs or parte, producing a great variety of olvious loeal defornities, in disproportion or malformation of special regions of the borly. If the local arrest of development is absolute, the defect caused by it is so great as to constitute a Monstrosity (q.v.), where whole organs nıay be absent. as the brain (crencephulice), the skull (acrania), the lower jaw (agnathia), all the limbe (amelus), or one or more of them (mono. brachius, monopus). Perverted development is seen in cases where parts normally separate become fused together, as in the 'siren-monster,' in which both lower limbs are welded into one taperin. extremity. The causes producing these congenital monstrosities and the lesser and more common deformities of the same class are very varied and often very obscure. Modern writerg have, however, male them a subject of special study nniler the name 'Teratolngy (teras, 'monster, logos, 'science'), and have devised experimental conditions which illustrate the subject. Thus, in the case of the embryo chick, Panum found that deformities could be produced by varying the tem. perature of the hatching apparatus, and varnishing the egg shells; while Dareste discovered that a like result occurs if the eggs be placed vertically instead of Jying on their sides ; and Gerlach, by vernishing the whole surface of the egg with the exception of a $Y$-shaped streak on une side, succeeded in pro. ducing a double-borlied chicken.

In the human subject the cause of the deformity may depend on purely mocluniosal conditions, as when the navel-string of the embryo becomes twisted round a limb and canses its madual separation and destruction (so-called 'intm-uterine amputation '). In many cases, however, the canne is much more recondite, and appenrs to depend upon a variety of cireumstances affecting the maternal organisation. In an ineressing propor. tion of cases which are carefully investigated, it ajpeans that maternal impressicus, the result of shock or unpleasant experiences, may have a con. siderable influence in producing defornities in the offspring. This has for long been a popular theory, and it is one that recent seientific olservation is tending to confirm, but only in a comparatively limited proportion of cases ; and it must be admitted that the majority of cases cannot be explained on any theory of causation as yet sugrrested.

The chief varieties of malformation, coming under the heading of congenital deformities, are the following: (1) As regards the number of parts. In the Siren, two lower extremities are fused into one mass, but dissection shows that all the constituent bones of the limbs may be present, though much distorted, in the combined structure. In the Cyclops, the eyes are similarly fused into one irregular structure occupying the centre of the face. (2) As regards the size of parts. This may involve the whole body, as in dwarfis, of whom there have been some remarkable peripatetic speci. mens: the Corsican fairy was only 2 feet it inches high; Mademoiselle Crachami, the smallest lady who ever lived, died at ten years of age, only 20 inches in height. This kind of deformity is not necessarily hereditary ; the father of Borowlaski, who was only 39 inches when thirty years old, had six children alternately short and tall; and dwarf women have brought forth infants as long, when extended, as their mothers. One limb only may be diminutive. Of course, deformities the nyjosite of these exist, such as giants, or instances of premature or excessive loenl growth. O'Byrne, the Irish giant, measured 8 feet 4 inches when he died at the age of twenty-two. Such individuals are generally subject to premature decay. One finger or one toe often grows to such abnormal dimen. sions as to necessitate its removal (local hyper. trophy). (3) As regards the shape and continuity of parta. Distortion may oceur from partial paralysis or irregular muscular action at an early stage of development, giving rise to Club.foot (q.v.), club-hand, \&c. ; or natural fisaures or aperturea which should close in the course of development may remain open, as in harelip, eleft palate, and spina bificla.

Acquired deformities arise in various ways as the result of injury or disease at any period after birth. Among injuries, burns, scalds, fractures, and dislocations are the most fertile causes of permanent deformity ; and among disenses, rickets, and other diserses of bone, leprosy, and rheumatic affections are common causen. Another group of these sflections, known as 'trade' deformities, sre directly traceable to the special work done by the person suffering from them.

Defregger, FRANz, painter, was born at Stronach, neur Lienz, 30th April 1835. He studied under Piloty at Munich, and himself became a professor in the Munich Academy.

Degas, Hilairg-Germain Edoard, one of the greatest impressioniat painters, born at $\mathrm{Paris}, 19 \mathrm{th}$ July 1834: See IMPRES810NISM. 
Degeneration, a biological term used to describe those not unfrequent cases where an entire organism falls below the structural level of its young stages, or where an organ in the same way loses its fullness of function, and becomes more or less atrophied, abortive, and simplified. Thus many parasitic worms, erustaceans, \&c. are emphatically simpler than their free-swimming larvæ, and the sessile adult Ascidian shows only traces of the vertebrate characters which are plain enough in the active young. Thus, too, a crustacean which starts with a well-developed eye, may exhibit the gradual loss of this on assuming a dark habitat. The term is best contined to cases where a level of structure exhibited during early life is more or less lost in the adult. Degeneration must be distinguished (a) from occasional abortion, (b) from Reversion (q.v.) to an ancestral type, and (c) from the occurrence of rudimentary and undeveloped organs where a character possessed by ancestral types remains more or less undeveloped, or shows itself only in embryonic life. Degeneration may be due to the environment, or to cessation of function, or to some more subtle constitutional cause. Absence of food, heat, light, \&c. may mean the absence of the necessary stimulus for the growth and maintenance of the organs, or superfluity of food may cause one system to preponderate over others. Nor can it be doubted that cessation of function checks the foodsupply to a given organ, and in other ways helps to bring about its degeneration. But on the other hand, some less obvious cause - the fatigue of early life, a constitutional sluggishness, \&c. may share in conditioning degeneration, as in the case of the majority of the Tunicata. Weismann and others, however, would explain degeneration by what they call the non-operation of natural selection. On this view, organs are not only developed but main. tained by natural selection, and if it happen that an organ is no longer an advantage in this struggle for existence (e.g. eyes in dark caves), then natural selection no longer maintains that organ, and it disappears in the course of generations. Weismann applies this ultra-Darwinian conception especially to cases which might be called non-development rather than actual degeneration-e.g. to the slightly developed wings of the Apteryx. Most cases of degeneration properly so called appear hardly to require his subtle explanation, but find a sufficient one in the nature of the environment, in the effects of stopped function, and in the constitution of the organism. The theory of the degeneration of man from a high state (see ADAM, FALL) has been superseded by the belief in a development from low savagery (see ANTHRoPOLOGY, ARCHEOLOGY).

See Ray Lankester, Degeneration (1880); and Weismann, Ueber den Rückschritt in der Natur (1887). Max Nordau, Degeneration (trans. 1895). See also, for instances, Ascidians, Cave-Animals, Crustacta, INseots, Parasitism; also Environment, Evolution, \&c.

De Gérando, Josepi Marie, Baron, was born 29th February 1772, at Lyons, of Italian blood. Fleeing from Paris to Germany, he entered (1797) Massena's army as a private, and wrote a treatise, 'crowned' by the Academy, Des Signes et de $l$ 'Art de Penser (1800). In 1802 appeared his De la Génération des Connaissances Humaines, a precursor of his Histoire de Philosophie (1803), long reputed the best. French work on the subject. It procured him, in the following year, admission into the Academy. He was appointed secretary-general to the Ministry of the Interior by Napoleon. But De Gérando is even better known by his philanthropic writings. His excellent work, Le Visiteur du Pauve (1820), obtained the Montyon prize, as did also his Du Perfectionnement Moral (1824).
De Gérando was elevated to the peerage in 1837 , and died 12th November 1842, vice-president of the Council of State.

Deggendorf, a town of Lower Bavaria, on the Danube, which is liere crossed ly two bridges, 39 miles NW. of Passau by rail, with manufactures of paper, linen, woollens, stoneware, and matches. Its church of the Holy Sepulchre is often visited by more than 30,000 pilgrims annually. Pop. 6446.

Degraded, in Heraldry, means placed upon steps or degrees.

Degree, the 360th part of the circumference of a circle; see Circle, Graduation. A degree of latitude is the length along a Meridian (q.v.), such that the difference of latitude between its north and south ends is one degree-i.e. from the two positions the altitude of the same star is seen to differ by one degree (see LATITUDE). Another definition is that two points on the earth's surface differ in latitude by one degree, when the verticals at these points make angles with the plane of the equator, differing by one degree. Were the earth perfectly spherical in shape, this distance along a meridian would be exactly equal to sto of the whole meridian, and would be the same at all parts of the earth's surface. But owing to its oblately spheroidal shape it increases from the equator, where the curvature is greater, to the poles, where it is less curved. From geodetical measurements made, it is found that at the equator the length of a degree of latitude is 362746.4 feet; while at the poles it is 366479.8 feet. 'The differences between the length of the degree of latitude in different latitudes, thus ascertained by actual measurement, is one of the proofs that the figure of the earth is not that of a sphere but that of an oblate ellipsoid.

A degree of longitude is the length between two meridians that make an angle of one degree at the poles, measured by the are of a circle parallel to the equator passing between them. It is clear that this space is greatest at the equator, and vanishes at the poles; and it can be shown that it varies with the cosine of the angle of latitude. The annexed table shows the lengths of a degree of longitude for places at every degree of latitude from $0^{\circ}$ to $90^{\circ}$. It is computed on the supposition that the earth is a sphere.

\begin{tabular}{|c|c|c|c|c|c|}
\hline $\begin{array}{c}\text { Degree } \\
\text { lat. }\end{array}$ & $\begin{array}{l}\text { English } \\
\text { miles. }\end{array}$ & $\begin{array}{c}\text { Degree } \\
\text { lat. }\end{array}$ & $\begin{array}{l}\text { English } \\
\text { iniles. }\end{array}$ & $\begin{array}{c}\text { Degree } \\
\text { lat. }\end{array}$ & $\begin{array}{l}\text { English } \\
\text { niles, }\end{array}$ \\
\hline 0 & 69.07 & 31 & $59 \cdot 13$ & 61 & $33 \cdot 46$ \\
\hline 1 & $69^{\circ} 06$ & 82 & 58.51 & 62 & $82 \cdot 40$ \\
\hline 2 & 69.03 & 83 & $57 \cdot 87$ & 68 & $31 \cdot 33$ \\
\hline 3 & $68 \cdot 97$ & 34 & $57 \cdot 20$ & 64 & $50-24$ \\
\hline 4 & $68 \cdot 90$ & 35 & 56.51 & 65 & $29 \cdot 15$ \\
\hline 5 & $68: 81$ & 36 & $55: 81$ & 66 & $28 \cdot 06$ \\
\hline 6 & $68 \cdot 62$ & 37 & $55^{\circ} 10$ & 67 & 26.96 \\
\hline 7 & 68.48 & 38 & $54: 37$ & 68 & 25.85 \\
\hline 8 & $68 \cdot 31$ & 39 & 53.62 & 69 & $24 \cdot 73$ \\
\hline 9 & $68 \cdot 15$ & 40 & $52 \cdot 85$ & 70 & $23 \cdot 60$ \\
\hline 10 & $67 \cdot 95$ & 41 & 52.07 & 71 & $22 \cdot 47$ \\
\hline 11 & $67 \cdot 73$ & 42 & $51 \cdot 27$ & 72 & $21 \cdot 32$ \\
\hline 12 & $67 \cdot 48$ & 43 & 50.46 & 73 & $20 \cdot 17$ \\
\hline 18 & $67 \cdot 21$ & 44 & $49 \cdot 63$ & 74 & 19.02 \\
\hline 14 & 66.95 & 45 & $48 \cdot 78$ & 75 & $17 \cdot 86$ \\
\hline 15 & $66 \cdot 65$ & 46 & $47 \cdot 93$ & 76 & $16 \cdot 70$ \\
\hline 16 & $66: 31$ & 47 & $47 \cdot 06$ & 77 & $15 \cdot 52$ \\
\hline 17 & $65 \cdot 98$ & 48 & $46 \cdot 16$ & 78 & $14 \cdot 35$ \\
\hline 18 & $65 \cdot 62$ & 49 & $45 \cdot 26$ & 79 & $18 \cdot 17$ \\
\hline 19 & $65 \cdot 24$ & 50 & $44: 35$ & 80 & 11.98 \\
\hline 20 & 64.84 & 51 & $48 \cdot 42$ & 81 & $10 \cdot 79$ \\
\hline 21 & $64 \cdot 42$ & 52 & $42 \cdot 48$ & 82 & 9.59 \\
\hline 22 & 63.97 & 63 & 41.53 & 83 & 8.41 \\
\hline 23 & $63 \cdot 51$ & 54 & $40 \cdot 56$ & 84 & $7 \cdot 21$ \\
\hline 24 & 68.03 & 55 & $39 \cdot 58$ & 85 & 6.00 \\
\hline 25 & $62 \cdot 53$ & 56 & $38 \cdot 58$ & 86 & $4: 81$ \\
\hline 26 & $62 \cdot 02$ & 57 & $37 \cdot 58$ & 87 & 861 \\
\hline 27 & $61 \cdot 48$ & 58 & $36 \cdot 57$ & 88 & 241 \\
\hline 28 & $60 \cdot 93$ & 59 & $35 \cdot 54$ & 89 & 1-21 \\
\hline 29 & $60 \cdot 35$ & 60 & $34 \cdot 50$ & 90 & 0.00 \\
\hline 80 & 5975 & & & & \\
\hline
\end{tabular}


Degrees, UNIVEnsity. In its original sig. nitication a degree was simply a certiticate that the person who held it was qualitied to take part in the public teaching of a university. In the fully developed medioval university there were the four faculties of arts, law, medicine, and theology; and in each of these faculties there were special degrees of its own. These degrees were the bacalaureate, the licentiate, and the doctorate, though, strictly speaking, the first was not a degree, since it did not confer the right of pullic teaching. For the attuimment of each degree certain subjects were prescribed for examination, as also a fixed term of study in con. nection with some university. Both the subjects and the periols of study varied with the progress of learning; but the different universities always sought to preserve a common standard. In Paris, at the close of the loth century, the terms of study requisite to qualify for teaching in the different faculties were the following: in arts, fonr years: in law, seven; in medicine, eight; and in theology, fourteen. In modern times a degree in arts is simply a certificate of a certain messure of requaintance with the subject to which it refers; but in the ease of the higher faculties, that is, of law, medicine, and theology, the degree also implies a license to exercise the functions of the professions that depend on these faculties. It was formerly an indispensable condition to obtain a degree that the knowledge it represented should have been acquired at one or other of the legally constituted universities; but of late years certain universities, such as that of London, have been founded, which grant degrees to persons who pass examinations on pre. seribed subjects without the necessity of university attendance. A still further departure from the original import of the term is seen in what are known as 'honorary degrees," Such degrees are conferred by universities on persons who have distinguished thenselves in spheres of life which have no direct connection with the studies for which they exist. Thus, eminent soldiers, artists, and even merchants, have received the degree of Doctor of Laws. Not a few scholastic bodies are even understood to grant degrees on purchase, or on other such easy conditions that the original significance of the degree is completely lost. In the middle ages the right to confer degrees was granted universities; and at the present day he claims the privilege of directly conferring degrees on whom he pleases. In Protestant countries the right can be granted only by the state. By an act of the reign of Henry VIII., the Archbishop of Canterbury received the right of conferring, degrees; but these, known as 'Lambeth degrees,' never earried with them the same privileges as those of Oxford and Cambridge. In the medieval universities, music made part of the curriculum of the faculty of arts, and doctors and bachelors of music are still created by some universities. The German doctorate in philosophy corresponds in some respects to the M.A. degree elsewhere. The degrees of dictor and bachelor of science are of comparatively recent in. stitution. For the usual abbreviations for degrees, see AbBreviations, See also UnIVERsities, Doctor; and for the Chinese system of degrees, see China, p. 190.-For degrees of relationship, see Consanguinity.

De Gubernatis, See Gubernatis.

Dehiscence (Lat., "gaping'), a technical term applied to the mode of opening of certain ripe fruits, those which do not open being termed indehiscent. See FRUIT.

Dehra, the capital of the Dehra Dún district in the North-western Provinces of India, is pleasantly situated in a mountain-valley, 2300 feet above sea level, and 100 miles NE. of Meerut. Pop. (1881) 18,959 ; ( 1891 ) 25,684 .

Deinneira, daughter of Cineus and Kthea, and sister of Meleager. She becane the wife of Hercules, but unwittingly caused his death by sending him the mantle of the centaur Nensus, which was anid to have the property of premerving love, but was really steeped in fatal poison. The poison entering lis frane, the hero suffered such agony that he ordered a funeral pyre to he erected in Mount (Ẽta, and cast himself into the flames, whereupon Deianeira hanged herself from grief.

Dei Ciratia (Lat., 'by the grace of God') is a formula taken from several apostolical expressions in the New Testament. It is believed to have been tirst formally used by the bishops at the Council of Ephesus, 431 A.D. Afterwards, it came to be appended by archbishops, bishops, abbots, monks, and even cliaplains, to their titles, in letters, and other documents, as a humble expression of dependence on the Most High. After the middle of the 13th century, the higher clergy wrote Dei ot Apostolicu sedis gratic, "by the favour of (iond and the apostolic see." In the British Islands, this style was generally dropped about the time of the Reformation, but it was oceasionally given to the Archbishops of Canterbury and York, even after the beginning of the $17 \mathrm{th}$ century. Many temporal princes, earls, and barons made use of the formula Dei Gratia; William II. and Edward III. of Eng. land employed it; and before the 15 th century, no idea of independence or of divine right seems to have been attached to it. But in 1442 King Charles VII. of France forbade its use by the Comte d'Armagnac, and in 1449 obliged the Duke of Bnr. gundy to declare that he used it withont prejudice to the rights of the French crown. These instances show that it had now begun to be regarded as belonging exclusively to sovereigns who owed no allegiance to any other earthiy potentate or power. In this way, what was originally a pious expression of humility came to be looked upon as an assertion of the doctrine of the 'divine right' of kings.

Deinotherium. See Dinotherium.

\section{Deipnosophists. See A THEN.zus.}

Deira, an ancient Anglian kingdom, extending from the Tees to the Humber, and westwards to the borders of Cumbria. With its northern neighbour, Bernicin, it was afterwards merged in the kingdom of Northumbria, but later both were earl. doms under the West Saxon kings.

Deir-el-kamar ('convent of the moon'), a town of Syria, formerly the capital of the Druses, 13 miles SSE. of Beyrout. It is situated on the elge of a deep and picturesque glen of Mount Lebanon, on the opposite side of which stands the palace Bteddin, the summer residence of the Christinn governor of Lehanon. Pop. 8000, mostly Maronites.

Deism properly means belief in a God, as opposed to atheism; but the term used to express this sense is Theism $\left(q . v_{0}\right)$. On the other hand, Deism is generally undersituod to iunply the denial of a revelation; and a Deist is one who holds the existence and providence of God, but grounds his belief on resson and evidence, rejecting the testimony of a revelation. The name is often used vaguely by way of reproach.

The term Deists, or Freethinkers, is usually employed to designate a series of writers who appeared in England in the $17 \mathrm{th}$ and 18 th centuries, and sought to establish Natural Keligion upon the basis of reason and free inquiry, in opposition to all positive religions, and without reference to super. natural revelation. They were critical, if not hostile, in their attitude towands Scripture, and 
denied miracles, the Trinity, and atonement by Christ; and they may fairly be taken as constituting one movement, thongh they by no means formed one school or agreed in the details of their teacling. Thus some believed and others rejected the immortality of the soul and human free-will, and they did not all teach the same doctrine as to the relation of God to the universe, some being almost pantheistic. They were not for the most part accurate scholars, and were rather acute than profound thinkers; but though their influence on English thought seemed for a time to be blotted out, they contributed largely to the progress of rationalism in Europe. The chief deists were Lord Herbert of Cherbury, called the 'Father of Deism' (died 1648), Blount, Tindal, Woolston, Toland, Lord Shaftesbury, Lord Bolingbroke, Collins, Morgan, and Chubb (died 1746). See the separate articles on these writers, also CHURCH History, ReLigion, Rationalism; Leland, View of the Deistical Writers (1754); Lechler, Geschichte des Englischen Deismus (1841); Hunt, Religious Thought in England (1872); Leslie Stephen, History of English Thought in the Eighteenth Century (1876).

Déjazet, Pauline Virginie, a great French actress, born at Paris, 30th August 1797. On the stage before she was five years old, she grew up playing children's and boys' rôles with marvellons precocity of intelligence and grace, but first awoke to a sense of her real greatness in an engagement at Lyons, where her playing of such parts as were then known as soubrettes endeared her to the citizens. In 1821 she began to play at the Gymnase, but her greatest triumphs were won at the Théatre du Palais-Royal, whither she betook herself in 1834. From 1844 to 1849 she played at the Variétés, next at various Paris theatres, in the provinces, and at London, till 1859, when she undertook the management of the FoliesDramatiques. She left the boards in 1868 , next year received a pension of 2000 francs, and died Ist December 1875. See Lives by Lecomte (1866 and 1892 ) and Duval (1876).

Dekker, Тномаs, dramatist, was born in London about 1570. He was a very prolific writer, but only a few of his plays were printed. In 1600 he published two comedies, The Shoemaker's Holiday, or the Gentle Craft, and The Pleasant Comedy of Old Fortunatus. The first of these pieces is one of the pleasantest of old plays, and the second abounds in poetry of rare beauty. Dekker's next play was Satiromastix, or the untrussing of the Humorous Poet (1602), in which Ben Jonson was held up to ridicule. In Every Man out of His Humour and Cynthia's Revels Jonson had made some satirical reflections on Dekker; and in The Poetaster (1601) he had assailed Dekker and Marston with bitter vehemence. Long afterwards, in 1619, Jonson told Drummond of Hawthornden that Dekker was a knave. Before the quarrel Jonson and Dekker had worked in harmony; in 1599 they wrote together two plays (which have not come down), Page of Plymouth and Robert the Second. In 1603 Dekker published a pamphlet entitled The Wonderful Year, which gives a heart-rending account of the sufferings caused by the plague. To the same year belongs the very amusing tract The Bachelor's Banquet, in which he describes with gusto the ills to which henpecked married men are forced to submit. His most powerful writing is seen in The Honest Whore (1604), of which the second part was published in 1630. Middleton assisted him in the first part. In 1607 he published three plays written in conjunction with Wehster, the Famous History of Sir Thomas Wyat (which has descended in a mutilated state), Westward Ho, and Northward Ho. A pamphlet entitled The Bellman of London (1608) grives a very lively account of the vagabonds of London; and Dekker pursued the subject further in Lanthorn and Candlelight (1608), which passed through several editions. The most famous of his pamphlets is The Gull's Hornbook (1609), in which the life of a town-gallant is racily depicted. The Roaring Girl (1611) was partly written by Dekker: but Middleton must take the chief credit for that excellent comerly. From 1613 to 1616 Dekker was confined in the King's Bench prison. Earlier in his career he had spent some time in the Counter prison. In each case his debts were the cause of his imprisonment. With Massinger he composed the Virgin Martyr; and Lamb was doubtless right in ascribing to Dekker the most beautiful scene (II. i.) in that play. The Sun's Darling, licensed for the stage in 1624, but not printed until 1656 , was written in conjunetion with Ford. A powerful tragedy, The Witch of Edmonton (posthumously published in 1658), was written by Dekker, Ford, and Rowley. We hear of Dekker in 1637, when he republished his Lanthorn and Candlelight under the title of English Villainies, and then he drops out of notice. His plays were collected in 1873 (4 vols.); and his pamphlets, which afford much valuable information about English social life in the early 17th century, were republished in 5 vols. in Dr Grosart's 'Huth Library.

De la Beche, Sir Henry Thomas, a wellknown geologist, was born near London in 1796. He was educated at the military school at Great Marlow, and entered the army in 1814. Three years after, he became a. Fellow of the Geological Society, of which he was afterwards made secretary, and eventually president in 1847 . In 1820 , while residing in Switzerland, he published a paper on the temperature and depth of the lake of Geneva. In 1824 he visited Jamaica, and published a paper on the geology of the island. Other works are a Manual of Geology (1831), Researches in Theoretical Geology (1834), and a Geological Observer (1853). He undertook to form a geologieal map of England; and soon after he had begun, the government, sympathising with his design, instituted the Geological Survey, and placed him at its head. He was founder of the Geological Museum in Jermyn. Street, and of the School of Mines. In 1848 he received the honour of knighthood; and in 1853 was elected a corresponding member of the Academy of Sciences of Paris. He died 13th April 1855.

De la Borde, Henry Francors, Count, a French general, born at Dijon, 21st December 1764 . The son of a baker, he enlisted at the outbreak of the Revolution, and by 1793 had risen to be general of brigarle. He distinguished himself in Spain at the Bidassoa (1794), next commanded a division on the Rhine under Moreau, was governor of Lisbon in 1807, and was ennobled in 1808. He declared for the emperor on his return from Elba. He died $3 d$ February 1833.

Delacroix, EuGÈnE, a French painter, chief of the Romantic school, was born at CharentonSaint-Maurice, near Paris, 26th April 1799. At the age of eighteen he entered the atelier of Pierre Guérin, a follower of David, and came under the far more powerful influence of his fellow-pupil, Géricault. In 1822 he exhibited his first work, 'Dante and Virgil,' the novel force of which attracted much attention and won the praise of M. Thiers among others. In 1824, Delacroix, who was now at the head of the new school of young painters, produced the 'Massacre of Scio,' which was entirely repainted after the artist had studied a work of Constable's. The July revolution left its impress on Delacroix, and in 1831 appeared his 
"Liberty directing the People on the Barricadea." In 1832 he made a voyage to Moroces, where he familiarised himself with novel effects of light and costumes. From this period, Delacroix contiuued to send forth picture after picture, lnesides desorating many publie huildings and churches. He also exvented a number of lithographs, including a series illustrating Hamlet, and one dealing with Faust, of which Goethe wrote that he found in these images all the inpressions of his youth.' In 1857 he wits chosen by the Institute to fill the pluce of Delaroche. He died August 13, 1863. The most striking quality of Delacroix's art is its invention, its impetuous imnginative force and vitality. He ainied at $\mathrm{a}$ powerful and dramatic expression of passion and emotion, and in the pnrsuit of this aim a sense of beauty was frequently lost. He was an admirable colourist, and his admirers have ranked him with Veronese and Rubens. His drawing. sometimes incorrect, is always spirited and full of vigour. See Lives by Morenu ( 1873), Burty (1880), and Chesneau (1885); and his Journal (1898).

Delagoa Bay, a Portuguese possession, is a large inlet of the Indian Ocean on the south-east const of Africa. Discovered by one of Vasco da Gama's lieutenants in 1502, it was ealled Bahia da Lagoa, from a rumoured great lake in the interior. Negotiations for the sale or cession of it to Britain have always been rejected by the Portuguese. In 1868 the Transvaal elaimed by proclamation the Maputa River, from its junction with the Pongola to its embouchure into the southern part of Delagoa Bay. England and Portugal resisted the claim and set up counter pre. tensions. The matter was referred to the arbitration of Marshal MacMahon, who in 1875 declared the southern portion of Delagoa Bay, including the Maputa River up to the Lobombo Mountains, to belong to Portugal. The bay stretches for 70 miles between $26^{\circ} 20^{\prime}$ and $25^{\circ} 30^{\circ} \mathrm{S}$. lat. It is 25 miles wide, and for size and accommodation is the finest natural harbour in South Africa ; in spite of islands and shoals its navigation is safe and easy, and the anchorage is commodious and well sheltered. The settlement of Lourenco Marques and surrounding country have been notoriously unhealthy; but of late years some drainage and other improvements have been carried out. The rivers Maputa, Tembe, and Umbelosi (joining to form the English River), and the Komati, fall into Delagoa Bay. The proximity of Delagoa Bay to the Transvaal goldfields greatly increased its commercial and political importance. For over half a century there were intermittent attenpts to establish com. munication between the Transvaul and Delagoa Bay. All failed till 1887, when a company was formed in London to work a concession from the Portuguese government for ninety years, for the construction of a railway from Delagoa Bay to the Transval (52 miles); but in 1889 -through intrigues by the Trunsvaal - the Portuguese government expropriated the company (largely English. men and Americans). An international arbitration was soon thereafter arranged, which did not report till 1900, when Portugal was adjudicated to pay $\$ 641,000$, to the grievous divippointment of the concessionaires, who had demanded over $£ 1,500,000$. The lines connecting with Pretoria ( 350 miles by rail from the coast) and with Johannesburg, \&e. were completed in $1890-95$, and both before and during the war of $1899-1900$ proved invaluable to the Transvaal

See Lourenco Mareurs, and works by Monteiro (1891) and Mon'tague (1899).

Delambre. JEAN JOSEPH, astronomer, born at Amiens, 29th September 1749, taught, and studied physicsand astronomy under Lalande. Thediscovery 151 of Uranus by Henchel in 1781 gave him the fint opportunity of attracting the attention of the learned world in general by preparing tables of the motion of the new planet. Boon aiter, he cons. menced the construction of new solsr tables, and tables of the motions of Jupiter and Saturn. Alons with Méchain, he was appointed by the French government, in 1792, to mensure the are of the meridian between Dunkirk and Barcelona, which was completed in 1799 (see MitRE, ARAGo). He was elected member of the Academy, and in 1803 perpetual secretary of the mathomational sece. tion of the Institute. The result of his measurements appeared in his great work, Bose du Syateme Metrique Decimal (1806-10). In 1807 he olitained the chair of Astronony at the College de France, rendered vacant by the death of Lalande, his master and friend. In 1814 he was appointed a member of the Council of Public Inatruction. He died at Paris, 19th August 1822. Delambre received a multitude of honours during his lifetime. He was a member of most of the learned bodies in Europe, and an officer of the Legion of Honour. His writings are very numerous. The principal are Traite d'Astronomie (1814), Histoire de l'Astronomie Ancienne (1817), Histoire de $l^{\prime}$ Astronomie du Mujer Age (1819), Histoire de l'Astronomie Moderne (1821), and Histoire de l'A stronomie au Dixhuitidme sidele (1827). Besides these, Delambre wrote several excellent Mémoires.

Delane, JонN THADEUs, editor of the Times newspaper, was the second son of a barrister, and was born in London, 11th October 1817. He received the earlier part of lis education in private schools, and at King's College, London, and finally went to Magdalen Hall, Oxford, where he took his degree in 1839. At the university, he was more famous for horsemanship than reading, and though bright and active-minded, he never profesed to the a scholar. After leaving Oxford he studied life in many forms, walked the hospitals, was called to the bar, and reported in the House of Commons and on circuit. Mr Walter had early marked Delane' copable character, and soon placed him on the Times staff; and in May 1841, not yet twenty-four, he became its editor. For thirty-six yeans Delane held this post, aided, however, for the greater part of this period by his brother-in-law and college friend, George Dasent $\left(q, v_{0}\right)$. Under his editorship, the Times attained a prodigious circulation, and an influence unparalleled in the history of journalism. He wrote no articles, but he contriluted excellent reports and letters. He merged his pensonality in his paper, and the history of his later life is the history of the extraordinary influence wielded by the leading journal. His exposure of the railway mania, his vehement attacks upon the management of the Crimean war, and his strong opposition to England's assisting Denmark in 1864, are among his best-remembered acts. He was aingularly shrewd in weighing public opinion, posesened remarkable foresight, and seldom made a mistake. Having resigned the editorship in 1877 , he died two years later, 221 November 1879. His succesaor was Thomas Chenery. A Life of Delane by Sir (i. Dasent was unnounced, but abandoned in deference to $\mathrm{Mr}$ Walter.

Delany, Mas (Mary Granville), was Inorn at Coulston, Wiltulive, 14th May 1700. The niece of Lord Lensdowne, she married first, in 1718, "fat, snuffy, sulky' Alexander Pendarves (1659-1724); and secondly, in 1743, the Rev. Patrick Delany (1685-1768), an Irish divise, Swift is friend, and the author of a dozen volumes. After his death she lived chiefly in London, till her own death at Windaor on 15th April 1788. Her much-admired 'paper mosaics,' or flower-work, lave long since 
faded ; but she is remembered through her patronage of Miss Burney, and by her Autobiogrophy and Correspondence ( 6 vols. 1861-62), with its gossip of the court and the literary society of her day.

De la Ramé, Lourse. See Ouida.

Delaroche, Hippolyte, known as PAUL, painter, the head of the modern Eclectic school of art in France, was born at Paris, 16th July 1797. $\mathrm{He}$ studied under Baron Gros, and between 1819 and 1823 acquired some note by painting scriptural subjects, but first excited public admiration in 1824, by his 'St Vincent de Paul preaching in the Presence of Louis XIII.', and 'Joan of Arc before Cardinal Beanfort.' 'These exhibit the earliest indications of that style for which he afterwards became famous - $a$ style which endeavoured to unite the picturesqueness of the romantic with the dignity of the classic school of art. In 1826 Delaroche produced his 'Death of President Durante;' and in 1827 his 'Death of Queen Elizabeth.' These pictures greatly increased his reputation, but the last is reckoned a failure by English crities. In 1831 he produced the 'Princes in the Tower,' a work of high merit; in 1833, 'Crom well contemplating the Corpse of Charles I.,' which is generally regarded as one of the first historical paintings of modern times. In 1834 appeared his 'Execution of Lady Jane Grey;' and in 1837 his 'Charles I. insulted by the Parliamentary Soldiers,' and his 'Strafford receiving Laud's Blessing on the Way to Execution.' From this period until 1841 he was engaged on what is probably his grandest workthe series of paintings on the wall of the semicircular saloon of the Ecole des Beaux Arts, in the execution of which he was aided by Armitage and other of his pupils. This composition, in which the style is simple, lofty, and chaste, contains $\mathbf{7 4}$ figures, comprising the greatest sculptors, painters, and architects in all history, according to Delaroche's judgment. It was excellently engraved by Henriquel Dupont, from a reduced copy made by the painter himself. Among his later works may be mentioned, 'Bonaparte at St Bernard' (1850); ' Marie Antoinette before the Revolutionary Tribunal' (1851); 'The Finding of Moses' (1852); 'Calvary' (1853); 'Christ in Gethsemane' (1854); 'The Girondins in the Coneierge' (1856); and, one of his best-known works, 'The Floating Martyr.' He also executed some striking portraits, including those of M. Guizot (1838), and M. Thiers (1856). He died November 4, 1856. The characteristic excellences of Delaroche are picturesqueness of conception, precision of handling, and accuracy of drawing. He has been accused, however, of want of fire, imagination, and depth, and it must be admitted that he very rarely, if ever, exhibits the highest qualities of creative genius. Delaroche was made a member of the Institute in 1832 , and professor of Painting in the Ecole des Beaux Arts in 1833. See Rees, Vernet and Delaroche (1880).

De Ia Rue, WARren, an eminent electrician, was born in the island of Guernsey, January 18, 1815. He was educated at Paris, and early entered his father's business-the manufacture of paperwares-for which his inventive ability and scientific knowledge enabled him to devise many new machines and processes. He took an active part in the Exhibitions of 1851 and 1862 ; was a member of the International Electrical Congress at Paris in 1861 ; and was president of the Royal Astronomical Society, and of the Chemical Society, and the London Institution. In 1878 he succeeded Spottiswoode as secretary of the Royal Institution, and in 1880 was elected a corresponding member of the French Académie des Sciences in the department of astronomy. His scientific work, done at his observ. atory at Cranford and at his private physical labor- atory, was of the highest value in the departments of astronomical pbotography and electricity, and its results were communicated from time to time to the Royal Society and the French Académie des Sciences. Died in London, April 19, 1889.

Delaunay, Louis ARskine, a French actor, was born 2lst March 1826, at Paris, and made his début in October 1846 at the Odeon. In the year 1848 he first trod the classic boards of the Théatre Français in the role of Durante, and here he soon procured an engagement and became secretary to the theatre in 1850. Till he retired (1887), lse was one of the most accomplished actors on the French stage. $\mathrm{He}$ has found some of his greatest parts in the plays of Hugo, Pailleron, De Musset, and Augiers.

Delavigme, Jean Françots Casimir, dramatist, satirist, and lyrist, was born at Le Havre on April 4, 1793. He became one of the most popular writers in France, after the publication in 1818 of his Messeniennes, satires directed against the monarchy of the Restoration. He then turned his attention to dramatic authorship and produced Les Vépres Siciliens (1819), a tragic piece, which was followed by the comedies, L'Ecole des Vieillards and Les Comédiens (1821). He was made an academician in 1825. As a lyrist and satirist, he espoused the cause of the patriots in Italy, Greece, and Poland, and of the democratic party in France, but although he appears to have been a sincere politician, he failed to give natural and original expression to his convictions. $\mathrm{His}$ tragedy of Louis $X I$., which was partly founded on Quentin Durward, and an adaptation of which is familiar to English playgoers, was brought out in 1833. Among his other dramas were Le Paria, Marino Faliero, Les Enfants d'Edouard, Don Juan d'A utriche (1835), and La Fille du Cid (1839). He died on December 11, 1843. He had no true poetic faculty ; neither was he a skilful dramatist, though his plays, when first produced, gained considerable popularity. In his day he was supported by the opponents of the Romantic school, but his medi. ocrity has come to be recognised by critics of all parties.

Delaware, one of the original states of the Americun Union, occupying part of the peninsula between the lower reaclies of the $\mid$ Coprright 1889, 1897, and Susquehanna and Chesapeake 1900 in the U. S. by J. B. Bay on the west, and the Dela- Lipplucoti Company.

ware River and Bay and Atlantic Ocean on the east. The state is bounded on the N. by Pennsylvania (the boundary there being an are of a circle), on the E. by the Delaware River and Bay and the Atlantic Ocean, and on the S. and W. by Mary. land. With an area of $2050 \mathrm{sq}$. m., or little more than that of Northumberland, it is the smallest of all the states and territories, except Rhode Island; in 1890 it was the forty-second in population. Save in a small hilly section in the north, nearly all the surface is low and level, and in the extreme south there is much swampy land; while the most southern two-fifths of the area is in great part a sandy region. The hill-district in the north presents a stony surface overlying azoic rocks, such as gneiss and granite, with patches of serpentine and limestone. A strip of highly fertile red clay lies south of the hill-country; and next southward occurs a productive and fossiliferous greensand for. mation, succeeded by a somewhat sandy belt, less fertile than the greensand, although the greater part of its extent is by no means unproductive. The coast-region has many salt-marshes, some of them dyked, and thus rendered tillable ; and farther inland is a considerable body of extremely rich alluvial soil. The western border of the state is generally well wooded, and in some places flat and marshy. The rivers of Delaware are mostly small, 
but many are navigable. In the north kaolin and Iron ore are found, and bog ore or limonite oceurs to some extent in other parts. The state is divided into three counties, New Castle in the north, Kent in the centre, and Sussex in the south.

The state is well provided with railroad facilities, and is crossed by a canal connecting the Delaware and Chesnpeake bays. The northern section has large and varied mnufacturing interests. Fishing and the taking of oysters and crabs are impori snt inclustries in Sussex county, and along the shores and tidal streams. Peaches and the various amall fruits, as well as market-gavden products, are leading articles of export; the principal cereal crops are maize, wheat, and oats. Pop. (1870) 125,015 ; (1880) 146,608 (of whom 26,448 were of pure or mixed African descent) : (1890) 168,493.

The principal towns are Wilmington (pop. in $1850,42,478$, in $1890,61,437)$, New Castle (4010) Dover, the state capital (3061), and Smyrna (2455).

Delaware's first permanent white settlements were made by Swedes and Finns who settled at Christiana (Wilmington) in 1638; for a Duteh settlement of 1630 at Hoornkill (now Lewes) was destroyed a year later by the Indians. The colony of New Sweden included a small part of Penn sylvania and a section of New Jersey. For several years the Dutch and Swedes contended for the possession of this region, till in $\mathbf{1 6 5 5}$ it passed under Dutch sway. After the transfer of New Amsterdam (now New York) to the English rule in 1664, Delaware became English also, being governed from New York until 1632, when William Penn became proprietary of the three Delaware counties, which, though attached to Pennsylvania, never formed any part of that colony. In 1776 a constitution was adopted, followed by another in 1791 ; and this was revised in 1831. Delaware was the first state to ratify (1767) the Federal constitution. It took no part in the secession movement, but retained its slaves until the passage of the 13th amendment. It offers several curions survivals, such as its divisiou into hundreds, and the retention of whipping-post and pillory. For map, see MARYLAND.

Delaware, Thomas WEST, LorD, the first governor of Virginia, arrived there from England in June 1610 , but nine months later was prostrated by ill-health, and died in 1618 .

\section{Delawares. See American Indins.}

Del Crederé Commission, the higher rate or allowance charged by a factor or agent, in respect of which he guarantees the solvency of the purchaser, and renders himself personally liable to his principal in case of the purchaser's failure to pay the price of the goods sold. It is not necessary that the contract be in writing. The amount of the premium is of course variable, but it is frequently double an ordinary selling commission.

Deleb Palm, or EThiopian FAN-PALM (Borassus athiopum), is very common and widely distributed throughout Central Africa, where it often practically replaces the date palm in the domestic economy of many negro tribes. Its large hard nut is eaten fresh, but also largely planted until ger. mination has fairly commenced; the young embryo thus laden with sugar, \&c., is then eaten raw or cooked.

Delectus (Lat., 'a selection'), the old name often applied to a selection of passages from Latin or Greek writers graduated in dilficulty for the use of young learners. None is 80 famous as Valpy's.

Delegation (Ital. delegazione), the term for. merly applied in Lombardy, Venice, and the States of the Church, both to the governor and governing court of a province and to the province itself. The number of such provinces varied, but was at one time nineteen. The delegate was always a prelate, and directly appointed by the pope. If he wiu a ear. dinal, he was called a Legate, and his province $\mathrm{A}$ Legation.

Delescluze, Lours Charles, French com. munist, was born at Dreux, 20th Octolver 1800 . His politics early drove him from France to jour. nalism in Belgium, but the February revolution opened to him a career in Paris, where his elever and facile pen quickly made him popular with tho rabble, but earned him from the authorities im. prisonment and a fine of 10,000 francs. Again at 'Paris in 1853, he was sentenced to two years' imprisonment, and was next transported to Cayenne, where he remained till 1859 . His experiences of his sufferings he gave in De Paris d Cayenne; Jour. nal d'un Transporte (1867). After his return he was quiet for some years, until his journal, Réveil, started in 1868 to advocate the doctrines of the International, brought him anew into trouble. In the infamous history of the Paris Commune he played a proninent part, and upon his head rests in great part the guilt of its nost execrable atrocities - the murder of the hostages, and the burning of the public buildings of the eity. He died on the last barricade, 28th May 1871.

Delfshaven, an old town in South Holland on the Mars, ly mile W. of Rotterdam, with which city it was incorporated in 1886 .

Delft, one of the most ancient towns of South Holland, is situated on the Schie, 8 miles NW. of Rotterdam by rail, and is intersected by numerons canals. Delft was noted from the 16 th to the 18 th century for its delft-ware (see POTTERY), but has now entirely lost its high reputation for this manu. facture, and not more than a few dozen persons are engaged in making earthenware. Of several interesting buildings, one, the town-hall (1618), is a picturesque and richly adorned edifice. The New Church (1476) contains a monument, more oruate than tasteful, to the memory of William I. of Orange, who was assassinated here, 10th July 1584. It also contains the tomb of Grotius, and the burial-vaults of the present royal family of Holland. The Old Church, a building of some note, contains the tomb of the naturalist, Leeuwenlroek, and of the great admiral, Van Tromp. Delft has also a state arsenal, an East Indian college, a polytechnic, and several hospitals. There are some manufactures of tine carpets, casks, baskets Pop. ( 1876 ) 23,804 ; (1888) 27,591; (189.5) 31,964

Delhi (Dehli), an imperial city of Northern India, and the chief conmercial and inclustrial centre of the Punjab, on the right bank of the Jumna, 13 miles from the railway junction of Ghazishad, 113 NNW. of Agra, and 954 NW. of Calcutta. It is walled on three sides, has ten gates, and stands on high ground, the grand series of buildings forming the famous palace of Shah Jehan, now the Fort, looking out over the river and a wide stretch of wooded and cultivated country. To the north, about a mile distant, rises the historic 'ridge,' crowned with memorials of the Mutiny, and commanding a fine view of the city, the domes and minarets of which overtop the encircling gruves. The yadens in the city, the suburbs, and the neighbonring country, are all richly wooded. Delhi is the terminus of the East Indian and Rajputana rail. ways, the former crossing the Jumns by a fine iron bridge. Fergusaon describes in detail the palace buildings, which are the splendid heritage of Mogul sovereignty. Briefly, they comprise the cathedral-like entrance hall, the diuxu-i-lihas, or audience hall, the divcan-i-cm, the rang mahal (now a mess-room), and several lesser pavilions, 
covering in all an area of 1600 feet by 3200 , exclusive of gateways. The beautiful inlaid work and carving of these buildings are the admiration of the world, and the diwan-i-khas is worthy of its famous inscription: "If there is a heaven on earth, it is this-it is this!' In the heart of the city stands the Jama Masjid ('great mosque'), one of the largest and finest structures of the kind in India, which also owes its origin to Shah Jehan. Among the notable monuments in the neighbourhood are the imperial tombs, including that of Hamayun, second of the Mogul dynasty; the old Kala Masjid, or black mosque; and the famous Kutab Minar, 10 miles to the south. The Minar, erected by Kutab-ud-din, founder of a dynasty, early in the 13th century, is 238 feet high, and tapers gracefully from a diameter of 47 feet at the base to 9 feet at the summit. It incloses a winding stairease, and is garlanded with inseriptions from the Koran. Modern Delhi is noted for its broad main streets, the chief being the Chandni Chauk, or Silver Street, with its high clock-tower, and the institute and museum. The Delhi College, once a famous oriental school, has been abolished, government having withdrawn the collegiate staff of teachers to concentrate the grant upon the central institution at Lahore. Delhi has a large trade in wheat and other produce, and its bazaars are noted for gold and silver work, precious stones, shawls, and costly fabrics. It is a great native banking centre. Across the river is the ruined fort of Salimgarh, and traces of an ancient city. Pop. (1891) 193,580, more than half Hindus.

The name Dilli or Dillipur first appears in lst century B.C., and is connected with the famous iron pillar of Raja Dhava, a solid shaft of metal, set up in the $3 d$ or 4 th century, which is 16 inches in diameter, and 50 feet long, and which is so firmly planted that only half of it is above ground. This indisputable relic bears a Sanskrit inscription. in which the name of the eity is mentioned. Delhi was the capital of the Afghan or Pathan, and afterwards of the Mogul, empire. It was taken by a British army under Lord Lake, September 8 , 1803 , and has ever since-if we except the brief period when it was held by the mutineers in 1857 -continued under British rule. In our own time, Delhi has been rendered memorable by the events of 1857. The march on the city of the mutineers from Meerut; the terrible 11th of May; the explosion of the powder-magazine by Willoughby and his heroic band; the assault, when the city was won (September 20 ) gate by gate and quarter by quarter-a success saddened by the death of the gallant Nicholson; the subsequent daring capture of the king of Delhi by Hodson of Hodson's Horse ; and the capture and shooting of his miscreant sons by the same officer, are memorable events in Indian history. A memorial to Willoughby was erected by government in 1888. In 1877 Delhi was the scene of the famous Durbar at which the Queen was proclaimed Empress of India. Delhi is now the most Europeanised of all the cities in the interior of India, and the removal of some of the old gates was among the improvements contemplated in 1888. - The district has an area of $1277 \mathrm{sq}$. m., and a pop. of 638,689 . The trade and mannfactures of the district centre in the town of Delhi. There is a branch of the East Indian Railway, and the Rajputana State Railway traverses the district for about 13 miles. Of about $820 \mathrm{sq}$. m. under cultivation, over a sixth are irrigated from government canals, and a smaller part by private enterprise. To the south, the district is rocky and barren. The soil along the alluvial margin of the Jurnna is fertile, but better crops are produced in the tract artificially irrigated by the Western Jumna Canal. - The division of Delli conprises the three districts of Delhi, Gurgaon, and Karnal, with an area of 5610 sq. m., and a pop. of over two nillions, nearly 75 per cent. of whom are Hindus.

Delibes, LEON, a French composer, born in 1836 at St Germain du Val, in the Sarthe, entered the Paris Conservatoire in 1848, and in 1855 produced an operetta, Denx Sacs de Charbon. At the Grand Opéra, where he became second director. in 1865, his music for the ballet La Source (1866) met with great success, and his ballet-music for Coppéliu (1870), his finest work, secured lis position as a composer. He wrote music for a third ballet and for three comic operas, one of which, $L_{e}$ Roi l'a dit (1873), became very popular. In 1880 Delibes was appointed professor in the Conservatoire. He died January 16, 1891.

Deli'lah (signifying, according to Bertheau, 'the delicate;' according to Ewald, 'the traitress'), the Philistine woman who betrayed Samson (q.v.).

Delille, JACQues, a writer extravagantly overrated in his lifetime, was born near Aigues.Perse in Auvergne, on June 22, 1738 . He was an illegitimate child, and was brought up by charity. Educated at the Collège de Lisieux in Puris, he distinguished himself as a scholar, and obtained a professorship in Amiens. His verse translation of the Georgics, published in 1769, had an extra. ordinary vogue, and was extolled far beyond its merits by Voltaire and other critics. Its author was made an academician in 1774, and, after holding a canonry at Moissac, was presented by the Comte d'Artois with the abbacy of Saint-Severin, the income of which amounted to 30,000 livres a year. Les Jardins, a didactic poem which $\mathrm{D}$ :lille published in 1782, found a vast body of readers, and was generally accepted as a masterpiece. The outbreak of the Revolution compelling Delille to leave France, he, travelled in Switzerland and Germany, and then removed to London, where he occupied himself for eighteen months in translating the Paradise Lost. After his return to France in 1802, he produced a translation of the Aneid (1804) and several didactic and descriptive works in verse-L'Imagination (1806), Les Trois Regnes (1809), and La Conversction (1812). He became blind in his old age, and died on May 1, 1813. During his life he was not only regarded by his countrymen as the greatest French poet of the day, but was even declared to be the equal of Virgil and Homer. His fame, however, suffered a rapid eclipse, and his lack of poetic genius is now generally admitted. He was merely a fluent versifier, whose knack of turning out ingenious paraphrases exactly suited the taste of his contemporaries. See Sainte-Beuve's Portraits Littéraires, vol. ii.

Deliquescence is the term applied to the property which certain substances have of absorbing moisture from the air, and becoming damp, and even running into liquid. Caustic potash, and the chlorides of calcium and magnesium, are examples of substances which undergo this change.

Delirium is a condition in which there is perversion of the mental processes. In its essential nature this symptom is analogous to insanity ; insanity is, in short, a similar state, unaccompanied by the obvious conditions which are the causes of delirium.

In health the mental processes correspond to present sensory impressions or to the memory of those which are past, but in delirium this correspondence ceases, and the results of cerebral activity bear no true relation to reality. De lirium has three well-known mental phenomena, any or all of which may be present in any indi- 
vidual instance. The mind may he possessed by false iless or delusions; sensory impressions may produce false perceptions or illusions; or there mny be fictitious perceptions or hallueinations, without the presence of any sensory impressions.

The more conmon causes of delirium are four. (1) Loeal diseases of the brain or its envelopes, as in the case of inflammation of the lining mem. branes (2) Toxic subatances circulating in the blood, which may have their origin within the system, as in the retention of waste products during the final stages of kidney disease, or may be introduced from without, such as the specific poisons of the acute infectious diseases, or active sulstances like aleohol. (3) High boly tenuera. tures, which may oceur apart from any blood. poison in a local intlammation of some distant orgnn. (4) Inanition, which may often be seen in the concluding periods of wasting diseases.

Delirium Tremens is the term employed to denote one of the acute phases arising in the course of chronic Aleoholism (q.v.). It is as a rule precipitated by a period of indulgence in excessive drinking, and shows itself at first in the form of general uneasiness and restlessness during the day, followed by sleeplessness, or disturbed sleep with distressing dreams, at night. These initial symptoms usher in the stage of delirium, always accom. panied by constant muscular tremors. The delirium almost invariably presents the three main varieties of mental disturbance-illusions, hallucinations, and delusions - to which reference has been made in the preceding article. An attack generally lasts about three days, but it may exist for a period of six or seven days, and, so far as is at present known, there is no means of shortening its duration. The chief danger lies in the great tendency to exhaustion which the disease shows. One attack appears to have a power of predispos. ing the individual who has suffered from it to subsequent recurrence. The affection frequently indnees some degree of mental weakness, and this is more likely to be the case in those who belong to families which have a hereditary tendency to insanity. As above mentioned, no means is known of entting short an attack, and the employment of drugs in this disease is of at least doubtful utility. The only rational treatment consists in the use of every expedient which ean tend to sustain the patient, and avert the great tendency to exhaustion of the vital centres.

De Lisle. See Leconte, Rougrt.

Delitzsch, a town of Prussian Saxony, on the Lobbler, 12 miles $\mathbf{N}$. of Leipzig by rail, with manu. factures of cigars, straw, leather, ivory, and wooden goouls. Pop. 8342.

Delitzseh, Franz, a learned theologian and Hebraist, born at Leipzig, Feloruary 23, 1813, studied theolony and orientalia at the university there, and became professor of Theology at Rostock in 1846, whence he was called to Erlangen in 1850 , and to Leipzig in 1867. Delitzsch's vast learn. ing and exeretical sagacity combined to give him a foremost place anong the more conservative German theolngians, while his great personal intuence over a generation of Leipzig students, and a long series of profoundly learned books, contrib. uted enormously to extend a sound knowledge of Ohl Testament exeresis not only in Germany. but in England and America. His earliest works were in the field of the post-biblical Jewish litern. ture, followed by his conmentaries on Habakkuk, Song of Solomon, Genesis, the Psalms; and to the complete commentary on the Old Testament, edited jointly with Keil, Delitzsch himself contributed the volumes devoted to Isaiah, Job, Solomon's Proverbs, Canticles, and Ecclesiastes. Later works are his Systom der biblimchen Pryehalogi: (1855). System der chriat. A pologetik (1869), Jesus und Hillel (1867), Jied. Handwerkerleben sur Zeil Jesu (1868). His commentary on Genewis (I887) made large concessions to the eritical theory of the Pentateuch. He died 3d March 1890.-Him son, Frizdnich DELitzsch, born ad september 1850 , has alrendy made a great reputation an an Aseyriologist by his Asayr. Studien (1874), lim translation of George Suith's Chaldean Account of Genesis (1876), his Assyr. Lesestuclie (18:6), Wo lag das Paradies? (1881), and his great Asyr. Wörterbuch (1887 et seq.).

Delius, Nrkolaus, a distinguished German Shakespearian critic, was born at Bremen, 19th September 1813, and studied philology at Bonn and Berlin, and in England and France. He finally settled in 1846 at Bonn, where he became extraordinary professor in 1855, and profensor in 1863 , and where he died 18th November 1888. His early lectures were on Sanskrit and the Romance tongues, but he afterwards devoted him. self to the English language and literature, and as a student of Shakespeare took a place that, in the opinion of most scholars, was second to none. A part from excursions of lesser importance in other fields of literature, he published Abhandlungen $z$. Shalispecte (1878), \&c. ; and his edition of Shakespeare's works (Elberfeld, 7 vols. $1854-61$; 5th ed. 2 vols. 1882) is an acknowledged masterpiece, its notes a marvel of terse sagacity.

Delivery in Sale. See SALE of Goods.

Delivery of a Deed. See DEED.

Della Crusean School. About the year 1785, a number of English residents at Florence endeavoured to amuse their lagging hours by writ. ing verses, which they published under the title of The Florence Miscellany. The insipidity, affectation, and fantastic silliness of these productions transcend belief; yet such was the poetic poverty of the time, that they soon found a crowd of admirers and imitntors. Taking the name of a Florentine Academy (q.v.), the Della Cruscans now began to print their precious lueubrations in England, chiefly in two daily newspapers called the World and the Oracle. 'While the epidemic malady was spreading from fool to fool,' as Giftori pungently says, one of the brotherhimal, a Mr Relert Merry, cane over from Flonence, and 'immediately announced himself by a sonnet to Love.' It was answered by one, 'Anna Matilda " (Mrs Cowley), who (as was the custom) praised it immoderately in language even more abourd than Merry's own. 'The fever now turned to a frenzy : Laura, Maris, Carlos, Orlando, Adelaide, and a thousand other nameless names, caught the infection; and from one end of the kingdom to the other all was nonsense and Della Crusca. But retribution followed, for Nemeais watches the counse of poetry as sharply as that of politices In 1794 Gifford produced his Beviad, and in 1796 his Mreviad. Rarely has literature witnesed such a sealping. It completely killed the school, and, indeed, it is only in these two poems that the memory of most of the unhappy Della Cruscan songsters has been preserved - an immortality which may be compared with that conferred by the Newgute Calendar.

Dellys. a port of Algeria, 50 miles $\mathrm{E}$ of Algiers, with a French garrison. Pop. 3564.

De Lolme. JoHx Lours, born at Geneva in 1740, was originally an alvocate in his native town, but about 1709 came to England, where, in spite of his literary activity, he livesl for several years in great poverty, always in debt and repeatedly in prison. Having inherited a emall 
property, he returned to his native country in 1775 , and died at a village in Switzerland, July 16, 1806. De Lolme's principal work is The Constitution of England; or an Account of the English Government; in which it is compared both with the Republican Form of Government and the other Monarchies in Europe. It was first published in French at Amsterdam in 1771; the English translation, by another hand apparently, did not appear till 1775. The work, which flattered England, threw no new light on the subject, long enjoyed a high reputation, and reached a tenth edition (with Life, 1853), but has long been superseded; its author was called by Isaac D'Israeli 'the English Montesquieu.' In 1772 he also published anonymously in English, A Parallel between the Englist' Government and the former Government of Sweden; ten years later, his History of the Flagellants; in 1796 an Essay containing Strictures on the Union of Scotland with England, and numerous political pamphlets. In 1816 Dr Busby tried to prove that De Lolme was Junius.

Delorme, Marion, a famons Frenchwoman, whose name figures too prominently in the history of the 17th century. She was born $3 d$ Oetober 1613 , in or near the town of Blois, and eame at an early period of her life to Paris, where her great beauty and brilliant wit soon gathered a group of wealthy and high-born lovers round her. Even the great Cardinal Richelieu was not insensible to her charms, and revenged himself for her contempt by causing her to be separated from the ill-fated young Cinq-Mars, her love for whom was the one ennobling passion of her life. Among her lovers were, in succession, the Duke of Buckingham, Saint-Evremond, the Duc de Brissac, the Chevalier de Grammont, and Emeri, the Superintendent of Finance. During the first disturbances of the Frondeurs, her house was the rallying-point of the chiefs of that party, and in consequence Mazarin was about to fling her into prison, when she suddenly died in 1650 . A curious tradition sprang up in France during the next century, to the effeet that Marion had not died, but escaped to London ; that she had married an English lord, had then returned to Paris, and married first a robber-chief, next a procurator of finance, and, finally, that she died in 1706 ; or, according to another account, even so late as 1741. Her story was treated by Victor Hugo in a drama; by Alfred de Vigny in his romance Cinq Mars. See Eugène de Mirecourt's imaginative Confessions de Marion Delorme (3 vols. 1851).

Delos (called also in ancient times Asteria, Ortygia), an island in the Grecian Archipelago, the smallest of the Cyclades, is situated between the islands Rhenea and Mykonus. According to the mythological account it was at first a floating island, but was fixed to the bottom by Zeus in order that it might become as safe abode to Leto for the birth of Apollo and Artemis. Its earliest historical inhabitants were Ionians, and it appears to have been the centre of a great periodical festival held in honour of Apollo, both on the mainland and in the islands. In 426 B.C. Delos was purified by the Athenians, all the tombs were removed from it, and it was declared pollution for any birth or death to take place on it. Four vears after they expelled the Delians from the island. After 146 B.c., when Corinth fell, Delos became the seat of extensive commerce. Its sacred associations, its great festival, its excellent harbour, and its situation in the direct route from southern Europe to the coasts of Asia, all combined to render it a port highly favoured by merchants. So great was the traffic of Delos that it is said 10,000 slaves ehanged hands here in a single day.
After flourishing for a considerable time, it was devastated in the Mithridatic war ( 87 B.C.), and from this calanity it never recovered. Little more than $1 \mathrm{sq}$. $\mathrm{m}$. in area, it was noted for its palmtrees, and also for its brass, and the brazen vessels which it manufactured. The town of Delos, which stood at the foot of Mount Cynthus, a granite erag 347 feet high, is now a mass of ruins. Still, however, the remains of the great temple of Apollo, and of the colossal statue raised in his honour, may be distinctly traced. Since 1877 extensive investigations have been prosecuted in its ruins by Homolle for the French Archæological Institute.

Delphi (now Kastri), an ancient Greek town in Phocis, celebrated chiefly for its famous oracle of Apollo, was situated about 8 miles $\mathrm{N}$. of an indentation in the northern shore of the Gulf of Lepanto, at the southern base of Parnassus. Its original name, and that by which Homer invariably speaks of it, was Pytho. It stood in the centre of a district renowned for its classical associations. Occupying the vale of the Pleistus, it was seated in a semicircle like the area of a grand natural theatre, backed towards the north by two lateral spurs of Parnassus. These lateral ranges extend east and west around Delphi, and give rise also, from the point at which they approximate, to the famous fountain of Castalia, the holy water of the Delphian temple. The earliest inhabitants of Delphi are said to have come from Lycorea, a town upon one of the slopes of Parnassus, the inhabitants of which are supposed to have been Dorians. From the Delphian nobles were at first taken the chief magistrates and the priests of the temple, while the Pythia or priestess who delivered the oracle, at first always a young maiden, but latterly always a woman not younger than fifty, was usually selected from some family of poor country-people. In the centre of the temple was a small opening in the ground, whence arose an intoxicating vapour, believed to come from the well of Cassotis; and the Pythia having breathed this, sat down upon the tripod or three-legged stool, which was placed over the chasm in the ground, and thence delivered the oracle, which, if not pronounced at first in hex. ameters, was handed over to a poet, employed for the purpose, who converted it into that form of verse. As the celebrity of the Delphic oracle increased, Delphi became a town of great wealth and importance, famous not only in Hellas, but also among the neighbouring nations. Here the Pythian games were held, and it was one of the two places of meeting of the Amphictyonic Council (q.v.). The fourth temple, though the first built of stone, was destroyed by fire in 548 B.C., and during the succeeding century a fifth and last one was built by the Amphictyors at the cost of 300 talents, or $£ 115,000$. It was hexastyle, fronted with Parian marble, and adorned with statuary by Praxias and Androsthenes. In 480 B.C. Xerxes sent a portion of his army to plunder the temple; but as they climbed the rugged path that led to the shrine, a peal of thunder broke overhead, and two huge crags tumbling from the heights crushed many of the Persians to death, while their comrades, struck with terror, turned and fled. It was plundered by the Phocians during the Sacred War, and was attacked by the Gauls in 279 B.C., who were said to have been repulsed like the Persians by portents. The splendour of Delphi subsequently excited the rapacity of many conquerors, and suffered severely by their attacks. Nero carried off from it 500 bronze statues; Constantine also removed many of its works of art to his own capital. In the time of Pliny, the number of statues in Delphi was not less than 3000 , and within the temple for a long time stood a golden 
statue of Apolio. The modern vows of Kastri now reenpies the site of Delphi, in the neighlnour. heod of the source of the still flowing Castalian spring. See A. Mommsen's Delphilice (1.eip. 18;8), vol. iii. (1886) of Bouché-Leclerg's Histoire de le Divination dans l'Antiquite, and the Cornhill Magasine (1882).

\section{Delphinapterus. See BeLuaA.}

Delphin Classies, an edition of the Greek and Roman classies (64 quarto volumes, 1674-1730) prepured by thirty-nine of the hest scholars of the time, under the editorship, originally, of Bossuet and Huet, tutors to the dauphin, son of Louis XIV. The title-pages bear the words, "In usum Serenissimi Delphini,' hence the name. Editions in octavo of particular authors, as Virgil and Horace, were often reprinted in England. The Delphin Classics are now esteemed of little value.

Delphinidae. See DoLPhis.

\section{Delphinium. See Larkspur.}

Delta is the alluvial deposit formed at the mouth of a river from the deposition of the particles which it has held in suspension or rolled forward upon its bed. The term was originally applied to the tract of land thus formed (mainly within historical times) by the Nile, which, being inclosed by two main l,ranches and the sea, has the form of the Greek letter $\Delta$, delta. The formation of deltas depends more upon the absence of opposing currents at the mouth of the river than upon the quantity of sediment held in suspension when it reaches the sea. Deltas are consequently of almost invariable occurrence in inland lakes, in the quiet estuaries of the nearly tideless Mediterranean, and in the sheltered bays and gulfs of other seas. When, on the other hand, there are strong ebb-tides, or powerful oceanic currents, the detritus is carried off in to the sea.

Delta Metal is an alloy eonsisting of copper and zine-in other words, brass-to which some manganese has been added in the form of ferromanganese, or spiegrel-eisen which contains manganese. A little silicon is also used, but enough of this is usually present in ferro-manganese. The iron added by the use of these substances should be kept small in quantity. Delta metal has similar properties to phosphor-bronze, if, indeed, some of it is not simply manganese-bronze. The silicon and the manganese modify the properties of copper in the same way as phosphorus does in the case of phosphor-bronze (see Brovze). Delta metal is used for parts of machinery and for ornamental work. See the patents of G. A. Dick, the inventor of delta metal, No. 5914, December 1883, and No.6172, April 1884.

Deluc, JEAN ANDRÉ, geologist and meteorologist, was horn at Geneva in 1727. Settling in Eng. Pand in 1773, he was appointed reader to Queen Charlotte, a post which be retained till his death at Windsor, 7th November 1817. He was anthor of thirteen works.

Deluge (through the French, from Lat. diluvium. 'a flood'). There is searcely any considerable race of men among whom there does not exist, in some form, the tradition of a great deluge, which lestroyed all the human race except their own progenitors. The classical story of Dencalion and Pyrrha is lut a typieal example of similar myths found everywhere, and savages and fathers of the church alike have argued that the shells, corals, and other marine objects often found on the tops of mountains, offered distinct prof of the historieal reality of a deluge. That the Noachian deluge recorded in Scripture covered the whole earth and destroyed all mankind save one family, was the universal opinion until towards the close of the $18 \mathrm{th}$ century, and is maintained even in Dean Buck. land's Reliquia Diluviense (1823), The organic remains, on which the science of palavontology is now founded, were resarted as its wrockm, and were held to prove that it had covered every known country, and risen over the highent hills. In the progress of geology, it soon beenme evident that most of the stratilied rucks demandenl an enplier origin than a few thousand years, and the influetoces of the delage was consequently restricted to the slightly altered superficin deposits; but many of these were, after a few years, found to belong to a period vastly anterior to any historical epoch, and to have been produced by long-continued and per. sistent agencies, differing totally from a temporary cataclysm. The more common molem opinion regards the flood of Noah as partial and local, although the universality seems fairly enough to be implied in the biblical deseription, and although the old theory has been revived by Sir Henry Howorth in his work, The Mammoth and the Flood (1887). M. Lenormant, the most brilliant as well as erudite of orthodox scholars, in his great posthu. mous Histoire Ancienne de l'Orient, argues the partial character of the flood from the absence of all record of a deluge among the black races of the world, as the negroes and Papuans; and another Catholic scholar, M. l'A blué Motais, in his interesting and learned work, Le Déluge Biblique (1885), maintains that this opinion is quite consistent with the exegesis of Scripture, with tradition, and the doctrine of the church, while it is the only theory that avoids all the ethnological and linguistic difficulties presented by the existence of the great negro and yellow races marked off so distinctly from the Noachian type. The deluge traditions of many primitive races are connected with religious mygteries, and it is scarcely true, as has often been asserted, that it is the Old Testament alone that gives a moral reason for the deluge sent upon the world. The Chaldean account discovered by George Snith presents a striking resenblance to the Genesis story, and agrees with it also in making the flood distinetly a divine retribution for human sin, although it of course diflers from the Jewish account in being polytheistic instead of monotheistic. The vessel in which Xisuthros, the Chublean Noah, sails, is a ship guided by a steersman, and others heside his own family are admitted into it. The flood is seven days at its height, and Xisuthros sends ont in suecession a raven, a dove, and a swallow. The ship finally rests on Rowandis, the highest mountain of Eastern Kurdistan, and the peak which supports the henvens, instead of upon Ararat, the northern or Armenian continuation of the range. Brbylonian tradition also confounds Noah with Enoch, for Xisuthros is taken to the skies immediately after coming out of the ark. I'wo deluge poens were analyamated together in an Akkadian epic, in twelve books, describing the adventures of Gizdhubar. A translation of Haupt's version is given by Sayce in his Fresh Light from the Ancient Moutuments; and see Prestwiteli, On Certain Phenomena belonging to the Clase of the Last Gieological Period (1895).

De Lunatico Inquirendo. See IssanITy.

Delungdung, a kind of Civet (q.v.).

Delusion. See HalkuciNations, Illusions,

Delvino, a town of Albania, 45 miles WNW. of Janina, with a trade in oil and fruit. Pop. 6000.

Demiales, an Athenian orator, who, a bitter enemy to Demosthenes, promoted engerly the Macedonian interest, and was sent away in snfety by Plitip when taken prisoner at Chroronea (338). but had not the grace to be honest even in his anti-patriotism, and was put to death for his treachery by Antipater in 318. 
Demand and Supply. In Political Economy demand has reference to the quantity of goods asked for in the market, and supply has reference to the quantity of goods offered. The laws of demand and supply may be thus stated: when the demand exceeds the supply, competition grows stronger among the buyers, and prices rise, and when the demand falls short of the supply, competition grows stronger among the sellers, and prices fall; or thus, falling prices tend to lessen the supply and increase the demand, while rising prices tend to increase the supply and lessen the demand. A rise in prices tends to encourage production, while a fall in prices tends to discourage it. Conversely, consumption is promoted by falling and lessened by rising prices. The result is that demand and supply continually tend to equilibrium. Under such a system it is assumed that buyers and sellers or producers and consumers are free to fix their own prices. In other words, the laws of supply and demand prevail under a system of free competition.

Demavend, MounT, an extinct voleano of Persia, forming the loftiest peak of the Elburz Chain, which separates the low shores of the Caspian Sea from the high tableland of Persia. The height hitherto has been usually marked as 14,700 feet, but has been fixed by the Russian Caspian Survey at 18,600 feet.

\section{Dembea, Lake. See Tzana.}

Dembinski, Henry, a Polish general, was born near Cracow, 16th January 1791, entered the Polish army in 1809, and fought under Napoleon against Russia and at Leipzig. In the Polish revolution of 1830 he so distinguished himself that for a short time he was commander-in-chief of the national army ; in $\mathbf{1 8 3 3}$ he entered the service of Mehemet Ali. On the outbreak of the Hungarian insurrection, Kossuth appointed him commanderin-chief of the Hungarian army. He drew up a plan of the campaign, but was hampered by the jealousy of Gorrgei; and after the defeat of Kapolna (February 26-28, 1849) he was forced to resign his command. At Kossuth's resignation Dembinski tled to Turkey, but in 1850 he returned to France, and died at Paris, 13th June 1864. He was author of Memoires (1833) and four other works.

Deme (Gr. dēmos), a subdivision of ancient Attica and of modern Greece. 'The demoi were townships or hundreds, subdivisions of the phulai, and were equivalent to the Dorian komai, Lat. pagi; in the time of Herodotus they were 100 in number ( 10 in each phule) ), afterwards 170 ; their origin was commonly referred to Theseus. The word demos early came to be applied to the commons, and survives significantly in our democracy and demagogue.

Demembré, or Dismenbered, a heraldic term

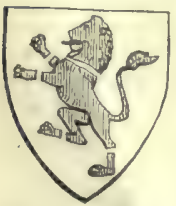
to signify that the members of an animal are cut from its body.

Dementia. See Insanity.

Demerara, one of the three counties of British Guiana (q.v.), between the Abari and the Essequibo, takes its name from the Demerara River, which rises in the Maccari Mountains, in about $4^{\circ} 40^{\prime} \mathrm{N}$. lat., and after a northerly

course of about 200 miles, enters

Dismembered. the Atlantic at Georgetown. The mouth is $1 \frac{1}{2}$
mile wide, but is obstructed by a bar at low tides; the stream is navigable for 90 miles, and has many flourishing settlements on its banks.

Demesne was that portion of the lands of a Manor (q.v.) which the lord of the manor reserved for his immediate use and occupation.
Demeter, the Ceres of the Romans, was one of the chief divinities of the Greeks. She was the earth-goddess, the patroness of agriculture and of fruits, and her name itself most probably meant Mother-Earth (gê mètêr ). She was the daughter of Cronus and Rhea, and was by Zeus the mother of Persephone (Proserpine), who was carried off while gathering flowers in the Nysian plain, in Asia, by Aidoneus (Pluto), the god of the nether world. Demeter wandered for some tinie in search of her daughter, and when she learned whither she had been carried, quitted Olympus in anger, and dwelt on earth among men, as at Eleusis, bringing blessings in her train. At length Zeus sent Hermes to bring back Persephone, and hoth mother and daughter then returned to Olympus, whereupon the earth again brought forth her fruits. As Persephone had eaten a part of a pomegranate in the under world, she was obliged to spend one-third of the year in the gloomy kingdom of her husband, returning to her mother the remainder of the year. Many later additions were made to this beautiful story, in which it is not difficult to see an allegorisation of the burial and revival of the seed-corn within the ground. The Latin poets made Enna, in Sicily, the scene of Proserpine's rape. The Eleusinia were held every year at Athens, in honour of Demeter and her daughter, as well as the Thesmophoria, both there and in other parts of Greece. The Athenians revered her especially as the originator of eivilised life and its arts, which all rest on the basis of agriculture. In art Demeter is represented fully clothed, a garland of corn-ears round her head, in her hand a sceptre, corn-ears, or a poppy, and sometimes with a torch and mystic basket. The worship of Demeter, known as Ceres, reached Rome from Sicily, and ultimately acquired great political importance. Her chief festival there was the Cerealia. See CEREs.

\section{Demetrius, or DMitri. See Russia.}

Demetrius Phalereus, so named from the Attic demos of Phalerus, a seaport of Athens, where he was born about 345 B.C., was distinguished as an orator and politician. Though descended from a family of neither rank nor property, by his abilities and energy he rose to the highest honours at Athens. He was educated along with Menander in the school of Theophrastus, entered upon public life about 325 , and soon made himself famous by his oratory. In 317 he was intrusted by Cassander with the government of Athens, and discharged its duties for ten years with such general satisfaction that the grateful Athenians heaped all kinds of honours upon him, and erected no fewer than 360 statues to his honour. During the later period of his administration he seems to have given himself up to dissipation; and when Demetrius Poliorcetes, king of Macedonia, approached Athens with a besieging army in 307 , Demetrius, having lost the sympathies and co-operation of the Athenians, was obliged to flee. All his statues were demolished except one. He retired first to Thebes, but afterwards found refuge in the court of Ptolemy Lagi, at Alexandria, where he lived for many years, devoting himself to literary pursuits. On the death of his protector, Demetrius was expelled from the court of Egypt, retreated to Busiris in Upper Egypt, and died there from the bite of an asp in 283. Demetrius was the last of the Attic orators worthy of the name. His style was graceful, insinuating, and elegant; bearing, however, in its luxuriousness and tendency to effeminacy, the marks of a declining oratory. The list of his works (fifty in number) given by Dio. genes Laërtius shows him to have been a man of most extensive acquirements. 
Dewi-bastion, in Fortifiention, differs from a Bastion $\left(q . v_{0}\right)$ in having only one tlank instead of two and no cur.

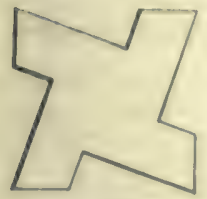

Demi-bastion. tain.

Demidofi, a Russian family distinguished for weslth and beneticence, is descended from Nikita Demidoff, originally a blacksmith at Tuls, who in the time of Peter the Great became famous as a manufacturer of arms, and amassed an immense fortune. of the numerous princes of the line, perhaps the most famous is Prince Anatol (1813-70), born at Moseow, but educated in France. He was always remarkable for his enthusiasm in letters and in the sciences; his principal work being his Travels in South-east Europe (4 vols. Paris, 183949). It contains very valuable scientific observations, and is magnificently illustrated.

Demi-lion, Demi-Rose, Demi-FLEUR DE LIS, \&o., in Heraldry, means, when an animal is spoken of, the upper half; and with an inanimate object, the dexter half parted per pale.

Demi-Iune, in Fortification, is the name formerly given to the work now called a Ravelin (q.v.). See Fortification.

Demi-monde (Fr. demi, 'half,' and monde, 'world,' or 'society '), a term that came into vogue from the title of a play by the younger Dumas (1855), as applied to a class of women in large towns, and especially Paris, whose disregard for the proprieties prevents their being more than half recognised by society. The word covers women of all degrees of disrespectability, provided only they respect the elegancies of life.-Demi-rep is a similar 18th-century word, compounded clumsily enough, for a woman of more than doubtful reputation.

Demir-Missar ('iron-castle"), a town of European Turkey, on a tributary of the Struma, 45 miles NE. of Saloniki. Pop. 8000.

\section{Demise. See LEAsE.}

Demisemiquaver, half a semiquaver, or the 32 part of a semibreve. See Music.

Dem'iurge (from Gr. dèmos, 'people,' and ergon, 'a work;' hence a 'handieraftsman') was the name given in the cosmogony of the Gnostics to the erentor or former of the world of sense. He was conceived as the archon or chief of the lowest order of the spirits or aons of the pleroma ; mingling with chaos, he formed in it a corporeal animated world. He created man, but could impart to him only his own weak prineiple, the psychē or sensuous soul; therefore the highest, the really good God, added the divine rational sonl, or pneumu. But the power of evil in the material body, and the hostile influ. ence of the merely sensuous demiurge, prevented the development of that higher element. The demiurge holding himself to be the highest God, could not bring his ereatures to the knowledge of the true Godhead; as the Jehovah of the Jews, he gave them the imperfect law of Moses, which pro. mised merely a sensuous happiness, and even that not attainable; and against the spirits of the hyle, or world of matter, he sent only a psychical, and therefore powerless Messiah, the man Jesus, Bee Gnosticism.

Demmin, an ancient town of Prussia, on the Peene, which is navigable for small vessels to this point, 29 miles 'S. of Stralsund hy rail. It has manufactures of machinery, bells, ironwares, sugar, lime, and bricks, and a trale in grain, wool, coal, and iron. Pop. (1885) 10,546 ; (1890) 10,852.

Democracy ('rule of the people,' from Gr. dèmos, 'the people,' and krateo, 'I rule') is a form of government in which power rests with the body of the citizens. It is opponed to monarelay, the rale of one; to aristnernoy, the mie of the "bent" or nobles; and to olizarchy, the rule of the few. It in government of the people by the people, and for the people, as opposed to government by a single chiel or a dominant class.

Demoeracy was a grent force in the ancient world, but as then prevalent it had certain charseteristices, which very clearly distinguish it from its modern forms. In antiquity the demoeracy was associated with the city. There was no system of representation by which the people spread over extensive territories could send deputies to speak and act for them in a common parliament. In the ancient democracies, the people were, in the original sense of the word, eitizens, whe personally appwared and spoke and voted in the asemblies. Another great feature in the ancient world was the exist. ence of a great number of slaves who had no political and few eivil rights-i.e a very large and important part of the jopulation were not reckoned among the citizens at all. Hence it will be seen that the 'people' in the ancient demoeracy was limited in number, eonsisting of a city popula tion, and excluding the labouring class or slaves. Thus constituted, the ancient democracy had a most interesting history. It attained to its highest and finest development in the Athens of Pericles hefore the outbreak of the Peloponnesinn war. Berides being a conflict for the headship of Greece between Athens and Suarta, that war was a strughle for supremacy in the Hellenic world between the deno. cratic and aristocratic principles, of which these cities were respectively the representatives and champions. It resulted in the overthrow of the Athenian demoeracy, but the struggle of the people against the rich and privileged classes continued in the Greek cities as long as they retained their independence. At Rome, too, the history of the city is to a large degree the record of popular struggle against the privileged and wealthy classes. Quiescent for about two liundred years after the reforms of the 4 th century B.C., it broke ont afresh at the time of the Gracchi, and ended with the triumph of a great clief of the demoeracy, Julius Casar. But this triumph ment the end of the republic, and the permanent rule of a single head, as consolidated under Angustus.

Among the Germanic tribes which overthrew the Roman empire, as among most peoples at a similar stage of development, the general body of freemen had considerable power. Bnt the term democracy properly refers to communities in a compantively advanced state of political evolution, and it would be an anachronism to apply the theories and problems connected with the word to nations still in the tribal stage.

With the growth of the republies of medieval Itrly, and of the cities of Flanders and Germeny, began a democratic movement similar in some re. spects to that of ancient times. It was similar, inssuruch as it was associated with city life, but is differed from the ancient democracy, in wo far an slavery censed to be an important factor, and the development of the medieval cities was controlled or affected by the great fendal states which had now risen. As the great molern states have become consoliclated, the cities which played so in portant a part in medieval life have been abeorled in then. The process has been a slow one, for Venice was an independent republic till the close of the 18th century. Hamburg was fully incorporated in the German empire only in 1888 . In the city life which thus came to a close, the struggle between rich and poor, between privileged elasees and the people, was more or leas present.

The modern demoeracy differs essentially from the ancient and medieval forms. The people no 
Ionger consist merely of a body of burgesses limited in number, but of millions of men inhabiting extensive countries. A government on such a basis is rendered possible through the representative system, by which the vast electorate choose a convenient number of deputies, on whom the legislative and other functions are conferred. Another important point of difference is the abolition of slavery, serfdom, and the other unfree conditions which formerly prevailed. Freedom of conscience, freedom in the choice of one's residence and profession, have been more or less fully realised. We must also note the progress towards the abolition of all privileged classes, and towards equality before the law.

The modern democracy, as we now see it, is the result of a gradual process of development continued through centuries amidst the severest struggles. Such struggle will appear to be inevitable, when we consider that democracies have grown up in large states in which absolutism formerly prevalled, and in which the military system prevails even yet. Among the decisive steps in the modern struggle of the people against the old classes and systems should be noted the long contest of the Dutch against Spain, the great English revolutions of 1642 and 1688, the war of American Independence in 1776, the great French Revolution of 1789 , and the revolutionary periods of 1830 and 1848. The English revolutions of 1642 and 1688 established parliamentary rule in England, though on a narrow basis. Yet they had the important result of proving the fitness of a new type of government, which further became a model for similar institutions in other countries. The greatest event in the evolution of democracy, however, was the French Revolution of 1789 ; though it failed for the time, it shook the old system to its foundations; it evervwhere spread new ideas, and raised questions that could not again be set aside. The revolution of 1830 showed that the reactionary conditions prevalent after Waterloo had no claim to permanency. The revolutionary movements of 1848 , which affected France, Italy, Austria, and Germany, were apparently a failure, yet they overthrew what remained of the Feudal system in western and central Europe. But the most significant thing connected with that period is the fact that only a few years afterwards universal suffrage was introduced in all the countries where its influence had been felt. Governments which had been most active in suppressing the revolution found it expedient to adopt its cardinal principles.

To England has been given the great historic mission of working out the methods on which the democracy has so far been realised. Her parliament, first constituted under Simon de Montfort and Edward I. in the 13th century, was, as we have seen, firmly established by the long contest with the Stuarts. After so many centuries of experience, trial, and struggle, the English parliament has become the mother of parliaments. England has not been the first, however, to bring democratic institutions to their full development. The Reform Bill of 1832 conferred the franchise on the middle classes: but it was not till the reforms of 1867 and 1885 that she has approximated to universal suffrage. The British government is now substantially a democracy, modified so far by older forms, the monarehy and the House of Lords. In many countries which have adopted parliamentary institutions, the power of the people is much more seriously curtailed; in Germany, for example, by a sovereign' claiming to be of divine right. The German emperor may be regarded as wielding a power co-ordinate with that of the people, and resting on the army. The position of his chancellor does not depend on a parliamentary majority-he is the servant of the emperor; yet while not depending on a parliamentary majority, he finds it expedient and even necessary to have one. The government of the United States, as also of the several states that constitute the Union, is democratic.

As we have seen, the distinctive features of the modern democracy are the widest personal freedom, by which each man has the liberty and responsibility of shaping his own. career; equality before the law ; and political power in the form of universal suffrage, exercised through the representative system. With these are associated universal education, and on the continent of Europe universal liability to military service. In Britain and the United States universal liability to military service exists also in theory as regards the militia. On the European continent it is a momentous fact imposed upon its peoples by the necessities of the struggle for existence, which the moral development of mankind has not yet been able so to regulate as to put an end to war. Anglo-Saxon countries are happily freer from such necessities. It is an interesting fact, however, that Prussia, which was the first great nation to adopt universal education, was also the first to introduce universal military service.

It is important to remember that the growth of the modern democracy has gone hand in hand with the general development of the most advanced nations of the world. The consolidation of the political power of the people is the result of farreaching causes operating on a great scale throughout the history of modern nations. The growth of the democracy is intimately connected with the growth of every other factor in the social life. For example, the different stages in the rise of the democracy could be paralleled by the improvements in the art of printing. The development of the democracy has on the one hand created the demand for cheap literature and cheap newspapers, but it has also on the other hand depended on the supply of them. Further, the growth of the cheap newspaper and of cheap literature depends on the industrial development, on the improvement of our technical capacities and resources, on man's growing mastery over nature. To the production of the daily newspaper a thousand technical appliances are subsidiary. Steam and electricity are the great forces that move the vast mechanism on which society is now based. In fact the growth of the demoeracy is intimately connected with an industrial and technical development which has culminated in the railway, the penny post, the electric telegraph, and the steam printing-press. The peculiar influence of the human voice has not been superseded, yet it is chiefly through the telegraph and the printing-press that the modern demoeracy obtains the education which the ancient democracy received in their popular assemblies and in the daily intercourse of the market-place.

Thus it will be seen that the democracy as we now have it is an outcome of the general historic movement of modern times, and that it is a fact which is not yet accomplished, but is still in process of making. What its ultimate results for good or evil may be, no man can predict. Scarcely any one, however, will deny that it has greatly raised the average level of intelligence and morality in modern nations. The life of the citizen from the day he enters the elementary school is a continual process of education, and it brings with it in abundant measure the discipline of responsibility. It carries with it also the safeguard of publicity. The public interests are protected by incessant watchfulness and public criticism. On the other hand, the drawbacks of democratic government are obvious enough. Such vast masses of electors are too much controlled by governments, caucuses, and 
special interests; real interests are concenled under party watchworda, and secrificed to them. Popular passions are liable to upset the plans of experienced policy, and the demagngue too often ousts the true statesman from his well-merited position in the esteem of the people. It mav be adeled that in the administration of foreign affains, the ehangefulness and publicity umully character. istic of the democracy place it at a disadvantage as compared with the secrecy, continuity, and tenacity of a government like tlint of Kussin.

Much has been written on the merits and de. merits, the advantares and disadvantages of the democracy. It really perhaps concerns us more to observe the fact that it is the inevitable outcome of the prevalent historic forces, that it has a great function in modern history, and that it is the duty of the citizen and statesman to do their luty under it, and to adapt it to the material, intellectual, and moral improvement of men.

Bee the articles Govennurnt, Representation; De Toepueville, Democracy in America (1862); Motley, Histuric Progreas of Amerieren Demacracy (1869): Freeman, Comparative Politicy (1873); Sir T. E. May, Demucrucy in Wurope (1878): Sir H. S. Maine, Popular Government (1885); Bryce, The American Commonvealth (1888); Lecky, Democracy and Liberly (1896).

Democrats, a political party in the United States. So early as Washington's first administration, a party known variously us Republicans or Democrats had already been formed, who desired to limit the federal power, and to increase that of the states and of the people; about 1808 the title of Republicans as synonymous with Democrats disappeared. See REPUBLICANS. Electing Jefferson president in 1801, the Democrats remained in power till 1841, and the administration was in their hands also in $1845-49$, in $1853-61$, and in $1885-89$. Demoeratic presidents have been Jefferson, Madison, Monroe, John Quincy Adams, Jackson, Van Buren, Polk, Pierce, Buchanan, Cleveland. For the positions taken by Democrats on the most prominent issues, see the article UNITED STATES. During President Cleveland's term of office the party committed itself to the principle of a reform of the tariff.

Demoeritus, an illustrious Greek philosopher, was born at Abders, in Thrace, about 470 or 460 B.c. Of his life little is known. The statement that he was first inspired with a desire for philosophic knowledgre lyy certain Magi and Chaldeans whom Xerxes had left at Aludera, on his Grecian expedition, is as untrustworthy as that which represents him as continually laughing at the follies of mankind. His extensive travels, how. ever, through a great portion of the East, prove the reality of this desire, as does also his ceaseless industry in collecting the works of other philo. sophers. Demoeritus was by far the most learned thinker of his age. He had also a high reputation for moral worth. He appears to have left a strong impression of his disinterestedness, modesty, and simplicity on the mind of the community, for even Timon the scoffer, who spared no one else, praised him. The period of his death is uncertain. He lived, however, to a great age. Only a faw frag. ments of his numerous physical, mathematical, ethical, and musical works are extant. These have been collected by Mullach (Berlin, 1843). Cicero praises his style, and Pyrrhon imitated it.

Democritus's system of philosophy is known as the atomic system, which is considered to have been founded by Leucippus. Its essence coneists in the attempt to explain the different phenomens of nature-not like the earlier Ionic philosophers, by maintaining that the original characteristic of matter were qualitutive, but that they were quantitative. He assumes, therefore, ss the ultimate elementary ground of nature, an infinite multitude of indivisible corporeal particlew, atome (see Aтом), and attributes to the a prisury motion derived from no higher principle. Thís motion brings the atoms into contuet with each other, and from the multitudinous combinntions that they form, springm that vast and varying aggregate called malure, whirh in presented is our eyes. Democritus did not acknowledge the preseuce of design in nature, but he adnitted that of 'law. 'The word chance,' he mays. 'is only an expression of human ignorance, He helieved strictly in secondary or plysical caunes, but not in a primary inmaterial cause. Life, conscious ness, thought, were, according to him, derived from the finest atoms; those inages of the sensuons phenomena surrounding us, which we call mental representations, were, according to him, only material impressions, caused by the more delicate atonis streaming through the pores of our orguns. Democritus boldly applied his theory to the gods themselves, whom he affirmed to be aggregates of atoms, only mightier and more powerful then men. His ethical system, spite of the groseness of his metaphysics, is both pure and noble. Such fragments of his writings as we posseas contain beautiful, vigorous, and true thoughts concerning veracity, justice, law, order, and the duties of rulers; while, in a spirit not alien to Cliristianity, he looks upon an inward pence of heart and eonseience as the lightest groxl. Epreurus (q.v.) and Lueretius (q.v.) developed his systen.

Demodex. See Acarts.

Demogeot. Jacquas Claudr, a French litterntever, born 5th July 1808 at Paris, lectured at Beauvais, Rennes, Bordeaux, and Lyons, and was appointed in 1843 to the chair of Rhetorie at the Lvcée St-Louis at Paris. Most of his books treat of the history of literature; the chief are Les Leltres et les Hommes de Lettres au XIX. Siede (1856); Histoire de la Litterature froncaise (1857), an admirable hand-book; Tableau de la Litterature frencaise au $X V I I$. Sidele (1859); and Histoire des Litteratures etrangères (2 volk. 1880). His poems are little known. He died 9th January 1804.

Demoiselle (Anthropoides), s genus of birds in the crane family (Gruidre), differing from the true cranes in having the head and neck quite fenthered, and the beak no longer than the head. The Demoiselle (A. virgo) is about 3 feet in length

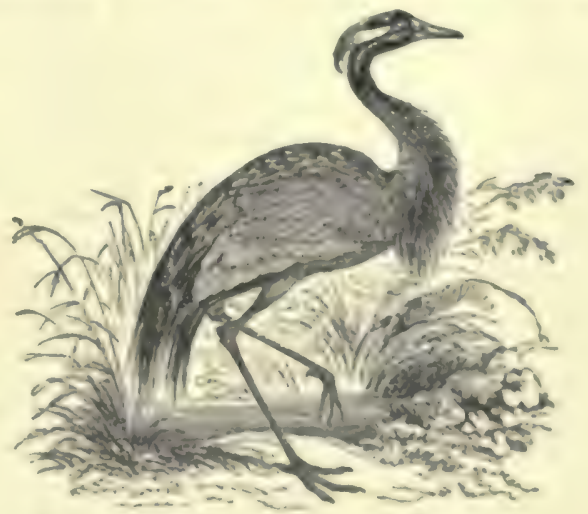

Man-Demoiselle (A melropoides vingo)

from the point of the bill to the tip of the tail, and the top of its head is abont 3 ? feet from the ground. It is remarkable, like its relatives, for elegance and symmetry of form, and grace of deportment. The fenther covering the upper part of the wing are much elongated, as in the cranes. The general 
colour of its plumage is gray, but the sides of the head are adorned with two elegant white tufts, and the breast bears long blackish feathers. The demoiselle is an African and Asiatic bird, but visits Greece and other parts of the south of Europe. To the same genus belongs the beautiful Stanley Crane ( $A$. paradisceus), a larger and taller bird found in the East Indies.

Demoivre, Abraham, a distinguished mathematician, was born at Vitry, in Champagne, 26th May 1667. A Protestant, he fled to England in 1688, after the revocation of the Edict of Nantes, and there long supported himself by private tuition and public lecturing. The appearance of Newton's Principia incited him to increased devotion to mathematical studies, and at last he ranked among the leading mathematicians of his time. He was a member of the Royal Society of London, and of the Academies of Berlin and Paris. The Philosophical Transactions of London are enriched by many contributions from his pen; and he was so esteemed by the Royal Society that they judged him a fit person to assist in the decision of the famous contest between Newton and Leibnitz for the merit of the invention of fluxions. He died in London, 27th November 1754. Among his published works are Annuities upon Lives (1725), Miscellanea Analytica de Seriebus et Quadraturis (1730); and The Doctrine of Chances (171S and 1738), dedicated to Sir Isaac Newton. Demoivre's name is well known from its association with a useful trigonometrical formula-viz. that, where $k$ is any real quantity, $\cos k \theta+\iota \sin k \theta$ is always one value of $(\cos \theta+\imath \sin \theta)^{k}$.

\section{Demonetisation. See BImetallism.}

Demonology, the doctrine that relates to demons, a body of spiritual beings inferior in rank to deities proper, but yet capable of influencing human affairs. The earlier and more widelyspread conception of the demon was merely that of a more or less powerful and intermediate agent between gods and men, at one time resolving himself into a kind of special guardian or patronspirit, at another acting as the minister of the divine displeasure. The gradual differentiation between the beneficent and the malignant qualities of demons resulted in the division into good spirits or guardian-angels and evil spirits or devils; and Christian theology, developing earlier Jewish ideas -themselves powerfully modified by the influence of Persian dualism-worked up the one class into an elaborate hierarchy of angels and archangels, the other into a formidable host of fallen angels or devils, considered as continually employed in frustrating the good purposes of God, and marshalled under one master-spirit, the devil proper or Satan, the supreme impersonation of the spirit of evil. The guardian-angel corresponds closely to such conceptions as the Roman genius and even the famous daimōn of Socrates. To primitive man the demon was but one of the thousand spiritual beings who controlled every one of the causes of nature, and whose favour must be purchased by constant tributes of respect and worship. It was perfectly consistent with primitive philosophy that the manes or ghosts of the dead should continue after death the influence they enjoyed in life, and thus should pass into the higher class of deities. The essential distinctions between the divine and the human that seem so fundamental to modern minds did not occur to those whose notions of the visible and invisible universe alike were entirely animistic; and thus we find that the savage makes no clear distinction between ghosts and demons, and that his conception of the demon is constructed on the model of the human soul, of course with any number of terrible and superhuman qualities superinduced. It is not merely family affection, but actual fear and considerations of pruaience, that lead to the worship of ancestors and of the dead; and the good or bad fortune of living men is attributed to the direct interference of the invisible spirits with. which the whole air around is swarming. These spirits may not only affect the fortume of the individual, but may even enter into his body, and cause internal diseases and such other inexplicable phenomena as frenzy, wild ravings, hysterical epilepsy, and the like. The very etymology of such words as catalepsy and ecstasy points plainly to a time when there was no metaphor in their meaning. Such is the explanation of disease offered at the present day by savage man all over the world, and such was also the belief of the semi-civilised ancient Egyptians and Babylonians. Indeed, it disappeared but slowly before the progress of scientific medicine, and continued to reappear in survivals strangely perplexing on any other explanation. Hence the function of the exorcist arises naturally as a means of effecting a cure by expelling the demon, and we find him daily exercising his skill in Africa, and even in China and India. A careful distinction is made by sorcerers as to whether the infesting demon possesses or obsesses his victim-i.e. controls him from the inside or the outside. In early Christian times those demoniacally possessed, or energumens, were grouped into a class under the care of a special order of clerical exoreists, and after the time of St Augustine the rite of exorcism came to be applied to all infants before baptism. Indeed, exorcists still form one of the 'minor orders' of the Catholic Church.

Reverting to the animistic theory of demonology, we find how well it harmonises with widely-spread notions in folklore of phantom-dreams-nightmare (A.S. mara, 'a erusher') ; the Slavonic vampires, or witch-ghosts, who suck the blood of living victims; incubi and succubi, like Adam's wife Lilith in the rabbinical story (Assyrian litit, 'a succubus'), demons who consort with women and men in their sleep and by whose means children may be engendered between demons and women; the Hindu rakshas, malignant and gigantic demoniacal ogres who can at will assume any shape; and witches, who have confessed a thousand times to being possessed with a familiar spirit, and who own allegiance in particular to the master-demon, Satan. Other embodiments of the spirit of evil are the Celtic and Teutonic Giants, and the Ogres of southern romance, who destroy men and devour their flesh; the Norse Trolls, one-eyed, maliguant but stupid monsters; the Drakos and Lamias of modern Greece; the Lithuanian Laume; the Russian fiery and flying snakes, Koshchei the Deathless, Baba Yaga, a hideous old hag who flies through the air in a fiery mortar, propelled with a pestle, and the Morskoi Tsar, or king of the waters, with his daughters, the ubiquitous swanmaidens of romance. No mythology is richer than the Slavonic in malignant male and female demons and fiends (chorti, 'devils'), gloomy shadows of old nature myths and degraded forms of the great deities of an earlier religion, a combination of the most heterogeneous elements flung together in the most perplexing confusion. Traces remain of an original dualism between a great black and a white god (Byelun); but besides this and those fiendish forms already mentioned, Mr Ralston enumerates the karliki, or fiendish dwarfs; lyeshuie, silvan demons resembling the fauns and satyrs of Greek mythology; vodyanuie, or watersprites; vozdushnuie, demons who ride the whirlwinds; domovuie, or domestic spirits like the Scotch brownies and the Lithuanian kaukas; and the rusalka, a kind of Naiad or Undine. 
Demons with specialised functions exist in myth. olugy everywhere, as the Japanese Oni, who bring on winds, themselves living at the centre of the storm; the Chinese air.dragons, whose battles bring on waterspouts; the demons of floods in old Egyptian and Akkadian mythology; the spectras ani phantons that infest the sea; the nixies of northern Europe, and the kelpies of Scotland, who hannt pools to drown unwary travellers, and naturally hate bridges, although elsewhere many bridges as well as other superhuman works have been erected, usually in miraculously short periods of time, by demons, often at the command of powerful magicians like Michnel Scott. Sometimes the devil even consents to build a church for the reward of the soul of the first that enters it. Others again are those sirens who, by their unearthly beauty or the charm of their singing, draw on unwary youths to their ruin; most famous of these, the romantic Lorelei of the Rhine. Again, particular animals, chiefly those with power to harm man, are favourite hosts for demons to inhabit, especially the serpent, but also the cat, the hedgehog, the hare, the fox, the he-goat, the raven, the wolf-the old Norse Fenris, and the dog, especially if black in colour, like the dog in Faust. The madness of dogs, with its peculiar horror, itself opens up a strange chapter in the history of demonology.

One of the most systematic of demonologies is that elaborated by the Moslem theologians. The Jinn (sing. Jinnee) were created two thousand years before Adam, but sinned against God and were degraded from their original high estate. The greatest among them was Iblees (Eblis), who was cast out by Allah for refusing to worship Adam as made of earth, he himself having been formed of smokeless fire. The Sheytáns form his host ; other species of subordinate fiends are the Jann, the least powerful, also 'Efreets (Afrits) and Márids, the last the most powerful. Eminent among the evil Jinn are the five sons of Iblees-Teer, who brings about calamities, losses, and injuries; ElAawar, who encourages debauchery; Sót, who suggests lies; Dásim, who causes hatred between man and wife; and Zelemboor, who presides over places of traffic. Inferior demons are the Ghoul, often in human form and devouring the bodies of the dead like the Russian werewolves; the Sealáh, found in forests; the Delhán, living in islands; and the Shikk, shaped like a human being halved lengthwise. The Jinn assume various shapes, sometimes as men of enormous size and portentous hideousness. They live chiefly on the mountains of Káf, which encompass the whole earth, and their evil intluence may be averted by talismans and invocations, and pre-eminently wise magicians like Solomon may command therr services. They consist of forty troops, each troop coutaining six hundred thousand. Dee chapter ii. of Lane's Ancibian Society in the Middle Ages (elited by Stanley Lane-Poole, 1883).

The subject of dualism, or the division of all the invisible powers into two great armies of good and evil demons, ranged under the supreme impersonations of good and evil, will be discussed under ZOROASTER, and here it is sufficient to say that it modified the whole later Jewish and Talmudic demonology, and resppeared in the Manichiean heresy. To it is due the distinction between the demon and the devil, a notion which seems funda. mental to the modern moral sense, but was foreign to the earlier demonology, sccording to which all the specially malignant qualities and the love of evil for its own sake hecome characteristic of the latter.' The Vritrn and the other night-powers, the Panis, of the Vedic hymns, are as yet hardly more than personifications of merely pliysical evil, not inherently and absolutely wicked; while the
Loki of the ancient Scandinavinns, their nenrest approximation $t$ a $a$ permonificution of evil, was rather a demigod than a devil, not ementially hostile to the other deitien, although be workin them mischief enough; and the four archilemons of the Rabbins, Samaé, Azazel, Amid, and Mnccathiel, seem to have been originally nothing more than personifieations of the clements an energies of the deity. Even the name Lueifer ('the light-bearer'), the fallen angel of the morn. ing star, fits ill with a conception of a devil utterly and hopelessly evil. The widely-apread belief that demons are lame accords well with a supposed fall from heaven and an original state of innocence. It is not a little striking at anyrute to find the marme characteristic in Hephaistos, Wayland the Smith, and the Persian Ashma-the Ammodeus of the Book of 'Tobit, the 'Diable Boiteux' of Le Bage. The sootiness of his abole and his blackness of colour are persistent characteristics, although, indeed, some West African negroes have a white devil. The usual cloven feet of the devil in European folk-tales, often the last mark of identification, when even the horns and the tail are hidden, is a reminiscence of the Greek satyr and the forest-aprites of old Teutonic and other folklore. The ugliness of the medieval representations of the devil in religious art, as may be seen in the fantastic gargoyles of many churches, was but a part of the early church policy of degradation to which the native deities were subjected, and from which sprung the medieval belief that the various gools of the old heathen world were the devils or degraded angels of Seripture. This notion is familiar to readen of Paradise Lost, although Milton makes an in. genious poetic use of it that is all his own. And even the medieval devil, with all his terror, had strange limitations to his power, especially perhaps in the folklore of the north. He is often Indicrously outwitted, and his machinations foilonl by some obvious enough device or verbal quibble. It is not merely the weakest saint upon his knees that can bafle his infernal schemes, but some country-fellow who beats him at his own weapons, and whom afterwards he will have in hell at no price. The old Seotch notion of Satan as grown so much the more dangerous from the accumulated wickedness and wisdon of six thousand years is hopelessly inconsistent with the archfiend of Norse folklore.

The early Christian iden of hell, the abode of the demons, owed many of its fentures to the Jew. ish Gelienna, with its perpetual tire, the horror of its sacrifices, and its loatheome worm; and the characteristics of Moloch and other primitive fire. grods became associaterl with the devil, degraderl from a fire-god to a mere powerful spirit. The Jinn of Arabian mythology, who are slaves of the lamp and ascend as clouds of smoke, serve aleo to ahow how fundamental was the notion of a fire. fiend which paseed, though under degraded form, into Christian theology. Consistent with this is the widespread belief in Europe that the devil cannot touch or eross running water, of which poetic nae is admirably male in the magniticent phan. tasy of Tam o' Shanter. Again, the struggle between Balder and the deadly powers of winter in the Norae mythology was spiritualised and ampli. fied into Christ conquering Denth and Hell and releasing the spirits from prison and the old nortli. ern idens of wintry cold personified into a poweriul and maligmant demon, under new influences jasserl to swell the attributes of the Christian devil, whoee dreary abode provided those torments of frost as well as fire faniliar to readers of Dante. Herein is the origin of the folklore notion that the lome of the demons was the north, and hence the inveterate 
English preference for burial on the south side of a church. No stories are more common than those of compacts with the devil, sometimes written in blood, by which a man gave away his soul for wisdom, wealth, power, or other gratifications to be enjoyed for a certain number of years. The classical story in this kind is that of Faust, which the genius of Goethe has marle an imperishable part of the intel. lectual birthright of Europe.

Raising the devil or his inferior demons was a feat within the power of the medieval sorcerers and masters of the black art, and elaborate formulas for the purpose are gravely given in the books of magic. This unholy art was made punishable by death by James I., and his law remained upon the statutebook of England till the reign of George II. The worship of the devil was a usual feature of the witches' sabbath, and the name is often applied still to the strange dances and other religious rites by which many tribes in India and elsewhere avert the anger of malignant deities. It must be understood that there is no conscious homage to the principle of evil as opposed to good, as the objects of worship are merely deities powerful for harm as well as for help, considered almost as entirely outside any moral considerations, like the demons of unmixed primitive religion everywhere.

See the articles ANGer, ANIMISM, DEvil, Evil, EXoRCISM, HELL, SERPENT-WORSHIP, WEHFWOLF, Witcheraft, Zornaster; also Horst, Demonomagie (2 vols. 1818), and Zauberbibliothek (6 vols. 1821-26); Ukert, Ueher Dämonen, Heroen, und Genien (1850); Bastian, Der Mensch in der Geschichte (3 vols. 18b0); 'I'ylor's Primitive Culture (2 vols. 1871); Roskoff's admirably learned Geschichte des Teufels (2 vols. 1869); and for its tacts, Moncure D. Conway's Demonology and Devil-lore ( 2 vols. 1879); also some of the older books, as Budin, De Magorum Demonomania (1581), and the like.

De Morgan, Augustus, son of Colonel De Morgan of the Indian army, was born in 1806, in Madura, Madras Presidency. Educated at several private schools, he 'read algebra like a novel' (novels themselves he devoured insatiably); but after four years at Trinity College, Cambridge, he graduated as only fourth wrangler (1827). As a result of his revolt from his early evangelical training, he did not take orders. He was appointed first professor of Mathematics in University College, London, after its foundation in 1828. In 1831 he resigned this office, but was reappointed in 1836 , and continued in that capacity till 1866. An energetic worker, he was secretary of the Astronomical Society (1831-38 and 1848-54), and held other offices therein. His writings are very numerons. Besides being a mathematician of the first order, he was extensively and minutely versed in the history of the mathematical and physical sciences. He also devoted himself to the development of the Aristotelian or "Formal' Logic, to which he has given so symbolical a shape as to make it seem like a branch of Algebra, and wrote on the calculation of Insurances and on the Decimal Coinage. His works include Elements of Arithmetic (1831); Algebra (1835); Numbers and Magnitude (1836); Trigonometry and Trigonometrical Analysis (1837); Essay on Probabilities (1838); Formal Logic (1847); Arithmetical Books (1847); Book of Almanaes (1850); Budget of Paradoxes (1872), reprinted from the Athenoum. De Morgan also wrote treatises on the Differential and Integral Calculus; and contributed largely to the Penny Cyclopoedia (850 articles). He died 18th March 1871. His library of abont 3000 volumes was purchased by Lord Overstone, and given to London University. See the Life by his wife (1882), whose reminiscences were published in 1895 .

Iemosthenes, an able Athenian general, who in 425 B.C. assisted Cleon to reduce Sphacteria, and who in 413 , being sent to Sicily to the relief of Nicias, fell, fighting bravely, into the hands of the Syracusans, and was put to death.

Demosthenes, the greatest orator of Athens and of Greece, was boru about 383 B.c. He lost his father at an early age. The considerable inheritance bequeathed to him was reduced by the neglect or the fraud of his guardians, and when he came of age he proceeded to prosecute them. The litigation was long and complicated, and though he gained verdicts in lis favour, most of his inheritance was irretrievably lost. The importance of this litigation was that it compelled Demosthenes to the study of the law, gave the first exercise to that doggedness and strength of will which was to mark him through life, and by reducing him to poverty, drove him to the pursuit of law as a means of living. At Athens the parties to a suit were compelled to plead their cause themselves, but they could not be prevented from getting their speeches composed for them by a professional 'speech-writer' or 'logographer.' Demosthenes became a logographer, and soon acquired a lucrative practice. Up to the age of thirty Demosthenes confined himself to ${ }^{6}$ speechwriting, and gained considerable reputation as a constitutional lawyer. His most famous constitutional law speech is one which he delivered personally in support of Ctesippus against Leptines (354 B.C.). He seems to have lacked by nature all the physical qualifications of a great orator, and to have acquired them solely by indefatigable self-discipline and training. At about the age of thirty he made his first appearance as a politician ; he continued to practise as a logographer until he was about forty, by which time he had made a fortune sufficient to enable him to devote himself exclusively to political life until he died, at the age of about sixty-one.

At the beginning of his political career danger threatened Greece from the north, from Macedonia, a country which though at that time considered by the Greeks as semi-barbarous, and of no account in Greek politics, was destined within the lifetime of Demosthenes to destroy the liberties and the political existence of Greece. Demosthenes' claim to fame as a statesman rests on the fact that he foresaw the danger threatened by Philip of Macedon from the beginning, and that he from the outset advocated \& policy which might have saved Athens and Greece. The three cardinal features of his policy were that the rich should submit to direct taxation for the purposes of the war; that the poor should submit, for the same purposes, to a diminution of the public expenditure on national festivals; and that rich and poor alike should render personal military service instead of employing mercentries. Intelligent as was the Athenian democracy, it was not intelligent enough to see that Demostlienes' forecast was right, and his opponents' wrong; and, consequently, it was only when events justified Demosthenes, that is to say, when it was too late, that his policy was adopted. Philip's attack on the state of Olynthrs gave occasion to the Olynthices, which, with the orations against Philip, the Philippics, are the greatest speeches made by Demosthenes. Athens made war with Philip on behalf of Olynthus, but having failed to save the city, found peace expedient. During the next few years $(346-340)$ Demosthenes was engaged in forming an anti-Macedonian party, and in indicting Eschines for betraying Athens in the negotiations for the peace just concluded with Philip. War again broke ont in 340 , ending in the fatal battle of Chreronea (338). But Athens, having learned to trust Demosthenes, did not withdraw her confidence. The philo-Macedonian party, however, were encouraged to seize on a proposal to present Demosthenes with a public 
crown as an occasion for his political destruction. The trial was at length held in 330, when in the famous speech On the Crown Demosthenen gloriously vindicated himself against Fischines. In $324 \mathrm{Har}$. palus, the treasurer of Alexander the Great (who hal succeeded Philip), absconded to Athens with An enormous sum of money. This money was placed in the state treasury, under the care of Demostlienes and others, and when Alexander demanded it, half was missing. Demosthenes was recused, conclemned, and eserped from prison into exile. The evidence does not seem to have war. ranted the verdict, which was probably given on political gromuda, Demosthenes having offended loth the Macedonian party and the extreme patriots. - In 323 Alexander died, and Demosthenes was recalled from exile to head a fruitless attempt to throw off the Macedonian yoke. The lattle of Crannon encled the revolt. Demosthenes fled to Calaurein, and being there captured by Macedonian troops, poisoned himself, 322 B.C.

Demosthenes began life with a nervous, timid nature, and, unfortunately, as a boy was allowed by his mother to shirk the physical exereises and gymnastic training which formed part of the ordinary education of the young Athenian. He grew up with a tendency to effeminacy, which showed itself in an affection for luxurious clothing, and still more in his conduct as a citizen soldier; for although at Chreronea he may have displayed no more cowardice than did the other Athenians who ran away, he was far from exhibiting the heroic bearing which distinguished Socrates at Delium. His timidity made him unsocial, and his waterdrinking habits eut him off still more effectually from society. His luxury may have reached the point of extravagance: he was certainly lavishly generous in the discharge of all claims on him, public and private. Whether his effeminncy amounted to immorality, as was charged against him, is a question which eannot be answered offhand in the negative. The natural defects which were to be seen in his private life may be traced in his public career; but here it is their conquest by force of will and determined adherence to a lofty purpose which has rightly given him his great name. His nervousness and timidity disqualified him for political life and public speaking; these defects he combated till he conquered them. His natural incapacity for amiability rendered him unsympathetic to the pleasure-loving Athenians; he compelled their respect by his intellectual power and the purity of his patriotism. The want of sympathy, however, he never overcame, and so he never obtained the hold over the Athenians which it would have been good for them that he should possess. In all democracies every politician who has led the masses at his own good-will has known on occasion how, if not to flatter, at least to say the thing that is pleasant; lut Demosthenes nature did not permit him to say pleasant things. Even this serious practical deficiency could not prevent his contemporaries from eventually recog. nising his force of character and steadiness of noble purpose. Still less has it weighed with posterity.

In the oratory of Demosthenes it is not difficnlt to trace the character of the man reflected. His reaplute hard work and his infinite capacity for taking pains are seen in the high finish which distinguished his speeches above those of every orator. His moroseness is mirrored in the abuse of which he was too great a master; his want of amiability in the absence of humour. His nervonsness betrays itself in his over-anxiety to argue, in his lack of ease and flow. But as in his life so in his speeches, all faults are blotted out by his unaffected earnestness, his entire devotion to his country, his intel- lectual loftiness, and his high politieal morality. These great qualities are the noures of the dignity, the pathos, the might, majenty, and dominion of his political orations. Even these qualities, how. ever, would not have mised him to the highese pinnacle in the fane of eloquence had lie not pose. sessed the ear and the mind of the artist in works, the former of which gave to his ppeeches the mos. vellous melouly they josmens, the latter the variety of vocabulary, which is one of Demonthenes characteristics. Nor must it be forgotten that the way for Demosthenes had been paved by great pre. decessons. The summit on which he stands rests on the labours of Lysias, Isocrates, and othens. Finally, oratory, to be great, must have great themes, and it is not in every age that they are forthcoming. Demosthenes hal the lot, tragic but triumphant, of saving, though all else was lost, the honour of his country.

For the life of Demosthenes, $\Lambda$. Schäfer's Demouthenes und seine Zeit (2d ed. 1882) eclipes all other works. good as are the hand-books of Brodribb (1877) and Butcher (1881). The most exhaustive literary eriticiom is contained in Blass's Attivehe Beredeamkeit (1877). 'The best text in that of Bekker (1854). Kennedy' English translation (5 vols, 1862-63) is a monument of schularship.

Demotica, a town of Europen Turkey, on a tributary of the Maritza, 31 miles \$. of Adrianople by rail. It is the seat of a Greek bishop, and has manufactures of silks and pottery. Pop. sovio. Charles XII. of Sweden resided here from Feb. ruary 1713 to October 1714 .

\section{Demotic Alphabet. See Hurogurucs.}

Dempster, THomas, a professor famous for his learning, and a miscellaneous and voluminous writer, was the son of Thomas, laind of Muiresk, A berdeenshire, and was born about 1579. He was educated at Turriff, Aberdeen, Cambridge, Paris, Louvain, Rome, and Douay. A zealous Catholic, he was elected to several provincial professorships, and at Paris he was for seven yeas professor in the Colleges des Grassins, de Lisieux, and de Plessy. But a brawl resulted, it is said, in Dempater's having to retreat to England. He soon returned to the Continent, lringing with him a beautiful wife, and at Pisa in 1616 obtaineal a professorship; but his wife's infidelities marring his peace, he removed to Bolngna, where he becamo professor of Humanities, and where his wife completed her shame by eloping. Pursuing the fuyitives, he was stricken with sickness, and died at Bologna, 6th September 1625. Dempster's not too veracious autobiography forms part of his Historia Ecolesiastion Gentis Scotormm (Bolngna, 1627 - an erudite work in which, however, his desire to magnify the merits of his country often induced him to forge the names of persons and books that never existed, and to unecrupulously claim as Scotehmen writers whose birthplace was doubtful. It was edited by David Irving for the Bannatyne Club in 3829 , and the manuscript is still preserved in the Bibliotheque Nationale, Paria There is a selection from his Latin poetry in Johnston's Delitice Poetamem Scotorum.

Demuleents (Lat. demulceo, 'I eoften ') bland and lubricating liquid sulestances, taken by' the mouth, for the purpose of soothing irritation of the mucous membranes, and promoting the dilution of the bloorl, and the increase of the eecretions. Demulcents are chiefly conaposed of Starch $\left(q, v_{0}\right)$, or Gum (q.v.), or of sulatances containing these, dissolved in water; sometimes also of oily masters, or the white of egge, and other alhuminous or gelatinons substances largely diluted. The decoction of althaea, or marsh-mallow, is a favourite form of demulcent. 
Demurrage is an allowance made to a shipowner by the freighter, for the detention of the ship in port beyond the specified time of sailing. The demurrage is properly the delay itself, but the term is generally used to signify the compensation due for the delay. A certain number of days, called lay-days or lie-days, are allowed for receiving and discharging cargo, and it is usually stipulated in charter-parties that the freighter may detain the vessel, either for a specified time, or as long as he pleases, after the expiration of these days, on paying so much per diem for overtime. Whether the days for which demurrage is due are vorking days (i.e. with Sundays and holidays excepted) or running days will, in the absence of special agreement, depend upon the custom of the port. All the ordinary causes of detention, such as port-regulations, the crowded state of the harbour, and the like, are at the risk of the freighter, and demurrage must be paid, though it be proved that the delay was inevitable. But demurrage is not due where the delay arose from detention of the ship by public enemy, or from hostile occupation of the port; and it cannot, of course, be claimed where the fault lay with the owners themselves, or the master or erew of the vessel. The demurrage ceases as soon as the vessel is cleared for sailing, though she should be prevented from actually doing so by adverse winds. When the days of demurrage are limited by special contract, and the ship is detained beyond them, the sum due as demurrage under the contract will be taken as the measure of the loss for the further time which may be claimed in the form of damages. It will be open, however, to both parties to show that the rate thus fixed per diem is either too high or too low. When the time allowed for loading and discharging expires, including the extra days if such be stipulated, the niaster will be entitled either to sail or to claim damage for detention.

The allowance of $1 \frac{1}{2} d$. per oz. claimed by the Bank of England for giving gold coin in exchange for bullion is also called demurrage.

Demurrer, in English law, is a form of pleading whereby a party, admitting, for the sake of argument, his opponent's allegations, says they are not sufficient in law to support his opponent's case. A demurrer must be argued in court before the pleadings can proceed further. Demurrer to evidence and demurrer to a criminal indictment are now obsolete. If a prisoner wishes to object to the sufficiency in law of an indictment, his best course is to plead to the indictment, and, if convicted, to move in arrest of judyment.

Demy', a particular size of paper. In that of printing paper, each sheet measures 22 inches by $17 \frac{1}{2}$; drawing-paper, 22 by 17 ; and writing-paper, 20 by $15 \frac{1}{2}$.

Demy (i.e. half-fellow), the name borne by the scholars of Magdalen College, Oxford.

Denain, a town in the French department of Nord, near the Scheldt and Selle rivers, 20 miles $\mathrm{NNE}$. of Cambrai by rail. It lies in the centre of an extensive coalfield, and has important ironworks, and with manufactures of beetroot sugar and brandy. An obelisk marks the scene of Marshal Villars' victory over the allies under Prince Eugene, 27th July 1712. Pop. (1872) 10,442 ; (1886) 16,115 ; (1891) 16,663 .

Dena'rius (deni, 'ten each'), the principal silver coin among the Romans, was equal to ten ases, but upon the reduction of the weight of the $a s$, the denarius equalled sixteen of it. It was first coined 269 B.C. Its weight at the end of the Roman commonwealth is estimated at 60 grains, while under the empire the weight was 52.5 grains of silver. The value of the denarius under the republic was thus rather more than $8 \frac{1}{2} d$., and of the later
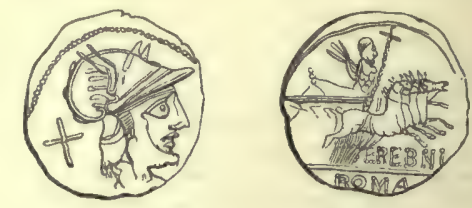

Denarius of the earliest kind, actual size; weight, $60^{\circ} 6$ grains.

period about $7 \frac{1}{2} \mathrm{~d}$. From denarius come the Persian dinar and the English slang deaner, 'a shilling.'

\section{Denary Seale. See Notation.}

Denbigh, a parliamentary and municipal borough, the county town of Denbighshire, 30 miles W. of Chester by rail. It stands near the middle of the vale of the Clwyd, on the sides and at the base of a rugged steep limestone-hill. The castle, whose imposing ruins crown this hill, was built in 1284 by Henry Lacy, Earl of Lincoln, on the site of a fortress erected by William the Conqueror. The newer part of Denbigh was built at the bottom of the hill, after the destruction and desertion of a great part of the town on the top of the hill, about 1550 . Denbigh has manufactures of shoes and leather; but it is more a place of genteel retirement than of commerce. Pop. (1851) 5498 ; (1891) 6412. With Ruthin, Holt, and Wrexham, Denbigh sends one member to parliament. In 1645 Charles I. took refuge in the castle after the battle of Rowton Heath. The garrison surrendered to the parliamentary forces after a siege of two months. It was shortly afterwards dismantled. The fortifications have an area of a square mile in extent. A lunatic asylum for the five counties of North Wales was erected near the town in 1848. A noble institution for the maintenance and education of twenty-five orphan girls, and twenty-five day pupils, was built here in 1860 , with funds in the hands of the Drapers' Company of London, from money left to them in 1540 by one Thomas Howell,

\section{a Welshman.}

Denbighshire, a county of North Wales, on the Irish Sea, and between the Dee and the Conway. With 8 miles of coast, it is 41 miles long, 17 broad on an average, and $603 \mathrm{sq} . \mathrm{m}$. in area, being the sixth in size of the Welsh counties. The surface is partly rugged and mountainons, with some beautiful and fertile vales, as the vale of the Clivyd, 20 miles by 7, and those of the Dee and Conway. In the north is a range of hills, convex to the coast. The highest hill is Cader Fronwen, 2563 feet; and many others rise above 1500 feet. The rocks are chiefly Silurian clay and graywacke slates, with some granite and trap, and bands of Devonian, Carboniferous, and Permian strata. There oceur coal, iron, slates, flags, millstones, limestone, lead, and copper. The chief rivers are the Dee, Conway, Elwy, and Clwyd. The Rhaiadr waterfall is 200 feet high in two parts. Llangollen vale is famed for romantic beauty and verdure, amid hills of savage grandeur. The climate is mild in the lower parts, but cold and bleak among the hills, where small hardy sheep and ponies are reared. About two-thirds of Denbighshire are under cultivation; its corn, cheese, butter, and live-stock are greatly esteerned. It is also well timbered. Salmon are caught in the rivers. The chief towns are Denbigh, Wrexham, Ruthin, Holt, Llangollen, Llanrwst, A bergele, and Ruabon. Pop. (1801) 60,299 ; (1841) 88,478; (1891) 117,872 . Den. bighshire returns two members to parliament. It was anciently occupied by the Ordovices, a powerful tribe, not entirely subdued by the Romans till the 
time of Agrionla. Of British or pre-Roman remains there till exist tunuli, two kistvaens or stone cells, harrows, and forts. 'T'o the times of the We-lsh and Saxon struggles are reforable the Pillar of kineg. near Llangollen, and the dikes of Otha and Watt. The dike of Utfa, king of Merein, to keep out the Welsh, was a ditwh, with small forts on nounds at intervals, and $\operatorname{man}$ from Herefordshire to the estuary of the Dee; Watt's dike ran on the east side of Offa's dike, and parallel to it. Wrexham Clumeh is one of the 'seven wonders of Wales.' Chirk Castle is a fine Edwardian mtronghold, lately restored.

Dendera (Gr. Tentyra; Coptic Tentore, prob alsy from Tri-n-Athor, the abode of Athor), a village of Upper Egypt, once a populous town, and the capital of the sixth nome of the "southern kingdom,' situated near the left bank of the Nile, in $23^{\circ} 13^{\prime} \mathrm{N}$. lut., $32^{\circ} 40^{\prime} \mathrm{E}$. long., is celebrated on account of its temple, one of the finest and best pre. served structures of the kind in Egypt, dating from the period of Cleopatra and the enrlier Roman emperors. The temple mensures 220 feet in length by about 50 in breadth, and has a noble portico or hypostyle hall supported on twenty-fou columns. The walls, columns, \&c. are covered with figures and hieroglyphice, among which are still to be seen the contemporary portraits in profile of Cleopatra and her, son; but the beauty of the Euptian queen is not apparent in her portrait, which belongs to almost the most decgraded period of conventional art in Egypt. On the ceiling of the portico is a zodiac, in which the erab is represented by a scarab. Beyond the portico are $a$ hall of six columns and several rooms, which once contained altars, the sacred borts, perfumes, vestments for the religious ceremonies, and offerings of first-fruits, and the like (Mariette, The Monuments of Upier Egypt). There are several other sacred buildings at Dendera, including a temple of Isis. The temples stand within a wall of unbaked bricks, 1000 feet long on one side, and in some parts 35 feet hichl. The people of Tentyra were peculiar for their detestation of the crocodile, which led to a violent religious war with the city of Ombos, where the reptile was worshipped.

Dendermonde (Fr. Termonde), a town of Belgium, in the province of Last Flanders, situated at the confluence of the Dender and the Scheldt, 18 miles E. of Ghent by rail. The principal buildings are the town house and the church of Notre Dame, containing two pictures by Van Dyck. The manufactures are linens, cottons, and beer. Louis XIV. besiegred it in vain in 1667 , but Marl. borough succeeded in taking it in 1706 . Its fortifications, destroyed in 1784 , were restored in 1822 . Pop. (1890) 9654 .

Dendrerpeton, a small lizard-like carboniferous amphitian, found by Lyell and Dawson in the interine of the hollow trunk of an upright sigil. laria in Nova Scotia. It belongs to the wholly extinct order of Stegocephala or Labyrinthodonts $(\mathrm{q} \cdot \mathrm{v}$ )

Dendrites, the name given to thin films of mineral matter which assume branching shapes that resemble moss or seaweed. These films occur as coatings on the faces of fissures and joints in rocks or on the surfaces of berlding-planes, and have often been mistaken for fossils. The hydrous oxide of manganese is the mineral that generally assumes this form.

Dendrolites (Gr. dendron, 'tree;" lithos, 'stone'), a general term sometimes applied to fossil stems, branches, or other fragments of trees.

Dendrology is that department of botany which deals with the natural history of trees and shrubs, See Arboriculture, TREE.
Dendrophis (Gr., 'tree-snake'), ngenus of non. venumous suakes in the mb-order (Colutriformen. They are tropleal, and especially oriental, in their distribution: diurnal netive and arburenl in habit; and feed chietly on tree-lizards. The heal is long and distinet from the neek, the sape in wide, the body and tail are very slender, the colours are vivid and like their surroundinga.

\section{D'Enghien. See ENaHs.}

Dengue, or Break-Bove FEVER, aleo enlled DANDY and BUCKET FEVER, is a disenese firwt certaisly known to have oceurred in $1759-80$ in

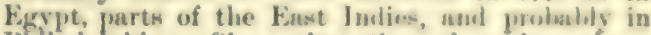
Philadelphia Since that time there have been great epulenies in India and Futher bulia 11 n.2425) America and West Indies (1826-28), Boutherm United States (1850), East Africa, Arahin, India, and Chins (1870-73), besides numerous minor outbreaks. The diserse occurs almost exclusively in the tropics, in hot weather, and in towns either near the sea-coast or on large rivers. It is charee. terised by sudden onset, with high fever, and ex. tremely violent pains in the bones, museles, and joints; by a remission, usually at the end of one or two davs, during which the patient feels almost well; and after one or two days more by a second period of fever, less severe than the finst, which lasts for two or three days. Each attack of fever is often accompanied by a well-marked skin. eruption. Though often followed by much emaciation and loss of strength, it is very rarely fatal or succeeded by serions after-effects. It cocurs almost always in well-marked epidemics; but observers are much divided npon the question whether it is communicable directly from the aick to the healthy. See Hirsch, Geographical and Historical Pathology, vol. i.

Denham, SiR JoHs, a Caroline poet, was the only son of an Irish judge, himself of English birth, and was born at Dublin in 1615. He was educated in London and at Trinity College, Oxford, where Wood tells us he was 'a slow dreaming young man, and more addicted to gam. ing than study - a taste from which his own essay against gaming (1651) did not cure him. In 1634 he married and went to live with his father at Egham in Surrey, an estate to which be succeeled four years later. At the outbreak of the Civil War he was high-sheriff of Surrey, and he immediately joined the king. He fell into Waller's hands on the capture of Farnham Castle, and was sent prisoner to London, but soon permitted to repair to Oxford. In 1641 he produced Sophy, a feeble tracresly which was scterl with great applatuse at Blackfriars Next year was issued his long poem, Cooper's Hill, a poetical description of the scenery around Egham, itself still read, but more famous in the merits of its greater succeson, Pope's Windsor Foneat, avowedly an imitation, and Garth: Claremont. The final form of the poem is that published in 1655 , all the changes in which, nccording to Pope, were made "with admirable judgment" Here first appeared its finest lines-the iamous. apostrophe to the Thames:

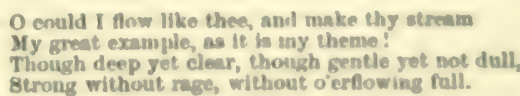

In 1647 Denham was engaged in the performance of secret servicess for Charles I., but these lweing diecovered, was obliged to flee to Holland ani France. In 1650 he collected money for the young king from the Seots renident in Poland, and he made several journeys into England on secret service. It the Restoration he was appointed surveyor-general of works, and created Knight of the Bath. He was a better poet than architeet, 
but he had Christopher Wren to his deputy. In 1665 he married a young girl, who soon showed such open favour to the Duke of York that the poor poet became crazy for a few months. Soon after his recovery his wife died suddenly, not without suspicion of poison-a charge, which Pepys evidently believed. Denham's last years were miserable betwixt poverty and the satires of Marvell, Butler, and others. He died early in 1669, and was buried in Westminster Abbey. His Elegy on Conley, written in the short interval between recovery from frenzy and his death, is one of his most successful poems, and is much less obscure and laboured, ungrammatical, and overladen with tedious moralising, than usual. His other works, as the Destruction of Troy, a paraphrase of part of the Eneid, and especially his satirical doggerel verses, are comparatively worthless. 'Nothing,' says Dr Johnson, 'is less exhilarating than the ludicrousness of Denham; he does not fail for want of efforts; he is familiar, he is gross; but he is never merry.' His fame rests securely on Cooper's Hill, but more securely still on the commendations of Dryden, Pope, Swift, and Johnson. He is especially eulogised for his strength, as Waller is for his sweetness; indeed, Dryden's critical judgment stands expressed in the words that Cooper's Hill. 'for the majesty of its style is and ever will be the standard of exact writing.

Denia, a port on the coast of the Spanish province of Alicante, near Cape St Martin. It exports grapes, raisins, and fruit, and has a population of $\$ 623$.

Demina, Carlo Giovanni Maria, an Italian author, was born 28th February 1731, at Revello, in Piedmont, studied at Turin, and in 1756 became professor of Rhetoric in the university of Turin. In 1777 he published anonymously at Florence his Discorso sull' Impiego delle Persone, in which he songht to show how monks might be transformed into useful members of society. This cost him his chair, and caused his banishment. In 1782 he went to Berlin on the invitation of Frederick the Great. Here he lived for many years, and wrote many historical works. In 1804 he dedicated to Napoleon his Clef des Lanques (1804), and was in consequence appointed imperial librarian at Paris, where he died 5th December 1813. - Denina's principal works are Delle Rivoluzioni d'Italia (3 vols. 1770) and Storia dell' Italia Occidentale (6 vols. 1810), besides works on ancient Greece, Frederick the Great, and Prussia.

Denis, ST, the traditional apostle of France and first Bishop of Paris, who suffered martyrdom in the $3 d$ century. He was sent from Rome about 250 to preach the gospel to the Gauls. After various detentions at Arles and other places, he arrived in Paris, where he made numerous proselytes. The Roman governor of this part of Gaul ordered Denis to be brought before him, along with other two Christians. As they continued firm in their faith, in spite of threats, they were cruelly tortured, and afterwards beheaded, in 272 or in 290. Gregory of Tours, Fortunatus, and the Latin martyrologists, state that the bodies of the three martyrs were thrown into the Seine, but were recovered and buried by a Christian woman. At a later period, a chapel was built over their tomb. In 636 King Dagobert founded on the spot an abbey, called St Denis, which soon grew to be one of the richest and most important in the whole kingdom, and was long the sepulchre of the French kings. The collection entitled the Acts of St Denis, written about the end of the 7 th or beginning of the 8th century, has no historical valne. The Greek Church identifies St Denis with Dionysius the Areopagite, first Bishop of Athens. The Western Church celebrates his memory on the 9th of October. For a long period his name was the war-cry of the French soldiers, who charged or rallied to the words 'Montjoye Saint-Denys!'

Denison. JoHN EvELYN, for fourteen years Speaker of the House of Commons, and afterwards Viscount Ossington, was born 27th January 1800, at Ossington, Nottinghamshire. Educated at Eton and Christ Church, Oxford, he entered parliament in 1823, and was a Lord of the Admiralty 1827-28. In 1872 he retired from the Speaker's chair, and shortly after was created Viscount Ossington. He was a D.C.L. of Oxford; and it was on his suggestion that the Speaker's Commentary to the Bible was undertaken. He died 7th March 1873. - His brother, GEoRgE ANThory Denison, Archdeacon of Taunton, was born in 1805, and educated at Eton and Christ Church, Oxford, in 1828 being elected a Fellow of Oriel. In 1843 he became Vicar of East Brent, Somerset; in 1851 Archdeacon of Taunton. In 1854 proceedings were taken against him for heresy, contained in three sermons on the Real Presence, and he was condemned to be deprived of all ecclesiastical preferments; but on appeal to the Court of Arches and the Privy-council, this judgment was quashed. He was a leader of the High Church party, opposed secular education, and advocated confession. He was chairman of the Committee of Convocation which condemned Essays and Reviews and Bishop Colenso's works, and died 21st March 1896. See his delightful Notes of my Life (2 vols. 1878-93).-Other brothers were Edward, Bishop of Salisbury (1801-54), and Sir William Thomas, Governor of New South Wales and Madras (1804-71).

Denman, Thomas, BaroN, was born in London, 23d February 1779, graduated at Cambridge, and entered Lincoln's Inn in 1806. He was associated with Brougham in the courageous defence of Queen Caroline (1820), and shared his consequent popularity. He sat in parliament from 1818-26, and was Attorney-general in Earl Grey's administration in 1830-32; he succeeded Lord Tenterden as Lord Chief-justice of England in 1832, and was raised to the peerage in 1834 . He retired from the bench in 1850, and died $22 \mathrm{~d}$ September 1854. See Memoir by Sir Joseph Arnould ( 2 vols. 1873). - His fourth son, the RIGHT HoN. GEORGE DENMAN, was born 23d December 1819, studied at Canbridge, and entered Lincoln's Inn in 1846. He represented Tiverton in parliament in 1859-65 and $1866-72$; in 1872 he was raised to the bench of the Court of Common Pleas, and in 1873 he became a judge of the High Court of Judicature. He retired in 1893, being made a Privy Councillor, and died 21 st September 1896.

Denmark (Dan. Danmark), the smallest of the three Scandinavian kingdoms, consists of the peninsula of Jutland and a group of islands in the Baltic, and is situated between $54^{\circ} 33^{\prime}$ and $57^{\circ} 45^{\prime}$ N. lat., and $8^{\circ} 4^{\prime}$ and $12^{\circ} 34^{\prime} \mathrm{E}$. long., excepting the small island of Bornholm, which lies in $15^{\circ} 10^{\circ}$ E. long. Denmark is bounded on the N. by the Skagerrak; on the $\mathbf{E}$. by the Cattegat, the Sound, and the Baltic ; on the S. by the Baltic, Little Belt, and Sleswick; and on the W. by the North Sea. The area of Denmark Proper is a little less, the population a little more, than half that of Scotland. The population of Denmark Proper in 1870 was $1,784,741$; in 1890 it had increased to $2,182,380$. In 1890 the population of Copenhagen was 312,859 (with subur: $/ \mathrm{s}, 375,251$ ); and there were besilles five Danish towns with more than 10,000 inhabitants-viz., Aarhuns (33,308), Odense (30,277), Aalborg $(19,503)$, Horsens $(17,290)$, and Randers $(16,617)$. 
The following talole gives the main divisions of the kingdom, along with its dependencies:

\begin{tabular}{|c|c|c|}
\hline & $\begin{array}{c}\text { Ares in } \\
\text { Ing. - }\end{array}$ & $\begin{array}{c}\text { Population in } \\
160 .\end{array}$ \\
\hline \multirow{4}{*}{ 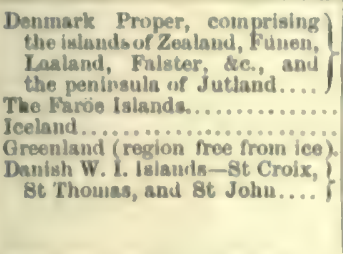 } & 14,791 & 2,182,395 \\
\hline & $\begin{array}{r}518 \\
40,800 \\
28,656\end{array}$ & $\begin{array}{l}12,955 \\
70,927 \\
10,516\end{array}$ \\
\hline & 188 & มี, 786 \\
\hline & 89,567 & $2,809,819$ \\
\hline
\end{tabular}

Except in Bornholm (q.v.), the surface of Denmark is very similar in every part of the kingdom, and is nniformly low, reaching its highest point in Eiers-Bavnehoj, in south-east Jutland, which is only 564 feet alove sea-level. The country presents little variety, except in its low isolated hills, but does not leave an impression of monotony in the islands and in the south-east of Jutland the landscape is broken by noble forests, green meadows, and fertile fields; and even in the west and north of the mainland the wide stretehes of moorland are clothed with heather, and have a solemn beauty of their own. The coast seldom rises even to low clift's ; generally it is tlat, skirted by sand-ridcres and shallow lacroons, especially along the west side, where the dunes cover an ares of nearly $225 \mathrm{sq} . \mathrm{m}$. The east coast is much indented by bays, useful for navigation and valuable for their fisheries; and here and in the islands are many good harbours. Both the continental portion and the islands are penetrated deeply by numerous fjorls, the largest being Limfjord, which intersects Jutland, and has insulated the northern extremity of the peninsula since 1825 , when it broke through the narrow isthmus which had separated it from the North Sea. There are alout seventy lighthouses along the shores of Denmark, and seven lightships (see SouND). From its formation, the kingilom can have no rivers, properly so called; its streams, called $A \alpha$, are mostly large brooks. There are several important canals, however, includ. ing in Jutland works for the canalisation of the Guden-Aa, its largest stream, and of the Limfjord; and lakes abound in all parts of the kingdon, the most considerable being found in Zealand. The centre and west of Jutland is nearly bare of wood, but in the other parts of the peninsula the forests cover nbout 215,000 acres, and in the islands over 291,000 acres. The beech, which flourishes more luxuriantly in Denmark than in any other land, is almost universally predominant, although three centuries ago the oak. now comparatively rare, was the characteristic Danish tree. Peat, which is got in sbundance from the bogs, brown coal or lignite, and seaweed generally take the place of wook as fuel. In minerals Denurk is poor. Porcelain clay and some conl are found in Bornholm, and fuller's earth, potter's clay, saltpetre, chalk, and a poor marble occur in several parts of the kingdom, while some amber is collected on the west cosst of Jutland. The climate is modified by vicinity to the sen, and is considerably milder, and the air more hunid, than in the more southern but continental Germany. Mists are frequent, as are also sea-fogs on the west coast; and rain, snow, or hail falle over the country on 150 days on an average in the yenr. The annual rainfall is 23 to 25 inclies. Westerly winds prevail; in the spring a cold, dry wind, known as the skai, blows from the north-west, and whirls clouds of fine sand from the const inland, frequently doing irreparable damage to the crops. The mean temperature ranges from $44^{\circ}$ to
47. F. The transition $f \mathrm{~mm}$ winter to atumer are rapid, and sencely broken by the intervention of spring or of antumn. The clinate is, however, not unhenlthy, except in the low-lying islands,

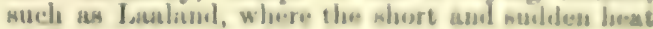
of the summer occasions fevers.

The soils of Jutland are generally licht, but those in the south-east part and in the imlanda are stronger; aloont 80 per cent. of the anes of Den. mark is productive, and of the remainder about one-sixth is in peat-bogs. Nearly half the popen. lation is engaged in ayriculture; the land for the most part is parcelled out into small holdings, and this is enconraged by the lawn, which since 1849 have prohilited the throwing of sunall farms into large estates. In 1890 , of 223,892 tenancies not 2000 were over 144 acres in extent ; there were 150,000 cottars and labourers cultivating land of from three to twelve seres; and the 'pensant farms,' varying from 12 to 144 acres-the ninjority under 50-numibered close upon 72,000 . A third of the whole kingdom is arable, while over twofifths is in meadow, pasture, or fallow land. Nearly four-fifths of the arable land is under oats, barley, or rye, and little over a twenty-third part under wheat. Flax, hemp, potatoes, and leguminous plants are also raised; lucerne has been introduced, and the cultivation of the beet-root has increased of late years. Barley in largely exported, lut the imports of brealstuffs greacly exceed the exports. The raising of cattle is taking more and more the place of arable farming in Denmark, and has now become one of the chief sources of wealth. Much progress has of late been made in this direction owing to the efforts of government and of various institutions; bull and stallion shows have been promoted by roval grants, breeding farms have been similarly encouraged, and the farmers have been instructed by lectures on the various forms of eattle disense and other subjects. The stock of horses, cuttle, and sheep is very large, and in 1895-98 there were exported an. nually 20,000 horses, 81,000 head of cattle, and 6000 sheep, mostly to Great Britain. Duiry prodnce has also hargely developed, owing to improved methods and to the co-operative dairy system, which is now worked successfully on a large scale. The value of the butter exported to Great Britain rose from $£ 767,190$ in 1870 to $£ 7,309,831$ in 1898 , the value of egrys from $f 67,654$ in 1878 to $£ 055,447$ in 1898 , and in 1898 the value of bacon 80 exported was over $£ 2,700,000$. The total value of the exports to the

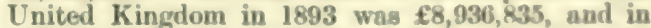
$1898 \mathrm{f11}, 703,384$; while the value of the imports from the United Kingdom was in $1898 £ 3,337,743$. Other exports to Britain are freah beef, pork (fresh and salted), hides, fish, and fish-oil. Much brandy and beer is produced.

About $2 \mathrm{~s}$ per cent. of the inhabitants are returnel as engrgeel in manufucturing imlusiries, which, although not yet of great importance, show a marked advance within recent vesm Machinery. porcelain and delf wares, and bricks aro leading manufactures: beet-root sugar refinerien are in. creasing, and the distilleries, though declining, are still numerous: there are ironworks, over eighty tobacco-factories, and several paper-mills in Copen. hagen, silkehorg, and elnewhere; and there are many large steam corn-mills Generally, in spite of the scareity of fuel in the country, steam-nills are taking the place of the windmilla, and though the perasunts still continue to manufasure much of what they require within their own bomes, linens and woollens, as well as wooden thoes, are now increasingly nade in factories. The fisheries (including the lobster and oyster fisheries) and the mereantile marine employ leas than $\$$ per cent. of the people. 
The principal articles of export are cattle, sheep, swine, butter, hams, hides, wool, grain, fish, eggs, meat, and wooden goods. Among the imports are textile fabrics, cereals, and flour, manufactures of metal and timber, coal, oil, salt, coffee, sugar, and tobacco. About two-thirds of the export traile is carried on in native vessels. The total value of the imports in 1890-97 ranged from $£ 17,057,000$ to $£ 23,155,000$; and of the exports in the same period, from $£ 12,990,000$ to $£ 18,229,000$. The bulk of the foreign trade is with Germany, Great Britain, and Norway and Sweden. The mercantile marine consists of 3700 vessels, including 370 steamships, with a total tonnage of 340,000 . There are 1600 miles of railway open, of which about 1100 miles belong to the state; and there are in all about 3700 miles of telegraph lines, of which nearly 3000 belong to the state.

Elementary education is widely diffused, although in this regard Denmark is no longer so preeminent as formerly ; it is compulsory for children between the ages of seven and fourteen years, poor parents paying only a nominal sum towards the government or parochial schools, of which there are about 3000 . There are training colleges for teachers, and classical and other higher education is afforded by a large number of colleges in the more important towns, with the university of Copenhagen (1300 students) for the centre of the entire system. Denmark has also $a$ theological seminary, a royal surgical college, a veterinary and agrieultural school, and numerous mili tary, technical, and commercial schools, while fifty 'people's high schools ' provide instruction in agri cultural subjects. There are three public libraries in Copenhagen, of which the Royal Library, with 500,000 volumes, is especially rich in oriental and Icelandic MSS. The established religion is Luth eran, to which the king must belong; but complete toleration is enjoyed in every part of the kinglom. The Reformation was introduced in 1536 , when the church revenues were seized by the crown. Denmark is divided into seven dioceses, in which there are 1360 parishes. There are only 31,000 persons not belonging to the Lutheran Cluurch, of whom 4000 are Jews, 3600 Roman Catholics, 2300 Methodists, 1000 Mormons, 4600 Baptists, and 2600 Irvingites.

The government of Denmark is a constitutional monarchy, the king being assisted by a cabinet of seven ministers. The crown was elective until 1660 , when the people and clergy, impelled by hatred towards the nobles, invested the sovereign (Frederick III.) with absolute power, and declared the succession to the throne hereditary. From that time the crown exercised absolute rule till 1831, when a constitution was granted. This proving unsatisfactory, was superseded in 1848 by the form of government which, with some alterations, Denmark now enjoys. The national assembly or Rigsdag consists of the Folkething and Landathing, which meet annually, the members receiving a fixed allowance during their sittings. The Landsthing is composed of sixty-six members, of 'whom twelve are nominated for life by the king, while the remainder are elected for a term of eight years by certain bodies representing the large taxpayers of the kingdom. The members of the Folkething, whose number is fixed by statute in the proportion of one to every 16,000 of the population, are elected for three years by practically universal suffrage. To this body all budgets must first be submitted ; but in the years 1877-87, when the government had a minority in the lower house, the king was induced to give the royal ratification to successive 'provisionary budgets,' which had never received the assent of the Rigsdag. Nevertheless the financial condition of Denmark is sound and prosperous. The total revenue in the period 1885-95 fluctuated from $£ 3,000,000$ to $£ 3,200,000$ a year; while the expenditure has repeatedly exceeded $£ 3,600,000$. Since the war of 1866 , the government hos maintained a comparatively large reserve fun to meet any sudden emergency. That fund stood in 1887 at $£ 990,000$. The total national debt is over $\mathfrak{1 0}, 000,000$, or about $\mathfrak{£ 5}$ per head of the population; but as the investments of the state (in telegraphs, \&c.) amount to nearly $£ 5,00 \mathrm{v}, 000$, this proportion is reduced to less than $£ 3$. The decimal system was introduced in 1875 , the unit being the krone, or crown, of 100 öre; the average rate of exchange is 18 kroner to the pound sterling. The Danish army numbers 1200 officers and 46,000 men, inclusive of the landwehr ; but only a sufficient establishment for garrison purposes is maintained, and the peace strength is 750 officers and 13,000 men. The total war strength is about $50,000 \mathrm{men}$, to. which an extra reserve of 14,000 could be added on emergency. Conscription prevails, and the period of military service is divided into eight years in the line and reserve, and eight in the extra reserve. The navy is recruited by levies from the coast districts. The fleet comprises some forty stenmers (of which ten are ironclads, but only one a firstclass battleship). The navy numbered in 1888,134 olficers and 1477 men. There were in 1897, 290 othicers and 1150 men. Besides Copenhagen (q.v.), there are no defensible fortresses, though there are antiquated forts at Helsingör (Elsinore) and Fredericia. The arsenal is at Copenhagen.

History. - The early history of Denmark is lost in the twilight of the saga-period, out of which loom dimly the figures of its heroes, their brave deeds, and daring voyages. Within its borders the Celts had first their home, and from its shores the Angles and Saxons sailed in the 5th century to the conquest of England; while in their place the Danes from Zealand settled on the deserted lands, extending their sway as far south as the Eider. One of their earliest kings, Harald Hildetand, fell in battle against the Swedes in 695 ; and shortly afterwards a branch of the Ynglinger occupied Jutland, where they held a footing for two centuries, One of their kings, Harald Klak, received baptism in 826 from Ansgar (q.v.); but the introduction of Christianity did not at once place any check on the long-rceustomed in. roads on Frankish territory, or on the piratical expeditions of the Vikings, although the country was soon torn by dissensions between the ad herents of the old and new faiths. Gorm the Old, who drove the Ynglinger from the peninsula, and first united the mainland and islands under one rule, was the bitter enemy of Christianity; and although his death in 936 gave fresh vigour to the diffusion of the new faith, yet even its ultimate success was only insured by the zealous support it received from Gorm's grandson, Canute (q.v.). On his death in 1035 the three kingdoms of his Anglo-Scandinavian empire separated, and his sister's son, Svend Estridsen (1047-76), ascended the throne of Denmark, founding a princely line that flourished 400 years. Internal dissensions and external wars weakened the country, and the introduction of a feudal system raised up a powerful nobility, and ground down the once free people to a condition of serfdom. Waldemar I. (1157-82) added Rigen to the other Wendish districts of Mecklenburg and Pomerania, and extended his sway over Norway also. Under Waldemar II. the conquests of Denmark extended so far into German and Wendish lands, that the Baltic was little more than an inland Danish sea. The jealousy of the German princes and the treachery of his vassals combined to rob him, however, of these brilliant conquests, and his death in 1241 was followed by a century of 


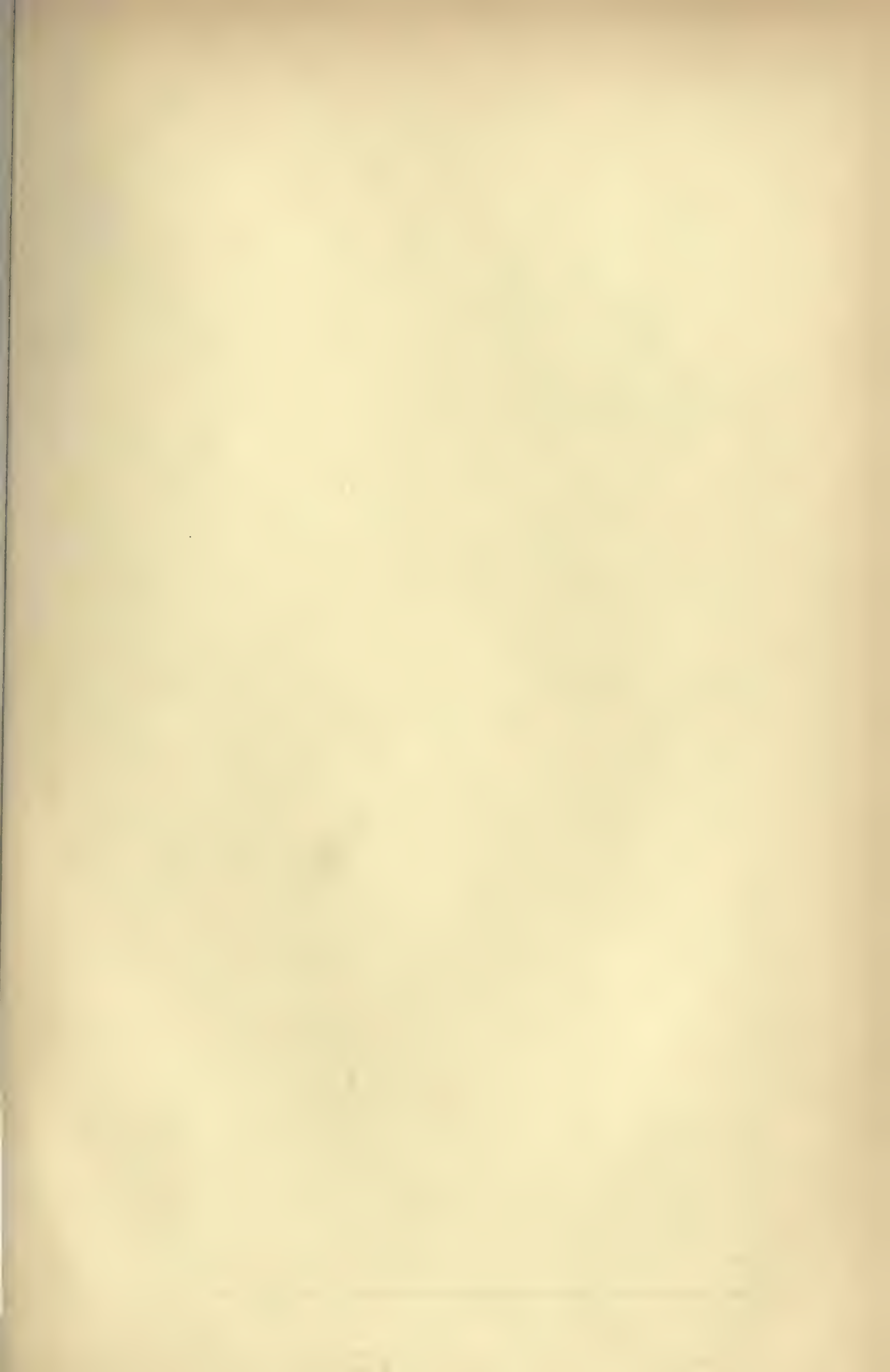




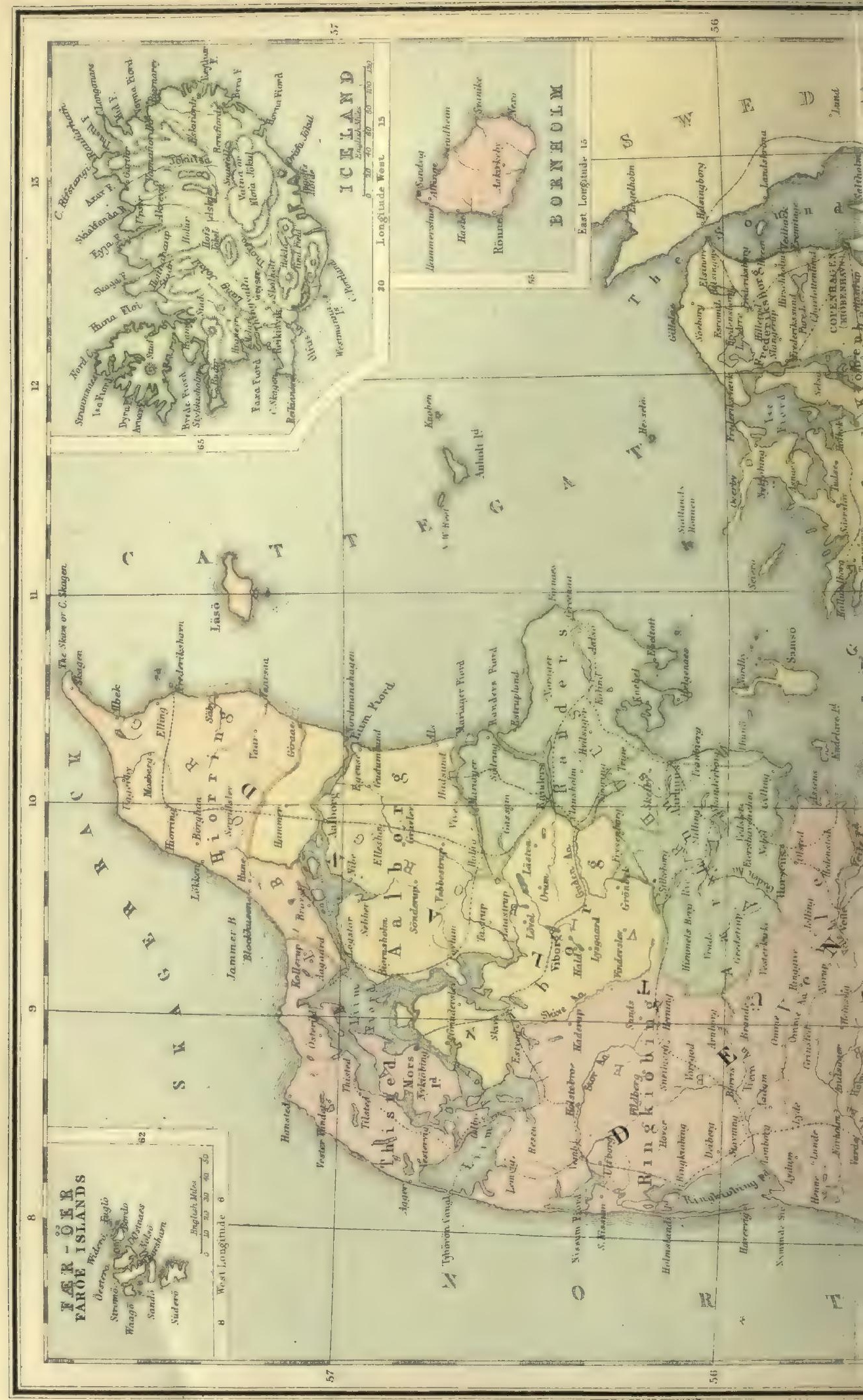




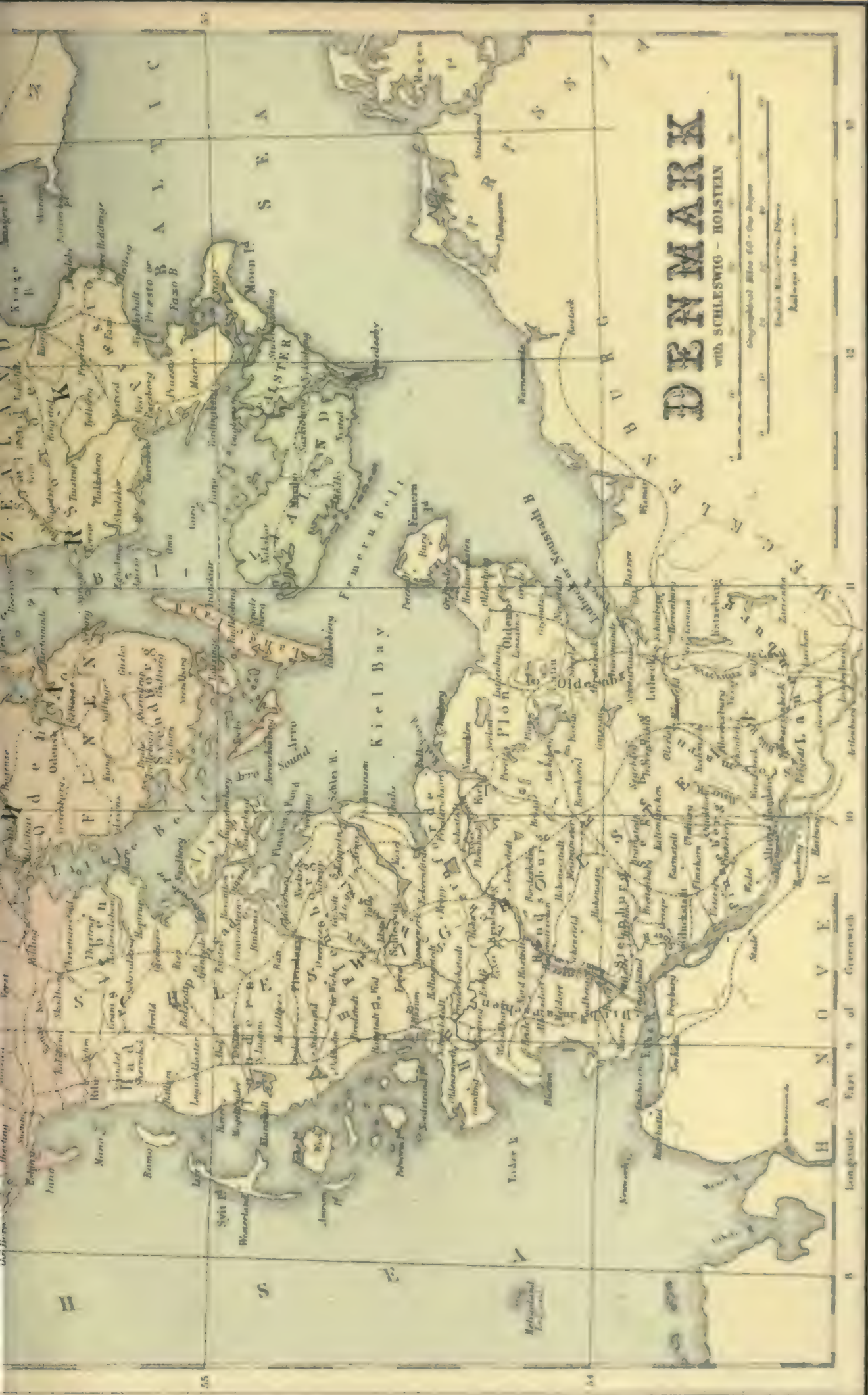



anarchy and inglorious decadence of the anthority. of the crown, during which the kingdom was brought to the brink of annihilation. Under his grent-urandson, Waldemar IV., Denmark made a trumsient recovery of the conquests of the older Waldemars, rousing the jealousy of the Hanseatic League (..$\left.v^{\circ}\right)$, and the national laws were coditied. From his death in 1375 till 1412, his daughter, the great Margaret, widow of Hakon VI. of Norway, ruled not only that country and Denmark, but in course of time sweden also, with so limht yet firm $\mathrm{a}$ hand that for once in the course of their history the three rival Seandinavian kingdoms were content to act in hamony. Margaret 's successor, Eric, the son of her niece, for whose sake she had striven to give permanence, by the act known as the Union of Calmar (1397), to the amalgamation of the three sovereignties into one, undid her glorious work with fatal rapidity, lost the allegiance and the crowns of his triple kingdom, and ended his disastrous existence in misery and obscurity. After the short reign of his nephew, Christopher of Bavaria (1440-48), the Danes exerted their ancient right of election to the throne, and chose for their king Christian of Oldenburg, a descendant of the old royal family through his maternal ancestress, Rikissa, the great-granddaughter of Waldemar II. Christian I. (1448-81), who was at the same time elected Duke of Sleswick and Holstein, was the founder of the Oldenburg line, which continued unbroken till the death of Frederick VII. in 1863. His reign was followed by half a century of international strugrgles in Scandinavia. The insane tyranny of Christian II. (q.v.) cost that monarch his throne and freedom; the Danes chose his uncle Frederick I. to be their king, while Siveden was for ever geparated from Denmark, and rose under the Vasas ( see Gustavus I.) to be a powerful state.

Under Christian III: (1536-59), the Reformation was established in Denmark. Christian IV. (q.v.), after his brief share in the Thirty Years' War, proved one of the ablest of all the Danish rulers. His liberal and wise policy was, however, cramped in every direction by the arrogant nobles, to whose treasonable supineness Denmark owes the reverses by which she lost $(1658)$ all the posses. sions she had hitherto retained in Sweden; and with the relinquishment of these, and consequently of the undivided control of the passage of the Sound, the country's former international importance came finally to an end. The national disgraces and abasement which followed led, in 1660, under Christian's son, Frederick III., to the rising of the people against the nobles, and their surreuder into the hands of the king of the supreme power. For the next hundred years, chiefly marked by wars with Sweden, the peasantry were kept in serfilom, and the middle classes depressed ; but by the end of the 18th century the peesants hail been gradually emancipated, while many improve. ments had been effected in the mode of administer. ing the laws, and the Danish kings, although autocrats, exercised a mild rule. The miseries of the reign of Frederick VI., who governed as regent from 1784, brought the country to the verge of ruin. Denmark having joined Russia in a compact of the Northern Powers hostile to England, \& Heet was sent into the Baltic, and considerable injuries wore inflicted by an attack on Copenhagen, in 1801, under Parker and Nelson. From this the country rallied; but in 1807 the British government, suspicious of an intention on the regent's part to violate his neutrality and take sides with Napoleon, demanded the surrender of the entire Danish navy, to be restored at the conclusion of pence. A refusal was followed by the bombardment of Copenhagen in September 1807, and the fleet was given up

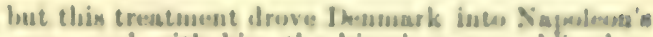
arms, and with him the kingelosm was obliged to co-operate until the clowe of 1813.

Hy the congress of Vienne, Denmark wes com. pelled to cedo Norway to \$woden. From this period a spirit of dincontent grew up in the duchiem, degenerating into mutus animuaity between tho Danish and German populacion, which led to en open rupture with Denuark in 1848, immedincely atter the accemsion of Frealerick Vil. (For tho whole question see SLKswick-Holstikix.) After alternate hostilities and armistices, the war was virtually concluded in 1850 , by the victury of the Danes at Idsted; but in 1803 the quarrel was renewed. On the death of Frederick in that year. Prince Christian of Sleswick-Hulatein-Glichibury ascended the throne under the title of Chrintinas IX., in eonformity with the act kumwn as the Treaty of London of 1852 , by which the snceesion to the Danish crown had leen settled on him and his descendants by his wife, Princess Louise of Hesee. Cassel, niece of King Christian VIII. of Dennuak. A pretender, backed by German influence and help, at once started up in the person of the eldest son of the Duke of Augustenborg, who asunied the title of Duke Frederick VIII. of Sleswick.Holstein; but his canse was speedily merged and lost sight of by Prussis and Austria in their direct aim of incor. porating the duchies with the German Confedera. tion. Denmark, unaided by England and France, allies on whose support she had relied, was forced to gor single-hauded into the unerjual contest. After a lrave but utterly futile attempt at resistance, the Danes found themselves furced to submit to the terms dictated by their powerful foes, and reaign not only Lamenhurg and Holstein, but the ancient crown-appanage of sleswick. By the peace of Vienna, 1864, the Danish king laumel humself to abide by the decision which Prussia and Austria should adopt in regard to the destiny of the severed Danish provinces. The dissensions between these two great powers, which led to the Austro-Prussian war of 1866, resulted in the triumph of Prusia. and since then the duchies have remained an in. tegral part of that state. Since the war, Denniark. although reduced to the narrow limits of the islands and Jutland, has recovered from its fall, and has greatly prospered, in spite of the spread of socinlistic opinions, and the politienl dissensions that have ranged the government and Landsthing, supported liy the press of the expital, agaimst the Folkething and majority of the people.

For the geography and atatisties, the best Daniah works are thoee of hraler. Trap, Crove, Falbe-Hansen, 0 . Nielwan, and Boharling: sev also Both (2d od. 2 vols. 1882-85), Mlis Ottés Denmark and Iceland (1881). MLurrey's Fandbook (6th ed. 1893), and Denmark; it History and Topormphy, Tanguage dv., by various specialists (Lond. 1891). For the history, worlos by l'nluctin-Muller, Barfod. Fabricius, Allen, and Thored, and Miss Otte's Seandinarian Hisfory (1875).

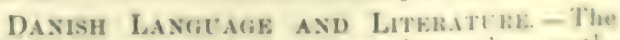
Dunish language has eprung from the south. enstern or Dnnish. Swerlish liranch of the a val. tungs (or lingua danica), which was the cumanon name by which the language of all the Scandi. mavians iras designated in the middle ages by the surthern races of the Teuturic sirk. Yinu lie ll th to the 13th century the Danish-Swedish branch of the Old Senndinavian became more and more markedly distinet from the Norwegian. Icelandic branch, through its replacing the olel diphthongs with single long vowels, and Iropping the initial $h$ lvefure $l, n$, and $r$, while the latter became chame. terised by a further nodification of the a sound, ly the lose of $v$ before $r$, and by a series of con. tractions of consonants. In the provincial laws of the 12th and $13 \mathrm{th}$ centuries, which (aver 
the Runic monuments) are the earliest specimens of this Danish-Swedish language, there are three dialects-that of Skaane (the southmost province of Sweden) and those of Zealand and Jutland, the first of which is nearest the old language, while the last two have deviated from it by dropping the final consonants from the old inflexional endings and changing their vowels $a, i, u$ to a less distinct $e$ or $a$, retaining, however, the hard mutes $p, k, t$ after vowels, as on the whole is still the case in Swedish and spoken Norwegian. The dialect of Zealand in the 14th and 15th centuries forms the foundation of modern Danish. The original vowels in almost all endings are there replaced by half-vowels, and the dental aspirate $p$ by $t$ or $d ; p, k$, $t$, when following long vowels, are changed to $b, g, d$; masculine and feminine are merged in one common gender; nouns have no other case-ending than the possessive $s$ for both numbers; verbs cease to indicate person (except in the imperative); and the singular number begins to supersede the plural, as it does every. where in the spoken language from the 16th century. Danish, like Swedish, retains the suffixed definite article, which is characteristic of the Scandinavian languages. Its form is -et in the neuter, en in the common gender, and -ne in the plural of both.

The intluence of the Hanseatic League and the Oldenburg dynasty (from 1448) brought in a great number of Low-German words, especially relating to navigation and trade; while that of the order of St Bridget contributed a considerable Swedish element. In the first half of the 16th century the Danish language was chiefly used by religious writers, and the translation of the Bible $(1550)$ is the first important monument of modern Danish. After this period Latin became once more the language of learning and culture, and for a century and a half there was no Danish writer of eminence. The influence of French was predominant in the 17th century, and that of HighGerman, which had been constant since the Reformation, culminated in the 18th century under the Struensee administration, when it was the language of government and public instruction. The result is, that Danish is indebted to German for fully one-third of its vocabulary. It was not till Holberg that the Danish written language began to be enriched from the stores of native expression in the spoken tongue. From the end of the 18th century revived study of Old Scandinavian and the development of a national poetic literature unfolded the language in a hitherto unsuspected richness and fullness, and since that time Danish prose has to a considerable extent worked itself out of its poverty and dependence. Danish is the softest of the Scandinavian languages, though less euphonious than Swedish. It is the language of the educated class in Norway, where it is considerably augmented from the native dialect, and is spoken with a somewhat harder pronunciation. The best histories of the language are by Petersen ( 2 vols. Copenhagen, $1829-30$ ) and Molbech (ib. 1846); grammars by Rask (2d ed. Lond. 1846), Lökke, Munch, Lyngby, Jessen, and Möbius (Kiel, 1871); and dictionaries by the Danish Academy (Copenhagen, 1793-1881), and Molbech ( $2 \mathrm{~d}$ ed. 2 vols. ib. 1859), who also produced a Dansk-Dialekt-Lexikon (ib. 1841) and a Dansk Glossarium (ib. 1853-66) for antiquated words. Ferrall, Repp, and Rosing's Danish and English Dictionary, in 2 parts (4th ed. Copenhagen, 1873 ), is the best for English students.

Literature.-After the Danish dialect had gradually separated itself from the Old Scandinavian as a softer and simpler speech, with a strong infusion of German ingredients, it was little used in writing down to the time of the Reformation. Saxo
Grammaticus (i.e. 'the learned') in the second half of the 12th century wrote in Latin his Historia Danica, the only literary production of medieval Denmark that retains any interest. The earliest writings in Danish are the church laws of Skaane (1162), and Zealand (1170), and the civil laws of Skaane (1160), Zealand (1170), and Jutland (1241); and after these \& number of chronicles, partly in verse, of which the best known is the Riimkrönike, which was the first Danish book printed (in 1495). It is essentially an abridgment of Saxo. The famous Danish ballads ealled Kompeviser ('hero-songs'), some of which are said to belong to the latter part of the 11th century, were handed down orally from generation to generation, and were fixst collected, to the number of 100 , by A. S. Vedel in 1591. In 1695 Peder Syv published a new edition with 100 more, and in 1812-14 appeared a selection of 222, edited by Abrahamson, Nyerup, and Rahbek. The most complete collection is in Svend Grundtvig's unfinished Gamle Folkeviser (5 vols. 1853-77). They are about 500 in number, and treat of the adventures of heroes, love, enchant. ment, spectres, and historical events, Doubtless they were sung to the dance, as is still the case in the Faróe Islands. They must have suffered much by their not being written down till the 16th and 17 th centuries.

The Reformation only emancipated Danish culture from Latin to bind it fast to German, which at the death of Frederick I. in 1533 was the language of the upper classes. About that time Cinristian Pedersen set up a printing-press at Malmö, at which he published a great number of popular books, and finally in 1550 the first complete translation of the Bible. Pedersen (14801554 ) is justly called the father of Danish literature. The hymns and translations of the Psalms by his contemporary Tausen (1494-1561), as also by Kingo (1634-1703), Vormondsen (1491-1551), and Arrebo (1587-1637), and the national history (10 vols. Copenhagen, 1595-1604) of Hvitfeld (1549-1609) were well received; but the Danish language was still banished from higher society till the advent of the Norwegian Holberg (1684-1754), the founder of Danish comedy. He found Denmark on the point of being absorbed in Germany. 'The common people,' he says, 'had no histories but dry lists of dates; no poetry but congratulatory verses; no theology but homilies and funeral sermons; and for plays, nothing but old stories about Adam and Eve.' He wrote histories of Denmark, of the Jews, and of the Church; and the irresistible humour of his comedies and satires covered with ridicule the imitators of foreign speech and manners. What Holberg did for Danish prose, another Norwegian, Tullin (1728-65), did for Danish poetry. Equally dissatisfied with the current imitations of the 17 th century court-poetry of France, and with the poetic reform of Klopstock (at Copenhagen from 1751), Tullin followed the guidance of the English poets Pope, Young, and Thomson, and in this was followed by most of his countrymen who were settled at Copenhagen, while the Danes elung to German models. Ewald (1743-81), an ardent disciple of Klopstock, was Denmark's first great lyric poet and tragic dramatist. His verse shows an unsurpassed mastery of form, and is expressed in pure, clear, and noble langnage. Wessel (1742-85), by his 'tragedy,' Love without Stockings (1772), a humorous parody of the Danish imitations of the classical French drama, succeeded in laughing them off the stage. Nordahl Brun (1745-1816), preacher and poet, Claus Frimann (1746-1829), "the Burns of the Norwegians,' Claus Fasting (1746-91), Jonas Rein (1760-1821), Jens Zetlitz (1761-1821), and 
others, formed thenselves (1772) into a 'Nor. wegian Society' at Copenhagen, under the leader. ship of Wensel. It was the literary manifeatation of the Norwegian aspiration to separate nation. ality, which afterwards led to the foundation of the university of Christiania in 1811. From the death of Wessel in 1785 to the beginning of the present century the literature becane entangled in rationalistic and political polemics, and produced little that is noteworthy. Its chief writers were P. A. Heibery (1758-1841) and Malte Konrad Brun (1775-1826), both of whom were driven into exile in 1799-1800, the latter afterwards famous as a geographer; the critic Ralibek (1760$1830)$; the dramatists Samso (1759-96) and Sander (1756-1819); and the lyrist Thaarup (1749-1821).

The poet and humorist Bagresen (1764-18026) forms the link between the $18 \mathrm{th}$ century and the early part of the 19th, when Danish literature took an entirely new departure, partly owing to the study of Kant, Fichte, and Schelling, and the influence of Schelling's follower Steffens (17731845); partly also to the strict censorship of the preas in force from the year 1799 . The educated classes turned from their controversies on points of literary criticism and theology to scientific inguiry; and the people, whose national feeling had been aroused by the French Revolution, by the share of Denmark in the Napoleonic wars, and especially by the events of 1801 and 1807 , the war with Sweden (1808), and the loss of Norway (1814), welcomed with enthusiasm the rise of a new sehool, led by the romantic poet Oehlenschliager (1779-1850), who was equally distinguished as a lyrieal and dramatic writer, and is still regarled by many as the greatest Danish poet. Contemporary with him were the poets SchackStaffeldt (1769-1826) and Grundtvig (1783-1872), afterwards more eminent as a theologian; Ingemann (1789-1862), long the most popular novelist of Denmark; J. L. Heiluerg (1791-1860), director of the royal theatre at Copenhagen, writer of numerons vaudevilles, and of the still popular national play, Elves' Hill (1828); Hauch (17911872), dramatist, novelist, and critic; and Blicher (1782-1848), who in his tales of Jutland was the first worker in the field which has since been cultivated in Germany by Jeremias Gotthelf and Berthold Auerbach. Of the other novelists of this periol the chief are Brosboill (b. 1820)); Fru Gyllemhurarg-Ehrensvärd (1773-1856), mother of 'J. L. Heiberg; Saint-Aubain, or 'Karl Bernhard ' (1798$1865)$; and the still more popular Winther (17961876), the eharming poet of Danish country life. Herz (1798-1870), from the time when his Ghost Letters (1830) surprised the public with a poetic revival of the muse of Baggesen, has, now with his lyric poems, now with his tales, now in romantic and national tragedies, now in comedies and light vaudevilles, provided his countrymen with artistic and attractive works. Overskou (1798-1874) in a skilful dramatist, and Hostrup (1818-92) a popular author of comedies. All these writers are sur. passed by Hans Christian Andersen (1805-75), whose wonderful stories are known throughout the civilised world. Less popular, but more pro. found, was the versatile writer Fr. Paludan-Miller (1809-76), who from his play Love at Court (1832) to his great epic poem Adam Uomo (1841-48) has wooed all the muses in succession. Here may be mentioned Hergsoie (b. 1835), writer of novels and popular works on scientific suljeets ; Goldschmidt (1819-87), editor of the influential democratic journals, The Corsair, North and South, and Home and Abroad, and afterwards anthor of numerons romances; Holst (1811-93), a writer of pleasing lyries and tales; Karand (1818-85), with his two collections of poems, $A$ Spring and $A n$ Autumn; the erotic and piquant and cometimes frivolon: song-writer Aarestrup (1800 56); and Lembeke (b. 1815), the translator of Shakenpeare.

A great impulse was given to all branches of science from the beginning of the $19 \mathrm{th}$ century. The leading theologians were Grundtvig, the enthusiastic champion of the faith of his fathern agaimat rationalism, and alvorates of a union of the Scandinsvian kingdoms, but with the church separated from the state; Mynster (1775-1850). Bisliop of Zealand; Clausen (1793-1877), the disciple of Schleiermacher, and theological opponent of Grundtvig : Martensen (1808-84), Bishop of Zealand, and author of standard works on systematic theology and ethiss; and Kierkegaard (1813-555), the most original thinker of Denmark. The chief exponents of philosophy were sibuern (1785-1872), Nielsen (b. 1809), and Bröchner $(1820-76)$; and in natural science the greateat nanes were those of Oensted $(1777-1851)$, the discoverer of electro-magnetism, the botanist Schonw (1789-1852), the geologist and chemist Forchhammer (1794-1864), and the zoologist and archa. ologist Steenstrup (b. 1813). Much has been done for the study of Scandinavian antiquity by the Sagubibliothek of Miller (17:6-18:4), and the researches of Finn Magnusson (1791-1846) in mythology, and of Thoinsen (1785-1865) and Worsare $(1821-85)$ in archreology. The chief 19th-century writers of national history have been Werlauff (1781-1871), Molbech (1783-1857), Allen (1811-77), Schiern (b. 1816), and K. P. PaludanMuiller (1805-82); and of the history of the national literature and language, Petersen (17811862). In philology, Rask (1787-1831) and Madvig ( 1804-86) have a European fame.

About 1850 the enthusiasm for the national past, which had been excited by Oehlenschläger in Denmark, and by Tegnér, Geijer, and others in Sweden, together with the hatred of Germany aroused by the war of $1848-50$, rose to a pitch of fanaticism. "The northern force which had con. trolled the world" was extolled by Plong and others as "the only means whereby the victory of the Cause of Humanity could be achieved.' After Ploug (b. 1813) the chief exponents of this great historic mission of the northern kingdoms were C. K. F. Molbech (1821-88), a euphonious lyrist and skilful dramatist, and translator of Dante; and Erik Bögh (b. 1822), a fertile writer of feuilletons and adapter of plays A cosmopolitan reaction net in about $18 \% 0$, led by Georg Brandes (b. 1842), who proved in his lectures on literature that Denmark was only a side-chapel in the temple of European thought and art, and that this overstrained 'Scandinavianism ' was but the northern phase of the reaction from the tentencies of the 18th century, which had been experienced in Eng. land, France, and Germany many years before. Braudes withdrew to Berlin for anme years from the storm of popular opposition. Not only in Den. mark, but in Nurway and swerlen nlso, his followens are now the prevailing party. The most conspicnous of these have been Jacubaen $(184 ;-85)$, the translator and adherent of Darwin, and author of Mogens (1872) and other novels; and (till in 18k3 he became a Conservative) Drachmann (b. 1846). Of recent writers, the most noteworthy are Schan. dorph (b. Isiv6). who is equally happy in his sketches of the Zealand peasant and the Copen. hagen snob; the verantile writer Hermenn Bang (b. 1858); and the dramatist Edvard Brandes (b. 1847), brother of Georg Brandes.

Of the three Scaufinavian nations, the Danes have shown the greatest aptitude for the imita. tive arts, and their art is comparatively the most. independent. While the painters of Sirway have been mostly trained at Disseldorf, and those of 
Sweden at Paris, the artists of Denmark have been especially attracted to Rome. The sculptor Thorwaldsen (q.v.) has left a great monument of his genius in the works contained in the Thorwaldsen Museum at Copenhagen. Of later artists may be mentioned the painters Marstrand, Carl Bloch, Exner, Kroyers, Henningsen, and Otto Bache. Of music, the chief composers in the 19th century have been Hartmann, Gade, and Heise.

See Nyerup and Rahbek, Den danske Digtekunsts Historie, 4 vols. (1800-8), and Udsigt over den danske Digtekunst under Frederik V.og Christian VII. (1819-28); Nyerup and J. E. Kraft, Almindeligt Litteraturlexikon for lianmark, Norge og Island (Copenhagen, 1818-2v); Petersen, Den danske Literaturs Historie, 6 vols. (185364); Overskou, Den danske Skueplads i dens Historie (185̃9-74); G. Brandes, Ludvig Holbeng og hans I id. (1884); the general treatises in Danish by Thortsen (181t; 6th ed 1866), Heiberg (1831), Molbech (1839), Ströın (1871), Erikson (Christiania, 1878), Winkel-Horn $(18-0)$, and Hansen (1884 et seq.); and in German by Strodtmann (1873), Wollheim de Fonseca (1874-77), and Winkel-Horn (1880). See also a part of Edmund W. Gosse's Studies in the Literature of Northern Europe (1879).

Denmery, Adolphe Philippe, a French dramatic writer of Jewish extraction, was born at Paris on June 17, 1811. His first employment was that of clerk to a notary ; but he soon became a successful dramatic author, and was so prolific that between 1831 and 1881 he produced, by himself or in concert with others, regular dramas, vaudevilles, and operatic texts, about two hundred in number. One of the most successful was the drama, Marie Jeanne (1845). He was ereator and mayor (1898) of the well-known Norman watering-place, Cabourg. Died January 25, 1899.

Dennewitz, a small village in the province of Brandenburg, Prussia, 42 miles SSW. of Berlin. Here was fought, on the 6th of September 1813, a battle in which 70,000 French, Saxons, and Poles, under Ney, were routed, after obstinate fighting, by 50,000 Prussians, under Bulow.

Dennis, ЈонN, critic, was born in London in 1657, the son of a prosperous saddler. He had his education at Harrow, and Caius College, Cambridge, where he graduated B.A. in 1679. After a tour through France and Italy, he took his place among the wits and men of fashion, and brought a sufficiently rancorous pen to the assistance of the Whig party. His acquaintance with Dryden and Wycherley and other distinguished wits, as well as his native bent, made him a playwright. His plays had but little success. Of the nine, the two most famous were Liberty Asserted (1704) and Appius and Virginia (produced 1709). Pope's Essay on Criticism (1711) contained a contemptuous allusion to the latter, answered by Dennis next month in Roflections, Critical and Sativical, which was the commencement of a long and embittered feud between the poet and the critic. Pope's Narrative of Dr Rabert Norris, concerning the Strange and Deplorable Frenzy of. John Dennis, an officer in the Custom.House (1713), was a virulent, vulgar, and officious attack made on Addison's behalf, but in which that genial author, through Steele, disavowed any complicity. Dennis was poor and blind during his last years. A few weeks after a theatrical performance, got up for his benefit by Pope and some others, he died, 6th January 1734. Dennis was embroiled in controversy all his life, and his naturally impatient temper became completely soured. He made many enemies, and his name, which his own writings could scarce preserve, will live for ever in their contempt and hate. He is one of the bestabused men in English literature. Swift lampooned him, and Pope not only assailed him in the Essay on Criticism, but finally 'damned him to everlasting fame' in the Dunciad. Yet he was no fool, and his Advancement and Reformation of Modern Poetry (1701) and The Grounds of Criticism in Poetry (1704) will still repay perusal. 'Spite of the growling of poor old Dennis,' says Mr Lowell, 'his sandy pedantry was not without an oasis of refreshing sound judgment here and there.'

Dénouement (Fr. dénouer, 'to untie'), a French term naturalised in England, applied generally to the termination or catastrophe of a play or romance; but, more strictly speaking, to the train of circumstances solving the plot, and hastening the catastrophe.

Dens, PETER, a well-known Roman Catholic theologian, was born in 1690, at Boom, near Antwerp. Little is known of his early life; but from the epitaph on his tomb in the chapel of the archiepiscopal college of Malines, it appears that he was reader in theology at Malines for twelve years, plebanus or parish priest of St Rumold's, and president of the College of Malines for forty years. He died 15th February 1775, in the eighty-fifth year of his age. The work which. has rendered Dens's name familiar, even to the Protestant public, is his Theologia Moralis et Dogmatica. It is a systematic exposition and defencein the form of a catechism - of every point of ethics and doctrine maintained by Roman Catholics, and is extensively adopted as the text-book of theology in their colleges. It appears to owe its popu. larity more to its being a handy and usable com. pilation than to any great talent exhibited by its author. The casuistical parts of the work have been severely criticised by Protestant moralists. An edition was published at Dublin in 1832.

Density. When of two bodies of equal bulk, one contains more matter than the other, it is said to have greater density than that other. Since weight is proportional to mass, the same numbers may be and are used to represent specific gravity and density. Lithium is the least dense metal known, its density being 0.59 if that of water be called unity. Ordinary air may be easily compressed so as to be denser than lithium. Iridium is probably the densest substance known, its density being 22.4 times that of water. Osmium, however, is very nearly if not quite as dense. The more ordinary metals stand in the following order as regards density : Aluminium, antimony, zinc, iron (wrought), copper, 'bismuth, silver, lead, gold, platinum.

\section{Dental Formula. See Teeth.}

Dentalium (Lat. dens, 'a tooth'), or Elephant's Tusk Shell, a remarkable genus of molluses, type of a small class called Scaphopoda. The shell is tubular, like an elephant's tusk, open at both ends, and lined by an almost completely tubular 'mantle.'

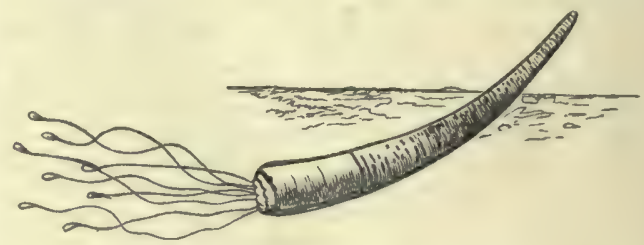

Dentalium, in natural position in sand.

The animal has an indistinct cylindrical head with a mouth at its extremity, surrounded by a circle of tentacles. Two pads at the base of the head and above the foot bear ciliated contractile filaments, possibly respiratory. The 'foot' is long and divided into three at the end. The mouth includes 
it maper. There are no eyec, but an ear-sae is present. Neither heart nor gills are leveloped. The sexes are similar and separate. The larva is eilisted and free-swimming. The type is of much zoolugical interest, lout its nftinitiess ure still un certuin. The animul lives with the anterior end plunged into the sand on the sea-posst, at depthe of ten to a liundred fathoms. By means of the foot they can ereep slowly. They feed on minute auimals, and have an almost cosmopolitan distri. bution. The class includes two or more other genera. D. entule oceurs off British cossts; and abut forty living speeies nre known. The genus occurs as a fossil from Carboniferous strata (or perhaps earlier) onwards. The shells are used for curreney and for ornament by the Indians of the northern Proitic coast of America. See Lacaze. Duthiers, Histoire des Dentales (1856-58).

Dentaria, or CORAL-ROoT (both names due to knobbed root-stock), is a small genus of Cruciferre, represented in Britain by the rare $D$. bulbifera, in which the upper leaves bear Bulbils $\left(q_{.} v_{0}\right)$, while the pods rarely ripen. The root-stock being pungent, was formerly dried as a remedy for toothache. I). diphylla, a North American species, is called Pepper-root from the same property. The name Coral-root is also applied to the orchid Corallorhiza, while the true Toothwort (q.v.) is Lathroa squamuria.

Dentex, a genus of acanthopterous fishes near perehes. One species ( $D$. vulgaris), the Dentex of the ancient Romans, abounds in the Mediterranean,

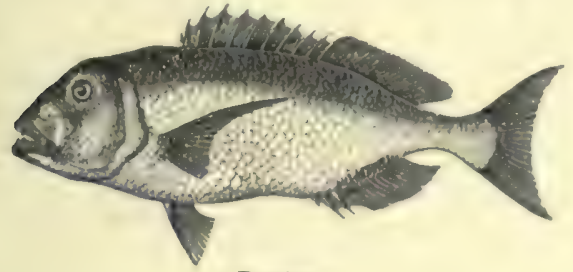

Dentex.

and has occasionally been taken on the southern shores of Britain. It is an excesaively voracious fish, with large sharp teeth, and attains a large size, sometimes three feet in length, and 20 to 30 pounds weight. Great numbers are taken in the mouths of rivers in Dalmatia and the Levant, where they are cut in pieces, and packed in barrels with vinegar and spices, just as the ancients used to treat them.

Dentifrice. See Tooth-POWDER.

Dentine, or IVORY, the principal constituent of maminalian teeth. See TLiтH.

Dentirostres, a somewhat old-fashioned title for one of the subdivisions of singing Passerine birds or Oscines. The term, as equivalent to "toothed. lilled,' is used in opposition to Conirostres ('cone. billed') and Tenuirostres ('glender-billed '). It would include warblers, thrushes, chatterers, crows, Se. but the character is purely adnptive to the better securing of the prey and the like, and is of little significance in classification.

Dentistry, the art of the dentist, or that of treating disease in the teeth (Dental Surgery), and of replacing these organs when lost (Mechanicol Dentistry). The art is a very ancient one. The Laws of the Twelve Tables (5th century B.C.) provided for the case of 'teeth bound with gold,' it being lawful in this connection to burn or loury gold with the dead person. An Etruscen skull found in 1885 had a set of animal's teeth artificinlly lixed in it. The dentistry of the United States has in recent times become specially colebrated.
(1) Dental Surgery. - The dionders to which the teeth are liable are those ariaing from defective development, such as imperfection in form or structure, irregularity of position, \&e; thowe, again, constituting diseasem nore properly no called, such as caries or dental decay, neerowis or death of a tooth, intlammation of the soft tinues, wuch as the gum, the central pulp or nerve, as it is popularly callest, neuralgie afteetions. Se.; lanely, thome arising from accidents of various kinds, such as blows, falls, and the like. For the constitutions and diserres of the teeth, see TrETH.

The object of the dentist, in treating decayed teeth, is twofold : he either attempts to arrent the deeny, and repair itw ravagen; or he resusnes the diseased tooth altogether. These operations, along with supplying artificial teetl when the natural ones are lost, constitute the main offices of dentistry.

Scaling. - This is a little operation, by which the accumulution of a substance termed 'tartar' is removed from the teeth. Tartar or selivary eal. culus is of different densities and colours, and is a deprosit from the saliva. It is most frequently found at the necks of the teeth, and looges in greatest quantity most commonly beloind the lower front-teeth. Where it accumulates it is generally accompanied by absorption of the gums, whereby the necks of the teeth are exposed, and they become loosened. Its removal is effected by little hoeshaped steel instruments, bent in a manner to reach more easily those situations in which the tartar is found. Their mode of use is by inserting the point of any one of them under the free edge of the muss of tartar, at the gum, and lifting it away from the backs of the teeth to which it is adhereut. The teeth are then freed from any particles stil] sticking about them, and their surface smoothed by being rubbed with pumice-powder or chalk. In certain diseased conditions of the structures about the necks of the teeth, considershle purulent discharges ocenr, and tartar frequently becomes largely deposited.

Regulating. - The teeth of the second, or per. manent or adult set, are very liable to be crowded and misplaced, one overlapping the other, or those of the upper jaw falling behind those of the lower when the mouth is closed, thus producing the prominent condition of the under jaw denominnted 'under-hung.' To remedy these defects, a variety of means have been adopted by dentixts ; the principle upon which all of them ret, however, being that of pressing the displaced tooth or teeth into the natural position. This, of conrse, requires that room or space should exist for them to be thus adjusted; and where this is not the case, the usual procedure is to remove one or more of the beck. teeth, or any others which it is less dexirable to preserve. In other coses the dental arch itself is nalformed, and may be enlarged by regulated pressure so an to afford more accommodation for the teeth, as well as to improve its contour. Sonve considerable time is necensary to complete the regulation of misplaced teeth; and even after they have assumed their proper powition, they require to be carefully maintained there, otherwine a tendency to resume their former irregularity onon manifests itself.

Stopping or Filling. - This is one of the mont important and delicnto operntions the dentint has to perform. The first step to be taken in filling or 'stopping' a tooth, is to clenr away all decayed and decaving sulstance. For this purnose, a number of slender digging and excavating steel instruments, termed 'excarators.' are requined. The 'dental-engine' is another valuable means of preparing the cavity for filling, and acts by menns of suall drills and file-headed points rapidly rotating, so as to cut away what is desired of 
the tooth substance. With these, the hollow in the tooth is scooped out and thoroughly cleaned. If pain be occasioned by this process, the obtunding of the tooth's sensitiveness, or ' destroying the nerve,' as it is called, had better at once be resorted to. This is performed in several ways. Where the tooth is single-fanged, as in front-teeth, the nerve, or more correctly the pulp, may be removed by passing a slender broach, or square and pointed brad-shaped, or slender serrated steel probe up into the central cavity of the tooth, with a slight rotary motion, so as to break up and remove the pulp. Where this cannot be done at once the best plan is to destroy the pulp by some caustic application, such as arsenious acid, chloride of zinc, car bolic acid, \&c., carefully applied, a variety of other substances being used for the same purpose.

The cavity being properly shaped and cleaned out until its walls are of sound and hard toothbone, is to be well dried, and the plug of stopping material inserted. Various substances are em ployed for this purpose, and the mode of using each is somewhat different. For temporary stoppings, pure gutta-percha is a serviceable material. A quantity sufficient to fill the cavity, and somewhat more, is to be gently warmed over a spirit-lampnot in hot water-and when quite plastic is to be firmly pressed with a blunt-pointed stopping-instrument or 'plugger' into all the interstices of the hollow in the tooth-more and more being pressed in, until the surface of the plug so formed is on a level with the surface of the tooth, when all superfluous portions should be removed, and the solid plug snoothly finished. Osteo-plastic fillings consist of varieties of the metallic oxychlorides and phosphates. They are inserted in a soft condition into the tooth, where they harden in the course of a few minutes.

Another variety of stopping-material consists of amalgams of different kinds. Many absurd statements have been made regarding the evil effects of amalgam stoppings, but the only real disadvantage attending their use is shrinkage, and that many of them get black in the mouth, and discolour the tooth, while some that do not get black are friable, and crumble away in a short space of time. Some of those containing copper exercise a beneficial action on the tooth-bone, but darken its colour very much. The amalgam is rubbed up with mercury to a firm, plastic consistence, and carefully introduced into the dried cavity in the same way as the gutta-percha plug.

Gold-stopping is an operation of a much more complicated and difficult description. The materials used here are either gold-foil-that is, thick goldleaf-or the peculiar form in which gold exists known as sponge-gold ; or again, 'pellets' of gold made up in a soft spongy condition of various sizes ready for use. In stopping a tooth with gold, even more care is necessary in preparing the cavity than what has been already inculcated. Its shape and condition must now be particularly taken into account, and the nearer it approaches to a cylindrical form the better. Various modes of pack ing the gold are adopted according to two conditions in which gold exists-namely adhesive, where each portion can be welded to the ather or non-rdhesive, where they are securely fixed merely by tightly wedging thein together. Nonadhesive gold can be made adhesive by heating it to redness. The surface of a gold plug, formed in any of these ways, should be well consolidated by hard pressure with a blunt plugger, or lightly hammered with a suitable mallet, and the superfluous portion being removed, it ought to le burnished until it assumes a brilliant metallic lustre.

Remedies.-Many remedies, more or less service- able, are in use for what is termed toothache -a disorder which, however, is not always one and the same in its nature. Their intention, in general, is either to destroy the nervous fibres existing in a tooth, or to narcotise and render them insensible. Among those acting in the former nianner are such as creasote, arsenious acid, carbolic acid, pepsine, chloride of zine, nitrate of silver, alum, tannin, \&c.; among those acting in the latter mode are chloroform, laudanum, ether, spirit of camphor, menthol, cocaine, \&c. In all cases the decayed eavity should previously be well cleaned out, otherwise the remedy employed may be altogether prevented from reaching the spot where it is intended to act.

Extraction.-This is the principal surgical operation falling to the dentist. It is perforned by means of instruments adapted to the special peculiarities of the tooth requiring removal, or to the circumstances in which it exists. The great matter is, that each tooth should be extracted in accordance with its anatomical configuration; and to accomplish this of course requires an intimate knowledge of the natural form proper to each of these organs individually; without this, it is impossible to extract any tooth upon a correct principle. The tooth is grasped, as far as the instrument can be made to do so, by that portion of the root or fang which just emerges from, or perhaps which is just within, the socket; it is then loosened, not exactly by pulling, but rather by moving it in a lateral or in a rotatory manner, in strict accordance with the respective character of fang possessed; and finally, on its being thus detached from its connection with the jaw, it is, with very little force, easily lifted from its socket.

Angesthetics are employed in the extraction of teeth in the same manner as for other surgical operations, where it is desirable to abolish pain. See AN ASTHESIA. Neither ether nor chloroform should be given by inexperienced hands, nor should both the giving of the anrsthetic and the extraction be attempted by one individual on any occasion. Nitrous oxide or laughing-gas is of much service, answering all the purposes of chloroform or ether in short operations. A combination of two or more of these anæesthetics has been employed with apparent success, such as nitrous oxide with ether. Freezing the gum, the injection into it of cocaine, and other modes of inducing insensibility, local or general, have been proposed from time to time, but one after another has been abandoned as unservice. able.

(2) Mechanical Dentistry.-The various conditions of the mouth requiring the adaptation of artificial teeth, range from cases where only one tooth may be wanting, to those where not a single tooth remains in the jaw, above or below. Accordingly, artificial teeth are spoken of as partial or complete sets - a partial set being one for either upper or lower jaw, where some of the natural teeth still remain; a complete set being one for either jaw, where none are left, or for both jaws, when both are in such circumstances.

The transplantation of the teeth of another individual is a very old usage revived every now and again, and equally often falling into desuetude; and implantation is a recent modification of the process.

The simplest form of partial sets is what is termed a pivoted tooth. This is an artificial tooth fixed in the mouth upon the fang or root of one whose crown has been lost by decay or otherwise. The most usual mode of procedure is as follows: An artificial tooth, as near ns possible to the colour and form of that to be replaced, is selected. This artificial tooth used to be the crown of a natural human tooth corresponding, to that lost, but is 
now one made in imitation of this, in a species of puttery.ware ealled mineral teeth. Usually this wath is aceurately fitted to the root by menus of a grold pin, inserted into the open central canal existIng in the root, the other extremity of the pin being attached to the substitute tooth.

Where more than one tooth is required, and occasionally even where only one is necessary, a 'plate' or 'base' is very exactly fitted either to the gum and palate as in 'suction' sets, or to the remaining teeth where they are to be the supports, more especially in what is called crown and bridge work; and to this base the artificial teeth required are fitted and fixed.

'This 'base' is frequently made of gold, silver, or platinum plate, of the thickness of card-board, of vulcanised cantchouc or vulcanite, or of celluloid -a compound of camphor and gun-cotton. An exact model of the gum and other parts upon which the plate is to rest is obtained by introducing unset Paris plaster, beeswax, or other modelling conpourd, softened by previous heating, into the patient's mouth, and pressing it forcibly upon those parts of which an impression is desired. On removing the wax or other substance from the mouth, Paris plaster is poured into the mould thus procured, and on its hard. ening, or 'setting,' this plaster-cast presents an exact counterpart of the gum. It is upon this plaster-model that all the subsequent operations are performed in fitting the artificial set.

Metallic-plate Sets. - Where the framework lying upon the gum is to be of gold or silver plate, or the like, it is necessary to procure, besicles the plastermodel, a metal one. This metal-model is generally cast in zinc, gun-metal, or some such material; and a counter-model of a softer metal, generally lead, is taken from this again, so that a complete pair of dies is in this way procured. The gold or other plate, cut of a convenient size, is then stamped between the two metallic dies, until assuming the precise form desired. It is then trimmed, and any more delicate adjustments made upon it, such as fitting and soldering bands or clasps to those parts where it is to embrace any teeth remaining in the month. The mode of fastening the teeth to the plate varies. One kind of teeth has a tube exteuding along their whole length, and these are fastened by means of a pin fixed to the plate, and passing up the tube. The other kind is provided with short platinum pins, fixed in the material of the tonth during its manufacture, to which pins a piece of gold or other plate is soldered, or a mass of gold fused upon them, and this, again, soldered to the framework of the set.

Another form of these plate sets or artificial dentures is where the plate - generally of platinum -has an arrangement suited for fusing a siliceous material to it and the teeth, so as to form an artificial gum. This is termed 'continuous gum work, ani is very effective althongh it has its disadvantages. Sometimes vulcanite sets are mounted with continuous gum work.

Vulcarite Sets. - The first step in the manufacture of a vulcanito set of teeth is to make a pattern set in wax, with the mineral teeth fixed in the wax. This pattern set is made upon and fitted to the plaster-model, and is adjusted to the wearer's mouth precisely as if it were the set to be worn. When everything is thus prepared, a duplicate of the wax. set is made in vulcanite - the vulcanite replacing the wax, and the mineral teeth being retained as they were. The process by which the vulcanite is made to take the place of the wax consists in imbedding the pattern set in Paris plaster, so that the inclos. ing mould of it, thus secured, may be separable into at least two parts. On these being taken ssunder, the wax of the pattern set is melted out with boil. ing water, leaving the teeth in silu. The wax is then replaced by raw vulcanite, which, on the mould being reclosed, is subjected to the usual process of vulcunising.

A base which is now mometimes umed is cheoplanty, or cast-metal, an alloy unually of tin and bismuth. This base is especially alapted for mouths in which the lower alveolar ridge is very flat, as its grent weight tends to keep the denture in position. The method of construction is the same, in the preliminary stages, as for a vulcanite mot. After the wax has been boiled out, the two halves of the mould are placed together, and the melted metal is poured in.

Dental Appliances.-The manufacture of dental apparatus is a very large and important one, and is carried on principally in London and the United States. A great many of the most important processes are mainly due to American invention or development. Principal among these are the process of vulcanising, the dental-engine, the rul, werdam, mineral teeth, the introduction of nitrous. oxide gas, and perhaps also the great improvements in the modern operating-chair. The introduction of the vulcanite base and mineral teeth has been the means of bringing the benefits of dentistry within the reach of thousands who conld not afford the expense of gold and silver plates. The dental-engine is an ingenious little machine, whereby the action of a treadle, conveyed tlirough a flexible arm, gives a rotary motion to a drill or burr, for operating in the patient's mouth. Electricity has recently been introduced as a motor for the dental-engine and other purposes.

To show how elaborately every posaible require. ment of the dentist is provided for by the manu. facturers, we may give a few instances Most makers offer a choice from about a hundred varieties of forceps for the extraction of teeth; the number of drills and burrs for the dental-engine provided by one maker for selection appmaches three hundred; while a manufacturer in Philadelphia keeps in stock nearly six hundred varieties of the 'plugger' (instruments for stopping teeth). There is besides an equally liberal choice in excavators, scalers, \&c., while the varieties in the makes of teeth are innumerable. It has been estimated that sixteen thousand ounces of fine gold are annually used for filling teeth; ten millions of mineral teeth are annually disposed of throughout the civilised world; and for the im. plantation of these in the mouth, independent of gold and other bases, sixteen tons of rubber are annually required.

For a more detailed nccount of dentistry, we must refer to the numerous and beautifully illus. trated works specially devoted to the subject, such as Litch's System of Denlistry, Tomes's Dental Surgery, Taft's Operative Dentistry, Richandson's Mechanical Dentistry; with the leseer works of Coleman, Hunter, Oakely Coles, J. Smith, Sewill, Rymes, and others.

Laves as to Dentistry. - In 1878 an set entitled the Dentists Act was passed with a view of amending the laws relating to dental practitionen In terms of this act, no one except qualitied medical practitioners and those band fide engaged in the practice of dentistry at the time of tho nct's passing can take or nse the title 'dentist, or any title signifying that he is registered, under a penalty of 120 . And in future any person desiring to become a dentist must unlergo a ceriain course of otudy, and have taken a degree or license. The curriculum of stady and the conduct of the exam. ination are under the regulations of the General Council of Medical Education ; and various dental lospitals and schools have heen estalolished for the instruction of the dental student. The degree in 
Great Britain and Ireland is L. D.S. (Licentiate in Dental Surgery). The only foreign degrees (both American) qualifying for registration in Britain are D.M.D. (Harvard) and D.D.S. (Michigan). In 1888 there were in practice in Great Britain and Ireland 977 licentiates under the new act, and 3889 practitioners registered as having been in practice before 1878 .

Dentition. See Teeth, Teething, Horse.

D'Entrecasteaux Islands, since 1884 part of the British protectorate of New Guinea, lie north of the south-eastern extremity of New Guinea. With an area of $1083 \mathrm{sq}$. m., they comprise three chief islands separated by narrow channels. They are named after the French admiral and explorer, Bruni D'Entrecasteaux (1739-93), who visited these waters in 1792. His name is also preserved in D'Entrecasteaux PoInt on the south-west coast of Western Australia; and in D'EnTRECASTEAUX CHANNEL, separating the south of Tasmania from Bruné Island.

Denudation, in Geology, means the laying bare of underlying rocks by the removal of superficial matter, and also the process by which the earth's surface is broken up and the loose material carried away. The more important agents of denudation are wind, rain, running water (springs, underground streams, brooks, and rivers), frost, snow, ice (glaciers), the sea (waves, breakers, currents), plants, and animals. The action of wind is seen in the erosion of rocks produced by the sand and grit which in certain dry regions is swept by the winds against projecting rocks, an action often resulting in the undermining of cliffs and the downfall of rock-masses. The sand produced by the superficial disintegration of rocks is carried forward and heaped up in the form of dunes or sandhills (see DRIFT). Rain is also a potent agent of denudation, its action being both chemical and mechanical. Rocks are more or less altered and decayed, and the decomposed materials carried ot in solution by rain-water. The more soluble rocks, such as rock-salt, gypsum, and limestone, readily succumb, but there are very few rocks indeed which are not more or less acted upon chemically by rain. So that in many places the rocks are thus 'weathered' to considerable depths, the decomposed crusts varying in thickness from a mere line up to many feet or even yards. The mechanical action of rain consists chiefly in the sweeping away of this disintegrated material, which often accumulates in hollows, forming what is called rain-wash. Running water acts also chemically and mechanically. Thus, the rain that sinks underground and rises to the surface again in springs, brings about many changes in rocks. Immense quantities of mineral matter are brought up in solution, and thus, in time, underground cavities are formed, especially in the more soluble rocks. In regions of calcareous rocks, the whole drainage is sometimes conducted underground, the ingulfed streams and rivers acting both chemically and mechanically, and giving rise to a large series of subterranean tunnels (see CAVE.) The action of underground water often brings about local subsidences, falls of rock, and great landslips. The denuding action of superficial terrestrial waters is seen in the excavation of gullies, ravines, and xiver-valleys, one of the most remarkable examples of river erosion being the Grand Cañon of the Colorado (q.v.), which is a chasm nearly 400 miles long, with approximately vertical walls rising to a height of 4000 to 7000 feet above the bed of the river.

Frost acts with great intensity at high levels and in high latitudes, but even in temperate regions its action is very marked and productive of great disin. tegration of rocks. Indeed, in the production of the weathered crusts of rocks, frost is hardly less active than rain. It is in aretic and mountainous countries, however, that its action is most conspicuous, The rocks under its influence are ruptured and shattered to such a degree that frequently the parent rock-masses become buried under shivered heaps of their own debris. Glaciers are likewise powerful denuding agents. They are not only instrumental in transporting the rockrubbish which is showered down upon them from overhanging cliffs, \&c. (see Boulders), but by means of the blocks and debris which they drag forward on their beds, they grind, furrow, and smooth the rocks over which they How. The peculiarly muddy character of the water that escapes from the terminal front of a glacier shows how powerful this erosive action must be, for the mud earried in suspension is simply the fine flour of the rocks which has resulted from the grinding action. The sea, again, acts like a great horizontal saw, which is continually rasping away the rocks along the coast. Cliff's are in this way undermined, rock-falls take place, and the tumbled rock-masses are by-and-by pounded down into shingle, gravel, and sand, which are hurled by the waves against the cliffs, and thus ere long the latter is again undermined, and further rock-falls take place.

The chief denuding agents have now been mentioned, but the destructive action of plants and animals cannot be ignored. Thus plants aid in the demolition of rocks by sending their roots into rockcrevices and werlging the masses asunder, and hence they aid the freer percolation of water, and prepare the way for the better action of frost. Vegetation also, by attracting rain, tends to increase the flow and erosive action of streams and rivers, while its decomposition yields to rain those organic acids which so greatly increase the chemical action of that agent. The destructive action of animals, again, is seen in the weakening of rocks on a sea-coast produced by the drilling and boring of Saxicava, Pholas, \&c., and by annelids, echini, and sponges. Rocks so weakened fall more readily before the battering of waves and breakers. Thus, the whole surface of the land, from the summits of mountains down to the sea-coast, is subject to denudation. Little change may be perceptible in a lifetime or even during many centuries, but an examination of the rocks shows that many thousands of feet of solid strata have been gradually removed from the surface of a country. Thus, in many districts where faults occur, no inequality at the surface betrays the presence of dislocations; the whole area has been reduced by denudation to the same level, hundreds or even thousands of feet of strata having been removed from the upcast side of the faults (see Dislocation). Some attempts have been made to form a rough estimate of the rate at which the general surface of the land is reduced by denudation. As the sediment of gravel, sand, and mud which a river carries down to the sea represents the actual loss sustained by the surface of the area drained by it and its tributaries, it is obvious that if we conld correctly estimate the amount of sediment transported to the sea by the rivers of any given area, we should at the same time ascertain the rate at which that area is denuded. Observation has shown that this denudation proceeds more rapidly in some regions than in others, and, therefore, that the work of no individual river can be taken as a standard by which to estimate the general rate of erosion all the world over. Much depends on physical and climatic conditions, and much on the geological structure of a country and the composition of its prevalent rockmasses. Thus, the Mississippi is said to remove 


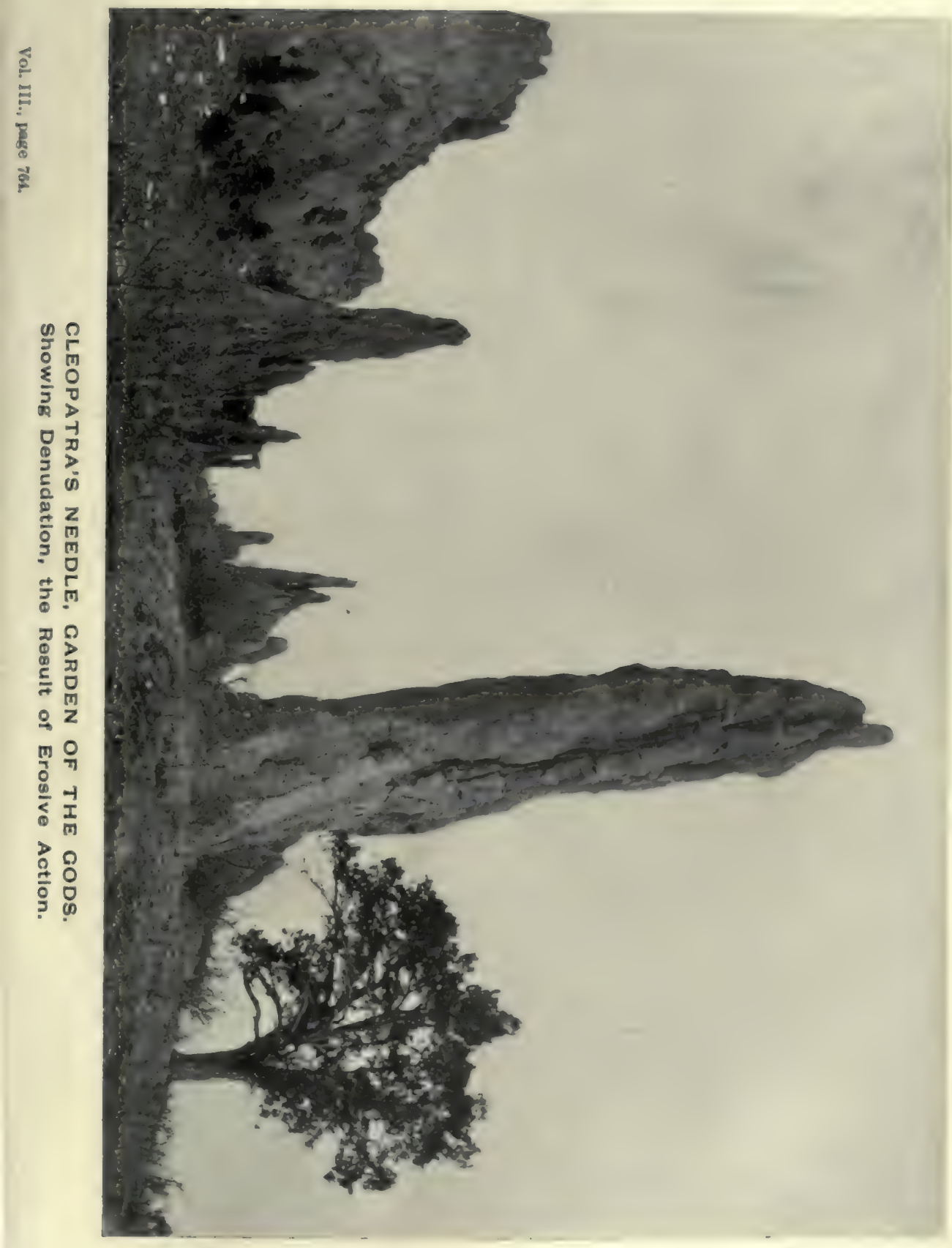



from the generil surface of its basin 1 foot in 6000 yenrs, the Rhone 1 foot in 1528 years, the Po I fout in $72 y$ years. To the matter mechanically susinendeal in the water or swept forward on the heals of rivers we have to add the matter carried in solution, which in many rivers is very considerable. Rivers like the Khine, the Danube, the Elbe, and the Rhone, contain in every 6000 parts by weight one part of dissolved mineral sulsstance. These rivers, therefore, carry seawards their own weight of dissolved matter in 6000 years. Thus, subaerial denudation progresses more rapidly than we should at first be led to suspect, and those geologiste who have made a special study of this question do not hesitate to assert that the action of the subaerial agents of denudation is far more effective than that of the sea, for whereas the action of the latter is confined to a narrow belt of land, that of the former has no such limitation. The whole land surface is exposed to attack, and the loose material carried down to the sea far exceeds in amount the waste of the coast-line by waves and breakers. See Playfair's Illustrations of the Huttonian Theory, Lvell's Principles of Geology, Croll's Climate and Time, and the standard textbooks of geology.

Denver, the capital of Colorado, is situated on the South Platte River, 922 miles W. of St Louis It lies on a level plain, 5196 feet above the sea beyond which rise the snow-eapped peaks and deep blue shoulders of the Rocky Mountains. Denver was founded on a barren waste, dry and treeless, in 1858, and the close of the civil war saw it a rising frontier town ; in 1870 the population was 4759 ; in $1880,35,629$; in $1890,106,713$; and in $1900,133,859$. In forty years the miningcamp had been transformed into the 'Queen City of the Plains,' with stately buildings of brick and yellow stone, and wide, shaded streets, provirled with the electric light, and with horse, cable, and electric tram-cars; and it has become the meeting-point of a great network of railways, with four direct routes to the east. It has an abundant water-supply, with 50 miles of distributing mains; many of the houses are heated by steam, supplied by a company owniug 5 miles of mains; and through the resident portion streams of water course past the unpaved foot-ways. The clear invigorating air and dry climate of Denver are famous; the mean annual temperature is $48^{\circ} \mathrm{F}$., and the rainfall 17 inches. Among the chief buildings are the city-hall, a handsome court-house and post-office, high school (1887), Episcopal cathedral, and the state capitol (commenced in 1886), 383 feet long by 313 wide; the town has also more than sixty churches, a university, and a number of public schools. Denver is the centre of a great agricultural and mining district, and has a large trade in cattle, hides, wool, and tallow. The value of its manufactures in 1890 - cottons and woollens, flour, machinery, earriages, \&e. - was stated at $\$ 30,500,000$ (as against $\$ 20,000,000$ in 1886). It is eliefly, lowever, to its position as the centre of a grent mining region that Deuver owes its marvellous progress; the diseovery, in 1878, of the fubulous weatth of the Leadville Hills attracted capital and emigration from all parts of the continent. It has a United States assaying mint, and is an important ore market; the duily receipts of ore in some yeurs amounts to near 600 tons, and the product of its great smelting-works is valued at about $\$ 25,000,000$, while much of the machinery used throughont the state is manufactured here. Denver has several suburbs, by which the total population is consiser. ably augmented. See also the article CoLorado.

Deoband, a town in the North-west Provinces of India, 15 miles N. of Muzaffarnagar by rail, with manufactures of fine eloth, and a trade in grain, sugar, and oil. More than half the intabitanis are Mohammedans. Pop. 19,500.

Deodand. A personal chattel which was the immediate and accidental occusion of the denth of a reasonable creature, was, by the law of England, forfeited to the crown, in order that it uight be applied to pious uses, or given to God (Deo dnn. dum), as the term implies. The law of deodand was abolished by statute in 1846 .

Deodar, \& petty native state in the Palanpur Superintendency, Bombay presidency, with an area of $440 \mathrm{sq} . \mathrm{m}_{\text {. }}$, and about 25,000 inhabitunts. It is a flat, open plain, with sandy soil and a hot climate; there are no rivers, and the numeronm ponds are not employed for irrigation. Claritied butter is the only export.

\section{Deodar. See Cedar.}

Deodorisers are chemical substances em. ployed for the purpose of absorbing or destroying the odoriferous principles evolved especially from decomposing animal and vegetable matter. Thus, freshly burned charcoal is a powerful deodoriser because it absorbs sulphurous acid gas, ammonia, and other odorous gases. They belong to the classes of substances known as Antiseptics (q.v.) and Disinfectants $\left(q, v_{0}\right)$.

D'Eon. See Eon de Beaumont.

Deontology (Gr. deon, "that which is binding,' and logos, 'a discourse '), a term for the science of duty, Ethies (q.v.).

Deori, a town in Nagpur district, 40 miles $\mathrm{S}$. of Ságar, and 1705 miles above sea-level. Pop. 7414.

leoxidation is the tern applied to the prucess of withdrawing the oxygen from a compound, as in the reduction of the native peroxide of iron in the smelting-furnaces to the condition of metallic iron. On the small seale, in experimental inquiries, the process of deoxidation may be carried on before the Blowpipe (q.v.), where the inner or reducing flame is essentially a deoxidising one.

Department (Fr. departement), a term used to denote a territorial division in France. Previous to the Revolution, France was divided into provinces; but in $1790 \mathrm{a}$ decree of the Assembly ordered the abolition of the old provincial divisions ( 34 in number), and the redistribution of the land into 83 departments. During the year 8 of the Revolution, these were increased to 98 ; in 1814 the Empire consisted of 130 ; and the war of 1870-71 reducer it from 89 to 87 , including the sndly dimin. ished department of Haut-Rhin. The departments, each presided over by a prefect, are again sub. divided into arrondissements. See FRANCE.

Dephlogisticated Air. See PHLogiston.

Depilatories (Lat. depilo, 'I pull out the hair.) are chemical agents employed for removing superfluous hair from the skin. They were exten. sively used by the ancients, bnt are now restricted in their employment to the face, and to the removal of the hair from the sealp in the treatment of certain diseases. They should only be used under medical aulvice.

Deponent, a term in Latin Grammar applied to verbs having a pnssive form but an active signification. They are so called hecruse they, as it were, lay down (Lat. depono) or dispense with the signification proper to their form. Such verbs had all ori imally a rellexive mesuing. like the midile voice in Greek verhs : thus, vescor, 'I ent,' menns radically, 'I feed myself.'-Deponent is also used for a person who makes a Depoeition $\left(q, v_{\text {。 }}\right)$.

Deposit, a term much used in Geology, to characterise those rocks which lave been formed from matter that has settled from suspension or 
solution in water. Thus, sandstone and shale are rocks composed of materials which have settled from suspension in water; while stalactites and stalacmites have been precipitated from solution in water. Deposits are cliaracterised according to the conditions under which they were formed, as marine, lacustrine, fluviatile, chemical, and so forth. See SEA, OozE, Abysmal Accumulations.

Deposit, in English law, is a branch of bailments, defined by Story to be ' $a$ bailment of goods, to be kept by the bailee without reward, and delivered according to the object and purpose of the trust.' See BAILMENT.

Deposition, the testimony of a witness set down in writing. Depositions are taken either by a judge or by a commissioner specially appointed by him for that purpose. The questions to which the depositions are answers are usually put by the legal representatives of the parties to the suit, under the control of the court or commissioner, and the answers are taken down by the elerk of court, or by a clerk specially appointed for the purpose. It is a rule in the laws of evidence of all countries that the deposition cannot be read where the witness might be himself produced, because his oral testimony is the best evidence, and secondary evidence is never admissible.

Depôt, in its military sense, is a place where stores, horses, or men are collected before being forwarded to the regiment or corps requiring them. By the Military Forces Localisation Act of 1872, the United Kingdom was divided into seventy brigade depôts. These were afterwards called regimental districts and re-numbered. See ARMY, Vol. I. p. 435.

\section{Depression, or Dip. See Horizon.}

De Profundis ('out of the depths'), the first words of the Vulgate version of the 129th psalm (A.V. 130th), which is one of the seven "penitential psalms,' and forms a portion of the liturgy of the Catholic Church, and is sung when the bodies of the dead are committed to the grave. A tender melancholy pervades the psalm, which, however, brichtens at the close under the conviction that with God there is 'plenteous redemption.'

Deptford, a town on the south bank of the Thames, 4I miles below London Bridge, but practically a part of London, and represented in its council by two members. In 1885 it was constituted a parliamentary borough, returning one member. Of the two parishes, St Nicholas, wholly in Kent, and close on the river-bank,

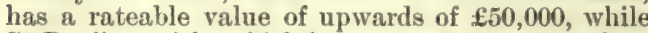
St Paul's parish, which is to a great extent modern and residential, stretches partly into Surrey, and has a total rateable value of close upon half a million. A roval dockyard, dating from the time of Henry VilI., was honoured by repeated visits from Queen Elizabeth, who here knighted Captain Francis Drake when he returned from his voyage round the world. It was closed in 1869 . Twenty-one acres of its site were bought by the corporation of London for $£ 94,640$, and were at a further outlay of $£ 230,000$ fitted up as a foreign cattle-market. Taking the year at 365 days, sheep and cattle are killed here at the rate of 93 every hour. The Royal Victualling Yard is also here, and as a specimen of its capacity, it may be stated that within a few hours of the official notification, 1500 tons of provisions were despatched for the relief of the starving inhabitants of Paris on the capitulation in February 1871. The Trinity House Corporation have property here ; and for sixteen years before his death, the Duke of Wellington as Master went in procession to St Nicholas Church with the Elder Brethren. Since then the ceremony has been disused, and the annual celebration takes place at Trinity Hall, London. Deptford was long famous for horticulture, but the gardens have mostly been built over or used for railway purposes. There is little shipbuilding now, but the General Steam Naviga tion Company employ a great many men here, and there are large and famous marine engineering establishments. In 1888-89 the Electric Lighting Company spent hundreds of thousands of pounds in erecting buildings and laying down plant for supplying London with light. Peter the Great worked here as a shipwright. Lord Howard of Effingham, John Evelyn, author of the Diary, Admiral Benbow, Grinling Gibbons, Captain Fenton the associate of Frobisher, and other famous persons, lived here; and Christopher Marlowe the dramatist, was killed here, and is buried in St Nicholas churchyard. Deptford is divided from Greenwich by the Ravensbourne, and over the creek there is a bridge where formerly the depe ford crossed the river. The lower portions of Deptford were improved in 1888-89, at a cost of about $£ 100,000$; the upper portions, New Cross, Brockley, and Hatcham, abound in pleasant residences. The population has grown rapidly, from 27,896 in 1851 to 76,732 in 1881 , and 101,326 in 1891.

Deputy, one who exercises power which properly belongs to another who has placed him in his stead. The appointment of a deputy does not free the principal from responsibility. See SHERIFF.

De Quincey, Thomas, author of Confessions of an English Opium-eater, and of many volumes of essays, criticism, and narrative, was born in Manchester on 15th August 1785. His father, Thomas Quincey, was a linen-merchant with a turn for literature; his mother, whose maiden name was Penson, was a woman of superior position and culture. Of eight children, Thomas was the fifth. An elder brother of imaginative temperament exercised much influence over him; and he records that he was profoundly impressed in childhood by the death of an infant sister. His early years were spent at a mansion built by his father near Manchester, named Greenhay ; there his father died of consumption in 1792, leaving his widow and family well provided for. Thomas attended school first at Salford, then at Bath grammar-school, later at Winkfield, Wiltshire, and lastly at Manchester grammar-school. He was an apt scholar; be could converse fluently in Greek at fifteen. In 1802, when he was seventeen years of age, his health failed; and as his guardians refused to remove him from school, he ran away, to wander and study in Wales. He was allowed a gninea a week; but restlessness and want of books and of social intercourse impelled him towards London. There, failing to raise money on his expectations, he underwent singular experiences and privations, related with picturesque power in the Confessions. Ultimately he was sent to Worcester College, Oxford, on the inadequate allowance of $£ 100$ a year. He disliked and perhaps despised the university system, and left in 1807 .

It was in Oxford that De Quincey first resorted to opium to allay pain; the use of the drug for that purpose, and also as a mental stimulant, subsequently became an overmastering and lifelong habit. His mother had now settled near Bath, and at Bristol De Quincey became acquainted with Coleridge's family; and through that connection visited Wordsworth and Southey at the Lakes. In 1808 he revisited Oxford; then went back to London, where he associated with Knight, Lamb, Hazlitt, and other men of letters. In 1809, having provided himself with an ample library, he settled to a literary career at Grasmere. 
Here, in 1816, he married Margaret Simumu, the doughter of a 'stalosman, ine of mature's

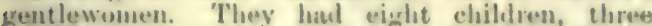
damghters and live sons, two of whom dimtin. guisherl themselves as soldions. For about a year

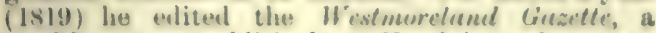
weokly paper published at kendal, and was an unlistiuguished contributor to Bluckwood's Mugazine, the Quarterly Review, and other periodicals, till, returning to London in 1821, his Confessions appeared in the London Magazine, and at once made him famous. His nom de plume, "The Eng. lish Opium-enter,' was used till he came to loe known by his proper name, in writing which he assumed the Norman prefix de. From London he returned to his wife and family at Grasmere, but finally left Westmorlund in 1828, and settled in Edinburgh ; and there, or at Lasswade, near Edinburm, with only an occasional visit to Glasgow, he lived and worked till his death, on 8th December 1859. Blackwood's, Tait's Magazine, and latterly Hogg's Instructor, were for upwards of twenty years the successive receptacles of his brilliant though often difluse and discursive papers. The Logic of Political Eronomy (184t), a philosophical contribution to that study, and a romantie story or novel, Klosterheim (1839)-his sole and not very successful effort in regular fiction-were issued as books; all his other writings appenred in magazines.

No 'periolical' writer' of the 19th century holds a like ligh and apparently permanent place in English liternture with De Quincey. Ot several collected editions of his works, the first was one issued in Ameriea (1852-55), in 20 vols.; a second, revised by De Quincey, in 14 vols.; nnother, extenied, in 17 vols, and a fifth, in 1889-91, in 14 vols, ed. by Prof. Masson. De Quincey's writings range over a vast field of literary and semi-philosophical speculation and discussion; and there, as well as in his narrative, historical, eritical, and bio graphical essays, almost fnultless refinement of style and marvellous mastery of plirase are conspicuous and charming. In criticism he is original and acute, if not exhaustive or profound ; in narrative he marshals facts and incidents in the most picturesque garl, and order; in argument he is always sultele, and often vigorous. His playful fancy and wealth of whimsical and humorous allusion enliven almost every topic, and the daring conception and gorgeous colouring of his opium-haunted dreams are not less admirable than the pomp and refinement of the languuge in which he clothes those weird and wondrous visions. De Quincey is, how. ever, often distressingly diffuse and provokingly addicted to complex involutions of phrase and statement-parenthesis within parenthesis. He is therefore at his best when those tendencies are under control, as in certain passages in the Con. fessions, or in the splendid apostrophes-exsmples of what he himself ealls 'impassioned prose' - that glorify such papers as 'Jonn of Arc.' See Page's (A. H. Japp's) Life and Writings of De Quincey (1877), and Memorials (2 vols. 1891); Masaon's De Quincey ('English Men of Letters' series, 1881), Selections (2 volk. 1888); Personal Rerollections, by the present writer (1886); Hogg's De Quincey and his Friends (1895).

Derajat', the fluvial portion of Daman $\left(q, v_{0}\right)$ itself a comparatively narrow strip in the Punjab, between the Suliman Mountains and the Inclus, and which, when duly irrigated, is singularly fertile. It is divicled into four districts, and has an area of $20,300 \mathrm{sq}$. 11., and a population (1891) of 1,643,600). - Dera Ghazi Klian, the capital of one of the districts, is abont 2 miles W. of the Indus. Pop. 27,886. - Dera Isnail Khan, enpital of another district, is 4 niles W. of the Indus. Pop. 26,884.
Derayeh, a town of Arabin, on the enswan route botween the Red Hea and the Pernian Gulf, 450 miles NE. of Mecen, was formerly the capital of the Wahabis, and had a population of 60,000 prior w) 18!9, when it was caken asud nearly dentronsed hy Ibralim Pasha. The capital was removed to kial. 6 miles $\mathrm{KN} \mathrm{L}_{\text {. }}$, and at prenent the place eonsiuts of five walled villayes, built among the ruins, with about 1500 indubitantm.

Derbend', or DrRbent ('gateway'), a port and eapital of the Russian districet of Dayshesian, on the west shore of the Caspian, 140 miles NW. of Baku. It is charmingly situated among vineyarda and orchards and fields of maize and madiler, on the declivity of a branch of the Caucasus, which liere approaches very close to the water's edge. Derbend is surrounded by ancient walls. The upuer eity forms the citadel, and contains the splendid palace of the ancient khann, now the residence of the Ruksian governor. The larbour is inaccessible to all but small vessels; but a considerable trade in done at the four large markets held here yearly. Silk and cotton fabrics, earthenware, and weapons are manufactured, and saffron is cultivated. Pop. 14,500. Derbend was for long considered the key of Persir on the north-west side. It wn: captured by the Arubs in 728, by the Mongols in 1220 , and frequently changed hands before it was formally incorporated with Russian Caucasia in 1813.

Derby, a parliamentary, municipal, and county borough and manufacturing town, the cajpital of Derbyshire, on the Derwent, 92 miles $8 \mathrm{E}$. of Liverpool and 129 NNW. of London. The Roman station of Derventiowas at Little Chester, n northem suburl, of Derty. It was a roval lorough in the time of Edward the Confeseor. Many early charters were granted to the bailifis and burgesses of Derby ; hut it was not till 1638 that it was placed uneler the jurisdiction of a mayor. It has sent two members to Parliament since 1295. The tower of All Saints (1509-27) is a grand example of Perpendicular architecture, 175 feet high, exclusive of the pinnacles, or 21 feet higher than the celebruted tower of Taunton. The Roman Catholic church of St Mary (1835) is a good specimen of Pugin's work. The ancient chapel of St Mary-oll-the-Brilge still exists. The municipal buildings are unattractive. There is a good free library and well-filled loenl musenm, occupy. ing handsome and suitable buildings, the gift of Mr M. T. Bass, for thirty-five years M.P. for Derby. The grammar-school is a modern erection, but was founded in 1162 . The clioicely-plantert arboretum (16 acres), near the central railway station, was the gift $(1840)$ of $\mathrm{Mr}$ Jueeph Strute. Derby is the headquarters of the Milland Kailway Company ; their vast offices, storehouses, workshops, and engineering establiwhments employ over $5(000)$ men. Perlyy being the centre of a great railway system, necess to all parts of the kinglom is direct, speedy, and frequent. Its manufactures are silk, cotton, elastic web, lnce, hoeiery, iron, lead, slıot, spar, porcelain, marble, colonra, and chemicals. Silk, one of its staple manuiactures. wa begun here firat in England by Jolin Lombe in 1719. The mill that he then erected still stands on an island in the Derwent. Porcelsin was manufactured here by the Duesbury fanily from 1756 till 1814; and the Derby Crown Porcelnin Company has recontly revived this benutiful industry with much sneces Richardson, the novelist, 'Wright of Derby, the painter, and Herleert Spencer, were natives; and Derloy is identified with the 'Stoniton' of George Eliot's Adam Bede Pop. (1841) 32,741; (1881) 81,168; (1891) 94, 100 . 
Derby, Earu of, a title conferred in 1485 on Thomas, second Lord Stanley, two months after Bosworth Field, where he and his family had greatly contributed to Richmond's victory. The Stanleys were descended from Adam de Aldithley, who attended Duke William to England, and whose grandson, having married the heiress of Thomas Stanley, of Stafford, exchanged the manor of Thalk in that county, which he had received as his wife's marriage-portion, for that of Stoneley, in the county of Derby, and afterwards assumed the surname of Stanley. In 1405 Sir John Stanley, who had married the heiress of Lathom, got a grant of the Isle of Man (q.v.), which he and his descendants ruled till 1736. James, seventh Earl of Derby (1606-5l), fought on the royalist side throughout the Great Rebellion, and, taken prisoner after Worcester, was beheaded at Bolton; his countess, Charlotte de la Trémouille, is famous for her heroic defence of Lathom House (1644) and of the Isle of Man (1651).

EDWARD GEOFFREY SMTTH STANLEY, fourteenth EARL OF DERBY, was born in 1799, at Knowsley Park, Lancashire. He was educated at Eton and Christ Church, Oxford, where, in 1819, he gained the Latin Verse prize (subject, Syracuse). He was elected member of parliament for Stockbridge in 1820 ; in 1825 he married the second daughter of the first Lord Skelmersdale; and in 1826 he represented Preston, but lost his seat in 1830 , on becoming Chief-secretary for Ireland under the adminis. tration of Earl Grey. A seat was soon found for him at Windsor. He took a distinguished part in the debates in favour of the Reform Bill, and signalised his Irish administration by two bold nieasures-one for National Education in Ireland, and another relative to the Irish Church Temporalities, which resulted in ten Irish bishoprics being abolished. The grievance of chureh-rates and firstfruits was also removed, and a graduated tax upon benefices and bishoprics substituted. In 1833 he became Secretary of State for the Colonies, and in the same year carried the bill for emancipating slaves in the West Indies. In 1834, being alarmed by the success of Mr Ward's motion for appropriating the surplus of the Irish Church temporalities to secular purposes, $\mathrm{Mr}$ Stanley seceded from the Whigs, carrying with him Sir James Graham, the Duke of Richmond, and the Earl of Ripon. In November, upon the dismissal of the Melbourne ministry, he declined to join the Peel administration, and the Stanleyites maintained an independent position for several years. He accepted, however, the colonial seals in 1841, and held them for four years. In 1844 he resigned his seat for North Lancashire, for which he had sat since 1832 , and was called to the Upper House in his father's barony of Stanley of Bickerstaffe, having for ten years before borne the courtesy title of Lord Stanley, through his father's succession to the earldom of Derby. In December 1845, when Sir Robert Peel determined to repeal the corn laws, he retired from the cabinet. In 1846 he put himself at the head of the Protectionists, who, headed in the Conmmons by Lord George Bentinck and $\mathrm{Mr}$ Disraeli, waged a stout but ineffectual opposition to the free-trade measures of Sir Robert Peel. He was now regarded as the leader of the great Conservative party.

In 1851, on the death of his father, he succeeded to the earldom. In February 1852, on the resignation of Lord John Rnssell, he was intrusted with the formation of an administration, which was, however, displaced in December following by a hostile vote of the House of Commons condemnatory of Disraeli's budget. On Wellington's denth (1852) he was elected Chancellor of the University of Oxford. In Feb- ruary 1858, when the Palmerston government resigned on the rejection of the Conspiracy Bill, he again became First Lord of the Treasury. At the meeting of parliament in the following year, his government brought forward a measure of parliarmentary reform. A hostile amendment having been moved by Lord John Russell, and carried, he dissolved parliament, and appealed to the country. When the new House of Commons reassembled in June 1859, a vote of want of confidence was carried against his government, and he resigned. He returned to power in 1866, and, in conjunction with Disraeli, passed the Reform measure of 1867. In 1868 he resigned the premiership in favour of Disraeli. His last speech in parliament was made (1869) in upposition to the disestablishment of the Irish Church. He died at Knowsley Park, Lancashire, October 23, 1869. Lord Derby was styled in his day 'the Rupert of debate,' and stood in the very first rank of parliamentary speakers. His power of invective was almost unequalled, and his vehement contentions with O'Connell on the Repeal of the Union did much to diminish the influence of the Irish agitator. Besides being an accomplished scholar, he was a keen sportsman and a popular landlord. But he cared little for office, and more than once injured the fortunes of his party by declining to form a ministry, notably on the fall of Lord Aberdeen in 1855. Lord Derby (who was offered the crown of Greece in 1862-63) published in 1864 a blank-verse translation of Homer's Iliad. See Lives by Kebluel (1890), and Saintsbury (1892).

EDWARd HENRY SMITH STANLEY, fifteenth EarL of Derby, K.G., D.C.L., LL.D., F.R.S., eldest son of the above, was born in 1826, and educated at Rugby and Trinity College, Cambridge, where he took firsts in classics and mathematics. In 1848 he was elected member of parliament for King's Lynn, and in 1852 was appointed Undersecretary for Foreign Affairs in his father's first ministry. After declining to join Lord Palmerston's ministry in 1855, Lord Stanley became Secretary for India in his father's second administration (1858-59), and carried the important measure which transferred the government of India from the Company to the crown. He was Foreign Secretary in the third Derby and first Disraeli ministries (1866-68). He succeeded his father in the earl. dom in 1869. In 1874 he again became Foreign Secretary under Disraeli; but resigned in March 1878, when the majority of the cabinet determined to support the tottering cause of Turkey by calling out the reserves and occupying Cyprus. After holding aloof from politics for several months, he definitely joined the Liberal party in 1880 , and was Secretary for the Colonies from 1882 to 1885 . In 1886 he declined to follow Mr Gladstone on the question of Home Rule for Ireland, allying limself with the Unionist party. Lord Derby, who was Lord Rector of Glasgow University in 1868-71, and of Edinburgh University in 1875-80, died at Knowsley, 2lst April 1893. His Speeches and Addresses, privately printed in 1893 , were published with a Memoir by Mr Lecky in 1894. His speeches on economical subjects are profound and convincing.

Derby Day is the second day, the Wednesday, of the Summer Meeting which takes place at Epsom in Surrey, usually towards the end of May, but sometimes early in June. Upon this day, the most important on the list, and that on which the best horses run, the famous Derby stakes, instituted by the Earl of Derby in 1780, are contended for. When the first Derby was run for, there were only 36 subscribers at 50 guineas each (with 25 guineas forfeit in case of non-starters); and for the first half-century the subscribers never numbered 90 but after 1830 there was a rapid increase, and in 
1879 ( which completed the century) there were 278 subscribers, and the value of the atakes axceeded 27000. Subsequently the numbers diminished till, in 1888, there were only 158 suberibers, and no more than nine horses ran, while the value of the stakes was $\mathbf{2 3 6 7 5}$. In onder to incrense the com. petitors in future, the conditions of the race were then altered. Since 1825 (when the subscription was changed from guinens to sovereigns) the fee has been $£ 50$ each, with $£ 25$ forfeit in case of nonstarters; and the value of the stakes has varied with the number of subscribers. Under the new rewnlations (coming intu overntion with the Derly of 1890 ) there is a fixed prize of not less than $\mathbf{f 5 0 0 0}$ for the winner, and amaller prizes for second and third; and any surplas from the entrance fees will also go to the winner. The full subseription is still $£ 50$, but there are two forfeits - viz $£ 10$ only if the declaration of forfeit is made about eighteen months prior to the race, or $£ 25$ if made about six months before the race. The entries are made abont two years before the race, when the animals are yearlings. The alteration of conditions proved attractive to racehorse owners, as the entries for the Derby of 1890 rose to 238. The Derby Day is a great English holiday. To be present at Epsom on that oceasion London empties itself, and proceeds to the Downs by modes of locomotion the most heterogeneous. For hours a continuous stream of carriages, gigs, dog-carts, vans, and vehicles of every description moves tumultuonsly along the road to Epsom. The benches of parlia ment are deserted; people of every condition come in countless numbers from all districts, and huge trains arrive every few minutes at the station, bringing their thousands, until the entire Downs are covered with a vast moving mass. At the Derby in 1861, the course, which is a mile and a half in length, was gone over in 2 minutes 43 seconds-the swiftest running, by 2 seconds, ever known on that course up to that time. In 1864 the race was run in the same time, although the horses carried $3 \mathrm{lb}$. more weight than before. In 1887 and again in 1888 the race was run in 2 minutes 43 seconds, although $4 \mathrm{lb}$. more hat been added to the weight. When the Derby was first instituted the weights were 8 stone for colts, and 7 stone $11 \mathrm{lb}$. for fillies; but they have been raised several times, until now colts have to curry $9 \mathrm{st}$. and fillies $8 \mathrm{st}$. $9 \mathrm{lb}$. It was run in 1896 in 2 minutes 42 seconds.

Derbyshire, an inland county of the north midland district of England, lies between Yorkshire on the north and Leicestershire on the south, and is flanked on the east by Nottinghamshire, and on the west by Staffordshire. The shire is of an irregular triangle shape, with the apex to the south: its greatest brealth is 34 miles, and its length 56 ; its area extends over 1029 sq. m., or 658,624 acres, Pop. (1841) 272,202; (1861) 339,327 (1881) 461,914: (1891) 520,886. Derbyshire is the twentieth of the English counties in aren, and the nineteenth in population. The surface of the county is much diversified, the soutl, being for the most part flat, the east of a varied and undulating ehar acter, but the north exceptionally hilly and rugged. The high land of the north, usually known a the Peak (which is the name of a district and not of any particular point or monntain), is the southern termination of the Pennine chain, and forms the watershed between the Trent and the Mensey. The chief summits are Kinder Scout, 2082 feet: Axe Edge, 1810 feet; Blakelow Stones, Man Tor, and Lord's Seat, all about 1700 feet. North Derbyshire is justly celebrated for its picturesque scenery. which chiefly centres in the valleys made through the limestone by the rivers Derwent and Wye. Matlock and Buxton, where there are warm mineral springs, are the two chief places of resort.
Other chief town are the fonp mnnirfpal borounds of Derliy, Clieaterfield, Glumop, and IIkewton (Isin?) and Aslibourne, Bnkewell, Befper, and Wirlcowerth. The county is divided into mix hundreds: High Peak. north-west; Sesurdale, north-eant; Wirkwworth. weat; Appletree, souch-weat : Morlenton and Litchurch, east ; and Hepton and Girewley, soush. Derbyshire now returns nine members to parlin. nesut ; two for the burough of Inerby, aud narven for

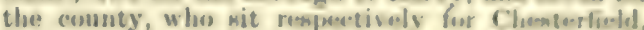
High Peak, Mid Derbywhire, Ilkeston, North. esstern Derbyshire, Southem, and Wentern. The county council consists of 80 mernberm.

In addition to important ooal-mining, chiefly in the esutern diviniun. Inerliswlite is ningularly wealthy for its area in a divenity of minernlu and metals; iron, leul, zine, sunugsneme, ropguer. Esp. sum, pipeclay and clsert for postloriem, unablile, fluor-spar, and alsbaster being all worked within its boundaries. The chief manufactures are cotton. silk, elastic web, wonted, metallic goodm, porcelain and pottery, and uorlile-xpar onnaments. Though more a manufseturing and mining than an agrieul. tural county, Derbyshire is not undistinguished for its pastoral and corn-growing jornerties. The chicef crops are wheat, barlev, and onter of the total area, 78 per cent. is under crops of all kinds, bare fallow, and grass. There is much permanent pas. ture and large sheep-walks in the Peak distriet. Several dairies of repute are in the south of the county, and their prosluce is chicefly taken by recently established cheese-factories on the Anerican principle. Ecclesiastically Derbyshire is now an archeleaconry of the new diocese of Southwell, and is divided into nineteen rural deaneries, and into 140 parishes There are ruins of abbeys at Dale and Beauchief, and peculiarly fine churches at Melbourne, Ashbourne, and Tideswell. The Saxon crypt and chancel of Repton, and the churchyard crosses of Eyam, Bakewell, Hope, \&e, are the oldest ecclesiastical remains of feudal and domestic building may bo named the eastlen of Castleton, Bolsover, and Duffield, the manor. house of South Winfield (ruin), Haddon Hall, and Hardwick Hall. Chatsworth $\left(q . v_{0}\right)$, the seat of the Duke of Devonshire, is unrivalled. The caves and numerous tumuli or 'lows ' lave yielded many evidences of prehistoric and Celtic man: whilat the traces of foman occupation are numerous. Arbelow, near Youlgreave, is the moot important 'stone circle ' in England next to Stonehenge. Though a turbulent county in English history, and ever taking part in all eivil tuminltu. Derbyshire has not furmished the vite of any retuark. able louttle nor pluyed any sperial pure in nutjusal ufluirs ; its chief historic sasoriation is the retreat in 1745 of Prince Charles Edward, Derby being the turning-point in his bold but rash enterpries. The county elnims a nativen. Flansteed the matmbo mer, Richardaon the novelist, Chantrey the neulptor. and Brindley the enyinen. Lombe firnt estaloliatied an English wilk-mill at Derly in 1719, and strute and Arkwright fint masle Engliah calicoes at Crow. ford in this connty in $17 \% 3$.

See Pendleton's History of Drobyah ive (1896): and the works of Dr Cox, (Juide to Derbyab ine. (Th wrobes of Derby. ehire (4 vola 1876 79). Thme Centuries of Derbuntire

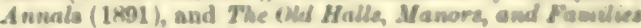
of Derbyabive (1Nell) ef mo.).

Derbyshire Veels is foitre (q.v.)

Derbyshire spar is Fluor Spar (q.V.)

Derehau. E.ısT, a plewsune, thriving market. town of Norfulk, 17 miles ( br mil 22) WNW. of Norwich. Here, in BSO, St Withberma founded a nunnery. It was burned by the Danes, but after. wards refounded and its cruciform church remains with a detached belfry (the "New Clocker') a foel of 1468, a good south porch, 8 t Withberga's well, 
and the grave of the poet Cowper. Bonner was a vicar, and Borrow a native. Dereham has manufactures of agricultural implements. Pop. (185̃) 3372 ; ( 1881 ) 5640 ; (1891) 5524 .

Derelict, a term in English law, signifying anything forsaken or left unoccupied, or wilfully cast away. So where the sea has receded from the shore, the land thus left uncovered is styled derelict. If the sea has in such case receded suddenly, the land becomes the property of the crown, but if gradually and imperceptibly, the gain goes to the owner of the adjacent lands.

A ship which has been wrecked is styled derelict, and this is the common use of the term. But it is necessary that the master and crew shall have abandoned the ship, without hope of recovery. The mere quitting of a ship for the purpose of procuring assistance from the shore, or other temporary cause, with the intention of returning to her again, does not make her derelict. When abandoninent has occurred, the first-comers are entitled to take temporary possession of the ship, and to claim salvage, either from the owners, the lord of the manor, or other person having right to wrecks unclaimed by the owners, or in the event of no claim from the crown. See Salvage, WRECKS.

Derg, LougH, the largest lake expansion of the river Shannon, between Tipperary and Galway and Clare, is 24 miles long, with an average width of 2 miles; greatest depth, 80 feet. Its surface is about 100 feet above the sea.-Another Lough Derg, in the south of Donegal county, is 3 miles by $2 \frac{1}{2}$, has many small isles and rocks, and wild dreary shores. Saint's Isle contains the remains of a priory. Station Island, the reputed entrance to St Patrick's Purgatory, was long the most celebrated place of pilgrimage in Ireland.

Dermatogen, the embryonic epidermis-layer of a plant embryo. See EMbryo.

Dermatology (Gr. derma, 'the skin,' and logos, 'a discourse'), the science of the management of the skin and of its diseases. See SkIN.

Dermatophytes (Gr. derma, 'the skin,' and phyton, 'a growth' or 'plant'), vegetable growths, chiefly of the lowest Fungi moulds, \&c., inhabiting the cuticle or epidermis, and giving rise to some forms of skin-disease, as Favus (q.v.), Pityriasis (q.v.), Ringworm (q.v.), \&e.

Dermestes, a common genus of beetles in the section Pentamera, including several species of formidable voracity. The most familiar of these is

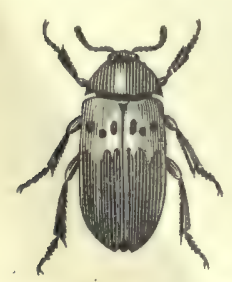
D. lardarius, often called the Bacon Beetle. In the open air it lives on dead animals, and is thus useful enough; but within doors it attacks bacon, cheese, dried meats, furs, cabinet collections, \&c. The brown larva are equally voracious. The insect itself is small, covered above with close, fine, black hairs, with the exception of the root of Dermestes lardarius. the wing-covers, which form a yellowish-brown band with

three dark spots on each side. Both adults and larvæ simulate death. Many other species are known on hides and the like. The larvo of some forms are occasionally utilised to clean small skeletons. The neighbouring genera Attagenus and Anthrenus also work great mischief.

Dermis. See SkIN.

Derrick, a kind of Crane (q.v.), so named after Derrick, an English 17th-century hangman.

Derry. See LONDONDERRY.
Dervísh, signifying 'poor', is a Persian word (derived from a root connected with 'door, indicating the door-to-door mendicancy of the dervish) of which the Arabic equivalent is Fakir (q.v.). It designates, in Mohammedan countries, a class of devotees who correspond in their various aspects with the monks, the mendicant friars, and the freemasons of medieval Europe. Soine are wanderers, depending upon alms, and often denianding charity with insolence; others are settled for the most part in convents, called Tekyas or Khânkâs, where they observe special rites, or devote themselves to solitary meditation and penance; others, again, are more like freemasons-ordinary tradesmen and labourers for most of the year, and exercising their special ceremonies only on stated occasions; whilst some, again, form a class of religious entertainers, who are hired out to chant their monotonons dirge or Zikr at public and private festivals. They belong to an intinity of orders or brotherhoods, among which the best known are the Kadiris (commonly known in Europe as the 'howling dervishes,' on account of their peculiar ehant), founded 1165 A.D. ; the Rifa' is (1182), formerly famous for their feats of eating glass and live coals and swallowing swords, and also for the ceremony, recently abolished, of the Dôseh, where the sheikh of one of their sub-orders (the Sa'dis) rode over the prostrate bodies of the faithful in the streets of Cairo the Mevlevis (1273), or 'dancing'-i.e. whirlingdervishes; the Nakhshibendis (1319); Bektashis (1357), whose founder blessed and named the famous corps of Janizaries (q.v.); the Jemalis (1750); and the Kalenderis, the 'calendars' of the Arabian Nights, who are under a vow of perpetual tramping: the names are taken from those of their founders.

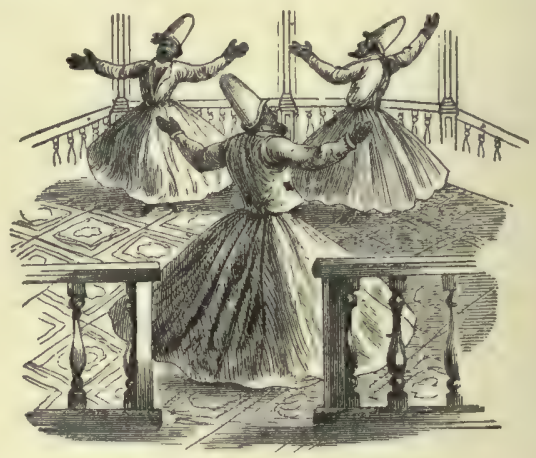

Mevlevis, or Dancing Dervishes.

The various orders have distinctive dresses, and the sheikh or pir who commands them is also distinguished from his followers by his robes. The conical cap of the Mevlevi is well known. The rites of the different orders when they meet together vary, but consist chiefly in prayers, religious dances, monotonous recitations of the name of God and of certain pious formulas. Frequently the devotees work themselves into a state of spiritual frenzy which is accompanied by extravagant, and, to the vulgar, miraculous, feats of strength and endurance, and not unfrequently terminates in an epileptic seizure. The dervishes and their performances are held in the deepest veneration by the people, and sultans have often held them in high respect, and bestowed large endowments upon their tekyas.

It is difficult to say when these religious orders took their rise. From the earliest times, pious persons in the East have held it to be meritorious to renounce earthly joys, to free themselves from the trammels of domestic and social life, and to 
devote their thoughts in poverty and retirement to the contemplation of God. In this sense, poverty is reoommended by Mohammed in the Koran, though monachism is distinctly repudiated. Tradition refers the origin of these onders to the earliest times of Islam, making the califo Abo-bekr and 'Ali found such brotherhoods; but most of them are of much later date. See Lane, Modern Egyptians, chap. X.; Hughes, Diet. of Islam; D'Ohsson's Tabl. Gen. de l'Empire Ottomane.

Derwent, the principal river of Tnsmania, issues from Lake St Clair, in the centre of the islund; flows tortuously to the sonth-erst; and enters Storm Bay at Hobart by an estuary 4 miles wide, after a counse of about 130 miles. Up to Hobart the Derwent is navigable for ships of any burden.

Derwentwater, a sheet of water, stretching south from Keswick, the most beatuiful of the Cumberland lakes. Lying 238 feet above sea-level, and engirt by steep wooded crags and hills, it is 3 miles long by 1 broad, and 72 feet deep at the leepest. Near its foot rises Castle Head (530 feet) commanding an exquisite view; whilst at its head are the celebrated Lodore Falls and Borrowdale (q.v.). This lake is an enlargement of the Derwent River, which traverses it ir its course towards the Irish Sea at Workinurton. It has several worled isles, besides a remarkable floating isle (see FLOATING IsLA ND). Perch are plentiful in the lake.

Derwentwater, JAMES RADCLYFFE, EARL or, one of the leaders in the rebellion of 1715 , was born in 1689, and educated in France. He succeeded as third earl in 1705 , on the death of his father, who had married Lady Mary Tudor, Charles II.'s daughter by Moll Davis. On the eve of the insurrection, at the close of 1714, warrants were issued on suspicion against several gentlemen in the north of England, and one, among others, against the young Catholic earl; but having been previously warned, he fled from Dilston, his seat in Northumberland, and found refuge in the cottage of one of his dependents. He soon afterwards placed himself at the head of a few retainers, under the impression that the whole body of the Jacobites either had risen, or were about to rise. From this point the history of the Earl of Deriventwater becomes the history of the Rebellion of 1715 (see JACOBITES), which ended in the disastrous encounter at Preston, where Derwentwater bore himself with the utmost heroism, but, with most of the rebel leaders, was taken prisoner, and conveyed to the Tower of London. Impeached of high treason at the opening of parliament, he was brought to trial in Westminster Hall, when he pleaded guilty, and threw himself upon the mercy of the king. His appeal was unavaling, and he was condemned to die. Every possible effort was nade by his kinsfolk and friends to obtain a pardon, but their exer tions were fruitless, and he was beheaded on Tower Hill, 24th February 1716. His youth and amiability, his rank and valour, combined to excite great eympathy for the hapleas earl. He is the hero of $a$ touching ballad of the lay, and of Dorothy Forster, Sir Walter Besant's chariing romance.

Derzhavin, Gabrikl Roma vowicz, the great poet of the age of Catharine, was born at Kasan, 3d July $1743\left(0.3_{1}\right)$, studied at the gymnasium of his native city, and in 1762 entered the army as a private soldier. His talents and superior education soon procured him promotion. In 1791 he lecame Secretary of State; in 1800, Inperial Treasurer and in 1802, Minister of Justice. He died 9th July 1816. His poetry shows a vigorous imagination and strong power of expreseion, though his imagery at times verges on bombast. His lyric pieces are full of fire. His noblest, as well as his most popu-
Lar ode, in his Address to the Deity, which hum been translated into the wentern lanyuayes $\mathrm{Hin}$ col.

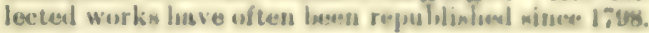

Desasuade'ro ('channel" or 'outlet ') the name of various water in south Amerien, of which the principal is the Hio Deanguadero in Bolivis $(q \cdot v$.$) .$

Desaix de Veygonx, Lovis Cuarles Ax. TOINK, a fanous French geneml, was bom of a gowh ohl family at St Hitairo-d'A yut, in Auvergme, August 17, 1768. Entering the irmy nt fifteen, in 1796 he covered himself with glory by his herrise conduct in Moreau's famous retreat through the Black Forest. Behind the ruinous fortreas of Kehl, Desaix resisted the Austrian army for more than two months, only eapitulating in Jannary 1797, when his ammunition was spent. His rveat. est achievement was the conquest of Epper Egypt, which he accomplished in 1799. aiter an eight months campaign. His own soldiers used to compare him to Bayard, while the inhabit ants named him 'the Just Sultan.' Desaix returned from Egypt just in time to take part in the battle of Marengo, in which he was killed by a musket-bullet, June 14, 1800.

Desaugiers, Marc, a once popular poet, whom some critics have set above Beranger, was born in 1772. After travelling alorond, he settled in Paris, where he became a writer of songs and vaudevilles, His subjects are generally love and wine; his verse is sweet and Howing. 'He is," says Mr Saintsbury, "the best light song-writer of France, with the single exception of Beranger.' He dier in 1827 .

Desbarres, Joseph Frederick W ALLET, mili. tary engineer, was lorn 1722 in England, of Huguenot parentage, and in 1756 sailed a lieutenant in the 60th foot for America, where he raised, and for a time commanded, a corps of field artillery. In 1757 he gained over the Indians who had cap. tured Fort Schenectady ; and at the siege of Quebec he was aide-de-camp to Wolfe, who was mortally wounded while Desbarres was making a report. $\mathrm{He}$ conducted the subsequent engineering opera. tions during the conquest of Canada, and was guartermaster general in the expedition that retowk Newfoundland (1762). He made a survey of tho coast of Nova Scotia in 1763-73, and afterwards prepared charts of the North American const for ford Howe. He was lieutenant-governor of Cape Breton (1784-1804), and of Prince Edward Island (1805-13), having attained the rank of colonel only in 1798. He died at Halifax, Nova Sentia, 24th October 1824, at the age of one hundred and two. His principal publication was the Atlantic Neptwase (4 vols. 1777), a splendid collection of charta.

Des'eant, in modieval music, wa the art of adding a part or parts to a melody or subject. The latter being almost invariably given to the tenor; descant came to signify generally the upper part, or air, of a piece. See Couxterposst.

Descartes, RevB (Latiniaed into Rrsat's CARTEsIUs), generally regarded as the father of modern philosophy, was born March 31 , 1506, at the village of I.a Inaye, near Tours. He was sent at the age of eight to the Jesuit College at La Fleche, where he soon beeame distinguished for his keenness of intellect, and mode great and rapid progress in languages, nuthematios, and atronomy. It was not long, however, before he hecame disatisfied with the doctrines and method of scholasticinm and felt it impossible to acruinse in what liad litherts been regarded as knowiedze. The first thing that be did after leaving college, as we are informed in his treatise on Metliod, was to a mandon books, and endeavour to efface frum his mind all 
that he had hitherto been taught, that it might be free to receive the impressions of truth, whencesoever they should come. In pursuance of his plan, he resolved to travel, and soon entered the army as a volunteer, serving suceessively in Holland, Bohemia, and Hungary. It was while he was in winter-quarters at Neuburg on the Danube (St Martin's Eve, 1619 , as he himself informs us) that there first dawned upon him the principles of the new method which he afterwards applied in philosophy and for the reorganisation of knowledge generally. So in 1621 he left the army, but continued to travel as a private gentleman, with occasional residences in Paris, till 1629. In that year he retired to Holland, where he lived in great seclusion for twenty years, devoted to the elaboration of his discoveries and the publication of his chief works. In time his doctrines attracted many disciples in the land of his adoption, but involved him at the same time in bitter controversy with the Dutch theologians. These unpleasant encounters had probably their share in inducing him to accept an invitation to go to Sweden, addressed to him by Queen Christina, who desired his learned intercourse and instruction. He left Holland in September 1648, but his constitution was not able to stand the rigour of the northern winter and the exposure involved in waiting upon the queen at five every morning for an hour's philosophical instruction. He died at Stockholm of inflammation of the lungs on February 11, 1650. Sixteen yeurs later, his body was brought to Paris, and buried in the church of St Genevievedu-Mont. In 1819 his remains were again transferred to St Germain-des-Près, where they now rest.

The grand object towards which Descartes directed his endeavours was the attainment of philosophical certainty. The way whereby he sought to attain this end is explained in the Discourse on Method (Discours de la Méthode, published in 1637). This small but extremely interesting and important treatise contains a history of the inner life of the author, tracing the progress of his mental development from its commencement in early years, to the point where it resulted in his resolution to hold nothing for true until he had ascertained the grounds of certitude. The author also, in the same treatise, lays down the methodical rules by which he resolved to guide his inquiries, and by the observance of which he hoped to arrive at absolute certainty, if indeed it were at all attainable. The results of his inquiries are indicated in the Discourse, but are exhibited more particularly in his Meditationes de Prima Philosophid (Amst. 1641), and the Principia Philosophia (Amst. 1644). Doubt, according to Descartes, is the philosophic starting-point, the solvent which we must bring to bear upon all our inherited beliefs and opinions. This doubt is to be distinguished from scepticism, which is a permanent state of mind and involves despair of truth. It is to be regarded simply as an instrument of philosophical inquiry, and as such has received the name of Cartesian doubt. Applying this test relentlessly to all that had hitherto borne the name of knowledge, Descartes found one, and only one proposition that seemed to him to stand firm, and of which the truth could not possibly be doubted: that proposition was that he existed, which he inferred from the fact of his possessing consciousness. He could not doubt that he felt and thought, and therefore he could not doubt that he, the feeler, the thinker, existed. This relation between conscionsness and existence he expressed by the memorable words: Cogito, ergo sum. On inquiring further into the ground of his certitude in the case of this proposition, Descartes was able to assign no further reason than that he saw very clearly that in order to think, it is necessary to exist.
He formulated, therefore, the following criterion of certainty - that whatever is clearly and distincily thought, must be true. Amongst these clear and distinct thoughts he soon recognised the idea of God as the absolutely Perfect Being. This idea, he reasoned, could not be formed in our minds by ourselves, for the imperfect can never originate the perfect ; it must be connate -i.e. part of the original structure of our understanding, and implanted there by the Perfect Being himself. Hence, from the existence of the idea of perfection, Descartes inferred the existence of God as the originator of it; he in ferred it also from the mere nature of the idea, because the idea of perfection involves existence. The latter is known as the ontological argument, which Deseartes thus reintroduced into modern philosophy. But if God exist, then we have a guarantee, according to Descartes, of the previously determined ground of certitude, for God the Perfect Being cannot deceive, and therefore what ever our consciousness clearly testifies may be implicitly believed.

The most general fundamental principle of the philosophical system of Descartes is the essential difference or dualism of spirit and matter-the thinking and the extended substances-a difference so great, according to Descartes, that they can exert no influence upon each other. Mind or spirit is pure consciousness, and matter is mere extension ; these attributes are mutually exclusive, and hence these two "ereated substances' can be united (as we find them, for example, in the human being) only through the intervention of the infinite substance or God. This doctrine led directly to the system called occasionalism, the principle of which was that body and mind do not really affect each other, God being always the true cause of the apparent influence of one on the other. A volition on our part is merely the occasion of God's producing a corresponding bodily motion, and similarly the material processes in the nerves and brain are only the occasion, not the cause, of the ensuing mental result. This doctrine was further developed by Leibnitz in connection with his doctrine of preestablished harmony (see LEIBNITZ). The human body being thus a mere machine accidentally united to a rational soul, it was an immediate consequence of the Cartesian doctrine that animals (in which the rational soul is absent) are literally automata; their cries no more imply feeling than the creaking of a machine. This ruthless product of logical consistency unfortunately led to eruelty in practice.

Descartes did not confine his attention to mental philosophy. His philosophy is in fact only the introduction to an elaborate system of physics. . In this department it is noteworthy that he completely discarded final causes and proposed to himself the explanation of all physical phenomena from matter and motion. His celebrated theory of vortices, devised to explain the motions of the heavenly bodies, held the field till it was superseded, after a stubborn resistance, by the Newtonian theory of gravitation. It was in mathematics, however, that Deseartes achieved the greatest and most lasting results. It was Descartes who first recognised the true meaning of the negative roots of equations; and we owe to him the theorem, which is called by his name, that an equation may have as many positive roots as there are changes of sign in passing from term to term, and as many negative roots as there are continuations of sign, and not more of either kind. He gare a new and ingenious solution of equations of the fourth degree; and first introduced exponents, and thereby laid the foundation for calculating with powers. He showed, moreover, how to draw tangents and normals at every point of a geometrical curve, with the exception of mechanical or trans. cendental curves; and what perhaps was his highest 
merit, be showed how to express the nature and the properties of every curve, ly an equation between two variable co-nrdinates ; thus, in fact, oriyinating A nulyficul Geometry, which has led to the lrighteme discoveries. Editions of Descartes' collected workm were published in Latin in 1697 and 1713, and in French by Consin in 1824-26. His chief philosophieal works have been translated into Euglish by Professor Veiteh. See Millet, Descartes, sa Vic, ses Travaux, ses Decouvertes (2 vols. 1867-71); Kuno Fischer, Deseartes and his School (Eng. trans. 1887); and English works by W. Cunningham (1877), Lowndes (1878), Mahaify (1880), and Martineau ( 1885 ).

Descendants. See Heir, Consanguintit, PEDIGRER, SUCCEssion.

Descent of Man. See Man, Darwixian THEORY.

Deschamps, Eustachs, a French poet, who was born at Vertus, in Chanipagne, in 1328. He was educated at Orléans University, and was in the course of his life a soldier, a magistrate, a court favourite, and a traveller in Italy and Hungary. He held several important posts in his native province, but his possessions were ravaged by the English, and he seems to have been a poor man when he died in 1415. He was both a popular and voluminous writer. He composed 1175 ballades, \& multitude of rondeaux, virelais, and other lyrics, besides a long poem of 13,000 lines, entitled the Miroir de Mariage - his works in all amounting to more than 100,000 lines, Deschamps was an ardent patriot, in whose verse hatred of the English and of the native oppressory of the French poor finds repeated and bitter expression, and his style is as a rule somewhat wanting in elegance and ease. Occasionally, as in his lament for Du Guesclin, his verse is both graceful and touching; and in one at least of his pieces, an apologue exposing the exactious of the rich, he gives proof of a grim and trenchant satiric faculty. The edition of his Poéties Morales, edited by M. Cropelet (1832), is superseded by the complete edition for the Old French Text Society hy the Marquis de Queux de Saint-Hilnire (1878-95). See the monograph by Sarradin (1878), and Besant's Early French Poets (1868).

Deseret, the name first adopted lyy the Mormons for what is now Utah. See Mormoss, UTAн.

Desert (literally, 'a solitary place ') is the geographical name applied to a barren and uninhabitable portion of the earth's surface. Four classes of desert may be distinguished.

(1) Ice-vocestes occupy the central platean of Greenland, the islands of the Aretic Sea, and probably the entire Antaretic continent. The ground is covered to an unknown depth by a vast ice-cap, rough and hummocky on the surface, and moving outwards to the coasts in a continual procession of glaciers.

(2) Tundras are Hat plains, little elevated above sea-level, fringing the Aretic shores of the northern continents, and specially characteristic in Siberia (q.v.). The soil remains frozen to a great depth all the year round, thawing superficially when the snow melts in summer, and becoming covered with cosrse moss and dwarfed Aretic plants.

(3) Arid wastes, or deserts in the popular sense of the word, oceur mainly in two zones encircling the world, and corresponding to regions of minimum rainfall (see CLIMATE). The more extensive extends from near the equator in an east-north-east direction across the whole breadth of North Africa, as the Great Sahara, Libyan and Nubian deserts, over the peninsula of Arabia, through Persia, Turkestan, the Gobi or Shamo Desert, in ahout $52^{\circ}$ N. lat, to the Pacific Ocean (see AsIA). The great Indian Desert in the Punjab is the only extension of this belt sonth of the Himnlayas. The ring is completed by the Greas Busin of North Ameries in $40^{\circ} \mathrm{N}$. lat. The southern zone, les complete, coupriwes the Kala. lari Dewert in south.weat Africa the interior of Australis, and small dintricts in the Argentine Republic and in the Andea. Deserts oceur at sll elevations, from considerable depths benenth nea. level to many thousand feet above it, and with all varieties of surface, from a flat expanse of

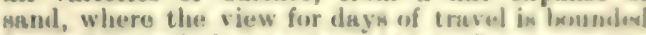
by a sharp circle as at sean, to row.ky mosustain. slopes rent by rough defiles all bare and chiselled by the driving sand. The esential character of an arid waste is its rainlessness, and the scarcity of water on the surface and of water-vapour in the atmosphere. Radiation in the elear air is intenwe. and desert climate is conseoquencly of an exmezor. ated continental type. The oand in the Baliara becomes heated to over $150^{\circ} \mathrm{F}$. during the day, and chilled below the freezing point at night, while the diurnal and seasonal extremes in the lofty deserts of Central A sis are much greater. Thus desert-regions are most effective in producing land and sea breesces and monsoon winds in consequence of the marked periodical changes in atmospheric density. Another effect is the Mirage (q.v.), a phenomenon which, combined with the indescribable horror of loneli. ness that oppresses the occasional traveller, probably accounts for the widespread snperstitions peopling deserts, ahove all other places, with evil and malicious spirits. The dreaded sand-mtorm or simoom is a kind of tornado or whirlwind which raises the sand in tall rotating colunns sweeping over the surface with tremendous velocity. Sand-dunes, sometimes several hundred feet in height, are raised by stealy winds, sud gralually shift their position, extending the bounds of the desert to leeward. Desert vecratation is extremely scanty, consisting mainly of liard prickly plants of the eactus, euphorbia, and spinifex kinds, whose glazed surface exhales little of the hardly-won moisture. Animsl life is correspondingly restricted both in variety and number of individuals. The Camel $\left(q_{0} \mathbf{v}_{0}\right)$ is par excellence the beast of burden for conducting traffic across arid wastes. When an overllowing river, such as the Nile, travenses a degert, the land becomes richly fertile in its immedi. ate neighbourhood, and wherever springs bubble up through the sand there are Oases (q.v.) bearing palm-trees and grass. Artificial irrigation, especially the sinking of artesian wells, bas done much to reclaim tracts of desert for agriculture in the Sahar (see Alogria), and to a less extent in Australia.

Geological considerations show that arid deserts are not permanent fentures of the earth's surface. The most level expanses have once formed part of the ocean.bed, or at least great inland seas. The orographical changres which ent off these seas and created inland drainage arens prolably at the nume time modified the rninfall of the locality. Excessive evaporation dried up the great lakes, lenving at present a series of dimmishing salt lakes without outlet, receiving rivers which dwindle down by evaporation as they flow. The only commercial conmoditiea yielded by deserts are the alts (common salt, borax, sodium enrbonate, and sometimes sodium nitrate) left in the dried-up lake-beda. These salt lakes are subject to alternate long periods of desiceation and flooding; during the former the ares of the desert extends, during the latter it contracts. These periods have been iraced ont in the case of the Great American Basin by a series of most interesting researches on the part of the United States Geological Survey.

(4) Temponary deserta or steppe-landa, borier the Asiatic deserts to the north and west. The saline steppes of the Caspian are true arid wastes 
but the typical steppes in South Russia are luxuriantly clothed with verdure and flowers in spring. In summer they form a dusty plain of withered herhage, and in winter are wind-swept wastes of snow. The grassy llanos of the Orinoco present a similar desert appearance in the dry season ; in the wet season they are inundated marshes which lurst into blade and bloom as the water subsides. The pampas of the Plate river-system under similar but less marked seasonal changes form a natural transition to the fertile prairie lands which, although naturally treeless, are always richly grassed.

Desertas, a group of three rocky islets in the Atlantic Ocean, to the SE. of Madeira, visited at certain seasons of the year by fishermen and herds. men.

Desertion from the army or navy is the crime of absence without leave, coupled with the intention of not returning to the service, or of avoiding some important duty, such as embarkation for a foreign station or aiding the civil power, however short the time of absence or the distance to which the absentee may have gone. Under the Army Act of 1881 the very common offence of quitting one regiment to join another (formerly charged as both "desertion and fraudulent enlistment"), inasmuch as it proves no intention to leave the service, is punishable by Court-martial (q.v.) as fraudulent enlistment only, but in the same way as desertion when not on active service-viz. by imprisonment up to two years for a first offence, and penal servitude for not less than five years for a second or subsequent offence, together with forfeiture of service, medals, \&c., to which may be added stoppages of pay for loss of kit, and discharge with ignominy. By thus distinguishing between desertion and fraudulent enlistment, the number of soldiers annually convicted of the former crime has been reduced by one-half ; short service, the abolition of Bounty (q.v.) on enlistment, and better education have had the effect of still further reducing this number. It is still, however, large (about 3000 ); and, beyond a published description of all absentees and deserters, recruiting officers have no means-such as formerly existed, when tattooing with the letter 'D' (erroneously called Branding, q.v.) always formed part of the sentence-of detect ing a man who has been convicted of this crime and discharged with ignominy, or who endeavours to fraudulently re-enlist. Thus individual men often join five or six regiments, deserting immediately from each in turn and selling their kits, which cost the country some $£ 4$ or $£ 5$ each. When apprehended considerable further expense is incurred in bringing them to trial and maintaining them in prison.

Desertion, or attempting to desert, when on active service, or under orders for active service, is much more rare, and is punishable with death. So is the crime of indneing a soldier to desert under those circumstances : and a civilian who is convicted of it, if subject to military law because accompanying a force in the field, as a newspaper correspondent or a camp-follower, is liable to this punishment. When not subject to military law, six months" imprisonment with hard labour may be awarded by any court of summary jurisdiction to a civilian who induces or assists a soldier to desert. Deserters from the United States army forfeit all pay and allowances due at the time of desertion. If in time of war, the penalty is death ; in peace, they suffer such penalty as a court-martial may direct.

Desertion is equally a crime when committed by a seaman of the royal navy. A sailor absent from three successive musters is a 'runaway ;' and when discovered and brought back, he is punished by a deduction from his pay. If his absence is continued, it amounts to desertion. All harbouring of deserters by other persons is punishable. In the navy of the United States, a temporary absence without leave with an apparent intention of returning to duty, is regarded as 'straggling,' but an alsence of ten days constitutes desertion. In either case the commanding officer decides the points, and causes the proper entries to be made on the ship's books.

\section{Desertion of the Diet. See DIET.}

Desertion of Wife and Children. See Husband and Wife, Parent and Child.

Desiccants, in Medicine, are substances with astringent properties, which are serviceable in checking secretion and exhalation.

Desiceation is the process of drying by the employment of heat, dry air, or chemical ayents which have an affinity for water. Examples of the class of desiccants or drying substances are fused chloride of calcium, quicklime, fused carbonate of potash, and oil of vitriol. The latter is employed by being placed in a separate vessel near the substance to be dried, and under a bell jar.

Not a few of the lower animals are said to be able to endure drying up without losing the power of recovery. Some of the Protozon form protective sheaths or cysts from which they emerge on the return of moisture. Nematodes or thread-worms (paste-eels) have been known to revive after fourteen years' desiccation, but trials beyond this limit were unsuccessful. With those animals the interesting fact has been noticed that the longer the period of desiccation, the longer the time required for recovery. Rotifers are also described as reviving after prolonged and thorough desiccation, but experiments have shown that, in the case in question at least, only the associated eggs retained their life. The eggs rupidly developed on the return of moisture; but the adult organisms proved to be really dead. The bear-animaleules or Tardigrades have been thoroughly desiccated and even heated to a high temperature without, it is said, losing power of revivification. A state of latent life is also assumed in consequence of cold, absence of stimulus, \&c., and a relative quiescence occurs natirally in hibernation, or pathologically in trance. Among the lower plants, resting spores, \&c., may survive desiccation; and, among the higher, seeds are well known to have a similar power. See HiberNation, INSECTS, LATENT LIFE, MUDFISHES, MUMMY-WHEAT (under Wheat) RotATOria, Tardigrada, Thread-Worms, Trance.

Design, Schools or. See, under ART, Art Instruction, vol. i. p. 456.

Desira'de, a small island of the West Indies, belonging to France, and lying 4 miles E. of Guadeloupe, with an area of $10 \mathrm{sq}$. m., and a population of about 1600 , engaged in fishery and the cultivation of cotton.

\section{Desman. See Musk Rat.}

Desmids (Desmidece) are a group of conjugate Algre (see ALGAs) related to diatoms, but readily distinguished from these by their bright green instead of brownish-yellow colour, their cellulose instead of silicified walls, and their general form, which is usually more or less deeply constricted in the middle line. As with diatoms the lower forms are, however, united in long chains, so indicating a relationship to the lower and filamentous Conjugatæ (Spirogyra, \&c.). About four hundred species have been described, but these are often variable and jll defined. All are inhabitants of fresh water, but chiefly occur in the standing pools of heaths and peat-mosses. They rarely form large aggrega- 
tions ; but usually occur araociated with flament. ous ulyse, diatoms, and other forms of microsenpic life. On account of the singular beasty of their general form they are much prized by the microscopint : their mode of division, too, is remarkable, yot akin to that of diatoms, the two halves of the cell being pressed apart at the median eonstriction
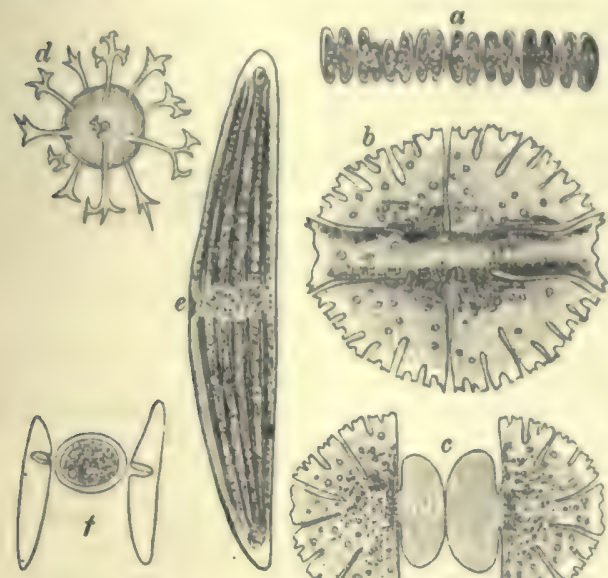

Desmids (mostly $\times 100)$ :

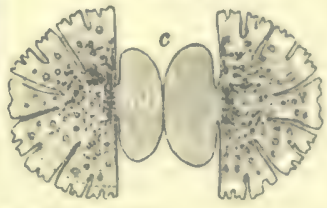

$\approx$, Continuous flament of Spharozasma veriebnatum; $b$, Micra sterias rotata; $c$, M. denticulata, dividing: $d$, Zygompore of tion.

by the development of two new bud-halves to complete them (see fig.), two new desmids being thus gradually formed, which become as synmetrical as the original one, yet with the two apparently similar halves of very unequal age. Conjugation also oceurs, with formation of a resting spore; the eyst of which may have peeuliar markings or hook-like prominences. See Ralfs' Desmidea ; Mierographic Dictionary, \&c.

Desmodium Gyrans. See Telegraph Plant, and (under Plants) Movements of PLants.

Des Moines, the capital and largeat city of lowa, is situated on the Des Moines River, at the morth of the Raccoon River, 174 miles W. of Davenport by rail. The river, which rises in the SW. part of Minnesota, flows generally SE. through Iowa, and enters the Mississippi at the SE. extremity of the state, after a course of about 550 miles. Founded in 1846, the city las a fine state. house $(\$ 3,000,000)$, a marble post-oftice and courthouse, a Baptist university, and a state library con. taining over 22,500 volumes. IIalf-a-dozen bridges over the two rivers connect the different parts of the town, and there is a public park, with fine groves of forest trees. The town contains severul foundries and planing and tlouring millk, besides manufactories of machinery, engines, boilers, railway cans, \&e. Pop. (1870) 12,035; (1880) 22,408; (1883) 32,469 ; $(1890) 50,093$.

Desmoneus, an American genus of elimbing palms which represent the rattans (Calansus) of East Indian forests.

Desmond. EARLS OF, a line formerly all. powerful in the south-west of Ireland, numberer fifteen of the title, dating from 1329, and ended with that Fitzgerald who rebelled against Elizabeth's government, sacked Youghal by night and murdered the people, and was proclaimed a traitor in 1579. He escaped the fate of the Spanish garrison at Smerwick (1580), and carried on the struggle for some time; but driven at last from his strongholds, he wandered about for over two years, and was finally killed, in 1583, in a calin in the Kerry mountains, where his hiding place foul beren betrayed to the Engliwh.

Desmoulins, Camille, a famoum figure in the French Revolution, was born ad March 1760, st Guine, in Picardy. He studied law along with Robespierre at the College Louis-le-Gmand, in Paris, but never practised owing to at stutter in his speech. His mind early lowerme filled with lofty but confused notions of elasical republicanism, which found vent on the eve uf the Revolution in his pamphlets, La Philosophic as Pereple Francaie (1788) and La France Libre (1789), the latter puls. lished the day after the inmurrection which dentroyed the Bastille, in promoting which its anthor played a conspicuous and dramatic part. His next writing was the brilliant and vigorous Discours de la Lan. terne aux Parisiens, which procured him the ainister title of 'Procureur-général de la lanterne." In November 1789 he issued the fint number of the Revolutions de France et de Brabant, which appeared weekly until July 1792 ( No. 86), and which for enu. bined brilliancy of wit and irony, polemie foree, power of sarcasm, and grace of form, remains with. out an equal in the whole range of journalism. His next paper, the Tribune des Patriotes, died in its fourth number. Camille had been a member of the Cordeliers' Club from its foundation, and early clung to the mighty Danton in an affectionate friendship of singular intensity. Elected by Paris to the National Convention which followed immediately after the march of the mob on the Tuileries (August 10), he voted with his party for the death of the king. In the struggle between the Girondists and the Mountain he took an active part, and in May 1793, urged on by Robespierre, published his truculent Histoire des Brissotins, with a gay heedlessness which had a terrible sueress, anil caused him soon afterwarls the must profound remorse. Danton himself had thundered against the Girondists, who made a fatal error in insisting upon the ineffectual impeachment of Marat, bui his great heart hlled with pity when their heads fell nuder the guillotine of the relentless and tri. umphant Mountain (Octoler 1793)。 On the 5th December of the same year came ont the Vicuxe Cordelier, a thrilling and eloquent expresaion of Camille's and Danton's longing for elemency. Robespierre, at first favourable, took fright at the reception of the papers after the thind, and sbandoned his old fellow-student to a fate of which his fragments of writings, as well as his letters and his young wife's jurnols and sernp. Inuhs. sluw us be had already a strange presentiment. It was only in December 1790 , after three years of love, that her father had permitted him to marry the bright young Lucile Duplessis, a girl of a fanciful and romantic temperament, then hardly twenty years old. Their brief married life was one of singular happiness, and in their denths they were harlly to In divided. Meantime Helwert and his party assailed him. and his freedom of wit made fatail enernies of Billaud. Varennes and Saint-Just. The last number of the Vienx Condelier that apprareyl in its author's lifetime was the sixth (Fubruary 1794). Already he had been twice accused before the Jacobin Club, when on the night of the suth March 1794 he was arrested with Danton and a group of their friends and partixnns. When formally asked his agr. tuefore the fervulutionary trilunnal, he replied: 'J ai l'age du san-culotte, Jésus, c'est-àdire trente-trois ans, Age fatal aux revolutionnaires. Camille's sensitive temperament could not face death with the boisterous heroism of the Titanic Danton. But on the scafiold he recovered the courage that had deserted him in the prison and on the tumbril. 'Thus thes,' he said, as he looked at the blood-stained guillotine, "the first apostle of 
Liberty ends:' and with the words, 'Oh my poor wife!' he laid his head under the fatal knife. A fortnight later Lucile followed him to the same doom, dying with the heroic courage of the martyr. Their story is nobly told in Jules Claretie's Camille Desmoulins and his Wife (trans. by Mrs Cashel Hoey, 1876 ).

Desna, a river of Russia, rising in the province of Smolensk, and flowing south-eastward to Briansk, and then south-westward till it falls into the Dnieper, almost opposite Kiev. It has a course of 550 miles, navigable nearly throughout, and is the channel of a large trade; its low banks are frequently inundated in spring. Its chief affluents are the Seim and the Snov.

De Soto, Fernando, Spanish discoverer, born at Jeres de los Cavalleros, in Estremadura, about 1496, of a good but impoverished family, accompanied Pedrarias Davila to Darien in 1519, served on the expedition to Nicaragua in 1527, and afterwards assisted Pizarro in the conquest of Peru, returning to Spain with a fortune of ' an hundred and fourscore thousand ducats.' Charles V. now gave him permission to conquer Florida at his own expense, and appointed him governor of Cuba ; and in 1538 he sailed from San Lucar with a richly equipped company of 600 men, 24 ecelesiasties, and 20 officers. The fleet anchored in the bay of Espiritu Santo (now Tampa Bay) on 25th May 1539 ; the ships were sent back to Cuba, and the long search for gold was begun. For three years, harassed by hostile Indians, lured onward by reports of wealth that lay beyond, the everdecreasing company continued their toilsome march over a route that cannot now be very clearly traced. In 1541 the Mississippi was reached and crossed, and the third winter was spent on Washita River. Returning to the Mississippi in the spring, De Soto, worn out by disappointments, died of a fever on its banks in June 1542; and that his death might be concealed from the Indians, his body, wrapped in a cloak, was lowered at midnight into the waters of the great stream he had discovered. In the following year his companions, reduced to half their original number, sailed down the river in seven frail boats, and finally reached the town of Panuco, in Mexico. See Lives by Wilmer (Phila. 1858), Abbott (N. Y. 1874), und Shipp (Phila. 1881).

Despard, EDWARD MARCUs, conspirator, was born in Queen's County, Ireland, in 1751, and at fifteen obtained an ensigncy. From 1772 till 1790 he did good service in the West Indies, both as a soldier and as superintendent of the new territory of Yucatan. He was then recalled on the most frivolous charges, which for two years were kept hanging over him; nor, when they were dismissed, could he get the least compensation. His complaints brought him two years' imprisonment ( 1798 1800 ), on his release from which he engaged in a crackbrained conspiracy to assassinate the king and to seize the Tower and Bank of England. For this, with six of his associates, he was drawn on a hurdle, hanged, and beheaded, 21st February 1803. - His brother, JoHN DESPARD (1745-1829), British general, was present at twenty-four engagements, mostly during the American War of Independence.

Despenser, Hugh LE. See EDward II.

Des Périers, Bonaventure, one of the most interesting prose-writers of the Renaissance period in France, was born at Autun in Burgundy about the year 1500. Little is known regarding his life beyond the fact that he was a member of the court of men of letters assembled by Marguerite of Navarre. In 1537 he published the Cymbalum Mundi, a work in dialogue, in which, under the pretence of attacking the superstitions of the ancients, he satirised the religious beliefs of his own day. The book raised a storm of indignation, against which Marguerite seems to have been powerless to shield Des Périers, who, rather than fall into the hands of his persecutors, is soid to have killed himself in 1544. His Nouvelles Récréations et Joyeux Devis were published in 1558. They consist of 129 short stories, both comic and romantic, and are admirable examples of narrative art, though the laxity of the Renaissance is frequently apparent in the writer's choice of sub. jects. The style is vivacious and elegant; indeed, Des Périers is one of the greatest masters of French prose whom the 16th century produced. Besides writing the Cymbalum Mund and the Joyeux Devis, it is by many critics believed that Des Périers was part author of the Heptameron associated with the name of Marguerite. See MARgARET of NAVARRE, and the edition of Des Périers' works by Lacour ( 2 vols. Paris, 1866).

Despoblado (Span., 'desert'), a treeless, uninhabited plateau, nearly 10,000 feet above the sen, on the Bolivian and Argentine frontier to the northeast of Antofagasta.

\section{Despoto Dagh. See RHodopk. \\ Despreaux. See BoIleat.}

Dessalines, JEAN JACQUES, emperor of Hayti, was born about 1758 in Guinea, Africa, and was at an early age imported thence into Hayti as a slave. He was bought by a French planter, whose name he afterwards assumed, and early became a prominent leader in the insurrection, second only to Toussaint L'Ouverture. In the struggle with the French he was always distinguished by his agility and swiftness of movement, as well as by his fearlessness and ferocious cruelty. After the first compromise he became governor of the southern part of the island, but soon began the war anew, and, after infamous cruelties, compelled the French to evacuate the island in October 1803. He was ereated governor in January 1804, when the people of the island declared theniselves independent, and on 8th Oetober had himself crowned as emperor of Hayti, under the name of Jean Jaques I, ; but his despotism, debauchery, and cruelty soon alienated from him the sympathy and support even of those who were formerly his firmest adherents. In 1806, while trying to repress a revolt, he was cut down by Christophe (q.v.), who succeeded him as emperor of Hayti.

Dessau, a town of North Germany, eapital of the duchy of Anhalt, is situated on the left bank of the Mulde, not far from its junction with the Elbe, 70 miles by rail SW. of Berlin. It is in general well built. Among the principal buildings are the ducal palace, a noble structure, built in 1748 , and improved in 1875 , with a valuable pieture-gallery and library; a town-hall, an elegant theatre, and several churches. The Philanthropinum of Basedow (q.v.) was here. The manufactures are sugar, woollen cloth, machinery, carpets, and there is a large trade in grain. Moses Mendelssohn was a native. Leopold, Prince of Anhalt-Dessau (1676-1747), a famous soldier in the wars of the 18th century, is popularly known as der alte Dessauer ('the old Dessauer'); his statue adorns the market-place. Pop. (1890) 34,658.

Destouches, Philippe, one of the chief conic dramatists of France in the 18th century, was born in 1680 . He wrote seventeen comedies, two of which, Le Philosophe Marié (1727), and Le Glorieux, his masterpiece (1732), are of a very high order of excellence. He died in 1754. His characters are truthfully drawn, and his plots interesting. In his style he imitated Boileau rather than Molière, and his verse has occasionally a happy epigrammatic turn. In his language he avoided the freedom 
of the older comedians, but the moral tone of his plays eannot be deacribed as high.

\section{Destructors. See Sewagr.}

Desuetude, in Seots law, that repeal or revocrtion of a legal enactment which is effected not by in subsequent contrary enaetment, but by the establishment of a contrary use, anctioned by the lapse of time and the consent of the community. Neither the word nor the iden attached to it in familier to the law of England-where the correaponding term is non-user. The rule in Fnglum is, thut a statute once formally enacted by the legisla ture, remains in foree, however unsuited it may be to the altered conditions of society, till it be repealed by another statute. The repeal may be by inplica. tion, but here the law watches with a jealous eye. Such repeal 'is to be understood,' says Blackstone, 'ouly when the matter of the later statute is so clenrly repugnant that it necessarily implies a negative." So far was this principle carried, that it wns formerly the rule, that if a statute repealing another was itself repealed afterwards, the first statute was revived without any formal words for that purpose. But thiss rule was changed by 13 and 14 Vict. chap. 21. In Scotland, an opposite principle prevailed, and it is still held that acts of parliament made hefore the Union may lose their force by disuse, without any express repeal, or 'go into desuetude,' as it is commonly said. The same may be said of the general orders (Acts of Sederunt, as they are called) of the Court of Session. But by desuetude is meant something more than mere non-use for a period of time, however great. There must be contrary use of a positive kind, inconsistent with the statute, and of such a kind as to prove the altered sense of the community; there must, in short, be consuetudinary law in a negative sense; and the 80 called desuetude thus amounts to a repeal of statute law by consuetudinary law.

Both rules are liable to objections. The result of that followed in England has been that statutes have remained on the statute-book with. out formal repeal after their enforcement had become morally impossible. A curious example of this occurred in the early part of this century, in which one of the parties to an ordinary civil suit challenged his adversary to 'judicial combat, founding his claim to do so upon an unrepealed statute, and it was held that in point of form his right could not be disputed (see DUEL). But since 1869 the English statutes have been by the Statute Law Revision Acts weeded to a great extent of all obsolete and inconsistent enactments, and a new edition of Revised Statutes has been published, containing as far as possible only such enactments as are in force. The rule in Scotland is the same as the English as regards all statutes made since the Union; but as regards the older Scotch statutes, the difficulty still exists, in dealing with enactments more or less forgotten or violated, how to determine what constitutes such eontrary use as to support the plea of desuetude. The eftect of the plea of desuetude has been curiously illustrated in some modern cases, where the validity of certain old Seots acts against Sabbath profanation was questioned. In two cases, in 1870 and again in 1887 ( when a person was eharged with keeping open a pie and lemonade shop in eontra vention of the Act of 1661 ), the plea of desuetude was disregarded.

Detachment, in its Military sense, is a smal but indefinite number of troops, sent from the main body of a regiment, brigade, division, or army, as the case may be, to perform some special duty. In the Royal Artillery the party of men who work one gun is called a "gun detrchment.
Detective, See PoLIcr, Vol. VIII. p. 285.

Determinants, in maflematical analyois, s symbolical method by which, inter atia, the nolu. tion of equations becumes a matter of mere inmpec. tion. The development of the method is due nuaiuly to the French mathematicin Couclıy (q.v.). The determinant is the sum of all the produet that can be formed from a group of quantitiea arranged as columns and rows in a square block: ench product containing as a factor one from earh horizontal row and one from ench column; the sign leing plus or minus, acending as the arrangement of rows from which it is taken requires an even or odd number of transposition to reduce it to the arrangement in the equare. The determinant of the third order $\left|\begin{array}{lll}a & b & c \\ a^{\prime} & b^{\prime} & c^{\prime} \\ a^{\prime \prime} & b^{\prime \prime} & c^{\prime \prime}\end{array}\right|$ is equal to $a b^{\prime} c^{\prime \prime}-a b^{\prime \prime} c^{\prime}+a^{\prime} b^{\prime \prime} c-a^{\prime} b c^{\prime \prime}+a^{\prime \prime} b c^{\prime}-a^{\prime \prime} b^{\prime} c$

Determinism. See WiLL。

Detmold, capital of the German principality of Lippe, on the Werre 47 miles SW. of Hanover by rail. The chief buildings are the old castle, the modern palace, and the theatre. Detmold has also a nuseum, a public library, a hospital, a gynınasium, and other schools. There are manufactures of tobacco, cards, and earved work in wood and stone, and hreweries. On a hill 2 miles from Detmold is a colossal statue of Arminius (q.v.). Pop. 9735.

Detri'tus, applied in Geology to accumulations formed by the disintegration of rocks, may consist of angular and subengular debris, or of more or less water-worn materials, such as gravel, sand, or clay, or an admixture of these. See Pleistockn

Detroit, the ehief commercial eity and port of entry of Michigan, and seat of justice of Wayne county, is situaterl on Detroit / Capyright ans 1err, an River, about 125 miles by water, 1900 in we 0.8 . by 3.

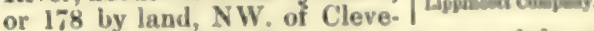

land, Ohio, with which it is connected by daily steamer and by railway lines. Railways also conneet with Chicago, 284 miles distant, and loy way of Windsor, on the opposite side of the river, the Grand Trunk Railway of Canada aftords direct communiention with the cities of the Dorminion, and a large number of vessels ply between this eity and the other ports on the Great Lakes. Its ares is about 30 square miles.

Detroit is substantially built, its streets are brond, well paved, and shaded, and its 20 public parks cuver about 900 acres. Chief among these is Belle Isle Park, an island (aren $7(x)$ aeres) chumingly situated in Detroit River and handsomely improved, and stretching from the city, with which it is connected by a draw brilge 3134 feret hong, to lake $S t$ Clair. The city is well supplied with water from the river. Its fire and police departments are excellent, and its 65 public schools with their 737 teachers afford accommodation and inatruction for ahout 30,000 pupils, the expenses for which in 1896 were $8508,781.87$. The principal mannfactures include iron products, rrilroad cars, Alour. malt liquors, cigars, leather, boots and shoes, stoves, irugs, \&c., with an annual value of $\$ 80,000,000$, ane the mercantile transactions embrace a lange trale in grain (12,000,000 bushels annually), flour, livestock, lumber, wool, pork, copper, \&e. The tonnage

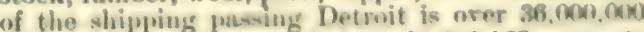

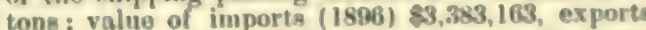
\$11, 908,120 . Of its 300 vescels, 150 are steanera. The streets are lighted with electricity (eost of plant $8630,141.72$ ), and many of them are lined with treos. The public building embrace a Catholic cathedral and nearly 200 churehes of almost all denonina tions, a city-hall ereeted at a cost of about $\$ 000,000$ a Board of Trade building, a convent, 3 general 
hospitals and a United States marine hospital, 5 opera houses and theatres, a new Federal Building (1889-97, costing $\$ 1,500,000$ ), a Free Pnblic Library with 150,000 vols., numerous banks and savings institutions, and daily, weekly, and monthly periodicals, several being in German. Detroit was held by the French 1610-1762, and by the British 176396, when it passed to the United States. It was totally destroyed by fire in 1805 . Incorporated as a city in 1824, it was the capital of the state from 1836 to 1847 , but was superseded by Lansing. Pop. (1880) 116,340 ; (1890) 205,876 ; (1894, state censiss) 238,264 ; (1900) 285,704.-DETROIT RIVER, so called, is the strait extending from Lake St Clair to Lake Erie, about 20 miles in length, with a depth sufficient to float the largest vessels.

Dettingen, a village of Bavaria, on the Main, 10 miles NW. of Aschaffenburg by rail (pop. 657), is noted as the scene of a battle during the war of the Austrian Succession, when, on 27th June 1743, George II. (q.v.) of England, commanding English, Hanoverians, and Austrians, defeated the larger French army under the Due de Noailles. This was the last time a king of England took the field in person.-There is another Dettingen (pop. 3500) 10 miles $\mathbf{E}$. of Reutlingen in Würtemberg.

Deuca'lion, son of Prometheus, and husband of Pyrrha. When Zeus had resolved to destroy the race of men by a flood, after the treatment he had received from Lycaon, Deucalion built an ark or ship, in which he and his wife floated during the nine days' flood which drowned all the other inhabitants of Hellas. On the subsidence of the waters the ark rested on Mount Parnassus. To repeople the world Deucalion and Pyrrha were told by the goddess Themis to throw behind them the bones of their mother. This they did with the stones of mother-earth, and fiom those thrown by Deucalion sprang up men, and from those by Pyrrha, women.

Deuteronomy ( $\mathrm{Gr}$. deuteronomion, the 'second' or 'repeated law'), the Greek name of the fifth book of the Pentateuch. It presents the third and latest phase of the development of the Mosaic legislation. Its great aim is to check the encroachments of idolatry, and to concentrate the national worship in the great sanctuary at Jerusalem, especially at the three annual festivals. It is instinct with the prophetic spirit, and lays stress on the great commandment to love and fear God with the whole heart as the sum of the whole law: According to Kuenen and Wellhausen it was composed in the reign of Josiah ; other crities think it cannot be later than the reign of Manasseh. See Bible, Pentateuch.

Deutsch, Emanuel Oscar Menahem, was born of Jewish parents at Neisse, in Silesia, October 28, 1829. His education was begun at the local gymnasium at the age of six, continued by his uncle, a learned rabbi, to whom he owed his mastery of Hebrew and Chaldee literature, and finally pursued at the university of Berlin. In 1855 he came to England to fill an appointment in the library of the British Museum, where 'for fifteen years with mighty ardour and magnificent industry he studied and wrote, enjoying life among his friends, yet more among his books; shedding sunshine wherever he went, attracting and attaching not a few.' He is best known to the outside world by his brilliant article on the Talmud in the Quarterly Review (1867), to which he also contributed an article on Islam (1869). He wrote excellent articles on the Targum and the Samaritan Pentateuch for Dr Smith's Dictionary of the Bible, and was a valued contributor to the first edition of Chambers's Encyclopcedia, for which he wrote nearly two hundred articles. His scholarship was seen to great advantage when he wrote on Phounician antiquities; and his remarkable comnand of a vigorous and poetic English style was shown in his articles in the Times on the Ecumenical Council. He died 12th May 1873 at Alexandria, whither he had gone in the hope of recovering the health which overwork had undermined. The dream of his life was to have written an elaborate work on the Talmud, of which his short essays and lectures gave brilliant promise ; but a mortal disease, added to official duties, deprived the world of the results of his unrivalled learning. A volume of his Literary Remains, with a sketch of his life by Lady Strangford, was published in 1874 .

Deutschbrod, a town of 5436 inhabitants, in the south-east of Bohemia, 15 miles from the Moravian frontier. Here in 1422 the Hussite general Ziska defeated the Emperor Sigismund.

\section{Deutz. See Cologne.}

Deutzia, a genus of Saxifragaceæ (sub-order Philadelphacer), natives of the north of India, China, and Japan. Some are favourite greenhouse plants in Britain, producing abundance of beautiful white flowers. The commonest species (D. scabra) is also becoming frequent in shrub. beries.

\section{Deux-ponts. See ZweIBrüCKEN. \\ Deux-Sèvres. See Sk̀vres.}

Devandig'ari (lit. 'town-seript of the gods'), the character most widely understood by Hindu scholars, in which Sanskrit works are usually printed, unless when in Roman letters. See SANSKRIT, Alphabet.

Devaprayaga (better Deoprayag), a village in the district of Garhwal, North-west Provinces of India, on a mountain side, 2266 feet above the sea, in the fork of the Alaknanda and the Bhagirathi, which join to form the Ganges (q.v.). Devaprayaga possesses a notable temple, and is a favourite place of pifgrimage for the Hindus.

Development is a term used in several special or technical senses. In mathematics it means the process by which any mathematical term is changed into another of equivalent value or meaning: in geometry specifically the unrolling of a cylindrical or conical surface, the unbending of any curved surface into a plane, is called development. The word is sometimes used of the whole field of

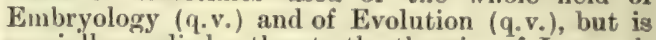
specially applied rather to the theories of Lamarck (q.v.) than to the Darwinian Theory (q.v.); see also the articles BIOLOGY, Heredity, MaN, VARIATION, WEISMANN. The history of every science, art, or invention is a history of progress and development. (See ANThropoloGy, ART, and the relevant sections of the articles on sciences, \&e., throughout the work. The word has its own meaning in Plotography $\left(q . v_{.}\right)$; in music the de. velopment of a musical phrase or subject is the unfolding of its capacities by modification of meloly, harmony, tonality, rhythm, \&e. (see SONATA); and development of doctrine is dealt with in the articles DOGMA (q.v.), Christianity, Newman, and Roman Catholic Church.

Dev'enter, an old Hanse town of Holland, in the province of Overyssel, on the Yssel, 11 miles NNW. of Zutphen by rail. It has an 11 th century cathedral and a fine town-house, and manufactures iron, carpets, tobaceo, beer, and gingerbread. Thomas à Kempis died here, and here Erasmus was ellucated. Pop. 23,351 (5000 Catholics).

De Vere. See Vere.

Deveron, a beantiful salmon river of $A$ berdeen and Banff shires, rising 3 miles SW. of the Buck of Cabrach, at an altitude of $1847 \mathrm{feet}$, and thence 
winding 62 miles north-eantward, till it falls into the Moray Firth at Banff. See Lauder's Moray Floods (18:30).

\section{Deviation. Seе Coмpass.}

Device (late Lat. divise, 'a drawing'), if in a wilter sense, applicable to emblems on shielils, such as described by Homer, is, in a more restricted $u s e$ of the word, a decoration with accompanying legend, assumed by an individual rather than a family, and for the purpose not of publicity, like the ladge (with which it has sometimes been confounded), but of mystitication, with covert allusion to the circumstances of the bearer. It is, in fact, a rebus or painted riddle, with a legend allusive to it, as the knot borne by Sir Thromas Heneage, of a shape suggestive of a heart, with the inscription 'Fast though untied;' and the heart borne by Lord Latimer, with the legend 'Dieu et ma fiancée.' See BADgE.

Devil, or Satan, the names applied in the New Testament and in Christian theology to the supreme impersonation of evil, considered as pos. sessing an objective existence outside of man, and placed at the heal of a host of inferior evil sjirits, whose continual occupation is to thwart the good purposes of God and the progress of his kingrlom in the hearts of men. Other names unerely suggest the same essential ideas of his nature and function, as the wicked one, the enemy, and the like. It seems certain that this conception was foreign to the early Jewish mind, with its strong grasp of the monotheistic idea in the person of the supreme Jehovah. It is Jehovah himself who hardens Pharaoh's heart, and sends a lying spirit among the prophets of Ahab, and it is he who is considered as the sole source of all power, the sender of pestilence and death as well as bleswings. In the exegesis of later days the serpent that tempted Eve in Eden, and the "Old Serpent" of the Apocalypse, were alike identified with Satan, although this interpretation certainly gains no support from the story in Genesis, where the tempter is as yet harlly more than a mere animal, although one of a family almost everywhere specially associated with evil.

It is significant that the name Satan oceurs but five times in the Old Testament : thrice in Job, where he presents himself among the 'sons of God' (Beni Elohim) before the Lord. Here he is the willing messenger of evil, but yet he is not representer as Job's spiritual enemy, nor yet as a distinet impersonation of evil. He is hardly more than an agent of one form of divine providence, by whose means Job is tried and lifted into a higher spiritual plane, and his energies hardly range out of the region of mere physical into that of moral evil. The Beni Elohim throughout are employed as the messengers of Jehovah, and carry aut his mercies and punishments alike, both bearing messatges of consolation and promise to the pat riarehs, and filling Saul's mind witl gloomy thoughts, appearing with drawn sword to Balaam, or destroying in one night a whole Assvrian host. The Jews had also their demonology like all primitive peoples, as may he seen in the seirim (satyrs, lit. 'he-goats') and the shedim, both rendered by 'devils ' in the authorised version, and perhaps also in the Azazel of Leviti. cus xvi.; but it was not till later that os special angel became differentiated from his brethren in the heavenly court, with the special function of the accuser of men, like the personification of a guilty conscience. In the vision of Zechariah we find him considered formally as the accuser of Israel. Undoubtedly also this eoneeption had already become greatly modified during the period of exile by contact with Persian dualism. Of course sueh a coneeption as Ahriman, the mighty author of evil and the antagonist almost on equal terms of
Ormurd, was completely foreigm to Jew ish mono. theism, yet the Jen inla Sutan gre w greatly tath in

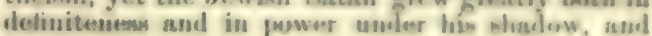
henceforth it is from bim direetly that moond and phywical harm towards men proceeds. Yet it must not be supposed that this was due to direct horrow. ing, and that the Jewish Satan was not nulostan. tially an original evolution of the native Jewinh mind. 'While Aluriman is physienl evil that has become moral evil also, mays M. Heville, 'Batan is moral evil hecoming phywical evil.

Persian influence superun sarmt plainly in the apoeryphal books of Tobit and Baruch, but the growth of the conception of the devil is seen also in the translation of the LXX., which rendens his name by diabolos, thus emphasising and perpetuating his special function is the accuser. Kow alvo he becomes located in his gloomy kingdom of hell, and is attended by troops of inferior fienda. He wayes warfare on mankind by intlicting physical and moral evil, and is considered as the agrent by whose means man fell from his original state of innocence. It was thus he who introduced death with all its horrons into the world, and corsecquently diseases, especially those of greater violence and obscurity, are the work of himself or his minions.

In the New Testament the conception of the personality of the devil and of a kingdom of demons holds its ground, but the whole subject is here treated with a kind of spiritual reserve, in a teaching that emphasises our own hearts and their inward temptations as the Bource of our evil thoughts and deeds, and connects moral evil inseparably with the earthly nature of man. The passagres which speak of a fall of angelic beings ( 2 Peter, ii. 4 ; Jude 6 ) occur in seriptures of sul. ordinate canonical rank: Jesus nowhere definem concretely the function of the devil; and the few positive statements about him-that the was a murderer from the beginning, and stood not in the truth,' that ' he is a liar' (John, viii. 44), and 'sinneth from the beginning' ( 1 Joln, iii. 8 ), scarcely furnish a sufficient foundation for a complete doctrine on this subject. Yet the impresaive manuer in which it is dwelt on by our Lord and his apostles shows that it is a necessary part of Christian teaching. The New Testament devil is an enemy of the divine, but yet an inferior and degraded spirit. He is the tempter of man, and even of the Son of Goxl, yet his temptations fall without effect upon upright purity, and through the Saviour's merits the individual Christian is also saved from his power, in spite of all the perilous temptations of his own flesh. Christ's gaving work is regarded as the virtual victory over the power of Satan, and the grand drama of the last decisive strugyles and final aubjuga. tion of the kingdom of the devil forms the con. clusion of New Testament prophecy.

The early theologians were unore literal and lews spiritual in their conceptions, and in their horror of heathen institutions came to identify the kinglon of the devil in a particular nanner with polytheism and the persecution they suffered under the Roman empire. Thus the devil again became a kind of rival of God, wholly nnequal but yet formidable. The strength of the belief in a powerful personal devil may be seen in the earliest heresies, those of the Gnowics and Manicharans, a main feature in which was an elaborate system of evil demons as enemies to man and almuet rivals to God. The early Christinns considered the gods of heathenism as indeed conquered by Chriat, but yet not ren. dered wholly powerlen, for as destraded demons and with intent to deceive they uttered oracles, and were present at sacrificen inhaling the sacrificial incense-an iden in perfect harmony with the growing naterialistic conception of the devile, 
and of hell their residence, a place blazing with eternal fire, and filled with every horror the im. agination could suggest. The belief in the objective personality of Satan was complete in the literalistic explanation of the 'descent into hell,' and the release of the 'spirits in prison. It was a literal conquest over an enemy, although by some it was explained almost as if due to superior cunning rather than superior power.

Exaggerated ideas of the devil's dangerous power prevailed throughout the dark and middle ages, whose deep melancholy faith and fantastic theory of the universe generated saints naturally on the one hand, and witches and sorcerers as naturally on the other. It was an involuntary exercise of the poetic faculty, through which the thoughts of their own hearts and of their own time became spirits, which they saw around them. Countless legends were originated of actual contests between individual saints and devils in one or other of a thousand forms. Safety from the devil could be found alone within the charmed ring-fence of the church, fortified by the ordained sacraments and by personal cleanness of life. Excommunication was synonymous with being 'delivered over to Satan,' to whom the popular imagination transferred freely all the lingering remnants of earlier demonologies, so that that particular form and those particular attributes became permanently associated with his appearance which medieval art has fixed and handed down to us. Lechery had ever been a persistent quality of the devil (from the literal interpretation of Gen. vi. 2), and the popular imagination working out this idea gave free play to a fearful but prurient fancy, which revelled in multiplying all the disgusting details of a witches'sabbath. Throughout the middle ages the devil was an absorbing idea, and the constant familiarity with him often bronght with it a penalty of contempt. In the old religions plays a principal part was usually assigned to him, and indeed he principally represented the comic element, as may still be seen in the pastorales of the Basques. The auditors might laugh for the moment to see the devil outwitted and then beaten, but they had not shaken off that fear which revenged itself in all the pitiless cruelties of witchcraft-the darkest chapter in the history of humanity.

The decadence of belief in the active external power of the devil was mainly due to the indirect effect of the Reformation and the progress of science. To no man was the devil ever more present than to Luther, but nevertheless it was mainly the movement he inaugurated that has driven the enemy back into the sphere of the abstract and the ideal. In later generations the sense of the supernatural has steadily decayed, and with it almost all the terrors of the devil ; but it cannot be said that with it has also disappeared a genuine religious spirit. The Christian man in the conscious weakness of his struggle against indwelling sin feels that he has no need to conjure up for himself an external suggester of temptationhe has devils enough in the treacherous inclinations of his own heart. And in assuming a personal devil to account for the evil side that there is in nature and in life, there remains the question to be answered whether we have not merely pushed back the most puzzling of, all questions a single stage, and whether we have contributed at all to the insoluble problem of the genesis of evil.

Kant (in 1793) defined the devil as the personification of 'radical evil.' Schleiermacher held that symbolic reference to the devil might fitly have a place in Christian discourse, but denied the possibility of his real existence, and in this he has been followed by Schenkel, Biedermann, Lipsius,
Pfleiderer, and others. Pfleiderer, estimating the critical result of the doctrine, finds that-whilst a twofold logical contradiction is involved in the idea of devils as the substantial existence of wickedness, and as supra-mundane creatures belonging to this world-devils represent the obverse of religious idealism, or empirical world-existence in its hostility to the Idea : in other words, the world on the side of its opposition to God, or the working for itself of finite and opposing existence as such, presenting itself as the sum and substance of evil. That the two forms of evil-the natural and the spiritual or moral-stand in inward connection, and form a universal (and accordingly metaphysical) power in the world, is the truth contained in the idea of the devil that has significance for the practice of worship. On the other hand the orthodox view is maintained more or less definitely by Licke, Von Hofmann, Luthardt, Rothe, Julius Müller, Martensen, and Dorner, who holds that though the doctrine cannot be completely constructed, it yet forms part of a consistent whole, and is of importance for the Christian, as distinguished from the heathen and Jewish conception of evil, as well as for the Christian life. See ATONEMENT, DEMONology, Evil, Exorcism, HeLl, WitchCraft ; also Roskoff's admirable Geschichte des Teufels (1869).

Devil-fish is a name used for the Octopus (q.v.), also for the Angler (q.v.), and, in America, for a gigantic species of ray (Cephalopterus vampyrus), with very large pectorals. Of the latter a specimen was found in Delaware Bay, $17 \frac{1}{4}$ feet by 18 feet, and weighing 5 tóns.

\section{Devil's Bit. See Scabious.}

Devil's IBridge, a popular name in most mountainous countries for bridges built over wild chasms. The most notable are (1) a bridge over the Reuss, in the Swiss canton of Uri, 11 mile W. of Andermatt, on the St Gothard Road, where the river, $\mathbf{4 5 9 3}$ feet above sea-level, forms a picturesque cascade of 100 feet. The new granite structure, built in 1830, spanning the stream with a single arch of 26 feet, fell in in August 1888, and trattic was for a time resumed on the old moss-grown bridge 20 feet below, which witnessed some severe fighting between the French and the Austrians and Russians in 1799. (2) A double bridge in Cardiganshire (sometimes called Pont-y-Mynach), 10 miles ESE. of Aberystwith, across a gorge, 114 feet deep, and over a mile long, traversed by the Mynach, which makes within a short distance four falls of from 18 to 110 feet. The lower bridge was constructed by the monks of Strata Florida in the 11 th century, the upper ( 20 feet over it) in 1753

Devil's Coach-horse (Ocy̆pus olens), a common British and European beetle, in the family Staphylinidæ. It has very much reduced wingcovers, and resembles many of its relatives in the habit of eurving its posterior body upwards, using the tip to adjust the wings under their covers.

\section{Devil's Dyke. See CAMBrIDGESHIRE.}

Devise, the conveyance of land by Will (q.v.).

Devizes, a municipal borough of Wiltshire, near the Kennet and Avon Canal, 50 miles WSW. of Reading, and 20 ESE. of Bath. It lies high at the mouth of Pewsey Vale, between the thinly peopled tracts of Salisbury Plain and the Marlborough Downs. According to Dr Guest, the old name Divise or Ad Divisas marked the ancient boundary between the English and Celts; anyhow, as a town, Devizes owes its origin to a splendid castle built here by Bishop Roger of Salisbury about 1132. It was stormed by Cromwell in 1645 , and now is represented by mere fragments. There are two churches with much interesting Norman work; a market-cross (1814), commemorating God's 
judgment on a perjuress in 1753 ; a fountain with a statue of Sothern Eatcourt (1879); a good museum; and a large corn exchange (1857). It has manufactures of snuff and malt, and in the seat of an important corn-market. From Henry V'III.' time till about 1820 Devizes was a great eloth mart; now its chief manufactures are snuff and agricultural implements. It returued two members till 1867, then one till 1885. Pop. (1851) 6554; (1891) 6426. See A History of Devies (1859).

Devonian System. The name proposed by Murchison and Sedgwick to replace the more characteristic and older term Old Red Bandstone, because the slaty and calciferous stratu in Devonshire contain a much more eopious and rich fossil fauna than the red arenaceous rocks of Scotland, Wales, and Herefordshire, with which they are believed to be upon the whole contemporaneous. The physical condition under which the strata in Devonshire were deposited differed greatly from those which marked the accumulation of the Old Rerl Sandstone, and there is still some doubt as to the precise correlation of the two sets of strata. Geologists, therefore, retain both names, and apenk of the Devonian and Old Red Sandstone system, or old Red Sandstone and Devonian system. See OLD RED SANDSTONE.

Devonport (before 1824 ealled Plymouth DOCK), a parliamentary and municipal borough, maritime town, and naval arsenal, in the south-west of Devonshire, on the east shore of the estuary of the Tamar (which is 4 miles long by $\frac{1}{2}$ mile bruad, and called the Hamoaze), 2 miles W NW. of Ply. mouth. It stands on high ground, and is separ ated from its growing suburbs of Stoke and Morice Town by the glacis of its fortifications, once im portant, but now dismantled. The streets are regular, and the footpaths of marble. Devonport is supplied with water from Dartmoor by a circuitous route of 30 miles. It owes its existence to the dockyard established here by William III. in 1689 and is one of the chief naval arsenals in Britain. The government establishments now stretch for nearly 4 miles along the left bank of the Hamonze. The original dockyard, extended from time to time until it contained six building-slips, was supplemented in 1844 by the formation at Morice Town of the Keyham Steam Yard and Factory, which communicates with the dockyard and gun-wharf (designed by Vanbrugh) by a tunnel. Farther up the river are an engineers' college, seamen's barracks, magazines, and powder-works; and the Hamoaze itself contains many men-of-war lving in ordinary, besides those in actual nervice. The official residences of the admiral of the port and of the lieutenant-governor of the western dis. trict are at Mount Wise, which is fortified. Here also are the chief barracks of the troops which garrison the 'three towns' of Plymonth, Devon port, and Stonehouse. The military hospital is on Stonehouse Creek. There are extensive commer. cial wharves with railway communication on Stone house Pool. Pop. of municipal borough (1841) 33,820 ; (1881) 48,939; ( 1891 ) 64,803 ; of parliamentary borough, which includes the adjacent township of East Stonehouse, 70,204. Devonport returns two members to parliament.

Devonshire, a maritime county, in the month. west peninsula of England, between the Bristol and the English Channel. Its grentest length is 70 miles; its ureatest breadth, 65 ; and it contnins $2586 \mathrm{sq}$. m., of which about three-fourths are under cultivation. The coast-line approaches 150 milea The north corst is the boldest, with several hills over 1000 feet. Its chief indentation is Bisleford Bay, 18 miles lroad and 8 deep, into which fall the Taw and the Torridge. The south coast is also lined with elifts, clief among them being the bold promontorial dintriet of the Ihit Heal und starn Point, the western horn of the great lany of which Portland is the eastern. Tor Bay is 8 by 81 milem. Plymouth Sound, the combined eutuary of the Tamer and Plym, is one of the finewt harbours in the kingdom, the anchorage ground extendisg ? miles inland from the brenkwater (wee PLYMotTu) by which the outer romiletend is protentarl. Desom. shire is hilly, the most elevated parts being the talsle. lands of Dartmoor in the sonth-weat, Exmoor in the north-west, running into somenot, and Black. down in the east. Thene are mainly open noor. lauds. Dartmonor (q.v.) in very roeky : the Jowor hills grassy. High Willhayse, on Dartmoot (2039 feet), is the highest point. Desoniun und Carlonit. erous strata occupy the greater part of the county ; next in importance are the granitic lons of I hart. moor, and the Triassic rocks in the enstern quarter. There are also archoean rocks, probably Silurian, with greensand, chalk, a Miocene deposit at Bovey Tracey, and many exposures of igneous rocks, in trusive and interbedded. Copper, tin, lead, iron. and manganese oceur in commercial quantities, with ores of several other metals; chins, terra. cotta, potter's, and pipe elays; granites, marbles, anthracite, lignite, gypsum, and other earthy minerals. The rivers of Devonshire are numernus The Tamar, 59 miles, is the longest, and dividen Devon from Cornwall; the Exe, 54 miles, which comes next, rises in Somerset. The other leading rivers-the Dart, Teion, 'l'uw, Torridge, and Plym, all from Dartmoor, have estuaries of commereial importance, as have also the Exe and Taum. The rer deer still run wild on Exmoor, and are hunted.

The climate of Devon, especiully in the south, is mild and humid, and not liable to great extrenes. Hence, several of the towns on the southern and eastern coasts have become fanous as health-reanrt. -notably Torquay ; and, on the north coast, Ilfracombe. Myrtles and aloes commonly flourish in the open air; and in specially favoured spots oranges and lemons, with a little protection, will thrive and fruit. The rainfall on Dartmoor is muelı greater than elsewhere in Devon, and the winters colder and more loracing. The climate is so invigoratim, however, that the Moor in rapidly growing into repute as a summer anatorium, and that the convict prison is regarded as a health-station. The county is most fertile, especially in slue Souch Hams, and on the 'red land' of the Vale of Exeter. The pastures are very rich, and dairy-farming and cattle-breeding are prominent in its agriculture. The red Devon cattle are one of the leading breeds: and the sheep and ponies of Dartmoor and Exmoor have more than a local reputation. 'Clotted cream,' produced by scalding, is a special product almost confined to Devon and Cornwall. Thero are extensive orchards, from which great quantities of cider are made; and various fruits are langely cultivated in special Incalities and sent to Londor and the Midlands by mil. The fisheries are exten. aive and valuable, the chief centres being Plymouth and Brixham. Though in the main agricultural, Devon has a varied industrinl charecter. Minimg and quarrying and clay-working are of conaidernble importance; and the manufactures include serges, lace, gloves; extensive potterios; manure, chem. ical, and soap worlen; paper-mills, breweries, and distilleries. The chief towns are the city of Exeter, Plymouth, Desongort, Torquay, Tiverton. Barnstaple. Stomehouse, Tavistock, Teignmouth. Newton, Dartmouth, and Brixham, Pop. (1801) 340,308; (1841) 532,958; (ISsI) 604,397; (IN91) 631,767. Under the Reform Aet of 1885 Exeter returns one member. Plymouth and Devenport two each, and the rest of the county is divided into eight single-member constituenciea. 
Devon adds to singular landscape charms, antiquarian attractions of a most comprehensive and varied character, prehistoric and medieval. The Romans had little to do with it beyond Exeter, which was an important station; the Saxons did not conquer it until the reign of Cynewulf; the Danes ravaged it in the 9 th and 10 th centuries, though they were at first repulsed with heavy loss; it was the scene of the western rebellion for the restoration of Roman Catholicism in 1549; Plymouth was the headquarters of the fleet which defeated the Armada in 1588, and the chief mainstay of the parliament in the west of England in the conflict with Charles I.; Brixham was the landingplace in 1688 of William of Orange. No county save Middlesex has given birth to so many eminent men-Raleigh, Drake, Hawkins, Marlborough, Monk, Coleridge, Hooker, Sir Joshua Reynolds, John Davis, Sir Humphrey Gilbert, Sir Richard Grenville, Bishop Jewell, Gay, St Boniface, Newcomen, Wolcott, Kingsley, John Ford, among them.

\section{Devomshire, Duke of. See Cavendish.}

Devrient, a family of German actors, of whom the most talented was Ludwig Devrient (1784-1832), distinguished both in comedy and in tragedy, and especially noteworthy as an exponent of Shakespearian characters.- - His nephew, Carl August (1797-1872), the eldest of the brothers Devrient, played lovers' parts, and was the husband of the diva, Madame Schröder-Devrient (1805-60).Philipp Eduard (1801-77), the second brother, was a delightful baritone singer in the early part of the century, and afterwards became a painstaking, though not a great actor. He was the author of a number of plays, and of the valuable Geschichte der deutschen Schauspielkunst (Leip. 5 vols. 1848-74); and with his son Otto (1838-94) he prepared an edition of Shakespeare. - Gustav Emil (1803-72), the youngest and most gifted of the three brothers, was most successful in tragic and emotional parts, and became identified in Germany with such characters as Hamlet, Tasso, and especially Posa.

Dew. The question of the origin of dew has been discussed since very early times, and many theories have been advanced on the subject. Among more recent writers, Gersten, followed by Du Fay, held that dew rose from the ground. Others believed that it fell from above, but no really systematic treatment of the subject appeared until the publication of Wells's Essay on Dew in 1814. Wells combated the opinion of Du Fay and Gersten, and showed that all the phenomena deseribed by them could be equally well explained by his theory. He asserted that the dew was condensed out of the air in contact with surfaces below a certain temperature. For every definite pressure and temperature of the atmosphere there is a definite amount of water-vapour per unit-volume which can be held in suspension. Hence, when air containing a certain amount of water-vapour is cooled below a particular temperature, the vapour is condensed. This temperature is called the dewpoint of the atmosphere under the given conditions as to pressure and quantity of vapour. At night the earth and objects at its surface are being cooled by radiation. If the rate of loss of heat by radiation is sufficiently rapid, the teniperature of the earth's surface, and consequently of the air in immediate contact with it, may fall below the dew. point. When this occurs, the moisture condenses on the surface in the form of dew. This is Dr Wells's theory regarding the formation of dew. He considered that the vapour had risen from the ground during the previous day, and that very fittle dew was formed from vapour which had just risen from the ground, although he admitted that nome might be so produced.
Wells's theory of the formation of dew is un. doubtedly correct, but, in a paper read in 1885 before the Royal Society of Edinburgh, Mr Jolnn Aitken has adduced evidence which shows that the greater part of dew is formed from vapour which has just risen from the ground and been trapped by the grass and other objects. Mr Aitken was led to this conclusion by three independent experimental methods. One of these consists in removing at sunset a portion of turf from the ground, placing it in a shallow metal pan and weighing it. The turf, still contained in the pan, is then replaced in the ground in good heat-communication with it. When reweighed after some time, it is invariably found to have lost weight. If the turf be covered by a metal tray so as to prevent escape of moisture, this loss of weight is largely obviated. Similarly, it is shown that moisture rises always during the night from bare soil, from roads, and from the driest earth.

Certain atmospheric conditious are necessary for the copious formation of dew. The sky must be clear, otherwise the clounds will radiate back much of the heat given off from the earth, and so will prevent the surface objects from cooling below the dew-point. The atmosphere must be calm, or the air in immediate contact with the ground will be carried away before it is completely saturated.

When the temperature of objects falls below the freezing-point, the dew is deposited in a solid state, and is known as hoar-frost. See Evaporation, METEOROLOGY.

Dewas', a native state of Central India, under British protection, held conjointly by two Rajput chiefs. Area under both chiefs, 290 sq. m. ; pop. 152,100 . The capital, Dewas, 20 miles $\mathrm{NE}$. of Indore, is a straggling town, with a pop. of about 12,000 .

Dewberry ( Rubus cresius) is distinguished from the Common Bramble (of which, indeed, many regard it as a mere sub-species) by its weaker and more prostrate glaucous stem, with scattered prickles, but without bristles or glandular hairs, also by the few large drupes, which make up its fruit, and which have a characteristic dew-like bloom, whence the name arises. The fruit is very sweet and agreeable, and makes an excellent wine. The dewberry of North America ( $R$. procumbens), abundant in the forests of Canada, is a delicions fruit, much superior to the British fruit of the same name, and more tart. The plant is of very humble growth, scarcely rising above the ground.

D'Ewes, Sir Simonds, antiquary, was born in 1602 at Coxden, near Chard, of Suffolk and Dorset parentage, and was educated under four masters in those two counties and in London, till in 1618 he entered St John's College, Cambridge. In 1623 he was called to the bar, but three years afterwards threw up his practice, malried the rich child-heiress Anne Clopton (1613-41), and received the honour of knighthood. He now devoted himself to his darling pursuits, numismatics and historical manuscripts, whence in 1640 he was called away to the Long Parliament as member for Sudbury. A Puritan but a moderate, he accepted a baronetcy (1641), sided with the parliament on the outbreak of the Civil War, was expelled by Pride (1648), and, 'withdrawing to Suffolk, died at Stowlang'toft Hall, 8th April 1650. He published little, but his transcripts of manuscripts, which else had perished, possess high value, as also do his Diaries, especially the portions relating to the Long Parliament, which have been ntilised by $\mathrm{Mr}$ Forster. His monumental Journals of Queen Elizabeth's Parliaments appeared in 1682; and his Correspondence, with an incomplete Autobiography, was edited in 1845 by $\mathrm{Mr}$ Halliwell (Halliwell. Phillipps). 
De Wette, Wilnelm Mantis Lввеввснт, bilslieal critic, was born at Ulla, Weimar, 12th January 1780. Studying from 1799 at Jena, under Griesbach and Paulus, he early adopted the philos. ophy of Fries. Extraordinary professor of. Exegesis at Heidelbers in $180^{\circ}$, and orilinary profemsor in 1809 , he was called to the newly-founded university of Berlin in 1810; hut los was disuissed and hanished from Prussis in 1819, in consequence of a letter he wrote to the mother of Sand, the asaassin of Kotzebue. Retiring to Ulls, he completed his Christliche Sittenlehre (3 vols. 1819-21), his edition of the Briefe, Sendschreiben und Bedenlen Luthers ( 5 vols. 1825-28), and the religious novel Theodor, oder des Zweiflers Weihe (1822; Eng, trans. 1849). In 1822 he was appointed professor of Theology at Basel, was honoured in 1829 with a seat in the Council of Education, and died there 16th June 1819. His great reputation as a biblical scholar rests on his Beitrïge sur Einleitung in das Alte Testament (2 vols. 1806-7), his Lehrbuch der hebräisch-jüdischen Archäologie (1814; 4th ed. 1864), and especially his very useful Lehobuch der Historisch-kritischen Einleitung in die Bibel (1817 und 1826 ), of which the Old Testument part had in 1869 reached ita 8th (Eng. truns. by Theodore Parker, 1843), and the. New Testament in 1860 its 6th edition (Eng. trans. 1858). His translation of the Scriptures, undertaken in conjunction with Augusti (6 vols. 1809-12; 4th ed. 1858); Commentar ïber die Psolmen (1829; 5th ed. 1856); and Kurzgefasstes Exegetisches Handbuch zum Neuen Testament (3 vols. 1836-48), have been extensively used by students, and the separate parts of the last-named work, as revised repeatedly by later scholars, have held their ground ever since. His works on dog. matic theology, Ueber die Religion (1827), and Dos Wesen des Christlichen Glaubens (1846), are less important. See the estimates of De Wette by $D$. Schenkel (1849), F. Lücke (1850), Hagenbach (1850), Wiegand (1879), and Stähelin (1880).

Dewey, GEORGE, American admiral, was born at Montpelier, Vermont, December 26th, 1837. He was graduated from the Naval Academy (fifth in his class) in 1858, and served two years on the Mediterranean station. As a lieutenant on the sloopof-war 'Mississippi' in Farragut's squadron, he took part in forcing the passage of the lower Mississippi in 1862. He continued in service after the war, and was promoted commander in 1872, cnptain in 1884, and commodore in 1896. Appointed to the command of the Asiatic squadron in 1898, on the outbreak of war with Spain he was ordered to proceed to the Philippine Islands, and to capture or destroy the Spanish fleet. 'T'his he did May 1st, 1898, destroying the Spanish vessels without losing one of his own men, for which exploit he was immediately promoted to be rear-admiral, receiving a sword of lonour and the thanks of congress; in 1899 he was made admiral, a rank held previously only by Far. ragnt and Porter. He took part in the eapture of Manila, and served on the Philippine commission, returning to the United States in 1899.

De Witt, JAN, a celebrated statesman of Holland, born at Dort in 1625, was the son of Jacob de Witt, from whom he inherited a hatred of the office of stadtholder, and of the family that filled it. He was carefully edueated, and early exhibited remarkable ability. Sent by the States of Hol. land in 1652 to Zealand, as one of the deputies to dissuade that province from alopting an Orange policy, he there secured complete confidence by his eloquence. Becoming the head of the oligarchic republican party, composed of the nobles and wealthier burgesses, De Witt opposed violently the popular Orange party (which upheld the young prince, afterward William III.), strivin; ( ) abulish the office of stadtholder, and to strip the House of Orange of all power. During the minurity of the prinee, the advantage was with De Wite and his party, and in 1654, on the conclusion of the war between England and Holland, a necret article was inserted in the treaty drawn up between lo Wilt and Cromwell, by virtue of which the Hone of Orange was to be deprived of all atate-officen. After the restoration of Charles II. De Wiut leaned more to the side of France, all the more when houtilities were renewed between Englund and Holland in 1665. During the two years war De Witt' influence declined, but his mar paled altugether when the designs of Louis XIV. ujmon the Spanish Netherland bevame manifest. The Orange party earried their point in the elevation of William to the family dignity of stadtholder; and on the invanion of the Netherlands hy Iamin XIV. in 1672, the Prince of Orange was appointed commander of the Dutch forces. The fint cam. paign proved unfortunate, which did not improve the temper of the people towands De With, who had previously resigned his office of grand pensionary. His brother, Cornelins, aceused of connpiring against the life of the stadtholder, was imprisoned and tortured. De Witt went to see his on his release. When they were coming ont of prison, they were attacked by an infuriated erowd, and were both murdered, August 20, 1672. The Statesgeneral demanded an investigation, and the punishment of the murderers, but the stadtholder did not take the necessary steps. De Witt was personally a man of upright character. Among his writings are his Memoirs $(1709)$ and his Letters (6 rols. 1723-25). See the Lives by Simons (1832-36), Knottenbelt (1862), J. Geddes (vol. i. Lond. 1879), and Pontalis (Eng. trans. 2 vols. 1885).

Dewsbury, a manufacturing town and manicipal and parliamentary horough in the West Riding of Yurkshire, on the Calder, 32 miles SW. of York; it is connected with Liverpool and $\mathrm{Hull}$ by the Calder navigation. It has a chamber of commerce (1861), an infirmary (1883) which cost $£ 17,000$, a new town-hall (1888) which cost $£ 30,000$, new county-courts, and St Augustine's grammar-school. It manufuctures extensively blankets, carpets, and yarns, and with Batley (q.v.) is the centre of the shoddy trade; it has also fuundries and minor industries. Dewsbury olstained a municipal charker in 1872. Pop. of municipal borough (1801) 18,148; (1851) 29,639 ; (1891) $29,54 \%$. The pus liauentaty borough was formed in 1867, and includes Batley and Soothill. Pop. of par. borough (1881) 69,531 : (1891) 72,986. It returns one member to parliament.

Dexter, in Heraldry, that side of a shield or armorial figure or composition which is to the left, not the right, of the spectator, becuuse it covens the right side of the warrior who carries ic.

Dextrine (syn. 'British gum,' 'torrefied starch'), When starch is carefully heated to $392^{\circ}\left(300^{\circ} \mathrm{C}\right.$. $)$ it becomes roluble in cold and hot water, and loses its gelatinous clumeter: it has also the property, when viewed by polarised light, of tuming the plane of jularisation to the riglit; inedice its mase. Stareh nuy be converted into dextrine by the long-con. tinued action of dilute acids at $\mathrm{a}$ high temperature also by theaction of Dinatase (q.v.). Dextrine an. starcli are isoureric, both being composed of $\mathrm{CsH}_{10} \mathrm{O}_{5}$ but they may be distinguished by the dingy purple tint which dexirine gives with iodine, instend of blue. More pliable and leas brittle when dry than gum-arabic, dextrine is often enbetituted for it in calico-printing, and for stiffening different goods; it is also applied to the back of postage-stampa.

Dey (Turkish debi, 'a maternal uncle') a name applied to the governor of Algiers before its 
conquest by the French. The name was formerly given to elderly people, especially among the Janizaries; hence came to be commonly applied at Algiers to the commanding-officer of that corps, who frequently became afterwards pasha or regent of that province. See BEG.

Dhar, a town of Central India, lying at an elevation of 1908 feet above the sea, 33 miles W. of Mhov. It has over 15,000 inhabitants, and preserves, in two large mosques of red stone and a fort defended by a high rampart and twenty-six towers, traces of bygone magnificence. It is the capital of a protected state of the same name, with an area of $1740 \mathrm{sq}$. m., and 169,474 inhabitants.

Dharmsala, a hill-station in the Punjab, 110 miles NE. of Lahore. Pop. 5500.

Dharwar, a town and district in the southern Mahratta country, in Bombay Presilency, separated by the river Tungabhadra from Madras. The town has no manufactures of importance, but a good deal of trade. Pop. 32,841. - The district has an area of $4600 \mathrm{sq}$. m., and a pop. of 1,051,314, mostly Hindus. The most interesting feature of the country is its suitableness for the growth of American cotton, which now occupies a third of the total acreage devoted to cotton. Cotton and silk cloth are manufactured in the district. The prevalent language is Canarese.

Dhole, the wild dog of India. See DoG.

Dholka, a town of India, in Bombay Presi. dency, 22 miles SW. of Ahmadabad, with a reputa. tion for the weaving of womeri's robes. It is surrounded by a mud wall 4 miles in circuit, and lies amid the ruins of nohle palaces and tanks, many dating from the early Hindu period. Pop. 18,500 .

Dholpore, a native state of Rajputana, in Central India, on the northern bank of the Chumbul, with an aren of $1200 \mathrm{sq} . \mathrm{m}_{\text {. }}$, and a pop. of 279,890, mostly Hindus. Capital, Dholpore, on the Chumbul, 34 miles S. of Agra by rail. A large fifteen days' fair is held here in Oetober, and iwo religious fairs are held every year at Machkund, a lake 3 miles to the west, with no fewer than 114 temples on its banks.

Dhunchee, or DHANCHI [Asschynomene (Sesbania) aculeata], an annual herbaceous plant cultivated in Bengal on account of its coarse hemp-like flbre. It is steeped and prepared very much like Sunn (q.v.). Other species are of similar use.

Dhwalagiri (Diwalagiri), once supposed to be the highest peak of the Himalayas, but now ascertained to be at most only the third in point of altitude, has a height of 26,826 feet above the sea. It is in Nepal, in $29^{\circ} \mathrm{N}$. lat, and $82^{\circ} 30^{\prime} \mathrm{E}$. long.

Diabase. See Basalt.

Diabe'tes (Gr., lit. 'a syphon,' from diabainō, 'I go or flow through'), a disorder of the general system, of which the principal symptom is a greatly increased flow of urine. Diabetes is of two distinct kinds: the one, diabetes insipidus, is a mere exaggeration of the water-excreting function of the kidneys, accompanied by extreme thirst, and hence called polydipsia (Gr., 'excess of thirst") by some anthorities; the other is a more complex disorder of the assimilation, consequent on the formation first, and the excretion by the kidneys afterwards, of an enormous excess of animal sugar (see SUGAR), the sugar being found in excess not only in the renal excretion, but in the blood, and in nearly all the secretions which have been examined. The pathology of this disease, called diabetes mellitus (Lat. mel, 'honey'), is very obscure, notwithstanding the numerous recent physiological researches which tend to throw light on the development of sugar in the animal organ- ism, especially in the liver, and which must undoubtedly be regarded as bearing on the solution of the problems connected with this disease. Unhappily, the cure of it is still entirely unknown, except in so far as it may be controlled or retarded by good management of the diet, drink, and clothing. The course of the disease, however, is very different at different periods of life. Before middle age it is severe, progressive, and almost invariably fatal. After that period precisely similar symptoms often appear, especially in gouty persons, but are so much less dangerous, and so much more easily controlled, that many authorities are nnwilling to place them in the same class as true diabetes. All diabetics are subject to progressive emaciation, and they often become subject to a chronic disease of the lungs, closely resembling true tubercular Consumption (q.v.); it is chietly in warding off this termination, or some other more quickly fatal, and in mitigating the symptoms of the malady, that the medical art can be of service.

The first fact observed in cases of diabetes is usually the increased flow of urine, when it becomes so great as to amount to a practical inconvenience; and also a considerable increase of the appetite, and an unquenchable thirst, which rarely fail to accompany the disease from the beginning, but often do not attract attention, or at least suggest the idea of anything wrong, till an advanced stage of the disorder. When the patient demands medical assistance he is usually somewhat thin; the pulse is quiet, the skin cool, the heat of the surface, indeed, habitually rather low and easily depressed. There is often a complete absence of perspiration, which gives a peculiar feeling of harshness to the surface, especially of the palms of the hands. With these symptoms the first approaches of pulmonary disease may concur. In the very last stages there is sometimes dropsy of the feet; and the urine may be natural in quantity, or even diminished. For the other characters of diabetic urine, see URINE. Diabetic persons bear excitement and fatigue, either mental or bodily, extremely badly ; and imprudence in this respect is not unfrequently followed by sudden or rapid collapse and death. The treatment consists mainly in removing from the diet, as far as consistent with comfort and due nourishment, everything which easily turns to the formation of animal sugar in the system, especially all excess of farinaceous food. The complete suppression of sugar-forming food, however, as recommended long ago by Rollo, has not been found possible in practice in the majority of cases. Bread composed of gluten of wheat without starch, or bran-cakes baked with eggs, or biscuits made of almonds, have been strongly recommended; and in most of the great capitals, as London and Paris, bakers may be found who regularly furnish bread suitable for this unfortunate class of sufferers ; indeed, any intelligent baker who will take the trouble may, under medical direction, be got to manufacture such bread when required; or it may be ordered in the form of cakes and biscuits, in quantities at a time, from London houses. It is of importance, however, that it be ascertained that the bread or flour supplied is really suitable; for Dr Pavy, one of the chief authorities on this disease, ascertained that some of the so-called foods for diabetics contain little less starch than ordinary bread. Saccharin (q.v.) has lately been of great service to diabetics, as it supplies the flavour of sugar without its objectionable properties. Medicines proper should be nsed only under the advice of the physician. There is no specific, and the unguarded use of strong remedies is to be condemned. Of all medicines that have been used, however, opium and morphia have been found most frequently use- 
ful in delaying the progreas of the disease. Flannel should be worn next the skin, and the languid funetion of the cutaneous perspiration aided by the warm bath, especially, perhups, the vapour bathe.g. that form known as the Rusian bath. The Turkish bath, which abstracts a large quantity of water through the skin, is less suitable to such cases.

Diablerets, a remarkable mountain of the Bernese . 1 lps, Switzerlume, on the frontiers of Bern and Valais, with a height of 10,651 feet above the sea. The Diablerets, with their four main peaks, are composed of limestone strata, the lower beds of which are so soft and shaly that they are easily disintegrated, and masses falling down into the valley from ahove cause the most terrible catas. troplies, as in 1714 and 1749.

Diacaustic. See CAustics.

Diachylon. See Plaster.

Diadochi. See Greece, Vol, V. p. 388.

Diaeresis (Gr., from diaireo, 'I divide'), a term used in Granmar to signify the resolution of a diphthong, or of a contracted syllable, into two syllables; as Lat. aura into aurai. The name is atso given to the mark ". placed above a vowel letter to indicate that it is to be independently pronounced, and not in conjunction with a preceding vowel; as in the above example, or in the word aerial. See UMLÁT.

IDiagnosis (Gr., from dia, 'through,' and gnösis, 'knowledge'), in Medicine, the discriminntion of diseases. It includes the study of all the vital phenomena of diseases, and also of their appesrances after death, in so far as this can aid their discovery during the life of the patient. It is usual to speak of rational or physiological dingnosis, or diagnosis by symptoms-i.e. changes chiefly functional, observed by the patient; and of physical diagnosis, or diagnosis by signs-i.e. objective phenomens appreciable by the senses of the observer. The latter method of diagnosis has been much enlarged in scope and increased in importance by the modern methods in medicine of Auscultation (q.v.) and Percussion (q. $\left.v_{0}\right)$, and also by the great advances made in physiological chem. istry, and by the use of the microscope. Skill in diagnosis is one of the highest gifts of the physician, and nothing distinguishes the man of long experience from the tyro more than this unerring insight into some unseen disease. See SтетноSCOPE, LARY NGOSCOPE, OPHTHALMOSCOPE, \&c.

Diagonal Seale. See Scales (MatuemaTICAL).

Dia'goras (surnamed the 'atheist'), a (ireek poet and philosopher, was born in Melos, an island of the Cyclades. He is said to have been a disciple of Democritus of Abdera, and he is alluded to by Aristophanes in the Clouds (424 B.C.). He seems to have been witty and fearless, and prohably treated the superstitions of the popular religion with contempt. He was formally accused of im. piety in 411 , and only saved his life by flight to Pallene, and afterwards to ('orinth, where he died. He wrote lyrics and a philosophical work, none of which have been preserved.

Dial and Dialling. A sun-dial is an instrument for measuring time by means of the motion of the sun's shadow east by a stile erected on its surface. It is an instrument of very grent antiquity, and before clocks and watches became common, it was in' generat use as a time-keeper. Some old sun-dials are very elaborate- - o.g. that at Glamis Castle, Forfarshire; and many bear quaint mottoes (cf. Leisure Hour, 1870, p. 413; and Mrs Gatty's Book of Sun-Dials, new ed. 1889). Dial-making was then an important branch of mathematical study now it is more an object of euriouity than ntilfity. A dial consints of two parts-the stile or gronsun. usually the edge of a plate of metal, always made parallel to the earth's, axis, and pointing cowards the north pole; and the diul-plune, which may bo of any hard substance, and on which are inarked the directions of the whalow for the neveral hour of the day, their halves, quarten, \&e. Dinis receive various namen, according moatly to the positions which they are constructed to oceupy. When the dial-plane is on the plane of the horizon, the dial in ealled a lorizontal dial; when perpendicular to that plane, a vertical dial. An equinoctial dial is one whose plane is parallel to the equinnetial plane. The south dial, nortlı dial, eant dial, weat dial, polar dial, declining dial, are named from the position of the dial-plane. The cylindrical dial is a dial drawn on the curved surface of a cylinder. The ring dial is an increnious suall portulble dial, but rather a curious toy than a philosophical inmtrument. A night or nocturnal dial is an instrument for showing the hour of the night by the shadow of the moon or stars. Moon-dials may be constructed relative to the moon's motion; or the hour may be found by the moon's shadow on a sun-dial. But because of the irregularity of the moon's motion, due to its varying speed at different parts of its orbit, the time so found is subject to considerable error.

Dialling. - The stile of a dial being parallel to the earth's axis, those familiar with spherical trigonometry will readily see that the problem of con. structing a dial resolves itself into that of ascertaining where the hour-lines cut a given circle, with a view to the graduation of the dial-plane. Suppose Pep (fig. 1), a hollow and transparent sphere, as of glass, to represent the earth; and suppose its equator divided into 24 equal parts by the meridians $a, b, c, d$, \&ce. one of them pasaing through a given place, say London (see HorizoN), at the point $a$. If the hour of twelve be marked at the equator, both on the latter meridian and that opposite it, and all the rest of the hours in onder on

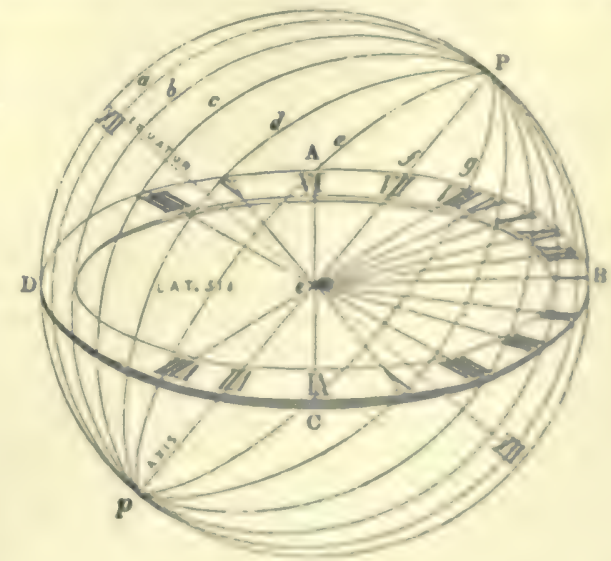

Fig. 1.

the other meridians, thoee meridian will be the hour-circles of Iondon, because, as the sus appeans to move round the earth in 24 hours, he will juas from one meridian to another in one hour. Then, if the sphere has an opaque axim, as Pep, terminat. ing in the poies $\mathbf{P}$ and $p$, the shadow of this axis would fall, in the courne of the day, on every par. ticular meridian and hour, as the sun came to the plane of the opponite meridian, and would thns show the time at London, and at all other places 
on the same meridian as London. If the sphere were cut through the middle by a plane $\mathrm{ABCD}$, in the rational horizon of London, and if straight lines were drawn from the centre, $\mathbf{E}$, of the plane to the points where its circumference is cut by the hour-circles of the sphere, those lines would be the hour-lines of a horizontal dial for London; for the shadow of the axis would fall upon each particular hour-line of the dial, when it fell upon the like hourcircle of the sphere. Similarly, if we suppose the sphere cut by any other plane facing the meridian, the hour-circles of the sphere will cut the edge of the plane in those points to which the hour-lines must be drawn straight from the centre; and the axis of the sphere will cast a shadow on these lines at the respective hours. The like will hold of any plane, whether it face the meridian or not, provided it do not coincide with it, or do not coincide with a plane through the poles, and perpendicular to the plane of the equator. In the latter case, the axis would have no elevation above the plane of the dial; in the former, the shadow would not move circularly.

The universal dialling cylinder, an invention of Ferguson's, is represented in fig. 2. ABCD is a

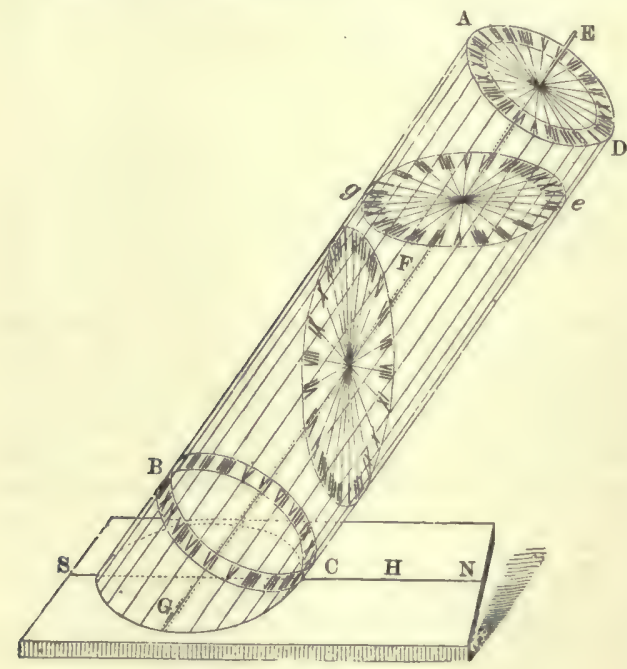

Fig. 2.

glass cylindrical tube, elosed at both ends with brass plates, on the centres of which a wire or axis, EFG, is fixed. The tube is either fixed to a horizontal board, $\mathrm{H}$, at an angle equal to the latitude of the place, or moves on a joint, so that it may be elevated till its axis is parallel to the earth's at any latitude. The 24 hour-lines are drawn on the outside of the glass, equidistant from one another, and parallel to the axis. The XII next $B$ stands for midnight; the XII next the board, for noon. When the axis is adjusted for the latitude, and the board levelled, with the line HN on the meridian, and the end towards the north, the axis EFG, when the sun shines, will serve as stile, and cast a shadow on the hour of the day among the parallel hour-lines. As the plate AD is parallel to the equator, and $\mathrm{EFG}$ perpendicular to it, right lines drawn from the centre to the extremities of the parallels will be the hour-lines of an equinoctial dial, and the axis will be the stile. A horizontal plate, ge, if put into the tube, with lines drawn from the centre to the several parallels cutting its edge, will be a horizontal dial for the given latitude; and similarly a vertical plate fronting the meridian, and touching the tube with its edge, with lines drawn from its centre to the parallels, will be a vertical south dial, the axis of the instrument in both cases serving for the stile; and similarly for any other plate placed in the cylinder. If, instead of being of glass, the cylinder were of wood, any of these dials might be obtained from it by simply cutting it in the planes of the plates, and drawing the lines on the surface of the section.

Dialling sometimes occurs as a term for surveying by help of a compass with sights, such as is called a 'miner's dial,' and is used especially in underground surveys and mine-surveying.

Dialect, in popular language, a local form of speech which differs from the general or received speech of the country, but is manifestly related to it. Still more popularly, dialect is considered to be a "corruption" of received speech, due to ignorance or carelessness, and is stigmatised as boorish. Both definitions are untenable. The last is so extremely wrong that it would be more correct to term received speech an artificial (as distinct from a natural or organic) 'corruption' of soine local form of speech which political or literary circumstances have imposed upon the whole country. The first definition labours under the disadvantage of supposing that there was from the first in any country a received form of speech which 'broke up' into dialects, just as the Latin language actually broke up into the Romance languages of to-day. And this leads to the ques. tion, How does a dialect differ from a language? Are the so-called Romance languages not rather dialects of Latin? Is not English collectively a dialect of Low German? Was not Latin itself a dialect of that original Aryan speech which we only know in such dialectal forms as Sanskrit, Greek, Latin, Gothic, \&c.? This is a question merely of the meaning we assign to words. It is well fitted for arguing, as Gil Blas argued (chap. i.), but it is of no practical value.

Without going into the very vexed question of the origin of language, we find that wherever two human beings are thrown together a spoken means of communication or language grows up ; that wherever a family is isolated a family language is generated; that when the family separates into many distinet families they carry with them some general and various particular forms of the original family speech; that where these families again separate the same process goes on, till the one original speech is broken up into a variety of local forms which differ but slightly from each other, and are usually, though strange, mutually intelligible. Wars, especially civil wars, conquests, defeats, changes of environment due to immigration and emigration, contact with others deriving from a different original family, produce harsher changes, till the groups become mutually unin. telligible. It is at this point that the old dialects may be considered to become languages. We have not to go far to seek examples. The slang of each nursery, school, college, profession, and handicraft illustrates the first ; the history of Europe furnishes abundant examples of the second. We may therefore have dialects or diversities of related speech without having a received speech at all. In the flourishing time of Greece, Herodotus wrote in lonic and Thucydides in Attic. There was not even a word for Greek, which, as separate from its dialectal forms, was unknown till long afterwards. In England the author of the first EnglishLatin dictionary, the Promptorium Parvulorum, apologises for writing in East Anglian, as beinc the only form of speech he knew. It was not till political domination called forth a court speech that the seed of a received speech was sown; but centuries of writers, each touching up the artificial changeling in his own way while using it to expresa 
vigorous thought, were required to build up our gyturiuns English speech.

Dialect, however, is by no means yet extinct, oven in England, though railways and school. boarils threaten its speedy amuihilation. Tho writer, who has been led to investignte the subject during the last twenty years, finds that we have still six great forms of local speechSouthern, Western, Eastern, Midland, Northern, and Lowland Seotch-further divisible into forty. two districts, each of which has generally numerous varieties. His object was to determine the pronunciation as at present existiug all over that part of England and Scotland which is not still Celtic; hence his distinctions are mainly based on pronunciation as referred to the oldest English form of literary speech, the West Saxon or Wessex, which, however, never prevailed over the whole country, and is not even the foundation of modern literary speech. Of this pronunciation he was obliged to omit one striking and cliaracteristic part-viz. the intonation or singsong of speech, which generally strikes a stranger first and most strongly, because he could not invent any practical means of expressing it, and it was very seldom indeed that he could hear it from native un. educated peasants. The two other paints to which we must look for distinctions are vocabu. lary and construction. Vocabulary is the point most generally considered, but it is often delusive as a means of separation, because it is so difficult to trace the area over which certain words prevail as distinct from those where they are not known. The nature of the investigations and their difticulty is well shown in Mr Thomas Hallam's 'Four Dialect Words, Clem, Lake, Nesh, and Oss [ = to starve, to play, tender, to offer], their modern dialectal range, meaning, pronunciation, etymology, and early or literary use' (English Dialect Suciety, 1835). With unusual words, however, or words with unusual significations, most glossariats con. sider that they are chiefly concerned, while at the same time the difficulty the writers feel in expreas. ing the sounds of the words-i.e. properly speaking, in actually conveying the words - renders their identification uncertain. This is different for literary languages where there is a conventional orthography and pronuneiation. The last eharaeteristic mark of dialects is their granmatical construction. It is surprising how little this point is attended to in most glossaries, so that the reader is generally left to discover the construction from the examples, and these in many cases are not sufficiently trustworthy for that purpose. It is the more satisfactory, then, to refer to such glossaries as Elworthy's West Somerset, with its separate grammar: Darlington's Folk-speech of South Cheshire, Miss Jackson's Shropshire Word-book; and Robinson's Mid-Yorkshire Glossary, in which pronunciation and grammar are well attended to, and examples are numerous and trustworthy.

In making the above division of English dialects, considered as new local forms of speech referred to one old local form, the Wessex, without any regard to received speech or spelling, the following are the principal distinctions relied upon, and the areas over which they extend.

(1) Southern takes in the whole south of England from Cornwall to Kent, extending northwards on the west to the north of Worcester, south of Warwick and Northampton, eastwards to the boundary of Oxford, and all south of the Thames. The marked characters are found in the western half, which die off enstwards, while westwards they exhibit signs of Celtic influence. Wilts, Donset, Somerset, and Gloucester show this form in its prime. These were the seat of the West Saxon tribes, and best preserve the mark of their origin.
The main character of all the souchern division is the pronunciation of $r$, especially where not belore a vowel, as in there, air ! The somare, in the prin. cipal region, is reverted, that is, tumed with it undenside to the lard palate, and its point directed towards the throat. This is the Englinh form of the (different) glottal $r$ of the Law (ierman dimtriet. It is not only strung in Wilts, Domet, and somernet, but also in Devon (where French u may likewing be heard), though it dies out through Cornwall, and in west Cornwall, which has comparatively revently become English, has hecomes that of reweriven speech. In Hampehire and enstwards it becomea milder, but on the whole it is still well marked even in Kent. It is the parent of received English $r$, which is little different from an imperfect $d$ when it does not become a simple vowel or is lowt. Initial $f$ and $s$ in Saxon words become $v$ and $z$. In construction the speech is peculiar in the general use of $I$ be for $I$ am, and ve am, you am, for soe are, yos are; in the general prefix of $a$ to the past participle - as I've a-done; the periphrastic form of the present tense, as $I$ do go for aimple $I$ go, without any implied emphasis; the use of the accuative $e x$, from Wessex hine, which is replnced by the dative him in literary speech ; and in one part of Somenset (near to, but west of, Yeovil) the use of ntch for the first personal pronoun $I$. In the east of Sussex and in Kent de, dis, dat, \&c. may be atill heard for the, this, that, \&e., but this is a comparative modernism.

(2) Western comprises most of Monmouth, Hereford, and Shropshire, and shows the intluence of the Welsh, which in early times prevailed over them; and Shropshire especially preserves a trilled Welsh $r$ which is in remarkable contrast to the southern and midland $r$.

(3) Eastern extends over the whole of the counties lying north of the Thames but east of Oxford and Leicester and south of Lincoln, embracing also the East Anglian peninsula of Norfolk and Suffolk. which two counties generally have a pronuneiation of to, do, soon, as if the vowel were nearly French $w$, much the same as in Devonshire. But this does not extend to the rest of the eastern, which bears a remarkable resemblance to received speech, being indeed that part of the country from which it originated. Essex is especially remarkahle for promouneing paper like pijer, a practice which of Inte years (subequently to the time of Dickens and Thackeray ) has erept into London, and may be heard from most newsbovs. Over Kent, Essex, Sulfolk, and Norfolk extends the land of $W e c$, where $w$ in used for $v$, but not conversely, as sine for vine, wan (rhyming man) for van, and so on.

(4) Midland occupies the whole middle region of England from the north of the three last named to, roughly speaking, a line drawn from Laneaster Bay on the west to the Humber on the enst. The speech of the large tract of country thus included is liy no means hemogrenesus. But the Southermer is at once surprised by the difference in the pro. nunciation of short o and $u$ in cume, up, and similar words, which in the greater part of this region resembles the (ierman o or Fresuch ru with a dash of 00 in foot, being really a transitional form between the well-known southern and Lowland Scotch sound and the oo in foot. This last sound, however, prevails in Lincolnshire and the south of Yorkshire. Lineolnwhire is remarkable for ite fractured or divided vowels, which Lord Tennysan writes with $\tilde{\alpha}$, but which really sound to a Londoner, and even to a native Lincolnshire man, both of whom vocalise their $r$, as if an $r$ were annexed, as air, arirnts, deend, doarnt, for Lord Tennysov's saany, saäints, deäd, doünt ( = say, saints dead, don't), and 80 on. In the extreme north of lincolnshire one in pronounced 60 , as noo, $c 00$, hoove, for nove, cove, 
house, which is not found at all in the other midland counties, but is an old form now characteristic of northern speech. In the western midland, mid and south Lancashire, Cheshire, Derbyshire, one of the most striking pronuuciations arises from the treatment of ow, which is pronounced ou in the south only, at the south-east of Lancashire and north-west of Derby, becoming the prolongation of $a$ in bat, cat in the south-west of Lancashire, of $a$ in father in the south of Yorkshire, and south Derby, and like eye nearly in Cheshire and north Staffordshire. The word for she is hoo in south Lancashire, north Derby, and Cheshire, and shoo in south Yorkshire. The definite article south of Cheshire, Derby, and Nottingham has the usual English form, but in Cheshire, north Derby, and Lancashire becomes the th in oath without any vowel, though often assimilated to a preceding $t$, and in south Yorkshire is reduced to $a$ simple $t$ ' without any vowel. In construction the most remarkable feature is the verbal plural in -en in the present tense, often singularly contracted. Thus an yo? is have-n you? dun they (with the peculiar $u$ ) is do-en, "do they ;' they known, they know-en, "they know, and so on. This prevails in Lancashire, Cheshire, Derbyshire, and the parts of Yorkshire adjoining, but is lost in most of south Yorkshire. It has disappeared recently in Nottinghamshire, is rare in the sonth midland, and practically disappears in Leicester. $I \mathrm{am}$ is used in this region, in contrast to the southern $I$ be. The $r$ is very light and quite different from the southern reverted $r$ and the Scotch strongly trilled $r$.

(5) Northern extends from the northern boundary of the midland to Scotland. Here ow becomes oo completely in most of Yorkshire, but remains in the first stage of transition from oo to ow in Cumberland and Westmoreland, The short $u$ in but, cut, is oo in foot. The vowels are much fractured or divided throughout north Lancashire, Cumberland, Westmoreland, and Yorkshire, but differently from the forms found in Lincolnshire, the sound of ee or ea in beer, bear, being prefixed. In the south-eastern part long $i$ becomes $a$ in father, which is not the case in the south-western part. The definite article becomes simple vowelless $t$ ' (being quite lost in Holderness, Yorkshire) up to a sinuous line through north Cumberland and south Durham, after which the usual form the is resumed and continued to the Scotch border. Instead of $I$ am, $I$ is is regularly used, at least till the is restored, and then generally $I \mathrm{am}$ is heard. In Northumberland a transition oceurs from the short oo in foot in such words as cut, up, through a sound more resembling. German $\ddot{o}$, and only slightly different from midland short $u$, to the regular southern and Scotch form which is established ahout Wooler. But the great peculiarity of Northumberland is the uvular (or as it is usually called, guttural) pronunciation of $r$, almost as in the north of France and Germany. This is apparently of recent origin, and hardly overlaps the county border on the south, while it is not heard beyond Berwick on the north. The neighbouring Scots cannot pronounce it.

(6) Lowland Scotch pervades all Scotland where Gaelic is not the common language-i.e. generally the south and east, including the Orkneys and Shetlands. Historically, the English language was transplanted into Scotland from the east of Yorkshire and Northumberland, but it now differs materially from the speech there used. The speech in the south of Scotland is probably the most ancient form. (See Dr J. A. H. Murray's Dialect of the Southern Counties of Scotland (1873), which is the classical work on the subject.) Phonetically, the southern form is remarkable for retaining ow when not followed by a consonant, and using oo when a consonant follows, as cow, hoose, whereas in the rest of Scotland they have coo, hoose, as in Yorkshire. Grammatically, it is remarkable for distinguishing the present participle from the verbal noun, both confounded as -ing in modern English, as 'dansŭn in dansin shoes.' As the English proceeded north to Edinburgh and round to the north of the Forth, this and other distinctions were lost. It is the middle Lowland Scotch, which subsequently spread to the west and south, that is usually known as Scotch by Englishmen, through Burns and Seott in modern times. It was a highly cultivated variety, but was always considered to be English by its older writers. North Lowland Scotch lies north of the Try, and has the well-known peculiarity of using $f$ for $w h$, and in Caithness there is the reduction of the definite article to its vowel $e$ alone. The Orkneys and Shetlands are Lowland Scotch engrafted on Norwegian, or Norn, as they term it-i.e. old Norse, which has occasioned many peculiarities both of pronunciation and construction, of which the general, but not universal, use of $d, t$, for the two sounds of $t h$ in the, teeth, need only be mentioned. For the evidence on which the above divisions are founded, with complete details and ex. amples, the reader is referred to Alexander $\mathrm{J}$. Ellis's Existing Phonology of English Dialects (1889), forming Part V. of his Early Enylish Pronuncication.

The above remarks refer to the existing forms of speech. Dr Morris in his prefaces to Hampole, Alliterative Poems, Dan Michel, \&c., has endeavoured, from the MSS., to determine the characteristics of our dialects in the Early English period. He admits only three-southern, midland, and northern, but divides the midland, 'which presents us with no one typical form,' into west and east midland.

All languages present a variety of local forms, which has just been partially illustrated for English; and in many of these the discrepancies are much greater than in English. Prince LouisLucien Bonaparte has done much not only with the English, but with the Basque, French, and Italian forms ; for the last, see also Papanti's collection, $I$ parlari Italiani in Certaldo (1875). The dialects of Low German have been treated by J. Winkler in his Dialektikon (1874). The Swedish dialects are being especially studied now. The High German and Swiss dialects have received much attention. Schmeller's Bavarian Dialects (Mundarten Bayerns, 1821) is a remarkable work. And so on.

Now to what end or purpose is this study of dialects pursued? They possess comparatively no literature having any attraction in itself. The modern forms are spoken only by the illiterate, and sound uncouth and harsh to an educated ear. They are not pursued for the ideas which they convey, but for the manner in which they convey them. They lead us to understand how a received or literary language was formed. They contain multitudes of 'missing links,' which serve to explain relations which might otherwise entirely baffle the student of language. Thus, there are two old formis, then pronounced as the present long ee and oo, which now appear as long $?$ and ow. How did this come about? It is evident that the people could not have suddenly left off one and taken up another. Now the actual transitional forms still exist, like fossils, in dialectal speech. Modern philology obliges us to leave the merely written forms and study living usages. This is only possible by studying existent local forms of speech, in other words, dialects.

There is a considerable literature of modern English dialects, but it labours under the disadvantage of generally not being genuine-i.e. not 
due to dialeot speakers themsolven, and when so due, as in Burns's poens, it is too apt to be unduly mixed up with modern received speech. Naturally, the born dialect speaker is not a literary man, as the writer of dialect works inevitably in Some of the best pieces of Cumberland speech (Gibeon) and High Furness dialect (Piketal $=$ Barber) have been written by men who had lived ouly a few years in the country, and had been attracted by the curious forms of the speech anong which they came. Others seem to have been written purely 'from the fun of the thing,' such us the Ersex 'Tiptree Fair' and 'John Noskes and Mary 8tiles,' and the Kent 'Dick and Sal.' One of the few modern books written with a desire to show the better side of the dialect as distinguished from its ludicrous side is the late Rev. W. Barnes's Dorset. shire poems. There are also many serious Cumberland poems given by Giluin. Nathan Hogrg's (Bairds) poens and the Exmoor Scolding, as edited by Elworthy, with the pronunciation and notes, deserve study as the work of natives. The legion of Lancashire and Yorkshire books is chiefly rollicking. But I'im Bobbin has become a classic. In Northumberland the Pitman's Pay takes a sinular position. Both have influenced the orthography used by other writers. In Seotland, besides Burns and Scott, must he mentioned the excellent A berdeenshire Johnny Gibb of Greshetneuk, and the same writer's Life among my ain Folk. Dennison's Orcadian Sketch Book is also first-rate.

The Biblionraphical List of works relating to dialects, including both glossaries and examples, publisherl by the English Dialect Society, which was founded in 1873, contains 200 pages; and the English Dialect Dictionary (1898 et seq. ), edited by Professor Joseph W right, is based on the Society's publications and collections.

Dialectic is a Greek word which signified originally 'the art of rational conversation,' but came to have a technical signification in the language of philosophy. At tinst it implied a regular and scientific method of treating general conceptions or general terms - a sort of anatomy of names, and through them of the things denoted. In the Socratic philosophy, and more especially in that of Plato, dialectic was thus the method of the highest and deepest kind of speculation. Aristotle gave another signification to the word. Accorling to him, a scientific proof or deduction is different from a dialectic proof, which is only a probable deduction. After this, dialectic came round to imply a kind of fencing in words, the art of so using the forms of rensoning as to confound your opponent, and make fallacies pass for truth. Dialectic is sometimes used as synonymons with logic. The Hegelian philosophy regards dialectic as at onee the methol of knowledge and of the evolution of the universe itself.

Dl'allage (Gr. diallage, 'interchange;' so called frum its changeable colsur), a mineral nearly allied to Augite $(\mathrm{q}, \mathrm{v} \cdot)$, and by some regarded as a variety of it. Its chemical composition is essentially the same. It is seldom found perfectly crystellised, but msually maseive, granular, or dis. seminated, and is characterised by its markedly laminated structure. It is lowwn, gray, or green in colour, but shows a kind of metallic lustre when broken across the cleavage. This is due to the presence of microscopic tubular inclusions or leaflets, which are disposed parallel to the cleavareplanes or lamine. Diaflage is a rock-forming miueral of some importance, occurring as a primary constituent of Grabro (q.v.).

Dialogue, a conversation between two or more persons, implying, however, greater unity and continuity of subject than an ordinary convensation. The ancient Greek philosophers were fond of this way of conducting their inventigntions and convey.

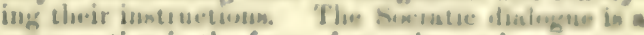
conversation in the form of question and enwwer, contrived that the pernon questioneal is leal hinaself to originate thome idean that the quentioner whates to bring before him. The dislogues of Plato sere os it were, philoeuphical draman, is which the Socratic method of investigation is brought to hear upon epeculative subjects One of the greatest nuasters in this form we Lucim, whoe kren-edyend and brilline wit was empecially adapted to it. The dislogre is but ill adapted to the expenition of modern acience, although elementary hand-hooks in the form of question and answer are still uselul as mupplying the student with series of concrete facts tersely expressed. Of the more eminent modern writers of the literary forms of dislogue, we may mention Erasmus in Latin : Leaking, Herder, and Wieland among the Gernans; Petrarch and Mnchiavelli in Italy; Fénelon, Fontenelle, and Diderot in France; and in England, Berkeley, Swift, Hurd, Harris, Helpe, and Landor in his Imaginary Conversations. Dialogue combined with action gives us the drama.

Dia'lysis. Bee Osmose, Dirfusiox.

Diamagnetism. Bodies such as iron, when placed in a field of magnetic force, temol tos nuve from places of weaker to places of atronger force. The opposite is true of bismuth and other sub. stances. Such substances are said to be dimmag. netic. For further information, see MAONET18M.

Diamantina, an epiecopal town, of mean appearance, in the Brazilinn state of Minas Geraes. It is the centre of a rich diamond district. and has mannfactures of cotton and goldware. Pop. 13,000.

Diameter, in Plane Geometry, is generally a straight line bisecting any system of parallel choonla of a conic section. The lines which it bisects are termed its ordinates. In the circle, ellipse, and hyperbola, every diameter passes through the centre of the curve, and is there bisercted; but it is only in the case of the circle that all dinmeters are equal. In the parabole, since the centre of the curve is at an infinite distance, all dinmeters are parallel to the axis.

Diamond (corrupted from adamant. q.จ.), a natural form of erystallised carbon, highly valued as a precious stone, but of much less valne than the ruby. The diamond erystalliaes in the enbic of monometric system, its common forms being the regular octahedron, the rhombic dodecahedron, and the six-faced octahedron. The faces are often curved, and the general form of the eryetal is more or lea rounded. Cleavage is perfect. parallel to the faces of the octaherlron-a fact which is often taken advantage of in splitting off frayments for the purpose of removing flawn. The surlace of the diamond frequently exhibits striae and triangular inupressions, while the interior may contain microscopic cavities and various incluaions. A diatiactly lamellar structure is by no menns uneomunon.

The lustre of the dismond is peculiar to itself. and hence termed "mamantine. In a metural con. dition, however, the surface often presents a dull lead-gray aemi-metallic lustre. The high refrnetive and disperaive powers of the dinmond produce. when the stume is julleisusly eat, a britlianes and 'fire' nnequalled by any other stone. The mean index of refraction is 24 , and the angle of total reflection about $24^{\circ} \mathbf{2 4}^{\prime}$; the latter accounts for the lustre, inasnuch as a large proportion of the inci. dent light is in a well-cut dumond reflected from the inner surface of the atone. The diamond, especialty when coloured, is highty phoephorescent, thut is to say, after exposure to brillian illumination it emits the rayn which it has aboorbed, and 
thus becomes self-luminous in the dark. Under the electric discharge in a highly-rarefied medium it exhibits beautiful phosphorescent phenomena, as pointed out by $\mathrm{Mr}$ Crookes.

The specific gravity of the diamond is about 3.52 , and its degree of hardness greater than that of any other mineral, being indicated by 10 in the ordinary scale. The excessive hardness serves to distinguish the diamond from other gem-stones : any stone which readily scratches ruby and sapphire must be a diamond. Notwithstanding its hardness the diamond is brittle, and hence the absurdity of the ancient test which professed to distinguish the diamond by its withstanding a heavy blow struck by a hammer when placed on an anvil.

Regarded formerly as a peculiar kind of rockcrystal, the chemical composition of the diamond remained for a long time extremely obscure. It was shown by the Florentine academicians Averani and Targioni, about 1695, that the diamond could be volatilised at a high temperature, their experiments having been made at the cost of the Grand. duke Cosmo III.

Newton in 1704 expressed the opinion that the diamond, from its high refrangibility, was probably an unctuous lody coagulated. In 1751 the Emperor Francis I. performed an experiment which showed that diamonds strongly heated in a furnace completely disappeared. Towards the latter part of the 18th century several French experimentalists, including Dareet and Macquer, examined the behaviour of diamonds at a high temperature; but it was reserved for Lavoisier in 1772 to demonstrate that while the diamond is extremely refractory if heated with total exclusion of air, it is readily combustible at a moderate temperature in the presence of air or oxygen, with production of carbonic acid gas. In 1797 the English chemist Smithson Tenmant satisfactorily showed the identity of diamond with carbon. In recent years highly refined researches on this subject have been made by Dumas, Stas, Roscoe, and Friedel, all tending to prove that the diamond is practically pure carbon. Chemists have generally experimented, for sake of economy, with impure specimens, and have thus obtained on combustion a considerable amount of ash, the nature of which has not been well ascertained. It has been shown, however, that the purer the diamond the smaller is the proportion of ash left on its combustion. Gustar Rose, shortly before his death, subjected diamonds, inclosed in a vessel free from air, to the intense heat of the voltaic are produced by a powerful dynamo constructed by Siemens of Berlin. Under these circumstances the gems became gradually incrusted with a dark coating of graphitic matter, and in some cases triangular depressions were developed on the faces, similar to those often observed in the South African diamond in its natural state.

As the chemical composition of the diamond is well known, it has often been supposed that carbon might be induced by artificial means to assume the characters of the gem. In $1880 \mathrm{~J}$. B. Hannay of Glasgow announced that he had succeeded in producing artificial diamonds by inclosing a mixture of paraffin spirit and bone-oil distillate, with metallic lithium, in a strong wrought-iron tube, and exposing it to prolonged heat in a reverberatory furnace. Specimens of diamantoid carbon were thus obtained, hut of small size, and it was found that these, when placed on the wheel, immediately crumbled. As the experiments offered no promise of commercial success, and were of so difficult and dangerous a character, they have not been repeated.

It is notable that the occurrence of diamonds has been recorded in a meteorite. Jeofeiff and
Latchinoff in examining the meteorite which fell on September 22, 1886, near Novi-Urei, government of Penza, South-east Russia, detected the presence of about 1 per cent. of diamantoid carbon.

An imperfect variety of diamond known as bort, or boart, occurs in the form of small spherical concretions with crystalline texture. Although unfit for use as an ornamental stone, it is employed when ground as an abrading agent; and the powder mixed with oil serves to feed the lapidary's wheel when cutting hard stones. Much of the bort of commerce is not the mineralogical variety, but consists of splinters, rough fragments, and imperfect erystals of ordinary diamonds. The diamonds used by the glazier for cutting glass are ordinary crystals with rounded faces, and are known as vitré diamonds. The eut, though only to the depth of about the 1 th of an inch, is sufficient to determine with precision the direction in which the glass shall break.

Carbon, or carbonado, is the name applied to an opaque, black, granular, or imperfectly crystallised variety of diamond found only in Brazil, where it was discovered in 1843. While its density is less than that of crystallised diamond, its hardness is much greater, and hence it is used in the arts, especially for mounting in the steel heads or crowns of the rotary diamond drills for rock-boring.

The art of cutting and polishing the diamond is said to have been discovered in 1456 by Louis de Berguem of Bruges. As now practised, the stone is first, if necessary, cleaved or split, and then 'bruted' or rubbed into shape. The faces of the stone thus "cut' are ground and polished on flat metal discs, fed with diamond dust and oil, and revolving with great rapidity by steam-power. Amsterdam is the chief home of this industry, and the trade is chiefly in the hands of Jews; but diamond cutting and polishing are also now extensively carried on in London, Antwerp, \&c. The common form of the diamond is either the brilliant or the rose cut. The brilliant resembles two truncated cones, base to base, the edge of the junction being called the girdle, the large plane at the top

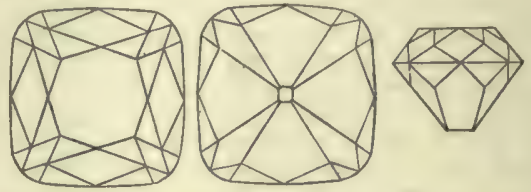

Fig. 1-Square-cut Brilliant.

is the table, and the small face at the base the culet; the sides are covered with symmetrical facets. Fig. 1 shows a square-cut brilliant, and fig. 2 a round-cut brilliant. The rose has a flat
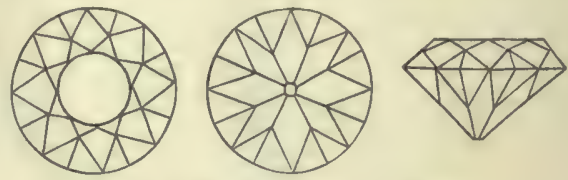

Fig. 2.-Round-cut Brilliant.

base, with sides formed of rows of triangular facets rising as a low pyramid or hemisphere; but this form of diamond is daily becoming less fashionable, and is therefore of comparatively little value. It is illustrated by fig. 3 .

India was formerly the only country which yielded diamonds in quantity, and thence were obtained all the great historical stones of antiquity. The chief diamond-producing districts are 
those (1) in the Moulras presillency, on the Kistron and Godavari rivers, commonly though improperly termed the Golconda region; $(2)$ in the Central
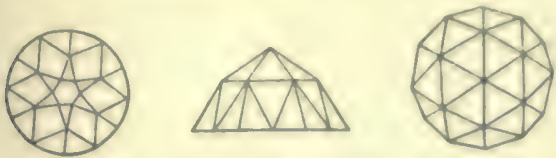

Fig. 3,-Rose-cut Diamond.

Provinces, including the mines of Sumbulpur: and (3) in Bundelkhand, where the Panna nines are situated.

At present the diamond production of India is insigniticant. It is notable, however, that in 1881 a fine diamond, weighing 67 carats, was found near Wajra Karur, in the Bellary distriet, Madras. The stone was cut into a brilliant weighing 24 s carats, and is known as the 'Gor-do-Norr.

Brazil was not regarded as a diamond-yielding country until 1727, when the true nature of certain crystals found in the gold washings of the state of Minas Geraes was first detected. Diamonds occur not only in this state, but also in Buhia, Goyaz, Matto Grosso, and Parana.. The geological conditions under which the mineral occurs have of late years been carefully studied by Pro. fessors Derby, Gorceix, and Chatrian. The diamonds are found in the sands and gravels of river-beds, associated with alluvial yold, specular iron ore, rutile, anatase, topaz, and tourmaline. In 1853 an extraordinary diamond was found by a negress in the river Bogagem, in Minas Geraes It weighed $254 \frac{1}{2}$ carats, and was cut into a brilliant of perfect water, weighing 125 carats (see fig. 4, b). This brilliant, known as the "Star of the South,' was sold to the Gaikwar of Baroda for $£ 80,000$.

Both the Indian and the Brazilian diamondfields have of late years been eclipsed by the re. markable discoveries of South Africa Althongh it was known in the last century that diamonds occurred in certain parts of South Afrion, the fact was forgotten, and when in 1867 they were fonnd near Hopetown, the discovery came upon the worki near Hopetown, The principal mines are situatesl in Griqualand West, but dimmonds are also worked in the Orange River Free State, as at Jagenafontein. in the Orange River Froe State, as at Jagenafontein. vings 'in the Vaal and Orange rivers. These sourees have occasionally yielded large stmes; one found in 1872 at Waldeck's Plant on the Vaal weivhed 288 sarats, and yielded a fine pale yellow brilliant known as the "Stewart."

It was soon found that the diamonds of South Africa were not contined to the river gravels, and 'dry diggings' came to be established in the so. called 'paus.' The principal mines are those of Kimberley, De Beer's. Du Toit's Pan, and Bultontein. At these localities the diamonds occur in a. serpentinous breceia, flling pipes or "chimneyn, generally regariled as volennic ducta, which rive irom unknown depthe and bunt through the ses. roumling shales. 'The 'blue rround," or volcanic breceia containing fragmente of various rockin cemented by a merjentingns paste, becomes altered by meteoric agents as it approaches the murface, and is converted into "yellow earth." At Kimberley the neighhouring schimtk, or 'reefin," are amociatert with sheets of a basaltie rock, which are pierced by the pipes. In the yenr 1887 the prodnction of the principal mines wes as follows :

\begin{tabular}{|c|c|c|}
\hline & eledbe In Carrete & Velea \\
\hline Kimberiey..... & $.1,894,852$ & e1, 410,307 \\
\hline De Beer's..... & $1,01.048$ & $1,0=6,0$ \\
\hline Du Tolt' Pan. & 66,$5 ; 6$ & Ox: $2 \times 2$ \\
\hline Bult fontetn.................. & $=602,240$ & $61: 202$ \\
\hline St Auguatine ............... & . 197 & $2 \%$ \\
\hline & $8,646,600$ & $\boldsymbol{e t , 0 0 8 , 8 0 0}$ \\
\hline
\end{tabular}

The great number of large stones found in the mines of South Africa, as compared with those of India and Bruzil, is a wtriking peculiarity. In the earliest days of African mining a diamond of about 8:3 carats was olutained from a Iswer. This stone when cut yielded a splendid colonrlen brilliant of 46. carats, known as the 'Star of South Africa, or as the 'Dudley,' since it afterwaris becane the property of the Countess of Dudley. Some of the

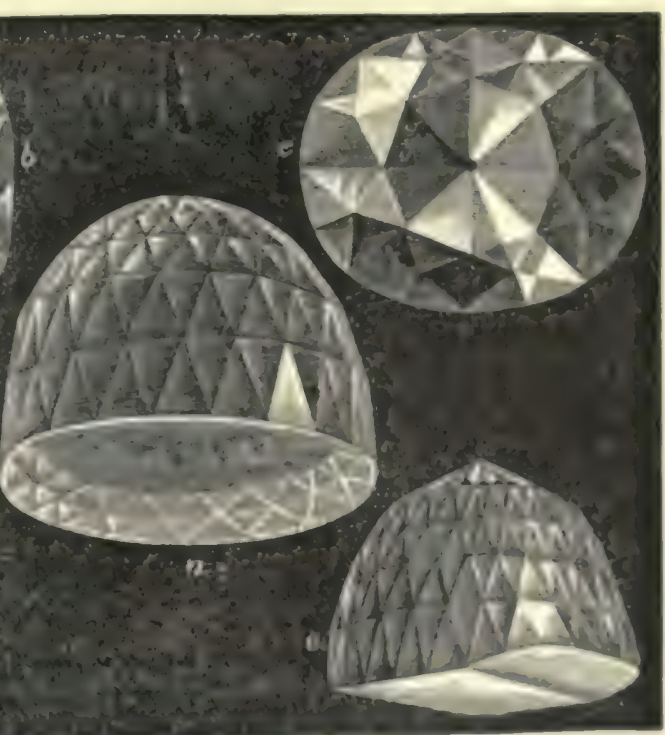

Fig. 4

Koh-1-uur ; d, Regent ; e, Orlotf-all setual ase.

African ntones are 'off coloured'-i.e of pale yellow or brown tints ; but a large gens of singular purity was found at Kimberley in $18 \mathrm{k}$. This is the famous "blue-white" dismond of 180 cames, known from the nume of its possensor as the 'Porter Rhudes" See CAPB Colory.

It has long been known that diamends ocenr in Australia, but hitherto the Anstralian otones have been all of small sixe, and it is notable that thene nre much more diffieult to eut, being harder than other diamonds. Although Victoris and South Anstralia have oceasionally vielded diamonds, it is New South Wales that has been the principal producer. The chief dismond localisies have been neat Mudree, on the Cudjegong River, and near Hingern, on the river Horton.

Borneo also yiekls diamonda. The stone known as the "Matan' is and to have been found in $178 \%$ in 
the Landak mines, near the west coast of Borneo. It is described as being an egg-shaped stone, indented on one side, and weighing, in its uncut state, 367 carats. Great doubt, however, exists as to the genuineness of this stone, and the Dutch experts who examined it a few years ago pronounced it to be simply rock-crystal. Among other diamond localities may be mentioned the Ural Mountains and several of the United States. The largest diamond yet recorded from North America was found at Manchester, Chesterfield county, Virginia. It weighed $23 \frac{9}{4}$ carats, and yielded, when cut, a brilliant known as the 'Ou-i-nur,' which weighed, however, only 11 妾 carats.

A few special diamonds, from their exceptional size or from the eircumstances of their history, deserve notice. Of all the great diamonds, the 'Koh-i-nur' is perhaps the most interesting (see fig. $4 ; c)$. While tradition carries it back to legendary times, it is known from history that the Sultan Ala-ed-din in 1304 acquired this gem on the defeat of the Rajah of Malwa, whose family had possessed it for many generations. In 1526 it passed by conquest to Humaiun, the son of Sultan Baber. When Aurungzebe subsequently possessed this stone, he ured it as one of the eyes of the peacock adorning his famous peacock throne. On the conquest of Mohammed Shah by Nadir Shah in 1739, the great diamond was not found among the Delhi treasures, but learning that Mohammed carried it concealed in his turban, Nadir, on the grand ceremony of reinstating the Mogul emperor on the throne at the conclusion of peace, offered to exchange turbans, in token of reconciliation, and by this ruse obtained possession of the gem. It was when Nadir first saw the diamond on unfolding the turban, that he exclaimed, 'Koh-i-nur,' or 'Mountain of Light,' the name by which the gem has ever since been known. At Nadir's death it passed to his unfortunate son, Shah Rokh, by whom it was ultimately given to Ahmed Shah, the founder of the Durani Afghan empire. By Ahmed it was bequeathed to his son, Taimur Shah; and from his descendants it passed, after a series of romantic incidents, to Runjit-Singh. On the death of Runjit, in 1839, the diamond was preserved in the treasury of Lahore, and on the annexation of the Punjab by the British in 1849 , when the property of the state was confiscated to the East India Company, it was stipulated that the Koh-i-nur should be presented to the Queen of England. It was consequently taken in charge by Lord Dal housie, who sent it to England in 1850. After the Great Exhibition of 1851, where it had been exhibited, it was injudiciously re-eut in London by Voorsanger, a skilful workman from Messis Coster's factory at Amsterdam. The re-cutting occupied 38 days of 12 hours each, and the weight of the stone was reduced from $186^{x}$ to $106 \frac{1}{16}$ carats. The form is that of a shallow brilliant, too thin to display much fire. According to Lady Burton, it is believed to bring ill-luck to its possessor.

Another famous Indian diamond is the 'Great Mogul' (fig. 4, a), which appears to have been found about 1650, in the Kollur mine, on the Kistna. It was seen by the French jeweller Tavernier at the court of Aurungzebe in 1665 , and is described as a rouna white rose-cut stone of 280 carats. Its subsequent history is unknown, and it is probable that at the sacking of Delhi by Nadir Shah in 1739 it was stolen and broken up. Some authorities have sought to identify the Great Mogul with the Kol-inur, and others with the Orloff.

The 'Orloff' ( $f$ g. $4, e$ ) is an Indian stone which was purchased at Amsterdam in 1776 by Prince Orloff for Catharine II. of Russia. The stone at one time formed the eye of an idol in a temple in the island of Seringham, in Mysore, whence it is said to have been stolen by a French soldier. It weighs 193 carats, and is mounted in the imperial sceptre of the Czar.

The 'Regent' is a famous diamond preserved among the national jewels in Paris. It was found in 1701 , at the Parteal mines, on the Kistna, by a slave, who escaped with it to the coast, where he sold it to an English skipper, by whom he was afterwards treacherously killed. Thomas Pitt, graudfather of the first Earl of Chatham, at that time governor of Fort St George, purchased the stone, and had it re-cut in London, whence it is often known as the 'Pitt." Its original weight was 410 carats, but it was reduced in cutting to 1368 ; the result, however, was a brilliant of fine water and excellent proportions. Pitt sold it in 1717 , through the finaneier John Law, to the Duke of Orleans, then Regent of France during the minority of Louis XV. The price paid was $£ 135,000$, and its value has since been estimated at $£ 480,000$ (see fig. $4, d$ ).

The large 'Sancy' is an historical diamond, about which many contradictory stories have been told. It appears that the Sancy was an Indian stone, purchased about 1570 by M. de Sancy, French ambassador at Constantinople. It passed temporarily into the possession of Henry III. and Henry IV. of France, and was eventually sold by Sancy to Queen Elizabeth of England. By James II. it was dis. posed of to Louis XIV., about 1695 , for $£ 25,000$. At the beginning of the 19th century it passed to the Demidoff family in Russia, and by them it was sold in 1865 to Sir Jamsetjee Jeejeebhoy. In 1889 it was again in the market, the price asked being $£ 20,000$.

Of coloured diamonds there are a few possessing historical interest. Diamonds occur of all tints, and when the colour is well pronounced, they are prized as fancy stones. A pale green diamond, weighing $48 \frac{1}{2}$ carats, is preserved in the Green Vaults at Dresden. But one of the most superb coloured diamonds at present known is the sapphire blue brilliant termed the 'Hope' diamond, valued at $£ 20,000$ to $£ 30,000$. This gem formerly belonged to Mr H. T. Hope, and weighs $44 \frac{8}{8}$ carats. It is believed to have been cut from the large blue diamond, weighing in the rough 1121 carats, sold by Tavernier to Louis XIV., which disappeared anid the troubles of 1792 . The two most wonderful coloured diamonds known after the Hope are an emerald green diamond of 6 grains, which is valued at $£ 1000$, and a ruby red diamond of 5 grains, valued also at $£ 1000$.

For further information on historical diamonds, see The Great Diamonds of the World, by E. W. Streeter (1882); and on diamonds generally, consult Precious Stones and Gems, by the same author (4th ed. 1884); Le Diamant, by $\mathbf{H}$. Jacobs and N. Chatrian (Paris, 1884); and Le Diamant, by $\mathrm{E}$. Boutan (Paris, 1886).

\section{Diamond Beetle. See WeEviL.}

Diamond Harbour, a port and telegraph station on the Húgli, 38 miles SSW. of Calcutta by rail, 41 by river. Formerly, the Company's ships anchored here; now there is not even a village at the spot, but a customs establishment is maintained, and shipping movements are telegraphed to Calcutta.

Diamond Necklace, THE, a wonderful piece of jewelry, made in Paris about the year 1775, and intended for Madame Dubarry, the favourite of Louis XV. She, however, was excluded from court on the death of Louis (1774), before the neck lace was finished. After being made, this beautiful ornament, adorned with 500 diamonds, was found to be so costly that no one could purchase it. It was valued at $1,800,000$ livres, equal to about $£ 80,000$ of modern money.

The Prince Cardinal de Rohan, a wealthy, vain, 
and profligate man, persunded by an adventuren named De Lamotte, who waited about court, that the queen (Marie Antoinette) regarded him with favour, becume completely infatuated with the Ider. One night in August 1784 the poor dupe had the huppiness of a moment is interview in the groves around Veranilles with the queen in the jerson of a girl who closely resembled her. De Lamotte had stated to the cardinal that the queen was desirous of obtaining this glorious necklace, and that not having sufticient inoney just then, she would sign an agreement to purchase it if the cardinal would become security. The cardinal consented. The agreement was approved of and sirned with the royal sivnature, as also with that of the cardinal, who, on the lat February 1785, carried off the treasure from the maker to Ver. railles, where it had been agreed the queen should send for it. In a few days De Lamotte and her husband, having disappeared from Paris, were busily engaged in selling the eeparate diamonds in the necklace. The whole transaction had been a trick; the messages from the queen, oral and written, were without foundation, the latter, indeed, being forged by a soi-disant valet, who was skilled in imitating handwriting. The plot was discovered by means of the maker of the diamond necklace, who, not receiving any money when the period of the first instalment had arrived, went to court, demanding to know if the necklace had been delivered to the queen. In a few months the cardinal found hinself in the Bastille, where some of those by whom he had been duped had already been lodged. In May 1786 the trial of the prisoners was brought to a close. De Lamotte was branded on each shoulder with the letter V (for voleuse, 'thief '), and was sentenced to perpetual imprisoument. Her husband, who had fled to England, was sentenced in his absence to the galleys for life. The cardinal and the girl who hal personated the queen were dismissel withont punishment. The queen was falsely snpposed by the populace of Paris to have had a part in the plot, and the odium resulting from it was heaped upon her, even at the last, when she sat on the tumbril that bore her through a raging and eursing mob to the guillotine.

See Carlyle's study, in his Esanys : Vizetelly's Story of the Dianond Nccklace (new od, 1880); and Frenoh works by Campardon (1863) and D'est Ange (1889).

Diauper. Seo Thomas (Christians of \$T).

Diana, an ancient Italian divinity, identified by the Romans with the Greek Artemis. She was a goddess of light, and she represented the moon, just as Dianus (Janus) did the sun. It is said that Servins Tullius was the first to introduce her worship at Rome, and apparently she was first worshipped by patricians only. See ARTEMIS.

Diana (1) OF Portiens, a favourite of Henry II. of France, was born in 1490 , the eldest danghter of Jean de Poitiers. Married at thirteen, she beeame a widow at thirty-two, and ere long attached the affections of the nineteen yesrs younger dauphin stimngly to herself. On his accession as Henry II. (1547) Diann enjoyed great influence, did much to reform the court, and brought its influence to bear strongly against the reforming party. She was made Duchess of Valentinois in 1548, retired from court to her castle Chatean d'Anet on the king's death in 1559 , and died in 1566. The splendic Chatean de Chenonceaux (q.v.) was given her by the king, but after her death was taken by Cathrine de' Medici. It still comtains many memorials of its most famous mistress, $-(2)$ Drast of France, Duchess of Angouleme, was borm in 1538, natural daughtor of Henry II. and a Pieslumonteme (accorrling to otluern, of Dimua of Poitiens), wes formally leyitimined, and maniod first to a son of the Duke of Parma, next to the eldeat non of the Constable de Montmonency. Bhe enjoyed great influence at court under Heary IV., superintended the education of the young prince, afterwards Loui XIIL, then retired from coun, and died without insue in 1619 .

Dianthus. Soe Carsatios, Prox.

Diapa'son ( $G$ r.), a term in munic by which the ancient Greeks desigmated the octave. The Prench use the term as equivalent to pitch. Diaperon is also the English name given to the fundamental stops of the Organ (q.v.).

Diaper, a tern mpplied to certain forma of flat or blightly relieved ornament. Any pasterm formed of a flural, leafy, geometric, or other device, repeated over a flat surface, is called diaper or diaper voork; but according to some authorities the device should be free from bounding lines forming squares, as a pattern of this nature should rather be called checker or checker wourk.

In textile fubrie the term appear to have been given at one time to silk fabrics with alnsoet any kind of repeated pattern npon them. It is an older name for figured silk than Damank iq.v.). The Byzantine Greelss called a eilk with moth pattens and ground of one colour diuspron, and the Jatins, following the Greeks, named such a fabrie diasper, which by a slight change became the Eng. lish word diaper. Chaucer refers to "cloth of goid diapred wele" (see Textile Fabrics, by the Rev. D. Rock, D.D.). Any kind of textile fuloric, paper, or leather, with a more or lees enriched geometrical pattern is, in a general way, anid to be diapered. But as regards textiles the term diaper nowadays is almost confined to undved linen with a woven diamond pattern, although cotton initations are mude. Accorling to the aixe of this pattern the stuff is ealled bird's-eye, phensant's-eye, fish-eye, or Rnsaia diaper.

In Architecture, diaper-work, or diapering, is a kind of decoration applied to plane surfaces, and consists of a small repented pattern either of conventional flowers, leaves, or other devices, curred or painted. The flower, or other object, is genesally inclosed by lines, fillets, or slender mould. ings, which constitute in themselves a sort of geometrical diapering. When the pattern is carved, it is generully sunk; and when painted, it consints of a darker shade of the anme colour as the plane surface, by which the effect of whadow is communicated to it.

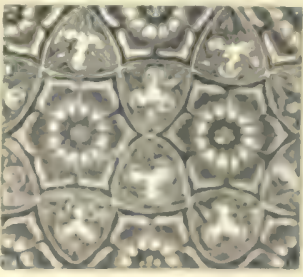

Dieper.
The accompanying illustration, from Blosani? Gothic Architceture, exhibits a very beantiful example of Decornted Englimb diapering. Is is taken fron Canterhury Cachedral. Is Profesevor Willis's book on this building other exanples are given.

\section{Diaphoretles. See StDonirics.}

Diaphragm, or MrDerve (Gr. diaphragma, 'a particion', is the mane applled in ana?oniy to designate the musculo-tendinous partition which in man and the mammalia genernlly reparase the cavity of the thorax from that of the ahdomen. It general form is that of a dome directed towards the chest, the lower part and sides being muscular. while the centrul or higheat portions consinta of an expanded tendon. The mnenlur filres hare an extensive origin from the circuuference of the 
visceral cavity-viz. posteriorly, a vertebral portion arising from the lumbar vertebre by two pointed processes, or crura, of unequal length, and from two fibrous bands, or arched ligaments, on each side of the bodies of the vertebræ: laterally, a costal portion arising from the cartilaginous and adjoining osseous parts of the lower six ribs; anteriorly, a

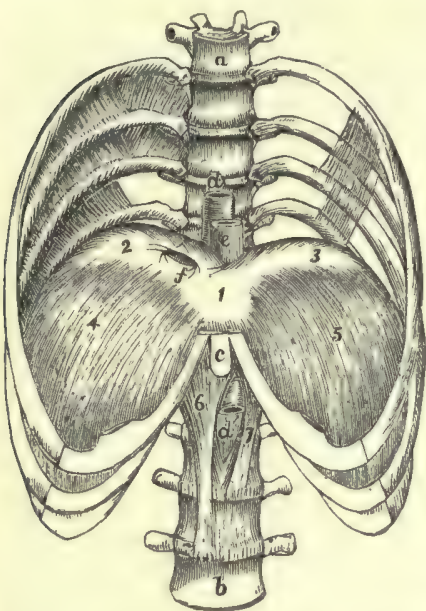

The lower part of the Thorax, opened to show the upper side of the Diaphragm from before:

$a$, sixth dorsal vertebra; $b$, fourth lumbar vertebra; $c$, ensiform cartilage; $d d^{\prime}$ aorta; $e$, vesoplagus; $f$, opening for inferior vena cava. 1, 2, 3, treloil tendon $; 4,5$, central portions of diaphragm 6 , right, and 7 , left crus of disphragm. sternal portion arising from the ensiform cartil. age of the sternum, or breast. bone. From these various points the muscular fibres converge to the cen. tral, trefoil, or cordiform ten. don, which forms the highest part of the diaphragm, and as its name indicates, consists of three lobes. The diaphragm presents three large perforations or fora$\min \alpha$; one. quadrilateral. placed in the highest part of the tendinous centre for the upward passage of the inferior vena cava ; one, oval in form, surrounded by

muscular fibres derived from the crura, for the passage of the cesophagus and pneumogastric nerves; the third, situated in front of the vertebre and bounded by tendinous fibres of the crura, transmits the aorta, thoracic duct, and large azygos vein

The upper surface of the diaphragm is in relation to the pleural membranes which inclose the lungs, and the pericardium which incloses the heart. The latter nembrane is intimately connected with the central tendon, which thus forms a fixed floor for the support of the heart. The lower surface, deeply concave in form, is lined by peritoneum, and has in apposition with it the stomach and spleen on the left side, the convex upper surface of the liver on the right side, and the kidneys, supra-renal capsules, and duodenum posteriorly.

When the diaphragm contracts, the arched portion becomes flatter, and the cavity of the chest being thereby enlarged, air rushes in to fill the vacuum, and expands the lungs during the act of inspiration. It is thus an inspiratory muscle, and in ordinary quiet breathing the central tendon on which the heart rests takes no share in this movement. Every contraction of the diaphragm must diminish the abdominal space and compress the abdominal viscera, and hence it aids in the expulsion of the freces and urine.

Spasmodic action of the diaphragm produces hrccough and sobbing. Stoppage of the action of the diaphragm, whether from great external pressure or from paralyais, is very speedily fatal.

DIAPHRAGM, a partition with a hole in it, employed not only in landscape and portrait lenses for photography, but also in telescopes, micro. Bcopes, and other optical instruments, for the purpose of cutting off the superfluous rays of light, and producing greater intensity or sharpness of the image, as well as to correct aberration.

Diarbekir, a town of Asiatic Turkey, capital of a province of the same name, is situated on the right bank of the Tigris, 390 miles $\mathrm{NW}$. of Bagdad. The town is surrounded by high strong walls, and commanded by a citadel built on a high basalt rock, against which the flat-roofed houses rise above each other in terraces. The population has dwindled to 40,000 , mostly Kurds and Armenians. The city is the residence of a pasha, and the seat of a Greek bishop, as also usually of the Jacobite patriarch of Antioch. It has 27 mosques and 12 churches, and numerous bazaars, fountains, baths, and caravanserais, although the last are now falling into decay. Indeed, only in the centre of the town are any of the buildings handsome; elsewhere ruins meet one at every step. Stagnant pools, weeds, and filth combine to produce fevers. Diarbekir had formerly extensive manufactures of silk and cotton goods, and an active commerce with Aleppo and Bagdad; and it still has considerable trade in raw products. The roads to the coast are equally bad and insecure, and the traffic with Bagdad is mostly by raft. The principal exports are wool, mohair, sheep and goats, copper ore, butter, gall-nuts, goat and kid skins, and furs; the imports include cotton and woollen goods, indigo, cotfee, sugar, buffalo-hides, petroleum, and soap. Diarbekir occupies the site of the ancient $A$ mida, which was fortified by the Emperor Constantine. It was eaptured by the Persians in 359, and retaken by Justinian; but in 502 the Persians once more became masters, and put 80,000 of the inhabitants to the sword. In 640 it fell into the hands of the Arabs of the Bekr tribe, whose name became identified with the district; but the Turkish official tible is still Kara Amid ('Black Amid,' from the colour of its basaltic walls). After many vicissitudes, the town passed into the hands of Sultan Selim in 1515.

Diarrhoe'a (Gr. dia, 'through,' and rheo, 'I flow') is the name applied to an increase in the discharges from the bowels, which are usually unduly liquid, sometimes overcharged with bile, and sometimes the contrary, and is, properly speaking, a symptom rather than a disease. Thus it often occurs in the course of diseases of the liver and spleen, of some forms of heart-disease, of many fevers and other acute diseases, and is a common complication of the advanced stage of Consumption (q.v.). Frequently, however, it is the most prominent, perliaps the only symptom of ill-health and it may then take rank as a disease, or rather as the generic name of a group of diseases, In this aspect the subject will be discussed here.

Diarrhwa is either simple, bilious, or choleraic ; the Iast form has already been discussed (see CHOLERA). The ancients applied the name lientery to a diarrhœe in which the dejections consisted of matters not digested, or very partially so; this form is, however, very unusual, at all events in Britain. Dysentery (q.v.) is also a form of diarrhoeal disease; as is the form of Fever (q.v.) called gastric, typhoid, or enteric fever. Simple and bilious diarrhoea probably often differ only in degree; they are both distinguished from the advanced stages of cholera and dysentery by the presence of abundance of biliary colouring matter in the stools, and by the absence of the distinctive features of the other two diseases as described elsewhere. Diarrhoea is almost always accompanierl at first by pain in the aldomen, sometimes severe or even agonising in character. According to its cautse and treatment, it may pass off in a few hours, or may persist for $n$ few weeks or months; or it may even prove fatal. 
Diarhowa has many varietios and many caumes: but the whole tribe of more or lese epidentic diarrhoeal diseares present certain relations in common, which have been studied of late years to a considerable extent from the preventive or sanitary point of view. Thus it is olwerved of all of these diseases, without exception, that they are more npt to prevail duing summer and nutumn than during the earlier sonsons of the year ; and it is also well established that their prevalence is to a great extent dependent on the intensity of the solar heat, so that a temperature alnove $60 \mathrm{~F}$. seems to be olmost essential, under ordinary circumstances, to their epidemic diffusion. Moreover, it has been shown that the decomposition of organic matter in the neighbourhood of human dwellinge, and the introduction of the products of decomposition into the food, drink, or air used by the healthy, has been a direct exciting eause of diarrhoea in a great number of instances where the disease has lieen locally epidemic; from which it is inferred that the real source of diarrhoal diseases is usually to be found in a morbid poison closely associated with the process of putrefaction, although not, perhaps, necessarily generated during that process. It lias been noticed that cold and wet sensons are the least fevourable to the production of diarrhoen, which is explained on the theory ahove alluded to by the rapid removal in such seasons of all organic debris; and there is little doubt that this explanation is correct, as the converse is equally true, the com. bination of heat with long-continued drought being almost sure to waken into life the epidemic seeds of diarrhcea. Again it is noticed that where drainage is imperfect and drinking water impure, diarrhoeal diseases are specially apt to oceur (see CHOLERA) the class of the population most apt to be affected being those who occupy low levels, or who are otherwise exposed to the influence of this aqueous or gaseous poison. Infants are especially apt to suffer from diarrhoe, and a large number of the infantile deaths in many English towns are caused either directly by this disease, or by the abuse of stimulants and nareotics for its cure.

Besides these epidemic diarrhœens, isolated cases of simpler and more obvious origin are very frequent. In some persons diarrhoea is the nsual result of catching cold-i.e. they suffer from catarrh of the digestive, instead of, as is most usual, the respiratory organs. But far more frequently diarrhœe results from unwholesome or indigestible food or drink, or from excessive indulgence even in what would otherwise not be hurtful. In all such eases the diarrhoea is to be regarded as beneficial: in fact it is the natural effort of the intestines to rid themselves of their objectionable contents, and should be encouraged rather than arrested. Diarrhoea occurring as an incident in prolonged constipation is to be explained in the same way, as due to irritation of the intestines by their hardened contents.

Acute diarrhoes should almost always be treated first by an aperient, as the unaided action of the intestines is often insufficient to expel irritating material. A full teaspoonful of Gregory's powder, or a tablespoonful of castor-oil with ten or fifteen drops of laudanum are especially useful. The food trken should be small in amount, and $M$ ensily digestible as possible. Milk, arrowroot, \&e, beet tea, toast, plain biscuits, are among the most suitable articles of diet. Pain may be alleviated by poul. tices or fomentations sprinkled with laudanum. A small dose of brandy often checks both the pain and the dirrroes. Should the disense not yield to these messures, opium, carminatives, and astringents should be administered. In some cases, especially of febrile diarrhoes, an emetic of ipecacuanha at the very beginning will sometimea remove the divenae with remerkablo rapillity ; and in most forms of diarrhoun it may be alleged chan this medicine (is dones of from one to five or oven ten grains ) is well

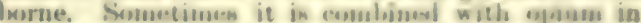
the form of Dover's poweler. In elownic diantivan (not the consequence of serions onganic dineane) careful regulation of the diet is of prime import. ance, and is generally accompranied by the adnition. tration of astringenta. But such caves are often very intractable, and no rules can be laid down that would apply to all. In a very large clase of eques, exprecially of infantile diarrlowa, de-jecholing upon a too acid state of the secretions, the leading remedy is chalk, either in powder or in the very cerviceable form of the mistura cretu (mixture of chalk) of the pharmacopoeiss, from one to three. desaert-spoonfuls of which may be given after every disturbance of the bowels. Lime-wnter, mixed with milk in the proportion of one to four or five, is eavily given to very young children, and serves nearly the same purpose.

The astringents nseful in diarrhos are very various. Those of vegetable origin are usually fins emplosed, alone or in combination. The most important are galls, oak-bark, kino, catechu, log. wood. The mineral astringents are chiefly malts of the heavier metals, iron, bismath, copper, lead, \&e. but also chalk and lime, and alum. Opium, one of the most powerful remedies, owes its usefulnems to other than astringent propertiea, and is very frequently given in combination with atringents --e.g. in chalk and gyium gowiler, eompun hi him powder, lead and opium pills. In many states of the system in which diarncea occurs, however, it is dangerous. It must never be given to young children, or in large doses to any one, withont medical advice. In some forms of diarrhar. especially in children, antiseptica are very useful e.g. carbolic acid, erensote; and it is probably to its antiseptic properties that corrosive sublimate (bichloride of mercury) owes its value when administered in minute doses.

Diary (Lat. diarium, 'a daily allowance for soldiers, ' 'diary, from dies, 'a day') means simply a dnily record of events or obeervatione made by an individual. In it the man of letters inscribes the daily results of his reading or his meditations: to the mercantile man it serves the purpose of an orler or memorandum book; while the pliysician finds it indispensable as a register of engngenents. Diaries in many forms and sizes are isoued every year, containing alwo so nuch miscellaneons information that in one book we have at once a diary and an almanac. The Ephemeris of the ancients was originally a military record or journal, a day-bonk or aceount-kouk, also a collection of tables show. ing the position of the heavenly bodies but jetrered into litwrature to mean a collection of reconds of what has happened on the same dny in varions years, or a mere genernl name for any form of periodical books or magazines.

Diaries have often furnished the hiatorian with invaluable material, supplying the almeenese of pabluce reconds, and furnishing minute and incinate details of manners and of motives that do far more to help us to understand the past than more formul recorth Such documents as Robert Baillie's Jourmala the Diarice of Pepya and Evelyn, and the Journals of Greville are among the most valuable sources of real histury. Bacon ways in ses voymgess. where there is nothing to be seen but sky and nea, men make diaries; but in land-travel, wherein so much is to be observed, they omit is, but unhappily this no longer holds of modern travellen.

Dlastase is a peculiar ferment developed during the fermination of all seods. An impure silution of diastase may be prooured by adding one part of 
hot water to two parts of ground malt (see BEER), or freshly germinated balley, and, after standing for a short time, straining through a cloth. The proportion of diastase in malt is not more than 1 part in 500 parts, and yet it performs important functions. Thus diastase has a powerful action upon stareh, and at a temperature of $150^{\circ} \mathrm{F}$. one part is considered powerful enough to change 2000 parts of starch into dextrine, and then into maltose, a variety of sugar. When obtained separately, diastase is a white tasteless substance, soluble in water and in weak alcohol, and having no action on gum or sugar. A similar principle is found in the saliva of animals, the action of which on starch is identical with that of diastase. When bread is masticated, the saliva is rapidly secreted, and the animal diastase converts the starch into sugar. See Germination, Cookery, Digestion.

\section{Diathermancy. See Heat.}

Dia'thesis (Gr. dia, 'through,' and tithèmi, 'I place or arrange'), a Greek word signifying a disposition or arrangement, and applied by the old medical authors to the predisposition or constitution of the body which renders it prone to certain diseased states. By recent writers the term is applied to the general constitutional tendency of an individual, to indicate not merely the class of diseases to which he is most likely to be liable, but also in many cases the manner in which his normal functions, both bodily and mental, are carried on ; and is thus opposed to Cachexia (q.v.), an unhealthy condition associated with actual disease. Though the study of diathesis apart from existing disease is very apt to lead to overrefinement and the pursuit of intangible abstractions, yet a proper appreciation of a person's constitutional proclivities or diathesis often enables a medical man to advise him how to regulate his life and habits to the best advantage-what to do and what to avoid-and may furnish important guidance as to his treatment in disease. The diatheses most usually recognised are the sanguine, the nervous or neurotic, the bilious, the lymphatic, the strumous, and the hromorrhagic. Numerous mixed varieties are also described by some writers.

Diatoms (Diatomaceae) are a group of algre which, on account of their microscopic interest and geological importance, have acquired an unusual share of scientific and even popular attention. They were discovered by Leeuwenhoek in 1702, and their movements by 0 . F. Muiller eighty years later; their thorough investigation, however, has only become possible with the development of the compound microscope.

The reader who wishes to view the diatoms other than as mere microscopic marvels must begin with a clear grasp of the structure and mode of life of the filamentous conjugate algæ, such as Spirogyra, and next observe that of those higher members of the group which we know as Desmids (see ALGA, DEsMIDS). These simpler forms understood, let him next imagine $a$ desmid (in which the characteristic division of the unicellular body into halves is distinetly but not too deeply marked) to become somewhat unequally developed; next let these be pressed together so that the larger half slides a little way over the smaller, much like the lid of a canister or the halves of a pill-box. I the two halves or shells of the cell-wall now become strongly silicified, the cellulose only remaining unaltered and flexible round the narrow 'girdle band' connecting them; next let variation arise in the general shape so that the original box-shape becomes elliptical or wavy, squared, or more often pointed, or even unsymmetrically curved; finally, let the siliceons shells become covered with the most delicate striations and markings, and these characteristically varied, not only from group to group, but from species to species. A gelatinous envelope may also be developed, or this may be secreted at one pole only, forming a stalk.

The living protoplasm shows less variation than might perhaps have been expected; it lines the siliceous shell, leaving a large central sap-cavity, often traversed by protoplasmic filaments. Very commonly, however, this is divided by a large central mass of protoplasm usually containing the nucleus, while similar accumulations may be formed

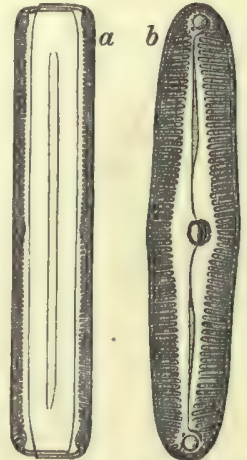

Fig. 1.

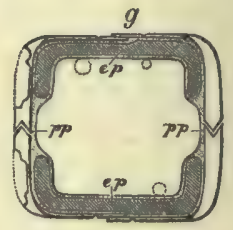

Fig. 2.
Pinnularia viridis: 1. a, Optical section through the unequal valves; $b$, side of one valve, showing markings and longitudinal slit.

2. Diagrammatic transverse section; $m p$, protoplasm contain ing endochrome-plates, ep; $g$, girdle band. Valves left unshaded, the left slowing depressions due to markings.

at the ends. The colouring matter may occur in minute granules, or be collected into one or two large 'endochrome-plates;' it consists of chlorophyll, masked by a closely allied yellow pigment (phycoxanthin). Starch is absent; oil is frequently present, either in minute vacuoles or collected into a single large drop.

The mechanism of the peculiar creeping or rather gliding movements has long baffled investigators; these, however, are not due to diffusion currents as some have maintained, nor to the agency of any ordinary cilia or pseudopodia, but seem to be effected by means of a locomotor band of protoplasm which is said to be protruded through a longitudinal slit in the surface of the siliceous shells (see fig. 1).

The mode of multiplication is primarily by division, and is effected on the same principle as in Desmids (q.v.). Thus the two halves of the diatom are not only of unequal ages, but since the new half is always formed within the previous one, a continuous diminution of size takes place. At a certain limit, however, division stops, and rejuvenescence may occur, with formation of a resting spore; more frequently, however, this is preceded by conjugation as in desmids, though sometimes complete union may not take place. The resultant 'auxospore' has a continuous cellu. lose coat, but develops within it, by rejuvenescence, a two-shelled diatom of the largest size, which issues to divide in turn.

Of the 2000 species, 400 are fresh-water, the remainder marine. Their distribution is ubiquitous, and the genera and even species seem little dependent upon temperature or climate, many being apparently cosmopolite, and some having been described as occurring in glacier water, yet also in hot springs. Their minute size and resistance to drying favour their distribution in the form of dust; hence the calcination of the dust 
which falls uyon ships in milloeenn las inen shown to yield an appreciable dintom residue. Every soil which is overflowed teems with them. notably, therefore, that of Figyot; hurlusur mud often contains one-fourth to one-half its volume of diatom shells, while in many parts of the world there veeur strata of purely dintomacesus origin, which are freyuently of vast area and considerable thickness. These are in all states of preservation and haxdness, from the loose Berymelil of Silseria and Lapland (which still contrins no much un. decomposed organic matter as to be mixed with flour in times of scarcity) to building stone, and even the extremely hand polishing slates of Tripoli. Diatomaceous deposits were found in Skye in 1886. The diatomite may be used for making dynamite, siliceous glazed paints, sterm-pipe ersings, de. Diatoms live in enormons abundance at the surface of the sea in cold, temperate, and arctic latitudes, and the mud of the sea-bottom is hence very largely composed of the shells of dead diatom, which are falling from the surface in a gentle but uncensing rain (see OozE). Kieselguhr, or infusorial earth, is useful for making Dynamite (q.v.), patent lamp-wicks, for lining safes or ice-stores, mntiseptic preparations, filtration, \&e. See the Challenger report on the Diatomacea (1885).

Diatonic (from the Greek) merns 'by tones,' or 'from tone to tone.' The diatonic species of the ancient Greeks - as distinguished from their chro. matic and enharmonic species-formed the foundation of their whole system of music, and was arranged in tetrachords (embryo scales) composed of one semitone and two whole tones. In modern music, the term is applied to (1) the natural or normal scale, major or minor, which proceeds mainly by whole tones; (2) the different species of intervals (usually reckoned as fourteen in number) oecurring between the various notes of that scale; and (3) music written wholly or for the most part in that scale.

Diaz, or Dias, Bartolomev, a Portuguese navigator of noble birth who Hourished during the latter half of the 15th century. His residence at the court of King John II. brought him into contact with many seientific men, among others the German cosmographer Behaim (q.v.). Diaz took a great interest in geographical discovery, and in August 1486 the king gave him the command of two vessels with a view to following up the discoveries alrealy male by Portuguese sil. venturers on the west conet of Africa. Diaz soon reached the limit which had been attaned in South Atlantic navigation, and first touched land in $26^{\circ} \mathrm{S}$. lat. Driven by a violent storm, he sailed round the southern extremity of Africa (see CAPE OF GOOD HOPE) without imnediately realising the fact, and discovered Algoa Bay. The discontent of his crew compelled him sorrowfully to return; and arriving in Lishon, Jecember $145 \%$, he was at first greeted with enthusiasm, but soon saw Vasco da Gama preferred before him, and was compelleal to act under the latter in the grand expodition of 1497. Vasco da Gama even sent him back to Portugal after they had reached the Cape Verd Isles. Three years after, he joined the expedition of Cabral, the discoverer of Braxil, but was lost in a storm, 29th May 1500.

Diaz, Porfrro, President of Mexico, Seo Mricico.

Diaz de la Peña, Narcisso Viroilo, painter, was born at Borleanx in 1807, of Spanish parentage, and, left an orphan at the age of ten, was educated by a Protestant clergyman at Bellevue, where a snake-bite occasioned tie amputation of a leg. At the age of fifteen he was apprenticed to a porcelain-painter, but he was ambitious of working in oils, and stwont IR3! began to exhituic in the Salon. Alandaning hiv unsucceasul efforts in the direction of histany and genre, he in time won fame by his lanisongen, which he peopled with nympho, loven, and atyr. Thene figures are badly dmwn, but as a colourít Diaz ranks bighly among the painters of the Romantic school in France, and to colvur he was content frankly to ancrifice form. He was aleo an exquisite painter of flower-pieces He died at Mentone, 18th November $18 \% 6$.

Diaz del Castillo, Bensal, the hiscorina of the conqueat of Mexico, was born abont the end of the 16th century, and was one of the hasudfal of heroes who accompanied Cortes to Mexien in 1519. He fought through the whole strugule, and afterwaris acomupanied the lueroie soung sandorul on his expedition northwards, and Curtea himnelf in his expedition to Honduras to punish the defection of his trusted lieutenant, Christoval de Olid. He died in Mexico about 1560 . His Historia verda. dera de la conquista de la $N$ ueva Eopaila $(3$ vola. Madrid, 1632) is invaluable to the historian as a sincere narration by an eye-witneas and sharer in the events narrated. With all the ignorance and supenstition of its age, it reveals great powers of observation and of vivid and vigorous deseription : while the mre romantic interest of the story itmelf. the heroism of Cortes sud his evompanionum, and their wonderful deeds and often tragis deaths, make the book a real epic.

Dibdin, Charlrs, musician and poet, wha born at Southampton in 1745. He early attracted notice by his singing, and, still a lov, mante his literary début in London, by writing and compose ing an operia called The Shepherd's Ari,fier, promlieced at Covent Garden Thentre in 1762. He subseqneatly lived an unsettled life as an actor and comyroser of stage-music. In 1788 he commenced giving a series of uusical entertninments in the city, which acquired a great celebrity; the finst of these was entitled The Whim of the Moment. After several vicisaitudes he withdrew from publie life in 1805 , the government in 1803 having granted him, in con. sideration of his literary nerits, a pension of $\mathbf{2 0 0 0}$. The pension was afterwards withdrawn by the Grenville government in 1807, which occasioned Diludin to return to public life with unfortubate financial results. He died 25th July 1814, Dilndin was an admirable writer of sea-songs, of which be composed nearly a hundred. Neptune, and not Apollo, seems to have inspired him. Theugh his work nowhere reaches the higher regions of poetry, and even his meamanship has boen impugned, yet it is handly too much to say that he is our fint writes of sea-songs, one or two of which have even been taken to the heart by the mariners of England. His verses smack of the briny deep, and reflect with astonishing felicity the ensy, childlike virtues and the fenrleas courage of the conventional Britiah tar. It is known that they helped is man the navy during the great atruggle with France, and s he himself ays in his sutobiography, "they have been quoted in mutinies to the rextnra. tion of order and discipline. Among Diblin's happient pieces are Poor Jack and Tom Bouding. or Poor tom as it was originally called. See his Proferrional Life (4 vols 1803 ), and for his consw the inacenmte edition by G. H. Davideon, with Life by George Hogarth $(1842)$ Dibdin wrote nearly seventy dramatic pleces - T wo of his sons. CHARLEs DIBDIx (1768-1833) and Thomas JoHs DIBDIY $(1771-1841)$ wrote songe and dramas tee The Dibdins, by $\mathrm{R}$ R. Dibdin (1848).

Dibdin, Tuosas Frocrarl, the bibliographer, was nephew of Charles Dihdin, the writer of seaangs, and was born at Calcutta in 1776 . He los 
both parentg when hardly four years of age, his father's death at sea having given Charles Dibdin the subject for his famous song, Tom Bowling. He was brought up by a maternal uncle, studied at St John's College, Oxford, tried law, but took orders in 1804. He proceeded D.D. in 1825 . Of his preferments the chief were the vicarage of Exning near Newmarket, and the rectory of St Mary's, Bryanston Square, London. He died 18th November 1847. His first contribution to bibliography was an Introduction to the Greek and Roman Classics (1802), which was followed by an unfinished new edition of Ames and Herbert's Typographical Antiquities (4 vols. 1810-19); Bibliomania (1809); The Bibliographical Decameron (1817); Bibliotheca Spenceriana (1814-15); Bibliographical, Antiquarian, and Picturesque Tour in France and Germany (1821); The Library Companion (1824); Bibliophobia (1832); Reminiscences of a Literary Life (1836); and Bibliographical, Antiquarian, and Picturesque Tour in the Northern Counties of England and Scotland (1838). All Dibdin's books aje valuable and interesting, but whimsical and flippant in style, and unhappily abounding in errors. Dr Dibdin was one of the founders of the 'Roxburghe Club' (1812).

Dibranchiata. See CEPHALOPODA.

Dice (plural of die), small eubes of ivory marked on their sides with black dots, from one to six. The points on the opposite sides of the dice should always sum seven-1.e. ace should be opposite to six (pronounced size); deuce to cinque (pronounced sanke); and trey to quatre (pronounced kater). Two dice are called a pair.

By 13 Geo. II. chap. 19, 'all games invented or to be invented with one or more die or dice' were prohibited, except backgammon and games played on a backgammon board. Hence hazard is illegal, and also raffles with dice, the latter being also forbidden as lotteries even if dice are not used. By 9 Geo. IV. chap. 18 (1828), a duty of twenty shillings was imposed on every pair of dice; in 1862 the duty was abolished.

The invention of dice is attributed to Palamedes (circa 1244 B.C.). But the use of cubes with numbered sides for gambling purposes is probably much earlier.

Dicentra, a genus of Fumariacer, of which one species, the 'Chinese lantern plant,' $D$. spectabilis (described by Linnæus in 1753, but only introduced from Asiatic into British flower-gardens in

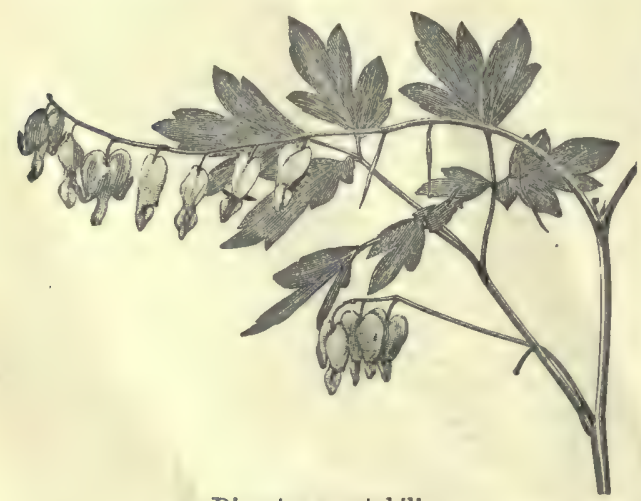

Dicentra spectabilis.

1846), has become a universal favourite on account of its long racemes of drooping, delicate, rosy-pink flowers. In America it is commonly known as 'Bleeding Heart.' It is a herbaceous perennial of easy propagation. There are several other North American species, one of which, $D$. formosa, is a favourite and very showy garden-plant. Owing, in the first instance, to a misprint, Dicentra has been as frequently called Dielytra, the original mistake having become consecrated by habit.

Dichlamy'deous, a term in botany applied $b_{y}$ De Candolle to distinguish those dieotyledonous flowers possessed of both calyx and corolla from his Monochlamydea, in which not more than one floral envelope is present.

Dichogamy. See (under Flower) FERTILISATION OF THE FLOWER, Vol. IV. p. 692.

Dicho'tomous (Gr., 'divided into two equal parts'), a term formerly vaguely used in botanical description to designate any appearance of branching by forking. Thus the stems of some phanerogams -e.g. mistletoe, doum palm, and many inflorescences -e.g. Caryophyllex, Begonias-appear forked, while an ordinary fern-frond has no such appearance. The progress of morphological research has, however, shown that true dichotomy-i.e. complete division of the growing point into two lateral apices, is really as characteristic of the development of the fern-frond as of such obviously dichotomous vegetation as that of Selaginella; while conversely the appearance of forking in plsanerogams comes about simply by the suppression of the growing point, and the development of two new axes froin opposite lateral buds. Outside the cryptogams, indeed, no case of true dichotomy has been described, with the doubtful exception of the roots of cycads. See Cryptogamia, Ferns, InfloresCence, Cycads, \&c.

Di'chroism (Gr. dis, 'twice,' chroma, 'a colour') is a term chiefly used in Crystallography to designate the property which many doublyrefracting crystals possess of exhibiting different colours when viewed in different directions. It, or the allied term Dichromatism, has also been applied to those fluids which appear of different colours when viewed by reflected and refracted light; when seen in thick or thin layers, \&c. For example, venous blood, or any blood impregnated with carbonic acid, hydrogen, or nitrogen, appears, when seen in moderately thin layers, to be of a purple colour; while in extremely thin layers it appears green.-For Dichroite, see CoRDIERITE.

Dick, JAMEs, a West Indian and London merchant, who was born at Forres, Morayshire, in November 1743, died 24th May 1828, and left over $£ 113,000$ to promote higher learning among the parish schoolmasters of Elgin, Banff, and Aberdeen shires. Examinations were instituted, and those schoolmasters who showed a satisfactory knowledge were awarded from the bequest a sum of money and an annual stipend as long as they remained efficient. The annual value of the bequest exceeds $£ 4000$, allowing a payment of about $£ 30$ to each teacher participating.

Dick, SIR ROBERT, major-general, was born at Tulliemet, in Perthshire, about 1785, fought in Sicily and Egypt, held a command at Busaco, TorresVedras, Ciudad Rodrigo, Salamanea, and Burgos, at Quatre Bras and Waterloo, and fell heading the assault at Sobraon, 10th February 1846.

Dick, ROBERT, a self-taught Scotch geologist and botanist (1811-66), was a native of Tullibody in Clackmannanshire, and from 1830 a baker in Thurso. His life was written by Dr Smiles (1878)

Dick, Tномаs, a popular religious and scientific writer, was born 24th November 1774, near Dundee. At a very early age he became devoted to the study of astronomy, and at twenty went to the university of Edinburgh with a view to the ministry in the Secession Church. Licensed in 1801, he preached 
some time; next kept school for ten years at Methven, and for ten years more at Perth. Mean. time he laboured laudably to promote popular edueation by 'Literary and Philonophical Sucleties' corresponding clusely to the Mechanics' Institutes of later days. His lirst bouk was The Christian Philosopher (1823), which quickly becmue popular. It success led Dick to devote himself to astronomy and literary work in a cottage near Broughty-Ferry, where he set up an observatory. His muny lмmks bromght him great popularity both in England and America, but very little pecuniary return. In 1847 he received a crown pension of $\mathfrak{£} 50$, supplemented by a loeal sulscription. He died at Broughty Ferry, 29th July 18.7. His llegree of ILI. I). wiss given him by Union College, New York, Other works were Celestial Scenery (1837), The Sidereal Heaven (1840), and The Practical Astronomer (1845).

Dickens, Charles, was born at Landport, now a great town, but then a little suburb of Portsmouth or Portsea, lying half a mile outside of the town walls. The date of his birth was Friday, February 7, 1812. His father was John Dickens, a clerk in the navy pay-oflice, and at that time attached to Portsmouth dockyard. The familiarity which the novelist shows with seaports and sailors is not, however, due to his birthplace, because his father, in the year 1814, was recalled to London, and in 1816 went to Chatham. They still show the room in the dockyard whore the elder Dickens worked, and where his son often came to visit him. The family lived in Ordnance Place, Chatham, and the boy was sent to a sehool kept in Gibraltar Place, New Road, by one William Giles. As a child he is said to have been a great reader, and very early began to attempt original writing. In 1821, Charles being then nine years of age, the family fell into tronble; reforms in the Admiralty deprived the father of his post and the greater part of his income. They had to leave Chatham and removed to London, where a mean house in a shabby street of Caunden Town received them. But not for long. The unfortunate father was presently arrested for debt and consigned to the Marshalsea, and Charles, then only ten years of age, and small for his age, was placed in a blacking-factory at Hungerford Market, where all he could do was to put the labels on the blacking-bottles, with half a dozen rough and rude boys. The degradation and misery of this occupation sunk deep into the boy's soul. He could never bear to speak of this time; it was never mentioned in his presence. Not only were his days passed in this wretehed work, but the ehild was left entirely to himself at night, when he made his way home from Hungerford Market to Camden Town, a distance of four miles, to his lonely bedroom. On Sundays he visited his father in the prison. Of counse such a neglected way of living could not continue. They presently found a lodging for him in Lant Street, close to the Marshalsea, where at least he was near his parents, and his father shortly afterwards recovering his liberty, they all went back to Caunden Town, and the boy was sent to school again. It was to a private school in the Hampetead Road, where he remained for three or four years of quiet work. It must have been then, one suspects, rather than at Chatham, that he becme so great a devourer of books. But he was never a scholar in any sense, and the books that he read were novels and plays. That the family fortunes were still low is proved by the fact that when he was taken from sohool no better place could be found for him than a stool at the desk of a solicitor. Meantime his father had obtained a post as reporter for the Morning Heruld, and Charles, feeling small love for the bopelese drudgery of a lawyer's oflice, resolved also to attempt the profewion of journalint. Ho tanght himelf whorthand with the resolution - oven the ragewhich he always threw intu every thing he under. took; and he frequented the Hritialn Muwenm daily in orier to supplement some of the shortoomings of his realing. In his seventeenth year he becrase a reporter at Doctons Commons. At thin periond all lis aubitions were for the muge. Ho would be an actor. All his life, indeed, he loved actiag and the thentre sbove all things. As an actor one feels certain that he would linve suceceded. He would have made an excellent conedian. Fortunately, bo was saved for better work.

It was not until he was two-sud-twenty that be succeeded in getting pernmaent employment on the staff of a Conden paper as a reporter. In thi capacity he was sent about the country to do work which is now mainly supplied by local reporters. It must be remembered that there were a yet no railways. He had to travel by stagescouch, by joost, by any means that offered. 'Y have heen upset," be said years afterwards, speaking of this time, "in almost every description of vehicle used in this country.

About this time he began the real work of his life. In Decenber 1833 the Mouthly Mugusine published his first original paper, called 'A Dinner at Popular Walk.' Other papers foilowexl, hut juosduced nothing for the contributor except the gratitication of seeing them in print, because the magazine could not afford to pay for anything. However, they did the writer the bent service possible, in enabling him to prove his power, and he presently made an arrangement with the editor of the Evening Chronicle to contribute papen and sketches regularly, continuing to aet as reporter for the Morning Chronicle, and getting his salary increased from five guiness to seven guineas a week. To be making an income of nearly four liundred pounds a year at the age of two or three and twenty, would be considered fortunate in any line of life. Sixty years ago sneh an income represented a much more solid success than would now be the case. The sketehes were collected and published in the beginning of the year 1836 , the author receiving a hundred and tifty pounds for the copyright. He afterwards bought it back for eleven times that amount. In the last week of Mnrch in the same rear appeared the fint number of the P'iclivick l'upers? three days aitorwands Dicheos matrried the daughter of his friend (ieworge Hogarth, ealitor of the Ereming Chronecle; und his early struggles were finished.

No article, however short, treating of Charlea Dickens, can avoid entering into the details of his early history with a fullues which would be out of all proportion to what follows, but for the remark. able fact that the events of his chillihood and his youth impressed his inagination and influenced the whole of his literary career so profoundly, that to the very end of his life there is not a single work in which some of the charncters, mome of the places, are not derived from his early recollections. Many other writers there are who have paned their childish days among the petstes gems, but none who have so remembered their ways, their speceh, asol their modes of thought. The Jianshalses prison of Little Dorrit is the place where for two years he went in and out. The Queen's Bench and it: Rules were close to the Marshalses; Bob sewryer; Indyings in Lant Street were his ows: Davis Coppertield, the friendles lad in the dings warehouse, was himself: the eathedral of Edwin Drood was that in whose shadow he had lived: Mrs Pipchin is his ald landlady of Camden Town : the most delightful features in Mr Micawber are borrowed from his own facher: the experiences of Doctors' Commons, the eolicitori elerks, the 
life in chambers, are all his own; while of individual characters the list of those which are known to be portraits more or less true to nature might be indefinitely extended. And yet, while he was always drawing on these early recollections, while they constantly furnished him with scenes and characters, he could not bear to speak of them, and no one except his friend and biographer, Forster, ever knew that he was, himself, with all the shabby, mean surroundings in early life, exactly such as David Copperfield.

The rest of Dickens's life has the interest which belongs to success after success. It was a long triumphal march. He had no failures; he suffered no defeats. There were times when his hand was not at its best, but never a time when his hand lost its power. This indeed seems the crowning happiness of a successful and singularly happy life, that when he was cut off-he died June 6,1870 -after fifty-eight years of continuous work, his brain was still as vigorous, his eye as keen, his hand as sure as in the first fresh running of his youth. It was indeed more than literary success which he achieved; he conquered the whole English-speaking world. This world, which now numbers nigh upon a hundred millions, loves him; all who can read his books love him, and shall continue to love him. This love cheered him in his life, and will keep his memory green. Of the solid wealth which he acquired, the honour he enjoyed, the friends who gathered round him, and the brave and resolute front which he always showed, there is no space here to speak.

The following is the list of Dickens's works in their order of appearance, omitting certain farces and pamphlets which belong to a more extended notice: Sketches by Boz (1836), The Posthumous Papers of the Pickwick Club (1837), Oliver Twist (1838), Nicholas Nickleby (1839), The Old Curiosity Shop (1840-41), Barnaby Rudge (1841), American Notes (1842), Martin Chuzzlewit (1843), The Christmas Tales-viz. The Christmas Carol, The Chimes, The Cricket on the Hearth, The Battle of Life, The Haunted Man, and The Ghost's Bargain (1843, 1846, and 1848); Pictures from Italy (1845), Dombey and Son (1846-48), David Copperfield (1849-50), Bleak House (1852-53), The Child's History of England (1854), Hard Times (1854), Little Dorrit (1855-57), A Tale of Two Cities (1859), The Uncommercial Traveller (1861), the Christmas numbers in Household Words and All the Year Round, Great Expectations (1860-61), Our Mutual Friend (1864-65), The Mystery of Edwin Drood (unfinished). This long roll by no means represents the whole work of this most active of mankind. Public readings both in this country and in America, private theatricals, speeches, letters innumerable, journeys many, pamphlets, plays, the conduct of a popular magazine-first called. Household Words and then All the Year Round-and an ever-present readiness to enjoy the society of his friends, fill up the space when he was not actually writing. That he could do so much was mainly due to his orderly and methodical habits, to his clearness of mind, and to a capacity for business as wonderful as his genius for fiction. He knew no rest from the day when he first attacked shorthand to the day when he fell from his chair in the fit from which he never recovered. He was incomparably the most active man, the hardest-working man of his age. In the history of letters there are many who have produced more work in bulk; there is not one who led a life so varied, so full, so constantly busy, so active and so rich.

It is as yet too early to speak with certainty as to the lasting popularity of his work as a whole. Very much of it owed its general success to the faithful delineation of manners already passed away.
He was the prophet of the middle class, and the manners of that great section of the community have greatly changed since the days when Charles Dickens lived among them and observed them. With the decay of these manners some part of present popularity must certainly pass out of his work : already a generation has appeared to whom a great deal of Dickens's work proves of no interest, because it portrays manners with which they are not familiar. They do not laugh with those who laughed fifty, forty, twenty years ago, becanse the people depieted have vanished. But when the second quarter of this century shall belong so truly to the past, that not one survives who can remember it, then these books will become a precious storehouse for the study and the recovery of part, and that a large part, of its life and manners.

Again, it is the essential quality of genius to create the type. In this Dickens has been more successful than any other novelist, ancient or modern. With him every leading character stands for his class. Squeers is the representative of the schoolmaster, then too common, ignorant, brutal, and grasping; Winkle is the Cockney sportsman; it is impossible to think of red tape without naming Mr Tite Barnacle; and so on through all the books. If he sometimes too plainly laliels his characters with their qualities and defects, it is a fault caused by his own clearness of conception and of execution. It is another note of genius to suffer every character to work out its own fate without weakness or pity, and though Dickens deals seldom with the greater tragedies of the world in his domestic dramas, necessity pursues his characters as grimly and certainly as in real life. The villain Quilp and his tool make us forget, in the amusement which they cause, their own baseness. But their creator is not deceived. He makes them bring their own ruin upon their heads. To be true, not only to the outward presentment and speech and thought of a character, but also to the laws which surround him, and to the consequences of his actions, is a rare thing indeed with those who practise the art of fiction. Further, in this art there are permissible certain exaggerations, as upon the stage. There is exaggeration of feature, exaggeration of talk, exaggeration of action. There are degrees of exaggeration, by which one passes through tragedy, comedy, farce, and burlesque; but in all there must be exaggeration. Dickens was master of exaggeration-if he sometimes carried it too far, he produced farce, but never burlesque. As for selection, which is perhaps the most important point after exagreration, it came to him by instinct he knew from the very outset how to select. It is by selection that the novelist maintains the interest of his story and develops his characters. There are countless things that are said and done in the progress of the history which have little interest and small bearing on the things which have to be told; and it is the first mark of the bad novelist that he does not know how to suppress irrelevant scenes. In the constructive branch of his art Dickens continually advanced. His earlier stories seem, like the Pickwick Papers, to be made up of scenes. Nicholas Nickleby is a long series of scenes brilliantly drawn, in which new characters are always appearing and playing their disconnected part and disappearing. But as he grew older his conception of the story itself grew clearer, and his arrangement more artistic. It is however in description that Dickens proved himself so great a master. He laid his hand by instinct upon the salient and characteristic features, and he never failed in finding the right-the only-words fit for their illustration. In description he is never conventional, always real, and yet he allows himself, here as in his scenes of character and dialogue, a certain 
exagrgerution which probluces the happiest effiecto. In the hunds of his initatom it becosnem grostemejue and intolerable.

As to his great and splendid gallery of portraits it is difficult to speak lriefly. The while of Lomulon life-the life of the streets, of the city, of the middle class-seems at first sight depicted in this gallery. Here are merchant, shopkeeper, and elerk, lawyer and client, moneylender and victim, dress. maker, actor-one knows not what. Yet there are great omissions. The scholar, the divine, the atateaman, the country gentleman are absent, partly lnecanse Dickens laul no knowledge of them, and partly because he forebore to hold them up to the ridicule which he loved to pour over his charucters. His methods imposed upon him certain limitations he aimed at commanding his readers' attention by compelling langhter and tens, but esperially laughter. He who can command neither the one nor the other is no true artist in fiction. But in his laughter and in his tears one feels always the kindly heart as well as the skilful hand. It is for the former-for the deeply human heart-even more than for the latter that the world will continue to love the memory of Charles Dickens.

See his Letters, edited by his daughter $(1880-82)$; hi Life by Forster (1871-74); the little Life by Marzial (1887), with bibliography by Anderson; Charles Dicken in Pen and Pencil, by F. G. Kitton (18x9); The Childhood of Dickens, by R. Langton (1891), his Letters to Wrikie Collins (1892) My Futher as I Reoall Him, by Misg Mamie Dickens (1897); and the study by G. Giesing (1898). See articlea Cruikshank, Bhowne (HabLot K.).

Diclinous, a Linnæan term for flowers posess. ing stamens or pistils only-Monocia Dicecia, and Polygamia.

Dicotyle'dons. The fact that the majority of young seedlings exhibit two small seed-leaves or cotyledons on germination must have been familiar from time immemorial, while the classificatory im. portance of this character in broadly separating the obviously flowering plants into two great groujus of dicotyledons and monocotyledons was thus naturally one of the earliest conceptions of systematic botany, having been adopted by Linnæus from Ray, and doubtless by him in turn from earlier writers. We now distinguish phanerogams into Gymnosperms (cycads, conifers, and gnetums), and Angiosperms characterised by the possession of a closed ovary : of these the monocotyledons and dicotyledons are the main alliances, the latter being on the whole the more evolved. The embryo of dicotyledons posseases, with rare exceptions ( usually due to parawitic degeneration-e.g. Demder, q.v.), two cotyledons facing each other, and more or leas embracing the plumule, while the slbumen is generally proportionally leses in quantity than in monocotyledons, and, in fact, is frequently abeorlsed altogether; these differences being explained through a more precocious acceleration of develop ment (see OVULK, SEED). The cotyledons usually develop equally, but one may be more or leas com. pletely arrested.

The fibro-vascular bundles of dicotyledons are open and collateral, with few exceptions arranged in a reticulated eylinier, which thus presents a single circle in transverse section. The paren chyma in which they lie is thus divided into two main regions the cortical layer or cellular en velope, and the pith; while the intermediate spokes of parenchymatous tissue connecting the pith and cortex through the meshes of the cylinder are the medullary rays. While the fibro-vaseular bundles of dicotyledons arise like those of cryptogams and monocotyledons, by the differen. tiation into wood and bast of a special strand of primitive embryonic tissue continuous with that of the growing point, they difter in 8 marked 150 tendeney to embryanis pendutence of a central layer of this as the Cambium $\left(q_{0} \nabla_{0}\right)$, and benee in so many groupe of dientyleslons there arimes thes mosociation of perensin halsit and continuose growth of stem to which we owe ons fasullier

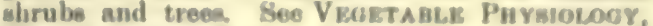
Wood, BArк, Bast. Since the cambium lien between the wood and baut, the new layen of wond are external to the older onew, hut those of lant internal to their predecemon: hence Lindley's name exogens was ajt to be minleading. The woltnene and delicacy of the cambium layer leade, when force is applied, to the easy meparation of the lant elements of the fibro-vancular bundles, alosg with the cortical parenchyms and epidemic layer, an the bark - a structure, or rather juxtaposition of stree. tures, unknown in Monusot veslons (q.v.)

The reticulated character of the bundles of the stem is aimilarly present in the leaf, which thus presents a marked contrast to the usually parallel venation of the monocotyledoni. The leaf also presents far greater variety of form and alaplation (see I.EAF).

The flower has most frequently its parts arranged in whorls of five, although four is alses a not uneosn. mon number; hence another very obvions distine. tion from monocotyledons, in which a 3 -meroms symmetry prevails. The outer perianth whorl is moet frequently green, as a calyx. Bee FLowen, Phanerociamia, and Verietrable Kinifims ; alao ANGIOSPERMS, and MoNocotYLEDONS.

Dícranum, a genus of moses, of which some are among the commoner Britiah forme Beo Mosses.

\section{Diftamnus. See DITtaxy。}

Dicta'tor, in the enrliest times, was the name of the higheat magistrate of the Latin Confederation, and in some of the Latin towns the title was continued long after theee towns were subjected to the dominion of Rome. In the Roman Republic the dictator was an extraordinary magistrate, irresponsible and endowed with absolute authority, whose original name was magister populi. The frequency of crises, or critienl periods, in the quick, aggressive growth of the Roman state, neorseitaied such an office. The fint dictator (T. Lancius or M. Valerius) was appointed 501 B. , $_{\text {, nino year }}$ after the expulsion of the Tarquins According to Livy, the immediate cruse of this dictatorship was a formidalole war with the Latins. In general. no one could be appointed dietator who had not been previously consul, and this condition was very rarely dispensed with. Niebuhr is of opinion that the dietator was originally ereacesl or electasl by the curis, like the kings, but it is more probleblo that the senate pased a decree ordering one of the consuls to name or proclnim (dicere) a dictator. Originally, of course, the dictntor was a patrician the fint pletwian who fillest the oftiee being $C^{2}$ Mareius Rutilus, 356 R.C. who was nominated by the plebeian conanl M. Poyillins Lanas. The dietatorahip could not laucfully be held longer than six monthe, nor was it ever so, except in

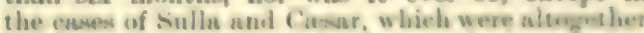

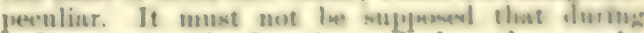
a dictatorship the functions of the other nagia. trates were poaitively enspended. The consuls and other regulas anthoritios continued to discluarge their proper duties but in subordination to the dictator ; being for the time simply his oflicers. The superiority of his power, when coupared wish that of the consuls, appenrs chiefly in these three points: he was far more independent of the senate: he had a more extensive power of punishment, withont any appeal; and he could not be called to accuant after his alulication of the dictatorahip for anything he had done during the period of his office. The 
limits of his power were as follows: he could not touch the treasury; he could not leave Italy; and he conld not ride through Rome on horseback without previously obtaining the permission of the people. While the consuls had only twelve lictors, the dictator was preceded by twenty-four, bearing the secures and fasces. To him also belonged the sella curutis and the toga protexta. The last legally elected dictator was M. Junius Pera, who entered on his office 216 B.C. From this time nominal dictators were frequently appointed for the purpose of holding the elections, but even these finally disappeared, 202 B.C.

Dictionary (late Lat. dictionarium), a book containing the words of a language alphabetically arranged, with their definitions and significations set forth more or less fully. In this respect it differs from a mere list or index, that it contains explanations about each word included within its scope, except where it is more convenient, by a cross-reference, to refer the reader for a part or the whole of the account of one word to what is said under some other word. There are several other terms that are used synonymously, or nearly so, with dictionary. The Greek word Lexicon is in common use for a dictionary of languages. It is not entirely so limited, however, in practice, as may be seen in such works as the Lexicon Juridicum of Calvinus or Kahl, which is just a dictionary of Roman and feudal law of the same kind as Sir Edward Tomlin's Law Dictionary is of English law. The word Encyclopoedia has generally a wider meaning; but in actual use we find books of reference of exactly the same kind styled indifferently dictionaries and encyclopædias. The terms Glos. sary and Vocabulary are nearly synonymous with a dictionary of a language; and Thesaurus, Catalogue, Directory, Gazetteer, and Index are sometimes used as titles where dictionary might be not inapplicable.

Dictionaries may be divided into two classes-(1) those whose object is to explain words and phrases and (2) those that aim at giving information about things.

(1) Dictionaries of language are, again, divided into various sub-classes or species, The most common kind-what, indeed, is understood by the term dictionary (and the equivalent Greek term Lexicon) when ased by itself-is an alphabetical list of the words composing any language either explained in the same language, or interpreted by the corresponding words of one or more other languages. To indicate that all the words of the language are included, the name Thesaurus ('Treasury') is sometimes used, as in the great Hebrew dictionary of Gesenius. The words used by particular authors or classes of authors are often explained in special dictionaries or lexicons, such as those to Livy, Cicero, Tacitus, Homer, Sophocles, Shakespeare, and the like. A Glossary is a dictionary of unusual terms, as archaic, provincial, or technical terms. An etymological dictionary is one in which the derivation of words is the sole or a prominent object.

(2) Dictionaries of things (Ger. Realwörterbücher), or of information, are also of various kinds. When the whole field of human knowledge is embraced, we have an alphabetical Encyclopæedia or Conversations-Lexicon. The name Encyclopaedia or Cyclopredia is sometimes given to dictionaries of specia departments of knowledge, as Anatomy and Physiology; but in all such eases dictionary seems the correcter term, as in the well-known dictionaries edited by Sir William Smith, which cover the whole ground of Bible terms, Greek and Roman biograpliy and mythology and antiquities, Christian antiquities, and Christian biography.

There is no kind of information, within wide or narrow bounds, that may not be thrown into the dictionary form. Dictionaries of apt quotations from the classics, the Seriptures, or the fathers were not unknown in the 17 th century. There are dictionaries of biography, of geography, of nautical terms, of dates, of architecture, of cookery, of political economy, of heraldry, of fortification -in fact, of every object of human knowledge and practice.

Dictionaries of language, in our sense of the word, are of modern origin. The Greeks and Romans had no idea of a book embracing all the words of their own or any foreign tongue. Glossaries, however, of unusual words and phrases were early current. The earliest work of the kind extant (though much interpolated) is the Homeric Lexicon (Gr. Lexeis Homerikai) of Apollonius, an Alexandrine grammarian of the time of Augustus. More extensive compilations, such as the Lexicon of Suidas (q.v.), and the Etymologicum Magnum (q.v.), were made in the middle ages. A real dictionary became first possible after the invention of printing. A broad and sure basis for Greek lexicography was laid by Henry Stephens (q.v.) in his Thesaurus (1572), on which the school of Hemsterhuis built further, and which has been greatly extended by the labours of Schneider, Passow, Seiler, Jakobitz, Rost, and Pape. The well-known work of Liddell and Scott (7th ed. 1883) is based on the great German one of Passow. The The saurus (1531) of Robert Stephens inaugurated Latin lexicography, which has been extended by Joh. Matth. Gesner, Forcellini, Ducange (medieval Latin), Scheller, Freund, Georges, Mühlmann, and Vanicek, and is well represented in English by Riddell and White, Andrews, Smith, and the Americans Lewis and Short. The earliest standard dictionaries of modern tongues were the Italian Vocabulario della Crusca (1612); the Dictionary of the French Academy (1694); and that. of the Academy at Madrid (1726-39). The great German Dietionary, begun in 1854 by the brothere Grimm, is still unfinished. Littré's French Dictionary ( 4 vols. and supplement) appeared in 1863-78. The materials collected by the Philological Society formed the main foundation for the great New English Dietionary, of which vols. i. and ii. were edited by Dr Murray (1888-93), in conjunction with Henry Bradley in vol, iii. and onwards. This splendid work follows a strictly historical method, and aims to give all the significations of every English word during the last seven hundred years, with a series of quotations illustrating its usage. English dictionary-making in its larger sense began with Dr Johnson (q.v.), the basis of whose work was an interleaved copy of Nathan Bailey's Diet. (1721-7).

The best complete English dictionaries at present in use are Richardson's, Worcester's, Webster's Iatham's edition of Johnson, Annandale's edition of Ogilvie's Imperial Dictionary, and especially the Century ( 6 vols. New York, 1889-91, edited by Whitney), and the Standard (2 vols. New York, 1893-95); for Scotch words, Jamieson (1808-25; ed. Donaldson, 1879-87); for etymology, those of Wedgwood, Edw. Müller (German), and Professor Skeat. The great Eng. Dialect Dictionary (ed. Wright) began in 1896, superseding Halliwell, T. Wright, \&c. For older English 'words, the chief are Alfric's Glossary (about 975), Way's edition (1843-65) of the Promptorium Parvulorum (about 1440), Bosworth's Anglo-Saxcon Dictionary (ed. Toller), Stratmann's MiddleEnglish Dictionary (ed. H. Bradley, 1891), Grein's Sprachschatz der Angelsächsischen Dichter, and Mätzner's Altenglische Sprach proben, \&c. ; as well also the Eng. words in Cotgrave's French-English Dict. (1611), Minsheu's Guide into Tongues (1617), \&o. - See BIOGRAPHY, EnoyoloPadia, Dialect, ENGlish, and articles on the various languages; also Vater's bibliography of dictionaries ( $2 d$ ed., by Jülg, 1847).

Dictyogens, a term proposed by Lindley for Monocotyledons (q.v.) with reticulated leaves. 
Diatys of Crete, a follower of lilomaconectas in the Trojan war, whose name is attached to a pro. fessed journal of the leading events of the contest. which has come down to us is Latin prose, under the title Ephemeris Belli Trojosi. An introduction relates how the narrative, inseribed in Phoniciun characters on bark-paper, was found in a cofler of tin in Dictys's tomb, which lam teeess lusst ppen ly an earthquake in the reign of Nero, aml huw the emperor caused it to be translated into Greek; this is accompanied by a letter from one Quintus Septimius, who claims to have prepared the condensed Latin version that follows. This dates probably from the 4th century A.D., and thumgh of no intrinsic value, was a chief source of the romances of the middle ages. The best editions are those of Dederich (Bonn, 1832 and 1837) and Meister (I,eip. 1872). See Dunger, Dictys-Septimius: uber dis ursprüngliche Abfrssung u, die Quellen der Ephemeris (Dresd. 1878).

Dicyemida, a family of very lowly multicellular organisms, parasitic in habit. They are found in euttle-fishes, while related organisms known as Orthonectida occur in a brittle-star and in a Nemertean worm. Professor $\mathrm{E}$. van Beneden has included them all under the title Mesozoa in contrast to the lower (single-celled) Protozon on the one hand, and the higher ( many - celled) Metazon on the other. The largest species of the genus Dicyema measures $5-7$ millimetres; the smallest is ten times less. These organisms hardly rise above the level of the embryonic gastrula, and some seem hardly to attain it, but it is still uncertain how much of this simplicity is primitive, and how much the result of degeneration. See $\mathbf{E}$. van Beneden and C. Julin, Archives de Biolugie (1882); Whitman, Mitth. Zool. Stat. Neapel (1883); Braun, Centrulblatt Bacteriol. (1887).

Dicynodon, an important type of Triasaic reptile, usually included in the order Anomodontia. They have been unearthed in Africe, India, and the Ural region, and more recently remains have been found in the Elgin Trias of Scotland. Our knowledge of them is largely due to Owen. They were terrestrial animals, and in some ways suggest affinities with tortoises, in others with mammals. In Dicynodon the lower jaw was incased in a horny beak, but the upper bore two huge teeth. In Oudenodon no teeth were present. See ChELovia, REPTILES.

Didache. See Apostles (ТЕaching of тне TWELVE).

Didactic Poetry, that kind of poetry which aims, or seems to aim, at instruction as its object, making pleasure entirely subervient thereto. It has been disputed whether or not the existence of a kind of poetry especially entitled to the name didactic is consistent with the very nature and object of the poetic art. For it is held that, to point ont instruction as the peculiar object of one kind of poetry, is to overlook the high aim of all poetry and that a prem may loe in the highese sense didactic, which yet is epic, dramatic, or lyric in its form; and the Book of Job, the Psalms, and other poems contained in the Sacred Scriptures, are quoted as examples. In the poems generally called diclactic, the information or instruction given in verse is accompanied with poetic reflections, illus. trations, and episodes. The Georgics of Virgil has been the model for most didactic poems, and no subject is so unpromising that it has not found some one to select it as a poetic theme. Examples of admirable suecess as combinations of argument and poetry are the Ars Poetica of Horace and the Essay on Criticism of Pope. The great poem of Lucretius, again, stands the masterpiece of the philosophical poem, which is represented in our own langunge by poems like the Nonce Tajpenses of Sir John Dasien, und the fiewery on Mlan of b'ope. See Poktuy

Didelphia. See Marsupiala.

Dialphis. Bee Oposstim.

Diderot, Dexis, wan born on (Octoher 18, 1713. at Langres, in Champagne, where hin fanily toul for two centuries been engaged in the manufacture of entlery. An eldeat non, he was intended for the church, and received his early training at the Jesuit school in his birthplace. After atndying at the Collège d'Harcourt in Paris, he offended his fatber by refusing to become either $\mathrm{a}$ lawyer or a physician, and was in conseguence flung upon his own resources. From 1734 until about 7 its he led life of haphazard, ill-paid toil as a tutor and a booksellers hack. In 1743 he married Annette ('hampion, \& young sempstress, against the winloew of her friends, and withont the knowledge of his family. After she had borne him a son, he por. suaded his wife to remove with the child to Langreas where she brought about a reconeiliation between Diderot and his father. His marriage, however, did not prove a happy one. During his wife: absence in Champagne he formed a liaison with a Madame Puisieux which lasted for several yeans: and later in life he became attached to a financier's daughter, Mademoiselle Voland, to whom he remained devoted until her death in 1774. His Penstes Philosophiques were burned by onder of the Parliament of Paris in 1746, and three yeans after. wards he underwent imprisonment for the opinions expressed in his Lettre sur les Avenglea. His nppointment to the exliturnip of an enryrloguerlia which the bookseller, Le Breton, had resolved upon publishing, assured him of a regular income, and gave him a commanding position in the world of letters. Le Breton's intention hal been merely to irsue an expanded version of the English Cyclopaedia of Ephraim Chambers, which had appenred in 1727. But in Diderot's hands the character of the work was transformed. He enliated nearly all the important French writers of the tine as con. tributors, and in place of a storehouse of nseful information, produced an engine of war for the philosophe party (see EvCYCLOPARDIA). For some twenty years he stood at his post in spite of dangers and drawbacks, before which even a strong man might pardonably have flincherl. The lumik was agrain and again threatened with prosecution; its sale was more than once prohibited; its editor ran a constant risk of imprisonment or exile. D'Alembert, at one time co-editor with Diderot, forsook him in despair at the obstacles to be over: come. But his marvellous energy, his varied know. ledge, above all, his faculty of rallving and inspiriting his follow-workers, enabled Diderot to carry his vast undertaking to a anceessful conclunion. The fint volume appenred in 1751 ; the last, in 1765. In his later years Diderot fell into pecuniary difficulties from which he was reacued by Catharine II. of Russis, who purchared his librury, but allowed it to remain in Paris, and installed him at a sulary $\mathrm{m}$ its caretaker. In 1775 he paid a vivie to his benefactreas, by whom he was most cordially received. He returned to Paris after epending five months in the palace of the empreas at $8 \mathrm{t}$ Peters.

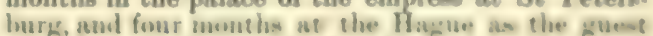
of Prince Galitzin. During his old age he lived prineipally in his study at the corner of the Rue Taranne, spending his days in reading and meditation, in directing the stadies of hin daughter-the only survivor of his four clildren, in the giving of gowh counsel, and the doing of good works. He died from a atroke of apoplexy on the s0th July 1784 .

One of the most prolific and versatile, Diderot was also one of the moet careless of writer. Ho 
worked in almost every department of literature. He was a novelist and a dramatist, a satirist, a philosopher, a critic of pictures and books; while as a letter-writer he was surpassed by none of his contemporaries. His published works are far from embodying the results of his labours as an author. He was ever ready to contribute without reward, often without acknowledgment, to the writings of others; he has been well termed the munificent prodigal of letters. His efforts in fiction include a story in the manner of Crébillon, described by Carlyle as 'the beastliest of all past, present, or future dull novels;' La Religieuse, a powerful story written with the object of exposing the evils of conventual life; and Jacques le Fataliste, a collection of short tales of which some are good and others indifferent, while one of them is a little masterpiece. Le Neveu de Rameau, an imaginary conversation between the author and a parasite of the great, is probably the strongest as it is the most curious of all Diderot's works. In the course of this dialogue, which was translated by Goethe, the follies and corruptions of society are laid bare with sardonic humour and piercing insight. Diderot's plays were somewhat unsuccessful examples of what was then known as tragédie bourgeoise, or of what we should now term melo. drama. His happiest dramatic efforts were two short pieces which were never acted, La Piece et la Prologue and Est-il Bon? Est-il Mechant? The letters which he addressed to Mademoiselle Voland, and which were first published some fifty years after his death, form the most interesting section of his voluminous correspondence. They give an entertaining and wonderfully vivid picture of the life that was led in the Baron d'Holbach's countryhouse at Grandval, the headquarters of the most advanced members of the philosophe party. As a critic Diderot stood far in advance of his contemporaries, and anticipated the Romanticists in advocating a return to nature and in seeking to free the drama from the trammels which had been imposed on it by the classical school. His criticisms bear the marks of over-hasty production, but their originality, shrewdness, and abounding vivacity more than atone for the lack of literary finish. His Salons, remarks on pictures exhibited at different times in Paris, are the earliest example of resthetic criticism in modern literature. His philosophical works include Pensées Philosophigues, La Promenade du Sceptique, Lettres sur les sourds et Muets, Lettre sur les Aveugles, La Rêve d'Alembert, Essai sur la Vie de Sénéque, L'Interprétation de la Nature, and a long criticism on Helvétius's treatise De l'Homme. Diderot has been frequently described as an atheist; whether justly or not is a matter very hard to decide. He was at one time deeply influenced by the naturalistic religion of Shaftesbury, and that writer's influence upon his mind was never wholly effaced. In certain passages he appears to write as a pantheist. But he never set forth his philosophy in consistent and systematic form.

Diderot is so unequal a writer that his works must be read in the mass before a just estimate can be formed of his extraordinary gifts. His keenest sayings, his most pregnant thoughts, are frequently imbedded in dullness. An indefatigable worker, he yet never took his work seriously enough. He lacked the faculty of concentration and the artist's mastering sense of form. His prose is not sustained at a high level of excellence; he sins grievously against good taste; his thoughts are not seldom crude and shallow; his mannerisms-notably his abuse of apostrophe-his 'sensibility' and his philosophe cant are not a little trying to the reader. But with all their defects his writings are wonderfully alive-fertile in original ideas - racy with a stimu- lating flavour which is all their own; abounding in careless felicities of phrase and in sayings which flash a new light into human nature; rich with the sap of a humour which resembles the humour of no other Frenchman, and which Carlyle has likened to the humour of Cervantes. Inferior to Voltaire and Rousseau as a literary craftsman, he was a deeper thinker than either; his knowledge of men was profound, and his learning was truly encyclopædic. Ardent and generous, though lacking in self-restraint, he was one of the best of friends and the most charming of companions. In the opinion of his contemporaries his powers as a conversationalist eclipsed his gifts as a writer. He appears to have possessed an unrivalled faculty of improvisation; to judge from the testimony of shrewd critics who listened to him, his talk was as pointed and pregnant in its substance as captivating in its eloquence. 'He who knows Diderot only in his writings,' said Marmontel, 'does not know him at all.

The most complete edition of his works is that by Assézat and Tourneur (20 vols, 1875-77). See the study by Rosenkranz (Leip. 1866); John Morley's Diderot and the Encyclopoedists (2 vols, 1878); E. Scherer's study (1880) ; Sainte-Beuve's Partruits Littéraires, Carlyle's Miscellanies; and French monographs by Reinach (1894), Collignon (1895), Ducros (1895), and Tourneux (1899).

Dido, or ELISSA, the legendary founder of Carthage, was the daughter of the Tyrian king Belus or Agenor, and the sister of his successor, Pygmalion. Pygmalion murdered her husband and uncle, Acerbas or Sichæus, a priest of Hercules. With the treasures of Sichrus; which Pygmalion had sought for in vain, and accompanied by many Tyrians, Dido eseaped to sea. She landed in Africa, not far from the Phwenician colony of Utica, and built a citadel called Byrsa (Gr. Bursa, 'the hide of a bull '), on a piece of ground which she had bought from the Numidian king Hiarbas. The meaning of the word Byrsa gave rise to the legend that Dido purchased as much land as could be encompassed with a bullock's hide. Once the agreement was concluded, she cut the hide into small thongs, and thus inclosed a large piece of ground, on which she built the eity of Carthage To avoid being compelled to marry Hiarbas, she stabbed herself on a funeral pile, which she had caused to be erected, and after her death was honoured as a deity by her subjects. Virgil ascribes the death of Dido to her unrequited passion for Eneas; but many of the ancient writers conceived that the poet had committed an anachronism in making her contemporary with the Trojan prince. In the common chronology, more than three hundred years separated the fall of Troy (1184 B.C.) from the founding of Carthage (853).

Didot, the name of a celebrated family of French printers and publishers.-Francors Didot (1689-1757) was the first of the family that attained eminence. His principal professional achievement was the publication of the Voyages of his friend the Abbé Prévost, a work in 20 volumes, perfect as regards the text, and enriched with a great number of engravings. Two of his sons, FrancoIs A mbroIse (1730-1804) and PIERRE FrançoIs (1732-1795), also acquired distinetion as printers, the former publishing editions of the Delphin elassics, while the latter improved the typefounding and paper-making arts.-HENRI (1765-1852), eldest son of Pierre Francois, made himself famous as an engraver and letter-founder, producing very beautiful 'microscopic' types.Pierre, eldest son of François Ambroise (1760 1853), still further increased the fame of the family. His Louvre editions of Virgil, Horace, Racine, and La. Fontaine are magnificent; and he it was who published Boileau's works and Voltaire's Henriade. 
He was himself an anthor,-His brother, Frems (1764-1836), as a printer, and espocially as an engraver and founder, raised the family name to the pinnacle of professional eminence. The perfect Roman charracters, used in the Louvres enlitions printed ly his eleler brother, were engraved and east ly him. He reviverl and devolonperl the stereotyping process, and produced singularly per. fect alitions of many elassical, French, and Eng. lish works. He loseme a deputy, and obtained some reputation as an anthor by his trageslies, La Reine de Portuged and La IJort d'Annilual, and several volumes of metrical trunslations from the classies, - Firmin sons, A мBroIsz FIRMIN (1790-1876) and HYACINTHE FIRMIN (1794-1880), aided by their sons, sustained the credit of the Paris house as Firmin Didot Frères; and the business still thrives under the present representatives. See the books on the family by Werdet (1864), Brunel (1871), and Wallon (1886).

Didunculus. See SamoA.

Didymium is a very rare metal found in the minerals Cerite, Allanite, \&c. Its symbol is Di, its atomic weight 142, and its specific gravity 6.5. It is found assuciated with Cerium and Lanthanum, and as the salts of the three metals have closely similar properties, their separation is very dificult. The salts of didymium are generally soluble and rose-coloured. The hydrated oxide is a gelatinous precipitate resembling alumina. Its compounds have nothing specially characteristic in their properties except the absorption bands in the spectrum. The metal, which has an iron-gray colour, with a yellowish tinge, tarnishes in the air, and burns brilliantly when feld in a flame.

Diebitsch, ЈоHN Chandes, Count, a Rusgian field-marshal, was born in Silesia in 1785, and male the campaigns of 1805 and 1812-14. In the Turkish war of 1829 his forcing a passage of the Balkans (Kulevtcha, \&e.) by dint of hard fighting was commemorated in the surname conferred on him of Sabalkanski ("crosser of the Balkans'). He died of cholera in February 1831, while endeavouring to suppress the insurrection in Poland.

Diedenhofen. See Thionville,

Diefenbach, Lorenz, a great philologist, was born at Ustheim, in the grand-duehy of Hesse, 29th July 1806, studied theology and philosophy at Giessen, travelled much, and was twelve years pastor and librurian at Sulms-Iaubreh. In 1848 he settled at Frankfort-on-Mrin, where he was second city librarian 1865-76. He died at Darm. stadt, 28th March 1883. His literary industry was enormous, embracing poetry and romances, as well as those more ponderous works by which his name will live. His greatest books-monuments of sameity and learning-are c'eltima (3 vols. 1839-40); Vergleichendes Wörterbuch der Gotischen Sprache (2 vols. 1846-51); Glasserium Latino Crermanicum media et infime atatis, a supplement to Dacange's well-known Glosesary (1857); Origined Europace; Hoch-und Niederdeutsches Worterbuch (with Willcker, 2 vols. 1874-85).

Dieffenbach, JoHANN FRIEDRICH, surgeon, was born at Kömigsberg, lot February 1794, and in 1832 berame extraurlimary, in 1840 ordinary, pro fessor of Surgery at Berlin, where he died, I1th November 1847. He was distinguished as an operstor, especially in the art of forming by trans. plantation new noses and lips. He wrote several works of no great importance on surgery, being little more than a brilliant operator.

Diego Garcia, an island of the Indian Ocean, in $7^{\circ} \mathrm{S}$. lat., and $72^{\circ}-73^{\circ} \mathrm{E}$. long.. extends in an irregular horseshoe shape, and is 20 miles long, embracing between its extremities three minor

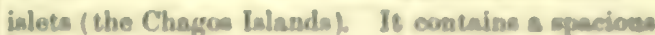
hay, and is very convenient for coaling parjosem.

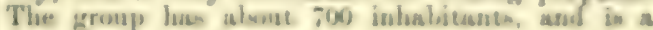
dependency of Mauritin

Wiege Suarez, the nane of a fine hay at the north end of Misulagasenr $(q, v$,$) , cedod to Prance$ by treaty in 1885 .

Diely'tra. Bee Dicextia.

Diepenbeck, Авваная уах, painter and draftsman, was born at Bois-le- Dne in 100\%, or according to other accounts, in 1596 . He mtodied under Rubens in Antwerp, and after a rewidence in Italy, returned to be an assistant of that painter. He lint devoted himself to slaw painting; but be soon turned to oil-painting and dewyming $\mathrm{Bx}$. amples of his work in oils are in Paris. Ireselen, and Vienna. His plates to Marolles Tableuse ds Temple des Muare (1655), engraved by Comelin Bloemaert, were much admired. He vimited Eng. lamel in the reign of Charles 1., where loe pasintos] some windows, and was much employed by the Duke of Neweastle, for whom he executed varions portraits and views, and drew the plates for that nobleman's famous folio on Honemanship (1657). These plates are valuable not only for their excel. lence, but for the number of portraits they contain. He was elected president of the Antwerp Academy in 1641, a rost which he retained till his desath in lifis.

Dieppe, a seaport in the French department of Seine-Inferieure, on the Englinh Chammel, to miles $\mathbf{N}$. of Rouen by rail. It is situnted nmong chalk cliffs, at the mouth of the river Arquen, and is regularly built. It has a castle (1433), now oceupied as barracks, commanding the town and the harbour, which admits vessels of 600 tons. Dieppe has a college and a nehool of navi:a. tion, and there is a fine Gothic church of the 13th century, as well as a handsome bathing establish. ment and casino. Being one of the principal watering-places of France, the town has a great accession of visitors during the summer months. It manufactures clocks, lace, and tobaceo; and its carved articles of horn, bone, and ivory have long been famons. There are also shipbuilding yonls and distilleries; and the fisheries, which are important, employ almost the whole of the pepulation of Pollet, one of the two suburbs of the town. In 1066 Duke Willian aniled from Dieppe to the conquest of England. It was then a mere village, but its importance steadily increased, until it reacher the heyday of its prosperity in the period between the middle of the 14th century and the end of the 17th. Expeditions sailed hence for the west coast of Africa where Petit Dieppe was founded at the mouth of the Gambia; and many of the early voyares to Canada were made from this port. A terrible bombandment by the Engliah and Dutch, however, deatroyed all but two or three beildings in 1694 and though rebuilt, the town never recovered its importance, and even before the rise of Harre hat alrealy sunh to a seromiary port. Nevertheless, packeti still ply regularly to New. haven. The town is a favourite landing-place of linulish touriats, and its import and export trade is chiefly with Englaud and Xarway. I'up. (1s:-2) 19,757 ; ( 1886 ) 22,599 ; (1891) 21 , : 182.

Diessinking, the art of engraving the die or staup used for striking the impresion on coins and medals, and for stamping thin plates of metal into varions shapes. The method of winking the dies used for coins or medals will serve to illustrute the general method of die-ainking. Suppose the coin to be of the size of a shilling : a cylindrical piece of carefully selected steel, abont three or four inche in length, and two in dismeter, is prepared by slightly rounding one end of the evliuder, then turning and amoothing upon the middle of this a 
flat face equal to the size of the coin. This blank die, which is carefully softened by the process of Annealing (q.v.), is then engraved with the device of the coin in intaglio. This is a very delicate and artistic operation, and is effected by a great number of careful touches with small and very hard steel tools. The face of the die is now protected with a thin coating of lampblack and linseed-oil, and then placed with its face downwards in a crucible containing animal charcoal. In this position it is raised to a cherry-red heat, then taken out, and hardened by being plunged into water. When properly tempered, it is in a state to be used for stamping the coin; but dies of superior workman ship, from which many impressions are required, are not thus directly used, as the expense of engraving is very great, and the risk of breakage considerable. This first engraved die, ealled the matrix, is therefore reserved only for making other dies. An impression in relief is made from this matrix on a small block of soft steel, which is called the puncheon; this is retouched and hardened, and from it the dies directly used for striking the coins or medals are impressed. When the engraving is not very costly, a small number of impressions required, or a soft metal is to be stamped, as in livery buttons, for example, the work is stamped directly from the engraved die or matrix. See Mint.

Die-engraving is a very ancient art, and was perhaps first suggested by the closely allied art of engraving gems. Notwithstanding the great num. ber of ancient Greek coins which have been preserved, it is stated by $\mathrm{Mr} \mathrm{R}$. S. Poole, of the British Museum, that only one of the many dies which were used for these has ever been found, or at least only one believed to be of undoubted authenticity. The Greek coins struck between the years 415 and 336 B.C. show that the art of engraving dies had then reached the highest point of excellence which it ever attained either in ancient or modern times. As works of art, the Italian medals of the 15th and 16th centuries come next in merit to Greek coins, but none of these of the 15th, and only the smaller sized ones of the 16th century time were struck from dies. All the others were cast either from wax models or from patterns made in other materials. The art of cutting dies, in the comparatively deep intaglio required for medals, consequently dates from the beginning of the 16th century. Since then, or soon after it, Germany, France, Russia, and England, as well as Italy, have all had many more or less famous dieengravers.

The engraving of dies for medals is perhaps that branch of the art which gives the greatest scope for artistic skill, although the work on those required for coins is nearly identical in its character. Comparatively few dies of new design are, however, required for coins, while many hundreds of medal dies are annually made in England. The medals struck from these are used for such purposes as awards at exhibitions, colleges, and schools; for prizes at various games, and in commemoration of various events. Copper, bronze, and tin are the metals most commonly employed for medals, the copper being usually 'bronzed" on the surface. A copper medal with a head in moderately high relief requires half a dozen blows in the screw-press to bring up a sharp impression; but some in very bold relief require to be struck with as many as thirty blows. The medal requires to be frequently annealed during the process. Coins are finished at one blow, so that the devices upon them are only in slight relief. When a coin or a medal is being struck, a steel collar, accurately fitted to the die, is used to prevent the metal from spreading.

Dies have been extensively applied in Birmingham and other places to the manufacture of many kinds of objects in sheet-metal. These are of all sizes, from those required for parts of jewelry up to dies weighing more than a ton. Large and heavy dies are, however, cast, and only in some cases finished with the graver-those for such articles as curtain-pole and comice ornaments being among the largest kinds worked up and finished with the die-cutter's tools. Dies have recently been used in America in the stamping or pressing of solid pieces of wood into lion's heads, rosettes, and other orna. ments, in high relief, to imitate wood-carving. By the same process similar ornaments, in bas-relief, are made in pieces of wood formed of several layers of veneers.

Dies Irae, the name generally given to the celebrated Latin hymn on the Last Judgment, from the first words of its first stanza :

\section{Dies iræe, dies ill \\ Solvet sæclum in favilla, \\ Teste David cum Sibylla.}

This incomparable hymn consists of seventeen such stanzas, with an eighteenth of four lines, and is based on the prophetic passage, Zephaniah, i. 14-18. It is probably the work of the Franciscan, Thomas de Celano, who died about 1255. The sublimity and force of its thoughts are well matched with the impressive solemnity of the verse, its stanzas of three lines, each with the same double rhyme, making the inmost soul tremble, 'as with three blows of a hammer,' says Guericke. It is said to have first appeared in the missals made at Venice about 1250 , and is one of the five 'Sequences' that have been universally used in the Roman Catholic Church since the Council of Trent. Its place is in the Missa in commemoratione omnium fidelium defunctorum. The Tridentine text, published in 1567 , is somewhat different from that in the old missals, and another and considerably inferior version appears on a marble tablet of unknown date, in a Franciscan church at Mantua. The Dies Iroe has been the subject of musical compositions by Palestrina, Haydn, Cherubini, and Mozart, and no religious poem has been more frequently translated. There are English translations by Crashaw, Macaulay, Lord Lindsay, Isaac Williams, and others. The opening stanzas are paraphrased in the Lay of the Last Minstrel, canto vi.

See Julian's Dictionary of Hymnology (1892) ; 'Fifty Versions of the Dies Irae' in the Dublin Review (1882); a list of ninety-two versions in the Athenceum ( July 1890 ); and C. F. S. Warren, The Dies Iroe (1897).

Diest, a town and fortress of Belgium, in the province of Brabant, on the river Demer, 37 miles SE. of Antwerp by rail, with manufactures of woollen goods, beer, and gin. Pop. (1890) 8572.

Diet. The different classes of food-stuffs, and the value or potential of different foods, are described in the article Foop. In the article DigEsTion the changes which the food undergoes in the alimentary canal are treated. It is here proposed to describe the quantity and quality of food which experience has shown to be required in order to preserve the body in health and vigour. Of course, no two individuals are alike, and the assumption will in the first place be made that an average healthy man of ordinary height and weight, and doing ordinary work, is alone under consideration.

In order to understand the requirements of the body in respect of food, it is necessary to bear in mind how complex the body is. Its chief activities are muscular and nervous, and not only have the brain and the muscular system to be fed, but in addition the various glands, cartilages, bones, and other tissues are all constantly requiring nourishment. If we examine all these tissues under the microscope, we see that although all are alike in some respects, yet that they differ one from another 
considerably in others. Their work, too, is differ. ant; and we should expeet, and experinent shows, that they require different food.

Just as the life of the whole body is the sum of the lives of the different parts (cells) of the body, sc) the food must contain that which is necessary for these parts. The body has frequently beei compared to a steam-engine, but, as we have seen, the buly is complex, and the comparian should rather be between it and a collection of stenn. engines, each one differing from the other in its futtern, use, mul the kimb of fuel rey uireed to stoke it. A steam-engine requires a store of fuel (containing the potential-power), by the combustion of which it moves. It also requires its parts to be repaired, and sometimes a new boiler or piaton is ne'essitry. In addition, it requires other things, so that it may work well, such as oil, which is neither burned nor used to build up the machine. In the same way the body, and each part of it, requires first, a store of fuel, from the combus. tion of which its energy or activity is obtained; secondly, material by which its wasted parta may be repaired; and, thindly, substances such as water, salt, \&c., which are required by the body, but which are neither burned nor used entirely in forming tissue. The term 'food "may then be appliesl to all that the horly requires from without and following out our comparison, corresponds with the stoking, mending, and oiling of a number of steam-engines,

Let us consider in the first place the food, which, like the fuel for the engine, the body requires in order to manifest its own peculiar activities. The coal of an engine contains carbon and hydrogen, which become oxidised by the oxygen of the air. As a result of this oxidation, we have heat and mechanical motion. In like manner the body receives food containing large quantities of carbon and hydrogen. At the same time oxygen is absorbed by the blood as it passes through the lungs. The digested food and the oxygen are taken by the blood to the tissues-muscles, brain, \&c. - and within these tissues a slow oxidation takes place, giving rise to the heat of the body as well as mechanical and other activities. Just as the steam-engine requires a sufficiency of coal, so the body requires a certain quantity of food. In both cases the supply of oxidisable material must have what may be termed a sufficient 'potential' - that is to sny, it must have the power of producing a certain amount of heat and mechanical motion. Some coals and some foods burn better than others, and their potential in that case is greater. Fat among the food-stuffis has the greatest potential, earboliyitrates and ullu. mens have less. It is obvious then that one cannot speak of the body requiring a certain weight of food per diem. This would mean nothing, for the value of different food-stuffis varies considerably, a pound of one kind of food being equivalent in potential, say, to twent; pounds of another. In arranging a diet one must carefully consider not only the quantity of form given, but in aldition une must calenlate its potential. The steam-angine may be driven at fulf or at half power, and in the latter case the amount of fuel required will be diminished. In the same way an individual doing hard work requires food with more potential, or, as we say, more nutritious food, than another living an easy and uneventful life, and still more than one confined to the house or to his bed.

There is yet another important point to be con sidered. In a steam-engine the production of heat is not what is sought as a result of the combustion within the steam-engine; the engineer construct. the machine with a view to obtaining the result of the combustion not in heat, but in mechanical motion. In the best machines, one-tenth of the mitential is converted into work, while the ruc, sino. tenths, is rojected into the atmosphero as beat. The butran mechanimm ean convert m much se one-6ish of the potential of its food into work. and elwis cos funr-fifths into hest. In the ease of the twinass machine, however, leet is very necomary, ewecially If the body be ill elothed or surrosnded by a enill medium. The powerleseneas of the hands when numbed with cold will illuntrate the necewity of a requinite temsersture. Warm clothing actnally saves food. Not only is the temperat ure of the body maintained in a eals elimate lov preventine its ens. duction and rudiation from the body by the ane of warm elosting, lut sppetite prompts the consump. tion of a large quantity of fixm, and entworialls itrmat kinds that contsin grent potentisl. The Eikimos devour great supplies of fat blubleer, and they are even said to prefer the taste of rancid oil to that of the less combustible sugar.

It has been found by experiment that a man of average height and weight, well clothed, in a temperate climate, and doing a fair day' work, reruires such quantity of food that the combestion of it, were it all converted into mechanical work, would raise 4000 tous one fout ligh, or, as it is expressed, 4000 foot-tons. This result has been arrived at by varying the diet until the minimum but sufficient quantity has been arrived at which will preserve the health and vigour. The poten. tial of the diet can be calculated by $\mathrm{an}$ inatru. ment called the calorimeter, which will give the heat producesl during the lurning of any cous. bustible substance, and from the heat produced the potential in respect to mechanical work can be calculated. In the subjoined table the poten. tials of one onnee of each of three important food. stuffis are given :

Fats (beef fat).

Proteide (albumen)

Carbohydmen (starch)

181 \&

15126

It will at once be seen how remlily one could cal. culate the amount of food-stuff capable of fnrrishing the body with fuel for twenty-four hours. All that is necessary will be to divide foco by the uumber of foot-tons which correspond with the article solected : the quotient is the number of ounces required. Thus 11 ounces of fat, or 24 ounces of albumen, or 26 ounces of starch would contain the secensary potential.

From what has already been said regarding the conplexity of the bodily mechnniam, it may be surnised that a single food-stuff (even if a quantity be taken which provides a sufficient potential) is incapable of stoking the body. Numerom experiments, snch a those conducted by the Gelatine Commission, by Dr Hammond, and others, indicate that the body is unable to maintain its natural vigour on a diet consisting solely of gelatine, or of starch, of nlbumen, or of fah \&e.

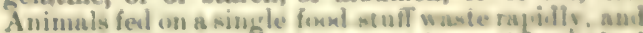
will refuse their food after a fow days with marked dislike, dying eventually of atarvation. At leat. two stnple articles of food must be kiven, mixed, even in this case, with many accesories, such as varions salts, anomatic subiances, \&c, in order thet health may be maintained.

lielig taught that the musular work of the bouly results from the oxidation of sisrugenous matter (albumen, both animal and regorable), but it b now known that all the clases of food-atuffis except the mineral unatters are asod by the muscles. Never. theleas proteids (nitrogenons food) are ceential, a we shal see on exporimental grousde, and from the fact that in the dietary of every nation, proteid matter is alwass present, combinevl at my rate with fat, generally with earlwhicheses as well.

In many parte of the worid man subsiste with- 
out the use of carbohydrates. The Eskimo and the North American Indian live entirely on the produce of the chase. The flesh of animals is rich in proteids and fats, but contains practically no carbohydrate. In the same way the Arab of the desert lives upon the flesh and milk of the camel, in districts where the date is not to be found. The use of carbohydrates is extensive in most temperate and tropical climates. Many of the inhabitants of India and Ceylon live chiefly on rice. Wheat, potatoes, and other vegetable foods, rich in carbohydrates, are staple articles of food both in Europe and America. In fact, within certain limits, man, like every other animal, is capable of adapting himself to the food produced by the district in which he lives. The French and Spanish peasants eat little meat, living on carbohydrates and vegetable proteids, and supplying necessary potential by an abundance of oil. The Sussex labourer consumes his beans, rich in vegetable proteids, and bacon, and does a good day's work on them. The Scotch labourer of a former generation lived on porridge and skimmed milk, with meat but once a week. The Arab of the Sahara, together with his family and his horse, subsist almost entirely on the date, while the Arab of the Nubian Desert hardly ever touches vegetable food. The diet of every man, under whatever circumstances, invariably contains proteids, although this may vary in its quantity. The universal use of proteid matter in some form or other suggests its importance, and this is fully borne out by the evidence of direct experiment. If proteid food be withdrawn from the diet altogether, nitrogenous matter continues to be eliminated from the body by the urine, although its supply is cut off. At the same time the body wastes, and death finally occurs. The experiments of Fick, Wislicenus, and Parkes show that during muscular exertion the body does not excrete any excess of nitrogen ; and the writer's own researches show that urea-the most important excretion which contains nitrogen -is not found in abnormal extent in muscular tissue after exhaustive exercise. It would appear, therefore, that nitrogenous matter is not used by the tissues for fuel, and that when proteid food is consumed, the muscles burn a non-nitrogenous substance which is formed from it. The nitrogen, in the form of urea, \&c., is carried by the blood to the kidneys, and at once excreted. We must look elsewhere than in the ordinary combustion of a muscle or brain cell for a use for the nitrogen which, as we have seen, is so necessary an article of food in the form of a proteid substance. In the child, the tissues which contain nitrogen in definite proportion are continually growing, and it will readily be seen that here, at anyrate, we have an important use for proteid diet-namely, to furnish the necessary nitrogen for the new tissue. Even during adult life we have tissue change and growth. The skin is continually growing in its deeper layers to replace its surface layers worn away by constant friction. In the same way the cells of the blood are always being broken down, and their places taken again by new ones continually forming. Although it is hardly probable that such complete changes take place in all the tissues of the body, yet, without the entire breaking down of individual cells, there are no doubt changes both integrating and disintegrating, which are constantly taking place. As a result of disintegrating changes nitrogenous matter in an effete form is being given off by the system, and it has to be replenished from without in a form which the body can use. The proteid food-stuff provides nitrogenous pabulum for the tissues which they assimilate, and build up new tissue material. For this reason proteid matter is indispensable. At the same time the system obtains from the proteid food non-nitrogenous fuel to be burned by the tissues; this property of supplying tissue fuel is shared with the carbohydrate and fatty food-stuffs. It has been found by experiment that an ordinary diet should contain one part of nitrogenous matter (proteids) to about four of nonnitrogenous diet (fat and carbohydrates). If less nitrogenous matter be given, the tissue consumption of nitrogen will not be supplied, and the body will waste. If a much larger quantity of nitrogenous food be taken, a nitrogenous surfeit occurs, and the body is called upon to digest this excess, and to eliminate an unnecessary quantity of the useless nitrogenous compounds which result.

We have seen then that an ordinary diet must contain sufficient potential, and in addition one part of proteid to four of non-proteid material should be present. The following table from $\mathrm{Dr}$ Parkes shows the proper proportions of solid waterfree food-stuffs in ounces required as daily food by an adult man :

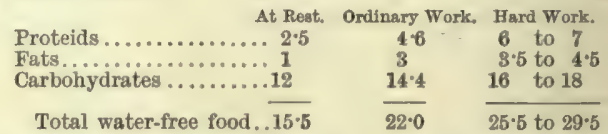

Taking the diet table for a man performing ordinary work, we have 4.6 of proteid, and $17^{\circ} 4$, or nearly four times as much non-proteid matter. It contains sufficient potential, for if the number of foot-tons which result from the combustion of an ounce of proteid, of fat, and of a carbohydrate be multiplied by the number of ounces of these substances given in the ordinary diet, it will be seen to amount to 4000 . This, as we have already seen, indicates a sufficient potentiality.

It now becomes an easy matter to construct a diet table of articles of food. Most of these have been analysed, and the amount of water, proteid, carbohydrate, or fat in each calculated.

TABLE FOR CALCULATING DIETS (Parkes).

\begin{tabular}{|c|c|c|c|c|c|}
\hline Articles of Food. & Water. & Protelds. & Fate. & $\begin{array}{c}\text { Carbo- } \\
\text { hydrates, }\end{array}$ & Salts. \\
\hline $\left.\begin{array}{l}\text { Uncooked beef } \\
\text { and mutton... }\end{array}\right\}$ & 75 & 15 & $8 \cdot 4$ & - & $1 \cdot 6$ \\
\hline Fat pork........ & 89 & $9 \cdot 8$ & $48 \cdot 9$ & & $2 \cdot 3$ \\
\hline Dried bacon .... & 15 & 8.8 & $73 \cdot 3$ & .. & $2 \cdot 9$ \\
\hline Smoked ham.... & $27 \cdot 8$ & 24 & $36 \cdot 5$ & $\because$ & . $10 \cdot 1$ \\
\hline White-fish...... & 78 & $18 \cdot 1$ & $2 \cdot 9$ & $\ddot{0}$ & 10 \\
\hline Poultry .......... & 74 & 21 & $8 \cdot 8$ & & $1 \cdot 2$ \\
\hline White bread.... & 40 & 8 & 1.5 & $49 \cdot 2$ & $1 \cdot 3$ \\
\hline Wheat-flour..... & 15 & 11 & $\overline{2}$ & $70 \cdot 3$ & 1.7 \\
\hline Barley-meal .... & 11:3 & $12 \cdot 7$ & 2 & 71 & 80 \\
\hline Rye........... & $13 \cdot 5$ & $13 \cdot 1$ & 2 & $69 \cdot 3$ & $2 \cdot 1$ \\
\hline Biscuits...... & 8 & $15 \cdot 6$ & 1.8 & 73.4 & 1.7 \\
\hline Rice ............ & 10 & 5 & $\cdot 8$ & $83 \cdot 2$ & 5 \\
\hline Oatmeal........ & 15 & $12 \cdot 6$ & $5 \cdot 6$ & 63 & 8 \\
\hline Maize ......... & $13 \cdot 6$ & 10 & 6.7 & $64 \cdot 5$ & $1 \cdot 4$ \\
\hline Macaroni........ & $13 \cdot 1$ & 9 & $\cdot 3$ & 76.8 & 8 \\
\hline Arrowroot...... & $15 \cdot 4$ & .8 & & $83 \cdot 3$ & .27 \\
\hline Dry peas ........ & 15 & 22 & 2 & 58 & $2 \cdot 4$ \\
\hline Potatoes........ & 74 & 2 & 16 & 21 & 1 \\
\hline Carrots. ........ & 85 & 160 & .25 & $8 \cdot 4$ & 1 \\
\hline Cabbage........ & 91 & $1 \cdot 8$ & 5 & 5.8 & 7 \\
\hline Butter............ & 6 & $3 \cdot 3$ & 88 & .. & $2 \cdot 7$ \\
\hline Fggr $\ldots . . . . .$. & 73 & $18 \cdot 5$ & $11 \cdot 6$ & $\ddot{*}$ & 1 \\
\hline Cheese............ & 36.8 & $33 \cdot 5$ & $24 \cdot 3$ & & $5 \cdot 4$ \\
\hline Milk. ........... & $86 \cdot 8$ & 4 & $3 \cdot 7$ & $4+8$ & $\cdot 7$ \\
\hline Cream ......... & 66 & 27 & 267 & $2 \cdot 8$ & 18 \\
\hline Sugar .......... & 3 & $\ldots$ & .. & $96 \cdot 5$ & -5 \\
\hline
\end{tabular}

Many articles of food owe their chief importance to their action as stimulants. Such are alcohol, tea, coffee, and beef-tea. Alcohol is no doubt burned within the body, and is a source of energy. Only a small quantity, however, can be so utilised, perhaps one ounce in every twenty-four hours in the case of an ordinary individual. As a source of energy, therefore, it is of little value, and such substances as fat, meat, bread, are capable of supplying the 
potential at a very much smaller cost. Alcohol taken with other food stimulaten the secretion of gastrio juice, assisting in that way the digentive process. At the same time, however, the gastric juice is unable to inet yuite so resulily upon the food, though this is hardly the case with diluted spirits, which form more wholesome beverages than wines or beer. No two individuals are the same, and while alcohol, in moderate doses, promotes aligestion in most persons, others suffer from its use. (See the article on the action of alcohol, Vol. I. p. 135). It should never be given in collapse and weakness without giving at the same time easily digrested food when that is possible. It excites the luily to great and often unnecessary activity, the potential for which it dow not supply. After wards greater weakness ensues from want of the necessiry fuel, which has not in the meanwhile been fortheoming. One should never drink without eating. Tea and coffee are both nervons stimulants, and at the same time they retard both gastric and salivary digestion.

Beef-ten is generally regarded as a food-stuff of high nutritive value. This is, however, not the case. It contains nothing besides salts and extractives, and has a very slight potential indeed. It has a stimulating effect, however, both on digestion and on the nervous system. From the mis. taken ideas generally held as to the nutritive pro. perties of this substance, thousands of invalids are annually starved to death (see BEEF-TEA). Beeftea made by infusing the beef in tepid water is more nutritious, especially if the beef be finely minced and eaten as well.

In addition to the stimulants that we have already considered are many substances known as condiments, auch as mustard, pepper, pickles, sauces. These are of utility in gratifying the palate, and in addition they probably stimulate the secretory juices. Sufficient information has not as yet been obtained as to their action on gastric and panereatic digestion. They certainly stimulate the flow of saliva, although the acid condiments will prevent the perfect action of the salivary ferment.

Common salt is a condiment, and at the same time it plays many other important parts in the animal organism. So necessary is it that both man and animals suffer great hardships if it be not gupplied in sufficient quantity. It is necessary for the formation of the gastric juice ; it is present in the blood and in all tissnes of the body.

Inorganic salts, such as sulphates, phosphates, are required for the formation of the skeleton, and salts of iron for the colouring matter of the blood. Organic salts, such as eitrates and tartrates, are also of importance. That food should be easily digested is a matter of great importance. The rapidity of digestion will depend upon the amount and quality of the digestive juices, the kind of ford, and the condition in which the form is eaten. Rice, tripe, whipped eggs, sago, tapioca, barley, milk, raw eggs, lamb, parsnips, potutues, hashes of chicken, fish, are all easily digessted sulsisures, Beef, mutton, pork, roast fowls, bread, veal, oysters, are digested more slowly. Insmuch a perfect digestion can only be sccomplished when the digestive juices have acted for some time on all parts of the ford taken, it follows that fine sulp. division of food is very essential. On this acconnt liquid food repidly disappears from the stomach, which retains for a longer time solid masees upon which the gastric juice acts with greater difficulty. When food is cooked it swells, its fbres and aolid particles are separated one from another, and it in more readily permeated by the gastrie and pan. creatic juices. In addition, starch bocomes gelatinous, and in that form is easily digested by the maliva and panerentie juice. The diet of early infautile lifus differon from that of the sulule, inoums. as it should contain no mtanch. Milk, tho naturnel food of the infant, is rich in fat, proteids, and a sugar called milk-mugar. There is in milk, bow. ever, an entire alaence of atarels, an article of funal which the infant is dentined to consume in such large quantities in later years. Moroover, during the finst few months of its extra-uterine eximtence the child is unable to animilate starch given with its food. On no socount, therefore, mast it be wupplied with bread, potatoen, rice, or other vegetmalse fond until the cutting of the teeth suggents a more molial diet. If the mother's milk be not in suftirient plenty, cow's milk diluted with one-third of water, with a pinch of angar, may be given, or condenmer milk diluted with twelve to twenty parth of water (see MiLK). Condensed milk, owing probubly to its very uniform composition, cannot be given alone for more than a few weeks together. It may, how. ever, be given once or twice a day for months, and children thrive on it, when they in addition are supplied with good cow's, or still better, with their own mother's milk.

In conclusion, it may be well to conrider the results which follow the neglect of the moet obvious rules of dietetics. As the reault of defi. cient food, one finds loses of muscular and nervous (w)wer, wasting of the tiasnes, and anemis If the leficiency be very great, feverish symptoms and great prostration result.

Many persons consume large quantities of fond quite out of proysortion to their sise or activit. In this case, owing to a 'habit of digestion, much of the food may pass through the digestive tract without being digested or assinilated. Under these circumstances the hearty eater is a wasteful eater, and is using for his own bodily needs only a fraction of the food he consumes. In addition, drspejsia in various forms, constipation, and diarrhoe are apt to follow, indicating functional derangements of the digestive apparatus. There is often a tendency, especially in advanced years, to absorb more nourishment than is necensary for stoking the body and for replenishing ordinary tissue waste. The excess is stored up in the form of fat, which aceumulates under the skin, ehiefly under that of the abdomen. In addition, the nutucles and internal organs are loaded with fat, the minute globules of which may be seen in the ultimate celfs of which the tissues ure cenmpmest. Hereditary tendency is well marked in cases of corpulency. In addition to corpulency, an exces of food is apt to engender various gavine troubles, engorgement of the liver, plethorn, and an excen of effete extractions in the blood and urine. It is probable that humanity suffers more from an exces than from a deficiency of food. An excese of animal is more serious than m everes of vereatile food. The nitrogenous extractions, derived from the incomplete assimilation of meat, when preseut in large quantity, eause many syuptoms, most of which are extremely obecure in their nature. These are provisionally epoken of as symptoms of gout. The ill effects which follow eurfeit are more severe in those lealing a sedentary and insetive life bodily activity producing more effcient oxidation of the food taken. A healthy and nlutemions man whose tastes have not beren en. slaved by the enlinary art instinctively adapes his foxyl in the nepuirements of his inoly. The cold of winter prompte the choice of subtantial and enengiaing food, while the heat of sumner suggests a ligliter dietary. After a conntry holi. day, on returning to a sedentary life one ai once reluces one's allowance of Leer. or expertes to pay the penalty that a disordered digention is certain to exact. During the agow is which 
humanity has been evolving, there has been a constant adaptation of taste and desire to the needs of the economy. The natural gustatory inclinations as a rule are a good indication of the bodily wants. As a rule wholesome things have a pleasant taste, and the reverse also holds good. It is all-important, however, that the satisfaction of mere gustatory pleasure be not allowed to monopolise too much of the energy of any individual. Under these circumstances a surfeit is certain to result. There is a well-known law in physiology to the effect that greater and greater stimuli have to be applied in order to produce a series of equal sensations. It follows that the excesses of the glutton and drunkard are out of all proportion to the actual pleasures these excesses produce, the wise man drinking and eating only in moderation.

See the articles on Cookery, Food, Drakstion, IndiGESTION; also Pavy, Food and Dietetics (1874): Sir H. Thompson, Food and Feeding (1880); Sir W. Roberts, Lectures on Dietetics and Dyspepsia (1885); Fothergill, Manual of Dietetics (1886).

Diet (Lat. dies, 'day'), a meeting of delegates or of dignitaries, held from day to day, for legislative or ecclesiastical purposes; the title was afterwards extended to such bodies themselves. The term is applied to the sessions of church assemblies in Scotland, but its chief use is as the specific title of the administrative assemblies of the German empire and some other continental states (see GERMANY).

Desertion of the Diet, in Scots law. The pro. ceedings under a criminal libel are in Scotland spoken of technically as a diet, and when the libel is abandoned by the public prosecutor, or where he fails to appear, he is said to desert the diet. The effect of a judgment of the court declaring that the diet has been deserted, is to free the accused from prosecution under the particular libel or writ, but not to prevent a new process being raised on the same grounds.

\section{Dietrich of Bern. See Theodoric.}

IDiez, Friedrich Christian, the greatest of Romance philologists, was born at Giessen, 15th March 1794, and educated at Giessen and Göttingen, with one short interval in 1813 of campaigning as a volunteer. In April 1818 he saw Goethe at Jena, and was directed by the sage to the lectures of Raynouard and the study of the Provencal tongue. From 1822 he lived at Bonn as a privat-docent, and in 1830 was there appointed professor of the Romance Languages, and there he died, May 29, 1876. His first work, Altspan. Romanzen (1821), was followed by a series of valuable works on the Romance languages, of which the greatest are his Grammatik der Romanischen Sprachen (3 vols. 1836-38; 5th ed. 1882), and the Etymologisches Wörterbuch der Romanischen Sprachen 12 vols. 1853 ; 5th ed. by A. Scheler, 1887 ; Eng. trans. 1864). These works discussed these languages for the first time from the comparative historical standpoint, and thus formed a sound foundation for all subsequent Romance philology. See the books on Diez, his life and work, by Sachs (1878), Breymann (1578), and Stengel (1883-94).

Difference, Calculus of Finite DifferENCES. Difference implies two quantities of the same kind, and means in arithmetic that quantity which must be added to the smaller in order to produce the larger, and in algebra that quantity which must be added to either to produce the other. Thus if the quantities be the numbers 5 and 7 , their arithmetical difference is 2, while their algebraical difference may be either +2 or -2 . The difference -2 arises from the fact that we may in algebra ask the question what must be added to 7 to produce 5 ? and the answer to this is -2 .

In certain groups of problems, chiefly relating to series, differences considered in a particular manner are of peculiar importance, constituting in fact a branch of higher algebra, which took its origin in Brook Taylor's Methodus Inerementorum (1715), and is now called the Method of Differences or the Calculus of Finite Differences. This method we shall briefly illustrate.

Suppose it were required to discover the law of formation, and thence to continue the series of numbers :
4, 3,
0, 1,
12 ,
$39, \quad 88$,
165.

It would be wrong to assume that only one law of formation will produce these eight numbers, just as it would be wrong to assume that only one curve could be drawn through eight given points; but for the full discussion of the difficulty here raised the reader must be referred to the chapter on Interpolation in any text-book on the subject. We shall, however, show how to find one law of formation, and use our figures to illustrate the elementary notation of the subject. The process is to take the difference between each term and the succeeding one, and so get the first series of differences, or, as it is called, the series of first differences; the process is repeated on the first differences, and so on, as follows :

$\begin{array}{lllllllll}\text { No. of term, } & 1 & 2 & 3 & 4 & 5 & 6 & 7 & 8\end{array}$

Given Series, $\left\{\begin{array}{llllllll}u_{1} & u_{2} & u_{3} & u_{4} & u_{5} & u_{6} & u_{7} & u_{8} \\ 4 & 3 & 0 & 1 & 12 & 39 & 88 & 165\end{array}\right.$

1st Differences, $\left\{\begin{array}{ccccccc}\Delta u_{1} & \Delta u_{2} & \Delta u_{3} & \Delta u_{4} & \Delta u_{5} & \Delta u_{6} & \Delta u_{7} \\ -1 & -3 & 1 & 11 & 27 & 49 & 77\end{array}\right.$

2d Differences, $\left\{\quad \Delta^{2} u_{1} \Delta^{2} u_{2} \Delta^{2} u_{3} \Delta^{2} u_{4} \Delta^{2} u_{3} \Delta^{2} u_{6}\right.$

3d Differences, $\left\{\begin{array}{c}-2 \\ \Delta^{3} u_{1} \Delta^{3} u_{2} \Delta^{3} u_{5} \Delta^{3} u_{4} \Delta^{3} u_{5} \\ 6\end{array}\right.$

The line of third differences suggests a law of formation, and enables us to continue the series as follows :

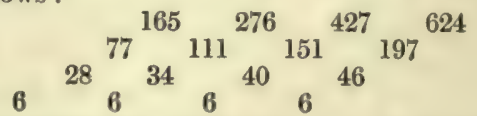

It could further be shown that if $u_{x}$ be the $x$ th term of the series above, then

$$
u_{x}=x^{3}-7 x^{2}+13 x-3
$$

The operation indicated by $\Delta$ is defined by the following equation, where $u_{x}$ means any function of $x$ :

$$
\Delta u_{x}=u_{x+1}-u_{x}
$$

or, if we denote the 1 added to $x$ by $\Delta x$, by the equation

$$
\frac{\Delta u_{x}}{\Delta x}=\frac{u_{x+1}-u_{x}}{1}
$$

or with the appearance at least of greater generality by

$$
\frac{\Delta u_{x}}{\Delta x}=\frac{u_{x+h}-u_{x}}{h}
$$

As a final example let us suppose $u_{x}=x^{2}$. Then we have, using equation (1) above,

$$
\begin{aligned}
\Delta u_{x} & =(x+1)^{2}-x^{2} \\
& =2 x+1
\end{aligned}
$$

This is a case of the direct problem of the caleulus, but there is also the inverse problem: Of what function is $2 x+1$ the difference? The solution to this is denoted by the symbols:

$$
\Sigma(2 x+1)=x^{2}
$$

or, strictly speaking, for reasons which we need not give, by

$$
\Sigma(2 x+1)=x^{2}+C ;
$$

and $x^{2}+\mathrm{C}$ is said to be the integrate of $2 x+1$. 
Between the Calculus of Finite Differences and the Differential Calculas (nee CALculus) (a title which means the ealeulus of intinitesimal differ. ences) there sre many importunt points of contrast and of similarity, which would be not lees clenrly appreciated if the maness were changerl, ans Brole all but suggested, the former to Calculus of Differences, the latter to Calculus of Limits.

The methods of the Calculus of Diflerences are in vogue among actuaries and others in dealing with statisties such as mortality tables; and from this ealculus are derived many formula of approxi. mation of great practical value, such as the rules for finding the ares of surfaces bounded by curved lines.

Differentiation, that organic progress which occurs when certain parts of a uniform whole become structurally different from the others, or when, in other words, the homogeneous becomes heterogeneous. Inequality in internal and external conditions of life brings about restriction of certain vital processes and the predominance of others, and as this division of function is established, diversity of structure results. Differentiation is the structural change which is associated with the physiological 'division of lalwour,' and the process is essentially the same whether it find expression in cells, tissues; organs, or entire organisms. See Division of LABour, Evolution, VARIATion, \&c.

Difraction. In general, light is propagated in straight lines in a homogeneous medium : but, if it be caused to pass through an opening which is not large in comparison with the wave-length of the light, the law no longer holds. Such phenomena are said to be due to diffraction. The subject will be found trested at greater length under LIGHT.

Diffusion. The particles of all material bodies, except such as may be totally devoid of heat, are in rapid motion. In the case of solid bodies the excursions of any one particle are limited to a small space; but in fluids a particle may move more or less freely throughout the whole space occupied. This intermixture of molecules may occur also when different fluids are placed in contact with each other, but it may be prevented by the existence of tension at the common surface (see SURFAck-TrNsion and Capillarity). When it does occur, the fluids are said to diffuse into each other.

Diff usion of Liquids. The diffusion of dissolved salts may obviously be considered under this healing. The phenomenon may be conveniently studied by introducing a strong solution of some highly-coloured salt, such as bichromate of potash, into the bottom of a tall glasa cylinder nearly filled with water. The rate of diffusion vuries with the nature of the liquids. Graham was the first to investigate the subject carefully. He filled a number of similar glass veseels with solutions of different salts. The mouths of these vessels were carefully ground so that they could be closed by means of glass plates. The different vessels were then placed in equal glass jars, and covered with water to a definite extent. Next the glase covers were cautiously withdrawn, and the diffusion was allowed to go on for a certain time. The rate at which each liquid diffused was thus obtained. Graham found that, for any one solution, the rate is proportional to the gradient of concentrationi. e. to the rate at which the quantity of salt dissolved per unit-volume varies per unit-length. Thus the law regulating diffusion of liquids in analogous to that which regulates the conduction of heat in a homogeneous solid. Hence the equations obtained by Fourier in his Theoris de la Chalcur apply to the problem under consideration.

Graham found also that rise of temperature

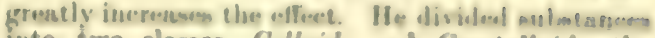
into two clasees, Colloids and Cryatullovids, the members of the firmt elne diffusing very mach more slowly than thowe of the second. Hif inven. tigations have been much extended by more revent observen employing various methoof of olwerva tion.

If two miscible liquid he meparated by a menbrane of bladder or of parcliment pnper, ke. diffusion takes place through the aeptum at netem which are usually very different for different liquide. This phenomenon is known as Unovese (q.v.). It was first shown lyy Nollet that, if a vessel filled with alcohol be closed by a piece of bladder and placed in water, the diffumion of the water is no much more rapid than that of the alcohol that the blaider is burnt becruse of the increase of the contents of the vesuel which it closes. By this means the various constituents of a mixture of colloid and eryetalloid suhatances may he separated to any desired extent. The rate at which liquids diffuse into each other through a septum depends greatly upon the molecular action between them and the septum.

Diffusion of Gases. - If two flasks, each filled with a different gas at a given preasure anil temperature, be placed in communication with each other, the gases will be found to interdifinse. The rate of interdifinsion is shown by theory to be nearly in inverse proportion to the aquare root of the product of the densitics of the two gaves. and the experimental results are in accorilance with the theory.

Effusion of Goses.-This is exhilited in the passage of a ges into vacuum under constans pressure through a small opening in a very thin plate otherwise impervious to it. The work done in the passage of a given volume of the gas is proportional to the pressure, and the expisalent kinetic energy is proportional to the product of the density and the square of the speed of effusion. Hence the speed for a given presure varies in. versely as the square mot of the denaity. Grahas. showed that this result of theory is elosely realised by experiment. He showed, further, thas when s discrepancy exists, it is due to the finite thicknes of the plate.

Transpiration of gases is the term to the pamage of guses under jressure through a fiue eapillary tulee. This sulijert was ulso investigaterl loy Graham, who found that the rate of lowases is not affected by the material of the tribe. This seems to indicate that the tube becomes conted internally with a thin film of gas, so that the opposition to the flow of gas is dne to Viscosisy $\left(q, v_{0}\right)$.

The rates at which different gaves pas thmugh fine unglazed earthenware are invervely a the square roots of their denaities. Hence we have a means of separating gases the densities of which are different (see ATMOLYS1s). If the septum be made of caoutchouc, which is not porons the pensage of gases still oceurs. The gas sems to com. hine with the matter of the septum on the ase side. to diffuee through it, and finnly to be given of on the other side. The pasange of come gases, meh an carbonic oxide, through hout cust-irun in analogous

Digamma is the name given by the gram. marians of the Ist century tas ean, the sinh letter of the primitive Greok alphabet, which had be. come obnolete, and was only known to them from inseriptione. The name wns given oving to a fancied resemblance of its form $f$ to a double gamma. Its sound was something like that of our a. It in found in Pelopoaneaian inscriptions as late as the 6ih century R.C., bus it houl dis. appeared from the alphatiet of Artic lefore the date of the ullest inscrifutiuns-i.e. before the 
middle of the 7th century B.C., although, as Bentley has proved, it must have been in use at the time when most of the Homeric poems were composed. It appears as the letter $F$ in the Latin alphabet, which was derived at a very early period from the alphabet of Eubœa. In later Greek, though discarded as a letter, it is retained in the form 5 as the numeral for 6 . See the articles on $F$ and $V$.

Digby, a small seaport of Nova Scotia, on St Mary's Bay, reputed for its curing of a variety of small herrings or pilchards ('Nova Scotia sprats'). There was a great fire in February 1899. Pop. 1951.

Digby, SIR KenelM, was born at Gayhurst, near Newport Pagnell, 11th July 1603. His father, Sir Everard Digby (1578-1606), in 1592 came into a large estate, but seven years later turned Catholic, and was hanged for his part in the Gunpowder Plot (q.v.). Kenelm himself was bred a Catholic, but in 1618, after a half-year in Spain, entered Gloucester Hall, Oxford (now Worcester College). He left it in 1620 without a degree, and spent nearly three years abroad, in Florence chiefly. At Madrid he fell in with Prince Charles, and following him back to England, was knighted, and entered his service. In 1625, after a singular courtship, he secretly married ' that celebrated beautie and courtezane,' Venetia Stanley (1600-33), who had been his playmate in childhood. With two privateers he sailed in 1628 to the Mediterranean, and on 11th June vanquished a French and Venetian squadron off Scanderoon. On his beloved wife's death he withdrew to Gresham College, and there passed two hermit-like years, diverting himself with chemistry and the professors' good conversation. Meanwhile he had professed the Protestant faith, but, 'looking back,' in 1636 he announced his reconversion to Archbishop Laud; and his tortuous conduct during the Great Rebellion was dictated, it seems, by his zeal for Catholicism. He was imprisoned by the Parliament (1642-43), and had his estate confiscated; was at Rome (1645-47), where he finished by 'hectoring at his Holiness;' and thrice revisited England (1649-51-54), the third time staying two years, and entering into close rela. tions with Cromwell. At the Restoration, however, he was well received, and retained his office of chancellor to Queen Henrietta Maria. He was one of the first members of the Royal Society (1663), and died 11th June 1665.

'The very Pliny of our age for lying,' said Stubbes of Digby, whom Evelyn terms ' an arrant mountebank.' Yet he was a friend of Descartes and Sir Thomas Browne (q.v.); he could appreciate the discoveries of Harvey, Bacon, and Galileo. In the Dietionary of National Biography (vol. xv. 1888) Mr S. L. Lee points out, that 'as a philosopher-an Aristotelian-Sir Kenelm undoubtedly owed much to Thomas White;' and he questions whether his much-vaunted 'powder of sympathy' was not really invented by Sir Gilbert Talbot. This powder-Digby professed to have learned the secret from a Carmelite who had travelled in the farthest East-was made of vitriol, and applied to a bandage, not to the wound itself. Anyhow, Digby's Discourse thereon (1658), like his Treatise of Bodies and of Man's Soul (1644), contains much that is curious, if little of real value; whilst in his Discourse concerning the Vegetation of Plants (1660), the chief of his other twelve works, he 'is said to have been the first to notice the importance of vital air or oxygen to plants.' See his bombastic Memoirs, dealing with his courtship (ed. Nicolas, 1827); his Scanderoon Voyage (Canden Society, 1868); and his Life 'by one of his descendants' (1896).
Digby, Kenelm HenRy, was born in 1800, youngest son of the dean of Clonfert. Having entered Trinity College, Cambridge, he took his B.A. in 1819, and three years later published the Broad Stone of Honour - "that noble manual for gentlemen,' as Julius Hare called it, 'that volume which, had I a son, I would place in his hands, charging him, though such admonition would be needless, to love it next to his Bible.' It was much altered and enlarged in the 1828 and subsequent editions (the latest 1877), its anthor having in the meantime turned Catholic. He died in London, where most of his long life was spent, on $22 \mathrm{~d}$ March 1880. Of fourteen other works ( 32 vols. 1831-74) all the last eight were poetry.

Digest, a name often given to the Pandects $(q . v$.$) of the civil or Roman law, because they$ contained 'Legalia præcepta excellenter digesta.'

Digester, PAPIN's, is a strong boiler with a closely fitting cover, in which articles of food may be boiled at a higher temperature than $212^{\circ}\left(100^{\circ}\right.$ C.). As its name implies, it was invented by Papin (q.v.), and a common form is the Autoclave, fig. 1 , where the lid can be turned round under elamps or ears, and thus be rendered steam-tight. Another form is given in fig. 2 , where a portion of the side
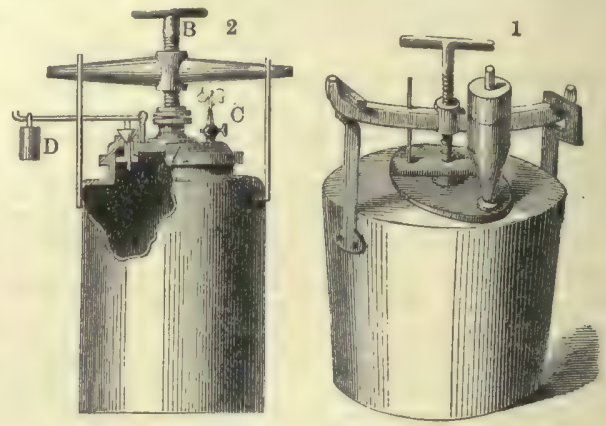

Papin's Digester.

is removed to exhibit the interior. The lid, $\mathbf{A}$, is fastened down by a screw, B, and the steam generated in the boiler is allowed to escape at a stopcock, $C$, or by raising the weighted valve, $D$. The increased pressure to which the contents of the boiler are exposed causes the boiling-point of the water to rise to $400^{\circ}\left(204^{\circ}\right.$ C. $)$, and occasionally higher. The digester is of great value as a means of preparing soups of various kinds, and especially in the extraction of gelatin from bones.

Digestion is the change which food undergoes in order to prepare it for the nutrition of the animal frame, and is carried on in the higher animals in the DIGESTIVE SYSTEM. In some of the lowest forms of animal life (amoebr) particles of food may be drawn into the body (which possesses no special organs at any part of its surface), and may then be digested. In higher organisms, however, parts have become evolved, which serve more especially the function of digestion. Thus in the common sea anemone there is a simple pouch which leads inwards from the centre of the cluster of tentacles. Into this fish and other food are drawn and digested, while the undigested parts are afterwards voided through the same aperture by which they entered. In still higher organisms, man himself included, this simple pouch is changed into a complex and greatly elongated tube, which is provided with one aperture (the mouth) by which food enters, and another aperture (the anus) through which undigested matter leaves the body. The whole digestive system is lined with a sort mem- 
brane, which is richly supplied with blood-vemels. This membrane is called the mucous membrane, and from it is secreted by the glands which it con. tains a viscid substance called mucus If the finger be thrust into the back of the month, and the mueous membrane gently sermpesl, the fluid which will achere to the finger is seen to be viscid it is secreted by the glands of the mouth. Not only mucus, but many other substances useful in digestion are formed by little glands in the mucons memlurane, so that the whole digestive system in bathed during digestion with fluid having a diges. tive action on the food. In addition there are other glands, such as the salivary, the liver, and the pancreas, which we may look upon as gland of the mucous membrane which have enormously developed. To so yreat an exterit have they in. creased in size that they have got far outside the digestive system, and have become situated in neigh. bouring parts of the body, only connected with the digestive system by their ducts or elongated mouths.

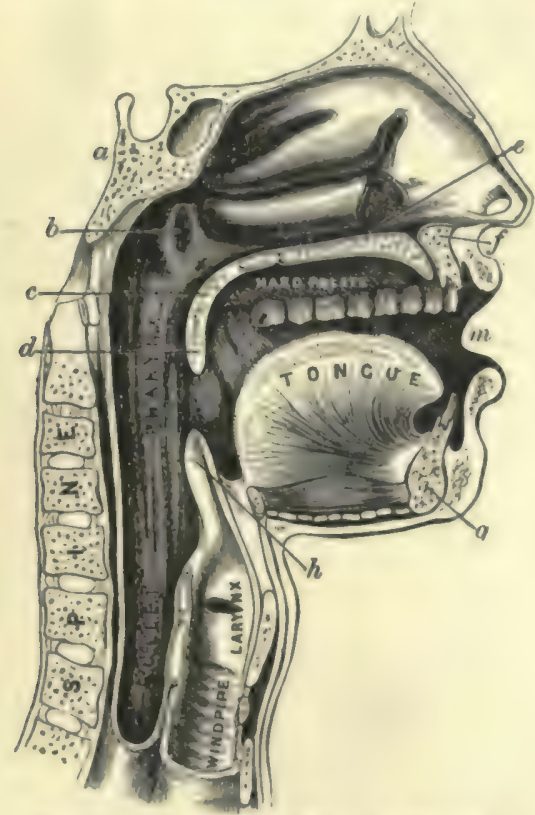

Fig. 1. Section through Mouth, Nose, ke: a, sphenoid bone; $b$, Euatachian tube; $c$ eoft palate; $d$, uvula ; $e$, nasal panage; $\rho$, upper jaw ; $g$, lower jaw; $h$, epiglottla; $m$, mouth.

Through these duct their secretions, like that of the microscopic mucous gland, pour into the cavity of the digestive system. Outside the mucous coat we have the muscular coat, the function of which is to move the food onwands in its counse, and to mix it with the digestive juices. In the mouth, throat, and the npper part of the gullet, the muscles which move the food onwards, as in swallowing, ane, when examined by the microscope, seen to be transversely striped, and like other striped muscles their contraction is rapid. In other parts of the digestive system, however, the muscular coat consists of smooth musele, and like all other smooth muscles this coat contracts slowly. On this account the food rapidly swallowed pases very slowly along the rest of the digestive system.

Having shown that the digestive system is a mucomuscular tube, we may now consider it more in detail. The month (fig $1, m$ ) is lined with mucous membrane, and into it is poured the secretion of three pairs of salivary glands-the parotids, situ- atol in front of the ear; the mabrunxillary, wichis

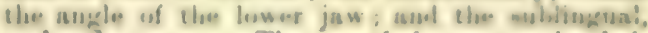
nnder the tongue. The mosuch is moet enimals is provided with hard timues-teeth, bouks-for the subdivision of food hefore it is swallowed. Vegte. table foeders, eating tough grains, rootw, and filsrew, have large molar of grinding teeth, while the ear. nivora have theme mane teeth morlified no as to present a eutting edge, with which and their pointed ennines ment is torn and eas luto jieces, which are then swallowed (soe TExтM). The inucous membrane of the mouth is covered externally by the mumclea of the eheek and lips. Into its eavity the muscular tongue projecta. On looking into the month with a looking-zlas, one sees back into the thront. The entrance to the throat will be observed to be hounded at the sides by two muacular eurtains panaing downwands obliquely to the sides of the root of the tongue. These are termed the anterior pillans of the fauces, and behind them, one on each side, are mames of lvmphoid tissue, subject to enlargement called the tonsils. Ahove, another curtain hangs down. It is called the soft palate, and separates the mouth from the hinder part of the nasal envity. Projecting from its centre is a little cone called the uvula (fig. 1). The cavity of the pharynx, or the interior of the throat, is another cavity lined by mucons menulyrue, with muscular walls. These usureles constrict it (constrictors). Below, the cavity pases into the gullet or assophagus, and in front of this tube runs the windpipe which communicates with the pharynx through the larynx, or organ of voice. Food will pass through the pharynx into the gullet; and air, dur. ing respiration, pasees through the pharynx on into the larynx and windpipe; a valve, ca!'sd the epiglottis, partly eloees the aperture of the larynx. The pharynx is common, therefore, both to the digestive system and the re. spiratory pasages. A bove, the pharynx communicates, as before described, with the mouth and also with the nose. One can demonstrate this latter fact by drawing smokeinto the mouth, and expelling it by the nostrils. This communication is closed during the net of swallowing, and also during the aing. ing of pure vowel. sounds, such as $a$, $\delta i$, and the clomure is effected chiefly by the elevation of the soft palate, which acts as a valve. The pharynx conmunicates in ad. dition with the mid.

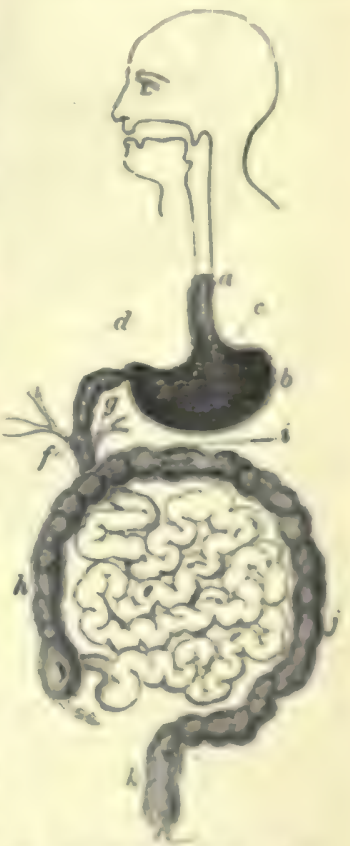

Fig. 2- Human Alimentary Careal:

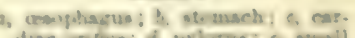

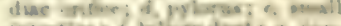

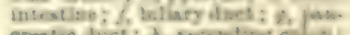
emalin dicest? A. sutestiog elles.

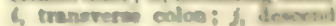
ing colon: is rweteren dle ear by the Enstachian tubes, and this may be rendered evident if the mouth and nose be closed, and a violent expirntory effort made at the ame time. As the presevre of air within the throat is increased, the Eustachian tubes which 
previously were collapsed now become distended, and a little wave of air at high pressure is forced into the middle ear, causing a buzzing sound. Occasionally the middle ear communicates with the external air through congenital or acquired apertures in the membrana tympani. In these cases smoke may be propelled from the throat out of one or both ears.

The gullet or cesophagus (figs, 1, 2, and 3) is a long tube passing from the pharynx to the stomach. Its mucons coat is loaded with very large mucous glands, which secrete a quantity of very viscid mucus. Its muscular walls contain striped fibres in the upper, unstriped in the lower part. The stomach itself is a greatly dilated part of the digestive system. Its shape is indicated in the fig. It may be said to consist of two parts, even in the human subject; a more complex arrangement is found in many animals, such as the ruminants. The large dilated portion into which the gullet opens is termed cardiac, and the opening the cardiac or cesophageal opening. The narrow part opening into the duodenum is the pyloric part, and the opening the pyloric opening. The whole is lined with mucous membrane, which, in the empty stomach, is thrown into projecting folds or ruges, but these folds are effaced when the organ is distended with food (fig. 3). In the

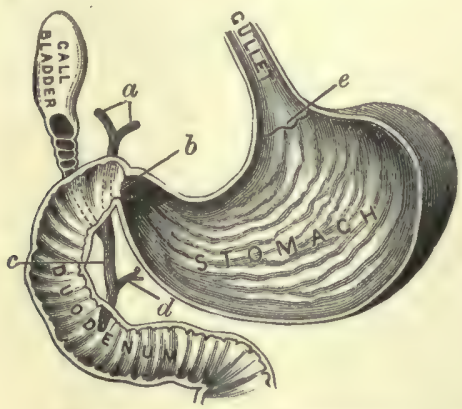

Fig. 3.-Section of the Stomach :

$a$, ducts of livex; $b$, pylorus ; $c$, bile duct; $d$, psncreatic duct $\ell$, cardiac orifice.

membrane are innumerable glands, which secrete the digestive juices of the stomach (fig. 4). If the surface of the membrane be examined with a strong pocket-lens, the apertures of these little glands may be seen. They run down from the surface into the deeper parts of the mucous membrane. They are lined by secreting cells. The greater number of glands situated in mucous membranes have the simple structure diagrammatically represented in fig. 4. Each gland has a mouth or short duct lined by cells. Below this the little tube is lined by cells which secrete the juice peculiar to the gland. This secreting part sometimes branches. Outside the gland blood-capillaries ramify, which supply the gland with nourishment, enabling it to manufacture the substances which it secretes. The gastric juice is acid, and the chief acid secreted is hydrochloric acid. This is formed at the cardiac, but not at the pyloric end. The substance called pepsine, which is necessary for digestion, is secreted by the whole of the glands. The cardiac glands therefore secrete both substances, and they possess two sorts of cells, those which form the hydrochloric acid being bigger and more granular than the other sort which secrete pepsine. The pyloric glands secreting pepsine have only one kind of cell similar to the pepsine-secreting cell of the cardiac end. Outside the vascular and glandular mucous coat, and united to it by a loose delicate layer-submucous coat-is the muscular coat. Thie is similar to that of the rest of the alimentary canal, except that there are in addition to the circular and longitudinal fibres, many oblique fibres. The eireular fibres are very thick indeed at the pyloric aperture, forming a circular sphineter band, which contracts and keeps back the food in the stomach until gastric digestion is nearly completed.

The food, now called the chyme, passes into the small intestine, a tube some 20 feet long. This tube, besides the muscular and mucous coats, possesses in addition an external coat of loose fibrous tissue, covered by a single layer of flat epithelial cells. This coat is prolonged into, and helps to form the mesentery, a membrane connecting the intestine with the abdominal walls, which are lined with a similar fibro-epithelial coat. This membrane is called the peritoneum, and is sometimes inflamed (peritonitis) as a result of cold, injuries, \&e. The small intestine is somewhat arbitrarily divided into three portions-the upper (duodenum), the middle (jejunum), and the lower (ileum). In all parts the muscular coat is sinilar to that of the rest of the digestive system. The mucous coat contains glands very like the pyloric glands of

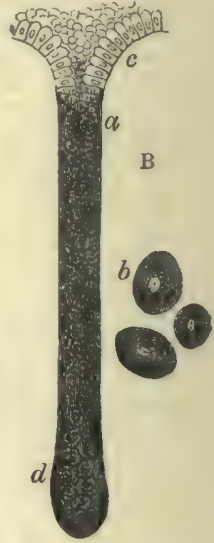

Fig. 4.

B, cardiac gland from the midale of the human stomach magnitled about 150 diameters: $a$, wall of the tube, lined with large oval nue lested cells; $b$, the leated cells; $b$, the columnar epithelium, occupying the upper parts of the tubes; $d$, blind extremity of the tube. c, nucleated cells of

kühn's follicles. These, however, rarely branch. They secrete the intestinal juice. In the duodenum, one finds in addition highly-branched glands called Brunner's. These extend right down into the submucous coat. Little is known concerning their function. In both the mucous and submucous coats, and generally involving both layers, are found masses of tissue-lymphoidsimilar to that found in a lymphatic gland (fig. 6). These are termed solitary glands, but it must be understood that they do not secrete any juice concerned in digestion. Their function is probably connected with the blood and the blood. corpuscles. Collections of these solitary glands,

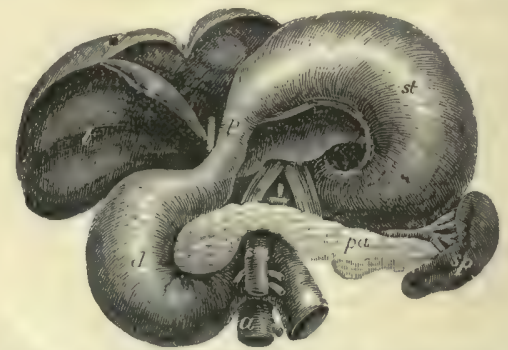

Fig. 5. - The under surface of the Stomach and Liver, which are raised to show the Duodenum and Pancreas: st, stomach; $p$, its pyloric end; $l$, liver; $q$, gall-bladder: $d$, duodenum, extending from the pyloric end of the stomach to the front, where the superior mesenteric artery, am, crosses the intestines ; $p a$, pancreas; $s p$, spleen; $a$, abdominal aorta.

forming oblong patches about two inches long, are called Peyer's patches. These are affected in typhoid fever. In addition to the follicles of 
Lieberkihn and the glands of Brunner, there ure two very important glandular struetures, the liver and the pancreas, which pour their digentive juices into the small intestine (fig. 8). The bile, which is the secretion of the liver, is formed continually by that organ, but the amount thus formed is grently influenced by the kind and quantity of food taken. It passes ont of the liver by the two hepatic ducts, and much of it pasees by the cystic duct into the gall-bladder, where it is stored up.

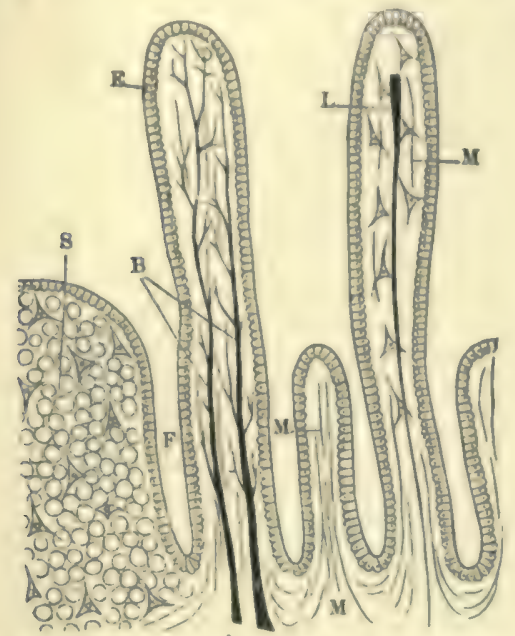

Fig. 6.-Section of Intestinal Mucous Membrane:

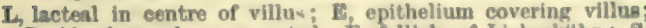
B, blood-vessels represented; F, follicle of Lieberkilhn; 8, part of a solitary gland; M, musenlar tibres.

From this the bile passes into the common bile dnct, which joins the duct of the pancreas, and the two open into the duodenum by a common aperture. The bile is to be looked upon not only as a digestive juice, but as a drain or channel of excretion, whereby effete and nseless matters are re moved from the body. The flow of bile is easily restrained, as by inflammation of the duet, or the presence of a tumour pressing on the duct, or a gall-stone. In this case, the bile already formed is reabeorbed with the blood, through the lymphatics, and we have jaundiee due to absorption of the colouring matter of the bile. The secretion of bile goes on before birth; the meconium of infants con. sisting chiefly of biliary matter. The panereas is very similar in structure to a salivary gland. It secretes the panereatic juice which pours with the bile into the digestive system. The mucous mem. brane of the small inteatine contrins, in eddition to the structures already mentioned, little projections called villi (fig. 6). These sre not, to any great extent at least, secretive, but they are im. portant absorbants. This property they share with the whole of the digestive system, through anv part of which, and especially through the walla of the stomach and small intestine, digested matter passes into the numerous blood-capillaries which form everywhere a dense network. The villi ane peculiar, however, for each one contains, in aldition to blood-vessels, a small lymph-vessel or lacteal. Nearly all the fat abeorhed by the diges. tive system is taken up by the little celle of the villi, and passes on into the lacteals, and thence to the blood (fig. 7). If some osmie acid, which blackens fat, be poured into the intestine of a milk. rabbit, killed during active digestion, and if the villi be examined with a microscope, they will be seen to have been blackened, especially at their

tipe, while the rent of the inteatine will have pre. morviol itm orilimary culour. On furctoer essususua. tion it will be meen that the fat lian been takinn up in microcopic globules by the celli covering the villi, and that they are pansing, in a way which is a yet not definitely settled, into the central lacteal.

The small intes. tine is a tube of great importance, and in order to in. crease its total area. the mucous mem. brane is elevater, in the upper part, into transverse folds

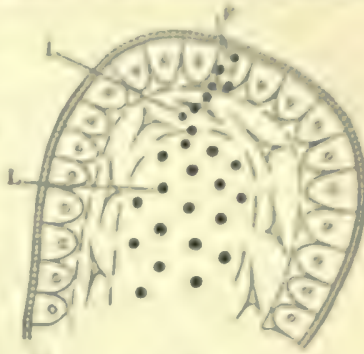

Fig. 7. - The Top of - Villus: Fat globules gre repoescoted an pare ing thrnogh one af the eplebeliat ollis, $\boldsymbol{P}$. on through the trovere of the vilius, I into the central lacteol, $\mathbf{L}$

(the valvulas conniventes, fig. 8).

The unabeorbed food, mixed with the varions secretions we have mentioned, now pasees into the large intestine, when both digestion and absorption go on, although to a less extent. The large inte. tine is only 5 feet in length, but its girth is much greater than that of the small intestine. It com. mences with the crecum, a dilated part, into which passees a little blind canal the vermiform apyen. dix), a large and important structure in some animals. The food remnant (freed matter) is prevented, under ordinary cireumstances, from pessing back into the small intestine, by a double fold of mucons membrane (the ilio-ereal valve, fig. 9). The large intestine ascends on the right side (ascend. ing colon), crosees over to the left side (transverse colon), and descends again (descending colon), and makes a bend (sigmoid flexure), and finally ter. minates in a somewhat enlarged portion (rectum).

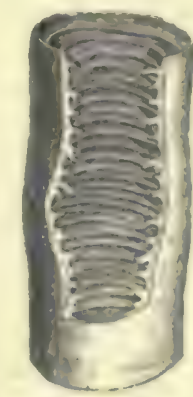

Fig. 8-Small Intestine distended alcohol, and laid the valvule cenDiventes. and hardened by open to show

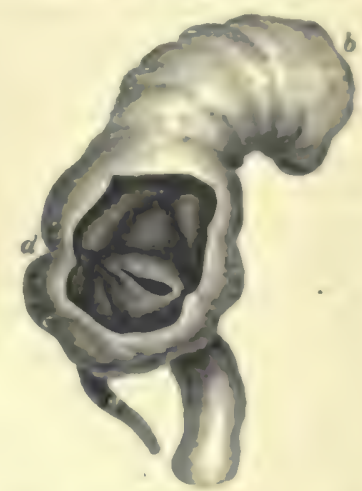

Fig. 9.-Coenm inflated dried. and opened to show tho ammer. ment of the valre:

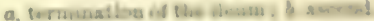

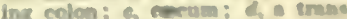

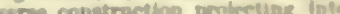

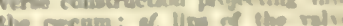

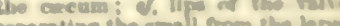

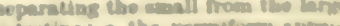

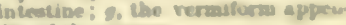
dix of the cincuni

The anal aperture is clooed by muaclen, an internal sphincter of non-atriped, and an external of ntriated filine. The mucoss membrune of the larso inteatine differs fmon that of the small intestine is contain. ing no villi, or Brunner glanda. Lieherkahn's and solitary glands are present, but the agsregivion of the latter into Pejer's patches is nuwhere to be found. 
Movements of Food in the Alimentary Canal.When food is taken into the mouth it is at once swallowed, unless it is in the solid form. In this case it is chewed or masticated; the use of which is to divide the solid fragments taken into a convenient size for swallowing, for which purpose it, in addition, is mixed with the viscid saliva and juices of the mouth. The chewed food, moreover, is more easily digested, inasmuch as the gastric and other juices can act more readily upon finely divided than upon larger masses of food. Many animals can hardly be said to masticate; such are the carnivora (dog, cat, \&c.), and they are not provided with grinding teeth. In most animals living on vegetable food, which frequently consists of hard grains, roots, and fibres, large flat grinding molars are found. In these animals, not only is the food finely divided in the mouth, but the food, largely consisting of starch, is partially digested by the saliva. In mastication, the head is firmly fixed by the powerful muscles of the neck, while the lower jaw is moved upon the upper. The lower jaw is approximated to the upper by powerful muscles (the temporal, masseter, and internal pterygoids), which pass upwards, and are attached to the side of the head and face. Their contraction may be felt by placing the hand in front of the ear and voluntarily contracting the jaws. The lower jaw is depressed by muscles which pass down the front of the neck. Most of these spring from the hyoid bone, which may be felt deep in the tissues of the neck above the 'Adam's apple.' Rotating movements and those of protrusion and retraction of the jaw are produced chiefly by the action of the pterygoid muscles. It is obvious that during mastication the food would naturally tend to escape from between the grinding surfaces of the teeth, and would collect within the mouth and outside the gums. This is prevented, however, by the muscles placed in the substance of the cheeks (buccinators) and lips (orbicularis oris). These keep the cheek and lip walls closely opposed to the outside of the teeth. On this account food will only escape from between the grinders into the interior of the mouth, from which it is collected and pushed back between the teeth by the muscular tongue.

The very complex muscular movements just described result from very perfectly co-ordinated nervous impulses, which pass from the brain to the muscles, and cause and regulate their contractions. One can masticate 'at will'- that is to say, one can consciously cause the muscles to contract. In order that the mastication may be effective, how. ever, it is necessary not only to know the sizes, but also to be aware of the ever-changing positions of the particles of food. This is effected by sensory nerves, which pass to the brain from the mucous membrane of the mouth. Although mastication is frequently voluntary, yet, like most other voluntary actions frequently performed, it can be performed reflexly. In this case the sensory impulses pass from the mucous membrane to the brain, and initiate appropriate motor impulses which pass to the muscles, without exciting attention and special volition in their passage.

$\Lambda \mathrm{s}$ a result of mastication, the food is gathered in the form of a round moist bolus on the upper surface of the tongue (see fig. 1). It is now ready to be swallowed. In the first place, it is pushed backwards by the tongue, and seized by muscles, many of which are attached to the hyoid bone, which can be felt to move during their contraction. According to the most recent investigation, the bolus is propelled with great rapidity through the pharynx and gullet into the stomach. If the finger be placed upon the hyoid bone, or Adam's apple, and the ear placed against the upper third of the back of a patient, the movement of the hyoid bone indicat. ing the commencement of swallowing is almost coincident with the passage of food down the gullet, which produces a very audible sound. Following the propulsion of the food downwards, there is a wave of contraction, which, commencing in the pharynx, travels downwards through the gullet. This, however, is comparatively slow. It is seen then that swallowing is not due to the falling of liquids down the throat. A horse drinks 'up hill,' and the jugglers, or indeed any one, can drink or swallow with the head vertically downwards.

When the food has reached the back of the mouth, the rest of the act of swallowing occurs irrespective of the action of the will. The nerves, which commence in the mucous membrane of the pharynx and gullet (sensory branches of vagus), carry impressions to the brain, which disengage of themselves the appropriate muscular movements without necessarily involving either the will or consciousness. Thus, in alcoholic stupor, or fainting from drowning, in both of which conditions consciousness is suspended, food and liquid placed at the back of the mouth are at once swallowed.

There is a possibility that during swallowing the food may go the wrong way-i.e. it may pass into the larynx and windpipe. It will be seen from the diagram that the food in its passage to the gullet must actually pass over the aperture of the larynx. It is prevented from passing into it by the elevation of the larynx (this can be felt by the hand placed on the throat), which pushes its aperture against and under the back of the tongue, which at the same time is pushed backwards. In addition, there is a valve called the epiglottis, which is pushed down over the larynx by the movement just described, and by muscular fibres, which act upon it for that especial purpose. If the epiglottis be destroyed, as by ulceration, gun-shot wounds, \&c., it is necessary for the patient to have the food he takes carried over the aperture of the larynx into the gullet by a feeding-tube. It is obvious that one cannot speak with the larynx shut, and with the larynx open we cannot safely swallow. Food is prevented from passing into the nose by the elevation of the soft palate which meets the constricting pharynx, and shuts off the eavity of the nose like a valve (fig. 1).

The walls of the stomach and intestine are, like the gullet, provided with muscular fibre. An external layer passes in the length of the gut, and within this is a circular laver. These muscles, unlike the museles of the limbs, contract slowly on stimulation, and they are outside the domain of voluntary action. During digestion they contract peristaltically, urging the food towards the rectum. The peristaltic waves may begin in any part of the gut and pass slowly downwards, followed at varying intervals by other waves. It is probable that what is called antiperistaltic waves may occasionally oceur, tending to bring the food back towards the mouth, for bilious matter is frequently vomited. the bile having in all probability passed upwards into the stomach by antiperistalsis from the duodenum.

Eructations are frequently caused by antiperis talsis, and by a movement of this kind food is brought back into the mouth for further chewing in the ruminants (sheep, oxen, \&c.). The peristalsis is particularly active during digestion, and is produced in great part by the food stimulating the mucous membrane. If a portion of the intestine or the stomach be removed from the body, peristalsis may continue or may be produced artificially, especially by irritating the mucous membrane. In the body the canal is under the influence of additional nerves (vagus), through which fibres the digestive processes are chiefly regulated among themselves. 
The peristaleis in the stomach is combined by irrentitar churning movementa

The act of vomiting is a rellex nervous aet. It ein be excited by stimulating the branches of the vagus nerve, which are distriluted to the stomach, as when indigentible and irritative food is taken; or enetics, such as musturd, hot water, or a hot salimesolution, tartar emetir, ipserecuanha, sulphate of zine, and alum are administered. By tickling the lack of the throat with a feather, the gloswo. phatrugral nerve is stimulated, and vomiting may renulily be jroduced. It is of frequent occurrence when painful irritation of the uterine nerves in pregnancy, of the nerves of the liver and kidneys during

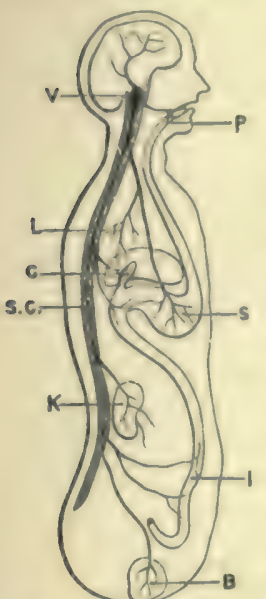

Fig. 10. - Sensory Nerves conoerned in Vomiting :

Nerves conie to vomiting centre V, taruugh spunal conl SC, from pharynx P, lumas L, gall-thladider $G$, stumach $\mathrm{S}$, kilney $\mathrm{K}$, intestine $\mathbf{I}$, and bladder the passage of a hepatic or renal stone, or indeed when irritation of any sensory nerves takes place. Nerveimpulses may pass to the brain through any one of these channels (fig. 10), or may be excited in the brain itself by the sight or smell or even the thought of any. thing disgusting, and they produce, if the person be conscious, a feeling of naurea. In any case there is a discharge of nerve-impulses, which, as a result of this stimulation, passes to the glands of the mouth through the chorda tympani nerve, and produces a rapid flow of saliva. In addition, motor nerves carry impulses to the muscular walls of the abdomen, and to the walls of the stomach itself. As a result of the muscular contraction which follows, the contents of the stomach are propelled upwards into the mouth. Just before vomit. ing an inspiration generally occurs, and the aperture of the larynx (glottis) is closed. The diaphragm-the muscle which separates the thorax from the abdomen - then becomes preased down upon the abdominal contents, and assists in the act of vomiting. Cases in which irritating or poisonous substances are swallowed are so frequent, that every one should be aware that a large quan. tity of hot liquid, especially if it contain much salt, or some mustard, forms a safe and speedy emetic. Ice is a valuable sedative, and often prevents vomiting. The undigeated food when it renches the lower part of the intestine (rectum), excites sensory nerves which carry impulses to the brain and spinal cord. A feeling of distension results, and voluntary contraction of the abdominal museles and of the diaphragm-an inspiration usually taking place-expels the undigested matter. This voluntary effort is aided by the contraction of the bowel itself, and by the relaxation of the band of muscular fibres (sphineters) which, during the intervals letween evacuations, remain contracted.

In many animals, such as the sheep, ox, and camel, the stomach consists of several cavities com. municating with one another. In the ox and sheep both the cardiac and the pyloric portions are each subdivided into two compartments. The carlias part consists of a very dilated cavity, the paunch (rumen), into which the food is passed as goon as swallowed. In addition there is a smaller part, the reticulum (honeycomb), so called from the folds of lining mucous membrane which intersect, forming a reticulum. The pyloric half is divided into two

parts. The palterium (manipliem), an ealled from the lamellated apjearance of itw mucous yetnbrane. communieates with the last divieion, the rennet stomach (abomasum, fig. 11 ).

Fluid pawen either into the fint, meond, or thind parts of the stonuch, and thence on into the fourth. Solid matter, such as sras, roots, \&ce, pnenen either into the peunch or reticulum. This is mixed with the saliva swallowed with it, and in addition it is mixed with juices formed by the mucons nembrane of these cavities. When the animal has finiwhed feeding, it lies down and rmmination cormmencem. Due in part to the contraction of the aldominal muscles and diaphragm, the food is propelied in the form of rounded pellets from the paunch and reti. culum up into the month. The pelle.ts are there thoroughly masticated, and are retumed in a pulpy condition to the stomach. Now, however, the food passes into the psalterium, and finally into the rennet stomach. It will be seen, therefore, that the consistency of the food determines into which part of the stomach it paseses. The walls of the stomach near the gullet are thrown into two folda
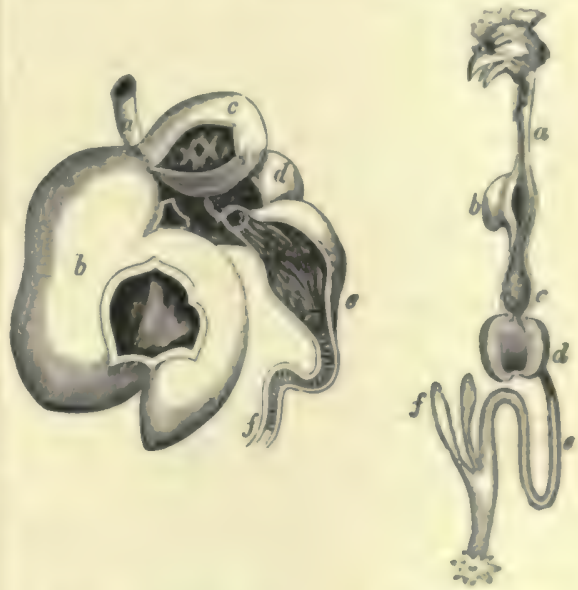

Fig 11-Compound Stomach of $\mathrm{Ox}$ :

a, cesophagus ; 8 , rumen, or paunch: $e_{0}$ reticulum, or aecond stomach: d, ormasum, of thind stominch; s, abom: of third stominch; 6 , abom.
susum, or fourth stomsech: sum, of fourth
Fig. 12,-Alimentary Canal of fuwl:

a, complubarts: $b$, crivp: $a$, yno ventriculing or socreisto ventriculas

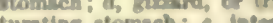
turating itomach: \& later tural eswal. f. imo lows carcal tubas indicatias th theorretical commencemest of linge intectine.

or lips which, when in contact, form a tube leading from the gullet into the panlterium. Along this tube the masticated and fuid food can pass. The mouthfuls of grass whichs are first swallowesl pases between their lips, and find their way at once into the paunch or reticulum.

In the bind some interesting modilientions in the structure of the alimentary canal are seen (fig. 12). The gullet at alwout the midille of its enurse is pro. vided with a ponch or arop. Into this the food passess, and is fucthed by a secretion formes liy ite glands. It is then propelled onwards into s dilated cavity, the proventrieulus, and is ncteri on log digros. tive juices. Thence it passen into the gizmnd. This cavity is provided with muscular walls of enormous thickneses in the ense of birds that are vesetable. feeders. It in lined by thick and corneous epithelium, and in its interior are generally found pieces of stone, chalk. Se. The ginzand is a powerful mill, which grinds the form into a moft puly, upun which the digestive juices ean realily act (neo BIRD) 
The Action of the Digestive Juices.-By digestion is meant that process by which food is rendered capable of passing through the walls of the digestive system into the blood-vessels and lymphatics, in such a form that it may be of use to, the economy. The most essential change which food undergoes is one of solution. Albumen, starch, fat, and other food-stuffs are quite insoluble in the circulating fluids of the body, and were they injected into the blood they would simply block up the smaller blood-vessels. During digestion these pass either into nearly allied chemical substances which are readily dissolved in water, or in the case of fat partly into a soluble soap, and partly into a state of microscopically minute subdivision. It is not sufficient, however, merely to have a soluble food-stuff in order that it may be absorbed and used by the body. Cane (table) sugar is soluble in water, but it is of no use as cane-sugar to the body. If injected into the blood-vessels, it is at once secreted by the kidneys. During digestion it is converted into another sugarless soluble, but in a form which can be used by the economy.

It must clearly be understood that food introduced into the stomach is not received into the system. It is still 'outside the body.' It is only when it has become absorbed, and has passed in a auitable form, carried by the blood, to the tissues of the brain, muscles, \&c., that it is made use of in so-called vital manifestations. The relief and stay that a meal gives is chiefly due to nervous action, the result of gastric distension. Clay and other non-nutritive matter may be swallowed, and will temporarily produce the same effect.

The digestion of food is brought about by the action of juices, the saliva, the gastric, pancreatic, intestinal, \&c. These are mixed with the finely divided food by the movements of the alimentary canal. The digestive juices are in all cases secreted by the microscopic cells which line the various glands opening into the digestive system. The digestive juice, whatever be its source, contains either an acid substance or an alkaline one, and in addition a substance termed an unorganised ferment. These ferments differ in many particulars from the organised ferments (bacteria, micrococci), found in putrefaction, diseases such as anthrax, scarlet fever, cholera, \&c. The latter are whole living cells, having definite parts or organs. They live and multiply, consume, and excrete in the fluid they inhabit. The digestive ferments are not whole cells, they are the products of cells. They are not the broken-down useless substances, such as carbonic acid, water, \&c., which all cells give out, and which an animal, like man (an aggregation of cells), exeretes. They consist of very complex active matter, of which we know almost nothing, and which we class with some other sub. stances of which we know little more, under the head 'albuminoids.' These ferments in fact possess many of the qualities of cells themselves. They are killed by the temperature of boiling water, like all other living things. They have a certain range of temperature, within which alone they evince activity, and within the limits of that range they are more active the higher the temperature. Then again they require the presence of water, in which fluid they are soluble. In their action they seem to be hydrolytic, that is, they produce important changes in the substances they attach by, amongst other things, adding the elements of water. These digestive ferments, together with the other constituents of the digestive juices, are secreted by the cells of the digestive glands. If we study these glands and their cells with the microscope, they all present several points of similarity. Each gland has a duct, which, as in the case say of the salivary glands, divides into several branches. The duct, or its branches in the latter case, terminate in the secreting tubules of the gland. These are. little tubes, which are lined by the secreting cells, leaving only a small cavity in the centre of each tubule for the escape of the secretion into the duct. Outside the tubule there is a dense network of fine bloodcapillaries, from which the liquor of the blood escapes, bathing the gland and the cells within it. These imbibe the liquor, and they have almost certainly the power of selecting such constituents of it as they require. The substances derived from the blood are used by the cells, which manufacture the juice which they excrete. The constituents of the excretion are not found, it will be observed, in the blood ; they result from chemical processes which go on within the cells, which use blood as a raw material. The cells are very small, being about चु아 th to $\frac{100}{100}$ th of an inch across. They have each a very thin envelope, within which the finely granular contents of the cell are seen. In the centre is a kernel or nucleus. During digestion the cell enlarges, and granules appear in it. These are the manufactured products : they are discharged into the duct of the gland.

We have now to consider how it is that the glands are regulated in their secreting powers, how it is that at certain times, and in sufficient quantity, the secreting juice is poured into the digestive system. This is brought about by the action of the nervous system. Although in some cases - e.g. the stomach, local nerve-cells placed in the walls of the digestive system itself, seem to regulate in part the secretion. yet in all cases nerve-cells placed in the brain are chiefly concerned. It was thought at one time that the brain acted by causing the blood-vessels of the gland to enlarge, and in consequence the foodsupply and secretion of the gland to become greater. That this is not the whole truth, is shown by the administration of belladonna. If a rather large dose of this drug be taken, the mouth becomes very dry and unpleasant, and it is difficult to speak and to swallow. In other words, the cells of the salivary glands are paralysed, and the customary flow of saliva is for the time being at an end. It is found, however, that during this condition the bloodvessels are by no means contracted. This experiment, together with others, suggests that although during the secretion of a digestive juice the bloodvessels dilate, the activity of the secreting cells is not always associated with the condition of the blood-vessels. The latter are undoubtedly under the influence of nerves (vaso-motor) which regulate their condition, and it is probable that the secreting cells are themselves under the influence of other nerves, which are special secreting nerves. We have already seen that in the ease of the movements of the digestive system, the motor-impulses which started from the central nervous system were called into action by sensory impulses starting from the mucous membrane of the digestive system. So in like manner the nervous impulses which pass to the blood-vessels and the glands are caused, in the first instance, by sensory impulses from the mucous membrane. If food be taken into the mouth, especially if it be 'tasty,' a secretion of saliva rapidly follows, and even the tickling of the mouth by a feather, or the stimulation of the mucous membrane with electricity, will produce the same result. In this case sensory impulses pass to the brain through such nerves as the lingual and glossopharyngeal, and reflexly excite the glands through the medium of the brain, the outgoing impulses passing through nerves such as the chorda tympani (fig. 13). See BRAIN. In the case of salivary secretion, the smell or sight of food may excite $a$ secretion. In this case the sensory impulses pass from the nose or eye along the nerves of these organs to the brain. When the thought of food produces a flow, 
this in due to the recalling of previons aight and smell impressions in the brain.

When forsl is pawmed inte the stomach, secretion occurs This too may result from mechanical irritution, as when through an opening (fistula) the muscous memalrame is brismlied with in ferther. In all cres the stomach, pale before, becomes suffused

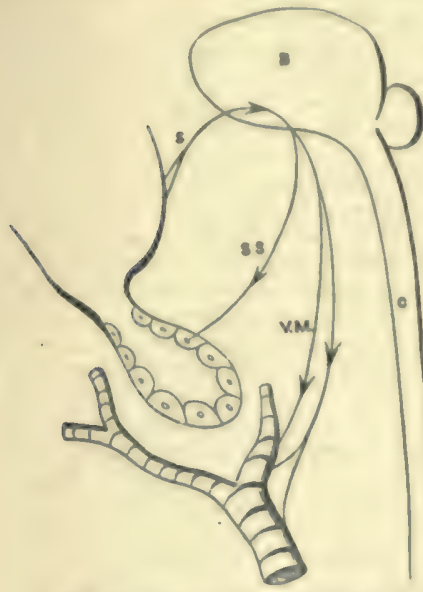

Fig. 18. - Nervous Meohaniam of Secretion :

B, brain ; C, spinal cord ; 8, aerve pase. ing from mucous membrane of mouth to brain; SS, nerve passing to cell in salivary ghat: V.M, nerve passing to blood-vessels of gland. with blood, and the gavtric juice is poured out. The flow of the intestinal juice, the panereatic juice, and bile, all follow the stimulation of the mucous membrane, and in all cases the blood-vessels en. large 30 as to give the cells a good supply of food, althongh, as we have seen, they themselves actually pass into a condition of activity, as a result of the influence of special secreting nerves.

We have now to consider the dirrestion of food. stuffs, and the parts that the varions glands play in this important process. For our present purpose it is sufficient to speak of fonds as belonging to four elasses: (1) Proteids - alhumens, globulins, de.-e.g. the white of eag, the chief constituent of mest, the gluten of bread. (2) Carbohydrates - starches, sugars, gums-e.g. potato-stareh, eane or grave sugar. (3) Fats and oils-e.g. suet, marrow, olive-oil. (4) Mineralee.g. water, table-salt, iron, phosphates. See also DiET, FooD.

Some few substances are absorbed without being digested at all; they do not need to be. Such are water and the minerals, although even many of these undergo some change or other. (impe-sugar is alsorlved, amd probahify proteids $t(x)$ are ofien sbsorbed to some extent at least. Fat is profoundly modified during digestion, although not as the result of any digesting ferment. It may be said, however, that the great mass of food-stuff which is classed under the heads of proteids and enroohydrates is all digested by the metion of ferment. like bodies. The saliva, of which shont 30 onnces are secreted during the 24 hours, contains a ferment termed ptyalin, which is capable of turning starch into a soluble sugar called grape-sugar, or accond. ing to other observers, into another soluble sugar termed maltose. This cen exsily be demonstrated in the following manner: Take a tiny pinch of ordinary starch powder, and shake it up with a tablespoonful of water. It will not dissolve. Then boil it, when the starch will swell up, forming a thin starch paste. Dilute a few drops of tincture of iodine with several volumes of water, and add a drop of this to a small quantity of the stareh paste. It will become of a rich blue colour. This is the test for starch. Now add to some of the origimal starch paste about one quarter of ite volume of saliva from the mouth, and keep the mixture by the fire at a temperature pleasant to the hand. In a minute or so take ont some of the starch in onder to test it again. The iodine no longer gives a blue colour, but produces a beantiful mahergany brown. This shows that the stare h has dreugresured, the brown oolour being the renction given by erythre. dextrine into which the mtarch has been converted. After a little timo another portion towted in a similar was gives no reaction a lusteles, the ory than dextrine having in its turn dimppeared. The starch is now converted into sugar. mixed with a little unconverted dextrine. This leing an achroodextrine, uncoloured like the erythro-dextrime by tincture of iodine,

$$
\begin{aligned}
& \text { sturch. Water. } \\
& \mathrm{C}_{6} \mathrm{H}_{10} \mathrm{O}_{3}
\end{aligned}+\mathrm{H}_{8} \mathrm{O}=\mathrm{C}_{4} \mathrm{H}_{19} \mathrm{O}_{6} \text {. }
$$

The ptyalin may be extracted from the maliva or from the sulivary glandis themuseliem. It dives wot appear to be much exhausted during its activits. anil lus the genteral eluarneters airesaly diman-ied of unorganived ferments. The aliva is alkaline, and the starrhy fowml is sou doutut purtly comwertest into sugar during its sojourn in the month and gullet by its action. When the food bas reached the stomach and the acid gastric juice has mixed with it, the saliva is unable to act, and is probubly killed. Any undigested starch is subeequently converted into sugar when the food reaches the small intestine by the pancreatic juice.

When the food reaches the stomach it canas a reflex secretion of gastric juice. This is but slowly produced when insipid heavy food, such as corgulated white of egg, lwsiled mest, sazo, dic., is eaten, but flows readily when soups, brotbo, and fluids containing salts and extractions in abund. ance are taken. Thus we have a scientific reason for comnencing a dinner with soup, preserving the pidce de réristance until the stomach has aecreted grastrie juice for its digrestion. The gastrie juice, several pounds of which are secreted daily, is scid in reaction containing free hydrochlorie acid. In addition lactic and butyric acids sre formed during the progress of digestion. The ferment peculiar to the stomach is termed pepeine, and it requires, unlike the ptyalin of the saliva, an acid medium for its action. Pepsine and hydrochloric acid convert proteids into substances termed peptonea. The latter nxlies are soluble in water, and are not congulated by Iniling like many of the proterits. In whlitions they puss readily through mon minal mombane. and are therefore easily absorbed. The protejd does not pass directly into the peptone, but like the starch is changed into at lesust one intermesliate body. In the fint ense the proteid becomes converted by the hydrochloric acid into what is called syntonin, or acid protein, and it is this syntonin which alone the pepaine has power to change iato peptome. The svintenin lwowns a propeptone which is intermedinte in its properties between a proteid and peptone itself. It is very probable that the whole change from proteid to peptone consinta in some simple change in the molevilar channcter of the proteid, together with the addition of water. A peptone may be ternied therefore a hylrated proteid, and the pepoine a hvedrolveic ferment Within the stomach, and wipuldes of twing resdily extracted from the stoniach of a calf, is a fermuent called the milk congulating fernient (rennet). This causes milk to coaysulate, and form a clot or euris. It suberquently contmcts and equeexes ont some fluid termed the whey. It is difticult to anaign any use to this ferment, for the scid of the gastrie juire would cause of itwelf the milk to condle. sull more diffieult is it to explain the exintence of a cimilar ferment in the penereatic juice, for we cannot suppoes that any milk can oven pases through the stomach to be enhierted to its wermon. The inilk indeed often forns dense dots which cannot afterwands be digented, and which causo considerable gastric irritation. Milk when drunk in 
frequently found to disagree with some stomachs but even in such cases it may often be 'sipped' with impunity. In this case the formation of large clots is prevented. Lime-water causes the milk to coagulate in small soft clots.

The products of digestion, peptone and sugar, together with water and many soluble salts, are absorbed into the blood-vessels which ramify in the gastric mucous membrane. When gastric digestion is over, the undigested food (chyme) passes through the relaxed pyloric sphincter into the small intestine. The chyme consists of some proteid and starchy matter, together with fat and oil and indigestible substances such as vegetable fibre, pure wax, cartilage, \&c. mixed with gastric juice. Intestinal digestion is an alkaline one, and all the digestive juices of this part of the digestive system are alkaline in their reaction. They soon counteract the acidity of the chyme, which now becomes alkaline. The proteids which remained undigested by the stomach are now acted upon by a ferment called trypsin found in the juice of the panereas. This converts the proteids into peptones through an intermediate propeptone. The pancreatic juice contains other ferments which operate during digestion, notably a hydrolytic ferment, similar in its action to ptyalin, whereby the remaining starch is converted into sugar. The juice itself is thick and viscons. It is strongly alkaline and secreted in rather small quantity. It is said to possess a ferment capable of splitting oil and fat into glycerine and fatty acid, which it does by adding water to the fat, which is then decomposed. The fatty acid unites with the free alkali present, and a soap is formed which is subsequently absorbed. The alkaline contents of the alimentary canal also emulsify fat-i.e. they cause it to become very freely divided, forming a milky fluid. The minute microscopic globules which result pass readily through the walls of the alimentary canal into the lymphatics (lacteals). The emulsification of an oil can readily be shown by adding about half its volume of carbonate of soda ( 3 per cent.) solution to cod-liver oil. The latter becomes at once very similar to milk in its appearance.

The intestinal juice, the secretion of Lieberkühn's follicles, is strongly alkaline. It assists in the digestion of starch and of proteid matter. In addition an important ferment called 'invertin,' is found. This has the power of changing eane into grape-sugar and an allied substance, læevulose. Both these bodies have the same formula, but differ from one another in their action on polarised light,

$$
\begin{aligned}
& \text { Cane-sugar. Water. Grape-sugar. Læevulose. } \\
& \mathrm{C}_{12} \mathrm{H}_{22} \mathrm{O}_{11}+\mathrm{H}_{2} \mathrm{O}=\mathrm{C}_{6} \mathrm{H}_{12} \mathrm{O}_{6}+\mathrm{C}_{6} \mathrm{H}_{12} \mathrm{O}_{6} \text {. }
\end{aligned}
$$

The importance of this ferment will be appreciated when we consider how large a quantity of food is taken in the form of cane-sugar, and that canesugar introduced into the blood is not of any use to the body, and is eliminated at once by the kidneys. The bile may be looked upon both as an excretion. from the body and as a digestive juice. The colouring of the freces and urine is due in part to a pigment hydrobilirubin (urobilin), which is an altered bile pigment. If bile is excreted rapidly, the freces are dark in colour, and they may be white owing to deficient exeretions. Many substances such as mucin, cholesterin, \&c. found in the bile are excreted to form part of the freces. On the other hand many bile constituents, such as the bile salts, are reabsorbed and used again in the economy. Bile has an important action in digestion, as may be shown by making biliary fistula in dogs, whereby the bile leaves the body at once through an aperture in the abdomen. In this case the animal loses flesh; the fat which it takes with its food passes nuabsorbed through its digestive system, and its excretions are offensive. The bile seems then to assist in fat absorption, and to have some antiseptic action whereby putrefaction is prevented or lessened within the digestive system. Bile assists in the absorption of fat not only by assisting in its enulsification, but also by helping in some way or other the epithelial cells, covering the villi to take up the minute fatty particles. In addition it is supposed to stimulate minute muscular fibres within the villi, which by their contraction pump the absorbed fat on into the larger lymphatics.

Within the small intestines most of the food undigested by the stomach is rendered fit for absorption. This takes place through the tissue of the mucous membrane; much of the sugar and peptones find their way into capillary blood-vessels. Absorbed products, and notably fat globules, pass into the lacteals, and thence into the blood, circulating through the veins at the root of the neck. The contents of the lacteals during absorption are called chyle. The contents of the small intestine pass into the large intestine, where digestion occurs to a very slight extent. Absorption is, however, more rapid, and the contents become far more solid as they pass towards the rectum, due to the deprivation of water and soluble substances. The absorptive power of the large intestine is important to remember; for injections per rectum of liquid food, especially if it has already been artificially digested, may frequently sustain life for long periods.

Artificial Digestion.-The digestive juices are occasionally defective in amount or in quality, and in this case they may be supplied artificially. All the digestive ferments may be separated by very simple processes from the glands which secrete them, and many may readily be obtained in the market. Pepsine and hydrochloric acid, taken with or before a meal, are often of great service, the most reliable preparations of pepsine being the ordinary pepsina porci. Food may be digested outside the body before its administration. Beeftea and milk-gruel may be prepared in the following way : To bring the food to the proper tempera ture, boil half of it, mix it with the other half, and keep warm near the fire.' To this add a preparation of the pancreatic ferments in the proportion given in the directions which invariably accompany the bottle containing the substance. The food should now be kept warm for an hour or so, and then boiled in order to prevent any further action of the ferment. It may be taken by the mouth or administered as an enema. Preparations of the pancreas are alone to be used in peptonising food outside the body, as pepsine preparations produce a bitter and unpleasant taste.. Panereatic preparations on the other hand are useless when taken with the food, as they are destroyed within the stomach.

See many separate articles throughout this work, such as those on Blood, Chyle, LYMPH, Bile, Saliva, PEPsin, ABDomen, Glands, Diff, Food, Cook krT, AlcoHOL. INDIGRSTION, \&c.; and the physiological handbooks of Huxley, Foster, and Landois.

Digging. See SPADE-HUSBANDRY.

Digit (Lat. digitus, 'a finger'), a term applied to the ten symbols of number, $0,1,2$, \&c. to 9 ; thus, 305 is said to be a number of three digits. Numbers were originally indicated by the fingers, and hence the name. Astronomers use digit to signify a twelfth-part of the diameter of the sun or moon, and speak of an eclipse of seven digits, meaning that seven-twelfths of the diameter is covered. 
Digita'11\%, a genus of Serophulariaces, natives chielly of the south of Europe and temperates purtas of Anir. One only, the Cummon Fuxplove (q.v.), (1). purpurea ), is is native of Britain. Other species have been introduced, notably $D$. lutea and grandi. furre, with yellow flowem. The botanical name Digitalis (late Iart. digritule, "the finger of at glove") refers, like the popular English name, to the form of the flowers.

The leaves of the Digitalis purpurea, collected before the expansion of the flowers and dried, are largely used in medicine, either in the form of powder, or as tincture or infusion. Digitalin granules, eontaining minute quantities of a mixture of the setive priseiples, are also employed. The leaves owe their activity to the presence of certain bodies, which have been named digitalin, digitalein, digitoxin, and digitonin, the three first mentioned having the characteristic digitalis action, while the fourth is ontirely different, and closely resemble: sapon in in its effects. The leaves and their preparations have a bitter taste. When given in large doses by the mouth, they produce violent vomiting and purging: this may prevent their absorption into the blood, but if absorbed, they may cause death by paralysing the heart's action. When the leaves are administered in medicinal doses, a peculiar action is exerted on the muscular substance of the heart and blood-vessels, eansing the former to beat more slowly, regularly, and powerfully, and contracting the latter. By this combined action the blood-pressure is raised, and if dropsy be present, a diuretic action is exerted. Digitalis is also used in many organic forms of heart-disense, in nervous and functional irregularity of the heart's action, in cardiac weakness from long-continued disease in cedema of the lungs, internal hemorrhages, and other conditions. When taken for a long time it may cause nausen and other digestive disturb. ances, and in a very few cases sudden and serious symptoms of poisoning come on. This constitutes the so called cumulative action of digitalis, In therepeutic doses digitalis should slow the pulse if too large doses be given, the pulse becomes rapid and irregular.

\section{Digitaria. See MrLlet.}

\section{Digitigrada. See Carnivora.}

Digne, a cathedral eity in the French department of Basses-Alpes, on the Bléonne, 70 miles NE. of Marseilles. Pop. 5414.

Dihong. See Brahmaputra.

Dijon, chief town in the French department of Cote-d'Or, formerly eapital of the old duchy of Burgundy, lies, spreal wut on a fertile plain at the foot of Mont Afrique (1916 feet), at the junction of the Ouche and Suzon, and on the Canal de Bourgogne, 196 miles $\mathrm{SE}$. of Paris by rail. Its import ance as a railway centre has rendered it of consoquence in the inner line of French defences toward the east, and atrong forts now crown the neighbouring hills The environs are exceedingly beautiful, and the town is well and regnlarly built; the streets are broad, the open squares numerous, and the old walls have been turned into tasteful bonle. vands. Of the medieval defences, the finthic castle built by Louis XI. still remains, employed as a gendarmerie barrack; formerly it was a state prison, in which, among others, Mirabean. Tous. saint L'Ouverture, and General Mack were con. fined. Among the publis buildinge, which are numerous and imposing, the chief are the cathedral, a massive Gothic structure, dating from the 13th century, with a wooden spire (1742), 301 feet high the churehes of Notre Dame (1252-1334), 8t Michel (1529), and others; in handsome theatro; the palai de justice; and the former palace of the Dukes of Burgundy, which, commenced in 1306, is now used a the town-hall, and enntain s rich menean, berides a library of 80,000 volumes and 900 mans. meripte. Dijon in also the mest of an imatientes with throe facultie - law, sclesce, and letters - and possenses, in aldition, a theoloyical ceminery, a wotsinie garden, and an acadeny of art. Thes manufactures include beer, brundy, woollen cloth. blankets, mustard, eandles, and pottery, and there is a noteworthy trade in flower and agrieuluaral produce; but Dijon's chief eommereial importanee in an the centre of the Upper Burzundy wine trade. Pop. (1872) 40,116 ; (1891) 78,794. The Dibia of the Komans, Dijon in the Sth century paned from the Burgundians to the Franka, in the 9 th wa rulerl by counts of its own, under the suzerainty of the bishops of Langres, but in 1007 was nnited to the duchy of Burgundy, of which it became the capital. On the death of Charles the Bold it came with Burgandy into the promesesion of France in 1477. In October 1870, after a sharp engagement before the city, Dijon enpitulaterl (s) a ferruan force. There was agais severe fighting here in January 1871. Charles the Bold, Crébilion, Immennet, and Ramean were natives, and close by is the birth. place of St Bernard, of whom there is a mtatne by Jouftiroy (1847). See the work by Chabeuf (1845).

\section{Dike. See Drke,}

Dilapidation, in English law, is where an incumbent auffers his parsonage-house or outhounes to fall down, or be in decay, for want of nervosary reparation; or pulls down or destroys any of the outhouses or buildings belonging to his living; or destroys woods, trees, \&e, for it in aaid to extend to committing or suffering any wilful waste on the inheritance of the church. Dilapidation is a species of the legal injury known as Waste (q.v.). $\boldsymbol{A}$ rector or vicar is bound to keep his residence and the chancel of the church in repair, but not to supply or maintain anything in the way of ornament, a painting, white-wnshing, or papering. An ecelesiastical person suffering the chureh-property to get out of repair is subject to an action for dilupidation at the instance of his succeseor; and the money so recovered must be applied to the repains. By 5 and 6 Vict. chap. 108, being an act to empower ecelesiastical corporations to grant long leases, it is provided that the incumbent shall not ve liable for dilapilation occurring during such leases. By $\mathbf{M}$ and 35 Vict. chap. 4, smended by 35 and 36 Vict. chap. 96, a surveyor of dilapidation is approinted in each diocese. Such surveyor, when so ordered by the bishop, may inepect and report on the building of a benefice which is not vacant. But the bishop can issue such orders only on receipt of a complaint from the archdescon, the rural dean, or the patron of the benefice, that the buildings of the benefice are dilapidated; and must give a month's previous notice to the incumbent, who is entitled to state written ohjertions to the rejwirt within a month, whereupon the bishop may eiliver call in another aurveyor to report on the isus of facts, or take connsel's opinion on the isues of lav, the incumbent paying the cone of such proceedingm. and being obliged to comply with the bishop's fina decirion. The incumbent muat execute the work

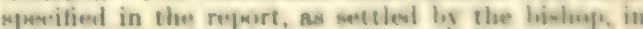
the manner and within the time therein proscritient. or ench longer time as the biahop mar appoint if writing. Or he may, with eoneent of the bibop and the patron, and the surveyor's apporosal, sato stitute uther works for them. The act nloo applies to cases of dilapidations in vacent benefices. The sum for repain named in the biahop's onder in those cases is a deht dne from the late incumbent. bis executom and administrutors to the new incuss. bent, and is recoverahle at law or in equity. For the corresponding soottish law, se Hznron, Mavse. 
Dilatory Pleas. See PLEA.

Dilemma. A true dilemma is defined by Whately as 'a conditional syllogism with two or more antecedents in the major, and a disjunctive minor.' The following dilemma, of the kind called destructive, will perhaps convey a clearer notion than any definition. 'If this man were wise, he would not speak irreverently of Scripture in jest; and if he were good, he would not do so in earnest; but he does it, either in jest or earnest ; therefore, he is either not wise, or not good.' There being two conclusions, one or other of which your opponent must admit, he is in a manner caught between them; hence we speak of the horns of a dilemma.

Dilettanté (pl. dilettanti, Ital.), in its original sense, is synonymous with an amateur, or lover of the fine arts. It is often used as a term of reproach, to signify an amatenr whose taste lies in the direction of what is trivial and vulgar, or of a critic or connoisseur whose knowledge is mere affectation and pretence. It is sometimes assumed, in a spirit of self-depreciation, by those who are unwilling that their critical aequirements, or artistic productions, should be judged by the rules which would be applied to those of persons who had made a professional study of art. It was in this sense that it was assumed by the Dilettanti Society, a body of noblemen and gentlemen by whose exertions the study of antique art in Eng. land has been largely promoted. The society was founded in 1734, and thirty years later it sent out an expedition to make drawings of the most remarkable artistic monuments of antiquity, under Chandler, the editor of the Marmora Oxoniensia: Revett, joint-author with Stuart of a great work, Athenian Antiquities; and Pars, as artist. They returned in 1766; and four splendid folios on the Antiquities of Ionia appeared in 1769, 1797, 1840, 1881. Other publications were Specimens of Ancient Sculpture (1809-35), Bronzes of Siris 1836, and Athenian Architecture (1851 ; new ed. 1889). See Lionel Cust's History of the Society (1898).

Diligence, in the Law of Scotland, is a term used in various significations. (1) It means the care incumbent on the parties to a contract with regard to the preservation of the subject matter. In this sense the term is also used in English law, which recognises three degrees of diligence- $(a)$ common, such as men in general exert in managing their own affairs; $(b)$ high, such as great prudence demands; and $(c)$ low, such as persons of less than common prudence take in connection with their own affairs. (2) The warrants issued by courts for enforcing the attendance of witnesses and the production of writings. (3) The process of law by which person, lands, or effects are attached either on Execution (q.v.) or in security for debt. In the second of these senses, it corresponds to the English subpoeno; and in the third, generally to execution.

Diligence, the name given in French-speaking countries to a public conveyance of the nature of a stagecoach.

Dilke, Charles Wentworth, an English critic and journalist, was born December 8 , 1789 , graduated at Cambridge, and served for twenty years in the navy pay-office. In 1830 he became proprietor of the Athenoum, and from that year until 1846 he filled also its editor's chair. He established the Daily News in 1846, and edited it for three years. He died at Alice Holt, Hants, August 10, 1864. A collection of his articles contributed to the Athenceum and Notes and Queries between 1848 and 1863 appeared in 1875 as The Papers of a Critic: with biographical sketch by his grandson, Sir Charles Wentworth Dilke, Bart.,
$M . P$. (2 vols.); the first volume treating Pope, Lady Mary Wortley Montagu, and Swift; the second, Junius, Wilkes, the Grenville Papers, and Burke. He is known also by his Old English Plays (6 vols. 1814).-Sir Charles WeNTworTh Dilke, only son of the preceding, was born in London, February 18, 1810, and educated at Westminster School, and Trinity Hall, Cambridge. He studied law, graduating as LL.B. in 1834, but did not enter upon the practice of his profession. One of the most active originators, as well as member of the executive committee, of the Great Exhibition of 1851, he was offered a knighthood by the Queen and a large pecuniary reward by the royal commission, but both offers he declined. In 1853 he was sent as a com. missioner to the New York Industrial Exhibition, and in 1862 he was one of the five royal commissioners for the second exhibition, in the January of which year he accepted $\mathrm{a}$ baronetcy. In 1865 he was returned to parliament for Wallingford, and in 1869 he was sent to Russia as the representative of England, to the horticultural exhibition held at St Petersburg. Here he died suddenly, 10th May of the same year.-Sir CHARLES WENTWORTH DILKE, son of the preceding, was born at Chelsea, September 4, 1843. He studied at Trinity Hall, Cambridge, where he graduated in 1866, being soon after called to the bar. His travels in Canada and the United States, Australia and New Zealand, he described in his Greater Britain: a Record of Travel in English-speaking Countries during 1866-67 (2 vols. 1868). He was returned to parliament for Chelsea in 1868 . He is a doctrinaire Radical in politics, and was once at least an avowed Republican, yet he held office as Under-secretary for Foreign Affairs, and afterwards President of the Local Government Board under Mr Gladstone. In 1885 he married the widow of Mark Pattison, herself the author of Claud Lorrain, sa Vie et ses Euvres (Paris, 1884), and The Shrine of Death (1886), a collection of stories. About the same time his name was much before the public in connection with a divoree case, and this led to his defeat at the Chelsea election in 1886, and subsequent compulsory retirement from public life. He still continued, however, to influence public opinion indirectly through the press. - His Position of European Politics (1887) was a collection of striking essays that had appeared anonymously in the Fortnightly Review.

Dill (Anethum), a genus of Umbelliferæ. The Common Dill ( $A$. graveolens) is an annual or biennial plant, which grows wild in cornfields in the East and in the countries around the Mediterranean, but is quite hardy in Britain. It has from a very early period been in general cultivation as an aromatic, stimulant, and carminative, being used in cookery like anise, and in medicine as dill water, \&e. A. Sowa is similarly cultivated, and used in Bengal, \&e.

Dilleniaceae, a tropical and subtropical order of thalamifloral dicotyledons, allied to Magnoliacer in habit as well as structure, and often of no less beautiful foliage and flowers. There are about two hundred species, generally astringent, and hence frequently useful in medicine and tanning; many yield excellent timber, and some also fruit, that of Dillenia speciosa being especially eaten in India.

Dillingen, a town of Bavaria, on the Danube, 51 miles WSW. of Ingolstadt by rail, with two monasteries, a royal high school, a seminary, and a girls' deaf-and-dumb institution. In the old castle the bishops of Augsburg formerly resided, and here they founded a university (1554-1804), which from 1564 was an active Jesuit centre. Pop. 5860 . 


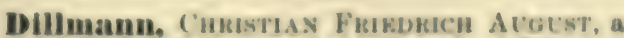
great Orientaliet, Inorn gosth April 1523, at Illingen, in Wurtesnberg. Alremaly as a stulecut at T'uhingers his studies uxder Ewald's influence had been turned to orientalis, and in $1846-48$ he vinited the libraries at Paris, London, and Uxford, cataloguing the Ethiopie MSS. at the last two, and returning to 'Tubingen to join its teachiug staff. In 1804 he accopted a call to Kiel, where he became professor of Uriental Languages in 1860 , but was transferred in 1864 to the chair of Old Testament Exegresin at Gieseen, which in 1869 he resigned to become Hengstenberg's successor at Berlin. Dillmann was beyond question the first anthority in Europe on the Ethiopic languages. The best books for the stulent in this ofmenre cloppartment of learning are lis Grammatik der Aethiopischen Sprache (1857), Lexicon Lisigue Athiopica (1865), and his Chrestomuthia Ethiopica (1866). Other works are his German translations of the Book of Enoch (1853), of the Book of Jubilees or the 'Little Genesis' (1849-51), and the Book of Adam (1853) in Ewald's Jahrbücher, as well as editions in the original of the first two; and an edition of the ancient Ethiopic translation of the Old Testament, Biblia Veteris Testamenti Athiopica (2 vols. 1853-72). His con. tributions to pure theology are Ueber den Ursmrumy der Alt-testamentlichen Religion (1865), Ueber die Propheten des alten Bundes (1868), and fresh editions for the 'Kurggefasstes Exegetisches Handbuch' of Hirzel's commentary on Job (1869), as well as of Knobel's commentaries on Exodus and Leviticus (1880), and on Genesis (1882). Dillmann became in $1877 \mathrm{a}$ member of the Berlin Royal Academy of Sciences, and contributed many papers to its issues. He was president of the fifth International Congress of Orientalists, nnd edited its $A$ bhandlungen ( 3 vols. 1881-82). Other works (1879-84) deal with the history of the Ethiopic kiugdom of Axum (q.v.). He died 4th. July 1894.

Dillon, JoHN, the son of John Blake Dillon (1816-66), who was a prominent member of the Young Ireland party, and member for County Tipperary in 1865-66. Born in New York in 185i he was educated at the Catholie University of Dublin, after which he hecame a doctor. He early identified himself with the Parnellite movement, and in 1880 was returned for County Tipperary. In the Honse of Commons Dillon somn becrune prominent for the violence of his language, while speeches delivered ly him in Ireland led to his imprisonment in 1881, 1881-82, and 1888. From 1883 to 1885 he was alseent from political life on acconnt of ill-healch; but in the latter year he renppeared, and was elected for East Mayo. 'Honest John Dillon' was one of the most promi. nent promotens of the "Plan of Campaign." In 1896-99 he was Justin M'Carthy's successor as shuirman of the main section of the Nationalists.

Dilman', a town of Northern Persia, in the province of Azerbijan, 75 miles W. of Tabrix. Pop. 6000 .

biluents, medicines for diluting the blow ant incrensing the excretions, especinlly the urine. The simplest and best of diluents is water: bnt all watery fluids, such as lemonale, soda-water, beer, infusions, ter, milk, \&c., are diluents. See DEMULCENTS.

Diluvium, a term formerly given by geologiste to those strata which they believed to have wer. formed by the Deluge, and more particularly to the boulder clay. The altered opinions as to the orivin of these beds have caused the word to fall into disuse in Britain. It is still used on the Con tinent, however, not in its origriual sense, but simply as a greneral term for the glacial and Anvio-glacial accumulations of the Pleistocone system. When

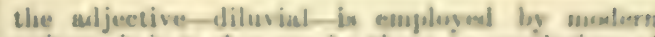

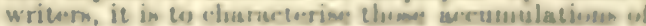
gravel or angular stouses which have lesen produced hy sudden or extmordinary enrrente of water.

Dime, a silver coin, the tenth jart of a United States dollar (seo DOLLAR), and equal to abous fivepence Englinh.

Dimension. In Geometry, a point, wince it has merely position, is said to have no, or to be of zero, dimensions; a line, straight or curved, in of one dimension - vix. length; a plane murface has two-length and breadth: while a solid is maid to be of three dimensions-length, brealth, and thick nees. Thus it will be mees that by the term dimension is meant a direction in which extension may be reckoned or measured. The three last-naned dimensions are found sutficient to determine all known forms of extension. Hence space is tri. dimensional. The possibility of space of higher dimensions existing has been much discumed. Since points, lines, and surfaces in general senernte by their motion lines, surfaces, and solid respectively, 80 it is held that some analogons generution of a fourth dimensional figure by one of three dimensions is conceivable. The subject, althwa interesting, is wholly speculative - In Algebra, the term dimension is employed in much the same sense as degres, to exprens the sum of the indices of those letters with reference to which the term containing them is considered- $-g_{0} x y, x^{2}$, are both of two dimensions, or of second degree; $x^{5} y, x^{3}$, are of three dimensions, or third degree, \&e.

Dimidiation, in Heraldry, a mode of mar. shalling arms, alopted chiefly before quartering and impaling according to the modern practice came into use, and subsequently retained to some extent in continental though not in English heraldry. It consists in eutting two conts of arms in half by a vertical line, and uniting the dexter half of the one to the sinister half of the other. Coats of busband and wife were often ao manshalled in England in the 13th and 14th centuries.

Dimity, a stout, figured cotton-fabric, used chiefly for bed-hangings und window enurtains. The figure or stripe is distinctly mised. Originally dimity was commonly white or of a single colour: but variegated dimities are now largely made; ane band or stripe of the cloth having a woven pattera in white alternating with a plain bend-Le the fabric is all white as it comes from the loom. $A$ pattern is afterwarls printerl in colours on the polnin bausl.

Dimorphism (Gr. dis, 'twice ; morphe, 'shape or form '), a technical term applied in Biolongy to canes where an organism appears in two different forma Thus in a colony of byuroids there may be "dimorphic persons'-respectively nutritive and reproductiv. and yet fundamentally the same in structure and origin. So too when the two sexes are murkedly different, the term sexnal dimorphism nuy be seed. Or the organisws may be different at certain navous and in certain conditions, $s$ in summer and winter Butterflies (q. . ) , or in the two kisds of common Primroes $\left(q_{.} v_{0}\right)$ and cowslip. Sometimes three different forms of butterfly are known in the same species, and to such cases the term trimarphism is converiently applied. The sume is troe of the common flower Lyehrum salicaria. In hydroid and medusoid colonies (e.g. Hydractinin and Siphomo. phora) the development af multiple forms result. ing from 'Division of Labour' $\left(q_{0} v_{0}\right)$ is descrilied as polymorphism. The nume term is obvionsly applicable to the different forms exhibited by some mocial Ant (q.v.). The sume not of terms may also be employed in referenere to different formis of the rame mineral, se see, under Flowra, $P e r$ tidiontion of the Flourer; allog FERTILISATIOS. 
An inorganic substance is in a somewhat analogous manner said to be dimorphous when it is capable of crystallising in two different forms or systems (see CrYstallography). A large number of substances have this property, of which sulphur, carbon, earbonate of lime, and iodide of mercury are the best examples. Thus carbon, as the diamond, crystallises, in the regular system, as octahedra, while as graphite, or Black Lead (q.v.), it forms hexagonal erystals belonging to the rhombohedral system. In some cases there is a great tendency for the one form of crystal to change spontaneously into the other form. The red iodide of mercury is a striking example of this. When heated, this substance is volatilised, and may be condensed on a glass plate as a yellow crystalline crust, consisting of rhombic plates. When this is rubbed, or even scratched, an immediate change takes place, the rhombic plates becoming broken up into octahedra, while the colour at the same time alters from yellow to a brilliant scarlet. So also when sulphur is crystallised from its solution in bisulphide of carbon, it yields transparent amber-coloured octahedra; but when melted sulphur is cooled, prismatic crystals are the result. In the course of a few days the prisms become opaque, owing to their being broken up into small octahedra, while conversely the octahedra, when heated to $230^{\circ}\left(110^{\circ} \mathrm{C}\right.$. $)$, are changed into smaller prismatic crystals. Those substances, such as sulphate and selenate of nickel, which crystallise in three systems, are said to be trimorphous.

Dimsdale, Thomas (1712-1800), an English physician who wrote several works on inoculation, was famous as an inoculator (making journeys in 1768 and 1784 to Russia to inoculate the Enpress Catharine and other magnates), and sat for Hertford in two parliaments.

Dinájpur, capital of a district in the Rajshahi division (Kuch Behar) of Bengal, stands 221 miles N. of Calcutta by rail, on the Purnabhaba River, which, through the Mahananda, enters the Lower Ganges. Pop. 13,200.-The district has an area of 4118 sq. m., and a pop. (1891) of $1,555,835$, almost entirely rural, and mainly of aboriginal descent. The Mussulmans slightly outnumber the Hindus.

Dinan, a very old town in the French depart. ment of Cotes-du-Nord, on the Rance, 30 miles NW. of Rennes, and 14 S. of St Malo. The situation of Dinan, on the summit of a steep hill of granite, and with the Rance flowing through a valley 250 feet below, is romantic in a high degree. The valley is crossed by a fine granite bridge of ten arches. The town is still partly surrounded by its old ivy-covered walls. The old castle of the Dukes of Brittany is now in part used as a prison. In the older district the streets are crooked, narrow, and steep; in some parts, the overhanging houses, and arcades resting on carved granite pillars, present many picturesque architectural features. The church of St Sauveur, a fine Romanesque church, contains the heart of the famous French warrior Bertrand du Guesclin, who here had a famous encounter with an English knight. The terraces around the town afford very charming views. Many English reside here. Pop. 9704. Four miles off lies the village of Corseult, on an old Roman site, where many antiquities have been found.

Dinant, a town of Belgium, oceupying a narrow site between the Meuse and a limestone hill, 17 miles S. of Namur by rail, and consisting mainly of one narrow street. On the cliff above stands the citadel (1530), and the Gothic church dates from the 13th century. There are manufactures of cotton, paper, leather, iron, \&c., with black marble quarries; and the gingerbread of Dinant, com- posed of rye-flour and honey, has an extensive sale. The place was formerly noted for its copper wares, familiarly known as Dinanderie. Pop. 6773. Dinant, which dates from the 6th century, has suffered greatly from frequent sieges. The present fortifications date from 1815 .

Dinapore (Dánápur), military headquarters of the district of Patna in Bengal, on the Ganges, 12 miles W. of Patna city by a road lined with houses throughout. It is divided into two parts, the Cantonments and the Nizamat, or eity proper. Pop. (1891) 44,419, of whom 25,000 resided within the Nizamat. In the mutiny of 1857 the three sepoy regiments stationed here rose in July, and escaped into Shahabad district, where they attacked Arrah (q.v.).

Dina'ric Alps, the name applied to the mountains connecting the Julian Alps with the Balkan system. The main range stretches from north-west to south-east, separating Dalmatia from Bosnia and Herzegovina, as far as the mouth of the Narenta; and a minor chain extends through the Dalmatian coast country. The mountains are principally calcareous; the highest summits are Orjen (6225) and Dinara (5940), and the mean height is 2300 feet.

Dindigal, a town in the presidency of Madras, 40 miles NNW. of Madura by rail, with an old fort, still in good preservation, commanding the approaches to Coimbatore from the south. It has a trade in hides, tobacco, coffee, and cardamoms. Pop. (1891) 12,865, mostly Hindus.

Dindorf, Wilhelm, a famous Hellenist, born 2d January 1802 at Leipzig, where his father Gottlieb Immanuel Dindorf (died 1812) was professor of Oriental Languages. In 1817 he began his studies in philology at Leipzig, under Gottfr. Hermann and Chr. Daniel Beck, declined a call to Berlin in 1827, and next year accepted an extraordinary professorship at Leipzig, which he resigned in 1833 to devote himself entirely to his literary activity. Here he died, 1st August 1883. Dindorf's long life gave many contributions of the first value to Greek scholarship, especially in the region of dramatic poetry. Among his works were the preparation of vols. 7-13 of the great Invernizzi-Beck edition of Aristophanes (1820-34), editions of Aristophanes, with notes and scholia (1835-39), of Aschylus (1841-51), Euripides (1834 63), Sophocles, with notes (1832-36), and a second vol. of the series of scholia to Sophocles, edited by Elmsley (1852), also an edition with annotations and scholia of Demosthenes (1846-51), all printed at Oxford. Other works are those on the metres of Eschylus, Sophocles, Euripides, and Aristophanes (1842); the lexicons to Sophocles (1871) and Aschylus (1873-76); his edition of the text of Homer (1855-56), and of the scholia to the Odyssey (1855) and the Iliad (1875-77). With Hase and his brother Ludwig (1805-71) he edited the Thesaurus Groece Linguoe of Stephanus (1832-65).

Dingelstedt, Franz von, German poet, bom near Marburg in 1814, was royal librarian at Würtemberg in 1843-50, intendant of the court theatres at Munich, Weimar, and Vienna in 1850 71 , and afterwards director of the Burg Theatre in Vienna. He was ennobled by the Austrian emperor, and died 15th May 1881. Besides several volumes of poems, displaying great versatility and considerable power, he published a series of novels, one fine tragedy (Das Haus der Barneveldt), essays, and translations and studies of Shakespeare. His collected works fill 12 vols. (1877).

Dingle, a seaport on the north side of Dingle Bay, in County Kerry, Ireland, 27 miles SW. of Tralee railway station, and $30 \mathrm{WNW}$. of Kil- 
larney. The chief expmrts are corn and butter. The harbour is landlocked. Pop. 1833.

Dinge (Canis dingo), a variety of dog found in

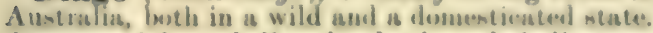
As marnupials are believed to be the only indigenous Austrulian mammals, it is probuble that this dog, which is found in a semi-fomsil stete in sone of the caves, was introduced by or with the earliest humsn

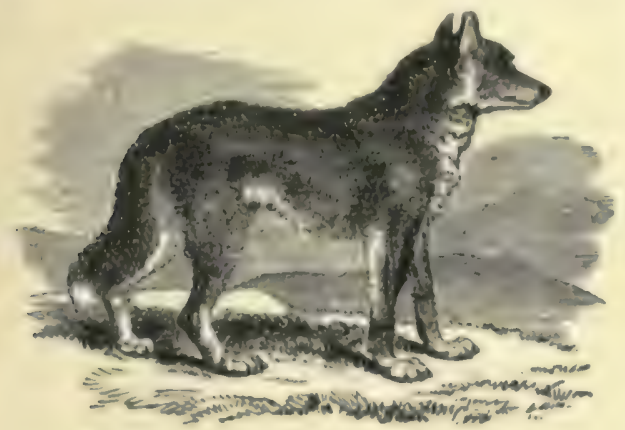

Dingo, or Australian Dog (Canis dingo).

inhabitants. The dingo has an elongated flat head, which is carried high ; the ears are short and erect, and are kept in that position when the animal runs; the fur is soft and predominantly tawny; the tail is bushy and kept low down. It is a very muscular, fieree animal, tamable if taken young. In the wild state it seldom barks. The wild forms, joined doubtless by recent runaways from domestication, used to work very great havoc among the sheep, but vigorous endeavours have vastly reduced their numbers and minimised their ravages. See Dog.

Dingwall (Scand. 'court hill,' see THuse), the county town of Ross-8hire, near the head of the Cromarty Firth, and at the entrance to the valley of Strathpeffer, $13 \frac{1}{2}$ miles NW. of Inverness (by rail 181). It has the county buildings (1845), a public park, a small harbour, and an obelisk, 57 feet high, which marks the grave of Sir George Mackenzie, first Earl of Cromarty. A royal burgh since 1226, it unites with Wick and four other towns to returm one member to parliament. Pop. (1861) 2099: (1881) 1921 ; (1891) 2283.

Dinkelsbuhl, an ancient walled town of Bavaria, on the Wormitz, 19 miles NNW. of Nordlingen by rail, with manufactures of cordage, hosiery, straw-hate, pencils, brushes, \&c. It was formerly a free city of the empire, and suffered much during the 'Thirty Yesrs' War. Pop. (1880) 5186 ; (1885) 4457; (1890) 4496; (1895) 457.

Dinocerata (Gr. deinos, 'terrible,' and keras, 'horn'), an extinct order of mamuals, approaching the elephant in size and movements, remains of which have been found extensively in the Eocene lacustrine sediments of southern Wyoming. The dinocerata include three genera-Uintatherium (most primitive type), Dinocerns (intermediate form), and Tinocers (youngeat and most special. ised). Alsout thirty more or less distinet forms have been recognised. The feet were plantigrade, the fore-foot heing larger than the hind.f(w)t, anil having five digits; the limbs were mavive and heavy, but shorter than in the elephant; the skull was long and narrow, supporting on top three separate transvense pairs of high osseous protuber. ances or horn-cores, while the canine teeth were enormously developed in the male, and formed short, trenchant, decurved tusks ; the naral bonee were elongated so as to form nearly half the length of the skull, though, as the neck was long enough to allow the heal to reach the grrund, there was probably no proboncis : finally, the brain was propor. tionstely arraller than in any other known mamual. and even less than in some reptiles. See Profeson

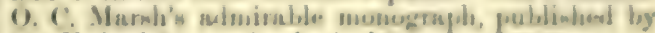
the United States Geological Survey (1884).

\section{Dinornis, See Mos.}

Dinomauria (Gr., 'terrible lizanda') an im. portust group of Mesozoie reptiles, known purty l,y their skeletons, pertly by their footprinta. They were gigantic forms, nome of them at leaut 80 feet in lensth, and many of their charmeters lead on to birds. Thus in the hip-girdle the probic hones were in many cases turned, not forwands as in other reptiles, but backwards as in binds; the leas were also in part bird-like: the fore-limb were leas developed than the lesgs some of the bonem apparently contained air-cavities, de. Atluntosaurus (q.v.), Stegosaurus, Igranodon (q.v.), and Megalosaurus (q.v.) are important types They leegin in Triassic strata, become very prominent in the Jurassic fauns, continue well repreasentex in the Chalk, and then terminate. A large number have been found in America, and onr knowledge of them is mainly due to the reserrches of Pope and Marsh. They were terremtrinl animals, thom h some, such as Iguanodon, frequented mashy ground. Some seem to have Ineen carnivoroms. others vegetarian. The group is a lange and varied one, gradually lecoming more defisesl in its limits and characters. The relations to other fossil reptiles will be discusaed under REPTILEa.

Dinothe'rium (Gr., "terrible beast'), a remarkable extinct animal, the cranial bones of which are found in the Miocene formations of Germany, France, \&c. The animal was provided, like the elephant and the walrum, wich a pair of long tusks ; but these projected from the end of the lower jaw, which is deflected downwards at a right angle to the body of the jaw. Both jaws possessed a serien of pro-molan and molars, the erowns of which were traversed by strong transverse ridges. The nasal envity wan large, apparently supplying altachment for a trunk, as in the elephant. Very little is known

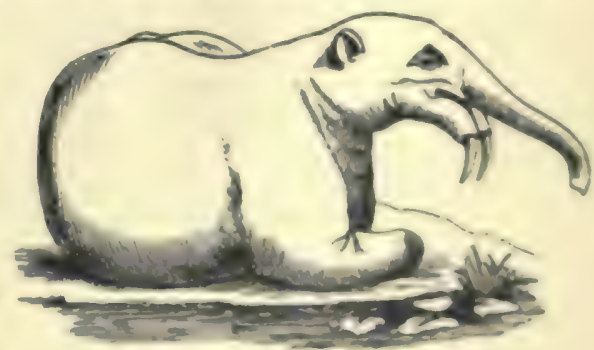

Dinotherium, as restured by Kaup.

of the skeleton except the skull (one example of which is 3f feet long); and hence the true pain. tion of the dimotherium has not been saturfactorily determined. Cuvier and Kaup have referred it in the neighbourbood of the tapir, suppoeing it to have been an inhabitant of lange lakex

Dinwiddie, RoRkr, colonial governor of Virginia, was hort is scotiand about 1600, and was governor of Virgisia from 17.52 to 1758 , when he was recalled, after precipitating the Freach and Indian war, and by hil ill-temper, avarice, and incompetence, rendering himself generally unbear. able to the Americans. He died in 17.0.

Dio Cassius. Bee Dion CAssics.

Dip'cesan is a biahop viewed in relacion to his own clergy or llock. 
Diocesan Courts. See Consistory and COMMISSARY.

Diocese (Fr., from Gr. dioikēsis, 'administration') the territory over which a bishop exercises ecclesiastical jurisdiction. The term occurs as early as the time of Demosthenes, to signify the treasury or department of finance. It is found in Cicero, both as a Greek and as a Latin word, as the special designation of districts in Asia Minor. At this time, the area denoted by this term was but a small one, for Cicero mentions that three dioceses were included in the single province of Cilicia. But in the organisation of the Roman empire introduced by Constantine the Great, the designation diocese was applied to the larger divisions, which were subdivided into provinces or eparchies. About the middle of the 5th century, the dioceses of the empire were-the East, Asia, Pontus, Thrace, Macedonia, Dacia, Illyria, Italy, Africa, Gaul, Spain, and Britain. The city of Rome, with its seven 'suburbicanian' provinces, constituted a diocese in itself, and was not included in that of Italy. The dioceses were governed collectively by four Prætorian Prefects, each of whom had several such territeries under his jurisdiction, and singly by officers ' styled Eparchs, Counts, or Vicars. The provinces (numbering one hundred and seventeen) were under Exarchs or Rectors. The government of the Christian church, as established by Constantine, was assimilated to this division, and the term diocese and others passed over to ecclesiastical matters. At first a diocese meant an aggregate of metropolitan churches or provinces, each under the charge of an archbishop, which had previously been called a parish, into a single jurisdiction under an exarch (Balsamon, ad Can. ix., Conc. Chalced.); and the actual distribution in the 4 th and 5th centuries was founded on, and closely corresponded to, the civil division. The four (later five) patriarchates corresponded to the four prætorian prefectures; and the diocese of the Orient contained fifteen provinces, all wnder the Patriarch of Antioch, till the erection of the patriarchate of Jerusalem in 450, when Palestine, Phœnicia, and Arabia were with drawn from Antioch to constitute the new jurisdiction ; Egypt, under the Patriarch of Alexandria, had six provinces; Asia, eleven; Pontus, eleven; Thrace, six; Macedonia, six ; Dacia, five; Italy, seventeen, of which seven were in the diocese of Rome; Illyria, six; Africa, six; Spain, seven; Gaul, seventeen; and Britain, five. In a later stage of the church's history, the term diocese is applied to a single metropolitanate or province (Greg. Mag. Epist., VII. ii. 17), and lastly it came to signify the local jurisdiction of any one bishop (a meaning already applied to it as early as the second Council of Carthage, in 390 A.D., canon v.), of whatever rank. It does not appear in England till the writings of Matthew Paris in the middle of the 13th century; Bede, for example, using only the terms episcopatus, provincia, ecclesia. On the other hand, it is found as the equivalent of 'parish' in canons of the councils of Agde (506 A.D.), Epaon (517), Orleans IV. (541), and also in the capitularies of Charlemagne, VII. c. 360 . England and Wales are divided ecclesiastic ally into two provinces-viz. Canterbury and York the former being presided over by the Primate of All England, and the latter by the Primate of England. Each of them is subdivided into dioceses, and these again into archdeaconries, rural deaneries, and parishes. See BISHOP.

Diocletian.

VALERIUS DIOCLETIANUS, Roman emperor (284-305 A.D.), was born of humble parentage near Salona, in Dalmatia, in 245. He inherited from his mother, Dioclea, the name of Diocles, which he afterwards enlarged into Diocletianus, and attached as a cognomen to Valerius, a name of the most patrician associations. He adopted a military career, and served with distinction under Probus and Aurelian, accompanied Carus on his Persian campaign, and finally, on the murder of Numerianus having been discovered at Chalcedon, he was proclaimed emperor in 284 by the army on its homeward march. The suspected assassin of Numerianus, the prefect Arrius Aper, he slew with his own hands, in order, it is alleged, to fulfil a prophecy communicated to him, while still a lad, by a Druidess of Gaul, that he should mount a throne as soon as he had slain the wild-boar (aper). Next year he commenced hostilities against Carinus, the joint-emperor along with the deceased Numerianus, who, although victorious in the decisive battle that ensued, was murdered by his own officers, thus leaving to Diocletian the undisputed supremacy. His first years of government were so molested by the incursions of barbarians, that, in order to repel their growing aggressiveness, he took to himself a colleague-namely, Maximianus - who, under the title of Augustus, became joint-emperor in 286. Diocletian reserved for him. self the charge of the eastern empire, and gave the western to Maximian. Still the attacks of the barbarians continued as formidable as ever. The empire was menaced by the Persians in the east, by the Germans and other barbarians in the west and in order to provide for its permanent security, Diocletian subjected it to a still further division. In 292 Constantius Chlorus and Galerius were proclaimed as Cresars, and the distribution of the Roman empire was now fourfold : Diocletian taking the East, with Nicomedia as his seat of govern. ment; Maximian, Italy and Africa, with Milan as his residence; Constantius, Britain, Gaul, and Spain, with Trêves as his headquarters; Galerius, Inyricum and the entire valley of the Danube, with Sirmium as his imperial abode. It was upon his colleagues that most of the burden of engaging actively in hostilities fell, as Diocletian seldom took the field in person. Among the conquests, or rather re-conquests, that were made under his rule, may be enumerated that of Britain, which, after maintaining independence under Carausius and Allectus, was in 296 restored to the empire; that of the Persians, who were defeated, and compelled to eapitulate in 298; and that of the Marcomanni, and others of the northern barbarians, who were driven beyond the Roman frontier. Diocletian, after twenty-one years' harassing tenure of government, desired to pass the remainder of his days in tranquillity. Accordingly, on the 1st of May 305, he abdicated the imperial throne at Nicomedia, and compelled his reluctant colleague, Maximian, to do likewise at Milan. He sought retirement in his native province of Dalmatia, and for eight years resided at Salona, devoting himself to philosophic reflection, to rural recreation, and to horticultural pursuits. Two years before his abdication, he was instigated by his colleague, Galerius, to that determined and sanguinary persecution of the Christians for which his reign is chiefly memorable. He died in 313.

Dio'dati, JEAN, a Calvinistic divine, was born at Geneva, 6th June 1576, became professor of Hebrew there in 1597 , pastor of the reformed church in 1608, and in 1609, on the death of Beza, professor of Theology. He was a preacher at Nimes from 1614 to 1617 , and at the Synod of Dort was representative of Geneva. Diodati, whose family was originally of Lucer in Italy, tried in vain to introduce the reformed doctrine in Venice. He is remembered chiefly through his Italian trans. lation of the Bible, issued (without imprint) at 
Cieneva in 1807, whichs was one of the lreat trasm. listions of the lieformation perimel, and in still in nase. Hin Anmotationee in Biblia (1607) are aleo of value. He died at Geneva, ad Oewober libs. See Budé, Vio de Jean Dioduti (Geneva, 1860)-A nephew, Снавlвs Diodati (eirea 1606-38), is re. membered a the friend of Milton. Son of a doctor who had settled in England, he was educated at st Paul's Sichuol, und 'Trinity Coblenge, Uxiord, and for the last nine years of his life practised medicine sear Chenter and in Blackfrians.

Diodon. See (ilobe-fism.

Diodo'rus Sife'ulus, a Greek historian, was trmu at Agyrium, in sirily. Little is known of his life beyond what is told by himself. He lived in the times of Julius Caesar and Augustus, travelled in Asia ami Enrojes, und lived a long time in Rome, collesting the materints of his great work, the comfyilation of which oreupied thirty years This work, the Biblinthike Historike, was a history of the world, in forty books, from the creation to the Gallic wars of Julius Caesar. It was divided by the anthor into three parts - the first of which, in six lnoks, comprises all the fireek and foreign mythical history down to the Trojan war; the second, in eleven books, contains the history from the year 1184 B.C. to the death of Alexander the Great; the third, in twenty-three books, continues the narrative of events from that date to the year 60 B.C. Of this great work, the lingt five books are extant entire; the next five books are wholly lost; the next ten are complete; and of the remainder of the work, considerable fragments have been pre. served in the Errerpta in Photius, and in the Ecloges prepared by command of Constantine Porphyrogenitus. Had Diodorus Siculus posseswed any powers either of criticism or of arrangement, his work would have been of the greatest importance; but he was in both respects so deficient, that his history has no practical value beyond what belongs to an immense mass of raw and now scarcely avaí. able material. His narrative is colourless and monotonous, and his diction, generally clear and simple, holds a sort of middle place between the pure Attie and the colloquial Greek of his time. The best editions of Diodorus Sieulus are Wesseling's (Amst. 1746), L. Dindorf's (1828-31), and Bekker's (1853-64) ; re-edited by Vogel (1888-93).

Dine'cious (Gr. dis, 'twice ;' and oikos, 'A habitation '), a term applied by Linnseus to plant in which separate individuals exclusively produce male and female flowers respectively. Great inportance was attached to this in the artiticial system of elassification; but diarcious species incur in all groups of plants indiflerently, however commonly hermaphrodite; and similarly, herma yhorlite forms oceur in groups usually dicecious. This is probably explaiued by regarding the com. plete separation of the seves as a phase of evolu. tion heyomd hermaphroxlitism which tends to ariso in plants as in animals, and from which reversion to hermaphroblitism may also readily oceur, probahly in conditions favourable to vegretativeness ispe Sex, Reproductios). Familiar exumper of dioecious plants may he meen in mosat spreciess of willow, or in the pink or white Lyehnis ( L. diurna and L. vespertina), or the Common Nettle (Urtice dioica). Amongst cultivated plants, hemp, spinach, and the date-pulm may be inatanced.

Diogenes, the Cynio philosopher, was a untive of Sinope, in Pontus, where he was born about 412 B. C. His father, a banker named Icesias or Icetas. was convicted of swindling, and so the young Diogenes had to leave Sinope and go to Athena. His youth had been that of a spendthrift and a rake, but at Athens his interest was arrested by the character of Antisthenes, who, however, re. pelled his fint sodvances Hut not even blows could restrain the enthunimutic andour of the young diwciple, and at length Antiathenes, moved with connpession, conservecel to solmit hise as a pupit. Finm an extravagant dehanchee, Jiopenes

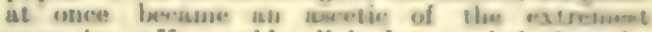
austerity. He would roll in hot and during the heat of sumumer; in winter, he would etulurace statue covered with snow. His elothing was of the conraest, his food of the plaines. Hin bed was the bare ground, whether in the open atreet of under the portlones. At length he found himuelf a permanent residenee in a tub which belonged to the letroum, or the temple of the Mother of the Gomb His eccentrie life did not comt him the reopect of the Athenians, who admired lim contempt for enm. fort, and allowed him a wide latitnde of comsnent and rebuke. Prnctical good was the ehief aim of his philosophy: for literature and the fine arts he did not concenl his dimlain. He laughed at mes of letters for reading the anferings of C'lymees, while neglecting their own ; at musicinns who spent in stringing their lyres the time which would have heen much better employed in making their own

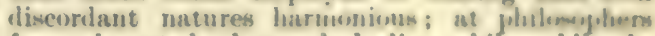
for gaxing at the heavenly bodies, while sablimely incognisant of earthly ones; at orntors who studied how to enforce truth, but not how to practies it. He was seized loy pirates on a voyage to . Fgim. and carried to Crete, where he was sold as a slave. When asket what business he undentumal, he answered : How to command men.' His pur. chaser was Xeniades of (iorinth: hut the slave soon came to rule the master, acujuired his froeslom, was appointed tutor to the children, and mwent him old age as one of the household. It was here that he had his interview with Alexander the Great. The king opened the conversation with: "I am Alexamiler the Great,' to which the philownjher answered: 'And I am Diogenes the Cinie.' Alexander then asked him in what way be conuld serve him, to which Diogenes rejoined: "You cas stand ont of the sunshine." Alexander is sajil to have been so struck with the Cyuie's self-posea. sion, that he went away reuarking: "If I were nos Alexander, I would be Diogenes.' The fulihmo. pher lived at Corinth till his death at the age of ninety, 323 b.C. See Hermann, Zur Geochichre

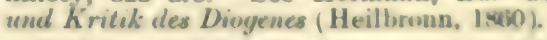

Diogenes Lifertius seems to have been born at Laerte, in Cilicis, and to have taken his surname from that town. Little is known of his histury luat it is most probable thas he flourinbes in the bal century A.D. His mane has been hept alive loy his Lores of the Philessophlers, a work in cen lanbis, in which he divites the philesoyplis of the Cireschs into the Ionio-beginning with Anaximander, and encing with Chrysipyus and Bpicurus and the Italian, founded by Pythayoras, and ending with Epicurus. The socracic shool was a part of the Ionic philosophy; to the Italian belang the Eleation with Heraclitus and the Sceptice. This work con. tains a great mon of interesting information regard. ing the private lives and habits of the moat eminent philowophers of antiquity. Though it to atterly worthles in reapect of plan, coherence, or criticiem, it yet contains ao many piquant anecdotes, ard many valuable quotatiuns from loet works shat

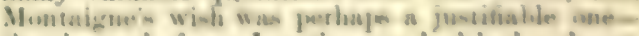
that inmtend of one Laertivs, wo hal had a dosen. The beat editions of Lmertine are thive of Hubnet (Loip. 1828-31) and Cobet (Paris, 1850 /.

\section{Dlomedea. 800 AlBatrosa.}

Diomede Islands, a group of three mall imlande (Fairway, Krusenstern, and Ratmanoff) in Behring Strait, forming, a it were, otepping-otonen between Asia and America. 
Diome'des, the bravest, after Achilles, of all the Greeks who took part in the Trojan war. The son of Tydeus, he is constantly called by his patronymic, Tydides. He vanquished in fight Hector and Eneas, the most valiant of the Trojans; and even Ares and Aphrodite, when they took the field on the Trojan side, were attacked and wounded by him. In the games instituted by Achilles in honour of Patroclus, he gained the prize in the chariot-race, and worsted the mighty Ajax in single combat. Along with Ulysses, he carried off the Palladium, on which the fate of Troy depended. On returning to Argos, to the crown of which he had succeeded after the death of Adrastus, he found that his wife had proved unfaithful in his absence, whereupon he sailed away to Italy, there married the daughter of King Daunus, and lived to a good old age. The towns of Beneventum, Venusia, Canusium, and Brundisium claimed to have been founded by him.

Dion, a Syracusan, whose sister became the second wife of the elder Dionysius the Tyrant while he himself was married to a daughter of Dionysius, his own niece. His close connection with the tyrant brought him great wealth, but his austere manners and devotion to philosophy made him hateful to Dionysius the Younger, who under the guidance of Philistus and his party disregarded the advice of Plato, and banished Dion. Thereupon he retired to Athens to devote himself to the study of philosophy under the guidance of Plato. His expedition to Syracuse resulted in his making himself master of the city ( 356 B.C.), but his severity made him unpopular among its luxurious citizens, and a plot was formed against him through which he was murdered in his own house three years later. His life was written by both Plutarcli and Cornelius Nepos, and he is the subject of a noble poem by Wordsworth.

Diona' $\mathbf{a}$, a very curious and interesting genus of Droseraceæ. Only one species is known, $D$. muscipula, sometimes called Venus's Fly-trap and the Carolina Catchfly Plant. It grows in marshy places in North and South Carolina. The remarkable insect-catching and digestive powers exhibited by the leaves are described under INSECTIVORous Plants.

Dion Cassius, surnamed Cocceianus, from the orator Dion Chrysostomus Cocceianus, most likely his maternal grandfather, a celebrated Greek historian, was born at Nicrea, in Bithynia, 155 A.D. About 180 he went to Rome, held successively all the high offices of state, was twice consul, and enjoyed the intimate friendship of Alexander Severus, who sent him as legate to Dalmatia and Pannonia. About 229 he retired to his native city, where he passed the remainder of his life. He is best known by his History of Rome, from the landing of Aneas in Italy down to 229 A. D., in eighty books, of which but nineteen, from the thirty-sixth to the fiftyfourth, have reached us complete. These embrace the history from the wars of Lueullus and Pompey against Mithridates, down to the death of Agrippa, 10 A.D. The first twenty-four books exist only in the merest fragments; of the last twenty we have only the 11th-century epitome of Xiphilinus. The Annals of Zonaras followed Dion Cassius so closely, that we may almost consider that work as an epitome. The position of Dion Cassius gave him free access to the national archives, and his work has considerable value for the imperial epoch of Roman history. His model was Thucydides, and he need not be abused because he did not equal his original. The best editions of his History are those of Sturz (1824), Bekker 1849, and L. Dindorf (5 vols. 1863-65; revised by Melber, 1890).

Dion Chryso'stomus ('the golden-mouthed'), an eminent Greek rhetorician, surnamed Cocceianus from his intimate friendship with the Emperor Cocceius Nerva, was born at Prusa, in Bithynia, about 50 A.D. His father, Pasicrates, paid great attention to his education, which was perfected by travel. He came to Rome under Vespasian, but had afterwards to leave the city, having had the misfortune to excite the suspicion of Domitian. He next visited-in the disguise of a beggar, and on advice of the Delphic oracle-Thrace, Mysia, and Scythia. On the accession of Nerva $(96$ A.D.) he returned to Rome, and lived in great honour under that ruler and his successor Trajan till his own death, about 117 A.D. As many as eighty of his orations are still extant, with fragments of fifteen others. They are, however, treatises rather than orations proper, discussing questions in politics, morals, and philosophy. These are well reasoned, clear, and eloquent, and are written in pure Attic Greek. Dion Chrysostomus was 'the first writer after Tiberius,' says Niebuhr, 'that greatly contributed towards the revival of Greek literature.' Good editions are by Reiske (1784), Emper (1844), Dindorf (1857), and Von Arnim (1893-95). 





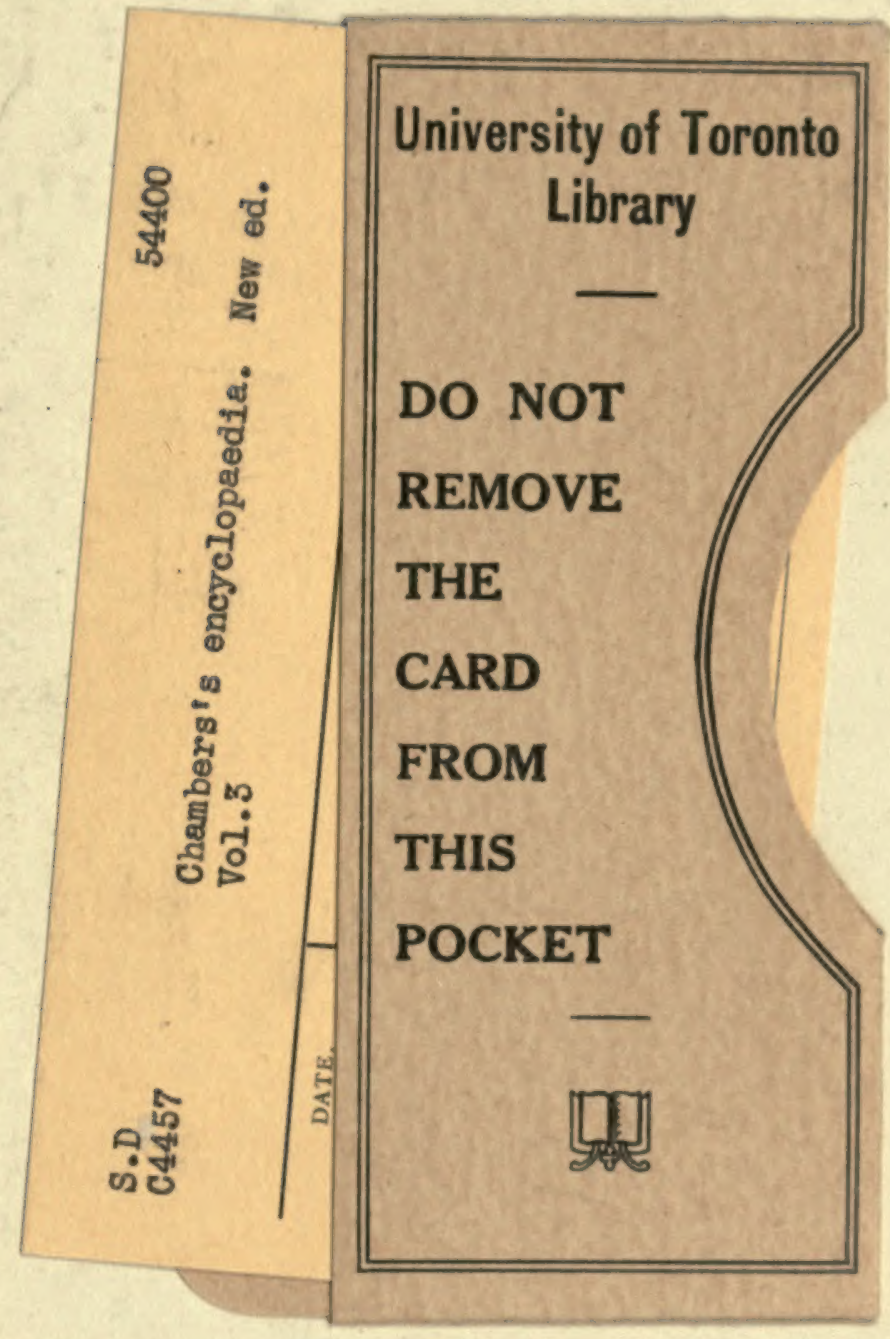


